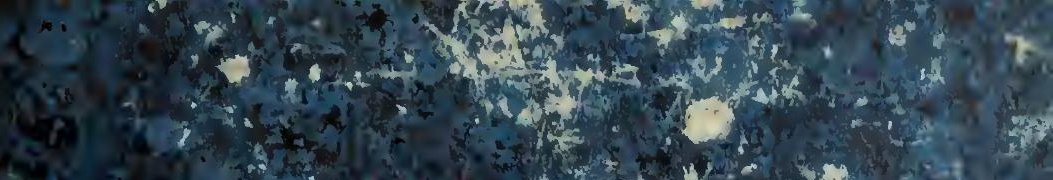

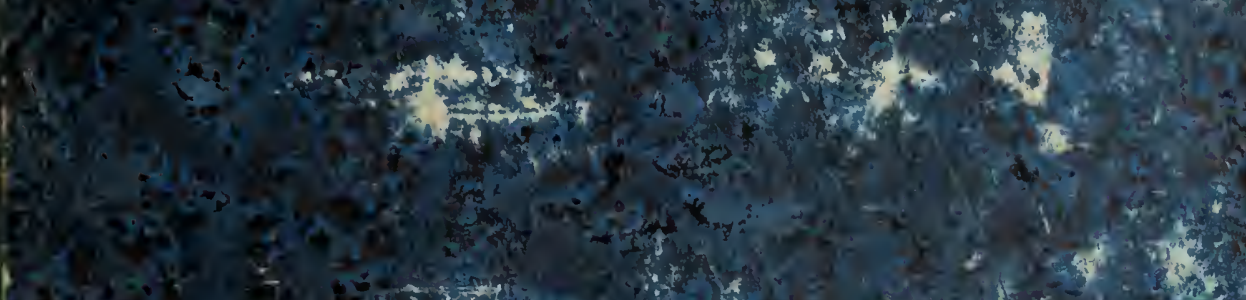

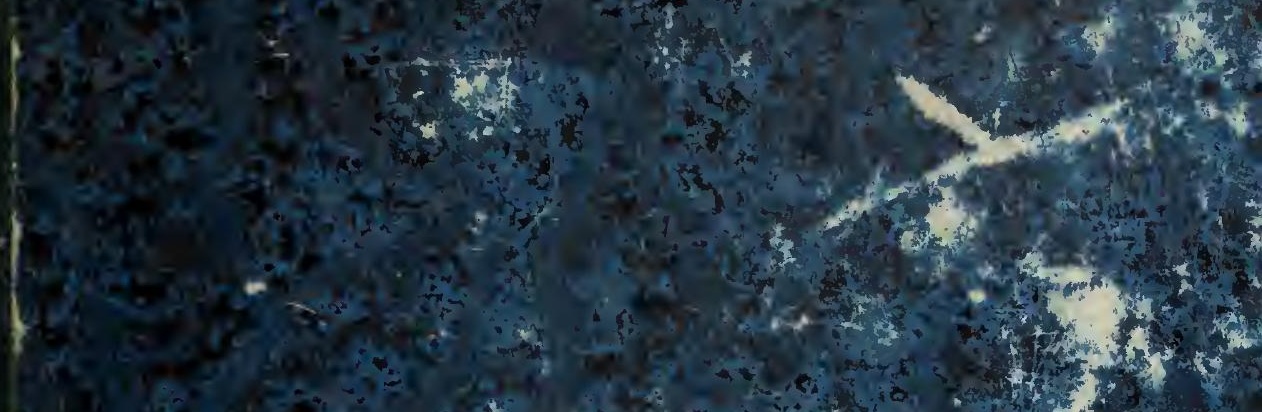
f.

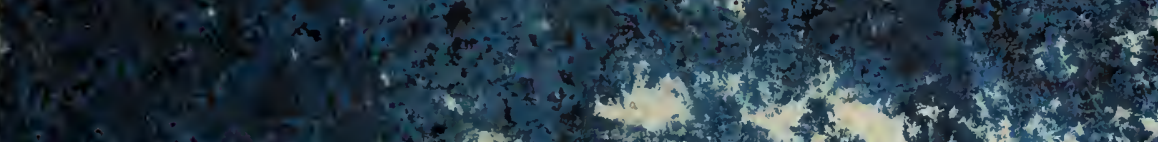

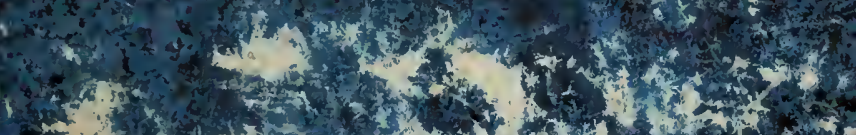

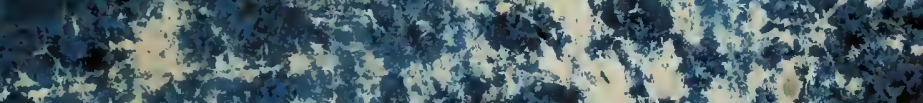

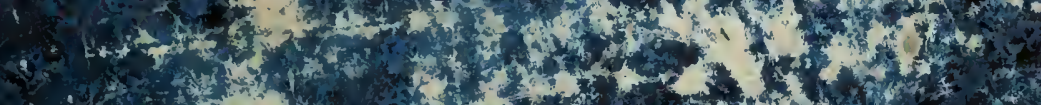

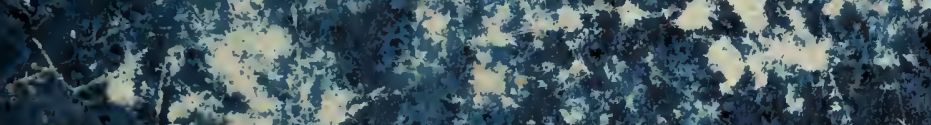

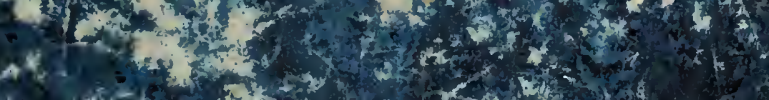
3.t.

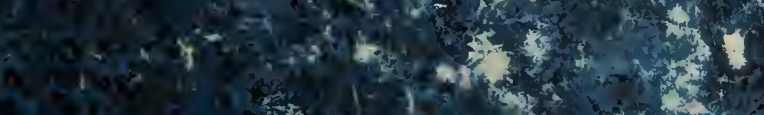

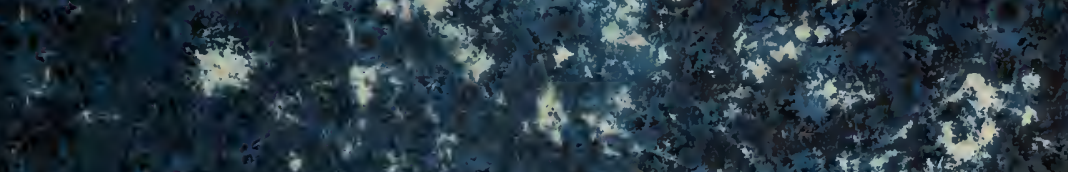

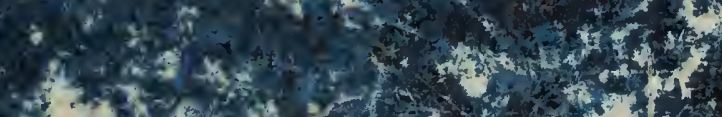

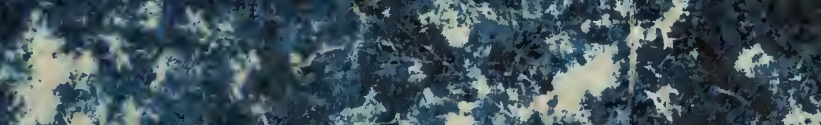

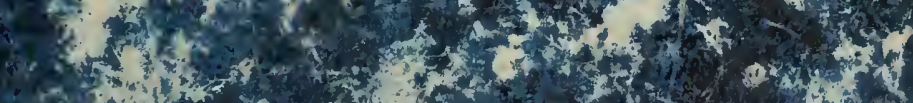

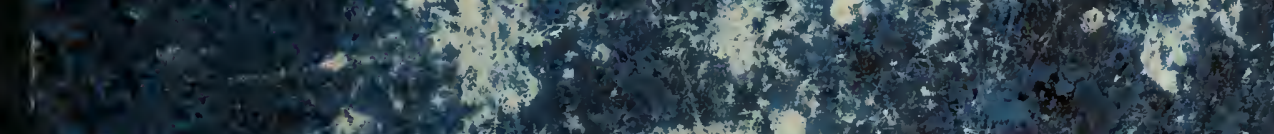

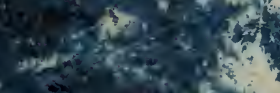

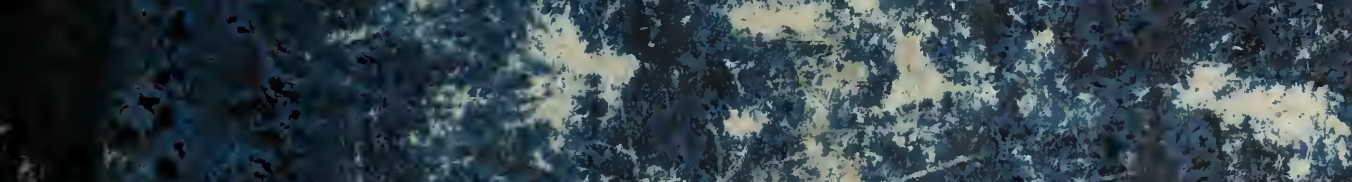

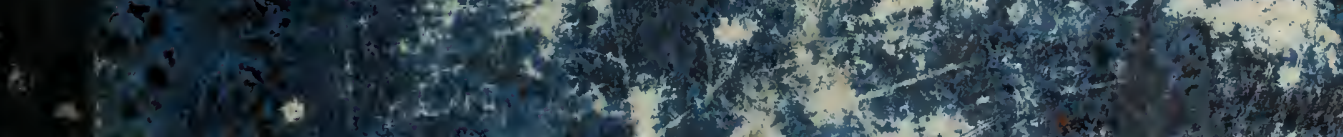

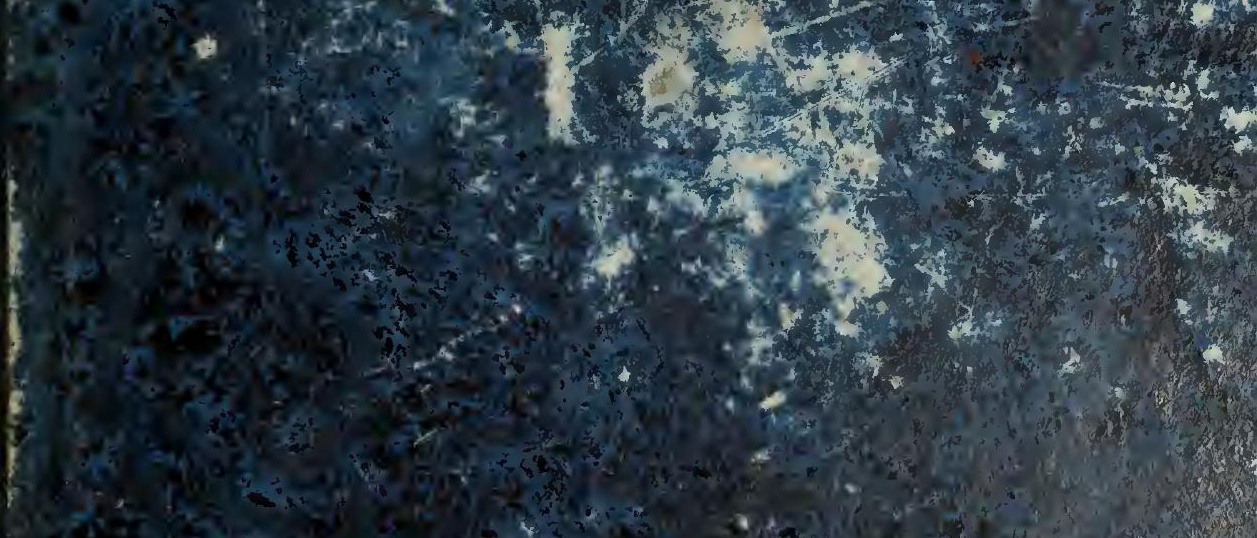




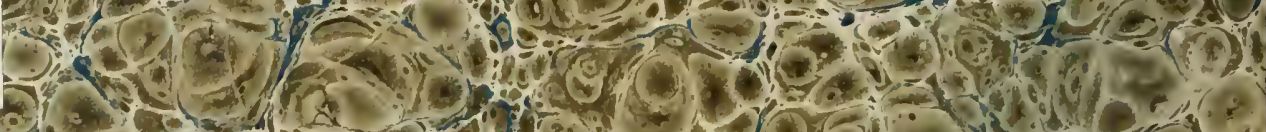

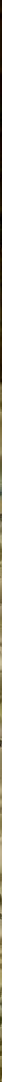

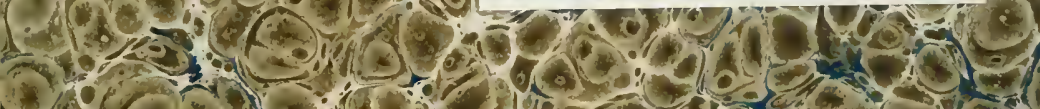
2. C R

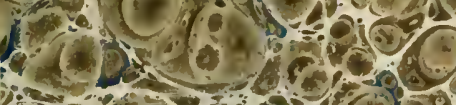

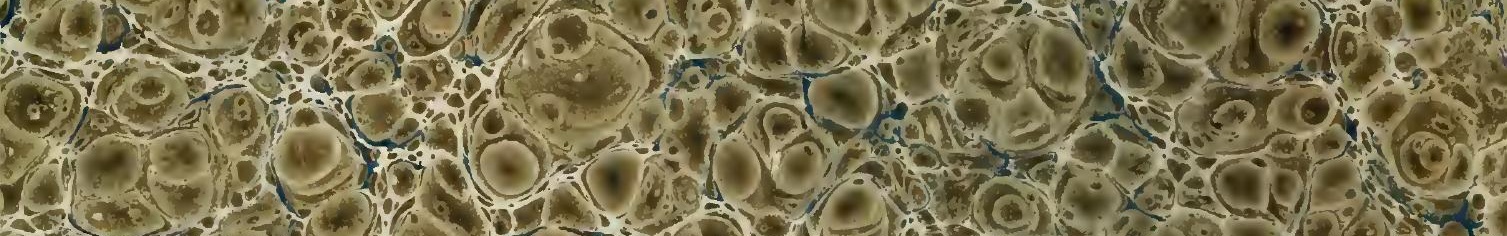

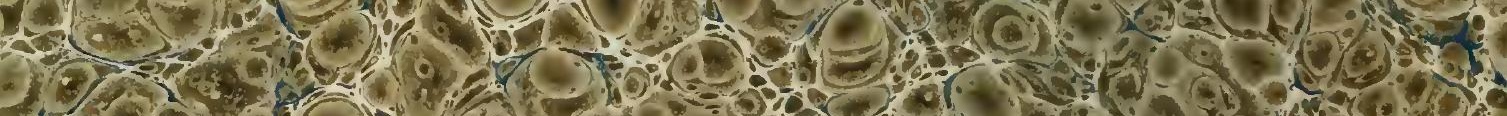

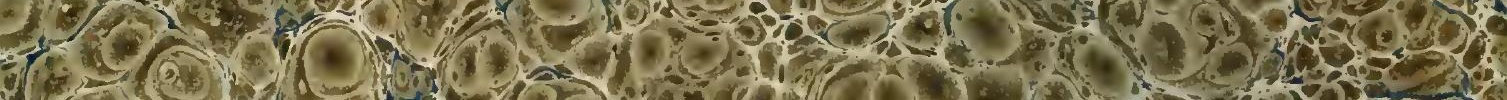

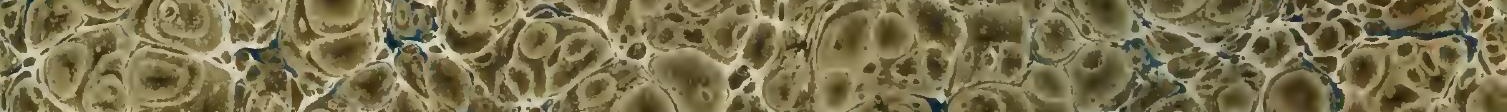

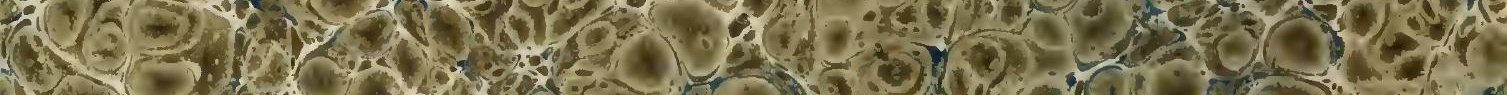

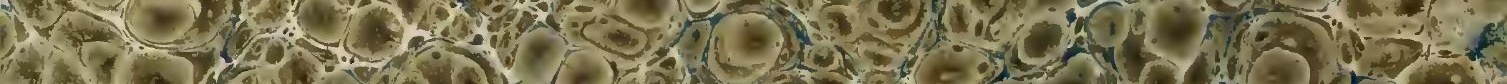

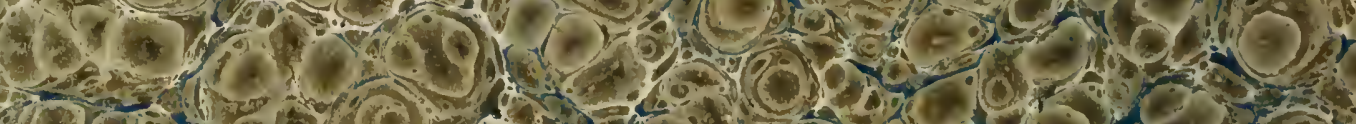

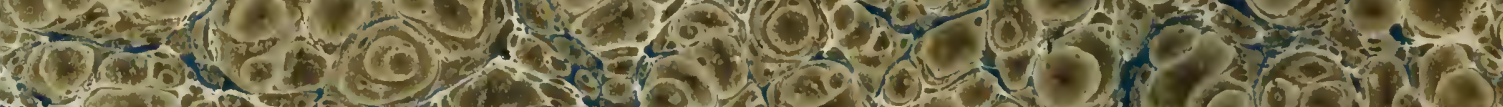

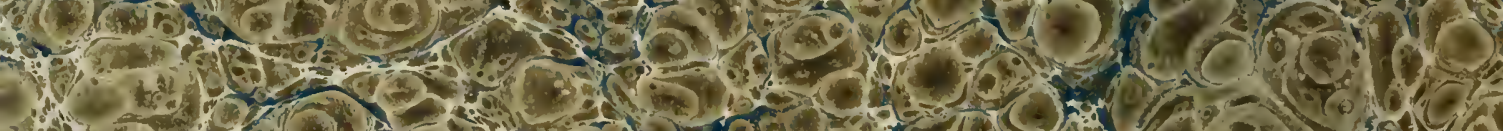

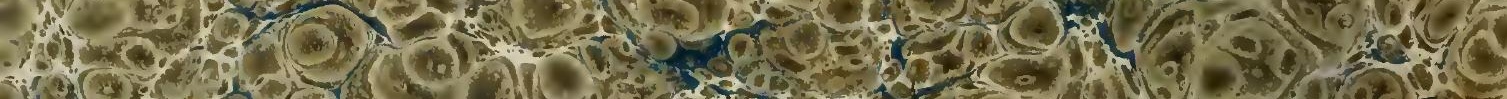

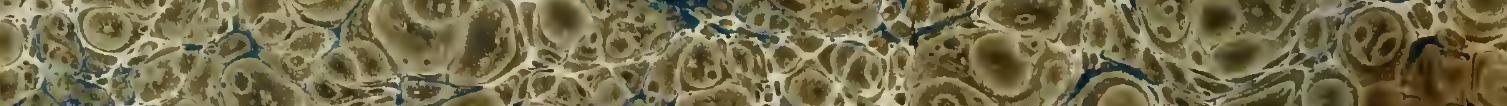

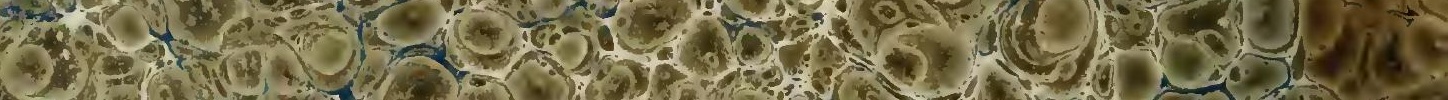




Digitized by the Internet Archive in 2010 with funding from University of Ottawa 



\section{OEUVRES}

(OMULIETES

\section{I)E BUFFON.}

TOME IV. 



\section{(EUVRES}

(i) (I) I. F I:S

I)E

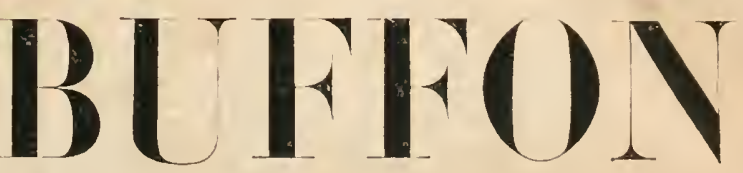

* AVE DES EXTRAITS DE DAUBENTON

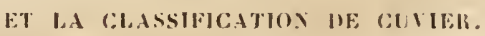

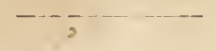

\section{TONE OUATRIEME}

U I MIFERES. - 1 .

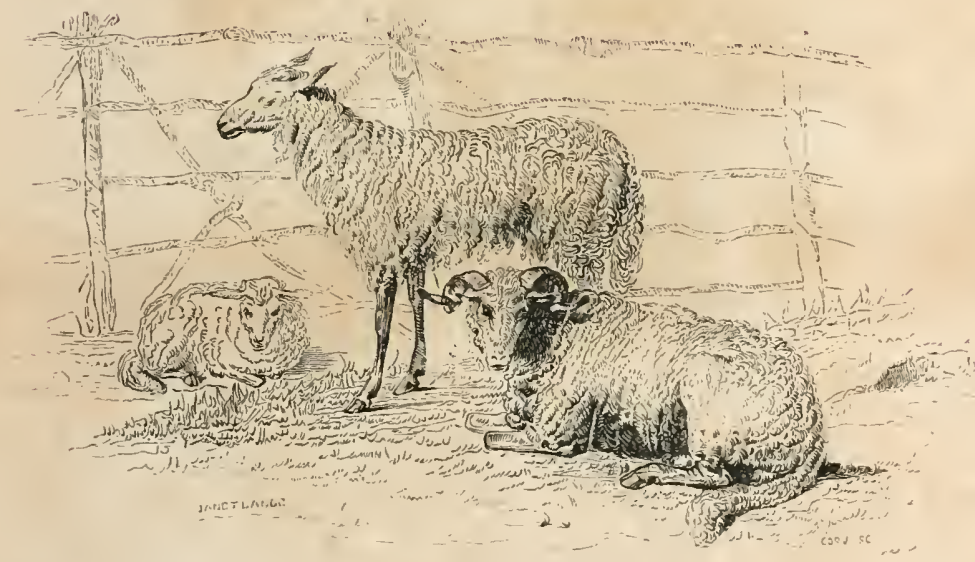

\section{PARIS}

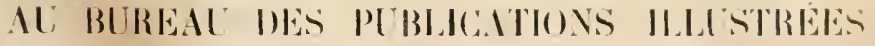

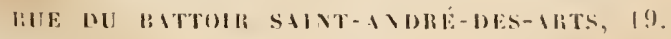





\section{HISTOIRE NATURELLE.}

\section{ANIMAUX CARNASSIERS.}

Jusqüici nous n'avons parlé que des animaux utiles : les animaux nuisibles sont en bien plus grand nombre; et quoiqu'en tout ce qui nuit paraisse plus abondant que ce qui sert, cependant tout est bien, parce que dans l'univers physique le mal concourt au bien, et que rien en effet ne nuit à la nature. Si nuire est détruire des êtres animés, l'homme, considéré comme faisant partie du système général de ces êtres, n'est-il pas l'espèce la plus nuisible de toutes? Lui seul immole, anéantit plus d'individus vivants, que tous les animaux carnassiers n'en dévorent. Ils ne sont donc nuisibles que parce qu'ils sont rivaux de l'homme, parce qu'ils ont les mêmes appétits, le même goût pour la chair, et que, pour subvenir à un besoin de première nécessité, ils lui disputent quelquefois une proie qu'il réservait à ses excès; car nous sacrifions plus encore à notre intempérance, que nous ne donnons à nos besoins. Destructeurs nés des êtres qui nous sont subordonnés, nous épuiserions la nature si elle n'était inépuisable, si par une fécondité aussi grande que notre déprédation, elle ne savait se réparer ellemème et se renouveler. Mais il est dans l'ordre que la mort serve à la vie, que la reproduction naisse de la destruction: quelque grande, quelque prématurée que soit donc la dépense de l'homme et des animaux carnassiers, le fonds, la quantité totale de substance vivante n'est point diminuée; et s'ils précipitent les destructions, ils hâtent en même temps des naissances nouvelles.

Les animaux qui, par leur grandeur, figurent dans l'univers, ne font que la plus petite partie des substances vivantes; la terre four- mille de petits animaux. Chaque plante, chaque graine, chaque partieule de matière organique contient des milliers d'atomes animés. Les végétaux paraissent être le premier fouds de la nature, mais ce fonds de subsistance, tout abondant, tout inépuisable qu'il est, suffirait à peine au nombre encore plus abondant d'insectes de toute espèce. Leur pullulation, tout aussi nombreuse et souvent plus prompte que la reproduction des plantes, indique assez combien ils sont surabondants : car les plantes ne se reproduisent que tous les ans, il faut une saison entière pour en former la graine; au lieu que dans les insectes, et surtout dans les plus petites espèces, comme celle des pucerons, uneseule saíson suffit à plusieurs générations. Ils multiplieraient donc plus que les plantes, s'ils n'étaient détruits par d'autres animaux, dont ils paraissent être la pâture naturelle, comme les herbes ef les graines semblent être la nourriture préparée pour eux-mêmes. Aussi parmi les insectes y en at-il beaucoup qui ne vivent qued'autres insectes; il y en a mème quelques espèces qui, comme les araignées, dévorent indifféremment les autres espèces et la leur : tous servent de pâture aux oiseaux, et les oiseaux domestiques et sa uvages nourrissent l'homme, ou deviennent li proie des animaux carnassiers.

Ainsi la mort violente est un usage presique aussi nécessaire que la loi de la mort naturelle; ce sont deux moyens de destruction et de renouvellement, dont l'un sert à entretenir la jeunesse perpétuelle de la nature, et dont l'autre maintient l'ordre de ses productions, et peut seul limiter le nombre dans les espèces. Tous deux sont des effets dépendants des causes générales: chaque individu qui nait, tombe de lui-mème au bout d'un temps; ou, lorsquil est prématurément détruit par les autres, e’est 
qu’il était surabondant. Eh! combien n’y en a-t.il pas de supprimés d'arance! que de fleurs moissonuées au printemps! que de races éteintes au moment de leur naissance' que de germes anéantis avant leur développement! L'homme et les animaux carnassiers ne vivent que d'individus tout formés, ou d'individus prè's à l'ètre: la chair, les œufs, les graines, les germes de toute espèce font leur nourriture ordin:ire; cela seul peut borner l'exubérance de la nature. Que l'on consi ière un instant qut Iqu'une de ces espèces inférieures qui servert de pàture aux autres, celle des harengs, par exemple; ils viemnent par milliers s'offrir à nos pêcheurs; et après avoir nourri tous les monstres des mers du nord, ils fournissent encore à la subsistance de tous les peuples de l'Europe pendant une partie de l'année. Quelle pullulation prodigieuse parmi ces animaux! et, s'ils n'étaient en grande partie détruits par les autres, quols seraient les effets de cette immense multiplication! eax seuls couvriraient la surface entière de la mer : mais bientôt se nuisant par le nombre, ils se corrompraient, ils se détruiraient eux-mêmes; faute de nourriture suff̂sante, leur fécondité diminuerait; la contagion et I disette feraient ce que fait la consommation; le nombre de ces animaux ue serait đ̆cuère augmenté, et le nombre de ceux qui s'en nourrissent serait diminué. Et, comme l'on peut dire la mème chose de toutes les autres espèces, il est donc nécessaire que les unes vivent sur les autre; ; et dès lors la mort violente des animaux est un usage légitime, innocent, puisqu'il est fondé dans la nature, et qu'ils ne naissent qu'à cette condition.

A rouons cependant que le motif par lequel on voudrait en douter fait houneur à l'humanité : les animanx, du moins ceux qui ont des sens, de la chair et du sang, sont des c̀tres sensibles; comme nous, ils sont capables de plaisir et sujets à la douleur. Il y a douc une espèce d inscusibilité cruelle, à sacrifier, sans récessité, ceux surtout qui nous approcheut, qui rivent a vec uous, et dont le sentiment se rélléchit vers nous en se marcquant par les signes de la douleur; car ceux dont la nature est différente de la nôtre ne peuvent guère nous affecter. La pitié naturelle est fondée sul les rapports que nous avons avec lobjet qui souffre; elle est d'autant plus vive que la ressemblance, la conformité de nature est plus grande : on souffre en royant souffril son semblable. Compassion, ce mot exprime assez que c'est une souffrance, une passion qu'on partage; cependant c'est moins l'homme qui souffre, que sa propre nature qui pâtit, qui se révolte machinalement et se met d'elle-nème à l'unission de clouleur. Liàne a moins de part que le corps à ce sentiment de pitié naturelle, et les animaux en sont susceptibles comme l'homme; le cri de la clonleur les ément; ils accourent pour se secourir; ils reculent à la vue d'un cadarre de leur espèce. Ainsi lhorreur et la pitié sont moins cles passious de l'ìme que des affectious naturelles, qui dépendent de la sensibilité du corps et de la similitude de la conformation; ce sentiment doit done diminuer à mesure cque les natures s'éloignent. Un chien qu'on frappe, un agneau qu'on égorgé, nous font quelque pitié; un arbre que l'on coupe, une huitre quion mord, ne nous en font aucune.

Dans le réel, peut-on douter que les animaux, dont l'organisation est semblable à la nôtre, n'éprourent des sensations semblables? Ils sont sensibles, puisqu ïls ont des sens; et ils le sont d'autant plus que ces sens sont plus actifs et plus parfaits. Ceux au contraire dont les sens sont obtus ont-ils un sentiment exquis? et ceux auxquels il manque quelque organe, quelque sens, ne mancuent-ils pas de toutes les sensations qui y sont relatives? Le mouvement est l'effet nécessaire de l'exercice du seutiment. Nous arons prouvé que, de quelque manière qu'un être fùt organisé, s il a du sentiment, il ne peut mancuer de le marquer au dehors par cles mouvements extérieur's. Ainsi les plantes, quoique bien organisées, sont des êtres insensibles, aussi bien que les animaux qui, cornme elles, n'ont nul mouvement apparent. Ainsi parmi les animanx, ceux qui nont, comme la piante appelée sensitive, qu'un mouvement sur eux-mêmes, et qui sont privés du mouvement progressif, n'ont encore que très-peu de sentiment; et enfin ceux mème qui ont un mourement progressif, mais qui, comme des autornates, ne font gu'un petit nombre de choses, et les font toujours de la mème façon, nont qu'une faible portion de sentiment, limitée à um petit nombre d'objets. Dans l'espèce humaine, que d'automates! combien l'édueation, la communication respective des idées n’augmententelles pas la quantité, la vivacité du sentiment? quellc difference à cet égard entro l'hommo 
sauvage et l'homme policé, la paysamine et la femme du monde! Et de mème parmi les animaux, ceux qui vivent avce nous deviemnent plus sensibles par eette communication, tandis que ceux qui demeurent saurages n'ont que la sensibilité naturelle, souvent plus sùre, mais toujours moindre que l'acquise.

Au reste, en ne considéraut le sentiment que comme une faculté uaturelle, et mème indépendamment de sour résultat apparent, c'est-àdiredes mourements qu'il produit nécessairement dans tous les êtres qui en sont donés, on peut eneore le juger, l'estimer et en céterminer à peu près les différents degrés par des rapports physiques, auxquels il me parait qu'on n'a pas fait assez d'attention. Pour que le sentiment soit au plus haut degré dans un corps animé,il faut que ce corps fasse un tout, lequel soitnon-seulement sensible dans toutes ses parties, mais encore composé de maniere que toutes ces parties sensibles aient entre elles une cor' espondance intime, en sorte que l'une ne puisse ètre ébranlée sans communiquer une partie de cet ébranlement ì cl.acune des antres. Il faut cie plus qu'il y ait un centre principal et unique auquel puissent aboutir ces différents ébranlements, et sur lequel, comme sur un point d'appui général et commun, se fasse la réaction de tous ces mouvements. Ainsil'homme, et les animaux qui par leur organisation ressemblent le plus à l'homme, seront les êtres les plus sensibles; ceux au contraire qui ne font pas un tout aussi complet, ceux dont les parties ont une correspondance moins intime, ceux cui ont plusieurs centres de sentimeni, et qui, sous une mème enveloppe, semblent noins r'cufermer un tout unique, un animal parfait, que contenir plusieurs centres d'existence séparés ou différents les uns des autres, seront des êtres beaucoup moins sensibles. Un polypequel'on coupe et dont les parties divisées vivent séparément; une guêpe dans la tête, quoique séparée du corps, se meut, vit, agit, et mème mange comme auparavaut; un lézard auquel, en retranchant une partie de son corps, on n'vite ni le mouvement, ni le sentiment; une écrer isse, dont les membres amputés se renourellent; une tortue, dont le cœur bat longtemps après avoir été arraché; tous les insectes dans lesquels les principaux viseères, comme le cour et les poumons, ne forment pas un tout au centre delianimal, mais sont divisés en plusicurs parties, s'ćtendent le long du corps, et font, pour ainsi dire, une suite de viscères, de romurs et de trachées; tous les poissons, dont les organes de la circulation et de la respiration n'ont que peu d'action et different beaucoup de ceux des quadrupèdes, et même de ceux des cétacées; enfin totis les animaux dont l'organisation s'éloigne de la nòtre, ont peu de sentiment, et d'autant moins (qu'elle en differe plus.

Dans l'homme et dans les animaux qui lui ressemblent, le diaphragme parait être le centre du sentiment: e'est sur cette partie nerveuse que portent les impressions de la douleur et du plaisir; c'est sur ce point d'appui que s'exelcent tous les mouvements du système sensible. Le diaphragme sépare transversalement le corps entier de l'animal, et le divise assez exactement en deux parties égales, dont la supérieure renferme le cœur et les poumous, et l'inférieure contient l'estomac et les intestins. Cette membrane est douée d'une ex trème sensibilité; elle est d'une si grande nécessité pour la propagation et la communication du mous ement et du sentiment, que la plus légère blessure, soit au centre nerveux, soit à la circonférence, ou même aux attaches du diaphragme, est toujours accompagnée de convulsions, et souvent suivie d'une mort violente. Le cerveau, (qu'on a dit être le siége des sensations, n’est donc pas le centre du sentiment, puisqu'on peut au contraire le blesser, l'entamer, sans que la mort suive, et qu'on a l'expérience qu'après avoir enlevé une portion considérable de la cervelle, l'animal n’a pas cessé de vivre, de se mouvoir, et de sentir dans toutes ses parties.

Distinguons donc la sensation du sentiment: la sensation n'est qu'un ébranlement dans le sens, et le sentiment est cette mème sensation devenue agréable ou désagréable par la propagation de cet ébranlement dans tout lesystème sensible: je dis la sensation devenue auréable ou désagréable, car c'est là ce qui constitue l'essence du sentiment; sou caractère unique est le plaisir ou la douleur, et tous les mourements qui ne tiennent ni de l'un, ni dè l'autre, quoiqu'ils se passent au-dedans de nous-mèmes, nous sont indifférents et ne nous afiec'ent point. C'est du sentiment que dépend fout le molirement extéricur' ct l'exereice de toutes les forces de l'animal; il n’agit cqu'autant qu'il est afiecté, c'est-à-dire autant qu'il sent ; et cette meme partie, que nous l'egardons comme le centredu sen 
timent, sera aussl le centre des forces, ou, si lon reut, le point d'appui commun sur lequel elles s'exercent. Le diaphragme est dans l'an:mal ce que le collet est dans la plante: tous deux les divisent transversalement; tous deux servent de point d'appui aux forces opposées ; car les forces qui dans un arbre poussent en haut les parties qui doivent former le tronc et les branches, portent et appuient sur le collet, aussi bien que les forces opposés qui poussent en bas les parties qui forment les racines.

Pour peu quion s'examine, on s'apercerra aisément que toutes les affections intimes, les émotions vives, les épanouissemenís de plaisir, les saisissements, les douleurs, les nausées, les defaillances, toutes les impressions fortes des sensations devenues agréables ou désagréables, se font sentir au-dedans du corps, à la région mème du diaphragme. Il n'y a au contraire nul indice de sentiment dans le cerveau, et l'on n'a dans la tète que les sensations pures, ou plutôt les représentations de ces mèmes sensations simples et dénuées des caractères du sentiment : seulement on se souvient, on se rappelle que telle ou telle sensation nous a été agréable ou désagréable; et si cette opération, qui se fait dans la tète, est suivie d'un sentiment vif et réel, alors on en sent l'impression au-dedans du corps et toujours à la région du diaphragme. Ainsi, dans le fotus, où cette membrane est sans exercice, le sentiment est nul, on si faible qu'il ne peut rien produire: aussi les petits mouvements que le fotus se donne sont plutôt machinaux que dépendants des sensations et de la volonté.

Quelle que soit la matière quiscrtde véhicule au sentiment, et qui produit le mouvement mus. culaire, il est sûr qu'elle se propage par les nerfs, et se communique dans un instant indivisible d'une extrémité à l'autre du système sensible. De quelque manière que ce mouvement s'opère, que ce soit par des vibrations comme dans des cordes élastiques, que ce soit par un feu subtil, par une matière semblable à celle de l'électricité, laquelle non-seulement réside dans les colps animés, comme dans tous les autres corps, mais y est mème continuellement régénérée par le mouvement du cour et des poumons, par le frottement du sang dans les artères, et aussi par l'action des causes extérieures sur les organes - les sens, il est encore sùr que les nerfs et les membranes sont les seules parties sensibles dans le corps animal. Le sang, la lymphe, toutes les autres liqueurs, les graisses, les os, les chairs tous les autres solides, sont par $u_{\mathrm{x}}$-mêmes insensibles: la cervelle l'est aussi ; ;est une substance molle et sans élasticicé, incapable des lors de produire, de propager ou te rendre le mouvement, les vibrations ou les ébranlements du sentiment. Les méninges au contraire sont très-sensibles; ce sont les enveloppes de tous les nerfs : elles prennent, comme eux, leur origine dans la tête; elles se divisent comme les branches des nerfs, et s'étendent jusqu'à leurs plus petites ramifications; ce sout, pour ainsi dire, des nerfs aplatis; elles sont de la mème substance; elles out à peu près le même de:rré d'élasticité; elles font partie, et partie nécessaire, du système sensible. Si l'on veut donc que le siége des sensations soit dans la tête, il sera daus les méninges, et non dans la partie mé. dullaire du cerveau, dont la substance est toute différente.

Ce qui a pu dommer lieu à cette opinion, que le siégre de toutes les sensations et le centre de toute sensibilité étaient dans le cerveau, e'est que les nerfs, qui sont les organes du sentiment, aboutissent tous à la cervelle, quon a regardée dès lors comme la seule partie commune qui pùt en recevoir tous les ébranlements, toutes les impressions. Cela seul a sufti pour faire du cerveau le principe du sentiment, l'organe essentiel des sensations, en un mot le sensorium commun. Cette supposition a paru si simple et si naturelle, qu'on n'a fait aucune attention à l'impossibilité physique qu'elle renferme, et qui cependant est assez évidente; car comment se peut-il qu'une partie insensible, une substance molle et inactive, telle qu'est la cervelle, soit l'organe mème du sentiment et du mouvement? comment se peut-il que cette partie molle et insensible, non-seulement recoive ces implessions, mais les conserve longtemps et en propaye les ébranlements dans toutes les parties solıdes et sensibles? L'on dira peut-ètre, d'après Descartes, ou d'après M. de la Peyronic, que ce n'est point dans la cervelle, mais dans la glande pinéale ou dans le corps calleux, que réside ce principe: mais il suffit de jeter les yeur sur la conformation du cerveau pour reconnaitre que ces parties, la glande pinéale, le corps calleux, dans lesquels on a voulu mettre le siége des sensations, ne tiennent point aux nerfs; qu'elles sont toutes environncées de la substance insensible de la cervelle, et séparées des nerís de ma- 
nière qu'elles ne peuvent en recevoir les mouvements; et dès lor's ces suppositions tombent aussi bien rue la première.

Mais quel sera donc l'usage, quelles seront les fonctions de cette partic si noble, si capitale? Le cerveau ne se trouve-t-il pas dans tous les animaux? n'est-il pas dans l'homme, dans les quadrupèdes, dans les oìseaux, qui tous ont beaucoup de sentiment, plus étendu, plus grand, plus considérable que dans les poissons, les insectes et les autres animaux, qui en ont peu? Dès qu'il est comprimé, tout mouvement n'estil pas suspendu? toute action ne cesse-t-elle pas? Si cette partic n'est pas le principe du mouvement, pourquoi y est-elle si nécessaire, si essentielle? pourquoi même est-elle proportionnelle, dans chaque espèce d'animal, à la quantité de sentiment dont il est doué?

Je crois pouvoir répondre d'une manière satisfaisante à ces questions, quelque difficiles qu'elles paraissent; mais pour cela il faut se prêter un instant à ne voir avec moi le cerveau que comme de la cervelle, et u'y rien supposer que ce que l'on peut $y$ apercevoir par une inspection attentive et par un examen réfléchi. La cervelle, aussi bien que la moelle alloigée et la moelle épinière, qui n'en sont que la prolongation, est une espèce de mueilage à peine organisé; on y distingue seulement les extrémités des petites artères qui y aboutissent en très-ñand nombre, et qui n'y portent pas du sang, mais une lymphe blanche et nourricière. Ces mêmes petites artères, ou vaisseaux lymphatiques, paraissent dans toute leur longueur en forme de filets très-déliés, lorsqu'on désunit les parties de la cervelle par la macération. Les nerfs au contraire ne pénètrent point la substance de la cervelle, ils n'aboutissent qu'à la surface; ils perdent auparavant leur solidité, leur élasticité; et les dernières extrémités des nerfs, c'est-à-dire les extrémités les plus voisines du cerveau, sont molles et presque mucilagineuses. Par cette exposition, dans laquelle il n'entre rien d'hy pothétique, il parait que le cerveau, qui est nourri par les artères lymphatiques, fournit à son tour la nourriture aux nerfs, et quel on doit les considérer comme une espèce de végétation qui part du cerveau par trones et par branches, lesquelles se divisent eusuite en une infinité de rameaux. Le cerveau est aux nerfs ee quela terre est aux plantes; les dernières extrémités des nerfs sont les racines, qui, dans tout végétal, sont plus tendres et plus molles que le trone ou les brauches; elles contiennent une matière ductile, propre à faire croitre et à nourrir l'arbre des nerfs; elles tirent cette matière ductile de la suisstance même du cerveau, auquel les artères rapportent continuellement la lymphe nécessaire pour y suppléer. Le cerveau, au lieu d'être le siége des seusations, le principe du sentiment, ne sera done qu'un organe de sécrétion et de nutrition; mais un organe très-essentiel, sans lequel les nerfs ne pourraient ni croitre, ni s'entretenir.

Cet organe est plus grand dans l'homme, dans les quadrupèdes, dans les oiseaux, parce que le nombre ou le volume des nerfs, dans ces animaux, est plus grand que dans les poissons et les insectes, dont le sentiment est faible par cette même raison; ils n'ont qu'un petit cerveau proportionné à la petite quantité de nerfs qu'il nourrit. Et je ne puis me dispenser de remarquer, à cette occasion, que l'homme n'a pas, comme on l'a prétendu, le cerveau plus grand qu'aucun des animaux; car il y a des espèces de singes et de cétacés qui, proportionnellement au volume de leur corps, ont plus de cerveau que l'homme; autre fait qui prouve que le cerveau n'est ni le siége des sensations, ni le principe du sentiment, puisqu'alor's ces animaux auraient plus de sensations et plus de sentiment que I homme.

Si l'on considère la manière dont se fait la nutrition des plantes, on observera qu'elles ne tirent pas les parties grossieres de la terre ou de l'eau; il faut que ces parties soient réduites par la chaleur en vapeurs ténues, pour que les racines puissent les pomper. De méme, dans les nerfs, la nutrition ue se fait qu'au moyen des parties les plus subtiles de l'humidité du celveau, qui sont pompées par les extrémités ou racines des nerfs, et de là sont portées dans toutes les branches du système sensible. Ce système fait, comme nous l'avons dit, un tout dont les parties ont une connexion si serrée, une corres pondance si intime, quion ne peut en blesser une sans ébranler violemnient toutes les autres: la blessure, le simple tiraillement du plus petit nerf, suffit pour causer une vive irritation dans tous les autres, et mettre le corps en convulsion; et l'on ne pent faire cesser la douleur et les convulsions qu'en coupant ce nerf au-dessus de l'endroit lésé; mais dès lors toutes les parties auxquelles le nerf aboutissait deviennent à 
jamais inmobiles, insensibles. Le cerveau ne deit pas ètre considéré comme partie du même genre, ni comme portion organique du systeme des nerfs, puisçuil n'a pas les mêmes propriétés, ni la même substance, nétant ni solide, ni élastique, ni sensible. J'avoue que lorsqu' on le comprine, on fait eesser l'action du sentiment; mais cela même proure que c'est un corps étranger à ce système, qui, acissant alors par son poids sur les extrémités des nerfs, les presse et les engourdit, de la même manière qu'un poids appliqué sur le bras, la jambe, ou sur quelque autre partie du corps, en engourdit les nerfs, et en amortit lesentiment. Il est si vrai que cette cessation de sentiment par la compression n'est qu'une suspension, un engourdissement, qu“à l'instant où le cerveau cesse d'être comprimé, le-sentiment renait et le mouvement se rétablit. J'avoue encore qu'en déchirant la substance médullaire, et en blessant le cerreau juscqu'au corps calleux, la convulsion, la privation de sentiment, et la mort mème suit : mais e'est qu'alors les nerfs sont entièrement dérangés, qu'ils sont, pour ainsi cire, déracinés et blessés tous ensemble et dans leur origine.

Je pourrais ajouter à toutes ces raisons des faits particuliers, qui prourent également que le cerveau n'est ni le centre du sentiment, ni le siége des sensations. On a ru des animaux et mème des enfants naître sans tête et sans cerveau, qui cependant avaient sentiment, mouvement et vie. Il y a des classes entières d'animaux, comme les insectes et les vers, dans lesquels le cerveau ne fait point une masse distincte ni un volume sensible; ils ont seulement une partie correspondante à la moelle allongée et à la moelle épinière. Il y aurait donc plus de raison de mettre le siége des sensations et cau sentiment dans la moelle épinière, qui ne manque à aucun animal, que dans le cerveau, qui n'est pas une partie générale et commune à tous les ètres sensibles.

Le plus grand obstacle à l'avancement des connaissances de l'homme est moins dans les choses mèmes que dans la manière dont il les considère : quelque compliquée que soit la machine de son corps, elle est encore plus simple que ses idées. Il est moins difficilo de voir la nature telle ru'elle est, que de la reconnaitre telle qu'on nous la présente : elle ne porte qu'un voile; nous lui donnons un mas que; nous la corlrrons de préjugés; nous supposons qü elle agit, qu'elle opère comme nous agissons et pensons. Cependant ses actes sont évidenis, et nos pensées sont ojseures; nous portons dans ses ouvrages les abstractions de notre esprit, nous lui prêtons nos moyens, nous ne juggeons de ses fins que par nos rues, et nous mêlons perpétuellernent à ses opérations, qui sont constantes, à ses faits, qui sont toujours certains, le produit illusoire ct variable de notre imagination.

Je ne parle point de ces systemes purement arbitraires, de ces hypothèses frivoles, imaginaires, dans lesquelles on reconnait à la première vue qu'on nous donne la chimère au lieu de la réalité; j'entends les métlıdes par lesquelles on recherche la nature. La route experimentale clle-mème a produit moins de vérités que d'erreurs. Cette voie, quoique la plus sûre, ne l'est néanmoins qu'autant qu'elle esi bien dirigée; pour peu qu'elle soit oblique, on arrive à des plages stériles, ou l'on ne voit obscurément que quelques objets épars : cependant on s'efforee deles rassembler, en leursupposant des rapports entre eux et des propriétés communes; et, comme l'on passe et repasse avec complaisance sur les pas tortueux qu'on a faits, le chemin parait frayé; et quoiqu'il n'aboutisse à rien, tout le monde le suit, on adopte la métbode, et l'on en recoit les consécjuences comme principes. Je pourrais en donner la preureen exposant à nu l'origine de ce que l'on appelle principes dans toutes les sciences, $a b-$ straites ou réelles : dans les premières, la base générale des principes est l'abstraction, c'est-àdire une ou plusicur's suppositions; dans les autres, les principes ne sont que les conséquences bonnes ou mauraises des méthodes que l'on a suivies; et, pour ne parler ici que de l'anatomie, le premier qui, surmontant la répugnance naturelle, s'av:sa d'ouvrir un corps humain, ne crut-il pas qu'en le parcourant, et en le disséquant, en le dirisant dans toutes ses parties, il en connaitrait bientôt la structure, le mécanisme et les fonctions? Mais ayant trouvé la chose infiniment plus compliquée qu'on ne pensait, il fallut bientôt renoncer à ces prétentions, ct l'on fut obligé de faire une méthode, non pas pour connaitre etjuger, mais seulement pour voir, et voir arec ordre. Cette méthode ne fut pas l'ourrage d'un seul homme, puisqu'il a fallu tous les sicules pour la perfectionner, et qu'crcore aujourd'hui elle occupe seule nos 
plus habiles anatomistes : cependant cette méthode n'est pas la scienee; ce n'est que le chemin qui devrait y conduire, et qui peut-être y aurait conduit en effet, si, au lieu de toujours marcher sur la même ligne dans un sentier étroit, on eût étendu la voie et mené de front l'anatomie de l'homme et eelle des animaux. Car quelle connaissance réelle peut-on tirer d'un objet isolé? le fondement de toute seience n'estil pas dans la comparaison que l'esprit humain sait faire des objets semblables et différents, de leur's propriétés analog̣es ou contraires, et de toutes leurs qualités relatives? L'absolu, s'il existe, n'est pas du ressort de nos connaissances; nous ne jugeons et ne pouvons juger des choses que par les rapports qu'elles ont entre elles. Ainsi, toutes les fois que dans une méthode on ne s'occupe que du sujct, qu'on le considère seul et indépendamment de ee qui lui ressenible et de ce qui en differe, on ne peut arriver à aucune connaissance réelle, encore moins s'élever à aucuu principe général; on ne pourra donner que des noms et faire des descriptions de la chose et de toutes ses parties: aussi, depuis trois mille ans que l'on dissèque des cadavres humains, l'anatomie n'est encore qu'une nomenelature, et à peine $a-t$-on fait quelques pas vers son objet réel, qui est la science de l'éeonomie animale. De plus, que de défauts daus la méthode elle-mème, qui cependant devrait être claire et simple, puisqu'elle dépend de l'inspection et n'aboutit qu'ì des dénominations! Comme l'on a pris cette connaissanee nominale pour la vraie seience, on nes'est occupé qu'à augmenter, ì multiplier le nombre des noms, au lieu de limiter celui des choses; on s’est appesanti sur les détails; on a voulu trouver des différences où tout était scmblable: en créant de nouveaux noms, on a cru domer des choses nouvelies; on a décrit avec une exacti= tude minutieuse lés plus petites parties; et la description dequelque partic encore plus petite, oubliće ou négligée par les anatomistes précédents, s'est appelée découverte. Les dénominations elles-mèmes, ayant souvent été prises d'objets qui n'avaient aucun rapport avec eeux qu'on voulait désigner, n'ont servi cừ̀ augmenter la confusion. Ce que l'on appelle testes et nates dans le cerveau, qu'est-ec autre chose, sinon des parties de cervelle semblables au tout, et qui ne méritaient pas un non? Ces noms, cmpruntés à l'aventure, ou cionnćs parr prẹ́ugé, ont ensuite produit eux-mêmes de nouveaux préjugés et des opinions de hasard; d'autres noms donnés a des parties mal vues, ou qui même n'existaient pas, ont été de nourelles sources d'erreurs. Que de fonetions et d'usages n'a-t-on pas voulu donner à la glande pinéale, à l'espace prétendu vide qu'on appelle la vouite dans le cerveau; tandis que l'uue n'est qu'une glande, et qu'il est fort douteux que l'autre existe, puisque eet espace vide n'est peut-être produit que par la main de l'anatomiste et la méthode de dissection "I

Ce qu'il y a de plus difficile dans les sciencer n'est done pas de connaitre les choses qui en font l'objet direct; mais e'est qu'il faut aupara vant les dépoutiller d'une infinité d'envelop pes dont on les a couvertes, leur òter tontes les fiusses eouleurs dont on les a masquées, eraminer le fondement et le produit de la méthode par laquelle on les recherche, en séparer ce que l'on y a mis d'arbitraire, et enfin tìcher de recomnaitie les préjugés et les erreurs adoptées que ce mélange de l'arbitraire au réel a fait nattre : il faut tout cela pour retrouver la nature; mais ensuite, pour la connaitre, il ne futut plus que la comparer avec elle-mème. Dans l'économie animale, elle nous parait très-mystérieuse et très-eachée, non-seulement parce que le sujet en est fort compliqué, et que le corps de l'homme esí de toutes ses productions la moins simple, mais surtout paree qu'on ne l'a pas comparée avee elle-mème, et qu'ayant négligé ces moyens de comparaison, qui seuls pouvaient nous donner des lumières, on est resté dans l'obscurité du doute, ou dans le vague des hypothèses. Nous avons des milliers de volumes sur la description du corps humain, et à peine a-t-on quelques mémoires commencés sur celle des animaux. Dans l'homme, on a reeomu, nommé, décrit les plus petites parties, taudis que l'on ignore si dans les animaux l'on retroure, non-seulement ces petites parties, mais mème les plus grandes: on attribue certaines fonctions ìde eertains organes, sans ètre informé si dans d'autres êtres, quoique privés de ces organes, les mêmes fonctions ne s'exercent pas; en sorte que, dims tontes ces explieations qu'on a voulu donner des différentes parties de l'économie animale, on a eu le double désarantage d'avoir d'abord attaqué le sujet le plus com-

- Vejez a ce sujel le discours de Stéuon. 
pliq̣ué, et ensuite d'avoir raisonné sur ce mème sujet sans fondement de relation, et sans le secours de l'analogie.

Nous avons suivipartout, dans le cours de cet ouvrage, une méthode très-différente : comparant toujours la nature arec elle-même, nous l'avons considérée dans ses rapports, dans ses opposés, dans ses extrêmes; et pour ne citer ici que les parties relatives à l'économie animale, que nous arons eu occasion de traiter, comme la génération, les sens, le mouvement, le sentiment, la nature des animaux, il sera aisé de recunnaitre qu'après le travail, quelquefois long, mais toujours nécessaire, pour écarter les fausses idées, détruire les préjugés, séparer l’arbitraire du réel de la chose, le seul art que nous ayons employé est la comparaison. Si nous avons réussi à répandre quelque lumière sur ces sujets, il faut moins l'attribuer an génic qu'à cette méthode que nous avons suivie constamment, et que nous avons rendue aussi générale, aussi éteridue que nos connaissances nous l'ont permis; et, comme tous les jour's nous en acquérons de nouvelles par l'examen et la dissection des parties intérieures des animaux, et que, pour bien raisonner sur l'économie animale, il faut avoir vu de cette façon au moins tous les genres d'animaux différents, nous ne nous presserons pas de donner des idées générales avant d'avoir présenté les résultats particuliers.

Nous nous contenterons de rappeler certains faits qui, quoique dépendants de la théorie du sentiment et de l'appétit, sur laquelle nous ne voulons pas, quant à présent, nous étendre davantage, suffiront cependant seuls pour prouver que l'homme, dans l'état de nature, ne s'est jamais borné à vivre d'herbes, de graines ou de fruits, et cu'il a dans tous les temps, aussi bien que la plupart des animanx, cherché à se nourrir de chair.

La diète pythagorique, préconisée par des philosophes anciens et nouveaux, recommandée même par quelques médecins, n’a jamais été indiquée par la nature. Dans le premier âge, au siècle d'or', l'homme, innocent comme la colombe, mangeait du gland, buvait de l'eau; trouvant partout sa subsistance, il était sans inquiétude, vivait indépendant, toujour's en paix avec lui-mème, avec les animaux: mais, dès qu'oubliant sa noblesse, il sacrifia sa liberté pour se réunir aux antres, la guerre, l'âge de fer, prịrent la place de l'or et de la paix; la cruauté, le goût de la chair et duu sang, furent les premiers fruits d'une nature dépravée, que les mœurs et les arts achevèrent de corrompre.

Voilà ce que dans tous les temps certains philosoples austères, sauvages par tempérament, ont reproché à l'homme en société. Rehaussant leur orgoueil individuel par l'humiliation de l'espèce entière, ils ont exposéce tableau, qui ne vaut que par le contraste, et peutêtre parce qu'il est bon de présenter quelquefois aux hommes des chimères de bonheur.

Cet état idéal dinnocence, de haute tempérance, d'abstinence entiere de la chair, de tranquillité parfaite, de paix profonde, a-t-iljamais existé? n'est-ce pas un apologue, une fable, où l'on emploie l'homme comme un animal, pour nous donner des lecons ou des exemples? peuton mème supposer qu'il y eủt des vertus avant la société? peut-on dire de bonne foi que cet état sauvage mérite nos regrets, que l'homme animal farouche fùt plus digne que l'homme citoyen civilisé? Oui, car tous les malheurs viennent de la société ; et qu'importe qu'il y eûi des vertus dans l'état de nature, s'il y avaii du bonheur, si l'homme dans cet état était setllement moins mallieureux qu'il ne l'est? La liberté, la santé, la force, ne sont-elles pas préférables à la mollesse, à la sensualité, à la vo lupté mème, accompagnées de l'esclavage? L privation des peines vaut bien l'usage des plaisirs ; et pour être heureux, que faut-il, sinon de ne rien désirer?

Si cela est, disons en même temps qu'il cst plus doux de végéter que de vivre, de ne rien appéter que de satisfaire son appétit, de dormir d'un sommeil apathique que d'ouvrir les yeux pour voir et pour sentir; consentons à laisser notre âme dans l'engourdissement, notre esprit dans les ténèbres, à ne nous jamais servir ni de l'une ni de l'autre, à nous mettre au-dessous des animaux, à n'ètre enfin que des masses de matière brute attacliées à la terre.

Mais au lieu de disputer, discutons; arrès avoir dit des raisons, donnons des faits. Nous avons sous les yeux, non l'état idéal, mais l'état réel de nature. Le sauvage babitant les déserts est-il un animal trimquille? est-il un homme heureux? Car nous ne supposerons pas avec un philosophe, l'un des plus fiers eenseurs de notre humanité ${ }^{1}$, quil y a une plus grande dis-

I J.-J. Rousseau. 
tance de l'homme en pure nature au sauvage, que du sauvage à nous; que les âges qui se sont écoulés avant l'invention de l'art de la parole ont été bien plus longs que les siècles qu“il a fallu pour perfectionner les signes et les langues, parce qu'il me parait que, lorsqu'on veut raisonner sur des faits, il faut éloigner les suppositions, et se faire une loi de n'y remonter qu'après avoir épuisé tout ce que la nature nous offre. Or nous voyons qu'on descend par deglés assez insensibles des nations les plus éclairées, les plus polies, à des peuples moins industrieux; de ceux-ci à d'autres plus grossiers, mais encore soumis à des rois, à des lois ; de ces hommes grossiers aux sauvages, qui ne se ressemblent pas tous, mais chez lesquels on trouve autant de nuances différentes que parmi les peuples policés; que les uns forment des nations assez nombreuses, soumises à des chefs; que d'autres, eu plus petite société, ne sont soumis qu'à des usages; qu'enfin, les plus solitaires, les plus indépendants, ne laissent pas de former des familles et d'ètresoumis à leurs pères. Un empire, un monarque, une famille, un père, voilà les deux extrêmes de la société : ces extrêmes sont aussi les limites de la nature; sì elle s'étendait au delà, n'aurait-on pas trouvé, en parcourant toutes les solitudes du globe, des animaux humains privés de la parole, sourds à la voix comme aux signes, les mâles et les femelles dispersés, les petits abandonnés, etc.? Je dis même qu'à moins de prétendre que la constitution ducorps humain fút toute différente de ce qu'elle estaujourd'hui, et que son accroissement füt bien plus prompt, il n'est pas possible de soutenir que l'homme ait jamais existé sans former des familles, puisque les enfants périraient s'ilsn'étaient secourus et soignés pendant plusieurs années; au lieu que lesanimaux nouveau-nés n'ont besoin de leur mère que pendant quelques mois. Cette nécessité physique suffit done seule pour démontrer que l'espèce humaine n'a pu durer et se multiplier qu'è la faveur de la société; que l'union des pères et mères aux enfants est naturelle, puisqu'elle est nécessaire. Or cette union ne peut manquer de produire un attachement respectif et durable entre les parents et l'enfant, et cela seul suffit encore pour qu'ils s'accoutument cntre eux à des gestes, à des signes, à des sons, en un mot, à toutes les expr'essions du sentiment et du besoin : ce qui est aussi prouvé par le fait, puis- que les sauvages les plus solitaires ont comme les autres hommes l'usage des signes et de la parole.

Ainsi l'étatde pure nature est un état connu; c'est le sauvage vivant dans le désert, mais vivant en famillle, connaissant ses enfants, connu d'eux, usant de la parole et sc faisantentendre. La fille sauvage ramassée dans lesbois de Champagne, l'homme trouvé dans les forêts d'Hanovre, ne prouvent pas le contraire : ils avaient vécu dans une solitude absolue; ils ne pouvaient donc avoir aucune idée de société, aucun usage des signes ou de la parole : mais s'ils se fussent seulement rencontrés, la pente de nature les aurait entrainés, le plaisir les aurait réunis; attachés l'un à l'autre, ils se seraient bientôt entendus, ils auraient d'abord parlé la langue de l'amour entre eux, et ensuite celle de la tendresse entre eux et leurs enfants : et d'ailleurs ces deux sauvages étaient issus d'hommes en société, et avaient sans doute été abandonnés dans les bois, non pas dans le premier âge, car ils auraient péri, nais àquatre, cing ou six ans, à l'àge, en un mot, auquelils étaient déjà assez forts de corps pour se procurer leur subsistance, et encor'e trop faibles de tête pour conserver les idées qu'on leur avait communiquées.

Examinons donc cet homme en pure nature, e'est-à-dire ce sauvage en famille. Pour peu qu'elle prospère, il sera bientôt le chef d'une société plus nombreuse, dont tous les membres auront les mèmes manières, suivront les mèmes usages et parleront la mème langue; à la troisième ou tout au plus tard à la quatrième génération, il y aura de nourclles familles qui pourront demeurer séparées, mais qui, toujours réunies par les liens communs des usages et du langage, formeront une petite nation, laquelle, s'augmentant avec le temps, pourra, suivant les circonstances, ou devenir um peuple, ou demeurer dans un état semblable à celui des nations sauvages que nous connaissons. Cela dépendra surtout de la proximité ou de l'éloignement où ces hommes noureaux se trouveront des hommes policés. Si sous un climat doux, dans un terrain aboudant, ils peuvent en liberté oceuper un espace considérable au-delà duquel ils ne reneontrent que des solitudes ou des hommes tout aussi neufs (qu'eux, ils demeureront sauvages et devicndront, suivant d'autres circonstances, ennemis ou amis de leurs voisius : mais lorsque sous unciel dur, 
dans une terre ingrate, ils se trouveront gênés entre eux par le nombre et serrés par' l'espace, ils feront des colonies ou des ilruptions, ils se répandront, ils se confondront avec les autres peuples dont ils seront devenus les conquérants ou les esclaves. Ainsi l'homme, en tout état, dans toutes les situations et sous tous les climats, tend également à la société; c'est un effet constant d'une cause nécessaire, puisqu'elle tient à l'essence mème de l'espèce, c'est-ä-dire at sa propagation.

Voilà pour la société; elle est, comme l'on voit, fondée sur lanature. Examinant de même quels sont les appétits, quel est le goùt de nos sturages, nous trouverous qu'aucun ne vit uniquement dẹ fruit, d'ierbes ou de graines; que tous préferent la chair et le poisson aux autres aliments; que l'eau pure leur déplait, et qu'ils cherchent les moyens de fiure cux-mèmes ou de se procurer ailleur's une boisson moins insipide. Les sauvages du midi boivent l'eau du palmier; ceux du nord avalent à longs traits l'huile d goutante de la baleine; d'autres font des boissons fermentées; et tous en général ont le goùt le plus déeidé, la passion la plus vive pour les liqueurs fortes. Leur industrie, dictée par les besoins de première nécessité, excitée par leurs appétits naturels, se réduit à faire des instruments pour la chasse et pour la peche. Un aic, des thehes, une massue, des filets, un canot, roila le sublime deleurs arts, quitous n'ont pour objet que les moyens de se procurer une subsistance convenable à leur goùt. Et ce qui convient à leur goùt, convient à la nature; car, comme nous l'avons déjà dit, l'homme ne pourrait pas se nourrir d'herbe seule; il périrait d'i. nanition sil ne prenait des aliments plus substantiels : n'ayant qu' un estomac et des intestins courts, il ne peut pas, comme le bouf, qui a quatre estomacs et des boyaux très-longs, jicndre à la fois un grand rolume de cette maigre nourriture, ce qui serait cependant absolument nécessaire pour compenser la qqualité par la quantité. Il en est à peu près de mème des firkits et des graines : elles ne lui suffiraient pas, il en faudrait encore un trop grand rolume pour fournir la quantité de molécules organiçues nécessaires à la nutrition; et, quoique le pain soit fait de ce qu'il y a de plus pur dans le bié, que le blé mème et nos autres grains et légumes, ayantété perfectionnés par l'art, soient plus substantiels et plus nourrissants que les graines qui n’ont que leurs qualités naturelles; l'homme, réduit au pain et aux legumes pour toute nourriture, trainerait à peine une vie faible et languissante.

Voyez ces pieux solitaires qui s'abstiennent de tout ce quia eu vie, qui, par de saints motifs, renoncent aux dons du Créateur, se privent de la parole, fuient la société, s'enferment dans des mur's sacrés contre lesquels se brise la nature; confinés dans ces asiles ou plutòt dans ces tombeaux vivants, où l'on ne respire que la mort, le visage mortifié, les yeux éteints, ils nejettent autour d'eux que des regards languissants; leur vie semble ne se soutenir que par efforts; ils premnent leur nourriture sans que le besoin cesse : quoique soutenus par leur ferveur (car l'état de la tète fait à celui dı corps), ils ne résistent que pendant peu d'années à cette abstinence cruelle; ils vivent moins qu'ils ne meurent chaque jour par une mort anticipée, et ne s'éteiguent pas en finissant de vivre, mais en acherant de mourir.

Ainsi l'abstinence de toute chair, loin de conrenir à la nature, ne peut que la détruire : si l'homme y était réduit, jl ne pourrait, du moins dans ces climats, ni subsister, ni se multiplier. Peut-être cette diète serait possible dans les pays méridionaux, oì les îruits sont plus cuits, les plantes plus substantielles, les racines plus succulentes, les graines plus nourries : cependant les brachmanes font plutòt une sectequ'un peuple; et leur religion, quoique très-ancienne, ne s'est guère étendue au-delà de leurs écoles, etjamais au-delà de leur climat.

Cette religion, fondée sur la métaphysique, est un exemple frappant du sort des opinions humaines. On ne peut pas douter, en ramassant lesdébris qui nous restent, que les sciences n'aient été très-anciennement cultivées, et perfectionnées peut-ètre au-delà de ce qu elles le sont aujourd'hui. On a su aı ant nous que tous les ètres animés contenaient des molécules indestructibles, toujours vivantes, et qui passaient de corps en corps. Cette vérité, adoptée par les philosophes, et ensuite par un grand nombre d'hommes, ne conserva sa pureté que peudant les siècles de lumière : une révolution de ténèbres ayant succedé, on ne se souvint des molécules organiques virantes, que pour imaginer que ce quil y avait de vivant daus lanimal était apparemment un tout indestructible qui se séparait du corps après la mort. On 
appela ce tout idéal une âme, qu'on regarda bientôt comme un être réellement existant dans tous les animaux; et joignant à cet être fantastique l'idée réelle, mais défigurêe, du passage des molécults vivantes, on dit qu'après la mort cette âme passait successivement et perpétuellement de corps en corps. On n'excepta pas l'homme; on joignit bieutôt le moral au nétaphysique; on ne douta pas que eet être survivant ne conservât dans sa transmigration ses sentiments, ses affections, ses désirs : les tètes faibles frémirent ! Quelle horreur en effet pour cette âme, Jorsqu'au sortir d'un domicile agréable, il fallait aller habiter le corps infect d'un animal immonde! On eut d'autres frayeurs ( chaque crainte produit sa superstition); on eut peur, en tuant un animal, d'égorger sa maítresse ou son père: on respecta toutes les bètes, on les regarda comme son prochain; on dit enfin qu'il fallait, par amour, par devoir, s'abstenir de tout ce qui avait eu vie. Voilà l'origine et le proxrès de cette religion, la plus ancienne $d u$ contin:nt des Indes, origine qui indique assez que la vérité, livrée à la multitude, est bientôt défigurée; qu'une opiniou philosophique ne devient opinion populaire qu'après avoir changé de forme; mais qu'au moyen de cette préparation, elle peut devenir une religion d'autant mieux fondée que le préjugé sera plus général, et d'autant plus respectée qu'ayant pour base des vérités mal entendues, elle sera nécessairement environnée d'obscurités, etpar conséquent paraîtra mystérieuse, auguste, incompréhensible; qu'ensuite, la crainte se mêlant au respect, cette religion dégénérera en superstitions, en pratiques ridicules, lesquelles cependant prendront racine, produiront des usages qui seront d'abord scrupuleusement suivis, mais qu, s'altérant peu à peu, changeront tellement avec le temps, que l'opinion même dont ils ont pris naissance ne se conservera plus que par de fausses traditions, par des proverbes, et finira par des contes puérils et des absurdités : d'oì l'on doit conelure que toute religion fondée sur des opinions humaines est fausse et variable, et qu'il n'a jamais appartenu qu'à Dieu de nous domner la vraie religion, qui, ne dépendant pas de nos opinions, est inaltérable, constante, et sera toujours la mème.

Mais revenons à notre sujet. L'abstinence entière de la chair ne peut qu'affaiblir la nacure. L'homme, pour se bien porter, a non-seulement besoin d'user de cette nouriture solide, mais mème de la varier. S'il vent aequérir une rigueur complète, il faut qu'il choisisse ce yui Jui convient le mieux; et, comme il ne peut se maintenir dans un état actif qu'en se procurant des sensations nom elles, il faut qu'il dome a ses sens toute leur étendue, qu'il se permetts ha variété des nets comme celle des autres objeis, et qu'il prévienne le dégoùt qu'oecasionne l'uniformité de nourriture; mais qu'il érite les excès, qui sont encore plus nuisibles que l'abstinence.

Les animaux qui n'ont qu'un estomac et Jes intestins courts sont forcés, comme l'bomme, à se nourrir de chair. On s'assurera de ce rapport et de cette vérité en comparant, au moyen de nos descriptions, le volume relatif $d u$ canal intestinal dans les animaux carnassiers et dans ceux qui ne vivent que d'hęrbes: on trouvera toujours que cette différenee dans leur manière de vivre dépend de leur conformation, et qu'ils prement une nourriture plus ou moins solide, relatirement à la eapacité plus oumoins grande du magasin qui doit la receroir.

Cependant il n'en faut pas conclure que les animaux qui ne vivent (jue d'herbes soient, par nécessité physique, réduits à catte seule nourriture, comme les animaux carnussiels sont, par cette mème nécessité, for és à se nourrir de chair : nous disons seulement que ceux gui ont plusieurs estomaes, ou des boyaux tres-amples, peuvent se passer de cet aliment substanticl et nécessaire aux autres; mais nous ne disons pas qu'ils ne pussent en user, et que si la naturc leur en̂t donné des armes, non-seulement prour se défendre, mais pour attaquer et pour saisis, ils n'en eussent fait usage et ne se fussent bientôt accoutumés à la ehair et au sang, piiscrue nous voyons que les moutons, les veaux, les chèves, les chevaux, mangent avidemcnt le lait, les œufs, qui sont des nourritures animales, et que, sans ètre aidés de l'habitude, ils ne refusent pas la viande hachée et assaisonnée die sel. On pourrait done dire que le goût pour la chair et pour les autres nourritures solicies est l'appétit général de tous les animaux, yui s'exerce a vec plus ou moins de véhémence ou de modération, selon la conformation particulière de chaque animal, puisqu'à prendre la nature entière, ce mème appétit se trouve nouseulement dans l'homme et dans les anim:ux guadrupèdes, mais aussi dans les oiseaux, dans 
les poissons, dans les insectes et dans les vers, auxquels en particulier il semble que toute chair ait été ultérieurement destinee.

1.a nutrition, dans tous les animaux, se fait par les molécules organiques qui, séparées du marc de la nourriture au moyen de la digestion, se mêlent avec le sang et s'assimilent à tou'es les parties du corps. Mais, indépendamment de ce grand effet, qui parait être le principal but de li nature, et qui est proportionnel à la qualité des aliments, îls en produisent un autre qui ne dépend que de leur quantité, c'est-à-dire de lcur masse et de leur volume. L'estomac et les boyaux sont des membranes souples, qui forment au dedans du corps une capacité très-considérable; ces membranes, pour se soutenir dans leur état de tension, et pour contre-balancer les forces des autres parties qui les avoisinent, ont besoin d'ètre toujours remplies en partie. $\mathrm{Si}$, faute de prendre de la nourriture, cette grande capacité se trouve entièrement vide, les membranes n'étant plus soutenues au dedans s'iffaissent, se rapprochent, se collent l'une contre l'autre; et c'est ce qui produit l'affaissement et la faiblesse, qui sont les premiers symptômes de l'extrême besoin. Les aliments, avant de servir à la uutrition du corps, lui servent done de lest; leur présence, leur volume est nécessaire pour maintenir l'équilibre entre les parties intérieures, qui agissent et réagissent toutes les unes contre les autres. Lorsqu'on neurt par la faim, e'est donc moins parce que le corps n'est pas nourri, que parce qu'il n'est plus lesté; aussi les animaux, surtout les plus gourmands, les plus voraces, lorsqu'ils sont pressés par le besoin, ou seulement avertis par la défaillance qu'occasionue le vide intérieur, ne cherchent qu'à le remplir, et avalent de la terre et des pierres. Nous avons trouvé de la glaise dans l'estomac d'un loup; j'ai vu des cochons en manger; la plupart des oiseaux avalent des cailloux, etc. Et ce n'est point par gout, mais par nécessité, et parce que le plus pressant n'est pas de rafraichir le sang par un chyle noureau, mais de maintenir l'équilibre des forces dans les grandes parties de la machine animale.

\section{LE LOUP.}

Ordre des carnassiers, famille des carnirores, tribu des digitigrades, genre chien (Cuvier).

Le loup est l'un de ces animaux dontl'appétit pour la chair est le plus véhément; et quoique avec ce goût il ait reçu de la nature les moyens de le satisfaire, qu'elle lui ait donné des armes, de la ruse, de l'agilité, de la force, tout ce qui est nécessaire en un mot pour trouver, attaquer, vaincre, saisir et dévorer sa proie, cependant il meurt souvent de faim, parce que l'homme lui ayant déclaré la guerre, l'ayant même proscrit en mettant sa tête à prix, le force à fuir, à demeurer dans les bois, où il ne trouve que quelques animaux sauvages qui lui échappent par la vitesse de leur course, et qu'il ne peut surprendre que par hasard ou par patience, en les attendant longtemps, et sourent en vain, dans les endroits ou ils doivent passer. Il est naturellement grossier et poltron; mais il devient ingénieux par besoin, et hardi par nécessité : pressé par la famine, il brave le danger, vient attaquer les animaux qui sont sous lia garde de l'homme, ceux surtout qu'il peut emporter aisément, comme les agneaux, les petits chiens, les chevreaux; et lorsque cette maraude lui réussit, il revient souvent à la charge, jusqu'à ce qu'ayant été blessé ou chassé et maltraité par les bommes et les chiens, il se recèle pendant le jour dans son fort, n'en sort que la nuit, parcourt la campagne, ròde autour des habitations, ravit les animaux abandonnés, vient attaquer les bergeries, gratte et creuse la terre sous les portes, entre furieux, met tout à mort avant de choisir et d'emporter sa proie. Lorsque ces courses ne lui produisent rien, il retourne au fond des bois, se met en quête, cherche, suit à la piste, chasse, poursuit les animaux sauvages, dans l'espérance qu'un autre loup pourra les arrêter, les saisir dans leur fuite, et qu'ils en partageront la dépouille. En fin, lorsque le besoin est extrême, il s'expose à tout, attaque les femmes et les enfants, se jette mème quelquefois sur les hommes, devient furieux par ces excès, qui finissent ordinairement par la rage et la mort.

Le loup, tant à l'extérieur qu'à l'intérieur, ressemble si fort au chien, qu'il parait être modeié sur la même forme; cependant il n'offre tout au plus que le revers de l'empreinte, et ne 


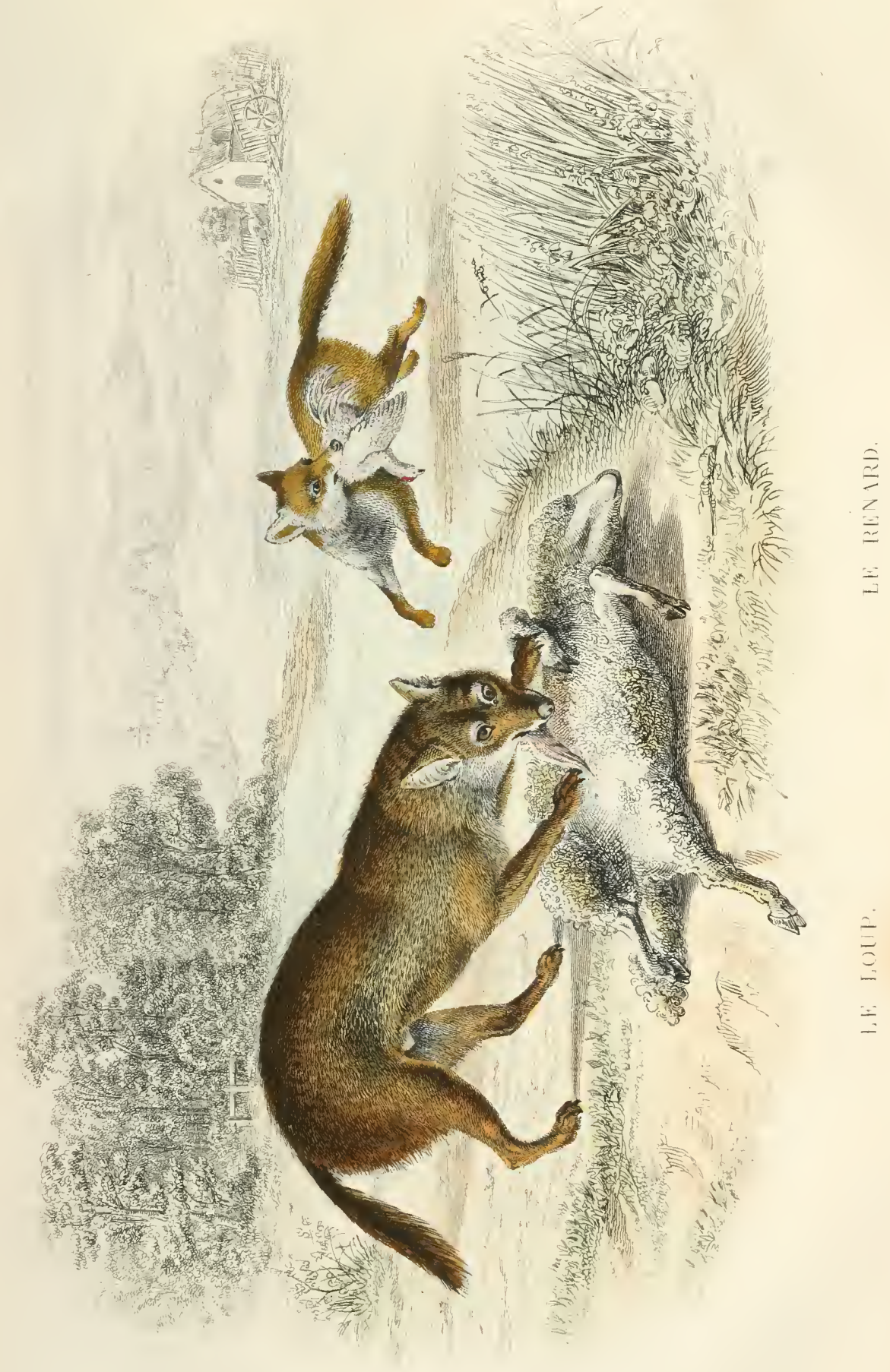



présente les mêmes caractères que sous une face, entièrement opposée : si la forme est semblable, ce qui en résulte est bien contraire; le naturel est si différent, que, non-seulement ils sont incompatibles, mais antipathiques par nature, ennemis par instinet. Un jeune ehien frissonne au premier aspect du loup; il fuit à l'odeur seule, qui, quoique nouvelle, ineonnue, lui répugne si fort, qu'il vient en tremblant se ranger entre les jambes de son maître : un mâtin, qui connaît ses forces, se hérisse, s'indigne, l'attaque avec courage, tâche de le mettre en fuite, et fait tous ses efforts pour se délıvrer d'une présence qui lui est odieuse; jamais ils ne se rencontrent sans se fuir ou sans combattre, et combattre á outrance, jusqu'à ce que la mort suive. Si le loup est le plus fort, il déchire, il dévore sa proie; le chien, au contraire, plus généreux, se contente de la victoire, et ne trouve pas que le corps d'un ennemi mort sente bon; il l'abandonne pour servir de pâture aux corbeaux, et mème aux autres loups; car ils s'entre-dévorent; et, lorsqu'un loup est grièvement blessé, les autres le suivent au sang et s'attroupent pour l'achever.

Le chien, mème sauvage, n'est pas d'un naturel farouche; il s'apprivoise aisément, s'attache et demeure fidèle à son maitre. Le loup pris jeune se prive, mais ne s'attache point : la nature est plus forte que l'éducation; il reprend avec l'âge son caractère féroce, et retourne, des qu'il le peut, à son état sauvage. Les chiens, mème les plus grossiers, cherchent la compagnie des autres animaux; ils sont uaturellement portés à les survre, à les accompagner, et c'est par instinct seul et non par éducation qu ils savent conduire et garder les troupeaux. Le loup est au contraire l'ennemi de toute société; il ne fait pas mème compagnie à ceux de son espèce : lorsqu'on les voit plusieurs ensemble, ec n'est point une société de paix, c'est un attroupement de guerre, qui se fait à grand bruit avec des hurlements affreux, et qui dénote un projet d'attaquer quelque gros animal, comme un cerf, un bœuf, ou de se défaire de quelqueredoutable màtin. Dès que leur expédition militaire est consommée, ils se séparent et retournent en silence à leur solitude. 11 n'y a pas même une grande habitude entre le mâle et la femelle; ils ne se cherchent qu'une fois par an, et ne demeurent que peu de temps ensemble. C'est en hiver que les louves deviennent en chaleur : plusieurs mâles suivent la même femelle, ct cet attroupement est encore plus sanguinaire que le premier : car ils se la disputent cruellement; ils grondent, ils frémissent, ils se battent, ils se déchirent, et il arrive souvent qu'ils mettent en pièces celui d'entre eux qu'elle a préféré. Ordinairement elle fuit longtemps, lasse tous ses aspirants, et se dérobe, pendant qu'ils dorment, avec le plus alerte ou le mieux aimé.

La chaleur ne dure que douze ou quinze jours, et commence par les plus v ieilles louves; celle des plus jeunes n'arrive que plus tard. Les mâles n'ont point de rut marqué, ils pourraient s'accoupler en tout temps; ils passent successivement de femelles en femelles à mesurequ'elles deviennent en état de les recevoir; ils ont des vieilles ¿̀ la fin de décembre, et finissent par les jeunes au mois de février et au commencement de mars. Le temps de la gestation est d'environ trois mois et demi, et l'on trouve des louveteaux nouveau-nés, depuis la find'a vril jusqu'au mois de juillet. Cette différence dans la clurée de la gestation entre les louves, qui portent plus de cent jours, et les chiennes, qui n'en portent guère plus de soixante, prouve que le loup et le chien, déjà si différents parr le naturel, le sont aussi pir le tempérament et p r l'un dis prin $\cdot i-$ paux résultats des fonctions de l'économie animale. Aussi le loup et le chien n'ont j..mais été pris pour le mème animal que par les nomenclateurs en histoire naturelle, qui ne connaissent la nature que superficiellement, ne la considèrent jamais pour lui donner toute son étendue, mais seulement pour la resserrer et la réduire a leur' méthode, toujours fautive, et souvent démentie par les faits. Le chien et la loure ne peuvent ni s'accoupler ', ni produire ensemble; il n'y a pas de races intermécliaires entre eux; ils sont d'un naturel tout opposé, d'un tempérament différent. Le loup vit plus longtemps que le chien; les louves ne portent qu'une fois par an; les chiennes portent deux ou trois fois. Ces différences si marquécs sont plus que suffisantes pour démontrer que ces animaux sont d'espèces assez éloignées : d'ailleurs, en y regardant de près, on reconnait aisément que, mème à l'extérieur, le loup diffère du chien par des caractères essentiels et constants. L'aspect de la tète est different, la forme des os l'est aussi ;

- Voyez les cxpériences que j’al faites à ce sujet, a l'arlicle des chiens. 
:e loup a la cavité de l'œil obliquement posée, l'orbite inclinée, les yeux étincelants, brillants peudant la nuit; il a le hurlement au lieu de l'aboiemeut, les mourements différents, la démarche plus égale, plus uniforme, quoique plus prompte et plus précipitée, le corps beäucoup plus fort et bien moins souple, les membres plus fermes, les màchoires et les dents plus grosses, le poil plus rude et plus fourré.

Mais ces animaux se ressemblent beaucoup par la conformation des parties intérieures. Les loups s'accouplent comme les chiens; ils ont comme eux la verge osseuse et environnée d'un bourrelet qui se gonfle et les empêche de se séparer. Lorsque les louves sont prètes à mettre bas, elles cherchent au fond du bois un fort, un endroit bien fourré, au milieu duquel elles aplanissent un espace assez considérable en coupant, en arraihant les épines avec les dents; elles y apportent eusuile une grande quantité de mo:isse, et préparent un lit commode pour leurs petiis : elles en font ordinairement cinq ou six, quelquefois sept, huit et mème neuf, et jamais moins de trois. Ils naissent les yeux fermés comme les chieus; la mère les allaite pendant quelques semaines et leur apprend bientòt à manģer de la chair, qu'tlle leur prépare en la màchaut. Quelque temps après elle leur apporte des mulots, des levrauts, des perdrix, des rolailles vis antes : les louveteaux commencent par jouer avec elles, et finissent par les étrangler; la lourc ensuite les déplıme, les écorche, les dichire, et en donne une part à chacun. Ils ne sortent du fort où ils out pris naissance qu'au bout de six semaines ou deux mois; ils suivent alors leur mère, qui les mène boire dans quelque trone d'arbre ou à quelque mare roisine; elle les ramène au gite, ou les oblige à se recéler ailleurs lorsqu'elle craint quelque danger. Iis la suivent ainsi pendant plusieur's mois. Quand on les attaque, elle les défend de toutes ses foroes, et ı̂ême arec fureur : quoịiuc clans les autres temps elle soit, comme toutes lis feinclles, plus timide cyue le màle, lorsqu'elle a des petits elle devient intrépide, semble ne rien claindre pour elle, et s'expose à tout pour les sauver : aussi ne l'abandoment-ils que quand leur education est faite, quand ils se sentent assez forts pour' n'avoir plus b som de secours; c'est ordinairement à dix mois ou un an, lor'squ'ils ont refait leurs premieres dents, qui tombent à six mois, et lor'squ'ils ont açuis de la force, des armes, et des talents pour la rapine. Les mâles et les femelles sont en état d'engendrer à l'âge d'environ deux ans. Il est à croire que les femelles, comme dans presque toutes les autres espèces, sont à cet égard plus précoces que les mâles : ce qu'il y a de sùr, c'est qu'elles ne deviennent en chaleur tout au plus tòt qu'au second hiver de leur vie, ce qui suppose dix-huit ou vingt mois d'âge, etqu'une louve que j'ai fait élever n'est entrée en chaleur qu'au troisieme hiver, c'est-à-dire à plus de deux ans et demi. Les chasseurs assurent que dans toutes les portées il y a plus de mâles que de femelles : cela confirme cette observation, qui paraît générale, du moins dans ces climats, que dans toutes les espèces, à commencer par celle de l'homme, la nature produit plus de mâles que de femelles. Ils disent aussi qu'il y a des loups qui dès le temps de la chaleurs'attachent à leur femelle, l'accompagnent toujours jusqu'à ce qu'elle soit sur le point de mettre bas; qu'alors elle se dérobe, cache soigneusement ses petits, de peur que leur père ne les dévore en naissant; mais que, lorsqu'ils sont nés, il prend de l'affection pour eux, leur apporte à manger, et que si la mère vient à manquer, il la remplace et en prend soin comme elle. Je ne puis assurer ces faits, qui me paraissent même un peu contradictoires. Ces animaux, qui sont deux ou trois ans à croîtle, vivent quinze ou vingt ans; ce qui s'accorde encore avec ce que nous avons observé sur beaucoup d'autres espèces, dans lesquelles le temps de l'accroissement fait la septième partie de la durée totale de la vie. Les loups blanchissent dans la vieillesse; ils ont alors toutes les dents usées. Ils dorment lor'syu'ils sont rassasiés ou fatigués, mais plus le jour que la nuit, et toujours d'un sommeil léger : ils borvent fréquemment; et dans les temps de sécheresse, lorsyu'il n'y a point d'eau daus les ornières ou dans lis vieux trones d'arbres, ils viennent plus d'une fois par jour aux mares et aux ruisseaux. Quoigue très-voraces, ils supportent aisément la diète; ils peuvent passer quatre ou cinq jours sans manger, poulvu qu'ils ne manquent pas d'eau.

Le loup a beancoup de force, surtout dans les parties antéricures du corps, dans les muscles du cou et de la màchoire. Il porte avec sá gueule un mouton, saus le laisser toucher à terre, et court en mème temps plus vite que les belger's, cn sorte qu'il n'y a que les chiens qui 
puissent l'atteindre et lui faire lâches prise. Il mord cruellement, et toujours avec d'autant pilus d'acharnement qu'on lui résiste moins; car il prend des précautions avec les animaux qui peuvent se défendre. 11 craint pour lui et ne se bat que par nécessité, et jamais par un mouvement de courage. Lorsqu'on le tire et que la ballelui casse quelque membre, il crie; et cependant, los squ'on l'achève à coups de bàton, il ne se plaint pas comme le chien : il est plus dur, moins sensible, plus robuste; il marche, court, rode des jours entiers et des nuits; il est infutigable, et c'est peut-être de tous les animaux le plus difficile à forcer à la course. Le chien est doux et courageux : le loup, quoique féroce, est timide. Lorsqu'il tombe dans un piége, il est si fort et si longtemps épouvanté, qu'on peut ou le tuer sans qu'il se défende, ou le prendre vivant sans qu'il résiste; on peut lui mettre un collier, l'enchainer, le museler, le conduire ensuite partout où l'on veutsans qu'il ose donner le moindre signe de colère ou même de mécontentement. Le loup a les sens trèsbons, l'œil, l'oreille, et surtout l'odorat; il sent souvent de plus loin quil ne voit; lodeur du carnage l'attire de plus d'une lieue; il sent aussi de loin les animaux vivants, il les chasse même assez longtemps en les suivant aux portées. Lorsqu'il veut sortir du bois, jamais il nemanque de prendre le vent; il s'arrête sur la lisière, évente de tous cótés et reçoit ainsi les émanations des corps morts ou vivants que le vent lui apporte de loin. Il préfère la ehair vivante à la chair morte, et cependant il dévore les voiries les plus infectes. Ilaime la chair humaine; et peutêtrc, s'il ćłaitle plus fort, n'en mangerait-il pas d'autre. On a vu des loups suivre les armées, arriver en nombre à des champs de bataille où l'on n'avait enterré que négligemment les corps, les découvrir, les dévorer aves une insatiable aviditć; et ces mêmes loups, accoutumés à la ehair humaine, sejeter ensuite sur les hommes, attayuer le berger plutòt que le troupeau, dévorer des femmes, emporter des enfants, etc. L'on a appelé ces mauvais loups, loups yaroux ${ }^{4}$, c'est-à-dire loups dont il faut se garer.

On est done obligé quel quefois d'armer tout un pays pour sedéfaire des loups. Les princes ont des écquipages pour cette chasse, qui n'est point désagréable, qui est ntile et mème néces

I Voyez la chasse du loup de Gaston Phobus. saire. Les chasseurs distinguent les loups en jeunes loups, vicux loups, et grands vieur loups; ils les connaissent par lespicds, c'est-á dire par les voies, les traces qu'ils laissent sur la terre : plus le loup est âgé, plus il a le pied gros; la louve l'a plus long et plus étroit, elle a aussi le talon plus petit et les ongles plus min ces. On a besoin d'un bon limier pour la cquèto du loup : il faut mème l'animer, l'encourager, lorsqu'il tombe sur la voie; car tous les chiens ont de la répugnance pour le loup, et se rahattent froidement. Quaud le loup est détourné , on amène les lévriers qui doirent le chasser; on les partage en deux ou trois laisses; cn n'en garde qu'une pour le lancer, et on mène les au. tres en avant pour servir de relais. On làche doned abord lespremiers à sa suite; un homme à cheval les appuie; on làche les seconds à sept ou huit cents pas plus loin, lorsque le loup est prêt à passer, et ensuite les troisièmes lorsque les autres chiens commencent à le joindre et à le harceler. Tous ensemble le réduisent bientôt aux dernières extrémités, et le veneur l'achève en lui donnant un coup de couteat les chiens n'ont nulle ardeur pour le fouler, et répugnent si fort à manger do sa chair, qu il faut la préparer et l'assaisonner lorsqu'on veut leur en faire curée. On peut aussi le chasser arec des chiens courants; mais comme il perce toujours droit en avant, ct qu'il court tout un jour sans être rendu, cette chasse est ennuy cuse, à moins que les chiens courants ne soient soutenus par des lévriers qui le saisissent, le liarcellent, et leur donnent le temps de l'approcher.

Dans les campagnes, on fait des battues à force d'hommes et de mâtins, on tend des piéges, on présente des appâts, on fait des fosscs, on répand des boulettes empoisunnées; tout cela n'empêche pas que ces amimaux ne soient toujours en même nombre, surtout clans les pays ou il y a beaucoup de bois. Les Anglais prétendent en avoir purgé leur ile; cependant on m'a assuré qu'il y en avait en Ecosse. Comme il y a peu de bois dans la partic méridionale de la Grande-Bretagne, on a eu plus de facilité pour les détruire.

La couleur ct le poil de ces animaux changent suivant les différents climats, et varient quelquefois dans le neeme pays. On trouve en France et en Allemagne, outre les lonps ordinaires, quelques loups à poil plus épais et tirant sur le jaune. Ces loups, plus sauvages ct moins 
nuisibles que les autres, n'approchent jamais ni des maisons, ni des troupeaux, et ne vivent quedechasse et non pas de rapine. Dans les pays du nord, on en trouve de tout blanes et de tout noirs; ces derniers sont plus grands et plus forts que les autres. L'espèce commune est trèsgénéralement répandue : on l'a trouvée en Asie, en Afrique et en Amérique comme en Europe. Les loups du Sénégal ressemblent à ceux de France; cependant ils sont un peu plus gros et beaucoup plus eruels : ceux d'Egypte sont plus petits que ceux de la Grèce. En Orient, ei surtout en Perse, on fait servir les loups à des spectacles pour le peuple : on les exerce dejeunesse à la danse, ou plutôt à une espèce de lutte contre un grand nombre d'hommes. On achète jusqu'à cinq cents écus, dit Chardin, un loup bien dressé à la darse. Ce fait prouve au moins qu'à force de temps et de contrainte ces animaux sont susceptibles de quelque espèce d'éducation. J'en ai fait élever et nourrir quelques-uns chez moi : tant qu'ils sont jeunes, c'està-dire dans la première et la seconde année, ils sont assez dociles, ils sont mème caressants; et, s'ils sont bien nourris, ils ne se jettent ni sur la volaille ni sur les autres animaux : mais à dixhuit mois ou deux ans ils reviennent à leur naturel ; on est forcé de les enchainer pour les empêcher de s'enfuir et de faire du mal. J'en ai eu un qui, ayant été élevé en toute liberté dans une basse-cour avec des poules pendant dix-huit ou dix-neuf mois, ne les avait jamais attaquées ; mais, pour son coup d'essai, il les tua toutes en une nuit sans en manger aucune; un autre, ayant rompu sa ehaine à l'àge d'environ deux ans, s'enfuit après avoir tué un chien avee lequel il était familier; une louve que j'ai gardée trois ans, et qui, quoique enfermée toute jeune et seule avec un mâtin de même àge dans une cour assez spacieuse, n'a pu, pendant tout ce temps, s'accoutumer à vivre avec lui, ni le souffrir, même quand elle devint en chaleur. Quoique plus faible, elle était la plus méchante; elle provoquait, elle attaquait, elle mordait le chien, qui d'abord ne fit que se défendre, mais qui finit par l'étrangler.

11 n'y a rien de bon dans cet animal çue sa penu. on en fait des fourrures grossières, qui sont chaudes et durables. Sa chair est si mauvaise qu'eile répugne à tous les animaux, et il n'y a que le loup qui mange volontiers du loup. ll exhale une odeur infecte par la gueule ' comme pour assouvir sa faim il avale indistinctement tout ce qu'il trouve, des chairs corrompues, des 0 s, du poil, des peaux à demi tannées et encore toutes couvertes de chaux, il vomit fréquemment, et se vide encore plus souvent qu'il ne se remplit. Enfin, désagréable en tout, la mine basse, l'aspect sauvage, la voix effrayante, l'odeur insupportable, le naturel pervers, les mœurs féroces, il est odieux, nuisible de son vivant, inutile après sa mort.

\section{ADDITION A L'ARTICLE DU LOUP.}

Nous avons dit dans l'histoire du loup qu'on les avait détruits en Angleterre. Il semble que, pour dédommagement, ces animaux aienttrouvé de nouveaux pays à oecuper. Pontoppidan prétend qu'il n'en existait point en Norwége, et que c'est vers l'année 1718 qu'ils s'y sont établis. Il dit que ce futà l'oecasion de la dernière guerre entre les Suédois et les Danois qu'ils passèrent les montagnes à la suite des provisions qui suivaient ces armées.

Quelques Anglais, qui ont travaillé à une zoologie dont ils ont exclu tous les animaux qui n'étaient pas bretons, m'ont fait reproche d'avoir dit qu'il y avait encore des loups dans le nord de leur île : je ne l'ai point affirmé, mais j'ai seulement dit que l'on m'avait assuré qu'il y en avait en Écosse. C'est mylord comte de Morton, alors président de la société royale, homme très-respectable, très-véridique, Écossais, possédant de grandes terres, qui m'a en effet assuré ce fait en $\mathbf{1 7 5 6}$. Je m'en rapporte à son témoignage encore aujourd'hui, parce quiil est positif, et que l'assertion de ceux qui ont travaillé à la Zoologie britanniçue n'est qu'un témoignage négatif.

M. le vicomte de Querhoënt dit, dans ses observations, qu'il y a, au cap de Bonne-Espérance, deux espèces de loups dont il a vu la peall, l'un gris tigré de noir, et l'autre noir. II ajoute qu'ils sont plus grands que ceux d'Europe et qu'ils ont la peru plus épaisse et la dent plus meurtrière; que néanmoins leur lâeheté les fait peu redouter, quoiqu'ils viennent quelquefois la nuit, comme les onces, dans les rues de la ville du Cap. 


\section{DESCRPTION DU LOUP.}

(EXThAIT DE DAUBENTON.)

On ne peut reconnaître les caractères distinctifs de la conformation du loup, relativement aux autres animaux, qu'en le comparant aux chiens, parce qu'il leur ressemble plus qu’a aucun autre anunal ; mais il y a tant de varietes dans les diverses races de l'espèce des chiens, que eet objet de comparaison cliange de forme et de couleur sous les yeux de l'observateur. A chaque gencration l'on voit des diflèrences dans la figure du corps des chiens métis et dans la qualité du poil ; chaque partie s'allonge ou se raccourcit, s'enfle ou s'efile; le poil croît à l'excès, on clisparait en entier; les couleurs prennent toutes sortes de teintes, etc. Les caractères de la conformation extérieure des chiens se multipliant et changeant ainsi chaque jour avec leurs races, on ne trouve presuju'aucune ilfference constante entre le chien et le loup; mais s'il y avait des chiens sauvages, les caractères de leur espèce paraitraient sans altération, et seraient fixes comme ceux des loups; alors on pourrait déterminer les différences qui sont entre ces deux espèces d'ani. maux. Pour supplèer en quelque facon au chien sauvage qui nous manque, il faut clıoisir parmi les chiens domestiques ceux qui ressemblent le plus au loup.

Le clıien-loup a été ainsi nommé parce qu'on lui a trouvé beancoup de ressemblance avec le loup par la longueur du poil et du museau, et par les oreilles droites : le chien le berşer a les mêmes caractères á peu près; mais le màtin et le grand danois ont encore plus de rapport au loup par leur taille et par les proportions du corps, quoi(pu'ils aient le poil court et les oreilles en partie pendantes. On sait que la longueur du poil clépend de la temperature du climat, et les oreilles pendantes sont uII effet de l'état de domesticité, selon l'opinion de Bufion, qui est fondée sur plusieurs observations ; par conséquent les mâtins et les danois ont plus déyéneré de l'espèce du chien sauvage que les chiensloups et les chiens de berger : cepenlant les màtins et les danois me paraissent plus ressemblants aux loups par l'habitude du corps; e'est pourquoi je prends le màtiı pour ohjet de compar ison dans la description du loup, d'autant plus que le mâtin a servi de sujet pour celle du chien.

Plus j’ai observé les chiens et les loups, soit à l'extérieur, soit à l'intẻrieur, plus je les ai compa rés les uns aux autres, tant les matles que les femelles, plus jaurais été porté à conclure de la ressemblance qui est dans leur conformation, qu'ils sont de la méme espèce, si Buffon n'avait tenté inutilement de faire accoupler le chien avec la louve. Aristole a fait mention de l'accouplement des Joups avec les cliiens, et cela me paraitrait moins impos. sible par la conformation des parties de la génération de ces animaux, que l'accouplement du taureau avec la jument, lont on prétend que i iennent les jumarts. Quoinue le taureau et la jument soient des animaux domestipues qui ont beaucoup plus dt docilite que les animaux sauvares, on dit qu'il faut prendre de grandes prcicautions pour les faire accoupler : peut-être parviendrait-on au mème but, si on prenait les mêmes prérautions pour les loups, après les avoir rendus domestiques dans une suite de générations. Mais en supposant yue ces animaux se mêlassent avec les chiens et quu'ils produisissent ensemble, il pourrait encore arriver qu'il n'en vint que des mulets, c'est-à-dire des individus stériles. D'ailleurs, le passage d'Aristote se riduit à dire que les loups s'accouplent avec les chiens dans le pays le Cyrène, et avec les tigres dans les Indes. Ce second fait étant hors de loute vraisemblance, on doit douter du premier, et on peut regarder le clien et le loup comme des animaux de deux diffèrentes espèces.

Les couleurs du loup sont le noir, le fauve, le gris et le blanc : la tète avait des teintes de ces trois couleurs; les lèrres et le bord des paupières ètaient noirs; il $y$ avait un nélange de noir, de fauve et de gris sur le dessus de la face extérieure des oreilles, sur le cou, sur les épaules, sur la face antérieure de l'avant-lıras, sur le dos, sur la partie supérieure des côtés du corps, sur la croupe, sur les lianclies, sur la face extérieure des cuisses, sur le còté supérienr de la queue et à l'extrénité, parce que la plupart des poils, et principalement les plus longs, étaien blancs près de la racine, ils avaient du noir au-dessus du blanc, ensuite du fauve, du blanc, et enfin du noir à l'extrémité. Le dessous de la face extérieure des oreilles était fauve roussâtre; la face extérieure du bras et de l'avant-bras, le reste des jambes de devant et le pied, la face extérieurc des jambes de derrirre, tlepuis le genou jusiju'an bout du pied, et le còté inférieur de la queue, étaient de couleur faure pale, et presque blanclıâre dans quelques endroits. Le bas des côtés dı corps, le ventre, les environs de l'anus et du scrotum avaieut une couleur mèlée de jaune pîle et tle blanc. Le tour des coins de la grueule, la machoire inférieure, la gorge, la poitrine, la face intérieure du bras et de l'avant-bras, de la cui-se, de la janbe, et d'une partie du tarse et dı ntétatarse, étaient d'un gris blanchả tre. Le poil de la tète au derant de l'ouverture de l'oreille, celui dı cou, de la partie antérieure du dos, des fesse: et de la queue, étaient les plus longrs, ils avaient jusqu'à cinq pouces; les autres sont beaucoup plus cuturts, principalement sur le museau et sur les oreilles : tous ces 
poils sont fermes et rudes; mais il y a entre enx un autre poil plus court, plus doux, et de conleur cendrée.

Le loup a le corps plus gros et les jambes plus courtes que le unatin, la tète plus large, le front moins élevé, le unuseau un peu plus court et plus gros, les yeux plıs pelits et plus éloignés l'un de l'autre, parce qu'il se trouve plus de distance entre les angles anterieurs des yeux du loup yuentre cenx des yeux du ınâtin, à proportion de c ll!e qui est entre les angles postérieurs des yeux de ces deux animaux; les oreilles du loup sont plus courtes et droiles en eutier. Le loup parait plus robuste que le mâtin, et beaucoup plus fort et plus gros ; mais la longrueur du poil contribue beaucoup à cette apparence, principalement le poil de la tête qui est au devant de l'ouverture des oreilles, celui du con, du dos, des fesses et de la queue, qui est fort g: osse. Le principal trail qui distingue la face du loup de celle du mattin est dans la direction de l'ourerture des paupières, qui est fort iuclinee, au lien d'ètre horizontale comme dans les chiens. Les yenx étincelants du loup sont le signe qui dinote le plırs sa fërocilé; ils animent sa face, et ses oreilles droites la relèvent.en la terminant; mais la petitesse des yeux fait paraitre le front fort éteutu et le museau très-allonıe. Ces parties, dénuées de traits, dounent au loup un faux air de doncem et de docilité, dont l'apparence n'est pas trompense dans les chiens mâtins, danois, braques, etc., qui ont le nuseau à peu près de même forme.

\section{LE LOUP DU MENIQUE.}

LE L.OUP RoLGE. (Cuvier.)

Comme le loup est originaire des pays froids, il a passé par les terres du nord, et se troure également dans les deux continents. Nous avons parlé des loups noirs et des loups gris de l'Amérique septẻntrionale : il parait que cette espèces'est repandue jusqu’à la Nouvelle-Espagne etau Mexique, et que, dans ce climat plus chaud, elle a subi des varietés, sans cependant avoir chaugé ni de nature ni de naturel; ear ce loup du Mexique a la mème figure, les mèmes appétits et les mèmes habitudes que le loup d'Europe ou le loup de l'Américue septentrionale, et tous paraissent ètre d'une seule et mème espèce. Le loup du Mexique, ou plutòt de la Vourelle-Espagne, où ou le trouve bien plus communément qu'au Mexique, a cinq doigts aux pieds de de- vant, quatre à ceux de derrière, les oreilles lon gues et droites, les yeux étincelants comme nos loups; mais il a la tête un peu plus grosse, Je cou plus épais et la queue moins velue; au-dessus de la gueule il a quelques piquanis aussi gros, mais moins raides que ceux du hérisson. Sur un fond de poil gris, son corps est marqué dequelques taches jaunes; la tête, de la mêne couleur que le corps, est traversée de raies brumes, et le front est taché de fauve; les oreilles sont grises comme la tète et le corps; il y a une longue tache fauve sur le cou, une seconde tache semblable sur la poitrine, et une troisième sur le ventre; Jes flanes sont marqués de bandes transversales depuis le dos juscu'au ventre; la queue est grise et marcfuée d'une tache fauve dans son milieu; les jambes sont rayées de haut en bas de gris et de brun '. Ce loup est, comme l'on voit, le plus beau des loups; et sa fourrure doit être recherchée par la variété des couleurs ${ }^{3}$ : mais, au reste, rien n'indique qu'il soit d'une espèce différente des nòtres, qui varient du gris au blauc, du blanc au noil et au mêlé, sans pour cela changer d'espèce; et l'on voit, par le témoignage de Fernandez, (jue ces loups de la Nourelle-Espagne, dont nous renons de donner la description d'après Recchi et Fabri, varient comme le loup d'Europe, puisque dans ce pays mème ils ne sout pas tous marqués comme nous renous de le dire, et qu'il s'en trouve qui sont de couleur uniforme, et même de tout blanes.

\section{l.E LOUP NOIR.}

Nous ne dommons la description de cet animal que comme un supplément à celle du loup , car nous les croyons tous deux de la mème espèce. Nous avous dit, dans l'histoire du loup, qu'il s'en trouve de tout blancs et de tout noirs dans le nord de l'Europe, et que ces loups noirs sont plus grands que les autres : celui-ci est venu du Canada; il était noir sur tout le corps, mais plus petit que notre loup; il avait les oreilles un peu

1 Xoloilscmuntli, l' pus Mexicanus. Fernand. Hist. natur. Mexic., p. 879 , fig. ihid.

2 On pourrait soupconner, à cause de la variélé des coulenrs, çue ce lomp du sl csique est un lynx ou loup-cerriei, dout l'espèce se troune, aussi bien yne celle du loup, dans les deux contınents : unais il sulfit de jeter les yeux sur la figure ‘ne nous a domméc Reccli, nour recomnaitre qu'elle ressemble toul à fail à celle dn loup, el point du tout à celle du lyox. 
plus grandes, plus droites, et plus éloignées l'une de l'autre; les yeux un peuplus petits, et qui paraissaient aussi un peu plus éloignés que dans le loup commun. Ces différences ne sont, à notreavis, que des variétés trop peu considérables pour séparer cet animal de l'espèce du loup : la différence la plus sensible est cellède la grandeur; mais, comme nous l'avons déjà dit plus d'une fois, les animaux qui sont communs aux deux coninents, c'est-à-dire ceux du nord de l'Europe et ceux de l'Amérique septentrionale, different tous par la grandeur, et ce loup noir de Canada, plus petit que ceux de l'Europe, nous parait seulement confirmer ce fait général : d'ailleurs, comme il avait été pris tout petit, et ensuite élevé à la chaine, la contrainte seule a peut-être suffi pour l'empêcher de prendre tout son accroissement. Nos loups ordinaires sont aussi plus petits et moins communs en Canada qu'en Europe, et les sauvages en estiment fort la peau. Les loups noirs, les loups-cerviers, les renards y sont en plus grand nombre. Cependant le renard noir y est aussi fort rare; il a le poil infiniment plus beau que le loup noir, dont la peau ne peut faire qu'une fourrure assez grossière.

Nous n'ajouterons rien de plus à la description que M. Daubenton a faite de cet animal, que nous avons vu vivant, et qui nous a paru ressembler au loup, non-seulement par la figure, mais par le naturel, n'étant devenu déprédateur qu'avec l'âge, et n'ayant, comme le loup, qu'une férocité sans courage qui le rendait lâche au combat, quoiqu'il y fût exercé.

\section{DESCRIPTION D'UN LOUP NOIR.}

\section{(EXTRATT DE DADBENTON.)}

Cet animal avait été pris fort jeune au Canada, et apporté en France par un officier de marine, qui le garda dans sa maison pendant quelque temps; mais l'animal étant devenu féroce en grandissant, il fut mis an combat du taureau à Paris, où il ne montra pas beaucoup de courage Iorsiun'on le fit entrer en lice : mais dès que l'on approchait de la loge où on le gardait, il entrait en fureur, se jetait brusquement en avant de toute la longueur de sa chaine, moutrait les dents et aboyait, non pas comme les chiens, mais seulement par des cris successifs et interrompus, qu'il ne répétait qu'après d'assez longs intervalles. Cet animal, quoique beau- coup plus petit que le loup, lui ressenublait par la forme du corps et de la tête, surtout par la position oblique des yeux ; mais les oreilles étaient plus pointues et plus éloignées l'une de l'autre que celles du loup; les yeux paraissaient plıs petits, et placés à une plus grande distance l'un de l'autre; la queue n'était pas si grosse, peut-être parce que l'animal se trouvait dans le temps de la mue et qu'il avait déjà perdu une partie de son poil. Celui qui était le long du dos, depuis le garrot jusqu’ả la croupe, avait plus de longueur que le poil du reste du corps, et formait une crinière qui ètait pius iongtie stir le garrot et sur la croupe que sur le dos et les lombes. Cet animal était noir en entier.

\section{LE RENARD.}

Orủre des carnassiers, famille des carnirores, tribu des digitigrades, genre chien. (Cuvier.)

Le renard est fameux par ses ruses, et mérite en partie sa réputation; ce que le loup ne fait que par la force, il le fait par adresse, et réussit plus souvent. Sans chercher à combattre les chiens ni les bergers, sans attaquer les troupeaux, sans trainer les cadavres, il est plus sûr de vivre. Il emploie plus d'esprit que de mouvement; ses ressources semblent être en lui-méme : ce sont, comme l'on sait, celles qui manquent le moins. Fin autant que circonspect, ingénieux et prudent, mème jusqu'à la patience, il varie sa conduite, il a des moyens de réserve qu'il sait n'employer qu'à propos. Il veille de près à sa conservation : quoique aussi infatigable, et mème plus léger que le loup, il ne se fie pas entièrement à la vitesse de sa course; il sait se mettre en sûreté en se pratiquant un asile où il se retire dans les dangers pressauts, où il s'établit, où il élève ses petits : il n'est point animal vagabond, mais animal domicilié.

Cette difference, qui se fait sentir même parmi les hommes, a de bien plus grands effets, et suppose de bien plus grandes causes parmi les animaux. L'idée senle du domicile présuppose une attention singulière sur soi-même; ensuite le choix du lieu, l'art de faire son manoir, de le rendre commode, d'en dérober l'entrée, sontautant d'indices d'un sentiment supérieur. Le renard en est doué, et tourne tout à son profit; il se loge au bord des bois, a portée des hameaux; il écoute le chant des coqs et le cri des volailles; il les saroure de loin; il prend habilement son 
temps, cache son dessein et sa marche, se gुlisse, se traine, rrive, et fait rarement des tentatives inutiles. S'il peut franchir les clòtures, ou passer pardessous, il ne perd pas un instant, il ravage la bassc-cour", il y met tout à mort, se retire elısuite lestement en emportant sa proie, quil cache sous la mousse, ou porte à son terrier ; il revient quelques moments après en chercher une autre, qu'il emporte et eache de même, mais dans un autre endroit; ensuite une troisième, une quatrième, ete., jusqüà ce que le jour ou le mouvement dans la maison l'avertisse quil fiut se retirer et ne plus revenir. Il fait lı mème manœuvre dans les pipćes et dans les boqueteaux oul lon prend les grives et les bícasses au lacet; il devance le pipeur, va de très-grand matin, et sourent plus d'une fois par jour, visiter les lacets, les gluaux, emporte successivement les oiseaux qui sont empètris, les depose tous en différents endroits, surtout au bord des chemins, dans les ornières, sous de la mousse, sous un genièvire; les y laisse quelquefois deux ou trois jours, et sait.parfaitement les retrouver au besoin. II chasse les jeunes levrauts en plaine, saisit quelquefois les lievres au gîte, ne les manque jamais lorsquills sont blessés, déterre les lapereaux dans les garennes, décou re les nids de perdrix, de cailles, prend la mère sur les œufs, et détruit une quantité prodigieuse de gibier. Le loup nuit plus au paysan, le renard nuit plus au gentilhomme.

La chasse du renard demande moins d'appareil que celle du loup; elle est plus facile et plus amusante. Tous les chiens ont de la répugnance pour le lomp, tous les chiens au contraire chassent le renard volontiers, et mème avec plaisir; car quoiqu’il ait l'odeur très-forte, ils le préîerent sou vent au cerf, au chevreuil et au licrre. On peut le chasser avee des bassets, des chicns courants, des briquets : dès qu'il se sent poursuivi, il court à son terrier; les bassets à jambes torses sont ceux qui se glissent le plus aisément. Cette maniere est bonne pour preud e une portée entière de renards, la mèı avee les petits; pendant qu'elle se defend et combat les bassets, on tâche de découvirir le terrier par dessus, et on la tue ou on la saisit vivante avec des pinces. Nais comme les terrier's sont souvent dans des rocher's, sous des troncs d'arbres. et quelquefois trop enfoncés sous terre, on ne réussit pas toujours. La façon la plus ordiniire, la plus agréable et la plus sûre de chasser le renard, est de commen-
I cer par boucher les terriers : on place les tireurs à portée, on quête alors a rec des bri juets; dès qu'ils sont tombés sur la roie, le renard gagne son gite, mais en arrivant il essuie une première décharge: s'il échappe à la lalle, il fuit de toute sa vitesse, fait un grand tour, ct revient en à son terrier, oì on le tire une seconde fois, eit où trouvant l'entrée fermée, il prend le parti de se sauver au loin, en percant droit en ar ant pour ne plus revenir. C'est alors qu'on se sert des chiens courants, lorsqu'on veut le poursuivre: il ne laissera pas de les fationer beaucoup, parce qu'il passe à dessein dans les endroits les plus fourrés, où les chiens ont grand peine àlesui re, et que, quand il prend la plaine, il va tres-loin sans s'arrêter.

Pour détruire les renards, il est encore plus commode dê tendre dles piéges, où l'on met de la chair pour appàt, un pigeon, une volaille vivante, etc. Je fis un jour suspendre à neuf pieds de hauteur sur un arbre les débris d'une halte de chasse, de la viande, du pain, des os, dès la première nuit, les renards s'é aient si fort exercés à sauter, que le terrain autour de l'arbre était battu comme une aire de grange. Le renard est aussi vorace quecarnassier; il mange de tout avec une égale avidité, des œufs, du lait, du fromage, des fruits, et surtout des raisins : lorsque les levrauts et les perdrix lui manquent, il se rabat sur les rats, les mulots, les serpents, les lézards, les crapauds, etc.; il en détruit un grand nombre; c'est là le seul bien qu'il procure. II est très-avide de miel; il attaque les abeilles sauvages, les guèpes, les frelons, qui d'abord tàchent de le mettı e en fuite en le perçant de mille coups d aigullon : il se retire en effet, mais c'est en se roulant pour les écraser; et il revient si souvent à la charge qüìl les oblige à abandonner le guêpier; alors il le déterre et en mange et le miel et lic cire. Il prend aussi les hérissons, les roule arec ses pie Is, et les force à s'étendre. Infin, il mange du po'sson, des écrevisses. des hannetons, ves sauterelles, etc.

Cet animal ressemble beaucoupau chien, surtout par les parties intérieures; cepen lant il en differe par la tête, qu'il a plus grosse à proportion de son corps; il a aussi les oreilles plus courtes, la queue beaucoup plus grande, le poil plus longet plus toufiu, les yeux plus inclinés. II en diffère encore par une mauvaise odeur très-forte qui lui est particulière, et enfin, par 
le caractère le plus essentiel, par le naturel; car il ne sapprivoise pas aisément, et jamais tout à fait: il languit lorsqu'il n’a pas la liberté, et meurt d'ennui quand on reut le garder trop longtemps en domesticité. Il ne s`accouple point avec la chieme '; s'ils ne sont pas antipathiques, ils sont au moins indiflérents. Il produit en moindre nombre, et une seule fois par an; les portéts sont ordinairement dequatre ou cinq, rarement de six, et jamais moins de trois. Lorsque la femelle est pleine, elle se recèle, sort rarement de son terrier, dans lequel elle prépare un lit à ses petits. Elle devient en chaleur en hiver, et l'on trouve déjà de petits renards au mois d'avril. Lorsqu'elle s'apercoit que sa retraite est découverte, et qu'en son absence ses petits ont été inquiétés, elle les transporte tous les uns après les autres, et va chercher un autre domicile. Ils naissent les yeux fermés; ils sont, comme les chiens, dix-huit mois ou deux ans à croitre, et vivent de même treize ou quatorze aus.

Le renard a les sens aussi bons que le loup, le sentiment plus fin, et l'oryane de la voix plus souple et plus parfait. Le loup ne se fait entendre que par des hurlements aflreux : le renard glapit, aboie ei pousse un son triste, semblable au cri du paon; il a des tons différents selon les sentiments difiérents dont il est affecté; il a la voix de la chasse, l'accent du désir, le son du murmure, le ton plaintif de la tristesse, le cri de la douleur, qu'il ne fait jamais entendre qu’au moment où il recoit un coup de feu qui lui casse quelque membre; car il ne crie point pour toute autre blessure, et il se laisse tuer à coups de bâton, comme le loup, sans se plaindre, mais toujours en se défendaut avec couraqe. Il mord dangereusement, opiniàtrément, et l'on est obligé de se ser ir d'uu ferrement ou d'un bàton pour le faire démordre. Son glapissement est une espèce dabıiement qui se fait par des sons semblables et très-précipités. C'est ordinairement ì la fin du glapissement qu’il donne un coup de voix plus fort, plus élesé, et semblable au cri du paon. En hiver, surtout pendant la neige et la gelée, il ne cesse de donner de la voix, et il est au contraire prescue muet en été. C'est dans cette saison que son poil tombe er se renouvelle. I'on fait peu de cas de

\footnotetext{
- Voyez les expetrlence que j"ai failes à ce sujet, anticle chien.
}

la peau des jeunes renards, ou des renards pris en été. La chair du renard est moins mauraise que celle du loup; les chiens et même les hom. mes en mangent en automne, surtout lorsquil s'est nourri et engraissé de raisins, et sa peau d'hiver fait de honnes fourrures. Il a le sommeil profond, on l'approche aisément sans l'éveiller. Lorsqu'il dort, il se met en rond comme les chiens ; mais lorsqu'il ne fait que sc reposer , il étend les jambes de derrjère et demeure étendu sur le ventre: c est dans cette posture qu'il épie les oiseaux le loug des hajes. Ils ont pour lư une si grande antipathie, que dès qu'ils l'apercoivent ils font un petit cri d'arertissement: les geais, les merles surtout, le conduisent du haut des arbres, répètent souvent le petit cri d'avis, et le suivent quelquefois à plus de deux ou trois cents pas.

$J$ 'ai fait élever quelques renards pris jeunes : comme ils ont une odeur très-forte, on ne peut les tenir que dans des lieux éloignés, dans des écuries, des étables, où l'on n'est pas à poriće de les voir sourent; et c'est pent-ètre par cette raison qu'ils s'apprivoisent moins que le loup, qu'on peut garder plus près de la maison. Dès l'âge de cinq à six mois les jeunes renards couraient après les canards et les poules, et il fallut les enchainer. J'en fis garder trois pendint deux ans, une femelle et deux mâles : on tenta inutilement de les faire accoupler avec des chiennes; quoiquils n'eussent jamais vu de femelles de leur espèce et quiis parusscut pressés du besoin de jouir, ils ne purent s'v déterminer, ils reiusèrent constamrnent toutes les chiemnes; mais dès qu'on leur présenta leur femelle légitime, ils la couvirent quoique enchânés, et flle produisit quatre petits. Ces mèmes renarcis yui se jetaient sur les poules lorsqu ils étaient en liberté, n'y touchaient plus dès qu'ils avaient leur chaine: on attachait sourent au. près d'eux une poule vivante, on les laissait passer la nuit ensemble, on les faisait même jeûner auparavant; malgré le besoin et la commodité, ils noubliaient pas quils étaient enchainés, et ne touchaient point ì la poule.

Cetie espèce est une des plus sujettes aux influences du climat, et l'on y trouve presque autant de varićtés que dans les espèces d'animaux domestiques. La plupart de nos remards sont roux, mais il s'en troure aussi dont le poil est gris a:genté; tous deux ont le bout de la queue blanc. Les derniers s'appellent en Bourgogue 
renards charbonniers ', parce qu'ils ont les pieds plus noirs que les autres. Ils paraissent aussi avoir le corps plus court, parce que leur poil est plus fourni. Il y en a d'autres qui ont le corps réellement plus long que les autres, et qui sont d'un gris sale, à peu près de la couleur des vieux loups; mais je ne puis décider si cette différence de couleur est une vraie varieté, ou si elle n'est produite que par l'àge de l'animal, qui peut-ètre blanchit en vieillissant. Dans les pays du Nord, il y en a de toutes couleurs, des noirs, des bleus, des gris, des gris de fer, des gris argentés, des blancs, des blancs à pieds fauves, des blancs à tête noire, des blancs arec le bout de la queue noir, des roux avec la gorge et le ventre entièrement blancs, sans aucun mélange de noir, et enfin des croisés qui ont une ligue uoire le long de l'épine du dos, et une autre ligne noire sur les épaules, qui traverse la première: ces derniers sont plus grands que les autres, et ont la gorge noire. L'espèce commune est pluts généralement répandue qu'aucune des autres : on la trouve partout, en Europe, dans l'A sie septentrionale et tempérée ; on la retroure de même en Amérique, mais elle est fort rare en Afrique et dans les pays roisins de l'équateur. Les royageurs qui disent en a voir' vu à Calicut et dans lés autres provinees méridionales des Indes ont pris les chacals pour des renards. Aristote lui-même est tombé dans une erreur semblable, lorsqu'il a dit que les renards d'Égypte étaient plus petits que ceux de Grèce : ces petits renards d'Égryte sont des putois, dontl'odeur estinsupportable. Nos renards, originaires des climats froids, sont devenus naturels aux pays tempérés, et ne se sont pas étendus vers le midi au delà de l'Espagne et du Japon. Ils sont originaires des pays froids, puisqu'on y trouve toutes les variétés de l'espèce, et qu'on ne les trouve que là ; d'ailleurs ils supportent aisément le froid le plus extrème; il y en a du côté du póle antarctique comme vers le póle arctique. La fourrure des renards blancs n'est pas fort estimée, parce que le poil tombe aisément; les gris argentés sont meilleur's, les bleus et les croisés sont recherchés à cause de leur rareté; mais les noirs sont les plus précieux de tous, c'est après la zibeline la fourrure la plus belle et la plus chère. On en troure au Spitzberg, en Groënland ${ }^{2}$, en Laponie, en Ca-

+ Ce n'est quiune variété du renard commun; quelques zoologistes ent ont fait, à tort, une espèce.

${ }^{3}$ Les renards abondent dans toute la Laponie. Ils sont rada, où il y en a aussi de croisés, et où l'espèce commune est moins rousse qu'en France, et a le poil plus long et plus fourni.

\section{PREMIĖRE ADDITION A L'ARTICLE DU RENALD.}

Les royageurs nous disent que les renards du Groënland sont assez semblables aux chiens par la tête et par les pieds, et qu'ils aboient comme eux. La plupart sont gris ou bleus, et quelques-uns sout blancs. IIs changent rarenent de couleur'; et (quand le poil dans l'espèce bleue commence à muer, il devient pâle, et la fourrure n'est plus boune à rien. Ils vivent d'oiseaux et de leurs œufs; et lorsqu'ils n'en peuvent pas attraper, ils se contentent de mouches, de crabes et de ce qu'ils pêchent. Ils font leurs tanières dans les fentes des rochers.

Au Kamtschatka, les renards ont un poil épais, si luisant et si beal, que la Sibérie n a rien à leur comparer en ce genre. Les plus estimés sont les chåtains-noirs, ceux qui ont lc rentre noir et le corps rouge, et aussi ceux $\dot{i}$ poil couleur de fer.

Nous arons parlé des renards noirs de Sibérie, dont les fourrures se vendent encore bien plus cher que celles de ces renards rouges ou châtaius-noirs de Kamtschatka.

En Norwége, il y a des renards blancs, des renards bais et des noirs; d'autres qui ont deux raies noires sur les reins: ceux-ci et les tout noirs sont les plus estimés. On en fait un trèsgrand commerce. Dans le seul port de Berghen on embarque, tous les ans, plus de quatre mille de ces peaux de renards. Pontoppidan, qui souvent donne dans le merveilleux, prétend qu'un renard avait mis par rangées plusieurs tètes de poissons à quelque distance d'une cabane de pêcheurs; quion ne pouvait guère deviner son but; mais que, peu de temps après, un corbeau qui vint fondre sur ces tètes de poissons, fut la proie du renard. Il ajoute que ces animaux se serrent de leur queue pour prendre les érrevisses, etc. '.

presque tous blancs, quolqu'il s'en rencontre de la conleur ordinaire. Les blancs sont les moins estimés; mais il s'en trouve quelquefois de noirs, et ceux-là sont les plus rares et les plus chers; leurs peaux sont quelquefois vendues quarante ou cinquante écus, et le poil en est si fin et si long. quil peud de tel côté que l'on veut; en sorte que, prenant la peau par la queue, le poil tombe du cóté des oreilles, etc. (@uvres de Regnard, tome I, page 175.)

' Histoire naturelle de la Norwége, par Pontoppidan; Journal étranger, Juin 1776 . 
DEUXIĖAE ADDITION.

On pourrait croire que l'espece du renard, dont nous avons indiqué plusieurs variétés, se serait répandue d'uin pôle à l'autre; car les voyageurs ont indiqué des animaux sous ce nom au Spitzberg et à la Terre-de-Feu, ainsi qu'aux iles Malouines. Le capitaine Phipps rapporte qu'on trouve des renards sur la grande terre de Spitzberg et daus les illes adjacentes; qu'à la vérité il n'y en a pas une grancle quantité, et qu'indépendamment de la couleur, çui est blanche, ils diffèrent encore de notre renard, en ce qu'ils ont les oreilles beaucoup plus arrondies, et qu'ils ont très-peu d'odeur. Il ajoute avoir' mangé de la chair de ces animaux, et l'avoir trouvée bonne '.

M. de Bougainville nous apprend qu'il n'a trouvé qu'une seule espèce de quadrupèdes dans les îles Malouines ou Falkland, et que cette espèce tient à celle du loup et du renard ${ }^{2}$. Cet animal se creuse un terricr; sa queue est plus longue et plus fournie de poils que celle du loup; il habite dans les dunes sur les bords de la mer; il suit les oiseaux qui sont très-nombreux dans ces iles; il se fait des routes avec intelligence, toujours par le plus court chemin, d'une baie à l'autre; il est de la taille d'un chien or'dinaire, dont il a aussi l'aboiement, mais faible; il détruit beaucoup d'œufs et de jeunes oiseaux ${ }^{3}$. Ces indications ne seraient pas suffisantes pour décider si les animaux du nord de notre continent sont les mèmes que ceux de l'Amérique australe et des îles Falkland : mais ayant reçu deux individus deces animaux des iles Falkland, et les ayant soigneusement comparés avec les renards de l'Europe, nous avons reconnu qu'ils étaient absolument de la mème espéce. Il en est de mème du renard blanc, qui probablement est de la mème race que les renards blanes du Spitzberg, dont le capitaine Phipps a parlé.

La peau de cet animal nous a été montrée par M. de Villemarais de La Rochelle, auquel je dois aussi des observations au sujet des genettes de France, et qui nous a dit qu'elle venait du Nord.

Sa longueur du bout du musełu à l'origine de

la queue élait de............ 1106

La hauteur du train de deraut. . . . . . 109

Celle du train de derrière. . . . . .... 144

\footnotetext{
1 Voyage du capitaine Phipps, p. 188.

${ }^{3}$ Le elien anlarctique; Canis sntarticus; Desmar

Voyage autour du monde. func I, in-\$o, page 113.
}

Il differe un peu de nos renards des pays tempérés, par la grandeur du poil qui est trèslong sur le corps, de même qu'aux jambes et aux cuisses. Il a les oreilles plus petites; la distance de l'œil à l'or'eille est tres-grande; le bout du nez et les naseaux sont rougeâtres.

$\begin{array}{ccccc}\text { Les longs poils qui distinguent cet animal des } & \text { p. } & \text { p. } & \text { I. } \\ \text { autres renards onl de longueur sur le dos.. } & 0 & \mathbf{2} & 0 \\ \text { Aux tlancs, sur tout le venlre et aux cuisses.. } & 0 & \mathbf{2} & \mathbf{9}\end{array}$

Il se trouve au-dessous de ces poils, qui sont longs et fermes, un duvet ou feutre très-doux et fol't touffu, d'un blanc jaunâtre.

Les poils des moustaches, qui sont blancs, ont p. p. I. de lougueur.................. 0 1 10

La quene a de longueur. ......... 128 Le trouçon.................. 1008

Celte queue est épaisse et garnie de poils dans toute sa longueur.

Les ongles des pieds sont presque égaux entre eux; ils sont blancs et crochus.

T. p. I. a...... 0 o 007 Celui de derrière.............. 0 0 0 6 Largeur à la base............... 0 o 0 s Épaisseur..................... 0 0

\section{DESCRIPTION DU RENARD.}

(EXTRait de DaUdeston.)

Le renard ressemble parfaitement au loup et aux ciriens par la conformation des parties interieures ; et, quoiqu'il diffère de ces animaux par l'labitude du corps, par le port et par le maintien, on ne trouve aucune diffèrence essentielle en observant chacun de ses membres en particulier, et en les comprarant à ceux du loup et des clicens : il y a mêtue beaucoup plus de variétés entre les chiens de diverses races, qu'entre le renard et le loup, ou les chiens qui ont le museau eflilé, les os petits, le poil long

${ }^{1}$ Buffon, dans l'article du renard et dans les deux additions, a confondu plusieurs espèces bien distinctes.

$1^{0}$ Le chien antarctique (Canis Antarcticus; Shaw.) habite les iles Malouines: M. F. Cuvier y réunit le culpeu cie Molina.

$2^{0}$ Le renard isatis (Canis Lagopus; Linné) babite les cou. trées voisines de la mer glaciale; Buffon en parle, tome XllI, page 272 édit. in-40 $)$. Il dilfère de lisalis, suppl. 3, p. 113, même édition.

$3^{0}$ Le renard noir ou argenté ( $C$ anis Argenlalus; $\mathbf{F}$. Cuvier) habite le nord de l'Amerifue et de l'Asie.

$4^{0}$ Le renard eroisé ('nnis Decussalus ; Geoffr.) habite le nord de l'Améripue. II. İ. Cuvier pense que celle espéce n'est peut-ètre qu'une variété đle la precédenle, dans lą̧uelle: il serait possible que l'on en̂t réuni deux animaus differents. 
et la quene touffue. Je ne doute pas que l'on ne parvînt à avoir des chiens qui ressembleraient plus au renard que le chien-loup ne ressemble au loup, si on faisait accoupler de petits danois et des chiens d'Irlande avec des chiens-loups ou des chiens de Sibèrie; les premiers donneraient aux métis ı̣ui viendraient de ce mélange le museau mince et effilé du renard, et les autres un poil aussi long et une quene aussi touffue que celle de cet animal. Il y a aussi sout lieu de croire que, si on le tirait des forets et des campagnes pour l'èlever daus les maisons, comme les chiens, il en dériverait plusieurs races, et quil s'en trouverait qui ressembleraient antant à certains chiens par la furme extérieure du corps, que par la conformation interieure. L'odeur qui s'exhale du corps des renards sauvages, et qui est peut-être la cause de l'aversion que les chiens ont pour ces animaux, changerait par les aliments et par le repos dans les renards domestiques, après une longue suite de gẻnérations; alors les chiens pourraient s'accoupler avec les renards, et produire par ce mélange des métis semblables aux, chiens de Laconie dont Aristote fait mention".

Le renard est d'une figure plus légère que le loup; les proportions de son corps marquent plus de souplesse; son museau, effile comme celui du lévri $\mathbf{l}^{\circ}$, annonce la finesse d'instinct dont l'animal est doué; mais le renard a les yeux situés et les oreilles dirigies comme le loup, et la tête à proroportion aussi grosse, tandis que le lévrier ressemble au mâtin par les yeux et les oreilles. La quene du renard est plus touffue que celle du loup, et si longue qu'elle touche la terre.

\section{L'ALCO.}

O: dre des carnassiers, fanille des carnirores, tribu des digitigrades, genre chien. (Curier.)

Nous avons dit qu'il y avait au Pérou et au Mexíyue, avant l'arivivéc des Européens, des animaux domestiques nommés alco, qui étaient de la grandicur et a peu près du même naturel que nus petits chiens, et que les Espagnols les. diaient appeles chu'ns du Hexique, chicus du $P \dot{i}, 0 u$, par cette convenance et parce qu'ils ont le même attachement, la même fidélité pour leurs maitres: en effet, l'espèce de ces animaux ne par:it pas être essentiellement différente de celle du chien, et d'ailleurs il se pourrait que le

\footnotetext{
4 Lacuuni canes ex vulpe et cane generantur. 1)e auin. lib. octavus, cap. 28.
}

mot alco fût un terme générique et non pas spécifique. Recchi nous a laissé la figure d'uiı de ces alcos, qui s’appelait, en langue mexicaine, yızcuinte porzolli; il était prodigreusement gras, et probablement dénaturé par l'etat de domesticité et par une nourriture trop aboudante; la tête est représentée sl petite qu'elle n'a, pour ainsi dire, aucune proportion avec la grosseur du corps; il a les orcilles pendantes, autre signe de domesticité ; le museau ressemble assez à celui d'un chien; tout le devant de la tète est blane, et les oreilles sont en partie fauves; le cou est si court qu'il n'y a point d'intervalle entre la tête et les épaules; le dos est arqué et couvert d'un poil jaune; la queue est blanche et courte, elle est pendante et ne descend pas plus ba: que les cuisses; le ventre est gros et tendu, marqué de taches noires, arec six mamelles très-apparentes; les jambes et les pieds sont blanes, les doigts sont comme ceux du chien, et armés d'ongles longs et pointus ' ${ }^{1}$. Fabri, qui nous a donné cette description, conclut, après unetrèslongue dissertation, que cetanimal est le mème que celui qu'on appelle alco, et je crois que son assertion est fondée; mais il ne faut pas la regarder comme exclusive, car il y a encore une antre race de chien en Amérique, à laquelle ce nom convient également; outre les cliens, dit Fernandès, que les Espagnols ont transport s d'Europe en Amérique, on y en trouve trois autres espèces qui sont asseZ semblables aux nôtres par la nature et les mœurs, et qui n'en differeut pas infiniment par la forme. Le premier et le plus grand de ces chiens américairs est celui qu'on appelle xoloilzcuinali; souvent il a plus de trois condées de longueur, et ce qui lui est particulier, c'est qu'il est tout nu et saus poil; il est seulement couvert d'une peau douce, unie et marquée de taches jaures et bleues. Le second est couvert de poil, et pour la grandeur est assez semblable à nos petits chiens de Maltc; il est marqué de blane, de noir et de jaune; il est singulier et agréable par sa difformité, ayant le dos bossu et le cou si court, qu'il semble que sa tète sorte immédliatement des épaules; on l'appelle michuacane:s, du nom de son pays. Le troisième de ces chiens se nomme tcchichi: il est assez semblablc à nos petits chiens; mais

1 Ytzcuinte porzotli. Canis mexicana.... Ad unguem auimal quod hic prostat, nauum, jingue el mansuetum efligiatum. mihi videtur illud esse quod Americani nomine communi Alco vocabaut. Fernand. 11 is, mex. p. 466 et $\$ 78$, fig. pag. 466. 



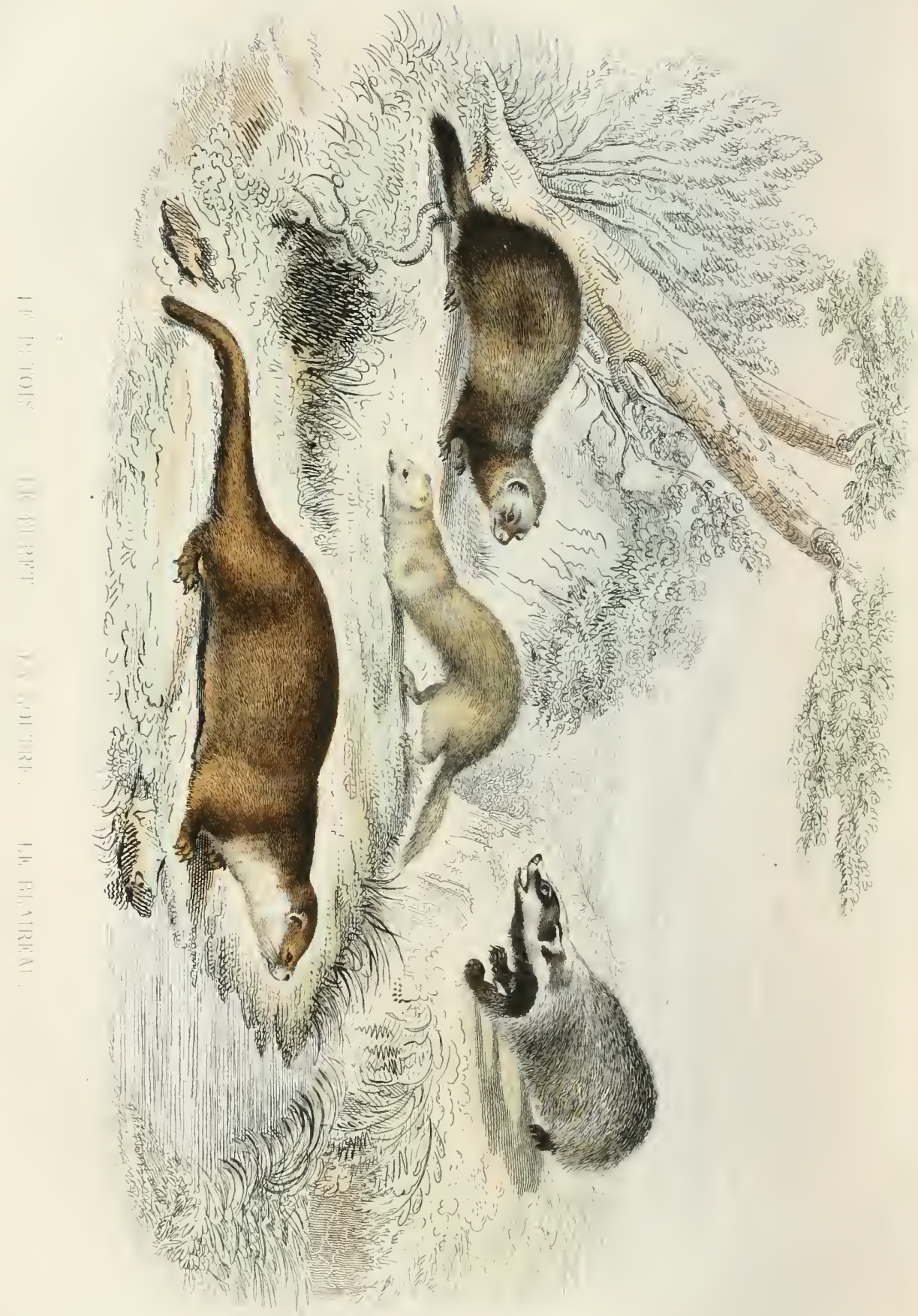


Il a la mine sauvage et triste. Les Américains en mangent la chair '.

En comparant ces témoignages de Fabri et de Fernandès, il est clair que le second ehien que ce dernier auteur appelle michuacanens, est le mèmerque l'ytzuinte porzolli, et que cete espèce d'animal existait en effet en Amérique avant l'arrivé des Européens; il doit en être de mème de la troisième espèce appelée techichi. Je suis donc persuadé que le mot alco était un nom générique qui les désignait toutes deux, et peut-être encore d autres races ou variétés que nous ne connaissous pas. Mais à l'égard de la première, il me parait que Fernandès s'est trompé surle nom et la chose; aucuu auteur ne ditqu'il se trouve des chiens nus à la NouvelleEspagne; eette race de chiens, vul airement appelés chieris turcs, vient des Indes et desautres pays les plus chauds de $I$ ancieu continent, et il est probable que ceux que Fernandès a vus en Amérique y avaient été transportés, $d$ autant plus qu il dit expressément qu'il avait vu cette espèce en Esjagine avant son dépari pour l'Amérique: ces deux raisons sont sufiisantes pour qu'on doive présumer que ce chien nu n’en était pas originaire, mais y avait été transporté ; et ce qui achève de le prouver, e'cst que cet animal n'avait point de nom américain, et que Fernandès, pour lui en donner un, emprunte celui de xoloitzcuinuli, qui est le nom du loup de Mexique; ainsi des trois espècesou varietés des chiens américains, dont cet auteur fait mention, il n'en reste que deux que l'on désignait indifléremment par le nom d'alco. Car indépendamment de l'aleo gras et potelé, qui servait de chien bichon aux dames péruvieunes, il $\mathrm{y}$ a vait un alco maigre et à mine triste qu'on employait à la chasse; et il est très-possible que ces animaux, quoique de races très-différentes en apparence de celles de tous nos chiens, soient cependant issus de la mème sonehe. Les chiens de Laponie, de Sibérie, d'Islande, ete., ont dù passer, comme les renards et les loups, d 'un continent à l'autre, et se dénaturer ensuite, comme les autres chiens, par le elimat et la domestieité. Le premier alco dout le eou est si court se rapproche du chien d'Islande; et le techichi de la Aourelle-Espagne est peut-ètre le mème animal que le houpar $a^{2}$ ou chi. n-crabe de la Guiane,

'Feruandès. Ilist. anim. Nov.-Hisł., p. 6 et 7, cap). XX; et p. 10, cap. XXI.

2 Canis ferus, major, caucrosus, vulgo dictus koupara. Barrère, Essai d'hist. nat. de la France L̇yuiu., 1, $1 / 49$. qui ressemble au renard par la figure, et au chacal par le poil; on l'a nommé chien-crabe, parce qu'il se nourrit principalement decrabes et d'autres crustacés. Je n’ai vu qu'une peau de cet animal de la Guiane, et je ne suis pas en état de décider s'il est d'une espèce particulière, ou si l'on doit le rapporter à celles du chien, du renard ou du ehaeal.

\section{LE BLAIREAU.}

Ordre des carnassiers, famille des carnivores, tribu des plantigrades, genrc Blaireau. (Cuviet.)

Le blaireau est un animal paresseux, détiant, solitaire, qui se retire dans les lieux les plus écartés, dans les bois les plus sombres, et s'y ereuse une demeure souterraine; il semble fuir la société, mème la lumière, et passe les trois quarts de sa vie dans ce sejour ténébreux, dont il ne sort que pour chereher sa subsistance. Conme il a le corps allongé, les jambes courtes, les ongles, surtout ceux des pieds de devant, très-longs et très-fermés, il a plus de facilité qu'un autre pour ouvrir la terre, y fouiller, y pénétrer, et jeter derrière lui les déblais de son exeavation, qu'il rend tortueuse, oblique, et qu il pousse quelquefois fort loin. Le renard, qui n a pas la même facilité puur creuser la terre, profite de ses travaux : ne pouvant le contraindre par la for'e, il l'oblige par adresse à quitter son domicile, en l'inquiétant, en fuisant sentinelle à l'entrée, en linfectant mème de ses ordures; censuite il s'en empare, l'élargit, l'approprie, ct en fait son terrier. Le blaireau, forcé à changer de manoir, ne change pas de pays; il ne va qu'à quelque distance travailler sur nouveaux frais à se pratiquer un autre gite, dont il ne sort que la nuir, dont il ne s'ćearte guère, et où Il revient dès qu il sent quelque danger. Il n’a que ce moven de se mettre en sûreté, car il ne peut échapper par la fuite; il a les jambes trop courtes pour pouroir bien courir. Les chiens l'atteignent promptement, lorsqu ils le surprennent à quelque distance de son trou : eependant il est rare qu'ils l'arrêtent tout à fait et qu'ils en viennent à bout, à moins qu'on ne les aide. Le blaireau a le poil très-épais, les jambes, la mâchoire et les dents très-fortes, aussi bien que les ongles; il se sert de toute sa force, de toute sa résistance et de toutes ses armes en se cotichant 
sui le dos, et il fait aux chiens de profondes blessur'es. Il a d'ailleurs la vie très-dure ; ilcombat longtemps, se défend courageusement, et jusqu'à la dernière extrémité.

Autrefois que ces animaux étaient plus communs qu'ils ne le sont aujourd'hui, on dressait des bassets pour les ehasser et les prendre dans leurs terriers. Il n'y a guère que les bassets à jambes torses qui puissent y entrer aisément : le blaireau se défend en reculant, éboule de la terre, afin d'arrêter ou d'enterrer les chiens. On ne peut le prendre qu'en faisant ouvrir le terrier par dessus, lorsqu'on juge que les ehiens l'ont acculé jusqu'au fond; on le serre avec des tenailles, et ensuite on le musèle pour l'empêcher de mordre : on m'en a apporté plusieurs qui avaient été pris de eette façon, et nous en a vons gardé quelques-1nns longtemps. Les jeunes s’apprivoisent aisément, jouent a vec les petits ehieus, et suivent eomme enx la personne qu'ils connaissent et qui leur domne à manger; mais ceux que l'on prend vieux demeurent toujours sauvares. lls ne sont ni malfaisants, ni gourmands, comme le renard et le loup, et cependant ils sont animaux earnassier's; ils mangent de tout ce (qu' on leur offre, de la chair, des œufs, du fromage, du beurre, du pain, du poisson, des fruits, des noix, des graines, des racines, etc., et ils préfèrent la viande crue à tout le reste. IIs dorment la nuit entière et les trois quarts du jour, sans cependant êtresujets à l'engourdissement pendant l'hiver, comme les marmottes ou les loirs. Ce sommeil fréquent fait qu'ils sont toujour's gras, quoiqu'ils ne mangent pas beaucoup; et c'est par la même raison qu'ils supportent aisément la diète, et qu'ils restent sonvent dans leur terrier trois ou quatre jours sais en sortir, surtout dans les temps de neige.

Ils tiennent leur domicile propre; ils n'y font jamais leurs ordures. On trouve rarement le mâleavec la femelle: Iorsqu' elle est prète à mettre bas, elle coupe de l'herbe, en fait une espèce de fagot, qu'elle traine entre ses jambes jusqu'au fond du terrier, où elle fait un lit commode pour elle et ses petits. C'est en été qu'elle mat bas, et la portée est ordinairement detrois ou de quatre. Lorsqu'ils sont un peu grands, elle Icur apporte ì manger; elle ne sort que la nuit, va plus au loin que dans un autre temps; elle déterre les nids des guêpes, en emporte le miel, perce les rabonillères des lapins, prend les jeunes lapereaux, saisit aussi les mulots, les lé- zards, les serpents, les sauterelles, les œufs des oiseaux, et porte tout à ses petits, qu'elle fait sortir souvent sur le bord du terrier, soit pour les allaiter, soit pour leur donner à manger

Ces animaux sont naturellement frileux; ceux qu'on élève dans la maison ne veulent pasquitter le coin $d u$ feu, et souvent s'en approchent de si près, qu'ils se brûlent les pieds, et ne guérissent pas aisément. Ils sont aussi fort sujets à la gale; les chiens qui entrent dans leurs terriers prennent le mème mal, à moins qu'on n'ait grand soin de les laver. Le blaireau a toujours le poil gras et malpropre; il a entre l'anus et la queue une ouverture assez large, mais qui ne communique point à l'intérieur et ne pénètre guère qu'à un ponce de profondeur; il en suinte continuellement une liqueur onctueuse, d'assez mauvaise odeur, qu'il se plait à sucer. Sa chair n'est pas absolument mauvaise à manger; et l'on fait de sa peau des fourrures grossières, des colliers pour les ehiens, des couvertures pour les cheraux, etc.

Nous ne connaissons point de variétés dans cette espèce, et nous arons fait ehercher partout le blaireau-cochon dont parlent les chasseurs, sans pouvoir le trouver. Dufouilloux dit quill y a deux espèce de tessons ou blérenux, les porchins et les chenins; que les porchins sont un peu plus gras, un peu plus blanes, un peu plus gros de corps et de tête que les chenins. Ces différences sont, comme l'on voit, assez légères; et il avoue lui-même qu'elles sont peu apparentes, à moins qu'on n'y regarde de bieu près. Je crois donc que cette distinction du blaireau, en blaireau-chien et blaireau-cochon, n'est qu'un préjugé, fondé sur ce que cet animal a deux noms, en latin meles et taxus, en français blaireau et taisson, etc., et que c'est une de ees erreurs produites par la nomenclature dont nousarons parlé dans le discour's qui est dans le volume précédent. D'ailleurs, les espèces qui ont des variétés sont ordinairement très-abondantes et très - généralement répandues ; celle du blaireau est au contraire une des moins nombreuses et des plus confinées. On n'est pas sùr qu'elle se trouve en Amérique, à moins que l'on ne r'egarde comme une variété de l'espèee, l'animal envoyé de la Nouvelle-Yorck, dont M. Brisson' ' a donné une courte descrip-

4 Meles supra alba, infra ex albo flavicans... Meles alba. II a , depuis le bout du museau jusqu'à l'origine de la quene, un pied neuf pouces de long; sa queue est longue de neuf pouces. 
tion, sous le nom de blaireau blanc. Elle n'est | sous le nom de carcajou, mais il n'a pas aupoint en Afrique; car l'animal du cap de BonneEspérance, décrit par Kolbe ${ }^{4}$ sous le nom de blaireau puant, est un animal différent; et nous doutons de la fussa de Madagasear, dont parle Flaccourt dans sa relation, page $\mathbf{1 5 2}$, et qu'il dit ressembler au blaireau de France, soit en effet un blaireau. Les autres voyageurs n'en parlent pas : le docteur Shaw dit 2 même qu'il est eutièrement inconnu en Barbarie. Il paraît aussi qu'il ne se trouve point en Asie; il n'était pas connu des Grees, puisque Aristote n'en fait aucune mention, et que le blaireau n'a pas mème de nom dans la langue grecque. Ainsi cette espèce, originaire du climat tempéré d'Europe, ne s'est guère répandue aû-delà de l'Espagne, de la France, de l'Italie, de l'Allemagne, de l'Angleterre, de la Pologne et de la Suède, et elle est partout assez rare. Et non-seulement il n'y a que peu ou point de variétés dans l'espèce, mais mème elle n'approche d'aucune autre : le blaireau a des caractères tranchés, et fort singuliers; les bandes alternatives qu'il a sur la tète, l'espèce de poche qu'il a sous la queue, n'appartiennent qu'à lui : et il a le corps presque blanc par dessus, et presque noir par dessous : ce qui est tout le contraire des autres animanx, dont le ventre est toujours d'une couleur moins foncée que le dos.

ADDition A L'ARTICLE DU BLAIREAU.

\section{LE CARCAJOU ${ }^{3}$.}

On a envoyé la peau bourrée d'un animal d'Amérique à M. Aubry, curé de Saint-Louis,

Ses yeux sont petits à proportion de la grandeur de son corps, ses oreilles courtes, ses jambes très-courles, ses ongles blancs. Tout son corps est couvert de poils très-épais, blancs dans loule la partie supérieure du corps, et d'un blanc jaunåtre dans la parlie inférieurc. On le trouve dans la NouvelleYorck, d'oủ il a été apporté à M. de Réaumur. l3risson, Règne animal, page 255 . On doit ajouter à cette description, qn'il est en tout plus petit, et quil a le nez plus court que notre blairean; et d'ailleurs ou ne voit pas sur la peau, qui est em. paillée, sil y a une bourse sous la queue.

1 Voyez la description du cap de Bonne-Espérance, par Kolbe. Amsterdam, 1741, tome 111 , page 64.

${ }^{3}$ Voyez les Voyages de M. Shaw. La 1laye, 1743, tom. I, D. 320.

- Cet animal ne diffère poiut du blaireau d'Europe; il appartient à la mẻme espèce, et ne pent mẻme çtıc considéré comme une variélé.

tant de rapport que je l'aurais pensé avec ect animal que j'ai dit être le mème que le glouton de notre nord ; car il semble même approcher de très-près de l'espèce de notre blaireau d'Europe : ses ongles me sont point faits pour déchirer une proie, mais pour creuser la terre; en sorte que nous le regardons comme une espèce voisine, ou mème comme une variété de l'espèce du blaireau; il ne faut que le comparcr avec la figure de notre blaireau, pour en reconnaître la ressemblance. Cependant il en diffère en ce qu'il n'a que quatre doigts aux pieds de derant, tandis que notre blaireau en a cinq; mais le cinquiène petit doigt, qui parait lui manquer, peut avoir été oblitéré dans la peau desséchée; il difiérait également du carcajou ou glouton par ce même caractère, car le glouton a aussi comme le blaireau cinq doigts aux pieds de devant; ainsi nous doutons beaucoup que cet animal, envoyé sous le nom de carcajou, soit en effet le vrai carcajou. Nous joignons iei la description de sa peau bourrée quj est bien conservée dans le cabinet de M. le euré de SaintLouis. On lui a assuré qu'il venait du pays des Esquimaux. Il a deux pieds deux pouces du bout du museau à l'origine de la queue; quoiqu'il ressemble beaucoup au blaireau, il en diffère par la couleur é la qualité du poil, qui est bien plus doux, plus soyeux et plus long; et ce n'est que par ce seul caractère qu'il pourrait se rapprocher du carcajou et du glouton du nord de l'Europe. Il est à peu près de la couleur dı loup-cervier, d'un blanc grisâtre; sa tête est rayée de bandes blanches, mais différemment de celle du blaireau. Les oreilles sont courtes et blanches; il a trente-deux dents, six incisives, deux canines fort grosses, quatre mâchelières de chaque còte, et le blaireau en a cinq. Le bout du nez est noirâtre. Les poils du corps, qui ont communément quatre pouces et demi ou cinq pouces, sont de quatre couleurs dans leur longueur, d'un brun clair depuis l'origine jusqu'à près de la moitié, ensuite fauve clair, puis noir près de l'extrémité qui est blanche; le dessous du corps est couvert de poils blanes; les jambes sont aussi couvertes de longs poils d'un brun muse foncé; les pieds de devant n'ont que rquatre doigts, et ceux de derrière cinq. Les ongles des pieds de der ant sont fort grands; le plus long a jusqu'il seize lignes, ct le plus long des pieds de derrière n'en a que scpt; la queuen'a que trois 
pouces huit ligues ae tronçon; elle est terminée par de longs po Is qui l'cuvirounent et qui sont de coultur fauve.

\section{DESCRIPIION DU BLAIREAU.}

(EXTRAIT DE DAUBENTON.)

Le blaireau a les oreilles et les jambes si courtes, yue le ventre semble toucher la terre; mais ce Iiest qu'une fausse apparence, qui vient dle la longrueur du puil. Celui du col'ps entier, à l'exception du museau, du front et des pieds, est aussi long yue le poil du veutre; il empèche de distinguer la fo me du corps, et le fait paraitre beaucoup plus gros qu il ne l'est rẻellement. Les oreilles sont presyue entièrement cachèes dans le poil, et on croirait yue la queue ne serait composee que de longs poils ejars, si on ne la touchait pour sentir le tronçon. Le museau est allongé comne celui des chiens à museau long, tels que les måtins, les danois, les chitus de berger, etc., et le nez du blaireau a la néme forme que celui des cliens. Les yeux sont petits, et le; oreilles courtes et rondes, à pen près comme celles des rats. La queue ne descend que jusquau talon, yui est peu eloigne de l'anus, parce que le genou est plié de façon que la cuisse el la jambe sont fort inclinees, et que leur direction ést pen éloignée de la ligne horizontale. Il y a ciny doigts à chaque pied : les ongles sont forts, et ceux des pieds de devant ont beaucoup plus de longueur que ceux des pieds de derrière.

Le poil du blaireau est de trois coulen!s, noir, blanc et roux; il y a sur la téte deux baudes noires et trois blanches. L'une des blanches a douze ou quatorze lignes de largeur, et elle s'étend sur le milieu de la tìte, depuis le bout du museau jusque sur le cou : de chayue còté de cette bande blanche il y en a une noire, qui a un pouce de largeur, qui commence à un deni-pouce de distance du nez, et qui s'étend jusque sur le cou. L'oil et l'oreille sont dans ces bandes noires, mais le poil du bord supérieur de l'oreille est blanc. Les deux clernières bandes sont placées au-dessous des noires, et ont à pen près la mème largeur que la bande blanche du milieu de la tète : les bandes hanches des còtés de la tète commenceut au bout dı museau, s'étendent le long des deux lèrres, et se prolongent audelà du coin de la bouche, jusque sur les cỏtés du cou. Le dessous ule la mâchoire infèrieure, la gorge, la face inférieure du cou, la poitrine, les aisselles, la face intérieure du bras, le ventre, les aines, la face intérieure de la cuisse et les quatre jambes sont noirs; la face supérieure et les côtés clu cou, les epaules, la face extérieure dı bras, le dos en entier, depuis le cou jusqu'à la queue, et la facc extérieure des cuisses, sout de couleur mêlée de blanc et de noir, avec quelques légères teintes de fauve, parce que la plupart des poils sont blancs sur environ la moitic de leur longueur, depuis la racine; il y a du faure pàle au-ulssus du blanc, du noir au-dessus du fauve, et ċu blanc à l'extrémite; il se trouve quelques poils qui sont noirs en entier, à l'exception de l'extrémité qui est blauche; les côtés du corps, la yueue et les alentours de l'anus sont de couleur mèlée de blanc sale et de roussâtre. Le poil de cet animal est rare et ferme ả $p$. ไ près comme les soies des cochons; le plus lunỹr it jusqu'à yuatre pouces : le blanc ou le blanc sait qui domine dans plusienrs endroits a fait donner au blaireau le nom cle grisart; on l'appelle aussi du nom de taisson, qui vient du nom latin taxus.

On a distingué deux sortes de blaireaux, et on a donné aux uns le nom de blaireau-chien, et aux autres celui de blaireau-coclıon, à cause de leur ressemblance avec le chien et avec le cochon. L'on reconnait aisément le blaireau-chien, c'est celui que je viens de décrire; il est assez commun en Europe: on prétend que le blaireau-cochon s'y trouve aussi, et quil y en a uièue en France; presque tons les auteurs en ont fait mention, et jai onĩ dire à plusieurs personnes qu'elles l'avaient vu; cependant, quelques recherches que jaie faites, je n’ai jamais pu l'avoir, et je suis très-porté à croire, par tous les renseignements que j'ai pris au sujet de cet animal, qu'il n'a jamais existé. Au moins il serait si différent du blaireau clien, que l'on ne derrait pas rapprocher ces deux animaux l'un de l'autre, au point de les appeler du mẻne nom de blaireau, et de les, réunir dans le mème cliapitre, comme l'ont fait tous les auteurs qui en (ont traité.

On n’a jamais été d’accorl sur les caractères qui distinguent le prétendu blaireau-cochon du blaireau-chien : selon quelques auteurs, il n'en diffère que par la furme des pieds et par le nombre des doigs; on croit que ce blairean doit avoir le pied fourchu; d'antres auteurs ajoutent qu'il a aussi le nuseau ressemblant à celui du coclion, mais aucun n'a fait mention du numbre ni de la ligure des dents, et on ne sait s'il a des défenses et d'autres rapports avec le cochon. Aussi la plupirt de ces auteurs avouent qu'ils ne l'ont pas vu, et il y a lieu rle croire que les autres s'en étaient rapportés à un préjuge vulgaire sur l'existence de ce blaireau : le premier qui en a écril a éte copié par les autres; ainsi leur autorite a maintenu le prejugé, qui se soutient encore à present. 


\section{LE KINK!IOU"}

Ordre des carnassiers, fanille des carnivores, tribu des plautigrades, genre hiaireau. (Curier.)

Je suis persuadé qque le carcajou d'Amériçue est le même animal que le glouton d'Europe, ou du moins qu'il est d'une espèce très-voisine; mais je dois observer que, faute d'ètre assez informé, je crois être tombé daus une méprise occasionnée par la ressemblance du nom et de quelques habitudes naturelles communes à deux animaux différents. J'ai cru que le linkajou était le même animal que le carcajon, et je n'ai reconnu cette erreur qu'à la vue de deux animaux dont l'un était à la foire Saint-Germain, en 1773, annoncé sur l'affiche, animal inconnu à lous les naturalistes; et il l'était en effet. Un autre tout pareil est encore actuellement vivant à Paris, chez M. Chauveau, qui l'a amené de la Nouvelle-Espagne; et M. Messier, astronome de l'Académie des Sciences, l'a nourr pendant deux ou trois ans. C'est celui que nous croyons ètre le vrai kinkajou. M. Chauveau pensait que ce pouvait être un accouchi ou un coati; il dit, qu'à la véritéil n'a ni le nez allongé ni la queue annelée du coati, mais qu'il a d'ailleursle même poil, les mêmes membres, le même nombre de loigts, et surtout des dents canines pareilles, et telles que M. Perrault les a fait dessiner pour le coati, e'est-à-dire anguleuses et cannelées sur les trois faces. M. Chauveau avoue qu'il diffère encore du coati par sa queue prenante, avec laquelle il se suspend et s'accroche à tout ce qu'il rencontre lorsqu'il veut descendre.

"Il ne la redresse mème, dit-il, que quand ses pieds sont assurés; il s'en sert heureusement pour saisir et approcher de lui les choses aux(quelles il ne peut atteindre; il se couche et dort dès qu'il voit le jour, et s'éveille à l'approche de la nuit. Alors il est d'une vivacité extr:ordinaire. Il grimpe avec unc grande lacilité, et furettepartout. II arrache tout ce qu'il trouve, soit en jouant, soit en cherchant des inscetes, sans cela on pourrait le laisser en liberté; et mème, avant d'ètre en France, on ne l'attachait pas du tout; il sortait et allait où il voulait pendant la nuit, et le lendemain matin on

' Bnffon a Intilulé la descriplion de cet animal seconde addilion a l'article du gloulon. C'est une erreur: le kinkajou forme un genre roisin de relui des blaireaux. le retrouxait tonjours conché à la même place; on vient à bout de l'éveiller en l'excitant pendant le jour, mais il semble que le soleil ou sa réverbér tion l'elfraie ou le suffoque. Il est assez caressant, sans cependant être docile; il sait seulement distinguer son maitre et le suivre. Il boit de tout, de l'eau, du café, du lait, du vin et mème de l'eau-de-rie, surtout s'il y a du sucre, et il en boit jusqu'ì s'enivrer, ce qui le rend malade pendant plusieurs jours; il monge aussi de tout indistinctement, du pain, de la viande, des légumes, des racines, principalement des fruits; on lui a donné longtemps pour nourriture ordinaire du pain trempé de lait, des léglimes et des fruits. 11 aime passionnément les odeur's et est tres-friand de sucre et de confitures.

" Il se jette sur les volailles, et e'est toujours sous laale qu'il les saisit; il parait en boire le sang, et il les laisse sans les déchirer; quand il a le choix, il préfere un canard à une poule, et cependant il craint l'eau. II a différents cris; quand il est seul pendant la nuit, on l'entend très-sou vent jeter des sons (qui ressemblent assez en petit à l'aboiement d'un chien, et il commence toujours par éternucr. Quand il joue et qu'on lui fait du mal, il se plaint $p$ r un petit cri pareil à celui d'un jeune pigeon. Quand il menace, il siffle à peu près comme une oic; quand il est en colère, ce sont des cris confus et éclatants. Il ne se met guère en colère que quand il a faim; il tire une langue d'une longueur démesurée lorsqu'il bâille; c'était une fcmelle, et l'on a cru remarquer que depuis trois ans qu'elle est en France, elle n'a éti qu'une fois en chalcur; el!e était alors presque toujours furieuse ${ }^{4}$."

Voici la description que $\mathrm{M}$. de Sève a faite d un animal tout semblable, qui était à la foire Saint-Germain, en 1773.

"Par le poil, dit-il, il a plus d’andlogie à 'a loutre, cu'aux autres animaux; mais il n'a point de membranes entre les doigts des pieds; il a la queue aussi longue que le corps, au lieu que celle de la loutre n'est que moitié de la longueur du corps. Il a bien eu marchant l'allure de la foune par son corps allon.é, mais il n'y ressemble pas par la queuc, ni par les formes de la tète, qui ont plus de rapport dans cette partie à celle de la loutre; l'œil est

Nole communiugue par $\mathbf{M}$. Simon Chauveau, M. de Buffon. 
plus gros que celui de la fouine, qui a le museau plus allongé; la tète, de face, tient un peu du petit chicu danois; il a une langue extrèmement longue et menue, qu'il allonge quelquefois dans la journée; cette langue est douce lorsqu'il lèehe. Car cet animal parait être d'un asse $\iota$ bon naturel; il était fort doux ce carême dernier, quand j'ai commencé à le dessiner ; mais le public, cui l'agace, l'a rendu méchant; à présent il mord quelquefois après avoir léché. Il est jeune, et ses dents ne me paraissent pas formées, comme je le dirai ci-après. 11 est d'un tempérament remuant, aimant à grimper; souvent il se tient sur son derriere, se gratte avec ses pieds de devant comme les singes, joue, retourne ses pattes l'une dans l'autre, et fait d'autres singeries. Il mange comme l'ćcureuil, tenant entre ses pattes les fruits ou lierbes qu'on lui donne. On ne Iui a jamais donné de viande ni de poisson. Lorsqu'il sirrite, il cherche à s'élancer, et son cri dans sa colère, tient benucoup de celui d'un gros rat. Son poil n'a aucune odeur. Il a la dextérité de se servir de sa queue pour accrocher les différentes choses qu'il veut attirer à lui. II se pend avec cette queue et aime à s'attacher de cette façon à tout ce qu’il rencontre. J'ai observé que ses pieds, dont les doigts ont une certaine longueur, se réunissent volontiers quand il marche ou grimpe; ils ne s'écartent point en s'appuyant, comme font les doigts des autres animaux, et les pieds ont par conséquent une.forme alloñée; il a aussi en marchant un peu les pieds en dedans. Enfin cet animal (au dire de Saint-Louis, oiseleur, rue de Richelieu à Paris, qui l'a acheté l'un parliculier) vient de la còte d'Afrique; on l'appelait kinkujou, et l'espèce en est rare : il se figure que c'est le nom de l'ile ou du pays d'où il vient, ne pourant aroir, par les personnes qui le lui ont vendu, les éclaircissements nécessaires : je dirai seulement que ce kinkajou, qui est femelle, tient en génélal plus de la loutre que des autres animaux, par rapport aux poils, qui sont courts et épais, mèlés de quelques poils plus longs. Les poils de la tète, comme ceux du corps ct de la queue, sont d'une teinte jaume olivâtre, mêlés de gris et de brun; par le luisant du poil qui est changeant à laspect du jour, il forme des tous différents, plus gris, plus verdàtres (qui est le dominant) ou plus bruns. Ce poil est de couleur grise blanchâtre dans la plus grande partie, et d'un fauve ver- dâtre-sale à l'extrémité; il est mélangéd'autres poils dont l'extrémité est de couleur brune, indépendamment de plus grands poils noirs, mêlés plus ou moins dans les autres poils, et qui forment à côté des yeux des bandes qui s'étendent ver's le front, et une autre au milieu qui s'alfaiblit vers le cou. L'œil tient beaucoup de celui de la loutre; la pupille est fort petite, et l'iris d'un brun musc ou roussàtre. L.e nuuseau est d'un brun noir, comme le tour des yeux. Le bout du nez est méplat, comme aux petits chiens, et les narimes très-arquées. L'ou verture de la bouche est de quinze lignes; les dents, qui paraissent jaunes, sont au nombre de trente-deux. Dans la mâchoire supérieure, il y a six incisives, comme dans la mâchoire infé. rieure, deux canines au-devant de chacune, e quatre màchelières de chaque côté aux deux mâchoires; ces dents canines sont très-grosses, la supérieure croise l'iuférieure. Aussi dans la màchoire inférieure $\mathrm{y}$ a-t-il un vide entre les incisives et la canine infórieure, pour y recevoir la supérieure. Les mâchelières paraissent peu fournies, surtout les dernières, qui annoncent la jeunesse de ce petit animal. Ainsi il a douze dents incisives, quatre canines, seize mâchelières, qui lui font trente-deux dents. Ses oreilles, plus longues que larges, sont arrondies à leurs extrémités, et couvertes d'un poil court de la couleur de celui du corps. Les côtés et le dessous du cou, le dedans des jambes, sont d'un jaune doré, extrêmement rif par endroits. Cette mème teinte dorée et plus foncée domine dans plusieurs endroits de la tète et des jambes de derrière. Le ventre est d'un blanc grisàtre, teint de jaune par endroits; la queue est partout garnie de poils; elle est grosse à l'origine du tronçon, et va en dimiuuant imperceptiblement, et finit en pointe à l extrémité. Il la porte horizontalement en marchant. Le dessous de ses pattes, qui est sans poil, est couleur de chair vermeille. Les ongles sont blanes, crochus, et faisant la gouttière en-dessous.

Longucur du corps entier, prise en ligne su-

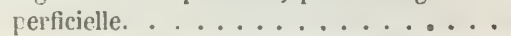

Lo:igueur du corps enticr, mesuréc en ligne droite................... 250

Longueur de la tẻte, du bout du museau à rocciput.................... 026

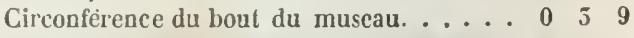

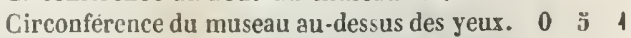
Distance entre le bout du museau et l'angle

pi. po. 1. $\begin{array}{lll}2 & 5 & 6\end{array}$ 6 1 
antérieur de l'xil. ............. 0 1 5 Mcine distance entre l'angle posterieur de

lowil.................... 0 \&

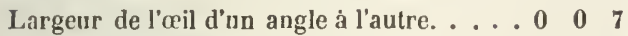

Ouverture de l'œil. . . . . . . . . . . . 0006

Distance entre les angles postérieurs des yeux

en ligne superficielle........... 0 0 0 (1)

La mème distance en ligne droite. . . . . . 00000

Circonférence de la tẻte entre les yeux et les

oreilles.................. 076

Longueur des oreilles. ............

Largeur de la base mesurée en ligne droite. . 0007

Longuenr du cou. ............. 019

Circonférence du cou. ............ 060 11

Ilauteur du train de devant. . . . . . . 0606

Longueur de l'a rant-bras depuis le coude jus-

qu'au poignet. ............. 0 o

Longueur de l'avant-bras près le coude. . . . $0 \begin{array}{lll} & 9 & 9\end{array}$

Épaisseur de l'avant-bras près le coude. . . . 012

Circonfẻrence du poignet. . . . . . . 0027

Circonfér ence du métacarpe. . . . . . . 0028

Longueur du poignet jusqu'au bout des ou-

gles.................. o 19

Circonférence du corps, prise derrière les

jambes de devant. ............ 01010 A

Circonférence du corps, prise à l'endroit le

plus gros.................. 011 6

Circonférence du corps devant les jambes dc derrière................ 0 9 10

Hauteur du train de derrière. ........ $0 \begin{array}{lll} & 7 & 3\end{array}$

Longueur de la jambe depuis le genou jusqu'au talon. ................... 0 4 7 Largeur du haut de la jambe. ....... 02 2

Epaisseur........................ 4

Largeur à l'endroit du talon. ........ 0 । 5

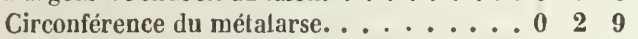

Longueur depuis le talon jusqu'au bout des

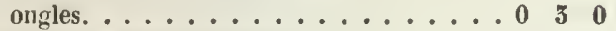
Largeur du pied de devant. ......... 011 Largeur du pied de derrière. . . . . . . 01212 Longueur des plus grands ongles. ...... 0 . 0 4 $4 \frac{1}{2}$ Largeur à la base. .............. 0 ( 50 Longueur de la queue. . . . . . . . . 139 Circonfẻrence de la queue à son origine. . . . $04 \quad 4 \quad 6$ J)iamètre de la queue à son origine ${ }^{4} \ldots \ldots 0 \quad 2 \quad 1$

Ia conformitédes noms de kinkajou etde carcajou m'a vait porté à croire, a vec tous les autres naturalistes, qu ils appartenaient au mème animal.Cependant, ayantrecherehédanslesancieis voyageurs, j’ai trouvé ce mème passage de Denis qui se trouve cité à l'article de l'élan et du renne, parce que j'a vaisimaginé que ce voyageur s'était trompé, en disant que le kinkajou, que je prennis alors pour le carcajou, ressemblait à un chat, d'autant que tous les autres voyageurs s'accordaient à donner au careajou une figure

1 Uescription donnee par M. de Sève. différente et semblable à celle du glouton. Voici done ce passage en entier.

"Le kinkajou ressemble un peu à un chat d'un poil roux brum; il a la queve longue et la relève sur son ros pliée en deux ou trois plis ; il a des griffes et grimpe sur les arbres oì il se couche tout de son long sur les branches, pour attendre sa proie et se jeter dessus pour la dévorer. Il se iette sur le dos d'un orignal, l'entoure de sa queue, lui ronge le cou au-clessus des oreilles jusqu'i-ce qu'il tombe. Quelque vite que puisse courir l'orignal, et quelque fort ciu'il puisse se frotter contre les arbres ou les buissons, le kinkajou ne lâche jamais prise; mais s'il peut gagner l'eau il est sauvé, parce qu'alors le kinkajou làche prise et saute à terre. II y a quatre ans qu'un kinkajou m'attrapa une génisse etlui coupa le cou. Les renards sont ses chasseurs; ils vont à la découverte tandis cpic le kinkajou est en embuscade, où il attend l'orignal, que les remards ne manquent pas de lui amener. "

Cette notice s'accorde assez avec la figure et la description que nous venous de donner de cet animal, pour présumer que c'est le mème, ct que le carcajou et le kinkajou sont deux animaux d'espèces distinctes et séparées, qui n'olit de commun entre eux que de se jeter sur les orignaux et sur les autres bètes faures pour ' 'n boire le sang.

Nous venons de dire que le kinkajou se troure dans les montagnes de la Nouvelle-Espagne, mais il se trouve aussi dans celles de la Jamaïque, oì les naturels du pays le nomment polo et non pas kinkajou. M. Colinson m'a enroyé le dessin de ce poto ou kinkajou dont je donne ici la notice suivante :

" Le corps de cet animal cst de conleur uniforme, et d'un roux mélé de gris ceudré, le poil court mais très-épais, la tète arrondie, le museau court, nu et noiràtre, les yeux bruns, les oreilles courtes et arrondies, des poils longs tout autour de la gueule, qui sont appliqués sur le museau et ne forment point de monstaches ; la langue étroite, longue, et que l'auimal fait sonvent sortir de sa gueule de trois ou quatre pouces; la queue de couleur uniforme, diminuant toujours de grosseur jusqu'à l'extrémité, qui se re-

I Description géographique et historique des coiles de l'Amérique septentrionale, par M. Denis. Paris, 1672, tome II, page 327. 
courbelorscpue l'animal le vent, et a vec laquelle il s'attache et peut saisir et serrer fortement; cette queve est plus longue que le corps, qui a quinze ponces, depuis le bout du nez jusqu'à l'extrémité du corps, et la queue en a dixsept.

Cet animal avat été pris dans les montagnes de la Jamaïque; il est doux et on peut le manier sans crainte; il est comme endormi la journée, et très-vif pendant la nuit : il diffère beaucoup de tous ceux dont le genre est déterminé ; sa langue n'est pas si rude que celle des chats ou des autres animaux du genre des viver $a$, auquel il a rapport par la forme de la tête et par celle des griffes. Il a autour de la bouche beaucoup de poils longs de deux à trois pouces, qui sont bouiclés et très-doux. Les oreilles sont placées bas et presque vis-à-vis de l'œil ; quand il dor't il se met en boule, à peu près comme le hérisson, ses pieds ramassés en devant et étendus sous les joues. Il se sert de sa queue pour tirer un poids aussi pesant que sou corps.

Il est évident, en comparant les deux dessins et la deseription de M. Colinson avec celle de M. Simon-Chauveau, qu'elles ont toutes deux rapport au mème animal, à quelques variétés près qui n'en changent pas l'espèce.

\section{ADDITION A I'ARTICLE DU KINIKAJOU.}

Nous avons reconnu que le kinkajou, que nous n'avions pas d'abord distingué du carcajou ou glouton d'Amérique, est néanmoins d'nne espèce toute différente : il ne nous reste qu'à ajouter une note que $\mathrm{V}$. Simon-Chanveau ${ }^{2}$ nous a donnée depuis sur les habitudes du kinkajou qu'il a gardé vivant durant plusieurs années.

"Son attitude favorite est d'ètre assis d'aplomb sur son cul et ses pattes de derrière, le corps droit avec un fruit dans les pattes de devant, et la queue roulée en volute horizontale.

"J'ai plusieurs fois pris la résolution, continue M. Simon-Chauveau, de vous ofiril cet animal vivant pour le soumettre à vos observations;

4 Note envoyée par \$. Colinson, à 31 . de Buffon, 12 décenbre 1766.

'Lettre ż M. de Buffon, datée de Paris le 31 janvier 1780. mais il venait dans ces instants me caresser s1 doucement et jouer autour de moi aver, tant de gaieté, que, séduit par ses gentillesses, je n'ai jamais eu le courage de m'en séparer. II est mort le 3 janvier de cette année (1780), et e'était le neuvième hiver qu'il passait à Paris, sans que le froid ni ancune autre chose eut pariu l'avoir incommodé.

\section{LA LOUTRE.}

Ordre des carnassiers, famille des carnirores, tribu des digitigrades, genre lontre (Cuvier).

La loutre est un animal vornce, plus avide de poisson que de chair, qui ne quitte guère le bord des rivières ou des lacs, et qui dépeuple quelquefois les étangs. Elle a plus de facilitéqu un autre pour nager, plus mêmeque le castor ; car il n'a des membranes qu'aux pieds de derrière, et il a les doigts séparés dans les pieds de devant, tandis que la loutre a des membranes à tous les pieds: elle nage presque aussi vitequ'ellemarche. Elle ne va point à la mer comme le castor, mais elle parcourt les eaux douces, et remonte ou descend les rivières à des distances considérables: souvent elle nage entre deux eaux, et y demeure asse: longtemps; elle vient ensuite à la surface, afin de respirer. A parler exactement, elle n'est point animal amplibie, c'est-à-dire animal qui peut vivre également et dans l'air et dans l'eau; elle n'est pas conformée pour demeurer dans ce dernier élément, et elle a besoin de respirer, à peu près comme tous les autres animaux terrestres : si même il arrive qu'elle s'engage dans mne nasse a la poursuite d'un poisson, on la tronve noyée, et l'on voit qu'elle n'a pas eu le temps d'en couper tous les osiers pour en sortir. Elle a les dents comme la fouine, mais plus grosses et plus fortes relativement au volume de son corps. Faute de poissons, d'écrevisses, de grenouilles, de rats d'eau, ou d'autre nourriture, elle coupe les jeunes rameaux, et mange l'écorce des arbres aquatiques: elle mange aussi de l'herbe nouvelle au printemps; elle ne craint pas plus le fr oid que l'humidité. Elle devient en chaleur en hiver, et met bas au mois de mars : on m'a souvent apporté des petits au commencement d'arril ; les portées sont de trois ou quatre. Ordinairement les jeunes animanx sont jolis : les jeunes loutres sont plus laides que les vieilles. La tête mal faite, 
les nreilles placées bas, des yeux trop petits et couverts, l'air obscur, les mouvements gauches, toute la figure ignoble, informe, un cri qui parait machinal, et qu'elles répètentà tout moment, sembleraient ammoncer un animal stupide; cependant Ia loutre devient industrieusea recl âge, au moins assez pour faire la guerre a vec grand avantage aux poissons, qui pour l'instinct et le sentiment sont très-inférieurs aux autres animaux : mais j'ai grand'peine à croire qu'elle ait, je ne dis pas les talents du castor, mais mème les habitudes qu'on lui suppose, comme celle de commencer toujours par remonter les rivières, afin de revenir plus aisément et de n'avoir plus' qu'ì se laisser entrainer au fildel'eau lorsqu'elle s'est rassasiée ou chargée de proie; celle d'approprier son domicile et d'y faire un plancher, pour n'ètre point incommodée de l'humidité; celle d'y faire une ample provision de poisson, afin de n'en pas manquer' ; et entin la docilité et la facilité de sapprivoiser au point de pêcher pour son maittre, et d'apporter le poisson jusque dans la cuisine. Tout ce que je sais, e'est que les loutres ne creusent point leur domicile ellesmêmes; (qu'elles se gîtent dans le premier trou qui se présente, sous les racines des peupliers, des saules; dans les fentes des rochers, et même dans les piles de bois à flotter; qu'elles y font aussi leurs petits sur un lit fait de bùchettes et d'herbes; que l'on trouve dans leur' gite des têtes et des arêtes de poisson; qu'clles changent souvent de lieu; qu'elles emmènent ou dispersent leur's petits au bout de six semaines ou de deux mois; que cen $x$ que $j$ 'ai voulu priver cherchaicnt à mordre, mème en prenant du lait, et avant que d'ètre assez forts pour mâcher du poisson; qu'au bout de quelques jours ils devenaient plus doux, peut-être parce qu'ils étaient malades et faibles; que, loin de s'accoutumer aisément à la vie domestique, tous ceux quej'ai essayé de faire élever sont morts dans le premier âge; qu'enfin la loutre est, de son naturel, sauvage et cruelle; que, quand elie peut entrer dans un vivier, elle $\mathrm{y}$ fait ce que le putois fait dans un poulailler; qu'elle tue beaucoup plus de poissons qu'elle ne peut en manger', et qu'ensuite elle en emporte un dans sa gueule.

Le poil de la loutre ne mue guère : sa peau d'hiver' est cependant plus brume et se vend plus cher que celle d'été: elle fait une très-boume

1 Vide Cessner, Hist. quadr., p. 685, ex Alberto, Bellonio, Sealigero, Olav magno, etc

No fourrure. Sa chair se mange en maigre, et a en effet un mauvais goût de poisson, ou plutòt de. marais. Sa retraite est infectée de la mauvaiss odeur des débris du poisson qu' elle y laisse pourrir; ellesent elle-mêmeassez mauvais. Les chiens la chassent volontiers et l'atteignent aisément, lorsqu'elle est éloignée de son gite et de l'ean; mais quand ils la saisissent, elle se défend, les mord eruellement, et quelquefois a vee tant de force et d'acharnement, qu'elle leur brise Jes os des jambes, et qu'il faut la tuer pour la fajre démordre. Le castor cependant, qui n’est pas un animal bien fort, chasse la loutre, et ne lui permet pas d'habiter sur les bords qu'il fréquente.

Cette espèce, sans ètre en très-grand nombre, est généralement répandue en Europe, depuis la Suède jusqu'à Naples, et se retıonve dans l'Amérique septentrionale ' ; elle était bicn connue des Grees, et se trouve vraisemblablement dans tous les climats tempérés, surtout daus les lieux où il y a beaucoup d'eau; car la loutre ue peut habiter ni les sables brúlants, ni les déserts arides ; elle fuit également les rivièies stériles et les fleuves trop fréqueutés. Je ne crois pas qu'clle se trouve dans les pays très-chauds; car le jiya ou carigueibcju", qu’on a appelí; loutre du Brésil, et qui se trouve aussi à Cay rì ne ${ }^{3}$, parait ètre d'une espèce voisine, mais différente: au lieu que la loutre de I'Amérique septentrionale ressemble en tout à celle d'Europe, si ce n'est que la fourrure est encore plus noire et plus belle que celle de la lontre de Suède ou de Moscovie.

\section{I $^{\text {re }}$ ADDition A L'ARTiCLE de la LOUTRE.}

Pontoppidan assure qu'en Norwége la iontre se trouve également autour des eaux salies comme autour des eaux douces; qu'clle établit sa demeure dans des monceaux de pierres, d'où les chasseur's la font sortir en imitant sal roix au moyen d'un petit sifflet: il ajoute qu'elle ne mange que les parties grasses du poisson, et

\footnotetext{
1 Voyez le Voyage de la llonlan, tome 11 , page 58.

${ }^{2}$ Jiya quæ el carigueibeju appellatur a brasilicusibus. Mareg., hist. Brasil.. page 25\%. I.ul'a Buasiliensis. Ray.5ynops. anima!. quadr., page 189 . Lutra jollice digilis bieviore. Linnæus. Lulra alıi coloris, macula sub gutture llavâ. 13risscu, Regn. itnimal, page 278.

s Lutra nigricans, caudì iepresså et glabrá. Barrère, Hlec. de la France équinoxiale, page 155 .
} 
qu'une loutre apprivoisée, à laquelle on donnait tous les jours un peu de lait, rapportait continuellement du poisson à la maison '.

\section{DEUXIEME ADDITION.}

Nous arons dit que la loutre ne paraissait pas susceptible d'éducation, et que nous n'ayions pu réussir à l'apprivoiser' ; mais des tentatives sans succès ne démontrent rien, et nous arons souvent reconnu qu'il ne fallait pas trop restreindre le pouvoir de l'éducation sur les animaux : ceux même qui semblent le plus s'y refuser cèdent néaumoins et s'y solimettent dans certaines circonstances; le tout est de rencontrer ces circonstances favorables et de trouver le point flexible de leur naturel, d'y appuyer ensuite assez pour former nne première habitưde de nécessité ou de besoin, qui bientôt s'assujettit toutes les autres. L'éducation de la loutre dont on va parler en est un exemple. Voici ce que M. le marquis de Courtivron, mon confrère à l'Académie des Sciences, a bien voulu m'écrire en date du 15 octobre 1779 , sur une loutre très-privée et très-docile qu'il a vie à Autun :

"Vous autorisez, monsieur, ceux qui ont quelques observations sur les animaux à vous les communiquer, mème quand elles ne sont pas absoltiment conformes à ce qui peut paraitre avoir été votre première opinion. En relisant l'article de la loutre, $j$ ' ai vu que vous doutez de la facilité qu'on aurait d'apprivoiser cet animal. Dans ce que je vais rous dire, je ne r apporterai rien que je n'aie vu, et que mille personnes n'aient ru comme moi, à l'abbaye de Saint-Jean-le-Grand, à Autun, dans les années 1775 et 17i6; j’ai vu, dis-je, pendant l'espace de près de deux ans, à différentes fois, une loutre femelle qui avait été apportée peu de temps après sa naissauce dans ce courent, et que les tourières s'étaient plu à élever; elles l'avaient nourrie de lait jusqu'à deux mois d'àge, qu'elles commencèrentà accoutumer cette jeune loutre à toutes sortes d'aliments ; elle mangeait des restes de soupe, de petits fruits, des racines, des légumes, de la viande et du poisson; inais elle ne roulait point de poisson cuit, et elle ne mangeait le poisson cru que lorsqu'il

\footnotetext{
1 Histoire naturelle de la Norwége, par Pontoppidan; Journal étranger. Juin 1756 .
}

était de la plus grande fraícheur: s'il avait plus d'un jour, elle n'y touchait pas. J'essayai de lui donner de petites carpes, elle mangeait celles qui étaient vives; et pour les mortes, elle les visitait en ouvrant l'ouĩc avec sa patte, la flairait et le plus souvent les laissait, même quand on les lui présentait arant de lui en donner de vives. Cette loutre était privée comme un chien; elle répondait au nom de loup-loup que lui avaient donné les tourières; elle les suivait et je l'ai vue revenir à lear voix du bout d'une vaste cour où elle se promenait en liberté, et, quoique étranger, je m'en faisais suivre en l'appelaut par son nom. Elle était familiarisée arec le chat des tourières, avec lequel elle avait été élevée, et jouait avec le chien du jardinier, qu'elle avait aussi connu de bonne heure: pour tous les autres chiens et chats, quand ils approchaient d'elle, elle les battait. Un jour j'avais un petit épagneul avec moi; elle ne lui dit rien d'abord; mais le chieu ayant été la flairer, elle lui donna vingt soufflets avec ses pattes de devant, comme les chats ont coutume de faire lorsquils attaquent de petits chiens, et le poursuivit à coups de nez et de tête jusqu'entre mes jambes; et depuis, toutes les fois qu'elle le vit, elle le poursuivit de mème. Tant que les chiens ne se défendaient pas, elle ne se servait pas de ses dents; mais si le chien faisait tète et roulait mordre, alors le combat devenait à outrance; et j’ai vu des chiens assez gros, déchirés et bien mordus, prendre le parti de la fuite.

"Cette loutre habitait la chambre des tourières, et la nuit elle couchait sur leur lit: le jour elle se tenait ordinairement sur une chaise de paille oì elle dormait couchée en rond; et quand la fantaisie lui en prenait, elle allait se mettre la tête et les pattes de derant dans un seau d'eau qui était à son usage; ensuite elle se secouait et venait se remettre sur sa chaise, ou allait se promener dans la cour ou dans la maison extérieure. Je l'ai vue plusieurs fois couchée au soleil; alors elle fermait les yeux : je l'ai portée, maniée, prise par les pattes et flattée; elle jouait avec mes mains, les mordait insensiblement, et faisait petites dents, si cela peut se dire, comme on dit que les clats font patte de velours. Je la menai un jour auprès d'une petite flaque d'eau, où la rivière d'Aroux en laisse lorsqu'elle est débordée: ce qui vous paraîtra surprenant, et ce qui m’étonnait aussi, c’est qu'elle parut craindre de voir de l'eau en si 
grand volume; elle n'y entra pas, passé le bord où elle se mouilla la tète comme dans le seau; je la fis jeter à quelques pas dans l'eau; elle recagna le bord bien vite avec une sorte d'effroi, et nous suivit, trè-contente de retrouver ses tourières. Si on peut raisomner d'après un seul fait et un seul individu, la nature paraît n'avoir pas donné à cet animal le même instinct qu'aux canards, qui barbottent aussitôt qu'ils sont éclos, en sortant de dessous une poule.

"Cette loutre était très-malpropre . le besoin de se vider paraissait lui prendre subitement, et elle se satisfaisait de même quelque part qu'elle fût, excepté sur les meubles, mais à terre et dans la chambre comme ailleur's; les tourières n'avaient jamais pu, même par des correctious, l'accoutumer à aller, pour ses besoins, à la cour, qui était peu éloignée; dès qu'elle s'était vidée, elle venait flairer ses excréments, ainsi que les chats, et faisait un petit saut d'allégresse cusuite, comme satisfaite de s'être débarrassée de ce poids.

"J'ai souvent eu occasion de voir cette loutre, parce que je ne passais point à Autun sans aller à l'abbaye de Saint-Jean-le-Grand, où madame de Comrtivron avait une tante; et j'ai diné dix fois avee la loutre qui était de très-bonne compagnie. On me l'offrit : je l'aurais acceptée pour la mettre enchainée sur le fossé de ma maison à Courtivron, où elle aurait eu occasion de se marier, si je n’avais reconnu la difficulté de l'enehaìner, à cause que le eou de cet animal est presque du mème diamètre de sa tète et son corps ; je pensai cqu'elle pourrait s 'éehapper, et multiplier cliez moi les loutres qui n'y sont que trop communes.

"Je me reproche de m'ètre si fort étendu sur cet article des loutres, comme susceptibles d'ètre bien apprivoisées; mais jai cru devoir vous domer un exemple de ce que j’ai vu dans notre Bourgogne : aiusi, sans recourir aux exemples de Danemarek et de Suède, s'ils existent tels que le P. Vanière, dans son poëme du Proedium rusticum, les a célébrés, voilà des choses sur lesquelles vous pouvez compter, et il n'y a rien de poétique dans ce que je vous dis. "

\section{DESCRIPTION DE LA LOUTRE.}

(EXTRAIT DE DAUBEXTON.)

Le corps de la loutre est à peu près aussi long et aussi gios que celui du blaireau; mais les jambes de la loutre sont beaucoup pius courtes. Cet animal a la tête jlate, le museau fort large et la máchoire du dessous plus étroite et moins longrue que celle du dessus; le cou est court, et si grus qu'il semble faire partie de la tète; le corps est fort allongé, les jambes sont très-courtes, et la queue est grosse à l'origine, et pointue à l'extrémité. Il y a de chaque côté du museau des moustaches composées de gros crins blancs et bruns; il y en a d'autres au-clessous de la màchoire inférieure: au-deli des coins de la bouche et près de l'angle postérieur des yeux; les plus longs de ces crins ont près cle trois pouces.

La loutre a deux sortes de poils, les uns plus longs et plus fermes que les autres, qui sunt une sorte de duvet soyeux de couleur grise blanchâtre sur la plus grande partie de sa longueur, et brune à la pointe. Les poils les plus longs sont gris blanchâtres sur la moitié de leur longueur depuis la racine, et de couleur lı'une très-luisante dans le reste de leur ét ndue jusqu’à la pointe: le brillanı de ces poils efface le brun, lorsqu'ils sont opposés au jour ; mais le brun parait senl sous les autres asperts sur toute la partie supérieure de cet animal, depuis le bout du museau jusqu'à la queue, sur la face extérieure des jambes et sur la face supérieure de la quene. Les côtés de la tête, la mâchoire infér ieure, la gorge, le dessous et les côtés du cou, la poitrine, le ventre, les aisselles, les aines, la face intérieure des jambes, sont de couleur blanchàtre et luisante, parce que les' longs poils ont cette couleur depuis la racine jusqu'à la pointe : le poil des pieds est fort court et de couleur brune, mêlèe d'une lágère teinte roussâtre; le dessus de la tête et le bout de la queue sont de couleur brune foncée, et mêmt noirâtre ; les plus longs poils du corps ont quatorye lignes. Les doigts tiemnent les uns aux autres paı une forte membrane, qui est plus longue dans les pit ds de derrière que dans ceux de devant, parce que les doigts des pieds de derrière sont les plus long: ; il y en a cinq dans chaque pied : les doigts des p.eds de devant et le pouce des pieds de derrière int de petits ongles crochus; ceux des quatre antres cloigts des pıtds de derrière sont les plus larges.

\section{LA FOUINE.}

Ordre des carnassiers, famille des carnirores, tribu des digitigrades, genre marte. (Curier.)

La plupart des naturalistes ont éerit que lat fouine et la marte étaient des animaux de la même espèce. Gessner et Ray ont dit, d'après Albert, qu'ils se mêlaient ensemble. Cependant ce fait, qui n'est appuyé par aucun autre témoignage, nous parait au moins douteux; et 
nous croyons au contralıe que ces animaux ne se mêlant point ensemble, fout deux espèces distinctes et séparées. Je puis ajouter aux raisons qu'en doune M. Daubenton, des exemples qui rendront la chose plus sensible. Si la marte était la fouine sauvage, ou la fouine la marte domestique, il en serait de ces deux animaux comme du chat sauvage et du chat domestique; le premier conserverait constamment les mêmes caractères, et le second varierait, comme on le voit dans le ehat sauvage, qui demeure toujours le même, et dans le chat domestique, qui yrend toutes sortes de couleurs. Au eontraire la fouine, ou, si l'on veut, la marte domestique, ne varie point: elle a ses earactères propres, particuliers, et tous aussi constants que ceux de la marte sauvace; ce qui suffirait seul pour prouver que ce n'est pas une pure variété, une simple différence produite par l'état de domesticité. Dailleurs, e'est sans aucun fondement quion appelle la fouine marle domestique, puisqu'elle n'est pas plus domestique que le renard, le putois, qui, comme elle, s'approchent des maisons pour y trouver leur proie, et qu'elle n’a pas plus d'habitude, pas plus de communication avec l'homme, que les autres animaux que nous appelons saurages. Elle diffère donc de la marte par le naturel et par le tempérament, puisque eelle-ci fuit les lieux découverts, habite au fond des bois, demeure sur les arbres, ne se tronve en grand nombre que dans les climats froids; au lieu que la fouine s'approche des habitations, s'établit mêne dans les vieux bâtiments, dans les greniers à foin, dans des trous de muraille; qu'enfin l'espèce en est généralement répandue en grand nombre dans tous les pays tempérés, et mème dans les climats chauds, comme à Madacrasear ${ }^{4}$, aux Maldives $^{3}$, et cu'elle ne se trouve pas dans les pays du nord.

La fouine a la physionomie très-fine, locil vif, le saut léger, les membres souples, le corps flexible, tous les mouvements très-prestes; elle saute et bondit plutòt qu'elle ne mar'che; elle grimpe aisénent contre les murailles qui ne sont pas bien euduites, entre daus les colombiers, les poulaillers, ete, mange les œufs, les pigeons, les poules, etc., en tue quelquefois un

\footnotetext{
1 Voyez les Voyages de Jean Struy's; Rouen, 1719, tome I, page 30.

\$Voyez le Voyage de lirançois Pyrard; Paris, 1619, tome I, page 132.
}

grand nombre et les porte à ses petits; elle p!end aussi les souris, les rats, les taupes, les oiseaux dans leurs uids. Nous en arons élevé une que nous arous garlée longtemps : elle s’apprivoise à un certaiı point; mais elle ne s'attache pas, et demeure tonjours assez saurage pour quion soit obligé de la tenir enchainée. Elle faisait la guerre aux ehats; elle se jetait aussi sur les poules dès qu'elle se trouvait à portée. Elle s'échappait sourent, quoique attachée par le milicu du corps : les premières fuis elle ne séloignait guère et revuait au bout de quelques heures, mais sans marquer de la joie, sans attachement pour personne. Elle demandait eependant à manger comme le chat et le chien; peu après elle fit des absenecs plus longues, et enfin ne revint plus. Elle avait alors un an et demi, àge apparemment auquel la nature arait pris le dessus. Elle mangeait de tout ee qu'on lui donnait, à l'exception de la salade et des herbes; elle aimait beaucoup le miel, et préférait le chenevis à toutes les autres graines. On a remaryué qu'elle burait fréquemment, qu'elle dormait quelquefois deux jours de suite, et qu'elle était aussi quelquefois deux ou trois jours sans dormir; qu'arant le sommeil elle se mettait en rond, cachait sa tète et l'enveloppait de sa queue; que, tant qu'elle ne dormait pas, elle était dans un mouvement contiuuel si violent et si incommode, que quand mème elle ne se serait pas jetée sur les volailles, on aurait été obligé de l'attacher pour l'empêcher de tout briser. Nous avons ell guelques autres fouines plus âgées, que l’on avait prises dans des pjéges; mais celles-làdemenrèrent tout-à-fait sauvagres ; elles mordaient eeux qui voulaient les toucher, et ne roulaient manger que de la chair erue.

Les fouines, dit-on, portent autant de temps que les chats. On trouve des petits depuis le printemps jusquen antomne, ce qui doit faire présumer qu'elles produisent plus d'une fois par an : les plus jeunes ne font rue trois on quatre petits; les plus âgées en font jusquà sept. Elles s'établissent pour mettre bas dans un magasin à foin, dans un trou de muraille, oì elles poussent de la paille et des herbes; quelquefois dans. une fente de rocher ou dans un tronc d'arbre, où elles portent de la mousse; ec lorsqu'on les inquiète, clles déménagent et transportent ailleurs leurs petits, qui grandissent assez vite : car celle que nous avons élevée avait au bout d’un an presque atteint sa 
grandeur naturelle, et de là on peut inférer que res animaux ne vivent que huit ou dix ans. Ils ont une odeur de faux muse, qui n'est pas absolument désagréable: les martes et les fouines, comme beaucoup d'autres animaux, ont des vésicules intérieures qui contiennent une matière odorante, semblable à celle que fournit la civette : leur chair a un peu de cette odeur; cependant celle de la marte n'est pas mauvaise à manger; celle de la fouine est plus désagréable, ct sa peau est aussi beaucoup moins estimée.

\section{DESCRIPTION DE LA FOUINE.}

(ExTHAIT DE DAUBENTON.)

La fouine a la tète petite, le corps allongé, et les jambes si courtes, qu'elle semble ramper sur la terre au lieu de marcher, quoiqu'il y ait beancoup d'agilite et de vitesse dans tous ses mouvements. I.a forme du corps ionne à cet animal ume grande facilité pour s'insinuer dans des ouvertures qui paraissent u'ètre pas proportionnées à sa grosseur'; il suffit que sa tèle puisse y entrer, pour que le reste du corps passe aisement ; aussi quelques naturalistes ont comparé a fouine et les animaux qui lui ressemblent à un ver, pour exprimer leur figure allongée $\mathrm{t}$ leur allure rampante : la belette est de ce nombre, et on la sroirait encore plus mince et plus Iongue à proportion que la fonine, parce que son poil est bien plus court; cette apparence est sans doute ce qui a fait prendre la lieleıe pour objet de comparaison, lorsque l'on a voulu désigner la fonine et les autres animaux dont le corpss a les mèmes proportions qu. celui de la belette. Son non latin a aussi fait partie de la dénomination de ces animaux, puisque les nomenclateurs l'ont donné au genre 7ui les comprend tous ${ }^{1}$. Je me serais conformé à ce plan, et j'anrais decrit ici la belette avant de faire la description de la fouine et des autres animaux dout la conformation a le plus de rapport à celle de la belette, s'ii n'y avait pas plus d'avantage à commencer par décrire l'animal le plus gros, parce que ses parties, étant plus apparentes, font discerner dans la suite les parties qui y correspondent dans l's animaux plus petits; c'est par cette raison que la helette ne doit être décrite qu'après la fouine, la marte. le putois et le furet.

La tôte de la foune est aplatie par le sommet et a une figure triangulaire; le bout du museau forme la pointe de ce triangle, et les oreilles se tronvent aux extrémités de la hase. Le musean est mince et pointı, et le nez avance au-delà des lévres. Cet animal a les yeux sailiants et fort èloignés l'un de

- Genus Inustelinum vermineurs, ele. l'autre; les oreilles sont courtes et rondes; le cou a peu de longueur, mais il est presque aussi gros que la tête; le corps n'a guère plus de grossfur; les jamber de devant sont encore plus courtes que celles de derrière, et la quiene est lougue et touffue.

La fonine a deux sor tes dle poils; l'un est doux à pen près comme un duvet et de couleur cendrée très-pàle, ou même blanchâtre; l'autre poil est plus Jong, plus ferme et moins abonilant que le duvet; il a aussi une conleur cendrée sur environ la moitié de sa longueur depuis la racine; cette partie du poil parait plus mince que le reste, qui est luisant et de con!eur hrune-noiràtre, avec quelque teinte de roussàtre qui ne paraiı qu'à certains aspects. Comme les poils bruns ne sont pas en assez grand nombre pour cacher le duret en entier, on voit sa couleur cendrée ou blanchâtre yui se mêle avec le brun roussâtre et le ıoir, de sorte que, sur la plus graude partie du corps, on aperçoit des nuances cle gris, de brun, de ronx, selon les diverses positions de l'aninual et ses différents monvements. Les quatre jambes et la queue sont noiràtres; le poil furme de la quene est le plus long; il a environ deux pouces. La poitrine et le ventre ont moins de brun et plus de couleur cendrée ou blancliâtre que le dos; il y a cleux bandes brunes qui s'étendent depuis les aisselles jusqu'aux aines, et sur la gorge une tache blanche qui s'étend sur une partie de la màcinoire inferieure, presque jusqu'aux oreilles, sur la face inférieure du cou, sur la partie an érieure de la poitrine et de chaque côté sur la face antérieure des bras jusqu'au pli du coule; il se trouve drns ce blanc de petites marques brunes qui sont placées différemment dans différents sujets; l'ètendue du blanc varie aussi plus que les couleurs des animanx sacivages ne varient pour l'ordinaire. Les plus longs poils des noonstaches de la fouine ont environ trois ponces de longueur; il y a des poils plus courts audelà des coins de la bouche, au-dessus de l'angle antérieur de l'œil, et au dessous de l'angle postérieur.

\section{LA MAR'TE.}

Ordre des carnassiers, famille des carnivores, tribu des digitigrades, genre marte. (Cuvier)

La marte, originaire du Nord, est naturelle à ce climat, et s'y trouve en si grand nombre, qu'on est étonné de la quantité de fourrures de cette espèce qu'on y consomme et qu'on en tire. Elle est au contraire en petit nombre dans les climats tempérés, et ne se trouve point dans les pays ehauds '. Nous en avons quelques-unes

II y a toule apparence que tes martes du payy dec snzicus 
dans nos bois de Bourgogne; il s'en trouve aussi dans la forêt de Fontainebleaur: mais en général elles sont aussi rares en France que la fouine y est commune. Il n'y en a point du tout en Angleterre, parce qu'il n'y a pas de bois. Elle fuit également les pays habités et les lieux découverts; elle demeure au fond des forêts, ne se cache point dans les rochers, mais parcourt les bois et grimpe au-dessus des arbres. Elle vit de chasse, et détruit une quantité prodigieuse d'oiseaux, dont elle cherche les nids pour en sucer les œufs; elle prend les écureuils, les mulots, les lerots, etc.; elle mange aussi du miel, comme la fouine et le putois. On ne la trouve pas en pleine campagne, dans les prairies, dans les cbamps, dans les vignes; elle ne s'approche jamais des habitations, et elle differe encore de la fouine par la manière dont elle se fait chasser. Dès que la fouine se sent poursuivre par un chien, elle se soustrait en gagnant promptement son grenier ou son trou : la marte au contraire se fait suivre assez longtemps par les chiens, a vant de grimper sur un arbre; elle ne se donne pas la peine de monter jusqu'au dessus des branches, elle se tient sur la tige, et de là les regarde passer. La trace que la marte laisse sur la neige parait ètre celle d'une grande bête, parce qu'elle ne va qu'en sautant et qu'elle marque toujours desdeux pieds à la fois. Elle est un peu plus grosse que la fouine, et cependant elle a la tèteplus courte; elle a les jambes plus longues, et court par conséquent plus aisémént: elle a la gorge jaune, au lieu que la fouine l'a blanche; son poil est aussi bien plus fin, bien plus fourni et moins sujet à tomber. Elle ne prépare pas, comme la fouine, un lit à ses petits; néanmoins elle les loge encore plus commodément. Les écureuils font, comme l'on sait, des nids audessus des arbres, avec autant d'art que les oiseaux Lorsque la marte est prête à mettre bas, elle grimpe au nid de l'écureuil, l'en chasse, en élargit l'ouverture, s'en empare et y fait ses petits: elle se sert aussi des anciens nids de ducs et de buses, et des trones de vieux arbres, dont elle déniche les pies-de-bois et les autres oiseaux. Elle met bas au printemps; la portée n'est que de deux ou trois : les petits naissent les yeux fermés, et cependant grandissent en peu de temps; elle leur apporte bicntót des oi-

( voisin du royaume de Congo) dont il est fait menlion dans I'Iistoire générale des voyages, tome $V$, page 87 , sont des fouines, et non pas des marles. seaux, des oufs, et les mène ensuite à la chass avec elle. Les oiseaux connaissent si bien leurs ennemis, qu'ils font, pour la marte comme pour le renard, le même petit cri d'avertissement; et une preuve que e'est la haine qui les anime, plutôt encore que la crainte, c'est qu ìls les suivent assez loin, et qu'ils font ce cri contre tous les animaux voraces et carnassiers, tels que le loup, le renard, la marte, le chat sauvage, la belette, et jamais contre le cerf, le chevreuil, le lièvre, etc.

Les martes sont aussi communes dans le nord de l'Amérique que dans le nord de l'Europe et de l'Asie; on en apporte beaucoup du Canada; il y en a dans toute l'étendue des terres septentrionales de l'Amérique, jusqu'à la baie de Hudson, et en Asie, jusqu'au nord du royaume de Tunquin et de l'empire de la Chine. Il ne faut pas la confondre avec la marte zibeline, qui est un autre animal dont la fourrure est bien plus précieuse. La zibeline est noire; la marte n'est que brune et jaune. La partie de la peau qui est la plus estimée dans la marte est celle qui est la plus brune, et qui s'étend tout le long du dos jusqu'au bout de la queue.

\section{DESCRIPTION DE LA MARTE.}

(ExTRAIT DE DAUBENTON.)

La marte ne diffère de la fouine que par les couleurs du poil; anssi les Latins comprenaient l'une et l'autre sous le nom de martes. Lorsqu'on les a distinguẻes par des noms différents, on à désigné dans leur dénomination les lieux où elles vivent; la marte est plus saurage que la fouine, elle habite les bois; on a cru q'ille restait dans les forêts de sapins, et on l'a appelée marte saurage ou marte des sapins. La fouine fréquente les lieux habités et se retire dans les rochers, mais elle va aussi dans les bois; on a prétendu qu'elle préférait les forêts de hêtres, et on lui a donné les noms de marte domestique et de marte des hêtres. Cet arbre était nommé fau en vieux langage français: il y a lieu de croire que le nom de foine et de fouine a été dérivé de fau. Quoi qu'il en soit, les noms niinflueront jamais sur la nature des choses, et les conséquences que l'on pourrait tirer de leur signification jetteraient souvent dans l'erreur, si on la croyait toujours fondee sur de bonures raisons. Le fait dont il s'agit en est un exemple; car les inartes et les fouines se trouvent dans toutes sortes de fo- 



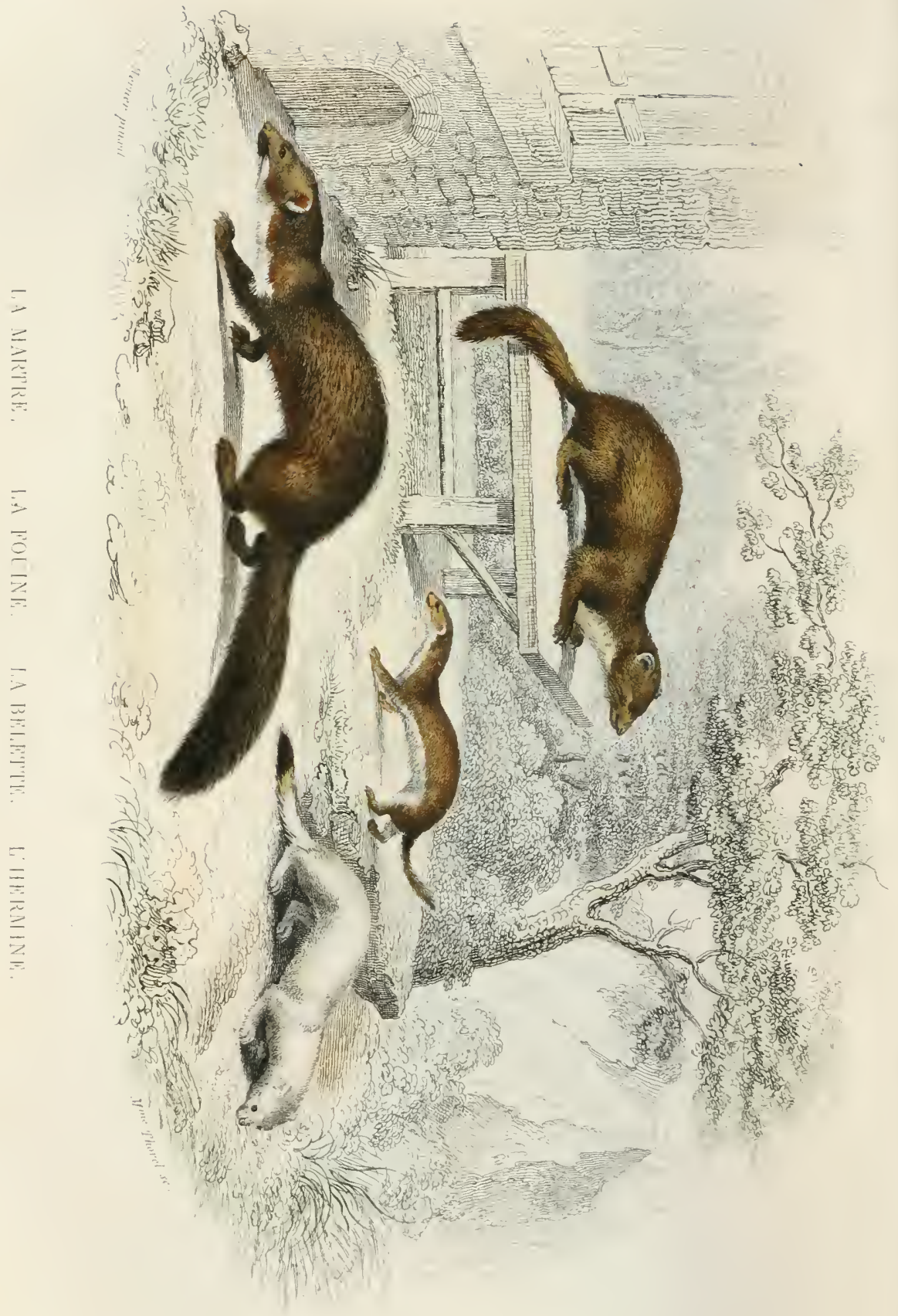


rèts, et même dans celles où on ne voit ni sapins ni hêtres. Les inartesqui m'ont servi de sujets pour la description de cet animal ont été prises en Bourgogne, dans des forêts où il n'y a point de sapins ni aucun autre arbre résineux, si ce n'est le genièvre : ce serait aussi saus fondement que l'on prendrait la fouine pour un animal domestique; quoiqu'elle vienue cliercher sa proie dans des lieux habités, elle n'est qu'un peu moins sauvage que la marte.

Plusieurs auteurs ont prétendu que la marte et la fouine étaient de differentes espèces, sans rapporter aucune raison qui autorise leur opinion; d'autres ont assuré que ces deux animaux étaient de la mème espèce, et qu'ils se mêlaient dans l'accouplement, mais ce fait n'a pas été prouvé; il ne parait au contraire que la marte et la fouine ne s'accouplent pas ensemble, parce que l'on ne voit point de métis qui viemuent de leur mélange. Ces métis, ou au moins quelques-uns d'eux, auraient la gorge teinte du jaune de la marte et du blanc de la fouine, car un des principaux caractères qui distinguent ces deux animaux l'un de l'antre est que la marte a la gorge jaune, et que celle de la fonine est blanche; d'ailleurs, les teintes de la couleur du poil, qui sont plus belles dans la marte, et le lustre, qui est plus brillant que daus la fouine, s'altéreraient dans les métis; on en verrait qui auraient le poil moins beau que celui de la marte, et plus beau que celui de la fouine; bientôt les métis se multiplieraient en grand nombre; ils se mêleraient avec les martes et les fouines de race pure, et par ce mélange les caractères distinctifs de ces races disparaîtraient dans la suite des générations, et auraient déjà disparu, si la marte et la fouine s'accouplaient ensemble.

C'est sur ces considérations que je me suis déterminć à décrire la marte séparément de la fouine, quoiyue ces deux animaux se ressemblent si parfaitement pour la forme extérieure du corps et pour la conformation des parties intérieures, qu'il n'y a que les couleurs du poil qui puissent les faire distinguer l'un de l'autre.

La marte qui m'a servi de sujet pour cette des. cription avait, comme la fonine qui a été décrite, deux sortes de poils, un duvet et des poils longs et fermes qui paraissent plus gros ver's leur extrémité que vers la racine. Le duvet était de couleur cendrée, très-légèrement teinte de couleur de lilas sur la plus grande partie de sa longueur, et de couleur fauve très-claire et presque blanchâtre à l'extrémité de cliayue poil ; les longs poils étaient de couleur cendrie semblable à celle du duvet sur environ la moitic de leur longueur; il y avait aussi un peu de fauve clair au-dessus du cendré, et le reste de chaque poil était luisant, de couleur brune mclee de roux plus ou moins apparent. Le corps de l'animal n'était pas assez garni de poils longs et fermes pour que le duvet en füt couvert en elltier; on voyait sa couleur blanchâtre qui élait nıê. lée avec le brun jaunâtre des longrs poils. Le bout du museau, la poitrine, les quatre jambes et la queue étaient d'un brun noiràtre, dans lequel il ne paraissait que peu de couleur fauve. La gorge, la partie inférieure du cou et la partie antérieure de la poitrine étaient de couleur mélée de blanc et d'orangé sale, qui paraissait plus ou moins foncr à différents aspects; il $\mathrm{y}$ avait an unilieu de ceite coulcur orangée deux petites taches brunes, placées l'une sur la gorge, et l'autre entre le cou et la poitrine. La partie postérieure dlu ventre étuit de couleur rousse; le borl et le dedans des oreilles avaient une couleur blanclıâtre, légèrentent teinte de jaunâtre.

\section{LE PUTOIS.}

Ordre des carnassiers, famille des carniv ores, tribu des digitigrades, genre marte. (Curier.)

Le putois ressemble beaucoup à la fouine par le tempérament, par le naturel, par les babitudes ou les mœurs, et aussi par la forme du corps. Comme elle, il s'approche des habitations, monte sur les toits, s'établit dans les greniers à foin, dans les granges et daus les lieux peu fréquentés, d'où il ne sort que la nuit pour chereher sa proie. Il se glisse daus les bassescours, monte aux volières, aux colombiers, où, saus faire autant de bruit que la fouine, il fait plus de dégàt; il coupe ou écrase la têteà toutes les volailles, et ensuite il les transporte une à une et en fait magasin; si, comme il arrive souvent, il ne peut les emporter entières, parce que le trou par où il est entré se trouve trop étroit, il leur mange la cervelle et emporte les tètes. Il est aussi fort avide de miel; il attaque les ruches en hiver, et force les abeilles à les abandonner. Il ne s'éloigne guère des lieux habités; il entre en amour au printemps: Ies màles se battent sur les toits et se disputeut la femelle; ensuite ils l'abandonnent, et ront passer l'été à la campagne ou daus les bois: la femelle, au contraire, reste daus son grenier jusqu'à ce qu'elle ait mis bas, et n'emmene ses petits que vers le milieu ou la fin de l'été; elle en fait trois ou quatre et quelquefois cinq, ne les allaite pas longtemps, et les accoutume de bonne heure à sucer du sang et des oufs. 
A la ville, ils virent de proie, et de chasse à la campagne; ils s'établissent pour passer l'été dans des terriers de lapins, dans des fentes de ro hers, dans des troncs d'arbres creux, d'où ils ne sortent guère que la nuit pour se répandre dans les champs, dans les bois; ils cherchent les nids des perdrix, des alouettes et des cailles; ils grimpent sur les arbres pour prendre ceux des autres oiseaux : ils épient les rats, les taupes, les mulots, et font une guerre continuelle aux lapins, qui ne peuvent leur échapper, parce qu'ils entrent aisément dans leurs trous; une serile famille de putois suffit pour détruire une ga. enne. Ce serait le moyen le plus simplepour diruinuer le nombre des lapins dans les endroits ou ils deviennent trop abondants.

Le putois est un peu plus petit quela fouine; il a la queue plus courte, le museau plus pointu, le 1 vil plus épais et plus noir; il a du blane sur le fiont, aussi bien qu'aux còtés du nez et autoui de la gueule. Il en diffère encore par la voix : la fouine a le cri aigu et assez éclatant, le putois a le eri plus obscur; ils ont tous deux, aussi bien cue la marte et l'écureuil, un grognement d'un ton grave et colère, qu'ils répètent souvent lorsqu'on les irrite. Enfin le putois ne ressemble point à la fouine par l'odeur, qui, loin d'ètre agréable, est au contraire si fétide, qu'on l'a d 'abord distingué et dénommé par là. C'est surtout lorsqu'il est échauffé, irrité, qu'il exhale et répand au loin une odeur insupportable. Les chiens ne veulent point manger de sa chair ; et sa peau mème, quoique bonue, est à vil prix, parce qu'elle ne perd jamais entierement son odeur naturelle. Cette odeur vient de deux folli ules ou vésieules que ces animaux ont auprès de l'anus, etqui liltrent et contiennent une matière onctueuse, dont l'odeur et très-désagréable dans le putois, le furet, la belette, le blai cau, etc., et qui n'est au contraire qu'une espèse de parfum dans la civette, la fouine, la marle, ete.

Le putois parait être un animaldes paystempérés: on n'eu trouve que peu ou point dans les pi ys du Nord, et ils sont plus rares que la fouine dans les climats méridionaux. Le puant d'Amérique est un animal différent, et l'espèce d'ı ptotois parait être confinée en Europe, depuis l'Italie jusqu'à la Pologne. Il est sûl que ces animaux eraignent le froid, puisqu'ils se Jetirent dins les maisons poury passer l'hiver, ct qu'(u) ne roit jamais de leu's traces sur la neige, dans les bois ou dans les champs éloigués des maisons; et peut-être aussi craignent-ils la trop grande chaleur, puisqu'on n'en troure point dans les pays méridionaux

\section{DESCRIPTION DU PUTOIS.}

(EXTRAIT DE DAUBENTON.)

Le putois est de la méme grosseur que la fouinc et la marte, et quoiau'il ait la quetie moins longue, il leur ressemble par la forme du corps, car cet animal est fort allongé, il a les oreilles et les jambes très-courtes, le sommet de la tète aplati, et le museau pointu; mais il diffère de la fouine et de la marte par les couleurs du poil.

Le tour de la bouche, les còtés du nez, le front, les tempes, la partie qui est entre l'oreille et le coin de la bouche, le bord de la face intérieure des oreilles sont blancs, tout le reste du corps est noir ou de conleur fauve; le nez et le tour des yeux, le dessous du cou, la partie antérieure de la poitrine, les épaules, les quatre jamibes et le bout de la queue sont noirs; la partie posterieure de la poitrine, le ventre et la jartie inférieure des còtés du corps ont une couleur fauve plus ou moins foncée, car elle est blanchâtre sur la plus grancle partie du ventre; il y avait une bante longitulinale et noirâtre sur le milieu du ventre, qui passait à l'endroit de l'orifice du prépuce ; la face supérieure de l'animal, depuis le front jusque près du bout de la quene, et la partie supérieure des còtés du corps, sont mêlées de noir et de fauve.

Le putois a, comme la fouine et la marte, deux sortes de poils, les uns sont plus fermes, plus lnisants et plus longs que les autres; dans les endroits qui sont mêlés de noir et de fauve, il n'y a que les longs poils qui aient du noir, ainsi cette couleur est plus ou moins apparente à proportion du nombre de ces poils; les plus longs se trouvent sur le dos et sur la queue, et ils ont environ un ponce et demi de longueur; celle des muustaches est à peu près la même.

Il exhale du corps de l'animal, et surtout des résicules qui sont à còtẻ de l'anus, une mauvaise odeurqui lui a fait donner le nom de puiois, pulorius, dérivè du mot latin putor, puanteur. Aussi les gens de la campagre le nomment le puant ou le punaisol; cette odeur approche de celle de la fouine, mais elle est beancoup plus désargréable 


\section{LE FURET.}

Ordre des carnassiers, famille des carnivores, tribu des digiligrades, genre marte ${ }^{4}$. (Cuvier.)

Quelques auteurs ont douté si le furet et le putois étaient des animaux d'espèces différentes ${ }^{2}$. Ce doute est peut-ètre fondé sur ce qu'il y a des furets qui ressemblent aux putois par la couleur du poil : cependant le putois, naturel aux pays tempérés, est un animal sauvage enmme la fouine; et le furet, originaire des climats chauds, ne peut subsister en France que comme animal domestique. On ne se sert point du putois, mais du furet, pour la chasse du lapin, parce qu'il s'apprivoise plus aisément; car d'ailleurs il a, comme le putois, l'odeur très-forte et très-désagréable; mais ce qui proure encore mieux que ce sout des animaux différents, e'est qu'ils ne se mêlent point ensemble, et qu'ils diffèrent d'ailleurs par un grand nombre de caractères essentiels. Le furet a le corps plus allongé ${ }^{3}$ et plus mince, la tète plus étroite, le museau plus pointu que le putois; il n'a pas le mème instinct pour trouver sa subsistance; il faut en avoir soin, le nourrir a la maison, du moins dans ces elimats :il neva pas s'établir à la canıpagne ni dans les bois; et ceux que I on perd dans les trous de lapins, et cuni ne reviennent pas, ne se sont jamais multi- pliés dans les champs ni dans les bois; ils périssent apparemment pendant l'hiver. Le furet virie aussi par la conleur du poil, comme les autres animaux domestiques, et il est aussi commun dans les pays chauds 4 , que le putois y est rare.

La femclle est dans cette espèce sensiblement plus petite que le màle: lorsqu'elle est en chalcur, elle le recherche ardemment, et l'on assure ${ }^{5}$ qu'elle meurt si elle ne troure pas à se satislaire; aussi a-t-ou soin de ne les pas sépa-

1 Cuvier dit que le furet n’est peut-ètre qu'une variété du putois.

2 Vid. Linnai Syst. nat. Mustela flavescente nigricans, ore alho, collari llavescente pulorius... Mustela sylvestris viverra dicta, an dislincta.

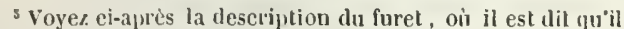
a quinze côtes, au lieu que le putois, la fonine et la marte n'cu ont que quatorze, el qu'il a aussi nn us de plus daus le slernimim.

4 Le furet se trowe cu Barlarie, el se nomme nimse. Voyez les Voyages dı docleur Shaw, Ansterdan, 1745, lome 1, page 322.

ride Gessner, IIist. animal. quadrup. pag, 763 rer. On les élève dans des tonneaux ou dans des caisses où on leur fait un lit d'étoupes; ils dorment presque continuellement. Ce sommeil si fréquent ne lcur tient lieu de rien; car dès qu'ils s'éveillent ils eherchent à manger : on les nourrit de son, de pain, de lait, etc. Ils produisent deux fois par an; les femelles portent six semaines: quelques-unes dévorent leurs petits presque aussitòt qu'elles ont mis bas, et alcrs elles deviemnent de nouveau en chaleur et font trois portées, lesquelles sont ordinairement de cinf ou six, et quelquefois de sept, huit, et mème neuf.

Cet animal est naturellement ennemi mortel du lapin: lorsqu'on présente un lapin, mème mort, à un jeune furet, qui n'en a jamais vu, il se jette dessus et le mord avec fureur: s'il est vivant, il le prend par le cou, par le nez, et lui suce le sang. Lorsqu'on le làche dans les trous des lapins, on le musèle, atin quill ne les tue pas dans le fond du terrier, et quil les oblige seulement à sortir et à se jeter dans le filet dont on couvre l'entrée. Si on laisse aller le furet sans muselière, on eourt risque de le perdre, parce qu'après avoir sucé le sang du lapin il s'endort, et la fumée qu'on fait daus le terrier n'est pas toujours un moyen sûr pour le ramener, parce que souvent il y a plusieurs issues, et qu'un terrier communique à d'autres, dans lesquels le furet s'engage à mesure que la fumée le gagne. Les enfants se servent aussi du furet pour dénicher les oiseaux; il entre aisément dans les trous des arbres et des murailles, et il les apporte au-dehors.

Selon le témoignage de Strabon, le fure a été apporté d'Afrique en Espagne, et cela ne me parait pas sans fondement, paree que l'Espague est le climat naturel des lapins, et lc pays oú ils étaient autrelois le plus abondants : on peut done présumer que, pour en diminuer le nombre, devenu peut-être très-incommode, ou fit venir des furets, avec lesquels on fait une chasse utile; au lieu qu'en multipliant les putois, on ne pourrait que détruire les lapius, mais sans ancun profit, ct les détruire peut-itre beaneoup au delide ee que l'on roudrait.

Le furet, quoique facile à apprisoiser, et mème assez docile, ne laisse pas d'ètre fort colère; il a une manvaise odeur en tout temps, qui devient bien plus forte lorsqu'il s'échaufie ou cu'on l'irrite; il a les y eux vif́s, ic regard enflammé, tous les mourements tres-souples; 
et il est en méme temps si vigoureux, qu'il vient aisément à bout d'un lapin qui est au moins quatre fois plus gros que lui.

Malgré l'autorité des interprètes et des commentateurs, nous doutons que le furet soit l'ic$t i s$ des Grecs. "L'ictis, dit Aristote, est une " espèce de belette sauvage, plus petite qu'un " petit chien de Malte, mais semblable à la be" lettepar le poil, par la forme, par la blau" cheur de la partie inférieure, et aussi par " l'astuce des mœur's; il s'apprivoise beaucoup; " il fait grand tort aux ruches, étant avide de ( miel : il attaque aussi les oiseaux; il a, comme " le chat, le membre génital osseux. " Hist. animal. lib. $I X, c a p .6$. Il parait $1^{\circ}$ qu'il y a une espèce de contradiction ou de malentendu à dire que l'ictis est une espèce de belette sauvage qui s'apprivoise beaucoup, puisque la belette ordinaire, qui est ici la moins sauvage des deux, ne s'apprivoise point. $2^{\circ}$ Le furet, quoique plus gros que la belette, n'est pas trop comparable au petit épagneul ou au chien bichon dont il n’approche pas pour la grosseur. $3^{\bullet}$ Il ne parait pas que le furet ait l'astuce des mœurs de la belette, ni même aucune ruse. Enfin, il ne fait aucun tort aux ruches, et n'est nullement avide de miel. J'ai prié M. Le Roy, inspecteur des chasses du roi, de vérifier ce dernier fait, et voici sa réponse : $\boldsymbol{M}$. de Buffon peut être assuré que les furets n'ont pas à la vérité un gout décidé pour le miel, mais qu'av'ec un peu de diète on leur'en fuit manger; nous en avons nourri pendant quatre jours avec du pain trempé dans de l'eau miellèe; ils en ont mangé, et même è assez grande quantité, les deux derniers jours: il est vrai que les plus faibles de ceux-là commencaient à maigrir d'une manière sensible. Ce n'est pas la première fois que M. Le Roy, qui joint à beaucoup d'esprit un grand amour pour les sciences, nous a donné des faits plus ou moins importants, et dont nous avons fait usage. J'ai essayé moi-nême, n'ayant pas'de furet sous ma main, de faire la même épreuve sur une hermine, en ne lui donnant que du miel pur à manger, et en mème temps du lait àboire; elle en est morte au bout de quelques jour's : ainsi ni l'hermine ui le furet ne sont avides demiel, comme l'ictis des anciens; et c'est ce qui me fait croire cque ce mot $i c t i s$ n'est peut ètre qu'un nom générique, ou que, s'il désigne yne espèce particulière, c'est plutòt la fouine ou le putois, qui tous deux en effet ont l'astuce de la belette, entrent dans les ruches, et sont très-avides de miel.

\section{DESCRIPTION DU FURET.}

(ExthatT DE DACBENToN.)

Le furet est plus petit que le putois, mais il n'en diffère, pour la forme du corps, qu'en ce qu'il a la tète moins large, et le museau plus étroit et plus allongé.

La couleur du poil des furets varie comme dans les autres animaux domestiques; il y a des furets qui ont, comme les putois, du blanc, du noir et du fauve plus ou moins foncé; on leur donne le nom de furets-putois; les autres sont en entier d'une couleur jaune, semblable à celle du buis; cette couleur a des teintes de blanc, parce que les poils longs et fermes qui se trouvent sur le furet comme sur la fonine, la marte et le putois, sont en partie blancs, tandis que les poils courts et doux sont jaunes en entier : le blanc et le jaune dominent successivement l'un sur l'autre, lorsque l'on regarde l'animal sous différents aspects. Les furets qui sont de couleur mêlée de blanc, de noir et de fauve, ressemblent très-parfaitement aux putois par ce mélange; car ils ont, comme les putois, le tour de la bouche, les cỏtés du nez et le front blancs; tout le reste du corps est noir ou de couleur fauve, etc. ; mais en général, la couleur fauve du furet que jai comparé au putois était plus teinte de jaune que celle de cet animal, et la queue du furet était presque entièrement noire; les plus longs poils avaient un pouce trois lignes, et les moustaches deux pouces et demi ; les furets mâles sont plus grands que les femelles.

\section{LA BELETTE.}

Ordre des carnassiers, famille des carnirores, tribu des digitigrades, genre marte. (Cuvier.)

La belette ordinaire est aussi commune dans les pays tempérés et chauds ', qu'elle est rare dans les climats froids; l'hermine, au contraire, très-abondante dans le Nord, n'est qu'en petit nombre dans les régions tempérées, et ne se trouve point vers le Midi. Ces animaux forment donc deux espèces distinctes et séparées. Ce qui a pu donner lieu de les confondre et de

1 La beletle se trouve en Barbarie; on la nomme fert-el steile. Voyez les Voyages du docteur Shaw; La Haye, 1743, tome I, page 322 . 
les prendre pour le même animal, c'est que, parmi les belettes ordinaires, il y en a quelquesunes qui, comme l'hermine, deviennent blanehes pendant l'hiver', même dans notre climat. Mais si ce caractère leur est commun, elles en ont d'autres qui sont très-différents : l'hermine, rousse en été, blanche en hiver, a en tout temps le bout de la queue noire: la belette, même celle qui blanchit en hiver, a le bout de la queue jaune; elle est d'ailleurs sensiblement plus petite, et a la queue beaucoup plus courteque l'hermine: elle ne demeurepas, comme elle, dans les déserts et dans les bois : elle ne s'écarte guère des habitations. Nous avons eu les deux espèces, et il n'y a nulle apparence que ces animaux, qui diffèrent par le climat, par le tempérament, par le naturel et par la taille, se mêlent ensemble : il est vrai que, parmi les belettes, il y en a de plus grandes et de plus petites; mais cette différence ne va guère qu'à un pouce sur la longueur entière du corps; au lieu que l'hermine est de deux pouces plus longue que la belette la plus grande. Ni l'une ni l'autre ne s'apprivoisent; elles demeurent toujours très-sauvages dans les cages de fer où l'on est obligé de les garder : ni l'une ni l'autre ne veulent mauger de miel; elles n'entrent pas dans les ruches, comme le putois et la fouine. Ainsi l'hermine n'est pas la belette sauvage, l'ictis d'Aristote, puisqu'il dit qu'elle devient fort privée, etqu'elle est fort avide de miel : la belette et l'hermine, loin de s'apprivoiser, sont si sauvages, qu'elles ne veulent pas manger lorsqu'on les regarde; elles sont dans une agitation continuelle, cherchent toujours à se eacher, et si l'on veut les conselver, il faut leur donner un paquet d'étoupes dans lequel elles puissent se fourrer : elles y trainent tout ce qu'on leur donne, ne mangent guère que la nuit, et laissent pendant deux ou trois jours la viande fraîche se corrompre avant que d'y toucher. Elles passent les trois quarts du jour à dormir; celles qui sont en liberté attendent aussi la uuit pour chercher leur proie. Lorsqu'une belette peut entrer dans un poulailler, elle n'attaque pas les coqs ou les vieilles poules, elle choisit les poulettes, les petits poussins, les tue par une seule blessure qu'elle leur fait à la tête, et ensuite les emporte tous les uns après les autres; elle casse aussi les out's, et les suce avec une incroyable avidité. En hiver, elle demeure ordiuairement daus les greuiers, dans les granges : souveut même elle $\mathrm{y}$ reste au printemps pour $\mathrm{y}$ faire ses petits daus le foin ou la paille: pendant tout ce temps, elle fait la guerre, avec encore $p$ is de succès que le ehat, aux rats et aux sourts parcequ'ils ne peuvent lui échapper, et qu'elıt ent'e après eux dans leurs trous; elle grimpe aux colombiers, prend les pigeons, les moineaux, etc. En été, elle va à quelque distance des maisons, surtout dans les lieux bas, autour des moulins, le long des ruisseaux, des rivières, se eache dans les buissons pour attraper des oiseaux, et souvent s'établit dans le creux d'un vieux saule pour y faire ses petits; elle leur prépare un lit avec de l'herbe, de la' paille, des feuilles, des étoupes. Elle met bas all printemps; les portées sont quelquefois de trois, et ordinairement de quatre ou de cinq. Les petits naissent les yeux fermés, aussi bien que ceux du putois, de la marte, de la fouine, etc.; mais en peu de temps ils premment assez d'accroissement et de force pour suivre leur mère à la chasse. Elle attaque les couleuvres, les rats d'eau, les taupes, les mulots, etc.; parcourt les prairies, dévore les cailles et leurs œufs. Elle ne marche jamais d'un pas égal; elle ne va qu'en bondissant par petits sauts inégaux et précipités; et, lorsqu'elle veut monter sur un arbre, elle fait un bond par lequel elle s'élève tout d'un coup à plusieurs pieds de hauteur; elle bondit de méme lorsqu'elle veut attraper un oiseau.

Ces animaux ont, aussi bien que le putois et le furet, l'odeur si forte, qu'on ne peut les garder dans une ehambre habitée; ils sentent plus mauvais en été qu'en hiver; et lor'squ'on les poursuit ou quion les irrite, ils infectent de loin. Ils marchent toujours en silence, ne donnent jamais de voix qu'on ne les frappe; ils ont un cri aigre et euroué qui exprime bien le ton de la colère. Comme ils sentent eux-mèmes fort mauvais, ils ne craignent pas l'infection. Un paysan de ma campagne prit un jour trois belettes noulvellement nées dans la careasse d'un loup (qu'on avait suspendu à un arbre par les pieds de derrière: le loup était presque entièrement pourri, et la mère belette avait apporté des herbes, des pailles et des feuilles pour faire un lit à ses petits dans la cavité du thorax.

\section{$1^{\text {re }}$ ADDITION A L'Aliticle DE LA BELETTE.}

Je dois eiter ici avec éloge et reconnaissance une lettre qui m’a été écrite par madame la com- 
tesse de Noyan, datée du château de la Mancelì̀re, en Bretagne, le 20 juillet 17 i.

"Vous ètes trop juste, monsieur, pour ne pas faìre réparation d'honneur à ceux que rous avez offensés. Vous avez fait un ontrage à la race de l'hermine, en l'annoneant comme une bête que l'on ne pouvait appri depuis un mois, que l'on a prise dans mon jardin, qui, reconnaissante des soins que je prends d'elle, vient m'embrasser, me lécher et jouer avec moi, comme le pourrait faire un petit chien. Elle est à peu près de la taille d'une belette, roussâtre sur le dos, le ventre et les pattes blanches; cinq belles petites grifles à ses jolies petites pattes; sa bonclıe bien fendue, et ses dents pointues comme des aicruilles; le tour des oreilles blaue; la barbe longue, blanche et noire, et le bout de la queue d'un beau noir. Sa vivacité surpasse celle de l'écureuil... Cette jolie petite bête jouissant de sa liberté jusqu’à l'heureque nous nous retirons, joue, vole nos sacs d'ouvrage, et tout ce qu'elle peut emporter. "

J'avoue que je ne me suis peut-être pas assez occupé de l'éducation des belettes et des hermines que j'ai fait nourrir ; car toutes m'ont paru également farouches. Je ne doute pas néanmoins de ce que me marque madame de Noyan, et d'autant moins que voici un second exemple qui confirme le premier.

M. Giély, de Mornas dans le comtat Venaissin, m’écrit dans les termes suivants :

"Un homme ayant trouvé une portée de jeunes belettes, résolut d'en élever ume, et le succès répondit promptement à ses soins. Ce petit animal s'attacha à lui, et il s'amusa à l'exercer un jour de fète dans une promenade publique, où la jeune belette le suirit constamment, et saus prendre le change, pendant plus desix cents pas, ct dans tous les détours ru’il fit à travers les spectateurs. Cet homme dommi ensuite ce joli auimal à ma femme. La méthode de les apprivoiser est de les manier souvent cn leur passant doucement la main sur le dos, mais aussi de les gronder et mème de les battre si elles morient. Elle est, comme la belette ordinaire et le roselet, rousse supérieurement et blanche inférieurement. Le fouct de la queue est d'un poil brun approchant du noir. Elle n'a que cing semaines, et j'ignore si, avec l'âge, ce poil du bout de la queue ne deviendra pas tout noir. Le tour des oreilles n'est pas blanc comme au roselet; mais clle a, comme lui, l'extrémité des deux pattes de devant blanche, les deux de derrière étant rousses même par dessous. Elle a une petite tache blanchesur le nez, et deux petites taches rousses oblongues, isolées dans le blanc, au-dessous des yeux, selon la longueur du museau. Elle n'exhale encore aucune mauvaise odeur; et ma fomme, qui a élevé plusieurs de ces animaux, assure qu'elle n'a jamais été incommodée de leur odeur', excepté le cas où quelqu'un les excédait et les irritait. On la nourrit de lait, de viande bouillie et d'eau; elle mange peu, et preud son repas en moins de quinze secondes: à moins qu'elle n'ait bien faim, elle ne mange pas le miel qu'on lui présente. Cet animal est propre; et s'il dort sur vous et que ses besoins l'éveillent, il vous gratte pour le $m$. ttre à terre.

" Au surplus, cette belette est très-familière et très-gaie: ce n'est pas contrainte ni tolérance, c'est plaisir, goût, attachement. Rechercher les caresses, provoquer les agaceries, se coucher sur le dos, et répondre à la main qui la flatte, de mille petits coups de pattes et de dents trèsaiguës, dont elle sait modérer et retenir limpression au simple chatouillement, sans jamnis s'oublier; me suive partout, me grimper et parcourir tout le corps; sinsiuuer dans mes poches, dans ma manche, dans mon sein, et de là m'inviter au badinage; dormir sur moi ; manger à table sur mon assiette, boire daus mon gobelet, me baiser la bouche, et sucer ma salive, qu'elle parait aimer beaucoup (sa langue est rude comme celle du chat); folatrer sans cesse sur mon bureau pendant que jécris; et jouer seule, et sans agacerie ni retour de ma part, avec mes mains et ma plume : voilà la mignarderie de ce petit animal... Si je me prète à son jeu, il le continuera deux heures de suite, et jusqu’à la lassitude '. "

Par une seconde lettre de M. Giély, de Mornas, du 15 aoùt 1775 , il $\mathrm{m}$ 'informe que sa belette a été tuée par accident, et il ajoute les observations suivantes :

" 10 Ses excréments commencaient à empuantir le lieu où je la logeais; il faut y apporter beaucoup de soins et de propreté, et la nourrir plus souvent d'œufs ou d'omelette aux herbes que de viande.

a $2^{\circ}$ Il ne faut pas la toucher ni la prendre peudant qu'elle prend son repas; dans ce court untervalle, elle est intraitable.

${ }^{1}$ Lellre de II. Giély à M. de Buffon. Nurnaa, 16 juiiı 1773. 
" 30 Elle me saigna des poussins qu'on avait placés à sa portée par inadvertance; mais elle n’a jamais osé attaquer de front de gros poulets que j'entraissais en cage; ils la harcelaient et la mettaient en fuite à coups de bec. Il était amusant d'observer les ruses et les feintes qu'elle employait pour tâcher de les surprendre. " $4^{\circ}$ Quant à sa familiarité et aux grâces de son badinage et même à son attachement, je n'ai rien avancé qui ne se soit soutenu jusqu'à sa fin prématurée. Seulement elle s'oubliait parfiois dans la chaleur de ses agaceries, et, comme par transport, elle serrait un peu trop les dents; mais la correction opérait d'abord l'amendement. Il faut, Iorsqu'on la corrige, la gronder, et la frapper postérieurement, etjamais vers la tète; ce qui les irrite.

" $5^{\circ}$ Elle n'avait pas beaucoup grossi, et était probablement de la petite espece; ear, lors de son accident, c'est-à-dire ayant plus de deux mois, tout son corps glissait encore dans le même collier. ")

On trouve dans l'IIistoire naturelle de la Norwége par Pontoppidan, les olsservations suivantes :

"En Norwége, l'hermine fait sa demeure dans des monceaux de pierres. Cet animal pourrait bien être de l'espèce des belettes. Sa peau est blanche, à l'exception dı cou, qui est taché de noir. Celles de Norwége et de Laponie conservent leur blancheur mieux que celles de Moscovie, qui jaunissent plus facilement; et c'est par cette raison que les premières sontrecherchées à Pétersbourg mème. L'hermine prend des souris comme les chats, et emporte sa proie quard cela lui est possible. Elle aime particulierementles œufs; et lorsque la mer est calme, elle passe à la nage dans les îles voisines des còtes de Norwége, où elie trouve une grande quantité d'oiseaux de mer. On prétend qu'une hermine venant à faire des petits sur une île, les ramène au continent sur un moreeau de bois, zu'elle dirige avec son museau. Quelque petit que soit cet animal, il fait périr les plus grands, tels que I élan et l'ours; il saute dans l'une de leurs oreilles pendant qu'ils dorment, et s'y aceroche si fortement avec ses dents, quils ne peuvent s'en débarrasser. II surprend de la mème manière les aigles et les cog̣s de bruyère, sur lesquels il s'attache, et, ne les quitte pas même lorsqu'ils s'euvolent, quela perte de leur sang ue les fasse tomber." $2^{\text {me }}$ ADDITION A L'ARTICLE DE LA BELETTE.

La belette, appelée moustelle dans le Vivarais, est naturellement sauvage ct carnassière; la chair toute crue est l'aliment qu'elle préfère: elle exhale une odeur forte, surtout lorsqu'elle est irritée.

Les belettes qu'on prend très-jeunes perdent leur caractère sauvage et revèche : ce caractère se change même en soumission et fidélité envers lemaitre qui pourvoit à leur subsistance.

Une belette que j'ai conservée dix mois, et qu'on avait prise fort jeune, perdit une partie de son agilité naturelle lorsqu'elle fut réduite en captivité, et que je l'eus attachée à la chaine. Elle mordait furieusement lorsqu'elle avait faim: on lui coupa les quatre dents canines très-aiguës, qui déehiraient les mains jusqu'à l'os. Dépourvue de ses armes naturelles, et n'ayant plus que des dents molaires ou incisives, peu propres à déchirer, elle devint moins féroce; et comme elle avait sans cesse besoin de mes services pour manger ou dormir, elle commenca à prendre de l'affection pour moi : car manger ou dormir sont les deux fréquents besoins de cet animal.

J'avais un petit fouet de fil qui pendait près de son lit : e'était un instrument de punition lorsqu'elle essayait de mordre, ou qu'elle se mettait en colère. Le fouet dompta tellement son earactère colérique, qu'elle tremblait, se couchait ventre à terre, et baissait la tète lor'squ'elle voyait prendre cet instrument. Je n'ai jamais vu la soumission extérieure mieux dépeinte dans ancun animal : ce qui prouve bien que les châtiments raisonnables employés à propos, accompagnés de soins, de caresses et de bienfaits, peuvent assujettir et attacher à I'homme les animaux sauvages quenous croy ons peu susceptibles d'éducation et de recomnaissanee.

Les belettes ont l'odorat exquis; elles sentent de douze pas un petit moreeau de viande gros comme un noyau de cerise et plié dans du papier.

La belette est très-vorace; elle mange de la viande jusqu'à ce qu'elle en soit remplic. Elle rend peu d'excréments ; mais elle perd presque tont par la transpiration et par les urines, qui sont épaisses et puantes.

J'ai été singulièrement surpris de voir un jour 
ma beiette, qui arait falm, rompre sa chaine de fil d'archal, sauter sur moi, entrer dans ma poche, déchirer le petit paquet, et dévorer en un instant la viande quej'y avais cachée.

Ce petit animal, qui m'était sỉ soumis, avait conservéd'ailleurs son caractère pétulant, cruel, et colérique pour tout autre que moi ; il mordait sans discrétion tous ceux qui voulaient badiner avee lui. Les chats, ennemis de sa race, furent toujours l'objet de sa haine; il mordait au nez les gros mâtins qui venaient le sentir ıorsqu'il était dans mes mains : alors il poussait un cri decolère et exhalait une odeur fétide qui faisait fuir tous le animaux, criant $c h i$, chi, chi, chi. J'ai vu des brebis, les chèvres, des chevaux, reenler à cette odeur; et il est certain que quelques maisons voisines où il ne manquait pas de souris, ne furent plus incommodées de ees animaux, tant que ma belette véeut.

Les poussins, les rats et les oiseaux étaient surtout l'objet de sa cruauté. La belette observe leur allure, et s'élance ensuite prestement sur eux : elle se plaît à répandre le sang, dont elle se soủle; et, sans être fatiguée du carnage, elle tue dix ou douze poussins de suite, éloignant la mère par son odeur forte et désagréable qu'on sent a la distance de deux pas.

Ma belette dormait la moitié du jour et toute la nuit : elle cherchait dans mon cabinet un petit recoin à côté de moí ; mon mouehoir ou une poche était son lit. Elle se plaisait à dormir dans le sein ; elle se repliaitautour d'elle-même, dormait d'un sommeil profond, et n'était pas plus grande, dans cette attitude, qu'une grosse noix du pays, de l'espèce des bombardes.

Lorsqu'elle était une fois endormie, je pouvais la déplier; tous ses muscles étaient alors relîchés et sans aucune tension: en la suspendant par la tête, tout son corps était flasque, se repliait et pourait faire le jeu du pendule cinc à six fois avant que la belette s'éveillât, ce qui pronve la grande flexibilité de l'épine du dos de eet animal.

Ma belette avait un goût décidé pour le badinage, les agaceries, les caresses et le chatouillement; elle s'étendait alors sur' le dos ou sur le ventre, se ruait et mordait tout doncement, comme les jeunes ehiens qui badinent. Elle avait même appris une sorte de danse; et lorsque je frappais a vec les doigts sur une table, elle tournait autour de la main, se levait droite, allait par sauts et par bonds, faisant entcndre quel- ques murmures de joie; mais bientôt fatiguée, elle se laissait aller au sommeil et dormait presque dans l'instant.

La belette dort repliée autour d'elle-même comme un peloton, la tête entre les deux jambes de derrière : le museau sort alors un peu au dehors, ce qui facilite la respiration; cependant, lorsqu'elle n'est pas couchée à son aise, elle dort dans une autre posture, la tête couchée sur son lit de repos; mais elle se plait et dort bien plus longtemps lorsqu'elle peut se plier en peloton; il faut pour cela qu'elle ait une place commode. Elle a vait pris l'habitude de se glisser sous mes draps, de chereher un des points du matelas qui forme un enfoncement, et d'y dormir des six heures entières.

La belette est très-rusée : l'ayant fouettée pour avoir fait ses ordures sur mes papiers, contre son usage, elle vint dormir auprès de moi sur ma table; la crainte l'éveilla souvent au moindre bruit : elle ne changea pas de place; mais elleobserva, les yeux ouverts, ma démarche, faisant semblant de dormir. Elle connaissait parfaitement le ton de caresse ou de menace, et j'ai été souvent surpris de trouver tant d'intelligence dans une bête si petite dans l'ordre des guadrupèdes.

Les phénomènes que nous présente la belette sont parfaitement expliqués. La belette a l'épine du dos très-flexible; elle se fourre dans des trous de sept lignes de largeur; elle se plie et replie en tous sens; son poil ou plutôt sa belle soie est très-fine et très-souple; une langue très-large pour le corps saisit toutes les surfaces plates, saillantes et rentrantes; elle aime à lécher; ses pattes sont larges et point racornies, courtes: le sens du toucher étant ainsi lépandu dans tout le corps de la bète, elle a appris à s'en servir, ce qui motive le jugement que nous portons de son intelligence. Ce sens est d'ailleurs très-bien servi par ceux de l'odorat et de la vue.

Lorsque j'oubliais de lui donner à manger, elle se levait de nuit, et se rendait d'une maison à une autre à Antragues, où elle mangeait chaque jour. Elle allait par les chemins les plus courts, deseendant d'abord dans un balcon et dans la rue, descendaut encore et montaut plusieurs marehes, entrant dans une basse-cour. passant à travers des amas de feuilies sèches de elıâtaigniers, de trois pieds de hauteur, pour prendre le plus court chemin; ce qui fait 
volr que l'odorat guide cet animal. Elle passait ensuite dans la cuisine, où elle mangeait à l'aise, après avoir fait un chemin de deux cents pas.

Le urâle est très-libertin : je l'ai vu se satisfaire sur un autre màle mort et empaillé; mille caresses et murmures de joie et de désir l'animaient: en sentant mes mains qui avaient touché ce cadavre, il reconnut une odeur qui lui plaisait si fort, qu'il restait immobile pour la sarourer à sou aise.

Ma belette bâillait souvent; elle se levait, après avoir dormi, en tiraillant ses membres et soulevant le dos en arc. Elle léchait l'eau en buvant; sa langue était âpre et hérissée de pointes. Elleronflait quelquefois en dormant, et avait communiqué son odeur forte et désagréable à une petite cage où elle avait son lit: son petit matelas ćtait aussi puant qu'elle-mème dans l'état de colere.

Ma belette souffrait impatiemment d'étre renfermée dans sa cage, et elle aimait la compagnie et les earesses; elle avait rongé à différentes reprises quatre petits båtons, pour se faire une issue pour sortir de sa prison.

Cet animal aime extrèmement la propreté; sa robe est toujours luisante.

En faisant observer un certain régime à ces bètes; on peut tempérer l'odeur forte qu’elles exhalent, et leur affreuse puanteur lorsqu'elles sont en colère. Le laitage adoucit beaucoup leurs humeurs, de même que le régime vécétal.

Les belettes ont les yeux étincelants et lumineux : mais cette lumière n'est point propre à cet animal, elle n'est point électrique et ne réside pas dans l'organe de la vue; ce n'est qu'une simple réflexion de lumière qui a lieu toutes les fois que l'œil de l'observateur est placé entre la lumière et les yeux de la belette, ou qu'une bougiese trouve entre les yeux de l'observateur et de l'animal. Ce phénomène est commun à un grand nombre de quadrupèdes et à quelques serpents ; et eette cause est prouvée par les expériences que j'ai lues, en 1780, à l'académie des Sciences, sur les yeux des chats, etc.

Les observations de M. de Buffou, la description anatomique de M. Daubenton, la lettre de Y. Giély (royez ei-dessus), et le présent détail, forment l'histoire complète de la belette. I. de Buffon dit, voyez ci-dessus, page 43 , que ces animaux ne s'apprivoisent pas et demeurent sauvages dans des cages de fer : je sais par expérience que cela est vrai lorsque les belettes sont prises vieilles, ou même à l'age de trois ou quatre mois. Pour donner aux belettes l'éducation dont elles sont susceptibles, et leur faire goûter la domesticité, il faut les prendre jeunes et lorsqu'elles ne peuvent s'enfuir : on fut obligé de couper les quatre dents canines de celle qu'on m'apporta à Antragues, et de la ehâtier souvent pour fléchir son caractère.

On voit, d'après tout ce que j'ai dit sur cet animal, que, quelque petit qu'il soit, c'est un de ceux que la nature a le moins négligés. Dans l'état sauvage, e'est le tigre des petits individus. Il se garantit, par son agilité, des quadrupèdes plus grands que lui; il est bien servi par l'oreille et par la vue. 11 est pourvu d'armes offensives dont il fait usage en peu de temps, avec une sorte de discernement: il aime le sang et le carnage, et se plait à la destruction sans qu'il ait mème besoin de satisfaire son appétit.

En état de domesticité, ses sens se perfectionuent et ses mœurs s'adoucissent par le châtiment. La belette devient susceptible d'amitié, de reconnaissance et de crainte; elle s'attache à celui qui la nourrit, qu'elle recomnait à l'odorat et à la simplc vue. Elle est rusée et libertine à l'excès; elle aime les caresses, le repos et le sommeil ; elle est gourmande et si rorace, qu'elle pèse jusqu'à un cinquième de plus après son repas. Sa vue est perẹante, son oreille bonne, l'odorat est exquis, le sens du toucher est répandu dans tout son corps, et la flexibilité de ce petit corps menu et long favorise infiniment la bonté de ce sens en lui-même. Tous ces phénomènes tiennent à l'état de ses sens qui sont achevés et parfaits!

Ces observations sur les habitudes de la belette en domesticité s'accordent parfaitement arec celles que mademoiselle de Laistre a faites sur cet animal, et qu'elle a bien voulu me communiquer par une lettre datée de Brienne, le 6 décembre 1782.

"Le hasard, dit mademoiselle cle Laistre, m’a procuré une jeune belette de la petite espèce. Sollicitée par quelqu'un à qui clle faisait pitié, et sa faiblesse m'en inspirant, je lui donnai mes soins. Les deux premiers jours, je la nourris de lait chaud; mais jugeant qu'il lui fallait des aliments qui eussent plus de consistance, je lui présentai de la viande crue, qu’elle

\footnotetext{
Extrait d'une lettre adressée à M. le comte de Buffon.
} 
mangea avec plaisir: depưs elle a vécu de bœuf, de veau ou de mouton indifféremment, et s'est privée au point qu il n'y a point de chien plus familier.

"J'ose vous assurer que ce petit animal ne préfere pas la victuaille corrompue; il ne se soucie pas même de celle qui est hâlée; c’est toujours la plus fraiche qu'il choisit : à la vérité, il mange avec avidité, et s'éloigne; mais souvent aussi il mange dans ma main et sur mes genoux; il préfére même de prendre les morceaux de ma main. Il aime beaucoup le lait: je lui en présente dans un vase, il se met auprès et me regarde; je lui verse peu á peu dans ma main, il en boit beaucoup; mais si je n'ai pas cette complaisance, à peine en goûte-t-il. Lorsqu'il est rassasié, il ra ordinairement dormir; mais il fait des repas plus légers, qui ne troublent point ses plaisirs. Ma chambre est l'endroit qu'il habite. Par des parfums, j'ai trouvé moyen de chasser son odeur : c'est dans un de mes matelas, oì il a trouvé moyen de s'introduire par un défaut de la couverture, qu'il dort pendant le jour ; la nuit, je le mets dans une boite grillée; toujours il y entre arec peine et en sort arec joie. Si on lui donne la liberté araut que je sois levée, après mille gentillesses qu'il fait sur mon lit, il y entre et vient dormir dans ma main ou sur mon sein. Suis-je levée la première, pendant une grande demi-heure, il me fait des caresses, se joue a vec mes doigts comme un jeune chien, saute sur ma tète, sur mon cou, tourne autour de mes bras, de mon corps, avec une légèreté et des agréments que je n'ai vus à aucun quadrupède.Je lui présente les mains à plus de trois pieds, il saute dedans sars jamais manquer. 11 a beaucoup de finesse et singulièrement de ruses pour renir à ses fins, et semble ne vouloir faire ce qu'on lui défend que pour agacer: dès que vous ne le regardez plus, sa volonté cesse. Comme il ne semble jouer que pour plaire, seul il ne joue jamais; et à chaque saut qu'il fait, à chaque fois qu'il tourne, il regarde si vous l'examinez: si vous cessez, il va dormir. Dans le temps qu'il est le plus endormi, le réreillez-rous, il entre en gaieté, agace et joue avec antant de grâce que si on ne l'eùt pas éveillé: il ne montre d'humeur que lorsqu'on l'enferme ou qu'on le contrarie trop longtemps ; et par de petits grognements, très-différents l'un de l'autre, il montre sa joie et son humeur.
"Au milicu de vingt personnes. ce petit animal distingue ma voix, cherche à me vorr, et saute par-dessus tout le monde pour venir à moi; son jeu avec moi est plus gai, ses caresses sont plus pressantes; avec ses deux petites pattes, il me flatte le menton avec des grâces et une joie qui peignent le plaisir. Je suis la seule qu'il caresse de cette manière; milleautres petites préférences me prourent qu'il m’est réellement attaché. Lorsqu'il me voit habiller pour sortir, il ne me quitte pas : quand avec peine je m'en suis debarrassée, j'ai un petit meuble près ma porte, il va s'y cacher; et lorsque je passe, il saute si adroitement sur moi, que souvent je ne m'en apercois pas.

"Il semble beaucoup tenir de l'écureuil par la vivacité, la souplesse, la voix, le petit orrognement. Pendant les nuits d'été, il criait en courant, et était en mourement presque toute la nuit: depuis qu'il fait froid, je ne l'ai point entendu. Quelqueiois le jour, sur mon lit, lorsqu'il fait soleil, il tourne, se retourne, se culbute, et grogne pendant quelques instants. Son penchant à boire dans ma main où je mets très-peu de lait à la fois, et qu'il boit toujours en prenant les petites gouttes et les bords où il y en a le moins, semblerait annoncer qu'il boit de la rosée. Paremient il boit de l'eau, et ce n'estqu'au grand besoin, et à defaut de lait; alors il ne fait que rafraichir sa langue une fois ou deux : il paraît même craindre l'eau. Pendant les chaleurs, il s'épluch it beaucoup : je lui fis présenter de l'eau dans une assiette, je l'agaçai pour l'y faire entrer; jamais je n'y pus réussir. Je fis mouiller un linge et le mis près de lui; il se roula dedans arec une joie extrême. Unc singularité de ce charmant animal est sa curiosite ; je ne puis ourrir une armoire, une boite, regarder un papier, qu'il ne vienre regarder a vec moi. Si, pour me contrarier, il s'écarte ou entre dans quelques endroits où je crains de le voir, je prends un papier ou un livre que je regarde avec attention; anssitòt il accourt sur ma main et parcourt ce que je tiens arec un air de satisfaire sa curiosité. J'observerai encorc qu'il joue avec un jeune chat et un jeune chien, l'un et l'autre déjà gros, se met autour de lcur cou, de leurs pattes, sur leur dos, sans qu'ils se fassent de mal, etc." 


\section{DESCRIPTION DE LA BELETTE.}

(EXTRAit DE DaUbentor.)

La belette est beancoup plus petite que la fouine, la marte, le putois et le furet; mais elle ressemble à ces animaux par la figure du corps, et elle n'en differe que par la longueur et la couleur du poil : cette diffërence de longueur est fort apparente sur la queue, qui n'est garnie que de poils très-courts.

La partie supérieure du museau et de la tète, du cou et du corps, les épaules, la face extérieure et antérieure des jambes de devant, la croupe, la queue, la face extérieure et le côté postérieur des cuisses et des jambes, et les pieds de derrière en entier, étaient de couleur brune, claire et légèrement teinte de jaunâtre. Toute la partie inférieure du corps depuis l'extrémité de la mâchoire de dessous jusqu'à la queue; la face intérieure et postérieure des jambes de devant, et la face intérieure et antérieure de la cuisse et de la jambe, étaient de couleur blanche. Il y avait, à quelque listance au delà des coins de la bonche, deux taches de la mème couleur que la partie supérieure lte l'animal. La longneur du poil n'était que de trois lignes.

On tronve des helettes de differrentes tongueurs; i! y en a qui n'ont que six pouces et demi depuis le bout du museau jusqu'à l'origine de la queue; et dans d'autres, cette longueur va jusqu'à sept pouces et demi : peut-être même y en a-t-il d'un peu plus longues, et de plus courles. C'est ce qui a fait croire à plusieurs personnes qu'il y avait deux sortes ile belettes, dont l'une a été appelée la petite belctte, et l'autre la belctle de moyenne graudeur, sans doute pour la distinguer de l'hermine, qui est plus graude, et que l'on nomme aussi belette à queue noire penilant l'èté, lorsqu'elle est à peu près de la meme couleur que la belette. Il ne parait pas que la lifference de longueur indique deux sortes de belettes, parce quej'en ai vu de différentes longueurs entre les deux extrêmes dont je viens de faire men. tion; la grandeur de.ces animaux peut hien varier d'un septième saus qu'ils soient de différentes races. On voit autaut et plus de variétés à cet égard daus la plupart des autres animaux, et mème dans rles hommes du mème pays et de la mème famille.

\section{L'HERMINE,}

\section{OU LE HOSELET.}

Ordre des carnassiers, famille des carnirores. tribu des digitigrades, genre marte. (Curier.)

La belette à queue noire s'appelle hermine $\mathrm{et}$ roselet; hermine lorsqu'elle est blanche, roselet lorscu'elle est rousse ou jaunâtre. Quoique moins commune que la belette ordinaire, on ne laisse pas d'en trouver beaucoup, surtout dans les an. ciennes forêts, et quelquefois pendant l'hiver dans les champs voisins des bois. Il est aisé de la distinguer en tout temps de la belette com mune, parcequ'elle a toujours le bout de la quene d'un noir foncé, le bord des oreilles et l'extrémité des pieds blanes.

Nous avons peu de chose à ajouter à ce que nous avons déja dit de cet animal, et à ce que II. Daubenton en écrit dans sa description : nous observerons seulement que, comme d'ordinaire l'hermine change de couleur en hiver, il y a toute apparence que celle dont il parle, et quic nous avions encore au mois d'avril 1758 , serait devenue blanche, et telle qu'elle était l'année passée lorsqu'on la pritau $1^{\mathrm{er}}$ mars 1757 , si ellc fủt demeurée libre; mais comme elle a été en. fermée depuis ce temps dans une cage de fer, qu'elle se frotte continuellement contre les barreaux, ct que d'ailleurs elle n'a pas essuyé toute la rigueur du froid, ayant toujours été à l'abri sous une arcade contrc un mur, il n'est pas surprenant qu'elle ait gardé son poil d'été. Ellc est toujours extrèmement sauvage; elle n'a rien perdu de sa mauvaise odeur : à cela près, c’est un joli petit animal, les yeux vifs, la physionomie fine, et les mouvements si prompts, qu ïl n'est pas possible de les suivre de l'œil. On l'a toujours nourrie aree des œufs et de la viande, mais elle la laisse corrompre avant que d'y toucher ; elle n'a jamais voulu manger du miel, qu’après avoir été privée pendant trois jours de toute autre nourriture, et elle est morte après en avoir mangé. La peau de cet animal est précieuse; tont le monde connait les fourrures d hermine; elles sont bien plus belles et d'un blanc plus mat que celles du lapin blane; mais ellis iaunissent avec le temps, et mème les hermines de ce climat ont toujours une légère teinte de jaune. 
Les hermines sont très-communes dans tout le Nord, surtout en Russie, en Norwége, en Laponie : elles y sont, comme ailleurs, rousses en été, et blanches en hiver; elles se nourrissent de petits-gris, et d'une espèce de rats dont nous parlerons dans la suite de cet ourrage, et qui est très-abondante en Norwége et en Laponie. Les hermines sont rares dans les pays tempérés, et ne se trourent point dans les pays chauds. L'animal du Cap de Bonne-Espérance, que Kolbe appelle hermine, et duquel il dit que la chair est saine et agréable au palais, n'est point une hermine, ni même rien d'approchant. Les belettes de Cayenne, dont parle M. Barrère, et les hermines grises de la Tartarie orientale et du nord de la Chine, dont il est fait mention par quelques royageurs, sont aussi des animaux différents de nos belettes et de nos hermines.

\section{DESCRIPTION DE L'HERMINE.}

Il y a beaucoup d'animaux qui ont plusieurs noms, quoiqu'il ne leur arrive aucun changement qui puisse les faire méconnaitre en différents temps; ainsi l'on ne doit pas ètre surpris de ce que l'hermine a deux noms dans notre langue, puisqu'elle change de couleur d'une manière si marquée, que l'hermine, vue dans une saison, parait ètre un animal différent de la mème hermine vue dans une autre saison. Pendant l'été elle ne diffère de la belette qu'en ce qu'elle est plus grande, qu'elle a la queue plus longue et noire à l'extrémité, et que le bord des oreilles et les doigts des quatre pieds sont blancs; au reste, ces deux animaux se ressemblent par la figure et par les couleurs. Aussi en été l'on donne à l'hermine le nom de belette à queue noire : mais en hiver, lorsque l'hermine perd la couleur brune-claire et jaunâtre de la belette, et çu'elle devient entièrement blanche, à l'exception du bout de la queue qui reste noir, elle est généralement connue dans cet état sous le nom d'hermine.

Le changement de couleur de l'hermine, quoique bien certain, n'est pas connu des gens qui habitent la campagne, et qui voient le plus souvent des hermines avec leur couleur blanche, et ces même animaux arec leur couleur brune dans un autre temps; alors ils les croient différents de l'hermine. On sait cepeudant que les hermines du Vord sont successivement blanches et brunes dans Ia mème année. Gessner fait nuention dı mème changement de couleur au sujet du roselet des mintagnes de Suisse, qui est le mème animal que nute hermine. On ne peut pas douter qu'elle ne change en effet de couleur, puisque l'on en trouve qui sont en partie brunes et en partie blanches sur la tète, sur le dos, et sur d'autres parties du corps, oủ les poils blancs sont mèlés avec les poils lyruns dans le temps de la mue. J'ai eu occasion de vérifier' ce fait d'une manière très-certaine, mais qui m’a laissé dans la suite un autre doute.

Au premier de mars 1797, étant à Montloard en Bourgogne, on m'apporta une hermine vivante que l'on renait de prendre aux environs de cette ville. Cet animal était entièrement blanc, à l'exception du bout de la queue qui était noir; le blanc avait une légère teinte de jaune, que l'on n'apercerait qu'à certains aspects. Je l'enfermai dans une cage de fer pour le faire nourrir au moins pendant un an, afin de voir en ijuel temps il deviendrait brun, et en quel temps i] reprendrait sa couleur blanche. Je ris bientôt quelques teintes de brun dans le blanc, et, dès le $\boldsymbol{9}$ du mème mois cle mars, il avait dejjà toute la face supérieure et les côtés du museau et de la tète de couleur brune roussâtre; cette couleur s'étendait le long du cou et du dos jusqu'à la croupe en forme de bande, qui avait un demi-pouce de largeur, et il paraissait quelques teintes de cette mème couleur sur la face extérieure des quatre jambes. Je vis en mème temps des tlocons de poils blancs qui s'étaient accrochés à une cloison de fil de fer, sous laquelle l'animal passait pour aller d'une loge à une autre; le frottement avait avancé la clıte du poil blanc, et avait formé la bande brune qui était le long du dos. Le 17 il ne restait plus que quelques poils blancs sur le museau, sur la tête, sur les cuisses et sur la queue. $A$ la fin du mois il n'y avait plus de blanc que sur les parties qui sont blanches dans la belette à queue noire. Pendant l'été suivant, on m'envoya de ces belettes prises dans le parc de Versailles et dans la furêt de Compiègne; je les comparai à mon hermine, et je n'y trouvai aucune différence.

Je m'attendais à voir paraître en automne quelques poils hlancs qui annonceraient un changement de couleur, mais je n'en vis aucun. Pendaut l'hiver suivant, la cage de l'hermine a été placée dans un lieu abrité, mais ouvert, parce que cet animal exhale une ouleur très-désagréable, et presque insupportable dans un lieu fermé. Le froid de l'hiver a duré longtemps et a été violent, cependaut l'hermine a conservé sa couleur brune comme dans l'été, jusqu'au mois de mars 1758. Elle mourut alors, parce que l'on changea sa nourriture ordinaire.

L'hermine est un pen pius grande que la belette, et beaucoup plus petite que le furet, le putois, la marte et la fouine. Ils ont tons la mème figure, quoiquilis different par les couleurs et par la longueur du poil ; celui de l'hermine a environ un demi-pouce de longueur sur le corps, et trois pouces 



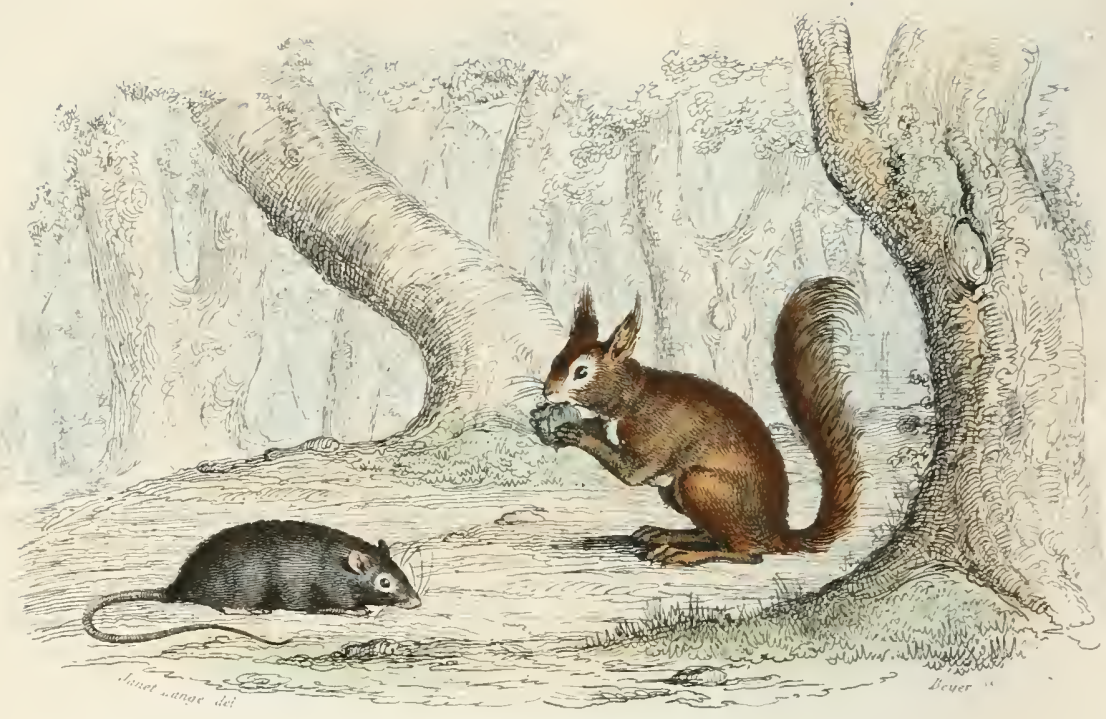

I.: R.TT

I. FCIRHIH.

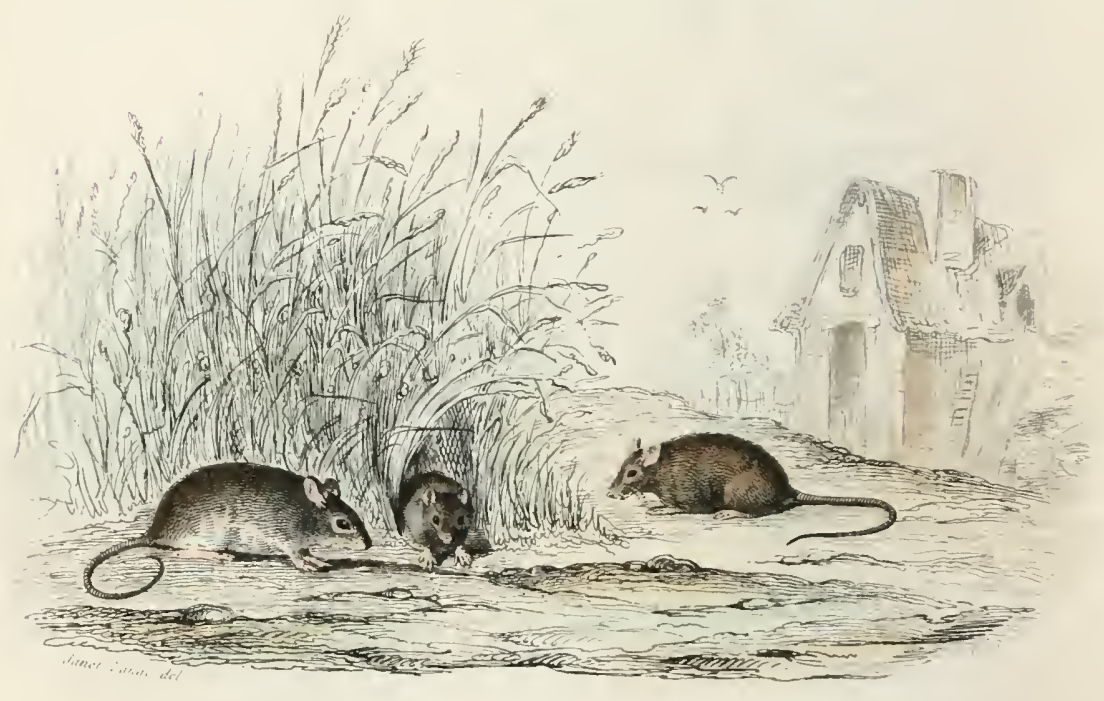

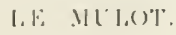

1.1 S(1) RIS. 
211 bout de la quene. Après avoir comparé ces animaux les uns anx autres, il m'a paru que l'hermine a plus de rapport à la belette qu'aux quatre autres; le furet a p.us de ressemblance avee le putois, et la marte avec la fouine, qu'avec aucun des autres.

\section{LE PÉrouasca.}

Ordre des carnassiers, famille des carnivores, tribu des digitigrades . genre marte. (Cuvier.)

11 y a encore en Russie et en Pologne, surtout en Volhynie, un animal appelé par les Russes perewiastia, et par les Polonais przciviaska, nom qu'on peut rendre par la dénomination de belelte à ceintures (mustcla procinctu), comme le dit Rzaezynski : eet animal est plus petit que le putois; il est couvert d'un poil blanchâtre, rayé transversalement de plusieurs lignes d'un jaune roux, qui semblent lui faire autant de ceintures; il demeure dans les bois et se creuse un terrier. Sa peau est recherchée et fait une jolie fourrure.

\section{L'ÉCUREUIL.}

\section{Ordre des rongeurs, genre écureuil. (Cuvier.)}

L'écureuil est un joli petit animal qui n'est qu'à demi sauvage, et qui, par sa gentillesse, parr sa docilité, par l'innocence mème de ses mœur's, mérıterait d'ètre éparơné : il n’est ni carnassier, ni nuisible, quoiqu'il saisisse quelquefois des oiseaux; sa nourriture ordinaire sont de's fruits, des amandes, des noisettes, de la fitine et du gland. Il est propre, leste, vif, trèsalerte, très-éveillé, très-industrieux; il a les yeux pleins de feu, la physionomie fine, le corps nerveux, les membres très-dispos : sa jolie figure est encor'e rehaussée, parée par une belle queue en forme de panache, qu'il r'elève jusque dessus sa tète, et sous laquelle il se met à l'ombre; le dessous de son corps est galloni d'un appareil tout aussi remarquable, et qui annonce de grandes facultés pour l'exercice de la génération. Il est, pour ainsi dire, moins quadrupède que les autres; il se tient ordinairement assis presque debout, et se sert de ses pieds de devant . comme d'une main, pour porter à sa bouche. An lieu de se cacher sous terre, il est toujour's en l'air ; il approche des oiseaux par sa légèreté ; il demeure comme eux sur la cimo des arbres, pareourt les forèts en sautant de l'un à l'autre, y fait aussi son nid, cueille les graines, boit la rosée, et ne descend à terre que quand les arbres sont agités par la violence des vents. On ne le trouve point dans les champs, dans les lieux découverts, dans les pay's de plaine; il n'approche jamais des habitations; il ne reste point dans les taillis, mais dans les bois de hauteur, sur les vieux arbres des plus belles futaies. Il craint l'eau plus encore que la terre, et l'on assure' que, lorsqu'il faut la passer', il se sert d'une écorce pour vaisseau, et de sa queue pour voile et pour gouvernail. $11 \mathrm{nc}$ s'engourdit pas comme le loir pendant l'hiver; il est en tout temps très-éveillé; et, pour peu que l'on touche au pied de l'arbre sur lequel il repose, il sort de sa petite bauge, fuit sur un autre arbre, ou se cache à l'abri d'une branche. Il ramasse des noisettes pendant l'été, en remplit les trones, les fentes des vieux arbres, et a recours en hiver à sa provision; il les cherche aussi sous la neige, qu'il détourne en grattant. Il a la voix éclatante, et plus peręante encore que celle de la fouine; il a de plus un murmule à bouche fermée, un petit grognement de mécontentement qu'il fait entendre toutes les fois qu'on l'irrite. Il est trop léger pour marcher; il va ordiuairement par petits sauts et quelquefois par bonds; il a les ongles si pointus et les mouvements si prompts, (qu'il grimpe en un instant sur' un hètre dont l'écorce est fort lisse.

On entend les écureuils, pendent les belles nuits d'été, crier en courant sur les arbres les uns après les autres ; ils scmblent eraind e l'ardeur du soleil ; ils demeurent pendant le jour à l'abri dans leur domicile, d'où ils sortent le soir pour s'exercer, jouer, faire l'amour et manger. Ce domicile est propre, chaud et impénétrable à la pluie : e'est ordinairement sur l'enfourchure

I Rei veritate nititur ynod Gesnerus ex Vincentio Beluancensi et olau magno refert: scinros, 'juando aquam fransire cupiunt, lignum levissimum aqux imponere; eique insidentes et camıả, non lamen $n t$ vult, erecti, sed contimu moti, velificantes ncyue flanle s'nto, sed tranquillo apuore Iransvehi, fund fide dignus, lidısifuc mens emissarins ad insulas Go. thlandix, plus simplici vice observavil of cum spoliis in littoribus ibidem colleclis redux mirabundus mihi retulit. Dissert. de scinro volante. l'lil. traus. $n^{\circ} 97$, pag. 38. Klein, de quadrup. pag. 53. 
d'un arbre qu'ils l'établissent; ils commeneent par transporter des buichettes qu'ils mêlent, qu'ils entrelacent avee de la mousse ; ils la serrent cusuite, ils la foulent, et donnent assez de eapacité et de solidité à leur ouvrage, pour y être à l'aise et en sủreté avec leurs petits : il n'y a qu'une ouv erture ver's le haut, juste, étroite, et qui suffit à peine pour passer: au-dessus de l'ouverture est une espèce de couvert en cône qui met le tout à l'abri, et fait que la pluie s'écoule par les côtés et ne pénètre pas. IIs produisent ordinairement trois ou quatre petits; ils entrent en amour au printemps, et mettent bas au mois de mai ou au commencement de juin. Ils muent au sortir' de l'hiver; le poil nouveau est plus roux que celui qui tombe. Ils se peignent, ils se polissent avec les mains et les dents; ils sont propres; ils n'ont aucune mauvaise odeur; leur chair est assez bonme à manger. Le poil de la queue sertà faire des pinceaux; mais leur peau ne fait pas une bonne fourrure.

II y a beaucoup d'espèces voisines de celle de l'écureuil, et peu de variétés dans l'espèce mème; il s'en trouve quelques-uns de cendrés, tous les autres sont roux. Les petits-gris, qui sont d'une espèce différente, demeurent toujours gris. Et sans citer les écureuils volants, qui sont bien différents des autres, l'écureuil blond de Cambaye, qui est fort petit et qui a la queue semblable à l'écureuil d'Europe; celui de Madagascar, nommétsitsilii , qui est gris, et qui n'est, dit Flaccourt, ni beau ni bon à apprivoiser'; l'écureuil blane de Siam, l'écureuil gris un peu tacheté de Bengale, l'écureuil rayé du Canada, l'écureuil noir, le grand écureuil gris de Virginie, l'écureuil de la Nouvelle-Espagneà raies blanches, l'écureuil blane de Sibérie, l'éeureuil varié ou le mus ponticus, le petit écurevil d'Amérique, celui du Brésil, celvi de Barbarie, le rat palmiste, etc., forment autant d'espèces distinctes et séparées.

\section{ADDITION A L'ARTICLE DE L'ÉCUREUIL.}

Les écureuils sont plutôt des animaux originaires des terres du Nord, que dles contrées tempérées; car ils sont si abondants en Sibérie qu'on en vend les peaux par milliers. Les Sibériens, à eeque dit M. Gmelin, les prennent avec des̉ espèces de trappes, faites à peu près comme des quatre en chiffre, dans lesquelles on met pour apjât un morceau de poisson fumé; et on tend ces trappes sur les arbres.

Nous avons déjà parlé des écureuils noirs, qui se trouvent en Amérique. M. Aubry, curé de Saint-Iouis, a dans son cabinet un écureuil qui lui a été enroyé de la Martinique, qui est tout noir : ses oreilles n'ont presque point de poil, ou du moins n'ont qu'un petit poil trèscourt : ce qui les distingue des autres écureuils.

M. de la Borde, médecin du roi a Cayenne, dit qu'il n'y a à la Guiane rqu'une seule espèce d'écureuil; qu'il se tient dans les bois; que son poil est rougeâtre, et qu'il n'est pas plus grand que le rat d'Europe; qu'il vit de graines de maripa, d'aouara, de comana, ete. ; qu'il fait ses petits dans des trous d'arbre, au nombre de deux; qu'il mord comme le rat, et que cependant il s'apprivoise aisément; que son cri est un petit sifflement; qu'on le voit toujours seul, sautant de branche en branche sur les arbres.

Je ne suis pas bien assuré que cet animal de la Guiane, dont parle M. de la Borde, soit un véritable écureuil, parce que ces animaux, en général, ne se trouvent guère dans les climats très-chauds, tels que celui de la Guiane. Leur espèze est, au contraire, fort nombreuse et trèsvariée dans les contrées tempérées et froides de l'un et de l'autre continent.

"On tronve, dit II. Kalm, plusieurs espèces " d'écureuils en Pensylvanie, et I'on élève de " préférence la petite espèce (l'écurcuil de terre), " parce gu'il est le plus joli, quoique assez dif" ficile à apprivoiser. Les grands écureuils font " beaucoup de dommage dans les plantations, " mais ils montent sur les épis et les coupent " cn deux pour en manger la moelle. llsarrivent "quelcuefois par centaines dans un champ, et "le détruisent sourent dans une seule nuit. On " a mis leur vie à prix pour tàcher de les dé. " truire. On mange leur chair; mais on fait peu "de cas de la peau ${ }^{1}$.... Jes écureuils gris sont " fort communs en Pensylvanie et dans plu" sieur's autres parties de l'Amérique septen" trionale. Ilsiessemblent ả ceux de Suède pour "la forme; mais cn été et en hiver, ils consel" vent leur poil gris, et ils sont aussi un peu "plus gros. Ces écureuils font leurs nids dans " des arbres creur, avec de la mousse ct de la " paille. Ils se nourrissent des fruits des bois;

' Foyage de lialm, Lome II, page 2 Łä. 
* mais ils préfêrent le maiss. lls se font des pro"visions pour l'hiver, et se tiennent dans leur " magasin dans le temps des grands froids. "Non-seulement ces animaux fout beaucoup " de tort aux mais, mais encore aux chènes, " dont ils coupent la fleur dès qu'elle vient à " paraitre; en sorte que ces arbres rapportent " très-peu de gland... On prétend qu'ils sont " actuellement plus nombreux qu'autrefois " dans les campagnes de la Pensylvanie, et " qu'ils se sont multipliés à mesure qu'on a " augmenté les plantations de maïs, dont ils " font leur principale nourriture. "

\section{LE PETIT-GRIS DE SIBERIE.}

Ordre des rongeurs, genre ceurenil. (Cuvier.)

VI. l'abbé Aubry, curé de Saint-Louis, conservait dans son cabinet un petit-gris de Sibérie, qui diffère assez du petit-gris des autres contrées septentrionales pour que nous puissions présumer qu'ils forment deux espèces distinctes. Celui-ci a de longs poils aux oreilles, la robe d'un gris clair, et la queue blanche et assez courte; au lieu que l'autre petit-gris a les oreilles uues, le dessus du corps et les flanes d'un gris cendré, et la queue de cette mème coulleur. Il est aussi un peu plus grand et plus épais de corps, et il a la queue considérablement plus longue que le petit-gris de Sibérie, dont voici les dimensions et la description.

Longueur da corps entier, mesuré en ligne p. p. 1 . droite. .................. 0 \% 9

Longueur de la téle depuis le bont du nuseau

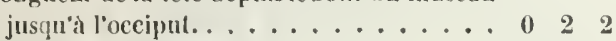

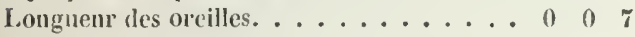
Longueur du tronçon de la queue. . . . . . 0050 Longneur des plus grauds ongles des pieds de devant................... 0 (... Longueur des plus grands ongles des pieds de

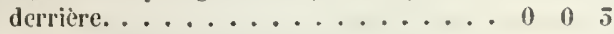

Le poil de ce joli petit animal a neuf lignes de longueur; il est d'un gris argenté à la superficie, et d'un grris foncé à la racine, ce qui domne à cette fourrure un coup d'œil gris de perle jaspé; celte couleur s'étend sur le dessus du corps, la tète, les flanes, les jambes et le commencement de la queue. Tout le dessus du corps, à conmencer de la mâchoire, est d'un beau blane; le dessus du museau est gris, mais le front, le sommet de la tète et les còtés des joues jusqu'aux oreilles, sont mèlés d'une légère teinte de roux, qui devient plus sensible au-dessus des yeux et de la mâchoire inférieure. Le dedans des oreilles est garni d'un poil plus gris que celui du corps; le tour et le dessus des oreilles portent de grands poils roux, qui forment une espèce de bouquet d'un pouce quatre ou cing lignes de longueur. La face externe de la moitié des jambes de devant est d'un faure mèlé de gris cendré; la face interne est d'un blane mêlé d'un peu de fauve; les jambes de derrière, depuis le jarret et les quatre pieds, sont d'un brun mélangé de roux. Les pieds de devant ont quatre doigts, et ceux de derrière en ont cinq. Les poils de la queue ont vingt et une lignes de longueur, et ceux qui la terminent à l'extremité ont jusqu'à deux pouces: cetre queue blanche, arec de si longs poils, parait très-différente de celle de l'autre petitgris.

\section{DESCRIPTION DE L'ÉCUREUIL.}

(ExtRaIt DE DAUbENTON.)

L'écureuil a la tête aplatie sur les còtés, et fort épaisse, le nez avancé, la lèvre supérieure dirigée obliquement en bas et en arrière, la lèrre inférieure trìs-courte, et les yeux gros, ronds, noirs, saillants, et placés dans la partic supérieure des còtés de la tête, un peu plus près des oreilles que dı nez. Le front est plat, et son plan se trouse dans la mème direction que celui du nez; la partie postẻrieure du sommet de la tète parait éleveee, et les oreilles sont placées de chaque còté; elles n'ont q i ine médiocre grandeur, mais elles sont terminées par un bouquet de poil qui semble les allonger beancoup ; ce poil est dirigé en liaut comme les oreilles, et un peurecourbe en arrière ; il a environ un pouce et demi de longuenr. Le cou est si court ulu'on ne le distingue presque pas de la lète et des épaules; le corps parail gros à proportion de sa longueur : le dos est ordinairement aryué. La queure est longue et touflue : les plus longs poils sont placés sur les côtés en forme de panache; l'écurenil relère sa quene et la porte quelquefois en avant au-dessus de son corps. Les jambes ont peu de longheur, mais les pieds sont grants et les doigts sont gros : le talon porte sur' la terre; ce point d'appui donne à l'animal beaucoup de facilite pour se dresser sur les pieds de derrière, et pour faire différents mouvements daus cette attitude. 
Les écureuils ont la face inférieure du cou, la poitrine, les aisselles, la face intérieure de l'arant. bras, et le ventre, de couleur blanche ; la mâclioire du dessous et la face intérieure de la cuisse sont blanches en entier, ou en partie rousses et en partie blanches. Les couleurs du reste du corps ne sont pas plus constantes; il y a quelquefois plus de roux que de brun, et d'antres fois plus de brun que cle gris ou de roux, et même plus de gris que de brun ou de roux. Les poils sont de couleur cendrée à la racine, et roux ou bruns à l'extrémité, ou alteruativement de couleur grise et de couleur cendrée ou brune, depuis la racine jusqu'à la pointe; de sorte qu'il se trouve du gris dans ciny ou six endroits différents sur le mème poil, ce qui est fort apparent sur les poils de la queue, parce qu'ils sont plus longs que les autres, et que les espaces colorés de blanc sont par conséquent plus étendus ; lorsque ces poils sont rangés de chaque côté dı tronçon, comme les barbes d'une plume, on voit deux ou trois bandes grises ou blanchâtres et autant de brunes on de roussâtres gui s'étendeut d'un bout à l'autre de la quene; lorsque les poils sont couchés, elle paraît. noiràtre, rousse, ou de couleur mêlée de noir et de roux. Sur les écurevils qui ont plus de brun que de roux, et sur ceux qui sont presque entièrement roux, les teintes de cette couleur rousse sont plus foncées sur les côtés de la tête et dı cou, sur les épaules, sur les quatre jambes, etc., que sur les autres parties de l’animal. Les plus grands poils du corps out près d'un pouce de longueur, et ceux de la yueue plus de deux pouces; les poils des moustaches sont noirs, les plus longs ont deux pouces et demi ; il y en a aussi quelques petits de même couleur audessons de l'ail, et au-dessus de son angle antérieur.

\section{LE GRAND ÉGUREUIL}

DE LA CÒTE DE MALABAR.

Ordre des rongeurs, genre écureuil. (Cuvier.)

Cet écureuil, dont M. Sonnerat nous a apporté la peau, est bien différent des nòtres par la grandeur et les couleurs du corps. Il a la queue aussi longue que le corps, qui a quinze pouces six lignes depuis le bout du museau jusqu'à l'origine de la quene, dix-sept pouces huit lignes suivant la courbare du corps, et les poils qui couvrent les oreilles ont une disposition différente des autres écureuils.

Si l'on compare donc cet écureuil à ceux de notre pays, c'est $\mathrm{m}$ géant.
Sa tête, du bout du nez à l'occiput, a. . . $\quad \begin{array}{cccc}0 & \mathbf{3} & 2\end{array}$ Du bout du nez à l'angle antérieur de l'œil. . $0 \begin{array}{lll}0 & \mathbf{1} & 6\end{array}$ De l’angle postérieur de l'ccil à l'oreille. . . . 0 o 10

La face supérieure de la tète est d'un brun marron, et forme une grande tache qui s'étend depuis le front jusqu'au milieu du nez: les autres parties de la tète sont couvertes d'un beau jaune orangé, et sur l'extrémité du nez cette couleur n'est que jaunâtre, mêlée d'un peu de blanc.

La couleur orangée règne aussi autour des yeux et sur les joues.

Les moustaches sont noires, et les plus longs p. p. I. poils ont de longueur. ............ 0 Il y a aussi près des tempes des poils longs de $\quad \begin{array}{lll}0 & \mathbf{1} & \mathbf{9}\end{array}$

Les oreilles sont couvertes d'un poil trèstonffu et peu long qui fait la houppe; ces poils, qui ont huit lignes de longueur, se présentent comme une brosse dont on aurait coupé les extrémités. La couleur de ces poils est d'un marron foncé, ainsi que la bande qui prend de l'oreillesur la joue en arrière, et tout ce qui couvre l'occiput. Entre les oreilles prend une bande blanche, inégale en largeur, qui sépare les couleurs de la tête et du cou; de l'occiput prend une pointe très-noire qui tranche sur le cou, les bras, et s'étend aux épaules sur le brun mordoré foncé qui couvre tout le corps et les flanes, ainsi que les jambes de derrière. Ce mème noir prend en bande au milieu du dos, et s'étend sur le train de derrière, les cuisses et la queue.

Le dessous de la mâchoire inférieure, du cou, du ventre et des cuisses, est blanc jaunâtre, ainsi que les jambes et les pieds de devant; mais cette couleur est plus orangée sous le ventre et les pieds de derrière. La queue a quinze pouces six lignes de longueur, et elle est couverte de longs poils très-noirs, qui ont deux pouces trois lignes.

Au reste, cet écureuil ressemble à notre écureil par toutes les formes du corps, de la tète et des membres; la seule différence remarquable est dans la queue et dans le poil qui couvre les oreilles. 


\section{L'ÉCUREUIL DE MADAGASCAR.}

Ordre des rongeurs, genre écureuil. (Cuvier.)

On connalt à Madagasear un gros écureuil qui ressemble par la forme de la tête et du corps, et par d'autres caractères extérieurs, à nos écureuils d'Europe, mais qui en diffère par la grandeur de la taille, par la couleur du poil, et par la longueur de sa queue. Il a dix-sept pouces de longueur en le mesurant en ligne superficielle, depuis le bout du museau jusqu'à l'origine de la queue, et treize pouces deux lignes en le mesurant en ligne droite; tandis quél'écureuil de nos bois n'a que huit pouces neuf lignes. De même, la tète, mesurée du bout du museau à l'occiput, a trois pouces quatre lignes, au lieu que celle de notre écureuil n'a que deux pouces. Ainsi cet écureuil d'Afrique est d'une espèce différente de celle des écureuils d'Europe et d'Amérique. D’ailleurs son poil est d'un noir foncé : cette couleur commence sur le nez, s'étend sous les yeux jusqu'aux oreilles, couvre le dessus de la tête ou du cou, tout le dessus du corps, ainsi que les faces externes des jambes de devant, des cuisses, des jambes de derrière et des quatre pieds. Les joues, le dessous du cou, la poitrine et les faces internes des jambes de devant sont d'un blane jaunâtre; le ventre et la face interne des cuisses sont d'un brun mêlé d'un peu de jaune; les poils du corps ont onze lignes de longueur. Laqueue, qui est toute noire, est remarquable en ce qu'elle est menue et plus longue que le corps, ce qui ne se trouve dans aucune autre espèce d'écureuils. Le troncon seul a seize pouces neuf lignes. sans compter la longueur du poil, qui l'allonge encore de deux pouces; il forme sur les côtés de la queue un panache qui la fait paraître plate dans son milieu.

\section{LES GUERLINGUETS.}

Ordre des rongeurs, genre écureuil. (Cuvier.)

Il y a deux espèces ou variétés constantes de ces pctits animaux à la Guiane, où ou leur donne ce nom. La première, sous le nom de grand guerlinguet ${ }^{1}$, est de plus du double plus grande

t Écureuil de la Guiane. que la seconde, que nous appelons petit yuerlinguel". Toutes deux nous ont été données par M. Sonnini de Manoncourt, et nous avons reconnu que ce sont les mêmes animaux dont M. de la Borde nous avait parlé sous le nom d'écureuil: j'en ai fait mention. J'ai eu raison de dire que je n'étais pas assuré que cet animal fut un véritable écureuil, parce que les écureuils ne setrouvent point dans les climats très-chauds. En effet, j’ai été bien informé depuis qu'il n'y a aucune espèce de vrais écureuils à la Guiane. L'animal qu'on y appelle guerlinguet ressemble à la vérité à l'éeureuil d'Europe par la forme de la tête, par les dents et par l'habitude de r'elever la queue sur le dos; mais il en difière en ce qu'il l'a plus longue et moins touffuc; et en général son corps n`a pas la même forme ni les mêmes proportions que celui de notre écureuil. La petite espèce de guerlinguet, qui ne diffère de la grande qu'en ce qu'elle est plus de deux fois plus petite, est encore plus éloignée de celle de notre écureuil ; on a même donné à ce petit animal un autre nom, car on l'appelle le rat de bois à Cayenne, parce qu’il n'est pas en effet plus gros qu'un rat. L'autre guerlinguet est à peu près de la même taille que nos écureuils de France, mais il a le poil moins long et moins roux; et le petit guerlinguet a le poil encore plus court, et la queue moins fournie que le premier : tous deux vivent des fruits du palmier; ils grimpent très-lestement sur les arbres, où néanmoins ils ne se tiennent pas coustamment, car on les voit souvent courir à terre.

Voici la description de ces deux animaux.

Le grand guerlinguet mâle n'a point de bouquet de poil aux oreilles, comme les écureuils; sa queue ne forme pas un panache, et il est plus petit, n'ayant que sept pouces cinq lignes depuis l'extrémité du nez jusqu'à l'origine de la queue; tandis que l'écureil de nos bois à huit pouces six lignes. Le poil est d'un brun minime à la racine, et d'un roux foncé à l'extrémité; il n’a que quatre lignes de longueur; il est d'un bruu marron sur la tête, lc corps, l'extérieur des jambes et la queue, et d'un loux plus pâle sur le cou, sur la poitrine, le ventre et l'interieur des jambes. Il y a mème du gris et du blane jaunâtre sous la màchoire et le cou; mais le roux pâle domine sur la poitrine et stur une partie du ventre, et cette couleur orangée du poil est mè-

1 Ecureuil nain. 
lée de nuances grises sur l'intérieur des cuisses. Les moustaches sont noires et longues d'un pouce neuf lignes. La queue est aussi longue que le corps entier, ayant sept pouces cinq lignes; ainsi elle est plus longue à proportion que celle de l'écureuil d'Europe; elle est plus plate que ronde et d'une grosseur presque égale dans toute sa longueur : le poil qui la couvre est long de dix à onze lignes, et elle est comme rayée de bandes indécises de brun et de fauve; l'extrémité en est terminée par des poils noirs. 11 y a aussi sur la face interne de l'avant-bras, proche du poignet, un faisceau de sept ou huit poils noirs qui ont sept lignes de longueur, et ce caractère ne se trouve pas dans nos écureuils.

Le petit guerlinguet n’a que quatre pouces trois lignes depuis l'extrémité du nez jusqu'à l'origine de la queue, qui, n'ayant que trois pouces trois lignes de long, est bien plus courte à proportion que celle du grand guerlinguet; mais du reste, ces deux animaux se ressemblent parfaitement pour la forme de la tête, du corps et des membres : seulement, le poil du petit guerlinguet est moins brun ; le corps, les jambes et la queue sont nuancés d'olivâtre et de cendré, parce que le poil, qui n’a que deux lignes de longueur, est brun cendré à la racine, et fauve à son cxtrémité. Le fauve foncé domine sur la tète, sur le bas-rentre et sur la face interne des cuisses; les oreilles sont garnies de poils fauves en dedans, au lieu que celles du grand guerlinguet sont nues. Les moustaches sont noires et composées de poils assez souples, dont les plus longs ont jusqu’à treize lignes; les jambes et les pieds sont couverts d'un petit poil fauve ; les ongles, qui sont noirâtres, sont larges à leur origine et crochus à leur extrémité, à peu près comme ceux des chats. La poitrine et le haut du ventre sont d'un gris de souris mêlé de roux, au lieu que dans le grand guerlinguet ces mêmes parties sont d'un roux pâle et blanchâtre. Les poils de la queue sont mélangés de brun et de faure; les testicules de ce petit guerlinguet étaient beaucoup plus gros que ceux du grand guerlinguet, à proportion du corps, quoique ces parties fussent, dans le grand guerlingnet, de la même grosseur que dans nos écureuils.

\section{LE RAT.}

Ordre des rongeurs, genre rat. (Cuvier.)

Descendant par degrés du grand au petit, du fort au faible, nous trouverons que la nature a su tout compenser ; qu'uniquement attentive à la conservation de chaque espèce, elle fait profusion d'individus, et se soutient par le nombre dans toutes celles qu'elle a réduites au petit, ou qu'elle a laissées sans forces, sans armes et sans courage : et non-seulement elle a voulu que ces espèces inférieures fussent en état de résister ou durer par le nombre, mais il semble qu'elle ait en même temps donné des suppléments à chacune, en multipliant les espèces voisines. Le rat, la souris, le mulot, le rat d'eau, le campagnol, le loir, le lérot, le muscardin, la musaraigne, beaucoup d'autres, que je ne cite point parce qu'ils sont étrangers à notre climat, forment autant d'espèces distinctes et séparées, mais assez peu différentes pour pouvoir en quelque sorte se suppléer et faireque, si l'une d'entre elles venait à manquer, le vide en ce genre serait à peine sensible : c'est ce grand nombre d'espèces voisines qui a donné l'idée des genres aux naturalistes; idée que l'on ne peut employer qu'en ce sens, lorsqu'on ne voit les objets qu'en gros, mais qui s'évanouit dès qu'on l'applique à la réalité, et qu'on vient à considérer la nature en détail.

Les hommes ont commencé par donner différeuts noms aux choses qui leur ont paru distinetement différentes, et en même temps ils ont fait des dénominations générales pour tout ce qui leur paraissait à peu près semblable Chezles peuples grossier's et dans toutes les langues naissantes, il n'y a presque que des noms généraux, c'est-à-dire des expressions vagues et informes de choses du même ordre, et cependant très-différentes entre elles : un chêne, un hètre, un tilleul, un sapin, un if, un pin, n'auront d'abord eu d'autre nom que celui d'arbre; ensuite le chêne, le hêtre, le tilleul se seront tous trois appelés chénes, Iorsqu'on les aura distingués du sapin, du pin, de l'if, qui tous trois se seront appelés sapin. Les noms particuliers ne sont venus qu'à la suite de la comparaison et de l'examen détaillé qu'on a fait de chaque espèce de choses. On a augmenté le nombre de ces noms à mesure qu'on a plus étudié et micux connu la nature: 
plus on l'examinera, plus on la comparera, plus il y aura de noms propres ct de dénominations particulières. Lorsqu'on nous la présente donc aujourd'hui par des dénominations générales, c'est-à-dire par des genres, c'est nous r'envoyer à l'ABC de toute connaissance, et rappeler les témèbres de l'enfance des hommes : l'ignorance a fait les genres, la science a fait et fera les noms propres, et nous ne craindrons pas d'augmenter lenombredes dénominations particulières, toutes les fois que nous voudrons désigner des espèces différentes.

L'on a compris et confondu sous ce nom générique de rat, plusieurs espèces depetits animaux: nous ne dommerons ce nom qu'au rat commun, qui est noirâtre et qui habite dans les maisons : chacune des autres espèces aura sa dénomination particulière, parce que ne se mêlant point ensemble, chacune est différente de toutes les autres. Le rat est assez comnu par l'incommodité qu'il nous cause : il habite ordinairement les greniers où l'on entasse le grain, où l'on serre les fruits, et de là descend et se répand dans la maison. Il est carnassier et même omnivore; il semble seulement préférer les choses dures aux plus tendres; il ronge la laine, les étoffes, les meubles, perce les bois, fait des trous dans les murs, et se loge dans l'épaisseur des planchers, dans les vides de la charpente ou de la boiserie; il en sort pour chercher sa subsistance, et souvent il y transporte tout ce qu'il peut trainer; il $\mathrm{y}$ fait même quelquefois magasin, surtout lorsqu'il a des petits. 11 produit plusieurs fois par an, presque toujours en été; les portées ordinaires sont de cinq ou six. Il cherche les lieux chauds, et se niche en hiver auprès des cheminées, ou dans le foin, dans la paille. Malgré les chats, le poison, les piéges, les appàts, ces animaux pullulent si fort qu'ils causent souvent de grands dommages; c'est surtout dans les vieilles maisons à la campagne, oủ l'on garde du blé dans les greniers, et où le voisinage des granges et des magasins à foin facilite leur retraite et leur multiplication, qu'ils sonten sigrand nombre qu'on serait obligé de démeubler, de déserter, s'ils ne se détruisaient eux-mèmes : mais nous avons vu par expérience qu'ils se tuent, qu’ils se mangent entre eux, pour peu que la faim les presse; en sorte que quand il y a disette à cause du trop grand nombre, les plus forts se jettent sur les plus faibles, leur ourrent la tète et mangent d'abord la cervelle, et ensuite le reste du cadavre : le lendemain la guerre recommence, et dure ainsi jusqu'à la destruction du plus grand nombre; c'est par cette raison qu'il arrive ordinairement qu'après avoir été infesté de ces animaux pendant un temps, ils semblent souvent disparaître tout à coup, et quelquefois pour longtemps. Il en est de même des mulots, dont la pullulation prodigieuse n'est arrêtée que par les cruautés qu'ils exercent entre eux, dès que les vivres commencent à leur manquer. Aristote a attribué cette destruction subite à.l'effet des pluies; mais les rats n'y sont point exposés, et les mulots savent s'en garantir, car les trous qu'ils habitent sous terre ne sont pas même humides.

Les rats sont aussi lascifs que voraces; ils glapissent dans leurs amours, et crient quand ils se battent. Ils préparent un lit à leurs petits, et lcur apportent bientôt à manger : lorsqu'ils com mencent à sortir de leur trou, la mère les veille, les défend, et se bat même contre les chats pour les sauver. Un gros rat est plus méchant, et presque aussi fort qu'un jeune chat; il a les dents de devant longues et fortes. Ie chat mord mal, et comme il ne se sert guère que de ses griffes, il faut qu'il soit non-seulement vigoureux, mais aguerri. La belette, quoique plus petite, est un emnemi plus dangereux, et que le rat redoute parce qu'elle le suit dans son trou : le combat dure quelquefois long-temps; la force est au moins égale, mais l'emploi des armes est différent : le rat ne peut blesser qu'à plusieurs reprises et par les dents de devant, lesquelles sont plutôt faites pour ronger que pour mordre, et qui, étant posées à l'extrémité du levier de la mâchoire, ontpeu de force; tandis que la belette mord de toute la mâchoire avec acharnement, et qu'au lieu de démordre, elle suce le sang de l’endroit entamé; aussi le rat succombe-t-il toujours.

On trouve des variétés dans cette espèce, comme dans toutes celles qui sont très-l1ombreuses en individus : outre les rats ordinaires, qui sont noirâtres, il y en a de bruns, de presque noirs, d'autre d'um gris plus blanc ou plus roux, et d'autres tout à fait blancs : ces rats blancs ont les yeux rouges comme le lapin blanc, la souris blanche, et comme tous les autres animaux qui sont tout à fait blancs. L'espèce entière, avec ses variétés, parait ètre naturelle aux climats tempérés de notre continent, et s'est beaucoup plus répandue dans les pays chauds 
que dans les pays froids. Il n'y en avait point en Amérique, et ceux qui y sont aujourd'bul, et en très-grand nombre, $\mathrm{y}$ out débarqué ar ec les Européens : ils multiplièrent d'abord si prodigieusenent, qu'ils ont été pendant longtemps le fléau des colonies, où ils n'avaient guère d'autres ennemis que les grosses couleurres qui les aralent tout vivants. Les navires les ont aussi portés aux Iucies orientales, et dans toutes les îles de l'Archipel Indien : il s'en trouve aussi beaucoup en Afrique. Dansle Nord, au contraire, ils ue se sont guère multipliés au-delà de la Suède; etce qu'on appelle des rats en Norwége, en Laponic, etc. , sont des animaux différents de nos rats.

\section{PREMIÈRE ADDITION A L'ARTICLE DU RAT.}

Dans les observations que M. le vicomte de Querhoënt a eu la bonté de me communiquer, il dit : que les rats, transportés d'Europe à l'Ile deFrancepar les vaisseaux, s'y étaieutmultipliés au point qu'on prétend qu'ils firent quitter l'ile aux Hollandais: les Français en ont diminué le nombre, quoiqu'il y en ait encore unetrès-grande quantité. Depuis quelque temps, ajoute $\mathbf{M}$. de Querhoëut, un rat de I'Inde commence à s'y établir; il a une odeur de muse des plus fortes, qui se répand aux environs des lieux qu'il habite, etl'on croit que, lorsqu'il passe dans un endroit où il y a du vin, il le faitaigrir. Il me paraît que cerat de l'Inde, qui répand une odeur de musc, pourrait étre le même rat que les Poltugais ont appelé cheroso, ou rat odoriférant. La Boullaye-le-Gouz en a parlé.

"Il est, dit-il, extrêmement petit; il est à peu près de la figure d'un furet; sa morsure est venimeuse: quand il entre dans une chambre, on le sent incontinent, et ou l'entend crier kric, kric, kric."

Ce même rat se trouve aussi à Maduré, où on le nomme rat de senteur. Les voyageurs hollandais en ont fait mention; ils disent qu'il a le poil aussi fin que la taupe, mais seulement un peu moins noir.

\section{DEUXIÈME ADDITION A L'ARTICLE DU RAT.}

L'espèce du rat paraît exister dans toutes les contrées hahitées ou fréquentées par les hommes; car, suivaut le récit des voyageurs, elle a été trouvée et reconnue partout, et même dans les pays nouvellement découverts. M. de Forster dit quele rat "se trouve dans les îles de la mer du Sud, et dans les terres de la Nouvelle-Zélande; qu'il y en a uue prodigieuse quantité aux iles de la Société, et surtout à Taiti, où ils vivent des restes d'aliments que les naturels laissent dans leurs huttes, des fleurs et des casses de l'erythrina corallodendrum, de bananes et d'autres fruits, et, à ce défaut, d'excréments de toute sorte : leur hardiesse va jusqu'à mordre quelquefois les pieds des naturels endormis. Ils sont beaucoup plus rares aux Marquises et aux iles des Amis, et on les voit rarement aux NouvellesHébrides ${ }^{1}$. "

Il est assez singulier qu'on ait trouvéles espèces de nos rats dans ces îles et terres de la mer du Sud, tandis quedans toutel'étendue du continent de l'Amérique ces mêmes espèces ne se sont pas trouvées, et que tous les rats qui existent actuellement dans ce nouveau continent y sout arrivés avec nos vaisseaux.

Suivant M. de Pagès ${ }^{2}$, il y a, dans les déserts d'Arabie, une espèce de rat très-différente de toutes celles que nous comnaissons.

"Leurs yeux, dit-il, sont vifs et grands, leurs moustaches, leur museau et le haut du front sont blancs, ainsi que le ventre, les pattes et le bout de la queue; le reste du corps est jaune et d'un poil assez long et très-propre: la queue est médiocrement longue; mais elle est grosse, de couleur jaune comme le corps, et terminée de blanc. Mes compagnons arabcs mangeaient ces rats après les avoir tués à coups de bâton, qu'ils lancent avec beaucoup d'adresse sur le chemin du quadrupède ou de l'oiseau qu'ils veulent attraper. "

\section{DESCRIPTION DU RAT.}

Le rat est plus petit que l'écureuil : il a la tète allongẻe, le museau pointu, la mâchoire du dessous très-courte, et beaucoup moins avancée que celle du dessus, les yeux gros, les oreilles grandes, larges et nues : le corps est long lorsque l'animal l'étend; mais il parait court dans l'attitule ordinaire, parce que le dos est alors ronté ; la quene est longue, presque entièrement nue, et couverie de petites écailles disposées sur des lignes circu.

1 Voyez le $2^{\circ}$ Voyage de Cook, tome V, p. 170.

Voyage autour du monde, manuscrit, par M. Pagè. 
|aires, yui l'entourent en forme de bandes ou d'anueaux ; il y a quelques poils courts placés entre ces bandes écailleuses :j'en ai compté jusquı’à deux cent cincuante sur une queue de rat qui avait six pouces cle longueur; mais il y aurait beaucoup de variété ‘lans ce nombre si on l'ohservait sur plusieurs individus, car tous les anneaux ne font pas le cercle entier, et ceux de l'extrémité de la queue n'ont que très-peu de largeur.

Le poil est de couleur cendrée noirâtre sur la face supérieure du museau, de la tète et du cou, sur les épaules, sur le dos, sur la partie supérieure des côtés du corps, et sur la croupe; tout le reste du corps a une couleur cendrée claire et presque grise; les moustaches sont noires, et leurs plus longs poils ont jusqu'à deux pouces et demi de longueur; les oreilles sont de couleur mêlée de cendré et de couleur de chair; les pieds ont les mêmes teintes de coulcur, et sont garnis de petits poils de couleur cendrée claire.

Les pieds et les doigts du rat sont à proportion beancoup moins longs que ceux de l'écureuil; le pouce des pieds de devant est très-court, on n'y voit que l'ongle; il y a sur la plante cinq tubercules, trois en avant et deux arrière : le pouce est bien formé dans les pieds de derrière, il se trouve fort éloignué du premier doìrt, comme dans les singes; les tubercules de la plante des pieds sont an nombre cle six, trois derrière les doigts, un derrière te pouce, et deux autres sur la partie in'érieure du mélatarse.

\section{LA SOURIS.}

Ordie des rongeurs, genre rat. (Cuvier.)

La souris, beaucoup plus petite que le rat, est aussi plus nombreuse, plus commune et plus généralement répandue: elle a le mème instinct, le mème tempérament, le même naturel, et n'en diffère guère que par la faiblesse et par les habitudes qui l'accompagnent; timide par nature, familière par nécessité, la peur ou le besoin font tous ses mouvements; elle ne sort de son trou que pour chercher à vivre; elle ne s'en écarte guère, y rentre à la première alerte, ne va pas, comme le rat, de maisons en maisons, à moins qu'elle n'y soit forcée, fait aussi beaucoup moins de dégâts, a les mœurs plus douces, et s'apprivoise jusqu'à un eertain point, mais sans s'attacher : comment aimer en effet ceux qui nous dressent des embûches? Plus faible, elle a plus d'ennemis auxquels elle ne peut échapper, ou plutót se soustraire que parsonagilité, sa petitesse même. Les chouettes, tous les oiseaux de nuit, les chats, les fouines, les belettes, les rats mème lui font la guerre; on l'attire, on la leurre aisément par des appâts, on la détruit à milliers; elle ne subsiste enfin que par son immense fécondité.

J'en ai vu qui avaient mis bas dans des souricières; elles produisent claus toutes les saisons, et plusieurs fois par an: les portées ordinaires sont de cinc ou six petits; en moins de quinze jours ils prennent assez de force et de croissance pour se disperser et aller chercher à vivre. Ainsi la durée de la vie de ces petits animaux est fort courte, puiscue leur accroissement est si prompt; et cela augmente encore l'idée (qu'on) doit avoir de leur prodigieuse multiplication. Aristote dit, qu'ayant mis une souris pleine dans un vase à serrer du grain, il s'y trouva peu de temps après cent vingt souris, toutes issues de la même mère.

Ces petits animaux ne sont points laids; ils ont l'air vif et mème assez fin : l'espèce d'horreur qu'on a pour eux n'est fondée que sur les petites surprises et sur l'incommodité qu'ils causent. Toutes les souris sont blanchâtres sous le ventre, et il y en a de blanches sur tout la corps; il y en a aussi de plus ou moins brunes, et de plus ou moins noires. L'espèce est généralement répandue en Europe, en Asie, en Afrique ; mais on prétend qu'il n'v en avait point en Amérique, et que celles (qui y sont actucllement, en grand nombre, viennent originairement de notre continent : ce qu'il y a de vrai, c'est qu'il parait que ce petit animal suit l'homme, et fuit les lieux inhabités, par l'appétit naturel qu’il a pour le pain, le fromage, le lard, l'huile, le beurre et les autres aliments que l'homme prépare pour lui-même.

\section{ADDITION A L'ABTICLE DE LA SOURIS.}

Nous avons dit que les souris blanches aux yeux rouges n'étaient qu'une variété, une sorte de dégénération dans l'espèce de la souris. Cette variété se trouve, non-seulement dans nos climats tempérés, mais dans les contrées méridionales et septentrionales des deux continents.

" Les souris blanches aux yeux rouges, a dit Pontoppidan, ont été trouvées dans la petite ville de Molle ou Roms-dallem: mais on ne sait si elles y sout indigènes, ou si elles y 
ont été apportées des Indes orientales. " Cette dernière présomption ne parait fondée sur rien; et il y a bien plus de raison de croire que les souris blanches se trouvent quelquefois en Norwége, comme elles se trouvent quelquefois partout ailleurs dans notre continent; et les souris, en général, se sont même actuellement si fort multipliées dans l'autre, qu'elles sont aussi communes en Amérique qu'en Europe, surtout dans les colonies les plus habitées. Le même auteur ajoute :

"Que les rats de bois et les rats d'ean ne peuvent vivre dans les terres les plus septentrionales de la Norwége, et qu'il y a plusieur's districts, comme celui de Hardenver, dans le diocèse de Berghen, et d'autres dans le diocèse d'Aggerhum, ou l'on ne voit point de rats, yuoiqu'il y en ait sur le bord méridional de la rivière de Vormen ; et que, lorsqu'ils sont transportés de l'autre côté, c'est-ì-dire à la partie boréale de cette rivière, ils y périssent en peu de temps; différence qu'on ne peut attribuer qu'à des exhalaisons du sol contradres à ces animanx."

Ces faits peuvent ètre vrais; mais nous avons souvent reconuu que Pontoppidan n'est pas un auteur qui mérite foi entière.

\section{DESGRIPTION DE LA SOURIS.}

La souris diffère peu dı rat pour la forme du corps, quoiqu'elle soit beancoup plus petite; elle a la queue plus velue et le poil plus court et plus doux.

Les conleurs du poil de la souris sont presque entièrement différentes de celles du rat; la face supérieure dı museau, de la lête et du cou, le dos, la croupe et la partie supérieure des còtés du corps sont de couleur mèlée de jaunâtre et de centré noirâtre, parce que les poils sont de couleur cendrée noiratre sur la plus grande partie de leur longueur depuis la racine; il y a du jaunâtre au-dessus dı cendré, et l'extrẻnité des plus longs poils est noirûtre : les côtés et le dessous de la tète, les fuatre jambes, le bas des côtés du corps, la poitrine et le ventre ont une couleur jaunàıre avec quelques teintes de centré; mais le jaunâtre domine sur toutes ces parties, et principalement aux alentours de l'anus et des parties de la génération : il n'y a sur les oreilles, sur les pieds et sur la quene qu'un poil si court et si fin, que l'on a peine à l'apercevoir.

Les souris, quoique du même âge, n'ont pas toule's les mèmes teintes de cendrẻ et de jannåtre, le cendré domine plus sur les souris qui se trouvent dans les granges, que sur celles qui habitent les maisons : cette differrence vient sans doute des aliments et de la température de l'air.

\section{LE MULOT.}

Ordre des rongeurs, genre rat. (Cuvier.)

Le mulot est plus petit que le rat, et plus gros que la souris; il n'habite jamais les maisons, et ne se trouve que dans les champs et dans les bois : il est remarquable par les yeux, qu'il a gros et proéminents, et il diffère encore du rat et de la souris par la couleur du poil qui est blanchâtre sous le ventre, et d'un roux brun sur le dos : il est très-généralement et très-abondamment répandu, surtout dans les terres élevées. Il paraît qu'il est longtemps à croitre, parce qu'il varie considérablement pour la grandeur : Ies grands ont quatre pouces deux ou trois lignes de longueur, depuis le bout du nez jusqu'à l'origine de la queue; les petits, qui paraissent adultes comme les autres, ont un pouce de moins : et, comme il s'en trouve de toutes les grandeurs intermédiaires, on ne peut pas douter que les grands et les petits ne soient tous de la mẻme espèce. Il y a grande apparence que c'est faute d'avoir comnu ce fait, que quelques naturalistes en ont fait deux espèces, l'une, qu'ils ont appelée le grand rat des champs $^{2}$, et l'autre, le mulot ${ }^{3}$. Ray, qui le premier est tombé dans cette erreur, en les indicuant sous deux dénominations, semble avouer qu'il n'en connait ${ }^{4}$ qu'une espèce : et, quoique les courtes descriptions qu'il donne de l'une et de l'autre espèce paraissent différer, on ne doit pas en conclure qu'elles existent toutes deux, $1^{\circ}$ parce qu'il n'en connaissait lui-même qu'une; $2^{\circ}$ parce rque nous n'en comnaissons

1 Cuvier en distingue deux espèces : le rat mulot el le mulot nain.

${ }^{2}$ Mus agrestis major, macronros Gesneri. Ray, Sinops. animal. quadrup., pag. 219.

Le grand rat des clamps. Mlus caudi longissimà fuscus, ad latera rufus... Mus campestris major. Brisson. Regn. animal. pag. 171.

"Mus domesticus medins. Ray, Sinops, animal quadrup. pag. 218.

Le mulot. Ilns caudi longà, suprà fusco llavesceus, infrj ex albo cinerescens. Brisson, llegn. aniınal. pag. $27 \%$.

4 De hảc specie mihi non undequaque satisfactum est. Ray Sinops. animal. quadrup. pag. 219. 
qu'une, et que, quelques recherches que nous ayons faites, nous n'en avons trouvé qu'une; $3^{\circ}$ parce que Gessner et les autres anciens naturalistes ne parlent que d'une, sous le nom de mus agrestis major, qu'ils disent êtr'e trèscommune, et que Ray dit aussi que l'autre, qu'il donne sous le nom de mus domesticus medius, et très-commune : ainsi il serait impossible que les uns ou les autres de ces auteurs neles eussent pas vues toutes denx, puisque de leur aveu tontes deux sont si communes; $4^{\circ}$ parce que dans cette seule et même espèce, comme il s'en trouve de plus grands et de plus petits, il est probable qu'on a été induit en erreur, et qu'on a fait une espèce des plus grands, et une autre espèce des plus petits; $5^{\circ}$ enfin, parce que les descriptions de ces deux prétendues espèces n'étant nulle part ni exactes ni complètes, on ne doit pas tabler sur les caractères vagues et sur les différences qu'elles indiquent.

Les anciens, à la vérité, font mention de cleux espèces, l'une, sous la dénomination de mus agrestis major, et l'autre sous celle de mus agrestis minor. Ces deux espèces sont fort communes, et nous les connaissons comme les anciens : la première est notre mulot; mais la seconde n'est pas le mus domesticus medius de Ray; c'est un autre animal qui est connu sous le nom de mulot à courte queue, ou de petit ratdes champs : et, comme il est fort différent du rat ou du mulot, nous n'adoptons pas le nom générique de petit rat des champs, ni celui de mulot à courle queue, parce qu'il n'est ni rat ni mulot, et nous lui donnerous un nom particulier '. Il en est de mème d'une espèce nouvelle qui s'est répandue depuis quelques années, et qui s'est beaucoup multipliće autour de Versailles, et dans quelques provinces voisines de Paris, qu'on appelle rats des bois, rats sauvages, gros rats des champs, qui sont très-vol:aces, très-méchants, très-nuisibles, et beaucoup plus grands que nos rats; nous lui donnerons aussi un nom particulier, parce qu'elle diffère de toutes les autres, et que, pour éviter toute confusion, il faut donner à chaque espèce un nom. Comme le mulot et le mulot à courte queue, que nous appellerons campagnol, sont tous deux très-communs dans les champs et dans les bois, les gens de la campagne les ont

- Je l'appelle campagnol, de son nom italien campaguoli. désignés par la différence qui les a le plus frappés: nos paysans, en Bourgogne, appellent le mulot la rate à la grande queue, et le campagnol la rate couette; dans dautres provinces on appelle le mulot le rat sauterelle, parcequ'il va toujours par sauts; ailleurs on l'appelle souris de terre lorsqu'il est petit, et mulot lorsqu'il est grand. Ainsi on se souviendra que la souris de terre, le rat sauterelle, la rate à la grande queue, le grand rat des champs, le rat domestique moyen, ne sont que des dénominations différentes de l'animal que nous appelons mulot.

Il habite, comme je l'ai dit, les terres sèches et élevées; on le trouve en grande quantité dans les bois et dans les champs qui en sont voisins; il se retire dans des trous qu'il trouve tout faits, ou qu'il se pratique sous des buissons et des trones d'arbres : il y amasse une quantité prodigieuse de glands, de roisettes ou de faines; on en trouve quelquefois jusqu'à un boisseau dans un seul trou; et cette provision, au lieu d'ètre proportionnée à ses besoins, ne l'est qu'à la capacité du lieu. Ces trous sont ordinairement de plus d'un pied sous terre, et souvent partagés en deux loges, l'une où il habite avee ses petits, et l'autre où il fait son magasin. J'ai souvent éprouvé le dommage très-considérable que ces animaux causent aux plantations; ils emportent les glands nouvellement semés; ils suivent le sillon tracé par la charrue, déterrent chaque gland l'un après l'autre, et n'en laissent pas un : cela arrive surtout dans les amnées ou le gland n'est pas fort abondant; comme ils n'en trourent pas assez dans les bois, ils viennent le chercher dans les terres semées, ne le mangent pas sur le lieu, mais l'emportent dans leur trou, où ils l'entassent et le laissent souvent sécher et pourrir. Eux seuls font plus de tortà un semis de bois que tous les oiscaux et tous les autres animaux eusemble. Je n'ai trouvé d'autre moyen, pour éviter ce grand dommage, que de tenảre des piéges de dix pas en dix pas dans toute l'étendue de la terre seméc: il ne faut qu'une noix grillée pour appàt, sous une pierre plate soutenue par une büchette; ils viennent pour manger la noix, qu'ils préferent au gland; comme elle est attachée à la buichette, dèsquils y touchent la pierre leur tombe sur le corps et les étouffe ou les écrase. Je me suis servi du même expédient contre les campagnols, qui détruisent aussi les glands; et comme l'on avait soin de m'apporter tout ce qui se 
trouvait sous les piéges, j’ai vu les premières fois, avec étonnement, que chaque jour on prenait une centaine tant de mulots que de campagnols, et cela dans une pièce de terre d'environ quarante arpents : j'en ai eu plus de deux milliers entrois semaines, depuis le 15 novembre jusqu'au 8 décembre; et ensuite en moindre nombre jusqu'aux grandes gelées, pendant lesquelles il se recèlent et se nourrissent dans leur trou. Depuis que j’ai fait cette épreuve, il y a plus de vingt ans, je n'ai jamais manqué, toutes les fois quej'ai semé du bois, de meservir du mème expédient, et jamais on n’a mal;. qué de prendre des mulots en très-grand nombre. C'est surtout en automne qu'ils sont en si grande quantité : il y en a beaucoup moins au printemps; car ils se détruisent eux-mêmes, pour peu que les vivres viennent à leur manquer pendant l'hiver: les gros mangent les petits. Ils mangentaussi lescampagnols, et même les grives, kes merles et les autres oiseaux qu'ils trouvent pris aux lacets; ils commencent par la cervelle, et finissent par le reste du cadavre. Nous avons mis dans un même vase douze de ces mulots vivants; on leur donnait à manger à huit heures du matin : un jour qu'on les oublia d'un quart d'heure, il y en eut un qui servit de pâture aux autres, le lendemain ils en mangèrent un autre : et enfin, au bout de quelques jours, il n'en resta qu'un seul; tous les autres avaient été tués et dévorés en partie; et celui qui resta le dernier avait lui-même les pattes et la queue mutilées.

Le rat pullule beaucoup, le mulot pullule encore davantage; il produit plus d'une fois par an, et les portées sont souvent de neuf et dix, au lieu que celles du rat ne sont que de cinq ou six. Un homme de ma campagne en prit un jour vingt-deux dans un seul trou; il y avait deux mères et vingt petits. Il est très-généralement répandu daus toute l'Europe: on le trouve en Suède, et c'est celui que M. Linnæus appelle mus caudá longá, corpore nigro flavescente, abdomine albo. Il est très-commun en France, en Italie, en Suisse: Gessner l'a appelé mus agrestis major. Il est aussi en Allemagne et en Angleterre; où on le nomme feld-musz. field-mause, c'est-à-dire rat des champs. Il a pour ennemis les loups, les renards, les martes, les oiseaux de proie, et lui-même.

\section{DESCRIPTION DU MULOT.}

Le mulot est plus gros que la souris; il a la tète à proportion beaucoup plus longue et plus grosse, les yeux plus grands et plus saillants, les oreilles plus allongées et plus larges, et les jambes plus longues.

La face supérieure et les côtés de la tète et du cou, le dos, la croupe, l'épaule, la face extérieure du bras et de l'avant-bras, la partie supérieure des côtés du corps, la face extérieure de la cuisse et de la jambe, sont de couleur faure mêlée d'une teinte noirâtre ; chaqụue poil est de couleur cendrée sur ha plus grande partie de sa longueur depuis la racine; il y a du fauve au-dessus du cendré, et l'extrénité des plus long:s poils est noire. Les côtés du museau et la face inférieure de la tête et dı con, le bas des côtés dı corps, la poitrine, le ventre, la face intérieure des quatre jambes et les pieds, sont blanchîtres, avec une teinte de cendré noirâtre sur tous les endroits où le poil est le plus long, parce qu'il est de conleur cendrée sur la plus grande partie de sa longneur, et blanc à l'extrémité. Il y a une petite tache fauve sur la partie antérieure de la poitrine; la queue est de couleur brune sur sa facc supérieure, et bianchâtre sur l'inférieure.

Il y a beaucoup de mulots dans les campagnes montneuses, sèches et stériles; on en trouve aussi dans les bois, mais en moindre nombre; les premiers sont les plus pétits, au moins en Bourgogne, où j’ai observé ces animaux : la longueur de leur corps depuis le bout du nez jusqu'à l'origrine de la queue, est rarement de trois pouces et demi, les autres ont plus de quatre pouces; mais j'en ai vu qui étaient de grandeur internérliaire; ainsi je crois qu'ils sont tous de la même espèce, d'autant plus qu'ils se ressemblent parfaitement, tant par la qualité et la couleur du poil, que par la figure extérieure et la conformation intérieure du corps.

\section{LE RAT PERGHAL.}

Ordre des rongeurs, genre rat. (Cuvier.)

Ce rat, dont M. Sonnerat nous a apporté la peau sous la dénomination de rat perchal, est plus gros que nos rats ordinaires.

p. p. l.

Sa longueur est de........... I $^{5} 2$

Longueur de la tète, du bout du nez à l'occi-

put................. 05

Elle est plus allongée que celle de nos rats; les oreilles uues, sans poil, sont de la forme et 
de la couleur de celles de tous les rats. Les jambes sont courtes, et le pied de derrière est trèsgrand en comparaison de celui de devant, puisqu'il a, du talon au bout des ongles, deux pouces, et que celui de devant n'a que dix lignes du poignet à l'extrémité des ongles. La queue, qui est semblable en tout à celle de nos rats, est moins longue en proportion, quoiqu'elle n'ait que huit pouces trois lignes de longueur.

Le poil est de couleur d'un brun musc foncé sur la partie supérieure de la tête, du cou, des épaules, du clos, jusqu'à la croupe et sur la partie supérieure des flanes; le reste du corps a une couleur grise plus claire sous le ventre et le cou.

Les moustaches sont noires et longues de denx pouces six lignes; la queue est écailleuse, comme par anneaux ; sa conleur est d'un brun grisâtre.

Les poils sur le corps ont de longueur onze lignes, et sur la croupe; deux pouces; ils sout gris à leur racine, et bruns dans leur longueur jusqu'à l'extrémité ; ils sont mélangés d'autres poils gris en plus grande quantité sous le ventre et les flanes.

Ce rat est très-commun dans l'Inde, et l'espèce en est nombreuse. Il habite dans les maisons de Pondichéry, comme le rat ordinaire dans les nôtres, et les habitants de cette ville lo t: ouvent bou à manger.

\section{LE PORG-ÉPIC DE MALACA.}

\section{Ordre des rongeurs, genre rat. (Cuvier.)}

Nous avons parlé et donné la figure d'un pore-épic des Indes orientales, et nous avons dit que ce porc-épic ue nous paraît être qu'nne variété de l'espèce du porcépic d'Italie; mais il existe dans les contrées méridionales de notre continent, et particulièrement à Malaca, une autre espèce de porcépic que nous avons fait dessiner vivant chez M. Aubry, curé de SaintLouis. Nous en avons vu un tout semblable, aussi vivant, entre les mains d'un marchand d'animaux, qui le faisait voir à Paris, au mois d'octobre 1777. Cette espèce diffère de l'espèce commune par plusieurs caractères très-sensibles, et surtout par la forme ct la longueur de la queue; elle est terminée par un bouquet de poils longs et plats, ou plutôt de petites lanières blanches semblables à des rognures de parchemin ; et la queue, qui porte cette houppe à son extrémité, est nue, écailleuse, et peut avoir le tiers de la longuenr du corps, qui est de quinze à seize pouces. Ce porc-épic de Malaca est plus petit que celui d'Europe; sa tête est néammoins plus allongée, et son museau, revêtu d'une peau noire, porte des moustaches de cinq à six pouces de longueur. L'œil est petit et noir ; les oreilles sont lisses, nues et arrondies : il y a quatre doigts réunis par une membrane aux pieds de devant, et il n'y a qu'un tubercule en place du cinquième; les pieds de derrière en ont cinq, réunis par une membrane plus petite que celle des pieds de devant. Les jambes sont couvertes de poils noiratres; tout le dessous du corps est blanc; les flanes et le dessus du corps sont hérissés de piquauts, moins longs que ceux du porc-épic d'Italie, mais d'une forme toute particulière, étant un peu aplatis et sillonnés sur leur longueur d'une raie en gouttière. Ces piquants sout blanes à la pointe, noirs dans leur milieu, et plusieurs sont noirs en dessus et blancs en dessous : de ce mélange résulte un reflet ou un jeu de traits blancs et noirâtres sur tout le corps de ce porc-épic.

Cet animal, comme ceux de son genre que la nature semble n'avoir armés que pour la défensive, n'a de même qu'un instinct repoussant et farouche. Lorsqu'on l'approche, il trépigne des pieds, et vient en s'enflant présenter ses piquants, qu'il hérisse et secoue. Il dort beaucoup le jour, et n'est bien éveillé que sur le soir; il mange assis et tenant entre ses pattes les pommes et autres firuits à pepin qu'il pèle avec les dents; mais les fruits à noỵau, et surtout l'abricot, lui plaisent davantage; il mange aussi du melon, et il ne boit jamais.

\section{LE RAT D'EAU.}

Ordre des rongeurs, genre rat. (Curier.)

Le rat d'eau est un petit animal de la grosseur d'un rat, mais qui, par le naturel et par les habitudes, ressemble beaucoup plus à la loutre qu'au rat: comme elle, il ne fréquente que les eaux douces, et on le trouve communément sur les bords des rivières, des ruisseaux, des étangs; comme elle, il ne vit guère que de 
poissons : les goujons, les mouteilles, les vairons, les ablettes, le frai de la carpe, du brochet, du barbeau, sont sa nourriture ordinaire; il mange aussi des grenouilles, des insectes d'eau, et quelcuefois des racines et des herbes. II n'a pas, comme la loutre, des membranes entre les doigts des pieds; e'est une crreur de Willughby, que Ray et plusieurs autres naturalistes ont eopié : il a tous les doigts des pieds séparés, et cependant il nage facilement, se ticnt sous l'eau longtemps, et rapporte sa proie pour la manger à terre, sur l'herbe ou dans son trou; les pẻcheurs l'y surpremnent quelquefois en cherchant des cerevisses; il leur mord les doigts, et elerehe à se sauver en se jetant daus l'cau. II a la tite plus courte, le museau plus gros, le poil plus hérissé, et la queue benucoup moins longue que le rat. II fuit, comme la loutre, les grands fleuves, ou plutôt les rivieres trop fréquentées. Les ehiens le chassent avee une espèce de fureur. On ne le trouve jamais dans les maisons, dans les granges; il ne cquitte pas le bord des eaux, en s'en éloigne mème pas autant que la loutre, qui quelquefois s'écarte et voyage en pays see à plus d'une licue. Le rat d'eau ne va point dans les terres élevées; il est fort rare dans les hautes montagnes, dans les plaine's arides, mais très-nombreux dans tous les vallons humides et marécageux. Les màles et les femolles se eherchent sur la fin de l'hiver' elles mettent bas au mois d'avril : les portées ordimaires sont de six ou sept. Peut-ètre ces animaux produisent-ils plusieurs fois par an, mais nous n'en sommes pas informés. Leur chair n'est pas absolument mauvaise; les paysans la mangent les jour's maigres eomme celle de la loutre. On les trouve partout en Europe, excepté daus le climat trop rigoureux du póle : on les retrouve en Égypte, sur les bords du Nil, si l'on en eroit Belon; cependant la figure qu’il en donne resscmble si peu à notre rat d'eau, que l'on peut soupcomner, avee quelque fondenent, que ees rats du Nil sont des animaux différents.

\section{LE RAT D'EAU BLANC.}

Ordre des rongeurs, genre rat. (Cuvier.,

On trouve en Canada le rat d'ean d'Europe, mais avec des couleurs différentes; il u' 'st brun que sur le dos, le reste du corps est blane ct fauve en cuelques endroits; la tête et le museau mème sont blanes aussi bien que l'extrémité de la queue; le poil parait plus doux et plus lustré que celui de notre rat d'eau : mais au reste tout est semblable, et l'on ne peut pas douter que ces deux animaux ne soient de la mème espèce; le blane du poil vient du froid du elimat, et l'on peut présumer qu'en recherchant les animaux dans le nord de l'Europe, on y trouvera, comme en Canada, ce rat d'eau blanc'.

\section{LE SCHERMAN}

oU

\section{RAT D'EAU DE STRASBOURG.}

Ordre des rongeurs, genre rat. (Cuvier.)

M. Hermann m'écrivit, le s octobre $\mathbf{1 7 7 6}$, en m'envoyant la figure d'un rat de ectte espèce : Ce petit animal a échappé à vos re" cherches, et je l'avais pris moi-mème pour * le rat d'eau commun; cependant il en diffère " par quelques caractères. II est plus petit; il a " la queue, le poil et les orcilles aifférents de " ceux d'un rat d'cau. On le comnait autour de "Strasbourg sous le nom de scherman. L'es" pece en est assez commure dans les jardins et " les prés qui sont proches de l'eau Cet animal " nage et plonge fort hien : on en trouve assez " souvent dans les nasses des pècheurs, et ils " font autant des dégàts dans les terrains eul" tivés. Ils creusent la terre, et il y a quelques " années que dans une de nos promenades pu" bliques, appeléc le Contade, hors de la ville, " un homme qui fait métier de prendre les " hamsters, en a pris un bon nombre dans les " mêmes piéges. "

Par ees indications, ct par la description que nous allons domer de ce petit animal, il me parait certain (qu'il est d'une espece différente, quoique voisine, de celle de notre rat d'eau, mais que ses habitudes naturelles sont à peu prìs les mėmes. Au reste, l'individu que M. Hermann a eu la bonté de nous enroyer pour le cabinet, y a été placé, et il est trìs-bien conserve. Il ne ressemble en effet à aucun des rats

1 La coulenr de ect animal varie cneore pins que ne le dit linilfous.

${ }^{2}$ ( iuvier le considere comme une variété de rat d'eau. 
dont nous avons donné les figures, qui tous ont les oreilles assez grandes; celui-ci les a presque aussi courtes que la taupe, et elles sont cachées sous le poil, qui est fort long. Plusieurs rats ont aussi la queue couverte de petites écailles, tandis que celui-ci l'a couverte de poil, comme le rat d'eau.

La longueur du corps entier, depuis l'extrémité du nez jusqu'à l'origine de la queue, est de six pouces: la queue est longue de deux pouces trois lignes; mais il nous a paru que les dernières vertèbres y manquent, en sorte que, dans l'état de nature, elle pent avoir deux pouces neuf lignes. La couleur du poil est en général d'un brun noirâtre mêlé de gris et de fauve, parce que le poil, qui a quinze lignes de longueur, est d'un noir gris à la racine, et fauve à son extrémité. La tête est plus courte, et le museau plus épais que dans le rat domestique, et elle approche par la forme de la tête du rat d'eau; les yeux sont petits; l'ouverture dela bouche est bordée d'un poil blane et court; les moustaches, dont les plus grands poils ont treize lignes de longueur, sont noires : le dessous du ventre est d'un gris de souris. Les jambes sont courtes et couvertes d'un petit poil noirâtre, ainsi que les pieds, qui sont fort petits; il y a, comme dans plusieurs rats, quatre doigts aux pieds de devant, et cinq à ceux de derrière ; les ongles sont blanes, et un peu courbés en gouttière. La queue est couverte de petits poils bruns et cendrés, mais moins fournis que sur la queuc du rat d'eau.

\section{LE CAMPAGNOL.}

Ords'e des rongeurs, genre rat. (Cuvier.)

Le campagnol est encore plus commun, plus généralement répandu que le inulot : celui-ci ne se trouve guère que daus les terres élevées; le campagnol se trouve partout, dims les bois, dans les champs, dans les prés, et mème dans les jardius. Il est remarquable par la grosseur de sa tête, et aussi par sa queue courte et tronquée, qui n'a guère qu'un pouce de long: il se pratique des trous en terre, où il amasse du grain, des nois ttes et du gland; cependant il parait qu'il préfère le blé à toutes les autres nourritures. Dans le mois de juillet, lorsque les blés sont mûrs, les campagnols arrivent de tous côtés, et font souvent de grands dommages en coupant les tiges du blé pour en manger l'épi : ils semblent suivre les moissonneurs; ils profitent de tous les grains tombés et des épis oubliés; lorsqu'ils ont tout glané, ils vont dans les terres nouvellement semées, et détruisent d'avance la récolte de l'aunée suivante. En automne et en hiver, la plupart se retirent dans les bois où ils trouvent de la faine, des noiseties et du gland. Dans certaines années, ils paraissent en si grand nombrequ'ils détruiraient tout, s'ils subsistajent longtemps; mais ils se détruisent eux-mèmes et se mangent ditns les temps de disette : ils servent d'ailleurs de pàture aux mulots, et de gibier ordinaire au renard, au chat sauvage, à la marte et aux belettes.

Lecampagnol ressemble plus au rat d'eau qu'à aucun animal par les parties intérieures, comme on le peut voir par ce qu'en dit M. Daubenton; mais à l'extérieur, il en diffère par plusieurs caractères essentiels : $1^{\circ} \mathrm{par}$ la grandeur; il n'a guère que trois pouces de longueur, depuis le bout du nez jusqu'à l'origine de la queue, et le rat d'eau en a sept; $2^{\circ}$ par les dimensions de la tête et du corps ; le campagnol est, proportionnellement à la longueur de son corps, plus gros que le rat d'eau, et il a aussi la tète proportionnellement plus grosse ; $3^{\circ}$ par la longueur de la queue, qui dans le campagnol ne fait tout au plus que le tiers de la longueur de l'animal entier, et qui dans le rat d'eau fait près des deux tiers de cette mème longueur ; $4^{\circ}$ enfin par le naturel et les mocurs; les campagnols ne se nourrissent pas de poisson et ne se jettent point a l'eau; ils vivent de gland dans les bois, de ble dans les clramps, et dans les prés, de racines tubereuleuses, comme celle du chiendent. Leurs trous ressemblent à ceux des mulots, et sont souvent divisés en deux loges; mais ils sont moins spacieux et beancoup moins enfoucés sous terre: ces petits animaux y habitent quelquefois plusieurs ensemble. Lorsque les femelles sont prètes à mettre bas, elles y portent des herhes pour faire un lit à leurs petits : clles produisent au printemps et en été; les portées ordinaires sont de cing ou six, et quelquefois de sept ou huit. 


\section{DESCRIPTION DU CAMPAGNOL.}

\section{(EXTRAIT DE DAUBENTON.)}

Le campagnol ressemble au rat d'eau par la forme du corps, et par la couleur et la qualité du poil ; il n'en diffère que par la grandeur, car il n'est pas plus gros qu'une souris; mais il est aisé de le distinguer de cet animal par les mêmes caractères qui font les différences plus apparentes entre le rat d'eau et le rat. Le campagnol a la tête plus lıérissée de poils, et les oreilles et la quene plus courtes que la souris et le mulot, et la tète plus petite que cet animal et plus grosse que la souris.

On a pris dans le parc de Versailles, au mois de mai 1758, un campagnol qui differait des autres en ce qu'il était en entier de couleur cendrée noirâtre, et qu'il paraissait avoir la quene plus longue, car elle avait un pouce neuf lignes, tandis que la longueur dle l'animal, depuis le bout du museau jusqu'à l’anus, n’était que de trois ponces sept lignes. Un campagnol de couleur ordinaire, pris en mẹme temps et dans le même parc, n'avait la queue longue que de dix lignes, quoique le corps ent trois pouces onze lignes de longueur: un autre campagnol, qui n'était long que de trois pouces huit lignes, avait la queue longue d'un pouce trois lignes. Le plus grand des animaux de cette espèce que j'ai vu avait le corps long de quatre pouces trois lignes, et la queue seulement d'un pouce; il différait aussi des autres par ses couleurs, car le dessus du corps ėtait jaunâtre avec une légère teinte de gris, et le dessous était mêlé de gris et de couleur cendrée, tandis que dans les autres que j'ai observés en très-grand nombre, le dessus du corps était mêlé de brun et de jaunâtre, et le dessous de jaune pâle, de blanc sale et de cendré. Je crois que ces différences dans les couleurs du poil, dans la grandeur du corps et de la queue, n'empêchent pas que ces animaux ne soient de la même espèce.

\section{LE COCHON D'INDE.}

Ordre des rongeurs, genre cobaje. (Cuvier.)

Ce petitanimal, originaire des climats chauds du Brésil et de la Guinée, ne laisse pas de vivre et de produire dans le climat tempéré, et même dans les pars froids, en le soignant et le mettant à l'abri de l'intempérie des saisons. On élève des cochons d'lnde en France; et, quoiqu'ils multiplient prodigieusement, ils n'y sont pas cn grand nombre, parce que les soins qu'ils demandent ne sont pas compensés par le profit qu'ou en tire. Leur peau n'a presque aucune valeur, et leur chair, quoique mangeable, n'est pas assez bonne pour être recherchée: elle serait meilleure, si on les élevait dans des espèces de garennes où ils auraient de l'air, de l'espace et des herbes à choisir. Ceux qu'on garde dans les maisons out à peu près le même mauvais goût que les lapins clapiers; et ceux qui ont passé l'été dans un jardin ont toujours un goût fade, mais moins désagréable.

Ces animaux sont d'un tempérament si précoce et si chaud, qu'ils se recherchent et s'accouplent cinq ou six semaines après leur naissance: ils ne prennent cepeudant leur accroissement entier qu'en huit ou neuf mois ; mais il est viai que c'est en grosseur apparente et en graisse qu'ils augmentent le plus, et que le développement des parties solides est fait avant l'âge de cinq ou six mois. Les femelles ne portent que trois semaines, et nous en avons vu mettre bas à deux mois d'âge. Ces premières portées ue sont pas si nombreuses que les suivantes; elles sont de quatre ou cinq; la secoude portée est de cinq ou six; et les autres, de sept ou huit, et mème de dix ou onze. La mere n'allaite ses petits que pendant douze ou quinze jour's; elle les chasse dès qu'elle reprend le mâle; c'est au plus tard trois semaines après qu'elle a mis bas; et, s'ils s'obstinent à demeurer auprès d'elle, leur père les maltraite et les tue. Ainsi ces animaux produisent au moins tous les deux mois; et ceux qui viennent de naître produisant de même, l'on est étonné de leur prompte et prodigieusemultiplication. A vec un seul couple, on pourrait en avoir un millier dans un an ; mais ils se détruisent aussi vite qu'ils pullulent : le froid et l'humidité les font mourir; ils se laissent manger par les chats saus se défendre; les mères même ne s'irritent pas contre eux : n'ayant pas le temps de s'attacher à leurs petits, elles ne font aucun effort pour les sauver. Les mâles se soucient encore moins des petits, et se laissent manger eux-mêmes sans résistance: ils n'ont de sentiment bien distinct que celui de l'amour; ils sont alor's susceptibles de colère: ils se battent cruellement, ils se tuent mèmequelquefois entre eux, lorsqu'il s'agit de se satisfaire et d'aroir la femelle. Ils passent leur vie à dormir, jouir et manger ; lcur sommeil est court, mais fréquent; ils mangent à toute heure du jour et de la nuit, et cher- 


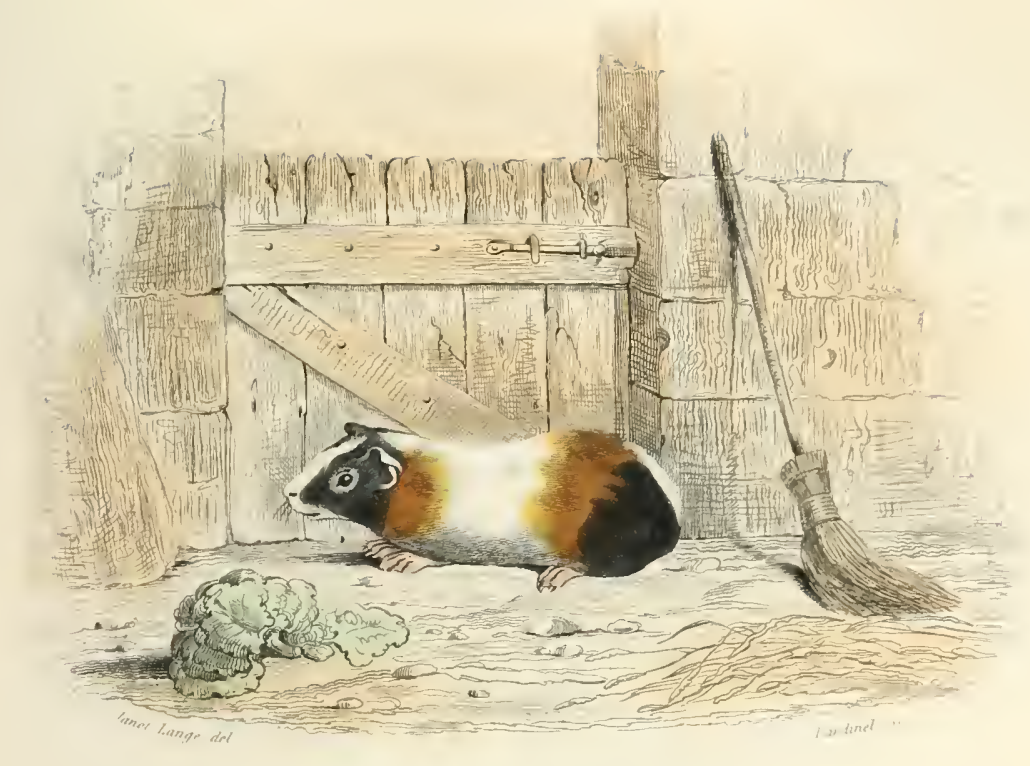

1.t. $\operatorname{cochox} \mathrm{D} 1 \mathrm{~N}) \mathrm{t}$

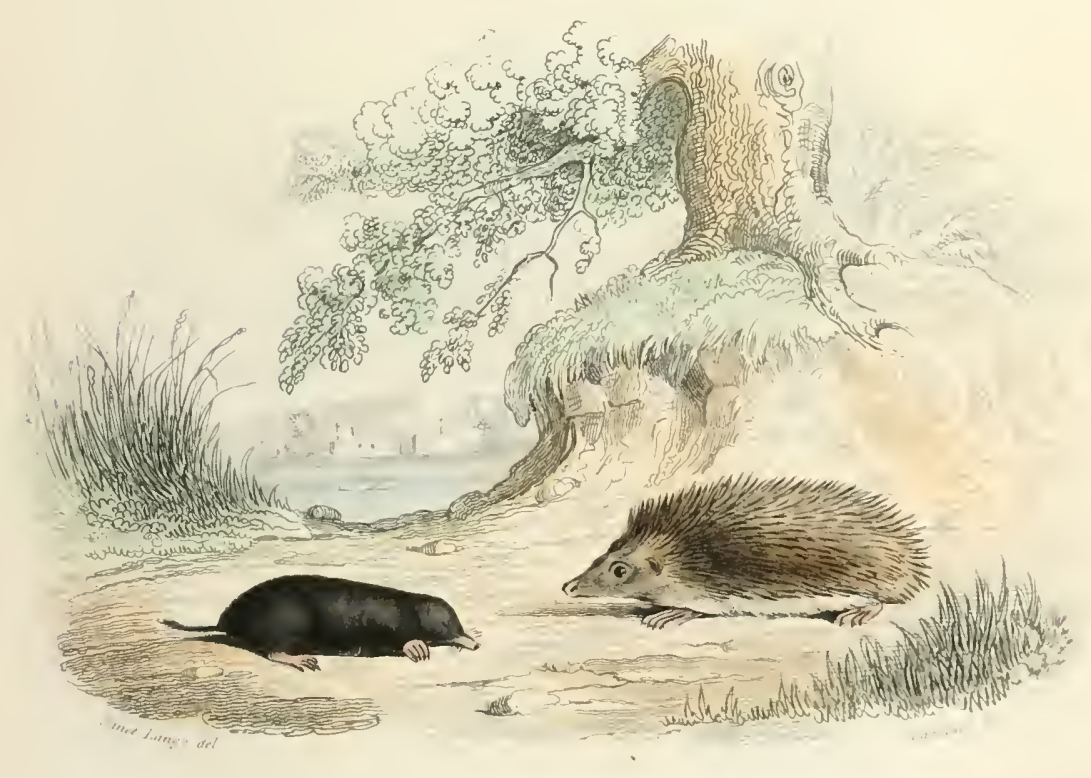

1.. T.1TPl.

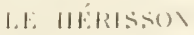



chent à joutir aussi souvent qu'ils mangent; ils ne boivent jamais, et cependant ils urinent à tout moment. Ils se nourrissent de toutes sortes d'herbes, et surtout de persil; ils le préferent mème au son, à la farine, au pain; ils aiment aussi beaucoup les pommes et les autres fruits. Ils mangent précipitamment, à peu près comme les lapins, peu à la fois, mais très-souvent. Ils ont un grognement semblable ir celui d'un petit cochon de lait : ils ont aussi une espèce de gazouillement qui marque leurs plaisirs lor'squ'ils sont auprès de leur femelle, et un cri fort aigu lor'squ'ils ressentent de la douleur. Ils sont délicats, frileux, et l'on a de la peineà leur faire passer l'hiver'; il faut les tenir dans un endroit sain, secet chaud. Lorsqu'ils sentent le froid, ils se rassemblent et se serrent les uns contre les autres, et il arrive souvent que, saisis par le froid, ils meurent tous ensemble. Ils sont natureslement donx et prives : ils ne font aucun mal ; mais ils sont également incapables de bien ; ils ne s'attachent point : doux par tempérament, dociles par faibresse, presque insensibles à tout, ils ont l'air d'automates montés pour la propagation, faits seulement pour figurer une espèce.

\section{L'APÉREA '}

Ordre tes rongeurs, genre cobaye. (liuvier.)

Cet animal, qui se trouve au Brésil, n'est ni lapin, ni rat, et parait tenir quelque chose de tous deux: il a environ un pied de longueur sur sept poures de circonférence, le poil de la même couleur que nos lièvres, et blanc sous le ventre; il a aussi la lèvre fendue de mème, les grandes dents incisives, et la moustache autour de la gueule et à côté des yeux; mais ses oreilles sont arrondies comme celles du rat, et elles sont si courtes qu'elles n'ont pas un travers de doight de hauteur' les jambes de devant n'ont que trois pouces de hauteur, celles de derrière sont un peu plus longues; les pieds de devant iont quatre doigts couverts d'une peau noire et munis de petits ongles courts; les pieds de derrière n'ont fue trois doigts, dont celui du milieu est plus long que les deux autres. L'apérea n'a point de queue : sa tète est un peu plus

4 Cuvier regarde l'apérea conime le cochon il'Iude à l'ćtat sauvage. allongée que celle du lièvre, et sa chair est comme ceile du lapin, auruel il ressemble par la manière de vivre. Il se recèle aussi dans des trous, mais il ne creuse pas la terre comme le lapin, c'est plutôt dans des fentes de rochers et de pierres que dans des sables qu' il se retire : aussi est-il bien aisé à prendre dans sa retraite. On le chasse comme un très-bon gíbier, ou du moins aussi bon que nos meilleurs lapins. Il me parait que l'animal dont Oviedo, et après Iui Charlevoix ${ }^{1}$ et Duperrier de Montfraisier, font mention sous le nom de cori, pourrait bien ètre le même que l'apérea"z; que dans quelques endroits des Indes occidentales, on a peut-itre élevé de ces animaux dans les maisons ou dans des garennes, comme nous élevons des lapins; et qu'enfin c'est par cette raison qu'il s'en trouve de roux, de blancs, de noirs, et de variés, de couleurs différentes : ma conjecture est fondée, car Garcilasso dit expressément qu'il y avait au Pérou des lapins champètres et d'autres domestiques, qui ne ressemblaient point à ceux d'Espagne ${ }^{3}$.

\section{DESGRIPTION DU COCHON D'INDE.}

(EXThaIT dE DAUBENTon:

Cet animal est informe, à peine voit-on ses jambes; le con est confundu avec le corps et la tète, que l'on ne reconnait que par les oreilles; le museau est ohtus, et la partie posterieure du corps n'est pas terminee par une queue, conme tlans la plupart des antres animanx. Lorsque le cochon d'Inde marche, son corps s'allonge; lorsqu'il est en repos, le corps se raccourcit et se gonfle à l'endroit des flancs; mais, soit dans le repos on dans le mouvement, on ne distingne, au premier aspect, ancune des parties de cet animal, excepté les oreilles, qui sont placées au-dessus de la tête. Elles se-

\footnotetext{
1 Ovierlo dit une le cor $i$ est conıme un petit lapin; quil y en a de tont blanes, et d'anties de conlenrs mélées. Histoire de Saint-Dumingue, par le P. Charlevoix, tone 1, page 35.

${ }^{2}$ Le cori des ludes espagnoles) est un pelit auitnal a quatre pieds, assez semblable a nos lapins et aux laupes; il a les oreilles petiles, et les porte tellement couchées sur le dos, qua peine les aperçoit-on; il na point de yueve. I.es uns sont tout blanes, les antres tont noirs, les antres mouchetés de noir et de blanc; il y cu a de tont rouges, et d'autres nonche. tés de rouge et de hinc... Ils sont privés, et ne font ancune orlure dans les maisons; ils mangent de l'ierbe et se nourrissenl de pen de chose; ils ont le goult et le fumct des mcilleurs lapius. Ilistoire des Voyages, par Duperrier de Montfraisier; Paris, 1707, page $3 \$ 3$.

${ }^{3}$ IIist. des Incas, tomic II, jage 267.
} 
raient assez grantles, ef leur direction verticale les tendrait fort apparentes, si le poil de l'occiput n'était presque ausci long et ne les couvrait en grarde partie : elles sont rondes, et elles ont beaucoup plus cle largeur que de hauteur.

De tous les animaux qui ont dẻjà été décrits dans cet ouvrage, le lièvre et le lapin sont ceux qui ont le plus de rapport au cochon d'Inde, surtout par la forme de la tète ; cependant celle du coclion d'Inde est à proportion beaucoup plus grosse, les oreilles sont beaucoup plus courtes, le front n'a point de convexité, le bout dn museau est beancoup plus gros que celui du lièvre et du lapin, la lèvre supérieurea beaucoup plus de hauteur; Quoique le cochon d'Inde ait le bec de lièvre, la lèvre n'est fendne que sur la moitié de sa hauteur; les ouvertures des narines sont rondes, èloiguées l'une de l'antre, et par couséquent for't différentes de celles du lièvre et du lapin, qui paraissent se confondre et ne former qu'une seule ligne transversale. Les yeux du cochon d'Inde sont ronds, gros et saillants.

Iln'y a dans les pieds de devant que quatre doigts, trois tubercules calleux sous le métacarpe, et un quatrième, plus gros que les trois autres, derrière le earpe. Les pieds de derrière n'ont que trois doigts, et deux tubercules calleux sous le métatarse, et une autre callosité qui occupe la face inférieure du tarse.

Le poil est lisse, il a jusqu'à un pouce de longueur; il n'est que d'une seule couleur, depuis la racine jusqu'à la pointe; mais les différentes parties du corps ont des taches fauves, blanclıes on noires, qui varient par la grandeur, par la figure et par la position, comme dans lous les animaux domestiques. Quelques cochons d'Inde sont blancs en entier, d'autres n'ont que des taches blanches et faures sans noir. $11 \mathrm{y}$ a aussi des variétés dans l'intensité de la couleur fauve; je l'ai vue fort vive et prespue orangée sur de jeunes iudividus, tandis qu’elle était pàle et presque éteinte sur des vieux : ceux-ci mont paru avoir le museau plus gros et plus hérissé de poil, ce qui les rend plus laids que les jeunes.

\section{LE HÉRISSON.}

Ordre des carnassiers, famille des insectivores, genre ไıérisson. (Curier.)

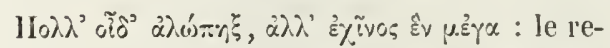
nard sait beaucoup de choses, le hérisson n'en sait qu'une graide, disaient proverbialement les anciens'. Il sait se défendre sans combattre,

- Zenodotus, Plutarchus et alii ex Archilocho. et blesser sans attaquer : n'ayant que peu de force et nulle agilité pour fuil, il a reçu de la nature une armure épineuse, avec la facilité d€ se resserrer en boule et de présenter de tous côtés des armes défensives, poignantes et qui relutent ses ennemis ; plus ils le tourmentent, plus il se hérisse et se resserre. Il se défend encore par l'effet même de la peur, il lâche sơn urine dont l'odeur et l'humidité se répandant sur tout son corps, achèvent de les dégouter. Aussi la plupart des chiens se contentent de l'aboyer et ne se soucient pas de le saisir : cependant il y en a quelques-uns qui trouvent moyen, comme le renard, d'en venir à bout en se piquant les pieds et se mettant la gueule en sang; mais il ne craint ni la fouine, ni la marte, ni le putois, ni le furet, ni la belette, ni les oiseaux de proie. La femelle et le måle sont également couverts d'épines depuis la tête jusqu'à la quene, et il n'y a que le dessous du corps qui soit garni de poils : ainsi ces mêmes armes, qui leur sont si utiles contre les autres, leur deviennent très-incommodes lorsqu'ils veulents'unir: ils ne peurent s'accoupler à la manière desau. tres quadrupèdes; il faut qu'ils soient face à face, debout ou couchés. C'est au printemps qu'ils se cherchent, et ils produisent au commencement de l'été. On m'a souvent apporté la mère et les petits au mois de juin : il y en a ordinairement trois ou quatre, et quelquefois cinq; ils sont blanes dans ce premier temps, et l'on voit seulement sur' leur peau la naissance des épines. J'ai roulu en élever quelques-uns: on a mis plus d'une fois la mère et les petits dans un tonneau avec une abondante provision, mais au lieu de les allaiter, elle les a dévorés les uns après les autres. Ce n'était pas par le besoin de nourriture, car elle mangeait de la viande, du pain, du son, des fruits; et l'on n'aurait pas imaginé qu'un animal aussi lent, aussí paresseux, auquel il ne manquait rien que la liberté, fùt de si mauvaise humeur et si fàché d'être en prison : il a mème de la malice et de la même sorte que celle du singe. Un hérisson qui s'était glissé dans la cuisine découvrit une petite marmite, en tira la viande et $\mathrm{y}$ fit ses ordures. J'ai gardé des måles et des femelles ensemble dans une chambré: ils ont vécu, mais ils ne se sont point accouplés. J'en ai lâché plusieurs dans mes jardins; ils n'y font pas grand mal, et à peine s'apercoit-on qu'ils y habitent : ils vivent de fruits tombés; ils 
fouillent la terre avec le nez à une petite profondeur; ils mangent les hannetons, les scarabées, les grillons, les ver's et quelques racines; ils sont aussi très-avides de viande, et la mangent cuite ou erue. A la campagne, on les trouve fréquemment dans les hois, sous les trones des vieux arbres, et aussi dans les fentes de roeher's, et surtout dans les monceaux de pierres qu'on amasse dans les ehamps et dans les vignes. Je ne clois pas qu'ils montent sur les arbres, comme le disent les naturalistes ', ni qu'ils se servent de leurs épines pour emporter des fruits ou des grains de raisiu; e'est aver la gueule qu'ils premment ce qu'ils veulent saisir; et cfuoiqu'il y en ait un grand nombre dans nos forcits, nous n'en avons jamais vu sur les arbres; ils se tiennent toujours au pied, dans un creux ou sous la mousse. Ils ne bougent pas tant qu'il est jour; mais ils courent, ou plutôt ils marehent pendant toute la nuit : ils approchent rarement des habitations; ils préfèrent les lieux élevés et sees, quoiqu'ils se trouvent aussi quelquefois dans les prés. On les prend à la main, ils ne fuient pas, ils ne se défendent ni des pieds ni des dents, mais ils se mettent en boule dès qu'on les touche; et pour les faire étendre, il faut les plonger daus l'eau. Ils dorment pendant I'hiver; ainsi les provisions cu'on dit qu'ils font pendant l'été leur seraient bien inutiles. Ils ne mangent pas beaucoup, et peuvent se passer assez longtemps de nourriture. Iis ont le sang froid à peu près comme les autres animaux qui dorment en hiver. Leur ehail n'est pas bonne à manger, et leur peau, dont on ne fait maintenant aucun usage, servait autrefois de vergette et de frottoir pour serancer le chanvre.

Il en est des deux espèces de hérisson, l'un à groin de cochon, et l'autre à muscau de chien, dont parlent quelques auteurs, comme des deux espèces de blaireau; nous n'en commaissons qu'une seule, et qui n'a même aucune variété dans ces elimats : elle est assez généralement répandue; on en trouve partont en Enrope, à l'exeeption des pays les plus froids, comme la Laponie, la Norwége, ete. Il y a, dit Flaccourt, des hérissons à Madagascar comme en France, et on les appelle sora. Le hérisson de

1 rbores ascendit, proma et pira decuttit, in istis sese $\$ 0$. lutat in spinis hareant. Sperling. Zijologia, Lipsix. 1661, lag. 281.
Siam, dont parle le P. Tachard, nous parait être un autre animal ; et le hérisson d'Américue " *, le hérisson de Sibérie ${ }^{2 * *}$, sont les espèees les plus voisines du hérisson commun; enfin le hérisson de Malaca ${ }^{3 * * *}$ semble plus approcher de l'espèce du porcépic que de celle du hérisson.

\section{ADDITION I l'ARTICLE DU HÉRISSON.}

J'ai dit ci-dessus que je doutais que le hérisson montàt sur les arbres, et qu'il emportât des fruits sur ses piquants. Cependant quelques chasseurs m'ont assuré avoir vu des hérissons monter sur des arbres, et emporter des fruits à la pointe de leur's piquants.

Ils m'ont dit aussi qu'ils avaient vu des hérissons nager, et traverser mème de grands espace d'eau avec assez de vitesse. Dans quelques campagnes, on est dans l'usage de prendre une peau de hérisson, et d'en couvirir la tête d'un veau lorsqu'on veut le sevrer; la mére se sentant piquée lui refuse le pis et s'éloigne.

Voici quelques observations sur des hérissons que j'ai fait élever en domesticité.

Le 4 juin 1781, on m'apporta quatre jeunes hérissons avec la mère. Leurs pointes ou épines étaient bien formées, ce qui parait indiquer qu’ils avaient plusieurs semaines d'àce. Je les fis mettre ensemble dans une grande volière do fil de fer, pour les observer commodément; ct l'on garnit de branches et de feuillages le fond de eette volière, afin de procurer à ces animaux une petite retraite pour dormir.

Pendant les deux premiers jours, on ne leur doma pour nourriture que quelques morceaux de bœuf bouilli, qu'ils ne mangèrent pas : ils en sucèrent seulement toute la partic succulente,

1 Echinus indicus albus. Ray, Sinops. animal. quadrup). pag. 252. Echinus americams albus. Albert Seba, vol. I, pag. 78. Acanthion echinalus, erinacens americanus albus Surinamensis. Klcin, de qualrup. pag. 66.

${ }^{2}$ Erinaceus Sibericus. Albert Seba, vol. J, pag. 66.

3 porcus aculealus sen lisirix malaccensis. Albert Scha. vol. 1, pag. 81. Aeauthion aculeis longisimis. IIistrix genuina l'orens acnlealus malaceensis, kilcin, de quadrup. p. 66 Histrix pedibus pentadaclylis, caudi Iruncalà. Limmeus. Erinacens auriculis pendulis.... Brisson, Regn. anim. nag. 185.

*Erinaceus Inauris ; Encycl. mćlhod. - C'est un coucndon. suivanl d'Azara.

"Erinacens sibericus; Erxlch. - C'est une variété du hérlsson d'Eurvice.

*. nérisson à oreilles pemlantes: Desm. 
sans manger les fibres de la chair. Le troisième jour, on leur douna plusieurs sortes d'herbes, telles que du seneçon, du liseron, etc.; ils n'en mangèrent pas. Ainsi on peut dire qu'ils jeûnèrent à peu près pendant ces trois premiers jours: cependant la mère n'en parut pas afraiblie, et donna souvent à teter à ses petits.

Les jours suivants, ils eurent des cerises, du pain, du foie de bœuf cru. lls sucaient ce dernier mets avec avidité, et la mère et les petits ne le quittaient pas, qu'ils ne parussent rassasiés. Ils mangèrent aussi un peu de pain, mais ils ne touchèrent pas aux cerises : ils montrèrent beaucoup d'appétit pour les intestins crus de la volaille, de même que pour les pois et les hrrbes cuites; mais, quelque chose qu'ils aient pu manger, il n'a pas été possible de voir leurs excréments, et il est à présumer (qu'il les mangent, comme font quelques autres animaux.

Il parait qu'ils peurent se passer d'eau, ou du moins que la boisson ne leur est pas plus cécessaire qu'aux lapins, aux lièrres, etc. Ils n'ont rien eu à boire pendant tous le temps qu'on les a conservés, et néanmoins ils out toujours été fort gras et bien portants.

Lorsque les jeunes hérissons voulaient prendre la mamelle, la mère se couchait sur le côté, comme pour les mettre plus à leur aise. Ces animaux ont les jambes si courtes, que les petils avaient peine à se mettre sous le ventre de Icur mère, si elle se tenait sur ses pieds; ils s'endormaient à la mamelle : la mère ne les ré、itllait pas; elle semblait mème n'oser se renuer dans la crainte de troubler leur sommeil. Voulant reconnaitre si cette espèce d'attention de la mère pour ses petits était un effet de son atrachement pour eux, ou si elle-mème n'était pas intéressée à les laisscr tranquilles, on s'apercut bientòt que quelque amour qu'clle en̂t pour eux, elle en avait encore plus pour la liherté. On ouvrit la volière pendant que ses petits dormaient; dès qu'elle s'en aperçut, elle se leva doucement, sortit dans le jardin, ct s'éloigna du plus vite qu'elle put de sa cage, où elle ne revint pas d'elle-même, mais où il fallut la rapporter. On a souvent remarqué que, lor'squ'elle était renfermée arec ses petits, elle employait ordinairement tout le temps de leur sommeil à rôder autour de la volière, pour tâcher, selon toute apparence, de trouver une issue propre à s'échapper, et qu'elle ne cessart ses manœuvres et ses mourements inquiets que lors- que les petits venaient à s'éreiller. Des lors il fut facile de juger que cette mère aurait quitté volontiers sa petite famille, et que, si elle sem. blait craindre de l'éveiller, c'était seulement pour se mettre à l'alrri de ses importunités; car les jeunes hérissons étaient si avides de la mamelle, qu'ils y restaient attachés souvent pendant plusieurs heures de suite. C'est pent-être ce grand appétit des jeunes hérissons qui est cause que les mères, emnuy ées ou excédées par leur gourmandise, se déterminent quelquefois à les détruire.

Dès que les hérissons entendaient marcher, ou qu'ils royaient quelqu'un auprès d'eux, ils se tapissaient à terre et ramenaient leur museau sur la poitrine, de sorte qu'ils présentaient en arant les piquants qu'ils ont sur le haut du front, et qui sont les premiers à se dresser; ils ramenaient ensuite leurs pieds de derrière en avant, et, à force d'approcher ainsi les extrémités de leur corps, ou plutôt de les resserrer l'une contre l'autre, ils se donnaient la forme d'une pelote ou d'une boule bérissée de piquants ou de pointes. Cette pelote ou boule n'est pas tout à fait ronde, elle est toujours plus mince vers l'endroit où la tête se joint à la partie postérieure du corps. Plus ils étaient prompts à prendre cette forme de boule, et plus ils comprimaient fortement les deux extrémités de leur corps : la contraction de leurs muscles parait être si grande alors, que, lorsqu'une fois ils se sont arrondis autant qu'il leur est possible, il serait presque aussi aisé de leur disloquer les membres, que de les alonger assez pour donner à leur corps toute son étendue en longueur. On essayait souvent de les étendre; mais plus on faisait d'efforts, plus ils semblaient opposer de résistance et se resserrer. Dans l'instant où ils prenaient la forme de pelote, on a remarqué qu'il se faisait un petit bruit de cliquetis, qui était occasionné par le frottement réciproque des pointes, lesquelles se dirigent et se croisent daus tous les seus possibles. C'est alors que le corps de ces animaux parait hér'ssé d'un plus grand nombre de pointes, et qu'ils sont vraiment sur la défensive. Lorsque rieu ne les in(quiète, ces mèmes pointes ou épines si lhérissées, quand il est question de se préserver, sont couchées en arrière les unes sur les autres, comme le poil lisse des autres animaux; néanmoins ceci n'a lieu que lorsque les hérissons, étant éveillés, jouissent du calme et de la tranquillité; 
ear, quand ils dorment, leur's armes sont prêtes, c'est-it-dire que leurs pointes se eroisent dans tous les sens, comme s'ils avaient à repousser une attaque. II semble donc que pendant leur sommeil, qui est assez profoud, la nature leur alt donné l'instinct de se prémunir contre la surprise.

Aureste, ces animaux n'ont pas les moyens d'en attaquer d'autres; ils sont naturellement indolents et même paresseux : leur repos semble être aussi néeessaire à leur genre de vie que la nourriture; et l'on pourrait dire avec assez de vérité, que leurs uniques et seules occupations sont de manger et dormir. En effet, ceux que nous avons nourris et élevés cherchaient à manger dès qu’ils étaient éveillés, et, quand ils avaient assez mangé , ils allaient se livrer au sommeil sur des fenillages. Ce sont lả leurs habitudes pendant le jour : mais pendant la nuit ils sont moins trancuilles; ils cherehent les limaçons, les gros scarabées, et autres inscetes dont ils font leur principale nourriture.

\section{DESGRIPTION DU HÉRISSON.}

(EXTRaIt de DAUbenton.)

De tous les animaux quadrupèdes qui se trouvent lans notre eliult, le lı́́risson est le seul qui soit couvert de piquants; il est aussi le seul ıui se pelotonne au point de cacher tous ses memhres. Dims cet état, il n'a aucune apparence de quadrupède ; on ne le voit que sous la forme d'une pelote hérisée de pointes; mais cette pelote n'est pas régulièrement roncle, elle a en quelıue manière la figure l'un rein fort épais : sa grande courbure convexe est formée par le dos de l'animal, dont le corps est courhé de façon que la tìte se trouve à l'un des bouts de la petite courbure concave du reiu, et la partie postérieure du corps à l'autre bont. Cette partie et la tête ne se touchent pas imméliatement, il reste un espace rempli par les pipuants du front et de la crompe du herisson, qui forment une concavité semblable à l'enfoncement d'un rein. Cet enfoncement est d'antant plus étroit que l'aniual fait plus d'efforts pour se courber et pour se pelotomner, ce yui arrive lorspu il est effriyci ou ilessc; alors on ne distingue aucune des patties de son corps : mais lorspu'il est plus tranguille et quil ne se tient pelotonné ıne pour prentre du repos, l'cnfoncement de la pelote qu'il forme est plus sramil, et on y voit le musean de l'animal, qui tonche anx deux pieds de devant; quelyuefois on aperçoit aussi les deux pieds de derrière, qui sont contre ceux de devant, et on voit entre les quatre pieds l'orifice du prépuce. Lorsque le liérisson quitte cette attitude pour se nettre sur ses jambes, il abaisse la convexité de son dos, il étend son corps, il porte la tète en avant, se dresse sur ses pieds, et marche comme les autres (quadrupèdes. Si on l'effraie par quelque bruit, si on le touche, ou si on le saisit, il se pelotonne aussitòt; mais ce mourement n'est pas si prompt que l'on ne puisse y distinguer diffërents temps: l'animal commence jar couber son dos et pencher la tète sur la poitrine; alors les yeux se ferment, la peau des cotés du corps s'étend en bas et enveloppe les jambes; enfin la peau de la croupe grlisse en dessous, et couvre la queue et les pieds de ilerrière.

Le hérisson, quoique dehout snr ses jambes, a le corps très-informe; e'est une masse oblongue, convexe en dessus, terminee en avant par un museau fort mince et montée sur quatre jambes si courtes, que l'on ne voit que les pieds; on ne distingue pas le cou. Cet animal a les oreilles larges, rondes et courtes, les yeux petits et saillants, et la queue fort mince et très-courte.

Les naturalistes ont distingué denx espèces de hérisson par des caractères tirés de la figure du museau; plusieurs anteurs prétendent que les uns ont le groin d'un cochon, et les autres le museau d'un chien; mais on n'a donné aueune description assez détaillée pour établir ce fait, et pour faire recomnaître les earactères de ces lleux prétendues espèces de hérisson. Les geus de la campague, qu: ont le mème préjugé, ne peuvent donner aucune raison précise le leur opinion, lorsqu on leur fait roir de près deux hérissons qüils assurent ètre d'espèces différentes; eependant ils se eroient d’autant mieux foncies dans leur assertion, yu'ils mangent de la ehair de ces animaux, et yuils croient préférer celle du hérisson à grvin de cochon, et rebuter celui qui a le museau de chien, parce qu’il répand une mauvaise odeur.

J'ai observé en Bourgogne deux hèrissous uàles, que les gens de la campagne me clisaient être, l'un de l'espèce à groin de cochon, et l'autre de l'espèce à museau de chien Le premier', élant pelotonné, avait six ponces luit lignes de longueur, eing pouces deux lignes de largeur et yuatre pouces d'épaisseur' il pesait une live ciny onces deux gros. Les plus grands pịuants avaient un pouce de lony, ils étaient ronds et avaient un tiers de ligne de diamètre sur la plus srande partie de l- ur longueur; les deux bouts étaient trés-minces et fort

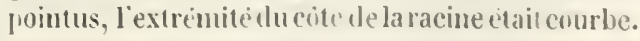
chayue pi(juant avait une couleur blandhitre sur la pointe et sur les deux tiers de sal longneur depuis la racine, et du brun noiràtre ou du noir au-des. 
sous de la pointe sur l? longueur d'environ deux lignes; mais cette coulenr était peı apparente sur le corps de l'animai, parce que la conleur blanchâtre dominait.

Le second lıérisson, eitant en pelote, avait six ponces trois lignes de longueur, quatre ponces dix lignes de largeur, et quatre pouces d'épaisseur; il pesait une livre une once cinq gros et demi. Les piquants avaient la mème longueur, la même grosseur, la même fịgure et les mêmes coulenrs que ceux de l'autre hérisson; mais la couleur brune noirâtre ou noire ếtait plus foncée et plus étendue, de sorte qu'elle dominait sur la couleur blanclsàtre. Cet animal avait une odeur forte et désasréable, quoiqu'elle approchât un peu de celle du uusc, tandis que l'autre bérisson n'avait que l'odeur qui est inséparable de la malpropreté dans les animaux.

Ces deux hérissons avaient des piquants sur toute la face supérieure du corps, depuis le sommet de la tête jusqu'auprès de l'origine de la quene, et sur les côtés du corns : le museau, le front, les côtés de la tête, la gorge, le dessous et les côtés du cou, la poitrine, les aisselles, le ventre, les aines, les fesses et les (juatre jambes étaient converts de deux sortes de poils; les uns avaient la mème consistance que les soies des coclions, quoiqu'ils fussent beaucoup plus petits; ils ètaient d'une couleur blanchâtre, mêlè d'une teinte de jaune ou de roux; les plus longs avaient seize lignes. Il se trouvait entre ces soies un poil plus abondant, frisé et gris, brun on châtain : il n'y avait sur les pieds et sur la queue qu'un poil court, lisse et peu fourni, qui semblait etre de même nature que les soies.

Ces deux animanx se ressemblaient parfaitement nar la figure dumuseau ; il ètait mince, et terminé yar un cartilage noir et arrondi : le nez était plus gros que la partie du museau qui y aboutissait; il n'avait en aucune $f$. çon la forme du groin des coclons, et il différait beancoup du nez des chiens, surtout en ce que le nez des hérissons eitait plus gros que la partie dı museau qui y touchait, que les ouvertures des narines étaient plus éloignẻes l'une de l'antre, et que les bords extérieurs de chaque narine étaient repliés en arrière et crénelés; d'ailleurs la lèvre supérieure ne s’étendait pas jusqu'au-dessous du nez, comme dans le chien. Il s'en fallait plus d'un demi-pouce que la lèvre inférieure ne fût aussi longue que le nez, ce qui rendait la màchoire du dessous et la face inférieure du museau en quelque façoı ressemblantes à la mâchoire du dessons et à la face inférieure du groin du cochon, et la grosseur du nez était encore une ressemblance entre ces hérissons et les cochons. Mais la différence essentielle consistait en ce que le nez du lıérisson ne s'èlevait pas, comme le groin du cochon : au-dessus de la partie du uruseau à la- quelle il touchait, qu’il n'était pas aplati par devant, et que les ouvertures des narines n'étaient pas dirigées en avant comme celles des coclıons. Cependant il paraissait qu'en génèral ces hérissons ressemblaient plus au cochon qu'au chien par la figure du museau, et plus au chien qu'au cochon par celle dı nez, considéré séparément.

J'ai observé plusieurs autres hérissons en Bour. gogne, et d'autres pris dans les parcs de Versailles et dans la foret de Compiègne; je les ai tous tron. vés ressemblants à ceux dont je viens de faire la description; et s'ils différaient par la grandeur ou par quelques teintes de couleurs, ces différences ne m'ont paru ètre que des variétés telles qu'il doit s'en trouver entre des individus de mème espèce en différents àges.

Cependant M. Perrault rapporte dans sa description du hérisson ', qu'il en a disséqué de deux espèces différentes; il s'exprime en ces termes :

"Les naturalistes font les liérissons de deux es"pèces, dont la différence est prise de la figure "du museau, qui estlong, pointu et semblable au "groin d'un pourceau dans les uns, et plus court, " plus mousse et semblable au museau d'un chien " dans les antres, dont l'espèce est appelée canine: "l'autre espèce est la plus comumne.

"Des quatre hérissons que nous avons disséqués, "il y en avait deux de cliacune de ces espèces; " mais nous les avons trouvés différenciés en antre " chose que dans la forme du museau; car ils ètaient " encore différents par la couleur de tout leur corps, " par la grosseur el par la figure de leurs piquants, " mais principalement par la grandeur de tout " l'animal, qui est la seule différence que Oppien " net entre les deux espèces de hérisson dont il " parle.

"La figure que nous avons tlonnee est celle du " hérisson à museau de chien, parce que c'est le " plus rare. "

Il faut en effet que ce hérisson à museau de chien, s'il existe, soit bien rare, car nous n'avons pas pu le trouver en dix ans, quelques reclierches que nous ayons faites.

M. Ray ${ }^{2}$ dit qu'il n'y a point en Angleterre de hérisson à groin de cochon, et qu'il dloute que l'on ell trouve ailleurs : c'est donc, selon cet anteur, le hérisson ì groin de cochon qui est, s'il existe, le plus rare; au contraire, M. Perrault croit que c'est le plus commun. Cette contrariété est une nonvelle induction contre l'existence d'une stconde espèce de lıérisson, et je soupưnıe qu'elle a été admise, parce que le museau du liérisson a quelques rapports au groin du cochon el au musean du

1 Mémoire pour servir à l'Hist. nat. des animaux, secondo partie, pag. 46.

2 Symopsis animal. (juadrup. . jag. 231. 
chien, comme je l'ai dejà fait remarquer : on a attribué ces caractères à dlifférents individus, tandis qu'ils sont rẻunis clans le mème.

\section{LA MUSARAIGNE.}

Ordre des carnassiers, famille des insectivores, genre musaraigne. (Cuvier.)

La musaraigne semble faire une nuance dans l'ordre des petits animaux, et remplir l'intervalle qui se trouve entre le rat et la taupe, qui, se ressemblant par leur petitesse, different beaucoup par la forme, et sont en tout d'espèces très-éloignées. La musaraigne, plus petite encor'e que la souris, ressemble à la taupe par le museau, ayant le nez beaucoup plus allongé que les mâchoires; par les yeux qui, quoiqu'm peu plus gros que ceux de la taupe, sont cachés de mème, et sont beaucoup plus petits que ceux de Ia souris; par le nombre des doigts, dont elle a cing à tous les pieds, par la queue, par les jambes, surtout celles de derrièı'e qu'elle a plus courtes que la souris; par les oreilles, et enfin par les dents. Ce très-petit animal a une odeur lorte qui lui est particulière, et qui répugne aux chats ; ils chassent, ils tuent la musaraigne, mais ils ne la mangent pas comme la souris. C'est aparemment cette mauvaise odeur ct cette répugnance des ehats qui a fondé le préjugé du venin de cet animal et de sa morsure dangereuse pour le bétail, et surtout pour leschevaux : cependant il n'est ni venimeux, ni mème capable de mordre; ear il n'a pas l'ouverture de la gueule assez grande pour pouvoir saisir la double épaisseur de la peau d'un autre animal, ce qui cependant est absolument nécessaire pour mordre; et la maladie des chevaux, que le vulgaire attribue à la dent de la musaraigne, est une enflure, une espèce d'anthrax, qui vient d'une cause interne, et qui n'a nul rapport avec la morsure, ou, si l'on veut, la piçûre de ce petit animal. Il habite assez communément, surtout pendant l'hiver, dans les greniers à foin, dans les éeuries, dans les granges, dans les cour's à fumier; il mange du grain, des insectes et des chairs pourries : on le trouve aussi fréquemment à la eampagne, dans les bois, où il vit de graines; et il se cache sous la mousse, sous les feuilles, sous les trones d'albres, et quelquelois dans les trous abandonnés par les taupes, ou dans d'autres trous plus petits qu'il se pratique lui-même, en fouillant avee les ongles et le museau. La musaraigne produit en grand nombre, autant, dit-on, que la souris, quoique moins fréquemment. Elle a le cri beaucoup plus aiguque la souris; mais elle n'est pas aussi agile à beaucoup près. On la prend aisément, parce qu'elle voit et cour't mal. La couleur ordinaire de la musaraigne est d'un brun mêlé de roux; mais il y en a aussi de celldrées, de presque noires, et toutes sont plus ou moins blanchâtres sous le ventre. Elles sont très-communes dans toute l'Europe; mais il ne paraît pas qu'on les retrouve en Amérique. L'animal du Brésil dont Marcgrave ${ }^{1}$ parle sous le nom de musaraigne, qui a, dit-il, le musean très-pointu et trois bandes noires sur le dos, est plus gros, et parait êtr'e d'une autre espèce que notre musarajgne.

\section{DESCRIPTION DE LA MUSARAIGNE.}

(EXTRAIT DR DAUBENTON.)

La musaraigne est à peu près de la grosseur d'une souris, mais elle en diffère beaucoup par la forme du corps, et surtout par celle de la tête, qui est fort allongèe. Le bout du museau a quelque rapport au groin d'un coelion; il n'e-t formé que par le nez, et par la lèvre supérieure, qui se prolonge beaucoup plus en avant que la lèvre inférieure; les ouvertures des narines sont placées de chaque cóté du bout du museau, au milieu de deux petits tubercules; les yeux sont si petits fu'on ne les roit qu'en regardant l'animal de près; les oreilles sont rondes, nues et fort courtes. Il y a cinq doigts bien formes dans les pieds de devant et dans ceux de derrière.

Le poil de la musaraigne est plus fin, plus doux el plus court que celui de la souris, mais d'une couleur un peu plus brume sur la tète et sur le dessus du corps, et d'un gris plus foncé sur le dessous. Tous les poils sont de conleur cendrée sur la plıs grande partie de leur longueur, et leur pointe est de couleur brune, mêlèe d'une très-légère teinte de fáuve sur le dessus et les côtés de la tête et du corps, et de couleur grise et jaunâtre sur le dessous depuis le bout de la mâchoire infẻrieure jusqu'à l'extrémité de la queue, qui n'est guère plus longue que celle du campagnol, et aussi pen garnie de poil.

4 Vid. Marcgravii Ilist. Brasil. pag. 229. 


\section{LA MUSARAIGNE D'EAU.}

Ordre des carnassiers, famille des insectivores, genre musaraigne. (Curier.)

Comme cet animal, quoique naturel à ce climat, n'était connu d'aucun naturaliste, et que c'est M. Daubenton qui le premier en a fait la découverte, nous renvoyons entièrement ce que l'on en peut dire à la description très-exacte qu'il en a donnée. J'aurai souvent occasion d'en user de même dans la suite dé cet ouvrage, attendu la diligence infinie avec laquelle il recherche les animaux, et les découvertes qu'il a faites de plusieurs espèces auparavant incomnues, ou confondues avec celles que l'on connaissait. Tout ce que je puis assurer au sujet de la musaraigne d'eau, c'est qu'on la prend à la source des fontaines, au lever et au coucher du soleil; que dans le jour elle reste cachée dans des fentes de rochers ou dans des trous sous terie, le long des petits l'uisseaux; qu'elle met bas au printemps, et qu'ordiuairement elle produit neuf petits.

\section{LA MUSARAIGNE MUSQUEE}

\section{DE L'INDE.}

Ordre des carnassiers, famille des insectirores, genre musaraigne. (Cuvier.)

Cette musaraigue, apportée de Pondichéry par M. Sonnerat, est beaucoup plus grande que la musaraigne de notre pays, qui n'a que deux ponces onze lignes; au lieu que celle-ci a ciur pouces deux lignes, le corps étendu.

Elle a la tête longue et pointue; le nez est effilé, et la mâchoire supérieure avance sur l'inférieure; les narines sont petites, et le bout du nez est séparé comme par deux petits tubercules; les yeux sont si petits qu'on a peine à les apercevoir.

Les oreilles sout courtes, rondes, nues et sans poil.

Les poils des moustaches et ceux du dessus des yeux sont grisâtres, et les plus grands ont sept lignes de longueur.

Les jambes scnt petites et courtes; il y a einc doigts à tous les pieds.
La queue a un pouce huit lignes de lougueur; elle est couverte de petits poils courts, et par. semée de grands poils fins et grisâtres.

La couleur du poil de cet animal est d'uu gris de souris on d'ardoise claire, teint de roussâtre qui domine sur le rez, le dos et la queue.

Cette musarajgne qui, à beaucoup d'égards , ressemble à la musaraigne d'Europe, a une odeur de musc si forte qu'elle se fait sentir dans tous les endroits où elle passe. Elle habite dans les champs, mais elle vieut aussi dans les maisons.

\section{LA TAUPE ROUGE D AMÉRIQUE.}

Ordre des carnassiers, famille des insectirores, genre taupe. (Cuvier.)

La première espèce est la taupe d'Amérique, qui a le poil roux mêlé de cendré clair, et qui n’a pas les pieds conformés comme ceux de la taupe d'Europe, n'ayant que trois doigts aux pieds de devant, et quatre à ceux de derrière, qui sont à peu près égaux, tandis que ceux des pieds de devant sont très-inégaux : le doigt extérieur est beancoup plus long que les deux autres, et armé d'un ongle plus fort et plus crochu; le second doigt est plus petit, et le troisième l'est encore beaucoup plus. J'ai dit à ce sujet que cette prétendue taupe était un autre animal que notre taupe d'Europe, et je crois devoir persister dans cette opinion, jusqu'à ce qu'elle ait été mieux observée et décrite plus en détail.

\section{LA 'TAUPE DE PENSYLVANIE'.}

ordre des caruassiers, famille des insectivores, genre taupe. (Curier.)

“ Il y a, dit M. Kalm, en Pensylvanie, une " espèce de taupe qui se nourrit principalement " de racines. Cet animal se creuse dans les " champs de petites allées souterraines, qui se " prolongent en formant des détour's et des si" nuosités... 11 a dans les pattes plus de force et " de raideur que beaucoup d'autres animaux, à " proportion de leur grandeur... Pour creuser

' On pense que c'est la mème espèce que la taupe ronge d'Anérique. 


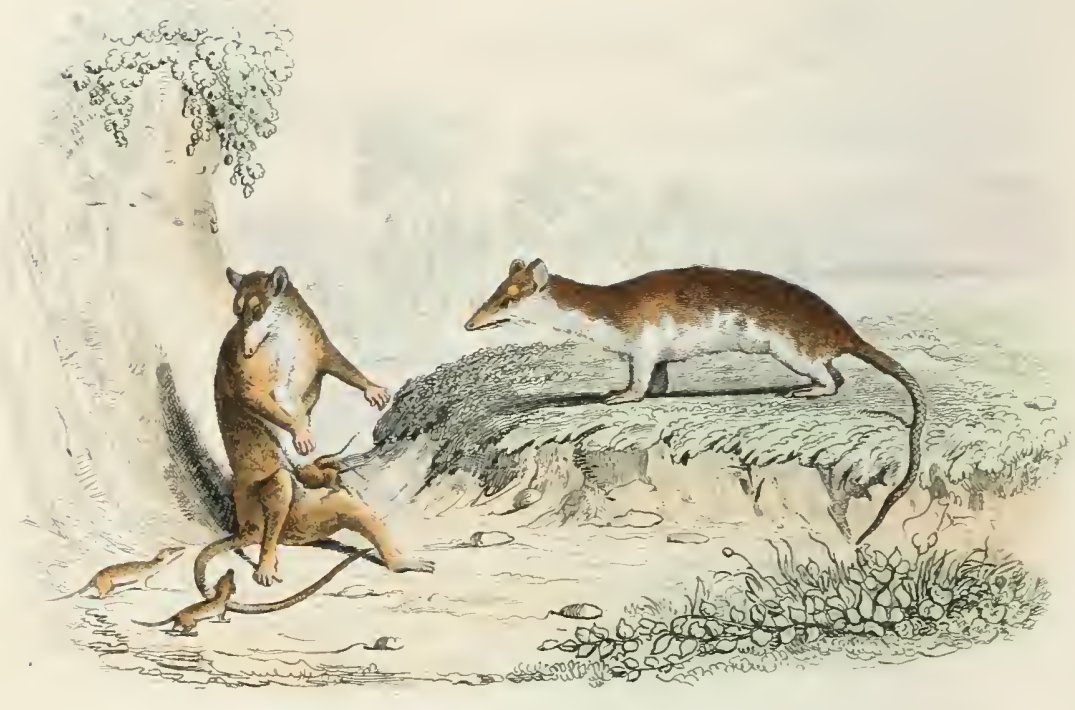

(Femelle) SIRIGIES (Male)

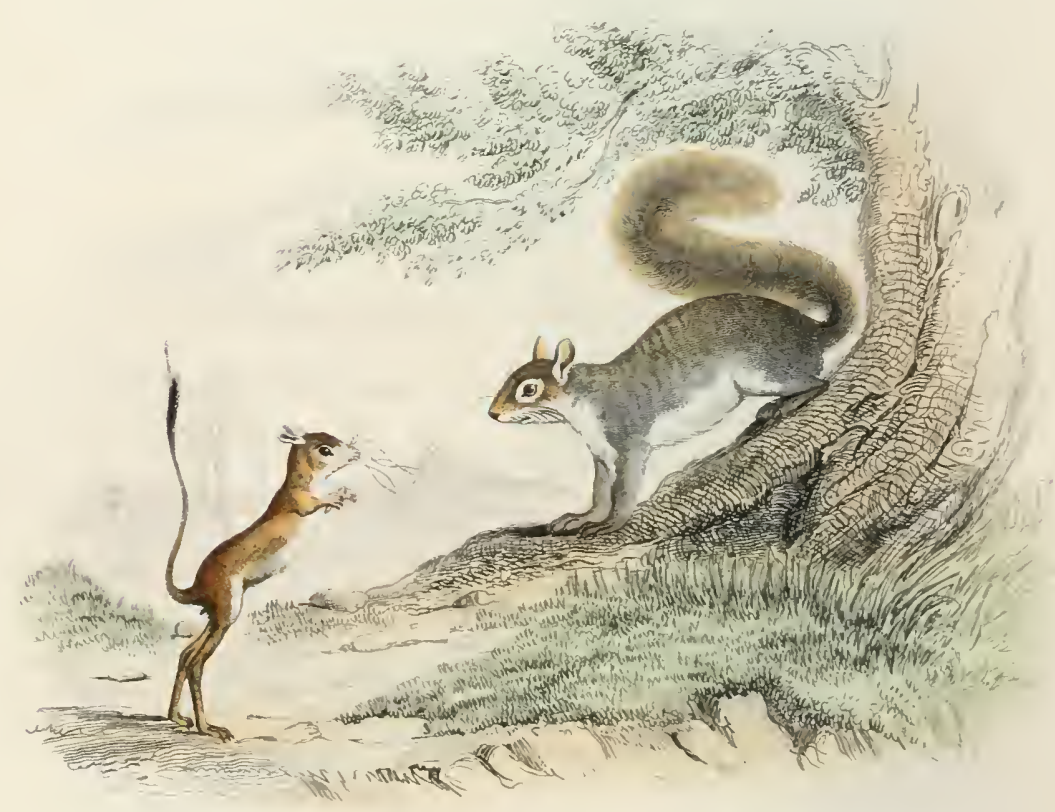

1. 1 (.I:R1301:1\%.

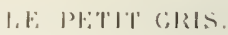


"I la terre il se sert de ses pieds comme des avi"rons... " M. Kalm en mit un dans son mouchoir; il s'aperȩut qu'en moins d'une minute il y avait fait quantité de petits trous qui avaient l'air d'a roir été percés avec un poincon... Il était très-méchant; et, dès que l'on mettait ou qu'il trouvait quelque chose sur son passage, il y faisait tout de suite, en mordant, de grands trous. "Je lui présentai, dit M. Kalm, mon " écritoire, qui était d'acier" : ll commença d'a" bord à le mordre; mais il fut bientôt rebuté "par la dureté du métal, et ne voulut mordre " après aucune des choses qu'on lui présentait. "Cet animal n'élève pas la terre en dôme, " comme les taupes d'Europe, il se fait seule" ment de petites allées sous terre ${ }^{1}$."

Ces indications ne sont pas suffisantes pour donner comnaissance de cet animal, ni même pour décider s'il est vraiment du genre des taupes.

\section{LA TAUPE DORÉE.}

Ordre des carnassiers, famille des insectirores, genre taupe ${ }^{2}$. (Curier.)

Enfin, pour n'omettre aucun des animaux du Nord, et même des plus petits, il parait qu'il y a eu Sibérie une sorte de taupe, qu'on appelle taupe dorée, et dont l'espèce pourrait être différente de celle de la taupe ordinaire, parce que cette taupe de Sibérie n'a point de queue, et qu'elle a le museau court, le poil mêlé de roux et de vert, et qu'elle n'a que trois doigts aux pieds de devant et quatre aux pieds de derrière, au lieu que la taupe ordinaire a cing doigts à tous les pieds. Nous ignorons le nom de cet animal dont Séba a donné la figure ${ }^{3}$.

\section{LA TAUPE.}

Ordre des caruassiers, famille des insectirores, genre taupe. (Curier.)

La taupe, sans ètre a veugle, a les yeux si petits, si couverts, qu'elle ne peut faire grand usage du sens de la vue: en dédommagement la nature lui a donné avec magnificence l'usage du sixieme sens, un appareil remarquable de réservoirs et de raisseaux, une quantité prodi-

' voy. de Kalm, lome 1I, pag. 355 ; Gottingen, 1757.

scl animal habite le cap de Bonne-Espérance, et non la sibérie.

Seba , vol. I, pag. 51 , table 32 ; mas. fig. 4 ; furmiua, fig. 5. If y a une erreur dans Séba pour l'habitation. gieuse de liqueur séminale, des testicules énormes, le membregénital excessivement long; tout cela secrètement caché à l'intérieur, et par conséquent plus actif et plus chaud. La taupe, à cet égard, est de tous les animaux le plus avantageusement doué, le mieux pourvu d'organes, et par conséquent de sensations qui y sont relatives : elle a de plus le toucher délicat, son poil est doux comme de la soie; elle a l'ouie trèsfine, et de petites mains à cinc doigts, bien différentes de l'extrémité des pieds des autres animaux, et presque semblables aux mains de l'homme; beaucoup de force pour le volume de son corps, le cuir ferme, un embonpoint constant, un attachement vif et réciproque du mảlc et de la femelle, de la crainte ou du dégoût pour toute autre societé, les douces habitules du repos et de la solitude, l'art de se mettre en sûrèté, de se faire en un instant un asile, un domicile, la facilité de l'étendre et l'y trouver', sans en sortir, un abondante sulssistance. Voilà s? nature, ses mœurs et ses talents, sans doute prérérables à des qualités plus brillantes et plus incompatibles avec le bonheur, que l'obseurité la plus profonde.

Elle ferme l'entrée de sa retraite, n'en sort presque jamais qu'elle n'y soit forcée par l'abondance des pluies d'été, lor'sque l'cau la remplit ou lorsque le pied du jardinier en affaisse le dôme. Elle se pratique une route en rond dans les prairies, et assez ordinairement un bovau long dans les jardins, parce qu'il y a plus de facilité à diviser et à soulever une terre meuble et cultivée qu'un gazon ferme et tissu de racines: elle ne demeure ni dans la fange ni dans les terrains durs, trop compactes ou trop pierreux; il lui faut une terre douce, fournie de racines esculentes, et surtout bien peuplée d'insectes et de vers, dont elle fait sa principale nourriture.

Comme les taupes ne sortent que rarement de leur domicile souterrain, elles ont peu d'cunemis, et échappent aisément aux animaux carnassiers : Icur plus grand fléau est le dóbordement des rivières; on les voit, dans les inondations, fuir en nombre à la nage, ct faire tous leurs efforts pour gagner les terres plus éler ées : mais la plupart périssent aussi bien que leurs petits qui restent dans les trous; sans cela, les grands talents (ju'elles ont pour la multiplication yous deviendraient trop incommodes. Elles s'acconplent vers la fin de l'hiver; elles ne portent pas 
HISTOIRE NATURELLE

longtemps, car on trouve déjà beancoup de petits au mois de mai : il y en a ordinairement quatre ou cinq dans chaque portée ; et il est aisé de distinguer, parmi les mottes qu'elles élèvent, celles sous lesquelles elles mettent bas : ces mottes sont faites avec beaucoup d'art, et sont ordinairement plus grosses et plus élevées que les autres. Je crois que ces animaux produisent plus d'une fois par an, mais je ne puis l'assurer; ce qu'il y a de certain, c'est qu'on trouve des petits depuis le mois d'avril jusqu'au mois d'aont: peut-ètre aussi que les unes s'accouplent plus tard que les autres.

Le domicile où elles font leurs petits mériterait une description particulière. Il est fait avec une intelligence singulière : elles commencent par pousser, par élever la terre et former une voute assez élevée; elles laissent des cloisons, des espèces de piliers de distance en distance; Elles pressent et battent la terre, la mêlent avec des racinès et des herbes, et la rendent si dure et si solide par-dessous, que l'eau ne pent pénétrer la vonite à cause de sa convexité et de sa solidité ; elles élèvent ensuite un tertre par-dessus, au sommet duquel elles apportent de l'herbe et des feuilles pour faire un lit à leurs petits : dans cette situation ils se trourent au-dessus du niveau du terrain, et par conséquent à l'abri des inondations ordinaires, et en mème temps à couvert de la pluie par la voûte qui recouvre le tertre sur lequel ils reposent. Ce tertre est percé tout autour de plusieurs trous en pente, qui descendent plus bas, et s'étendent de tous côtés, comme autant de routes sonterraines par oì la mère táupe peut sortir et aller chercher la subsistance nécessaire à ses petits; ces sentiers souterrains sout fermes et battus, s'étendent à douze ou quinze pas, et partent tous du domicile comme des rayons d'un centre. On y trouve, aussi bien que sous la vonte, des débris d'oignons de colchique, qui sont apparemment la première nourriture qu'elle donne à ses petits.

On voit bien par cette disposition qu'elle ne sort jamais qu’à une distance considérable de son domicile, et que la manière la plus simple et la plus sûre de la prendre avec ses petits est de faire autour une tranchée qui l'environne en entier et qui coupe toutes les communications ; mais comme la taupe fuit au moindre bruit et qu'elle tâche d'emmener ses petits, il faut trois ou quatre hommes qui, travaillant euscmble avec la bêche, enlèvent la motte tout entière, ou fassent une tranchée presque dans un moment, et qui ensuite les saisissent ou les attendent aux issues.

Quelques auteurs ${ }^{4}$ ont dit mal à propos que la taupe et le blaireau dormaient sans mauger pendant l'hiver entier. Le blair ean, comme nous l'avons dit ${ }^{2}$, sort de son trou en hiver comme en été pour chercher sa subsistance, et il est aisé de s'en assurer par les traces qu'il laisse sur la neige. La taupe dort si peu pendant tout l'hiver, qu'elle pousse la terre comme en été, et que les gens de la campagne disent, comme par proverbe: Les taupes poussent, le dégel n'est pas loin. Elles cherchent à la vérité les endroits les plus chands : les jardiniers en prennent souvent autour de leurs conches aux mois de décembre, de janvier et de février.

La taupe ne se trouve guère que dans les pays cultivés; il n'y en a point dans les déserts arides ni dans les climats froids, où la terre est gelée pendant la plus grande partie de l'année. L'animal qu'on a appelé taupe de Sibérie ${ }^{3}$, qui a le poil vert et or, est d'une espèce différeute de nos taupes, qui ne sont en abondance que depuis la Suède ${ }^{4}$ jusqu'en Barbarie ${ }^{5}$, car le silence des voyageurs nous fait présumer qu'elles ne se trouvent point dans les climats plus chauds. Celles d'Amérique sont aussi différentes: la taupe de Virginie est cependant assez semblable à la nôtre, à l'exception de la couleur du poil, qui est mèlé de pourpre foncé; mais la taupe rouge d'Amérique est un autre animal. Il y a seulement deux on trois variétés dans l'espèce commune de nos taupes; on en trouve de plus ou moins brunes, et de plus ou moins noires : nous en avons vu de toutes blanches, et Séba fait mention ${ }^{6}$ et domne la figure d'une taupe tachée de noir et de blanc, qui se trouve en

1 Lirsus, meles, erinaceus, Ialpa, vespertilio per hiemen dormiunt abstemii. Linnxi Fauna suecica, Stockolmix, 1746, pag 8.

3 voyez l'articlc du blaireau.

6 Vid. Albert. Seba, Amstelxdami, 1754, vol. I, pag. 5.

4 Vid Linnæi Fann. suecic.; Stockolm , 17/6, pag. 7.

5 Voyez les Voyages du docteur Shaw; Amsterdam, 175. lome I, pag. 322 .

${ }^{6}$ Celle taupe a été trouvée en Ost-Frisc, dans le grand clicmin. Elle est un peu plus longue que les taupes ordinaires, dont au resle elle ne diffire que par la pean, qui est toule marbre sur le dos et sous lc ventre de taches blanches el noires, uans lesquelles pourtant on distingue comme un melange de poils gris aussi fins que de la soie. Le museau de cet animal est long et hérissé d'uu long poil; les yeux sont si pelils quel'on a de la peine à découvrir l'ouverlure des paupic̀rcs. Albert Scba, vol. 1, pag. 68 . 
Ost-Frise, et qui est un peu plus grosse que la taupe ordinaire.

\section{ADDITION A L'ARTICLE DE LA TAUPE}

Pontoppidan assure que la taupe ne se trouve en Norwége que dans la partie orientile du pays, et que le reste de ce royaume est tellement rempli de rochers qu'elle ne peut s'y établir 1.

Depuis la publication du volume de mon ouvrage, ou j’ai donné la description de la taupe, il a paru un très-bon Mémoire de M. de la Faille sur l'histoire naturelle de cet animal, imprimé en 1769 , dont je crois devoir donner ici l'extrait, parce que ce Mémoire contient plusieurs observations nouvelles et quelques faits qui ne m'étaient pas connus.

Selon M. de la Faille, on peut distinguer en Europe einq taupes différentes :

10 Celle de nos jardins, dont le poil est fin et d'un très-beau noir ;

$2^{\circ}$ La taupe blanche, qui ne diffère de la taupe noire commune que par la couleur. Elle est plus commune en Hollande qu'en France, et se trouve encore plus fréquemment dans les contrées septentrionales;

$3^{\circ}$ La taupe fauve, qui, selon lui ne se trouve guère que dans le pays d'Aunis, et qui a le poil d'un roux clair, tirant sur le ventre-de-biche, sans aucune tache, ni mélange. 11 parait que c'est une nuance dans l'espéce de la taupe blanehe, seulement elle est un peu plus grosse; mais M. de la Faille n'en a vu qu'un seul individu, qui avait été pris près de la Rochelle, dans le mème terrain que la taupe blanche;

$4^{\circ}$ La taupe jaune vérdàtre ou coulcur de citron, rui se trouve dans le territoire d'Alais en Languedoe. Elle est d'une belle conleur de citron, et l'on prétend que cette couleur n'est due qu'ì la qualité de la terre qu'elle habite. C'est entre le bourg d'Aulas et les hameanx qu'on appelle les Carrières, dans le diocèse d'Alais, que se trouve cette taupe citron;

5o La taupe tachetée ou variće quion trouve daus plusieurs contrées de l'burope. Celles de l'Ost-Frise ont tout le corps parsemé de taches blanches et noires; cn Suisse, en Angleterre et

'Ilist, nat de la Norwége, par l'oulojulutan. Jumnal a' ranger ; juin 1756. dans le pays d'Aunis, elles ont le poil noir varié de fauve.

Indépendamment de ees cinq races de taupes qui se trouvent en Furope, les voyageurs parlent d'une taupe de l'ile de Java, dont les quatre pieds sont blanes, ainsi que la moitié des jambes; en Amérique, eelles de Virginie ont le poil noirâtre et luisant, mélé d’un pourpre foncé. Toutes ces tálupes ne paraissent être que de simples variétés de l'espèce de la taupe commune, parce qu'elles n'en diffèrent que par les couleurs; mais il y en a d'autres qui semblent constituer des espèces différentes, parce qu'elles different de la taupe commune, non-seulement par les couleurs, mais par la forme du corps et des membres.

\section{DESCRIPTION DE LA TAUPE.}

(EXTHAJT DE DALBENTON.)

La taupe a heaucoup de rapport avec les musaraignes, et surtont avec la musaraigne d'eau, par le museau el par le poil; mais elle en diffëre à d'autres égards, principalement ar les jambes et par la quene. Le corps de la taupe parait très-informe, il est oblong et presque cylindrique; il pose sur la terre, et on n'y distingue en devant qu'un museau pointu, en arrière une queuc fort courte, et de chaque côté les pièls, qui semblent tenir im. médiatement au corpc, et même les pieds de devant paraissent placés à côtẻ et un peu au-dessous de la tête. L'extrémité dı museau s’étend de trois lignes et demie au delà rle l'extrémité de la mâchoire du dessous el des dents incisives de la mâchoire dı dessus; il est terminé, comme celui du coclıon, par une sorte de boutoir ou se trouvent les ouverlures des narines.

La lèvre du dessus s'étend depuis le boutoir jus. quaux dents incisives; elle est double, car il y a un feullet membraneux qui se tétache de celte lèvre à l'endroit des premières dents mâch lières, ct qui tourne antour des canines et des incisives. Ce feuil. let a peu de saillie devant les dents incisives du militu; mais devant les autrts incisives et les canines, il ıle-cend jusıjıe sur la lèvre dı dessous. La lèvre supérieure faisaut partie lu bout du museau, la houche doit s'ouvrir lorsque l'animal remue le boutoir en fouillant dans la terre; alors il en entrerait dans la bouche si le feuillet membraneux pui est sur les dents nen empechait, car il y a un espace vide entre les premières dents maichelières et les rents canines à l'endroit oì le feuillet descend le plus lias. 
Les yeux de la taupe sont extrêmement petits, on ne les voit qu'en observant l'animal de très-près, lorsque la direction des poils n'a point été dérangée. Alors les poils forment un vide qui se trouve à sept lignes au delà des coins de la bouche, un peu au-dessus en ligne oblique : on aperçoit dans cet endroit, entre les poils sur la peau, un point noir et luisant qui est l'oil, et qui marque le centre d'un espace dégarni de poil, qui a envi on deux lisnes de diamètre.

Les oreilles nont point de conques; elles ne sont marquées au dehors que par l'orifice du conduit auditif externe, dont le bord est un peu saillant au-dessus ile la peau dans la portion inférieure du cercle qu'il forme. L'orifice de l'oreille est placé à une distance de l'œil à peu près égale à celle đui se trouve entre l'cil et le boutoir; pour voir cet orifice, il faut écarter le poil qui l'entoure et qui le courre entièrement.

Le pied de devant est beaucoup plus gros que le pied de derrière, et il a plus de rapport, par sa forme, à une main qu'à un pied; il est situé le façon que la paume est tournée en arrière, et que les doigts sont dirigés obliquement en dehors et en bas. Le poignet est caché dans le poil, et il a peu de grosseur ; le métacarpe est fort large, il paraît sec et nerveux; les doigts sont fort courts, mais les ongles ont autant de longueur que les doigts. Le pied de derrière ressemble à celui du rat.

La queue est écaillense comme celle des rats, mais garnie d'un poil plus long; l'anus est saillant, et fort éloigné de l'origine de la quene.

Le poil de la taupe est doux, luisant et d'une conleur cendrée, qui prend différentes teintes lorsqu'on le voit sous différents aspects. En regardant par devant, depuis la tête jusqu'à la queue, les poils, étant couchés en arrière, paraissent de couleur cendrée claire, et luisante; au contraire, en regardant par derrière, depuis la queue jusıu'à la tête, les poils paraissent noirs sans luisant, mais ils ne sont que noirâtres sur la poitrine et sur le ventre, et il y a une teinte le fauve sur la mâchoire inférieure et sur le milieu du ventre.

\section{LA TAUPE DE CANADA.}

Oedie des carnassiers, famille des insectivores, genre taupe. (Curier ${ }^{4}$.)

Une autre espèce de taupe est celle que M. de Faille a fait graver à la suite de son Mémoire.

- Nous nous sommes assurés, dit M. Cuvier, par l'inspection de ses dents, que c'est une vraie taupe ct non pas un orex. C'est le coudylure d'lliger; mais les caraclères pris de la figure de la Faille et de Buffon en sont faux.
M. de la Faille dit qu'elle se trouve au Canada, et qu'elle n'a été indiquée par aucun auteur. Voici la courte description qu'il en donne.

"Ce quadrupède u’a de la taupe vulgaire que " quelques parties; dans d'autres, il porte un " caractère qui le rapproche beaucoup plus de " la classe des rats; il en a la forme et la légè" reté : sa queue, longue de trois pouces, est " noueuse et presque nue, ainsi que ses pieds, a qui ont chacun cinq doigts; ils sont défendus " par de petites écailles brunes et blanches, qui " n'en courrent que la partie supérieure. Cet " animal est plus élevé de terre et moins ram. " paut que la taupe d'Europe; il a le corps ef" filé et couvert d'un poil noir, grossier, moins " soyeux et plus long; il a aussi les mains moins " fortes et plus délicates... Les yeux sont ca" chés sous le poil. Le museau est relevé d'une " moustache qui lui est particulière, et ce mu" seau n'est pas pointu, ni terminé par un car" tilage propre à fouiller la terre; mais il est " bordé de muscles charnus et très-déliés, qui " ont l'air d'autant d'épines : toutes ces pointes " sont nuancées d'une belle couleur de rose, et " jouent à la volonté de l'auimal, de façon " cu'elles se rapprochent et se réumissent au " point de ne former qu'un corps aigu et très" délicat, et quelquefois aussi ces muscles épi" neux s'ouvrent et s'épanouissent à la manière " du calice des fleurs; ils enveloppent et renfer" ment le conduit nasal, auquel ils servent d'a" bri. Il serait difficile de décider à quels au" tres usages qu’à fouiller la terre cet animal " fait servir une partie aussi extraordinaire... "Cette taupe se trouve au Canada, où cepen" dant elle n'est pas fort commune. Comme clle " est forcée de passer la plus grande partie de " sa vie sous la neige, elle s'accoutume proba" blement à vivre en retraite, et sort fort peu " de sa tanière, mème dans le beau temps. Elle " manœuve comme nos taupes, mais avec plus " de lenteur : aussi ses taupinières sont-elles peu " nombreuses et assez petites. "

M. de la Faille conserve dans son cabinet l'individu dont il a fait graver la figure, et on lui doit en effet la comnaissance de cet animal singulier. 


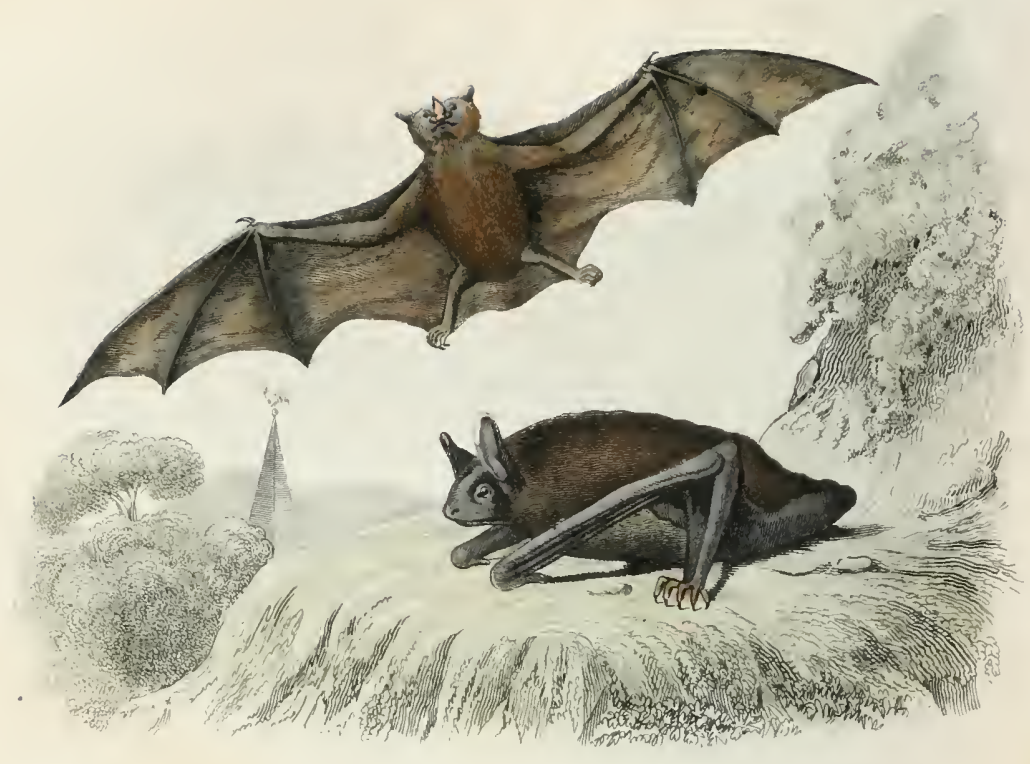

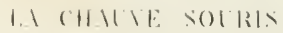

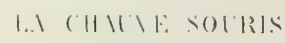

(the-dir-lante)

$\{1$ ommunte

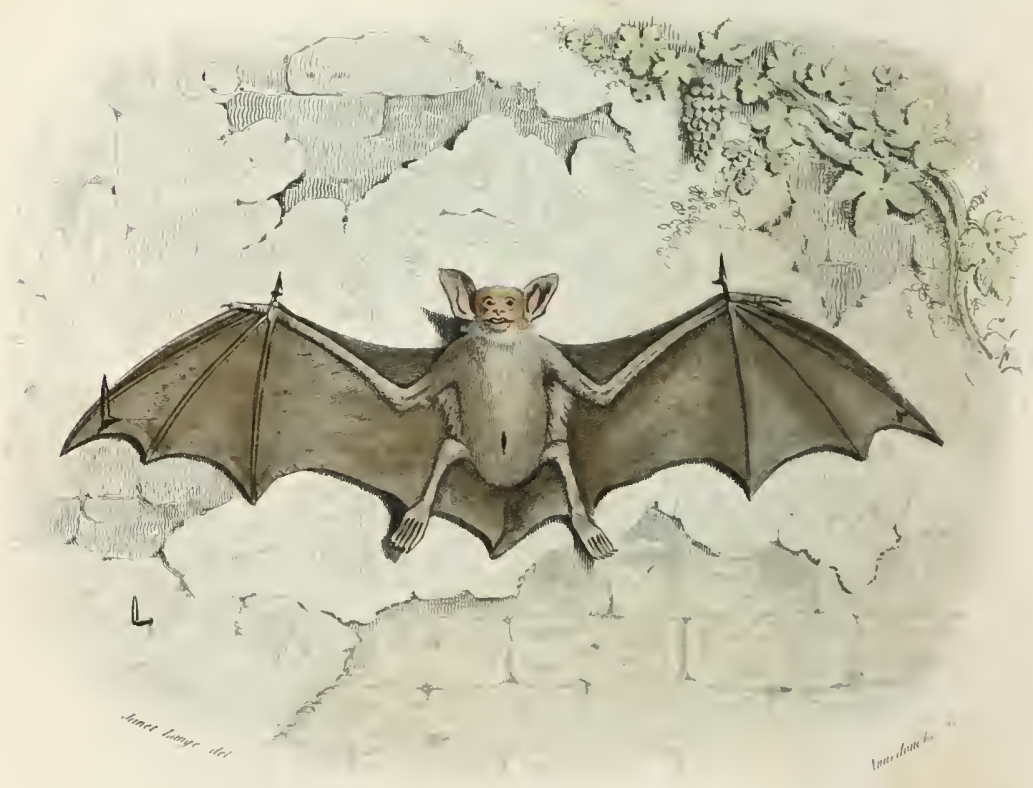

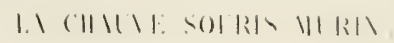




\section{LA CHAUVE-SOURIS}

Ordre des carnassiers, famille des cheiroptères, genre chauve-souris. (Cuvier.)

Quoique tout soit également parfait en soi, puisque tout est sorti des mains du Créateur, il est cependant, relativement à nous, des êtres accomplis, et d'autres qui semblent être imparfaits ou difformes. Les premiers sont ceux dont la figure nous parait agréable et eomplète, parce que toutes les parties sont bien ensemble, que le corps et les membres sont proportionnés, les mouvements assortis, toutes les fonctions faciles et naturelles. Les autres, qui nous paraissent hideux, sont ceux dont les qualités nous sont . $u$ isibles, ceux dont la nature s'éloigne de la nature commune, et dont la forme est trop différente des formes ordinaires desquelles nous avons reçu les premières sensations, et tiré les idées qui nous servent de modèles pour juger. Une tête humaine sur un cou de cheval, le corps couvert de plumes, et terminé par une queue de poisson, n'offrent un tableau d'une énorme difformité que parce qu'on y réunit ce que la nature a le plus éloigné. Un animal qui, comme la chauve-souris, est à demi quadrupède, à demi volatile, et qui n'est en tout ni l'un ni l'autre, est, pour ainsi dire, un être monstre, en ce que réunissant les attributs de deux gemres si différents, il ne ressemble à aucun des modèles que nous offrent les grandes classes de la nature: il n'est qu'imparfaitement quadrupède, et il est encore plus imparfaitement oiseau. Un quadrupède doit avoir quatre pieds, un oiseau a des plumes et des ailes; dans la chauve-souris, les pieds de devant ne sont ni des pieds ni des ailes, quoiqu'elle s'en serve pour voler et qu'elle puisse aussi s'en servir pour'se trainer. Ce sont en effet des extrémités difformes, dont les os sontmonstrueusement allongés, et réunis par une membrane qui n'est couverte ni de plumes, ni même de poils, comme le reste du corps : ce sont des espèces d'ailerons, ou, si l'on veut, des pattes ailées, où l'on ne voit que l'ongle d'un pouce comrt, et dont les quatre autres doigts très-longs ne peuvent agir qu'ensemble, et n'ont point de mouvements propres, ni de fonctious séparées; ce sont des espèees de mains dix fois plus grandes que les pieds, et en tout quatre fois plus longues que le corps enticr de l'animal; ce sont, en un mot, des parties qui ont plutôt l'air d'un caprice que d'une produc. tlon régulière. Cette membrane couvre les bras; forme les ailes ou les mains de l'animal, se réunit à la peau de son corps, et enveloppe en même temps ses jambes, et même sa queue, qui, par cette jonction bizarre, devient, pour ainsi dire, l'un de ses doigts. Ajoutez à ces disparates et à ces disproportions du corps et des membres, les difformités de la tête, qui souvent sont encore plus grandes : car, dans quelques espèces, le nez est à peine visible, les yeux sont eufoncés tout près de la conque de l'oreille, et se confondent avee les joues; dans d'autres, les oreilles sont aussi longues que le corps, ou bien la face est tortillée en forme de fer à cheval, et le nez recouvert par une espèce de crête: la plupart ont la tête surmontée par quatre oreillons; toutes ont les yeux petits, obscurs et couverts, le nez ou plutôt les naseaux informes, la gueule fendue de l'une à l'autre oreille; toutes aussi cherchent à se cacher, fuient la lumière, n'habitent que les lieux ténébreux, n'en sortent que la nuit, y rentrent au point du jour pour demeurer collées contre les murs. Leur mouvement dans l'air est moins un vol qu'une espèce de voltigement incertain, qu'elles semblent n'exécuter que par effort et d'une manière gauche: elles s'élèvent de terre avec peine; elles ne volent jamais à une grande hauteur; elles ne peuvent qu'imparfaitement précipiter', ralentir, ou même diriger leur vol: il n'est ni très-rapide ni bien direct; il se fait par des vibrations brusques dans une direction oblique et tortueuse : elles ne laissent pas de saisir en passant les moucherons, les cousins, et surtout les papillons phalènes qui ne volent que la nuit; elles les avalent, pour ainsi dire, tout entiers, et l'on voit dans leurs excréments les débris des ailes et des autres parties sèches qui ne peuvent se digérer. Etant un jour descendu daus les grottes d'Arcy pour en examiner les stalactites, je fus surpris de trouver sur un terrain tout couvert d'albatre, et dans un lieu si ténébreux etsi profond, une espèce deterre qui était d'une tout autre nature; c'était un tas épais et large de plusienrs pieds d'une matière noirâtre, presque entièrement composée de portions d'ailes et de pattes de mouches et de papillons, commo si ces insectes se fussent rassemblés en nombre immense et réunis dans ce lieu pour y périr et pourrir ensemble. Ce n'était cependant autre chose que de la fiente de chauve-souris, anon- 
celée probablement pendant plusieur's années dans l'endroit de ces voûtes souterraines, qu'elles habitaient de préférence; car, dans toute l'étendue de ces grottes, qui est de plus d'un demi-quart de lieue, je ne vis aucun autre amas d'une pareille matière, et je jugeai que les chauves-souris avaient fixé dans cet endroit leur demeure commune, parce qu'il y parvenait encore une très-faible lumière par l'ouverture de la grotte, et qu'elles n'allaient pas plus avant pour ne pas s'enfoncer dans une obscurité trop profonde.

Les chauves-souris sont de vrais quadrupèdes; elles n'ont rien de commun que le vol avec les oiseaux ; mais comme l'action de voler suppose une très-grande force dans la partie supérieure du corps et dans les membres antérieurs, elles ont les muscles pectoraux beaucoup plus forts et plus charnus qu'aucun des quadrupèdes, et l'on peut dire que par là elles ressemblent encore aux oiseaux; elles en different par tout le reste de la conformation tant extérieure qu'intérieure : les poumons, le cœur, les orgames de la génération, tous les autres viscères sont semblables àceux des quadrupèdes, àl'exception de la verge, qui est pendante et détachée, ce qui est particulierà l'homme, aux singes et aux chauves-souris; elles produisent, comme les quadrupèdes, leurs petits vivants; enfin elles ont, comme eux des dents etdes mamelles: l'on assure qu'elles ne portent que deux petits, qu'elles les allaitent et les transportent même en volant. C'est en été qu'elles s'accouplent et qu'elles mettent bas; car elles sont engourdies pendant l'hiver: les unes se recouvrent de leurs ailes comme d'un manteau, s'accrochent à la voûte de leur souterrain par les pieds de derrière, et demeurent ainsi suspendues; les autres se collent contre les murs ou se récèlent dans des trous; elles sont toujour's en nombre pour se défendre du froid : toutes passent l'hiver sans bouger, sans manger, ne se réveillent qu'au printemps, et se recèlent de nouveau vers la fin de lautomne. Elles supportent plus aisémentla dièteque le froid; elles peuvent passer plusieur's jour's sans manger, et cependant elles sont du nombre des animaux carnassiers; car lorsqu'elles peuvent entrer dans une office, elles s'attachent aux quarticrs de lard qui y sont suspendus, et elles mangent aussi de la viande crue ou cuite, fraiche ou corrompue.

Les naturalistes qui nous ont précédés ne connaisscnt que deux espèces de chaures-souris. M. Daubenton en a trouvé cinq autres, qui sont, aussi bien que les deux premières espèces, naturelles à notre climet; elles y sont même aussi communes, aussi abondantes, et il est assez étomnant qu'aucun observateur ne les eût remarquées. Ces sept espèces sont très-distinctes, très-différentes les unes des autres, et n'habitent même jamais ensemble dans le même lieu.

La première, qui était connue, est la chauvesouris communeou la chauve-souris proprement dite'.

La seconde est la chauve-souris à grandes oreilles, que nous nommerons l'oreillard", qui a été aussi reconnue par les naturalistes et indiquée par les nomenclateurs ${ }^{3}$. L'oreillard est peut-être plus commun que la chauve-souris; il est bien plus petit de corps; il a aussi les ailes beaucoup plus courtes, le museau moins gros et plus pointu, les oreilles d'une grandeur démesurée.

La troisième espèce, que nous appellerons la noctule ${ }^{4}$, du mot italien nottula, n'était pas connue : cependant elle est très-commune en France, et on la rencontre même plus fréquemment que les deux espèces précédentes. On la trouve sous les toits, sous les gouttières de plomb des châteaux, des églises, et aussi dans les vieux arbres creux : elle est presque aussi grosse que la chauve-sonris; elle a les oreilles courtes et larges, le poil roussâtre, la voix aigre, perçante, et assez semblable au son d'un timbre de fer.

Nous nommerons sérotine ${ }^{5}$ la quatrième espèce, qui n'était nullement connue; clle est plus petite que la chauve-somris et que la noctule; elle est à peu près de la grandeur de l'oreillard: mais elle en diffère par les oreilles, qu'elle a courtes et pointues, et par la couleur du poil;

'Vespertilio murinus. Linn.

${ }^{2}$ Le vespertilion oreillard; vespertilio auritus. Linn. Genre piteropus. Geolf.

${ }^{5}$ vespertilio. Aldrovand, Avi, pag. 571 .

Vespertilio auriculis quateruis. Jonst. Avi, pag. 34.

Vespertilio vulgaris, auriculis duplicibus. Klein, de quadrup. pag. 61.

La petite chanve-sonris de notre pays. Vespertilio murini coloris, pedibus omnibus pentadactylis, auriculis duplicilus... Vespertilio minor. Brisson, Regn. animal, pag. 226.

4 Le vespertilion noctule: vespertilio noclula. Cuvier, Desm.

5 Le vespertilion sérotine; verpertilio serolinus. Cuvier, Destr. 
DESCRIPTION DES CHAUVES-SOURIS.

elie a les alles plus noires et le poil d'un brun plus foncé.

Nous appellerons la cinquième espèce, qui n'était pas connue, la pipistrelle', du mot italien pipistrello, qui signifie aussi chauve-souris. La pipistrelle n'est pas, à beaucoup près, aussi grosse que la chauve-souris on la noctule, ni même que la sérotine ou l'oreillard. De toutes les chauves-souris c'est la plus petite et la moins laide, quoiqu'elle ait la lèvre supérieure fort renflée, les yeux très-petits, très-enfoncés, et le front très-couvert de poil.

La sixième espèce qui u'était pas conıue sera nommée barbastelle ${ }^{2}$, du mot italien barbastel.o, qui signifie encore chauve-souris. Cet animal est à peu près de la grosseur de l'oreillard: il a des oreilles aussi larges, mais bien moins longues. Le nom de barbastelle lui convient d'autant mieux, 'qu'il parait avoir une grosse moustache, ce qui cependant n'est qu'une apparence occasionnéepar le renflement des joues, qui forment un bourrelet au-dessus des lèvres : il a le museau très-court, le nez fort aplati, et les yeux presque dans les oreilles.

Enfin nous nommerons fer-à-cheval ${ }^{3}$ une septième espèce, qui n'était nullement connue; elle est très-frappante par la singulière difformité de sa face, dont le trait le plus apparent et le plus marqué est un bourrelet en forme de fer à cheval autour du nez et sur la lèvre supérieure. On la trouve très-communément en France dans les murs et dans les caveaux des vieux châteaux abandonnés. II y en a de petites et de grosses, mais qui sont au reste si semblables par la forme, que nous les avons jugées de la même espèce; seulement, comme nous en avons beaucoup vu sans en trouver de grandeur moyenne entre les grosses et les petites, nous ne décidons pas si l'âge seul produit cette différence, ou si êest une variété constante dans la même espèce ${ }^{4}$.

' Le vespertilion pipistrelle; vespertilio pipistrellus. $\mathrm{Cn}$. vier, Desm.

${ }^{3}$ Le vespertilion barbastelle; vespertilio barbastellus. Desm.

'Le rinolphe bifer; rinolphus lihastatus. Desm.

'Il n'est point de famille qui ait besoin, plus que les chanves-somris, dune revne faite sur mature, et non par voie de compilation. (Cuvier.)

\section{DESCRIPTION DES CHAUVES-SOURIS.}

(BXTRAIT DE DAUBENTON.)

Lorsqu'on voit les chauves-souris voltiger à la fai . ble lumière du crépuscule, la forme de leurs ailes peut les faire regarder comme des oi-eaux : mais je suis surpris que des naturalistes qui ont dủ les observer de près aient méconnu les caractères tle quadrupèdes quiu'ont ces animanx, et se soient mepris au point de les mettre au rang des oiscaux. Toutes le figures que nous avons des claauves-souris, même dans les livres d histore natur lle, les représentent avec les ailes étendies : navait-on jamais remarqué que ces ailes sont des jambes, lorsque l'animal est en repos, et qu'il a quatre jam. bes comme les autres quadrupètes? Commencons lonc par décrire la chauve-souris dais cette altitude de repos, avant de la faire voir dans celle où ses deux jambes de levant deviennent des ailes qui la soutiennent en l'air.

Les jambes des ehaures-souris paraissent absolument différentes de celles des autres quall rupèrles, et en effet elles sont dirigées el même conformées d'une manière très-particulière. Le tonde se trouve près du genou; l'avant-bras est Cort long, et s'étend obliquement de hant en bas, et de derrère en derant, anssi loin que le nez de l'inimal; le poignet pose sur la terre, et on ne roit dans les pieds de devant 'qu'un senl doigt, gui est le potice, et qui s'étend en arrière; le genou est aıssi élevé que le dessus de la croupe; la jambe a une direction verticale de haut en bas, et les cinq doint= du pied de derrière sont dirigés en dehors, et anss longs les uns que les antres; le bris est et undu horizontalement de devant en artière, et la cuisse rerticalement de bas $t \mathrm{t}$ l:aut; le bra: est caché derrière l'avant-bras, et la cuisse derrière la jaube; ils sont de plus enveloppes aree l'avant-bras et la jambe dans des membranes cliffonnees, yłui cachent la quene et prisque tonte la partie posté. rieure dı corps de l'an'mal.

Les différentes parlies des janubes de la chanvesouris, dirigées d'une manière si extraordinaire, n’annoncent pas une démarehe aisce; aussi cet animal se traine-t-il au lieu de marcher : cependant, it l'aide de ses quatre jambes, il porte son corps en avant, à eôté et en arrière. Danı l'état dle repos, la poitrine et le venıre s'appuient sur la terre sans que les quatre pieds souliennent le poids du corps; ils l'empershent seulement de chanceler et de tomber de có'ć.

Pour aller en aran!, la chaure-souris lère les pieds de devant tous les deux à lit fois, et les porte à une petite distance de l'eudroit où ils étaient; en mème tempss, bo pouce de chitglic pied se dirige en 
dehors, et 1 anmmal s'accroche avecl'ongle an point d’appui yui se rencontre; il étend en arrière les deis pieds de derrière, de façon que les cinj doists de chaque pied sont aussi dirigés en arrière; il s'appuie sur la plante du pied, et s'affermit à l'aide des ongles les doigts : alors, il soulève son corps sur les jambes de derant, et il se porte en avant en flèchissant lebras sur l'avant-bras : ce mouvement est facilité par l'extension des jambes de derrière, qui poussent aussi le corps en avant. Pour faire un second pas, il porte en avaut les pieds de derrière en mème temps que ceux de devant, mais en laissant toujours les doigts des pieds de derrière dirigés en arière. Cette allure, quoique pesante, parce que le corps retombe sur la terre à chaque pas, est quelquefois assez prompte lorsque les pieus rencontrent chacun un bon point d'appui ; mais il arrive souvent, ı̣ue le ponce des pierls de devant ne saisit qu'un corps (pui cède, alors les pieds glissant en arrière n'ont fait qu'une vaine tentative : si l'un des pieds a porté sur un point fixe, l'autre ne soutenant pas eigalement le corps de l'animal, il ne fait qu'un faux pas. De mème, le secours des pieds de derrière est fort incertain, parce que les ongles étant dirigés en arrière, il n'y a que la plante du pied qui puisse servir de point d'appui pour porter le corps en avant, et le pied glisse souvent en arrière, lorsque la jambe s'étend pour pousser le corps. J'ai vu aussi des chauves-souris qui portaient en avant les pieds de devant et ceux de derrière l'un après l'auire, comme les autres animaux quadrupièdes.

Lorsque la chauve-souris veut aller de còté, elle écarte de ce méme côté l'un de ses pieds de devant en l'éloignant de l'autre et se soulève sur les deux jambes: par ce mouvement, la partie antérieure du corps se porte de côté, parce qu'elle retombe à une distance égale de deux pieds. Pour reculer, la chauve-souris commence par étendre en arrière les jambes de derrière, ensuite elle soulève son corps sur les jambes de devant, tandis que les autres le tirent en arrière en se fléchissant. Cette dernière allure est assez ordinaire à certaines chanves-souris, qui ont les doigts des pieds de derrière le plus souvent dirigés en arrière; elles se suspendent en s'accrocìant par ces doights, et préfèrent cette attitude pour se reposer : je n'en ai vu que d'une seule espèce ainsi suspendues; les autres restent sur leurs quatre pierls, et se rassemblent en groupe pour s'écluauffer mutuellement, surtout lorsqu'elles sont dans cles lieux froids.

La démarche l'es chauves-souris étant toujours pesante, et souvent fort lente, diffère peu de leur état de repos; aussi ne prennent-elles cette allure que lorsqu'elles sont engourdies ou fatiguees, on lorsque le grand jour ne leur permet pas de sortir de leur retraite, ni d'apercevoir les olijets : mais, dès que la lumière est proportionnée à la faiblesse de leurs yeux, et que la qualité de l'air leur est propre et met en mouvement les insectes yui leur servent de pâture, elles developpent de longues ailes, prennent l'essor, s'élèvent et s'abaissent en l'air, et parcourent rapidement de longs espaces.

Revenons à la chanve-souris portée sur ses quatre jambes, pour examiner le développement de ses ailes. J'ai déjà dit que l'on ne royait dans les pieds de devant qu'un seul doigt, qui ėtait le pouce ; il $\mathrm{y}$ a de plus quatre doigts fort longs, étendus contre l'avant-bras, replies près du coude par leur extrémité, et enveloppés d'une membrane chiff: nnée. Lorsque la chauve-souris veut prendre son vol, elle éloigne ses quatre doigts l'un de l'autre, la membrane qui les enveloppe se tend et forme une aile; cette même membrane se prolonge au delà du quatrième doigt jusqu'an corps dle l'animal, enveloppe le loras et la cuisse, et s'étend au delà jusqu'à la queue, quielle enveloppe encore, comme les quatre jambes et les quatre doigts du pied de devant.

La membrane de la chauve-souris est souple, et a si peu d'épaisseur, qu'elle est à demi-transparente; elle est si forte, que l'on a de la peine à la déchirer. En regardant à travers, on $y$ aperçoit quelques vaisseaux sanguins et des fibres musculeuses qui froncent lorsque les ailes sont pliées, et qui y forment, dans cet état, de petites cavités placées en files conme les mailles d'un réseau. En dechirant cette membrane, on effile des fibres blanchâtres qui découvrent le tissu dont elle est composée.

Le bras, l'avant-bras, les quatre doigts des pieds de devant, la cuisse et la jambe n'ont que très-peu de clıair, et ressemblent à des parties d'un squelette qui seraient enveloppées d'un crêpe. Le premier doigt est placé près du second; il y a beaucoup plus de distance entre le second et le troisième cloigt qu'entre le premier et le second; le troisième est encore plus éloigné du quatrième que du second. Le bord postérieur de la membrane forme de chaque còté de l'animal quatre échancrures, la première entre le second et le troisième doight, la seconde entre le troisième et le quatrième, la truisième entre le quatrième cloigt et la jambe, et la quatrième entre la jambe et la queue, dont la dernière fausse vertèbre est en parie dègagée de la membrane. Ces échancrures symétriques ont été imitées par les lessinateurs, et servent d'ornements dans les cartouches et autres dessins.

Lorsque la cliauve-souris cesse de voler et de pose sur la terre, elle fléchit les quatre doigıs des piecls de devant le long de l'avant-bras, et elle s'appuie sur le pouce et sur le poignet.

Isa tête de cet animal parait confondue arec le corps, on n'y voit que le museau et les oreilles, 
qui sont fort grandes; on aperçoit à peine les yeux pres(yue cachés dans le poil, qui est long sur toutes les espèces de chauves-souris. Les auteurs d'histoire naturelle qui ont fait mention de ces animaux n'en ont connu jusqu'à présent qu'une ou deux espèces dans notre climat; cependant j'en ai trouvé aisément un plus grand nombre, dès que j'ai commencé à les observer; et, en quatre ans, je suis parvenu à en rassembler sept espèces trèsdiffẻrentes, dont j'ai déjà rapporté les caractères dans un Mémoire sur les chauves-souris, lu àl'Académie royale des Sciences. La plupart de ces caractères dépendent dı nombre des dents, de la grandeur et de la forme des oreilles et du museau, et sınt détaillés dans la description suivante de chaque espèce de chauves-souris.

\section{LA CHAUVE-SOIRIS ORDINAIRE.}

\section{LE Vespertilion murin. (Cuv.)}

La chaure-souris a le museau gros et allongé, le nez large, la bouche et les oreilles fort grandes, et les yeux petits; la partie inférieure des bords intérieur et extérieur de la conque de l'oreille forme de claque côté un lobule, et il y a entre ces deux lobules un oreillon placé an levant de l'orifice du conduit auditif externe; il a peu de largeur, mais sa longueur égale à peu près la moitié de celle de la conque de l'oreille; les cinq doigts des pieds de derrière sont presque aussi longs les uns que les autres.

Le sommet de la tête, le dessus du cou, les épaules, le dos, la crouje et les cuisses étaient de couleur cendrée pâle, et légèrement teinte de jaunâtre. Lorsque l'on écartait les poils, on rojait une couleur noirâlre qu'ils avaient sur la plus grande partie de leur longueur depuis la racine. La gorge, le dessous du cou, les aisselles, la poitrine, le venire et tout le dessuns du corps, étaient de conleur hlanche, mêlée de quelques légères teintes de jaunâtre : on voyait aussi du noirâtre lorşue les poils étaient écartés, parce qu’ils étaient de cette couleur, comme cenx du dessus du corps, sur la plus grande partie de leur longueur depuis la racine.

Les lèvres et la mâclıoire du dessous étaient rousses; le nez et les oreilles avaient une coulemr grisc lirant sur le lrun très-clair ; la membrane des ailes et lle la queve, les jambes et les pieds avaient en partie ces menuranes teintes, et étaient en partie noirîtres. Les poils de cet animal avaient environ trois lignes de longneur; la quene était engage dans sa membrane jusqqu'à son extrómitć.

\section{L'OREILLAIR.}

\section{LE VESPERTILION OREILLARD.}

En jetant les yeux sur cet animal, on roit qu'il ne pouvait pas ètre mieux nommé, puisque ses oreilles sont excessivement grandes; leur lougutur est égale à celle du corps entier, dppuis leur base jusqu'à l'anus; elles sont aussi très-larges, car leur largeur fait plus des deux tiers de leur longueur. Ces oreilles sont minces, prescjue transparenies, et de ligure ì peu près ovale; elles forment, à quelque distance de leur bord antérieur, un pli longrtudinal, et saillant en arant; il $\mathrm{y}$ a quelques poils le long de ce pli : il y avait un lobule sur le bord interne, à quelque distance de la tète; les deux oreilles se touchaient par la partie inférieure de leur bord interne, et se réunissaient l'une à l'autı par une membrane yui avait une ligne de hauteur at-dessus du front. 'Toutes les parties d'une oreille si étendue doivent être fort apparentes, aussi at-elle un oreillon placé au devant du conduit auditif, qui est si grand qu'il paraî ètre une seconte oreille; il est long, étroit et pointu par le bout. L'oreille a un mouvement bien sensible, elle se replie et s'abaisse en delırs, de sorte que son extré mité approclıe de l'épaule, et que, dans cette situation, les deux oreilles prennent à peu près la forme des cornes d'un bélier : on voit dans leur tissu des fibres transversales, placées à quelquc distance les unes des autres, qui forment des rides dans le nême sens, lorsque l'oreille se replie. Les yeux sont petits, ronils, et placés au-devant des oreilles ; le museau est long, pointu et courert de longs poils entre les reux.

Les ailes ont peu de longuenr, et sont de couleur brune on noiratre : la membrane de la yuene m’a paru à proportion plus grande que les ailes, elle avait les mẻmes couleurs. Le poil du dessus ilı museau, du cou, des epaules et du corps, etait do couleur mêlée de noirâtre el de gris roussittre, parce que chaque poil était noirâtre sur la plus grande partie de sa lonsueur depuis la racine; il y avait du roussâtre au-dlessus clu noirâtre, et la pointe était lorune. Le dessous de ia tète, du cou, des épaules et du corps, avait me conleur metce de noirâtre et de gris, parce que les poils rtaient en partie noirâtres et en partie gris; mais la teinte noirâtre du dessus du corps n'était, à proprement parler, qu' un gris roussittre, el le gris du dessous du corps ètait aussi un peu coussitre : le poil de cet animal était long, il avait environ trois lignes. 


\section{LA NOCTULE.}

\section{LE VESPERTILION NOCTULE.}

La noctule est au moins anssi grande que la chame-souris mais elle a les jambes plus courtes, le nez un preu moins allongé et le front moins convexe; les oreilles sont bien moins longues : quoique presque aussi larģres, lem extrémité est arrondie; ell's ont sur la partie infèrieure du bord interne, près de l'œil, un lobule arrondi, et sur li partie inférieure du bo:d externe, près dı coin de la bouclı, un autre lolute de figure très-irrégulière; il y a an-rlevant de l'orifi"e dlu contuit anditif exterme un oreillon fort com't et arrondi Les yeux sont très-petits, et placés au-dlessous des angles aıtériemrs des oreilles. Le poil de cet animal a deux ligne: de longueur, et une couleur fauve teinte de lrun; le bout du museau, les ailes, la membrane de la quene, et les pieds sont de couleur noirâtre.

\section{LA SÉROTINE.}

\section{LE V'ESPERTILION SÉROTINE.}

La sérotine est à peu près de la mème grandeur que le fer-à-cheval : elle a le museau allongé les oreilles sont courtes et larges, leur bord extérienr a une échancrure au-dessous de l'extrèmité, qui est arrondie : il y a au devant du conduit anditif un oreillon fort court. Le poil de la face supérieure du corps est mèlé ile brun et de fauve très-peu foncès; la face inférienre a lies couleurs encore plus pîles, qui ne sont que dı jamnâtre et du cendré très-clair : la membrane des ailes et de la queue a une couleur noiratre.

\section{LA PIPISTRELLE.}

\section{IE VESPERTILION PIPISTRELLE.}

La pipistrelle est très-petite; la tête est bien proportiounce an reste du corps, et les oreilles, quoique grandes, ne le sont jas excessivement. Le nez est petit, mais la lèvre supérieure forme um renflement de chaque coite de la mâchoire; les yeux sont ronds, très-petits et enfoncés entre le renflement de la lèvre et l'oreille. Le front est couvert de poil assez long, qui grossit la tète; les oreilles sont larges, arrondies par l'extrémitè, et ćchancrées par le côté extérieur; l'intérieur forme un angle saillant; il y a au dedans de la conque de l'oreille un oreillon bien apparent, qui est placé au devant de l'orifice clı conduit anditif externe.
Le poil dı dessus de la tète et du corps est de couleur brune, avec une teinte de jaunâtre; le poil du dessous dlı corps a plus de jaunâtre et moins de lorun; mais, lorsqu'il est rebroussé, il parait presque entièrement b:um noirâtre, parce que la plus grande partie de chaque poil est de celie coulemi, " q qu’il n'y a que l'extrémité qui soit jannâtre. Les plus longs poils ont demx lignes et rlemie de longueur. Le nez, les lèvr's, les oreilles, les jambes, la quene et la membrane des jambes et àe la yuene, sont noirâtres.

\section{LA BARBASTELLE}

\section{LE VESPERTILION BARBASTELLE.}

Ia barhastelle a de longues et larges oreilles, qui se tonchent l'une l’autre par la partie inferieure de leur bord interne, de façon yju'en regardant cet animal e: face on ne voit ni le front ni la tète; le musean est fort petit, on l'aperçoit au-dessous des borls internes des oreilles. Le nez forme un tubercule aplati, et situé immédiatement an-dessus de la bouche; les ouvertures des narines se trouvent derrière le hord supérieur dle ce tubercule. Le chanfrein est enfoncé, et rlégarni de poil depuis les narines jusqu'aux oreilles; cet espace est de couleur brune noiràtre. Il y a de chaque còté deux petits sillous qui aboutissent à chaque onverture des narines, de sorte qu'eı serrant le museau de l'animal, le sillon antériem de chaque côté se replie sur sa longueur, et forme un tuyau dont le bord tonche à celui de l'orifice de la narine. Les joues sont grosses et renflees, et semblent, an premier coup d'œil, ètre des moustaches qui surmontent les lèves; les yeux sont très-petits, ronds, et placés au devant des conques des oreilles. Chaque conque est double, parce qu'il y a un oreillon au devant de le conque dans le milieu, entre l'œil et lurifice du canal auditif externe; cet oreillon a environ la moitié de la lauteur de la conque.

Le poil de la barbastelle est de couleur brune noinâtre sur tout le corps, excepté sur la gorge, sur la poitrine et sur le ventre, où il est mèlé de gris et de brum; les plus longs poils sont sur le dos; ils ont jusqu à cinq lignes de longueur; la quene ne deborde que très-p̣eu au delà de la membrane qui l'enveloppe.

\section{LE FER-A-CHEVAL}

\section{LE RHINOLPIE BIJER.}

L'étrange conformation de la face de cet animal le rend fort hideux; il semlile porter sur le museau 
l'empreinte d'un fur de ciıcval, d'où vient son nom. Je n'ai trouvé, pendant longtemps, que des individus de grandeur moyenne entre la pipistrelle et la barbastelle ; enfin, j'en ai vu quelques-uns bcancoup plus grands : comne ils differaient à quelques égards des premiers, que j'ai observés en très-grand nombre, j'ai décrit séparément les uns et les autres, et je commence par la description des petits.

Le bord convexe de la membrane en forme de fer-à-cheval, était placé au-dessus de la lèvre sıpérieure ; cliaque branche se prolongeait à côté des narines, qui se trouvaient derrière le bord concave : cette membrane avait environ une ligne de largenr sur toute sa longueur. La cloison des narines s'étenclait de clıquue côté au-llessus de leurs orifices, de facon qu'elle avait une face supérieure rontle et concave; sur le bout postérieur de cette face, il s'èlevait une lame étrớle et pointue à l'extrémité: derrière cette lame il s'en tronvait une autre à peu près carrée, qui faisait corps avec la lame étroite, et qui était posce verticalement le long du elıanfrein ; elle avait environ une ligne de hanteur : il sortait de la base cle cette scenile lame une autre membrane triangulaire, qui s'étendait obliquement en arrière ; elle avait ılenx lignes et demie de longneur, et une ligne et clemie de largeur dans le bas.

Les yeux étaient fort petits tt très-enfoncés; ils se tronvaient placés chacun entre l'oreille et la lame triangulaire clont il a cté fait mention. Les oreilles étaient grandes, larges à la lbase, et teruninées par une pointe un peu recourbee en dehors ; le bora intérieur de l'oreille était convexe, l'extérieur etait concave a-dessous de la pointe, et convexe près de la base de l'oreille; il formait an-rievant un grand lobule, mais il n'y avait point d'oreillon.

Le poil était très-doux, il avait jusqu’à quatre lignes de longueur ; la face inférieure du corps était d'un blanc sale ; la face supérieure avilit la mème coulear arec des teintes de cendré lrun; les oreilles et la membrane des ailes et de la queue élaient de couleur noirâlre.

Ces animaux restaient pendant le jour suspcnilus par les pieds de tlerrière, et enveloppés de leurs ailes.

On en a trouvé dans un caveau du chateau de Monibaril de beaucoup plus grands que ceux dont jo viens de faice la description; ils avaient à peu près la mème gran!enr que la chanve-souris et la noctule : leurs dimensions sont rapportées dans le table. Au reste, ils ne differaient des petits que par quelyues teintes de conlcur et par quelques parties mieux développées dans les membranes fui etaient sur le nez, snr le clanfrein et an devant du front, sans doute parce que ces ani- maux étaient plus vieux. La membrane qui formait le fer-ḋ-cheval avait une ligne et demie de larseur dans les endroits les plus larges ; elle était échancrée sur le milien de son bord antérieur. La lame triangulaire, qui s'étendait obliquement en arrière, avait trois lignes de longueur; celle de sa ba:e était de trois lignes et demie : il y avait, sur la face antéricure de cette lame, six cavités, trois de ehaque côté, placées de façon que les deux premières se trouvaient à une ligne au-dlessous de la pointe du triangle, et n'étaient sćparées l'une de l'autre que par une cloison fort mince; les deux secondes n'étaient aussi séparées des deux premières et des deux troisièmes que par une cloison très-mince; mais il y avait ume ligne de distance ent:"e les deux secondes, et deux lignes entre les deux troisièmes, qui étaient ì la base dı triangle.

Le poil avail jusqu’à cinọ lignes de longueur ; la partie inférieure du corps élait d'un gris teint de jaunàtre; le clessus du corps avait une couleur mèlée de cendré clair et de roux, parce que les poils étaient de couleur cendrée claire ou grise sur la plus grande partie de leur longueur, et roussitte à l'extrémité : il y avait aussi une bande brune qui s'étendait de chaque côté depuis l'oreille jusqu'à l'entre-deux des épaules, et une troisième qui se prolongeait depuis l'entre-deux des épaules, le long du dos ; ces handes venaient de ce que l'extrénité des poils était brune.

L'un de ces animaux était femelle et avait mis bas depuis pen cle temps, car ses mamelons ctaient très-grauds, ils avaient jusqu’̀̀ deux lignes de longueur et une ligne de largeur; ils étaient fort minces, et ils ressemblaient à des papilles tle la panse d'un bouf. Ils étaitnt au nombre de quatre. deux sur la partie postérieure de lit poitrine, un de claque côté, an milieu d'une alvéole dégarnie de poi!, qui avait trois lignes de dianière, et deux autres places au devant lu puhis, à deux lignes de distance de la vulve, et éloignés l'un de l'autre seulement d'une ligne.

\section{LA ROUSSETTE * .}

\section{LA ROUGETTE ${ }^{* * 2}$ ET LE VAMPIRE ${ }^{* * * 3}$}

Ordre des carnassiers, famille des cheiroptèes, genre chauve-souris. (Cuvier.)

La roussette et la lougette nous paraissent faire deux especes distinctes, mais qui sont si

\footnotetext{
${ }^{*}$ La roussette de luuffon, Cur.

La rousselle, vulgajremeut le chien-volant.

" La rousselle: à collier, ciuv.

${ }^{2}$ La rougelle. lie chien-rolant à col rouse.

"- Le pluyllostome vampire, Cuv., Geofr.

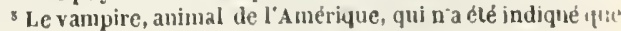


voisines i'une de l'autre, et qui se ressemblent à tant d'égards, que nous croyons devoir les présenter ensemble: la seconde ne diffère de la première que par la grandeur du corps et les couleurs du poil. La roussette, dont le poil est d'un roux brun, a neuf pouces de lougueur, depuis le bout du museau jusqu'à l'extrémité du corps, et trois pieds d'envergure lorsque les membranes qui lui servent d'ailes sont étendues. La rougette, dont le poil est cendré brun, n'a guère que cing pouces et demi de longueur, et deux pieds d'envergure; elle porte sur le cou un demi-colliel d'un rouge vif, mêlé d'orangé, dont on n'apercoit aucun vestige sur le cou de la roussette. Elles sont toutes deux à peu près des mêmes climats chauds de l'ancien continent; on les trouve à Madagascar', à l'île de Bourbon, à Ternate, aux Plilippines et dans les autres îles de l'archipiel Indien, où il paraît qu'elles sont plus communes que dans la terre ferme des continents voisins.

On trou ve aussi, dans les pays les plus chauds du Nouveau-Monde, un autre quadrupède volant, dont on ne nous a pas transmis le nom américain, et que nous appellerons vampire, parce qu’il suce le sang des hommes et des animaux qui dorment, sans leur eauser assez de douleur pour les éveiller. Cet animal d'Amérique est d'une espèce différente de celles de la roussette et de la rougetle, qui, toutes deux, ne se trouvent qu'en Afrique et dans l'Asie méridionale. Le vampire est plus petit que la rougette, qui est plus petite elle-même que la roussette. Le premier, lorsqu'il vole, paraît être de la grosseur d'un pigeon; la seconde, de la grandeur d'un corbeau; et la troisième, de celle d'ume grosse poule. La rougcte et la roussette ont toutes deux la tète assez bien faite, les oreilles courtes, le museau bien arrondi, et à peu près de la forme de celui d'un chien: le vampire, au contraire, a le museau plus allongé; il a l'aspect hideux comme les plus laides cliauves-souris, la tèteinforme et surmontée de grandes oreilles fort ouvertes et fort droites; il a le nez contrefait, les narines en entomnoir, arec unc membrane au-dessus, qui s'élève en forme de corne ou de crête pointue, et qui augrmenite

frar les noms vagues de grande chauve-souris d'Amérifue, ou fle chien-volant de la Nouvelle-Espagise.

1 Aux iles de Ilaseareigne el de Madagascar, les cliauves-souris sont grosses comme des poules, el si communes, que quelquefois jen ai vu l'air obscurci. Leur cri esl Éouvantable. Voyage de Madagascar, par le V.; Paris, 1722, 1. 83 el 245. de beaucoup la difformité de la face. Ainsi, l'on ne peut douter que cette espèce ne soit tout autre que celles de la roussette et de la rougette. Le vampire est aussi malfaisant que difforme: il inquiète l'homme, tourmente et détruit les animaux. Nous ne pouvons citer un témoignage plus authentique et plus récent que celui de M. de la Condamine: «Les chauves-souris, dit-il, " qui sucent le sang des chevaux, des mulets, " et même des hommes, quand ils ne s'en ga“ rantissent pas en dormant à l'abıri d'un pavil" lon, sont un fléau commun à la plupart des " pays chauds de l'Amérique. Il y en a de mon" strueuses pour la grosseur' : elles ont entière( ment détruit à Borja, et en divers autres en" droits, le gros bétail que les missionnaires y * avaient introduit, et qui commençit à s'y " multiplier. " Ces faits sont confirmés par plusieurs autres historiens et voyageurs. Pierre Martyr, qui a écrit assez peu de temps après la conquête de l'Amérique méridionale, dit qu'il y a dans les terres de l'isthme de Darien des chauves-souris qui sucent le sang des hommes et des animaux pendant qu'ils dorment, jusçu'à les épuiser, et même au point de les faire mourir. Jumilla ' assure la même chose, aussi bien que Dom George Juan et Dom Antoine de Ulloa ${ }^{2}$. Il parait, en conférant ces témoignages, que l'espèce de ces chauves-souris qui sucent le sang est nombreuse et très-commune dans toute I'Amérique méridionale : néanmoins, nous n'a-

4 Dans l'Amérique méridionale les chauves-souris sont en. core un fléau si cruel et si funeste, qu'il faut l'aroir ćprouvé pour le croire; il y en a de deux sortes, les unes sont de la grosseur de celles que nous voyons en Esjagne. les antres sont si grosses qu'elles ont trois quarts d'aune de longueur d'un bout rle l'aile à l'autr. . Les mnes el les aulres sunt d'adroiles sangsues s'il en ful jamais, qui rôdent. loute la ruit your hoire le sang des humnes et des bc̀les : si ceux rue leur état oblige de dormir par terre n'ont pas suin. de se courrir depuis les pieds juæ ju'à la téle, ce q̨ui est extrèmement incommode dius des pays aussi chauds, ils doivents'atlendre à ctre piqués des chaures-suuris : à l'égard de ceux qui dorment dans d's maisons, sons des mosyniteros, quand ils n’amaient que le front découvert, ils en sont infailliblement mordus ; et si par malbeur ces viseaux leur piquent une veine, ils passent des bras du sommeil dans ceux de la mort, à cause de la quantité de saug qu'ils perdent sans s'en apercevoir, taut leur piquure est sublile, or:tre que, ballant lair avec leurs ailes, elles rafraichissent le durmeur auquel elles ont dessein d'oler la vie. Histoire naturelle de l'Orénoque, par le père Juinilla. traduile de l'espagnol, par M. Eidous; Aviguon, 1758, t. 11I, page 100.

${ }^{2}$ L.es chauves-somris sont communes à Carthagène; elles saignent fort adroitement les hahitanls en leur lirant assez de sang, sans les éveiller, pour les affaiblir extrêmement. Extrait de la lielation historique dı Voyage de l'A mérique méridionalc, par D. George Juan et D. Anloine de Ulloa, etc.; Biblio. thèuue raisounée, tome 44. prag. 409. 
vons pu juscu'ici nous en procurer un seul individu; mais on peut voir dans Seba la figure ut la deseription de eet animal, dont le nez est si extraordinaire, que je suis très-étonné que les voyageur's nel'aient pas r'emarqué et ne se soicnt point écriés. sur cetle difformité, qui saute aux yeux, et de laquelle cependant ils n'ont fait aucune mention. Il se pourrait done que l'animal étrange dont Seba nous a donné la figure, ne fủt pas celui que nous indiquons ici sous le nom de vampire, e'est-à-dire celui qui suce le sang; il se pourrait aussi que cette figure de Seba fùt infidèle ou chargée; et enfin, il se pourrait que ce nez difforme fût une monstruosité ou une variété accidentelle, quoiqu'il y ait des exemples de ces difformités constantes dans quelques autr'́s espèces dechauves-souris : le temps éclaircira ces obscurités, et fixera nos incertitudes.

A l'égard de la roussctte et de la rougette, elles sont toutes deux au cabinet duroi, et elles sont venues de l'ìle de Bourloon. Ces deux espèces ne se trouvent que dans l'ancien eontinent, et ne sont nulle part aussi nombreuses en Afrique et en Asie que celle du vampire l'est en Amérique. Ces animaux sont plus grands, plus forts et peut-être plus méchants que le vampire ; mais c'est à force ouverte, en plein jour aussi bien que la nuit, qu'ils font leur dégât : ils tuent les volailles et les petits animaux; ils se jettent même sur les hommes, les insultent et les blessent au visage par des morsures eruelles; et aucun voyageur ne dit qu'ils sucent le sang des hommes et des animaux endormis.

Les anciens comnaissaient imparfaitement ces quadrupèdes ailés, qui sont des espèees monstres ; etil est viaisemblable quec'est d'après ces modèles bizarres de la nature, que leur imagination a dessiné les harpies. Les ailes, les dents, les griffés, la eruauté, la voracité, la salcté, tous les attributs difformes, toutes les facultés nuisibles des harpies, conviennent assez it nos loussettes. Hérodote ${ }^{1}$ parait les avoir indiquées lorsqu'il a ditqu'il y avait de grandes chauves-sour'is qui incommodaient beaucoup les hommes qui allaient recucillir la casse autour des marais de l'Asie; qu'ils étaient obligés de se couvril de cuir le corps et le visage, pour se garantil de

11 érodot , lib. 5. Nota. Il est singulier que Pline, qui nons a transmis comme vais tant de faits apocryphes et mine merveillenx, accuse ici Ilérodole de mensonge, et clise cpue ce fait des chanves-souris qui se jetlent sm les hommes nost qu'un conle de la vieille et fabulense antiyuite. leurs morsures dangereuses. Strabon parle de très-grandes chauves-souris dans la Mésopotamie, dout la chair est bonne à manger. Parmi les moder'nes, Albert, Isidore, Sealiger, ont fitit mention, mais vaguement, de ces grandes chauves-souris. Linscot, Nicolas Mathias 2, Francois Pyrard ${ }^{3}$, eu ont parlé plus précisément, et Oliger Jacobeus ${ }^{4}$ en a donné une courte description a vec la figure : enfin, l'ou en trouve des descriptions et des figures bien faites dans Seba et dans Edwartz, Iesquelles s'accordent a vec les notres.

Les roussettes sont des animaux earnassiers, voraces, et qui mangent de tout; ear, lorsque la chair ou le poisson leur manque, elles se nourrissent de végétaux et de Iruits de toute espèce $^{5}$; elles boivent le suc des palmiers, et il est aisé de les enivrer et de les prendre, en mettant à portée de leur retraite des vases remplis d'eau de palmier ou de quelque autre lifucur fermentée. Elles s'attachent et se suspendent aux arbres avec leurs ongles : elles vont oldi-

1 In Mesopotamia inter Euphratis convertiones, est maxima vespertilionum multitudo, qui longè majores sumt, quám in cateris locis. Capimntur, et in esum condiuntur; Strab, lib. I6.

${ }^{2}$ Nicolas Mallias, dans son Voyage imprimé à Visurghourg, en suédois, dit, page 125, yue ces grandes clıanyes-somrıs volent en troupe pendant la nuit, quiclles boivent du suc des pilmiers eu si grande ‘uantité qu'elles s'enivrent el toubent comme morles au pied des arlres; que lui-mcme en arait fris une dans cet étal, el que, l'ayant allachée avec des clous à une muraille, eille rongea les clons of les arrondit avec ses dents comme si on les eût limés; il dit aussi que son musean ressemblait à celui d'un renard.

${ }^{3}$ On voit dans l'ile de Saint-Lanrent et aux Mlaldises des chanves-souris jlus grosses yne des corbeanx. Voyage de l'yrard. Paris, 1619, tome $I$, pages 58 ol 152.-Les chanves-somis volent eu plein jour daus le Malabar; elles sont grosses comme des chats, et on les inange sans rijugnance. Extrait de la lielation des Missions dı 'Tranquchar. Bibliollépue misomíe, lome 52, , pag. $19 \%$

4 II y a deux de ces chauves-souris dans le Muscum I'cginm Ilaffnix, 1696, pag. 12. tah. 5. lig. 5. 11 dit que clacme de ces chauves-souris était grande comme un corluan; quelles avaient, de la tèle en bas, un picel de longneur; que le m- mbre génital avait dewx ponces de long: et it ajonle, d'aprés Linscot, que les Indiens les mangent te les troment ausi bomes gue des perdix.

${ }_{5}$ sux iles Manilles, on voit sur les arhres une infinilé de graudes chawes-souris ıpui pendent atlachés les mes aux autres sur les arbres, et pui prennent lemr vol à l'antrée tle la mit, pour aller cherclier leur nonrrilure dans des bois fort éloignés : elles volent yuelquefois en si grand moulure et st scrées qu'elles olscurcissent l'air de leurs grande's ailes, qui onf quelquefois six palmes d'élendue : elles savenl discerner, dans l’épaissem des lois, les allores dome les fruils son! mir's: elles les dévorent, pendant toute ia nuil, avec un liruit , jui se fail entendre de demx milles, et vers le jomr elles retument rers lcur's retrites. Les Indicus, qui voient manger lemrs meillcurs fruils par ces animaux. lem fonl la guerre, non-sculement pour se venger, mais punr se mourril de leur chair, a

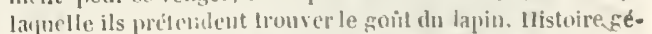
liérale des Voyages, par .M. l'abbé l'revost, tome 10, pag. 589. 
nairement en troupe, et plus la nuit que le jour ; elles fuient les lieux trop fréquentés, et demeurent dans des déserts, surtout dans les îles iuhahitées. Elles se portent au coit avec ardeur. Le sexe dans le mâle est très-apparent : la verge n'est point engagée dans un fourreau comme celle des quadrupèdes; elle est hors du corps, à peu prés comme dans l'homme et le singe' Le sexe des femelles est aussi fort apparent; elles nont que deux mamelles, placées sur la poitrine, et ne produisent qu'en petit nombre, mais plus d'une fois par an. La chail de ces animaux, surtout lorsqu'ils sont jeunes, n'est pas mauvaise à manger; les lndiens la trouvent borme; et ils en comparent le goût à celui de la perdrix ou du lapin.

Les voyageurs de l'A mérique s’accordent à dire que les grandes chauves-souris de ce nonveau contiuent sucent, sans les éveiller, le sang des hommes et des animaux eudormis. Les voyageur's de l'Asie et de l'A frique, qui font mention de la roussette ou de la rougette, ne parlent pas de ce fait singulier : néammoins leur silence ne fait pas une preure complète, surtout y ayant tant de conformité et tant d'autres ressemblances entre les roussettes et ces grandes chauressouris que nous avons appelées rampires. Nous arons done cru devoir examiner comment il est possible que ces animaux puissent sucer le sang sans causer en mème temps une douleur au moins assez sensible pour' éveiller une personne endormie. S'ils entamaient la chair avec leurs dents, qui sont très-fortes et grosses comme celles des autres quadrupedes de leur taille, l'homme le plus profondément endormi, et les animaux suı tout, dont le sommeil est plus léger que celui de l'homme, seraient brusquement réveillés par la douleur de cette morsure; il en est de mème des blessures qu'ils pourraient laire arec leurs ongles : ce n'est done qu'arec la langue qu'ils peuvent faire des ouvertures assez subtiles dans la peau, pour en tirer du sang et ourrir les veiues sans causer une vive douleur. Nous n'avons pas été à portée de voir la langue du vampire; mais celle des roussettes, que M. Daubenton a examinée arec soin, semble indiquer la possibilité du fait : cette langue est pointue et hérissée de papilles dures,

\footnotetext{
${ }^{4}$ In hoc animali uterque sexus dignoscebalur : nam eorum aliquot qui milí conspecti sunt, satis longum exertumque penem hahebant quales ferè simiarum est. Carul. Clısii. Exolic., Raplıclingix, 1605, tome 1I, pas. $9 \%$.
}

très-fines, très-aignuës, et dirigées en arrière; ces pointes, qui sont très-fines, peuvent s'in: sinuer dans les pores de la peau, les élargir, et pénétrer assez arant pour que le sang obéisse à la succion continuelle de la langue. Mais c'est assez raisonner sur ce fait, dont toutes les circonstances ne nous sont pas bien connues, ct dont quelques-unes sont peut-ètre exagérées ou mal l'endues par les écrivains qui nous les ont trausmises.

\section{ADDITION A L'ARTICLE DE LA ROUSSETTE ET DE} LA ROUGETTE.

J'ai trouvé, dans une note de M. Commerson, qu'il a vu à l'ile de Bourbon des milliers de grandes chauves-souris (roussettes et rougettes), qui voltigeaient, sur le soir, en bandes comme les corbeaux, et se posaient particulièlement sur les arbres de vaccoun, dont elles mangent les fruits. Il ajoute que, prises dans la bonne saison, elles sont bonues à manger; que leur gout approche absolument de celui du lièvre, et que leur chair est également noire.

Feu M. de la Nux, qui était mon correspondant dans cette mème ìle, m'a enroyé, depuis l'impression de mon ourrage, quelques observations et de très-bonnes réflexions critiques sur ce que j'ai dit de ces animaux. Voici l'extrait d'une très-longue lettre fort instructive qu'il m'a écrite, à ce sujet, de l'ile de Bourbon, le 2 í octobre 1772 .

J’aime égalemnt, me dites-rous, monsieur, dans rotre lettre du 8 mars 1750 , j’aime également quelgu'un qui m’apprend une vérité ou qui me relève "l'une erreul; ainsi écrivez-moi, je vous sup. plie, en tonte liberté et toute franchisc.... Olı! pour' le coup, je réponds, monsieur, on ne peut pas mieux à rotre noble invitation. Je nai point hésité de me lirrer aux détails et je ne reux point excusı $r$ ma prolixité, bien fàclıé mème de n'en savoir pas plus sur les rousscttes. pour aroir ì vous en dire davanlage. Les preuves ne peuvent être trop multiplièes (me semble) quand il s'agit de combattre des erreurs accréditées depuis longtemps. L'on dirait que l'on n'a vu ces animaux qu'arecles yeux de l'effroi; on les a trouvés laids, monstrucux; et, sans autre examen que la première inspeclion de leur figure, on leur a fait des mours, un caractère et des labitudes quils n'ont point du tout, comme si la nichanceté, la férocité, la malpropre. té, ètaient inséparables de la laideur. 
M. de la Nux observe que, dans ma description, le volume de la roussette est exagéré, ainsi que le nombre de ces animaux; que leur eri n'a rien d'épouvantable. 11 ajoute qu'un homme, ouvrant la bouche et rétrécissant le passage de la voix, en aspirant et respirant successivement avec force, domne à peu près le son rauque du cri d'une roussette, et que cela n'est pas fort effrayant. 11 dit encore que, quand ees animaux sont tranquilles sur un grand arbre, iis ont un gazouillement de société léger, et qui n'est point déplaisant.

Pline a eu raison, dit-il, de traiter de fabuleux le récit d'Hẻrodote: les roussettes, les rougettes, au moins dans ces îles, ne se jettent point sur les hommes; elles les fuient, bien loin de les attaquer. Elles mordent et mordent très-dur, mais c'est à leur corps défendant, quand elles sont abattues, soit par le court-bâton, soit par le coup de fusil, ou prises dans des filets; et quiconque en est mordu ou ègratigné, n'a qu'à s'en prendre à sa maladresse et non à une férocité que l'animal n'a point.

Le volume des roussettes est ici plus approchant du vrai... Les chanves-souris volent en plein jour dans le Malabar. Cela est vrai des roussettes, et non des rougettes. Les antres volent en plein jour: cela veut senlement dire qu'on en voit voler, de temps à autre, dans le cours du jour, mais une à une et point en troupes. Alors elles volent trèslıaut et assez pour que leur ampleur paraisse moinare de plus de moitié. Elles vont fort loin et à tire-d'ailes, et je crois très-possible qu'elles traversent de cette île de Bourbon à l'île de France en assez peu de temps (la distance est au moins de trente lieues). Elles ne planent pas comme l'oiseau de proie, comme la frégate, etc. : mais, dans cette grande élévation au-dessus de la surface de la terre, de cent, peut-être deux cents toises et plus, le mouvement de leurs bras est lent; il est prompt quand elles volent bas, et d'autant plus prompt qu'elles sont plus proches de terre.

A parler exactement, la roussette ne vit pas en sociétẻ ; le besoin d'aliments, la pâture les réunissent en troupes, en compagnies plus ou moins nom: breuses. Ces compagnies se forment fortuitement sur les arbres de hautes futaies, ou chargès on à proximité des fleurs ou des fruits qui leur conviennent. On voit les roussettes y arriver successivement, se pendre par les griffes de leurs pattes de derrière, et rester li tranquilles fort longtenıps, si rien ne les effarouche: il y en a cependant toujours quelques-unes, de temps en temps, iqui se détachent et font eompragnic. Mais, qu'un oisean de proie passe an-iless!ls de l'arbre, que le tomnerre vienne de éclater, qu'il se tire un coup de fusil ou sur elles ou dans le canton, ou que, déjà pourchassées et effarouchées, elles entrevoient au-dlessous d'elles quelqu'un, soit chasseur ou autre, elles s'envolent toutes à la fois, et c'est pour Jors qu'on voit en plein jour de ces compagnies, qui, quoique bien fournies, n'obscurcissent point l'air; elles ne penvent voler assez serrées pour cela : l'expression est an moins hyperbolique. Nais dire, on roit sur les arbres une infinite de grandes chauves-souris qui pendent atlachées les unes aux antres sur les arbres, e'est dire assez mal une fausseté, ou du moins une absurdité. Les roussettes sont trop liargneuses pour se tenir ainsi par la main ; et, en emsidérant leur forme, on reconnaît aisément l'impossibilité d'une pareille chaine. Elles branchent ou au-rlessus ou au-dessous, on à côté les unes des autres, mais toujours une à une.

Je dois placer ici le peu que j'ai à dire tles rougettes. On n'en voit point voler de jour. Elles vi. vent en sociéte dans de grands ereux d'árbres pourris, en nombre quelquefois de plus de quatre cents. Elles ne sortent gue sur le soir à la grande brune, et rentrent avant l'aube. L'on assure, et il passe en cette ile pour constant, que, quelle que soit la quantité d'individus qui composent une de ces sociétés, il ne s'y trouve qu'un senl unàle : je n’ai pu vérifier le fait. Je dois seulement dire que ces animaux sédentaires parviennent à une haute graisse; que, dans le commencement de la colonie, nombre de gens peu aisés et point délicats, instruits sans doute par les Marleccasses, s'approvisionnaient largement de cette graisse pour en apprèter leur manger. Jai vu le temps oi un bois de ehauvessouris (e'est ainsi qu'on appelaii les retraites te nos rougettes) était une vraie trouvaille. Il était facile, comme on en peut juger, de défendre la sortie de ces animaux, puis de les tirer en vie un à un, on de les étouffer par la funée, et de façon ou dlautre de connaittre le nombre de femelles et de mâles qui eomposaient la socièté : je n'en sais pas plus su' cette espèce. Je reviens à la note... Autre hyperbole. Le bruit que ces amimaux font pendent le muit, en devorant en gronde troupe les fruits mürs quils savent discerner dans l'épaisseur des bois.... En lisant cela, qui n'attribuera ce prétendu bruit à l'acte de mastication? le bruit que l'on entend de fort loin, et de jour comme de nuit, est eelui naturel à ces animaux quaud ils sont $\mathrm{cn}$ colère et quand ils se disputent la pâture, et il ne faut pas croire que les ronssettes ne mangent que la nuit. Elles ont l'xil hon ainsi (que l'oulorat, elles voient très-bien le jour : il n’est puint merveillenx qu'elles discernent dans l'épaisseur des bois les fruits, les graines mùres ainsi que les fleurs. D'ailleurs, les bananes de toute espece, dont elles sont très-friandes, les pèches et les autres fruits que les Indiens cultivent, ne sont point daus 
l'épaisseur des bois... La roussette est un bon gibier... Oui, pour qui peut vainere la répugnance qu'inspire sa figure. La jeune, surtout de quatre à einy mois, léjà grasse, est en son genre aussi bonne que le pintadeau, que le marcassin dans le leur. Les vieilles sont dures, bien que très-grasses, dans la saison des fruits qui leur conviennent, e'està-dire pendant tout l'été et une bonne partie de lautomme. Les mâles surtont acquièrent en vieillissant un fumet déplaisant et fort... Il n'est pas autrement exact de dire en général : les Indiens en mangent. On sait que l'Indien ne mange d'aucun animal, qu'il n'en tue aucun. Peut-être bien les Maures, les Malaves en mangent-ils; certainement bien des Européens en mangent : ainsi, dans le vrai, on mange des roussettes dans l'Inde, quoique l'Indien, proprement dit, n'en mange pas. Dans cette île on mange des roussettes et des rougetles.

Après l'examen ci-ılessus, je viens au corps de l'histoire; il a besoin de rectilication. Et pour preuve, je n'ai qu'à opposer ce que je connais des roussettes, ce que j'en ai vu, et ce qu'en ont imagine les autres, d'après lesquels l'historien de la nature a parlé.

Les roussettes et les rougettes sont naturelles daus les iles de France, de Bourbon et de Madagascar. Il y a cinquante ans et plus (en 1772) que j'habite celle de Bourbon. Quand j'y arrivai, en septembre 172.2, ces animaux étaient aussi communs, mème dans les quartiers đẻjà établis, qu’ils y sont rares actuellement. La raison en est toute naturelle. $1^{\circ} \mathrm{La}$ forêt n'ètait pas encore éloignẻe des établissements, et il leur faut la forêt; aujourd'hui elle est très-reculée. $2^{\circ}$ La roussette est vivipare, et ne met au jour yu'un seul petit par an. $5^{\circ}$ Elle est chassée pour sa viande, pour sa graisse, pour les jeunes individus, pendant tout l'été, tout l'automne et une partie de l'hiver, par les blancs au fusil, par les nègres au filet. Il faut que l'espèce diminue beaucoup et en peu de temps ; outre qu'abandonnant les quartiers établis pour se retircr Jans les lieux qui ne le sont pas encore, et dans l'intérieur de l'île, les nègres marrons ne les épargneut pas quand ils le peuvent.

Le temps des amours de ces animaux est ici vers le mois de mai, c'est-à-dire, en général, dans le milieu de l'automne. Celui rle la sorlie des fretus est environ un mois après l'équinoxe du printemps; ainsi la durée de la gestation est de quatre et demi à einy mois. J'ignore celle de l'accroissement des petits; mais je sais qu'il paraît fait au solstice d'hiver, e'est-à-ilire à peu près au bout de huit mois, depuis la naissance. Je sais de plus quion ne voit plus de petiles roussettes, passé avril et mai, tempıs autuel on distingue aisément les vieilles des jeunes, par les couleurs plus vives des robes de celles- ci. Les vieilles grisonnent, je ne sais pas au bout de quel temps, et c'est pour lors qu'elles sont trèsdures, les mâles surtout : c'est pour lors que ceuxci sentent très-fort, comme je l'ai dejà dit; qu'il n'y a que des nègres qui puissent en liıanger, et qu'il n'y a de bon que leur graisse, dont en général l'espèce est assez bien pourvue depuis la fin du printemps jusqu'au commencement de l'liver.

Ce n'est certainement pas la chair, de quelque espèce que ce soit, qui fournit l'embonpoint des roussettes et des rougettes, ni même qui fait le moindrement partie de leur nourriture; ce n'est pas de la viande qu'il leur faut. Bref, ces animaux ne sont du tout point carnassiers; ils sont et ne sont que frugivores. Les bananes, les pèches, les goyaves, bien des sortes de fruits dont nos forêts sont successivement pourvues, les baies de guy et auIres, voilà de quoi ils se nourrissent, et ils ne se nourrissent que de cela. Ils sont encore très-friands de sucs de certaines fleurs à ombelles, telles entre autres eelles de nos bois puants, dont le nectureum est très-succin. Ce sont ces fleurs très-ahondantes en janvier et février, plus généralement au cour de l'êté, qui attirent vers le bas de notre île les roussettes en grand nombre: elles font pleuvoir à terre les étamines nombreuses de ees fleurs, et il est très-probable que c'est pour la succion du nectareum des lleurs à ombelles, peut-ètre encore de nombre d'autres fleurs de genres différents, que leur langue est telle que l'apprend l'exacte et savante lescription quien a donnée M. Daubenton. Jobserverai que la mangue est un fruit dont la peau est résineuse, et que nos animaux n'y tonclicnt point. Je sais qu'en cage on leur a fait manger du pain, des cannes de sucre, etc. Je n'ai pas su si ou leur avait fait manger de la viande, crue surtout, mais en eussent-elles mangé en cage, ce n'est point dans l'ètat d'esclavage que je les considère, il change trop les mceurs, les caractères, les lıabitudes de tous les animaux. Dans le très-vrai, l'ıomme n'a rien à craindre de ceux-ci pour lui personnellement ni pour sa volaille. Il leur est de toute impossibilite de prendre, je ne dis pas une poulc, mais le moindre petit oiseau. Une roussette ne peut pas, comme un faucon, conme un épervier, etc., fondre sur une proie. Si elle approche trop la lerrc, elle y tombe et ne peut reprendre le vol qu'en grimpant contre quelque appui que ce puisse è̀re, fütce un homme qu'elle rencontrât'. Une fois à terre,

- J'ai vu une roussette, tonte jeune encore, entrer au vo: daus ma maison à la grande brume, s'abattre exaetement aux pieds d'une jeune négresse de seut à huit aus, et incontinent grimper le long de cet enfant, „ui, par bonlıeur, était proche de unoi. Je la débarrassai assez promptement pour yue les crochels des ailes ni eussenl point encure alteint ou ses épaulcs ou son visage. 
elle ue peut que s'y trainer maussadement et assez lentement : aussi ne s'y tient-clle que le moins de temps qu'elle peut; elle n'est point laite pour la course. Voudrait-elle attraper un oiseau sur une branche, la degaine avec layuelle elle est sourent obligce d'en parcourir une pour aller vers le bout mettre le vent dans ses voiles, pour aller prendre son vol, montre évidemment que telles tentatives ne lui réussiraient jamais. Et, afin de me mieux faire entendre, je lois dire yue, pour s'envoler, ces aniuanx ne peurent, comme les oiseaux, s'élancer clans l'air ; il faut qu'ils le battent des ailes à plusieurs reprises avant le dépendre les griffes de leurs pattes de l'endroit ou ils se sont accrochés; et puelque pleines que soient les voiles en quittant la plince, leur poids les abaisse, et pour s'élever, ils parcourent la concavitc d'une courhe. Mais la place ou ils se trouvent, quand il faut jartir, n'est pas tonjours commode pour le jeu libre de leurs ailes; il jent se trourer des branches trop procles yuil'empècheraient; et, dans cette conjoncture, la roussette parcourt la branelıe jusıu'à ce qu'elle puisse premlre son essur sans risyue. Il arrice asse\% souvent, dans une nombreuse troupe de ces fuadrupèdes volants, surprise, ou par un coup de tonnerre, ou un coup de fusil, ou par tel autre épouvantail subit, et surprise sur un arbre tle médiocre hauteur, conmue dle ving.t à trente pieds, sous les brancles; il arrive, dis-je, assez ordinairement que plusieurs tombent jusqu’à terre avant d'avoir pu prendre l'air nécessaire pour les soutenir, et on les voit inco:tinent remonter le lonm des arbres yui se trouvent à leur portée, pour prendre leur vol silôt qu'elles le peuvent. Que l'on se représente des royageurs chassant ces animanx yu'ils ne conmaissent point, dont la forme et la ligure leur causent un crrtain effroi, enlourés tout à coup diun l:ombre de roussettes, tombes de leur faite; que ynelgu'un de la bande se trouve empêtré d'une ou deux toussettes grimpantes, et que, elıerchant à se débarrasser et s'y prenant mal, il soit égratigné, mème mordu, ne roila-t-il pas le thine d'une relation qui ferá les roussettes féroces, se ruant sur les lommes, clierchant à les blesser au visage, les devorer, etc.? Et, an bout du compte, cela se réduira à la rencontre fortuite d'animaux d'espèces bien differentes, qui avaient grand'peur les uns des autres. J'ai dit plus haut, qu'il fallait la forêt aux rousseltes; on voit bien ici (pue c'est par instinct de conservation qu'elles la cherchent, et non par caractère sauvage et faronche. A ce yue j’ai dejì fait commaître des roussettes et dles rougettes, si j'ajoute qu'elles ne domnent point sur la charogne, fue naturellenent elles ne mangent point à terre, qu’il faut qu'elles soient appendues pour prentre leur nourriture, j’anai, je pense, détruit lo prejugé yui les fait carnivores, ruraces, méchantes, cruelles, etc. Sije dis de plus que leur rol est aussi lourd, aussi bruyant, surtout proclue de terre, ufue celui des vampirces doit l'ètre peu, lloit être léger, jaurai, par ce dernier caractère, éloigné considérablement (ncore une espèce de l'autre.

De ce que l'on voit parfois des roussette raser la surface de l'eau, à peu pròs comme fait l'hirondelle, on les fait se nourrir de poisson, on en a fait des pècheurs, et il le fallait bien, dès qu'on voulait gu'elles nangeassent le tout. Cette chait ne leur convient pas plus yue toute antre. Lucore une fois, elles ne se nourrissent que de vigetaux. C'est pour se baigner qu'elles rasent l'eau; ct, si elles se soutienment au vol plus près de l'eau qu'elles ne le peuvent de la terre, c'est que la résistance de celle-ci intercepte le battement des ailes, yui est libre sur l'eau. De ceci resulte évidemunent la propreti naturelle des roussettes. J'en ai bien vu, jen ai bien tué, je n'ai jamais tronvé sur aucure d'elles la moindre saleté; elles sont aussi propres yue le sont en géniral les oiseaux.

La roussette n'est pas de ces animaux que nous sommes portés à trouver beaux; elle est mene diplaisante à voir en mouvement et de près. Il n'y a gu'un seul point de vue, et il n'y a yu'une seule attitude yui lui soit avantagense relativenent à nous, dans layuelle on la voié avec une sorte de plaisir, dans laquelle tout ce quelle a tle luileux, de monstrueux disparait. Brancliee à un arlire, elle s'y tient la tête en bas, les ailes pliée's et exactement playuees contre le corjs : ainsi sa voilure, qui fait sa lifformité, de mềue que ses pattes de derrière, qui la soutienment à l’aiıle des griffes dont elles sont armées, ne paraissent poim. Lim ne voit en pemlint qu'un corps roml, potele, vẻı d'une robe d'un brum foncé, tris-propre et bien colorié, auquel tient une tête dont la plıysionomie a quelque chose de vif et de lin. Toilà l'attitude de repos des roussettes; elles n'ont que celle-lì, et c'est celle dans laquelle elles se tiemnent le plus longtemps pendant le jour. Quint au point le vue, c'est à nousi a le choisir. Il faut se placer lle manière à les voir dlaus un demi-racenurci, c'est-ìdire à l'ólcivation au-tlessus de terre dle quiraute à soixante pieds, et dans une distance de cent cinyuante pieds, plus ou moins. Maintenant, yu'on se représente la tète d'un grand arbre grarnic, dans son pourtour et dlans son milieu, de cent, cent cinçuante, peut-être deux cents de pareilles girandoles, n'ayant de mourement que colui que le vent donne aux branches, et l'on se fera lidlee l'un tableau qui m'a toujours paru curieux, et qui se fait regarder avec plaisir. Dans les calnints les plus riches en sujets dhistoire naturelle, on ne man]ue pas de placer une rous: ctle ployce of dans toute l'étendue de son envergure; de sorte yu'on la unon- 
tre daus son action et dans tout son laid. Il faur drail, !ne semble, s'il était possible, en montrer, à coité ou au-dessus, quelı̣u'une clans l'attitucle naturelle dı repos : on ne voit jamais les roussettes à terre tranquilles sur leurs quatre jambes.

Je terminerai ces notes en disant que la roussette el la rougette fournissent une nourriture saine. On n’a jamais entendu dire que qui que ce soit en ait été incommodé, quoiune nombre de fois on en ait manté avec excès. Cela ne doit point surpren lre, dès que l'on sait bien que ces animaux ne vivent que de fruits mîrs, de sucs et de fleurs, et peut-ètre rles exsudations de nombre d'arbres. Je le soupconnais fortement; le passage d'Hérodote me le fait croire : mais je ne l'ai pas assez vu pour donner la close comme une vérité constante.

\section{LE MOLOSSE A VENTRE BRUN.}

Ordre des carnassiers, famille des cheiroptères, genre chaure-souris. (Curier.)

Le museau de cette chaure-souris est très-gros, les lèvres sont longues, t'i le nez est bien formé. Les oreilles sont arrondies et tris-larges; elles se touchent l'une l'autre pa! leur base au-dessous du front; elles forment un pli en avant, qui s'étend depuis le ronduit auditif jusquau bord te la conque, à deux lignes de distance de l'enciruit oủ les deux oreilles se touchent; il y a mue concavite sur la face interne de la conque de chaque côté de ce pli : l'oreillon est conrt, large et arrondi. Le sommet et le derrière de la tête, le dessus et les còtés clu cou, les épaules, le dos el la croupe ont une coulemr cendrée brune; le milien du ventre est brun; le reste le cette partie, la poitrine, la gor qe, etc., ont une couleur cendrée sans teinte de brun. La membrane des ailes et rle la queve est d'un brun noirâtre: l'avant-bras, les doigts des pieds de devant et la jambe sont de conleur cendreje. Il sort de la membrane une portion de la quene longue re sept linnes, et composie de cinq fausses vertebres.

\section{LE MOLOSSE MLLOT'YOLANT.}

Ordre des carnassiers, famille des cheiropteres, genre chaure-souris. (Curier.)

Cette chaure-souris parait être tle même espèce que celle qui est rapportée sous le numéro précident, quoiqu'elle en diffère à quelques igards; elle est plus petite ; car elle n'a qu'ın pouce luuit lignes de longueur, depuis le bout des lèvres jusiju’à l'anus.

La tête est moins charnue, et par conséquent le museau est mouns gros et le nez encore mieux formé que celui de la chauve-souris qui vient d'être dérrite. Toute la face supérieure du corps est de couleur fauve, mêlée d'une teinte de centré. La face inférieure est d'un blanc sale, tirant sur le cendré et un peu sur le fauve. La membrane des ailes et de la queue a des teintes de brun et ile fauve.

Il u'y a point de dents incisives dans la mâclıire inférieure; cependant on y roit des apnarences d'alvéoles, qui donnent lieu de croire qu'i! y a peutêtre eu des dents. Les différences de couleur, de grandeur et mẻme de figure, qui se tromvent entre cette chauve-souris et celle du numéro précédent, peuvent venir de l'âge et dı desséclıment : elles sont toutes les deux dans l'esprit-de-vin depuis longtemps.

\section{LE NYGTĖRE GAMPAGNOL-VOLAN'T.}

Ordre des carnassicrs, famille des cheiroptères, genre chauve-souris. (Curier.)

Cette chaure-souris a le nez, le chanfrein, le front ct le sommet de la tête conformés d'une manière irès-particulière. Le cartilage du nez est presque nul, et le front est très-enfoncé. Les narines ne sont pas séparées l'une de l'autre, comme dans la plupart des autres animaux, par une cloison qui s'étencle en avant; elles sont placées chacune au devant d'une petite gouttière, ouverte d'un bout à l'autre par le dessus; le bord interne de cette routtière est fort petit; l'externe est plus gros, et termimé, à son extrémité postérieure, par un petit oreillon. Les borils extermes dles deux gouttières se réunissent au-dessus de la lève supèrieure, et forment, par cette rémuion, l'extrémité d'un grand sillon, yui s'étend, depuis la lèvre du dessus le long du chanfrein jusqu’au front, ou il y a une fos:e large, profonde et nue; mais les bords de la fosse ont de longs poils. Celui de la tète, à l'exception du sommet, et celui de la gorge, de la poitrine et in ventre sont de couleur blanchàtre avec quelı̣uc légère teinte le fauve : le poil du sommet et du clerriẻre de la tête, du dessus du cou, des épaules, du tos et le la croupe, est d'um brun ronssâtre : la longneur des plus longs poils est de quatre lignes et demie. Les oreilles et la membrane des ailes et de la queue ont différentes teintes de brun noirâtre et de brun roussâtre. La queue est enveloppée 
dans sa membrane jusqu'à l'extrémité : les ongles sont jaunâtres. Cet animal est conservè clans l'esprit-ile-vin.

Cette chaure-souris a trente dents, savoir, quatre incisives à la mâclıoire du dessus et six dans celle du dessous, et dans chaque michoire deux canines et huit mâchelières; tontes les incisives de la nàchoire supérieure sont placées l'une contre l'autre, elles ont cliacune deux lobes; celles du dessous ont aussi deux on trois lobes. La première mâchelière du dessous , quoique grosse, n'a qu'une pointe.

\section{NYCTÈRE DE LA THÉBAIDE.}

Ol'die des carnassiers, famille des cheiroptères, genre chauve-souris. (Cuvier.)

Elle a dix ponces d'envergure; elle ne diffère de la précélente qu'en ce que la couleur blanchàtı du dessous du corps est mèlée d'une teinte de cen lré, et ıue la membrane des ailes n'a point de roussâtre. Cette chauve-souris est desséchée : elle a èté apportée du Sénégal par M. Adanson.

\section{VESPERTILION KIRIVOULA.}

Ordre des carnassiers, famille des chciroptères, genre clsaure-souris. (Cuvier.)

Cette clauve-souris a le nez fort petit ; les oreilles sont terminées par une pointe dirigce en delors, et il y a une petite cichancrure sur le bord externe au-dessous de la pointe; l'oreillon est fort allongé, car il a plus de deux lignes de longueur; il est étroit à la base et pointu à l'extrénité les oreilles sont inclinciss en avant, et presque entièrement caclies dans le poil, qui est long; il a sur tout le corps environ deux lignes te longueur. Celui du chanfrein, du front, du dessus de la tète, du dessus du cou, des épaules, du dos et de la croupe a une couleur fauve bJonde; la mâchoire inférieure, la poitrine et le ventre ont le poil de couleur blanduatre, teinte de fauve. La membrane des ailes et de la queue est mèlée de fauve et de brun; le fauve parait principalement le lon's de l'avantbras et des doigis, sur le bord de la membrane, depuis le quatriène doigt du pied de devant jus qu'au pied de drrière, et autour de la yueve, qui est engagée dans la membrane.

\section{CHATIEE-SOURIS}

FER-DE-LANCE.

Dans le grand nombre d'espèces de chauvessouris qui n'étajent ni nommées ni connues, nous en avons indiqué quelques-unes par des noms empruntés des langues étrangères, d'autres par des dénominations tirées de leur caractère le plus frappant: il y en a une que nous avons appelés le fer-i-cheval, parce qu'elle porte au devant de sa face un relief exactement semblable à la forme d'un fer à cheval. Nous nommons de même celle dont il est iei question le $f_{e} r$-de-lance, par'e qu'elle présente unc crêle ou membrane en forme de trèfle très-pointu, et qui ressemble parfaitement à un fer de linec garni de ses oreillons. Quoique ce caractere suffise seul pour la faire leconnaitre et distinguer de toutes les autres, on peut encole ajouter qu'elle n'a presque point de queue, qu'elle est à peu près du mème poil et de la mème grosseur que la chauve-souris commune, mais (qu'au lieu d'aroir comme elle, et comme la plupart des autres chaures-souris, six dents incisives à la mâchoire inférieure, elle n'en a que quatre. Au reste, cette espèce, qui est fort commune en Amérique, ne se trouve point en lurope.

Il y a an Sénégal une autre chauve-souris qui a aussi une membrane sur le nez; mais cette membrane, au lieu d'avoir la forme d'un fer de lance ou d'un fer à cheval, comme dans les deux chauves-souris dont nous venons de faire mention, a une figure plus simple et ressemble à une feuille ovale. Ces trois chauressouris étant de différents climats, ne sont pas de simples varuétés, mais des espèces distinetes et séparées. M. Daubenton a domné la deseription de cette chauve-souris du Sénégal, sous le nom de la feuille, dans les Mémoires rle l'Acudémie des Sciences, année 1759, page 374.

Les chauves-souris, qui ont déjà de grands lapports avec les oiscaux par leur vol, par leurs ailes et par la force des museles pectoraux, paraissent s'en approcher encore par ces membranes ou crêtes qu'elles ont sur la face : ces parties excédantes, qui ne se présentent d'abord que comme des difformités superflues, sont les caractères réels et les nuances visibles de l'ambiguité de la nature entre ces quadrupédes volants et les oiseaux; ear la plupart de ceux-el ont anssi des menllianes it des elètes 
autour du bec et de la tète, qui paraissent tout aussi superflues que celles des chauves-souris.

\section{DESCRIPTION DE LA CHAUVE-SOURIS} FER-DE-LANCE.

Cet animal est une espèce de chauve-souris qui a beaucoup de rapport arec celle que nous avons nommée le fer-cit-cheral, à cause de la forme singulière du nez, qui n'est pas moins remarquable par sa figure extraordinaire dans la chauve-souris dont il s'agit ici; il ressemble à un fer de lance qui a deux branches à sa base : on pourrait aussi comparer la figure étrange de ce nez à celle d'un trèfle qui n'aurait point de pédicule, et dont le lobe du milieu serait plus grand que les deux autres, et aurait la forme d'un fer de lance; mais ces trois lohes ne sont pas rẻellement séparés; la membrane n'est pas fendue comme elle le parait, elle est seulement plieee, et elle forme une petite gouttière, à l'origine de laquelle se trouve l'ouverture cle chacune des narines : la partie de la membrane qui est au-dessous de celle qui ressemble à un fer de lance est saillante au-dessus de la lèrre et sur les còtès du museau, où il se trouve une éminence qui est formeje par la pean, et qui semble servir de base pour appuyer les petits lobes du trèfle. Le museau est large ; il y a sur le devant de la lèvre inférieure une figure triangulaire marquée par une peau grenue; les oreilles sont grandes et ont sur le còté externe une longue échancrure, qui commence auprès de la pointe; il y a un petit oreillon pointu. La membrane des ailes s'étend de neuf lignes plus loin que la quene, qui est très-courte. Le poil de tout le corps et la membrane des ailes et de la quene ont une couleur lorune, foncẻe ou noirâtre: cette chauve-souris a trois pouces sept lignes de longueur, depuis le bout dủ museau jusqu'à l'origine de la quetue, et un pied sept pouces d'envergire.

Les dents sont au nombre de trente-deux, comme celles de la noctule, de la sérotine, de la barbasrelle, de la roussette et de la rougette; il y quatre incisir es, deux canines et dix mich lielic̀ es à chaque màchoire; les deux incisives supéricures tu milieu sont beancoup plus grandes et plus iarges une les autres, qui sont très-petites, de même que les quatre du dessous; les deux premières mâclie. lières de ebaque côté sont petites, les trois autres sont grosses. Quoiquil y ait cinq chaures-souris qui aient trente-deus dents, commele fer-de-lance, cependant celle-ci diffère des cinq autres par la situation et la figure des dents ; il n'y a que la roussette et la rougette qui aient, comme le fer-delance, quatre incisives à chaque mâchoire; mais elles ont douze mâchelières à la màchoire du des. sous, et seulement huit à celle du dessus; tandis que dans le fer-de-lance, il y en a dix à chacune des mâchoires

La clıauve-souris fer-de-lance a heaucoup de rapport à celle qui a été décrite dans cet ourrage, sous le nom de fer-à-cheval, et à celle dont j'ai donnẻ la description dans les Mẻmoires de l'Académie royale des Sciences, sous le nom de feville. Ces trois chauves-souris ont des membranes saillantes à l'endroit du nez; mais il y a de grandes differences dans la figure de ces membranes : cell de la feuille est en forme de plaque ovale posée verticalement, elle ressemble à une feuille; c'est pourquoi j'en ai donné lc nom à celte chauve-souris; elle est fort étendue à proportion de la grandeur de l'animal, elle a huit lignes de longueur et six de largeur, et la chaure-souris n'a que deux pouces un quart de longueur, prise depuis le bout du museau jusqu'à l'anus ; les oreilles sont près de deux fois aussi longues que la membrane du nez, elles se touchent l'une l'antre par leur bord interne, depuis lenr origine jusqu’à la moitié de leur longueur; elles ont un oreillon qui est fort étroit et pointu à l'extrémité, et qui na que la moitiè de la longueur de l'oreille; cette clıauve-souris n'a point dequeue; son poil est d'une belle couleur cendrẻe, avec quelques teintes de jaunattre; elle m’a été communiquée par M. Adanson, qui l'a apportée du Sénégal : elle ressemble à la chauve-souris ferit-cheral par le nombre et la situation des dents, et principalement en ce qu'elle n'a point de dents incisires supérieures; ces deux chaures-souris diffèrent du fer-de-lance par ce caractère et par le nombre des dents.

J'ai vu une autre chaure-souris dn Sénégal, qui manque de dents incisives supérieures, comme le fer-à cheval et la feuille: mais elle a deux dents mâchelières de plus à la màchoire du dessus, et en tout vingt-huit dents Elle est à peu près de même grandenr que la chaure-souris for-ci-rheval; elle a le musean large et allongé, les oreilles de médiocre grandeur, et un oreillon fort conrt, trèslarge et arrondi; le dessus du curps a une couleur brune, et le dessous est nèlè de brun moins foncé et de couleur cendrée; le bout de la quene est dè. gagé de la memlurane, comme dans la chauve-souris dont j'ai dnimné la clescription dans les Hémoires de l'Académie roỵale des Sciences, tmnée 1759, sous le nom de marmotte volante, avec la description d'une autre chazve-souris, que j'ai nommee ratvoltunt, dont il n'a pas encore èté fait mention dans cette lisstoire naturelle; elle m'a aussi été communiquece par NI. Adanson, qui l’a apportée du Sénégral ; elle est à peu près do même grandeur sue. la noctule; elle a le museau court et gros, les oreilles larges, et un orcillon très-petit; le dessus 
du corps est brun; le dessous est mêlé de blanc sale et de fanve; la membrane des ailes et de la quene a des teintes de brun et de gris; le bout de la queue est dégagé de la membrane; les dents sont au nombre de vingt-six, il y a deux incisives et deux canines à chaque mâchoire, luit màchelières à la mâchoire du dessus, et dix à celle du dessous.

\section{ADDITION A L'ARTICLE DES CHAUVES-SOURIS.}

M. Pallas, qui nous a donné des descriptions dedeux chauves-sourisqu'il regardecommenouvelles, et dont j'ai cru devoir faire copier les figures, avertit que la chanve-souris fer-de-lance, dont j'ai donné la description, ne doit pas être confondue avec la chauve-souris donnée par Seba, sous la dénomination de la chauve-souris commune d'Amérique. M. Pallas dit avoir vu les deux espèces, et qu'après les avoir comparées, il s'est assuré qu'elles sont très-dilliérentes l'une de l'autre. Je ne puis que le remercier de m'avoir indiqué cette méprise.

II nous donne ensuite la description d'une de ces chauves-souris nouvelles, qu'il dit être des Indes, et qu'il appelle céphalole, laquelle est cn efl'et difl'érente de toutes les chauves-souris que nous avous décrites dans notre ouvrage: voici l'extrait de ce qu'en dit M. Pallas.

Cette espèce de chauve-souris, jusqu'à présent inconnue des naturalisıs, se trouve aux îles Moluyues, d'où on a envoyé deux individus femelles à M. Schlosser, à Amsterdam. La femelle ne prorluit qu'un petit; on pent le conjecturer parce que M. Pallas, dans la dissection qu'il a faite d'une de ces femelles, n'a trouvé qu'un foetus.

Il appelle cette chauve-somis céphalote, parce qu'elle a la têteplus grosse à proportion du corps que les autres chauves-souris; le cou y est aussi plus distinct, parce cu'il est moins couvert de poil.

Cette chauve-souris, continue M. Pallas, diffère de toutes les autres par les dents, qui ont quelpue ressemblance avec les dents des souris ou même les hérissons, paraissant plutòt faites pour entauer les fruits que pour dichirer une proie; les dents canines, dans la màchoire supérieure, sont séparées par denx petites denıs; et ılans la mìchoire inférieure, ces petites dlents manquent, et les denx canines de cette mîchoire sont comme les incisives dans les sonris.
Je crois devoir rapporter ici une table du nombre et de l'ordre des dents dans les espèces de chauves-souris, et qui m'a été communiquéc par M. Daubenton. On verra d'autant mieux par cette table, que la cliauve-souris céphalote, et une autre dont je parlerai tout à l'heure, sous le nom de chauve-souris-musaraigne, sont de nouvelles espèces qui n’ont été indiquées que par M. Pallas.

\begin{tabular}{|c|c|c|c|c|c|c|}
\hline $\begin{array}{c}\text { NOAIS } \\
\text { des } \\
\text { CHalives-sOURts. }\end{array}$ & 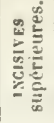 & 资 & 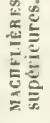 & 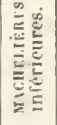 & 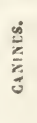 & $\frac{1}{c}$ \\
\hline I.e fer-à-cheval.... & 0 & 4 & $g$ & 10 & 4 & 20 \\
\hline La lenille.............. & 0 & 4 & 8 & 10 & 4 & $2 f$ \\
\hline Le rat-volant............ & 2 & 2 & 8 & 10 & 4 & 26 \\
\hline Le mulot-volant.......... & 2 & 2 & 8 & 10 & 1 & 26 \\
\hline La marniotte-iolanle..... & 2 & 6 & 8 & 8 & 4 & 28 \\
\hline Le lérot-volant .......... & 0 & 4 & 10 & 10 & 4 & 28 \\
\hline Le eampagnol-volant..... & 4 & 6 & 8 & 8 & 站 & 3!) \\
\hline Lad boclule ............. & 4 & 6 & 8 & (1) & 4 & 52 \\
\hline La séroline............. & 4 & 6 & 8 & 10 & 4 & 5) \\
\hline Le chien-volant. ......... & 4 & 4 & 8 & 12 & 4 & 52 \\
\hline La roussetre............. & 4 & 4 & 8 & 12 & 4 & $5: 3$ \\
\hline La pipistrelle........... & 4 & 6 & 10 & 10 & 1 & 54 \\
\hline l,oreillar $\ldots . . . \ldots \ldots$. & 4 & 6 & 10 & 12 & 4 & $5(6$ \\
\hline La chanve-sonris ........ & 1 & 6 & 12 & 12 & 4 & 38 \\
\hline Le muscardin-volant..... & 4 & 6 & 12 & 12 & 4 & 58 \\
\hline Le fer-de-lancc.......... & 4 & 4 & 10 & 10 & 4 & 52 \\
\hline La céplıalote............ & 2 & 0 & 6 & 10 & 4 & 22 \\
\hline La chauve-souris nusaraigne. & 4 & 4 & 6 & 6 & 4 & 24 \\
\hline
\end{tabular}

La queue de cette chauve-souris céphalote n'est pas longue; elle est, dit M. Pallas, situce sous la membrane entre les deux cuisses. La forme des narines est un caractère par lequel on pent distinguer, au premier coup d'neil, cette chauve-souris de tontes les autres. La forme de la pupille des yeux diffère aussi de celle des autres chauves-souris; la poitrine a une plus grande amplitude, et ressemble plus que dans aucune autre espèce à la poitrine des oiseaux.

On peut voir la description détaillée des parties extérieures et intérieures de cet animal dans l'ouvrage de M. Pallas. Nous nous contenterous d'en extraire ici les dimensions principales.

p. p. 1

Envergure............... 120

Longueur de l'animal jusqu'à l'origine de la

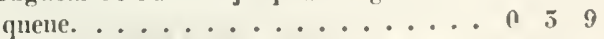

Longueur de la tête. .................... 015

Largeur de la lète. ............. 0000

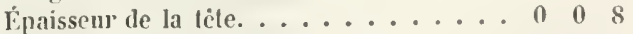

Longneur des oreilles. ........... 0 0 0

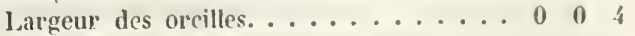

Longueur de l'humerus des ailes. . . . . (n) 1 8

Longucur de l'arant-bras. ....... () 25

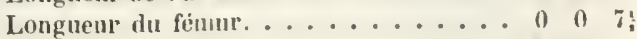

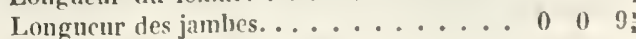

Longueur de la yuenc. .......... (1 100 
S.ongueur de la partie de la queue au delà de la membrane................ 000 $05 \frac{1}{2}$

La seconde espèce de chauve-souris, donnée par M. Pallas sous la dénomination de Vespertilio soricinus, ou chauve-souris-musaraigne, est du genre de celles qui n'ont point de queue, et qui portent une feuille sur le nez; mais e'est la plus petite espèce de ce genre; elle est assez commune dans les régions les plus chaudes de l'Amérique, comme aux îles Carä̈bes et à Surinam. Il parait que la figure en a été donnée par Edwards. Cette chauve-souris a le museau plus long et plus menu que les autres, el e'est ce qui fait qu'elle a aussi un plus grand nombre dc dents. La langue est très-singulière, tant par sa longueur que par sa structure. Le màle et la femelle ne different presque en rien que par les parties sexuelles.

p. p. 1 .

Envergure. ................... 08 8

Lougueur de l'animal jusqu'à la queıe. . . $0 \begin{array}{lll}0 & 2 & 1\end{array}$

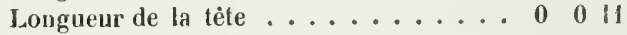

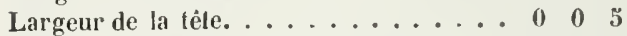

Longueur de la feuille au-dessus du nez. . . $\begin{array}{llll}0 & 0 & 0\end{array}$

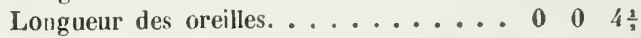

Longueur du lobe interne de l'oreille. . . . $\begin{array}{llll}0 & 0 & 2\end{array}$

Largeur de l'oreille. ................. 004

Longueur de l'humérus............... 0 1 0

Longueur de l'avant-bras. ............ 0 i 4

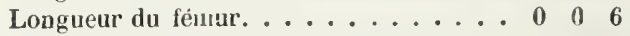

Longueur des jambes. .................. 0 u 6

Longueur des pieds avec les ongles. . . . $\begin{array}{cccc}0 & 0 & 6 \frac{1}{*}\end{array}$

Je renvoie à l'ouvrage de H. Pallas, pour le détail de la description des parties extérieures et intérieures de cet animal, que ee savant naturaliste a faite avec beaucoup de soin et de précision.

NOUVELLE ADDITION A L'ARTICLE DES CHAUVESSOURIS.

\section{LA GRANDE SÉROTINE}

DE LA GUIANE.

Il nous a été apporté une grande chauresouris de Cayenne, et qui nous parait assez différente de celle dont nous avons domné la description sous le nom de vampire, pour qu'on doive la regarder comme formant une autre $e s$ - pèce, quoique toutes deux se trouvent dans le mème pays. C'est à celle que nous avous appelée sérotine de notre climat, que cette grosse chauve-souris de la Guiane ressemble le plus; mais elle en diffère beaucoup par la grandeur, la sérotine n'ayant que deux pouces sept ligues, au lieu que cette chaure-souris de la Guiaue a cinq pouces huit lignes de longueur; elle a cependant le museau plus long, et la tête d'une forme plus allongée et moins couverte de poils au sommet, que celle de la sérotine : les oreilles paraissent aussi être plus grandes, ayant treize lignes de longueur, sur neuf lignes d'ouverture à la base; en sorte qu'indépendamment de la très-grande différence de grandeur et de l'éloignement des climats, cette chauve-souris de la Guiane ne peut pas ètre regardée comme une variété dans l'espèce de la sérotine. Cependant, comme elle ressemble beaucoup plus à la séro“ tine qu'à aucune autre chauve-souris, nous l'avous désignée par le nom de la grande sérotine de la Guiane, afin que les voyageurs puissent la distingucr aisément du vampire et des autres chauves-souris de ces climats éloignés.

Elle avait, avant d'ètre desséchée, près de deux pieds d'envergure, et elle est très-commune aux environs de la ville de Cayenne. On voit ces grandes chauves-souris se rassembler en nombre le soir, et voltiger dans les endroits déconverts, surtout au-dessus des prairies; les tette-chèvres ou engoulevents se mêlent avec ces légions de chauves-souris, et quelquefois ces troupes mêlées d'oiseaux et de quadrupèdes volants sont si nombreuses et si serrées, que l'horizon en paraît couvert.

Cette grande sérotine a les poils du dessus du corps d'un roux marron; les côtés du corps d'un jaune clair. Sur le dos, le poil est long de quatre lignes ; mais, sur le reste du eorps, il est un peu moins long que celui des sérotines de l'Europe; il est très-court et d'un blanc sale sous le ventre, ainsi que sur le dedans des jambes: les ongles sont blanes et crochus. L'envergure des membranes qui lui ser'vent d'ailes est d'environ dix-huit pouçes; ces membranes sont de couleur noirattre, ainsi que la queue. 


\section{DU VAMPIRE.}

M. Roume de Saint-Laurent nous a écrit de la Grenade, en date du 18 avril 1778, au sujet de lagrande chauve-souris ou vampire de l'île de la Trinité. Les remarques de ce judicieux observateur confirment tout ce que nous avions dit et pensé d'abord sur les blessures que fait le vampire, et sur la manière particulière dont il suce le sang, et dont se fait l'excoriation de la peau dans ces blessures. J'en avais, pour ainsi dire, deviné la mécanique : cependant, l'amour de la vérité et l'attention scrupuleuse à rapporter tout ce qui peut servir à l'éclaircir, m'avaient porté à donuer sur ce sujet des témoignages qui semblaient contredire mon opinion; mais j'ai vu qu'elle était bien fondée, et que MM. de Saint-Laurent et Gauthier ont observé tout ce que j’avais présumé sur la manière dont ces animaux font des plaies sans douleur, et peuvent sucer le sang jusqu'à épuiser le corps d'un homme ou d'un animal, et les faire mourir.

\section{LA GRANDE CHAUVE-SOURIS.}

\section{FER-DE-LANGE DE LA GUIANE.}

Cettechauve-souris male, envoyée de Cayenne par M. de la Borde, est très-commune à la Guiane : elle est assez grande, ayant quatre pouces du bout du museau à l'auus; ses ailes ont d'envergure seize pouces quatre lignes. Un poil assez serré couvre tout le corps, la tète et les cótés ; la membrane des ailes est noirâtre et garnie d'un petit poil ras. Elle diffère des chauvessouriscommunes en cequ'ellen'a point de queue: les oreilles sont doites, un peu courbées en dehor's, arrondies à leur's extrémités, et sans oreillon. Au-dessus de la lèvre supérieure est la membrane saillante en forme d'un fer de lance, dont le bord est coneave à la partie inférieure, et qui diffère par là de celle du fer-de-lance, dont les larges rebords ressemblent à un fer à cheval : cette membrane est brunâtre comme les oreilles.

Le poil de cette chauve-souris est très-doux, couleur de musc foncésur tout le corps, excepté sur la poitrine et sur le ventre, où cette couleur est un peu grisâtre; les plus longs poils sont sur le dos, où ils ont trois lignes de longueur.

II n'y a point de dents incisives à la matchoire IV. supérieure, mais il y a deux canines en haut comme en bas.

Longueur de la tête, depuis le museau jusqu'à l'ocp. I. ciput.................. 13

Distance entre le bout du museau et l'angle antérieur de l'œil. . . . . . . . . . . 0 6: Distance del'œil eutrel'angle postérieur et l'oreille 0 Longueur des orcilles. . . . . . . . . . 0 \%

Distance entre la base des deux oreilles. . . . 08

Longueur de l'avant-bras, depuis le coude jusqu'au poignet.............. 210

Longueur depuis le poignet jusqu'au bout des doigts................... 5 5

Longueur de la jambe, depuis le genou jusqu'au talon................... 4 Longueur depuis le talon jusqu'au bout des ongles $\begin{array}{lll}0 & 6\end{array}$ Longueur totale de l'aile.......... 8 11

Largeur la plus grande du poignet aux échancrures............... 210

Cette espèce a quatre dents incisives à la mâchoire inférieure, sans en a voir à la supérieure. Le défaut de queue la distingue de la chauvesouris fer-à-cheval, avec laquelle ellea beaucoup de rapports; et le nombre de ses dents la sćpare de la chauve-souris musaraigne, qui a quatre dents incisives à chaque mâchoire.

\section{LE MOLOSSE AMPLEXICAUDE.}

Cette chauve-souris, dont la longueur, du bout du museau à l'anus, est de trois pouces quatre lignes, a été envoyée de Cayenne par M. de la Borde. Elle est commune dans la Guiane, et généralement à peu près de la grosscur de notre noctule. Elle a, comme toutes les chanves-souris, les yeux petits, le bout du nez saillant, les joues allongées et aplaties sur les côtés; le bout du nez est large; la distance entre les deux naseaux est d'une ligne et demie; la longueur de la tète, du bout du museau à l'occiput, est de dix lignes. Les oreilles, qui sont aplaties sur les còtés, prennent du milieu du front en formant plusieurs plis, et s'étendent sur les joues en s'aplatissant sur le conduit auditif; l'orcillon, qui est placé au-devant de ce conduit, est petit, large et rond à son extrémité. Cette forme écrasée qu'ont les oreilles, et le rebord supérieurqui est saillant, donnent à cette chauvesouris un caractère qui la distingue de toutes les autres espèces. Mais un caractere qui lui est encore propre, c'est d'aroir les ailes très-longues et fort étroites; elles ont quinze pouces deux 
lignes d'envergure; chaque aile a sept pouces de longueur sur deux pouces à sa plus grande largeur. L'os du bras parait attaché au corps, plus bas que daus d'autres chauves-souris, ce qui balance la grande longueur des ailes. La membrane des ailes, qui couvre les jambes et la queue, est de couleur brune ou grisâtre. La queue, enveloppée dans la membrane, a treize lignes de longueur; elle est étroite et terminée par un petit crochet.

Le poil sur le corps a deux lignes et demie de longueur; sa couleur est d'un brun-marron foncé ou noirâtre, qui s'étend sur la tête; la conleur est moins foncée sous le ventre, et cendrée sur les côtés : la face et les oreilles sont de même couleur que les ailes. Le nez, les joues et les mâchoires sont couverts d'un duvet ou poil très-rourt.

La mâchoire supérieure n'a point d'incisives; il y a, de chaque côté, une grande canine et une petite dent pointue qui l'accompagne. La mâchoire inférieure a deux très-petites incisires qui se touchent; les deux canines d'en bas finissent en pointe, et leur côté présente un sillon, dans la cavité duquel s'appliquent les canines supérieures.

Le nombre de ces dents incisives, ainsi que la forme des oreilles, empêche qu'on ne les confonde avec les chauves-souris déjà décrites par les naturalistes, et dont aucune n'a, comme elle, la mâchoire supérieure sans incisives, et la mâchoire inférieure armée seulement de deux dents incisives ou tranchantes. Cependant elle a de très-grands rapports avec celle que $\mathbf{M}$. Gmelin a comprise dans son ouvrage, sous le nom de vespertilio lepturus, quoique celle-ci ait quatre dents incisives à la mâchoire d'eu bas; et ce qui les rapproche de plus près, c'est que les deux dents incisives qui garnissent la mâchoire inférieure de la chauve-souris dont il est ici question, sont très-petites et divisées en deux, de manière qu'on peut aisément croire qu'elle en a quatre à cette même mâchoire.

\section{LE LOIR.}

Famille des rongeurs, genre rat. (Cuvier.)

Nous connaissons trois espèces de loirs, qui, comme la marmotte, dorment pendant l'hiver: le loir, le lérot et le muscardin. Le loir est le plus gros des trois, le muscardin est le plus petit. Plusieurs auteurs ont confondu l'une de ces espèces avec les deux autres, quoiqu'elles soient toutes trois très-distinctes, et par conséquent très-aisées à reconnaître et à distinguer Le loir est à peu près de la grandeur de lécureuil; il a, comme lui, la queue couverte de longs poils : le lérot n'est pas si gros que le rat; il a la queue couverte de poils très-courts, arec un bouquet de poils longs à l'extrémité : le muscardin n'est pas plus gros que la souris; il a la queue courerte de poils plus longs que le lérot, mais plus courts que le loir, avec un gros bouquet de longs poils à l'extrémité. Le lérot diffère des deux autres par les marques noires qu'il a près des yeux; et le muscardin, par lá couleur blonde de son poil sur le dos. Tous trois sont blancs ou blanchâtres sous la gorge et le rentre; mais le lérot est d'un assez beau blanc, le loir n'est que blanchâtre, et le muscardin est plutôt jaunàtre que blanc dans toutes les parties inférieures.

C'est improprement que l'on dit que ces animaux dorment pendant l'hiver : leur état n'est point celui d'un sommeil naturel ; c'est une torpeur, un engourdissement des membres et des sens, et cet engourdissement est produit par le refroidissement $d u$ sang. Ces animaux ont si peu de chaleur intérieure, qu'elle n'excède guère celle de la température de l'air. Lorsque la chaleur de l'air est, au thermomètre, de dix degrés au-dessus de la congélation, celle de ces animaux n'est aussi que de dix degrés. Nous arons plongé la boule d'un petit thermomètre dans le corps de plusieurs lérots vivants; la chaleur de l'intérieur de leur corps était à peu près égale à la température de l'air; quelquefois même le thermomètre plongé, et, pour ainsi dire, appliqué sur le cœur, a baissé d'un demidegré ou d'un degré, la température de l'air étant à onze. Or, l'on sait que la chaleur de l'homme, et de la plupart des animaux qui ont de la chair et du sang, excède en tout temps trente degrés : il n'est donc pas étonnant que ces animaux, qui ont si peu de chaleur en comparaison des autres, tombent dans l'engourdissement dès que cette petite quantité de chaleur intérieure cesse d'être aidée par la chaleur ex. térieure de l'air; et cela arrive lorsque le thermomètre n'est plus qu'à dix ou onze degrés au dessus de la congélation. C'est là la vraie cause de l'engourdissement de ces animaux; cause 
que l'on ignorait, et qui cependant s'étend généralement sur tous les animaux qui dorment pendant l'hiver : car nous l'avons reconnue dans les loirs, dans les hérissons, dans les chauvessouris; et, quoique nous n'ayons pas eu oceasion de l'éprouver sur la marmotte, je suis persuadé qu'elle a le sang froid, comme les autres, puisqu'elle est, comme eux, sujette à l'engourdissement pendant l'hiver.

Cet engourdissement dure autant que la cause qui le produit, et cesse avec le froid : quelques degrés de chaleur au-dessus de dix ou onze suffisent pour ranimer ces animaux ; et, si on les tient pendant l'hiver dans un lieu bien chaud, ils ne s'engourdissent point du tout; ils vont et viennent, ils mangent et dormcut seulement de tenips en temps, comme tous les autres animaux. Lorsqu'ils sentent le froid, ils se serrent et se mettent en boule pour offrir moins de surface à l'air et se conserver un peu de chaleur : e'est ainsi qu'on les trouve en hiver dans les arbres creux, dans les trous des murs exposés au midi; ils y gisent en boule, et sans aucun mouvement, sur de la mousse et des feuilles. On les prend, on les tient, on les roule sansqu'ils remuent, sans qu'ils s'étendent; rien ne peut les faire sortir de leur engourdissement qu'une chaleur douce et graduée : ils meurent lorsqu'on les met tout à coup près du feu; il faut, pour les dégourdir, les en approcher par degrés. Quoique dans cet état ils soient sans aucun mouvement, qu'ils aient les yeux fermés, et qu'ils paraissent privés de tout usage des sens, ils senteut cependant la douleur lorsqu'elle est très-vive; une blessure, une brủlure leur fait faire un mouvement de contraction et un petit cri sourd, qu'ils répètent même plusieurs fois : la sensililité intérieure subsiste donc aussi bien que l'action du cœur et des poumons. Cependant il est à présumer que ces mouvements vitaux ne s'exercent pas dans cet état de torpeur avec la mème force, et n'agissent pas avec la même puissance que dans l'état ordinaire; la circulation ne se fait probablement que dans les plus gros vaisseaux, la respiration est faible et lente, les sécrétions sont très-peu abondantes, les déjections nulles : la transpiration est presque nulle aussi, puisqu'ils passent plusieurs mois sins manger, ce qui ne pourrait être, si dans ce temps de diète ils perdaient de leur substance autant, à proportion, que dans les autres temps où ils la réparent eu prenant de la nourriture. Ils en perdent cependant, puiscque dans les hivers trop longs ils meurent dans leurs trous. Pent-être aussi n'est-ce pas la durée, mais la rigueur du froid qui les fait périr; car, lorsqu'on les expose à une forte gelée, ils meurent en peu de temps. Ce qui me fait croire que ce n'est pas la trop grande déperdition de substance qui les fait mourir dans les grands hivers, c'est qu'en automne ils sont excessivement gras, et qu'ils le sont encore lorsqu'ils se raniment au printemps : cette abondance de graisse est une nourriture intérieure, qui suffit pour les entretenir et pour suppléer à ce qu'ils perdent par la transpira. tion.

Au reste, comme le froid est la senle cause de leur engourdissemeut, et qu'ils ne tombent dans cet état que quand la température de l'air est au-dessous de dix ou onze degrés, il arrive souvent qu'ils se raniment même pendant l'hiver; car il y a des heures, des jours, et même des suites de jours, dans cette saison, où la fiqueur du thermomètre se soutient à douze, treize, quatorze, cte., degrés; et, pendant ce temps doux les loirs sortent de leurs trous pour chercher à vivre, ou plutôt ils mangent les provisions qu'ils ont ramassées pendaut l'automne, et qu'ils y ont transportées. Aristote a dit, et tous les naturalistes ont dit après Aristote, que les loirs passent tout l'hiver sans manger, et que, dans ce temps même de diète, ils deviennent extrêmement gras, que le sommeil seul les nourrit plus que les aliments ne nourrissent les autres animaux. Le fait non-seulement n'est pas vrai, mais la supposition même du fait n'est pas possible. Le loir, engourdi pendant quatre ou cinq mois, ne pourrait s'engraisser que de l'air qu'il respire. Accordons, si l'on reut ( et c'est beaucoup trop accorder), qu'une partic de cet air se tourne en nourriture : en résultera-t-il une augmentation si considérable? cette nourriture si légère pourra-t-elle mẻme suffire à la déperdition continuelle qui se fait par la transpiration? Ce qui a pu faire tomber Aristote dans cette erreur, e'est qu'en Grèce, oủ les hivers sont tempérés, les loirs ne dorment pas continuellement, et que, prenant de la nourriture, peut-itre abondamment, toutes les fois que la chaleur les ranime, il les aura trouvés très-gras, quoique engourdis. Ce qu'il y a de vrai, e'est qu'ils sont gras en tout temps, et plus gras en automne qu'eu été : leur chair est 
assez semblable à eelle du cochon d'Inde. Les loirs faisaient partie de la bonne chère chez les Romains; ils en élevaient en quantité. Varron donne la manière de faire des garennes de loirs, et Apicius celle d'en faire des ragoûts. Cet usage n'a point été suivi, soit qu'on ait eu du dégoût pour ces animaux, parce qu'ils ressemblent aux rats, soit qu'en effet leur chair ne soit pas de bien bon goût. J'ai ouï dire à des paysans qui en avaient mangé, qu'elle n'était guère meilleure que celle du rat d'eau. Au reste, il n'y a que le loir qui soit mangeable; le lérot a la chair mauvaise et d'une odeur désagréable.

Le loir ressemble assez à l'écureuil par les habitudes naturelles; il habite, comme lui, les forêts; il grimpe sur les arbres, saute de branche en branche, moins légèrement à la vérité que l'éeureuil, qui a les jambes plus longues, le ventre bien moins gros, et qui est aussi maigre que le loir est gras : cependant ils vivent tous deux des mêmes aliments; de la faine, des noisettes, de la châtaigne, d'autres fruits sauvages, font leur nourriture ordinaire. Le loir mange aussi de petits oiseaux qu'il prend dans les nids. Il ne fait point de bauge au-dessus des arbres comme l'écureuil, mais il se fait un lit de mousse dans le trone de ceux qui sont ereux : il se gîte aussi dans les fentes des rochers élevés, et toujours dans des lieux sees; il eraint l'humidité, boit peu, et deseend rarement à terre; il diffère encore de l'écureuil en ce que celui-ci s'apprivoise, et que l'autre demeure toujours sauvage. Les loirs s'aceouplent sur la fin du printemps; ils font leurs petits en été; les portées sont ordinairement de quatre ou de cinq : ils eroissent vite, et l'on assure qu'ils ne vivent que six ans. En Italie, où l'on est encore dans l'usage de les manger, on fait des fosses dans les bois, que l'on tapisse de mousse, qu'on recouvre de paille, et où l'on jette de la faine : on choisit un lieu sec à l'abri d'un rocher exposé au midi; les loirs s'y rendent en nombre, et on les y trouve engourdis vers la fin de l'automne; e'est le temps où ils sont les meilleurs à manger. Ces petits animaux sont courageux et défendent leur vie jusqu'à la dernière extrémité : ils ont les dents de devant très-longues et très-fortes; aussi mordent-ils violemment : ils ne eraignent ni la belette ni les petits oiseaux de proie; ils échappent au renard, qui ne peut les suivre au-dessus des arbres : leurs plus grands ennemis sont les chats sauvages et les martes.
Cette espèce n'est pas extrêmement répan. due: on ne la trouve point dans les climats très-froids, comme la Laponie, la Suède; du moins les naturalistes du nord n'en parlent point; l'espèce de loir' qu'ils indiquent est le muscardin, la plus petite des trois. Je présume aussi qu'on ne les trouve pas dans les elimats très-chauds, puisque les voyageurs n'ent font aucune mention. Il n'y a que peu ou point de loirs dans les pays découverts, commel'Angleterre; il leur faut un climat tempéré et un pays couvert de bois : on eu trouve en Espagne, en France, en Grèce, en Italie, en Allemagne, en Suisse, où ils habitent dans les forèts, sur les collines, et non pas au-dessus des hautes montagnes, comme les marmottes, qui, quoique sujettes à s'engourdir par le froid, semblent chercher la neige et les frimas.

\section{LE LÉROT.}

\section{(LE LOIR LÉROT.)}

Famille des rongeurs, genre rat. (Cuvier.)

Le loir demeure dans les forêts, et semble fuir nos habitations; le lérot au contraire habite nos jardins, et se trouve quelquefois dans nos maisons; l'espèce en est aussi plus nombreuse, plus généralement répandue, et il y a peu de jardins qui n'en soient infestés. Ils se niehent dans les trous des murailles; ils courent sur les arbres en espalier, choisissent les meilleurs fruits, et les entament tous dans le temps qu'ils commencent à mûrir : ils semblent aimer les pêches de préférence; et, si l'on veut en conserver, il faut avoir grand soin de détruire les lérots. Ils grimpent aussi sur les poiriers, les abricotiers, les pruniers ; et, si les fruits doux leur manquent, ils mangent des amandes, des noisettes, des noix, et mème des graines légumineuses : ils en transportent en grande quartité dans leurs retraites, qu'ils pratiquent en terre, surtout dans les jardins soignés, ear dans les anciens vergers on les troure sourent dans de vieux arbres creux; ils se font un lit d'herbes, de mousse et de feuilles. Le froid les engourdit, et la ehaleur les ranime. On en trouve quelquefois huit ou dix dans le même lieu, tous engourdis, tous resserrés en boule au milieu de leurs provisions de noix et de noisettes. 
Ils s'accouplent au printemps, produisent en été, et font cinq ou six petits qui croissent promptement, mais qui cependant ne produisent eux-mèmes que dans l'année suivante. Leur chairn'est pas mangeable comme eelle du loir ; ils ont même la mauvaise odeur du rat domestique, au lieuque le loir ne sent rien; ils ne deviennent pas aussi gras, et manquent des feuillets graisseux qui se trouvent dans le loir, et qui enveloppent la masse entière des intestins. On trouve des lérots dans tous les climats tempérés de l'Europe, et même en Pologne, en Prusse; mais il ne parait pas qu'il y en ait en Suède, ni dans les pays septentrionaux.

\section{LE MUSCARDIN.}

\section{(LE LOIR MUSCARDIN.)}

Famille des rongeurs, genre rat. (Cuvier.)

Le muscardin est le moins laid de tous les rats; il a les yeux brillants, la queue touffue et le poil d'une couleur distinguée; il est plus blond que roux : il n'habite jamais dans les maisons, rarement dans les jardins, et se trouve, comme le loir, plus souvent dans les bois, ou il se retire dans les vieux arbres creux. L'espèce n'cn est pas, à beaucoup près, aussi nombreuse que celle du lérot : on trouve le museardin presque toujours seul daus son trou, et nous avons eu beaucoup de peine à nous en procurer quelquesuns : cependant, il parait qu'il est assez commun en Italie; que mème il se trouve dans les climats du nord, puisque M. Limnæus l'a eompris dans la liste qu'il a donnée des animaux de Suède : et, en mêne temps, il semble qu'il ne se trouve point en Angleterre; car M. Ray, qui l'avait vu en Italie, dit que le petit rat dormeur, qui se trouve en Angleterre, n'est pas roux sur le dos comme celui d'Italie, et qu'il pourrait bien être d'une autre espèce. En France, il est le mème qu'en Italie, et nous avons trouvé qu'Aldrovande l'avait bien indiqué : mais cet auteur ajoute qu'il y en a deux espèces en Italie, l'une rare dont l'animal a l'odeur du musc, l'autre plus eommune dont l'animal n'a point d'odeur; et qu'i Bologne on les appelle tous deux muscardins, a cause de leur ressemblance, tant par la figure que par la grosseur. Nous ne connaissons quel'une de ces espèces, et e'est la seconde; car notre muscardin n'a point d'odeur, ni bome ni mauvaise. Il nanque, comme le lérot, des feuillets graisseux qui enveloppent les intestins dans le loir : aussi ne devient-il pas si gras; et, quoiqu'il n'ait point de mauvaise odeur, il n'est pas bon à manger.

Le muscardirr s'engourdit par le froid, et se met en boule comme le loir et le lérot; il se ranime, comme eux, dans les temps doux, et fait aussi provision de noisettes et d'autres fruits secs. Il fait son nid sur les arbres, eomme l'écureuil; mais il le place ordinairement plus bas, entre les branches d'un noisetier, dans un buisson, etc. Le nid est fait d'herbes entrelacées ; il a environ six pouces de diamètre, et n'est ouvert que par le haut. Bien des gens de la campagne m'ont assuré qu'ils avaient trouvé de ces nids dans des bois taillis, dans des haies, qu'ils sont environnés de feuilles et de mousse, et que dans chaque nid il $\mathrm{y}$ avait trois ou quatre petits. Ils abandonnent le nid dès qu'ils sont grands, et cherchent à se gîter dans le creux ou sous le trone des vieux arbres; et e'est là qu'ils reposent, qu'ils font leur provision, et qu'ils s'engourdissent.

\section{LE SURMULOT.}

\section{(LE RAT SURHULOT.)}

\section{Famille des rongeurs, genre rat. (Curier.)}

Nous domnons le nom de surmulot à une nouvelle espèce de mulot, qui n'est connue que depuis quelques années. Aucun naturaliste n'a parlé de cet animal, à l'exception de M. Brisson, qui, le comprenant dans le genre des rats, l'a appelé rat des bois. Mais, comme il diffère autant du rat que le mulot ou la souris, qui ont leurs noms propres, il doit avoir aussi un nom particulier, surmulot, comme qui dirait gros, grand mulot, auquel en effet il ressemble plus qu'au rat par la couleur et par les habitudes naturelles. Le surmulot est plus fort et plus méchant que le rat; il a le poil roux, la queue ex trêmement longue et sans poil, l'épine du dos arquée comme l'écureuil, et le corps beaucoup plus épais, des moustaches comme le chat. Ce n'est que depuis neuf ou dix ans que cette espèce s'est répandue dans les euvirons de Paris. L'on ne sait d'où ces animaux sont venus, mais ils ont prodigicusement multiplié ; et l'on n'en 
sera pas étonné, lorsqu'on saura qu'ils produisent ordinairement douze ou quinze petits, souvent seize, dix-sept, dix-huit, et même jusqu'à dix-neuf. Les endroits où ils ont paru pour la première fois, et où ils se sont bientôt fait remarquer par leurs dégâts, sont Chantilly, IFarly-la-Ville et Versailles. M. Leroy, inspecteur du parc, a eu la bonté de nous en envoyer en grande quantité, vivants et morts ; il nous a mẻme communiqué les remarques qu'il a faites sur cette nouvelle espèce. Les mảles sont plus gros, plus hardis et plus méchants que les femelles : lorsqu'on les poursuit et qu'on veut les saisir, ils se retournent et mordent le bâton ou la main qui les frappe : leur morsure est nonseulement cruelle, mais dangereuse; elle est promptement suivie d'une enflure assez considérable, et la plaie, quoique petite, est longtemps à se fermer. Ils produisent trois fois par an : ainsi, deux individus de cette espèce en font, tout au moins, trois douzaines en un an. Les mères préparent un lit à leurs petits. Comme il y en avait quelques-unes de pleines dans le nombre de celles qu'on nous avait envoyées vivantes, et que nous les gardions dans des cages, nous avons vu les femelles, deux ou trois jours avant de mettre bas, ronger la planche de leur cage, en faire de petits copeaux en quantité, les disposer, les étendre, et ensuite les faire servir de lit à leurs petits.

Les surmulots ont quelques qualités naturellesqui semblent les rapprocher des rats d'eau : quoiqu'ils s'établissent partout, ils paraissent préférer le bord des eaux ; les chiens les chassent comme ils chassent les rats d'eau, c'est-àdire avec un acharnement qui tient de la fureur. Lorsqu'ils se sentent poursuivis, et qu'ils ont le choix de se jeter à l'eau ou de se fourrel dans un buisson d'épines, à égale distance, ils choisissent l'eau, y entrent sans crainte, et nagent avec une merveilleuse facilité. Cela arrive surtout lorsqu'ils ne peuvent regagner leurs terriers; car ils se creusent, comme les mulots, des retraites sous terre, ou bien ils se gitent dans celles des lapins. On peut, a vec les furets, prendre les surmulots dans leurs terrier's; ils les poursuivent comme des lapins, et semblent même les chercher avec plus d'ardeur.

Ces animaux passent l'été dans la campagne ; et, quoiqu'ils se nourrissent principalement de fruits et de grains, ils ne laissent pas aussi d'être très-carnassiers: ils mangent les lapereaux, les perdreanx, la jeune volaille; et, quand ils entrent dans un poulailler, ils font comme le putois, ils en égorgent beaucoup plus qu'ils ne peuvent en manger. Vers le mois de novembre, les mères, les petits et tous les jeunes surmulots quittent la campagne et vont en troupe dans les granges, où ils font un dégât infini ; ils hachent la paille, consomment beaucoup de grains, et infectent le tout de leur ordure. Les vieux mâles restent à la campagne; chacun d'eux habite seul dans son trou : ils y font, comme les mulots, provision pendant l'automue de gland, de faìne, etc. ; ils le remplissent jusqu'au bord, et demeurent eux-mêmes au fond du trou. Ils ne s'y engourdissent pas comme les loirs; ils en sortent en hiver, surtout dans les beaux jours. Ceux qui vivent dans les granges en chassent les souris et les rats; l'on a même remarqué, depuis que les surmulots se sont si fort multipliés aux environs de Paris, que les rats y sont beaucoup moins communs qu'ils ne l'étaient autrefois.

\section{LE POUC.}

Famille des rongeurs, genre rat. (Cuvier.)

Rzaczynski fait mention d'un autre animal que les Russes appeHent pouck ; il est plus grand que le rat domestique; il a le museau oblong; il creuse la terre, se fait un terrier, et dévaste aussi les jardins. Il y en avait en si grand nombre auprès de Surez en Volhynie, que les habitants furent obligés d'abandonner la culture de leurs jardins. Ce pouc pourrait bien êtrele même que Seba' nomme rat de Norwége, et dont il donne la description et la figure.

\section{LE ZEMNI.}

Famille des insectirores, genre taupe. (Cuvier.)

Il y a en Pologne et en Russie un autre animal, appelé ziemni ou zemni, qui est du mème

1 Mus ex Norveglâ ciıero-fuscus ; rostro gaudet suilto, capite longinsculo, brevibus latisque auriculis, promisso mystacis ntrinque ad latera narium rigenle; dorsum ejus latum et incurvum est, abdomen pendulum, femora grossa, pedum digiti longi acutis unguibus ad fodiendım adaplatis; lalparum enim instar in erutis sub terrâ antris degit; pilus ex diluto cinere fuscus est; Seba, vol. II, pag. 64, fig., t. 63 , fig. 5. 
genre que le zisel, mais qui est plus grand, plus fort et plus méchant: il est un peu plus petit qu'un chat domestique; il a la tête assez grosse, le corps menu, les oreilles courtes et arrondies : quatre grandes dents incisives qui lui sortent de la gueule, dont les deux de la màchoire inférieure sont trois fois plus longues que les deux de la måchoire supérieure; les pieds très-courts et couverts de poils, divisés en cinq doigts et ornés d'ongles courbes; le poil mollet, court ct de couleur de gris-de-souris ; la quene médiocrement grande; les yeux aussi petits et aussi cachés que ceux de la taupe. Rzaczynski a appelé cet animal petit chien de terre (canicula subterranea : cet auteur me parait être le seul qui ait parlé du zemni, qui néanmoins est fort commun dans quelques provinces du Nord '. Son naturel et ses habitudes sont à peu près les mêmes que celles du hamster et du zisel : il mord dangereusement, mange avidement, et dévaste les moissons et les jardins; il se fait un terrier ; il vit de grains, de fruits et de légumes, dont il fait des magasins dans sa retraite, où il passe tout le temps de l'hiver.

\section{LA TAUPE}

\section{Du}

\section{GAP DE BONNE-ESPÉRANCE.}

\section{( LE PETIT RAT TAUPE DU CAP.)}

Ordre des carnassiers, famille des insectivores, genre taupe. (Cuvier.)

On trouve une taupe au cap de Bonne-Espérance, et dont la peau bourrée nous a étédounée par M. Sonnerat, correspondant du Cahinet. Cette taupe ressemble assez à la taupe ordinaire par la forme du corps, par les yeux, qu'elle a très-petits, par les oreilles, qui ne sont point apparentes, ct par la queue, qu'il laut chercher dans le poil, et qui est à peu près de la même longueur que celle de notre taupe ; mais elle en diffëre par la tête, qu'clle a plus grosse, et par le museau, qui ressemble à celui du cochon-d'Inde. Les pieds de devant sont aussi différents; le poil du corps n'est pas noir, mais

' Repartitur hoc animal in Podolia, Ukraina, Volbynia circa Suraz, Chodaki, Rienki, Mossezenica, Sezurowee et alibi ; non raro cernitur ab agricolis ibidem vomeribus. Rzaczynski, Auclarium Polonix, pag. 323 et 326. d'un brun minime avec un peu de fauve à l'ex-trémité de chaque poil; la queue est couverte de grands poils d'un jaune blanchâtre; et cn général lc poil de cette tanpe du Cap est plus long que celui de la taupe d'Europe. Aiusi, l'on doit conclure de toutes ces différences que e'est une espèce particulière, et qui, quoique voisine de celle de la taupe, ne peut pas être regardée comme une simple variété.

\section{ADDITION A L'ARTICLE DE LA TAUPl: DU CAP DE BONNE ESPÉRANCE.}

Depuis la publication de eet article, j'ai reecu de M. Allamand une description plus exacte de cette taupe du Cap, avec une figure faite sur l'animal vivant. Voici ce que cet habile naturaliste a publié cette aunée (1781) sur cet animal, que je n'avais guère pu qu'indiquer d'après WM. Sonnerat et de la Caille.

II. de Buffon a donné une figure de cette taupe, faite d'après une peau bourrée, yui Jui a été donnée par M. Sonnerat, et il ne lui élait pas possible d'en donner une meilleure, parce pu'un tel animal ne peut pas ètre transporté vivant en Europe; mais cette ligure représente si imparfaitement sou original, que je u’ai pas liésité l'en donner une meilleure. $M$. Gordon mien a enroyé le dessin.

Cette taupe ressemble à la taupe urdinaire par les habiludes et par la forme du corps; mais aussi elle en diffère en des parties si essentielles, que M. de Buffon a eu raison de dire que c'tait une espèce particulière, qui ne pouvait pas ètre regardie cumne une simple varieté. Sa longueur est de sept ponces, et son poil est d'un brun minime, yui devient plus foncé et presune noir sur la tète; vers les côtés et sous le ventre, il est d'un blanc cenure ou bleucitre.

La têle de cette taupe est presque aussi lıante que longue, et elle est termince par un museau aplati, et non pas allongé comme cclui de nos taupes : cependant elle a ceci de commun aree ces dernières, c'est que son museau ressemble à une espèce de boutoir, de coulenr de chair, oi l'un voil les ouvertures des narines, comme dans le cochon, mais qui n'avance point au deli des dents. La gueule est environnee d'une bande blanche de la largeur de quatre ou eing lignes, qui passe andessus du museau, il en part inuelyues long- poils blanes qui forment une espice de mostache. Elle a à chaqne michoire deux dents incisives fort longues, qui paraissent mème quand la gueule est fermee; celles d'en haut sont de la longueur de 
quatre lignes, et celles d'en bas de plus de six : ses yeux sont extrêmement petits et placés presque à égale distance du museau et des oreilles; ils occupent le centre d'une tache ovale blanche, dont ils sont environnés, ce qui fait qu'on n'a pas dle peine $\dot{a}$ les trouver, comme dans nos taupes; ses oreilles riont point de conque qui paraisse en dehors, tout ce qu'on en roit extérieurement consiste dans l'orifice du canal auditif, qui est assez grand, et dont le rebord a un peu de saillie; cet orifice est aussi placé au milieu d'une tache blanche; enfin, il y a une troisième tache de la même couleur au-dessus de la tête; et c'est à cause de ces différentes taches, quion la nomme au Cap blesmol ou taupe tachetée; ses pieds ont tous cinq doigts munis de forts ongles ; ils sont sans poils en dessus, mais i!s en ont d'assez longs en dessous; ceux dedevant sont faits comme ceux de derrière, et ils n'ont rien qui ressemble à ceux des taupes d'Europe, qui sont beaucoup plus grands que les pieds postérieurs; et dont la figure approclie de celled dune main dont la paume serait tournée en arrière.

Sa queue, qui ne surpasse pas sept ou huit lisnes, est couverte de longs poils de la même cou.eur yue ceux des côtés.

Ces taupes ressemblent encore aux nòtres par leurs labitudes; clles vivent sous terre : elles y creusent des galeries, et elles font beaucoup de mal aux jardins. M. Gordon a vu, fort avant dans l'intérieur du pays, une espèce bcaucoup plus petite et de conleur d'acier; aussi lui en donne-t-on le nom : mais quant au restc elle ètait tout à fait semblable à celles que nous venons de décrire. Ce que nous en arons dit est une nouvelle preuve du peu d'attention que Kolbe a donné à ce qu'il a vu; en parlant de la taupe du Cap, voici comment il s'cxprime :

" Il y a des taupes au Cap, etmème en fort grande " quantité, qui ressemblent, à tous égards, à celles " que nous arons en Europe, ainsi je n'ai rien à " dire sur ce sujet; " il aurait donc pu se passer d'en faire un article, où il n'est question que du piége qu'on leur tend, en leur faisant tirer une corde qui fait partir un coup de fusil qui les tue, et même encore je doute qu'on se donne la peine de faire tant d'appareil pour un aussi petit animal que cette taupe ; le piége parait plutòt ètre tendu pour une autre taupe, dont il sera question dans l'article suivant, mais dont Kolbe n'aura connu que le nom, cependant il serait dangereux de prendre ces animaux avec la main, ils sont méchants et mordent bien fort.

M. de Buffon, dans l'article intéressant qu'il a donné de la taupe ordinaire, a remarqué que pour la dédommager du sens de la vue, dont elle est presque privee, la nature lui a accordé arec magnificence les organes qui servent à la génération. La taupe du Cap aurait besoin du même dédommagement, mais j'ignore si la nature a été si libérale d son égard.

Dans le journal d'un voyage entrepris par l'or dre du gourernement du Cap, il est dit, dans une note de l'éditeur, que cette taupe ressemble plus au hamster qu'à tout autre animal de l'Europe. Jc ne comprends pas ou l'auteur de cette note trouve la ressemblance. Si l'on compare la figure que j'en donne ici avec celle du hamster, je doute qu'on trouve aucun rapport entre elles.

\section{LA GRANDE TAUPE D'AFRIQUE.}

\section{(LE RAT TAUPE DES DUNES.}

Une seconde espèce est la taupe du cap de Bonne-Espérance, dont nous venons de faile mention. Ces taupes d'Afrique, suivant M. l'abbé de la Caille, sont plus grosses que celles d'Eulope, et si nombreuses dans les terres du Cap, qu'elles y forment des trous et des élévations en si grand nombre, qu'on ue peut les parcourir à cheval, sans courir risque de broncher à chaque pas.

\section{LA GRANDE TAUPE DU CAP.}

Nous ajouterons à toutes ces nouvelles espèces de taupes celle dont MM. Gordon et Allamand nous ont donné la description et la figure, sous la dénomination de grande taupe du Cap ou taupe des Dunes, et qui est en effet si grande et si grosse, en comparaison de toutes les autres, qu'on n'a pas besoin de lui donner un autre nom que celui de grande taupe, pour en distinguer et reconnaitre aisément l'espèce.

Cet animal, dit M. Allamand, a été jusqu'à prósent inconnu à tous les naturalistes, et vraisemblablement il l'aurait été encore longtemps, sans les soins toujours actifs de M. le capitaine Gordon, qui ne néglige aucune occasion d'enrichir l'histore naturelle par de nouvelles décourertes ; c'est lui qui m'en a envoyé le dessin. Je nomme cet animal, avec les habitants du Cap, la taupe des Dunes, et c'est un peu malgré moi ; je n'aime pas ces noms composés; et d'ailleurs celui de taupe lui convient encore moins qu'à la taupe du Cap, que j'ai décrite ci-devant. J'aurais sonhaité de pouvoir lui donner le nom par lequel les Hottentots le désignent ; mais 
il est lui-mẻme composé et fort dur à l'oreille, c'est celui de kauw howba, qui signifie taupe hippopotame. Les Hottentots l'appellent ainsi à cause de je ne sais quelle ressemblance qu'ils lui trouvent avec ce gros animal ; peut-être faut-il la chercher dans ses dents incisives, qui sont très-remarquables par leur longueur. Quoi qu’il en soit, s’il diffère de la taupe à quelques égards, il a anssi cliverses aflinités avec elle, et il n'y a point d'autre animal clont le nom lui convienne mieux.

Ces taupes habitent dans les Dunes qui sont aux environs dı cap dle Bonne-Espćrance et près de la mer: on n'en trouve point dans l'intérieur du pays. Celle-ci était un mâle, dont la longueur, depuis le museau jusqu'à la quene, en suivant la courbure du corps, était d'un pied; sa circonférence, prise derrière les jambes de devant, était de dix pouces, et de neuf devant les jambes de derrière; la partie supérieure de son corps était blanchâtre, avec une légère teinte de jaune, qui se changeait en couleur grise sur les côtés et sous le ventre.

Sa tête n'était pas ronde comme celle de la taupe du Cap ; elle était allongée et elle se terminait par un museau plat, de couleur de chair, assez semblable au boutoir d'uncochon; ses yeux étaient fort petits, et ses oreilles n'étaient marquées que par l'ouverture du canal auditif, placée au milieu d'une tache ronde plus blanche que le reste du corps. Elle avait à chaque mâchoirc deux dents incisives qui se montraient, quoique la gueule fût fermée; celles d'en bas élaient fort longues, celles d'en lıaut étaient beaucoup plus courtes; aı premier coup d'ceil il semblait qu'il y en eût quatre; elles étaient fort larges, et cliacune avait par devant un profond sillon qui la partageait en deux et la faisait parait re double ; mais par derrière elles étaient tout à fait unies. Ses dents molaires étaient au nombre de huit dans chaque mâchoire ; ainsi, avec les incisives elle avait vingt-deux dents en tout. Les infẻrieures avançaient un peu au-clelà des supérieures : mais ce qu'elles offraient de plus singulier, c'est qu'elles étaient mobiles, ct que l'animal pouvait les écarter ou les réunir à volonté : faculté qui ne se trouve dans aucun quadrupède qui me soit connu.

Sa queue était plate et de la longueur de deux pouces six lignes ; elle était couverte de longs poils qui, tle même que ceux qui formaient ses moustacles, et ceux de dessous ses pattes, étaient raides comme des soies de cochon.

11 y avait à claque pied cinq doigts, munis d'ongles fort longs et blanchàtres.

On voit, par cette description, que, si ces animaux surpassent de beaucoup les autres taupes en grandeur et en grosseur, ils leur resscmblent par les yeux et par les oreilles ' mais il y a plus encore, ils vivent comme elles sous terre; ils y font des trous profonds et de longs boyaux; ils jettent la terre comme nos taupes en l'accumulant en de très-gros monceaux ; cela fait qu'il est dangereux d'aller à clıeval dans les lieux où ils sont ; souvent il arrive que les jambes des chevaux s'enfoncent dans ces trous jusqu'aux genoux.

Il faut que ces taupes multiplient beaucoup, car elles sont très-nombreuses. Elles vivent de plantes et d'ognons, et par conséquent elles causent beancoup de dommage aux jardins qui sont près des Dunes. On mange leur chair, et on la dit fort bonne.

Elles ne courent pas vite, et en marchant elles tournent leurs pieds en dedans, comme les perroquets ; mais elles sont très-expéditives à creuser la terre. Leur corps touche toujours le sol sur lequel elles sont : elles sont méchantes; elles mordent très-fort, et ili est dangereux de les irriter.

\section{LE TUCAN.}

Famille des insectivores, genre taupe. (Cuvier.)

Fernandez donnc le nom de tuean à un petit quadrupéde de la Nouvelle-Espagne, dont la grandeur, la figure et les habitudes naturelles approchent plus de celles de la taupe que d'aucun autre animal : il me parait que c'est le même qu'a décrit Seba, sous le nom de tauperonge d'Amérique; au moins les descriptions de ces denx auteurs s'accordent assez pour qu'on doive le présumer. Le tucan est pent-être un pen plus grand que notre taupe; il est comme elle gros et charnu, avec des jambes si courtes, que le ventre tombe à terre: il a la queue courte, les oreilles petites et rondes, les yeux si petits, qu'ils lui sont, pour ainsi dire, inutiles; mais il differe de la taupe par la couleur du poil, qui est d'un jaume roux, et par le nombre des doigts, n'en ayant que trois aux pieds de devant, et quatre à ceux de derrièrc, au lieu que la taupc a cinq doigts à tous les pieds : il pourrait en différer encore, en ce que sa chair est bonne à manger, et qu'il n'a pas l'instinct de la taupe pour retrouver sa retraite lorsqu'il en est sorti : il creuse à chaque fois un nou veau trou ; en sorto que, dans certaines terres qui lui conviennent, les trous que font ce's animaux sont en si grand nombre et si près les uns des autres, qu'on ne peut y marcher qu'avec précaution. 


\section{LA MARMOTTE.}

(LA MARMOTTE DES ALPES.)

Famille des rougeurs, genre rat. (Cuvier.)

De tous les auteurs modernes qui ont ecrit sur l'histoire naturelle, Gessner est celui qui, pour le détail, a le plus avancé la science; il joignait à une grande érudition un sens droit et des vues saines: Aldrovande n'est guère que son commentateu', et les naturalistesdemoindre nom ne sont que ses copistes. Nous n'hésiterons pas à emprunter de lui des faits au sujet des marmottes, animaux de son pays ${ }^{1}$, qu'il connaissait mieux que nous, quoique nous en ayons nourri comme lui quelques-unes à la maison. Ce que nous a vons observé se trouvant d'accor'd avec ce qu'il en dit, nous ne doutons pas que ce qu'il a observé de plus ne soit également vrai.

La marmotte, prise jeune, s'apprivoise plus qu'aucun animal sauvage, et prescue autant que nos animaux domestiques; elle apprend aisément à saisir un bâton, à gesticuler, à danser, a obéir en tout à la voix de son maitre. Elle est, comme le chat, antipathique avec le chien ; lorsqu'clle commence à être familière dans la maison, et qu'elle se croit appuyée par son maitre, elle attaque et mord en sa présence les chiens les plus redoutables. Quoiqu'elle ne soit pas tout à fait aussi grande qu'un lièvre, elle est bien plus trapue, et joint beaucoup de force à beaucoup de souplesse. Elle a les quatre dents du devant des mâchoires assez longues et assez fortes pour blesser cruellement; cependant, elle n'attaque que les chiens, et ne fait mal à personne, à moins qu'on ne l'irrite. Si l'on n'y prend garde, elle ronge les meubles, les étoffes, et perce même le bois lorsqu'elle est renfermée. Comme ellea les cuisses très-courtes, et les doigts des pieds faits à peu près comme ceux de l'ours, elle se tient souvent assise, et marche, comme lui, aisément sur ses pieds de derrière ; elle porte à sa gueule ce qu'elle saisit avec ceux de devant, et mange debout comme l'écureuil : elle court assez vite en montant, mais assez lentement en plaine; elle grimpe sur les arbres ; elle monte entre deux parois de rochers,

\footnotetext{
1 Gessner était Suisse; et c'est un des hommes qui font le plus d'honneur à la nation.
}

entre deux murailles voisines : et c'est des marmottes, dit-on, que les Savoyards ont appris à grimper pour ramoner les cheminées. Elles mangent de tout ce qu'on leur clonne, de la viande, du pain, des fruits, des racines, des herbes potagères, des choux, des hannetons, des sauterelles, etc.; mais elles sont plus a vides de lait et de beurre que de tout autre aliment. Quoique moins enclines que le chat à dérober, elles cherchent à entrer dans les endroits où l'on renferme le lait, et elles le boivent en grande quantité en marmottant, c'est-à-dire en faisant, cornme le chat, une espèce de murmure de contentement. Au reste, le lait est la seule liqueur qui leur plaise; elles ne boivent que très-rarement de l'eau, et refusent le vin.

La marmotte tient un peu del'ours et un peu du rat pour la forme du corps; ce n'est cependant pas l'arctomys ou le rat-ours des anciens, comme l'ont cru quelques auteurs, et entre autres Perrault. Elle a le nez, les lèvres et la forme de la tète comme le lièvre, le poil et les ongles du blaireau, les dents du castor, la moustache du chat, les yeux du loir, les pieds de l'ours, la queue courte et les oreilles tronquées. La couleur de son poil sur le dos est d'un roux brun, plus ou moins foncé : ce poil est assez rude, mais celui du ventre est roussâtre, doux et touffu. Elle a la voix et le murmure d'un petit chien lorsqu'elle joue ou quand on la caresse; mais lorsqu'on l'irrite ou qu'on l'effraie, elle fait entendre un sifflet si percant et si aigu, qu'il blesse le tympan. Elle aime la propreté, et se met à l'écart, comme le chat, pour faire ses besoins; mais clle a, comme le rat, surtout en été, une odeur forte qui la rend très-désagréable; en automne, elle est très-grasse. Outre un très-grand épiploon, elle a, comme le loir, deux feuillets graisseux fort épais : cependant elle n'est pas écalement grasse sur toutes les parties du corps; le dos et les reins sont plus chargés que le reste d'une graisse ferme et solide, assez semblableà la chair des tétines du bœuf. Aussi la marmotte serait assez bonne à manger, si elle n'avait pas toujours un peu d'odeur, qu'on ne peut masquer que par des assajsonnements très-forts.

Cet animal, qui se plait dans la région de la neige et des glaces, qu'on ne trouve que sur les plus bautes montagnes, est cependant sujet plus qu'un autre à s'engourdir par le froid. C'est ordinairement à la fin de septembre ou au commencement d'octobre qu'elle se recèle dans sa 
retraite, pour n'en sortir qu'au commencement d'avril. Cette retraite est faite avec précaution, ct meublée avec art : elle est d'abord d'une grande capacité, moins large que longue, et très-profonde; au moyen de quoi elle peut contenir une ou plusieurs marmottes sans que l'air s'y corrompe. Leurs pieds et leurs ongles paraissent être faits pour fouiller la terre; et elles la creusent en effet avec une merveilleuse célérité; elles jettent au dehors, derrière elles, les déblais de leur excavation : ce n'est pas un trou, un boyau droit ou tortueux, e'est une espèce de galerie faite en forme d'Y grec, dont les deux branches ont chacune une ouverture, et aboutissent toutes deux à un cul-de-sac, qui est le lieu du séjour. Comme le tont est pratiqué sur le penchant de la montagne, il n'y a que le culdesac qui soit de niveau : la branche inférieure de l'Y grec est en pente au-dessous du cul-desac; et c'est dans cette partie, la plus basse du domicile, qu'elles font leurs excréments, dont l'humidité s'écoule aisément au dehors : la branche supérieure de l'Y grec est aussi un peu eu pente, et plus élevée que tout le reste; c'est par là qu'elles entrent et qu'elles sortent. Le lieu du séjour est non-seulement jonché, mais tapissé fort épais de mousse et de foin; elles en font ample provision pendant l'été : on assure même que cela se fait à frais ou travaux communs; que les unes coupent les herbes les plus fines, que d'autres les ramassent, et que tour à tour elles servent de voitures pour les transporter au gîte : l'une, dit-on, se couche sur le dos, se laisse charger de foin, étend ses pattes en haut pour servir de ridelles, et ensuite se laisse trainer par les autres, qui la tirent par la queue, et prennent garde en même temps que la voiture ne verse. C'est, à ce qu'on prétend, par ce frottement trop souvent réitéré, qu'elles ont presque toutes le poil rongé sur le dos. On pourl'ait cependant en donner une autre raison; c'est qu'habitant sous la terre, et s'occupant sans cesse à la creuser, cela seul suffit pour leur peler le dos. Quoi qu'il en soit, il est sûr qu'elles demeurent ensemble et qu'elles travaillent en commun à leur habitation : elles y passent les trois cuarts de leur vie; elles s'y retirent pendant l'orage, pendant la pluie, ou dès qu'il y a quelque danger; elles n'en sortent même que daus les plus beaux jours, et ne s'en éloignent guère : l'une fait le guet, assise sur une roche élevée, tandis que les autres s'amusent à jouer sur le gazon, ou s'occupent à le couper pour en faire du foin; et, lorsque celle qui fait sentinelle apercoit un homme, un aigle, un chien, etc., elle avertit les autres par un coup de sifflet, et ne rentre elle-même que la dernière.

Elles ne font pas de provisions pour l'hiver; il semble qu'elles devinent qu'elles seraient inutiles : mais, lorsqu'elles sentent les premières approches de la saison qui doit les engourdir, elles travaillent à fermer les deux portes de leur domicile, et elles le font avec tant de soin et de solidité, qu'il est plus aisé d'ouvrir la terre partout ailleurs que dans l'endroit qu'elles ont muré. Elles sont alors très-grasses; il y en a qui pèsent jusqu'à vingt livres : elles le sont encore trois mois après; mais peu à peu leur embonpoint diminue, et clles sont maigres sur la fin de l'hiver. Lorsqu'on décourre leur retraite, on les trouve resserrées en boule et fourrées dans le foin; on les emporte tout engourdies; on peut même les tuer sans qu'elles paraissent le sentir : on choisit les plus grasses pour les manger, et les plus jeunes pour les apprivoiser. Une chaleur graduée les ranime, comme les loirs; et celles qu'on nourrit à la maison, en les tenant dans des lieux chauds, ne s'engourdissent pas, et sont mème aussi vives que dans les autres temps. Nous ne répéterons pas, au sujet de l'engourdissement de la marmotte, ce que nous avons dit à l'article du loir : le refroidissement du sang en est la seule cause, et l'on avait observé avant nous que dans cet état de torpeur la circulation était très-lente aussi bien que toutes les sécrétions, et que leur saug, n'étant pas renouvelé par un chyle nouveau, était sans aucune sérosité. Voyez les Transactions philosophiques, n. 397. Au reste, il n'est pas sûr qu'elles soient toujours et constamment engourdies pendant sept ou huit mois, comme presque tous les auteurs le prétendent. Leurs terriers sont profonds; elles y demeurent en nombre; il doit done s'y conserver de la chaleur dans les premiers temps, et elles y peuvent manger de l'herbe qu'elles y out amassée. M. Altmann dit même, dans son Traité sur les animaux de Suisse, que les chasseurs laissent les marmottes trois semaines ou un mois dans leur caveau, avant que d'aller troubler leur l'epos; qu'ils ont soin de ne point ereuser lorsqu'i! fait un temps doux, ou qu'il souffle un vent chaud; que sans ces précautions les marmottes se réveillent, et creusent plus avant; mais 
qu'en ouvrant leurs potmites dans le temps des grands froids, on les trouve tellement assoupies, qu'on les emporte facilement. On pent done dire qu’à tous égards elles sont comme les loirs, et que, si elles sont engourdies plus longtemps, c'est qu'elles habitent un climat où l'hiver est plus long.

Ces animaux ne produisent qu'une fois l'an : les portées ordinaires ne sont que de trois on quatre petits ; leur accroissement est prompt, et la durée de leur vie n'est que de neuf ou dix ans : aussi l'espèce n'en est ni nombreuse ni bien répandue. Les Grees ne la connaissaient pas, ou du moins ils n'en ont fait aucune mention. Chez les Latins, Pline est le premier qui l'ait indiquée sous le nom de mus alpinus, rat des Alpes : et en effet, quoiqu'il y ait dans les Alpes plusieurs autres espèces de rats, aucuue n'est plus remarquable que la marmotte, aucune n'habite comme elle les sommets des plus hautes montagnes : les autres se tiennent dans les vallons, ou bien sur la croupe des collines et des premières montagnes; mais il n'y elı a point qui monte aussi haut que la marmotte. D'ailleurs, elle ne descend jamais des hauteur's, et parait être particulièrement attachée à la chaîne des Alpes, où elle semble choisir l'exposition du midi et du levant, de préférence à celle du nord ou du couchant. Cependant il s'en trouve daus les Apennins, dans les Pyrénées et daus les plus hautes montagnes de l'Allemagne. Le bobak de Pologne ${ }^{1}$, auquel M. Brisson ${ }^{2}$, et, d'apres lui, MM. Arnault de Nobleville et Salerne ${ }^{3}$ ont donné le nom de marmotte, diffère de cet animal, non-seulement par les couleurs du poil, mais aussi par le nombre des doigts; car il a cinq doigts aux pieds de devant: l'ongle du pouce parait au dehors de la peau, et l'on trouve au dedans les deux phalanges de ce cinquième doigt, qui manque en entier dans la marmotte. Ainsi, le bobak ou marmotte de Pologne, le monax ou marmotte de Canada, le cavia ou marmotte de Bahama, et le cricet ou marmotte de Strasbourg, sont tous les quatre des espèces différentes de la marmotte des Alpes.

\footnotetext{
1 vid. Auctarium IHist. nat. P'olonix, auth. Rzaczynski, pag. 327.

Brisson, Reg. animal, pag. 165.

- Histoire naturelle des Animaux, par M. Aruault de Nobleville et Salerne. Paris, 1756. Onvrage utile et où les faits sont rassemblés avecautant de soin que de discernement.
}

\section{DESCRIPTION DE LA MARMOTTE.}

Quoique la marmotte dorme pendant l'hiver, comme le loir, le lérot et le muscardin, elle diffère plus de ces animaux par la conformation des parties intérieures, que du rat, de la souris, du mulot, etc.; cependant elle diffère encore beaucoup de ceux-ci comme des autres par la figure extérieure. La marmotte a quelque rapport avec le lièvre et le lapin par le museau qui est court et gros, et par la forme de la tète qui est allongée et un peu arquée à l'endroit dı front ; cependant, le front et le sommet de la tète sont plus larges et plus aplatis. Les yeux sont placés sur les côtés de la tète, comme ceux du lièvre; la lèvre supérieure fait en quelque sorte le bec de lièvre, car elle est fendue en partie, et sillonnée jusqu’à la cloison des narines; mais les oreilles sont bien différentes de celies du lièvre et du lapin, elles ont encore moins de longueur que celles des rats, à peine paraissent-elles au-dessus du poil, qui a peu de longueur sur la tête, excepté à l'endroit des joutes, où il est beaucoup plus long: cette différence de longueur produit la fausse apparence du renflement de chaque còté de la tète. La lèvre du dessous est beaucoup plus courte que celle dı dessus; le cou a très-peu de longueur; le corps est gros et fort étoffé ; la croupe est rabature ; la quene a le plus souvent une direction horizontale en arrière, elle est garnie de longs poils : les jambes sont courtes, et le paraissent encore davantage, parce qu'elles ne sont jamais bien étendtues, et que le carpe et le tarse portent en entier sur la terre. Les pieds de devant sont un peu tournés en dedans et v'ont que quatre doigts; il y en a cinq dans les pieds de derrière, qui sont au contraire un peu tournés en delıors. Lorsque l'animal s'arrète et se repose, il se pelotonne en partie, le dos est fort arque, la poitrine, le ventre et l'origine de la queue portent sur la terre, la tète est inclinée vers la poitrine, le museau tonche les pieds de devant, et la quene est repliée du còté du corps. Souvent l'animal quitte en partie cette attitude, et lève la tète; c'est alors qu'il paraîtavoir quelque expression dans la physionomie, quoique son gros museau semble toujours indiquer la stupidité.

Le sommet de la tête, le dessus du cou, les épaules, le dlos et les flancs de la marmotte qui a servi de sujet pour cette description étaient noirs, avec des teintes de gris et de cendré, parce qu'il y avait de deux sortesde poils, les uns plus longs, plıs fermes et noirs, les autres plus courts, plus doux, et gris ou cendrés, qui étaient une espèce de duvet; les côtés de la tète avaient les poils en partie gris et en partie noirâtres; les oreilles étaient grises, le bout du museau, le dessons de la màchoire inférieure et du cou, les jambes de devant, le dessous 
et les còtés de la poitrine, le ventre, la face inté- | rieure de la cuisse et de la jambe, et les quatre pieds avaient une couleur rousse, mèlée de noir, de gris, et mème de cendré, parce que le duvet. était cendré, et queles poils, fermes at longs, avaient du noir, du gris et du fanve. La croupe et la face extérieure de la cuisse et de la jambe étaient d'une couleur brune roussâtre ; les poils de la queue avaient une couleur noire avee du brun roussâtre dans quelques endroits; ces poils n'étaient pas dans leur entier; les plus longs poils se trouvaient au delà des épaules, et avaient un pouce et demi de longueur; les ongles étaient longs, fort pointus et noirâtres; il y avait de gros tubercules sous les pieds, trois derrière les doigts des pieds de devant, deux sous le carpe, l'un à côté de l'autre, et cing sous le mètatarse.

\section{LE SOUSIICK.}

(LE SOUSLIK OU ZISEL.)

Famille des rongeurs, genre rat. (Cuvier.)

On trouve à Casan et dans les provinces qu'arrose le Wolga, et jusque dans l'Autriche, un petit animal appelé souslik en langue russe, dont on fait d'assez jolies fourrures. Il ressemble beaucoup au campagnol par la figure; il a comme lui la queue courte : mais ce qui le distingue du campagnol et de tous les autres rats, e'est que sa robe, qui est d'un gris fauve, est semée partout de petites taches d'un blane vif et lustré; ces petites taches n'ont guère qu'une ligne de diamètre, et sont à deux ou trois lignes de distance les unes des autres; elles sont plus apparentes et mieux terminées sur les lombes de l'animal que sur les épaules et la tète. M. Pennant, gentilhomme anglais, très-ver'sé dans l'histoire naturelle, et qui connaît très-bien les animaux, a eu la bouté de me domer un de ses sousliks, qu'on lui avait envoyé d'Autriche, comme un auimal incomnu des naturalistes, et qui n'avait point de nom dans ee pays; je le reconnus pour être le mème que celui dont j'avais une fourrure, et dont M. Sanchès ${ }^{1}$ m'avait fourni la notice suivante: "L.es rats que l'on " appelle souslilis se premnent en grand nombre " sur les barques chargées de sel, dans la ri- vière de Kama, qui descend de Solikamskie, " où sont les salines, ct vient tomber dans le

- R. Sanchès, ci-devant premicr médeciu de la cour de Russie.
" Wolga, au-dessus de la ville de Casan, au " confluent de Teluschin : le Woiga depuis "Simbuski jusqu'à Somtof est couvert de ees " bateaux de sel, et c'est dans les terres voisi" nes de ees livièles, aussi bier que sur les ba" teaux, qu'on prend ces animaux; on leur a " donné le nom de souslik, qui veut dire friand, " parce qu'ils sont tres-avides de sel. "

Nous donnons ici la figure de eet animal, qui nous manquait. M. le prince Galitzin a eu la bonté de demander, à la prière de M. de Buffon, huit sousliks, et de domner tous les ordres nécessaires pour les faire arrirer vivants jusqu'en France. Il s'adressa pour cela à MI. le général Betzki, qui les enroya à M. le marquis de Beausset, alor's ambassadeur de France à la cour de Pétersbourg. Ces huit petits animaux arrivèrent vivants à Pétersbourg, après un long royage depuis la Sibérie; mais ils ont péri dans la traversée de Pétersbourg en France, quoiqu'on eît eu les plus grandes attentions, tant pour leur nourriture que pour les autres soins nécessaires à leur eonservation. On avait re. commandé de Sibérie de ne leur donner à manger que du blé et du ehènevis, de les laisser à l'air autant qu'on pourrait, d'empècher seulement que l'eau des grandes pluies ne les inondât dans leur caisse, de leur mettre dans cette mème eaisse une forte épaisscur de sable assez lié pour ne pouvoir s'ébouler, paree que, dans leur état de nature, ils font leurs trous dans les terres légères.

Ces animaux habitent ordinairement les déserts, se font des tanières sur les pentes des montagnes, pourvu que le fond de la terre soit noir. Leurs tanières ne sont pas égales en profondeur; elles sont de sept ou huit pieds de longueur, jamais droites, mais tortueuses, ayant deux, trois, quatre et eing sorties : leur distance est aussi inégale, ayant depuis deux jusqu'à sept pieds de séparation. Ils pratiquent dans ces tanières différents endroits, où, en temps d'été, ils font leurs provisions pour l'hiver. Dans les terres labourées, ils ramassent, pendant lo temps de la moisson, les épis de froment, de même que la graine des pois, do lin et du ehanvre, qu'ils mettent séparément l'un de l'autredans les endroits préparés exprès et d'avance à lintéricur de leurs tanières. Dans les endroits incultes, ils ramassent des graines de différentes herbes. En été, ils se nourrissent de grains, d'herbes, de racines ct de jeuncs 
souris. Pour peu qu'elles soient grosses, le souslik ne peut en faire sa proie. Indépendamment des magasins où ces animaux gardent leur's provisions d'hiver, ils se pratiquent encore dans leurs tanières des endroits pour reposer, et qui en sont distants de quelques pieds. Ils rejettent leurs ordures hor's de leurs retraites. Les femelles portent depuis deux jusqu’à cinq petits ; ils naissent aveugles et sans poil, et ne commencent à voir que quand le poil paraît. On ne sait pas au juste le temps de la gestation des femelles.

\section{LE ZISEL.}

\section{LA MARMOTTE SOUSLIK.}

\section{Famille des rongeurs, genre rat. (Cuvier.)}

Quelques auteurs, entre autres M. Linıæus, ont douté si le zisei ou ziesel' (citellus), était un animal différent du hamster (cricetus) : il est vrai qu'ils se ressemblent à plusieurs égards, et qu'ils sont à peu près du même pays ${ }^{2}$; mais ils diffèrent néanmoins par un assez grand nom. bre de caractères pour que nous soyons convaincus qu'ils sont d'espèces réellement différentes. Le zisel est plus petit que le hamster; il a lc corps long et menu comme la belette, au lieu que le hamster a le corps assez gros et ramassé comme le rat; il n'a point d'oreilles extérieures, mais seulement des trous auditifs cachés sous le poil; le hamster, à la vérité, a les oreilles courtes, mais elles sont très-apparentes et fort larges. Le zisel est d'un gris plus ou moins cendré et d'une couleur uniforme; le hamster est marqué, de chaque côté sur l'avant du cor'ps, de trois grandes taches blanches : ces différences, jointes à ce que ces deux animaux, quoique habitants des mêmes terres, ne se mê-

1 Ius noricus, quem citellum appellant, in terræ cavernis habitat; ei corpus ut mustelæ domesticx longum et tenue, cauda admodım brevis. color pilis ut cuniculorum quorundam pilis, cinereus, sed obscurior. Sicut talpa caret anribus, sed non caret foraminibus quibus sinum ut avis lecipil. Dentes labet muris dentium similes; ex lujns etiam pelibus quanquam non sint pretiosæ vestes solent confici. Georg. Agrieolæ de animantibus subterraneis. Brasil. 1561, pag. 488.

Citellus, Mus noricus Agricolæ ein Zeisel. Shwenckfeld Theriotropheum Silesiæ. Lignicii, 1604, pag. 86.

Mus noricus vel citellus. Gessner. Ilist. quad. pag. 737.

${ }^{2}$ Nota. Le hamster se trouve en Blisnie, en Tluringe, dans le pays de Hanovre; le zisel, en Hongric, en Antriche et en Pologne, où on l'appelle susct. lent pas, et que les espèces subsistent séparées, suffisent pour qu'on ne puisse douter qu'elles soient en effet deux espèces différentes, et quoiqu'ils se ressemblent, en ce qu'ils ont tous deux la queue courte, les jambes basses, les dents semblables à celles des rats, et les mêmes habitudes naturelles, comme celle de se creuser des retraites, d'y faire des magasins, de dévaster les blés, etc. D'ailleur's, ce qui n'aurait dû laisser aucun doute à des naturalistes un peu instruits, quand mème ils n'auraient pas vuces deux animaux, c'est qu'Aglicola, auteur exact et judicieux, dans son petit traité sur les animaux souterrains, donne la description de l'un et de l'autre, et les distingue si clairement, qu'il n'est pas possible de les confondre 1 . Ainsi nous pouvons donner pour certain que le hamster $\mathrm{ct}$ le zisel sont deux animaux différents, et peutêtre d'espèces aussi éloignées que celle de la belette l'est de celle du rat.

\section{LE JE\RASCHKA,}

ou

\section{LA MARMOTTE DE SIBÉRIE.}

Famille des rongeurs, genre rat. (Cuvier.)

L'animal de Sibérie que les Russes appellent jevraschlia est une espèce de marmotte, encore plus petite que le monax du Canada. Cette petite marmotte a la tête ronde et le museau écrasé; on ne lui voit point d'oreilles, et l'on ne peut même découvrir l'ouverture du conduit auditif qu'en détournant le poil qui le couvre. La longueur du corps, y compris la

' Istius (viverræ scilicet) ferocitatis est etiam agri vastator et Cereris hostis hamster quem quidam cricetum nominant... Existit iracundus et mordax... In terræ cavernis habitat non aliter atıue coniculus, sed anguslis, et idcirco pellis qua parte utrinçue coxim tegit a pilis cst nuda. Major paulo quàm domestica mustela existit, pedes labet admodum breves: pilis in dor'so color est fere lcporis, in vent re niger, in lateribus rutilus ; sed utrinque latus maculis albis numero distinguitur. Suprema capitis pars ut etiam cervix, cumdem quem dorsum habet colorem; temnora rutila sunt, guttur est candidum. Caudx quæ ad tres digitos transversos longa ut similiter leporis color. Pili antem sic inhærent cuti ut ex ea difficuller evelli posscnt. $A c$ cutis (quidem à carne faciliüs avellitur ¿uàm pili ex cute radicitus extrahantur, atque ob hanc causam et varietalem pelles ejus sunt pretiosæ. Georg. Agricol. de anim. subt., jag. 490.

II suffit de comparer celte description du hamster avcc celle que le mème auteur donne du zisel, prour être trèsconviaincu que ces deux animaux sont fort différents l'un de l'autre 
tête, est tout au plus d'un pied: la queue n'a guère que trois pouces; elle est presque ronde auprès du corps, et ensuite elle s'aplatit, et son extrémité parailt tronquée. Le colps de cet animal est assez épais; le poil est fauve, mêlé de gris, et celui de l'extrémité de la queue est presque noir. Les jambes sont courtes; celles de derrière sont seulement plus longues que celles de devant. Les pieds de derrière ont cing doigts et cinq ongles noirs et un peu courbés; ceux de devant n'en ont que quatre. Lorsqu'on irrite des animaux, ou seulement cfu'on veut les prendre, ils mordent violemment, et font un cri ajgu comme la marmotte; quand on leur donne à manger, ils se tiennent assis, et portent à leur gueule avec les pieds de devant. Ils se recherchent au printemps et produisent en été; les portées ordinaires sont de cing ou six ; ils se font des terriers où ils passent l'hiver, et où la femelle met bas et allaite ses petits. Quoiqu'ils aient beaucoup de ressemblance et d'habitudes communes avec la marmotte, il parait néanmoins qu'ils sont d'une espèce réellement différ'ente; car dans les mêmes lieux, en Sibérie, il se trouve de vraies marmottes de l'espèce de celles de Pologne ou des Alpes, et que les Sibériens appellent surok', et l'on n'a pas remarqué que ces deux espèces se mêlent, ni qu'il y ait entre elles aucune race intermédiaire.

\section{LE BOBAK.}

L'on a donné le nom de marmotte de Strasbuurg au hamster, et celui de marmotte de Pologne au bobak; mais autant il est certain que le hamster n'est point une marmotte, autant il est probable que le bobak en est une; car il ne diffère de la marmotte des Alpes que par les couleur's du poil; il est d'un gris moins brun ou d'un jaune plus pâle; il a aussi une espèce de pouce, ou plutôt un ongle aux pieds de devant; au lieu que la marmotte n'a que quatre doigts à ses pieds, et que le pouce lui manque.

${ }^{4}$ Les Tartares, dit kubruquis, ont force marmottes on lirons, qu'ils appellent sogur, qui s'assemblent vingt et trente ensemble dans mue graude fosse, l'hiver, oil ils dorment six mois durant; ils prennent loree de ces bêtes-là. Voyages en Tartarie, page 25.-Ce sogur de kuhruquis doit être le mème animal que le jevraselıa de Gmelin, puisque l'autre marmolte s'alyrelle surok; ou bien l'auteur a pris surok pour sogur.
Du reste, elle lui ressemble en tont ; cequi peut faile présumer que ces deux animaux ne forment pas deux espèces distinctes et séparées. Il en est de même du monax ou marmulle du Canada, que quelques voyageurs ont appelé sifJleur; il ne parait différer de la marmotte que par la queue, qu'il a plus longue et plus garnie de poils. Le monax du Canada, le bobak de Pologne, et la marmotte des Alpes, pourraient donc n'ètre tous trois que le même animal, qui, par la différence des elimats, aurait subi les variétés que nous venons d'indiquer'. Comme cette espèce habite de préférence la région la plus haute et la plus froide des montagnes; comme on la trouve en Pologne, en Russie et dans les autres parties du nord de l'Europe, il n'est pas étomnant qu'elle se retrouve au Canada, où seulement elle est plus petite qu'en Europe '; et cela ne lui est pas particulier, car tous les animaux, qui sont communs aux deux continents, sont plus petits dans le nouveau que dans l'ancien.

\section{LE MONAX,}

OD

\section{MARMOTTE DU CANADA.}

\section{(MARMOTTE MONAX.)}

Cette espèce de marmotte me parait différer des autres marmottes en ce qu'elle n'a que quatre doigts aux pieds de devant, tandis que la marmotte des Alpes et le bobak, ou marmotte de Pologne, en ont cind, comme aux pieds de derrière. Il y a aussi quelque différence dans la forme de la tête, qui est beaucoup moins couverte de poil. La queve est plus longue et moins fournie dans le monax que dans notre marmotte; en sorte qu'on doit regarder eet animal du Canada, comme une espèce voisine, plutót que comme une simple variété de la marmotte des Alpes. Je présume qu'on peut rapporter à cette espèce l'animal dont parle lo baron de la Hontan 2 , et qu'il nomme siffleur. Il dit qu'il se trouve dans les pays septentrionaux du Canada; qu'il approche ru lièvre pour

La marmotte des Alpes et celle de Pologne (Bobak) ont un pied et demi depuis l"extrémité du museau jusqu"à l'origine de la uneue. Le monax, on marnolte de Canada, n'a que quatorze ou quinze ponces de longueur.

${ }^{2}$ Voyage du barou de la lloutan, tome I, pag. 93. 
la grosseur; mais qu'il est plus court de corps, que la peau en est fort estimée, et qu'on ne recherche cet animal que pour cela, parce que la chair n'en est pas bonne à manger. Il ajoute que les Canadiens appellent ces animaux siffleurs, parce qu'ils sifflent en effet à l'entrée de leurs tanières lorsque le temps est beau. Il dit avoir entendu lui-même ce sifflet à diverses reprises. On sait que nos marmottes des Alpes sifflent de même et d'un ton très-aigu '

\section{MARMOTTE DE KAMTSCHATKA.}

Les voyageurs russes ont trouvé, dans les terres du Kamtschatka, un animal qu'ils ont appelé marmotte, mais dont ils ne donnent qu'une très-légère indication : ils disent seulement que sa peau ressemble de loin, par ses bigarrures, au plumage varié d'un bel oiseau; que cet animal se sert, comme l'écureuil, de ses pattes de devant pour manger, et qu'il se nourrit de racines, de baies et de noix de cèdre (Hist. gën. des Voy., t. XIX, p 253 ). Je dois observer que cette expression, noix de cèdre, présente une fausse idée; car le vrai cèdre porte des connes, et les autres arbres, qu'on a désignés par le mème nom de cèdre, portent des baies.

\section{L'OURS.}

\section{(L'OURS BRUN D'EUROPE.)}

Ordre des carnassiers, famille des carnivores, tribu des plantigrades, genre ours. (Cuvier.)

Il n'y a aucun animal, du moins de ceux qui sont assez généralement connus, sur lequel les auteurs d'histoire naturelle aient autant varié que sur l'ours : leurs incertitudes, et mêmeleurs contradictions sur la nature et les mœurs de cet animal, m'ont paru venir de ce qu'ils n'en ont pas distingué les espèces, et qu'ils rapportent quelquefois de l'une ce qui appartient à l'autre. D'abord, il ne faut pas confondre l'ours de terre avec l'ours de mel, appelé communément ours blanc, ours de la mer Glaciale; ce

\footnotetext{
+ Le Monax est une espèce de marmolte bien dislincte, ainsi que I'a fait connaitre M. F. Cuvier. Il habite le Canada seulement; et c'est à tort qu'on a confondu avec fui le Cuniculus Bahamensis de Catesby,qui est le Capromys do M. Desmarest. DESM. 1825.
}

sont deux animaux très-différents, tant pour la forme $d u$ corps, que pour les habitudes naturelles; ensuite il faut distinguer deux espèces dans les ours terrestres, les bruns et les noirs ', lesquels, n'ayant pas les mêmes inclinations, les mêmes appétits naturels, ne peuvent pas être regardés comme des variétés d'une seule et même espèce, mais doivent être considérés comme deux espèces distinctes et séparées. De plus, il y a encore des ours de terre qui sont blancs $^{2}$, et qui, quoique ressemblants par la couleur aux ours de mer, en diffèrent par tout le reste autant que les autres ours. On trouve ces ours blancs terrestres dans la grande Tarta$\mathrm{rie}^{3}$, en Moscovie, en Lithuanie et dans les autres provinces du nord. Ce n'est pas la rigueur du climat qui les fait blanchir pendant l'hiver, comme les hermines ou les lièvres; ces ours naissent blancs, et demeurent blancs en tout temps : il faudrait done encore les regarder comme une quatrième espèce, s'il ne se trcuvait aussi des ours à poil mèlé de brun et de blanc, ce qui désigne une race intermédiaire entre cet ours blanc terrestre et l'our's brun ou noir' ; par conséquent l'ours blane terrestre n'est qu'une variété de l'une ou de l'autre de ces espèces.

On trouve dans les Alpes l'ours brun assez communément, et rarement l'ours noir, qui se trouve au contraire en grand nombre dans les forêts des pays septentrionaux de l'Europe et de l'Amérique. Le brun est féroce et carnassier; le noir n'est que farouche, et refuse constamment de manger de la chair. Nous ne pouvons pas en donner un témoignage plus net et plus récent que celui de M. du Pratz. Voici ce qu'il en dit dansson Histoire de la Louisiane ${ }^{4}$ : "L'ours parait $t^{5} l^{\prime} h i v e r$ dans la Louisiane, parce "que les neiges qui couvrent les terres du " nord, l'empêchant de trouver sa nourriture, "le chassent des pays septentrionaux; il vit de " fruits, entre autres de glands et de racines, " et ses mets les plus délicieux sont le miel et " le lait : lorsqu'il en rencontre, il se laisserait

1 Nous comprenons ici sous la dénomination d'ours bruns ceux qui sont bruns, fauves, roux, rougeátres; et par cetle d'ours noirs, ceux qui sont noiràtres, aussi bien que wut à fait noirs.

${ }^{2}$ L'ours blanc d'Europe; c’est une variété albine de l'ours bruil.

${ }^{5}$ Voyez Relation de la Grande-Tartarie. Ansterdam, 1737 , in-12, pag. 8.

4 Voyez l'IIistoire de la Louisiane, par M. Lepage du Pratz, Paris, 1658, il1-12, tome Il, pag. 77 el suivantes.

${ }^{5}$ Il 8 agit ici de l'ours noir, et non de l'ours brun. 
" plutôt tuer que de quitter prise. Malgré la " prévention où l'on est que l'ours est carnas- sier, jeprétends, avec tous ceux de cette pro" vince et des pays circonvoisins, qu'il ne l'est " nullement. Il n'est jamais arrivé que ces ani- maux aient dévoré des hommes, malgré leur ( ) multitude et la faim extrême qu'ils souffrent " quelquefois, puisque même, dans ce eas, ils " ne mangent point la viande de boucherie a qu'ils rencontrent. Dans le temps que je de" meurais aux Natchés, il y eut un hiver si " rude dans les terres du nord, que ces ani" maux descendirent en grande quantité; ils " étaient si communs, qu'ils s'affamaient les " uns les autres, et étaient très-maigres; la " grande faim les faisait sortir des bois qui bor" dent le fleuve; on les voyait courir la nuit "dans les habitations, et entrer dans les cours " qu n'étaient pas bien fermées; ils y trou- vaient des viandes exposées au frais, ils n'y " touchaient point, et mangeaient seulement " les grains qu'ils pouvaient rencontrer. C'était " assurement dans une pareille occasion, et dans " un besoin aussi pressant, qu'ils auraient dû " manifester leur fureur carnassière, si peu " qu'ils eussent été de cette nature. Ils n'ont ja" mais tué d'animaux pour les dévorer; et pour " peu qu'ils fussent carnassiers, ils n'abandon" neraient pas les pays couverts de neige, où " ils trouveraient des hommes et des animaux " à discrétion, pour aller au loin chercher des " fruits et des racines, nourriture que les bêtes " earnassières refusent de manger. " M. du Pratz ajoute dans une note que, depuis qu'il a écrit cet article, il a appris avec certitude que, dans les montagnes de Savoie, il y a deux soltes d'ours : les uns noirs, comme ceux de la Louisiane, qui ne sont point carnassiers ; les autres rouges, qui sont aussi earnassiers que les loups. Le baron de la Hontan dit (tome I de ses Voyages, page 86) que les ours du Canada sont extrêmement noirs, et peu dangereux; qu'ilsn'attaquent jamăis les hommes, à moins qu'on ne tire dessus et qu'on ne les blesse. Et il dit aussi (tome II, page 40) que les our's rougeàtres sont méchants, qu'ils viennent effrontément attaquer les chasseurs, au lieu que les noirs s'enfuient.

Wormius a écrit ' qu'ou connait trois our's en Norwége : le premier (bressdiur), très-grand, qui n'est pas tout à fait noir, mais brum, et qui

1 Vid. Mus. Worm. !̣ag. 518.

Iv. n'est pas si nuisible que les antres, ne vivant que d'herbes et de feuilles d'arbres; le second (ildgiersdiur), plus petit, plus noir, carnassier, et attaquint souvent les chevaux et les autres animaux, surtout en automne; le troisième (myrebiorn) qui est le plus petit de tous, et qui ne laisse pas d'être nuisible. Il se nourrit, dit-il, de fourmis, et se plait à renverser les fourmilières. On a remarqué (ajoute-t-il sans preurc) que ces trois espèces se mêlent, et produisent ensemble des espèces intermédiaires; que ceux qui sont carnassiers attaquent les troupeanx, foulent toutes les bêtes comme le loup, et n'en dévorent qu'une ou deux; que, quoique carnassiers, ils mangent des fruits sauvages; et que, quand il y a une grande quantité de sorbes, ils sont plus à craindre que jamais, parec que ce fruit acerbe leur agace si fort les dents, qu'il n'y a que le sang et la graisse qui puissent leur ôter cet agacement qui les empêche de manger. Mais la plupart de ces faits rapportés par Wormius me paraissent fort équivoques; ear il n'y a point d'exemple que des animaux dont les appétits sont constamment différents, comme dans les deux premières espèces, dont les uns ne mangent que de l'herbe et des feuilles, et les autres de la chair et du sang, se mêlent ensemble et produisent une espèce intermédiaire. D'ailleurs, ce sont iei les ours noirs qui sont carnassiers, et les bruns qui sont frugivores; ce qui est absolument contraire à la vérité. De plus, le père Rzaczynski, Polonais, et M. Klein, de Dantzick, qui ont parlé des ours de leur pays, n'en admettent que deux espèces, les noirs et les bruns ou roux; et parmi ces derniers, des grands et des petits. Ils disent que les ours noirs sont les plus rares, que les bruns sont au contraire fort communs; que ce sont les ours noirs qui sont les plus grands et qui mangent les fourmis, ct enfin que les grands ours bruns ou roux sont les plus nuisibles et les plus carnassiers. Ces témoignages, aussi bien que ceux de M. du Pratz et du baron de la Hontan, sont, comme l'on voit, tout à fait opposés ì celui de Wormius que je viens de citer. En effet, il parrait certain que les ours ronges, roux ou bruns, qui se trourent non-seulement en Savoie, mais dans les hautes montagnes, dans les vastes forèts, et dans presque tous les déserts de la terre, dévorent les animaux vivants, et mangent même les voiries les plus infectes. Lees ours noir's n'habitent guère que les paly sfroids; mais 
on trouve des our's bruns ou roux dans les climats froids et tempérés, et même dans les régions du midi. Ils étaient communs chez les Grees; les Romains en faisaient venir de Libye pour servir à leurs spectacles : il s'en trouve à la Chine, au Japon, en Arabie, en Égypte, et jusque dans l'île de Java. Aristote parle aussi des ours blanes terrestres, et regarde cette différence de couleur comme accidentelle, et provenant, dit-il, d'un défaut dans la génération. Il y a donc des ours dans tous les pays déserts, escarpés ou couverts; mais on n'eu trouve point dans les royaumes bien peuplés, ni dans les terres découvertes et cultivées : il n’y ell a point en France, nou plus qu'en Angleterre, si ce n'est peut-être quelques-uns dans les montagnes les moins fréquentées.

L'ours est nor-seulement sauvage, mais solitaire; il fuit par instinct toute société ; il s'éloigne des lieux où les hommes ont accès; il ne se trouve à son aise que dans les endroits qui appartiennent encore à la vieille nature: une caverne antique dans des rochers inaccessibles, une grotte formée par le temps dans le tronc d'un vieux arbre, au milieu d'une épaisse forêt, lui servent de domicile:il s'y retire seul, y passe une partie de l'hiver sans provisions, sans en sortir pendant plusieurs semaiues. Cependant, il n'est point engourdi ni privé de sentiment, comme le loir ou la marmotte ; mais, comme il est naturellement gras, et qu'il l'est excessivement sur la fin de l'automne, temps aurjuel il se recèle, cette abondance de graisse lui fait supporter l'abstinence, et il ne sort de sa bauge que lorsqu'il se sent affamé. On prétend que c'est au bout d'environ quarante jours que les mâles sortent de leurs retraites, mais que les femelles y restent quatre mois, parce qu'elles y font leurs petits. J'ai peine à croire qu'elles puissent non-seulement subsister, mais encore nourrir leurs petits sans prendre elles-mêmes aucune nourriture pendant un aussi long espace de temps. On convient qu'elles sont excessivement grasses lorsqu'elles sont pleines; que d'ailleurs, étant vêtues d'un poil très-épais, dormant la plus grande partie du temps, et ne se donmant aucun mouvement, elles doivent perdre trèspeu par la transpiration : mais, s'il est vrai que les mâles sortent au bout de quarante jours, pressés par le besoin de prendre de la nourriture, il n'est pas naturel d'imaginer que les femelles ne soient pas encore plus pressées du même besoin après qu'elles ont mis bas, et lorsque, allaitant leurs petits, elles se trouvent doublement épuisées, à moins que l'on ne venille supposer qu'elles en dévorent quelques-uns avec les enveloppes et tout le reste du produit superflu de leur accouchement : ce qui ne me parait pas vraisemblable, malgré l'exemple des chattes, qui mangent quelquefois leurs petits. Au l'este, nous ne parlons ici que de l'espèce des our's bruns, dont les mâles dévorent en effet les oursons nouveau-nés, lorsqu'ils les trouvent dans leurs nids; mais les femelles, au contraire, semblent les aimer jusqu'à la fureur : elles sont, lorsqu'elles ont mis bas, plus féroces, plus dangereuses que les mâles; elles combattent et s'exposent à tout pour sauver leurs petits, qui ne sont point informes en naissant, comme l'out dit les anciens, et qui, lorsqu'ils sont nés, croissent à peu près aussi vite que les autres ani maux : ils sont parfaitement formés dans le sein de leur mère; et si les fotus ou les jeunes oursons ont paru informes au premier coup d'œil, c'est que l'ours adulte l'est lui-même par la masse, la grosseur et la disproportion du corps et des membres; et l'on sait que, dans toutes les espèces, le foutus ou le petit nouveau-né est plus disproportionné que l'animal adulte.

Les ours se recherchent en automne : la femelle est, dit-on, plus ardente que le mâle; on prétend qu'elle se couche sur le dos pour le recevoir, qu'elle l'embrasse étroitement, qu'elle le retient longtemps, etc. : mais il est plus certain qu'ils s'accouplent à la manière des qua. drupèdes. L'on a vu des ours captifs s'accoupler et produire: seulement on n'a pas observé combien dure le temps de la ģestation. Aristote dit qu'il n'est que de trente jours. Comme personne n'a contredit ce fait, et que nous n'avons pu le vérifier, nous ne pouvons aussi ni le nier, ni l'assurer; nous remarquerons seulement qu'il nous parait douteux : $\mathbf{1}^{\circ}$ parce que l'ours est un gros animal, et que plus les animaux sont gros, plus il faut de temps pour les former dans le sein de la mère; $2^{\circ}$ parce que les jeunes ours croissent assez lentement ; ils suivent leur mère, et ont besoin de ses secours pendant un an ou deux; $3^{\circ}$ parce que l'ours ne produit qu'en petit nombre, un, deux, trois, quatre, et jamais plus de cinq : propriété commune avec tous les gros animaux, qui ne produisent pas beaucoup de petits, et qui les portent longtemps; $4^{\circ}$ parce que l'ours vit vingt ou vingt-cing ans, et que le 
temps de la gestation et celui de l'accroissement sont ordinairement proportionnés à la durée de la vie. A ne raisonner que sur ces analogies, qui me paraissent assez fondées, je croirais donc que le temps de la gestation dans l'ours est au moins de quelques mois. Quoi qu'il en soit, il paraît que la mère a le plus grand soin de ses petits; elle leur prépare un lit de mousse et d'herbes dans le fond de sa caverne, et les allaite jusqu'à ce qu'ils puissent sortir avec elle. Elle met bas en hiver, et ses petits commencent à la suivre au printemps. Le mâle et la femelle n'habitent point ensemble; ils ont chacun leur retraite séparée, et même fort éloignée. Lorsqu'ils ne peuvent trouver une grotte pour se gîter, ils cassent et ramassent du bois pour faire une loge qu'ils recouvrent d'herbes et de feuillés, au point de la rendre impénétrable à l'eau.

La voix de l'ours est un grondement, un gros murmure, souvent mêlé d'un frémissement de dents qu'il fait surtout entendre lorqu'on l'irrite; il est très-susceptible de colère, et sa colère tient toujours de la fureur, et souvent du caprice : quoiqu'il paraisse doux pour son maître, et même obéissant lorsqu'il est apprivoisé, il faut toujours s'en défier, et le traiter avec circonspection, surtout ne le pas frapper au bout du nez ni le toucher aux parties de la génération. On lui apprend à se tenir debout, à gesticuler, à danser; il semble même écouter le son des instruments, et suivre grossièrement la mesure; mais, pour lui donner cette espèce d'éducation, il faut le prendre jeune, et le contraindre pendant toute sa vie; l'ours qui a de l'âge ne s'apprivoise ni ne se contraint plus : il est naturellement intrépide, ou tout au moins indifférent au danger. L'ours sauvage ne se détourne pas de son chemin, ne fuit pas à l'aspect de l'homme : cependant on prétend que par un coup de sifflet on le surprend, on l'étonne au point qu'ill s'arrête et se lève sur les picds de derrière : c'est le temps qu'il faut prendre pour le tirer, et tâcher de le tuer; car, s'il n'est que blessé, il vient de furie se jeter sur le tireur, ct l'embrassant des pattes de devant, il l'étoufferait s'il n'était secouru.

On chasse et on prend les ours de plusicurs façons en Suède, en Norwége, en Pologne, etc. La manière, dit-on, la moins dangereuse de les prendre est de les enivrer en jetant de l'enude-vie sur le miel, qu'ils aiment beaucoup, et qu'ils cherchent daus les trones d'arbres. A la
Louisiane et en Canada, où les ours noirs sont très-communs, et où ils ne nichent pas dans des cavernes, mais dans de vieux arbres morts sur pied, et dont le cœur est pourri, on les prend en mettant le feu dans leurs maisons'. Comme ils montent très-aisément sur les arbres, ils s'établissent rarement à rez de terre, et quelquefois ils sont nichés à trente et quarante pieds de hauteur. Si c'est une mère avec ses petits, elle descend la première, on la tue avant qu'elle soit à terre; les petits descendent ensuite, on les prend en leur passant une corde au cou, et on les emmène pour les élever ou pour les manger, car la chair de l'ourson est délicate et boune : celle de l'ours est mangeable; mais, comme elle est mêlée d'une graisse huileuse, il n'y a guère que les pieds, dont la substance est plus ferme, qu'on puisse regarder conıme une viande délicate.

La chasse de l'ours, sans être fort dangereuse, est très-utile lorsqu'on la fait avec quelque succès : la peau est de toutes les fourrures grossières celle qui a le plus de prix, et la quantité d'huile que l'on tire d'un seul ours est fort considérable. On met d'abord la chair et la graisse cuire ensemble dans une chaudière : la graisse se sépare; " ensuite, dit M. du Pratz, " on la purifie en y jetant, lorsqu'elle est fondue " et très-chaude, du sel en bonne quantité, et " de l'eau par aspersion: il se fait une détonaa tion, et il s'en élève une fumée épaisse, qui " emporte avec elle la mauvaise odeur de la " graisse. La fumée étant passée, et la graisse " étant encore plus que tiède, on la verse dans " un pot où on la laisse reposer huit ou dix " jours; au bout de ce temps, on voit nager " dessus une huile claire, qu'on enlève avec " une cuiller : cette huile est aussi bonne que la " meilleure huile d'olive, et sert aux mêmes " usages. Au-dessous, on trouve un saindoux a aussi blanc, mais un peu plus mou que le " saindoux de porc; il sert aux besoins de la " cuisine, et il ne lui reste aucun goût désagréa" ble, ni aucune mauvaise odeur. » M. Dumont, dans ses Mémoires sur la Louisiane, s'accorde avec M. du Pratz, et il dit, de plus, que d'uu seul ours on tire quelquefois plus de cent vingt pots de cette huile ou graisse; que les sau rages en traitent beaucoup avec les Français; qu’elle

4 Mémoire sur la Louisiane, par II. Dumon:. Paris, 1753 , pas. 75 et suivantes. Ilistoire de la Louisiane par M. Lepage du Pratz, tome 11, page 87. 
est très-belle, très-saine et très-bonne; qu'elle ne se fige guère que par un grand froid; que, quand cela arrive, elle est tout en grumeaux, et d'une blancheur à éblouir ; qu'on la mange alor's sur le pain en guise de beurre. Nos épiciers-droguistes ne tiennent point d huile d'ours; mais ils font venir de Saroie, de Suisse, ou du Canada, de la graisse ou axonge qui n'est pas purifiée. L'auteur du Dictionnairedu commerce dit même que, pour que la graisse d'ours soit bonne, il faut qu'elle soit grisâtre, gluante, et de mauvaise odeur, et que celle qui est trop blanche est sophistiquée et mêlée de suif. On se sert de cette graisse comme de topique pour les hernies, les rhumatismes, etc. ; et beaucoup de gens assurent en avoir ressenti de bons effets.

La quantité de graisse dont l'ours est chargé le rend très-léger à la nage; aussi traverse-t-il sans fatigue des fleuves et des lacs. "Les ours " de la Louisiane, dit M. Dumont, qui sont " d'un très-beau noir, traversent le fleuve mal"gré sa grande largeur : ils sont très-friands " du fruit des plaqueminiers; ils montent sur " ces arbres, se mettent à califourchon sur une " branche, s'y tiennentavec une deleurs pattes, a et se servent de l'autre pour plier les autres - branches et approcher d'eux les plaquemines. "Ils sortent aussi très-souvent des bois pour " venir daus les habitations manger les patates. " et le maiss. "En automne, lorsqu'ils se sont bien engraissés, ils n'ont presque pas la force de marcher ${ }^{1}$, ou du moins ils ne peuvent courir ${ }^{2}$ aussi vite qu' un homme. lls ont quelquefois plus de dix doigts d'épaisseur ${ }^{3}$ de graisse aux côtés et aux cuisses : le dessous de leurs pieds est gros et enflé; lorsqu'on le coupe, il en sort un suc blanc et laiteux. Cette partie parait composée de petites glandes qui sont comme des mamelons; et e'est ce qui fait que pendant l'hiver, dans leurs retraites, ils sucent continuellement leurs pattes.

L'ours a les seus de la vue, de l'ouie et du toucher, très-bons, quoiqu'il ait l'œil très-petit relativement au volume de son corps, les oreilles courtes, la peau épaisse et le poil fort touffu. Il a l'odorat excellent, et peut-ètre plus exquis

\footnotetext{
1 Voyage du baron de la Hontan, page 86.

${ }^{2}$ Histoire de la Louisiane, par M. du Pratz, page 85.

sxtrait d'un ouvrage danois cité par M.I. A rnault de No. bleville et Salerne. Hist. Nat. des animaux. Paris, 1757, t. V1, page 374.
}

qu'aucun autre animal; car la surface fntérieure de cet organe se trouve extrêmement étendue: on y compte ${ }^{-1}$ quatre rangs de plans de lames osseuses, séparés les uns des autres par trois plans perpendiculaires; ce qui multiplie prodigieusement les surfaces propres à recevoir les impressions des odeurs. Il a les jambes et les bras charnus comme l'homme, l'os du talon court et formant une partie de la plante du pied, cinq orteils opposés au talon dans les pieds de derrière, les os du carpe égaux dans les pieds de devant; mais le pouce n'est pas séparé, et le plus gros doigt est eu dehors de cette espèce de main, au lieu que dans celle de l'homme il est endedans : ses doigts sont gros, courts et serrés l'un contre l'autre, aux mains comme aux pieds; les ongles sont noirs, et d'une substance homogène fort dure. Il frappe avec ses poings, comme l'homme avec les siens; mais ces ressemblances grossières avec l'homme ne le rendent que plus difforme, et ne lui donnent aucune supériorité sur les autres animaux.

\section{ADDITION A L'ARTICLE DE L'OURS.}

M. de Musly, major d'artillerie au service des États-Généraux, a bien voulu me donner quelques notices sur des ours élevés en domesticité, dont voici l'extrait:

" A Berue, où l'on nourrit de ces animaux, dit M. de Musly, on les loge dans de grandes fosses carrées, où ils peuvent se promener : ces fosses sont couvertes par dessus, et maçonnées de pierres de taille, tant au fond qu'aux quatre côtés. Leurs loges sont maçounées sous terre au rez-de-chaussée de la fosse, et sont partagées en deux par des murailles, et on peut fermer les ouvertures tant extérieures qu'intérieures par des grilles de fer qu'on y laisse tomber comme à une porte de ville. Au milieu de ces fosses, il y a des trous dans de grosses pierres, où l'on peut dresser debout de grands arbres: il y a de plus une auge dans chaquefosse, qui est toujours pleine d'eau de foutaine.

" Il y a trente-un ans qu'on a transporté de Savoie ici deux ours bruns fort jeunes, dont la femelle vit encore. Le mâle eut les reins cassés, il y a deux mois, en tombant du haut d'un ar-

'Étienne Lorentinus, Éphem. d'Allem. Décur. I. I, Ann. 8 et 10, pag. 405, cité par MM. Arnault de Nobleville et Salerne. II ist. Nat. des animanx, tome Vl, page 366 . 
bre qui est dans la fosse. Ils ont commencé d'engendrer à l'âge de cinq ans, et depuis ce temps ils soni entrés en chaleur tous les ans au mois de juin, et la femelle a toujours mis bas au commencement de janvier : la première fois elle n'a produit qu'un petit, et, dans la suite, tantôt un, tantòt deux, tantôt trois, mais jamais plus; et les trois dernières années, elle n'a fait qu'un petit chaque fois. L'homme qui en a soin croit qu'elle porte encore actuellement ( 17 octobre 1771). Les petits, en venant au monde, sont d'une assez jolie figure, couleur fauve, avec du blanc autour du cou, et n'ont point l'air d'un ours; la mère en a un soin extrème. Ils ont les yeux fermés pendant quatre semaines; ils n'ont d'abord guère plus de huit pouces de longueur, et trois mois après ils ont déjà quatorze à quinze ponces, depuis le bout du museau jusqu'à la racine de la queue, et du poil de près d'un pouce. Ils sont alors d'une figure presque ronde, et le museau paraît ètre fort pointu à proportion du reste, de façon qu'on ne les recommait plus. Ensuite, ils deviennent fluets pendant qu'ils sont adultes : le blanc s'efface peu à peu, et de fauvesils deviennent bruus.

" Lor'sque le mâle et la femelle sont accouplés, le mále commence par des mouvements courts, mais fort prompts, pendant environ un quart de minute; ensuite il se repose deux fois aussi longtemps sur la femelle et sans se dégager ; puis il recommence de la mème manière jusqu'à trois ou quatre reprises; et l'accouplement étant consommé, le màle va se baiguer dans l'auge jusyu'au cou. Les ours se battent quelquefois assez rudement avec un murmure horrible : mais, daus le temps des amours, la femelle a ordinairement le dessus, parce qu'alors le mâle la ménagc. Les fosses qui étaient autrefois dans la ville ont été comblées, et on en a fait d'autres entre les remparts et la vieille enceinte. Ces deux ours ayant été séparés pendant quelques heures pour les transporter l'un après l'autre dans les nouvelles fosses, lor'squ'ils se sont retrouvés ensemble, ils se sont dressés debout pour s'embrasser avec transport. Après la mort du mâle, la femelle a paru fort affligée, et n'a pas voulu prendre de nourriture qu'au bout de plusieurs jours. Mais, à moins que ces animaux ne soient élevés et nourris ensemble dès leur tendre jeunesse, ils ne peuvent se supporter; et lorsqu'ils y ont été habitués, celui qui survit re veut plus en souffrir d'autres.
"Les arbres que l'on met daus les fosses tous les ans, au mois de mai, sont des mélèzes verts, sur lesquels les ours se plaisent à grimper : néanmoins ils en cassent quelquefois les branches, surtout lorsque ces arbres sont nouvellement plantés. On les nourrit avec du pain de seigle, que l'on coupe en gros morcearux et que l'on trempe dans de l'eau chaude. Ils mangent aussi de toutes sortes de fruits; et quand les paysans en apportent au marché, qui ne sont pas mûrs, les archers les jettent aux ours par ordre de police. Cependant on a lemarrfué qu'il y a des ours qui préfèrent les légumes aux fruits des arbres. Quand la femelle est sur lc point de mettre bas, on lui donne force paille dans sa loge, dont clle se fait un rempart, après qu'on l'a séparée du mâle, de peur qu'il ne mange les petits; et quand elle a mis bas, on lui donne une meilleure nourriture qu'à l'ordinaire. On ne trouve jamais rien de l'enveloppe, ce qui fait juger qu'elle l'avale. On lui laisse les petits pendant dix semaines; et, après les en avoir séparés, on les nourrit pendant quclque temps avec du lait et des biscuits.

“ L'ours en question, que l'on croyait pleine, fut munie de paille comme à l'ordinaire dans le temps que l'on croyait qu'elle allait mettre bas; elle s'en fit un lit où elle resta pendant trois semaines, sans avoir rien produit. Elle a mis bas à trente-un ans, au mois de janvier 1771 , pour la dernière fois. Au mois de juin suivant, elle s'est eucore accouplée; mais au mois de janvier 1772 , à trente-deux ans, elle n'a plus rien fait. Il serait à souhaiter (qu'on la laissât vivre jusqu'au terme que la nature lui a fixé, afin de le connaitre.

" Il y a des ours bruns an mont Jura, sur les frontières de notre canton, de la FranchcComté et du pays de Gex : quand ils descendent dans la plaine, si c'est en automne, ils vont dans les bois de châtaigniers, où ils font un grand dégât. Dans ce pays-ci, les ours passent pour avoir le sens de la vue faible, mais ceux de l'oüe, du toucher, et de l'odorat trèsbons '. ")

En Norwégc, les ours sont plus communs dans les provinces de Berghem et de Dronthein que dans le reste de cette contrée. On en distingue

"Extrait de deux lettres écrites par M. de Mnsly, major d'artillerie aı service de IIollande, à M. de Buffon, l'une datée à Berne lo $\$ 7$ oclobre $\$ 771$, et l'autre datée à La llaye le 5 juiu 1772. 
deux races, dont la seconde est considérablement plus petite que la première. Les couleurs de toutes deux varient beaucoup : les uns sont d'un brun foncé, les autres d'un brun clair, et même il y en a de gris et de tout blancs. Ils se retirent au commencement d'octobre dans des tanières ou des liuttes qu'ils se préparent euxmêmes, et où ils disposent une espèce de lit de feuilles et de mousse. Comme ces animaux sont fort à craindre, surtout quaud ils sont blessés, les chasseurs vont ordinairement en nombre, au moins de trois ou quatre; et comme l'our's tue aisément les grands chiens, on n'en mène que des petits qui lui passent aisément sous le ventre, et le saisissent par les partics de la génération. Lorsqu'il se trouve excédé, il s'appuie le dos contre un rocher ou contre un arbre, ramasse du gazon et des pierres qu'il jetteà ses ennemis ; et c'est ordinairement dans cette situation qu'il recoit le coup de la mort ?

Nous avons vu à la ménagerie de Chantilly un ours de l'Amérique ${ }^{2}$; il était d'un très-beau noir, et le poil était doux, droit et long comme celui du grand sapajou, que nous avous appelé le coaita. Nous n'avons remarqué d'autres différences dans la forme de cet ours d'Amérique, comparé à celui d'Europe, que celle de la tête, qui est un peu allongée, parce que le bout du museau est moins plat que celıi de nos ours.

On trouve dans le journal de l'expédition de M. Bartram une notice d'un ours d'Amérique, tué près de la rivière Saint-John, à l'est de la Floride.

"Cet ours, dit la relation, ne pesait que quatre cents livres, quoique le corps eût sept pieds de longueur depuis l'extrémité du nez jusqu'à la queue. Les pieds de devant n'avaient que cinq pouces de large. La graisse était épaisse de quatre pouces : on l'a fait fondre, et on en a tiré soixante pintes de graisse, mesure de Paris ${ }^{3}$. $)$

\section{DESCRIPTION DE L'OURS.}

(EXTRAIT DE DAUBENTON.)

L'ours est couvert d'un long poil qui le rend informe en caclant les contours de presque tontes

\footnotetext{
' Hist. naturelle de la Norwége, par Pontoppidam. Journal étranger; juin $\mathbf{1 7 5 6 .}$

${ }^{2}$ Lours noir. Desm. - Ursus americanus, Pall.

3 Lettre de M. Collinson à M. de Buffon. Londres, 6 février 1767.
}

les parties de son corps; on ne voit distinctement que le museau et les pieds, cependant on reconnait aisément que le corps est gros à proportion de sa longueur, et que les jambes sont courtes, parce que les pieds de devant posent sur la terre jusqu'au poignet, et les pieds de derrière jusqu'au milieu de la plante. La tète a quelques rapports à celle du loup par sa forme et par la position oblique de ses yeux; ils sont plus petits que ceux de cet animal le nez est plus large, les oreilles sont plus courtes et arrondies, le museau est plus relevé par le bout; les narines sont plus grandes et percées différemment, car il y a une scissure qui coupe leur bord extérieur; le con est peu apparent; le garrot parait fort élevé, parce qu'il est couvert d'un poil long et hérissé; la croupe est ravalée, la queue a peu de longueur, et les pieds de devant sont un peu tournés en dedans.

Il y a présentement à Paris, dans l'établissement où l'on fait voir au public des combats d'animaux, trois ours qui diffèrent un peu les uns des antres par la couleur du poil ; l'un des trois vient de Savoie; on le dit âgé de quatre ans; il a le dessus du museau de couleur fauve obscure, le garrot et le bas des quatre jambes noirs ou noirâtres; tout le reste du corps est mêlé de fauve pâle et de cendré brun, parce que les poils sont de couleur cendrée brune sur la plus grande partie de leur longueur, et de couleur fauve pâle à la pointe.

Le second des trois ours qui sont au combat des animaux vient de Savoie comme le premier; on croit qu'il a dix ans; sa couleur est brune noirâtre sur tout le corps, excepté le garrot, le devant des épanles, les aisselles et la poitrine, qui ont une teinte de faure.

Le troisième ours vient de Suisse; onl'appelle ours doré, parce qu'il a les teintes de fauve de la tète et dı corps claires et plus vives. On dit qu'il a huit ans.

Tons les poils de l'ours ne sont pas fermes et luisants à l'extrèmité, il n'y a que les plus longs, entre lesquels il se trouve une sorte de duvet; ils ont trois ou quatre pouces, et le duvet environ deux pouces.

\section{L'OURS BLANG.}

\section{( L'OURS BLATC DE LA MER GLACIALE.)}

Un animal fameux de nos terres les plus septentrionales, c'est l'ours blanc. Martens et quelques autres voyageurs en ont fait mention, mais aucun n'en a donné une assez bonne description pour qu'on puisse prouoncer affirmativement qu'il soit d'une espèce différente de celle de 


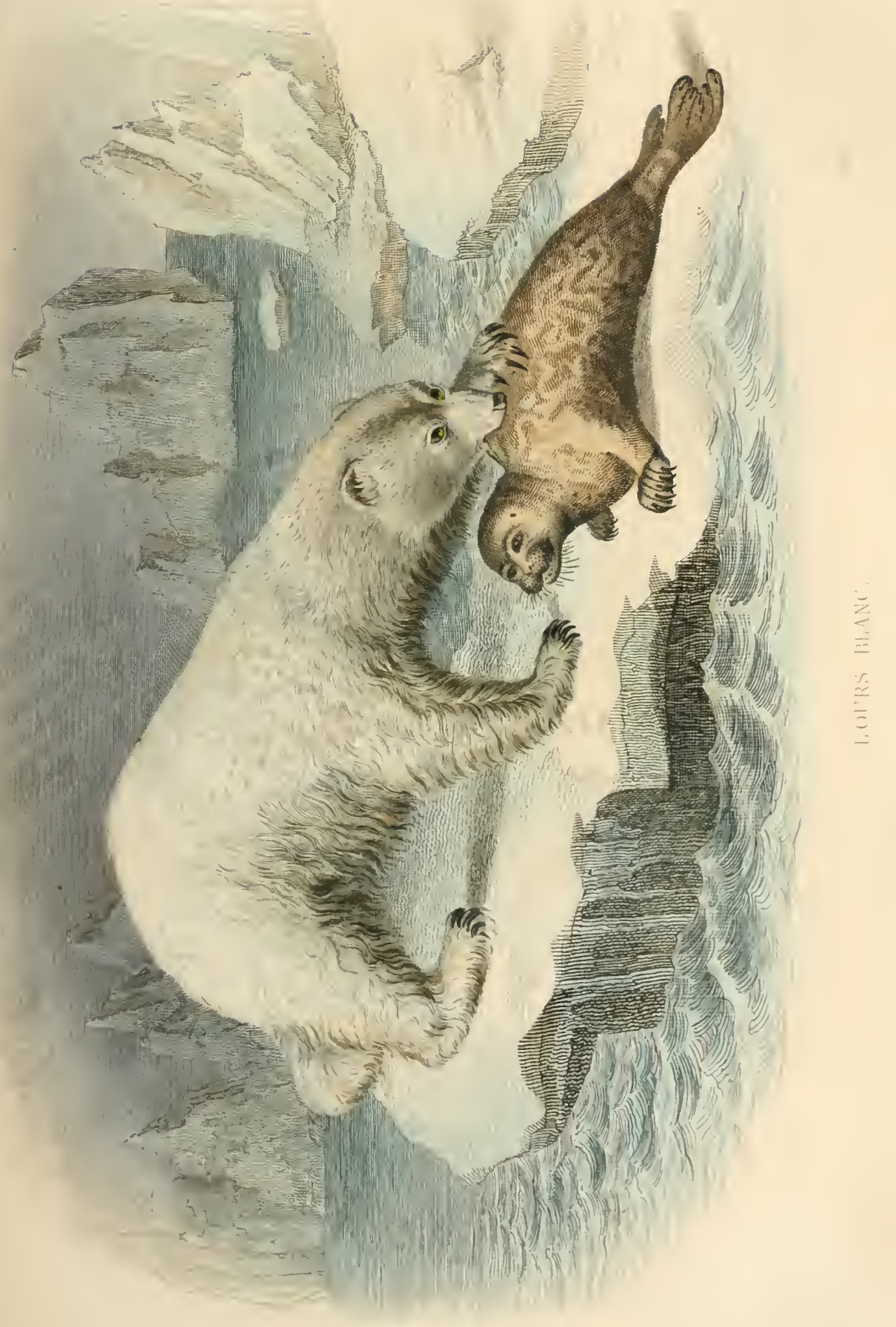



l'ours : il paraitt seulement qu'on doit le présumer, en supposant exaet tout ce qu'ils nous en disent; mais, comme nous savons d'ailleurs que l'espèce de l'our's varie beaucoup suivant les différents climats, qu'il y en a de bruns, de noirs, de blancs et de mêlés, la couleur devient un earactère nul, et par conséquent la dénomination d'ours blanc est iusuffisante, si l'espèce est différente. J'ai vu deux petits ours apportés de Russie qui étaient entièrement blanes `; néanmoins ils étaient très-certainement de la même espèce que notre ours des Alpes. Ces animaux varient beaueoup aussi pour la grandeur : comme ils vivent assez longtemps, et qu'ils deviennent très-gr'os et très-gras dans les endroits où ils ne sont pas tourmentés, et où ils trouvent de quoi se nourrir largement, le earactère tiré de la graudeur est encore équivoque : ainsi, l'on ne serait pas fondé à assurer que l'our's des mer's du nord est d'une espèce particulière, uniquement parce qu'il est blanc et qu'il est plus grand que l'ours commun ${ }^{2}$. La différence dans les habitudes ne me parait pas plus déeisive que celle de la couleur et de la grandeur. L'ours des mers du nord se nourrit de poisson; il ne quitte pas les rivages de la mer; et souvent même, il habite en pleine eau sur des glacons flottants : mais, si l'on fait attention que l'ours en général est un animal qui se nourrit de tout, et qui, lorsqu'il est affamé, ne fait aucun choix; si l'on pense aussi qu'il neeraint pas I'eau, ees habitudes ne paraitront pas assez différentes pour en conclure que l'espèce n'est pas la même; ear le poisson que mange l'ours des mers du nord est plutôt de la ehair; c'est principalement les cadavres des baleines, des morses et des phoques, qui lui servent de pâture; et cela dans un pays où il n'y a ni autres animaux, ni grains, ni

\footnotetext{
- On trouve des ours blancs terrestres, non-sculement en Russie, mais en Pologne, en Sibérie et même en Tartarie. Les montagnes de la Grande-Tartarie fournissent quantité d'ours blanes, dit l'auteur de la Relation de la Grande-Tartarie, page 8. Ces ours de montagnes ne fréquentent pas la mer, et cependant sont blancs; ainsi cette couleur parait plutôt venir de la différence du climat que de celle de l'élément qu'habitent ces animaux.

${ }^{2}$ Ursus in Polonia variat, maximus nigricans, minor fulvus, minimus argentinus, in confiniis Moschowiæ, pilis nigris et argentei coloris mixti... ex urso occiso pellis letracta fere ad ulnas sex protendebatır in terri chelmensi, altera in Palatinatu Braclaviensi, tertia ad ulnas quinque in Bondargonto pago Palatinatûs Pomeraniæ... non rarc ex Lithuania advehuntur Gedanum pelles octo pedum. Rzaczynski; Auet. pag. 322. Nota. Ce passage prouve qu'il y a des ours terrestres blancs, et aussi grands que les ours blancs des uners du nord
}

fruits sur la ter'e, et où par conséquent il ne peut subsister que des productions de la mer. N'est-il pas probable que, si l'on transportait nos ours de Savoie sur les montagnes du Spitzberg, n'y trouvant nu]le nourriture sur la terre, ils se jetteraient à la mer pour y chercher leur subsistanee?

La couleur, la grandeur et la facon de vivie ne suffisant pas, il ne reste pour earactères différentiels que ceux qu'on peut tirer de la forme : or, tout ce que les voyageurs en ont dit se réduit à ee que l'ours des mers du nord a la tête plus longue que notre ours, Ie corps plus allongé, le poil plus long et le crâne beaucoup plus dur. Si ces caractères ont été bien saisis, et si ces différences sont réelles et considérables, elles suffiraient pour constituer une autre espèee; mais je ne sais si Martens a bien vu, et si les autres qui l'ont copié n'ont pas exagéré t. "Ces our's blanes (dit-il) sont faits tout autrement " que les notres: ils ont la tête longue, sem“ blable à celle d'un chien, et le cou long aussi; " ils aboient presque comme des ehiens qui sont " enroués; ils sont avec cela plus déliés et plus " agiles que les autres ours; ils sont à peu près " de la même grandeur; leur poil est loug et " aussi doux que de la laine; ils ont le museau, " le nez et les griffes noirs.... On dit que les " autres our's ont la tête fort tendre; mais e'est " tout le contraire pour les ours blanes: quelques " coups de massue que nous leur donnassions " sur la tête, ils n’en étaient point dutont étour" dis, quoique ees coups eussent pu assomner " un bœuf. " On doit remarquer dans cette deseription : 1o que l'auteur ne fait pas ces ours plus grands que les autres ours, et que par conséquent on doit regarder comme suspect le témojgnage de ceux qui ont dit que ees ours de mer avaient jusqu'à treize pieds de longucur ${ }^{2}$. 2o Que le poil aussi doux que de la laine ne fait pas un caractère qui distingue spćcifquement ees ours, puisqu'il suffit qu'un animal habite souvent dans l'eau, pour que son poil devienne plus doux et mème plus touffu : on roit cette même différence dans les eastor's d'eau et dans les castor's terriers; ceux-ei, gui habitent plus

\footnotetext{
- Anderson, dans son Hisloirc d'Islande et de Groêulaud, tome II, page 47. Filis, dans sont loyage à la baie de Iludson, tome 1 , page 56 .

${ }^{2}$ On porta à bort un uns blanc y'un avait tué; sa pcau avait treize pieds de longueur. Troisicuc voyage des Hollandais par le Nord, page 35.
} 
la terre que l'eau, ont le poil plus rude et moins fourni; ct ce qui me fait présumer que les autres différences ne sont ni réelles ni même aussi apparentes que le dit Martens, e'est que Dithmar Blefken, dans sa description de l'Islande, parle de ces ours blancs, et assure en avoir vu tuer un en Groënland, qui se dressa sur ses deux pieds comme les autres ours; et, dans ce récit, il ne dit pas un mot qui puisse indiquer que cet ours blane du Groënland ne fût pas entièrement semblable aux autres ours '. D'ailleurs, lorsque ces animaux trouvent quelque proie sur terre, ils ne se domment pas la peine d'aller chasser en mer; ils dévorent les remnes et les autres bêtes qu'ils peuvent saisir; ils attaquent même les hommes, et ne manquent jamais de déterrer les cadavres ${ }^{2}$ : mais la disette où ils se trouvent souvent dans ces terres stériles et désertes les force de s'habituer à l'eau; ils s'y jettent pour attraper des phoques, de jeunes morses, des petits baleineaux; ils se gîtent sur des glaçons où ils les attendent, et d'où ils peuvent les voir venir, les observer de loin; ct tantqu ils trourent que ce poste leur produit une subsistance aboudante, ils ne l'abandonnent pas : en sorte que, quand les glaces commencent à se détacher au printemps, ils se laissent emmener, et voyagent avec elles : et, comme ils ne peuvent plus regagner la terre, ni même abandomer pour longtemps le glaçon sur lequel ils se trouvent embarqués, ils périssent en pleine mer; et ceux qui arrivent avec ces glaces sur les cótes d'Islande ou de Norwége ${ }^{3}$ sont affamés au point de se jeter sur tout ce qu'ils rencontrent pour le dévorer; et c'est ce qui a pu augmenter

' Habet Islandia coloris albi ingentes ursos... in Groenlandia ursum magnun el album habuimus obviam, qui neque nos timelhat, neque nostro clamore abigi poterat, verum recta ad nos tanquam ad certam prædam contendebat; cumque propius nos accessisset, is bonbarda trajeclus, ibi demum ercetus posterioribus petibus tanquam homo stabat, donec terlio trajiceretur, atque ita exanimatus coneidit. Dithmar Blefken, Island. Lugd. Bat. 1607, pag. 94.

${ }^{2}$ Les ours blancs vivent de baleines mortes, et c'est près de cescharognes que l'on en trouve le plus; lls mangent aussi les hommes en vie lorsqu'ils en peuvent surprendre; s'ils viennent à sentir l'endroit où l'on a enterré un corps mort, ils savent fort bien le déterrer, ôler toutes les pierres dont la fosse est converte, et ouvrir ensuite le cercueil, pour manger ce corps. Recueil des Voyages du Nord, tome 1f, page 116.

${ }^{5}$ Quand les glaces sont détachées du Groënland septentrional, et quielles sont poussées vers le midi, les ours blancs qui se trowent dessus n'en osent sortir; et comme ils abordent ou en Islande ou en Norwége à l'endroit où les glaces les portent, ils deviennent enragès de faim; ct l'on dit d'étranges listoires des ravages que font alors ces animaux. Recueil lles royages du Nord, tome 1 , page 100. cncore le préjugé que ces ours de mer sont d'une espèce plus féroce et plus vorace que l'espèce ordinaire. Quelques auteurs se sont mème persuadé qu'ils étaient amphibies comme les phoques, et qu'ils pouvaient demeurer sous l'eau tout aussi longtemps qu'ils voulaient; mais le contraire est évident et résulte de la manière dont on les chasse: ils ne peuvent nager que pendant un petit temps, ni parcourir de suite un espace de plus d'une lieue : on les suit avec une chaloupe, et on les force de lassitude; s'ils pouvaient se passer de respirer, ils se plongeraient pour se reposer au fond de l'eau; mais s'ils plongent, ce n'est que pour quelques instants; et, dans la crainte de se noyer, ils se laissent tuer à fleur-d'eau '.

La proie la plus ordinaire des ours blanes sont les phoques 2, qui ne sont pas assez forts pour leur résister; mais les morses, auxquels ils enlèvent quelquefois leurs petits, les percent de leurs défenses et les mettent en fuite : il en est de même des baleines; elles les assomment par leur masse et les chassent des lieux qu'elles habitent, où néanmoins ils ravissent et dévorent souvent leurs petits baleineaux. Tous les ours ont naturellement beaucoup de graisse; et ceuxei, qui ne vivent que d'animaux chargés d'huile, en ont plus que les autres; elle est aussi à peu près semblable à celle de la baleine. La chair de ces our's n'est, dit-on, pas mauvaise à manger, et leur peau fait une fourrure trèschaude et très-durable ${ }^{3}$.

${ }^{1}$ Cet ours blanc nagea en mer quasí l'espace d'un mille ; nous le poursuivimes vivement avec trois esquifs, et après que nous l'eûmes lassé, il fut surmonté et lué. Trois navigalions des Hollandais au Nord, par Gerard deVeira : Paris, 1599 , page $110 .-11$ nagent diune pièce de glace à l'antre el plongent : lorsque nous les poursuivions dans nos chaloupes, ils plongeaient à un bout et sortaieut de l'eau à l'autre exlŕmilć : ils savent anssi fort bien courir à terre. Recueil des voyages du Nord, tome II, page 116 . - Sur la cỏle de Spilzberg, un ours blanc entra dans l'eau et nagea plus d'une lieue au large: on le suivit avec des chaloupes, et on le lua, etc. Troisième Voyage des 11 ollandais, page 3.4 .

${ }^{2}$ Quand on eut achevé de luer cet ours biane, on lui fendit le ventre, oủ l'on trouva des morceaux de chien-marin encore entiers, avec la peau et le poil qui étaient des marques qu'il ne venait que d’ètre dévoré. Troisiène Voyage des Hollandais par le Nord, page 56.

${ }^{5}$ Les ours blancs ront à la quête des lonps et des chiens marins, el sont avides des baleineaux, qu'ils trouvent friands sur lous les autres poissons... Ils craignent les baleines, qui les sentent et les poursuivent par une antipathie naturelle, parce qu'ils mangent leurs petits. Recueil des Voyages du Nord, tome I, page 99. - Les peaux des ours blancs sont diun grand soulagement pour ceux qui voyagent en hiver; on prépare ces pcanx à Spitzbcrg mème, en les jelaut dans de la sciure quion fait bien chauffer, et (pui dic celte maniere tire 


\section{ADDITION A L'ARTICLE DE L'OURS BLANC.}

Il paralt certain que l'ours de mer est fort différent de celui de terre, et qu'on peut le regarder comme formant une espèce particulière. La tête surtout est si longue en comparaison de celle de l'ours ordinaire, que ce caractère seul suffirait pour en faire deux espèces distinctes; et les voyageurs ont eu raison de dire que ces ours sont faits tout autrement que les nôtres, qu'ils ont la tête beaucoup plus longue et le cou aussi plus long que les ours de terre. D'ailleurs, dans ee dessin de l'ours de mer, il parait que les extrénités des pieds sont fort différentes de celles des pieds de l'ours de terre : celles-ci tiemnent quelque chose de la forme de la main humaine, tandis que l'extrémité des pieds de l'ours de mer est faite à peu près comme celle des grands chiens ou des autres animaux carnassiers de ce gemre. D'ailleurs il paraît, par quelques relations, qu'il y a de ces our's de mer beaucoup plus grands de corps que nos plus grands ours de terre. Gérard de Veira dit positivement qu'ayant tué un de ces ours, et ayant mesuré la longueur de la peau après l'avoir écorché, elle avait vingt-trois pieds de longueur; ce qui serait plus du triple de celle de nos plus grands ours de terre'. On trouve aussi, dans le recueil des Voyages du Nord, que ces ours de mer sont bien plus grands et bien plus féroces que les autres. Mais il est vrai que, dans ce même recueil, on trouve que, quoique ces ours soient faits tout autrement que les notres, et qu'ils aient la tête et le cou beaucoup plus longs, le corps plus délié, plus effilé et plus agile, ils sont néanmoins à peu près de la même grandeur que nos ours ${ }^{2}$.

Tous les voyageurs s'accordent à dire qu'ils different encore de l'ours commun en ce qu'ils ont les os de la têle beaucoup plus durs, et si durs en effet que, quelque coup de massue

toute la graisse des peaux et les desseche.... Leur graisse est comme du suif, clle devient aussi claire que l'huile ou graisse de baleine après yu'on l'a bien fondue; on s'en sert ordinairement pour les lampes, et elle ne sent pas si mauvais que l'huile de poisson. Nos mariniers la vendent pour lmile de baleine. La chair de ces ours est grasse et blanclıatre... Leur lait est fort blanc et gras. Troisieme Voyage des llollandais , tome II, page 115.

1 Trois navigations admirables failes par les IIollandais an Septentrion. Paris, 1599, pages $110 \mathrm{el} 111$.

${ }^{2}$ Reencil des Voyages du Nord. Ronen, 1716, tome II, page 115 et suivantes. qu'on puisse leur donner, ils ne paraissent point en ètre étourdis, cuoique le coup soit assez fort pour assommer un bouf, et à plus forte raison un ours ordinaire. Les relateurs conviennent aussi que la voix de ces ours marins ressemble plutôt à l'aboiement d'un chien enroué qu'au cri ou au gros murmmre de l'ours ordinaire. Robert Lade assure qu'aux environs de la rivière de Rupper on tua deux ours de mer d'une prodigieuse grosseur, et que ces animaux affamés et féroces avaient attaqué si furieusement les chasseurs, qu'ils avaient tué plusieurs sauvages et blessé deux Anglais. On trouve, pages 34 et 35 du troisieme Voyage des Hollandais au Nord, qu'ils tuèrent sur les côtes de la Nouvelle-Zemble un ours de mer dont la peau avait treize pieds de longueur ; en sorte que, tont considéré, je serais porté à croire que cet animal, si célèbre par sa férocité, est en effet d'une espèce plus grande que celle de nos ours.

\section{LE CASTOR.}

\section{(LE CASTOR ORDINAIRE ${ }^{1}$.)}

Ordre des rongeurs, genre eastor. (Cuvier.)

Autant l'homme s'est élevé au-dessus de l'état de nature, autant les animanx se sont abaissés au-dessous : soumis et réduits en servitude, ou traités comme rebelles et dispersés par la force, leurs sociétés se sont évanonies, leur industrie est devenue stérile, leurs faibles arts ont disparu; chaque espèce a perdu ses qualités générales, et tous n'ont conservé que leurs propriétés individuelles, perfectionnées dans les uns par l'exemple, l'imitation, l'éducation, et dans les autres par la crainte et par la nécessité où ils sont de veiller continuellement à leur sûreté. Quelles vues, quels desseins, quels projets peuvent avoir des esclaves sans âme, ou des relégués sans puissance? Ranıper ou fuir, et toujours exister d'une manière solitaire, ne rien édifier, ne rien produire, ne rien transmettre, et toujours languir dans la calamité, déchoir,

\footnotetext{
1 Nous n'avons $p$ encore constaler si les castors ou bievres qui vivent dans desterriers le long du Rluoue, dı l)anube, dı Weser et d'autres rivières, sont différents, par l'espicee, de celui d'smérique, ou si le voisinage des homunes les empêclıc de bålir.

En 1825 et 1821 , les jouruaux ont faitmention de l'existence de castors rémuis en famille et construisant des digues, er Pologne et en Russie, comme daus le nerd de l'Amérique.
} 
se perpétuer sans se multiplier, perdre, en un mot, par la durée autant et plus qu'ils n'avaient acquis par le temps.

Aussi ne reste-t-il quelques vestiges de leur merveilleuse industrie que dans ces contrées éloignées et désertes, ignorées de l'homme pendant une longue suite de siècles, où chaque espèce pouvait manifester en liberté ses talents naturels, et les perfectionner dans le repos en se réunissant en société durable. Les castors sont peut-être le seul exemple qui subsiste comme un ancien monument de cette espèce d'intelligence des brutes, qui, quoique infiniment inférieure par son principe à celle de l'homme, suppose cependant des projets communs et des vues relatives; projets qui, ayant pour base la société, et pour objet une digue à construire, une bourgade à élever, une espèce de république à fonder, supposent aussi une manière quelconque de s'entendre et d'agir de concert.

Les castors, dira-t-on, sont parmi les quadrupèdes ce que les abeilles sont parmi les insectes. Quelle différence! Il y a dans la nature, telle qu'elle nous est parvenue, trois espèces de sociétés qu'on doit considérer avant de les comparer : la société libre de l'homme, de laquelle, après Diel , il tient toute sa puissance; la société gênée des animaux, toujours fugitive devant celle de l'homme; et enfin la société forcée de quelques petites bêtes qui, naissant toutes en même temps dans le même lieu, sont contraintes d'y demeurer ensemble. Un individu pris solitairement et au sortir des mains de la nature n'est qu'un être stérile, dont l'industrie se borne au simple usage des sens; l'homme lui-même, dans l'état de pure nature, dénué de lumières et de tous les secours de la société, ne produit rien, n'édifie rien. Toute société, au contraire, devient nécessairement féconde, quelque fortuite, quelque aveugle qu'elle puisse ètre, pourvu qu'elle soit composée d'êtres de même nature : par la seule nécessité de se chercher ou de s'éviter, il s'y formera des mouvements communs, dont le résultat sera souvent un ouvrage qui aura l'air d'aroir été conçu, conduit et exécuté avec intelligence. Ainsi, l'ouvrage des abeilles, qui, dans un lieu donné, tel qu'une ruche ou le creux d'un vieux arbre, bâtissent chacune leur cellule; l'ourrage des mouches de Cayenne, qui, non-seulement font aussi leurs cellules, mais construisent même la ruche qui doit les contenir, sont des travaux purement mécaniques qui ne supposent aucune intellgence, aucun projet concerté, aucune vue générale; des travaux qui, n'étant que le produit d'une nécessité physique, un résultat de mouvements communs ${ }^{1}$, s'exercent toujours de la même façon, dans tous les temps et dans tous les lieux, par une multitude qui ne s'est point assemblée par choix, mais qui se trouve réunie par force de nature. Ce n'est donc pas la société, c'est le nombre seul qui opère ici ; c'est une puissance aveugle, qu'on ne peut comparer à la lumière qui dirige toute société. Je ne parle point de cette lumière pure, de ce rayon divin, qui n'a été départi qu'à l'homme seul ; les castors en sont assurément privés, comme tous les autres animaux : mais leur société n'étant point une réunion forcée, se faisant au contraire par une espèce de choix, et supposant au moins un concours général et des vues communes dans ceux qui la composent, suppose au moins aussi une lueur d'intelligence qui, quoique très-différente de celle de l'homme par le principe, produit cependant des effets assez semblables pour qu'on puisse les comparer, non pas dans la société plénière et puissante, telle qu'elle existe parmi les peuples anciennement policés, mais dans la société naissante chez les hommes sauvages, laquelle seule peut, avec équité, être comparée à celle des animaux.

Voyons done le produit de l'une et de l'autre de ces sociétés; voyons jusqu'où s'étend l'art du castor, et où se borne celui du sauvage. Rompre une branche pour s'en faire un bâton, se bâtir une hutte, la couvrir de feuillages pour se mettre à l'abri, amasser de la mousse et du foin pour se faire un lit, sont des actes communs it l'animal et au sauvage. Les ours font des huttes, les singes ont des bâtons; plusieurs autres animaux se pratiquent un domicile propre, commode, impénétrable à l'eau. Frotter une pierre pour la rendre tranchante et s'en faire une hache; s'en servir pour couper, pour écorcer du bois, pour aiguiser des flèchès, pour creuser un vase; écorcher un animal pour se revêtir de sa peau, en prendre les nerfs pour faire une corde d'are, attacher ces mêmes norfs à une épine dure, et se servir de tous deux comme de fil et d'aiguille, sont des actes purement individuels que l'homme en solitude peut tous exécuter sans

1 Voyez les preuves que j'en ai données daus le discours sur la nature des animaux. 
etı’e aidé des autres; des actes qui dépendent de sa seule conformation, puisqu'ils ne supposent que l'usage de la main : maîs couper et transporter un gros arbre, élever un carbet, construire une pirogue, sont au contraire des opérations qui supposent nécessairement un travail commun et des vues concertées. Ces ouvrages sont aussi les seuls résultats de la société naissante chez les nations sauvages, comme les ouvrages des castors sont les fruits de la société perfectionnée parmi ces animaux : car il faut observer qu'ils ne songent point à bâtir, à moins qu'ils n'habitent un pays libre, et qu'ils n'y soient parfaitement tranquilles. Il y a des castors en Languedoc, dans les îles du Rhône; il y en a en plus grand nombre dans les provinces du nord de l'Europe:mais comme toutes ces contrées sont habitées, ou du moins fort fréquentées par les hommes, les castors y sont, commetous les autres animaux, disper'sés, solitaires, fugitifs ou cachés dans un terrier; on ne les a jamais vus se réunir, se rassembler, ni rien entreprendre, ni rien construire; au lieu que dans ces ter'res désertes, où l'homme en société n'a pénétré que bien tard, et où l'on ne voyait auparavant que quelques vestiges de l'homme sauvage, on a partout trouvé les castor's réunis, formant des sociétés, et l'on n'a pu s'empêcher d'admirer leurs ouvrages. Nous tâcherons de ne citer que des témoins judicieux, irréprochables, et nous ne donnerons pour certains que les faits sur lesquels ils s'accordent : moins portés peutêtre que quelques-uns d'entre eux à l'admiration, nous nous permettrons le doute, et mème la eritique, sur tout ce qui nous paraitra trop dilficile à croire.

'Tous conviennent que le castor, loin d'avoir' une supériorité marcquée sur les autres animaux, parait au contraire être au-dessous de quelques uns d'entre eux pour les qualités purement individuelles; et nous sommes en état de confirmer ce fait, ayant cncore actuellement un joune castor vivant, qui nous a été envoyé du Canada ${ }^{1}$, et que nous gardons depuis près d'un an. C'est un auimal assez doux, assez trauquille, assez familier, un peu triste, mème un peu plaintif, sans passions violentes, sans appétits véhéments, ne se donnant que peu de mouvement, ne faisant d'efforts pour quoi que ce

- Ce castor, qui a été pris jenne, m’a été euvoyé an commenoement de l'année 1758, par M. de Montbelliard. capitaine dans Royal-Artillerie. soit; cependant, occupé sérieusement du désir de sa liberté, rongeant de temps en temps les portes de sa prison, mais sanș fureur, sans précipitation, et dans la seule vue d'y faire une ouverture pour en sortir; au reste, assez indiff'erent, ne s'attachant pas volontiers '; ne cherchant point à nuire et assez peu à plaire. Il paraît inférieur au chien par les qualités relatives qui pourraient l'approcher de l'homme; il ne semble fait ni pour servir, ni pour commander, ni même pour commercer avec une autre espèce que la sienne: son sens, renfermé dans lui-même, ne se manifeste en entier qu'avec ses semblables; seul, il a peu dindustrie personnelle, encore moins de ruses, pas même assez de défiance pour éviter des piéges grossiers: loin d'attaquer les autres animaux, il ne sait pas même se bien défendre; il préfère la fuite au combat, quoiqu'il morde cruellement et avec acharnement lorsqu'il se trouve saisi par la main du chasseur. Si l'on considère done cet animal dans l'état de nature, ou plutôt daus son état de solitude et de dispersion, il ne paraitra pas, pour les qualités intérieures, au-dessus des autres animaux : il n'a pas plus d'esprit que le chien, de sens que l'éléphant, de finesse que le renard, ete. Il est plutôt remarquable par des singularités de conformation extérieure, que par la supériorité apparente de ses qualités intérieures. Il est le seul parmi les quadrupẻdes qui ait la queue plate, ovale, et couverte d'écailles, de larjuelle il se sert comme d'un gouvernail pour se diriger dans l'eau; le seul qui ait des nageoires aux pieds de derriere, et en même temps les doiggts séparés dans ceux de devant, qu'il emploie comme des mains pour porter à sa bouche; le seul qui, ressemblant aux animaux terrestres par les parties antérieures de son corps, paraisse en même temps tenir des animaux aquatiques par les parties postérieures : il fait la nuance des quadrupèdes aux poissons, comme la chauve-souris fait celle des quadrupèdes aux oiseaux. Mais ces singularités seraient plutôt des défauts que des perfections, si l'animal ne savait tirer de cette conformation, qui nous parait bizarre, des avantages uniques, et qui le rendent supérieur à tous les autres.

Les eastors commencent par s'assembler au

4. Klein a cependant écrit qu'il en avait nourri un pendant plusieurs années, qui le suivait el l'allait cbercher comme les chiens vonl diercher leurs maitres. 
mois de juin ou de juillet pour se réunir en société; ils arrivent en nombre et de plusieurs côtés, et forment bientôt une troupe de deux ou trois cents : le lieu du rendez-vous est ordinairement le lieu de l'établissement, et c'est toujours au bord des eaux. Si ce sont des eaux plates, et qui se soutiennent à la même hauteur comme dans un lac, ils se dispensent d'y construire une digue: mais dans les eanx courantes, et qui sont stijettes à hausser ou baisser, comme sur les ruisseaux, les rivières, ils établissent une chausscé; et par cette retenue ils forment une espèce d'étang ou de pièce d'eau, qui se soutient toujours à la même inauteur. La chaussée traverse la rivière comme une écluse, et va d'un bord à l'autre; elle a sonvent quatre-vingts ou cent pieds de longueur sur dix ou douze pieds d'épaisseur à sa base. Cette construction paraît énorme pour des animaux de cette taille, et suppose en effet un travail immense'; mais la solidité avec laquelle l'ouvrage est construit étonne encore plus que sa grandeur. L'endroit de la rivière où ils établissent cette digue est ordinairement peu profond; s”il se trouve sur le bord un gros arbre qui puisse tomber dans l'eau, ils commencent pour l'abattre, pour en faire la pièce principale de leur construction. Cet arbre est souvent plus gros que le corps d'un homme; ils le scient, ils le rongent au pied, et sans autre instrument que leurs quatre dents incisives, ils le coupent en assez peu de temps, et le font tomber du côté qu'il leur plaît, c'est-à-dire en travers sur la rivière, ensuite ils coupent les branches de la cime de cet arbre tombé, pour le mettre de niveau et le faire porter partout également. Ces opérations se font en commun:plusieurs castors rongent ensemble le pied de l'arbre pour l'abattre; plusieurs aussi vont ensemble pour en couper les branches lorsqu'il est abattu; d'autres parcourent en même temps les bor'ds de la rivière, et coupent de moindres arbres, les uns gros comme la jambe, les autres comme la cuisse; ils les dépècent et les scient à une certaine hauteur pour en faire des pieux : ils amènent ces pièces de bois, d'abord par terre jusqu'au bord de la rivière, et ensuite par eau jusqu'au lieu de leur construction; ils en font une espèce de pilotis servé, qu'ils enfoncent en-

1 Les plus grands castors pèsent cinquante ou soixante livres, el n'ont guére que trois pieds de longucur depuis ic bout du museau jusqu'a l'origine de la upueuc. core en entrelaçant des branches entre les pieux. Cette opération suppose bien des difficultés vaincues; car, pour dresser ces pieux et les mettre dars une situation à peu près perpendiculaire, il faut cqu'avec les deuts ils élèvent le gros bout contre le bord de la rivière, ou contre l'arbre qui la traverse, que d'autres plongent en même temps jusques au fond de l'eau pour y cleuser avec les pieds de devant un trou, dans lequel ils font entrer la pointe du pieu, afin qu'il puisse se tenir debout. A mesure que les uns plantent aiusi leurs pieux, les autres vont chercher de la terre qu'ils gâchent avec leurs pieds et battent arec leur queue; ils la portent; dans leur gueule et avec les pieds de devant, et ils en transportent une si grande quantité, qu'ils en remplissent tous les intervalles de leur pilotis. Ce pilotis est composé de plusieurs rangs de pieux, tous égaux en hauteur, et tous plantés les uns contre les autres; il s'étend d'un bord à l'autre de la rivière, il est rempli et maçonné partout. Les pieux sont plantés verticalement du côté de la chute de l'eau: tout l'ouvrage est au contraire en talus du cóté qui en soutient la charge, en sorte que la chaussée, qui a dix ou douze pieds de largeur à sa base, se réduit à deux ou trois pieds d'épaisseur au sommet; elle a donc non-seulement toute l'étendue, toute la solidité nécessaire, mais encore la forme la plus convenable pour retenil l'eau, l'empêcher de passer, en soutenir le poids, et en rompre les efforts. Au bas de la chaussée, c'est-à-dire dans la partie où elle a le moins d'épaisseur , ils pratiquent deux ou trois ouvertures en pente, qui sout autant de dícharges de superficie qu'ils élargissent on rétrécissent selon que la rivière vient à hausser ou baisser; et, lors que par des inondations trop grandes ou trop subites il se fait quelques brèches à leur digue, ils savent les réparer, et travaillent de nouveau dès que les eaux sont baissées.

Il serait superflu, après cette exposition de leurs travaux pour un ouvrage public, de donner encore le détail de leurs constructions particulières, si dans une histoirel'on ne devait pas compte de tous les faits, et si ce premier grand ouvrage n'était pas fait dans la vue de rendre plus commodes leurs petites habitations : ce sont des cabanes, ou plutôt des espèces de maisomnettes bâties dans l'eau sur un pilotis plein, tout près du bord de leur étang, avec deux issues, l'une pour aller à terre, l'autre pour se 
leter à l'eau. La forme de cet édifice est presque tonjours ovale ou ronde. Il y en a de plus grands et de plus petits, depuis quatre ou cinq jusqu'à huit ou dix picds de diamètre : il s'en trouve aussi quelquefois qui sont à deux ou trois étages; les murailles ont jusqu'à deux pieds d'épaisseur; elles sont élevés à plomb sur le pilotis plein, qui sert en même temps de fondement et de plancher à la maison. Lor'squ'elle n'a qu'un étage, les murailles ne s'élèvent droites qu’à quelques pieds de hauteur, au-dessus de laquelle elles prennent la courbure d'une voûte en anse de panier; cette voûte termine l'édifice et lui sert de couvert : il est maçonné avec solidité, et enduit avec propreté en dehors et en dedans; il est impénétrable à l'eau des pluies, et résiste aux vents les plus impétueux; les parois en sont revêtues d'une espèce destuc si bien 'gâché et si proprement appliqué, qu'il semble que la main de l'homme y ait passé : aussi la quene leur sert-elle de truelle pour appliquer ce mortier qu'ils gâchent avec leurs pieds. Ils mettent en œuvre différentes espèces de matériaux, des bois, des pierres et des terres sablonneusesqui ne sont point sujettes à se délayer par l'eau : les bois qu'ils emploient sont presque tous léger's et tendres; ce sont des aulnes, des peupliers, des saules, qui naturellement croissent au bord des eaux et qui sont plus faciles à écorcer, à couper, à voiturer, que des arbres dont le bois serait plus pesant et plus dur. Lorsqu'ils attaquent un arbre, ils ne l'abandonnent pas qu'il ne soit abattu, dépecé, transporté; ils le coupent toujours à un pied ou un pied et demi de hauteur de terre. IIs travaillent assis; ct, outre I'avantage de cette situation commode, ils ont le plaisir de ronger continuellement de l'écorce et du bois dont le goût leur est fort agréable, car ils préfèrent l'écorce fraiche et le bois tendre à la plupart des aliments ordinaires; ils en font ample provision pour se nourrir pendant l'hiver'; ils n'aiment pas le bois sec. C'est dans l'eau et près de leurs habitations qu'ils établissent leur magasin ; chaque cabane a le sien proportionné au nombre de ses habitants, qui tous y ont un droit com-

4 La provision, pour huit on dix castors, est de vingt-cinq ou tren!e pieds en earré, sur huit ou dix pieds de profondenr ; ils n'en apportent dans leurs eabanes que quand ils sont conpés menus, el tout prêts à manger : ils aiment mieux le bois frais que le bois flutté, et vont de temps cn temps pendant thiver en manger dans les bois. Ménoire de l'Académie des Sciences, année 1704. - Mémoire de II. Sarrasin. mun, et ne vont jamais piller leurs voisins. On a vu des bourgades composées de vingt ou de vingt-cinq cabanes : ces grands établissements sont rares, et cette espèce de république est ordinairement moins nombreuse; elle n'est le plus souvent composée crue de dix ou douze tribus, dont chacune a son quartier, son magasin, son habitation séparés; ils ne souffrent pas que des étrangers viennent s'établir dans leurs enceintes. Les plus petites cahanes contiennent deux, quatre, six , et les plus grandes dix-huit, vingt, et même, dit-on, jusqu'ì trente castor's, presque toujours en nombre pair, autant de femelles que de mâles : ainsi, en comptant même au rabais, on peut dire que leur société est souvent composée de cent einquante ou deux cents ouvriers associés, qui tons ont travaillé d'abord en corps pour élever le grand ouvrage public, et ensuite par compagnie pour édifier des habitations particulières. Quelque nombreuse que soit eette société, la paix s'y maintient sans altération; le travail commun a resserré leur union ; les commodités qu ils se sont procurées, l'abondance des vivres qu'ils amassent et consomment ensemble, servent à l'entretenir; des appétits modérés, des goûts simples, de l'aversion pour la chair et le sang, leur ôtent jusqu'à l'idée de rapine et de guerre: ils jouissent de tous les biens que l'homme ne sait que désircr. Amis entre eux, s'ils ont quelques ennemis audehors, ils savent les éviter; ils s avertissent en frappant avec leur queue sur l'eau un coup qui retentit au loin dans toutes les voûtes des habitations; chacun prend son parti, ou de plonger dans le lac, ou de se recéler dans leurs murs qui ne craignent que le feu du ciel ou le fer de l'homme, et qu'aucun animal n'ose entreprendre d'ouvrir ou renverser. Ces asiles sont nonseulement très-sûrs, mais encore tres-propres ct très-commodes : le plancher est jonché de verdure; des rameaux de buis ct de sapin leur servent de tapis, sur lequel ils ne font ni ne souffrent jamais aucune ordure. La fenètre qui regarde sur l'eau leur sert de balcon pour se tenir au frais et prendre le bain pendant la plus grande partie du jour : ils s'y tiennent debout, la tète et les parties antéricures du corps élevées, et toutes les parties postérieures plongées dans l'eau. Cette fenêtre est percéc avec précaution; l'ouverture en est assez élcrée pour ne pouvoir jamais être fermée par les glaces, qui, dans le climat de nos castors, ont quekque- 
fois deux ou trois pieds d'épassseur; ils en abaissent alors la tablette, coupent en pente les pieux sur lesquels elle était appuyée, et se font une issue jusqu'à l'eau sous la glace. Cet élément liquide leur est si nécessaire, ou plutôt leur fait tant de plaisir, qu'ils semblent ne pouvoir s'en passer : ils vont quelquefois assez loin sous la glace; c'est alor's qu'on les prend aisément en attaquant d'un cóté la cabane, et les attendant en même temps à un trou qu'on pratique dans la glace à quelque distance, et où ils sont obligés d'arriver pour respirer. L'habitude qu'ils ont de tenir continuellement la queue et toutes les parties postérieures du corps dans l'eau, parait avoir changéla nature de leur chair : celle des parties antérieures jusqu'aux reins a la qualité, le goût, la consistance de la chair desanimaux de la terre et de l'air; celle des cuisses et de la queue à l'odeur, la saveur et toutes les qualités de celle du poisson. Cette queue, longue d'un pied, épaisse d'un pouce, et large de cinc ou six, est même une extrémité, une vraie portion de poisson attachée au corps d'un quadrupède; elle est entièrement recouverte d'écailles et d'une peau toute semblable à celle des gros poissons : on peut enlever ces écailles en les râclant au couteau; et lorsqu'elles sont tombées, l'on voit encore leur empreinte sur la peau, comme dans tous nos poissons.

C'est au commencement de l'été que les castors se rassemblent; ils emploient les mois de juillet et d'août à construire leur digue et leurs cabanes; ils font leur provision d'écorce et de bois daus le mois de septembre; ensuite ils jouissent de leurs travaux; ils goûtent les douceurs domestiques: c'est le temps du repos : c'est mieux, c'est la saison des amour's. Se connaissant, prévenus l'un pour l'autre par l'habitude, par les plaisirs et les peines d'un travail commun, chaque couple ne se forme point au hasard, ne se joint pas par pure nécessité de nature, mais s'unit par choix et s'assortit par goût : ils passent ensemble l'automne et l'hiver ; contents l'un de l'autre, ils ne se quittent guère; à l'aise dans leur domicile, ils n'en sortent que pour faire des promenades agréables et utiles; ils en rapportent des écorces fraìches, qu'ils préferent à celles qui sont sèches ou trop imbibées d'eau. Ies femelles portent, dit-on, quatre mois; elles mettent bas sur la fin de l'hiver, et produisent ordinairement deux ou trois petits. Les mâles les quittent à peu près dans ce temps; ils vont à la campagne jouir des douceurs et des fruits du printemps; ils reviennent de temps en temps à la cabane, mais ils n'y séjournent plus : les mères y demeurent occupées à allaiter, à soigner, à élevєฯ leurs petits, qui sont en état de les suivre au bout de quelques semaines; elles vont à leur tour se promener, se rétablir à l'air, mangerdu poisson, des écrevisses, des écorces nouvelles et passent ainsi l'été sur les eaux, dans les bois. Ils ne se rassemblent qu'en automne, à moins que les inondations n'aient renversé leur diguc ou détruit leurs cabanes; cal alors ils se réunissent de bonne heure pour en réparer les brèches.

Il y a des lieux qu'ils habitent de préférence, où l'on a vu qu'après avoir détruit plusieurs fois leurs.travaux, ils venaient tous les étés pour les réédifier, jusqu'à ce qu'enfin, fatigués de cette persécution, et affaiblis par la perte d plusieurs d'entre eux, ils ont pris le parti de changer de demeure et de se retirer au loin dans les solitudes les plus profondes. C'est principalement en hiver que les chasseurs les cherchent, parce que leur fourrure n'est parfaitement bonne que dans cette saison; et lor'sque, après avoir ruiné leur's établissements, il arrivequ'ils en prennent en grand nombre, la société trop réduite ne se rétablit point; le petit nombre de ceux qui ont échappé à la mort ou à la captivité se disperse ; ils deviennent fuyards; leur génie, flétri par la crainte, ne s'épanouit plus; ils s'enfouisseut eux et tous leurs talents dans un terrier, où, rabaissées à la condition des autres animaux, ils mènent une vie timide, ne s'occupent plus que des besoins pressants, n'exercent que leurs facultés individuelles, et perdent sans retour les qualités sociales que nous veuons d'admirer.

Quelque admirables, en effet, quelque merveilleuses que puissent paraitre les choses que nous venons d'exposer au sujet de la société et des travaux de nos castors, nous osons dire qu'on ne peut douter de leur réalité. Toutes les relations faites en différents temps par un grand nombre de témoins oculaires ${ }^{4}$ s'accordent sur

1 royez, sur l'histoire des castors, olaủs Magnus dans sa Description des pays septentrionaux; les royages du baron de la Hontan, tonı 11, jag. 1ว̈5 et suiv.; le susæum Wormianum, page 320 ; l’ulistoire de I'Amérique seplentriouale par Bacqueville de la Polerie. Ronen, 1722, tome I, page 153; Mémoire sur le castor, par $\mathbf{~}$. Sarrasin, inséré dans les Mé. moires de l'Académie des Sciences, année 1704; la Relalion d'un voyage en Acadie, par Dierville, Rouen, 1708, p. 126 et suiv.; les Nouvelles Découvertes daus l'Amérique septen- 
tous les faits que nous avons rapportés; et si notre récit diffère de celui de quelques-uns d'entre eux, ce n'est que dans les points où ils nous ont paru enfler le merveilleux, aller au-delà du vrai, et quelquefois même de toute vraisemblance : car on ne s'est pas borné à dire que les castor's avaient des mœurs sociales et des talents évidents pour l'arehitecture; mais on a assuré qu'on ne pouvait leur refuser des idées générales de police et de gouvernement; que, leur société étant une fois formée, ils savaient réduire en eselavage les voyageurs, les étrangers; qu'ils s'en servaient pour porter leur terre, traîner leur bois; qu'ils traitaient de méme les paresseux d'entre eux qui ne voulaient, et les vieux qui ne pouvaient pas travailler; qu'ils les renversaient sur le dos, les faisaient servir de charrette pour voiturer leurs matériaux; que ces républicains ne s'assemblaient jamais qu'en nombre impair, pour que dans leurs conseils il y eût toujours une voix prépondérante; que la société entière avait un président; que chaque tribu avait son intendant; qu'ils avaient des sentinelles établies pour la garde publique; que, quand ils étaient poursuivis, ils ne manquaient pas de s'arracher les testicules pour satisfaire à la cupidité des chasseurs; qu'ils se montraient ainsi mutilés pour trouver grâce à leurs yeux, etc., etc. '. Autant nous sommes éloignés de croire à ces fables, ou de recevoir ces exagérations, autant il nous parait diffieile de se refuser à admettre des faits constatés, confirmés, et moralement très-certains. On a mille fois vu, revu, détruit, renversé leurs ouvrages; on les a mesurés, dessinés, gravés; enfin, ce qui ne laisse aucun donte, ce qui est plus fort que tous les témoignages passés, c'est que nous en avons de récents et d'actuels; c'est qu'il en subsiste eneore, de ees ouvrages singuliers, qui, quoique moins com-

Irionale, Paris, 1697, page 133; l'Ilistoire de la NouvelleFrance, par le P. Charlevoix, Paris, 1744, tome 1I, page $98 \mathrm{ct}$ suiv.; le Voyage de Robert Lade, traduit de l'anglais par M. l'abbé Prevost, tome 1I, page 226; lc Grand Voyage au pays des llurons, par Sagard Théodat, Paris, 1632, p. 319 el suiv.; le voyage à la baie de Iludson, par Ellis, Paris, 1749, toine 11, pages 61 ct 62. Voyez aussi Gessner, Aldrovande, Jonlıston, Klein, etc., à l'article du Castor ; le Traité du Cas. Lor, par Jeaı Marius, Paris, 1746; l'Histoire de la Virginie, Iraduite de l'anglais, Orléans, 1707, yage 106; l'llisloire $\mathrm{Na-}$ turelle du P. lizaczinsky, à l'article du Castor, etc., ele.

-Voyez Élien et tous les ancicns, à l'exception de Plinc qui nie ce fait avec raison. Voyez aussi, sur les autres faits, la plupart des anteurs que nous avons cités dans la note précédente. muns que dans les premiers temps de la découverte de l'Amérique septentrionale, se trouvent cependant en assez grand nombre pour que tous les missionnaires, tous les voyageurs, même les plus nouveaux, qui se sont avancés dans les terres du nord, assurent en avoir rencontré.

Tous s'accordent à diı qu'outre les castors qui sont en société, on rencontre partout dans le même climat des castors solitaires, lesquels rejetés, disent-ils, de la société pour leurs défauts, ne participent à aucun de ses avantages, n'ont ni maison, ni magasin, et demeurent, comme le blaireau, dans un boyau sous terre; on a même appelé ces castors solitaires, castors terriers : ils sont aisés à reconnaitre; leur robe est sale, le poil est rongé sur le dos par le frottement de la terre; ils habitent, comme les autres, assez volontiers au bord des eaux, où quelques-uns même ereusent un fossé de quelques pieds de profondeur, pour former un petit étang, qui arrive jusqu'à l'ouverture de leur terrier, qui s'étend quelquefois à plus de cent pieds en longueur, et va toujours en s'élevant, afin qu'ils aient la facilité de se retirer en haut à mesure que l'eau s'élève dans les inondations; mais il s'en trouve aussi, de ces eastors solitaires, qui habitent assez loin des eaux dans les terres. Tous nos bièvres d'Europe sont des castors terriers et solitaires, dont la fourrure n'est pas, à beaucoup près, aussi belle que celle des castors qui vivent en société. Tous diffèrent par la conleur, suivant le climat qu'ils habitent. Dans les contrées du nord les plus reculées, ils sont tous noirs, et ce sont les plus beaux : parmi ces castors noirs, il s'en trouve quelque fois de tout blanes, ou de blanes tachés de gris, et mêlés de roux sur le chignon et sur la croupe'. A mesure qu'on s'éloigne du nord, la couleur s'éclaircit et se mêle; ils sont couleur de marron dans la partie septentrionale du Canada, châtains vers la partie méridionale, et jaunes ou couleur de paille chez les Illinois ${ }^{2}$. On trouve des castors en Amérique, depuis le trentième degré de latitude nord, jusqu'au soixantième et au-delà: ils sont très-communs vers le nord, et toujours en moindre nombre, à mesure qu'on avance vers le midi. C'est la même chose daus

- Castor albns canda horizontaliter plana; Brisson, Regn. animal., pag. 94 el suiv.

${ }^{2}$ Hlistoire de la Nonvelle-France par lc P. Cliarlevoix; Paris, 1744, tome 11 , pages 91 et suivantes. 
l'ancien continent; on n'en trouve en quantité que dans les contrées les plus septentrionales, et ils sont très-rares en France, en Espagne, en Italie, en Grèce et en Egypte. Les anciens les connaissaient : il était défendu de les tuer, dans la religion des Mages. Ils étaient communs sur les rives du Pont-Euxin; on a même appelé le castor, canis ponticus : mais apparemment que ces animaux n'étaient pas assez tranquilles sur les bords de cette mer, qui en effet sont fréquentés par les hommes de temps immémorial, puisqu'aucun des anciens ne parle de leur société ni de leurs travaux. Elien surtout, qui marque un si grand faible pour le merveilleux, et qui, je crois, a écrit le premier que le castor se coupe les testicules pour les laisser ramasser au chasseur', n'aurait pas manqué de parler des merveilles de leur république, en exagérant leur génie et leurs talents pour l'architecture. Pline lui-même, Pline, dont l'esprit fier, triste et sublime, déprise toujours l'homme pour cxalter la nature, se serait-il abstenu de comparer les travaux de Romulus à ceux de nos eastor's? Il paraît done certain qu'aucun des anciens n'a connu leur industrie pour bâtir; et quoiqu'on ait trouvé dans les derniers siècles des castors cabanés en Norwége, et dans les autres provinces les plus septentrionales de l'Europe, et qu'il y ait apparence que les anciens castor's bâtissaient aussi bien que les castors modernes, comme les Romains n'avaient pas pénétré jusque-là, il n'est pas surprenant que leurs écrivains n'en fassent aucune mention.

Plusieurs auteurs ont écrit que le castor, étant un animal aquatique, ne pouvait vivre sur terre et sans eau. Cette opinion n'est pas vraie; ear le castor que nous avons vivant, ayant été pris tout jeune en Canada, et ayant été toujour's élevé dans la maison, ne connaissait pas l'eau, lorsqu'on nous l'a remis; il craignait et refusait d'y entrer : mais l'ayant une fois plongé et retenu d'abord par foree dans un bassin, il s'y trouva si bien au bout de quelques minutes, qu'il ne cherchait point à en sortir : et lorsqu'on le laissait libre, il y retournait trèssouvent de lui-même; il se vautıait aussi dans la boue et sur le pavé mouillé. Un jour il s'échappa, et descendit par un escalier de cave dans les voûtes des carrières qui sont sous le terrain du Jardin-Royal; il s'enfuit assez loin,

'11ist. animal, lib. 6, cap. 34. en nageant sur les mares d'eau qui sont au fond de ces carrières : cependant dès qu'il vit la lumière des flambeaux que nous y fimes porter pour le chercher, il revint à ceux qui l'appelaient, et se laissa prendre aisément. II est familier saus être caressant ; il demande à manger à ceux qui sont à table; ses instances sout un petit cri plaintif et quelques gestes de la main : dès qu'on lui donne un morceau, il l'emporte, et se cache pour le manger à son aise. Il dort assez souvent, et se repose sur le ventre; il mange de tout, à l'exception de la viande, qu'il refuse constamment, cuite ou crue : il ronge tout ce qu'il trouve, les étoffes, les meubles, le bois; et l'on a été obligé de doubler de fer-blanc le tonneau dans lequel il a été transporté.

Les castors habitent de préférence sur les bords des lacs, des rivières et des autres eaux douces : cependant il s'en trouve au bord de la mer, mais c'est principalement sur les mers septentrionales, et surtout dans les golfes méditerrané qui reçoivent de grands fleuves, et dont les eaux sont peu salées. Ils sont ennemis de la loutre; ils la ehassent, et ne lui permettent pas de paraître sur les eaux qu'ils fréquentent. La fourrure du castor est encore plus belle et plus fournie que celle de la loutre : elle est composée de deux sortes de poils; l'un, plus court, mais très-touffu, fin comme le duvet, impénétrable à l'eau, revêt immédiatement la peau : l'autre, plus long, plus ferme, plus lustré, mais plus rare, recouvre ce premier vêtement, lui sert, pour ainsi dire, de surtout, le défend des ordures, de la poussière, de la fange : ce second poil n'a que peu de valeur; ce n'est que le premier que l'on emploie dans nos manufactures. Les fourrures les plus noires sont ordinairement les plus fournies, et par conséquent les plus estimées; celles des castors terriers sont fort inférieures à celles des castor's cabanés. Les eastors sont sujets à la mue pendant l'été, comme tous les autres quadrupèdes; aussi la fourrure de ceux qui sont pris dans cette saison n'a que peu de valeur. Ia fourrure des castors blancs est estimée à cause de sa rareté; et les parfaitement noirs sont presque aussi rares que les blanes.

Mais indépendamment de la fourrure, qui est ce que le castor fournit de plus précieux, il donne encole une matière dont on fait un grand usage en médecine. Cette matière, que l'on a appelé casloreum, est contenue dans deux 
grosses vésicules, que les anciens avaient prises pour les testicules de l'animal. Nous n'en donnerons pas la description ni les usages ', parce qu'on les trouve dans toutes les pharmacopées ${ }^{2}$. Les sauvages tirent, dit-on, de la queue du castor une huile dont ils se servent comme de topique pour differents maux. La chair du castor, quoi(jue grasse et délicate, a toujours un goût amer assez désagréable : on assure qu'il a les os excessivement durs; mais nous n’avons pas été à portée de vérifier ce fait, n'eu ayant disséqué qu'un jeune. Ses dents sont trèsdures, et si tranchantes, qu'elles servent de couteau aux sauvages pour couper, creuser et polir le bois. Ils s'habillent de peaux de castors, et les portent en hiver le poil contre la chair. Ce sont ces fourrures, imbibées de la sueur des sauvages, que l'on appelle castors yras, dont on ne se sert que pour les ouvrages les plus grossiers.

Le castor se sert de ses pieds de devant comme de mains, avec une adresse au moins égale à celle de l'écureuil : les doigts en sont bien séparés, bien divisés; au lieu que ceux des pieds de derrière sont réunis entre eux par une forte membrane; ils lui servent de nageoires, et s'élargissent comme ceux de l'oie, dont le castor a aussi en partie la démarche sur la terre. Il nage beaucoup mieux qu'il ne court : comme il a les jambes de devant bieu plus courtes que celles de derrière, il marche toujours la tête baissée et le dos arqué. Il a les sens très-bons, l'odorat très-fin, et même susceptible; il parait qu'il ue peut supporter ni la malpropreté, ni les manvaises odeur's : lor'squ'on le retient trop longtemps en prison, et qu'il se trouve forcé d'y faire ses ordures, il les met près du seuil de la porte, et, dès qu'elle est ouverte, il les pousse dehors. Cette habitude de propreté leur est naturelle, et notre jeune castor ne manquait jamais de nettoyer ainsi sa chambre. A l'âge d'un an, il a donné des signes de chaleur, ce qui parait indiquer qu'il avait pris dans eet espace de temps la plus grande partie de son accroissement : ainsi, la durée de sa vic ne peut

- Voyez le Traité du castor, par Marius et Francus. Paris, 1746, in-12.

: On prétend que les eastors forl sortir la liqueur de leurs vésicules en les pressant avec le pied, quielle leur dome de l'appétit lorsqu'ils sont dégoůlés, et que les sauvages en fruttent les piéges qu'ils leur lendeut pour les y attirer. Ce qui paralt plus certain, c'est „u'iis se servent de cette liqueur pourse graisser le poil. être bien longue, et c'est pent-être trop que de l'étendre à quinze ou vingt ans. Ce eastor était très-petit pour son âge, et l'on ne doit pas s'en étomner, ayant presque, dès sa naissance, toujour's été contraint, élevé, pour ainsi dire à sec; ne connaissant pas l'eau jusqu'à l'âge de neuf mois, il n’a pu ni eroitre, ni se développer comme les autres, qui jouissent de leur liberté et de cet élément qui parait leur être presque aussi nécessaire que l'usage de la terre.

\section{ADDITION A L'ARTICLE DU CASTOR.}

Nous avons dit que le castor était un ammal commun aux deux continents; il se trouve en effet tout aussi fréquemment en Sibérie qu'au Canada. On peut les apprivoiser aisément, et même leur apprendre à pêcher du poisson, et le rapporter à la maison. M. Kalm assure ce fait.

" J'ai vu, dit-il , en Amérique des castor's tellement apprivoisés, qu'on les envoyait à la pèche, et qu'ils rapportaient leurs prises à leur maître. J'y ai vu aussi quelques loutres, qui étaient si fort accoutumées avec les chiens et avec leurs maîtres, qu'elles les suivaient, les accompagnaient dans le bateau, sautaient dans l'eau, et, le moment d'après, revenaient avec un poisson '."

"Nous vimes, dit M. Gmelin, dans une petite ville de Sibérie, un castor gu’on élevait dans la chambre et qu'on maniait comme on voulait. On m'assura que cet animal faisait quelquefois des voyages à ume distance considérable, et qu'il enlevait awx autres castors leurs femelles, qu'il ramenait à la maison, ot qu'après le temps de la chaleur passé clles s'en retournaient scules, et sans qu'il les conduisit ${ }^{2}$. ")

\section{DESCRIPTION DU CASTOR.}

(EXTHAIT DE DALBENTON.)

Le castor ressemble au rat d'eau prar la forme de la tête, à l'exception cles oreilles, qui sont à proportion plus courtes; le chanfrein m'a paru plus arqué, et le sommet de la téte plus aplati. Le mu.

- Vuyage de Kalm, lome II, j)age 350.

* Vyage de Kamtschatha page 75. 
seall est grus el court; le poil est si hérissé sur la tic qu il en caulue la vaie forme, et qu'il couvre en partie les yeux, qui sont beaucoup plus petits que ceux du rat d'eau. Le cou est court, et il paraît aussi gros yue la tète. Le corps a plus de longueur à proportion que celui de la marmotte, mais il esi aussi gros, surtout dans la partie postérieure: les jambes sont très-courtes, principalement celles de devant, dont les pieds sont un peu tournés en dedans; les pieds de derrière le sont beaucoup plus, de façon qu'on ne les voit presque pas lorsque le castor marche.

La qieue a une conformation fort extraordinaire; elle est très-large, en partie garnie de poil, et en partie écailleuse. L'origine lu tronçon de la queue du castor qui a servi de sujet pour cette description etait garnie de poil sur la longueur de trois pouces depuis l'anus; cette portion de la queue avait environ deux pouces et demi de largeur, et un pouce et demi d'épaisseur: le reste arait une forme approchante de l'ovale, cependant elle était terminee par une pointe : cette autre portion avait luuit ponces de longueur, trois ponces huit lignes de largeur dans le milieu, et environ huit lignes d'épaisseur ; elle était couverte d'écailles sur la face superieure, sur linferienre et sur les bords : les cicailles du dessus étaient un peu convexes; celles dı dessous araient une légère concavité, et celles des còtés étaient les plus petites; les plus grandes a'aient, lans la partie qui paraissait à découvert, trois lignes et remie de largeur, et deux ligues de Iongueur. L'animal porte toujours sa quene étendue horizoutalement en arrière ; elle n'est que peu flexible, cependant il en frappait la terre assez fort pour faire un bruit qui s'entendait de loin; il en frappait aussi l'eau; en nageant il s'en servait comme d'un aviron, en la liaussant et la baissant, ou en la tournant obliquement sur sa largeur.

Les pieds de devant sont fort petits; ils avaient chacun cinq doigts, que l'animal tenait fort écartés les uns des autres en marchant; les deux premiers étaient à proportion plus petits que les antres, et avaient des ongles longs, étroits et pointus; ceux des trois autres doigts étaient plus larges et sans pointe; les ongles du troisième et du quat rième doigt avaient autant de longueur que celıi du second, mais l'ongle du cinquième doigt était plus court.

Les pieds le derrièreétaient beaucoup plus grands que ceux de devant; ils avaient aussi chacun cinq doigts beaucoup plus longs, et il se trouvait entre eux une forte membrane. Le troisìme doişt était ve plus long, mais il avait moins de grosseur que le quatrième; les oncrles de ces deux doigts citient longs, larges et quarres; ceux du prenier et du cin niene ctaient moins larges et pointus : le se- cond doigt avait deux ongles, l'un en partie audessus et en partie à còté le l'autre; l'ongrle supérieur et externe était pointı, l’ongle inférieur et interne était large et arroncli par le bout.

La démarche du castor est lourde et contrainte, parce que ses jambes de lerrière sont mieux con. formeses pour nager que pour narcher : comme elles ont plus de longueur que celles de devant, et qu'elles sont terminces par un grand piel, l'animal semble faire ile plus grands pas avec le train de derrière (ju'avec celıi de devant : et en effet, il est oljige de faire de plus grands mourements, qui jettent la croupe alternativenıent à droite, à gatuche, comme il arrive aux canarls : cependant le castor ne laisse pas de marcher assez vite; il est rrai que ce ri’est jas à propor'ion des efforts qu'il fait.

Lorsque le castor est arrêté, il a le dos très-arqué et la croupe ravalee de façon yue, la partie posterieure du corps posant sur la terre, ce point d'appui, joint à ceux des pieds le clerrière, yui portent aussi sur la terre jusqu'au bout du talon, donne a l'animal une assiette très-commode puur élever la partie antérieure du corps, comme font les écureuils et les rats. Dais cette attitucle, il se sert de ses pieds de devant comme de mains pour tâter, pour saisir, pour porter à sa bouche, et aıssi pour s’appuyer contre les plans verticaux : alor'sle dos est en ligne droite; mais lorsyue l'animal est, pour ainsi dire, debout sans aucun appui, le dos est très-arqué et la tète fort basse.

Le castor a deux sortes de poils : l'un plus ferme et plus long que l'autre, qui est une sorte de duvet doux comme de la soie, et disposé par tlocons comme de la laine; il s'était mème pelotonné comme du feutre sür le dos de l'animal Ce cluvet avait une couleur cendrée sur le dos, et une couleur de gris de perle sur le ventre : partout la pointe était brune jaunitre. Les longs poils avaient une couleur cendreje sur environ les denx liers the leur longueul depuis la racine, l'autre tier's tait de couleur brune, teinte de roux et luisante, qui prenait direrses nuances à divers aspects, et qui en avait toujours de différentes sur différentes parties du corps : cette couleur ćait d'un roux très-ardent sur le dessus le la tête et du cou, sur le dos, sur les còtés du corps et sur la croupe. L.es poils étaient luisants lorsqu'on se plaçait an devant de l'animal pour le regarler, naais ils n'avaient plus tle brillant, et le roux ćtait moins ardent lorsquon ètait placc en arrière. La poitrine et les jambes de derrière étaient brunes; les côtés de la tète avaient une couleur rousse très-pâle, les quatre pieds citait nt hruns, les crins des moustaches avaient teux pouces et demi de longueur; ils ctaient gros et noirs. La partie ćcailleuse de la quene avait une couleur grise. 
Le castor tui a servi de sujet pour la description recédente n'avait pas encore atteint toute la granleur à laquelle il devait parvenir par la suite, c'est ourquoi jai pris les dimensions sur un castor de a ménagerie de Versailles, qui m'a paru avoir out son accroissement : il est d'une couleur plus oncie que celle de notre castor.

On ne doute pas que le bièvre ne soit le même nimal que le castor : quoiqu'il y ait encore des lievres en Languedoc, nous n'avons pu avoir leces animaux pour le comparer au castor ; ils sont présent très-rares : cepenilant il y a au Cabinet un ied de devant et un pieıl de derrière dı côté gaııhe, et la longue dent du còté droit de la nutchoire nférieure d'un bièvre du Gardon. J'ai comparé ces arties à celles qui y correspondaient dans notre astor, et je n'ai aperçu aucume difléreure de fi ure : le double ongle du second doigt du pied de lerrière, que je cite par préférence, parce que 'est un caractère très-particulier, se trouvait dans e pied du bièvre conme dans celıi du castor, et vait précisément la mčme conformation. Le poil ui tient aux deux pieds du bièvre a une couleur noins brune que dans le castor, et presque jaınâre; mais ce poil a peut-être été décoloré par la haleur du feu auquel il a été exposé, lorsque l'on I fait desséclıer ces parties dı bièvre.

\section{L'ONDATRA ET LE DESMAN.}

Ordre des rongeurs, geure rat. (Curier.)

L'ondatra et le desman sont deux animaux fu'il ne faut pas confondre, quoiqu'on les ait apselés tous deux rats musqués, et qu'ils aient fuel jues caractères communs : il faut aussi les listinguer du pilori ou rat musqué des Antilles ; zes trois animaux sont d'espèces et de climats lifférents. L'ondatra se trouve en Canada, le Jesman en Laponie, en Moscovie, et le pilori i la Martinique et dans les autres íles Antilles.

L'ondatra ou rat musqué du Canada diffère du desman en ce qu'il a les doigts des pieds tous séparés les uns des autres, les yeux très-apparents ct le muscau fort court; au lieu que le desmau ou rat musqué de Moscovie a les pieds de derrière réunis par une membrane ', les yeux

' Oculi exigui et vix conspicui... I) Igiti majores nembranis connexi ad commolius natandum, rostri pars superior firma, prominula et pene unciam longa, nigricans eapue forma pradita, ut instar suis aut talpa terram vertere possit. Clusii exotic. auct. page 375 . extrêmement petits, le muscau prolungù comme la musaraigne. Tous deux ont la queue plate, et ils diffèrent du pilori ou rat musqué des Antilles, par eette conformation et par plusieurs autres caractères '. Le pilori a la queue assez courte, cylindrique ${ }^{2}$ comme celle des autres rats, au licu que l'ondatra et le desman l'ont tous deux fort longue. L'ondatra ressemble par la tète au rat d'eau, et le desman à la musaraigne.

On trouve dans les Mémoires de l'Académic royale des Sciences, année 1725, une description très-ample et très-bien faite de l'ondatra sous le nom de rat musqué. M. Sarrasin, méclecin du roi à Québec et correspondant de l'Académie, s'est oceupé à dissé(fuer un grland nombl’e de ces animaux, dans lesquels il a observé des choses singuliè:'es. Nous ne pouvons pas douter, en comparant sa description avec la notre, que ce rat musqué du Canada, dont il a été donné la deseription, ne soit notre ondalra.

L'ondatra est de la grosseur d'un petit lapin et de la forme d'un rat. Il a la tête courte et semblable à celle du rat d'eau, le poil luisant et doux, avec un duvet fort épais au-dessous du premier poil, à peu près comme le castor. Il a la queue longue et couverte de petites écailles comme celle des autres rats, mais elle est d'une forme différente : la queue des rats communs est à peu près cylindrique, et diminue de grosseur depuis l'origrinejusqu'à l'extrémité; celle du rat musqué est fort aplatie ver's la partie du milieu juscuuà l'extrémité, et un peu plus arrondie au commencement, c'est-à-dire à l'origine; les faces aplaties ne sont pas horizontales, mais

'L.es l'ats musqués des Antilles, que nos Francais appel. lcut piloris, font lc plus souvent leurs retraites dans Ic 8 trous de la terre comme les lajuins; aussi ils soul prestune de Ja même grosscur ; mais pour la figure ils n'ont ricı de celle des gros rats quion voit aillcurs, sinon fue la plupart ont le poil du ventre blanc comue les glirons, et celui du reste du corps noir ou tanné; ils exhalent une odeur musquée qui abat le curur et qui parfume si fort l'endroit de leur rctrate, qüil est fort aisé de le discerner. Ilistoire naturelle des Antilles. Rotlerdam, 1658, jage 12 \%.

${ }^{2}$ Les piloris sont une esprece de rats de bois deux ou trois fois plus gros que les rats ordinaires; il sont prestpue blancs; leur quenc es! fort courte; ils sentent le musc extraordinairement. Nouveau voyage aux iles de 1 ', Imérique. $1^{\prime}$ aris 1722. tone 1, page 458 . - l.es piloris se (rouvent a la IIartinique et daus unclyues anlres iles des Antilles : ce sont des rats inusqués de mêne forme que les rats $\mathrm{l}^{*}$ Europe, mais d'une si prodigieuse grandeur, que quatre de nos rats ne pesent pas un pilori.... Its nichent justue dans li's cases, mais ne peuplent pas tant yue les antres rats eommuns... Ces piloris soul naturels dans l'ite de la dlartinique et non pas les autres rats

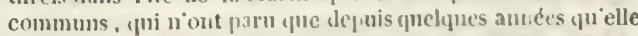
est fiépuenté des naviles, etc. llistuire générale des Antilles par le père du Tertre, l'aris, 166\%, tome 11, page $\mathbf{3 0 2}$ 
verticales, en sorte qu'il semble que la queue ait été serrée et comprimée des deux còtés dans toute sa longueur. Les doigts des pieds ne sont pas réunis par des membranes, mais ils sont garnis de longs poils assez serrés, qui suppléent en partie l'effet de la membrane, et donnent à l'animal plus de facilité pour nager. Ila lesoreilles très-courtes et non pas nues comme le rat domestique, mais bien couvertes de poils en dehors et en dedans; les yeux grands et de trois lignes douverture : deux dents incisives d'environ un pouce de long dans la mâchoire inférieure, et deux autres plus courtes dans la mâchoire supérieure : ces quatre dents sont trèsfortes, et lui servent à ronger et à couper le bois.

Les choses singulières que M. Sarrasin a observées dans cet animal sont : $\mathbf{1}^{0}$ la force et la grande expansion du muscle peaucier, qui fait que l'animal, en contractant sa peau, peut resserrer son corps et le réduire à un plus petit volume; $2^{\circ}$ la souplesse des fausses côtes qui permet cette contraction du corps, lacjuelle est si considérable, que le rat musqué passe dans des trous où des animaux beaucoup plus petits ne peuvent entrer ; $3^{\circ}$ la manière dont s'écoulent les urines dans les femelles, car l'urètre n'aboutit point, comme dans les autres quadrupèdes, au-dessous du clitoris, mais à une émiuence velue située sur l'os pubis; et cette éminence a un orifice particulier qui sert à l'éjection des urines : organisation singulière qui ne se trouve que dans rquelques espèces d'animaux, comme les rats et les singes, dont les femelles ont trois ouvertures. On a observé que le castor est le seul des quadrupèdes dans lequel les urines et les excréments aboutissent également à un réceptacie commun, (qu'on pourrait comparer au cloaque des oiseaux. Les femelles des rats et des singes sont peut-ètre les seules (qui aient le conduit des urines et l'orifice par où elles s'écoulent absolument séparés des parties de la génération; cette singularité n'est que dans les femelles; car, daus les màles de ces mèmes espèces, l'urètre aboutit à l'extrémité de la verge, comme dans toutes les autres especes de quadrupèdes. M. Sarrasin observe, 40 que les testicules, qui, comme dans les autres rats, sont situés des deux côtés de l'anus, deviemnent trèsgros dans le temps du rut pour un animal aussi petit : gros, dit-il comme des noix muscudes; majs quapres ce tempsils diminuent prodigieu- sement, et se réduisent au point de n'avoir pas plus d'une ligne de diamètre; que ron-seule. ment ils changent de volume, de consistance et de couleur, mais même de situation d'une manière marquée; il en est de même des vésicules séminales, des vaisseaux déférents, etc. Toutes ces parties de la gériération s'oblitèrent presque entièrement après la saison des amours. Lestesticules, qui, dans ce temps, étaient au-dehors et fort proéminents, rentrent dans l'intérieur du corps; ils sont attachés à la menubrane adipeuse, ou plutôt ils y sont encla vés, ainsi que les autres parties dont nous venons de parler. Cette membrane s'étend et s'augmente par la surabondance de la nourriture jusqu'au temps du rut: les parties de la génération, qui semblent être des appendices de cette membrane, se développent, s'éteudent, se gonflent et acquièrent alors toutes leurs dimensions; mais lorsque cette surabondance de nourriture est épuisée par des coïts réitérés, la membrane adipeuse, qui maigrit, se resserre, se contracte et se retire peu à peu du côté des reins ; en se retırant elle entıaine avec elle les vaisseaux déférents. les résicules séminales, les épididymes et les testicules, qui deviemnent légers, vides et ridés au point de n'ètre plus reconnaissables. Il en est de mème des vésicules séminales qui, dans le temps de leur gonflement, ont un pouce et demi de longueur, et ensuite sont réduites, ainsi que les testicules, à une ou deux lignes de diamètre. $5^{\circ}$ Les follicu. les qui contienment le musc ou le parfum de cet animal sous la forme d'une humeur laiteuse, et qui sont voisins des parties de la génération, éprouvent aussi les mêmes changements; ils sont très-gros, très-gonflés, et leur parfum très. fort, très-exalté, et mème très-sensible à une assez grande distance daus le temps des amours; ensuite ils se rident, ils se flétrissent et entin s'oblitèrent en entier. Ce changement dans les follicules qui contiennent le parfum se fait plus promptement et plus complétement que celui des parties de la génération : ces follicules, qui sont communs au deux sexes, contiennent un lait fort abondant au temps du rut; ils ont des vaisseaux excrétoires qui aboutissent dans le mâle à l'extrémité de la v'erge et vers le clitoris dans la femelle, et cette sécrétion se fait ets'évacue à peu près au mème endroit que l'urine dans les autres quadrupèdes.

Toutes ces singularités, qui nous ont étéindlquées par M. Sarrasin, étaient dignes de l'atten- 
tlon d'un habile anatomiste, et l'on ne peut assez le louer des soins réitérés qu'il s'est donnés pour constater ces espèces d'accidents de la nature, et pour voir ees ehangements dans toutes leurs périodes. Nous avons déjà parlé de changements et d'altérations à peu pries semblables à celles-ci dans les parties de la génération du rat d'eau, du campagnol et de la taupe. Voilá donc des animaux quadrupédes qui, par tout le reste de la conformation, ressemblent aux autres quadrupèdes, desquels eependant les parties de la génération se renouvellent et s'oblitèrent chaque année, à peu près comme les laitances des poissons, et comme les vaisseaux séminaux du calmar dont nous a vons décrit les changements, l'anéantissement et la reproduction : ce sont là deces nuances par lescruelles la nature rapproche secrètement les êtres qui nous paraissent les plus éloignés, de ces exemples rares, de ces instances solitaires qu'il ne faut jamais perdre de vue, paree qu'elles tiennent au système général de l'organisation des ètres, et qu'elles en réunissent les points les plus éloignés. Mais ce n'est point ici le lieu de nous étendre sur les conséquences générales qu’on peut tirer de ces faits singuliers, non plus rue sur les rapports immédiats qu'ils ont avec notre théorie de la génération : un esprit attentif les sentira d'avanee, et nous aurons bientòt occasion de les présenter avec plus d'avantage en les réunissant à la masse totale des autres faits qui y sont relatifs.

Comme l'ondatra est du mème pays que le castor, que, comme lui, il habite sur les eaux, qu'il est en petit à peu près de la même figure, de la mème couleur et du même poil, on les a souvent eomparés l'un à l'autre; on assure même qu'au premier coup d'œil on prendrait un vieux ondatra pour un eastor qui n'aurait qu'un mois d'âge ; ils diffèrent cependant assez par la forme de la queue, pour qu'on ne puisse s'y méprendre; elle est ovale et plate horizontalement daus lecastor; clle est très-allongée et plate vertiealement dans l'ondatra. Au reste, ces animaux se ressemblent assez par' le naturel et l'instinct. Les ondatras, comme les castor's, vivent en société pendant l'hiver; ils font de petites cabanes d'envirou deux pieds et demi de diamètre, et quelquefois plus grandes, où ils se réunissent plusieurs familles ensemble: ce n'est point, comme les marmottes, pour y dormir pendant cinqou six mois, e'est seulement pour' se mettre à l'abri de la rigueur de l'air : ces cabanes sont rondes et eouvertes d'un dôme d'un pied d'épaisseur; des herbes, des joncs entrelacés et mêlés avee de la terre grasse qu'ils pétrissent avec les pieds, sont leurs matériaux. Leur construetion est impénétrable à l'eau du ciel, et ils pratiquent des gradins en dedans, pour n'être pas gagnés par l'iuondation de celle de la terre. Cette cabane, qui leur sert de retraite, est couverte pendant l'hiver de plusieurs pieds de glaces et de neiges sans qu'ils en soient incommodés. Ils ne font pas de provisions pour vivre comme les castors, mais ils creusent des puits et des espèces de boyaux au-dessous et à l'entour de leur demeure, pour ehereher de l'eau et des racines. Ils passent ainsi l'hiver fort tristement, quoique en société, car ce n'est pas la saison de leurs amours; ils sont privés pendant tout ce temps de la lumière du ciel : aussi, lorsque l'haleine du printemps commence à dissoudre les neiges et à découvrir les sommets de leurs habitations, les ehasseurs en ouvrent le dòme, les offusquent brusquement de la lumière du jour, et assomment ou prennent tous ceux qui uont pas eu le temps de gagner les galeries souterraines quils se sont pratiquées, et qui leur servent de derniers retranchements où on les suit encorē, car leur peau est préeieuscet leur chair n'est pas mauvaise à manger. Ceux qui échappent à la main du ehasseur quittent leur habitation à peu près dans ce temps; ils sont errants pendant l'été, mais toujours deuxả deux, carc'est le temps des amours. Ils vivent d herbes et se nourrissent largement des productions nouvelles que leur offre la surface de la terre : la membrane adipeuse s'étend, s'augnente, se remplit par la surabondance de cette bonne nourriture; les follicules se renouvellent, se remplissent aussi; les parties de la génération se dérident, se gonflent ; et è est alors que ces animaux prennent une odeur de nusc si forte, qu'elle n'est pas supportable; cette odcur se fait sentir de loin, et quoique suave' pour les

\footnotetext{
1 Le rat musqué de l'Amérique septentrionale est un pen plus gros et un peu plus long que le rat d'ran de France ; son éléucut estl'ean, mais il ne laisse pas d'al'er queiqueluis à terre; il a la tuene plate, ello est de hunit ou dix ponces de long, de la largenr d'un doigt, couverle de petıtes écailles noives; la pean ronsse, conlenr de minime-brun; le poil en est fort lin, assez long: il porte des rognons proche les lesticules qui ontl'odeur de unse très-agréable, ct n"est point incommode aे lous ceux aे yui le musc donne des incommodités. Si on le tur: l'biver, pendant que la peau est bonne pour funrer, les rognons ne sentent rien: at printemps lis com-
} 
Eıropéens, elle déplait si fort aux sauvages, qu'ils ont appelé puante une rivière sur les b)rds de laquelle habitent en grand nombre ces rats musqués, qu'ils appellent aussi ruts puants.

Ils produisent une fois par an, et cinq ou six petits à la fois : la durée de la gestation u'est pas longue, puisqu'ils n'entrent en amour qu'au commencement de l'été, et que les petits sont déjà grands au mois d'octobre, lorsqu'il faut suivre leurs père et mère dans la cabane qu'ils construisent de nouveau tous les ans; car on a remarqué qu ils ne reviennent point à leurs anciennes habitations. Leur voix est une espèce de gémissement que les chasseurs imitent pour les piper et pour les faire approcher: leurs dents de devant sont si fortes et si propres à ronger, que, quand ou enferme un de ces animaux dans une caisse de bois dur, il y fait en très-peu de temps un trou assez grand pour en sortir, et e'est encore une de ces facultés naturelles qu’il a communes avec le castor, que nous n'a vons pu garder enfermé qu'en doublant de fer blanc la porte de sa loge. L'ondatra ne nage ni aussi vite, ni aussi longtemps que le castor; il va plus souvent a terre; il ne court pas bien, et marche encore plus mal en se berçant à peu près comme une oie. Sa peau conserve une odeur de muse qui fait qu'on ne s'en sert pas rolontiers pour fourrure; mais on emploie le second poil ou duvet dans la fabrique des chapeaux.

Ces animaux sont peu farouches, et, en les prenant petits, on peut les apprivoiser aisément; ils sont même très-jolis lorsquiils sont jeunes. Leur queue longue et presque ine, qui rend leur figure désagréable, est fort courte dans le premier âge: ils joueut innocemment et aussi lestement que des petits chats; ils ne mordent point ${ }^{1}$,

wencent à prorudre leur senteur, qui dure jusqu'à l'automne... Pour la chair, elle n'a point le goît de musc, elle est execllente à nuinger. Description de l'Amrique septentrionale, par Denys. Paris, 1672, lome 11, jage 2.\%8.-Les rats uiusqués de Canadi répaudent une odeur adnirable; la civette et la gazelle n'exhalent rien de si Lort ni de si doux. Voyage de la Hontan. La llaye, 1776, tome I, page 93. - Les sauvages de l'Amérique n'aiment point l'odeur que répand le rat musqué ; ils lui ont mẻne donné le non de puant, tant cette odeur leur déplait. Mémoire de l'Académie royale des Seiences, année 1725 , page $\mathbf{3 2 7}$.

${ }^{1}$ Les rats musqués de Canada, que les Hurons appellent ondatra, paissent l'herbe sur terre et le blanc des jones autour des lacs et des rivières ; il y a plaisir à les voir manger et faire leurs pelits tours quand ils sont jennes. Jen avais un tres-joli : je le nourrissais du blane des jones et d'une certaine lierbe semblable au chien-dent : je faisais de ce petit animal tout ce que je voulais, sans qu'il me mordlt aucunc- et on les nourrirait aisément si leur odeur n'était point incommode. L'ondatra et le desmar sont, au reste, les seuls animaux des pays septentrionaux qui donnent du parfum : car l'odeur du castoreum est très-désagréable, et ce n'est que dans les climats chauds qu'on trouve les animaux (qui fournissent le vrai musc, la civette et les autres parfums.

Le desman ou rat musqué de Moscovie nous offrirait peut-être des singularités remarquables et analogues à celles de l'ondatra; mais il ne parait pas qu'aucun naturaliste ait été à portée de l'examiner vivant, ni de le disséquer : nous ne pouvons parler nous-mêmes que de sa forme extérieure, celui qui est au cabinet du roi ayant été envoyé de Laponie dans un état de dessèchement qui n’a pas permis d'en faire la dissection; je n'ajouterai donc à ce que j'en ai dejaj dit que le seul regret de n'en pas saroir' da vantage.

\section{LE RATON}

Ordre des carnassiers, famille des carnivores, tribu des plantigrades, genre raton. (Cuvier.)

Quoique plusieurs auteurs aient indiqué sous le noın de coati l'animal dont il est ici question, nous avons eru devoir adopter le nom qu'on lui a douné en Angleterre, afin d'ôter toute équivoque, et de ne le pas confondre avec le vrai coati, dont nous donnerons la description dans l'article suivant, non plus qu'avec le coatimondi, qui cependant ne nous parait être qu'une variété de l'espèce du coati.

Le raton que nous avons eu vivant, et que nous avons gardé pendant plus d'un an, était de la grosseur et de la forme d'un petit blaireau. Il a le corps court et épais, le poil doux, long, touffu, noiràtre par la pointe, et gris par dessous; la tête comme le renard, mais les oreilles rondes et beaucoup plus courtes; les yeux grands, d'un vert jaunâtre; un bandeau noir et transversal au-dessus des yeux; le museau effilé, le nez un peu retroussé, la lèvre inférieure moins avancée que la supérieure; les dents comme le chien, six incisives et deux canines

ment; anssin'y sont-ils pas sujets. Voyage de Sagard Theodal. Paris, 1632, pages 522 et 323 . La plante dont M. Sarrasin dit que le rat musqué se, nourrit le plus volontiers cst le calamus aromaticus. 
en haut et en bas; la queue touffue, longue au moins comme le corps, marquée par des anneaux alternativement noirs et blanes dans toute son étendue; les jambes de devant beaucoup plus courtes que celles de derrière, et cinq doigts à tous les pieds, armés d'ongles fermes et aigus; les pieds de derrière portant assez sur le talon pour que l'animal puisse s'élever et soutenir son corps dans une situation inclinće en avant. Il se sert de ses pieds de devant pour porter à sa gueule : mais, comme ses doigts sont peu flexibles, il ne peut, pour ainsi dire, rien saisir d'une seule main; il se sert des deux à la lois, et les joint ensemble pour prendre ce qu'on lui donne. Quoiqu'il soit gros et trapu, il est cependant fort agile: ses ongles, pointus comme des épingyles, lui donnent la facilité de grimper aisément sur les arbres; il monte légèrement jusquu'au-dessus de la tige, et court.jusqu'à l'extrémitédes branches; il va toujours par sauts; il gambade plutôt qu'il ne marche, et ses mouvements, quoique obliques, sont tous prompts et légers.

Cet animal est originaire des contrées méridionales de l'Amérique : on ne le trouve pas dans l'ancien continent; au moins les voyageurs qui ont parlé des animaux de l'Afrique et des Indes orientales n'en font aucune mention : il est au contraire très-commun dans le elimat chaud de l'A mérique, et surtout à la Jamaïque ${ }^{1}$ où il habite dans les montagnes, et en descend pour manger des cannes de sucre. On ne le trouve pas en Canada, ni dans les autres parties septentrionales de ce continent; eependant il ne craint pas excessivement le froid. M. Kílein ${ }^{2}$ en a nourri un à Dantzick, et celui que nous avions a passé une nuit entière les pieds pris dans de la glace, sams qu'il ait été incommodé.

Il trempait dans l'eau, ou plutôt il détrempait tout ce qu'il voulait manger : il jetait son pain dans sa terrine d'eau, et ne l'en retirait que quand il le voyait bien imbibé, à moins qu'il ne fuit pressé par la faim; car alor's il prenait la nourriture sèche, et telle quon la lui présentait; il furetait partout, mangeait aussi de tout, de la chair crue ou cuite, du poisson, des œufs, des volailles vivantes, des grains, des racines, etc.; il mangeait aussi de toutes sortes d'insectes; il se plaisait à chercher les araignées,

'Voyez. l'Ilistoire naturelle de la Jamaī(jue, par llans Sloane. Lomdres, 1725, in-folio, toure 13, page 529 , en anglais.

${ }^{2}$ Klein, de (quadrupı.. page 62. et Iorsqu'il était en liberté dans un jardin, il prenait les limacons, les hamnetons, les vers. Il aimait le suere, le lait, et les autres substances donces par dessus toute chose, à l'exception des fruits, auxquels il préférait la chair et surtont le poisson. Il se retirait au loin pour faire ses besoins : au reste il était familier et même caressant, sautant sur les gers qu'il aimait, jouant volontiers et d'assez bonne grâce, leste, agile, toujours en mouvement : il m'a paru tenir beaucoup de la nature du maki, et un peu plus des qualités du chien.

\section{ADDITION A L'ARTICLE DU RATON.}

M. Blanquart des Salines m'a écrit de Calais, le 29 octobre 1775, au sujet de cet animal, dans les termes suivants :

" Mon raton a vécu toujours enchaîné avant qu'il m'appartint : dans cette eaptivité, il se montrait assez doux, quoique peu caressant. Les personmes de la maison lui faisaient toutes le même accueil, maiss il les recevait différemment; ce qui lui plaisait de la part de l'une le révoltait de la part d'une autre, sans que jamais il prit le change. "

(Nous avons observé la même chose au sujet du surikate.)

"Sa chaine s'est rompue quelquefois, et la liberté le rendait insolent; il s'emparait d'un appartement, et ne souffrait pas qu'on y abordât. Ce n'était (qu'avec peine (qu'on raccommodait ses liens. Depuis son séjour chez moi, sa servitude a été fréquemment suspendue. Sans le pcrdre de vue, je le laisse promener aree sa chaine, et chacque fois mille gentillesses in'expriment sa reconnaissance. 11 n'en est pas ainsi quand il s'échappe de lui-même; alor's il rôde quelquefois trois ou quatre jours de suite sur les toits du voisinage, et descend la nuit dans les cours, entre dans les poulailler's, étrangle la volaille, lui mange la tète, et n'épargne pas surtout les pintades. Sa claine ne le rendait pas plus humain, mais seulement plus circonspect; il employait alors la ruse, et familiarisait les poules aree lui, leur permettait de venir partager ses repas; et ee n'était qu'après leur avoir inspiré la plus grande sécurité, qu'il en saisissait une et la mettait (n pieces. Quelques jeunes chats ont de sa part éprouvé le mème sort... Cet animal, quoique très-léger, n'a que des mouvements obliques, et je donte qu'il 
puisse attraper d'autres animaux à la course. Il ouvre merveilleusement les huîtres; il suffit d'en briser la charnière, ses pattes font le reste. Il doit avoir le tact excellent. Dans toute sa petite besogne, rarement se sert-il de la vue ni de l'odorat : pour une huitre, par exemple, il la fait passer sous ses pattes de derrière; puis, sans regarder, il cherche deses mains l'endroit le plus faible; il y enfonce ses ongles, entr'ourre les ćcailles, arrache le poisson par lambeaux, n'en laisse aucun vestige, sans que, dans cette opération, ses yeux ni son nez, qu'il tient éloignés, lui soient d'auenn usage.

" Si le raton n'est pas fort reconnaissant des carcsses qu'il recoit, il est singulièrement sensible atx mauvais traitements. Un domestique de la maison l'avait un jour frappé de quelques coups de fouet : vainement cet homme a-t-il cherché depuis à se réconcilier : ni les œufs, ni les sauterelles marines, mets délicieux pour cet animal, n'ont jamais pu le calmer. A son approche, il entre dans une sorte de rage; les yeux étincelants, il s'élance contre lui, pousse des cris de douleur; tout ce qu'on lui présente alors, il le refuse, jusqu'à ce que son ennemi disparaisse. Les accents de la colère sont chez lui singuliers; on se figurerait entendre tantôt le sifflement du courlis, tantôt l'aboiement enroué d'un vieux chien.

"Si quelqu'un le frappe, s'il est attaqué par un animal qu'il croie plus fort que lui, il n'oppose aucune résistance; semblable à un hérisson, il cachesa tète et ses pattes, forme de son corps une boule : aucune plainte ne lui échappe; dans cette position, il souffrirait la mort.

" J'ai remarqué qu'il ne laissait jamais ni foin ni paille dans sa niche; il préfère de couclıer sur le bois. Quand on lui domne de la litière, il l'écarte dans l'instant même. Je ne me suis point apercu qu'il fuit scmsible au froid; de trois hivers il en a passé deux exposé à toutes les rigueurs de l'air. Je l'ai vu couvert de neige, n'ayant aucun abri et se portant très-bien... Je ne pense pas qu'il recherche beaucoup la chalcur; pendant les gelćes dernières, je lui faisais domner séparément et de l'eau tiède et de l'eau presque glacée pour détremper ses aliments; celle-ci a constamment eu la préférence. Il lui était libre de passer la nuit daus l'écurie, et souvent il dormait daus un coin de má cour.

" Le défaut de salive, ou son peu d'abondance, est, à ce que j'imagine, ce qui engage cet animal a laisser pénétrer d'eau sa nourriture. Il n'humecte point une viande fraiche et sanglante; jamais il n'a mouillé une pêche ni une grappe de raisin ; il plonge au contraire tout ce qui est sec au fond de sa terrine.

"Les enfants sont un des objets de sa haine; leurs pleurs l'irritent; il fait tous ses efforts pour s'élaneer sur eux. Une petite chienne qu'il aime beaucoup est sévèrement corrigée par lui quand ellc s'avise d'aboyer avec aigreur. Je ne sais pourquoi plusieurs animaux détestent également les cris. En 1770, javais cinq souris blanches, je m'avisai par hasard d'en faire crier uue, les autres se jetèrent sur elle; je continuai, elles l'étranglèrent.

" Ce raton est une femelle qui entre en chaleur au commencement de l'été. Le besoin de trouver un mâle dure plus de six semaines : pendant ce temps, on ne saurait la fixer : tout lui déplaît; à peine se nourrit-elle; cent fois le jour elle passe entre ses cuisses, puis entre ses pattes de devant, sa queue touffue, qu'elle saisit par le bout avec ses dents, et qu'elle agite sans cesse pour frotterses parties naturelles. Durant cette crise, elle est à tout moment sur le dos, grognant et appelant son mâle; ce qui me fernit penser qu'elle s'accouple dans cette attitude.

"L'entier accroissement de cet animal ne s'est guère fait en moins de deux ans et demi.

\section{DESCRIPTION DU RATON.}

(EXTRAIT DE DAUBENTON.)

Le raton qui a servi de sujet pour cette description était à peu près de la g. osseur du blaireau, et mème il ressemblait en quel que facon à cet aninıal par la forme du corps, mais il en différait en ce qu'il avait le museau mince et effilé comme celui du renard, le nez un peu retroussé, et la lèvre inférieure heaucoup moins avancée que le nez. La tèle était de la même grosseur que celle dı renari, et les oreilles avaient la même situation, mais elles étaient plus courtes, et arrondies à l'extrémité; les yeux avaient aussi la même grandeur que ceux dı renard, ils ćtaient de couleur bleue verdàtre, et il y avait sur l'xil gauche une tache qui l'offusquait entièrement : la queue resstmblait à celle du chat sauvage, car elle était longue, tonffue, et il y avait d'un bout à l'autre des anneaux de différentes couleurs.

Les jambes de devant étaitnt beaucoup plus courtes que celles de derrière, de sorte que l'ani- 
mal étant posé sur les quatre pieds avait le train de derrière plus élevé que celui de devant, et dans cette attitude le dos était vonté. Lorsqu'il marchait, il ne posait sur la terre que la pointe des pieds, comme les chiens ; mais lorsqu'il était en repos, il s'appuyait aussi sur le talon : ce nouveau point d'appui lui donnait de la facilité pour s'élever sur les pieds de derrière, et pour sontenir son corps dans une direction oblique, et même verticale. Cette attitude était aussi ordinaire à cet animal qu'aux lièvres, aux rats, aux écurcuils, etc. ; car toutes les fois qu'il mangeait, il prenait ses aliments avec les deux pieds de devant, pour les porter à sa bouche; il ne pouvait pas les saisir ni les empoigner avec un seul pied, parce que les doigts ne pliaient que trèspeu : il soutenait entre ses deux pieds le morceau qu'il voulait manger, il le frottait en tenant les doigts tendus; lorsqu'il trouvait de l'eau, il ne manquait jamais d'y plonger ses pieds sans quitter son morceau, et de le frotter comme s'il avait voulu le laver, mais c'était en effet pour le détremper, car souvent il le laissait dans l'eau, et ne le frottait que lorsqu'il en était dẻjà imbibé; il trempait ainsi toutes sortes d'aliments, même dans l'eau la plus froide. On l'a trouvé pendant une grande gelée ayant les leux pieds pris dans la glace qui s'était formée dans la terrine où on lui donnait de l'eau. Lorsque la faim le pressait, il mangeait tout ce qu'il trouvait sans le frotter ni le tremper dans l'eau.

Il était très-carnassier; lorsqu'il se trouvait en liberté, il furetait dans les angles des murs et dans les trous, sous les pierres et sous les plantes, en un mot dans tous les coins, pour chercher des insectes, comme des araignécs, des limaces, des limaçons, etc., et des animaux tels que des taupes, des souris, des grenouilles, etc. Il mangeait la chair des poi soms avec plus d'avidité que celle des animaux yุuiurupedes et des oiseaux. En général, cet animal mangeait de toute chair crue, cuite, et même assaisonnée, cependaut le fromage fermenté el la unoutarde lui répugnajent; il était fort avide de lait, de crêune, de sucre, et de tout ce qui était coulit au sucre; il mangeait aussi des fruits, mais seulement au defaut de la chair des auimaux; il buvait en lapant comme les cliens, et en humant conme les chevaux.

Ce raton était très-familier, et même fort caressant ; il connaissait ceux qui l'approchaient souvent, et qui lıi ılonnaient à nanger; il badinait comme les chiens et les chats. Il avait beaucoup d'agilité, et il grimpait sur les arbres très-légèrement; i] était presque toujours en mouvement pentant le jour, et il avait une allure fort singulière étant à la chaine; il décrivait un arc de cerele en faisant tles pas à droitc avec les jambes de devant, et lorsqu il rencontrait la chainc il passait les pieils le der. rière par dessus en sautant, ensuite il revenait a gauche de la même manière, et il continuait cette allure pendant des lıures entières. Au moindre hruit qu'il entendait, il se dı essait sur les pieds de derrière, et se tenait élevé pour écouter et pour découvrir la cause de ce Joruit : il avait beaucoup d'instinct et de vivacité. Je crois que les animaux de cette espèce s'apprivoiseraient comme les cliens, car celui-ci était fort docile, et n'a mordu que les gens qui l'approclıaient trop brusquement, ou qui voulaient lui arracher sa proie. Il se retirait au plus loin pour rendre ses excréments, et les recouvrait comme les chats.

La couleur de cet animal était du gris mêlé de noir et d'une teinte de fauvc; les lères et le nez étaient noirs : il y avait une hande longitudinale de couleur brune-noiråtre, qui s'étendait depuis le nez jusqu'au-dessus dı front, et une autre bande transversale de la mẻme couleur, et beaucoup plus large, qui passait de clıaque còté sur les yeux et a!r-dessous, et qui se prolongeait sur la partie postérieure de la mâchoire du dessous. Le dessus du front, le sommet et le derrière de la tête, le dessus du cou, l'épaule, le dos, la eroupe, la partie supćrieure des côtés du corps et la face extérieure de la cuisse avaient une rouleur mẻlće de gris, de noir, et d'une légère teinte de fauve. Les poils étaient de deux sortes; les uns plus courts, plus doux et plus nombreux que les autres formaient une espèce de duvet de couleur cendrée brune; les poils longs et fermes ètaient de couleur cendrée claire près de la racine; ils avaient une couleur blanclıe ou blanchâtre au-dessus dı cendré, et leur extrémité était noire, de sorte que le poil étant hérissé, comme il l'etait ordinairement, on royatt le blanchâtre au-dessous du noir. et le noirau-dessus du blanchâtre. Les colés du museau, le menton, le dessus des yeux, les côtés dle la tète, les oreilles, les côtés du cou, le bras, l'avant-loras, le pied de devant, le bas des cotés du corps, la jambe et le pied de lerrière ètnient de couleur blanche ou blanchâtre, mais le duvet de ces parties élait de couleur de uarron, yui paraissait dans quelques endroits, principalentent derrière la partic inférieure de l'orcille, sur la parlie postérieure de la michoire du dessous, et : ur la partie inférieure de la jambe; le dessous du cou, la poitrine et le ventre étaient de couleur roussâtre mẻlce de blanc. Il y aviit sur la face supérieure et sur les cótés de la quene des bandes transversales de couleur noire mêlée de roux, et l'extrémité était de la mème couleur; les bandes qui se trouvaient près de lorigiue de la quene étaient plus ẻtroites et moins éloignées les unes des aulres que celles qui étaient près de l'extrimite : l'espace qui siparait les bandes avait une couleur grise et blanchâtre.

Le plus loug poil de cet animal était surlesfesses, 
il avait environ trois pouces de longueur ; les moustaclıes etaient blanclies et longues de deux pouces et demi. La tète et les pienls n'avaient qu'un poil fort cuut ; celui du reste du corps était long et lıérissé. La plante des piecls et. les ongles avaient une couleur brune.

\section{DU RATON-CRABIER.}

Ordre des carnassiers, famille des carnivores, tribu des plantigrades, geure raton. (Cuvier.)

Voici un animal qui nous a été envoyé de Cayenne par M. de la Borde, sous la dénomination impropre de chien-crabier, et qui n'a d'autre rapport ivec le crabier que l'habitude de manger également des crabes; mais il tient beaucoup du raton par la grandeur, la forme et les proportions de la tête, du corps et de la queue; et comme nous ignorons le nom qu'il porte dans son pays natal, nous lui domnerons, en attendant que nous en soyous informés, la dénomination de raton-crabier, pour le distinguer et du raton et du crabier, dont nous avons donné les figures.

Cet animal a été envoyé de Cayenne avec le nom et l'indication suivante : chien-crabier adulte, femelle prise nourrissant trois petits.

Mais, comme nous venons de le dire, il n'a nul rapport apparent avec le crabier; il n'en a ni la forme du corps, ni la queue écailleuse. Sa longueur, depuis le bout du museau jusqu'à l'origine de la queue, est de vingt-trois pouces six lignes, et par conséquent elle est à peu près égale à celle du raton, qui est de vingt-deux pouces six lignes; les autres dimensions sont proportionnellement les mèmes entre ces deux animaux, à l'cxception de là queue qui est plus courte et beaucoup plus mince dans cet animal que celle du raton.

La couleur de ce raton-crabier est d'un fauve mêlé de noir et de gris : le noir domine sur la tête, le cou et le dos; mais le fauve est sans mélange sur les côtés du cou et du corps : le bout du nez et les naseaux sont noirs. Les plus grands pouls des moustaches ont quatre pouces de longueur, et ceux du dessus de l'angle des yeux ont deux ponces deux lignes. Une bande d'un brun noirâtre environne les yeux, et s'étend presque jusqu'aux oreilles; elle passe sur le museau, se prolonge et s'unit au noir du sommet de la tête. Le dedans des oreilles est garni d'un poil blanchâtre, et une bande de cette mème couleur rigne au-dessus des yeux, et il y a une tache blanche au milieu du front; les joues, les mâchoires, le dessous du cou, de la poitrine et du ventre, sont d'un blauc jaunátre; les jambes et les pieds sont d'un brun noirâtre, celles de devant sont couvertes d'un poil court; les doigts sont longs et bien sépar'és les uns des autres. La queue est enviromnée de six anneaux moirs, dont les intervalles sont dun fauve grisâtre; ‘e qui établit encore une différence entre cet animal el le vrai raton, dont la queue lougue, grosse et touffue, est smoinmpnt annelée sur la face supérieure. Cos cucus esperees de ratons diffèrent encore entre elles par la couleur du poil, qui, dans le raton, est, sur le colps, d'un noir mèlé de gris et de fauve pâle, et, sur les jambes, de couletr blanchâtıe, au lieu que, dans celui-ci, il est d'un fauve mêlé de noir et de gris sur le corps, et d'un brun noirâtre sur les jambes. Ainsi, quoique ces deux aninaux aient plusieurs rapports entre eux, leurs différences nous paraissent suffisantes pour en faile deux espèces distinctes.

\section{LE CON'Il.}

Ordre des carnassiers, famille des carnivores, tribu des plantigrades, genre coati. (Curier:)

Plusieurs auteur's ont appelé conti-mondi l'animal dont il est ici question, nous l'avons eu vivant, et après l'avoir comparé au coati indiqué par 'Tlievet, et décrit par Marcgrave, nous avons recounu que c'était le mème animal qu'ils ont appelé coafi tout court : et il y a toute apparence que le coati-mondi n'est pas un animal d'une autre espèce, mais une simple variété de celle-ci; car Marcgrave, après aroir donné la deseription du coati, dit précisément qu'il y a d'autres coatis qui sont d'un brun noiratre, que l'on appelle au Brésil coati-mondi pour les distinguer des autres : il n'admet donc d'autre différence entre le coati et le conti-mondi, que celle de la couleur du poil, et dès lors on ne doit pas les considérer comme deux espéces distinctes, mais les regarder comme des variétés dans la mème espèce.

Le coati est très-différent du raton que nous avous déerit précédenment; il est de plus petite taille; il a le corps et le cou bcaucoup plus 
allongés, la tête aussi plus longue, ainsi que le museau, dont la mâchoire supérieure est terminée par une espèce de groin mobile, qui déborde d'un pouce ou d'un pouce et demi audelà de l'extrémité de la mâchoire inférieure; ce groin retroussé en haut, joint au grand allongement des mâehoires, fait paraitre le museau courbé et relevé en haut. Le eoati a aussi les yeux beaueoup plus petits que le raton, les oreilles eneore plus eourtes, le poil moins long, plus lude et moins peigné; les jambes plus courtes, les pieds plus longs et plus appuyés sur le talon : il avait, comme le raton, la queue ammelée', et cinq doigts à tous les pieds.

Quelques per'sommes pensent que le blaireaucochon pourrait bien être le coati, et l'on a rapporté ${ }^{2}$ à cet animal le taxus suillus, dont Aldrovande domne la figure:mais si l'on fait attention que le blaireau-cochon dont parlent les ehasseur's est supposé se trouver en France, et mème dans les climats plus froids de notre Europe, qu'au contraire le coati ne se trouve que dans les elimats méridionaux de l'autre continent, on rejettera aisément cette idée, qui, d'ailleurs, n'est nullement fondée ${ }^{3}$; car Ia figure domnée par Aldrovande n'est autre chose qu'un blaireau, anquel on a fit un groin de cochon. L'auteur ne dit pas qu'on ait dessiné cet animal d'après nature, et il n'en donne aucune description. Le museau très-allongé et le groin mobile en tous sens suffisent pour faire distinguer le coati de tous les autres animaux; il a, comme l'our's, une grande facilité à se tenir debout sur les pieds de derriere, qui portent en grande partie sur le talon, lequel mème est terminé par de grosses callosités qui semblent le plonger au-dehor's, et augmenter l'étendue de l'assiette du pied.

Le coati est sujet à manger sa queue, qui, lorsgu'ellc n'a pas été tronquée, est plus longue que son corps; il la tient ordinairement élevée, la fléchit en tous sens, et la promène avee facilité. Ce goùt singulier, et qui parait contre nature, n'est cependant pas particulier au coati : les singes, les makis, et quelques auties animaux à queue lonoue, rongent le bout de leur

'Il y a anssi des coatis clont la yuene est d'une seule couleur; mais comme ils ne dillèrent dos autres yue par ce seul caractère, cette diff'rence ne nous parait pas suffire pour en faire ılenx espeeces, et nous estimons yque ce n'est qu'un variétć dans la même espèce.

2 Vid. Brisson, Reg. pag. 265.

${ }^{3}$ Voyez ce que nous avons dit du blaireau-cochon. queue, en mangent la ehair et les vertèbres, et la raccourcissent peu à peu d'un quart out d'un tiers. On peu tirer de là une induction générale; c'est que dans les parties très-illongées, et dont les extrémités sont par conséquent très-éloignées des sens et du centre du sentiment, ce mème sentiment est faible, et d'atutant plus faible que la distance est plus grande ot la partie plus menue: car, si l'extrémité de lit queue de ces animaux était une partic fort sensible, la sensation de la douleur serait plus forte que celle de cet appétit, et ils conserveraient leur qucue avec autant de soin que les autres partics de leur corps. An reste, le eoati est un inimal de proie qui se nourrit de chair et de sang, qui, comme le renard ou la fouine, egorge les petits animaux, les volailles ', mange les ceufs, cherehe les nids des oiseaux ${ }^{2}$; et c'ast probablement par cette conformité de naturel, plutòt que par la ressemblance de la fouine, qu'on a regardé le coati comme une 'spèce de petit renard ${ }^{3}$.

3 Vid. Jarcgrav. Hist. Brasil, page 228.

${ }^{2}$ Voyez les Singularités de la France antarctique, par Thevet, page 96.

${ }^{5}$ Vulpes minor, etc. Barrère, Ilist. Nat. de la France é(quinoxiale.

Nota. On trouve dans le seplième volume de l'Académie royale des sciences de Suède, un mémoilte de M. Liunarus sinr le coati-mondi. Nous croyuns devoir mpporter icil'ex!r:tit yue l'antenr de la Bjbliothèque raisonnéc a fait de ce mémoire. sans prétendle garantir les faits qui y sont rapyor tés.

a. Linnasus dome dans un memoire l'lustoire naturelie "du coati-mondi. Cet animal se trouve égalentent daus l"A- mérique méridionale et dans la septentrionale. Il apuroclie " cle l'ours par' la longırenr de ses jambes de derrière, sa lète " peuclıée, son puil épais, et par scs pattes; mais il est petit " el lanilier, et sa quene est furt longue et rayée de diflè" renles couleurs. M. le prince successen de suèle avait fait "présent diun dle ces animanx à $M$, Linnirus, qui l"a entreteu " assez longtemps dans sa maison anx dépens des doucenrs a qu'il ponvait attrajer, et puclquefois de cenx de sa basse" cour, où le coati-mondi, malgré le droit de l'hospitalité, * emportait dles tét'sà coups de lents, et humait le sang. Il est " remarquable par son extrène opiniatreté à ne ricn faire ^ contre son gré. Malgré sa petitesse, il se défentait arec une * force extriotulinaire lorsyu'on le faisait narcher malgré lui, " et se cramponmait contre les jambes les personnes, dont il " allait familièrement ravager les poches et confis fuer ce " quil y tronvait à sa bienséance. Cette opiniâtrelé a son rea mede : le coati craint extrcinemeut les soies de cochon, la a moindre brosse lui faisait ıuitter prise. Un uâtin l'étrangla " ın jour tø'il s'était sauvé claus un jardin du voisinage, et * M, Linnens en domne l’anatomie. Son genre de vie était assez " extraotdinaire; il domuat depuis minuit just]u à mili, veila lait le reste du jour, et se promenait regulierenent rlemis

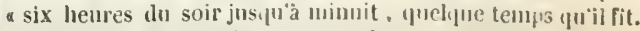
* C’est apualemument le temps une la uature a assigné à cette * espèce d'animanx daus lemr patrie, pour ponrvoir à leurs - Jjesoins, et fronr allè à la cluasse des oiseanx et à la découa verte de leu's urufs, qui font leur principale nourriturc. Bibliollı̨̀ue raisonıẻe, tome $\mathbf{X L I}$, partie I, jage 25. 


\section{ADDITION A L'ARTICLE DU COATI.}

Quelques personnes qui ont séjourné dans l'Amérique méridionale m'ont informé que les coatis produisent ordinairement trois petits, qu'ils se font des tanières en terre comme les renards, que leur chair a un mauvais gout de venaison, mais qu'on pent faire de leurs peaux d'assez belles fourrures. Ils m ont assuré que ces animaux s'apprivoisent fort aisément, qu'ils deviennent mème très-caressants, et qu'ils sont sujets à manger leur queue, ainsi que les sapajous, guenons, et la plupart des autres animaux à longue queue des climats chauds. Lorsqu'ils ont cette habitude sanguinaire, on ne peut pas les. en corriger; ils continuent de ronger leur queue, et finissent par mourir, quelques soins et quelque nourriture qu'on puisse leur donner. Il semble que cette inquiétude est produite par une vive démangeaison ; mais peutètre les préserverait-on du mal qu ills se font, en couvrant l'extrémité de la queue avec une plaque mince de métal, comme l'on couvre quelquefois les perroquets sur le ventre pour les empècher de se déplumer.

\section{AUTRE ADDITION A L'ARTICLE DU COATI.}

Un autre animal de Cayenne, qui a rapport avec le précédent, est celui qui a été moutré vivant à la foire de Saint-Germain, en 1768 ; il avait quinze pouces de longueur du bout du nez à l'origine de la queue, laquelle était longue de huit pouces, plus large et plus fournie de poils à sa naissance qu'à son extrémité. Cet animal était bas de jambe, comme nos fouines ou nos martres. La forme de la tête est fort approchante de celle de la fouine, à l'exception des oreilles qui ne sont pas semblables.Le corps est couvert d'un poil laineux ; il y a cinq doigts à chaque pied, armés de petits ongles comme ceux de nos fouines.

\section{L'AGOUTI}

Ordre des rongeus, genre cabiri. (Cuvier.)

Cet animal est de la grosseur d'un lièvre, et a été regardé comme une espèce de lapin ou de gros rat par la plupart des auteur's de nomenclature en histoire naturelle; cependant il ne leur ressemble que par dc très-petits caractères, et il en differe essentiellement par les habitudes naturelles. Il a la rudesse de poil et le grognement du cochon; il a aussi sa gourmandise, il mange de tout avec voracité; et lorsqu'il est rassasié, rempli, il cache, comme le renard, en différents endroits ce qui lui reste d'aliments, pour le trouver au besoin. Il se plait à faire du dégât, à couper, à ronger tout ce qu'il trouve. Lor'squ'on l'irrite, son poil se hérisse sur la croupe, et il frappe fortement la terre de ses pieds de derrière ; il mord cruellement ${ }^{1}$. Il ne se creuse pas un trou comme le lapin, ni ne se tient pas sur terre à découvert comme le lièvre:il habite ordinairement dans le creux des arbres et dans les souches pourries. Les fruits, les patates, le manioc sont la nourriture ordinaire de ceux qui fréquentent autour des habitations ; les feuilles et les racines des plantes et des arbrisseaux sont les aliments des autres, qui demeurent dans les bois et les savanes. L'agouti se sert, comme l'écureuil, de ses pieds de devant pour saisir et porter à sa gueule; il court d'une trèsgrande vitesse en plaine et en montant; mais comme il a les jambes de devant plus courtes que celles de derrière, il ferait la culbute s'il ne ralentissait sa course en descendant. Il a la vue bonne et l'ouie très-fine; lorsqu'on le pipe, il s'arrête pour écouter. La chair de ceux qui sont gras et bien nourris n'est pas mauvaise à manger, quoiqu'elle ait un petit goût sauvage et qu'elle soit un peu dure : on échaude l'agouti comme le cochon de lait, et on l'apprète de mème. On le chasse avec des chiens : lorsqu'on peut le faire entrer dans des cannes de sucre coupées, il est bientôt rendu, parce qu'il y a ordinairement dans ces terrains de la paille et des feuilles de canne d'un pied d'épaisseur, et qu'à chaque saut qu'il fait il enfonce dans cette litière, en sorte qu'un homme peut sou vent l'atteindre et le tuer avec un bâton. Ordinairement il s'enfuit d'abord très-vite devant les chiens, et gagne ensuite sa retraite, ou il se tapit et demeure obstinément caché : le chasseur, pour l'obliger à en sortir, la remplit de fumée; l'animal, id demi souffocjué, jettedes cris douloureux ct plaintifs, et ne parait qu'à toute extrémité. Son cri, qu'il répète souvent lorsqu'on l'inquiète

1 Cel aninal est fort méchant; les capucins doolinde au Brésil en élevaient un à qui ils avaient arraché les rlenty dans sa jennesse, el malgré celte précaution il étendait son désordre aussi loin que pernetlait sa chaine. Histoire des Indes par Souchu de Rennefort, page 203. 
ou qu'on l'irrite, est semblable à celui d'um petit cochon. Pris jeune, il s'apprivoise aisément; il reste à la maison, en sort seul et revient de lui-même. Ces animaux demeurent ordinairement dans les bois, dans les haies; les femelles y cherchent un endroit fourré pour préparer un lit à leur's petits; elles font ce lit avec des feuilles et du foin. Elles produisent deux ou trois fois par an; chaque portée n'est, dit-on, que de deux : elles transportent leur's petits, comme les chattes, deux ou trois jours après leur naissance; elles les portent dans des trous d'arbres, où elles ne les allaitent que pendant peu de temps : les jeunes agoutis sont bientôt en état de suivre leur mère et de chercher à vivre. Ainsi le temps de l'aceroissement de ces animaux est assez court, et par conséquent leur vie n'est pas bien longue.

II parait que l'agouti est un animal particulier à l'Amérique; il ne se trouve pas dans l'ancien continent : il semble ètre originaire des parties méridionales de ce nouveau monde; on le trouve très-communément au Brésil, à la Guiane, à Saint-Domingue, et dans toutes les iles : il a besoin d'un climat chaud pour subsister et se multiplier; il peut cependant vivre en France, pourvuqu'on le tienne à l'abri du froid dans un lieu sec et ehaud, surtout pendant l'hiver; aussi n'habite-t-il en Amérique que les contrées méridionales, et il ne s'est pas répandu dans les pays froids et tempérés. Aux îles, il n'y a qu'une espèce d'agouti, qui est celui que nous déerivons; mais it Cayenne, dans la terre ferme de la Guiane, et au Brésil, on assure qu'il y en a deux espèces, et que cette seconde espèce, qu'on appelle agouchi, est constamment plus petite que la première. Celle dont nous parlons est certainement l'agouti : nous en sommes assurés par le témoignage de gens qui ont demeuré longtemps à Cayenrie, et qui connaissent également l'agouti et l'agouchi, que nous n'avons pas encore pu nous procurer. L'agouti que nous avons eu vivant, et dont nous domnons ici la deseription et la figure, était gros comme un lapin; son poil étiit rude et de couleur brune un peu mèlée de roux : il avait la lève supérieure fendue comme le lièvre, la queue eneore plus courte que le lapin, les oreilles aussi courtes que larges, la màchoire supérirure avancée au delà de l'inférieure, le museau comme le loir, les dents comne la marnotte, le cou long, les jambes grèles, quatre doigts aux pieds de devant, et trols à ceux de derrière. Maregrave, et presque tous les naturalistes après lui, ont dit que l'agouti avait six doigts aux pieds de derrière: M. Brisson est le seul qui n'ait pas copié cette erreur de Maregrave : ayant fait sa description sur l'animal même, il n'a vu, comme nous, que trois doigts aux pieds de derrière.

\section{ADDITION A L'ARTICLE DE L'AGOUTI.}

Nous avons peu de chose à ajouter à ce que nous avons dit de l'agouti. M. de la Borde nous écrit seulement que c'est le quadrupède le plus commun de la Guiane: tous les bois en sont pleins, soit sur les hauteurs, soit dans les plaines, et mème dans les nıarécages.

"Il est, àit-il, de la grosseur d'un lièvre: sa peau est dure et proprea a faire des empeignes de souliers, qui durent très-longtemps. Il n'a point de graisse; sa chair est aussi blanche et presque aussi bonne que celle du lapin, ayant le même goût et le mème fumet. Vieux ou jeune, la chair en est toujours tendre; mais ceux du bord de la mer sont les meilleurs. On les prend avec des trappes, on les tue à l'affùt, on les chasse a vee des chiens. Les Indiens et les Nègres, qui savent les siffler, en tuent tant qu'ils veulent. Quand ils sont poursuivis, ils se sau rent à l'eau, on bien ils se cachent, comme les lapins, dans des trous qu'ils ont ereusés, ou dans les arbres creux. Ils mangent avec leurs pattcs, comme les écureuils : leur nourriture ordinaire, et quils cachent souvent en terre pour la retrouver au besoin, sont des noyaux de maripa, de tourlouri, de corana, etc.; et lorsqu'ils ont caché ces noyaux, ils les laissent quelquefois six mois dans la terre sans y toucher. lls peuplent autant que les lapins; ils font trois ou qua. tre petits, et quelquefois einq, dans tontes les saisons de l'année. Ils n'habitent pas en nombre dans le même trou; on les y trouve seuls, on bien la mère ave ses petits. Ils s̀apprivoisent aisément et mangent à peu près de tout : devenus domestiques, ils ne vont pas courir loin, et reviennnent ì la maisou volontiers : cependant, ils conservent un peu de leur lnumeur sauvage. En général, ils restent daus leurs trous pendant la nuit, a moins culil ne fasse clair de lume; mais ils courent pendant la plus grandé partie du jour, et il y a de certaines contrées, comme vers l'embouchure du fleure des Ama. 
zones, où ces animaux sont si nombreux, qu'on les rencontre fréquemment par vingtaines. "

\section{L'AKOUCHI.}

Ordre des rongeurs, genre cabiai. (Cuvier.)

L'akouchi est assez commun à la Guyane et dans les autres parties de l'Amérique méridionale; il dilfère de l'agouti, en ce qu'il a une queve, au lieu que l'agouti n'en a point; l'akouchi est ordinairement plus petit que l'agouti, et son poil n'est pas roux, mais de couleur olivàtre: voilà les seules différences que nous connaissions entreces deux animaux, qui néanmoins nous paraissent suffisantes pour constitucr deux espèces distinctes et séparées.

\section{ADDITION A L'ARTICLE DE L'AKOUCHI.}

Nous avons donné une notice au sujet de l'akouchi, et nous avons dit que c'était une espèce différente de l'agouti, parce qu'il a une quene et que l'agouti n'en a point. Il en diffère encore beaucoup par la grandeur, n'étant guère plus gros qu'un lapereau de six mois. On ne le trouve quedans les ngrands bois; il vit des mèmes fruits et il a presque les mèmes habitudes que l'agouti. Dans les iles de Sainte-Lucic et de lá Grenade, on lappelle agouti; sa chair est un des meilleurs gibiers de l'Amérique méridionale; elle est blanche et a du fumet comme celle du lapereau. Lorsque les akouchis sont poursuivis par les chiens, ils se laissent prendre plutôt que de se jeter à l'eau. Ils ne produisent qu'un petit ou deux tout au plus (à ce que dit M. de la Borde, mais je doute de ce fait). On les apprivoise aisément dans les maisons; ils ont un petit cri, qui ressemble à celui du cochon d'Inde, mais ils ne le font entendre que rarement.

Mul. Aublet et Olivier m'ont assuré qu’à Cayenne on appelle l'agouti le lièvre, et l'akouchi le lapin, mais que lagouti est le meilleurà manger ; et, en parlant du gibier de ce pays, ils m'ont dit que les tatous sont encore meilleurs à manger, à l'exception du tatou kabassou qui a une forte odeur de muse; qu'après les tatous, le paca est le meilleur gibier, parce que la chair en est saine et grasse, ensuitc l'agouti, et en- fin l'akouchi. Ils assurent aussi qu'on mange le cougouar rouge, et que cette viande a le goút du veau.

\section{ANIMAUX \\ DE LANCIEN CUNTINENT.}

Les plus grands animaux sont ceux qui sont les mieux comnus, et sur lesquels en généril il y a le moins d'équivoque ou d"incertitude : nous les suivrons done dans cette énumération, en les indiquant à peu près par ordre de grandeur.

Les éléphants appartiennent à l'ancien continent, et ne se trouvent pas dans le noureau. Les plus grands sont en Asıe, les plus petits en Afrique; tous sont originaires des clinats les plus chands : et quoiqu'ils puissent vive dans les contrées tempérées, ils ne peurent y multiplier; ils ne multiplient pas mème dans leur pays natal lorscu'ils ont perdu leur liberté : cependant l'espèce en est assez nombreuse, quoique entièrement confinée aux seuls climats méridionaux de l'ancien continent; et nonseulement elle n'est point en Amérique, mais il ne s'y trouve mème aucun animal qu'on puisse lui comparer, ni pour la grandeur, ni pour la figure.

On peut dire la mème chose du rlhinocéros, dont l'espèce est beaucoup moins nombreuse que celle de l'éléphant; il ne se trouve que dans les déserts de l'Afrique et dans les forêts de l'Asie méridionale, et il n'y a en Amérique aucun animal qui lui ressemble.

L'hippopotame habite les rivages des grands fleuves de l'Inde et de l'Afrique: l'espèce en est peut-ètre encore moins nombreuse que celle du rhinocéros, et ne se trouve point en Amérique, ni mème dans les climats tempérés de l'ancien continent.

Le chameau et le dromadaire, dont les espèces, cquoique très-voisines, sont diflérentes, et qui se trouvent si communérnent en Asie, en Arabie et dans toutes les parties orientales de l'uncien continent, étaient aussi inconnus aux Indes occidentales que l'éléphant, l'hippopotame et le rhinocéros. L'on a très-mal à propos 
donné le nom de chameau au lama ${ }^{1}$ et au pa$\cos ^{2}$ du Pérou, qui sont d'une espèee si différeute de celle du chameau, qu'on a c ru pouvoir leur donner aussi celui de moutons; en sorte que les uns les ont appelés chameaux, et les autres moulons du Pérou, (fuoique le pacos n'ait rien de commun que la laine avec notre moutoll, et que le lama ne ressemble au chameau que par l'allongement du cou. Les Espagnols ${ }^{3}$ transportèrent autrefois de vrais chameaux au Pérou; ils les avaient d'abord déposés aux îles Canaries, d'où ils les tirèrent ensuite pour les passer en Amérique : mais il laut que le climat de ce nouveau monde ne leur soit pis favorable; car, quoiqu'ils aient produit daus cette tel'le étrangère, ils ne s'y sont pas multipliés, et ils n'y ont jamais été qu'en très-petit nombre.

Ia girafe ${ }^{4}$ ou le camelo-pardalis, animal très-grand, très-gros et très-remarquable, tant par sa forme singulière que par la hauteur de sa taille, la longueur de son cou et celle de ses jambes de devant, ne s'est point trouvé en Amérique; il habite en Afrique et surtout en Fthiopie, et ne s’est jamais répandu au delà des tropiçues, dans les climats tempérés de l'ancien continent.

Nous verrons, dans un article de ce volume, que le lion n'existait point en Amérique, et que le puma du Pérou est un animal d'une espèce différente. Nous verrous de mème que le tigre et la panthère ne se trouvent que daus l'ancien continent, et que les animaux de l'Amérique méridionale auxquels on a donné ces noms sont d'espèces différeutes. Le vrai tigre, le seul qui doive eonserver ce nom, est un animal terrible, et peut-être plus à eraindı́e yue le lion : sa férocité n'est eomparable à rien; mais on peut juger de sa force par sa taille; elle est ordinairement de quatre à cinq pieds de hauteur sur neuf, dix et jusyu'à treize et quatorze pieds de longueur, sans y comprendre la queue. Sa peau

Camelus dorso levi, gibbo pectorali. Liım. Syst, Natur. edit. $\mathrm{X}$, pas. 63. - Camelu q pilis brevissinis restitus... Camelus Peruanus, le chamriu du Pérou. 13risson, Regne animal, page 56. - Ovis Peruana, Maregriv. Ilist. Bras., pag. 243.

${ }^{2}$ Cinnelus tophis nuilis, corpore lanato. Linn. Syst. Natur. edil. $X$, pag. 66. - Canuelus pilis prolixis toto corpore restitus. La Vigogue, Brisson, Règue animal, jage s7. - Ovis Pe ruana pacos ılicla. Maregrav, Ilist. Brasil. pag 244.

"Voyez l'Inistoire nalurelle des Indes, de Joscph Acostil traduite par liobert Renaud. Paris, 1600 , dequis la page A4 jusqüà la page 208. Voyez aussi l'nlistoire des lncas. Paris, 174h, tome 11, page 266 et suiv.

4 Giriffa quan Arahes Zurnapa, Graci et Latiui Camelopartaliu nominant. Bellon, obs. pag, 118. n'est pas tigrée, c'est-à-dire parsemée de taches arrondies; il a seulement sur un fond de poil fauve des bandes noires qui s'étendent transversalement sur tout le corps, et qui forment des anneaux sur la queue clans tonte sa longneur : ees seuls caractères suffisent pour le distinguer de tous les animaux de proie du nouveaumonde, dont les plus grands sont à peine de la taille de nos mátins ou de nos lévriers. Le léopard et la panthère de l'Afrique ou de l'Asie n'approchent pas de la grandeur du tigre, et cependant sont encore plus grands que les animaux de proie des parties méridionales de l'Amérique. Pline, dont on ne peut iei révoquer le témoignage en doute, puisque les panthères étaient si communes, qu'on les exposait tous les jours en grand nombre dans les spectacles de Rome; Pline, dis-je, en indique les caractères essentiels, en disant que leur poil est blanchátre et que leur robe est variće partout ' de táches noires, semblables à des yeux; il ajoute que la seule différence qu'il y ait entre le mâle et la femelle, e'est que la femelle a la robe plus blanehe. Les animaux d'Amérique auxquels on a donué le nom de tigres, ressemblent beaucoup plus à la panthère qu'au tigre; mais ils en different encore assez pour qu'on puisse reconnaître clairement qu'aucuu d'eux n'est précisément de l'espèce de là panthère. Le premier est le jaguar ou jaguarı ou janowara, qui se troure à la Guiane, au Brésil et daus les autres parties méridionales de l'Amériçue. Ray avait, avee quelque raison, nommé cet animal pard ${ }^{2}$ ou lynx du Brésil; les Portugais l'ont appelé once ou onça, pare qu'ils avaieut précédemment domné ce nom au lynx par corruption, et ensuite a la petite panthère des Indes; et les Français, sans fondement de relation, l'ont appelé tiyre ${ }^{3}$, car il n'a rien de commun avec cet aisimal. Il diffère aussi de la panthère par la grandeur du corps , par la position et la figure des taches, parl la couleur et la longueur du poil, cui est crejpé dans la jeunesse, et qui est toujours moins lisse que celui de la panthère : il en diffèrecneore

4 'antheris in candido breves macularum oculi varias... et farlos, cui mares sunt, appellunt in eo onni genere croberrimo in ifrica Syriatue; (uidam al) is Paulheras candore solo discernum, nec adlute aliam differentiam iuveni. Plin., 1list. nat. lib. V111, eap.17.

2 Pardus an Iynx Brasiliensis, jaguard dieta. Marcgr. Kay, Synops. quadrup., [1ag. 166.

${ }^{3}$ Gios tigre de la Guyane, Desmarchais, tome III, page 299.

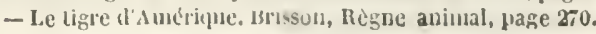


par le naturel et les mours; il est plus sauvage et ne peut s'apprivoiser, etc. Ces différences, cependant, n'empêchent pas que le jaguar du Brésil ne ressemble plus à la panthère qu'à aucun autre animal de l'ancien continent. Le second est celui que nous appellerons couguar, par contraction de son nom brésilien cuguacuara ', que l'on prononce cougouacou-ara, et que nos Français ont encore mal à propos appelé ligre rouge; il diffère en tout du vrai tigre et beaucoup de la panthère, ayant le poil d'une couleur rousse, uniforme et sans taches ; ayant aussi la tête d'une forme différente et le museau plus allongé que le tigre ou la panthère. Une troisième espèce à laquelle on a encore donné le nom de tigre, et qui en est tout aussi éloignée que les précédentes, c'est le jaguarète ${ }^{2}$, qui est à peu près de la taille du jaguar, et quil lui ressemble aussi par les habitudes naturelles, mais quii en diffère par quelques caractères exté. rieurs : on l'a appelé tigre noir, parce qu'il a le poil noir sur tout le corps, avec des taches encore plus noires, qui sont séparées et parsemées comme celles du jaguar. Outre ces trois espèces, et peut-être une quatrième qui est plus petite que les autres, auxquelles on a donné le nom de tigres, il se trouve encore en Amérique un animal qu'on peut leur comparer et qui me parait avoir été mieux dénommé, c'est le chatpard, qui tient du chat et de la panthère, et qu'il est en effet plus aisé d'indiquer par cette dénomination composée que par son nom mexicain llacoosclotl $^{3}$ : il est plus petit que le jaguar, le jaguarète et le couguar, mais en mème temps il est plus grand qu'un clat sauvage, auquel il ressemble par la figure; il a seulement la queue beaucoup plus courte et la robe semée de taches noires, longues sur le dos et arrondies sur le ventre. Le jaguar, le jaguarète, le couguar et le chat-pard sont donc les animaux d'Amérique auxquels on a mal à propos donné le nom de tigres. Nous avons vu vivants le couguar et le chat-pard; nous nous sommes donc assurés qu'ils sont chacun d'une espèce différente entre

\footnotetext{
${ }^{4}$ Cuguacu-ara, Pison, IIist. nat. Ind., page 104. - Le tigre rouge, Barrère, Hist. Fr. équin. page 163. - Le tigre rouge, Brisson, Règne animal, page 272.

${ }^{2}$ Juguarète, Pison, Hist. nat. Ind., page 103. - Once, espèce de tigre, Desmarehais, tome 1II, page 300 - Le tigre noir, Erisson, liègue auimal. lage 271.

"Vide Hernandez, Hist. Mex., pag. 512. - Chat-pard. Hist. de l'Académie des Sciences, ou Mémoires pour' servir à l'Histoire des aninaux, tome II, part. I, page 109. - Chat-pard, Brisson, Rés she animal, page 273.
}

eux, et encore plus différente de celle du tigre et de la panthère; ct à l'égard du puma et du jaguar, il est évident, par les descriptions de ceux qui les ont vus, que le puma n'est point un lion, ni le jaguar un tigre : ainsi nous pouvons prononcer sans scrupule que le lion, le tigre et même la panthère ne se sont pas plus trourés en Amérique que l'éléphant, le rhinocéros, l'hippopotame, la girafe et le chameau. Toutes ces espèces ayant besoin d'un climat chaud pour se propager, et n'ayant jamais habité dans les terl'es du Nord, n'ont pu communiquer ni parvenir en Amérique. Ce fait général, dont il ne parait pas qu'on se fùt seulement douté, est trop important pour ne le pas appuyer de toutes les preuves qui peuvent achever de le constater : continuons donc notre énumération comparée des animaux de l'ancien continent avec ceux du nouveau.

Personne n'ignore que les chevaux, non-seulement causèrent de la surprise, mais même donnèrent de la frayeur aux Américains, lorsqu'ils les virent pour la première fois. Ils ont bien réussi dans presque tous les climats de ce nouveau continent, et ils y sont actuellement presque aussi communs que dans l'ancien '.

Il en est de mème des ânes, qui étaient également inconnus, et qui ont également réussi dans les climats chauds de ce nouveau continent : ils ont même produit des mulets qui sont plus utiles que les lamas pour porter des fardeaux dans toutes les parties montagneuses du Chili, du Pérou, de la Nouvelle-Espagne, etc.

Le zèbre ${ }^{3}$ est encore un animal de l'ancien continent, et qui n'a peut-être jamais été transporté ni vu dans le nouveau; il parait affecter un climat particulier, et ne se trouve guère que

'Tous les chevaux, dit Gareilásso, qui sont dans les lndes espagnoles, viennent des chevaux qui furent transportés d'Andalousie, d'abord dans lifie de Cuba et dans celle de Saint-Domingue, ensuite à celle de Barlovento, où ils multiplièrent si fort, qu'il s'cn répandit dans les terres inhabitées, oi ils devinrent sauvages, tt pullulèrent d'autant plus, qu'il n'y avait point d'animaux féroces dans ers lles, qui pussent leur nuire, et parce qu'il y a de l'herbe verte loute l'année. Histoire des Incas, Paris, 1744. - Ce sont les Français qui ont peuplé les iles Anlilles de chevaux; les Espagnols n'y en avaient point laissé comme dans les autres iles et dans la terre ferme du nonveau continent. M. Aubert, second gouverneur de la Guadeloupe, a commencé le premier pré dans celte ile, et y a fait apporter les premiers chevanx. llistoilc générale des Antilles, par le Père du Tertre. Paris, 1667, tome Il, page 289.

${ }^{2}$ Zebra, Ray, Syn. quad. pag. 69. - Edwards, Gleanings of nitural History. London, 1758 , page's 27 et 29.-Ane sauvaze, Kolbe, tome 111, page 22. - Le zèbre ou l'âne rayé, 13rsson, Regne animal, page 101. 
dans cette partie de l'Afrique qui s'étend depuis l'équateur jusqu'au Cap de Bonne-Espérance.

Le bœuf ne s'est trouvé ni dans les îles ni dans la terre ferme de l'Amérique méridionale. Peu de temps après la découverte de ces nouvelles terres, les Espagnols y transportèrent d'Europe des taureaux et des vaches. En 1550 on laboura pour la première fois la terre avee des bœufs ${ }^{4}$ dans la vallée de Cusco. Ces animaux multiplièrent prodigieusement dans ce continent, aussi bien que dans les îles de SaintDomingue, de Cuba, de Barlovento, ete. Ils devinrent même sauvages en plusieurs endroits. L'espèce de bœuf qui s'est trouvée au Mexique, à la louisiane, etc. ${ }^{2}$, et que nous avons appelée bœuf sau vage ou bisolı, n'est point issue de nos boufs; le bison existait en Amérique avant qu'on y en̂t transporté le bœuf d'leurope, et il diffère asser de celui-ci pour qu'on puisse le considérer comme faisant une espèce à part. Il porte une bosse entre les épaules; son poil est plus doux que la laine, plus long sur le devant du corps que sur le derrière, et crèpé sur le cou et le long de l'ćpine du dos; la couleur en est brune, obscurément marquée de quelques taches blanchâtres. Le bison a de plus les jambes courtes; elles sont, comme la tête et la gorge, couvertes d'un long poil : le mâle a la queue longue avee une houppe de poil au bout, comme on le voit à laqueue du lion. Quoique ces différences m'aient paru suffisantes, ainsi qu'à tous les autres naturalistes, pour faire du bœuf et du bison deux espèces différentes, cependant je ne prétends pas l'assurcr affirmativement: comme le seul caractère qui différencie ou identifie les espéces est la faculté de produire des individus qui ont eux-mèmes celle de produire leurs semblables, et que personne ne nous a appris si le bison peut produire avec le bœuf, que probablement même on n'a jamais essayé de les mêler ensemble, nous ne sommes pas ell état de prononeer sur ce fait. J'ai obligation à M. de la Nux, ancien conseiller au conseil royal de l'ile de Bourbon, ct correspondaut de l'académie des sciences, de m'avoir appris, par sa lettre datée de l'île de liourbon, du 9 oetobre 1759 , que le bison ou bocuf it bosse de l'ile de Bourbon produit avee

' Voyez l'îlistoire des Incas, Paris, 1744, tome 1I, pages 266 et suiv.

${ }^{2}$ Voyez l'Ilistoire du Nouveau-Nonde, par Jean de Lact, Lexde, 1640 , liv. X, chą, Iv.

IV. nos bœufs d'Europe; et j'avoue que je regardais ce bouf à bosse des Indes plutôt comme un bison que comme un bœuf. Je ne puis trop remereier M. de la Nux de m'avoir fait part de cette observation, et il serait bien à désirer qu’à son exemple les personnes habituées dans les pays lointains fissent de semblables expériences sur les animaux : il me semble qu'il serait faeile à nos habitants de la Louisiane d'essayer de mèler le bison d'Amérique avec la vache d'Europe, et le taureau d'Europe avec la bisonne: peutetre produiraient-ils ensemble, et alor's on serait assuré que le bouf d'Europe, le bœuf bossu de lîle de Bourbon, le taureau des Indes orientales et le bison d'Amérique ne ferajent tous qu'une seule et même espèce. On voit par les expériences de M. de la Nux que la bosse ne fait point un caractère essentiel, puisqu'elle disparait après quelques générations; et d'ailleurs j’ai reconnu moi-meme, par une autre obser ation, que cette bosse ou loupe que l'on voit au chameau, comme au bison, est uii caractère qui, quoique ordinaire, n'est pas constant, et doit être regardé comme une différence aceidentelle dépendante peut-être de l'embonpoint du corps : car j'ai vu un chameau maigre et malade qui n'avait pas même l'apparence de la bosse. l'autre caractère du bison d'Aniérique, qui est d'avoir le poil plus long et bien plus doux que celui de notre bœuf, parait eneore n'être qu'une différence qui pourrait venir de l'influence du climat, comme on le voit dans nos chèves, nos chats et nos lapins, lor'squ'on les compare aux chèvres, aux chats et aux lapins d'Angora, qui, quoique très-différents par le poil, sont cependant de la même espèce. On pourrait done imaginer, avec quelque sorte de vraisemblance (surtout si le bison d'Amérique produisait aree nos vaches d'Europe), que notre bœuf aurait autrefois passé jar les terres du Nord contiguës à celles de l'Amérique septentrionale, et qu'ensuite ayant descendu dauns les régions tempérées de ce nouveau monde, il aurait pris avec le temps les impressions du climat, et de bœuf serait devenu bison. Mais jusqu'à ce que le fait essentiel, c'est-í-dire la ficulté de produire ensemble, en soit comnu, nous nous croyons en droit de dire que notre bouf est un animal appartenant à l'ancien continent, et qui n'existait pas dans le nouveau avant d'y avoir été transporté.

Il y avait encore moins de brebis que de 
brufs en Amérique; elles y ont été transportées d'wurope, et elles ont réussi dans tous les climats chauds et tempérés de ce nouveau continent: mais quoiqu'elles $y^{\prime}$ soient assez prolifiques, elles y sontcommunément plus maigres, et les moutons ont en général la chair moins succulente et moins tendre qu'en Europe: le climat du Brésil est apparemment celui qui leur convient le mieux, car c'est le seul du NouveauMonde où ils deviennent excessivement gras ${ }^{2}$. L'on a transporté à la Jamaique non-seulement des brebis d'Europe, mais aussi des moutons ${ }^{3}$ de Guinée, qui y ont également réussi : ces deux espèces, qui nous paraissent être différentes l'une de l'autre, appartiennent également et uniquement à l'ancien continent.

Il en est des chèvres comme des brebis : elles n'existaient point en Amérique, et celles qu'on $y$ trou ve aujourd'hui et qui y sont en grand nombre viennent toutes des chèvres qui y ont été transportées d'Europe. Elles ne se sont pas autant multipliées au Brésil "que les brebis; dans les premiers temps, lorsque les Espagnols les transportèrent au Pérou, elles y furent d'abord si rares, qu'elles se vendaient jusqu'à cent dix ducats pièce ${ }^{5}$; mais elles s'y multiplièrent ensuite si prodigieusement, qu' elles se donnaient presque pour rien, et que l'on n'estimait que la peau : elles y produisent trois, quatre et jusqu'à cinq chevreaux d'une seule portée, tandis qu'en Europe elles n'en portent qu'un ou deux. Les grandes et les petites iles de l'Amérique sont aussi peuplées de chèvres que les terres du continent; les Espagnols en ont porté jusque dans les iles de la mer du Sud ; ils en avaient peuplé l'ile de Juan-Fernandès ${ }^{6}$, où elles avaient extrêmement multiplié : mais comme c'était un secours pour les flibustiers, qui dans la suite coururent ces mers, les Espagnols résolurent de détruire les chèvres dans cette île, et pour cela ils y làchèrent des chiens qui, s'y étant multipliés à leur tour, détruisirent les chèvres dans toutes les parties acces-

1 Voyez l'Histoire dn Bı'ésil , par Pison et Marcgrave.

2 Voyez l'Histoire du Nouveau-Monde, par Jean de Laet. Leyde, 1610 , liv. XV, clıap. xv.

' Ovls Guineeusis seu Angolensis Maregravii, lib. VI, cap. $x$, Ray, Sinopsis, page 75 . Voyez l'llistoire de la Jamaĭ une, par llans-Sloane: Londres, 1707 , vol. 1 , page 75 de l'Introduclion.

${ }^{4}$ Voyez l'Histoire du Nouveau-II onde, liv. XV. clap. xv.

'Voyez. l'1lisloire des Incas, tome 11, page 322.

- voyez le voyage autour du monde, par Anson, liv. II, page $(0)$. sibles de l'ile; et ces chiens y sont derenus si féroces, qu'actuellement ils attarjuent les hommes.

Le sanglier, le cochon domestique, le coclion de Siam ou cochon de la Chine, qui tous trois ne font qu'une seule et même espèce, et qui se multiplient si facilement et si nombreusement en Europe et en Asie, ne se sont point trouvés en Amérique. Le tajacou ', qui a une ouverture sur le dos, est l'animal de ce continent qui en approche le plus: nous l'avons eu vivant, et nous avons inutilement essayé de le faire produire avec le cochon d'Europe; d'ailleurs il en diffère par uu si grand nombre d'autres caractères, que nous sommes bien fondés à prononcer qu'il est d'une espèce différente. Les cochous transportés d'Europe en Amérique y ont encore mieux réussi et plus multiplié que ies brebis et les chèvres. Les premières truies, dit Garcilasso ${ }^{2}$, se vendirent au Pérou encore plus cher que les chèvrcs. La chair du bœuf et du mouton, dit Pison ${ }^{3}$, n'est pas si bonne au Brésil qu'en Europe; les cochons seuls y sont meilleurs et y multiplient beaucoup. Ils sont aussi, selon Jean de Laet ${ }^{4}$, devenus meilleurs à Saint-Domingue qu'ils ne le sont en Europe. En général, on peut dire que, de tous les animaux domestiques qui ont été transportés d'Europe en Amérique, le cochon est celui qui a le mieux et le plus universellement réussi. En Canada comme au Brésil , c'est-à-dire dans les climats très-froids et très-chauds de ce nou veau monde, il produit, il multiplie, et sa chair est également bonne à manger. L'espèce de la chèvre, au contraire, ne s'est multipliée que dans les pay's chauds ou tempérés, et n'a pu se maintenir en Canada: il faut faire venir de temps en temps d'Europe des boucs et des chèvres pour renouveler l'espèce, qui par cette raison y est trèspeu nombrense. L'àne, qui multiplie au Brésil, au Pérou, etc., n'a pu multiplier en Canada : l'on n'y voit ni mulets, ni ànes, quoique en différents temps l'on y ait transporté plusieurs couples de ces dernier's animaux, auxquels $l \epsilon$

4 Tajacu. Pison, Ind., page 98. - Tajacu, aper Mexicanus moschiferıs. Ray, Synops. quadrup., page 97. - Le sanglier dı Mexique. Les Français de la Guiane l'appellent cochon noir, Brisson, Règne animal, page 111.

${ }^{2}$ Voycz l'1lisloire des Incas, Paris, 1744 , tome II, pages 266 et suivanles.

side Pison, Ilist. Nat. Brasil., cum app. Marcgravii.

1 Voyez l'Histoire du Nouveau-Monde, par Jean de Laet. Leyde, 1640, chap. Iv, page 3. 
froid scmble ôter cette force de tempérament, cette ardeur naturelle, qui dans ces climats les distinguent si fort des autres animaux. Les chevaux ont à peu près également multiplié dans les pays chauds et dans les pays froids du continent de l'Amérique; il paraît seulement' qu'ils sont devenus plus petits; mais cela leur est commun avec tous les autres animaux qui ont été transportés d'Europe en Amérique: car les boufs, les chèvres, les moutons, les cochons, les chiens, sont plis petits en Canada qu'en France; et, ce qui paraitra peut-être beaucoup plus singulier, c'est quetous les animaux d'Amérique, même ceux (jui sont naturels au climat, sont beaucoup plus petits en général que ceux de l'ancien continent. La nature semble s'être servie dans ce nouveau moncie d'une autre échelle de grandeur; l'homme est le seul qu'elle ait mesuré avec le mème module: mais, avant de donner les faits sur lesquels je fonde cetle observation générale, il faut achever notre énumération.

Le cochon ne s'est done point trouvé dans le Nouveau-Monde, il y a été transporté; et nonseulement il y a multiplié dans l'état de domesticité, mais il est même devenu sauvage ${ }^{2}$ en plusieurs endroits, et il y vit et multiplie dans les bois, comme nos sangliers, sans le secours de l'homme. On a aussi transporté de la Guinée au Brésil ${ }^{3}$ une autre espèce de cochon, différente de celle d'Europe, qui s'y est multipliéc. Ce cochon de Guinée, plus petit que celui d'Europe, a les oreilles fort longues et très-pointues, la queue aussi fort longue et traînant presque à terre; il n'est pas couvert de soies longues, mais d'un poil court, et il parait faire une espèce distincte et séparée de celle du cochon d'Europe : car nous n'avous pas appris qu'au Brésil, où l'ardeur du climat favorise la propagation en tout genre, ces deux espèces se soient mẻlées, ni qu'elles aient mème produit des mulets, ou des individus féconds.

Les chiens, dont les races sont si variées et si nombreusement répandues, ne se sont, pour ainsi dire, trouvés en Amérique que рат échan-

\footnotetext{
4 Voyez l'Histoire de la Jamaīnue, par Hans-Sloane, Londres, 1707 ef 1725 .

"Les cochons d'Europe ont beaucoup multiplié dans toules les ludes occilentales; ils y sont devemus samves, et on les ehasse comme le sanglier, dont ils ont pris le naturel et la féroeité. Ilisloire Nalurelle des Indes, par Josęul Acosta, Paris, 1600, page's 41 el snivantes.

- Vide Pison, llist. Nat. Brasil. cum app. Maregravii.
}

tillons difliciles à comparer et à rapporter au total de l'espèce. Il y avait à Saint-Dominguo de petits animaux appelés yosqués, semblables à de petits chiens; mais il n'y avait point de chiens semblables à ceux d'Europe, dit Garei. lasso ; et il ajoute que les chiens d'Europequ'on avait transportés à Cuba et à Saint-1)ominguc, étant devenus sauvages, diminuèrent dans ces îles la quantité du bétail aussi devenu sauvage ; que ces chiens marchent par troupes de dix o't douze; et sont aussi méchants que des loups. II n'y avait pas de vrais chicns aux Indes occi. dentales, dit Joseph Acosta ', mais seulement des an imaux scmblables à de petits chiens, ( ju'au Pérou ils appelaient alcos, et ces alcos s'attachent à leur maitre et ont à peu pres aussi le naturel du chien. Si l'on en croit le pere Charlevoix ${ }^{2}$, qui sur cet article ne cite pas ses garants, "les goschis de Saint-Domingue étaiert " Je petits chiens muets qui servaient d'amu. a sement aux dames ${ }^{3}$; on s'en servait aussi à la " chasse pour éventer d'autres animaux; ils " étaient bons ${ }^{4}$ à manger, etfurent d'une grando " ressource dans les premières famines que les "Espagnols essuyèrent : l'espèce aurait man " qué dans l'ile, si on n'y en avait pas apporté " de plusieurs endroits du continent. Il y en " avait de plusieurs sortes; les uns avaient la " peau tout à fait lisse, d'autres avaient tout le " corps couvert d'une laine fort douce; le plus - grand nombre n'avait qu'une espèec de duvet " fort tendre et fort rare. La même variété de v rouleurs qui se voit parmi nos chiens se ren- contrait aussi dausccux-lá, et plus grande en" core, parce que toutes les coulcurs s'y trou" vaient, et même les plus vives. "Si l'espèce des goschis a jamais existé avece ces singularités que lui attribue le père Charlevoix, pourquoi les autres anteurs n'en font-ils pas mention? et pourquoi ees animaux, qui selon lıi élaient répandus non-seulement dans l'ile de SaintDomingue, mais en plusieurs endroits du continent, ne subsistent-ils plus aujourd'hui; ou plutòt, s’ils subsistent, comment ont-ils perdu toutes ces belles singularités? Il est y raisembla-

1 Voyez l'Histoire Natnrelle des Indes, par Joseph A costa pages 46 et suivantes. Voyez anssi l'Hlistoire dı Nourean. Ionde, par Jean de Laet, Leyde, 1640 , liv. X. chap. 1.

2 Foyez l'ulisloire de l'ile Sainl-1)mingue, pal' le pire Charlevoix. Paris, 1750, tome I, pages 55 el suiranles.

${ }^{5}$ Y avait-il des dames à Saint-1)omingue, lorsqu'on en 6 t la décomverte?

4 La clıair du chieu n'est pas bonne à manger. 
ble que le gosehis du père Charlevoix, dont il dit n'avoir trouvé le nom que dans le père Pers, est le gosqués de Galleilasso ; il se peut aussi que le gosqués de Saint-Domingue et l'aleo du Pérou ne soient que le même animal, et il paraît ecrtain que ect animal est celui de l'Amérique qui a le pkas de rapport avee le chicn d'Lurope. Quelques auteurs l'ont regardé comme un vrai chien. Jean de Laet ' dit expressément que, daus le temps de la découverte des Indes, il y avait à Saint-Domingue une petite espéce de chiens dont on se servait pour la chasse, mais qui étaient absolument muets. Nous avons vu, dans l'histoire du ehien 2 , que ces animaux perdent la faeulté d'aboyer dans les pays chauds; mais l'aboiement est remplacé par une espèce de hurlement, et ils ne sont janais, comme ces animaux trouvés en Amérique, absolument muets. Les ehiens transportés d'Europe ont à peu près également réussi dens les contrées les plus chaudes et les plus froides d'Amérique, au Brésil et an Canada, et ce sont de tous les animaux ceux que les Sauvages ${ }^{3}$ estiment le plus: cependant ils paraissent avoir changé denature; ils ont perdu leur voix dans les pays chauds, la grandeur de la taille dans Ies pays froids, et ils ont pris presque partout des oreilles droites: ils ont done dégénéré, ou plutôt remonté à leur espèce primitive, qui est celle du chien de berger, du chien à oreilles droites, qui de tous est celui qui aboie le moins. On peut done regarder les chiens commeappartenant uniquement à l'ancien eontinent, où leur naturene s'est dereloppere tout entière que dans les régions tempérées, et oì elle paraît s'ètre variće et perfectionnée par les soins de l'homme, puisque, dans tous les pays non policés et dans tous les elimats excessivement chauds ou froids, ils sont également petits, laids et prescue muets.

L'hyène , qui est à peu près de la grandeur du loup, est un animal connu des aneiens, et que nous avons vu vivant; il est singulier par l'ouverture et les glandes qu'il a situées comme celles du blaireau, desquelles il sort une humeur d'une odeur très-forte : il est aussi trèsremarquable parsa longue erinière, qui s'étend

\footnotetext{
- Voyez l'Ilistoire úu Nouvean Monde, par Jean de Laet, liv. XV, chap. XV.

Voyez l'arlicle du Chien.

- Voyez l'llistoire du Nouveau-.llonde, par Jean de Laet. liv, XV, chap. $x v$, page šls.

- Ilyrna. Aristotelis, Ilist. animal. - Dabuli Arabum. Cliarieton Exer, page 15.
}

le Iong du cou et du garrot; par sa voracité, qul lui fait déterrer les cadarres, et dévorer les chairs Ies plus infectes, ete. Cette vilaine bête ne se trouve qu'en Arabie ou dans les autres provinces méridionales de l'Asie; elle n'existe point en Europe, et ne s'est point trourée dans le Nouvcau-Monde.

Le chacal ${ }^{1}$, qui, de tous les animaux, sans même en excepter le loup, est celui dont l'esw pèce nons parait approcher le plus de l'espèce du chien, milis qui, cependant, en differe par des caractères essentiels, est un animal trèscommun en Arménie, en Turquie, et qui se trouve aussi dans plusieurs autres provinces de l'Asie et de l'Afrique; mais il est absolument étranger au nouveau continent. Il est remarquable par la couleur de son poil, qui est d'un jaune brillant : il est à peu près de la yrandeur d'un renard. Quoique l'espèce en soit très-nombreuse, elle ue s'est pas étendue jusqu'en Europe, ni même jusqu'au nord de l'Asie.

La genette 2, qui est un animal bien connu des Espagnols, puisqu'elle babite en Espagne, aurait sans doute été remarquée si elle se fùt trou rée en Amérique; mais, comme aucun de leurs historiens ou de leurs vovageurs n'en fait mention, il est elair que e'est encore un animal particulier à l'ancien continent, dans lequel il habite les parties méridionales de l'Europe, et celles de l'Asie qui sont à peu près sous cette mêne latitude.

Quoiqu'on ait prétendu que la civette se trouvait à la Nouvelie-Espagne, nous pensons que ce n'est point la civette de l'Afrique et des Indes, dont on tire le muse que l'on mêle et prépare avec celui que l'on tire aussi de l'animal appelé hium à la Chine; et nous regardons la vraie civette comme un animal des parties méridionales de l'ancien continent, qui ne s'est pas répandu vers le nord, et qui n’a pu passer dans le nouveau.

Les chats étaient, comme les chiens, tout-àfait étrangers an Nouveau-Monde, et je suis maintenant persuadé que l'espèce n'y existait point, quoique j'aie cité ${ }^{3}$ un passage, par le-

4 Lupus aureus... Jackall. Ray, Synops, quadrup., page 174. - Asiaticum animal. Adil uuneupatum. Bellon, Obs., paget60. - Canis flavus., Le Loup doré. Brisson, Règne animal, page $25 \%$.

Genelta, Bellon, Observ., page 76. - Genelta. Catus Ilis. paniæ Genelhuealus. Cliarlelon, Exer., page 20. - La geuetıe, Brisson, lègn. A nimal, page $2: 2$.

voyez larticle du Chat. 
quel il parait qu'un homme de l'équipage de Christophe Colomb avait trouvé et tué sur la còte de ces nouvelles terres un chat sauvage : je n'étais pas alor's aussi instruit que je le suis aujourd'hui de tous les abus que l'on a fait des noms, et j'avoue que je ne connaissais pas encore assez les animaux pour distinguer nettement dans les témoignages des voyageurs les noms usurpés, les dénominations mal appliquées, empruntées ou factices; et l'ou n'en sera peut-être pas étonné, puisque les nomenclateurs, dont les recherches se bornent à ce seul point de vue, loin d'avoir éclairci la matière, l'ont encore embrouillée par d'autres dénominations et des phrases relatives à des méthodes arbitraires, toujours plus fautives que le coup d'œil et l'inspection. La pente naturelle que nous avons à comparer les choses que nous voyous pour la première fois à celles qui nous sont déjà connues, jointe à la difficulté presque invincible qu'il y avait à prononcer les noms donnés aux choses par les Américains, sont les deux causes de cette mauvaise application des dénominations, qui, depuis, a produit tant d'erreurs. Il est, par exemple, bien plus commode de donner à un animal nouveau le nom de sanglier ${ }^{4}$ ou de cochon noir, que de prononcer son nom mexicain quauh-coyamelt ; de même, il .était plus aisé d'en appeler un autre renard américain, que de lui conserver son nom brasilien tananduaguacu; de nommer de mème mouton ou chameau du Pérou des animaux qui, dans cette langue, se nomnaient pelon ichiatloquitli: on a de mème apprelé cochon d'eau le cubiai ou cabionara, ou capybara, quoique ce soit un animal très-différent d'un cochon; le carigueibeju s'est appelé loutre. II en est de même de presque tous les autres animatux du Nouveau-Monde, dont les noms étaient si barbares et si étrangers pour des Européens, qu'ils cherchèrent à leur en donner d'autres par des ressemblances, quelquefois heureuses, avec les animaux de l'aucien continent; mais souvent aussi par de simples rapports, trop éloignés pour fonder l'application de ces dénominations. On a regardé comme des lièrres et des lapins cing ou six espèces de petits animaux qui n'ont guère d'autre rapport avec les lièvres et

- Voyez le Voyage de Desmarelıais, lome IIr, page 112 , de l'Essai sur l’histoire naturelle de la lirance é(juinoxiale, par Barrère, Paris, 1740, avec l'1listoire din Ilexique, par Ilermandes, page 637 , el l'llistoire de la Nouvelle-Espague, par Fernaudez, page 8. les lapins, que d'avoir, comme eux, la chair bonne à manger. On a appelé vache ou élan un animal sans cornes ni bois, que les Américains nommaient tapiierete au Brésil, et manipouris à la Guiane; que les Portugais ont ensuite ap. pelé anla, et qui n'a d'autre rapport avec la vache ou l'élan, que celui de leur ressembler un peu par la forme du corps. Les uns ont comparé le pali ou le paca au lapin; et les autres ont dit qu'il était semblable à un pourceau de deux mois. Quelques-uns ont regardé le philandre comme un rat, et l'ont appelé rat de bois; d'autres l'ont pris pour un petit renard. Mais il n'est pas nécessaire d'insister ici plus longtemps sur ce sujet, ni d'exposer dans un plus grand détail les fausses dénominations que les voyageurs, les historiens et les nomencla. teurs ont appliquées aux animaux de l'Amérique, parce que nous tâcherons de les indiquer et de les corriger, autant que nous le pourrons, dans la suite de ce discours et lorsque nous traiterons de chacun de ces animaux en particulier.

On voit que toutes les espèces de nos animaux domestiques d'Europe, et les plus grands animaux sauvages de l'Afrique et de l'Asie, manquaient au Nouveau-Monde. Il en est de même de plusieurs autres espèces moins consi dérables, dont nous allons faire mention le plus succinctement qu'il nous sera possible.

Les gazelles, dont il y a plusieurs espèces différentes, et dont les unes sont en Arabie, les autres dans l'Indle orientale, et les autres en Afrique, ont toutes à peu près également besoin d'un climat chand pour subsister et se multiplier : elles ne se sont done jamais étendues dans les pays du nord de l'ancien continent, pour passer dans le nouveau; ainsi, ces espèces d'Afrique et d'Asie ne s'y sont pas trouvées: ii parait seulement qu'on y a transporté l'espèce qu'on a appelée gazelle d'Afrique, et que Hernandès nomme algozel' ex Africa. L'animal de la Nouvelle-Espagne, que le mème auteur appelle temamaçame, que Séba désigne par le nom de cervus, Kilein par celui de tragulus, et M. Brisson ${ }^{2}$ par celui de gazelle de la Nou. velle-Espąne, parait aussi differer, par l'espice, de toutes les gazelles de l'aneien continent.

- Voyez LIernandés, Historre dı Mexique, page - Vojez le Regne aniınal, par М. Brisson, page 70. 
On serait porté à imaginer que le chamois, qui se plait dans les neiges des Alpes, n'wurait pas craint les glaces du nord, et que de là il aurait pu passer en Amérique ; cependant il ne s'y est pas trouvé. Cet animal semble affecter non-seulement un climat, mais une situation particulière : il est attaché aux sommets des hautes montagnes des Alpes, des Pyrénées, etc.; et, loin de s'être répandu dans les pays éloignés, il n'est jamais descendu dans les plaines qui sont au pied de ces montagnes. Ce n'est pas le seul animal qui affecte constamment un pays, ou plutôt une situation particulière : la marmotte, le bouquetin, l'ours, le lynx ou Joup-cervier, sont aussi des animaux montagnards, que l'on trouve très-rarement dans les plaines.

Lebuffle, qui est un animal des pays chauds, et qu'on a rendu domestique en Italie, ressemble encore moins que le bœuf au bison d'Amérique, et ne s'est pas trouvé dans ce nouveau continent.

Le bouquetin se trouve all-dessus des plus hautes montagnes de l'Europe et de l'Asie; mais on ne l'a jamais vu sur les Cordillières.

L'animal ' dont on tire le musc, et qui est à peu près de la grandeur d'un daim, n'habite que quelques contrées particulières de la Chine et de la Tartarie orientale: le chevrotin ${ }^{2}$, que l'on connait sous le nom de pctit cerf de Guinée, parait confinć dans certaines provinces de l'Afrique et des Indes orientales, etc.

Le lapin, qui vient originairement d'Espagne, et qui s'est répandu dans tous les pays tempérés de l'Europe, n'était point en Amérique; les animaux de ce continent auxquels on a donné son nom sont d'espèces différentes, et tous les vrais lapins qui s'y voient actuellement y ont été transportés d'Europe ${ }^{3}$.

Les furets, qui ont été apportés d'A frique en Europe, où ils ne peuvent subsister sans les soins de l'homme, we se sont point trouvés en Amérique; il n'y a pas jusqu'à nos rats et nos souris qui n'y fussent inconnus : ils y ont passé a vec nos vaisseaux, et ils ont prodigieusement multiplié dans tous les lieux habités de ce nouveau continent.

Voilà donc à peu près les animaux de l'an-

\footnotetext{
+ Hiam, animal musci, Boym , flor. sinen., 1656.-Animal moschiferun. Ray, Synops. quadrup., page 127.

${ }^{2}$ Chevrotin. Brisson, Règne animal, page 95.

Voyez 1 Histoire des Incas, Paris , 1744, lome 11, p. 322 et suiv antes.
}

cies coutinent : l'éléphant, le rhmocéros, l'hippopotame, la girafe, le chameau, le dromadaire, le lion, le tigre, la panthère, le cheval, l'âne, le zèlore, le bouf, le buffle, la brebis, la chèvre, le cochon, le chien, l'hyène, le chacal, la genette, la crvette, le chat, la gazelle, le chamois, le bouquetin, le chevrotin, le lapin, le furet, les rats et les souris; aucuns n'existaient en Amérique lorsqu'on en fit la découverte. Il en est de même des loirs, des lérots, des marmottes, des mangoustes, des blaireanx, des zibelines, des hermines, de la gerboise, des makis et de plusieurs espèces de singes, etc., dont aucune n'existait en Amérique à l'arrivée des Européens, et qui, par conséquent, sont toutes propres et particulières a l'ancien continent, comme nous tâcherons de le prouver en détail, lorsqu'il sera question de chacun de ces animaux en particulier.

\section{$\ldots$ \\ ANIMAUY' \\ DU NOUVEAU-MONDE.}

Les animaux du Nouveau-Monde étaien! aussi inconnus pour les Européens que nos at. maux l'étaient pour les Américains. Les seuls peuples à demi civilisés de ce nouveau contincnit étaient les Péruviens et les Mexicains : ceux-ci n'avaient point d'animaux domestiques; les seuls Péruviens avaient du bétail de deux espèces, le lama et'le pacos, et un petit animal qu'ils appelaient alco, qui était domestique dans la maison, comme le sont nos petits chiens. Le pacos et le lama, queFernandès appelle peruichcalt $^{3}$, c'est-à-dire, en anglais, bétail péruvien, affectent, comme le chamois, une situation particulière. Ils ne se trouvent que dans les montagnes du Pérou, du Chili, de la Nouvelle-Espagne. Quoiqu'ils fussent devenus domestiques chez les Péruviens, et que, par conséquent, les hommes aient favorisé leur multiplication et les aient transportés ou conduits dans les contrées voisines, ils ne se sont propagés nulle part; ils ont même diminué dans leur payss natal, oì l'espèce en est actuellement moins nombreuse

'Peruich-call, Fernandès, Hisl. Nov. Hisp., page 11.(amelus Peruanus glama diclus. Ray, Synops quadrup. page 145. - Camelus, seu Camelo-congener Peruvianum, langerum, pacos diclum. Idem, ibid., page 147. 
ju'elle ne l'était avant qu'on y eût transporté e bétail d'Europe, qui a très-bien réussi dans outes les contrées méridionales de ce continent.

Si l'on y réfléchit, il paraîtra singulier que, lans un monde presque tout composé de naturels sauvages, dont les mœurs s'approchaient beaucoup plus que les nôtres de celles des bètes, il n'y eût aucune société, ni même aucunc habitude entre ces hommes sauvages et les animaux qui les environnaient: puisque l'on n'a trouvé des animaux domestiques que chez les peuples déjà civilisés, cela ne prouve-t-il pas quel'homme, dans l'état de sauvage, n'est qu'une espèce d'animal incapable de commander aux autres, et qui, n'ayant, comme eux, que ses facultés individuelles, s'en sert de mème pour chercher sa subsistance et pourvoir à sa sûreté eir attaquant les faibles, en évitant les forts, et sans avoir aucune idée de sa puissance réelle et de sa supérioxité de nature sur tous ces êtres, rqu'il ne cherche point à se subordonner? En jetant un coup d'œil sur tous les peuples entièrement, ou mème à demi policés, nous trouverons partout des animaux domestiques : chez nous, le cheval, l'âne, le bœuf, la brebis, la chèvre, le cochon, le chien et le chat; le buffle en Italie, te renne chez les Lapons; le lama, le paco et l'alco chez les Péruviens; le dromadaire, le chameau et d'autres espèces de bœufs, de brebis et de chèvres, chez les Orientaux; l'éléphant mème chez les peuples du Midi : tous ont été soumis au joug, réduits en servitude ou bien admis à la société; tandis que le sauvage, cherchant à peine la société de sa femelle, craint ou dédaigne celle des animaux. Il est vrai que, de toutes les espèces que nous avons rendues domestiques dans ce continent, aucune n'existait en Amérique; mais, si les hommes sauvages dont elle était peuplée se fussent anciennement réunis, et qu'ils se fussent prêté les lumières et les secours mutuels de la société, ils auraient subjugué et fait servir à leur usage la plupart des animaux de leur pays : car ils sont presque tous d'un naturel doux, docile et timide; il y en a peu de malfaisants et presque aucun de redoutable. Ainsi, ce n'est ni par fierté de nature, ni par indocilité de caractère que ces animaux ont conservé leur liberté, évité l'esclavage ou la domesticité, mais par la scule impuissance de l'homme, qui ne peut rien en effet que par les forces de la société; sa propagation mème, sa multiplication en dépend. Ces terres immenses du Nouveau-Monde n'étaient, pour ainsi dire, que parsemćes de quelques poignées d'hommes; et je crois qu'on pourrait dire qu'il n'y avaif pas, dans toute l'Amérique lorsqu'on en fit la découverte, autant d'hommes qu'on en compte actuellement dans la moitié de l'Europe. Cette disettedans l'espèce humaine faisait l'abondance, c'est-à-dire le grand nombre, dans chaque es pèce des animaux naturels au pays ; ils a vajent beaucoup moins d'ennemis et beaucoup plus d'espace; tout favorisait donc leur multiplication, et chaque espèce était relativement trèsnombreuse en individus : mais il n'en était pas de même du nombre absolu des espèces; elles étaient en petit nombre, et, si on le cornpare avec celui des espèces de l'ancien continent, on trouvera qu'il ne va peut-être pas au quart, et tout au plus au tiers. Si nous comptons deux cents espèces d'animaux quadrupèdes ${ }^{1}$ dans toute la terre habitable et connue, nous en trouverons plus de cent trente espèces dans l'ancien continent, et moins de soixante-dix dans le nouveau; et si l'on en ôtait encore les espèces communes aux deux continents, c'est-à-dire celles seulement qui, par leur nature, peurent supporter le froid, et qui ont pu communiquer par les terres du nord de ce continent dans l'autre, ou ne trouvera guère que quarante espèces d'animaux propres et naturels aux terres du Nouveau-Monde. $\mathrm{La}$ nature vivante $\mathrm{y}$ est done beaucoup moins agissante, beaucoup moins varice, et nous pouvons même dire beaucoup moins forte ; car nous verrous, par l'énumération des animaux de l'Amérique, que non-senlement les espèces en sont en petit nombre, mais qu'en général tous les animaux y sont incomparablement plus petits que ceux de l'ancien continent, etqu'il n'y en a aucun en Amérique qu'on puisse comparer à l'éléphant, au rhinocéros, à l'hippopotame, au dromadaire, à la girafe, au buffle, au lion, au tigre, ete. Le plus gros de tous les animaux de l'Amérique méridionale est le tapir ou tapiierete ${ }^{2}$ du Brésil. Cet animal, le plus grand de tous, cet éléphant du Nonreau-

1 M. Linneus, dans sa dernière édition, Stokholm, 1758, neu compte que cent soixante-sepl. M. Rrisson, dans son hègne animai, en indiøue deux cent-soixanle; mais il faul en retrancher peul-être plus de suixante, qui ne sont que des variétés, et non pas des especes dislinctes el différentes.

${ }^{2}$ Tapilerete, Brasiliensilus. Pison, Hist. Nal., pag. 101. Marcgravii llist. Brasil., page 220. - 1] aypoury, manipouris. Barrère, llist. Fr. éu.. page 161. - Le tapir ou manjpouris. Brisson, Règne animal, page 119. Les Portugais l'appellent anta. 
Monde, est de la grosseur d'un veau de six mois ou d'une très-petite mula ; car on l'a comparé à l'un et à l'autre de ces animaux, quoiqu'il ne leur ressemble en rien, n'étant ni solipède, ni piedfourelıu, mais fissipède irrégulier, ayant quatre doigts aux pieds de devant et trois à ceux de derrière : il a le corps à peu près de la forme de celui d'un cochon, la tète eependant beaucoup plus grosse à proportion, point de défenses ou den's canines, la lèvre supérieure fort allongée et mobile à volonté. Le lama, dont nous avons parlé, n'est pas si gros que le tapir', et ne paraît grand que par l'allongement du cou et la bauteur des jambes. Le pacos est encore de beaucoup plus petit.

Le cabiai ' qui est, après le tapir, le plus gros animal de l'A mérique méridionale, ne l'est cependant pas plus qu'un coehon de grandeur médiocre: il differe autant qu'aucun des précédents de tous les animaux de l'aneien continent; car, Iuo:qu'on l'ait appelé cochon de marais ${ }^{2}$ ou cochon d'eau, il diffère du cochon par des caractères essentiels ct très-apparents; il est fissipède, ayant comme le tapir quatre doigts aux pieds de devant et trois à ceux de derrière ; il a les yeux grands, le museau gros et obtus, les oreilles petites, le poil court, et point de queue. Le tajacou ${ }^{3}$, qui est encore plus petit que le cabiai et qui ressemble pius au cochon, surtout par l'extérieur, en diffère beaucoup par la conformation des parties intérieures, par la figure de l'estomac, par la forme des poumons, par la glosse glande et l'ouverture qu'il a sur le dos, etc.; il est donc, comme nous l'avons dit, d'une espèce différente de celle du cochon : et ni le tacajou, ni le cabiai, ni le tapir, ne se trouvent nulle part daus l'ancien continent. 11 en est de mêrne du tamandua-guacu ou ouariri ${ }^{4}$, et du ouatiriou ${ }^{5}$, que nous arons appelés fourmiliers ou mangeur's de fourmis : ees animaux, dont les plus gros sont d'une taille au-dessus de la médioere, paraissent ètre particuliers aux terres de l'Amérique méridionale; ils sont très-singulicrs, en ce qu'ils n'ont point de dents, qu'ils ont

- Capibara Brasiliensibus. Marcgravii Ilist. Brasil.,p. 250.

- Sus maximus palusl ris. larrère, Ilist. Fr. é $\{u$ in., p. 160.

- Cochon dean, Voyages de Desmarchais, torne III, p. 514.

${ }^{3}$ Tajacu. Pison, Hist. Nat., page 98. - Tajacu. Caaigoara Brasiliensibus. Irareg., II ist. Brasil., page 229. - Coyametl. Fernandè, Ilist. Nov. Hisp., page 8.

- Tamandua-guacu sive major. Pison, Jist. Xat., page $\mathbf{3 2 0}$. Le fourmilier-tamanoir. Irisson, Rigne animal, page 2 f.

- Tamandua minor flavescens. Ouiliriouau. Barrere, llist. Pr. ér., page 163. la langue cylindrique comme celle des oiseaux qu'on appelle pies, l'ouverture de la bouche trèspetite, avee laquelle ils ne peuvent ni mordre ni presque saisir : ils tirent seulement leur langue, qui est très-longue, et, la mettant à portée des fourmis, ils la retirent lorsqu'elle en est chargée, et ne peuvent se nourrir que par cette industrie.

Le paresseux ', que les naturels du Brésil appellent ai ou hai, à cause du cri plaintif $a i$ qu'il ne cesse de faire entendre, nous parait ètre aussi un animal qui n'appartient qu'au nouveau continent. Il est encore beaucoup plus petit que les précédents, n'ayant qu'environ deux pieds de longueur; etil est très-singulier, en ce qu'il marche plus lentement qu'une tortue, qu'il n'a que trois doigts, tant aux pieds de devant qu'à eeux de derrière, que ses jambes de devant sont beaucoup plus longues que celles de derrière, qu'il a la queue très-courte, et qu'il n'a point d'oreilles. D'ailleurs, le paresseux et le tatou sont les seuls parmi les quadrupèdes qui, n'ayant ni dents incisi ves ni dents canines, ont seulement des dents molaires cylindriques et arrondies à l'extrémité, à peu près comme celles de quelques cétacées, tels que le cachalot.

Le cariacou de la Guiane, que nous avons eu vivant, est un animal de la nature et de la grandeur de nos plus grands chevreuils; le mâle porte un bois semblable à celui de nos chevreuils, et qui tombe de même tous les ans; la femelle n'en a point : on l'appelle à Cayenne biche des bois. Il y a une autre espèce qu'ils appellent aussi petit cariacou, ou biche des ma. rais ou des Paletuviers, qui est considérablement plus petite que la première, et dans la. quelle le mâle n'a point de bois : j'ai soupconné, à cause de la ressemblance du nom, que le cariacou de Cayenne pouvait être le cuguacu ${ }^{2}$ ou cougruacou-apara du Brésil ; et ayant confronté les notices que Pison et Maregrave nous ont données du couguacou, avee les caractères du cariacou, il nous a paru que c'était le mème animal, qui cependant est assez différent de notre chevreuil pour qu'on doive le regarder comme faisant une espèce différente.

Le tapir, le cabiai, le tacajou, le fournilier,

'Al, ou paresseux. Desmarchais, tome III, page $\mathbf{3 0 0 . -}$ Ouaikaré. Barrère, 11jst. Fr. éłnin., page 154.

${ }^{2}$ Cugnacu-ete., Cugnacu-apara. P'ison, II ist. Nat., page 97. - Marcgr. Hist. Hrasil., page 253. - Biche des Palétuviers. lliche de bois. Barrère, Hlist. Fr. éq., page 151. 
le paresseux, le carlacou, le lama, le pacos, le bison, le puma, le jaguar, le couguar, le jaguarète, le chat-pard, etc., sont donc les plus grands animaux du nouveau continent; les médiocres et les petits sont les cuandus ou gouandous ${ }^{1}$, les agcutis ${ }^{2}$, les coatis, les pacas ${ }^{3}$, les philandres $^{4}$, les cochons d'Inde ${ }^{5}$, les apéreas ${ }^{6}$ et les tatous ${ }^{7}$, que je erois tous originaires et propres au Nouveau-Monde, quoique les nomenclateurs les plus récents parlent d'une espèce de tatous des Indes orientales, et d'une autre espèce en Afrique. Comme c'est seulement sur le témoigrage de l'auteur de la description du cabinet de Séba, que l'on a fait mention de ces tatous africains et orientaux, cela ne fait point une autorité suffisante pour que nous puissions $y$ ajouter foi : car on sait en général combien il arrive de ecs petites erreurs, de ees quiproquo de noms et de pays lorsqu'on forme une collection d'histoire naturelle : on achète un animal sous le nom de chauve-souris de Ternate ou d'Amérique, et un autre sous celui de tatou des Indes orientales; on les annonce ensuite sous ces noms dans un ouvrage où l'on fait la description de ce cabiuct, et de là ces noms passent dans les listes de nos nomenclateurs, tandis qu'en examinant de plus près, on trouve que ces chauves-souris de 'Ternate ou d'Amérique sont des chauves-souris ${ }^{8}$ de France, et que ces tatous des Indes ou d'Afrique pourraient bien être aussi des tatous d'Amérique.

Jusqu'ici nous n'avons pas parlé des singes, paree que leur histoire demande une discussion particulière. Comme le mot singe est un nom géuérique, que l'on applique à un grand nombre d'espèces diflérentes les mes des autres, il r'est pas étommant que l'on ait dit qu'il se trou-

- Cuankln [Basiliensibus. Pison, Hist. Nat., page 99. Maregr.. Ilist. Br., jage 235. - Cionandou. lialrère , llist. lir. éf., pag. 153. - Chat-épineux, 1)esuarchais, tome 111, p. 303. - I, porc-épic d'Amériçne, lirissun, litgne animal, p. 129.

${ }^{2}$ voye\% les articles de l’Agontirl du Coali.

- Paca. Pison, Hist. Nat., flag. 101. L'aca Brasiliensibus. Maregr., Llist. Br., pag. 224. - Ourama. Pak., Barrèce , llist. Pr. $e_{\tau l}$, pag. 1:52.

- Corigneya Brasiliensibus. Maregr., Ilist. Mr., page 2:2. Opossull. Jean de Laet, pag. 82, - Le philandre. Brisson, Règne animal, pages 286 et suivantes.

v Voyez l'arlicle du Cochon d'Inde.

- Aperea Braslliensibus, Marcgr., Ilist. Br., pag. 223. - Le lapin du Brésil. Brisson, llegne animal, jage 169.

"Taton, Armadillo, Ayolochilli. Hernandes, Ilist. Mex., page 314.

- Voyez. l'article des Chauves-Sonris. Voyez aussi la cleserlןtion du Cabinet de Séba , vol. I, pagc :7, oi il donne les figures de l'armallille d'Afriphe, et la page $6: 2$, ou il dome celle de l'ar'unadille orientale. vait des singes en grande quantité dans les pays méridionaux de l'un et de l'autre continent : mais il s'agit de savoir si les aninaux que l'on appelle singes en Asie et en Afrique sont les mêmes que les animaux auxquels on a donné ce même nom en Amérique : il s'agit même de voir et d'examiner si, de plus de trente espèces de singes que nous avons eus vivants, une seule de ces espéces se trouve également dans les deux continents.

Le satyre ' ou l'homme des bois, qui par sa conformation parait moins différer de l'homme que du singe, ne se trouve qu'en Afrique ou dans l'Asie méridionale, et n'existe point en Amérirgue.

Le gibbon ${ }^{2}$, dont les jambes de devant ou les bras sont aussi lougs que tout le corps, y compris mème les jambes de derrière, se trouve aux grandes Indes et point en Amérique. Ces deux espèces de singes, que nous avons eus vivants, nont point de queue.

Le singe ${ }^{3}$ proprement dit, dont le poil est d'une couleur verdâtre mèlée d'un peu de jaune, et qui n'a point de queue, se trouve en Afrique et dans quelques autres endroits de l'ancien continent, mais point dans le nouveau. Il en est de même des singes cynocéphales, dont on connait deux ou trois espèces : leur museau est moins court que celui des précédents; mais comme eux ils sont sans queue, ou du moins ils l'ont si courte qu'on a peine à la voir. Tous ces singes qui n'ont point de queue, ceux surtout dont le museau est court, et dont la face approche beaucoup de celle de l'homme, sont les vrais singes; et les cinq ou six especes dont nous verons de parler sont toutes naturelles et particulières aux elimats chands de l'ancien continent, et ne se trouvent mulle part dans le nouveau. On peut done déjà dire qu'il n'y a point de vrai singe en Amérique

Le babouin ${ }^{4}$, qui est un animal plus gros qu'un dogue, et dont le corps est raceourei, ramassé à peu près conme celui de l'hỵene, est

I Satyrus indicus, Omang-oulang Indis, et homn sỵlvestris dictus, Charleton, Exer., pag. 16. - L'homme des bois. Brissun, Rigne animal, page 189.

2 Ce singe, que nous arons vu virant, el que $\mathbf{M}$. Dupleix avait anené de Pondichéry, n'est iuslìué daus ancune no menclature.

sinuia simpliciler diela. Ilay, synops. quadrup., pas. 119.

4 Pajio. Ray. Synops. pluadrup, pas. 158. - Bahio Charleton, Exer. pas. 16. -Cebus-papio. Bahoon. Hyxna Cicsueri. Klein, de Qnadrup., lag. 89. - Babouin. Mém. de Kolbe, lome 111, page $33 .-1$ risson, Regne animal, pag: 193. 
fort différent des singes dont nous venons de parler; il a la queue très-courte et toujours droite, le museau allongé et large à l'extrémité, les fesses nues et couleur de sang, les jambes fort courtes, les ongles forts et pointus. Cet animal, qui est très-fort et très-mécliant, ne se trouve que dans les déserts des parties méridionales de l'ancien continent, et point du tout dans ceux de l'Amérique.

Toutes les espèces de singes qui n'ont point de queue, ou qui n'ont qu'une queue trèscourte, ne se trouvent done que dans l'aneien continent; et parmi les espèces qui ontde longues queues, presque tous les grands se trouvent en Afrique; il y en a peu qui soient même d'une taille médioere en Amérique : mais les animaux qu'on a désignés par le nom générique de petits singes à longue queue y sont en grand nombre. Ces espèces de petits singes à longue queue sont les sapajous, les sagouins, les tamarins, ete. Nous verrons, dans l'histoire particulière que nous ferons de ces animaux, que tous ces singes d'Amérique sont différents des singes de l'Afrique et de l'Asie.

Les makis ${ }^{1}$, dont nous connaissons trois ou quatre espèces ou variétés, et qui approchent assez des singes à longue queue, qui comme eux ont des mains, mais dont le museau est beaucoup plus allongé et plus pointu, sont encore des animaux particuliers à l'ancien continent, et qui ne se sont pas trouvés dans le nouveau. Ainsi tous les animaux de l'Afrique ou de l'Asie méridionale qu'on a désignés par le nom de singes ne se trouvent pas plus en Amérique que les éléphants, les rhinocéros ou les tigres. Plus on fera de recherches et de comparaisons exactes à ce sujet, plus on sera conyancu que les animaux des parties méridionales de chacun des eontinents n'existaient point dans l'autre, et que le petit nombre de ceux qu'on y trouve aujourd'hui ont été transportés par les hommes, comme la brebis de Guinée qui a èté portée au Brésil; le eochon d'lnde, qui au contraire a été transporté du Brésil en Guinée, et peut-être encore quelques autres espèces de petits animaux, desquels le voisinage et le commerce de ces deux parties du monde ont favorisé le transport. Il y a environ cing cents lieues de mer entre les côtes du Brésil et celles de

' Simia sciurus langinosus fuscus, etc. Gasophil. Petiver, 'abl. 17, fig. V. Prosimia fusca. Le maki. Brisson, Règne tuim., jages $220 \mathrm{cl}$ suiv. la Guinée; il y en a plus de deux mille des cótes du Pérou à celles des Indes orientales : tous ces animaux qui par leur nature ne peuvent supporter le elimat du nord, ceux mème qui, pouvant le supporter, ne peuvent produire dans ee mème climat, sont donc confinés de deux ou trois cótés par des mers qu'ils ne peuvent traverser, et d'autre côté par des terres trop froides qu'ils ne peuvent habiter sans périr : ainsi l'on doit cesser d'être étonné de ce fait général, qui d'abord parait très-singulier, et que personne avant nous n'avait mème soupęonné, savoir, qu'aucun des animaux de la zone torride dans l'un des continents ne s'est trouvé dans l'autre.

\section{ANIMAUX}

\section{COMMUNS AUX DEUX CONTINENTS.}

Nous arons vu, par l'énumération précédente, que, non-seulement les animaux des climats les plus chauds de l'Afrique et de l'Asie manquent à l'Amérique, mais même que la plupart de eeux des elimats tempérés de l'Europe y manquent également. II n'en est pas ainsi des animaux qui peuvent aisément supporter le froid et se multiplier dans les climats du nord; on en trouve plusieur's dans l'Amérique septentrionale, et quoique ce ne soit jamais sans quelque différence assez marquée, on ne peut cependant se refuser à les regarder comme les mèmes, et à croire qu'ils ont autrefois passé de l'un à lautre continent par des terres du nord, peut-être encore actuellement inconnues, ou plutôt aneiennement submergées; et cette preuve, tirée de l'histoire naturelle, démontre mieux la contiguité presque continue des deux continents vers le nord, que toutes les conjeetures de la géographie spéculative.

Les ours des lllinois, de la Louisiane, etc. , paraissent être les mêmes que nos ours; ceux. là sont seulement plus petits et plus noirs.

Le cerf du Canada, quoique plus petit que notre cerf, n'en differe an reste que par la plus grande hauteur du bois, le plus grand nombre d'andouillers et par la queue qu'il a plus longue.

Il en est de mème du cherreuil qui se trouve 
su midi du Canada et dans la Louisiane, qui est aussi plus petit, et qui a la queue plus longue que le ehevreuil d'Europe; et encore de l'orignal, qui est le même animal que l'élan, mais qui n'est pas si grand.

Le renne de Laponie, le daim de Groënland et le karibou de Canada me paraissent ne faire qu'un seul et même animal. Le daim ou eerf de Groënland, décrit et dessiné par Édouard ', ressemble trop au renne pour qu'on puisse le regarder comme faisant une espèce différente; et à l'égard du karibou, dont on ne trouve sulle part de deseription exacte, nous avous eependant jugé par toutes les indications que nous avons pu recueillir, que c'était le même animal que le renne. M. Brison ${ }^{2}$ a cru devoir en faire une espèce différente, et il rapporte le karibou au cervus buryundicus de Jonston; mais ce cervus burgundicus est un animal inconnu, et qui, sûrement, n'existe ni en Bourgogne, ni en Furope : c'est simplement un nom que l'on aura donné à quelque tète de cerf ou de daim dont le bois était bizarre; ou bien il se pourrait que la tète de karibou qu'a vue M. Brisson, et dont le bois n'était composé, de chaque côté, que d'un seul merrain droit, long de dix pouces, avee un andouiller près de la base, tourné en avant, soit en effet une tête de remne femelle, ou bien une jeune tête d'une première ou d'une seconde année : car on sait que dans le renue la femelle porte un bois comme le mâle, mais beaucoup plus petit, et que, dans tous deux, la direction des premier's andonillers est en avart; et enlin, que, dans cet animal, l'étendue et les ramificntions du bois, comme dans toutes les autres qui en portent, suivent exactement la progression des années.

I.es lièvres, les écureuils, les hérissons, les rats musqués, les loutres, les marmottes, les rats, les musaraignes, les chauves-souris, les taupes, sont aussi des espèces (pu'on pourrait renarder comme communes au deux continents, quoique, dans tous ces genres, il u'y ait aucune espèce qui soit parfaitement semblable en Amérique ì celles de l'Europe; et l'on sent qu'il est bien diflicile, pour ne pas dire impossible, de prononcer si ce sont réellement des espèces dillérentes, ou seulement des variétés

- Voyez A Natural Ilistory of birds by George Edwards L.

¿Brissun, hegue animal, page 91. de la même espèce, qui ne sont devenues constantes que par l'influence du climat.

Les eastor's de l'Europe paraissent être les mêmes que ceux du Canada : ces animaux préferent les pays froids, mais ils peuvent aussi subsister et se multiplier daus les pays tempérés. Il y en a eneore quelques-uns en France dans les îles du Rhône; il y en avait autrefois en bien plus grand nombre, et il paraît qu'ils aiment encore moins les pays trop peuplés que les pays trop chauds. Ils n'établissent leur société que dans des déserts éloignés de toute habitation; et clans le Canada même, qu'on doit encore regarder comme un vaste désert, ils se sont retirés fort loin des habitations de toute la colonie.

Les loups et les renards sont aussidesanimaux communs aux deux continents : on les trouve dans toutes les parties de l'Amérique septentrionale, mais avec des variétés; il y a surtout des renards et des loups noirs, et tous y sont en général plus petits qu'en Europe, comme le sont aussi tous les autres animaux, tant ceux qui sont naturels au pays, que ceux qui y ont été transportés.

Quoique la belette et l'hermine fréquentent les pays froids en Europe, elles sont au moins très-rares en Amérique. Il n'eu est pas absolument de mème des martes, des fouines et des putois.

La marte du nord de l'Amérique parait ètre la même que celle de notre nord; le vison du Canada ressemble beaucoup à la fouine, et le putois rayé de l'Amérique septentrionale n'est peut-ètre qu'une variété de l'espèce du putois de l'Europe.

L.e lynx ou loup-cervier, qu'on trouve en Amérique comme en Europe, nous a paru le même animal : il habite les pays froids de préférence, mais il ne laisse pas de virre et de multiplier sous les climats tempérés, et il se tient ordinairement dans les forèts et sur les montagnes.

Le phoca ou veau marin parait confiné daus les pays du nord, et se trouve également sur les cotés de l'Europe et de l'Amérique septentrionale.

Voilà tous les animaux, à très-peu près, qu'on peut regarder comme communs aux deux contiments de laneien ef du nouveau monde; et dans ce nombre, qui, comme l'on voit, n'est pas considérable, on doit en retraucher peut- 
ètre encore plus d'un tiers, dont les espèces, quoique assez semblables en apparence, peuvent cependant être réellement différentes. Mais, en admettant même dans tous ces animaux l'identité d'espèce avec ceux d'Europe, on voit que le nombre de ces espèces communes aux deux continents est assez petit, en comparaison de celui des espèces qui sont propres et particulières à elacun des deux : on voit de plus qu'il n'y a, de tous ces animaux, que ceux qui habitent ou fréquentent les terres du nord, qui soient communs aux deux mondes, et qu'aucuns de ceux qui ne peuvent se multiplier que dans les pays chauds ou tempérés ne se trouvent à la fois dans tous les deux.

Il ne parait donc plus douteux que les deux continents ne soient ou n'aient été contigus vers le nord, et que les animaux qui leur sont communs n'aient passé de l'un à l'autre par des terres qui nous sont incommues. On serait fondé à croire, surtout d'après les nouvelles découvertes des Russes au nord de Kamtschatka, que c'est avec l'Asie que l'Amérique communique par des terres contiguës : et il semble, au contraire, que le nord de l'Europe en soit et en ait toujours été séparé par des mers assez considérables pour qu'aucun animal quadrupède n'ait pu les franchir : cependant les animaux du nord de l'Amérique ne sont pas précisément ceux du nord de l'Asie; ce sont plutôt ceux du nord de l'Europe. Il en est de même des animaux des contrées tempérées. L'argali ${ }^{1}$, la zibeline, la taupe dorée de Sibérie, le musc de la Chine ne se trouvent point à la baje d'Hudson, ni dans aucune autre partie du nord-ouest du nouveau continent; on trouve au contraire, daus les terres du nord-est de l'Amérique, nonseulement les animaux communs à celles du nord en Europe et en Asie, mais aussi ceux qui semblcnt être particuliers à l'Europe seule, comme l'élan, le renne, etc.; néanmoins, il faut avouer que les parties oricntales du nord de l'Asie sont encore si peu comnues, qu'on ne peut pas assurer si les animaux du nord de l'Europe s'y trouvent ou nes'y trourent pas.

Nous arons remarqué, comme une chose très-singulière, que, dans le nouveau continent,

\footnotetext{
1 Argali, animal de Sibérie, dont \$. Gmclin donue une honne description dans te premier lome de ses Voyages. prage $\mathbf{3 6 8}$, et qu'il croit être le mème auimıl que le musimon un mouflun des anciens. Pline a parlé de cel animal, ct Gessner en fait mention daus son II istoire des quatrupèdes, pages 834 et 035
}

les animaux des provinces méridionales sont tous très-petits, en eomparaison des animaux des pays chauds de l'ancien continent. Il n'y a, en effet, nulle comparaison pour la grandeur de l'éléphant. du rhinocéros, de l'hippopotame, de la girafe, du chameau, du liou, du tigre, etc., lous animaux naturels et propres à l'ancien continent; et du tapir, du cabiai, du fourmilier, du lama, du puma, du jaguar, etc., qui sont les plus grands animaux du NouveauMonde: les premiers sont quatre, six, huit et dix fois plus gros que les derniers. Une autre observation, qui vient encore à l'appui de ce fait général, c'est que tous les animaux qui ont été transportés d'Europe ell Amérique, comme les chevaux, les ânes, les bœufs, les brebis, les chèvies, les cochons, les ehiens, etc. : tous ces animaux, dis-je, y sont devenus plus petits; et que ceux qui n'y ont pas été transportés et qui y sont allés d'eux-mêmes, ceux, en un mot, qui sont communs aux deux mondes, tels que les loups, les renards, les cerîs, les chevreuils, les élans, sont aussi considérablement plus petits en Amérique qu'en Europe, et cela sans aucune exception.

Il y a donc, dlans la combinaison des éléments et des autres causes physiques, quelque chose de contraire à l'agrandissement de la nature vivante dans ce nouveau monde : il y a des obstacles au développement et peut-être à la formation des grands germes; ceux même qui; par les douces influences d'un autre climat, ont recu leur forme plénière et leur extension tout entière, se resserrent, se rapetissent sous te ciel avare et dans cette terre vide, où l'homme en petit nombre était épars, errant; où, loin d'user en maitre de ce territoire comme de son domaine, il n'avait nul empire; où, ne s'étant jamais soumis ni les animaux ni les éléments, n'ayant ni dompté les mers, ni diriogé les fleures, ni travaillé la terre, il n'était en lui-mème qu'un animal du premier rang, et n'existait pour la nature que comme un être sans conséquence, une espèce d'automate impuissant, in. capalsle de la réformer ou de la seconder : clle l'avait traité moins en mère qu'en marâtre en lui refusant le sentiment damour et le désil vif de se multiplier. Car, quoique le sauvage du Nouveau- Monde soit à peu près de même stature que l'homme de notre monde, celit ne suffit pas pour qu'il puisse faire une exception au fait général du rapetissement de la nature vivante 
dans tout ce continent. Le sauvage est faible et petit par les organes de la génération; il n'a ni poil, ni barbe, et nulle ardeur pour sa femelle: quoique plus léger que l'Européen, paree qu'il a plus d'habitude à courir, il est cependant beaucoup moins fort de corps ; il est aussi bien moins sensible; et cependant plus craintif et plus lâche; il n'a nulle vivacité, nulle activité dans l'âme; celle du corps est moins un exercice, un mouvement volontaire, qu'une nécessité d'action causée par le besoin : ôtez-lui la faim et la soif, vous détruirez en même temps le principe actif de tous ses mouvements; il démeurera stupidement en repos sur ses jambes ou couché pendant des jours entiers. Il ne faut pas aller chercher plus loin la cause de la vie dispersée des sauvages et de leur éloignement pour la société : la plus précieuse étincelle du feu de la nature leur a été refusée ; ils manquent d'ardeur pour leur femelle, et, par conséquent, d'amour pour leurs semblables : ne connaissant pas l'attachement le plus vif, le plus tendre de tous, leurs autres sentiments de ce gemre sont froids et languissants; ils aiment faiblement leurs pères et leurs enfants. La société la plus intime de toutes, celle de la même famille, n'a donc chez eux que de faibles liens; la société d'une famille à l'autre n'en a point du tout: dès lol's, nulle réunion, nulle république, nul état social. Le physique de l'amour l'ait ehez eux le moral des mœurs; leur cour est glacé, leur société froide et leur empire dur. Ils ne regardent leurs femmes que comme des servantes de peicie ou des bêtes de somme, qu'ils ehargent, sans ménagement, du fardeau de leur chasse, et qu’ils forcent sans pitié, sans recomnaissance, à des ouvrages qui, souvent, sont au-dessus de leurs forces : ils n'ont que peu d'eufants; ils en ont peu de soin : tout se ressent de leur premier' défaut; ils sont indifférents, parce qu'ils sont peu puissants; et cette indifférence pour le sexe est la tache originelle qui flétrit la nature, qui l'empêche de s'épanouir, et qui détruisant les germes de la vie, coupe en même temps la racine de la société.

L'homme ne fait done point d'exception ici. La nature, en lui refusant les puissances de l'amour, l'a plus maitraité et plus rapetissé qu'aucun des animaux. Mais, avant d'exposer les causes de cet effet général, nous ne devons pas dissimuler que si la nature a rapetissé dans le Nouveau-Moude tous les animaux quadrupè- des, elle parait avoir maintenu les reptiles et. agrandi les insectes : car, quoique au Sénégal il y ait encor'e de plus gros lézards et de plus longs serpents que dans l'Amérique méridionale, il n'y a pas à beaucoup près la même différence entre ces animaux qu'entre les quadrupèdes; le plus gros serpent du Sénégal n’est pas double de la grande couleurre de Cayenne; au lieu qu'un éléphant est peut-ètre dix fois plus gros que je tapir qui, comme nous l'avons dit, est le plus grand (quadrupède de l'Amérique méridionnale. Mais, à l'égard des insectes, on peut dire qu'ils ne sont nulle part aussi grands que dans le Nouveau-Monde. Les plus grosses araignées, les plus grands scarabées, les chenilles les plus longues, les papillons les plus étendus se trouvent aı Brésil, à Cayenne et dans les autres provinces de l'Américue méridionale; ils l'emportent sur prespue tous les insectes de l'ancien monde, non-seulement par la grandeur du corps et des ailes, mais aussi par la vivacité des couleurș, le mélange des nuances, la variété des formes, le nombre des espèces et la multiplication prodigieuse des individus dans chacune. Les crapauds, les grenouilles et les autres bêtes de ce genre sont aussi très-grosses en Amérique. Nous ne dirons rien des oiseaux ni des poissons, parce que, pouvant passer d'un monde à l'autre, il serait presque impossible de distinguer ceux qui appartiennent en propre à l'un ou à l'autre; au lieu que les insectes et les reptiles sont à peu près, comme les quadrupèdes, confinés chacun dans son continent.

Voyons donc pourquoi il se trouve de si grands reptiles, de si gros insectes, de si petits quadrupèdes et des hommes si froids dans ce nouveau monde. Cela tient à la qualité de la terre, à la condition du ciel, au degré de chaleur, à celui d'humidité, à la situation, à l'élévation des montagnes, à la 'quantité des eaux courantes ou stagnantes, à l'étendue des forèts, et surtout à l'état brut dans lequel on y voit la nature. La chaleur est, en général, beancoup moindre dans eette partie du moncle, et l'humidité beaucoup plus grande. Si l'on compare le froid et le chaud dans tous les decrrés de latitude, on trouvera qu'à Quéhec, c'est-it-dire sous celle de Paris, l'eau des fleuves gèle tous les ans de quelques pieds d'épaisseur; qu'une masse encore plus épaisse de neige y couvre la terre pendant plusieurs mois; que l'air y est si 
froid, que tous les oiseaux fuient et disparaissent pour tout l'hiver, etc. Cette difiérence de température sous la même latitude dans la zone tempérée, quoique très-grande, l'est peut-être encore moins que celle de la chaleur sous la zone torride. On brûle au Sénégal, et sous la même ligne on jouit d'une douce température au Pérou: il en est de même sous toutes les autres latitudes qu'on voudra comparer. Le continent de l'Amérique est situé et formé de facon que tout concourt à diminuer l'action de la chaleur: on y trouve les plus hautes montagnes, et, par ła même raison, les plus grands fleuves du monde. Ces hautes montagnes folment une chaine qui semble borner vers l'ouest le continent dans toute sa longueur : les plaines et les basses terres sont toutes situées en-decà des montagnes, et s'étendent depuis leur pied jusqu'à la mer, qui, de notre côté, sépare les continents. Ainsi le vent d'est, qui, comme l'on sait, est le vent constant et général entre les tropiques, n'arrive en Amérique qu'après a voir traversé une très-vaste étendue d'eau, sur laquelle il se rafraichit; et c'est par cette raison qu'il fait beaucoup moins chaud au Brésil, à Cayenne, etc., qu'au Sénégal, en Guinée, etc., oú ce même vent d'est arrive chargé de la chaleur de toutes les terres et des sables brûlants qu'il parcourt en traversant et l'Afrique et l'Asic. Qu'on se rappelle ce que nous avons dit zu sujet de la différente couleur des hornmes, et, en particulier, de celle des Nègres ; il paraît démontré que la teinte plus ou moins forte du tanné, du brun et du noir dépend entièrement de la situation du climat; que les Nègres de Nigritie et ceux de la cóte occidentale de l'Afrique sont les plus noirs de tous, parce que ces contrées sont situées de manière que la chaleur y est constamment plus grande que dans aucun autre endroit du globe, le vent d'est, avant d'y arriver, ayant à traverse. des trajets de terre immenses ; qu'au contraire, les Indiens méridionaux ne sont que tannés, et les Brasiliens bruns, quoique sous la même latitude que les Nègres, parce que la chaleur de leur climat est moindre et moins constante, le vent d'est n'y arrivant qu'après s'ètre rafraîchi sur les eaux et chargé de vapeurs humides. Les nuages, qui interceptent la lumière et la chaleur du soleil, les pluies qui rafraîchissent l'air et la surface de la terre, sont périodiques et durent plusieurs mois à Cayenne et dans les autres contrées de l'Améri- que méridionale. Cette première causc rend donc toutes les côtes orlentales de l'A mérique beaucoup plus tempérées que l'Afrique et l'Asie; et, lor'sque après être arrivé frais sur ces côtes, le vent d'est commence à reprendre un degré plus vif de chaleur en traversant les plaines de l'Amérique, il est tout à coup arrêté, refroidi par cette chaine de montagnes énormes dont est composée toute la partie occidentale du nonveau continent; en sorte qu'il fait encore moins chaud sous la ligne au Pérou qu'au Brésil et á Cay enne, etc., à cause de l'élévation prodigieuse des terres: aussi, les naturels du Pérou, du Chili, etc., ne sont que d'un brun rouge et tanné, moins foncé que celui des Brasiliens. Supprimons pour un instant la clıâne de Cordilières, ou plutôt rabaissons ces montagnes au niveau des plaines adjacentes, la chaleur eût été excessive vers ces terres occidentales, et l'on eût trouvé des hommes noirs au Pérou et au Chili, tels qu'on les trouve sur les côtes occidentales de l'Afrique.

Ainsi, par la seule disposition des terres de ce nouveau continent, la chaleur y serait déjà beaucoup moindre que dans l'ancien, et en mème temps nous allons voir que lhumidité y est beaucoup plus grande. Les montagnes étant les plus hautes de la terre, et se trouvant opposées de face à la direction du vent d'est, arrêtent, condensent toutes les vapeurs de l'air, et produisent par conséquent une quantité infinie de sources vives, qui, par leur réunion, forment bientôt des fleuves les plus grands de la terre. Il y a donc beaucoup plus d'eaux courantes dans le nouveau continent que dans l'ancien, proportionnellement à l'espace : et cette quantité d'eau se trouve encore prodigieusement augmentée par le défaut d'écoulement; les hommes n'ayant ni borné les torrents, ni dirigé les fleuves, ni séché les marais, les eaux stagnantes couvrent des terres immenses, augmentent encore l'humidité de l'air et en diminuent la chaleur. D'ailleurs, la terre étant partout en fliche et couverte dans toute son étendue d'herbes grossières, épaisses et touffues, elle ne s'écliauffe, ne se sèche jamais : la transpiration de tant de végétaux, pressés les uns contre les autres, ne produit que des exhalaisons humides et malsaines; la nature, cachée sous ses vieux vêtements, ne montra jamais de parure nouvelle dans ces tristes contrées; n'étant ni caressée ni cultivée par l'homme, jamais elle n'a- 
vait ouvert son sein bienfaisant; jamais la terre n'avait vu sa surface dorée de ces riches épis qui font notre opulence et sa fécondité. Dans cet état d'abandon, tout languit, tout se corrompt, tout s'étouffe: I'air et la terre, surchargés de vapeurs humides et nuisibles, ne peuvent s'épurer ni profiter des influences de l'astre de la vie: le soleil darde inutilement ses rayons les plus vifs sur cette masse froide; elle est hor's d'état de répondre à son ardeur; elle ne produira que des êtres humides, des plantes, des reptiles, les insectes, et ne pourra nourrir que des hommes froids et des animaux faibles.

C'est done principalement paree qu'il y avait peu d'hommes en Amérique, et parce que la plupart de ces hommes, menant la vie des animaux, laissaient la nature brute et négligeaient la terre, qu'elle est demeurée froide, impuissante à produire les principes actifs, à développer les germes des plus grands quadrupèdes, auxquels il faut, pour croitre et se multiplier, toute la chaleur, toute l'activité que le soleil peut donner à la terre amoureuse ; et e'est par la raison contraire que les insectes, les reptiles et toutes les espèces d'animaux qui se traînent dans la fange, dont le sang est de l'eau, et qui pullulent par la pourriture, sont plus nombreuses et plus grandes dans toutes les terres basses, humides et marécageuses de ce nouveau continent.

Lorsqu'on réfléchit sur ces différences si marquées qui se trouvent entre l'ancien et le nouveau monde, on serait tenté de croire que celuici est en effet bien plus nouveau, et qu'il a demeuré plus longtemps que le reste du globe sous les eaux de la mer; car, à l'exception des énormes montagnes qui le bornent vers l'ouest, et qui paraissent être des monuments de la plus haute antiquité dı globe, toutes les parties basses (ie ce continent semblent être des terrains nouvellement élevés et formés par le dépôt des fleuves et le limon des eaux. On y trouve en effet, en plusieurs endroits, sous la première couche de la terre végétale, les coquilles et les madrépores de la mer, formant déjà des banes, des masses de pierre à chaux, mais d'ordinaire moins dures et moins compactes que nos pierres de taille qui sont de même nature. Si ce continent est réellement aussi ancien que l'autre, pourquoi y a-t-on trouvé si peu d'hommes? pourquoi y étaient-ils presque tous sauvages et dispersés? pourquoi ceux qui s'étaient réunis en société, les Mexicains et les Péruviens, necomptaient-ils que deux ou trois cents ans depuis le premier homme qui les avait rassemblés? pourquoi ignorajent-ils encore l'art de transmettre à la postérité les faits par des signes durables, puisqu'ils avaient déjà trouvé celui de se communiquer de loin leurs idées, et de s'écrire en nouant des cordons? pourquoi ne s'étaient-ils pas soumis les animaux, et ne se servaient-ils que du lama et du pacos, qui n'étaient pas, comme nos animaux domestiques, résidants, fidèles et dociles? Leurs arts étaient naissants comme leur société, leurs talents imparfaits, leurs idées non développées, leurs organes rudes et leur langue barbare : qu'on jette les yeux sur la liste des animaux '; leurs noms sont pres-

- Pelon ichiatl oquitli. - Le lama.

Tapiierete an Brésil, maypoury ou manjpouris a la Gniane. - Le Lapir.

Tamandua-guacu au Brési], ouariri à la Guiane.-Le lama. noir.

Ouatiriouaou à la Guiane, ai ou hai au lirésil. - Le pares. seux.

Aiotochtli au Mexiyue, tatu ou tatupeba au Brésil, clicquinchum à la Nouvelle-Espagne. - Le Laton.

Tatu-ete au Brésil, taton-kabassou à la Guiane. - Le tatouet.

Macallchichiltic ou temamacama, animal qui ressemble à quelques égards à la gazelle, et qui n'a pas encore d'aulre nom que celui de gazelle de la Nouvelle-Espagne.

Jiya ou carigueibeju, animal qui ressemble assez à la loutre, et que par celte raison l'on a nomné lontre du Brésil.

Quaulitla coymatl ou quapizotl au Mexique, ou caaigoara au Brésil. - Le tajaca on tajacou.

Tlacoozclotl ou tlalocelotl. - Le chat-pard.

Cabionara ou capybara. - Le cabiai.

Tlatluahısi ocelotl an Mexique, janowara on jaguara au Brésil. - Le jaguar.

Cuguacu arana, ou cuguacu ara, ou cougonacou ara. Le couguar.

Tlayuatziı an Mexiđque, aouaré à la Guiane, carigneya au Brésil. - Le philandre.

Hoitzlaıuatzin, animal ıui ressemble au porc-épic et qui n'a pas encore d'autre nom que celui de porc-épic de la Nionvelle-Espagne.

Cuandu, ou gouandou, animal qui ressemble encore au porc-épic, que loon a nommé porc-épic du Brésil, et qui peut-ètre est le même que le précédent.

Tepe-maxtlaton au sexiyue, maragnao, ou maracaia an Brésil. - Le marac, Cet animal a la peau manpuée comme celle d'une panthère; il est de la forme et de la grossenr d'un chat; on l'a appelé ınal à propos chat-tigre, ou chat sauvage tigré, puisque sa robe est marquée comme celle de 'a panthère, et non pas comme celle du tigre.

Quauhtechalletl thiltic, ou tlilocotẹvilliu, aniusal yui resssemble à l'écureuil, et qui n'a pas encore d'autre nom yıe celui décureuil noir.

Quimichpallan, ou assapanick, aninal qui ressemble à l'écurenil volant, et qui penl-ẻlre es! le minc.

Yzquicpatı. - Ia mouffetle. C'est un animal qu'on a appelés petit-renard, renard d'Inde, blairean de surinam, nais ı ui n'est ni renard, ni blaireau; conme il répand une odeır en:pestée el qui suffoque. mème à une assez grande distance, nous l'appellerons monfette.

Xoloilzcuiutli, on cuetlachtli, animal qui a quelque res- 
que tous si difficiles à prononcer, qu'il est étomnant que les Européens aient pris la peine de les écrire.

Tout semble donc indiquer que les Américains ćtaient des hommes nouveaux, ou pour micux dire des hommes si anciennement dépaysés, qu'ils avaient perdu toute notion, toute idée de s:e monde dont ils étaient issus. Tout semble s'accorder aussi pour prouver que la plus grande partie descontinents del'A mérique était une terre nouvelle, encore hors de la main de l'homme, et dans laquelle la nature n'avait pas eu le temps d'établir tous ses plans, ni celui de se développer dans toute son étendue; que les hommes y sont froids et les animaux petits, parce que l'ardeur des uns et la gr'andeur des autres dépendent de la salubrité et de la chaleur de l'air ; et que, dans quelques siècles, lorsqu'on aura défriché les terres, abattu les forèts, dirigé les fleuves et contenu les eaux, cette même terre deviendra la plus féconde, la plus saine, la plus riche de toutes, comme elle paraît déjà l'être dans toutes les parties que l'homme a travaillées. Cependant nous ne voulons pas en conclure qu'il y naîtra pour lors des animaux plus grands : jamais le tapir et le cabiai n'atteindront ¿ la taille de l'éléphant ou de l'hippopotame; mais au moins les animaux qu'on $y$ transportera ne diminueront pas de grandeur, comme ils l'ont fait dans les premiers temps : peu à peu l'homme remplira le vide de ces terres immenses, qui n'étaient qu'un désert lorsqu'on les découvrit.

I.es premiers historiens qui ont écrit les conquètes des Espagnols ont, pour augmenter la gloire de leurs armes, prodigieusement exagéré le nombre de leurs ennemis. Ces historiens pourraient-ils persuader à un homme sensé qu'il y avait des millions d'hommes à Saint-Domingue et à Cuba, lorsqu'ils disent en mème temps (ju'il n'y avait parmi tous ces hommes ni monarchie, ni république, ni presque aucune soı iété; et quand on sait d'ailleurs que, dans ces lieux grandes fles voisines l'une de l'autre, et en même temps peu éloignées de la terre ferme lil continent, il n'y avait en tout que cinc espèces d'animaux quadrupèdes, dont la plus grande était à peu près de la grosseur d'un écureuil ou d'un lapin? Rien ne prouve mieux que

semblance avec le loup. et qui n'a pas encore d'autre nom que celui de loup du Mexique , etc. ce fait comblen la nature était vide et déserte dans cette terre nouvelle. " On ne trouva, dit " de Laet, dans l'ile de Saint-Domingue que fort " peu d'espèces d'animaux à quatre pieds. " comme le hutias, qui est un petit animal peu " différent de nos lapins, mais un peu plus " petit, avec les oreilles plus courtes et la queue " comme une taupc... le chemi, qui est pres" que de la même forme, mais un peu plus " grand que le hutias... le mohui un peu plus " petit que le hutius... Le cori pareil en gran" deur au lapin, ayant la gueule comme une " taupe, sans queue, les jambes courtes; il y en " a de blancs $\epsilon t$ de noirs, et plus souvent mêlés " des deux : c'est un animal domestique et " grandement privé... De plus une petite espèce "de chiens, qui étaient absolument muets. " Aujourd'bui ily a fort peu de tous ces animaux, par'e que les chiens d'Europe les ont détruits. " Il n'y avait, dit Acosta, aux iles de Saint" Domingue et de Cuba, non plus qu'aux Ana tilles, presque aucuns animaux du noureau " continent del'Amérique, et pas un seul des ani" maux semblables à ceux d'Europe'. " "Tout "ce qu'il y a aux Antilles, dit le père du Ter" tre, de moutons, de chèvres, de chevaux, de " bœufs, d'ânes, tant dans la Guadeloupe que " dans les autres îles habitées par les Français, " a été apporté par eux; les Espagnols n"y cn a mirent aucun, comme ils ont fait daus les au" tres îles, d'autant que les Antilles étant daus " ce temps toutes couvertes de bois. le bétail - n'y aurait pu subister sans herbages . " M. Fabri, que j'ai déjà eu occasion de citer dans cet ouvrage, qui avait erré pendant quinze mois dans les terres de l'ouest de l'Amérique, au-delà du fleuve Mississipi, m'a assuré qu'il avait fait souvent trois et quatre cents lieues sans rencontrer un seul homme. Nos officiers qui ont été de Québec à la belle rivière d'Ohio, et de cette rivière à la Louisiane, conviennent tous qu'on pourrait souvent faire cent et deux cents lieues dans la profondcur des terres sans rencontrer une seule famille de sauvages. Tous ces témoignages indiquent assez jusqu'à quel point la nature est déserte dans les coutrées mème de ce nouveau continent, où la température est la

I Voyez l'Histoire Naturelle des Indes, par Joseph Acosta, Iraduclion de Retuaud. Paris, 1600 , page 144 et suivanles.

2 Voyez l'Hisloire générale des Antilles, par le père du Tertre, l'aris, 1667, tome I, page $289 \mathrm{et}$ suiv., où l'on doit observer qu'il y a plusienrs choses emprunlées de Joseph icosta. 
plus agréable; mais ce qu'ils nous apprennent de plus particulier et de plus utile pour notre objet, c'est à nous défier du témoignage postérieur des descripteurs de cabinet ou des nomenclateurs, qui peuplent ce noureau monde d'animaux, lesquels ne se trouvent que dans l'ancien, et qui en désignent d'autres comme originaires de certaines contrées, où cependant jamais ils n'ont existé. Par exemple, il est clair et certain qu'il n'y arait originairement dans l'ile Saint-Domingue aucun animal quadrupède plus fort qu'un lapin ; il est encore certain que, quand il y en aurait eu, les chiens européens, devenus sauvages et méchants comme des loups, les auraient détruits : cependant on a appelé chat-tigre ou chat-tigrét de Saint-Domingue le marac ou maracaia du Brésil, qui ne se trouve que clans la terre ferme du continent. On a dit que le lézard écailleux, ou diable de Java, se trouvait en Amérique, et que les Brasiliens l'appelaient tatoe, tandis qu'il ne se trouve qu'aux Indes orientales. On a prétendu que la civette ${ }^{2}$, qui est un animal des parties méridionales de l'ancien continent, se trouvait aussi dans le nouveau, et surtout à la NouvelleEspagne, sans faire attention que les civettes étant des animaux utiles, et qu'on élève en plusieurs endroits de l'Afrique, du Levant et des Indes, comme des animaux domestiques, pour en recueillir le parfum dont il se fait un grand cornmerce, les Espagnols n'auraient pas manqué d'en tirer le mème avantage et de faire le même commerce, si la civette se fùt en effet trouvée dans la Nouvelle-Espagne.

De la même manière que les nomenclateurs ont quelquefois peuplé mal à propos le NouveauMonde d'animaux qui ue se trouvent que dans l'ancien continent, ils out aussi trausporté dans celui-ci ceux de l'autre : ils ont mis des philandres aux Indes orientales, d'autres à Amboine, des paresseux à Ceylan; et cependant les philandres et les paresseux sont des animaux d'Amérique si remarquables, l'un par l'espèce de sac qu'il a sous le ventre et dans lequel il porte ses petits, l'autre par l'excessive lenteur de sa démarche et de tous ses mourements, qu'il ne serait pas possible, s'ils eussent existé aux Indes orientales, que les voyageurs n'en eussent fait mention. Séba s'appuie du témoignage de Fran-

\footnotetext{
' Pelis silvestris, Tigrimus, Séba, vol. I, page 77.

${ }^{2}$ Brisson, Regue animal, page 258.
} iv. cois Valentin, au sujet du philandre des Indes orientales; mais cette autorité devient, pour ainsi dire, nulle, puisque ce François Valentin connaissait si peu les animaux et les poissons d'Amboine, ou que ses descriptions sont si mauvaises, qu'Artédi lui en fait le reproche, et déclare qu'il n'est pas possible de les reconnaitte aux notices qu'il en dome.

Au reste, nous ne prétendons pas assurer affirmativement et généralement que de tous les animaux qui habitent les climats les plus chauds de l'un ou de l'autre continent, aucun ne se trouve dans tous les deux à la fois; il faudrait, pour en ètre physiquement certain, les avoil' tous vus : nous prétendons seulement en étre moralement sûr, puisque cela est évident pour tous les grands animaux, lesquels seuls ont été remarqués et bien désignés par les royageurs; que cela est encore assez clair pour la plupart des petits, et qu'il en reste peu sur lesquels nous ne puissions prononcer. D'ailleur's, quand il se trouverait à cet égard quelques exceptions évidentes (ce que j'ai bien de la peine à imaginer), elles ne porteraient jamais que sur un trèspetit nombre d'animaux, et ne détruiraient pas la loi générale que je viens d'établir, et qui me parait être la seule boussole qui puisse nous gruider dans la comaissance des animaux. Cette loi, qui se réduit ì les juger autant par le climat et par le naturel, que par la figure et la conformation, se trouvera très-rarement en défaut, et nous fera prévenir ou reconnaitre beaucoup d'erreurs. Supposons, par exemple, qu'il soit question d'un animal d'Arabie, tel que l'hyène: nous pourrons assurer, sans crainte de nous tromper, qu'il ne trouve point en Laponic, et nous nedirons pas, comme quelques-uns de nos naturalistes, que l'hyène et le gllouton sont le même animal. Nous ne dirons pas, avee Kolbe, que le renard croisé, qui habite les parties les plus boréales de l'ancien et du noureau contincut, se trouve en même temps au cap de BommeEspérance, et nous trouverons que l'animal dont il parle n'est point un l'enard, mais un chacal. Nous reconnaitrons que l'animal du cap de Bomne-Espérance, que le même auteur désigne sous le nom de cochon de terre, et qui vit de fourmis, ne doit pas ètre confondu arec les fourmiliers d'Amérique, et qu'en effet cet animal du Cap est rraisemblablement le lézard écailleux, qui n’a de commun avec les fourmiliers que de manger des fourmis. De même, s'il eút 
fait attention que l'élan est un animal du Nord, il n'eut pas appelé de ce nom un animal d'Afrique, qui n'est qu'une gazelle. Le phoea, qui n'habite que les rivages des mers septentrionales, ne doit pas se trouver au cap de Bonne-Espérance '. La genette, qui est un animal de l'Espagne, de l'Asie mineure, ete., et qui ne se trouve que dans l'ancien continent, ne doit pas être indiquée par le nom de coati, qui est américain, comme on ke trouve dans M. Klein. L'ysquiepatl du Mexique, animal qui répand une odeur empestée, et que par cette raison nous appellerons mouffette, ne doit pas être pris pour un petit renard ou pour un blaireau. Le coati-mondi d'A mérique ne doit pas être confonAu, comme l'a fait Aldrovande, avec le blaireaucochon, dont on n'a jamais parlé que comme d'un animal d'Europe. Mais je n'ai pas entrepris d'indiquer ici toutes les erreurs de la nomenelature des quadrupèdes; je veux seulement prouver qu'il y en aurait moins si l'on eût fait quelque attention à la différenee des climats; si l'on eût assez étudié l'histoire des animaux, pour reconnaître, comme nous l'avons fait les premiers, que ceux des parties méridionales de ehaque continent ne se trouvent pas dans tous les deux à la fois; et enfin, si l'on se fùt en même temps abstenu de faire des noms génériques, qui confondent ensemble une grande quantité d'espèces, non-seulement différentes, mais souvent très-éloignées les unes des autres.

Le vrai travail d'un nomenclateur ne consiste pas ici à faire des recherches pour allonger sa liste, mais des comparaisons raisonnées pour la raceoureir. Rien n'est plus aisé que de prendre, dans tous les auteurs qui ont décrit des animaux, les noms et les phrases, pour en faire une table, qui deviendra d'autant plus longue, qu'on examinera moins : rien n'est plus diffieile que de les comparer avec assez de discernement pour réduire cette table à sa plus juste dimension. Je le répète, il n'y a pas, dans toute la terre habitable et connue, deux cents espèces d'animaux quadrupèdes, els y comprenant même les singes pour quarante : il ne s'agit donc que de leur assigner à chacun leur nom, et il ne faudra, pour posséder parfaitement cette nomenclature, qu'un très-médiocre usage de sa mémoire, puisqu'il ne s'agira que de retenir ees

- Vovez le Règne animal, par M. Brisson, page 230 , oú il est dit, d'après liolbe, pus le ploca, est appelé chien marin par les habitauts du cap) de Bonnc-Espérance. deux cents noms. A quoi sert-il done d'avolr fait pour les quadrupèdes des elasses, des genres, des méthodes, en un mot, qui ne sont que des échafaudages qu'on a imaginés pour aider la mémoire dans la connaissance des plantes, dont le nombre est en effet trop grand, les différences trop petites, les espèces trop peu constantes, et le détail trop minutieux et trop indifférent pour ne pas les considérer par blocs, et en faire des tas ou des genres, en mettant ensemble celles qui paraissent se ressembler le plus? Car, comme dans toutes les productions de l'esprit, ce qui est absolument inutile est toujours mal imaginé et devient souvent nuisible, il est arrivé (qu'au lieu d'une liste de deux cents noms, à quoi se réduit toute la nomenclature des quadrupèdes, on a fait des dictionnaires d'un si grand nombre de termes et de phrases, qu'il faut plus de travail pour les débrouiller, qu'il n'en a fallu pour les composer. Pourquoi faire du jargon et des phrases lorsqu'on peut parler elair, en ne prononceant qu'un nom simple? Pourquoi changer toutes les acceptions des termes, sous le prétexte de faire des classes et des genres? Pourquoi, lorsque l'on fait un genre d'une douzaine d'animaux, par exemple, sous le nom de genre du lapin, le lapin même ne s'y trouve-t-il pas, et qu'il faut l'aller chercher dans le genre du lièvre? N'est-il pas absurde, disons mieux, il n'est que ridicule de faire des classes où l'on rassemble les genres les plus éloignés, par exemple, de mettre ensemble dans la première l'homme et la chauvesouris, dans la seconde l'éléphant et le lézard écailleux, dans la troisième le lion et le furet, dans la quatrième le cochon et la taupe, dans la cinquième le rhinocéros et le rat, etc. Ces idées mal conçues ne peuvent se soutenir : aussi les ouvrages qui les contiennent sont-ils successivement détruits par leurs propres auteurs; une édition contredit l'autre, et le tout n'a de mérite que pour des écoliers ou des enfants, toujours dupes du mystère, à qui l'air méthodique paraît scientifique, et qui ont enfin d'autant plus de respect pour leur maître, qu'il a plus d'art à leur présenter les ehoses les plus claires et les plus aisées, sous un point de vue le plus obscur et le plus dificieile.

En comparant la quatrième édition de l'onvrage de M. Linnæus avec la dixième que nous

1 Vide Linnai, Syst. Nat. Holmix, 1758, tone 1, pages 18 et 19. 
venons de citer, l'homme n'est pas daus la première classe ou dans le premier ordre avec la chauve-souris, mais avee le lézard écailleux; l'éléphant, le cochon, le rhinocéros, au lieu de se trouver, le premier avec le lézard écailleux, le second avec la taupe, et le troisième avec le rat, se trouvent tous trois ensemble avec la musaraigne: au lieu de einq ordres ou classes principales, anthropomorpha, ferce, glires, jumenta, pecora, auxquelles il avait réduit tous les quadrupèdes, l'auteur', dans cette dernière édition, en a fait sept, primates, brutc, ferœ, bestice, glires, pecora, belluse. On peut juger, par ces changements essentiels et très-généraux, de tous ceux qui se trouvent dans les genres, et combien les espèces, qui sont cependant les seules choses réelles, y sont ballottées, transportées et mal mises ensemble. Il y a maintenant deux espèces d'hommes, l'homme de jour et l'homme de nuit ', homo diurnus sapiens, homo nocturnus troglodytes : ce sont ${ }^{2}$, dit l'auteur, deux espèces très-distinctes, et il faut bien se garder de croire que ee n'est qu'une variété. N'est-ce pas ajouter des fables à des absurdités ? et peut-on présenter le résultat des contes de bonnes femmes, ou les visious mensongères de quelquesvoyageurs suspects, comme faisant partie principale du système de la nature? De plus, ne vaudrait-il pas mieux se taire sur les choses qu'on ignore, que d'établir des caractères essentiels et des différences générales sur des erreurs grossières, en assurant, par exemple, que dans tous les animaux à mamelles, la femme seule a uu clitoris; tandis que nous savons, par la dissection que nous avous vu faire de plus de cent espèces d'animaux, que le clitoris ne manque à aucune femelle? Mais j'abandonne cette critique, qui cependant pourrait être beaucoup plus longue, parce qu'elle ne fait point ici mon principal objet; j'en ai dit assez pour que l'on soit en garde cuntre les erreurs, tant générales que particulières, qui ne se trouvent nulle part en aussi grand nombre que dans ces ouvrages de nomenclature, parce que, voulanty tout comprendre, on est forcé d'y réunir tout ce que l'on ne sait pas au peu qu'on sait.

1 Linn. Syst. Nat. ed. X. Holmix, 1758 , pages 20 et 24.

${ }^{2}$ Speciem troglody $t x$ ab homine sapiente dictinctisslmam , nec nustri generis illan nec sanguinis esse. statura qquanvis simillimam, dubitu non est; nc itayue varietatem credas quam vel sola membraua niclitans absolute negat. Linnæi Syst. Nat., editt. X, pag, 24.
En tirant des conséquences générales de tout ce que nous avons dit, nous trouverons que l'homme est le seul des êtres vivants dout la nature soit assez forte, assez étendue, assez flexible, pour pouvoir subsister, se multiplier partout et se prêter aux influences de tous les climats de la terre : uous verrons évidemment qu'aucun des animaux n'a obtenu ce grand privilége; que, loin de pouvoir se multiplier partout, la plupart sont bornés ct confinés dans certains climats, et mème dans des contrées particulières. L'homme est, en tout, l'ourrage du ciel; les animaux ne sont, à beaucoup d'égards, que des productions de la terre: ceux d'un continent ne se trouvent pas dans l'autre; ceux qui s'y trouvent sont altérés, rapetissés, changés souvent au point d'être méconnaissables. En faut-il plus pour être convaincu que l'empreinte de leur forme n'est pas inaltérable; que leur nature, beaucoup moins constante que celle de l'homme, peut se varier, et même se changer absolumeut avec le temps; que, par la mème raison, les espèces les moins parfaites, les plus délicates, lesplus pesantes, les moins agissantes, les moins armées, etc., ont déjà disparu ou disparaîtront? Leur état, leur vie, leur ètre dépendent de la forme que l'homme donne ou laisse à la surface de la terre.

Le prodigieux mammouth, animal quadrupède, dont nous avons souvent considéré les ossements énormes avec étonmement, et que nous avous jugé six fois au moins plus grand que le plus fort éléphant, n'existe plus uulle part; et cependant on a trouvéde ses dépouilles en plusieurs endroits éloignés les uns des autres, comme en Irlande, en Sibérie, à la Louisiane, etc. Cette espèce était certainement la première, la plus grande, la plus forte de tous les quadrupèdes : puisqu'elle a disparu, combien d'autres, plus petites, plus faibles et moins remarquables ont dù périr aussi sans avoì laissé ni témoignages, ni renseignements sur leur existence passée! Combien d'autres espèces s'étant dénaturées, c'est-à-dirce perfectionnées ou dégradées par les grandes vicissitudes de la terre et des eaux, par l'abandou ou la culture de la nature, par la longue influence d'un climat devenu contraire ou favorable, ne sont plus les mèmes qu'elles étaient autrefois ! Et, cependant, les animaux quadrupèdes sont, après l'homme, les êtres dont la nature est la plus fixe et la forme la plus constante : celle des 
oiseaux et des poissons varie davantage; celle des insectes, encore plus; et si l'on descend jusqu'aux plantes, quel'on ne doit point exclure de la nature vivainte, on sera surpris de la promptitude arec laquelle les espèces varient, et de la facilité qu'elles ont à se dénaturer en prenant de nouvelles formes.

Il ne serait donc pas impossible que, même sans intervertir l'ordre de la nature, tous ces animaux du Noureau-Monde ne fussent, dans le fond, les mèmes que ceux de l'ancien, desquels ils auraient autrefois tiré leur origine; on pourrait dire qu'en ayant été séparés dans la suite par des mers immenses on par des terres impraticables, ils auront, avec le temps, reçu toutes les impressions, subi tous les effets d'un climat devenu nouveau lui-même, et qui aurait aussi changé de qualité par les causes mêmes qui ont produit la séparation; que par conséquentils se seront avec le temps rapetissés, dénaturés, etc. Mais cela ne doit pas nous empêcher de les recarder aujourd'hui comme des animaux d'espèces différentes: de quelque cause que vienne cette différence, qu'elle ait été produite par le temps, le climat et la terre, ou qu elle soit de même date que la création, elle n'en estpas moins réelle. La nature, je l'avone, est dans un mourement de flux continuel; mais c'est assez pourl'homme de la saisir dans l'instant de son siècle, et de jeter quelques regards en arrière et en avant, pour tâcher d'entrevoir ce que jadis elle pouvait être, et ce que, dans la suite, elle pourrait devenir.

Et, àl'éxard de l'utilité particulière que nous pourons tirer de ces recherches sur la comparaison des animaux, on sent bien qu'indépendamment des corrections de la nomenclature, dont nous avons donné quelques exemples, nos comnaissances sur les animaux en seront plus étendues, moins imparfaites et plus sûres; que nous risquerons moins d'attribuer à un animal d'Amérique ce qui n'appartient qu’à celui des Indes orientales, qui porte le même nom; qu'en parlant des animaux étrangers sur les notices des voyageurs, nous saurons mieux distinguer les noms et les faits, et les rapporter aux vraies espèces; qu'enfin, l'histoire des animaux que nous sommes charcé d'écrire en sera moins fautive, et peut-être plus lumineuse ct plus complète.

\section{LE I.ION.}

(LE FELIS LION.)

Ordre des carnassiers, famille des carnirores, tribu des digitigrades, genre chat. (Cuvier.)

Dans l'espèce humaine, l'influence du climat ne se marque que par des variétés assez légères, parce que cette espèce est une, et qu'elle est très-distinctement séparée de toutes les autres espèces : l'homme, blanc eu Europe, noir en Afrique, jaune en Asie, et rouge en Amérique, n'est que le mème homme teint de la couleur du climat: comme il est fait pour régner sur la terre, que le globe entier est son domaine, il sẹmble que sa nature se soit prêtée à toutes les situations ; sous les feux du midi, dans les glaces du nord, il vit, il multiplie; il se trouve partout si ancienuement répandu, qu'il ne parait affecter aucun climat particulier. Dans les animaux, au contraire, l'influence du climat est plus forte et se marque par des caractères plus sensibles, parce que les espèces sont diverses et que leur nature est infiniment moins perfectionnée, moins étendue que celle de l'homme. Non-seulement les variétés dans chaque espèce sont plus nombreuses et plus marquées que dans l'espèce humaine, mais les différences mêmes des espèces semblent dépendre des différents climats: les unes ne peuvent se propager que dans les puys chauds, les autres ne peuvent subsister que dans des climats froids. Le lion n’a jamais habité les régions du nord, le renne ne s'est jamais trouvé dans les contrées du midi ; etiln'y a peut-ètre aucun animal dont l'espèce soit, comme celle de l'homme, généralement répandue sur toute la surface de la terre: chacun a son pays, sa patrie naturelle, dans laquelle chacun est retenu par la néecssité physique; chacun est fils de la terre qu'il habite, et e'est dans ce sens qu'on doit dire que tel ou tel animal est originaire de tel ou tel climat.

Dans les pays chauds, les animaux terrestres sont plus grands et plus forts que dans les pays froids ou tempérés; ils sont aussi plus laardis, plus féroces; toutes leurs qualités naturelles semblent tenir de l'ardeur du climat. Le lion, né sous le soleil brùlant de l'Afrique et des Indes, est le plus fort, le plus fier, le plus terri- 


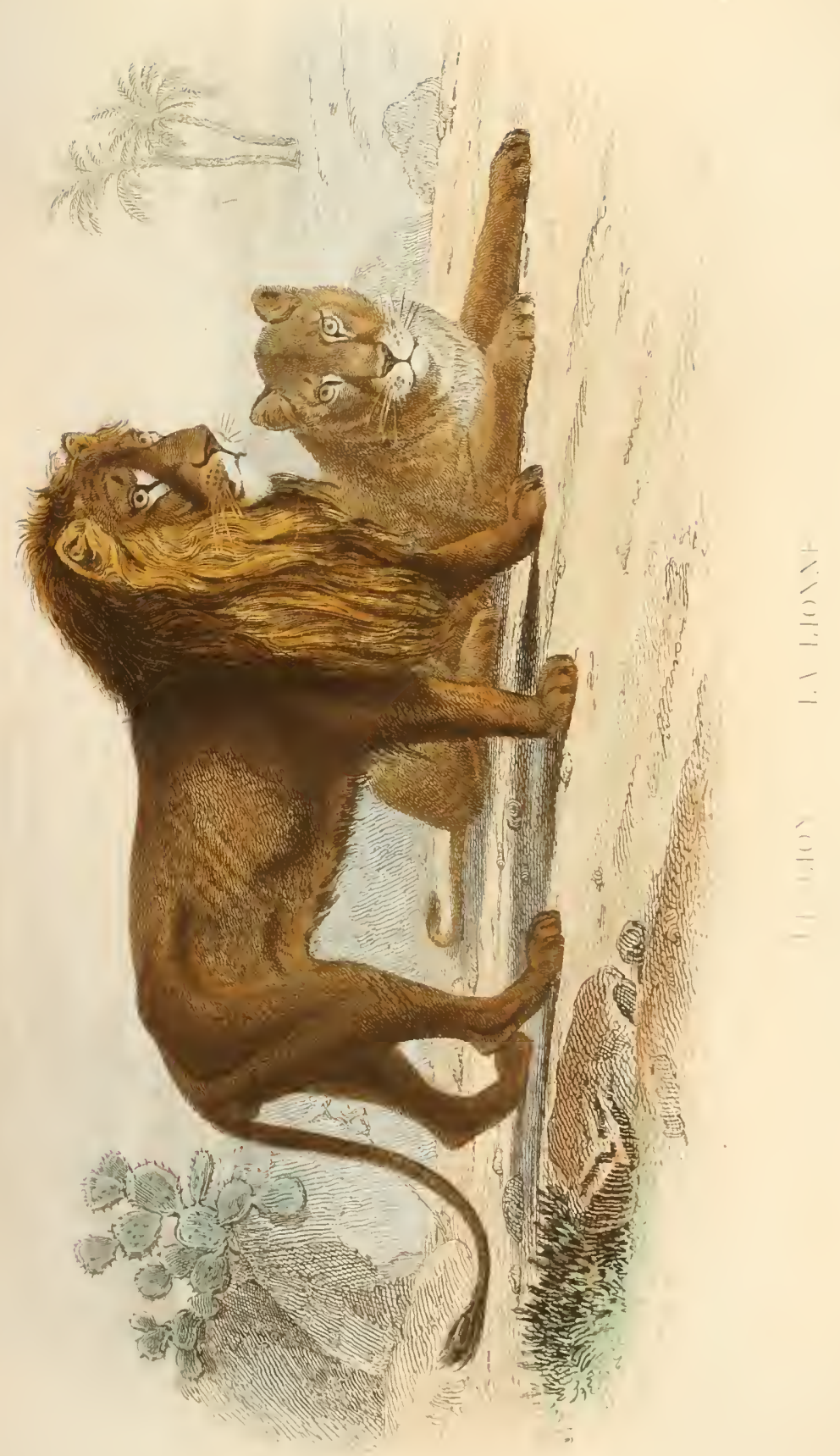



ble de tous : nos loups, nos autres animaux carnassiers, loin d'ètre ses rivaux, seraient à peine dignes d'être ses pourvoyeurs '. Les lions d'Amérique, s'ils méritent ce nom, sont, comme le climat, infiniment plus dou x que ceux de l'A fi' ique; et, ce qui prouve évílımment que l'excès de lcur férocité vient de l'excès de la chaleur, c'est que, dans le mème pays, ceux cui habitentles hautes montagnes, oi l'aiı' est plus tempéré, sont d'un naturel différent de ceux qui demeurent dans les plaines, ou la chaleur est extrême. Les lions du mont Atlas ${ }^{2}$, dont la cime est quel(puefois couverte de neige, n'ont ni la hardiesse, ni la force, ni la férocitédes lions du Biledulgerid ou dı Zaara, dont les plaines sont couveries de sables brùlants. C'est surtout dans ces déserts ardents que se trou vent ees lions terribles, pui sont l'effroi des voyageurs et le fléau des provinces voisines: heureusement l'espèce n’en est pas très-nombreuse; il parait mème (fu'elle diminue tous les jour's : ear, de l'a veu de ceux qui ont parcouru cette partie de l'Africque, il ne s'y trouve pas actuellement autant de lions, à beaucoup près, (qu'il y en avait autrefois. Les Romains, dit M. Shaw, tiraient de la Libye, pour l'usage des spectacles, einquante fois plus de lions qu'on ne pourrait y en trouver aujourd'hui. On a remarqué ảe mème qu'en Turquie, en Perse et dans l'Inde, les lions sont maintenant beaucoup moins eommuns qu'ils ne l'étaient anciemement ; et , comme ce puissant et courageux animal fait sa proie de tous les autres animaux, et n'est Jui-mème la proie d'aueun, on ne peut attribuer la diminution de quantité dans son espèce, qu'à l'augmentation du nombre diuns eclle de l'homme; ear il faut avouer que la foree de ce roi des animaux ne tient pas contre l'adresse d'un Ilottentot ou d'un Nègre, qui souvent osent l'attaquer tète à tète avec des armesassez légères. I.e lionn'ayant d'autres ennemis que l'homme, et son espèce se trouvant aujourd'hui réduite à la eincruantième, ou, si l'on veut, à la dixième partie de ce quielle était autrefois, il en résulte que l'espéce humaine, au lieu d'avoir souffert une diminution considérable depuis le temps des Y.omains (comme bien des gens le prétendent),

- Il y a une espice de Iynx quion appelle le ponrvoyeur du lions.

2 Voyez l'Afrique d'Ogilby, pages 15 el 16 ; et l'llistoire gènérale des Voyages, par M. l'abbé Prevosi, lome V. page 86. s'est au contraure augrmentée, ćtendue et plus nomỉreusement répandue, mème dans les contrées, comme la libye, où la puissance de l’homme parait avoil été plus grande dans ce temps , qui était à peu plès le siècle de Carthage, qu'elle ne l'est dan; le siecle présent de Tmnis et d' $\Lambda$ lger.

C'industrie de l'homme augmente avec le nombre: celle des animaux reste toujours la même : toutes les espècés nuisibles, comne celle du lion, paraissent ètre reléguées et rérluites à un petit nombre, non-sculement paree que l'homme est partout derenu plus nombreux, mais aussi parce qu'il est devenu plus habile, et quil a su finhripuel des armes terjibles auxquelles rien ne peut résister: heureux s'il n'eût jamais combinć le fer et le feu gue pour la destruction des lions ou des tigres !

Cette supériorité do nombre et d'industrie dans l'homme, qui brise la force du lion, en énerve aussi le comage, cotte qualite, quoique naturelle, s'cxalte ou se tempéi c dans l'animal, suivant l'usage heureux ou malheureux (ju'il a fait de sa force. Daus les vastes cléserts du Zaara, dans ceux qui semblent séparer deux raees d'hommes très-dilférentes, les Nègres et les Maures, entre le Sénégal ct les extıémités de la Mauritanie, dans les terres inhabitées qui sont au-dlessus du pays des Hottentots, et, en général, dans toutes les parties méridionales de l'Afrique et de l'Asie, où l'homme a dédaigné d'habiter, les lions sont encore en assez grand nombre, et sont tels que la nature les produit. Accoutumis à mesurer leurs forces avec tous les aumaux qu'ils rencontrent, l'babitude de vaincre les rend intrépides et terribles; ne commaissant pas la puissance de l'homme, ils u'en ont mulle crainte; n’ayant pas ép:onvé la force de ses armes, ils semblent les braver. I.es blessures les irritent, mais sans les effrayer ; ils ne sont pas mème déconcertés a l'aspect du grand nombre: un senl de ces lions du désert attaque souvent une car wane entiere, et lorsyu'aples un combat opiniàtre et violent il se sent afficibli, au lien de fuir il continue de se battre en retraite, en faisant toujours face ct sans jamais tourner le dos. L.es lions, au contraire, qui habitent aux environs des villes et des bourgades de l'Inde et de la Barbarie, ayant comnu l'homme et la foree de ses armes, ont perdu leur courage au point d'obéir à sál voir menaçante, de n’oser l'attaquer, de ne se jeter que sur le menu bé- 
tail, et enfin de s'enfuir, en se laissant poursuivre par des femmes ou par des enfants, qui leur font à coups de bàton quitter prise et làcher indignement leur proie.

Ce chargement, cet adoucissement dans le sıaturel du lion, indique assez qu'il est susceptible des impressions qu'on lui donne, et qu'il ảoit avoir assez de docilité pour s'apprivoiser jusqu'à un certain point, et pour recevoir une espèce d'éducation : anssi l'bistoire nous parle de lions attelés à des chars de triomphe, de lions conduits à la guerre ou menés à la chasse, ct qui, fidèles à leur maitre, ne déployaient leur force et leur courage que contre ses ennemis. Ce qu'il y a de très-sûr, c'est que le lion, pris jeune et élevé parmi les auimaux domestiques, s'accoutume aisément à vivre et mème à jouer innocemment arec eux; qu'il est doux pour ses maitres et même caressant, surtout dans le premier àge; ct que, si sa férocité naturelle reparait quelquefois, il la tourne rarement contre ceux qui lui ont fait du bien. Comme ses mouvements sont très-impétueux et ses appétits fort véhéments, on ne doit pas présumer que les impressions de l'éducation puissent toujours les balancer' : aussi y aurait-il quelque danger à lui laisser souffrir trop longtemps la faim, ou à le contrarier en le tourmentant hors de propos: nou-seulement il s'irrite des mauvais traitements, mais il en garde le souvenir et parait en méditer la vengeance, comme il conserve aussi la mémoire et la reconnaissance des bienfaits. Je pourrais citer ici un grand nombre de faits particuliers, daus lesquels j'avoue que j’ai trouvé quelque exagération, mais qui, cependant, sont assez fondés pour prouver au moins, płr leur réunion, que sa colère est noble, son courage magnanime, son naturel sensible. On l'a souvent vu dédaigner de petits ennemis, mépriser leurs insultes, et leur pardonner des libertés offensantes; on l'a v'u, réduit en captivité, s'ennuyer sans s'aigrir, prendre au contraire des habitudes douces, obéir it son maitre, flatter la main qui le nourrit, donner quelquefois la vie à ceux qu'on avait déroués à la mort en les lui jetant pour proie, et comme s'il se fuit attaché par cet acte généreux, leur continuer ensuite la même protection, vivre tranquillement avec eux, leur faire part de sa subsistance, se la laisser même quelquefois enlever tout entière, et souffrir plutót la faim que de perdre le fruit de son premier bienfait.
On pourrait dire aussi que le lion n'est pas cruel, puisqu'il ne l'est que par nécessité, qu'il ne détruit qu'autant qu'il consomme, et que, dès qu'il est repu, il est en pleine paix ; tandis que le tigre, le loup, et tant d'autres animaux d'especce inférieure, tels que le renard, la fouine, le putois, le furet, etc., donnent la mort pour le seul plaisir de la donner, et que, dans leurs massacres nombreux, ils semblent plutôt vou. loir assouvir leur rage que leur faim.

L'extérieur du lion ne dément point ses grandes qualités intérieures : il a la figure imposante, le regard assuré, la démarche fière, la voix terrible; sa taille n'est point excessive comme celle de l'éléphant ou du rhinocéros; elle n'est ni lourde, comme celle de l'hippopotame ou du bouf, ni trop ramassée, comme celle de l'hyène ou de l'ours, ni trop allongée, ni déformée par des inégalités comme celle du chameau: mais elle est au contraire si bien prise et si bien proportionnée, que le corps du lion parait ètre le modèle de la force jointe à l'agilité : aussi solide que nerveux, n'étant chargé ni de chair ni de graisse, et ne contenant rien de surabondant, il est tout nerfs et muscles. Cette grande force musculaire se marque au dehors par les sauts et les bonds prodigieux que le lion fait aisément; par le mouvement brusque de sa queue, qui est assez fort pour terrasser un homme; par la facilité avec laquelle il fait mou voir la peau de sa face et surtout celle de sou front, ce qui ajoute beaucoup à la physionomie ou plutòt à l'expression de la fureur; et enfin, par la faculté qu'il a de remuer sa crinière, laquelle non-seulement se hérisse, mais se meut et s'agite en tous sens, lorsuu'il est ell colère.

A toutes ces nobles qualités individuelles le lion joint aussi la noblesse de l'espèce : j'entends par espèces nobles dans la nature, celles qui sont constantes, invariables, et qu'on ue peut soupconner de s'ètre dégradées. Ces espèces sont ordinairement isolées et seules de leur genre; elles sont distinguées par des caractères si tranchés, qu'on ne peut ni les méconnaitre, ni les confondre arec aucune des autres. A commencer par l'homme, qui est l'ètre le plus noble de la création, l'espèce en est unique, puisque les hommes de toutes les races, de tous les climats, de toutes les couleurs, peuvent se mèler et produire ensemble, et qu'en même temps l'on ne doit pas dire qu'aucun animal appartienne à 
l'homme, ni de près ni de loin, par une parenté naturelle. Dans le cheval l'espèce n'est pas aussi noble que l'individu, parce qu'elle a pour voisine l'espèce de l'âne, laquelle paraît même lui appartenir d'assez près, puisque ces deux animaux produisent ensemble des individus, qu'à la vérité la nature traite comme des bâtards indignes de faire race, incapables même de perpétuer l'une ou l'autre des deux espèces desquelles ils sont issus, mais qui, provenant du mélange des deux, ne laisse pas de prouver leur grande affinité. Dans le chien, l'espèce est peut-ètre encore moins noble, parce qu'elle paraît tenir de près à celle du loup, du renard et du chacal, qu'on peut regarder comme des branches dégénérées de la même famille. Et, en descendant par degrés aux espèces inférieures, comme à celles des lapins, des belettes, des rats, etc., on trouvera que chacune de ces espèces en particulier ayant un grand nombre de branches collatérales, l'on ne peut plus reconnaître la souche commune ni la tige directe de chacune de ces familles devenues tropnombreuses. Enfin, dans les insectes, qu'on doit regarder comme les espèces infimes de la nature, chacune est accompagnée de tant d'espèces voisines, qu'il n'est plus possible de les considérer une à une, et qu'on est forcé d'en faire un bloc, e'est-à-dire un genre, lorsqu'on veut les dénommer. C'est là la véritable origine des méthodes, qu'on ne doit employer en effet que pour les dénombrements difficiles des plus petits objets de la nature, et qui deviennent totalement inutiles et même ridieules lorsqu'il s'agit des êtres du premier rang : classer l'hommeavec le singe, le lion avec le chat; dire que le lion est un chat a crinière et à queue longue, c'est dégrader, défigurer la nature, au lieu de la décrire ou de la dénommer.

L'espèce du lion est done une des plus nobles, puisqu'elle est unique, et qu'on ne peut la confondre avec celle du tigre, du léopard, de l'once, ete.; st qu'au contraire ces espèces, qui semblent être les moins éloignées de celle du lion, sont assez peu distinctes entre elles pour avoir été confondues par les voyageurs, et prises les unes pour les autres par les nomenclateur'

Les lions de la plus grande taille ont environ

- Voyez l'article des Tignres, où il est parlé des animaux auxquels on a domné mal à jropos ce nom. huit ou neuf pieds de longueur' ${ }^{\text {, }}$ depuis le mufle jusqu'à l'orjgine de la queue, qui est ellemême longue d'environ quatre pieds. Ces grands lions ont quatre ou cinq pieds de hauteur. Les lions de petite taille ont environ cinc pieds et demi de longueur sur trois pieds et demi de hauteur, et la quene longue d'environ trois pieds. Le lionme est dans toutes les dimensions d'environ un quart plus petite que le lion.

Aristote distingue deux espèces de lions, les uns grands, les autres plus petits : ceux-ci, dit-il, ont le corps plus court à proportion, le poil plus crépu, et ils sont moins courageux que les autres; il ajoute qu'en général tous les lions sont de la même couleur, c'est-à-dire de couleur fauve. Le premier de ces faits me paraît douteux; car nous ne connaissons pas ces lions à poil erépu; aucun voyageur n'en a fait mention; quelques relations, qui d'ailleurs ne me paraissent pas mériter une confiance entière, parlent seulement d'un tigre à poil frisé, qui setrouve au cap de Bonne-Espérance; mais presque tous les témoignages paraissents'accorder sur l'unité de la couleur du lion, qui est fauve sur le dos, et blanchâtre sur les côtés et sous le ventre. Cependant $A$ Elien et Appien ont dit qu'en Éthiopie les lions étaient noirs comme les hommes; qu'il y en avait aux Indes de tout blanes, et d'autres marqués ou rayés de différentes coulcurs, rouges, noires ct blẹues : mais cela ne nous paraît confirmé par aucun témoignagequ'on puisse regarder commeauthentique; car Mare-Paul, Vénitien, ne parle pas de ces lions comme les ayant vus, et Gessuer remar que avec raison qu'il n'en fait mention que d'après Alien. Il paraît au contraire qu'il y a trèspeu ou point de variétés dans cette espèce, que les lions d'Afrique et les lions d'Asie se ressemblent en tout, et que si ceux des montagnes different de ceux des plaines, e'est moins par les couleurs de la robe que par la grandeur de la taille.

Le lion porte une crinière, ou plutôt un long poil, qui couvre toutes les parties antérieures de son corps ${ }^{2}$, et qui devient toujours plus longue à mesure qu'il avance eu âge. La lionne

I Un lion forl jemue, disséqué par .u., de l'Aca lémic, avai sepl pieds el demi de long, depuis l"eutrinité du mufle jus. qu'an commencement de la quene. el quatre pieds el demi de hauteur, depuis le haut du dos jusqu'd terre. loyez. les Memoires pour servir à l'bistuire des animanx. l'aris, 1676.

${ }^{2}$ Celle criniere nes pas du criu, m is du poil a-sez doux e! lisse, comtare celui du resle du colos. 
n'a jamais ces lon's poils, quelque vieille qu'elle soit. I'animal d'Amériçue que les Européens ont appelé lion, et que les naturels du Pérou appellent pruma, n'a point de crinière; il est aussi beaucoup plus petit, plus faible et plus poltron que le vrai lion. Il ne serait pas impossible que la douceur du climat de cette partie de l'Amérique méridionale en̂t assez influé sur la nature du lion, pour le dépouiller de sa crinière, lui ôter son courage et réduire sa taille; mais ce qui parait impossible, e'est que cet animal, qui I'habite que les climats situés entre les tropiques, et auquel la ıature parait avoir fermé tous les chemins du nord, ait passé des parties méridionales de l'Asie ou de l'Afrique en Amérique, puisque ces continents sont séparés vers le midi par des mers immenses : e'est ce qui nous porte à croirc que le puma nest point un lion tirant son origine des lions de l'aneien continent, et qui aurait ensuiłe dégénéré dans le elimat du Nouveau-Monde; mais rue c'est uin animal particulier à l'Amériquue, comme le sont aussi la plupart des animaux de ce nouveau continent. Lorsque les Européens en firent la découverte, ils trouvèrent en effet que tout y était noureau; les animaux quadrupèdes, les oiseaux, les poissons, les insectes, les plantes, tout parut ineomnu, tout se trouva différent de ce qu'on avait vu jusqu'alors. Il fallut cependant dénommer les principaux objets de cette nouvelle nature : les noms dupays étaient pour la plupart barbares, très-difficiles à prononcer et encore plus à retenir : on emprunta done des noms de nos langues d'Europe, et surtout de l'espagnole et de la portugaise. Dans cette disolte de dénominations, un petit rapport dans la forme extérienre, une légère ressemblance de taille et de figure, suffirent pour attribuer à ces objets inconnus les noms des ehoses connues; de là les incertitudes, l'équivoque, l c confusion, qui s'est cncore augmentée, parcequ'en même temps qu'on donnait aux produetions du Nouveau-Mlonde les dénominations de celles de l'ancien continent, on y transportait continuellement, et dans le nème temps, les espèces d'animaux et de plantes quon n'y avait pas trouvées. Pour se tirer de cette obscurité et pour ne pas tomber à chacue instant dans l'erreur, il est done nécessaire de distinguer soigneusement ce (ui appartient en propre à l'un ct à l'autre continent, et de tâcher de ne s'en pas laisser imposer par les dénominatious actuelles, lesquelles ont presque toules été mal appliquées. Nous faisons sentir toute la nécessité de cette distinction dans un article de ce volume, et nous donnons en même temps une énumération rai. sonnće des animoux originaires de l'Amérique et de ceux qui y ont été transportés de l'ancien continent. M. de la Condamine, dont le témoignage mérite toute confiance, dit expressément qu'il ne sait pas si l'animal que les Espagnols de I'Amérique appellent lion, etles naturels du pays de Quito puma, mérite le nom de lion : il ajoute (ju'il est beaucoup plus petit que le lion d'Afrique, et que le mâle n'a point de crinière '. Fresier dit aussi que les animaux qu'on appelle lions au Pérousont bien différents des lions d'Afripue; qu'ils fuient les hommes, qu'ils ne sont à craindre yue pour les troupeaux; et il ajoute une chose très-remarquab!c, c'est que leur tête tint de celle du loup el de celle du tigre, et qu'ils ont la queue plus petite que l'un et l'autre ${ }^{2}$. On trouve, dans des relations plus anciennes, que ces lions d'Amérique ne ressemblent point àceux d'A frique; qu'ils n'en ont ni la grandeur, ni la fierté, ni la coulcur; qu'ils ne sont ni rouges, ni fauves, mais gris; qu'ils nont point de crinière, et qu'ils ont l'habitude de monter sur les arbres : ainsi ces animaux difièrent du lion par la taille, par la couleur, par la forme de la tête, par la longueur de la queue, par le manque de crinière, et enfin par lıs habitudes naturelles, caractères assez nombr'ux et assez essentiels pour faire cesser l'équivoque du nom, et pour que, dans la suite, l'on ne confonde plus le puma d'A mérique avec le vrai lion, le lion de I'Afrique ou de l'Asie.

Quoique ce noble animal ne se trouve que dans les clima!s les plus chauds, il peut cependant subsister et vivre assez longtemps daus les pays tempérés; peut-être mème avec beaucoup de soin pourrait-il y multiplier. Gessner rapporte qu'il naquit des lions dans la ménagerie de Florence; W'illugby dit cu'à Naples une lionne, enfermée avec un lion dans la même tanière, avait produil cinc petits d'une seule portée. Ces exemples sont rares, mais, s'ils sont vais, ils suffisent pour prouver que les lions ne sont pas absolument étrangers au climat tempéré ; ce-

4 Vi)jez le Voyage de l'Aunérique mérilionale, page 24 el suivintes.

2 Voyez le Voyage de Fresier à la mer lu Sud. I'aris, 1716, p.age 1.52 
pendant, il ne s'en trouve actuellement dans aucune des parties méridionales de l'Europe; et, dès le temps d'Homère, il n'y en avaitpoint dans le Péloponèse, quoiqu'il y en eût alors, et même encoredu temps d'Aristote, dans la Thrace, la Macédoine et la Thessalie. II paraît donc que, dans tous les temps, ils ont constamment donné la préférence aux elimats les plus chauds, qu'ils se sont rarement habitués dans les pays tempérés, et (qu'ils n'ont jamais habité dans les terres du nord. Les naturalistes que nous venons de citer, et qui ont parlé de ces lions nés à Florence et à Naples, ne nous ont rien appris sur le temps de la gestation de la liomne, sur la grandeur des lionceaux lorscuu'ils vionnent de naltre, sur les degrés de leur accroissement. Alien dit que la lionue porte deux nucis; Philostrate et Fdouad WVot disent, au contraire, qu'elle porte six mois : s'il fallait opter entre ces deux opinions, je serais de la dernière; cir le lion est un animal de grande taille, et nous sivous qu’en général, dans les gros animaux, la durée de la gestation est plurs longue qu'elle ne l'est dans les petits. Il en est de mème de l'accroissement du corps : les anciens et les modernes conviemnent que les lions nouveau-nés sont fort petits, de la grandeur à peu près d'ume belette, c'est-à-dire de six ou sept pouces de longueur; il leur futut donc au moins (puelques années pour grandir de huit ou neuf pieds : ils disent aussi queles lionceaux ne sont en état de marcher que deux mois après leur naissance. Sans domner une entière confinuce au rapport de ces fitits, on peut présumer, avee assez de vaisemblance, que le liou, attendu la grandeur de sa taille, est aı moins trois ou quatre ans à croitre, et qu'il doit vivre environ sept fois trois ou quatre ans, e'est-à-dire à peu près vingt-eing ans. Le sicus de Saint-Martin, maitre du combat du taureatu a Paris, qui a bien voulu me communiquer les remarques qu'il avait fuites sur les lions qu'il a nourris, m'a fait assurer qu'il en avait gardé quelques-uns pendant seize ou dix-sept ans; et il croit qu'ils ne vivent guère que vingt ou vingt-cleux ans : il en a gardé d'autres pendant douze ou quinze ans, et l'on sent hien que dans ces lions cilptifs le manque d'excreice, la contrainte ct l'ennui, ne peuvent qu'affaiblir leur santé et abréger leur vic.

Aristote assure, en deux eudroits difiérents de son ouvrage sur la grénération, que la lionne produit cinq ou six petits de la première portée, quitreou cincy de la seconde, trois on quatre de la troisieme, deux on trois de la quatrième, un ou deux de la cinquième, et qu'après cette dernière portée, qui est toujours la moins nombreuse de toutes, la lionne devient stérile. Je ne crois point celte assertion fondée; car, dans tous les animaux, les premières et les dernières portées sont moins nombreuses que les portées intermédiaires. Ce pliilosoplie s'est encore trompé, et tous les naturalistes, tant anciens que modernes, se sont trompés d'alprès Iui, lorsqu’ils ont dit que la lionne niavait que deux mamelles; il est très-sûr qu'elle ell a quatre, et il est aisé de s'en assurer par la seule inspection. Il dit aussi cfue les lions, les ours, les renards, nalssent informes, presyue inarticulés, et l'on sait, à n'en pas douter, qu'à leur naissance tous ces animaux sont aussi formés que les autres, et que tous leurs membres sont distincts et développés. Enfin, il assure que les lions s'accouplent à rebours, tandis qu'il est de mème démontré par la seule inspection des parties du mâle, et de leur direction lorsqu elles sont dans l'état propre à l'accouplement, qu'il se fait à la manière ordinaire des autres quadrupèdes. J'ai cru devoir faire mention en détail de ces petites erreurs d'Aristote, parce que l'autorité de ce grand homme a entraíné presque tous ceux qui ont écrit apres lui sur l'histoire naturelle des animaux. Cequ'il dit encore au sujet du cou du lion, qu'il prétend ne contenir (qu'un seul os, rigide, inflexilsle et saus division de vertèbres, a été démenti par l'expérience, qui mème nous a domné sur cecla un fáit très-général, e'est que, dans tous les yuadrupèdes, sans en excepter aucun, et mème daus l'homme, le cou est composé de sept vertibres ', ni plus ni moins, et ces mèmes sept vertibres se trouvent dans le cou du lion, comme dans celui de tous les autres animaux quadrupèdes. Un autre fait encore, e'est qu’en rénéral les animaux carnassices ont le cou beancoup plus court que les animaux frugiroles, et su'tout que les animaux ruminants; mais cette difiérence de longueur dans le cou des quadrupedes nedépend que de la grandeur de chaçue vertèbre, et non pas de leur nombre, qui est toujours le même: on peut s'en assurer en jetant les yeux sur l'immense collection de squelettes qui so

\footnotetext{
I.aî , espece de paresseux, eu a neut.
} 
trouve maintenant au Cabinet du Roi; on verra qu'à commencer par l'éléphant et à finir par la taupe, tous les animaux quadrupèdes ont sept vertèbres dans le cou, et qu'aucun n'en a ni plus ni moins. A l'égard de la solidité des os du lion, qu'Aristote dit étre sans moelle et sans cavité, de leur dureté qu'il compare à celle du caillou, de leur propriété de faire feu par le frottement; c'est une erreur qui n'aurait pas dù être répétée par Kolbe, ni même parvenir jusqu'à nous, puisque, dans le siècle même d'Aristote, Épicure s'était moqué de cette assertion.

Les lions sout très-ardents en amour : lorsque la femelle est en chaleur, elle est quelquefois suivie de huit ou dix mâles, qui ne cessent de l'ugir autour d'elle et de se livrer des combats furieux, jusqu'à ce que l'un d'entre eux , vainqueur de tous les autres, en demeure paisible possesseur et s'éloigne avec elle. La lionne met bas au printemps et ne produit qu'une fois tous les ans; ce qui indique encore qu'elle est occupée pendant plusieurs mois à soigner et allaiter ses petits, et que, par conséquent, le temps de leur premier accroissement, pendant lequel ils ont besoin des secours de la mère, est au moins de quelques mois.

Dans ces animaux, toutes les passions, mème les plus douces, sont excessives, et l'amour maternel est extrême. La lionue, naturellement moins forte, moins courageuse et plus tranquille que le lion, devient terrible dès qu'elle a des petits; elle se montre alors avec encore plus de hardiesse que le lion; elle ne connait point le danger; elle se jette indifféremment sur les hommes et sur les animaux qu'elle rencontre; elle les met à mort, se charge ensuite de sa proie, la porte et la partage à ses lionceaux, auxquels elle apprend de bonne heure à sucer le sang et à déchirer la chair. Dordinaire, elle met bas dans des lieux très-écartés et de difficile accès; et lorsqu'elle craint d'être découverte, elle cache ses traces en retournant plusieurs fois sur ses pas, ou bien elle les efface avec sa queue : quelquefois mème, lor'sque l'iıquiétude est grande, elle transporte ailleurs ses petits, et quand on veut les lui enlever, elle devient furieuse et les défend jusqu'à la dernière extrémité.

On croit que le lion n'a pas l'odorat aussi parfait ni les yeux aussi bous que la plujout des autres animaux de proic : on a romuryuć que la grande lumière du soleil parait l’incom- moder; qu'il marche rarement dans le milleu du jour; que c'est pendant la nuit qu'il fait toutes ses courses; que, quand il roit des feux allumés autour des troupeaux, il n'en approche guère, etc. On a observé qu'il n'évente pas de loin l'odeur des autres animaux, qu'il ne les chasse qu'à vue et non pas en les suivant à la piste, comme font les chiens et les loups, dont l'odorat est plus fin. On a même donné le nom de guide ou de pourvoyeur du lion à une espèce de lyux auquel ou suppose la vue perçante et l'odorat exquis, et on prétend que ce lynx accompagne ou précéde toujours le lion pour lui indiquer sa proie : nous connaissons cet animal, qui se`trouve, comme le lion, en Arabie, en Libye, etc., qui, comme Jui, vit de proie, et le suit peut-être (quelquefois pour profiter de ses restes; car, étant faible et de petite taille, il doit fuir le lion plutòt que de le servir.

Le lion, lorsqu'il a faim, attaque de face tous les animaux qui se présentent: mais comme il est très-redouté, et que tous cherchent à évitel sa rencontre, il est souvent obljgé de se cacher et de les attendre au passage; il se tapit sur le ventre dans un endroit fourré, d'où il s'élance avec tant de force, qu'il les saisit souvent du premier bond. Dans les déserts et les forèts, sa nourriture la plus ordinaire sont les gazelles et les singes, quoiqu'il ne prenue ceux-ci que lorsqu'ils sont à terre; car il ne grimpe pas sur lcs arbres comme le tigre ou le puma. Il mange beaucoup à la fois et se remplit pour deux ou trois jours; il a les dents si fortes qu'il brisc aisément les os, et jl les avalc avec la chair. On prétend qu'il supporte longtemps la laim : comme son tempérament est excessivement chiıd, il supporte moins patiemment la soif, ef boit toutes les fois qu'il peut trouver de l'eau. II prend l'eau en lapant comme un chien; mais au licu que la langue du chien se courbe en dessus pour laper, celle du lion se courbe en dessous; ce qui fait qüil est longtemps à boire et cquil perd beaucoup d'eau. II lui faut environ quinze lives de chair cruc chaque jour : il préfère la chair des animaux vivants, de ceux surtout quil vient d'égorger; il ne se jette pas volontiers sur des cadarres infects, et il aime micux chasser unc nouvelle proie rue de retourner chercher les restes de la première : mais, quoicfue d"ordinaire il se nourrisse de chair fraiche, son haloinc est très-forte, et son urine a une odeur insupportable. 
Le rugissement du lion est si fort que quand il se fait entendre, par échos, la nuit, dans les déserts, il ressemble au bruit du tonnerre. Ce rugissement est sa voix ordinaire : car quand Il est en colère il a un autre cri, qui est court et réiléré subitement; au lieu que le rugissement est un cri prolongé, une espèce de grondement d'un ton grave, mêlé d'un frémissement plus aigu. Il rugit cinc ou six fois par jour, et plus souvent lorsqu'il doit tomber de la pluie '. Le cri qu'il fait lorsqu'il est en colère est eneore plus terrible que le rugissement : alors il se bat les flanes de sa queue, il en bat la terre, il agite sa crinière, fait mouvoir le peau de sa faee, remue ses gros sourcils, montre des dents menaeantes, et tire une langue armée de pointes si dures, qu'elle suffit seule pour éeorcher la peau et entamer la chair sans le secours des dents ni des ongles, qui sont, après les dents, ses armes les plus cruelles. II est beaucoup plus fort par la tète, les màchoires et les jamles de devant, que par les parties postérieures du corps. Il voit la nuit, comme les elats; il ne dort pas longtemps et s'éveille aisément; mais e'est mal à propos que l'on a prétendu qu'il dormait les yeux ouverts.

La démarche ordinaire du lion est fière, grave et lente, quoique toujours oblique : sa course ne se fait pas par des mouvements égaux, mais par sauts et par bonds, et ses mouvements sont si brusques qu'il ne peut s'arrèter á l'insiant et qu il passe presque toujours son but. Lorsqu'il saute sur sa proie, il fait un bond de douze ou quinze pieds, tombe dessus, la saisit avee les pattes de devant, la déchire avec les ongles, et ensuite la dévore avec les dents. Tant qu'il est jeune et qu'il a de la légèreté, il vit du produit de sa ehasse, et quitte rarement ses déserts et ses forêts, où il trouve assez d'animaux sauvages pour subsister aisément; mais lorsqu'il devient vieux, pesant et moins propre à l'exereice de la chasse, il s'approche des lieux fréquentés et devient plus dangereux pour l'homme et pour les animaux domestiques : seulement on a remarqué que, lorsqu'il voit des hommes et des animaux ensemble, c'est toujours sur les animaux qu'il se jette et jamais sur les hommes, à moins qu'ils ue le frappent; car alors il recon-

‘ C'est du sieur Saint-Martin, maitre du Combat du Tanrean, yni a nourri julusienrs lions, que nous tenons ces dernjers faits. naít à merveille celui qui vient de l'offenser, et il quitte sa proie pour se venger. On prétend qu'il préfère la chair du chameau à celle de tous les autres animaux; il aime aussi beaucoup celle des jeunes éléphants ; ils ne peuvent lui résister lorsque leurs défenses n'ont pas encore poussé, et il en vient aisément à bout, à moins que la mère n'arrive à leur secours. L'éléphant, le rhinoeéros, le tigre et l'hippopotame, sont les seuls animaux qui puissent résister au lion.

Quelque terrible que soit eet animal, on ne laisse pas que de lui donner la chasse avee des chiens de grande taille et bien appuyés par des hommes à cheval; on le déloge, on le fait retirer; mais il faut que les ehiens et mème les chevaux soient aguerris auparavant, car presque tous les animaux frémissent et s'enfuient a la seule odeur du lion. Sa peau, quoique d'un tissu ferme et serré, ne résiste point à la balle, ni même au javelot; néanmoins on ne le tue presque jamais d'un seul coup : on le prend souvent par adresse, comme nous prenons les loups, en le faisant tomber dans une fosse profonde qu'on recouvre avee des matières légères, au-dessus desquelles on attache un animal vivant. Le lion devient doux dès qu'il est pris; et, si l'on profite des premiers moments de sa surprise ou de sa honte, on peut l'attacher, le museler et le conduire ou l'on reut.

La chair du lion est d'un gout désagréable et fort; cependant les Nègres et les Indiens ne la trouvent pas mauvaise et en mangent sour ent : la peau, qui faisait autrefois la tunique des heros, sert à ces peuples de manteau et de lit; ils en gardent aussi la graisse, qui est d'une qualité fort pénétrante, et qui mème est de quelque usage daus notre médecine ${ }^{2}$.

\section{DESCRIPTION DU LION.}

(EXTBAIT DE DALBENTOX.)

Quoicue le lion n'ait pas la taille des grands animaux, les proportions de son corps annoncent tant de foree quiil suflit de voir cet animal pour le

- Vojez l'Hislolre générale des Voyages, tome $V$, page 86. II. labbé Prevost qui, cotume tont le monde sait, écrit avec autant de claleır que déléginse, y fait une fort belle iles. cription du lion, de ses yualilés el de ses habitudes nalırelles.

2 Voyez l Ilistoire Xalurelle des Animan, par M!M. Arnaud de Nobleville el Salerue. P'aris, 1757, Lone Y, part. 2, v. 112 
croire capable de résister à ceux qui le surpassent de beaucoup en grandeur. Le lion a la tête trèsgrosse; sa face est entouree d'un poil fort long; le sommet de la lête, les tempes, les jones, la uàcloire infrrieure, le cou, le garrot, les épaules, les coudes, la poitrine et le ventre sont aussi converts de poils longs: tout le reste du corps n'a qu'un poil très-court, à l'exception du bout de la queue, qui est revêtu d'un houg̣uet de iongrs poils. Le mulle, c'est-à-dire le nuseau, est très-gros, et terminé en avant par une face plate, arrondie, formée par le bont du nez et des lèvres; celle du dessus est fendue en bec de iièvre et pendante de chaque còté, connie dans les dogues. Le clianfrein est plat et suit la même direction que le front ; cependant le front est enfoncé, et forme un sillon entre les boris. supérieurs des orbites, qui sont fort élevés. L'angle externe de cliague cil est placé plus haut que l'interne, nais cette ohliquité est moindre que tlans le loup. Les oreilles sont courtes, arrondies, et presque emièrement cachẻes dans le long poil qui couronne le frout; l'autre poil long, qui tient aux tempes, aux joues et an menton, contribue à faire paraître la tète encore plus grosse cu'elle ne l'est en effet; ct le long poil du dessus de la tête cache la partie supérieure du front, et le raccourcit, ce qui met d'autant plus en évidence la grosseur du mutle : ce contraste donne à la physionounie du lion un air lourd et stupide. La crinière, 'pui surcharse la partie antérieure du corjs, semble laisser à nu la partie postérieure, et la rendre trop peu t loffée. La queute est longue el forte; elle a plus de dianètre à son originequ'à son extrénité. Les jambes sont grosses et charmues; les pieds ont peu de longueur : on voit dans ceux de devant rue le poigutet est fort près des doigts, et, dans les pieds de derrière, qu'il y a peu de distance entre les doigts et le talon. Les ongles du lion ont une couleur blanchatre; ils sont grands et pliés en gouttière ètroite et fort profonde à la base; ils sont très-croclıus : leur pointe ne peut pas s'émousser, parce qu'elle ne touche jamais à la terre, l'ongle élant toujours relevé lorsıne l’animal n'est pas clans le cas de s'en scrvir pour saisir sa proie; la dernière platange dles ipualre doigis de claque pied re-te relevie et plice en arrière avec l'ongle qui y tient; il est caclıe dans le poil yui a plus de lougueur sur les doigts yue sur les jambes : dans cet état, les doigts sont très-courts, puisqu'ils n'ont que deux phalanges l'une au bout de l'autre.

J'ai vu, en 175\%, au Combat du Taureau à $\mathrm{Pa}$ ris, un grand lion d'Afrique, dont les dimensions sont rapportées lans la table. Le long poil de sa lète a ait une coultur faure claire ; celui rles oreilles chait noir sur la face cxterne, et faure sur l'interne. Le poil du cou et in garrot, qui formais la crinière, ét ait le plus long ; il avait jusqqu’à quinze pouce; ; sa couleur. était mèlće de brun et de fauve funcé, car chaque poil avait une couleur fauve à la racine et à l'extrémité, et ẻtait brun slans le milieu de sa loigueur. Le poil des ćpaules, de la poitrine et du ventre avait les mèmes couleurs que celui ru cou, mais il ètait moins long; celui de la face. clu dos, des côtés du corps, de lit croupe, de la face extérieure des quatre jambes, de la face supérieure des pitds de devant, du dessus et des còtés de la queue, n’avait au jus qu'un pouce; il était de couleur fauve mêlée d'une teinte olivâtre; le brun dominait sur la plus grande partie de la face, à l'exception l'une tache blanchâtre, qui était au. dessus de l'angle antérieur de chaque oil, et d'une petite bande de mène couleur, qui se trouvait audessous de cet angle. La bonche était bordée d'un poil brun noirâtre, excepté sur le bout du mulle, ou les lèvres étaient blanches. Les parties extérieures de la génération, la face intérieure des jambes, les pieuls de clerrière, et le clessous de la queue, avaient une couleur fauve très-claire et même blancluàtre; le bouquet de poils longs du bout de la queue était noir et loug de quatre pouces; les poils qui étaient entre les doigts avaient une conleur brune noilâtre, les moustaclıes étaient blan. ches, et avaient jusculà quatre pouces de lougueur.

On m’a fait voir aussi, au Combat du Taureau, un lion d'Asie qui avait à peı près les mênes conleurs que celui d'Afrique clont je viens de faire mention; mais il était plus bas et plus court; il avait la tète plus ronde, la crinière moins longue. Les jambes de devant étaient torses, de sorte que les poignets se toucliaient, comme dans les chiens bassets à jambes torses. Il y a eu au Combat du Taureau, à ce que l'on m'a assuré, trois lions d' $\mathrm{A}$. sie, qui avaient chacun tous ces caractères; mais je suis très-porté à croire que la courbure des janbes de ces lions est plutôt un vice contracté dans leur frison qu'ume conformation yropre à tous les lions le l'Asie, comme nous avons vu des jambes torses à un cerf qui avait étẻ renfermé pendant longtemps daus un petit enclos.

la lionne n'a point de crinière; on roit distinctement le tour de la face, le dessus du front, les oreilles en entier, le sommet de la tête, le cou, les épaules, les bras, le devant de la poitrine, etc. Toutes ces parties, qui sont cacliées par la crinière du lion, étant à léconvert dans la liomne, lui don. stent une apparence très-différente; et, en effet, elle a la tète plus petite et beanco:ip plus courte que le lion, le front moins enfonce, tous les traits moins exprimés, etc. Les ongles sont plus petits, et il y a d'antres diffërences dans les proportions du corps de ces deux animaux.

Cette lionne n'avait le poil lnng que de quatre ou ciny lignes sur tout le corpr, excepté le dedans des 


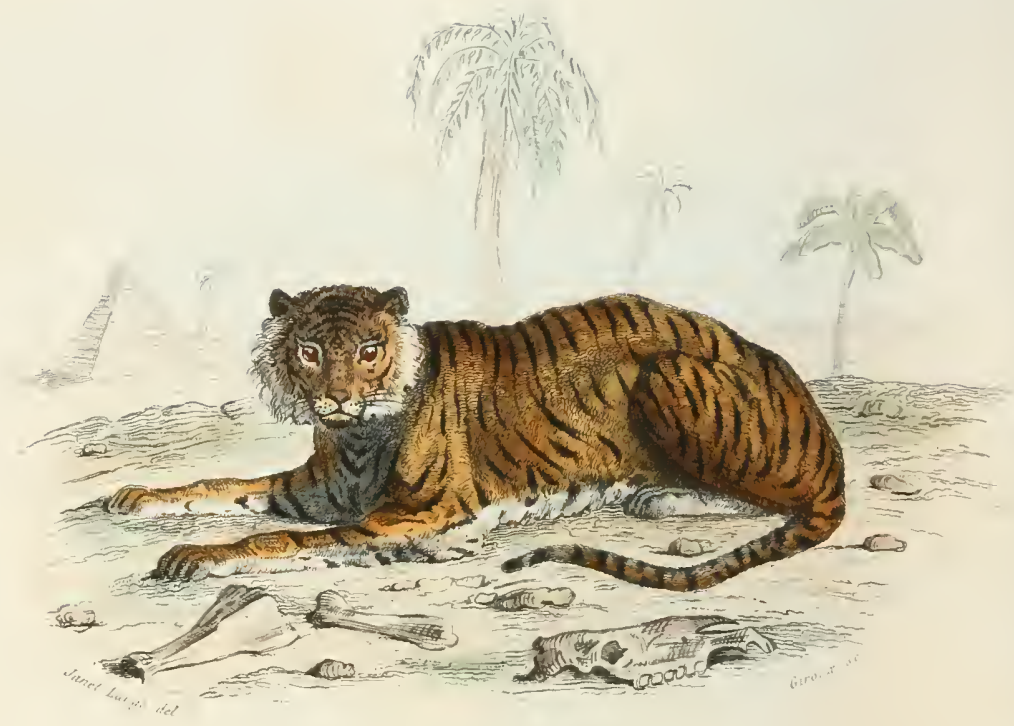

L.E. TICRE

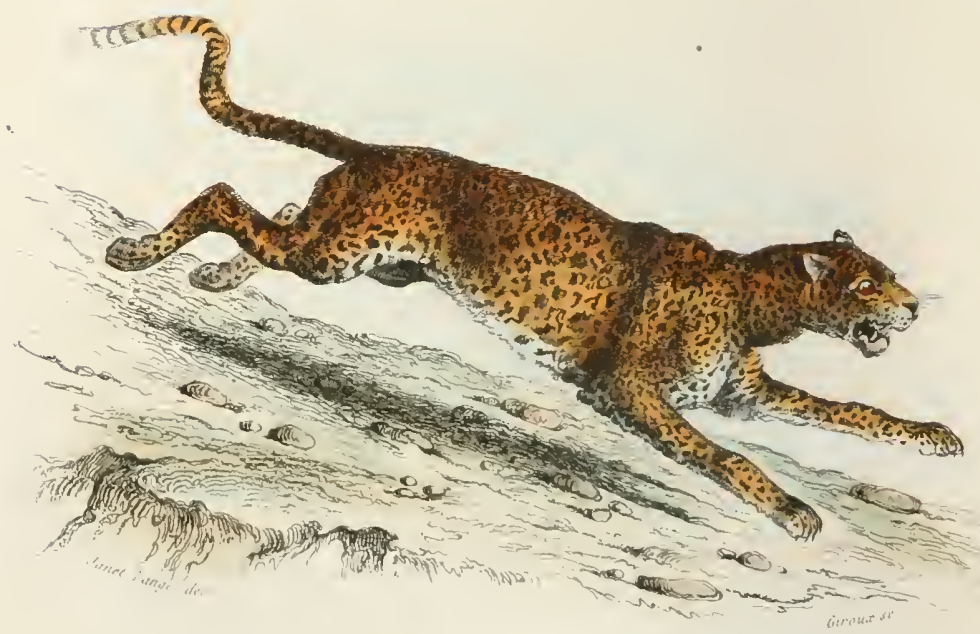

I.I P.INTIIERK 
oreilles, où il élait long de trois ponces, et le bout de la quene, dont le houguet avait deux pouces de longueur. Les moustaches étaient composées de soies grosses, fermes et blinches comme celles du lion; elles avaient jusqu'à quatre pouces et demi.

Le poil avait une couleur fauve plus on moins foncie, avec quelque mélauge de noir et des taches de cette même couleur en quelques endroits; la face, le dessus et le derrière de la tète, le dehors des oreilles, le dessus du cou, les cpaules, la face extérieure des jambes de devant, le dos, les côtes du corps, la croupe, les cuisses, la face extérieure des jambes de derrière, et le dessus de la quene, étaient de couleur fauve avec une légère teinte de brun, parce qu'un grand nombre de poils avaient l'extrémité brune. T'out le reste du corps était de conleur fauve très-claire et mème blanclıatre sous la mâchoire inférieure, sous le cou, sur le poitrail, sur les aisselles, sur la partie postérieure cles bras, sur le has-ventre, et sur la partie intérieure les cuisses et des jambes. Il y avait une tache noire de chaque côté de la lèvre inférienue près tles coins de la bonche; l'intérieur de cette lèvre, le bord de la lèvre clu dessus, le tour des paupières, et l'endroit des sourcils, étaient aussi de couleur noire : on voyait une grande tache de même couleur sur le côté postérieur de la face externe des oreilles; le bout de la yuene avait aussi une couleur noirâtre sur la longueur de yuatre pouces.

\section{LES TIGRES.}

Oride des carnassiers, famille des carnivores, tribu des digitigrades, genre (hat. (Curier.)

Comme le nom de tigre est un nom générigue qu'on a domné à plusieurs animaux d'espèces différentes, il faut commencer par les distinguer les uns des autres. Les léopards et les panthères, que l'on a souvent confondus ensemble, ont tous deux été appelés ligres par la plupart des voyageurs; l'once on l'ouca, qui est une petite espèce de panthère qui s'apprivoise aisément et dont les Orientaux se servent pour la chasse, a été prise pour la pauthère, et désignée, comme elle, par le nom de tigre. Le lynx ou loup-cervier, le pourvoyeur du lion, que les Tures appellent caraclioulah, et les Persans siyahgush, ont quelquefois aussi reçu le nom de panthere ou d'onec. 'lous ces animaux sont communs en Afrigue et dans toutes les parties pléridionales de l'Asie; mais le vrai tigre, le seul qui doit porter ce nom, est un animal rare, peu connu des anciens, et mal décrit par les modernes. Aristote, qui est en histoire naturelle le guide des uns et des autres, n'en fait aucune mention. Pline dit seulement que le tigre est un animal d'une vitesse terrible, lremenda velocitatis animal, et il donne à entendre que, de son temps, il était bien plus rare que la panthère, puisque Auguste fut le premicr qui présenta un tigre aux Romains pour la dédicace du théatra de Marcellus, tandis que dès le temps de Scaurus, cet édile avait enroyé cent cinquante panthères, et qu'ensuite Pompée en a vait fait venir quatre cent dix, et Auguste quatre cent vingt, pour les spectacles de Rome; mais Pline ne nous donne aucune description, ni même ne nous indique aucun des caractères du tigre. Oppien et Solin, qui ont écrit après Pline, paraissent être les premiers qui aient dit que le tigre était marqué par des bandes longues, et la panthère par des taches rondes : c'est en effet l'un des caractères qui distingue le vrai tigre, non-seulement de la panthère, m..is de plusieurs autres animaux qu'on a depuis appelés tigres. Strabon cite Mégasthène au sujet du vrai tigre, et il dit, d'après lui, qu'il y a des tigres aux Indes qui sont une fois plus gros que des lions. Le tigre est done un animal féroce d'une vitesse terrible, dont le corps est marqué de bandes longues, et dont la taille surpasse celle du lion. Voilà les seules notions que les anciens nous aient domnées d'un animal aussi l'emarquable : les moderues, comme Gessner et les autres naturalistes qui ont parlé du tigre, n’ont presque rien ajouté au peu qu'en ont dit les anciens.

Dans notre langue, on a appelé peaux de tigres ou peaux tigrées toutes les peaux à poil comrt, qui se sont trouvées varićes par des taches arrondies et séparées : les royageurs, par tant de cette fausse dénomination, ont à leur tour appelé tigres tous les animaux de proie dont la peau était ligréce, e'est-à-dire marquée de taches séparées. MM. de l'Académic des sciences ont suivi le torrent, et ont appelé tigres les animaux à peau tigrée qu ils ont disséqués, et qui cependant sont très-différents du v'ai tigre.

La cause la plus générale des écpuivorpues et des incertitudes qui se sont si fort multipliées en historre uaturelle, e'est, comme je l'ai indiqui dans l'article précédent, la nécessité oủ l'ou 
s'est trouvé de donner des noms aux producticns inconnues du Nouveau-Monde. Les animaux, quoique pour la plupart d'espèce et de nature très-différentes de ceux de l'ancicn continent, ont reçu les mêmes noms dès qu'on leur a trouvé quelque rapport ou quelque ressemblance avec ceux-ci. On s'était d'abord trompé en Europe, en appelant tigres tous les animaux à peau tigrée d'Asic et d'Afrique : cette erreur transportée en Amérique y a doublé; car ayant trouvé dans cette terre nouvelle des animaux dont la peau était marquée de taches arrondies et séparées, on leur a donné le nom de tigres, quoiqu'ils ne fussent ni de l'espèce du vrai tigre, ni même d'aucune de celles des animaux à peau tigrée de l'Asie ou de l'Afrique auxquels on avait déjà mal à propos donné ce même nom; et comme ces animaux à peau tigrée qui se sont trouvés en Amérique sont en assez grand nombre, et qu'on n'a pas laissé de. leur donner à tous le nom commun de tigre, quoiqu'ils fussent très-différents du tigre et différents entre eux, il se trouve qu'au lieu d'une seule espèce qui doit porter ce nom, il y en a neuf ou dix, et que par conséquent l'histoire de ces animaux est très-embarrassée, trèsdifficile à faire, parce que les noms ont confondu les choses, et qu'en faisant mention de ces animaux l'on a souvent dit des uns ce qui devait être dit des autres.

Pour prévenir la confusion qui résulte de ces dénominations mal appliquées à la plupart des animaux du Nouveau-Monde, et en particulier à ceux que l'on a faussement appelés iigres, j'ai peusé que le moyen le plus sûr était de faire une énumération comparée des animaux quadrupèdes, dans laquelle je distingue : $1^{\circ}$ ceux qui sont naturels et propr'es à l'ancien continent, c'est-à-dire à l'Europe, l'Afrique et l'Asic, et qui ne se sont point trouvés en Amérique lorsqu'on en fit la découverte; $2^{\circ}$ ceux qui sont naturels et propres au nouveau continent, et qui n'étaient point commus dans l'ancien; $3^{\circ}$ ceux qui, se trouvant également dans les deux continents, saus avoir été tıansportés par les hommes, doivent être regardés comme conmuns à l'un et à l'autre. Il a fallu pour cela recueilir et rassembler ee qui se trouve épars au sujet des arimaux, dans les voyageurs et dans les premiers historiens du Nouveau-Monde: c'est'le précis de ces recherches que nous domnons arce quelque confiance, parce que nous les croyons utiles pour l'intelligence de toute l'histoire naturelle, et en particulier de l'histoire des animaux'.

\section{LE TIGRE.}

\section{(LE FÉLIS TIGRE.)}

Ordre des caruassiers, famille des carnirores, tribu des digitigrades, genre chat. (Cuvier.)

Dans la classe des animaux carnassiers, le lion est le premier, le tigre est le second; ct comme le premier, mème dans un maurais genre, est toujours le plus grand et souvent le meilleur, le second est ordinairement le plus méchant de tous. A la fierté, au courage, à la force, le lion joint la noblesse, la clémence, la magnanimité; tandis que le tigre est bassement féroce, cruel sans justice, c'est-à dire saus nécessité. Il en est de même dans tout ordre de choses où les rangs sont donmés par la force : le premier, qui peut tout, est moins tyran que l'autre, qui, ne pouvant jouir de la puissance plénière, s'en venge en abusant du pouvoir qu'il a pu s'arroger. Aussi le tigre est-il plus à craindre que le lion : celui-ci souvent oublie qu'il est le roi , e'est-à-dire le plus fort de tous les animaux ; marchant d'un pas tranquille, il n'attaque jamais l'homme, à moins qu'il ne soit provoqué; il neprécipite ses pas, il ne court, il ne chasse quequand la faim le presse. Le tigre, au contraire, quoique rassasié de chair, semble toujours être altéré de sang; sa fureur n'a d'autres intervalles que ceux du temps qu'il faut pour dresser des embûches ; il saisit et déchire unenouvelle proie avec la même rage qu'il vient d'exercer, et non pas d'assouvir, eu dévorant la première ; il désole le pays qu'il habite, il ne craint ni l'aspect ni les armes de l'homme; il égorge, il dévaste les troupeaux d'animaux domestiques, met à mort toutes les bêtes sauvages, attaque les pctits éléphants, les jeunes rlinocéros, et quelquefois méme ose braver le lion.

La forme du corps est ordinairement d'aceord avec le naturel. Le liou a l'air noble; la hauteur de ses jambes est proportionnée à la longueur de son corps; l'épaisse et grande crinière qui couvre ses épaules et ombrage sa face, son re-

\footnotetext{
- Voyez les trois discours, $1^{\circ}$ sur les animaux de l'ancien con'inent, $2^{\circ}$ sur les animaux du Nouveau-Monde, et $5^{2}$ sur les anjmaux conmuns aux deax continents, qui sont placés
} cu tèle de ce chapitre. 
gard assuré, sa démarche grave, tout semble annoncer sa fière et majestueuse intrépidité. Le tigre, trop long de corps, trop bas sur ses jambes, la tête nue, les yeux hagards, la langue couleur de sang, toujours hors de la gueule, n'a que les caractères de la basse méchanceté et de l'insatiable cruauté; il n'a pour tout instinct qu'une rage constante, une fureur aveugle, qui ne connait, qui ne distingue rien, et qui lui fait souvent dévorer ses propres enfants, et déchirer leur mère lor'squ'elle veut les défendre. Que ne l'eût-il à l'excès cette soif de son sang l ne pût-il l'éteindre qu'en détruisant, dès leur naissance, la race entière des monstres qu'il produit !

Heureusement pour le reste de la nature, l'espèce n'en est pas nombreuse, et paraît confinée aux climats les plus chauds de l'Inde orientale. Elle se trouve au Malabar, à Siam, au Bengale, dans les mémes contr'ées qu'lıabitent l'éléphant et le rhinocéros; on prétend méme que souvent le tigre accompagne ce dernier', et qu'il le suit pour manger sa fiente, qui lui sert de purgation ou de rafraîchissement:il fréruente avec lui les bords des fleures et des lacs; car comme le sang ne fait que l'altérer, il a souvent besoin d'eau pour tempérer l'ardeur qui le consume; et d'ailleurs il attend près des eaux les animaux qui y arrivent, et que la chaleur du climat contraint d'y venir plusieurs fois chaque jour : c'est là qu'il choisit sa proie, ou plutôt qu'il multiplie ses massaeres; car souvent il abaudonne les animaux qu'il vient de mettre à mort pour en égorger d'autres; il semble qu’il cherche à gouter de leur sangr; il le savoure, il s'en eniv^e; et lorsqu'il leur fend et déchire le corps, c'est pour y plonger la tête et pour sucer à longs traits le sang dont il vient d'ouvrir la source, qui tarit presque toujours avant que sa soif ne s'éteigne.

Cependant quand il a mis a mort quelques gros animaux, comme un cheval, un luffle, il ne les éventre pas sur la place, s'il eraint d'y être inquiété : pour les dépecer à sou aise, il les emporte dans les bois, en les trainant avec tant de légèreté, que lit vitesse de sa course parait à peine ralentie par la masse énorme qu'il entraîne. Ceei seul suffirait pour faire juger de

'Vide Jac. Ilontii Ilist. Nat. In1. or. Amsterdan, 1658, p. B4. Voyez aussi le lkecueil des royages de la Compunguie des Indes. Amsleviam, 1702, toune VII, 1)age $278 \mathrm{el}$ suiv. Voyases de Sclioullıu au, Indes oricalales. sa force; mais, pour en donner une idée plus juste, arrêtons-nous un instant sur les dimen. sions et les proportions du corps de cet animal terrible. Quelques voyageurs l'ont comparé, pour la grandeur, à un cheval', d'autres à un buffle ${ }^{2}$, d'autres seulement ont dit qu'il était beancoup plus grand que le lion ${ }^{3}$. Mais nous pouvons eiter des témoignages plus récents, et qui méritent une entière confiance. M. de la Lande-Magon nous a fait assurer qu'il avait vu aux Indes orientales un tigre de quinze pieds, en y comprenant sans doute la longueur de la queue: si nous la supposons de quatre ou einc pieds, ce tigre avait au moins dix pieds de longueur. Il est vrai que celui dont nous avous la dépouille au Caloinet du Roi n'a (qu'environ sept pieds de longueur, depuis l'extrémité du mu . seau jusquu'à l'origine de la queue; mais il avait été pris, amené tout jeune, et ensuite toujours enfermé dans une loge étroite à la ménagerie, où le défaut de mouvement et le manque d'espace, l'ennui de la prison, la contrainte du corps, la nourriture peu convenable ont abrégé sa vie et retardé le développement, ou même réduit l'aceroissement du corps. Nous avons vu dans l'histoire du celf ${ }^{4}$, que ces animaux pris jeunes et renfermés dans des pares trop peu spacieux, non-seulement ne prennent pas leur eroissance entière, mais même se déforment et deviennent rachitiques et bassets, ar ec des jambes iorses. Nous sarons d'ailleurs par les dissections que nous avons faites d'animaux de toute espéce élevés et nourris dans des ménageries, qu'ils ne parviennent jamais à leur grandeur entière; que leur corps et leurs membres, qui ne peuvent s'exercer, l'estent au-dessous des dimensions de la nature; que les parties dont l'usage leur est absolument interdit, comme celles de la génération, sont si petites et si peu développées dans tous ces animaux eaptifs et célibataires, qu'on a de la peine à les trouver, et que souvent elles nous ont paru presque entière-

1 Yoyez les Voyages de l)ellon, page 10 f et suiv.

${ }^{2}$ Les tigres des Indes, dit la buniluye-le-fiuz, sout prodigieusement grands; $j^{\prime}(n)$ ai i $u$ des peaux julus longues et f.hus larges que celles des brufs, ils s'adouncut quelipuefois a manger des hommes. el ell plusicurs embloits des ludes il n'y va point de voyagenrs sans etre bien armés, parce yue cet animal, ctant de la figure d'un clat, se hauave sur les picds de derrière pour sauter sul celui y de la loullaye-le-Gouz. Paris, 1657 , pages 246 et 247.

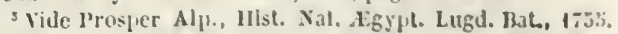
page 257 - Et wollon, page 65.

- vojez l article du cerf. 
ment ohlitérées. La seule différence du climat pourrait encore produire les mèmes effets que le manguc d'exercice et la captivité : aucun animal des pays chauds ne peut produire dans les climats froids, y fût-il mème très-libre et trèslargement nourri ; et, comme la reproduction n'est qu'une suite naturelle de la pleine nutrition, il est évident que la première ne pouvant s'opérer, la seconde ne se fait pas complétement, et que, dans ces animaux, le froid seul suffit pour restreindre la puissance du moule intérieur, et diminuer les facultés actives du déloppement, puisqu'il détruit celles de la reproduction.

II n'est douc pas étomnant que ce tigre dont le squelette et la peau nous sont venus de la ménagerie du roi ne soit pas parvenu à sa juste grandeur : cependant la seule vue de cette peau bourrée donne encore l'idée d'un animal formidable, et l'exameu du squelette ne permet pas d'en donter. L'on voit sur les os des jambes des rugosités qui marquent des attaches de muscles encore plus fortes que celles du lion; ces os sont aussi solides, mais plus courts, et comme nous l'arons dit, la hauteur des jambes dans le tigre n'est pas proportionnéc à la grande longueur du corps. Ainsi cette vitesse terrible dont parle Pline, ct que le nom ' même du tigre paraît indiquer, ne doit pas s'entendre des mouvements ordinaires, de la démarche, ni même de la célérité des pas dans une cour'se suivie ; il est évident qu'ayant les jambes courtes, il ne peut marcher "ni courir aussi vite que ceux qui les ont proportionnellement plus longues : mais cette vitesse terrible s'applique très-bien aux bonds prodigieux qu'il doit faire sans efforts; car en lui supposant, proportion gardée, autant de force et de souplesse qu'au chat, qui lui ressemble beaucoup par la conformation, et qui, dans l'instant d'un clin d'œil, fait un saut de plusieur's pieds d'étendue, on sentira que le ti-

4 Tigris vocabulum est lingua Armeniæ, natn ibi et sagitta et quod vehementissimum llumen, dieitur tigris. Varro, de lingua latina. - Persa et Medi sagillan ligrim uuncupant. Gessn. 11ist. quadru!., page 956.

${ }^{2}$ Ce que dit l'line, que cet animal est diune vitesse terrible, est une erreur, dit Boutius; car au contraire il est lent à courir, et èest à eause de cela yu'il atlaupe plus volontiers les hommes que les aninaux qui cumrent bien, comme les cerli, le: sangliel's, les bufiles, les boufs sumages, yn il nattaque lous quien se meltant en ennbuseade; il se jelle imp̨étueusement sur lenr tète, el terrasse diu seul comp de patte les animaux les plus forls. Bont., p. 55 et 54.11 est, comme lour voit, fort peu aisé de concilier ces faits avec les expressious de Pline. gre, dont le corps est dix fois plus long, peut dans un instant presque aussi coult faire un bond de plusieurs toises. Ce n'est done point la célérité de sa course, mais la vitesse du saut que Pline a voulu désigner, et qui rend en effet cet animal terrible, parce qu'il n'est pas possible d'en éviter l'effet.

Le tigre est peut-être le seul de tous les animaux dont on ne puisse fléchir le naturel : ni la force, ni la contrainte, ni la violence ne penvent le dompter. Il s'irrite des bons comme des mauvais traitements; la douce habitude, qui peut tout, ne peut rien sur cette nature de fer ; le temps, loin de l'amollir en tempérant les humeur's féroces, ne fait qu'aigrir le fiel de sa rage:il déchire la main qui le nourrit, comme celle qui le frappe; il rugit à la vue de tout être vivant; chaque objet lui parait une nouvelle proie, qu'il dévore d'avance de ses regards avides, qu'il menace par des frémissements affreux mêlés d'un grincement de dents, et vers laquelle il s'élance souvent, malgré les chaînes et les grilles qui brisent sa fureur sans pouvoir la calmer.

Pour achever de donner une idée de la force' de ce cruel animal, nous croyons devoir eiter ici ce que le père Tachard, témoin oculaire, rapporte d'un conıbat du tigre contre des éléphants. "On avait élevé, dit cet auteur, une " haute palissade de bambous d'environ cent " pas en carré. Au milieu de l'enceinte étaient " entrés trois éléphants destinés pour combattre le tigre. Ils avaient une espèce de grand plastron, en forme de masque, qui leur couvrait la tête et une partie de la trompe. Dès que " nous fümes arrivés sur le lieu, on fit sortir de " la logequi était dans un enfoncement un tigre " d'une figure et d'une couleur qui parurent " nouvelles aux Français qui assistaient à ce " combat; car, outre qu'il était bien plus grand, " bien plus gros et d'une taille moins effilée que ceux que nous avions vus en Franee, sa peau n'était pas mouchetée de même; mais, au lieu de toutes ces taches semées sans ordre, il a vait de longues et larges bandes en forme de cer" cle; ces bandes, prenaut sur le dos, se rejoi" guaient par-dessous le ventre, et, continuant "le long de la queue, y faisaient comme des

4 Indi tigrim elephanto robustiorem inulto existimant. Nearchus seribit Indos refer're tigrim esse maximiequi magniludiue, velocilate et viribus bestias ommes superate, elephantum etian, insilientem in caput ejus, facile sulfocaı'e, Gessu. Hist. quadrup., page 937. 
- amneaux blanes et noirs, placés alternative" ment, dont elle était toute couverte. La tête " n'avait rien d'extraordinaire, non plus que " les jambes, hors qu'elles étaient plus grandes " et plus grosses que celles des tigr'es commun, " quoique celui-ci ne füt qu'un jeune tigre qui " avait encore à croître; car $\mathbf{M}$. Constance nous " a dit qu'il y en avait dans le royaume de plus "gros trois fois que celuj-là, et qu'un jour, " étant à la chasse avec le roi, il en vit un de " fort près qui était grand comme un mulet. Il " y en a aussi de petits dans le pays, semblables " à ceux qu'on apporte d'Afrique en Europe, et " on nous en montra un le mème jour à Louvo. "On ne lâcha pas d'abord le jeune tigre qui " devait combattre, mais on le tint attaché par " deux cordes, de sorte que, n'ayant pas la "liberté de s'élancer, le premier éléphant qui " s'approcha lui domna deux ou trois coups de " sa trompe sur le dos : ce choc fut si rude que "le tigre en fut renversé, et demeura quelque " temps étendu sur la place, sans mouvement, " comme s'il cût été mort. Cependant, dìs " qu'on l'eut délié, quoique cette première at" taque en̂t bien rabattu de sa furie, il fit un " cri horrible, et voulut se jeter sur la trompe " de l'éléphant qui s'avancait pour le frapper; * mais celui-ci, la repliant adroitement, la mit "à couvelt par ses défenses, qu’il présenta en " même temps, et dont il atteignit le tigre si à " propos qu'il lui fit faire un grand saut en " l'air. Cet animal en fut si étourdi rru'il n'osa " plus approcher. Il fit plusieurs tours le long " de la palissade, s’élaneant quelquefois vers "les personnes qui paraissaient vers les gale" ries. On poussa ensuite trois éléphants contre " lui , qui lui domnèrent tour à tour de si rudes " coups, qu'il fit encore une fois le mort, et ne " peusa plus qu'à éviter leur rencontre:ils l'eus" Sent tué sans doute, si l'on n'eùt fait finir le " eombat." Il est clair, par la deseription même du pere Tachard, que ce tigre qüil a vu combattre des éléphants est le vrài tigre, qui parut aux Francais un animal nouveau, parce que probablement ils n'avaient vu en France dans Ies ménageries que des panthères ou des léopards d'Afriçue, on bien des jaguars d'Amérique, et que les petits tigres quil vit à I.ouvo n'étajent de mêne que des panthères. On sent aussi, par ee simple récit, quelle doit être la force et la fureur de cet animal, puisque celui ei, quoique jeune encore, et n'ayant pas pris tout son accroissement, quoique rédutt en cap. tivité, quoique retenu par des liens, quoique seul contre tros, était encore assez redoutable aux colosses qu'il combattait pour qu'on füt obligé de les couvris d'un plastron daus toutes les parties de leurs corps que la nature n'a pas cuirassées comme les autres d'une enveloppe impénétrable.

Le tigre dont le père Gouie' a communiqué à l'Aeadémie des sciences une deseription anatomic|ue, faite par les pères jésuites à la Chine, paraît être de l'espèce du vrai tigre, aussi bien que celui que les Portugais ont appelé tigre royal, dupuel M. Perrault fait mention dans ses mémoires sur Jes animaux, et dont il dit que la description a été faite à Siam. Dellon, dans ses Voyages, dit expressément que le Malabas est le pays des Indes où il y a le plus de tigres; yu'il y en a de plusieurs espèces; mais que le plus grand de tous, celui que les Portugais appellent tigre royal, est extrêmement rare, qu'il est grand comme un cheval, etc.

Le tigre royal ne paraît done pas faire unc espèce particulière et différente de celle du vrai tigre; il ne se trouve qu'aux Indes orientales, et non pas au Brésil, comme l'ont éerit quelquesuns de nos naturalistes. Je suis même porté à croire que le vrai tigre ne se trouve qu'en Asie et daus les parties les plus méridionales de l'Afrique, dans l'intér'jeur' des terı'es ; ear la plupart des voyageurs qui ont fréquenté les còtes de l'Afrique parlent, à la vérité, de tigres, et disent mème cu'ils y sont très-communs ; néanmoins, il est ajsé de voir, par les notices mêmes qu'ils domment de ces animaux, que ce ne sont pas de vrais tigres, mais des léopards, des panthères ou des nnees, etc. Le docteur Shaw dit expressément qu'au royaume de Tunis et d'Alger, le lion et la panthère tiennent le premier rang entre les bêtes féroces, mais que le tigre ne se trouve pas dans cette partie de la Barbarie.

- On ne commail gnère es Europe que les ligres dont la peau est mouclıclée de taches; mais, dans la Tarlarie el dans la cline, ou en connalt anssi dont la peau est rayée de bandes noires; ct même, en ces pays-là, on prélcud qque ce sont deux especes differentes, quoiqu'ils ne paraissent pas avoir d'autres differences que colle-la. Le tigre rayé que les jésuites de la Chine tisséquèrent, ct qui avail ċè tué à la chasse par l'enjpercur, avec quatre autres, ne pesait que deux cent soixansecinq lirres; aussi n' était-il pas des plus grands ; un des autres yesait quatre cents livres. Celui qui fut disséqué avait un tiers de l'estomac pleiu de vers, et l'on ne pouvait pas dire qu'il fùt corrompu. Quel(pu'un, qui était présent, dit qu०on avait louvé la même chose à un autre tigre quil avait vu ouvrir à Macao. Hisl, de l'Académie des Sciences, année 1690, p. 51. 
Cela parait vrai, car cefurent des ambassadeurs Indiens, et non pas des Africains, qui présentèrent à Auguste, dans lc temps qu'il était à Samos, le premier tigre qui ait été vu des Romains ; ct ce fut aussi des Indes qu'Héliogabale fit venir ceux qu'il voulait atteler à son char pour contrefaire le dieu Bacchus.

L'espèce du tigre a done toujours été plus rare et beaucoup moins répandue que celle du lion : cependant la tigresse produit, comme la lionne, quatre ou cinq petits. Elle est furieuse en tout temps, mais sa rage devient extrême lorsqu'on les lui ravit; elle brave tous les périls; elle suit les ravisseırrs, qui, se trouvant pressés, sont obligés de lui relâcher un de ses petits; clle s'arrête, le saisit, l'emporte pour le mettre à l'abri, revient quelques instants après, et les poursuit jusqu'aux portes des villes ou jusqu'à Icurs vaisseaux ; et lorsqu'elle a perdu tout espoir de recouvrer sa perte, des cris forcenés et lugubres; des hurlements affreux, expriment sa douleur cruelle, et font encore frémir ceux qui les entendent de loin.

Le tigre fait mouvoir la peau de sa face, grince des dents, frémit, rugit comme le fait le lion, mais son rugissement est différent : quelques voyageurs l'ont comparé au cri de certains grands oiseaux.

Tigrides indomitæ rancant, ruginntque leones. Auctor PHLOMEdE.

Ce mot rancant n'a point d'équivalent en fiancais; ne pourrions-nous pas lui en donner un, et dire : "Les tigres rauquent et les lions rugissent? ") car le son de la voix du tigre est en effet très-rauque ${ }^{1}$.

La peau de ces animaux est assez estiméc, surtout à la Chine : les mandarins militaires en couvrent leurs chaises daus les marches publiques; ils en font aussi des couvertures de coussins pour l'hiver. En Europe, ces peaux, quojque rares, ne sont pas d'un grand prix. On fait beaucoup plus de cas de eclle du léopard de Guinée et du Sénégal, que nos fourreurs appellent tigre. Au reste, c'estla seule petite utilité qu'on puisse tirer de eet animal très-nuisible, dont on a prétendu que la sueur ${ }^{2}$ était un venin

1 Les tigres de l'est de l'Asie sont d'une grosseur et d'une légèreté surprenante; ils ont ordinairement le poil d'un roux fanve... Ils rugissent comme les lions; leur cri scul pénèlre dhorrenr. Voyage de Coreal. Paris, 1722, tome 1, page 173.

2 Ilistulre naturelle de Sian, par Gervaise, I'aris, 1688 paģe 56. et le poil de la moustache un poison ${ }^{4}$ sûr pour les hommes et pour les animaux; mais c'est assez du mal très-réel qu'il fait de son vivant, sans chercher encore des qualités imaginaires et des poisons dans sa dépouille; d'autant que les Indiens mangent de sa chair et ne la trouvent ni malsaine, ni mauvaise; et que, si le poil de sa moustache, pris en pilule, tue, e'est qu'étant dur et raide, une telle pilule fait dans l'estomac le même effet qu'un pacpuet de petites aiguilles.

\section{ADDITION A L'ARTICLE DU TIGRE.}

Un jeune tigre que nous avons vu vivant à la foire Saint-Germain, en 1784 , avait, me. suré en ligne droite, du bout du nez à l'origine de la queue, quatre pieds trois pouces cinqlignes; et, en suivatat la courbure du corps, cinq pieds trois pouces.

Celui dont nous avons dépouille au Cabinet du Roi était beaucoup plus grand, parce quil était plus âgé.

Sa peau, bourrée, a, de longueur, six pieds six pouces: il nous a paruqueles bandes transversales, et qui descendent presque perpendiculairement sur les flanes, étaient beaucoup plus noires dans l'animal vivant, qu'elles ne le sont sur la peau bourrée, dont la couleur s'est probablement effacée.

Ce grand tigre, qu'on appelle tigre royal, est, comme je l'ai dit, moins répandu, et l'espèce en paraît moins nombreuse que celle des léopards et des onces.

On pourrait voir, dans l'ouvrage que M. le chevalier d'Obsonville va publier sur les animaux de l'Inde, plusieurs faits intéressants sur les habitudes naturelles de ce cruel animal, qui fait la désolation des pays qu'il habite.

\section{DESCRIPTION DU TIGRE.}

(EXTRAIT DE DAUBENTON.)

On a eu, il y a plusieurs années, à la ménagerie de Versailles, un tigre qui y mourut; sa pean tul empaillée; elle a été apportẻe dans la suite an $\mathrm{Ca}$ binet d'histoire naturelle. Autant que l'on peut juger de la taille de ce tigre par ce qui en reste, jc

1 La Chine illustrée, par kircher, traduction de Dalquier Ansterd. 1670, pages 110 et 111 . 
rois qu'il avait près de six pieds et demi de lonzueur, depuis le bout du nez jusqu'à l'origine de la jueue, qui est longue de deux pieds sept ou lunit jouces; le sommet de la tète est large, et les oreiles sont courtes et fort éloignées l'une de l'autre. 11 arail que la forme du corps avait beancoup deraport à celle de la panthère ; on pourra prendre queljue illée de cette ressemblance en comparant la fi;ure du tigre, dessinće d'après la peau empailléc, ıvec les figures des panthères, qui ont été dessinées l'après ces animaux vivants.

La peau du tigre dont il s'agit a de longues tashes noires sur un fond de couleur fauve ou blanshâtre avec une teinte jaunâtre dans quelques enlroits : le nez et les còtés du nez sont fauves sans mcume tache. Les tempes, le front et le sommet le la tète ont des taches noires sur un fond de coueur fauve; ces taches sont fort irrégulières, presjue toutes en forme de bandes dirigées en diffe:ents sens; celles du bas du front ont peu de longueur el de largeur : il y a de cliaque côté de a partie moyenne du front une taclıe presque ovale, t au-dessus de ces taches une bande étroite et peu upparente, qui traverse le dessus du front, et dont es deux extrémites sont recourbées en bas et en ledans; il sort du milieu de cette bande deux autres bandes un peu plus larges et beaucoup plus apparentes, qui se recourbent en dehors et s'étendent jusqu'aux oreilles; enfin le sommet de la tête est traversé par une autre bande qui ne va pas jusqu'aux oreilles.

Les poils ne sont longs que d'un pouce, ou un pouce et demi, excepté sur les còtés de la tète audessous des oreilles, où ils ont jusqu'à quatre pouces et lemi. Ceux de ces longs poils yui paraissent à l'extérieur, lorsqu'on resarle l'animal de cỏté, sont fauves; unais en les ecartant, on voit qu'ils recouvrent d'autres poils d'un fauve plus clair, et audessous de ceux-ci on en trouve yui sont blanclıatres et légèrement teints de jaunàtre; on les voit en regardant l'aninal en face, et on y distingue des bandes qui s'étendent de haut en bas et qui sont formées par des flocons de poils noirs. Le dessus et les còtés du cou, le garrot, l'épaule, la face externe du bras et de l'avant-bras, le dos, les cỏtés de la poiirine et du ventre, la croupe, la face externe de la cuisse, la jambe, et enfin les quatre pieds sont de couleur fauve, et la plupart de ces différentes parties ont des bandes noires. Ces bandes sont peu apparentes sur le cou, et diriges obliquement de clevant en arrière et dedans en dehors; celles du garrot, du dos et de la croupe sont plus apparentes et transversales : elles sont en plus grand nombre que sur les còtés du corps; celles des jambes de derrière sont plus étroites, moinsapprarentes et tout es à peu près transversales, mais quelquesuns se croisent ou forment des mailles de figure très-irrégnlière. Le bout de la quetue est noir, et le reste est entouré de plusieurs anneaux de même couleur noire sur un fond de couleur fauve trèsclaire et même blanchâtrc; le fauve est plus foncé près de l'origine de la queue, et les bandes y sont dirigées en diffërents sens, au lieu de former des anneaux. La lèvre supérieure est blanchåre et parsemée de petites taclies noires : il y a un cercle blanchâtre et teint de jaunâtre autour des yeux, et au-dessus une grande taclıe de mème couleur avec quelques marques noires. Le bas des joues, la mâchoire du dessous, la gorge, la face infeirieure du cou, la face interne des jambes de devant, la poitrine et le ventre sont de couleur blanchâtre avec une légère teinte de jaunâtre : il y a sur le bas des joues, sur la màclıoire du dessous et sur la gortre, des bandes noires et irrégulières ; sur les cỏtés et sur la face inférieure du cou, des bandes obliques qui commencent à quelque distance des oreilles, et qui se réunissent près de la poitrine : il y a aussi quelques bandes transversales sur les côtés postérieur et antérieur de la jambe de devant: la partie postérieure de la poitrine et la jırtie antérieure clu ventre ont plusieurs bandes courtes, largres $t$ t 1 ransversales. Les poils qui sont sur les cỏtés et sur le bout des doigts ont une couleur blanchàtre légèrement teinte de jaunàtre.

La tête du squelette du tigre ressemble beaucoup à celle du lion, cependant elle est moins grande; elle a le museau plus court et moins gros, l'ouverture des narines et les orbites des yeux moins grandes, le front moins enfonce, les apophyses orbitaires de l'os frontal et des os de la pommette plus petites, les arcades zygomatiques plus convexes, en delıors, et l'occiput plus saillant en arrière, quoipue l'arète qui s'étend sur le sommet soit moins élevée.

Le tigre a trente dents, semblables à celles du lion et du cliat.

La branche inférieure de l'apoplyse accessoire de la sixième vertèbre ne diffère de celle du lion qu'en ce que la partie postérieure est un peu plus large. Les apoplıyses épineuses des quartiers, cinquieme et sixième vertèlıre du cou sont beaucoup plus courtes que celles du lion.

Les vertèbres dorsales, les côtes, le sternum, ressemblent à ces mènıes os vus dans le lion; les apophyses accessoires des vertelbres lombaires ont moins de longueur yue celles du lion, et ne sout pas recourbces en declans : les os du bassin ressemblent à ceux du lion. Il y a dix-sept fausses vertèbes dans la queuc du squelette qui scrt de sujet pour celte description ; mais leur nombre n'est pas complet, il en manque quelques-unes à l'extrénité.

L'omoplate est presque carrée; l'épine suit une diagonale de ce carre. Les os du bras, de l'avant- 
bras, de la cuisse, de la jambe et des pieds ne diffèrent de ceux du lion, d'une nanière apprarente, qu'en ce qu'ils sont à proportion flus courts, et qu'ils ont des rugosités qui marquent des attaclies de nuscles encore plus fortes que dans le lion, principalement sur le devant de la partie noyemue inferieure de l'humerus et de la partie moyenne supérieure dı tibia.

\section{LA PANTHERE, L'ONCE,}

\section{E'T LE LÉOPARD.}

\section{(le felis Panthère, Cuv., le felis léo- PARD ${ }^{1}$, Cuv.)}

Ordre des carnassiers, famille des carnivores, tribu des digitigrades, gente chat. (Curier.)

Pour me faire mieux entendre, pour éviter le faux emploi des noms, détruire les équivoques et prévenir les doutes, j'obscrverai d'abord qu'avee les tigres dont nous venons de donner l'his-

\footnotetext{
1 La plus grande confusion règne encore dans la synonymie des grancles espèces de cluats à pelage marqné de taelıes noires et ocellées sur un fond farve; espèces pui toutes ont recu indistinetement les noms de panthere, de léopard, de jüuar et d'once. M. G. Cuvier, dans un yremier travail, Anı. du Musénm d'IIst. Nat., tonre XIV, regardait comme étant Ia panthère, felis pardus, Linn., l'animal que Buffon désigne ainsi, et qu'il a figuré, pl. 11 de l'édition de l'inprimerie royale, et II caractérisait cette espéce par sa taille, plus grande que celle de son léoplard, et par les sir ou sept lignes longitudinales de taclies en roses gu'il remarquait sur ses flanes. Son Ieopard, felis leopardus, anyuel il rapportait avec doute la planche 1 \& de l'édition des OEuvres de Buffon de l'imprimerie royale, serait plus petit que la panthère, et aurail dix rangées rle taches en roses sur chaque flane, au lieu de six on sept. Enfiu il considerait l'once, dont Buffon donwe une figure, wanche 15 , élition de linurinerie royale, comme une variété de la paullì̀re.
}

Dans ses recherehes sur les ossements fossiles, 2e édition, I. G. Cuvier arlunt les mêmes déterminations; $r t$ il ajoute que les peaux à fond peu colore cul s'y rapportent (celle lle l'onee de Buffon ) étant assez fréquuemunent apporlćes des prarties de l'A sic gui avoisinent la chime, il se pourrait qu' elles applartinssent à une espèce particulière.

selon le mine naturaliste, la pantlière et le léoparcl hab:teraient également l'Afrił̧uc, mais la première dans les ré. gions septentrionales de ce continemt, et la seconde dans les contrées méridjonales.

II. Temminek, dans une monographie des felis, a proposd une délermination différente de ees deux animaux. Selon lul, le felis loopardus, de Linnée. ou son léopard, principalement caracterisé par une queue assez conrte et par une taille asser grande serait la panthere de II cuvier ef celle de Buffon, planche 208. citée plus hant. La figure du léoparıl. plancls 209, $17^{0} 2, s^{\circ}$ y rapporterait anssi, ile mime une celle que M.F. Covier a donnée dans ses mammifires ltulwgraphiés. Enfin le melas d.' Pérou, on janthère noire d̦ Java, ne serait quirune variété de cetle espećce. l'once pourrait, ainsi quue l'a soupçouné M. G. Cuvier, ère regardé comme apnartenaut à une espice particuliere. L.e felis pardus, de Linnée, ou sa toire et la descrijtion, il se trouve encore dans l'aneien continent, e'est-à-dire en Asie et en Afrique, trois autres especes d'animaux de ce genre, toutes trois difiérentes du tigre, et toutes trois differentes entre clles. Ces trois espèces sont la panthere, l'once et le léopard, lesquelles non-sculement ont été prises les unes pour les autres par les naturalistes, mais mème out été confondues avec les espèces du même genre qui se sont trouvées en Amérique. Je mets à part, pour le moment présent, ces espèces que l'on a appelées indistinctement tigres, panthères, leopards, dans le Nouveau-Monde, pour ne parler que de celles de l'ancien continent, et afin de ne pas confondre les choses et d'exposer plus nettement les objets qui y sont relatifs.

La premiere espèce de ce genre, et qui se trouve dans l'ancien continent, est la grande panthère, que nous appellerons simplement panthère', qui était connue des Grecs sous le nom de pardalis, des anciens Latins sous celui de panthera, ensuite sous le nom de pardus, et des Latins modernes sous celui de leopar$d u s$. Le corps de cet animal, lorsqu'il a pris son accroissement entier, a cinq ou six pieds de longueur, en le mesurant depuis l'extrémitédu muse: u jusqu'à l'origine de la queue, laquelle est longue de plus de deux pieds : sa peau est, pour le fond du poil, d'un faure plus ou moins foncé sur le dos et sur les côtés du corps, ê d'unc couleur blanchâtre sous le ventre; elle est marquée de taches noires en grands anneaux ou en forme de roses : ces anneaux sont bien séparés les uns des autres sur les còtés du corps, évidés dans leur milieu, et la plupart ont une ou plusieur's taches au centre, de la mème couleur que le tour de l'anneau: ces mèmes anneaux, dont les uns sont ovales et les autres circulaires, ont somvent plus de trois pouces de diamètre; il n'y a que des taches pleines sur la tête, sur la poitrine, sur le ventre et sur les jambes.

panthère, dont la taille est plus petite que celle dur léopard, ct dont la yuene est plus longue proportionueliement, aurait éte esgalement incomuse à Buffon of à M. G Curier, et ello nicsisterait point dans les galeries du Muséum d'Histoire na. turclle de Parrs.

Eulin, suivant le mème autenr, le léopard serait également propre a toules les contrées de l'A frique. îl'Inde el aux lles de la Sonde. .lava et Suntatra ; tandis que la panthère neesigterait que dans ees tlerniers licux et dans le Bengale, et ue se trouverait point en Afrique. IEs.n.

- Celte dernière figure est celle l'un jagıar, ainsl que 3. Curicr l'a reconnu. 
La seconde espèce est la petite panthère d'Opplen, à laquelle les anciens n'ont pas domné de nom particulier, mais que les voyageurs modernes out appelée once, du nom co:rompu lynix ou lınx. Nous conserverons à cet animal lo nom d'once, qui nous parait bien applipué, paree qu'en effet il a quelque rapport avee le lynx; ilest beancoup plus petit que la panthère, n'ayant le corps que d'environ trois pieds et demide longrueur, ce cui est à peu près la taillo dulynx : il a le poil plus long que la panthere, la queue beaucoup plus longue, de trois picels de longueur et quelquefois davantage, quoique lecorps de l'once soit en tout d'un lier's an moins plus petit que ealui de la panthère, dont la queue n'a guère que deux pieds on deux pieds et demi tout au plus. Le fond du poil de l'once est d'un gris blanchitre sur le dos et sur les eotés du corps, et d'un gris encore plus blane sous le ventre, au lieu efue le dos et les còtés du cosps de la panthère sont foujours d'un fauve plus ou moins foncé : ies taches sont à peu près de la même forme et de la mème grandeur' dans l'une etdans l'autre.

Ia troisième espèce, dont les anciens ne font aueune mention, est un animal du Sénégil, de la Guinée et des autres pays méridionaux que les anciens n'avaient pas découverts : nous l'appellerons léopard, qui est le nom qu'on a mal i propos appliqué à la grande panthere, et que nous emploierons, comme l'ont fait plusicurs voyageurs, pour désigner l'animal du Sénéxal, dont il est iei (question. II est un peu plus gland que l'once, mais beaucoup moins (fue la panthère, n'ayant gucre plus de quatre pjeds de longueur. Laquene a deux pieds oudeux pieds et demi ; le fond du poil, sur le dos et sur les eòtés du corps, est d'une couleur fauve plus ou moins foncée; le dessous du ventre est blanchaitre, les taches sont en ammeaux ou en roses, mais ces anneaux sont beancoup plus petits que ceux de la panthère ou de l'onee, et la plupart sont composés de yuatre ou einq petites taches pleines : il y a aussi d : ces taches pleines disposées irré gulièement.

Ces trois animaux sont, comme l'on voit, très-différents les uns des autres, ct sont chaemu de leur espece. Le's mareliands fourreurs appellent les peaux de lit premicre espeee, peaux de panthères, ainsi nous n'anrous pass changé cenom puisqu'il est en usage; ils appellent celles de la seconde espècepeauxde ligre's d' tirique: ce nom est équivoque, et nous avons adopté celui d'once; enfin, ils appellent improprement peaux de tigres celles de l'animal que nous appelons ici léopard.

Oppien connaissait nos deux premieres espèces, e'est-it-dire la pauthere et l'once; il a dit le premier qu'il y avait deux especes de pantheres: les unes plus grandes et plus grosses, les autres plus petites, et cependant semblables par la forme du corps, par la variété et la disposition des taches; mais qui difléraient par la longueur de la queue, que les petites ont beaucoup plus longue (fue les graudes. Les Arabes ont imbliqué la gramde patuthire par le nom al nemer (nemer en retranchant l'article), et la petite par le nom al phel ou al fhed ( phel ou fled en retranchant l'article); ce dermier nom, (quoique un peu corrompu, se recomnat dans eelui de frudh, gui est le nom actuel de eet animal en Barbarje. "Le faadh, dit le doeteur " Shaw, ressemble au léopard (il veut dire la ( panthère), en ce qu'il est tacheté comme lui ; ( mais il en differe à d'autıes ćgards: il a la " peau plus olyscure et plus grossiere. et u'est " pas si farouche. "Nous apprenons d'ailleurs par un passage d'Albert, commenté par Gessner, que le phet' on flued des Arabes s'est appelé en italien et dans quelques autres langues de l'Europe leunza ou lonza. On ne peut doac pas douter, en rapplochant ees indications, que la petite panthire d'oppien, le phet ou le fhed des Arabes, le faudh de la Barbarie, l'onze ou l'once des Europérns, ne soient le mene animal. II y a grande appar'nce aussi que èest le pard ou pardus des anciens, et la panthera de Pline; puisqu'il dit, fue le fond ${ }^{2}$ de son poil est blane, au lieu que celui de la grande pauthere est, comme nous l'avons dit, d'une con. leur fauve plus ou moins foncée: d'ailleurs, il est tres-probahle que la petite panthice s'est appelée simplement pard ou pardus, et qu'on est venu ensuite à nommer la grande panthère leoparl ou leopardus, paree qu'on a imigriné (que éétait ume espèee métive qui s'était agrandie par le secours et le mélange de celle du lion; mais comme ce prejugé n'est mullement fondé, nous avons preféré le nom ancien et primitif de pranihère au nom composé et plus nouveau de léoparl, que nous a vous applicpuéà l’animal nou-

Aphed, id est leopardus uminor. Alherlus.

2 I'unlheris in candido breves macularum oculi. I'lin., Hist.

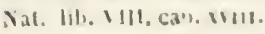


veau qui n'avait encore que des noms équivoques.

Ainsi l'once diffère de la panthère en ce qu'il est bien plus petit, qu'il a la queue beaucoup plus longue, le poil plus long aussi èt d'une couleur grisc ou blanchâtre; et le léopard diffère de la panthère et de l'once en ce qu'il a la r'obe beaucoup plus belle, d'm fauve vif et brillant, quoique plus ou moins foncé, avec des taches plus petites, et la plupart disposées pargroupes, comme si chacune de ces taches était formée de quatre taches réunies.

Pline, et plusieurs autres après lui, ont écrit que, dans les panthères, la femelle avait la robe plus blanche que le mâle : cela pouvait êtrcviai de l'once; mais nous n'avons pas observé cette différence dans les panthères de la ménagerie de Versávilles, c cui ont été dessinées vivantes ${ }^{1}$ : s'il y a done quelque différence dans la couleur du poil entre le mâle et la femelle de la panthère, il faut que cette différencene soit pas bien constante ni bien sensible. On trouve à la vérité des nuances plus ou moins fortes dans plusieurs peaux de ces animaux que nous arous comparées ; mais nous croyons que cela dépend plutôt de la différence de l'âge ou du climat que de celle des sexes.

Les animaux que MM. de l'Académie des sciences ont décrits ${ }^{2}$ et disséqués sous le nom de tigres, et l'animnal décrit par Cajus ${ }^{3}$ dans Gessner, sous le nom d'uncia, sont de même espèce que notre léopard; on ne peut en douter, en comparant la figure et la description que nous en dommons ici avec celles de Caïus et celles de M. Perrault. Il dit, à la vérité, que les animaux décrits et disséqués par MiM. de l'Académie des sciences sous le nom de tigres ne sont pas l'once de Caïus ^; les seules raisons qu'il en domne sont que celui-ci est plus petit et qu'il n'a

1 Cette figure de la panthere femelle de Buffon est celle d'un animal de l'espéce du jaguar d'A mériçue. Desı.

2 Mẻmoire pour servir à l'bistoire des animaux, partie III, page 3.

8 ('cssner, Hist. quadrup., page 825.

4 Nons observerons que les éditenrs de la troisième partic des Mlétnoires pour servir à l'histoire des animaux ont laissé passer dans l'impression une faute qu il est io autant plus nécessaire de eorriger, qu'clle est plus répétée. On a éerit par. tout ours an lien d'once; il est dit. page 5 , ligne 28 : “ L'ours décrit par Caius dans Gessner. - Page $8:$ a Lours que Caïus at déerit., - Pağe 18, ligne 11 : "Liours of le léopard." Page 18 : " Deseription très-exacte quili a donnée d'in ours. D Il est évident quil faut substituer dans ces quatre endroils le mot once à celui d’ours, puisque l'animal dont il esl question a élé décrit par Caïus sous le nom d'uncia dans Gessner. Ilist. quadrup., page 825. pas le dessous du corps blanc: cependant, si M. Perrault eût comparé la description entière deCaĩus avec les sujets ([u'il avait sous les yeux, je suis persuadé qu'il aurait reconnu qu'ils ne différaient en rien de l'once de Caïus. Comme il pourrait rester sur cela des doutes, j’ai cru qu'il était nécessaire de rapporter ici les parties essentielles de cette description de Caïus, (qui, quoique faite sur un animal mort, me parait fort exacte. On y observera que Caïus, sans donner précisément la Iongueur du corps de l'animal qu'il déerit, dit qu'il est plus grand qu'un chien de berger et aussi gros qu'un dogue, quoique plus bas de jambes : je ne vois done pas pourquoi M. Perrault dit cque l'once de Caius était bien plus petit que les tigres disséqués par MM. de l'Académie des sciences. Ces tigres n'avaient que quatre pieds de longueur, en les mesurant depuis l'extrémité du museau jus(ju'à l'origine de la queue; le léopard que nous décrivons ici, et qui est certainement le mèmeanimal que les tigres de M. Perrault, n'a aussi qu'environ quatre pieds; et si l'on mesure un dogue, surtout un dogue de forte race, on trouvera qu'il excède souvent ces dimensious. Ainsi, les tigres décrits par MM. de I'Académie des sciences ne différaient pas assez de l'uncia de Caïus par la grandeur, pour que M. Perrault fùt foudé à conclure de cette seule différence que ce ne pouvait être le mème animal. La seconde disconvenance, e'est celle de la couleur du poil sur le ventre; M. Perrault dit qu'jl est blanc; et Caïus qu'il est cendré, c'est-à-dire blanchâtre : aiusi, ces deux caractères, par lesquels M. Perrault a jugé que les tigres disséqués par MM. de l'Académic n'étaient pas l'once de Caïus, aurajent dû le porter à prononcer le contraire, surtont s'il eùt fait attention que tout le reste de la description s'accorde parfaitement. On ne peut done pas se refuser à regarder les tigres de MMI. de l'Académie, l'uncia de Caïus et notre léopard, comme le même animal, et je ne conçois pas pourquoi quelques-uns de nos naturalistes ont pris ces tigres de MI. Perrault pour des animaux d'Amérique, et les ont confondus avec le jaguar.

Nous nous croyons done certains que les tigres de M. Perrault, l'uncia de Caïus et notre léopard, soutlemêmeanimal : nous nouscroyons également assurés que notre panthère est le mème animal que la pantlière des anciens. 
Elle en diffère à la vérité par la grandeur, mais elle lui ressemble par tous les autres earactères; et, comme nous l'avons déjà dit plusieurs fois, on ne doit pas être étonné qu’un animal élevé dans une ménagerie ne prenne pas son aceroissement entier, et (qu'il reste au-dessous des dimensions de la nature. Cette différence de grandeur nous a tenu nous-même assez longtemps dans la perplexité; mais après l'examen le plus long, et nous pouvons dire le plus serupulcux, après la comparaison exacte et immédiate des grandes peaux de la panthère, qui se trouvent chez les fourreurs, avec celle de notre panthère, il ne nous a plus été permis de douter, et nous avons vu clairement que ce n'étaient pas des animaux differents. La panthère que nous décrivons ici et deux autres de la même espèce, qui étaient en même temps à la ménagerie du roi, sont venues de la Barbarie: la régence d'Alger fit présent à Sa Majesté des deux prenières, il y a dix ou douze ans; la troisième a été achetée pour le roi, d'un juif d'Alger.

Une autre observation que nous ne pouvons nous dispenser de faire, e'est que des trois auimaux dont nous domnons ici la description sous les noms de panthère, d'once et de léopard, aueurn ne peut se rapporter à l'animal que les naturalistes ont indiogué par le nom de pardus ou de leopardus. Le pardus de M. Linnæus et le léopard de M. Brisson, qui paraissent être le même animal, sont désignés par les phrases suivantes: Pardus, felis cauda clongata, corporis muculis superioribus orbiculatis, inferioribus virgatis. Syst. Nat., édit. 10, p. 41. Le léopard, Felis cx albo flavicans, maculis nigris in dorso orbiculatis, in ventre longis, variegata. Regn. anim. p. 272. Ce caractère des taches longues sur le ventre, ou allongćes en forme de verges sur les parties inférieures du corps, n'appartient ni à la panthère, ni à l'onee, ni au lćopard, desquels il est iei question. Cependant, il paraît que e'est de la panthere des anciens; du panthera, pardulis, pardus,leoparlus de Gessmer; du pardus, panthera de Prosper Alpini; du panthera varia Africana de Pline; de la panthère, en un mot, qui se trouve en Afrique et aux Indes orientales que ees auteurs ont entendu parier, et qu'ils ont désignée par les phrases que nous venons de citer. Or, je le répete, aucun des trois animaux que nous dćerivons ici, quoique tous trois d'espèce différente, n'ont ce caractère de taches lougues et en forme de verges sur les parties inférieures; et, en même temps, nous pouvous assurer, par les recherches que nous avons faites, que ces trois espèces, et peut-être une quatrième dont nous parlerons dans la suite, et qui n'a pas plus que les trois premières ce caractère des taches longues sur le ventre, sont les seules de ce genre qui se trouvent en Asie et en Afrique; en sorte que nous ne pouvons nous empêcher de regarder comme douteux ce caractère, (qui fuit le fondement des phrases indicatives de ces nomenclateurs. C'est tout lo contraire dans ces trois animaux, et peut-êtie dans tous ceux du mème genre; car, noll-seulement ceux de l'A frique et de l'Asie, mais ceux mème de l'Amérique, lorsqu'ils ont des taches longues cn forme de verges ou de trainées, les ont toujours sur les parties supéricures du corps, sur le garrot, sur le cou, sur le dos, et jamais sur les parties inférieures.

Nous remarquerons encore que l'animal dont on a donné la description dans la troisiène partie des Mémoires pour servir à l'histoire des animaux, sous le nom de panthère ${ }^{1}$, est un animal différent de la pantlière, de l'once et du léopard, dont nous traitons ici.

Enfin, nous observerons qu'il ne faut pas confondre, en lisant les anciens, le panther avec la panthère. La panthère est l'animal dout il est ici question; le panther du scoliaste d'Homère et des autres auteurs est une espèce de loup timide que nous croyons être le chacal, comme nous l'expliquerons lorsque nous donnerons l'histoire de cet animal. Au reste, le mot pardalis est l'ancien nom gree de la panthère; il se donnait indistinetement au mâle et à la femelle. Le mot pardus est moins ancien: Lucain et Pline sont les premiers qui l'aient employé; celui de leopardus est encore plus nouveau, puisqu'il parait que e'est Jule Capitolin qui s'en est servi le premier, ou l'un des premiers : et d l'égard du nom mème de panthera, c'est un mot que les anciens Iatins ont dérivédu grec, mais que les Grees n’ont jamais employé.

Après avoir dissipé, autant qu'il est en nous, les ténèbres dont la nomenclature ne cesse d'obscurcir la nature; après avoir exposé, pour pré-

- Mémoires pour ecrvir a l'histoire des animaux, partıe II lage 3. 
venir toute écruivoque, les figures exactes des trois animaux dont nous traitons ici, passons à ce qui les concerne chacun en particulier.

La panthère que nous avons vue vivante a l'air féroce, l'œil inquiet, le regard cruel, les mouvements brusques et le cri semblable à celui d'un dogue en colère; elle a même la voix plus forte et plus rauque que le chien irrité : elle a la langue rude et très-rouge, les dents fortes et pointues, les ongles aigus et durs, la peau belle, d'un fauve plus ou moins foncé, semée de taches noires arrondies en anneaux, ou réunies en forme de roses, le poil court, la queue marquée de grandes taches noires all-dessus, et d'anneaux noir's et blanes vers l'extrémité. La panthère est de la taille et de la tournure d'un dogue de forte race, mais moins haute de jambes.

Les relations des voyageurs s'accordent avec les témoignages des anciens au sujet de lagrande et de la petite panthère, e'est-à-dire de notre panthère èt de notre once. Il parait qu'il existe aujourd'hui, comme du temps d'Appieu, dans la partic de l'Afrique qui s'étend le long de la mer Méditerranée, et dans les parties de l'Asie, qui étaient connues des anciens, deux espèces de panthères: la plus grande a été appelée panthère ou léopard, et la plus petite once, par la plupart des voyageurs. Ils conviennent tous que l'onces'apprivoise aisément, qu'on le dresse à la chasse ' et qu'on s'en sert à cet usage en

- Lcs Persans ont une certaine bête appelée once, qui a la peau tachetée comme un tigre, mais qui est fort douce et fort privée. Un cavalier la porte en trousse à cheval, et ayant apercu la gazelle, il fait descendre l'once, qui est si légère , quen trois sauts ette sante au cou de la gazelle, quoiquelle coure d'une vitesse incroyablc. La gazelle est ıne espèce de petit cherreuil dont le pays est rempli ; l'once l'étrangle aussitót avec ses dents aigues ; mais si par malheur elle manque son coup et que la gazelle lui échappe, elle demeure sur la place, lıontense et confuse; et dans ces moments un enfant la pourrait prendre sans quı'elle se défendit. Voyage de Tavernier. Rouen, $\mathbf{1 7 1 3}$, tome 11 , page $\mathbf{2 6 . . . ~ P o u r ~ l e s ~ g r a n d e s ~ c h a s - ~}$ ses on se sert des bètes fẻroces dressées à cliasser, lions, léopards, tigres, panthères, onces; les Persans appellent ces dernières bètes Youzze. Elles ne font point de mal aux hommes; un cavalier en porte une en croupe, les yeux bandés arec un hourrelet, attaclıćc par une clıaine, et se tient sur la route des bêtes qu'on relance, et qu'on lin fait passer devant elle le plus près fu'on peut; quand le cavalier en apercoit quelqu'une, il débande les yeux de l'animal, et lui tourne la tête du côté de la bête relancée ; s'il l'apercoit, il fait un cri, s'élance à grands sauts, se jette dessus la bète, et la terrassc s'il la manque après quelques sauts, il se rebute d'ordinaire et sarrête; on va le prendre, et pour le consoler, on le caresse. . J'ai vu cette sorte de chasse en Hircanie, l'an 1666 .. Il y a de ces bêtes dressées qui font la chasse finement, se Irainant sur le ventre le long des haies et des buissons jusqu'à
Perse et dans plusieurs autres provinces del'Asie; qu'il y a des onces assez petits pour qu'un cavalier puisse les porter en croupe, qu'ils sont assez doux pour se laisser manier et caresser avec la main. La panthère parait être d'une nature plus fière et moins flexible: on la dompte plutôt qu'on ne l'apprivoise ; jamais elle ne perd en entier son caractère féroce, et lorsqu'on veut s'en servir pour la chasse ${ }^{1}$, il faut beaucoup de

ce qu’elles soient procbe de la proie, et alors elles s'élancent dessus. Voyage de Chardin en Perse etc. Amsterdam, 1711, tome II, pages 32 et 33 . Voyez aussi le Voyage autour du IIonde, de Gemelli Carreri. Paris, 1719, tome II, pages 96 et 212 , oú cependant l'auteur parait avoir emprunté plusicurs clıoses de Chardin... Quo tempore perveni Alexandriam duos pardos... Vidi apud Antonium Calepium... Usque adeo cicures erant et mansueti, ut semper in lectulis decumbentes dormiebant... Carne eos nutriebat : sæpe à nobis cum pardo ibatur ad venandas gazellis, et puguan inter ipsos pulcherrimam quæ fiebat admirabamur, præsertim gazellæ artificium cum pardo cornibus durissimis armatæ pugnando; sed eatn tamen multo fatigatam atque ex pugna admodum defessam interimebat. Cairi postea vidimus quandam mulierem quinque catulos recentes a panthera effusos, ex Arabe coemisse eosque ut feles aluisse... Erant omnino visu pulcherrimi, albicabant colore maculis parvis rotundis toto corpore evariati... Parum quidem differenti:e inter pardum quidem et pantlieram observavimus intercedere : panthera quiden major et toto corpore est et capite atque multo ferocior, Prosp. Alp. hist. Egyp.; part. I; Lugd. Batav., 1753, p. 258 . Accepi a quodam oculato teste in anla regis Galliarum, leofardos duorum generum ali; magnitudine tantum differentes, majores vituli corpulentia esse, humiliores, oblongiores; alteros minores ad canis molem accedere, et unum ex minoribus aliquando ad spectaculum regi exhibendum, a bestiario ant venatore, equo insidente a tergo super stragnlo aut pulvino velii, alligatum catena et lepore objecto dimitti quem ille saltibus aliq̨ut bene magnis asseculis jugulet. Gessı., Hist. quadrup., page 831..... Emmanuel, roi de Portugal, enroya à Léon $\mathbf{X}$ une panthère dressée à la chasse. Ilist. des conquêtes des Portugais, par le P. Lafiteau. Paris, 17jj, 1. 1, page 525. Cette panthère était un once, car l'auteur dit aıssi qu'on se sert en Perse de l'once ou panthère pour chasser les gazelles ; qu'on fait venir ces animaux d'Arabie, et qu'ils sont assez privés pour qu'on puisse les porter en croupe à cheval.

1 Tigres ex Ethiopia in Egyptum convectas vidimus, ctsi nullo modo cicuratæ hæ mansuefiant, neque unquam ferinam naturam relinquant; sunt lexnis quam similes et forma et colore albicante, rotundis macul s fulvescentibus evariatix, sed lexnis longe majores sunt. Prosp. Alp. hist. Egypt., pag. 237... Quand on a découvert quel ques gazelles, on tâche de les faire apercevoir au léopard, que l'on tient enchainé sur une petite charrette ; cet animal rusé ne se met pas incoutinent à courir après, comme on pourrait l'imaginer; mais il s'en va tournant. se cachant et se courbant pour les appro. cher de prẻs et les surprendre; et comme il est capable do faire cong ou six sants ou bonds dune vitesse incrovable quand il se sent à portée, il s’ẻlance dessus. les étrangle el se soûle de leur sang, du coenr et de leur foie: et s"il manque son coup, ce qul arrive assez souvent, il en demeure là; auss serait-ce en vain qu'il prétendrait les prendre à la course, varce qu'elles courent bien mieux et plus longtemps que lus: le maftre ou gouverneur vient ensuite bien doucement autour de lui, le flattaut et lui jetant des morceaux de chair. el en l'amusant ainsi, il lui met des lunettes qul lui couvrent les yeux, l'enchaine et le remet sur la charrette. Voyase de Bernier, daus le Mogol. Amst., 1710, tome II, page 213 et sui- 
soins pour la dresser, et encore plus de précautions pour la conduire et l'exercer. On la mène sur une clsarrette, enfermée dans mue cagre, dont on lui ouvre la porte lorsque le gibier paraît; elle s'élance vers la bête, l'atteint ordinailement en trois ou quatre sauts, la terrasse et l'étrangle: mais si elle maugue son coup, elle devient furieuse et se jette (quelquefois su' son maître, qui d'ordinaire prévient ce danger en portant avee lui des morceaux de viande, ou des animaux vivants, comme des agneaux, des chevreaux, dont il lui en jette un pour calmer sa fureur.

Au reste, l'espèce de l'once parait ètre plus nombreuse et plus répandue que celle de la panthère: on la trouve très-communément en Barbarie, en Arabie et dans toutes les parties méridionales de l'Asie, à l'exception peut-être de l'Égypte '; elle s'est même étendue jusqu'ì la Chine, oì on l'appelle hinen-pao ${ }^{2}$.

Ce qui fait qu'on se sert de l'once pour la chasse dans les climats chauds de l'Asie, c'est que les elicus ${ }^{3} y$ sont très-rares; il n'y a, pour ainsi dire, que ceux qu'on y transporte, et encore perdent-ils en peu de temps leur roix et leur instinct : d'ailleur's, ni la panthère, ni l'once, ni le léopard ne peuvent souffrir les chiens; ils semblent les chercher et les attaquer de préférence sur toutes les autres betes ${ }^{4}$. Eu Europe, nos ehiens de chasse n'ont pas d'autres ennemis que le loup; mais, daus un pays rempli de tigres, de lions, de panthères, de léopards et d'onces, qui, tous sont plus forts et plus cruels que le loup, il ne serait pas possible de conserver des chiens. Au reste, l'once n'a pas l'odorat aussi fin que le chien: il ne suit pas les bêtes à la piste, ill ne lui serait pas vantes. II parail que c'est la grande panthère dont il s'acil ici, parce qu'on n'est pas obligé de prendre tant de précautions avec l'once.

'Il n’y a proint de lions, ni de tigres, ni de léopards en Égyple. Descrip. de l'Égypte, par Mascrier. La Ilaye, 17\%0, tome II, page 125

2 Hincn-pao. C'est une espèce de léopard ou de panthère que l’on voit dans la province de Pékin ; il n’est pas si féroce que les tigres ordinaires. Les Chinois en font grand cas. Relation de la Cline, par Thévenot, l'aris, 1696, page 19.

${ }^{3}$ Comine les Naures, à Surate et sur les cútes ıle Malabar, nout point de chiens pour cliasser les gazelles et les dains. ils tichent de suppléer à ce défaut par le moyen des léopards apprivoisés qu'ils dres cut à cet exereice. Ces aniuluax se jettent adroitement sur la proie; et guand ils l'ont attrapée ils ne la quittent poist, et s'y tiennent fermement attaclıés. Voyage de Jean Ovington. Paris, 1725, tome I, page 278.

- Les léopards sont enuemis mortels des cliens, et ils en dévoreut autant qu'ils peuvent en reucontrcr. Voyage dle Le Maire, 1695 , page 99 . possible non plus de les atteindre dans une course suivie; il ne chasse qu'à vue, et ne fait, pour ainsi dire, gue s'élancer et se jeter sur le gibier : il saute si légèrement, qu'il franchit aisément un fossé ou une muraille de plusieurs pieds; souvent il grimpe sur les arbres pour attendre les animaux au passage et se laisser tomber dessus : cette manière d'attraper' la proie est commune à la panthère, au léopard et à l'once.

Le léopard ${ }^{1}$ a les mèmes mours et le mème naturel (fue la panthère; et je ne vois nulle part qu'on l'ait apprivoisé comme l'once, ni que les Nègres du Sénégal et de Guinée, où il est très-commun, s'en soient jamais servis pour la chasse. Communément, il est plus grand que l'once et plus petit que la panthère; il a la cqueue plus comrte que l'once, quoiqu'elle soit longue de deux pieds ou de deux pieds et demi.

Ce léopard du Sénégal ou de Guinée, auyuel nous avons applicjué particulièrement le nom de léopard, est probablement l'animal que l'on appelle à Congo engoi ${ }^{2}$; e'est peut-ètre aussi l'autamba ${ }^{3}$ de Madagasear. Nous rapportons ces

4 Le léopard de Guinée est d'ordinaire de la hauteur el de la grosscur d'un gros chien de boncher' ; il est féroce, sauv age et incapable d'etre apprivoisé; il se jelte avec furie sur tuntes sortes d animaux, mêue sur les homues; ce que ne fout pas les lions et les tigres de cette côte de Guinée, à muin: qu'ils ue soient extrêmement pressés de la faim. Il a quelque cluose du lion et quelque ehose du grand chat sauvage; sa pean est toute mouchetée de taches jomles, noires, de différentes teint s, sur un fond grisâtre; il a la teie mediocrement grosse, le museau court, la guenle lisg", hien armé de dents, dout les femues du pays se fout des colliers; il a la langue pour le unoins aussi rude que celle dı lion; ses yeux sont vifs ct daus un mouvement contiuuel, son regard est cruel; il ne respire que le carnage : ses oreilles rondes ct assez courtes scul tuujours droltes; il a le cou gros et court, L's cuisses épaisses. les prieds larges, cinq dolg̈ts à ceux de devant, et ı̨ualıe à ccux de derrière, les uns et les autres armés de griffes fortes, aiguës et tranchautes; il les frue eomme les doigts de la main, ef liche rarenient sa proie, „ןu'il déchire avec les ongles autant (qu'ilvec les dents. Quohjuil soit fort carmassier et qüil minge heancoup, il est toujours milere : il fenple beancoup); mais il a pour ennemi le tigre, qui, étant plus fort el plus alerte, en détruit mn grand nombre. I.es Nègres prenuent le tigre, le léopard, le lion, dans des fosses profundes, recourertes de roseaux el d'un peu de terre, sur lapnelle ils mettent quelques bètes mortes jom appâts. Voyage de l)esurarchai i, t. I. 1. 202.... l.e tigre du Sénégial est fllus furieur que le lien ; sa laateur et sa longueur est presque comme celle d'un lévier : il attayue indifléremment les lrommes et les trites. Les Nères les tuent avec leurs zagayes et leurs lleches, alin dien avoir la pean: ıuclque percé quil soit de leurs coups, il se défeud tant quil a wm reste de vie, et il cu tue tonjours yuel, pues-uns. voyage de Le Maire. Paris, 1695, page 99.

${ }^{2}$ Les tigres de Cougos"apprellenl Engoi dans le p̧ays. Voyage de Francois 1)rack. Paris, I641, page 105... Recueil des Voya ges qui ont servi a l'ublissement de la Compaguie des Indes. Ansterd., 1702, tome 1V, page 5:6.

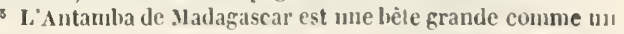
chien, qui a la tète ronde; et, au rapport des Jegres, elle a la 
noms, parce qu'il serait utile, pour la connaissance des animaux, qu'on eût la liste de leurs noms dars les langues des pays qu'ils habitent.

L'espèce du léopard parait être sujette à plus de variétés que celle de la panthère et de l'once: nous avous vu un grand nombre de peaux de ce léopard qui ne laissent pas de différer les unes des autres, soit par les nuances du fond du poil, soit par celles des taches dont les anneaux ou roses sout plus marqués et plus terminés dans les unes que daus les autres; mais ces anmeaux sont toujours de beaucoup plus petits que ceux de la panthère ou de l'once. Dans toutes les peaux du léopard, les taches sont chacune à peu près de la mème grandeur, de la même figure, et c'est plutôt par la force de la teinte qu'elles diffèrent, étant moins fortement exprimées dans les unes de ces peaux et beaucoup plus fortement dans les autres. La couleur du fond du poil ne diffère qu'en ce qu'elles sont d'un fauve plus ou moins foncé; mais, comme toutes ces peaux sont à très-peu près de la même grandeur, tant pour le corps que pour la queue, il est très-vraisemblable qu'elles appartiennent toutes à la même espèce d'animal, et non pas à des animaux d'espèce différente.

La panthère, l'once et le léopard n'habitent que l'Afrique et les climats les plus chauds de l'Asie; ils ne se sont jamais répandus dans les pays du nord, ni mème dans les régions tempérées. Aristote parle de la panthère comme. d'un animal de l'Afrique et de l'Asie, et il dit expressément qu'il n'y en a point en Europe. Ainsi, ces animaux qui sont, pour ainsi dire, confinés dans la zone torride de l'ancien continent, n'ont pu passer dans le nouveau par les terres du nord; et l'on verra par la description que nous allons donner des animaux de ce geure qui se trouvent en Amérique, que ce sont des espèces différentes que l'on n'aurait pas dủ confondre arec celles de l'Afrique et de l'Asie, comme l'ont fait la plupart des auteurs qui ont écrit la nomenclature.

Ces animaux en général se plaisent dans les forêts touffues, ct fréquentent souvent les bords des fleuves et les environs des habitations isolées, où ils cherchent à surprendre les animaux domestiques et les bêtes sauvages qui viennent

ressemblance diun léopard : elle dévore les hommes et le bétail, et ne se trouve que dans les endroits les plus déserts de l'ile. Voyage de Madagascar, par Flacourt. Paris, 1661, pase 154. chercher les eaux. Ils se jettent rarement sur les hommes, quand même ils seraient provoqués : ils grimpent aisément sur les arbres, ou ils suivent les chats sauvages et les autres animaux qui ne peuvent leur échapper. Quoiqu'ils ne vivent que de proie et qu'ils soient ordinairement fort maigres, les voyageurs prétendent que leur chair n'est pas mauvaise à manger : les Indiens et les Nègres la trouvent bonne; mais il est vrai qu'ils trouvent celle du chien encore meilleure, et qu'ils s'en régalent comme si c'était un mets délicieux. A l'égard de leurs peaux, elles sont toutes précieuses et font de très-belles fourrures : la plus belle et la plus chère est celle du léopard; une seule de ces peaux coûte huit ou dix louis, lorsque le fauve en est vif et brillant, et que les taches en sont bien noires et bien terminées.

\section{LE JAGUAR.}

\section{(LE FÉlis Jaguar, Cuv.)}

Ordre des carnassiers, famille des carnirores, tribu des digitigrades, genre chat. (Cuvier.)

Le jaguar ressemble à l'once par la grandeur du corps, par la forme de la plupart des taches dont sa robe est semée, et même par le naturel : il est moins fier et moins féroce que le léopard et la panthère. Il a le fond du poil d'un beau fauve comme le léopard, et non pas gris comme l'once; il a la queue plus courte que l'un et l'autre, le poil plus long que la panthère et plus court que l'once; il l'a crêpé lorsqu'il est jeune, et lisse lorsqu'il devient adulte. Nous n'arous pas vu cet animal vivant; mais on nous l'a envosé bien entier et bieu conservé dans une liqueur préparée, et c'est sur ce sujet que nous en avons fait le dessin et la description. Il avait été pris tout petit, et élevé dans la maison jusqu'à l'âge de deux ans, qu'on le fit tuer pour nous l'envoyer ' ; il n'avait douc pas encore ac-

- Cet animal nous a été enroyé sous le nom de chat-tigre, par M. Pagès, médecin du roi au Cap, dans l'ile Saint-Domingue. Il me inarque, par la leltre qui était jointe à cel envoi, que cet aninal était arrivé à Saint-Domingue par un raisseau espagnol qui l'avait amené de la Grande-Terre, oì il est très. commun : il ajoute qu'il avait drux ans quand il l'a fait tuer ; qu'il u’était pas si gros, ct ‘u’il s'est renflé dans l'espril de tafia ; qu'il buvait, mangeait el faisail le mème cri qu'un chat qui u'est pas privé; qu'il miaulait, et qu'ilmangeait plus volontiers 


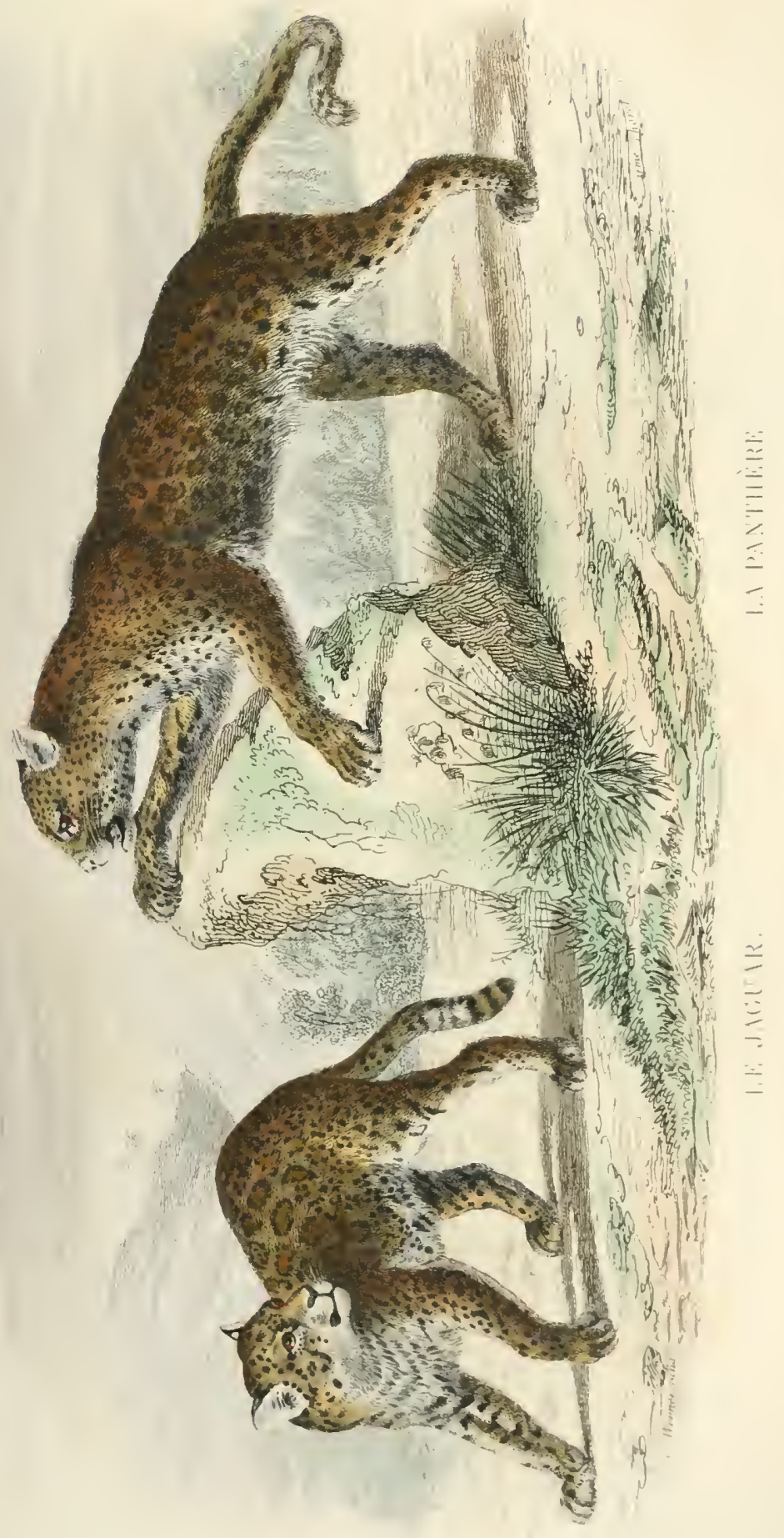





\section{DU JAGUAR.}

juis toute l'étendue de ses dimensions natureles : mais il n'en est pas moins évident, par la ;eule inspection de cet animal âgé de deux ans, ju'il est à peine de la taille d'un dogue ordiaaire ou de moyenne race, lorsqu'il a pris son ıceroissement entier. C'est cependant l'animal c plus formidable, le plus cruel; c'est, en un not, le tigre du Nouveau-Monde, dans lequel a nature semble avoir rapetissé tous les genres l'animaux quadrupèdes. Le juguar vit de proie somme le tigre; mais il ne faut, pour le faire fuir, que lui présenter un tison allumé, et même, lorsqu il est repu, il perd tout courage et toute vivacité; un ehien seul suffit pour lui donner la chasse: il se ressent en tout de l'indolenee du climat; il n'est léger, agile, alerte, que quand la faim le presse ${ }^{4}$. Les Sauvages, naturellement poltrons, ne laissent pas de redouter sa rencontre ; ils prétendent qu'il a pour eux un gout de préférence, que quand il les trouve endormis avec des Européens, il respecte ceux-ci, et ne se jette que sur eux ${ }^{2}$. On conte la même chose du léopard ${ }^{3}$; on dit qu’il pré-

encore le poisson que la viande. Pison et Maregrave disent de même, que les jaguiırs du Brúsil aimenl bearcoup le poisson. Le nom de chat-tigl'e, que lui domne M. Pagis, ne nous a jas empêch de le reconnatie jour le jaguar, parce que ce nom du lJrésil niest pas en usage parmi les Francais es colonies, et qu'ils appelluu indistinctement cliats-ligres les chats-pards et les ligres. Lc chat-ligre, dit Ianyier, lome III, page 306 , qui est très commun daus la baie de Camprèce, a les jambes combles rt le corps ramassé, comme un untin: mais, par la téte, le poil, et la manière de guctler sa jroie, il ressemble au ligre. Nole de I3nlfon.

L'individu dont il sogit n'est nas le vrai jaguar; il se rapporte très-vraisumblablement a une espeec baueoup plus pelile que celle de cet animal, et assez voisine de celle de loce. lot, listinguíes, il y a peu de temps, par M. Frédédric Cuvier, qui lui a dumé le nom de Cuxt, leelis mitis. Ilesmarest.

411 y a des tigres au lBrésil, lesıpuels, étant agités par la rage đle famine, sonl comagenx; mais, élant tepus, devirnneıt si läches, quils sadonuent incontinent à liuir de peur des chicus, Description des Indes orientales, par llerrera. Ansterd., I622, p. 232.- Il y a une grande quantite sle tigres an Brésil, que la faim reml très-légers et lrès à craindire; mais, étant rassasiés, ce qui est almirahle, ils sont si poltrons it si pesants, que le moindre chieu de berger leur doune la fuite. Hisloire des Indes, par Maffée. Paris, 1663, page 69.-Il y a des tigres antour de l'orlo-Bello, dont les envirous sont assez diserts; apunremment que ce sont des tigres de pelile espicee, puisıu'un houme seul eu vient a hout arec une lance on une antre arme blanclic, et lui conpe les palles l'une apres l"autre, quand l"animal se dresse pour l'atta(puer. Voyage de Lom Jum et l) Antoine de Lllıa. Extrait de la thibliotlèęue raisonné, t. XLIV, page 413.

2 لl'ai oü qưlıuefois contrr que ces ligres étaient animés contreles Indiens, ct quils n'assaillaient point les Espagnols, ou bien pen; qu'ils allaient quel(puefuis prendre et choisir un Indien endormi au milien les Espagnols, et qu'ils l'emportaient. I istoire Naturelle des Indes, par Joseph deosta. l'aris 1600 , page 410.

- La province de Bamba, au royaume de Congo, a des tigícs fère les hommes noirs aux blancs, qu'il sembla les connaitre à l'odeur, et qu'il les choisit la nuit comme le jour.

Les auteurs qui ont éerit l'histoire du Nouveau-Monde ont presque tous fitit mention de ect animal, les uns sous le nom de tigre ou de léopard, les autres sous les noms propres (qu'il portait au Brésil, au Mexique, ete. Les premiers qui en aient donné une description détaillée sont Pison et Marcgrave : ils l'ont appelé jaguara au lieu de janouara, qui était son nom en langue brasilienue ${ }^{1}$; ils out aussi indiqué un autre animal du mème genre et peut-ĉtre de la mème espéce sous le nom de jaguarele. Nous l'avons distingué du jaguar dans notre énumération, comme l'ont fait ees deux anteurs, parce qu'il y a quclque apparence (jue ce peuvent ètre des animaux d'espéce différente; cependant, eomme nous n'avons vu que l'un de ces deux animaux, nous ne pouvons pas décider si ce sont en effet deux espèces distinctes, ou si ce n'est qu'une varieté de la mème espèce ${ }^{2}$. Pison et Mlaregrave disent que le jaguarete diffère du jaguar en ec qu'il a le poil plus court, plus lustré et d'une couleur toute différente, ćtant noir, semé de taches encore plus noires. Mais, au reste, il ressemble si fort au jaguar par la forme du corps, par le naturel et par les habitudes, qu’il se pourrait que ee ne fùt quiune variété de lí mẻme espèec ; d'autant plus qu'on a dù remarquer, par le témoignage mème de Pison, que, dans le jaguar, la coulcur du fond du poil et celle des taches dont il est marqué varient dans les differents individus de cette meme es-

qui n'attayuent jamais les hommes hlucs, unais qui se tuent

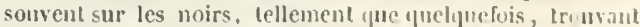
deux hommes, l'un blanc et l'autre noir, qui ilorment l'un pres de l'antere, ces animanx vont de furie contre le hoir sans offenser le blanc en ancune sorte. Voyage autour du .1londe, par Francois l'rack. Paris, 16 \$1, pag. 10s.

I Il y a au Lrésil une bete ravissante yue les Saurages appel. lent Jamouara, laquelle est presque auss hante des jambes qu'un lévrier, mais ayant de grands poils autour du mentum (il eutend les proils de la mousticlie), la peau fort belle el higarrée, comme celle d'un once; elle lui ressemble ar ssi hien fort en tout le reste. Voyage par Jean de Lery. Paris, 1578, page 162.-Le Janouara est ume espece donce, grande conme un dogue d'Anglelerre, ayant la peau fort riche el tont. mar-

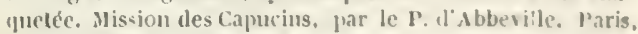
1614, mage 231.-1.e Janonara dn Brésil ne vit ıue de proie; il est de la taille d’un lévrier, il a la pean tachelíe. Vuyage de Corkal, tome I, page 175.

${ }^{2}$ Lanimal que buffon veut désigner est ce chat-ligre yui lui a élé enroyés te Saint-Domingue par M. I’agés, el ijui est d une espece toute différente de celle du vrai jaguar, c'est-ìdire le Chali de M. I. Cuvier. 
pèce. Il dit que les uns sont marqués de taches noires, et les autres de taches rousses ou jaures; et à l'égard de la différence totale de la couleur, e'est-à-dire du blanc, du gris, ou du fauve au noir, on la trouve dans plusieurs antres espèces d'animaux : il y a des loups noirs, des renards noirs, des écureuils noirs, ete. Et si ces variations de la nature sont plus rares dans les animaux sauvages que dans les animaux domestiques, c'est que le nombre des hasards qui peuvent les produire est moins grand dans les premiers, dont la vie étant plus uniforme, la nourriture moins variée, la liberté plus grande que dans les derniers, leur nature doit être plus constante, c'est-à-dire moins sujette aux changements et à ces variations qu'on doit regarder comme accidentelles, quand elles ne tombent que sur la couleur du poil.

Le jaguar se trouve au Brésil, au Paraguay, au Tucuman, à lá Guiane, au pays des Amazones ', au Mexique ${ }^{2}$, et dans toutes les contrées méridionales de l'Amérique : il est cependant plus rare à Cayenne que le conguar, qu'ils ont appelé tigre rouge; et le jaguar est maintenant moins commun au Brésil, (qui parait ètre son pays natal, quiil ne l'était autrefois : on a mis sa tète à prix; on en a beaucoup détruit, ct il s'est retiré loin des còtes, dans la profondemr des terres. Le jaguarete a toujours été plus rare, ou du moins il s’éloigne encore plus des lieux habités; et le petit nombre de voyageurs qui en ont fait mention paraissent n'en parler que d'après Maregr.ıve et Pison.

\section{I.E JAGUAR DE IAA GUHANE ${ }^{3}$.}

Ordre les carnassiers, famille des caruivores, tribu des digiligrades, genre chal. (Curier.)

II. Sonini de Manoncourt a fait quelques bommes observations sur les jaguars de la Guiane, que je crois devoir publier.

"Le jaguar, dit-il, n’a pas le poil erèpé lors-

+ On trouve le jaguar dans les lerres du Maragnon. Hist.ire de la Missiun des Capucius daus l'ile du .laragnon, par le P. d'Abbeville. Paris, 1614, page 231.

3 On voit dans les montagues dı Yexiyne un animal féro: quion apprelle un once, qui est de la forme el d: la Laille d'un loup-cervier, mais ıni a des serre's, el dont la léle ressembie lavaulage à celle d'un ligre. Vovage de Voodes kogers, lraduit de l'anglais. Amst. 1710, lome 11, page 42.

' Cel arlicle se rapporte à l'espece dis rai jaguar. Félis Onca, des naturalistes d'anjonrl'hui.
" qu'il est jeune, comme le dit M. de Bufion. "J'ai ı u de très-jcunes jaguars qui avaient le " poil aussi lisse que les grands. Cette observa" tion in'a été confirmée par des chasseurs in" struits. Quant à la taille des jaguars, jose $\epsilon \mathbb{B}$ " core assurer qu'eile est bien au-dessus de " celle que leur donne H. de Buffon, lorsqu'il " dit qu'il est à peine de la taille d'un dogue or" dinaire ou de moyenne race, quand il a pris " son accroissement entier. J'ai eu deux peaux " de jaguars, que l'on m'a assuré appartenir à " des sujets de deux ou trois ans, dont l'une " avait près de cinq pieds de long, depuis le "bout du museau jusqu'à l'origine de la quene, "laquelle al deux pieds de longueur. Il y en a " de bien plus grands. J'ai vu moi-mème, daus " les forèts de la Guiane, des traces de ces ani" maux, qui fuisaient juger, ainsi que l'a dit "M. de la Condamine, que les tigres ou les " animaux que l'on appelle ainsi en Amérique, " ne différaient pas en grandeur de ceux d'A" frique. Je pense mème qu'à l'exception du " vrai tigre (le tigre roral), celui de l'Amérique " est le plus grand des animaux auxquels on a " donné cette dénomination, puisque, selon "M. de Buffon, la panthère, qui est le plus " grand de ces animaux, n'al que cing ou six - pieds de longueur lorsqu'elle a pris son ac" croissement entier, et que bien certainement " il existe en Amérique des quadrupédes de ce "genre qui passent de beancoup cette dimen"sion. La couleur de la peau du jaguar vario " suivant l'àge: les jeunes l'ont d'un faure " très-foncé, presque roux et même brun; cette " couleur s'éclaireit à mesure que l'animal "vieillit.

" Le jaguar n'est pas aussi indolent ni aussi " timide que quelques royageurs, et, d'après " eux, M. de Buffon, l'ont écrit : il se jette sur " tous les chiens qu'il reneontre, loin d'en avoir "peur; il fait beaucoup de dégát dans les trou"peaux : ceux qui laalitent dans les déserts de " la Guyame sont minc dangtreux pour les " hommes. Dans un royage que j'ai fait dans a ces graudles forèts, nous fümes tourmentis " pendant deux nuits de suite par un jaguar, " malgré un très-grand feu que l'on avait eu " soin d'allumer et d'entretenir. Il ròdait conti"nuellement autour de nous : il nous fut im" possible de le tirer; car, dès qu'il se voyait " conché en joue, il se glissait d'une manière " si prompte, qu'il disparaissait pour le mo- 
- ment : il revenait ensuite d'un autre côté, et - nous tenait ainsi continuellement en alerte. - Malgré notre vigilanee, nous ne pùmes jamais " venir à bout de le tirer. II continua son ma" nége durant deux nuits entières; la troisième, " il revint; mais, lassé apparemment de ne " pouvoir venir à bout de son projet, et royant " d'ailleurs que nous avions augmenté le feu, " duquel il eraignait d'approeher de trop près, ' il nous laissa, en hulant d'une maniere efa froyable. Son eri, hou, hou, a quelque chose " de plaintif, et il est grave et fort comme ee" lui du boeuf.

"Quant au goût de préférence que l'on sup" pose au jaguar pour les naturels du pays plu" tot que pour les nègres et les blanes, je pré" sume fort que e'est un conte. A Cayemne, " j'ai trouvé eette opinion établie : mais j'ai " voyagé avee les Sauvages dans des endroits " ou les tigres d'une grandeur démesuréc étaient " eommuns; jamais je n’ai remarqué qu’ils " aient une peur bien grande de ces animaux. "Ils suspendaient, comme nous, leurs hamaes "à des arbres, s'éloignaient à une certaine dis" tance de nous, et ne prenaient pas la mème " précaution que nous d'allumer un grand feu; " ils se contentaient d'en faire un très-petit, " qui, le plus souvent, s'éteignait dans le cours " de la nuit. Ces Sauvages étaient eependant " habitants de l'intérieur des terres, et connais" saient par consé(fuent le danger (qu'il y avait " pour eux; j'assure qu'ils ne prenaient aucune " précaution, et (qu'ils paraissaient fort peu émus, " quoique entouris de ees animaux."

Je ne puis m'empicher de remarquer ici que ce dernier fait proure, comme je l'ai dit, que e's animaux ne sont pas fort dangereux, du moins pour les honmes.

"La ehair des jaguars r'est pas bomme à " manger. Ils font la guerre avee le plus grand * avantage à toutes les espèes de yuadrupèdes " du nouveau continent, qui tuus les fuient et " Jes redoutent. Les jaguar's nont point de plus a cruel ememi que le foumilier ou tamanoir, " quoiqu’il n'ait point de dents jour se défen" dre. Dès (qu'il est attaqué par un jaguar, il se " couche sur le dos, le saisit avee ses griffes, " qu'il a d'une gr'indeur prodignicuse, l'étoulfe " et le déchire. "

\section{IE JAGUMR}

\section{DE LA NOUVELIL ISPAGNE.}

(kétss cunti, F. Cuv.)

Ordıe des carnassiers, famille des ('ar uivor'os, Iribu des digitigrades, geore chat. (Cuvier.)

Dans le mois de juin dernier (1775), il a été slomé à M. Lebrun, inspecteur-général du domaine, un jaguar femello, envoyé de la Youvelle-Espagne, qui était fort jeune, puisqu'il n'avait pas toutes ses dents, et qui a grossi depuis qu'il est à Chaillot, oir M. de Sève l'a dessiné au commencement d'octobre. Yous estimons qu’il pouvait avoir neuf à dix mois d'ảge. Sa longueur, du museau jusyirà l'amus, était d'un pied onze pouces, sur treize à quatorze ponces de hauteur au train de derrière.

Le jaguar qui est gravé avait deux pieds ciucf pouces quatre lignes de longueur, sur un pied (guatre pouces neuf lignes de hauteur au train de derrière; mais il avait deux ans. Au reste, il y a une grande conformité entre ces deux animaux, quojoue de pays differents. II y a quelcues différences dans la forme des taches, qui ne paraissent ètre que des varictés individuelles. L’iris est d'un brun tirant sur le verdatre; le bord des yeux est noir, avee une bande blanche au-dessus comme au-dessous; la couleur du poil de la tète est d’un fauve mẻlé de gris. Cette méme teinte fait le fond des taches du corps, (qui sont bordées ou mouchetées de bandes noires. Ces taches et ces bandes sont sur un fond d'un blane sale roussàtre, et tirant plus ou moins sur le gris. Le's oreilles sont noires, et ont une grande tache tres-blanche sur la partie externe; la quenc est fort grande et bieu fournie de poil.

\section{LE COUGUAR.}

(rélıs couguar, Cur.)

Ordre des raruassiers, faubille des carraisures, tribu des digitigrades, geure chat. (Cuvier.)

Le couguar a la taille aussi longue, mais moins étoffée cure le jacruar; il est plus levreté, plus eftilé et plus haut sul ses jambes; il a la téte pe- 
tite, la queue longue, le poil court et de couleur presque uniforme, d'un roux vif, mèlé de quelques teintes noirâtres, surtout au-dessus du dos; il n'est marqué ni de bandes longues comme le tigre, ni de taches rondes et pleines comme le léopard, ni de taches en anneaux ou en roses comme l'once et la panthère; il a le menton blanchâtre, ainsi que la gorge et toutes les parties inférieures du corps. Quoique plus faible, il est aussi féroce et peut-être plus cruel que le jasguar. Il parait être eucore plus acharné sur sa proie ", il la dérore sans la dépecer; dèsqu'il l'a saisie, il l'entame, la suce, la mange de suite, et ne la quitte pas qu'il ne soit pleinement rassasié.

Cet animal est assez commun à la Guiane; autrefois on l'a vu arriver à la nage et en nombre dans l'ile de Cayenne ${ }^{2}$, pour attaquer et dévaster les troupeaux : c'était, dans les commenecments, un fléau pour la colonie; mais peu à peu on l'a chassé, détruit et relégué loin des habitations. On le trouve au Brésil, au Paraguay, au pays des Amazones; et il y a graude apparence que l'animal qui nous est indiqué dans rpuelques relations, sous le nom d'ocorome ${ }^{3}$ dans le pays des Moxes au Pérou, est le mème que le couguar, aussi bien que celui du pays des Iroquois ${ }^{\star}$, qu'on a regardé comme un tigre, quoiqu'il ne soit point moucheté comme la panthère, ni marqué de baudes longues comme le tigre.

Le couguar, par la légèreté de son corps et la plus grande longueur de ses jambes, doit mieux courir que le jaguar et grimper aussi plus aisément sur les arbres : ils sont tous deux également paresscux et poltrons dès qu'ils sont rassasiés; ils nattaquent presque jamais les hommes, à moins qu'ils ne les trouvent endor-

1 Cuguacu arana. Tizre rouge, ou plutút Bay ronge, qui est le plus goulu et le plus carnassier de tous, Barrère, Ilist. de la France écjuin., page 166.

2 Yoyage de Desmarchais, p. 500. - l a colonie de Cayenne n'eut jas de plus grand flésu à essuyer que celui des tigres. Voyage de Voodes Kogers. Ansterd., 1710, tome 111, page 28.

s Locorome, du pays des 11 oxes, au Pérou, est de la grandeur d'un grand chien; sou poil est roux, sou museau pointu, ses dents fort affilées. Lettres éditiantes, dixième reeueil. $\mathbf{P a -}$ ris, 1715. - Second volume des Voyagr's de Coréal. Paris, 1722, page 352 .

4 On trouve, au pays des Iroquois, des tigres de conleur de petit-gris, quỉ ne sont point nıouclıetés; ils ont la queue fort longue, et donnent la chasse an porc-épie. Les Iroquois les tuent jlus souvent sur les arbi'es qu'à terre..... Quelques-uns ont le poil rougeàtre; tous l'ont très-fin, et leurs peaux lont de très-bonnes fourrures. Ilistoire de la Nouvelle-France, par le P. Charlevoix. Paris, 1744, tome 1, page 272. mis. Lorsqu'on veut passer la nuit ou s'arrêter dans les bois, il suffit d'allumer du feu "pour les empêeher' d'approcher. Ils se plaisent à l'om. bre dans les grandes forêts; ils se cachent dans un fort ou nème sur un arbre touffu, d'où ils s'élancent sur les animaux qui passent. Quoiqu'ils ne vivent que de proie et qu'ils s'abreuvent plus souvent de sang que d'eau, on prétend que leur chair est très-bonne d̀ manger. Pison dit expressémeut qu'elle est aussi bonne que celle du veau; d'autres la comparent à celle du mouton. J'ai bien de la peine à croire que ce soit en effet une viande de bon goût; j'aime mieux m'en rapporter au témoignage de Desmarchais, qui dit que ce qu'il y a de mieux dans ces auimaux, c'est la peau, dont on fait des housses de cheval, et qu'on est peu friand de leur chair, qui, d'ordinaire, est maigre et d'un fumet peu agréable.

\section{ADDITION A L'ARTICLE DU COUGUAR.}

\section{COUGuar de PENSYLYANIF.}

Le jaguar, ainsi que le couguar, habite dans les contrées les plus chaudes de l'Amérique méridionale; mais il y a une autre espèce de couguar, qui se trouve dans les parties tempérées de l'Amérique septentrionale, surtout dans les montagnes de la Caroline, de la Géorgie, de la Pensylvanie, et des provinces adjacentes. Le dessin de ce couguar m'a été envoyé d'Angleterre parfeu M. Collinson, avec la descriptiou ci-jointe. Si elle est exacte, ce couguar ne laisse pas de différer beaucoup du couguar ordinaire, auquel on peut le comparer. Voici ce que m'en a écrit alors M. Collinson.

Le couguar de Pensylvanie diffère beaucoup, par sa taille et frar ses dimensiuns, du couguar de Cayenne. Il est plus bas de jambes, beaucoup plus long de corps, la queue aussi de trois ou quatre pouces plus longue. Au reste, ils se ressemblent parfaitement par la couleur du poil, par la forme de la tète et par celle des oreilles. Le cou-

1 I.es Indiens des bords de l'Orénoque, dans la Guiane, allument du feu pendant la nuit pour épouvanter les tigres. qui no osent approcher du licu où ils sont tant que le feu brùle. On n'a rien à craindre de ces tigr's, quand mème ils seraicul en grand nombre, tant que le feu dure. Histoire Naturelle de l'Orénoque, par le P. Joseph Jumilla, traduite de l'espagnol. Avignon, 1758, tome $\amalg$, page 3. 
guar de Pensylvanie, ajoute M. Collinson, est un animal remarquable par son corps mince et trèsallongé, ses jambes courtes et sa longue quene. Voici ses dimensions :

Longueur du corps, depuis le museau jusqu'à

l'anus. .............. 5 4 4 0

congueur de la quene. . . . . . . 260

Longueur des jambes de devant. ...... 100

Longueur des jannles de derrięre. . . . . 1 I 50

Itauteur du corps ì l'arant. . . . . . . 1990

Ilauteur du corps à l'arrière. ....... 1100

Circonférence du corps à l'endroit le plus

gros.................... 230

M. Edwards, dont l'habileté dans l'art du dessin et les connaissances en histoire naturelle méritent les éloges de tous les amateur's des sciences, m'a envoyé quelques gravures qu'il n'avait pas encore publiées, et cui sont relatives au dessin envoyé par feu M. Collinson.

\section{COUGUAR NOIR.}

M. de la Borde, médecin du roi, à Cayenue, m'écrit qu'il y a, dans ee continent, trois animaux de ces espèces voraces, dont le premier est le jaguar, et que l'on appelle tigre ; le second, le couguar, qu'on nomme tigre rouge, à cause de la couleur uniforme de son poil roux; que le jaguar est de la grandeur d'un gros dogue, et qu'il pèse environ deux cents livres; que le couguar est plus petit, moins dangereux et en moindre nombre que le jaguar dans les terres voisines de Cayeme, et que ces deux animaux sont environ six ans it prendre leur aceroissement entier.

Il ajoute (ju'il y a une troisième espèce assez commune dans ce mème pays, que l'on appelle tigre noir ; et c'est celui que nons ayons appelé conguar noir.

La tète, dit M. de la Borde, est assez semblable à celle des couguars; mais il a le poil noir et long, la quene for longue aussi, avec d'assez. forles moustaches. 11 he pèse gruère que quarante livres. Il fait ses petits dans des trous d'arbres creux.

Ce couguar noir pourrait bien ètre le même animal que Pison et Maregrave ont indiqué sous le eom de jaguarclle ou jayuar à gooil noir, et dont aucun autre royageur' n'a fait mention sous ce même nom de jaguarelte; je trouve sculement dans une note de MI. Sonini de Manoneourt que le jaguarclle s'appelle à Cayemne tigre noir ; qu'il est d'une espèce différente de celle du jaguar, étant d'une plus petite taille et ayant lc corps fort effilé. Cet animal est trèsméchant ct très-carnassier; mais il est assez rare dans les terres voisines de Cayenne.

Les jaguars et les conguars, continue M. de la Borde, sont fort conmuns dans toutes les terres qui avoisinent la riviere des $\Delta$ mazones, jusqu' celle de Sainte-Marthe; leur pean est assez tendre pour que les Indiens leur envoient des flèclies qui pénètrent avant, poussées avec de simiples sarbacanes. Au reste, tous ces animaux ne sont pas absolument avides de carnage; une seule proie leur suffit. On les rencontre presque toujour's seuls, e: quelquefois deux ou trois ensemble quand les lemelles sont en chaleur.

Lorsqu'ils sont fort affames, ils attaquent les raclies et les boufs en leur santant sur le dos; ils enfoncent les griffes dle la patte gauche sur le cou, et lorsque le bœuf est courbé, ils le déchirent, et trainent les lambeaux de la chair dans le bois, après lui aroir ouvert la poitrine et le ventre pour looire tout le sang, dont ils se contentent pour une première fois. Ils couvrent ensuite arec des branches les restes de leur proie, et ne s'en écartent jamais guère; mais, lorsque la clıair commence à se cor rompre, ils n'en mangent plus. Quelguefois ils se 'mettent à l'affit sur des arbres pour s'elancer sur les aninaux qui viennent à passer. Ils suivent aussi les troupes de coclions sauvages et tombent sur les trinneurs; mais, s'ils se laissent une fois entourer par ces animaux, ils ue trouvent de salut yue dans la fuite.

Au reste, les jaguars, ainsi que les conguars, ne sont pas absolument féroces, et n'attaquent pas les hommes, à moins qu'ils ne se sentent blessés; mais ils sont intrejpides contre les attaques des eliens, et vont les preudre près des liabitations: lorsque plusieurs chicns les poursuivent et les forcent à fuir par leur nombre, ils grimpent sur les arbres. Ces animaux ròdent souvent le long des bords de la mer, et ils mangent les cufs yue les tortues viennent y déposer. Ils mangent aussi des cainans, des lezzards et du poisson, quelquefois les bourgeons et les feuilles tendres des palétuviers. Ils sont bons nageurs et traversent des rivières très-larges. Pour mentre les caimans, ils se conchent ventre à terre au bord de la rivière, et battent l'eau pour faire du bruit, alin d'attirer le caïman, qui ne manujue pas de venir aussitit et de lever la tète, sur laquelle le jaguar se jette; il le tue et le traine plus loin pour le manger à loisir.

Les Indiens pretendent que les jaguars attirent l'agouti en contrefaisant son cri; mais ils ajoutent qu'ils attirenı aussi le caiman par un cri semblable 
à celui ites jeunes dlìns, ou en contrefaisant la voix d'un homme qui tousse, ce qui est plus difficile, à croire.

Ces animaux carnassiers détruisent beaucoup de chiens de chasse qu'ils surprennent à la poursuite du gibier. Les Indiens prétendent qu'on peut préserver les chiens de leur attaque, en les frottant avec une certaine herbe dont l'odeur les éloigne.

Quand ces animaux sont en chaleur, ils ont une espèce de rugrissement effrayant, et qu on entend de fort loin. Ils ne font ordinairement qu'un petit, qu'ils déposent toujours dans de gros troncs d'arbres pourris. On mange à Cayenne la clıair de ces animaux, surtout celle des jeunes, qui est blanche comme celle du lapin ${ }^{1}$.

Le corguar, réduit en captivité, est presque aussi doux que les autres animaux domestiques.

J'ai vu (dit l'auteur des Recherches sur les Américains) un couguar vivant, cliez Ducos, maitre des bêtes étrangères : il avait la tranquillité d'un chien et beaucou ? plus que la corpulence d'un trèsgrand logue; il est liaut monté sur ses jambes, ce qui le rend svelte et alerte; ses dents canines sont coniques et très-grandes. On ne l'avait ni désarmé ni enmuselé, et on le conduisait en laisse.... II se laissait flatter de la main, et je ris de petits rarcons monter sur son dos et s'y tenir à califourchon. Le nom de tigre poltron lui a été bien ilonne ${ }^{2}$.

\section{DESCRIPTION DU COUGUAR.}

(ExTRAIT DE DAUBENTON.)

Le couguar a le corps long et effile, la queue trainante et cylindrique, les jambes longues et grosses, et la tête fort petite en comparaison dı reste lu corps ; les oreilles ressemblent à celles du chat, mais elles sont plus courtes. Cette description a été faite sur un couguar femelle, yui avait le sommet de la tête plus aplati que le chat, et le front moins élevé, le museau plus long, plus gros, plus large : le chanfrein était un peu arqué et le bout du nez arrondi; cependant le nez était plus saillant que celui du chat, car il paraissait plus avancé que la lèvre supérieure, tandis que, tlans le clıat, il semble être plus reculé; les tubercules de la plante des pieds, les doigts et les ongles ne différaient de ces mèmes partics, vues clans le chat, que pour la grandeur.

\footnotetext{
1 Extrait des observations de M. de la Horde, envoyies a M. de Buffon en 1774 .

"Defense tles R Lr\% s sur les Americains, page 86.
}

Les còtés de la tère et l'occiput, le dessus du cou, les épaules, le dos, les lombes, la croupe, la queue à l'exception de son extrémití, les côtés du corps et la face externe des quatre jambes avaient une couleur faure, plus ou moins foncée et mêlée de teintes noirîtres sur quel |ues parties, parce que la pointe dles poils y était nuire; cette teinte de noirou de noirâtre ne paraissait que sur le cou et le long du cos et des lombes jusqu'à la queue : la couleur fauve la plus foncée était sur la cuisse à l'endroit de la fesse; le bout de la queue était noirâtre. Le chanfrein, le tour des yeux, le front et le dessus de la tête avaient une couleur fauve, terne et mèlée de gris et le noirâtre. Le gris était fort apparent au-dessus et au-dessous des yeux; la face interne de l'oreille avait une couleur blanche légèrement teinte de fauve; la face externe était de couleur noirâtre, avec des teintes de fauve et de gris; il y avait du poil on des cils noirs sur le bord de la panpière supérieure; les yeux étaient bordés de noir; l'endroit des moustaches avait aussi une conleur noire; le reste de la lèvre du dessus était blanc avec quelques teintes de fauve; la lèvre de dessous et la gorge araient une couleur blanche sans mélange; le dessous du cou ètait d'une couleur faure, pâle, mèlée dle blanchâtre. La partie antérieure de la poitrine et la face interne du bras avaient une coulenr blanche arec un cendré et dn fauve, qui paraissaient lorsque l'on écartait les poils, parce qu'ils ėtaient de couleur cendrée près de la racine, blancs à la pointe el fauves sur le milieu de leur longueur : le fauve et le cendré étaient aussi apparents que le blanc sur la face interne de l'avantbras et de la jambe ; la partie postérieure de la poitrine et le ventre avaient un peu de blanc dans leur milieu; ils étaient au reste de même couleur que les côiés du corps; la face interne de la cuisse était blanche avec quelques légères teintes de centré et de roussâtre, parce que cliaque poil avait ces tein. tes près de la racine et du blanc dans le reste de sa longueur. Les plus longs poils étaient à l'aine; ils avaient jusqu'à deux pouces el demi de longueur; ceux du dos, des lombes, des cótés n'étaient longs que d'environ un pouce; les crins des moustaches étaient en partie noiritres et en grande partie blancs; les plus longs n'avaient pas plus de deux ponces et clemi.

\section{L'OCELO'T. \\ ( Mílis ocelot, Cuv.)}

Ordl'c des carnassicrs, fanille des carnirores, tritı des digitigrades, genre chat. (Curier.)

L'ocelot cst un animal d'Amérique, féroce et carnassicr, que l'on doit placer à côté du ja- 
guar, du couguar, ou immédiatement après; car il en approche pour la grandeur, et leur ressemble par lenaturel et par la figure. Le mâle et la femelle ont été apportés vivants à Paris par M. Lescot, et on les a vus à la foire SaintOvide, au mois de septembre de cette année 1764. Ils venaient des terres voisines de Carthagène, et ils avaient été enlevés tout petits à leur mère, au mois d'octobre 1763 : à trois mois d'âge, ils étaient déjà devenus assez forts et assez cruels pour tuer et dévorer une chicnne qu'on leur avait donnée pour nourrice; à un an d'âge, lorsque nous les avons vus, ils avaient environ deux pieds de longueur, et il est certain qu'il leur restait encore à croittre, et que, probablement, ils n'avaient pris alors que la moitié ou les deux ticrs de leur entier aceroissement. On les montrait sous le nom de chaltigre; mais nous avons rejeté cette dénomination précaire et composée, avec d'autant plus de raison qu'on nous a envoyé, sous ce mème nom, le jaguar, le serval et le margay, qui eependant sont tous trois différents les uns des autres, et différents aussi de celui dont il est ici question.

Le premier auteur qui ait fait mention expresse de cet animal, et d'une manière à le faire reconnaittre, est Fabri : il a fait graver les dessins qu'en avait faits Rechi; et en a composé la description d'après ces mêmes dessins, qui étaient coloriés; il en donne aussi une espèce d'histoire, d'après ce que Grégoire de Bolivar en avait écrit et lui en avait raconté. Je fais ces remarques dans la vue d'éclaircir un fait qui a jeté les naturalistes dans une espèce d'erreur, et sur lequel j'avoue que je m'étais trompé comme eux : ce fait est de savoir si les deux animaux dessinés par Recechi, le premier avee le nom de llallauhqui-oceloll, et le second avec celui de llacoozlotl, llaloceloll, et ensuite décrits par Fabr'i comme étant d'espèces différentes, ne sont pas le méme animal. On était fondé à les regarder, et on les regardait en effet comme différents, quoique les figures soient assez semblables, parce qu'il ne laisse pas d'y avoir des différences dans les noms, et méme dans les deseriptions. J'avais done cru que le premier pouvait être le mème que le jaguar, en sorte que, dans la nomenclature de cet animal, j'y ai rapporté le nom mexicain tlatlauthqui-oceloll : or ce nom mexicain ne lui appartient pas; ct depuis que nous avons v'u les animaux male et femelle dont nous parlons iei, je me suis persuadé que les deux qui ont été décrits par Fabri ne sont que ce même animal, dont le premier est le mâle, et le second la femelle. Il fallait un hasard comme celui que nous avons eu, et voir ensemble le mâle et la femelle pour reconnaitre cette petite erreur. De tous les animaux à peau tigrée, l'ocelot mâle a certainement la robe la plus belle et la plus élégamment variée' ; celle du léopard même n'en approche pas pour la vivacité des couleurs et la régularité du dessin; et celle du jaguar, de la panthèreou de l'once en approche encore moins ; mais, dans l'ocelot femelle, les couleurs sont bien plus faibles, et le dessin moins régulie:, et c'est eette différence très-apparente qui a pu tromper Recehi, Vabri et les autres. On verra, en comparant les figures et les deseriptions de l'une et de l'autre, que les différences ne laissent pas d'être considérables ; ct qu'il manque à la robe de la femelle beaucoup de fleurs et d'ornements qui se trouvent sur celle du mâle.

Lorsque l'ocelot a pris son entier accroissement, il a, selon Grégoire de Bolivar, deux pieds et demi de hauteur sur environ quatre pieds de longueur; la quene, quoique assez longue, ne touche cependant pas la terre lorsqu'elle est pendante, et, par conséquent, elle n'a guère que deux pieds de longueur. Cet animal est très-vorace, il est en méme temps timide; il attaque rarement les hommes; il craint les chiens, et, dès qu il en est poursuivi, il gagne les bois et grimpe sur un arbre : il y demeure, et même y sćjourue pour dormir et pour épier le gibier ou le bétail, sur lecpuel il s'élance dès qu'il le voit à portée. Il préfère le sang à la chair , et c'est par cette raison qu'il détruit un grand nombre d'animaux, parce qu'au lieu de se rassasiciv"n ", "dévorant, il ne fait que se désaltérer en leu. suleant le sang ${ }^{2}$.

4 Universum corpus puleliro roseo ine subrubet colore. excepto inferiore venlre qui allicat polius; inaculis rosarum eftigic nigcicantibus omuibus intra suave rnbenten colorem, tolum ita corpus, pedes el cauda ordine ynodan distiaguarttur ut elegantem pline hnic animali acu pichun tapelem vel perijetasma impositum crederes : sunt anlem macula hie in dorso et capite rulundiores majoresıuc : versus ventrem vero pedes!nue oblonginsenlie el multo minores. Fubri apud $11 \mathrm{er}$. uand. llist. Iex., page $\mathbf{8 9 8 .}$

${ }^{2}$ lampier parle de ce méme animal sons le nom de chatligre, et roici ce qu"il eu dit : - Le chat-ligre des tertes de Ia - baie de Campiche esl de lit grosseur de jos chieus qquon fais - baltie arec les tameanx; il a les jambes courtes, le corps - lamassé, el à pen piès cunme celui d’un milin; mais - prour tont le resle, cest-a-dire la léte, le poil, la manière 
Dans l'etat de captivité il conserve ses mœurs; rien nc peut adoucir son naturel féroce, rien ne peut calmer ses mouvements inquiets; on est obligé de le tenir toujours en cage. " $\mathrm{A}$ trois " mois (dit M. Lescot), lorsque ces deux petits " eurent dévoré leur nourrice, je les tins en " cage, et je les y ai nourris avec de la viande " fraîche, dont ils mangent sept à huit livres " par jour; ils fraient ensemble, mâle et femelle, " comme nos chats domestiques. Il règne entre a cux une supériorité singulière de la part du " mále : quelque appétit qu'aient ces deux ania maux, jamais la femelle ne s'avise de rien " prendre que le mâle n'ait sa saturation, et "qu'il ne lui envoie les morceaux dont il ne " veut plus. Je leur ai donné plusieurs fois des " chats vivants; ils leur sucent le sang jusqu'à " ce que mort s'ensuive; mais jamais ils ne les " mangent. J'avais embarqué pour leur subsis" tance deux chevreaux; ils ne mangent d'au" cune viande euite ni salée. "

Il paraist, par le témoignage de Grégoire de Bolivar, que ces animaux ne produisent ordinairement que deux petits, et celui de M. Lescot semble confirmer ce fait; car il dit aussi ('il'on avait tué la mère avant de prendre les d'ux petits dont nous venons de parler. II en est de l'ocelot comme du jaguar, de la panthère, du léopard, du tigre et du lion : tous ces animaux, remarquables par leur grandeur, ne produisent qu'en petit nombre, au lieu que les chats, qu'on pourrait associer à cette même tribu, produisent en assez grand nombre; ce qui prouve que le plus ou le moins dans la production tient beaucoup plus à la grandeur qu'à la forme.

a de quêter la proie, il ressemble fort au tigre (jagnar), ex- cepté quil n'est pas tont à fail si gros : jl y en a ici une - grande yuantité ; ils dévorent les jcunes veaux et le gibier, a quon y Irouve eu abonlance, aussi sont-jls moins a crain- dre prur celi même quits ue manquent pas de pâture... lls a ont la mine altière ct le regard farouche. $v$ Voyage de 1)anpier, tome 111 , page 506.

\section{LE MARGAY ET LE GUÉPARD.}

\section{(LE FELIS MARGaY, LE FELIS GUÉPARD.)}

Ordre des carnassiers, famille des carnivores, tribu des digitigrades, genre chat. (Curier.)

Le margay est beaucoup plus petit que l'oeelot; il ressemble au chat sauvage par la grandeur et la figure du corps; il a seulement la tête plus carréc, le museau moins court, les oreilles plus arrondies et la queue plus longue: son poil est aussi plus court que celui du chat sauvage, et il est marqué de bandes, de raies et de taches noires sur un fond de couleur faure. On nous l'a envoyé de Cayenne sous le nom du chat-tigre, et il tient en effet de la nature du chat et de celle du jaguar ou de l'ocelot, qui sont les deux animaux auxquels on a donné le nom de tigre dans le nouveau continent. Selon Fernandès, cet animal, lorsqu'il a pris son accroissement en entier, n'est pas tout à fait si grand que la civette; et selon Marcgrave, dont la comparaison nous paraît plus juste, il est de la grandeur du chat sauvage, auquel il ressemble aussi par les habitudes naturelles, ne vivant que de petit gibier, de volailles, ete.; mais il est très-difficile à apprivoiser, et ne perd même jamais son naturel féroce. Il varie beaucoup pour les couleurs, quoique ordinairement il soit tel que nous le présentons ici. C'est un animal très-commun à la Guiane, au Brésil et dans toutes les autres provinces de l'Amérique méridionale. Il y a apparence que c'est le même qu'à la Louisiane on appelle pichou ${ }^{4}$; mais l'espèce en est moins commune dans les pays tempérés que dans les climats chauds.

Si nous faisons la révision de ces animaux eruels, dont la robe est si belle et la nature si perfide, nous trouverons dans l'ancien continent le tigre, la panthère, le léopard, l'once, le serval : et, dans le nouveau, le jaguar, l'ocelot et le margay, qui, tous trois, ne paraissent être que des diminutifs des premiers, et qui, n'en ayant ni la taille ni la force, sont aussi

\footnotetext{
4. I. pichou esl une espece de chal pitois aussi hant yue le tigre, mais moins gros, dont la peau est assez belle; cest un grand deslrucleur de volailles; mais, par bonheur, il n'est pas commun is la l.onisiane. Ilistuìe de la Louisiane, par le Page (h) l'aly, lome 11 , page 92, fig., page 67.
} 
imides, aussi lâches que les autres sont intréiides et fiers.

Il y a encore un animal de ce genre, qui semle différer de tous ceux que nous venons de oommer; les fourreurs l'appellent guépard. Vous en avons vu plusieurs peaux, elles ressemlent à celles du lynx par la longueur du poil; nais les oreilles n'étant pas terminées par un jinceau, le guépard n'est point un lynx : il n'est ussi ni panthère ni léopard; il n'a pas le poil :ourt comme ces animaux, et il diffère de tous zar une espèce de crinière ou de poil long de [uatre ou cinq pouces qu'il porte sur le cou et untre les épaules; il a aussi le poil du ventre ong de trois à quatre pouces, et la queue à moportion plus courte que la panthère, le léoard ou l'onee; il est à peu près de la taille de se. dernier animal, n'ayant qu'environ trois jieds et demi de longueur de corps. Au reste, a robe, qui est d'un fauve très-pâle, est parsemée, comme celle du léopard, de taches noi'es, mais plus voisines les unes des autres et plus petites, n'ayant que trois ou quatre lignes le diamètre.

J'ai pensé que cet animal devait être le même que celui qu'indique Kolbe sous le nom de louptigre; je cite ici sa description ' pour qu'on puisse la comparer avec la nôtre. C'est un animal conmun dans les terres voisines du cap de BonneEspérance. Tout le jour il se tient dans des fentes de rochers ou dans des trous qu'il se creuse en terre; pendant la nuit, il va ehereher sa proie : mais comme il hurle en chassant son gibier, il avertit les hommes et les animaux, en sorte qu'il est assez aisé de l'éviter ou de le tuer. Au reste, il paraît que le mot guépard est dérivé de lépard; c'est ainsi que les Allemands et les Hollandais appellent le léopard. Nous avons aussi reconnu qu'il y a des variétés dans cette espèce, pour le fond du poil et pour la couleur

4 11 est de la taille d'un chien ordinalre, et quelıuefois plus gros; sa tête est large comme celle des dogues que l'on fait battre en Angleterre contre les taureaux; il a les máchoires grosses, aussi bien que le museau et les yeux; ses deuts sout fort tranchantes; son poil est frisé comme celui d'un chien barbct, et tacheté comme celui dı ligre; il a les pattes larges et armées de grosses griffes, (qu'il retire quind il vent. comme les chats; sa quene est cunrle... Il a pour mortels cuncuis le lion, le tigte et le téopart, qui lui domuent très-souvent la chasse; ils le poursuivent jusinue daus sa tauière, se jettent sur lui et le mettent en pièces. Description du eap de IbomseFspérance, pir Kolbe, lome 111 , pag. 69 et 70. Nota. L'animal auquel cet auteur dombe le nom de tigre est celui tı!e nons avons appelé léopard, et celui quil nomme léopard est la panthere. des taches; mais tous les guépards ont le caractère commun des longs poils sous le ventre, et de la crinière sur le cou

ADDition A L'ARTICLE DU JAGUAR OU LÉOPARD.

Nous donnons iei la figure d'un animal de l'espèce des léopards ou des jaguars; le dessin nous en a été enroyé par feu Ml. Collinson, mais sans nom et sans aucune notice. Et comme nous ignorons s'il appartient à l'ancicn ou au nouveau continent, et qu'en même temps il differe de l'once et du léopard par la forme des taches, et plus encore du jagruar et de l'ocelot, nous ne pouvons déeider anquel de ces animaux on doit le rapporter : sculement il nous parait. qu'il a un peu plus de rapport avec le jaguar qu'avec le léopard ${ }^{4}$.

\section{ADDITION A L'ARTICLE DU MARGAY}

Nous devons rapporter à l'article du margay le chat-tigre de Cayenne, dont M. de la Borde parle dans les termes suivants:

La peau du chat-tigre est, commecelle de l'onec, fort tachetce; il est un peu moins gros que le renard, mais il en a toutes les inclinations. On le trouve conmunẻment à Cayenne dans les bois. Il dẻtruit leaucoup de gibier, tels que les agroutis, akouchis, perdrix, faisans et autres viseaux quil prend dans leurs nids quand ils sont jeunes. Il est fort leste pour trimper sur les arbres ou il se tient caclıć. II ue court pas vile et toujours en santant. Son air, sa marche, sa manière de se coucher, ressemblent parfaitement à celles du chat. J'en ai vu plusieurs dans les maisons de Cayenne, qu'on tenait enchainés; ils se laissaient un peu toucher sur le dlos; mais il leur reste toujours dims la figure un air féroce. On ne leur donuait pour nourriture que du poisson et de la viande cuite on crue; tout autre aliment leur répugne. Ils produisent en toutes saisons, soit l'été, soit l'hiver, et font deux petits à la fois dans des ereux darbres pourris.

Il y a un autre chat-tigre, ou plutit une espéce de chat sauvage à la Caroline, duquel feu M. Collinson m a envoyé la notice sujvante:

Le màle élail de la grandeur al'un chat commun; il avail dix-neuf punees anylais, du nez à la queue

- Cet auimal neest aulre que le guéparı]. 
qui était de quatre pouces de long, et avait huit anneaux blancs comme le mococo. La couleur était d'un brun clair, mêlé de poils gris; mais ce qu'il avait de plus remarquable sont les raies noires, assez larges, placees en forme de rayons tout le long de son corps, sur les côtés, depuis la tête jusqu'à la yueue. Le ventre est d'une couleur claire avec des taches noires; les jambes sont minces, tachetées de noir; ses oreilles avaient une large ouverture; elles étaient couvertes de poils fins. Il avail deux larges taches noires très-remarquables sous les yeux, de chaque côté du nez; et de la partie la plus basse de cette tache joignant à la lèrre, il part un boụuet de poils raides et noirs. La femelle est de taille plus mince : elle était tonte gris-roussâtre, sans ancune taclıe sur le dos, seulement une tache noire sur le ventre qui était blanc sale'.

\section{LE SERVAL.}

\section{(LE Felis SaUvage.)}

Or'ure des carnassiers, famille des carnivores, tribu des digitigrades, genre chat. (Curier.)

Cet animal qui a véeu pendant quelques années à la Ménagerie du Roi, sous le nom de chat-tigre, nous paraît être le même que celui qui a été décrit par MM. de l'Académie sous le non de chat-pard; et nous ignorerions peutetre encore son vrai nom, si M. le marquis de Montmirail ne l'eùt trou vé dans un Voyage italien, dont il a fait la traduction et J'extrait. "Le maraputé, que les Portugais de l'Inde ap" pellent serval (dit le P. Vincent-Marie), est " un animal sauvage et féroce, plus gros que le " chat sauvage et un peu plus petit que la ci" vette, de laquelle il diffère en ce que sa tête " est plus ronde, et plus grosse relatirement " au volume de son corps, et que son front pa" rait crensé dans le milieu. Il ressemble à la " panthère par' les couleur's du poil, qui est fauve " sur la tête, le dos, les flanes, et blane sous " le ventre, et aussi par les taches qui sont dis" tinctes, également distribuées et un peu plus " petites que celles de la panthère; ses ycux " sont très-brillants, ses moustaches fournies de " soies Inngues et raides; il a la queue courte, " les pieds grands et armés d'ongles longs et " crochus. On le trouve dans les montagnes de

"l'Inde: on le roit rarement à terre; il se tient

'Lettre de M. Collinson à sI de Buffon, 25 décemisre 1766.
" presque toujours sur les arbres, où il fait son " nid et prend les oiseaux, desquels il se nour" rit:il saute aussi légèrement qu'un singe a d'un arbre à l'autre, et avec tant d'adressc " et d'agilité, qu'en un instant il parcourt un " grand espace et qu'il ne fait, pour ainsi dire, " que paraitre et disparaitre. Il est d'un natu"rel féroce; cependant il fuit à l'aspect de "l'homme, à moins qu'on ne l'irrite, surtout " en dérangeant sa bauge; car alors il devient " furieux, il s'élance, mord et déchire à peu " près comme la panthère. "

La captivité, les bons ou les mauvais traitements, ne peuvent ni dompter ni adoucir la férocité de cet animal; celui que nous a vons vu à la Ménagerie était tonjours sur le point de s'élancer contre ceux qui l'approchaient: on n'a pu le dessiner ni le décrire qu'à traver's la grille de sa loge. On le nourrissait de chair comme les panthères et les léopards.

Ce serval ou maraputé du Malabar et des In. des ${ }^{1}$ nous paraît être le même animal que le chat-tigre du Sénégal et du cap de Bonne-Espérance, qui, selon le témoignage des royaguitis", ressemble au chat par la figure, et au tigre ( c'est-à-dire à la panthère ou au léopard) par les taches roires et blanches de son poil. "Cet " animal, disent-ils, est quatre fois plus gros " qu'un chat; il est vorace et mange les singes, "les rats et les autres animaux."

Par la comparaison que nous avons faite du serval avec le chat-pard décrit par MM. de l' $A$ cadémie, nous n'y a vons trouvé d'autres difiérences que les longues taches du dos et les anneaux de la queue du chat-pard, qui ne sont pas dans le serval; il a seulement ces taches $d u$ dos placées plus près que celles des autres parties du corps; mais cette petite disconvenance fait une différence trop légère pour qu'on puisse douter de l'identité d'espèce de ces deux animaux.

\footnotetext{
411 y a à Sagori (\{le sur le Gange) des elats-ligres qui sont gros comme un monton. Nonveau royage par le siem Luillier, Rolterdam, 1726 , page 90.

2 Voyage de Le Maire, page 198. - t.e chat-de-bois, ou le chat-ligre, est le plus gros de tous les chats sanvages du Cap; son hal,itation est dans les bois, et i) est fachelé a j, 11 près comme un ligre. La preau de ces animan donne dexecllentes fournurs pour la chalemr et pour lornement; a anssi se vendentelles fort bien au Cap. Description du cap de Bonne Espé rance, prar liolbe, tome III, page s̃o.
} 


\section{DESCRIPTION DU SERVAL.}

(ExTRAit DE, DAUBENTON.)

Le serval est plus grand que le chat sauvage; mais il m’a paru n'en différer, pour la forme du corps, qu'en ce qu'il a le museau un peu plus long, les oreilles plus grandes et la queue plus courte: celui qui a servi de sujet pour cette description avait le corps à proportion plus étoffé que le chat sauvage, et mème que les chats domestiques, peutetre parce qu'il avait été nourri penclant longtemps dans une loge à la Ménagerie de Versailles. M. Perrault avait đéjà observé que le serval, dont nous présumons qu'il a dlonné la description sous le nom de chat-pard, était si gras, que son cou semblait être plus court que celui du chat. Quoique la figure que M. Perrault a jointe à cette rlescription diffère de celle que nous en donnons ici, et qui a été dessinée avec heaucoup d'exactitude sur l'animal vivant, il u'y a cepeudaut guère lieu de dlouter que ces deux figures n'aieut cté faites sur des animaux de mème espèce. J'ai vu, par la description de M. Perrault, que le chat-pard qui en était le sujet ressemblait beancoup à l'animal dont il s'agit ici pour la grandeur et les proportions du corps, et je n'y ai remaiqué pour les couleurs du poil que de légères différences, telles que l'on en trouve entre des individus de mème espèce d'animaux sauvages.

Le dessus du museau était de couleur cendrée, teinte de brun; le front, le sommet, le derrière et les cỏtés de la tète, la face externe des oreilles, le dessus et les còtés dı cou, le dos, les còtés du corps, la quene, la face externe des jambes de devant et les jambes de derrière en entier avaient une couleur fauve plus ou moins foncée et mẻlée de roussätre, et mième de ccuilré dans quelq̨ues endroits. Le bout du museau, le dessous du cou et la face interne des jambes de devant avaient une couleur blanclie ou blanchâtre: toutes ces parties étaient parsemées de taches noires ou noiritres et mêne grises; elles élaient fort petites sur la tète et sur le bas des jamhes; il $\mathrm{y}$ avait des bandes noires et transversales sur la face exlerne des oreilles et sur le haut de ba face interne de l'avant-bras, et quatre ou cinq anneaux de mème couleur noire sur le bout de la quene; les yeux ćtaient entourés d'un cercle blanc; la nuchoire inférieure, le ledans des oreilles, la gorge, la poitrine et le ventre avaient aussi une couleu lilanche; le poil a paru un peu plus gros que celui du clıat, mais à peu près dle mème longueur.

Je n'ai pu observer cet animal qu'ì travers la grille de sa loge; ainsi il ne m'a pas éte possible de prendre les dimensions des différentes parties de sont corps, ni de distinguer exactement le détail des couleurs de son poil.

\section{LE LYNX OU ILOUP-CERVIER.}

\section{(LE FELIS LYNX.)}

Ordre des carnassicr's, famille des carnirores, Iribu des digitigrades, genre chat. (Cuvier.)

Messieurs de l'Académie des sciences nous ont donné une très-bonne deseription du lyn $x$ on loup-cervier, et ils ont discuté, en eritiques éclairés, les faits et les noms qui ont rapport à cet animal dans les écrits des anciens : ils fout voir que le Iynx d'Alien est le mème animal que celui qu'ils ont déerit et disséqué, sous le nom de loup-cervier, et ils censurent avec raison ceux qui l'ont pris pour le thos d'Aristote. Cette discussion est mêlée d'observations et de réflexions qui sont intéressantes et solides. En général, la description de cet animal est une des mieux faites de tout l'ouvrage; on ne peut même les blàmer de ce qu'après avoir prouvé que cet animal est le lyn $x$ d'Alien et non pas le thos d'Aristote, ils ne lui aient pas conservé son vrai nom lynx, et qu'ils lui aient donné en francais le même nom que Gaza a donné en latin au thos d'Aristote. Gaza est en effet le premier qui, dans sa traduction de l'histoire des animaux d'Aristote, ait traduit $\theta u ́ s$ par lupus-cervarius; ils auraient dù seulement avertir que, par le nom de loup-cervier, ils n'entendaient pas le lupus-cervarius de Gaza ou le thos d'Alistote, mais le lupus-cervarius ou le chaus de Pline. Il nous a aussi parn qu'après avoir très-bien indicqué, d'après Oppien, qu'il y avait deux espèces ou deux races de loups-cerviers, les uns plus grands qui chassent et attaquent les daims et les cerfs, les autres plus petits qui ne chassent guère (fu'au lièrre, ils ont mis ensemble deux espèces réellement différentes; savoir, le lyux marqué de taches, qui se trouve communément dans les pays septentrionaux, et le lynx du l.evant ou de la Barbarie, dont le poil est sans taches et de couleur uniforme. Nous avons vu ces deux animaux vivants : ils se ressemblent à bien des égards; ils ont tous deux un long pinceau de poil noir au bout des oreilles : ce caractère particulier, mr lequel Aslien a le premier indiqué le lyon, n’appartient cu effet qu'à ces deux animaux; et 
c'est probablement ce qui a déterminé MM. de l'Académie à les regarder tous deux comme ne faisant qu'un. Mais, indépendamment de la différence de la couleur et des taches du poil, on verra, par l'histoire et la description suivantes, que très-vraisemblablement ce sont des animaux d'espèces différentes.

M. Klein dit que les plus beaux lynx sont en Afrique et en Asie, principalement en Perse; qu'il en a vu un à Dresde qui venait d'Afrique, qui était bien moucheté et qui était haut sur ses jambes; que ceux d'Europe, et notamment ceux qui viennent de Prusse et des autres pays septeutrionaux, sont moins beaux; qu'ils n'ont que peu ou point de blane, qu'ils sont plutôt roux avec des taches brouillées ou cumulées (maculis confluentibus, etc.). Sans vouloir nier absolument ce que dit ici M. Klein, j'avone que je n'ai trouvé nulle part ailleurs que le lynx habitât les payss chauds de l'Afrique ct de l'Asie. Kolbe est le seul qui dise qu'il est commun au cap de Bonne-Espérance, et qu'il ressemble parfaitement à celui du Brandebourg en Allemagne; mais j'ai reconnu tant d'autres méprises dans les Mémoires de cet auteur, que je n'ajoute presque aucune foi à son témoignage, à moins qu'il ne s'accorde avec celui des autres. $0 r$, tous les voyageurs disent avoir vu des lynx. ou loups-cerviers à peau tachée dans le nord de l'Allemagne, en Lithuanie, en Moscovie, en Sibérie, au Canada et dans les autres parties septentrionales de l'un et de l'autre continent; mais aucun, du moins de tous cenx que j'ai lus, ne dit avoir rencontré cet animal dans les climats chauds de l'Afrique et del'Asie. Les lynx du Levant, de la Barbarie, de l'Arabie et des autres pays chauds, sont, comme nous l'avons dit ci-dessus, d'une conleur uniforme et sans taches: ce ne sont done pas ceux dont parle M. Klein, qui, selon lui sont bien mouchetés, ni ceux de Kolbe, qui ressemblent, dit-il, parfaitement à ceux du Brandebourg. Il serait difficile de concilier ces témoignages avec ce que nous savons d'ailleurs : le lynx est certainement un animal plus commun dans les pays froids que dans les pays tempérés, et il est au moins très-rare dans les pays chauds. Il était, à la vérité, connu des Grecs ${ }^{1}$ et des Latins; mais cela

\footnotetext{
4 Les Grecs, qui dans leurs fictions ne laissaient pas de conserver les vraisemblances, et surtout les circonstances des temps et des lieux, on dit que c'était un roi de Scythie qui avait été changé en lyux; ce qui parait indiquer que le lynx était un animal de Scythie.
}

ne suppose pas qu'il vînt de l'Afrique on des provinces méridionales de l'Asie : Pline dit, au contraire, que les premiers qu'on vit à home du temps de Pompée, avaient été envoyés des Gaules. Maintenant, il n'y en a plus en France, si ce n'est peut-être quelques-uns dans les Pyrénées et les Alpes; mais aussi, sous le nom de Gaules, les Romains comprenaient beaucoupde pays septentrionaux, et d'ailleurs toutle monde sait qu'aujourd'hui la France est bien moins froide que ne l'était la Gaule. Les plus belles peaux de lynx viennent de Sibérie ${ }^{1}$, sous le nom de loup-cervier, et de Canada"; sous celui de chat-cervier, parce que, ces animaux étant, comme tous les autres, plus petits dans le nouveau que dans l'ancien continent, on les a com. parés au loup pour la grandeur en Europe, et au chat sauvage en Amérique ${ }^{3}$.

Ce qui paraît avoir décu M. Klein, et qui pourrait encore en tromper beaucoup d'antres moins habiles que lui, e'est $1^{0}$ que les anciens ont dit que l'Inde avait fourni des lynx au dicu Bacchus ${ }^{4} ; 2^{0}$ que Pline a mis des lynx en Éthio$p^{5}{ }^{5}$, et a dit qu'on en préparait le cuir et les

- On trouve en Russie beaucoup de loups-cerviers qui ont la peau belle, quoiqu'ils ne valent pas ceux de Sibérie. Nouveau Mémoire sur la Grande-Russie. Paris, 1725, toine II, page 73 .

a 11 y a, dans les bois du Canada, beancoup de loups on plutôt des chats-cerviers, car ils n'ont du loup qu'une espice de hurlement; en tout le reste ils sont, dit M. Sarrasin, ex genere felino. Ce sont de vrais chasseurs yui ne vivent que di gibier qu'ils peuvent attraper, et qu'ils poursuivent jusqu“à la cime des plus grands arbres; leur chair est blanche et bonne à manger ; leur poil et leur peau sont fort connus en France; c'est une des plus belles fourrures de ce pays, et qui entre le plus dans le commerce. Histoire de la Nouvelle-France, par le Pére Charlevoix, tome IIt , page 333.

- Le loup-cervier de l'Amériyue septentrionale est une espèce de chat, mais bien plus gros; il monte aussi sur les arbres, vit d'animaux qu'il attrape; le poil en est grand, d'un gris blanc, c'est une boune fourrure; la chair en est blanche et très-bonne à manger. Description des côtes de l"Amérique septenlrionale. Paris, $\mathbf{1 6 7 2}$, tome II, page $\mathbf{4 1 .}$

\section{Victa recemifero lyucas dedit India Baccho.}

$$
\text { oride, Metam. }
$$

5 Plinii, Hist. Nat., lib. VIII, cap, XXI ; et lib. XXVIII, cap. ViIl. - On observera que Pline ne parle ici que du lynx, et uon pas du lıpus-cervarius; que toutes les vertus et propriétés du poil, des ongles, de l'urine, etc., nont rapporl qu'a l'animal qu'il appelle lynx, et qu'il cite comme un animal extraordinaire, un monstre d'Éthiopie; et qu'il n'est pas ici question dn lonp-cervier, puisqu'il assure posilivement yue celui-ci avait été envoyé des Gaules aux spectacles de Ronne. La seule chose qui pourrait faire soupçonner que le chaus, ou Iupns-cervarius de Pline ne serait pas nutre loup-cervier, c'est qu'il dit qu'il a la figure du loup et les taches de la panthere; mais ce doute s'évanouira lorsqu'on considérera loutes les citconstances, et qu'on se rappellera d'ailleurs que, de tous les animaux de proie qui se trouvent dans les pays septentrionaux, le lonp-cervier est le seul dont la robe soit taclıée comme celle de la panthère. 
sngles à Carpathos, aujourd'hui Scarpantho ou Zerpanto, ŝle de la Méditerranée, entre Rhodes et Candie; $3^{\circ}$ que Gessner a fait un article particulier du lynx d'Asic ou d'Afrique, lequel article contient l'extrait d'une lettre d'un baron de Balicze : "Vous n'avez pas fait men" tion, dit-il à Gessner, dans votre livre des ani"maux, du Jynx indien ou africain : comme - Pline en a parlé, l'autorité de ce grand homme " m'a engagé à vous envoyer le dessin de cet " animal, afin que vous en parliez. Il a été des" siné à Constantinople : il est fort différent du "loup-cervier d'Allemagne, il est beaucoup "plus grand; il a le poil beaucoup plus rude et "plus court, ete. " Gessner, sans faire d'autres réflexions sur cette lettre, se contente d'en rapporter la substance, et de dire, par une parenthèse, que le dessin de l'animal ne lui est pas parvenu.

Pour que l'on ne tombe plus dans la même méprise, nous observerons : $1^{\circ}$ que les poëtes et les peintres ont attelé le char de Bacehus de tigres, de panthères et de lynx, selon leur caprice, ou plutôt parce que toutes ces bêtes féroces, à peau tachée, étaient également consacrées à ce dieu ; 20 que c'est le mot $\operatorname{lyn} x$ qui fait iei toute l'équivoque, puisqu'il est évident, en comparant Pline avec lui-meème ', que l'animal qu'il appelle lynx, et qu'il dit être en Éthiopie, n'est nullement celui qu'il appelle chaus ou lupuscervarius, qui venait des pays septentrionaux; que c'est par ce même nom, mal appliqué, que le baron de Balicze a été trompé, quoiqu'il rega:de le lynx indien comme un animal différent du luchs d'Allemague, c'est-à-dire de notre lynx ou loup-cervier : ce lynx indien ou africain, qu'il dit être beaucoup plus grand et mieux taché que notre loup-cervier, pourrait bien n'être qu'une sorte de panthère. Quoi qu'il en soit de

- Pompeii Magni primum ludi ostenderunt claum, quem Galli raphium vocabant, effigic lupi, partorum maculis. Plinii, lib. VIII, eap. XIX. - Sunt in eo genere (scilicet luporuin ), qui cervarii vocantur, ynalem e Gallia in Pompeii Mlagui arena spectatum diximus. Plin., lib. vIII, cap. XX11. Lyncas vulgo frequentes et sphingas, fuseo pilo, mammis in pectore geminis, Etluiopia generat, multaque alia monstro similia. Plin., lib. VII , cap. XXI. - Il est clair, en comparant ces trois passages, (nue le chans et le lunus-cervarius sont le mèure animal, et que le lyux en est un autre. La seule clıose qu'un puisse ici reprocher à Pline, c'est que, trompé apparemment par le nom, il dit que cet animal a lit ligure du loup (effigie lupii). J.e loup cervier est, comme le loup commun, un animal de proie; il en approclie encore par la grandeur du corps; il a, comme lui . une espece de hurlement on de cri prolongé; mais pour tout le reste Il en diffère absolument. cette dernière conjecture, il paralt que le lynx ou loup-cervier dont il est ici question ne se trouve point dans les contrées méridionales, mais sculement dans les pays septentrionaux de l'ancien et du nouveau continent. Olaüs dit qu'il est commun dans les forêts du nord de l'Europe : Olearius assure la même chose en parlant de la Moscovie : Rosinus Lentilius dit que les lynx sont communs en Curlande, en Lithuanie, et que ceux de la Cassubie ${ }^{1}$ (province de la Poméranie) sont plus petits et moins tachés que ceux de Pologne et de Lithuavie: enfin, Paul Jove ajoute à ees témoignagesqueles plus belles peaux de loup-cervier viennent de la Sibérie ${ }^{2}$, et qu'on en fait un grand commeree à Ustivaga, ville distante de six cents milles de Moscou.

Cet animal qui, comme l'on voit, habite les climats froids plus volontiers que les pays tempérés, est du nombre de ceux qui ont pu passer d'un continent à l'autre par les ter res du Nord; aussi l'a-t-on trouvé dans l'Amérique septentrionale. Les voyageurs ${ }^{3}$ l'ont indiqué d'une manière à ne s'y pas méprendre, et d'ailleurs on sait que la peau de cet animal fait un objet de commerce de l'Amérique en Europe. Ces loups-cerviers de Canada sont seulement, comme je l'ai déja dit, plus petits et plus blanes que ceux d'Europe; et e'est cette différence de grandeur qui les a fait appeler chats-cerviers, et qui a induit les nomenclateurs ${ }^{4}$ à les regarder

1 Anctuarium, IIst, Nat. Polonix, Gabriele Rzaczynski Gellani, 1742.

${ }^{2}$ Vide Aldrov., de quadrup. digit., pag. 96.

${ }^{3}$ On voit cneore chez les Gaspésicus trois sortes de loups. Le loup-cervier est d'un poil argenté; il a deux cornichons à la tête (il veut dire aux oreilles), yui sont de poil tout noir. La viande en est assez bonne, quoigu'elle sente un peu trop le sauvageon : cet animal est plus affreux à voir que cruel; li peau en est très-bonne pour en faire des fourrures. Nouvelle Relation de la Gasprsie, par le père Chritien L'clerı. I’aris, 1691, page 488. - Au pays des llurons, les loups-cervicrs sont plus fréquents que les loups communs, qui y sont assez rares. Voyage de Saguar Theodat. Paris, 1632, page 307. - En Amérique se voient bêtes ravissantes, comme léopards et loupscerviers, mais des lious nullement. Singularités de la France antarctique, par Thevet. Paris, 13308 , page 105.

4 I. Linneus, qui demeure à L psal, et yui doil connaltre cet auimal, puisqu'il se trouve en Suede et daus les pays circunvoisins, avait d'aboril distingué le lonp-cervier du cliat-cervier. 11 nommait le premier felis canda truncala, corpore rufescente maculato. Syst. Nat., edit. $1 \%$, pag. 64 ; et edit. 11 , page 4 . Il nommait le second felis cauda truncata, corpore albo naculato. Syst, Yat. Idem, ibiden. Il nomme mene en suédois le premier warglo, et le second kattlo. Fanua Suec., pag. 2. Mais, dans sa deruière édition, il ne distiugue plus cı's animaux, et il ue fait mention que d'une seule espèce, yu๖l indique par la phrase suivante: felis cauda abbreviata, ajpice atra, auriculis apice barbatis, et dunt il donne une cuurte ct bonne description. Il parait donc yue cet auteur, qui d'aburd 
comme des animaux d'espece différente' . Sans vouloir prononcer décisivement sur cette question, il nous a paru que le chat-cervier de $\mathrm{Ca}$ nada et le loup-cervier de Moseovie sont de la même espèce, 10 parce que la différence de grandeur n'est pas fort consiclérable, et qu'elle est à peu près relativement la même que celle qui se trouve entre les animaux communs aux deux continents : les loups, les renards, ete., étant plus petits en Américque qu'en Europe, il doit'en être de même du lyux ou loup-eervier; $2^{\circ}$ paree que dans le nord de l'Europe mêrme, ces animaux varient pour la grandeur, et que les auteurs font mention de deux espèces, l'une plus petite et l'autre plus grande; 30 enfin, parce que ces animaux affectant les mêmes climats, et étant du même naturel, de la même figure, et ne différant entre eux que par la grandeur du corps et quelques nuances de couleur, ces caractères ne me paraissent pas suffisants pour les séparer et prononcer qu'ils soient de deux eśpèces différentes.

Le lynx, dont les anciens ont dit que la vue était assez perẹante pour pénétrer les corps opaques, dontl'urine avait la mer'veilleuse propriété de devenir un corps solide, une pierre précieuse, appelée lapis lyncurius, est uu animal fabuleux, aussi bien que toutes les propriétés qu'on lui attribue. Ce lynx imaginaire n'a d'autre rapport avec le vrai lynx que celui du nom. Il ne faut done pas, comme l'ont fait la plupart cles naturalistes, attribuer à celui-ci, qui est un être réel, les propriétés de cet animal imaginaire, à l'existence duquel Pline lui-même n'a pas l'air de croire, puisqu'il n'en parle que comme d'une bète extraordinaire, et qu'il le met à la tête des sphynx, des pégases, des licornes et des autres prodiges ou monstres qu'enfante l'Ethiopie.

Notre lynx ne voit pas à travers les murailles; mais il est vrai (qu'il a les yeux brillauts, le regard doux, l'air agréable et gai. Son urine ne fait pas de pierres précieuses, mais seulement il la recouvre de terre, comme font les

distinguait le loup-cervier du clıat-cervier est venu à penser comme nous que toms deux n'étaicnt que le unême animal.

1 Felis alba maculis nigris variegata, cauda brevi..... Calus cervarius, Ic chal-cervier. - lelis auricularum apicibus pilis longissinis prixlitis, cauda brevi... Lyıx, le loup-cervier. urisson, lkesu. anim., pag. 271 et 275 .

2 Lynces ambe (nagne et parva) corporis figura similes eunt, et similiter utrisine oculi suaviter lulgent, facies ulrisque alacris perlucet, jarrum utrisque capul, etc. Oppianus. chats, auxquels ils ressemble beaucoup, et dont il a les mours et mème la propreté. Il n'a rien du loup qu'une espèce de hurlement, qui, se faisant entendre de loin, a dû tromper les ehas. seurs, et leur faire croire qu'ils entendaient un loup. Cela seul a peut-être suffi pour lui faire donner le nom de loup, auquel, pour le distinguer du vrai loup, les chasseurs auront ajouté l'épithète de cervier, parce qu'il attaque les cerfs ou plutôt paree que sa peau est variée de taches à peu près comme celles des jeunes cerfs, lorsqu'ils ont la livrée. Le lyux est moins gros que le loup ', et plus bas sur ses jambes; il est communément de la grandeur d'un renard. II diffère de la panthère et de l'once par les carac. tères suivants : il a le poil plus loug, les taches moins vives et mal terminées, les oreilles bien plus grandes, et surmontées à leur extrémil: d'un pinceau de poils noirs, la queue beancu:! plus courte et noire à l'extrémité, le tour des yeux blanes, et l'air de la face plus agréable et moins féroce. La robe du mâle est micux mar. quée que celle de la femelle : il ne court pas de suite comme le loup, il marche et saute comme le chat. II vit de chasse et poursuit son gibier jusqu'à la cime des arbres; les chats sauvages, les martes, les hermines, les écureuils ne peuvent lui échapper; il saisit aussi les oiseaux; il attend les cerfs, les chevreuils, les lièvres au passage et s'élance dessus ; il les prend à la gorge; et lorsqu'il s'est rendu maitre de sa vietime, ileu suce le sang et lui ouvre la tête pour maugrer la cervelle; après quoi souvent il l'abandonue pour en ehercher une autre : rarement il retourne à sa première proie, etc'est ce qui a fait dire que de tous les animaux le lynx était celui (qui avait le moins de mémoire. Son poil change de couleur suivant les climats et la saison; les fourrures d'hiver sont plus belles, meilleures et plus fournies que celles d'été. Sa chair, comme celle de tous les animaux de proie, n'est pas bonne à manger.

\section{DESCRIPTION D'UN LYNX.}

(ExtRAit de DaLbentoN.)

I.e lynx a été appelé loup-cervier, plutòt jar rapport à ses mours qu’à sa figure ou à sa couleur, car il ressemble au chat par la forme du corps et

' Lyuces nostra lupis minores sunt, lergo maculosic. Stum. pliniss. 
ses coulenrs n'ont de commm arec celles du cerf que des teintes de fauve qui se frouvent daus heaucoup d'autres animaux. Le lynx a le nez et le chanfrein moins relevés que le clıat, et l'angle postćrieur des yeux plus reculé vers l'oreille, qui est moins longue et moins arrondie à l'extremité que celle du chat : il y avait sur la poirite des oreilles du lynx qui a servi de sujet pour cette description, et yui était femelle, un bompuet de poils noirs, en forme de pinceau, dont les plus longs araint jusqu’à un pouce et demi; les jambes et les pierls de cet aninal étaient gros : la queue avait peu de longueur et semblait avoir été coupée en partie, quoigu'elle fuit bien entière.

Le poil avait differentes teintes de fanve, lle blanc et de noir: le nez, le front, le clessus et les côtés de li tête, le los, les épaules, la face extérieure des jambes de devant justu'au bout des doigts, les côtés de la poitrine et du corps, les lonbes, la croupe, la face postćrieure de la yuene abaissée, la face extérieure le la cuisse et le la jambe, le tarse, le mélatarse et le clessus des pieds de derrière araient une conlemr fanve, ronssitre et presque éteinte, mẻlée de hlane, de gris, le brun et de noir, parce gue la plupart des poils étaient blancs, gris, bruns ou noirs à la pointe: le blanc et le gris étaient mêlés par nuances égales avec le fauve, mais le brun et le noir formaient de petites taches et presque des bandes le long du dos et des lombes; les taches lirmes les plus apparentes élaient sur l'épaule et sur la cuisse, et les noires sur les lèvres, principalement à l'endroit des moustaches, sur l'avant-bras et sur le devant de la jambe. La mâchoire inférieure, la gorge, le dessous du cou, la face intérieure des jambes de devant, la poitrine, le ventre, la face interieure cle la cuisse et de la jambe, et la face interieure de la quene, avaient une couleur blanche mc̀le d'une lérrire leinte lle fauve et de nuelınes taches noires, principalement sur la face intérieure de l'avantbras; le bort des paupières était noir, et il y arait sur chaque paupière une bancle blanche mêlée d'une teinte de fauve; le poil du dedans de la conque de l'oreille etait blanc, le bord avait une couleur fauve lrès-pale, la face exterience de la conıue était noirâtre sur la base, noire près lles bords et de la pointe, et blanche daus le milieu; le bout de la yueue avait une couleur noire, et sur la longueur de trois pouces. Les poils de cet animal étaient doux ct longs d'un pouce et demi au plus ; les pieds de devant avaient cing doigts, et ceux de derricre seulement quatre: tous les pieds étaient garuis de poils en cntier, à l'exception des tubercules, rlont le nombre et la forme ciaient les mèmes que clans le cliat.

\section{LE CARACAL.}

\section{(LE FELIS CARACAL.)}

Ordre des carnassiers, famille des carnivorcs, tribu des digiligrades, genre chat. (Curier.)

Quoique le earacal ressemble au iynx par la grandeur et la forme du corps, par l'air de la tête, et qu'il ait, comme lui , le caractère singulier, et pour ainsi dire, unique, d'un long pinceau de poil noir à la pointe des oreilles, nous avons présumé, par les diseonvenances qui se trouvent cntre ces deux animaux, qu'ils étaient d'espèces différentes. Le caracal n'est point moucheté comme le lynx; il a le poil plus rucle et plus court, la quene beaucoup plus longue et d'une coulcur uniforme, le muscau plus allongrí, la mine beaucoup moins donce, et le naturel plus féroce. Le lymx n'habite que dans les pays froids ou tempérés; le caracal ne se trouve (que dans les climats les plus chauds. C'est autant par cette différence du naturel et du climat que nous les avons jugés de deux espèces différentes, que par l'inspection et par la comparaison de ces deux animaux que nous arons vus vivants, èt qui, comme tous ceux que nous avons donnés jusqu'ici, ont été dessinés et décrits d'après nature.

Cet animal est commun en Barbaric, en Arabie et dans tous les pays qu'habitent le lion, la panthère et l'once. Comme eux, il vit de proie : mais étant plus petit et bien plus faible, il a plus de peine à se procurer sa subsistance; il n'al, pour ainsi dire , que ec que les autres lui laissent et souvent il est forcé à se contenter de leurs res. tes. Il s'éloigne de la panthère, parce qu'elle exerec ses cruautés lors mème qu'elle est pleinement rassasiée; mais il suit le lion qui, dès qu'il est repu, ne fait de mal à personne; le caracal profite des débris de sa table, et quel(quefois mème il l'accompagne d'assez près, parce que, grimpant légèrement sur les arbres, il ne eraint pas la colèe du lion, qui ne pourrait l'y suive comme fait la panthere. C'est par toutes ces raisons que l'on a dit du caracal qu'il était le guide ' on le pourvoyeur du lion ; que celui-

- Les karacoulaes sont des animaux un peu plus grands yuc des cluats, et fails de mẻue; ils ont les orcilles longues de pré: de lemi-picl, et noires, el cest d"oì ils tirent leur num, qui siguifie oreilie noire. Ils servent de chiaoux aux lions (conuno disent les gens du jays); car ils vonl (levastl eux yuelques pas. 
ci, dont l'odorat n'est pas fin, s'en servait pour éventer de loin les autres animaux, dont il partageait ensuite avec lui la dépouille '.

Le caracal est de la grandeur d'un renard mais il est beaucoup plus féroce et plus fort : on l'a vu assaillir, déchirer et mettre à mort en peu d'instants un chien d'assez grande taille cui, combattant pour sa vie, se défendait de toutes ses forces. Il ne s'apprivoise que très-difficilement ; cependant, lorsqu'il est pris jeune et ensuite élevé avec soin, on peut le dresser à la chasse, qu'il aime naturellement et à lacuelle il réussit très-bien, pourvu qu'on ait l'attention de ne le jamais lácher que contre des animaux qui lui soient inférieurs et qui ne puissent lui résister; autrement, il se rebute, et refuse le service dès (qu'il y a du danger. On s'en sert aux Indes pour prendre les lières, les lapins et même les grands oiseaux, qu'il surprend et saisit avec une adresse singulière.

et sont comme leur guide pour les conduire aux lieux où il $\mathrm{y}$ a de yuoi maıger, et pour récompense ils en ont leur part: quand cet animal api elle le lion, il semble que ce soit la voix d'une personne qui en appelle une autre, quoique pourtant la voix en soit plus elaire. Voyage de Thévenot. Paris, 1664, tome 1t, pages 11 t et 115.

- Je vis dans une cage de fer un animal que les Arabes nomment le quide du lion. Il est très-ressemblant au chat; c'est ponrquoi quelques-uns l'apuellent chat de Syrie; et jen ai vı un autre à florence apuelé de ce nom : il est assez faronclse; si quelyu'un tàchr de relirer la viande ıu'il lui a présentée, il so met en une grande furie, et, si on ne l'apaise, II s'élance infailliblement sur lui. II a de pelits flocons de poil au sommot des ureilles, et il est appelé le guide dı lion parce tjue, à ce tjuon dit, le Jion n'a pas J'odorat bien fin; si bien ঐue, se joignant à cet animal, qui l'a très-aigu, ıl suit par ce moyen la proic, et, layant prise, il en ionue une partie à son conducteur. Voyage d'Orient, dı père Philipue, carmedéchaussé. 1.yon, 1669, liv. 11 , pages 76 et 77. - Le gat el clıallah des Arabes, que les Persans app llent siyah-gu.h, et les Tures kirra kulak, èest-á-dire le chat noir ou be chat aux oreilles noires, comne son uom poute daus ces trois langues, est de la grandeur d'un gros cbat. Il a le corps d'un lunu tirant sur le ronge, le vintre doune couleur plus claire et queluuefois tacheté, Je musean noir et les oreilles d'un grisloncé, dont les bouts sont garnis d'une pelite louffe dun poil nou et raidle comme celle du lymx. La tigure de cet animal, donure jur Charleton, est très-différente du siyah-guslı te Barbarie, ıui a la téte plus ronde avec les lères noires; Imis du reste il jessemble entierement à un chat. Voyage tle Shaw, La llayi, 1745, tome I, pages 320 et 521 . Nola. La figure donué " par charlcton péch en ce uque le poil n'y est pas expriné et yue la tẻte est, pour ainsi dire, clıuve, ce yui lui dote de sa rondeul'; mais il ucn est pas muius vrai yue le sijah-gush de Charleton el ceini de Barbarie, lout parle ici le docteur Shaw, sont lous leux des aninaux de la meme esjèce que notre caracal.

\section{DESCRIPTION DU CARACAL}

(EXTBAIT DE DAEBENTOX.)

Le caracal est à peu près de la grandeur (lu lynx; il lui ressemble beaucouj pour la forme du corps, et il a, comme le lynx, un bouquet de poils noirs en forme de pinceau à la pointe des oreilles. Je n'ai pas pu suivre le détail de la description du caracal, parce que je n'ai vu qu'un individu de cette espèce yui est ḋ la Menagerie de Versailles, encore ne l'ajjeçu'entrevu à travers la grille d'une loge obscure. Cet animal est si sauvage, qu’il cherche toujours à se cacher, et si féroce, que l'on ne peut le toucher, ni mème l'approcher; cepentlant, il m'a paru avoir beaucoup de rapport au chat pour la figure du corps, (quoipu il ait le museau plus long et la queuc plus courte.

L'extrémité du museau est blanche; le dessus et les côtés du museau, le front et le sommet de la tête ont une coulcur fauve teinte de brun; les yeux sont bordés de blanc; il $\mathrm{y} \mathrm{a}$, près des coins de la houche une tache de mème couleur, et au-dessus de l'œil, de chaque côté du front, une petite bande fort étroite, blanchâtre el dirigcé de devant en arriere, les bords des oreilles sont blancs : Ia face externe est noire, la face interne est de coulcur blanchâtrc dans le milieu, et de couleur fauve-roussàtre près des hords. Le dessus du cou et le dos sont de couleur fauve teinte de brun : cette couleur forme une hande qui est traversée sur le garrot par une autre hande de mène couleur, comme une croix de mulet; les côtés du cou et du corps, la face externe des jambes et les pieds ont une cunleur isa. belle: excepté le haut de la face externe de l'avaut-bras et de la cuisse qui est roussåtre; la mãchoire du dessous est blanche, le dessous du cour, le ventre et la face interne des jambes sont blanchâtres avec une teinte de fauve pille, la poitrine a une couleur fauve terne, avec des taclies hrumes noiràtres, et la queue est de couleur faure roussàtre.

ADDITION A L'ARTICLE DU WNX FT A CELUI DU CARACAL.

\section{(LE LYXX DU CANADA.)}

Ordre des carnassiers, famille des carnivores, tribu te, digitigrades, genre chat. (Cuvicr.)

Ce lynx de Canada, qui est au Cabinet du roi, n'a que deux pieảs trois ponces de long, 
depuis le bout du nez jusqu'à l'extrémité du corps, qui n'est élevée que de douze à treize pouces; le corps est couvert de longs poils grisâtres, mêlés de poils blanes, moucheté et rayé de fauve, les taches plus ou moins noires; la tête grisâtre, mêlée de poils blancs et de fiuve clair, et comme rayée de noir en quelques endroits. Le bout du nez est noir, ainsi que le bord de la mâchoire inférieure; les poils des moustaches sont blancs, longs d'environ trois pouces. Les oreilles ont deux pouces trois lignes de hauteur, et sont garnies de grands poils blanes en dedans, et de poils un peu fauves sur les rebords ; le dessus des oreilles est couvert de poils gris-de-souris, et les bords exterieurs sont noirs; à l'extrémité des oreilles il y a de grands poils noirs, qui se réunissent et forment un pineeau très-menu de sept lignes de hauteur. La queue, qui est grosse, courte et bien fournie de poils, n'a que trois pouces neuf lignes de longueur : elle est noire depuis l'extrémité jusqu'à moitié, et ensuite d'un blane roussâtre. Le dessous du ventre, les jambes de derrière, l'intérieur des jambes de devant et les pattes sont d'un blanc sale; les ongles sont blancs et ont six lignes de longueur. Ce lynx a beaucoup de ressemblanee par les taches et par la nature de son poil avee celui qui le précède, mais il en diffère par la lonqueur de la queue et par les pinceaux qu'il a sur les oreilles : on peut done regarder cet animal du Canada comme une variété assez distincte du lynx ou loup-eervier de l'ancien continent. On pourrait mème dire qu'il s'approche un peu de l'espéee du earacal par les pinceaux de poils qu'il a sur les orcilles; néanmoins il en diftère encore plus que du lynx, par la longueur de la queue et par les couleurs du poil. I'ailleurs, les earacals ne se trouvent que dans les climats les plus chands, au lieu que les lynx ou loups-cerviers préfèrent les pays froids. Le pinceau de poil au bout des oreilles, qui parait faire un earactire distinetif, parce qu'il est fort apparent, ll'est cependant qu'me chose accidentelle, et qui se trouve dans les animaux de cette espece, et mème dans les ehats domestiques et sauvages. Nous en avons donné un exemple dans l'addition a l'article du chat. Ainsi, nous persistons à eroire que le lỵx, ou loup-cervicr d'Amériçue, ne doit ŝtre regardé que comme une variété du loup-cervier d'Europe.

Le lynx de Norwége, déerit par Pontoppidan, est blanc ou d'un gris clair-scmé de taches foncées. Ses griffes, ainsi que celles des autres lynx, sont comme celles des chats; il voùte son dos, et saute comme eux avec beaucoup de vitesse sur sa proie. Lorsqu'il est attaqué par un ehien, il se renserse sur le dos et se défend avee ses griffes, au point de le rebuter bien vite. Cet auteur ajoute qu'il y en a quatre espèces en Norwége; que les uns approehent de la figure du loup, les autres de celle du renard, d'autres de celle du ehat, et enfin d'autres (qui ont la tête formée comme celle d'un poulain. Ce dernier fait, que je crois faux, me fait douter des précédents. L'auteur ajoutedes choses plus probables.

Le loup-cervier, dit-il, ne court pas les chamıs, il se cache dans les bois et dans les eavernes; il fait sa retuaite tortueuse et profonde, et on l'en fait sortir par le feut et la fumće. Sa vue est perçante; il voit de très-loin sa proie. Il ne mange souvent d'une brebis ou d'une chèvre une la cervelle, le foie et les intestins, et il creuse la terre sous les portes pour entrer dans les bergeries.

L'espèce en est répandue non-seulement en Europe, mais dans toutes les provinces du nord de l'Asie. On l'appelle chulon ou cheluson en Tartarie. Les peaux en sont fort estimées, et, quioiqu'elles soient assez communes, elles se vendent également cher en Norwége, en Russie, et jusqu'à la Chine, où l'on en fait uu grand usage pour des manchons et d'autres fourrures.

Un fait qui prouve encore que les pinceaux au-dessus des oreilles ne font pas un caractere fixe, par lequel on doive séparer les especes dans ces animaux, e'est qu'il existe dans cette partie du royaume d'Alger, qu'on appelle Constantine, une espèce de caracal sans pinceaux au bout des oreilles, et qui, par lá, ressemble au lynx, mais qui a la queue plus longue. Son poil est d'une couleur roussâtre avec des raies longitudinales, noires depuis le cou jusçùà la queuc, et des taches séparćes sur les llanes, posées dans la mème dircetion, une demi-ceinture noire au-dessus des jambes de devant, et une bande de poil rude sur les quatre jambes, qui s'étend depuis l'extrémité du pied jusqu'au dessus du tarse; et ce poil est retroussé en haut, au lieu de se diriger en bas comme le poil de tout le reste du corps ${ }^{\text {. }}$

I'ai dit à l'article du caraeal, que le mot gal-

. Note communiquce par $\mathbf{M}$. Ie chevalier Bruce, a $\mathbf{M}$. ue Buffon. 
el-challah signifiait ehat aux oreilles noires. M. le chevalier Bruee m'a assuré qu'il signifiait chat du désert. Il ak vu dans la partie de la Nubie qu'on appelait autrefois l'ile de Méroé un caracal qui a quelque différence avec celui de Barbarie, dont nous avons donné la figure. Le caracal de Nubie a lá face plus ronde, les oreilles noires en dehor's, mais scmées de quelques poils argentés. Il n'a pas la croix de mulet sur le garrot, comme l'ont la plupart des caracals de Bärbarie. Sur la poitrine, le ventre et l'intérieur des cuisses, il y a de petites taches fauves claires, et non pas brunes-noiràtres comme dans le caraeal de Barbarie. Ces petites différences ne sont que de légères variétés, dont on peut encore augmenter le nombre; car il se trouve, même en Barbarie, ou plutôt dans la Libye, aux environs de l'ancienne Capsa, un caracal à oreilles blanches, tandis que les autres les ont noires. Ces cearicals à oreilles blanches ont aussi des pinceaux, mais courts, minces et noirs. Ils ont la queue blanche à l'extrémité et eeinte de quatre amneaux noirs, et quatre guêtres noires, derricre les quatre jambes, comme eelui de Nubie; ils sont aussi beaucoup plus petits que les autres caracals, n'étant guère que de la grosseur d'un grand chat domestique; les oreilles, qui sont fort blanches en dedans et garnies d'un poil fort touffu, sont d'un roux vif en dehor's '. Si cette différence dans la grandeur était constante, on pourrait dire qu'il y a deux espèces de caraeals, qui se trouvent également en Barbarie, l'une grande à oreilles noires et longs pinceaux, et l'autrc, beancoup plus petite, il oreilles blanches et à très-petits pinceaux. II parait aussi que ces animaux, qui varient si fort par les oreilles, varient également par la forme et la longueur de la queue, et par la hauteur des jambes; carr MI. Edwards nous a en royé la figure d'un earacal de Bengale, dont la queue et les jambes sont bien plus longues que dans le caracal ordinaire.

\section{NOUVELLF, ADDITION A L'ARTICLE DU LYNX ${ }^{2}$.}

Nous donnons ici la figure d'un lyux du Mississipi, dont les oreilles sont encore plus dé-

\footnotetext{
'Note communiquée par M. le chevalier Bruce, à M. de Buffon.

${ }^{2}$ II. Cuvier place cet animal dans l'espèce dn felis canadeusis.
}

pourvues de pinceaux que celles du Iynx du Canada, et dont la queue, moins grosse ct rnoins touffue, et le poil d'unc couleur plus claire, scmblent le rapprocher davantage du lynx ou loup-eervier d'Europe; mais je suis persuadé que ces trois animarx, dont l'un est de l'Europe et les deux autres de l'Amérique seplentriouale, ne forment néanmoins qu'une scule et même espèce. On a vait envoyé eelui-ci à feu MI. l'alshé Aubry, curé de Saint-Louis, sous le nom de chat-tigre du Mississipi; mais il we fant que le compitrer a vec le lynx dont nous avons donné la description, pour reconnaitre évidemment quiil ne fait qu'une variété dans l'espèce du lynx, quoiqu'il n'ait point de pinceaux ct que la quene soit fort petite.

Il a, du nez à l'origine de la queue, deux pieds cinq pouces de longueur; la queue est fort courte, n'ayant que trois ponees trois lignes, au lieu que celle du lynx d'Europe a six pouces six lignes. Celle du lynx du Canada est beaucoup plus grosse et plus fournie; mais elle est tout aussi courte que celle du lyux du Mississipi, dont la robe est aussi de couleur plus uniforme et moins variée de taches, que dans le lynx de l'Europe et dans celui du Canada : mais ces légères différences n'empèchent pas qu’on ne doive regarder ces trois animaux comme de simples variétés d'une seule et mème espèce.

\section{L'HYÈE.}

\section{(L'HY⿱宀NE RAYÉE.)}

Ordre des carnassiers, fanille des carnirores, tribu des digitigrades, genre chien. (Cuvier.)

Aristote nous a laissé deux notices au sujet de l'hyène, qui, seules, suffimient pour fiure recomnaitre cet animal et pour le distinguer de tous les autres; néanmoins, les voyageurs et les naturalistes l'ont confondu avee quatre autres animaux, dont les esperes sont toutes quiltre différentes entre elles et différentes de celle del'lyyène. Ces animaux sont le chaeal, le glouton, lia civette et le babouin, qui, tous quatre, sont carnassiers et féroces comme l'hỵène, et qui ont chacun quelques petites convenances, et quelques rapports particuliers avec elle, lesquels ont donné lieu à la méprise et à l'erreur. Le chacal se trouve à peu près dans le mème pays : il approche, comme l'lıyène, de la formedu loup; 


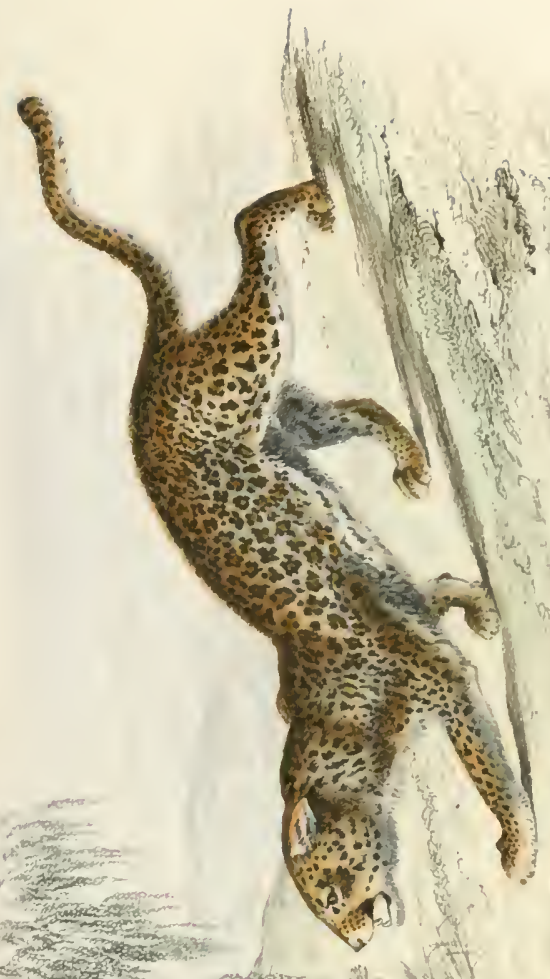

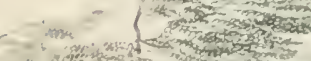

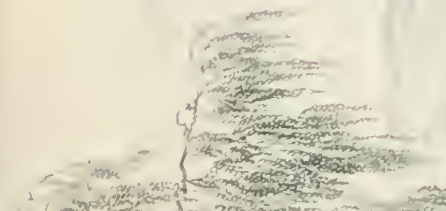

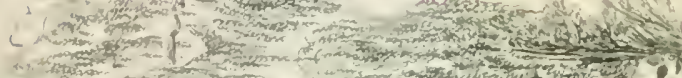

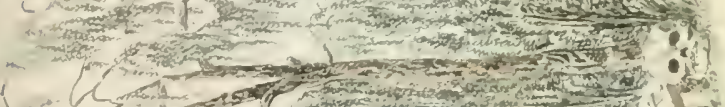

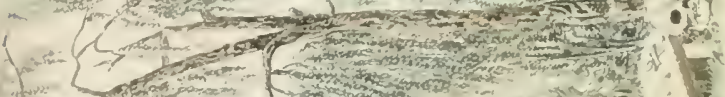

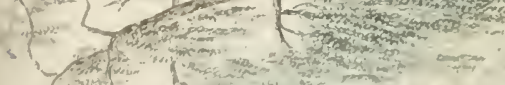
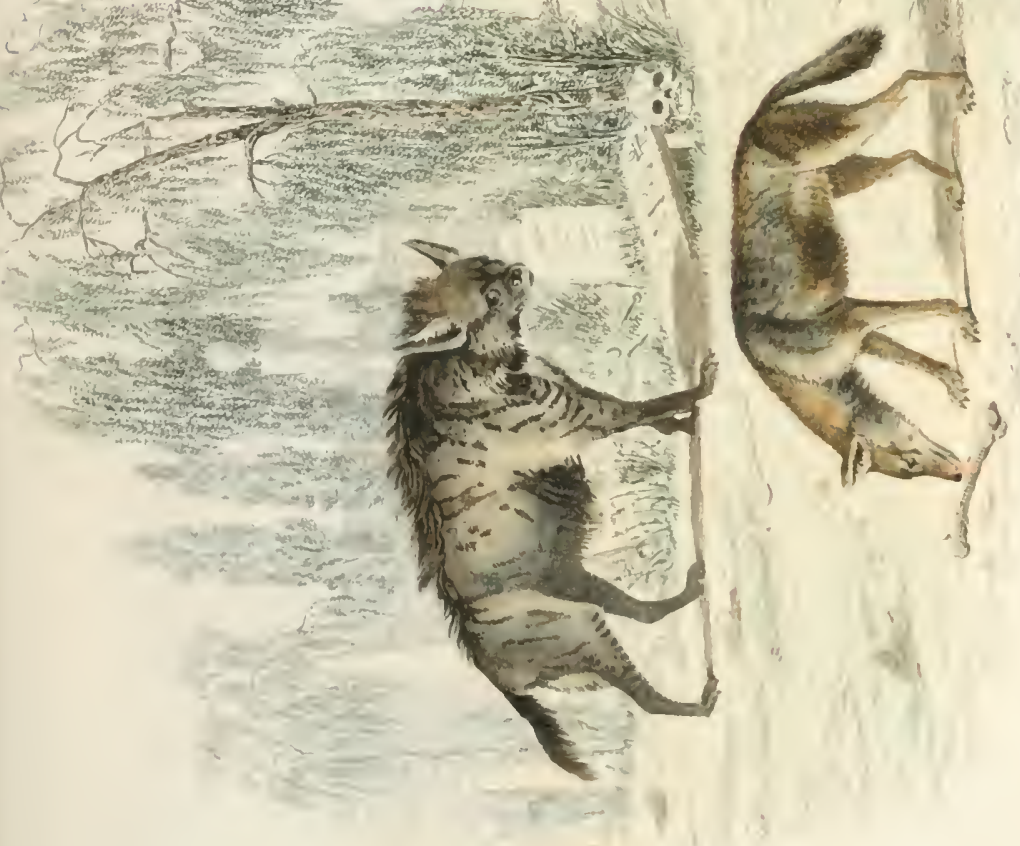

comme elle, il vit de cadavres et fouille les sépultures pour en tirer les corps : e'en est assez pour qu'on les ait pris l'un pour l'autre. Le gloutor a la même voracité, la même faim pour la chail' corrompue, le même instinct pour déterrer les morts; et, quoiqu'il soit d'un climat fort diffélent de celui de l'hyène et d'me figure aussi très-différente, cette seule convenance de naturel a suffi pour que les auteurs les aient confonclus. La civette se trouve aussi dans le même pays que l'hyène : elle a, comme elle, de longs poils le long du dos et une ouverture ou fente particulière : earactères singuliers qui n'appartiemment qu'à quelques animaux, et qui ont fait croire àt Belon que la civette était l'hyène des anciens. Et à l'égard du babonin, qui ressemble cneore moins à l'hyène que les trois autres, puisqu'il a des mains et des pieds, comme l'homme on le singe, il n'a été pris pour elle qu'à cause de la j'essemblance du nom: l'hyène s'appelle dubbah en Barbarie, selon le doeteur Shaw; et le babouin se nomme dubuh, selon Marmol et Léon l'Africain; et comme lebabouin est du même elimat, qu'il gratte aussi la terre, et qu'il est à peu près de la forme del'hyène, ces convenanees ont trompé les voyageurs, et ensuite les maturalistes qui ont eopié les voyageurs ; ceux même qui ont distingué nettement ces deux animaux n'ont pas laissé de conserver à l'hyène le nom dabuh, qui est celui du babouin. L'hỳ̀ne n'est done pas le drebuh des Arabes, ni le jesef ou sesef des Africains, comme le disent nos naturalistes ${ }^{1}$; et il ne fant pas nou plus la eonfondre aree le deeb de barbarie. Mais, afin de prévenir pour jamais cette confusion de noms, nous allons domer en peu de mots le précis des reeherehes que nous avons faites au sujet de ees animaux.

Aristote donne deux noms à l'hyène; communément il l'appelle hycena et quel(juefois glunus : pour être assuré que ces deux noms ne désignent que le même animal, il suffit de comparer les passages ${ }^{2}$ oit il en est question.

' Cluarloton, Exercit. pag. 14, - Brisson, Règne animal, page 23 \%

${ }^{2}$ Ilyana colore lupi prope est, sech hirsutior, et juba per totum dorsum prodita est. (onorl intem de ea lertur, genitale simul et maris et firninx camblem frahere, commentitimm est : sed virile similiter; at,jue in In, is, et camibus habetur. Quod vero fomineum esse vildelur, sull e.unda positnm esl, figura simile genitali famina, sed sine ullo meatu. Sub hoc meatus excrementorum est. Quin etjam famina lyyxua pripter sum illud ctiam simile, "It mas habet sub caula sine ullo meatu, a quo excrementorum meatus est, atque sub con genitale verum
Les aneiens ratins ont conservé le nom d'hyæ$n \iota$, et n'ont point adoplé celui de glanus; on trouve seulement dans les Latins modernes le mot de grnnus ou gannu.s ${ }^{1}$ et celui de belbus ${ }^{2}$ pour indiquerl'hyène. Selon Rhasis ${ }^{3}$, les Arabes ont appelé l'hyène kabo ou zabo, noms qui paraissent dérivés du mot zeeb, qui, dans leur langue, est le nom du loup. Fin Barbarie, l'hyène porte le nom de dubbah, comme on pent le voir par la courte deseription que le docteur Sluaw nous a donnće de cet animal. En Turquie, l'hyène se nomme zirllam, selon Nieremberg ${ }^{5}$; et en Perse Ifastaar, suivant Kimpfer ${ }^{6}$; et castar, selon Pietro della Valle ${ }^{7}$ :

c. ntinetur. Vulvam eliau ly'ana firmina, ul celer hujusce modi famina animantes luabet.Sed raro lyyanil faunina capilur, jam interundecim numero, unam tanluni cepisse venat or retu. lit quidam. Lib. II, еap. XXXII. - Quam antem alii gianun, alii hyanam apqellint, curpore nom minore, quam lupus est, julıa qua equus, sed seta duriore. Iongioreque, el per rotum dorsım porrectir. Molitur lire in-idjas homini, eanes etiam vomitionem hominis imitamberpit, el segulcra cffodit lı!rmanx avi.la earuis, ac erıit. Alrist. Ilist. anim., I. VIII, c. I.

1 Gessı. Hist. quadrup., pag. 5535 .

2 Bélbi, id est, hyian , decen fnerunt sub Gordiano homa. Juhius Capitolinus. Idem, jijirlem.

B Gessner. IIist. quadr., jag. 53̈3.

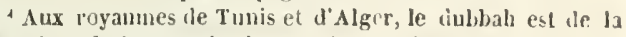
graucieur dı louj)... II a le cou si excessivenent raile, une lorsqu'il vat l'garuler lerrière lui, ou seulement de crilé, il est ohligé de toumer tout le corpa, comme les cochons, les tessons et les crocodiles. Sa coulenr est d'un brun sumbre. tirant sur le ronge, avec quelyues raies d'un brun chcos e plus obscur; le poil de la nupue du con est presifue de la grandeur dine paume, mais muins rude yue les soies de coclon. Il a les pieds grands et bien armés, dunt il se sert pour remuer la lirre et en retirer les rejetons dn palmier et iliulres ratines, et puelyueforis des corps mon ts... Apre; le lion et li panthere, le dubbili est le plus fruce el le plus eruel de tons les animanx da lit Barbarie. Comme celle bite est jun vin: diune crinière, qu'telle a lie la peine à tourner la léte, et yuille funille daus les sćpulcres, il $y$ a toute apjarence que cest l'hyène des anciens. loyages de shaw, lome I, frage 520.

${ }^{8}$ Euseb. Nieremberg. Ilist. Xat. Antverpia, 165̃, pag. 181. ${ }^{6}$ Kaftaar, id est, taxus poreirus, sive hyana veterum (Vid, in Tab. $\$ 4,11^{0}$ 4.) animal est [orci, sen scroplha gramlioris, maguitudinem ejustlenı fue forman corporis obtimens, si ca(u)t, candam el fecles excipio. Pilis vestitur longis, ineanis, in ora dorsi , purcino more, lusgioribus, pene spillanalibus. apicibus nigr'is; eaput lıabet lupinowon dissinile, rostro nigro. fronte longiori, oeulis rostro puropinyuioribus nigris el volubililıs, auribus nutlis, fuscis et acuminatis; canula tlonalur mielonga, villis densis longiuribus vestita, cireulisıne nigricantibus ad decorem intercepta. Crura in orbem yuondan modo variegala, posteriora prioribus sunt Jongiora; pedes in quaternos ungues divisi, quos lujpino more cuntrahit, ne videantur. Corpus habet striis a dorso ventre tems pictum paucis. latis el in:epuatilus, alternatim fuscis et nigris... Mira vi terram efforlit, caveruisque aluditum se illalebrare anal : diu sine cibo virit, et raptu viclum tua ril... Ferox et carmurora lieslia

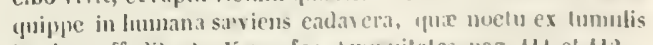
impigre effodil, ele. Kiempifer, Amo nilates, pras. 111 et $11: 2$.

$7 \mathrm{Je}$ is a schiras un cerlain animil vivant, que l:s l'ersans nomment cu teur langue castar, ansi fuissant quiun gros chieu, tgui victait pas encore, à ce yuu je crujs, daus sa pur $r$ fection; il aviat la granderur, la forme e't la cumleur d'un tigre 
ce sont là les seuls noms qu'on doive appliquer à l'hyène, puisque ce sont les seuls sous lesqucls on puisse la reconnaître clairement : il nous parait cependant très-vraisemblable, quoique moins évident, que le lycaon et la crocuta des Indes et de l'Éthiopie, dont parlent les ancicns, ne sont pas autres que l'hyène. Porphyre' dit expressément que la crocute des Indes est l'hyène des Grees; et, en effet, tout ce que ccux-ci ont écrit, et même tout ce qu'ils ont dit de fabuleux au sujet du lycann et de la crocute convient à l'hyène, sur laquelle ils ont aussi débité plus de fables que de faits. Mais nous bornons ici nos conjectures sur ce sujet, afin de ne nous pas trop éloigncr de notre objet présent, et parce que nous traitcrons, dans un discours à part, de ce qui regarde les animaux fabuleux et des rapports qu'ils peuvent avoir avec les animaux réels.

Le panther des Grees, Je lupus canarius de Gaza, le lupus armenius des Latins modernes et des Arabes, nous paraissent être le mème ani$\mathrm{mal}$; et cet animal est le chacal, que les Turcs appellent cical, selon Pollux, thacal, suivant Spon et Wheler; lesGrces modernes zuchalia, les Persans, siechal ou schachal, les Maures de Barbarie, deeb ou jackal. Nous lui conserverons le nom cliacal, qui a été adopté par plusieurs voyageurs, et nous nous contenterons de remarquer ici qu'il differe de l'hyène nonseulement par la grandeur, par la figure, par la couleur du poil, mais aussi par les habitudes naturelles, allant ordinairement en troupe, au lieu que l'hyène est un animal solitaire : les nouveaux nomenclatcurs ont appelé le chacal, d'après Kæmpfer, lupus aureus, parce qu'il a le poil d'un fauve jaune, vif et brillant.

Le chacal est, comme l'on voit, un animal très-différent de l'hyène. Il en est de même du glouton, qui est une bête du Nord, reléguée dans les pays les plus froids, tels que la Laponie, la Russie, la Sibérie; inconnue même dans les régions tempérées, et qui, par conséquent, n'a jamais habité en Arabie, non plus que dans

(il entend la panthère), et la têtc avec le ınuseau effilé d'un pourceau. Iion dit qu'il se nourrissait de chair humaine, et qu'il fouillait les tombeanx et les sépulcres pour manger les cadavres; ce qui ma fait juger depnis que ce pourrait ètre l'hyène des Latius; quoi qu'il en soit, c'était un animal faronche, y̧ue je n'avais jamais vu. Voyage de l'ietro della Valle. Rouen, 1745. Lome $V$, page 345 .

- Porphyrius in eo oper quod inscripsit de abstinenlia ab usu carninm, hyæıam dicit ab Indis apuellari crocutam. Gillius apud Gessnerum, Hisl. quadrų., pag. 550 les autres climats chauds où se trouve l'hyène: aussi en diffère-t-il à tous égards. Le glouton est à peu près de la forme d'un très-gros blaìreau; il a les jambes courtes, le ventre presque à terre, cinq doigts aux pieds de devant comme à ceux de derrière, point de crinière sur le cou, le poil noir sur tout le corps, quelquefois d'un fauve brun sur les flancs. Il n'a de commun avec l'hyène que d'ètre très-vorace; il n'était pas connu des anciens, qui n'avaient pas péné,tré fort avant dans les terres du Nord. Le premier auteur qui ait fait mention de cet animal est Olaüs; il l'a appelé gulo à cause de sa grande voracité : on l'a ensuite nommé rosomak en langue sclavonne', jerff ct wildfras en allemand: nos voyageurs francais l'ont appelé glouton. Il y a des variétés dans cette espèce, aussi bien que dans celle du chacal, dont nous parlerons dans l'histoire particulière deces animaux ; mais nous pouvons assurer d'avance que ces variétés, loin de les rapprocher, les éloignent encore de l'espèce de l'hỳ̀ne.

La civette n'a de commun avec I'hyène que l'ouverture ou sac sous la queue, et la crinière le long du cou et de l'épine du dos; elle en diffère par la figure, par la grandeur du corps, étant de moitié plus petite : clle a les oreilles velues et courtes, an lieu que l'hyène les a longues et nues; elle a, de plus, les jambes bien plus courtes, cinc doigts à chacue pied, tandis que l'hyène a les jambes longues et n'a que quatredoigts àtous les pieds; la civettene fouille pas la terre pour en tirer les cadarres : il est donc très-facile de les distinguer l'une de l'autre. A l'égard du babouin, qui est le papio des Latins, il n'a étépris pour l'hyène que par une équivoque de noms, à laquelle un passage de Léon l'Africain, copié par Marmol, semble avoir donné lieu. "Le dabuh, disent ces deux au" teurs, est de la grandeur et de la forme du " loup; il tire les corps morts des sépulcres." La ressemblance de ce nom dabuh avec dubbah, qui est celui de l'hỳène, ct cette avidité pour les cadavres, communc au dabuh et au dubbah, les a fait prendre pour le mẻme animal, quoiqu'il soit dit expressément dans les mêmes passages que nous venons de citer que le dabuh a des mains et des pieds comme l'homme, ce qui convient au babouin et ne peut convenir à l'hyène.

1 Ilistoire de Laponie, par Scheffer. Paris, 1678, pag. 314. - Rzaczyuski, Auct. Ilist. Nat. Polon., pag. 311. 
On pourrait eneore, en jetant les yeux sur la figure du lupus marinus de Belon, copié par Gessner, prendre cet animal pour l'hyène; car cette figure donnée par Belon ressemble beaucoupà celle de notre hyène : mais sa description ne s'accorde point avec la nôtre, en ce qu'il dit que e'est un animal amphibie, qui se nourrit de poisson, qui a été vu quelquefois sur les côtes de l'océan Britanni(que, et que, d'ailleurs, Belon ne fait aucune mention des caractères singuliers qui distinguent l'hyène des autres animaux. Il se peut que Belon, prévenu que la eiyctte était l'hyène des anciens, ait donué la figure de la vraie hyène sous le nom d'un autre animal qu'il a appelé lupus murinus, et qui certainement n'est pas l'hyène; car, je le répète, les caractères de l'hyène sont si marqués et même si singulier's, qu'il est fort aisé de ne s'y pas méprendre: elle est peut-être le seul de tous les animaux quadrupèdes qui n'ait, comme je viens de le dire, que quatre doigts, tant aux pieds de devant cqu'à eeux de derrière; elle a, comme le blaireau, une ouverture sous la queue, qui ne pénètre pas dans l'intéricur du corps; elle a les oreilles longues, droites et nues, la tête plus carrée et plus courte que celle du loup; les jambes, surtout celles de derrière, plus longues; les yeux placés comme ccux du chien; le poil du corps et la crinière d'une couleur gris obscur, mêlé d'un peu de fauve et de noir, avec des ondes transversales et noiratres : elle est íe la grandeur du loup et paraît seulement avoir le corps plus court et plus ramassé.

Cet animal sauvage et solitaire demeure dans les caverues des montagnes, dans les fentes des rochers ou dans des tanières qu'il se creuse luimêrne sous terre: il est d'un naturel féroce; et quoique pris tout petit', il ne s'appriroise pas. II vit de proie comme le loup; mais il est plus fort et parait plus hardi : il attaque quelquefois

- Hyxnam marem Ispahani curiositatis causa alebal dives quidan Gaber seu imnicola, suburbii Gabristian, captam dum ukera sugeret, in latibulis vicini montis. Ad eam spectandam progressus, bestian co silu depiuxi, yuo in fovea subdiali duarum orgyarun profunditatis (cui inclusa servabatur) cubantem inveni. Desjelerio nostro posscssor ommi cx parte satisfacturus, eam educi quoyne curavit in arean; quod ut tnto fieret, demisso fune rostrum prius illayucabal; mox descendentes servi frotracta utrinjue liblra funiculo ex pilis contorto, strenue colligabant. Hoc facto educitur, laxaloyuc fune, qui rostrum firnabat, bestia latius discurrere peruillitur, non semel afprehensa, morc athletico in terram projicitur, so variis lacessitur vexationibus; quibus illa irrilo nocendi les hommes; il se jette sur le bétail', suit de près les troupeaux et souvent rompt, dans la nuit, les portes des étables et les elôtures des bergeries : ses yeux brillent dans l'obscurité, et l'on prétend qu'il roit mieux la nuit que le jour. Si l'on en croit tous les naturalistes, son cri ressemble aux sanglots d'un homme qui vomirait avec effort, ou plutôt au mugissement du veau, comme le dit Kæmpfer, témoin auriculaire ${ }^{2}$.

L'hyène se défend du lion, et ne eraint pas la panthère, attaque l'once, laquelle ne peut lui résister: lorsque la proie lui manque, elle creuse la terre avec les pieds, et en tire par lambeaux les cadarres des animaux et des hommes que, dans le pays qu'elle habite, on enterre également dans les champs. On la trouve dans presque tous les climats chauds de l'Afrique et de l'Asie; et il paraît çue l'animal appelé Parasse à Madagascar $^{3}$, qui ressemble au loup par la figure, mais qui est plus grand, plus fort et plus eruel, pourrait bien être l'hyène.

Il y a peu d'animaux sur lesquels on ait fait autant d'histoires absurdes que sur celui-ci. Les ancieus ont écrit gravement que l'hyène était mêle et femelle alternativement ; que, quand elle portait, allaitait et élevait ses petits, elle demeurait femelle, pendant toute l'année; mais que, l'année suivante, elle reprenait les fonctions du mále, et faisait subir à son compagnon le sort de sa femelle. On voit bien que ce conte n'a d'autre fondement que l'ouverture en forme de fente que le mâle a, comme la femelle, indépendamment des parties propres de la génération, qui, pour les deux sexes, sont dans l'hyène semblables à celles de tous les autres animaux. On a dit qu'elle savait imiter la voix lumaine, retenir le nom des berger's, les appeler, les charmer, les arrêter, les rend'e immo-

nisu obluclata, sulinde nugitun edidit vitulim sinillimum. Narrabant Gabri sic fricuatam nuper se opposuice duobus leonibus, quos aspectante oculo ser'nissimo in fugan verterit. Kampfer, Ananitates, pag. $112 \mathrm{cl} \$ 13$.

1 En Abyssinie, Ics loups sont petits el forl laches; mais on y roit un animal, nommé byene, extrimenenl harti fl car. nassier : il allaque les gens cu plein jour comnse la nuil, et rompt souvent les porles et les clótures des hergeric's. Histoire de l'Abyssinie, par Ludolf, jage $\$ 1$.

Kampfer, in loco sujura citalo.

- Il se trouve à Madlagascar lles animanx yue les halitants appellent [arasses, de: la nature du lump, mais encure plus voraces. Mcomoires pour servir a l hisloire des ludes orieulales. 1702, prage 168. - Voyez aussi l'Histulre de l'Urénxplue, par Joseph finnilla. A vigmun, 1758, tome 111 , page 603, ou jl paralt que l'auleur a copié le passage quue nous venons de ciler. 
biles; faire en même temps courir les bergères, leur faire oublier leur troupeau, les rendre folles d'amour, ete..... Tout cela peut arriver sans hyène; et je finis pour qu'on ne me fasse pas le reproche que je vais faire à Pline, qui paraît avoir pris plaisir à compiler et raconter ces fables.

\section{ADDITION A L'ARTICLE DE L'HYÉNE.}

Nous donnons ici la figure d'une hyène mâle, qui était vivante à la foire de Saint-Germain, en 1773 , parce que celle que nous avons donnée d'abord n'est pas correcte par la difficulté qu'eut le dessinateur à la faire mettre en situation de la bieu voir. Cette première hyène était trèsféroce; au lieu que celle dont nous donnons ici la figure, ayant été apprivoisée de jeumesse, était fort douce : car, quoique son maitre l'irritât souvent avec un bàton pour lui faire hérisser sa crinière lor's du spectacle, l'instant d'après elle ne paraissait pas s'en souvenir; elle jouait avec son maitre, qui lui mettait la main dans la gueule sans en rien craindre. Au reste, cette hyène étant absolument de la même espèce, et toute semblable à celle dont nous avons donné la description (voyez ci-après); nous n'avons rien à ajouter, sinon que cette dernière avait la queue toute blanche sans aucun mélange d'autre couleur; elle était un peu plus grande rue la première, car elle avait trois pieds deux pouces, mesurée avec un cordeau, du bout du museau à l'origine de la queve. Elle portait la tète encore plus baissée cu'elle ne parait l'être dans le dessin. Sa hauteur était de deux pieds trois pouces. Son poil était blauc, mêlé et rayé de taches noires plus ou moins grandes, tant sur le corps que sur les jambes.

Il existe, dans la partie du sud de l'île de Meroé, une hyène beaucoup plus grande et plus grosse que celle de Barbarie, et qui a aussi le corps plus long à proportion, et le museau plus allongé et plus ressemblant à celui du chien, en sorte qu'elle ouvre la gueule beancoup plus large. Cet animal est si fort, qu'il enlève aisément un homme, et l'emporte à unc ou deux lieues sans le poser à terre. Il a le poil trèsrude, plus brun que celui de l'autre hyène; les bandes transversales sont plus noires; la crinière ne rebrousse pas du côté de la tête, mais lu côté de la queue. Mi. le chevalier Bruce a observé le premier que cette hyène, ainsi que celle de Syrie et de Barbarie, et probablement de toutes les autres espèces, ont un singulier défaut: c'est qu'au moment qu'on les force a se mettre en mouvement, elles sont boiteuses de la jambe gauche; cela dure pendant environ une centaine de pas, et d'une manièresi marquée, qu'il semble que l'animal aille culbuter du côté gauche, comme un chien auquel on aurait blessé la jambe gauche de derrière ${ }^{4}$.

\section{DESCRIPTION DE L'HYĖNE.}

(EXTRAIT DE DACBEvTON.)

L'hyène est à pen près de la grandeur dı loup, et a quelque rapport avec cet animal par la forme extérieure de la tête et du corps, quoiqu'elle soit d'une espèce bien différente : la tête semble, au premier coup d'oil, ne diffërer de celle dı loup qu'en ce que les oreilles sont plus grandes, mais, en l'observant en détail, on voit qu'elle a plus de largeur, que le nez est beaucoup moins sallaut, ct que le museau a moins de longueur; les oreilles sont pointues par le bont, minces et presque entièrement dégarnies de poil sur leurs faces tant extérieure qu'intérieure; le nez n'est pas plus avancé que la lèvre supérieure : ainsi, la partie du nez qui est au-dessus des ouvertures des narines forme à peu près un angle droit avec le chanfrein et la face antérieure du museau, au lien de former un angle aigu comme dans le loup et dans la plupart des chiens, surtout dans les mitins; les yeux de l'hyène sont posés comme ceux du chien; l'ouverture des paupières n'est pas dirigée obliquement comme le loup. L'hyène n'a que quatre doigts à cluaque pied, sans aucun restige du cinquième; il $\mathrm{y}$ a un gros turbercule sur la partie externe de la face interne dı carpe, an lieu que ce tubercule est placé, dans le chien, sur le milieu de cette face: au reste, les turbercules de la plante les piels et les ongles, qui sont noiraitres, ressemblent à ceux des cliens-mâtins.

L'hyène qui a servi de sujet pour cette description ètait de couleur grise el junnàtre avec des taches et des banles noires oแ noirâtres; il y avait tout le long du con et du dos, depuis la tête jusqu'à la queue, une crinière dont les plus longs poils se trouvaient sur la partie postérieure du dos et avaient environ neuf pouces sle long; ils étaient de couleur grise, ligrèrement teints de jaunitre sur la plus grande partie de leur longueur, et noirs à l'extrèmité, de sorte que cette crinière paraissait

1 Note communicuée par M. le chevalier Blnce à M. de Buffon. 
de couleur mêlée de gris et de noir; le chanfrein et le bout du museau étaient bruns; le dessus et les côtés de la tête avaient une couleur fauve; la bouche et les paupières étaient bordées de noir; il y avait quelques taches de cette couleur au-dessus et atı-dessous de l'angle postérieur de l'oril ; la frorge ètait noiràtre; les côtés du con avaient des taches noires ou noirâtres près de la tète, et des bandes transversales de même couleur près de l'cipaule. Cette partie, les còtés de la poitrine et du corps, les tlancs et la face extérieure de la euisse avaient nussi tles bantles noires qui s'étendaient de lıat en has sur un fond de couleur grise, légèrement teinte de jaunatre : la queue avait quelques teintes de brun sur un fonil gris. La poitrine, le ventre, les aisselles, les aines et la face interne des quatre jambes avaient yuelyuts taches brunes ou noirutl'es sur un fond jaunattre; la face externe du bras et de l'avant-bras était parsemée de plusieurs taches noires placées fort près les unes des autres; la face externe de la jambe avait aussi des taches de mème couleur, dont la plupart ćtaient en forme de bandes transversales et irrégulières. Les pieds avaient une couleur fauve, plus foncée que celle du sommet de la tête et mèlée de noiritre. Les poils des moustaches élaient en partie gris et en partie bruns; ils avaient jusqu'à un demi-pied de longueur.

\section{IAA CIVETTE et IE ZIBET.}

\section{(LA CivetTe vulgaire. - LA CivetTe ZibEt.)}

Ordie des carnassiers, famille des carnivores, tribu des digitigrades, genre eivelte. (Cuvier.)

La plupart des naturalistes ont cru qu'il n'y avait qu'une espèce d'animal qui fournit le parfum qu'on appelle la eivette: nous avons vu deux de ees animaux (qui se ressemblent à la vérité par les rapports essentiels de la conformation, tant à l'intérieur qu'à l'extérieur, mais qui cependant diffèrent l'm de l'autre par' un assez grand nombre d'autres caractères, pour qu'on puisse les regarder comme faisant deux espèces réellement différentes. Nous a vons conservé au premier de ces animaux le nom de civette, et nous avons domné au second celui de zibet, pour les distinguer. La eivette dont nous domnons iei la description nous a paru être la même que la civette décrite par MM. de l'Académie des sciences, dans les mémoires pour servir à l'histoire des animaux; nous eroyons aussi qu'elle est la même que celle de Caims dans Gessner, p. 837, et la même encore que celle dont Fabius Columna a donné les figures (tant du mâle que de la femelle) dans l'ouvrage de Jean Faber, qui est à la suite de celui de Hernandès.

La seconde espèce que nous appelons le zibet, nous a paru être le mème animal que celui qui a été décrit par M. de la Peyromie, sous le nom d'anional du musc, dans les mémoires de l'Académie des seiences, année 1731: tous deux diffèrent de la civette par les mêmes caractères, tous deux manquent de eriniere ou plutôt de longs poils sur l'épine du dos, tous deux ont des anneaux bien marqués sur la queue, au lien que la civette n'a ni crinière ni anneaux apparents. Il fant avouer cependant que notre zibet et l'animal du muse de 11 . de li Peyronnie ne se ressemblent pas assez parfaitement pour ne laisser ancun doute sur leur identité d'espèee : les anneaux de la queue du zibet sont plus larges que ceux de l'animal du musc ; il n'a pas un double collier; il a la queue plus courte à proportion du corps; mais ces différences nous paraissent légères, et pourraient bien n'être que des varićtés accidentelles auxquelles les civettes doivent être plus sujettes que les autres animaux sauvages, puisqu'on les élève et qu'on les nourrit comme des animaux domestiques, dans plusieurs endroits du Levant et des Indes. Ce (u'il y a de certain, e'est que notre zibet ressemble beaucoup plus à l'animal du muse de $\mathrm{V}$, de la Peyronnie (u'à la civette et que par conséquent on peut les regarder comme des animaux de même espèce, puisqu'il n'est pas même absolument démontré gue la civette et le zibet ne soient pas des variétés d'une espèce unique : car nous ne savons pas si ces animaux ne pourraient pas se mêler et produire ensemble; et lorsque nous disons qu'ils nous paraissent être d'espèces diflérentes, ce n'est point un jugement absolu, mais seulement une présomption très-forte, puisqu'elle est fondée sur la différenee constante de leurs earactères et que c'est cette constance des différences qui distingue ordinairement les espèces réelles des simples variétés.

L'animal que nous appelons ici eivette se nomme Falanoucà Nadagascar, nzime ou nzfusi à Congo, kankan en Fithiopie, kastor dans la Guinée. C'est la civette de Guinée : ear nous sommes sutrs que celle que nous avons eue avait été envoyeée vivante de Gunée à St.-Domingueà 
un de nos correspondants, qui, l'ayant nourrie quelque temps à Saint-Domingue, la fit tuer pour nous l'envoyer plus facilement.

Le zibet est vraisemblablement la civette de l'Asie, des Indes orientales et de l'Arabie, oü on la nomme zebct. ou zibet, nom arabe qui signifie aussi le parfum de cet animal, et que nous a vons adopté pour désigner l'animal même; il diffère de la civette en ce qu'il a le corps plus allongé et moins épais, le musean plus délié, plus plat ê un peu concave à la partie supérieure, au lieu que le museau de la civette est plus gros, moins long et un peu convexe. Il a aussi les oreilles plus élevées et plus larges, la queue plus longue et mieux marquée de taches ct d'anneaux, le poil beaucoup plus court et plus mollet : point de crinière, c'est-à-dire de poils plus longs que les autres sur le cou, ni le long de l'épine du dos; point de noir au-dessous des yeux, ni sur les joues, earactères particuliers et très-remarquables dans la civette. Quelques voyageurs avaient déjà soupconné qu'il y avait deux espèces de civettes; mais personne ne les arait recomnues assez clairement pour les décrire. Nous les avons vues toutes deux, et, après les avoir soigneusement comparées, nous les arons jugées d'espèce ct peut-être de climat différents.

On a appelé ces animaux chats musqués ou chats-civettes; cependant ils n'ont rien de commun avec le chat que l'agilité du corps ; ils ressemblent plutôt au renard, surtout par la tête. Ils ont la robe marquée de bandes et de taches, ce qui les a fait prendre aussi pour de petites panthères par ceux qui ne les ont vus que de loin; mais ils different des panthères à tous autres égards. Il y a un animal qu'on appelle la genette, qui est taché de même, qui a la tète à peu près de la mème forme, et qui porte, comme la civette, un sac dans lequel se filtre une humeur odorante : mais la genette est plus petite que nos civettes; eile a les jambes beaucoup plus courtes et le corps bien plus mince : son parfum est très-faible et de peu de duréc; au contraire le parfum des civettes est très-fort; celui du zibet est d'une violence extrême, et plus vif encore que celui de la civette ${ }^{1}$. Ces li-

\footnotetext{
1 Malgré torre l'attention qu'ou a depuis longtemps de rassembler à la viénageric différents animaux étrangers, ce sont les denx seuls de cette espece qui y aient parn, et les seuls, dans le nombre des animax musquès qui on y ait vus, qui alent donné un si grand parfum. Mímoire de M. de la l'ey-
}

queurs odorantes se trouvent dans l'ouverture que ces deux auimaux ont auprès des parties de la génération : c'est une humeur épaisse, d'une consistance semblable à celle des pommades, et dont le parfum, quoique très-fort, est agréable, au sortir même du corps de l'animal. Il ne faut pas confondre cette matière des civettes avecle musc, qui est une humeur sanguinolente, qu'on tire d'un animal tout différent de la civette ou du zibet: cet animal qui produit le musc est une espèce de chevreuil sans bois, ou de chèvre sans cornes, qui n'a rien de commun avec les civettes, que de fournir comme elles un parfum violent.

Ces deux espèces de civettes n'avaient donc jamais été nettement distinguées l'une de l'au. tre: toutes deux ont été quelquefois confondues arec les belettes odorantes ', la genette et le 'hevreuil du musc; ou les a prises aussi pour l'hyène. Belon, qui a donné une figure et une description de la civette, a prétenducue c'étoit l'lỵène des anciens ${ }^{2}$; son erreur est d'autant plus excusable qu'elle n'est pas sans fondement : il est sûr que la plupart des fables que les anciens ont débitées sur l'hyène ont été prises de la civette; les philtres qu'on tirait de certaines parties de l'hyène, la force de ces philtres pour exciter àl'amour, indiquentassez la vertu stimulante que l'on conmait à la pommade de civette, dont on se sert encole à cet effet en Orient. Ce qu'ils ont dit de l'incertitude du sexe dans l'hyène convient encore mieux à la civette; cál: le mâle n'a rien d'apparent au dehors que tro:s ouvertures tout à fait pareilles à celles de la femelle, à laquelleil ressemblesi fort par ces parties extérieures, qu'il n'estguère possible des'assurer' du sexe, autrement que par la dissection : l'ouverture au-dedans de laquelle se trouve la liqueur; ou plutôt l'humeur épaisse du parfum, est entre les deux autres et sur une même ligne droite qui s'étend de l'os sacrum au pubis.

Une autre erreur qui a fait beaucoup plus de progrès que celle de Belon, c'est celle de Grégoire de Bolivar au sujet des climats où se trouve

ronuie, inséré dans ceux de l'Académie les seicnces, année 1731, pag. 444. Il est queslion, dans ce passage, de l'animal du muse, que nuns crojons ètre le même que notre zibet.

- Aldrovande a dil yne la belelle odorante, ynon apjelle à la Virginic cosam, ettait la civelte. Atdrov., de Quadrup. digit., page 512. Céle crreur a élé adoptée par Haus Slozne, qui, dans son Ilistoire de la Jamaīıne, dit qu'il y a des cirettes a la lirginic.

${ }^{2}$ Eellon, Observ. Paris, 1553, fol. 93. 
l'animal civette: après avoir dit qu'clle est commune aux Indes orientales et ell Afrique, il assure positivement qu'elle se trouve aussi, et même en très-grand nombre, dans toutes les parties de l'Amérique méridionale. Cette assertion qui nous a été transmise par Faber, a été copiée par Aldrovande, et ensuite adoptée par tous ceux qui ont éerit sur la civette: "ependant il est certain que les civettes sont des animaux des elimats les plus chauds de l'ancien continent, qui n'ont pu passer par le Nord pour aller daus le nouveau, et que réellement et daus le fait il n'y a jamais eu en Amérique d'autres oivettes que celles qui y ont été transportées des iles Pluilippines et des côtes de l'A frique. Comme cette assertion de Bolivar est positive, et que la miemne n'est que négative, je dois donner les raisons particulières par lesquelles on peut prouver la fausseté du fait. Je eite ici les passages de Faber en entier ', pour qu'on soit en état d'en juger, ainsi que des remarques que je vais faire à ce sujet : $1^{\circ}$ la figure donnée par Faber, p. 538, lui avait été laissée par Recchi sans deseription ${ }^{2}$; cette figure a pour inscription animal zibethicum americanum; elle ne ressemble point du tout à la civette ni au zibet, et représente plutôt un blaireau; $2^{\circ}$ Faber donne la description et les figures de deux civettes, l'une femelle et l'autre mâle, lesquelles ressenblent à notre zibet; mais ees civettes ne sont pas le même animal ${ }^{3}$ que celui de la première fi-

4 Iloc animal (ziluethicum scilicel) nascitur in multis Iudix orleulatis atque occidentalis partibus, cnjusmodi in orientali suul provincix Benrala, Ceilan, Sumatra, dava major el minor, Malipur ac plures alix.... In Nova-IIispania vero sunt provincia de Qualemala, Canjege, Nicaragua, de Yera-Cruce, Florida et magna illa insula Saneti-Dominici, aut Ili ipagnola, Cuba, Malalino, Guadalupa, et alix... In regno Peruano animal hoc magua copia reperilur, in Paragıay, Tncmman, Chiraguanas, Sancla-Cruce, de la Sierra, Jungas, Audes, Clidchiaproias, Quizos, Timana, novo regno, et in ommibus provinciis magno llumiue Ilarağnone confinilus, qua circa hoc ferme sine numero ad dno Leucarmu millia sun extensa. Mul lo adluc plura ejusmodi animalia nascuntur in l3rasilia, ubi mereatura vel camhium zibethi sive algalix exereitatır. Nova-Hisp. aniur., Nardi Antonli Receli imagines et nomina

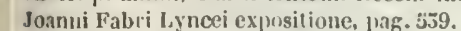

2 Vuici ce que dit Faber, dans sa Préface, au snjet de ses conmentaires sur les animanx dont il va traitel. Non jtane sis nescius, hos in animalia, fuos undo commentarios elinus mera uostra eonserlpfos esse industria ac conjectura, ad yuasnam animantium nostrorum species illa reduci possint, cum iı aulographo, praeler mudum nomคn el exactam picturam, de hisloria nilil quidem renerialur l'ag. $\$ 63^{\circ}$.

- Faber est oblige de dire luj-minte que eos ligures nese ressemblent jas. Quantum hac icon ab illa Iresicana differat, ipsa paglna ostendit. Ego clinut is et regionis differentian plurimum posse non nego. l’ag̃. 581 . gure, et les deux secondes ne représent des animaux d'Américue, mais cles cirettes de l'ancion continent ( ue Fal)ius Columna, confr'ère de Faber à l'Académie des Lyncei, avait fait dessiner à Naples, et descuelles il lui avait euvoyé la description et les figures. $3^{\circ}$ Après avoir eité Grégoire de Bolirar au sujet des eljmats où se trouve la civette, Faber finit par admirer la grande mémoire de Bolivar ${ }^{1}$ et par dire qu'il a entendu de sa bouclie ce récit a vec toutes ses circonstances. Ces trois remarques suffiraient seules pour rendre très-suspect le prétenduanimal zibellicum americanum, aussi bien que les assertions de Faber empruntées de Bolivar; mais ce qui achève de démontrer l'erreur, e'est que l'on trouve dans un petit ouvrage de Fernandès sur les animaux d'Amérique, à la fin du volume qui conticnt l'Histoire naturelle du Mexique de Hernandès, de Recehi et de Faber que l'on trouve, dis-je, chap. 34, paye 11, un passage qui contredit formellement Bolival, et où Fernandès ${ }^{2}$ assure que la civette n'est point un animal naturel à l'Amérique, mais que de son temps on avait commencé à en amener quelques-umes des iles Philippines ${ }^{3}$ à la Nouvelle-Espague. Enfin, en réunissant ee témoignage positif de Fernandès avec eelui de tous les voyageurs qui disent que les cirettes sont en effet très-communes aux îles Plilippines, aux Indes orientales, en Afrique, et dont aucun ne dit en avoir vu en Amérique, on ne peut plus douter de ce que nous avons avancé dans notre énumération des animaux des deux continents; et il restera pour certain, quojque.

1 Nlicor profecto Gregorii nostri smmmam in animalium perquisitione industrian et tenacissinum eornm qux vidit unquam memorian. Juro tibi, mi lector, bec onmia qux hactenus ipsius ab ore el scriptis hansi, el postlac dieturus smun, plura rarioraque illims ifsum ope libri menoriter descripsisse, el per compendiun ynodammnodo (cum inter collocpuia protractiora el jam plura afferal) lantun cullrasisse. P.18. 540 .

2 De Xluro a quo Gallia rocata corraditur, cap. Xxxus. Non me latel vulgare esse, hoc felis vocari genus llivjanis, quancuam advenam, non indigenam, verum qui ex iısulis Philipjucis coppit jan in lıanc Noram-Ilispraniam adfriri. Ilist. anim.elmiuer., Nov.-His|., I. I, à liran isc. Fernamles, 1). 11.

"La civelle se tonve aux iles bhilippines, tans les monta. gnes; sa peau ressemble assez à celle d'un ligre: ello n'est pas moins sauvage que lui, mais clle est beanconp plus petile. Ils la prenuent, la lient, et, après lui aroir vité la civelte, qui est declans ume petile lumrse quiell' a dessous la quene, ils la lais. seut en liberté pour la reprendre une antre fois. Irelations de divers voyages, par Thévenut. l'aris, 1695. Relation des lles Plíliplusu's, page 10.- On trouve quautifí de cisctles dans les monlagnes des iles Plilippines. llistoire générale des voyges, tome $X$, lag 597 . 
tous les naturalistes aient écrit le contraire, que la civette n'est point un animal naturel de l'Amérique, mais un animal particuljer et propre aux climats chauds de l'ancien contiuent, et qui ne s'est jamais trouvé dans le nouveau, qu'après y avoir été transporté. Si je n'eusse pas moi-mème été el garde contre ees espèces de méprises qui ne sont que trop fréquentes, nous aurions donné notre civette pour un animal amérieain, paree qu'elle nous était venue de Saint-Domingue; mais ayant recherehé le mémoire et la lettre de M. Pagès ' qui nous l'avait envoyée, j’y ai trouré qu'elle était venue de Guinée. J'insiste sur tous ces faits particulier's comme sur autant de preuves du fait général de la différence réelle qui se trouve entre tous les animaux des parties méridionales de chaque continent.

La civette et le zibet sont done tous deux des animaux de l'ancien continent; elles n'ont entre elles que les différences extérieures que nous avons indiquées ei-devant: eelles qui se trouvent dans leurs parties intérieures et dans la structure des r'éservoirs qui contiennent leur parfum, ont été si bien indiquées, et les réservoirs eux-mèmes déerits avee tant de soins par MII. Morand ${ }^{2}$ et de la Peyromie, que je ne pourrais que répéter ce quils en disent. Et, à l'égard de ce qui nous reste à exposer au sujet de ees deux animaux, comme ee sont ou des choses qui leur sont communes, ou des faits cqu'il serait bien diflieile d'appliquer'à l'un plutôt qu'à l'autr'e, nous avous eru devoir l'éunir le tout daus un seul et même article.

Les civettes (e'est-à-dire la cirette et le zibet, ear je me servirai maintenant de ce mot au pluriel pour les indiquer toutes deux), les civettes, dis-je, rnoirgue orjginaires et natives des climats les plus chauds de l'Afrique et de

+ Ia civette a été anneuéo le Guinée; elle se nomrissail des fruils de ec pays; mais elle unangeait anssi lréc-voluntiers de la viande. Promlant lont le trmops quielle a eté vivante, elle répandait me orlenr de musc insontemalble à une tres-grande tislance. Quand elle a été morte, jai eu leancoupl le peine a en soutcuir lodeur dans la clamlue. Je lui ai tronvé une fente précisément sur le serolım, qui était use ouverture commune de denx poches juiclle avat, une de clıanne côté ales testicules. Ces poches étaient pleines l’une hunıcur grise, ćpaisse et gluante, mêléc de foils assez lougs, qui étaient de la mème couleur de cenx une jai fromes latus ees poches. Ces sacs pouvaient avoir environ mu pouce el lemi de profondeur; leur diamètre est lueaucoup plus gland à l'ouverlure que daus le fond. Extrail du Mémolue de .M. Pagès, mériecin du roi, à Sainl-bomingue, Jalé du cau le 6 seplembre 1759

- Mém. de l'A cad. royale des scienees, anuéc $1728 \mathrm{et} 1731$.
l'Asie, peuvent cependant vivre lans les pays tempérés et même froids, pourvu qu'on les défende aree soin des injures de l'ail', et ru'on leur domne des aliments suceulents et choisis; on en nourrit un assez grand nombre en Hollande ou l'on fait conmerce de leur' parfum. I.a civelte faite à Amsterdam est préférée par nos counmerçants à celle qui vient du L evant ou des Indes, qui est ordinairement moins pure : celle qu'on tire de Guinée serait la meilleure de toutes ${ }^{1}$, si les Nègres ainsi que les Indiens et les Levantins ${ }^{2}$ ne la falsiflaient en y mèlant des sues de régétaux, comme du laudanum, du storax et d'autres drogues balsamiques et odoriférantes. Pour recueillir ce parfum, ils mettent l'animal dans une cage étroite ou il ne peut se tourner, ils ouvrent la cage par le bout, tirent l'animal par la queue, le contraignent à demeurer dans cette situation en mettant un bâton à travers les barreaux de la eage, au moyen du-

1 On voit quantité de civeltes à Malabar : cicst un jefit ani. mal à peu près fait comme un chat, à la réserve que sun mu. seau est plus proiutu, qu'il a les grifles moins dangerenses, el crie autremeut; le parfun qu'il produit s'engendre comme vue espèce de gi'aisse dans une ouverture qu' il a sous la quene; on la tire de lemps en temps, et elle ne foisonne qu autanl que la civette cst bien nourrie. On en fait m grand trafic a Cale. cut; mais, à moins de la cueillir soi-mone, elle ${ }^{2}: t$ fresque loujunrs falsiliée. Voyage de Dellon, page 11.-Optimum zi. belhi geuus ex Guinea advehitur, sincerilate eximium. Joannes llıgo.

2 Le chat qul produit la civelle a la lète et le museau d'uu renarl; il cst grand et tacheté conme le chat-ligre; il csl trèsfaronclı : on eu tire tons les deux jours la civelte, qui n'es! qưune curtaine mucosité on sueur épitisse, qu’il a suus la queue dans une concavits, elc. Voyage de Le Maire. Paris 1693, pages 100 et 101. C'est la civette de Guinée dont parle ici ce voyagur. - Je vis an Caire. daus la maison d'un rénitieu, plusienrs animanx liers extrèmement, de la grandeu prestue diun chien couchant, mais plus grossiers, ef de forme toute semblable a nos chats; ils les appellent chals ınısqués, e les gardent dans des cages... Pour en venit à bout, et de peu qu'ils ne morileut, ils les tiennent séparément dans des cage de bois bieu fortes, mais si ifroiles, que l'auimal ne pent pa s'y tumner... ils ouvent ensuite la cage frat derricie antau quil eu faut pour lirer les jambes le l'animal delors, san qu il pussis se tommer pour blesver eciui pui les tieut; cl ayan rauilsst: lat civelle, ils les remeltent dedans, tenant toujour lanimal bien serré. Vuyage de l'ictro della Valle. Ronen 1743, fome I pare 401.-Les cirelles, yison nomme en arab sebide, soul niturellement sillvages et se tiem, ent tans le monlağues d'Élhiopie. On eu transporte bealiconj en Europe ear 011 les premel pelites, el on les nourril dans iles cages d bois bieı furt's, où on letr donus à manger dı lait, de la fa rine, du blé cuit. da rizet guelyuefois de la viande, elc. liA. fricue de Marmol, fome I. page 5̈. - Voyez anssi le loyag

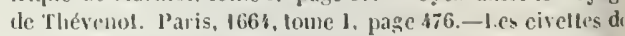
liile de Java rendent hien antant de parfum ture celles de cui née, mais il nest pas si blane ni si hou. Suite de la Relation d'Atimn Olearius, fome 11, page 550.-1udigenx ita loc pig mentum atulterant, ut ausim affirmare mullum zibelhum siu cerım ad nos deferi, Prosp. Alp., Ilist. A:gypl., Lugil. Hat 173.;, page 239. 
quel ils lui gènent les jambes de derrière; ensuice ils font entrer une petite euiller dans le sac cqui contient le parfum; ils raclent avee soin toutes les parois intérieures de ce sae et mettent la matière qu'ils en tirent dans un vase cu'ils couvrent avec soin. Cette opération se répète deux ou trois fois par semaine. La quantité de l'humeur odorante dépend beaucoup de la qualité de la nourriture et de l'appétit de l'animal; Il en rend d'autant plus cqu'il est mieux et plus délieatement nourri : de la chair erue et hachée, des œufs, du riz, des petits animaux, des oiseaux, de la jeune volaille, et surtout du poisson, sont les mets cqu'il faut lui offrir, et varier de manière à entretenir sa santé et exciter son goût; il lui faut très-peu d'eau, et (quoiqu'il boive rarement, il urine fréquemment, et l'on ne distingue pas le mâle de la femelle à leur manière de pisser.

Le parfum de ces animaux est si fort, qu'il se communique à toutes les parties de leur corps : le poil en est imbu et la peau pénétrée au point que l'odeur' s'en eonserve longtemps après leur mort, et que de leur vivant l'on ne peut en soutenir la violence, surtout si l'on est enfermé dans le même lieu. Lorsqu'on les échaufle en les irritant, l'odeur s'exhale eneore

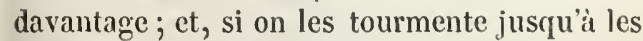
faire suer, on reeueille la sueur qui est aussi très-parfumée et qui sert à falsifier le vrai parfum ou du moins à en augmenter le volume.

Les eivettes sont naturellement farouches et mème un peu féroces; cependant on les apprivoise aisément, au moins assez pour les appro. elier et les manier sans grand danger. Filles ont les dents fortes et tranehantes, mais leurs ongles sont faibles et émoussés. Elles sont agiles et même légères quoique leur corps soit assez épais; elles sautent comme les chats et peuvent aussi courir comme les ehiens. Elles vivent de

1 Is réservoir qui contient la liqueur odorante de la civette est au-dessous de l'auus ct au-tlessus d'un aut'e orifice, si semblable daus les rleux sexes, que, sans la dissection, tontes les civeltes parail raient femelles... Conume on a remarqué ıue les civeltes sont ineonmodées de celle liøucur ynand les vaisscaux qui la contiennent en sout trop pleins, on leur a troure aussi des museles dont elles se servent pour comprimer ces vaisseaux et la raire sortir. Quoiguelle soit en plus grande quautité dans ces réservoirs, et qu'elle s'y perfectiome mieux, il y a lieu de croire yüelle se répand anssi en suenr par toute li peau: en effet, le poil des deux civelles sentait bon, et surlout eclui dı mile était si parfuné, que, quand on avait passé la main dessus, elle en conservait longtemps une odeur agréable. llistoire de l'Acarlémie des sciences depuis sonétablissenent. l'aris, 1733, tomc I, jages 82 et 83. chasse, surprennent et poursuivent les petits animaux, les oiseaux; elles cherchent, comme les renards, à entrer dans les basses-cours pour emporter les volailles. Leurs yeux brillent la nuit, et il est à croire qu'elles voient dans l'obseurité. Lorsque les animaux leur manquent, elles mangent des racines et des fruits; elles boivent peu et n'habitent pas dans les terres bumides; elles se tiennent volontiers dans les sables brûlauts et dans les montagnes arides. Elles produisent en assez grand nombre dans leur elimat; mais, quoiqu'elles puissent vivre dans les régions tempérées et qu'elles y rendent, comme dans leur pays natal, leur liqueur parfumée, elles ne peuvent y multiplier. Elles ont la voix plus forte et la langue moins rude que le ehat; leur cri ressemble assez à celui d'un ehien en colère.

On appelle en franeais civette l'humeur onetueuse et parfumée que l'on tire de ces animaux; on l'appelle zibet ou algallia en Arabie, aux Incles et dans le Levant, où l'on en fait un plus grand usage qu'en Europe. On ne s'en sert presque plus dans notre médecine; les parfumeurs et les confiseurs en emploient encore dans le mélange de leurs parfums. L'odeur de la civette, quoique violente, est plus suave que eelle du muse : toutes deux ont passé de mode lorsqu'on a connu l'ambre, ou plutôt dès qu'on a su le préparer, et l'ambre méme qui était, il n'y a pas longtemps, l'odeur par excellence, le parfum le plus exquis et le plus noble, a perdu de sa vogue, et n'est plus du goút de nos gens délicats.

\section{ADDITION A L'ARTICLE DE LA CIVETTB.}

M. de Ladebat a envoyé en 1772, à M. Bertin, ministre et seerétaire d'état, une civette vivante. Cet animal avait été donné par le gouverneur hollandais du fort de la Mine, sur la eôte d'Afrique, au eapitaine d'un des navires de M. de Ladelat père, en $1:-70$. Elle fut débarquée à Bordeaux au mois de novembre 1 ; 72 : elle arriva très-faible; mais, après quelques jours de repos, elle prit des forees, et au bout de eing à six mois elle a grandi d'en viron quatre ponces. On l'a nourrie avee de la chair crue et cuite, du poisson, de la soupe, du lait. On a eu soin de la tenir chaudement pendant l'hiver ; car clle parait beaucoup souflitir du froid, et 
elle devient moins méchante lorsqu'elle y est exposée '.

\section{DESCRIPTION DE LA CIVETTE.}

\section{(EXTHAIT DE DAUBENTON.)}

Le (u)rps de la civette est moins allongé que celui du zilset; elle a le museau plus gros et le chanfrein arııué en delıors, tandis que celıi du zibet l'est en dedans; les oreilles de la civette sont plus courtes et plus étroites; aut reste, ces deux animaux ont beancoup de rapport l'un à l'autre par la forme du nez, de la tète, du cou et des jambes. La queue de la civette était noins longue que celle du zibet; il se trouvait aussi quelque différence dans les pieds, car le pouce des pitcls de derrière de la civette était de trois lignes plus près du second doigt, et il y avait deux petits tubercules sur le milieu de la face inférieure du métatarse; et le tubercule qui était derrière le métacarpe était plus grand que dans le zilhet, et en formait un second plus petit à son côté intérieur. Les ongles étaient plus gros et avaient uнe couleur noire.

Le poil de la civette qui a servi de sujet pour cette description était pilus long, plus dur et plus hérissé que celui du zibet; il y avait aussi, conme dans cet animal, une sorte de duvet fort doux, de conleur cendrẻe brune. Le poil était de différentes conleurs mêlées de blanc, de blanclıâtre, de gris, de jaunatre, de brun et de noir : ces conleurs étaient disposées par landes et par taches. L'endroit des moustaches de chaque côté du nez a vait une couleur grise blanchàtre: le chanfrein, le tour les yeux, les joues, la partie de la lèrre du dessus qui ètait au-delà des moustaches, la mâchoire inférieure en entier, la partie antérieure de la poitrine, l'aisselle, f'avant-luras, la parti- inférieure de la janbe, les quatre pieds et le bout de la quene étaient de couleur lrune mèlée de noirâtre; il y avait aussi du gris sur li poitrine. Le front, le sommet, les cótés, le derrière de la tète et le ventre étaient de coulenr grise mèlée de noiràtre et d'une légère teinte de jamnatre sans taclies, ni bandes. Les oreilles avaient du brun noiratre sur leur paitie inférieure et du trris jaunattre sur leur partie supérienre. Cette mème couleur mêlée de jaunâtre, de gris et mène dle blanchâtre, etait sur le cou et sur tout le reste du corps avec des bandes et des taches noires; il y avail, sur chacpue còté du cou, ume bande qui commençait à upuelque distance de $\mathrm{l}_{\mathrm{a}}$ base de l'oreille, qui s'ètendait en ligne droite le long ilu cou, et qui descenulat devant l'épaule: sur la face inférieure dı cou, une granle tache terminée en avant par quatre branc!es, dont denx

+ Lettre de M. de Ladebat à M, de Buflon. Buıd an!? . 5 un. vombre, 1772 remontaient de clsaţue côtẻ du cou; sur le dos une large bande qui s'étendait depuis le cou jusqu'au milieu de la queue; sur les côtés du dos el sur les épaules de petites taches, sur les lombes deux on trois handes parallèles à la large bande du nilieu: elles étaient interrompues dans qquelques endroits. de sorte qu'elles paraissaient formées par de longues taches réunies; sur les còtés de la poitrine, sur les flancs, sur la croupe, sur la face extérieure de la cuisse et sur la jambe, des taches plus grandes que celles des épaules et des còtés du dos : enfin, sur la face inférieure de la queue, une bande et cinç ou six taches noires en forme de demi antneaux placés alternativement entre d'autres demianneaux de couleur grise jaunâtre.

Le poil de la cirette était plus gros, plus ferme et plus long que celui du zibet, principalement sous le ventre et sur le dos, ou il formait une sorte de crinière qui s'étendait tout le long du corps depuis le con jusqu'an milieu de la queue, et ıui était composée de poils longs de quatre ou cint pouces : ceux du ventre avaient jusqu'à deux pouces et demi de longueur; ceux des épaules et de la cuisse n'avaient qu'environ un pouce, et ceux du museau et des quatre pierls étaient très. courts.

\section{I,A GENETTE.}

( La Civette-genette, Cuv.)

Ordre des carnassiers, famille des carnirores, tribu de.s digitigrades, genre cirelte. (Cuvier.)

La genette est un plus petit animal que les civettes; elle a le corps allongé, les jambes courtes, le museau pointu, la tète effilée, le poil doux et mollet, d'un gris cendré, brillant et marqué de taches noires, rondes et séparćes sur les còtés du corps, mais qui se réunisseut de si près sur la partie du dos, qu'elles paraissent former des bandes noires continues, qui s'étendent tout le long du corps; elle a aussi, sur le cou et le long de l'épine du dos, une espèce de crinière ou de poil plus long, qui forme une bande noire ct continue depuis la tète jusuruà la queue, laquelle est aussi longue que le corps et marquée de sept ou huit anneaux alternativement noirs et blanes sur toute sa longueur: les taches noires du cou sont en forme de bandes, et l'on roit au-dessous de chaque œil une marque blanche très-apparente. La geuette a sous la queue et dans le même endroit que les civettes une ouverture ou sae dans lequel se filtre une espèce de parfum, maís faible et dont l'odeur ne se conserve pas. Elle est un peu 
plus grande que la fouine, qui lui ressemble beaucoup par la forme du corps aussi bien que par le naturel et par les habitudes; seulement il parait qu'on apprivoise la genette plus aisément: Belon dit en avoir vu dans les maisons à Constantinople, qui étaient aussi privées que des chats, et qu'on laissait courir et aller partout, sans qu'elles fissent ni mal ni dégât. On les a appelées chats de Constantinople, chats d'Espagne, chals-genelles; elles n'ont cependant rien de commun avec les chats, que l'art d'épier et de prendre les souris : e'est peut-être parce qu'on ne les trouve guère que dans le Levant et en Espagne qu'on leur a donné le surnom de leurs pays; car le nom mème de genelle ne vient point des langues anciennes, et n'est probablement qu'un nom nouveau pris de quelque lieu planté de genêt, qui, comme l'on sait, est fort commun en Espagne, où l'on appelle aussi genels des chevaux d'une certaine race. Les naturalistes prétendent que la genette n'habite que dans les endroits humides et le long des ruisseaux, et qu'on ne la trouve ni sur les montagnes, ni dans les terres arides. L'espèce n'en est pas nombreuse, du moins elle n'est pas fort répandue; il n'y en a point en France ni dans aucune autre province de l'Europe, à l'exception de l'Espagne et de la Turquie. Il Iui faut donc un climat chaud pour subsister et se multiplier : néanmoins il ne parait pas qu'elle se trouve dans les pays les plus ehauds de l'Afrique et des Indes; car la fossane, qu'on appelle genetle de Madagascar, est une espèce différente, de larguelle nous parlerons ailleurs.

La peau de cet animal fait une fourrure légere et très-jolie : les manchons de genette étaient à la modeil y a quelques années, et se vendaient fort clıer; mais comme on s'est avisé de les contrefaire, eu peigniunt de taches noires des peaux de lapins gris, le prix en a baissé des trois quarts, et la mode en est passée.

\section{ADDITION A L'ARTICLE DB LA GENETTE.}

J'ai dit, à l'article de la genette, que l'espèce n'en est pas fort répandue; qu'il n'y en a point en France ni dans aucune province de l'Lurope, à l'exceptiou de.l'Espagne et de la Turquie. Je u’étais pas alors informé qu'il se trouve des genettes dans nos provinces méridionales, et qu'elles sunt asse $\%$ communes cu Poitou, ou elles sont connues sous le nom de genettes même par les paysans, qui assurent qu'elles n'liabitent que les endroits humides et le bord des ruisseaux'.

M. l'abbé Roubaud, auteur de la gazette d'Agricullure et de plusicurs autres outrages utiles, est le premier qui ait annoncé au publie que cet animal existait en France dans son état de liberté; il m'en a mème envoyé une, cette année 1775 , au mois d'avril, qui avait été tuée à Civray en Poitou, et c'est bien le mème animal que la genette d'Espagne, à quelques variétés près dans les couleurs du poil. Il se trouve aussi des genettes dans les provinces voisines.

"Depuis trente ans que j'habite la province de Rouergue, m'écrit M. Delpech, j'ai toujours vu les paysans apporter des genettes mortes, surtout en hiver, chez un marchand, qui m'a dit qu'il y en avait peu, mais qu'elles habitaient aux environs de la ville de Villefranche, et qu'elles demeuraient pendant l'biver dans des terriers, à peu près comme les lapins. Je pourrais en envoyer de mortes s'il était uécessaire ${ }^{2} . "$

\section{NOUVELLE ADDITION A L'ARTICLE DE LA} GENETTE ${ }^{3}$.

M. Solnnerat, correspondant du Cubiuet, nous a envoyé le dessin d'un animal, sous lit dénomination de chat musqué du cap de Bonne-Espérance, mais qui nous parait ètre du genre des genettes. Par la comparaison que nous en avons faite avec celle de la genette de Frauce et arce la genette d'Espagne, elle nous parait avoir plus de rapport avec celleci : cependant cette genette du Cap en diffire par la couleur du poil, qu'elle a beaucoup plus blanc; elle n'a pas, comme l'autre, une tache blanche au-dessous des yeux, parce que sa tête est entièrement blanche, tandis que la genette d'Espagne a les joues noires, ainsi que le dessus du museau. Les taches noires du corps, diuns cette genette du Cap, sont aussi différemment distribuées; et comme les terres

4 Fitrait des Afliches dı Poiton, du jeudi 10 férrier 1774.

${ }^{3}$ 1.ellre de M. lelpech, maitre-es-arts, à M. de lbuffor. Villefranche. - Honergue, 6 aont 1731 .

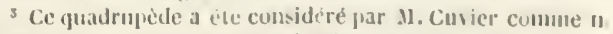
dilférant pas de la gonelle ordinaire. 
dı сар) de Bome-Espérance sont fort ćloignées de l'Espagne et de la France, où se trouvent ces deux premiers animaux, il nous parait que ee troisième animal que l'on a rencontré à l'extrémité de l'Afrique doit être regardé comme une espèce différente, plutôt que comme une variété de nos genettes d'Europe.

\section{DU BIZAAM '.}

Ordre des carnassiers, famille des earnivores, tribu des digitigrades, genre civette. (Cuvier.)

M. Wosmaer a donné la description d'un animal sous le nom de chat bizaam, dans une feuille imprimée à Amsterdam, en 1771, dont voici l'extrait :

"Sa grandeur est à peu près celle d'un chat " domestique. Ia couleur dominante par tout le " corps est le gris cendré clair, rehaussé de ta" ches bruines. Au milieu du dos règne une raie " noire jusqu'à la cqueue, qui est à bandes noi* res et blanches, mais la pointe en est noire " ou d'un brun très-foncé. Les pattes de devant u et de derrière sont brunes en dedans, et grises " tachées de brum en dehors; le ventre et la " poitrine sont d'un gris cendré. Aux deux cô" tés de la tête et sur le nez, se voient des raies " brunes; au bout du nez et sous les yeux, il y " a des taches blanches. Les oreilles, rondes et " droites, sont couvertes de poils courts et gris; " le nez est noir, et de chaque côté sont plu" sieurs longs poils bruns et blanes. Les pattes " sont armées de petịtes griffes blanches et cro" chues qui se retirent en dedans.

"Cc joli animal était d'un naturel un peu " triste, sans cependant être méchant; on le " tenait à la chaine. Il mangeait volontiers de "la viande, mais surtout des oiseaux vivants. "On ne l'a pas entendu miauler; mais, quand " on le tourmentait, il grommelait et soufflait "comme un chat."

M. Wosmaer dit aussi qu'il a nourri ce chat bizaam pendant trois ans, et qu'il n'a jamais senti qu'il eût la plus légère odeur de musc; ainsi ceux qui l'ont appelé chat musqué l'out apparemment confondu avec la eivette ou la genette du Cap; néanmoins ces deux animaux ne se ressemblent point du tout · ear M. Wosmaer

\footnotetext{
- Cuvier rapporte cet animal à l'espece de la genette.
}

compare le bizaam au margay. "De tous les " animaux, dit-il, que M. de Buffon nous a fait " connaître, le margay de Cayenne est celui " qui a le plus de ressemblance avec le chat bi"zaam, quoique, en les comparant exactement, " le margay ait le museau bien plus menu et " plus pointu; il diffère aussi beauroup par la " queue et la figure des taches."

J'observerai à ce sujet que ces premières différences ont été bien saisies par M. Wosmaer; mais ces animaux diffèrent encore par la grandeur, le margay étant de la taille du chat sauvage, et le bizaam de celle du chat domestique, c'est-à-dire une fois plus petit. D'ailleurs, le margay n'a point de raie noire sur le dos; sa queue est beaucoup moins longue et moins pointue; et ce qui achève de décider la différence réelle de l'espèce du margay et de celle du bizaam, c'est que l'un est de l'ancien continent, et l'autre du nouveau.

\section{$3^{e}$ ADDITION A L'ARTICLE DE LA GENETTE.}

Une genette femelle ${ }^{1}$ nous a paru différer assez de la femelle genette pour mériter d'être décrlte. On la montrait à la foire Saint-Germain, en 1772 ; elle était farouche et cherchait à mordre. Son maitre la tenait dans une cage ronde et étroite, en sorte qu'il était assez difficile de la dessiner. On ne la nourrissait que de viande; elle avait la physionomie et tous les principaux caractères de la genette; la tête longue et fine, le museau allongé et avancé sur la mâchoire inférieure, l'œil grand, la pupille étroite, les oreilles rondes, le poil de la tête et du corps moucheté, la queue longue et velue. Elle était un peu plus grosse que la genette que nous avons décrite, quoiqu'clle füt encore jeune, car clle avait grandi assez considérablement en trois ou quatre mois. Nous n'avons pu savoir de quel pays elle venait: son maitre l'avait achetée à Londies sept ou huit mois auparavant. C'est un animal vif et sans cesse en mouvement, et qui ne se repose qu'en dormant.

- M. G. Cuvier le premier a reconnu que cet animal constiluait une espèce différente de celle de la genetle; et $\mathbf{M}$. F. Cuvier a confirmé ce fait en élablissaut le genre paradoxure dout il est le lype, et qui est principalement caraclérisé par la propriété qu'a la pueue de s'enıouler en dessous jusquà sa base, sans néanımoins ètre prenaule. Plusieurs autres carnassiers des Indes, Irès-roisins des civettes, se rapprocheut par le mèine caractèe de la civelle noire, ou pougounié, et sont maiutenant placés dans le inème genre. (Note de $\mathbf{H}$, Desınar.) 
Cettegenette avait vingt pouces de longueur, sur sept pouces et demi de hauteur; elle avait le dessus du cou plus fourni de poil que l'autre genette; celui de tout le corps est aussi plus long; les anneaux circulaires de la queue sont moins distincts, et mêmeil n'y a point d'anneaux du tout au-delà du tiers de la queue : les moustaches sont beaucoup plus grandes, noires, longues de deux pouces sept lignes, couchées sur les joues et non droites et saillantes, comme dans les chats ou les tigres, le nez noir et les narines très-arquées; au-dessus du nez s'étend une raie noire, qui se prolonge entre les yeux, laquelle estaccompagnée de deux bandes blanchâtres. II y a une tache blanche au-dessus del'œil, et une bande blanche au-dessous. Les oreilles sont noires, mais plus allongées et moins larges à la base que les orcilles de la première genette. Le poil du corps est d'un blane gris, mêlé de grands poils noir's dont le reflet parait former des ondes noires; le dessus du dos est rayé et moucheté de noir; le reste du corps moucheté de même, mais d'un noir plus faible ; le dessous du ventre blanc, les jambes et les cuisses noires; les pattes courtes; cinc doigts à chaque pied; les ongles blancs et crochus, la queue longue de seize ponces, grosse de deux pouces à l'origine : dans le premier tiers de sa longueur, elle est de la couleur du corps, rayée de petits anneaux noirs assez mal terminés. Les deux autres tiers de la queue sont tout noirs jusqu'à l'extrémité.

Longueur du bout du museau à l'angle exté-

rieur de l'œil. .............. 018 Ouverture d'un angle à l'autse. . . . . . . 00000 Distance entre les angles extéricurs des yeux. 000011 Distance entre l'angle postèrieur de l'ouil à

l'oreille................. 0 0 011 Longueur de l'oreille. ........... 015 Largeur à la base............. 0 o 10

\section{I.A FOSSANE.}

(la civette fossane, Cuy.)

Ordre des earnassiers, famille des carnirores, tribu des digitigrades, genre cirette. (Cuvier.)

Quclques voyageurs ont appelé la fossane genette de Madagascar, paree qu'elle ressemble à la genettc par les couleurs du poil, et par quelques autres rapports : cependant elle est constamment plus petite; et ce qui nous fait penser que ce n'est point une genette, c'est qu'elle n'a pas la poche odoriférante qui, dans cet animal, est un attribut essentiel. Comme nous étions incertains de ce fait, n'ayant pu nous procurer l'animal pour le disséfuer, nous avons consulté par lettres M. Poivre, qui nous en a envoyé la peau bourrée, et il a cu la bonté de nous répondre dans les termes suivants: Lyon, 19 juillet 1761. "La fossane que j'ai ap" portée de Madagascar est un animal qui a les " mœur's de notre fouine: les habitants de l'ile " m'ont assuré que la fossane måle étant en " chaleur, ses parties avaient une forte odeur " de musc. Lorsque j'ai fait empailler celle qui " est au Jardin du Roi, je l'examinai attenti"vement; je n'y découvris aucune poche, etje " he lui tronvai aucunc odeur de parfum. Jai " élevé un animal semblable à la Cochinchine, " et un autre aux îles Philippines; l'un et l'autre " étaient des mâles, ils étaient devenus un peu " familiers, je les avais eus très-petits, et je ne " les ai guère gardés que deux ou trois mois : " jen'y ai jamais trouvé de poche entre les par" ties que vous m'indiquez; je me suis seule" ment aperçu que leurs excréments avaient "I'odeur de cenx denotre fouine. Ils mangcaient " de la viande et des fruits, mais ils préféraient " ces derniers et montraient surtout un goût " plus décidé pour les bananes, sur lesquelles " ils se jetaient avec voracité. Cet animal est " très-sauvage, fort difficile à apprivoiser; et " quoique ćlevé bien jeune, il conserve toujours " un air et un caractère de férocité, ce (qui m’a " paru extraordinaire dans un animal qui vit " volontiers de fruits. L'œil de la fossane ne " présente qu'un globe noir fort grand, comparé " à la grosseur de sa tête, cequi donne à cet ani" mal un air méchant."

Nous sommes très-aises d'avoir cette oceasion de marquer notre reconnaissance à M. Poive, qui, par gout pour l'lıistoire naturelle, et par amitié pour ceux qui la cultivent, a donné au Cabinet un assez grand nombre de morceaux rares et précieux dans tous les genres.

Il nous parait que l'animal appelé berbé en Guinée est le même que la fossme, et que par conséquent cette espèce se trouve en Afrique comme en Asie. "Le berbé, disent les voya"geur's', a le museau plus pointu et le corps " plus petit que le chat; il est marqueté comme " la civette. "Nous ne comnaissons pas d'animal 1 Vuyagc en Guinée par Busman, page 256, fis. p 1, p. 252. 
auquel ces indications, qui sont assez précises, conviemnent mieux qu'à la fossane.

\section{LE PU'TOIS RAYÉ DE L'INDE.}

\section{(L.A CIVETTE RAYÉE.)}

Ordre des carnassiers, famille des carnirores, tribu des digitigrades, genre marte. (Curier.)

Cet animal, que M. Sonnerat a rapporté de l'Inde, et que dans son Voyage il a nommé chat sauvage de l'Inde, ne nous parait pas être du genre des chats, mais plutôt de celui des putois. Il n'a du chat ni la forme de la tête, ni celle du corps, ni les oreilles, ni les pieds, qui sont courts dans les chats et longs dans cet animal, surtout ceux de derrière; ses doigts sont courbés comme ceux des écureuils ; les ongles crochus comme ceux des chats, et c'est probablementce dernier caractèrequi a induit M. Sonnerat à regarder cet animal comme un chat : cependant sou corps est allongé comme celui des putois, auxquels il ressemble encore par la forme des oreilles, qui sont très-différentes de celles des chats.

Cet animal, qui habite la côte de Coromandel, a quinze pouces de longueur du bout du museau à l'anus; sa grosseur approche de celle de nos putois. La tète, qui a quatre pouces du nez à l'occiput, est d'une couleur brune mêlée de fauve; l'orbite de l'œil est très-grande et bordée de brun ; la distance du museau à l'angle antérieur de l'œil est de dix lignes, et celle de l'angle postérieur à l'oreille est de quatorze lignes. Le tour des yeux, le dessous du nez et les joues sont d'un fauve påle; le bout du nez et les naseaux sont noirs, ainsi que les moustaches et les poils au-dessus des yeux. Lioreille est plate, ronde, et de la forme de celle du putois ; elle est nue, et il y a seulement quelques poils blanchâtres autour du conduit auditif. Six larges bandes noires s'étendent sur le corps, depuis l'occiput jusqu'au-dessus du croupion, et ces bandes noires sont séparées les unes des autres alteruativement par cinq longues bandes blanchàtres et plus étroites. Le dessous de la mâchoire inférieure est fauve très-pâle, de même que la face intérieure des jambes de devant; la face extérieure du bras est brune, mélangée de blanc sale; la face exterue des jambes de derrière est brune, mêlée d'un peu de fauve et de blanc gris ; les cuisses et les jambes de derrière ont la face interne blanche, et en quelques endroits fauve pâle; tout le dessous du ventre est d'un blanc sale; le plus grand poil de dessus le corps a huit lignes.

La queue, longue de neuf pouces, finit en pointe; elle est couverte de poils bruns, mêlés de fauve comme le dessus de l'occiput. Les pieds sont longs, surtout ceux de derrière; car ceux de devant ont, y compris l'ongle, seize lignes de longueur, et ceux de derrière vingt et une lignes. Les cinqdoigts de chaque pied sont couverts de poils blanchâtres et bruns; les ongles des pieds de devant ont trois lignes, ceux des pieds de derrière quatre lignes.

Il y a six dents incisives et deux cauines, en haut comme en bas.

\section{LA SARICOVIENNE.}

\section{(LA LOUTRE D'AMÉRJQUE.)}

Ordre des carnassiers, fanille des caruivores, tribu des digitigrades, genre glouton. (Curier.)

"La saricovienne, dit Thevet, se trouve le "long de la rivière de la Plata; elle est d'une " nature amphibie, demeurant plus dans l'eau " que sur la terre. Cet animal est grand comme " un chat, et sa peau, qui est mèlée de gris et de " noir, est fine comme velours; ses pieds sont " faits à la semblance de ceux d'un oiseau de " rivière : au reste sa chair est très-délicate et " très-bonne à manger. " Je commence par ci . ter ce passage, parce que les naturalistes ne connaissaient pas cet animal sous ce nom, et qu'ils ignoraient que le carigueibeju du Brésil, qui est le même, eût des membranes entre les doigts des pieds. En effet, Marcgrave, qui en donne la description, ne parle pas de ce caractère, qui cependant est essentiel, puisqu'il rapproche, autant qu'il est possible, cette espèce de celle de la loutre.

Je crols encore que l'animal dont Gumilla fait mention sous le nom de Guachi ' pourrait bien

- On tronve sur les rivières qui se jettent dans l'Orénoque une grande quantité de cluiens d'eau, que les Indiens appellent guachi $i$ cet animal nage avec beaucoup de légèreté, $\mathrm{e}^{t}$ se nourrit de poisson; il est amphibie, mais il vient auss chercher sa nourriture sur terre; il creuse des fosses sur lo rivage daus lesquelles la femelle met bas ses petits. Il ne creusc point ces fosses à l'écart, mais dans les cndroits où ilo 
étre le même que la saricovienne, et que c'est une espèce de loutre commune dans toute l'Amérique méridionale. Par la description qu'en ont donnée Marcgrave et Desmarchais 1, il parait que cet animal amphibie est de la grandeur d'un chien de taille médiocre; qu'il a le haut de la tête rond comme le chat, le muscau un peu long comme celui du chien, les dents et les moustaches comme le chat; les yeux ronds, petits et noirs; les oreilles arrondies et placées bas; cinq doigts à tous les pieds; les pouces plus courts que les autres doigts, qui tous sont armés d'ongles bruns et aigus; la queue aussi longue que les jambes de derrière; le poil assez court et fort doux, noir sur tout le corps, brun sur la tête, avec une tache blanche au gosier. Son cri est à peu près celui d'un jeune chieu, et il l'entrecoupe quelquefois d'un autre cri semblable à la voix du sagouin. II vit de crabes et de poissons, mais on peut aussi le nourrir avec de la farine de manioc délayée dans de l'eau. Sa peau fait une bonne fourrure, et quoi(ju'il mange beaucoup de poisson, sa chair n'a pas le goût de marais; elle est au contraire trèssaine et très-bonne à manger.

\section{ADDITION A L'ARTICLE DE I.A SARICOVIENNE.}

Je trouve dans les notes communiquées par M. de li Bolde, qu'il y a à Cayenne trois espèces de loutres: la noire, qui peut peser quarante ou cinquante livres; la seconde, qui est jaunàtre, et qui peut peser vingt ou vingt-cinq livres; et une troisiène espèce beaucoup plus petite, dont le poil est grisàtre, et qui ne pèse que trois ou quatre livres. Il ajoute que ces animaux sont très-communs à la Guyane, le long de toutes les rivières et des marécages, parce que le poisson y est fort abondant; elles vont mène par troupes quelquefois fort nombreuses : elles sont farouches et ne se laissent point approcher : pour les avoir, il faut les sur-

vivest en commun, et oi ils viennent se divertir. J'ai vu et examine avee soin leurs tanières: lon ne saurait rien voir le plus juopre; ils ne latissent pas la moindre herbe aux envi. rons; ils amonceltent à l'écarl les aréles des poissons yu'ils mangent, et, à force de sauter, d'aller et de venir, ils firaliqueut des chemms très-propres el tris-commoles, Ilistuire defOrénoque, par Gumilla, lome 111, page 29. - Nota. Ces caractères conviennent à la saricovienne; mals il nous furait yue le nom de guachi a élé mal appliyué iei, et qu'il ajpar. tient a lespece de mouffelte que nous arons aypelće coase.

1 voyage de Desmarchais, lome 111, page 306. prendre; elles ont la dent cruelle, et se défendent bien contre les chiens : elles font leurs petits dans des trous qu'elles creusent au bord des eaux; on en élève souvent dans les maisons. J'ai remarqué, dit M. de la Borde, que tous les animaux de la Guyane s'accoutument facilement à la domesticité, et deviennent incommodes par leur grande familiarité.

M Aublet, savant botaniste, que nous avons déjà cité, et M. Olivier, chirurgien du roi, qui ont demeuré tous deux longtemps à Cayeune et dans le pays d'Oyapok, m’ont assuré (qu'il y avait des loutres si grosses, qu'elles pesaient jusqu'à quatre-vingt-dix et cent livres; elles se tiennent dans les grandes rivières qui ne sont pas fort fréquentées, et on voit leur têtc audessus de l'eau; elles font des cris que l'on entend de très-loin; leur poil est très-doux, mais plus court que celui du castor ; leur couleur ordinaire est d'un brun minime : ces loutres vivent de poisson, et mangent aussi les glaines qui tombent dans l'eau sur le bord des fleuves ${ }^{1}$

\section{UNE LOUTRE DE CANADA ?}

Ordre des carnassiers, famille des carnirores, tribu des digitigrades, geure marte. (Cuvier.)

Cette loutre, beaucoup plus grande que notre loutre, et qui doit se trouver dans le nord de l'Europe comme elle se trouve en Canada, m'a fourni l'occasion de chercher si ce n'était pas le même animal qu'Aristote a findiqué sous le nom de latax, qu'il dit ètre plus grand et plus for't que la loutre; mais les notions quil en donne ne convenant pas en entier à cette grande loutre, et la trouvant, d'ailleurs absolument semblable à la loutre commune, à la grandeur près, j’ai jugé que ce n'était point une espèce particulière, mais une simple variété dans celle de la loutre. Et comme les Grees, et surtout Aristote, ont eu grand soin de ne donner des noms différents qu'à des animaux réellement diffé-

+ Ces adilitions sont relatives, en ce qui concerne les deux pins grosses loutres yuon y distingue, a la loutre ci-lessus décrilc sous le nom de saricovienne, el aussi vraisemublablement à me seconde cspece, voisine le celle-ci. Quant à la troisieme ou la plus petite, il est probable yuclle se rapporte à l'espèce de sarigue à piels palmés, quion a désignace sous le now d'yapok.

3 Cel animal, peu connu, ne différe peut-ítre pas de la vraie loure marine, diente cl-après. 
rents par l'espèce, nous nous sommes convaincus que le latax est un autre animal. Dailleurs les loutres, comme les castors, sont communément plus grandes et ont le poil plus noir et plus beau en Amérique ' qu'en Europe. Cette loutre de Canada doit en effet être plus grande et plus noire que la loutre de France. Mais, en cherchant ce que pouvait être le latax d'Aristote (chose ignoréc de tous les naturalistes), j'ai conjecturé que c'était l'animal indiqué par Belou sous le nom de loup marin, et j'ai cru devoir rapporter ici la notice d'Aristote sur le latax, et celle de Belon sur le loup marin, afin qu'on puisse les comparer ${ }^{2}$.

Aristote fait mention dans ce passage de six animaux amplibies; et de ces six nous n'en connaissons que trois : le phoca, le castor et la loutre; les trois autres, qui sont le latax, le satherion et le satyrion, sont demeurés inconnus, parcequ'ils ne sont indiqués que par leurs noms et sans aucune description. Dans ce cas, comme dans tous ceux où l'on ne peut tirer aucune induction directe pour la connaissance de la chose, il faut avoir recours à la voie d'exclusion; mais on ne peut l'employer avec succès que quand on connaît à peu près tout : on peut alor's conclure du positif au négatif, et ce négatif devient par ce moyen une comnaissance positive. Par exemple, je crois que, par la longue

- Les Jontres de l'Amérique septentrionale diffèrent de celles de France ell ce qu'elles sont toutes communément plus longues et plus noires; il s'en trouve qui le sont bien plus les unes que les autres; il y en a d'aussi noires que du jais : cellesci sont fort rechercliées el fol t chères. Description de l'Amérique septentrionale, par Denys, tome It, page 280 .

2 Sunt inter quadrupedes ferasque, quæ victum ex lacu et fluviis petant, at vero a mari nullum, præterquam vitulus marinus. Sunt elian in loe genere fiber, satherinm, satyrium, lustris, latax, qux latior lutre est, dentesque liabet robustos, quippe quæ noctu plerumque egrediens, virgulta proxima suis dentibus ut ferro præcidat; lustris etian hominewn mordet, nec desistit, ut ferunt, uisi ossis fracli erepitum senserit. Lataci pilıs durus, specie inter pilum vitulj marini et cervi. Arist., Hist. auim., lib. Vtu, cap. v. - Le loup marin. - Dautant gue les Anglais n'ont point de loups sur leur terre, - nalure les a pourveus dune bète an rivage de leur mer, si - forl approclsante de uotre loup, que si ce n’étoit qu'il se - jelte plutót sur les poissons que sur les ouailles, on le diroit - du toul semblable à notre bête lant ravissante; considéré - li corpulance, le poil, la tète (qui toutefois est fort grande) - et la (unene moult approchante an loup lerrestre; mais para ce que celui-cy (comme dit est) ne vit que de poissons, et - n'a élé ancumement connu des anciens, il ue mª semblé - notalle que les animaux de double vie cy-dessus allégués. - par quoi j'en ai bien voulu mettre le pourtrail. belon, de la Nature des Poissons, page 18. - Nota. La ligure est à la page 19, et ressemble plus a liyyeue qu'à aucun autre animal; mais ce ne peut ètre l'hyèue, car elle n'est point amphibie, elle ne vit pas de poissons et d'ailleurs elle est d'un climat tout diffèrenl. étude que j'en ai faite, je connais à très-peu près tous les animaux quadrupèdes : je sais qu'Aristote ne pouvait a voir aucune comnaissance de. ceux qui sont particuliers au continent de l'Amérique : je comnais aussi parmi les quadrupèdes tous ceux qui sont amphibies, et j'en sépare d'abord les amphibies d'Amérique, tels que le tapir, le cabiai, l'ondatra, etc. Il me reste les amphibies de notre continent, qui sont l'hippopotame, le morse ou la vache marine, les phoques ou veaux marins, le loup marin de Belon, le castor, la loutre, la zibeline, le rat d'eau, le desman, la musaraigne d'eau, et, si l'on veut, l'ichneumon ou mangouste, que quelques-uns ont regardé comme amphibie, et ont appelé loutre d'Égypte. Je retranche de ce nombre le morse ou la vache marine, qui, ne se trouvant que dans les mers du Nord, n'était pas conmue d'Aristote; j'en retranche encore l'hippopotame, le rat d'eau, et lichneumon, parce qu'il en parle ailleurs, et les désigne par leurs noms; j'en retranche enfin les phoques, le castor et la loutre, qui sont bien connus, et la musaraigne d'eau, qui est trop ressemblante à celle de terre pour en avoir jamais été séparée par le nom : il nous reste le loup marin de Belou, la zibeline et le desman, pour le latax, le $s a$. therion et le satyrion : de ces trois animaux il n'y a que le loup marin de Belon qui soit plus gros que la loutre : ainsi c'est le seul qui puisse représenter le latax; par conséquent la zibeline et le desman représentent le satherion et le $s a-$ tyrion. L'on sent bien que ces conjectures, que je crois fondées, ne sont cependant pas du nombre de celles que le temps puisse éclaircir davantage, à moins qu'on ne découvrît quelques manuscrits grees jusqu'à présent incomnus, oi ces noms se trouveraient employés, c'est-à-dire expliqués par de nouvelles indicatlons. 


\section{DE LA SARICOVIENNE}

ov

\section{LOUTRE MARINE 1.}

Urdre des cannassiers, famille des carnivores, tribu des digitigrades, genre glouton. (Cuvier.)

Nous avons dit, à l'article de la loutre saricoviemne ou carigueibeju de Maregrave, que cet animal paraissait se trouver sur la plupart des côtes poissonneuses et des embouchures des grands lleuves, dans les plages désertes del'Amérique méridionale; mais nous ignorions alors que ce mème animal se retrouve au Kamtschatka et sur les côtes et les iles de toute cette partic du nord-est de l'ancien continent, et sans que la différence de clinat paraisse avoir influć sur l'espèce, quui semble ètre partout la méme. Ces saricoviennes du liamtschatka ont été soignensement déerites par M. Steller, et l'on ne peut douter, en comparant sa deseription avec celle de Maregrave, que l'espèce de ees saricovienues du Kamtsehatka ne soit la mème que celle du carigueibẹu ou saricoviemne de l'Amérique: on verra de méme que les lions marins, les ours marins et la plupart des phoques se retrouvent les mèmes dans les mers les plus éloignéés les unes des autres et sous les elimats les plus opposés.

Les kusses qui demeurent au Kamtschatka domment à la saricovienue le nom de bobr ou castor, quoiqu'elle ne ressemble au castor que par la longueur de son poil, et qu'elle n'ait que peu de rapport avec lui par sa forme extérieure; car e'est une véritable loutre, à laquelle non-seulement nous rapportons ces grandes loutres de la Guyane et du Brésil , dont nous avons parlé, mais aussi cette loutre du Canada dont nous ayons donné la notice, et qui parait étre de la taille et de l'espèce des saricoviennes.

On voit ces saricoviennes ou loutres marines sur les còtes oriculales du Kamtschatka ct dims les iles voisines, depuis le cinquantième dlegré jusyu'au cinc(uante-sixième, el il ne s'en trouve que peu ou point dans la mer intéricure à l'oc-

- La loutre marine aurail phintiol de la ressemblance, par les proportions de ses membirs, avee la lentre çue Buffon a décrite sons le noun dis lomtre de lanalia. cident du Kamtschatka, nì au-delà de la tıolsième lle des Kuriles. Elles ne sont ni féroces ui farouches, étant mème assez sédentaires dans les lieux (ju'elles ont choisis pour demeure; elles semblent eraindre les phocfues, ou du moins elles évitent les endroits (qu'jls babitent, et n'aiment que la société de leur espèce. On les voit en trè-grand nombre dans toutes les iles inhabitées des mers orientales du liamtschatka: il y en avait, en 17.42, une si grande quantité à l'lle de Behring, que les Russes en tuèrent plus dle huit cents. "Comme ces animaux n'avajent jamais vu d'hommes auparavant, dit M. Steller, ils n'étaient ni timicles ni sauvages; ils s'approchaient mème des feux que nous allumions, jusqu'à ce qu'instruits par leur malheur, ils commencerent à nous fuip'."

Pendaut l'hivel', ces sallicoriennes se tiemnent tantòt daus la mer", sur les glaces, et tantôt sur le rivage; en été, elles entrent dans les fleuves et vont même jusque daus les laes d'eau douce, oì elles paraissent se plaire beaucoup; dans les jours les plus chauds, elles cherchent, pour se reposer, les lieux frais et ombragés. Eu sortant de l'eau, elles se secouent et se corrchent en rond sur la terre comme les chiens; mais, avant que de s'endormir, elles cherchent à recomnaitre, par l'odorat plutôt que par la rue, qu'elles ont faible et courte, s'il n'y a pas quelque enuemi à eraindre daus les curilons. Elles ne s'éloignent du rivage (qu'à de petites distances, afin de pouvoir regaguer promptement l'ean dans le péril ; ear, quoiqu'elles eourent assez vite, un homme ieste peut néinmo:ns les atteindle; mais en revinche elles nagent avec une très-grande célérité et comme il leur plalt, c'est-it-dire, sur le ventre, sur le dos, sur les cotés et mème dans une situation presque perpendiculaì'e.

Le mâle ne s'attache qu'ì une seule femelle, avec laquelle il va de compagnie, et qu'il parait aimer beaucoup, ne la quittant ni sur mer ni sur terre. Il y a apparenee qu’ils s'aiment en effet daus tous les temps de l'année; car on voit des petits nouveau-nés daus toutes les saisons, et quelquefois les pères et mere's sont e'ncore suiv is par des jeunes de difléments âges des portées précédontes, paree yue leur's petits ne les quittent que quand ils sont adultes et qu`ils peuvent former une nouvelle famille. Les fo

1 Novi Commenlarii Inademix Petropol., Iome 11, 1781 
melles ne produisent qu'un petit à la fois, et très-rarement deux. Le temps de la gestation est d'environ huit ì neuf mois; elles mettent bas sur les côtes ou sur les iles les moins fréquentées; et le petit, dès sa naissance, a déjà toutes ses dents, les eanines sont seulement mo:ns avancées que les autres : la mère l'allaite pendant près d'un an, d'où l'on peut présumer qu'elle n'entre en chaleur qu'environ un an après qu'elle a produit. Elle aime passionnément son petit, et ne cesse de lui prodiguer des soins et des earesses, jount continuellement avec lui, soit sur la terre, soit dans l'eau : ellelui apprend à nager, et, lorsqu'il est fatigué, elle le prend dans sa gueule pour lui donner quelques moments de repos. Si on vlent à le lui enlever, elle jette des cris et des gémissements lamentables : il faut même user de préeautions lor'squ'on veut le lui dérober; ear, quoique douce et timide, elle le defend avee un courage qui tient du désespoir, et se fait souvent tuer sur la place plutót que de l'abandonner'

Ces animaux se nourrissent de crustacées, de coquillages, de grands polypes et autres poissons mous, qu'ils viennent ramasser sur les grèves et sur les rivages fangeux lorsque la marée est basse: car ils ne peuvent demeurer assez longtemps sous l'eau pour les prendre au fond de la mer, n'ayant pas, comme les phoques, le trou ovale du cour ouvert. Ils mangent aussi des poissons à écailles, comme des anguilies de mer, ete., des fruits rejetés sur le rivage en été, et même des fucus, faute de tout autre aliment; mais ils peuvent se passer de nourriture pendant trois ou quatre jours de suite. Leur chair est mejlleure à manger que celle des phoques, surtout eelle des femelles, qui est grasse et tendre lorsud'elles sont pleines et préles à mettre bas; celle des petits, qui est très-délicate, est assez semblable à la chair de l'agneau, mais la ehair des vicux est ordiuairement très-dure'. "Ce fut, dit M. Steller, no-

1. lies Russes jelés dans cetle lle (de Behriug), après s ètre - réscrvi une provision de huil eents livres de farine, prour - faire le trajet dı Kauslseliatha des yue la saison el leur sane ti le permeltraient, eurent recours aux lontres marincs; mn " de ces animaux leur fournissail (puaraute ou ciupuante li-

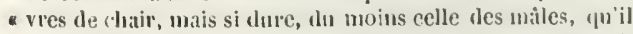
- fallair la liacher et laavaler presque sans macher ; on en jur- parail les viscères pour les malatles. 1)u reste, (quoique - M. Steller prétende que la lontre est honne contre le scor- but, M. Muller en doute, puivine les kusses qui moururent * de cette unaladie en avaient mangé comme les autıes; ce- pendaut on en tua beaucoup, même quand on eut cessé de tre nourriture principale à l'ỉle de Behring; elle ne nous fit aucun mal, quoique mangée scule et sans pain, et souvent à demi-erue : le foie, les rognons et le cour sont absolument semblables à ceux du veaú.

On voit souvent au Kamtschatka et dans ies îles Kuriles, arriver les saricoviennes sur des glacons poussés par un vent d'orient qui règne de temps en temps sur ces côtes en hiver. Les glaçons qui viennent du côté de l'Amérique sont cu si grande quantité, (qu'ils s'amonc(')lent et forment une étendue de plusicurs mil. les de longueur sur la mer. Les chasseurs s'exposent, pour avoir les peaux des saricovieusics, à aller fort au loin sur ces glacons avec des pattins qui ont cinq ou six pieds de long sur environ huit pouces de large, et qui par conséquent leur domnent la bardiesse d'aller dans les endroits où les glaces ont peu d'épaisseur ; mais, lorsque ces glaces sont poussées au large par un vent contraire, ils se trouvent souvent en danger de périr, on de rester quelquefois plusieurs jours de suite errants sur la mer avant que d'être ranmenés à terre, aree ces mémes glaces, por un vent favorable. C'est dans les mois de février, de mar's et d'avril qu ils font cette cliasse périlleuse, mais très-profitable; car ils prennent alors une plus grande quastité de ces animaux qu'en toute autre saison: cependant ils ne laissent pas de les chasser en été, en les cherchant sur la terre, où souvent on les trouve endormis : on les prend aussi, dans cette méme saison, avec des filets que l'on tend dans la mer, ou bien on les poursuit en eanot jusqu'à ce qu'on les ait forcés de lassitude.

Leur peau fait une tres-belle fourrure : les Chinois les achètent presque toutes, et ils les paient jusqu'a soixante-dix, quatre-vingts et cent roubles chacune; et c'est par cette raison qu’il en vieut très-peu en Russie. La beauté de ees fourrures varie sulvant la saison : les meilleures et les plus belles sont eelles des saricoviemnes tućes aux mois de mars, d'avril et de

- s'en nourrir, parce (pue les jeaux en sont Irès-belles et va- lent aux Russes, gui les vont porter à la Chine, jusqu'd qua- tre-vingls ou cenl roubles la piecre; aussi raunassa-1-on neuf - cents de ces jeaux al la claasse tes loutres, qui dura jus(yu au " mois de mirs : alors elles disparurent, et l'équipage rut re- cours à la jicelic des clieus, des curs el des lions yue la mer a lew olfrit. voyage de beluring; llistoire générale des Voyages, tome XIX, page 379.

1 Novi Commentiuli Academix Petropol., tome II, 1751. 
mai. Néanmoins ces fourrures ont l'ineonvénient d'être épaisses et pesantes ; sans cela elles seraieut supérieur'es aux zibelines, dont les plus belles ne sont pas d'un aussi beau noir. Il ne faut cependant pas croire que le poil de ces saricoviennes soit également noir dans tous les individus : car il y en a dont la couleur est brunâtre, comme celle de la loutre de rivière, d'autres qui sont de couleur argentée sur la tête; plusieurs qui ont la tête, le menton et la gorge variés de longs poils très-blanes et très-doux; enfin, d'autres qui ont la gorge jaunátre, et qui portent plutot un feutre crépu, brun et court sur le corps, qu'un véritable poil propre à la fourrure. Au reste, les poils bruns ou noirs ne le sont que jusqu'à la moitié de leur longueur : tous sont blancs à leur racine, et leur longueur est en tout d'environ un pouce on un pouce et demi sur le dos, la queue et les eotés du corps : ils sont plus eourts sur la tête et sur les membres; mais au-dessous de ce premier loug poil il y a, eomme dans les ours marins, une espèce de duvet ou de fentre qui est de couleur brune ou noire eomme l'extrémité des grands polls du corps. On distingue aisément les peaux des femelles de eelles des mâles, parce qu'elles sont plus petites, plus noires, et qu'elles ont le poil plus long sous le ventre : les petits ont aussi, dans le premier âge, le poil noir ou très-brun et très-long ; mais ì einq ou six mois ils perdent ce brau poil, et à un an ils ne sont eouverts que de leur feutre, et les longs poils ne le recouvrent que dans l'année suivante. La mue se fait, dans les adultes, d'une manière différente de celle des autres animaux : quelques poils tombent aux mois de juillet et d'arout, et les autres prement alor's une couleur un peu plus brune.

Communément les sarieoviennes ont environ deux pieds dix pouces de longueur, depuis le bout du nuseau jusqu'à l'origine de la queve, qui a douze ou treize pouces de long; leur poids est de soixante-dix à quatre-vingts livres. La saricovienne ressemble d la loutre terrestre par la forme du corjes, qui seulement est beaucoup plus épais en tous sens; toutes deux ont les pieds de derrière plus près de l'anus que les autres quadrupèdes. Les oreilles sont droites, coniques et couvertes de poil, comme dans l'ours marin; elles sont longues de près d'un pouce sur autant de largeur, et distantes l'une. de l'autre d'environ eing pouces. Les yeux et les paupières sont assez semblables à ceux du lièvre et sont à peu près de la méme grandeur : la couleur de l'iris varie dans différents individus; car cette couleur est brune dans les uns et noirâtre dans les autres : il y a une membrane au grand angle de chaque œil, comme dans les our's marins, mais qui ne peut guère couvrir l'œil qu'à moitié. Les narines sont très-moires, ridées et sans poil, et les lèvres sont d'une épaisseur à peu près égale à celles du phoque commun. L'ouverture de la gucule est médiocre, n'ayant qu'environ deux pouces trois lignes de longueur depuis le bout du muscau jusqu'à l'angle; la mdchoire supéricure s'avance d'un demi pouce sur la mâchoire inférieure: toutes deux sont garnies de moustaches blanehes dirigrées en bas, et dont les poils raides ont trois pouces de longueur à cóté des eoins de la gucule, mais qui ne sont longs que d'un ponce auprès des narines. La machoire supérieure est armée de quatorze dents : il y a d'ahord quatre incisives très-aiguës et longurs de deux lignes, ensuite une canine de ehaque côté, de figure conique, un peu recourbée en arrière et d'environ un pouce de longueur; après les canines il y a quatre molaires de ehaque eóté, qui sont larges et épaisses, surtout celles du fond, et ces dernières dents sont très-propres à easser les cocpuilles et broyer les erustacées.

Dans la máehoire inférieure, le nombre des dents est ordinairement de seize : il y a d'abord, comme dans la mâchoire supéricure, quatre incisives et deux canines; ees dernières n'ont qu'environ huit lignes de longueur; mais il y a einq dents molaires de chaque còté, dont les deux dernières sont situćes dans la gorge : ainsi le nombre total des dents de la saricovienne est de trente ordinairement; néinmoins comme il y a des individus qui ont aussi einc dents molaires de chaque eoté à la máchoire supérieure, il se troure que ee nombre de dents est quelquefois de trente-deux. La langue, depuis son insertion jusqu'à son extrémité, est longue de trois pouces trois lignes sur une largeur d'un demi ponce seulement; elle est garnie de papilles et un peu fourchue à l'extrémité.

Les pieds, tant ceux de devant que ecux de derriere, sont couverts de poil juscuu'auprès des ongles, et ne sont point engagés dans la peau ; ils sont apparents et extéricurs eomme ceux des quadrupèdes terrestres, en sorte que la saricovienne peut marcher et courir, quoique 
assez lentement. Ceux de devant n'ont que ouze ou douze pouces de longueur et sont plus courts que ceux de derrière, qui ont quatorze ou quinze pouces, ce qui fait que cet animal est plus élevé par le train de derrière, et que son dos parait un peu voûté. Les pieds de devant sont assez semblables, par les ongles, à ceux des chats, et ils diffèrent de ceux de la loutre terrestre en ce qu'ils sont réunis par une membrane qui est couverte de poil. La plante du pied, qui est brune avec des tubercules par dessous, est arrondie et divisée en cinq doigts : les deux du milieu sont un peu plus longs que les autres, et l'interne est un peu plus court que l'externe. Ces ongles crochus des pieds de devant servent à détacher les coquillages des rochers. Les pieds de derrière ont aussi cinq doigts qui sont de mème joints par une membrane velue, et qui ont la forme de ceux des oiseaux palmipèdes; le tarse, le métatarse et les doigts de ces pieds de derrière sont beaucoup plins longs et plus larges que ceux des pieds de devant; les ongles en sont aigus, mais assez courts; le doigt externe est un peu plus long que les autres, qui vont successivenent en diminuant, et la peau de la plante de ces pieds de derrière est aussi de couleur brune ou noire comme dans les pieds de devant.

La queue est tout à fait semblable à celle de la loutre de terre, c'est-à-dire plate en dessus et en dessous, seulement elle est un peu plus courte à proportion du corps; elle est recouverte d'une peau épaisse, garnie de poils trèsdoux et très-serrés.

La verge du mâle est contenue dans un fourreau sous la peau, et l'orifice de ce fourreau est situé à un tiers de la longueur du corps : cette verge, lougue d'enviran huit pouces, contient un os qui en a six; les testicules ne sont point renfermés dans une bourse, mais seulement recouverts par la peau conmune; la vulve de la femelle est assez grande et située à un ponce au-dessous de l'anus.

Nous devons observer que l'animal indiqué par M. Kracheninnikow, sous le nom de castor marin, pourrait bien être le même que la saricovienne, quoiqu'il le dise aussi grand que celui qu'il nomme chat marin, et qui est l'oul's marin; car il y a des saricoviennes beaucoup plus grandes que celles dont nous venons de donner les dimensions d'après M. Steller; et on en a vu à la Guyane et au Brésil de beau- coup plus grosses que celles du Kantschatka d'ailleurs il parait, par lindicatior même de M. Kracheninnikow, que son castor marin a les mêmes habitudes que la saricovienne qui porte le nom de bobr ou castor chez les Russes de Sibérie. M. Steller, qui a demeuré si longtemps dans les parages du Kamtschatka, et qui en a décrit tous les animaux, ne fait nulle mention de ce castor marin gros comme l'ours marin, et il $y$ a toute apparence que M. Kiacheninnikow n'en a parlé que sur des relations peut-être exagérées. On peut ajouter à ces preures les inductions que l'on peut tirer du résultat des obselıations de différents royageurs au Kamtschatka, dont la récapitulation se trouve tome XIX, page 365 des Toyages, où il est dit " que les peaux de castors marins sont "d'un profit considérable pour la Russie; que " les Kamtschatdales peuvent, avec ces peaux, " acheter des Cosaques tout ee qui leur est né" cessaire, et que les Cosaques troquent ces " fourrures pour d'autres efiets avec les mar" chands russes, qui gagnent beaucoup dans le " commerce qu'ils en font à la Chine, et que le " temps de la chasse des castors marins est le " plus favorable pour lever les tributs; car les " Kamtschatdales donnent un castor pour un " renard ou une zibeline, quoiqu'il vaille au " moins cing fois davantage, et qu'il se rende " quatre-vingt-dix roubles, etc. " On voit que tout cela se rapporte à la saricovieme, et qu'il y a toute apparence que Kracheninnikow s'est trompé lorsqu'il a dit que son castor marin était aussi grand que son chat marin, c'est-àdire l'ours marin.

Au reste, la saricovienne, qui s'appelle bobr ou castor en langue russe, est nommée liaikon en langue kamtschatdale, lialaga chez les Koriaques, et rakikon chez les Kouriles.

Je dois ajouter qu'ayant l'ecu de la Guyanc de nouvelles informations au sujet des saricoviennes d'Amérique, il paraît qu'elles varient beaucoup par la grandeur et pour la couleur : l'espèce cu est commune sur les còtes basses et à l'embouchure des grandes rivières de l'Amérique méridionale'.

Leur peau est très-épaisse, et leur poil est ordinairement d'un gris plus ou moins foncé et quelquefois argenté; leur cri est un son rauque

- Ce qui suit se rapporte a l'listoire de la loutre d'Amélique, ou vraie saricovienne. 
et enroué. Ces animaux vont en troupes et fréquentent les savanes noyées; ils nagent la tête hors de l'eau et souvent la gucule ouverte; quelquefois même, au lieu de fuir, ils entourent en grand nombre un canot en jetant des eris, et il est aisé d'en tuer un grand nombre. Au reste, l'on dit qu'il est assez difficile de prendre une saricoviemne dans l'eau, lors même qu'on l'a tuée; qu'elle se laisse aller au fond de l'eau dès qu'elle est blessée, et qu'on perdrait son temps à attendre le moment où elle pourrait reparaitre; surtout si e'est dans une eau courante qui puisse l'entraîner.

Les jaguars et couguars leur font la guerre et ne laissent pas d'en ravil et d'en manger beaucoup; ils se tiennent à l'affût, et lorsqu'une saricovienne passe, ils s'élancent dessus, la suivent au fond de l'eau, l'y tuent et l'emportent ensuite à terre pour la dévorer.

Nous avons dit, d'après le témoignage de M. de la Borde, qu'il y a à Cayenne trois espèces de loutres très-différentes par la grandeur : les deux plus grandes de ees loutres paraissent être des saricoviennes, qui se ressemblent si fort par la forme, que l'on peut sans difficulté les rapporter à une seule et même espèce, d'autant qu'on doit remarquer comme un fait général, que dans l'espèce de la saricovienne, ainsi (que daus celle du jaguar et de plusieurs autres animaux des contrées presque désertes, ils sont plus petits dans les lieux voisins des habitations que dans la profondeur des teri’es, parce qu'on les tue plus jeunes et qu'on ne leur donne pas le temps de prendre leur entier accroissement.

\section{LE SURIKA'TE.}

Ordre des carnassiers, famille des carnirores, tribu des digitigrades, gemre civelte. (Cuvier.)

Cet animal a été aelıcté en Hollande sous le nom de surikate; il se trouve à Surinam et dans les autres provinees de l'Amérique méridionale. Nous l'avons nourri pendant puelque temps; et ensuite M. de Sève, qui a dessiné avec autant de soin que d'intelligence les animaux de notre ouvrage, ayant gardé celui-ci vivant pendant plusieursmois, ma communiqué les remarques qu'il a faites sur ses habitudes naturelles. C'est un joli animal, très-vif et très-adroit, marchant quelquefois debout, se tenant souvent assis, avec le corps très-droit, les bras pendants, la tête haute et mourante sur le cou comme sur un pivot; il prenait cette attitude toutes les fois qu'il voulait se mettre auprès du feu pour se chauffer. Il n'est pas si grand qu'un lapin, et ressemble assez par la taille et par le poil à la mangouste; il est seulement un peu plus étoffé, et a la queue moins longue; mais par le museau dont la partie supérieure est proéminente et relevée, il approche plus du coati que d'aucun autre animal. Il a aussi uı caractère presque unicque, puisqu'il n'appartient qu'à lui et à l'hyène; ces deux animaux sont les seuls qui aient également quatre cloigts à tous les pieds.

Nous avions nourri ce surlkate d'abord avec du lait, parce qu'il était fort jeune; mais son goût pour la chair se déclara bientòt; il mangeait avee avidité la viande crue, et surtout la chair de poulet; il cherehait aussi c̀ surprendre les jeunes animaux : un petit lapin qu'on élevait dans la même maison serait devenu sa proie si on l'eût laissé faire. Il aimait aussi beatcoup le poisson et encore plus les œufs; on l'a vu tirer avee ses deux pattes rémies des œufs qu'on renait de mettre dans l'eau pour cuire : il refusait les fruits et même le pain ì moinsqu'on ne l'eùt máehé ; ses pattes de devant lui sel'vaient comme à l'écureuil pour porter à sa gueule. 11 lapait en buvant comme un chien, et ne buvait point d'eau, à moins qu'elle ne fùt tiede : sa boisson ordinaire était son mrine, quoiqu'elle cuit une odeur très-forte. Il jouait avee les chats et toujours imnocemment; il ne faisait aucun mal aux enfants, et ne mordait qui que ce soit que le maitre de la maison qu'il avait pris en aver'siou. Il ne se servait pas de ses dents pour ronger, mais il exercait sourent ses ongles el grattait le plátre et les carreaux jusqu'à ce qư̈il les enit dégradés : il était si bien apprivoisé (qu'il eltendait son nom; il allait seul par toute la maison et revenait dès qu'on l'appelait. Il avait deux sortes de voix, l'aboiement d'un jeuue ehien lorsqu'il s'enmuyait d'ètre seul ou qu'il entendait des bruits extraordinailes : et au contraire lorsqu'il était excité par des earesses, ou qu'il ressentait quelque mouvement de plaisir, il faisait un bruit aussi vif et aussi frappé que celui d'une petite erécelle touruée rapidement. Cet animal était femelle, et paraissait souvent être en chaleur, (quoiçue dans un climat trop) 
froid, et qu'il n'a pu supporter que pendant un hiver, guelque soin gue l'on ait pris pour le nour'ir' et le chauffer.

\section{ADDITION A L'Aliticle DU SURIKATE.}

Nous avons dit que le surikate ne faisait aucun mal aux enfants, qu'il ne mordait que quelques personnes adultes, et entre autres le maitre de la maison quil avait pris en aversion. J'ai appris depuis, qu'en effet il ne mordait ni la femme ni les enfants de cette maison; mais qu'il a mordu nombre d'autres personnes des deux sexes. M. de Sève a observé que e'était par l'ołorat qu'il était induit à mordre. Lorsque quelqu'un le prenait, le cartilage du bout du nez se pliait pendant qu'il flairait, et suivant l'odenr' qu'il l'ecevait de la personne, il mordait ou ne mordait pas. Cela s'est trouvé constamment sur un assez grand nombre de gens qui ont rissqué l'épreuve, et ce qu'il y a de singulier, e'est que quand il avait mordu une fois quelqu'un, il le mordait toujours; en sorte qu'on ne pouvait pas dire que ce fùt par humeur ou par caprice. Il y avait des gens qui lui déplaisaient si fort, qu'il cherchait à s'échapper pour les mordre; et quand il ne pouvait pas attraper les jambes il se jetait sur les souliers et sur les jupons, qu'il déchirait; il employait mêmequelquefois la ruse pour approcher les personnes qu'il voulait mordre.

M. Vosmaër, dans une note de sa description d'un écurcuil volant, fait une remarque qui m'a paru juste et dont je dois témoigner ici ma reconnaissance.

" M. de Buffon (dit M. Vosmaër) a vraisemblablement été trompé sur le nom de surikate et sur le lieu de l'origine de cet animal, qui a été envoyé l'été dernjer par M. Tulbağh à $\mathrm{S}$. A. S. monseigneur le prince d'Orange. Il n'appartient point à l'Amérique, mais bien à l'Afrique. Ce petit animal, dont on m'avait adressé deux de sexe différent, mais dont la femelle est morte pendant lc voyage, n’a pas été connu de Kolbe, qui du moins n'en fait aucune mention; et il parait qu'il ne se trouve que fort avant dans les terres, ce qu'on peut inférel de la lettre de M. le gouverneur, que je r'cẹs en même temps, et où il est dit: " J'ai encore remis, audit ca- pitaine, deux petits animaux vivants, mâle * et femelle, auxquels nous ne pouvons cenen- a dant donner de nom, ni les rapporter à au" cune autre espèce, attendu qu'on meles a en " voyés pour la première fois, et de bien loin, " des déserts et montagnes de pierres de cette " vaste contrée. Ils sont fort doux, gentils et " mangent de la viande fraîche, cuite ou crue, " des ceufs crus et des fourmis, quand ils peu" vent en attraper. Je souhaite que ces petits " animaux arrivent en vie; puisque je ne crois " pasqu'on en ait encore vu en Europe de pa"l'eils."

Ce témoignage de M. Tulbagh est positif, et ce que dit auparavant M. Vosmaër est juste : j'y souseris avec plaisir; car quoique j'aie eu cet animal vivant pendant longtemps, et que je l'aie déerit et fait représenter, je n'étais assuré ni de son nom, ni de son climat originaire que par le rapport d'un marchand d'animaux, qui me dit l'avoir acheté en Hollande sous le nom de surikate, et qu'il venait de Surinam. Ainsi nous dirons maintenant qu'il ne se trouve point à Surinam, ni dans les autres provinces de l'Amérique méridionale, mais en Afrique dans les terres montagneuses, au-dessus du cap de Bonne-Espérance. Et à l'égard du nom, il ne fait rien à la chose, et nous changerous volontier's celui de surikate lorsque nous serons mieux infor'més.

\section{DESCRIPTION DU SURIKATE.}

(EXTRAIT DE DAUBENTON.)

Le surikate qui a servi de sujet pour cette description ètait un peu plus gros qu'un surmulot; il avait beaucoup de ressemblance avec la mangouste par la figure du corps et principalement par celle des oreilles; mais il ressemblait, par la forme du museau., plus au coati qu'd̀ aucun des animaux qui ont eté décrits dans cet ouvrage. Le bout dı museau s'étendait de la longueur de quatre lignes plus en avant que la lèrre de dessous; de sorte que le nez était saillant comme celui des cochons : l'animal le mouvait et le contournait en haut lorsquil roulait flairer ou nordre; les narines ressemblaient à celles du chien, mais le nez n'avait pas, comme celui du chien, un sillon qui s'étendit depuis l'entre-deux des narines jusqu'à la lèrre: cet espace était convexe : les yeux étaient grands et les oreilles 1 rès-courtes et arrondies. Il n'y arait que quatre doigts à chaque pied : les ongles étaient fort longs, pliés en gouttière et de couleur noire; la 
plante des pieds avait beaucoup de longueur, surtout dans les pieds de derrière.

L.e nez, le tour des yeux et les oreilles étaient noirs; le chanfrein avait une conleur lorune; les côtés de la tête et du museau, et le dessous de la màchoire inférieure, étaient de conleur blanche ou blanchâtre. Tout le reste de sa tête, le cou, le dos, la croupe, les côtés du corps, l'épaule, le loras, la face externe de l'avant-bras, de la cuisse el de la jambe, étaient de couleur unclée de blanc, de brun, de jaunâtre et de noir. Il y avait leux sortes ile poils; le plus long et le plus ferme était de couleur noire près de la raciue; on voyait plus haut successivement du blanc, du noir et du blane, et enfin la pointe était noire; l'autre poil était plus courı, plus doux et de couleur brune jaunâtre. La poitrine, le ventre, la face interne de l'avalt-loras, de la cuisse et de la jambe et les quatre pieds, étaient de couleur jaunâtre. La queue avait la mẻme couleur, excepté le côtẻ supérieur qui était mêlé de noir, et l'extrémité (pui était noire. Les plus longs poils avaient jusqu'à un pouce et demi de longueur.

\section{LA MANGOUSTE.}

Ordre des carnassiers, famille des carnivores, tribu des digiligrades, genre cirette. (Cuvier.)

La mangouste est domestiçue en Égypte comme le chat l'est en Europe, et elle sert de même à prendre les souris et les ratss ${ }^{1}$; mais son goût pour la proie est encore plus vif, et son instinct plus étendu que celui du chat; car elle chasse également aux oiseaux, aux quadrupèdes, aux serpents, aux lézards, aux insectes, attaque en général tout ce qui lui parait vivant, et se nourrit de toute substance animale. Son courage est égal à la véhı́mence de son appétit; clle ne s'effraie ni de la colère rles chiens, ni de la malice des chats, et ne redoute pas même la morsure des scrpents : clle les poursuit avec acharmement, les saisit et les tue, quelque venimeux qu'ils soient; et lorsqu'elle commence à ressentir les impressions de leur venin, elle va chercher des antidotes, et particulièrement une racine ${ }^{2}$ que les Indieus

1 Mihi ichnemmon fuil utilissimus ad mures ex neo cubiculo fugaulos... umm alui a quo murimm dlamna plane cessarunt si quideu quotyuot offendebal interimebat, longeque ad hos ueeandos fugandosque fele est ichmumon utilior. Prosp. Alp., Descriph. Aigyul., lib. IV, page 250 .

- Primum antidotum... radix est planta malaice IIampaddu-Tanah, id est, fel terrx dicta at sapore amarissimo... Lusi- ont nommée de son nom, et qu'ils disent être un des plus sûrs et des plus puissants remèdes contre la morsure de la vipère ou de l'aspic. Eille mange les œufs du crocodile, comme ceux des poules et des oiseaux; elle tue et mange aussi les petits crocodiles ${ }^{1}$ quoirgu'ils soient déjà trèsforts peu de temps après qu'ils sont sortis de l'œuf; ct comme la fable est toujours mise par les hommes à la suite de la vérité, on a prétendu qu'en vertu de cette antipathie pour le crocodile, la mangoustc.entrait dans son corps lorsqu'il était endormi, et n'en sortait qu'après lui avoir déchiré les viscères.

Les naturalistes ont cru qu'il y avait plusicurs espèces de mangoustes, parce qu'il y en a de plus grandes et de plus petites, et de poils différents; mais si l'on fait attention qu'étant souvent élevées dans les maisons, elles out dû, comme les autres animaux domestiques, subir des variétés, on se persuadera facilement que cette diversité de couleur et cette différence de grandeur n'indiquent que de simples variétés, et ne suffisent pas pour constituer des espèces, d'autant que dans deux mangoustes que j'ai vues vivantes et dans plusieurs autres dont les peaux étaient bourrées, j’ai reconnu les nuances intermédiaires, tant pour la grandeur que pour la conleur, et remarqué que pas une ne différait de toutes les autres par aucun caractère évident et constant; il parait seulement qu'en

tanisibidem Raja seu radix mungo appellata a inustela qua. dau seu viverra Indis mungustia... appellata qux radicem monstrasse et ejus nsum... prima... prodidisse credilnr... Indi igitur... præcipne (ұui Sumatram el Javan incolunt, sive nsım a mustela ediscti sint sive cası tuodan invenerinl radiceu pro explorat, habent antidoto. Kampler, Anınit., p. 374. - Dans l'Inde, il est me racine (jui ne produit ui tronc, ni branches, ni feuilles, qui s'appelle cliri, nom qu'elle tire d'n animal qui sait seul la recumnalte el la trouver. Cet animal est granul comme une marte, et lui ressemble assez pour la forme, excepté qu'il est un peu plus eorsé (corpulento); la couleur (le son poil esl obscure, upti est dur, tmmlu ê hêrissé comme celui des sangliers, mais moins lonğ; sa quene est charmue, lisse et unie comme celle de la marte. L'antipathie yue cet animal a pour les serpents est extraordintire, el il ne semble s'oceuper yuä leur tendre des embûches... Les ehasseurs ont ubservè quıiil va délerver la racine dont nons venons de parler, suit pronr se gnerir. soit pour se frés rver de l'effel uln venin... on la resarde comme le neilleur antidote que I'Inde fournisve. Voyage du P'. Vineent al a rie, Iraduclion communiquece par M. le maryus de Montulrail.

+ L'ichneumon ou ral de l'haraon est une espece de petit cochon sauvage, joli el tres-aise a apprivoiser, qui a le poil herissé comme un porc-thic; il esl cmemi des autres rats. et surtont des crocolile: : non-sendiment il throre leurs arufs. dont il se nourrit mais il allayne encore arec courage les petits crocodiles, llont il silt renir a houl, en les premant par le con, au défaul de lil lite. Deseription de i'Égyte, par Maillet, p. 31. 
Fgypte, où les mangoustes sont pour ainsi dire domestiques, elles sont plus grandes qu'aux Indes où elles sont sauvages!.

Les nomenelateurs qui ne veulent jamais qu'un être ne soit que ce qu'il est, c'est-à-dire qu'il soit seul de son genre, ont beaucoup varié au sujet de la mangouste. M. Linnæus en avait d'abord fait un blairean, ensuite il en fait un furet; Hasselquist, d'après les premières lecons de son maitre, en fait aussi un blaireau; messieurs Klein et Brisson l'ont mise dans le genre des helettes; d'autres en ont fait une loutre, et dautres un rat. Je ne cite ces idées que pour faire voir le peu de consistance qu'elles ont dans la tête même de ceux qui les imaginent, et aussi pour mettre en garde contre ces dénominations qu'ils appellent génériques, et qui pres(une toutes sont fausses, on du moins arbitraires, vagues et équivoques ${ }^{2}$.

4 Cet ichneumon, dit Elwards, venait des Indes orientales et était fort petit; jen aj vı nn autre venu d'Égypte qui était plus du double... La seule dilférence qu'il y avait, outre la srandeur, entre les denx ichneumons, c'est yue colui d'Égypte avait une petite touffe de poil à l'extrémité de la queue, an lieu que la queue de celui des Indes se terminait en pointe, et je crois que cela fait deux espèces distioctes et séparées, parceque celui des Inrles, qui était si petit en comparaison de celui d'Egypte, avajt cependant pris son entier accroissement. Elwatds, page 199. Nota. Ces différences ne mont pas paru suffisantes pour ctablir deux espèces, attendu yư entre les plus petites et les plus grandes, c'est-à-dirc entre treize et vingt-deux pouces de longueur, il sen tronve d'intermédiaires. comme de quinze et dix-sept pouces de grandeur. Seba, qui a domné la figure ct la description (vol. I, pag. 66, tab. XLt) d'une de ces petites mangoustes qu'il avait cue vivante, et qui lui venait rle Ceylan, dit quelle était très-malpropre et qu'on navail pu l'apprivoiser; cette difference de naturel pourrait faire penser que cette petite mangouste est dune espèce différente des autres : cepuendant elle ressemble si fort à celles dont nous avous parlé, qu on ne pent douter que ce ne soit le nième animal; et l’ailleurs je puis assurer moi-mène avoir vu une de ces petites mangoustes qui était si privée que son maitre (M. le président de Robien), qui l'aimait beancoup, la portait tonjours dans son chapeau, et faisait à tont le inonde l'éloge de sa gentillesse et de sa propreté.

? Hasselquist termine sa longue ct sèche description de la mangouste par ces mots : a Galli in $\mathrm{Kgy}$ pto conversantes qui - omuilus rebus quas non cognoscunt, sua imponunt nomina - ficla, appellarmnt hoc animal rat de Pharaon. Quod sequu- ti qui latina relationes de Egypto dederunt, $\mathrm{AI}_{\text {pin, Belon, }}$ a untrem Pharaonis effinxerunt." Si cet homme eft senlemeut In Belon et Alpin, quil cite, il aurait vu que ce ne sont pas les Francais ıpui ont donè le nom de rat de L'ıa'aon à la mangouste, mais les $\dot{\mathbf{E} g y p t i e n s}$ mêucs; et il se serait abstem de prendre de bi occasion de mal parler rle notre nation; mais l'on ne doit pas etre surpris de tronver l'imputation d'un pédant dans l'ouvrage diun écolier : eu effel, cette description de la mangonste, ainsi que celle de la girafe el de quelines antres animanx, donuées par ce nomenclateur, up pourront jannais servir quä excéder cenx qui vondraicut s'ennuyer à les lire: 10 Parce (pu'elles sont sans ligures, et que le mombre des mots ne peut suppléer à la représentatiou; un coup d'œeil vant unieux daus ce genı'e qu'un long détail de paroles 2 parce que
La mangouste habite volontiers aux bords des eaux : dans les inordations, elle gague les terres élevées, et s'approche souvent des lieux habités pour y chercher sa proie. Elle marche sans faire aucun bruit, et selon le besoin elle varie sa démarche : quelquefois elle porte la tête haute, raccourcit son corps, ct s'élève sur ses jambes; d'autres fois elle a l'air de ramper et de s'allonger comme un serpent; souvent elle s'assied sur ses pieds de derrière, et plus sou. vent encore elle s'élance comme un trait sur la proie qu'elle veut saisir. Elle a les yeux vifs et pleins de feu, la physionomie fine, le corps très-agile, les jambes courtes, la queue grosse et très-longue, le poil rude et sourent hérissé. Le màle et la femelle ${ }^{1}$ ont tous denx une ourer-

ces mots ou paroles sont la plupart d'un latin barliare, on plutit ue sont d'aucune langue : $\tilde{3}^{\circ}$ parce que la méthude de ces descriptions n'est quine rontine que tout homme peut sujvre, et qui ne suppose ni génie, ni mème d'intelligence: 4o parce que la description étant trop minutieuse. les caractères remarquables, singuliers et distinctifs de l'être qu'on décrit, y sont confondus avec les signes les plus obscur's, les plus indifférents et les plus équiroques : $\check{5}^{\circ}$ enfin, parce que le trop grand nombre de petits rapports et de combinaisons précaires dont on est obligé de charger sa mémoire, rendent le travail du lecteur pins grand que celni de l'auteur, et les lais-ent tons les deux aussi ignorants qu'ils étaient. I'ne preure quavec cette routine on se dispense de lire et de s'instruice, c'cst $1^{\circ}$ I a fausse imyutation que l'auteur fait aux Francais au sujet du rat de Plaraon; c'est $2^{\circ}$ l'erreur qu'il commet en donnant à cet animal le nom arabe nems, tandis que ce mot irabe est le nom du furet et non pas celui de la mangouste; il ne fallait pas mème saroir l'arabe pour éviter cette faute, il anrait suffi d'avoil lu les Voyaoes đle cenx sfui l'araient précédé dans le mème pays; ; $5^{\circ}$ l'onission qu'il fait des choses essen. tielles, en niême temps qüil s'étend sans mesure sur les indifférentes; par exenıjle, il viécrit la sirafe anssi minutieusement que la mangruste, et ne laisse pas que de manquer le caractère essentiel, qui est de savoir si les cornes sont permanentes ou si elles tombent tous les ans : dans vingt fois plus de paroles qu'il n'en faut, l'ou ne trouve pas le mot nécessaire et l'on ne peut juger par sa tescription si la girafe est du genre des cerfs ou de celui des bœufs. Mais c'est assez s'arrèter sur une critique que tont homme sensé ne manquera pas de faire, lorsque de pareils ourrages lui tomberont entre les mains.

4 Les habitants d'Alexandric nourrissent une bète n $n$ mmée ichneumon, qui est particulierement trouvée en Égypte. On la peut apprivoiser ès maison tout ainsi comme un chat ou un chien. Le vulgaire a cessé de le nommer par son nom ancien, car ils le nomment en leur lingage, rat de Pharaon. Or, nous avons vi que les paysans en apportaient des petits :tu marché d'Alexandric, où ils sont bien recueillis pour en nourrir ds maisons, à cause qui ils cliasseut les rats... les serpents, etc. Cet animal est caulcleux en feiant sa piture... il se nonrrit indif. léremment dle toutes viandes vivcs, comme d'escarbots. lézards, caméléons, et généralement de tontes espéces de serpents, de gremonilles, rats et souris; il est friand des oiscanx, des ponles el poulets : quand il est comrounch, il hérisse son poil... il a une particulière marque, c'est un gr.ınd pertuis tont entuné de poils hors le condnit de l'ixcrement, ressenublant quasi an membre lionteux tes femelles, lejpel couduit il ouvre lorsqu'il a grand chand. Belon, Obs., feuill. 93, verso. 
ture remarquable et indépendante des conduits naturels, une espèce de poche dans laquelle se filtre une humeur odorante : on prétend que la mangouste ouvre cette poche pour se rafraichir lorsqu'elle a trop chaud. Son museau trop pointu et sa gueule étroite l'empêchent de saisir et de mordre les choses un pell grosses : mais elle sait suppléer par agilité, par courage, aux armes et à la force qui lui manquent; elle étrangle aisément un chat, quoique plus gros et plus fort qu'elle; souvent elle combat les chiens, et, quelque grands qu'ils soient, elle s'en fait respecter.

Cet animal croit promptement et ne vit pas longtemps '. Il se trouve en grand nombre dans toute l'Asie méridionale ${ }^{2}$, depuis l'Égypte jusqu'à Java; et il paraît qu'il se trouve aussi en Afrique, jusqu'au cap de Bomme-Espérance ${ }^{3}$ : mais on ne peut l'élever aisément, ni le garder longtemps dans nos elimats tempérés, quelque soin qu'on en prenme; le vent l'incommode, le froid le fait mouril : pour'éviter l'un et l'autre, et conserver sa chaleur, il se met en rond et cache sa tête entre ses cuisses. Il a une petite voix douce, une espèce de murmure, et son cri ne devient aigre que lorsqu'on le frappe et qu'on l'irrite. Au reste la mangouste était en vénération chez les anciens Égyptiens, et mériterait bien encore aujourd'hui d'ètre multipliée, ou du moins épargnée, puisqu’elle détruit un grand nomire d'animaux nuisibles, et surtout les erocodilis dont elle sait trouver les œufs, quoique cachés dans le sable : la ponte

- Feles el ichneumon tot numero pariunt quol canes, vescunturque eisilem, vivunt circiter annos sex. Arist., Ilist. anim., lib. Vl, cap. 35.

${ }^{2}$ Nungos alunt rura calentis Asix onnis, usque atl Gangem, etian in is regionilons in quibns radix mungo nunquam ger-

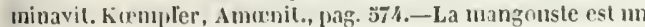
pelit animal très-joli, fail à peu près comme nos belettes de France... mais diuc coulenr incomparablement plus belle.. Le blanc et le noir dominent sur charpe poil, el il y a me espice de rouge yui fait la nuance entre le noir et le Hanc. Sa quene est couverte d'un poil avec les memes nuances, et plus long yue echii du corbs. Il a la tite couverte d'un petit poil ras; ses yeux sunt groset scs oreilles courtes et arrondies : cette mangonste avait deux pienls et demi de long depuis ta líle jusqu'à l'extrémité de ld ruene... Elle venait du royaume de Cillicut, et a été apportíe en liranee dans un vaissean de notre escalre; elle a vécu a Paris cinı mois; elle était rlevenue fort familière. Curiosit. de la Nat. el de l'Art.,Paris, 1703. page. 211.

'Lichinenmon est de la grandeur du chat, mais il a la forme d'une unusaraigne... Tout son corps est couvert de poils longs, railles, rayés et tadietés de blanc, de noir et de jaune. Cet animal, yui est très-commun dans les campagnes du Cap, est grand destructeur de serpents el d'oiseaux. Description du Cap de Bonne-Espérance, par Kolbc, lom. III, chap. 3. de ces animaux est si nombreuse ', qu'il y aurait tout à craindre de leur multiplication, si la mangouste n'en détruisait les germes.

\section{ADDITION A L'ARTICle DE LA MaNgOUSTE ${ }^{2}$.}

Il existe encore une grande mangouste, qui nous parait former une variété daus l'espèce des mangoustes; elle a le museau plus gros et un peu moins long, le poil plus hérissé et plus long, les ongles aussi plus longs, la queue plus hérissée et aussi plus longue à proportion du $\operatorname{col}^{2} \mathrm{ps}$.

\section{DESCRIPTION DE LA MANGOUSTE ${ }^{3}$.}

\section{(EXTRAIT DE DACBENTON.)}

La mangouste est à peu près de la grandeur de la foune; elle ressenible aussi beaucoup à cet animal pour sa figure; car elle a le sommet de la tête aplati, le bout du museau pointu, la tèts: petite, les oreilles courtes et rondes, le cou court et presque aussi gros que la tète, le corps allongé, les jambes courtes et la queue longue, mais moins touffue à l'extrémité que celle de la fouine.

Le poil de la mangouste cst dur et coloré de blanchàtre et de noirâtre; ces couleurs se succèdent trois, quatre ou cinc fois l'une à l'autre dans la longneur des poils; le noirâtre est pen foncé, et il y a une teinte de roussître sur le poil de la gorge, de la poitrine et des jambes : celui du bout du museau, du poignet et des pieds, est fort court et de couleur mèlée de noiratre et de roux, les plus longs poils ont jusqu' à deux ponces et demi : il se trouve entre ces poils durs une sorte de duvet plus court et de couleur roussitre.

Les dents, les doigts et les ongles ressemblent aux dents, aux doigts et aux ongles le la fouine par le nombre, la position et la forme, excepté les

1 Le plus grand service que lichneumon rende à lÉgypte est de briser les oufs de crocodiles partont ou il les reneunIre; c'est pour cela que les anciens E̊gptien lui rendaient un culte religieux. Voyage de $\mathbf{l}$ aul Lueas, tome 111 , jage 205 . - C'élait avec justice yue les anciens Égyliens réveraient Iichueumon ou rat de Plaraon. L'on dit iple de qualre eents aufs que le crocolile pond a la fois. pour en sanver quelįuesuns de la fureur de cel enucmi mortel de son espece, il est obligé de les iransporter dans quelyues petites iles, lorsine le Nil s'est reliré. Description de l'Égyple, par II aillel, Lome IL, lage 129.

${ }_{3}$ Ce quadrupède a élé consilléré par II. Geoffroi comme formant une esjece distincte.

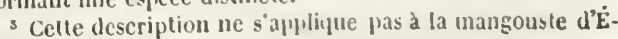
gyple. 
deux dents incisives extérieures de la mâchoirc du dessus, qui sont à proportion plus petites daus la mangouste.

Celle qui a servi de sujet pour cette description était dessẻchée et bourrie; elle avait vingt-deux pouces de longueur depuis le bout du musean jusqu'à l'origine de la queue, qui était lonł̧ue de vingt pouces.

J'ai vu une autre mangouste qui était dans le même état que la précédente, et qui Jui ressemblait parfaitement pour la forme du corps et pour la qualité et les cuuleurs du poil, mais elle était beancoup plus petite, car elle n'avait que treize à quatorze pouces de long depuis le bout du museau jusqu'à l'origine de la queuc, dont la lougueur n'était que de neuf ou dix pouces; j'ai aussi vu une mangouste vivante qui était à peu près de cette rrandeur; en comparant ces deux mangoustes avec celle qui a servi de sujet pour cette description, on trouvc: une différence de grandeur si considérable, qu'elle a fait croire que la petitc mangouste était d'une espèce différente de la grande; mais il me paraît qu'il en est des mangoustes comme des belettes; elles sont de différentes grandeurs, quoique de même espèce : j'en ai vı une, yui était desséclıée et bourrée, parfaitement l'essemblante à celles lont j'ai fait mention, et de grandeul moyenne entre les petites et la grande; car elle avait dixsept pouces de longueur, depuis le bout du musean jusyu'd l'origine de la quene, qui n'était pas entière.

\section{LE VANSIRE 4}

Ordre des carnassiers, famille des carnivores, tribu des digitigrades, gen'e civelte. (Curier.)

Ceux qui ont parlé de cet animal l'ont pris pour un furct, auquel en efiet il ressemble à beaucoup d'égards : cependant il en diffère par des caractères qui nous paraissent suffisants pour en faire une espèce distincte et séparée. Le vansire a douze dents mâchelières dans la mâchoire supérieure, au lieu que le furet n'en a que huit; et les mâchelières d'en bas, quoique en égal nombre de dix dans ces deux auimanx, ne se ressemblent ni par la forme ni par la situation respective ; d'ailleurs le vansire diffère par la coulenr du poil de tous nos furets, quoique ceux-ci, comme tous les animaux que l'bomme prend soin d'élever et de multiplier, varient beancoup entre eux, même du mâle à la femelle.

\footnotetext{
- L'insire de (iongo pourrait bien être le vansire de Mada. gascar.
}

Il nous paraît que l'animal indiqué par Seba sous la dénomination de belette de Java, qu'il dit que les habitants de cette île nomment $k 0$. ger-Angan, et qu'ensuite M. Brisson' a nommé le furcl de Java, pourrait bien être le même animal que le vansire : c'est au moins de tous les animaux connus celui duquel il approche le plus. Mais ce qui nous empêche de prononcer décisivement, e'est que la description de Seba n'est pas assez complète pour qu'on puisse établir la juste comparaison qui serait nécessaire pour juger sans scrupule. Nous la mettons sous les yeux du lecteur, pour qu'il puisse lui-même la comparer avec la nôtre.

\section{ADDITION A L'ARTICLE DU VANSIRE.}

Le vansire est, comme nous l'avons dit, un animal de Madagascar et de l'intérieur de l'A frique, qui ressemble beaucoup au furet, à l'exception du nombre et de la forme des dents, et de la longueur de la queue qui est beauceup plus grande dans le vansire que dans notre furet. Nous donnons ici la description d'un animal qui nous a été envoyé de la partie orientale de l'A. frique, sous le nom de neipse ${ }^{2}$. Par sa forme aussi bien que par cette dénomination, j'ai reconnu que c'était une espèce de furet; car nems ou nims est le nom du furet en langue arabe; et ces furets d'Arabie, ou ces nems ressemblent beaucoup plus au vansire qu’à nos furets d'Enrope. Voici la description qu'en a faite M. de Sève.

"Le nems est un vrai furet, à le considérer dans le détail de sa forme et de sa souplesse : quand il marche, il s'allonge et parait bas de jambe. II a beaucoup de conformité avec nos furets. Celui-ci était mâle et avait treize pouces dix lignes de longueur du museau à l'anus, le tronçon de li queue, un pied; la hauteur du train de devant est de cinq pouces six lignes; celle du train de derrière, six pouces six lignes; l'oreille est sans poil et de la mème forme que celle du furet commun. Son œil est vif et l'iris d'un fauve foncé. Son museau, qui est très-fin,

1 Javanica hac mustela, hic representata, collo et corpore cst brevioribus quam nostras; caput tegentes pill obscure spadicei sunt, rufi qui dorsum, dilute vero llavi qui ventrem vestiuut, cauda interim in apicem acutum et nigricantem desinente. Seba, vol. I, pag.78.

a Cet animal est regardé, par M. Geofroy-Saint-Hilairc. comme appartenant à une espece distlncte. 
ne m'a pas paru avoir des moustaches. Tout le corps est couvert d'un poil long, jaspé d'un brun foncé, mêlé d'un blanc sale qui a dix lignes de longueur, ce qui fait que par ses rayures il ressemíle au lapin riche. Le ventre est couvert d'un poil fauve clair sans mélange. Le fond du poil de la tête, autour de l'œil, est d'une couleur jaunâtre claire, et sur lenez, les joues, les autres parties de la face où le poil est court, un ton fauve plus ou moins brun par endroits règrec partout sans mélange, se continue et se perd en diminuant dans les parties de la tête au-dessus des yeux. Ses jambes sont eouvertes d'un poil ras fauve foncé; les pattes ont quatre doigts et un petit doigt par derrière. Les ongles sont petits et noirs; la queue, qui est an moins du double plus longue que celle de nos furets, est très-grosse au commencement du troncon, et très-menue au bout qui finit en pointe. De grands poils jaspés , comme sur le corps, couvrent cette queue. Cet animal ne boit point, à ce qu'a dit avoir observé le gareon qui en a soin. "

\section{NOUVELLE ADDITION A L'ARTICLE DU VANSIRE.}

M. Forster a bien voulu m'envoyer les remarques suivantes an sujet de cet animal . „J'ai " vu, dit-il, à la ménagerie du cap de Bonne"Espérance, un animal du geure des mangous" tes, qui venait de l'ile de Madagasear, et qui " répondait exactement à la description du van" sire donnée par M. de Buffon. Il se plaisinit " beaucoup d̀ ètre dans un baquet renpli d'can, " d'où il sortait de temps en temps. Le garde " qui prenait soin de la ménagerie nous assura "que lorsqu'on tenait cet animal pendant quel" que temps à sec et hor's de l'eau, il s'y replon" geaitavec empressement dès qu'on lui en lais" sait la liberté. La figurequ'en a donnée M. de "Buffon est assez exacte, mais elle parait un " peu trop allongée, parce qu'elle a été donnée " sur une peau bourrée de cet animal, et d'ail" leurs le poil est plus eourt que celui du van" sire de la ménagerie du Cap. Ce dernier était " à peu près de la taille de la marte ordinaire; " sa queue égalait en longucur celle du corps " jusqu'àla tête; son poil était de couleur brune " noiràtre; il y avait cing doigts à chaque pied, - bien divisés et sans membranes. Les dentsin-
" cisives étaient au nombre desix, tant en haut " qu'en bas; il y avait huit mâchelières à cha. " que mâchoire, c'est-à-dire quatre de cha" que côté, et les canines étaient isolées, ce qui " fait en tout trente-deux dents. L'animal mar" chait comme les mangoustes, en appuyant "sur letalon. »

\section{DESCRIPTION DU VANSIRE.}

(BXTIAIT DE DAUBENTON.)

La vansire que je déris a été apporté de Madagascar sous le nom de $v^{\prime}(m)$-shiru, dunt je fais celui de vansire pour en faciliter la prononciation; on a donné cet aumal pour un furet; il est empaille, et il ne reste avec la peau que les os des jiieds et de la tête: les dents y sont toutes bien conservées; elles ressemblent à peu près aux lents du furet, le la fouine, de la mangouste, etc., mais elles en díffèrent pour la situation des mà helières: le vansire en a douze en haut et dix en bas; par ce caractère il est bien différent de la fouine et de la mangouste, qui out au contraire dix mâchelières supérieures et douze inférieures; il diffère encore plus du furet, qui n'a que luuit mâchelières en haut, et quoiqu'il y en ait dix en bas comme dans le vansire, il se tromve aussi des diffirences entre ces leux animaux par rapport à ces deuts mảchelières inférieures qui ne se ressemblent que par le nombre, sans se corresfondre par la figure ni par la position. Le vansire n'est donc pas un fuet : il me parait être une espèce d'animal particulière qui a rapplort au furet, à la fonine, à la mangouste par lı forme allon rée de son corps, par le museau pointu, far les oreilles courtes, etc.

Le poil est moins long gue celui de la founc et de la marte; ses eouleurs somt les mèmes sur to'tes les parties du corps; il parait de couleur brune fon. cée lorsyu'on le voit de loin, mais en le regardant de près on aperçoit qu'il y a un dluvet brun entre les poils fermes, et que ces puils ne sont bruns que vers la racine; le reste a du noiratre et du ruussilIre qui se suecedent par petits intervalles jusıu'id la pointe; ces deux couleurs occupent successivement toute la longueur des poils de la queue : ceux du corps ne sont longs ujue de sept ou huit lignes.

Il y a cinq doigts à chaque pied; les dents sont an nombre de trente-luuit, saroir : six incisives et cleux canines à clıqque mâchoire, douze måclıclières supérieures et dix inferieures, comme il a c'éjà clè dit.

Ce vansire a treize ponces de longuenu depuis le bout ılı museau jusqừ̀ l'urigrine dle la queue, dont le irongon est long de sept pouces; les poils s'etendent de deux jouces et demi au delà. 


\section{LA PETITE FOUINE}

\section{DE MADAGASCAR.}

Ordre des carnassier's, famille des caruivores, tribu des digitigrades, genre marle. (Cuvier.)

Il y a plusicurs variétés dans l'espèce de la fouine; nous donnons ici la deseription d'une petite fouine qu'on trouve à Madagascar.

La longueur du corps, du bout du nez à l'orip. p. 1. gine de la queue, est de. . . . . . . . .

Elle a, comme toutes les fouines, les jambes courtes et le corps allongé; sa tête est longue et menue; les oreilles sont larges et courtes; la queue est couverte de poils.

I.e troncon de celle queue est de..... 0 .

Ia longueur totale de la quene, $\mathrm{y}$ compris

celle du poil, est de. .......... 080

I.es poils de l'extrénité de la queue ont. . $\begin{array}{llll}0 & 2 & 5\end{array}$

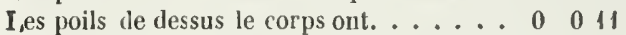

Leur couleur est un brun roussâtre, oumuse foncé teint de fauve rouge, ce qui est produit par le mélange des poils qui sont d'un brun foncé dans la longueur, et fauve rouge à la pointe : ce fauve foucé ou rougeàtre est le dominant aux faces latérales de la tête, sous le ventre et le cou. Cette petite fouine diffère de nos founes par la couleur qui est plus rougeàtre, et par la qucue qui est toufiue, longue, couvertedegrands poils, large à son origine, et qui se termine en une pointe très-dćliée.

\section{LE GRISON.}

(LE GLOUton grison, Cuv.)

Ordre des carnassier's, famille des carnirores, tribu des plantigrades, genre glouton. (Curier.)

Voici une espèce voisine de celle de la belette et de l'hermine, et que nous ne connaissons pas encore. C'est encore M. Allamand qui en a donné le premier la description et la figure sous le nom de grison, diuns le quinzième volume del'édition de Hollande de mon ouvrage, et je ne puis mieux faire que de rapporter ici cette description en entier.
"J'ai recu, dit il de Surinam, le petit animal qui est décrit ci-après; et dans la liste de ce que contenait la caisse où il était renfermé, il était nommé belette grise, d'où j'ai tiré le nom de grison, parce que j'ignore celui qu'on lui donne dans le pays où il se trouve, et qui indique assez bien sa couleur. Toute la partie supérieure de son corps est couverte de poils d'un brun foncé et dont la pointe estblanche, ce qui forme un gris où le brun domine; mais le dessus de la tète et du cou est d'un gris plus clair, parce quelà les poils sont fort courts, et que ce qu'ils ont de blanc égale en longueur la partie brune. Le museau, tout le dessous du corps et les jambes, sont d'un noir qui contraste singulièrement arec cette couleur grise, dont il est séparé de la tête par une raie blanche qui prend son origine à une épaule et passe par dessous les oreilles, au-dessus des yeux et du nez, et s'étend jusqu'à l'autre épaule.

" La tête de cet animal est fort grosse à proportion de son corps; ses oreilles, qui forment presque un demi-cercle, sont plus larges que hautes; ses yeux sont grands : sa gueule est armée de dents mâchelières et de dents canines fortes et pointues. Il y a six dents incisives dans chaque mâchoire; mais il n'y a que celles des extrémités des deux rangées qui soient visibles, les ưuatre intermédiaires sortent à peine deleurs alvéoles. Les pieds, tant ceux de devant que de derrière, sont partagés en cinq doigts, armés de forts ongles jaunâtres. La queue, qui est assez longue, se termine en pointe.

" La belette est celui de tous les animaux de notre continent auquel celui-ci a le plus de rapport: ainsi, je ne suis pas surpris qu'il m'ait été envoyé de Surinam, sous le nom de belette grise. Cependant ce n'est pas une belette, quoiqu'il lui ressemble par le nombre et la forme de ses dents; il n'a pas le corps aussi allongé, et scs pieds sont beaucoup plus hats. Je ne connais aucun auteur ni voyageur qui en ait parlé, et l'individu qui m’a été envoyé est le seul que j'aie vu. Je l'ai montré à diverses personnes qui avaient séjourné longtemps à Surinam, mais il leur était incomnu: ainsi, il doit ètre rare dans les lieux d'où il est originaire, ou il faut qu'il habite dans des endroits peu fréquentés. Celui qui me l'a envoyé ne m’a marqué aucune particularité propre à ćclaircir son histoire naturelle; c'est pourquoi je n'ai pu faire autre chose que de décrire sa figure." 


\section{LE TAYRA, oU LE GALERA.}

\section{(LE GLOUTON TAIRA.)}

Ordre des carnassiers, fanille des carnivores, tribu des plantigrades, genre glouton. (Cuvier.)

Cet animal, dont M. Browne nous a donné la description et la figure, est de la grandeur d'un petit lapin, et ressemble assez à la belette ou à la fouine; il se creuse un terrier, il a beancoup de force dans les pieds de devant, qui sont considćrablement plus courts que ceux de derrière ; son museau est allongé, un peu pointu et garni d'une moustache; la máchoire inférieure est beaucoup plus courte que la supérieure; il a six dents incisives et deux canines à chaque mâchoire, sans compter les mâchelières; sa langue est rude comme celle dı chat; sa tête est oblongue; ses yeux, qui sont aussi un peu oblongs, sont à une égale distance des oreilles et de l'extrémité du.museau ; ses oreilles sont plates et assez semblables à celles de l'homme; ses pieds sont forts, et faits pour creuser : les métatarses sont allongés, il y a cinq doigts à tous les pieds ; la queue est longue et droite, et va toujours en diminuant; le corps est oblong et ressemble beaucoup à celui d'un gros rat; il est couvert de poils bruns, dont les uns sont assez longs et les autres beaucoup plus courts. Cet animal nous paraît être une petite espèce de fouine ou de putois. M. Limnæus a soupçonné avec quelque raison que la belette noire du Brésil pourrait bien être le galera de M. Browne, et en effet les deux descriptions s'accordent assez pour qu'on puisse le présumer ; au reste, cette belette noire du Brésil se trouve aussi à la Guyane, où elle se nomme tayra ${ }^{\prime}$; et je soupconne que le nom de galera, dont M. Browne ne domne pas l'origine, est un mot corrompu et dérivé de tayra, qui est le vrai nom de cet animal.

\footnotetext{
- Mustela maxima atra mosclum redolens. Tayra.-Grosse belette. Cet animal, en se frottanl contre les arbres, y laisse une espèce d'hnmcur onctueuse qui sent beanconp le musc. Barrère, llistoire naturelle de la France équinoxialc, p. 153 et 136
}

\section{LA GR ANDE MARTE}

\section{DE LA GUYANE.}

\section{(LE GLOUTON TAÏRA.)}

Ordre des carnassiers, famille des carnirores, tribu des digitigrades, genre marte. (Curier.)

Cet animal, qui nous a été envoyéde Cayenue, est plus grand que notre marte de France; il a deux pieds de longueur depuis le bout du nez jusqu'à l'origine de la queue. Son poil est noir, à l'exception de celui de la tête et du cou jusqu'aux épaules, qui est grisâtre ; le bout du nez et les naseaux sont noirs; le tour des yeux et des máchoires, ainsi que le dessus du nez, sont d'un brun roussátre. Il y a douze dents incisives, six en haut et six en bas: ces dernières sont les plus petites; les canines sont très-fortes, et nous n'avons pu compter les måchelières. II y a, comme dans la fouine et la marte de France, de longs poils en forme de moustaches de chaque côté du museau : les oreilles sont larges et presque rondes, comme celles de nos fouines; il a sur le cou une grande tache d'un blanc jaune, qui descend en s'élargissant sur la poi. trine. Tous les pieds ont cinq doigts avec des ongles blanchátres courbés en gouttières; les ongles des pieds de devant ont six lignes de longueur, et ceux de derrière cinq seulement.

La queue, qui a dix-huit pouces de long, et dont l'extrémité finit en pointe, est couverte de poils noirs comme celui du corps, mais longs de deux ou trois pouces. Cette queue est plus longue à proportion que celle de notre marte ; car elle est des trois quarts de la longueur du corps, tandis que dans cette dernière elle n'est que de la moitié.

\section{I,A ZIBELINE.}

\section{( LA MARTE ZIBELINE.)}

Ordre des carnassiers, famille des carnirores, tribu des digitigrades, genre marte. (Cuvier).

Presque tous les naturalistes ont parlé de la zibeline, sans la connaitre autrement que par sa fonrure. M. Gmelin est le premier qui en ait domné la figure et la description: il en vit 
deux vivantes chez le gouverneur de Tobolsk. " La zibeline ressemble, dit-il, à la marte par a la forme et l'babitude du corps, et à la belette " par les dents : elle a six dents incisives assez "longues et un peu courbées, avec deux lon" gues dents canines à la mâchoire inférieure, " de petites dents très-aiguës à la mâchoire su" périeure, de grandes moustaches autour de "la gueule, les pieds larges et tous armés de " cinq ongles. Ces caractères étaient communs "à ces deux zibelines; mais l'une était d'un " brun noirâtre sur tout le corps, à l'exception "des oreilles et du dessous du menton, où le " poil était un peu fauve; et l'autre, plus petite " que la première, était sur tout le corps d'un " brun jaunátre, avee les oreilles et le dessous " du menton d'une nuance plus pâle. Ces cou" leurs sont celles de l'hiver; car au printemps " elles changent par la mue du poil : la première " zibeline, qui était d'un brun noir, devint en " été d'un jaune brun, et la seconde, qui était " d'un brun jaune, devint d'un jaune pâle. J'ai " admiré, continue M. Gmelin, l'agilité de ces " animaux; dès qu'ils voyaient un chat, ils se "dressaient sur les pieds de derrière, comme " pour se préparer au combat. Ils sont très" inquiets et fort remuants pendant la nuit : " pendant le jour, au contraire, et surtout après " avoir mangé, ils dorment ordinairement une "demi-heure ou une heure; on peut dans ce "temps les prendre, les secouer, les piquer" " sans qu'ils se réveillent. "Par cette deseription de M. Gmelin, on voit que les zibelines ne sont pas toutes de la mème couleur, et que par conséquent les nomenclateurs, qui les ont désignées par les taches et les couleurs du poil, ont employé un mauvais caractère, puisque nonseulement il changedans les différentes saisons, mais qu'il varie d'individu à individu, et de climat à climat '

Les zibelines habitent le bord des fleuves, les lieux ombragés et les bois les plus épais; elles sautent très-igilement d'arbre en arbre,

4 Des denx zibelines dont parle M. Gınelin, la première venait de la province de Tunskein, et la seconde de celle de Beresowien. On trouve aussi dans sa Relation de la Sibérie, que, sur la montagne de Sopka-Sinaia, il y a des zibelines noires à poil court, auxquelles il est difendu de domer la cluase: quinne semblable espece de zibcline se trouve aussi plus avaut daus les montagnes, de même que ehez les Calmouks Vrangai. J'ai vu, dit-il, quel(pues-unes de ces peanx que - des Calmouks avaient apportées; clles sont connues sous - le noin te zibelines de Kangaraga. Voyage de Gmelin, tome 1, page 217 . et craignent fort le soleil, qui change, dit-on, en très-peu de temps la couleur deleur poil. On prétend 'qu'elles se cachent et qu'elles sont er. gourdies pendant l'hiver; cependant e'est dans ce temps qu'on les chasse et qu on les cherche de préférence, parce que leur fourrure est alors bien plus belle et bien meilleure qu'en été. Elles vivent de rats, de poissous, de graines de pin et de fruits sauvages. Elles sont très-ardentes en amour; elles ont pendant le temps de leur chaleur une odeur très-forte, et cn tout temps leurs excréments sentent mauvais. On les trouve principalement en Sibérie, et il n'y en a que peu dans les forêts de la Grande-Russie, et encore moins en Laponie. Les zibelines ${ }^{2}$ les plus noires sont celles qui sont le plus estimées. La différence cqu'il y a de cette fourcure à toutes les autres, c'est qu'en q̨uelque sens qu'on pousse le poil, il obéit également, au lieu que les autres poils pris à rebours font sentir quelque raideur par leur résistance.

La ehasse des zibelines se fait par des criminels confinés en Sibérie, ou par des soldats qu'on y envoie exprès, et qui y demeurent ordinairement plusieurs années : les uns et les autres sont obligés de fournir une certaine quantité de fourrures à laquelle ils sont taxés. Ils ne tirent qu'à balle seule pour gâter le mons qu'il est possible la peau de ces animaux: et quelquefois, au lieu d'armes à feu, ils se servent d'arbalètes et de très-petites flèches. Comme le succès de cette chasse suppose de l'adresse et encore plus d'assiduité, on permet aux officiers d'y intéresser leurs soldats, et de partager avec eux le surplus de ce qu'ils sont obligés de fournir par semaine, ce qui ne laisse pas de leur. faire un bénéfice très-considérable ${ }^{3}$.

Quelques naturalistes ont soupconné (que la zibeline était le satherius d'Aristote, etje crois leur conjecture bien fondée. La finesse de la

4 Rzaezynski, auct., pag. 318.

2 La zibeline diffère de la marte en ce qu'elle est plus petite et qu'elle a les poils plus fius et plus longs ; les véritables zihelines sont damassées de noir, et se premuent en Tarlarie; il s'en tronve peu en Iaponie : plus la couleur du poil est noire, et plus elle est recherclice, et vandra quelquefois soixanle écus, quoique la pean ñit que quatre doigts de langeur; on en a vo de blanches el de grises. liegnard, Lume l, page I fi. Schaffer dit de même qu'il se lronve quelųuefois des zibelines blanches. Histoire de la Laponie, jage 318.

${ }^{3}$ Un colonel peut tirer de ses sept amuées de service à la chasse des zibeliues environ quatre mille écus de profit, les subalternes a proportion, el chaque soldat six on sept cents écus. Voyage du P. A rril, p. 169.-Voyez aussi la Relation de la Moscovie, par La Neuville. Paris, 1698, page 217. 
fourrure de la zibcline indicque qu'elle se tient souvent dans l'eau; et quelques voyageurs ${ }^{1} \mathrm{di}$ sent qu'elles ne se trouvent en grand nombre que dans les petites illes, où les chasseurs vont les ehercher. D'autre côté, Aristote parle du salherius comme d'un animal d'eau, et il tc joint à la loutre et au castor. On doit encore présumer que du temps de la magnificence d'Athènes, ces belles fourrures n'étaient pas inconnues dans la Grèce, et que l'animal qui les fournit avait un nom : or, il n'y cn a aucun qu'on puisse appliquer à la zibeline avec plus de raison que celui de satherius, si en effet il est vrai que la zibeline mange du poisson ${ }^{2}$ et se tiemne assez souvent dans l'eau pour etre mise au nombre des amphibies.

\section{ADDITION A L'ARTICLE DE LA ZIBELINE.}

Nous n'avons rien à ajouter à ce que nous avons dit de la zibeline, que qủelques faits rapportés par les royageurs russes, et qui ont été insérés dans les derniers volumes de l'Histoire générale des Voyages.

"Les zibelines vivent dans des trous; leurs nids sont ou dans des creux d'arbres, ou dans leur's troncs couverts de mousse, ou sous leurs racines, ou sur des hauteurs parsemées de rochers. Elles construisent ces nids de mousse, de branches et de gazon. Elles restent dans leurs trous ou dans leurs nids pendant douze. heures en hiver comme en été, et le reste du temps elles vont chercher leur nourriture. En attendant la plus belle saison, elles se nourrissent de belettes, d'hermines, d'écureuils et surtout de lièvres. Mais dans le temps des fruits, elles mangent des baies, et plus volontiers lc fruit du sorbier. En hiver, elles attrapent des oiseaux et des coqs de bois. Quand il fait de la neige, elles se retirent dans leurs trous ou elles restent quelquefois trois semaines. Elles s'accouplent au mois de janvier. Leurs amours durent un mois, et sourent excitent des combats silnglants entre les mâles. A près l'accouplement, elles gardent leurs nids environ quinze jours.

\footnotetext{
- Les chasseurs vont chercher les zibclines dans de pelites lles où elles se retirent; ils les tuent avee une espèce darbalèle, ete. Voyage dı l'. Avril, page 168.

${ }^{2}$ In umbrosis saltibus versilur semper insidiator aviculis... in escam assumil mures, pisces, was rubras. Raaczynski, auct. 1lisl. Nat. l'ol., pag. 318.
}

Elles mettent bas ver's la fin de mars, et font depuis trois jusqu'à cinq petits qu'elles allaitent pendant quatre ou six scmaines.

"On ne les chasse qu'en hiver, et les chasseurs vont ensemble jusqu'au nombre de quarante à cette chasse; ils y vont en canot, et premuent des provisions pour trois ou quatre mois. Ils ont un chef qui, arrivé au lieu đu rendez-vous, ainsi que tous les chasseurs, assigne à chaque bande son quartier, et tous les chasseurs doivent lui obéir. On écarte la neige où l'on veut dresser des piéges; chaque chasseur en dresse vingt par jour. On choisit un petit espace auprès des arbres; on l'entoure, à une certaine hautem, de pieux pointus; on le couvre de petites planches, afin que la neige ne tombe pas dedans; on y laisse une entrée fort étroite, au-dessus de laquelle est placée une poutre qui n'est suspendue que par un léger morceau de bois, et sitôt que la zibeline y touche pour prendre le morceau de viande ou de poisson qu'on a mis pour amorce, la bascule tombe et la tue. On porte toutes les zibclines au conducteur général, ou bien on les cache dans des trous d'arbres, de crainte que les Tunguses ou d'autres peuples sauvages ue viennent les enlever de force. Si les zibelines ne se p." :nent pas dans les piéges, on a r'ecours aus iilitis. Quand le chasseur a trouvé la trace d'un deces animaux, il le suit jusqu'à son terrier, et l'oblige d'en sortir au moyen de la fumée du feu qu'ilallume; il tend son filet autour de l'endroit où la trace finit et se tient dleux ou trois jours de suite aux aguets avec son chien; ce fillet a treize toises de long, sur quatre ou cinq pieds de hant. Lorsque la zibeline sort de son terrier, elle manque rarement de se prendre, et quand ellc est bicn embarrassée dans le filet, les chiens l'ćtranglent. Si on les voit sur les arbres, on les tue à coups de flèches, dont la pointe est obtuse pour ne point endommager la peau. La chasse étant finie, on regagne le rendezvous genéral, et on se rembarque aussitôt que les rivières sout devenues navigables par lo dégel." 


\section{LE PEKAN ET LE VISON.}

\author{
(LA MARTE PEKAN.)
}

Ordre des carnassiers, famille des carni yores, tribudes digitigrades, genre marte. (Cuvier.)

Il y a longtemps que le nom de pekan était en usage dans le commerce de la pelleterie du Canada ', sans que l'on en connût mieux l'animal auquel il apparticnt en propre: on ne trouve ce nom daus aucun naturaliste, et les voyageurs l'ont employé indistinctement ${ }^{2}$, pour désigner différents animaux, et surtout les mouffettes; d'autres ont appelé renard ou chat sauvage l'animal qui doit porter le nom de pekan; et il n'était pas possible de tirer aucune connaissance préeise des notices courtes et fautives que tous en ont données. Il en est du vison comme du pekun, nous ignorons l'origine de ces deux noms, et personne n'en savait autre chose, sinon qu'ils appartiennent ì deux animaux de l'Amérique septentrionale. Nous les avons trouvés, ces deux animaux, dans le cabinet de M. Aubry, curé de Saint-Louis, et il a bien voulu nous les prèter pour les décrire et les faire dessiner.

Le pekan ressemble si fort à la marte, et le vison à la fouine, que nous croyons qu'on peut les regarder comme des variétés dans chacune de ces espèces ${ }^{3}$; ils ont non-seulement la même forme du corps, les mêmes proportions, les mêmes longueurs de queve, la mème qualité de poil ; mais encore le même nombre de dents et d'ongles, le même instinet, les mêmes habitudes naturelles : ainsi nous nous croyons fondés à

1 Youn des peaux qu'on tire du Canada, avec leurs valeurs en $1685 . . .$. Les pekans, chils sauvages on enfauts dn diable, valent I liv. 13 sous la peau. Voyage de La IHontan, Lome II, biage 39.

${ }^{2} 11$ répand une puintenr insupporlable. Les Français lui donneut, dans le cimatla, le noun d Eufaut du diable on bête puanle; eppentaut ynelyues-mus l'appelleut pekan. Voyage de hith, page \$12, artic'e traduit par II. Te maruguis de \$lon!mirail.

3 Je serais asse porté à croire (nue l'animal indiqné par Sagard Théoulat, sons te nom de ollay, punrail citre le mème que le vison. "L'oltay, dit ce voygeur, esl grand comme un a pelit lapin; il a le proil te's-noir, et si domx, poli ct bean. a qüil semble de la paune. Les Canadieus font grand cas de a ees peanx, desquelles ils font des tohes. voyage au pays des thurons, page 508. Jl ny a an Camada aucu animal auquel cette indieation convienne mienx yn'au vison. regarder le pekan comme une variété dans l'espèce de la marte, et le vison comme unc variété dans celle de la fouine, ou du moins comme des especes si roisines, qu'elles ne présentent aucune différence réelle. Le pekan et le vison ont seulement le poil plus brun, plus lustré et plus soyeux que la marte et la fouine; mais cette différence, comme l'on sait, leur est commune avec le castor, la loutre et les autres animaux du nord de l'Amérique, dont la fourrure est plus belle que celle de ces mêmes animaux dans le nord de l'Europe.

\section{ADDITION}

\section{A L'AR'TICLE DE L'HERMINE.}

\section{(LA MARTE HERMINE.)}

Je dois citer ici arec éloge et reconnaissance une lettre qui m'a été écrite par madame la comtesse de Noyan, datée au chàteau de la Mancelière, en Bretagne, le 20 juillet 1771.

"Vous êtes trop juste, monsieur, pour ne pas faire réparation d'honneur à ceux que vous avez offensés. Vous avez fait un outrage it la race de l'hermine en l'annoneant comme une bête que l'on ne pouvait appriroiser. J'c'n ai une depuis un mois que l'on a prise daus mon jardin, qui, recomnaissante des soins que je prends d'clle, vient m'embrasser, me lécher et jouer avec moi comme le pourrait faire un petit chieu. Elle est à peu près de la taille d'une belette, roussâtre sur le dos, le ventre et les pattes blanches; cinq belles petites griffes i ses jolies petites pattes; sa bouche bien fendue et ses dents pointues comme des aiguilles; le tour des oreilles blane, la barbe longue, blanche et noire, et le bout de la queue d'un benu noir. Sa vivacité surpasse celle de l'éeureuil... Cette jolie petite bête, jouissant de sa liberté jusqu'à l'heure que nous nous retirons, joue, vole nos saes d'ouvrages et tout ce qu'elle peut emporter."

J'aroue que je ne me suis peut-citre pas assez oceupé de l'éducation des belettes et des hermines que j’ai fait nourrir; car toutes m'ont paru également furouches. Je ne cloute pas néammoins de ce que me marque madane de 
Noyan, et d'autant moins que voici un second exemple qui confirme le premier.

M. Giely de Mornas, dans le comtat Venaissin, m'écrit dans les termes suivants :

"Un homme ayant trouvé une portée de jeunes belettes, résolut d'en élever une, et le succès répondit promptement à ses soins. Ce petit animal s'attacha à lui, et il s'amusa à l'exercer un jour de fète dans une promenade publique, où la jeune bclette le suivit constamment, et sans prendre le change pendant plus de six cents pas, et dans tous les détour's qu'il fità travers les spectateurs. Cet homme donna ensuite ce joli animal à ma femme. La méthode de les apprivoiser est de les manier souvent en leur passant doucement la main sur le dos, mais aussi de les gronder et mème de les battre si elles mordent. Elle est comme la belette ordinaire et le roselet, rousse supérieurement et blanche inférieurement. Le fouet de la queue est d'un poil brun approchant du noir; elle n'a que cinq semaines, et j'ignore si avec l'âge ce poil du bout de la queue ne deviendra pas tout noir. Le tour des oreilles n'est pas blanc comme au roselet, mais elle a comme lui l'extrémité des deux pattes de devant blanche, les deux de derrière étant rousses mème par dessous. Elle a une petite tache blanche sur le nez, et deux petites taches rousses oblongues, isolées dans le blanc au-dessous des yeux, selon la longueur du museau. Elle n'exhale encore aucune mauvaise odeur, et ma femme, qui a élevé plusieur's de ces animaux, assure qu'elle n'a jamais été incommodée de leur odeur, excepté les cas oì quelqu'un les excédait et les irritait. On la nourrit de lait, de viande bouillie et d'eau; elle mange peu et prend son repas en moins de quinze secondes; à moins qu'elle n’ait bien faim, elle ne mange pas le miel qu'on lui présente. Cet animal est propre, et, s'il dort sur vous et que ses besoins l'éveillent, il vous gratte pour le mettre à terre.

"Au surplus cette belette est très-familière et très-gaie: ce n'est pas contrainte ni tolérance, c'est plaisir, goût, attachement. Rechercher les caresses, provoquer les agaceries, se coucher sur le dos, et répondre à la main qui la flatte de mille petits coups de pattes et de dents très-aiguës, dont elle sait modérer et retenir l'impression au simple chatouillement, sans jamais s'oublier; me suivre partout, me grimper et parcourir tout le corps; s'insinuer dans mes poches, dans ma manche, dans mon sein, et de là m'inviter au badinage, dormir sur moi, manger à table sur mon assiette, boire dans mon gobelet, me baiser la bouche et sucer ma salive qu'elle parait aimer beaucoup (sa langue est rude comme celle du chat); folátrer sans cesse sur mon bureau pendant que j'écris, et jouer seule et sans agacerie ni retour de $\mathrm{m}$ ? part avec mes mains et ma plume : voilà la mignarderie de ce petit animal... Si je me prète :i son jeu, il le continuera deux heures de suite et jusqu'à la lassitude. »

Par une seconde lettre de M. Giely de Mornas, du 15 août 1775 , il m'informe que sa belette a été tuée par accident, et il ajoute les observations suivantes :

" $1^{0}$ Ses excréments commençaient à $\mathrm{cm}$ puantir le lieu où je la logeais; il faut y apporter beaucoup de soins et de propreté, et la nourrir plus souvent d'œufs ou d'omelettes aux herbes que de viande.

" $2^{\circ}$ II ne faut pas la toucher ni la prendre pendant qu'elle prend son repas: dans ce colirt intervalle elle est intraitable.

" 30 Elle me saigna des poussins qu'on avait placés à sa portée par inadvertance, mais elle n'a jamais osé attaquer de front de gros poulets que j'engraissais en cage; ils la harcelaient et la mettaient en fuite à coups de bec. Il était amusant d'observer les ruses et les feintes qu'elle employait pour tâcher de les surprendre.

" $4^{\circ}$ Quant à sa familiarité et aux grâces de son badinage et même à son attachement, je n’ai rien avancé qui ne se soit soutenu jusqu’à sa fin prématuree. Seulement elle s'oubliait par fois dans la chaleur de ses agaceries, et comme par transports elle serrait un peu trop les dents; mais la correction opérait d'abord l'amendement. Il faut, lorsqu'on la corrige, la gronder et la frapper postérieurement, et jamais vers la tête, ce qui les irrite.

" 50 Elle n'avait pas beaucoup grossi, et était probablement de la petite espèce; car lors de son accident, e'est-à-dire ayant plus de deux mois, tout son corps glissait encore dans le mème collier."

On troure dans l'Histoire naturelle de la Norwége, par Pontoppidan, les observations suivantes :

"En Norwége, l'hermine fait sa demeure dans des monceaux de pierres. Cet animal 
pourrait bien être de l'espèce des belettes. Sa peau est blanche, à l'exception du cou qui est taché de noir. Celles de Norwége et de Laponie conservent leur blancheur mieux que celles de Moscovie, qui jaunissent plus faeilement; et c'est par cette raison que les premières sont recherchées à Pétersbourg même. L'hermine prend des souris comme les chats, et emporte sa proie quand cela lui est possible. Elle aime particulièrement les oufs, et lorsque la mer est calme, elle passe à la nage dans les îles voisines des côtes de Norwége, où elle trouve une grande quantité d'oiseaux de mer. On prétend qu'une bermine, venant à faire des petits sur une île, les ramène au continent sur un morceau de bois qu'elle dirige avec son museau. Quelque petit que soit cet animal, il fait périr les plus grands, tels que l'élan et l'ours; il saute dans l'une de leurs oreilles pendant qu'ils dorment, et s'y aceroche si fortement avec ses dents, qu'ils ne peuvent s'en débarrasser. II surprend de la même manière les aigles et les cơs de bruyère, sur lesquels il s'attache, et ne les quitte pas même lorsqu'ils s'envolent, que la perte de leur sang ne les fasse tomber. ")

\section{LES MOUFFETTES.}

Ordre des carnassiers, trilı des digitigrades, genre marte. (Guvier.)

Nous donnons le nom générique de mouffetle à trois ou quatre espèces d'animaux, qui renferment et répandent, lor'squ'ils sont inquiétés, une odeur si forte et si mauvaise qu'elle suffoque comme la vapeur souterraine qu'on appelle mouffette. Ces animaux se trouvent dans toute l'étendue de I'Amérique' méridionale et tem-

4 Dans les terres voisiucs du détroit de Jagellan, nous vímes 11 antre animal à qui nous domuines le nom de grondeur ous de souflleur, parce suril ne voit pas plus tôt cunelqu'un qun'il gronde, sonffle et gratte la terre avec ses pieds de devimt, quoi |un il ı' ait ponr Lonte défense que son derrière qu'il tourne d'abord vers celui inui l'approche, et d'ou il fitt sortir des exeréments d’unc orleur la pilus délestable qunil y ait an monte. Yogare du cap. Woou. Suite des Vuyages de Dampier, tome $\mathrm{V}$, page 181. - Il y a an Péron lieancoup de petits renards, parui lesquels il faut remarquer cenx qui rendent une odenr insupportab!e ; ils entrent lit muit dlaus les villes, ct, quelepue fermées que soient les fenctres, on lez sent de plus de eent pas; henreusement que le nombre cu est pelit, ear ila empuantiraicnt le monde entier. Uist, des Incas, tome II, page 269. pérée; ils ont été désignés indistinctement par les voyageurs sous les noms de puants, bétes puantes, enfants du diable ${ }^{1}$, etc., et non-seulement on les a confondus entre eux, mais avec d'autres qui sont d'espèces très-éloignées. Hernandès ${ }^{2} \mathrm{a}$ indiqué assez clairement trois de ces animaux. Il appelle le premier ysquicpatl, nom mexicain que nous lui conserverions s'il était plus aisé de le prononcer; il en donue la description et la figure, et e'est le mème animal dont on trouve aussi la figure dans l'ouvrage de Seba : nous l'appellerons coase du nom squash qu'il porte dans la Nouvelle-Espagne ${ }^{3}$. Le second de ces animaux que Hernandès nomme aussi ysquiepall, est eelui que nous appellerons chinche, du nom qu'il porte dans l'Amérique méridionale ${ }^{4}$. Le troisième, que Hernandès nomme conepall, et auquel nous conscrverons ce nom, est le même que celui qui a été donné par Catesl)y ${ }^{5}$, sous la dénomination de pulois d'Amérique, et par M. Brisson sous celle de putois rayéb. Eufin nous eonnaissons encore une quatrième espèce de mouffette à laquelle nous donnerons le nom de zorille,

- Une sorte de foulne, qu'on a nomméc enfant dn diable ou bète puante, parce que sou urinc, qu'elle lảche quand elle esı ponrsuivie, empeste l'air à un tlemi-quart rle lieue à la ronde, est d'ailleurs un fort joli animal; elle est te la grandeur d'un petit chat, mais plus grosse; d'un poil luisant tirant sur lc gris, avec deux lisnes blanches qui lui forment sur le dos une figme ovale depuis le con jusqu'a la quene; celte queue est touffue comme celle du renard, et elle la retresse comme fait l'écurenil. llistoire de la Nouvelle-Jrance. par le l'. Charlevoix, tome 1II, page 535.-Nota. Cet animal est colni que nous appellerons ici conepate, du nom yniil porte an sexique.

2 Ysuniejatl seu vulpecula que Maĩzinm torrefactum amulatur colore. Gemus primum... sunt el alia duo lıujus vulpeeule genera ealem forma et nalura quorum alterum yspujepatl etiam vocatum fasciis multis candentilus clistiuguitur, alterum vero conepatl seu vulpecula pnerilis unica tantum utrinupe ducta perine caulam ipsam codem modo delata. Ilernaul., Hist. Mex., pag. 332, fig., ibid.

s Le supuash est un animal à quatre pieds, plus gros qu'um chat; sa tèle ressemlıle as-ez à celle clu reuarıl; il a les orejlles courles et des griffes aiguis qui luí servent à escalaler les arbres tout comme un elıat; il a la pean couverte diun poil court, fin et jaunatre; la chair en est tris-boune ct fort saine. Voyage de Dampier, tome III, page 502.

4 Le chinche est le viverra mephilis de Gmel. Desm., 1836. 5 Ilistoirc naturelle de la Caroline, par Catesby. l.ondıes. 1745, tome 11, page 62, fis.., ibill. Voici la description quien dome cet auteur : - Cel animal, par sa laille, ${ }^{\prime}$ esl pas fort a différent du putois commun, si ce n'est que son nez est un - peu jus long: tous ceux que jai vus itaienl noirs ct hlanes. - quojipuiis ne fussent pas marques ale la méme manière; cea lıi-ci avait une raie blanche pui s'élendait depuis le dera rière de la Iète, loul du long du milieı dı dos jusı puan cron- jion, avee qualre aulres raies de chaque colé qui étaient " paralleles à la premiere.

- Mustela nigra, tanis in turso alihis, pulorus striatus. Le putols rayé. Briss., Regu. animal., pag. 250. 
qu'elle porte au Pérou et dans quelques autres endroits des Indes espagnoles '.

C'est à M. Aubry, curé de Saint-Iouis, que nous sommes redevables de la connaissance de deux de ces animaux; son goût et ses lumières en histoire naturelle brillent dans son cabinet, qui estun des plus curieux de la ville de Paris : il a bien voulu nous communiquer ses richesses toutes les fois que nous en avons cu besoin; et ce ne sera pas ici la seule occasion que nous aurons d'en marquer notre recomnaissance. Ces animaux, que M. Aubry a bien voulu nous prêter pour les faire dessiner et graver, sont le coase, le chinche et le zorille. On peut regarder ces deux derniers comme nouveaux, car on n'en trouve la figure dans aucun auteur.

Le premier de ces animaux est arrivé à M. Aubry souslenom de pekan, enfant du diable, ou chat sauvage de Virginie. J'ai vu que ce n'était pas le pekan; j'ai rejeté les dénominations d'enfant du diable et de chat sauvage comme faetices et composées ; et j'ai reeonuu que c'était lc même animal que Hernandès a décrit sous le nom ysquiepatl, et que les voyageurs ont indiqué sous celui de squash; et c'est de cette dernière dénomination que j'ai dérivé le nom coase que je lui ai donné. Il a environ seize pouces de long, y compris la tête et le corps; ila les jambes courtes, le museau mince, les oreilles petites; le poil d'un brun foncé, les ongles noirs et pointus; il habite dans destrous, dans des fentes de rochers, où il élève ses petits ; il vit de scarabees, de vermisseaux, de petits oiseaux : et lorsqu'il peut entrer dans une basse-cour, il étrangle les volailles, desquelles cependant il ne mange que la cervelle. Lorsqu'il est irrité ou effrayé il rend une odeur abominable : c'est pour cet animal un moyen sủr de défense; ni les hommes ni les chiens n'osent en approcher. Soll urine, qui se mêle apparemment avec cette vapeur empestée, tache et infecte d'une manière indélébile. Au reste il parait que cette manvajse odeur n'est point unc chosehabitıelle. "On m'a envoré de Surinam cet ani" mal vivant, dit Seba ${ }^{2}$, et je l'ai conservé en " vie pendant tout un été dans mon jardin où a jele tenais attaché avec une petite chalne : il

Le zorille est un animal du genre des martes.

"Ysquiepatl, dont la couleur ressemble a celle du mais brâlé... sa tẹte ressemble à celle doun petit renarl, et son groin es! a peu près comme celui du coclion; les $A$ us ricains l'appellent quasje. Seba, vol. I, page 68.
" ne mordait personne, et lorsqu'on lui donnah " à manger on pouvait le manier comme un " petit chien. Il creusait la terre arec son mu. " seau en s'aidant des deux pattes de devant, " dont les doigts sont armés d'ongles longs et " recourbés. Il se cachait pendant le jour dans " une espèce de tanière qu'il avait faite lui" même; il en sortait le soir, et, après s'ètre " nettoyé, il commenẹait à courir et courait " ainsi toute la nuit à droite et à gauche aussi " loin que sa chaine lui permettait d'aller; il " furetait partout portant le nez en terre. On " lui donnait chaque soir à manger, et il ne pre" nait de nourriture que ce qu'il lui en fallait, a sans toucher au r'este; il n'aimait ni la chair " ni le pain ni quantitéd'autres nourritures; ses a délices étaient les panais jaunes, les chevret" tes crues, les chenilles et les araignées... Sur " la fin de l'automne on le trouva mort dans sa " tanière, ill ne put sans doute supporter le " froid. Il a le poil du dos d'un châtain foncé, " de courtes oreilles, le devant de la tète rond, " d'une couleur un peu plus claire que le dos, " et le ventre jaune. Sa queue est d'une lon"gueur médiocre, couverte d'un poil brun et " court; on y remarque tout autour comme des "anneaux jaunâtres. "Nous obscrverons que quoique la description et la figure données par Seba s'accordent très-bien a vec la description et la figure de Hernandès, on pourrait néanmoins douter encore que ce fủt le même animal, parce que Seba ne fait aucune mention de son odeur détestable, et qu'il est difficile d'imaginer comment il a pu garder dans son jardin, pendant tout un été, une bête aussi puante, et ne pas parler en la décrivant, de l'incommodité qu'elle a dù causer à ceux qui l'approchaient. On pourrait done croire que cet animal, donné par Seba sous le nom d'ysquiepatl, n'est pas le véritable, ou bien que la figure donnéc par Hernandès a été appliquée à l'ysquicpatl, tandis qu'elle appartenait peut-être à un autre animal: mais ce doute, qui parait d'abord fondé, ne subsistera plus quand on saura que eet animal ne rend cette odeur empestée que quand il est irrité ou pressé, et que plusicurs personnes cn Amérique en ont éleré et apprivoisé '.

De ces quatre espèces de mouffettes, que

Malgré l'incommode propriété de ces animaux, les Ang’ais, les lirançais, les Suédois el les Sau ages de l"Amćcique septentrionale en appriroisent que'quefois; on dit qualors ils suisent comme les animaux domestiques, et quils ue la- 
zous venons d'indiquer sous les noms de couse, "onepate, chinche et :orille, les deux dernières xppartiennent aux climats les plus chauds de 'Amérique méridionale, et pourraient bien I'être que deux variétés et non pas deux espèces lifférentes. Les deux premières sont du climat empéré de la nouvelle-Espagrie, de la Louiiane, des Illinois, de la Caroline, ete., et me raraissent être deux espèces distinctes et difféentes des deux autres, surtout le coáse, (qui a e caractère particulier de ne porter que quatre mgles aux pieds de devant, tandis que tous les utres en ont cinf. Mais au reste ces animaux mt tous à peu près la même figure, le mème nstinet, la même mauvaise odeur, et ne diflè'ent, pour ainsi dire, que par les couleur's et la longueur du poil. Le coase est, comme on vient le le voir, d'une couleur brune assez uniforme, st n'a pas la queue toulfue comme les autres. i.e conepate ${ }^{+}$a sur un foud de poil noir cinc

thent leur urine que quand on les messe on quion les bat; orsque les Sanvages en tucnt quelques-uns, ils leur eonjent a vessie, alin que la chair, "nu ils trouvent bonne à manger, ae prenne pas l'odeur de l'urine; $j$ 'ai sonvent reneontré des , Anglais et des Français qui mont dit en avoir mangé et l'avoir tronvée f'un très-hon gontt, qui approchait, selon enx, de celni alun coclion de tait; les Européens ne font aucun cas de sir peau à cause de son épaisseur et de la longueur de son poil; mais les Sanvages se servent de ces peaux ponr faire des bonrses, etc. Voyage fle Kalm, page 417 , article tradnit par M. le maryuis de Montmirail.

${ }^{1}$ Les $\Lambda$ nglats appellent polecat une espèce d'animal que lom trouve comunuément, non-seulement en Pensylvanic, mais dlans d'antres prays pulus an nord et an sud en Améripur?; oul l'appelle vulgairment skunck dims la Nouvelle-lork: les Suéduis qui sont taus ee pays le nomment fiskalte... Cet animal ressimble brancoup à la marte; il est à peu près de la mème grossemr, et ordinitircment d'une enuleur noire, it is cependant sur le dos nue ligne blanche longitudinale. 't me de charue côté de la mème conleur et de liı mêne longncur; on en voit, mais rarenent, yni sont prespue tout blanes ... Cet animal fait ses pelits égalenent dans dles crenx d'arbur's et ales terriers, it ne reste pas sentement sur terre, mais il roonte sur les arbres. Il e'st ennemi des oiseanx, il brise leurs: aufs et mange leurs petits; et quand il pent entrer dans un ponlailler, il y fait mo grand ravage.... Quand il est chasses, soit par les chiens, soit par les liommes, il conrt tant yn'il peut ou grimpe sur un arlye; et lorsupiil se tronve trèspressé, il lance sen urine contre cenx qui le poursuivent.... l'orleur all est si forle ru'clle suflorpe; s'il tombait une gontte de celte linueur empestée dins les yeux, on comrait risipue de perilre la vue; ef yuand il en tombe sur les habits, elle lemr imprime une odenr si forte, in'il est très-diflicile de la faire passer; la jupart des chiens se relutent et s'enfuient dès ‘u'ils en sont fraprés; il faut plus dinn nois pour enlever celte odeur d'une éfuffe... ulaus les trois on sent founvent cette odenr de:très-loin. En 1749, il vint un de ces :mimanx près de la ferme on je lngeais : c'était en liver et jern.

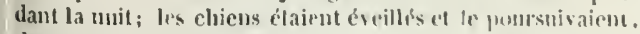
dans le moment il se répaulit une odeur si fétide, quictant dans mon lit, je pensai cire suffopue; les vaclues benglicient ile tontes leurs forces... Sur la lin de la mime anné il s'en glissa un autre dans notre cave, mais il ne répandit pas la plua légere bandes blanches qui s'étendent longitudinalement de la tète à la queue. Le chinche ${ }^{1}$ est blane sur le dos et noir sur les flanes, arec la tète toute noire, à l'exception d'une bande blanche qui s'étend depuis le chignon jusqu’au chanfrein du nez; sa queue est très-toufiue et fournie de très-longs poils blanes mélés d'un peu de noir. Le zorille ${ }^{2}$, qui s'appelle aussi nupurita $^{3}$, parait ètre d'une espèce plus petite: il a néammoins la queve tout aussi jelle et russi fournie que le chinche, dont il differe par li

odeur, jarce quil the la répanul yue quand il est classé un

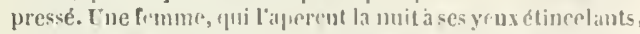
le tua, et dans le moment il gemulit la eave diue telle ne?eur, que non-senlenent cette f'mme en fut malade pendant quelques jours, mais une le pain, la vianule ef les antres juruvisiuns qu'on conservait dans cette rave furent tellempnt infectés, fuion ne put rien en conserver, el quil lallut tout jetre delırs. Voyage de Kalın, page $\$ 12$ et suiv., arlicle tradnit par M. le marquis de .Montmirail.

- Cet animal ('st apyelé chinche par les naturels ılu Brésil: il est de la grosseur d'un de nos chats, il a la lite lonsuc, se rétrécissant depnis sa partie antérieure jusıu”a l'rxtréusité de la mâchoire supérieure (pui avance au delà ıle la michoire inférieure, les deıx formant une gueule fendue jusı ư aux petits cantlus on angles extériours des yenx; ses yeux sont lungs, et leur longneur est fort rébrécic, l'uséc ust noire, et tout le reste est blanc; ses oreilles sont larges ef juresine semblables à celles d'un homme, les cartilages (jui les composent ont leurs bords renversés en dedans, leurs lubes on patties inférienres pendent un pen on bas: ct toute la disposition de ces oreilles marque que cet animal a le sens ile l'ouie furt dilicat: denx handes blanches, prenant leur origine sul Ja tite, passent an-dessus des oreilles en s'éhuignant l'nue de l'antre et vont se terminer en are aux cotfés du ventre : ses pieds sont courts, les palles divisées en cinı dujgts, munies a leur extrémilé de cinc ongles noirs. longs of puintus, yui lui servent à creuser son terrier; son dos est vonle. semblable à celui d'un cochon. et le dessons du ventre est tont plat; sa tuene, anssi longue que son colps, ne diffère pas de celle d'un renaril: son poil est d'un gris olssenr et long comme celui ile nos cliats; il fait sa demenre dans la terre comme nos lapins, mais son terrier nest pas si profond. on me dit que la manvaine otenre de cet animal était prodnite nar son urine, yn'il la répand sur sa yncue, el quil s'en sert conme de gompillon pour la disper. sel et pour laire luir ses ennemis par cutte odeur horrilule:

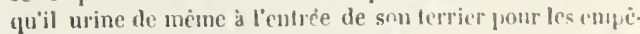
cher d'y entrer; („nil est fort friant d'uiseanx et de vuiailles, et que ce sont ces animaux tpui détruicent principalenent les oiseaux daus les eampagnes de Buénos-Ayres. Jomrual du P. Fenillée. P'aris, 1714, page $272 \mathrm{et}$ suiv

2 I.e zorilia de la Nouvelle-Espagne est grand comme un chat, d'un poil blane et noir, arec une très-belle quene: lorsqu'il est poursuivi, il soarite pur pisser : e'est sa difense: car la juanteur de cet excriment est st forte, qurelle enojoisomne l'air à cent pas à la roule, et arréte cenx qui le poursuivent. Voyage de Gemelli Carreri, 1. 11, page 212 et 213.

8 Le unapurita des bords de jopenoune est mu jetit animal le plus hean et en mème temps le plus détestable yu on puisse voir : les blanes de l'Amérigme l'appellent mapurua, et les Indiens mafutiliøui; il a te eorps tu ut taché de llanc el de noir: sa quene est garnie d'un tres-bean poil il est vif, méelıant el lavali... se liant sur ses arnes dunt jai iprousé l'effot au point dien etre suffo pue... il liche des vents yui empes. teut, nime de loin... l.es mdiens ecpendant mangent sa chair

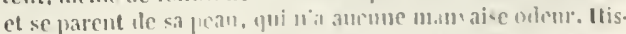

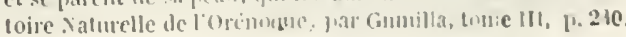


disposilion des taches de sa robe; elle est d'un fond noir sur lequel s'étendent longitudinalement des baudes blanches depuis la tête jusqu'au milieu du dos, et d'autres espèces de bandes blanches transversalement sur les reins, la croupe et l'origine de la queue, qui est noire jusqu'au milieu de sa lonqueur, et blanche depuis le milieu jusqu'à l'extrémité, au lieu que celle du chinche est partout de la même couleur. Tous ces animaux ${ }^{4}$ sont à peu près de la même figure et de la mème grandeur que le putois d'Europe : ils lui ressemblent encore par les habitudes naturelles, et les résultats physiques de leur organisation sont aussi les mêmes. Le putois est de tous les animaux de ce continent celui qui répand la plus mauvaise odeur; elle est seulement plus exaltée dans les mouffettes, dont les espèees ou variétés sont nombreuses en Amérique, au lieu que le putois est seul de la sienne dans l'ancien continent: car je ne erois pas que l'auimal dout Kolbe parle sous le nom de blairean puant, et qui me parait être une véritable mouffette, existe au cap de BomneEspérance eomme naturel au pays; il se peut qu'il y ait été transporté d'Amérique, et il st

4 Il y a a la Louisiane une espèce d'animal assez joli, mais qui de plus d'une lieue empeste l'air de son urine, c'est ce qui le fait nommer la bête puante ; eile est grosse comme un chat : le mâle est d'nn très-beau noir, el la femelle anssi noire est hordée de blanc; son œil est très-vif... elle est à juste titre nounmée puante, car son odeur infecte... Un jour. j'en fuai nne, mon ehien sauta dessus et revint à moi en la secouant; une goutte de son sang, et sans doule aussi de son urine tomba sur mon habit qui était de coutil de chasse, et mempesta si fort que je fus contraint de retouruer ehez moi au plus vite changer de vêlements, ete. llisl. de la Louisiaue, par Le Page du Pratz, I. I1, J. 86 et 87 . - Lorsurun de ces animaux est attaqué par un chien, pour paraltre plus terrible, il change si fort sa figure en hérissant son poil et se ramassant tout le corps, qu'il est presque tont rond, ce qui le rend ètrange et affreux en mène temps; cependaut cet air menacant ne suffisant pas pour épouvanter son cunemi, il emploie, pour le repousser. un moyen beanconp plus efficace ; ear il jette de quel jues conduits secrets une odeur si empeslée, (ju'il empoisonne l'air fort loiu autour de lui, si bien (pue hommes et animaux out uu grand empressement à s'cn éloigner; il y a les chien a à qui cefte odeur est insup portable. eł ellc les olılige à laisser échapper leur proie; il y cn a diautres qui, enfoneant leur nez dans la terre, renonvellent leurs attapues jusuju'à ce qu'ils aient tué le putois; mais rarenıen!, dans la suite, sc soucient-ils de poursuivre un gibier si désagréable, qui les fait sonlfrir pendant quatrc on cinq lieures. I.es Indiens cepcndant en regardent la chair counne une délicatesse, J'en ai mange et je l'ai trouvée de bon gontt; j’en ai vu quion a apprivoisćs quand ils étaient encore petits; ils sont devenus doux et fort vifs, ct ils nexerçaient point cette faculté, a laquelle la peur ct l'intér rèt de leur préservation les forcent peut-čtre d'avoir reconrs. L.cs putois se cachent daus le creux des arbres et des rochers : on On trouve dans jresque tout le continent septentrional de l'Amérique; ils se numrrissent d'insectes et de finits sauvages. Histoire Xalurelle de la Caroline, par Catcoby, 1. 11, 1., 62. pent aussi que Kolbe, qui u'est point exact sur les faits, ait emprunté sa description du P. Zuchel qu'il cite comme ayant vu cet animal au Brésil. Celui de la Nouvelle-Espagne que Fernandès indique sous le nom de ortohua, me pa. rait être le même animal que le zorilla du Pérou; et le tepemaxlla du même auteur pourrait bien être le conepate, qui doit se trouver à la Nouvelle-Espagne, comme à la Louisiane et à la Caroline.

\section{DESCRIPTION DU COASE.}

\section{(BITBAIT DB DAUBENTON.)}

Cet animal, qui a été envoyé de Virginie, sous les noms de pekun, chat somrage on cufant dus diable, esț très-différent du chat, et il diffère aussi du pekan, dont il est fait mention dans ce volume, par plusieurs earactères, principalement par le nombre des doigts, il est plus petit que le pekan; il n'a que seize pouces de longueur, depuis le bout du mu-eau jusqu'à l'origine de la quene : quoique je n'aie vu qu'une peau desséchée et bourrée du coase, il ma paru avoir le museau beaucoup plus long, les oreilles plus grandes, les jambes plus courtes et les pieds plus petits que le pekan. Les dents ressemblaient autant à celles de la fonine que les dents du pekan, et le coase était plus ressemblant à la fouine qu'au pekan par la figure de la tête et di corps en entier, excepté la queue qui était peu touffue, le tronçon n'avait que six pouces de longıeur, et le poil ne s'étendait au rlelà que d'un pouce et demi. Hiais la plus grande diffërence qu'il y ait entre le coase et les pekans, les fouines, les putois, etc., est dans le nombre des doigls, le coase n'en a que quatre aux pieds de derant, tandis que ces autre: animaux en ont cinq aux pieds de derant comme à cenx de derrière, les ongles sont noirâtres et ressemblent julus par leur forme aux ongles des fouines qui à ceux des pekans.

Le poil et le duvet sont de couleur de marron sur tout le corps, il y a un mélange de arris sur la tête : le poil esı très-Jrillant, le plus long a environ un pouce el demi, celui de la quene n’a guère plus de longueur. Les moustaches sont noires et longues de plus de deux ponees. 


\section{LA MOUFFETTE DU CHILI.}

\section{(LA MOUFFETTE D'AMÉRIQUE.)}

Ordre des carnassiers, tribu des digitigrades, genre mouffette. (Cuvier.)

M. Dombey, correspondant du Cabinet du oi, et que nous avons eu occasion de citer pluieurs fois, nous a apporté la dépouille d'un inividu de cette espèce. Cette mouffette se trouve $u$ Chlli, et appartient à la famille du zorille, $d u$ onepate, et d'autres animaux appelés bètes uantes, et qui se trouvent également dans l'Anérique méridionale. Ses habitudes, sur lesvelles nous n'avons reçu ancune observation articulière, doivent être assez semblables it elles de ces animaux puants dont elle se raproche par sa conformation, ainsi que par la istribution de ses couleurs. L'individu dont ous avous vu la peau bourrée était mâle. Il vait la tête large et courte, les oreilles rondes t un peu aplaties, le corps épais ct large à endroit des reins, les cuisses larges et charnes, les jambes courtes, les pieds petits, einq oigts it chaque pied, et les ongles longs, crohus et recourbés en gouttiere '. Sa queue, reevée au-dessus du dos comme celle des éeuenils, était large et garnie de poils touffus, ongs de près de trois pouces. Le poil qui courait sa tète, son corps, ses jambes, et le dessus le sa queue ver's l'origine de cette partie, a vait n quelques endroits un pouce de longueur, et tait d'un brun noiraitre et luisant; le reste du ıil ([ui garnissait sa queue ctait blane, et l'on oyait sur le dos deux larges bandes blauches [ui se réunissaient en une seule ${ }^{2}$.

\section{LE GLOUTON.}

\section{(LE Glouton proprement dit, Cuv.)}

Ordre des carnassiers, genre glouton. (Cuvier.)

Le glouton, gros de corps et bas des jambes, 'st à peu près de la forme d'un blaireau, mais

Long le le plus long des pieds te devant avait onze limnes le longuciar; ce celui des jueds de derrière einy lignes.

Cet individu avait niu pied sept ponees trois lignes depuis

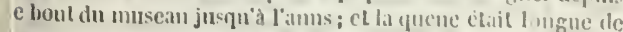
ept ponees untatre lignes, rn y comprenant la longueur du voil : les denls manupuaient à la dépouille. il est une fois plus épais et plus grand; il a la tête courte, les yeux petits, les dents très-fortes, le corps trapu, la queue plutôt courte que longue et bien fournic de poils à son cxtrémité. II est noir sur le dos, et d'un brun roux sur les flanes; sa fourrure est une des plus belles et des plus recherchées. On la trouve assez communément en Laponic et daus toutes les terres voisines de la mer du Nord, tant en Europe qu'en Asie; on le retrouve sous le nom de carcrijou au Canada, et dans les antres parties de l'Amérique la plus septentrionale; il y a même toute apparence que l'animal de la baje de Hudson, que M. Edwards a donné sous le nom de quick-hatch ou wolverenne', petit ours ou louveteau, selon son traducteur, est le mème que le careajou de Canada, le même que le glouton du nord de l'Europe; il me parait aussi que l'animal indiqué par Fernandès sous le nom de lepeylscuilli, ou chien de montagne, pourrait bien être le glouton, dont l'espèce s'est peut-être répandue jusque dans les montagnes désertes de la Nouvelle-Espagne.

Olaüs Magnus me parait être le premier qui ait fait mention de cet animal : il dit qu'il est de la grosseur d'un grand chien, qu'il a les oreilles et la face d'un ehat, les pieds et les ongles très-forts, le poil brun, long et touffu, la queue fournie comme eclle du renard, mais plus courte. Sclon Schrefer, le glouton a la tète ronde, les dents fortes et aiguës, semblables à cclles du loup, le poil noir, le corps large et les pieds courts comme ceux de la loutre. La IJontan, qui a parlé le premier du careajou de l'Amérique septentrionale, dit : "Figurez-vous un double blaireau. c'est l'image la plus ressemblante que je puisse vous donner de eet animal. "Selon Sarrazin, qui probablement n'eu avait vu que de petits, les earcajous n'ont guère que deux pieds de longueur de corps et huit pouces de queue : "1ls ont, dit-il, la tète fort courte " et fort grosse, les yeux petits, les mâchoires " très-fortes, et garnies de trente-deux dents " bien tranchantes. "Le petit ours ou louveteau d'Edwards, qui me parait itre le meme animal, était, dit 'et auteur, une lois aussi gros qu'un renard; il avait le dos arqué, la tète basse, les jambes courtes, le ventre presque trainant à terre, la queuc d'une longueur médiocre et

- Les noms de carcajon el de wolvereune sunt aujourdhul considérés comme se rapportant à un blalreau de l'Amérique septentriniale. 
touffue vers l'extrémité. Tous s'accordent à dile qu'on ne troure cet animal que dans les parties les plus septentrionales de l'Europe, de l'Asie et de l'Amérique; 11. Gmeliu ${ }^{4}$ est le seul qui semble assurer qu'il royage jusque dans les pays chauds. Hais ce fait me parait très-suspect, pour ne pas dire faux : M. Gmelin, comme quelques autres naturalistes, a peut-être confoudu l'hyène du midi arec le glouton du nord qui se ressemblent en effet par les habitudes naturelles, et surtout par la voracité, mais qui sont à tous autres égards des animaux très-différents.

Le glouton n'a pas les jambes faites pour courir ; il ne peut même marcher que d'uu pas lent, mais la ruse supplée à la légèreté qui luj manque; il attend les animaux au passage: il grimpe sur les arbres pour se lancer dessus et les saisir avec avantage; il se jette sur les élans et sur les rennes, leur' entame le corps, et s'y attache si fort avec les grilfes et les dents, que rien ne peut l'en séparer; ces pauvres animaux précipitent en vain leur course, en vain ils se frottent contre les arbres et font les plus grands efforts pour se délivrer; l'ennemi assis sur leur croupe ou sur leur cou continue à leur sucer le sang, à creuser leur plaie, à les dévorer en détail avec le mème acharnement, la même avidité, jusqu'ì ce qu'il les ait mis à mort ${ }^{2}$; il est, dit-on, inconcerable combien de temps le glouton peut manger de suite, et combien il peut dérorer de chair en me seule fois.

Ce que les royageurs en rapportent est peutêtre exagéré : mais en rabattant beaucoup de leurs récits, il en reste encore assez pour ètre convaincu que le glouton est beaucoup plus vorace qu'aucun de nos animaux de proie,

1 Le glouton est le seul dont on puisse dirc, comme de l'homme, qu'il vit aussi bicn sous la ligne qu"au pöle. On le roit partout, il court du midi au nord, et du nord au midi, pourvu qu'il trouve à manger. Voyage de Gmelin, tome 111, page 492 et suiv.

${ }^{2}$ Le gluutou est un animal carnassier, un peu moins grand que le loup; il a le puil rude, long et d'un brun qui approche du noir, surtout sur le dos; il a la ruse de grimper sur un arbre ponr y guetter le giluier; et lursıue quelugue animal passe, il s'élance sur son dus, et sait si bien s'y accrocher par le moyen de ses griffes, quil lui en mange me partie, et que le pauvre animal, après bien des efforts inutiles pour se délaure d'un hote si inconmole, tombe cufin par terre et devient la proie de son ennemi. "f fant au moins trois des plus forts léviers pour attaquer cetle bitte, encore lem tonne-t-elle hien de la peine. Les Russes font graud cas de la pean du glouton. Ils lemploirnt ordinairement à des manchous jour les hommes et des bordures de bonuets. Relation de la Giande-Tartaric. Ansterdam. 1757, page 8. aussi l'a-t-on appelé le vautour des quadrupedes. Plus insatiable, plus déprédateur que le loup, il détruirait tous les autres arimaux s'il avait autant d'agilité ; mais il est réduit à se traîner pesamment, et le seul animal qu'il puisse prendre à la course est le castor, duquel il vient très-aisément à bout, et dont il attaque quelquefois les cabanes pour le dévorer avec ses petits, Jorsqu ills ne peuvent assez tôt gagner l'eau, car le castor le devance à la nage, et le glouton, qui roit échapper sa proie, se jette sur le poisson; et lorsque toute chair vivante vient à lui manquer, il cherche les cadavres, les déterre, les dépèce et les dévore jusqu'aux os.

Quoique cet auimal ait de la finesse et mette ell œuvre des ruscs réfléchies pour se saisir des autres animaux, il semble qu'il n'ait pas de sentiment distinct pour sa conservation, pas même l'instinct commun pour son salut : il vient à l'homme ou s'en laisse approcher ', sans ap-

4 Les ourriers aperçurent de loin un animal qui marchait eux gravement et à pas complès, que (juelques-uns prirent pour un ours, et d'autre - jnur un glouton; ils allèrent an devant de cet animal, quils recounurent a la fiu pour un glou. ton, et, après qu'ils lui eurent donné quelques bons coups de perche, ils le prirent encore en vie; ils me l'apportèrent aussitót... Daprès les rapports que les chasseurs de Sibérie $\mathrm{m}^{\circ}$. vaient faits depuis plusienrs années sur l'adresse de cet animal, soit pour tourner les autres animaux et suppléer par la ruse d la legèretẻ ıue la nature lui a refusée, soit pour éviter les embohches des hommes, je fus très-étonné de voir arıiver celıi-ci de jropos délibéré au-devant de nous pour clıerclıer la inort. lsbrand-ides l'appelle un animal méchant, qui ne vit que de rapine: : 11 a coutume. dit-il, de se tenir sur les arbres tran- quil'e, et de s'y cacher comme le lynx jusqu'à ce qu'il passe a un cerf, un élaı, nu chevrenil, un lièrre, etc.; alors il s'é-

- Lance avec toute la rapidité d'une neche sur l'aninal, lui

- enfonce ses dents dans le corps et le ronge jusyu'à ce rưil

- expire, après yuoi il le dérore à son aise et avale jusıu'au - poil et à la peau. In waivode qui gardait cluez lui pour son - plaisir un glonton le fit un jour jeter dans leau, et lächa - sur lui une couple de chiens. mais le glouton se jeta auscitòt - sur la tète d'un de ces cliens. et le tint sous l'eau jusquaz - ee qu'il l'eùt suffoqué..... - L'adresse dont se sert le glouton pour surprendre les animaıx (eontinue M. Guelin) est confirmée par tous les fhasseurs... Quoiqu'il se repaisse de tous les animaux vivants ou morts, il aime de préfércuce le renne... Il épie les gros animaux comme un voleur de grand chemin, ou lien ils les surp̧rond quand ils dorment an gite.. Il recher che tous les piéges que les chasseurs tendent pour prendre les différentes r'sjeces d'animaux, et il ne s'y laisse pas attrajer. L.es chasseurs de renards bleus ef blancs (isatis), qui se (iennent dans le voisinage de la mer Glaciale, se plaignent heau. conp̧ du tort que leur fait le glontom. On l'apprelle ainsi avec raison, parce qu'il est incroyable ce qu'il pent manger : je nai jamais fntendu dire. quoique je l'aie demandé julus cur: fois a des chasseurs de joufession, que cet animal se presa cntre deux arbres ponr vider son corps, et y faire do la plac ' par force pour satisfaire de nouveau et plus prompic ment son insutiahle voracité. Cela me parait ctre la fable d'ur nituraliste, on la fiction diun peintre. Voyage de Ginelin, tome III, page 492. C’est Olaūs qui le prenied a écrit cette fable. 
parence de crainte. Cette indifférence, qui paraît annoncer l'imbécillité, vient peut-ètre d'une cause très-différente; il est certain (que le glouton n'est pas stupide, puisqu'il trouve les moyens de satisfaire à son appétit toujours pressant et plus qu'immodéré; il ne manque pas de courage, puisqu'il attaque indifféremment tous les animaux qu'il rencontre, et qu'à la vue de l'homme il ne fuit ni ne marque par aucun mouvement le sentiment de la peur spontanée: s’il manque donc d'attention sur lui-mème, ce n'est point indifférence pour sa conservation, ce n'est qu'habitude de sécurité. Comme il habite un pays presque désert, qu’il y rencontre très-l’árement des hommes, qu'il n'y comuait point d'autres ennemis; que toutes les fois ru'il a mesuré ses forces avec les animaux, il s'est trouvé supéricur, yl marche avec confiance et n’a pas le germe de lá crainte, qui suppose (puelque épreuvo malheureuse, quelque expérience de sa faiblesse: on le voit par l'exemple du lion qui ne se détourne pas de l'homme, à moins qu'il n’ait éprouvé la force de ses armes, et le glouton, se trainant sur la neige dans son ciimat désert, ne laisse pas d'y marcher en toute séeurité,et d'y l'égner en lion moins par sa force que par la faiblesse de ceux qui l'environnent.

L'isatis, moins iort, mais beaucoup plus léger' que le glouton, lui sert de pourvoyeur; celuici le suit à la elıasse, et souvent lui enlève sa proie avant qu'il l'ait entaméc : au moins il la partage; car au moment que le glouton arrive, l'isatis, pour n'ètre pas mangé lui-mème, abandomne ee qui lui reste à manger. Ces deur animaux se creusent également des terriers; mais leur's autres habitudes sont différentes : l'isatis va souvent par troupe, le glouton marche seul, ou quelquefois avee sal femelle. On les trouve ordinairenent ensemble dans leur terrier. Les chiens, mène les plus courageux, eraignent d'approcher et de conbattre le glouton; il se défend des pieds et des dents, et leur fait des blessures mortelles; mais comme il ne peut ćchapper par la fuite, les hommes en viennent aisément à bout.

La chair dı glouton, comme celle de tous les animaux volaces, est tris-mauvaise à manger; on ne le cherche que pour 'n avoir la peau, qui fait une très-bonne' et magnifique four-

4 On dit que le glontun est un animal partieulier an pays du Nord... Il est de couletur moiriline, le's proils comme le reuard, pour la longueur el l'énaisseur, matis plus lius el pus rure : on ne met au-dessus que celles de la zibeline et du renard noir, et l'on prétend que quand elle est bien choisie, bien préparée, eile a plus de lustre qu'aucune autre, et que sur un fond d'un beau noir, la lumière se réfléchit et brille par parties comme sur une étoffe damassée.

ADDITION A L'ARTICLE DU GLOUTON.

Cet animal m'a été envoyé vivant des par. ties les plus septentrionales de la Russic; il a néanmoins véeu pendant plus de dis-huit mois à Paris : il était si fort privé, qu'il n'était aucunement féroce et ne faisait de mal à persomne. Sia volacité a été anssi exagérée que sa cruauté; il est vai qu’il mangeait beaucoup, mais i! n'importunait pas vivement ni fréruemment quand on le privait de nour'iture. Il avait deux pieds deux pouces de longueur, depuis le bout du nez jusqu'à l'origine de la queue; le museau noir jusqu'aux sourcils, les yeux petits et noirs; depuis les sourcils jusqu'aux orcilles, le poil était blanc mèlé de brun; les oreilles fort courtes, e'est-il-dire d'un pouce de longueur; le poil ras sur les oreilles; sous la màchoire inférieure il était tacheté de blanc, ainsi ru'entre les deux pieds de devant; les jambes de devant ont onze pouces de longueur, depuis l'extrémité des ongles jusqu'au corps; celles de derriere un pied; la queue huit pouces, y eompris quatre pouces cảe poil à son extrémité; les quatre jambes, la queue et le dessus du dos noils, ainsi que le dessous du ventre; au nonbril une tache blanche; les parties de la génération rousses; le poil roux, depuis les épaules jusqu'a l'origine de la queue; le poil intérieur ou duvet blane; il n'est pas aussi épais dans ces cudroits que sur le dos; les pieds de devant, depuis le talon jusqu'au bout des ongles, longs de trois pouees neuflignes, cinc ongles fort crochus et sćparés, celui du milieu d’un pouce et demi de long; eing durillons sous les ongles, (quatre se tenant ensemble et formant sous le pied un demi-cerele et un autre au talon; cinq ongles de méme aux pieds fe derriere, neuf durillons et point de talon. Largeur du pied de de-

doux, ce qui fail que les peaur on sont très-rechereluées et forl chices, menc en sueble. Arliele extrait el traduit. A ppollou. Megatiui, llistoria Gulonis. Vienna-Austria, 1681. 
vant, deux ponces et demi; longueur des pieds de derrière, quatre pouces neuf lignes ; largeur des pieds de derrière, deux pouces neuf lignes. Six deuts incisives à la màchoire supérieure, dont une de chaque coté, un peu plus grosse que les quatre autres; deux grosses dents de sept lignes de longueur uu peu crochues; cing dents màchelières, dont une du côté de la gorge entre en dedans de la gueule, et dont deux sont beaucoup plus grosses que les autres trois. Cinq dents mâchelières à la màchoire inférieure, dont une fort grosse; deux grandes dents un peu crochues, et six petites presque rases; un peu de poil de deux ponces de longueur autour de la gueule et au-dessus des yeux.

Cet animal était assez doux; il craint l'eau , il a peur des clievaux et des hommes habillés de noil"; il marche en sautant, mange considérablement. Quand jl avait bien maugé, et qu’il restait de la viande, il avait soin de la cacher dans sa cage et de la couvir de paille. En buvant il. lape comme un chien; il n'a aucun cri. Quand il a bu, il jette arec ses pattes ce qui reste d'eau par-dessous son ventre. Il est rare de le voir tranquille, parce qu'il se remue toujours. 11 mangerait plus de quatre livres de viande par jour si on les lui donnait; il ne mange point de pain, et mange si goulument presque sans mâcher qu'il s'en étranglet.

Cet animal, qui n'est pas rare dans la plupart des contrées septentrionales de l'Europe, et mème de l'Asie, ne se trouve fréquemment en Norwége, selon Pontoppidan, que dans le diocèse de Drontheim. Il dit que la peau en est très-précieuse, et qu'or ne le tíre point à coups de fusil pour ne la pas endommager; que le poil en est doux et d'un noir nuancé de brun et de jaune.

\section{NOUVELLE ADDITION A L'ARTICLE DU GLOUTON.}

J'ai dit que le glouton n'est pas rare dans les coitrées septentrionales de l'Europe et mème de l'Asie. M. Kracheninnikow rapporte à ce sujet qu'il y a au Kamtschatka un animal appelé glouton, dont li fourrure est si estimée, que pour dire qu'un homme est richement habillé, on dit qu'il est vètu de fourrure de glouton. "Les femmes de Kamtschatka, dit-il, ornent " leurs chereux avec les pattes blanehes de cet

- Description donnée par M. de Scre.
" animal, et elles en font très-grand cas; ce". pendaut les Kamtschatdales en tuent si peu, " qu'ils sont obligés d'en tirer des Jakutskis qui " leur reviemment fort cher. Ils préferent les " blanches et les jaunes, quoique les noires et " les brunes soient plus estimées... Ils ne peu"vent faire un plus grand présent à leurs fem" mes ou à leurs maitresses que de leur don" ner une de ces peaux, et c'est pourquoi elles " se vendaient autrefois depuis trente jusqu"à " soixante roubles; ils donnent pour deux de " leurs pattes jusqu'à deux castors marins (sari( covicunes). On trouve aussi beaucoup de ces " gloutons dans les environs de Karaga, d'Ana" dirska et de Kolima. Ils sont très-adroits à la " chasse des cerfs, et voici la manière dont ils " s'y prennent pour les tuer. Ils montent sur " un arbre avec quelques brins de cette mousse " qu'ils ont coutume de manger; lorsquils en " voient venir quelques-uns, ils la laissent tom" ber à terre, et, prenant le moment que le cerf - s'approche pour la manger, ils s'élancent sur " son dos, le saisissent par le bois, lui crèrent * les yeux et le tourmentent si fort, que ce mal" heureux animal, pour mettre fin à ses peines " et se débarrasser de son ennemi, se heurte la "tète contre un arbre, et tombe mort sur la " place. Il n'est pas plus tòt à bas que le glou" ton le dépèce par morceaux, cache sa chair " dans la terre, pour empècher que les autres " animaux ne la maugent, et il n'y touche point " qu'il ne l'ait mise en sùreté. Les gloutons qui " se trouvent aux environs du fleure Léna s’y " prenneut de la même manière pour tucr les " chevaux. Cependant, quelque cruels que pa" raissent ces animaux, on les prive aisément, " et ils paraissent alors bien moins voraces."

\section{LE CHACAL ET LADIVE '.}

Ordre des carnassiers, tribu des digitigrades, genre chien. (Curier.)

Nous ne sommes pas assurés que ces deux noms désignent deux animaux d'espèces différentes; nous sarons seulement que le chacal est plus grand, plus féroce, plus difficile à appricoiser' que l'adive ${ }^{2}$, mais qu'au reste ils pa-

- L'adive n'est, selon Cuvier, qu'une espece factice, et ne diffère point du clıacal.

${ }^{2}$ Du lemps de charles $1 \mathrm{X}$, beaucoup de femmes à la cour avaient des adives au lien de jetits chiens. 
du chacal est donc répandue dans toute l'Asie, depuis l'Arméniejusqu'au Malabar ${ }^{1}$, et se trouve aussi en Arabie, en Barbarie ${ }^{2}$, en Mauritanie, en Guinée ${ }^{3}$ et dans les terres du Cap; il semble

les pieds plus hauts : son poil était court et lacheté; ses pattes, à proportion de son corps, étaient prodigieusement épaisses... Il avait la tête aussi fort grosse, plate et large, avec des dents cliacune de la longueur d'un doigt et an dela... Il a aux pieds des griffes d'une épouvantable grosseur. Voyage de Bosman, page 531.

111 y a au Bengale des chiens samyages appelès jacqueparels ou chiens criards, dont le poil est rouge: ils viemnent en troupe toutes lcs nnits aboyer effroyablement le lung du Gange, leur roix et leurs cris sont si différen!s et si confus quion ne neut s'entendre parler; ils ne se détomruent pas yuand les Naturcs passent près đi eux... Ces animaux sont communs presque dans tontes les lndes. Voyage d"Innigo de Biervillas, première partie, pagc 178. - Il 5 a an IIaduré une espéce de chien sauvage eqnon prendrait plutòt ponr un renard; les Indiens l.appellent nari et les Porlugdis atiba.. Lorsque je voyageais la nuit, jentendais ces animaux hurler à lonle houre. Let tres édiliantes, $\mathbf{x} \mathrm{Il}^{e}$ recueil, page $98 .-11$ se trouve à Guzarate une espèce de chien sanvage qu' ils appellent jackals. Relation de Yandelslo; suite doléarius, tome 11, prage 25\%.-On voit un grand nombre de jackales on jacha!s an pays de Malabar; jen i vu arssi dans les bois de Ceylan, ils sont de la figure du renard, particulièrement par la ynene. . lls sont fort friands de chair bumaine... lls suivaient notre armuce, et déterraient nos morts... Tous ent ndions sourent la nuit les cris effroyables de ces animaux, qui ressembleut assez à ceux des chicns irrités... Ils crient à diverses reprises comme s'ils se répondaient. Recneil des Voyages de la Compagnie des Indes orientales, tome V1, page 980.-Toul le pays de Calicut est aussi rempli de renards 'chacals) qui viennent la nuil jușue dans la ville, et chassent conme font ici les chiens, et on v'entend antre bruit toutes les nuits par les jardins et cliemins. Voyage de Fr. Pyrard, tome 1, pige 127.-Le schekale est nne espèce de clien sauvage... Il y eu a une si grande quautilé aux environs de Sourate, que nous ne pouvions nous entendre parler à cause dı grand bruil qu' ils faisaient, criant distinclement oua, oua, oua, qui approche de laboi dn chien; cet animal est friand des corps morls... Il y en a anssi en quantité dans les déserts d'A rabie, le loing du Tigre, de l'Euphrale et dans l'Égypte. Voyage de la Boulaye-le-Gouz, page 23.4 .

2 Aux royaunjes de Tunis et d'Alger, le deab on jackal est d'une coulcur plus obscure que le reisard, et à peu près de la mĉme granleur; il glapit tous les soirs dans les villages el dans les jardins, se nourrissant, comme le dubbah, de racines, de fruits et de charcgnes. Voyage de Shaw, tome I, page 520 . C'est 1 liyène.

s On trouve en Guinée, et plus comınunément encore dans le pays d'Acra et dans celui d'Aquanboé, un animal trés. cruel, que nos gens appellent jackals.... Ils viennent la nui jusque sons les murailles dı fort que nons avons á Acra. jour tåcher d'enlever des élables les pourceanx, les inontons, etc. Voyage de Bosman, page 2:9. Voyez, idem, pages 351 et 532 . - Les chiens sauvages de Congo, qu'on apuelle mebbia, sont ennemis mortels de tous les autres quadrupèdes; ils ne différent pas beancoup de nos chiens courants; nn les roit conrir par troupes de trente et de quarante, quelquefois mème en plus grand noubre... lls altaquent tontes sories d'animaux, et ordinairement en viennent à bout par le nombre. ils n'attaçuent peint les hommes. Voyage du P. Zuchel à Congo et en Éthiopie, page 295, cité par Kolbc. Le chien sanvage du cap de Bonne-Espérance ressemble à ceux de Congo, décrits par le P. Zuchel, etc. Description du cap de Boune-Espérance, par Kollee, partic III, page $48 .$. II y a au Cap un auimal dont lespèce approche beaucoup de celle du renard; Gessner et d'autres l'ont aupelé renard croisé, les Européens du Cap lui qu'elle ait été destinée à remplacer celle du loup' qui manque ou du moins qui est très-rare dans tous les pays chauds.

Cependant, comme l'on trouve des chacals et des adives dans les mèmes terres, comme l'espèce n'a pu être dénaturée par une longue domesticité, et qu'il y a constamment une différence considérable entre ces animaux pour la graudeur et même pour le naturel, nous les regarderons comme deux espèces distinctes, sauf à les réunir lorsqu'il sera prouvé, par le fait, qu'ils se mèlent et produisent ensemble. Notre présomption sur la différence de ces deux espèces est d'autant mieux fondée, qu'elle paralt s'accorder avec l'opinion des anciens. Aristote, après avoir parlé clairement du loup, du renard et de l'lyyène, indique assez obscurément deux autres animaux du mème genre, l'un sous le nom de panther, et l'autre sous celui de thos; les traducteurs d'Aristote ont interprété panther par lupus canarius, et thos par lupris cervurius, loup-canier, loup-cervier. Cette interprétation indique assez qu'ils regardaient le panther et le thos comme des espèces de loups: mais j'ai fait voir à l'article du lynx que le $l u$ pus cervarius des Latins n'est point le thos des Grees : ce lupus corvarius est le même que le chaus de Pline, le mème que notre lynx ou loupceivier, dont ancun caractère ne convient au thos. Homère, en peignant la vaillance d'Ajax, qui seul se précipite sur une foule de Troyens, au milieu desquels Ulysse blessé se trouvait engagé, fait la comparaison d'un lion qui, fondnut tout à coup sur des thos attroupés autour d'un cerf aux abois, les disperse et les chasse comme de vils animaux. Le scoliaste d'Homère interprète le mot thos par celui de panther, qu'il dit être une espèce de loup faible et timide : ainsi le thos et le panther ont été pris pour le même animal par quelques anciens Grees : mais : Iristote paraît les distinguer, sansleur domner néanmoins des caractères ou des attributs différents. "Les thos, dit-il, ont toutes les parties internes " semblables à celles du loup... Ils s'accouplent " comme les chiens, et produisent deux, trois " ou quatre petits, qui naissent les yeux fer.

donnent le nom de jackals, et les Hottentots celui de zenlle on kenlie. Id., part. Jh, page 62.

J'ai olsservé qu'il n'y a guère de loups en Hircanic, ni dans les autres provinces de la Perse, mais qu"il s'y trouve partout un animal dont le cri est effroyable, quils appellent cliacal. Il $\mathrm{eu}$ reut particulièrement aux corps morts quil dcterre. Voyage de Cuardin, tome 1I, page 29. 
" més. Le thos a le corps et la queue plus longs "que le chien, avee moins de havieur, et quoi" quil ait les jambes plus courtes, il ne laisse " pas d'avoir autant de vitesse, parce que étant " souple et agile, il peut sauter plus loin... Le " lion et le thos sont ennemis, parce que vivant " tous deux de chair, ils sont forcés de prendre "leur nourriture sur le mème fonds, et par con" sérquent de se la disputer... Les thos aiment " l'homme, ne l'attaquent point et ne le erai" gnent pas beaucoup; ils se battent contre les " chiens et avec le lion, ce qui fait que daus le " mème lieu oi ne trouve guère des iions et des " thos. Les meilleurs thos sont ceux qui sont "les plus petits; il y en a de deux espéces, " quelques-uns même en font trois. "Voilà tout ce (pu'Aristote a dit au sujet des thos; et il en dit infiniment moins sur le panther: on netronve qu'un seul passage dians le mème chapitre trenteeing du sixieme livre de son Histoire des animaux. "le panther, dit..il, produit quatre pea tits; ils ont les yeux fermés comme les petits " loups lors de leu: naissance. " En companant ces passages avec celui d'Homère et avec ceux des autres auteurs rees, il me parait presque certain que le thos d'A ristote est le grand chacal, et que le panther est le petit chacal ou l'adive. On voit qu'il admet deux espèees de thos, qu'il ne parle du panther qu'une seule fois, et pour ainsi dire à l'oceasion du thos : il est donc tres-probable que ce panther est le thos de la petite espece ; et cette probabilite semble devenir une certitude par le témoignage d'oppieri, qui met le panther au nombre des petits animaux, tels que les loir's et les cluats.

I.e thos est donc: le chacal, et le panther est l'adive; et soit qu'ils forment deux especes différentes ou qu`ils n'en fassent qu'une, il est certain que tout ce que les anciens ont dit du thos et du panther convient au chacal et à ladive, et ne peut s'appliquer à d'autres animaux; et si jusqu’à ce jour la vrait signification de ces noms a été ignorée, s’ils ont toujours été mal interprétés, éest parce que les tradueteurs ne comraissaient pas les animaux, et que les naturalistes moderues, qui les conmaissaient peu, n'ont pu les réformer.

Quoique l'espèce di loup soit fort voisine de celle du ehien, celle du chacal ne laisse pas de trouver place entre lesileux. I.e chacalou adive, eomme dit Belosi, cst bele entre loup et chien; avec la férocité do loup il a en effet un peu de la familiarité du chien; sa voix est un hurlement mèlé d'aboiement et de gérnissements ${ }^{1}$; il est plus criard que le chien, plus vorace que le loup. Il ne va jamais seul, mais toujonls par troupes de vingt, trente oli quarante; ils se rassemblent ehaque jour pour faire la guerre et la chasse; ils vivent de petits animaux, et se font redouter des plus puissants par le nombre; ils attaguent toute. espèce de bétail ou de volailles presqu'à la vue des houmes; ils entrent insolemment et sans marquer de crainte dans les berneries, les étables , Ies écuries, et lorsqu’ils n'y tromvent pas autre chose, ils dévolent le cuil des harnais, des bottes, des souliers, et emportent les lanières qu'ils n'ont pas le temps d'avaler. Faute de proie vivante, ils déterıent les eadaves des animaux et des hommes : oll est obligé de battre la terre sur les sépultures, et d'y mèler de grosses épines pour les empècher de la gratter et four ; car une épaisseur de quelques pieds de terre ne suffit pas pour les rebuter $^{2}$; ils travaillent plusieurs ensemble, ils accompagnent de cris lugubres cotte exhumation, et lorsqu'ils sont une fois accoutumés aux cadavres humains, ils ne cessent de courir les cimetières, de sujve les armées, de s'ittácher aux caravanes : ce sont les corbeaux des quadrupèdes : la ehair la plus infecte ne les dégoùte pas; leur appétit est si constant, si réhément,

Il est diune be!le cmuleu jame, plus petit pue le luup, marchant tonjours en troupes, japant loutes Jes muits... Vorace et voleur, ensorte qu'il empurte non-senlement ce qui est ion à manger, mais meme les chapeaux. les souliers, les brides tes chevanx, et toul ce ynil peut attraper. (H)-er. ale Bclon, pag. 165. - Jachai pene ommen (1rientem inhabitat: lieslia aslnta, andax el furacissima est... Interdin circal numtes latet, noclu pervigil el vag!ns est, catervatim pradalmal excurrit in rura et pagus... Clubitum nuctu edunt execrabi.en ejulatui humaun non dissimilem (puem inlerdun vox latranlium yuasi caimu interstrepit : mulyne inclannanli ommes acclamant, quolepnot roecm e loquinguo audiunt. Kample $r$, Amunil. exolic., pag. $415,-$ Ver's le canal de la mer Noire, il y a heatconp de siacalles ou ehiens sauvages qui ne ressemblent pas mal à des renarls. surlout par le museau. (On croit yüils sont engeudric des loups et des chieus: jls font le soir, cl yuel quefuis bi n avaut dans la nuit, des hurlenents effroyables... lls soul fout méchants et aussi dangereux yue les loups. Voyage de Corneille Lelmun, foi. Paris, 1711.

2 Les allives sont tres-avides de cadavres, particulierement de cadlares lımmains. Quand les chretiens vout euterrer quel-

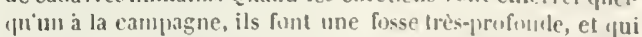
nest pas sultisanto pour yu ils ne déterrent jas le corps; c cest pour fuoi lon a contune de fonler avec les fieds la terre que jon jelle dans la losse, et d'y joimulre des prerres el des épines qui, bessant ces animanx, les enmèchent de foniller phus avanl. Le nom adive vent dire loup en langue arabe; sa fi. fure, son poil, el sa voracile sout bicn analigues à ce uom; mais sa graudemr, sal familiarité el sa st:ipidité en donnent une idve différenle. Vuyage du l'. Irr. Vincent-Marie, c, MIII, article traduil par M. le marquis de Montmirail. 
que le cuir le plus sec est encore savoureux, et que toute peau, toute graisse, toute ordure animale leur est également bonne. L'hyène a ce mème goùt pour la chair pourrie; elle déter:e aussi les cadarres, et c'est sur le rapport de cette habitude que l'on a souvent confondu ces deux animaux, quoique très-différents l'un de l'autre. L'hyène est une bête solitaire, silencieuse, très-sauvage, et qui, quoique plus forte et plus puissante que le chacal, n'est pas aussi incommode, et se contente de dérorer les morts, sans troubler les vivants; au lieu que tous les royageurs se plaignent des cris, des vols et des excès du chacal ', qui réunit l'impudence du chien à la bassesse du loup, et qui, participant dela nature des deux, semble n'ètre qu'un odieux composé de toutes les mauvaises qualités de l'un et de l'autre.

\section{ADDITION A L'ARTICLE DU CHACAL.}

Le dessin d'un petit chacal m'a été envoyé d'Angleterre, sous le simple nom de chacal. MI. le cheralier Bruce m'a assuré que cette espèce était commune en Barbarie, ou on l'appelle thaleb, et comme la figure ne ressemble pas à la description que nous a vons donnée du chacal, je suis persuadé que c'est celle de l'adive ou petit chacal dont nous allons parler, et qui differe du grand chacal par la figure autant que par les mours, puisqu'on peut appriroiser celui-ci et l'élever' en domesticité, au lieu que nous n’avons pas appris que le grand chacal ait été rendu domestique nulle part.

\footnotetext{
4 Jackalls are in so great plenty about the gardens, that they pass in numbers like a pack of hounds in full cry every eveniug, giving not only disturbance by their noise, but making free with the poultry and other provisions, if very good care is not laken to keep then out of Uneir reach. The Nat. Hist. of Alejo, by Alex. Russel. London, 1756. - 11 y a beaucoup de chacals autour du mont Caucase; cet auinal ne ressembie pas mal au renard. Il deterre les morts, et dis sore les animaux et les charognes. On enterre les morts en Orient sans bière et dans leur suaire. J'y ai vu en plusieurs endroits router de grosses pierres sur les fosses, uniquement à cause de ces bẻtes, pour les empêcher de les ouvrir et de dévorer les eadavres. La Mlingrélie est couverte de ces chacals; ils assiégent quelquefois les maisous, et font des hurlements épouvantahles; 1 pis est qu'ils font de grands dégats dans les troupeaux et les haras. Voyage de Chardin, page 76 .
}

\section{LE PETIT CHACAL,}

od

\section{CHACAL-ADIVE.}

Ordre des carnassiers, tribu des digitigrades, genı'e chien. (Cuvier.)

La peau de cet animal, donnée au Cabiizet tiu roi par M. Sonnerat, sous le nom de renard des Indes, est celle d'un chacal adive. Quoique ce dernier ait été fait d'après un dessin envoyé d'Angleterre sans description, on reconnait toujours dans les caractères l'espèce que l'on retrouve ici dans cette peau, où il y a peu de différences marquées avec l'adive.

Ce chacal-adive, qui a de longueur vingt et un pouces du nez à l'occiput, et vingt-trois pouces dix lignes suivant la courbure du corps, est un peu plus petit que le renard, et plus léger dans les formes; sa tête, qui a cinq pouces trois lignes du bout du nez à l'occiput, est longue et menue, le museau est e'filé, ce qui lui rend la physionomie fiue; les yeux sont grands et les paupières inclinées comme dans tous les renards.

Les couleurs de cet adive sont le fauve, le gris et le blanc : c'est le mélange de ces trois couleurs où le blanc domine, qui fait la couleur générale de cet animal. La tête est fauve mêlée de blanc sur l'occiput, autour de l'oreille, aux joues, et plus brunâtre sur le nez et les mâchoires; le bord des yeux est brûuatre. De l'angle antérieur de l'œil part une bande qui s'élargit au coin de l'œil, et s'étend jusque sur la mâchoire supérieure; celle qui part de l'angle postérieur est étroite, et se perd en s'affaiblissant dans la joue sous l'oreille. Le bout du nez et les naseaux, le contour de louverture de la gueule et le bord des paupières sont noirs, ainsi que les grands poils au-dessus des yeux, et les moustaches dont les plus grands poils ont trois pouces deux lignes de longueur; tout le dessous du cou, la partie supérieure du dos, les épaules et les cuisses sont de couleur grisâtre, mais un peu plus fauve sur le dos et aux épaules; la partie extérieure des jambes de devant et de derrière est d'un fauve foncé, mais pảle sur le dessus du pied ; la face interne est blanche et faure, pàle en partie.

Le pied de devant a cinc doigts, dont le premier, cqui fait pouce, a l'ongle placé au poignet. Le plus grand ongle a huit lignes. Le pied de der- 
ric̀re n'a que quatre doigts, et a les onglesplus petits, puisque le plus grand n'a que einq lignes; les ongles sont un peu courbes et en gouttière. La queue est longue de dix pouces six lignes; elle est étroite à son origiine, large et touffue dans sa longueur; sa couleur est d'zin fauve pâle, teint de blane jaunâtre et de brun foncé jusqu'à plus d'un tier's de son extrémité; avee quelques taches de mème couleur sur la face jostérieure. La lougueur des poils est de vingtdeux lignes.

\section{L'ISATIS.}

Ordre des caruassiers, Iribu des digitigrades, genre chien. (Guvier.)

Si le nombre des ressemblances engénéral, si laparfaiteconformité des parties intérieuressuffisaient pour assurer l'unité des espèces, le loup, le renard et le chien n'en formeraient qu'une seule; car le nombre des ressemblances est beaucoup plus grand que celui des différences, et la similitudedes parties internes est entière : cependant ces trois animanx forment trois espèces non-seulement distinctes, mais encore assez éloignées pour admettre entre elles d'autres espèces; et comme celle du chacal est intermédiaire entre le chien et le loup, l'espèce de l'ísatis se trouve placée de mème entre le renard et le chien. Jusqu'à ce jour l'on n'avait regardé cet animal que comme une variété dans l'espèe du renard; mais la desuription qu'en a donnce M. Gmelin, et de laquelle nous ferons ici l'extrait, ne permet plus dedouter que ce ne soient deux espèces différentes.

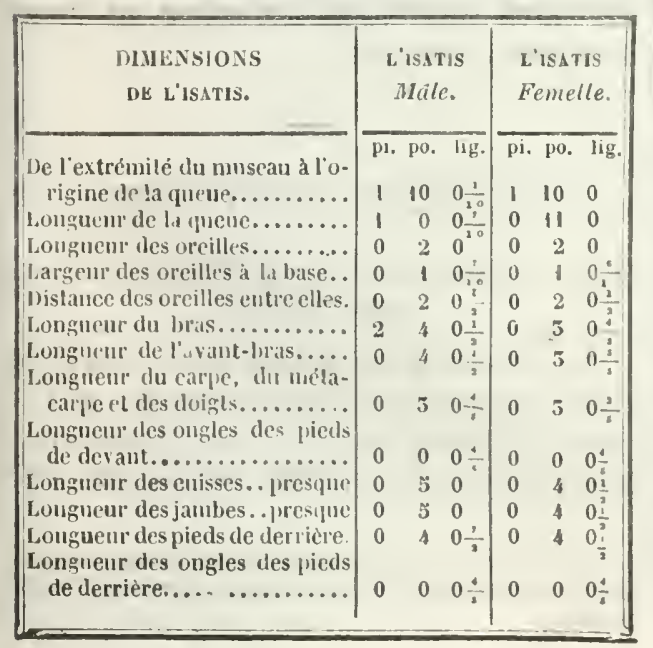

L'isatis (dont nous donnons ici les dimensions du mâle et de la femelle) est très-commun dans toutes les terres du nord, voisines de la mer Glaciale, et ne se trouve guère en deçà du soixanteneuvième degré de latitude. II est tout à fait ressemblant au renard par la forme du corps et par la longueur de la queue, mais par la tête il ressemble plus au chien; il a le poil plus doux que le renard commun, et son pelage est blane dans un temps, et bleu-cendré dans d'antres temps. La tète est courte à proportion du corps; elle est large auprès du cou et se termine par un museau assez pointu; les oreilles sont presque rondes; il $y$ a eing doigts et einq ongles aux pieds de devant, et seulement quatre doigts et quatre ongles aux pieds de derrière. Dans le mâle, la verge est à peine grosse comme une plume à écrire; les testicules sont gros comme des amandes et si fort eachés dans lepoil, qu'on a peine ì les trouver. Les poils dont tout le corps est couvert sont longs d'environ deux ponces; ils sont lisses, touffus et doux commede la laine; les narines et la màchoire inféricure ue sont pis revètues de poil; la peau est apparente, noire et nue dans ses parties.

L'estomae, les intestins, les viscères, Jes vaisseaux spermatiques, tant du mâle que de la femelle, sont semblibles à ceux du chien; il y a de mème un os dans la verge, et le squelette entier ressemble à celui d'un renard.

La voix de l'isatis tient de l'aboiement du chien et du glapissement du renard. Les marchands qui font commerce de pelleteries distinguent deux sortes d'isatis, les uns blancs et les autres bleu-cendré; ceux-ci sont les plus estimés; et plus ils sont bleus ou bruns, plus ils sont eher's. Cette différence dans la couleur du poil ne fait pas qu'ils soient d'espèces différentes; des chasseur's expérimentés ont assuré à M. Gmelin, que dans la même portée il se trouvait des petits isatis blanes et d'autres cendrés, ainsi l'un n’est qu'une variété de l'autre.

Le climat des isatis est le Nord, et les terres qu ils habitent de préférence sont celles des bords de la mer Glaciale et des fleures qui y tombent. Ils aiment les lieux décourerts et ne demeurent pas dans les bois : on les trouve dans les endroits les plus froids, les plus montueux et les plus nus de la Norwége, de la Laponie, de la Sibérie, et mème en Islande '. Ces aui-

- C'est vraisemblablement en vorageaut sur des glaşons que tes renards se sout glissés en Islande; il s'eu Irouve en 
maux s'accouplent au mois de mars; et ayant les parties de la génération conformées comme les chiens, ils ne peuvent se séparer dans le temps de l'accouplement. Leur chaleur dure quinzejours ou trois semaines : pendant ce temps ils sont toujours à l'air', mais ensuite ils se retirent dans des terriers qu'ils ont creusés d'a vance : ces terriers qui sont étroits et fort profonds ont plusicurs issues; ils les tiennent propres, et y portent de la mousse pour être plus à l'aise. La durée de la gestation est, comme dans les chiennes, d'environ neuf semaines : les femelles mettent bas à la fin de mai ou au commencement de juin, et produisent ordinairement six, sept ou huit petits. Les isatis qui doivent ètre blancs sont jaunâtres en naissant, et ceux qui doivent ètre bleu-cendirés sont noirâtres, et leur poil à tous est alor's très-court : la mère les allaite et ies garde dans le terrier pendant cinq ou six semaines, après quoi elle les fait sortir et leur apporte à manger. Au mois de septembre, leur poil a déjä plus d'un demi-pouce de longueur. Les isatis qui doivent devenir blanes le sont déjà sur tout le corps, à l'exception d'une bande longitudinale sur le dos, et d'une autre transversale sur les épaules qui sont brunes, et e'est alors que l'isatis s'appelle renard croisé, mais cette croix brune disparait a vant l'hiver, et alor's ils sont entièrement blancs, et leur poil a plus de deux ponces de longueur : vers le mois de mai il commence à tomber, et la mue s'achève en entier dans le mois de juillet : ainsi la fourrure n'en est bonne qu'en hiver.

L'isatis vit de rats, de lièvres et d'oiseaux, il a autant de finesseque le renard pour les attraper; il se jette à l'eau et traver'se les lacs pour chercher les nids des canards et des oies; il en mange les ouf's et les petits, et n'a pour ennemis dans ces climats déserts et froids que le glouton, qui lui dresse des embîches et l'attend au passage.

Comme le loup, le renard, le glouton et les autres animaux qui habitent les parties du nord de l'Europe et de l'A sie ont passé d'un continent à l'autre, et se retrouvent tous en Amérique, l'isatis doit s'y trouver aussi, et je présume que le renard gris-argenté de l'Amérique septentrio-

grande quantilé dans celte ile; ils ne sont point rongeitres; il y en a peu de noirs, et communément ils sont gris on blenitres en élé. el blanes en hiver; $e^{\prime e s t ~ d a n s ~ c e l l e ~ d e r n i c r e ~ s a i-~}$ son que leur fonrrure est la ineillenre. Ilist. Nat. de l'Islande, par Anderson, tome 1, page 56. nale, dont Casteby a donné la figure, pourrait bien être l'isatis, plutôt qu'une simple variété de l'espèce du renard.

\section{DE L'ISATIS '.}

Par une lettre datée de Londres, le 19 février 1768 , M. Collinson m'écrit dans les termes suivants :

"Un de mes amis, M. Paul Demidoff, Russien, qui admire vos ouvrages, vous envoie le dessin d'un animal qui n'est point encore décrit, appelé cossac. Il vient des grands déserts de Tartarie, situés entre les livières Jaîc, Em. $b a$, et les sources de l'Irlish. Ces cossacs y sout en si grand nombre, que les Tartares en apportent tous les ans cinçuante mille peaux à Orembourg, d'où on les porte en Sibérie et en Turquie.

Il y a du bout du nuseau à l'origine de la p. p. I. queue................ 1 i 11

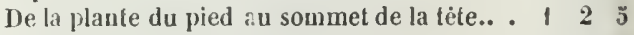
De la plante du pied an-dessus des épaules. . 01110 Longueur de la lète. . . . . . . . . . 0 o ž 2 Longueur des oreilles........... 0 0 22 Dislance entre les oreilles ......... 0.0050 Longueur de la quene.............. 0 10 0

La forme de la tête, le doux regard et l'aboiement de cet animal, semblent le rapprocher du ehien; néanmoins il a de commun avec le renard sa queue et sa fourrure très-belle et trèsdouce. Son sang est d'une nature ardente, et il répand une assez mauraise odeur par la respiration, comme le chacal et le loup."

11 m'a paru, par ce dessin et encore plus par cette courte description de XI. Demidoff et par celle de M. Gmelin, que cet animal est l'isatis dont nous avons parlé.

\section{LE CHIEN DE SIBERIE.}

Ordre des carnassiers, tribu des digitigrades, genre chien. (Gurier.)

Nous avons donné la figure d'un chien de Sibéric, dessiné d'après nature vivante, dont jai domé la description. En le comparant avee le chien de Sibérie, on verra que ee sont deux

' I'isalis on renard blew, dont il est fait mention ci-avan! est un animal du nord de l'ancien continent bien différent de celıi-cl. 
races assez semblables; mais qui diffèrent néanmoins par la grandeur du poil, par celle de la queue, des jambes, celui-ci les ayant plus courtes et le poil considérablenient plus long, plus soyeux et tout blanc. '

\section{L'ANONYME.}

Cet animal, dont nous ignorons le nom, et que nous appellerons l'anonyme en altendant qu'on nous dise son nom, a quelques rapports avec le lièvre, et d'autres avec l'écureuil. Voici ce que M. Bruce m'en a laissé par écrit.

"Il existe daus la Libye, au midi du lac (pu'on " appelait autrefois I'alus Tritonides, un très" singulier animal, de neuf à dix pouces de long; " avec les oreilles presque aussi longues que la " moitié du corps, et larges à proportion; cr qui " ne se trouve dans aucun animal (juadrupede, " à l'exception de la chauve-souris oreillard. II " a le museau presque comme le renard, et ce" pendant il paraît tenir de plus près ì l'écu" reuil; il vit sur les palmiers et en mange le "fruit; il a les ongles courts, (füil peut encore "retirer. C'est un très-joli animal: sa couleur " est d'un blanc mêlé d'un peu de gris et de "fauve clair" l'intéricur des oreilles n'est nu "que dans le milien; elles sont couvertes d'un "petit poil brun mêlé de fauve, et garnies en " dedans de graunds poils blanes; le bout \&u uez " noir; la quene lauve et noire à son extrémité : " elle est assez lougue, mais d'une fornuc difié"rente de celle des écureuils, et tout le poil, " tant du corps que de la queue, est très-doux "au toucher."

\section{LE SARIGUE, oU L'OPOSSUN.}

\section{(LE DIDELPHE QUATRE-Q:IL.)}

Famille des marsupiaux, genre sarigue. (Curier.)

Le sarigue ou l'opossum est un animal de l'Amérique, qu il est aisé de distinguer de tous les autres par deux caracteres tres-singulicrs.

' Cel arliele, ayant élé omis lanı. l'histoire (les chiens do)-

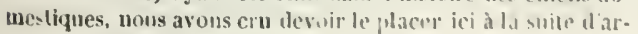

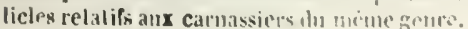

Le premier de ces caractères est que la femelle a sous le ventre nue ample cavité dans layuelle elie recoit et allaite ses petits. I.e second est que le mâle et la femelle ont tous deux le premier doigt des pieds de derrière sans ougle et bien sépari des autres doigts, tel qu'est le pouce dans la main de l'homme, tandis que les quatre autres doigrts de ces mèmes pieds de derrière sont placés les uns contre les autres et armés d'ongles crochus, comme dans les pieds des autres quadrupedis. I.e premier de ces caractères a úté saisi par la plupart des voyageurs et des naturalistes, mais le second leur a vait entierement échappé : Edward Tyson, médecin anglais, parait etre le prem cro qui l'ait observé ; il est le seul (qui ait donné mne bonne deseription de la femclle de ect animal, imprimée a Londres, en 1698, sous lo litre le Carigueya seu Marsupia'e americanum, or the Anatomy of an Opossum. Et quelques années apres, Will. Cowper, célèbre anatomiste anrlais, communiqua à Tyson, par une lettre, les observations qu'il avait faites sur le male. Les autres auteurs, et surtout les nomenclateurs, ont ici, comme partnut ailleurs, multiplié les êtres sans nécessité, et ils sont tombés daus plusieurs erreurs que nous ne pouvons nous dispenser de relever.

Notre sarigue, ou si l'on reut l'opossum de Tyson, est le méme animal (que le grand philandre oriental de Seba, vol. l, puye $61, p l .39$ : lou n'en sammait douter, puisque de tous les animaux dont Seba domne les figures et auxquels il ipplicpue le nom philandre, d'opossum ou de carigueya, celui-ci est le seul qui ait les deux caractères de la bourse sous le ventre et des pouces de derriele sans ongle. De meme lion ue peut douter que notre sirligue, qui est le mème que le grand philandre oriental de Seba, ne soit un animal maturel aux climats chatids du Youveau-lionde; ear les deux sarigues que nous arons au Cubinet du Roi nous sont venus d'Améripue : eclui que 'ly son a disséqué lui avait été enoréc do Virrinie. It de Chamvallon, entrespondiunt de l'Aeademie des seiences à la Martinique, qui nous a dome un jeune sarigue, a reeounu les deur autres pour de vrais sarigues ou opossums de l'Imerique.

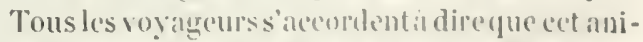
mall se troureau Bresil, a lit Vouvelle-Espagne, a la Virorinice, aux. Antilles, ede, et aucun ne dit ('u avoil v a

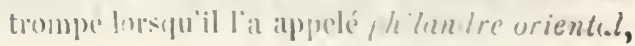


puisqu'on ne le trouve que dans les Indes occidentales. Il dit que ce philandre lui a été envoyé d'A mboine sous le nom de coescoes avee d'autres curiosités; mais il convient en mème temps qu'il a ait été apporté à Amboine d'autres pays plus éloignés. Cela seul suffirait pour rendre suspecte la dénomination de philandre oriental, car il cst très-possible que les voyageurs aient transporté cet animal singulier de l'Amérique aux Indes orientales : mais rien ne prouve qu'il soit naturel au climat d'Amboine, et le passage mème de Seha, que nous venons de citer, semble indiquer le contraire. La source de cette erreur de fait, et même celle du nom coescoes, se trouve dans Pison, qui dit quaux Indes orientales, mais à Amboine seulement, on trouve un animal semblable au sarigue du Brésil, et quion lui donne le nom de couscous. Pison ne eite sur cela ni autorité ni garants; il serait bien étrange, si le fait était vrai, que $\mathrm{Pi}$ son assurant positivement que cet animal ne se trouve qu’ạ Amboine dans toutes les Indes orientales, Scba dit au contraire que celui gu ui lui a été envoyé d'Amboine n'en était pas natif, mais y avait été apporté de pays plus éloignés. Cela seul prouve la fausseté du fait a vance par Pison, et nous verrons dans la suite le peu de fond que l'on peut faire sur' ee qu'il a écrit au sujet de cet animal. Seba, qui ignorait done de quel pays venait son philandre, n'a pas laissé de lui domer l'épithète d'oriental : cependant il est certain que c'est le mème animal que le sarigue des Indes occidentales; il ne faut, pour s'en assurer, que comparer sa figure, $p l .39$, avec la nature. Mais ce qui ajoute encore à l'erreur, c'est qu'en méme temps que ect auteur domne au sarigue d'Amérique le nom de grand philindre oriental, il nous préscnte un autre animal, (füil croit être différent de celui-ci, sous le nom de philandre d'Amérique (pl. 36 , figures 1 et 2 ; , et qui eependant, selon sa propre ciescription, ne diffère du grand philandre oriental qu'en ce qu'il est plus petit et que la tache au-dessus des yeux est plus brune; différences, comme l'on voit, très-aceidentelles et trop légères pour fonder deux espèces distinctes: car il ne parle pas d'un autre différence qui serait beaucoup plus essentielle, si elle existait réellement, comme on la voit dans la figure; c'est que ce philandre d'Amérique (Sebı, $p l$. 36, fig. 1 et 2) a un ongle aigu aux pouces des pieds de derrière, tandis que le grand philandre oriental (Seba, $p l .39$ ) n'a point d'ongle à ces deux pouces. Or, il est certain que notre sarigue, qui est le vrai sarigue d'Anérique, n’a point d'ongles aux pouces de derrière. S'il existait done un animal avec des ongles aigus á ecs pouces, tel que celui de la planche 36 de Seba, cet animal ne serait pas, comme il le dit, le sarigue d'Amérique. Nais cen'est pas tout : cet autcur donne encore un troisième animal sous le nom de philandre oriental ( $p l .38, f(y .1)$ : duquel au reste il ne fait nulle mention dans 1 . deseription des deux autres, et dont il ne parle que d'après François Valentin, auteur qui, comme nous l'aıons déjà dit, mérite peu de confiance; et ce troisième animal est encore le même que les deux premiers. Il nous parait done que ces trois animaux des planches de Seba n'en font clu'un seul. II y a toute apparence que le dessinateur, peu attentif, aura mis un ongle pointu aux ponces des pieds de derrière comme aux pouces des pieds de devant et aux autres roigts dans les figures des planches 36 et 38 , et que, plus exact dans le dessin de la planche 39, il a représenté les pouces des pieds de derrière sans ongle, et tels qüils sont en effet. Nous sommes done persuadés que ces trois animaux de Scha ne sont que trois individus de la mème espèce; que cette espèce cst la même que celle de notre sarigue; que ces trois individus étaient seulement de différents àges, puisquiils ne diffèrent entre eux que par la grandeur du corps et par quelques nuances de couleur, principalement par la teinte de la tache au-dessus des yeux, (jui est jaunàtre dans ${ }^{\circ}$ les jeunes sarigues, tels que celui de la filitnche 36 de Seba. fig. 1 ct 2 , et qui est plus brume dans les sarigues adultes, tel que celui de la planche 39 ; difiérence qui d'ailleurs peut prov enir du temps plus ou moins long que l'animal a été conservé dans l'esprit-de- in, toutes les couleurs du poil s'affiblissant ar ec le temps dans les liqueurs spiritueuses. Seba convient lui-même que les deux animaux de ses plimches 36, fig. 1 et 2 ; et 38, fig. 1 , ne different que par la grandeur et par quelques muanees de couleur; il convient encore que le troisieme animal, c'est-à-dire celuri de la plunche 39 , ne diff'cre des deux autres qu'en ce qu'il est plus gland, et que la tache au-dessus des yeux n’est pas jaunatre, mais brune. Il nous parait donc certain que ces tiois animaux n'en font qu'un seul, puisqu'ils n'ont entre eux que des diffé- 
rences si petites qu'on doit les regarder comme de très-légères variétés, avec d'autant plus de raison et de fondement, que l'auteur' ne fait aucune mention du scul caractère par lequel il aurait' pu les distinguer', e'est-ì-dire de cet ongle pointu aux pouces de derrière qui se voit aux figures des deux premiers et qui manque au dernier. Son seul silence sur ce caractere prouve que cette différence n'existe pas réellement, et que ees ongles pointus aux pouces de deririère, dans les figures des planches 36 et 38 , ne doivent être attribuées qu'à l'inattention du dessinateur.

"Seba dit que, selon Francois Valentin, ce " philandre, planche 38 , est de la plus grande " espèce qui se voit aux Indes orientales, et " surtout ehez les Malayes, où on l'appelle l'e"landor Aroé, e'est-à-dire lapin d'Aroé, "quoique Aroé ne soit pas le seul lieu où se " trouvent ces animaux; qu'ils sont communs " dans l'ile de Solor; qu'on les élève même avee "les lapins auxpuels ils ne font aucun mal, et " (qu'on en mange également la chair que les ha"bitants de cette ile tronvent excellente, ete. " Ces faits sont très-douteux pour ne pas dire faux. Premièrement, le philandre, planche 38, n'est pas le plus grand des Indes orientales, puis(jue, selon l'auteur même, celui de la planche 39, qu'il attribue aussi aux Indes orientales, est plus grand. En second lieu, ce philandre ne ressemble point du tout à un lapin, et par eonséquent il est bien mal nommé lapin d'Aroé. Troisièmement, aucun voyageur aux Indes orientales n'a fait mention de ect animal si remarquable; aucun n'a dit qu'il se trouve ni dans l'ile de Solor, ni dans auc'un autre endroit de l'ancien continent. Scba lui-même paraît s'apercevoir non-seulement de l'incapacité, mais aussi de l'infidélité de l'auteur qu'il cite: Cujus equidem rei, dit-il, fides sit pones autorem. At mirum lamen estquod D. Valcutinus philandri formam haud ita descripserit prout se habet et uti nos ejus icones ad vivum fuctas progressis labulis exhibuimus. (Volume 1, page 61.) Mais pour achever de se démontrer a soi-mène le peu de confiance que mérite en effet le témoignage de ect auteur, François $\mathrm{Va}$ lentin, ministre de l'église d'Amboise, qui ecpendant a fait imprimer en cinq volumes in-folio l'Histoire naturelle des Indes orientales ', il suf-

\footnotetext{
' Ond en nieuw Oost-Indien, elc. Dordrecht, Jean Braam,
}

fit de renvoyer à ce que dit Artédi ' au snjet de ce gros ouvrage, et aux reproches que Seba ${ }^{2}$ mème luj fait avee raison sur l'erreur grossière qu'il commet, en assurant " que la poche de " l'animal dont il est question est une matrice " dans laquelle sont conẹus les petits; et qu'a" près avoir lui-même disséqué le philandre, il " n'en a pas trouvé d'autre; que si cette poche " n'est pas une vraie matrice, les mamelles " sont, à l'égard les petits de cet animal, ce "que les pédicules sont aux fruits; qu'ils res" tent adhérents à c'es mamelles jusqu'à ce qu'ils " soient mûrs; et qu'alors ils s'en séparent, " comme le fruit quitte son pédicule lorsqu'il a "acquis toute sa maturité, ete. "Le vrai de tout ceci, c'est que Valentin, qui assure que rien n'est si commun que ees animaux aux Indes orientales, et surtout à Solor, n'y en avait peut-ètre jamais vu; que tout ce qu'il eu dit, et jusqu'à ses erreurs les plus évidentes, sont eopićes de Pison et de Marcgrave, qui tous deux ne sont eux-mêmes, à cet égard, que les copistes de Ximénès, et qui se sont trompés en tout ce qu'ils ont ajouté de leur fond; car Maregrave et Pison disent expressément et affirmativement, ainsi que Valentiu, que la poche ${ }^{3}$ est la vraie matrice où les petits du sarigue sont concus. Maregrave dit qu'il en a disséqué un, et qu'il n’a point trouvé d'autre matrice à l'intérieur; Pison renchérit encore sur lui en disant qu'il en a disséqué plusieur's, et qu'il n'a jamais trouvé de natrice à l'intéricur'; et c'est là où il ajoute l'assertion, toute aussi mal fondée, que eet animal se troure a Amboine. Quion juge maintenant de yucl poids doivent être ici les antorités de Maregrave, de Pison et de Valentin, et s"il serait raisonnahle d'ajouter foi au témoignage de trois hommes dont le pice. mier a mal vu, le second a amplitić les erreurs du premier, et le dernier a copic les deux autres. Je demanderais volontiers pardon à mes lee-

- Mlnlla seripsil Franciscus Valentimus, quie Judarus apella credalt.... Ila comparalus est hie liber lielgicus, nt historicorum naturalium gemuinorum et eruditorum oculos nollo mor lo ferre possit. Arledi Ielillyologia Ilist. litleraria, l.ugd. Ilat., 1758, pages 35 et 56 .

${ }^{2}$ Inde anlem yuam licpuidissime detegifur error a I. Fran. eisco Valentino commissus circa hisloriam hornm animalium. Tum. III, pag. $273 . . .$. Etror abstums valdic el cnormis, inde Forsan ortum dusit yuol vir isle hanc aninualiusn spectem hand debile examinaveril, elc. Sela, vul. 1, pag. 64.

s Ilace lursa ipse nterus est animalis, nam alium non habel, uti ex sectione illius comperi : in hac semen concipitur el catuli formantur. Nlarcg., Hist. Brasillens., pag. 223. 
teurs de la longueur de cette discussion critique; mais lorsqu il s'agit de relever les erreurs des autres, on ne peut ètre trop exact ni trop attentif, mème aux plus petites choses.

M. Brisson, dans son ouvrage sur les Quadrupèdes, a entièrement adopté ce qui se trouve dans celui de Seba : il le suit ici à la lettre, soit dans ses dénominations, soit daus ses descriptions, et il parait même aller plus loin que son auteur, en faisant trois espèces réellement distinctes des trois philandres, planches 36,38 et 39 de Seba; ear s'il eut recherché l'idée de cet auteur, il eût recomnu qu'il ne donne pas ses trois philandres pour des espèces réellement différentes les unes des autres. Seba ne se doutait pas qu'un animal des climats chauds de l'Amérique ne dùt pas se trouver aussi dans les climats chauds de l'Asie; il qualifiait ces animaux d'Orientaux ou d'Américains, selon qu'ils lui arrivaient de l'un ou de l'autre continent; mais il ne domne pas ses trois philandres pour trois espèces distinctes et séparées; il parait elairement qu’il ne prend pas à la rigueur le mot d'espèce, lorsqu'il dit, page 61: "C'est ici la plus grande espèce de " ces animaux, " et qu'il ajoute: "Cette femelle " est parfaitement semblable ( simillima) aux " femelles des philandres d'Américque; elle est * seulement plus grande, et elle est couverte " sur le dos de poils d'un jaune plus foncé. ") Ces différences, comme nous l'avons déjà dit, ne sont que des variétés telles qu'on en trouve ordinairement entre des individus de la mème espèce à différents àges; et dans le fait, Seba n’a pas prétendu faire une division mćthodique des animaux en classes, genres et espèces; il a seulement donné les figures des différentes pièces de son Cabinet distinguées par des numéros, suivant qu'il voyait quelques différences dans la grandeur, daus les teintes de couleur ou dans l'indication du pays natal des animaux qui composaient sa collectiou. Il nous parait donc que sur cette seule autorité de Seba, M. Brisson u'était pas fondé à faire trois espèces différentes de ces trois philandres, d'autant plus qu'il n’a pas mème employé les caractères distinctifs exprimés daus les figures, et qu'il ne fait aucune mention de la différence de l'ongle qui se trouve aux pouces des pieds de derrière des deux premiers et qui manque au troisieme. M. Brissou devait donc rapporter à son no 3 , c'est-à-dire à son philandre d'Auboine, p. 289, toute la nomenclature qu'il a mise à son philandre, $n^{\circ} 1$, page 276 , tous les noms et synonymes qu'il cite ne convenant qu'au philandre, $n^{\circ} 3$, puisque c'est celui dont les pouces des pieds de derrière nont point d'ongle. Il dit en général que les doigts des philandres sont onguiculés, et il ne fait sur cela aucune exception; cependant le philandre qu'il a vu au Cabinet du Roi, et qui est notre sarigue, n'a point d'ongle aux pouces des picds de derrière, et il parait que c'est le seul qu'il ait vu, puisqu'il n'y a dans son livre que le $n^{0} 1$ qui soit précédé de deux étoiles. L'ouvrage de M. Brisson, dailleur's très-utile, pèche principalement en ceque la liste des espèces y est beaucoup plus grande que celle de la nature.

Il ne nous reste maintenant à examiner que la nomenclature de M. Linnæus : elle est sur cet article moins fautive que celle des autres, en ce que cet auteur supprime une des trois espèces dont nous venous de parler, et qu'il réduit à deux les trois animaux de Seba. Ce n'est pas avoir tout fait, car il faut les réduire à un, mais du moins e'est avoil fait quelque chose ; et d'ailleurs il emploie le caractère distinctif des pouces de derrière sans ongle, ce qu'aucun des autres, à l' exception de Tyson, n'avait ob servé. La description que M. Limæus dome du sarigue, sous le nom de marsupialis, no 1 , didelphis, etc., nous a paru bomne et assez conforme à la nature; mais il y a inexactitude dans sa distribution et erreur dans ses indications : ect auteur, qui sous le nom d'upossum, $n^{\circ} 3, p .55$, désigne un animal différent de son marsupialis, $n^{0} \mathbf{1}$, et qui ne cite à cet égard que la seule autorité de Seba, dit cependant que cet opossum n'a point d'ongle aux pouces de derrière, tandis que cet ongle est très-apparent dans les figures de Seba; il aurait au moins dù nous avertir que le dessinateur de Seba s'était trompé; une autre erreur, c’est d'avoir cité le maritacaca de Pison comme le mème animal que le carigucya, tandis que dans l'ouvrage de Pison, ces deux animaux, quoique annoncés dans le même chapitre, sont cependant domnés, par Pison même, pour deux animaux différents, et qu'il les décrit l'un après l'autre. Mais ce qu'on doit regarder comme une crreur plus considérable que les deux premières, c'est d'aroir fait du même auimal deux espèces différentes; le marsupialis, $\mathbf{n}^{0} \mathbf{1}$, et l'opossum, $n^{\circ} 3$, ne sont pas des animaux diffé- 
rents; ils ont tous deux, suivant M. Linmæus même, le marsupium ou la poche; ils ont tous les pouces de derriere sans ongle, ils sont tous deux d'Amérique, et ils ne different ( toujours selon lui) qu'en ce que le premier a huit mamelles, et que le second n'en a que deux et la tache au-dessus des yeux plus pàle : or ce dernier caractère est, comme nous l'avons dit, nul, et le premier est au moins très-équivoque; carle nombre des mamelles varie dans plusieurs espèces d'animaux, et peut-ètre plus dans celleci que dans une autre, puisque des deux sarigues femelles que nous avons au Cabinct du roi, et qui sont certainement de même espèce et du mème pays, l'une a cinq et l'autre a sept tétines, et que ceux qui ont observé les mamelles de ces animaux ne s'accordent pas sur le nombre: Marcgrave, qui a été copié par beaucoup d'autres, en compte huit; Barrere dit qu'ordinairement il n'y en a que quatre, etc. Cette différence qui se trouve dans le nombre des mamelles n'a rien de siugulier, puisque la même variété se trouve dans les animaux les plus connus, tels que la chienne qui en a quelquefois dix, et d'autres fois neuf, huit ou sept ; la truie qui en a dix, onze ou douze; la vache qui en a six, einq ou quatre, la chèvre et la brebis qui en ont quatre, trois ou deux; le rat qui en a dix ou huit; le furet qui en a trois a droite et quatre à gauche, etc., d'où l'on roit qu'on ne peut rien établir de fixe et de certain sur l'ordie et le nombre des mamelles, qui varient dans la plupart des animaux.

De tout cet examen que nous veuons de faire avee autant de scrupule que d'impartialité, il résulte que le philander opossum seu carigueyu brasiliensis, pl. 36, fig. 1, 2 et 3 ; le philander orientalis, pl. 38 , fig., 1 ; et le philander orientalis maximus, pl. 29 , fig. 1 de Seba, vol I, pag. 56,61 et 64 ; que le philandre, $n^{\circ} 1$, le philandre oriental, $\mathrm{u}^{\circ} 2$, et le $\mathrm{phi}$ landre d'Amboine, n. 3, de M. Brisson. p. 286, 288 et 289 ; et enfin que le marsupialis, $n^{\circ} 1$, et l'opossum, $\mathrm{n}^{\circ} 3$, de $\mathrm{M}$. Linnæus, édilion $\mathrm{X}$, parges 5.4 et 55 , n'indiquent tous qu'un seul et mème animal, et que cet animal est notre sarigue, dont le climat unique et naturel est l'Amérique méridionale, et qui no s'est jamais trouvé aux Grandes-lndes que comme etranger et après y avoir cté transporté, Je crois avoir levésur cela toutes les incertitudes; mais il reste encore des obscurités au sujet du ciribi, que
Maregrave n'a pas donné comme un animal différent du carigucya, et que néanmoins .Jonston, Seba, et MM. Klein, Limnæus et Brisson, qui n'ont écrit que d'après Marcograve, ont présenté comme une espéce distincte et différente des précélentes. Cependant on trouve dans Marcgrave les deux noms carigueya, laiibi à la tête du mème article: il y est dit que cet animal s'appelle cariqueya au Brésil, et triili:au Paraguay (carigueya Brusiliensibus, aliquibusjupatima, Petiguaribustaiibi). On trouve ensuite une deseription du carigueya tirée de Ximénes, apres layuelle on en trouve une autre de l'animal appelé taiibi par les Brasiliens. cachorro domato par les Portugais, ct booschratte ou rat des bois parles Hollandais. Naregrase ne dit pas que ce soit un animal different du carigueya; il le donne au contraire pour le mále du carigueya (pedes et digitos ha. bet ut femellajam descripta). Il parait clairement qu'au Paraguay on appelait le sarigue mâle et femelle taiibi, et qu'au Brésil on donnait ce nom de taiibi au seul màle, et celui de carigueya à la femelle. D'ailleurs les différences entre ces deux animaux, telles qu'elles sont indiquées par leurs descriptions, sont trop légères pour fonder sur ces dissemblanees dcux espèces différentes, la plus sensible est celle de la couleur du poil, qui dins le carigueya est jaune et brune, alu lieu qu'elle est grise diuns le taiibi, dont les poils sont blanes ' en-dessous et bruns ou noirs à leur extrémité. Il est done plus que probable que le taiibi est en effet le mâle du sarigue. II. IRay parait ètre de cutte opiniou, lorsqu'il dit, en parlant du carrigueva et du taibi, an specie, an sexu lantum a procedenti diversum. Cependaut malgré l'autorite de Maregrave et le doute très-raisonnable de Ray, Seba donne (p]. $36, n^{\circ}$ 4) la ligure d'un animal femelle auquel il applique, sans aucun grarant, le nom de taiibi; et il dit en meme temps que ce taibi est le méme animal que le llaquatzin de Hernandes : éest ajouter lit méprise à l'erteur: ear, de l'a veu mème de Scba? 2 . son taiibi, qui est femelle, lla point de poche

Le poil tu rat de bois est d'un trés-bean gres argenli, (In en voit mène qui sonl fonl blancs el d'un tres-l ean lılanc: la femelle a sous le veulre nue hourse yuti souvie it se ferme

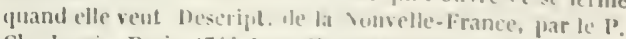
Charlevoix. Paris, 17 \$, lowe IIl, jage sis.

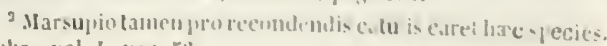


sous le ventre, et il suffisait de lire Hernandès pour voir qu'il donne à son tlaçuatzin cette poche comme un principal caractère. Le taiibi de Seba ne peut done être le tlaquatzin de Hernandès, puisqu'il n'a point de poche, ni le taiibi de Maregrave, puisqu'il est femelle; e'est certainement un autre animal assez mal dessiné et encore plus mal décrit, auquel Seba s'est avisé de donner le nom de taiibi, et qu'il rapporte mal à propos au tlaquatzin de Hernandès, qui, comme nous l'avons dit, est le mème que notre sarigue. MIMr. Brisson et Linnæus ont, au sujet du taiibi, suivi à la lettre ce qu'en a dit Seba; ils ont copié jusqu'à son erreur sur le tlacpuatzin de Hcrnandès, et ils ont tous deux fait une espèce fort équivoque de cet animal, le premier sous le nom de philandre du Brésil $^{\prime}, \mathrm{n}^{\circ} 4$, et le second souscelui de philander ${ }^{2}$, $\mathrm{n}^{\circ}$ 2. Le vrai taiibi, e'est-à-dire le taiibi de Maregrave et de Ray, n'est donc point le taiibi de Seba, ni le philander de M. Linnæus, ni le philandèr du Brésil de M. Brisson, et ceux-ci ne sont point le tlaquatzin de Hernandès. Ce taiibi de Seba (supposé qu'il existe) est un animal différent de tous ceux qui avaient été indiqués par les auteurs précédents : il aurait fallu lui donner un nom particulier et ne le pas confondre, par une dénomination équivoque, avec le taiibi de Maregrave, qui n'a rien de commun avec lui. Au reste, commele sarigue mále n'a point de poche sous le ventre, et qu'il diffère de la femelle par ce caractère si remarquable, il n'est pas étonnant qu'on leur ait donné à chacun un nom, et qu'on ait appelé la femelle carigueya, et le mâle laiibi.

Edward Tyson a, comme nous l'avons déja dit, décrit et disséqué le sarigue femelle avec soin. Dans l'individu qui lui a servi de sujet, la tête avait six ponces, le corps treize, et la queue douze de longueur' les jambes de devant six pouces ${ }^{3}$, et celles de derrière quatre et de-

+ Plilauder pilis in exortu albis, in extremitate nigrieantibus vestita... Plıilamuler Brasiliensis, lc plilanure dı Brésil. liegn. anim . pag. 290.

${ }^{2}$ Plilander, Didelphis cauda basi pilosa, auriculis pendu. lis, matumis qualernis. Syst. mat., ed. X, jag. $59, n^{0} 2$.

s Tyson r'ccounait lni-mème que dans le syuelelte les os des jambes de devant élaient julus comts que ceud des jambes de derrière; et Maregrave, dans sa description, dit aussi que Jesjanbes de devaut étaient jlus conrtes que celles de derrière ; ces lifférences ne proviemnent yue de la différenle ma. niere de les mesurer, et c'est jar cette raison que dans nus descriptions nons ne domnons pas les mesures des jambes en bloc, et que nous détaililons celles de clıacune des jartios yui compusenl la jaube. mi de hauteur; le corps quinze à seize pouces de circonférence, la queue trois pouces de tour à son origine, et un pouce seulement vers l'extrémité; la tête trois pouces de largeur entre les deux oreilles allant toujours en diminuant jus. qu'au nez; elle est plus ressemblante à celle d'un cochon de lait qu'à celle d'un renard ; les orbites des yeux sont très-inclinées dans la direction des oreilles au nez; les oreilles sont arrondies et longues d'environ un pouce et demi; l'ouverture de la gueule est de deux pouces et demi en la mesurant depuis l'un des angles de la lèvre jusçu'à l'extrémité du museau ; la langue est assez étroite, et longue de trois pouces, rude et hérissée de petites papilles tournées en arrière. Il y a cinq doigts aux pieds de devant, tous les cinq armés d'ongles crochus; autant de doigts aux pieds de derrière, dont quatre seulement sont armés d'ongles, et le cinquième, qui est le pouce, est séparé des autres; il est aussi placé plus bas et n'a point d'ongle : tous ces doigts sont sans poils et recouverts d'une peau rougeâtre; ils ont près d'un pouce de longueur; la paume des mains et des pieds est large, et il y a des callosités charnues sous tous les doigts. La queue n'est couverte de poil qu'à son origine jusqu'à deux ou trois pouces de longueur, après quoi c'est une peau écailleuse et lisse dont elle est revêtue jusqu'à l'extrémité : ces écailles sont blanchâtres, à peu près hexagones et placées régulièrement, en sorte qu'elles n'anticipent pas les unes sur les autres; elles sont toutes séparées et environnées d'une petite aire de peau plus bruneque l'écaille. Les oreilles, comme les pieds et la queue, sont sans poil : elles sont si minces qu'on ne peut pas dire qu'elles soient cartilagineuses; elles sont simplement membraneuses comme les ailes des chauves-souris : elles sont très-ouvertes, et le conduit auditif parait fort larğe. La mâchoire du dessus est un peu plus allongée que celle du dessous; les narines sont larges, les yeux petits, noirs, vifs et proéminents; le cou court, la poitrine large, la moustache comme celle du chat. Le poil du devant de la tète est plus blane et plus court que celui du corps ; il est d'un gris-cendré mêlé de quelques petites houppes de poils noirs ct blanchâtres sur le dos et sur les còtés, plus brun sur le ventre, et encore plus foncé sur les jambes. Sous le ventre de la femelle est une fente qui a deux ou trois pouces de longueur: cette fente est forméc par deux peaux (jui coun- 
sosent une poche velue à l'extérieur et moins zarnie de poil àl'intérieur; cette poche renferme es mamelles : les petits nouveau-nés y enrent pour les sucer, et prennent si bien l'habiude de s'y cacher qu'ils s'y réfugient, quoique léjà grands, lorsqu'ils sont épouvantés. Cette poche a du mouvement et du jeu; elle s'ouvre 3t se referme à la volonté de l'animal. Le mécanisme de ce mouvement s'exéeute par le moyen de plusieurs muscles et de deux os qui nappartiennent qu'à cette espèce d'animal : ces deux os sont placés au-devant des os pubis auxquels ils sont attachés par la base; ils ont environ deux pouces de longueur, et vont toujours en diminuant un peu de grosseur depuis la base jusqu'à l'extrémité ; ils soutiennent les muscles qui font ouvrir la poche et leur servent de point d'appui : les antagonistes de ees muscles servent ì la resserrer et à la fermer si exactement que dans l'animal vivant l'on ne peut voir l'ouverture qu'en la dilatant de force avec les doigts. L'intérieur de cette poche est parsemé de glandes qui fournissent une substance jaunâtr'c d'unesi mauvaise odeur, qu'elle se coinmunique à tout le corps de l'animal : cependant lorsqu'on laisse sécher cette matière, non-seulement elle perd son odeur désagréable, mais elle acquiert du parfum qu'on peut comparer à celui du musc. Cette poche n'est pas, comme l'ont avancé faussement Marcgrave et Pison, le lieu dans lequel les petits sont concus ; la sarigue femelle a une matrice à l'intéricur, différente à la vérité de celle des autres animaux, mais dans lađuelle les petits sont conçus et portés jusqu'au moment de leur naissance. Tyson prétend que dans cet animal il y a deux matrices, deux vigins, quatre cormes de matrice, quatre trompes de Fallope et quatre ovaires. M. Daubenton n'est pas d'accórd avec Tyson sur tous ces fitits ; mais en comparant sa descrip)tion avec celle de 'Tyson, on verra qu'il est au moins très-certain que dans les orgaues de la génération des sarigues il y a plusieurs parties doubles qui sont simples dans les autres animaux. Le gland de la verge du mâle et celui du clitoris de la femelle sont fourchus et paraissent doubles. I.e vagini, qui est simple ì l'entrée, se partage ensuite cu deux canaux, etc. Cette confolmation est en général très-singulière ct différente de celle de tous les atutles animaux quadrupèdes.

Le sarigue est uniquement originaire des contrées méridionales du Nouveau-Monde; il paraît seulement qu'i] n'affecte pas aussi onstamment que le tatou les climats les plus chauds. On le trouve non-seulement au Brésil, à la Gıyane, au Mexique, mais aussi à la Floride, en Virginie ${ }^{1}$ et dans les autres régions tempérées dece continent. Il est partout assez counmun, paree qu'il produit souvent et en grand nombre; la plupart des anteurs disent guatre ou cing ${ }^{2}$ petits, d'autres six ou sept : . Iarerrave assure avoir vu six petits virants dans la poche d'une femelle ${ }^{3}$; ces petits a vaient euvirou deux pouces de longueur; ils ćtaient déjà fort agiles; ils sortaient de la poche et y rentraient plusieurs fois par jour. lls sont bieu plus petits lorsqu'ils naissent; certains royageurs disent qu'ils ne sont pas plus gros que des mouches au moment de leur naissance 4 , e'est-à-dire quand ils sortent de la matrice pour entrer dans la poche ct s'attacher aux mamelles. Ce fait n'est pasaussi exagéré qu'on pourrait l'imaginer; car nous avons vu nous-mêmes, dans un animal dont l'espèce est voisine de celle du sarigue, des petits attachés à la mamelle qui n étaient pas plus gros que des fèves; et l'on peut présumer avec beaucoup de vraisemblance que, dans ces animaux, la matrice n'est, pour ainsi dire, que le lieu de la conception, de la formation et du premier développement du foetus, dont l'exelusion étant plus précoce que dans les autres quadrupèdes, l'aceroissement s'achève dans la bourse ou ils entrent au moment de leur naissance prématurée. Personne n'a observé la durée de la gestation de ces animaux, que nous

1 Les opossums sont communs dans la Virginie el dans la Nour'lle-Espagne. H. Nat. des Intille s. Hollerdam, 1638, 1.122.

${ }^{2}$ Quaternos quinusse parit catulos, quos uteru conceptons. editosque in lucen, alvi cavitate yuadan dum adhuc parvuli sunt, condit et servat, etc. Hernand. Ilist. Mex, pag. $\mathbf{3 j 0}$.

s llace ipsa quan describo bestia sex catulos vivos et omnibus membris absolutos, sed sine pilis, in hac bursa labebat, yui elian line inde in ea movebantur; yuilubel catılus dus. bus digitis eral longus, elc. Maregiave. Ilist. Bras., pag. 222. - Ils ont un sac sous le ventre dans leyuel ils portent leurs petits, yui sont parfois six ou sept diune ventre. Descrip. du Youveau-Monde, par de Laēt, page 483.

La femelle du possum a un donble ventre, ou julutót une membrane pendante qui lui cuurre lout le ventre, sans y ètre atlachée, el dont on peut regarder l'interieur lorsyuelle a une fois portè des petits. An derricre de celle menubrane il s a une ouverture oin lon peut prasser la main, si on ne l'a pas grosse. C'est ici un les jeluls se retireul, soit puour éviter yuelque dimget, soil fuur teler uu ju ur durmur. Ils sis sut decetle unavière jusqua ce djuils suieul en état de clicreher påture d'eux-mèmes.... J'ai su mui-meme de ces petils attachés à la tétime, lorsçu'ils nititienl pas plus gros quine mov:che, et

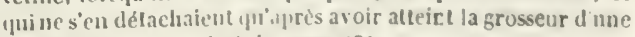
souris. Ilist. de la Virginie, page :20. 
présumons être beancoup phis courte que dans les autres; et comme c'est un exemple singulier dans la nature que cette exclusion précoce, nous exhortons ceux qui sont à portée de voir des sarigues vivants dans leur pays natal de tâcher de savoir combien les fentelles portent de temps, et combien de temps encore après la naissance les petits restent attachés à la mamelle avant que de s'en séparer. Cette observation, curieuse par elle-mème, pourrait devenir utile, en nous indiquant peut-être quelque moyen de conserver la vie aux enfants venus avant le terme.

Les petits sarigues restent donc attachés et comme collés aux mamelles de la mère pendant le premier âge, et jusqu'à ce qu'ils aient pris assez de force et d'accroissement pour se mou voir aisément. Ce fait n'est pas douteux; il n'est pas mêrue particulier à cette seule espèce, puisque nous arons vu, comme je viens de le dire, des petits ainsi attachés aux mamelles dans une autre espèce, que nous appellerons la marmose, et de laquelle nous parlerons bientôt. Or cette femelle marmose n'a pas, comme la femelle sarigue, une poche sous le ventre où les petits puissent se cacher : ce n'est donc pas de la commodité ou du secours que la poche prête aux petits cque dépend uniquement l'effet de la longue adhérence aux mamelles, non plus que celui de lear accroissement dans cette situation immolile. Je fais cette remarque afin de prévenir les conjectures que l'ou pourrait faire sur l'usage de la poche, en la regardant comme une seconde matrice, ou tout au moins comme un abri absolument nécessaire à ces petits prématurément nés. Il y a des auteurs 'qui prétendent qu'ils restent collés à la mamelle plusieurs semaines de suite; d'autres disent ${ }^{2}$ qu'ils ne demeurent dans la pocheque pendant le premier mois de leur ầe. On peut aisément ourrir cette poche de la mère, regarder, compter et même toucher les petits saus les incommoder; ils ne quittent la tétine, qu'ils tiennent avee la

\footnotetext{
1 Les petits sont cullis à la létiue, el cest là oỉ ils croissent à vue d'uxil pendant plusieurs semaines de suite, justu'a ce qu'ils aicnt acquis de la force, qüils onvrent les yeux ct que leur poil soit venu : alots il tombent dans la membrine, dou ils sort'nt et entreut à leur guise. Uist. de lis Virginic. Amst, 1707 , page 220.

3 Septem plus misusve ut plurimum ano pas tu excludit firtus, yu is donec menstruaiu atulem a!lingant, jro lubilu nunc alvo recondit, nunc iterum prodit. $R$ \&lp. IJamor. apud Nierembers, pag. 157.
}

gueule, que quand ils ont assez de force pour marcher; ils se laissent alors tomber dans la poche et sortent ensuite pour se promener et pour chercher leur subsistance "; ils y entrent souvent pourdormir, pourtéter, et aussi pour se cacher Iorsqu'ils sont épourantés; la mère fuit alors et les emporte tous; elle ne parait jamais avoir plus de ventre que quand il y a longtemps qu'elle a mis bas et que ses petits sont déjà grands; car dans le temps de la vraie gestation on s'apercoit peu qu'elle soit pleine.

A la seule inspection de la forme des pieds de cet animal, il est aisé de juger qu'il marche mal et qu'il court lentement; aussi dit-on ${ }^{3}$ qu'un bomme peut l'attraper sans mème précipiter ses pas. En reranche il grimpe sur les arbres " avec une extrème facilité; il se cache dans le feuillage pour attraper des oiseaux ${ }^{5}$, ou bien il se suspend par la queue dont l'extrémitéestmusculeuseet flexible commeune main,

- C'est clans sa poche qu'après aroir nis bas elle retire ses pelits, qui s'altachent à ses tétincs, s'y nourrissent de son lait et s'y élèvent comme dansun sirr asile où ils sont toujours chau. dement.. Dis que les pelits sont ass z Corts poux po:uvoir sortir et courir ur l'herbe, la mere ouriant sa poche leur donne issue. etc. Irémuires de la Loujsiane, par Jumont, paze 81. 2 La mere les met au monde nus et areugles, el les jurcnant en-uile arec les doigts des jieds de devant, elle les met dans sa bourse, qui est comme une especc de matrice, elle les échauffe doucement.. enfin elle ne les tire pas de là qu'ils ne jouissent de la lumiere, alors elle les transporte sur quelizue colline oí elle ne prévoit point de danger, el a yaut uuvert sa bourse, elle les en fait sortir, les expose aux rayons du solcil, les amuse en jouant avec eux; au moindre bruit on sur le sompcon du moindre langer, elle rajplelle aussitót s's pelits par un cri, tic, lic, tic, les juel-, obéssant alors à leur mère, reviennent à elle et se recachent dans la bourse, ctc. Seba, vol. I, page 5̌6. - Lorsiue la mère entend qualque bruit ou quelque muvement rui lui fail ombrage, ell fait un certain cri, et, à ce signal, yui est counu des petits, on les voit ausitút courir à leur mèrc et rentrer d'où ils sont sortis. Mérnoires ỏe la Louisiane, page 85.

5 Cet animal est si lent qu'il est très-facile de l"att raper. Mémoires de la Louisiane, par bumont, page 85. - On ne roit ordinairement point d'animal marcher si leulemeut, rt jen ai pris souvent a mon pas ordiuare. Histoire te la louisiane, par .I. le l'sge du H'ratz, Inme II, page 95.

+ Scandit arhores incredibili prumcilate. IIernani.. Ilist. Mex. pag. 550 . - 11 monle sur les arbres d'une admirable vitesse, t prite grand dommage aux oiseaux domesti,jurs, à la facon du renard; au reste il ne fait nul mal. De Laēt, frage 1'3. - IIoc animal fructilus arborum vescitur. Idenque al " solum ob id arbores scantit, sed etian cum catulis in crn mena iuclusis, magna agilitate de arbore in arboren transilit. Petıus Marly', Oceau, decad. 1, lib. 11: pag. 21.

5 Fortel animal instar vulpis aut matis : mordax est: vescitur libeuter gallitis, quas rapit ut vulpes, ct arloores scandencle avilus iusidialur : vescilur guonue acchari caunis; (juilus sustentavi jer yuatuor seplimanas in cubiculu mo: tandem funi cui alligatum erat se implicans, ex compressione. obiit. Marcgrav. "Ilist. Bras., pag. 225.

- Cauda... ıృua mordicus limileryue yuidquid apprehendit retinet. Hernand., Ilist. Mex, pag. $530 .-$ Sa queue est faite 
en sorte qu'il peut scrrer et même environıcr de plus d'un tour les corps qu'il saisit: il reste quelquefois longtemps dans cette situation saus mouvement, le corps suspendu, la tète cu bas; il épie et attend le petit gibier au passage " d'autres fois il se balance pour sauter' (l'un allbre à un autre, à peu près comme les singes à queue prenante, auxquels il ressemble aussi par la conformation des pieds. Quoique carnassier, et mêmc avide de sang qu'il se plaît à sucer, il mange assez de tout ${ }^{2}$, des reptiles, des insectes, des cannes de sucre, des patates, des racines, et même des feuilles et des écorces. On peut le nourrir comme un animal domestique $^{3}$ : il n'est ni féroce ni farouche, et on l'apprivoise aisément; mais il dégoûte par sa mauvaise odeur qui est plus forte que celle du renạrd 4, et il déplaît aussi par sa vilaine figure ; car indépendamment de ses oreilles de chouette, de sal queue de serpent et de sa gueule fendue jusqu'auprès des yeux, son corps paraît toujours sale, paree que le poil, qui n’est ni lisse ni frisé, est terne et semble être couvert de boue ${ }^{5}$. Sa

pour s'accrocher, ear, en le prenant par cet endroil, il s'entortille aussitôl autour du lloigt... l.a femrlle étant prise, souffre, sans doumer le moindre signe de vie, firon la suspende par la

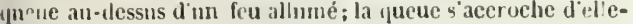
mèm, et lit mère périt ainsi avee ses petits, sans que rien suit (apable de lui desserrer la pean de sil puche. Histuire de

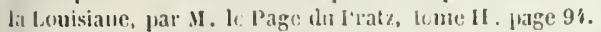

II est tres-lriand des oise anx et de la volaille; aussi culre( il hardiment daus les bassis-coms el dans les poulaillers. I] va mène daus les champs m.mger le mithi guon y’ a semé.

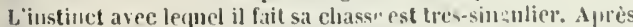

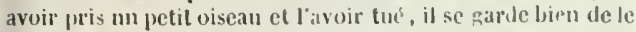
Inimger, il le pose proprament dans mue belle place déconverte proche de yurlyne gros arlore; ensuite munlant sur cet arbre el se suspendant jar la quene à celle de ses branches qui est l. phlus voisine de l'oisean, il altemd patiemuruen en cet èlat que ynelıjue autre oiseau carnassier vienue jour l enlever; alors il se jette dessus, et fait sa proie de l'un et de l'autre. Mém. de la l.ouisiane, par l)mont, jage 84. - If chasse la nuil el fait la guerre aux volailles, dont il suce le sang et yn il ne mange jamais. Hist. de li Louisiane, par II. le I'age du Pratz, page 93.

${ }^{2}$ 'escitur coliortalilus yuas vulpecularum unstelarumye sil. vestrium more jugulat, illarum sangninem absorbens, cxtera innoxium ac simplicissinum animal... Pascitur eliam fructibns, fare, olenibus, frumentaceis, aliisune, veluti nos experimeulo cognovirums, alentes istud doni, ac in delicis lobeutes. Ilernandes, Ilist. Mex., Jage 5;0,-11 grimpe légèrement su les arbres el se monril d'viseaux; il fait la cliasse anx poules comme le renard, mais, au défunt de proie, il se nourrit de frnits. Ilist. Nat. des Aitilles. Rollerdam, 1658 , jage 121.

s Vietifat carnilus et frnctilus, herbis et pane; ideoque a multis animi gratia domi mutritur. Maregrav, Ilist. Iras.. piage 222.

- Les caranues on sarigoys sont semblables ans renards d'Espagne, mais i's sonf plus jelits ef sentent plus manvai de beazcup. Descript. des Indes oecidentales, par de daēt, page 85.

5 Ils sont hidenx à voir el lemr peau farait loujours comverte mauvaise odeur réside dans la peau, car sa chair n'est pas mauvaise à manger ' ; c'est même un des animaux que les Sauvages chassent de préférence, et duquel ils se nourrissent le plus volontiers.

\section{DISSCRIPTION DU SARIGLE.}

(EXTRAIT DE nAUBENTON.)

Lc sarirne a lr museau très-Jong; la bonclue cst si grande que les commissures des lèves se trouvent au-lessous des yeux; le clanfrein, lo front et le sommet de la tète sont sur un mème plan en ligne droite, de sint te que le front ria point de convexité. Les oreilles sont grandes, rundes, minces et denuées de poil. La lévre superieure ne sẻtend pas autant en avant que le nez; on roil les deux dents canines ile la mitchoirede dessus qui sortent hor's de la bouche et qui descendent de chaque cỏté de la lèrre du dessous. Le cartilage du nez est plat, fort large et partage en deux parlies égales par un petit sillon verlical; les ouvertures des nariutes sont fort éloignées l'une de l'autre, et placées ehacune à la partie superieme du burl lateral de ce carti. lage. La quene a autant de longueur que le corps et la tète de l'animal; elle est pointue à l'extrẻmité el garnie de poil sur la longueur de deux pouces et demi depuis son origine; le reste est revilu ile petites écailles romme la ifuene du rat, du surmulot, etc., et il sort de petits poils entre ces cicailles. Chayue pied a cinı] doigls: dans les pieds de de-

de bone. Mémoires de la Lovisiane, par Dumont, page 85.Sun poil csl gris, 'l quoịne fin, il n’est jamais lissé. l.es femmes des naturels le filent el en font des jarretieres, yuielles leignent ensuite en ronge. Ilist. de la Lunisiane, par M. le l'age du l'ral, tome 18 , page 9 I.

'Testatur ipse Raphe comedisse loc animal, et esie grati et salubris mutrimenti. Nicremlierg. Hist. Nat. peregrin., pag. 157.-Carnibus hujus animalis nou solum fndi libentis. sine vescuntur, verum etiam liane cxterormn animalimu quascumque carnes gnstu, suavilate nobilitalas, antccellere pradicant. Quapropter legitur in historia Indica, ynod habilatores insulie Cubie observantes magnam hornm aninalimm quantuaten vagantimu super arbures secus littora iusula crescentes, clanculam acedentes, el de imptoviso, magut impein arborem excutieutes, has belluas cadere in annam cogunt; fuuc immalantes illas apprehcudunf, postea in cilos mullifarie commul. Aldrov., de Cuadrug. digil., lıb. II, pag. 225. - La chair des rats sauvages est fort bonne, on la mange, et ils oul à peu près le gon̂t du cochon de lait. Mémoires de la lonisiane. pall liumont, page $8 \mathbf{5}$. - La chair de cel animal est d'mu très-hon goil, et apjiroche fort de celle du cochon de lait. Ilist. de la I.ouisiame, par M. le Page du Pralz, page 91. - I.e sarigoy cot un animal puant, dont la chair est cependant fort bonue. liygage de coreal. l'aris, 172a, lome 1, page 176 
vant le doigt du milieu est un peu plus long que le second et le quatrième, qui sont aussi plus longs que le premier et le cinquicme; mais le second est égal au troisic̀ne, et le premier au cinquième. Dans les pieds de derrière le pouce est fort ćcarté des autres doigts et beaucoup plus gros. Il y a entre le premier os du métatarse et le second une pean làche et épaisse, qui forme un tubercule près de l'origine du pouce : les trois premiers loigts sont semblables les uns aux autres, et plus longs que le quatrième. Le pouce n'a point d'ongle, il est terminé par un gros tubercule rond; les quatre autres doigts out chacun un petit nngle pliẻ en gouttière et pointı. Les cing doigts rles pieds de levant ont aussi chacun un ongle, qui ne diffère de ceux des pieds de derrière qu'en ce qu'il est plus petit. Tous ces ongles sont très-mobiles; il parail que l'animal peut les avancer et les retirer en arrière à son gré, de façon que la pointe de l'onsle ne se trouve pas si avancée que le tubercule qui termine le doigt; mais la dernière phalange des doigts ne peut pas se glisser à côte de la seconde, comme dans le clıat, le lion, la panthère, etc.; elle se renverse seulement sur la seconde.

Le poil était rle couleur brune roussâtre sur toute la face supirieure du corps depuis le bout du museau jusqu’à la partie écailleuse de la queue et sur la face externe de la cuisse, de la jambe, dı bras et d'une parlie de l'avant-bras. La tête était d'un brun plus roussatre que le; antres parties; leur couleur brune arait une teinte de gris très-luisante, parce que la pointe des plus longs poils était de cette couleur ; ils avaient cinq à six lignes de longueur. I.e poil qui se tronviit à la base des oreilles était de couleur de blanc sale : il y avait une tache de cette mème couleur de chaque côté de la tete, au-devant de l'oreille el au-dessus de l'œil. Le hout du museau, la lèvre du dessus, la face interne du bras, de l'avant-bras, de la cuisse et de la jambe, et une partie de la face externe de l'avant-loras, les quatre pieds en entier, et toutc la face inférieure de l'animal, depuis le bout du museau jusţu'à l'origine de la quene avaient aussi une couleur de blanc sale; on voyait sur le ventre quelque mélange de roux; la partie écrilleuse de la queue était en partie brune et en partie blanchâtre.

La longueur de cet animral in'était que de neıf pouces et demi depuis le bout du museau jusqu'à l'origine de la queue, qui avait neuf pouces un quart : ce sarigue était femelle et avait sous la partie postérieure du ventre une poche qui reufernait des petits.

La poche du sarigue est formée par une duplicalure de la peau qui vicnt du pubis, du ventre et de la face interne des cuisses, et qui couvre les aines et le ventre, dont la peau fait les parois internes et supérieures de la poche; la duplicature de la peau fait les parois inférieures; lorsque les parois inférieures sont bien étendues contre les pa. rois supérieures, leurs bords forment une fente longitudinale qui s'étend depuis environ le mılien le la région ombilicale presque jusquau bout dn ventre. La duplicature de la peau renferme des muscles qui, en se contractant et en se dilatant, ferment et ourrent la fente qui est l'orifice de la poclie : ces muscles ont pour point d'appui deux os articulés avec les os pubis. La poclie a beaucoup de profondeur en arrière et sur les côtés, mais en avant l'extrémité de son orifice, en forme de fente, tient au ventre. Il y avait du poil roux sur les parois interieures de la poche du sarigue dont il s'agit ici.

Le fond de cette poche est fort étroit, mais elle devient dc plus en plus anıple juscju’à ses bords, de sorte que son oritice etant ouvert avait un pouce et demi de hauteur et dix lignes de largeur dans la femelle de sarigue décrite ici. Il se trouvait sur les parois internes et supérieures de la poche, yui étaient formées par la peau du ventre de l'animal, cinq grands mamelons dont les plus longs avaient jusqu'à six lignes; ils étaient ajlatis sur leur longueur et presque pointus à l'extrémité; ils avaient une ligne et demie de largeur à leur origine; quatre de ces mamelons formaient un carré par leur position, parce qu'ils se trouvaient places deux de chaque côté, les uns vis-à-vis des autres; le cinquième était au milieu de ce carré. Il y avait dans celte poche quatre petits sarigues, qui paraissaicnt avoir été tués avec la mère pieu de temps après leur naissance, car ils n'avaient pas encore les yeux ouverts; leur longueur n'était que d'environ deux pouces depuis le sommet de la téte jusquà l'origine de la quetre, qui n'avait pas un pouce et demi de long. On distingruait lejà leur sexe; deux des quatre étaient måles et les deux autres femelles : on voyait l'orifice de la poche qui commençait à se former sous le ventre des deux femelles. Ces quatre petits sarigues etaient tous renfermès [resquen entier clans la poclse placée sous le rentre de la mère ; il ne paraissait au-delıors que la queue et les jambes de derritre de quelyues-uns : ils n'avaient encore qu'un petit poil peil apparent.

Lneautre femelle de sarigue qui ètait plus grande que la précédente, et dont les dimensions sont rapportées dans la table, avait sept mamelons placés sur mne glande mammaire longue de deux pouces, large d'un pouce et demi et épaisse de six ou sept lignes; les mamelons étaient longs de cinq ou six lignes, rangés sur cette glande en deux files de trois chacune, le septième se trouvait placé au centre d'un carré que formaient les quatre mamelons antérieurs des files. La glande manmaire, quoique grande et saillante, laissait de l'espace vide, principalement dans les cỏtés, contre lesai- 
nes et les liancs de l'animal. Les bords de la poche étant rapprochés formaient ıne fente longitudinale longue de truis pouces, et la profoncleur de l'intérieur était de deux ponces en arrière et sur les côtés; l'orifice étant ouvert en entier avait à peu près deux pouces de diamètre. Il s'est trouvé dans la poche un petit sarigue à peu près de la mème grandeur que les petits de l'autre femelle dont il a dejà été fait mention. On a reprisente le petit sarigue attache au mamelon du milien; son corps et les trois mamelons du côte gauche sont couver's par les parois inférieures de la bourse.

\section{LA MARMOSE.}

\section{(LE DIDELPIIE MARMOSE.)}

Ordre des marsupiaux, fanille des pédimanes, genre sarigue. (Cuvier.)

L'espèce de la marmose parait être voisine de eelle du sarigue; elles sont du mème elimat dans le mème contiuent, et ces deux animaux se ressemblent par la forme du corps, par la conformation des pieds, par la queue prenante qui est couverte d'écailles dans la plus grande partie de sa longueur, et n'est revêtue de poil qu'a son origine; par l'ordie des dents, qui sout en plus grand nombre que dans les autres quadrupèdes. Mais la marmose est bien plus petite que le sarigue; ele a le museau encore plus pointu: la femelle n'a pas de poche sous le ventre comme celle du sarigue; il y a seulement deux plis longitudinaux près des cuisses, entre lesquels les petits se placent pour s'attaeher aux mamelles. Les parties de la génération, tant du mâle que de la femelle marmoses. ressemblent par la forme et par la position i celles du sarigue; le gland de la verge du male est fourchu eomme celui du sarigue ; il est placé dans l'anus ; et eet oriliee, dans la fenselle, parait c̀tre aussi l'orifice de la vulve. La maissance des petits semble ètre eneore plus précoce dans l'espèce de la marmose r pue dans celle du sarigue: ils sont à peine aussi gros que de petites fèves lorsqu'ils uaissent et (qu'ils vont s'attacher aux mamelles; les portées sont aussi plus nombreuses. Nous avons vu dix petites marmoses, chaeune attachée à um mamelon, et il y atvait eucore sur le ventre de la mere quatie mamelons vaeants, en sorte qu'elle avait en tout qua- torze mamelles. C'est prineipalement sur les femelles de eette espece qüil faudrait faire les observations fue nous avons indiquées dans l'article précédent; je suis persuadé que ees animaux mettent bas peu de jours après la conception, et que les petits au moment de l'exclusion ne sont encore que des foetus (jui, même comme foctus, n'ont pas pris le (juart de leur aceroissement. L'accouchement de la mere est toujours une fausse-couche tres-prématuríe, et les fuctus ne sauvent leur vie nassinte qu'en s'attachaut aux manelles sans jamais les quilter, jusqu’a ce qu’ils aient acepuis le méme degré d'accovissement et de force yu'ils auraicnt pris naturellement dans la matrice, si l'exclusion ueût pas été prématurée.

La marmose a les miemes inclinations et lis mêmes moeurs que le sarigue: tous deus se creusent des terrici's pour se réfucrier; tous deux s'acerochent aux brunches des arlwes par l'rixtrémité de leur queue, et s'élancent de là sur' les oiseaux et sur les petits auimaux · ils mangent aussi des fruits, des rraines et des racines; mais ils sont encore plus friands de poisson et d'écrevisses, qu’ils pèchent, dit-on, avec leur queue. Ce fait est très-douteux et s'accorde fort mal avec la stupidité naturelle qu'on r'(proche à ces animaux, qui, selon le témoignaýc de la plupart des voyageurs, ne savent ui so mouvoir à propos, ni fuir, ni se défendre.

ADDition a L'ARTICLE DE LA MARMOSE

On sait qu'en génélal les sarigues, manmoses et eayopollins portent également leurs petits dans une poche sous le ventre, et que ces petits sont attachés à la mamelle longtemps a vaut d'atvoir pris leur aceroissement entier. Ce fait. l'u des plus singuliers de la nature, me faisait di sirer des éclaireissements áu sujet de la epenérition de ces animaux, qui no maissent pas à terme comme les autres. Voici ce que M. Roume de Saint-Laurent m'en a écrit en memroyant lu eatulogue du Cabinet d'histoire naturefle qu'il a fait à lible de li Girenade.

"Des personnes digne's de erovance, dit M. de Saint-Laurent, m'ont issuré avoir trouré des femelles the manicou (marmose), dont les petits n'étaient point encore formés ; on royait 
au bout des mamelons de petites bosses claires, dans lescuelles on trouvait l'embryon ébauché. Tout extraordinaire que ce fait doive paraitre, je ne puis le révoquer endoute, et je vais ajouter ici la dissection que je fis d'un de ces animaux, en 1767, qui peut domner quelques lumières sur la façon dont la génération s'effectue dans cette espèce.

"La mère avait clans son sac sept petits, au bout d'autant de mamelons auxquels ils étaient fortement fixés, sans qu'ils y adhérassent; ils avaient environ trois lignes de longueur, et une ligne et demie de grosseur; la tête était fort grosse à proportion du corps, dont la partie antérieure était plus formée que la postérieure; la (pueue était moins avancée que tout le reste. C'es petits n'avaient point de poil; leur peau, trèsfine, paraissait sanguinolente; les yeux ne se dislinguaient que par deux petits filets en eercles. Les cornes de la matrice étaient gonflées, fort longues, formant un tour et se portant ensuite vers les ovaires: elles contcnaient un mucus blanc, épais et parsemé de globules d'air nombreux. L'extrémité des cornes se terminait par des filets gros comme de forts crins, d'une substance à peu près semblable à celle des trompes de Fallupe, mais plus blanche et plus solide. On suivait ces filets jusque daus le corps glanduleux des mamelles, ou ils aboutissaient chacun à des mamelons, sans que l'on pût en distinguer la fin, parce qu'elle se confondait dans la substance des mamelles. Ces filets paraissaient ètre creux ct remplis dı mème mucus qui était contenu dans les cornes: peut-être les petits embryous, produits dans la matrice, passent-ils dans ces canaux pour se rendre aux mamelons contenus dans le sac. ")

Cette olsservation de M. de Saint-Laurent mérite assurément beaucoup d'attention; mais elle nous paraît si siugulière, qu'il serait bon de la répéter plus d'une fois, et de s'assurer de cettemarehetrès-extraordinaire des foetus, et de leur passage immédiat de la matrice aux mamelles, et du temps où se fait ce passage après la conception; il faudrait pour cela élever et nourir un certain nombre de ces animaux, et dissépuer les femelles, peu de temps après leur avoir donné le mâle, à un jour, deux jours, trois jours, quatre jours apres l'accouplement; on pournit saisil te progrès de leur développement, et recomnaitre le temps et la manière dont is passent réellement de la matrice aux ma- mellcs qui sont renfermées dans la poche de l, mère.

\section{DESCRIPTION DE LA MARMOSE.}

(EXTRAIT DE DACBENTOX.)

I. a marmose est de beaucoup plus petite que le sarigue; mais elle n'en diffère, pour la forme du corps, qu'en ce qu'elle a le uuseau plus pointu et lus oreillps moins arrondies; le sommet de la tète est un peu convexe, et l'extréunité dle la queue se recourbe en cleilaus.

Il y a plus de différence entre la marmose et le sarigue claus les couleurs du poil que dans la figure du corjs; les yeux de la malmose sont enturres d'une bande noirâtre, qui est plus large au-llevant de l'œil et sur la paupière supérieure qu'en arrière et sur la paupière inféri ure : l'endroit des moustataclies est de couleur lırune. Le sommet de la tête, l'occiput, le dessus et les còtés du cou, l'ćpaule, le dos, la partie supérieure des côtés du corps, la croupe, l'origine de la queue et la face externe du bras, de l'avant-bras, de la cuisse et de la jambe sont de couleur mêlée de cendré et de fauve, parce que clarpue poil a une couleur cendrèe sur la plus grande partic de sa longueur depuis la racine, et une teinté de fauve à l'extrémité. La lèvre supérieure, depuis le: moustaches jusqu'aux coins de la bouche, les cótés de la tête, la mâchoire inférieure, la gorge, la poitrine, le ventre, le bas des còtés du corps et la face interne lu bras, de l'avantbuas, de la cuisse et de la jambe sont d'une couleur blanchâtre, légèrement teinte le fauve sur les cótis du corps et du cou, entre le cendré de la partie supérieure du corps et la couleur blanchâtre le la partie inférieure : l'entre-deux des yeux et le chanfrein ont aussi une couleur faure. La ¡queue nist revètue de poil que sur la longueur d'environ trois lignes; tout le reste est gimi de fort petites écailles. Le poil des pieds est trèscourt et de couleur blanchitre, très-légèrement teinte de fauve. Les doigls et les ongles ressemhlent à ceux du sarigue pour le nombre et pour la forme.

\section{LE CAYOPOLLIN.}

\section{(LE DIDELPHE CAYOPOLLIN.)}

Ordre des marsupiaux, famille des pédimanes, genre sarigue. (Cuvier.)

Le premicr auteur qui ait parlé de ceì anj. mal est Fermandes. I.e cayopollin, dit.il, est 
un petit animal un peu plus grand qu'un rat, ressenblant au sarigue par le museau, les oreilles et la queue qui est plus épaisse ct plus forte que celle d'un rat, et de larjuelle il se sert comme d'une main. Il a les orcilles minces et diapluanes, le veutre, les jambes et les pieds blaues. Jes petits, lor'scu'ils ont peur, ticmment la mère emlurassée; elle les élève sur les arbres. Cette espèce s'est trouvéc daus les montagnes de la Nouvelle-Espagne. Nieremberg' a copié mot at mot ces indications de Feruandes, et n'y a rien ajouté. Seba, qui le premier a fait dessiner et graver cet animal, n'en donne aucune deseription; il dit se..lement (fu’il a la tête un peu plus épaisse et la queue un tant soit peu plus grosse que la marmose, et que, quoicu'il soit du même genro, il est cependant d'un autre climat, et mème cl'un autre continent; et il se contente de renvoyer à Nieremberg et à Jonston pour ce quion peut désirer de plus au sujet de cet animal : mis il parait évidemment que Nieremberg et jonston ne l'ont jamais vu, et qu'ils n'en parlent que d'après Fernandès. Aucun de ces trois auteurs n'a dit qu'il füt originaire d'Afrique; ils le donnent au contraire comme natturel et particulier aux moutagnes des climats chauds de l'Amérique; et e'est Seba seul qui, sans autorité ni garants, a prétendu qu’il était africain. Celui ruc nous avons vu venait certainement d'Amériçue; il était plus grand, et il avait le museau moins pointu et la quene plus longue yue lit marmose; en tout il nous a paru approcher encore plus que la marmose de l'espece du sarigue. Ces trois animanx se ressemblent beancoup par la conlormation des parties intéricures ct extérieures, par les os surnuméraires du bassin, par la forme des pieds, par la naissance prématurée, la longue et continuelle adhérence des petits aux mamelles, et enfin par les autres habitudes de nature; ils sont aussi tous trois du Nouveau-Monde et du mème climat: on ne les trouve point lans les pays froids de l'Améripue; ils sont naturels aux contrées méridionales de ce continent, et peuvent vive dauns les régions tempérées. $\Lambda$ u reste ce sont fous des animaux très-laids; leur gueule fendue comme celle d'un brochet, leurs oreilles de ehaure-souris, leur queur de couleure et leurs pieds de singe présentent une

- Ens. Vierembers, 11 st. Xat. Peregl, lib. IX, cap. 5 , page 138. forme bizarre, qui devient encore plus désagréable pas la mauvaise odeur quills exhalent, ct par la lenteur et la stupidité dont leurs actions et tous leurs mouvements paraissent accompagnés.

\section{DESCRIPTION DU CAYOPOLLIY.}

(EXTRAT DE DALBENTOX.)

Le cayopollin qui a servi de sujet pour cette description était plus grand que les uarmoses, dont il a éte fait mention dans la deseription de ces animanx. Il leur ressemblait heancoup par les pro. portims des parties du corps, excepte le museau qui était plus épais, les oreilles qui claient moins grantes, ef la queue qui arait plus de longueur. II $y$ avait des diffrrences plus apjarentes dans les cunle:ss du poil : les yeux etaient seulement bordes de noiritre, mais non pas entourés d'une bante de celle couleur comme ceux de la marmose. Une bande étroite de mème couleur noiràtre s'étendait le long du milieu du chanfrein, le reste du chanfrein était de coulenr grise cendrie. Le frunt, le sommet de la tète, l'occiput, le dessus et les cótes du cou, l'épaule, le dos, les còtés du corps, la croupre, la plartie de la queue qui était revélue de poil, la face externe du bras, de l’avant-bras, de la cuisse et de la jambe, le dessus du mitacarpe et du melatarse avaient une couldur cendree, mêle le fauve et de gris; chaque pail etait de couleur cendrci sur la phlus grande partie de sa longueur clepuis la mocine, et la pointe avait une couleur fauve ou grise; le fauve dominait sur l'occiput et sur le cou. Les colés de la títe, la maidhoire inférieure, la gorge, le dessous lu cou, la poitrine, le ventre, la face interne du bras, le l'arant-luras, de la cuisse et de la jambe ctaient de couleur jaunàtre très-păle et presque hlanchiatre. Les phs longs poils araient ein! linnes; ceux tles pieds itaient très-courts: les oreilles n'en avaient que sur la face extérieure de leur base. Les moustaches ctaient longues de quinze lignes. I.es pieils, les doigts et les ongles ressemblaient à ceux de la marmose et du sarigue. La quene n'était courerte de poil quie sur la longueur d'un ponce dix lignes llepuis mo origine; le reste était revètu d'écailles à proportion plus grandes que celles de la queue de la marmese; un vorait yuelyues petits poils entre ces tcaill.s. La partie erailleuse de la puene avait différentes coulcurs; elle etait brune sur environ le tiers de sa loneneur du cote de la partie sarnie de poil, et it ny arait sur le reste que des taches bro nes sur

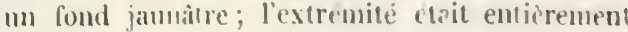
jaunàtre. 


\section{LE PHILANDRE DE SURINAM.}

(LE DIDELPHE CAYOPOLLIN.)

Ordre des marsupiaux, famille des pédimanes, genre sarigue. (Curier.)

Cet animal est du mème climat et d'une espèce voisine de celles du sarigue, de la marmose, du cayopollin et du phalanger. Sibylle Mérian est le premier auteur qui en ait donné la figure, avec une courte indication. Ensuite Seba a donné pour la femelle la figure même de Mérian, et pour le mâle une nouvelle figure avec une espèce de description. Cet animal, dit-il, a les yeux très-brillants et environnés d'un cercle de poil brun foncé; le corps couvert d'un poil doux ou plutôt d'une espèce de laine d'un jaune roux ou rouge, clair sur le dos; le front, le museau, le ventre et les pieds sont d'un. jaunc blanchâtre; les oreilles sont nues et assez raides; il y a des longs poils en forme de moustaches sur la lèvre supérieure et aussi au-dessus des yeux; ses dents sont, comme celles du loir, pointues et piquantes; sur la queue, qui est nue et d'une couleur pâle, il y a dans le mâle des taches d'un rouge obscur qui ne se remarquent pas sur la queue de la femelle : les pieds ressemblent aux mains d'un singe; ceux de devant ont les quatre doigts et le pouce garnis d'ongles courts et obtus, au lieu que des cinq doigts des pieds de derrière, il n'y a que le pouce qui ait un ongle plat et obtus, les quatre autres sont armés de petits ongles aigus. Les petits de ces animaux ont un groguement assez semblable à celui d'un petit cochon de lait. Les mamelles de la mère ressemblent à celles de la marmose. Seba remarque avec raison que dans la figure donnce par Mérian, les pieds et les doigts son mal représentés. Ces philandres produisent cinq ou six petits; ils ont la queue très-longue et pronante oomme celle des sapajous : les petits montent sur le dos de leur mère et s'y tiennent en accrochant leur queue à la sienne; dans cette situation, qui leur est familière, elle les porte et transporte avec autant de sûreté yue de légèreté.

\section{ADDITION}

\author{
ACX ARTICLFS
}

\section{DU SARIGUE, DE LA MARMOSĹ,}

ET DU CAYOPOLLIN.

M. de La Borde, médecin du roi à Cayenne: m'a écrit qu'il avait nourri dans un petit tonneau trois sarigues, où ils se laissaient aisément manier. Ils mongent du poisson, de la viande cuite ou crue, du pain, du hiscuit, etc. Ils sont continuellement à se lécher les uns les autres; ils font le même murmure que les chats, quand on les manie.

"Je ne me suis pas apercu, dit-il, qu'ils eussent aucune mauvaise odeur. Il y a des espèces plus grandes et d'autres plus petites ${ }^{4}$. Ils portent également leurs petits dans une poche sous le ventre; et ces petits ne quittent jamais la mamelle,meme lorsqu'ils dorment. Les chiens les tueut, mais ne les mangent pas. Ils ont un grognement qui ne se fait pas entendre de fort loin; on les apprivoise aisément; ils cherchent à entrer dans les poulaillers, où ils mangent la volaille, mais leur chair n'est pas bonne a manger ; dans certaines espèces elle est mème d'une odeur insupportable, et l'animal est appelé puant par les habitants de Cayenne."

Il ne faut pas confondre ces sarigues puants de M. de La Borde avec les vrais puants ou mouffettes, qui forment un genre d'animaur très-différents de ceux-ci.

M. Vosmaër, directeur des Cabinets d'Histoire naturelle de S. A. S. M. le prince d'Orange, a mis une note, $p .6$ de la description d'un écureuil volant, Amsterdam, 1767 , dans laquelle il dit :

"Lc coescoes est le bosch ou beursrull des Indes orientales, le philander de Seba, et le didelphis de Linnæus. Le savant M. de Bufion nie absolument son existence aux Indes orieutales, et ne l'accorde qu'au Nourcau-Monde en particulier. Nous pouvous néanmoins assurer à ce célèbre naturaliste, que Valentin et Seba

\footnotetext{
t On mia nouvellement envoyé pour le Cabiuet une peau de ces petits sarigues de Cayeune, yui n'avait que trois pouces et demi de longucur, quoique l'animal fùt adulte, et que la queue eñt quatre pouces et demi.
} 
ont fort bien tait de placer ces animaux tant en Asie qu'en Amérique. J'ai moi-mème reçu l'été deruier, des Indes orientales, le mâle et la femelle. La même espèce a aussi été envoyée à M. le docteur Schlosser, à Amsterdam, par un ami d'Amboine, quoique pour moi je n'en connaisse pas d'autres (fue ('eux-ei, de sorte qu'ils ne sont pas si communs. La principale différence entre le coescoes hes indes orientales, et celui des Indes occidentales, consiste, suivint mon observation, dans la conleur du poil, qui, au mâle des Indes orientales, est tout à fait blanc, un peu jaunâtre. Celuj de la femelle est un peuplus brun, avec une raie noire ou plutôt brune sur le dos. La tète de celui des lndes orientales est plus courte, mais le màle me parait l'avoir un peu plus longue que la femelle.

Les oreilles, daus cette espéce, sont beaucoup plus courtes qu'à celle des Indes occidentales. La deseription de la seconde espece, dont parle aussi Valentin, est trop diffuse pour pouvoir s'y rapporter a vec quelque certitude. "

Je ne doute pas que M. Vosmaër n'ait reçu des lndes orientales des auimanx mâles et femelles sous le nom de coescoes ; mais les différences qu'il indique lui-même entre ces coescoes et les sarigues pourrajent déjà faire penser que ce ne sont pas des animaux de même espèce ${ }^{1}$. J'ilvoue néanmoins que la critique de M. Vosmaër est juste, en ce que j'ai dit que les trois philanders de Seba n'étaient que le même animal, tandis cu'en effot le troisième, e'est-ídire celui de lit $) l .39$ de Seba, est un animal différent, et (jui se trouve réellement aux Plıilippines, et peut-être dans quelques autres endroits des Indes orientales, où il est connu sous le nom de coescoes ou cuscus ou cusos ${ }^{2}$. J'ai trouvé dans le Voyage de Christophe Barchewitz la notice suivante.

"Dans l'ile de Lethy il y a des cuscus ou cusos, dont la ehair a à peu près le gout de celle du lapin. Cet animal ressemble beaueoup pour la couleur à une marmotte; les yeux sont petits, rouds et brillants, les pattes courtes, et la queue, qui est longue, est sans poil. Cet animal saute d'un arlore à un autre comme un écurevil, et alor's il fait de sa queue un erochet, avec Irquel il se tient aux brinches pour man-

- Ces anima.ix sont en effet d'espuce el de genre difiérents. Celni dont M. Vosmaër parle est le phalanger roux.

${ }^{2}$ Le philandre orieutal de la pl. 39 de seba doit ètre rayporté au tidel phe crabier d'A méripue ger plus facilement les fruits. Il répand une odeur désagréable qui approche de celle du renard. Il a une poche sous le ventre, dans laquelle il porte ses petits, qui entrent et sortent par-dessous la queue de l'animal. Les vieux sautent d'un arbre à l'autre en portant leurs petits dans cette poche. ")

Il parait, par lecaractère de la poche sous le ventre et de la queue prenante, que ce cuscus ou cusos des Indes orientales est en effet un animal du même geure que les philanders d'Amérique; mais cela ne prouve pas qu ils soient de la mème espéce d'aucun de čux du nouveau continent. Ce serait le seul exemple d'ume pareille identité. Si M. Vosmaër eùt fait graver les figures de ces coescoes, comme il le dit dans le texte, on serait plus en 'tat de jugrer, tant de la ressemblance que des diflérences des coescoes d'Asie, avee les sarigues ou philanders de I'Amérique; et je demeure toujours persuadé que ceux d'un continent ne se troureront pas dans l'autre, à moins qu'on ne les y ait apportés. Je renvoie sur cela le lecteur à ce que j'en ai dit, pag. 255 et suivantes de ce volume.

Ce n'est pas qu'absolument parlant et mème raisommant philosophiquement, il ne fut possible qu'il se trouvât dans lés climats méridionaux des deux continents quel(jues animaux qui serajent précisément de la mème espèce. Nous avons dit ailleurs ', et nous le répetons ici, que la mème température doit faire daus les différentes contrées du globe les mèmes effets sur la nature organisće, et par eonséquent produire les mèmes étres, soit animaux, soit végétaux, si toutes les autres eirconstances étaient, comme la température, les mèmes à tous égards; mais il ne s'agit pas iei d'une possibilité philosophique qu'on peut regarder comme plus ou moins probable; il s'agit d'un liait ct d'un fait très-général, dont il est aisé de prósenter les nombreux et très-nombreux excmples. Il est certain qu’au temps de la découverte de l’A mérique il nexistait dans ce nouveau monde aucun des animatux que je vais nommer : l'éléphant, le rhinocéros, l'hippopotame, la girafe, le ehameau, le dromadaire, le buifle, le cheval, l'àne, le lion, le tigre, les singes, les babouins, les guenons, et nombre d"autres dont j'ai fait l'inumération, et que de môme le tapir, le lamia, la vigogne, le péeari, le ja-

- Theorie de la Terre, sccond Memoire. 
guar, le couguar, l'agouti, le paca, le coati, l'unau, l'aï, et beaucoup d'autres dont j'ai donné l'énumération, n'existaient point dans l'ancien continent. Cette multitude d'exemples dont on ne peut nier la vérité ne suffit-elle pas pou' qu'on soit au moins fort en garde lorsqu'il s'agit de prononcer, comme le fait ici II. Vosmaër, que tel ou tel animal se trouve également dans les parties méridionales des deux continents?

C'est à ce cuscus ou cusos des Indes quion doit rapporter le passage suivant.

* Il se trouve, dit Mandeslo, aux lles Moluques un aninal quion appelle cusos; il se tient sur les arbres, et ne vit que de leur's fruits. Il ressemble à un lapin et a le poil épais, frisé et rude, entre le gris et le roux; les yeux ronds et vifs, les pieds petits, et la gueue si forte, quiil s'en sert pour se prendre aux branches afin d'atteindre plus aisément aux fruits '. "

Il n'est pas question dans ce passage de la poche sous le ventre, qui est le caractère le plus marqué dés philanders; mais je le répète, si le cuscus ou le cusos des Indes orientales a ce earactère, il est certainement d'une espèce qui approche beaucoup de celle des philanders d'Amérique, et je serais porté à penser qu’il en diffère à peu près comme le jaguar diffèie du léopard. Ces deux derniers animaux, sans ètre de la mème espèce, sont les plus ressemblants et les plus roisins de tous les animaux des parties méridionales des deux continents.

\section{LE CIIABIE!}

\section{(LE SARIGUE CRABIER.)}

Ordre des marsupiaux, famille des pédimanes, genre sarigue. (Curier.)

Le nom de crabier, ou chien erabier, (que l'on a donné à cet animal, vient de ce qu'il se nourrit principalement de crabes. Il a très-peu cle rapport an chien ou au renard, auquel les royageurs ont voulu le comparer. Il aurait plus de rapport avec les sarigues, mais il est beancoup plus gros, et d'ailleurs la femelle du crabier' ne porte pas, commela femelle du sarigue, ses petits dans une poche sous le ventre : ainsi le cra-

- Voyage de Mandesln, suite doléarius, tome II, page 38 . L's suiv. bier nous parait être d'une espece isolée et différente de toutes celles que nous avons décrites.

On remarquera la longue queue écailleuse et nue, les gros ponces sans ongle des pieds de derrière, et les ongles plats des pieds de devant. Cet animal, que nous conservons au Cabinet du roi, était encore jeune lorsqu'on nous a envoyé sa dépouille : il est måle, et voici la description que nous en avons pu faire.

La longuetir du corps entier, depuis le bout du nez jusqu'à l'origine de la queue, est d'en iron dix-sept pouces.

La bauteur du train de devant, de six pouces trois lignes, et celle du train de derrière de six pouces six lignes.

La quene, qui est grisâtre, écailleuse et saus poil, a quinze ponces et demi de longueur, sur dix lignes de grosseur à son commencement; elle est très-menue à son extrémité.

Comme cet animal est fort bas de jambes, il a de loin quelque ressemblance avec le chien basset : la tête même n'est pas fort différente de celle d'un chien; elle n'a que quatre pouces une ligne de longueur, depuis le bout du nez jusqu'a l'occiput. L'œil n'est pas grand; le bord des paupières est noir, et an-dessus de l'œil se tronvent de longs poils qui ont jusqu'à quinze lignes de longtieur; il y en a aussi de semblables à cỏté de la joue vers l'oreille. Les moustaches autour de la gueule sont noires, et ont jusqu'à dix-sept lignes de long. L'ouverture de la gneule est do près de deux pouces; la mâchoire supérieure cst armée de chaque côté d'une dent canine crochue et qui excède sur la mâchoire inférieure. L'oreille, qui est de couleur brune, parait tomber IIn peu sur elle-mème, elle est nue, large et ronde à son extrémité.

Le poil du corps est laineux et parsemé d'ilu . tres grands poils raides, noirâtres, qui vont en augmentant sur les cuisses et vers l'épine du dos qui est toute couverte de ces longs poils; ce qui forme à cet animal une espèce de crinière, depuis le milieu du dos jusqu'au commencement de la quene. Ces poils ont trois pouces de longueur; ils sont d'un blane sale à leur origine jusqu'au milieu, et ensuite d'un brun minime jusqu'à l'extrémité. Le poil des còtés est d'uu blanc jaune, ainsi que sous le ventre; mais il tire plus sur le fauve rers les épaules, les euisses, le cou, la poitrine et la tète, oú cette teinte de faure est mélangée de brun dans quelques endroits Les cotés du cou sont fauves. Les jambes 
et les pieds sont d'un brun noirâtre; il y a cinq doigts à chaque pied; le pied de deviunta un pouce neuf lignes; le plus grand doigt neuf lignes, et l'ongle en gouttière deux lignes; les doigts sont un pcu pliés, eomme ceux des rats; il n'y a que le ponce qui soit droit. Les pieds de derrière ont un pouee huit lignes, les plus grands doigts neuf lignes, le pouce six lignes; il est gros, large et écartécomme dans les singes; l'ongle en est plat, tandis que les ongles des quatre autres doigts sont crochus et excèdent le bout des doigts. Le pouce du pied de devant est droit et n'est point écarté de l'autre doigt.

M. de La Borde m'a écrit que eet animal était fort commun à Cayenne, et qu'il habite toujour's les palétuviers et autres endroits maréeageux.

(1) 'st, dit-il, fort leste pour' gr'imper sur les arbres, sur lesquels il se tient plus souvent qu'à terre, surtout pendant le jour. II a de bonnes dents, et se défend contre les chiens. Les crabes font sa prineipale nourriture, et luj profitent, car il est toujours gras. Quand il ne peut pas tirer les crabes de leur trou avee sa patte, il y introduit sa queue, dont il se sert eomme d'un crochet. Le crabe, qui lui serre quelquefois la queue, le fait crier; ce cri ressemble assez à celui d'un homme; et s'entend de fort loin; mais sa voix ordinaire est une espece de grognement semblable à celui des petits cochons. 11 produit quatre ou cinq petits, et les dépose dans de veux arbres creux. Les naturels du pays en mangent la ehair, qui a quelques rapports à celle du lievve. Au reste, ees animaux se familiarisent aisémeut, et on les nourrit à la maison comme les chieus et les chats, c'est-ì-dire avec toutes sortes d'aliments : ainsi leur goùt pour la chair du crabe n'est point du tout un goùt exclusif."

"On prétend qu'il se trouve dans les terres de Cayenne deux espèces d'animaux, auxquels on domne le mème nom de crabiex, parce que tous deux mangent des crabes. Le premier est celui dont nous venons de parler; l'autre est non seulement d'une espece différente, mais parait même êlre d'un autre genre. Il a la queue toute garnie de poil, et ne prend les crabes qu'aree ses pattes. Ces deux animaux ne se ressemblent que par la tète, et diffèrent par la forme et les proportions du corps, aussi bien que par la conformation des pieds et des ongles '. "

\section{LE SARIGUE DES ILLINOIS.}

\section{(LE DIDELPHE AUX OREILLES BICOI.ORES, )}

Ordre des marsupiaux, famille des pédimanes, genre sarigue. (Cuvier.)

Ce sarigue nous parait n'être qu'une variété dans cette espèce, mais les différences sont néanmoins assez grandes pour que nous ayons eru devoir en parler. Ce sarigue se trouve dans le pays des Illinois, et differe de l'autre par la couleur et par le poil qui est long sur tout le corps; il a la tète moins allongée et entièrement blanche, à l'exeeption d'une tache brunatre qui prend du coin de l'œil et finit en s'affaiblissant du còté du nez, dont l'extrémité est lá seule partie de la face qui soit noire; la queue est éeailleuse et sans poil dans toute sa longueur, au lieu que celle de l'autre sarigue est garnie de poil depuis son origine jusqu'ì plus des trois quarts de sa longueur. Cependant ces différences ne me paraissent pas suffisantes pour e'onstituer deux espèces; et d'ailleurs comme le elimat des $111 \mathrm{i}$ nois et celui du Mississipi où se trouve le premier sarigue ne sont pas éloignés, il y a toute apparence que ce second sarigue n'est qu'une simple variété dans l'espèee du premier.

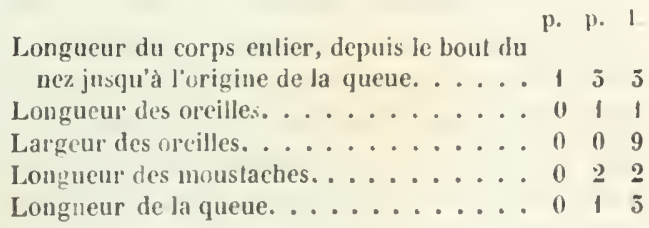

Les oreilles sont d'une peau lisse, semblable à du parchenin brun, sans aucun poil en dedans ni en dehors; le poil qui couvre le eorps jusqu’à la queue, ainsi que lés jambes, est d’un brun plus ou moins nuancé de cendré, et mèlé de longs poils blanes qui ont jusqu' il deux pouces trois lignes sur le clos, et deux ponees six lignes près de la queuc: le dessous du corps est d'un cendré blanchàtre. 11 y a cincr doigts à tous les pieds; le ponce ou doint interne des pieds de derriere a un ongle plat qui n'excede pas la chair; les autres ongles sont blanes et cror ehus. 


\section{LE SARIGUE A LONGS POILS.}

\section{(LE DIDELPHE AUX OBEILles BICOLORES.)}

Ordre des marsupiaux, famille des pédimanes, genre sarigue. (Guvicr.)

Voici un autre sarigue mâle à longs poils, qui est d'un quart plus grand que le précédent, etqui en diffêre aussi par la quene, qui est beaucoup plus courte à proportion. La longueur de ce sarigue est de vingt pouces trois lignes du bout du museau jusqu'à l'origine de la queue, au lieu que l'autre n'a que quinze pouces trois lignes; la tète est semblable dans tous deux, à l'exception du bout du nez qui est noir dans le précédent, et couleur de chair dans celui-ci; les plus grands poils des moustaches ont près de trois pouces de longueur. Il y a encore une petite différence, c'est que dans le sarigue illinois, les deux dents incisives du milieu de la mâchoire supérieure sont les plus petites, tandis que dans celui-ci, ees deux mêmes dents incisives sont les plus grandes. Ils different encore par les couleurs du poil, qui, dans ce sarigue, est brun sur les jambes et les pieds, blanchatre sur les doigts, et rayé sur le corps de plusieurs bandes brunes indécises, une sur le dos jusqu'auprès de la queue, et une de chaque côté du corps qui s'étend de l'aisselle jusqu'aux cuisses; le cou est roussâtre depuis l'oreille aux épaules; et cette couleur s'étend sous le ventre et domine par endroits sur plusieurs parties du corps ; la queue est écailleuse et garnie à son origive de poils blanes et de poils bruns. Nous ne déeiderons pas par cette simple comparaison de l'identité ou de la diversité de ces deux espèces de sarigues, qui tontes deux pourraient bien n'être que des variétés de celle du sarigue commun.

\section{LE TOUAN.}

\section{LE DIDELPHE TOUAN.)}

Ordre des marsupiaux, famille des pédimanes, genre sarigue. (Cuvier.)

Un petit animal nous a été envoyé de Cayenne par M. de La Borde, sous le nom de touran, et nous ne pouvons en rapporter l'espèce qu'au genre de la belette. Dans la conte notice que M. de La Borde nous a laissée de cet animal, il est dit seulement qu'il était adulte, qu'il se tient dans les trones d'arbres, et qu'il se nourrit de vers et d'insectes. La fomelle produit deux petits qu' elle porte sur le dos.

Ce touan adulte n'a que cinq pouces neuf lignes de longueur, depuis le bout du museau jusqu'à l'origine de la queue; il est plus petit que la belette d'Europe, qui a communément six pouces six lignes de long, mais il lui ressemble par la forme de la tête et par celle de son corps allongé sur de petites jambes; il en diffère pi I' les couleurs du poil. La tête n'a qu'un pouce de longueur : la queue a deux pouces trois lignes, au lieu que la queue de notre belette d'Europe n'est longue que de quinze lignes, et n'est pus comme celle du touan grosse et épaisse ì sa naissance, et très-mince à son extrémité. Le touan a cinq doigts armés d'ongles à chaque pied : le dessus du museau, de la tête et du corps jusqu'auprès de la queue, est couvert d'un poil noirâtre; les flanes du corps sont d un roux vif; le dessous du cou et du corps entier d'un beau blanc : les còtés de la tête, ainsi que le dessus des quatre jambes, sont dun roux moins vif que celui des flancs. La queue est couverte, depuis son origine jusqu'à un tiers de sa longueur, d'un poil semblable à celui qui couvre les jam. bes, et dans le reste de la longueur, elle est sans poil ; l'intérieur des jambes est blane comme le dessous du corps. Tout le poil de ce petit animal est doux au toucher.

\section{LA PETITE LOUTRE}

\section{DE LA GUIANE.}

(LE CHIRONECTE YAPOCK.)

Ordre des marsupiaux, famille des pédimanes, genre sarigue. (Cuvier.)

Un petit animal nous a été envoyé de Guiane, sous le nom de petite loutre d'eau douce de Caycnne; elle nous parait ètre la troisième espèce dont parle M. de La Borde. Elle n'a que sept pouces de longueur, depuis le bout du nez jusqu'à l'extrémité du corps : cette petite loutre a la queue sans poil, comme le rat d'eau, longue de six pouces sept lignes, et cinq lignes de grosseur à l'origine, allant toujours en diminuant jusqu'à l'extrémité qui est blanche tandis que tout le reste de la queue est brun; et au lieu de poil elle est couverte d'une peau gre- 
nue, rude comme du chagrin ; elle est plate pardessous et convexe par-dessus. Les moustaches ont un pouce de long aussi bien que les grands poils qui sont au-dessus des yeux; tout le dessous de la tête et du corps est blanc, ainsi que le dedans des jambes de devant. Le dessus et les cótés de la tẻte et du corps sont marqués de grandes taches d'un brun noirâtre, dont les intervalles sont remplis par un gris jaunâtre. Les taches noires sont symétriques de chaque eôté du corps; il y a une tache blanche au-dessus de l'œil : les oreilles sont grandes et paraissent un peu plus allongées que celles de nos loutres. Les jambes sont fort courtes; les pieds de devant ont cinq doigts sans membranes; les pieds de derrière ont aussi cinq doigts, mais avec des membranes.

\section{LE PHALANGER.}

\section{le phalanger Roux, le phalanger TACHETŕ! !)}

Ordre des marsupiaux, famille des pédimanes, genre phalanger. (Cuvier.)

Ces animaux, qui nous ont été envoyés mâle et femelle sous le nom de rats de Surinam, ont beaucoup moins de rapport avec les rats qu'avec les animaux du même climat dont nous avous donné l'histoire sous les noms de marmose et de cayopollin. On peut voir par la description très-exacte qu'en a faite M. Daubenton, combien ils sont éloignés des rats, surtout à l'intérieur. Nous avons done eru devoir rejeter cette dénomination de rats le Surinam, comme composée, et de plus comme mal appliquée : aucun naturaliste, aucun voyageur n'ayant nommé ni indiqué cet animal, nous avons fait son nom, et nous l'avons tiré d'un caractère qui ne se trouve dans aucun autre animal : nous l'appelons phalanger, parce qu'il a les phalanges singulièrement eonformées, et que de quatre doigts qui correspondent aux cinq ongles, dont ses pieds de derrière sont armés, le premier est soudé avee son voisin, en sorte que ce double doigt fait la fourche, et ne se sépare qu'à la dernière phalange pour arriver aux deux ongles. Le

- I,e phalanger regarilé enmme le mâle par buffon, el celui quil a considéré comme femelle, appartiemneut à deux espèces distinctes. Le premier est le phalanger taclıeté, et le second le phalanger roux. pouce est séparé des autres doigts et n'a point d'ongle à son extrémité. Ce dernier caractère, quoique remarquable, n'est point unique; le sarigue et la marmose ont le pouce de même, mais aucun n'a comme celui-ci les phalanges soudées.

Il parait que ces animaux varient entre eux pour les conleurs du poil, comme on le peut voir par les figures du mále et de la femelle. Ils sont de la taille d'un petit lapin ou d'un tres-gros rat, et sont remarquables par l'excessive longueur de leur queue, l'allongement de leur museau et la forme de leurs dents, qui seule suffirait pour faire distinguer le phalanger de la mitmose, du sarigue, des rats, et de toutes les autres espèces d'animaux auxquelles on voudrait le rapporter.

\section{ADDITIONS ET CORRECTIONS A L'ARTICLE DU PHALANGER.}

Nous étions mal informés lorsque nous avons dit que les animaux auxquels nous avons donné le nom de phalanger appartenaient au nouveau continent. Un marchand dont je les ai achetés me les avait donnés sous le nom de rats de Surinam, mais probablementil avaitété trompé luimême. 11. Pallas est le premier qui ait remarqué eette méprise, et nous sommes maintenant assurés que le phalanger se trouve dans les Indes méridionales et mêmedans les terres australes, comme à la Nouvelle-Hollande. Nous sarons aussi qu'on n'en a jamais vu dans les terres de I'Amérique. 11. Banks ' dit avec raison que je me

I. Banks parcourant la campagne prit un animal te la - classe des opossums; cétait une fomelle, el jl prit en nutre - deux petits; il trouva qüils ressemblaient beaucoup an qua- drupede décril par M. de Buffon sous le noun de plalanger; - mais ce u'est pas le nème. Cet auteur sujpose que culte es- pèce est particulière à l'Amérį̣ue, mais il s'est surrement - trompe en ce point; il est frobable que le phalanger esl in- digene de's Indes orientales, puisque l'animal que prit - M. Banks avail quelque analogic avec luj par la conforma- tion extraordinaire de ses pieds, en quoi il differe de tuns - Ies antres tjuadrupédes. voyage aulour du monde. 1. IV, page 56.-Je erois que celte eritique est juste, ct yue le phalanger appartient en effet aux climats des Indes orientale's et mér'iutionales; mais quoiqu'il ait queluque ressemblance avec les opossums ou sarigues, je n'ai pas dif qu il fût du meme genre; j’ai au contraire assuré cuitil différait de tous les sarigues, marmoses el cayopolins, jar la conformation des jicds. qui me paraissait unique dans cette esprece. Amsi je ne me. suis pas trompié en avancant que le gemre des opossums ou sarigues appartieut an nowveau continent, et he se trour: nulle part dans l'ancien. Au reste, l'editeur du Voyage de M. Cook s'est certainemeut trompé lui-mème en disant que 
suis trompé, et qu'il a trouvé dans la NonvelleHollande un animal qui a tant de rapports avec le phalanger, qu'on doit les regarder comme deux espèces très-roisines.

\section{LE POLATOUCHE.}

\section{(LE POLATOUCHE D'AMÉRIQUE.)}

Ordre des rongeurs, genre écurenil. (Cuvier.

Nous avons mieux aimé conserver à cetanimal le nom qu'il porte dans son pays natal, que d'adopter les noms vagues et précaires que lui ont donné les naturalistes; ils l'ont appelé rat volant, écureuil volant, loir volant, Rat de Pont, rat de Scythie, etc. Nous exclurons tant que nous pourrons de l'Histoire naturelle ces dénominations composées, parce que la liste de la nature, pour être vraie, doit être tout aussi simple yu'elle. Le polatouche est d'une espèce particulière qui se rapproche seulement par quelques caractères de celles de l'écureuil, du loir et du rat; il ne ressemble à l'écureuil que par la grosseur des yeux et par la forme de la queue, qui cependant n'est ni aussi longue, ni 'ournie d'aussi longs poils ; il approche plus du loir par la figure du corps, frar celle des oreilles qui sont courtes et nues, par les poils de la queue qui sont de la mème forme et de la mème grandeur que ceux du loir; mais il n'est pas comme lui sujet ì l'engourdissement par l'action du froid. Le palatouche n'est done ni écureuil , ni rat, ni loir, quoiqu'il participe un peu de la nature de tous trois.

M. Klein est le premier qui ait donné une description exacte de cet animal dans les Transactions philosophiques, année 1733. Il était cependant connu longtemps auparavant; on le trouve également dans les parties septentrionales de l'ancien et du nouveau continent ';

lanimal trouvé par M. Bauks était de la classe des opossuns ou sarigues; car le plualanger n'a poinl de poche sous le ventre *

- Les IHnrons du Canada ont de trois sortes d'écureuils... Les plus estimés sont lcs écurenils volants, nommés $s a$ houesquanta, qui ont la couleur cendrée, la tête un peu grosse, el sout musis d'une pame qui leur prend des deux cólés d'une patte de derrière à celle de devant, lesquelles ils étemdent quand ils veulent voler.... lls produsent lrois on qualre pelits, elc. Voyage au pays des IImrons, par Sigard Théulat, pages 305 et 306 . - It y a uu aulıe petit animal que les Indieus de Virginie appellenl assapanick, el les An-

- 1. Buffon se trompe lui-meme ici. M. Desmarets assure que les phalangers femelles sont poursus d'une puche ventrale. il est seulement plus commun en Amérique qu'en Europe, où il ne se trouve que rarement et dans quelques provinces du nord, telles que la Lithuanie et la Russie. Ce petit animal habite sur les arbres comme l'écurcuil ; il va de branche en branche; et lor'squ'il saute pour passer d'un arbre à un autre ou pour traverser un espace considérable, sa peau qui est lâche et. plissée sur les côtés du corps se tire au-dehors, se bande et s'élargit par la direction contraire les pattes de devant qui s'étendent en avant et de celles de derrière qui s'étendent en arrière dans le mouremeut du saut. La peau ains: tendue et tirée en dehors de plus d'un pouce augmente d'autant la surface du corps sans en accroitre la masse, et retarde par conséquent l'accélération de la chute, en sorte que d'un seul saut l'animal arrive à une assez grande distance : airsi ce mourement n'est point un rol comme celui des oiseaux, ni un voltigement comme celui des chauves-souris, qui se font tous deux en frappant l'air par des vibrations réitérées : c'est un simple saut dans lequel tout dépend de la première impulsion dont le mouvement est seulement prolongé et subsiste plus longtemps, parce que le corps de l'animal présentant une plus grande surface à l'air, éprouve une plus grande résistauce et tombe plus lentement. Ou peut voir dans la description qui est à la suite de cet article le détail de la mécanique et du jeu de cette extension singulière de la peau, qui n'appartient qu'an polatouche, et qui ne se trouve dans aucun autre animal : ce seul caractère suffirait donc pour le distinguer de tous les autres écureuils, rats ou loirs; mais les choses mêmes les plus singulières de la nature sont-elles jamais uniques? Devraiton s'attendre à trouver' dans le mème genre un autre animal avee une pareille peau, et dont les prolongements s'étendent non-seulement

glais escurieu-volant, lequel en élargissant les jambes et élendant la peau, comme si c’élail des ailes, vole par fois trente on quarante verges de dix pieds de long. Histoirc dn Nouveau-Monde, par Jean de Laët. Leyde, 1640. Liv. III, page 88. - Les écureuils volants sont de la grosseur d'un grus ral, couleur de gris blanc : ils sont aussi entlormis yue les autres sout éveillés; on les appelle volants, parce qu'ils volent d'm arbre a l'autre par le moyen d'une certaine peau qui s'etend en forme d'ailes. lorsqu'ils font ces petits vols. Voyage de la Hontau, toue 11, page 42. - Les écurenils volanls vieunent du nord de l'Amériçue, mais on en a depuis pen trouvé en Pologne. Voyez. Edwards, Ilist. Nat. of Birds, lage 191 ; cl Ciltesby, llisl. Nat, de la Carol., tome 1I, pag, 78 el 77. 
d'une jambe á l'autre, mais de lı tête à la quucue? Cet animal, dont la figure et la description nous ont été données par Seba sous le nom d'écureuil volant de $\mathbf{V}$ irginie, parait assez différent du polatouche pour constituer une autre espèce: cependant nous ne nous presserons pas de prononcer sur sa nature; il est probable que e'est un animal dont l'espece est réellement existante et différente de celle du polatouche ; mais ce pourrait être aussi une simple variété dans celte espèce, et peut-être enfin n'est-ce qu'une production accidentelle ou une monstruosité: car aucun voyageur, aucun naturaliste n’a fait mention de cet animal: Seba est le seul qui l'ait vu dans le cabinet de Vincent, et je me défie toujours de ces descriptions faites dans des cabinets, d'après des animaux que souvent on ajuste pour les rendre plus extraordinaires.

Nous avous vu et gardé longtemps le polatouche vivant ; il a été bien indiqué par les voyageurs. Sagard Théodat, Jean de Laët, Fernandès ', la Hontan, Denys ${ }^{2}$, en ont tous fait mention, ainsi que MM. Catesby, Dumont ${ }^{3}$, le Page de Pratz ${ }^{4}$, etc. : et MM. Klein, Seba et Edwards en ont donné de bonnes descriptions avec la figure. Ce que nous avons vu nous-mèmes de cet animal s'accorde très-bien avec ce qu'ils en disent : communément il est plus petit que l'é-

Qıjmichpallan seu mus volans fusco pito nigroque promiseue ugitır, yui prope brachia el crura esI prolixior ac parvarum alarım furınd... Esl autem exteris nious, parvo et murino capite, miguis auriculıs, ete. Feınaıd. Ilist. Nuv.e Ilisjl., frag 9. Cet aulenr sc brumpe cn ce yu'il dit que ce sunt de longs poils yui lui tiennent lien d'ailes, au lieu quue ce sont en effet des purol.ungements de la peau.

${ }^{2}$ Len écnrenils vinlants unt le joil un peu plus noir que cenx de lira:ıce : ils out Iles ailes yui l's prement du trajn de derrière a celui de devant, ynil souvient de la largar de deux bous dirigls ; cenl un.. perite toile furt inince, couverte dessus al'un prtit poil follel: tonte sa volée ne peut aller qu’a trente un ynarante pas; mais $\left.s^{\circ} i\right]$ vole d'un arbre à un autre. il voler, bieu le alouble. Description géographique de l'Améri pue septeniriunale par Denys. Paris, 1672, tome 11, p. 33! ct 332.

s es écurruils sont fort communs à la Lonisiane, où l'on en distingue (le deur surtes; les u is sınt en toul semblables a ceux tune nous connaissons en Fralice; les seconds sont diuse couleur un jeu plus cemljose. el ont a leurs deux patles de devinture rsjece ale pran ou de membane, an moyen de

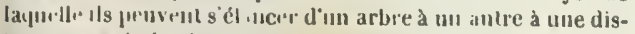

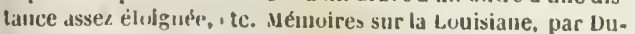
Inont, pages 81 el 82.

4 Lcs écurru.ls voliuts sont ains! nommés parce quiil-sautent d'un arbre à un autre í la distan e dle vingt-ciny á Ire its

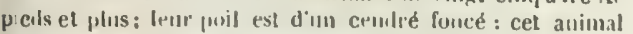
est le la grosseur al un ral; ses patles de derrière bemment à celles de llevand par teux memhranes ipi le soutiennent en

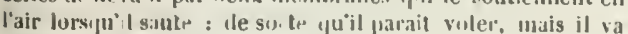
toujours eu buissaut. etc. II:stuire de Ia Luuisjane, par \$I. Ie Paye du Praiz, lome ll, page 98. cureuil ; celui que nous avons eu ne pesait guère que deux onces, c'est-à-dire autant qu'une chauve-souris de la moyenne espece, et l'écureuil pèse huit ou neufonces. Cependant il y en a de plus grands: nous avons une peau de polatouche, dont on verra ci-après la description, qui ne peut provenir que d'un animal plus grand que le polatouche ordinaire.

Le polatouche approche, en quelque sorte, de la chauve-souris par cette extension de la peau qui, dans le saut, réunit les jambes de devant à celles de derrière, et qui lui sert ả se: soutenir en l'air : il parait aussi lui ressembler un peu par le naturel, car il est tranquille et , pour ainsi dire, endormi peudant le jour; il ne prend de l'activité que le soir. Il est très-facile à apprivoiser ; mais il est en mème temps sujet à s'enfuir, et il faut le garder dans une cage ou l'attacher avec une petite chaine. On le nourrit de pain, de fruits, de graines; il aime surtout les boutons et les jeunes pousses du pin et du bouleau; il ne eherche point les noix et les amandes comme les écureuils. II se fait un lit defeuilles, dans lequel il s'ensevelit et où il demeure tour le jour; il a'en sort que la nuit et quand la fáim le presse. Comme il a peu de vivacité, il devient aisément la proie des martes et des autres animaux qui grimpent sur les arbres : aussi l'espèce subsistante est-elle en très. peit nombre, quoiqu'il produise ordinairemen! trois ou quatre petits.

\section{DESCRIPTION DU POLATOUCHE ',}

ExTHATE DE DACBENTON.

Le polatouclıe a en génẻral plus de rapport aux rats qu'á l'ćcureuil par la forme est rieure du corps el par la qualite du poil, et plus à l'écureuil qu'à lout autre animal par les p rties iuterieures; il est à peu près de la wrancleur du lérot; il ressemble heaucoup à l'écure.ıil par la ligure de la tète, quoiquiil ait le nez à proportion moins gros, les oreilles plus eloinnées l'une de l'auıre, etl les yeux précisément aussi gros el aussi saillants que ceux de l'écureuil, malıgré la difference de grandeur qui est entre ces deux animaux. Les oreilles du pulatouche :ont nues, minces et transparentes comme celles des rals: la upueue a le longrs poils sur les cỏlés coume la uneue de l'écureuil et dı loir, mais ces foils sont pis courts pue ceur de l'écureuil, et à peu près de la méme longueur que ceux du loir.

- Celle description se rapporte à l'espece du polatonch I) Iméri,jue, oclun M. Desmarel. 
Le polatouche a quatre doigs et. quelques vestiges du pouce dans les pieds de d.vant, ef pualre doigts avec le pouce entier dans les pierls de derrière conme l'écurenil et les rats ; uais tous les doigts sont à proportion moins lon:s et moins gros yue ceux de l'écureuil, et à peu près tle la me̊me grandeur unue crux lin lérot.

Le polatouche diffère des rats, de l'ćcureuil et de tout autre animal connu, prar des prolongements de la peau du dos, du ventre et les jamhes qui s'ètendent de la longueur d'environ un pouce de chaque cótẻ du corps, de la longueur de neuf lignes sur le coté extérieur de l'avant-bras, seulement de trois lïnes sur le còtẻ extẻrieur de la jambe, et de ciuq lisnes à l'endroit du pli du coude ; ces prolongements embrassent le coude $e^{\imath}$ le genou, et se terminent au carpe et au tarse lorsque l'animal est en repos; lorsqu'il marclıe et qu'il court, ou qu'il nage, les prolongements de la peau sont peu apparents; mais lorsqu'on le jette en l'air, il les étend, et alors la partie antérieure du prolongement de l'avant-bras forme une sorte d'oreillon parce qu'elle est soutenue par un os long et déliè que l'on sf nt sous la pean et qui s'articule avec le carpe. Le polatonclıe ne peut pas rester en l'air, s'élever ni voler réellement par le mojen de ses prolongements étendus, mais il se porte ublinuement en avant et en bas, et il retarde sa cliute, parce que le volume de son corps étant beaucoup plus étendu, quoique sa masse ne soit pas plus pesante, il oppose plus de résistance à l'air. A insi cet animal peut bien passer en l'air d'un lieu ì un an. tre, pourvu que l'endroit d'où il part soit plus élevé que celui ou il doit arriver, à propurtion de la distance qui est entre deux : il peut ainsi se soutenir dans sa clute en tombant d'une certaine hauteur; mais il ne tomberait certainement pas de bien launt sans se tuer, parce que le volume qu'il oppose à l'air ne serait pas capable de le soutenil contre l'accélération de sa chule si elle durait trop longtemps. Il ne m'a pas parı qu'il frappàt l'air avec ses prulonrements comme les oiseaux avec leurs ailes; il agite seulement sa queue en lui faisant faire des ondulations de còté et d'un hout a l'autre. Le rola. touche nage, comme les autres aumaux, sans ćtenare les prolongements de sa peau, et, ynoi.jue le poil soit mouille, l'animal se soutient en l'air comme s'il ètait sec, et il peut voler à sa manière en sortant de l'eau.

Le polatouche qui a servi de sujet pour cette description, étanı ètendu avec ses p olongements, avait toute la face supérieure de la tête, du corṇs, des jambes et de la queue de couleur mèle de centré et de jaune, exceptè une tarlı hlanchitue qui était au-dessus de chanue oil ; le tour cles yeux avait une couleur cendrée noirâtre; le les: us: de Ia tête ot du cou était de couleur inêlée de cendlé clair et de jaunâtre; le dos, la croune, la face su. périeure des prolongements et des jambes avaien: les mèmes couleurs, mais le cendré était nuirảtr. et le jaune plus fonce; la face superieure de la queue avait ı. ne teinte jaunâtre mèlèe avec dı cen tré-brun ; tous les poils ètaient de couleur cendrée près de la racine, et jaune à l'extrémité. La face inferienre de l'aniual, depuis le bout du musean jusqu’à l'origine de la queue, était de couleur blanclie avec quelıues teintes de jau "e sur le bord des prolongements de la peau du corps et sur les poils du còté extèrieur de la cuisst et de la jambe; la face inferieure de la queue avait une couleur jaunâtre : les plus lonıs poils étaient sur la queıe; ils avaieut luuit lignes de lıngueur; celle des poils du corps était de quatre ou cinı lignes, et même de six :errière la cuisse: les moustaches avaient deux pouces de longueur, et elles étaient noires.

\section{LE TAGUAN}

ou

\section{GRAND ÉCUREUIL VOLANT.}

\section{(Le polatouche taguan.)}

\section{Ordre des rongeurs, genre écureuil. (Cuvier.)}

Nous a vons dit qu'il existe de plus gránds polatouches que ceux dont nous avons donné la description, et que nous avions au Cabinet une peau qui ne peut provenir que d'un animal plus grand que le polatouche ordinaire. M. Iaubenton a fait la description de cette peiu. Elle a en effet cing pouces et demi de long, tandis que la peau du polatouche ordinaire n'a guère que quatre pouces de longueur; mais cette différence n'est rien en comparaison de celle qui se trouve, pour la grandeur, entre notre polatouche et le taguan des Indes orientales, dont la déponille a été envoyée de Mahé à S. A. S. monseigneur le prince de Condé, qui a eu assez de bonté pour me la faire voir et en conférer avec moi. Ce grand écureuil volant, conservé dans le très-riche cabinet de Chantilly, a vingttrois pouces de longueur, depuis le bout du nez jusqu'à l'ex trémité du rorps. 11 se trouve nonseulement à Mahé, mais aux iles Philippines, et vraisemblablement dans plusieurs autres endroits des Indes méridionales. Celui-ci a été pris dans les terres voisines de la cóte du Malabar: c'est un géant en comparaison du polatouche de Russie et mème de celui d'Amérique; car com- 
munément crux-cì n'ont que quatre pouces et demi ou ciny pouces tout au plus. Néanınoins le taguan ressemble pour la forme au palatouche dont il a les principaux caractères, tels que le prolongement de la peau qui est tout à fait conforme; mais comme il en differe excessivement par la graudeur et assez évidemment par d'autres caracteres que je vais indiquer, on doit en faire une espèce séparée de celle dlu polatouche, et e'est par cette raison que nous l'avons indiqué par le nom de laguan qu'il porte aux îles Philippines, selon le témoignage de quelques voyageurs.

Le taguan difière done du polatouche: $1^{\circ} \mathrm{par}$ la grandeur, ayant vingt-trois pouces de longr, tandis que le polatouche n'en a pas eing; $2^{\circ}$ par la queue, qui a près de lingt-un pouces, tandis que celle du polatouche n'a guere que trois pouces et demi: d'ailleurs la (fueuc n'est point aplatie comme celle du polatouche, mais de forme ronde, assez semblible à celle du cliat, ct couverte de longs poils bruns noiràtres. $3^{\circ} 11$ paraît que les yeux et les oreilles de ce grand ćcureuil volant sont placés et enfoncés comme ceux du polatouche, et que les moustaches noires sont relativement les mèmes; mais la tête de c'e grand écureuil volant est moins grosse à proportion du corps que celle du palotouche. $4^{\circ}$ La face est toute noire; les cotés de la tète et d's jou's sont mêlés de poils noiratres et de poils blanes; le dessus du nez et le tour des yeux sont couverts des mèmes poils noirs, roux et blanes. brricre les oreilles sont de grands poils d'un b)'un musc ou minime, qui couvrent les côtés du cou, ee yui ne se roit point sur le polatouche. l.e dessus de la tète et de tout le corps, jusques auprès de la queue, est jaspé de poils noirs et hane's où le noir domine; car le poil blane est noiratre à son origine, et ne devient blane qu'à un tiers de distance de son extrémité. Le dessous du corps est d'un blane gris terne, et cette couleur s'étend jusque sous le ventre. $5^{\circ}$ Le prolongement de la peau est couvert au-dessus de poils d'un brun musc, et en dessous de poils cendrés et jaunatres. Les jambes sont d'un roux noir qui se réunit au-dessus de la queue, et rond la partic supéricure de la queue brune. Cette nuance de brun augmente imperceptiblement jusqu'au noir, qui est la couleur de l'extrémité de la queue. $6^{\circ}$ Les pieds de ce grand ícureuil rolant oast le mème nombre de dojerts une ceux du polatouche; mais ees doigts sont couverts de poils noi:'s, tandis que ceux su polatouche le sont de poils blanes. Les ongles sont courbes et assez minces, et leur empattement est large et crochu à l'extrémité, comme dans les chats. Ces rapports et celui de la ressemblance de la queue ont fàit donner à cet animal la dénomination de chrel volunt, par ceux qui l'avaient apportí. A u reste, le plus grand ongle des pieds de devant avait eing lignes et demie de longueur, et le plus grand ongle des pieds de derriere cing lignes seulement, quoiqu'il soit d'une forme plus allongée que ceux de devant.

On peut voir la figure de cet animal rare que 11. de Sève a dessiné aussi parfaitement que l'état de sá dépouille pouvait le permettre. Nous lui avons donné le nom de targuan, en conséquence d'un passage que nous avons trouvé dans les voyageurs, et que je dois rapporter ici :

"Les iles Philipines sont le seul endroit ou l'on voie une espece de chat volant, de la grandeur des lièvres et de la couleur des renards, auxquels les insulaires domnent le nom de $t a$ guan. Ils ont des ailes comme les chauves-souris, mais couvertes de poil, dont ils se servent pour sauter d'un arbre à l'autre, à la distance de trente palmes. "

Après avoir rédigé cet article, l'ouvrage de M. Vosmaër, qui contient la description de quelques animaux quadrupèdes et de quelques oiseaux, m'est tombé entre les mains. J'y ai vu avec plaisir la deseription de ce grand écureuil volant, et quelques notices au sujet du politouche ou petit écureuil volant.

M. Vosmaër dit qüil a vu deux petits polatouches vivants, mais qu'ils u’ont pas véeu longtemps à la ménagerie de S. A. S. monseigneur le prince d'Orange.

( Ils dormaient, dit-il, presque toute la journée. Quand on les poussait vivement, ils faisaient bien un petit saut comme pour voler; mais ils s'esquivaient d'abord avec frayeur, car ils sont peureux. Ils aiment beaucoup la chaleur, et si on les découvrait, ils se fouraient au plus vite sous de la laine qu'on leur donnait pour se coucher. Leur nourriture était du pain trempé, des fruits, ete., qui ils mangeiient de la mème façon que les écureuils avec leurs pattes de devant et assis sur leur derriere. A l'approche de la nuit on lis voyait plus en mouvement. La différence du climat influe certainement beaucoup dans le changement de nature 
deces petits animanx, qui paraissent fort délicats. "

Ce que je viens de citer, d'après M. Vosmaēr, est très-conforme à ce đ̧üu j'ai vu moi-même sur plusieurs de ces petits animaux. J en ai encore ictuellement un ( 17 mars 1775 ) vivant dans whe cage, au fond de laquelle est une petite cabanc faite exprès. Il se tient tout le jour fourré clans du coton, et n'en sort guère que le soir pour prendre sa nourriture. Il a un très-petit cri, comme une souris, qu'il ue fait entendre que quand on le force à sortir de son coton; il mord même assez serré, quoique ses dents soient tres-petites. Son poil est de la plus grande finesse au toucher. On a de la peine à lui faire étendre ses membranes; il faut pour cela le jucher haut et l'obliger à tomber, sans quoi il ne les développe pas. Ce qu'il y a de plus singulier dans cet animal, c'est qu'il parait extrêmement frileux, et je ne concois pas comment il peut se garantir du froid pendant l'hiver dans les climats septentrionaux, puisqu'en France si on ne le tenait pas dans la chambre, et qu'on ne lui donnât pas de la laine ou du coton pour se coucher et même pour s'envelopper, il périrait en peu de temps.

A l'égard du taguan ou grand écureuil volant, voici ce qu'en dit N. Vosmaër'

"Le polatouche décrit par M. de Buffon a sans contredit une grande conformité avec celui-ci; il a les membranes pareilles au polatouche, non pas pour voler, mais pour se soutenir en l'air quand il saute de branche en branche.

"Le grand écureuil volant que je décris ' ne m'a été envoyé qu'en peau desséchée. M. Allamand a donné une description abrégée de cet animal, d'après un sujet femelle, conservé à Leyde dans le Cabinet de l'academie.

"Valentin est le premier qui en ait parlé; il dit qu'il se trouve dans l'ile de Gilolo. ll appelle ces animaux des civeltes voluntes; il dit qu'ils ont de fort longues queues à peu près semblables à celles des guenons. Lorsqu'ils sont en repos on ne voit point leurs ailes; ils sont sauvages et peureux; ils ont la tête rousse avec un mẻlange de gris foncé; les alles ou plutôt les

\footnotetext{
- Co nom me parait plus propie que celui de chat volant, sous lequel cet animal nous est antrement connu. La tċte, les dents et les griffes, ont plus de rapport avec les écureui!s que n'en a la simple queue velue, qui est parliculière au chat. L'éç thete de volant convient d'ailleurs assez a cause du grand : : - que fatt l'anjmal
}

membranes, collvertes de poils en dedans et $\rho_{11}$ dehors. Ils mordent fortement et sont en éta! de briser très-facilement une cage de bois dan: une seule nuit; quelques-uns les appellent des. singes volants. Ils se trouvent aussi à l'ile de Ternate, où l'on prit d'abord cet animal pour un écureuil, mais il avait la tète plus effilée et ressemblait davantage à un coescoes, ayant Ic poil gris depuis le museau, avec une raie noire le long du dos jusqu'au derrière. La peau était adhérente au corps et s'étendait; elle est garnie d'un poil plus blanc par dessous et blanc comme celui du ventre. Lorsqu'il saute d'un arbre à l'autre, il étend ses membranes et il paralt comme s'il était aplati.

- Dans l'ouvrage de M. l'abbé Prévost, on trouve un passage relatif à cet animal, qu'il dit, d'après les Lettres édifiantes, se trouver aux Iles Philippines, où on l'appelle taguan.

a J'ai vu quatre pièces relatives à cet animal, l'uue au cabinet de Leyde, l'autre au cabinet de M. Heeteren à la Haye, tous deux femelles, de couleur cbåtain clair sur le corps, plus foncé sur le dos, et le bout de la queue noirâtre. La différence de sexe se connaissait à six petits mamelons placés à distance égale en deux rangs à la poitrine et au ventre. Les deux màles étaient dans le cabinet de S. A. S. monseigneur le prince d'Orange.

Voici la description que M. Vosmaër donne de cet animal :

\section{Dimensions prises à la mesure du Rhin.}

Longueur du corps de l'animal. . . . . . . p. p. 5

Largeur du corps, les membranes étendues, prise auprès des pieds de devant. .... 0 \& 0

Largeur du corps, les membranes étendues, prise auprès des pieds de derrière.. . . . 0000

Longueur de la queue jusqu'à l'extrémité du poil.................. 180

Les pieds de devant étaut écartés, la ligne de distance entre le bout des ongles d'un côté

à l'autre donne.............. 106 Et celle des pieds de derrière. ....... 1 s 0

La tête est plus pointue que celle d'un écureuil.

"Les oreilles petites, pointues, couvertes en dehors d'un poil brun clair très-court et trèsfin, les yeux sont surmontés de deux longs poils d'un brun fauve; les paupières paraissent sans poils. Il y a des deux cótés du museau plusleurs poils on monstaches, longs, noirs et très-rai- 
les. Le nez est sans poils ; les dents sont comme celles des écureuils au nombre de deux en dessus, et deux en dessous, d'un jaune foncé; les intérieures sont fort longues; les dents molaires se trouvent aussi au fond du museau.

"Ses pieds de devant et de derrière, surtout ceux-ci, sont comme cachés sous la peau à voler, qui les recouvre presque jusqu'aux pattes, dont les antérieures sont divisées en quatre doigts tout noirs, les deux du milieu plus longs que les autres, surtout le troisième. Celles des pieds postérieurs sont aussi noires, et ont cinq doigts, quatre desquels sont d'égale longueur; mais le cinquième, qui est l'intérieur, est beaucoup plus court, et ne parait que comme un simple appendice. Les onglets sont fort grands et aigus, noirs en devant, blanes en dessous, et larges à leur origine. Les articulations de ces doigts sont semblables à celles des écureuils.

" La peau à voler, qui, dans notre figure, se montre étendue entre les pieds de devant et ceux de derrière, est le plus mince au milieu, où elle a environ quatre pouces de largeur de chaque côté, et ne passe pas l'épaisseur du fin papier des Indes. Ailleurs elle est cependant iussi fort mince, d'un tissu clair, et garnie de petits poils chátains. Près des pieds de devant et le derrière, elle devient plus épaisse ou s'élève in forme de coussinet, plus large aux cuisses, ('t allant en se rétrécissant vers l'extrémité des pattes. Cette partie est couverte de poils bruns et noirs, fort serrés. Sur les pattes de devant elle parait lâche et pend aupres ou par-dessus comme IIn lambeau qui est rond et revêtu de poils drus. Les bords extérieurs de cette peau sont courbés d'une lisière épalsse de poils noirs et gris.

"La partie supérleure de la tête, le dos et l'origine de la queue sont garnis de poils drus, assez longs, noirs à leur partie inférieure, et les sommités ou extrémités, pour la plupart, d'un blanc grisâtre.

" Les poils de la quene sont noirs, plus gris vers le corps, et dispersés de façon que la queue parait ètre ronde.

"Les joues, à côté de la tête, sont d'un grls brun; le gosier d'un gris blanchátre clair, ainsi ' fue la poitrine, le ventre et en dessous vers la queue. La peau à voler a aussi en dessous des poils gris, mais fort clair-semés. »
AdDition a l'article dU TAGUali.

Je dois mentionner ici un taguan, qui, quoique beaucoup plus petit que celui dont la dépouille est conservée dans le cabinet de S. A.S. monseigueur le prince de Condé, me parait néanmoins ètre de la même espèce. Il a été envoyé des cótes du Malabar à M. Aubry, curé de Saint-Louis, et il est maintenant au cabinet du roi. Il n'a que quinze pouces neuf lignes de longueur, ce qui ne fait que les deux tiers de la grandeur de celui de monseigneur le prince de Condé; mais aussi est-il évidemment be ucoup plus jeune, car à peine voit-on les dents molaires hors des gencives. Il a, conıme les écureuils, deux dents incisives en haut et deux en bas; la tête paraît être petite à proportion đu corps; le nez est noir; le tour des yeux et les mâchoires sont noirs aussi, mais mêlés de quelques poils fauves. Les joures ct le dessus de la tête sont mèlés de noir et de blanc; les plus grands poils des moustaches sont noirs et ont un pouce dix lignes de longueur; les oreilles sont, comme dans les écureuils, garnies de grands poils noirâtres qui ont jusqu'à quatorze lignes de longueur derrière les oreilles, les poils sont d'un brun marion, et ils ont plus de longueur que ceux du corps. Le dessous du cou est d'un fiure foucé, mélangé de noir; les bras ou jambes de devant jusqu'au poignet où commence le prolongement de la peau, sont, ainsi (pue cette peau elle-même, d'un noir mélangé de fauve ; le dessous de cette peau est d'une couleur cendrée, mêlée de fauve et de brun. Tout le poil de dessous le corps, depuis le sommet de la tete jusqu'à la queue, est jaspé de noir et de blanc, et cette deruière couleur domine en quelques en droits; la longueur de ce poil est d'environ un pouce. Les cuisses, au-dessous du prolongement de la peau, sont d'un fauve où le noir domine; les jambes et les pieds sont noirs. Les ongles qui ont cinq lignes de longueur sont assez courts. Le dessous du corps est d'un blanc gris qui s'étend jusque sous le cou. La queue, longue d'un pied einq pouces, et garnie de longs poils qui ont dix-huit lignes de longueur : ce poil est d'un gris noir à l'origine de la queus, , t devlent toujours plus noir jusqu'à l'extrém:té.

En comparant eette description et la figure de ce taguan a vec celle du taguan di cabinet de. Chantilly, on n'y trouvera qu'une seule dific rence qui d'abord pourrait paraitre essentielle; 
c'est, que its oreilles de ce grand tagruan ne paraissent pas garnies de poils, au lieu que celles de celui-ci en sont très-bien fournies : mais cette différence n'est pas réelle, parce que la tête $d u$ taguau de Chantilly avait é.é maltraitée et même mutilée, tandis que celui-ci a été soigneusement couservé, et est arrivé des Indes en trèsbon état. On doit donc s'en rapporter, pour la connaissance exacte de cet animal, à cette dernière figure, plutòt qu à la première

\section{I.E PETIT-GRIS.}

\section{(L'ÉCUREUIL GHIS.)}

Orilre des raugeurs, genre écureuil. (Cuvier.)

On trouve dans les parties septentrionales de l'un et de l'autre continent l'animal que nous dommons ici sous le nom de Petit-i, ris; il ressemble beaucoup à l'écureuil, et n'en difièreà l'extérieur que par les caractères suivants : il est plus grand que l'écureuil; il n’a pas le poil roux, mais d'un gris plus ou moins foncé; les oreilles sont délıuées de ces longs poils qui surmontent l'extrémité de celles de l'écureuil. Ces différences, qui sont constantes, paraissent suffisantes pour constituel une espèce particul'ère à laquelle nous aıous donné le nom de Petitgris, parce quel'on connait sous cemème nom la fourrure de c'et imimal. I'lusieus auteurs prétendent que les petits-gris d' Europesont différents de ceux d'Améliyue; q.e ces petits-gris d'Europe sont des écureuils de l'espèce commune, dont li saison change seulement li couleur dans le climat de notre nord. Sans vouloir nier absolument ce dernier fait, quj cependant ne nous parait pas assez constaté, nous regardons le petit-gris d'Europe et celui d'Amérique ımme le mème anirnal, et comme une espèce distincte et séparée de celle de l'écureuil commun : car on trouve dins l'Amérique septentrionale et dans le nord de l'Europe nos écureuils; ils y sont de la mème grosseur et de la mème couleur; c'est-á-dire d'un rouge ou roux plus ou moins vif, selon la lempérature du pays; et en méme temps on y voit d'autres écureuils qui sont plus grands, et dont le poil est gris ou noiràtre daus toutes les saisons. Dailleurs la fourrure de ces petits-irris est beaucoup plus fine et plus douce que celle de nos écureuils : aiusi nous croyous pouvoir assurer que ce sont des animaux dont, les dif- frerences étant constantes, les espèces, quoique voisines, ne se sout pas melées, et doivent par conséquent aroir chacuue leur nom. II. Regluard ' dit aftirmativement que les petits-gris de la Laponie sont les mêmes animaux que nos écureuils de France : ce témoignage est si positif, qu'il serait sufiisant, s'il n'était pas contred.t par d'autres témuignages; mais M. Regnard, qui nous a donné d'excellentes pièces de tliéâtre, ne s'était pas fort o cupé d'histoire naturelle, ef il n'a pas demeuré assez longtemps en Laponie pour avoir vu de ses yeux les écureuils changer de couleur. Il est vraj que des naturalistes, entre autres M. I.innæus, ont écrit que dans le nord le poil de l'écureuil change de couleur en hiver ${ }^{2}$. Cela peut être vraj : car les lièvres, les

1 Ces petils-gris sont ce que nous appelons écurevils en France, yui changent leur cuuleur rousse Jorayue l'luiver el les neiges leur en fout prendre une grise; jlus ils sont avant vers le nord. el p'us il, siont gris : les lapons leur font beaucoup la guerie peudant l'hiver. el leurs chiens sunt si bieu lisits à ceıte cliasse, yüils n'en laisseul passer aucuns sans les apercevuir sur les arbies les plus élevés, et avert.r pur lu aboientuent les Lapons qui étaicut avec nous. Nuus en tu isne. quelyues-mus à cuups de fusil, car lıs Lapons navaien! papour lors leurs lleches rundes avec li'syuelles ils les assumment, et uous eùmes le plaisir de les voir ecorelier avec unc vitesse surprenante. Ils commencent a faire la classe aux $\mu \mathrm{e}$ tits-gris yers la Saint-Nichel, el lous les Lajons géuéraltun'nt s'occuy nt à cet emploi, ce yui fait ıu’ils soul a grand marché, et yu on en dunne un timbre pour un e.cu; ce timbre esl composé de (puarante peaux. Ma:s il n'y a poinl de onar. hall.

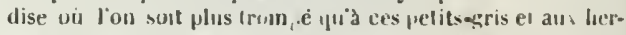
mines, parce yue vous achetez la marchanise sans la voir el yue la peau est relournce, en vorte yque la linirua:e est t"l

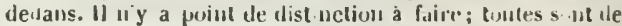

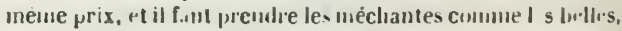
чui ne coilew pas plus les unes yur les antres Nums apurimes avec nus Lamns une $p a$. l:cularité surprenarite twehant

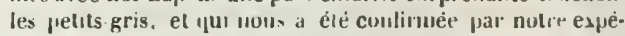
rience : vu ne rincumlre fras tomours le ces anim:ux dans une mene yu.utité; ils changent bien suuent de pays, et l"un n en tronvera pas mu daus I, ut mu liver ou l'année pré-

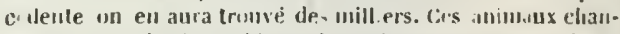
gent ule contrée; lurstuils veulent aller rn un antre rndroit,

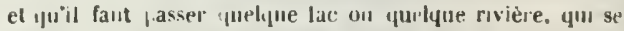

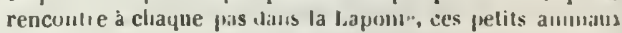
prrumenl une écurc. de fiu ou de bunleau guilis tur ul sur le burd de l eau, sur latu-dle ils se meltent el s'abandonnont ainsi an gre du veut. épvat lenr quene eu furup ile vuiles.

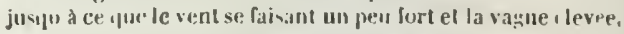
elle reuvere en mine temus ot le vaims n el le pilute. (ie

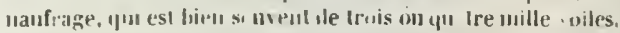
euridhit ordinatrement fuelyues I.apuns yui trunvent cos deLivis sur le rivaze, el les funt servid à leur us.ıge ur.liudire.

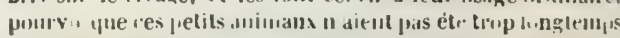
sur le s.ils.: il y en a yuantule yui font nur lav ga iun heu-

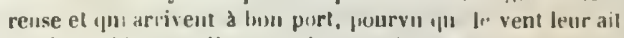
élé favoralıle él qu il a ait puint causé de lempret. sur l'ian,

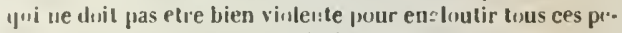
lits bátiments. Cetle parien larite pourrail passer pumr ui co .t. si je ne la tenais par ma pupre expérience. Euvres d.

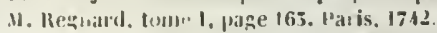

${ }^{3}$ Scmins vil gillis.. Labilat in ab bur.lus Ire puens, astate ruber, hjenie inedus. Vauna Suecica. p. 9. Stuclibulen, 17 .fi. 
loups, les belettes changent aussí de couleur dasis ce climat; mais c'est du fauve ou du roux au blinc que se fait ce changement, et non pas du fauve ou du roux au gris cendré. Et, pour ne parler que de l'écureuil, M. Linnæus, dans le Fuuna Suecica, dit, eslale ruber, hyeme incınu, il change donc du rouge au blanc, ou plutót du rouge au blanchâtre; et nous ne croyons pas que cet auteur ait eu de fortes rajsous pour substituer, comme il l'a fait, à ce mot incunus celui de rinereus, qui se trouve dans s.I desniere édition du Systema nuturce. II. Ilein ' assure au contraire que les écureuils „ulou' de Dantzick, sont rouges en hiver comme 'n été, etqu'il y en a communément en Pologne le guris et de moirâtres qui ne changent pas plus de couleur que les roux. Ces écureuils gris noirîtres se retrouvent en Canada ${ }^{2}$ et dans toutes les parties septentrionales de l'Amérique. Ainsi nous nous croyons fondés á regard er le petit-gris ou, si l'on veut, l'écureuil gris, comme un animal commun aux deux continents, et d'une espece diférente de celle de l'écureuil ordinaire.

D'ailleurs, nous ne voyons pas que les éeureuils, qui sont en assez grand nombre dans nos forèts, se réunissent en troupes : nous ne voyons p:Is qu'ils voyagent de compagnie, qu'ils s'approchent des eaux, ni qu'ils se hasardent à traverser les rivières sur des écorces d'arbı'es; ils diiffrent donc des petits-gris. non-seulement p.ır la grandeur et la couleur, mais aussi par les habitudes naturelles : car quoique ces navigations des petits-gris paraissent peu croyables, elles sont attestéts par un si grand nombre de témoins ${ }^{3}$, que nous ne pouvons les nier.

- Sciurus vulgaris... Eslate ruber, hyeme cinereus. Syst. Nitl., ed. X, p.n. 63.

. Sciurus vulgaris rubicundus... Nostrates tam in silvis iquam 11 rascis sulgat evel hyeme et astate rut ri... In Pulunia uti-

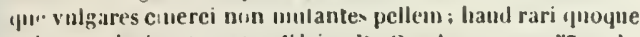
vulgares nigricantes. cte. Klei», lle Quadrup, pag. $5 \overline{5}-$ in thraind. inter scuros coloris ruliti. ugricantes speclantur. Rz.lczynski. antet. Itist. Nat. Polon.. pag. 321.

2 Les iscurleux de Virginie approchent fort de la grandeur de nus connuls: ils smit huirs un meles de nuir el de blanc Turtefuis la pulus gramle partie sont cendrés Descriptimu des lıules occidintales. par deau te laēt, păge 88. - ta plus line

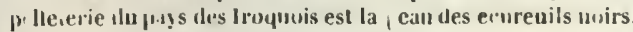
Let ammal est gros comme un ellat de trois mois. d'une grande vivacité, fort doux el tiès-facıle a apprivoiser. L.es tro-

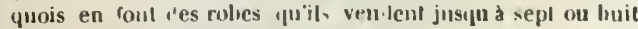
pialules. Ilistoire de la Nunvelle-France, par le P. Cliarlevoix, lume 1, page 273. P.ris, 1714.

- Rci veritate uititur. yuud Gesnerus ex v'lucentio Belua-

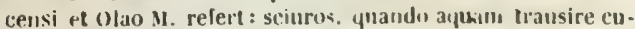

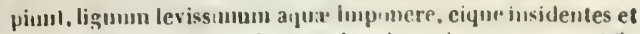
cillili brulanen it vult, erecla sed cuntimu westa, veliti-
Au reste, de tous les animaux quadrupédes non domestiques, l'écureuil est peut-être celul qui est le plus sujet aux variétés, ou du moins celui dont l'espéce a le plus d'espèces voisines. L'écureuil blanc de Sibérie' ne paralt être qu'une variété de notre écureuil commun. L'écureuil noir ${ }^{2}$ et l'écureuil gris foncé 3 , tous deux de l'Amérique, pourraient bien n'ètre aussi que des variétés de l'espèce du petit-gris. L_écureui] de Barbarie, le palmiste et l'écureuil suisse, dont nous parlerous dans l'article suivant sont trois espèces fort voisines l'une de l'autre.

On a peu d'autres faits sur I histoire des petits. gris. Fernandes dit que l'écureuil gris ou nolrâtre d'd mériçue se tient ordinairement sur les arbres et particulièrement sur les pins; qu'jl se nourrit de fruits et de graines, (quil en fait provision pour l'hiver, quil les dépose daus le creux d'un arbre où il se retire lui-méme pour passer la mauvaise saison; qu'il y fait aussi ses petits, etc. Ces habitudes du petit-gris sont encore différentes de celles de l'écureuil, leçuel se construit un nid au-dessus des arbres comme font les oiseaux. Cependant nous ne prétendons pas assurer positivement que cet écureuil noirâtre de Fernandès soit le mème que l'écureuil gris de Virginie, et que tous deurx soient aussi les mêmes que le petit-gris du nord de l'Europe: nous le disons seulement comme une chose qui nous parait ètre très-vraisemblable, parce que ces trois animaux sont à peu près de la mène grandeur, de la mème couleur et du méme climat froid; qu'ils sont précisément de la mème forme, et qu'on emploie également leurs peaux dans les fourrures qu'on appelle petit-y ris.

eantes. neque flante vento, sed tranquillo aquore trausv hi ; quod file dignus fidusifue mens emussarius ad iusulas Goth. ?an lia plus simplici vice observavit, el cun spoliis in lituribus ibidem cullectis redux, miralundus unihi rellulit. Iisserlatio de Seciuro volanle. Trausacl. Augl.. $n^{n}$ 427, jag. 38 Klein, lie Quadrup. flag. 35. - Comice intrrdunn sciurus navigat. I.inn., Syst. Nat., pag. 63, ed. X.

- Sciumis albus sibericus. L'ecureuil blane de Sibéric. Firsson, Regil. aliill., pag $15 \%$.

'Sciurus mexieauus. Hernanu., II st. Mexic., [1ag. \$82. -Scurins niger. L'écnreuil nuir. Brissuls. Ihegn. anın., p. 151.

- L'écurcuil d'Auréripue. Stba, vul. I, p ge 78, pl. ALVII.

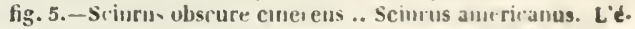
curenil d'sutrique, lirissul, liegn. anim., pag. 152. 


\section{DESCRIPTION DU PETIT-GRIS.}

\section{EXTBAIT DE DALBETTON.)}

Le Petit-gris ${ }^{1}$ ressemble à l'écureuil par la forme du corps, mais il en diffère beaucoup par les couleurs du poil. Celıi qui a s+rvi de sıjet pour cette description, n'arait point de bouquets tle poils andessus des oreilles; il ètait plus grus que l'écureuil; son poil n'arait que de très-légères teintes de roux sur le museau, sur le sommet et les cótés de la tẻte, sur les nr.ille's, sur le dos et sur la quene; il y avait une tache de couleur rousse très-foncée sur la face supérieur: du métatarse. Le dessus du musea', le front, le sommet de ld téte et locciput avaient des teintes de gris et de noir mẻlées avec le fauve; les mémes teintes formaient une large hande qui s'étendait depuis I tutre-deux des épanles jusyu'au milieu du dos. Le tour des yeux était d'un blanc jaunâtre, et autour de ce blanc il y avait du jaune; la lèrre inférieure et les joues étai nt mélées de hlanc sale et de gris; la base des oreilles et la partie infẻrienre de leur face interne etaient blauches. Le dessus et les côtés du cou, l'èpanle, la face extérieure du bras et de l'avantbras, le dessus des pieds de devant, les cotés tle la poitrine et dı corps, la partie posterieure du dos, la croupe, la face exterieure de la cuisse et de la jambe avaieıt des teintes de blanc, de noir et de fauve. Le poil de toutes ces parties élait de rouleur cendrée, noirâtre près de sa racine; plus laaut il était alternativement de coule:ır fauve, ou blanclıâtre, ou blanclıe, et de couleur noire. La mâchvire inférieure, la gorge, le dessous du cou, les aisselles, la face intérieure du bras et de l'avantbras, la poitrine, le ventre, les aines el la face intérieure de la cuisse et cle la jambe ètaient d'un blanc nıẻlé de quelques teintes de cendré et le jaunåtre; ceite dernière couleur dominait aux aleutours des parties de la génération et de l’anus. La queue étant étendıe en panache ıvail dı blanc sur ses bords; le milieu était mẻlé de hlanc, de noir et de fauve, parce que les poils avaient sıccessivement du noir et du fauve et la poinse blanclie. Le poil du corps avait jusqu'd nenf ou dix lignes de longueur, et celui de la queue plus de deux pouces.

+ Cet animal est l'écureuil gris d'Amériane, et non le pelitgris dle Sibérie.

\section{LE PALAlOSE}

\section{LE BARBARESQUE ET LE SUISSE.}

\author{
'L'éc:ureuil palmiste. - L'Écureuil barba- \\ RESQUE. - L'ÉCUREUIL SUISSE.)
}

Ordre des rongeurs, genre écureuil. (Curier.)

Le palmiste est de la grosseur d'un rat ou d'un petit ćcureuil ; il passe sa vie sur les palmiers, et c'est de là qu’il a tiıé son nom: les uns l'appellent rat-paliniste, et les autres l'écureuil des pulmiers; et comme il n'est ni écureuil, ni rat, nous l'appellerons simplement palmiste. Il a la tète a peu près de la même forme que celle du campagnol, et couverte de même de poils hérissés. Sa longue queue n'est pas trainante comme celle des rats; il la porte droite et relevée verticalement, sans cependant la renverser sur son corps comme fait l'écureuil : elle est couverte d'un poil plus long que celui du corps, mais bien plus court que le poil de la queue de l'écureuil. Il a sur le milieu du dos, tout le long de l'épine, depuis le cou jusqu'a la queue, une bande blanchátre accompagnée de chaque cóté d'une bande brune, et ensuite d'une autre bande blanchàtre. Ce caractère si marqué, par lequel il parait qu'on pourráit dlistinguer le palmiste de tous les autres animaux, se trouve à peu près le mème dans l'écureuil de Barbarie et dans l'écureuil suisse, qu'on a aussi appelé écureuil de terre Ces trois animaux se ressemblent a tant d'égarts, que M. Ray a pensé quils ne faisaient tous trois qu'une seule et même espèce; mais si l'on fait attention que les deux premicrs, c'est-à-dire le palmiste $e$ : l'écureuil de Barbarie, que uous appelons bas baresque, ne se trouvent que dans les climat chauds de l'ancien continent; (illau contrail le suisse ou l'écureuil suisse déesit par Lister Catesby et Edwards, ne se trouvi: que dans lt régions froides et tenupérées du Nouv'au-Mond. on jugera que ce sont des espècts différentes et en effet, en les examinaut de plus près, on voit que les bandes brunes et blanches du suisse sout disposées dans un autre ordre que celles du palmiste; la bande blanche qui s'étend, dans le palmiste, le loug de l'épine du dos, est noire' ou brune dans le suisse; les bandes blanches sont à côté de la noire, comme les noires sout coté de la blanche dans le palmiste; et l'ir:?. 
leur's, il n'y a que trois bandis blanches sur le palmiste, au lieugu ill y en aquatre sur le suisse. Celui-ci renverse sa queue sur son corps, le palmiste ne la renverse pas, il n'habite que sur les arbres, le suisse se tient à terre, et c'est cette diflérence qui l'a fait appeler écureuil de lerre; enfin, il est plus petit que le palmiste : ainsi l'on ne peut douter que ce ne soient deux animaux différents.

A l'égard du barbaresque, comme il est du même continent, du même climat, de la même grosseur et à peu près de la même figure que le palmiste, on pourrait croire qu'ils seraient tous deux de la même espèce et qu'ils feraient sculement variété dans cette espèce. Cependant en comparant la deseription et la figure du barbaresque ou écureuil de Barbarie, donnée par Caius et copiéc par Aldrovande et Joluston, a vec la description et la figure que nous donnons jei du palmiste, et en comparant ensuite la figure et la description de ce mème écurcuil re Barbarie, donnée par Edwards, on y trouvern des différenees très-remarquables et qui indiquent assez que ce sont des animaux différents : nous les avons tous deux au Cabinet du Roi aussi bien que le suisse. Le barlaresque a la tête et le chanfrein plus arqués, les oreilles plus grandes, la queue garnie de poils plus touflus et plus longs, que le palmiste; il est plus écureuil que rat, et le palmiste est plus rat cqu'écureuil par la forme du corps et de la tète. Le harbaresque a quatre bandes blanches, au lieu que le palmiste n'en a (que trois; la bande blanche du milieu se trouve dans le palmiste sur l'épine fu dos, tandis que dans le barbaresque il se trouve surla nème partic une bande noire mèlíe dle roux, ete. Au reste, ees animaux ont à peu près les mèmes habitudes et lemèmenaturel que l'écureuil commun; commelui, le palmiste et le barbaresque vivent de fruits, et se servent de leur's pieds de devant pour les saisir et les porter à leur gueule; ils ont la mème voix, le mème eri, le même instinct, la même agilité ; ils sont très-vifs et très-doux; ils s'apprivoisent fort aisément, et au point de s'attacher à leur demeure, de n'en sortir que pour se promener, d'y revenir ensute d'cux-mèmes sans ètre âppelés ni contraints; ils sont tous deux d'une très-joliefigure; leur robe, rayée de blane, est plus belle que celle de l'écureuil ; leur taille est plus petite, leur corps est plus léger et leurs mouvements sont aussi prestes. Le palmiste et le barbaresque se ticnnent, commc l'écureuil. au-dessus des arbres; mais le suisse se tient à terre et s'y pratique, comme le mulot, une retraite impénétrable à l'eau : il est aussi moins docile et moins doux que les deux autres; il mord sans ménagement, à moins qu'il ne soit entièrement apprircisé. Il ressemble done plus aux rats ou aux mulots qu'aux écureuils, par le naturel et par les mœurs.

\section{ADDITION A L'ARTICLE DU PALMISTE.}

Nous a vons dit que cet animal passait sa vic sur les palmiers, et qu'il se trou rait principalement en Barbarie ; on nous a aussi assuréqu'on le trouvetrès-communémentau Sénégal, dans le pays des nègres Jalofes, et dans les terres roisines du Cap-Vert. Il fréquente les licux découverts et voisins des habitations; et il se tient encore plus souvent dans les buissons à terre, que sur les palmicrs. Ce sont de petits animaux très-vifs ; on les voit pendant le jour, traverser les chemins pour aller d'un buisson it l'autre; et ils demeurent à terre aussi sou rent au moins que sur les arbres.

\section{DESCRIPTION DU PALMISTE.}

(EXTRAIT I)E DACBENTON.)

Le Palmiste qui a servi de sujet pour cette de:cription n'etait pas alılte; il avait beauroup ule rapport an campasnol par la forme de la téte ini était couverte par un poil lıérissé: les oreilles ctaitu? courtes, larises et garuies de poil primipalement sur leur face intrue. La quene avait a's muins antant de longuemr que le corps et la tite de l'animal en entier; elle ctait revètue de poils plus longs que cenx du curps, car ils avaient quatre li mn s lle longueur, landis que celle du poil du corps u'elait que de trois lignes. Il y avait cinq doigts int pieds de derriere, el senlement quatre a ceux de llevant; on n'apercevait à l'enclroit dn ponce qu'un trèspetit unbercule.

Le poil du dessus de la tète, depuis le lout dı musean jusqu'à l'oeciput, étint le couleur nẻlèe de roussâtre et de brun; le dessus du cou, les coités de la tète et ln con, la parlie antíriemre du dos, l'épaule et la face externe le l'avaut-loras ava nt des teintes de brun et dle gris, on de hlanc sale. Il y avait sept bundes, quatre lormes et trois de conleur de hlanc sale ıui s"etendaient sur le dos et sur les lombes jusqu'à l'origine de la quene : l'une dos 
baudes banclıátres se trowait placeje le long du nulieu du dos el des lombes, tlle était fort étroite: on voyait de cha iue côté de cette bande błanclıâtre une large bande brune, ensuite une bande blanchåtre un peu plus large que celle du milieu, et enfin une bande brune á peu près de la mème largeur que la bande blanclıatre qui la précédail. Toute la face inférieure du corps de l'animal, depuis le bout du museau jusqu'à l'origine de la queue, avait une couleur blanchaitre presque grise. La couleur du poil de la queue était mêlée de gris et de brun noirâtre qui semblait former des anneaux fort étroits; clıayue poil avait du noir près de la racine, du gris au-dessus du noir, et enfin du noir à la pointe.

J'ai observé un autre palmiste qui était empiillé, et qui ma paru de mème espèce que le prècédent; il avaiı sur le dos ırois bandes blanclıâtres lègèrement teintes de jaun et longitud.nales, mais il était plus grand que le jeune palmiste, aussi il en ılifférait par les couleurs du poil. La face superieure lu corps, àl'exception des trois bandes dont ii vieut d'être fait niention, avait une couleur mêlée de roussàtre, de wris et de brun noiràtre : la face inférieure ètait de couleur blanche avec yuelyues tein. tes de jaune. Les p.ils de la queue formaient un panaclie; ils avaient jusqu’à onze lignes de lıngueur; chaque poil était de couleur roussâtre à son origine; il avait ensuite du noir, du roussâtre, du noir, et enfin l'extrémité était blanche, de sorte qu'en regardant la queue par-dessous on voyait de chayue cỏté du tronçon une large bande roussàtre parallèle au ironçou, et ensuite une baude étroite et noire, une banıle ètroite et roussâtre, une large bande noire, et enfin une large bande blanche.

\section{LE COQUALLIN'.}

\section{(L'Écuneuil Coquallin.)}

Ordre des rongeurs, genre écurenil. (Cuvier.)

J'ai reconnu que cet animal, qui nous a été envoyé d'Amérique, sous le nom d'écureuil orangé, était le mème que Felnandez ${ }^{2}$ a indiqué sous celui de Quaugtcrllolqu"pachli ou Coztiocotrquallin; mais, comme ce's mots de la langue mexicaine sont trop difliciles à prononcer pour nous, j’ai abrégé le dernier et j'en ai fait $c$ quallin, qui sera dorénavant le nom de cet animal. Cé n'est point un écureuil, quoiqu'il

M. F. Cuvier pense que cal écureuit ne diffère pas spécifiquement de f'écurenil capistrale de $\mathbf{M}$. lHosc.

${ }^{2}$ Fr. Fernandez. Ilist. anim. Nov.-Hispan.. cap Xxur, pag $x$. lui ressemble assez par la figure ct par le pana. che de la queve; (ar il en diffère non-seulement par plusieurs caractères extérieurs, mais aussi par le naturel et les mours.

Le coquallin est beaucoup plus grand que l'écureul : in duplam fere crescit muynitudinern, dit Fernandez. C'est un joli animal et très-remarquable par ses couleurs : il a le ventre d'un beau jaune, et la tête, aussi bien que le corps, variés de blanc, de noir, de brun ct d'orangé. II secouvre de sa yueue comme l'écureuil; mais iln'a pas, comme lai, des pinceaux de poil à l'extrémité des oreilles. Il ne monte pas sur les arbres; il habite, comme l'erureuil de terre, que nous a vons appelé suisse, dans des trous et sous les racines des arbres; il y fait sa bauge, et y élève ses petits : il remplit aussi son domicile de grains et de fruits pour s'en nourrir pendant l'hiver; il est défiant et rusé, et même assez farouche pour ne jamais s'apprivoiser.

Il parait que le coquallin ne se trouve que dans les parties méridionales de l'Amérique. Les écureuils blonds ou orangés des Indes orientales sont bien plus petits, et leurs couleur's sont uniformes; ce sont de vrais ćcureuils qui grimpent sur les arbres et $\mathbf{y}$ font leurs petits, all lieu que le coquallin et le suisse d'Amérique se tiennent sous terre comme les lapins, et n'ont d'autre rapport avec l'écureuil que de lui ressembler par la figure.

\section{L'AYE-AYE.}

\section{(L'AYE-AYE MADECASLE.)}

Ordre des rongeurs, genre écureuil. (Curier.)

Aye-aye est une exclamation des habitants de Madagascar, que M. Sonnerat a cru devoir appliquer à cet animal, qui se trouve dans la partie ouest de cette ile. II dit " qu il ne se rap" proche d'aucun genre, et qu'il tient du maki, " de l'écureuil et du singe. Ses oreilles plates et " larges, ressemblent beaucoup à celles de la " chauve-souris; ce sont deux peaux noires " presque lisses, parsemées de quelques longs " poils noirs terminés de blanc, qui forment la " robe. Quoique la queue paraisse toute noire, " cependant les poils à leur base sont blanes " jusqu'ì la moitié. Son caractère principal, ct " un des plus singuliers, est le doigt du milieu 
de ses pjeds de devant; les deux dernières articulations sont très-longrues, grèles, dénuées de poils : il s'en sert pour tirer les vers des trous d'arbres, et pour les pousser dans son cosier; il semble aussi lui être utile pour s'accrocher aux branches. Cet animal parait terrier, ne voit pas pendant le jour, et son wil, couleur d'ocre de rue, est comme celui du ehat-huant. II est très-paresseux et par consé(juent tries-doux; celui-ci restait toujours couché, et ce n'est qu'en le secouant plusicurs fois qu'on venait a bout de le faire remuer. II a vécu près de deux mois, n'ayant pour toute ( nourriture que du riz cuit; il se servait, pour le manger, de ses deux doigts, comme les Chinois, de baguettes."

J'ai examiné de près la peau d'un de ces unimaux, yue M. Sommerat, ma domée pour e Cabinet du Roi; il m'a paru se rapproelier lu genre des écureuils plus que d'aucuu autre; I a aussi quelyue rapport a l'espece de gerboise fue j'ai donnée sous le nom de Tarsier.

L's pieds semblent faire un caractère unique et très-distinctif, par la longueur des doigts aux pieds de devant.

Longueur de l'auimal, mesuré en ligne droile depus le bout du museau jusqu'à l'origine

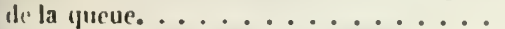
Suivant la contbuse du corps. . . . . . . Longurur de la tite depuis le bout dn musean jusqu’à l'occiput. . . . . . . . . . . l.ougueur de la jambe de devant, depuis le cousle jusqu'au poignet. . . . . . . . . Longuenr depuis le poignet jusquau bout des ongles. . . . . . . . . . .

Longueur de la jambe depuis le genou jusqu'au talou. .....................

Longueur depuis le talon jusquau bout des ungles................... 0 \& \& Longueur du tronçon de la queue. ..... 1330

La couleur de cet animal est d'un brun musc mèlé de noir et de gris cendré; il a sur la tête, autour des yeux, sur le corps, aux cuisses et aux jambes, une couleur de musc foncé, dans lacjuelle néanmoins le noir domine sur le dos, et en plusieurs endroits du corps et des jambes. La queue est tout à finit noire; les cótés de la tète, le cou, la mâchoire et le ventre sont grisâtres; des poils laineux, de cette couleur grise, sontau-dessous des griands poils noirs ou blan's, de deux outrois pouces de lour, qui sont sur le corps at les jambes; mais les jambes et les roisses sont d'un lorun rougeatre: le noir do- mine à l'approche des pieds, qui sont couverts de petits poils de cette couleur.

La tète a la forme de celle de l'écurcil; il y a deux incisives au-devant de chaque mâchoire. Les oreilles sont grandes, mues et sans poil, larges à leur ouverture, droites et rondes à leur extrémité.

Elles ont de longucur. . . . . . . . . . . p. $\begin{array}{cccc}0 & 2 & 1 & 1\end{array}$

Largeur au conduil auditir. ....... 0 (...

Il y a autour des yeux une bande brumitre, et les paupières sont noires.

Et au-dessus des yenx il y a de grands poils noil's qui ont de longueur. . . . . . 0 0 2 5

Ceux qui sont aux cỏtés des joues ont. . . . () 110

Le pied des jambes de devant, pris depuis le poignet jusqu'á l'extrémité des doigts , a. . 00 a

p. 1 . 1 .

Le doigt intérieur qui rail pouce.. . . I l l'ongle 6

Le prentier doigt interue après le pouce $29-6$

Le second doigt qui est le plus mince et grèle, "l’ayant qu'une ligne d'épaisseur, a de longueur. ..... 2 ; - i

Le troisième doigt. . . . . . . . 52 -

Le qualrième doigt on le premier ex-

terne............. \& $9-6$

Les pieds de drrrière ont de longueur,

jusqu'à l'extrèmité des doigts. . . $32-1 i$

Ces doigts qui ont deux lignes de largeur , sont à peu près égaux en grosseur; mais le premier doigt qui fait ponce et qui a de longueur douze lignes, a un ongle de trois pouces six lignes, qui est large et plat comme ceux des makis. Ce caractère de doigt l'éloigne beaucoup du genre de l'écur'euil.

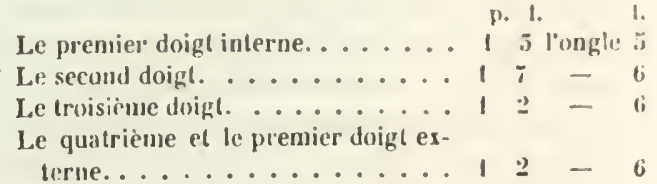

Ces ongles sont bruns, crubes et ea gonttiere I.es poils de la quicue ont de longueur. .......... 3 i

Ces poils sont rudes comme du crin. Tout le temps que M. Sonnerat a eu cet animal vivant, il ne lui a jamais vu porter la queue élevée conme les écureuils; il ne la portait que trainante. De tous les animaux qui ont le pouce aplati, le larsier est celui çui se rapproche le plus de l'aye-aye; ils ont cutre eux ce caractere commun, et de plus ils se ressemblent par la puene yui est longuc et couverte de poils, par les oreilles droites, mues et transparentes, et 
par ce poil laineux qui couvre immédiatcment la peau. Il y a aussi quelque rapport de ressemblance dans les pieds; car le tarsier a les doigts très-longs. Cet aye-aye était femelle : elle avait deux manelons dans la partie inférieure du ventre; ces mamelons avaient cinq lignes de hauteur.

Voyez l'article de l'aye-aye dans le Toyage de il. Sonncrat, aux Indes orientales, $t$. II. pag. $1: 7$. Il a eu vivants le mâle et la femelle.

\section{LE CABIAI. \\ (LE CABIAI CAPYBARE.)}

Ordre des rongeurs, genre cabiai. (Cuvier.)

Cet animal d'Amérique n'avait jamais paru en Europe, et c'est aux bontés de M. le duc de Bouillon que nous en devons la connaissance : comne ce plince est curieux d'animaux étranger's, il 'm'a quelquefois fait l'honmeur de m'appeler pour les voir; et, par amour pour le bien, i! nous en a donné plusieurs : celui-ci lui avait été envoyé jeune, et n'était pas encore tout à fait adulte lorsque le froid l'a fait mourir. Nous a vons donc été à portée de le comnaitre et de le décrire, tant à l'extérieur qu'à l'intérieur. Ce n'est point un cochon, comme l'ont prétendu les naturalistes et les voyageurs; il ne lui ressemble même que par de petits rapports, et en difière par de grands caractères : il ne devient jamais aussi grand : le plus gros cabiai est à peine égal à un cochor de dix-huit mois; il a la tète plus courte, la gueule beaucoup moins fendue, les dents et les pieds tout dif́fírents; des membranes entre les doigts, point de queue ni de défeuses; les yeux plus grands, les oreilles plus courtes; et il en diffère encore autant par le naturel et les mours, que par la conformation. Il habite souvent dans l'eau, où il nage comme une loutre, $y$ cherche de même sa proie et vient manger au bord le poisson (ju'il prend et gu'il saisit a vec la gueule et les ongles; il mange aussi des grains, des fruits ct des cammes de sucre. Comme ses pieds sont longs et plats, il se tient souvent assis sur ceux de derrière. Son cri est plutôt un braiement comrne celui de l'âue, qu'un grognement comme celui du cochon. Il ne marche ordinairement que la nuit, et presque toujours de compagnie, sans s'éloigner du bord des eaux : car cornme court mal à cause de ses longs pieds et de se jambes courtes, il ne pourrait trouver son sa lut dans la fuite; et, pour échapper a ceux qu le chassent, il se jette à l'eau, y plonge, et v. sortir au loin, ou bien il y demeure si long temps qu'on perd l'espérance de le revoir. S: chair est grasse et tendre; mais elle a plutot comme celle de la loutre, le goût d'un mauvai poisson que celui dune bonne viarde : cepen dant on a remarqué que la hure n'en était pa mauvaise, et cela s'accorde avec ce que l'ol sait $d u$ castor, dont les parties antérieures on le goût de la chair, tandis que les parties pos térieures ont le goùt de poisson. Le cabiai es d'un naturel tranquille est doux, il ne fait ujma ni querelle aux autres animaux : on l'apprivnisı sans peine; il vient à la voix et suit assez vo lontiers ceux qu'il connait et qui l'ont bies traité. On ne le nourrissait à Paris qu'arec di l'orge, de la salade et des fruits; il s'est bie porté tant qu'il a fait chaud. Il parait, par lo grand nombre de ses mamelles, que la femelk produit des petits en quantité. Nous ignorons I temps de la gestation, celui de l'accroissement et par conséquent la durée de la vie de cet ani mal. Nos habitants de Cayenne pourront nou: en instruire; car il se trouvent assez commune. ment à la Guiane aussi bien qu’au Brésil, au: Amazones et dans toutes les terres basses di l'Amérique méridionale.

\section{ADDITION A L'ARTICLE DU CABIAI.}

Nous n'arons que peu de choses à ajouteı aux faits historicques, et rien à la descriptior très-exacte que nous avons donnée de cet ani. mal d'Amérique. MI de La Borde nous a seu. lement écrit qu'il est fort commun à la Guiane. et encore plus dans les terres qui avoisinent $I$ fleuve de l'Amazone, où le poisson est très abondant : il dit que ces animaux ront tou jours par couple, le mâle et la femelle, et qu les plus grands pèsent environ cent livres. Il fuient les endroits habités, ne quittent pas I bord des rivières, et s'ils a percoivent quelqu'un: ils se jettent à l'eau, sans plonger comme les loutres, mais toujours nageant comme les co. chons; quelquefois néanmoins ils se laissenı aller au fond de l'eau, et y restent mème asse? longtemps. On en prend sourent de jeunes qu'on 
evé dans les maisons, où ils s'accoutument aiment à manger du pain, du mil et des légues, quoique dans leur état de nature ils vivent incipalement de poisson. Ils ne font qu'un tit; ils ne sont nullement dangereux, ne se tant jamais ni sur les hommes ni sur les chiens. zur chair est blanche, tendre et de fort bon út. Ce dernier fait semble contredire ce que sent les autres relateurs, que la chair du caai a plutôt le goût d'un maurais poisson que lui d'une bonne viande. Cependant il se pour it que la chair du cabiai vivant de poisson t ce mauvais goût, et que eelle du cabiai viunt de pain et de grain füt en effet trèsinue.

Au reste, comme nous avons eu à Paris cet imal vivant, et que nous l'avons gardé longmps, je suis persuadé qu'il pourrait vivre dans itre climat ; e'est par erreur que j'ai dit qu'il ait mort de froid. J'ai été informé depuis I'il supportait fort bien le froid de l'hiver, ais que comme on l'avait enferme dans un enier, il se jeta par la fenêtre et tomba dans I bassin ou il se noya; ce qui ne lui serait pas rivé s'il n'eût pas été blessé dans sa chute $r$ les bords du bassin.

\section{DESCRIPTION DU CABIAI.}

\section{(EXIRAIT de DALDENTUN.)}

Le cabiai a quelques rapports avec le cochon $r$ la rpualite du poil et par la forme du curps, de croupe et des jaubes; ces caractères lui ont fait mner le nom de cochon: et parce qu'il se plait Ins l'eau, yu'il plonge et qu'il nage avec d'autant us de facilité, qu'il a des nageoires entre les duigts, I l'a noumué rochon d eau pour le distinguer du ai co tın ; mais les caractères distinctifs sont en and numbre entre ces deux animaux; on en oure dans la forme de la tète, du nuseau, des ux, dles oreilles, du con; il y a aussi de grandes fferences ilan- les dents et daus les pieds. La plus ande est par rapport à la ifueue, car le cabiai ell a point; cette partie manıpue aussi au pr cari, l'agouti, au cochon d'Inde, etc. : ce dernier me rait jusqu'à présent avoir plus de rapport au caai que tout antre animal.

La tẻte du caliai est lungue, ses còtẻs sont aplas, le museau a beanco (p) plus d'éraisseur que de rgeur; la lèvre du dessous est moins a ancee que nez: celle du tersus a une echancrure au-lesus du nez, et laisse les dents incisives superienis a deconver, quoipue la bouche soil fermce, unerture de la bouche est fort petite. Cet animal a le nez. rond et de couleur cendrée noiratre, les oidvertures des narines eloignées l'une de l'autre et presque roudes, les yeux noirs et beaucoup plus grands que ceux du coclion; les cartilages ıles pau. pières noirs, les oreilles courtes, Iroites, nues, échancrées à l'extréunité et de mème couleur que le uez, le cou gros et très-court, le corps étuffé, h croupe ravalee, les janbe, courtes, principalement à l'eulroit dı métararıe; le fried de llerrière por. tait sur l. terre le plus souvent jưqu’ " jarret, c'est-a-dire jusqua an talon. Le proignet et les jieds étaient presque entièrement mus et de cuuleı cendrèe noiråtre; il y avait quatre doints aux pieds de devant, le second doint était le plus gros et le plus avancé, le premier et le troisième elaient moins gros et fllacés un peu en arrière, le quatrièute était le plus petit et le julus reculé; les piecks de derrière n'avaient que trois lluigts, ils étaient à proportion plus grands que cems iles pieds de devant, le doigt du milieu 'tait le plus gra il de tous, ceux des cótés étaient umins avancés, les ınglıs élait’nt plats et noirâlres. Il se trouvait entre les doizts une pe. tite nareoire formée par un prolongement de la peau, semblable à celıi yui est eutre les iluigts des coqs, des poules, etc.; il ı'y avail qu'un petit Iubercule à l'enilroit de la queue.

Le poil tait rare et de mènte qualité que les soies du coclıon, mais plus lin; celıi du dessus de la tête et du corps et de la face externe des jambes Itait noir sur la plus grande partie de sa longueur depuis son origine: il y avait au-dessus dı nuir une couleur fauve, et il etait noir à la pointe ; le proil du tonr des yeux, du dessous de la tèie et celui du corps et de la face interue des jambes n'avait y̧uine couleur fauve: les plus longues soies etaieut sur le dos et avaient environ deux ponces el demi de lowgueur; les crins des muustaclits elaient noir: et en partie détruits.

\section{I.E PACA.}

(LE PACA FAUVE.)

Ordre des rongeurs, faumille des lierres, genre cabia.. (Curier.)

Le paca est un animal du Nouveau-Monde , qui se creuse un terrier comme le lapin, auquel on l'a souvent comparé, et auquel cependant il ressemble très-peu : il est beaucoup plus grand que le lapin, etmeme que le lière; il a lecorps plus gros et plus ramassé, la tìte ronde et le museau court; il est gras ct replet, it il ressemble plutiot', par la forme du coops, à un jeune cochon, dont il a le groguement, l'allure

- Iloc genus auimallum pilis et vnce porcellum referunt, dentibu el figurt ca,flls, ef ctiam magutudine custrulun 
et la manière de manger; car il ne se sert pas, comme le lapin, de ses pattes de devant pour porter à sa gueule, et il fouille la terre, comme le cochon, pour trouver sa subsistance. Il habite le bord des rivières ', et ne se trouve que dans les lieux humides et chauds de l'Amérique méridionale. Sa chair est très-bonne à manger $^{2}$, et si grasse qu'on ne la larde jamais; on mange même la peau ${ }^{3}$, comme celle du cochon de lait : aussi lui fait-on continuellement la guerre. Les chasseur's ont de la peine à le prendre vivant, et quand on le surprend dans son terrier, qu'on découvre en devant et en arrière, il se défend et cherche même à se venger en mordant avec autant d'acharıement que de vivacité. Sa peau, quoique couverte d'un poil court et rude, fait une assez belle fourrure ',

auribus murem : sunt(pue singularia et sui generis Ray, Synops. Quaurup., pag. 227. II es! certaiı, comme le dit Ray, que cel animal est de son geure; il aurait pu ajouler qu"il ressemble cucore \$n rochon de lait par la forme du corps, par le gont el la blatuchenr de la chair, par la graisse et par l'épaisseur ıle la jueaı; i et il auraiı ın dıre yüil a le corps plus grus, plus graud et plus roud yue le lapju.

- Les pacas sont semblables aux petils pou ceaux de deux mois. ¿lesıuels il s en trouve une grande yuantité... princił̨alement auprès des rivages de la rivière de Saint-Franco.s. Desiviptiun des Indes iccidenlales, par l)e Laët, pige 484.

${ }^{2}$ Le paca est le , lus gras de tons les animanx de cayenne; sa chajr est exlremenn'nt boune et de bun font. Voyage à Cayenne en 1652, par Ant. Binet, page 3:0. P’aris, 1664. - Le pak est unc espèce de lapin fort connu; sa clıair esl beaucrup meil eure que celle de l'agoutj Barrère, líst. Fr équin., page 158. - Les paks du Brésil sont grands et ont la tèle el le nus'au s'mblahles aux chats, la peau grise, la couleur sombre tachelée de blanc; la chair extrèmement bonne et douce. Descript. des Indes occirlent., par Ilerrera, 1. 252. \& msterd., 1622.

- Le paca a le museau rond comme celui i"un cliat, la peau noire el marquelée de quelıues taches blanches; non-seulement la clıair, mais encore la peau en est rélicieuse, tendre et recherclýe dans les plıss délıcats festins. Histoire des lades, par Maffée, page 70. Paris, 1665.-Paca inagnitudine est porcelli, pingni +1 crasso corpore, et circiler decem digitos longo; capile instar cuniculorum nostrorum crasso; auribus, pilis nudis el panlum aculis; nares habet amplas ; os inferius brevius superiori : rimam instar leporis, non tampn fisiurá. barbam felinam, siu leproriuam prolixam, et post oculos [1onè aures iterım tales jilos : crura priora pauló breviora yosterioribus; in pedibus digiti quatuor : canda brevissima ut aguli ; pili corporis sunt umlıræ coloris, breves et ad tactum duri. In Jateribus antem secundim longitudinem maculas habet cinereas, in ventre albicat. Cibum oblatum ficdibus non tenet nt aguti, sed in terrå positum devorat, instar suis, alywe at eumilem pede modum grunnit. Carnem habet eximiann et pinguem, ifa ut non liaheat opus lardo quando assatur, unde L usitanis caca rea! vocatur illorum venalio. Marcgrave, Hist. Bras., pag. 224. Nola que Marcgrave s"est trompé en ne donuant d̀ cet animal que quatre doigts à chanje jicd; il est certain qu'il en a cinı a tuus les pieds ; lc pouce est senlement beauciup plus connl yue les autres doigts, el il n'est apparent que par !'ongle.

4.e pas on pague est un animal de la graudeur d'un pelit. (sien brayue, il a la tèle bizarre el forl mal faitı, Ia chair presuque de mème gont que celle du veau; et quant à sa peau, étant parce qu'elle est régulièrement tachée sur lea côtés. Ces animaux produisent souvent et cu grand nombre: les hommes et les animaux de proie en détruisent beaucoup, et cependant l'espèce en est toujours à peu près également nom. breuse : elle est naturelle et particuliere à l'Amérique méridionale, et ne se trouve nulle part dans l'ancien continent.

\section{ADDITION A L'ARTICLE DU PACA'.}

Comme nous n'avons donné que la figure dessinée sur un très-jeune paca qui n'aıait pas encore pris la moitié de son accroissement, et qu'il nous est arrivé un de ces animaux vivant qui était déjà plus grand que celui que nous avons décrit, je l'ai fait nourrir dans ma maison, et depuis le mois d'août dernier 1774 , jusqu'à ce jour 28 mai 1795 , il n'a cessé de grandir assez considérablement. Le sieur Trécourt a rédigé a vec exactitude des observations sur sa manière de vivre; et je vais en donner i.i l'extrait.

On a fait construire pour cet animal une petite loge en bois, dans laquelle il demeurait assez tranquille pendant le jour, surtout lorsqu'on ne le laissait pas manquer de nourriture. Il semble mème affectionner sa retraite tant que le jour dure, car il s'y retire de lui-mème après avoir mangé ; mais dès que la nuit vient, il marque le désir violent qu'il a de sortir en s'agitant continuellement, et en déchirant avec les dents les barreaux de sa prison; chose qui ne lui arrive jamais pendant le jour, à moins que ce ne soit pour faire ses besoins : car nonseulement il ne fait jamais, mais même il ne peut souffrir aucune ordure dans sa petite demeure; il va pour faire les siennes au plus loin qu'il peut. Il jette souvent la paille qui lui sert de litière dès qu'elle a pris de l'odeur, comme pour en demander de nouvelle; il pousse cette

fort belle et tachelée de blanc, gris et noir, si ou en a rait parderà, elle serait bien riche en fourrure. Histoire d'un Vioyage au Brésil, par l)c Léry, page 157.

On trouve au Naraguon des animaux nommés pacs, un yeu plus grands que le couatis et tont ronds, ayant la tète grusse el courte, les oreilles fort petites, la quene pas plus longue quin netit doigt; sa peau est fort belle, pourtant un poil fort court tout marųueté de blanc el de noir. Missiın au Ma

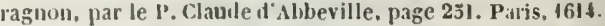

- Le paca dont il est pluestion dans cet article constitue une espèce différente du précédent, ainsi que l’a fait connattre M. F. Cuvier. Ce zoologiste l’a désigné sous la dénurr ination particulière de PıCs BAUx. 
vieille paille dehors avec son museau, et va chercher du linge et du papier pour la remplacer. Sa loge n'était pas le seul endroit qui parût lui plaire, tous les recoins obseurs semblaient lui convenir; il établissait souvent un nouveau gite dans les armoires qu'il trouvait ouvertes, ou bien sous les fourneaux de l'office et de la euisine; mais auparavant il s' $v$ préparait un lit, et quand il s'était une fois donné la peine de s'y établir, on ne pouvait yue par force le faire sortir de ce nouveau domicile. La propreté semble ètre si naturelle à cet animal, qui était femelle, que lui ayant donné un gros lapin mâle, Jans le temps qu'elle était en chaleur, pour tenter leur union, elle le prit en aversion au moment qu'il fit ses ordures dans leur cagre cominune. Auparavant elle l'avait assez bien reçu pour en espérer quelque chose ; elle lui faisait mème des avances très-mar(quées en lui léchant le nez, les oreilles et le corps; elle lui laissait même presque toute la nourriture, sans chercher à la partager; mais dès que le lapin eut infecté la eage, elle se retira sur-le-champ dans le fond d'une vieille armoire, où elle se fit un lit de papier et de linge, et ne revint à sa loge que quand elle la vit nette et libre de l'hòte malpropre qu'on lui a vait donné.

Le paca soccontume aisément à la vie domesticque; il est doux et traitable tant qu'on ne cherche point à l'irriter; il aime qu'on le flatte, et lèche les mains des per'sonnes qui le caressent; il connait fort bien eeux qui prennent soin de lui, et sait parfuitement distinguer leur voix. Lorsqu'on le gratte sur le dos, il s'étend et se couche sur le ventre; quelquefois mème il s'exprime par un petit cri de reconmaissance, et semble demander que l'on continue. Néanmoins il n'aime pas (ju'on le saisisse pour le transporter, et il fait des efforts très-vifs et tres-réitérés pour s'échapper.

11 a les muscles très-forts et le corps massif: cependant il a la peau si sensible, (que le plus léger attouchement suffit pour lui causer une vive émotion. Cette grande sensibilité, quoique ordinairement accompagnée de douceur, produit qualquefois des accès de colère, lorsqu'on le contrarie trop fort ou qu'il se présente un objet déplaisant: la seule vue d'un chien qu'il ne commait pas l: met de mauvaise humeur. (m l'a vu renfermé dans sid lose, en mordre la porte et farre en sorte de l'ourir, paree gu'il vemait d'entres un chien etranger dans la chambre.
On erut d'abo:d qu'il ne voulait sortir (que pour faire ses besoins; mais on fut assez surpris, lors'fu'étant mis en liberté, il s'élanea tout d'un coup sur le chien, qui ne lui faisait aucun mal, et le mordit assez fort pour le faire crier : néanmoins il s'est aecoutumé en peu de jours avec ce mème clien. Il traite de mème les gens qu'il ne counait pas et qui le contrarient; mais il ne mord jamais ceux rui ont soin de lui. II n'aime pas les enfants, et il les poursuit assez volontiers. Il manil'este sa colère par une espèce de elaquement de dents, et par un grogrnement qui précède toujours sá petite fureur.

Cet animal se tient souvent debout, e'esta-dire assis sur son derrière, et quelquefois il demeure assez longtemps dans cette situation; il a l'air de se pejgner la téte et la moustache avec ses pattes, (qu'il lèche et humeete de salive à claque fois; souvent il se sert de ses deux pattes à la fois pour se peigner; ensuite il se gratte le corps jusqu'aux endroits où il peut atteindre avec ces mèmes pattes de devant; ct pour achever sa petite toilette, il se sert de celles de derrière, et se gratte dans tous les autres endroits qui peuvent être souillés.

C'est cependant un animal d'un grosse corpulence et qui ne parait ni délicat, ni leste, ni léger; il est plutòt pesant et lourd, ayant à peu près la démarche d'un petit cochon. Il court rarement, lentement et d'assez mauvalise grâce ; il n'a de mouvements vifs que pour sauter, tantòt sur les meubles et tantôt sur les choses qu il veut saisir on emporter. Il ressemble eneore au cochon par sa peau blanche, épaiss: et qu'on ne peut tirer ni pineer, paree qu'elle est adhérente à la ehair.

Quoiqu'il n'ait pas encore pris son entier aceroissement, il a déjà dix-huit pouces de longueur dans sa situation naturelle et renflée; mais lorsqu il s'étend, il a près de deux pieds depuis le bout du museau jusqu’à l'entrémité du corps; au lieu que le paea dont nous avons donné la deseription n'avait que sept pouces einq lignes : différence qui ne provient néan-. moins que de celle de l'âge, ear du r'ste ces deux animaux se ressemblent en tout.

La hauteur, prise aux jumbes de devant daus celui que nous déerivons actuellement, était de sept ponces, et cette hauteur, prise aux jambes de dervière, était d'envirou meuf pouces et demi; ('n sorte qu'en mareluant son clerriere parait toujours bien plus haut que si tète. Cette partie 
postérieure du corps, qui est la plus élevée, est aussi la plus épaisse en tous sens; elle a dixneuf pouces et demi de circonférence, tandis que la partie antérieure du corps n'a que quatorze pouces.

Le corps est couvert d'un poil court, rude et clair-semé, couleur de terre-d'ombre et plus foncé sur le dos, mais le ventre, la poitrine, le dessous du cou et les parties intérieures des jambes, sont au contraire couverts d'un poil blanc sale; et ce qui le rend très-remarquable, ce sont cing espèces de bandes longitudinales formées par des taches blanches, la plupart séparées les unes des autres. Ces ciuq bandes sont dirigées le long du corps, de manière qu'elles tendent à se rapprocher les unes des autres à leurs extrémités.

La tète, depuis le nez jusqu'au sommet du front, a prìs de einq pouces de longueur, et elle est fort convexe. Les yeux sont gros, saillants et de couleur brunâtre, éloignés l'un de l'autre d'environ deux pouces; les oreilles sont arrondies et u'ont que sept à huit lignes de longueur, sur une largeur à peu près égale à leur base : elles sont plissées en forme de fraise, et recouvertes d'un duvet très-fin presque insensible au tact et à l'œil. Le bout du nez est large, de couleur presque noire, divisé en deux comme celui des lièıres : les narines sont fort grandes. L'animal a beaucoup de force et d'adresse dans cette partie, car nous l'avons vu sourent soulever avec son nez la porte de sa loge, qui fermait à coulisse. La mâchoire inférieure est d'un pouce plus courte et moins avancée que la mâchoire supérieure, qui est beaucoup plus large et plus longre. De chaque côté et vers le bas de la ináchoire supérieure, il règne une espèce de pli longitudinal dégarni de poil dans sou milieu, en sorte que l'on prendrait, au premier coup d'œil, cet end'oit de la mâehoire pour la bouche de l'animal en le royant de côté; car sa bouche n'est apparente que quand elle est ouverte, et n'a que six ou sept lignes douverture : elle n'est éloignée que de deux ou trois lignes des plis dont nous venous de parler.

Chaque mâchoire est armée en devant de deux dents incisives fort longues, jaunes comme du safran, et assez fortes pour couper le bois. Gu a vu cet animal, en une seule nuit, faire un unnu dans une des planches de sa lo:e, assez grand pour y passer sa tête. Sa langue est étroite, épaisse et un peu rude. Ses moustaches sont composées de poils noirs et de poils blanes, pla. cés de chaque côté du nez, et il a de pareilles moustaches plus noires, mais moins fournies, de chaque côté de la tête au-dessous des oreilles. Nous n'avons pu voir ni compter les dents máchelières par la forte résistance de l'animal.

Chaque pied, taut de devant que de derrière, a cinq doigts, dont quatre sont armés d'ongles longs de cinq ou six lignes. Les ongles sont couleur de chair ; mais il ne faut pas regarder cette couleur comme un caractère coustant ; car dans plusieurs animaux, et particulièrement dans les lièvres, on trouve souvent les ongles noirs, tandis que d'autres les ont blanchâtres ou couleu: de chair. Le cinquième doigt, qui est l'interue, ue parait que quand l'animal à la jambe levée, et n'est qu'un petit éperon fort court. Entre les jambes de derrière, à peu de distance des parties naturelles, se trouvent deux mamelles de couleur brunâtre. Au reste, quoique la queue ne soit nullement apparcute, on trouve néan. moins, en la reclierchant, un petit bouton de deux ou trois lignes de longueur qui parait en être l'indice.

Le paca domestigue mange de tout ce qu'on veut lui donner, et il parait avoir un très-grand appétit. On le nourrissait ordinairement de pain; et soit qu'on le trempât clans l'eau, dans le vin, et mème dims du vinaigre, il le mangeait également; mais le sucre et les fruits sont si fort de son goût, que lorsqu'ou lui en présentait il en témoignait si joie pall des bonds et des sauts. Les racines et les legumes étaient aussi de son goût : il mangeait également les navets, le céleri, les oignons, et mème l'ail et l'échalotte. Il ne refusait pas les choux ni les herbes, méme. la mousse et les écorces de bois; nous l'avous souvent vu manger aussi du bois et du charbou dans les commencements. La viande était ee qu il paraissait aimer le moins ; il u'en mangeait que rarement et én très-petite quantité. On pourrait le nourrir aisément de grains, car s*uvent il en cherchait dans la paille de sa litière. Il boit conme le chien, en soulevant l'eau avec la langue. Son urine est fort épaisse, et d une odeur insupportable. Sa fiente est en petites crottes, plus allongées que celles des lapins et de's lièvres.

D après les petites observations que nous reInons de rapporter, nous sommes très-portés d̀ croire quon pourrait naturaliser cette espece 
en France; et eomme la chair en est bonne à manger, et que l'animal est peu difficile à nourrir, ce serait une acquisition utile. Il ne parait pas craindre beaucoup le froid; tet d'ailleurs., pouvant creuser la terre, il s'en garantirait aisément pendant l'hiver. Un seul paca fournirait autant de bonne chère que sept ou huit lapins.

M. de La Borde dit que le paca habite ordinairement le bord des rivières, et qu'il construit son terrier de manière (ju'il peut y entrer ou en sortir par trois issues différentes.

a Lorsqu'il est poursuivi, il se jette à l'eau, dit-il, dans laçuelfe il se plonge en levant la tête de temps en temps ; mais enfin, lorsqu'il est assailli par les chiens, il se défend très-vigoureusement. "Il ajoute " que la chair de cet animal est fort estimée à Cayenne, (qu'on l'échaude comme un cochon de lait, et que, de ruelque manière qu'on la prépare, elle est excellente. ")

Le paca babite seul son terrier, et il n'en sort ordinairement que la nuit pour se procurer sa nourriture. Il ne sort pendant le jour que pour fuire ses besoins, car on ne trouve jamais aucune ordure dans son terrier ; et toutes les fois qu'il rentre, il a soin d'en boucher les issues avec des feuilles et de petites branches. Ces animaux ne produisent ordinairement(qu'un petit, qui ne quitte la mère que quand il est adulte; et mème, si c'est un mâle, il ne s'en sépare qu'après s'ètre accouplé aveć elle. Au reste, on en connait de deux ou trois espèces à Cayenne; et l'on prétend qu'ils ne se mêlent point ensemble. Les uns pèsent depuis quatorze jusqu'à vingt livres, et les autres de vingtcincl à trente livres.

\section{DESCRIPTION DU PACA '.}

(EXTRAIT DE DAUBENTON.)

Cette description a été faite sur un paca fort jeune, comme on le verra par les dimensions des parties extérieures de son corps, rapportées dans la table. Sa tète avait en quelq̧ue façon la forme d'un nuf, dont le petit bout se troavait a l'extrémité du museau; la lèrre inférieure était d'un demi-ponce moins avance que le nez, de sorte que la lève supériemre avait beancoup de longueur; elle était inclince obliquement en arrière et en bas, et fendue dlans le milieu en bee de lièrre : quoique le nez füt large, les narines itaient

- Liauimal dont la description suit est le Pacis paurg.

iv. placées sur ses côtés, aussi y avait-il une grande distance entre leurs ourertures; elles étaient longues, un pen concaves en dessus, convexes en dessous et dirigées de devant en arrière. Les oreilles étaient arrondies et courtes, mais les moustaches itaient fort longues, car elles avaient tlejà plus d'un ponce et demi de longueur : il se trourait au-dessous et un peu au delà de l’angrle postérieur de l'œil, un bouquet de poil qui ctait presque aussi gros et aussilong que les moustaches; il y avait plusieurs longs poils au-dessus de l'ril. Le cou était presque anssi gros que la tête; le corps ètait gros et court. Le poil formait un épi à l'endroit de la queue, qui manyue en entier dans cet animal. Les jamlies étaient courtes : chaque pied avait ciny doigts, mais le ponce était très-petit, on li'en voyait que l'onylc : les doigts et les ongles des pieds de derrière ctaient plus grands que ceux des pieds de devant: tous les ongles avaient une couleur jaunatre; ils étaient droits etavaient peu de largeur.

Le poil n’avait au plus ru'une ligne et demie de longueur; il était ferme, il avait une couleur de marron sur le dessus du musean, de la tite et du cou, sur le dos, sur le liaut des côtes de la tète, du cou et du corps, sur la croupe, sur l'épaule, sur la face externe des jambes et sur les pieds; le reste de la tite, du corps et des jambes itait de couleur jaunàtre très-faible, et mème blanchàtre. Il y avait de petites taches roniles de cette mème couleur jaunàtre, d'une ou deux lignes de diamètre, placées en plısieurs files longitudinales sur les côtés de l'animal; les plus longues ctaient au nombre de trois et s'étendaient tepuis la tète, sur les cỏtẻs du cou, sur les cpaules, les còtes ulu corps et la face externe de la cuissc, presque jusqu’à l'endroit de la queue. Les taches de plusieurs de ces files se touchaient et formaient une banule continue. Il y avait sur l'épaule et sur le bras, et principalement sur la cuisse et sur la jambe beaucoup le taches autres que celles des trois tiles dont il a ete fait mention: ces autres taches formaient d'autres files plus courtes, ou étaient placćes irrégulièrenent.

\section{LE HAMSTER.}

Ordre des rongeurs, geure raf. (Curier.)

Le hamster est un rat des plus fameux et des plus nuisibles; et si nous n'avons pas domné son histoire aree eclle des autres lats, e'est qu'alor's nous ne l'arions pas nous n'arons pu nous le procurer que dans ces derniers temps; encole est-ce aux attentions constantes de. AI. Ie malreuis de Montmirail pour tout ce qui peut contribuer à l'avancement de 
l'histoire naturelle, et aux bontés de M. de Waitz, ministre d'état du prince landgrave de Hesse-Cassel, que nous sommes redevables de la connaissance précise et exacte de cet animal. Ils nous en ont envoyé deux vivants arec un mémoire instructif sur leurs mœurs et leur's habitudes naturelles. Nous avons nourri l'un de ces animaux pendant quelques mois pour l'olyserver, et ensuite on l'a soumis à la dissection pour faire la deseription et la comparaison des parties intérieures avec celles des autres rats. On verra que par ces parties intérieures le hamster ressemble plus au rat d'eau qu'à aucun autre animal; il lui ressemble encore par la petitesse des yeux et la finesse du poil ; mais il n'a pas la queue longue comme le rat d'eau; il l'a au contraire très-courte, plus courte que le campagnol, qui, comme nous l'avons dit, ressemble aussi beaucoup au rat d'eau par la conformation intérieure. Le hamster nous parait être à l'égard du campagnol ce que le surmulot est à l'égard du mulot: tous ces animaux vivent sous terre, et paraissent animés du même instinct; ils ont à peu près les mêmes habitudes, et surtout celle de ramasser des grains et d'en faire de gros magasins dans leurs trous. Nous nous étendrons done beaucoup moins sur les ressemblances de forme et les conformités de nature, que sur les différences relatives et les disconvenances réelles qui séparent le hamster de tous les rats, souris et mulots dont nous avons parlé.

Agricola est le premier auteur qui ait domné des indications précises et détaillées au sujet de cet animal : Fabricius y a ajouté quelques faits; mais Schwenckfeld a plus fait que tous les autres; il a disséqué le hamster, et il en doune une description qui s'accorde presque en tout a vee la nôtre. Cependant à peine a-t-il été cité par les naturalistes plus récents, qui tous se sont contentés de copier ce que Gessner en a dit: nous croyons done devoir à cet autcur la justice de eiter en entier ses observations ; et, en y ajoutant celles de M. de Waitz, nous aurons tout ee qu'on peut désirer au sujet de cet animal.

"Les établissements des hamster's, dit M. de "Waitz, sont d'une construetion différente se" lon le sexe et l'âge, et aussi suivant la qua" litě du terrain. Le domicile du mâle a un " conduit oblique, à l'ouverture duquel il y a - un monceáu de terre exhaussé, A une di-
" stance de cette issue oblique, il y a un seul " trou qui descend perpendiculairement jus" qu'aux chambres ou caveaux du domicile: " il ne se trouve point de terre exhaussée au" près du trou; ce qui fait présumer que l'issue " oblique est creusée en commençant par le de" hors, et que l'issue perpendiculaire est faite " de dedans en dehors, et de bas en haut.

" Le domicile de la femelle a aussi un cor" duit oblique et en même temps deux, trois et " jusqu'à huit trous perpendiculaires, pour " donner une entrée et sortie libres à ses petits: " le mâle et la femelle ont chacun leur demeure " séparce ; la femelle fait la sienne plus pro" fonde que le mâle.

"A côté des trous perpendiculaires, à un ou " deux pieds de distance, les hamsters des " deux sexes ereusent, selon leur âge et à pro" portion de leur multiplication, un, deux, " trois et quatre caveaux particuliers, qui sont " en forme de voûte, tant par-dessous que par"dessus, et plus ou moins spacieux suivant la " quantité de leurs provisions.

"Le trou perpendiculaire est le passage or" dinaire du hanister pour entrer et sortir. "C'est par le trou oblique que se fait l'expor" tation de la terre: il parait aussi que ce con" duit, qui a une pente plus douce dans un des " caveaux et plus rapide dans un autre de ces " cav'eaux, sert pour la circulation de l'air dans " ce domicile souterrain. Le caveau où la fe" melle fait ses petits ne contient point de pro" vision de grain, mais un nid de paille ou "d'herbe. La profondeur du caveau est très" différente: un jeune hainster dans la pre" mière année ne donne qu'un pied de profon"deur à son caveau; un vieux hamster le " creuse souvent jusqu'à quatre ou cinq pieds : " le domiciie entier, y compris toutes les com" munications et tous les caveaux, a quelque" fois huit ou dix pieds de diamètre.

"Ces animaux approvisionnent leurs maga" sins de grains sees et nettoyés, de blé en épis, " de pois et fèves en cosses, qu'ils nettoient en. " suite dans leur demeure, et ils transportent " au dehor's les cosses et les déchets des épis " par le conduit oblique. Pour apporter leurs "provisions, ils se servent de leurs abajoues, " dans lesquelles ehacun peut porter à la fois "plus d'un quart de chopine de grains net" toyés.

" Le hamster fait ordinairement ses pro- 
- vissions de grains à la fin d'aoút: lorsłu'il a " rempl: ses magasins, il les courre et en bou" che soigneusement les avenues avec de la " terre, ce qui fait quion ne découvre pas aisé" ment sa demeure; on ne la reconnaît que par "le monceau de terre qui se trouve auprès du " conduit oblique dont nous arons parké : il " faut ensuite chercher les trous perpendieu" laires et découvrir par-là son domicile. Le " moyen le plus usité pour prendre ces ani" maux est de les déterrer, quoique ce travail " soit assez pénible à cause de la profondeur et de l'étendue de leur's terriers. Cependant un lomme exercé à cette espèce de chasse ne " laisse pas d'en tirer de l'utilité; il trouve or- dinairement dans la boune saison, c'est-à-dire " en automne, deux boisseaux de bons grains "dans chaque domicile, et il profite de la peau " de ces animaux dont on fait des fourrures. "Les hamsters produisent deux ou trois fois " par an, et einc ou six petits à eluacue fois, et " souvent davantage: ii y a des amnées où ils " paraissent en quantité innombrable, et d'au" tres où l'on n'en voit presque plus; les an"ncees humides sont celles où ils multiplient " beaucoup, et cette nombreuse multiplication " cause la disette par la dévastation générale "des blés.

a Un jeune hamster, âgé de six semaines ou " deux mois, creuse déja son terrier; cependant il ne s'accouple ni ne produit dans la " première anuéc de sa vie.

"Les fouines poursuivent vivement les ham" sters, et eu détruisent un grand nombre; elles " entrent aussi dans leurs terriers et en pren" nent possession.

"Les hamsters ont ordinairement le dos "brun et le ventre noir. Cependant il $\mathrm{y}$ en a " qui sont gris, et cette différence peut prove" uir de leur àge plus ou moins avancé. Il s'en * trouve aussi quelques-uns qui sont moirs. "

Ces animaux s'entre-détruisent mutuellement comme les mulots : de deux qui étaient dans la mène eage, la femelle dans une nuit étrangla le màle, et après avoir coupé les muscles qui attachent les mâchoires, clle se fit jour dans son corps, où elle dévola une partie des visec̀res. Ils font plusicurs portées par an, et sont si nuisibles, que dans quelques états $\mathrm{d}^{\prime} \mathrm{Al}$ lemagne leur tête est à prix; ils y sont si communs que leur fourrure est à très-bon marehé.

Tous ces fuits, que nous avons extraits du
Mémoire de M. de Waitz et des Observations de M. de Montmirail, nous paraissent certains, et s'accordent aree ce que nous savions d'ailleurs au sujet de ces animaux ; mais il n'est pas également certain, comme on le dit dans ce même Mémoire, qu'ils soient engourdis et mème desséchés pendant l'hiver, et qu'ils ne reprennent du mourement et de la vie qu'au printemps. Le hamster que nous avons eu vivant a passé l'hjver dernier 1762-63, dans une chambre sans feu, et où il gelait assez fort pour glacer l'eau: eependant il ne s'est point engourdi et n'a pas cessé de se mouvoir et de manger à son ordinaire; au lieu que nous arons nourri des loirs et des lérots qui se sont engourdis à un degré de froid beaucoup moindre. Nous ne croyons done pas que le hamster se rapproche des loirs ou do la marmotte par ce rapport, et c'est mal à propos que quelques-uns de nos naturalistes l'ont appelé marmotte de Strasbourg, puisqu'il ne dort pas comme la marmotte, et qu'il ne se trouve pas à Strasbourg.

ADDITION A L'ARTICLE DU HAMSTER OU RAT DE BLÉ.

On trouve dans la Gazette de Littérature du 13 septemlore 1774 , un extrait des observations faites sur le hamster, et tirées d'un ouvrage allemand de $\boldsymbol{M}$. Sulzer, que j'ai cru devoir donner ici.

"Le rat de blé, en allemand ham ster, ne pouvait être mieux décrit ni plus commodement qu’à Gotha, où dans une seule année on en a livré onze mille einq cent soixante-cquatorze peaux à l'hôtel-de-ville; dans une autre, cinquante-quatre mille quatre cent vingt-neuf, ct une troisieme fois, quatre-vingt mille ecnt trente-neuf. Cet animal habite en général les pays tempérés ; quand il est irrité, le cocur lui bat jusqu'a cent quatre-vingts fois par minute; le poids du cerveau est à celui de tout le corps, comme 1 est à 193.

"Ces rats se fout des magasins, où ils placent jusqu'à douze livres de grains. En hiver la femelle s'enfonce fort a vant dans la terre. Cet animal est courageux; il se défeud contre les chiens, contre les ehats, contre les hommes : il est naturellement querelleur, ne s'accorde pas arce son espece, et tue quelquefois daus sa furie sa propre famille. Il dévore ses sembla- 
bles lorsqu'ils sont plus faibles, aussi bien que les somris et les oiscaux, et il vit avec cela de toutes sortes d'herbes, de fruits et de grains : il boit peu. La femelle sort plus tard que lc mâle de sa retraite d'hiver; elle porte quatre semaines et fait jusqu'à six petits. Il ne faut que quelques mois pour que les petites femelles deviennent fécondes. L'espèce de rat qu'on nomme illis ${ }^{1}$ tue le hamster.

"Quand l'animal est dans son engourdissement, on n'y observe ni respiration, ni aucune sorte de sentiment. Le cœur bat néanmoins environ quinze fois par minute, comme on s'en aperçoit en ouvrant la poitrine; le sang demeure fluide; les intestins immobiles ne sont pas irritables; le coup électrique même ne réveille pas l'animal; tout est froid en lui : au grand air il ne s'engourdit jamais. "M. Sulzer rapporte par quels degrés il passe pour sortir de son engourdissement. "Cet animal n'a guère d'autre utilité que celle de détruire les souris; mais il fait bien plus de mal qu'elles."

Nous eussions désiré que M. Sulzer eût indiqué précisément le degré de froid ou de manque d'air auquel ces animaux s'engourdissent; car nous répétons ici affirmativement ce que nous venons de dire, que dans une chambre sans feu où il gelait assez fort pour $\mathrm{y}$ glacer l'eau, un hamster qui y était dans une cage ne s'engourdit pas pendant l'hiver de 1763. On va voir la pleine confirmation de ce fait dans les additions que M. Allamand a fait imprimer à la suite de mon ouvrage, et que je viens de recevoir.

\section{ADDITION DE L'ÉDITEUR HOLLANDAIS A L'AR-} TICLE DU HAMSTER.

" Le hamster est un quadrupède du gemre des souris, qui passe l'hiver à dormir, comme les marmottes. Il a les jambes basses, le cou court, la tète un peu grosse, la bouche garnie de moustaches des deux côtés, les oreilles grandes et presque sans poil, la queue courte et à demi nue, les yeux ronds et sortant de la tête, le poil mèlé de roux, de jaune, de blanc et de noir : tout cela ne lui donne pas la figure fort revenante. Ses mœurs ne le rendent pas plus recommandable. Il n'aime que son propre in-

\footnotetext{
1 L'iltis désigne le putois et non pas le rat.
}

dividu, et n’a pas une seule qualité sociable. Il attaque et dévore tous les autres animaux dont il peut se rendre maitre, sans excepter ceux de sa propre race. L'instinct mème qui le porte vers l'autre sexe ne dure que quelques jours, au bout desquels sa femelle n'éprouverait pas un meilleur sort, si elle ne prenait pas la précaution d'éviter la rencontre de son ingrat, ou de le prérenir et de le tuer la première. A ces qualités odieuses, la nature a néanmoins su en allier d'autres, qui, sans rendre cet animal plus aimable, lui font mériter une place distinguée dans l'Histoire naturelle des animaux. Il est du petit nombre de ceux qui passent l'hiver dans un état d'engourdissement, et le seul en Europe qui soit pourvu de bajoues. Son adresse à se pratiquer une demeure sous terre, et l'industrie avec laquelle il fait ses provisions d'hiver, ne méritent pas moins l'attention des curieux.

"Le hamster n'habite pas indifféremment dans toutes sortes de climats ou de terrains. On ne le trouve ni dans les pays trop chauds, ni dans les pays trop froids. Comme il vit de grains et qu'il demeure sous terre, une terre pierreuse, sablonneuse, argileuse, lui convient aussi peu que les prés, les forèts et les endroits bourbeux. Il lui faut un terroir aisé à creuser, qui néanmoins soit assez ferme pour ne point s'écrouler. Il choisit encore des contrées fertiles en toutes sortcs de graines, pour' n'ètre pas obligé de chercher sa nourriture au loin, étant peu propre à faire de longues courses. Les terres de Thuringe réunissant toutes ces qualités, les hamsters s'y trouvent en plus grand nombre que partout ailleurs.

"Le terrier que le hamster sc creuse à trois ou quatre pieds sous terre, consiste pour l'ordinaire en plus ou moins de chambres, sclon l'âge de l'animal qui l'habite. La principale est tapissée de paille, et sert de logement; les autres sont destinées pour y conserver les provisions, qu'il ramasse en grande quantité dans le temps des moissons. Chaque terrier a deux trous ou ourertures, dont celle par laquelle l'animal est arricé sous terre, descend obliquement. L'autre, qui a ěté pratiquée du dedans en dehor's, est perpendiculaire et sert pour entrer et sortir.

"Les terricrs des femelles, qui ne demeurent jamais avec les mâles, different des autres en plusieurs points. Dans ceux où elles mettent bas, on roit rarement plus qu'une chambre de 
ovision, parce que le peu de temps que les pets demeurent avec la mère n'exige pas qu'elle nasse beaucoup de nourriture; mais au lieu un seul trou perpendiculaire, il y en a jusl'à sept ou huit qui servent à donner une enée et une sortie libres aux petits. Quelquefois mère, ayant chassé ses petits, reste dans ce rrier; mais pour l'ordinaire elle s'en pratique n autre, qu'elle remplit d'autant de provisions ue la saison lui permet d'en ramasser.

"Les hamsters s'accouplent la première fois ers la fin du mois d'avril, où les mâles se renent dans les terrier's des femelles, avec lesuelles ils ne restent cependant que peu de urs. S'il arrive que deux mâles cherchant felelle se rencontrent dans le même trou, il élève un combat furieux entre eux, curi pour ordinaire finit par la mort du plus faible. Le ainqueur s'empare de sa femelle, et l'm et l'auc, qui dans tout autre temps se perséculent et entretuent, déposent leur férocité naturelle endant le peu de jours que durent leurs mours. Ils se défendent même réciproquement ontre les agresseurs. Quand on ouvre un terer dans-ce temps-là, et que la femelle s'aperoit qu'on veut lui enlever son mari, elle s'éunce sur le ravisseur, et luj fiait souvent sentir i fureur de sa vengeance par des morsures rofondes et douloureuses.

"Les femelles mettent bas deux ou trois fois ar an. Leur portéc n'est jamais au-dessous de ix, et le plus souvent de seize à dix-huit petits. a crue de ces animaux est fort prompte. A l'âo le quinze jours ils essaient déjà à ereuser la erre: peu après la mère les oblige de sortir du errier, de sorte qu'à l'ìge d'environ trois senaines ils sont abandonnés à leur propre conluite. Cette mère montre en général fort peu le tendresse maternelle pour ses petits : elle qui lans le temps de ses amour's défend si coura;eusement son mari, ne connaît que la fuite fuand sa fumille est menacée d'un danger; son mique soin est de pourvoir à sa propre conserration. Dans cette vue, dès qu'elle se sent pour;uivie, elle s'enfonce en crensant plus avant lans la terre, ce qu'elle exéente avec une cé érité surprenante. Les petits ont beau la suirre, elle est sourdo à leurs cris, et clle bouche même la retraite qu'elle s'est pratiquée.

" Le hamster se nourrit de toutes sortes d'hęrbes, de racines et de grains que les différentes saisons lui fournissent. Il s'accommode même très-volontiers de la chair des autres animaux dont il devient le maitre. Comme il n'est pas fait pour les longues courses, il fait le premier fonds de son magasin par ce que lui présentent les champs voisins de son établissement, ce qui est la raison pourquoi l'on voit sourent quelques-unes de ses chambres remplies d'une seule sorte de grains. Quand les champs sont moissounés, il va chercher plus loin ses provisions, et prend ce qu'il troure dans son ehemin pour le porter dans son habitation et l'y déposer sans distinction. Pour Ini faciliter le transport de sa nourriture, la nature l'a pourvu de bajoues de chaque côté de l'intéricur de la bouche. Ce sont deux poches membraneuses, lisses et luisantes en dehors, et parsemées d'un grand nombre de glandes en dedans, qui distillent sans cesse une certaine humidité, pour les tenir souples et les rendre capables de résister aux aceidents, que des grains souvent raides et pointus pourraient causer. Chacune de ses bajoues peut contenir une once et demie de grains, que cet animal, de retour dans sa demeure, vide moyennant ses deux pieds de devant, qu'il presse extérieurement contre ses joues, pour en faire sortir les grains. Quand on rencontre un hamster, ses poches remplies de provisions, on peut le prendre arec la main sans risquer d'ctre mordu, parce que dans cet état il n'a pas le mouvement des mâchoires libre. Nais, pour peu qu'on lui laisse du temps, il vide promptement ses poches et se met en défense. La quantité de provisions qu'on trouve dans les terriers varie suivant l'áge et le sexe de l'animal qui les habite. Les vicux hamster's amassent jusqu'à cent livres de grains, mais les jeunes et les femelles se contentent de beaucoup moins. Les uns et les autres s'en servent, non pour s'en nourrir pendant l'hiver', temps qu'ils passent à dormir et sans manger. mais pour avoir de quoi vivre après leur' réveil au printemps, et pendant l'espace de temps qui précède leur engourdissement.

"A l'approche de l'hiver, les hamsters se retirent dans leurs habitations souterraines, dont ils bouchent l'entrée avee soin. Ils y restent trancuilles et vivent de leurs provisions, jusqu’à ce que le froid étant devenu plus sensible, ils tombent dans un état d'engourdissement semblable au sommeil le plus profond. Quand après ce temps-là on ourre un terrier, qu'on recomnait par un monceau de terrequi se trouve 
auprès du condultoblique dont nous a vons parlé, on y voit le hamster nollement couché sur un lit de paille menue et très-douce. Il a la tète retirée sous le ventre, entre les deux jambes de devant: celles de derrière sont appuyées contre le museau. Les yeux sont fermés, et quand on veut écarter les paupières, elles se referment dans l'instant. Les membres sont raides comme ceux d'un animal mort, et tout le corps est froid au toucher comme la glace. On ne remarque pas la moindre respiration ni autre signe de vie. Ce n'est qu'en le disséquant dans cet état d'engourdissement qu'on voit le cœur se contracter et se dilater; mais ce mourement est si lent, qu'on peut compter à peine quinze pulsations daus une minute, au lieu qu'il y en a au moins cent cinquante dans le mème espace de temps, lorsque l'animal est éveillé. La graisse cst comme figée; les intestius n'ont pas plus de chaleur que l'extérieur' du corps, et sont insensibles à l'action de l'esprit-de-vin et mème à l'huile de vitriol qu'on y verse, et ne marcquent pas la moindre irritabilité. Quelque douloureuse que soit toute cette opération, l'animal ne parait pas la sentir beancoup: il ourre quelquefois la bouche, comme pour respirer; mais son engourdissement est trop fort pour séveiller entierement.

"On a cru que la cause de cet engourdissement dépendait uniquement d'un certain degré de froid en hiver. Cela peut ètre mai à l'égard des loirs, des lérots, des chauves-souris; mais pour mettre le hamster clans cet état, l'expérience prouve qu'il faut encore que l'air extérieur n'ait aucun accès à l'endroit où il s'est retiré. On peut s'en convaincre en enfermaut u hamster dans une caisse remplie de terre et de paille : on aura beau l'exposer au froid le plus sensible de l'hiver et assez fort pour glacer l'eau, on ne parviendra jamais à le faire dormir ; mais dès qu'on met cette caisse à quatre ou cinq pieds sous terre, qu'li faut a voir soin de.bien battre, pour empêcher l'air extérieur d'y péuétrer, on le trouvera au bout de huit ou dix jours engourdi comme dans son terrier. Si l'on retire cette caisse de la terre, le hamster se réveillera au bout de quelques heures, et se rendormira de nouveau, quand on le remet sous terre. On peut répéter cette expérience avec le même succès, aussi longtemps que le froid durera, pourvu qu'on observe d'y mettre l'intervalle de temps nécessaire. Ce qui prouve encorc que l'absence de l'air extérieur est une des cau. ses de l'engourdissement du hamster, c'est que, retiré de son terrier au plus gros de l'hiver, il se réveille immanquablement au bout de quel. ques heures, quand on l'expose à l'air. Qu'on fasse cette expérience de jour ou de nuit, cela est indifférent, de sorte que la lumière n'y a aucune part.

"C'est un spectacle curieux de voir passer un hamster de l'engourdissement au réveil. D'abord il perd la raideur des membres; ensuite il respire profondément, mais par de longs intervalles: on remarque du mouvement dans les jambes; il ouvre la bouche comme pour báiller, et fait entendre des sons désagréables et semblables au râlement. Quand ce jeu a duré pendant quelque temps, il ouvre enfin les yeux et tâche de se mettre sur les pieds; mais tous ses mouvements sont encore peu assurés et chancelants, comme ceux d'un homme irre. Il réitère cependant ses essais, jusqu’à ce qu’il parvienne à se tenir sur ses jambes. Dans cette attitude il reste tranquille, comme pour se reconnaltre et se reposer de ses fatigues; mais peu à peu il commence à marcher, à ınanger et àagir, comme il faisait avant le temps de son sommeil. Ce passage de l'engourdissement au réveil demande plus ou moins de temps, selon la température de l'endroit ou se trouve l'auimal. Si on l'expose à un air sensiblement froid, il faut quelquefois plus de deux heures pour le faire éreiller, et dans un lieu plus tempéré, cela se fait en moins d'une heure. Il est vraisemblable que dans les terriers cette catastrophe arrive imperceptiblement, et que l'animal ne sent aucune des incommodités qui accompagnent un rércil forcé et subit.

"La vie du hamster est partagée entre les soins de satisfaire aux besoins naturels et la fureur de se battre. Il paraît n'avoir d'autres passions que celle de la colère, qui le porte à attaquer tout ce qui se trouve en son chemin, sans faire attention à la supériorité des forces de l'emnemi. Ignorant absolument l'art de saurer sa vie en se retirant du combat, il se laisse plutót assommer de coups de bàton que de céder. S’il trouve le moyen de saisir la main d'un homine, il faut le tuer pour se débarrasser de Iui. La grandeur du cheval l'effraie aussi peu que l'adresse du chien; ce dernier aime à lui dommer la chasse: quand le hamster l'aperçoit de loin, il commence par vider ses poches, si 
par hasard il les a remplies de grains; ensuite il les enfle si prodigieusement, que la tète et le cou surpassent beaucoup en grosseur le reste du corps; enfin il se redresse sur ses jambes de derrière, et s'élance dans eette attitude sur l'ennemi; s'il l'attrape, il ne le quitte qu'après l'avoir tué ou perdu la vie; mais le chien le prévient pour l'ordinaire, en cherchant à le prendre par derrière et à l'étrangler. Cette fureur de se battre fait que le hamster n'est en paix avec aucun des autres animaux. Il fait même la guerre à ceux de sa race, sans en excepter la femelle. Quand deux hamsters se rencontrent, ils ne manquent jamais de s'attaquer réciproquement, jusqu'à ce que le plus faible suecombe sous les coups du plus fort, qui le dévore. Le combat entre un mâle et une femelle dure pour l'ordinaire plus longtemps que celui de mâle à mâle. Ils commencent par se donner la chasse et se mordre; ensuite chacun se retire d'un autre coté, comme pour prendre haleine : peu après ils renouvellent le combat, et continuent à se fuir et à se battre jusqu'à ce que l'un ou l'autre succombe. Le vaincu sert toujours de repas au vainqueur.")

\section{DESGRIPTION DU HAMSTER.}

\section{(EXTRAIT DE DAUBENTON.)}

Le hamster est de la grandeur du rat; il m'a paru n'en différer pour la forme du corps qu'en ce que sa tète est plus grande, ses yeux plus petits et sa queue beaucoup plus courte. Le front, le dessus de la tète, le dos, le haut de la croupe et les côtés du corps, sont de couleur fauve terne mêlée de cendré, parce que les poils ont une couleur cendrée sur la plus grande partie de leur longueur depuis la racine; il y a du fauve au-dessus du cendré et du noirâtre à l'extrémité, et mème il se trouve des poils noirâtres en entier. Le haut des côtés de la lête et du cou, le dessous les yeux, le bas des còtés du corps, la face extérieure de la cuisse et de la jambe, le bas de la croune et les fesses sont de conleur rousse ou roussatre : le bout du museau, le bas des côtės de la tête, la face externe du lıras, les cỏtés de la poitrine et les pieds, sont d'une cou leur jaunâtre très-påle; cette couleur forme trois grandes taclıes de cliaque côté de l'animal. La gorge, le dessous du cou, l'avant-bras, le dessous de la poitrine, le ventre, la face interne de la cuisse, le devant et la face interne de la jambe et le dessous du talon, sont le couleur de marron très-foncée, et même noiråtre dans quelı̣ues en-
Les oreilles sont grandes, arrondies et en partie nues; la queue est très-courte, revêtue de poils roussàtres vers son origine, et presque nue dans le reste de sa longueur, où elle n'a que de très-petits poils fort rares. Les pieds ont cinq doigts, mais le pouce des pieds de devant est trèspeu apparent; on n'y distingue qu'un tubercule et un petit ongle, comme dans l'écureuil, le rat, la souris, etc

\section{LE LEMING.}

Ordre des rongeurs, genre rat. (Curier.)

Olaüs Magnus est le premier qui ait fait mention du leming; et tout ce (ju'en ont dit Gesnier, Scaliger, Ziegler, Jonston, ete., est tiré de cet auteur; mais Wormius, après des recherches plus exactes, a fait l'histoire de cet animal, et voici la description qu'il en domne. " Il a, dit" il, la figure d'une souris, mais la queue plus " courte, le corps long d'environ einq pouces, " le poil fin et taché de diverses couleurs, la par" tie antérieure de la tête noire, la partie supé" ricure jaunâtre, le cou et les ćpaules noirs, le " reste du corps roussâtre, marqué de quelques " petites taches noires, de différentes figures " jusqu’à la queue, qui n'a qu'un demi-pouce " de longueur, et qui est couverte de poils " jaumes noiratres. L'ordredes taches, non plus " que leur figure et leur grandeur, ne sont pas "Ies mèmes dans tous les individus. Il y a au" tour de la gueule plusieurs poils raides en forme de moustaches, dont il y en a six de chaque côté beaucoup plus longs et plus raides " que les autres. L'ouverture de la gueule est " petite; la lève supérieure est fendue comme " dansles écureuils. Il sort de la màchoire supé" rieure deux dents longues ineisives, aiguës " un peu courbes, dont les racines pénètrent " jusqu'à l'orbite des yeux; deux dents sem" blables dans la mâchoire inférieure qui cor"respondent àcelles du dessus; trois mieluelières " de chaque còté, éloignées des dents incisives; " la première des màchelières fort large est com" posée de quatre lobes, la seconde de trois, la "troisieme plus petite, chacune de ees trois " dents ayant son alvéole séparé, et toutes situées dins l'intéricur' du palais à un intervalle assez grand; la langue assez ampie et s'éten"dant jusqu’à l'extrémité des leuts incisıres. 
"Des débris d'herbe et de paille qui étaient a dans la gorge de cet animal doivent faire pen" ser qu'il rumine. Les yeux sont petits et noirs; " !es oreilles couchées sur le dos, les jambes de " devant tris-courtes, les pieds couverts de " poils et armés de cinq ongles aigus et courbés, " dont celui du milicu est très-long, et dont le " cinquième est comme un petit pouce ou " comme un ergot de coq, situé quelquefois as" sez liaut dans la jambe. Toutle ventre estblan" chatre, tirant un peu sur le jaune, etc. "Cet animal, dont le con'ps est épais et les jambes fort courtes, ue laisse pas de courir assez vite. Il habite ordinairement les montagnes de Norwége et de Laponie : mais il en descend quelquefois en si grand nombre dans de certaines années ${ }^{1}$ et dans de certaines saisons, qu'on regarde l'arrivée des lemings comme un fléau terrible, et dont il est impossible de se délivrer; ils font un dégât affreux dans les campagnes, dévastent les jardins, luinent les moissons, et ne laissent rien que ce qui est serré dans les maisons, où lieureusement ils n'entrent pas. lls aboient à peu près comme de petits chiens; lorsqu'on les frappe avec un bàton, ils se jettent dessus et le tiennent si fort a vec les dents, qu'ils se linissent enlever et transporter à quelque distance, sans vouloir le quitter; ils se creusent des trous sous tcre, et vont comme les taupes manger les racines; ils s'assemblent dans de certains temps, et meurent pour ainsi dire tous ensemble; ils sont tries-courageux et se défendent contre les autres animaux. On ne sait pas trop d'où ils vennent; le peuple croit qu’ils tombent arec la pluie. Le màle est ordinairement plus grand que

1 On a remarqué que les lemings ne paraissent pas régul èrement luns les ans, mais en certain temus, à limproviste et

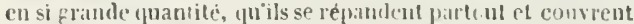
bunte la lerre... Ces pelites bẻles, bien loin d'avoir peur el de s'enfuir (puand dles eutendenl marcher les prissanls, soul an contraire hardies el couragenses, yout all-devant de ceux qui les attapunt, crient el japuent prespue leut de mème que des jetits chirus; si on les veut baltre, elles ue se soveient ni du biton ni des lallebardes, sautant et s'elancant contre ceux

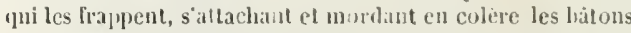
de conx tui les veulent tu'r. Ces animaux ont crei de parliculier, quils n'entrent jumais duns les maisons ni dans les cabanes pour y laire dn dommage; ils se liement tonjonrs caclués daus les broussailles el le lung des coteaux; (ұuclıue. fois ils se font la gnerre, se parlageant comme eu denx an mees le long des lacs et des prés.. Les hermines et les renards sont leurs emuenis et en mangent beaucoup. . L'herbe renaissante fait mourir ces jelits anmanx; il senble qu'ils se fassent aussi monrir eux-ıeemes; on en voil de pendus a des branches d'arbres; on peut croire aussi quils se jellent dans l'eau par troupes comme les hirondelles. II is loire de la La ponie, par Scheffer, page 322. la femelle, et a aussi les taches noires plus grandes. Ils meurent infailliblement au renouvellement des herbes. Ils vont aussi en grandes troupes sur l'eau dans le beau temps; mais s'il vient un coup de vent, ils sont tous submergés. Le nombre de ces animaux est si prodigieux, que, quand ils meurent, l'air en est infecté, et cela occasionue beaucoup de maladies; il semble même qu'ils infectent les plantes qu'ils ont roncées, car le pâturage fait alor's mourir le bétail. La chair des lemings n'est pas bonne à mangel; et leur peau, quoique d'un beau poil, ne peut pas servir à faire des fourrures, parce qu'elle a trop peu de consistance.

\section{LE LÉROT A QUEUE DORÉE.}

\section{(L'ÉCHIMYS HUPPÉ.)}

Ordre des rongeurs, tribu des échimys, genre rat. (Cuvier.)

Nous donnons ici, d'après M. Allamand, la description de ce petit animal qui ressemble au lérot par la taille, la figure et la forme de la queue, mais qui par li position et la forme des oreilles, et par la couleur dorée de la moitié de la queue, ressemble au muscardin; il semble donc faire une espèce moyenne entre celles de ces deux animaux. "C'est, dit " M. Allamand, à M. le docteur Klockner " qu'on doit la comnaissance de ce petit lérot; " il l'a reçu de Surinam, sans aucune notice ni " du nom qu'on lui donne dans le pays, ni des " lienx où il habite. Jusqu'à présent il n'a ja" mais été décrit, ni même connu, quoiqu'il soit " marqué de façon à s'attirer l'attention. Les " nomenclateurs à systèmes ne manqueront pas " de le ranger dans la classe des glires ou luirs " de M. Linnæus, et effectivement il mérite bien autant d'y avoir place que le rhinocéros; et sans doute ils en feront un membre de la " famille des rats, qui comprend tant d'autres " animaux qui en approchent moins que celui" ci. Mais sans chercher à déterminer le genre " auquel il appartient, j"en donnerai une descrip" tion exacte qui m'a été fournie par.M. Klock" uer, qui, toujours zélé pour l'avancement " de l'histoire naturelle, a bien voulu me la com" muniquer en m'envoyant l'animal mème, afin " que je pusse mieux me con vaincre deson exac" titude. J'ai d'abord été embarrassé sur le uom 
- que je lui donnerais. Je n'aime pas ces noms " composés qui déterminent l'espèce à laquelle " on doit rapporter l'animal qui le porte, lor's" qu’il n'est pas très-évident qu’il en soit. Ce" pendant j'ai eru devoir adopter celui que lui " a donné M. Klockner, qui est en droit de le " désigner par celui qu’il juge le plus conve- nable: il l'a appclé lérot à queue dorée, sans " prétendre qu“il tombe dans cet engourdisse" ment causé par le froid aux loirs d'Europe : " un quadrupède habitant de la zone torride ne " paraît pas devoir y ctre sujet. Quelque con" formité de figure et surtout sa quene, avee " celle de nos lérots, lui a fait préférer cette "dénomination à toute autre.

"C'est par la singularité et la beauté de ses " couleurs que eet animal se fait remar(fuer. "Son corps est de couleur maron tirant sur " le pourpre, plus foneće aux côtés de la tète et " sur le dos, et plus claire sous le ventre. Cette " couleur s'étend sur la queue à une petite dis" tance de son origine: là les poils flus et courts " qui la couvrent deviemnent tout à fait noirs " jusqu'à la moitié de sa longueur, oil jls sont " plus longs, et oi ils prement, sans aucume " nuance intermédiaire, une belle couleur d'o" range, approchant de celle de l'or, et qu'ils "gardent jusqu'à l'extrémité de la queue. Une " longue tache de cette même couleur jaune orne " aussi le front ; elle prend son origine au-dessus " dunez; là elle est fort étroite; cnsuite elleva en " s'élargissant jusqu'a la hauteur des oreilles ou " elle finit. Cet assemblage de couleurs si fort " tranchantes, et si rares daus les quadrupedes, "offre un coup d'ocil tres-frappant. Sa tète est " fort grosse, à proportion de son corps; il a le " museau et le front étroits, les yeux petits. "Ses oreilles présentent une large ouverture, " mais elles sont courtes, et ne s'élèrent pas " Jusqu au-dessus de la tète: elles sont couvertes " en dehor's et en dedans de poils tres-fins, et il " y en a de plus longs sur leurs bords, mais il "faut les regarder de près pour les apercevoir. "La mâehoire supérieure avanee sensiblement " au-delí de l'inféricure; l'os du nez est assez "élevé, et le haut du museau cst couvert de " poils, ee qu'on ne voit guère daus les antres "quadrupèdes. La lève de dessus est fendue " du haut en bas, comme dans tous les animaux a de ce geure, et les bords de la fente vont en " s'ecartant vers les côtés ; ce qui donne à l'exv trémité du groin la forme d'un triaugle iso-
" cèle. Cette division laisse voir deux dents in" cisives fort blanches et courtes; il y en a " aussi deux à la mâchoire inférieure, mais qui " sontplus grandes.Cettemảchoire, a vecla lèvre " qui la couve, est plus reculée du coté de la " gorge.

"Aux deux côtés de la lère sunéricure, il " y a une touffe de longs poils d'uu brun som"bre; leur Jongueur surpasse celle de la tète: "ceux qui forment la partie inférieure de cette " moustache sont moins longs, et dirigés en " bas. Derrièe chaque oil, il y a une verrue " d'ou partent aussi six longs poils, et il y en a " deux de même longueur placées au-dessus "des ycux.

"Les jambes de devant sont courtes ; Jeurs " pieds ont ([uatre longs doigts armés d'ongles " crochus et aigus; plus haut est un petit bou" ton obtus qui forme une espece de pouce, " mais sans ongle. Au-dessous de ces pieds il y" " a cinc émincneestres-lemarquables, couvertes "d'une peau mince et fort douce au toucher". a Les jambes de derriere sont plus longues, et "leurs pieds ont cing doigts, qui sont "ussi " plus longs que eeux de devant, et sont de " mème garnis d'ongles erochus et pointus, ex" cepté les deux doigts intérieurs clont les on" gles sont un peu obtus. La plante de ees pieds " postéricurs ressemble ì eelle des antérieurs; " mais les protubéranees qu'on y voit sont plus ( glaudes.

" La queue est fort longue et très-épaisse " près du corps; mais son diametre diminue à " mesure qu'elle s'en éloigne, et elle se termine " en pointe. Quand on en ćearte un peu les poils, " our voit que sa peau cst ćeailleuse comme eclle " du rat.

"Au derrière de la tete et tout le long du dos, " parmi les poils dont l'animal est couvert, il y " en a qui sont plats et de la bonģueur d un ponce; " ainsi ils s'élevent au-dessus des autres: ils sont " aussi plus raides, et résistent da vantag̣e quand " on les touche. Ils paraissent sortir de petits cétuis "transparents; leur nombre va en diminuant " sur les côtés et ils deviennent plus petits; " sous le ventre ils dispanaissent tout à fiit " Leur conformation est assez singuliere : près " du corps ils sont eylindriques et fort minces, " ensuite ils deviennent plits, et leur litreur" " augmente jusqu’á égaler une demi-ligne; "après quoi ils se terminent en une pointe fort " fiuc. Dans la partic plate du milieu, les bords 
" sont relevés, et forment une espèce de gout- tière, dont le fond, vu au microscope, pat" rait jaumátre et transparent, et dont les cótés a sont bruns; ce qui occasionne un double re" flet de lumière qui donne ce coloris pourpré a dont j'ai parlé.

( Le corps, à l'exception du ventre, est " couvert d'une peau, ou plutôt d'un cuir fort 1 rude.

" L'animal qui vient d'être décrit est une " femelle qui a luuit petites mamelles; il y en a "deux entre les cuisses, les six autres sont " placées obliquement en s'écartant de côté et " d'autre, et les deux dernières sont entre les " jambes de devant.

"Il parait être fait pour grimper sur les ar" bres dont il mange les fruits. C'est dommage " (qu'un si joli animal ne soit conmu que par ce " seul échantillon, dont les couleurs ont sans " doute perciu une partie de leur beauté daus la " liqueur où il a été mis pour être envoyé. On " se formera une idée juste de sa grandeur par a les dimensions suivantes.

* Longueur du corps, depuis le bout du mu" seau jusqu'à l'origine de la queue.. . . . 00 5 0

. Longueur de la queue........... 0069

"Longueur de la tète, mesurée depris le com" mencement du nez jusqu'au-dessus du "front, et suivant sa courbure....... "Circonférence de la tète, mesurée entreles " yeux et les oreilles........... 0211

. Circonférence du cou............ 0228

" Longueur des oreilles. . . . . . . . . . 00003

- Leur largeur. ............... 0040

* Circonférence du corps, mesurée derrière

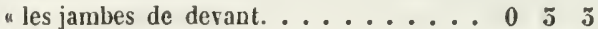

"Circonférence du corps, mesurée devant les a jambes de derrière........... 0 . 50

"Longueur des jambes de derant, depuis les "doigts jusqu'au coude. ......... 0 1 6

- Longueur des jambes entières, depnis l'é- paule jusqu'aux doigts. ........ 0220

- Longueur des jambes de derrière, depuis " Ies doigts jusqu'au genou. . . . . . . . 0112

- Longueur totale depuis la hanclse jusqu'à - l'extrémité des doigts. . . . . . . . . .

\section{LES GERBOISES ‘.}

Ordre des rongcurs, genre rat (Cuvier.)

Gerboise est un nom générique que nous employons ici pour désigner des animaux remarquables par la très-grande disproportion qui se trouve entre les jambes de derrière et celles de devant, celles-ci n'étant pas si grandes que les mains d'une taupe, et les autres ressemblant aux pieds d'un orseau Nous connaissons dans ce genre quatre espèces ou rariétés bien distinctes : $1^{\circ}$ Le tarsier dont nous ferons mention ci-après, qui est certainement d'une espèce particulière, parce qu'il a les doigts faits comme ceux des singes, et qu'il en a cinq à chaque pied. $2^{\circ}$ Le gerbo ou gerboise proprement dite, qui a les pieds faits comme les autres fissipèdes, quatre doigts aux pieds de devant et trois à ceux de derrière. $3^{\circ}$ L'alactaga dont les jambes sont conformées comme celles du gerbo, mais qui a cinq doigts aux pieds de devant et trois à ceux de derrière, avec un éperon qui peut passer pour un pouce ou quatrième doigt beaucoup plus court que les autres. $4^{0} \mathrm{Le} d a$ man israël ou agneau d'Israël, qui pourrait bien être le même animal que M. Linnæus a désigné par la dénomination de mus longipes, et qui a quatre doigts aux pieds de devant et cinq à ceux de derriere.

Le gerbo ${ }^{2}$ a la tête faite à peu près comme celle du lapin, mais il a les yeux plus grands ct les oreilles plus courtes, quoique hautes et amples, relativement à sa taille. Il a le nez couleur de chair et sans poil, le museau court et épais, l'ouverture de la gueule très-petite, la màchoire supérieure fort ample, l'inférieure étroite et courte; les dents commecelles du lapin; des moustaches autour de la gueule, composées de longs poils noirs et blancs. Les pieds de devant sont très-courts et ne touchent jamais la terre : cet animal ne s'en sert que comme de mains pour porter à sa gueule. Ces mains portent quatre doigts muuis d'ongles, et le rudi-

+ Buffon forme ici un petit groupe sous le nom de gerboises, dans lequel il réunit des animaux fort differents. $1^{\circ} \mathrm{Le}$ tarsier, qui est voisin des makis et par conséquent se rapproche des singes; $2^{0}$ les deux rongeurs à grands pieds de derrière, le gerbo et l'alactaga, qui doivent conserver la désiguation générique de gerboises; et $3^{\circ}$ le daman du voyageur Slraw, qu'on doit rapporter à l'espece du gerbo, et qui n'est pas te daman des noinenclateurs. (Desmarets.)

- La Gebiorse gerbo. 
ment d'un cinquième doigt sans ongle. Les pieds de derrière n'ont que trois doigts, dont celui du milieu est un peu plus loug que les deux autres, et tous trois gamis d'ongles. La queue, est trois fois plus longue (que le corps; elle est couverte de petits poils raides, de la même couleur que ceux du dos, et au bout elle est garnie de poils plus longs, plus doux, plus touffus, qui forment une espèce de houppe noire au commencemént et blanche à l'extrémité. Les jambes sont nues et de couleur de chair, aussi bien que le nez et les oreilles. Le dessus de la tête et le dos sont couver'ts d'un poil roussâtre; les flanes, le dessous de la tête, la gol'ge, le ventre et le dedans des euisses sont blanes; il y a au bas des reins, et près de la queue, une grande bande noire transversale en forme de croissant.

L'alactaga ' est plus petit qu'un lapin, et il a le corps plus court; ses oreilles sont longues, larges, nues, minces, transparentes et parsemées de vaisseaux sanguins très-apparents; la mâchoire supérieure est beaucoup plus ample que l'inféricure, mais obtuse et assez large à l'extrémité : il y a de grandes moustaches autour de la gueule; les dents sont comme celles des rats; les yeux grands, l'iris et la paupière bruns; le corps est étroit en avant, fort large ct presque rond en arrière; la queue très-Iongue et moins grosse qu'un petit doigt : elle est couverte, sur plus des deux ticrs de sa longueur, de poils courts et rudes; sur le dernier tiers ils sont plus longs, et encoŕe beaucoup plus longs, plus touffus et plus doux vers le bout ou ils forment une espece de touffe noire au commencement, et blanche à l'extrémité. Les pieds de devant sont très-courts; ils ont eing doigts; ceux de derrière qui sont très-longs n'en ont que quatre, dont trois sont situés en avant, et le quatrième est à un pouce de distance des autres : tous ees doigts sont garnis d'ongles plus courts dans ceux de devant, et un peu plus longs dans ceux de derrière. Le poil de cet animal est doux et assez long, fauve sur le dos, blane sous le ventre.

L'on voit, en comparant ces deux deseriptions, dont la première est tirée d'Edwards et d'Jasselquist, et la seconde de Gmelin, que cesanimaux se l'essemblent presque autant qu’il est possible; le gerbo est seulement plus petit que l'alactaga, et n'a que quatre doigts aux

- La Gerboise al actiga. pieds de devant, et trois à ceux de derrière sans éperon, au lieu que celui-ci en a cinq aux pieds de devant, et quatre, c'est-à-dire, trois grands et un éperon à ceux de derrière : mais je suis très-jorté à croire que cette différence n'est pas constante; car le docteur Shaw, qui a donné la description et la figure d'un gerloo de Barbarie, le représente avec cet éperon ou quatrièmedoigt aux pieds de derrière; et M. Edwalds remarque (qu'il a soigneusement observé les deux gerbos (ru'il a vus en Angleterre, et qu'il ne leur a pas trouvé cet éperon : ainsi ce caractère qui paraitrait distinguer spécifiquement le gerbo et l'alactaga, n'étant pas constant, devient nul et marque plutôt l'identité que la diversité d'espèce. La différence de grandeur ne prouve pas non plus que ce soient deux espèces différentes; il se peut que MM. Edwards et Ilasselquist n'aient décrit que de jeunes gerbos, et M. Gmelin un vieux alactiga. Il n'y a que deux choses qui me laissent quelque doute : la proportion de la queue qui est beaucoup plus grande dans le gerbo que dans l'alactaga, et la différenee du climat où ils se trouvent. Le gerbo est commun en Circassic ${ }^{1}$, en Égypte ${ }^{2}$, en Barbarie, en Arabie, et l'alactaga en Tartarie, sur le Volga et jusqu'en Sibérie. Il est rare que le mème animal habite des climats aussi différents; et lorsque cela arrive, l'espèce subit de grandes variétés : e'est aussi ce que nous présumons être arrivé à celle du gerbo dont l'alactaga , malgré ses différences, ne nous paraft être qu une variété.

Ces petits animaux eachent ordinairement leurs mains ou pieds de devant dans leur poil; en sorte qu'on dirait qu'ils n'ont d'autres pieds que ceux de den'ière. Pour se transporter d'un licu à un autre, ils ne marchent pas, c'est-àdire, qu'ils n'avaneent pas les pieds l'un apres lautre; mais ils sautent très-légèrement et tres-vite, à trois ou quatre pieds de distance,

- On Irouve en Circassie, aussi bien qu'en Perse, en Ara bie el aux cuvirons de Babjlone, nne espèce de mulot appelo jerbuah eu arabe, de la grandeur el coulcur a peu pre's diuu ćcurenil..... Quand il saute, il s'élance à cing ou six pieds de terre... Il quitte quelyuefois les champs el se fourre dans les maisons. Vuyage doléarius, page 177.

${ }^{2}$ En Esypte, je vis de pelits anintaux qul comraient tres-fort sur leurs deux jambes de derrière ; elles élaient si longues, qu'ils semblaient monlés sur des échasses. Ces animaux terrent comme les lajins. On en prit sept que jemportai; il w'en est resté denx yue jai apjurlés en Prance, vu ils ont récu a la Ménageric du Iroi freadaut deux ans. Voyage de Paul Lucas, tome 11, page it 
et toujours debout comme des oiseaux. En repos, ils sont assis sur leurs genoux; ils ne dorment que le jour et janais la muit. Ils mangent du grain et des herbes comme les lièrres; ils sont d'un naturel assez doux, et néanmoins ils ne s'apprivoisent que jusqu'à un certain point. Ils se creusent des terriers comme les lapins, et en beancoup moins de temps; ils y font un magasin d'herbes sur la fin de l'été, et dans les pays froids ils y passent l'hiver.

Comme nous n'arons pas été à portée de faire la dissection de cet animal, et que M. Gmelin est le seul qui ait parlé de la conformation de ses parties intérieures, nous donnons ici ces observations en attendant qu'on en ait de plus préeises et de plus étendues.

A l'égard du daman ou agneau d'Israël, qui nous parait être du genre des gerboises, parce qu'il a comme elles les jambes de derant trèscourtes en comparaison de celles de derrière, nous ne pourous mieux faire, ne layant jamais ru, que de citer ce qu'en dit le docteur Shaw, qui était à portée de le comparer arec le gerbo, et qui en parle comme de deux espèces différentes. "Le daman Israël, dit cet auteur, " est aussi un animal du mont liban, mais éga"lement commun dans la Syrie et dans la "Phénicie. C'est une bête innocente qui ne fait " point de mal, et qui ressemble pour la taille " et pour la figure au lapin ordinaire, ses dents " de devant étant aussi disposées de la même " manière; sculement il est plus brun et il a les " yeux plus petits, et la tète plus pointue, ses " pieds de devant sont courts, et ceux de der"rière longs, dans la même proportion que "ccux du jerboa (gerbo). Quoi(u'il se eache " quelquefois dans la terre, sa retraite ordinaire " est dans les trous et fentes des lochers; ce qui " me fait croire, continue 11. Shaw, que c'est " cet animal plutôt que le jerboa ( gerbo) qu'on " doit preindre pour le saphan de l'Écriture: " personne n'a pu me dire d'où vient le nom a moderne de daman Israël, qui signifie agneau - d'Israël. „ Prosper Alpin, qui avait indiqué cet animal avant le docteur Shaw, dit que sa chair est excellente à manger, et qu'il est plus gros que notre lapin d'Europe : mais ce dernier fait parait douteux, car le doctcur Shaw l'a retranché du passage de Prosper Alpin, qu’il cite au reste en enticr.

\section{LA GERBOISE OU GERBO}

ET

\section{LA GERBOISE DU CAP.}

(LA GERBOISE GERBo. - LE PEDETÉS DU CAP.)

Ordre des rongeurs, genre ral (Curier.)

Nous domnons ici la figure de la gerboise (gerbo), qui manquait dans notre ouvrage, où nous a vons cionné une courte histoire des différentes espèces de gerboises, et une description particulière de celle-ci, tirće d'Edwards et d'Hasselquist. Les petites difiérences qu'on pourrait y remarquer ne seraient tout au plus qu'une légère variété dans cette espèce, dont les couleurs et la longueur des pattes de devant et des ongles ne paraissent pas constantes '.

Il existe dans le désert de Barca une gerboise différente de celle-ci, en ce qu'elle a le corps encore plus mince, les oreilles plus longues et arrondies, et à peu près également larges du haut en bas; les ongles des quatre pieds beaucoup plus courts, et les couleurs en général moins foncées ; la bande sur les cuisses moins marquée ; les talons noirs ; la pointe du museau beaucoup plus aplatie. On voit que ces disconvenances sont encore assez légères, et qu'on peut les regarder comme de simples variétés.

Les gerboises se trouvent dans tous les climats de l'Afrique, depuis la Barbarie jusqu'au eap de Bonne-Espérance; on en roit aussi en Arabie et dans plusieurs autres contrées de l'Asie : maisil parait qu'il y en a de grandeur trèsdifférente, et il est assez étomnant que dans ces animaux ¿t longues jambes, il s'en trouve de vingt et même de cent fois plus gros que les petites gerboises dont nous arons parlé. "J'ai vu, dit M. le vicomte de Qucrhoënt, à la Ménagerie du Cap, un animal pris daus le pays, qu'on nomme lièvre sauleur ${ }^{2}$. Il est de la grandeur du lapin d'Europe; il a la tête à peu près comme lui, les oreilles au moins de la mĉme longueur, les pattes de devant très-courtes et très-petites; il s'en sert pour porter à sa gueule, et je ne crois pas qu'elles lui scrvent beaucoup

4 Cetle figure est celle de la Graboise gerbo.

2 Cel animal est le PeDetes du CAP, ou Helays Mater, lequel est très-éloigné des gerboises par un grand nombre de caractères. 
à marcher; il les tient ordinairement ramassées dans son long poil qui les recouvre entièrement: les pattes de derrlere sont grandes et grosses; les doigts du pied, an nombre de quatre, sont longs et separés; la queue est de la longueur du corps au moins et couverte de longs poils couchés; le poil du corps est jaunâtre; le bout des oreilles ct de la queue sont de la même couleur; les yeux sont noirs, grands et saillants. On le nourrissait de feuilles de laitue. Il aime beaucoup à ronger; on lui mettait exprès dans sa cage de petits morceaux de bois pour l'amuser.

M. Forster nous a communiqué un dessin de cette grande gerboise ou lièvre sauteur du Cap. Cedessin était accompagnéde la notice suivante : "Cette gerboise, dit-il, a cinq doigts au x pieds de devant et quatre à ceux de derrière : les ongles du devant sont noirs, longs, minees et courbés; ceux des jambes de derriere sont bruns, gros, courts, de figure conique, un peu courbés vers l'extrémité : l'acil est noir et fort gros; le.nez et les naseaux sont d'un brun roux; les oreilles sont grandes, lisses, nues en derlans, et convertes en dehors d'un petit poil court qui est couleur d'ardoise. La tète ressemble assez à celle des petites gerboises; il y a des moustaches autour de la gueule et aux angles des yeux. Les jambes ou plutòt les bras de devant sont trèscourts et les mains fort petites; les jambes de derriere, au contraire, sont très-grosses et les pieds excessivement longs. La queue, qui est aussi fort longue et fort chargée de poil, parait mince à sa naissance et fort grosse à son extrémité ; elle est d'un fauve foncé sur la plus grande partie de sa longueur, et d'un brun miuime vers le bout. Les jambes et les pieds sont d'un fauve pâle mêlé de gris; la couleur du corps et de la tête est d'un jaune pâle presque blane; les cuisses et le dessous du corps sont plus james; tout le dessus du corps, ainsi que l'extrémité de la mâchoire, le dessus du nez, les mains, ont une teinte de fauve; le derrière de la tète est couvert de grands poils mélés de noir, de gris et de faure. "Au reste, nous pensons que eette gerboise du Cap décrite par MI. de (uerhoènt et par M. For'ster, est la même que celle dont M. AIlamand a donné l'histoire et la ligure, $p l$. 15, de l'Histoire naturelle, édition de Hollande.

Il nous parait aussi que l'animal que nous décrivons sous le nom de tarsier, est du mème genre que les gerboises, et qu'il appartient ì l'ancien contiment. Aucunc esvece de gexboises, grandes et petites, ne se trouvant qu'en Afrique et en Asie, nous me pourons guère douter que le tarsier ne soit de l'une ou de l'autre de ees parties dir monde .

J'ai vu plusieurs figures de gerboises dessinées d'après des pièces antiques, et surtout d'après une ancienne médaille de Cyrène, qui portait en revers une gerboise, dont la figure ne ressemble point à eelle de la gerboise dont le docteur Sliaw a donné la description, sous le nom de daman Israël; ear clle cn diffère beaucoup par la grandeur, par la forme de la tête, par les yeux et par plusieurs autres caractères. II est aisé de clémontrer que le docteur Shaw s'est trompé en rapportant le daman Istaël à cette espèce de gerboise. Celle qui est dessinée sur la múdaille de Cyrène est une vraie gerboise, etn'a nul rapport avec le daman. Dans d'autres grarures, tirées des marbres antiques d'Ox fort, j'ai vu la figure de quelques gerboises, dont les unes avaient les pattes de devant, et surtout les oreilles, beaucoup plus longues que eelles dont nous donnons iei les figures; mais au reste ces gerlooises gravéez sur des marbres antiques ne sout pas assez bien représentées pour pouvoir les rapporter aux espèces que nous venons d'indiquer.

ADDITION DE M. LE PROFESSEUR ALLAMAND A L'ARTICLE DE LA GERBOISE OU GERBO.

(Daus l'histoire des gerljoises, M. de Buffon distingue quatre espèces différentes de ees animaux : mais il n'eu a vu qu'une qui est celle du tarsier; aussi est-ce la seule dont il ait donné la figure. Ce qu'il a dit des trois autres est tiré des auteurs qui en ont parlé avant lui; il a cmprunté entre autres la deseription du gerlo qui appartient à la seconde espèce de M.H. Edwards et Hasselquist. Cet animal est actuellement vivant a Amsterdam, chez le docteur Kilockner, qui a bien voulu nous communiquer ce qu'il a offert de plus remariquable. C'est en faisant usage de ses observations, que nous allons ajouter quelques particularités ì eelles que. II. de Bufton cu a rapportées.

1 Le tarsier, ponru de mains a ponee opposable aux quatre meubres, ct dont le système dentaire est tris-semblable à celui des animaux de la famille des nakis, est fort dloigne des gerbojses par toutes les parties de son organisation. 
"La description que celui-ci en a faite, est très - exacte. On retrouve dans le gerbo de M. Klockner tout ce qu'il en a dit, à l'exception de cette grande bande noire transversale, en forme de croissant, qui est au bas des reins près de la queue : c'est une femelle, et peutétre cette bande ne se voit-elle que sur le mâle; ce qui me porte à le croire, e'est que j'ai mis dans le cabinet de l'académie de Leyde la pean d'un autregerbo femelle, où cette bande ne paraît pas non plus.

"M. Klockner a recu cette gerboise de Tunis : la caisse dans laquelle elle lui a été apportée était garnie en dedans de fer-blanc; elle en avait enlevé avec ses dents quelques pièces, et en avait rongé le bois en différents endroits. Elle fait la même chose dans la cage où elle est actuellement gardée; elle n'aime pas à ètre renfermée : cependant elle n'est point farouche; car elle souffre qu'on la tire de son nid et qu'on l'y remette avec la main nue, sans qu'elle morde jamais. Au reste, elle ne s'apprivoise que'jusqu'à un certain point, comme l'a remarqué M. de Buffon; car elle ne parait mettre ancune différence entre celui qui lui donne à manger etdes étrangers. Lorsqu'elle esten repos, elle est assise sur ses genoux, et ses jambes de derrière, étendues sous le ventre, atteignent presque ses jambes de devant, en formant une espèce d'are-de-cercle : sa queue alors est posée le long de son corps; dans cette attitude, elle recueille les grains de blés ou les pois dont elle se nourrit: c'est a vec sespattes de devant qu'elle les porte à sa bouche, et cela si promptement, qu'on a peine à en suivre de l'œil les mouvements; elle porte chaque grain à sa bouche, et en rejette l'écorce, pour ne manger que l'intérieur.

"Quand elle se meut, elle ne marche pas en avancant un pied devant l'autre, mais en sautant comme une sauterelle, et en s'appuyant uniquement sur l'extrémité des doigts de ses pieds de derrière : alors elle tient ses pieds de devant si bien appliqués contre sa poitrine, qu'il semble qu'elle n'en a point. La figure qu'en offre la planche, la représente dans l'attitude où elle est quand elle se prépare à sauter, et il est difficile de concevoir comment elle peut se soutenir; quelquefois même son corps forme, avec ses jambes, un angle plus aigu encore: mais pour l'ordinaire elle se tient dans une situation qui approche plus de la perpendiculaire.
Si on l'épouvante elle saute à sept ou huit pieds de distance; lorsqu'elle veut grimper sur une hauteur, elle fait usagede ses quatre pieds; mais lorsqu'il faut descendre dans un creux, elle traine aree soin ses jambes de derrièresans s'en servir, et elle avance en s'aidant uniquement des pieds de devant.

(Il semble que la lumière incommode cet animal : aussi dort-il pendant tout le jour, et il faut qu'il soit bien pressé par la faim, pour qu'il lui arrive de manger quand le soleil luit encore: mais dès qu'il commence à faire obscur, il se réveille, et durant toute la nuit il est continuellement en mouvement, et e'est alors seulement qu'il mange. Quand le jour parait, il rassemble en tas le sable qui est dispersé dans sa cage; il met par dessus le coton qui lui sert de lit, et qui est fort dérangé par le mouvement qu'il vient de se domner; et après avoir raccommodé son nid, il s'y fourre jusqu'à la nuit suivante.

"Pendant le voyage qu'il a fait de Tunis à Amsterdam, et qui a été de quelques mois, on l'a nourri de gruau ou de biscuit sec, sans lui donner à boire. Dès qu'il fut arrivé, le premier soin de M. Klockner fut de lui présenter un morceau de pain trempé dans l'eau, ne doutant pas qu'il ne fút fort altéré; mais il ne voulut point y toucher, et il préféra un biscuit dur : cependant M. Klockner, ne soupconnant pas qu'il pùt se passer d'eau, lui donna des pois verts et des grains de blé qui en étaient imbibés; mais ce fut inutilement, il n'en goùta point; il fallut en revenir à ne lui donner que du manger see sans eau; et jusqu'à présent, depuis une année et demie, il s'en est bien trouvé.

"Quelques auteurs out rangé cet animal parmi les lapins, auxquels il ressemble par la couleur et la finesse de son poil, et par la longueur de ses oreilles; d'autres l'ont pris pour un rat, parce qu'il est à peu près de la même grandeur'; mais il n'est ni lapin ni rat: l'extrême disproportion qu'il $\mathrm{y}$ a entre ses jambes de devant ct celles de derrière, et l'excessive longueur de sa queue, le distinguent des uns et des autres. Il forme un genre à part et mème très-singulier avee l'alactaga, dont M. Gmelin nous a donné la description et la figure; mais qui approche si fort de notre gerbo, qu on ne peut le regarder, a vec $M$. de Buffon, quecomme une variété de la même espèce.

" Il ne faut pas oublier que le gerbo a autour de la bouche une moustache composée de poils 
assez raides, parmi lesquels il y en a un de côté d'une longueur extraordinaire, puisqu'il est long de trois pouces.

"Je me suis servi de la peau bourrée qui est dans le Cabinet de l'académie de Leyde, pour prendre les dimensions que voici :

Longueur du corps entier, mesuré en ligne droite depuis le bout du museau jusqu'à

l'anus..................... 06 7

Longueur des oreilles. ............... $0 \begin{array}{lll}0 & 0 & 10\end{array}$

Distance entre l'oreille et l'œil. . . . . . . 0000

Longueur de l'œil d'un angle à l'autre. . . . 007006

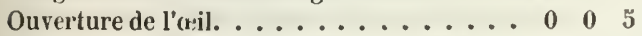

Distance entre l'oil et le bout du museau. . $\begin{array}{lll}0 & 1 & 0\end{array}$

Circonférence du bout du museau. . . . . . $0 \begin{array}{llll}0 & 2 & 6\end{array}$

Circonférence de la tête, entre les yeux et les oreilles................... 0 5 0

Circonférence du corps, prise derrière les jambes de devant. ............... 055

Circonférence prise devant les jambes de der-

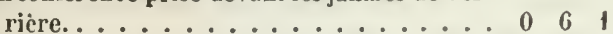

Longueur des jambes de devant, depuis l'extrémité des doigts jusqu'à la poitrine. . . . $00 \begin{array}{llll}0 & 0 & 10\end{array}$ Longueur des jambes de derrière, depuis l'extrémité des pieds jusqu'à l'abdomen. . . . 0070 Longueur de la queue. ........... 08 80

"Ces dimensions sont celles du gerbo dontj'ai la dépouille, et elles sont à peu près celles du gerbo de M. le docteur Klockner, et de presque tous ceux qui ont été déerits par les naturalistes; il $y$ en a cependant qui sont beaucoup plus grands. Prosper Alpin, en parlant du daman ou agneau d'Israël, que $M$. de Buffon range avee raison au nombre des gerboises, avait déjà dit que cet animal est plus gros que notre lapin d'Europe, ce qui a paru douteux au docteur Shaw et même à M. de Buffon. A présent nous sommes certains que cet auteur n'a point exagéré. Toute l'Europe sait que MIM. Banks et Solander, animés d'un zèle, je dirais presque héroïque, pour avancer nos connaissances dans l'astronomie et dans l'histoire naturelle, ont entrepris le tour au monde : à leur retour en Angleterre, ils ont fait voir deux gerbos qui surpassent en grosseur nos plus grands lièvres ${ }^{1}$; en courant sur leurs deux pieds de derrière ils mettent en défaut les meilleurs chiens. Ce n'est là qu'une des moindres curiosités qu'ils ont apportées avec eux ; ils en ont fait une ample collection, qui leur fournira de quoi remplir un millier de planches. On prépare, par ordre de l'amirauté d'Angleterre, une relation de leur

- c'étaicnt des kanguroos de la Nourelle-Hollande. voyage : on y verra des particularités très-intéressantes sur un pays des Terres Australes que nous ne connaissons jusqu'à présent, quedenom; ie veux parler de la Nouvelle-Zélande, etc. "

SECONDE ADDITION A L'HISTOIRE DES GeRbotSES, par M. Allamand.

"Dans l'histoire que j'ai donnée du gerbo, j'ai remarqué que Prosper Alpin a eu raison de dire que le daman, qui appartient au genre des gerboises ', était plus gros que notre lapin d'Europe. J'ai avancé cela, fondé sur ce qu'on m'a. vait écrit d'Angleterre, que M. Banks, revenu de son voyage autour du monde, avait apporté un de ces animaux qui surpassait en grosseur nos plus grands lièvres. A présent je suis en état de dire quelque chose de plus positif sur cet animal, dont M. Banks a eu la bonté de me faire voir la dépouille, et dont nous avons la description et la figure dans la relation du voyage de M. le capitaine Cook. II diffère de toutes les espèces de gerboises décrites jusqu'à présent, non-seulement par sa grandeur, qui approche de celle d'une brelis, mais encore par le nombre ou l'arrangement de ses doigts. Parkinson, qui était parti a vee M. Banks en qualité de son dessinateur, et dont on a publié les Mémoires, nous apprend qu'il avait cinq doigts aux pieds de derant, armés d'ongles crochus, et quatre à ceux de derrière; comme c'était un jeune, qui n'était pas encore parvenu à toute sa grandeur, il ne pesait que trente-huit livres; sa tète, son con et ses épaules, étaient fort petits en comparaison des autres parties de son corps; ses jambes de devant avaient huit pouces de longueur, et celles de derrière en avaient vingtdeux; il avançait en faisant de très-grands sauts et en se tenant debout; il tenait ses jambes de devant appliquées à sa poitrine, et elles paraissaient ne lui servir qu'à creuser la terre; sa queue était épaisse à son origine, et son diamètre allait en diminuant jusqu'à son extrémité ; tout son corps était couvert d'un poil gris de souris foncé, excepté à la tête et aux oreilles,

1 Nota. I.e daman du docteur Shaw appartient en eflet au genre des gerboises; mais nous verrons les raisons qul nous persuadent que le doctcur Shav a mal appliqué à cet animal le noun de daman. 
qui avaient quelque ressemblance avec celles d'un lièvre.

"Par cette description, on voit que cet animal n'est pas le gerbo, qui a quatre doigts aux pieds de devant et trois à ceux de derrière; ni le daman ou agneau d'Israël, qui a quatre doigts aux pieds de devant, et cinc à ceux dederrière', avec lequel par conséquent je n'aurais pas dû le confondre: l'alactaya est l'espèce des gerboises qui en approche le plus par le nombre des doigts; il en a cinq aux pieds de devant et trois à ceux de derrière, avec un éperon qui peut passer pour un pouce ou quatrième doigt, comme le remarque $\mathbf{M}$. de Buffon : mais la différence de grandeur, la distance des lieux et la diversité du climat oì ces deux animaux se trouvent, ne permettent guère de les regarder comme'une seule et même espèce. Celui que M. Banks nous a fait connaître, est habitant de la Nouvelle-Hollande, et l'alactaga est commun en Tartarie et sur le Wolga.

" Nous avons actuellement en Hollande un animal vị̣ant, qui pourrait bien être le même que celui de la Nouvelle-Hollande : on en jugera par la description suivante, dont je suis redevable à M. le docteur Klockner, à qui j'ai dû aussi celle que j'ai donnée ci-devant du petit gerbo $^{2}$.

" Cet animal a été apporté du cap de BonneEspérance par le sieur Holst, à qui il appartient; il a été pris sur une montagne nommée Snenwberg, située à mne très-grande distance du Cap, et fort avant dans les terres; les paysans hollandais lui donnent le nom de Acrdmannetje, de Springendehaas ou Lièvre sautant; il est de la grandeur d'un lièvre ou d'un lapin; son pelage est de couleur fauve par le haut, mais de couleur de cendré sur la peau, et cntremélé de quelques poils plus longs, dont la pointe est noire; sa tête est fort courte, mais large et plate entre les oreilles, et elle se termine par un museau obtus qui a un fort petit nez; sa mâchoire supérieure est fort ample et cache l'inférieure, qui est très-courte et petite; il n'est point de quadrupède connu qui ait l'ouverture de la gueule si en arrière au-dessous de la tète.

"Lesoreilles sont d'un tiers plus courtes que

\footnotetext{
1 Cela est vral dı prétendı daman du doeteur Shaw, ciui est une gerboise, mais faux à l'égard du véritable daman, qui n'a que trois doigts aux pieds de derrière. Voyez ci-après son artiele.

Il est de nouveau question ici du PEDETÉs de CAP.
}

celles du lapin ; elles sont fort minces et tran parentes au grand jour; leur partie supérieure est noirátre, l'inférieure est de couleur' de chair et plus transparente que la partie supérieure. Il a de grands yeux à fleur de tête, d'un brun tirant sur le noir; ses paupières sont garnies de cils et surmontées de cinq ou six poils trèslongs. Chaque mâchoire est garnie de deux dents incisives très-fortes; celles de la supérieure ne sont pas si longues que celles de la mâchoire infěrieure : Ia lèvre d'en haut est garnie d'une moustache composée de longs poils.

Les pieds de devant sont petits, courts et situés tout près du cou : ils ont chacun cinq doigts aussi très-courts, placés sur la mème ligne; ils sont armés d'ongles crochus de deux tiers plus grands que les doigts mêmes; il y a au-dessous une éminence charnue sur laquelle ces ongles reposent. Les deux jambes de derrière sont plus grandes que celles de devant; les pieds ont quatre doigts, dont les deux intérieurs sont plus courts que le troisième, qui est un tiers plus grand que l'evtiricur; ils sont tous garnis d'ongles, dont le... élevé, et qui sont concaves en dessons.

"Le corps est étroit en avant et un peu plus gros en arrière; la queue est aussi longue que le corps; les deux tiers en sont couverts de longs poils fauves, et l'autre tiers de poils noirs.

"Comme les autres sortes de gerboises, il ne se sert que de ses pieds de derrière pour marcher, ou, pour parler juste, pour sauter : aussi ces pieds sont-ils très-forts, et si on le prend par la queue; il en frappe avec beancoup de violence. On n'a pas pu déterminer la longueur de ses plus grands sauts, parce ru'il ne peut pas exercer sa force dans le petit appartement où il est renfermé : dans l'état de liberté, on dit que ces animaux font des sauts de vingt à trente pieds.

"Son cri est une espèce de grogriement. Quand il mange, il s'assied en étendant horizontalement ses grandes jambes et en courbant son dos. Il se sert de ses pieds de devant comme de mains pour porter sa nourriture à sa gueule : il s'en sert aussi pour creuser la terre, ce qu'il fait avec tant de promptitude, cu'en peu de minutes il peut s'y enfoncer tout à fait.

"Sa nourriture ordinaire est du pain, des racines, du blé, ete.

"Quand il dort, il prend une attituke singulière, il est assis avee les genoux étendus : il 
met sa tête à peu près entre ses jambes de derriere, et avec ses deux pieds de devant il tient aes oreilles appliquées sur ses yeux, et semble aunsi protéger sa tête par ses mains. C'est pendant le jour qu'il dort, et pendant la nuit il est ordinairement éveillé.

"Par cette deseription, on voit que cet animal doit ètre rangé dans la classe des gerboises décrites par M. de Buffon, mais qu'il en diffère cependant beaucoup, tant par sa graudeur que par le rombre de ses doigts. Nous en cionnons ici la figure, qui, quoiqu'elle ait beancoup de rapport avec celle que nous avons donnée du ger'ho, en diffère cependant assez pour qu'on ne puisse pas les confondre : nous avons fait graver, au bas de la planche, les pieds de eet animal, pour qu'on comprenne mieux ce que nous en avons dit.

" S’il est le même animal que celui (fui a été déerit dans la relation du Voyage du capitaine Cook, comme il y a grande apparence, la ligure qui s'en trouve dans l'ouvrage anglais et dans la traduction française n'est pas cxacte; la tête en est trop longue; ses jambes de devant ne sont jamais dans la situation où elles sont représentées comme pendantes ver's le bas; le nôtre les tient toujours appliçuées à sa poitrine, de facon que ses ongles sont placés immédiatement sous sa màchoire inféricure; situation qui s'accorde avec celle que lem. donne l'auteur anglais, mais (jui a été mal exprimée par le dessinateur ct par le graveur.

"Voiei les dimensions de notre grand gerloo, qui feront mieux connaître combien il differe de toutes les autres espèces décrites:

Longueur du corps mesure en ligne droile,

1. p. I. depuis le hout du museau jusqu'à l'origine

de la queve. ......................... 20

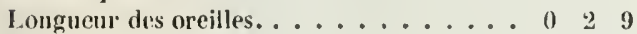

Bistance entre les y'rux.. . . . . . . . $0 \begin{array}{lll}0 & 2 & 0\end{array}$

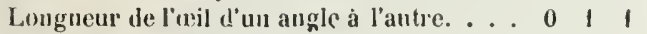

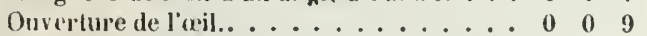

Circonference du corps, prise derricre les jambes de devant. .............. 0 |l 0

Circonférence prise devant les jambes de derricre................. 1 1 0 \% 2

Irateur des jambes de devant, depuis l'ex. trémilé des ongles jusıüà la poitrine. .

Longuenr des jambes de derrìre, depnis l'ex-

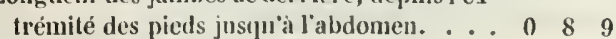

Longueur de la queue.. . . . . . . 1 \& 9

En comparant ces deseriptions de M. Allamand et en résumant les observations que l'ou vient de lire, nous trou verons dans ee geliric cos gerboises quatre especes bien distinetement connues: $1^{\circ}$ la gerboise ou gerbo d'Eàwards, d'Hassel(juist et de M. Allamand, dont nous avons clonné la description, et à lapuelle nous laissons simplement le nom de gerboise, en persistant à lui rapporter l'alactaga, et en lui rapportant encore, comme simple variété, la gerboise de Barca, de $\mathbf{H}$. le chevalier Bruce'; $2^{\circ}$ notre tarsier, qui est bien du geure de la gerboise et mème de sa taille, mais ([ui néanmoins forme une esjèce différente, puisyu il a cing doigts à tous les pieds; $3^{\prime)}$ la graude gerboise ou lièvre sauteur du Cap, que nous venons de recomnaitre dans les deseriptions de MM. de Querhoënt, Forster et Allamand; $4^{\circ}$ la lies-arande gerboise de la Fouvelle-Hollande, appelée lianguroo par les naturels du pays. Elle approche de la grosscur d'une brebis, et par conséruent est d'une espèce beaticoup plus forte que celle de notre grande gerboise ou lievre satuteur du Cap, quoifue M. Allamand semble les rapporter l'une a l'autre. Nous n'ayons pas cru devoir copier la figure de cette gerboise, donnce dins le premier voyage du capitaine Cook, parce qu'elle nous parait trop défectueuse : mais nous devons rapporter ici ce que le célèbre navigitteur a dit de ce singulier animal, qui jusquá ce jour ne s'est trouvé uulle part que daus le continent de la Nouvalle-Hollande.

"Comme je me promenais le matin à peu de distance du vaisscau, dit-il (a la baie d'bindeavour, cóte de la Nouvelle-Hollande), je vis un des animaux que les gens de l'é(quipage m'avaient déerits si souvent; il etait d'une ligrere couleur de souris, et ressemblait bean'oxp par. la grossem et la figure à un lévrier, et je l'aurais es elfet pris pour un chicn sauvage, si au lieu de courir il n'avait pas sauté comme un lieve ou un daim.... M. Banks, qui vit imparfitement eet animal, pensal que son espece etait encore inconmuc... Un des jour's suivants, comme nos gens partaient au premier crepuscule du matin pour aller chercher du gibier, ils virent quatre de ees animaux, dont deux furent tresbien chassés par le lévrier de M. Banks; mais ils lelaisscrentbientòtderricre ensitutant par-dessug l'herbe longue et épaisse qui ('mpêchatit le chien de courir. On observa que ces animaux ne mar-

- Pallas a séparé l'espeèce du gerbo de celle de l'alactaga, et son opinion est adoptée par tons les domenclateurs. La gerboise de larca est une variété dn gerbo. 
cliaient pas sur' leur's quatre jambes, mais qu'ils sautaient sur les deux de derrière, conme le gerbui ou mus jaculus... Knfin, M. Gore, mon lieutenant, faisant peu de jours après une promenade dans l'intérieur du pays avec son fusil, cut le bonheur de tuer un de ces quadrupèdes rizi avaient été si souvent l'objet de nos spécuInt? aucun autre déjà connu, pour qu'on puisse en faire la comparaison: sa figure est très-analogue à celle du geerbo, à qui il ressemble aussi par ses mourements; mais sa grosseur est fort différente, le gerbo étant de la taille d'un rat ordinaire, et cet animal, parvenu à son entière croissance, de celle d'un mouton. Celui que tua mon lieutenant était jeune; et comme il n'avait pas encore pris tont son accroissement, il ne pesait que trente-huit livres. La tête, le cou et les épaules, sont très-petits en proportion des autres parties du corps. La queue est presque aussi longue rue le colps; elle est épaisse à sa naissance et elle se termine en pointe à l'extrémité, Les jambes de devant n'ont que luit pouces de long, et celles de derrière en ont vingt-dleux. II marche par sauts et par bonds; il tient alor's la tête droite et ses pas sont fort longs; il replie ses jambes de devant tout près de la poitrine, et il ne parait s'en servir que pour crenser la terre. La peau est couverte d'un poil court, gris ou couleur de souris foncé; il faut en excepter la tête et les oreilles, qui ont une légère ressemblance avec celle du lièvre. Cet animal est appelé kanguroo par les naturels du pays... Le même M. Gore, dans une autre chasse, tua un second kanguroo, qui, a vec la peau, les entrailles ct la tête, pesait quatre-vingt-quatre livres ; et néanmoins en l'examinant nous reconnùmes quilil n'avait pas encore pris toute sa croissance, parce que les dents mâchelières intérieures n'étaient pas encore formées... Ces animaux paraissent ètre l'espèce de quadrupèdes la plus commune à la Nouvelle-Hollande, et nous en remeontrions presque toutes les fois que nous allions dans les bois."

On voit clairement par cette deseription historique que le kanguroo, ou très-grande gerboise de la Nourelle-Hollande, n'est pas le même animal que la grande gerboise ou lièvre santeur du cap de Bonne-Espérance; et MIM. Forster, qui ont été à portée d'en faire la comparaison atrec le kanguroo de la Nouvelle-Hollande, ont pensé commc nous, que c'étaient denx espèces différentes dans le genre des gerboises. D'un autre còté, si l'on compare c'e que dit le docteur Shaw de l'animal qu'il appelle daman, avec la deseription du lievre sauteur, on reconnaitra aisément que ces deux animaux ne sont qu'une seule et mème espèce, et que ce sa vant royageur s'est trompé sur l'application du nom damau, qui appartient à un animal tout différent. On peut aussi inférer de ce qui vient d'ètre dit que' l'espèce du lièvre sauteur appartient non-sculement à l'Afrique, mais encore à la Phénicie, la Syrie, et autres régions de l'Asie-Mineure, dont la communication avec l'Afrique est bien établie par l'Arabie, pour des animaux surtoul qui vivent dans les sables brùlants du désert En séparant done le vrai daman des gerboises, nous devons indiquer les caracteres qui les distinguent.

\section{LE PORG-ÉPIG.}

\section{(LE PORC-ÉPIC COMNUN.)}

Famille tes rongeurs, genre porc-épic. (Cuvier.)

Il ne faut pas que le nom de pore-épineux qu'on a donné à cet animal dans la plupart des langues de l'Europe nous induise en erreur, et fasse imaginer que le porc-épic soit en effet un cochon chargé d'épines : car il ne ressemble au cochon que par le grognement ; par tout le reste il en differe autant quancun autre animal, tant pour la figure que pour la conformation intérieure : au lieu d'une tête allongée, surmontéc de longues oreilles, armée de défenses et terminée par un boutoir; au lieu d'un pied fourchu et garni de sabots comme le cochon, le porcépic a comme le castor la tête courte, deux grandes dents incisives en avant de chaque mâchoire, nulles défenses ou dents canines, le museau fendu comme le lièvre, les oreilles rondes et aplaties, et les pieds armés d’ongles: au lieu d'un grand estomac avec un appendice en forme de capuchon, qui dans le cochon semble faire la nuance entre les ruminants et les autres animaux, le pore-épic n'a qu'un simple estomac et un grand coeum: Ics parties de la génération ne sont point apparentes au dehor's comme dans le cochon mâle; Jes testicules du porc-épic soni recélés au-dedans et 


renfermés sous les aines; la verge n'est point apparente; et l'on peut dire que par tous ces lapports aussi hien (fue par la queue courte, la Inngue moustrche, la lèvre divisée, il approche beaucoup plus du lièvre ou du castor que du cochon. Le hérisson, qui comme le pore-épie est armé de piquants, ressemblerait plus au cochon; car il a le muscau long et terminé par une espèce de groin en boutoir ; mais toutes ces ressemblances étant fort éloignées, et toutes les dilférences étant présentes et réelles, il n'est pas douteux que le pore-épic ne soit d'une espèce particulière et différente de celle du hérisson, du eastor, du lièvre ou de tout autre animal auruel on voudrait le comparer.

Il ne fuut pas non plus ajouter foj it ce cque disent prescye unanimement les voyageurs et les naturalistes yui donnent à cet animal la fat('ulté de lancer ses piqquants à une assez grande distance et avee assez de foree pour pereer ct blesser p’ofondémeint; ni s'imaginer avec eux ¿que c'es piquants, tout séparés qu’ils sont du (orjes de l'animal, ont la propriété très-extraor'inaire et toute particulière de pénétrer d'euxmimes et par leur's propres forces plus avant dans les chairs, dès que la pointe y est une fois entrée : ce dernier linit est purement imaginaire ( llestitué de tout fondement, de toute raison. le premier est aussi faux que le second ; mais au moins l'erreur parait fondée sur' ce que l'animal, lors(ju'il est inrité ou sculement ağité, redresse ses piquants, les remue; et que, conmue il y a de ces piquants qui ne tiennent à la peau que par une espèce de filet ou de pédieule délié, ils tombent aisément. Nous avons vudespores-ćpics vivants, et jamais uous ne les avons vus, (quoique violemment excités, darder leurs picfuants. On ne peut done trop s'étonner que les auteurs les plus graves, tant anciens que modernes, que les royageurs les plus sensés, soient tous d’accord sur un fait aussi faux. Quelques-uns d'entre 'ux disent avoir eux-mèmes été hlessés de cette espece de jaculation; d'autres assurent qu'elle se fait avec tant de raideur, que le dard ou pi(quant peut percer une planche' à quelques pas de distance. L.e merveilleux, qui n'est que le faux (yui fuit plaisir à croire, augmente et erolt

1 Lorsque le porc-épic esl cn furie, il s'élance arec une ex-

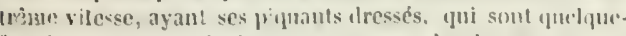

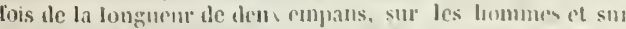

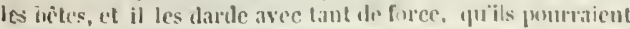
pereer une planche. Voyage en Guined, par ljosm,an, I' trecht, 1705, pige $23 \%$. à mesure (pu'jl passe par un plus grand nombre de têtes; la vérité perd au contraire en faisant la même route; et malgré la négation positive que je viens de graver au bas de ces deux faits, je suis persuadé qu'on écrira encore mille fois après moi, comme on l'a fuit mille fois auparavant, que le pore-épic darde ses picjuants, et que ces piofuants, sépácés de l'animal, entrent d'eux-mêmes dans les corps oủ leur' pointe est engagée ${ }^{1}$.

Le porcépic, quoique originaire des climats les plus chauds de l'Afiriue et des Indes, peut vivreet se multiplier dans des pays moinschauds, tels que la Perse, l'Espagne et I'Italie. Agricola dit que l'espèce n'a été transportée en Europe que dans ces derniers siecles : elle se trouve en Espagne, et plus commurément en ltalie, surtout dans les montagnes de l'Apennin, aux environs de Rome; e'est de là que M. Mauduit, qui, par' son goût pour l'histoire naturelle, a bien voulu se charger de cuelques-unes de nos commissions, nous a envoyé celui qui a servi ì M. Daubenton pour sil description. Nous avons cru devoir donner la figure de ce por’épic d' Italie, aussi bien que celle du porépic rles Indes; les petites différences qu'on peut remarquer entre les leux sont de légères varjétés dépendantes du climat, ou peut-ètre mème ne sont que des différences purenent individuelles.

Pline et tous les naturalistes ont dit, d'après Aristote, que le porcépic', comme l'ours, se cachait pendant l'hiver, et mettait bas au bout de trente jours. Nous n'avous pu vérifiel ces faits; et il est singulier (ju'en Italie, où ce' ani-

4 fo 11 fant cependint excijter du nomble de crs inya-

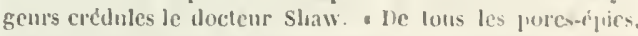
- dit-il, que jai vus en granl noubre en Afripıe, je nicu aj - rencontré aucun qui, quelyue c'bose que l'un fil juur l'irri- ter, daribil ancume de ses pointes; lour maniere ordinaire

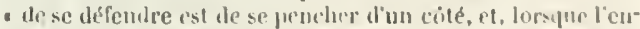
- nemi s'est approche dissez prics, de se relever fort ite el " le le pipuer de l'antre., Voyage de Shaw, Iraduit de l'anglais, tome 1, page 1:25. - Nivta.20 Le P’. Vincent-Marie nr dit point du lomt que le porc-épic Janee des piłnumts; il as:me seulement „jue, yuand il rencontre des serpents ave lesignels il e'sl lujours en gucre, il se met eu boule, carlant sps pieds et sa lite, et se loule sur cux arre ses pinjuanls jusiju'a leur

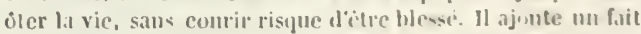
que nous croymos très-rrai, cirst yu’il se forme clans l'estomac du porc-épic des hizoards de différentes sertes; J's ums ne sont que des anus de racines enveloppre's d'une tronte, les

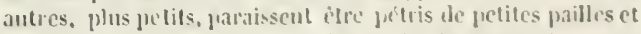
de pumbe de pierre; de les plus polits de lous, yui ne sunt

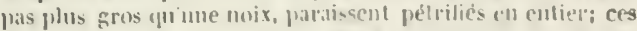

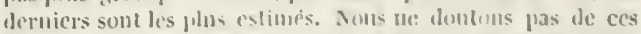
I.tits, ayant trouve mus-unemes m liezonot di la prenière sorte, cest-à-dire nue atgasmuile dans leslonac du poreépic yui nous a élé e'moyés d'Italie. 
mal est commun, et où de tout temps il y a cu at hons physiciens ef d'excellents obser rateurs, il ne se soit trouve personne qui en ait écrit l'histoire. Aldrovande n'a fait sur cet article, comme sur beaucoup d'autres, que copier Gessner; et MU. de l'Académie des sciences, qui ont dé rit et disséqué huit de ces animaux, ne disent piesque rien de ce qui a rapport à leurs habitudes naturelles : nous savous seulement, par le témoignage des yoyagems et des gens qui en out élevé dans des ménageries, que dans l'état de domesticité le porcépric n’est ni féroce ni farouche, quiil n'est que jaloux de sa liberté; qu'i l'aide de ses dents de devant, qui sont fortes et tranchantes comme celles du castor, il coupe le bois et perce 'aisément la porte de sa loge. On saic aussi qu'on le nourrit aisément avec de la mie rle pain, du fromage et des fruits; que dans l'état de liberté il vit de racines et de graincs sauvages; que quand il peut entrer dans uu jardin, il y fait un grand dégát et mange les légumes avec avidité ; cu'il devient glas comme la plupart des autres animaux, vers la fin de l'été; et que sa chair, quoique un peu fade, n'est pas mauvaise à manger.

En considérant la forme, la substance et l'organisation des picquants du porcépic, on reconnaitaisément que ce sont de vrais tuyaux de plumes auxquels il ne manque que les barbes pour ètre de vraies plumes : par ce rapport, il fait la nuance entre les quadrupedes et les oiseaux. Ces piquants, surtout ceux qui sont voisius de la fueue, soment les uns contre les autres lorsfue l'auimal marche; il peut les redresser par la contraction du muscie peaussier, et les relever à peu près comme le paon ou le corg d'Inde relèvent les plumes de leur queue. Cemuscle de la peau a done la méme force, et est à peu près conformé de la mème façon dans le porcépic et daus certains oiseaux. Nous saisissons ces rapports, quoicue assez fugitils: c'est toujours fixer un point clans la nature, qu: nous fuit et qui semble se jouer par la bizarrerie de ses productions de ceux qui reulent la connaitre.

' Nous arons en Guinée des pores-épics. Ils croissent jusqu'ả la hauleur de deux pieds on deux pieds et demi, et ils ont les dents si fortes et si aftilées, unuancun bois ue peul lemrésister; jen mis une fris un dans un tonucan, mimaginant qu'il serait bien garde; mais, dans l'espace d'une muit, il le rongea si bien, qu'il le perga et en sorlit; il le perç neme dans le milien ou les douves sout ie plus enurbees eu delors. Voyage de Bosmau, page $25 \%$.

\section{DESCRIPTION DU PORC.EPIC}

(EXTRSIT DE DALBENTON.)

Le pole-epic a beaucoup de rapport au liéris: on, parce que ces deux animaux sont couverts de piquants; mais ils ilffèrent beaucoup l'un le l'autre pour la forme de plusieur's parties du corps, et mème pour les piquants.

La tète du porc-épic est longue et aplatie sur les côtcis; le musear est gros, il a beancoup plis d'e. paisseur que le largeur, il ressemble au museau du lièvre, en ce que la lèvre supérieure est femulue presque jusqu'aux narines, dont les onver ures sont oblongues ei paralleles á l'ourerture de la bouclıe; les yeux sont petits et les oreilles larges et courtes; elles resstublent en quelque manière à ceiles des singes par leur contuur, parce qu'elles sont appliquées contre la tête, et qu'elles ont des cavites et des iminences. Les dents incisives ressemblent à celles des rats, des écureuils, du castor, etc.; celles ulu dessous percent la lèrre inférjeure qui les enveloppe comme un fourreau; le cou est gros, le corps rentlé et la quene courte et de figure conique; il y a cinc loigts bien formés aux pieds de derrière, et seulement, quatre anx pieds de derant, arec un tubercule revètu d'un ongle à l'endroit du pouce; les ongles sont prespile cylindriques et un peı courbes.

Les plus grands piquauts du porc-épic sont sur la partie postéricure dı dos; ils avaient juspưà neuf pouces de longrueur sur lindividu qui a servi de sujet pour cette description, mais peut-être en avait-il perdu le plus grands, car il avait eité Iué aux environs lle Rome an milieu de l'élé, et pent. être aussi lui avait-on arraciı́ les piquants les plus saillants; ceux qui restaient sur la partie postérieure du dos n'ètaient pas tous dle mème grandeur ni de même grosseur; les plus pelits n'avaient que yuatre pouces de longueur, le diamètre variait depuis deux jusqu'à trois lignes. Tous ces piquants éaient pointus aux deux bouts et colorés de noiråtre et de blanc jaunâtre par grands amneaux qui se succedaient jusqu’à cinc; fois d'un bout à l'antre des piquants: ceux qui etaient sur la croupe, sur les cuisses et sur les lancs ne différajent de ceux du los qu'en ce yu'ils ctajent plus petits; il y en avait le blancs de clatgue côté dle l'origrine de la quene; parmi les gros piquants du dos, il s'en trourait l'autres moins gros et beaucoup plus longs; mais la quene citait hẻrissce de tuyaux que l'on ne peut pas nomuer des piguants, car ils semblent avoir été coujés transversalement par le bout; ils sont creux, ils sont ouverts à leur extrémite; ils n'ont ıu'environ deux lignes de diamètre et près d'un ponce et demi de longueur; ils tiement à un pédi. 
cule très-délié, et longr de trois quarts dle pouce, qui s implante dans la peau; ces tuyaux sont placés tout le long de la queue à des distances les uns des autres; ils sont colorés de brun et de blanc jannatre; leur's parois sont très-minces et sonores, car ils fout un bruit semblable à un cliquetis, en heurtant les uns contre les antres, lorsque l'animal agite sa quene.

Le derrière de la tête, le cou, la partie antérienre du dos, les épaules, la poitrine, le ventre et les quatre jambes étaient couverts de petits piquants de couleur brune noiratre, de diffirentes longueurs, pointus on terminés par un filanent trèsflexible; il y avait des piquants déliés sur le sommet cle la tête; ils avaient plus d'un pied cle longueur, ils étaient en partie bruns et en partielılanes; le bout du museau et les pieds etaient courerts de petites soies brunes et raides; les moustaches élaient composées de soies noires et luisantes qui araient plus d'un demi-pied de longueur. Entre les piquants il se tronve de longrues soies brunes ou jaunâtres; l'animal redressait les longues soies de sa tête en forme de panache; il élevait et abaissait à son gre les pir|uants de son corps; et lorspu'il était irrite, il frappait des pieis de derrière contre terre; et, en aritant sa queue, il faisait sonner les pirpants tont elle élait revètue.

\section{LE COENDOU.}

\section{(LE PORC-ÉPIC COUIY.)}

Famille des rongeurs, geme porc-épic. (Cuvier.)

Dans chaque article rue nous arous à traiter, il se présente toujours plus d'erreurs à détruire que de vérités à exposer : ecla vient de ce que l'histoire des animaus, n'a, dims ces dernicrs temps, été traitée que par des gens ì préjugés, à méthodes, et qui prenaient la lisle de leurs petits systemes pour les registres de la natme. Il n'existe en Amérique aucun des animaux du climat chand de l'ancien continent, et réciproquement il ne se trouve sous la zone brulante de l'Afrique et de l'Asie aucun de ceux de l'Amérique méridionale. Le pore-épic est, comme nous l'avons dit, originaire des pays chands de l'ancien monde; et ne l'ayant pas trouvé dans le nouveau, on n'a pas laissé de donnel son nom aux animaux (qui ont paru lui ressembler, et particulic̀rement à celui dont il est ici question. D'autre còté, l'on a transporté le coendou d'Ancérique aux Indes orientales; et l'ison, qui vraiscmblablement ne commassait point le poreépic, a fait graver dans bontius, qui ne parle que des animanx du micli de l'Asie, le coendou d'Amérique, sous le nom et la deseription du vrai porc-épic; en sorte qu’à la première vue on serait tenté de croire que ect aninal existe également en Amérique et en Asie; cependant il est aisé de reconnaître, arce un pen d'attention, que Pison, qui n'est ici, conme pres'fue partout ailleurs, que le plagiaire de Marcglave, a non-senlement copié sa figure du coendou, pour l'insérer dans son Histoire du Irrésil, mais qu'il a cru devolr la eopier cncore pour la transporter dans l'ourrage de Bontius, ciont il a été le rédacteur et l'éditeur. Ainsi, quoiqu'on trouve dans Bontius la figure du coendou, l'on ne doit pas en conchure qu il existe di Java ou dans les autres parties de l'Asic múridionale, ni prendle cette figure pour celle dlu porc-épic, aupuel en effet le cocudou ne ressemble que paree qu'il a comme Iui des picuants.

C'est à Ximénès, et ensuite à Hernandès, que l'on doit la première comnaissance de eet animal; ils l'ont indiqué sous le nom de hoit:llacuatsin que lui donnaient les Mexicains. Le llacnatsin est le sarigue, et hoilsllacualsin doit se traduire par sarigue-épineux. Ce nom avait été mal appliqué, ear ees animaux se ressemblent assez peu : aussi Maregrave n"a point adopté cette dénomination mexieaine, et il a donné cet animal sous son nom brasilien, cuandu. qui doit se promoncer couandou. La seule chose qu'on puisse reprocher a Maregrave, e'est de n'avoir pas recemun que son euandu du brésil était le mème animal que J'hnitatlacuatzin du Mexique, d’autant que sa description et sa figure s'aceordent assez avec celles de Helualn. dès, et que de Lacit, qui a été l'éditcul et le commentateur de l'ouvage de Maregivac dit expressément que le tlacuatzin épineux de . liménes et le cuandu ne sont rasisemblatilement que le même animal. Il parait en rassemblant le peu de notices répulses que nous ont dommés les voyageurs sur ees animaux, quil y en a deux variétés que les uaturalistes ont, d'apres P'ison, insćrées dans leurs listes comme deux especes différentes, le grand et le petit enandu: mais ee qui prouve d'ahorel l'erreur ou la népligence de Pison, cest que, quoiqüil domme. ces coendous dims denx articles sciparés cloignés l’un cle l'autre ot rüil paraisse les legarder comme étint de deux especes différentes, il les represente ecpendant lous deux par la mime figure; ainsi nous nous croyons bien fon- 
đés à prononcer que ces deux u'en font qu'un. Il y a aussi des naturalistes qui non-seulement ont fait deux espèces du grand et du petit coendou, mais en ont encore séparé l'hoitztlacuatzin en les donnant tous trois pour des animaux dilférents; et j'aroue que, quoiqu'il soit trèsvraisemblable que le coendou ct l'hoitztlacuatzin sont le mème animal, cette identité n'est pas aussi certaine que celle du grand et du petit coendou.

Quoi qu'il en soit, le coendou n'est point le porc-épic; il est de beaucoup plus petit; il a la tête à proportion moins longue et le museau plus court; il n'a point de panache sur la tète ni de feote à la lèvre supérieure; ses piquants sont trois ou quatre fois plus con'ts et beaucoup plus menus; il a une longue queue, et celle du pore-épic est très-courte; il est carnassier plutòt que frugivore, et cherche à surprendre les oiseaux, les petits animaux, les volailles', au lieu que le porc-épic ne se nourrit que de légrumes, de racines et de fruits. II dort pendant le jour comme le hérisson, et court pendant la nuit; il monte sur les arbres ${ }^{2}$ et se retient aux branches arec sa queue, ee que le porc-épic ne fait ni ne pourrait faire. Sa chair ${ }^{3}$, disent tous les voyageurs, est très-bonne à manger : on peut l'apprivoiser. Il demeure ordinairement dans les lieux élevés, et on le trouve dans toute l'étendue de l'Amérique, depuis le Brésil et la Guiane juş̧u'à la Louisiane et aux parties méridionales du Canada; au lieu que le porc-épic ne se trouve que dans les pays chands de l'ancien continent.

En transportant le nom du pore-épic au coendou, on lui a supposé et transmis les mèmes facultés, eelles surtout de lancer ses piquants; et

\footnotetext{
1 Ce fait, assuré par Marcgrave et Pison, n'est pas certain, car llermandes dit, an contraire, que l'hoitztlacuatzin se nourrit de fruits.

2 Scandit arbores sed tarlo gressu, quia pollice caret; descessdens anten caudaun circumvolvit ne labalur, almodum enim metuit lapsum, nec salire potest. Marcgrav., Hist. Nat. liras , pag. 255.-Nous vimes un porc-épic sur un pelit arbre yue nous conpaimes pour avoir le plaisir de voir tomber eet animal... Il est fort gras et on en mange la chair. Voyage de la Iloulan, tome I, page $\$ 2$.

3 Carnem habet bonam et pergratam, nam assatam sxpe comedi, ct ab incolis valde astimatır. Margr., pag. 25j. - II est bon a manger, on le met au feu pour le faire griller conme un cochon; mais auparavant les fenmes sauvages en - arrachent tous les poils de dessus le dos (c'est-à-dire tous les piquants) qui sont les plus grands, ct elles en font de beaux ouvrages... Étant brủlé, bien ròti, lavé et mis à la broche, il vant un cochon de lait; il est très-bon bouilli, mais moins bon que rôti. Description de l'Anérique, par Denis, tome II page 524.1 'aris, 1672 .
}

il est ćtonnant que les naturalistes et les roya. geur's s'accordent sur ce fait, et que Pison qui devait être moins supertitieux qu'un autre. puisqu il était médecin, dise gravement que les piquants du coendou entrent d'eux-mèmes el par leui propre force dans la chair et percent le eorps jusqu’aux viscères les plus intimes. Riilj est le seul qui ait nié ces faits, quoiqu'ils paraissent éridemment absurdes. Mais que de choses absurdes ont été niées par des gens sensés, et qui eependant sont tous les jours affirmées par d'autres gens qui se croient encore plus sensés!

\section{ADDITION A L'ARTICLE DU COENDOU.}

La Guiane fournit deux espèces de coendlous. Les plus grands pèsent douze à quinze lirres. Ils se tiennent sur le haut des arbres et sur les liancs qui s’élèvent jusqu’aux plus hautes branches. Ils ne mangent pas le jour. Leur odeur est très-forte, et on les sent de fort loin. lls forit leurs petits dans des trous darbres au nomlre de deux. Ils se nourrissent des feuilles de ces arbres, et ne sont pas absolument bien communs. Leur viande est fort bome: Les Negres l'aiment autant que celle du paca. Suivant M. de La Borde, les deux espéces ne se mêlent pas; on ne les trouve deux à deux que quand ils som! en chaleur; dans les autres temps ils sont seuls. et les femelles ne quittent jamais l'arbre où elle's font leurs petits. Ces animaux mordent quand on s'y expose, sans cependant serrer beaucoup.

Ceux de la petite espèce peurent peser six livres; ils ne sont pas plus nombreux que les alltres; les tigres leur font la guerre, et on ne les troure jamais à terre pendant le jour.

Nous avons parlé ailleur's de ces deux espéces de coendous, lesquelles existent en effet dams les climats chauds de l'Amérique méridionale.

\section{DESCRIPTION DU COENDOU.}

\section{(EXTRAIT DB DAUBENTON.)}

Le coendon diffère du porc-épic en ce qu'il a le museau plus court, en ce que sa lèrre supérieure n'est pas fendue, que ses narines sont rondes, et principalement en ce qu'il a une longue quene couverte de piquants. Le coendou qui a servi de sujet pour celte clescription était plus petit que le 
porc-épic, car il n'avait que seize ou dix-seot pouces de long depuis le bout du museau jusqu'à l'origine de la yueue, dont la longueur ćtait de neuf ponces : le bout du museau, les janbes et Jes jpieds avaient des poils raidles comme dı crin; ils étaient bruns, excepté quelques-uns de ceux des jambes qui avaient une couleur jaunâtre; la peau du ventre el de la poitrine avait été déchire; tout le reste dı corps ctait couvert ile piịuants, entremèlés de longs poils; les piquants les plus longs n'avaient que deux pouces et demi, les plus gros se trouvaient sur la partie postérieure du dos, sur la croupe et sur le dessus de la quene; ils avaient environ une ligne de diamètre, ils étaient pointus aux deux bunts et de couleur blanchâtre-jaunàtre dans la plus grande partie de leur longueur; la pointe avait une couleur noiràtre qui se mêlait avec le jaunâtre par des teintes de brun el de roussitre; les autres piyuants ne differaient cle ceux-ci qu'en ce qu'ils étaient plus petits et plus serris les uns contre les autres, le surte que l'on ne voyait que lemr jointe noirâtre, exceptć sur la tête el sur le dessuus dı cou, viu le jaunatre cles piejuants citait fort apparent: cet animal était non-seulement lierisse cle picuants, mais uncore de longrues soies qui sortaicut d'entre les pirjuants et qui ctaicut en assez grand nombre pour les caclıc sur le dos, sur les còtés du corps, sur les côtés et surle clessuus de la tête; elles étaient plus rares sur le cou et sur la téte; les plus longues de ces soies avaient quatre ou cinc pouces, elles éaient en partie lormes ou noiratres, et en partic jaunâtres; celles des côtés de la ųuene étaient en entier de cette couleur; les moustaches avaient moins de longueur que eelles du porc-epic ; leurs crins étaient plus dciliés et noirs; il y avait ciny doigts aux piets de derriere, et seulenent (juatre à ceux de devant, avec un tuhereule it l'endroit du pouce; les ongles citaient grancls, crochus, trèspointus et de couleur noire et jaunâtre; cenx des piets de derrière avaient plus cle longueur que ceux les pieds de devant.

\section{LE COENDOU A LONGUE QUEUE.}

\section{(LE PORG-ÉPIC COENnOU.)}

Fanille des rongeur's, genre porc-ipic. (Cuvier.)

Un autre animal á picpuants, qui ue nous citait pas eonnu, a ćté apporté de Caycme a Parris avec la collection de M. Malonet, intendant de cette colonic.

11 est plus grand que le coendou.

Sil longucur, du bout du museau à l'origine,

de la quene est de. . . . . . . . . . 200

Lougueur de la yucue. . . . . . . . 156
Il est couvert de piquants noir's et blanes à la tète, sur le corps, les jambes et une partie de la queue; et sa longue queue le distingue de toutes les autres espèces de ce gemrc. Elle n'a pas de houppe ou bouquet de piquants à son extrémité, comme celle des autres pores-épies.

Le diamètre de la queue, mesurée à son origine, est de vingt-une lignes; elle va en diminuant et finit en pointe. 11 n'y a sur cette gucue d'autres piquants que ceux rle l'extrémité đlu trone, qui s'étendent jusquiau milicu de la queue; elle est noirâtre et couverte d'écailles depuis ce milieu jusqu'à son extrémité; et le dessous de cette quene jus(ju'au milieu, èstà-dire jusqu'à l'endroit où s'étendent les piquants, est couvert de petits poils d'un brun clair. Le reste est garni d'écailles en dessus comme en dessous.

La tète du coendou ressemble plus à celle du pore-épic de Malaca qu'à tout autre; cependant elle est uu pen moins allongée : les plus grands poils des moustaches, qui sont noirs, ont qua. tre pouces cing lignes de longueur.

Les oreilles nues et sans poil ont ifuelques piquants sur le bord. Au reste, il n'a pas les picfuants aussi grands que les pores-épics d'l talie, et par ee caractere il seripproche du coendou. La pointe de ces piquants est blanche, le milieu noir, et ils sont hanes à l'orgrine : andi le blane domine sur le noil.

Les plus longs piquants sur le corps ont. . . $\begin{array}{cccc}0 & 2 & 8\end{array}$ Sur les jambes de devant. . . . . . . n 016 Sur celles de derricre. .......... 0 (1) 1 .

Il y a quelyues poils longs de deux pouces et demi, interposés entre les pi(puants sur lo haut, les jambes de devant et de derriere.

Il n'y a point de membrane enfre les doints des pieds de devant, qui sont au nombre de quatre. Ceux de derriere ont cincy doights. mais le pouce est peu excidant ; cos doights sont eouverts de poils brums et courts : Ies ongles sont bruns, courbes et en gouttiere.

Ciest à ce coendou à longur queuc que nous eroyons devoir rapporter ee (que M. lioume d. Saint-Ianent a cevit clans les notices (fuil । bien voulu nous adressire des objets (fui compusent sa riche collection d'histoire maturelle.

"Ce coendou, dit-il, (pui est un indivtủu jeune, mest venue de l'ile de la Trinite; sa longrueur est d'onviron un pied. I.a queue a dix potiees de long; elle ast couverte de piguants 
sur la moitié de sa longucur, où ils finissent en s'accourcissant par gradation: le reste de la qucue est recouvert par une peau grise, remplie des rides trausversales très-près les unes des autres et très-profondes. Les piquants les plus longs ont environ deux pouces un quart; ils sont blancs à leur origine et à leur extrémité, et noirs au milieu. Le poil ne se laisse apercevoir que sur le ventre, où les piquants sont trèscourts : les moustaches sont déliées, noires, et ont environ trois pouces de longueur. Le plus graud des ongles des quatre doigts de devant a cing lignes de longueur, ceux des pattes de derrière sont de la mème longueur ; il n’a que quatre doigts onglés aux pattes de dlerrière, avec un tubercule un peu plus allongé que celui des pattes de devant. Cet individu diffère de celui décrit dans l'Histoire naturelte de M. de Buffon, en ce qu'il a la queue plus longue à proportion et en partie nue; qu'il n'a que quatre doigts onglés derrière; que les ongles paraissent moins grands que ceux de l'animal représenté dans ce même ourrağe, et qu'il n'a pas le corps garni de poils plus longs que les piquants : les bouts des piquants de celui-ci sont blanes, et ceux du premier sont noirs.

\section{L'URSON.}

\section{(LE PORC-ÉPIC URSON.)}

Famille des rongcurs, genıe porc-épic. (Curıer.)

Cet animal n’a jamais été nommé : placé par la nature dans les terres désertes du nord de l'Amérique, il existait indépendant, éloigné de l'homme, et ne lui appartenait pas même par le nom, qui est le premier signe de son empire. Hudson ayant découvert la terre où il se trouve, nous lui donnerons un nom qui rappelle celui de son premier maître, et qui indique en même temps sa nature poignante et hérissée; d'ailleurs il était nécessaire de le nommer, pour ne pas le confondre avec le pore-épic ou le coendou auxquels il ressemble par quelques caractères, mais dont cependant il diffère assez à tous autres égards, pour qu'on doive le regarder comme une espèce particulière et appartenant au climat du Nord, comme les autres appartiennent à celui du Midi.

BIM. Edwards, Ellis et Catesby ont tous trois parlé de cet animal. Les figures données par ces deux premicrs auteurs s'accordent avec la nôtre, et nous ne doutons pas que ce ne soit le même animal ; nous sommes même très-portés à croire que celui dont Seba donne la figure et la description sous lenom de porc-épic singulier des Indes orientales, et qu'ensuite MM. Klein, Brisson et Limmæus ont chacun indiqué dans leurs listes par des caractires tirés de Seba, pourrait être le même animal que celui dont il est ici question. Ce ne serait pas, comme on l'a vu, l'unique et première fois que Seba' au. rait donné pour orientaux des animaux d'Amérique; cependant nous ne pouvous pas l'assurer pour celui-ci comme nous l'avons fait pour plusieurs autres animaux : tout ce que nous pouvons dire, c'est que les ressemblances nous paraissent grandes, et les différences assez légères, et que comme lon a peu vu de ces animaux, il se pourrait que ces mêmes différences ne fussent que des variétés d'individu à individu, ou même du mâle à la femelle.

L'urson aurait pu s'appeler le castor épineux: il est du inême pays, de la même grandeur et à peu près de la même forme de corps; il a, comme lui, à l'extrémité de chaque mâchoire, deux dents incisives, longues, fortes et tranchantes. Indépendamment de ses piquants qui sont assez courts et presque cachés dans le poil, l'urson a, comme le castor, une double fourrure, la première de poils longs et doux, et la seconde d'un duvet ou feutre encore plus doux et plus mollet. Dans les jeunes, les piquants sont a proportion plus grands, plus apparents, et les poils plus courts et plus rares que dans les adultes ou les vieux.

Cet animal fuit l'eau et craint de se mouiller; il se retire et fait sa bauge sous les racines des arbres creux. Il dort beaucoup et se nourrit principalement d'écorce de genièvre : en hiver, la neige lui sert de boisson; en été, il boit de leau et lape comme un chien. Les sauvages mangent sa chair et se servent de sa fourrure, après en avoir ôté les piquants qüils emploient au lieu d'épingles et d'aiguilles.

\section{DESCRIPTION DE L'URSON.}

(EXTRAIT DE DAUBENTOY.)

L'urson diffère principalement du porc-épic en ce quil a les piquants plus petits, et en srande partie cachés sons de longs poils; il a aussi le mu. 
seau moins grros et plus court; les oreilles sont trèspetites et entièrement recouver'ies par le poil.

Les plus grands piquants ỉe cet animal ont deux pouces et demi de longueur et une ligne de dianı̀tre, ils sont en partie blanes ou jaunàtres, et en partie bruns ou noirâtres; ils se trouvent sur la croupe et sur la queue, et y sont apparents, tandis que cenx du reste dı corps sont couverts par les poils longs, fermes et noirs qui ont jusqu'à six pouces de longueur sur les lombes; leur pointe est de couleur blanche jaunâtre; il y a entre ces longs poils et les pirjuants, une sorte de duret de couleur cendrée brune qui a quatre ou ciny pouces le lonnueur sur les lombes; il est fort épais et presque droit, il se trouve sur toutes les parties du corps, excepté sur les pieds; les piquants manquent aussi sur les pierls, sur les jambes, sur le ventre et sur la quene; ces parties n’ont que dles poils serrès comme des hrosses et de couleur brune noiratre ou noire; il y a quelques teintes de bai sous la queue.

\section{IE TENREG ET LE TENDRAC.}

\section{LE TENLEC SOYEUX OU TANREC. - LE TENBEC ÉPINEUX OU TENDRAC.}

Famille des insectivores, genre tenrec. (Cuvier.)

Les tenrecs ou tendracs sont de petits animaux des Indes orientales qui resscmblent un peu à notıe hérisson, mais qui cependant en diffèrent assez pour constituer des espèees différentes: ce qui le prouve, indépendamment de l'inspection et de la eomparaison, e'est qu'ils ne se mettent point en boule comme le hérisson, et que dans les mêmes endroits où se trouvent les tenrees, comme a Madagasear, on y trouve aussi des hérissons de la mème espèce que les nòtres, qui ne portent pas le nom de tenrec, mais qui s'appellent sora.

II parait qu'il y a des tenrees de deux espèces, ou peut-être de deux races diflérentes : le premier, qui est à peu près grand comme notre hérisson, a le muscau en proportion plus long que le second; il a aussi les oreilles plus apparentes et beaucoup moins de piquants que le sceond, auquel nous a vons domné le nom de temdrac pour le distinguer du premier. Ce tendrac n'est que de la grandeur d'un gros rat; il a le musean ct les oreilles plus courtes que le tenree. Celui-ci est couvert de piquants plus petits, mais aussi nombreux que ceux du hérisson : le tendrac av contraire n'en a que sur la tète, le cou et le garrot; le reste de son corps est couvert d'un poii rude assez semblable aux soies du cochon.

Ces petits animaux, qui ont les jambes trèscourtes, ne peuvent marcher que fort lentement; ils grognent comme les pourceaux ; ils se vautrent comme eux dans la fange ; ils aiment l'eau et y séjournent plus longtemps que sur terre; on les prend dans les petits canaux d'eau salée et dans les lagunes de la mer. Ils sont très-ardents en amour et multiplient beaucoup. Ils se creusent des terriers, s'y retirent et s'engourdissent pendant plusieurs mois : dans cet état de torpeur, leur poil tombe et renait après leur révcil. Ils sont ordinairement fort gras, et quoique leur chair soit fade, longue et mollasse, les Indiens la trouvent de leur gout, et en sont même fort friands.

\section{ADDITION A L'ARTICLE DU TENREC.}

M. de Brugnières, médecin du roi, très-habile botaniste, qui a été envoyé pour faire des recherches d'histoire naturelle aux Terres Australes, en 1772 , nous a donnć un petit animal que nous avons reconnu ètre un jeune tenrec. Il ve differe de l'autre que par sa petitesse et par trois bandes blanchâtres, qui nous paraissent être la livrée de ce jeune animal. La première de ces bandes s'étend depuis le museau tout le long de la tète, et contimue sur le cou et sur l'épine du dos: les deux autres bandes sont chacune sur les flanes; et comme tous les aur. tres caracteres, notamment la forme du museau, les longs poils parsemés sur le corps, la couleur noire des piquants, ctc., se trouvent, dans ce petit tenrec, semblables à ceux du grand, nous avons cru être fondés à n’en faire qu'une seule et même espèce.

\section{ADDITION A L'ARTICLE DU TENDRAC.}

Un très-petit tendrac a été envoyé de l’ile de France par M. Poivre à II. Aubry, curé de Saint-Louis : il ne nous parait différer de notre tendrac que par sa petitesse et par quelques bandes blanches qui semblent être la livrée de cet animal fort jeume. On a ćcrit à M. le curé de Saint-Louis (ju’il se trouve à Madagasascar, et que les Français de cette contrée le comais. saient sous le nom de rat-épic. Voici les di- 
mensions et la courte deseription de ce trèspetit animal.

I.ongueur dı corps entier, depuis le bout du ne\% jusqu'à l'extrémité du corps près de l'aus.............................. 0 Distance du bout du nez à l'oril. . . . . . . 0 o 196 Distance entre l'oil et l'oreille.. . . . . . . $0 \begin{array}{llll}0 & 0 & 3\end{array}$ Longueur de la tète, depuis le bout du nez

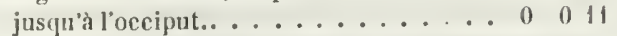
Lougueur des piquants. ........... 0 0 0 Longueur des grands ongles des pieds de derant.................... 0 O 02 Longueur des grands ongles des pieds de der-

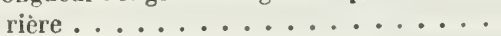

Cet animal a le museau très-allongé et presque pointu; sa tête est couverte d'un poil d'un roux noirâtre, et le corps, qui est couvert du même poil, porte une grande quantité de piquants d'un blane jaunâtre, qui semblent se réunir par bandes irrégulières. On remarque au-dessus du nez une bande d'un blane jaunátre, qui s'étend jusqu'au commencement du dos, et se termine en pointe à ses deux extrémités : cette bande blanche est du même poil que le brun du corps et des côtés de la tête : ce poil est assez rude, mais cependant fort délié en comparaison des piquants. Le dessous du cou et du corps est d'un blanc jaune, ainsi que les jambes et les pieds, qui sont néanmoins un peu mêlés de brun. Les plus grands poils des molistaches ont huit lignes de longueur. Les pieds ont chaeun cinq doigts, et l'on ne voit dans ce trèspetit animal aucume apparence de queue '.

\section{DESCPIPTION}

\section{DU TENDRAC ET DU TENREC.}

(EXTRAIT DE DALBENTON.)

Le tendrae ressemble au hérisson; mais il est beaucoup plus fretit, si celui qui a servi de sujet pour cette description avait pris toute sa granleur, ear il n’ètait guère plus gros qu'une taupe; le nez ressemblait à celui du hérisson, autant ųue j’ai pu en jugrer sur un individu desséché; les yeux mont paru plus petits que eeux du locrisson, mais le tendrac était ressenblant à cet aninal par le museau mince et allongé, par les oreilles cotirtes et arronrlies, les jaubes eourtes, ete.; il étail courert de piquants semblibles à cenx du hérisson, les plus longs avaieut sept lignes; ils etaient tous de couleur blanchatre vers la racine et la pointe, le reste avait une couleur roussaitre foncie; le museau, le front,

\footnotetext{
- Cel animal est le TexBec naYB.
}

les côtés de la tête, la gorge, le dessous du con, la poitrine, les aisselles, le ventre, les aines, les fesses et les quatre jambes étaient couverts d'un poil blan! elıatre, rare, fin ei dur. 11 se trourait sur le muscau quelçues poils jaunattres qu:i avaient ju“çu’à ıleux pouces deux lignes; il y avait ciun doignts à cliaque pied, la queue était très-courte et couverte de ritquants; la longneur de ce tenulrac était de cinq [ouees dix ligues depuis le bout clu museau juśgu'à l'o. rigine de la qqieue; il y avait onze liynes de distance entre le bout du nuseau et l'xil, et trois lignes elltre l'œil et l'oreille.

Le tenree était plus grand que le tendrac; il arait le museau à proportion plus long, les oreilles moins courtes ; je ne lui ai point trouvé de queue, il était desséché et bourré; il n'avait de rrais piquants que sur le front, sur les tempes, sur le sommet et le derrière de la tête, sur le dessus et les còtés du cou, sur les épaules et sur le garrot; ils étaient jamnâtres vers la racine et à la pointe, le reste etait noir; les plus longs avaient plus d'un ponce, et furmaient une sorte de luppe au-lessus de la tête; le dos, la croupe et les còtés du corps étaient couverts de soies qui avaient les mèmes couleurs que les piquants; les plus longues étaient sur le dos et avaient plus d'un ponce; il se trouvait parmi ees soies des poils jaunàtres, et d'autres pilus gros et noirs, dont quelques-uns a vaient an moins deux pourees de longueur. Le museau, la gorre, le d:ssous du cou, la poitrine, le ventre et les jambes étaient couverts de poils durs, fins et de couleur jaunâtre et nême roussàtre sur les pieds; il y avait sur le museau quelques longs poils de cette couleur. La longueur de ce tenrec élait de sept pouces neuf lignes depuis le bout du museau juyu à la partie postérieure du corps : il y avait un pouce et demi tle distance entre le bout du musean et l'ail, et un demi-ponce entre l'œil et l'oreille.

\section{LE TAMANOIR, \\ LE TAMANDUA ET LE FOURMILIER.}

LE FOURMLIER TAMATOIR. - LE FOURMLLER TAMANDUA - LE FOURMILIER DIDACTYLE.

Ordı'e des édentes ordinaires, genre fournilier.(Curier.)

11 existe dans l'Amérique méridionale trois cspèces d'animaux à long museau, à gueule étroite et silus aucune dent, à langue ronde et longue qu'iis insinuent dans les foumilières, ct cqu'ils retirent pour avaler les fourmis dont ils font leur prineipale nourriture. Le premier de ces mangeurs de fourmis est celui que les Brasiliens appellent tamendua-guacu, c'est-à-dire 
grand tamandua, et auquel les Francais habitués en Amérique ont donné le nom de tamanoir : c'est un animal qui a environ quatre pieds de longueur depuis l'extrémité du museau jusqu'a l'origine de la queue; la tête longue de quatorze à quinze pouces; le museau très-allongé; la queue longue de deux pieds et demi, couverte de poils rudes et longs de plus d'un pied; le cou court, la tête étroite, les yeux petits et noirs, les oreilles arrondies, la langue menue, Jongue de plus de cleux pieds, cu'il replie dans sa gueule lorsqu'il la retire tout entière. Ses jambes n'ont qu'un pied de hauteur ; celles de devant sont un peu plus hautes et plus menues que celles de derricre : il a les pieds rouds; ceux de devant sont armés de quatre ongles, dont les deux du milieu sont les phus grands; ceux de derriere ont eing ongles. Les poils de la queue, comme ceux du corps, sont mêlés de noil et de blanchatre; sur la queue ils sont disposés en forme de panache : l'animal la retourne sur le dos, s'en couvre tout le corps lorsuru'il veut dormir ou se mettre à l'abri de la pluie et de l'ardeur du soleil ; les longs prils de la queue, comme ceux du corps, ne sont pas ronds dans toute leur étendue, ils sont plats à l'extrómité et secs au toucher comme de l'herbe desséchée. L'animal agite frécjuemment et brusquement sa quene lorsqu'il est irrité; mais il la laisse trainer en marchant quand il est tranquille, et il balaie le chemin par où it passe : les poils des parties antérieures de son corps sont moins longs que ceux des parties postérieures; ceux-ci sont tournés en arrière et les autres en avant; il y a plus de blanc sur les parties antérieures, et plus de noir sur les parties postérieures : il y a aussi une bande noire sur le poitrail, qui se prolonge sur les còtés du corps et se termine sur le dos pres des lombes: les jambes de derrière sont presque noires; eclles de devant presque blanches, avee une grande tache noire vers leur milieu. Le tamanoir marche lentement; nu homme peut aisément l'atteindle à li course : ses pieds paraisrent moius faits pour mareher que pour grimper et pour saisil des corps arrondis; aussi serre-t-il avee une si grande foree une branclue ou un bâton, (ju il nest pas possible de les lui ar'acher.

Le second de ces animantux est celui que les Amérienins appellent simplement tamandua, et auquel nous conserverons ce nom : il est beau- coup plus petit que le tamanoir; Il n'a qu'environ dix-huit pouces depuis l'extrémité du museau jusqu'à l'origine de la queue : sa tête est longue de cing pouces, son museau est allongé et courbé en dessous; il a la queue longue de dix pouces et dénuéc de poils à l'extrémité; les oreilles droites, longues d'un pouce ; la langue ronde, longue de huit pouces, placée dans une espèce de gouttière ou de canal creıx au-declans de la mâchoire inférieure; ses jambes n'ont guère que quatre ponces de hauteur; ses pieds sont de la mème forme et ont le mème nombre d'ongles que ceux du tamanoir, c'està-dire quatre ongles à ceux de devant et cing à ceux de derriere. Il grimpe et serre aussi bien que le tamanoir, et ne marche pas nicux; il ne se couvre pas de sa quene, qui ne pourait pas lui servir d’abri étant en partic dénuée de poil, lequel d'aill cur's est beaucoup plus court (jue celui de la queue du tamanoir : lorsqu'il dort, il cache sa tête sous son cou et sous șes jumbes de devant.

Le troisieme de ces animaux est celui yue les naturels de la Guiane appellent oualiriouaou. Nous lui domons le nom de fourmilier pour le distinguer du tamanoir et du tamandua. 11 est encore beaucoup plus petit que le tamandua, puisqu'il n'a que six ou scpt pouees de longucme depuis l'extrémité du museau jusqu'à l'origine de la queue : il a lil líc longue de deux pruces, le museatu proporlionnellement beaucoup moins allongé gue celui clu tamanoir ou du tamandua; sa queue, longnue de sept pouces, est recourlée en dessous par l'extrémité, (qui est dégarnie de poils ; sál laugus. est étroite, un peu aplatie et assez longue; le cou est presçue nul, la tète est ilssez glosse il proportion du corps; les yeux sont placés bas et peu éloignés des cuins de la gucule; le's oreilles sont petites et cachées daus le puil ; lis jambes nont que trois prouces de latuteur; Ies pieds de devant n'ont que deux ongles, dont l'externe est bien plus gros at bien plus longr que l'interne; les piads de derriere en ont qualtre. Le poil du corps est long d'environ neuf ligues; il est doux au toucher et d'une couleur brillante, d'un roux mélé de jaune vif. I.e's pieds ne sont pas fuits pour mateher, ma is punr grimper et pour saisir; il monte sur les arbre's et se suspend aux branches par l'extrémitc de sa quelue.

rious ne conuaisons dans ee genre d'animaus 
que les trois espèces desquelles nous venous de donner les indications. M. Brisson fait mention, d'après Seba, d'une quatrième espèce sous le nom de fourmilier aux longues oreilles; mais nous regardous cette espèce comme douteuse, parce que dans l'énumération que fait Seba des animaux de ce genre, il nous a paru qu'il y avait plus d'une erreur; il dit expressément : "Nous " conservons dans notre Cabinet six espèces de " ces animuux mangeurs de fourmis : " cependant il ne donne la description que de einc; et parmi ces cinq animaux, il place l'ysquiepall ou mouffette, qui est un animal non-seulement d'une espèce, mais d'un genre très-éloigné de celui des mangeurs de fourmis, puisqu'il a des dents, et la langue plate et courte comme celle des autres quadrupèdes, et qu'il approche beaucoup du genre des belettes ou des martes. De ces six espèces prétendues et conservées dans le cabinet de Seba, il n'en reste done déjà que quatre, puisque l'ysquiepatl, qui faisait la cinquième, n'est point du tout un mangeur de fourmis, et qu'il n'est question uulle part de la sixième, à moins que l'auteur n'ait sous-entendu comprendre parmi ces animaux le pangolin', ce (fu'il ne dit pas dans la description qu'il donne ailleurs de cet animal. Le pangolin se nourrit de fourmis; il a le museau allongé, la gueule étroite et sans aucune dent apparente, la langue longue et ronde; caractères qui lui sont communs avec les mangeurs de fourmis : mais il en differe, ainsi que de tous les autres quadrupèdes, par un caractère unique, qui est d'avoir le corps couvert de grosses écailles au lieu de poil. D'ailleurs c'est un animal des climats les plus ehauds de l'ancien continent, au lieu que les mangeurs de fourmis, dont le corps est couvert de poil, ne se trouvent que dans les parties méridionales du Nouveau-Monde. II ne reste done plus que quatre espèces au lieu de six annoncées par Seba, et de ces quatre espèces, il n'y en a qu'une de recommaissable par ses descriptions : e'est la troisicme de celles que nous décrivons ici, c'est-ì-dire, celle du fourmilier, auquel, à la vérité, Seba ne donne qu'un doigt à chaque pied de devant ${ }^{2}$, quoiqu'il

1 C'est le non que nous dounerons an lẻzard écaillenx.

${ }^{2}$ No $^{0}$ 3. Tanıandua ou Coali d'A $A$ mérique blanche différente. cet animal est tout à fait diflérent dı précédent il cutend celui de la planche Xxxvil, fig. $n^{0} 2$. Voyez la nole suivanle). La tête en est beauconp plus courte et les oreilles beaucoup plus petites, les yeux un peu plus grands et la partie inférieıre du muscau taut soit peu plus longue. Leurs langues sont plus cu ait deux, mais qui, malgré ren caractères manchot, ne peut etre autre que notre tourmilier. Les trois autres sont si mal décrits qu’i] n'est pas possible de les rapporter à leur véritable espèce. J'ai cru devoir eiter ici ces deseriptions en entier, non-seulement pour prouver ce que je viens d'avancer, mais pour donner une idée de ce gros ouvrage de Selsa, ct pour qu'on juge de la confiance qu'on peut accorder à eet éerivain L’animal qu'il désigrue par le nom de tamandua murmecophaye d'A. mérique, tome I, page 60 , et dont il donne la figure, planche $37, n^{\circ} 2$, ne peut se rapporter a aucun des trois dont il est ici question; il ne faut, pour en être convaincu, que lire la description de l'auteur'. Le second, qu'il indique sous le nom de tamandua guacu du Brésil, ou

ressemblantes; l'une et l'antre est longue et étroite, et propre à prendre et à avaler des fourmis. Les épiules sont larges, le corps court et épais; les pieds de devant présentent un doigt armé d'un ongle large et conrbe. Les jambes et les pieds de derrière imitent ceux d’un singe. Son poil blanchâtre et laineux est plus court (pue celui dı précédent; il en est de mème cle sa queue crépne; cet animal est complé parmi un des plus rares de son espèce. Les Éthiopiens de Surinam les appellent Coati, et racontent que quand ils se sentent pris ils se mettent tellement en rond, ayaut leurs pieds si fortement attaclıés l'un contre l'autre, qu'à moins qu'ils ne se redres. sent d'eux-mêmes, il ne serail pas possible d'en venir â bout de force. Ils menrent daus un moment dès quion les treinpe dans l'esprit-de-vin ou dans la liqueur kilduivel. Seba, vol. I, pages 60 et $61, \mathrm{pl}$. XXXvII, fig. $\mathrm{n}^{0} \mathbf{3}$.

4 No $^{\circ}$. Tamandua myrmecoplage d'Anériụue. Cet animal est extrêmement commun dans les Indes occidentales; mais nous nen avons jamais vu qu'on ent transporlé des Indes orientales, ni entendu dire qu'il s'en trouvàt. (gnelipues savants se font des idées toutes merveilleuses de cet animal; les uns le prennent puur le lion formicarius, les autres pour le formica-leo, ceur-ci pour le formica-vulpes, et les antres pour le formica-lupus. M. Poupart, page 253 des $M$ lino res de l'Académie royale des Sciences, année $170 \%$, a remal'pué ıute cet animal était gris, semblable à une araignée, et qu"il tendait unène des embùches aux fourmis. Cette comparaison ne nous parait pas fort juste. Bastamantanus, qui a fail un lirre entier sur les reptiles dont il est fait mention daus les Livres sainls, regande le Murmcco-len, nom que quelifues piersonues liii donnent, pour une espèce d'scarbot quiou appelle escarbot $\operatorname{cor}^{-n u}$, el que les Allemands nomment cerf-rolant (tont ceci est, comme lion voit, fort important et fort utile pour la description d'un animal quadrupede); mais, continue l'auteur, lontes ces descriptions et plusieurs autres n'expriment point la nature de cet animal, dont nous donnons la figure jrise sur l'original : celni ułue l'on voit ici est isearnal, convert dim poil doux et comme la laine, au con court, aux epatr les larges, a la tiete et au nusein long et étroit, d'où sort ume longue langue propre à prendre et à avaler les fouruis, quıi Ini servent de nourriture. I.a sagesse đu Créatenr a donué à ces animaux les organes qui leur étaient nécessaires pour qu'ils pussent se pourvoir de lem nourriture à leur goult et à leur volonté. Les pattes de devaut, ainsi tue celles d"un ours, ont chacune, outre les doigts ordinaires, Irois autres doigts qui ont crù par-dessus les autres et qui sont armés llun ongle crochu, leyuel est principalenent l'es-grand dans le doigt du milieu. C:est là avec (puoi ils grattent la terre el en tirent 
lours qui mange les fourmis ', pages 6.5 el 66, îl. $40, f i g . \iota^{0} 1$, est indiqué d'une manière vitgue et équiroque : cependant je penserais,

les nirls de fourmis. Les narines, placées trés-proche de la guenle, sont étroites, rudes et garnies de poil, dont ils se servent pour llairer oú est leur inanger. Les orcilles sont oblongnes ou pendantes; les pieds de derrière, dans cette espèce de tamandna comme daus les ours, sont partagés en ciny doigts, garnis d'ongles longs el croclus, et sont sontenus, 0mtre rela, sur des talons très-larges. La quene longue el velue finit en pointe, et ils s'en servent, ainsi yue les singes, à se tenir.fortement attachés aux arbres : la partie proplre à la génération dans les miles est remaryuable ; ils portent leurs testicules cachés sous la pean et en dedans. Les lourmis, tant grandes que pelites, deviennent la proie de ces animaux, qui, à leur tour, servent aux hommes, surtont dans la médecine. Seloa, vol. I, page 60, pl. XXXVll, tig. $n^{0} 2$. e Il faut etre bien " aveuglément contiaut pour établir uquclupe chose sur une - parcille description, et pour la rapuorter an tamanoir ou " tamandua-guacu, comme l'a fait N. Linnxus, st de ne " domer en mèue tempris a cet animal que trois doigts anx " pieds de devant, tandis que, par eette description uèue, it a lu a trois ontre les doigts on dinalres, trois, dit-on, iqui ont a crû par--clessus les autres, chose absurde et cuni aurait di "firire dlouter de tout le reste. "

1 $x^{0} 2$. Tamandua-guacu dn Jrésil, on l'ours qui mauge les fon mis. C'est ici la plus grande de tuntes les espèces d'animanx que nous ayons vus. Mtrcgrave la nomme la mandua turacu, et Cardan urius-formicarius, c'est-à-dire l'ours ı̧ui mange les foumis. Cet animal a le corps long, les ćpaules lantes et larges, la tète fort ćlendue, le museau diminus nt insensiblement, et les narines amples et onvertes. Sa fongue langue, quil pent tirer en avant d'un huitième de coudée, ce qui lui est très-avantageux pour attraper les fourmis, finit en une pointe dont le bout forme un petit rond: ses oreilles sout longues et peuduntes; ses yenx assez grands sont défendus par d'épaisses paupières; son museau est long, tout ridé, garni de peu de poil; sa tète, qui est plate et petite, est couverte the puils assez pressés; tuut le reste du corps de cet animal est volu de poils longs et épais assez semblibles à des soies tle cochon, mais yıi cependant près de la prean deviement cotonneux et plus lius; leur contenr cst d'un chàtain clair, et sous le veutic d'un brun plus foncé ; le dessns de la ytieue, qui est longue et tinissant en pointe, est d'un fauve clair; sa femelle, ici dépeinte, a luit tetles đuni sortent hors dn v'utre, à savoir, trois de chaçne cuté, et denx entre les pieds de devant. Des tínoins dignes de foi rapjurtent ini elle met bas à chanue portée autant de petils quielle a de tettes, en quoi elle aurait conformité avec les truies qui ue mettent las beauconp de petits d'une ventrée que lorsquielles out plusieu's lettes. L.es pieds de devant et de derriere ne differeut de ceux rqu'ou a diecrits au $n^{0} 2$ de la planche précédente (il anrait dủ dire de la planche XXXVIII; ear la planclue précédente à celle-ci est la X.XXIX, ou il n'est pas (fuestion des mangeurs de furmis), qu'en ce quils sont plus grands; les plus grosses foumis lui servent de nourriture.

Nous conservons dans notre cabinet six especes de ces animanx mangeu's de fourmis, pui different entre eux ou par une forme particulière, on par la tite, les pieds et les ougles.

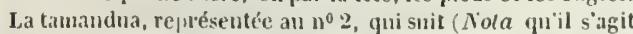
ici de l'ysuniepatl, qui est plus differente d un tamandua qu'us chat ne l'est d'un chieu), est d'un quart plus petite que celle-ci, et a aussi la tète, f's oreilles et les yeux plus petits : Bon pied de devant a un senl ongle, fort et erochu; et celui de derrière a trois duigts et trois ongles, an lieu yne les quatre autres espices ont cinc toigts arme's d'aulant d'ongles. Leur poil est doux, cotonneux, de la coutenr de celui d'un jeune lièvre. La cinquième esuèce de tamandua est de lia méme hgure, dion poil rouge paite yui est sur le dos d'un blanc argenté, et deseons d'un cendré jaunàtre; cette espèce a quatre tet. asec MM. Kilein et Linnæus, que ce pourrait être le rai tamandua-guacu ou lamanoir, mais si mal décrit et si mal représenté, que M. Linnaus a réuni sous une seule espece le premier et le second de ces animaux de Seba, c'est-à-dire celui de la planche $37, f i g .11^{0} 2$, et celui de la $p l$. 40, fig. $n^{0} 1$. M. Brisson a regardé ee dernier comme une espece particulicre; mais je ne crois pas que l'établissement de cette espèce soit fondé, nou plus que le reproche qu'jl fait à M. Klein de l'avoir confondue avec celle du tamanoir: il parrit que le seul reproche qu'on puisse faire it M. líleju est d'aroir joint à la bonne description qu'il nous donne de cet animal, dout la peau bourrée est couservée dans le Cabinet de Dresde, les indications fitutives de Seba. Enfin le troisieme de ces animaux est si mal déerit, que je ne puis me persuader, malgré la confiance que j'ai a MM. Linnaxus et Brisson, gu'on puisse, sur la deseription et la figure de l'auteur, rapporter, conme ils l'ont fait, cet animal au tariandua-i, que j'appelle simplement tamandua: je demande seulement qu'on lise encore cette description' ', et qu'on

tes et quatre mamelons, denx sous les jambes de devant it deux soms celles de derricre cette cinunieme espéce, qui est de la meme figure que celle yui la précede, est douc encure une e-pice d'ysuniepatl et non pas de tamandua). La sixicme espèce a le uuuscau plus long et les oreilles dressces cummuc celies d'un renard; tontes ces especes n'unt point de dents. Seba, vol. 1, pag. 63 et 66, tab. 40, lig. $13^{0}$ 1. On ue sail ce a que veut dire ici l'auteur, ni ce que ce peut ètre que cette - sixieme espece; vn voit seulement qüil se contredit d'une - manière manifeste lorsqu'il avance que tontes ces especes - nont point de donts, puisque l'ys juiejatl, yni est nommé- ment compris dans les six, a des dents, et mène un granil - uombre. En voila plus yu'il nen fant purr juger de l'vu. - vrage et de l'auteur. Il est fácheux que la plupart des gens a qui fout des cabiuets d'histoire naturelle ne soir'ul pas assez a iustruits, et que, pour satisfaice leur petite vanite et faire - valoir leur collection, is eutreprennent d'en jublier des - Iescriptions tonjours remplies d'exagérations, d'erreurs el - de bevin's qui demandent plus de temps jour ètre réfor* mées yuil u'en a fallu pour les cicrire. a

1 Tamandua d'Amérique petit, ou le mangenr de fournis, dépeint avec un uid de ces insectes. Voila comme il embrasse avec les ongles de ses pieds de devant le uid cle fourmis, desquels il fait unipuement ses repas. Vojez sa téte oblongue. mince, étroite, ses courtes oreilles, son musean pointu yui cache sa langue, grande et menue, avec lanuelle il attrape les fourmis et les avale, ainsi que nous nous proposons de le montrer à l'reil dans les planches yni suivout (il ne muntre. rien daus les planclues suivautes; sa tite, ses janbes, ses picds, sa queue et le desant he son corps sont jannes jaillis; le derrière du corus eut diun roux bruu; il porte en basudunliere, sur la poitrine, uu baudrier de poils soyeux yui se perdent vers le milieu du dus avec les autres soies yui commencont des lors a le couvrir; sa queue est courte, presuue rase et recourbe en dedaus. Seha, vol. II, page 18, tah. 17, fig. 1102. Nola. Les deruiers caractères de cetle description con. vieuneut assez au tamauJua, mais, en géuéral, elle est trop peu exacte four yue l'on puisse lassurer. 
juge. Quelque désagréables, quelque ennuyeuses que soient des discussions de cette espèce, on ne peut les éviter dans les détiils de l'histoire naturelle: il faut, avant d'écrire sur un sujet, sourent très-peu connu, en écarter autant qu'il est possible toutes les obscurités, marquer en passant les crreurs qui ne manquent jamais de se trouver en nombre sur le chemin de la vérité à laquelle il est souvent très-difficile d'arriver, moins par la faute de la nature que par celle des naturalistes.

Ce qui résulte de plus certain de cette critique, c'est qu'il existe réellement trois espèces d'animaux auxquels on a douné le nom commun de mangeurs de fourmis; que ces trois espèces sont le tamanoir, le tamandua et le fourmilier; que la quatrième espèce, domnée sous le nom de fourmiliers aux longues oreilles par M. Brisson, est douteuse aussi bien que les autres espèces indiquées par Seba. Nous avons vu le tamanoir et le fourmilier; nous en avons les dépouilles au Cabinet du Roi; ces espèces sont certainement très-différentes l'une de l'autre, et telles que nous les avons décrites; mais nous n'arons pas vu le tamandua, et nous n'en parlons que d'après Pison et Maregrave, qui sont les seuls auteurs qu'on puisse consulter sur cet animal, puisque tous les autres n'ont fait que les copier.

Le tamandua fait, pour ainsi dire, la moyenne proportionnelle entre le tamanoir et le fourmilier pour la grandeur du corps; il a, comme le tamanoir, le museau fort allongé, et quatre doigts aux pieds de devant; mais il a, comme le fourmilier, la queue dégarnie de poil à l'extrémité, par laquelle il se suspeud aux branches des arbres. Le fourmilier a aussi la mème habitude. Dans cette situation ils balancent leur corps, appro hent leur museau des trous et cles crenx d'arbres; ils y insinuent leur longue langue et la retirent cusuite brusquement pour avaler les inseetes qu’elle a ramassés.

Au reste ces trois animaux qui different si fort par la grandeur et par les proportions du corps, ont néanmoins beaucoup de choses communes, tant pour la conformation que pour les habitudes naturelles; tous trois se nourrissent de fourmis, et plongent aussi leur langue dans le miel et dans les autres substances licuides ou visqueuses : ils ramassent assez promptement les miettes de pain et les petits morceaux de viande hachée; on les apprivoise et on les élève aisé- ment; ils soutiemnent longtemps la privation de tonte nourriture; ils n'avalent pas toute la liqueur' qu'ils prennent en buvant, il en retombe une partic qui passe par les narines; ils dorment ordinairement pendant le jour, et changent de lieu pendant la nuit; ils marchent si mal qu'un homme peut les atteindre f:icilement à la course dans un lieu découvert. Les Saurages mangent leur chair qui cependant est d'un très-mau vais goût.

On prendrait de loin le tamanoir pour un grand renard, et c'est par cette raison que quelques royageurs l'ont appelé renard améri. cain; il est assez fort pour se défendre d'ur gros chien et mème d'un jaguar. Lorsqu'il en est attaqué, il se bat d'abord debout, et, comme l'ours, il se défend avee les mains dont les ongles sont meurtrières; ensuite il se couche sur le dos pour se servir des pieds comme des mains, et dans cette situation il est presque invineible et combat opiniàtrément juscuu'à la dernière extrémité, et mème lorsqu'ii a mis à mort son emnemi, il ne le làche que très-longtemps après : il résiste plus qu un autre iu combat, paree qu'il est couvert d'un grand poil touffu, d'un cuir fort épais, et qu'il a la chair peu sensible et la vie très-rlure.

Le tamanoir, le tamandua et le fourmilier sont des animaux naturels aux climats les plus chauds de l'Amérique, c'est-à-dire au Brésil, à la Guiane, aux pays des Amazones, ete. On ne les troure point en Canada ni dams les autres contrées froides du Nouveau-Monde; on ne doit done pas les retrourer daus l'ancien continent : cependant Kolbe et Desmarehais ont écrit qu'il y avait de ces animaux en Afrique, maisil me parait qu’ils oat confondu le pangolin ou lézard éeailleux avec nos fourmiliers. C'est peut-ètre d'après un passage de Marcgrar e où il est dit: Tamandua-guacu Brasiliensibus, Congensibus ( ubi et frequens est) umbuil dictus, que Kolbe et Desmarchais sont tombés dans cette erreur ; et en effet si Maregrave entend par Congensibus les naturels de Congo, il aura dit le premier que le tamanoir se trouvit en Afrique, ce qui cependant n'a été confirme: par aucun autre témoin digne de foi. Naregrave lui-mẻme n'avait certainement pas vu l'animal en Afrique, puisqu'il avoue qu'en Amérique mème il n'en a vu que les dépouilles. Desmarchais en parle assez raguement; il dit simplement qu'on trouve cet animal cn Afrique comme 
en Amérique, mais il n'ajoute aueune circonstance qui puisse prouver le fait : et à l'égard de Kolbe, nous comptons pour rien son témoignage; car un homme qui a vu au cap de Bonne-Espérance des élans et des loups-cerviers tout semblables à ceux de Prussc, peut bien aussi y avoir vu des tamandua. Aucun des auteurs qui ont éerit sur les productions de l'Afrique et de l'Asie n'ont parlé des tamanduá, et au contraire tous les voyageurs et presulue tous les historiens de l'Amérique en font mention précise; de Lery, de Laët, le P. d'Abheville, Maffé, Faber, Nieremberg et IrI. de la Condamine, s'accordent à dire avec Pison, Barrire, ete., que ce sont des animaux naturels aux pays chauds de l'Amérique. Ainsi nous ne doutons pas que Desmarchais et Kolbe ne se soient trompés, et nous croyons pouvoir assurer de nouvan que ees trois espèces d'animaux n'exisicut pas dans l'ancien continent.

\section{ADDITION A L'ARTICLE DU TAMANOIR.}

Nous avons donné la figure du tamanoir cl. rand fourmilier; mais, commic le dessin n'a cité fitit que d'apı̀̀s unc peau qui avait été assez mal próparée, il n’est pas aussi exact que celui qu'on trouvera iei, yui a cété fait sur un animal envoyé de la Guiane, bien empaillé, à M. Mauduit, doeteur en médecine, dont le eabinet ne contient (jue des choses préeicuses, par les soins que cet habile maturaliste prend de recueillir tout ee qu'il y a de plus lare, et de maintenir les animaux et les oiseaux dans le meilleur état possible. Quoique le tamanoir que nous domons ici soit précisément de la même espèce que celui de l'article qui précède, on verra néanmoins qu'il a le museau plus court, li distance de l'oil à l'oreilie plus petite, les pieds plus courts; ceux du devant nont que quatre ongles, les deux du.milieu tries-grands, les deux de côté forts petits, einc ongles aux pieds de derriere, et tous ees ongles noirs. Le museau juscju’ax oreilles est couvert d'un poil lorum fort court; près des oreilles le poil commenee à devenir plus grand; il a deux pouees et demi de longucur sur les còtés du corps; il est rude au toucher, comme celui du sanglier. Il est mèlé de poils d'un brun foncé, et d'autres d'un blanc sale. La bande noine du corps n'a point de petites taches b!anches déciclées et qui la bordent, comme dans le tamanoir décrit d'abord: celui-ei a trois pieds onze pouces de longueur', e'est-à-dire trois pouees de plus que le premier. Voici ses autres dimensions :

p. p. 1 .

Hauteur du train da derriẹre. . . . . . . 1 ₹ 7

Longueur $d u$ bout $d n$ museau a l'angle de

l'oil. ................. 0 ₹

Ouverture de l'ail.............. 0 . 0 . 6

Ouverture de la bouche. ............ 011

Ouverture des narines.. ......... 0 ... 0 .

Distance de l'oril à l'oreille. . . . . . . . 0 0 21

Grandeur de l'oreille. ........... 0 (... 12

Longueur du cor. ............ 0 8 \&

Longueur du tronçon de la tneur........ . . 1 9)

Longueur du pied de derant.. . . . . . . . 0 . 50

Longueur de l'ergot interne......... 0.000

Longueur de ce mème ergot à son origine. . $\begin{array}{lll}0 & 0 & 4\end{array}$

Longueur de l'ergot stuivat. . . . . . . 0 1 8

Sa largeur à son origine...........

Longueur de l'ergot exterieur. . . . . . . 0 . 0 .

Sa largeur à son origine. . . . . . . . 00000

Longueur du troisième ergot....... 0 n 25

Sa largeur à son origine........... o o

Longueur du pied de derriere. . . . . . . 0 0 50

Longueur de l'ergot interne.......... 0 . 0 i

Longueur des trois autres ergots. . . . . . () 1 10

Largenr à l'origine. . . . . . . . . . 0 . 0 (1)

Longueur de l'ergot externe. . . . . . . . . 0 ( 11

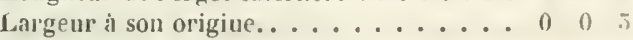

M. de La Borde, médecin du roi à Cilyenne, m’a envoyé les ol)servations suivanles ail suj(t de ect auimal.

"Le tamanoir habite Ies bois de la Guiane. On y en eonnait de deux especes; les individus de la plus grande pèsent juscuià eent livres. Ils courent lentement et plus lourdement (pu'un eochon; ils traversent les glandes rivieres it lit nage; et alors il n'est pas difílicile de les assommer à coups de bîton. Dans les bois on les ture a coups de fusil; ils n'y sont pas fort eommuns, quoique les chiens refusent de les chas. ser.

1) Le tamanoir se sert de ses grandes grifies pour déchirer les ruches des poux de hois qui se trouvent partout sur les arbres, sur lesquels il grimpe facilement. II faut prendre garde d'approcher de eet animal de trop pres, car ses griffes font des bl'ssure's profondes : il se défent mème avee avantage eonlre les animaux les plus féroces de cec continent, icls que les jiguars, rouguars, ete.; il les dichire aree ses griffes, dont les muscles et les teadous sont d'une 
grande force; il tue beaucoup de ehiens, et e'est par cette raison qu'ils refusent de le cliasser.

"On voit souvent des tamanoirs dans les grandes savanes incultes. On dit qu'ils se nourrissent de fourmis; leur estomac a plus de capacité que celui d'un homme. J'en ai ouvert un qui avait l'estomac plein de poux de bois, cu'il avait nouvellement mangés. La strueture et les dimensions de sa langue semblent prouver qu'il peut aussi se nourrir de fourmis. Il ne fait qu'un petit dans des trous d'arbre près de terre; lor'sque la femelle nourrit, elle est très-dangereuse, même pour les hommes. Les gens du commun à Cayenne mangent la ehair de cet animal; elle est noire, sans graisse et sans fumet. Sa peau est dure et épaisse, sa langue est d'une forme presque conique eomme son museau. "

M. de La Borde en donne une description anatomique, que je n'ai pas cru devoir publier ici, pour lui laisser les prémices de ee travail qu'il me parait avoir fait avec soin.

"Le tamanoir, continue M. de La Borde, n'accuiert son accroissement entier qu'en quatre ans. II ne respire que par les narines; à la première vertèbre qui joint le cou avec la tête, la traehée-artère est fort ample; mais elle se rétréeit tout à coup; et forme un conduit qui se continue jusqu'aux narines, dans cette espèce de cornet qui lui sert de mâchoire supérieure. Ce cornet a un pied de longueur, et il est au moins aussi long que le reste de la tète. II n'a aueun conduit de la traehée-artère à la gueule, et néanmoins l'ouverture des narines est si petite, qu'on avait de la peine à y introduire un tuyau de plume à écrire. Les yeux sont aussi très-petits, et il ne voit que de eôté. La graisse de cet animal est de la plus grande blaneheur. Lorsqu'il traverse les eaux, il porte sa grande et longue quene repliée sur le dos et jusque sur la tête."

MM. Aublet et Olivier m'ont assuré que le tamanoir ne se nourrit que par le moyen de sa langue, laquelle est enduite d'une humeur visqueuse et gluante, a vee laquelle il prend̉ les insectes. Ils disent aussi que sa chair n'est point mauvaise à manger.

aDdition a L'article du TAMANDUA.

Nous eroyons devoir rapporter ì l'espèce du tamandua, l'animal dont nous donnons iei la ders cription, et duquel la dépouille bien préparén était au eabinet de M. le duc de Caylus, et se voit actuellement dans le Cabinet du Roi. Il est différent du tamanoir, non-seulement par la grandeur, mais aussi par la forme. Sa tête est à proportion bien plus grosse : l'œil est si petit, qu'il n'a qu'une ligne de grandeur, encore estil environné d'un rebord de poils relevés. L'oreille est ronde et bordée de grands poils noirs par-dessus. Le corps entier n'a que treize pouees depuis le bout du nez jusqu'à l'origine de la queue, et dix ponces faibles de hauteur. Le poil de dessus le dos est long de quinze lignes; eelui du ventre, qui est d'un blanc sale, est de la mème longueur. La quene n'a que sept pouces et demi de longueur, couverte partout de longs poils fauves, avec des bandes ou des anneaux d'une teinte légèrement noirâtre.

Il n'y a, dans toute cette description, que deux caractères qui ne s'aceordent pas avee celle que Maregrave nous a donnée du tamandua. Le premier est la queue qui est partout garnie de poils, au lieu que celui de Maregrave a la queue nue à son extrémité; le seeond, c'est qu'il y a cinq doigts aux pieds de devant dans notre tamandua, et que celui de Maregrave n'en avait que quatre: mais, du reste, tout convient assez pour qu'on puisse eroire que l'animal dont nous donnons ici la description est au moins une variété de l'espèce du tamandua, s'il n'est pas précisément de la mème espece '.

M. de La Borde semble l'indiquer dans ses Observatious, sous le nom de petit tamanoir.

" Il a, dit-il, le poil blanchattre, long d'environ deux pouces; il peut peser un pen plus de soixante livres; il n'a point de dents, mais il a aussi des griffes fort longues; il ne mange que le jour comme l'autre, et ne fait (qu'un petit. Il vit aussi de mème, et se tient dans les grands bois; sa chair est bonne a mauger, mais on le trouve plus rarement que le grand tamanoir. ")

J'aurrais bien désiré que $\mathrm{M}$. de La Borde m'eùt envoyé des indications plus précises et plus dé. taillées, qui auraient lixé nos ineertitudes au sujet de cette espèce d'animal.

Voici ee qu'il m'écrit en mème temps sur le petit fourmilier.

1 Celte figure arait été faite d'après une pean de coati dont on avait prolongé artiliciellement le unseau. La description doit donc en ètre considérée comme nulle. 
- Il a le poil roux, luisant, un peu doré, se nourrit de fourmis, tire sa langue, qui est fort longue et faite comme un ver, et les fourmis s'y attachent. Cet animal n'est guère plus grand qu'un écureuil. Il n'est pas difficile à prendre ; il marche assez lentement, s'attache comme le paresseux sur un bâton qu'on lui présente, dont il ne cherche pas à se détourner, et on le porte ainsi attaché où l'on veut. II n'a aucun cri; on en trouve souvent d'accrochés à des branches par leurs griffes. Ils ne font qu'un petit dans des creux d'arbres, sur des feuilles qu'ils charrient sur le dos. Ils ne mangent que la nuit; leurs grifies sont dangereuses, et ils les serrent si fort qu'on ne peut pas leur faire lâchel prise. Ils ne sont pas rares, mais difficiles à apercevoir sur les arbres."

M. Vosmaër a fait une critique assez mal fondée de ce que j'ai dit au sujet des fourmiliers 1.

"Je dois remarquer, dit-il, contre le sentiment de 11. de Buffon, que l'annće passée M. Tulbagh a envoyé un animal sous le nom de porc de terre, qui est le myrmécophaye de Linnaus ; en sorte que Desmarchais et Kolbe ont raison de dire que eet animal se trouve en Afrique aussi bien qu'en Amérique; à juger de celui-ci, qui a été envoyé daus l'esprit-de-vin, varaissaut ètre tout nouvellement né, et ayant léjà la grandeur d'un bou cochon de lait, l'auimal parfait doit étre d'une taille fort consilérable. Voici les principales différences, autant yuion peut les reconnaitre à cet animal si jeune.

- Le groin est à son extrémité un peu gros, rond et aussi comme écrasé en dessus. Les oreilles sont fort grandes, longues, minces, pointues et pendantes. Les pieds de devant ont quatre doigts, le premier et le troisième d'une longueur égale, le second un peu plus long, et le quatrième ou l'extérieur un peu plus court que le troisieme. Les quatre onglets sont fort longs, peu crochus, pointus, et à peu près d'une écale grandeur; Jes pieds de derrière ont cinq doigts, dont les trois intermédianies sont presune égatlement longs, et les deux extérieurs beaucoup plus courts; les onglets en sont moins grands, et les deux extérieurs les plus petits. Sa cueue, sans ètre fort longue, est grosse, ct se termine en pointe. l.es deux myrmécophages de Scba, tome I, planche 3i, fir. 2, et planche 40, fiy. 1, sont certainement les mèmes, et ne différent entre eux que pall la couleur; la ligure en est fort bonne. C'est une espece particulière, tout à fait différente du tamanduaguacu de Maregrave, ou tamanoir de M. de Bufton. "

On croirait, après la lecture de ce passage, que je me suis trompé au sujet de cet auima!, donné par Seba, planche 37, $n^{\circ} 2$. Cependant j'ai dit précisément, puge 316 de ce volume, ce que dit ici M. Vosmaër. Voici comme je me suis exprimé : L'animal que Seba désigne par le nom de tamandua myrmécophage d'Amérique, tome I, page 60 , et dont il donne la figure, planche $37, n^{\circ} 2$, ne peut se rupporter i aucun des trois dont il est ici question. Or, les trois animaux d'Amérique dont j'ai parlé sont le tamanoir, le tamandua, et le petit fourmilier; done tout ce que dit ici M. Yosmaër ne fait rien contre ce que jai avancé, puisque ce que j’ai avancé se réduit à ce que le tamanoir, le tamandua et le fourmilier ne se trouvent qu'en Amérique, et non dans l'ancien continent. Cela est si positif, que M. Vosmaër ne peut rien y opposer. Si le myrmécophage de Seba, $p l$. 37, fig. 2, se trouve en Afrique, cela prouve seulenent que Seba s'est trompé, en l'appelant myrmécophage d'Américfue; mais cela ne prouve rien contre ce que j'ai avincé, et je persiste, avec toute raison, à soutenir que le tamanoir, le tamandua et le fommilier ne se trouvent qu'en Amérique et point en Afripue '.

\section{DESCRIPTION DU TAMANOIR.}

(EXTKIT IOE HULENTOS.)

Le erine dı tamanoir est fort pelit; mais son musean est si loug, que la téte entière fait plus du liers de la longueur de l'animal depuis le bout des levresjusugu'i l'origine de la unene; la longruenr du unuseau est à peu près les deux tiers de celle tle lit tète el presique le puart de celle du corps entier, y compris le crane el le musean. C'est comme si le musean d'un cheval de taille midiocre avait deux pieds de longueur, tandis yu’il n'a yne treize on quatorze jonces, quoiput prarmi les animanx de notre clinat le eleval suit un de ceux pui ont le museau le plus longr, è est-à-dire qui unt les yeux

- ciest fonctenope nu cap on cochon de terre.

+ nescriplion diun glaud seureuit volint, page 6 . II. 
le plus iloignés du bout des lèvres. Le museau du tamanoir est presque cylindrique, il a peu de diamòtre; il n'est guère plus gros près des yeux qu'à sou exirémité; la bouche est petite; les ouvertures des narines se trouvent fort près l'une de l'autre au-levant du museau, à deux lignes au-dessus du hord de la levre; les yeux sont petits à proportion de la longrueur du museau, et placés sur les côtés de la tête; les oreilles sont courtes, arrondies et fort éloinnèes des yeux; plles étaient nues: le crâne a une forme allongie et presque cylindrique depuis les oreilles justu'aux yeux. Le tamanoir a le cou court, le corps allongé et efflanqué, la queure longue et les jambes courtes. Les pieds de derrière ont cing doigts, et ceux de devant seulement quatre; les deux du milieu sont plus gros, et portent des ongles beaucoup plus grands que les deux autres doigts des pieds de devant et que ceux des pieds de derrière; le doigt infériem des pieds de devant est placé plus lıaut que le second, comme dans la plupart des antres animaux. La dernière plaalange des doigls a une gouttière longitudinale sur sa face supérieure, depuis le milieu de sa longuenr jusqu’à l'extrémité.

Le poil du museau est court, incliné en avant, dèlié, ferme, et néanmoins doux sous la main lorsqu'elle suit sa direction. Il était de couleur mòlée de gris, de brun et de noirâtre : le poil de la tête ne différait de celui du museau qu'en ce qu’il était un pen plus long. Il y avait depuis l'occiput, le long du cou, du dos et des lombes jusqu’à la queue, un poil long en forme de crinière ; il était de plus en plus long à mesure (ju'il se trouvait plus près de la queue; sa plus grandle longueur était de treize on quatorze ponces : la crinière était disposée en ipi ou molette sur le garrot, de sorte que le poil de la portion de la crinière, qui s'étendait depuis le garrot jusqu'à l'occiput, était dirigé en avant, et celui du reste de la crinic̀re, depuis le garrot jusıu’̀̀ la queue, élait dirigé en arrière : chaque poil avait une couleur blanchâtre teinte le jaunâtre très-pâle sur la plus grande partie de sa longueur depuis la raciue; le reste éiait noir, excepté la pointe (jui avait aussi une couleur jaunâtre très-pâle et presque blanclıâtre : ce mélange de noir et de blanclıâtre s'étendait de chaque côté de la crinière, le longr du dos jusqu'à me large bande entièrement noire qui couvrait le dessous du cou et qui s'étendait sur les épaules et le long des côtés de la poitrine jusqu’au conmencement des lombes. Les jambes de devant et le bas des còtés de la poitrine étaient de conleur blanchàtre teinte de jaunâtre, excepté la face externe du bras qui avait un mẻlange dle noir, et les pieds qui étaient noirs; il y avait aussi une grande tache noire sur le laut de la face externe de l'avant-bras. Le dessous de la poitrine, le ventre, les flancs, les jambes de derricre et la queue étaient noirs avec quelģue mélange de hlaıchatre, princi. palement sur les pieds de derrière. Les poils de la queue araient environ un pied de longueur; cenx du corps n'avaient au plus (pu'um demi-pied : les poils du haut des còtés du corps, ceux de la poitrine et du ventre étaient beaucoup moins longs, et ceux de la face externe des jambes de devant étaient encore plus courts. Les grands poils du tamanoir n'étaient cylindriques que sur une partie de leur longueur depuis la racine, le reste était plat, et il y avait sur le milieu de claque face une petite gouttière longitudinale : la partie cylindrique était creuse d'un bout à l'autre et assez ferme, quoique les parois du tuyau qu'elle formait fussent minces ; la partie aplatie avait peu de consistance, elle était flexible comme de l'herbe sèche; elle avait environ six fois plus de largeur que d'épaisseur, prise sur les bords qui avaient le double de l'épaisseur du milieu où étaient les gouttières ; l'extrémité du poil élait fourchue. En tirant clıacune des branches de cette bifurcation, on fendait très-aisément le poil dans son épaisseur tout le long de la partie plate; mais lorsqu'on arrivait à la partie cylindrique on ne pouvait plus la diviser aisément; il semblait que l'aplatissement de l'antre partie y eût fait deux plis qui l'avaient disposée à se rléchirer comme dı papier qui a été plie. Cette partie plate paraissait ètre desséchée; peut-ètre gu’elle est cylindrique sur l'animal vivant, el que le vide de l'intérieur dı poil est rempli de ruelque lıumem.

\section{DESCRIPTION DU FOURMILIER.}

(EXTha]T DE DAUBENTON.)

La ligure du fourmilier est fort différente de celle des autres amimaux quadrupèdes; il a le musean et les pieds conformés d'une manière très-particulière. La tête est assez bien proportionnée au reste du corps pour sa grosseur, mais le museau est fort elfilé et un peu recourhè en bas; les yeux sont placés près des coins de la bouche, et les oreilles se trourent sur la partie inférieure des côtés de la tête, à peu près à égale distance du bout du museau et de locciput; elles sont très-petites, minces, arrondies et entièrement cacliées dans le poil : le cou de l'animal est presque nul. La queue a autant de longnueur que le corps et la tête; elle est pointue, et recourbẻe en dessous par l'extrémité; sa face inférieure a, sur la longueur de deux pouces et deni depuis la pointe, une peau dénuée rle poil et sem. blable à celle de la plante des pieds. On voit par cette conformation que le fourmilier se sert de sa queue comme d'une main pour saisir differents corps, et pour s'accroclier et se suspendre à divers points 
d'appui. Les pieds ressemblent aussi à dles mains et paraissent être plus propres pour embrasser les corps cylinclriques, comme des branches d'arbres, Ine pour marcher à plate-terre : les pieds de devant ont, comme les pieds de derrière, une sorte de talon qui, à la vérité, u’est pas aussi large ni aussi saillant, mais qui forme une convexite en arric̀re comme le talon de l'ours, flu coati, etc. La plante des quatre pierls s'éteud jusqu'aux ougles. Fis rigueur, on ne devrait pas mettre cet anima] dans la elasse des fissipèıles, car on n’y voit point à l'extérieur de doights séparés les uns des antres; on ne peut juger de leur nombre que par celıi iles ongles; il y en a deux à chaque pied tle devant et quatre à chaque pied de derrière : 1ous ces onıles sont courbes, pointus et pliés en gouttière très-serrée; ils ont une conleur jaunâtre, et ils prolongent la concavité de la plante $l e s$ pièls, qui est très-profonde et assez régulière, principalement dans les pieds tle derrière; l'ongle externe des pieds rle devant est fort grand, linterne est heaucoup plus pet it et à peu près de la unêne grandeur que cenx des pieds dle derriere, yui sont tous les quatre semblables les uns aux autres.

Te poil est touffn et doux comme de la soie; sa longneur s'étendait jusqu’à neuf lignes sur le fourutilier qui a servi de sujet pour cette description, et qui était femelle; son poil avait nne couleur jauniare mélée de teimes roussâtres, et même d'un tres-bean roux dans' quelyues endroits; ces teintes étaient à la pointe des poils, c'est ce qui formait sur le dos de l'animal, dejuis l'occiput juscju’a l'origine cle la queue, une bande large d'environ un demi-ponce, d'un très-bean roux, et des teintes de celte même couleur sur les côtés du corps. Le poil est très-luisant, et par conséquent ses couleurs sont fort brillantes.

Sur un autre individu, anssi femelle, la bande rousse du dos était très-peu apparente, et il y avait. du lirun dans les endroits oì on voyait rles teintes ronsses sur le sujet de cette deserifution. Tn autre fourmilier avait une banle rousse le long rle la poitrine et clu ventre, mais il n'en paraissait joint sur le dos.

\section{LE PANGOLIN ET LE PHATAGIN.}

CE PANGOLIN A GRCSSE QUEUE. - I.E PANGOLIN J'AFRIQUE OU PITATAGIN,

Ordre des identis ordinaires, genre pangolin. (Cuvier.)

Cos animaux sont vulgairement commus sous fe nom de lésards écailleux: nous avons eru devoir rejeter cette dénomination, 10 parce qu'elle est composée ; $2^{\circ}$ parce (qu'elle est ambi. guë et qu'on l'applique à ees deux espéces; $3^{\circ}$ parce quu'elle a ćté mal imaginée; ces animaux étant non-seulement d'un autre genre, mais mème d'une autre classe que les lézards, qui sont des reptiles ovipares, au lien que le pangolin et le phatagin sont des quadrupèdes vivipares : ces noms sont d'ailleurs ceux (pu'ils portent dans leur pays natal; nous ne les avons pas eréés, nous les avous seulement adoptés.

Tous les lézards sont recouverts en entier et jusque sous le ventre d'une peau lisse et bigarrée de taches qui représentent des écailles; mais le pangolin et le phatagin n'ont point d'écailles sous la gorge, sous la poitriue, ni sous le ventre : Ic phatagin, comme tous les autres quadrupèdes, a du poil sur toutes ces partics inférieures du corps, le pangolin n'a qu'une peau lisse et sans poils. Les ćcailles qui revètent et couvrent toutes les autres parties du corps de ces deux animaux ne sont pas collées en entier sur la peau; elles y sont seulement infixées et fortement adhérentes par leur partie inférieure: elles sont mobiles comme les piquants du poreépic, et elles se relèvent ou se rabaissent à la volonté de l'animal; elles se hérissent lor'squ'il est irrité; elles se hérissent encore plus lorsqu'il se met en boule comme le hérisson. Ces écailles sont si grosses, si dures et si poignantes qu'elles rebutent tous les animanx de proie; e'est une euirasse offensive qui blesse antant qu'elle l'ésiste: les plus eruels et les plus afiamés, tels pur le tigre, la panthere, ete. ne font que de vains efforts pour dévorer ées animaux armés; ils les foulent, ils les roulent, mais en mène temps ils se font des blessures douloureuses des qüils veulent les saisil : ils ne peuvent ni les violenter, ni les écraser, ni les étouffer en les surchargeant de leur poids. Le renard, qui eraint de prendre arec la gुneule le hérisson en boule dont les piguants lui déchirent le palais et la langue, le force cependant à s'étendle en le foulant aus pieds et le pressant de tout son poids; cies que la tête parait, il la saisit par le bout du muscau ef met ainsi le hérisson à mort : mais le pangolin et le phatagin sont do tous les animaux, sans en excepter même le porépic, ceux dont l'armure est la plus forte et la plus offensive, en sorte qu'en contractant leur corps et présentiut leurs armes, ils bravent la fureur de tous ieurs ennemis. 
Au r'este, lorscue le pangolin et le phatagin se resserrent, ils ne premnent pas, comme le hérisson, une figure globuleuse et uniformc : leur corps ell se contractant se met en peloton, mais leur grosse et longue queue reste au-dehors et sert de cercle on de lien au corps. Cette partic extérieure, par laquelle il parait queces animaux pourraient être saisis, se délend d'elle-même : elle est garnie dessus et dessous d'écailles aussi dures et aussi trimcliantes que celles dont le corps est revètu, et comme clle est convexe endessus et plate en dessous, et qu'elle a la forme à peu près d'une demi-pyramide, les còtés anguleux sont revètus d'écailles en équerre pliées ì angle droit, lesquelles sont aussi grosses et aussi tranchantes que les autres; en sorte que la queue parait ètre encore plus soigneusement armée que le corps, dont les parties inférieures sont dépourvues d'écailles.

Le pangolin est plus gros que le phatagin, et cependant il a la queue beatcoup moins longue; ses pieds de devant sont garnis d'écailles jusqu'à l'extrémité, au lieu que le phatagin a les pieds, et mème une partie des jambes de devant dégarnis d'écailles et couverts de poil. I.e pangolin a aussi les écailles plus grandes, plus épaisses, plus convexes et moins camnelées que celles du phatagin, qui sont armées de trois pointes très-piquantes; au lien que celles du pangolin sont sans pointe et uniformément tranchantes. Le phatagin ' a du poil aux parties inférieures : le pangolin n'en a point du tout sons le corps; mais, entre les écailles qui lui convrent le dos, il sort quelques poils gros et longs comme des soies de cochon, et ces longs poils ne se trouvent pas sur le dos du phatagin. Ce sont li toutes les différences essentielles que nous ayons remarquées en observant les dépouilles de ces deux animanx qui sont si différents de tous les autres quadrupèdes, qu'on les a regardés comme des espèces de monstres. Les différences que nous venous d'indiquer étant générales et constantes, nous croyons pouroir assurer que le pangolin et le phatagin sont deux animaux d'espèces distinctes et séparées : nous avons reconnu ces rapports et ces différences non-seulement par l'inspection des trois sujets que nous arons rus, mais aussi par la comparaison de tous ceux qui ont été observés par les voyageurs et indiqués par les naturalistes.

\footnotetext{
+ Le platagin à longue queue est propre an Séućgal el a la cote sle Guinéc. (Curık.)
}

Le pangolin a jusqu'it six, sept et lutit pieds de grandeur, y compris la longueur de la queue, lorsqu'il a pris son accroissement entier : la queue, qui est a peu près de la longueur du corps, parait être moins longue quand il est jeune : les écailles sont aussi moins grandes, plus minces et d'une couleur plus pâle; elles premment une teinte plus foncée lorsque l'animal est adulte, et elle's acquièrent une dureté si grande qu'elles résistent á la balle du mousquet. Le phatagin est, comme nous l'a vons dit, bien plus petit que le pangolin; tous deux ont queiques rapports avec le tamanoir et le tamandua; comme eux, le pangolin et le phatagin ne vivent que de fourmis; ils ont anssi la langue très-longue, la gueule étroite et sans dents apparentes, le corps très-allongé, la queue aussi fort longue et les ongles des pieds à peu près de la mème grandeur et de la même forme, mais non pas en même nombre : le pangolin et le phatagin ont cinq ongles à chaque pied, au lieu que le tamanoir et le tamandua n'en ont que quatre aux pieds de devant; ceux-ci sont couverts de poils, les autres sont armés d'écailles; et d'ailleurs ils ne sont pas originaires dlu même continent: le tamanoir et le tamandua se trouvent en Amérique; le pangolin et le phatagin, aux Indes orientales et en Afrique, ou les Nègres les appellent quogels ${ }^{1}$; ils en mangent la chair

I On trouve dans les bois un animal a quatre pieds, que les Nèrres appelleul Qungelo. Depuis le cou jusquà l"exlrónité

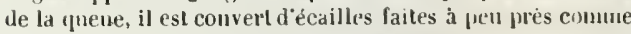
les feuilles de l'arlichant, un y,eu plus pointues : eiles son] serrées, asse $z$ épaisses tusuffisamment lottes pour le défendre des grilfes el des dents des animaux yui l'altayueut. Les tigres et les léopards lui donnent la chasse sans relàclı", et nout pas de peiıe a le joindre, parce quil s'en faut bieı yül aille aussi viteıue ces animaux; il ne laisse pas de fuir; mais, comme il esl bientit attrapé, el yue ses ongles el sa gueule lıi seraient de faibles défenses contre des animanx yui ont d* terribles dents et des grilfes bien furtes el bien aiguẻs, la nature lui a enseigue le se mellre en boule en pliant sa quene sous sou veutre $\mathrm{ct}$ se ram issant de telle manière, qu'il ue frésente de tons culés que les pointes de ses écailles. Le lique ou le léoparal ont beaule tun'uer doucement avec len's grilfes, ils se piquteul dès „üits veulent le faire uu peu luulentent, et sont contraiuls de lo laisser en repos. Les Nigres l'assommeut à coups de britou, l'écorcheut, vendent sa peau aux blancs el uangent s.t cliail' ils disent quièle est blanche et délicale. Sa tìte el son museau, que sa ligure promrait faure prendre pour une lète el un bec decanard, renferme une langue extrementent lougue. imbibée d'une liqueur unchuense et tenace; il cherche le: fommilieres et le lieu le passage de ces insech's ; il iteul sä langue el la foure daus leur trou ou l'aplatil sur le plassago: ces insecles y coureut aussitót attirés par l'odeur, et y denıeıreul enipètrés dans la liıneur oncluense; et quand l'animal seul tpue sa laugne est bien cliargée de ces insectes. il la retire et en fait sa curéc. Cel animal n'est point méchant, it uatta. que prrsonne, il ne cherche qu'à vivre, et pourvu qu'il (rouve des fourmis, il est content et fait bonne chere. Les plus granils 
qu'ils trouvent délicate et saine, ils se servent des ćcallles à plusieurs petits usages. Au reste, te pangolin et le phatagin n'ont rich de rebutant que la figure; ils sont doux, jumocents et ne font aucun mal : jls ne se nourrissent que d'inscetes. Ils courent lentement et ne peuvert échapper à l'homme qu'en se eachant dans des trous de rocher's ou dans des terriers qu'ils se creusent et oì ils font leurs petits. Ce sont deux espèces extraordinaires, peu nombreuses, assez inutiles, et dont la forme bizarre ne parait exister que pour faire la premicre nuance de la figure des quadrupèdes à celles des reptiles.

\section{DESCRIPTION DU PANGOLIN.}

'EXTRAT UE MILHENTON.)

Le pangolin' 'a tant de ressemblance pour la forme du corpis avec les lézards, quon lui en a souvent donné le nom ; et il est couvert d'ecailles si grandes I siapparentes, qu'on l’a désigné par la dénomination de lesard écuilleux. Il a, comme le lézard, la tète petite, Je cou court et gros, le corps lons, les jambes courtes et la rueue fort longrue, très-grosse a son origine, com exe en dessus, plate en dessous et terminée en pointe. Le musean est allongé et étroit par le bout, le nez ressemble à celui des chiens, les yeux sont très-petits, et les conduits des oreilles se trowvent près des yeux et nont point de conque. Le con est plus gros que la tête, parce que les ceailles qui le couvrent sont plus grandes, et par conséquent plus épaisses et plus saillantes que celles de la tète : les cicailles du corps et des jambes cachent aussi toutes les proportions te cet animal et le rendent prespue informe. Il a cint doigts à claque pied, (qui ne sont apparents que par leurs ongles; et ces ongles ẻtaient, dans le pangolin qui a servi de sujet pour cetle description, ì pen près aussi grands yue cenx du tamanoir, mais de couleur blanchâtre; la dernière phalange des cloigts, qui n’a qu'une goutlière Inngitulinale sur sa face supérieure dans cet animal, est entièrement fendue a son extrennite, dans le pangolin, et il y a dans la cavite de l'ongle une lame le meme substance yue l'ongle, qui tient à sa parlie suprienre ol qui s'ctent entre les deux branches de la bifurcation de la ternière phalange du doint: les ongles des pieds dedevant sont plus grands que ceux des pirds de derrière; celui du milien est le plus lons, et le dernier

quion ait vus de celle espece avaient lutit pieds te longucur, y compris la quene qui eu a hien puatre. Vuygae de lesmarchais, lome 1. page $200 \mathrm{et} 2 \mathrm{l}$.

- Cette description est celle du pangolin in grosir queue. de clarpue coté est plus petit que l'avant dernier : dans les pieds ie devant l'ongle qui se tronve au còté extérieur dı doigt dı milieu est plus grand que l'ongle qui se tronve au côté intérieur.

Le pangolin est couvert d'écailles sur toutes les parties de son corps, excepté le desscus de la tête cl du cou, les aisselle:, la poitrine, le ventre, les aires et la face interne des quatre jambes, qui nont füune peau nue; la plante des piecls est couverte de petites aspérités. Il y a entre les ćcailles le cet animal quelqures poils durs comme des soies de cochon et de couleur brunc à l'extrémite; le reste du poil est jaurutre jusqu'a sa racine. Les écailles sum de differentes grandeurs et de lifferentes formes; les polus grandes se 1 rouvent à l'origine de la quene; celle du milien, yui est la plus grande de tontes, a, dans le sujet que je décris, trois ponces trois lignes de largeur, un ponce dix lignes de longuenr et une ligne et demie d'ipaissenr dans le milien, mais les bords sont fort minces; les plus petites sont sur la tète et sur les pierls; il y en a qui nont pas trois lignes de largenr. La substance de toutes ces écailles ressemble à celle de la corne; elles sout fort dures, elles ont une conlenr roussâtre, elles sont un peu convexes sur leur face extérieure, et concaves sur l'intérieure; la plupart sont terminces en arrière par me pointe mousse, le cóté antérieur tient à la peau, et une partie de la face intérieure jusquià un relioicl que forme cette face au dela duquel l'écaille s'étenil en recourement sur la partie antérieure de l'écaille qui est placce en arrière. Celles des côtés de la quene sont pliees en gonttière sur leur longueur, et appliquces de facon qu'elles forment une arcite de chaque còté de la quene, et qu'elles s'étendent sur ses deux faces inférieure el superieure. Les écailles de la partie inferieure des cotés dı corps et celles qui sont sur les jambes de derriere au-1lessus du talon ont, sans être pliẻes en goutlière, une pelite arêle longitudinale sur le milien de lenr face extérienre. Toutes les ecailles ont sur celte mème face de pretites stries. qui aboutiraient à la pointe de l'écaille comme à um centre commun si elles étaient apparentes dan: tonte leur étendne; mais il parait que le frutlement les a détrnites en usant l'écaille dans les endroits qui y sont exposés.

\section{LE COCHON IIE TERliE.}

\section{(L'ORVCTEROPE DU CAP.)}

Ordre des edentés, ramille des or! cleropes. (Curicr.)

Nous avons dit et répété souvent quaueune espece de's animaux de l'A frique ne s'est trou- 
véc dans l'Amériøue méridionale, et que réciproguement aueun des animaux de cette partic de l'A mérique ne s'est trou vé dans l'ancien continent. L'animal dont il est ici question a pu induire en erreur des observateurs peuattentifs, tels que M. Vosmaër : mais on va voir, par sa description et par la comparaison de sa figure avec celle des fourmiliers d'Amérique, qu'il est d'une espèce très-différente, et qu'il n'a guère d'autres rapports avec eux, que d'ètre de même privé de dents, et d'avoir une langue assez longue pour l'introduire dans les fourmilières. Nous avons done adopté le nom de cochon de terre, que Kolbe donneà ce mangeur de fourmis, de préférence à celui de fourmilier, qui doit être réservé aux mangeurs de fourmis d'Amériłue, puisque en effet cet animal d'Afrique en diffère essentiellement par l'espèce, et mème par le genre. Le nom de cochon de terre est relatif à ses habitudes naturelles et même à sa forme, et e'est celui sous lequelil est communément counu dans les terres du Cap. Voici la deseription que M. Allamand a faite de cet animal dans le noureau supplément à mon ourrage.

" M. de Buffon semble aroir épuisé tout ce qu'on peut dire sur les animaux mangeur's de fourmis : l'artiele qu'il en a dressé doit lui aroir coùté beaucoup de peine, tant à cause des recherches qu'il a dù faire de tout ce qui a été dit de ces animanx, que de la nécessité où il a été de relever les fantes de ceux qui en ont parlé avant lui, et particulièrement de Seba. Celui-ci ne les a pas sculement mal déerits, mais il a encore rangé parmi eux un animal d'un genre très-différeut.

"M. de Buffon, après a voir dissipé la confusion qui régnait dans l'histoire de ces animaux, n'admet que trois espèces de mangeurs de fourmis, le tamanoir, le tamandua et celui auquel il a conservé le nom de fourmilier; mais ensuite il a donné la description d'un animal çui semble être une nourelle espèce de tamandua, plutot qu'une simple variété; enfin il conclut de tout ce qu'il a dit, que les mangeurs de fourmis ne se trouvent que dans les pays chauds de l'Amérique, et qu'ils n'existent pas dans l'aneien continent. Il est vrai que Desmarchais et Kolbe disent qu'il y en a en Afrique; mais le premier affirme simplement la chose sans en rien dire de plus, ni sans en apporter ancune preuve; quant à Kolbe, son témoignage est si suspect, que M. de Buffon a été très-autorisé à n’y pas ajouter f́oi. J'ai pensé comme lui au sujet de Kolbe, et je n'ai point eru qu'il y eût des mangeurs de fourmis en Afripue; mais MI. le capitaine Gordon m'a tiré de l'erreur où j'étais : il m'a envoyé la dépouille d'un de ces animaux tué au cap de Bonne-Espérance, où ils sont connus sous le nom de cochons de terre; c'est préeisément celui que Kolbe leur donne : ainsi je lui fais réparation d'a roir révocpué ici en doute sa véracité, et je suis persuadé que M. de Buffon lui rendra la même justice. Il est vrai que M. Pallas a confirmé le témoignage de Kolbe par ses propres observations; il a donné la description d'un foctus de mangeur de fourmis, envoyé du eap de Bonne-Espérance au cabinet de S. A. S. monseigneur le prince d'Orange; mais un fœetus, dénué de son poil, était peu propre à donmer une juste idée de l'animal dont il tirait son origine, et il pouroit avoir eté envoyé d'ailleurs au Cap; cependant le nom de cochon, par lequel on l'avait désigné, a commencé à me faire revenir de mon préjngé eontre Kolbe.

( J'ai fait remplir la peau que M. Gordon m'i envoyée, ee qui m'a très.bien réussi ; et c'est d'après eette peau bourrée que j’ai fait graver la figure de la planche 11. Si l'on duit appeler mangeur de fourmis un animal qui n'a point de dents, et qui a use langue fort longue qu'il enfonce cians les fourmilières, pour avaler ensuite les fourmis qui s'y attachent, on ne peut pas douter que celui qui est représenté ici n’en mérite le nom; cependant il diffère très-fort cies trois espèces décrites par Mr. de Buffon, et que je crois, a rec lui, être particulières àl' Amérique.

" Il est à peu près aussi gros et aussi grrand que le tamanoir, comme on le verra par les dimensions que j'en domnerai. Les poils qui couvrent sa tête, le dessus de son corps et sa queuc, sont très-courts, et tellement couchés et appliqués sur sa peau, qu'ils semblent y ètre collés; leur conleur est d'un gris sale, un peu approchant de celui du lapin, mais plus obscur; sur les flanes et sous le ventre ils sont plus longs 't d'une couleur roussàtre; ceux qui courrent les jambes sont aussi beaucoup plus longs, ils sont tout à fait noirs et droits.

"Sa tête est presque un cóne tronqué, un peu comprimé ver's son extrémité; elle est terminée par un plan ou plutôt par un boutoir, tel que celui d'un cochon, dans lequel sont les trousdes narines, et qui avance de près d'un pouce au 
delà de la máchoire inféricure; celle-ci est trèspetite. Sa langue est longue, fort mince et plate, mais pius large que dans les autres mangeurs de fourmis, qui l'ont presque eylindrique; il n'a absolument aucune dent. Ses yeux sont beaucoup plus près des oreilles que du museau; ils sont assez grands, et d'un angle à l'autre ils ont un pouce de longueur. Ses oreilles, assez sem. blables à celles des cochons, s'élèvent à la hauteur de six pouces, et se terminent en pointe; elles sont formées par une membrane presque aussi mince que du parchemin, et couvertes de poils à peine remarquables, tant ils sont courts. J'ignore si dans l'animal vivant elles sont pendantes comme daus les tamandua : M. Pallas dit qu'elles le sont, mais il en juge d'après celles du foelus, où leur longueur doit leur firire prendrecette position, sans gu'on en doive conclure qu'elles l'aient dans l'animal lorsqu'il est hol's du ventre de sa mère. Sa queue surpasse le tier's de la longueur de tout le corps; elle est fort grosse à son origine, et va en diminuant jusqu'à son extrénité. Ses pieds de devant ont quatre doigts, ceux de derricre en ont eing, tous armés de forts ongles, dont les plus longrs sont aux pieds postérieurs, ear ils égalent en longueur les doigts mêmes; ils ne sont pas pointus, mais arrondis à leur extrémité, un peu recourbés et propres á ereuser la terre. Il ne parait pas qu'il puisse s'en servir pour saisir fortement ou pour se défendre, comme les autres mangreurs de fourmis; cependant il doit avoir beaucoup de force daus ses jambes, qui sont trèsgrosse proportionnellement à son corps

"On wit par cette description que cet animal est très-différent du tamanoir, par son poil, sa couleur, sa tète et sa queue: il surpasse aussi fort en grandeur le tamandua, dont il diffère de mème par son pelağe, par sa couleur et par ses ongles; je ne dis rien de sa différence avee le foumilier, avec lequel persomne ne le ronfondra. Il appartient done à une quatricime ('spèce inconnue jusquà présent; et tout ee que j'en sais de certain, e'est que eet inimal foure sa langue dans les fourmilières, qu'il avale les fourmis qui s'y attachent, et qu'il se rache en terre dans des trous. Quoicqu'il ait une queue qui ressemble un peu à celle du tamandua, je doute qu’il s'en serve comme lui pour se suspendre à des branches d'arbres; elle ne me pal'nit pas pour cela assez flexible, et les ongles ne sont pas faits pour grimper.
"Comme je l'ai déjà dit, ou lui donne au Cap le nom de cochon de terre; mais il ressemble au cochon, et cela encore très-imparfaitement, uniquement par sa tête allongée, par le boutoir qui la termine, et par la longueur de ses oreilles: d'ailleurs il en diffère essentiellement par les dents, qu'il n'a pas; par sa queue, et principalement par ses pieds, aussi bien que par la conformation de tout son corps.

"Au défaut de bonnes autorités sur ce qui regarde ee mangeur de fourmis (car èest le nom que je crois devoir lui donner pour le distinguer des trois espèces décrites par M. de Buffon), je mettrai ici en note ce que liolbe en a dit '; il a été plus exact dans la description qu'il en a faite qu'il ne l'est ordinairement.

Voici ses dimensions :

Longueur du corps, depuis le boul du museau jusqu'à l'origine de la queue. . . . . . . Circonference du milieu du corps. . . . . 2 280 Longueur de la léle............. 0 11 0 La circonfèrence entre les yeux et les orcilles. $\quad 1,0$

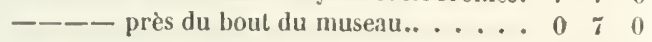

Longueur des oreilles. . . . . . . . . 0060 Distance entre leurs bases. ........... 0 2 200

Longucur des yeux mesurée d'un angle à

l'autre.................... 010

Distance des yeux aux oreilles. . . . . . . . 0 . - - au bout du museau. . . . . . . 0 i

1 a La quatrième espèce des coclıons se nomme cochon de - terre. Il ressenble très-fort anx cochons ronges. (Nota. - l’ourquoi aux cuclions runges? il ne leur ressemble pas phus - par la conleur yuianx autres.) Il a senlement la tele plus - lungue et le groin plus pointa; il ria absolument pnint de * dents, el ses suies ne sout pas si fortes. Sa langue est longue * et aflifie; sa quene est longue; il a aussi les jambes lungues " elfortes; la lerre lui sert de demeure; il sंy ereuse une arotle, onviage qu'il fail avec beaneoup de vivacité ef de " promplitude; et s'il a senlement la tète et les deux pit ds de a devant dans la lerre, il s'y erauponne si bien que l'homme - le plus robuste ne samait len arracher.

- Lorsıu'il a faim, il va chercher une fourmilière; ales quil a a fait cette bome trouvaille, il regarde tout antınr rle lui a pour voir si tout est tranuuille et sol ny a poiul de dhuzer ; a il ne mange jamais saus avoir pris celte péeanlion : alors il a se couche, et, flacant son groin tout prés de la fummilière, il * tire la langue lant pu'il peut, les fummis monteut dossus en * foule, et des ıu'elle est bien converte, il la relire et !es gule

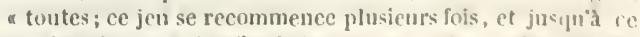
* un'il soit rassasic. Atin dis luj procurer jufus aisénent celte " uourture, la nalure toute sage a fait eu sorle que la partic

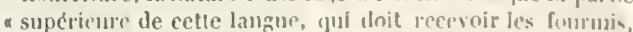
a est tonjours couverte el comme enduite diune nalicre viv. " yuense el gluante, jui curpeche ces fanloles animaux de' sen

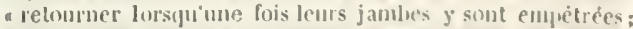
- c'est la leur manière de manger. Ils ont la chair de fort bou " goùt et tres-saine; les Furopjéens at les Itotlentuts ront - souvent a la cluase de ces auimaux; rien nest plus facile - que de les tuer; il ne faut que lenr lomier un petil coun de - biton sur la léle." Description du cap de Ronue-Espérapce, par kollse, lonse 111, page 43. 


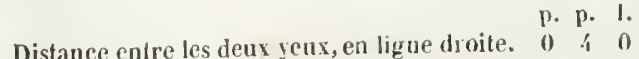
Longueur de la gueue............. 90 Sa circonférence près le l'anus...... 150

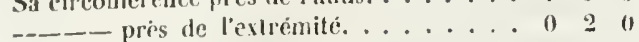
Longueur des jambes de devant..... 100 Leur circonférence près du corps. ..... 01110

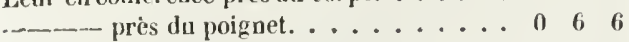
Longueur des jambes de derrière. .... 1 I 0 Leur circonfèrence près du corps. . . . . 1000 - - près du talon........... 0 7 6

\section{LES TATOUS.}

Ordre des édentès, genre talou. (Cuvier.)

Lorsquel'on parle d'un quadrupède, il semble que le nom seul emporte l'idée d'un animal couvert de poil : et de même, lorsqu'il est question d'un oiseau ou d'um poisson, les plumes et les ćcailles s'offrent à l'imagination, et paraissent ¿tre des attributs inséparables de ces êtres. Cependant la nature, comme si elle voulait se soustraire à toute méthode et échapper à nos vues les plus générales, dément nos idées, contredit nos dénominations, méconnait nos caractères et nous étonne encore plus par ses exceptions que yar ses lois. Les animaux quadıupèdes qu'on doit regarder comme faisant la première classe de la nature vivante, et qui sont, après l'homme, les ètres les plus remarrquables de ce monde, ne sont néanmoins ni supérieurs en tout, ni séparés par des attributs coustants, ou des caractères uniques, de tous les autres ètres. Le premier de ces caractères, qui constitue leur nom et qui consiste à a voir quatre pieds, se retrouve dans les lézards, les grenouilles, etc., lesquels néammoins diffèrent des cuadrupiedes à tant d’autres ćgards, (ju’on en a fait avec raison une classe séparée. La scconde propriété générale, qui est de produire des petits vivants, n'appartient pas uniquement aux quadrupèdes, puis(u'elle leur est commune avecles cétacés. Est enfin le troisième attribut qui paraissait le moins écui vorfue, parce qu’il est le plus apparent, et qui consiste ì c̀tre couvert de poil, se trouve pour, ainsi dire, en contradiction avec les deux autres dans plusieurs espèces qu'on ne peut cependant retrancher de l'ordre des quadrupèdes, puis(ju'a l'execption de ce seul caractère, elles leur ressemblent par tous les auties. Et comme ces exceptions apparentes de la nature ne sont dans le réd que les nuances (qu'elle emploie pour lapprocher les ctres même les plus éloignés, il ne fiut pas perelıe de vue ces lapports sluguliels, et tâchë de les saisir à mesure (qu'ils se présentent. Les tatous, au lieu de poil, sont couverts, comme les tortues, les écrevisses et les autres crustacés, d'unc croùte ou d'un têt solide; les pangolins sont al'més d'écailles assez semblables á celles des poissons; les pores-épies portent des especes de plumes piquantes et sans barbe, mais dont le tuyau est pareil à celui des plumes des oiseaux : aiısi dans la classe seule des quadrupedes, et par leca. ractère mêmele plus constant et le plus apparent des animaux de cotte classe, qui est d'ètı couverts de poil, la nature varie en se rapprochant des trois autres classes très-dilférentes, et nous rappelle les oiseaux, les poissons á écailles et les crustacés. Aussi faut-il bien se garder de jugcr la nature des êtres pa' un seul caractire, il se. trouverait toujours incomplet et fautif : souvent mème deux et trois (aractères, quelque généraux qu'ils puissent ètre, ne suffisent pas encore; et ce n'est, comme nous l'avous dit et l'edit, que par la réunion de tous les attributs et par l'énumération de tous les caractères yu'ou peut juger de la forme essentielle de chacune des productions de la mature. Une bomne descriptiol et jamais de délinitions, une exposition plus scrupuleuse sur les différences (jue sur les ressemblances, une attention particuliere aux exceptions et aux nuances mème les plus lingres, sont les vraies rigles, et jose dire, les seuls moyens cque nous ayons de comnitre la nature de chaque chose: et si l'ont eût employé à bien déclire tout le temps qu'on a perdu i définir et à faire des méthodes, nous u' eussionspas trouvé l'Histoire maturelle au bereeau; mous aurious moins de peine à lui oter ses hochets, à la drbarrasser de ses langes: nous aurions pent-itre avancé son àge, car nous cussions plus écrit pour la seience et moins contre l'erreur.

Mais revenous à notre objet. Il existe done parmi les animaux (puadrupèdes et vivipares plusieurs especes d'aumaux qui ne sont pas cowerts de poil. Les tafous font eux seuls un genue entier, dans lecuel on peut compter plusieurs especes qui nous paraissent ètre réellement distinctes et séparcées les unes des autres : dans toutes, l'animal est revetu d'un tit semblable pour la susbtance a celle des os ; ce tit couve la tète, le cou, le dos, les flanes, la crompe et la queue jusqu’à l'extrémité; il est lui-mème reconvert au dehors par un cuir mince. lisse et transparent : les seules parties sul lesfjuelles eo 
têt ne s'étend pas, sont la gorge, la poitrine et le ventre qui présentent une peau blanche et grenue, semblabe à celle d'une poule plumée; et en regardant ces parties avec attention, l'on y voit de place en place des ludiments d'écailles rui sont de la même substance que le tèt du dos. La peau de ces animaux, même dans les endroits où elle est le plus souple, tend donc à devenir osseuse ; mais l'ossification ne se r'éalise en entier (qu’où elle est le plus épaisse, e’est-à-dire, sur les parties supérieures et extérieures du corps et des menibres. Le têt qui recourre toutes ces parties supérieures n'est pas d'une seule pièce comme celui de la tortue; il est partagé en plusieurs bandes sur le corps, lesquelles sont attachées les unes aux autres par autant de membranes qui permettent un peu de mouvement et de jeu dans cette armure. Le nombre de ces bandes ne dépend pas, comme on pourrait l'imaginer, de l'âge de l'animal; les tatous qui viemment de naître et les tatous adultes ont, dans la mêmeespèce, le mème nombrede bandes: nous nous en sommes convaincus en eomparant les petits au grands, et quoique nous ne puissions pas assurer que tous ces animaux ne se mêlent ni ne peuvent produire ensemble, il est au moins très-probable, puisque cette différence du nombre des bandes molsiles est constante, que ce sont ou des espèces réellement distinctes, ou au moins des variétés durables et produites par l'influence des divers climats. Dans ectte incertitude que le temps seul pourra fixer, nous avons pris le parti de présenter tous les taitous ensemble et de faile néanmoins l'énumération de chacun d'eux, comme si c'élaient en effet autant d'espices particulieres.

Le Père d'Abbeville nous paraît être le premier qui ait distingué les tatous par des noms ou des épithètes qui ont été pour la plupart adoptés pạ les auteurs (pui ont écrit après lui. Il en indique assez clafremeat six especes : [o le latououassou, qui probablement est celui que nous appellerons kabassou; : $2^{n}$ le trutouète, que Maregrave a aussi appelé tatuete, et auquel nous conserverons ee nom; 30 le tritou-peb qui est le tampeba ou l'cneuberto de Maregrave, aurguel nous conserverons ce dernier nom; fu le tatou-apar qui est le talu-яlpura de Maregrave, auquel nous conserverons encore son nom; 6o le fatou-ouinchum qui nous parat être le méme que le cirquinchum, et que nous appellerons cirquineon; in le tatou-miri, le phus petit de tous, çui pourrait bien être celui que nous appellerons cachicame. Les autres voyageurs ont confondu les espèces, ou ne les ont indiquées que par des noms génériques. Naregrave a distingué et décrit l'apar, l'encoubert et le tatuète; Wormius et Grew ont décrit le cachicame, et Grew seul a parlé du cirquincon; mais nous n'arons eu besoin d'empiunter que les descriptions de l'apar et du cirrfuinçon, car' nous avons vu les (juatre autres espèces.

Dans toutes, i l'exception de celle du circjuincon, l'animal a deux bouclier's osseux, l'un sur les épaules etl'autresurla croupe; ces deu x boucliers sont chacun d'une seule pièe, tandis que la euirasse, qui est osseuse aussi ct qui courre le corps, est divisće transversalement et partagée en plus ou moins de bandes moljiles et séparées les unes des autres par une peau flexible. Mais le cirquincon n’a qu'un bouclier, et e'est celui des épaules; la croupe, au lieu d'ètre couverte d'un bouclier, est revètue jusqu'à la queue par des bandes moliles pareilles à celles de la cuirasse du corps. Nous allons domner des indications claires et de courtes deseriptions de cluacume de ces espèces. Dans la première la cuirasse qui est entre les deux boucliers est composée de trois bandes; dans la sceonde elle l'est de six; dans la troisième de huit; dans la quatrième de neuf; dans la einquieme de douze, et enfin dans la sixieme il n'y a, comme nous venons de le dire, que le bouclier des épaules qui soit d'une seule piece; l'armure de la eroupe, ainsi (jue celle du corps, sont partagées en bandes mobiles qui s'érendent depuis le bouclier de's épaules jusqu'ì la quene, et qui sont au nombre de dixluit.

\section{L.APAR}

nu

\section{LE TATOU A TROIS BAYIIES.}

(LE TATOU APAll.)

Ordre des ćdentés, femre tatou. Curier.)

Le premier auteur gui ait indipué eot animal par une deseription. est Chanles de l'Éluse (C,/usius) : il ne l'a déerit que d'apres me figure; mais on recombil aisement aux ealactires qu'elle représente, et qui sont trois bandes mobiles sur le dos, et la pueue fris-courte, que c'est le meme anjmal que celui dont Macograve 
nous a donné une bonne description sous le nom de tatu-upara. Il a la tête oblongue et presque pyramidale, le museau pointu, les yeux petits, les oreilles courtes et arrondies, le dessus de la tête couvert d'un casque d'une seule pièce. Il a cinc doigts à tous les pieds : dans ceux du devant les deux ongles du milieu sont tres-grands, lesdeux latéraux sont plus petits, et le cinquième, qui est l'extérieur et qui est fait en forme d'ergot, est encore plus petit que tous les autres; dans les pieds de derrière les cinq ongles sont plus courts et plus égaux. La quueue est trèscourte; elle n'a que deux pouces de longueur, et elle est revêtue d'un têt tout autour. Le corps a un pied de longueur sur huit pouces dans sa plus grande largeur. La cuirasse qui le couvre est partagée par (uratre commissures ou divisions, et composée de trois bandes mobiles et transversales qui permettent à l'animal de se courber t de se contracter en rond; la peau qui forme les comnissures est très-souple. Les boucliers (qui couvrent les épaules et la croupe sont composés de pièces à cinq angles très-élégamment rangées : les trois bandes mobiles entre ces deux boucliers sont composées de pièces carrées ou barlongues, et chaque pièce est chargée de petites écailles lenticulaires d'un blane jaunâtre. Maregrave ajoute que quand l'apar se couche pour clormir, ou que quelgu'un le touche et veut le prendre avec la main, il rapproche et rémnit, pour ainsi dire, en un point ses quatre pieds, ramène sa tète sous son ventre, et se courbe si parfaitement en rond, qu'alors on le prendrait plutòt pour une coquille de mer que pour un animal terrestre. Cette contraction si serrée se fait au moyen de deux grands muscles qu'il a sur les côtés du corps, et l'homme le plus fort a bien de la peine à le desserrer et à le faire étendre avec les mains. Pison et Rai n'ont rien ajouté à la description de Maregrave qu'ils ont entièrement adoptée; mais il est singulier que Seba, qui nous a domné une figure et une description qui se rapportent évidemment à celle de Maregrave, non-senlement paraisse l'ignorer puisqu'il ne le cite pas, mais nous dise arec ostentation qu'aucun naturaliste n'a conmu cet animal, qu'il est exlrêmement rare, qu'il ne se trouve que dans les contrées les plus reculées des Indes orientales, etc., tandis que c'est en effet l'apar du Brésil très-bien déerit par Maregrave, et dont l'espèce est aussi connue qu'aucune autre, non pas aux Indes orientales, mais en Amérique, oì on le trouve assez communément. La seule différence réeile qui soit entre la description de Seba et celle de Maregrave, est que celui-ci donne à l'apar cing doigts à tous les pieds, au lieu que Seba ne lui en donne que ruatre. Liun des deux s'est trompé, ear c'est évidemment le même animal dont tous deux ont entendu parler.

Fabius Columna a donné la description et les figures d'un têt de tatou desséché et contracté en boule, qui parait avoir quatre bandes mobiles. Nais comme cet auteur ne connaissait en aucune manière l'animal dont il décrit la dépouille; qu'il ignorait jusqu'au nom de tatou, duquel cependant Belon avait parlé plus de cinquante ans auparavant; que dans cette ignorance Columna lui compose un nom tiré du grec(cheloniscus); que d'ailleur's il avoue que la déponille qu'il décrit a été recollée et qu'il y manquait des pièces, nous ne croyons pas qu'on doive, comme l'ont fait nos nomenclateurs modernes, prononcer qu'il existe réellement dans la nature une espèce de tatou à quatre bandes mobiles; d'autant plus que depuis ces indications imparfaites données en 1606 par Fabius Columna, on ne trouve ancune notice dans les ouvrages des maturalistes de ce taton à quatre bandles, qui, s’il existait en effet, se serait certainement retrouvé dans quelques cabinets, ou bien aurait été remarqué par les voyageurs.

\section{LENCOUBERT}

ou

\section{LE TATOU A SIX BANDES.}

\section{(LE TATOU ENCOUBERT).}

Ordre des édentes, genre tatou. (Cuvier.)

L'encoubert est plus grand que l'apar; il a le dessus de la tète, du cou et du corps entier', les jambes et la queue tout autour, revètus d'un tèt osseux très-dur et composé de plusieurs pièces alssez grandes et très-élégamment disposées. 11 a deux boucliers, l'ur sur les épaules et l'autie sur la croupe, tous deux d'une seule pièce; il y a seulement au delà du bouclier des épaules et près de la tête une bande mobile entre deux jointures, qui permet à l'animal de courber le cou. Le bouclier des épaules est formé par cinq rangs parallèles, qui sont composés de 
pièces dont les figures sont à cinq ou six angles avee une espèce d'ovale dans chacune. La euirasse du dos, e'est-à-dire la partie du tèt qui est entre les deux boucliers, est partagée en six bandes qui anticipent peu les unes sur les autres et qui tiennent entre elles et aux boucliers par sept jointures d'une peau souple et épaisse; ces bandes sont composées d'assez grandes pièces carrées et barlongues: de cette peau des joinlures il sort quelques poils blanchattres et semblables à ceux qui se voient aussi en très-petit nombre sous la gorge, la poitrine et le ventre; toutes ces parties inférjeures ne sont revêtues (que d'une peau grenue et non pas d'un tèt osseux eomme les parties supérieures du corps. Le bouclier de la eroupe a un hord dont la mosaïque est semblable à eelle des bandes mobiles, et pour le reste il est composé de pièces à peu près pareilles à celles du bouclier des épaules. Le têt de la téte est long, large et d'une seule pièce jusqu'i la bande mobile du cou. L'encoubert a le museau aigu, les yeux petits et enfoncés, la langue étroite et pointue, les oreilles sans poil et sans têt, nues, courtes et brunes comme la peau des jointures du dos; dir-huit dents de grandeur médiocre à ehaque màchoire; cing doigts à tous les pieds avec des ongles assez longs, arrondis et plutôt étroits que larges ; la tète et le groin à peu près semblables à eeux du eochon de lait; la queue grosse à son origgine, et diminuant toujours jusqu'à l'extrémité oì elle est fort menue et arrondie par le bout. La coulcur du corps est d'un jaune roussàtre ; l'innimal est ordinairement épais et gras, et le màle a le membre génital fort apparent. II fouille la terre aree une extrème facilité, tant a l'aide de son groin que de ses ongles; il se hit un terrier ou il se tient pendant le jour, et n'en sort que le soir pour (hercher sa sub)sistanee : il boit souvent; il vit de fruits, de racines, d'insectes et d'oiseaux, lorsçu'i] en peut saisir.

\section{LE TATUETE}

ou

\section{DE TATOU A HUTT BANDES.}

(LE TATOU PEBA.)

Ordre des cedentés, genre tatou. Cuy er.)

Le tatuète n'est pas si grand à beancoup près que l'encoubert; il a la léte petite, le musean pointu, les oreilles droites, uu peu allongrées, la queue eneore plus longue et les jambes moins basses à proportion que l'encoubert; il a les yeux petits et noirs, quatre doigts aux pieds de devant et einc à ceux de derrière; la tète est couverte d'un casque, les épaules d'un bouelier, la croupe d'un autre bouclier, et le corps d'une cuirasse composée de huit bandes mobiles (fui tiemnent entre elles et aux boucliers par neuf jointures de peau flexible. La queue est revêtue de mème d'un têt composé de huit anneaux mobiles et séparés par neuf jointures de peau flexible. La conleur de la cuirasse sur le dos est d'un gris de fer ; sur les flancs et sur la queue elle est d'un gris blanc avee des taches gris de fer. Le ventre est couvert d'une peau blanchàtre, grenue ct semée de ruelques poils. L'individu de eette espère qui a été décrit par Maregrave avait la tète de trois pourees de longueur, les oreilles de près de denx, les jambes d'environ trois pouces de hauteur, les deux doigts du milicu des pieds de devant d'un pouce, les ongles d'ur demi-pouce; le eorps, depuis le cou jusqu'à l'origine de la queue avait sept pouees et la queue neuf ponces de fongneur. Le têt des boncliers parait semé de petites taches blanches proéminentes et larges comme des lentilles; les bandes mobiJes cui forment la euirasse du corps sont ma!quées par des figures triangulaires : ce tèt n'est pas dur; le plus petit plomb suffit pour le percer et pour tuer l'animal, dont la ehair est fort blanche et très-bonne it manger.

\section{LE GACHISAlE:}

()I

\section{LE TATOU A NEUF BANOLS.}

(LE TATOU PEEA.)

Ordre des cidentes, genre tatou. (Cuvier.)

Nieremberg n'a, pour ainsi dire, qu'indiyuc' cet animal dans la deseription imparfite quil en donne; Wormins et Grew l'ont beaucoup mieux décrit: l'individu qui a servi de sujet ż Wormius était ardulte et des plus grands de celte espece : colui de Grew ćtait plus jeune et plus pretit: nous ne donnerons pas ici leurs deserip. tions 'n chlier, d'autant gun'elles s'accordent 
avec la nôtre, et que d'ailleurs il est à présumer que ce tatou à neuf bandes ne fait pas une espèce réellement distincte du tatuète qui n'en a que huit, et auquel, à l'exception de cette différence, il nous a paru ressembler à tous antres égards. Nous avons deux tatous à huit bandes qui sont desséchés et qui paraissent être deux mâles; nous avons sept ou huit tatous à neuf bandes, un bien entier qui est femelle, et les autres desséchés, dans lesquels nous n'avons pu reconnaitre le sexe : il se pourrait donc, puisque ces animaux se ressemblent parfaitement, que le tatuète ou tatou à huit handes nit le mâle, et le cachicame ou taton à neuf bandes, la femelle. Ce n'est qu'une conjecture que je hasarde ici, parce que l'on verra dans l'article suivant la description de deux autres tatous, dont l'un a plus de rangs que l'autre sur le bouclier de la croupe, et qui cependant se ressemblent à tant d'autres égards qu'on pourrait penser que cette différence ne dépend que de celle du sexe; car il ne serait pas hors de toute vraisemblance que ce plus grand nombre de rangs sur la croupe, ou bien celui des bandes mobiles de la cuirasse, appartinssent aux femelles de ces espèces comme nécessaires pour faciliter la gestation et l'accouchement dans des animaux dont le corps est si étroitement cuirassé. Dans l'indi vidu dont Wormius a décrit la dépouille, la tête avait cinq pouces depuis le bout du museau juscu'aux oreilles, et dix-huit pouces depuis les oreilles jusqu'à l'origine de la queue, qui était longue d'un pied, et composée de douze anneaux. Dans l'individu de la même espèce décrit par Grew, la tête a vait trois ponces, le corps sept ponces et deni, la queue onze ponces. Les proportions de la tête et du corps s'accordent; mais la différence de la queve est trop considérable, et il y a grande apparence que dans l'individu déerit par Wormius, la queue avait été cassée, car elle aurait eu plus d'un pied de longueur: comme dans cette espèce la queue diminue de grossemr au point de n'ètre à l'extrémité pas plus grosse fu'une petite alène, et qu'elle est en même temps très-fragile, il est rare d'avoir une dépouille où la queue soit entière comme dans celle ıp'à décrite Grew. L'individu décrit par M. Daubenton s'est trouvé aroir à très-peu près les mêmes dimensions et proportions que celıi de Grew.

\section{I.E K\BASSOU}

0!1

\section{LE TATOU A DOUZE BANDES.}

(LE TATOU TATOUAY.)

Ordre des edentés, genre tatou. (Cuvier)

Le kabassou nous parait être le plus grand de tous les tatous: il a la tête plus grosse, plus large, et le museau moins effilé que les autres; les jambes plus épaisses, les pieds plus gros, la queue sans tèt, particularité qui seule suffirait pour faire distinguer cette espèce de toutes les autres; cinq doigts à tous les pieds, et douze bandes mobiles qui n'anticipent que peu les unes sur les autres. Le bouclier des épaules n'est formé que de quatre ou cinq rangs, composés chacun de pièces quadrangulaires assez grandes; les bandes mobiles sont aussi formées de grandes pièces, mais presque exactement carrées : celles qui composent les rangs du bonclier de la croupe sont à peu près semblables à celles du bouclier des épaules; le casque de la tète esı aussi composé de pièces assez grandes, mais irrégulières. Entre les jointures des bandes mobiles et des autres parties de l'armure s'échappent quelques poils pareils à des soies de cochon; il y a aussi sur la poitrine, sur le ventre, sur les jambes et sur la queue des rudiments d'écailles qui sont ronds, dur's et polis comme le reste du têt, et autour de ces petites écailles on voit de petites houppes de poils. Les pièces qui composent le casque de la tète, celles des deux boucliers et de la cuirasse étant proportionnellement plus grandes et en plus petit nombre dans le kabassou que dans les autres tatous, l'on doit en inférer qu'il est plus grand que les autres : dans celui qu'on a représenté, la tète a vait sept pouces, le corps vingt et un ; mais nous ne sommes pas assurés que celui-là soit de la même espèce que celui-ci ; ils ont beaucoup de choses semblables, et entre autres les douze bandes mobiles; mais ils diffèrent aussi à tant d'égards, que c'est déjả beaucoup hasarder que de ne mettre entre cux d'antre difiérence que celle du sexe. 


\section{LE CIRQUINCON}

ou

\section{L.: TATOU A DIX-HUIT BANDES.}

LE TATOU ENCOIHERT.

Ordre des cdentes, genre tutou. (Cuvier.)

11. Grew est le premier quii ait décrit cet animal, dont la dépouille était consesvée dans le Calbinet de Ja Société royale de Londres. Tous les autres tatons ont, comme nous venons de le voir, deux boucliers chacun d'une seule piece, le premicr sur les épaules, et le second sur la (roupe; le ciryuneon n'en a yu'un, et e'est sur les épaules. On Ini a donné Je nom de tatou-belelle, parce qu'ila la tète à peu près de la mème forme que celle de la belette. Daus la deseriptions de ect animal, domée par Grew, on trouve qu'il avait le erorps d'environ dix ponces de long, la tète de trois pouces, la queue de r'ing, les jambes de deux ou trois ponees de hauteur, le devant de la tête large et plat, les yeux petits, les oreilles longues d'un pouce, ('incy doigts aux quatre pieds, de grands ongles jongs d'un ponce aux trois doigts du milieu, des ongles plus eourts aux deux autres doigts; l'armure de la tète et celle des jambes composées d'écailles arrondies, d'environ un quart de pouce de diamètre; l'armure du cou d'une seule pièce, formée de petites ćécilles carrées; le bouelier des épaules aussi d'une senle piece, et composé de plusieurs rangs de pareilles petites écailles carrées. Ces rangs du bonclier, dans cette esprece comme dans toutes les autres, sont continus et ne sont pas séparés les uns des autres par une peau flexible; ils sont adhérents par symphyse. Tout le reste du corps, depuis le bouclier des épaules jusqu'a la queue, est couvert de bandes mobiles et séparées les unes des autres par une membrane souple; ces bandes sont au nombre de dix-huit : les premières du còté des épaules sont les plus larges; elles sont composées de petites pièces carrées et barlongues : les bandes postérieures sont finites de pièces rondes et carrées, et l'extrémité de l'armure près de la queve est de figure parabolique. La moitié antérieure de la queue est euriromnéc de six anueaux dont les pieces sont composées de petits carrés; la seconde moitić de la queue jusquà l'extrémité est couverte d'écailles irrégnlières. La poitrine, le ventre et le's meilles sont nus comme dans les autres espéees. Il semble que de tous les tatous celui-ci ait le plus de facilité pour se contracter et se serrer eu boule, à cause du grand nombre de ses bandes mobiles, qui s'étendent jusçu'à la queue.

Ray a técrit, comme nous, le eirquiucon d'après Grew : M. Brisson parait s'ètre conformé à la description de Ray, aussi a-t-il très-bien désigné eet animal, qu'il appelle simplement armadille. Mais il est singulier que M. Linnæus, qui devait a voir les descriptions de Grew et de Rily sous les yeux, puisqu'il les cite tous deux, ait indicuécemèmeanimal commen’ayant qu'une bande, tandis qu'il en a dix-huit. Cela ne peut ètre fondé que sur une méprise assez évidente, qui consiste à aroir pris le talu seu armadillo africanus de Seba pour le latu mustelinus de Grew, lesquels néammoins par les descriptions mèmes de ces deux auteurs sont très-différents l'un de l'autre. Autant il parait certain que l'animal décrit par Grew est une espèce réellement existante, autant il est douteux que celui de Seba existe de la maniere au moins dont il le déerit. Selon lui, cet armadille afrieain a l'armure du corps entier partagée én trois parties. Si cela est, l'armure du dos, atu lieu d'ètre composée de plusieurs bandes, est d'une seule piece, et eette piece unipue ent seulement séparée du bouclier des épaules et de celui de la croupe, (jui sont aussi chacun d'unc seule piece: e'est la le fondement de l'erreur de M. Linnæus; il a, d'après ce passage de Sebit, nommé cet armadille unicinctus tegmine triperlito. Cependant il était aisé de voir que cette indication de Seba est équivoque et erronće, puisfyu'elle n'est uullement d'aceord avee les ligures, et qu'elle indique en effer le kiculussou ou tatou à douze bandes, comme nous l'avons prouvé dans l'article précédent.

Tous les tatous sont originaires de l'Amerique; ils étaient inconmus avinut la déconverte du Noureau-IIonde : les ancieusn' en ont jannais fuit mention, et les royageurs modemes ou monveaux en parlent tous comme d'animans naturels et particuliers an Mesicjue, au Brés.l à la Guiane, ete.; ancun ne dit en avoir trouvé I'espice esistante an Asie ni en Afrique: quel- 
ques-uns ont seulement confondu les pangolins et les phatagins ou lézards ćeailleux des Indes orientales avec les armadilles de l'A mérique; quelques autres ont penséquiil s'en trouvait sur les côtes oceidentalesde l'A frique, paree qu'on en a quelquefois transporté du Brésil en Guinée. Belon ', qui a écrit il y a plus de deux cents ans, et qui est l'un des premiers qui nous en ait donné une courte description arec la figure d'un tatou dont il avait vu la dépouille en Turquie, indique assez qu'il venait du nouveau continent. Oviedo, de Léry, Gomara, Thevet, Antoine Herrera, le P. d Abbeville, Francois Ximenès, Stadenius, Monard, Joseph Acosta, de Laët, tous les auteurs plus récents, tous les historiens du Nouveau-Monde, font mention de ces animaux comme originaires des contrées méridionales de ce continent. Pison, qui a écrit postérieurement à tous ceux que je viens de eiter, est le seul qui ait mis en avant, sans s'appuycr d'aucune autorité, que les armadilles se trouvent anx Indes orientales, aussi bien qu'en Amérique : il est probable qu'il a confondu les pangolins ou lézards écailleux avee les tatous. L.es Espagnols ayant appelé armadillo ces lézards écailleux, aussi bien que les tatous, cette erreur's'est multipliée sous la plume de nos descripteurs de eabinets et de nos nomenelateurs, qui ont non-seulement admis des tatous aux Indes orientales, mais en ont eréé en Afrique, quoiqu'il n'y en ait jamais eu d'autres dans ces deux parties du monde, que eeux qui y ont été transportés d'Amérique.

Le climat de toutes les espèces de ces animaux n'est donc pas équivoque; mais il est plus difícile de déterminer leur grandeur relative dans chaque espece. Nous avons comparé dans cette vue, non-sculement les dépouilles de ta-

4 a Et pomr ce que l'animal donl nous avons déjò ci-devant - parlé, quion nomme un taluu, sest trouvé entre leurs a mains, leguel tontefois est apportí de la Guinée et de la - Terre-Nenve, dont les anciens nien ont point parks, néan- moins nuws a semble bon den bailler le portrait.

- Ce qui fail quion voit cilte bite ji commune en plu. a sieurs cahinets elètre jortée en si loinglaiu priys, est que - nature l'a armée de dure escorce et larges ćcailles à la ma- nière d'un corcelet, el aussi yu'on peut aisénent ôter sa - claair dle leans sans rien perdic de sa naîe figure. Jà l'avons - Jit esfrece de hérisson du Brésil. Car elle se ritire en sus - écailles comme nu hérisson en ses épines. kille n'excìde - puinl la grandeur d’un moyen pourcelet : anssi est-elle - épece de pourceau, ayant jambes, pieds el musean de - mêne; car on l'a déjà vue vive en firance, el se nourrit - de grains el de fruits. Observations de lielon, l’aris, 1535, page 211 tous que nous arons en grand nombre au Cabsnet du l'oi, mais encore celles que l'on conserve dans d'autres cabinets; nous arons aussi comparé les indieations de tous les auteurs avec nos propres descriptions, sans pouvoir en tirer des résultats précis : il paraît seulement que les deux plusgrandes espèces sont le kabassou et l'encoubert, queles petites espèces sont l'apar', le tatuete, le cachicame et le cirquincon. Dans les grandes espèces le tèt est beaucoup plus solide et plus dur que dans les petites; les pièces qui le com posent sont plus grandes et en plus petit nom bre; les bandes mobiles anticipent moius les unes sur les autres, et la chair aussi bien que la peau est plus dure et moins bonne. Pisou dit que celle de l'encoubert n'est pas mangeable; Nieremberg assure qu'elle est nuisible et trèsmalsaine; Barrière dit que le kabassou a une odeur forte de musc; et eu même temps tousles autres auteurs s'aceordent à dire que la chair de l'apar et surtout celle du tatuete sont aussi blanehes et aussi bonnes que celle ducochon de lait; ils disent aussi que les tatous de petite espèce se tiennent dans les terrains humides et habitent les plaines, et que ceux de grande espèce ne se trourent que dans les lieux plus élevés et plus secs '.

Ces animaux ont tous plus ou moins de facilité à se resserrer et à contracter leur corps en rond; le défaut de la cuirasse, lorsqu'ils sont coutractés, est bien plus apparent dans ceux dont l'armure n'est eomposée que d'un petit nombre de bandes ; l'apar, qui n'en a que trois, ol'ire alors deux grands vides eutre les boueliers et l'armure du dos; aueun ne peut se réduire aussi parfaitement en boule que le hérisson; ils ont plutòt la figure d'une sphère fort aplatie par les pôles.

Ce tèt si singulier dont ils sont l'erêtus est un vérital)le os composé dè petites pièces contiguës, et cui sans ètre mobiles ni articulćes, excepté aux commissures des bandes, sont réunies par symplyse et peurent toutes se séparer les unes rles antres, et se séparent en effet si on les met au feu. Lorsque l'animal est vivant, ces petites pieces, tant eelles des houelicers que celles des bandes mobiles ${ }^{2}$, prêtent et obéissent

4 Dans les bois de l'Orénoque et de la ciniane, on tronve des armadilles qualre fois plus gros que ceux des plaines. Iliswire Naturelle de l'Orénogue, par Gumilia, lome 11. page 7. 2 Cet aumal (il est ici que-tion du taton à neuf haudes) csl fort sensible; il se plaignait ct se metlail en loule tes que je pressais un peu ses écailles : je remarymai yue tous ees rangs. 
rir quelque facon à ses mouvements, surtout it c'lui de contraction; si cela n'était pás, il serait diflicile de concevoir qu'avee tous ses efforts il Jui fút possible de s'arrondir. Ces petites pieces offrent, suivant les diverses espèces, des figures différentes toujours arrangées régulièrement comme de la mosaïque trés-élégamment disjosée: la pellicule ou le cuir mince dont Je têt est revêtu à l'extéricur, est ure peau transparente qui fait l'effet d'un vernis sur tout le corps de l'animal; cettepean releve de beaucoup et change même les reliefs des mosaïques, qui paraissent difiérents lorsqu'elle est enlevéc. $\mathrm{Au}$ reste, ce tit osseux n'est qu'une enveloppe indépendante de la charpente et des autres parties intérieures du corps de l'animal, dont les os et les autres parties constituantes du corps sont composées ct organisces comme celles de tous les autres cruadrupedes.

I.es tatous en général sont des animaux immo. eents et qui ne font aucun mal, a moins quion ne les laisse entrer dans les jardins, où ils mangent les melons, les patites et les autres légumes ou racines. Quoique originaires des climats chauds de l'Amérique, jls peuvent vive dans les elimats tempérés; j'en ai vu un en Languedoc, il y a plusieurs ammées, qu'on nourrissait à la maison, et qui allait partout saus fiure aucun đé.at. Ils marchent aree vivacité, mais ils ne peurent, pour ainsi dire, ni sauter ni courir, ni grimper sur les arbres, en sorte qu'ils ne peuvent guere céchapper jar la fuite à ceux qui les poursuivent : leurs senles ressources sont de se eacher dans leur terrier, ou, sils en sont trop éloignés, de tácher de s'en lintre mn avant que d'ètre atteints; il ne leur faut yue guelques moments, car les taupes ne ereusent pas la terre plus vite que les tatous. On les prend quelquefois par la queue avant qu'ils n'y soient totalemont enfoncés, et ils font alors une telle résistance ', qu'on leur casse la qucue sans amener

aulre le mowrement gu"ils avaient pour s'emboifer les uns sIII les autres, on avaiout encore $u$ antre le long de l"epine dudus par le umyon durpucl ils sétendaient et s'ilargissaient, cle. Numean Voyage aux lles de l'Améripuse, lone IJ, lage $58 x$.

' Lal plupart des cachicamos se cruient cu sủreté lorsıu'ils on pu mefle leur tíle el um. partie de lemrs corpus dans leurs

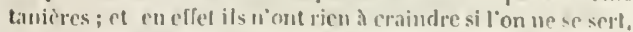

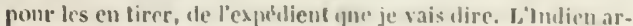
rive et saisitl'animal pa" la yuene, quij est fort longue; l'arma. dille ourre ses icallese les some si fort comber las parois ale sa lanière, une l'bulien lui arracles pluliol la yuene yue de

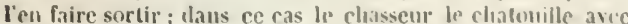
un hiton on arec lo bont s, son are, et ansitit il serre ses le corps; pour ne les pas mutiler, il faut ouvrir le terrier par devant, ctalors on les prend sans (yujils puissent faire aucune résistance: dés yu'ou les tient ils se resserrent en boule, et pour les faire étendre on les mot près du feu. Leur tèt, quoirque dur et rigide, est cependant si sensible que, quand on le touche un peu ferme avec Je dojot, l'animal en ressent une impression assez vive pour se contracter en entier. Lorsyu'ils sont dans des terriers profonds, on les en fait sortir en y faisant entrer de la fumée ou couler de l'eau : on prétend qu'ils demenrent daus leurs terriers sans en sorlir pendant plus d'un tiers de l'ammée; ce qui est plus vrai, e’est qu’ils s'y retirent pendant le jour et qu ils ne en sortent yue la muit pour derelner leur subsistance. ()n chasse le tatou avee des petits eliens, yui l'alteiguent bientot; il u'attend pas mème quiils soient tout près de lui pour s'arreter et pour se eoutracter en rond ; dans cet citat on le prenel et on l'emporte. S'il se trouve au bord d'un précipice, il cellappe aux chicns et aux chasseurs; il se resserre, se laisse tomber, et roule comme une boule sans briser son écaille et sans ressentil aucun mal.

Ces animaux sont gras, replets et très-féconds: le mâle marcque, par les parties exlérieures, de grandes ficultés pour la génération: la femelle juoduit, dit-on, eharue mois quatre petits; aussi l'espèce en est-elle très-nombreuse lit comme ils sont bousà manger, ou leschasse de toutes les manicres : on les prend aisément avee des piécres que lon tend atu hord des eaux et dans les autres lieux humides ef chauds fyu’ils habitent de préférence; ils ne s'éloignent jamais beaucoup de leurs terriers qui sont très-prom fonds et qu'ils tâchent de regagner des qu’ils sont surpris. On prétend qu'jls ne crifguent pas la morsure des serpents à somette, quoiqui elle soit aussi dangereuse (jue celle de la vipire; (on dit qưils viyent en pais aveces reptiles, et que l'on en trouve souvent dans leurs trous. L.es sauvages se servent du tìt des tatous à plusieurs usages : ils le peignent de différentes conleurs; ils en font rles corbeilles, des boites et d'autres petits vaisseaux solides et légers. Monard, Ximenes, et plusicurs autres aprèseux. ont attribue d'admirables propriétés médicinales a difrerentes parties de ces animaux. Ils ont

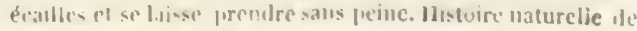
lingume par ciumilla. 
assuré que le têt réduit en poudre et pris intérieurement, méme à petite dose, est un puissant sudorifique; que l'os de la hanche, aussi pulvérisé, guérit du mal vénérien ; que le premier os de la queue appliqué sur l'oreille fait entendre les sourds, etc. Nous n'ajoutons aucune foi à ces propriétés extraordinaires; le tèt et les os des tatous sont de la même nature que les os des autres animaux. Des effets aussi merveilleux ne sont jamais produits que par des vertus imaginaires.

\section{ADDITION A L'ARTICLE DES TATOUS.}

" L'encoubert' mâle a quatorze ponces de longueur sans la queue. 11 est assez conforme à la description qui se trouve dans I'Histoire naturelle; mais il est bon d'observer qu'il est dit, dans cette description, que le bouclier des épaules est formé par einq bandes ou rangs parallèles de petites pièees à cing angles aree un ovale dans chaeune. Je pense que cela varie, car celui que j'ai dessiné a le bouclier des épaules compose de six rangs parellèles, dont les petites pieces sont des hexagones irréguliers. Le Louclier de la eroupe à dis raugs parallèles , composés de petites pièees droites, qui forment comme des carrés; les rairgs qui approchent de l'extrémité vers la queue perdent la forme carrée et deviennent plus arrondis. La queue, qui a été coupée par le bout, a actuellement quatre ponces six lignes; je l'ai faite dans le dessin de six pouces, paree qu'elle a quinze lignes de diamètre à son origine, et six lignes de diamètre au bout coupé. En marchant il porte la queue haute et un peu courbée. Le troncon est revètu d'un tèt osseux conme sur le corps. Six bandes inégales par gradation eommencent ce troncon; elles sont composées de petites pièces hexagones irrégulières. Latète a trois pouces dix lignes de long, et les oreilles un pouce trois lignes. L'œil, au lieu d'ètre enfoncé, comme il est dit daus l'Histoire naturelle, est à la vérité trèspetit, mais le globule est élevé et très-masqué par les paupieres qui le couvrent. Son corps est fort gras, ct la peau forme des rides sous le ventre; il y a sur eette peau du ventre nombre de petits tubercules, d'où partent des poils blanes assez longs, et elle ressemble à celle d'un din-

' C'est le Lalou enconbert. don plumé. Le têt, sur la plus grande langeur du eorps, a six pouces sept lignes. La jamise de devant a deux pouces deux lignes, celle de derriere trois ponces quatre lignes. Les ongles de la patte de devant sout tres-longs; le plus grand a quinze lignes, celui de cóté quatorze lignes, le plus petit dix lignes; les oagles de la patte de derrière ont au plus six lignes. Les jambes sont courertes d'un cuir écailleux jannátre jusqu'aux ongles. Lorsque eet animal marchi, il se porte sur le bout des ongles de ses pattes de devant; sat rerge est fort longue; en la tirant elle a six ponces sept lignes de long, sur près de quatre lignes de grosseur, en repos, ce qui doit beaucoup augmenter dans l'érection. Quand cette verge s'allonge d'elle-mème, elle se pose. sur le ventre en forme de limacon, laissant environ une ligne ou deux d'espace dans les circonvolutions. On m'a dit que quand ces animaux veulent s'aceoupler la femclle se couche sur le dos pour recevoir le màle. Celui dont il est question n'était âgé que de dix-huit mois. "

M. de La Borde rapporte, dans ses observattions, qüil se trouve à la Guiane deux espèces de tatous : le tatou noir, cqui peut peser dix-lunit à vingt livres, et qui est le plus grand; l'autre, dont la couleur est brune ou plutòt aris de fer, a trois griffes plus longues les unes que les autres ; sa queue est mollasse, sans cuirasse, couverte d'une simple peau sans ćeaille : il est bien plus petit que l'autre et ne pèse qu'euviron trois livres.

"Le gros tatou, dit M. de Lia Borde, fait huit petits, et mème jusqu ii dix, daus des trous qu'il creuse fort profonds. Quand on veut le découvrir, il travaille de son côté à rendre son trou plus profond, en descendant presque perpendiculairement. Il ne court que la nuit, mange des vers de terre, des poux de bois et des fournis : Sal chair est assez bomne à manger et a un peu du gout du cochon de lait. Le petit tatou gris cendré ne fait que quatre ou cinq petits; mais il fouille la terre encore plus bas que lautre, et il est aussi plus diflicile à prendre : il sort de son trou pendaut le jour quand la pluicl'inonde, autrement il ne sort que la nuit. On troure toujours tees tatous seuls, et l'on comnait qu'ils sout dans leurs trous lorsquion en voit sortir un grand nombre de certaines mouches qui suivent ces animaux à l'odeur. Ouand on ereuse pour les prendre, ils erensent aussi de leur còté, jetant la terre en arriere, et bouchent tel- 


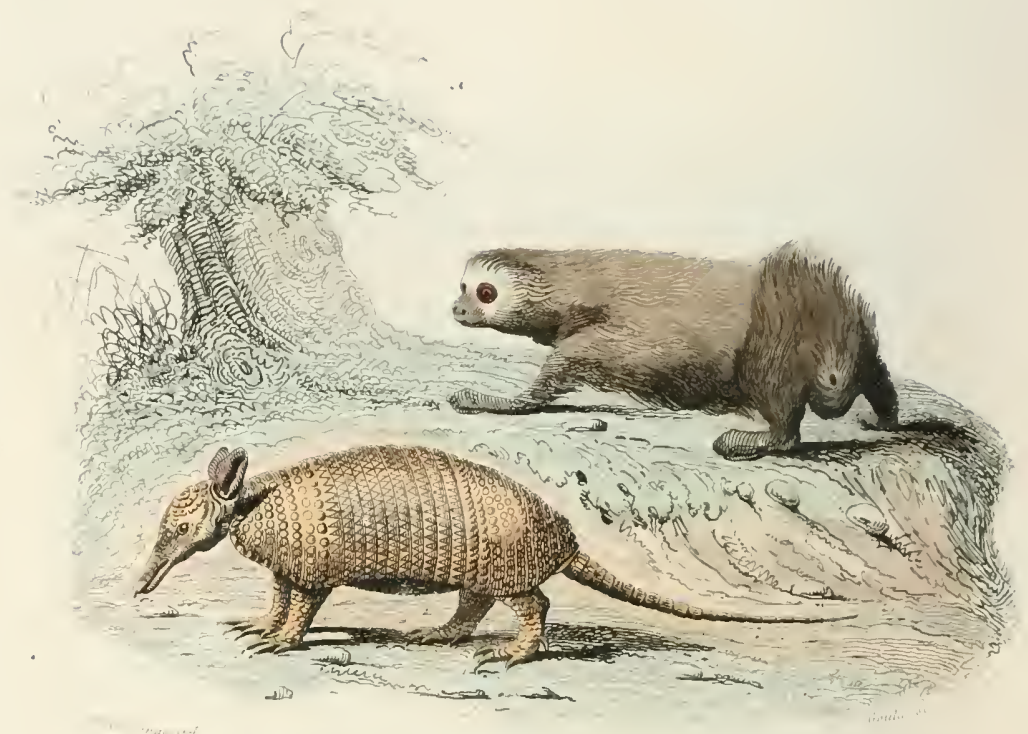
1.E 'TTOL A NET B.ANDES
L' IXIT .
(cichicante)

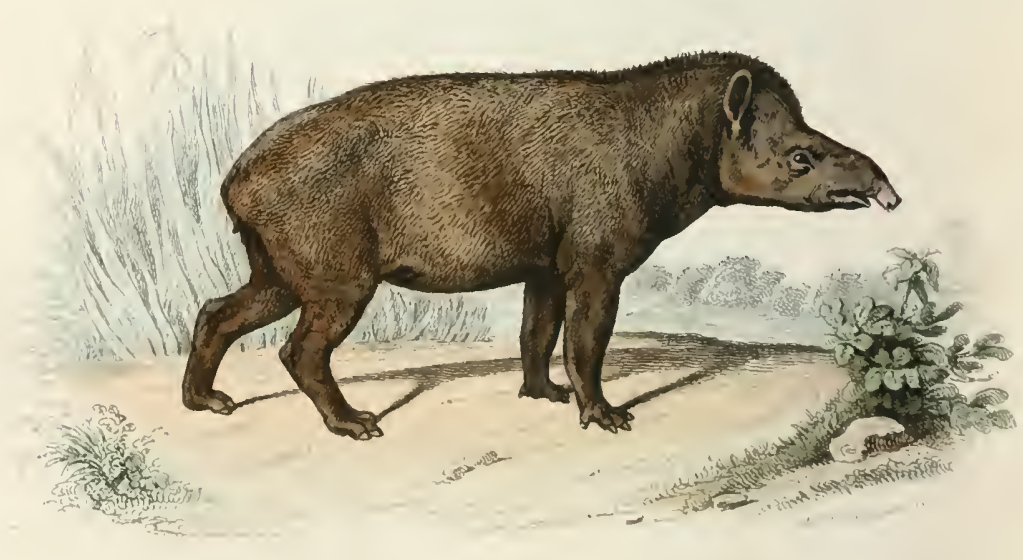

I.I: T:IיIR. 
lement leurs trous qu'on mo saurait les en faire surtir en y faisant de la liumée. Ils font leurs petits au commencement de la saison des pluies. "

Il me parait qu'on doit rapporter le grand tatou noir, dont parle ici M. de La Borde, au kabassou, qui est en effet le plus grand de tous les tatous; ct que l'on pent de même y rapporter' le petit tatou gris de fer ou tatuète, quoique II. de La Borde dise que sa queue est sans euirasse, ce qui mériterait d'être vérifié.

Il y a encore un tatou à neuf handes mobiles et in très-longue queue. La description se trouve dans les Transaetions philosophiques, volume $L I V$, planche 7. M. William Watson, docteur cn médecine, a donné la deseription de ce tatou, dont voici l'extrait : Cet animal était vivant it Londres, chez mylord Southwell; il venait d'Amérique; cependant la figure que cet auteur en donne dans les 'Transactions philosophicques n'a été dessince qu'après l'animal mort, et c'est par cette raison qu'elle est un peu dure et raide. Cet animal pesait sept livres, avoir du. poids, et n'était que de la grosseur d'un chat ordinaire; c'était un mâle qui avait mème asse\% grandi, pendant quelques mois qu'il a véeu chez mylord Southwell; on le nourrissait de viande et de lait; il refusait de manger du grain et des fruits. Ceux qui l'ont apporté d'Amérique ont assuré qu'il fouillait la terre pour s'y loger.

\section{DESCRIPTION DES TATOUS.}

(ЕхтRAT IE nALBENTON.)

Les tatous peuvent ètre comparis au pangolin ct an phatagin, pour l'enseloppe dure dont ils sout revitus au lieu du poil qui conve le corps de presque tous les quatrupèles: cepentant l'enveloppe des tatous est très-differente des écailles du pango- lin et du platagin par sa forme et par sa sulstance; éest une sorte de tèt osseux disposé par grandes pièces, sur la tète, sur le corps, sur une partie tles jambes et sur la queue de l'animal, et chacune de ces grantes pieces est composee d'autres plus petites, qui, par la rignlarite de leur arrangement, en font une espece de mosaīgne. L'enreloppe dure des tatous ne sétend pas sur tontes les parties de leur corps; le dessous de la liste, la poitrine, le sentre el lit face interieure des quatre janbes ne sont revertus que d'une pean scmblable à celle des autres quadrupides; aussi cette pean suit tous les contours des parties qu'elle revèt : mais l'enveloppe osseuse rtant très-dure, et par conséquent peul flexible, ne donne au corps des tatous qu'une ligure grossière et presque informe; de sorte que l'ou ne distingne ni le con, ni les épanles, et que les hras et les cuisses sont cachés sous cette enveloppe.

Le cachicame, ou tatou à neuf handes, est la senle espèce dont nous ayons eu des individus assez hien conserves pour les dicrire +11 entier, tant à l'intérieur an’à l'extérieur; c'est pourquoi la description du cachicame se trunve ici lit première.

\section{LE CACHICAWE,}

OU TAROU A NEUF WANIES.

(EXTRAIT DE DALBFTOY.

Le cachicame ' a la tite petite, longue el ètroite, le museau fort allongé, très-effilè el terminé par une sorte de groin, la bonclie grande, les yeux pe. tits et places sur les còtés de la tète, les oreilles longues et peu eloignces l'une de l'autre, la quene en forme de cone très-allongé et furt pointu, les jambes courtes et les pieds petits. Il y a ciny doigls aux pieds de derrière et seulement quatre à ceux c!e devant: les deux doigts du milieu de ceux-ci sont beancoup plus longs gue les autres; le doigt ex. terne du milien a plus de longueur que linterne; le troisième doigrt des pieds de derrière est le plut: long; le quatrieme est un peu plus court que le s:cont; le premier et le cinquième sont les plus court. et placés l'un vis-ḋ-vis de l'autre. Les ongles sont longrs, jaunâtres, ètroits, presque plats et peu courbés.

Les flus grandes pieces de l'enveloppe osseuse courrent les épaules et la cronps; le lét des épaules s'ctend $\mathrm{n}$ avan jusqu'à la tète, en arrière jus ju’an dos, et il descend de chayne coté juscun an courle: il est composé de petites jièces adhicrentes les unes aux autres et dispostes en dix-sept rangs lien distincts à quelque dlistance au-dessus de ses bords inféricurs; ; quelques-uns dles rangs se rémnissent sur les bords inlérieurs et dlans le milieu du tèt, de sorte que l'on n'y en compte qu'environ quatorze: tans les ranges sont courbes en arc de cercle et concentrignes; lenr concaviti est en arant, de faģon que le premier rang jui est le filus court embrasse le con de l'animal. Le lit de lit croupe s'iteml depuis le dos jusiqu a l'origine de la quene et alescend de chargue còté justuan genou; il est compuse d'em iron vingt-rfuatre rangs de petites prèces; ces rangs sont courbes en are de cercle et concentriynes comme renr du tit des ipanles; leur concavité est en arrière; le dernier, qui est très-court,

'. Cest le tatou peha, qun so rapporte itur espices insariles par cimelin dans le systema naluia, suus les nonis dedasipas seplemeinclus, oclocinclus el novemrinclus. 
embrasse l'origine de la queve. Dans chaque rang ılu têt des épaules et de celui đle la rroupe les petites pieces ont me figure lıxagone, presque anssi régrulière yue celle des alvéoles des gâteaux de cire des abeilles; elles sont placées exactement les unes contre les autres sans laisser aucun vide; on ne les listingue que par les jointures qui sont entre elles, encore ne les aperçoit-on que sur la face interne dı têt : car à l'extérieur, il paraît composé de tubercules de differentes grandeurs, dont les plus grands sont rangés sur des files qui font reconnaitre les rangs des petites pieces qui composent le tèt : ces grands tubercules sont un peu éloignnés les uns cles auires; l'intervalle qui reste entre eux est rempli par d'autres tubercules plus petits et de figuré irréguliere.

Le dernier rang des pièces du tèt des épaules et le premier rang du têt de la croupe sont composés de piẻces oblongues plus grandes que celles des autres rangs; elles ont cliacune, sur leur face externe, une empreinte en forme de triangle allonge dont la base est en arrière, et qui ressemlle en quelipue façon à un ongle. Il y a entre le dernier rang du tòt des épaules et le premier rang du têt de la crompe neuf autres rangs de semblables pièces avec des empreintes triangulaires et dix jointures 1ransversales remplies par une peau souple: clıacun de ces neuf rangs d'empreintes triangulaires appartient à une partie de l'enveloppe osseuse de l'animal séparée des autres, de sorte que le tèt est divisé sur le dos en neuf bandes transversales qui descendent jusqu'au bas de: cottés dı corps ; mais le rang d'enpreintes triangulaires qui paraissent à l'extérieur dı corps de l'animal sur chaque bande osseuse, et qui aboutissent par leur pointe et par leur base à la peau les jointures, ne fait pas toute la largeur de la bande; elle se prolonge en avant sous la peau de la jointure et anticipe sous la bande unui la pricéde. Cette confommation donne à l'animal ta facilité d'allonger son têt et de le raccourcir, de courher l'epine du dos et de la redresser. Lorsqu'elle est droite, l'animal ćtant sur se: jambes, cha!'une des bandes osscuses est un? partie cachée sous celle qui la précède; la premiere bande s'itend sous le dernier rang du têt des épaules, et le premier rang dı têt de la croupe s'étenıl sous la demière bande : mais lorsque l'animal plie l'épine du dos pour approelier sa tète de sa quene, la peau des jointures des bandes s'étend; chloque bande itant attirie en avant sort de dessuns la banle qui la suil; le dernier rang du tò des épanles ne recouvre plas rien de la premic̀re bandc, et la nière sort en entier de dessous le premier rang du tit de la eroupe: par ce mourement l'animal allonge son enveloppe et se pelotonne comme un lıérisson. (In voit par cette exposition que le dernies räugg du têt des épaules et le prenier rang du têt de la croupe font clacun la fonction d'une demj. bante; aussi ils ont, comme il a dejjà été dit, des empreintes triangulaires différentes de celles des autres rangs et semblables à celles de la partie des baudes qui est à découvert; ils ressemblent donc à ces bandes à l'extérieur de l'animal; ainsi l'on cruirait qu'il aurait onze bandes, si l'on n'avait égard qu'aux rangs d'empreintes triangulaires : mais c'est le nombre des jointures qui doit décider dı nombre des bandes; il n'y en a point au-devant du dernier rang du têt des épaules ni derrière la partie moyenne du premier rang du tèt de la croupe; les jointures ne sont qu'au nombre dedix, et par conséquent les bandes mobiles au nombre de neuf. Ccpendant il y a cneore de courtes jointures derrière les extrémitès du premier et mème du second rang du têt de la croupe; mais elles ue s'ètendent pas loin et ne peuvent rendre mobiles que les deux bouts dle ces rangs : ces petites jointures donnent à l'animal une facilité de plus pour courber son enveloppe lorsqu'il veut se pelotomer. Toutes ces jointures mobiles sont nécessaires pour ce mourement, car il ne parait pas que les hancles ni les autres parties de l'enveloppe puissent plier; les pièces qui les composent allièrent fortement les unes aux autres; on ne peut les séparer qu'en faisant effort comme pour les casser; nais la séparation s'en fait toujours "dans leurs joints qui sont une sorte d'articulation : elle m'a senblé immobile autant que j'en ai pu juger sur des dépouilles desséchées. En les faisant calciner, toutes les pièces se détachent d'elles-mèmes, elles devienuent sonores et blanches : en les cassant, j'ai vu qu'elles étaient conposées d'une partie solide et compacte, et d'une partie cellulaire et spongieuse comme un os, par exemple, comme le pariétal d'un lapin, que j'ai fait calciner avec quelques pièces des bandes d'un cachicame. Les pièces qui portent l'empreinte d'un triangle apparent à l'extérieur du têt ont la forme d'un earré long, lorsqu'on les voit en entier: les grands côtés de ce carré suivent la longueur du corps de l'animal; leur face interne est unie; il y a ıu rebord transversal sur la face externe à l'endroit oì la peau de la jointure commence à ourrir celte face.

Le tèt de la tête s'éteni depuis les oreilles jusqu'au hout du museau et descend de clıaque còté jusqu'aux angles des yeux; il a une échancrure à l'endroit lle la paupière supérieure; il est compose de pièces de lignures irrégulières. Il se trouve quelques pièces osseuses et :emblables à celle du têt entre les coins de la bouche et les yeux, au-dessous des yeux et sur les côtés du cou. La face externe dts oreilles, le has des jambes et les pieds sont ausci revêtus de semblables pièces osseuses: mais elles sont très-petites sur les orcilles.

La queue est revêtue en entier d'un tèt osseux 
composé de petites pièces disposees en anneaux ou rangées en quinconce: il y a rlepuis l'origine lle la yueue jusqu’à environ la moitić dè sa longueur douze anneaux bien distincts, dont la largeur prise au-dehors de la queue était de près d'un demipouce, sur le sujet de cette description; excepté les premiers qui étaient plus étroits. Ces anneaux anticipent un peu les uns sur les autres, le bord postérieur de elıacun s'étend sur le bord antérieur de l'anneau qui le suit, et y adhère par une peau qui forme une articulation mobile comme celles qui sont entre les bantes du clos. Au moyen de ces articulations, la queue se courbe en tont sens, en haut, en bas et de còte. Chayue annean est composé de trois rangs de petites pièces; celles dlu rang du milieu sont hexagones; celles dı rang antéricur et du postérieur n'ont que cing faces : le reste ile la queue au-delà des ammeaux est revêtu de petites pièces en forme.d'écailles, et en effet elles glissent un pen les unes sur les autres dans les différents monvements de la gureue. Son lèt forme trois cannelures qui s'étendent le longdu cóté inférieur, excepté près de l'origine de la queue, oir elles lisparaissent.

La face extèrieure de toutes les petites pièces de l'enveloppe osseuse du cachicane est revètue d'une f:ellicule dure, luisante et jaunàtre, qui étant exposée au feu se contourne comme un parchemin, butullonne, s'enllamme et se réluit en cluarbon : cette pellicule est transparente et parait vie mène rature que l'écaille de tortue; elle s'enlève aisément lorsque le têt est desséché; et après l'avoir enlevée on voit, sur les pièces osseuses qu'elle recouvrait, les inégalités de leur surface, leurs joints eldes trous qui se trouvent dans les pièces osseuses et dans leurs jointures, et qui saus loute ont rapport à la pellicule pour douner passage à ses vaisseaux, à ses nerfs ou à ses attaclies.

Les parties llu cachicane qui sont revètues de tégument serıblables à ceux des autres quatrupèdes unt aussi des poils ou des soies jaunitres assez rares et disposées par petits houquets : il y a de semMables soies sur tes joints des petites pièces de l'enveloppe osseuse et principalement sur les jointures rles bandes du dos.

\section{LE TATUÈTE,}

\section{DI 'TATOU A HUIT BANDES '.}

(EATHAT DE DAUHENTON.

Je niai vu que des tatuètes lesséches, aiusi je n'ai pu les comparcr aux carhiomes que par les lam"ties extérieures du corps, et ie u'y ai trumé quatres differences yue dans le nombre des bandes

- Ciest uncore le fatou peba ou cachicame. mohiles du tèt dà dos; le tatuète n'en a que huit, tandis que le cachicaule en a neuf; au reste, ils sc ressemblent parfaitement. Cependant on pretend qu'ils sont d'especes differentes, mais cette opinion n'est pas unanime, il est resté quelyue doute à cc sujet. Je pense que ce doute se serail confirmé, si les auteurs de nomenclatures avaieut eu sous les yeux des tatous de phrsieurs espèces et les avaient scrupuleusement ohservés dans toutes leurs parties, au moins à l'exterieur. Ils auraient reconnu que même par rapport aux bandes du tèt des tatous, le nombre de ces bandes n'est jas le seul ca. ractère aurjuel on doive avoir égard pour determiner les espèces : la forme et le nornbre des pièces dont chayue bande est composée ne sont peut-ètre pas moins tlécisifs que le nombre des landes; voici ce qui me le fait croire. J'ai comparé les uns aux autres des tatous de trois espèces Irès-ılistinctes quii sont au Cabinet du Roi, savoir : le cachicane qui est le tatou à neuf bandes; le kabassou qui est le. tatou à douze baudes, et l'encoubert qui est le tatou à six bancles. J'ai trouvé qu'il y arait d'aussı grandes différences dans la forme et le nombre des pièces dont les bandes de clacune de ces espèces de tatous sont composces, que dans le nombre des bandes : au contraire, les pièces dont sont composcies les bandes des tatuctes ressemblent très-parfaitement pour la forme à celles des cachicames. Quant au nombre des pièces de cnaque bande, jai compté celles de la première, de la cinquième et de la dernière bande dle lunit caclicames; j'ai tronvé des variétés dans ce nombre, mais à prendre les termes moyens, ils sont les mèmes que ceux du nombre des pitces des bindes de deux tatuètes, qui sont les seuls que j'aie vus. La ressemblance entro les cachicamer et lestatuet es s'etend bien julus loin; car je n'y ai aperçu ancune difference dans les tèts les épaiıles, de la croupe, de la tète, des jambes et de la queue; dans la ligure du museau, de la tète, des oreilles, du corps, de la ojueue, etc.; lans le nombre et la forme des doigts et des ongles; dans la situation, la forme el le nombre des dents, ni mòne, pour ainsi dire, dans les varietes de ce nombre qui se trowrent dans les tatuètes comme dans les cachicames; ces animaux ne diflèrent donc uniquement au’ence que les uns ont dans le lit du dos une bande de plus que les autres. Parmi tant de rapports dans la conformątion de l'animal, il fandrait examiner de quelle valeur peut citre une telle difference daus le nombre des pices de son enveloppe osseuse. J'ai chiji fail remarquer qu'il y a des varietes dans le nombre des pièces dont les handes sont composies dans plusieurs carlijancs: sur huit que jai observes, l'ull a jusqu à soixantetrois pieces dans la dernière bande, et un autre n'en a que cinquante Irois; celte difference e'st à pen près d'un sixieme: il $y$ a aussi des varièics tan- 
le nombre des pièces qui cumposent les rangs du tèt des épaules et de celui de la croupe. Puisyue le nombre des pièces n'est pas constant dans les rangs transversaux des têts des épaules, du dos et de la croupe dans différents cachicames, pourquoi voudrait-on que le nombre de ces pièces fít plus constant dans les rangs longitudinaus? En supposant (fu'il y ait une pièce de plus ou de moins dans ces rangs longitudinaux, comme on le voit dans les caclicames relativement aux tatuètes, la diffèrence n'est que d'un cinquantième, puisqu'ils ont environ cinıuante pièces dans chaque rang longitudinal, savoir : dix-sept du tèt des épaules, huit ou neuf du têt du dos, et à peu près vingt-puatre du tèt de la croupe. Cette différence dun cinquantième est bien plus légrère que celle d'un sixième yui se trouve dans le nombre des pièces de la dernière laande des cachicames; par conséquuent, elle ne me parait pas suffisante pour determiner une espèce : celle dı tatuète sera done douteuse tant que l'on naura pas d'autres connaissances sur la conformation intérieure ou sur les propriétés de cet animal, et que l'on ignorera si ces deux animaux se mẻlent et produisent ensemble.

\section{LE KABASSOU,}

\section{OU TATOU A DOUZE BANDES ?}

I.e kabasson a, comme le cachicame et le tatuète, une enveloppe osseuse, divisée eu grandes pièces qui recouvrent les épaules, le dos et lacroupe, et en plus petites pièces qui sont sur la tète et sur la face externe des jambes. Le têt dı dos est aussi divisé, comme celui du eachicame et dı tatuète, en plusieurs bandes transversales et mobiles; mais il en diffère en ce que ces bandes sont au nombre de douze, au lieu de neuf qui se tronvent sur le dos du cachicame, et de huit sur celui du tatuète. Le kabasson diffère encore de ces lenx autres tatous par le nomlure et l'empreinte des pièces dont ces bandes et les tèts des épaules, de la croupe et de la (queue sont composés; par la figure et la disposition du tèt de la queue, jar la forme de la tête, des pieds et des ongles, par la longueur de la queue et par le nombre des doigts. Le kabasson a la tète et le museau plus courts et plus larges que le cachicame et le tatuète, le sommet de la tête noins convexe, les oreilles plus larges et beancoup plus éloignées l'ume de l'antre, la quene mo:ns grosse à son origine et heancoup plus courte, les jambes et les pieds plus gros. Il a cinq doights à clıaque pied : les ongles ont une couleur brume; ceux des pieds de devant sont pour la plupart beaucoup plus grands que ceux des pieıli de derrière, et ont une forme particulière; ils sont plićs en gouttière étroite el inegale, de sorte que le cité externe a deux fois aulant de largeur yue le còté interne ; l'ongle du doigt dı milieu est à proportion plus grand que les autres; celui du ponce est aussi petit que ceux des pieds de derrière : les doigts des pieds de devant ne sont marqués à l'extérieur que par les ongles; dans les pieds de derrière, le cinquième doigt est fort petit et fort éloigné du quatrième.

Le têt des épraules est composé de piètes de mo. saïque, qui sont beancoup plus grandes que celles du cachicame et dı tatuète; aussi les rangs sont en moindre nombre dans le kabassou, et le nombre des pièces de chaplue rang n'est pas la moitié de celui des pièces qui leur correspondent sur le cachicame et sur le tatuète dansles bandes mobiles, dans le tèt des épaules et dans celui de la croupc; les rangs de ce dernier tèt ne sont (ju'au nombre de dix. Les petites pièces qui composent le têt des épaules sont de figures approchantes du carré, mais irrégulières; celles du têt de la croupe sont moins irrégulières, et les pièces des bandes mobiles du dos sont exactement carrées. Toutes sont reconvertes d'une pellicule de couleur mèlée de jaunature et de hrun : les empreintes de ces pellicules sont légères et n'ont que l'apparence de gerçures; cependant sur les plus grandes pièces, ces gergures prennent la figure d'un cercle folacé an milie: ile chaque pièce. En élevant la pellicule, on découvre la pièce osseuse qui est blanche $\mathrm{ct}$ qui porie des empreintes relatives à celles de la pellicule. Les douze handes mobiles du dos n'anticipent que tris. peu les unes sur les autres; le dernier rang du tix des épaules ne s'étend aussi que très-peu sur la première bande du dos, ni la dernière bande sur le premier rang du tèt de la croupe.

Les pièces du tèt de la tète sont de fígure irrégulière comme celles du cachicame, mais plus grandes, et par conséquent en moindre nomhre. La face externe des oreilles est revêtue de très-pietiles pièces osseuses, comme dans le cachicame.

La quewe n'est pas recouverte d'un tèt, comme celle du caclicame et du tatuète, mais senlement l'une peau Jrune semblable à celle du dessous de la tète, à celle dı cou, de la poitrine, dı ventre et des jambes; mais loutes ces parties el la qu: ne sont parsemces de petits tulerenles en forme de disques jaunâtres on brums, luisants, durs et de mème nature que la pellicule qui couvre les pirces du tèt; les plus grands se trouvent sur les jambes: ccux de la poitrine sont disposes par liles transversales éloignées les unes des autres. Il y a de petites soies jaunàtres ou brunes, placées prar bou. quets à la circonférence de ces disques; il y a aussi de rareilles soies entre les écailles des tôts. 


\section{L'ENCOUBERT,}

() TATOU A SIX BANDES ${ }^{4}$.

(EXTRAIT DE DALBENTON.)

Je u'ai vu que l'enveloppe osseuse d'un enconbert. Cette dépouille avait treize pouces et demi de longueur depuis la partie intérieure du têt de la tête jusıu’à la partie postérieure du tèt cle la croupe. La partie superieure de celui des épaules n'avait que cinq rangs de petites pièces : mais il s'en trouvait justu'à sept sur les parties latérales : la plupart de ces pièces étaient de figures irrégulièr'es à quatre, cing ou six côtés ; leur surface externe avait pour empreinte un ovale dans le nilieu et de petites convexités sur les bords de la pièce autour de l'ovale; toutes les parties du lèt des épaules et des autres tèts qui composaient l'enveloppe osseuse dont il s'argit étaient dẹponillées de leurs pellicules.

Les landes mobiles dı dos étaieut au nombre de six, elles u'anticipaient que très-peu les unes sur les autres; les pièces qui les composaient n’ètaient guère jlus nombreuses que celles des bancles du liabassou, il u’y en avait qu'environ trente daus clatpue loande: mais ces pièces étaient grandes, carrécs et oblongues; elles avaient pour empreinte deux cannelures longitudinales dont la direction n'était pas fort éloignce de former un ovale sur le milicu de la pièce, comme sur celle du tèt des épaules: les pièces du dernier rang de ce tèt, et celles du premier rang du tèt de la croupe, étaient semblables à celles des bandes mobiles comme daus le cachicame, le tatuète, etc. ; les autres pièces du lèt de la eroupe ressemblaient au plus grand nombre de celles du tit des ipaules.

Il y avait entre le tèt de la tête et celui des éraules, à l'eudroit du cou, une bande trausiersale, mobilc et courte; car elle n'était composée que de Iunit pièces, yui ressemblaieu: à celles des bandes mobilos du dos. Le bord antérieur de la bande du cou élait recouvert par la parlie postérieure du tèt de la tìte, et le bord postérieur de la bande dlu cou recouvrait la partie antérieure du têt des épaules.

Le tèt de la tète était à proportion plus longr et beancoup plus large que celui de la téte du cachicame, du tatuete et du kabasson : les pieces tont il était conjosé avaient beaucoup le rapport ì celles du té des épaules et de celui de la croupe; il clait échancré de charpue cóte aux endroils des youx et des oreilles : il denotait par son élendue que la tite le lemouliert est plus grosse ct plus harge que celle du kabassou, et yue le unsean est aussi plus

'Cest le tatom enconbert, anjuct il fanl réntir le cirquincon ale burfon. large et heaucoup plus court. Mais la différence la plus remarquable était dans la bande mobıle qui tenait au tèt de la tète et à celui des épaules. et oui rendait l'enveloppe osseuse de l'animal continue depuis le bout du museau jusqu’à l'origine de la quene.

\section{L.UNAU E'T L'AI.}

(LE BRADYPE UNAU. - LE HRADYPE Aï.)

Ordre des édentés, famille des tardigrades, fenıe bradype. (Cuvier.)

Lon a donné à ces deux animaux l'épithèts de paresseux, à cause de la lenteur de leurs mouvements et de la difficulté qu'ils ont à marcher : mais nous avous eru devoil leur conselver les noms qu'ils portent dans leur pays natal, d'abord pour ne les pas confondre aree d'autres animaux presque aussi paresseux qu'eux, et encore pour les distinguer nettement l'un de l'autre: car', quoiqu'ils se ressemblent à plusieurs égards, ils dillèrent néaumoins tant à l'extérieur qu'à l'intérieur, par des caractères si marqués, qu'il n’est plus possible, lorsqu'on les a cxaminés, de ies prendre l'un pour l'autre, ni même de douter qu'ils ne soient de deux espèces très-éloignées. L’unau n'a point de queue et n'a que deux ongles aux pieds de devant; l'aì porte une queue courte et trois ongles a tous les pieds. L'unau a le museau plus long, le fiont plus élevé, les oreilles plus apparentes que l’aï; il a aussi le poil tout différent : à l'iutéricur, ses visceres sont autrement situés, et conformés différemment dans quelques-unes de leurs parties. Nais le caractere le plus distinctif, et en nème temps le plus singulier, e'est que l'unau a quarante-six cotes, tandis que l'a n'en a que vingt-huit : eela seul suppose deux espèces très-éloignées l'une de l'autre; et ce nombre de guarante-six cótes dans un animal dont le corps est si court est une espece d'excés ou d'erreur de la nature; car de tous les animaux, mème des plus grands, et de ceux dont le corps est le plus long, relativement à leur grosseur, aucun n'a tant de cherrons à sa charpente. Léléphant n’a que quarante còtes, le cheval trente-six, le blaireau trente, le chien vingt-six, l'homme vingt-quatre, ete. Cette dilférence dans la construction de l'unau et de i'aï suppose plus de distance entre ces deux especes, quil u'y en a entre celles du chich ct 
du eñat, điui ont le même nombre de cótes; car les différences extérieures ne sont rien en comparaison des différences intérieures; celles-ci sout, pour ainsi dire, les causes des autres qui n'en sont que les effets. L'intérieur dans les êtres vivants est le fond du dessin de la nature; c'est la forme constituante, c'est la vraie figure; l'extérieur n'en est que la surface on même la draperie; car, combien u'avons-nous pas vu, dans l'examen comparé que nous avons fait des animaux, que cet extérieur souvent très-différent recouvre un intérieur parfaitement semblable; et qu'au contraire la moiudre différence intérieure en produit de très-grandes à l'extérieur, et change même les habitudes naturelles, les facultés, les attributs de l'animal ! Combien n'y en a-t-il pas qui sont armés, couverts, olnés de parties excédantes, et qui cependant, pour l'organisation iutérieure, ressemblent en entier à d'autres qui en sont dénués! Mais ce n'est point ici le lieu de nous éteudre sur' ce sujet, qui, pour être bien traité, suppose nonseulement unc comparaison réfléchic, mais un développement suivi de toutes les parties des êtres organisés. Nous dirons seulement, pour revenir à nos deux auimaux, qu'autant la nature nous a paru vive, agissante, exaltée dans les singes, autant elle est lente, contrainte et resserrée dans ces paresseux; et c'est moins paresse que misère; c'est défaut, c'est dénûment, e'est vice daus la conformation; poiut de dents incisives ni canines, les yeux obscurs et couverts; la màchoirc aussi lourde qu'épaisse, le poil plat et semblable à de l'herbe séchée, les euisses mal emboitées, et presque hors des hanches, les jambes trop courtes, mal tournées, et encore plus mal terminées; point d'assiette de pied, point de pouces, point de doigts séparément mobiles; mais deux ou trois ongles excessivement lougs, recourlés en dessous, qui ne peuvent se mouvoirqu'ensemble, et nuisent plus à marcher gu'ils ne servent à grimper : la lenteur, la stupidité, l'abandon de son ètre, et mème la douleur habituelle, résultant de cette confor'mation bizar'e et négligée ; point d'armes pour attaquer ou se défendre; nul moyen de sécurité, pas même en grattant la terre; uulle ressource de salut dans la fuite : confinés, je ne dis pas au pays, mais à la motte de terre, à l'arbre sous lequel ils sont nés; prisonniers au milieu de l'espace; ne pouvant parcourir gu'une toise en une heure; grimpant arecpeine, se traínant avec douleur; une volx plaintive et par accents entrecoupés qu'ils n'osent élever que la muit; tout annonce leur misère, tout nous rappelle ces monstres par défaut, ces ébauches imparfaites mille fois projetées, exécutées par la nature, qui, ayant à peine la faculté d'exister, n'out dû subsister qu'un temps, et ont été depuis effacés de la liste des êtres : et en effet, si les terres qu'habitent et l'unau et l'aï n'étaient pas des déserts, si les hommes et les animaux puissants $s^{\prime} y$ fussent anciennement multipliés, ces espèces ne seraient pas parvenues jusqu'ì nous; elles eussent été détruites par les autı'es, comme elles le seront un jour. Nous avons dit qu'il semble que tout ce qui peut êtr'c, est; ceci paraît en être un indice frappant; ces paresseux font le dernier terme de l'existence dans l'ordre des animaux qui ont de la chair et du sang; une défectuositéde plus les aurait empèchés d. subsister. Regarder ces ébauches comme des ètres aussi absolus que les autres; admettre des causes finales pour de telles disparates, et trouver que la nature y brille autant que dans sc beaux ouvrages, c'est ne la voir que par ui? tube étroit, et prendre pour sou but les fins di notre esprit.

Pourquoi n'y aurait-il pas des espèces d'animaux créés pour la misère, puisuge dans l'espèce humaine, le plus grand nombre y est voué dès la naissance? Le mal à la vérité vient plus de nous que de la nature : pour un malheureux qui ne l'est que parce qu'il est né faible, impotent ou difiorme, que de millions d'hommes le sont par la seule dureté de leurs semblables! Les animaux sont en général plus hemeux; l'espèce n'a rien à redouter de ses individus: Ie mal n'a pour eux qu'une source; il en a deux pour l'homme; celle du mal moral, ru'il a luimème ouverte, est un torrent qui s'est aceru comme une mer, dont le débordement courre et afflige la face entière de la terre; dans le pluysique, au contraire, lemal est resserré dans des bornes étroites, il va rarement seul: lo bien est sourent au-dessus, ou du moins de niveau. Peut-ou douter du bonheur des animaux, s'ils sont libres, s ilsont la faculté de se procurer aisément leur subsistance, et s'ils manquent moins que nous de la santé, des sens et des organes nécessaires nu relatifs au plaisir? Or, le commun des animaux est à tous ces égards très-richement doué; et les espèces disgraciées de l'unan et de l'aï sont peut-être les seules que lanatureait maltraitées, 
les seules qui nous offrent l'image de la misère innée.

Voyons-la de plus près. Faute de dents, ces pauvres animaux ne peuvent ni saisir une proie, ni se nourrir de chair, ni même brouter l'herbe; réduits à vivre de feuilles et de fruits sanvages, ils consument du temps à se trainer au pied d'un arbre; il leur en faut encore beaucoup pour grimper jusqu'aux branches; et pendant ce lent et triste exercice qui dure quelquefois plusieurs jour's, ils sont obligés de supporter la faim, et peut-être de souffrir le plus pressant besoin : arrivés sur leur arbre, ils n'en descendent plus, ils s'acerochent aux branches, jls le dépouillent par parties, mangent suceessivement les feuilles de chaque rameau, passent ainsi plusicurs semaines sans pouvoir délayer par aucune boisson cette nourriture aride; et lorsqu'ils ont ruiné leur fonds, et que l'arbre est entièrement nu, ils y restent encore, retenus par l'impossibilité d'en descenỏre : enfin, quand le besoin se fitit de nouveau sentir, qu'il presse ct qu'il devient plus vif que la erainte du danger de la mort, ne pouvant descendre, ils se laissent tomber et tombent très-lourdement comme un bloc, une masse sans r'essort ; car leurs jambes, raides et paresseuses, n'ont pas le temps de s'étendre pour rompre le coup.

A terre, ils sont livrés à tous leurs ennemis : comme leur chair n'est pas absolument mauvaise, les hommes et les animaux de proie les cherehent et les tuent. II parait qu'ils multiplient peu, ou du moins que s'ils produisent fréquemment, ce n'est qu'en petit nombre; ear' ils n'ont que deux mamelles. Tout coneourt done ì les détruire, et il est bien diffieile que l'espèce se maintienne. II est vrai que quoiqu'ils soient lents, gauches et presque inhabiles au mouvement, ils sont durs, forts de corps et vivaces; (qu'ils peuvent supporter longtemps la privation' de toute nourriture; que couverts d'mu poil épais et sec, et ne pouvant faire d'exereice, ils dissipent peu et engraissent par le repos, quelque maigres que soient leurs aliments; et que, quoiqu'ils n'aient ni bois, ni cornes sur la tète, ni sabots aux pieds, ni dents incisives à la mâchoire inférieure, ils sont cependant du nombre des animaux ruminants, et out comme eux plu-

\footnotetext{
1 ll me fut f,it present diu unan en vie, lequel je gardai bien l'espace de vingt-six jonrs, jendant lesyuels jumais il ne voulut ui manger ni b irce. Singnlar. de la France am. par Thevec, page 99.
}

sieurs estomaes; que par conséquent ils peuvent compenser ce qui manque a la qualité de la nourriture par la quantité qu'ils en prennent ì la fois; et ce qui est encore extrèmement singulier, e'est qu'au lieu d'aroir, comme les ruminants, des intestins très-longs, ils les ont trèspetits et plus courts que les animanx carnivores. L'ambiguité de la nature parait à découvert par ce contraste : l'unau et l'ai sout certainement des animaux ruminants; ils ont quatre estomaes, et en même temps ils manquent de tous les caractères, tant extérieurs qu'intéricurs, qui apjartiennent génćralement à tous les autres animaux ruminants. Encore une autre ambiguïté, c'est qu’au líeu de deux ouvertures audehors, l'une pour l'urine et l'autre pour les exeréments, au lieu d'un orifice extéricur et distinet pour' les parties de la génération, ces animaux n'en ont qu'un seul, au fond duquel est un égout commun, un cloaque comme dans les oiseaux. Mais je ne finirais pas si je voulais m'étendre sur toutes les singularités que présente la conformation de ces auimaux : on pourra les voir en détail dans l'excellente deseription qu'en a faite M. Daubenton.

$\mathrm{Au}$ reste, si la misère qui résulte du défaut de sentiment n'est pas la plus grande de toutes, celle de ces animaux, quoique très-apparente, pourrait ne pas être récelle; car ils paraissent très-mal ou très-peu sentir: leur air norne, leur regard pesant, leur résistance indolente aux coups qu`ils reçoivent sans s'émonvoir, annoncent leur insensibilité; et ce qui la démontre, e'est qu'en les soumettant au scalpul, e!n leur' arrachant le cœur et les viscères, ils ne menrent pas à l'instant. Pison, qui a fait cetle dure expérience, dit que le cœur séparé du corps battait encore vivement pendant une demiheure, et que l'animal remuait toujours les jambes comme s'il n'eùt été qu'assoupi. l'all ces rapports, ee quadrupède se rapproche nou-seulement de la tortue, dont il a déji la lenteur, mais encore des autres reptiles et de tous ceur qui n'ont pas un eentre de sentiment unique et bien distinct. Or, tous ces ètres sont misélable's sans être malbeureux; et dans ces productions les plus négligées, la nature parait toujour's plus en mère qu'en marâtre.

Ces deux animaux appartienuent également, l'un et l'autre, aux terres méridionales du nouveau continent, et ne se trourent nulle part dins l'aneien. Nous arons déjà dit que l'éditcur du 
cabinet de Seba s'était trompé, en dounant à l'unau le nom de paresseux de Ceylan; cette erreur adoptée par MIM. Ḱlein, Linnæus et Brisson est encore plus évidente aujourd'hui qu'elle ne l'était alors. M. le marquis de Montmirail a un unau vivant, qui lui est venu de Surinam ; ceux que nous arons au Cabinet du Roi viennent du même endroit et de la Guiane; et je suis persuadé qu'on trouve l'unau, aussi bien que l'aï, daus toute l'étendue des déserts de l'Amérique, depuis le Brésil au Mexique; mais que, comme il u'a jamais fréquenté les terres du Nord, il n'a pu passer d'un continent à l'autre; et si l'on a vu quelques-uns de ces animaux, soit aux Indes orientales, soit aux côtes de l'Afrique, il est sûr qu'ils y avaient été transportés. Ils ne peuvent supporter le froid; ils craignent aussi la pluie: les alternatives de l'humidité et de la sécheresse altèrent leur fourrure, qui ressemble plus à du chanvre mal serancé, qu'à de la laine ou du poil.

Je ne puis mieux terminer cet article, que par des observations qui m'ont été communiquées par M. le marquis de Montmirail, sur un unau qu'on nourrit depuis trois ans dans sa ménagerie. "Le poil de l'unau est beancoup plus doux " que celui de l'aï... Il est à présumer que tout " ce que les voyageurs ont dit sur la lenteur ex" cessive des paresseux ne se rapporte qu'à l'aï. "L'unan, quoique très-pesant et d'une allure " très-maladroite, monterait et descendrait plu" sieurs fois en un jour de l'arbre le plus élevé. " C'est sur le déclin du jour et dans la nuit qu'il " paraît s'animer davantage; se qui pourrait " faire soupconner qu'il voit très-mal le jour, " et que sal vue ne peut lui servir que dans l'ob" scurité. Quand j'achetai cet animal à Amster" dam, on le nourrissait avec du biscuit de mer, " et l'on me ditque daus le temps de la verdure " il ne fallait le nourrir qu'avee des feuilles. On " a essayé en effet de lui en donner : il en man" geait volontiers quand elles ćtaient encore "tendres; mais du moment où elles commen" çaient à se déssécher et à être piquées des " vers, il les rejetait. Depuis trois ans que je le " conserve vivant dans ma ménagerie, sa nour" riture ordinaire a été du pain, quelquefois des " pommes et des racines, et sa boisson du lait. "Il saisit toujours, quoique avec peine, dans " une de ses pattes de devant, ce qu'il veut " manger, et la grosseur du morceau angmente - la difficulté qu'il a de le saisir avee ses deux
" ougles. Il crie rarement; son eri est bref et " ne se répète jamais deux fois dans le même " temps. Ce eri, quoique plaintif, ne ressemble " point à celui de l'aï, s'il est vrai que ce son $a i$ " soit celui de sa voix. La situation la plus na" turelle de l'unau, et qu'il parait préférer à " toutes les autres, est de se suspendre à une " branche, le corps renversé en bas; quelque" fois même il dort dans cette position, le qua" tre pattes acerochées sur un mème point, son " corps décrivant un are. La force de ses mus" cles est incroyable: mais elle lui devient int" tile lorsqu'il marche; car son allure n'en est " ni moins contrainte ni moins vacillante. Cette " conformatiou seule me parait être une cause " de la paresse de cet animal, qui n'a d'ailleurs " aucun appétit violent, et ne reconnait point " ceux qui le soignent."

ADDITION A L'ARTICLE DE L'UNAU ET DE L'Aï.

On connait à Cayenue, dit M. de La Borde, deux espèces de ces animaux, l'une, appelée paresseux-honteux, l'autre mouton-paresscux: celui-ci est une fois plus long que l'autre, et de la mème grosseur; il a le poil long, épais et blanchâtre, pèse environ vingt-ciuq livres. II se jette sur les hommes depuis le haut des arbres, mais d'une maniëre si lourde et si pesante, qu'il est aisé de l'éviter. Il mange le jour comme la nuit.

a Le paresseux-honteux a des taches noires, peut peser douze lirres, se tient toujours sur les arbres, mange des feuilles de bois canon, qui sont réputées poison. Leurs boyaux empoisonnent les ehiens qui les mangent, et néanmoins leur chair est bonne à manger; mais ce n'est que le peuple qui en fait usage.

"Les deux espèces ne font qu'm petit qu'ils portent tout de suite sur le dos. Il y a grande apparence que les femelles mettent bas sur les arbres, mais on n'en est pas sur. Ils se nourrissent de feuilles de monbin et de bois canon. Les deux espèces sont également communes, mais un peu rares aux environs de Cayenne. lls se pendent quelquefois par leurs griffes à des branches d'arbres qui se trouvent sur ies rivières, et alors il est aisé de couper la brarche et de les faire tomber dans l'eau; mais ils lie làchent point prise et $y$ restent forment attachés aver leurs pattes de devaut. 
"Pour monter sur un arbre, cet animal étend nonchalamment une de ses pattes de devant qu'il pose ie plus haut qu'il peut sur le pied de l'arbre; il s'aceroche ainsi avec sa longue griffe, lève ensuite son corps fort lourdement, et petit à petit, pose l'autre patte, et continue de grimper ainsi. Tous ees mouvements sont exécutés avec une lenteur et une nonchalance inexprimables. Si on en élève dans les maisons, ils grimpent toujours sur quelques poteaux ou mème sur les portes, et jls n'aiment pas à se tenir à terre. Si on leur présente un bâton lor'squ'ils sont i terre, ils s'en saisissent tout de suite, et montent jusqu'à l'extrémité, où ils se tiennent fortement accrochés avec les pattes de devant, et serrent avec tont le corps l'endroit ou ils se sont ainsi perehés. Ils ont un petit eri fort plaintif et langoureux qui ne se fait pas entendre de loin."

On voit que le paressenx-mouton de $\mathbf{M}$. de ra Borde est celui que nous avons appelé unau, et que son paressem-honteux est l'ä̈, dont nous avons donné, dans ce volume, les descriptions.

M. Vosmaër, habile naturaliste ct directeur des Cabinets de S. A. S. monseigneur le prince d'Orange, m'a reproché deux choses que j'ai dites au sujet de ces animaux : la première, sur la manière dont ils se laissent quelquefois tomber d'un arbre. Voici les expressions de M. Yosmaër.

"On doit absolument rejeter le rapport de M. de Buffon, qui prétend que ces animaux (l'unau et l'aï), trop lents pour descendre de l'arbre, sont obligés dese laisser tomber comme un bloc lorsqu'ils veulent ètre à terre. ")

Cepemdant je n'ai a vancé ce fitit que sur le rapport de témoins oculaires, yui mont assuré avoir vu tomber ect animal quelquefois à leurs pieds : et l'on voit que le témoignage de $\mathbf{I}$. de La Borde, médecin du roi à Cayenne, s’aceorde avec ceux qui mont raconté le fait, et que par conséquent, l'on ne doit pas (comme le dit II. Vosmaër) absolument rejeler mon rapport a cel egard.

Le second reproche est micux fondé. J'ivoue très-volonticr's que j'ai fait une méprise, lorsque j'ai dit que l'unau et l'aỉ n'avaicht pass de dents, et je ne sais point du tout maurais grré à M. Vosmaër d'aroir remarqué eette erreur, , pui n'est venue que d'une inattention. J'ane antant une personne qui me releve d'une erreur, qu'une autre qui m'apprend une vérité, parce qu'en effet une erreur corrigée est une vérité.

\section{LE KOURI, \\ OU LE PETIT UXIU.}

Ordre des éden!és, famille des tardigrades, genre bra. dyge. (Cuvier,)

Voici un animal dont l'espèce est voisine de celle de l'unau : il est à la verité de moitié plus petit; mais il lui ressemble beancoup par la forme du corps. Cet animal a eté trouvé dans une habitation de la Guiane frameaise; il était dans la basse-cour au milicu des poules, et il mangeait avec elles; c'est, dit-on, lescul individu de cette espèce que l'on ait vu a Cayenne, d'ou il nous a ćté envoyé pour le Cabinet du Roi, sousle nom de funri; mais nous n’avons eu aucune information sur' ses habiludes naturelles, et nous sommes obligés de nous restreindre a une simple description.

Ce petit unau ressemble au grand par un caractère essentiel : il n’a, comme lui, que deux doigts aux pieds de devant, au lieu que l'aï en a trois, et par conséfuent il est d'une espece différente de celle de l'aï; il n'a que douze ponces de longueur, depuis l'extrémité du nе\% jusquà l'origine de la queue; tandis que l'unau. dont nous avons donné l'histoire et la descrip. tion clans ce volume, avait dix-sept pouces six limnes : eependant ee petit unau paraissait itre adulte. Il a, comme le grand, deux doints aux pieds de devant et trois it ceux de derriere : mais il en differe non-seulement parl la taille, mais encore par son poil qui est d'un brun inusc nuancé de grisâtre et de fauve; et ee poil est bien plus court et plus terne en conlenr que dans le grand unau; sous le ventre il est d'une couleur de muse elair, nuancé de eendre, et cette couleur sćclaircit encore dasantage sous le con jusqu'aux épaules, ou il forme eomme une bande faible de fauve paile. Les plus grand. ongles de ce petit unau n'ont que neuf lignes, tandis yue ceux du grand ont un ponce sept lignes et demic.

Yous avons eu le grand unau vivant; mass comme nous nitrons pu farire la description du petit que d'apres une pealu bourrée, nous ne sommes pas en état de prononcer sur toutes ies diflerences yui peurent se tronse entre ces deux animaux : nous presumons néanmoins 
qu'ils ne forment ciu'une seule et mème espèce, dans laquelle il se trouve deux races, l'une plus grande, et l'autre plus petite.

J'ai dit, d'après M. de La Borde, que le paresseux qu'il nomme mouton se jette sur les hommes depuis le haut des arbres; cela a été mal exprimé par M. de la Borde. Il est certain qu'il u'attaque pas les hommes; mais, comme tous les paresseux en général ne peuvent descendre des arbres, ils sont forcés de se laisser tomber, et tombent quelquefois sur les hommes. M. de La Borde, dans ses nouveaux Mémoires, indique quatre espèces de paresseux, savoir: le paresseux-cabri, le paresseux-mouton, le paresseux-dos-brûlé, et le nouveau paresseux que nous venons d'appeler kouri. Comme il ne donne point la description exacte de ces quatre espèces, que nous ne pouvons les comparer avec celles que nous connaissons, nous présumons seulement que son paresseux-cabri et son paresseux-mouton sont notre aï et notre unau. Il nous a envoyé une peau qui nous paraît être celle de son paresseux-dos-brùlé, mais qui n'est pas assez bien conservée pour que nous puissions juger si elle vient d'm animal dont l'espèce soit différente de celle de l'aï, à laquelle cette peau nous paralt ressembler, plus qu'à celle de l'unau.

\section{DESCRIPTIOY DE L'UNAU.}

(eXTRATT DE DAUBENTON.

Liunau qui a servi de sujet pour cette description était à pen près de la grosseur d'un blairean, mais il était moins elerẻ sur ses jambes; elles semblent n’ètre faites ni pour soutenir cet animal debout, ni pour le porter l'un lieu à un autre, mais seulement pour l'acerocher aux points d'appui yu' il peut atteindre. Il a la tìte ronde, le museau saillant, le nez gros et arrondi, les narines ovales, les yeux ronds, les paupières gonflées on forme de bourrelet, le front et le sommet de la tète clerés, les oreilles très-courtes, arrondies, fort cipaisses, presque mues, très-reculées en arrière et entièrement cachées sous le poil : le cou paraît aussi gros que la tète, parce qu'il est couvert par un poil long, dirigé en arrière comme celui du corps. Le poil de la eroupe est dirigé en sens contraire, et forme une sorte de crinière transversale an-dessus de la croupe en reneontrant le poil du dos : les pieds sont à froportion plus longs que les jambes depuis le poignet et le talon jusqu'au bout des doigts; il n'y a que denx doigts aux pieds de devant, et trois aux pieds de derrière; les ongrles sont fort lungs et courhes.

Lorsque l'unau est en repos sur ses jambes, le poignet et le talon portent sur la terre; l'avant-bras est dirirgé obliquement en avant, le coule s'élève pea au-dessus de terre : la jambe proprement dite est inclinee et forme un angle droit avec la cuisse, de façon que la partie inférieure de la croupe reste toujours plus bas que le genou. La démarclie de cet animal est très-contrainte; pour faire 111 pas, au lieı de porter en avant la jambe de devant, il fait senlement glisser le pied sans étendre les doigts; les ongles restent fléchis en arrière, et le pied ne porte que sur leur convexité et sur le poignet sans que la plante touche la terre : ce mouvement ne se fait pas directement en avant, mais un peu obliquement en dehors. La jambe et le pied de derrière sont encore plus écartẻs en dehors, de sorte que le pied décrit $m$ are de cercle lorsque l'animal veut le porter en avant, et durant ce mouvement les ongles restent couchés en arrière comme ceux des pieds de devant; le pied ne portant que sur lenr convexité et sur le talon sans que la plante ap. puie sur la terre. Une telle démarche ne peut être pronpte ni même facile, anssi lanimal semble ne marcher que malgré lui, et lorsqu il y est cont aint pour satisfaire ses besoins; cependant il est moins lent quion ne l'imaginerait d'après une conformation si peu propre au mouvement progressif : il m'a semblé quilil allait plus vite que les tortues, et que son allure avait du rapport avec celle des cliauvessouris lorequ'elles marchent sur leur quatre pieds sans s'aider de leurs ailes.

L'unau a beaucoup plus de facilité à gravir et à se suspendre en l'air qu'à marcher sur la terre; alors il étend ses ongles et il s'en sert comme de crochets en les appuyant sur tout ce qui peut les arrêter. Ses ongles étant longs, crochus, pointus et très-forts, ils le sontiennent si aisement unuil semble se plaire dans l'attitude où son corps est pendant et ses pieds accroehes en haut; il y reste volontiers pendant longtemps, et même pour se reposer il se suspend à demi en se dressant sur ses fesses et en aceruchant ses pieds de devant et ceux de derrière à une petite laauteur pour soutenir son corps dans une situation verticale, c'est dans cette attitude yu il passe la nuit; mais s'il n'avait pas un point d'appui pour accrocher ses pieds de devant, il ne pourrait tenir son corps droit; lorsquion le force à s'asseoir, ses jambes de derrière se dirigeut en clehors de chaque còté au point d'être toutes les deux sur une mème ligne. Quelque facilité çüil ait à gravir par la conformation de ses ongles, il est lourd et très-maladroit pour tout ce qui dépend des mouvements de ses jambes et de son corps. J'ai vu celui qui a servi de sujet pour cette description 
se suspentre par les quatre pieds au rebord qui ètait antour d'une table à jouer, ainsi suspenclu il touruait antour de cette table, mais il ne pourait pas monter lessus.

L'unau saisit avec le pied de devant comme avec une main, et s'en sert pour porter ses aliments à sa bonche; mais ce n'est ıu'une main très-imparfaite, elle n'a que deux doiırıs, conme je l'ai łléjà fait observer, et deux grands ongtes; ces doigts et ces ongles ne font l'office que d'un seul doirt, car ils ne s'écartent pas l'un de l'autre, ils s'ćtendent el se flechissent ensemble; l'animal, en approchant de son poignet l'extrémité de ses ongrles, serre les choses qu'il veut saisir et les enlève. Celıi que j’ai vu mangeait pen; on le nomrissait avee du pain desseché an four, et on lui donnait pour boisson ulu lait mèlé avec de l'eau : le plus souvent il se susprendait par trois de ses pierls, et il mangeait arec lo quatrième la tête en bas. Lorsqu'on l'oligiqeait à marcher trop long-temps, il jelait des cris faib): s et plaintifs. Il ainait la claalemr; moins il faisait clian I, plus il dormait; quelpuefois son sommeil durait pendant dix-huit leures : il avait pen dodoral, et il pranassait n'avait pas home ne. Cel animal est vivant lans la ménagerie de $\mathbf{1 1}$, le marquis de bontminail.

\section{LE PECARI OU LE TAJACU.}

\section{(LE PECARI A COLLIER.)}

Ordre des fachydermes ordinaires, genre cochon. (Cuvier.

L'espece du pecari est une des plus nombrenses et rles plus remarquabies parmi les aninaux du Nouveau-Monde. Le peeari ressemble au premicr coup d'xil à uotre sanglicr, ou plutòt au cochou de Siam (jui, conme nous l'avous dit, nest, ainsi que notre cochon domestique, qu'une variété du sanglier on cochon sauvage; aussi le pecari a-t-il été appelé sanglier ou cos:hon d'Amérique : cependant il est dune espèce particulière, et qui ne peut se mèler avec celle de nos sangliers ou cochons, comme uous ious eu sommes assurés par des essais réitérés, ayant nourri et gardé pendant plus de fleux ans un pecari avec des truies, sans yu’il ait rien produit. Il differe encore du cochon parr plusieurs eajactères essenticls, tant à l'extérieur qu'à l'intéljeur. 11 est de moindre corpulence et plus bas sur ses jambes; il a l'estomac et les intestins différemment conformés, il n'a point de qucue; ses soies sont beaucoup plus rudes que eelles du sanglier; et enfin, il a sur le dos, prés de la eroupe, une fente de deux ou trois lignes de largeur, qui pénètre à plus d'un pouce de profondeur, par laquelle suinte une humcur ichoreuse fort abondante et d'une odeur très-désagréable : c'est de tou!s les animaux le seul qui ait une ouverture dans cette régjon du corps; les civettes, le blai reau, la genette, ont le réservoir de leur parfum au-dessous des parties de la généralion; londatra ou rat musqué de Canada, le muse ou chevreuil de musc l'ont sous le ventre. La liqueur qui sort de eette onverture que le pecari a sur le dos est fommie par de grosses glandes que MI. Daubenton a déerites avee soin, aussi bien que toutes les autres singularités de conformation (qui se trourent dans cet animal. (in en voit aussi une bonne deseription fate par Tyson dans les Iransactions philosophiyues, $n^{\circ} 153$. Je ne m'arreterai pas à exposer en détailles observations de ees deux habiles anatomistes, et je remarquerai seulement que le docteur Tysou s'était trompé en assurant que cet animal avait trois estomaes, ou, comme le dit Ray, un gésicr et deux estomaes. M. Daubentou démontre clairement qu'il n'a qu'un seul cstomac, mais partagé par deux étranglements qui en font paraitre trois; qu'il n'y a quiune serle de ces trois poehes qui ait une issue de sortic ou pylore, et que par conséquent on ue doit regarder les deux autres poches que comme des appendiees, ou plutòt des portions du mème estomac, et non pas comme des estomaes difiérents.

l.e pecari pourrait devenil animal domestique comme le cochon : il est à peu près dlu mìne. naturel, il se nourrit des mèmes aliments; sá chair, quoique plus sèche et moins chargée de lard que eelle du cochon, n'est pas mannaise à manger; elle deviendrait meilleure par la castration. Lorspuon veut manger de ectte viunde, il fiut aroir grand soin denlever au malle nonseulement les parties de la génération, comme l'on fait au sanglicr, mais encore toutes les glandes qui aboutissent ì l'onverture du loj dans le màle et daus la femelle : il faut meme faire ees operations au moment qu'on met it mort l'animal; car si l'on attend sculement une demi-heure, sa chair prend une odeur si forte qu'elle u'est plus mangeable.

Les pecaris sont trés-mombrenx dans tons lıs elimats chauds de l'Amérique méridionale; jls vont ordinairement par troupes, et sont quelquefois rleux ou trois cents ensemble: ils ont le 
memeinstinct queles cochons pour se défendre, et mème pour attaquer cenx surtout qui veulent ravirleurs petits; ils se secourent mutuellement, ils enveloppent leurs ennemis, et blessent souvent les chiens et les chasseurs. Dans leur pays natal ils occupent plutôt les montagnes que les lieux bas; ils ne cherchent pas les marais et la fange comme nos sangliers ; ils se tiennent dans les bois où ils vivent de fruits sauvages, de racines, de graines : ils mangent aussi les serpents, les crapauds, les lézards qu'ils écor'chent auparavant avec leurs pieds. Ils produisent en grand nombre, et peut-être plus d'une fois par an; les petits suivent bientòt leur mère et ne s’en séparent que quand ils sont adultes. Onles apprivoise, ou plutòt on les prive aisément en les prenant jeunes : ils perdent leur férocité naturelle, mais sans se dépouiller de leur grossièreté; car ils ne connaissent personne; ne s'attachent point à ceux qui les soignent : seulement ils ne font point de mal, et l'on peut, sans inconvénient, les laisser aller et venir en liberté; ils ne s'éloignent pas beaucoup, reviennent d'eux-mêmes au gite, et n'ont de querelle qu'auprès de l'auge ou de la gamelle, lorsqu'on la leur présente en commun. Ils ont un grognement de colère plus fort et plus dur que celui du cochon, mais on les entend très-rarement crier ; ils soufflent aussi comme le sanglier lorsqu'on les surprend et qu'on les épourante brusquement; leur haleine est très-forte; leur poil se hérisse lorsqu'ils sont irrités; il est si rude qu'il ressemble plutôt aux piquants du hérisson qu'aux soies du sanglier.

L'espèce du pecari s'est conservée sans altération et ne s'est point mêlée avec celle du cochon marron; e'est ainsi qu'on appelle le cochon d'Europe transporté et devenu sauvage en Amérique : ces animaux se rencontrent dans les bois et vont même de compagnie sans qu'il en résulte rien; il en est de même du cochon de Guinée qui s'est aussi multiplié en Amérique, après y avoir été transporté d'Afrique. Le cochon d'Europe, le cochon de Guinée et le pecari sont trois espèces qui paraissent être fart voisines, et qui cependant sont distinctes et séparées les unes des autres, puisqu'elles subsistent toutes trois dins le mème climat sans mélange et sans altération. Notre sanglier est le plus fort, le plus robuste et le plus redoutable des trois, le pecari quoique assez féroce est plus faible, plus pesant et plus mal armé ; ses gran- des dents tranchantes qu'on appelle defenses sont beaucoup plus courtes que dans le sanglier; il craint le froid et ne pourrait subsister sans abri dans notre climat tempéré, comme notre sanglier ne peut lui-même subsister dins les climats trop froids : ils n'ont pu ni l'un ni l'autre passer d'un continent à l'autre par les terres du Nord; ainsi l'on ne doit pas regarder le pecari comme un cochon d'Europe dégénéré ou déna. turé sous le climat d'Amérique, mais comme un animal propre et particulier aux terres méridionales de ce nouveau continent.

Ray et plusieurs autres auteurs ont prétendu que la liqueurdu pecari, qui suinte par' l'ouverture dudos, est une espèce de muse, un parfum agréable, mème au sortir du cor'ps de l'animal; que cette odeur agréable se fait mème sentir d'assez loin, et parfume les endroits où il passe et les lieux qu'il habite. J'aroueque nousarons éprouvé mille fois tout le contraire : l'odeur de cette liqueur, au sortir du corps de l'animal, est si désagréable que nous ne pouvions la sentir, ni la faire recueillir sans un extrème dégoùt; il semble seulement qu'elle des ienne mouns fétide en se desséchant à l'air'; mais jamais elle ne prend l'odeur suave du musc ni le parfum de la civette, et les naturalistes auraient parlé plus juste s'ils l'eussent comparée à celle du castoréum.

\section{ADDITION A L'ARTICLE DU PEC.IRI.}

M. de La Borde dit, dans ses Observations, qu'ily a deux espèces de pecari à Cay cone, bien distinctes et qui nese mẻlent ni ne s'accouplent ensemble. La plus grosse espèce, dit-il, a le poil de la mâchoire blane; et des deux còtés de la mâchoire il y a une tache ronde de poils blancs, de la grandeur d'un petit écu : Ie reste du corps est noir; l'animal pèse environ cent livres. La plus petite espèce a le poil roux, ct ne pèse ordinairement que soixante livres.

C'est la grandle espèce dont nous a vons donné la description et la figure; et à l'égard de la petite espece, nous ne croyons pas que cette différence dans la couleur du poil et la grandeur du corps, dont parle M. de La Borde, puisse ètre autre chosequ une variété produite par l'àge ou par quelque autre circonstance accidentelle.

I. de La Borde dit néanmoins que ceux de la plus grande espèce ne courent pas comme 
ceux de la petite après les eliens et les hommes; il ajoute que les deux especes habitent les grands bois, qu'ils ront par troupes de deux ou trois cents. Dans le temps des pluies, ils habitent les montagnes; et lorsque le temps des pluies est passé, on les trouve coustamment daus les endroits bas et marécageux. Ms se nourrissent de fruits, de graines, deracines, et fouillent aussi les endroits boueux pour en tirer des rers et des insectes. On les chasse sins chiens et en les suivant à la piste. On peut les tirer aisément et en tuer plusieurs, ear ces auimaux au lieu de fuir se rassemblent et domment (que]quefois le temps de recharger et de tirer plusieurs coups de suite. Cependant iis poursuivent les ehiens et quelquefois les hommes. II raconte qu'étant un jour à la chasse de ces animaux avee plusieurs autres personnes, et un scul eliien qui s'était, à leur aspect, réfugié entre les jambes de son maitre, sur un rocher ou tous les chasseurs étajent montés pour se mettre en sưreté, ils n'en furent pas moins investis par la troupe de ces eochons, et qu'ils ne cessèrent ìe faire feu sans pouvoir les foreer à se retirer, qu'apres en avoir tué un grand nombre. Cependant, dit-il, ces animanx s'enfuient lorsqu'ils ont été chassés plusiemrs fois. Les petits que l'on prend à la chasse s'apprivoisent aisément, mais ils ne veulent pas suivre les autres coehons domestiques, et ne se mêlent jamais avec eux. Dans leur état de liberté, ils se tiennent sour ent dans les marécages et traversent quelquefois les grandes rivières ; ils font beaucoup de ravages dans les plantations. Leur ehair, dit-il, est de meilleur goût, mais moins tendre que celle dis cochons domestiques; elle ressemble à eclle du lière et n'a ni lard ni graisse. Ils ne font que deux petits, mais ils prod.uisent dams toutes les saisons. II faut avoir soin, lorsquon les tue, d'oter la glande qu'ils ont sur le dos : eette glande répand une odeur fétide qui donmerait un mauvais goût à la viaude.

M. de La Borde jasle d'une autre espèce de cochon (pui se nomme patira, et qui se trouve également dans le eontinent de la Guiane. Je vais rapporter ec qu'il en lit, quoique javoue qu'il soit dilfieile d'en tirel atucume conséquenve. Je le cite dans la vue que MI de La Borde lui-meme ou quelque autre observateur poura nous dommer des renseignements plus préeis et des clescriptions un peu plus détaillées.

"Le patira est de la grosseur du peeari de la
" petite espèce; il en diffère par une ligne de " poils blanes qu'il a tout le long de l'épine du " dos, depuis le eou jusqu’à la queue.

"Il vit dans les grands bois, dont il ne sort " point. Ces animaux ne vont jamais en nom"breuses troupes, mais seulement par familles. "Ils sont cependant très-communs, ne quittent " pas leur pays natal. On les chasse avec des " ehiens, ou méme sans chiens, si l"on ne veut " pas s'en servir. Quand les chiens les poursui"vent, ils tiennent ferme, et se défendent cou" rageusement. Ils se renferment dans des trous "d'arlores ou dans des ereux en terre que los " tatous kabassous ont ereusés, mais ıls y ell" trent à reculons et autant cqu'ils peurent y te" nir"; et si peu qu'on les agace, ils sortent tout "de suite. Et pour les prendre à leur sortie, on " commenee par faire une enceinte avee du " branchage; ensuite un des chasseurs se porte " sur le trou, ume fourche à la main, pour les "saisir par le cou à mesure qu'un antre chas" seur les fait sortir, et les tue avee un sabre. "S'il n'y en a qu'un dans un trou, et que le " chasseur n'ait pas le temps de le prendre, il " en bouche la sortic et est sur de retrouver l. " lendemain son gibier. Sa chair est hien supé" rieure à celle des autres cochons. On les ap" privoise aisément lorsqu"on les prend petits; " mais ils ne peurent souffrir les chiens qu iils "attaquent à tout moment. Ils ne font jamais " plus de deux petits à la fois, et toutes les sai" sons de lamnéc sont propres ì leur généra" tion. Ils se tiennent foujours dans des maréca"ges, à moins qu'ils ne soient tout à fait "inondés.

" Le poil du patira n'est pas si dur que eclui " du sanglier ou même du cochon domestique: " ce poil est comme celui du pecari, dour et "pliant. Les patiras suivent leur maitre lors" (qu’ils sont apprivoisés; ils se laissent manie" " par eenx qu'ils comnaissent, et menacent de "la tête et des dents ceur qu'ils ne commaissent "pas."

AUTRE ADDITION I L'ARTICLE DU PECAII. (I.F PICART TAJACI.)

Je suis maintenant assuré par plusiours tí moignages gu'il ruste on elfict demx especes distinctes diuns le greme des pecaris ou tajacus. f.a plus ginde espece est celle dont nous a vous 
donné la deseription; mais nous n'avons pas encore pu nous procurer un seul individu de la seconde espèce. On nomme eet animal putira, etil est eu général beaucoup plus petit que le peeari. Les patiras ont dans leur jeunesse une bande noire tout le long de l'épine du dos; mais ils deviennent bruns et presque noirs sur tont le colps, à mesure qu'ils vieillissent. Les patiras ront, ainsi que les peearis, par grandes troupes, et on les chasse de même; la seule différence, indépendamment de la grandeur, qui soit bien remarquable entre ces deux espèces si voisines l'une de l'autre, e'est que le patira a les jambes sensiblement plus menues que le peeari : mais comme ils ne se mêlent point ensemble, quoique babitant les mèmes terres, ou doit les regaider comme deux espèces ou du moins comme deux races très-distinctes; et ces deux especes ou laces sont les seules qui soient bien constatées. Il nous est arrivé pour le Cabinet du Roi une peau bourrée d'un jeune pecari âgé de trois semaines, qui est beancoup plus petit qu'un cochou de lait de mème âge, et dont les couleur's sont bien plus faibles que celles du pecari adulte, auquel il ressemble par tous les autres cal'actères.

\section{LE BABIROUSSA.}

\section{(LE COCHON BABIROUSSA.)}

Ordre des pachyde:mes ordinaires, genre cochon. (Curier.)

Quoique nous n'ayons au Cabinet du roi que la tite de ect animal, jl est trop remarquable pour que nous puissions le passer sous silence. Yous les naturalistes l'ont regardé eomme une espèce de cochon, et cependant jl n'en a ni la tète, ni la taille, ni les soies, ni la queue: il a les jambes plus hautes et le museau moins long ; il est couvert d'un poil court et doux comme de la laine, et sa queue est terminée par une touffe de catte laine; il a aussi le corps moins lourd et moins épais que le cochon; son poil est gris, mèlé de roux et d'un peu de noir; ses oreilles sont courtes et pointues: mais le earactere le plus remarquable, et qui distingue le babiroussa de tous les autres animaux, ce sont quatre énormes défenses ou dents canines dont les deux moins longues sortent, comme celles des sangliers, de la meichoire inféricure; et les denx autres qui sont beaucoup plus grandes, partent de la mâchoire supérieure en perçant les joues, ou plutòt les lèvres du dessus, et s'étendent en courbe jusqu'au-dessous des yeux; et ces défenses sont d'un très-bel iroire, plus net, plus fin, mais moins dur que celui de l'éléphant.

La position et la direction de ces deux défenses supérieures qui percent le museau du babiroussa, et qui d'abord se dirigent droiten haut, et ensuite se recourbent en cercle, ont fait penser à quelques physiciens, même habiles, tels que Grew, que ees défenses ne devilient point ètre regardées comme des dents, mais comme des cornes : ils fondaient leur sentiment sur cc que tous les alvéoles des dents de la màchoire supérieure ont dans tous les animaux l'ourcl'ture tournée en bas: que daus le babiroussa comme dans les autres, la mâchoire supérieure a tous ses alvéoles tournés en bas tant pour les mâchelières que pour les incisires, tandis que les seuls alréoles de ees deux grandes défenses sont au contraire tournés en haut; et ils coneluaient de là que le earactère essentiel de toutes les dents de la màchoire supérieure étant de se diriger en bas, on ne pouvait pas mettre ces défenses qui se dirigent en haut au nombre des dents, et qu'il fallait les regarder comme des cornes: mais ces physieiens se sont trompés. La position ou la direction we sont que des circonstances de la chose et n'en sont pas l'essence : ces défenses, quoique situées d'une ma nière opposée à celle des autres dents, n’en sont pas moins des dents; ce n'est qu'une singularité dans la direction qui ne peut ehanger la nature de la chose, ni d'une vraie dent eanine en faire une fausse colne d'ivoile.

Ces éuormes et quadruples défenses donnent à ces animaux un air formidable; cependant ils sont peut-être moins dangereux que nos sangliers; ils vont de même en troupe, et ont une odeur forte qui les décèle, et fait que les chiens les ehassent avee sueès; ils grognent terriblement, se défendent et blessent des dćfenses de dessous; ear celles du dessus leur nuisent plutôt qu'elles ne servent. Quoiq̣ue grossiers et féroces ecmme les sangliers, ils s'apprivoisent aisément, et leur chair, qui est très-bonne is manger, se corrompt en assez peu de temps Comme ils ont aussi le poil fin et la peau mince, ils ne résistent pas à la dent des chiens, rui les chassent de préférence aux sangliers et en vicnnent facilement à bout. Ils s'acerochent à cies 
branches avec les défenses d'en haut, pour reposer leur tète ou pour dormir debout. Cette habitude leur est commune avec l'éléphant, qui pour dormir sans se coucher, soutient sa tête en mettant le bout de ses défenses dans des trous qu'il creuse à cet effet dans le mur de sa $\log e$.

Le babiroussa diffère encore du sanglier par ses appetits naturels : il se nourrit d'herbes et de feuilles d'arbres, et ne cherche point à entrer dans les jardins pour manger des légumes, au lieu cue, dans le mème pays, le sangliel vit de fruits sauvages, de racines, et dévaste souvent les jardins. D'ailleurs ces animaux, qui vont également en troupe, ne se mêlent jamais; les sanglier's vout d'un còté, et les babiroussas de l'autre. Ceux-ci marchent plus légèrement; ils ont l'odorat très-fim, et se dressent souvent contre desarbres, pour éventer de loin les chicns et les chasseurs : lorsqu'ils sont poursuivis longtemps et sans relàche, ils courent se jeter à la mer, où, nageant avec autant de facilité que des camards, ct se plongeant de mème, ils échappent très-souvent aux chasseurs; car ils nagent très-longtemps, et vont quelquefois à d'assez grandes distances et d'une île à une autre.

Au reste, le babiroussa se trouve non-seulement à l'ile de Bouro ou Boero, près d'Amboine, mais encore dans plusieurs autres endroits de l'Asie méridionale et de l'Afrique, comme aux Célèbes, à Estrila, au Sénégal, à Madagascar : car il parait que les sangliers de cette île, dont parle F laccourt, et dont il dit que les mâles principalement ont deux cornes à còté du nez, sont des babiroussas. Nous n'avons pas été à portée de nous assurer (que la femelle manque en effet de ees deux délenses si remarquables dans lo mâle; la plupart des auteurs qui ont parlé de ces animaux semblent s'aceorder sur ce fuit que nous ne pouvons ni confirmel ni détruire.

\section{ADDITION A L'ARTICLE DU Habiroussa.}

Truus n'avons donné que les faits historiques relatifs au babiroussil, et la deseription de sa tête dépouillée des chairs; nous donnons ici la deseriptlon de ect auinal d'après deux esquisses, dont l'une nous a été domnée palr M. Sommerat, correspondant du Cabinet du roi, où l'animal était représenté delswut, 't l'autre m'a été euvoyée d'Augleterre par M. P'emnant, où l'a- nimal étnit couché sur le ventre. Cette dernière esquisse envoyéc par M. Pennant était surmontée de l'inscription suivante: Un babiroussa de l'île de Banda, dessiné d'après nature; sa couleur est noiratre; il croît en grandeur comme le plis grand cochon, et sa chair est très-bonne ì manger.

\section{LE TAPIR oO LANTA.}

Ordre despachydermes ordinaires, genre tapir. (Curicr.)

C'estici l'animal le plus grand de l'A mérifye, de ce nouveau monde, où, comme nous l'arons dit, la nature vivante scmble s'ètre rapetissée, ou plutôt navoir pas eu le temps de parvenir à ses plus hautes dimensions. Au lieu des masses colossales que produit la terre antique de l'Asie, au lieu de l'élephant, du rhinocéros, de l'hippopotame, de la girafe et du chameau, nous ne trouvons dins ces terres nourelles que des sujets modeiés en petit: des tapirs, des lamas, des vigognes, des cabiais, tous vingt fois plus petits que cenx qu'on doit leur comparer dans l'ancien continent : et non-seulement la matière estici prodigieusement épar'née, mais les formes mêmes sont imparfaites et paraissent avoir été négligées ou manquées. Les animaux de l'Amérique méridionale, qui seuls appartiennent en propre à ce nouveau continent, sont presque tous sans défenses, sans c'ornes et sans queue; leur figure est bizarre, leur corps et leurs mem. bres mal proportionnés, mal unis ensemble; ct quelques-uns, tels que les fourmiliers, les paresseux, ete., sont d'urenature si misérable, yu'ils ont à peine les facultés de se mouvoir et de manger. Ils trainent avec douleur une vie languissante dans la solitude du désert, et ne pouraient subsister dans une terre habitéc, où l'honme et les animaux puissants les auraicut bicutot détruits.

Le tapir est de la grandeur d'une petite vache ou d'un zél)u, mais sims cornes et sans queuc; les jambes courtes, le corps arqué, conmuc celui du cochon, portant une livrée dans sa jeunesse, comme le cerf, et ensuite un pelage uniforme d'un brun foncé; la tète grosse et longue arec une espèce de trompe, comme le rhinocéros; dix dents incisives et dix molaires à chaque mâchoire, caractère (pui le sćpare entièrement du genre des bouts et des autres inimaux ruminants, cte. Au leste, comme nous n'avons do 
ret animal que quelques dépouilles, et un dessin que M. de la Condamine a eu la bonté de nous donner, nous ne pouvons mieux faire que de citer ici les descriptions qu'en ont faites, d'après nature, Marcgrave et Barrère, et présenter en mème temps ce qu'en ont dit les voyageurs et les historiens.

11 parait que le tapir est un animal triste et ténébreux, qui ne sort que de nuit, qui ne se plaît que dans les eaux, où il habite plus souvent que sur la terre; il vit dans les marais, et ne s'éloigne guère du bord às fleuves ou des lacs : dès qui il est menacé, poursuivi ou blessé, il se jette à l'eau, s'y plonge et y demeure assez de temps pour faire un grand trajet a vant de reparaltre. Ceshabitudes, qu'il a communesavec l'hippopotame, ont îait croire à quelques naturalistes qu'il était du même genre, mais il en differe autant par la nature, qu'il en est éloigné par le climat; il ne faut pour en être assuré que comparer les descriptions que nous venons de citer avec celle que nous donnons de l'hippopotame. Quoique habitant des eaux , le tapir ne se nourrit pas de poissons, et quoiqu'il ait la gueule armée de vingt dents incisives et tranchantes ${ }^{1}$, il n'est pas carnassier : il vit de plantes et de racines, et ne se sert point de ses armes contre les autres animaux; il est d'un naturel doux, timide, et fuit tout combat, tout danger. A vec les jambes courtes et le corps massif, il ne laisse pas de courir assez vite, et il nage encore mieux qu'il ne court. Il marche ordinairement de compagnie et quelquefois en grande troupe. Son cuir ${ }^{2}$ est d'un tissu très-ferme et si serré, que souvent il résiste à la balle. Sa chair est fade et grossière ${ }^{3}$, cependant les Indiens la mangent. On le trouve communément au Brésil, au Paraguay, à la Guiane, aux Amazones",

\footnotetext{
'Quoịue le tapirousson ait les dents tranchantes el aiguës, cependaut il n’a d'autre résistance que la fuite; il n'est mullement dangerenx; les Sauvages le tuent à coups de llèehes ou le prenuent dans des chansse-trapes. Vuyage de de Lery, p. 132.

${ }^{2}$ Les Sanvages eslinent merveileusement le tapiroussou a cause de sa pean; car, funand ils l'écorchent, ils coupeut en rond tout le cuir du dos, el après qu'il est bien sec, ils en font ules rondelles aussi grandes que le fond d'uu moyen tonnean... El celte piean ainsi séchée est si dure, que je ne crois pas yu"il $\mathrm{y}$ ait fleche qui juisse la percer. lilenit.

- La chair du inaniponri est grossière et d'un goût désagréable Leltres édifiantes, XXIVe recueil, page 377.

' On trouve dans les environs de la rivière dis Ainzones un animal appelé danta, de la grandeur diune mule, et qui lıi ressemble fort en couleur el cu la forme du corps. Riclalion de la rivière des Amazones, par Christophe dicma, tume II. pase 177,-L'élan, qui se rencontre dans quelıues cantons hoisés de la Cordelière de Quito, n'est pas rare dans
}

et dans toute l'étendue de l'Amérique mérìdionale, depuis l'extrémité du Chili jusquu'à la Nouvelle-Espagne'.

ADDITION A L'ARTICLE DU TAPIR OU MAIPOURI.

Cetanimal, qu'on peut regarder comme l'èls. phant du Nouveau-Monde, ne le représente néanmoins que très-imparfaitement parla forme et en approche encore moins par la grandeur: il sera facile d'en faire au juste la comparaison; car j'ai cru devoir donner ici une seconde description du tapir qui est plus exacte que celle qui avait été faite sur une esquisse dessinée par feu $\mathrm{Y}$. de la Condamine; celle-ci a été prise sous nos yeux et sur l'animal vivant, auquel notre climat ne convient guère; car après son arrivée il n'a vécu que très-peu de temps à Paris entre les mains du sieur Ruggieri, qui cependant en avait beauconp de soin.

On voit que l'espèce de trompe qu'il porte au bout du nez n'est qu'un vestige ou rudiment de celle de l'èléphant; c'estle seul caracière de conformation par lecquel on puisse dire que le tapir ressemble à l'éléphant. M. de La Borde, médecin du roi à Cayenne, qui cultive avec succès différentes parties de l'Histoire naturelle, m'écrit que le tapir est en effet le plus gros de tous les quadrupèdes de l'Anzérique méridionale, et qu'il y en a qui pèsent jusqu'à cinq cents livres : or ce poids est dix fois moindre que celui d'un éléphant de taille ordinaire, et l'on n'aurait jamais pensé à comparer deux animaux aussi disproportionnés, si le tapir, indépendamment de cette espèce de trompe, n'avait pas quelques habitudes semblables à celles de l'éléphant. II va très-souvent à l'eau pour se baigner et non pour y prendre du poisson, dont il ne mange jamais , car il se nourrit d'berbes comme l'éléphant et de feuilles d'arbrisseaux : il ne produit aussi qu'un petit.

Ces animaux fuient de méme Ic roisinage des lieux habités, et demeurent aux envirens des marécages et des rivières, qu'ils traversent soutrent pendant le jour et mème pendant la nuit. La femelle se fait suive par son petit, et l'accoutume de bonne heure à entrer dans l'eau, où

les bois de l'A mazone, ni clans ceux de la Guiane. Je donne ici le nom délan a l animal que les Espagnols et les Portngais connaissent sous le nom de danta. Voyage de la rivière des Amazones, par M. de la Condamine, page 165.

'Lne nouvelle espèce cle Iapir, plus grande que celle d'Ainérique, a été découverte dans l'Inde par feu M vuyancel. 
il plonge et joue devant sa mère, qui semble hui donner des lecons pour cet exercice: le père n'a point de part à l'éducation; car l'on trouve les mâles toujours seuls, à l'exception du temps où les femelles sont en chaleur.

L'espèce en est assez nombreuse dans l'intérieur des terres de la Guiane, et il en vient de temps en temps dans les bois qui sont à quelque distance de Cayenne. Quand on les chasse, ils se réfugient dans l'eau où il est aisé de les tirer, mais quoiqu'ils soient d'un naturel tranquille et doux, ils deviennent dangereux lorsuu'on les blesse: on en a vu se jeter sur le canot d'où le coup était parti, pour tâcher de se venger en le renversant. Il faut aussi s'en garantir dans les forêts : ils y font des sentiers ou plutôt d'assez larges chemins battus par leurs fréquentes allées et venues; car ils ont l'habitude de passer et repasser toujour's par les mèmes lieux, et il est à craindre de se trouver sur ces chemins, dont ils ne se détournent jamais '; parce que leur allure est brusque, et que sans chereher à offenser, ils heurtent rudement tout ce qui se rencontre devant eux. Les terres voisines du haut des rivières de la Guiane sont habitées par un assez grand nombre de tapirs, et les bords des eaux sont coupés par les sentiers qu'ils y pratiquent; ces chemins sont si frayés que les lieux les plus déserts semblent, au premier coup d'œil, ètre peuplés et fréquentés par les hommes. Au reste, on dresse des chiens pour chasser ces animaux sur terre et pour les suivre dans l'ean : mais, comme ils ont la peau très-ferme et très-épaisse, il cst rare qu'on les tue du premier coup de fusil.

Les tapirs n'ontpas d'autre cri qu'une espèce de sifflet vif et aigu, que les chasseurs et les Sauvages imitent assez parfaitement pour les faire approcher et les tirer de près. On ne les voit guère s'écarter des cantons qu'ils ont adoptés. Ils courent lourdement et lentement; ils n'attaquent ni les hommes ni les animaux, à moins que les chiens ne les approchent de trop

\footnotetext{
- Un voyageur $m$ ’a riconté qqu'il avait failli être la victime de sou peu d'expérience à ce sujet; que ulans un voyage par terre il avait altachésou hamac a deux arbres pour y passer la nuit, el ine le hamac traversait un clienin batlu par les lapirs. Vers nenf à dix luenres du soir, il entendif un grand bruit dans la forèt, éélait un tapir qui venait de son cûté : il n'ent que le temps de se jeter liors de son liamac et de se serrer conlre un arbrc. L'animal ne s'arrèta point, il tit sauter le lıamac aux branches, et froissa cet homme contre l'arbre; ensuite, sans se détonrner deson s ntier balln, il passa au milien de quelıtues negres qui dormaient à terre auprès d'un grand feu, et il ne leur fit aucun mal.
}

près ; car dans ce cas ils se défendent avec les dents et les tuent.

La mère tapir parait avoir grand soin de son petit : non-seulement elle lui apprend à nager, jouer et plonger dans l'eau, mais encore lorsqu'elle est à terre, elle s'en fait constamment accompagner ou suivre, et si le petit reste en arrière, elle retourne de temps en temps sa trompe, dans laquelle est placé l'organe de l'odorat, pour sentir s'il suit ou s'il est trop éloigné, et clans ce cas elle l'appellc et l'attend pour' se remettre en marche.

On en élève quelques-uns à Cayenne en domesticité; ils vont partout sans faire de mal : ils mangent du pain, de la cassave, des fruits ; ils aiment qu'on les caresse et sont grossièrement familiers, car ils ont un air pesant et lourd, à peu près commele cochon. Quelquefois ils vont pendant le jour dans les bois et reviennent le soir à la maison ; néanmoins, il arrive souvent lorsqu'on leurlaisse cetteliberté qu'ils en abusent et ne reviennent plus. Leur chair se mange, mais n'est pas d'un bon goût; elle est pesante, semblable pour la couleur et par l'odeur à celle du cerf. Les seu!s morceaux assez bons sont les pieds et le dessus du cou.

M. Bajon, chirurgien du roì à Cayenne, a envoyé à l'Académie des seiences, en 1774 , un Mémoire au sujet de cet animal. Nous croyons devoir donner par extrait les bomes observations de MI. Bajon, et faire remarquer en mème temps deux méprises qui nous paraissent s'être glissées dans son écrit, qui d'ailleur's mérite des éloges.

"La figure de cet animal, dit M. Bajon, approche en général de celle du cochon ; il est cependant de la hauteur d'un petit mulet, ayant le corps extrèmementépais, porté sur des jambes très-courtes; il est couvert de poils plus gros, plus longs que ceux de l'ìne ou du cheval, mais plus fins et plus courtes que les soies du cochon, et beaucoup moins épais. Il a une crinière dont les crins, toujours droits, nesont qu'un peu plus longs que les poils du reste du corps; elle s'étend depuis le sommet de la tète jusqu'au commencement des épaules. La tète est grosse et un peu allongée, les yeux sont petits et très-noirs, les oreilles courtes, ayant pour la formequelques rapports a vec celles du cochon; il porte au bout de sa mâchoire supéricure une trompe d'envi. ron un pied de long, dont les mourements sont très-souples, et daus laquelle réside l'organe de 
l'odorat; il s'en sert comme l'éléphant, pour ramasser des fruits, qui font une partic de sa nourriture : les deux ouvertures des narines partent de l'extrémité de la trompe. Sa queue est trèspetite, n'ayant que deux pouces de long; elle est presque sans poils.

"Le poil du corps est d'un brun légèrement foncé; les jambes sont courtes et grosses; les pieds sont aussi fort larges et un peu ronds. Les pieds de devant ont quatre doigts, et ceux de derrière n'en ont que trois : tous ces doigts sont enveloppés d'une corne dure et épaisse; la tète, quoique fort grosse, contient un très-petit ecrveau. Les mâchoires sont fort allongées et garnies de dents, dont le nombre ordinaire est de quarante ; cependant il y en a quelquefois plus et quelquefois moins. Les dents incisives sont tianchantes, et e'est dans celles-ci qu'on observe de la variété dans le nombre. A près les incisives on trouve une dent canine de chaque còté, tant supéricurement qu'inférieurement, qui a beaucoup de rapport aux défenses du sanglier. On trouve ensuite un petit espace dégarni de dents, et les molaires suivent après, qui sont très-grosses et ont des surfaces fort étendues.

" En dissécuant le tapir ou maipouri, la première close qui m'avait frappé, continue M. Bajon, e'est de voir qu'il est animal ruminant... L.es pieds et les dents du maipouri n'ont poutant aucun rapport avec ceux de nos animaux ruminants... Cependant le maipouri a trois poches ou estomacs considérables qui communément sont fort pleins, surtout le premicr que j'ai toujours trouvé comme un ballon.... Cet estomac répond à la panse du bœuf : mais ici le résean ou bonnet n'est presque point distinct; de sorte que ces deux parties n'en font qu'unc. Le deuxième estomac nommé le feuillet est aussi fort considérable, et ressemble beaucoup à celui du bœuf, avec cette différence que les feuillets en sont beaucoup plus petits, et que les tuniques en paraissent plus minces. Eufin le troisieme estomac est le moins grand et le plus mince; on n'y observe dans l'intéricur quede simples rides, et je l'ai presque toujours trouvé plein de matière tout à fait digérée. Les intestins ne sont pas bien gros, mais très-longs; l'animal rend les matières en boules, à peu près comme celleg du cheval."

de suis obligé de contredire ici ce qu'arance M. Bajon, et d'assurer en mème temps que cet animal n'est point ruminant, et n'a pas trois estomacs comme il le dit. Voici mes preuves. On nous avait amené d'Amérique un tapir ou maipouri vivant; il avait bien supporté la mer et était arrivé à vingt lieues de Paris, lorsque tout à coup il tomba malade et mourut : on ne perdit pas de temps à nous l'envoyer, et je priai M. Mertrud, habile chirurgien-démonstrateur en anatomie aux Écoles du Jardin du Roi, d'en faire l'ouverture et d'examiner les parties intérieures : chose très-familière à M. Mertrud, puisque c'est lui qui a bien voulu disséquer, sous les yeux de M. Daubenton, de l'Aeadémie des scicnces, la plupart des animaux dontnous arons donné les deseriptions. M. Mertrud joint d'ailleurs à toutes les connaissances de l'art de l'anatomie une grande exactitude dans ses opérations. De plus, cette dissection a, pour ainsi dire, été faite en ma présence, et M. Daubenton le jeune en a suivi toutes les opérations, et en a rédigé les résultats; enfin M. de Sève, notre dessinateur, qui voit très-bien, y était aussi. Je ne rapporte cescirconstances que pour faire voir à M. Bajon, que nous ne pouvons nous dispenser de le contredire sur un premier point très-essentiel : c'est qu'au lieu detrois estomacs, nousn'cr avons trouvé qu'un seul dans eet animal. La capacité en était à la vérité fort ample et en forme d'une poche étranglée en deux endroits, mais ce n'était qu'un seul viscère, un estomac simple et unique qui n'avait qu'une seule issue daus le duodenum, et non pas trois estomacs distincts et séparés, comme le dit M. Bajon : cependant il n'est pas étonnant qu'il soit tombé dans cette méprise, puisque l'un des plus célèbres anatomistes de l'Europe, le docteur Tyson, de la Société royale de Londres, s'est trompé en disséquant le pecari ou tajacu d'Amérique, duquel au reste il a donné une très-bonne description dans les Transactions philosophiques, $\mathrm{n}^{\circ} 153$. Ty son assure, comme M. Bajon le dit du tapir, que le pecari a trois estomacs, tandis qu'il n'en a réellement qu'un seul, naais partagè à peu près comme celui du tapir par deux étranglements qui semblent au premier coup d'œil en indiquer trois.

Il nous parait done certain que le tapir ou maipouri n'a pas trois estomacs, et qu'il n'est point animal ruminant; car nous pouvons encore ajouter à la preuve que nous venons d'en donner, que jamais cet animal, qui est arrivé vivant jusqu'auprès de Paris, n'a ruminé. Ses 
conducteurs ne le nourrissaient que de pain, de grain, etc. Mais cette méprise de M. Bajon n'empêche pas que son Mémoire ne contienne de très-bonnes observations; l'on en va juger par la suite de cet extrait, dans lequel j'ai eru devoir interposer quelques faits qui m'ont été communiqués par des témoins oculaires.

" Le tapir ou maïpouri mâle, dit M. Bajon, est constamment plus grand et plus fort que la femelle; les poils de la crinière sont plus longs et plus épais. Le cri de l'un et de l'autre est précisément celui d'un gros sifflet; le cri du mâle est plus aigu, plus fort et plus perçant que celui de la femelle. Les parties de la génération du mále semblent avoir un rapport très-grand avec celles du cheval ou de l'áne, elles sont situées de la méme facon; et on observe sur le fourreau, comme dius le cheval, à peu de distance des testicules, deux petits mamelons trèspeu apparents qui indiquent l'endroit des mamelles. Les testicules sont tris-gros et pisent jusqu'à douze ou quatorze onees chacun.... La verge est grosse et n'a qu'un corps eaverueux. Dans son état ordinaire, elle est renfermée dans une poche considérable, formée par le fourreau; mais lorsqu'elle est en érection, elle sort tout entière comme celle du clueval. "

Une des femelles que M. Bajon a disséquées avaitsix picds de longueur, et paraissait n'avoir pas encore porté. Ses mamelles, au nombre de deux, n'étaient pas bien grosses; elles ressem. blent en tout à celles de l'ânesse ou de la jument; la vulve était à un bon pouce de l'anus.

Les femelles entrent ordinairement en chaleur aux mois de novembre et de déecmbre; chaque mâle suit une femelle; et e'est là le seul temps oil l'on trouve deux de ces animaux ensemble. Lorsque deux mâles se rencontrent auprès de la mềne femelle, ils se battent et se blessent cruellement. Quand la femelle est pleine, le mále la quitte et la laisse aller seule; le temps de la gestation est de dix à onze mois, ear on en voit de jeunes des le mois de septem. bre. Pour mettre bas, la femelle ehoisit toujours un endroit élevé et un terrain see.

Cet animal bien loin d'ètre amphibie, comme quelques naturalistes l'ont dit, vit contiunellement sur la terrè, et fait constamment son gite sur les collines et dans les endroits les plus sees. Il est vai (ju'il fréquente les lieux marécageux; mass c'est pour y chereher sa subsistance, et paree qu'il y trouve plus de feuilles et d'herbes que sur les terrains élevés. Comme il se salit beaneoup dans les endroits marécageux, et qu'il aime la propreté, il va tous les matins et tous les soirs traverser quelque rivièce ou s: laver dans quelque lac. Malurré sa grosse masse, il nage parfaitement bien, et plonge aussi fort adroitement : mais il n'a pas la faculté de rester sous l'eau plus de temps que tout autre animal terrestre; aussi le voit-on à tout instant tirer sa trompe hors de l'eau pour res. pirer. Quand il est poursuivi par les chiclis, il court aussitót vers yuelque rivière yu'il traverse promptement pour tâclıer de se soustraire à leur poursuite.

Il ne mange point de poisson; sa nourriture ordinaire sont des rejetons et des pousses tendres, et surtout des fruits tombés des arbres. C'est platòt la nuit que le jour qu'il cherche sa nourriture; eependant il se promène le jour, surtout pendant la pluie. Il a la vue et l'ou!e tres-fines : au moindre mouvement qu'il enteıd, il s'enfuit et fait un bruit considérable dans le bois. Cet animal très-solitaire est fort doux et mème assez timide; il n'y a pas d'exemple qu'il ait cherché à se défendre des hommes. 11 i en est pis de même avec les chiens : il s'en défend très-bien, surtout quand il est blessé ; il les tue même assez souvent, soit en les mordant, soit en les foulant aux pieds. Lorsqu'il est éleví en domesticité, il sensble ètre susecptible d'attachement. M. Bajon en a nourri un quon lu apporta jeune, et cui n'était encore pas plus gros qu'un mouton; il parvint à l'élever fort grand, et cet animal prit pour Ini une espece d'amitić; il le distinguait à merveille au milicu de plusieurs persomnes; il le suivait comme un chien suit son maitre, et paraissait se plaire beau'oup aux caresses qu’il lui faisait; il lui léchait les mains; enfin il allait seul se promencr dans les bois, et quelquefois fort loin, et il ne manciuait jamais de revenil tous les soirs d'assez bume heure. On en a vu un autre, également ajprivoisé, se promener daus les lues de Cayene, aller à la campagne en toute liberté et rev euil claque soir; néamnoins lorsqu'on voulut l'rmbarquer pour l'amener en Europe, des qu'il fut à bord du navire, on ne put le tenir ; il eassa des cordes trè-fortes avec lespuelles on l'arait aitaché; il se préeipita dans l"eau, gagna le rivege a la nage et cutra daus un fort de palétuvicis, à une distanee assez considerable de la ville; on le crut perdu; mais le mème soir il se rendit a 
son gite ordinaire. Comme on avait résolu de l'embarquer, on prit de plus grandes précautions, qui ze réussirent que pendant un temps; car, environ moitié chemin de l'Amériqueen France, la mer étant devenue fort orageuse, l'animal se mit de mauvaise humeur, brisa de noureau ses liens, enfonça sa cabane et se précipita dans la mer d'où on ne put le retirer.

L'hiver, pendant lequel il pleut presque tous les jours à Cayenne, est la saison la plus farorable pour chasser ces animaux avec succès.

"Un chasseur indien qui était à mon service, dit M. Bajon, allait se poster au milieu des bois, il donnait cinq à six coups d'un sifflet fait exprès, et qui imitait très-bien leur cri ; s'il s'eu trouvait quelqu'un aux environs il répondait tout de suite; et alors le chasseur s'acheminait doucement vers l'endroit de la réponse, ayant soin de le faire répéter de temps en temps, et jusqu'à ce qu'il se trouvât à portée de tirer. L'animal, pendant la sécheresse đe l'été, reste au contraire tout le jour couché ; cet Indien allait alors sur les petites hauteurs et tâchait d'en découvrir quelqu'un et de le tuer au gite : mais cette manière est bien plus stérile que la première. On se sert de lingots ou de très-grosses balles pour les tirer, parce que leur peau est si dure, que le gros plomb ne fait que l'égratigner; et avec les balles et mème les lingots, il est rare qu'on les tue du premier coup : on ne saurait croire combien ils ont la vie dure. Leur chair n'est pas absolument mau vaise à manger : celle des vieux est coriace, et a un goùt que bien des gens trouvent désagréable; mais celle des jeunes est meilleure et a quelque rapport avec celle du veau. "

Je n'ai pas cru devoir tirer par extrait du Mémoire de M. Bajon les faits anatomiques; je n’ai cité que celui des prétendus trois estomaes, qui néanmoins n'en font qu un : j'espère que M. Bajon le reconnaltra lui-même, s'il se donne la peine d'examiner de nouveau cette partie intérieure de l'animal.

Une autre remarque qui me paraít nécessairc et que nous croyons devoir faire, quoique nons ne soyons pas aussi certains du fait que de celui du seul estomac, e'est au sujet des cornes de la matrice. M. Bajon assure que dans toutes les femelles qu'il a disséquées, l'extrémité des trompes qui répond aux ovaires est exactement fermée, et que leur cavité n'a absolument aucune communication avec ees parties. a J'ai, dit-il, soufflé de l'air dans ces tron. pes, et je l'ai pressé avec force; il ne s'eri est point échappé, il n'en est point entré du cơté des ovaires. Cette extrémité des trompes qu'o appelle le pavillon ou le morceau frangé parait être terminé en rond, et on observe à l'extéricur de son extrémité plusieurs culs-de-sac, que l'on dirait d'abord être autant de comrua nications avec son intérieur : mais ils sont formés par des replis membraneux, produits par la membrane qui leur est fournie par les ligaments larges, au moyen de laquelle membrane les trompes se trourent attachées aux ovaires. L'entière oblitération de l'extrémité des trompes, qui répond aux ovaires, est un phénomène qui portera sans doute quelque atteinte au système ordinaire de la génération. La notuveauté, l'ímportance et la singularité de ce phénomène, ajoute M. Bajon, a fait que je me suis mis en garde contre mes propres ob. servations. J'ai donc cherché à m'assurer du fait par de nourelles recherches pour qu'il ne me restât point de doute; de sorte que la dissection de dix à douze femelles, que j'ai faite dans l'espace de trois à quatre mois, m'a mis à même de pouvoir attester la réalité du fait, tant dans les jeunes femelles que dans celles qui avaient porté; car j'en ai disséqué qui avaient du lait dans les mamelles, et d'autres qui étaient pleines. $D$

Quelque positive que soit cette assertion, et quelque nombreuses que puissent être à cet égard les observations de MI. Bajon, elles ont besoin d'être répétées, et nous paraissent si opposées à tout ce que l'on sait d'ailleurs, que nous ne pourons y ajouter foi.

Voici maintenant les notes que j'ai recueillies pendant la dissection que M. Mertrud a faite de cet animal à Paris.

L'estomac était situé de manière qu'il paraissait également étendu à droite comme à gauche; la poche s'en terminait en pointe, moins allongée que dans le cochon, et il $\mathrm{y}$ avait un angle bien marqué entre l'œsoplage et le pylore, qui faisait une espèce d'étranglement, et la partie gauche était beaucoup plus ample que la droite : le colon avait beaucoup d'ampleur ; il était plus étroit à son origine et à son extrémité que dans son milieu; la grande circonférence de l'estomac était de trois pieds un pouce; la petite circonférence de deux pieds six lignes. 
Longucur du foie. Épaisseur du foie. ..................... 050 Largeur du foie. ............. 1 1 10 Il n'y a voit point de résicule de fiel, mais seu lement un conduit biliaire qui s'ourrait dans le duodenum á cỏté du canal pancréatique. Longueur de la rate. .......... 160 Largeur de la rate. ............. 022 Ėpaisseur de la ratc............ 0 1 0 Hauteur du cœur. ............... 0 5 50 Circonférence du cocur. ......... 120 Le trou oval était fermé.

Diametre de l'aorte. ............. 0 1. 10

Longueur des intestins grèles depuis le pylore

jnsquau cøeum. ............ 58220

Circonférence des intestins gréles dans les en-

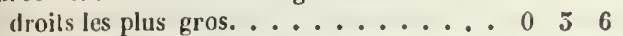
Circonférence dans les endroits les plus petits. $\begin{array}{llll}0 & \mathbf{5} & \mathbf{3}\end{array}$ Longueur du coccum. .......... 1100 Circonfërence du crecum à l'endroit le plus

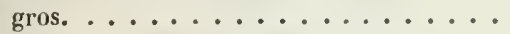
Circonférence du colon à l'endroit le plus gros. Circonférence du colon à l'endroit le plus pastit. Circonferrence du rectum à l'endroit le plus

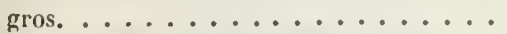
Circonfèrence du rectum à l'endroit le plus petit................... 0 i 0 Centre nerveux. ............... 0 \& 40 Longueur des reins. ........... 0 0 8 . 0

Largeur des reins. ............ 0 \& 48 Épraisseur des reins. ............. 0 1 10 Diamètre de la vulve. ............ 0 1 10 Longueur du vagiu. ........... 0 औ Longueur du corps de la matrice. . . . . . . 0072 Longueur des cornes de la matrice. . . . . 00 ॥ Grande circonférence de la vessic. . . . . . 2888 Petite circonférence de la ressie. . . . . . 110 4 Longueur de l'urètre. . . . . . . . . 0 0 56

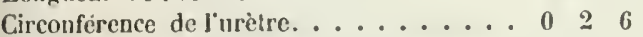

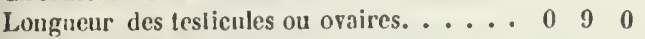
Largeur des lesticules. . . . . . . . . . 007006 l.paisseur des lesticules. .......... 0 0 $01 \frac{1}{2}$ Longucur de la langue. ........... 1220 Longneur de l'animal, depuis le bout du nez à l'aus. ................. 5 10 Hauteur du train de derrière. . . . . . . 284 Ilauleur du train de derant ........ 272 Longueur de l'œil d'un angle à l'autre. . . . $0 \begin{array}{lll}0 & 1 & 1\end{array}$

Dans le temps que l'on a fait cette dissection et pris les mesures précédentes, nous n'avions pas encore reçu le Mémoire de M. Bajon. Nous eussions sans doute examiné de beaucoup plus près l'estomae et surtout les cornes de la matrice de cet animal; mais, quoicue cet examen ultérieur n'ait pas été fait, nous sommes néanmoins convaincu qu'il n'a qu'un estomac, ct, en mème temps, persuadé qu'il y a communication entrc les ovaires et l'extrémité des trompes de la matrice.
Au reste le tapir, qui est le plus gros quadrupède de l'Amérique méridionale, ne se trouve que dins cette partie du monde. L'espèce ne s'est pas étendue au delà de l'isthme de Panama, et c'est probablement par ce qu'il n'a pu franclir les montagnes de cet isthme; car la température du Mexique et des autres provinces idjacentes aurait convenu à la nature de eet animal, puisque Samuel Wallis, et quelques autres voyageurs disent en avoir trouvé, ainsi que des lamas , jusque dans les terres du détroit de Magellan.

ADDITION DE L'ÉDITEUR HOLLANDAIS (M. LE PROFESSEUR aLlaMaid), a l'article dU TAPIR,

"Quoique les tapirs soient assez communs dans les parties de l'Amérique méridionale où les Européens ont des établissements, et qu'on en voic quelquefois dans les basses-cours des particuliers, où on les nourrit arec les autres animaux domestiques, il est ecpendant fort rare qu'on en transporte en Europe. Je ne crois pas même que jusqu'à présent on y en ait vu plus d'un, qui a été montré à Amsterdim, eu 170.4 sous le nom de cheval marin, et dont un peintre de ce temps-là a fait des dessins qui se conservent dans les collections de quelques eurieux, mais qui représentent cet animal si imparfaitement, qu'on ne saurait l'y reconnaitre. M. de Buffon lia janais vu le tapir", non plus que les autres naturalistes qui en ont parlé; dans l'histoire qu'il en a domnée, il a été obligé de copier la description qui en a été faite par Maregrave et par Barrère, et de citer ce qu'en ont dit les royageurs : la figure qu'il y a ajoutée lui a été communiquée par MI. de la Conda. mine, et e'est la seule qui en donne une idée passable; c'est mème la seule qui en ait été faite : car il faut compter pour rien celle que Maregrave en a publiće, et qui a été copiée par Pison; clle est trop mauvaise pour qu'elle mérite aucune attention.

"Depuis quelques semaines nous arons ici, en Hollande, deux de ees animax, dont l'un est promené de ville en ville pour étre montré dans les foires, et l'autre est dans la ménagcric du prinee d'Orange, qui cst peut-itre la plus

- Ce qui était vrai pour ke Iemps vì M. Allanamel a terit: mais depuis le lapir ma clé bien cumu, el je l'ai fait dessiner d'apres nature, comme on vicut de te voir. 
iniércssante de l'Europe pour un naturaliste, vu le grand nombre d'animaux rares qu'ron y envoie tous les ans, tant des Indes orientalcs, qlie d'Afrique et d'Amérique. Le tapir qui est diuns cette ménagerie est un mâle; l'autre est une :emelle. I.e premier est représenté dans la glunche $1 \mathrm{X}$. Si l'on compare cette figure arec coile que $\mathrm{M}$. de Buffon a donnée, d'après le dessin qui lui a été fourni par M. de la Condamine, on y trouvera des différences assez sensibles. Ia plinche $X$ représente la fenelle dans une attitude que cet animal prend sourent.

" Maregrave a domné une très-bonne description du t.pir, et M. de Bufrom ne l'ayant jamais vu, ne pouvait rien faire de mieux que de la rapporter toute comme il l'a fait. Cependant, comme quelques particularités lui sont échappées, j’ajouterai ici les observations que j’ai faites sur l'animal même. Celuj qui est dans la ménagerie du prince d'Orange doit être fort jeune, si au moins cet animal parvient à la grandeur d'une petite rache, comme le disent quelques voyágeurs : il égale à peine la hauteur d'un cochon, avee lequel même il est aisé de le confondre si on le voit de loin. Il a le corps fort gros à proportion de la taille; il est arojué vers la partie postérjeure du dos, et terminé par une large croupe assez semblable à celle d'un jeune poulain bien nourri. La couleur de sa peau et de son pelage est d'un brun foncé qui est le même par tout le corps. II faut promener sa main sur son dos pour s'apercevoir qu'il y a des poils qui ne sont pas plus grands que du duvet; il eu a très-peu aux flancs, et ceux qui couvrent la partic inférieure de sou corps sont assez rares et courts. Il a une crinière de poils noirâtres d'un pouce et demi de hauteur, et raides comme des soies de coclson, mais moins rudes au toucher, et qui diminuent en longueur à mesure qu'ils s'approchent des extrémités : cette crinière s'étend dans l'espace de trois pouces sur le front, et de sept sur le cou. Sa tête est fort grosse et levée en bosse près de l'origine du museau. Ses oreilles sont presque rondes et bordées dans leur contour d'une raie blanchâtre. Ses yeux sont petits et placés à une distance presque égale des oreilles et de l'angle de la bouche. Son groin est terminé par un plan circulaire, à peu près semblable au boutoir d'un cochon, mais moins large, son diamètre n'égalant pas un pouce et demi; et c'est lit oủ sont les olivertures des narines, qui, cornme celles de l'éléphant, sont à l'extrémité de sa trompe, avec laquelle le nez du tapir a beaucoup de rapport; car il s'en sert à peu près de la mème façon. Quand il ne l'emploie pas pour saisir quelque chose, cette trompe ne s'ćtend guère au delá de la lèrre inférieure, et alors elle est toute ridée circulairement; mais il peut l'allonger presque dun demi-pied et mème la tourner d'un côté et d'autre pour prendre ce qu'on lui présente, mais non pas comme l'éléphant, avec cette espèce de doigt qui est au bout supérieur de sa trompe, et avec lequel j'ai vu un de ces animaux relever un sou de terre pour le donner à son maitre. Le tapir u'a poirit ce doigt ; il saisit avec la partie inférieure de son nez allongé, qui se replic pour cet effet en dessous. J'ai eu le plaisir de lui voir prendre de cette manière plusieurs murceaux de pain que je lui offrais, et qui paraissaient être fort de son goût. Ce n’est donc pas simplement la lève, comme celle durhinocéros, qui lui sert de trompe c'est son nez qui, à la vérité, lui tlent aussi lieu de lèrre; car quand il l'allonge, en levant la tète pour attraper ce qu'on lui présente, elle laisse à découvert les dents de la mâchoire supérjeure; en dessus elle est de couleur brune, comme tout le reste du corps, et presque sans aucun poil ; en dessous elle est de couleur de chair ; on peut voir que c'est un fort muscle, susceptible d'allongement et de contraction, qui, en se courbant, pousse dans la bouche les aliments qu'il a saisis.

"Les jambes du tapir sont courtes et fortes; les pieds de devant ont quatre dojgts, trois antérieurs, dont celui du milieu est le plus long; le quatrième est au còté extérieur; il est placé plus haut et il est plus petit que les autres : les pieds de derrière n'en ont que trois. Ces doigts sont terminés par des ongles noirs, pointus et plats; on peut les comparer aux sabots desanimaux à pieds fourchus; ils environnent et renferment toute l'extrémité des doigts; chaque doigt est marqué d'une raie blanche à l'origine des ongles; la queue mérite à peine ce nom, ce n'est qu'un tronçon gros et long comme le petit doigt, et de couleur de chair en dessous.

Maregrave dit que les jeunes tapirs portent la livrée, mais qu'ils la perdent quand ils sont adultes, et sout partout de couleur de terre d'ombre, sans aucune tache de différentes couleurs ; comme c'est là le cas du tapir que je décris, on en pourrait conclure qu'il n'est pas aussi jeune que sa taille semble l'indiquer. 
" Cet animal est fort doux; il s'approche de ceux qui entrent dans sa loge; il les suit familièrement, surtout s'ils ont quelque chose à lui domner, et il souffre d'en ètre caressé. Je n’ai pu remarquer dans sa physionomie cet air triste et mélancolique qu'on lui prête, et qui pourrait bien avoir été confondu avec la douceur qu'annonce son regard.

"ll ne m'a pas été possible de compter exactement ses dents incisives; il ne les découvrait pas assez longtemps pour que je pusse m'assurer de leur nombre, et quand je voulais lui relever son nez pour les mieux voir, il secouait fortement la tête et m'obligeait à làcher prise. Il m'a semblé cependant qu'il y en avait huit à chaque mâchoire, très-bien arrangées', et de la grosseur des dents incisives de l'homme. Marcgrave dit qu'il en a compté dix à chaque mâchoile; les dents canines ne m'ont pas paru les surpasser en grandeur et ne sortaient point hors de la bouche, comme la figure donnée par M. de la Condamine a M. de Buffon semblerait le faire croire; quant aux dents mâchelières, je n'ai pu les apercevoir.

\section{Voici les dimensions de ces principales parties.}

\section{Longueur du corps, depuis le bout du musean}

jusqu'à l'anus............. 420

Iauteur du train de devant. ....... 250

Hauteur du train de derrière. . . . . . . 260 Longueur de la tète, depuis le bout du mu-

scau jusqu'aux oreilles. ......... 1220

Longueur des oreilles. . . . . . . . . $0 \begin{array}{lllll} & 0 & 3 & 6\end{array}$

Distance des yeux aux oreilles........ $0 \begin{array}{lll} & 4 & 6\end{array}$

Circonférence du cou près la tèle. . . . . 2 2000

Circonfẻrence du cou près des épaules. ... 2 280

Longueur de la queue........... () 26

Hauteur du ventre par-dessus la terre.... 120

Longueur du plus grand ongle, tant des pieds

de devant que de derrière. ....... 0 , 16

"Je n'ai point ru la femelle dont j'ai parlé èdessus, et qu'on promène dans nos foires; mais une persomne qui s'intéresse à tout ce qui peut contribuer à la perfection de notre édition l'a observée avec soin, et voici le résultat des remarques qu'elle m'a communiquées.

"Cette femelle est un peu plus grande que

4. M. Allamand n'a pas pu voir tontes les dents ineisives du tapir, mais nous les avons vues, et elles sont an ikmbre de dix en haut el de dix en bas :

- N. Desmorels assure oue lo rral nombro de ces dente cal de six a chayue moctoolre le mâle que je viens de décrire; on la nourrit avec du pain de seigle, du gruau cuit, des herbes, ete.; clle aime surtout les pommes, qu'elle sent de loin; elle s'approche de ceux qui en ont, et fourre son groin dans leur poche pour les $y$ prendre. Au reste, elle mange tout ce cqu'on lui présente, des carottes, du poisson, de la viande, et jusqu'à ses propres excréments quand clle a faim.

" Elle connait son maitre autant qu'un cochon connait celui qui le nourrit; clle est fort douce; elle ne fit entendre aucun son de voix; l'homme qui me l'a fait voir, dit que quand elle est fatiguée ou irritée, elle pousse un ceri aigrn, qui ressemble à une sorte de sifflement : le màle, qui est dans la ménagerie du prince d' $\mathrm{O}$ range, fait la mène chose, si je dois m'en mpporter à celui à qui la garde en est confiée.

"Ses poils sont, comme ceux du màle, trèscourts ou presque nuls sur le dos; elle en a quelques-uns plus sensibles à la mâchoire inférieure, aux flancs, et derrière les pieds de devant. Ses oreilles sont bordées de petits poils très-fins, d'un blane jaunâtre. Elle u'a point de crinière comme le mâle, nais seulement là oú elle devrait être, cquelques poils éloignés les uns des autres, et plus longs que ceux du reste du corps. La erinière scrait-elle une marque qui différencierait les sexes, comme cela se voit dans le lion et dans d'autres animaux?

"Elle a deux mamelles longues d'un demiponce, entre les jambes de derrière.

"Elle a deux dents canines à chaque mìchoire, et celles de la mâchoire supéricure sont plus grandes que eelles d'en bas; ce qui est le contraire de ce quion voit dans les cochons, et de ee que présente la figure qu'a donnée M. de Buffon. Il n'y a pas eu moyen de compter ses dents incisives.

"Lorsqu'elle étend son nez, ses narines offrent de larges ouvertures, et elles se referment quand elle le retire; la même chose arrive au màle.

" Elle a beancoup de force dans ses der.ts; on lui voit quelyuefois transporter d'un cudroit à un autre la crèche dans laquelle ou lui donne à manger.

"Son attitude favorite est de sasseoil sur ses pieds de derrière comme un chien et e'est li l'attitude la plus agréable ou l'on puisse la voir; aussi est-ce celle diuns laquelle on l'a représentée $(p l . X)$. 
Yoici les dimensions de cette femelle.

Longueur du corps, depuis le bout du museau jusqu'á l’anus............. 5110

Jlanteul du train de derant. . . . . . . 280

Hauleur du train de derrière.. . . . . . . 296

Longueur de la tète, depuis le bout du groin jusqu'aux oreilles.................... 120

Distance des yeux aus oreilles. . . . . . . 0075

Circonférence de la tète, prise à l'origine des

michoires................ 1 s 0

Circonférence de la tète, prise derant les oreilles. ................. 230

Longueur de l'oil d'un angle à l’antre. . . . . 012

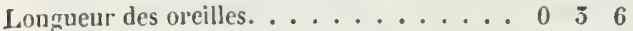

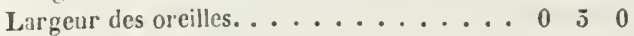

Girconfèrence des oreilles près de la lète. , . $0 \begin{array}{llll}0 & \mathbf{7} & 0\end{array}$

Dislance entre les orcilles. . . . . . . . 0060

Circonfireace du cou près les épaules. . . 2100

Circon'erence du corps, derrière les jambes

de derant. ................ 590

Circonférenc 2 du milieu du corps. . . . . $4 \begin{array}{ccc}4 & 5 & 0\end{array}$

Circonférence devant les jambes de derriere. $4 \begin{array}{lll}4 & 0 & 6\end{array}$

Longueur de la queus. . . . . . . . . 022

Hauleur des jamites će derant jusqu'á la poi-

trine................. 120

Hauteur des jamhes de derrièı. ..... 140

Circonfèrence des jambes de derant. . . . . $0 \begin{array}{llll}0 & 8 & 6\end{array}$

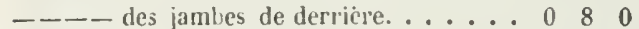

Longueur du plus grand ongle des pieds de devant................... 0 1 5

1 ongueur du plus grand ongle des pieds de

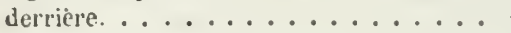

018

"Dans nos colonies américaines, on donne le nom de buffle aux tapirs, et je ne sais pour(quoi; ils ne ressemblent en rien aux animnux ufui portent ce nom. n

\section{DE LA NATURE.}

\section{PREMIERE VUE '.}

La nature est le système des lois établies par 2 Créateur, pour l'existence des choses et pour la succession des êtres. La naturc n'est point

1 En plaçant ce discours en tète du douzième volnme de l'élition de l'Imprimerie Ruyale, Buffon y a joint la note suivante, sous forme d'averlissement.

- Colnme les détails de l'llistoire naturelle ne sont intéressants que pour cenx qui s'appliquent uniquement à celte sci'nce, et que dlans une exposition anssi longue que celle de l'histoire particulière de lous les animaux. il règue nécessairement trop d'uniformité, nous avons cru une la plupart de nos leckurs nous sauraicut gré de couner de temps en temps le fil d'une inethode qui nons contraint, par des discours dans les.juels nous donnerous nos réllexions sur la nature en général. el traiterons de ses effets en grand. Xisus retournerons ensuite á nos détails avec plus de couraze; car j’aruue qu'il en faut pour s'occuper contiuuellement de petits utijets dont l'examen exize la plus froide patience, ct ne permet rien au génic. , une chose, car cette chose serait tout : la na. ture n'est point un être, car cet être serait Dieu; mais on peut la considérer comme une puissance vive, immense, qui embrasse tout, qui anime tout, et qui, subordonnée à celle du premier être, n'a commencé d'agir que par son ordre, et n'agit encore que par son concours ou son consentement. Cette puissance est de la puissance divine la partie qui se manifeste; e'est cn mème temps la cause et l'effet, le mode ct la substance, le dessein et l'ourrage : bien différente de l'art humain dont les productions ne sont que des ourrages morts, la nature est ellemême un ouvrage perpétuellement vivant, un ouvrier sans cesse actif, qui sait tout employer, qui travaillant d'après soi-mème, toujours sur le méme fonds, bien loin de l'épuiser le rend inépuisable: le temps, l'espace et la matière sont ses moyens, l'univers son objet, le mouvement et la vie son but.

Les effets de cette puissance sont les phénomènes du monde : les ressorts qu'elle emploie sont des forces vives, que l'espace et le temps ne pcuvent que mesurer et limiter sans jamais les détruire; des forces qui se bal.ıncent, qui se confondent, qui s'opposent sans pouroir s'anéantir : les unes pénètrent et transportent les corps, les autres les échauffent et les animent. L'attraction et l'impulsion sont les deux principaux instruments de l'action de cette puissance sur les corps bruts; la chaleur et les molécules organiques vivantes sont les principes actifs qu'elle met en œurre pour la formation et le développement des êtres organisés.

Avee de tels moyens que ne peut la nature? Elle pourrait tout si elle pourait anéantir et créer; mais Dieu s'est réservé ces deux extrêmes de pouroir : anéantir et créer sont les attributs de la toute-puissance; altérer, changer, détruire,- développer, renouveler, produire, sont les seuls droits qu'il a voulu céder. Ministre de ses ordres irrévocables, dépositaire de ses immuables décrets, la nature ne s'écarte jamais des lois qui lui ont été preserites; ellen'altère rien aux plans qui lui ont étć tracés, et dans tous ses onvrages elle présente le sccau de l'iternel : cette empreinte divine, prototype inaltérable des existences, est le modèle sur lequel elle opère, modèle dont tous les traits sont exprimés en caractères ineffaçables et prononcés pour jamais; modèle tonjours neuf, que le nombre des moules ou des copies, 
quelque infini qu'il soit, ne fait que renouveler.

Tout a done été créé et rien encore ne s'est anéanti ; la nature balance entre ces deux limites sans jamais approcher' ni de l'une ni de l'antre : tâchons de la saisir dans quelques points de cet espace immense (qu'elle remplit et par'court depuis l'origine des siècles.

Quels objets! Un volume inmense de natière qui n'eût formé qu'uneinutile, une épouvantable masse, šil n’eût été divisé en parties séparées par des espaces mille fois plus immenses : mais des milliers de globes lumineux, placés à des distanees inconcevables, sont les bases gui servent de fondement à l'édifice du monde; des millions de globes opacques, cireulant autour des premiers, en composent l'ordre et l'arehitecture mouvante. Deux forces primitives agitent ces grandes masses, les roulent, les transportent et les animent; chacune agit ì tout instant, et toutes deux, combinant leurs efforts, tracent les zones des sphères célestes : établissent dans le milieu du vide pes lieux fixes et des routes déterminées; et c'est du sein mème du mouvement que nait l'é(quilibre des nondes et le repos de l'univers.

La première de ces forces est également répartie; la seconde a été distribuće en mesure inégale. Chaque atome de matière a une même quantité de force d'attraction, chaque globe a une quantité différente de foree d'impulsion: aussi est-il des astres fixes et des astres errants, des globes qui ne semblent ètre faits que pour attires, et d'autres pour pousser ou pour être poussés; des sphères qui ont reçu une impulsion commune dans le mème sens, et d'autres une impulsion particuliere; des astres solitaires et d'autres aceompagnés de satellites: des corps de lumières et des masses de ténćhres; des planètes dont les différentes parties ne jouissent que sueeessivement d'une lumière empruntéc ; des comètes qui se perdent dans l'obscurité des pro. fondeurs de l'espace, et reviemnent après les siecles se parer de nouveaux feux; des soleils qui paraisseut, disparaissent et semblent alternativement se rallumer et s'éteindre; d'autres qui se montrent une fois et s'évanouissent ensuite pour jamais. Le ciel est le pays des grands érénements; mais ì peine l'oul humain peut-il les saisir : un soleil qui périt et qui eause lis catastrophe d'un monde, ou d'un systeme de mondes, we fait d'autre effet à nos yeux que celui d'un feu follet qui brille et qui s’éteint:
Thomme bolné à l'atome terrestre sur lequel il végète, voit cet atome comme un monde et ne voit les mondes que comme des atomes.

Car cette terre qu'il habite, à peine reconnaissable parmi les autres globes, et tout à fait invisible pour les sphères éloignées, est un million de fois plus petite que le soleil qui l'éclaire, et mille fois plus petite que d'autres planètes qui comme elle sont subordomnées à la puissance de ect astre, et forcées à circuler autour de lui. Saturne, Jupiter, Mars, la Terre, Vénus, Mer. cure et leSoleil occupert la petite partie des cieux que nous appelons notre univers. Toutes ces planctes avec leurs satellites, entraínées par un monvement rapide dans le mème sens et presque dans le méme plan, composent une roue d'un vaste diametre dont l'essicu porte toute la charce, lequel, tournant lui-méme avee rapidité a dù s'échauffer, s'embraser et répandre la chaleur et la lumière jusqu'aux extrémités de la cireonférence : tant que ces mouvements dureront (et ils seront éternels, à moins que la main du premier moteur ne s'oppose et n'enıploie autant de force pour les détruire qu'il en a fallu pour les eréer), le soleil brillera et remplira de sa splendeur toutes les sphères du monde; et comme dans un système ou tout s'attire, rien ne peut ni se perdre, ni s'éloigner sans retour. la quantité de matière restant toujour's la méme, cette source féeonde de lumière et de vie ne s'épuisera, ne tarira jamais; car les autres soleils gui lancent aussi continuellement leurs feux rendent à notre soleil tout autant de lumière qu'ils en reçoivent de lui.

Les cometes en beaucoup plus grand nombre que les planètes, et dépendantes comme elles de la puissance du soleil , pressent aussi sur ce foyer commun, en augmentent la charge, et contribuent de tout leur poids à son embrasement: elles font partie de notre univers, puisqu'elles sont sujettes, comme les planètes, à l'attraetion du soleil; mais clles n'ont rien de commun entre elles ni avee les planètes, dans leur mourement d'impulsion ; elles eireulent chacune dans un plan different et décrivent des orbes plus ou moins allongés dans des périodes differentes de temps, dont les unes sont de plusieurs années, et les autres de quelques siceles. L.e soleil tournant sur lui-méme, mais au reste immobile au milieu de tout, sert en meme temps de flambeau, de forer, de pivot à toutes ces parties de la machine du monde. 
C'est par sa grandeur méme qu'il demeure immoljile et qu'il régit les autres globes: comme la force a été donnée proportionnellement ä la masse, qu il est incomparablement plus grand qu'aucune des comètes, et qu'il contient mille fois plus de matière que la plus grosse planète, lles ne peuvent ni le déranger, ni se soustraire à sa puissance, qui, s'étendant à des distances immenses, les contient toutes, et lui ramène au bout d'un temps cellès qui s'éloignent le plus; quelques-unes même à leur retour s'en approchent de si près, qu'après avoir été refi'oidies pendant des sìcles, elles éprourent une chaleur inconcevable; elles sont sujettes à des vicissitudes étranges par ces alternatives de chaleur et de froid extrêmes, aussi bien que par les inégalités de leur mouvement, qui tantòt est prodigieusement accéléré et ensuite infiniment retardé : ce sont, pour ainsi dire, des mondes eu désordre, en comparaison des planètes, dont les orbites étant plus régulières, les mouvements plus égaux, la température toujours la mème, semblent ètre des lieux de repos, où, tout étant constant, la nature peut établir un plan, agir uniformément, se développer successivement dans toute son étendue. Parmi ces globes choisis entre les astres errants, celui que nous ha. hitons parait encore être privilégié: moins froid, moins éloigné que Saturne, Jupiter, Mars, il est aussi moins hrûlant que Vénus et Mercure qui paraissent trop voisins de l'astre de la lumière.

Aussi, avec quelle magnificence la nature ne brille-t-elle pas sur la terre! une lumière pure, s'étendant de l'orient au couchant, dore successivement les hémisphères de ce globe; un élément transparent et léger l'environne; une chaleur douce et féconde anime, fait éclore tous les germes de vie; des eaux vives et salutaires servent à leur entretien, à leur accroissement; des éminences distribuées dans le milieu des terres arrêtent les vapeurs de l'air', rendent ces sources intarissables et toujours nouvelles; des cavités immenses faites pour les recevoir, partagent les continents. L'étendue de la mer est aussi grande que celle de la terre : ce n'est point un élément froid et stérile, c'est un nouvel empire aussi riche, aussi peuplé que le promier. Le doigt de Dieu a marqué leurs confins : si la mer anticipe sur les plages de l'oceident, elle laisse à découvert celles de l'orient. Cette masse Immense d'eau, inactive par elle-même, sult les impressions des mouvements célestes; elle balance par des oscillations régulières de flux et de reflux ; elle s'élève et s'abaisse avec l'astre de la nuit ; clle s'élève encore plus lor'squ'il concourt avec l'astre du jour, et que tous deux réunissant leurs forces dans le temps des equinoxes, causent les grandes marees : notre correspondance avec le ciel n'est nulle part micux marquée. De ces mouvements constants et généraux résultent des mouvements variables et particuliers, des transports de terre, des dépòts (qui forment au fond des eaux, des éminences semblables à celles que nous voyons sur la surface de la terre; des courants qui, suivant la direction de ces chaines de montagnes, leur donnent une figure dont tous les angles se correspondent, et coulent au milieu des ondes comme les eaux coulant sur la terre, sont en effet les fleuves de la mer.

L'air encore plus léger, plus fluide que l'eau, obéit aussi à un plus grand nombre de puissances ; l'action éloignée du soleil et de la lune, l'action immédiate de la mer, celle de la chaleur qui le raréfie, celle du froid quile condense, y causent des agitations continuelles : les vents sont ses courants; ils poussent, ils assemblent les nuages; ils produisent les météores et transportent au-dessus de la surface aride des continents terrestres les vapeurs humides des plages maritimes; ils déterminent les orages, répandent et distribuent les pluies fécondes et les rosées bienfaisantes; ils troublent les mouvements de la mer; ils agitent la surface mobile des eaux, arrêtent ou précipitent les courants, les font rebrousser, soulèvent les flots, excitent les tempêtes: la mer irritée s'élève vers le ciel, et vient en mugissant se briser contre des digues inébranlables qu'avec tous ses efforts elle ne peut ni détruire ni surmonter.

La terre, élevée au-dessus du niveau de la mer, est à l'abri de ses irruptions; sa surface émaillée de fleur's, parce d'une verdure toujours renouvelée, peupléc de mille et mille espèces d'animaux différents, est un lieu de repos, un séjour de délices, où l'homme, placé pour seconder la nature, préside à tous les êtres; seul entre tous, capable de connaitre et digne d'admirer, Dieu l'a fait spectateur de l'univers et témoin de ses merveilles ; l'étincelle divine dont il est animé le rend participant aux mystères divins : c'est par cette lumière qu'il pense et réfléchit; c'est par' elle qu'tl volt et lit dans lo livro 
du monde, comme dans un exemplaire de la divinité.

La nature est le trône extérieur de la magnificence divine : l'homme qui la contemple, qui l'étudie, s'élève par degrés au trône intérieur de la toute-puissance; fait pour adorer le Créateur, il commande à toutes les créatures; vassal du ciel, roi de la terre, il l'ennoblit, la peuple et l'enrichit; il établit entre les êtres vivants, l'ordre, la subordination, l'harmonie; il embellit la nature même, il la cultive, l'étend et la polit, en élague le chardon et la ronce, y multiplie le raisin et la rose. Voyez ces plages désertes, ces tristes contrées où l'homme n'a jamais résidé, couvertes ou plutôt hérissées de bois épais et noirs clans toutes les parties, des arbres sans écorce et sans cime, courbés, rompus, tombant de vétusté, d'autres en plus grand nombre, gisants au pied des premiers pour pourrir sur des monceaux déjà pourris étouffent, ensevelissent les germes préts à éclore. La nature, qui partont ailleurs brille par sa jeunesse, parait ici dans la déerépitude; la terre surchargée par lepoids, surmontée par les débris de ses productions, n'offre au lieu d'une verdure florissante, qu'un espace encombré, traversé de vieux arbres, chargé de plantes parasites, de lichens, d'agaries, fruits impurs de la corruption : dans toutes les parties basses, des eaux mortes et croupissantes faute d'être conduites et dirigées; des terrains famgeux qui, n'étant ni solides ni liquides, sont inabordables, et demeurent également inutiles aux habitants de la terre et des caux; des marécages qui, couverts de plantes aquatiques et fétides, ne nourrissent que des insectes vénéneux, et servent de repaire aux animaux immondes. Entre ces marais infects qui occupent les lieux bas, et les forêts décrépites qui couvrent les terres élevées, s'étendent des espèces de landes, des savanes qui n'ont lien de commun arce nos prairies; les mauvaises herbes y surmontent, y étouffent les bonnes; ce n'est point ce gazon fin qui semble faire le duvet de la terre, ce n'est point cet pelouse émaillée qui annonce sa brillante fécondité ; ce sont des végétaux agrestes, des herbes dures, épineuses, entrelacées les unes dans les autres, qui semblent moins tenir à la terre qu'elles ne tiement entre elles, et qui, se desséchant et repoussant sucecssivement les unes sur les autres, forment une bourre grossière épaisse de plusieurs pleds.
Nulle route, nulle communication, aul vestige d'intelligence dans ces lieux sauvages: l'homme obligé de suivre les sentiers de la bète farouche, s'il veut les parcourir; contraint de veiller sans cesse pour éviter d'en derenir la proie; efirayé de leurs rugissements, saisi du silence même de ces profondes solitudes, rebrousse chemin, et dit: La nature brute est hideuse et mourante; e'est moi, moi seul qui peux la rendre agréable et vivante: desséchons ces marais, animons ces caux mortes en les faisant couler, formons-en des ruisscaux, des canaux, employons cet élément actif et dévorant qu'on nous avait caché et que nous ne devons qu'ì nousmêmes; mettons le feu à cette bourre superflue, à ces vieilles forêts déjà à demi consommées ; achevons de détruire avec le fer ce que le feu n'aura pu consumer : bientôt au lieu du jone, du nénuphar, dont le crapaud composait son venin, nous verrons paraitre la renoncule, le trèfle, les herbes douces et salutaires; des troupeaux d'animaux bondissants fouleront cette terre jadis impraticable; ils y trouveront une subsistance abondante, une pâture toujours renaissante; ils se multiplieront pour se multiplier encore: servons-nous de ces noureaux aides pour achever notre ouvrage; que le bouf soumis au joug emploie ses forces et le poids de sa masse à sillonner la terre, qu'elle rajeunisse par la culture: une nature nouvelle va sortir de nos mains.

Qu'elle est belle cette nature cultivée! que par les soins de l'homme elle est brillaute et pompeuscment parée! II en fait lui-même le principal ornement; il en est la production la plus noble : en se multipliant, il en multiplie le germe le plus précieux; elle-mème aussi semble se multiplier arec lui; il met an jour, par son art, tout ce qu'elle recélait dans son sein; que de trésors ignorés! que de rijchesses nouvelles! Les fleur's, les fruits, les grains perfectionnés, multipliés à l’infini ; les espèces utiles d'animanx transportées, propagées, augmentées sans nombre; les espèees nuisibles réduites, confinées, reléguées : l'or, et le fer plus nécessaire que l'or, tirés des entrailles de la terre : les torrents contenus, les fleures dirigés, resserrés; la mer même soumise, reconnue, traverscé d’un hémisphère à l'autre; la terre accessible partout, partout rendue aussi vivante que féconde; dans les vallées de riantes pralries, dans les plafnes de riches paturagen ou 
des moissons encore plus riches; les collincs chargées de vignes et de fruits, leurs sommets couronnés d'arbres utiles et de jeunes forêts ; les déserts devenus des cités habitées par un pcuple immense qui, eirculant sans cesse, se répand de ces centres jusquaux extrémités; des routes ouvertes et fréquentées, des communications établies partout comme autant de témoins de la force et de l'union de la société; mille autres monuments de puissance et de gloire démontrent assez que l'homme, maitre du domaine de la terre, en a changé, renouvelé la surface entière, et que de tout temps il partage l'empire avec la nature.

Cependant il ne règne que par droit de conquéte : il jouit plutôt qu'il ne possède; il ne conserve que par des soins toujours renouvelés: s'ils cessent, tout languit, tout s'altère, tout change, tout rentre sous la main de la nature: elle reprend ses droits, efface les ouvrages de l'homme, courre de poussière et de mousse ses plus fasteux monuments, les détruit avec le temps, et ne lui laisse que le regret d'avoir perdu par sa faute ce que ses ancètres avaient conquis par leurs travaux. Ces temps oin l'homme perd son domaine, ces siècles de barbarie pendant lesquels tout périt, sont toujours préparés par la guerre, et arrivent avec la disette et la dépopulation. L'homme qui ne peut que par le nombre, qui n'est fort que par sa réunion, qui n'est heureux que par la paix, a la rureur de s'arnier pour son malheur et de combattre pour sa ruine : excité par l'insatiable avidité, aveuglé par l'ambition encore plus insatiable, il renonce aux sentiments d'bunanité, tourne toutes ses forces contre lui mème, cherche à s'entre-détruire, se détruit en effet; ct, après ces jours de sang et de earnage, lorsque la fumée de la gloire s'est dissipée, il roit d'un cil triste la terre dévastée, les arts ensevelis, les nations dispersées, les peuples affaiblis, son propre bonheur ruiné et sa puissance réelle anéantie.

GRAND DIEU! dont la scule présence soutient la nature et maintient l'harmonie des lois de lunivers; vous qui du trône immobile de l'Empyrée voyez rouler sous vos pieds toutes les sphères célestes sans choc et sans confusion, qui du sein du repos reproduise à chaque instant leurs mouvements immenses, et seul régissez dans une paix profonde ce nom. bre infini de cieux et de mondes; rendez, rendez enfin le calme à la terre agitée! Qu'elle soit dans le silence! qu'à votre voix la discorde et la guerre cessent de faire retentir leurs clumeurs orgueilleuses! DIEU DE BoNTÉ, auteur de tous les étres, vos regards paternels cmbrassent lous les objets de la création; mais l'homme est votre être de choix; vous avez éclairé son âme d'un rayon de votrc lumière immortelle; comblez vos bienfaits en pénétrant son cœur d'un trait de votre amour. Ce sentiment divin se répandant partout, réunira les natures ennemies; thomme ne craindra plus l'aspect de l'homme; le fer homicide n'ar. mera plus sa main; le feu dévorant de la guerre ne fera plus tarir la source des générations; l'espèce humaine, maintenant affaiblie, mutilée, moissonnée dans sa fleur, germera de nouveau et se multipliera sans nombre; la nature accablée sous le poids des fléaux, slérile, abandonnée, reprendra bientót, avec une nouvelle vie, son ancienne fécondité; nous, Dieu biexfaiteur, nous la seconderons, nous la cultiverons, nous l'observerons sans cesse pour vous offrir à chaque instant un nouveau tribut de reconnaissance et d'admiration.

\section{DE LA NATURE.}

\section{SECONDE VUE.}

Un individu de quelque espece qu'il soit, n'est rien dans l'univer's; cent individus, mille ne sont encore rien; les espèces sont les sculs êtres de la nature; êtres perpétuels, aussi anciens, aussi permanents qu' elle, que pour mieux juger, nous ne considérons plus comme une collection ou une suite d'individus semblables, mais comme un tout independant du nombre, indépendant du temps; un tout toujours vivant, toujours le mème; un tout qui a été compté pour un dans les ouvrages de la création, et qui par conséquent ne fait qu'une unité dans la nature. De toutes ces unités, l'espèce humaine est la première; les autres, de l'éléphant jusqu'ì la mite, du cèdre jusqu'à l'hysope, sont en seconde et en troisième ligne; et quoique différente par la forme, par la substance, et même jar la vie, chacune tient sa place, subsiste par 
elle-même, se défend des autres; et toutes ensemble composent et représentent la nature vivante, qui se maintient et se maintiendra comme elle s'est maintenue: un jour, un siècle, un âge, toutes les portions du temps ne font pas partie de sa durée; le temps lui-même n'est relatif qu'aux individus, aux êtres dont l'existence est fugitive; mais celle des espèees étant constante, leur permanence fait la durée, et leur différence le nombre. Comptons done les espèces comme nous l'avons fait, domnons-leur' à chacune un droit égal à la mense de la nature; elles lui sont toutes également eheres, puscqu'a chacune elle a donné les moyens d'ètre et de durer tout aussi longtemps ([u'elle.

Faisons plus, mettons aujourd'lu ui l'espèce à la place de l'individu : nous avous vuruei étal pour l'homme le spectacle de la nature, imaginons qu'elle en serait la vue pour un ètre qui représenterait l'espèce humaine entière. Lorsque dans un beau jour de printemps nous voyons la verlure renaitre, les fleurs s'épanouir, tous les germes éclore, les abeilles revirre, l'hirondelle arriver, le rossignol clianter l'amour, le bélier cn bondir, le taureau en mugir, tous les êtres vivants se chereher et se joindre pour en produire d'autres, nous n'arons d'autre idée que celle d'une reproduction et d'une nouvelle vie. Lorsque dans la saison noire du froid et des frimas l'on voit les natures devenir indifférentes, se fuir au lieu de se chercher; les habitants de l'air déserter nos elimats, ceux de l'eau perdi'e leur liberté sous des voûtes de glace; tous les insectes disparaître ou périr, la plupart des animaux s'engourdir, se creuser des retraites; la terre se durcir, les plantes se sćcher, les arbies dépouillés se courber, s’affaisser sous le poids de la neige et du givre; tout présente l'idée de la langueur et de l'anéantissement. Mais ces idées de renouvellement et de destruetion, ou plutôt ces images de la mort et de la vie, quelque grandes, quelque générales qu'elles nous paraissent,ne sont qu'individuelles et particulières; l'homme, comme individu, juge ainsi la nature : l'être que nous avons mis à la place de l'espèce la juge plıs grandement, plus généralement; il ne roit dans cette destruction, dans ce renouvellement, dans toutes ces suceessions que permanence et durće; la saison d'une année est pour lui la même que celle de l'année précédente, la même que eelle de tous les siecles; le millième animal dans l'ordre des générations, est pour lui le mème que le premier animal. Et en effet, si nous vivions, si nous subsistions à jamais, si tous les êtres qui nous environnen: subsistaient aussi tels quils sont pour toujour's, et que tout fut perpétuellement comme tout est aujourd'hui, l'idée du temps s'ćvanouirait et l'individu deviendrait l'espèce.

Et pourquoi nous refuserions-nous de considérer la nature pendant quelques instants sous ee nouvel aspect? A la vérité l'homme en ve. nant au monde arrive des ténèbres; l'âme aussi nue que le corps, il nait sans connaissance comme sans défense; il n'apporte que des qualités passives; il ne peut que reeevoir les impressious des objets et laisser affeeter ses organes; la lumière brille longtemps à ses yeux avant que de l'éclairer : d'abord il reçoit tout de la nature et ne lui rend rien; mais dès que ses sens sont affermis, des qu'il peut comparer ses sensations, il se réfléchit vers l'univers, il forme des idées, il les conserve, les étend, les combine : l'homme, et surtout l'homme instruit, n'est plus un simple individu, il représente en grande partie l'espèce lummaine entière : il a eommencé par recevoir de ses pères les connaissances qui leur avaient été transmises par ses aïeux; ceux-ci ayant trouvé l'art divin de tracer la pensée et de la faire passer à la postérité, se sont, pour ainsi dire, identifiés avec leurs neveux; les nôtres s'identifieront avec nous. Cutte réunion, dans un seul homme, de l'expérience de plusieurs siècles, reeule à l'infini les limites de son ctre: ce n'est plus un individu simple, borné, comme les autres, aux sensations de l'iustant présent, aux expériences du jour actuel; e'est à peu près l'ètre que nous avons mis à la place de l'espèce entière; il lit dans le passé, voit le présent, juge de l'avenir ; et dans le torrent des temps qui amène, entraine, absorbe tous les individus de l'univer's, il trouve les espèces constantes, la nature invariable. Ia relation des ehoses étant toujours la mème, l'ordre des temps lui parait nul; les lois elu renouvellement ne font que compenser a ses yeux celles de la permanence: une suecession continualle d'ètres, tous semblables entre cux, n'écpirant en effet qu'à l'existence perpétuelle dun seul de ces ètres.

A quoi se rapporte done ce grand appareil des générations, cette immense profusion de germes, dont il en avorte mille et mille pour un qui réussit? qu'est-ce que cette propagation, 
cette multiplieation des êtres qui, se détruisant et se renouvelant sans cesse, n'offrent toujours que la méme scène, et ne remplissent ni plus ni moins la nature? d'ou viemnent ees alternatives de mort et de vie, ees lois d'aceroissement et de dépérissement, toutes ees vicissitudes individuelles, toutes ces représentations renouvelées d'une seule et même chose? elles tienuent à l'essénee même de la nature, et dépendent du premier établissement de la machine du monde; fixe dans son tout et mobile dans chacune de ses parties, les mouvements généraux des corps célestes ont produit les mouvements par ticuliers du globe de la terre; les forces pénétrantes dont ces grands corps sont animés, par lesquels ils agissent au loin, et réeiproquement les uns sur les autres, animent aussi chaque atome de matière, et eette propension mutuelle de toutes ces parties les uries vers les autres est le premier lien des ètres, le principe de la consistance des ehoses, et le soutien de l'harmonie de l"univers. Les grandes combinaisous ont produit tous les petits rapports : le nouvement de la terre sur son axe ayant partagé en jours et en nuits les espaces de la durée, tous les êtres vivants (jui habitent la terre ont leur temps de lumière et leur temps de ténèbres, la veille et le sommeil : une rrande portion de l'économic animale, celle de l'action des sens et du mouvement des membres, est relative à cette première combinaison. Y aurait-il des sens ouverts à la lumière dans un monde où la nuit serait perpétuelle?

L'inclinaison de l'axe de la terre produisant, dans son mourement annuel autour du soleil, des alternatives durables de ehaleur et de froid, que nous avons appelées des saisons, tous les êtres végétants ont aussi, en tout ou en partie, leur saison de vie et leur saison de mort. La chute des feuilles et des fruits, le desséchement des herbes, la mort des insectes, dépendent en entier de cette sceonde combinaison. Dans les climats où elle n'a pas lieu, la vie des végétaux n'est jamais suspendue; chaque insecte vit son âge: et ne voyons-nous pas, sous la ligne, où les quatre saisons n'en font qu'me, la terre tonjours fleurie, les arbres continuellement verts, et la nature toujours au printemps?

La constitution particulière des animaux et des plantes est relative à la température générale du globe de la terre, et cette température dépend de sa situation, c'est-à-dire de la dis- tance à laçuelle il se trouve de celui du soleil : a une distance plus grande, nos animaux, nos plantes ne pourraient ni vivre ni végéter; l'eau, la séve, le sang, toutes les autres liqueurs, perdraient leur fluidité:à une distance moindre, elles s'évanouiraient et se dissiperaient en vapeur's : la glace et le feu sont des éléments de la mort; la chaleur tempérée est le premier germe de la vie.

Les molécules vivantes répandues dans tous les corps organisés sont relatives, et pour l'action et pour le nombre, aux molécules de la lumière qui frappent toute matière et la pénètrent de leur chaleur. Partout où les rayons du soleil peuvent échauffer la terre, sa surface se vivifie, se couvre de verdure et se peuple d'animaux: la glace mème, dès cul'elle se résout en eau, semble se féconder; cet élément est plus fertile que celui de la terre, il reçoit avee la chaleur le mouvement et la vie. La mer produit à chaque saison plus d'animaux que la terre n'en nourrit; elle produit moins de plantes; et tous ces animaux qui nagent à la surface des eaux, ou qui en habitent les profondeurs, nayant pas, comme ceux de la terre, un fonds de subsistance assuré sur les substances végétales, sout for'és de vivre les uns sur les autres; et e'est à cette combinaison que tient leur immense multiplieation, ou plutôt leur pullulation sans nombre.

Chaque espèce et des uns et des autres ayant été créée, les premiers individus ont servi de modèle à tous leurs desceudants. Le corps de chaque animal ou de chaque végétal est un moule auquel s'assimilent iudifféremment les molécules organiques de tous les animaux ou régétaux détruits par la mort et consumés par le temps; les parties brutes qui étaient entrées daus leur composition retournent ì la masse commune de la matière brute : les parties organicques, toujours subsistantes, sont reprises par les corps organisés; d'abord repompées par les régétaux, ensuite absorbées par les animaux qui se rourrissent de végétaux, elles servent au développement, ì l'entretien, à l'aecroissement et des uns et des autres; elles constituent leur' vie, et, cireulant continuellement de corps en corps, elles animent tous les êtres organisés. Le fonds des substances vivantes est done toujours le même; elles ne varient que par la forme, c'est-à-dire par la différence des représentations: dans les siècles d'abondance, dans les temps de la plus grande population, le nombre des hommes, des animaux domestiques et des 
plantes utiles scmble occuper et couvrir en entier la surface de la terre; celui des animaux féroces, des insectes nuisibles, des plantes parasites, des herbes inutiles, leparait et domine à sou tour dans les temps de disette et de dépopulation. Ces variations, si sensibles pour l'homme, sont indifférentes à la nature; le ver à soie, si précicux pour' lui, n'est pour elle que la chenille du mûrier. Que cette chenille du luxe disparaisse, que d'antres chenilles dévorent les herbes destinées à engraisser nos bœufs, que d'autres enfiu minent, avant la récolte, la substance de nos épis, qu'en général l'homme et les espèces majeures dans les animaux soient affamćes par les espèces infimes, la nature n'en est ni moins remplic, vi moins vivante : elle ne protége pas les unes aux dépens des autres, elle les soutient toutes; mais elle méconnaît le nombre dans les individus, et ne les voit que comme des images successives dine seule et mème empreinte, des ombres fugitives dont l'espece est le corps.

Il existe done sur la terre, et dans l'air et dans l'eau, une quantité déterminće de matière organique que rien ne peut détruire : il existe en même temps un nombre déterminé de moules capables de se l'assimiler, qui se détruisent et se renouvellent à chaque instant, et se nombre de moules ou d'individus, quoique variable dans chaque espèce, est au total toujours le méme, toujours proportionné à cette quantité de matière vivante. Si elle était surabondante, si elle n'était pas, dans tous les temps, également employée et entierement absorbée par les moules existants, il s'eu formerait d'autres, et l'on verrait paraître des especesıou velles; parce que cette matic̀'e vivante ne peut demeurer' oisive, parce qu'elle est toujour's agissante, ct quथٌ suffit qu'elle s'unisse avec des parties brutos pour former des corps organisés. C'est à cette grande combiuaison, ou plutòt à cette invariable proportion, que tient la forme mème de la Nature.

Et comme son ordonnance est fixe pour le nombre, le maintien ct l'équilibre des espèces, olle seprésenterait loujours sous la même face, et serait, dans tous les temps et sous tous les climats, absolument et relativement ka même, si son habitude ne variait pas, autant qu'il est possible, dans toutes les formes individuelles. L'empreinte de charque espèce est un ty'pe dont les principaux traits sont gravés en caractères ineffaçables et permanents à jamais; mais toutes les touches accessoires varient : aucun individu ne ressemble parfaitement à un autre, aucune espèce n'existe saus un grand nombre de variétés. Dans l'espèce liumaine, sur laquelle le sceau divin a le plus appuyé, l'empreinte ne laisse pas de varier du blane au noir, du petit au grand, ete. : le Lapon, le Patagon, l'Hottentot, l'Européen, l'Américain, le Nègre, quoique tous issus du mème père, sont bien éloignés de se ressembler comme frères.

Toutes les especes sont done sujettes aux différences purement individuelles: mais les varićtés constantes, et qui se perpétuent par les générations, n'apparticnnent pas également à toutes : plus l'espèce est élevée, plus le týje en est ferme, et moins elle admet de ces variétés. L'or'dre, dans la multiplication des animaux, étant en raison inverse de l'ordre de grandeur, et la possibilité des différences en raison dircete du nombre dans le produit de leur génération, il était nécessaire qu’il y eût plus de variétés dans les petits animaux (pue dans les grands : il y a aussi, et par la mème raison, plus d'espèces voisines. L'unité de l'espèce étant pllus r'esserrée dans les grands animaux, la distance qui la sépare des autres est aussi plus étendue. Que de variétés et d'espèces voisines accompágnent, suivent ou précédent l'éeureuil, le rat et les antres petits animaux, tandıs que l'éléphant marche seul et sans pair à la tête de tous !

La matière brute qui compose la masse de la terre v'est pas un limon vicrge, une sulsstance intacte et qui n'ait pas subi des altérations : tout a été remué par la force des grands et dles petits agents; tout a été manié plus d'une fois par la main de la nature. Le globe de la terre a été pénétré par le feu, et ensuite recouvert et travaillé par les caux; le sable qui en remplit le dedans est une matière vitrée; Ies lits épais de glaise qui le recourrent au-dehors ne sont que ce mème sable décomposé par le séjour des eaux; le roc vif, le granit, le grès, tous les cailloux, tous les métaux, ne sout encore que cette mème matière vitrée, dont les parties se sont réunies, pressćes ou séparées, selon les lois deleuraffinité. Toutes ces substances sont parfaitement brutes; elles existent et existeraient indépendamment des animaux et des régétaux; mais d'autres substances, en très-grand nombre et qui paraissent également brutes, tirent leur origine du détriment des colys organisés; les mar- 
bres, les pierres à chaux, les graviers, les craies, les marnes ne sont composés que de débris de coquillages et des dépouilles de ces petits animaux quj, transformant l'eau de la mer en pierre, produisent le corail et tous les madrépores, dont la variété est innombrable et la quantité presque immense. Les charbons de terre, les tourbes et les autres matières cqui se trouvent aussi dans les couches extérieures de la terre, ne sont que le résidu des régétaux plus ou moins détériorés, pourris et consumés. Enfin d'autres matières en moindre nombre, telles que les pierres ponces, les soufres, les màchefers, les amiantes, les laves, ont été jetées par les volcans et produites par une seconde action du feu sur les matières premières. L'on peut réduire à ces trois grandes combinaisons tous les rapports des corps bruts et toutes les sulsstances du règne minéral.

Les lois d'affinité par lesquelles les parties constituantes de ces différentes substances se séparent des autres pour se réunir entre elles, et former des matières lıomogènes, sont les mêmes que la loi générale par laquelle tous les corps célestes agissent les uns sur les autres; elles s'exercent également et dans les mêmes rapports des masses et des distances : un globule d'eau, de sable ou de métal agit sur un autre globule, comme le globe de la terre agit sur celui de la lune : et si jusqu'à ce jour l'on a regardé ces lois d'affinité comme différentes de celles de la pesanteur, e'est faute de les avoir bien conçues, bien saisies; c'est faute d'a voir embrassé cet objet dans toute son étendue. La figure, qui dans les corps célestes ne fait rien ou presque rien à la loi de l'action des uns sur les autres , parce quela distance est très-grande, fait au contraire presque tout lorsque la distance est très-petite ou nulle. Si la lune et la terre, au lieu d'uné figure sphérique, avaient toutes deux celle d'un cylindre court, et d'un diamètre égal à celui de leurs sphères, la loi de leur action réciproque ne serait pas sensiblement altérée par cette différence de figure, parce que la distance de toutes les parties de la lune à celles de la terre n’aurait aussi que très-peu rarié ; mais si ces mèmes globes derenaient des cylindres très-étendus et voisins l'un de l'autre, la loi de l'aetion réeiproque de ces deux corps paraitrait fort différente, parce que la distance de chacune de leurs parties entre elles, et relativement aux parties de l'autre, aurait prodigieu- sement changé : ainsi, dès que la figure entre comme élément dans la distance, la loi parait varier, quoique au fond elle soit toujours la même.

D'après ce principe, l'esprit humain peut encore faire un pas, et pénétrer plus avant dans le sein de la nature. Nous ignorons quelle est la figure des parties constituantes des corps; l'eau, l'air, la terre, les métaux, toutes les matières homogènes sont certainement composées de parties élémentaires semblables entre elles, mais dont la forme est inconnue. Nos neveux pourront, à l'aide du calcul, s'ouvrir ce nouveau champ de connaissances, et savoir à peu près de quelle figure sont les éléments des corps ; ils partiront du principe que nous venons d'établir, ils les prendront pour base. Toute matière s'attire en raison inverse clu carré de la distance : el celle loi genérale ne paraít varier, dans les altractions particulières, que par l'effet de la figure des parties constituantes de chaque substance, parce que cettc figure entre comme élément dans la distance. Lorsqu'ils auront donc acouis, par des expériences reitérées, la comnaissance de la loi d'attraction d'une substance particulière, ils pourront trouver par le calcul la figure de ses parties constituantes. Pour le faire mieux sentir, supposons, par exemple, qu'en mettant du vif-argent sur un plan parfaitement poli, on reconmaisse par des expériences que ce métal fluide s’attire toujours en raison inverse du cube de la distance; il faudra chercher, par des règles de fausse position, quelle est la figure qui dome cette expression; et cette figure, sera celle des parties constituantes du vif-argent. Si l'on trouvait par ces expériences que ce métal s'attire en raison inverse du carré de la distance, il serait démontré que ses parties constituantes sont sphériques, puisque la sphère est la seule figure qui donne cette loi , et qu'à quelque distance que l'on place des globes, la loi de leur attraction est toujours la mème.

Newton a bien soupconné que les affinités chimiques, qui ne sont autre chose que les attractions particulières dont nous venons de parler, se faisaient par des lois assez semblables à celles de la gravitation; mais il ne parait pís aroir vu que toutes ces lois particulières n'étaient que de simples modıfications de la loi générale, et qu'elles n'en paraissaient différentes que parce qu'à une très-petite distance la figure des atomes qui s'attirent, fait autant et plus 
que la masse pour l'expression de la loi, cette figure entrant alors pour beaucoup dans l'élément de la distance.

C'est cependant à cette théorie que tient la connaissance intime de la composition des corps bruts : le fonds de toute matière est le même : la masse et le volume, e'est-à-dire la forme serait aussi la même, si la figure des parties constituantes était semblable. Une substance homogène ne peut différer d'une autre qu'autant que la figure de ses parties primitives est diflérente: celle dont toutes les molécules sont sphériques doit être spécifiquement une fois plus légère qu'une autre dont les inoléeules seraient cubiques, paree que les premières ne pouvant se toucher que par des points, laissent des intervalles égaux à l'espace qu'elles remplissent; tandis que les parties supposées enbiques peuvent se réunir toutes sans laisser le moindre intervalle, et former par conséquent une matière une fois plus pesante que la première. Et quoique les figures puissent varier à l'infini, il paraît qu'il n'en existe pas autant dans la nature que l'esprit pourrait en concevoir'; car clle a fixé les limites de la pesanteur et de la légèreté : l'or et l'air' sont les deux extrèmes de toute densité; toutes les figures admises, exécutées par la nature, sont done comprises entre ces deux termes, et toutes celles qui auraient pu produire des substanees plus pesantes ou plus légères ont été rejetées.

Au reste, lorsque je parle des figures employées par la nature, je n'entends pas qu'elles soient nécessairement ni même exactement scmblables aux figures géométriques qui existent dans notre entendement; e'est par supposition que nous les faisons régulières, et par abstraetion que nous les rendons simples. Il n'y a peutêtre ni cubes exacts, ni sphères parfaites dans l'univer's ; mais comme rien n'existe sans forme, et que selon la diversité des substances, les figures de leurs éléments sont différentes, il y en a nécessairement qui approchent de la sphère ou du cube, et de toutes les autres figures régulières que nous avous imaginées : le préeis, l'absolu, l'abstrait, qui se présentent si souvent à notre esprit, ne peuvent se trouver dans le réel, parce que tout y est relatif, tout s'y fait par nuanees, tout s'y combine par approximation. De mème, lorsque j'ai parlé d'une substance qui serait entièremeut pleine, parce qu'elle serait composée de parties cubiques, et

เv. d'une autre substance qui ne serait qu'à moitié pleine, paree que toutes ses parties constituantes seraient sphériques, je ne l'ai dit que par comparaison, et je n'ai pas prétendu que ces substances existassent dans la réalité; car l'on voit par l'expérience des corps transparents, tels que le verre ; qui ne laisse pas d'ètre dense et pesant, que la quantité de la matière y est trèspetite en comparaison de l'étendue des intelvalles; et l'on peut démontrer que l'or, qui est la matière la plus dense, contient beaucoup plus de vide que de plein.

La considération des forees de la nature est l'objet de la mécanique rationnelle; celui de la mécanique sensible n'est que la combinaison de nos forces particulières, et se réduit à l'art de faire des machines : cet art a été cultivécle tout temps, pai la nécessité et pour la commodité ; les anciens y ont excellé comme nous : mais la mécanique rationnelle est une science née, pour ainsi dire, de nos jours. Tous les philosophes, depuis Aristote à Descartes, ont raisomécomme le peuple sur la nature du mouvement; ils ont unanimement pris l'effet pour la cause : ils ne connaissaient d'autres forces lue celle de l'impulsion, encore la connaissaient-ils mal ; ils lui attribuaient les effets des autres forces, ils voulaient y ramener tous les phénomènes du monde. Pour que le projet eût été plausible et la chose possible, il aurait alu moins fallu que cette impulsion, qu'ils regardaient comme cause unique, fùt un effet général et constant qui appartint à toute matiere, qui s'exereât continucllement dans tous les lieux, dans tous les temps: le contraire leur était démontri ; ne voviaient-ils pas que dans les corps en repos eette foree n'existe pas, que dans les corps lancés son effet ne subsiste qu'un petit temps, qu'il est bientôt détruit par les résistances, que pour le renouveler il faut une nouvelle impulsion; que par conséquent, bien loin qu'elle soit une canse générale, elle n'est au contraire yu'un effet particulier et dépendant d'effets plus généraux?

Or, un effet général est ee qu'on doit appeler une cause; car la cause réelle de eet effet genéral ne nous sera jamais connue, parce que nous ne connaissons rien que par comparaison, et que l'effet étant supposé général et appartenant également à tout, nous ne pourons le comparer à rien, ni par conséquent le connaitre autrement que par le fait : ainsi l'attraction, ou, si l'on veut, la pesanteur, étant un efiet gèné- 
ral et conmun à toute matière, et démontré par le fait, doit être regardée comme une cause; et c'est à elle qu'il faut rapporter les autres causes particulières et même l'impulsion, puisqu'elle est moins générale et moins constante. La difficulté ne consiste qu'à voir en quoi l'impulsion peut dépendre en effet de l'attraction : si l'on réfléchit à la communication du mouvement par le choc, on sentira bien qu'il ne peut se transmettre d'un corps à un autre que par le moyen du ressort, et l'on reconnaitra que toutes les bypothèses que l'on a faites sur la transmission du mouvement dans les corps durs ne sont que des jeux de uotre esprit qui ne pourraient s'exécuter dans la nature : un corps parfaitement dur n'est en effet qu'un être de raison, comme un corps parfaitement élastique u'est encore qu'un autre être de raison; ni l'un ni l'autre n'existent dans la réalité, parce qu'il n'y existe rien d'absolu, rien d'extrème, et que le mot et l'idée de parfait n'est jamais que l'absolu ou l'extrême de la chose.

S'il n'y avait point de ressort dans la matière, il n'y aurait donc nulle force d'impulsion : Iorsqu'on jette une pierre, le mouvement qu'elle conserve ne lui a-t-il pas été communiqué par le ressort du bras qui l'a lancée? lorsqu'un corps en mouvement en rencontre un autre en repos, comment peut-on concevoir qu il lui communique son mouvement, si ce n'est en comprimant le ressort des parties élastiques qu'il renferme, lequel se rétablissant immédiatement après la compression, donne à la masse totale la même force qu'il vient de recevoir? On ne comprend point comment un corps parfaitement dur pourrait admettre cette force, ni recevoir du mouvement; et d'ailleurs il est très-inutile de chercher à le comprendre, puisqu'il n'en existe point de tel. Tous les corps, au contraire, sont doués de ressort; les expériences sur l'électricité prouvent que sa force élastique appartient généralement à toute matière : quand il n'y aurait donc dans l'intérieur des corps d'autre ressort que celui de cette matière électrique, il suffirait pour la communication du mouvement; et par couséquent c'est à ce grand ressort, comme effet général, qu'il faut attribuer la cause particulière de l'impulsion.

Maintenant si nous réfléchissons sur la mécanique $\mathrm{du}$ ressort, nous trouverons que sa force dépend elle-mème de celle de l'attraction: pour le roir clairement, figurons-nous le ressort le plus simple, un angle solide en fer, ou de toute autre matière dure ; qu'arrive-t-il lorsquenous le comprimons? nous forcons les parties voisines du sommet de l'angle de fléchir, c'est-à-dire de s'écarter un peu les unes des autres; et dans le moment que la compression cesse, elles se rapprochent et se rétablissent comme elles étaieut auparavant. Leur adhérence, de laquelle résulte la cohésion du corps, est, comme l'on sait, un effet de leur attraction mutuelle; lorsque l'on presse le ressort, on ne détruit pas cette adhérence, parce que, quoiqu'on écarte les parties, on ne les éloigne pas assez les unes des autres pour les mettre hors de leur sphère d'attraction mutuelle ; et par conséquent, dès qu'on cesse de presser, cette force, qu'on remet pour ainsi dire en liber'té, s'exerce, les parties séparées se rapprochent, et le ressort se rétablit. Si au contraire par une pression trop forte on les écarte au point de les faire sortir de leur sphère d'attraction, le ressort se rompt, parce que la force de la compression a été plus grande que celle de la cohérence, c'est-à-dire plus grande que celle de l'attraction mutuelle qui réunit les parties. Le ressort ne peut donc s'exercer qu'autant que les parties de la matière ont de la cohérence, c'està-dire autant qu'elles sont unies par la force de leur attraction mutuelle; et par conséquent le ressort en général qui seul peut produire l'impulsion, et l'impulsion elle-mème, se rapportent à la force d'attraction, et en dépendent comme des effets particuliers d'un effet général.

Quelque nettes que me paraissent ces idées, quelque fondées que soient ces vues, je ne m'attends pas à les voir adopter; le peuple ne raisonnera jamais que d'après ses sensations, et le vulgaire des physiciens d'après des préjugés : or' il faut mettre à part les unes, et renoncer aux autres pour juger de ce que nous proposons. Peu de gens en jugeront donc, et c'est le lot de la vérité; mais aussi très-peu de gens lui suffisent, elle se perd dans la foule ; et quoique toujours auguste et majestueuse, elle est souvent obscurcie par de vieux fantomes, ou totalement effacée par des chimères brillantes. Quoi qu'il en soit, c'est ainsi que je vois, que j'entends la Nature (et peut-ètre est-elle encore plus simple que ma vue) : une seule force est la cause de tous les phénomènes de la matière brute; et cette force, réunie avec celle de la chaleur, produit les molécules vivantes desquelles dépendent tous les effets des substances organisées. 


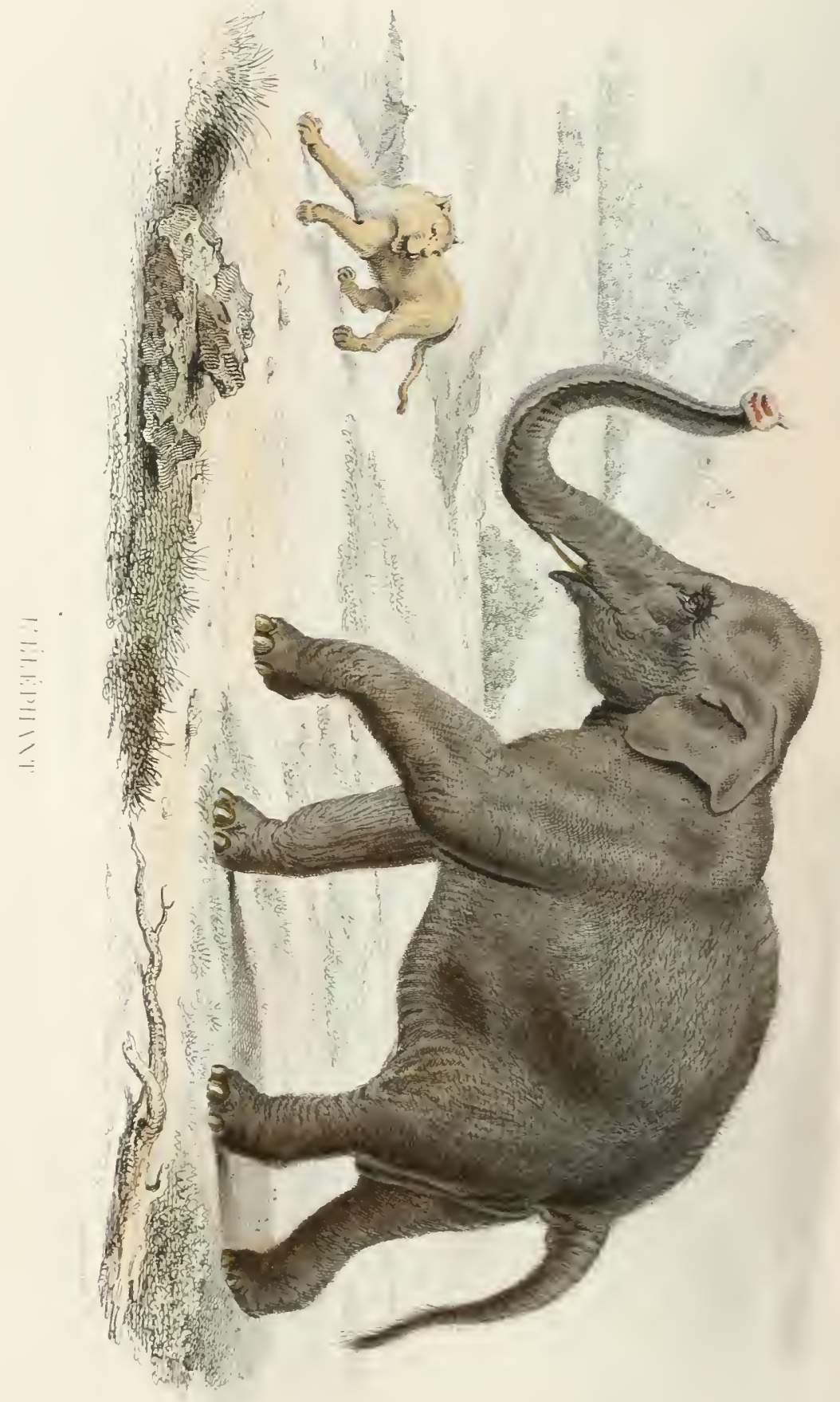




\section{L'ÉLEPHANT.}

ELÉPHANT D'ASIE. — ÉLÉPHANT D'AFRIQUE.

Ordre des pachydermes, famille des proboscidiens, genre eléphaut. (Cuvier.).

L'éléphant est, si nous voulons ne nous pas compter, l'être le plus considérable de ce monde: il surpasse tous les animaux terrestres en grandeur, et il approche de l'homme, par l'inteliigence, autant au moins que la matière peut approeher de l'esprit. L'éléphant, le chicn, le castor et le singe, sont, de tous les êtres animés, ceux dont l'instinct est le plus admirable : mais cet instinct, qui n'est que le produit de toutes les facultés tant intérieures qu'extérieures de l'animal, se manifeste par des résultats bien différents dans eliacune de ces espèces. Le chien est naturellement, et lorsqu'il est livré à lui seul, aussi cruel, aussi sanguinaire que le loup; seulement, il s'est trouvé dans cette nature féroce un point flexible, sur lequel nous avons appuyé: le naturel du chien ne differe done de celui des autres animaux de proie, que par ce point sensible qui le rend susceptible d'affection et capable d'attachement; e'est de la nature qu'il tient le germe de ce sentiment, que l'bomme ensuite a cultivé, nourri, développé par une ancienne et constante société avec cet animal, qui seul en était digne; qui, plus susceptible, plus capable qu'un autre des impressions étrangères, a perfectionné dans le commerce toutes ses facultés relatives. Sa sensibilité, sa docilité, son coúrage, ses talents, tout, jusqu'à ses manières, s'est modifié par l'exemple, et modelé sur les qualités de son maitre: l'on ne doit done pas lui aceorder en propre tout ce qu'il parait avoir; ses qualités les plus relevées, les plus frappantes, sont empruntées de nous; il a plus d'aequis que les autres animaux, parce qu'il est plus à portée d'aequérir; que loin d'avoir comme cux de la répugnance pour l'homme, il a pour lui du penchant; que ce sentiment doux, qui n'est jamais muet, s'est annoncé par l'envie de plaire, et a produit la docilité, la fidélité, la soumission constante, et en mème temps, le degré d'attention nécessaire pour agir en eonséquenee et toujours ohéir à propos.

Le singe, au contraire, est indocile autant qu'extravagant; sa nature est en tout point également revẻche: nulle sensibilité relative, nulle connaissance des bons traitements, nulle mé- moire des bienfaits; de l'éloignement pour la société de l'homme, de l'hor'eur pour la contrainte, du penchant à toute espèce de mal, ou pour mieux dire, une forte propension a faire tout ce qui peut nuire ou déplaire. Mais ces défauts réels sont compensés par dę perfections apparentes; il est extéricurement conformé comme l'homme; il a des bras, des mains, des doigts; l'usage seul de ces parties le rend supérieur pour l'adresse aux autres animaux, et les rapports qu'elles lui donnent avec nous par la similitude des mouvements et par la conformité des actions nous plaisent, nous décoivent et nous font attribuer à des qualités intérieures ce qui ne dépend que de la forme des membres.

Le castor, qui paraît être fort au-dessous du chien et du singe par les facultés individuelles, a cependant reçu de la nature un don presque é(quivalent à celui de la parole : il se fait entendre à ceux de son espice, et si bien entendre qu'ils se réunissent en société, qu'ils agissent de concert, (qu'ils entreprennent et exécutent de grands et longs travaux en commun; et cet amour social, aussi bien que le produit de leur intelligence réciproque, ont plus de droit à notre admiration que l'adresse du singe et la fidélité du chien.

Le chien n'a done que de l'esprit (qu'on me permette, faute de termes, de profaner ce nom), le chien, dis-je, n'a done que de l'esprit d'emprunt; le singe n'en a que l'apparence, et le castor n'a du sens que pour lui seul et les siens. L'éléphant leur est supéricur à tous trois; il réunit leur's qualités les plus éminentes. La main est le principal organe de l'adresse du singe; l'éléphant au moyeu de sa trompe, qui lui scrt de bras et de inain, et avec laquelle il peut enlever et saisir les plus petites choses comme les plus grandes, les porter à sa bouche, les poser sur son dos, les tenir embrassées, ou les lancer au loin, a donc le mème moyen d'adresse que le singe; et en même temps il a la doeilité du chien, il est comme lui susceptible de recomnaissance et capable d'un fort attachement; il s'accoutume aisément à l'homme, se soumet moins par la force que par les bons traitements, le sert avec zèle, avec fidélité, avec intelligence, ete. Enfin l'éléphant, comme le castor, aime la société de ses semblablés, il s'en fait entendre; on les voit souvent se rassembler, se disperser, agir de concert, et s'ils n'édifient rien, s'ils ne travaillent point en commun, ce 
n'est peut-être que faute d'assez d'espace et de tranquillité : car les hommes se sont très-anciennement multipliés dans toutes les terres qu'habite l'éléphant : il vit donc dans l'inquiétude, et n'est nulle part paisible possesseur d'un espace assez grand, assez libre pour s'y établir à demeure. Nous arons vu qu'il faut toutes ces conditions et tous ces avantages, pour que les talents du castor se manifestent, et que partout où les hommes se sont habitués, il perd son industrie et cesse d'édifier. Chaque ètre dans la nature a son prix réel et sa valeur relative : si l'on veut juger au juste de i'un et de l'autre dans l'éléphant, il faut lui accorder au moins l'intelligence du castor, l'adresse du singe, le sentiment du chien, et $y$ ajouter ensuite les avantages particuliers, uniques de la force, de la grandeur et de la longue durée de la vie; il ne faut pas oublier ses armes ou ses défenses, avec lesquelles il peut percer et vaincre le lion; il faut se représenter que, sous ses pas, il ébranle la terre; que de sa main' ' il arrache les arbres; que d'un coup de son corps il fait brèche dans un mur; que terrible par la force : il est encore invineible par la seule résistance de sa masse, par l'épaisseur du cuir qui le couvre; qu'il peut porter sur son dos une tour armée en guerre et chargée de plusieurs hommes; que seul, il fait mouvoir des machines et trausporte des fardeaux que six chevaux ne pourraient remuer ; qu'à cette for'ce prodigieuse, il joint encore le courage, la prudence, le sang-froid, l'obéissance exacte; qu'il conserve de la modérition, même dans ses passions les plus vives; qu'il est plus constant qu'impétueux en amour; que daus la colère, il ne méconnait pas ses amis; qu'il n'attaque jamais que ceux qui l'ont offensé; qu'il se souvient des bienfaits aussi longtemps que des injures; que n’ayant nul gont pour la chair et ne se nourrissant que de vécétaux, il n'est pas né l'ennemi des autres animaux; qu'enfin, il est aimé de tous, puisque tous le respectent et n'ont nulle raison de le craindre.

Aussi leshommes ont-ils eu daus tous les temps pour ce grand, pour ee prenier animal une es-

4 La force de l'éléfhant est si grande, qu'clle ne se peut presıue reconnaitre, sinon par l'expérience; jeu ai vu un porter avec les dents deux canous de fonte, attachés et liés enaenule par des cábles, et pesant chacun trois unilliers: il les enleva seul ef les emporta l'espace de cim cents pas. J'ai ъ a aıssi un éléplıant tirer des navires et des galeres cu tırre el les mettre a llot, Voyages de Fr. l’yrard, tome 11 , page 336. Paris, 1619. pèce de vénération. Les anciens le regardaient comme un prodige, un miracle de la nature (et c'est en effet son dernier effort); ils ont beaucoup exagéré ses facultés naturelles; ils lui ont attribué sans hésiter des qualités intellectuelles et des vertus morales. Pline, Ælien, Solin, Plutarque et d'autres auteurs plus modernes n'ont pas craint de donner à ces animaux des mœurs raisonnées, une religion naturelle et innée, l'observance d'un culte, l'adoration quotidiennedu soleil et de la lune, l'usage de l'ablution arant l'adoration, l'esprit de divination, la piété en. vers le ciel et pour leurs semblables qu'ils assistent à la mort, et qu'après leur décès ils arrosent de leurs larmes et recouvrent de terre, etc. Les Indiens, prévenus de l'jdée de métempsycose, sont encore persuadés aujourd'lıui, qu'un corps aussi majestueux que celui de l'éléphant ne peut être animé que par l'âme d'un grand homme ou d'un roi. On respecte à Siam ', à Laos, à Pé$g^{2}$, etc., les éléphants blancs, comme les mânes vir antes des empereurs de l'Inde; ils ont chacun

1 -2 M. Constance mena I. l'ambassadeur voir l'éléphant blanc, qui est si estimé dans les Indes et qui est le sujet de tant de guerres : il est assez petit et si vieux, qu'il est tout ridé ; plusieurs mandarius sont destinès jour cn avoir soin, et on ne le sert qu'en vaisselle dor; au ruoins les deux bassins qu'vn avait mis devant hui etaient d'ur massif d'une grandeur cxtra: rdinaire. Son appartement est magnifique, et le lam. bris du pavillon ou il est logé est fort proprenient doré. Premier Voyage du P. Taclıard, page 259. Paris, 1686. - Dans une naison de caıpagne du roi, à une lieue de Sian, sur la rıvière, je vis un pelit éléplıat blanc ‘juon lestine pour ètre le successeur de celui qui est da:s le palais, yue lon dit arolr près de truis cents ans; ce petit elejphant est un peu plus gros qu'un bouf; il a beaucoup de mandarins à son service: et, à sa considération, l'on a de grands égaris pour sa ınère et pour sa tanle que l'on éléve avec lui. Idem, jage $27 \overline{5}$.

Lorsque le roi de Pégu va se promener, les quatre éléphants blanes marchent devant lui. ornés de pierrerics et de divers enjolivements d'or. Recueil des royages de la Cumpagnie des Indes de Hollande, tome 111 , page $\mathbf{4 3}$... Lorsque le roi de Péguveu donuer audience, lon améne devant lui les quatre élé. phants blancs, qui lui font la révérence en levant leur trompe, onvrant lenr gneule. jetant trois cris bien rlistincti et sagenouillant. Quand ils sout relevés, on les remène á leurs écuries, oủ on leur (lonne à unanger ả clacun dans un vaisseau itor grand comme un quart de touneau de bière; on les lave d"une eau yui est dans nu antre vaisseau d'argent, ce yui se fait le plu suuvent deux fois par jonr... Pendant quion les panse ainsi, ils sout sous un dais qui a butt supports, yui sont tenus par autant de domestiques, afin de les garantir te l'ardeur dil soleil. Eu allant aux valsseaux où est leur eau et leur nourriture, ils sont précédés de trois trompettes dont ils ea. tendent les accords, et marchent avec beaucoup de gravité. réglant leurs pas par le son de ces intruments, elc. ldem, lome 11I. plage 40.-Les Pégnans tienuent les ríléphants hlancs pour sacrés. et ayant su que le roi de Siam en avait deux, ils y "uvoyerent des aublossadeurs jour offrir tont le prix quion en desirerilt. I.e roi de Sian ne youlut pas les vendre : celni de l’égu, offensé de ce refus, vint, et non-seulenent les ealeva jar force, mais il se rendit tout le pays tributaire. Idem, tome 11 , page 225 . 
un palais, une maison composée d'un nombreux domestique, une vaisselle d'or', des mets choisis, des vetements magnifiques, et sont dispensés de tout travail, de toute obéissance; l'empereur vivant est le seul devant lequel ils lléchissent les genoux, et ce salut leur est rendu par le monarque; cependant les attentions, les respects, les offrandes les flattent sans les corrompre; ils n'ont done pas une âme humaine; cela seul ievrait suffire pour le démontrer aux Indiens.

En écartant les fables de la crédule antiquité, en rejetani aussi les fictions puériles de la superstition toujours subsistante, il reste encore assez à l'éléphant, aux yeux mèmes du philosophe, pour qu'il doive le regarder comme un être de la première distinction; il est digne d'ètre connu, d'ètre observé; nous tâcherons donc d'en écrire l'histoire sans partialité, c'est-à-dire sans admiration ni mépris; nous le consiclérerous d'abord dans son état de nature lorsqu'ilestindépendant et libre, ti ensuite dans sí condition de servitude ou de domesticité, où la volonté de son maitre est en partic le molvile de la sienne.

Dans l'état de sauvage, l'éléphant n'estni sanguinaire, ni féroce : il est d'un naturel doux, et jamais il ne fait abus de ses armes ou de sa force; il ne les emploie, il ne les exerce que pour se délendre lui-mème ou pour protéger ses semblables. Il a les mocurs sociales; on le voit rarement errant ou solitaire. Il marche ordinairement de compagnie; le plus ágé conduir la troupe, le second d'àge la fait aller et marche le dernier; les jeunes et les faibles sont au milicu des autres; les mères portent leurs petits et les tiennent enubrassés de leur trompe. Ils ne gardent cet ordre que dans les marehes périlleuses, lorsfu'ils vont paitre sur des terres cultivées; ils se promènent ou voyagent arec moins de préeaution dans les forêts et dans les solitudes, sans cependant se séparer absolument ni mème s'ćcarter assez loin pour être hor's de portéedes sccours et des avertissements : il y en a néanmoins quelques-uns qui s'égarent ou qui trainent après les autres, et ce sont les seuls que les chasseurs osent attayuer; ear il faudrait une petite armée pour assaillir la troupe entiere, et l'on ne pourrait la vainere sans perdre beascoup de monte : il serait meme dangereux de lemr faire ia moindre injure '; ils vont droit à l'offenseur,

I Les Negres rapporlent ımanimsement de ces animamx, цие s'ils rencontrent quely'tun d.ms un bois, ils ne lui font ancun unal, fourvi qu'il ne les altaque foint: Inais turils tlevien- etquoique la masse de leur cor'ps soit très-pesante, leur pas est si grand qu ils atteignent aisément l'hommele plus léger a la course; ils le percent de leurscléfenses, ou, le sáisissant a vec la trompe, le lancent comme une pierre et achèvent de ie tuer en le foulantaux pieds. Ia is ce n'est quelorsqu'ils sont provoqués qu'ils font ainsi main-basse sur les hommes; ils ne font aucun mal à ceux (jui ne les cherchent pas : cependant, commeils sont susceptibles et clélicats sur le fait des injures, il est bon d'éviter leur rencontre, et les voyageurs qui fréfuentent leur pays allument de grands feux la nuit et battent de la caisse pour les enpêcher d'approcher. On prétend (fue lorsqüils ont une fois été attaqués par les hommes, ou quils sont tombés dans quelque embukclie, ils ne l'oublient jamais et qu'ils cherchent à se venger en toute occasion. Comne ils ont l'odorat excellent ('t peut-ètre plus parfait qu'atucun des animaux, a cause de la grande citendue de leur nez, l'odeur de l'homme les frappe rle très-loin ; ils pourraient aisément le suivre à la piste. Les anciens ont écrit que les éléphants arrachent l'herbe des endroits oủ le chasseur a passé, et qu'ils se la donnent de main en main, pour que tous soient informés du passage et de la marche de l'ennemi. Ces animaux aiment le bord des fleuves, les profondes vallées, les lieux ombralgés et les terrains humides; ils ne peurent se passer d'eau et la troublent avant'que de la boire: ils en remplissent sourent leur trompe, soit pour la porter a leur bouche ou seulement pour se rafraichir le nez et s'amuser en la répandant ì flot ou l'aspergeant a la ronde. Ils ne peuvent supporter le froid et souffrent aussi de l'excés de la chalcur; car, pour éviter la trop graude ardeur du soleil, ils s'enfoncent autant qu'ils peuvent dans la profondeur des forets les plus sombres; ils se mettent aussi assez souvent dans l'eau : le volume énorme de leur corps leur nuit moins qu'il ne leur aide à nager; ils enfoucent moins dans l'eau que les autres animaux, et d'ailleurs la longueur de leur trompe (pu'ils redressent en haut et par la-

nent furieux lorsquion Ieur tire dessus el quon ne les blese pas a mort. voyage de cinizée. jur Bosman, page 2ı. - l'é. léfhant samvage est veun en funrsuivant un hemue qri lui disail de's injures, el il sest tronve pris an trelunchet. Jusmal dı Vuyage de Siam, jar liahbe te cihuisy. Paris, 1657, p. 242. - Cesx yni insultent on ugui font du mal a leslephant doirent bien prentre garde a enx, car ils n' unllient jas aisement les

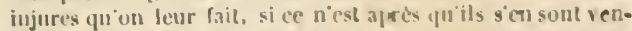
fés. Reencil des Voyage's de la Cannpagnie des Indes de IJolIande, 'ome I, page 113. 
quelle ils respirent, leur ôte toute crainte d'être submergés.

Leurs aliments ordinaires sont des racines, des herbes, des fenilles et du bois tendre: ils mangent aussi des fruits et des grains; mais ils dédaignent la chair et le poisson. Lorsque l'un d'entre eux trouve quelque part un pâturage abondant, il appelle les autres et les invite à venir manger avec lui. Comme il leur faut une grande quantité de fourrage, ils ehangent souvent de lieu, et lorsqu'ils arrivent à des terres ensemencées, ils y font un dégât prodigieux; lcur corps étant d'un poids énorme, ils écrasent ct détruisent dix fois plus de plantes avec leurs pieds qu'ils n'en consomment par leur nourriture, laquelle peut monter à cent cinquante $\mathrm{li}$. vres d'herbes par jour : n'arrivant jamais qu'en nombre, ils dévastent done une campagne en une heure. Anssi les Indiens et les Nègres cherchent tous les moyens de prévenir leur visite et de les détourner; en faisant de grands bruits, de grands feux autour de leurs terres cultivées; souvent, malgré ces précautions, les éléphants viennent s'en emparer, en chassent le bétail domestique, font fuir les hommes et quelquefois renversent de fond en comble leurs minces habitations. Il est difficile de les épouvanter, et ils ne sont guère susceptibles de crainte; la seule chose qui les surprenne et puisse les arrèter, sont les feux d'artifice, les pétards qu'on leur lance, et dont l'effet subit et promptement renouvelé les saisit et leur fait quelquefois rebrousser chemin. On vient très-rarement à bout de les séparer les uns des autres; car ordinairement ils prennent tous ensemble le même parti d'attaquer, de passer indifféremment ou de fuir.

Lorsque les femelles entrent en chaleur, ce grand attachement pour la société eède à un scntiment plus vif : la troupe se séparc par couples que le désir avait formés d'avance; ils se prennent par choix, se dérobent, et dans leur marche l'amour paraît les précéder et la pudeur les suivre; car le mystère accompaene leurs plaisir's. On ne les a jamais vus s'aecoupler; ils eraignent surtout les regards de leurs semblables, et connaissent peut-être mieux que nous eette volupté pure de jouir daus le sileuce, et de ne s'oceuper que de l'oljet aimé. Ils cherchent lesbois les plus épais; ils gagnent les solitudes les plus profondes pour se livrer, sans témoins, sans trouble et sans réserve à toutes les impulsions de la nature : elles sont d'autant plus vives et plus durables, qu'elles sont plus rares et plus longtemps attendues. La femelle portedeux ans; lorsqu'elle est pleine, le måle s'en abstient, et ce n'est qu'à la troisième année que renaît la saison des amours. Ils ne rroduisent qu'un petit, lequel au moment dr: sa naissance a des dents, et est déjà plus gros qu’un sanglier : cependant les défenses ne sont pas encore apparentes; elles commencent à percer peu de temps après; et à l'âge de six mois elles sont de quelques pouces de longueur : I'éléphant à six mois est déjả plus gros qu'un bœuf, et les défenses continuent de grandir et de croitre jusqu'à l'àge avancé, pourvu que l'animal se porte bien et soit en liberté; car on n'imagine pas à quel point l'esclavage et les aliments apprètés détériorèut le tempérament et changent les habitudés naturelles de l'éléphant. On vient à bout de le dompter, de le soumettre, de l'instruire; et comme il est plus fort et plus intelligent qu'un autre, il sert plus à propos, plus puissamment et plus utilement : mais apparemment le dégoùt de sa situation lui reste au fond du cceur ; car quoiqu'il ressente de temps en temps les plus vives atteintes de l'amour, il ne produit ni ne s'aceouple dans l'état de domesticité. Sa passion contrainte dégénère en fureur: ne pouvant se satisfaire sans témonis, il s'indigne, il sirrite, j) devient insensé, violent, et l'ou a besoin des chaines les plus fortes et d'entraves de toute espèce pour arrêter ses mouvements et briser sa colère. Il diffère done de tous les animaux domestiques que l'homme traite ou manie comme des ètres sans volonté; il n'est pas du nombre de ces eselaves-nés que nous propageons, mutilons ou multiplions pour notre utilité: ici l'individu seul est eselave, l'espèce demeure indépendante et refuse constamment d'aceroitre au profit du tyran. Cela seul suppose dans l'éléphant des sentiments élevés au-dessus de la nature eommune des bètes : ressentir les ardeurs les plus vives et refuser en mème temps de se satisfaire, entrer en furcur d'amour et conserver la pudeur, sont peut-ètre le dernier effort des vertus humaines, et ne sont dansee majestueux animal que des actes ordinaires, auxquels il n'a jamais manqué; l'indignation de ne pouvoir s'accoupler sans témoins, plus forte que la passion mème, en suspend, eu détruit les effets, excite en mème temps la colère, et fait que dans ces moments il est plus dangereux que tout autre animal indompté. 
Nous voudrions, s'il était possible, douter de ce fait; mais les naturalistes, les historiens, les voyageurs, assurent tous de eoneert que les éléphants n'ont jamais produit dans l'état de domesticité. Les rois des Indes en nourrissent en grand nombre; et après avoir inutilement tenté de les multiplier comme les autres animaux domesticues, ils ont pris le parti de séparer les máles des femelles, afin de rendre moins fréquents les aceès d'une chaleur stérile qu'accompagne la fureur. Il n'y a done aucun éléphant domestique qui n'ait été sauvage autparavant, et la manière de les prendre ${ }^{1}$, de les dompter, de les soumettre, mérite une attention partieulière. Au milieu des forèts et dans un lieu voisin de ceux qu'ils fréquentent, on choisit un espace qu'on environne d'une forte palissade; les plus gros arbres de la forêt servent de pieux prineipaux contre lesquels on attache les traverses de charpente qui soutiennent les autres pieux : cette palissade est faite à claire-voie, en sorte qu'un homme peut y passer aisément; on y laisse une autre grande ouverture, par laquelle l'éléphant peut entrer, et

- J'allai voir la grande chasse des éléphants, qui se fait en la forme suirante. Le roi envoic grand nombre de femelles en eompagnie, et quand elles unt éfe plusieurs jours dans les bois et qu'il est averti qu'on a trouvé des eléphants, il envoie trente ou yuarante mille hommes yni font une trìs-grande enceinte daus l'endroit oi sont les éléphants; ils se postent de qualre en quatre, de vingt à vingt-einy jieds de distanec les uns des autres, et à elrayue campement on fuit un feu, élevé de trois pieds de terre on environ. Il se lait une antre eneeinte d'éléphauts de guerre, distants les uns des autres d'environ cent el eent eimumante pas. et dans Ins endroits où les ébéphants pourraient sortir plus aisément, les éléplıants de guerre sout plus fréųuents : eu plusieurs ticux it y a dı eanou, che l'on tire yuand les éléphants sanvages venlent foreer le passage, ear its eraignent forl le fen: tons les jours on diminue ectle eneeinte, et à la lin etle est très-petite, et les feux ne ne sont pas à plus de ciny on six pas les uns des antres. Conme ers fléphants entendent du bruit autour d'eux, its n'osent pas s'enfuir, unoiugne pourtant it ne laisse pas de s'en sauver quelqunes-nus, ear on ma dit qu'il y avait quelques jours yu'il s’en était sauvé dix. Quand on les vent prendre. on tes fait entrer dans une place cutourée de pienx, on il y a quclipes arbres entre lesquels un homme peut facilement passér. 11 y a une autre enceinte d'éléphants do guerre et de soldats, dlans laquelle il y entre des hommes montés sur des elćphanls, fort atroits à jeter des eordes aux jambes de derricre des élépliants, qui, lorsịn'ils sont atticlies de ectte manière, sınt mis entre denx éléphants privés, entre t'squels il y en a un intre чuni les pousse par derrière, de sorte yu'il est obligé te marchure ; et yuand il vent faire le méchant, les antres lui donuent des conus de trompe. On les mina surs des toits, et on les attacha de la miuse manière unue Is préeçlent: jen vis prendre dix, et on ure dit cuill y eu avait cent quaraute dins l'onceinte. l.e roi y était prísent, il dounail ses orlle's pour tout ce uni était nécessaire. Relation de lambassiate de it. le chevalier de Chammont à la eour du roi de sian, page 91 et suivautes. Paris, 1686. cette baie est surmontée d'une trappe suspendue, ou bien elle reçoit une barrière qu'on ferme. derrière lui. Pour l'attirer jusque dans eette en ceinte, il faut l'aller chercher ; on conduit une femelle en chaleur et privée, dans la forêt, et lorsqu'on imagine étre à portée de la faire entendre, son gouverneur l'obligre à faire le eri d'amour; le mâle sauvage y répond à l'instant et se met en marche pour la joindre : on la fait mareher elle-même en lui faisint de temps en temps répéter l'appel; elle arrive la première à l'enceinte où le mâle, la suirant ì la piste, entre par la mème porte ¿ dès qu'il se voit enfermé, son ardeur s'évanouit; et lorsqu'il aperȩoit les chasseurs, elle se ehange en fureur : on lui jette des cordes à nœuds coulants pour l'arrèter; on lui met des entraves aux jambes et al la trompe; on amène deux ou trois éléphants privés et conduits par des hommes adroits; on essaie de les attacher avee l'éléphant sauvage; enfin l'on vient à bout par adresse, par tourment et par earesse, de le dompter en peu de jours. Je n'entrerai pas à cet égard dans un plus grand détail, et je me contenterai de citer les voyageurs qui ont été témoins oculaires de la chasse des éléphants ${ }^{\text {; }}$ elle est différente, suivant les diffé-

- A un quart de lieue de Louvo, il y a une espéce d'amphithéâtre dont la figure est d'un granil earré long, entouré de hautes murailles terra.sées, sur lesıuelles se plaecut les spectatenrs. Le long de ces murailles, cu dedans, tigne: un' palissade de gros piliers lichés en terre à deux pieds l'un de l'autre, derrière lesuquels les chasspurs se retirent lırsuu"ils sont poursuivis par les éléphants irrités. On a pratipné mue lort grande onverture vers la camplaysue. et vis-à-vis, du cúté de la ville, on en a faitune plus petite, qui conduit dans une allée étroile par où un éléphant peut passer à peine, et cette allé aboutit à une manic̀re de grande remise ou lion achève de le lompter.

Lorsune le jour destiné à eette ehasse est veru, les chasseur's eutrent dans les bois, montés sur des cléphimis lemelles quiou a dressées à celte exercice, el se couvient de fcuslles d'arbres, atin de n’être pas vus par les éléphants sauvages. Quaud ils unt avaneb daus la foret, et qu'ils jugent yu"il p'u! y avoir quelque éléfliant aux environs, ils font jeter aux feuelles certaius cris jropres à altirer les uales, yjut y" réprondent aussilot par des lumements effroyables. Alurs les eliasseurs, les sentaut à une juste distance, returnent sur leurs fats, et menent duucement les lemelles du eỏle de l'auphitheitre dout uous senons de flarler: les éléphants sanvage's ne manquent jantis de les suivre; eclui que nons vines dumpter entra avec elle's, et dès yu'il y fut, un Ferma la barriere; les femelles continuèrent leur ehemin an Iravers de

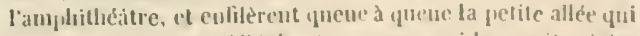

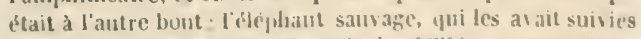
jusyue-là, sétant arreté à l'entrée du dilile, un se servit de

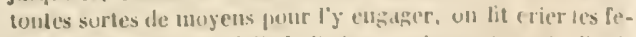

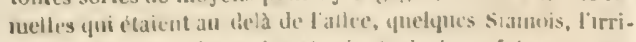
tant en frappant des mains et criant filusieurs fuis pat, pht,

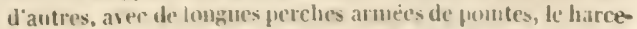
laient. et ynand ds en étaient pursuivis, ils se glisaieut en- 
rents pay's, et suivant la puissance et les facultés de ceux qui leur font la guerre; car au lieu de construire, comme les rois de Siam, des murailles, des terrasses, ou de faire des palissades,

trc les piliers et s'allaient cacher derrière la palissade, que léléphant ne pouvait franchir; enfin, après avoir poursuivi plusieurs chasseurs, il s'attacha à un senl avec une extrème fureur; l'homme se jeta dans l'allée, l'éléphant courut après lui, mais dès qu'il y fut entré il se trouva pris, car, celui-ci s'étant sauvé, on laissa tomber deux coulisses à propos, l'une devant et l'autre derrière, de sorte que ne pouvant ni avancer, ni reculer, ni se retourner, it fit des efforts étonnants et poussa des cris terribles. On tâcha de l'adoucir en lui jetant des seaux d'eau sur le corps, en le frottant avec des feuilles, en lui versant de l'huile sur les oreilles, et ou tit venir auprès de lui des éléphants privés màles et femclles, qui le caressaient avec leurs trompes. Cependant on lni attachait des cordes $\mu$ ardessous le ventre et aux pieds de derrière afin de le tirer de là, et on continuait à lui jeter de l'eau sur la trompe et sur le corps pour le rafraichir. Enfin on fit approcher un éléphant privé, de ceux qui ont coutume d'instruire les nouveau-venns : un officier était monté dessus, qui le faisait avancer ou reculer, pour montrer à l'éléphant sanvage qu'il n'avait rien a craindre et qu'il pouvait sortir : en effet. on lui ouvrit la porte, et il suivit l'autre jusqu' au bout de l'allée : dès qu'il y fut, on mit à ses cótés deux éléphants que l'on attacha avec lui, un autre marchait devant et le tirait avec une cordc dans le chemin qu'on lui roulait faire faire, pendant qu'un quatrieme le faisait avaucer à grands coups de tète qu'il lui donnait par derrière jusqu" à une espèce de remise, ủ on l'attacha à un gros pilier fait exurès, qui tourne comme un cabestan de navire. On le laissa là jusqu au lendemain pour lui laisser passer sa colère; mais tandis qu il sc tourmentait autonr de cette colonne, un bramine, $c^{*}$ est-à-dire de ces prétres indiens (qui sont à Siam en assez grand nombre), habille de blanc, s'approcha monté sur un éléphant, el tournant doucement autour de celui qui était attaché, l'arrosa d'une certaine eau consacrée à leur manière. qu'il portait dans un vase d'or : on croit que cette cérémonie fait perdıe à l'éléphant sa férocité naturelle et le rend propre à servir le roi. Dis le lendemain il commenca à aller avec les antres, et au bout de quinze jours il est entièrement apprivoisé. Premier Voyage du P. Tachard, page 298 et suiv.

On n'eut pas plutôt descendu de clieval et monté sur des éléphants qu'on avait préparés, que le roi parut, suivi d'un frand nombre de mandarins montés sur des élephants de guerre. On suivit et on s'enfonça dlans les bois environ une lieuc, jusquu'à l'enclos oij ét aient les éléphants sauvages. Céttait uu parc carré, de trois on quatre cents pas géométriques, dont Iss côtés étaient fermés par de gros pieux; on y avait pourtant laissé de grandes ouvertures de distance en distance. fl y avait quatorze éléplants de toute grandeur. D'abord qu'on fut arrivé, ın fit une enceinte d'envirou cent éléphants de guerre,

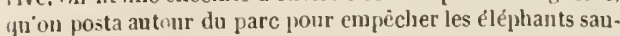
vages de franchir les jalissades; uons étions derrière cette haie et tout auprès du roi. On poussa dans l'enceinte du parc une douzaine d'éléplıants privés des plus forts, sur chacun desquels deux hommes étaient montés, avec de grosses corđcs à nuevuds coulants, dont les bouts étaient attachés aux élèpluants yı' ils montaient. Ils couraient d'abord sur l'élépliant quils voulaient prendre, qui, se woyant poursuivi, se présentait à la barrière pour la forcer et pour s'enfuir; mais tout était bloqué d'éléphants de guerre. par lesquels il était repoussć dans l'enceinte; et comme il fuyait daus cet espace, les chassenr's yui étaient moutés sur des élépliants privés jetaient leurs nouds si à propos dans les cndroits où ces anjmaux tevaient mettre leur pied, quils ne unanquaient guère de les prendre : en effet, tout fut pris dans une hemre. Ensuite on attacha.it chaque èléphant sauvage. et l'on mettait à ses cótés demx eléphants prives, avec lesquets on devait les

\section{des parcs et de vastes enceintes, les pauvres} Nègres' se contentent des piéges les plus simples,

laisser pendant quinze jours pour ètre apprivoisés par lenr moyen. Idem, page 540.

Nous eûmes peu de jours après le plaisir de la chasse aux éléphants; les Siameis sont fort adroits à cette chasse, et ils ont plusieurs manières de prendre ces animaux. La plus facile de toutes, et qui n'est pas la moins divertissante, se fait par le moyen des éléphants femelles. Quand il y en a une en chaleur, on la mène dans les bois de la forèt de Louvo, le pasteur qui la conduit se met sur son dos et s'entoure de feuilles pour' n'être pas aperçu des éléphants sauvages; les cris de la femelle privée, quelie ne manque pas de faire à un certain signal du pas!eur, attire les élépbants d'alentour qui l'entendeut et qui se inettent aussitót à sa suite. Le pastenr ayant pris garde à ces cris mutuels, reprend le chemin de Louvo, et va se rendre à pas lents avec toute sa suite, qui ne le quitte point, dans une enceinte de gros pieux faite expres, à un quart de lieue de Louvo, et assez près de la forèt. On avait ainsi ramassé une assez grande troupe d'étephants, parmi lesquels il $n$ 'y en avait quiun grand et assez difficile à prendre et à dompter... Le pasteur qui conduisait la femelle sortit de cet enclos par un passage étroit fait en allée, de la longueur d'un èléphant; aux deux bouts $\mathrm{jl}$ y avait deux portes à coulisse.s qui s'abattaient et se levaient aisément. Tous les autres petits éléphants suivirent les uus apres les autres les traces de la femelle à diverses reprises; mais un passage étroit étonna le grand éléphant sauvage, qui se retira toujours; on fit revenir la femelle plusieurs fois; il la suivait jusqu"à la porte, mais il nc voulut jamais passer outre, comme s'il eût eu quelque pressentiment de la perte de sa liberté qu'il y allait faire. Alors plusieurs Siamois, qui étaient dans le parc, s'avancèrent pour le faire avancer par force, et vinrent l'attaquer avec de longiles perches, de la pointe desquelles ils lui donnaient de grands coups. Ijéléphant en colère les poursuivait avec beaucoup de fureur et de viteste, et aucun d"enx ne lui aurait assurément échappé s'ils ne se lussent promptenzent retirés derrière des piliers qui formaient la palissade, contre lesquels cette bète irritée rompit trois ou quatre fois ses grosses dents. Dans la chaleur de la poursuite, un de ceur qui l'altaquaient le plus vivement et qui en était aussi le plus vivement suivi, s'alla jeter en fuyant entre les deux portes, où l'éléphant courut pour Ic tuer; mais dès qu'il fut entré, Ic Siamois s'échappa par un petit entre-deux, et cet animal s'y trouva pris, les denx portes s'étant abattues en mème temps; et quoiqu'il s'y debattit, il y demeura. Pour l'apaiser, on lui jeta de l'eau à plein seau, et cependant on lui attachait des cordes aux jam. bes et au cou; quelque temps après qu'il se fut bien fatigne, on le fit sortir par le moyen de deux éléphants privés qui le tiraient par devant avec des cordes, et par deux autres qui le poussaient par derrière jusqu’à ce qüil fût altaché à un gros pilier, autour duquel il lui était seulement libre de tourner. Cue heure après, il devint si traitable, quinn Siamois monta sur suil dos, et le lendemaiı on le détacha pour le mener à l'écurie avec les autres. Second Voyage dı P. Tachard, p. 332 et 335 .

Quoique cet animal soit grand et saivage; on ne laisse pas d'en prendre quantité en Éthiopie, de la façon que je vais dire. l)ans les forèts épaisses où il se retire la nuit, on fait ine enceinte avec des pieux cntrelacés de grosses branclies. et on lui laisse un passage yui a une petite porte tendue con. tre terre. Lorsque l'éléphant est entré, on la tire en haut de dessus un arbre avec une corrle et on l'enferme, puis on descend et on le tue à coups de fleches; mais si, par hasard, on le manque et qu'il sorte de l'enceinte, il tue tout ce qu'il rencontre. L'Afrique de $\mathbf{N a r m o l . ~ P a r i s , ~ 1 6 6 7 , ~ t o m e ~} 1$, page 58. La chasse des éléphants se lait de diverses manières : en des endroits, où lion tend des chausse-trappes, par le mojen desyuelles ils tombent dans quelque fosses. ois on les tire aisément quand on les a blen embarrassés. En d'autres, on se sert 


\section{DE L'ÉLÉPHANT.}

en creusant sur leur passage des fosses assez profondes pour qu'ils ne puissent en sortir lorsqu'ils y sont tombés.

L'éléphant, une fois dompté, devient le plus doux, le plus obéissant de tous les animaux ; il s'attache à celui qui le soigne, il le earesse, le prévient, et semble deviner tout ce qui peut lui plaire; en peu de temps, il vient à comprendre les signes et même à entendre l'expression des sons; il distingue le ton impératif, celui de la colère ou de la satisfaction, et il agit en conséquence. 11 ne se trompe point à la parole de son maitre; il reçoit ses ordres avec attention, les exécute avec prudence, avec empressement, sans préeipitation; ear ses mouvements sont toujour's mesurés, et son caractère paraît tenir

d'une femelle apprivoisée, qui est en clzaleur et que l'un mène en un lieu étruit où on l'attache; elle y fait venir le mále par ses cris; yuand il y est, on l'euferme par le moyen de quelyues barrières faites exprès, ju'on pousse pour l'empècher de surtir, et cependant (ju'il t'ouve la femelle sur le dos, il labite avec elle contre l'usage dles autres bites. II tàche après cela de se relirer; mais comme il ya el vient pour trouver une sortie, les chiassurs qui sont sur la muraiile ou sur quelque autre lieu élevé, jettent quantite de petites et grosses cordes, avec quelyues chaines, par le moyen desquelles ils embarrassent tellement sa trompe et le reste de son eorps, qu'ils en approchent ensuite saus danger; et après qu'ils ont pris quelques précautions nécessaires, ils l'emmènent à la eompagnnie de deux autres éléphants rpui sunt apprivoisés, et qu'ils ont amenés exprès pour lui donner excuple, on pour le menacer sil fait le mauvais... Il $\mathrm{y}$ a encore d'autres piéges pour prendre les éléphants, et chaque pays a sa manière. Relation d'un Voyage, par Thévenot. Paris, 1664, tome 111, page 151.-Les liabitants de Ceylan font des fosses bien profondes qu'ils convrent de planches qui ne sont point jointes, et les planches sout con crtes cie paille, anssi bien que le vide qui est entredeux. La unit, lorsque les éléphants passent sur ces fosses, ils y tombent et n'en peuvent sortir; si bien qu'ils y périraient de faim, si on ue lenr faisait porter à manger par des esclaves, à la vue desquels ils s'accoutument, et ainsi ils s'appri-

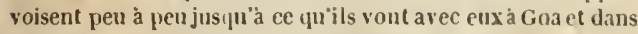
les autres pays voisins pour gagner leur vie et celle de leurs maitres. Divers Memoires tonchant les Indes orientales, premier discours, lome II, page 237 . Recneil des Voyages dle la Compagnie dirs Indes. Amsterl. 1711. Comme les Eurnpéens paient les dents des éléplants arsez cher, c'est un motif qui arme continuellement les Negres contre l'éléphant. Ils sattronpent (puelquefois pour eette chasse, avee Jenrs fleches et leurs zagayes. Mais leur méthode la plus commune est celle des fossés, (ju'ils creusent dans les bois, qui leur réussissent d'autant mieux, qu'on ne peut guère se tromper à la trace des eléphants... On les prenid en deux façons, ou en leur prépa. rant des fosses couvertes de branclies d'arhires, dans lesipuelles ils tombent sans y prendre garde, on à la chasse qui se fail de cette sorte. Dans l'ile tle Ceylan, oi il y a une trèsgrande multitude déléphants. ceux rpui s'ocenpent a leur chasse ont des éléphants femelles yu'ils ippellent Alias. Dìs quils savent „ju'il y a en quelyue lien quelyues-lans de ces animanx encore sauvages, ils y vont, menant avec enx deux de ces alias, qu'ils relielient anssilót qu'ils déconvrent un male; elles s'en approchent des deux cótés, et l'ayant mis au milien, l'y retienneut si serré, qu'il lul est impossible de s'enfuir. Voyage d'Orient du P. Philippe de la très-sainte Trinité Lyon, 1669 , page 361 . de la gravité de sa masse. On lui apprend aisṕment à fléchir les genoux pour donner plus de facilité à ceux qui veulent le monter; il earesse ses amis a vee sa trompe, en salue les gens qu'or. lui fait remarquer; il s'en sert pour enlever des fardeaux et aide lui-méme à se charger; il se laisse rêtir et semble prendre plaisir à se voir couvert de harnais dorés et de housses brillantes. On l'attèle, on l'attache par des traits à des chariots ', des charrues, des navires, des cabestans ; il tire également, continủment et sans se rebuter, pourvu qu'on ne l'insulte pas par des coups donnés mal à propos, et qu on ait l'air de lui savoir gré de la bonne volonté avec laquelle il emploie ses forces. Celui qui le conduit ordinairement est monté sur son cou et se sert d'une verge de fer ${ }^{2}$, dont l'extrémité fait le erochet, ot qui est armée d'un poinçon avec lequel on le pique sur la tète, à còté des oreilles pour l'avertir, le détourner ou le presser; mais souvent la parole suffit, surtout s'il a eu le temps de faire connaissance complète avec son conducteur et de prendre en lui une entière confiance : son attachement devient quelquefois si fort, si durable et son affection si profonde, qu'il refuse ordinairement de servir sous tout autre, et qu'on l'a quelquefois vu mourir de regret d'a-

' Voici ce que j’ai vu moi-mème de l'éléplıant. Il y a toujours à Goa quelyues éléphants pour servir à la construction des navires: je vins un juur au hord du fleuve, pioche duquel on en faisait un trés-gros dans la méme ville de $G$ ina, ou il y a une grande place remplie de poutres pour cet effet; quel. qu's hommes en liajent de fort pesantes par lo bout avec une corde qu'ils jetaient à úléphant, lequei se l'ćtaut purtée à la bonche et en ayant fait deux tours à sa trompe, les irainait lui seul, sans aucun conducteur, an lieu oul'on coustı uisait le navire, yuon n'avait fait que de luimontrer une fois ; et que]quefois it en trainait de si gronses, que vingt lumnes el possible encore davantage ne les en-sent pu renuer. Ilais ce yue je remarquai te plus etomnant fut que Jorsqu"il rencontrait sur son chemin d'autres poutres qui l'empucluaeut de tucer la sienne. en y mettanl le pred dessuus, il en enlevidt le buat en liant. atin qujelle pint aisénent cunrir par-dissus les autres. Que pourrait faire davantage le plus raisonnable homme du monde? Voyage dorient lu P. Plilippe de la tres-sainte Trinilẻ. Lyon, 1669, page 397.

${ }^{2}$ Celui ųui conduit l'élẻphant se met à cheval sur le cou, il ne le conluit pas avec une loride on un freiu, ot ue le pịnue avec ancume sorte de pic, mais avee une grosse verge de fer fort pintue par le bout, dont il se sert au lien d'éperons, yui est erochue d'un côté, et dont le crochet est extrimement furt et pointu, qui sert aussi de licide en le piquant aux oreilles, au inuseau et oi ils savent qu'il est plus sensible; ce f(r, qui tuerait tout autre animąl, fait a peine impression sur la prau dle léléphant: $\mathrm{et}$ souvent mème lorspüil est en furie. il ne suflit pas pour le retenir en son devoir. Vuyage de t'ietro della Ville, tume $[V$, page $257,-1)$ eux oftieiers montés l'unsur la croupe et l'autre su' le cou. gouveruent l'elepliaut avec un grand erochet de ler. Premier Voyage du $\mathbf{P}$. Tachard, page 275 
voir, dans un accès de colère, tué son gouverneur.

L'espèce de l'éléphant ne laisse pas d'être nombreuse, quoiqu'il ne produise qu'une fois et un seul petit tous les deux ou trois ans : plus la vic des animaux est courte, et plus leur production est nombreuse. Dans l'éléphant la durée de la vie compense le petit nombre, et s'il est vrai, comme on l'assure, qu'il vive deux sièeles et qu'il engendre jusqu'à cent vingt ans, ehaque couple produit quarante petits dans cet espace de temps : d'ailleurs n'ayant rien à craindre des autres animaux, et les hommes même ne les prenant qu'avec beaucoup de peine, l'espèce se soutient et se trouve généralement répandue dans tous les pays méridionaux de I'Afrique et de l'Asie; il y en a beaucoup à Ceylan, au Mogol, à Bengale, à Siam ', à Pégu, et dans toutes les autres parties de l'Inde; il y en a aussi, et peut-être en plus grand nombre, dans toutes les provinces de l'Afrique méridionale, à l'exception de certains cantons qu'ils ont abandonnés, parce que l'homme s'en est absolument emparé. IIs sont fidèles à leur patrie et constants pour leur climat; car, quoiqu'ils puissent vivre dans les régions tempérées, il ne parait pas qu'ils aient jamais tenté de s'y établir ni même d'y voyager; ils étaient jadis inconnus dans nos elimats. Il ne parait pas qu'Homère, qui parle de l'ivoire, connùt l'animal qui le porte. Alexandre est le premier qui ait montré l'éléphant ả l'Europe ; il fit passer en Grèce ceux qu'il a vait conquis sur Por'us, et ce furent peut-être les mêmes que Pyrrhus, plusieurs années après, employa contre les Romains dans la guerre de Tarente, etavec lesquels Curius vint triompher a Rome. Anuibal ensuite en amena d'Afrique, leur fit passer la VIéditerranée, les Alpes, et les conduisit, pour ainsi dire, jusqu'aux portes de Rome.

De temps immémorial les Indiens se sont servis d'éléphants à la guerre : chez ces nations mal disciplinées, e'ćtait la meilleure tronpe de l'armée, et tant que l'on n'a combattu qu'arec le fer, celle qui décidait ordinairement du sort des batailles. Cependant l'on voit par l'histoire, que les Grees et les Romains s'accoutumèrent

'M. Couslance $\mathrm{m}$ a dit que le roi de Siam en a bien vingt mille dans tout son royaume, sans compter les sanvages cui sont dans les bois et daus les monlages; on en prind (puelquefois jusųu'a cimquante, soixante et ıxine qualre-viıgts à la fois dans une seule clıasse. Premier voyage du P. Tachard, page 288. bientót à ces monstres de guerre; ils ouvraient leurs rangs pour les laisser passer; ils ne cherchaient point à les blesser, mais lançaient tous leurs traits contre les conducteurs qui se pressaient de se rendre, et de calmer les éléphants dès qu'ils étaient séparés de leurs troupes; et maintenant que le feu est devenu l'élément de la guerre et le prineipal instrument de la nort, les éléphants qui en craignent et le bruit et la flamme, seraient plus embarrassants, plus dangereux qu'utiles dans nos combats. Les rois des Indes font encore armer des éléphants en guerre, mais e'est plutot pour la représentation que pour l'effet : ils en tirent cependant l'utilité qu'on tire de tous les militaires, qui est d'asservir leurs semblables; ils s'en servent pour dompter des éléphants sauvages. Le plus puissant des monarques de l'Inde n'a pas aujourd'hui deux cents éléphants de guerre; ils en ont beaucoup d'autres pour le service et pour porter les grandes cages de treillage, dans lesquelles ils font voyager leurs femmes : c'est une monture très-sûre, car l'éléphant ne bronche jamais; mais elle n'est pas douce, et il faut du temps pour s'accoutumer au mourement brusque et au balancement continuel de son pas; la meilleure place est sur le cou; les secousses y sont moins dures que sur les épaules, le dos ou la croupe. Mais dès qu'il s'agit de quelque expédition de chasse ou de guerre, chaque éléphant est toujours monté de plusieurs hommes '. Le conducteur se met à califourchon sur le cou; les chasseurs ou les combattants sont assis ou debout sur les autres parties du corps.

Dans les pays heureux où notre canon et nos arts meurtriers ne sont qu'imparfaitemeut connus, on combat encore avec des éléphants ${ }^{2}$; a Cochin et dans le reste du Malabar ${ }^{3}$ on ne se

- De tousles animanx, ce sont ceux qui rendent plus de service à la gnerre, car on place fort commodément sur eux ¡uatre hommes qui peuvent aisément se servir du mousquet, de l'arc el de la lanee. Recueil des Voyages de la Compagnie des Indes de llollande. Second voyage de Vau der Hagen, lome 11 , page 0 j.

2 Lorsıute les éléphants sont menés à la guerre, ils servent à deux diverses fonctions, car on les charge ou dune petite tour de hois, du sommet de lapueile deux soldals comballent, (11) l'on atlache des épées à leurs trompes avec des chaines de fer, et on les làche ainsi contre l"aruée ennemie upüils assailleut généreusement et qu'its mettraient indubitablement en pieces, si on ne les repoussait arec des lances yuj jeltent le feu; parce que, conme loun sait que les éléphants sont épouvantés par le fcu, on en apprète dartificicl an boul des lances pour les mellre en fuite. Vuyage dorient, par le P. Pluilippe, p. $36 i$.

(1) ue se sert point a Cochin, loun plus que dans le riste du Malabar, de cavalerie pour la guerre; ceux qui doivent 
sert point de chevaux, et tous ceux qui ne combattent pas à pied sont montés sur des éléphants. Il en est à peu près de mème au Tonquin ${ }^{1}$, à Siam, à Pégu ${ }^{2}$, où le roi et tous les grands seigneurs ne sontjamais montés que sur des éléphants : les jours de fètes, ils sont précédés et suivis d'un nombreux cortége de ces animaux pompeusement parés de plarpues de métal brillantes, et couverts des plus riches étoffes. On environne leur ivoire d'ammeaux d'or et d'argent; on leur peint les oreilles et les joues; on les couronne de guirlandes; on leur attache des somnettes; ils semblent se complaire à la parure, et plus on leur met d'ornements, plus ils sont earessants et joyeux. Au reste l'Inde méridionale est le seul pays où les éléphants soient policés à ce point : en A frique on sait à peine les dompter. Les Asiatipues, trèsancieunement eivilisés, se sont fait une espèce d'art de l'éducation de l'élćphant, et l'ont instruit et modifié selon leurs mou's. Mais de tous les Africains les seuls Carthaginois ont autrefois dressé des éléphants pour la guerre, parce rue dans le temps de la splendeur de leur république, ils étaient peut-ìtre eneore plus civilisés que les Orientaux. Aujourd'hui il n'y a point d'éléphants sauvages daus toute la partie de l'Afrique qui est en-decà du mont Atlas : il y en a même peu au-delà de ces montagnes jusqu'au fleuve du Sénégal ; mais il s'en trouve déjit beaueoup au Sénégal ${ }^{3}$ mème, en Guinée,

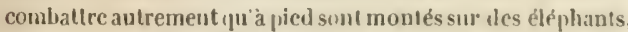
dont il y a quantité danıs les montignes, et ces élćphants des montagues sont les julus grands rles Indes. Relatiou d'un Voyage, par thevenot, tome 111 , page 261 .

+ Dans le royaume de Tominin, les dimies de condition montent ordinairement sur oles éléplaants ıui sont extrènuement hauls et gros, et qui portent, sans ancun danger, une tour avec six hommes dedans, et un autre homme sur leur con, qui les conduit. Il Ginio vagante del conte duretio degli anzi. In P'arma, 1691, tome I, page 282.

${ }^{2}$ Nous avons vu des éléplants qui ont des dents l'ıne

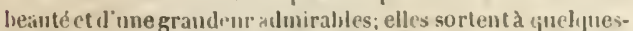
unsplus te yuatre pieds hors de la bonche, et sont garnies I'rspace pn espace de cercles d'or, d'argent et de cuivre. l'remier Voyage te Tachard, page 275. - Les princes font ennsister leur grandenr et leur pouv oir à nourril beaucoup dité-

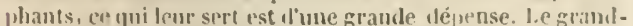
migul cu a puluieurs milliers. l.e roi de Marduré, le semgueur de . Varsingue el de Bisuagar, le poides Naireset eelui de Mansul en out plissil'urs eent:innes, gut ils distinguent en trois clase ses; les plus grands sont purur le serviee imméliat do puince ;

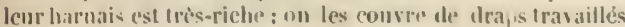
en or et couverts de: perles: leurs deuts somt ormies dior trèslin et d'argent, el (puelyuefois on les conve de diamants; cenx d'une taille moyenne sont pour la gnerre, et les petits pour l'nsage el le service ordinaire. Voyage du P. Vincent Marie de Saiute-batherine de sirune chapo. 1l. (Cet article a été traduit de litance, par M. Ie maryuis de Montmuail.)

- Les élépluants, dont je voyais tous les jours un grand nom. au Congo ${ }^{1}$, à la côte des Dents ${ }^{2}$, au pays d'Ante $^{3}$, d'Aera, de Benin et dans toutes les autres terres du sud de l'Afrique ${ }^{4}$, jusquà celles qui sont terminées par le cap de BonneEspérance; à l'exception de quel(pues provinces tres-peuplées, telles que Fida ${ }^{5}$, Ardra, ete.

bre se répanure sur les hords dn Heuve Sénégal, ne métonnaient plus. Le 5 novembre je me promenais dans les bois qui sont vis-à-vis le village de $\mathrm{D}$ : gana, $\boldsymbol{j}$ apercus quantité de leurs traces toutes fraiches; je les suivis eonstammeut pendant près de deux lienes, et eutin je découvris cinł de ces animuux, dont trois se vantraient dans leur soujl, à la manière lles cochons, ct le quatriènf était debont avec son fretit, manıeant les extrémités des lranches d'un acacia qu'il renail le roupre : je jugeai jar comparaison de la hauteur de l'arbre conIre lépucl f́tiit cet élriphant, qu’il avaıt au moins ouze à douze pieds ilepuris la jlante des pieds justpu à la crompe; ses défeuses surtaient de la longueur de près de truis pieds. Ounique na présence ue les ent pas émus, je prnsai qu'il était a propos deume retirer : cu poursuivant ma roule, je rencontrai des inupessions bien uaryuées de leurs pas, yue je unesurai, r.les avaient pres atun pied el demi de diametre; leur tirnte. qui ressemblait à celle du theval, formait de's buules de stut à luit funcés d'épaisseur. Voyage au Sénégal, far M. A danson. Paris, 1747, page 75.- Vuye 2 aussi le loyage de le Maire pages 97 el 98.

Voyer le Voyage de Guinée, par G. Bosman. C'treclst, 1705, lage 245.

1 Daus la jrovince de Pamba, qui est au royaume de Congo, on tronve heaucoup d'éléphants, à canse le la grande quantité de forêts et de rivières dont le pays est plein. Vuyage de Fr. Drack. Paris, 16\$1, pages $1-4$. Voyez aus-i. dans le liecueil des Voyages de la Conpragnie des lubles ile llullande, le Voyage de Van der lroeck, tune IV, jage 316 . Voyez aussi H genjo vagante del conte Aurelio, lons: 11 , jage 475 et suiv.

${ }^{3}$ Le furmier pays oil liun tronve le jus sonvent des éléphants, ciest cet eudroit de la cite yue lon appelleen flamand Tand-Kut, on cole tes tents, à tanse de lit grande yuaulité de ilenı-d'élı́phant s qu'on y tuafipue; ensuile vers la citte-d'or

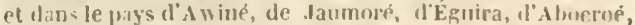
d'Ancoberet d'. Ixim, ou I on ch tue climpe jurl un grasd nimblie, ut plus un pays est désprt et inhabité, plus y reulu. contre-t-on dicliphants et d'autres animaux sauvages. boyge le Guiné, jar Gıill. Busman, page 241.

${ }^{3}$ Le: frays d'Ante aboude ausi en éléphants, puisque nonsenlenuent on en tue yquantité daus la terre ferme, uais yuils vienucul presune tous les jours sur les bords de la mer el smis nos forts d"ou nos gens peuvent les voir, ret y foul de grainds rarages; aleuuis le bay d dule jusquà cehi d"Aera. on nen trunve pas tantque dans les liemx ti-clessus nommets. parce "fue ces flays cutre dute el Acra, out ité depuis longlemps passablement bien penplés, cacepté celni de Felı, qui uepuis cimy on six ans a été jur sque désert, ce qui lait quon

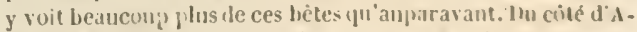
eril on en lue toutes les aunes un erand wmmbre, paree yue dans ces ynartiers-la il y a hien du pays désert it inhabule.... Dans le priys de benin, coume aussi à Rion de Calloar, Camerones et dans plosienrs autres pays et rivieres dalmontonr, il y a une si graudc quantité de ces animax, qu'on a peine aे $s^{\prime} i$. maginer eommeut les habitanls jeurent ou osent y demenper. Ideu, page 216.

+ Au-dessus dela hale desainte-1lélène le paysest parlagé cu deux parties par la rivière des Étiphants, qui a étés aiasi

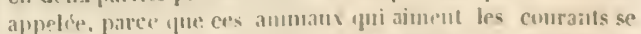

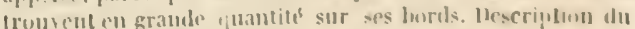

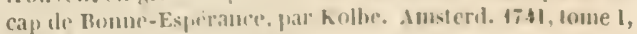
page :14; el tome III, jaige 12.

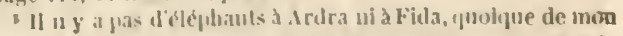
tcmps un y en ail tué un; mais les Xìgres avouérent qne cela 
On en troure de mème en Abyssinie, en Éthiopie, en Nigritie, sur les côtes orientales de l'Afrique et dans l'intérieur des terres de toute cette partie du monde. II y en aussi dans les grandes îles de l'Inde et de l'Afrique, comme à Madagasear ', à Java ${ }^{2}$, et jusques aux Philippines $^{3}$.

Après avoir conféré les témoignages des historiens et des voyageurs, il nous a paru que les eléphants sont actuellement plus nombreux, plus fréquents en Afrique qu'en Asie; ils y sont aussi moins défiants, moins sauvages, moins retirés dans les solitudes : il semble qu'ils connaissent l'impéritie et le peu de puissance des hommes auxquels ils ont affaire dans cette partie du monde; ils viennent tous les jours et sans aucune crainte jusqu'à leurs habitations ${ }^{4}$; ils traitent" les Nègres avec cette indifférence naturelle et dédaigneuse qu'ils ont pour tous les animaux; ils ne les regardent pas comme des êtres puissants, forts et redoutables, mais comme une. espèce cauteleuse, qui ue sait que dresser des embùches, qui n'ose les attaquer en face et qui ignore l'art de les réduire en servitude. C'est en effet par eet art connu de tout temps des Orientaux, que ces animaux ont été réduits à un moindre nombre : les éléphants sauvages, quils rendent domestiques, deviennent par la captivité autant d'etnuques volon-

n'étail point arrivé dans l'espace de soixante ans; ainsi, je crois que s'y étant égaré, il pouvait y ètre venu d'aillenrs. Voyage de Guinée, par Bosman, page 24 ö.

- Dans liile de Madagascar se trouvent tant d'éléphants, qu'on n'estime contrée du monde en produire davantage : au moyen de quoi s'y fait grand trafic de marchandises divoire, comme semblablement eı une autre ille voisine appelée Cuzibet; et par le jugement des marchands ne se retire pas du resı du monde si grande quantilé de dents d'éléphants (qui est le vrai ivoire) que l'on en trouve en ces deux iles. Descr. de l'Ind. orient., par Marc l'aul. Paris, 1556. liv. Ill, ch. Xxsux, page 114.

Les animaux qui se. Irouvent dans l'ile de Java, sont $1^{\circ}$ des éléphauts quion appriroise el quon lone cnsuite pour travailler. Recueil des Voyages de la Compagnie des Indes de IIollande, tome 1, page $411,-$ A Tuban les IIollandais virent les éléphants du roi de Java, qui sont chacuu sous un petit toit parliculier, soutenu par quatre piliers au milieu; el dans le milieu de l'espace qui est sous ce toit, il y a un gramı piru auquel l'eléphant est altaché par une chaine. ldem. tome I, page 526.

${ }^{3}$ L'ile de Maudanar est la seule des Philippines qui ait des eléphants, parce que les insulaircs ne les apprivoisent pas comme l'on fait à Siam et à Comboya; ils y sont extrcinement multipliés. Voyage autour du monde, par Gemelli Larreri. Paris, 1716, tome $V$, page 209.

4 Les éléfuants passent souvent les nuits dans les villages, et craignent si pen les licux fré̀uentés, quau licu de se détourıer (puanul ils voient les maisons des Nègres, ils passemt tout droil, et les renversent cn marchant comme une coquille de uoix. Voyage de le Maire, page 98. taires dans lesquels se tarit chaque jour la source des générations; au lieu qu'en Afrique, où ils sont tous libres, l'espece se soutient et pourrait même augmenter en perdant darantage, parce que tous les individus travaillent constamment à sa réparation. Je ne vois pas qu'on puisse attribuer à une autre cause cette différence de nombre dans l'espèce : car en considérant les autres effets, it parait que le climat de l'Inde méridionale et de l'Afrique orientale est la vraie patrie, le pays naturel et le séjour le plus convenable à l'éléphant; il y est beaucoup plus grand, beaucoup plus fort qu'en Guinée et dans toutes les autres parties de l'Afrique occideutale. L'Inde méridionale et l'Afrique orientale sont donc les contrées dont la terre et le ciel lui conviennent le mieux ; et en effet il craint l'excessive chaleur; il n'habite jamais dans les sables brùlants; et il ne se trou ve en grand nombre dans le pays des Nègres, que le long des rivières et non daus les terres élevées; au lieu qu'aux Indes, les plus puis: sants, les plus courageux de l'espèce et dont les armes sont les plus fortes et les plus grandes, s'appellent éléphants de montagne, et habitent en effet les hauteurs oì l'air étant plus tempéré, les eaux moins impures, les aliments plus sains, leur nature arrive à sou plein développement et acquiert toute son étendue, toute sa perfection.

En général, les éléphants d'A sie l'emportent par la taille, par la force, etc., sur' ceux de l'Afrique; et en particulier ceux de Ceylan sont encore supérieurs à tous ceux de l'Asie, non par la grandeur, mais par le courage et par l'intelligence : probablement ils ne doivent ces qualités qu’à leur éducation plus perfectionnée à Ceylan qu'ailleurs; mais tous les voyageur's ont célébré les éléphants de cette ile, ou comme l'on sait le terrain est groupé par montagnes, qui ront en s'élevant à mesure qu'on avance vers le centre, et ou la chaleur, quoique trèsgrande, n’est pas aussi excessive qu'au Sénégal, en Guinée et dans toutes les autres parties oc('identales de l'Afrique. Les anciens, qui ne connaissaient de cette partie du monde que les terres situées entre le mont Atlas et la Méditerranée, avaient remarqué que les éléphants de la Lybic étaient bien plus petits que ceux des Indes : il n'y cn a plus aujourd'hui dans cette partie de l'Afrique, et cela prouve encore, comme nous l'avons dit à l'article du Lion, que 
les hommes y sont plus nombreux de nos jours qu'ils ne l'étaient dans le siècle de Carthage. Les éléphants se sont retirés à mesure que les homınes les ont inquiétés; mais en voyageant sous le ciel de l'Africue, ils n'ont pas changé de nature; car ceux du Sénégal, de la Guinće, ete., sont, comme l'étaient ceux de la Libye, beaucoup plus petits que ceux des grandes Indes.

La force de ces animaux est proportiounelle à leur grandeur: les éléphants des Indes portent aisément trois ou quatre milliers; les plus petits, c'est-à-dire ceux d'Afrique, enlèvent librement un poids de deux cents livres avec leur trompe et le placent eux-mêmes sur leurs épaules; ils prenment dans cette trompe une grande quantité d'eau qu'ils rejettent en haut ou à la ronde, à unc ou deux toises de distance; ils peuvent porter plus d'un millier pesant sur leur's défenses : la trompe leur sert à casser les branches des arbres, et les défenses à arracher les arbres mêmes. On peut encore juger de leur force par la vitesse de leur mouvement, comparcée à la masse de leur corps : ils font au pas ordinaire à peu près autant de chemin qu'un cheval en fait au petit trot et autant qu'un cheval au galop lorsqu'ils courent, ce qui dans l'état de liberté ne leur arrive guère que quand ils sont animés de colère ou poussés par la crainte. On mène ordinairement au pas les éléphants domestiques: ils font aisément et saus fatigue yuinze ou vingt lieues par jour, et quand on veut les presser, ils peuvent en faire jusqu'à trente-cing ou quarante. On les entend mareher de trè-loin, et l'on peut aussi les suivre de très-prés à la piste; car les traces qu'ils laissent sur la terre ne sont pas équivoques, et dans les terrains où le pied marque, elles ont quinze ou dix-huit pouces de diamètre.

Un éléphant domestique rend peut-ètre à son maitre plus de services que cinq ou six chevaux', mais il lui faut du soin et uue nourriture ábondante et choisic; il coute environ quatre francs ou cent sous ${ }^{2}$ par jour à nourrir.

1 Le jrix cles éléphants est plus considérable quion ue pourrait limaginer ; on en a vil vendre depuis mille pagodes d'or justu"à yuinze mille: roupies, c'est-a-dire ılepuis upuf à dix milte livres jusıu"à trente-six mille livres. Notes de M. de

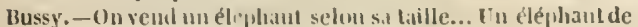
Ceylan vaul an moius luit unille pardaous, el quand il est

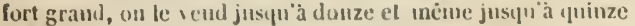
mille partions. Hist. de l'ile de Ceylab, par kibeyro. Tréyoux, 1701, page 1\%.

'Leséteplants conlent chacun (mviron une demi-pislole par jour à nourrir. Relation d'un vogage, far Thevenot. page 161. - Ceuxyui sout privés sont forl delicals en teur vivre,
On lui donne ordinairement du riz cru ou cuit , mêlé a vec de l'eau, et on prétend qu'il faut cent livres de riz par jour pour qu'il s'entretienne dans sa pleine vigueur; on lui donne aussi de l'herbe pour le rafaîchir, ear il est sujet à s'échauffer; et il faut le mener à l'eau et le laisser baigner deux ou trois fois par jour. Il apprend aisément à se laver lui-même; il prend de l'eau dans sa trompe, il la porte à sa bouche pour boire, et ensuite en retournant sa trompe, il en laisse couler le r'este a flot sur toutes les parties de son corps. Pour douner une idée des services qu'il peut rendre, il suffira de dire que tous les touncaux, sacs, payuets, qui se transportent d'un licu à un autre dans les Indes, sont voiturés par des éléphants ; yu'ils peuvent porter des fardeaux sur leur corps, sur leur cou, sur leurs défenses, et mème avec leur gueule, en leur présentant le bout dune corde qu'ils serrent avec les dents; que joignant l'intelligence da force, ils ne cássent ni r'endommagent rien de ce qu'on leur confie; qu'ils font tourner et passer ces paquets du bord des eaux dins un bateau sans les laisser mouiller, les posant doucement et les arrangeant où l'on veut les placer; que quand ils les ont déposés dans l'endroit qu'on leur montre, ils essaient avec leur trompe s'ils sont bien situés, et que quand e'est un tonucau qui roule, i!s vont d'eux-mèmes chercher dés pierres pour' le caler et l'établir solidement, ele.

Lorsque l'éléphant est bien soigné, il vit longtemps, quoique en captivite, et l'on doit présumer que dans l'état de liberté sa vie est encore plus longue. Quelques auteurs ont écrit qu’il vivait (juatre ou cing cents ans; d'autres, deus ou trois cents, et d'autres enfin, cent vingt, cent trente ou cent cinqante ans'. Je crois que le

et leur faut bailler du riz bien euit et accommodé avec du

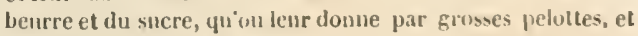
leur fan bien cenl livres de riz par clanue juur, wutre qu'il lenr laut bailler des feuiltes d'arlure, principalement de figuier dlinde, yoe nous appelumbananes, et les Turcs plantenes, pour les lairaichir. Voyage de 'J - Vovez aussi les Voyagr's de la lbutlaje-le-t ivuz. Paris, 1556, page 250; el le Recueil des voyages de la Conjagnie des Indes de Hollande, tome l. page $\$ 75$.

t Les éléphants croissenl jusıu'à la moitié rle leur áge, et vivent ordinarement cenl compante ams. Iujage de Jrack autour du moude, jage 104. Les cléphats portent deux ans,

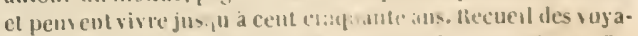

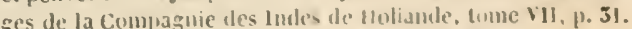
- Noiolist.nt lonles les reluerches que jai faites avee a-sez

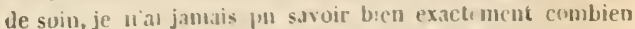

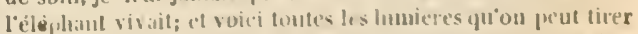
de cenx yni gunernent ces animaux : ils ue sdveul vous dire 
terme moyen estle vrai, et que si l'on s'est assuré que des éléphants captifs vivent cent vingt ou cent trente ans, ceux qui sont libres et qui jouissent de toutes les aisances de la vie et de tous les droits de la nature doivent vivre au moins deux cents ans; de même si la durée de la gestation est de deux ans, et s'il leur faut trente ans pour prendre tout leur aceroissement, on peut encore être assuré que leur vie s'étend au moins au terme que nous venons d'indiquer. Au reste, la captivité abrége moins leur vie que la disconvenance du climat; quelque soin qu'on en prenne, l'éléphant ne vit pas longtemps dans les pays tempérés, et encore moins dans les climats froids: celui que le roi de Portugal envoya à Louis XIV en 1668 , et qui n'avait alors que quatre ans, mourut à dix-sept ans, au mois de janvier 1681, (t ne subsista que treize ans dans la ménagerie de Versailles, où cependant il était traité soigneusement et nourri largement: on lui donnait tous les jours quatre-vingts livres de pain, douze pintes de vin et deux seaux de potage, où il entrait encore quatre ou cing livres de pain, et de deux jours l'un, au lieu de potage, deux seaux de riz cuit dans l'eau, sans compter ce qui lui était donné par ceux qui le visitaient; il avait eneore tous les jours une gerbe de blé pour s'amuser, car après avoir mangé le grain des épis, il faisait des poignées de la paille, et il s'en servait pour chasser les mouches; il prenait plaisir à la rompre par petits morceaux, ce qu'il faisait fort adroitement avee sa trompe, et comme on le menait promener presque tous les jours, il arrachait de l'herbe et la mangeait. L'éléphant qui était dernièrement à Naples, où, comme l'on sait, la chaleur est plus grande qu'à Paris, n'y a cependant véeu qu'un petit nombre d'années : ceux qu'on a transportés vivants jusqu'à Pétersbourg périssent successivement, malgré l'abri, les couvertures, les poëles. Ainsi l'on peut assurer que cet animal ne peut subsister de luimême nulle part en Europe, et encore moins s'y multiplier. Mais je suis étonné que les Portugais, qui ont connu, pour ainsi dire, les premier's le prix et l'utilité de ces animaux dans les Indes orientales, n'en aient pas transporté dans le climat chaud du Brésil, où peut-être, en

autre chose, sinon que tel éléphant a été entre les mains de leur jère, de leur aïeul et de leur bisaienI; et supplatant le lempx que ces gens-là onl vécu, il se trouve quelquefois qu'il monte à cent vingt on cent trente ans. Voyage de Tavernier, Rouen, 1713, tome III, pages 242 et 243. les laissant libres, ils aurasent peuplé. La couleur ordinaire des éléphants est d'un gris ceridré ou noirâtre : les blanes, comme nous l'avons dit, sont extrèmement rares, et on eite ceux qu'on a vus en differents temps dans quelques endroits des Indes, où il s'en trouve aussi quelques-uns qui sont roux, et ces éléphants blancs et rouges sont très-estimés. Au reste, ces variétés sont si rares qu'on ne doit pas les regarder comme subsistantes par des races distinctes dans l'espèce, mais plutôt comme dis qualités accidentelles etpurement individuelles; cal's`il en était autrement, on connaîtrait le pays des éléphants blanes, celui des rouges et celui des noirs, comme l'on connait les climats des hommes blanes, rouges et noirs. "On " trouve aux Indes des éléphants de trois sortes, " (ditle P. Vincent Marie): les blanes, qui sont " les plus grands, les plus doux, les plus paisi( bles, sont estimés et adorés par plusieurs na" tions, comme des dieux; les roux, tels que " ceux de Ceylan, quoiqu'ils soient les plus pe" tits de eorsage, sont les plus valeureux, les a plus forts, les plus nerveux, les meilleurs " pour la guerre; les autres, soit par inclination ( naturelle, soit parce qu'ils reconnaissent en " eux quelque chose de plus excellent, leur por" tent un grand respeet; la troisième espèce est " celle des noirs, qui sont les plus communs et " les moins estimés. "Cet auteur est le seul qui paraisse indiquer que le elimat particulier des éléphants roux ou rouges est Ceylan; les autres voyageurs n'en font aucune mention. Il assure aussi que les éléphants de Ceylan sont plus petits que les autres; Thévenot dit la même chose dans la relatiou de son Voyage, pag. 260 , mais d'autres disent ou indiquent le contraire. Enfin le P.Vincent Marie est encore le seul qui art écrit que les éléphants blanes sont les plus grands : le P. Tachard assure au contraire que l'éléphant blane du roi de Siam était assez petit, quoiqu'il fùt très-vieux. Après avoir comparé les témoignages des voyageurs au sujet de la grandeur des cléphants dans les différents pays, et réduit les différentes mesures dont ils se sont servis, il me parait que les plus petits éléphants sont ceux de l'Afrique occidentale et septentrionalc, et que les anciens, qui ne eonnaissaient que cette partie septentrionale de l'Afrique, ont eu raison de dire qu'en général les éléphants des Indes étaient beaucoup plus grands que ceux de l'Afrique. Mais dans les terres orientales de 
cette partie du monde qui étaient inconnues des anciens, les éléphants se sont trouvés aussi grands, et peut-être même plus grands qu'aux Indes; et dans cette dernière région, il parait que ceux de Siam, de Pégu, ete., l'emportent par la taille sur ceux de Ceylan, qui cependant, de l'aveu unanime de tous les voyageurs, sont les plus courageux et les plus intelligents.

Après avoir indiqué les principaux faits au sujet de l'espèce, examinons en détail les facultés de l'individu, les sens, les mouvements, la grandeur, la force, l'adresse, l'intelligence, etc. L'éléphant a les yeux très-petits relativement au volume de son corps, mais ils sont brillants et spirituels; et ce qui les distıngue de ceux de 'ous les autres animaux, e'est l'cxpression pathétique du sentiment et la conduite presque réfléchie de tous leurs mouvements: il les tourne lentement et avec douceur vers son maitre ; il a pour lui le regard de l'amitié, celvi de l'attention lor'squ'il parle, le coup d'œil de l'intelligence quand il l'a écouté, celui de la pénétration lorsqu'il veut le prévenir; il semble réfléchir, délibérer, penser et ne se déterminer qu'après avoir examiné et regardé à plusieurs tois et sans précipitation, sans passion, les signes auxquels il doit obéir. Les chiens, dont les yeux ont beaucoup d'expression, sont des animaux trop vifs pour qu'on puisse distinguer aisément les nuances successives de leurs sensations; mais comme l'éléphant est naturellement grave et modéré, on lit, pour ainsi dire, dans ses yeux, dont les mouvements se suceèdent lentement ', l'ordre et la suite de ses affections intérieures.

Il a l'ouie très-bonne, et cet organe est à l'extérieur, comme celui de l'odorat, plus marqué dans l'éléphant que daus aucun autre animal; ses oreilles sont très-grandes, beaucoup plus longues, mème à proportion du corps, que cclles de l'âne, et aplaties contre la tète, comme celles de l'homme : elles sont ordinairement pendantes; mais il les relive et les remue avec une grande facilité : elles lui servent à essuyer ses yeux ${ }^{2}$, à les préserver de l'incommodité de la poussière et des mouches. Il se délecte au

4 Les yeus de l'éléplant sont très-petits proportionnellement à la tète, el eneore plus jetits proportionuellement au corps, mais ils sont très-vifs et éveillés, el il les remute d'une façon quni lui donne foujours l'air peusif et rèveur. Voyage aux Indes orientales de P. Fr. Vincent-Marie de Sainte-Catberine de Sienne, ele. Yenise, 1685 , en ilalien, in- $4^{\circ}$, page 396 , traduit par M. le marquis de Montmirail.

${ }^{2}$ Les oreilles de l'éléphant sout très-grandes.... 11 les remue son des instruments et parait aimer la musique : il apprend aisément à marquer la mesure, à se remuer en cadence et à joindre à propos quelques accents au bruit des tambours et au son des trompettes. Snn odorat est exquis et il aime avec passion les parfums de toute espèce et sur tout les fleurs odorantes; il les choisit, il les cueille une à une, il en fait des bouquets, et après en avoir savouré l'odeur, il les porte à sa bouche et semble les goûter : la fleur d'orange est un de ses mets les plus délicieux; il dépouille avec sa trompe un oranger de toute sa verdure, et en mange les fruits, les fleur's, les fenilles et jusqu'au jeune bois. Il choisit dans les prairies les plantes odoriférantes, et dans les bois il préfère les cocotier's, les hananiers, les palmiers, les sagous; et comme ces arbres sont inoelleux et tendres, il en mange non-seulement les fenilles et les fruits, mais même les brauches, le trone et les racines; car quand il ne peut arracher ces arbres avec sa trompe, il les déracine avee ses défenses.

A l'égard du sens du toucher', il ne l'a pour ainsi dire que dans la trompe; mais il est aussi délicat, aussi distinct daus cette espèce de máin que dans celle de l'homme. Cette trompe, composée de membraues, de nerfs et de muscles, est en même temps un membre eapable de moıvement et un organe de sentiment : l'animal peut non-seulement la remuer, la fléchir, mais il peut la raccourcir, l'allonger, la courher et la tourner en tout sens. L'extrémité de la trompe est terminée par un rebord qui s'allonge par le dessus en forme de doigt; c'est par le moyen de ce rebord et de cette espèce de doigt que l'éléphant fait tout ce que nous faisons avee les doights; il ramasse à terre les plus petites pièces de monnaie ; il cueille les herbes et les fleurs en les choisissant une à une; il dénoue les cordes, ourre et ferme les portes en tournant les clefs et poussant les verrous; il apprend à tracer des caractères réguliers avec un instrument aussi petit quine plume. On ne peut même disconvenir que cette main de l'éléphant n'ait plusieurs avantages sur la nôtre : elle est d'abord, comme on vient de le voir, également flexible et tout aussi adroite pour saisir, palper en gros et toueher en détail. Toutes ces opérations se font par le

continuellement avec gravité, et olles défendent ses yeux rle tous les pelits animaux nuisıbles. Ideu, ibid.... Voyez aussi les Mémoires pour servir à lilyisloire des auimaux, partie III, page 107. 
moyen del'appendice en manière de doigt situé à la partie supérieure du rebord qui environne l'extrémité de la trompe, et laisse dans le milieu une concavité faite en forme de tasse, au fond de laquelle se trouvent les deux orifices des conduits communs de l'odorat et de la respiration. L'éléphant a donc le nez dans la main, et il est le maitre de joindre la puissance de ses poumons à l'action de ses doigts, et d'attirer par une forte succion les liquides, ou d'enlever des corps solides très-pesants en appliquant à leur surface le rebord de sa trompe, et faisant un vide au dedans par aspiration.

La délicatesse du toucher, la finesse de l'odorat, la facilité du mouvement et la puissance de succion se trouvent donc à l'extrémité du nez de l'éléphant. De tous les instruments dont la nature a si libéralement muni ses productions chéries, la trompe est peut-être le plus complet et le plus admirable; c'est non-seulement un instrument organique, mais un triple sens, dont les fonctions réunies et combinées sont en même temps la cause, et produisent les effets de cette intelligence et de ces facultés qui distinguent l'élénhant et l'élèvent au-dessus de tous les animaux. Il est moins sujet qu'aucun autre aux erreurs du sens de la vue, parce qu'il les rectifie promptement par le sens du toucher, et que, se servant de sa trompe comme d'un long bras pour toucher les corps au loin, il prend, comme nous, des idées nettes de la distance par ce moyen; au lieu que les autres animaux (à l'exception du singe et de quelques autres, qui ont des espèces de bras et de mains ) ne peuvent acquérir ces mèmes idées qu'en parcourant l'espace avec leur corps. Le toucher est de tous les sens celui qui est le plus relatif à la connaissance; la délicatesse du toucher donne l'idée de la substance des corps; la flexibilité dans les parties de cet organe donne l'idée de leur forme extérieure, la puissance de succion celle de leur pesanteur, l'odorat celle de leurs qualités, et la longueur du bras celle de leur distance : ainsi, par un seul et même membre, et pour ainsi dire, par un acte unique ou simultané, l'éléphant sent, apercoit et juge plusieurs chosesà la fois : or une sensation multiple éçuivaut en quelçue sorte à la réflexion : donc, quoique cet animal soit, ainsi que tous les autres, privé de la puissance de réfléchir, comme ses scnsations se trou vent combinées dans l'organe mème, qu'elles sont coutemporaines, et pour ainsi dire indivises les unes avec les autres, il n'est pas étonnant qu'il ait de lui-même des espèces d'idées et qu'il acquière en peu de temps celles qu'on veut lui transmettre. La réminiscence doit être ici plus parfaite que dans aucune autre espèce d'animal ; car la mémoire tient beaucoup aux circonstances des actes, et toute sensation isolée, quoique très-vive, ne laisse aueune trace distincteni durable; mais plusieurssensations combinées et contemporaines font des impressions profondes ct des empreintes étendues : en sorte que si l'éléphant ne peut se rappeler une idée par le seul toucher, les sensations voisines et accessoires de l'odorat et de la force de succion, qui ont agi en même temps que le toucher, lui aident à s'cn rappeler le souvenir. Dans nousmèmes, la meilleure manière de rendre la mémoire fidèle est de se servir successivement de tous nos sens pour considérer un objet, et c'est faute de cet usage combiné des sens que l'homme oublie plus de choses qu'il n'en retient.

Au reste, quoique l'éléphant ait plus de mémoire et plus d'intelligence qu'aucun des animaux, il a cependant le cerveau plus petit que la plupart d'entre eux, relativement au volume de son corps; ce que je ne rapporte que comme une preuve particulière que le cerveau n'est point le siége des sensations, le sensorium commun, lequel réside au contraire dans les nerfs des sens et dans les membranes de la tète : aussi les nerfs qui s'étendent dans la trompe de l'éléphant sont en si grande quantité, qu’ils équivalent pour le nombre à tous ceux qui se distribuent dans le reste du corps. C'est donc en vertu de cette combinaison singulière des sens et des facultés uniques de la trompe, que cet animal est supérieur aux autres par lïntelligence, malgré l'énormité de sa masse, malgré la disproportion de sa forme; car l'éléphant est ein même tenps un miracle d'intelligence et un monstre de matière : le corps très-épais et sans aucune souplesse; le cou court et presque inflexible; la tête petite et difforme; les oreilles excessives et le nez encore beaucoup plus excessif ; les yeux trop petits, ainsi que la gueule, le membre génital et la queue; les jambes massives, droites et peu flexibles; le pied si court '

- II n'y a point d'animal qui n'ait le pied plus grand, à proportion, quel'homme, si ce u'est l'éléphant quil l"a encore plus vetit, et par conséquent „u'ancun anlre animal... Les pieds étaient si petits, qnon peut dire yn'ils ne se voyaient point. parce que les doigts étaienl renfermés el recourerts par la peau 
et si. petit qu'il parait être nul; la peau dure, épaisse et calleuse : toutes ces difformités paraissent d'autant plus, que toutes sont modelées en grand; toutes d'autant plus désigréables à l'œil, que la plupart n'ont point d'exemple dans le reste de la nature; aucun animal n'ayant ni la tête, ni les pieds, ni le nez, ni les oreilles, ni les défenses faites ou placées comme. celles de l'éléphant.

Il résulte pour l'animal plusieurs inconvénjents de cette conformation bizarre; il peut à peine tourner la tète; il ne peut se tourner luimême, pour rétrograder, qu'en faisant un cilcuit. I.es chasseur's, qui l'attaquent par derrière ou par le flane, évitent les effets de sa vengeance par des mouvements circulaires; ils ont lc temps de lui porter de nouvelles atteintes pendant qu'il fait effort pour' se tourner contre eux. Les jambes, dont la rigidité n'est pas aussi grande que celle du cou et du corps, ne fléchissent néanmoins que lentement et difficilement, elles sont fortement articulées avec les cuisses. Il a le genou comme l'homme, et le pied aussi bas: mais ce pied sans étendue, est aussi sans ressort et sans force, et le genou est dur et sans souplesse : cependant, tant que l'éléphant est j(une et qu'il se porte bien, il le fléchit pour se 'coucher, pour se laisser' ou monter ou charger; mais dès qu'il est vieux ou malade, ce mouvement devient si difficile qu'il aime mieux dormir debout, et que si on le fait coucher par force, il faut ensuite des machines pour le relever et le remettre en pied. Ses défenses, qui deviennent avec l'àge d'un poids énorme, n'étant pas situces dans une position verticale, comme les cornes des autres animaux, forment deux longs levier's cui, dans cette position presque horizontale, fatiguent prodigieusement la têtc et la tirent en bas; en sorte que l'animal est quelquefois obligé de faire des trous dans le mur de sa loge pour les soutenir et se soulager de leur poids. Il a le désavantage d'avoir l'organe de l’odorat très-éloigné de celui du goût, l'incommodité de ne pouvoir rien saisir à terre avec sa bouche, parce (jue son cou court ne peut plier pour laisser laaisser assez la tête; il faut qu'il preme sa nourriture, et mème sa boisson, avec le nez; il la porte ensuite non pas à l'entrée

des jambes, lesquelles descendaient tout d'une venue jusqu"à terre, et paraissaient comme le trone d'un arbre seie en travers. Mémoires pour servir à l'u listoire des animanx, pages 102 etlo5. de la gueule, mais jusqu'à son gosier ; et lors que sa trompe est remplie d'eau, il en fourre l'extrémité jusquà la lacine de la langue, apparemment pour rabaisser l'épiglotte et pour empêcher la liqueur, qui passe avee impétuosité, d'entrer dans le laryux; car il pousse cette eau par la force de la mème haleine qu'il avait em. ployée pour la pomper, elle sort de la trompe avec bruit et entre dans le gosiel avec précipitation: la langue, la bouche, ni les levires ne lui servent pas, comme aux autres animaux, à sucer ou laper sa boisson.

De là paraît résulter une conséquence singulière, e'est que le petit éléphant doit téter avec le nez et porter ensuite à son gosier le lait qu'il a pompé; cependant les anciens ont écrit qu’il tétait avec la gueule et non avec la trompe; mais il y a toute apparence qu'ils n'a vaient pas été témoins du fait et qu'ils ne l'ont fondé que sur l'analogie, tous les animaux n'ayant pas d'autre manière de téter. Mais si le jeune éléphant avait une fois pris l'usage ou l'halsitude de pomper avec la bouche en sucant la mamelle de sa mère, pourquoi la perdrait-il pour tout le reste de sa vie? pourquoi ne se sert-il jámais de cette partie pour pomper l'eau lorsqu'il est à portée? pourquoi ferait-il toujours une action double, tandis qu'une simple suffirait? pourquoi ne lui voit-on jamais rien prendre avec sa gueule que ec qu'on jette dedins lor'squ'elle est ouverte? etc. II parait done tres-vraisemblable que le petit éléphant ne tète qu'avee la trompe. Cette présomption est non-seulement prouvée par les faits subséquents, mais ello est encore fondée sur une meilleure analogie que celle qui a décidé les anciens. Nous avons dit qu'en général les animaux, au moment de leur uaissance, ne peurent être avertis de la présence de l'aliment dont ils ont besoin, par aucun autre sens que par celui de l'odorat. L'oreille $\mathrm{est}$ certainement très-imutile à cet effet; l'oil l'est également et très-évidemment, puisque la plupart des animaux n'ont pas les yeux ouverts lorsqu'ils commencent à téter; le toucher ne peut que leur indiquer vaguement et également toutes les parties du corps de la mère, ou plutót il ne leur indique rien de relatif à l'appétit; l'odorat seul doit l'avertir, e'est non-seulement une espèce de goût, mis un avant-goùt qui précède, accompagne et ditermine l'autre. L'éléphant est donc averti, comme tous les autres animaux, par cet avant-gocil, de la présence de 
l'aliment; et comme le siége de l'odorat se trouve ici réuni avee la puissance de succion à l'extrémité de sa trompe, il l'applique à la mamelle, ('ll pompe le lait et le porte ensuite à sa bouche pour satisfaire son appétit. D'ailleurs, les deux mamelles étant situées sur la poitrine, comme aux femmes, et n'ayant que de petits mamelons très-disproportionnés à la grandeur de la gueule du petit, duquel aussi le cou ne peut plier, il faudrait que la mère se renversât sur le dos ou sur le côté, pour qu'il pût saisir la mamelle avec la bouche, et il aurait encore beaucoup de peine à en tirer le lait à cause de la disproportion énorme qui résulte de la grandeur de la gueule et de la petitesse du mamelon : le r'eloord de la trompe que l'éléphant contracte autant quill lui plait, se trouve au contraire proportionné au mamelon, et le petit éléphant peut aisément par son moyen téter sa mère, soit debout ou couchée sur le côté. Ainsi tout s'accorde pour infirmer le témoignage des anciens sur ee fait, cư̈ils ont avancé sans l'avoir vérifié, car aucun d'eutre eux, ni même aucun des modernes que je connaisse, ne dit avoir vu léter l'éléphant ; et je crois pouvoir assurer que si quelçu un vient dans la suite à l'observer, on verra quilil ne tète point avec la gueule, mais avec le nez. Je crois de même que les anciens se sont trompés en nous disant que les éléphants s'accouplent à la manière des autres animaux; que la femelle abaisse seulement sa croupe pour recevoir plus aisément le mâle: la position des parties parait rendre impossible cette situation d'accouplement; l'éléphante n'a pas, comme les autres femelles, l'orifice de la vulve au bas du ventre et voisin de l'anus : cet orilice en est à deux pieds et demi ou trois pieds de distance, il est situé presque au milieu du ventre : d'autre côté, le mâle n'a pas le membre génital proportionné à la grandeur de son corps, non plus qu'il celle de ce long intervalle, qui, dans la situation supposée, serait en pure perte. Les naturalistes et les voyageurs s'accordent à dire que l'éléphant n’a pas le membre génital plus gros ni guère plus long que le cheval; il ne lui serait done pas possible d'atteindre au but dans la situation ordinaire aux quadrupèdes; il faut que la femelle en premne une autre et se renverse sur le dos. De Feynes et Tavernier' l'ont dit positivement; mais j'aroue que

\footnotetext{
- Blen que l'éléphant ne louche plus la femelle depuis yu’il
}

j'aurais fait peu d'attention à leurs témolgnages, si cela ne s'accordait pas avec la position des parties, qui ne permet pas à ces animaux de se joindre autrement '. Il leur faut donc pour' cette opération plus de temps, plus d'aisance, plus de commodités qu'aux autres, et c'est peut-être par cette raisou qu ïls ne s'accouplent que quand ils sont en pleine liberté et lorsqu'ils ont en effet toutes les facilités qui leur sont nécessaires. La femelle doit non-seulement consentir, mais il faut encore qu'elle provoque le mâle par' une situation indécente, qu'apparemment elle me prend jamais que quand elle se croit sans témoins. La pudeur n'est-elle done qu'une vertu physique qui se trouve aussi dans les bêtes? elle est au moins, comme la douceur, la modération, la tempérance, l'attribut général et le bel apanage de tout sexe féminin.

Ainsi l'éléphant ne tète, ne s'accouple, ne mange ni ne boit comme les autres animaux. Le son de sa voix est aussi très-singulier : si l'on en eroit les anciens, elle se divise, pour ainsi dire, en deux modes très-différents et fort inégaux : il passe du son par le nez, ainsi que par la bouche; ce son prend des inflexions dans cette longue trompette, il est rauque et filé commecelui d'un instrument d'airain, tandis que la voix qui passe par la bouche est entrecoupée de pauses courtes et de soupirs durs. Ce fait, avancé par Aristote, et ensuite répété par les naturalistes et même par quelques voyageur's, est vraisemblablement faux ou du moins n'est pas exact. M. de Bussy assure positivement que l'éléphant ne pousse aucun cri par la trompe : cependant, comme en fermant exactement la bouche, l'homme même peut rendre quelque son par le nez, il se peut que l'éléphant, dont le nez est si grand, rende des sons par cette voie lorsque sa bouche est fermée. Quoi qu’il en soit, le cri de l'éléplant se fait entendre de

en clialeur, Ceci est parliculièrement remarquable de la femelle de l'éléphant, que lorsqu'elle entre en chaleur elle rainasse toutes sorles de feuillages et d'herbages, dont elle se fait un lit fort propre avec une manière de chevet, et èlevé de quatre ou cinq pieds de terre, où, contre la nature de toutes les autres bètes, elle se couche sur le dos pour allendre le míle, qu'clle appelle par ses cris. Voyage cle Tavernier, t. III, page $2: 0$.

4 J'avais écrit cet article lorsque ja ai reçu des notes de M. de Bussy, sur l'éléplıant; ce fail, que la posilion les parlies in'avait indiqué, se trouve pleinemeut confirmé par son témoiguage. ¿ liéléplıant (dit M. de Bussy) s'accouple d'une fas on - singulière; la femelle se conche sur le dos, et le malle sap- puyant sur sesjambes antérieures, ct flẻchissant ev arrière - les postéricures, ne touchent à la femelle quaurant yuil a en a besoin pour le coit. 
plus d'une lieue, et cependant il n'est pas effrayant comme le rugissement du tigre on du lion.

L'éléphant est encore singulier par la conformation des pieds et par la texture de la peau: il n'est pas revêtu de poil comme les autres quadrupèdes; sa peau est tout à fait rase; il en sort seulement quelques soies dans les gerẹures, et ces soies sont très clair'semées sur le corps, mais assez nombreuses aux cils des paupières, au derrière de la tête, dans les trous des oreilles et au-dedans des cuisses et des jambes. L’épiderme dur et calleux a deux espèces de rides, les unes en creux et les autres en relief; il parait déchiré par gerçures et ressemble assez bien à lécorce d'un vieux chêne. Dans l'homme et dans les animaux, l'épiderme est partout arthérent à la peau ; dans l'éléphant, il est seulement attaché par quelques points comme le sont deux étoffes piquées l'une sur l'autre. Cet épiderme est naturellement sec et fort sujet à s'épaissir; il acquiert souvent troisou quatrelignes d'épaisseur par le desséchement successif des différentes couches qui se régénèrent les unes sous les autres : c'est cet épaississement de l'épiderme qui produit l'éléphantiasis ou lèpre sèche, à laquelle l'homme, dont la peau est dénuée de poil, comme celle de l'éléphant, est quelcuefois sujet. Cette maladie est tries-ordinaire à l'éléphant; et pour la prévenir les Indiens ont soin de le frotter souvent d'huile et d'entretenir par des bains frèquents la souplesse de la peau : elle est très-sensible partout où elle I'est pas calleuse, daus les gercures et dans les autres endroits où elle ne s'est ni desséchée ni durcie. La piçùre des mouches se fait si bien sentir à l'éléphant, (qu'il emploie non-sculement ses mouvements naturcls, mais mème les ressources de son intelligence pour s'en délivrer : il se sert de sa queue, de ses oreilles, de sa trompe pour les frapper; il fronce sa peau partout oì elle peut se contincter, et les écrase entre ses rides; il prend des branches d'arbres, des rameaux, des poignées de longue paille pour les cliasser; et Jorsque tout cela lni mancine, il ramasse de la poussiere avee sa trompe et en couvre tous les endroits sensibles; on l'a vu se poudrer ainsi plusicurs fois par jour et se poudrer à propos, éest-í-dlire en sortant du baiu .

\footnotetext{
- On nous a dit yue l'éléphant de versailles se roulait tuujunrs sur la poussière quand il s'that haigué, ce qu"il fuisait le flus souvent qu'il pourait, ol nous avons temaryué yı'il se
}

L'usage de l'eau est presque anssi núcessitire à ces animaux que celui de l'air et de la terre; lor'scu'ils sont libres, ils quittent rarement le bord des rivières; ils se mettent souvent dans l'eau jusçu'au ventre, et ils y passent (queique's heures tous les jours. Aux Indes, ou l'on a appris à les traiter de l:ı manière qui convient le mieux à leur naturel et à leur tempérament, on les lave avee soin et on leur donne tont le temps néccssaire et toutes les facilités possibles pour se laver eux-mémes ' ; on nettoic leur peau en la frottant avec de la pierre ponce, et ensuite on leur met des essences, de l'huile et des couleurs.

La conformation des pieds et des jambes est encore singulière et différente dans l'éléphant de ce qu'elle est dans la plupart des autres animaux: les jumbes de devant paraissent avoir plus de hauteur que celles de derriere; cependant celles-ci sont un peu plus longues; elles ne sont pas pliées en deux endroits comme les jambes de derrière du chevall ou du bouf, daus lesquels la cuisse est presque entièrement engagée dans la croupe, le genou très-près du ventre, et les os du pied si élevés et si longs qu'ils paraissent faire une grande partic de la jambe: dans l'éléphant, au contraire, cette partic est très-courte et pose à terre; il a le genou comme l'homme au milieu de la jambe et non pas près du ventre. Ce pied, si court et si petit, est partagé en cinq doigts, qui tous sont recourerts par la peau et dont aucum n'est apparent au-

jet ait de la proussière anx endroits oi il ne s'en était pas atlacié́ quautl il se vautrait, el qu'il avait accontumé de chasser les monches ou ave me poignie de paille pu il promat

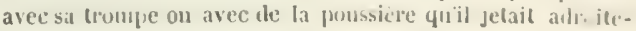
meulsur les endroits oit il se sentait p.4ne. 11'y ayant lien

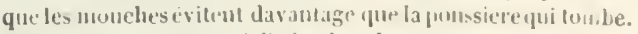
Mćmones pour servir à l'nlistoire des animaux, partic II, pages 117 el 118.

1 sur les luuit ou neuf heures avant midi nous fümes au

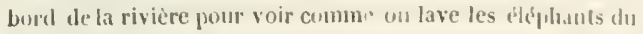
roi el des grands seigneurs; lielsphaut entre daus l'ean jusquia ventre, nl, se couchant sur un colti, prend a diverses fois de l'cau avee sa troupe yu'il jelle sur eelui yui est a l'uir pour le trien laver; le maltre vient ensuite avec une espece ule

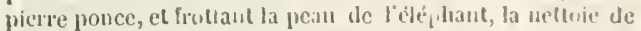
toutes les ordures qui ont pu s'y amisser. Ouelipus-mus

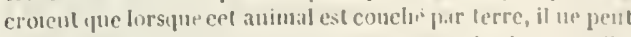
se relcver te sui-nème, ce yui est hu'n enntraire a ce yur jai

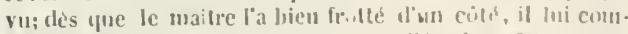

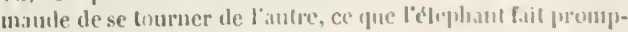
temrut, ec après qüil est hien lavé dis temx cild's, il stort de

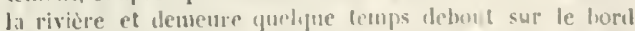

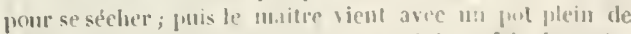

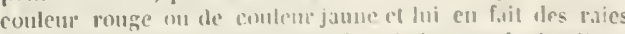
sur le front, intumr ies youx, sur la joilrine sur le derricre; le freflant eusuite d'huile de coyne punr lui reufoncer les uerfs, Voyage de Tavimier, Ronen, 1713 , tome 111 , pages 261 cl 265. 
dehors. On voit seulement des espèces d'ongles, dont le nombre varie, quoique celui des doigts soit constant; car il y a toujours cinc doigts a chaque pied, et ordinairement aussi cing ongles '; mais quelquefois il ne s'en trouve que quatre $^{2}$, on mème trois; et dans ce cas, ils ne correspondent pas exactement à l'extl’émité des doints. Au reste, cette variété, (qui n'a été observée que sur de jeunes éléphants transportés en Europe, parait être purement accidentelle et dépend varaisemblablement de la manièe dont l'éléphant a été traité dans les premiers temps de son accroissement. La plante du pied est revêtue d'une semelle de euir dur comme de la corne et qui déborde tout autour : c'est de cette même substance dont sont formés les ongles.

Les oreilles de l'éléphant sont tres-longues; jl s’en sert comme d'un éventail; il les fait remuer et clarpuer comme il lui plait. Sa queue n'est pas plus longue que l'oreille, et n'a ordinairement que deux pieds et demi ou trois pieds de longueur : elle est assez menue, pointue et garnie à l'extrémité d'une houppe de gros poils ou plutòt de filets de corne noirs, luisants et solides; ce poil ou cette corne est de la grossemr et de la force d'un gros lil-de-fer, et un homme ne peut le casser en le tirant avec les mains, quoiqu’il soit élastique et pliant. Au reste cette houppe de poil est un ornement très-recherché des Négresses, qui y attachent apparemment quelque superstition"; une quene d'eléphant se vend quelquefois deux on trois esclaves, et les nègres hasardent souvent leur vie pour tâcher

\footnotetext{
'MI. de l'Aeitémic royale des scinnces nous avaient recommandé d'examiner si tous les éléphants avaient des ongles anx pieds, nons n'eu avons pas vu un senl gui n'en eùt cinq à cluaque pièl a l'extrémité des ciuy gros doigls; mais leurs doigts sout si courts quä peine sortent-ils de la masse du pied. P'vemier voyage dı P'. Tachari, page 273.

2 'lous ceux qui ont écrit de léléphlant, meltent ciuy ongles a chacue piod, mais il $1{ }^{\circ} \mathrm{y}$ en avail que trois dans notre sujet; le petit indien dont il a été jarlé en avail yuatıe, tant aux pieds de devant qu’à ceux de derriere; la vérité est pourtant qu'il y a cing doigts à clazpne pird. Mémoires pour servir à l'ılistoire des animaux, pattie 111, page 103.

s Ilerolla ob-erve qu'un gland nombre de païens dans ces contrées, surtout les Saggas, ont une sorle de dévotion pour la queue de l'éléphant. Si la mort leurenlève un de leurs ehefs, ils conservent en sou honueur mue le ces quenes, a layuelle ils rmdent un culle, fonde sur lopinion qu'ils ont de sa force. Its entreprennent des chasses ex]'res pour la couper, mais elle doil èlrec coupée d'un seul comp; l'animal doit être vivant, sans quou la superstition ne Ini altribuerait aucune vertı. Histoire générale des Voyages, par M. l'abbé Prevost, tome V, page 79.
}

de la couper et de l'enlever à l'animal vivant Outre cette houppe de gros poils qui est a l'extrémité, la queue est couverte, ou plutôt parsemée, dans sa longueur, de soies dures et plus grosses que celles du sanglier; il se trouve aussi de ces soies sur la partie convexe de la trompe et aux paupières où elles sont quelquefois longues de plus d'un pied : ces soies ou poils aux deux paupières ne se trouvent guère que daus l'homme, le singe et l'éléphant.

Le climat, la nourriture et la condition influent beaucoup sur l'accroissement et la grandeur de l'éléphant; en général, ceux qui sont pris jeunes et réduits à cet âge en captivité, n'arrivent jamais aux dimensions entières de la nature. Les plus grands éléphants des Indes et des cotes orientales de l'A frique ont quatorze pieds de hauteur; les plus petits, qui se trouvent au Sénégal et daus les autres parties de l'Afrique occidentale, n'ont que dix ou onze pieds; et tous ceux qu'on a amenés jeunes en Europe ne sont pas élevés à cette hauteur. Celui de la ménagrerie de Versailles, qui venait de Congo, n’avait que sept pieds et demi de hauteur à l'âge de dix-sept aus; en treize ans qu il vécut, il ne grandit que d'un pied, en sorte qu'à quatre ans, lorsqu'il fut envoyé, il n'avait que six pieds et demi de hauteur'; et comme l'accroissement va toujours de moins en moins, on ne peut pas supposer que s'il fuit arrivé à l'âge de trente ans, qui est le terme ordinaire de l'accroissement entier, il ent acquis plus de huit pieds de hauteur : ainsi la condition ou l'état de domesticité réduit au moins d'un tiers l'accroissement de l'animal, nou-seulement en hauteur, mais dans toutes les autres dimensions. La longueur du corps, mesurée depuis l'œil jusqu'a l'origine de la queue, est à peu près égale à sa hauteur prise au niveau du garrot. Un éléphant des lndes, de quatorze pieds de hauteur, est done plus de sept fois plus gios et plus pesant que ne l'était l'éléphant de Versailles. En comparant l'aceroissement de cet animal à celui de l'homme, uous trouverons que l'enfant ayant communément trente et un pouces, c'est-à-dire la moitié de sa hauteur à deux ans, et prenant son accroissement entier en vingt ans, l'éléphant qui ne le prend qu'en trente, doit avoir la moitié de sa hauteul à trois ans; et de même, si l'on veut juger de l'énormité de la masse de l'éléphant, on trouvera, le volume du corps d'un homme étant. supposé de deux pieds et 
demi cubiques, que celui du corps d'un éléphant de quatorze pieds de longueur, et auquel on ne supposerairt que trois pieds d'épaisseur et de largeur moyenne, serait cinquante fois aussi gros ', et que par conséquent un éléphant doit peser autant que cinquante hommes.

"J'ai vu, dit le P. Vincent Marie, quelques " éléphants, qui avaient quatorze et quinze " pieds de hauteur ${ }^{2}$ avec la longueur et la gros" seur proportionnées. Le mâle est toujours plus " grand que la femelle. Le prix de ces animaux " augmiente à proportion de la grandeur, qui " se mesure depuis l'œil jus(fu'à l'extrémité du " dos; et quand cette dimension atteint un cer" tain terme, le prix s'aceroit comme celui des " pierres précieuses. Les éléphants de Guinée, " dit Bosman, ont dix, douze ou treize pieds de " haut ${ }^{3}$; ils sont incomparablement plus petits "que ceux des Indes orientales, puisque ceux " qui ont écrit l'histoire de ces pays-liz doment " à ceux-ci plus de coudées de haut que ceux-là " n'en ont de pieds. J'ai vu des éléphants de " treize pieds de haut, dit Ldward Terri, et j'ai " trouvé bien des gens qui m'out dit en avoir " vu de quinze pieds de haut ${ }^{4}$." De ces témoignages et de plusieurs autres qu'on pourrait encore rassembler, on doit conclure que la taille la plus ordinaire des éléphants est de dix ì onze pieds, que ceux de treize et de quatorze pieds de hauteur sont très-rares, et que les plus petits out au moins neuf pieds lorsyu'ils ont pris tout leur accroissement dans l'état de liberté. Ces masses énormes de matière ne laissent pas, comme nous l'avons dit, de se mouvoir avec beaucoup de vitesse; elles sont soutenues par quatre membres qui ressemblent moins à des jambes qu'a des pilier's ou des colonnes massives de quinze ou dix-huit pouecs de diamètre, et de cinq ou six pieds de hauteur; ces jambes sont done une ou deux fois plus longues que celles de l'homme: ainsi, (quand l'éléphant ne ferait qu'un pas tandis qu'un homme en fait deux, il le surpasserait à la course. Au reste, le pas ordinaire del'éléphaut n'est pas plus vite

Peirère, daus la vie de Gassendi, dit quiil fit peser un elephant, el qu'il se trouva peser trois mille cing cents livres. Cel eléphant étail apparemment très-petil, car celui dout nous venons de suppuler les dimensions que nons avons pent. étre trop réduites, péserait an moins huif milliers.

'Nola. Cespieds sont probablement des pieds romains.

- Nota. Ce sont probablement des pieds du Mhin.

- Voyage aux Indes orieutales, par Edward Terri , phge I5.

vota. Ce sont peut-être des pleds anglais. que celui du cheval; mais qualid on le pousse, il prend une espèce d'amble qui, pour la vitesse, équivaut au galop. Il exécute donc arec promp. titude et mème avec assez de liberté tous les mouvements directs; mais il manque absolument de facilité pour les mouvements obiiques ou rétrogrades. C'est ordinairement dans les ehemins étroits et ereux où il a de la peine as seretourner, qque les Negres l'attaquent et lui coupent la yueue, qui pour cux est d'un aussi grand prix que tout le reste de la bete. Il a beaucoup de peine à descendre les pentes trop rapides; il est obligé de plier les jambes de derrière, afin qu'en descendant, le devant du corps conserve le niveau avec la croupe, et que le poids de sal propre masse ne le préeipite pas. Il nage aussi tres-bien, quoique la forme de ses jambes et de ses pieds paraisse indiquer le contraire; mais, comme la capacité de lit poitrine et du ventre est tres-grande, que le volume des poumons et des intestins est énorme, et que toutes ces grandes parties sont remplies d'air ou de matieres plus légeres que l'ean, il enfonce moins qu'un autre; il a des lors moius de résistance à vainere, et peut par conséquent nager plus vite, en faisant moins d'efforts et moins de mouv ement des jambes que les autres. Aussi s'en sert-on très-utilement pour le paissage des rivières; outre deux pièces de eanon de trois ou quatre livres de balles, dont on le charge dans ces oceasions, on lui met encore sur le corps une infunité d'équipages, indépendamment de quantité de persomnes qui s'atta. chent à ses oreilles et à sa queue pour passer l'eau; lor'squ'il est ainsi chargé, il nage entre deux eaux, et on ne lui voit que la trompeqüil tient élevée pour respirer.

Quoique l'éléphant ne se nourrisse ordinalrement que d'herbes et de bois tendre, et qu'il lui faille un prodigieux volume de cette espece d'aliment pour pouroir en tirer la quantité de molécules organiques nécessaire à la nutrition d'm aussi vaste corps, il n'a cependant pas plusieurs estomaes comme la plupart des animaux qui se nourrissent de mème; il n'a qu'un estomac; il ne rumine pas: il est plutôt conformé comme le ehevil, que comme le bocuf ou les autres animaux ruminants: la panse qui lui manque est suppléée parr la grossemre et l'etendue des intestins et surtout du eolon, rui a deux ou trois pieds de diamietre sur quinze ou vingt de longucur; l'estomace est en tout bien plus 
petit que le colon, n'ayant que trois pieds et demi ou quatre pieds de longueur, sur un pied ou un picd et demi dans sa plus grande largeur. Pour remplir d'aussi grandes capacités, il faut que l'animal mange, pour ainsi dire, continucllement, surfout lorscu'il n'a pas de nourriture plus substantielle que l'herbe: aussi les éléphants saurages sont presque toujours occupés à arracher des herbes, cueillir des feuilles ou rasser du jeune bois; et les domestiques auxquels on donne une grande quantité de riz, ne laissent pas encore de cueillir des herbes dès qu'ils se trouvent à portée de le faire. Quelque grand que soit l'appétit de l'éléphant, il mange avec modération, et son goût pour la propreté l'emporte sur le sentiment du besoin; son adresse à séparer avec sa trompe les bonnes feuilles d'avec les mauvaises, et le soin qu'il a de les bien secouer pour qu'il n'y reste point d'insectes ni de sable, sont des choses agréables à voir. Il aime beaucoup le vin, les liqueurs spiritueuses', l'eau-de-rie, l'arac, ctc. On lui fait faire les corvées les plus pénibles et les entreprises les plus fortes, en lui montrant un vase rempli de ces liqueurs, et en le lui promettant pour prix de ses travaux. Il parait aimer aussi la fumée du tabac; mais elle l’étourdit et l'enivre. Il craint toutes les mauvaises odeurs, et il a une horreur' si grande pour le cochon, que le seul eri de cet animal l'émeut et le fait fiuir.

Pour achever de donner une idée du naturel et de l'intelligence de ce singulier animal, nous croyons devoir domner ici des notes qui nous ont été communiquées par M. le marquis de Nontmirail, lequel non-seulement a bien voulu les demander et les recucillir, mais s'est aussi donné la peine de traduire de l'italien et de l'allemand tout ce qui a rapport à l'histoire des animaux dans quelques livres qui m'ćtaient inconnus; son goût pour les arts et les sciences, son zèle pour leur avancement, sont fondés sur un discernement excpuis et sur des connaissances très-étendues dans toutes les parties de l'Histoire naturelle. Nous publierons done, a rec autant de plaisir que de recomnaissance, les bontés dont il nous honore et les lumières que nous lui devons : l'on verra dans la suite de cet ourrage, combien nous aurons d'oceasions de rappeler son nom. "On se sert. de l'éléphant pour le " transport de l'artillerie sur les montagnes, et " c'est là où son intelligence se fait mieux sentir. - Voici comme il s'y prend : peudant que les
" bœufs attelés à la pièce de canon font effort " pour la trainer en haut, l'éléphant pousse la " culasse a vec son front, et à chaque effort qu'il "fait, il soutient l'affüt avee son genou qu il " place à la roue: il semble qu'il comprenne ce a qu'on lui dit. Son conducteur veut-il lui faire " faire quelque corvée pénible, il lui explique " de quoi il est question, et lui détaille les rai" sons qui doivent l'engager à obéir : si l'élé" phantmarque de la répugnance à ce qu'il exige " de lui, le Cornac (c'est ainsi qu'on appe!le " soll conducteur) promet de lui donner de l'il"rac ou quelque chose quil aime: alors l'ani" mal se prète à tout. Mais il est dangereux de " Iui manquer de parole; plus d'un cornac en " a été la victime. Il s'est passé à ce sujet, dans - le Dekan, un trait qui mérite d'être rappor" té , et qui, tout incroyable qu'il parait, est " cependant exactement vrai. Un éléphant vea nait de se venger de son cornac en le tuant; " sa femme, témoin de ce spectacle, prit ses " deux enfants et les jeta aux pieds de l'animal " encore tout furieux, en lui disant : Puisque " tu as tué mon mari, ôte-moi aussi la vie, " ainsiqu'àmes enfants. L'éléphants'arrêta tout " court, s'adoucit, et comme s"il eût été touché " de regret, prit avec sa trompe le plus grand " de ces deux enfants, le mit sur son cou, l'a" dopta pour son cornac et n'en voulut point " souffrir dantre.

"Si l'éléphant est vindicatif, il n'est pas " moins rec'onnaissant. Un soldat de Pondichéri, " qui avait coutume de porter à un de ces ani" maux une certaine mesure d'arac chaque fois " qu'il touchait son prèt, ayant un jour' bu plus "que de raison, et se voyant poursuivi par la " garde qui le voulait conduire en prison, se "réfugia sous l'éléphant et s'y endormit. Ce " fut en vain que la garde tenta de lauracher " de cet asile; l'éléphant le défendit avec sa " trompe. Le lendemain le soldat, revenu de " son ivresse, frémit à son réveil de se trouver " couché sous un animal d'une grosseur si " énorme. L'éléphant, qui sans doute s'opercut " de son effroi, le caressa avec sa trompe pour " le rassurer, et lui fit entendre qu'il pouvait " s'en aller.

"L'éléphant tombe quelquefois dans une es" pèce de folie qui lui ôte sa docilité et le rend (" même très-redoutable : on est alor's obligé de "le tuel. On se contente quelquefois de l'atla" cheravee de grosses chaines de fer dans l'espé 
4 rance qu'il viendra à résipiscence. Mais quand " il est dans son état naturel, les doulcurs les " plus aiguës ne peuvent l'engager à faire du " mal à qui ne lui en a pas fait. Un éléphant, "furieux des blessures ju'il avait recues à lá " bataille d'Hambour, courait à travers champs * et poussait des cris affreux; un soldat qui, " malgré les avertissements de ses camarades, " n'avait pu fuir, peut-être paree qu'il était "blessé, se trouva à sa rencontre : l'éléphant " craignit de le fouler aux pieds, le prit avec " sa trompe, le plaça doucement de còté, et " continua sa route. "Je n'ai pas eru devoir rieu retrancher de ces notes, que je viens de Iranscrire; elles ont été clonnées à M. le malquis de Montmirail par .M. de Bussy, qui a demeuré dix ans dans l'Inde, et qui peudant ce long séjour y a servi très-utilement l'état et la nation. Il ávait plusicurs éléphants à son serviee; il les montait trés-souvent, les royait tous les jours et était à portée d'en voir beaucoup d'autles et de les observer. Ainsi ces notes et toutes les autres que jai citées, avec le nom de M. de Bussy, me paraissent mériter une égale confiance. MM . de l'A calémie des Scienees nous ont aussi laissé quelques faits qu'ils avajent appris de ceux qui gouvernaient l'éléphant à la Ménagerie de Versajlles, et ees faits me parais sent aussi mériter de trouver place iei. "L'élé" phant semblait connaitrequand on se moquait " de lui, et s'en souvenir pour s'en venger " quand il en trouvait l'oecasion. A un homme "qui l'avait trompé, faisant semblant de lui " jeter quelque chose dans la gueule, il lui clon" na un coup de trompe qui le renversa et lui "rompit deux côtes; ensuite de yuoi il le foula " aux pieds et lui rompit une jambe, et s'étant "agenouillé, lui voulut enfoncer ses défeuses " dans le ventre, lesquelles n'entrèrent que dans " la terre aux deux cótés de la cuisse, qui no "fut point blessée. Il écrasa un autre homme, " le froissant contre une muraille pour le mème " sujet. Un peintre le voulait dessiner en une " attitude extraordinaire, qui était de tenir sa " trompe levée et la gueule ouverte; le valet du " peintre, pour le faire demeurer en cet état, " lui jetait des fruits dans la gucule, et le plus " souvent faisait semblant d'en jeter : il eu fut " indigné, et comme s’il eủt conmu que l'envie * yue le peintre avait de le dessiuer était la cause " de rette importunité, au lieu de s'en preudre " au valet, il s'adressa au maitre, et lui jeta par
" sa trompe une quantité d'eau, dont il gáta le " papier sur lequel le peintre dessinait.

"Il se servait ordinairement bien moins de " sa force que de son adresse, laquelle était " telle qu'il s’òtait avec beaucoup de facilité " une grosse double comroie dlont il avait la " jambe attachée, la défaisant de la boucle et de "l'ardillon; et comme on eut entortillé cette " boucle d'une petite corde renouće à beancoup " de nœuds, il dénouatit tout sius rien lompre. "Une nuit, après s'ètre ainsi dépetré de sa " courroie, il rompit la porte de sa loge si " adroitement que son gouverneur n'en fut " point éveillé; de là il passa daus plusieurs " cours de la Ménagerie, brisant les portes fer" mées, et abattant la macomneric quand elles " étaient trop petites pour le litisser pisser, et " il alla ainsi dans les loges des autres animáux, "ce qui les épouranta tellement quils s'en"fuirent tous se eacher dans les lieux les plus "reculés du pare. "

Enfin, pour ne rien omettre de ce qui peut contribuer à faire comnaitre toutes les facultés naturelles et toutes les qualités acquises d'un animal si supérieur aux autres, nous ajouterons encore quelques faits que nous arons tirés des voyageurs les moins suspects. "I,éléphant, a mème sauvage (dit Ic P. Vincent Jarie) ne "laisse pas d'avoir des vertus : il est généreux " et tempérant; et quand il est clomestique on "l'estime par sa douceur et sa fidélité enver's " sou maitre, son amitié pour eclui qui le gou"verne, etc. S'il est destiué ì servir immedia" tement les princes, il commait sa fortune it " conserve une gravité convenable à son emploi; " si au contraire on le destine à des travaux " moins honorables, il s'attriste, se trouble ct " laisse voir clairement qu'il s'abaisse maleré " lui. A la guerre, dans le premier choc, il est " impétueux et fier ; il est le méne quaubl il est " enveloppé par les chasseurs, mais il perd le " eourage lorsqu'il est vaincu.... Il combat avec " ses défenses, et ne eraint rien tant que de per"dre sa trompe, qui par sa consistance est fit" eile à couper.... A A reste, il est uaturellement a cloux; il nattaque personne à moins quion ne "loffense; il semble même se plaire en eom. " pagnie, et il aime surtout les cufants, il les " earesse et parait reconuatre en eux leur in" nocence."

"L'éléphant (dit François Pyrard) est l'ani" mal qui a le plus de jugement et de conuals- 
- sance, de sorte qu'on le dirait avoir quelque - usage de raison, outre quiil est infiniment " profitable et de scrvice à l'homme. S'il est " question de monter dessus, il est tellement " souple, obéissant, et dressé pour se ranger à la " commodité de l'hornme et qualité de la per" sonne qui s'en veut servir, que, se pliant bas, " il aide lui-même à celui qui veut monter dessus " et le soulage avec sa trompe.... Il est si obéis" sant, qu'on lui fait faire tout ee que l'on veut, " pourvu qu'on le prenne de douceur.... Il fait " tout ce qu'on lui dit, il caresse ceux qu'on " lui montre, etc. "

"En dounant aux éléphants (disent les voya" geurs hollandais) tout ce qui peut leur plaire, " on les rend aussi privés et aussi soumis que le " sont les hommes. L'on peut dire qu'il ne leur " manque que la parole.... Ils sont orgueilleux " et ambiticux; mais ils se souvieunent du bien " qu'on leur a fait et ont de la reconnaissance, " jusque-là qu'ils ne manquent point de baisser " la tète pour marque de respect en passant dea rant les maisons oủ ils ont été bien traités.... "Ils se laissent conduire et commander par un " enfant; mais ils veulent être loués et chéris. "On ne saurait se moquer d'eux, ni les injurier, "quils ne l'entendent; et ceux qui le font doi"vent bien prondre garde á eux, ear ils seront " bien heureux s'ils s'empêchent d'être arro" sés de l'eau des trompes de ces animaux, ou "d'être jetés par terre, le visage contre la pous" sière."

"Les éléphants (dit le P. Philippe) appro" chent beaucoup du jugement et du raisonne" ment des hommes.... Si on compare les singes " aux éléphauts, ils ne sembleront que des ani" maux très-lourds et très-brutaux; et en effet " les ćléphants sont si honnètes, qu'ils ne sau" raient souffrir qu'on les voie lorsqu'ils s'aca couplent; et si de hasard quelqu'un les avait - vus en cette action, ils s'en vengeraient ina failliblement, etc.... Ils saluent en fléchissant " les genoux ct en baissant la tète; et lorsque - leur maitre veut les monter, ils lui présentent a si adroitement le pied quil s'en peut servir " comme d'un degré. Lorsqu'on a pris un élé" phant sauvage et qu'on lui a lié les pieds, le " chasseur' l'aborde, le salue, lui fait des excuses * de ce qu'il l'a lié, Jui proteste que ce n'est " pas pour lui faire injure..., lui expose que la " plupart du temps il avait faute de nourri- ture daus son premier etat, au licu que désor-
" mais il sera parfaitement bieu traité, qu'il lui a en fait la promesse, etc. Le chasseur n'a pas " plus tôt achevé ce discour's obligeant, que l'é" léphant le suit comme ferait un très-doux " agneau. Il ne faut pas pourtant conclure de là " que l'éléphant ait l'intelligence des langues; " mais seulement qu'ayant une très-parfaite " estimative, il connait les divers mouvements " d'estime ou de mépris, d'amitié ou.de haine. " et tous les autres dont les hommes sont agi" tés envers lui, et pour cette cause il est plus " aisé à dompter par les raisons, que par les " coups et par les verges.... II jette des pierres " fort loin et fort droit avec sa trompe, et il s'en " sert pour verser de l'eau avec laquelle il se "Iave le corps."

"De cinq éléphants (dit Tavernier) que les " chasseurs avaient pris, trois se sauverent, " quoiqu'ils eussent des chaines et des cordes " autour de leur corps et même de leurs jam" bes. Ces gens-là nous dirent une chose sur" prenante et qui est tout à fait admirable, si " on peut la croire : c'est que ces éléphants ayant " été une fois attrapés et étant sortis du piége, " si on les fait entrer dans les bois, ils sont dans " la défiance et arrachent avec leur trompe une " grosse branche dont ils vont, sondant partout " avant que d'asseoir leur pied, s'il n'y a point " de trous à leur passage pour n'ètre pas attra" pés une seconde fois; ce qui faisait désespé" rer aux chasseurs, qui nous contaient cette " histoire, de pouvoir reprendre aisément les " trois éléphants qui leur étaient échappés..... " Nous vimes les deux autres éléphants qu'ou " avait pris. Clacun de ces éléphants sauvages " était entre deux éléphants privés; et autour " des sauvages il y avait six hommes teuant des " lances à feu, qui parlaient à ces animaux, en " leur présentant à manger, et disant en leur " langage : Prends cela et le mange. C'étaient " de petites bottes de foin, des moreeaux de " suere noir et du riz euit avec de l'eau et force " grains de poivre. Quand l'éléphant sauvage " ne voulait pas faire ce qu'on lui commandait, " les hommes ordonnajent aux éléphants pri" vés de le battre, ce qu'ils faisaient aussitôt, " l'un Je frappant sur le front et sur la tète avec " sa trompe, et lorsqu'il faisait mine de se rea vancher contre celui-lá, l'autre le frappait de " son côté; de sorte que le pauvre éléphant " saurage ne savait plus où il en était, ce qui " lui apprenait à obéir." 
"J'ai plusieurs fois observé (dit Edward - Terri) que l'éléphant fait plusieurs choses qui " tiennent plus du raisonnement humain que " du simple instinct naturel qu'on lui attrilue. " Il fait tout ce que son maitre lui commande. " S'il veut qu'il fasse peur à cquelqu'un, il s'a" vance vers lui avec la même fureur que s'il a Je voulait mettre en pièces; et lorsqu'il en est " tout proche, il s'arrête tout court sans lui falre " aucun mal. Si le maitre veut faire affront it " un autre, il parle à l'éléphant, qui prendra " avee sa trompe de l'eau du ruisseau et de la " boue, et la lui jettera au nez. Sa trompe est " faite d'un cartilage; elle pend entre les dents. "Quelques-uns l'appellent sa main, à cause " qu'en plusieurs occasions elle lui rend le - mème service que la main fait aux hommes... " Le Mogol en a qui servent de bourreaux aux " criminels condamnés à mort. Si leur conduc" teur leur commande de dépècher prompte" ment ces misérables, il les mettent en pièces " en un moment avec leurs pieds; et au con" traire, s'il leur commande de les faire lan"guir, ils leur rompent les os les uns après les " autres, ct leur font souffrir un supplice aussi "cruel que celui de la roue."

Nous pourrions citer encore plusieurs autres faits aussi curieux et aussi intéressants que ceux qu'on vient de lire; mais nous aurions bientôt excédé les limites que nous avons tâché de nous prescrire dans cet ouvrage : nous ne serions pas mème entrés dans un si grand détail, si l'éléphant n'était de tous les animaux le premier à tous égards, celui par conséquent qui méritait le plus d'attention. Nous n'avons rien dit de la production de son ivoire, parce que M. Daubenton nous parait avoir épuisé ce sujet dans sa description des différentes parties de l'éléphant. On verra combien d'observations utiles et nouvelles il a faites sur la nature et la qualité de l'ivoire dans ses différents états, et en même temps on sera bien aise de savoir (qu'il a rendu a l'éléphant les défenses et les os prodigieux qu'on attribuait au mammouth. J'avoue que j'étais moi-mème dans l'incertitude à ect égard : j'avais plusicurs fois considéré ces ossements énormes et je les avais comparés avec le squelette d'éléphant que nous avons au Cabinet du Roi, que je savais être le squelette d'un éléphant presque adulte; et comme avant d'avoir fait I'histoire de ces animaux, je ne me persuadais pas qu'il pùt exister des éléphants six ou sept fois plus gros que celui dont je voyais le squelette; que d'ailleurs les gros ossements n'a vaient pas les mèmes proportions que les os correspondants dans le squelette de l'éléphant, j'avais cru, comme le vulgaire des naturalistes, que ces grands ossements avaient appartenu à un animal beaucoup plus grand, et dont l'espéce s'était perdue ou avait été détruite. Mais il est certain, comme on l'a vu dans cette histoire, qu'il existe des éléphants qui ont jusqu'à quatorze pieds de hauteur, e'est-à-dire des éléphants six ou sept fois plus gros (car les masses sont comme les cubes de la hauteur) que celui dont nous avons le squelette, et qui n'arait que sept pieds et demi de hauteur : il est certain d'ailIcur's, par les observations de M. I)aubenton, que l'âge change la proportion des os, et que lorsque l'animal est adulte ils grossissent considérablement quoiqu'ils aient cessé de grandir; enfin, il est encore certain, par le témoignagu des royageurs, qu'il y a des défenses d'éléphants qui pèsent chacune plus de cent vingt livres '. Tout cela rémni, fait que nous ne doutons plus que ces défenses et ces ossements ne soient en effet des défenses et des ossements d'éléphant. M. Sloane l'avait dit, mais ne l'avait pas prouvé : M. Gmelin l'a dit encore plus aflirmativement ${ }^{2}$ : et il nous a donné sur cela des faits

I. Éden renı témoignage rqu'il mesura plısieurs défenses d'éléphant, auxquelles il tromva nenf pieds d. longueur, quo dauires avaient lipatissenr de la cuisse d'un lomme, el que d'autres yesaint quatre-ringt-dix livres; on protend qull s'en trome en Afripue qui júsent jusijuà ceut viugl-cinq livres chacume... Lis verygenrs anglits rapportirent aussi de

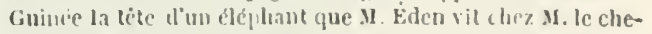
valier fudde, elle étail si grosse łue les us seuls "l le crine, sans y comprendre les defenses, pesaient ewvirun deux cents livres; de sorte quau jugement de l"anteur, elle en aurat di peser cimy cents daus la totalité de st"s plarties. Ilistuire g nérale des Voyages, lume 1. page 224.-1.opes pril plaisir à piser plusieurs dents déléshant, dont chacume étatit environ deux cents livres. Idem, tume $\mathrm{V}$, page 79.-Ia graudeur des cléphants pent ètre commue par leurs demts quion a ramanés. dont yuclunes-unes out ćté trouvées du poids de deux ceuts lives. Voyage de Ir.ıck, page 104.-An loyame de I, ow ango, j'achetai deux dents d'éléplant, qui étwent de la méme bète, qui pesaicul chatcune cent viug-six lives Vuyage de la Compragnir des tudes le tlollande, tome 15, jage 319.-I.es dents des clespliants, an cilp de lumbe-lispirance, sont trésgrosses, elles jèsent de suixante à cenl vinğ livres. Descript. du cap de Bomne-Espérance, par liolbe, tome 111. jage 12.

2 La qquantilé prodigieuse d’us quiou trouve par-ci par-là, sous terre, lans la sibérie, sont snrtont une chose de tant d'imporlance, que je crois faire plaisir a bien des lectenrs de leur joconer lavantage de tromer ici rassembli lont ce yut manquail justü à présent a l'listoire naturelle de res os.

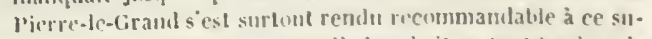
jel anx naturalistes, el conme il cherchaic en tont a suive la uature dans ses routes les plits cachies, il ordonua entre alllics, ell 1722, a tous ceux uni rencontreraieut quelque part 
curieux, et que nous avons cru devoir rapporter ici; mais M. Daubentou nous paraît être le premier qui ait mis la chose hors de doute, par des mesures précises, des comparaisons exactes

des cornes de mammouth de s'attaclier singuliêrement à ra. masser tous les autres os appartenant à cet anímal, sans en excepter un senl, et de les envoyer à Pétersbourg. Ces ordres furent publiés dans toutes les villes de Sibérie, et entre autres dakutzk, ou d'abord, après la pulblication, un siusclicwoi, appelé W'asilei Ollasow, s'engagea par écrit devant Nichaēle Petrowitsch Ismailow, capitaine-lieutenant de la gardc et woywode de l'endroit, à se transporter dans les cantous inférieurs de la Léna pour clrercher des os de mammouth, et il y fut dẻpèclié la mème année 25 avril. l'année d'après, un autre s’adressa a la chancellerie de Jakutzk, et lui représenta qüil s'était transporté arec son fils, vers la mer, pour chercher des os de mammouth, et que vis-à-vis Surjatoi-Noss, a environ deux cents verstes de ce lieu et de la mer, il avait trouvé, dans un terrain de tourbe, qui est le terrain ordinaire de ces districts, unc tête de mammouth à laquelle tenait une corne, et aupres de laquelle il y avait une autre corne du mème animal, qui l'avait peut-ètre perdue de son vivant; qu’à peu de distance de là, ils avaient tiré de la terre une autre tète arec des cornes d'un animal qui leur était inconnu, que cette tètc ressemblait assez à une tète de bœuf, mais qu'elle avait les cornes au-dessus du nez, et que par rapport à un accident qui lui était arrivé à ses yeux, il avait èté obligć de laisser ces têtes sur les licux; quayant appris l’ordonnance de Sa Majesté, il suppliait de détacher son fils avec Jui vers listJanskoje, Simowic et vers la iner; le woywode lui accorda sa demande et le fit jartir sur-le-champ. Un tro:sieme sluschew oi de Jakutzk représenta à la chancellerie, en 1724, qu il arait fait un voyage sur la rivière de Jelon, et qu'il avait cn le bonheur dc trouver sur cette rivière, daus un rivage escarpé, une tète de mammouth fraiche, avec corne et toutes ses parties, qu'il l'avait tirée de terre et laissẻe dans un endroit oủ il sau. rait la retrouver, qu'il priait qu'on le détachát avec deux hommes accontumés à chercher de pareilles choses; le woywode y consentit pareillement. Le cosaque se mit bientôt après en route, il retrouva la tète et toutes ses parties, à l'exception des cornes; il n'y avait plus que la moitié d'une corne qu'il apporta avec la tête à la chancellerie de Jakutzk. I) apporta quelque temps après deux cornes de mammouth, qüil avait trouvées aussi sur la rivière de Jelon.

Les Cosaques de Jakutzk furent charmès, sous prétexte d'aller chercher des cornes de marnmonth, de trouver moyen de faire d'aussi beanx voyages. On leur accordait cing ou six chevaux de poste, pendaut quiun seul aurait suffi, et ils pouvaient employer les autres au transport de leurs propres marcluandises. Un pareil avantage devait les beauconp encourager... Un Cosą̧ne de Jakutzk, appelé I wanselsku, deınanda à la chancelleric quion l'envoyát dans les Simowies d'Alaseisch ct de kowymisch, ponr y chercher de ces sortes d'os et dı vrai cristal; il avait déjà vécu dans lesdits lieux et y avait amassé des choses remarquables, et curoyé réellement à Jakutzk quelques-uns de ces os. Rien ne parut plus important que cette expédition, et le cosaque fut enroyé à sa destination le 21 d'auril 1725 .

Nasar-Kolescliow, commissaire d'Indigirsk, envoya en 1725 à Jakutzk, et de là à Irkurtzk, le squel lte d'une tète extraordiuaire, qui, à ce quion un'a dit, avait deux arschines moins trois werschok de loug, nne arschine de haut, et qui ètait munie de deur corne: et d'une dent de mammoutlı; ce squelette est arrivé le 14 octobre 1725 à Irkintzk, et j'en ai trouvé la relation daus la chancellerie de cette villc. On m'a assuré aussi que le inçne homme a fourni une corne de mammouth après.

Tout ceci, tel que je l'ai ramassé des différentes relations, regarde, pour la plus grande partie, une mc̀nc espèce d'os, savoir: $1^{\circ}$ Tons ceux qui se trouvent dans le Cabinet impérial et des raisons foudées sur les grandes comnaissances qu'il s'est acquises dans la science de l'anatomie comparée.

de Pétersbourg sous le nom d'os de mammoulh, auxquels tous ceux qui roudront les confronter arec les os d'éle. fhant ne pourront disputer une parfaite ressemblanco avec ces derniers. $2^{\circ}$ on voit, par les relations ci-dessus, qu'on a trouvé dans la terre des tẻtes d'un animal tout à fait différent d'un élểhant, et qui, particulièrement par rapuort à la figure des cornes, ressemblait à une tète de bnuf plutút qu'à celle d'un éléphant. D'ailleurs cet animal ne peut pas avoir été aussi gros qu'un éléphant, et j’en ai vu nne tété à Jakutzk, qui avait été envoyée d'Anadirskoi-Ostrog, et qui, selon ce qu'on ma dit, était parfaitement semblable à celle que Portn-jagin arait trouvée. J'en ai eu moi-mėme une d'Ilainskoi-Ostrog, que j’ai envoyée au Cabinet impẻrial à Pèters. bourg. Entin, jai appris que sur le rivage du Nischnaja Tunguska on trouve non-seulement par-ci par-lả de pareilles tê. tes, mais encore d'autres os, yui, certainement, ne sont pas des os d'éléphants, tels que des omoplates, des os sacrés. des cs innominés, des os de hanches et des os de jambes, qui, vraisem. blablement, appartiennent à cette même espècc d'animanx anxquels on doit attribuer le:dites tètes, et que, sans contredit, on ne doit pas exclure du genre des boufs. Jai vu des os de janıbes et de hanches de cette espece, dont je ne saurais rien dire de particulier, sinon qu'en comparaisou de leur grosseur, ils miont paru extrèmement courts. Ainsi on trouve en Sibèrie denx sortes d'os en terre, dont anciennement oun "estimait au. cuns que ceux qui resscmblent parfaitement aux dents saillan. tes d'éléphants; mais il semble que, depuis l"ordonnance im. périale, on a conmencé à les consiulérer tous cu général, ct que, comıne les premiers avaient déjà occasionné la fable de l'animal mammoutb, on a rangé ces derniers dans la mème classe ; car quoiquion connaisse avec la moindre attention que ces derniers sout d'un animal tout à tait différent du premier, on n'a pas laissé de les confondre cnsemble. C'est encorc une erreur de croire, avec Isbranıl-ldes et ceux qui suivent ses rêveries, qu'il n'y a que les nontagnes qui s'ètendent depuis la rivière de Ket vers le nord-est. et, par conséuuent, aussi les environs de Mangasca et de Jakutzk, yui soient remplis de ces os d'éléphants; il s'en trouve non-semlement dans toute la Sibérie et dans ses districts les plus méridionaux, comme dans les cantons smpérieurs de l'lrtisch, dlu Toms et de la Léna, mais encore par-ci par-là, en Russie et mème cu bien des endroits en Allemagne, oủ ils sont connus sous le nom d'ivoirc fossile, ebur fossile, ct cela avec beaucoup de raison; car tont liroire qu'on travaille en Allemaguc vient des dents d'éléphants yue nous tirons des Indes, et l'ivoire fossile ressemble parfaitement à ces deuts, sinon qu'il est pourri. Dans les climats un peu chands, ces dents se sont anollies ct changées en ivoire fossile; mais dans ccux oủ la terre reste continuellement gelée, on tromie ces dents très-ftaiches pour Ja plupart. De là peut aisément dériver la fable quion a souvent trouvé ces os et autres eusanglantés; cette fable a étè gravement débitée par Isbrand-Ides, et aurès lui yar Muller *, qui out été copiés jar d'autres avec unc assurance, comme s"il n' $y$ avait pas lieu d'en donter; et, comme une fiction va rarement seule, le sang qu'on prétenul avoir trouvé sur ces os a enfanté une autre ficfion de l'animal mammouth, dont on a conté que dans la Sibéric il vivait sous terre, qn'il y mourait quelquefois et était enterré sous les décombres, et tout cela pour rendre raison du sang quion prétendait trourer à ces os. Juller nous donne la descriution du mammouth : Cet animal, dit-il, a yuatre ou cinq annes de hant, et environ trois brasses de long, il est d'unc coulcur grisatie, ayant la tete fort longue et le front très-large; des deux cótés, précisément au-dessous des yeux, il a des cornes quil peut mouvoir et croiser comme il vent. u a la facultè de s'étcndre considérablement en ınarchant, et de - Mcurs el usages des ostlaques, dans le recueil des Voyages au uord, page 380. 
PREMIÈre ADDITION A L'ARTICLE DE L'ÉLÉPHANT.

Je donne ici la description d'un éléphant qui était à la foire Saint-Germain, en 1773 ; c'était une femelle qui avait six pieds sept pouces trois lignes de longueur, cinc pieds sept pouces de hauteur, et qui n'était âgée que de trois ans neuf mois. Ses dents n'étaient pas encore tontes venues, et ses défenses navaient que six pouces six lignes de longueur. La tête était très-grosse, l'oxil fort petit, l'iris d'un brun foncé. La masse de son corps informe et ramassée paraissait varier à ehaque mouvement, ch sorte que cet animal semble être plus difforme daus le premier âge que quand il est adulte; la peau ćtait fort brune avec rles rides et des plis assez frérguents; les deux mamelles, arce des mamelons apparents, sont placées dans l'intervalle des deux jambes de devant.

se rétrécir en un pelit volume; ses jattes jessemblent à celles d'un ou's par leur prosseur. Isbrand-Ides est assez sincère pour avoner que, de lous ccux yu'il a tuestionnés snr cet animal, il n'a trouvé personne qui lni ait tht avoir vu un manmouth vivant... Les lètes el les autres os, qui s'accorlent avec ceux ıles éléfuluals, ont été autrefois, sans contredit, des par. lies réelles de l'éléphant. Nous ne devous pas refuser toute croyance à cette quantité d'os d'áléplınt, et je présume que les éléphants, pour éviter leur destruction daus les grandes révolutions de la t'rue, se sont éclıpıés de leur endroit natal, et se sont disper'se's de toutes parts tant (pu'ils ont pu; leur sort a été différeut, les uns ont été bien loin, les autres ont pu mêne après leur mort avoir été transpurtés lort loin par queliue inondation ; eeux, au contrairé, qui, élant eucore en vie, se sont trop écartés vers le nord, doirent nécessairèuent y avoir payé le tribut de leur délicatesse; d'autres encore, sans avoir été si loin, ont pu se noyer dars une inondation on périr de lassitude... L til grosseur de ces os ne doit pas nous arrèter, les dents saillantes unt jusyüà guatre arsclines de long et six pouces de diamètre (M. de Strahtenberg dit jus. (ุu’a neuf), et les plus lortes jèsent jusıu'à six à sept puds. J'ai fait voir dans un autre endroit quit $y$ a des clents frai-

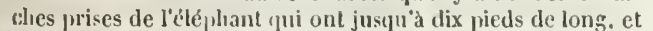
qui pèsent cent, cent quarante-six, cent suisante et cent soixante-lunit livres... Il y a des morceaux d'ivoire fossile qui ont une alplarenee jaunitre et qui jaunissent par la suite des temps, et d'autres qui sunt bruns comme des noix de coeos on phus clairs, ct enfin, d'autres qui sunt d'un bliu noiritre. Les tenis tjui nont pas été bien gelées dans la terre et ont resté perulant „puelyue temps exposées à l'uffet de l'air, sont sujettes à tlevenir filus on muins jantes ou brumes, et elles prenneut d'iutre's conlins suivant l'es|cece d'bunidité qui y agit (') se joisuant aे l'air : aussi, suivant ce que lit 1 . de stralılinberg, on trouve quelquelois des unorceanx diun bleu noir thans ces dents corrommens... II scrail à sumbititer, pour le bien de l'llistoire Nalurelle, inon commint, powr les antres os y juon trouve en Sibétic, liespice d'animal aupuel ils ap-

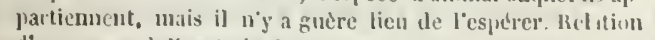
d'un voyage a kantsehatka, par M.Gmelin, imprime en 1753 à l’étershourg, en lamgrue russe. La traduction de cet article Ii'a d'aboril été communiguée par M. de l'Isle, de l'Acaulémie des Sciences, et cusuite par M. le maryuis de Muntnirail, yุui en a fait la tyaluction sur l'original allemand, inpriné à Goltingue eu 1752.
Dimensions de cet animal

1). p. 1.

Longueur du corps, mesuré en ligne droile.. $6 \begin{array}{ccc}6 & \mathbf{7} & \mathbf{3}\end{array}$

Hauteur du train de devint. ....... 410 j

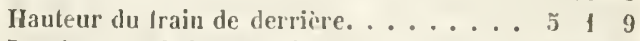

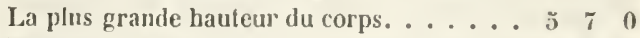

Hauteur du ventre. ............ 256

Longueur de la tète depuis la màchoire jus-

qu'à l'occiput. ................ 11 il

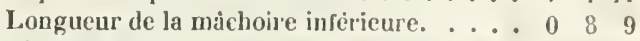

Distance entre le bout de la michoire infé-

ricure et l'augle de l'reil. . . . . . . . . 2 2539

Distance entre l'angle postérieur et l'orejlle. . $\begin{array}{llll}0 & 10 & 5\end{array}$

Longueur de l'œil d'un angle á l'autre. . . $0 \begin{array}{lll}0 & 2 & 4\end{array}$

Largenr enlre les deux yeux......... I 110

Longuenr des oreilles en arrière. ..... 1 ; 7

Hauteur de l'oreille. . . . . . . . . 12 . 1

Circonférence dn cou. ........... 5 .

Circonference du corps, derrière les jambes

de devant. ................. 7 \& 8

Circonféreuce du corps, devant les jambes de

derrił̀re............... ₹ 8 ร

Circonférence du corps à l'endroit le plus gros. $\begin{array}{ccc}8 & 0 & 7\end{array}$

Longueur du Ironçon de la queue. . . . . . 2 2 1

Circonférence de la queue à son origine.. . . . $1 \begin{array}{lll}1 & 1 & 9\end{array}$

Largeur le l'avant-bras, depuis le coude jus-

qu'au poignet................... 16

Largeur du baut de la jambe. . . . . . I 109

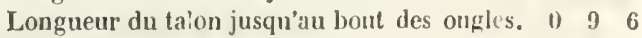

Largeur du pied de derant . . . . . . . . . $0 \begin{array}{ccc}0 & 8 & 5\end{array}$

Largeur du pied de derrière. . . . . . . . 0 ( 0 10

Longueur des plus grands ougles...... 0 . 1 1)

Largeur. . . . . . . . . . . . . 0 n 50

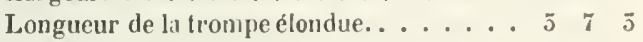

Il nous a paru, en comparant le mâle et la femelle, que nous avons tous deux vus, le prémier en 1771 , et l'autre en $17 \% 3$, qu'en général la femelle a les formes plus grosses et plus charnues que le mâle, au point qu'il ne serait pas possible de s'y tromper: seulement elle a les oreilles plus petites à proportion que le mâle ; mais le corps paraissait plus renflé, la tête plus grosse et les membres plus arrondis.

Dans l'espéce de l'éléphant, comme dans toutes les autres espèces de la nature, la femelle est plus douce gue le mâle; celle-ci ctait mème caressante pour les gens qu'clle ne connaissait pas, au lieu que l'éléphant mâle est souvent redoutable. Celui que nous avons vu en $17 i$, était plus fier, plus indiflérent et beancoup) moins traitable que cette fomelle. Ciest d'après ce mâle que M. de Sève a dessiné la trompe et l'extrémité de la rerge représcutées. Daus l'était de repos cette partic ne parait point du tout à l'extéricur; le ventre semble étre absolument uni, et ce n'est que dans le moment ou l'animal veut uriner, que l'extrémité sort du fourreau, 
comme on le voit représenté. Cet éléphant mâle, quoique presque aussi jeune que la femelle, était, comme je viens de le dire, bien plus difficile d̀ gou verner. Il cherchait mème à saisir avee sá trompe les gens qui l'approchaient de près, et il a souvent arraché les poches et les basques de l'habit des curieux. Ses maitres mêmes étaient obligés de prendre avee lui des précautions, au lieu que la femelle semblait obéir avee complaisance. Le seul moment ou on l'a vue marquer de l'humeur a été celui de son emballage dans son caisson de voyage. Lorsqu'on vonlut la faire entrer dans ce caisson, elle refusa d'avancer, et ce ne fut qu'à force de contrainte et de coups de poinçon dont on la piquait par derrière, qu'on la força d'entrer dans cette espèce de cage qui servait alors à la transporter de ville en ville. Irritée des mauvais traitements qu'elle venait d'essuyer, et ne pouvant se retourner dans cette prison étroite, elle prit le seul moyen qu'elle avait de se venger; ce fut de semplir sa trompe et de jeter le volume d'un seau d'eau au visage et sur le corps de celui qui l'avait le plus harcelée.

Au reste, on a représenté la trompe vue pardessous, pour en faire mieux connaitre la structure extérieure et la flexibilité.

J'ai dit, dans l'histoire naturelle de l'éléphant, qu'on pouvait présumer que ces animaux ne s'accouplaient pas à la manière des autres quadrupèdes, paree que la position relative des parties génitales dans les individus des deux sexes parait exiger que la femelle se renverse sur le dos pour recevoir le mảle. Cette conjecture qui me paraissait plausible ne se trouve pas vraie, car je crois qu'on doit ajouter foi à ce que je vais rapporter d'aurès un témoin oculaire.

M. Marcellus Bles, seigneur de Moërgestal, écrit de Bois-le-Duc, dans les termes suivants :

"Ayant trouvé dans le bel ouvrage de M. le comte de Buffon, qu'il s'est trompé touchant l'accouplement des éléphants, je puis dire qu'il y a plusieurs endroits en Asie et en Afrique, ou ces animanx se tiennent toujours dans les bois écartés et presque inacessibles, surtout dans le temps qu'ils sont en chaleur; mais que dans lìle de Ceylan, oủ jai demeuré douze ans, le terrain étant partout habité, ils ne peuvent pas se cacher si bien, et que les ayant constamment observés, jai vu que la partie naturelle de la femelle se trouve en elfet placée presque sous le milieu du ventre, ce qui ferait croire, comme le dit M. de Buffou, qua les mâles ne peuvent la couvrir à la façon des autres quadrupèdes : cependant il ny a qu'une légère différence de situation ; j'ai vu, lorsqu'ils veulent s'accoupler, que la femelle se courbe la téte et le cou, et appuie les deux pieds et le devant du corps éga. lement courbés, sur la racine d'un arbre comme si elle se prosternait par terre, les deux pieds de derrière restant debout et la croupe en haut, ce qui donne au màle la facilité de la couvrir, et d'en user comme les autres quadrupèdes. Je puis dire aussi que les femelles portent leurs petits neuf mois ou environ. Au reste, il est vrai que les éléphants ne s'accouplent point lorsqu'ils ue sont pas libres. On enchaine fortement les màles quand ils sont en rut, pendant quatre à cinq semaines; alors on voit parfois sortir de leurs parties naturelles une grande aboudance de sperme, et ils sont si furieux pendant ces quatre ou cinq semaines, que leurs cornacs ou gouverneurs ne peuvent les approcher sans dauger. On a une annonce infaillible du temps où ils entrent en chaleur; car, quelques jours avant ce temps, on voit couler une liqueur huileuse qui leur sort d'un petit trou qu'ils ont à chaque còté de la tète. Il arrive quelquefois que la femelle qu'on garde à l'écurie dans ce temps s'échappe et va joindre dans les bois les éléphants sauvages; mais quelques jours après son cornac va la chescher et l'appelle par son nom tant de fois qu'à la fin elle arrive, se soumet av'ec docilité, et se laisse conduire et renfermer; et c'est dans ce cas où l'on a vu que la femelle fait son petit à peu près au bout de neuf mois."

Il me parait qu'on ne peut guère douter de la première observation sur la manière de s'accoupler des éléphants, puisque M. Marcellus Bles assure l'av oir vue; mais je crois qu'on doit suspendre son jugement sur la seconde observation, touchant la durée de la gestation, qu'il dit n'être que de neuf mois, tandis que tous les voyageurs assurent qu'il passe pour constant que la femelle de l'éléphant porte deux ans.

SECONDE ADDITION A L'ARTICLE DE L'ÉLÉPHANT.

Jai rapporté l'extrait d'une lettre de M. Marcellus Bles, seigneur de Moërgestal, au sujet de l'accouplement des éléphants; etil a eu la bonté de m'en éerire une autre le 25 janvier $1 ; 76$, dans laquelle il medonue tonnaissance de quel- 
ques faits que je crois devoir rapporter jei.

Les Hollandais de Ceylan, dit M. Bles, ont toujours un certain nombre d'éléphants en réserve, pour attendre l'arrivée des marchands du continent de l'Inde, qui y viennent acheter ces animaux dans la vue de les revendre ensuite aux princes indiens: souvent il s'en trouve qui ne sont pas assez bien conditionnés, et que ces marchands ne peuvent vendre; ces éléphants défectueux et rebutés restent à leur maître pendant nombre d'annces, et l'on s'en sert pour la chasse des éléphants sáuvages. Quelquefois il arrive, soit par la négligence des gardiens, soit autrement, que la femelle, lorsqu'elle entre en chaleur, dénoue et rompt pendant la muit les cordes avee lesquelles elle est toujour's attachée par les pieds; alors elle s'enfuit dans les for'èts, y cherche les éléphants sauvages, s'accouple et devient pleine : les gardiens vout la chercher partout dans les bois en l'appelant par son nom , elle revient dès lors sans contrainte et se laisse ramener tranquillement à son étable : c'est ainsi quion a reconnu que quelques femelles ont produit leur petit neuf mois après leur fuite; en sorte qu’il est plus que probable que la duréede la gestation n'est en effet que de neuf mois. Ia hauteur d'un éléphant nouveau-né n'est guère que de trois pieds du Rhin : il croît jusc[u'à l'àge de seize ì vingt ans, et peut vivre soixante-dix, quatre-vingts et même cent ans.

I.e même M. Bles ditqu'il n'a jamais vu, pendant un séjour de onze années qu'il a fait à Ceylan, que la femelle ait produit plus d'un petit à la fois. Dans les grandes chasses qu'on fait tous les ans dans cette ile, auxquelles il a assisté plusieurs fois, il en a vu souvent prendre quarante a cinquante, parmi lesquels il y avait des éléphants tout jeunes; et il dit qu'on ne pouvait pas reconnaitre quelles étaient les mères de chacun de ces petits éléphants, car tous ces jeunes animaux paraissent laire mense commune: ils tettent indistinctement celles des femelles de toute la troupe qui ont du lait, soit qu'elles aient elles-mèmes un petit en propre, soit qu'elles n'en aient point.

M. Mareellus Bles a vu prendre les éléphants de trois manieres différentes. Ils vont ordinairement en troupes séparées quelquefois à une lieue de distance l'une de liaitre; la premièe manière de les prendre est de les entourer par un attroupement de quatre? ou cing cents hom mes, qui, ressermant toujou's ees animaux de plus près en les épouvantant par des cris, des pétards, des tambours et des torches allumées, les forcent à entrer dans une espèce de pare entouré de fortes palissades dont on ferme ensuite l'ouverture pour (ju'ils n'en puissent sortir.

La seconde maniere de les chasser ne demande pas un si grand appareil ; il suffit d'un certain nombre d'hommes lestes et agriles à la course qui vont les cluercher dans les bois : ils ne s'atta(puent qu'aux plus petites troupes d'éléphants qu'ils agacent et inquietent au point de les mettre en fuite: ils les suivent aisément a la course, et leur jettent mou deux lacs de cordes tres-fortes aux jambes de derrière : ils tiennent toujours le bout de ces corles jusqu'à ce qu'ils trouvent l'occasion favorable de l'entortiller autour d'un arbre; et lorsqu'ils parviennent à arrèter ainsi un éléphant sauvage daus sa course, ils amènent à l’instant deux éléphants privés, auxquels ils attachent l'éléphant sauvage, et, s'il se mutine, ils ordonnent aux deux apprivoisés de le battre avec leur trompe jusqu’à ce qu'il soit comme étourdi ; et enfin ils le conduiseut au lieu de sa destination.

La troisième manièle de prendreles éléplıants, est de mener quelques femelles apprivoisées dans les forêts; elles ne manquent guère d'attirer quelqu'un des éléphants sauvages et de les séparer de leur troupe: alors une partie des chasseurs attaque le reste de cette troupe pour lui faire prendre la fuite, tandis que les autres chasseurs se rendent maitres de cet éléphant sauvage isolé, l'attachent avec deux femelles, et l'amènent aiusi jusqu'à l'étable ou jusqu'au pare oil on veut le garder.

Les éléphants dans l'état de liberté, vivent dans une espèce de société durable; chaque bande ou troupe reste séparée et n'a ancun commerce avec d'autres troupes, et même ils paraissent s'entr'éviter très-soigneusement.

Lorsqu'une de ces troupes se met en marche pour voyager ou changer de domicile, ceux des mâles qui ont les défenses les plus grosses et et les plus longues marchent a la trite; et s'ils reneontrent dans leur route une risiere un peu profonde. ils la passent les premiers à la nage, et paraissent sonder le terrain du rivage opposé ; ils donnent alors un signal par un son de leur trompe, et dis lors la troupe avertic entre dans la riviere, et nageant en file, les ciléphants adultes transportent leurs petits en se les donnant, pour ainsi dire: do main en main; apres quoi 
tous les autres les suivent et arrivent au rivage où les premiers les attendent.

Uneantre singularité remar'[uable, c'est que, quoiqu'ils se tiennent toujour's par troupes, on trouve cependant de temps en temps des éléphants séparés et errants seuls et éloignés des autres, et qui ne sont jamais admis dans aucune compagnie, comme s'ils étaient bannis de toute société. Ces éléphants solitaires ou réprouvés sont très-méchants; ils attaquent souvent les hommes et les tuent; et tandis que, sur le moindre mouvement et à la vue de l'homme (pourvu cu'il ne se fusse pas avec trop de précipitation), une troupe entière déléphants s'éloignera, ces éléphants solitaires l'attendent non-seulement de pied ferme, mais même l'attaquent avec fureur, en sorte qu'on est obligé de les tuer à coups de fusil. On n'a jamais rencontré deux de ces éléphants farouches ensemble; ils vivent seuls et sont tous màles; et l'on ignore s'ils recherehent les femelles, car on ne les a jamais vus les suivre ou les accompagner.

Une autre observation assez intéressante, c'est que dans toutes les chasses auxquelles II. Marcellus Bles a assisté, et parmi des milliers d'éléphants qu'il dit avoir vus dans l'île de Cevlan, à peine en a-t-il trouvé un sur dix qui fût armé de grosses et grandes défeuses; et quoique ces éléphants aient autant de force et de vigueur que les autres, ils n'ont néanmoins que de petites défenses minces et obtuses, qui ne parviennent jamais qu'à la longueur d'un pied à peu près, et on ne peut, dit-il, guère voir, avant l'âge de douze à quatorze ans, si leurs défenses deviendront longues ou si elles resteront à ees petites dimensions.

Le même M. Marcellus Bles m'a écrit en dernier lieu qu'un particulier, homme très-instruit, établi depuis longtemps daus l'intérieur de l'ile de Ceylan, l'avait assuré qu il existe dans cette fle une petite race d'éléphants qui ne deviennent jamais plus gros qu'une géuisse : la même chose lui a été dite par plusieurs autres persounes dignes de foi; il est vrai, ajoute-t-il, qu'on ne voit pas souvent ces petits éléphants, dont l'espèce ou la race est bien plus rare que celle des autres : la longueur de leur trompe est proportionnće à leur petite taille; ils ont plus de poil que les autres éléphants; ils sont aussi plus sauvages, et au moindre bruit, s'enfuient dans l'épaisseur des bois.

Les éléphants dont nous sommes actuclle- ment obligés d'aller étudier les mœurs à Ceylan ou dans les autres climats les plus chauds de ia terre, ont autrefois existé daus les zones aujourd'hui tempérées, et mème dans les zones froides; leurs ossements trouvés en Russie, en Sibérie, Pologne, Allemagne, Franee, Italie, etc., démontrent leur ancienne existence dans tous les climats de la terre; et leur retraite suecessive vers les contrées les plus chaudes du globe à mesure qu'il s'est refroidi. Nous pouvons en douner un nouvel exemple; M. le prince de Porentrui, évèque de Bâle, a eu la bouté de m'envoyer une dent molaire et plusieurs autres ossements d'un squelette d'éléphant trouvé dans les terres de sa principauté, à une trèsmédiocre profondeur: voici ce qu'il a bien voulu m'en écrire en date du 15 mai de cette année 1780. "A six cents pas de Porentrui, sur "la gauche d'un graud chemin que je viens de r faire construire pour communiquer avec Béa fort, en excavant le flanc méridional de la " montagne, l'on découvrit, l'été dernier, à " quelques pieds de profondeur, la plus grande " partie du squelette d'un très-gros animal. Sur " le rapport qui m'en fut fait, je me transpor" tai moi-même sur le lieu, et je vis que les ou" vriers avaient déjà brisé plusieurs pièces de " ce squelette, et qu'on en avait enlevé quel" ques-unes des plus curieuses, entre autres la "plus grande partie d'une très-grosse défense " qui avait près de cinq pouces de diamètre à " la racine, sur plus de trois pieds de longueur; " ce qui fit juger que ce ne pouvait être que le " squelette d'un éléphant. Je vous avouerai, " monsieur, que , n'étant pas naturaliste ,j'eus " peine à me persuader que cela fùt; je remar-

" quai cepeudant de très-gros os, et particuliè" rement celui de l'omoplate que je fis déterrer : " j'observai que le corps de l'animal, quel qu'il " fùt, était partie dans un rocher, partie en un " sac de terre, dans l'anfiactuosité de deux ro" chers; que ce qui était dans le rocher était pé" trifié, mais que ce qui était dans la terre était " une substance moins dure que ne le sont or" dinairement de pareils os. L'on m'apporta un " morceau de cette défense que l'on a vait brisée " en la tirant de cette terre où elle était deve" mue mollasse: l'enveloppe extérieure ressem" blait assez à l'ivoire ; l'intérieur était blanchà" tre et comme savonneux. On en brûla une "parcelle, et ensuite une autre parcelle d'une " véritable défense d'éléphant; elles domnèrent. 
- l'uneet l'autre une huiled'une odeur à peu près " pareille. Tous les morceaux de cette première " défense ayant été exposés quelque temps à " l'air, sont tombés insensiblement en poussière,

: Il m'est resté un morceau de la mâchoirc " pétrifiée avec quelques-unes des petites dents : " je les fis voir à M. Robert, géographe ordi" ulaire de Sa Majesté, qui m'ayant témoigné a que ce morceau d'histoire naturelle ne dépa"rerait pas la belle collection que vous avez " dans le jardin du Roi, je lui dis (qu'il pouvait " vous l'offir de ma part, et j'ai l'homneur de " yous l'envoyer."

J'ai recu en effet ce morceau, et je ne puis qu'en témoigner ma respectueuse reconnaissance à ce prince, ami des lettres et de ceux qui les cultivent. C'est réellement une très-grosse dent molaire d'éléphant, beaucoup plus grande qu'aucune de celle des éléphants vivant aujourd'hui. Si l'on rapproche de cette découverte toutes celles que nous a vons rapportées de squelettes d'élépliants trouvés en terre en différentes parties de l'Europe, et dont la note ci-jointe que nous communique M. l'abbé Bexon, indique encore un plus grand nombre, on demeurera biels convaincu qu'il fut un temps où notre Europe fut la patrie des éléphants, ainsi que l'Asic septentrionale, où leurs dépouilles se trouvent en si grande quantité. Il dut en être de mème des rhinocéros, des hippopotames et des chameaux. On peut l'emarquer entre les argalis ou petites figures de fonte, tirées des anciens tombeaux trouvés en Sibéric, celles de l'hippopotame et du chameau; ee qui prouve que ces animaux, qui sont actuellement inconuus dans cette contrée, y subsistaient autrefois : l'hippopotame surtout a dù s'en retirer le premier, et presque en même temps que l'éléphant; et le chameau, quoique moins étranger aux pays tempérés ou froids, n'est cependant plus connu dans ce pays de Sibérie que par les monuments dont on vient de parler : on pent le prouver par le témoignage des voyageur's récents.

"Les Russes, disent-ils, pensèrent que les cha" meaux seraicut plus propres que d'autres ani" maux au transport des vives de leurs cara" vanes dans les déserts de la Sibérie méridio" uale : ils firent en conséquenee venir à Jakutzk " uu chameau pour' essayer son service : les ha"bitants du pays le regarderent comme un " moustre qui les eftraya beaucoup. La petite * vérole commengait il faire des ravages dans
" leur's bourgades; les Jakutes s'imaginèrent " que le chameau en était la cause... et on fut " obligé de le renvoyer; il mourut même dans " son l'etour, et l'on jugea avec fondement que " ce pays était trop froid pour qu'il pût y sub" sister et encore moins y multiplier. "II faut donc que ces figures du chameau et de l'hippopotame aient été faites en ce pays clans un temps où on y avait encore quelque comnaissance et quelque souvenir de ces animaux. Cependant nous remarquerons, à l'égard des chameaux, qu'ils pouvilient être comnus des anciens Jakutes; ear M. Guldenstaedt assure qu'ils sout actuellement en nombre daus les gouvernements d'Astracan et d'Orembourg, aussi bien que daus quelques parties de la Sibérie méridionale, et que les Calmoukes et les Cosaques ont mème l'art d'en travailler le poil. Il se pourrait done, absolument parlant, que les Jakutes eussent pris comnaissance du chameau dans leurs voyilges au midi de la Sibéric : mais, pour l'hippopotame, nulle supposition ne peut en rendre la counaissance possible à ce peuple : et dès lors on ne peut rapporter cqu'au refroidissement successif de la terre, l'ancienne existence de ces animaux, ainsi que des éléphants, dans cette contrée du nord, et leur migration forcée dans celles du midi.

Après avoir livré à l'impression les feuilles précédentes, j’ai reçu un dessin fait aux Indes, d'un jeune éléphant tétant sa mère. C'est à la prévenante honnêteté de M. Gentil, chevalic.' de l'ordre royal et militaire de Saint-Louis, qui a demeuré vingt-huit ans au Bengale, que je dois la comnaissance d'un fait dont je doutais. Le petit éléphant ne tette pas par la trompe, mais par la gueule, comme les autres animaux. M. Gentil en a été souvent témoin, et le dessin a été fait sous ses yeux.

\section{DESCRIPTION DE L'ÉLEPHANT.}

(EXTRAIT DE DAUBEXTO:.)

Quoique l'on sache que l'éléplıant est le plus grand de tous les yuadrupedes, on serait surpris, en royant pour la premic̀re fois un animal qui a jusqu'i quatorze pieds de hauteur et plus de vingtcinc pieds de longueur lorsyu'il tient sa trompe étendue en avant. Quelle énorme différence de cette masse prodigiense an pe! it volume de la souris ou 
des musaraignes! A ussi l'pléphant paraît surchargé de son propre poids : ses jambes ressemblent à quatre piliers nal dressés, qui soutiennent son corps informe, dont le dos est vouté, la croupe ravalée et les tlanes presque aussi renflés que les cỏtés. La tète lient au corps.juresque saus apparence du con; elle est termince en arrière par deux convexités placées l'une à côté de l'autre entre de très-lariges oreilles. Les yeux sont excessivement petits, et séparés par un large espace relevé en bosse. L.e museau est très-liffërent de celui de tout autre quadrupède; on n y voit que l'origine d'une très-longue trompe, qui pend entre deux longues défenses; on n'aperçoit la bouche yu'en regardant derrière la trompe, qui tient lien de lèrre supérieure; celle du dessous se termine en pointe. La queue de l'animal est courte et très-mince, surtout en comparaison de la trompe, qui ressemble à une grosse et longue queue placée en avaut. Les pieds sont très-petits, ronds et difformes; on n'y distingue que des ongles; enfin l'éléphant en repos sur ses jambes est un animal informe et colossal, qui semble ètre arrèté et affaissé par la pesanteur de sa masse; sa longue face, oì l'on ne roit que de petits yeux, sans nez. ni bouclue, rend sa physionomie stupide; la trompe, qui cache la bonclıe, qui tient lien de nez, et qui est accompagnée de deux longues défenses, fait une conformation étrange et unique pour le museau d'un quadrupède. A des apparences si défavorables, qui reconnaittrait l'auimal le plus adroit et le plus intelligent de tons les animaux?

L'auteur de la nature a mis, sous la pliysionomie stupide de l'éléplıant, un instinct admirable; les parties de son corps ont tant de vigueur et de force, que la masse énorme qu'elles composent se meut avec facilité et même avecpromptitude : sonvent il marche très-vite, et il s'agite avec furie; ses jambes, qui paraissent si raides, se plient comme celles des autres animaux; il se couche et il se relève avec loute l'aisance que peut permettre lit pesanteur de son corps. La trompe, cet organe particulier à l'éléphant, est le principal agent qu'il emploie pour ses besoins et pour sa léfense: la force dont les grands animaux sont seuls capables, l'agilité et l'adresse qui sont le partage des petits animaux, sont réunies lans celle trompe; elle est plus forte que la patte du tigre et te l'ours, et aussi adroite que la main du singe.

La trompe de l'éléplıant est, à proprement parler, son nez prolongé en formede tuyau el terminé par les ouvertures des narines, qui sont en effet au bout de la trompe. Le groin des cochons, the la taıpe, des musaraignes, du raton, du coati, etc. , a quelque rapport arec celte trompe, en ce qu’il est allongé et molvile; mais la trompe a de plus la propriété de faire les fonctions d'un bras long et nerveux et d'une main très-adroile, aussi bien que les fonctions du nez. La trompe tle l'iléplant de ireize piedi et demi de hauteur, a environ lunit pieds de longueur au-dlelırs de la bouche, cinq pieds et demi de circonférence près de la bouche, et un pied et temi près de l'extrèmité, c'est un luyau de figure conique, irrégulière, fort allongé, tronqué et évasé par le bout : le cóté supérieur de ce tuyau est convexe el cannelé sur sa largeur, et le cóté inférieur est aplati et a deux rangs lungitudinaux de petites éminences qui ressemblent aux pieds des vers à soie et de la plupart des autres chenilles. La première portion de la trompe se trouve à l'endroit de la lèrre supérieure et de l'extrómité du nez des aıtres animaux, et en tient lieu, puisque le cỏté intérieur sert de lèrre, et que les narines sont placies au-dedans; car la trompe est creusée dans toute sa longueur, et sa cavité est divisée par une cloison longitudinale en deux canaux yui se prolongent et s'étendent en haut sur le devant de la mảchoire supérieure ; ensuite ils se courbeni en dedans et descendent jus(fu'au palais, où ils terminent chacun par un orifise; ils ont aussi clıacun un autre orifice à l'extréunité de la trompe. On a vu dans ces canaux, à l'entroit ou ils se courbent avant d'entrer dans les os de la tète, une lame cartilagrineuse mobile et disposée de façon à faire soupçommer qu'elle ferme le canal, et qu'elle empêche que l'eau, ciont l'éléphant remplit sa trompe, n'entre dans les conduits du nez, ou se trouvent les organes de lodorat. L'éléplıant peut mouvoir sa trompe en tout sens, l'allonger et la raccourcir sans elanger le diamètre des deux canaux du dedaus; ainsi la respirat on n'y est gènée dans aucume situation le la trompe, et l'ean y reste jusqu’à ce que l'animal l'en fasse sortir par une expiration ; chaque canal est formé par une membrane lisse et ferme, qui fait ses parois intérieures, et la trompe est revètue au-clehors par une autre membrane : la substance qui est entre celte membrane extérieure et celles des canaux est composée de muscles longitudinaux, relativement à la direction cle la trompe et d'autres muscles Iransversaux, qui ne sont pas circulaires, mais ıui šétendent au com raire comme des rayons, depuis les membranes des cauaux jusqu'à la membrane exterieure lle la trumpe : tous ces muscles sont en tres-grand nombre et peuvent se contracter ou se dilater dans une portion de la trompe, ou sur un le ses cotés, saus que les autres eprouvent le mème monvement. Dès lors on peut concevoir comment la trompe se meit en tout sens, s`allonge et se raccourcit sans que le diamètre des canaux intrieurs varie beancoup de longnewr, puisque les muscles n'embrassent pas ces canaux ; leurs attaches sout placces le facon quils tirem en thehors les membranes des camaux iutericurs, et yüils ne tendent 
qu'à dilater ou contracter, qli’à augmenter ou diminuer l'épaisseur de la substance, qui est entre les membranes des canaux et la membrane extérieure : par exemple, en contractant cette substance dans le cỏté droit de la trompe, et par conséquent, en la rendant plus épaisse, ils font courber la trompe de ce mème còté; et duraut ce mouvement la substance du côté gauche se dilate et s'amincit. Si la contraction se fait eigalement dans tout le tour de la trompe, elle se raccoureit sans se courber, etc.; les muscles étant très-nombreux, il s'en trouve assez pour opérer toutes sortes d'inflexions dans la trompe avec une force et une vitesse extrêmes; les plus surprenantes se font à l'extréınité. Elle est terminee par une coneavité, au fond de laquelle sont les trous des narines, et dont le bord est saillant; la partie inférieure de ce bord a plus d'épaisseur que les parties latérales, et la partie supérieure est allongée en forme de doigt, pui a envirou cinq pouces de longueur : ce prolongement, et tout le reste des bords de l'extrémité de la trompe et la concavité qu’ils forment peuvent prendre différentcs figures suivant les besoinsdel'animal. C'est par le moyen de cet organe qu'il saisit différentes closes, comme arec un doigt ou comme arec une main; il ramasse un grain de blé, le fétu le plus délié, etc. Il fait des opérations qui demandent une adresse et une précision dont on ne croirait pas qu'un si gros animal fùt capable. lorsqu'il veut enlever un corps uni et trop ètendu pour ètre saisi, il applique exactement les bords de l'extrémité de sa trompe sur ce corps, et en retirant son haleine, il pompe si bien l'air, qu'il parvient à enlever un corps très-pesant; en plongreant l'extrémité de celte trompe dans l'eau, il l'attire et en remplit toute la capacité des leux canaux de l'iuterieur; ensuite il retire sa trompe et la garde pleine d'eau, quoiqu'il lui fasse faire de grands mouvenents, et mime quoiyuil la contourne en spirale: il peut faire jaillir cette eau au loin; mais pour l'ordinaire, il la boit en portant le bout de sa trompe dans sa bo:ıche, où il laisse couler l'eau.

La bouche est très-pelite et presıue enticrement caclice derrière les défenses et la base de la trompe. Linimal replie sa trompe pour porter à sa bouclıe tous ses aliments, tant solides que li puicles : il cueille l'herbe, il ramasse le foin, toujours avec cette main et ce doigt qui sont au bout de la trompe; il eu fait de petites bottes qu’il porte justyu'au fond de sa bouche.

I.es défenses sont le très-longues dents; elles sortent au tehors tle la bouche; elles sont dirigées obliquement en has, en arant et en dehors, et recourlices cu haut.

L'ouverture des paupières de l'éléplant est très-petite, et le globe les yeux n'a jas le tiers de la grosseur du globe de l'uil dı boxuf, à pro- portion de la grandeur du corps de cliacun de ces animaux.

II y a de chaque cóté de la tête de l'éléphant, entre l'oil et l'oreille, l'orifice d'un conduit gros comme le doigt, guui aboutit à une glande placée sous la peau : on dit qu'il sort de ces conduts une humeur huileuse lorsyue l'animal est en chaleur.

Les oreilles de l'éléphant sont, à ce que l'on a prétendu, pius grandes à proportion que celles dle tout autre animal ; mais il faut certainement en excepter la chauve-souris que nous avons nommce Oreil. lard, parce que ses oreilles sont si longues qu'elles ont les trois (yuarts de la longueur du corps entier, et parce qu'elles ont aussi heancoup de largeur. Celles de l'éléplıant varient tle graudeur dans diffirents sujets, car les oreilles du modèle de l'cléphant de Naples sont moins gramles que celles le l'éléphant de la Ménagerie tle Versailles, dont M. Perrault a douné la description; et les oreilles d'un petit éléphant intlien, uont le mème auteur fait mention, étaient encore moins grantles que celles de l'éléphant de Naples. Les oreilles de l'iléphant out quelque rapport, pour la firrure, à celles des singes; elles sont étendues en lıaut, en arrière et en bas; elles sont minces sans rebords; if y a une petite échancrure au bout de la partie postérieure de chaque oreille du modèle de l'éléphant de Naples.

La queue est terninée par un petit bouquet de très-gros crins, et clescend jusquaux talons.

Les jambes de devant sont plus longues que celles de derrière, cependant elles ne commencent à être dégagées du corps yuau-dessus du coule, qui parait être marqué à l'extérieur par un gros tubercule placé au cóté externe et postérieur the lit partie supérieure de la jambe; le levant de cetle partie est très-renflé et forme une sorte tle mollet qui indirue la grossem et la force des muscles; ce renflement se troure, à proprement prarler, au devant de la partic inferieure du luas et lie la partie supérieure de l'avaut-Inas : l'entruit du poignet est le moins gros de ioute la jambe de devant.

Les jambes te derrière somt tıès-courles ; ıl n'y il que la jambe proprement dite, et pent-etre le genou, qui soient degarges du corps. Le devant de lit partie inferieure tle la cuisse t'st très-rentle tel s'ctend en avant, de manière qu'elle forme an-dessous du flane ume naissance d'are qui aboutit an ventre; il y a derricre la jambe, froprentent dite, au-clessus du pied, un renflement yui parait formu par le ialon, et au derant un autre renllement plis petit : l'endroit le moins gros de la jambe de der. rière est au-dessus de ce's rentlements.

Les pieds de devant nont pas jus de longueur que ceux de derrière, mais ils sont un peu plus larges. I'ai observi les ongles d'un jeune clejpliant 
empaillé qui est au Cabinet du Roi ; j'ai trouvé ces on chles bicu formés ; leur substance est semblable à celle ries ongles tes animaux fissipèdes : ils ont plus de largeur que de longueur ; ils sont convexes. On voit très-distinctement les couches successives qui se sont formies tans leur accroissement : leur bord inféricur est mince et saillant, enfin ce sont de rrais ongles; cepentant M. Perrault, dans sa description anatomique de l'éléplıant, ne les regarde que comme des prolongements de la plante des pieds. " La corne qui garnissait la plante des pieds, ainsi qu'une scmelle, dit cet atteur, tébordait comme si elle était cachée par la pesanteur de tout le corps, et formait quelques ongles mal formés.n I'éléphant de la Ménagerie de Versailles, dont il s'agissait dans la description de MI. Perrault, étant Jeaucoup plus avancé en âge que celui dont j'ai vu les ongles, devait avoir la semelle de la plante cles piels plus épaisse et plus dlure; mais était-elle de substance de corne semblable à celle des ongles? Au moins il me parait, par ce que j'ai vu sur notre jeune élephant, que les ongles de cet animal ne sont pas des prolongements formés par une extension forcée de la semelle dr la plante des pieds, qui vienne à déhorder au tlehors. Les ongles de ce jeune éléphant étaient sćparés de la semelle du pied par un joint fort apparent; ils étaient dirigés en bas, et même courbés en dedlans par leur extrénité inférieure; ils auraient dû au contraire ¿tre dirigés et courbés en lıaut, s’ils n’araient été formés que par l'extension de la semelle, et dans ce cos la senelle aurait dî ètre plus dure on au moins aussi dure sur la plante dı pied que dans les prolongements en forme d'ongles; au contraire, les ongles de notre jeune élépluant sont beancoup plus durs que la semelle, et de subslance de corne très-décidée, tandis que la semelle n'est que cartilagineuse. Je ne doute pas que les prolongements qui se trouvaient à la partie postérieure des pieds de derrière de l'éléplıant le la Ménaserie rle Versailles, ne fussent des productions de la semelle, comme le lit M. Perrault; mais u'y arait-il aucune difference entre les ongles et ces prolongements qui ne sont pas dans tous les indivilus, tandis qüils ont tous des ongles? La semelle du jenue élephant commençait à déborder tans quel(jues endroits, ct il parait qu'avec le temps clle aurait pu former de grands prolongemenis. Le nombre des ongles de l'éléplıant varie, car celui de la Ménagerie de Versailles n'en avait que trois à clatpue picd; le petit éléplıant indien en avait quatre; le mollèle tle l'éléplıant de Naples et le jeune éléphant empaillé, en ont cincy aux pieis de levant, et seulement quatre aux pieds de derrière; les ongles dı milieu sout beaucoup plus grands que les ongles extérieurs; lans le jeune éléplant, ils ont tous à peu près la mème forme; mais dans le moclète de celui de Na. ples, les ongles des pieds de devant sont plus longs que ceux des pieds de derrière; ils ont des cannelures transversales très-apparentes; ils sont coupés carrément par le bout, et dirigés obliquement à droite dans les deux pieds : ces mèmes ongles étaient au contraire dirigés à gauche dans l'élépliant de la Ménagerie de Versailles : les ongles de notre jeune éléphant sont bien placés et bien dirigés relativement au pied. J'ai fait faire des coupes dans les plus grands, et j'ai trouvé sous ces ongles deux osselets joints l'un contre l'autre dans l'un de ces ongles, et un peu séparés dans un autre; en enlevant la semelle sous le plus grand ongle du pied de derrière, j’ai aussi trouvé un osselet; il n'est resté que ces os dans les pieds du jeune éléphant empaillé, ainsi je ne peux pas assurer que celui qui touche à l'ongle soit la troisième plıalange du doigt; mais je n'en douterais pas si M. Perrault n'avait dit que les ongles n'ont point de rapport aux doigts, et qu'il manque une phalange dans clıaque doigt et dans le pouce. Au moins est-il certain que les ongles de notre jeune éléplıant ont rapport aux os. selets qui sont derrière.

L'éléphant a peu ile poil ; celui de la Ménagerie de Versailles n'en avait que sur la trompe, sur les paupières et sur la queue; c’étaient des crins ou des soies de sanglier, èloignées les unes des autres ; ces soies étaient noires, luisantes, de même grosseur dans toute leur longueur, car elles n'étaient pas pointues ; leur extrémité paraissait avoir été coupée : les plus longues avaient un pouce et demi ; mais celles qui formaient une houppe au bout de la queue étaient longues de trois ou quatre pouces. Les cils de la paupière inférieure avaient jusqu'à lunit pouces, et ceux de la paupière supérieure seulement un pouce et demi. Il y a des éléphants qui ont des soies sur tout le corps, mais très-rares et peil apparentes.

La peau a des rides creuses, comme les lignes qui sont sur' la paume de la main de l'homme, et des rides saillantes formées par des callosités de l'épiderme, qui est gercé et couvert de crasse. En plusieurs endroits, les ritles creuses sont plus ou moins eloignces les unes des autres; tlles ont différentes lirectious ou s'entrecoupent en tlifièrents seus : l'éléphant de Versailles u’en avait jas sur le front ni sur les oreilles : dlans les endroits ou il ne se trouvait point de callosités dans l'épiderme, il n'ètait pas fllus epais que du gros papier; mais il avait jusqu'à trois lignes d'épaisseur dans les endroits calleux.

Le jeune éléphant ciesscché qui est au Cabinet du lioi, a du poil sur toutes les parties du corps, principalemet sur le dos. L'épiderme est enlevè dans quelques endroits ; il a clẻjà l'élaisseur d'environ la sixième partie d'une ligne ; sa face externe, vue à la loupe, est grenue comme du clayrin; les 


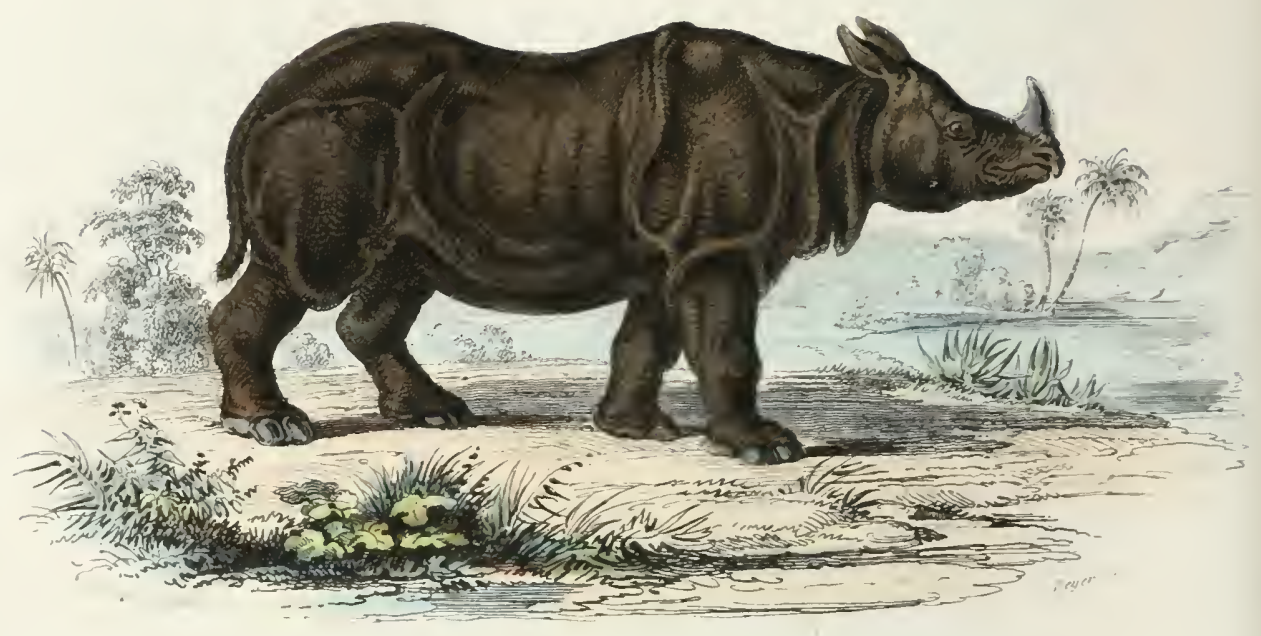

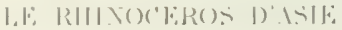

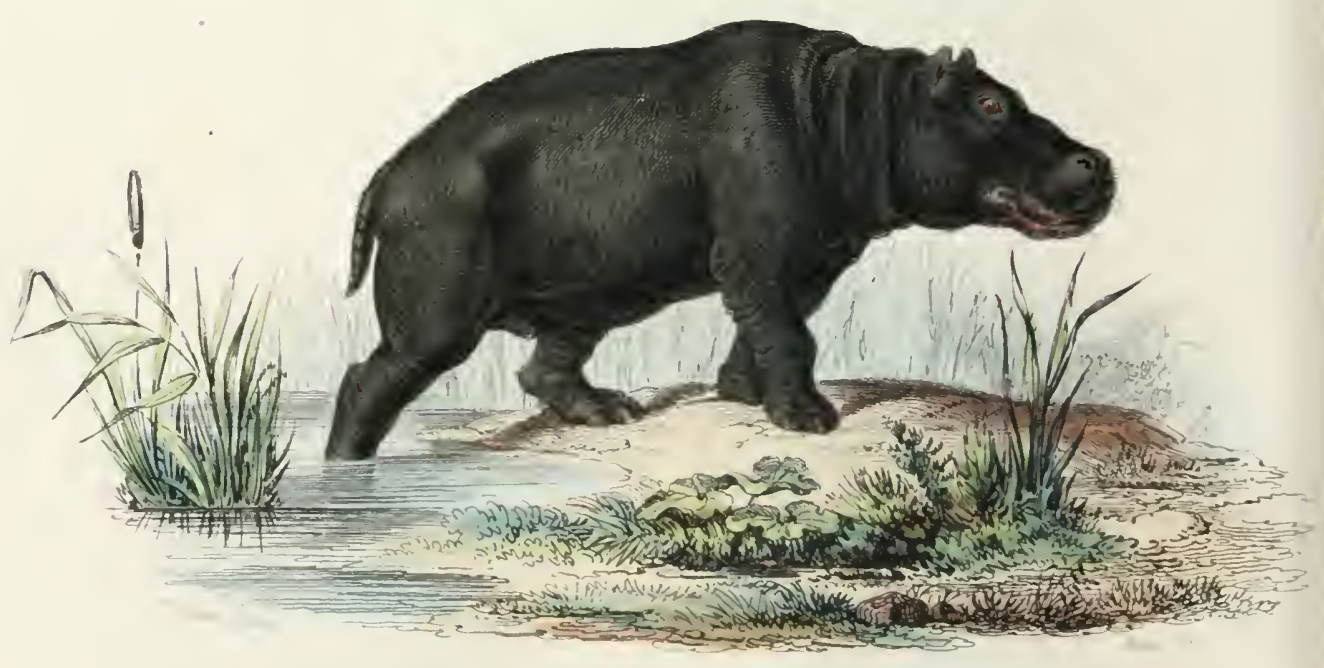

I. IIII, 
rides creuses ou gerçures sont dejjà marquées; on roit aussi les trous à travers lesquels passent les poils. La face interne de l'épiderme a autant de petites cavités qu'il y a de convexités sur l'externe; les bords de ces cavités forment des figures à quatre, cincj ou six côtés; on voit aussi sur la face interne les trous à travers lesquels passent les poils, et des reliefs qui correspondent aux rides creuses de l'autre face. La peau a de petites ćlćvations yui correspondent aux cavités de la face interne de l'épiderme, et qui s'y engrènent; on roit aussi sur la peau des trous d'oi sortent les poils. L'épiderme du jeune eléphant est de couleur grise cendrée; celui de l'éléphant de la Ménagerie de Versailles était de couleur grise brune dans le temps que l'animal fut disséqué ; et à présent il est encore à peu près le cette couleur, (jui a été un peu noircic par le temps et le desséchement. On distingue sur la face externe de l'épiderıne de eet ćlíplıant les différentes eouches dont il est composé; tlans les endroits oi toutes les couclies sont conservées, les tubercules ont beancoup plus de grosseur que dans les endroits ou les couches externes ont été enlevées. Conme tous les tubercules de la face externe sont plus gros et plus élevés sur l'élćplant de la Mćnagrerie de Versailles que sur lejeune, les cavités de la face interne sont aussi plus larges et plus profondes, et les élévations de la peau sont plus liautes. Les bords des cavités le la face interne de l'ipiderme forment des figures à plusieurs côtés, lont les angles ne sont pas aussi bien exprimes que sur l'épiderme du jeune éléplıant; mais eependant ces cavités ne sont pas rondes, comme le dit M. Perrault. Je n'ai pas vu non plus qu'il y en̂t sur la peau de l'éléplıant de la Ménageric des élévations runcles et différentes de celles yui sont pointues, comme M. Perrault le fait remarquer; il m'a paru que ces élivations ćtaient de différentes grandeurs en différents endroits et dirersement inclinces, mais toutes à peu près de même liğure : il est vrai que je n'ai eu que quelıues lambeaux de la peau te eet élephant; ils ont trois, quatre et mème jusqu'à sept lignes d'épraisseur ; la couleur te la face externe de la peaı est jaunâtı e sous l'épiderme, celle du jeune éléplıant a aussi une couleur jaunàtre, mais jus pâle, et les tubercules de la peau sont ronds et non pas pointus, comme ceux ile la peau de l'eléphant de la Ménarcrie de Versailles.

\section{LE RHINOCEROS '.}

\section{(LE RHINOCÉROS DFS INDES. - LE RHIYOCÉROS D'AFRIQUE, CUV.)}

Ordre des pachydermes, genre rhinocéros. (Cuvier.)

Après l'éléphant, le rhinocéros est le pius puissant des animaux quadrupedes : il a au moins douze pieds de longueur, depuis l'extrémité du museau jusqu'il l'origine de la queue, six à sept pieds de hauteur, et la circonférence du corps à peu près égale à sa longueur. Il approche done de l'éléphant pour le volume et par la masse; c't s'il parait bien plus petit, e'est que ses jambes sont bien plus courtes à proportion que celles de l'éléplaut; mais il en diffère beaucoup par les facultés naturelles et parl'intelligence, n’ayant reçu de la nature que ec qu'elle accorde assez communément à tons les quadrupèdes, privé de toute sensibilité dans la peau, manquant de mains et d'organes distincts pour le sens du toucher, n'ayant au lieu de trompe qu'une lèvre molsile, dans laquelle consistent tous ses moyens d'adresse. Il n'est guère supérieur aux autres animaux que par la force, la grandeur et l'arme offensive qu'il porte sur le nez, et qui n'appartient qu'à lui : cette arme est une corne tres-dure, solide dans toute sa longueur, et placée plus avantageusement que les cornes des animaux ruminants : celles-'i ne munissent que les parties supérieures de la tète et du cou, au lieu que la corne du rhinocéros défend toutes les parties antéricures du museau et préserve d'insulte le mufle, la bouche et lit face; en sorte une le tigre attaque plus volontiers l'éléphant, dont il saisit la trompe, que le rhinocéros qu'il ne peut coiffer sans risquer d'ètre éventré : ear le corps et les membres sont recouverts d'une enveloppe impénétrable; et cet animal ne craint ni la grifie du tigre, ni l'ongle du lion, ni le fer, ni le feu du chasscur: sa peau est un cuir noirâtre de la même conleur, mais plus épais et plus dur que celui de l'éléphant. Il n'est pas sensible comme lui à la piqûure des mouclies: il ne peut aussi ni froncer, ni contracter sa peau : elle est seulement plissće par de grosses rides au cou, aux épaules et à la

- Cuvier distingue quatre especes de rlinocéros, savoir : lo rhinucéres đles Indes, le alinucéros de Java, le rhinocéros de Sumatra et le rlinoceios d'. frípue. 
croupe pour faciliter le mouvenent de la tête et des jambes, qui sont massives et terminées par de larges pieds armés de trois grands ongles. II a la tête plus longue à proportion que l'éléphant, mais il a les yeux encore plus petits, et il ne les ourre jamais qu'à demi. La mâchoire supérieure avance sur l'inférieure, et la lèvre du dessus a du mouvement et peut s'allonger jusqu'à six ou sept pouces de longueur; elle est terminće par un appendice pointu, qui donne à cet animal plus de facilités qu'aux autres quadrupèdes pour cueillir l'herbe et en faire des poignées à peu près comme l'éléphant en fait avec sa trompe : cette lèvre musculeuse et flexible est une espèce de main ou de trompe trèsincomplète, mais qui ne laisse pas de saisir avec force et de palper avec adresse. Au lieu de ces longues dents d'ivoire qui forment les défenses de l'éléphant, Je rhinocéros a sa puissante corne et deux fortes dents incisives à chaque mâchoire ; ces dents incisives qui manquent à l'éléphant sont fort éloignées l'ume de l'autre dans les mâchoires du rhinocéros; elles sont placées une à une à chaque coin ou angle des mâchoires, desquelles l'inférieurc est coupée carrément en devant, et il n'y a point d'autres dents incisives dans toute cette partie antérieure que recouvrent les lèvres; mais indépendamment de ces quatre dents incisives placées en avant aux quatre coins des máchoires, il y a de plus vingt-quatre dents molaires, six de chaque côté des deux mâchoires. Ses oreilles se tiennent toujours droites; elles sont assez semblables pour la forme à celles du eochon, seulement clles sont moins grandes à proportion du corps : ce sont les seules parties sur lesquelles il y ait du poil ou plutôt des soies. L'extrémité de la queue est, comme celle de l'éléphant, garnie d'un bouquet de grosses soies très-solides et très-dures.

M. Parsons, célèbre médecin de Londres, auquel le république des lettres est redevable de plusieurs découvertes en histoire naturelle, et auquel je dois moi-même de la reconnaissance pour les marques d'estime et d'amitié dont il m'a souvent honoré, a publié en 1743 une His. toire naturelle du rhinocéros, de laquelle je vais dommer l'extrait d'autant plus volontiers que tout ce qu'écrit M. Parsons me parait mériter plus d'attention et de confiance.

Quoique le rhinocéros ait été vu plusieurs fois daus les spectacles de Rome, depuis Pom- pée jusqu’à Héliogabale, quoiqu'il en soit renu plusieurs en Europe dans ces demiers siècles, et qu'enfin Bontius, Chardin et Kolbe l'aient dessinć aux Indes et en Afrique, il était ecpendant si mal représenté et si peu décrit, qu’il n'était connu que tres-imparfaitement, et qu'à la vue de ceux qui arriverent à Londres en 1739 et $1 \mathbf{7 1 1}$, on reconnut aisément les erreurs ou les caprices de ceux qui avaient publié des figures de cet animal. Celle d'Albert Durer, qui est la première, est une des moins conformes à la nature : cette figure a cependant été copiée par la plupart des naturalistes, et quelques-uns même l'ont encore surchargée de draperies postiches et d'ornements étrangers. Celle de Bontius est plus simple et plus vaaie; mais elle pêche en ce que la partie inférieure des jambes y est mal représentée. Au contraire, celle de Chardin présente assez bien les plis de la peau et les pieds; mais au reste, elle ne ressemble point à l'animal. Celle de Camerarius n'est pas meilleure, non plus que celle qui a été faite d'après le rhinocéros vu à Londres en 1835 , et qui a été publiée par Carwitham en 1739. Celles enfin que l'on voit sur les anciens pavés de Præneste, et sur les nédailles de Domitien, sont ex trêmement imparfaites; mais au moins elles n'ont pas les ormements imaginaires de celle d'Albert Durer. M. Parsons a pris la peine de dessiner lui-nême' cet animal en trois vues 4 Nota. Un de nos savants physiciens (M Demours) a fait des remarques à ce snjel, que nous ne devons pas ometire. - La figure, dit-il, du rhinocéros que $\mathbf{1}$. 1'arsons a ajoutée à a son Mémoire, et qu'il a dessinée lui-mèmed'aprés le natı. - rel, est si différente de celle qul fut gravée à Paris en 1749. - d'après un rhinocéros qu'on voyait alors à la foire de Saint- Germain, qu'on aurait de la peine à y reconnaitre le mème animal. Celui de \$I. Parsons est plus court, et Ics plis de la - peau en sont en plus pelit noinbre, moins marqués, ct quel- ques-uns placés un peu différenment; la tête surlout ne res- semble presque en rien à celle du rhinocéros de la foire - Saint Germain. On ne saurait cependant douter de l'exacti- tude de M. Parsons, et il faut chercher dans l'äge el le sexe - de ces deux animaux la raison des différences sensibles yu'on - apercoit dans les figures que lon a données de liun cl te - l'autre. Celle de .M. Parsons a été dessinée d’après un rlui- nocéros mảle, ıui n’avait que dcux ans; celle que j'ai cru - devoir ajouter ici l'a été d après le tableau du célelore s. Ou- dry, le peiutre des animaux, et qui a si fort excellé en ce - genre; it a peint de grandeur naturelle, et d'aprés le vivant, - le rhinocéros de la foire Saint-Germain, qui était unc fe- melle, et qui avait au moins huit ans; je dis au moins huit - ans, caril est dit dans l'inscription qu'on roit an bas de l'es- tampe de Charpentier qui a pour titre s l'érilable porlrait - d'un Rrunocéros vivanl, quel on roil à la fuire sainl-Ger- main a Paris, que cet aninal ava t trois ans quand il fut pris - en $174 t$ lans la province d'Assem, appartenaut au $\mathbf{~} \mathbf{0} 0 \mathrm{gol}$ : - et huit lignes plus bas, il est dit qu'il u'avait qu'un mois quand - quelques Indiens l'aitrapèrent avec des cordes, après en - avoir tué la mère à coups de flèches; ainsi il avait an moins - huit aus, et pourait en avoir dix ou onze. Cette différence 
différeutes, par devant, par derrière et de profil; il a aussi dessiué les parties extérieures de la génération du mâle, et les cornes simples et doubles, aussi bien que la queue d'autres rhinocéros dont ces parties étaient conservées dans des cabinets d'bistoire naturelle.

Le rhinocéros quỉ arriva à Londres en 1739 avait été envoyé du Bengale. Quoique trèsjeune, puisqu'il n'avait que deux ans, les frais de sa nourriture et de son voyage montaient à près de mille livres sterling; on le nourrissait avee du riz, du suere et du foin : on lui domnait par jour sept livres de riz, mêlé avec trois livies de sucre, qu'on lui partageait en trois portions : on lui donnait aussi beaucoup de foin et d'herbes vertes, qu'il préférait au foin ; sa boisson n'était que de l'eau dont il buvait ì la fois uue grande ffuantité. Il était d'un naturel tranquille et se laissait toucher sur tontes les parties de son corps; il ne devenait méchant que quand on le frappait ou lorsqu'il avait faim, et dans l'un et l'aulie cas on ne pouvait l'apaiser qu'en lui donnant à manger. Lor'squ'il était en colère, il sautait en avant et s'élevait brusquement à une grande hauteur, en poussant sa tête avec furie contre les murs, ce cu'il faisait avec une prodigieuse vitesse, malgré son air lourd et sa masse pesante. J'ai été souvent témoin, dit M. Parsons, de ces mouvements que produisaient l'impatience ou la colère, surtout les matins avant qu'on ne lui apportât sou riz et son sucre : la vivacité et la promptitude des mouvements de cet animal m'ont fait juger, ajoutet-il, qu'il est tout à fait indomptable et qu'il atteindrait aisément à la course un homme qui l'aurait offensé.

Ce rhinocéros, à l'âge de deuxans, n'était pas

- dáge estune raison vraisemblable des différences sensibles - ifue l'ou trouvera entre la figure de M. Jarsons el celle de - M. Ondry, dont le tahlean, fait par ordre dit roi, ful alors - exposé au salon de peinture. Je remarquerai seulement que - M, Oulry a donné à la défeuse de son rhinocéros plus de - longueur (nue vien avail la corne du rhiıocéros de la foire a Saint-(iermain, que j'ai vu et examiné avec beaucoup d'at- leution, el que cette partic est rendne plus fidelement dans - l'estampe de Cliarpentier. Aussi est-ce d’après celte estampe - qu'on a dessiné la corue de celle figure, qui, pour lont le - reste, a élé lessinée el réduite d'après le tableau de M. Ou- dry. L'animal qu'elle représenle avait été pesé environ un - an auparavaut, à slullgard dansleduché de Wurtemberg, a et il pesait alors cing mille livres. 11 m ingeait, selon le raj. - porl du capitane Dowwemont-Van-cle-seer, qui lavail - conduit en Europe, soixante livres le foin el vingt lives de - pain par jour. Il était Irès-privé, el d'une agililè surpre. - naule, vul'énormité de sa masse, el son air exlrènement - louril, Ces remarques sont judicieuses el pleines de sens, comme tout ce (piécrit M. Demours. plus haut qu'une jeune vache, qui n'a pas encore porté; mais il avait le corps fort long et fort épais. Sa tète était très-grosse à proportion du corps: en la prenant depuis les oreilles jusqu'à la corne du nez, elle formait une courbe concave dont les deux extrémités, e'est-à-dire le bout supérieur du museau et la partie près des oreilles sont fort relevées. La corne n'avait eneore qu'un pouce de hauteur; elle était noire, lisse à son sommet, mais avec des rugosités à sa base et dirigée en arrière. Les narines sont situées fort bas et ne sont pas à un pouce de distance de l'ouverture de la gueule. La lèvre inférieure est assez semblable à celle du bœuf, et la Jèvre supérieure ressemble plus à celle du cheval, avec cette différence et cet avantage que le rhinocér'os peut l'allonger, la diriger, la doubler en la tournant autour d'un biton, eb saisir par ce moyen les corps qu'il reut approcher de sa gueule. La langue de ce jeune rhinocéros était douce comme celle d'un veau. Ses yeux n'avaient nulle vivacité; ils ressemblent à ceux du cochon pour la forme, et sont situés très-bas, c'est-à-dire plus près de l'ouverture des narines que dans aucun autre animal. Les oreilles sont larges, minces a leur extrémité et resserrées à leur origine par une espèce d'anneau ridé. Le cou est fort court; la peau forme sur cette partie deux gros plis qui l'enviromment tout autour. Les épaules sont fort grosses et fort épaisses; la peau fait à leur jointure un autre pli qui deseend sous les jambes de devant. Le corps de ce jeune rhinocéros était en tout très-épais et ressemblait très-bien à celui d'une vache prête à mettre bas. Il y a un autre pli entre le corps et la croupe ; ce pli descendau-dessous des jambes de derrière; et enfin, il y a encore un autre pli qui environne transversalement la partie inférieure de la croupe à quelque distance de la queue. Le ventre était gros et pendait presque à terre, surtout à la partie moyenne Les jambes sont rondes, épaisses, fortes, et toutes sont courbées en arrière à la jointure : cette jointure, qui est recouverte par un pli très-remarquable quand l'animal est couché, disparait lorsqu'il est debont. La queue est menue et courte relativement au volume du corps; celle de ce rhinocéros n'avait que seize on dix-sept ponees de longucur; elle s'élargit un peu à son exlrémitć ou clle est gamie de quelques poils courts, gros et durs. Ia verge est d'une forme assez cxtraordinaire; clle est con- 
tenue dans un prépuce ou fourrau comme celle du cheval, et la première elıose qui parait audehors daus le temps de l'érection, est un second prépuce de couleur de cliair, duque: ensuite il sort un tuyau creux en forme d'entonnoir évasé et découpé, comme une fleur-de-lis, lequel tient lieu de gland et forme l'extrémité de la verge : ce gland bizarre par' sa forme cst d'une couleur de chair plus pàle que le second prépuce. Dans la plus forte érection, la verge ne s'étcndait (qu'à huit pouces hor's du corps; on Iui procurait aisément cet état d'extension en frottant l'animal sur le ventre avec des bouclıons de paille lorscqu'il était couché. La direction de ce membre n'était pas droite, mais courbe et dirigée en arrière ; aussi pissait-il en arrière et à plein canal à peu près comme une vache : d'où l'on peut inférer que dans l'acte de la copulation, le mâle ne courre pas la femelle, mais qu'ils s'accouplent croupe à croupe. Elle a les parties extérieures de la génération faites et placées comme celles de la vache, et elle ressemble parfaitement au mâle pour la forme et la grosseur du corps. La peau est épaisse et impénétrable; en la prenant aree la main dans les plis, on eroirait toncher une planche de bois d'un demi-pouce d'épaisseur. Lorsqu'elle est tannée, dit le docteur Grew, elle est excessivement dure et plus épaisse que le euir d'aucun autre animal terrestre : elle est partout plus ou moins converte d'incrustations en forme de gales ou de tubérosités, qui sont assez petites sur le sommet du cou et du dos, et qui par degrés deviennent plus grosses en desecndant sur'es côtés; ! cs plus larges de toutes sont sur les épaules et sur la croupe; elles sont encore assez grosses sur les cuisses et les jambes, et il y en a tout autour et tout le long des jambes jusqu'aux pieds; mais cutre les plis, la peau est pénétrable et mème délicate et aussi douce au toucher que de la soie, tandis que l'extérieur du pli est aussi rude que le reste; cette peau tendre qui se trouve dans l'intérieur des plis est d'une légère couleur de chair, et la peau du ventre est al peu près de mème consistance et de mìme couleur. Au reste, on ne doit pas comparer ees tubérosités ou gales dont nous venons de parler à des écailles, comme l'ont fait plusieurs auteurs; ce sont de simples durillons de la peau, qui n'ont ni régularité dans la figure, ni symétrie dans leur position respective. La souplesse de la peau dans les plis domue au rhimocéros la facilité du mouvement de la tête, du cou et des membres : tout le corps, à l'exception des jointures, est inflexible et comme cuirassé. M. Parsons dit en passant, qu'il a observé une qualité très-particulière dans cet animal, e'est d'écoulter avec une espèce d'attention suivie tous les bruits qu'il entendait; de sorte que, quoique endormi ou fort occupé à manger ou à satisfaire d'autres besoins pressants, il s'éveillait à l'instant, levait la tète et écoutait avec la plus constante attention, juscu'à ce que le bruit qu'il entendait eủt cessé.

Enfin, après avoir donné cette description exacte du rhinocéros, M. Parsons examine s'il existe ou non des rhinocéros à double corne sur le nez; et après avoir comparé les témoignages des anciens et des modernes, et les monuments de cette espèce qu'on trouve dans les collections d'Histoire naturelle, il conclut avec vraisemblance que les rhinocéros d'Asie n'ont communément cqu'une corne, et que ceux d'Afrique en ont ordinairement deux.

Il est très-certain qu'il existe des rhinocéros qui n'ont qu'une corne sur le nez, et d'autres qui en ont deux : mais il n'est pas également certain que cette variété soit constante, toujours dépendante du climat de l'A frique ou des Indes, et qu'en conséquence de cette seule différence on puisse établir deux espèces distinctes dans le genre de cet animal. Il parait que les rhinocéros qui n'ont cu'une corne l'ont plus grosse et plus longue que ceux qui en ont deux : il y a des cornes simples de trois pieds et demi, et peutêtre de plus de cyatre pieds de longueur sur six et sept pouces de diamétre àla base; il y a aussi des cormes doubles qui ont jusqu'à deux picds de longueur. Communément ces cornes sont brunes ou de couleur olivâtre; cependant il s'en trouve de grises et même quelques-unes de blanches; elles n'ont qu'une légère concavite en forme de tasse sous leur base, par lacpuclle elles sont attachées à la peau du nez; tout le reste de la corne est solide et plus dur que la corne ordinaire : e'est aree cette arme, dit-on, que le rhinocéros attaque et blesse quelquefois mortelIcment les éléplıants de la plus haute taille, dont les jambes élevées permettent au rhinocéros, qui les a bien plus eourtes, de leur porter des coups de boutoir et de corme sous le ventre, où la peau est la plus sensible et la plus pénétrable; mais aussi lorsqu'il manque son premier coup, l'élépluant le terrassc et le tue. 
La corne du rhinocéros est plus estimée des Indiens que l'ivoire de l'éléphant, non pas tant à cause de la matière, dont cependant ils font plusieurs ouvrages au tour et au ciseau, mais à cause de sa substance même, à laquelle ils accordent plusicurs qualités spéeifiques et propriétés médicinales '; les blanches comme les plus rares sont aussi celles ru'ils estiment et qu'ils recherehent le plus. I)ans les présents que le roi de Siam envoya à Louis XIV, en $1686^{2}$, il y avait six cornes de rhinocéros. Nous en avons au Cabinet du roi douze de différcntes grandeurs, et une entre autres qui, quoique tronquée, a trois pieds huit pouces et demi de longueur.

Le rhinocéros, sans être ni féroce, ni carnassier, ni même extrêmement farouche, eš cependant intraitable ${ }^{3}$; il est à peu près en grand ce que le cochon est en petit, brusque et hrute,

- Aux parlies de Bengale proche du Gange, les rhinocéros ou licornes, que lion appelle vulgairement dbades, sont trèscommunes, et lion en apporle à Goa yuanlilè de curnes; elles ont environ deux palnes de circonlèrence tu eỏlé quiclles sont atlachées au front, et allanł peu à jen et finissant en poinle; elles servent d'armes défensives à ees animaux. lilles sont d'unc couleur olscure, et les tasses quion en fait pour boire sont très-estimées, vu uu'elles ont nalurellement ta propriélé de clıasser dehors la malignité d'une Jiqueur qui serait empoisonnéc. Voyage dı P. Philippre, page 371.-Tontes les parties du corps du rlinocéros sont iné.licinales : sa corne est surtout un puissant antidote contre mutes sorles de proisons, et les Siamois en font un grand tralic arec les nattions voisines; il y en a qui sont quelquefols ventues plus de cent écus; celles qui sont d’un gris clair el monchetées de blane sont les plus estimées des Chinois. Ilistoire naturelle de Siam, par Nic. Gervaise. Paris, 1688, page 5.4.-L.eurs cornes, leurs dents, leurs ongles, leur chair, leur peau, leur sang, leurs exeréments mème cl leur eau, toul cul esl estimé el recherché par les Indiens, qui y trouvent des remèdes pour diverses inalaclies. Voyage de la Compaguie des Indes de Ilollande, t. I, p. 417. - Sa corne sort d'entre ses deux naseaux, el te est fort épaisse par le bas, el vers le haul clle devient aiguë; elle est d'un vert brun, et nom pas noir, ainsi que queloues-nns lont écril; quand elle est plusgrise ou qu'elle tire sur le blanc, elle se vend plus cher; mais elle est tonjours chère, ear on l'estime anssi beaneoup aux Indes. Ilem, tome VII, page 177.

${ }^{2}$ Parmi les présents que le roi de Siam envoya en Fiance en 1686, il y eut six cornes sle rhinocéros; elles sonl extrèmement estimées dans tout YOrient. Le chevalier Vernali a écril de laalavia en Anglelerre, fue les corues, les dents, les ongles et le sang des rhinocéros sont des antillotes, el guits ont le même usiıge dans la Plıarnacopée des Inules, que la thériaque dans celle ule l'Enıope. Voyage dela Coinpagnie des Indes de 1 loliande, lome VII, page $18 \%$.

${ }^{8}$ Claadin dil, tome $\mathbf{1 1}$, page 400 , que les Abysins apprivojsent les rlinocéros, qu'ils les élèvent au travail comme on fiit les élíplıants, Ce fail me paralt très-cloutenx. Aneun aulje voyageur lien fait mention, et il est sì (quà Bengale, à Siam et dans les autres parties de l’Inde mérilionale, vii le rhino. céros est fuent-ètre eurore plus commun qu'en Éthiople a cl on lon esl accoulumé à apurivoiser les dépluants, il est regardé comme un animal intomplable, et dont on ne pent faire aucun usage pour le service domestiggue. sans intelligence, sans sentiment et sans doeilité : il faut mème (ju'il soit sujet à des aceès de fureur, que rien ne peut calmer; car celui ( [u'Emmanuel, roi de Portugal, envoya au pape en 1513, fit périr le bâtiment sur lequel on le transportait; et celui cfue nous avons vu a $\mathrm{Pa}$ ris ces années dernières s'est noyé de mème en allant en Italie. Ces animaux sont aussi, comme le coehon, très-enclins à se vautı'er daus la boue et à se rouler dans la fange. Ils aiment les lieux lıumides et maréeageux, et ils ne quittent guère les bords des rivières. On en trouve en Asie et en Afrique, à Bengale, à Siam, ḋ Laos, au Mogol, à Sumatra, à Java, en Abyssinie, eı lítiopie, au pays des Anzicos, et jus(qu'au cap) de Bonne-Espérance : mais en général l'espece en est moins nombreuse et moins répandue que eelle de l'éléplrant : il ne produit de même rưun seul petit à la fois, et à des distanees de temps assez considérables. Dans lo premier mois, le jeune rhinocéros n'est guère plus gros (qu'un chien de grande taille '. Il n'a point en naissant de corme sur le nez ${ }^{2}$, quoirfu'on en voie déjả le rudiment dans le fixtus; à deux ans eette corne n'a encore poussé que d'un pouce, et à six aus elle a neuf à dix pouces; et comme l'on comnait de ces cornes qui ont près de quatre pieds de longeur, il parilt qu'elles eroisent au moins jusqu'au moyen âge ou peut-être pendant toute la vie de l'animal, cqui doit être d'une assez longue durée, puiscpue le rhinocéros déerit par M. Parsonsn'avaità deux ans qu'environ la moitié de sa laateur; d'où l'on peut inlérer'eue c'et animal cloit vivre, comme i'homme, soixante-dix ou quatre-vingts ans.

Sans pouvoir devenir utile comme l'éléphant, le rhinocéros est aussi nuisible par la conson:mation, et surtout par le prodigrieux dégait qu'il fait daus les eampagnes; il n'est bon que par sa dépouille : sa chair est excellente au goùt des Indiens et des Nègres ${ }^{3}$; Kolbe dit en avoir sou-

+ On en a vu un jemne qui neétail pas plus granıl qư un chien ; il suivait alors son mailtre partont, et il ne buvait que du lait de buflle; mais il ne véent pas plns de trois semaines. Jes dents commencaient a lui sortir. Vogage de la Cumpagnie des Indes de llullande, tome V11, páge 483.

2 On voyait dans le bout dn ne $\iota$ de ces deux jeunes rhinocéros la marquje de la corne qui devait leur jous:er, parce que, comme ils ctrient tout jennes, ils nen avaient pas encore; à cet ìge-liı néanmoins ils étalent aussi gros el aussi grands quinu de nos l.aufs; mais ils sonf fort las des janlecs, particulierement te celles de devant, qui sunt plus courtes que celles de derrière. Voyage de Pietro della Valle, tome 15 , jage 235.

s Un mange la ethair du rhinocéros, el ces peuples la trou- 
vent mangé et ave beaucoup de plaisir. Sa peau fait le euir le meilleur et le plus dur qu'il y ait au monde ${ }^{4}$; et non-seulement sa corne, mais toutes les autres parties de soll corps, et même son sang, son urine et ses excréments sont estimés comne des antidotes contre le poison ou comme des remèdes à plusieurs maladies. Ces antidotes ou l'emèdes tirés des différentes parties du rhinocéros ont le mème usage dans la pharmacopée des Indes, que la thériaque dans celle de l'Europc. Il y a toute apparence que la plupart de ces vertus sont imagiuaires : mais combien n'y a-t-il pas de choses bien plus recherchées qui n'ont de valeur que dans l'opinion?

Le rhinocéros se nourrit d'herbes grossières, de chardons, d'arbrisseaux épineux, et il préfere ces aliments agrestes à la douce pâture des plus belles prairies : il aime beaucoup les cannes de sucre, et mange aussi de toutes sortes de grains. N'ayant nul goût pour la chair, il n'inquiète pas les petits animaux, et ne craint pas les grands, vit en paix avec tous et même avec le tigre, qui souvent l'accompagne sans oser l'attaquer. Je ne sais donc si les combats de l'éléphant et du rhinocéros ont un fondement réel. Ils doivent au moins être rares, puisqu'il n'y a nul motif de guerre, ni de part ni d'autre, et que d'ailleurs ou n'a pas remarqué qu'il y eût aucune espèce d'antipathie entre ces animaux; on en a vu même en captivité ${ }^{2}$ vivre tranquillement et sans s'offenser ni s'irriter l'un contre l'autre. Pline est, je crois, le premier yui ait parlé de ces combats du lhinocéros et de l'éléphant : il parait qu'on les a forcés à se battre dans les spectacles de Rome ${ }^{3}$; et c'est probablement de là que l'on a pris l'idée, que quand

vent excellente; ils tirent mème quelque utilité de son sang, qu'ils ramassent avec soin, pour en faire un remede propre laguérison des maux de poitrine. Histoire naturelle de Sian, par Gervaise, page 35.

'Sa peau est d'un bean gris lirant sur le noir, comme celle des éléplıants, mais plus rude et plus épaisse : je n’ai point vil d'aumal qui en ail une senblable... Celte pean est converte partout, hormis an cou et à la lẻle, lle petits nouds ou durillons fort senblables à ceux des écailles de tortues, etc. Voyage de Cliardin, tome 111 , page 13 .

${ }^{3}$ La relation hollandaise qui a pour tilıe, l'Ambassade de Chine, fait une description de cet animal tout à fait fausse, surtout en ce qu'elle porte que c'est un des principaux ennemis de l'éléplıanI; ear ce rlınoéros-ci était dans une mème écurie avee deux éléfuants, et je les ai vus diverses fois l'un auprès de l'autre clans la Place-Royale, sans sc marıuer la ınoindre antipluthie. Un ambassadeur d'Étljiopie avait amené cet animal en présent. Voyage de chardin, tome III, page 45.

${ }^{B}$ Les Romains ont pris fllaisir à faire combaltre le rlyiuocéros et l'éléphant pour quelque speetacle de grandeur. Sinfular. de la France antaretique, par André Tlievet, page 11. ils sont en liberté et dans leur état naturel, ils se battaient de même; mais encore une fois, toute action sans motif n'est pas naturelle; c'est un effet sans cause qui ne doit point arriver ou qui n'arrive que par hasard.

Les rhinocéros ne se rassemblent pas en troupes, ni ne marchent en nombre comme les éléphants; ils sont plus solitaires, plus sauvages et peut-être plus difficiles à chasser et à vaincre. Ils n'attaquent pas les hommes ', à moins qu'ils ne soient provoqués; mais alors ils prennent de la fureur et sont très-redoutables. L'acier de Damas, les sabr.; du Japon n'entament pas leur peau; les javuots et les lances ne peuvent la percer"; elle résiste même aux balles du mousquet; celles de plomb s'aplatissent sur ce cuir, et les lingots de fer ne le pénètrent pas en entier : les seuls endroits absolument pénétrables dans ce corps cuirassé, sont le ventre, les yeux et le tour des oreilles ${ }^{2}$; aussi les chasseurs, au lieu d'attaquer cet animal de face et debout, le suivent de loin par ses traces, et attendent pour l'approcher les lueures où il se repose et s'endort. Nousavons au Cabinet du roi un fotus de rhinocéros, qui nous a été envoyé de lìle de Java, et qui a été tiré hor's du corps de la mère : il est dit dans le mémoire qui accompagnait cet enroi, que vingt-huit chasseurs s'étant assemblés pour attacuer ce rhinocéros, ils l'avaient d'abord suivi de loin pendant quelques jours, faisant de temps en temps marcher un ou deux hommes en avant, pour reconnaitre la position de lanimal; que par ce moyen ils le surprirent endorni, s'en approchèrent en silence et de si près, qu'ils lui lâchèrent tous ensemble leurs vingt-huit coups de fusil dans les parties infériewres du bas-ventre.

${ }^{1}$ Les rhinocéros n'allayuent pas ordinairement, et ils ne se mettent en furcurque quand ils sont altaqués, mais alors ils sont de la deruiere férocité; ils grognent comme des pourceaux, ils renversent les arlores el tout ce qui se prèsente de. vaut eux. Voyage de la Compagnie des Indes de IIollande, tome ViI, page 278 .

${ }^{2}$ On le tue difficilement, et on ne l'altaque jamais sans péril d'en ċtre déchiré. Ceux y pui s'adomuent à cette chasse ont pourtant tronvé les moyens de se garantir de sa fureur; car, comme cet animal aime les lieux marécageux, ils l'obserwent quand ils'y retire, et se caclıant dans les buissons au-dessous du vent, ilsattendent qu'il se soit couché soit pour s'endormir ou pour se vautrer, afin de le tirer près des oreilles, qui est le seul endroit où il peut ètre blessé à mort. Ils se mettent an-dessous dus vent, parce que le rhinocéros a cela de propre qu'il découvre lout par l'odorat; de sorte que, quoiqu il ait des yenx, il ne s'en sert néaumoins jamais que l'odorat $n$ 'ait été frappé par l'objet qui se présente à la rue. Uistoire natu. relle de Siam, par Gervaise, page 35. 
On a vu, par la description de M. Parsons, que cet animal a l'oreille bonne et mème trèsattentive : on assure aussi qu'il a l'odorat excellent; mais on prétend qu'il n'a pas l'œil bon, et qu'il ne voit, pour ainsi dire, que devant lui. La petitesse extrême de ses yeux, leur position basse, oblique et enfoncée, le peu de brillant et de mouvement qu'on y remarque semblent confirmer ce fait. Sa voix est assez sourde lorsqu'il est tranquille; elle ressemble en gros au grognement du cochon; et lorsqu'il est en colère, son cri devient aigu et se fait entendre de fort loin. Quoiqu'il ne vive que de végétaux, il ne rumine pas ; ainsi il est probable que, comme l'éléphant, il n'a qu'un estomac et des boyaux très-amples, et qui suppléent à l'office de la panse. Sa consommation, quoique considérable, n'approche pas de celle de l'éléphant; et il parait par la continuité et l'ćpaisseur non interrompue de sa peau, qu'il perd aussi beaucoup) moins que lui par la transpiration.

\section{PREMIERE ADDITION A L'ARTICLE DU RHI- NOCÉROS.}

Nous avons vu un second rhinocéros nouvellement arrivé à la Ménagerie du roi, au mois de septembre 1770. Il n'était âgé que de trois mois, si l'on en croit les gensquil l'a vaientamené; mais je suis persuadéqu'il avait au moins deux ou trois ans; car son corps, y compris la tête, avait déja huit pieds deux pouces de longueur sur cinq pieds six pouces de hauteur; et huit pieds deux pouces de circonférence. Obser vé un an après, son corps s’était allongé de sept pouces; en sorte qu'il avait, le 28 aoùt 1771 , huit picds neuf pouces, y compris la longueur de la tìte, cinq pieds neuf ponces de hauteur, et huit pieds neuf pouces de circonférence. Observé deux ans après, le 12 aoùt 1772 , la longueur de son corps, y compris la tête, était de neuf pieds quatre pouces; la plus grande hauteur, qui était celle du train de derriere, de six pieds quatre pouces, et la hauteur du train de devant était de cincf pieds onze pouces seulement. Sa peau arait la couleur' et la mème apparence que l'écorce d'un vieil orme, tachetée en certains endroits de noir et de gris, et dans d'autres repliée en sillons profonds, qui formaient des espèces d'écailles. Il n'avait qu'une corne de coulcur brume, d'une substance ferme et dure. Les yeux sont petits et saillants ; les oreibles larges et assez ressemblantes à celles de l'âne. Le dos, qui est creux, semble être couvert d'une selle naturelle; les jambes sont courtes et très-grosses, les pieds arrondis par-derrière, a rec des sabots par-devant, divisés en trois parties. La queue est assez semblable à celle du bocuf, et garnie de poils noirs à son extrémité. Lal verge s'allonge sur les testicules, et s'élève pour l'écoulement de l'urine que l'auimal pousse assez loin de lui, et cette partic parait fort petite relativement à la grosseur du corps; elle est d'ailleurs très-remarquable par son extrémité, qui forme une cavité comme l'embouchure d'une trompette : le fourreau ou l'étui dont elle sort est une partie charnue d'une chair vermeille semblable à celle de la verge; et cette même partie charnue qui forme le premier étui sort d'un second fourreau pris dans la peau comme dans les autres animaux. Sa langue est dure et rude au point d'écorcher ce qu'il lèche : aussi mange-t-il de grosses épines sans en ressentir de douleur. Il lui faut environ cent soixante livres de nourriture par jour; les Indiens et les Africains, et surtout les IIottentots, en trouvent la chair bonne à manger. Cet animal peut devenir domestique en l'élevant fort jeune, et il produirait dans l'état de domesticité plus aisément que l'éléphant.

" Je n'ai jamais pu concevoir (dit avec raison M. P.) pourquoi on a laissé en Asie le rhinocéros dans son état sauvage sans l'employer ì aucun usage, tandis qu'il est soumis en Abyssinie, et y sert ì porter des fardeaux. "

"II. de Buffon (dit M. le chevalier Bruce) a conjecturé qu'il y avait au centre de l'Afrique des rhinocéros à deux cornes; cette conjecture s'est vérifiée. En effet, tous les rhinocéros que jai vus en Abyssinie ont deux cornes : la première, e'est-à-dire la plus proche du nez est de la forme ordinaire; la seconde, plus tranchante à la pointe, est toujours plus courte que la première; toutes deux naissent en même temps, mais la première croit plus vite que l'autre et la surpasse en grandeur, nou-seulement pendant tout le temps de l'accroissement, mais pendant toute la vie de l'animal. D

D'autre part M. Allamand, très-labile naturaliste, éerit à M. Daubenton, par une lettre datée de Leyde, le 31 octobre 1766, dans les termes suivints :

Je me rappelle une chose qu'a dite $M$. Par- 
sons dans un passage cité par M. dẻe Buffon. II soupçonneque les rhinocéros d'A sie n'ont qu'une corne, et que ceux du cap de Bonne-Espérance en ont deux; je soupęonnerais tout le contraire. J'ai reçu de Bengale et d'autres endroits de I'Inde, des têtes de rhinocéros toujours à doubles cornes, et toutes celles qui me sont venues du Cap n'en avaient qu'une. ")

Ceci parait prouver ce que nous avons déjà dit, que ces rhinocéros à doubles cornes forment une variété dans l'espèce, une race particulière, mais qui se trouve également en Asie et en Afrique.

SECONDE ADDITION A L'ARTICLE DU RHINOCÉROS, PAR M. LE DOCTEUR ALLAMAND.

"M. de Buffon a très-bien décrit le rhinocéros d'Asie, et il en a donné une figure qui est fort exacte; il n'avait aucune raison de soupconner que le rhinocéros d'Afrique en différât ; aucune relation n'a insinué que ces animaux ne fussent pas précisément semblables dans tous les lieux où ils se trouvent; il y a cependant une très-grande différence entre cux. Ce qui frappe le plus quand on voit un rhinocéros, tel que celui que M. de Buffon a déerit, ce sont les énormes plis de sa peau qui partagent si singulièrement son corps, et qui ont fait croire, à ceux qui ne l'ont aperçu que de loin, qu'il était tout couvert de boucliers. Ces plis ne se font point remarquer dans le rhinocéros d'Afrique, et sa peau parait tout unic; si l'on comparc la figure que j'en donne dans la planche 5, avec celle qu'en a domnée $\mathbf{M}$. de Buffon, et qu'on fasse abstraction de la tête, on ne dirait pas qu'elles représentent deux animaux de la même espèce. C'est encore à M. le capitaine Gordon que l'on doit la connaissance de la véritable figure de cerhinocéros d'A frique, et l'on verra dans la suite que l'Histoire naturelle lui a bien d'autres obligations: voici le précis de quèlques remarques qu'il a ajoutées au dessin qu'il m'en a envoyé.

"Le rhinocéros est nommé nabal par les Hottentots qui prononcent la première syllabe de ce mot avec un claquement de langue, qu'on ne saurait exprimer par l'écriture. Le premier coup d'ocil qu'on jette sur lui fait d'abord penser à l'hippopotame, dontil differe cependant tr'es-fort par la tête; il n'a pas non plus la peau aussi épaisse, et il n'est pas aussi difficile de la percer qu'on le prétend. M. Gordon en a tué un à la distance de cent dix-huit pas avec une balle de dix à la livre ; et pendant le voyage qu'il a fait dans l'intérieur du pays avec M. Ie gouverneur Plettenberg, on en a tué une douzaine, ce qui fait voir que ces animaux ne sont point à l'épreure des coups de fusil. Je crois cependant que ceux d'Asie ne pourraient pas être facilement percés ; au moins j'en ai porté ce jugement en examinant la peau de celui dont $M$. de Buffon a donné la figure, et que j’ai eu occasion de voir ici.

"Les rhinocéros d'Afrique ont tout le corps couvert de ces incrustations en forme de gales ou tubérosités, qui se voient sur ceux d'Asie, avec cette différence, qu'en ceux-ci clles ne sont pas parseméeségalement partout; il y en a moins sur le milieu du corps, et il n'y en a point à l'extrémité des jambes; quant aux plis de la peau, comme je l'ai dit, ils sont peu remarquables. M. Gordon soupconne qu'ils ne sont produits que par les mouvements que se donnent ces animaux, et ce qui semblerait confirmer cette eonjecture, e'cst la peau bourrée d'un jeune rhinocéros de la longueur de cinq pieds, que nous avons ici, où il ne parait aucun pli. Les adultes en ont un à l'aine, profond de trois pouces, un autre derrière l'épaule d'un ponce de profondeur, un derrière les oreilles, mais peu considérable, quatre petits devaut la poitrine et deux au-dessus du talon. Ceux qui se font remarquer le plus et qui ne se trouvent point sur ccux d'Ásie sont au nombre de neuf sur les côtes, dont le plus profond ne l'est que d'un demi-pouce; autour des yeux ils ont plusieurs rides qui ne peuvent pas passer pour des plis.

" Tous ceux que MI. Gordon a vus, jeunes et vieux, avaient deux cornes, et s'il y en a en Afrique qui n'en aient qu'une, ils sont inconnus aux habitants du cap de Bonne-Espérance; ainsi j'ai été dans l'erreur quand jai écrit à M. Daubenton, que j'avais raison de soupeonner que les rhinocéros d'Asie avaient deux cornes, pendant que ceux du Cap n'en ont qu'une : j'arais reçu de ce dernier endroit des têtes à une seule corne, et des Indes des têtes à deux cornes, mais sans aucune notice du lieu où avaient habité ces animaux. Depuis, il m'est arrivé souvent de recevoir des Indes des productions du Cap, et du Cap des curiosités qui y ont été envoyées des Indes; c'est là ce qui m'avait jeté 
dans l'erreur, que je dois rectifier ici. La plus grande de ces cornes est placée sur le nez; celle qui est représentée ici était longue de scize pouces, mais il y en a qui ont huit il neuf pouces deplus, sans quel'animal soit plus grand

"Elle est aplatie en dessus et comme usée en labourant la terre; la seconde corne avait sa base à un demi-ponce au-dessous de la première, elle était longue de huit pouces. L'une et l'autre sont uniquement adhérentes à la peau et placées sur une éminence uniequi est au devant de la tête; en les tirant fortement en arrière on peut les ébranler, ce qui me fait un peu douter de ee que dit Kolbe des prodigieux effets que le rhinocéros produit. Si on l'en croit, il déracine a vee sa corne les arlores, il enlève les pierres qui s'opposent à son passage et les jette derricre lui fort haut it une grande distance avec un très-grand bruit; en un mot, il abat tous les eorps sur lesquels elle peut avoir quelque prise. Une corne si peu adhérente et si peu ferme ne semble guc̀re propre à de si grands efforts : aussi M. Gordon m'écrit que le rhinocér'os fait bien autant de mal avee ses pieds cqu'avic sa tête...

"Ce rhinocéros a les yeux plus petits que l'hippopotame; ils ont peu de blane; le plus grand diametre de la prumelle est de huit lignes, et l'ouverture des paupières est d'un pouce; ils sont situés aux còtés de la tête, presque à égale distance de la bouche et des oreilles; ainsi cette situation des yeux démontre la fausseté de l'opinion de Kolbe, qui dit que le rhinocéros ne peut voir de côté, et qu'il n'aperȩoit que les objets qui sont en droite ligne devant lui. Il aurait pcine à voir de eette dernière manière, si les yeux ne s'élevaient pas un peu au-dessus des rides qui les environnent. II parait cependant qu'il se fie plus sur son odorat et son ouie que sur sa rue, aussi a-t-il les nascaux fort ouverts et longs de deux pouces et demi; ses oreilles ont neuf pouces en longueur, et leur contour est de deux pieds; leur bord extérieur est garni de poils rudes, longs de deux pouees et demi, mais il n'y en a point en dedans.

"Sa couleur' est d'un brun obscur, qui devient couleur de chair sous le ventre et dans les plis; mais comme il se vautre fréquemment dans la bouc, il parait avoir lil couleur de la terre sur laquelle il se trouve; il a sur le corps quelques poils noirs, mais très-clairsemés, entre les tuhérosités de sa peau et au-dessus des yeux.
"Il a vingt-huit dents en tout, savoir : six molaires à chaçue eôté des deux mâchoires, et deux incisives en haut et en bas. Les dents d'en haut semblent être un pcu plus avancées, de manière qu'elles recourrent celles de dessous, lorsque lagueule est fermée ; la lèrre supérieure n'avance que d'un ponce au delà de l'inférieure. M. Gordon n'a pas eu occasion de voir s'il la peut allonger et s'en servir pour saisir ee qu'il veut approcher de sa gucule.

"Sa queue a environ un pied et demi delongueur; son extrémité est garnie de quelques poils, longs de deux pouces, qui partent de cluaque côté, comme de deux espèces de coutures; cette queue est ronde par dessus et un peu aplatie en dessous.

" Les pieds ont trois doigts munis d'ongles ou plutótde sabots; la longueur des pieds de devant égale leur largeur, mais ceux de derriere sont un peu allongés; j'en domnerai les dimensious ì la fin de ect article. 11 y a sous la plante du pied une semclle épaisse et mobile.

"La verge de ce rluinocéros était précisément comme celle qui a été décrite par M. Parsons, terminée par un gland qui a la figure d'une fleur, et de couleur de chair; sa longueur est de vingtsept pouces, et à peu près aux deux tiers de cette longueur elle parait r'ecourbée en arrière, aussi dit-on que e'est en arrière que l'animal jette son urine. M. Gordon m'en a envoyé un dessin fort exact; mais commeil s'accorde parfaitement arec celui qu'en a domé M. Parsons, Philosophical Transactions, $n^{0} 470$, il n'est pas nécessaire que je le joigne ici ; les testicules sont en dedans du corps vers les aines, et au devant de la verge sont situés deux mamelons, au lien que dans l'hippopotame ils sont en arrière. Ce dernier animal a une vésicule du fiel placée à l'extrémité de son foie, mais le rbinocéros n'eu a point.

"Ces rhinocéros sont actuellement assez avant dans l'intérieur du pays; poul' en trouver, il faut s'avanecr à cent quarante lieues daus les terres du Cap. On n'en voit guère que deux ou trois ensemble; quelquefois eependant ils marchant en plus grande compagnie, ct en marchant ils tiennent leur tète baissée comme les eochons; ils courent plus vite qu'un eheval; le moyen le plus sur de les ériter est de se tenir sous le vent : car leur reueontre est dangereuse.

"Ilstournent souvent la têtede côté et d'autce 
en courant; il semble quils prennent płaisir à creuser la terre avec leurs cornes : quelquefois ils y imprinent deux sillons par le balancement de leur tète, et alors ils sautent et courent à droite et à gauche, en dressant leur queue, comme s'ils avaient des vertiges. Leur's femelles n'ont jamais qu'un petit à la fois ; elles ont aussi deux cornes, et quant à la grandeur, il y a entre elles et les màles la même différence qu'entre les hippopotames des deux sexes, e'est-àdire que cette différence n'est pas considérable. Leur cri est un grognement suivi d'un fort sifflement qui ressemble un peu au son d'une flûte. On n'entend point parler au Cap de leurs prétendus combats avec les éléphants.

"Voici les dimensions du rhinocéros dont j’ai donné la figure : il a été tué par. M. le capitaine Gordon, près de la source de la rivière Gamka ou rivière des Lions. "

Longueur du corps, depuis le bout du mup. p. 1 . seau jusqu'à l'origine de la queue, prise en droite ligne. ................. 9530 - - prise.en suirant la courbure du corps. $11 \quad 0 \quad 3$

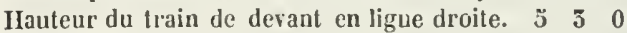
- _ du traiu de derrière. . . . . . . . 4880

Longueur de la tète............ 2000

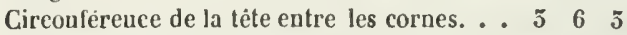
- - derrière les oreilles. . . . . . . . . 5 5006

Longueur de la plus longue corue. . . . . 1440

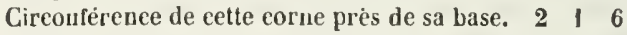
Longueur de la plus petite corne. ...... $0 \begin{array}{lll}0 & 8 & 0\end{array}$ Circonférence de cette corne près de sa base. $\quad 1 \quad 6 \quad 6$ Contour de la partie supérieure du museau. 156 - - de sa partie inférieurc. . . . . . I I 26

Longueur de l'ourerture des narines. . . . . $0 \begin{array}{llll}0 & 2 & 6\end{array}$ des oreilles.............. 0 . 9 9 0

Contour des oreilles le long du hord exté-

rieur. ..................... 200

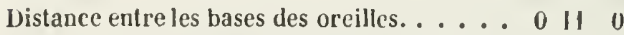

Circonférence du corps, derrière les jamhes

de derant. .................. 8 5 9

- - derant les jambes de derrière. . . . . 7110

- — du milieu du corps. . . . . . . . . 9909

Largeur du corps en derant de la poitrine. . 210

_- - du derrière du corps en ligne dioite. 240

Circonférence des jambes de derant près du

corps.................... 565

—— près du poignet. .......... 11996

—- dans l'endroit le moins ćpais. . . . I I 60

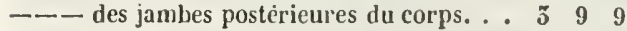

- - au-dessus du talon.......... 1100

- - dans l'endroit le plus étroit. ..... 1440

Longueur de la plante du pied antéricur. . . 0060

Sa largeur. . . . . . . . . . . . . 0090

Longueur de la plante du pied de derrière. . 0070

Sa largeur..................... 0 i 9

Longueur de la verge. . . . . . . . . 250

Sa circonférence.près du corps. . . . . . I 7
Sa cireonférence au-dessus de son premicr fourreau. ................. 0 \& 6 - - là oủ le gland commence en forme de fleur................... 0 5 6

\section{DESCRIPTION DU RHINOCÉROS.}

\section{(EXTRATT DE DACBENTON.)}

Le rhinocéros est réputé le plus gros des qua. drupèdes après l'éléphant; cependant il y a lieu de croire que l'hippopotame est au moins aussi grand que le rlinocéros, et on ne peut pas douter que la vaclse marine n'ait plus de longueur. Le rhinocéros a quelque rapport à l'ẻléphant par la masse informe de son gros corps; mais ses jambes sont beaucoup plus courtes, et il en diffère autant que des autres quadrupèdes, car il a plusieurs caractères qui lui sont particuliers. Celui qui a servi de sujet pour cette description était à Paris il y a douze ans; il n'avait pas la moitié de la hauteur d'un gı and éléplıant, car il n'ètait haut que de cinq pieds, comme on le verra par les dimensions rapportées dans la table. Il était femelle et n'avait an plus qu'ouze ans. Le bas de son ventre n'était qu'à un pied et demi au-dessus de la terre: la longueur de son corps, depuis le bout du museau jusqu'à l'origine dela queue, avait le double de sa liauteur, tandis que dans l'éléphant la longueur et la hauteur sont presque égales.

Ce rhinocèros avait la tête aplatie sur les côtés, et élevée au sommet en forme de gibbositẻ, sur la. quelle les oreilles se trouraient placées fort près l'une de l'autre. La lèrre du dessus était plus arancće que celle du dessous et terminée par une pointe mobile qui s'allongeait, se raccourcissait et prenait différentes inflxions au gré de l'animal: la lèrre inférieur semblait être coupée carrẻment en de. vant. Les ouvertures des narines etaient placées de chaque còté au-dessus de la lèrre supérieure; elles fornaient chacune une double sinuosité, comme une $S$ renversée, et s'étendaient en arrière jusqu'au-dessus des coins de la bouclie. Les yeux étaient très-petits, placés presque aussi loin des oreillesque du bout du museau. Les oreilles étaient droites, longues et pointues, leur base se trourait entource par un pli de la peau. Il y avait au milieu du chanfrein, à clistance presque égale des yeux et du bout llu museau une corne de figure conique, recombée en arrière; elle n'avait pas un pied de longueur, se base formait un ovale d'un pied de circonférence, dont le grand diamètre suivait la longueur de la tête.

Cet animal avait le cou fort gros et très-court, le corps ètoffé et rentlé sur les cỏtćs. La queue était courte, et n'avait de crins qu'à l'extrèmité. Les 
jambes étaient grosses et courtes : il n’a paru que le poignet formait dans les jambes de devant une éminence saillante en arrière, à peu près comme le talon dans les jambes de derrière : il $\mathrm{y}$ avait trois ongles ou sabots à chaque pied: celui du milieu ctait plus gros que les deux autres.

La pean formait de grosses rides très-saillantes, conme des bourrelets ou des plis. Plusieurs de ces plis s'étendaient autour du cou du rhinocéros qui a servi de sujet pour cetle description : il y avait deux plis qui environnaient le cou en entier comme des colliers; ils se réunissaient au-rlessous et pendaient comme un fanon; deux autres plis traversaient la partie supérieure et postérieure du cou, et aboutissaient par chacune de leurs extrénités à un pli qui s'étendait obliquement depuis le devant del'épaule jusque vers le garrot. Il se trouvait derrière le garrot un pli qui descendait de claquue cóté derrière l’ẻpaule, le bras et la partie supérieure de l'avant - bras ; il se courbait et se prolongeait en avant sur cette partie de l'avant-luras. Il y avait audessus de la croupe un autre pli qui descendait de chaque còté sur le llane jusqu'au devant du genou, et plus bas, en se courbant en arant sur le ventre. Un autre pli s'étendait en travers sur le laut le la cuisse depuis le flanc jusqu'à l'origine de la queue; et enfin il y en arait un autre qui etait placé transversalement sur la partic inférieure de la jambe au-dessus du talon; ces plis avaient jusqu’à trois ou quatre pouces de hauteur. La peau du rhinocéros est fort épaisse et très-dure, mais elle cède aux mouvements de l'aninal à l'endroit des plis qu'elle forme, aussi la plupart se trouvent placés et disposés de façon à suivre les mouvements de la tète et desjambes; la peau est donce, unie et de eouleur rouge pâle dans la profondeur des plis, et sous les parties anterieure et posterieure du ventre; le reste de la peau est rude, brune, parsemée de tubercules plats qui ressemblent à des crontes et qui sont de differentes grandeurs; les plus giands sont sur les épaules, sur les cỏtés du corps, sur la croupe et sur les jambes. M. de Jussieu m'a fait voir un morceau de peau de rlinocéres desséclıce qui avait jusqu’à ciuq lignes dépaisseur; le diametre de ses tubercules était d'environ un demipouce. L'épiderme avait peu d'épaisseur; il était brun et il se séparait aisement de la peau. Les tubercules sont déjai très-apparents sur la peau du foctus du rlinocéros.

Ia substance de la corne du rhinocéros est de même nature que les cornes du taureau, du bélier du bouc, des gazelles, etc. Autan' que j’ai pu juger de la grandeur et dle la ligure ile celte come, par celles qui sout an Cabinet du Roi, il parait qu'eile a jusqu’ à yuatre pieds tle longueur et jeutètre frius. Sa forme ajproche de celle d'un cone plus ou tnoins allonge; sa base est roncle ou ovale; le grand diamètre de celles qui sont ovales suit la longueur du chanfrein : il y a sous cette base une concavite, dont la profondeur est au plus d'un pouce huit lignes. La corne se recourbe on arrière à quelque distance au-lessus de son extrémité inférieure; cette courbure subsi-te jusqu'à l'extrẻmité supérieure dans la plupart de ces cornes; mais la plus grande de celles qui sont au Cabinet du roi a l'extrémité sujérieure recoubée en avant. Il y a sur plusieurs de ces cornes un sillon longitudinal. Elles sont tontes de couleur olivàtre cendrée ou noiràtre. La concavite de leur base est recouverte d'une sorte d'écorce; lorsqu'elle est enlevee, on aperçoit sur les parois de la concavité de petits orifices qui sont placés les uns contre les autres et qui ont de la profondeur. La corue etant coupee transversalement, et le plan de celte coupe ctant poli, on y voit à l'oil nu, mais plus distinctement a l'aide dune loupe, de petits disques, placés très-près les uns des autres; on distingue, au milien de chacun de ces disques, un petil espace qui parait creux, et qui semble correspondre aux oritices de la base. Lorsque l'on a coupé la corne longitudinalement, on distingue sur le plan de cette coupe, après l'avoir poli, des fibres longitudinales très-apparentes. La corne ètant usée à l'extèrieur, il reste sur quelques endroits de sa surface des fibres raides, flexibles et serrées comme les soies d'une brosse; on aperçoit aussi ces soies sur le plan de la coupe transversale près de la base; de façon qu'il y a lien de croire que la corne du rhinociros est composce le soies réunies en faisceau et adlıćrentes les unes aıx autres très-fortement; mais pas assez intimement pour qu'elles ne puissent se séparer, puisqu'on les voit sur la face extérieure de la corne aussi dis. tinctes que les soies d'une lrosse. $\Lambda$ yant decouvert cette structure de la corne du rhinocéros, jai tåché de voir celle des cornes du bouf et des autres animaux qui ont des curnes à peu près đle mème substance; $\mathrm{j}$ ai aussi aperçu leur structure; mais je lai trouve diflérente de celle de la corne du vlinoceros.

Ce rlinocciros avait vingt-luuit dents, quatre en avant, une de clıaque còté de la pantie antérieure de cliacune des madioires, et six molaires, aussi de clıarue cóté đles mâchoires; la première des molaires était fort eloirnce de la dent de devant. Il y avait teux mamelles sur le ventre. 


\section{DE LA MARMO'TTE DU CAP,}

\author{
ET DU DAMAN',
}

Ordre des pachydermes. (Cuvier.)

C'est encore à M. Allamand, savant naturaliste et professeur à Leyde, que nous devons la première connaissance de cet animal. M. Pallas l'a indiqué sous le nom de cavic capensis, et ensuite M. Vosmaër sous la dénomination de marmolle bâtarde d'Afrique. Tous deux en donnent la même figure tirée sur la même planche, dont M. Allamand nous avait envoyé une gravure. Il marquait à ce sujet à M. Daubenton :

"Je vous envoie la figure d'une espèce de cabiai ( je ne sais par quel autre nom le désigner )que j’ai reçuedu cap deBonne-Espérance. II n'est pas tout à fait aussi bien représenté que je le désirerais; mais, comme j’ai cet animal empaillé dans mon cabinet, je vous l'enverrai par la première occasion si vous souhaitez de le voir." "

Nous n'avons pas profité de cette ofire trèsobligeante de M. Allamand, parce que nous avons été informés peu de temps après qu'il étaitarrivé en Hollande un ou deux de ces animaux vivants, et que nous espérions que quelque naturaliste en ferait une bonne deseription. En effet, MM. Pallas et Vosmaër ont tous deux décrit cet animal, et je vais donner ici l'extrait de leurs observations.

"Cet animal, dit M. Vosmaër, est connu au cap de Bonne-Espérance sous le nom de blaireau des rochers, vraisemblablement parce qu'il fait son séjour eutre les rochers et dans la terre, comme le blaireau auquel néanmoins il

- La marmotte et le daman sont le même individı. Cuvier en donne la notice suivante dans son Règne animal. a Cet animal a exaclement les mėmes molaires que le rhinoceros; mais sa mâchoire supéricure a deux fortes incisives recourbées, et, dans lajennesse, deux très-petites canines; l'inférienre a quatre dents incisives sans canines : on compte quatre duigts à ses pieds le devant et trois a ses pieds de derrière; tous avec des espèces de très-petits sabots minces et arrondis, excepté le doigt interne de derrière, qui est armé d'un ongle crochu et oblique. Ses oreilles et son museau sont courts; son corps est eonvert de poils et ne porte qu'un tubercule an lien de queue. Son estomac est divisé en denx poches, et outre in gros cocum et plissieurs dilatations au colon, il y a, vers le milieu de celui ci, deux appendices analogues aux coccuns des oiscaux. ne ressemble point. Il ressemble plus à la marmotte, et cependant il en differe... C'est Konlbe qui le premier a parlé de eet animal, et il a dit qu'il ressemble mieux à une marmotte qu'à un blaireau. "

Nous adopterons done la dénomination de marmotte du Cap, et nous la préférerons à celle de cavia du Cap, parce que l'animal dont il est ici question est très-différent du cavia ou eabiai: $\mathbf{1}^{\circ}$ par le climat, le cavia ou cabiai étant de l'Amérique méridionale, tandis que celui-ci ne se trouve qu'en Afrique; $2^{\circ}$ parce que le nom de cavia est un mot brasilien, qui ne doit point être transporté en Afrique, puisqu'il appartient au cavia cuui est le vrai cabiai, et au cavia-cobaya qui est le cochon d'Inde; 3॰ enfin parce que le cabiai est un animal qui n'habite que le bord des eaux, qui a des membranes entre les doigts des pieds, tandis que la marmotte du Cap n'habite que les rochers et les terres les plus sèches qu'ellepent creuser avec ses ongles.

- Le premier animal de cette espèce, dit M. Vosmaër, qui ait paru en Europe, a été envoyé à M. le prince d'Orange par M. Tulbagh, et on en conserve la dépouille dans le cabinet de ce prince. La couleur de ce premier animal diffère beaucoup de celle d'un autre qui est arrivé depuis; il était aussi fort jeune et très-petit; celui que je vais déerire était un mâle, et il m'a été envoyé par 11 . Berg-Meyer d'Amsterdam... Le genre de vie de ces animaux, suivant les informations qui m'en ont étédonnées, est fort triste, dormant sourent pendant la journée. Leur mouvement est lent et s'exécute par bonds; mais dans leur état de nature, peut-ètre est-il aussi vif que celui des lapins; ils poussent frécquemment des cris de courte durée, mais aigus et perçants."

Je remarquerai en passant que ce caractère rapproche encore cet animal de la marmotte; car on sait que nos marmottes des Alpes font souvent entendre un sifflet fort aigu.

"On nourrissait en Hollande cette marmotte du Cap, continue M. Vosmaër, a vec du pain et diverses sortes d'herbes potagères. Il est fort vraisemblable que ces animaux ne portent pas longtemps leurs petits, qu'ils mettent bas souvent et en grand nombre. La forme de leurs pieds parait aussi dénoter qu'ils sont propres à fouir la terre. Cet animal étant mort à Amsterdam, je le donnai à M. Pallas pour le disséquer. 
a Il ressemble beaucoup pour la taille au lapin commun, mais il est plus gros et plus ramassé : le ventre est surtout fort gros. Les yeux sont beaux et médiocrement grands ; les paupières ont en dessous et en dessus quelques petits poils courts et noirs, au-dessus desquels on en voit cinq ou six aussi noirs, mais longs, qui sortent à peu pries du coin de la paupière intérieure, et retournent en arrière vers la tête. Il y a de pareilles moustaches sur la lèvre supérieure vers le milieu du museau.

"Le nez est sans poil, noir, et comme divisé par une fine conture qui descend jusque sur la lèvre : les narines paraissent comme un cordon rompu au milieu : sous le museau, vers le gosier et sur les joues on voit quelques longs poils noirs plus ou moins longs et tous plus raides que l'autre poil ; des poils de même espèce sont semés de distance en distance sur tout le corps... Le palais de la bouche a lunit cannelures ou sillons profonds; la langue est fort épaisse, passablement longue, garnic de petits mamelous et ovale ì son extrémité. La mâchoire supérieure a deux dents forts longues, saillantes au devant du museau et écartées l'une de l'autre; elles ont la forme d'un triangle allongé et aplati. Les dents de la mâchoire inférieure sont posées au devant du muscau ; clles sont coupantes, fort serrées et au nombre de quatre; elles sont assez longues, plates et larges.... Les dents molaires sont assez grosses, quatre en haut et quatre en bas de elaaque côté; on en pourrait compter une einquième plus petite que les antres.... Cet animal a les jambes de derant fort courtes et eachées à moitié sous la peau du corps. Les pieds sont nus et ne présentent qu'une peau noire. Ceux de devant ont quatre doigts, dont trois très-apparents et celui du milieu le plus long; le quatrième, qui est au còté extérieur, est beaucoup plus cour't que les autres et comne adhérent au troisième; le bout de ees doigts est armé d'ongles courts et ronds, attachés à la peau de la mème façon que nos ongles. I.es pieds de derrière ont trois doigts dont il u'y a que celui du milieu qua ait un ongle courbe; le doigt extérieur est un peu plus court que les autres. L'animal saute sur' ses pieds de derrière comme le lapin.... 11 n'y a pas le moindre indice de queue; l'anus se montre fort long, et le prépuce en bourrelet rond découvre un peu la verge. La coulenr du poil est le gris ou le brun faure, comme le poil des lich vres on des lapins de garenne. Il est plus foncé sur la tète et sur le dos, et il est blanchâtre sur la poitrine et le ventre. II y a aussi une bande blanclıâtre sur le con tout près des épaules : cette bande ne fuit point un collier, mais se termine a la hauteur des jambes de devant, et en général le poil est doux et laineux. n

Nous ne dommerons pas ici la description des parties intérieures de eet animal, on la trouvera dans l'ourrage de M. Pallas, qui a pour titre : Spicilegia zoologica. Cet habile natuliste l'a faite avee beaucoup de soin, et il fandrait la copier en entier pour ne rien perdre de ses observations.

\section{DU DAMAN ISRAEL'.}

C'est à M. le chevalier Bruce que nous devons l'exacte comnaissance et la vraie description du daman, déjà bien indiqué par Prosper Alpin, et mal à propos rapporté par le docteur Schaw à la grande gerlsoise. Voiei ce que m'a écrit á ce sujet cet illustre royageur : a Le daman-israël n'est point une gerboise; il est mal indiqué par notre docteur Shaw, qui dit que ses pattes de devant sont courtes en comparaison de eelles de derrière, dans la mème proportion que celles des gerboises; ce fuit n'est point vrai : voici la figure de ect animal que j'ai dessinée moi-mène. Il est fort commun aux euvirons du Mont-Liban et encore plus dans l'Arabie-Pétrée; il se troure aussi dans les montagnes de l'Arabie-Heureuse, et dans toutes les parties hautes de l'Abyssinie; il est de la forme et de la grandeur d'un lapin; les jambes de devint un peu plus courtes que eelles de derricre, mais non pas plus que le lapin; un caractère trèsdistinct, e'est qu'il n'a point du tout de queue, et qu'il a trois doigts à chaque patte, à peu près comme ceux des singes, sans allcum ongle, et environnés d'une chair molle d'une forme ronde; par ce caractère et par le manque de queue, il parait approcher du loris; les oreilles sont petites et courtes, courertes de poil en de-

- Ia dénominalion de daman esf celle qul préraut pour dé. signer ce yuadrupede, que l'on croit être le Saphan les Israélites. 
daus comme en dehors, par ou il difière encore du lapin; tout le dessous du corps est blanc, et le dedans à peu près de la couleur de nos lapins sauvages; il lui sort sur le dos et sur tout le dessus du corps et des cuisses, de longs points isolés, d'un noir fort luisant. Ces animaux vivent toujours dans les cavernes des rochers et non pas dans la tere, puiscu’ils n'ont point d'ongles. "D'après le dessin de M. Bruce, il parait que le docteur Shaw s'est trompé; et ce qui le confirme encore, e'est que ne voulant pas s'en tenir à ce que Prosper Alpin avait dit du daman, que sa chair est excellente à manger, et qu'il est plus gros que nolre lapin d'Europe; il a retranehé ce dernier fait du passage de Prosper Alpin, qu'il cite au reste en entier. Il faut donc rectifier ce que j'en ai dit moi-même, et rendre à Prosper Alpin la justice d'avoir indiqué le premier le daman-isıaël, et de lui avoir donné ses véritables caractères.

Au reste, il ne paraît pas douteux que ce daman ou agneau d'Israël ne soit le saphan de l'Écriture-Sainte. MI. le chevalier Bruce dit qu'il l'a vu, non-seulement dans les différentes parties de l'Asie, mais jusqu'en Abyssinie; mais il existe dans les terres du cap de Bonne-Espérance une autre espèce de daman que M. Sonnerat nous a rapporté. Ce daman du Cap diffère du daman-israël par plus de rondeur dans la taille, et aussi parce qu'il n'a pas autant cle poils saillants ni aussi longs que ceux du daman-israël; il a de plus un grand ongle courbe et creusé en gouttière au cloigt intérieur du pied de derrière, ce qui ne se trouve pas dans les pieds du daman-israël. Ces caractères nous paraissent suffisants pour faire une espèce distincte de ce daman du Cap, et le séparer, comme nous le faisons ici, de celle du daman de Syrie, avec lequel néammoins il a la plus grande lessemblance par la grandeur et la conformation, par le nombre de doigts et par le manque de queue.

Au reste, nous devons ajouter ici qu'à l'inspection seule de ce daman du Cap, nous l'avons recounu pour le mème animal que celui dont nous avons donné la description sous le nom de marmolte $d u$ Cap, en avertissant en méme temps que je n'adoptais cette dénomination que provisionnellement, et en attendant que je fusse mieux informé de la nature et du vrai nom de cet animal; ainsi il fuut rapporter à ce daman du Cap ce que nous avons dit de cette prétendue marmolke, et onsore tout ce que nous donne
M. Allamand, d'après M. Klockner', sur ce mème animal, sous la dénomination de Klipdaas ou Blaireau de roches, en observant que par la seule conformation de ses pieds, il ne doit pas ètre mis daus le genre des blaireaux, et que c'est mal à propos qu'on lui en a appliqué le nom. Voiej ce qu'en dit ce savant naturaliste dans ses additions à mon ouvrage :

a MM. Pallas et Vosmaër croient que cet animal se creuse des trous en terre comme notre marmotte ou rotre blaireau, et cela, disentils, parce que ses pieds sont propres à cette opération; mais à en juger par ces mémes pieds, on serait porté à croire qu'il ne s'en sert jamais pour un pareil usage, car ils ne paraissent point propres il creuser; ils sont courerts en dessous d'une pcau fort douce, et les doigts sont armés d'ongles courts et plats, qui ne s'étendent point au delà de la peau; cela nindique guère un animal qui gratte la terre pour s'y former une retraite. M. Pallas dit, à la vérité, que les ongles sont très-courts ou plutòt qu'il n'en a point, pour qu'en creusant ils ne s'usent pas contre les rocher's, au milieu desquels ces animaux habitent; cette raison est ingénieusement trouvće; mais ne serait-on pas autorisé aussi à dire, et peut-ètre avec plus de fondement, que la nature ne leur a donné des ongles si courts, que paree qu'ils n'ont pas besoin de s'en servir pour creuser? Au moins estil sûr que celui qui est à Amsterdam ne les cmploie pas à cela; jamais ou ne le voit gratter ou creuser la terre...

"M. Vosmaër dit que ces animaux sont lents dans leurs mouvements; cela est viai, sans doute, de celui qu'il a ru; mais MI. Pallas nous apprend qu'il était mort pour avoir trop mangé: aussi ne pourrait-on pas supposer que la graisse dont il était surchargé le rendait lourd et pesant? Au moins ceux que M. Klockner a observés ne sont point tels : au contraire, ils sont très-prestes dans leur's mouvements; ils sautent avec beaucoup d'agilité de haut eu bas, et tombent toujours sur leurs quatre pattes; ils aiment à ètre sur des endroits élevés; leurs jambes de derrière sont plus longues que celles de devant, ce qui fait que leur démarche ressemble plus à celle du cochon d'Inde que de tout autre animal; mais ils ont celle du cochon quand ils courent; ils ne dorment point pendant le jour ; quand le jour arrive, ils se retirent dans leur nid, ou ils se four'eut an milieu du 
foin, dont ils se couvrent tout le corps. Ou dit qu'au Cap, ils ont leur nid dans les fentes des rochers, où ils se font un lit de mousse et de feuilles d'épines qui leur servent aussi de nourriture, de même que les autres feuilles qui sont peu charnues ; au moins celui qui est à Amster. dam parait les preférer aux racines et au pain qu'on lui donne. Il ne mange pas volontiers des noix ni des amandes. Quand il mâche, sa mâchoire inférieure se meut comme celle des animaux qui ruminent, quoiqu'il n'appartienne point à cette classe. Si l'on peut juger de toute l'espèce par lui, ces animaux ne parviennent pas aussi vite à toute leur grandeur que les cochons d'Inde. Quand il a été pris, il était de la grosseur d'un rat, et était vraisemblablement âgé de einq ou six semaines; depuis onze mois qu'il est dans ce pays, il n'a pas encore la taille d'un lapin sauvage, quoique ces animaux parviennent à celle de nos lapins domestiques.

"Les Hottentots estiment beaucoup une sorte de remède que les Hollandais nomment pissat de blaireau; e'est une substance noirâtre, sèche et d'assez mauvaise odeur, qu'on trouve dans les fentes des rochers etdans des cavernes; on piétend que c'est à l'urine de ces bêtes qu'elle doit son origine. Ces animaux, dit-on, ont la coutume de pisser toujours dans le même endroit, et leur urine dépose cette substance, qui, séchée avec le temps, prend de la consistance. Cela est assez vraisemblable; celui qui est à Amsterdam làche presque toujours son urine dans le même coin de la loge où il est renfermé.

"Sa tête est petite ì proportion de son corps; ses yeux n'ont guère que la moitié de la grandeur de ceux du lapin; sa mâchoire inférieure est un peu plus courte que celle de dessus; ses oreilles sont rondes et peu élevées; elles sont bordées de poils très-fins, mais qui deviennent plus longs à mesure qu'ils approchent de ceux de la tête; son cou est plus haut que large, et il en est de mème de tout le corps ; ses pieds de devant sont sans poils en dessous et partagés en lobes; en dessus, ils sont couverts de poils jusqu'ì la racine des ongles. M. Vosmaër dit que ses pieds sont nus, eela ne doit s'entendre que de la partie inférieure. Quand il court, les jambes de derrière ne parnissent guère plus longues que celles de devant. Leurs pieds n'ont que trois doigts, dont deux sont toujours appliqués contre terre quand ils marchent : mais le troisième ou l'intérieur est plus court et séparé des deux autres; quelque mouvement que l'animal fasse, il le tient toujours élevé. Ce doigt est armé d'un ongle dont la construction est singulière. M. Vosmaër se contente de dire qu'il a un ongle courbe; M. Pallas n'en dit pas davantage, et la figure qu'il en a donnée ne le fait pas mieux connaitre. Cet ongle forme une gouttière, dont les bords sont fort minees; ils se rapprochent à leur origine, et s'éloignent en avancant au devant, puis ils se recourbent en dessous, et ils se réunissent en se terminant en une petite pointe qui s'étend dans la eavité de la gouttière, presque jusqu'a son milieu. Ces ongles sont situés de facon que la cavité de celui du pied droit est en partie tournée vers celle du pied gauche, et en partie vers en bas: placés au bout du doigt, que l'animal tient toujours élevé, ils ne touchent jamais le sol sur lequel il marche. Il ne parait pas vaisemblable qu'ils servent à jeter en arrière la terre, comme M. Pallas l'a soupcomné; ils sont trop tendres pour cela. M. Klockner a mieux vu quel était leur usage : l'animal s'en sert pour se crratter le corps et se délivrer des insectes ou des ordures qui se trouvent sur lui; ses autres ongles, vu leur figure, lui seraient inutiles pour cela. Le Créateur n'a pas voulu qu'aucun des animaux qu'il a formés manquassent de ce qui leur était néeessaire pour se délivrer de tout ee qui pourrait les incommoder.

"On voit sur le corps de notre klipdaas quelquels poils noirs parsemés, un peu plus longs que les autres. C'est une singularité qui mérite d'ètre remarquée: cependant je n'en voudrais pas conclure avee M. Pallas que ees poils peuvent être comparés aux épines du porc-épic ; ils ne leur ressemblent en rien.

"La longueur du corps de cet animal, que M. Klockner a observé à Amsterdam, est, depuis le museau jusqu à l'anus, de onze pouces trois quarts. Celui que j'ai placé au Cabinet de notre académie n'a que dix pouces, mais celui qui a été décrit par MI. Pallas était long d'un pied trois pouces trois lignes; et la longueur de sa tête égalait trois pouces quatre lignes : celle de l'individu d'Amsterdam n'était que de trois pouces et demi.

"I.es femelles de ces animaux n'ont que quatre mamelles, deux de chaque cóté; et si elles font plusieurs petits à la fois, comme il est très-vraiscmblable, e'est une nouvelle confir- 
mation de ce qu'a dit M. de Buffon, savoir, que le nombre des mamelles n'est point relatif, dans chaque espèce d'animal, au nombre des petits que la femelle doit produire et allaiter. "

ADDITION ET CORRECTIONS A L'ARTICLE DE LA MAR'MOTTE DU CAP DE BONNE-ESPĹRANCE.

Nous avions donné à cet animal le nom de marmotte du Cap, d'après Kolhe et M. Vosmaër, parce qu'en effet il a quelque ressemblanec avec la marmotte : cependant il n'est point du genre des marmottes, et n'en a pas les habitudes ; mais M. Allamand nous a informés qu'on appelait llipdaus ce même animal, auquel on donnait aussi le nom de blaireau des rochers. D'après la figure qui nous a été envoyée par ce célèbre naturaliste, nous avons adopté le nom de lilipdaus, parce qu'en effet il n'est ni du. geure des marmottes, ni de celui des blaireanx.

M. le comte de Mellin, que nous avons déjà eu oceasion de citer avec éloge, m'a envoyé le gravure faite d'après le dessin qu'il a fait lui-même de cet animal vivant, et il a eu la bonté d'y ajouter plusieurs observations intéressantes sur ses habitudes naturelles. Voici l'extrait de la lettre qu'il m'a écrite à ce sujet:

"Monsieur le comte a donné l'histoire d'un " petit animal auquelil a douné le nom de mar" Molteducap de Bonne-Espérance. Permettez" moi, monsieur le comte, de vous dire que cet " animal n'a dans ses mœurs aucune ressem"blance avec la marmotte. J'en ai recu une fe" melle du cap de Bonne-Espérance qui vit en- core et que j'ai donnée à ma sœur, la comtesse "Borke, qui l'a présentement depuis quatre " ans. Jc l'ai peinte d'après nature, et j'ai l'hon" neur de vous envoyer une gravure faite d'a* près cette peinture, et qui représente ce petit * animal très au naturel. Celle qui est dans G votre ouvrage, copiée de celle qui sc trouve " dans les Spicilegia zoologica de M. Pallas, " est absolument manquée. Le genre đe vic de " ces petits animaux n'est pas aussi triste que "le prétend M. Vosmaër : toutau contraire, il " est d'un naturel gai et dispos; cela dépend a de la manière dont on le tient. Pendant les - premières semaines que je l'ivais, je le tins " toujours attaché avec une ficelle à sa petite
" loge, et il passa la plus grande partie des " jours ct des nuits à dormir blotti daus saloge, " et que pouvait-il faire de mieux pour suppor" ter l'ennui de l'eselavage? mais depuis qu'on a lui permet de courir en liberté par les cham" bres, il se montre tout autre; il est non-seu" lement très-apprivoisé, mais mème suscep" tible d'attachement. Il se plait à être sur les " genoux de sa maitresse; il la distingue des " autres, au point que quand il est enfermé dans " une chambre et qu'il l'entend venir, il rc" connait sa démarché, il s'approche de la porte, " se met aux écoutes, et si elle s'en retourne " sans entrer chez lui, il s'en retourne triste" ment et à pas lents. Quand on l'appelle, il " répond par un petit cri point désagréable, et " vient promptement chez la personne qui le " demande. Il saute très-légèrement et avec " beaucoup de précision; il est frileux et cher" che de préférence à se coucher tout au haut " du poële sur lequel il saute en deux sauts; il " ne grimpe pas, mais il saute aussi légèrement " que les chats, sans jamais rien renverser. Il " aime à être tout à côté du feu, et comme le " poële de la chambre est ce que nous nom" mous un windofen qu'on chauffe par une es" pèce de cheminée praticuée dans le poële, et a qu'on ferme d'une porte de fer, il est déjà " arrivé qu'il s'est glissé dans le poële pendant a que le bois y brûlait; et comme on avait fermé " la porte sur lui, ne sachant pas qu'il y était, " il souffrit une chaleur bien violente pendant " quelques minutes, jusqu’à ce qu'il mît le nez " à la petite porte de fer qui est pratiquée dans " la grande porte, et qu'on avait laissée ouverte " pour y faire entrer l'air, sur quoi on le fit " sortir promptement : quoiqu'il se fùt brûlé le " poil des deux côtés, cet accident ne l'a pas " rendu plus prévoyant, et il recherche encore " torijours à être bien près du feu. Ce petit ani" mal est extrêmement propre, au point qu'on " l'a accoutuméà se servir' d'un pot pour y faire " ses ordures et y làcher son eau; on remarqua " que pour se vider, il lui fallait un lieu com( mode et une attitude particulière: car alors " il se dresse sur les pattes de derrière, en les " appuyant contre un mur ou quelque chose de a stable, qui ne recule pas sous lui, et il pose " les pieds de devant sur un bàton ou quelque " chose d'élevé, en léchant sa bouche a vec sa " langue pendant tout le temps que l'opération - dure. On dirait qu il se décharge avec peine, 
" et pour profiter de l'inclination qu'il a pour la " propreté, on lui a préparé un lieu commode, " une espèce de chaise pereée, clont il se sert " toujours.

"II se nourrit d'herbes, des fruits, de patates " qu'il aime beaucoup crues et euites, et même " il mange du bœuf fumé; mais il ne mange " que de cette viande, et jamais de la crue, ni " d'autres viandes : apparemment que, pendant " son transport par mer, on lui a fiait connaitre " cette nourriturequi doit cependant être souvent " variée, car il se lasse bientôt, et perd l'appétit "lorscu'on lui donne la même pendant plusieurs " jours. Alors il passe une journéc entière sarıs " manger, mais le lendemain il répare le temps " perdu; il mauge la mousse ct l'écorce du " chêne, et sait se glisser adroitement jusqu'au " fond de la caisse à bois, pour l'eniever des " buiches qui en sont encore couvertes. Il re " boit pas ordinailement, et ce u'est que lors- qu’il a mangédu bouf salé qu’on l’a vu boire "fréfuemment. Il se frotte dans le sable comme "les oiseaux pulvérateurs, pour se défaire de " la vermine qui l'incommode, et ce n'est pis " en se vautrant comme les chiens et les renards, " mais d'une manière tout étrangère à tout " autre quadrupède, et exactement comme le " faisan ou la perdrix. Il est toujours très-dispos " pendant tout le cours de l'année, et il me pa" rait être trop éveillé pour imaginer qu i] puisse " passer une partie dé l'hiver dans un état de " torpeur, comme la marmotte ou le loir. Je ne - vois pas non plus qu'il puisse se creuser un " terrier commeles marmottes ou les blaireaux, " n'ayant ni des ongles erochus aux doigts, ni " ceux-ci assez forts pour un travail aussi rude. * Il ne peut que se glisser dans les ere'asse's " des rochers, pour y établir sa demeure, et " pour échapper aux oiseaux de proie qu'il - craint beaucoup; au moins cliaque corneille "que le nôtre voit voler, lorsqu'il est assis sur " la fenètre, place favorite pour lui, l'alarme; " il se précipite d'abord et court se eacher dans " sa loge, d'où ne il sort que longtemps après, " lorscu'il imagine le danger passé. 11 ne mord " pas violemment, et quoi(ju'il en fasse desten" tatives lorsqu'on l'irrite, il ne peut guere se a défendre à coups de dents, pas mène contre " le petit épagneul de sa maitresse, qui, jaloux " des faveurs quon lui prodigue, prend quel" (quefois (puerelle avec lui. Il ne trouve proba" blement en état de liberté son salut que dans
" la fuite et dans la célćrité de ses sauts, ta" lent très-utile pour ce petit animal qui, selon " le rapport des voyagcurs, habite les rochers " du sud de l'A frique. Quoiqu'il engraisse beau- coup lorsqu'on le tient enfermé ou à l'attache, " il ne prend guère plus d'embonpoint qu'un - autre animal bien nourri, dès qu'on lui donne " pleine liberté de courir et de se donner de "l'exercice." .

\section{L'HIPPOPOTAME.}

\section{(L'inppopotaye AMrIIDIE, Cuv.)}

Ordre des pachydermes, genre hippopotame. (Cusier.)

Quoicjuc l'Juippopotame ait été célćbró de toute antiquité; que les livres saints en fassent mention, sous le nom de behemoth; que la figure en soit gravée sur les obélisques d'Égrpte, et sur les médailles romaines, il n'était cependant qu'imparfaitement connu des anciens. Aristote ue fait, pour ainsi dire, que l'indiquer, et dans le peu (ju'il en dit, il se trouve plus d'erreurs que de faits vrais. Pline, en copiant Aristote, loin de corriger ses erreur's, semble les confirmer et en ajouter de nouvelles. Ce n'est que vers le milieu du seizième sicele que l'on a eu quelgues indications précises au sujet de cet animal. Belon, étaut alors à Constantinople, en vit un vivant, duquel néanmoins il n'a donné qu'une connaissance imparfaite; car les deux figures qu'il a jointes à sa description ne représentent pas l'hippopotame qu'il a vu, mais ne sont que des copies prises du revers de la médaille de l'empereur Adrien, et du colosse du Nil à Rome. Ainsi l'on doit encore reculer l'époque de nos conmaissanees exactes sur cet animal, jusqu'en 1603, que Federico Zerenghi, chirugien de Narni en Italie, fit imprimer à Taples l'histoire des deux hippopotames qüil avait pris vivants, et tués lui-mème en Fgypte, dans une grande fosse qu'il avait fait creuser aux emirons du Nil, près de Damiette. Ce petit ourrage, écrit en italien, parait avoir été négliọé des naturalistes coutemporains, et a été depuis absolument ignoré; cependant, e'est le seul qu'on puisse regarder comme original sur ce sujet. La description que lanteur doune do l'hippopotame est aussi la seuie qui 
soit bonne; et elle nous a paru si vraie, que nous croyons devoir en donner ici la tiaduction et l'extrint.

"Dans le dessein d'avoir un hippopotame, "(dit Zerenghi), j'apostai des gens sur le Nil, " qui, en ayant vu sortir deux du fleure, firent a une grande fosse dans l'endroit où ils avaient " passé, et recouvrirent cette fosse de bois léger, " de terre et d'herbes. Le soir, en revenant au " fleuve, ces hippopotames y tombèrent tous "deux : mes gens vinrent m'avertir de cette " prise; j'accourus avec mon janissaire; nous " tuâmes ces deux animaux en leur tirant à " chacun dans la tête trois coups d'arquebuse "d'un calibre plus gros que les mousquets or" dinaires. Ils expirèrent presqquesur-le-champ, " et firent un cri de douleur qui ressemblait un ". peu plus au mugissement d'un buffle qu'au " hennissement d'un cheral. Cette expédition "fut faite le 20 juillet 1600 : le jour suivant je - les fis tirer de la fossie et écorcher avec soin; " l'un était mâle, et l'autre femelle; $j$ 'en fis sa"ler Les peaux: on les remplit de feuilles de " cannes de sucre pour les transporter au Caire, " où on les sala une seconde fois avec plus d'at" tention et de commodité; il me fallut quatre - cents livres de sel pour chaque peau. A mon " retour d'Égypte, en 1601, j'apportai ces " peaux à Venise et de là à Rome; je les fis " voir à plusieurs médecins intelligents. Le doc" teur Jérùme Aquapendente et le célèbre Al" drovande furent les seuls qui reconnurent " l'hippopotame par ces dépouilles; et comme "l'ouvrage d'Aldrovande s'imprimait alors, il " fit, de mon consentement, dessiner la figure, " qu’il a donnée dans son livre, d'après la peau " de la femelle.

"L'hippopotamea la peau très-épaisse et très-

" dure, et elle est impénétrable, à moins qu'on

" ne la laisse lougtemps tremper dans l'eau. Il

" n'a pas, comme le disent les anciens, la gucule

" d'une grandeur médiocre; elle est an contraire

" énormément grande; il n'a pas, comme ils le

" disent, les pieds divisés en deux ongles, mais

" en quatre; il n'est pas grand comme un àne,

" mais beaucoup plus grand que le plus.grand

" cheval ou leplus gros buffle; il n'a pas la queue

" comme celle du cochon, mais plutòt comme

* celle de la tortue, sinon qu'elle est incompara-

" blement plus grosse : il n'a pas le museau ou

" le nez relevé en haut, il l'a semblable au " buffle, mais beaucoup plus grand : il n'a pas
" de crinière comme le cheval, mais seulement " quelques poils courts et très-rares; il ne hen(" nit pas comme le cheral, mais sa voix est " moyenne entre le mugissement du buffle et le " hennissement du cheval : il n'a pas les dents " saillantes hors de la gueule, car, quand la " bouche est fermée, les dents, quoique extrê" mement grandes, sont toutes cachées sous les "lèvres... Les habitants de cette partie de l'É- gypte l'appellent Foras elbar, ce qui signifie "le cheval de mer... Belon s'est beaucoup trom"pé dans la description de cet animal; il lui " donne des dents de cheval : ce qui ferait croire " qu'il ne l'aurait pas vu, comme il le dit; car " les dents de l'hippopotame sont très-grandes " et très-singulières.... Pour lever tous les doua tes et fixer toutes les incertitudes, continue "Zerenghi, je donne ici la figure de l'bippo" potame femelle : toutes les proportions ont " été prises exactement d'après nature, aussi " bien que les mesures du corps et des mem" bres.

" La longueur du corps de cet hippopotame, "prise depuis l'extrémité de la lèvre supé"rieure jusqu'à l'origine de la queue, est à " très-peu près de onze pieds deux pouces de "Paris.

- La grosseur du corps en circonférence est " d'environ dix pieds.

"La hauteur, depuis la plante du pied jus" qu'au sommet du dos, est de quatre pieds cinq " pouces.

"La circonférence des jambes auprès des " épaules est de deux pieds neuf pouces.

"La circonférence des jambes prise plus bas, “ est d'un pied neuf pouces et demi.

"La hauteur des jambes, depuis la plante des " pieds jusque sous la poitrine, est d'un ried " dix pouces et demi.

"La longueur des pieds, depuis l'extrémité " des ongles, est à peu près de quatre pouces et " demi.

"Les ongles sont aussi longs que larges, et ont "à peu près deux pouces deux lignes.

"Il y a un ongle pour chaque doigt, et qua" tre doigts pour chaque pied.

"La pean sur le dos est épaisse d'un pouce. "La peau sur le ventre est épaisse d'environ " sept lignes.

" Cette peau est si dure lorsqu elle est dessé" chée, qu'on ne peut la percer en entier d'un " coup d'arquebuse. Les geus du pays cn font do 
- grands boucliers; ils en coupent aussi des laa nières, dont ils se servent comme nous nous " servons du nerf de boeuf. Il y a sur la surface " de la peau quelques poils très-rares, de cou- leur blonde, que l'on n'apercoit pas au pre" mier coup d'œil; il y en a sur le cou qui sont - un peu plus gros que les autres; ils sont tous " placés un à un à plus ou moins de distance a les uns des autres; mais sur les lèvres, ils fora ment une espèce de moustaclse, car il en sort " dix ou douze du même point en plusicurs en" droits. Ces poils sont de la même couleur que " les autres, seulement ils sont plus durs, plus " gros et un peu plus longs, quoique les plus " grands ne le soient que de cinq lignes et de" mie.

" La longueur de la queue est de onze pouces " quatre lignes.

" La circonférence de la queue prise à l'ori" gine est d'un peu plus d'un pied.

"La circonférence de la queuc, prise à son " extrémité, est de deux pouces dix lignes.

" Cette queue n'est pas ronde; mais depuis " le milieu jusqu'au bout, elle est aplatic à peu " près comme celle d'une anguille. Il y a sur " la peau de la quene et sur celle des cuisses " quelques petites écailles rondes, de couleur " blanchattre, larges comme de grosses lentilles.

"On voit aussi de ees petites écailles sur la poi" trine, sur le cou et sur quelques endroits de "la tête.

"La tête, depuis l'extrémité des lèvres jus" qu'au commencement du cou, est longue de " deux pieds huit pouces.

" La circonférence de la tète est d'cuviron " cinq pieds quatre pouces.

"Les oreilles sont longues de deux pouces " neuf lignes.

" Les oreilles sont larges de deux pouces " trois lignes.

" L.es oreilles sont un peu pointues et gar" nies en dedans de poils épais, courts et fins,

* de la mème couleur que les autres.

"Les yeux out d'un angle à l'autic deux a pouces trois lignes.

"Les yeux ont d'une paupière il l'autre " treize lignes.

"Les narines sont longues de deux pouces " quatre ligues.

" Elles sont larges de quinze lignes.

" La gueule ouverte a de largeur un pied six " pouees quatie lignes.
" Cette gueule est de forme carrée, et elle " est garnie de quarante-quatre dents de fi" gures différentes.... Toutes ces dents sont " d'une substance si dure qu'elles font feu avec "le fer : ce sont surtout les dents canines " ( sanne), dont l'émail a cette dureté; la sub" stance intérieure de toutes ces dents n'est " pas si dure... Lorsque l'hippopotame tientla " bouche fermée, il ne paraît aucune dent au " dehors : elles sont toutes couvertes et ca" chées par les levres, qui sont extrêmement " grandes.

"A l'égard de la figure de l'animal, on pour" rait dire qu'elle est moyenne entre celle du " buffle et celle du cochon, parce qu'elle parti" cipe de l'une et de l'autre, à l'exception des "dents incisives, qui ne ressemblent à celles " d'aucun animal: les dents molaires ressemblent " un peu en gros à celles du buffle ou du che" val, quoiqu'elles soient beaucoup plus gran" des. La couleur du corps est obscurc et noirà" tre... On assure que i'hippopotame ne produit " qu'un petit, qu'il vit de poisson, de crocodiles, " et mème de cadavres et de chair; cepéndant " il mange du riz, des grains, etc., ete.; quoique. " à considérer ses dents, il paraisse que la na" ture ne l'a pas fait pour paître, mais pour dé"vorer les autres animaux. " Zerenghi finit sa description en assurant que toutes ses mesures ont été prises sur l'hippopotame femelle, à laquelle le mảle ressemble parfaitement, à l'exception qu'il est d'un tier's plus grand dans toutes ses dimensions. Il serait à souhaiter que la figure donnée par Zerenghi fùt aussi bonne que sa description : mais eet animal ue fut pas dessiné vivant. Il ditlui-mème qu’il fit écorcher ses denx hippopotames sur le lieu où il venait de les prendre, (qu'il ne rapporta que les peaux, et que e'est d'après celle de la femelle qu'Aldrovande a donné sa fig̣ure. Il parait aussi que c'est d'après la mème peau de la femelle, conservée dans du sel, que Fabius Columna a fait dessiner la figure de cet animal; mais la description de Fabius Columna, quoique faite avec érudition, ne vaut pas celle de Zerenghi, et l'on doit mème lui reprocher de n'avoir cité que le nom et point du tout l'ourrage de cet auteur, imprimé trois ans avant le sien, et de s’ètre écarté de sa deseription en plusieurs points essentiels, siuns en lonner aucune rason. Par exemple, Columna dit que de son temps, en 1603, Federico Zerenglui a apporté d'Égypte en Italie 
un hippopotame entier conservé dans du sel, tandis que Zerenghi lui-même dit qu'il n'en a rapporté que les peaux; ensuite Columna donne au corps de. son hippopotame treize pieds de longueur, quatorze pieds de circonférence, et aux jambes trois pieds et demi de longueur; tandis que par les mesures de Zerenghi, le corps n'avait que onze pieds deux ponces de longueur, dix pieds de circonférence, et les jambes un pied dix pouces et demi, etc. Nous ne devons done pas tabler sur la description de Fabius Columna, mais sur celie de Zerenghi, et l'on ne peut excuser ce premier auteur, nì supposer que sa description ait été faite sur un autre sujet; car il est évident, par son propre texte, qu'il l'a faite sur le plus petit des deux hippopotames de Zerenghi, puisqu'il avoue lui-même que, quelques mois après, Zeringhi fit voir un second hippopotame beaucoup plus grand que le premier. Ce qui me fait insister sur ce point, c'est que personne n'a rendu justice à Zereughi, qui cependant est le seul qui mérite jei des éloges; qu'au contraire tous les naturalistes, depuis cent soixante ans, ont attribué à Fabius Columna ce qu'ils auraient dû donner à Zerenghi; et qu'au lieu de rechercher l'ouvrage de celuici, ils se sont contentés de copier et de louer celui de Columna, quoique cet auteur, très-estimable d'ailleurs, ne soit sur cet article ni origìnal, ni exact, ni même sincère.

La description et les figures de l'hippopotame que Prosper Alpin a publiées plus de cent ans après sont encore moins bonnes que celles de Columna, n'ayant été faites que d'après des peaux mal conservées; et M. de Jussieu, qui a ćerit sur l'hippopotame, en 1724, n'a donné la deseription quedu squelette dela têteet lespieds.

En comparant ces descriptions, et surtout celle de Zerenghi, avec les indieations que nous avons tirées des voyageurs ', il parait que l'hip-

4 Il y a dans le Nil des hippopotames on chevanx marins; et il s'en prit un à Girge l'an I6j̊, qu'on amema aussitüt au Caire, où je le vis la méme année an mois de févier, màs il était mort. Cet animal élait de conleur quasi tannée; il avait le derrière tirant à celui du buffle; tontes ses jambes étaient plus courtes et grosses; sa grandeur était scublable à celle d'un chamean, son mufle à celni d'un bceuf; il avait le eorps deux fois gros comme un bouf, la tête pareille à eclle d'un cheval, mais plus grossc, les yeux petits; son encolure était fort grosse, l'orcille petite, les maseanx for't gros el onverls. les pieds très-gros, assez grands et presutue ronds, el avec quatre doigts à cliacun, comme ceux du croeodile, petite queue comme l'éléphant, et peu ou point de poil sur la pean, nou plus (pue l'ćléplıant; il avait cu la máchoire d'cu bas quatre dents grosses et longues d'un demi-pied, dout deıx étaient popotame est un animal dont le corps est plus long et aussi gros que celui du rhinocéros, que ses jambes sont beaucoup plus courtes ${ }^{1}$, qu’il a la tète moins longue et plus grossc á proportion rlu corps; qu'il n'a de comes ni sur le nez comme le rhinocéros, ni sur la tête commeles animaux ruminants; que son cai de douleur tenant autant du hennissement du cheval que du mugissement du buffle, il se pourrait, comme le disent les auteurs anciens et les royageurs modernes ', que sa voix ordinaire fut'semblable au hennissemeut du cheval, duquel néanmoins il diffère à tous autres égards; et si cela est, l'on peut présumer que ce seul rapport de la ressemblance de la voix a suffi pour lui faire donner le nom d'hippopotame, qui veut dire cheval de riviere; comme le hurlement du lyux, qui ressemble en quelque sorte à celui du loup, l'a fait appeler loup cervier. Les dents incisives de l'hippopotame, et surtout les deux canines dans la màchoire inférieure, sont très-lon-

crochues et grosses comme des cornes de bœuf. Plusieurs disaient d'abord que c'était un buffle marin. mais je reconnus arec quelques autres que ceétait un chcral marin, vu la description de ceux qui en ont écrit; il fut amené mort au Caire par les janissaires, qui le tuèrent à conjs de mousquet en lerre, où il était venu pour paitre; ils lui tirèrent plusieurs coups sans lc faire tomber, car à peine la balle perçait-elle tonte la peau, comme j'ai remarųué; mais ils lui en tirèrent un qui Ini donna dans la mâchoire, et le jeta bas. Il y arait lono-temps qu'on n'avait vu de ces animaux an Caire. Relation d'un Voyage du Levant, par M. Thévenot. Paris, 1664, tome. I, pages 491 cl 492.

${ }^{1}$ Les pieds de l'hippopotane sont si bas el si courts, qu'ils ne prassent pas qualre doigts hors de terre. Belon, des Poissons, page 17.- " Crura e terra ad ventrem pedes tres cuin dimidio." Fabius Columna, pag. 31. Nota. Les témoignages de Belon et de Columna sur la longueur des jambes de l'hippopotame diffèrent troj pour qu'on puisse adopter l'une ou l'autie de ces mesures, et l'on doit observer que l'hippopotame que Belon a vu vivant était fort jerme et forl gras, quil devait, par conséquent, avoir le ventre gros et pendant; qu'au contraire, la pcau de celui que décrit Colunına, qui est le même que celui de Zerenghi, avait élé desséchéc dans dı sel; et, par conséquent, Columna ne pouvait pas assurer, eomme il l'a fait, que le ventre de cet animal n'titait pas rond, mais plat. Ainsi la mesure de Belon est trop courte pour un hippopotame adulte, ct celle de Colnmua est.trop longue pour un hippopotame vivant; et ce yue l'on doit inférer de tontes denx, c'csl qu'en général le ventre de cet animal n'cst guère ţu'à un pied el demi de terre, et çue ses jambes noont pas denx pieds de longueur, comme le dit Zerenghi.

2 . Vocem equinam cdit illius gent is relatione. , Prosp. Al pin., Egypt. Hist. nat., lib. IV, jrag. 248.-Morella dit qu'il vil dans le llewve Zaïre un eheval de rivière qui bennissait eomme un cheval. Ilistoire générale des Voyages, par M. l'abbé Prérost, tome $r$, page 950 . Cet animal n’a tiré le nom quion lui donne que de son hennissement. Voyage de Schouten. liecueil des voyages de la Compagnie des Indes de IIollande, tonte $\mathrm{V}$, page 4:0.-L hippopotame lienuil d'une manière pen différente de eelle dn cheval, mais avec une si grande foree, qu'on l'entend distinctement d'un bon quart de lieuc. Voyage au Sćnégal, par M. Adanson, page 73. 
gues, très-fortes, et d'une substance si dure qu'elle fait feu contre le fer : c'est vraisemblablement ee qui a donné lieu à la fable des anciens, qui ont débitéquel'hippopotame vomissait le feu par la gucule. Cette matière des dents canines de l'hippopotame est si blanche, si nette et sì dure, qu'clle est de beaucoup préférable à l'ivoire pour faire des dents artificielles et postiches '. Les dents incisives de l'hippopotame, surtout eelles de la mâchoire inférieure, sont très-longues, cylindriques et camnelées : les dents cauines, quui sont aussi très-longues, sont courbées, prismatiques et coupantes, comme les défenses du sanglier. Les dents molaires sont earrées ou barlongues, assez semblables aux dents mâchelières de l'homme, et si grosses qu'une seule pèse plus de trois livres; les plus graudes incisives et canines ont jusqu'it douze et mème seize ponces de longueur, et pèsent quelquefois douze ou treize livres chacune.

Enfin, pour donner une juste idée de la grandenr de l'hippopotame, nous emploierons les mesures de Zereughi, en les augmentant d'un tiers, parce que ees mesures, eomme il le dit Iui-même, n'ont été prises que d'après la femelle qui était d'un tiers plus pietite que le mâle dans toutes ses dimonsions. Cet hippopotame unále avait par conséquent seize pieds neuf pouces de longueur', depuis l'extrémité du museau jusqu'à l'origine de la queue, quinze pieds de eirconférence, six pieds et demi de hauteur, environ deux pieds dix pouees de longueur de jambes, la tête longue de trois pieds et demi, et grosse de huit pieds et demi en circonférence; la gueule de deux pieds quatre pouces d'ouverture, et les giaudes dents longues de plus d'un pied.

Avee d'aussi puissantes armes et une force prodigieuse de corps, l'hippopotame pourrait se renelre redontable à tous les animaux; mais il est naturellement doux; il est d'ailleurs si pesant et si lent à la course, (qu'il ne pourrait attraper aucun des (yuadrupiedes. Il nage plus vite qu'il ne court; il chasse le poisson et en fitit şa proie; il se plait dans l'ean et y sćjourne aussi volontiers que sur la terre : cependant is n'a pas,

1 C'est au cap Mesurarle, en A frique, qu'on trouve les belles dente de cleval marin, les phus blanche's eh les phus nelles: les

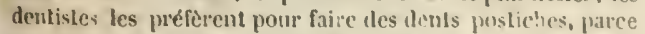
qu'elles jaunissent bien moins que l'ivoire, ef pul illes sont beaucump plus blanches et plus elures. Voyage ile Desmarchais, lome 1I, jage $\$$ \$8. comme le castor ou la loutre, des membranes entre les doigts des pieds, et il parait qu'il ne nage aisément que par la grande capacité de son ventre, qui fait que, volume pour volume, il est à peu près d'un poids égal à l'eau. D'ailleur's, il se tient longtemps au fond de l'eau, et y marche comme en plein air ; et lorsqu'il en sort pour paitre, il mange des cannes de sucre, des jones, du millet, du riz, des racines, ete. ; il en consomme et détruit une grande quantité, et il fait beaucoup de dommage dans les terres cultivées; mais comme il est plus timide sur terre que dans l'eau, on vient aisément à bout de l'écarter'; il a les jambes si courtes qu'il ne pourrait échapper par la fuite, s'il s'éloignait du bord des eaux : sa ressource, lorsqu'il est en danger, est de se jeter à l'eau, de s'y plonger et de faire un grand trajet avant de reparaitre. 1I fuit ordinairement lorsqu'on le chasse : mais si l'on vient à le blesser, il s'irrite, et, se retournant avec fureur, se lance contre les barques, les saisit avec les dents, en enlève souvent des pièces, ct quelquefois les submerge. "J'ai vu, dit " un voyagreur, l'hippopotame ouvrir la gueule, " planter une dent sur le bord d'un bateau et " une autre au second bordage depuis la quille, " e'est-à-dire à quatre pieds de distance l'une " de lautre, pereer la planche de part en part, " faire conler ainsi le bateau à fond.... J'en ai " vu un autre le loug du rivage de la mer, sur "lequel les vagues pousserent une chaloupe " chargée de quatorze muids d'eau, qui de" meura sur son dos à sec; un autre coup de " mer vint qui l'en retira sans qu'il parùt du " tout avoir senti le moindre mal.... Lorsque "les nègres vout à la píche dans leurs canots " et qu'ils reucontrent un hippopotame, ils lui " jettent du poisson, et alors il passe son che" min sans troubler davantage leur pèche. Il " fait le plus de mal lorsqu'il peut s'appuyer " contre terre; mais quand il flotte sur l'eau, "il ne peut que mordre. Une fois que notre " ('haloupe était auprès du rivage, je le vis se "mettre dessous, la lever aree son dos au-des" sus de l'ean et la renverser avee six hommes "qui étaient decians : mais par bonheur il ne "leur fit ancun mal. - Nous n'osions pas, dit " un autre voyageur, irriter les hippopotames " dans leau, depuis une aventure qui pensa " ètre funeste à trois hommes : ils ćtaient allés " aree un petit canot pour en tuer un dans une " riviere ou il y avait huit ou dix pieds d'eau; 
" après l'avoir découvert au fond où il marchait * selon sa coutume, ils le blessèrent avec une " longue lance; ce qui le mit en une telle furie , " qu'il remonta d'abord sur l'eau, les regarda "d'un air terrible, ouvrit la gueule, emporta " d'un coup de dent une grosse pièce du rebord a du canot, et peu s'en fallut même qu'il ne le * renversât : mais il replongea presque aussitòt " au fond de l'eau. " Ces deux exemples suffisent pour douner une idée de la force de ces animaux. On trouvera quantité de pareils faits dans l'Histoire générale des voyages, où M. l'abbé Prévost a présenté a'vec avantage, et avec cette netteté de style qui lui est ordinaire, un précis de tout ce que les voyageurs ont rapporté de l'hippopotame.

Au reste, cet animal n'est en grand nombre que dans quelques endroits, et il paraît même que l'espèce en est confinée à des climats particuliers, et qu'elle ne se trouve guère que dans les fleuves de l'Afrique. La plupart des naturalistes ont écrit que l'hippopotame se trouvait aussi aux Indes; mais ils n'ont pour garants de ce fait que des témoignages qui me paraissent un peu équivofues; le plus positif de tous serait celui d'Alexandre dans sa lettre à Aristote, si l'on pouvait s'assurer par cette même lettre que les aninaux dont parle Alexandre fussent réellement des hippopotames : ce qui me donne sur cela quelques doutes, c'est qu'Aristote, en décrivant l'hippopotarae dans son Histoire des animaux, aurait dit qu'il se trouvait aux Indes aussi bien qu'en Égypte, s'il eût pensé que ces animaux, dont lui parle Alexandre dans sa lettre, eussent été de vrais hippopotames. Onésicrite et quelques autres auteurs anciens ont écrit que l'hippopotame se trouvait sur le fleuve Indus; mais les voyageurs modernes, du moins ceux qui méritent le plus de confiance, n'ont pas confirmé ce fait : tous s'accordent à dire que cet animal se trouve dans le Nil, le Sénégal ou Niger', Ia Gambri, le Zaire et les autres grands fleuves, et même dans les laes de l'Afrique, surtout dans la partie méridionale et orientale; aucun d'eux n'assure positivement qu'il se trouve en Asie: le P. Boym est ie seul qui semble l'indiquer; mais son récitme parait suspect, et, selon moi, prouve seulement que cet animal est commun an Mosambique et dans toute cette partie oricntale de l'Afrique. Aujourd'hui l'hippopotame, que les anciens appelaient le cheval du Nil, est si rare dans le bas Nil, que les babitants de lEgypte n'en ont aucune idée et en ignorent le nom; il est également inconnu dans toutes les parties septentrionales de l'Afrique, depuis la Méditerranée jusqu'au fleuve Bambot, qui coule au pied des montagnes de l'Atlas. Le climat que l'hippopotame habite actuellement ne s'étend done guère que du Sénégal à l'Éthiopie, et de là jusqu'au cap de Bonne-Espérance.

Comme la plupart des auteurs ont appelé l'hippopotame cheval marin ou bouf marin, on l'a quelquefois confondu avec la vache marine, qui est un animal très-différent de l'hippopotame, et qui n'habite que les mers du nord. Il parait done certain que les bippopotames que l'auteur de la description de la Moscovie ditse trouver sur le bord de la mer près de Petzora, ne sont autre chose que des vaches marines, et I'on doit reprocher à Aldrovande d'avoir adopté cette opinion sans examen, et d'avoir dit en conséquence que l'hippopotame se trouvait dans les mer's du nord; car non-seulement il n'habite pas les mers du nord, mais il parait même qu'il ne se troure que rarement dans les mers du midi. Les têmoignages d'Odoard Barbosa et d'Edward Vuot, rapportés par Aldrovande, et qui semblent prouver que les hippopotames habitent les mers des Indes, me paraissent presque aussi équivoques que celui de l'auteur de la Description de la Moscovie; et je serais fort porté à croire avec M. Adanson" que l'hippopotame ne se trouve, au moins aujourd'hui, que dans les grands fleuves de l'Afrique. Kolbe ${ }^{2}$, qui dit en avoir vu plusieurs au

1 En remontant le Niger, nous arrivàmes dans un quartier où les hippopotames ou chevalwx marins sont fort com. muns. Cet animal, le plus grand des amphibies, ue se trouve que dans l'eau douce des rivières d'Afrique; et, une chose digne de remarque, c'est que l'on n'en a eucore observé que dans celte partie du monde, a laynelle il semble étre particulièremeut attaché. On lui donne communément la figure d'un bœuf; c'est, à la vérité, l'animal auquel il rcssemble davantage: mais il a les jambes plus courtcs, et la tête d'une grossear démesurée. Quant à la grandeur, le cheval marin peut prendre le pas après l'éléphant et le rlinocéros : ses måchoires sont armées de quatre défenses, avec lesquelles Il détache les racines des arbres qui lui servent de nonrriture; il ne peut rester longtemps sous l'eau saus respirer, et c'est ce qui l'oblige de porter de temps en temps la tête au-dessus de sa surface, comme fait le crocodile. Voyage au Sénégal, par II. Adanson. Paris, 1757 , page 75 .

'Hippopotame ou chpval marin. Si nous donnons a cet animal l'épilbète de marin, ce n'est pas que ce soit une espèce de poisson, ni qu'il vive toujours dans la mer : il vient chercher sa nourriture sur le sec, et s'il se retire dans la mer ou dans une rit'ière, ce n'esl que pour se metlre en sûreté; 83 nourriture orliuaire estl'herbe; des que la faim le presse, II sort de l'eau, dans lacpuelle il se condie toujours tout étendu. 
cap de Bonne-Espérance, assure qu'ils se plongent également dans les eaux de la mer et dans celles des fleuves : quelques autres auteurs rapportent la même chose. Quoique Kolbe me paraisse plus exact qu'il ne l'est ordinairement dans la description qu'il donne de cet animal, l'on peut douter qu'il l'ait vu aussi souvent qu'il le dit, puisque la figure qu'il a jointe à sa description est plus mauvaise que celles de Columna, d'Aldrovande et de Prosper Alpin, qui, cependant, n'ont été faites que sur des peaux bourrées. Il est aisé de reconnaître qu'en général les deseriptions et les figures de l'ouvrage de Kolbe n'ont été faites ni sur le lieu ni d'après nature : les descriptions sont éerites de mémoire; et les figures ont, pour la plupart, été

Lorsqüil lève la tête hors tle l'eau, il commence par la tourner de tous côtés vers les bords pour voir s'il n'y a pas de danger. et il sent $u$ honmue à une distance considérable; $s^{\prime i l}$ aperçoit tuelyuc chose, il se replonge dans l'eau, et y restera trois heures sans bouger... Cet animal pèse, pour l'ordinaire, deux mille ciny cents on trois mille livres... Le cheval marin, soit ponr la couleur, soit pour la laille, ressemble au rhinocéros, seulcment il a les jambes un peu plus courles; sa lête, comme le dit Tellez (liv. I, chap. 8), ressemble plus à celle du cheval ordinaire qu'à celle de tont autre animal, et c'est de là qu'il a uris son nom; il a la bouehe beaucoup plus grande que le cheval, et, à cet égard, il approche plus du bœuf; ses narines sont fort grosses, elles se remplissent d'eau, yu'il fait jaillir lorsıu'il se lève du fond de la mer ou de la rivière qui lini a servi de lit; il a les oreilles et les yenx fort petits; ses jambes sont courles, épaisses et de mème grosseur dejuis le baut jus. qu'en bas; il n'a pas la corne du pied fendue comme le bœuf, mais elle est partagée en quatre parties ; ̀̀ l'cxtrénité et sur chacune de ces parties, on voit des manières de petites cannelures gui vont en forme de vis; sa queuc est courte comme celle de l'éléphant, et on y voit tant soit peu de poil, ct mème fort court : c'est tout ce que lc cheval marin en a.

Les mamelles de la femelle de cet animal pendent entre les jambes de derrière, comme on le voit dans les vaches, mais elles sont fort petiles à propórtion de la grosseur de leur corps, aussi bien que les mamelons. J'ai souvent vu des femelles donner à téter à leurs petits, qui étaieut déjà de la taille d'une brebis.... La peau ru clieval marin a plus d'm ponce d'épaisseur, el, outre cela, elle est si dure, yu'il est très-difficile de les tuer, mème d'un coup de balle. Les Européens du Cap visent toujours à la lête : comme la pean y est tendre, et quelle y touche l'os, on pent aisément la percer; rarement ils donnent a cet animal le coup de mort dans mn antre eudroit.

Il n'y a rien dans le cheval uarin qui soit plus remaryuable que ses dents de la makehoire d'en bas; il y en a quatre grosses, denx de chaque cóté, dont l'une est croclune cl l'antre droite : clles sont é paisse's comme mue corne de burus, longues d'environ un pied et deui, el pèsent une douzaine de livres chacune; leur blancheur, qui est très-éclatante, a ceci de partieulier qu elte se conserve sans qu il y artive jamais d'allératien, qualité que n'a pas l'ivoire, qui jaunit en vieillissant: aussi sont-elles plus estimies que les deuts déléphant.

La chair de ect animal est un manger très-délicieux, soit rólie, soil bonillie, el elle est si estince an Cap, qu'clle sy vend donze el yuinze snus la livre; cest le présent le plus agréable que l'on puisse faire; la glaisse se vend autant ene la viande, elle est fort douce et très-saine, on s'eu sert au licu de beurre, elc. Description du cap de Boune-Esprance, par liulbe, tom. III, chap. 3. copiées ou prises d'après celles des autres naturalistes; et en particulier la figure qu'il donne de I'hippopotame ressemble beaucoup au cheropotame de Prosper Alpin.

Kolbe, en assurant donc que l'hippopotame séjourne dans les eaux de la mer, pourrait bien ne l'avoir dit que d'après Pline, et non pas d'après ses propres observations : la plupart des autres auteurs rapportent que cet animal se trouve seulement dans les lacs d'eau douce et dans les fleuves, quelquefois à leur embouchure, et plus souvent à de très-grandes distances de la mer; il y a même des voyageurs qui s'étonnent, comme Merolla, qu'on ait appelé l'hippopotame cheval marin, parce que, dit-il, cet animal ne peut souffrir l'eau salée. Il se tient ordinairement dans l'eau pendant le jour, et en sort la nuit pour paître; le mâle et la femelle se quittent rarement. Zerenghi prit le mâle et la femelle le même jour, et dans la même fosse. Les voyageurs hollandais disent qu'elle porte trois ou quatre petits; mais ce fait me parait très-suspect et démenti par les témoignages que cite Zerenghi : d'ailleurs, comme l'hippopotame est d'une grosseur énorme, il est dans le cas de l'éléphant, du rhinocéros, de la balcine, et de tous les autres grands animaux qui ne produisent qu'un petit, et cette analogie me parait plus sûre que tous les témoignages.

\section{ADDITION A L'ARTICLE DE L'IIIPPOPOTAME.}

Comme nous n'avions donné la figure que d'un foctus d'hippopotame, nous avons cru devoir ajouter ici celle d'un jeune hippopotame mâle, dont la dépouille bien entière a été envoyée à S. A. S. M. le prince de Condé, et se voit dans son magnifique Cabinet d'histoire naturelle à Chantilly. Ce très-jeune hippopotame venait de naitre: car il n'a que deux pieds onze pouces trois lignes de l'extrémité du nez jusqu'au bout du corps; la tète dix pouces de longueur, sur einq pouces dix lignes daus sa plus grande largeur : cette tête vue de face ressemble à celle d'un bouf sans cornes. Les oreilles, petites et arrondies par le bout, n'ont que denx pouces deux lignes; les jambes sont grosses et courtes. Le pied ticnt beancoup de celui de l'eléphant: la queue nest longue que de trois pouces onze lignes, et elle est couverte, comme tout 
le reste du corps, d'un cuir dur et ridé. Sa forme est ronde, mais large à son origine, et plus aplatie vers son extrémité, qui est arrondie au bont en forme de petite palette, en sorte que l'animal peut s'en aider à nager.

Par une note que m'a communiquée M. le chevalier Bruce, il assure que dans son voyage en Abyssinie, il a vu un grand nombre d'hippopotames dons le lac de Tzana, situé dans la Haute-Abyssinie; à peu de distance des vraies sources du Nil, et que ce lac Tzana, qui a au moins seize lieues de Iongueur sur dix ou douze de largeur, est peut-être l'endroit du monde où il y a le plus d'hippopotames. Il ajoute qu'il en a vu qui avaient au moins vingt pieds de longueur, avec les jambes fort courtes et fort massives.

Nous avons reçu de la part de M. L. Boyer de Calais, officier de marine, une petite relation qui ne peut appartenir qu'à l'hippopotame.

"Je crois, dit-il, devoir vous faire part de l'histoire d'une fameuse bête que nous venons de détruire à Louangue. Cet animal, qu'aucun marin ne connaìt, était plus grand et plus gros qu'un cheval de carrosse. Il habitait la rade de Louangue depuis deux ans. Sa tête est monstrueuse et sans cornes, ses oreilles sont petites, et il a le moufflon du lion. Sa peau n'a point de poil, mais elle est épaisse de quatre pouces. Il a les jambes et les pieds scmblables à ceux du bœuf, mais plus courtes. C'est un amphibie qui nage très-bien, et tonjours entre deux caux ; il ne mange que de l'herbe. Son plaisir était d'enfoncer toutes les petites chaloupes on canots, et après qu'il avait mis à la nage lemonde qu'elles contenaient, il s'en retournait sans faire de mal aux hommes. Mais comme il ne laissait pas que d'ètre incommode et même nuisible, on prit le parti de le détruire : mais on ne put en venir à bout avec les armes à feu; il a le coup d'œil si fin, qu'à la seule lumière de l'amorce il était bientôt plongé. On le blessa sur le nez d'un coup de hache, parce qu'il approchait le monde de fort près, et qu'il était assez fumilier; alors il devint si furieux, qu'il renversa toutes les chaloupes et canots sans exception. On ne réussit pas mieux avec un piége de grosses cordes, parce qu'il s'en aperęut, et que dès lors il se tenait au loin. On crut pouvoir le joindre à terre ; mais il n'y vient que la nuit, s'en retourne avant le jour, et passe tantòt dans un endroit, tautót dans un autre. Cependant, comme on avait remarqué qu'il ne s'était pas éloigné d'un passage pendant plusieurs jours de suite, nous fümes cinq nous y embusquer la nuit, armés de fusils chargés de lingots, et munis de sabres. L'animal ayant paru, nous tirâmes tous ensemble sur lui : il fut blessé dangereusement, mais il ne resta pas sur le coup, car il fut encore se jeter dans un étang voisin oủ nous le perdimes de vue, et ce ne fut que le surlendemain que les Nègres vinrent dire qu'ils l'avaient trouvé mort sur le bord de l'étang. Je pris deux dents de cet animal, longues d'un pied et grosses comme le poing; il en avait six de cette taille, et trois au milieu dupalais, beaucoup plus petites. Ces dents soụt d'un très-bel ivoire. "

\section{ADDITION}

DE L'ÉdTTEUR hOLLANDAIS ( $M$. LE PROFESSEUR ALLAMAND) A L'ARTICLE DE L'HIPPOPOTAME.

"Il ne manque à la description que $\mathrm{M}$. de Buffon a domnée de l'hippopotame adulte, d'après Zerenghi, gu'une figure qui représente au vrai cet animal. M. de Buffon, toujours original, n'a pas voulu copier celles que différents auteurs en ont publiées; elles sont toutes trop imparfaites pour qu'il ait daigné en faire usage: et quant à l'animal mème, il ne lui était guère possible de se le procurer ; il est fort rare dans les lieux même dont il est originaire, et trop gros pour être transporté sans de grandes difficultés. On en voit à Leyde, dans le Cabinet des curiosités naturelles de l'Université, une peau bourrée qui y a été envoyée du cap de Bonne-Espérance. Quoiqu'elle y soit depuis près d'un siècle, elle a été si bien préparće, qu'elle offre encore à présent la figure exacte de cet animal : elle est soutenue par des cercles de fer et par des pièces de bois assez solides, pour que le desséchement n'y ait produit que des altérations peu considérables. Comme e'est vraisemblablement la seule curiosité de ce genre qui soit en Europe, je crois que tous ceux qui aiment l'histoire naturelle me sauront bon gré de la leur avoir fait connaitre par la gravure, et d'en avoir enrichi le magnifique ouvrage de M. de Buffou. Ainsi la planche que nous ajoutons ici représente l'hippopotame mieux qu il n’a été représenté jusqu'à présent, ou plutôt 
c'est la seule figure que l'on en ait; car dans toutes les autres qui ont été publiées, cet animal n'est pas reconnaissable, si l'on en excepte celic qui se trouve dans un livre hollandais, où il est question du léviathan dont il est parlé dans l'Écriture-Sainte, et qui a été faite sur le même modèle que l'on a copié ici, mais les proportions y ont été mal observées.

"Il serait inutile de joindre ici une descripsion de ce monstrueux' animal : il n'y a rien à ajouter à celle que MM. de Buffon et Daubenton en ont donnée. Je me contenterai d'en indiquer les dimensions, prises avec exactitude. La mesure que j’ai employéc est celle du pied de Paris. "

Longueur du corps, depuis l'extrémitẻ de la levre supérienre jusqu'à l'origine de la queue. ................

Hauteur depuis la plante des pieds jusqu'au sommet du dos. ............

Longueur de la léte depuis le bout du museau jusqu'à locciput. .............

Circonférence du bout du muscau. .....

Circonférence du museau, prise au-dessous des yeux. .............. \& \& 0

Longueur de la gueule ouverte.. . . . . . $0 \begin{array}{ccc}0 & 9 & 6\end{array}$

Contour de la gueule ouverte. . . . . . 5 5 II 0

Longueur des dents canines, hors de la gen-

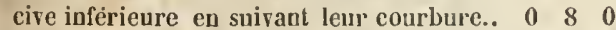

Longueur des dents incisives de la màchoire inférieure................ 0 \& 0

Distance entre les deux nascaux. ...... 0 \% 49

Dislance entre le bout du museau et l'angle antérieur de l'œil. ........... 180

Distance entre l'angle postérieur et l'oreille. . $\begin{array}{llll}0 & 5 & 0\end{array}$

Longueur de l'ail d'un angte à l'autre. . . . 020

Distance entre les angles antérieur's des yeux eu suivant la eourbure du chanfrein. . . . 0101010

La mème distance en ligne droite. . . . . . . 0090

Circonférence de la tẻte, entre les yeux et les oreilles...............4 4 116

La longueur des oreilles n'a pu ėtrémesurée, parce qu'elles se sont trop affaissées par le desséchement.

Largeur de la lase des oreilles, mesurée sur le courbure extérieure...........

Distance entre les deux oreilles, prise dans le bas...................... 092 Longueur du cou. ............ 1000

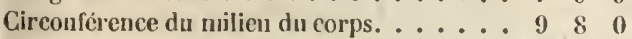
Longueur du tronçon de la queue . . . . . 0010 Circoufcérence de la queue à sou origine ... $0 \begin{array}{llll}0 & 10 & 4\end{array}$ Hauteur des jambes, depuis la plante des pieds jusque sous ta poitrine ou le veutre. . 1 \& 0

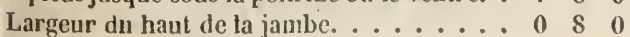

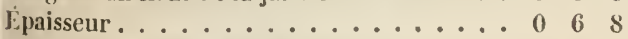
Largeur à l'endroit du talon. ........ 0 \% 410 Circunférence du métatarse ........ 120
Largeur du pied de devant. ............ 0 7 8

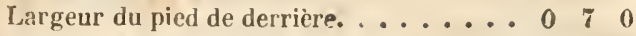

Largeur des plus grands sabots. ...... $0 \begin{array}{llll} & \mathbf{3} & 0\end{array}$

Comme la figure du jeune hippopotame que j'ai fait dessiner dans le cabinet de S. A. S. M. le prince de Condé diffère de celle que M. Allamand a fait graver d'après la peau bourrée du cabinet de Leyde, et qu'elle ressemble plus à une nouvelle figure, donnée par M. le docteur Klockner, d'après une autre peau d'hippopotame du cabinet de monseigneur le prince d'Orange, j'ai préféré de donner ici la figure de ce dernier hippopotame, d'après celle de M. Ḱlockner ${ }^{4}$; et je crois devoir y joindre une note aree quelques observations du même auteur, que j'ai fait traduire du hollandais.

\section{ADDITION}

A L'HistoIRE DE L'HIPPOPOTAME DE M. DE BUEFON, PAR M. LE DOCTEUR KLOCKNER, D'AMSTERDAM.

\section{NOTES.}

“ Je m'étonne que M. de Buffon ne eite pas un passage remarquable de Diodore de Sicile, touchant l'hippopotame ou cheval de rivière, d'autant plus que cet auteur ancien y observe que la voix de cet animal ressemble au hennissement du cheval, ce qui peut-être lui a fait domner le nom d'hippopotame ou cheral de fleuve. M. de Buffon appuie son sentiment sur cette singularité des témoignages des auteurs anciens et des royageurs modernes; et Diodore de Sicile doit certainement tenir le premicr rang parmi les anciens, puisque non-sculement il a voyagé lui-même en Eggpte, mais qu’il passe encore, avee justice, pour un des meilleurs historiens de l'antiquité. Quoi quiil en soit, je placerai ici ce passage, où il est dit: "Le Nil " nourrit plusieurs espèees d'animaux, dont " deux entre autres méritent de fixer notre at" tention, qui sont le crocodile et l'hippopotame. "Celui-ci est long de cinc coudées; il a les pieds " fourchus comme les bêtes à cornes, et de cha"que côté trois dents saillantes, plus grandes "que les défenses d'un sanglier. La masse en( tière du corps ressemble beaucoup à celle de

1 Nous avons supprimé celte lişure comme inutile. 
a l'éléphant. Sa peau est tiès-dure et très$\checkmark$ ferme, et peut-être plus que celle d'aucum a autre animal. Il est amphibie, se tenant " pendant le jour au fond de l'cau, où il se meut " et agit comme sur la terre même, où il vient " la nuit pour paître l'herbe des campagnes. Si " cet animal était plus fécond, il causerait de " grands dommages à la culture des Égyptiens. "La chasse de l'hippopotame exige un nombre * de personnes qui cherchent à le percer avec " des dagues de fer. On l'assaillit avec plusieurs " barques jointes ensemble, et on le frappe " avec des harpons de fer, dont quelques-uns " ont des angles ou des acraux ; on attache à "quelques-uns de ces dards une corde, et on " laisse ensuite l'animal se débattre jusqu'à ce " qu'il ait perdu ses forces arec son sang. La " chair en est fort dure et de difficile diges" tion."

Voilà peut-ètre la meilleure description que l'on trouve de cet animal chez les anciens, car Diodore-ne s'est trompé que sur le nombre des doigts.

\section{OBSERVATIONS}

Faites en préparant la pean de l'hippopotame qui se trouve maintenant dans le cabinet d'histoire naturelle de S. A.S. monseigneur le prince d' Orange;

PAR J. C. KLOCKNER, DOCTEUR EN Mí́deCINE, A AMSTERDAM.

" J'ai reçu fort sèche, de La Haye, la peau uc cet hippopotame, avec la tête qui s'y trouvait enveloppée. Cette peau avait été premièrement salée, puis séchée, et ensuite on avait pris la peau d'un jeune hippopotanse (qui de même est placé dans le Cabinet de S. A. S.) trempée de saumure, et on l'avait mise encore mouillée dans celle-ci; après quoi, le tout avait été emballé dans de la grosse toile et expédié du cap de Bonne-Espérance pour la Hollande. La petite peau et la tête occasionnaient par conséquent une odeur infecte de graisse gàtée ou rance, ce qui avait attirć les insectes qui ont beaucoup endommagé la graude peau, qui se trouvait la première et la plus exposée.

"Lorsque j’eus trempé la tête, elle se gonfla beaucoup. Le báillement ou l'ouverture de la gueule était de plus de seize pouces, mesure
d'Amsterdam '. Les lèvres inféricure et supérieure étaient assez larges pour couvrir et euvelopper toutes les dents de l'animal, ce qui naturellement se fait avec d'autant plus de facilité, que les longues dents ou dents canines inférieures, qui sont courbes, glissent par-dessus les supérieures, en forme de ciseaux, et passent le long de la courbure des dents canines supérieures, dans un étui formé par la peau de la lèvre et par les gencives. Entre les dents de devant ou dents incisives, et entre les dents cylindriques et molaires, de même qu'entre la langue et les dents incisives, il y a une peau lisse et dure, et le palais est plein de hoches ou entaillures. La langue avait été coupée... On avait de même coupé beaucoup de chair des deux còtés de la tête ou des mâchoires, et la graisse qui s'y trouvait était presque toute gátée. Cependaut le tout était encore mêlé de muscles très-forts; et ce qui se trouvait de plus sur le devant dans les lèvres inférieure et supérieure était d'une chair rouge et blanche de la couleur d'une langue de bœuf.

" Immédiatement derrière les dents canines et inférieures, on voyait dans la lèvreinférieure, dans l'endroit où commence la mâchoire, une grosseur qui, en fermant la gueule, remplissait l'ourertur'e qui se fait derrière les dents canines. Cette ouverture, quoique remplie, s'est rétrócie de moitié en se séchant, de même que les lèvres.

"Sous les oreilles, autour du conduit auditif, qui est singulièrement petit, il y avait beaucoup de graisse, de même que dans les orbites des yeux.

"Les oreilles sout placées comme sur une éminence, et de manière qu'il s'y forme tout autour des plis en ceicles. L'élévation de l'oreille droite s'est beaucoup rétrécie en séchaut, mais on l'apercoit encore distinctement à l'oreille gauche.

"On sait que les oreilles de l'hippopotame sont très-petites ; mais celles de notre sujet présentent encore une sirgularité que je dois observer, savoir, que les bords supérieurs ou cercles des deux oreilles avaient été rongés égalcment, selon mon estimation, de la moitié ou de trois quarts de pouce: ce qui vraisemblablement est l'ouvrage des insectes de terre ou d'eau,

1 Le pied d'amsterdam ne fail que dix pouces cinq lignes trois points du pied de roi de France. 
mais qu'ils doivent avolr fait du vivant de l'animal, puisque les bords rongés se trouvaient déjà recouverts d'un nouvel épider'me. L'intérieur des oreilles était bien garni d'un poil fin et serré, mais il n'y en avait que,très-peu au dehors.

" İes yeux doivent avoir été fort petits, puisque l'ouverture était extraordinairement petite en raison de la grandeur de l'animal. Cette petitesse des yeux de l'hippopotame se trouve confirmée par plusieurs rapports. Les yeux que j’ai placés dans mon sujet sont peut-être un peu plus grands que les naturels; mais lorsque j'en avais mis de plus petits, ils paraissaient ne pás convenir à l'animal, et je fus par conséquent obligé de lui en donner de plus grands.

"Les rarines vont extérieurement en baissant de biais, a vee une petite ou verture; ensuite elles se joignent par une ligne courbe dans l'intérieur, et puis remontent derechef. Lorsque la peau était sèche, on n'apereevait qu'à peine ces conduits ou tuyaux; je les ai un peu élargis avant de les faire sécher.

"Les dents sont si dures qu'on en tire facilement du feu avee un acier. J'en ai vu tirer avec une lime d'un morceau de la dent d'un autre hippopotame.

Je dois remarquer ici que je n'ai trouvé que trente-deux dents dans la tète de l'hippopotame, ce qui ne s'aceorde pas avee la deseription de Zerenghi, ni avee eelle de M. Daubenton. Le premier dit en avoir trouvé quarante-quatre dans ses hippopotames, et le second trente-six dans la tête qui se trouve dans le Cabinet du Roi. Cette différence m'a rendu attentif; mais je puis assurer qu'on n'apercevait aucune marque que quelques dents en fussent tombées, sinon une des dents incisives, qui paraît avoir été cassée avec force. J'y ai trouvé quatre dents canines, qui sont placées perpendiculairement, huit dents incisives, quatre dans la mâchoire supérieure, dont la position est perpendieulaire, et quatre dans la mâchoire inférieure qui sout posćes horizontalement, comme on peut le voir dans la figure. De plus, j’ai trouvé deux dents molaires daus chaque mâchoire inférieure, et trois dents placées devant les dents molailes, qui ont la for'me d'une quille. Dans les mâchoires supérieures jai trouvé dans chacune trois dents molaires, et deux de ces dents de figure eylindrique. Il y a entre ces dents de figure eylindrigue un espace d'un demi-pouce.
"Je dois obselver que communément les hippopotames ont trente-six dents, comme nous l'avons dit, savoir: quatre incisives en haut, et quatre incisives en bas; deux canines en haut, et deux canines en bas; douze mâchelières en haut, et couze mâchelières en bas. Je l'ai vérifié sur trois têtes qui sont anciennement au Cabinet, et en dernier lieu sur une quatrième tête qui m'a été envoyée, en décembre 1775, par M. de Sartine, ministre et secrétaire d'état au département de la marine. La dernière des mâchelières, au fond de la gueule, est beaucoup plus grosse, plus large, et plus aplatie sur la tranche que les einq autres mâchelières; mais je serais porté à croire que le nombre de ees dents mâchelières varie suivant l'âge, et qu'au lieu de vingt-r[uatre il peut s'en trouver vingt-huit et mème trente-deux, ce qui ferait quarante-quatre en tout, comme le dit Zerenghi.

"Les lèrres supérieure et inférieure se trouvent garnies, à des distances assez considérables, de petites touffes de poil, qui, comme des pinceiux, sortent d'un tuyau ou racine. J'en ai compté environ vingt. Pour faire une observation plus exacte, j'ai placé une tranche de la raeine sous le mieroscope, et j'ai vu sortir sept racines d'un tuyau. Ces sept racines se partagent ou se fendent ensuite, et forment chacune plusieurs poils, qui forment des espèces de pinceaux.

"Aux còtés de la gueule, où se fait le bâillement, ver's le bas, on roit des poils fins qui sont plus serrés que les autres.

"De plus, on aperçoit par-ci par-là, sur le corps, quelques poils lares; maisil ue s'en trouve presque point aux jambes, aux flanes ni sous le ventre.

"L'extrénité et les parties tranchantes inférieure et supérieure de la queue étaient garnies de poils ou pinceaux comme au nez, mais un peu plus longs.

"Je n’ai pu découvrir le sexe de cet animal. $11 \mathrm{y}$ avait près du fondement une décompure triangulaire, de la grandeur decing it six pouces, ouje pense que les parties génitales étaient placées; nais comme on n'en avait laissé aucune marque, il ne m'a pas été possible d'en déterminer le sexe.

"La peau du ventre, près des pieds de derrière, avait un ponce nenf lignes d'épaissear; les insectes y avaieut aussi fait un trou, ce qui 
Jonnait toute facilité de mesurer cette épaisseur. La substance de cette peau était blanche, cartilagineuse et coriacée, et dans cet endroit elle était bien séparée de la graisse et de la chair. Plus haut, vers le dos, on avait coupé et enlevé beaucoup de peau, sans doute pour la rendre plus légère et plus facile à ètre transportée ; c'est par cette raison que je n'ai trouvé la peau, vers l'épine du dos, épaisse que d'un pouce en y passant un poinçon.

"Les doigts étaient garnis d'ongles; la peau entre les doigts était fort ample, et je crois que les pieds de cet animal, lorsqu'il était vivant, étaient plutôt plats qu'arrondis. Le talon, qui se retire en arrière et en haut, parait trèspropre à nager; le sabot, quoique épais et durillonné, est néanmoins flexible.

"Je joins iciplusieurs mesures, eu avertissant qu'elles n'ont été prises qu'après que la peau a été empaillée, et que je me suis servi de la mesure d'Amsterdam. "

Longueur du corps entier, mesuré en ligne droip. p.

te, depuis le milieu du nez jusqu’à la queue, du cóté droit. . . . . . . . . . 1010 - depuis le milieu du nez jusqu'à la quene, mesurée eu ligne courbe, du côté gauche.. • 157

_- du milieu du nez, mesurée par-dessus

la tête........................

Nota. La raison de ta différence de ces mesures vient de ce que l'animal tourne la tête du côté droit.

Longueur de la tète.. . . . . . . . . . Circoufèrence de la tête, mesurée derrière les oreilles................ - mesurée devant les oreilles. .......

__ entre les jeux et les oreilles. ..... - sur l'élévation de l'orifice des yeux. . . - Entre les yeux et le nez. . . . . .

Nots. Cette dernière mesure est prise an-dessus du båiltement qu'on avait laissé pour faire voir les dents. La gueule est cuverte, de manière ıque les deux dents canines se touchent à un demipouce près.

Circonférence de la lèvre supérieure, d'un bord à l'autre, en passant dessus la lère. . . . .

Largeur de la lèvre supérieure, en traversant en ligne droite le palais. . . . . . . .

Circonférence de la lèvre inféricure, mesurée pai-dessous...............22

Largeur de la lèrre inférieure, d'un bord à l'au-

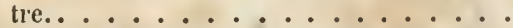

Distauce des narines, prise à l'ouverture supéricure................... 0

—— prise à l'ouverture inférieure. . . . . $0 \quad 0 \quad 5 \%$

Largeur des narines au milieu.. . . . . 0

Longueur des narines. . . . . . . . p. p.

Distance entre les oreilles et les yenx.. . . $0 \quad 6$

- - d'une oreille ả l'autre. ...... 12

Longueur des oreilles.......... 0 1!

Largeur des oreilles. . . . . . . . 02

Distance entre les deux paupières lorsqu'elles

sont ouvertes................ 0 1\%

Longueur des yeux, d'un coin à l'autre. . . $0^{\circ}$ 1

Distance entre les orifices des yenx. .... 10

Hauteur de l'avant-train, depuis la plante des pieds jusque sur le dos. . . . . . . 64

IIauteur de l'arrière-train, depuis la plante des pieds jusque sur la croix. . . . . . 5

Circonférence du corps, derrière les jambes de devant............ 100

- - au milieı. ......... 106

___ derant les pattes de derrière..... 109

Hauteur, depuis la terre jusqu'au ventre, dans le milieu. . . . . . . . . . 07

- derrière les pattes de devant. . . . . 009

- - deraut les pattes de derrière . . . 09

Circonférence du cou derrière la tête. . . $6 \begin{array}{cc}6 & \text { a }\end{array}$

- - au milieu. ........ 77

—_ dessus la poilrine.. . . . . . $8{ }^{\frac{7}{2}}$

Circonférence des pattes de devant, près de la poitrine......... 510

Girconfërence au milieu. ....... $52 \frac{1}{3}$

— au-dessus du sabot. . . . . . 25

Circonférence des pattes de derrière, près du corps............ \& 7

- - au-dessus du genou. ....... $28 \frac{1}{\frac{1}{2}}$

- - au-dessus du sabot. . . . . . $25 \frac{2}{2}$

Longueur des pattes de derant, depuis le ialon jusqu'au ventre.......... $15 \frac{1}{\mathrm{~s}}$

___ des pattes de derrière, depuis le talon jusqu'au ventre. .......... $17 \frac{1}{4}$

Longueur des doigts aux pattes de devant jusqu'au bout de l'ongle.. ....... 02

Circonférence des doigts derrière les ongles.. • $\quad 0 \quad 8$ i

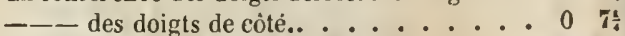

Longueur des doigts du côté extérieur. . . . . $0 \quad 0 \quad 3$

- _ des doigts de devant des pattes de der-

rière. ................ $01 \div$

- - des doigts extérieurs des pattes de der-

rière............... $01 \frac{}{4}$

__ des ongles des pattes de derrière et de derant................... 02

Circonférence des ongles à leur naissance. . . 0 4:

Longueur de la queue. ....... 14

Circonférence à la naissance nù elle est roude. $\quad \begin{aligned} & 5 \\ & \mathbf{3}\end{aligned}$

Largeur de la queue au milieu, où elle commence à derenir plate. ........... $05^{\frac{5}{6}}$

- - à l'extrémité. ............. $022 \frac{2}{2}$

Grosseur de la queue au milieu. ..... 0

- - de la queue au bout. . . . . . . 00 0

Lougueur des dents canines inférieures, mesnrées sur leur courbure. . . . . . . $07 \%$

_- mesurẻe eu ligne droite. . . . . . 0

Circonférence des dents, près la racine. . . 0 0 5

- au milieu. .......... 0 3:

— sur le tranchant. . . . . . . . 044

Longueur de lenr découpure inclinée. . . . $0 \quad 3 \frac{0}{4}$

Largeur des dents canines à leur raciue. . . 0 0 2: 
Largeur au inilieu............... 02

I.ongucur des dents canines supérieures. . . $0 \quad 0 \quad 2 \frac{5}{8}$

Circonférence. . . . . . . 0 4:

Distance des dents canines inférieures l'une de

lautre.............. 011

Longueur des dents incisives, ou des deur plus longues dents saillantes. .......

Leur circonférence. ......... 0 . 5

Dislance de l'une à l'autre. . . . . . . $00 \frac{0}{\frac{7}{6}}$

Longueur des pelites dents incisives, à côlé des grandes..................... $00^{2}$

Leur dislance des grandes. . . . . . . $000 \frac{1}{2}$

Distance entre celles-ci et les dents canines. . . 0

Longueur des dents molaires de la máchoire superieure, mesurées l'une après l'aulre.. .

Leur hauteur.. . . . . . . . .

Leur largeur. . . . . . . . . .

Longneur de denx aulres dents extraordinaires, de ligure cylindrique ou de quilles, distanles des dents molaires. . . . . . . .

Longnear des deux dents molaires de la màchoire inférieure. . . . . . . .

Hauteur des deux dents molaires de la måchoire inférieure. ...........

Leur largeur.. . . . . . . . .

Longueur des trois dents extraordinaires, de forme cylindrique, éloignées des dents molaires. ...............

Leur largeur. . . . . . . . . .

Longueur des deux dents incisives cyliudriques ćloignées de la dent cauine : cellequi se trouve le plus proche de la courle dent canine, tonbe en màchant perpendiculairement contre la petile dent horizoutale qui se irouve du cỏlé exlérieur de la màchoire inférieure. .

Longueur de la seconde, qui se trouve un peu plus sur le devant, el qui est un peu plus lougue el plus grosse; celle-ci tombe en michant droit à côlé, aussi du còté extérieur de la grande dent horizontale, où l'on peut facilement distinguer combien elle est usée; de mème que l'endıoit usé près des alveioles de la grande deut canine, cause par le frotlement de la pelite. . . . . . . .

Longueur du poil qui sc Ironve anx lèvres supérieure et inférieure, avec la racine. . . .

Longueur du poil qui se trouve aux còtés trancliauls et a l'exirémité de la queue, ce poil étant au reste semblable à celui des lèvres. .

Nots. Le poil de ta parlie supérieure de la queue est tombé en cupaillant l'aninal; ta tigure ınonIre la quene comme elle a été.

"Lorsque l'on compare cette mesure avee celle de la femelle de l'hippopotame de Zerenghi, et si l'on prend garde à la différence des mesures, on verra fiteilement qu'elles sont à peu près égales, ou du moinsqu'elles approchent beaucoup l'une de l'autre.

" On m'a dit que eet hippopotame était fort avancé dans tes terres du Cap, et mème près de
- l'endroit nommé les Montagnes de neige, lorsqu'il a été tiré par un paysan, nommé Charles Marais, d'extraction francaise. Ce pay san en a fait tenir les peaux à M. de Piettenberg, gouverneur du Cap, qui les a envoyées à S. A. S. Ce rapport m'a été fait par un neveu de C. Marais, qui se trouve a Amsterdam. Suivant le dire de cet homme, qui assure le tenir de la bouche de Marais même, l'hippopotame est fort agile à la course, tant dans la boue ct la fange, que sur la terre ferme; et il court si vite, que les paysans, quoique bons ehasseurs, n'osent tirer sur lui lorsqu'il se trouve hors de l'eau. Mais ils l'épient au soleil couchant : alors cet animal élève la partie supérieure de la tête hors de l'eau, tient ses petites oreilles dans une continuelle agitation pour écouter s'il n'entend aucun bruit. Lorsque quelque objet qui peut lui servir de proie se fait voir sur l'eau, il s'élance sur lui, et part eomme une flèche de l'are, pour s'en rendre maittre. Tandis que l'hippopotame est oceupé de cette manière à écouter en nageant ou flottant sur l'eau, on cherche à le tirer à la tête. Celui que j'ai empaillé avait été tiré entre l'œil et l'oreilledroite ; t le jeune, qui est placé de même au Cabinet de S. A. S., avait été tiré ou harponné dans la poitrine, comme on pouvait le voir facilement. L'hippopotame, Iorsqu'il se sent blessé, plonge sous l'eau, et marche ou nage jusqu'à ce qu'il perde le mouvemeut avee la vie. Alors, par le moyen de vingt bœufs, plus ou moins, on le tire sur le rivage où on le dissèque. Un hippopotane qui a toute sa croissance donne ordinairement deux mille livres de lard, qu'on sale et qu'on envoie au Cap, où il se vend fort eher. On assure que ce lard est fort bon, et qu'il surpasse toutes les autres graisses pour le goût. II ne cause jamais d'aigreurs; et quand il est exprimé, il fournit une huile douce et blanche comme de la crème: on recommande mème ce lard en Afrique comme un remède souverain contre les maladies de poitrine.

"Par la quantité indiquée de lard qu’on tire ordinairement de l'hippopotame qui a atteint toute sa eroissance, on est confirmé dans la remarque qu'on a déjà dù faire par les mesures données : savoir que c'(st un animal d'une gran. deur et d'une pesanteur surprenantes.

"Quelques soins que je me sois donnés pour rendre cette pièce aussi légère qu'il était possible, je me suis vu contruint de me servir de tout ce qui pouvait aider ì la soutenir, et je 
crois qu'elle pèse quatre mille livres, y compris la planche sur laquelle je l'ai placée.

" Avant que je finisse ces observations, j'ajouterai ici quelques singularités relatives à l'histoire naturelle de l'hippopotame, qui ne se trouvent pas dans la description précédente.

" On a vu que l'hippopotame doit peut-être son nom à la ressemblance qu'il y a entre sa voix et le hennissement du cheval. Cependant nous avons des relations certaines qui assurent que son cri ressemble plus à celui de l'éléphant, ou aux sons roulants et bégayants d'une persomne née sourde. Quoi qu'il en soit, l'hippopotame forme encore une autre espèce de son ronflant lorsqu'il dort, ce qui le fait découvrir de loin. Pour prévenir le danger qu'il court par là, il se couche pour l'ordinaire sur des terrains marécageux, dans les roseaux, dont ou ne peut approcher que difficilement.

" Je n'ai trouvé nulle part la particularité que je tiens du parent de Marais, touchant la grande agilité de cet animal. On assure au contraire constamment qu'on l'attaque plus volontiers sur terre que dans l'eau, ce qui serait contradictoire s'il était aussi léger à la course. Selon quelques autres historiens, on lui coupe le passage à la rivière par des arbres et des fossés, parce que l'on sait qu'il préfere de regagner l'eau, plutôt que de combattre ou de fuir à terre. Il se trouve, à cet égard, plus avantageusement dans l'eau, où il n'a aucun animal à eraindre. Le grand requin et le crocodile évitent l'hippopotame et n'osent pas s'engager au combat avec lui.

" La peau de l'hippopotame est extrêmement dure sur le dos, la croupe et la partie extérieure des cuisses et des fesses, de sorte que les balles de fusil coulent par-dessus, et que les flèches en rebondissent. Mais elle est moins dure et moins épaisse sous le ventre et aux parties intérieures des cuisses, où l'on cherche à le tuer ou à lui enfoncer le dard. Il a la vie fort dure et ne se rend pas facilement; c'est pourquoi l'on cherche à lui easser, paradresse, les.pattes, en le tirant areede gros mousquets chargés de lingots ; quand on y réussit, on est, pour ainsi dire, maitre de l'animal. Les Nègres, qui attaquent les recquins et les crocodiles avec delongs couteaux et desja velots, craignent l'hippopotame, qu'ils n'oseraient peutêtre jamais combattre s'ils ne couraient pas plus vite que iui. Ils croient néanmoins que cet animal est plus ennemi des Blancs que des Nègres.
"La femelle de l'hippopotame fait son petit a terre; elle l'y allaite et nourrit, et ensuite elle lui apprend de bonne heure à se réfugier dans l'eau au moindre bruit.

"Les Nègres d'Angola . de Congo, d'Elmina, et en général de toute la côte occidentale d'Afrique, regardent l'hippopotame conme une de ces divinités subalternes qu'ils nomment fétiche. Ils ne font cependant aucune difficulté d'en manger la chair, lorsqu'ils peuvent se resdre maitres d'un de ces animaux.

" Je ne sais si j'ose citer ici le passage du père Labat, où il dit que cet animal, qui est très-sanguin, sait se tirer lui-même du sang d'une manière particulière. Pour cet effet, cet animal cherche, dit-il, la pointe tranchante d'un rocher, et s'y frotte jusqu'à ce qu'il se soit fait une ouverture assez considérable pour en laisser couler le sang. Il se donne alors beaucoup de mouvement pour le faire sortir en plus grande quantité ; et lorsqu'il juge qu'il en a perdu assez, il se roule dans la fange, afin de fermer la blessure qu'il s'est faite. On ne trouve rien d'impossible dans ce rapport; mais comment le père Labat a-t-il découvert cette singularité?

" Outre les usages sus-mentionnés de la peau et des dents, on assure que les peintres indiens se servent du sang de cet animal pour leurs couleurs.

\section{NOUVELLE ADDITION}

\section{A L'ARTICLE DE L'HIPPOPOTAME.}

Comme les feuilles précédentes ${ }^{1}$ étaient déjà imprimées, j’ai reçu de la part de MI. Schneider des observations récentes sur cet animal, qui ont été rédigées par M. le professeur Allamand, et publiées à Amsterdam au commence. ment de cette année 1781 . Voici l'extrait de ces observations :

"Ce que M. de Buffon a dit de l'hippopotame était tout ce qu'on en pouvait dire de plus exact dans le temps qu'il écrivait cet article. Il me parut alors qu'il n'y manquait qu'une planche qui représentât mieux cet animal, qu'il n'est reprécsenté dans les figures que diver's auteurs en ont

1 Les feuilles dont il est ici question sont les premières du sixième volume des Suppléments de l'édition in-10 publie en 1782. Elles renferment des additions aux articles du bumle. de l'élépliant et du chameau. 
données. Je pris la liberté d'en ajouter une à la description de M. de Buffon, faite d'après une peau bourrée, qui est dans le Cabinet de l'Université de Leyde depuis plus d'un siècle.

"Deux années après, j'en donnai une meilleure; une peau récemment envoyée aü Cabinet de S. A. S. Mgr le Prince d'Orange me servit de modèle. Elle avait été très-bien préparée par M. le docteur Klockner ; je l'accompagnai de quelques remarques intéressantes qui m'avaient été communiquées par $M$. le capitaine Gordon.

" Je croyais que cela suffisait pour faire bien connaitre cet animal, lorsque le même II. Gordon m'envoya, au commencement de cette année 1780 , deux dessins qui représentaient un hippopotame mâle et une femelle, faits d'après les animaux mêmes, au moment qu'on venait de les tuer. Je fus frappé, en les comparant avee les figures que j'en avais donnćes, et je vis clairement que la peau d'un si gros animal, quoique préparée et dressée avec tout le soin possible, était bien éloignée de représenter au juste sou original : aussi n'hésitai-je pas à faire graver ces deux dessins; on les trouvera dans les planches I et II.

"M. Gordon a encore eu la bonté d'y joindre des descriptions et de nouvelles observations très-curieuses, qu'il a eu fréquemment occasion de faire. Son zèle infatigable pour les nouvelles découvertes, et pour l'avancement de l'Histoire naturelle, l'a engagé à pénétrer beaucoup plus avant dans l'intérieu' de l'Afrique, qu'il ne l'avait fait encore; et si les hippopotames sont devenus rares aux environs du cap de Bonne-Espérance, il les a trouvés très-nombreux dans les lieux où il a été. On n'en doutern pas quand on saura que, pour sa part, il en a tué neuf, et que dans une chasse à laquelle il a assisté avec M. de Plettenberg, gouverneur du Cap, on en a tué vingt-un en quelques heures de temps, et que mème ce ne fut qüà son intercession qu'on n'en fit pas 111 plus grand carnage. Cette chasse se fit sur la rivic̀re qu'il a nommée Plellenbery, à peu près à 7 decrrés de longitude ì l'est du Cap, et ì 30 degrés de latitude méridionale. Le nombre de ces animaux doit done ètre fort grand dans tout l'intérieur de l'Afrique, où ils sont peu inquictís par les habitants. C'est là où il les faut roir pour ies hien connaitre, et jamais personne n'en a eu une plus belle occasion que II. Gordon; aussi eu a-t-il profité en les observant avec les yeux d'un véritable naturaliste. En donnant l'extrait de ce qu'il m'en a écrit, je suppose que le lecteur se souvient du contenu des articles de cet ouvrage, oit il est parlé de ces animaux.

Lorsque les hippopotames sortent de l'eau, ils ont le dessus du corps d'un brun bleuâtre qui s'éelaircit en descendant sur les côtés, et se termine par une légère teinte de conleur de chair; le dessous du ventre est blanchâtre: mais ces différentes coulcurs deviennent plus foncées partout, lorsque leur peau se sèche. Dans l'intérieur et sur les bords de leur's oreilles, il y a des poils assez. doux et d'un brun roussâtre; il y en a aussi de la méme couleur aux paupières, et par-ci par-là quelques-uns sur le corps, particulièrement sur le cou et les cótés, mais qui sont plus courts et fort rudes.

"Les mâles surpassent toujours les femelles en grandeur', mais non pas d'un tiers, comme l'a dit Zerenghi, si l'on en excepte les dents incisives et eanines, qui dans la femelle peurent en effet être d'un tiers plus petites que dans le male. M. Gordon a tué une femelle dont la longueur du corps était de onze pieds, et le plus grand hippopotame mâle qu'il ait tué était long de onze pieds huit pouces neuf lignes. Ces dimensions diffèrent beaucoup de celles qu'a données Zerenghi : car, à en juger par les dimensions de la femelle qu'il a déerite, le mâle, d'un tiers plus grand, devait ètre long de seize pieds neuf pouces; elles diffèrent plus encore de celles des hippopotames du lae de Tzana, dont quelques-uns, suivant M. Bruce, ont plus de vingt pieds en longueur. Des animaux de cette dernière grandeur seraient éuormes; mais on se trompe facilement sur la taille d'mn animal quand on en juge uniquement en le vovant de loin et sans pouroir le mesurer.

"Le nombre des dents varie daus les hippopotames suivant leur îge, comme. M. de l3uffon l'a soupcomné : tous ont cuatre dents incisives et deux eanines dans chaque michoire; mais ils diffèrent dans le nombre des molaires: colui dont j'ai donné la figure avait trente-six clents en tout ; M. Gordon en a vu un qui avait vingtdeux dents dans la machoire superieure et vingt dans linférieure. Il ma envoys une tite qui en a dix-huit dans la michoire d'en bas et dixneuf dans celle d'en haut: mais ces dlents surnuméraires ne sont ordinairement que de pe- 
tites pointes qui préeèdent les véritables molaires, et qui sont peu fermes.

"La largeur de la partie de la mâchoire supérieure, qui forme le nuseau est de seize pouces et un quart, et son contour, mesuré d'un angle de la gueule jusqu'à l'autre, est de trois pieds trois pouces; la lèvre supérieure avance d'un pouce par-dessus l'inférieure et cache toutes les dents : à côté des incisives antérieures d'en haut, il y a deux éminences clıarnues qui sont reçues dans deux cavités de la mâchoire inférieure, quand la gueule se ferme.

"L'hippopotame a les yeur petits; leur plus loug diamètre est de onze lignes, et leur largeur de neuf et demie; la prunelle est d'un bleu obseur, et le hlane de l'œil parait peu.

"La queue varie en longueur dans ces animaux : celui qui est représenté ici en avait une de la longueur d'un pied trois ponces six lignes; son contour à son origine était d'un pied sept ponces: là, elle a une forme un peu triangulaire, et un des côtés est plat en-dessous : ainsi, ayant un mouvement perpendiculaire, elle bouche exactement l'ouverture de l'anus; vers son milieu, ses cótés s'aplatissent, et son articulation lui permettant un mouvement horizontal, elle peut servir à diriger l'animal (quand il nage. Au premier coup d'œil, elle paraît couverte d'écailles, mais qui ne sont que des rides de la peau; les bords extérieurs de cette queue semhlent être des coutures arrondies.

"Le pénis, tiré hors de son fourreau, est long de deux pieds un ponce six lignes, et ressemble assez à celui du taureau; sa circonférence près du corps est de neuf pouces; et à un pouce de son extrémité, elle est de trois pouces neuf lignes : quand il est tout à fait retiré, sa pointe est recouverte par des anneaux charnus et ridés qui terminent le fourreau ; c'est sur la base de ce fourreau, du cỏté de l'anus, que sont placés les mamelons. Dans plusicurs des hippopotames que M. Gordon a examinés, il a trouvé que le fourreau même était entièrement retiré en dedans du corps, aussi bien que le péns, et que le veutre étilit tout à fait uni ; s'il paraissait dans les autres, c'était par l'elfet des mouvements qu'ils avaient éprouvés quand on les avait tirés à terre. Les testicules ne sout pas renfermés dans un scrotum extérieur; jls sont en dedans du corps, et ne paraissent point eu de. hors ; on peut les sentir à traver's l'épaisscur de la peau : ainsi tout ce qui appartient à ces parties est caché en dedans, excepté dans les temps du rut.

"Dans la femelle, au-dessous de l'cntrée du vagin, est un follicule qui a environ deux pouces de profondeur, mais ou l'on ne peut voir aucune ouverture en dedans: il ressemble assez à celui de l'hyène, excepté qu'il est audessous de la vulve, au lieu que dans l'hyène il est situé entre l'anus et la queue. L'hippopotame femelle n'a point de mamelles peudantes, mais seulement deux petits mamelons; quand on les presse, jl en jaillit un lait doux et aussi bon que celui de la vache.

"Les os de ces animaux sont extrêmement dur's; dans un os de la cuisse, scié en travers, on trouva un canal long de cinq pouces et de dix lignes de diamètre, assez ressemblant à la cavité oú est la moelle : cependant il n'y en avait point immédiatement après la mort; mais on y vit uu corps fort dur, où l'on croyait remarquer du sang.

"La largeur du pied de devant est égale à sa longueur; l'une et l'autre est de dix pouces : la plante du pied de derrière est tant soit peu plus petite; elle a neuf pouces neuf lignes dans ses deux dimensions. Ces pieds sont propres pour nager; car les doigts peuvent se mouvoir, s'approcher les uns des autres et se plier en des. sous. Les ougles sont un peu creux, comme les sabots des autres animaux. Le dessous du picd est une semelle fort dure, séparée des doigts par une fente profonde; elle n'est pas horizontale, mais un peu en biais, comme si l'animal en marchant avait plus pressé son pied d'un còté que de l'autre : aussi les a-t-il tous un peu tournés en dehors. Commeil a les jambes courtes et les jointures pliables, il peut appliquer et presser ses jambes contre le corps; ce qui lui facilite encore les mouvements nécessatires pour nager. Aidé de quelques hommes, M. Gordon a roulé, comme un tomeau, un grand hippopotame hors de l'eau, sur' un terrain uni, sans que les pieds lissent un obstacle sensible.

"Quoique les hippopotames passent une partie de Icur vic dans l'eau, ils ont cependant le trou orale fermé. Quand is sont parrenus à toute leur grandeur, le plus long diamètre de leur cour est d'un pied...

" II. Gordon s'est assuré, par l'ouverture de plusieurs hippopotames jeunes et adultes, que ces animaux n'ont qu'uu seul estomac et ne ru- 
minent point, quoiqu'ils ne mangent que de l'herbe cu'ils rendent en pelotte et mal broyée dans leurs ex‘réments.

" J'ai dit · i-devant, continue M. Allamand, qu'il me parnissait très-douteux que les hippopotames mangeassent des poissons; à présent je puis dire qu'il est presque certinin qu'il n'en mangent pas. Dans une trentaine de ees animaux, dont M. Gordon a fiit ouvril les estomacs en sa présence, il n'y a trouvé que de l'herbe, et jamais aucun reste de poisson. J'ai dit aussi qu'il n'y avait pas d'apparence qu'ils entrassent dans la mer ; on peut roir, dans l'endroit eité, les raisons que j'avais pour' penser' ainsi, et M. de Buffon semble avoir été dans la mème idée. Les nouvelles olsservations de M. Gor:lon m'ont désabusé : il a tué un hippopotame à l'embouchure de la riviere Gambous, nì l'eau était salée; il en a vu dans la baie de Sainte-Hélène, et il en a vu sortir d'autres de la mer à deux lieues de toute rivière. A la vérité ils ne s'éloignent pas beaucoup de terre; la nécessité d'y venir prendre leur nourriture ne le leur yermet pas : ils ront le long des côtes d'une rivière i l'autre, cependant cela suffit pour prou ier qu'ils peuvent vivre dans l'eau salée, et justifier en quelque façon ceux qui leur ont donué le nom de chevaux marins, aussi bien que Kolbe, qui suppose qu'ils vivent indifféremmerit dans les rivières et dans la mer. Ceux qui habitent dans l'intérieur du pays 12 'y ront vraisemblablement jamais : si ceux qui en sont pries y entrent, ce n'est pas pour aller fort loin, à cause de la raison que je viens de dire, et cette même raison doit les engager à préférer les rivières.

" Lorsqu'ils se rencontrent au fond de l'eau , il: cherehent à s'éviter; mais sur terre il leur arrive souvent de se battre entre eux d'une nialière terrible : aussi en voit-on fort peu qui llaient pas quelques dents cassées ou quelques cieitrices sur le corps, dont on voit des marques dauns les figures des planches 1 et 2 ; en se battant ils se dressent sur leurs pieds de derrière, et e'est dans cette attitude qu'ils se mordent.

"Dans les lieux ou ils sont peu inquétés, ils ne sont pas fort craintifs; yuand on tire sur eux, ils viennent voir ce que c'est : mais (quind une fois ils ont appris à comnitite l'effet des ar-

1 Planclies inutiles mes à feu, ils fuient devant les hommes en trottant pesamment, comme les cochons; quelque. fois même ils galopent, mais toujour's pesamment : cependant un homme doit marcher bien vite pour être en ćtat de les suive. M. Gordon en a accompagné un pendant queleque temps; mais, quoiqu'il courût très-vite, si la course avıit été plus Iongue, l'lippopotame l'aurait devaneé.

"M. de Buffon a eu raisou de rérocquer en doute ce que disent quel(ques voyageurs des femelles hippopotames, e'est qu'elles portent trois on quatre petits : l'analogie l'a conduit à regarder ce fait comme très-suspect ; l'observation en démontre la fausseté. M. Gordon a vu ouvrir plusieurs femelles pleines, et jamais il n'y a trouvé qu'un seul petit; il en a tiré un du corps de la mère, qu'il a eu la bonté de m'enroyer : ce fortus, qui était presque entièrement formé, était longr de trois pieds deux pouces; le cordon ombilical était parsemé de petits boutons de couleur rouge; ses ongles étaient mous et élastiques; on pouvait déjá lui sentir les dents, et ses yeux avaient à peu près leur forme et toute leur grandeur. Dès qu'un jeune hippopotame est né, son instinct le porte à courir is l'eau, et quelquefois il s'y met sur' le dos de sa mère.

La chair de l'hippopotame, comme il a été dit ci-devant, est fort bonue au gout et trèssaine; le pied ròti est surtout un morceau délicat, de mème que la queue. Quand on fait cuire son lard, il surnage une graisse que les paysans aiment fort : e'est un remède qu'on estime beatucoup au Cap, en exagérant cependant ses qualités.

"Pour bien fixer nos idées sur la srandeur de ces animaux, et sur la proportion (qu'il y a entre celle du mâle et de la femelle, je donnerii ici leurs dimensions telles qu'elles ont étć prises par M. Gordon sur deux des plus grands sujets qu'il ait eu oceasion de voir, (quoiqu'elles different de celles qu'on peut prendre sur des peaux bourrées; on sera surpris qu'elles s'accordent si bien avee celles que Zerenghi a domnies : je les ai aussi vérifiées sur la peau d’un grand hippopotame mâte que S. A. S. Mar le prince d'Orange a en la bonte de me domner, pour ètre placée au Cabinet des euriosites naturelles que j'ai formé daus l'L Iniversitéde Le yde. Cette peau, réermment chroyée du eap de Bonne-Espérance, est mrivec cutière et bien conservée, 
jai heureusement réussi à la faire dresser suivant le dessin que j’ai reecu de M. Gordon, de manière qu'elle offre aussi exactement qu'il est possible la figure de l'animal vivant.

\section{DESGRIPTION DE L'HIPPOPOTAME.}

(EXTRATT DE DAUBENTON. ;

Nous n'avons point vu d'hippopotame adulte; cette description n'a pour sujets qu'un fotus et iles têtes décharnées d'hippopotames, qui sont au Cabinet du Roi, et les os des pjeds, yui nous ont été communiqués par M. Bernard de Jussieu.

Le foetus est représenté, conclié sur une table près des instruments d'anatomje, qui doivent servir à le dissé(juer; on aperçoit à travers une fenêtre dans le lointain un grand hippopotame, copie d'après la figure qu'en a donnće Fabius Columna ; cet hippopotame est sur les borls du fleuve du Sénégal, désigné par un Baolab.

Le museau est très-gros en comparaison de la tète et du corps ; il est beaucoup plus gros que celui l'un fotus de cheval ou de tanreau, il a plus de rapport à un mulle de lion; le museau de l'hippopotame est terminé en avant par une face plate que la bouche partage inécalement, car la lèvre inférieure ne fait qu'un ticrs de cette face ; la lèvre supérieure est plus saillante sur les côtćs de la bouche que la lèvre inférieure ; îl y a déjà sur celle-ci une échancrure de clıaque côté à l'endroil que les dents canines doivent occuper dans la suite; les narines sont placées sur la partie supérieure du bout du museau; elles sont ovales et disposées de façon que leurs extrémités postérieures sont plus éloignées l'une de l'autre que les antérieures; les orbites des yenx sont saillants, principalement par leur partie supérieure; les yeux sont petits et placés sur le haut des côtés de la tête ; les oreilles sont très-petites et arrondies; le cou est presque anssi gros que la tète; le corps est court et étoffé; la quene n'a que très-peu de largeur, elle est aplatie sur les côtés de son extrémité; les janbes sont fort courtes, surtout la jambe proprement dite; car le talon est très-près de la fesse, il est au contraire fort éloigné cles doigts ; cependant la plante du pied ne s'étend guère plus loin que les doigts; l'hippopotame les a fort courts et mème fort imparfaits ; il y en a quatre à chaque pied, les denx ulu milieu ne sont séparés l'un del'autre que sur la longrueur de trois lignes au delà des sabots ; le doigrnt externe de chaque cóté est reculé à sept lignes de distance du sabot du doigt interne, mais il n'est séparé de ce doigt que sur la longueur de cinq lignes au delà de son propre sahot; les deux sabots et les deux doigls du milien sont un pen plus grands çue les sabots et les doigts exterues : il n' y a pres(jue aucune différence tans le foetus, contre les roigts des pieds de devant et ceux des pieds de dervière, ni entre ceux du pied droit et ceux du pied gauche.

J'ai vu le pied d'un hippopotame, qui avait onzc à douze pouces de citconférence à l'enilroit du poignet : c'était le pierl gauche; le second doight avait un peu plus de longueur que le troisième, ces denx doigts avaient quatie pouces de circonférence, et les deux autres environ trois pouces; ceux du milieun nétaient éloignẻs de l’antre qu» sur la longueur d'envirun trois lignes au delà des sabots comme dans le foetus ; mais les doigts externes étaient reculés jusqu’à un pouce et demi de distance des sabots des doigts interues; ils n'étaient séparés de ces doigts que sur la longueur d'un pouce; les sabots des doigts du milieu ont environ quator\%e lignes de longueur dans le milieu, et autant de largeur à la base; tous les sabots étaient minces et avaient une couleur mẻlée de brun et de jaunàtre; l'épitlerne de ce pied et de ce poignet était tombé; la fleau avait une couleur jaunâtre, et élait ridée en différents sens, elle avait jusqu'à deux lignes et demie d'épaisseur.

Celle cle la peau du fietus n'est que ilenviron deux lignes dans les endroits les plus épais; elle a une couleur brume et olivatre ; elle est aussi ridée en différents sens, principalement en travers, relativement à la longueur du corps ; il y a quelques poils naissants autour des narines et de la bouclıe sur le bout du nurseau, autour des oreilles et autour de l'extrémité de la queue, qui est plate; ces poils sont blonds, ceux de la queue ont quatre lignes le longueur.

Ce fous a son cordon ombilical, qui est long d'un pied, large de huit on neuf lignes, el cpais de deux ou trois lignes; il est parsene de tubercules d'une ou deux ligues de dianètre et même fus, en partie affaissés et racomis par l'impression de l'esprit-dle-vin. 


\section{DE LA DÉGENERATION}

\section{DES ANIMAUX.}

Dès que l'homme a commencé à changer de ciel, et qu'il s'est répandu de climats en climats, sa nature a subi des altérations: elles ont été légères dans les contrées tempérées, que nous supposons voisines du lieu de son origine : mais elles ont augmenté à mesure (ju'il s'en est éloigné; et lorsque, après des siècles écoulés, des continents traversés, et des générations déjà dégénérées par l'influence des différentes terres, il a voulu s'habitue' dans les climats extrèmes, et peupler les sables du Midi et les glaces du Nord, les changements sont devenus si grands et si sensibles, qu'il y aurait lieu de croire que le nigre, le lapon et le blane forment des espèces différentes, si d'un côté l'on n'était assuré qu'il n'y a eu qu'un seul homme de eréce, et de l'autre que ce blanc, ce lapon et ce nègre, si dissemblants entre eux, peuvent cependant s'unir ensemble et propager en commun la grande et uniçue famille de notre genre humain. Ainsi leurs taches ne sont point originelles; leurs dissemblances u'étant qu'extérieures, ces altérations de nature ne sont que superficielles; et il est certain que tous ne font que le même homme, qui s'est verni de noil sous la zone torride, et qui s'est tanné, rapetissé par le froid glacial de la sphère du pole. Cela seul suffirait pour nous démontrer rquil y a plus de foree, plus d'étendue, plus de flexibilité dans la mature de l'homme yue dans celle de tous les autres êtres; car les végétaux, et presque tous les animaux sont confinés chacun à leur terrain, à leur climat: et cette étendue dans notre nature vient moins des propriétés lu corps que de celles de l'âme; e'est par elle que l'homme a cherché les secours qui étaient nécessaires à la délicatesse de son corps ; c'est par elle qu'il a trouvé les movens de braver linclémence de lair, et de vainere la dureté de la terre. Il s'est, pour ainsi dire, soumis les éléments; par un seul rayon de son intelligence, il a produit celui slu f'eu, qui n'existait pas sur la surface de la terre; il a su se vètir, s'abriter, se loger; il a compensé par l'esprit toutes les facultés yui manquent à la matière; et saus être ni si fort, ni si grand, ni si robuste que la plupart des aninaux, il a su les vaincre, les dompter, les subjuguer, les confiner, les chasser et s'emparer des espaces que la naturo semblait leur avoir exclusivement départis.

La grande division de la terre est celle des deux continents; elle est plus ancienne que tous nos monuments : cependant l'homme est encore plus ancien; car il s'est trouvé le même dans ces deux mondes: I'Asiatique, l'Européen, le nègre, produisent également arec l'A méricain; rien ne prouve micux qu'ils sont issus d'une seule et méme souche que la facilité qu'ils ont de se réunir à la tige commune: le sang est différent, mais le germe est le mẻme; la peau, les cheveux, les traits, la taille ont varié sans que la forme intérieure ait changá; le type en est général et commun : et s'il arrivait jamais par des révolutions qu'on ne doit pas prévoir, mais seulement entrevoir dans l'ordre génciral des possubilités que le temps peut tout's amener; s'il arrivait, dis-je, que l'homme fùt contraint d'abandouner les climats qu'il a autrefois envahis pour se réduire à son pays natal, il reprendrait avec le temps ses traits originax, sá taille primitive et sa couleur naturelle. Le rappel del'homme à son climat amènerait cet eff’et : le mélange des races l'amènerait aussi bien plus promptement; le blanc avec la noire, ou le noir avec la blanche, produisent éralement un mulatre dont la couleur est brune, è est-il-dne, mclée de blane et de noir; ce mulatre avec un blanc produit un second mulatre moins brun que le premier; et si ce second mulatre s'unit demème a un individu de race blanche, le troisieme mulitre n'aura plus qu'une nuance ligère de brun, qui disparaitra tout à fait daus les générations suivantes. Il ne faut done que cent cinquante ou deux cents ans pour laver la peatu d'un negre par cette voie du mólange avec le sang du blanc; mais il faudrait peut-jtre un as. se' grand nombre de siecles pour produire ce mème eflet par la seule influenec du climat. Depuis qu'on transporte des negres en Amerique, c'est-i-dire depuis eurron deux cent cinquante ans, l'on ne s'est pats apereñ que les familles noires (pui se sont soutenues sans inélange aient perolu fuelques nuanees de lent trinte origrinclle; il est vai que ee climat de I'Amérifue mériclionale stant par lui-mème asse\% chatud pour brunir ses habitunts, on ne doit pis sótomner que les niveres y demeurent noirs. Pour faire l'expérience du changement de couleur dans l'espece humaine, il faudrait trans. 
porter quelques individus de cette race noire du Sénérgal en Danemarck, oủ l'homme ayant communément la peau blanche, les chevenx blonds, les yeux bleus, la différence du sang et l'opposition de coulcur est la plus grande. Il fandrait cloitrer ces nègres avec leurs femelles, et conserver scrupuleusement leur race sans leur permettre de la eroiser : ce moyen est le seul qu'on puisse employer prour savoir combien il faudrait de temps pour réintégrer à cet égard la nature de l'homme, et, par la mème raison, combien il en a fallu pour la char ger du blane au noir.

C'est là la plus grande altération que le ciel ait fait subir à l'homme, et l'on voit qu'elle n'est pas profonde. La couleur de la peau, des cheveux et des yeux, varie par la seule influence du climat; les autres changements, tels que ceux de la taille, de la forme des traits et de la qualité des eheveux, ne me paraissent pas dépendre de cette seule cause; car, dans la race des nègres, lesquels, comme l'on sait, ont pour la plupart la tête courerte d'une laine crèpue, le nez épaté, les lères épaisses, on trouve des nations entières avec de longs et rais cheveux, avec des traits réguliers; et si l'on comparait dans la race des blanes le Danois au Calmouek, ou seulement le Finlandais au Lapom clont il est si voisin, on trouverait entre eux autant de différence pour les traits et la taille, qu'il y en a dans la race des noirs : par conséquent il faut admettre pour ces altérations, qui sontplus profondes que les premières, quelques autres causes réunies avee celle du climat. La plus générale et la plus directe est la qualité de la nourriture; e'est principalement par' les aliments que l'homme recoit l'influence de la terre qu'il habite : celle de l'air et cur ciel agit plus superficiellement; et taudis qu'elle aitère la surface la plus extérieure en changeant la couleur de la peau, la nourriture agit sur' la forme intérieure par ses proprictés yui sont constamment relatives à celles de la terre cqui la produit. On voit dans le mème pays des différences marquées entre les hommes qui en oceupent les hauteurs, et eeux qui demeurent dans les lieux bas; les habitants de la montagne sont toujours mieux faits, plus vifs et plus benux que ceux de la vallée : à plus forte raison dans des elimats éloignés du climat primitif, dans des climats où les herbes, les fruits, les grains et la chair des animaux sont de qualité et même de substance différentes, les hommes qui s'en nourrissent doivent devenir différents. Ces im. pressions ne se font pas subitement ni mème dans l'espace de gruelques annces; il faut du temps pour que l'homme reçois e la teinture du ciel; il en faut encore plus pour que la terre lui transmette ses (qualités; et il a fallu des siecles joints à un usage toujours constant des mèmes nourritures, pour influpr sur la forme des traits, sur la grandeur du corps, sur la sulstance des chereux, et produire ces altérations intérieures, qui, s'étant ensuit's pespétuées par la génération, sont devenues les caractères généraux et constants auxquels on reconnalt les races et même les nations différentes qui composent le genre humain.

Dans les animaux, ces effets sont plus prompts et plus grands, parre qu'ils tiennent á la terre de bien plus près que l'homme; parce que leur nourriture étant plus uniforme, plus constamment la mème, et n'étant nullement préparée, la qualité en est plus décidée et l'influence plus forte; parce que d ailleur's les animaux ne pouvant ni se rêtir, ni s'abriter, ni faire usage $d i^{\prime}$ l'élément du feu pour se réchauffer, ils demetirent nument exprosés, et pleinement livrés it l'action de l'air et a tontes les intempéries du climat: et c'est par cette raison que clacun d'eux a, suivant sa nature, choisi sa zone et sa contrée; c'est par la mème raison qu'ils y sont retenus, et quau lieu de s'étendre ou de se disperser comme l'lsomme, ils demeurent pour la plupart concentrés dans les lieux qui leur conviennent le mieux. Et lorsque, par des révolutions sur le globe ou par la force de l'homme, ils ont été coutraints d'abandonner leur terre natale, cu'ils ont été clıassés ou relégués dans des climats éloignés, leur nature a subi des altérations si grandes et si profondes, qu'elle n'est pas recomnaissable à la première vue, et que pour la juger il faut avoir recours à linspection la plus attentive, et méme aux expériences et à l'analogie. Si l'on ajoute à ces eauses naturelies d'altérations dans les animaux libres, celle de l'empire de l'homme sur ceux qu'il a réduits en servitude, on sera surpris de voir jusqu’à quel point la tyrannie peut dégrader, défigurer la nature; on trouvera sur tous les animaux esclaves les stigmates de leur captivité et l'empreinte de leurs fers; on verra que ces plaies sont d'autant plus grandes, d'antant plus incurables, qu'elles sont plus anciennes, et que dans 
l'état où nous les avons réduits, il ne serait | peut-être plus possible de les réliabiliter, ni de leur rendre leur forme primitive, et les autres attributs de nature que nous leur avous enler és.

Le température du elimat, la qualité de la nourriture et les maux d'esclavage, voilà les trois causes de changement, d'altération et de dégénération dans les animaux. Les effets de chacune méritent d'être considérés en particulier, et leurs rapports vus en détail nous présenteront un tableau au-devant duquel on verra la nature telle qu'clle est aujourd'hui, et dans le lointain on apercevra ce qu'elle était avant sa décradation.

Comparons nos ehétives brebis avec le mouflon dont elles sont issues : celui-ci, grand et léger comme un cerf, armé de cornes défensives et de sabots épais, couvert d'un poil rucle, ne craint ni l'inclémence de l'air, ni la voracióé du loup; il peut non-seulement éviter ses enuemis par la lègèreté de sa course, mais il peut aussi leur résister par la force de son corps, et par la solidité des armes dont sa tète et ses pieds sont munis. Quelle différence de nos brebis auxqquelles il reste à peine la faculté d'exister en troupeau, qui mème ne peuvent se défendre par le nombre, qui ne soutiendraient pas sans abri le froid de nos hivers, enfin qui toutes périraient si l'homme cessait de les soigner et de les protéger. Dans les climats les plus chauds de l'Afrique et de l'Asie, le mouflon, qui est le père commun de toutes les races de cette espèce, parait avoir moins dégénéré que partont ailleurs ; quoique réduit en domesticité, il a conservé sa taille et son poil : seulement il a beaucoup perdu sur la grandeur et la masse de ses armes. Les brehis du Sénégal et des lndes sont les plus grandes des brebis domestiques, et celles de toutes dont la nature est la moins dégradée : les brebis de la Barbarie, de l'Égypte, de l'Arabie, de la Perse, de l'Arménie, de la Calmouquic, etc., ont subi de plus grands ehangements ; clles se sont, relativement à nous, perfectiouncés à certains égards et vieiées à d'autres: mais comme se perfectionner ou se vicier est la même chose relitivement à la nature, elies se sont toujour's dénaturées; Icur poil rude s"est chingé en une laine fine; leur yuene, s'etant chargée d'une masse de graisse, a pris un volume incommode et si grand, que linnimal ne peut la traber qu'in ec peine; of en mene temps (qu'il s'est bouffi d'une matière superflue, et (u'il s'est paré d'une belle toison, il a perdu sa force, son agilité, sa grandeur, et ses armes ; car ces brebis a longue et large queue n'ont guère que la moitié de la taille du mouflon. Elles ne peuvent fuir le danger ni résister à l'ennemi; elles ont un besoin continuel des secours et des soins de l'homme, pour se conserver et se multiplier. La dégradation de l'espèce originaire est encore plus grande dans nos climats : de toutes les qualités du moufflon, il ne reste rien a nos brebis, rien à notre bélier, qu’un peu de vivacité, mais si douce, qu'clle cèle encore à la houlette d'une herrèere ; la timridité, la failslesse, et mème la stupidité et l'abandon de son être, sont les seuls et tristes restes de leur nature dégradée. Si l'on voulait la relever pour la force et la taille, il fuudrait unir le mouflon arec notre brebis flandrine, et eesser de propager les races inférieures; et si, comme chose plus utile, nous voulons dévouer cette espèce à ne nous donner que de la bonne chair et de la belle laine, il faudrait au moins, comme l'ont fait nos voisins, choisir et propager la race des brebis de Barbarie, qui, transportée en Espagne et même en Angleterre, a très-bien réussi. La force du corps et la grandeur de la taille sont des attributs masculins; l'embonpoint et la beauté de la peau sont des qualités féminines. Il fandrait done, dans le procédé des mélanges, observer cette difiérence, donner à nos bélicrs des femelles de Barbarie pour avoir de belles laines, et donner le mouffion à nos brebis pour en relever la taille.

Il eu scrait à cet égard de nos chèvres comme de nos brebis; on pourrait, en les mèlant avec la chève d'Angora, changer Jeur poil et le rendre aussi utile gue la plus belle laine. L'ispéce de la chèvre en général, quoique fort clérenérée, l'est cependant moins que celle de la brebis dans nos elimats; elle parait l'etre clavantage dans les pays chauds de l'Afrique et des Indes. Les plus petites et les plus faibles de toutes les ehèves sont celles de fiuincé, de Juda, etc., et dans ces mèmes climats l'on trouve au contraire les plus grandes et les plus fortes brehis.

L'espèce du bocuf est celle de tous les animaux domesticues sur liquelle la monrriture parait avoir la plus grande influenere; il devient d'une taille prodicgieuse dians les contrées vỉ le pàturage estriche et toujoursteniassant Les anciens 
ont appelé taureaux-éléphants les bœufs d'Éthiopie et de quelques autres provinees de l'Asie, où ces animaux approchent en effet de la grandeur de l'eléphant. L'abondance des herbes et leur qualité substantielle et suceulente produisent cet effet: nous en avons la preuve même dans notre elimat; un bœuf nourri sur les tètes des montagnes vertes de Savoie ou de Suisse aequiert le double du volume de celui de nos bœufs, et néanmoins ces bœufs de Suisse sont comme les notres enfermés dans l'étable et réduits au fourage pendant la plus grande partie de l'année : mais re qui fait cette grande difference, c'est qu'en Suisse on les met en pleine pâture, dès que les neiges sont fondues, au lieu que dans nos provinces on leur interdit l'entrée des prairies jusqu'après la récolte de l'herbe qu'on réserve aux chevaux. Ils ne sont donc jamais ni largement ni convenablement nourris ; et ce serait une attention bien nécessaire, bien utile à l'état, que de faire un réglement à cet égard, par lequel on abolirait les vaines pâtures en permettant les enclos. Le climat a aussi beaucoup influé sur la nature du bœuf: dans les terres du nord des deux continents, il est couvert d'un poil long et doux comme de la fine laine; il porte aussi une grosse loupe sur les épaules, et cette difformité se trouve également dans tous les bœufs de l'Asie, de l'Afrique et de l'Amérique. Il n'y a que ceux d'Europe qui ne soient pas bossus ; cette race d'Europe est cependant la race primitive à laquelle les races bossues remontent par le mélange dès la première ou la seconde génération : et ce qui prouve encore que cette race bossue n'est qu'une variété de la première, c'est qu'elle est sujette à de plus grandes altérations et à des dégradations qui paraissent excessives; ear il y a dans ces bœufs bossus des différences énormes pour la taille; le petit zébu de l'Arabie a tout au plus la dixième partie du volume du taurecu-ćléponant d'Ethiopie.

En général, l'influence de la nourriture est plus grande, et produit des effets plus scusibles sur les animaux qui se nourrissent d'herbes ou de fruits: eeux au contraire qui ue vivent que de proie, varient moins par cette cause que par linfluence du climat, parce que la chair est un aliment préparé et déja assimilé a la nature de l'animal carnassier qui la dévore; au lieu que l'herbe elant le premier produit de la terre, clle en a toutes les proprictés : et transmet immédia- tement les qualités terrestres à l'animal qui s'en nourrit.

Aussi le chien, sur lequel la nourriture ne parait aroir que de légeres influences, est néanmoins celui de tous les animaux carnassiers dont l'espèee est la plus variée; il semble suivre exactement dans ses dégradations les différeuces du climat : il est nu dans les pays les plus chauds, couvert d'un poil épais et rude dans les contrées du Nord, paré d'une belle robe soyeuse en Espagne, en Syrie, où la douce température de l'air change le poil de la plupart des animaux en une sorte de soie. Mais, indépendamment de ces variétés extérieures qui sont produites par la seule influence du climat, il y a d'autres altérations dans cette espèce qui pron viennent de sa condition, de sa captivité, ou, si l'on veut, de l'état de société du chien avec l'homme. l'augmentation ou la diminution de la taille viennent des soins que l'on a pris d'unir ensemble les plus grands ou les plus petits individus ; l'accourcissement de la queue, du museau, des oreilles, provient aussi de la main de l'homme. Les chiens auxquels de génération en génération on a coupé les oreilles et la queue, transmettent ces défauts en tout ou en partie à leurs descendants. J'ai vu des chiens nés sans queue, que je pris d'abord pour des monstres individuels dans l'espèce; mais je me suis assuré depuis que cette race existe, et qu'elle se perpétue par la génération. Et les oreilles pendantes, qui sont le signe le plus général et le plus certain de la servitude domestique, ne se trouvent-elles pas dans presque tous les chieus? Sur environ trente races différentes, dont l'espèce est aujourd'hui composée, il n'y en a que deux ou trois qui aient conservé leurs oreilles primitives. Le chien de berger, le chien-loup et les chiens du Nord ont seuls les oreilles droites. La voix de ces animaux a subi comme tout le reste d'étranges mutations. 11 semble que le chien soit devenu eriard avec l'homme, qui, de tous les ètres qui ont une langue, est celui qui en use et abuse le plus : car, dans l'état de nature, le chien est presque muet; il n'a qu'un hurlement de besoin par accès assez rares. Il a pris son aboiement dans son eommerce arec l'homme, surtout a rec l'homme policé : car lorsqu'on le transporte dans des climats extrèmes et chez des peuples grossiers, tels que les Lipons ou les Nègres, il perd son aboiement, reprend sa roix naturclle qui cst lc hurlement, et derient mêne 
quelquefois absolument muet. Les chiensà oreilles droites, et surtout le chien de berger, qui de tous est celui qui a le moins dégénéré, est aussi celui qui donne le moins de voix. Comme il passe sa vie solitairement dans la campagne et qu'il n'a de commerce qu'avec les moutons et quelques hommes simples, il est comme eux sérieux et silencieux, quoique en même temps il soit tres-vif et fort intelligent. C'est de tous les chiens celui qui a le moins de qualités aequises et le plus de talents naturels; e'est le plus utile pour le bon ordre et pour la garde des troupeaux, et il serait plus avantageux d'en multiplier, d'en étendre la race cue celles dles autres chiens, qui ne servent qu'il nos amusements, et dont le nombre est si grand, ([u'il n'y a point de ville où l'on ne put nourrir un nombre de familles des seuls aliments que les chiens consomnent.

L'itat de domesticité a beancoup contribué à faire varier la couleur des animaux : elle est en général ordinairement fauve ou noire. Le chien, le bœuf, la chève, la brebis, le cheval, ont pris toutes sortes de couleurs; le cochon a changé du noir au blanc; il paratit que le blane, pur et sans aucune tache, est à cet égard le signe du dernier degré de dégénération, et qu'ordinairement il est accompagné d'imperfections ou de défauts essentiels. 1)ans la raee des hommes blanes, ceux (qui le sont beaucoup plus que les autres et dont les cheveux, les sourcils, la barbe, etc., sont naturellement blanes, ont souvent le défauts d'ètre sourds, et d'avoir en meme temps les yeux rouges et faibles: daus la latee des noirs les nergres blanes sont encore d'une nature plus faible et plus défectueuse. Tous les animaux absolument blanes ont ordinairement ces mèmes défauts de l'oreille dure et des veux rouges: cette sorte de dégrénération, fuoicue plus liréquente dans les animaux clomestiques, se montre aussi quelquefois rlaus les especes libres, comme dans celles des éléphants, des cerfs, des daims, des guenous, des taupes, des souris; et dans toutes, cette couleur est toujours aceompagnée de plus on moins de faiblesse de corps et d'hébeitation des seus.

Mais l'espéce sur lacjuclle le poids de l'esclavage parait avoil le plus appuré et fait les impressions les plus profondes, e'est celle du chaincau. Il mait avee des loupes sur le dos, et des cailosités sur la poitrine et sur les grenoux : ces callosités sont des plaies évidentes oceasionnées par le frottement; car elles sont remplies de pus et de saug corrompu. Conume il ne marche jamais qu'avec une grosse charge, la pression du fardeau a commencé par empêcher la libre extension et l'accroissement uniforme des parties musculeuses du dos, ensuite elle a fait gonfler la chair aux endroits voisins; ct comme, lorsque le chameau veut se reposer ou dorrnir, on le contrannt d'abord à s'abattre sur ses jamibes repliées, et que peu à peu il en prend l'habitude de lui-méme, tout le poids de son colps porte pendant plusieurs heures de suité, charque jour, sur sit poitrine et ses genoux; et la peau de ces parties, pressée, frottée contre lat terre, se dépile, se froisse, se dureit et se désorganise. Le lama, qui, comme le chamealu, pásse sá vie sous le furdeau, et ne se repose aussi qu'en s'abattant sur la poitrine, a de semblables callosités qui se perpétuent de mème par la génç⿰tion. Les babouius et les guenons dlont la posture la plus ordinaire est d'ètre assis, soit en veillant, soit en dormant, ont aussi cles callosités au dessous de la récrion des fesses, et cette peau calleuse est même devenue inhérente aux os du derriere contre lespuels elle est continuellement pressée par le poids du corps : mais ces callosités des babouius et des guenons sont sèches et saines, parce ([u'elles ne proviennent pas de la contrainte des entraves ni du faix accablant d'un poids étranger, et qu'elles ne sont atu contraire que les efiets des habitukles naturelles de l'animal, qui setient plus volontier's et plus longtemps assis que daus aucune autre situation. Il en est de ces callosités dles guenons comme de la double semelle de peau que nous portons sous nos pieds : cette semelle est une eallosité naturelle que notre habitude constante à marelierou rester debout rend plus ou moins épaisse, ou plus on moins dure, selon le plus ou moins de frottement que nous faisons éprourer it la plante ole mos pieds.

Les animaux sauvages, n'étant pas imméciatement soumis a l'empile de l'homme, ne sont pas sujets à d'aussi grandes altérations que les animatux domestiunes; leur nature parait varier suivant les difforents climats, mais nulle part elle n'est dégradce. S'ils étaient absolument les maitres te ehoisir leur climat et leur nourriture, ces altérations seraient encore moindres : mais, comme de tout remps ils unt éti chassés, lelégevés par l'hommes, ou mome par cems d'entı cux gui out le plus de force et de méciraucete, 
la plupart ont été contraints de fuir, d'abandonner leur pays natal, et de s'habituer dans des terres moins heureuses. Ceux dont la nature s'est trouvée assez flexible pour se prêterà cette nouvelle situation se sont répandus au loin, tandis que les autres n'ont eu d'autre ressource que de se confiner dans les déserts voisins de leur pays. Il n'y a aucune espece d'animal, qui, comme celle de l'homme, se trouve généralement partout sur la surface de la terre : les unes, et en grand nombre, sont bornées aux terres méridionales de l'ancien continent; les autres, aux parties méridionales du Nou r eau-Nonde; d'autres, en moindre (quantité, sont confinées dans les terres du Nord, et, au lieu de s'étendre vers les contrées $d u$ Midi, elles ont passé d'un continent à l'autre par des routes jusqu'it ce jour incomnues; enfin, quelques autres espèces n'habitent que certaines montagnes ou certaines vallées, et les altérations de leur nature sont en général d'autaut moins sensibles qu'elles sont plus confinées.

Le climat et la nourriture ayant peu d'influence sur les animaux libres, et l'empire de l'homme en ayant encore moins, leurs principales variétés viennent d'une autre cause; elles sont relatives à la combinaison du nombre dans les individus, tant de ceux qui produisent, que de ceux qui sont produits. Dans les espèces, comme celle du chevreuil où le mâle s'attache à sa femelle et ne la change pas, les petits démontrent la constante fidélité de leurs parents par leur entière ressemblance entre eux : dans celles, au contraire, où les femelles changent souvent de mâle, comme dans celle du cerf, il se trouve des variétés assez nombreuses; etcomme dans tontela nature il ny a pas un seul individu qui soit parfaitement ressemblant à un autre, il se trouve d'autant plus de variétés dans les animaux, que le nombre de leur produit est plus grand et plus fiéquent. Dans les espèces où la femelle produit einq ou six petits, trois ou quatre fois par an, de màles différents, il est nécessaire que le nombre des variétés soit beaucoup plus grand que dans celles où le produit est annuel et unique; aussi les espèces inféricures, les petits animaux qui tous produisent plus souvent et en plus grand nombre que ceux des espèces majeures, sont-elles sujettes à plus de variétés. La grandeur du corps, (qui ne parait ètre qu'une quantité relative, a néanmoins des attributs positifs et des droits réels dans l'ordon- nance de la nature; le grand y est aussi fixe que le petit y est variable; on pourra s'en convaincre aisément par l'énumération que nous allons faire des variétés des grands et des petits animaux.

Le sanglier a pris en Guinée des oreilles trèslongues et couchées sur le dos; à la Chine, un gros ventre pendant et des jambes fort courtes; au cap Vert et dans d'autres endroits, des défenses tres-grosses et tournées comme des cornes de bouf; dans l'état de domestieité, il a pris partout des oreilles à demi-pendantes, et des soies blanches dans les pays froids ou tempérés. Je ne compte ni le pecari ni le babiroussa dans les variétés de l'espèce du sanglier, parce qu'ils ne sont ni l'un ni l'autre de cette espèce, quoiqu'ils en approchent de plus près que d'aucune autre.

Le cerf, dans les pays montueux, secs et chauds, tels que la Corse et la Sardaigne, a perdu la moitié de sa taille, et a pris un pelage brun a vec un bois noirâtre; dans les pays froids et humides, comme en Bohême et aux Ardennes, sa taille s'est ag̨randie, son pelage et son bois sont devenus d'un brun presque noir, son poil s'est allongé au point de former une longue barbe au menton. Dans le nord de l'autre continent, le bois du cerf s'est étendu et ramifié par des andouillers courbes. Dans l'état de domesticité, le pelage change du fauve au blanc; et à moins que le cerf ne soit en liberté, et dans de grands espaces, ses jambes se déforment et se courbent. Je ne compte pas l'axis dans les variétés de l'espèce du cerf; il approche plus de celle du daim et n'en est pent-être qu'une viriété.

On aurait peine à se décidel sur l'origine de l'espèce du daim; il ı'est nulle part entièrement domestique, ni nulle part absolument saurage; il varie assez indifféremment, et partout du fauve au pie et du pie au blanc: son bois et sa queue sont anssi plus grands et plus longs suirant les différentes laces, et sa chair est bonne ou mauraise sclou le terrain et le climat. On le trouve comme le cerf dans les deux contiments, et il parait ètre plus grand en Virginie et dans les autres provinces de l'Amérique tempérée, qu'il ne l'est en Europe. Il en est de méme du cherreuil; il est plus grand dans le nouveau que dans l'ancien continent : mais au reste toutes ses variétés se réduisent à quelques différences dans la couleur du poil qui change 
du fauve au brun; les plus grands cherreuils sont ordinairement fauves, et les plus petits sont bruns. Ces deux espeeres, le cherreuil et !e daim, sont les seuls de tous Jes animanx communs aux deux continents, (pui soient plus glands et plus forts dans te nouveau que dans Pancien.

L'âne a sulji peu de variétés, même dans sa condition de servitude la plus dure; car sa nature est dure aussi, et résiste égralement aux mauvais traitements et aux incommodités d'un climat fàcheux et d'une nourriture grossière. Quoiqu'il soit originaire des pays chauds, il pent vivre; et même se multiplier sans les soins dle l'homme, dlans les climats tempérés. Autrefois il y avait des onagres ou anes sauvages dans tous les deserts de l'Asic-Nlineure : aujourd'hui ils $y$ sont plus rares, et on ue les trouve en grande quantité que dans ceux de la Tatarie. Le mulet de Danurie ", appeléc zigitlui par l's Tatares Monguux, est probablement le mème animal que l'onagre des autres provinces de l'Asie; il n'en differe que par' la longueur et Ies couleurs du poil, çui, selou M. Bell, parait ondé de brun it de blane 2. Ces onagres czigithais se trouvent dans les forêts de la Tatarie juscqu'au cinquante et unième et eincquante-deuxième degrés; et il ne faut pas les confondre avee les zèbres, dont les couleurs sont bien plus vives et bien autrement tranchées, et (qui d'ailleurs forment une espèce particulière presque aussi différente de celle de l'àne que de celle du cheval. La seule dégénération remar(quable dans l'âne en domesticité, e'est (fue sa peau s'est ramollie et qu'elle a perdu les petits tubereules qui se trouvent semés sur la peau de l'onagre, de laquelle les Levantins font le cuir grenu, quion appelle chagrin.

Le liève est d'une nature flexible et ferme en méme temps, car il est répandu daus presque turis les climats de l'ancien continent, et par-

a Mulus Mauriens focenndus, Czigitlıa, Mougolorum in Maıria. Mus. Pefrepolitanum, pag. 553.

2 "In the forests near Kuznetsky, on the river Tom, one of - the somecist the river (oby, in lat 31 et 32 , are will asses. * I have secu many of their skins ; they have in all resprets - Iles shape of the head. tait ambl homfs of the common ass, but - lheir skiu is wated and mululaled while and hrown. Bell's - travels to Chini. v Nola. Il se pumrait cpue .1. Bell, yni dit

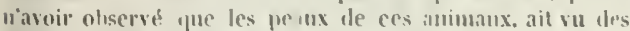
heaux de zelores; car le's antre's voyagums ne disent pas que

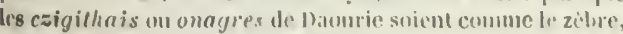

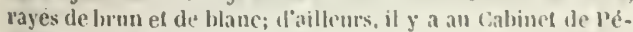
tersbourg des peamx de zelores ef des framr te czigilhais. quon moutre égalemeul aux voyageurs. tout il est à trés-peu près le mênıt : sculement son poil blanchit pendant l'hiver dans les climats très-froids, et il reprend en été sa couleur naturelle, qui ne varie que dı fauve au roux. La qualité de la chair varie de mênıe; Ies lièvres les plus rouges sont toujours les meilleur's à manger. Mais le lapin, sans ètre d'me nature aussi flexible que le lièvre, puisquil est beancoup moins répandu, et que mème il parait confiné à de certaines contrées, est néanmoins sujet à plus de variétés, parce que le lièrre est sauvage partout; an lieu que le lapin est presque partout a demi domestique. Les lapins clapiers ont varié pour la eouleur du fauve au gris, au blane, au noir; ils ont aussi varié par la grandeur, la quantité, la qualité du poil. Cet animal, qui est originaire d'Espagne, a pris en Tatarie une queue longue, en Syrie du poil touffu et pelotonné comme du feutre, ete. On trouve quelyuefois des lièrres noirs dans les pays fíoids. On prétend aussi qu'il y a dans la Norwége et dans quelques autres provinees du nord, des lièvres qui ont des cornes. M. Klein ' a fait graver deux de ces lièrres cornus. Il est aisé de junger, à l'inspection des figures, que ces cornes sont des bois semblables au bois du chevreuil. Cette variété, si elle existe, r'est qu'individuelle et ne se manifeste probablement que dans les endroits oủ le lièvre ne trouve point d'herbes, ct ne peut se nourrir que de substances ligueuses, d'é. corce, de boutons, de feuilles darbres, de li. chens, ete.

L'élan, dout l'espèce est confinée dans le nord des deux eontiments, est seulement plus petit en Amérique (qu'en Europe, et l'on voit par les énormes bois que l'on a trouvés sous terre en Canada, en Russie, en Siljérie, cte., qu autrefois ces animaux étaient plus grands ųu'ils ne le sont aujourd'hui : peut-ètre cela vient-il de ce quils jouissaient en toute tranquillité de leurs forets, et que, n'étant point inquićtés par l'homme, qui n’avait pas encore pénétré dans ces elimats, ils étaient maitres de choisir leur demeure dans les endroits ou l'air, la terre et l'eau leur convenaient le micux. Le renne, que les Lapons ont rendu domestique, a, par cette raison, plus changé que l'élan, qui n’a jamais été réduit en servitude. Les remues saurages sont plus grands, plus forts et d'un poil plus noir que les rennes domestiques : reus-ei ont

\footnotetext{
- kleiu, de Cual., pag. \$2, lab. 11, lig. ad 5 sx.
} 
beaucoup varié pour la couleur du poil, et aussi pour la grandeur et la grosseur du bois. Cette espèce de lichen ou de srande mousse blanche qui fait la principale nourriture du renne, semble contribuer beaucoup par sa qualité à la formation et à l'aceroissement du bois, qui proportionmellement est plus grand dans le renne que dans ancune autre espèce; et c'est peut-ètre cette même nourriture cui , dans ce climat, produit du bois sur la tète du lièvere, comme sur celle de la femelle du renne; car dans tous les autres climats, il n'y a ni lièvres cornus, ni aucun animal dont la femelle porte du bois comme le mâle.

L'espèce de l'éléphant est la seule sur laquelle l'état de servitude ou de domesticité n'a jamais influé, parce que dans cet état il refuse de produire, et par conséqueut de transmettre à son espèce les plaies ou les défauts occasionnés par sa condition. Il n'y a dans l'éléphant que des variétés légères et presque individuelles : sa couleur nąturelle est le noir ; cependant il s'en trouve de roux et de blanes, mais en très-petit nombre. L'éléphant varie aussi pour la taille suivant la longitude plutòt que la latitude du climat; car sous la zone torride, dans laquelle il est, pour ainsi dire, renfermé et sous la mème ligne, il s'élève jusqu’à quinze pieds de hauteur dans les contrées orientales de l'Afrique, tandis que dans les terres oecidentales de cette mème partie du monde, il n'atteint guère qu'à la hauteur de dix ou onze pieds; ce qui prouve que, quoique la grande chaleur soit nécessaire au plein développement de sa nature, la chaleur exeessive la restreint et la réduit à de moindres dimensions. Le rhinocéros parait ètre d'une taille plus uniforme et d'une grandeur moins variable; il semble ne difiérer de lui-mème que par le caractère singulier qui le fait différer de tous les autres animaux, par cette grande corne qu'il porte sur le nez; cette corne est simple dans les rhinocéros de l'Asie, et double dans ceux d'Afrique.

Je ne parlerai point ici des variétés qui se trouvent dans chaque espèce d'animal carmassier, parce cu'elles sont très-légères, attendu que de tous les animaux, ceux qui se nourrissent de chair, sont les plus indépendants de l'bomme, et qu'au moyen de cette nourriture déjà piéparée par la nature, iis ne recoivent presque rien des qualités de la terre qu'ils habitent; que d'ailleurs ayant tous de la force et des armes, ils sont les maitres du choix de leur terrain, de leur climat, etc., et que par conséquent les trois causes de changement, d'altération et de dégénération dont nous avous parlé, ne peuvent avoir sur eux que de très-petits effets.

Mais après le coup d'œil que l'on vient de jeter sur ces variétés qui nous indiquent les altérations particulières de chaque espèce, il se présente une considération plus importante et dont la vue est bien plus étendue; e'est celle du changement des espèces mèmes, c'est cette dégénération plus ancienue, et de tout temps inmémoriale, qui parait s'ètre faite dans chaque famille, ou si l'on veut dans chacun des genr'es sous lesquels on peut comprendre les espèces voisines et peu différentes entre elles. Nous n'avons dans tous les animaux terrestres que quelques espèces isolées, qui, comme celle de l'homme, fassent en même temps espèce et genre; l'éléphant, le rhinocéros, l'hippopotane, la girafe, forment des genr'es ou des espèces simples qui ne se propagent qu'en ligne directe et n'ont aucune branche collatérale : toutes les autres paraissent former des familles dans lesquelles on remarque ordinairement une souche principale et commune, de laquelle semblent être sorties des tiges différentes et d'autant plus nombreuses, que les individus, dans chaque espèce, sont plus petits et plus féconds.

Sous ce point de rue, le cheval, le zèbre et l'âne, sont tous trois de la mème famille : si le cheval est la souche ou le trone principal. le zèbre et l'âue seront les tiges collatérales : le nombre de leurs ressemblances entre eux étant infiniment plus grand que celui de leurs différences, on peut les regarder comme ne faisant qu'un mème genre, clont les principaux carac. tères sont clairement énoncés et communs à tous trois : ils sont les seuls qui soient vraiment solipèdes, e'est-ì-dire qui aient la corne des pieds d'une seule pièce sans aucune apparence de doigts ou d'ongles; et quoiqu'ils forment trois espèces distinetes, elles ne sont cependant pas absolument ni nettement séparèes, puis(que l'âne produit avec la jument, le cheval avee l'ânesse, et qu'il est probable que si l'on vient à bout d'apprivoiser le zèbre et d'assouplir sa nature samvage et récaleitrante, il produirait aussi avec le cheral et l'àne, comme ils produisent entre eux.

Et ce mulet qu'on a regardé de tout temps 
comme une production viciée, comme un monstre composé de deux natures, et cque, par cette raison, l'on a jugé incapable de se reproduire Jui-même et de former lignée, n'est cependant pas aussi profondément lésé qu'on se l’imagine d’après ce préjugé, puiscpu'il n'est pas réellement infécond, etque sa stérilité ne dépend que de certaines circonstanees extéricures et particulières. On sait que les mulets ont souvent produit dans les pays chauds; l'on en a même quelques exemples dans nos elimats tempérés : mais on ignore si cette génération est jamais provenue de la simple union du mulet et de la mule, ou plutòt si le produit n'en est pas dî à l'union du mulct avec la jument, ou encore à celle de l'âue avec la mule. Il y a deux sortes de mulets : le premier est le grand mulet ou mulet simplement dit, qui provient de la jonction de l'âne à la jument; le second est le petit mulet provenant du cheval et de l'ânesse, (pue nous appellerons bardeau pour le distinguer de l'autre. I.es anciens les connaissaient et les distinguajent comme nous par deux noms différents : ils appelaient mulus le mulet provenant de l'áne et de la jument, et ils dommaient les noms de rívvos, hinnus, burdo, au mulet provenant du cheval et de l'ìnesse. Ils ont assuré que le mulet, mulus, produit avec la jument un animal auquel ils domnaient aussi le nom de ginnus ou himnus. Ils ont assuré de mème que la mule, mula, concoit assez aisément, mais c[u'elle ne peut que rarement perfectionner son firuit; et ils ajoutent que quoiqu'il y ait des exemples assez fréquents de mules qui ont mis bas, il faut néanmoins regarder cette production comme un prodige. Mais (qu'est-ce qu'un prodige dans la nature, sinon un effet plus rare que les autres? Le mulet peut donc engendrer, et la mule peut concevoir, porter et mettre bas dans de certaines eirconstances : ansi il ne s'agirait que de faire des expériences pour savoir quelles sont ces circonstances, et pour acquéril de nouveaux faits dont on pourrait tirer de grandes lumières sur la dégénération des espèces par le mélange, et par eonsé(quent sui' l'unité ou la diversité de chaque genre. Il faudrait, pour réussir à ees expéricnces, dommer le mulet à la mule, ì la jument et à l'àesse; faire la mème chose avec le bardeau, et voir ee yui résulterait de ces six accouplements dilférents. Il fiudrait aussi domner le cheval et l'âne à la mule, et faire la mème chose your Ir petite mulo ou fe- melle du bardeau. Ces épreuves, quoique assez simples, n'ont jamais été tentées dans la vue d'en tirer des lumières; et je regrette d€ u'ètre pas à portée de les exécuter : je suis persuadé qu'il en résulterait des connaissances que je ne fais qu'entrevoil', et que je ne puis donner que comme des présomptions. Je crois, par exemple, que de tous ces accouplements, celui du mulet et de la femelle bardeau, et celui du bardeau et de la mule pourmient bien manquer absolument; que celui du mulet et de la mule, et celui du bardeau et de sa femelle pourraient peutêtre réussir, quoique bien rarement : mais en mème temps, je présume que le mulet produirait avec la jument plus certainement cu'avec l'ânesse, et le bardeau plus certainement avec l'ânesse qu'avec la jument; qu'enfin le cheval et l'âne pourraient peut-être produire avec les deux mules, mais l'âne plus surrement que le cheval. Il faudrait faile ces épleuves dans un climat aussi chaud, pour le moins, que l'est notre Provence, et prendre des mulets de sept ans, des chevaux de cinc et des anes de quatre ans, parce qu'il y a cette dilférence dans ces trois animaux pour les áges de la pleine puberté.

Voici les raisons d'analogie sur lesquelles sont fondées les présomptions que je viens d'indiquer. Dans l'ordonnance commune de la nature, ce ne sont pas les mâles, mais les femelles, qui constituent l'unité des espèces : nous savons par l'exemple de la brebis qui peut servir à deux mâles diftérents et produire également du bouc et du bélier, que la femelle influe beaucoup plus que le mâle sur le spécifique du produit, puisque de ees deux mâles dilférents il ne nait que des ağneaux, e'est-i-dire des individus spécifiquement ressemblants à la mère : aussi le mulet ressemble-t-il plus à la jument qu'à l'âne, et le bardeau plus à l'ânesse qu'au cheval : des lor's le mulet doit produire plus suirement avec la jument quavec linesse, et le bardeau plus suremont avec l'ânesse quiavec la jument. De mème le cheval et l'âne pourraient peut-étre produire avec les deux mules, parce qu'étant femelles elles ont, quoique viciées, retenu chacune plus de propriétés spécidiques que les mulets mâles : mais l'ane doil produire avec elles plus cortainement que le cheval, parce qu'on a remarqué tue l'âne a plus do puissance pour 'ugendrer, mème avec la jument, (quen'un a le cheval; ear il corrompt et 
détruit la génération de celui-ci. On peut s'en assurer en dommant d'abord le cheval-étalon à des juments, et en leur domnant le leudemain, ou même quelques jours après, l'âne au lieu du cheval; cesjuments produiront presque toujours des mulets et non pas des chevaux. Cette observation, qui mériterait bien d'ètre constatée clans toutes ses circonstances, parait indiquer que la souche ou tige principale de cette famille pourrait bien être l'àne et non pas le cheval, puisque l'âne le domine dans la puissance d'engendrer , même avec sa femelle; d'autant que le contraire n'arrive pas, lorsqu'on donne l'âne en premier et le cheval en second, à la jument; celui-ci ne corrompt pas la génération de l'àne, car le produit est pl'esque toujours un mulct: d'autre côté la mème chose n'arrive pas, quand on domme l'âne en premier et le cheval en second à l'ânesse : car celui-ci ne corrompt ni ne détruit la génération de l'âne. Et à l'égard des accouplements des mulets entre eux, je les ai présumés stériles, parce que de deux natures déjà lésées pour la génération, et qui par leur mélange ne pourraient manquer de se léser davantage, on ne doit attendre qu'uu produit tout d̀ fait vicié ou alssolument nul.

Par le mélange du mulet avec la jument, du bardeau avec l'ânesse, et par celui du cheval et de l'âne avec les mules, on obtiendrait des individus qui remonteraient à l'espèce et ne seraient plus que des demi-mulets, lesquels nonseulement auraient, comme leurs parents, la puissance d'engendrer avec ceux de lcur espèce originaire, mais peut-ètre même auraient la faculté de produire entre eux, parce que n'étant plus lésés çu'à demi, leur produit ne serait pas plus vicié que ne le sont les premier's mulets; et si l'union de ces demi-mulets ćtait encore stérile, ou que le produit en fùt et rare et dificile, il me parait certain qu'en les rapprochaut encore d'un degré de leur espèce originaire, les individus qui en résulteraient, et qui ne seraient plus lésés qu'au quart, produiraient entre eux, et formeraient une nouvelle tige, qui ne serait précisément ni celle du cheval ni celle de l'âne. Or, comme tout ce qui peut être a été amené par le temps, et se trouve ou s'est trouvé daus la nature, je suis tenté de croire que le mulet fécond dont parlent les anciens, et qui, du temps d'Aristote, existait en Syrie dans les terres au delà de celles des Phéniciens, pouvait bien être une race de ces demi-mulets ou de ces quarts de mulets, yui s'était formée par les mélanges que nous venons d'indiquer; car Aristote dit expressément que cès mulets feconds ressemblaient en tout, et autant qu'il est possible, aux mulets inféconds; il les distingue aussi trés-clairement des onagres ou anes sau. vages dont il fait mention dans le mème chapitre, et par consérquent on ne peut rapporter ces animaux qu'à des mulets peu viciés, et qui auraient couselvé la faculté de reproduire. Il se pourrait encore que le mulet fécond de Tatarie. le czigithai dont nous avons parlé, ne fut pas l'onagre ou âne sauvage, mais ce même mulet de Phénicic, dont la race s'est peut-ètre maintenue jusqu'à ce jour ; le premier' voyageur qui pourra les comparer, confirmera ou détruira cette conjecture. Et le zèbre lui-même, qui ressemble plus au mulet qu'au cheval et qu'à l'âıe, pourrait bien avoir eu une pareille origine; la régularité contrainte et symétrique des couleurs deson poil , qui sont alternativement toujours disposées par bandes noires ct blanehes, parait indirquer qu'elles proviennent de deux espèces différentes, qui, dans lcur mélange, se sont séparées autant qu'il ćtait possible; car, dans aucun de ses ouvrages, la nature n'est aussi tranchée et aussi peu nuancée que sur la robe du zèbre, où elle passe brusyuement et alternativement du blanc au noir et du noil au blanc sans aucun intermède dans toute l'étendue du corps de l'animal.

Quoi qu'il en soit, il est certain par tout ce que nous venons d'exposer, que les mulets en général, qu’on a toujours accusés d'impuissance et de stérilité, ne sont cependant ni réellement stériles, ni généralement inféconds; et que ce n'est que dans l'espèce particulière du mulet provenant de l'âne et du cheval que cette stérilité se manifeste, puisque le mulet qui provient du bouc et de la brebis est aussi fécond que sa mère ou son père; puisque dans les oiseaux la plupart des mulets (pui provicunent d'especes différentes ne sont point infeconds : e'est donc dans la nature particulière du cheval et de l'âne qu'il faut chercher les causes de l'infécondité des mulets qui en proviemnent; et, au lieu de supposer la stérilité comme un défaut général et nécessaire dans tous les mulets, la restreindre au contraire au seul mulet provenant de l'âne et du cheval, et encore domner de grandes limites à cette restriction, attendu que ces mémes mulets peurent devenir féconds dans de 
certaines eirconstances, et surtout en se rapprochant d'un degré de leur espèce originaire.

Les mulets qui proviemnent du cheval et de l'àne ont les organes de la génération tout aussi complets que les autres animaux : il ne manque rien au mâle, rien à la femelle; ils ont une grande abondance de liqueur séminale ; et comme l'on ne permet guère aux mâles des'accoupler, ils sont souvent si pressés de la répandre, qu'ils se couchent sur le ventre pour se frotter entre leurs pieds de devant qu'ils replient sous la poitrine : ees animaux sont done pourvus de tout ce qui est nécessaire à l'acte de la générátion ; ils sont même très-ardents, et par conséquent très-indifférents sur le choix; ils ont à peu près la mème véhémence de goût pour la mule, pour l'ânesse et pour la jument : il n'y a done nulle difficulté pour les aceouplements. Mais il faudrait des attentions et des soins particuliers, si l'on voulait rendre ces accouplements prolificues : la trop grande ardeur, surtout dans les femelles, est ordinairement suivie de la stérilité, et la nule est au moins aussi ardente que l'ànesse : or l'on sait que celle-ci rejette la liqueur séminale du màle, et que, pour la faire retenir et produire, il faut lui donner des coups ou lui jeter de l'eau sur la eroupe afin de calmer les convulsions d'amour qui subsistent après l'accouplement, et (qui sont la cause de cette réjaculation. L'ânesse et la mule tendent donc toutes deux par leur trop grande ardeur à la stérilité. L'âne et l'ânesse y tendent encore par une autre eause : comme ils sont originaires des climats chauds, le froid s'oppose à leur génération, et e'est par cette laison qu'on attend les elraleurs de l'été pour les faire accoupler : lor's(yu'on les laisse joindre dans d'attres temps, et surtout en hiver, il est rare que l'imprégnation suive l'alcouplement, mène réitéré; et ce choix du temps (qui est nécessaire au succès de leur génération, l'est aussi pour la conservation du produit; il faut (jue l'ànon naisse dans un temps chand, antrement il périt ou languit; et comme la gestation de l'anesse est d'un an, elle met bas dans la mème saison (qu'elle a concu : ceci prouve assez combien la chaleur est néeessaire, non-seulement à la fécondité, mais même à la pleine vie de ces animaux. Cóst encore par cette meme raison de la trop srande ardeur de l.x fomelle, gu'on lui domne lo mâle pres(pue immédiatement après fu'clle a mis bas; on ne lui laisse que sept ou huit jours de repos ou d'intervalle entre l'accouchement et l'accouplement : I'ânesse, affaiblie par sa couche, est alors moins ardente; les parties n'ont pas pu clans ce petit espace de temps reprendre toute leur raideur; au moyen de quoi la conception se fait plus surement que quand elleest en pleine force, et que son ardeur la domine. On prétend que dans cette espèce, comme dans celle du chat, le tempérament de la fenselle est encore plus ardent et plus fort que celui du mảle : cependant l'àne est un grand exemple de ce renre; il peut aisément saillir sá femelle ou une autre plusicurs jours de suite et plusicurs fois par jour ; les premières jouissances, loin d'éteindre, ne font qu'allumer son ardeur ; on en a 11 s'excéder sans y ètre incités autrement que pas la force de leur appétit naturel ; on en a vu mourir sur le elamp de bataille, après onze ou douze conflits réitérés presque sans intervalle, et ne prendre pour subvenir à eette grande et rajpide dépense que quelques pintes d'ean. Cette mime chaleur qui le consume est trop vive pour être durable ; l'àne-étalon est bientòt hor's de combat et même de service, et c'est peut-être parl cette raison que l'on a prétendu que la femelle est plus forte et vit plus longtemps que le màle : ce qu'il y a de certain, c'est qu'avec les ménagements que nous avons indiques, elle peut vivre trente ans, et produire tous les ans pendant tonte sa vie; au lieu que le màle, lorsquion ne. le contraint pas à s'abstenir de fernelles, alouse de ses forces an point de perdre en peu d'années la puissance d'engendrer.

L'âne et l'ànesse tendent donc tous denx it la stérilité par des propriétés commumes, et aussi par des qualités différentes; le chesal et la jument y tendent de mème par d'autres voies. On peut douner l'étalon à la jument neuf ou dis jours apres (qu'clle a mis bas, et elle pent produire cing ou six ans de suite; mais apres celit elledevient stérile. Pour entretenir sa fécondite, il fant mettre un intervalle d'un an entre cha('unc de ses portées, et la traiter differemment de l’ânesse; au lieu de lui dommer l'étalon alprés qu'elle a mis bas, il faut le lui réserver pour l'année suivante, ct attendre le temps ou sa chaleur se mauifeste par les humeurs qu'elle jette; et meme aver ces attentions, il est rare yu’elle soit féconde au delá de l'àge de vingt ans. I'autre coté, le cheval, quoicfue moins ardent et plus délieat que l’àne, conserve néanmoins phus longtemps la faculte d'engendrer. 
On a vu de vieux chevaux, qui n'avaient plus la force de monter la jument sans l'aide du palefrenier, trouver leur vioneur dès qu'ils étaient placés, et engendrer à l'àge de trente ans. La liqueur séminale est non-seulement moins abondante, mais beaucoup moins stimulante dans le cheval que dans l'âne; car souvent le cheval s'accouple sans la répandre, surtout si on lui présente la jument avant qu'il la cherche; il parait triste dès qu'il a joui, et il lui faut d'assez grands intervalles de temps pour que son ardeur renaisse. D'ailleurs, il s'en faut bien que dans cette espèce tous les accouplements, même les plus consommés, soient prolifiques : il y a des juments naturellement stériles, et d'autres, en plus grand nombre, qui sont très-peu fécondes; il y a aussi des étalons, qui, quoique vigoureux en apparence, n'ont que peu de puissance réelle. Nous pourons ajouter à ces raisons particulières une preuve plus évidente et plus générale du peu de fécondité dans les espèces du chẹval et de l'âne; ce sont de tous les animaux domestiques cenx dont l'espèce, rquoique la plus soignée, est la moins nombreuse; dans celles du bœuf, de la brebis, de la chèrre, et surtout dans celles du cochon, du chien et du chat, les individus sont dix et peut-être cent fois plus nombreux que dans celles du cheval et de l'âne : ainsi leur peu de fécondité est prouvée par le fait, et l'on doit attribuer à toutes ces causes la stérilité des mulets qui proviennent du mélange de ces deux espèces naturellement peu fécondes. Dans les espèces, au contraire, qui, comme celle de la chèvre et celle de la brebis, sont plus nombreuses et par consécuent plus fécon'les, les mulets provenant de leur mélange ne sont pas stériles, et remontent pleinement à l'espèce originaire dès la première génération; au lieu qu'ril faudrait deux, trois et peut-être quatre générations, pour que le mulet provenant du cheval et de l'ane pût parvenir à ce mêne degré de réhabilitation de nature.

On a prétendu que de l'accouplement du taureau et de la jument il résultait une autre sorte de mulet : Columelle est, je crois, le premier qui en ait parlé; Gessner le cite, ct ajoute qu'il a entendu dire (qu'il se trouvait de ces mulets auprès de Grenoble, et qu'on les appelle en francais jumarts. J'ai fait venir un de ces jumarts de Dauphiné ; j'en ai fait venir un autre des Pyrénées, et j'ai recomnu, tant par l'in- spection des parties extérieures que par la dissection des parties intérieures, que ces jumarts n'étaient que des bardeaux, e'est-il-dire des mulets provenant du cheval et de l'ânesse : je crois done ètre fondé, tant par cette observation que par l'analogie, à croire que cette sorte de mulet n'existe pas, et que le mot jumarl n'est qu'un nom chimérique, et qui n'a point d'objet réel. La nature du taureau est trop éloignée de celle de la jument, pour qu'ils puissent produire ensemble; l'un ayant quatre estomacs, des cornes sur la tète, le pied fourchu, etc.; l'autre étant solipède et sans cornes, et n'ayant (qu'un seul estomac. Et les parties de la génération étant très-différentes tant par la grosseur que pour les proportions, il n'y a nulle raison de présumer qu'ils puissent se joindre avec plaisir, et encore moins avec succès. Si le taureau a vait à produire avee quelque autre espèce que la siemne, ce serait avec le buffle qui lui res. semble par la conformation et par la plupart des habitudes naturelles; cependant nous n'avons pas entendu dire qu'il soit jamais né des mulets de ces deux animaux, qui néanmo:ns se trouvent dans plusieurs lieux, soit en domesticité, soit en liberté. Ce que l'on raconte de l'accouplement et du produit du cerf et de la vache m'est à peu près aussi suspect que l'histoire des jumarts, quoique le cerf soit beaucoup moins éloigné, par sa conformation, de la nature de la vache, que le taureau ne l'est de celle de la jument.

Ces animaux, qui portent des bois, quoique ruminants et conformés à l'intérieur commeceux qui portent des cornes, semblent faire un genre, une famille à part, daus laquelle l'élan est la tige majeure, et le renne, le cerf, l'axis, le daim et le cherreuil sont les branches mineures et collatérales; car il n'y a que ces six espèces d'animaux dont la tête soit armée d'un bois branchu qui tombe et se renouvelle tous les ans; et indépendamment de ce caractère générique qui leur est commun, ils se ressemblent encore beancoup par la conformation et par toutes les habitudes naturelles : on obtiendrait done plutòt des mulets du cerf ou du daim mêlé a vec le renne et l'axis, que du cerf et de la vache.

On serait encore mieux fondé à regarder toutes les brebis et toutes les chèvres conme ne faisant qu'une mème famille, puisqu'elles produisent ensemble des mulets qui remoutent directement, et dès la première génération, à 
l'espèce de la brebis; on pourrait même joindre à cette nombreuse famille des brebis et des chèvres celle des gazelles et celle des bubales, qui ne sont pas moins nombreuses. Dans ce genre, qui contient plus de trente espèces différentes, il paraît que le mouflon, le bouquetin, le chamois, l'antilope, le bubale, le condoma, ete., sont les tiges principales, et que les autres u'en sont que les branches accessoires, qui toutes ont retenu les caractères prineipaux de la souche dont elles sont issues, mais qui ont en mème temps prodigieusement varié par les influences du climat et les différentes nourritures, aussi bien que par l'état de servitude et de domesticité auquel l'homme a réduit la plupart de ces animaux.

Le chien, le loup, le renard, le chacal et l'isatis forment un autre genre, dont chacune des espèces est réellement si voisine des autres, et dont les individus se ressemblent si fort, surtout par la conformalion intéricure et par les parties de la génération, qu'on a peine à concevoir pourquoi ces animaux ne produisent point ensemble : il m'a paru, par les expérienees quej'ai faites sur le mélange du chien avec le loup et avec le renard, que la répugnanee a l'aceouplement venait du loup et du renard plutòt que du chien, c'est-à-dire de l'animal sauvage et non pas de l'animal domestique; car les chiennes que j'ai mises à l'épreuve auraient volontiers souffert le frenard et le loup, au lieu que la louve et la femelle renard n'ont jamais voulu souffrir les approches du chien. L'état de domesticité semble rendre les animiux plus lihertins, e'est-ì-dire moins fidèles à leur espiece: if les rend aussi plus chauds et plus féconds; ear la ehienne peut produire et produit mème assez ordinairement deux fois par an, au lieu que la louve et la femelle renard ne portent qu'une fois dans une année; et il est à présumer que les chiens sauvages, c'est-à-dire les chiens qui ont été abandonnés dans des pays déserts, ('t (qui se sont multipliés dans l'ile de Juan-Feruandès, daus les montagnes de Saint-Domingue, ete., ne produisent qu'une fois par an, comme le renard et le loup : ce fait, s'il était constaté, confimmerait pleinement l'unịté du genre de ees trois animaux, qui se ressemblent si fort par la conformation, qu'on ne doit attribuer qu'ì quelques eireonstances extérieures leur répugnance à se joindre.

Le chien parait etre l'espice moyenne et i.. commune entre celles du renard et du loup: les anciens nous ont transmis comme deux faits certains que le chien, dans quelques pays et dans quelques circonstances, produit avec le loup et avec le renard. J'ai voulu le vérifier, et quoique je n'aie pas réussi dans les épreuves que j'ai faites à ce sujet, on n'en doit pas conclure que cela soit impossible; car je n'ai pu faire ces essais que sur des animaux captifs, et l'on sait ciue dans la plupart d'entre eux la captivité seule sufit pour éteindre le désir et pour les dégoùter de l'aceoupiement, mème avee leurs semblables; a plus forte raison eet état foreć doit les empécher de s'unir avee des individus d'une espece étrangòre: mais je suis persuadé que dans l'état de liberté et de célibat, e'est-il-dire de privation de sa femelle, le ehien peut en effet s'unir au loup et au renard, surtout si, devenu sauvage, il a perdu son odeur de domesticité, et s'est en mème temps rapproché des mocurs et des habitudes naturelles de ces animaux. Il n'en est pas de même de l'union du renard avee le loup, je ne la crois guere possible : du moins dans la nature actuelle, le contraire parait,démontré par le fait, puisque ces deux animaux se trouvent ensemble dans ie mème climat et daus les mèmes terres, et que se soutenant chacun dans leur 'spece sans se chereher, sans se môler, il faudrait supposer une dégénération plus ancienne que la mémoire des hommes pour les réunir à la méme espèee: e'est par cette raison que j’ai dit que celle du chien était moyeme entre eelles du renard ct du loup; elle est aussi commune, puisquille peut se méler avee tontes deux; et si quelque chose pourait indiquer qu'originairement toutes trois sont sortics de la meme souche, c'est ce rapport commun qui iapproehe le renard du loup, et me parait en réunir les especés de plus près que tous les autres rapports de conformité daus la figure et l'organisation. Pour réduire ces deux espèces à l'unité, il faut done remonter à un état de nature plus ancien: mais, dans l'citat aetuel, on doit regarder le loup et le renard comme les tiges majeures du grenre des cind animaux que nous avons indiques ; le chicu, le chacal et l'isatis, n'en sont que les branches littérales, et elles sont placécs cintre les deux premieres ; le chacal participe du chien ct du loup, et l'isat is du chacal et du renard : aussi parait-il, par un assez grand nombre de témoinnages, que le ehacal et te chien produsent aisémeut 
ensemble; et l'on voit, par la description de l'isatis et par l'histoire de ses habitudes natureiles, (qu'il ressemble presque entièrement au renard par la figure et par le tempérament, qu'il se trouve également dans les pays froids, mais qu'en même temps il tient du chacal le naturel, l'aboiement continu, la voix criarde et l'habitude d'aller toujours en troupe.

Le chien de bergel, que j'ai dit être la souche première de tous les chiens, est en mème temps celui qui approche le plus de la figure du renard; il est de la même taille; il a , comme lui, les oreilles droites, le museau pointu, la queue droite et traînante; il approche aussi du renard pár la voix, par l'intelligence et par la finesse de l'instinct: il se peut donc que ce chien soit originairement issu du renard, sinon en ligne droite, au moins en ligne collatérale. Le chien, qu'Aristote appelle canis laconicus, et qu'il assure provenir du mélange du renard et du chien, pourrait bien être le même que le chien de berger, ou du moins avoir plus de rapport avec lui qu'avec aucun autre chien: on serait porté à imaginer que l'épithète laconicus qu'Aristote n'interprète pas, n'a été donnée à ce chien que par la raison qu'il se trouvait en Laconie, province de la Grèce, dont Lacéclémone était la ville principale; mais si l'on fait attention à l'origine de ce chien laconic, que le même auteur dit venir du renard et du chien, on sentira que la race n'en était pas bornée au seul pays de Laconie, et qu'elle devait se trouver également dans tous les pays oì il y avait des renards; et c'est ce qui me fait présumer que l'épithète laconicus pourrait bien avoir été employéc par Aristote dans le sens moral, e'està-dire pour exprimer la brièveté ou le son aigu de la voix; il aura appelé chien laconic ce chien provenant du renard, parcequ'il n'aboyait pas comme les autres chiens, et qu'il avait la voix courte et glapissante comme celle du reuard. Or, notre chien de berger est le chien qu'on peut appeler laconic à plus juste titre, ear c'est celui de tous les chiens dont la voix est la plus brève et la plus rare: d'ailleurs, les caractères que donne Aristote à son chien laconie conviennent assez au chien de berger, et c'est ce qui a achevé de me persuader que c'était le même chien.

Le genre des ánimaux cruels est l'un des plus nombreux et des plus variés ; le mal semble, ici comme ailleurs, se reproduire sous toutes sortes de formes et se revêtir de plusieurs nätures. Le lion et le tigrre, comme espeees isolées, sont en premiere ligne; toutes les autres, savoir : les panthères, les onces, les léopards, les guépards, les lynx, les caracals, les jaguars, les couguars, les ocelots, les servals, les margais et les chats, ne font qu'une même et méchante famille, dont les différentes branches se sont plus ou moins étendues, et ont plus ou moins varié suivant les différents climats: tous ces animaux se ressemblent par le naturel, quoiqu ils soient très-différents pour la grandeur et par la figure; ils ont tous les yeux étincelants, le museau court, et les ougles aigus, courbés et rétractibles; ils sont tous nuisibles, féroces, indomptables; le chat, qui en est la dernière et la plus petite espèce, quoique réduit en servitude, n'en est ni moins perfide ni moins volontaire; le chat sauvage a conservé le enractère de la famille; il est aussi cruel, aussi méchant, aussi déprédateur en petit, que ses consanguins le sout en grand; ils sont tous également carnassiers, également ennemis des autres animaux. L'homme, avec toutes ses forces, n'a jamais pu les détruire; on a de tout temps employé contre eux le feu, le fer, le poison, les piéges : mais comme tous les individus multiplient beancoup, et que les espèces elles-mêmes sont fort multipliées, les efforts de l'homme se sont bornés à les faire reculer et à les resserrer dans les déserts, dont ils ne sortent jamais sans répandre la terreur et causer autaut de dégât que d'effroi. Un seul tigre échappé de sa forêt suffit pour alarmer tout un peuple et le forcer à s'armer; que serait-ce si ces animaux sanguinaires arrivaient en troupe, et s'ils s'entendaient comme les chiens sauvages ou les chacals dans leurs projets de déprédation! Ia nature a donné cette intelligence aux animaux timides : mais heureusement les animaux fiers sont tous solitaires; ils marchent seuls, et ne consultent que leur courage, e'est-à-dire la confiance qu'ils ont en leur force. Aristote a vait remarqué avant nous que de tous les animaux c pui ont des griffes, e'est-à-dire des ongles ('rochus et rétractibles, aucun n'était sociable, aucuu n'allait en troupe: eette observation, qui ne portait alor's que sur quatre ou cinq especes, les seules de ce genre qui fussent counues de son temps, s'est étendue et trouvée vraie sur dix ou douze autres espèces clu'on a découvertes depuis. Les autres animaux carnassiers, tels gue 
les loups, les renards, les chiens, les ehacals, les isatis, qui n'ont point de griffes, mais seulement des ongles droits, vont pour la plupart en troupes, et sont tous timides et même lâches.

En comparant ainsi tous les animaux et les rappelant chacun à leur genre, nous trouverons que les deux cents espèces dont nous a vons donné l'histoire peuvent se réduire à un assez pctit nombre de familles ou souches principales, desquelles il n'est pas impossible que toutes les autres soient issues.

Et pour mettre de l'ordre dans cette réduction, nous séparerons d'abord les animaux des deux continents; et'nous observerous qu'on peut réduire à quinze genres et à neuf espèces isolées, non-seulement tous les animaux qui sont communs aux deux continents, mais encore tous ceux qui sont propres et particuliers à l'aneicu. Ces genres sout, $1^{0}$ celıi des solipèdes proprement dits, (jui contient le cheval, le zèbre, l'âne, avec les mulets féconds et inféconds; $2^{0}$ celui des grands pieds-fourchusà cornes creuses, savoir, le bouf et le buffle avec toutes leurs variétés; $3^{0}$ la grande famille des petits pieds fourchus à cornes creuses, tels'que les brebis, les chèvres, les gazelles, les chevrotins, et toutes les autres espèces qui participent de leur nature $; 4^{0}$ celle des pieds-fourchus, à cornes pleines ou bois solides qui tombent et qui se renouvellent tous les ans : cette famille contient l'élan, le renne, le cerf, le daim, l'axis et le chevreuil $; 5^{0}$ celle des pieds-fourchus ambigus, qui est composée du sanglier et de toutes les variétés du cochon, telles que celui de Siam d̀ ventre pendant, celui de Guinée, longues oreilles pointues et couchées sur le dos, celui des Canaries, à grosses et longues défenses, etc.; $6^{0} \mathrm{lc}$ genre très-étendu des fissipèdes carnassiers à griffes, c'est-à-dire à ongles crochus et rétractibles, dans lequel on doit comprendre les panthères, les léopards, les guépards, les onces, les servals et les chats, avec toutes leurs variétés; $7^{0}$ celui des fissipèdes carnassiers à ongles non rétractibles, qui contient le loup, le renard, le chacal, l'isatis et le chien, avec toutes leurs variétés; $8^{0}$ celui des fissipèdes carnassicrs à ongles non rétractibles, a vec une poche sous la quene : ce genre est composé de l'hyène, de la civette, du zibet, de la genette, du blai- reau, ete. ; $9^{0}$ celui des fissipedes carnassier's à corps très-allongé, avec cinç doights à chaque pied, et le pouce ou premier ongle séparé des autres doigts : ce genre est composé des fouines, martes, putois, furets, mangoustes, belettes, vansires, etc.; $10^{\circ}$ la nombreuse famille des fissipèdes, qui ont deux grandes dents incisives à chaque máchoire et point de piquants sur le corps : elle est composée des lièvres, des lapins, et de toutes les espèces d'écureuils, de loirs, de rnarmottes et de rats; $11^{\prime \prime}$ celui des fissipèdes, dont le corps est couvert de piquants, tels que les pores-épies et les hérissons; $12^{0}$ celui des fissipèdes couverts d'écailles, les pangolins et les phatagins; $13^{0}$ le genre des fissipèdes amphibies, qui contient la loutre, le castor, le desman, les morses et les phoques; $14^{0}$ le genre des quadrupèdes qui contient les singes, les babouins, les guenons, les makis, les loris, etc.; $15^{0}$ enfin celui des fissipèdes ailés, qui contient les roussettes et les chauves-souris, arec toutes leurs varićtés. Les neuf espèees isolées sont : l'éléphant, le rhinocéros, l'hippopotame, la girafe, le chameau, le lion, le tigre, l'ours ct la taupe, qui toutes sont aussi sujettes ì un plus ou moins grand nombre de variétés.

De ces quinze genres et de ces neuf espèces isolées, deux especes et sept genres sont communs aux deux continents : les deux espèces sont, l'ours et la taupe; et les sept genres sont: $1^{0}$ celui des grands pieds-fourchus à cornes creuses, car le bouf se trouve en Américue sous la forme du bison; $2^{0}$ celui des pieds-fourchus à bois solides, car l'élan se trouve au Canada, sous le nom d'orignal, le renne sous celui de caribou, et l'on troure aussidans presque toutes les provinces de l'Amérique septentrionale, des cerfs, des daims et des chevreuils; $3^{0}$ celui des fissipèdes carnassiers a ongles non rétractibles, car le loup et le renard se trouvent dans le Nouveau-Honde comme dans l'ancien; $4^{0}$ celui des fissipèdes à corps très-allongé; la fouiue, la marte, le putois se trouvenit en Amérique comme en Europe; $5^{0}$ l'on y trouve aussi une partic du genre des fissipèdes qui ont deux grandes dents incisives à chaque mâchoire, les écureuils, les marmottes, les rats, etc. ; $6^{0}$ celui des fissipèdes amphibies; les morses, les phoques, les easter's et les loutres existent dans le nord du nouveau continent comme dans celui de l'ancien; $7^{\circ}$ le genre des fissipèdes ailes $y$ existe aussi en partie, car on y trouve des chaures-souris et des vampires, qui sont des espèces de roussettes. 
II ne reste donc que huit genres et cinq espèces isolées, qui soient propres et particuliers à l'ancien continent : ces huit genres ou familles sont, $1^{0}$ celle des solipèdes proprement dits; car on n'a trouvé ni chevaux, ni ânes, ni zèbres, ni mulets dans le Nouveau-Monde; $2^{0}$ celle des petits pieds-fourchus à cornes creuses; car il n'existait en Amérique ni brebis, ni chèvres, ni gazelles, ni chevrotains; $3^{0}$ la famille des cochons ; car l'espèce du sanglier ne s'est point trouvée dans le Nouveau-Monde; et quoique le pecari avec ses variétés doive se rapporter à cette famille, il en diffère cependant par des caractères assez remarquables, pour qu'on puisse l'en séparer. $4^{0}$ II en est de mème de la famille des animaux carnassiers à ongles rétractibles : on n'a trouvé en Amérique ni panthères, ni léopards, ni guépards, ni onces, ni servals; et quoique les jaguars, couguars, ocelots et margais paraissent être de cette famille, il n'y a aucune de ces espèces du Nouveau-Monde qui se trouve dans l'ancien continent, et réciproquement aucune espèce de l'ancien continent qui se soit trouvée dans le nouveau. $5^{0} \mathrm{Il}$ en est encore de même du genre des fissipèdes dont le corps est couvert de piquants; ear, quoique le coëndou et l'urson soiènt très-voisins de ce genre, ces espèces sont néanmoins très-différentes de celles des pores-épics et des hérissons; $6^{0}$ le genre des fissipèdes carnassiers à ongles non rétractibles, avec une poche sous la queue; car l'hyène, les civettes et les blaireaux n'existaient point en Amérique ; $7^{0}$ les genres des quadrumanes; car l'on n'a trouvé en Amérique ni singes, ni babouins, ni guenons, ni makis; et les sapajous, sagouins, sarigues, marmoses, ete., quoique quadrumanes, diffèrent de tous ceux de l'ancien continent; $8^{0}$ celui des fissipèdes couverts d'écailles : le pangolin ni le phatagin ne se sont point trouvés en Amérique ; et les fourmiliers, auxquels on peut les comparer, sont couverts de poil, et en different trop pour qu'on puisse ies réunir à la mêne famille.

Des neuf espèces isolées, sept, savoir : l'éléphant, le rhinocéros, l'hippopotame, la girafe, le chameau, le lion et le tigre, ne se trourent que dans l'ancien monde; et deux, savoir: l'ours et la taupe, sont communes aux deux continents.

Si nous faisons de neême le dénombremen: desamimaux propres et particuliers au NouveanNonde, nous trouverous qu'il y en a cuvirou cinquante espèces différentes, que l'on peut réduireà dix genres, et quatre espèces isolées. Ces quatre espèces sont : le tapir, le cabiai, le lama et le pecari : encore n'y a-t-il que l'espèce du tapir qui soit absolument isolée; car celle du pecari a des variétés, et l'on peut réunir la vigogne au lama, et peut-être le cochon d'Inde au cabiai. Les dix genres sont, $1^{\circ}$ les sapajous, huitespèces; $2^{\circ}$ les sagouins, six espèces; $3^{\circ}$ les philandres ou sarigues, marmoses, cayopollins, phalangers, tarsiers, etc.; $4^{0}$ les jaguars, couguars, ocẻlots, margais, etc.; 50 les coatis, trois ou quatre espèces; $6^{\circ}$ les mouffettes, quatre ou cinq espèces; 70 le genre de l'agouti, dans lequel je comprends l'accouchi, le paca, l'apérea et le tapéti; $8^{\circ}$ celui des tatous, qui est composé de sept ou huit espèces; $9^{\circ}$ les fourmiliers, deux ou trois espèces; et $10^{\circ}$ les paresseux, dont nous connaissons deux espèces, savoir : l'unau et l'aï.

Or, ces dix genres et ces quatre espèces isolées, auxquels on peut réduire les cinquante espèces d'animaux qui sont particuliers au Nouveau-Monde, quoique toutes différentes de celles de l'ancien continent, ont cependant des rapports éloignés qui paraissent indiquer quelque chose de commun dans leur formation, et qui nous conduisent à remonter à des causes de dégénération plus grandes et peut-être plus anciennes que toutes les autres. Nous arons dit qu'en général tous les animaux du 'NoureauMonde étaient beaucoup plus petits que ceux de l'ancien continent; cette grande diminution dans la grandeur, quelle qu'en soit la cause, est une première sorte de dégénération, qui n’a pu se faire sans beaucoup influer sur la forme, et il ne faut pas perdre de vue ce premier cffet dans les comparaisons que l'on voudra faire de tous ces animaux.

Le plus grand est le tapir, qui, quoiqu'il ne soit que de la taille d'un âne, ne peut cependanit être comparé qu'à l'éléphant, au rhinocéros et à l'hippopotame; il est dans son continent !c premier pour la grandeur, comme l'éléphant l'est dans le sien; il a, comme le rhinocéros, la lèvre supérieure musculeuse et avancée; et comme l'hippopotame, il se tient souvent dans l'eau. Seul, il les représente tous trois à ces petits égards; ct sa forme, qui en tout tient plus de celle de l'âne que d'aucune autre, semble être aussi dégradée que sa taille est diminuée. Le chcral, l'âne, le zèbre, l'éléphant, le shinocé-" 
ros et d'hippopotame, n'existaient point en Amérique, et n'y avaient même aucun représentant, c'est-à-dire qu'il n'y a vait dans ce Nouveau-Monde aucun animal qu'on pût leur comparer, ni pour la grandeur ni pour la forme: le tapir est celui dont la nature semblerait être la moins éloignée de tous; mais en même temps elle parait si mèlée et elle approche si peu de chacun en particulier, qu'il n'est pas possible d'en attribuer l'origine à la dégénération de telle ou telle espèce; et que, malgré les petits rapports que cet animal se trouve avoir avec le rhinocéros, l'hippopotame et l'âne, on doit le regarder non-seulement comme étant d'une espèce particulière, mais même d'un genre singulier et différent de tous les autres.

Ainsi le tapir n'appartient ni de près ni de loin à aucune espèce de l'ancien continent, et à peine porte-t-il quelques caractères qui l'approchent des animaux auxquels nous venons de le comparer. Le cabiai se refuse de même à toute comparaison; il ne ressemble à l'extérieur à aucun autre animal, et ce n'est que par les parties intérieures qu'il approche du cochon d'Inde, qui est de son même continent, et tous deux sont d'espèces absolument différentes de toutes celles de l'ancien continent.

Le lama et la vigogne paraissent avoir des signes plus significatils de leur ancienne parenté, le premier avec le chameau, et le second avec la brebis. Le lama a, comme le chameau, les jambes hautes, le cou fort long, la tête légère, la lèvre supérieure fendue; il lui ressemble aussi par la douceur du naturel, par l'esprit de servitude, par la sobriété, par l'aptitude au travail; e'était, chez les Anuéricains, le premier et le plus vitile de leurs animaux domestiques : ils s'en servaient comme les Arabes se servent du chameau pour porter des fardeaux : voilà bien des convenances dans la nature de ces deux animaux, et l'on peut encore $y$ ajouter celles des stigmates du travail ; car, quoique le dos du lama ne soit pas déformé par des bosses, comme celui du chameau, il a néanmoins des callosités naturelles sur la poitrine, parce qu'il a la même habitude de se reposer' sur cette partie de son corps. Malgré tous ces rapports, le lama est d'une espece très-distincte ct triè-différente de celle du chameau : d'abord il est beaucoup plus petit et n'a pas plus du quint ou du tiers du volıme du clameau ; la forme de son corps, la qualité et la couleur de son poil sont aussi fort différentes; le tempérament l'est encore plus : c'est un animal pituiteux, et qui ne se plaît que dans les montagnes, tandis que le chameau est d'un tempérament sec, et habite volontiers dans les sables brủlants : en tout, il y a peut-être plus de différences spécifiques entre le chameau et le lama, qu'entre le chameau et la girafe. Ces trois auimaux ont plusieurs caractères communs, par lesquels on pourrait les réunir au même genre; mais en même temps, ils diffèrent à tant d'autres égards, qu'on ne serait pas fondé a supposer qu'ils sont issus les uns des autres; ils sont roisius et ne sont pas parents. La girafe a près du double de la hauteur du chameau, et le chameau le double du lama : les deux premiers sont de l'ancien continent, et forment des espèces séparées ; à plus forte raison, le lama, qui ne se trouve que dans le Nouveau-Monde, est-il d'une espèce éloignće de tous les deux.

Il n'en est pas de même du pecari : quoiqu'il soit d'une espèce différente de celle du cochon, il est cepeudant du même genre; il ressemble au cochon par la forme et par tous les rapports apparents ; il n'en diffère que par quelques petits caractères, tels que l'ouverture qu'il a sur le dos, la forme de l'estomac et desintestins, ete. On pourrait donc croire que cet animal serait issu de la même souche que le cochon, et qu'autrefois il aurait passé de l'ancien monde dans le nouveau, où, par l'influence de la terre, il aura dégénéré au point de former aujourd'hui une espèce distincte et différente de ceile dont il est originaire.

Et à l'égard de la vigogne ou paco, quoiqu'clle ait quelques rapports avec le brebis par la laine et par l'habitude du corps, elle en diffère à tant d'autres égards, quion ne peut regarder ces espèces ni comme voisines ni comme alliées; la vigogne est plutòt une espèce de petit lama, et il ne parait par aucune indice qu'elle ait jamais passé d'un continent à l'autre. Ainsi, des quatre espèces isolées qui sont particulièies au Nouveau-Nonde, tous, savoir : le tapir, le cabiai et le lama avec la rigogne, paraissent appartenir en propre et de tout temps à ce continent; au lieu que le peeari, qui fait la quatrième, semble n’ètre qu'une espece dógénéréc du genre des cochons, et aroir autrefois tiré son origine de l'ancien continent.

En examinant et compillint, dans la mème I vue, les dix gemres auxquels nous avons réduit 
les autres animaux particuliers à l'Amérique méridionale, nous trouverons de même, nonsculement des rapports singuliers dans leur nature, mais des indices de leur ancienne origine et des sigues de leur dégénération. Les sapajous ct les sagouins ressemblent assez aux guenons ou singes à longue quene pour qu'on leur ait domé le nom commun de singe: cependant nous avons prouvé que leur's espèces et même leur's genres sont différents, et d'ailleurs il serait bien difficile de concevoir comment les guenons de l'ancien continent ont pu prendre en Amérique une forme de face différente, une queue musclée et prélieusile, une large cloison entre les narines et les autres caractères, tant spécifiques que génériques, par lesquels nous les avons distinguées et séparées des sapajous : cependant comme les singes, les babouins et les guenons ne se trouvent que dans l'ancien contient, on ıloit regarder les sapajous et les sagouins comme leurs représentants dans le nouveau; car ces animaux ont à peu près la même forme, tant it l'extérieur qu'à l'intérieur, et ils ont aussi beancoup de choses communes dans leurs habitudes naturelles. Il en est de même des makis dont ancune espèce ne s'est trouvée en Amérique, et qui néanmoins paraissent y être remplacés ou représentés par les philandres, c'està-dire par les sarigues, marmoses et autres quadrumanes à muscau pointu, qui se trouvent en grand nombre dans le nouveau continent et nulle part dans l'ancien; seulement il faut observer (qu'i] y a beaucoup plus de différence entre la nature et la forme des makis et de ces quadrumanes américains, qu'entre celle des gruenons cf des sapajous; et qu'il y a si loin d'un sarigue, d'une marmose ou d'un phalanger, à un maki, qu'on ne peut pas supposer qu'ils vicument les uns des autres, sans supposer en même temps que la dégénération peut produire des effets égaux àj ceux d'une nature nouvelle; ear la plupart de ces quadrumanes de l’Amériçue ont me poehe sous le ventre; la plupart ont dix dents à la màchoire supérieure et huit à l'inférieure; la plupart ont la queue préhensile, tandis que les makis ont la queue lâche, n'ont point de poche sous le ventre, et n'ont que quatro dents incisives à la mâchoire supérieure, et six à l'inféricure. Ainsi, quoique ees animaux aient les mains et les doigts conformés de la même manière, ct ([u'ils se ressemblent aussi par l'allongement du museau, leurs espèces ct même leurs genres sont si différents, si éloignés : gu'on ne peut pas imaginer qu'ils soient issus les uns des autres, ni que des disparités aussi grandes et ausśi générales aient jamais été produites par la dégénération.

Au contraire, les tigres d'Amérique, que nous avons indiqués sous les noms de jaguars, couguars, ocelots et margais, quoique d'espèces différentes de la panthère, du léopard, de l'once, du guépard et du serval de l'ancien continent, sont cependant bien certainement du même genre : tous ces animaux se ressemblent beaucoup tant à l'extérieur qu'à l'intérieur'; ils ont aussi le même naturel, la même férocité, la même véhémence de goût pour le sang; et ce qui les rapproche encore de plus près pour le grenre, e'est qu'on les comparant, on trouve que ceux du même continent diffèrent autant et plus les uns des autres que ceux de l'autre continent. Par exemple, la pantlière de l'Afrique diffère moins du jagular du Brésil, que celuici ne diffère du couguar, qui cependant est du même pays; de mème le serval de l'Asie et le margai de la Guiane sont moins différents entre eux, qu'ils ne le sont de tous ceux de leur propre continent. On pourrait donc croire avec assez de fondement que ces animaux ont eu une origine commune, et supposer qu'ayant autrefois passé d'un continent à l'autre, leurs différences actuelles ne sont venues que de la longue influence de leur nouvelle situation.

Les mouffettes ou puants d'Amérique et le putois d'Europe paraissent être du même geure. En général, lorsqu'ur genre est commun aux deux continents, les espèces qui le composent sont plus nombreuses dans l'ancien que daus le nouveau. Ici c'est tout le contraire : on y trouve quatre ou cinq espèces de putois, tandis que nous n'en avons qu'un, dont la nature parait mème inférieure on moins cxaltée que celle de tous les autres; en sorte (qui ì son tour le Nouveau-Monde paraît avoir des représentants dans l'ancien; et si l'on ne jugeait que par le fait, on croirait que ces animaux ont fait li route contraire, et ont autrefois passé d'Amérique en Europe. Il en est de même de quelques autres espèces : les chevreuils et les daims, aussi bien que les mouffettes, sont plus nombreux tant pour les variétés que pour les espèces, et en mème temps plus grands et plus forts dans le nouveau continent que dasis l'ancieu; on pourrait done imaginer qu'ils en sont originaires : 
mais commenous ne devons pas douter que tous les animaux en général n’aient été créés dans l'ancieıl continent, il faut nécessairement admettre leur migration de ce continent ì l'autre, et supposer en même temps, cqu'au licu d'avoir, comme tous les autres, dégénéré dans ce Nouveau-Monde, ils s'y sont au contraire perfectionnés, et que par' la convenance et la faveur du climat, ils ont surpassé leur première nature.

Les fourmiliers, qui sont des animaux trèssinguliers, et dont il y a trois ou cquatre espèces dans le Nouveau-Monde, paraissent aussi avoir leur's représentants dans l'ancien; le pangolin ct le phatagin leur ressemblent par le caractère unique de n'avoir point de dents, et d'ètre forcés comme eux à tirer la langue et vivre de fourmis. Mais si l'on reut leur supposer une origine commune, il est assez étrange qu'au lieu d'écailles qu'ils portent en Asie, ils se soient couverts de poils en Amérique.

A l'égard des agoutis, des pacas et des autres du septième genre des animaux particulier's au nouveau coutinent, on ne pent les comparer qu'au lièvre et au lapin, desquels cependant ils diffêrent tous par l'espèce; et ce qui peut faire douter 'qu'il y ait rien de commun dans leur origine, c'est que le lièvre s'est répandu dans presque tous les climats de l'ancien continent, sans que sa nature se soit altérée et siuns qu'il ait subi d'autres ehangements que dans la couleur de son poil. On ne peut done pas imaginer avec fondement que le climat d'Amérique ait fait ce que tous les autres climats n'ont pu faire, et qu'il euit changé la nature de nos lièvres au point d'cn faire ou des tapétis et des apérea qui n'out point dequeue, oudes agoutis ämuscau pointu, à oreilles courtes et rondes, on des paeas à grosse tète, à oreilles courtes, à poil ras et rude, avee des bandes blanehes.

Enfin, les coatis, les tatous et les paresseux sont si différents, non-sculement pour l'espèce, mais aussi pour le genre de tous les animaux de l'aneieu continent, qu'on ne peut les conlparer à aucun, et qu'il n'est pas possible de leur supposer rien de conmun dans leur origine, ni d'attribuer aux effets de la dégénération les prodigieuses différences ıpui se trouvent dans leur nature, dont nul autre animal ne peut nous donner ni le modèle ni l'jdéc.

Ainsi de dix genres et de quatre espices iso. lées, auxquels nous a vons tâché de réduire tous les animaux propres et particuliers au NouveauMonde, il n'y en a que deux, savoir : le genre des jaguar's, des ocelots, etc.; et l'espece du pecari, arec ses variétés, qu'on puisse rapporter avec quelque fondement aux animaux de l'ancien continent. Les jaguars et les ocelots peuvent ètre regardés comme des especes de léopards ou de panthères, et le pecari comme une espèce de cochon. Ensuite il y a cing genres et une espèce isolée, savoir, l'espèce du lama, et les genres des sapajous, dessagouins; des mouffettes, des agoutis et des fourmiliers, qu'on peut comparer, mais d'une manière équivoque et fort éloignée, au chamean, anx guenons, au putois, au lièvre, et aux pangolins ; et enfin il reste quatre genres et deux espèces isolées, savoir : les philaudres, les coatis, les tatous, lespa esseux, le tapir et le cabiai, qu'on ne peut ni rapporter ni méme comparer à aucun des genles ou des espèces de l'aneien continent. Cela semble prouver assez que l'oricine de ces animaux particuliers au Nouveau-Nonde ne peut être attribuée à la simple dégénération; quelque grands, quelque puissants qu'on voulût en supposer les effets, on ne pourra jamais se persuader avec quelque apparence de raison que ces animaux aient été originairement les mèmes que ceux de l'ancien continent : il est plus raisonnable de penser qu'autrefois les deux continents étaient contigus ou contimus, et que les espèces qui s'étaient cantonnées dans ces contrées du Noureau-Monde, parce yu'elles en avaieut trouvé la terre (t le ciel plus convenables à leur nature, y furent renfermées et séparées des autres par l'irruption des mers lorsqu'elles divisèrent l'Afrique de l'Amerique. Cette cause est naturelle et l'on peut en imaginer de semblables, et qui produiraient le mène? effet. Par excmple, s'il arrivait jamais que li mer fit une irruption en Asie de l'orient au couchant, et qu'elle séparît du reste du continent les terres méridionales de l'Afrique et de l'Asie, tous les animaux qui sont propres et particuliers à ces contrées du midi, tels que les éléphants, les rhinocéros, les girafes, les zèbres, les oranursoutangs, ete, se trouveraient, relativement aux autres, dans le meme cals que le sont actuellement ceux de l'A mérique méridionale; ils seraient entierement et alssolument séparés de ceux des contrées tempérées, et on aurait tort de leur cherelxer une origine commune et de vouloir les rappeler aux espices ou aux grenres 
qui peuplent ces contrées, sur le seul fondement qu'ils auraient avec ces derniers quelque ressemblance imparfaite ou quelques rapports éloiginés.

Il faut done, pour rendre raison de l'origine de ces animaux, remontel aux temps où les deux continents n'étaient pas encore séparés; il faut se rappeler les premiers changements qui sont arrivés sur la surface du globe; il faut en méme temps se représenter les deux cents espèces d'animaux quadrupèdes réduites à trente-huit familles : et, quoique ce ne soit point là l'état de la nature celle qu'elle nous est parvenue, et que nous l'avons représentée, que ce soit au contraire un état beaucoup plus ancien, et que nous ne pouvons guère atteindre que par des inductions et des rapports presque aussi fugitifs que le temps qui semble en avoir effacé les traces; nous tâcherons néanmoins de remonter par les faits et par les monuments encore existants à ces premiers âges de la nature, et d'en présenter les époques qui nous paraìtront clairement indiqućes.

\section{DES MULETS.}

En conservant le nom de mulet à l'animal qui provient de l'âne et de la jument, nous appellerons bardeau celui qui a le cheval pour père et l'ânesse, pour mère. Personne n'a jusqu'à présent oloservé les différences qui se trouvent entre ces deux animaux d'espèce mélangée. C'est néanmoins l'un des plus sûrs moyens que nous ayons pour reconnaître et distinguer les rapports de l'influence du mâle et de la femelle dans le produit de la génération. Les observations comparées de ces deux mulcts, et des autres métis qui proviennent de deux espèces différentes, nous indiqueront ces rapports plus précisement et plus évidemment que ne le peut faire la simple comparaison de deux individus de la même espèce.

Nous avons fuit représenter le mulet et le bardeau, afin que tout le monde soit en état de les comparer, comme nous allons le faire nousmèmes. Dabord le bardeau est beaucoup plus petit que le mulet : il para!t done tenir de sa mèrel'ànesse les dimensions du corps ; ct le mulet, beaucoup plus grand et plus gros que le baldeaı, les tient également de la jument sa mère. La grandeur et la grosseur du corps paraissent donc dépendre plus de la mère que du père dans les espèces mélangées. Maintenant, si nous considérons la forme du corps, ces deux animaux, vus ensemble, paraissent être d'unc figure différente, le bardeau a l'encolure plus mince, le dos plus tranchant, en forme de dos de carpe, la croupe plus pointue et ovalée, au lieu que le mulet a l'avant-main mieux fait, l'encolure plus belle et plus fournie, les côtes plus arrondies, la croupe plus pleine et la hanche plus unie. Tous deux tiennent done plus de la mère que du père, non-seulement pour la grandeur, mais aussi pour la forme du corps. Néanmoins il n'en est pas de même de la tête, des membres, et des autres extrémités du corps. La tête du bardeau est plus longue et n'est pas si grosse à proportion que celle de lâne, et celle du mulet est plus courte et plus grosse que celle du cheval. Ils tiennent done pour la forme et les dimensions de la tête plus du père que de la mère. La queue du bardeau est garnic de crins à peu près comme celle du cheval; la queue du mulet est presque nue comme celle de l'âne; ils r'essemblent donc encor'e à leur père par cette extrémité du corps, Les oreilles du mulet sont plus longues cue celles du cheval, et les oreilles du bardeau sont plus courtes que celles de l'âne : ces autres extrémités du corps appartiennent done aussi plus au père qu'à la mère. Il en est de même de la forme des jambes, le mulet les a sèches comme l'âne, et le bardeau les a plus fournies. Tous deux ressemblent donc par la tête, par les membies, et par les autres extrémités du corps, beaucoupplus à leur père qu'à leur mère.

Dans les années 1751 et $\mathbf{1 7 5 2}$, j'ai fait accoupler deux boues avec plusieurs brebis, et j'en ai obtenu neuf mulets, sept mâles et deux femelles. Frappé de cette différence du nombre des mâles mulets à celui des femelles, je pris quelques informations pour tâcher de savoir si le nombre des mulets mâles qui provienment de l'âne et de la jument excède à peu près dans la même proportion le nombre des mulets : aucune des réponses que j'ai reçes ne détermine cette proportion, mais toutes s'accordent à faire le nombre des mâles mulets plus grand que celui des femelles. On verra dans la suiteque M. le marquis de Spontin-Beaufort, ayant fait accoupler un chien avec une lonve, a obtenu quatre mulets, trois màles et uue femelle. Enfin, ayant fait des questions sur des mulets plus aisés à 

procréer, j'ai su que, dans les oiseaux mulets, le nombre des mảles excède encore beaucoup plus le nombre des mulets femelles. J'ai dit, à l'article du serin des Canaries, que de dix-neuf petits provenus d'une serine et d'un chardonneret, il n'y en avait que trois femelles. Voilà les seuls faits que je puisse présenter comme certains sur ce sujet, dont il me parait pas qu'on se soit jamais oceupé, et qui cependant mérite la plus grande attention; car ce n'est qu'en réunissant plusieurs faits semblables qu'on pourra développer ce qui reste de mystérieux dans la génération par le concours de deux individus d'espeees différentes, et déterminer la proportion des puissances effectives du mâle et de la femelle dans toute reproduction.

De mes neuf mulets provenus du bouc et de la brebis, le premier naquit le 15 avril. Observé trois jours après sa naissance et comparé avec un agneau de même âge, il en différait par les oreilles qu'il avait un peu plus grandes, par la partic supéricure de la tète qui était plus large, ainsi que la distance des yeux; il avait de plus une bande de poil gris blane depuis la nuque du cou jusqu'à l'extrémité de la queue; les quatre jambes, le dessous du cou, de la poitrine et du ventre, étaient couverts du même poil blane assez rude; il n'y avait un peu de laine que sur les flanes entre le dos et le ventre, et encore cette laine courte et frisée était mèlée de beaucoup de poil. Ce mulet avait aussi les jambes d'un pouce et demi plus longues que l'agneau du même âge. Observé le 3 mai suivant, e'està-dire dix-huit jours après sa naissance, les poils blanes étaient en partie tombés et remplacés par dẹs poils bruns, semblables pour la couleur à ceux du boue et presque aussi l'udes. La proportion des jambes s'était soutenue ; ce mulet les avait plus longues que l'agneau de plus d'un pouce et demi: il était mal sur ses longues jambes et ne marehait pas aussi bien que l'agneau. Un accident ayaut fait périr ect agneau, je n'observai ee mulet que quatre mois après, et nous le comparâmes avec une brebis du mème Age. Le mulet avait un ponee de moins que la brebis, sur la longueur qui est depuis l'entredeux des yeux jusqu'au bout du museau, et un demi-ponce de plus sur la largeur de la tête prise au-dessus des yeux, àl'endroit le plus gros. Ainsi la tète de ee mulet était plus grosse et plus courte que celle d'une brebis du mène agge; la courbure de la mâchoire supérieure prise à l'endroit des coins de la bouche, avait près d'un demi-pouce de longueur de plus dans le mulet que dans la brebis. La tête du mulet n'était pas couverte de laine; mais elle était garnie de poils longs et touffus. La queue était de deux pouces plus courte que celle de la brebis.

$\mathrm{Au}$ commencement de l'aunée 1752, j'obtins de l'union du boue avec les brebis huit autres mulets, dont six måles et deux femelles. II en est mort deux avant qu'on ait pu les examiner ; mais ils ont paru ressembler à ceux qui ont vécu et que nous allons décrire en peu de mots. Il en avait deux, l'un mâle et l'autre femelle, qui avaient quatre mamelons, deux de chaque côté, comme les boucs et les chèvres; et, en général, ces mulets avaient du poil long sous le ventre et surtout sous la verge comme les boues, et aussi du poil long sur les pieds, principalement sur ceux de derrière. La plupart avaient aussi le chanfrein moins arqué que les agneaux ne l'ont d'ordinaire, les cornes des pieds plus ouvertes, e'est-à-dire la fourche plus large et la queue plus courte que les agneaux.

J'ai rapporté, dans le premier volume del'Histoire naturelle des quadrupèdes, à l'article du chien, les tentatives que j'ai faites pour unir un chien avec une louve; on peut voir toutes les précautions que j'avais cru devoir prendre pour faire réussir cetfe union. Le chien et la louve n'avaient tous deux que trois mois au plus, lorsqu'ou les a mis ensemble, etenfermés dans une assez grande cour sans les contraindre autrement, et sans les enehainer. Pendant la première année ces jeunes animaux vivaient en paix et paraissaient s'aimer. Dans la seconde année ils commencèrent à se disputer la nourriture, quoiqu'il y en eùt au delà du nécessaire: la querelle venait toujours de la louve. Après la seconde année les combats devinrent plus fréquents. Pendant tout ee temps la louve ne donna aucun signe de chileur; ce ne fut qu'it la fin de la troisième année qu'on s'aperçut qu'elle avait les mèmes symptòmes que les chieunes en chaleur : mais, loin que cet état les rapprochât l'un de l'autre, ils n'en devinrent tous deux que plus féroces; et le ehien, au lieu de couvrir la louve, finit par la tuer. De eette épreuve j'ai cru pouvoir conelure, que le loup n'est pas tout á fait de la mème nature que lc ehien, que les espèces sont assez séparées pour ne pouvoir les rapprocher aisément, du moins dans ces climats. Et je m'exprime dans 
les termes suivants : "Ce n'est pas que je pré" tende, d'une minièze décisive et absolue, que " le renard ct la louve ne se soicut jamais, dans " aucun temps ni dans aucun climat, mêlés " a vec le chien : les anciens l'assureut assez po" sitivement pour qu'on puissc avoir encore sur " cela quelques doutes, malgré les épreuves que " je viens de rapporter; ct j'avoue qu'il faudrait - un plus grand nombre de pareilles épreuves " pour acquérir sur ce fait une certitude en" tière. "J'ai eu raison de mettre cette restriction à mes conclusions; car M. le marcquis de Spontin-Beaufort, ayant tenté cette même union du chien et de la louve, a très-bien réussi, et dès lors il a trouvé et suivi mieux que moi les routes et les moyeus que la nature se réserve pour rapprocher quelquefois les animaux qui paraissent être incompatibles. Je fus d'abord jufor'mé du fait par une lettre que M. Surirey de l'oissy me fit l'honneur de m'écrire, et qui est concue dans les termes suivants :

A Namur, le 9 juin 1775.

"Chez Mi. le marquis de Spontin, à Namur, a été élevée une très-jeune louve, à laquelle on a donné pour compagnon un presque aussi jeune chien depuis deux ans. Ils étaient en liberté, venant dans les appartements, cuisine, écuric, etc.; très-caressants, sc couchant sous la table et sur les pieds de ceux qui l'entouraient. Ils ont vécu le plus intimengent.

- Le chien est une espèce de natin-braque très-vigoureux. La nourriture de la louve a été le lait pendant les six premiers mois; ensuite on lui a donné de la viande crue qu'elle préfé rait à la cuite. Quand elle mangeait, persomnen'osait l'approcher : en unautre tempson en faisait tout ce (qu'on voulait, pourvu qu'on ne la maltraitât pas. Elle caressait tous les chiens qu'on lui conduisait,jusqu'au moment qu'elle a donné la préférence à son ancien compagnon: elle eutrait en furcur depuis contre tout autre. C'a ćté le 25 mars dernier qu'elle a été couverte pour la première fois : ses amours ont duré seize jours avec d'assez fréquentes répétitions, et clle a donné ses petits le 6 juin à huit heures du matin : ainsi le tempis de la gestation a été de soixante-treize jours au plus. Elle a jeté quatre jeunes de couleur noirâtre. II y en a avec des extrémités blanches aux pattes et moitić de la poitrine, tenant en cela du chien, qui est noir et blane. Depuis qu'clle a mis bas, clle est grondante et se hérisse contre ecux qui approchent; elle ne recounait plus ses maltres; elle étranglerait le chien même s'il était à sa portée.

" J'ajoute qu'elle a été attachéc à deux chaines depuis une irruption qu'elle a faite à la suite de son galant, qui avait franchi une muraille chez un voisin qui a vait une elrienne en chaleur; qu'elle avait ćtranglé à moitié sa rivale; que le cocher a été pour les séparer à grands coups de báton et la reconduire à sa loge, oủ par imprudence recommençant la correction, elle s'est animée au point de le mordre à deux fois dans la cuisse, ce qui l'a tenu au lit six semaines par les incisions cousidérables qu'on a été obligé de faire. "

Dans ma réponse à cette lettre, je faisais mes remereiements à M. de Boissy, et j'y joignais quelques réfiexions pour éclaircir les doutes qui me restaient encore. M. le marquis de Spontin ayant pris communication de cette réponse, eut la bonté de m'écrire lui-mème dans les termes suivants :

\section{A Namur, le 14 juillet 1773.}

" J'ailu avec beaucoup d'intérèt les réflexions judicieuses que rous faites à M. Surirey de Boissy, que j'avais prié de vous mander pendant mon absence un événtement auquel je n'0sais encore m'attendre, malgré la force des apparences, par l'opinion que j'avais et que j'aurai toujours comme le reste du monde, de l'excellence et du mérite des savants ouvrages dont vous avez bien voulu nous ćclairer. Cependant, soit l'effet du hasard ou d'une de ces bizarreries de la nature, qui, comme vous dites, se plalt quelque fois à sortir des règles générales, le fait est incontestable, comme vous allez en convenil' vous-même, si vous voulez bien ajouter foi à ce que j'ai l'homneur de vous écrir'e; ce dont j'ose me flatter d'autant plus, que je pourrais autoriser le tout de l'aveu de deux eents personnes au moins, qui, comme moi, ont été témoius de tous les fuits que je vais avoir I homueur de vous détailler. Cette louve avait tout an plus trois jours quand je l'achetai d'un paysan quil'avait. prise dans le bois, après en avoir tué la mère. Je lui fis sucer du lait pendant quelques jours, jusqưà ce qu'elle pût manger de la viande. Je recommandais à ecux qui devaient en a voir soin, de la earesser, de la tourmenter entinuellement pour'tâcher de l'apprivoiser au moins avece eux; clle finit par devenir si familière, que je pou- 
vais la mener à la chasse dans les bois, juscju'à une licue de la maison sans risquer de la perdre; elle est mime revenue quelquefois seule pendant la nuit, les jours que je n'avais pu la ramener. J'étais beaucoup plus sur de la gárder auprès de moi quand j'arais un chien; car elle les a toujours beaucoup aimés, et eeux qui avaient perdu leur répugnancenaturelle jouaient avec elle comme si e'eủt été deux animaux de la mème espéce. Jusque-là elle n'avait fait la gruerre qu'aux chats et aux poules, qu'elle étranglait d'abord sans en vouloir manger. Dès rfu'elle eut atteint un an, sa férocité s'étendit plus loin, et je commencai à m'apereevoir (ju'elle en voulait aux moutons et aux chiennes, surtout si elles étaient en folic. Dés lors je lui ótai la liberté, et je la faisais promener à la chaine et muselée; car il lui estarrivé souvent de se jeter sur son conducteur yui la contruriait. Elle avait un an au moins, fuand je lui fis fure la conuaissance du chien gui l'a couverte. Elle est en ville dans mon jardin, à la chaine, depuis les delniers jours du mois de novembre passé. Plus de trois eents persomnes sont venues la voir dans ee temps. Je suis logé presque au centre de la ville : ainsi on ne peut supposer ru'un loup serait venu la trouver. Des qu'clle commenca à cutrer en elsalcur, elle prit un tel goût pour le chicn, et le chien pour clle, yu'ils luurlaient afireusement de part et d'autre quand ils ll'etaient pas ensemble. Elle a été couverte le 28 mars pour la premiere fois, et depuis, de!ı. fois pill jour pendant deux semaines environ. Ils restaient attachés près d'un fuart d'heure à chaque fois, pendant lequel temps la louve paraissait souflrir beaucoup et se plaindre, et le chien point du tout. Trois semaines apres on sapereut aisément qu'clle était pleine. Lo 6 juin clle domma ses petits au nombre de cquatre, qu'elle mourrit eneore à présent, quoiqu'ils aient cinc semaines et des dents très-pointues et assez longues. Ils ressemblent parfaitement ì de petits ('hiens, ayaut les oreilles assez longues et pendantes. II y en a un equi est tout il fiit noir avec la poitrine blanche qui était la conleur du chien. I.es autres auront, crois, la eouleur de la louse. II ont tous le poil beaucoup plus rude que les dhiens ordinaires. II n'y a qu'une chienne qui.est renue avec la queue tris-eourte, de meme que le chien qui n'en avait presque pas. Hs promettent ditre grands, forts et tris-méchauts. Lil mere en a un soin extraordinaire........ Je doute si ja la Gitrderai davantage, en ayant été dégoùté par un accident qui est arrivé à mon eocher, qui cn a été mordu à la cuisse si fort, qu'il a été six scmaines sur son lit sans pouvoir se bouger : mais je parierais volontiers quu'en la raldant, elle aura encore des petits avee ec mème ehien qui est blane avec de grandes taches noires sur le dos. Je crois, monsieur, avoir répondu, par ce détail, à vos observations, et j'ispere (jue rous ne douterez plus de la vérité de eet événement singulier. "

Je n'en doute pas, en effet, et je suis bien aise d'avoir l'ocension d'en témoignel publiquement ma recounaissance. r"est beaucoup gagner que d'acequcirir dans l'listoire de la Niture un fait mie; les moyens sont toujours difticiles, et comme l'un voit, tres-souvent dangereux; c'était par celte derniere raison que j'avais seruestré la louve et mon chicn de toute socicité; je eraignais lesaceidents en laissant vive ma louve en liberté. J'avais précédemment élevé un jeune loupqui, jusqu'i l'âge d'un an, n'avait fait áucun mal et suivait son maîtıe it peu pres comme uı chien : mais dies la seconde annéc il commit tant d'excès qu'il fallut le eondamner ì la mort. J'etais done assuré que ces animaux, quoique adoucis par l'éducation, repremment avec l'àge leur férocité naturelle; et en voulant présenir les inconvénients qui ne peuvent inanquer d'en résulter, ef tenant ma louve toujours enferméc avec le chicn, javoue que je n'avais pas sunti que je premais une mauraise nréhode : eal dans cet état d'eselavage et d'ennui, le naturel de li louve au lieu de sadoucir, s’aigrit au point qu'elle était plus féroce que dans l'état de nature ; et le ehien ayant cité séparé de si bonme heure de ses semblahles et de toute societi, avait pris un caractere sauvage et cruel, que la mauvaise humeur de la louve ne faisait qu irriter en sorte que dans les dernières annécs lemr antipathic devint si grande, qu’ils ne elerebaicont qu'à s'entre-dívorer. Dans l'épreuve de Y. Io marquis de Spontin, tout s'est passe diffigemment. I.e ehien était dans l'état ordinaios; il avait toute la donceme et toute's les atutres yuillités que eet animal do ile acquiert dans le e.ammeree de l'homme. I a louve d'autre part a yant été élevie en toute liherté et familierement di: son has atue avee le chien, qui, par cette hahitude sans contrainte, avait perdı sil répugnan.e' pour elle, etait dercuue susceptible d'aflection 
pour lui; elle l'a donc bien recu lorsque l'heure de la nature a sonné; et quoiqu'elle ait paru se plaindre et souffrir dans l'accouplement, elle a eu plus de plaisir que de douleur, puisqu'elle a permis qu'il fût réitéré chaque jour pendant tout le temps qu'a duré sa chaleur. D'ailleurs le moment pour faire réussir cette union disparate a été bien saisi : e'était la première chaleur de la louve; elle n'était qu'à la seconde année de son âge; elle n'avait done pas encore repris entièrement son naturel féroce. Toutes ces circonstances et peut-être quelqques áutres dont on ne s'est point apercu, ont contribué au succès de l'accouplement et de la production. Il semblerait donc, par ce qui vient d'être dit, que le moyen le plus sûr de rendre les animaux infidèles à leur espèce, c'est de les mettre comme l'homme en grande société, en les accoutumant peu à peu avec ceux pour lesquels ils n'auraient sans cela que de l'indifférence ou de l'antipathie. Quoi qu'il en soit, on saura maintenant, grâces aux soins de M. le marquis de Spontin, et on tiendra dorénavant pour chose sûre, que le chien peut produire avec la louve, même dans nos climats. J'aurais bien désiré qu'après une expérience aussi heureuse, ce premier succès eùt engagé son illustre auteur à tenter l'union du loup et de la chienne, et celle des renards et des chiens. Il trouvera peut-ếtre que c'est trop exiger, et que je parle ici arec l'enthousiasme d'un naturaliste insatiable : j'en conviens, et j'avoue que la découverte d'un fait nouveau dans la nature m'a toujour's transporté.

Mais revenons à uos mulets. Le nombre de mâles dans ceux que j'ai obtenus du bouc et de la brebis, est comme sept sont à deux; dans ceux du chien et de la louve ce nombre est comme trois sont à un; et dans ceux des chardonnerets et de la serine, comme seize sont à trois. Il parait donc presque certain que le nombre des mâles qui est déjà plus grand que celui des femelles dans les espèces pures, est encore bien plus grand dans les espèces mixtes. Le mâle influe donc en général plus que la femelle sur ta production, puisqu'il donne son sexe au plus grand nombre, et que ce nombre des mâles devient d'autant plus grand que les espèces sont moins voisines. Il doit en etre de mème des races différentes: on aura en les croisant, c'est-à-dire en prenant celles qui sont le plus éloignées, on aura, dis-je, non-seulement de plus belles productions, mais des mâles en plus grand nombre.
J'ai souvent tâché de deviner pourquoi dans aucune religion, dans aucun gouvernement, le mariage du frère et de la sœur n'a jamais été autorisé. Les hommes auraient-ils reconnu par une très-ancienne expérience, que cette union du frère et de la sœur était moins féconde que les autres, ou produisait-elle moins de mâles et des enfants plus faibles et plus mal faits? Ce qu'il y a de sûr, c'est que l'inverse du fait est vrai, car on sait, par des expériences mille fois répétées, qu'en croisant les races au lieu de les rémuir, soit dans les animaux, soit dans l'homme, on ennoblit l'espèce, et que ce moyen seul peut la maintenir belle et même la perfectionner.

Joignons maintenant ees faits, ces résultats d'expériences et ces indications, à d'autres faits constatés, en commençant par ceux que nous ont transmis les anciens. Aristote dit positivement, que le mulet engendre avec la jument un animal appelé par les Grees hinnus ou ginnus. Il dit de même que la mule peut concevoir aisément, mais qu'elle ne peut que rarement perfectionner son fruit. De ces deux faits qui sont viais, le second est en effet plus rare que le premier, et tous deux n'arrivent que dans des climats chauds. M. de Bory, de l'Académie royale des Sciences, et ci-devant gouverneur des îles de l'Ámérique, a eu la bonté de me communiquer un fait récent sur ce sujet, par sa lettre du 7 mai 1770 , dont voici l'extrait :

"Vous rous rappelez peut-être, monsieur, que M. d'Alembert lut ì l'académie des Sciences, l'année dernière $\mathbf{1 7 6 9}$, un lettre dans laquelle on lui mandait qu'une mule avait mis bas un muleton, dans une habitation de l'ile Saint-Domingue; je fus chargé d'écrire pour vérifier le fait, et j'ai l'honneur de vous envover le certificat que j'en ai reçu... Celui qui m'éerit est une persome digne de foi. 11 dit avoir vu des mulets couvrir indistinctement des mules et des eavales, comme aussi des mules couvertes par des mulets ct des étalous. "

Ce certificat est un acte juridique de notoriété, signé de plusieurs témoins et dùment contrơlé et légalisé. Il porte en substance, que, le 14 mai 1769 , M. de Nort, chevalier de SaintLouis et ancien major de la Légion royale de Saint-Domingue, étant sur son habitation de la Petite-Ause, on lui amena une mule qu'on lui dit être malade; elle avait le ventre très-gros, et il lui sortait un boyau par la vulve. M. de: 
Nort la croyant enflée, envoya chereher une espèce de maréchal nègre, qui avait coutume de panser les animaux malades; que ce nègre étant arrivé en son absence, il avait jeté bas la mule pour lui faire prendre un breuvage; que l'instant d'après la chute il la délivra d'un mulet bien conformé, dont le poil était long et trèsnoir; que ce muleton a vécu une heure; mais qu'ayant été blessé ainsi que la mule par sa chute forcée, ils étaient morts l'un et l'autre, le muleton le premier, c'est-à-dire presque en naissant, et la mule dix heures après: qu'ensuite on avait fait écoreher le muleton, et qu'on a envoyé sa peau au docteur Mathi, qui l'a déposée, dit M. de Nort, dans le eabinet de la Société royale de Londres.

D'autres témoins oculaires, et particulièrement M. Cazavant, maitre en chirurgie, ajoutent que le muleton paraissait ètre à terme et bien conlormé; que par l'apparenee de son poil, de sa tète et deses oreilles, il a paru tenir plus de l'áne que les mulets ordinaires; quẻ la mule avait les mamelles gonflées et remplies de lait; que lorsque l'on apercut les pieds du muleton sortant de la vulve, le nègre, maréchal ignorant, l'avait tiré si rudement, qu'en arrachant de force le muleton, il avait oceasionné un renversement daus la matrice, et des déchirements qui avaient oecasionné la mort de la mire et du petit.

Ces faits, qui me paraissent bien constatés, uous démontrent que dans les climats chauds, la mulepent non-seulement concevoir, mais perfectionner et porter ì terme son fruit. On ma écrit d'Espagne et d'Italic, qu'on en avait plusieur's exemples; mais aucun des fitits (qui m'ont flé transmis u’est aussi bien vérilié que eclui que je viens de rapporter : seulement il nous reste à savoir si cette mule de Saint-Domingue ne tenait pas conception de l'âne plutôt que du mulet; la ressenblanee de son muleton au premier plus qu'au sceond de ees animaux paraitrait l'indiquer : l'ardeur du tempérament de l'âne le rend peu délicat sur le choix fos femelles, et le porte à reehereher presque également l'ânesse, la jument et la mule.

11 est done eertain que le mulet peut engendrer et guc la mule peut produire; ils ont, comme lesautres animaux, tous les organes convenables et la licpueur nécessaire à la scénération : seulement ces animaux d'espece mixte sont beaucoup moins féconds, ct toujours plus tardifs que ceux d'espèce pure ; d'ailleurs ils u'ont jamais produit dans les climats froids, et ce n'est que rasement qu'ils produisent dans les patys chauds, et encore plus rarement dans les contrées tempérées; dès lors leur infécondité, sans être absolue, peut néanmoins ètre regardée comme positive, puisque la production est si rare yu'on peut à peine en citer un eertain nombre d'exemples : mais on a d'abord eu tort d'assurer (qu'ab)solument les mulets et les mules ne pouvaient engendrer, et ensuite on a eu encore plus grand tort d'avancer que tous les autres auimaux d'espéces mélangées etaient comme les mulets hors d'état de produire; les faits que uous avons rapportés ei-devant sur les métis produits par le bouc et la brebis, sur ceux du chien et de la louve, et partieulierement sur les métis des serins et des autres oiseaux, nous démontrent que ces métis ne sont point inféconds, et que quelques-uns sont même aussi féconds à peu près que leurs père et mère.

Un grand défaut, ou pour mieux dire un vice très-fré(fuent dans l'ordre des connaissances humaines, e'est qu'une petite erreur particulic̀re et souvent nominale, qui ne devait occuper que sa petite place en attendant qu'on la détruise, se rípand sur toute la chaine des choses (jui peuvent y avoir rapport, et devient par là une erreur de fait, une tr's-grande er'reur, et forme un préjugé général, plus difficile à déraciner que l'opinion particulière qui lui sert de base. Un mot, un nom qui, comme le mot mulet n'a dù et ne devait encore représcnter que l'idéc parìculière de l'animal provenant de l'âne et de la jument, a été mal à propos appliqué à l'animal provenant du cheval et de l'ânesse, et ensuite encore plus mal à tous les animaux quadrupèdes et à tous les oiseaux d'espèces málangées. Et comme dans sa première acception, ce mot mulet renfermait l'idée de l'infécondité ordinaire de l'animal provenant de l'àne et de la jument, on a, sans autre exameu, transporté cette mème idće d'infécondité à tous ${ }^{\circ} l e s$ ètres auxquels on a donné le même nom de mulet: je dis à tous les étres; ear, indépendamment des animaux quadrupèdes, des oiseaux, despoissons, on a fait aussi des mulets dans les plantes, auxquels on a , sans hésiter, domné, comme à tous les autres mulets, le défaut génćral de l’infécondité; tandis que dans le réel auem de ces itres métis n'est absolimeńt infécoud, et que de tous, le mulet proprement dit, e'est-ì-dire l'aumal qui seul doit 
porter ce nom, esi aussi le scul dont l'infécondite, sans itre absolue, soit assez positive pour qu'on puisse le reararder comme moins fécond ru'aucun autre, e'est-ì-dire comme infécond dans l'ordre ordinaire de la nature, en compalaison des animaux d'espèce pure et mème des autres animaux d'espèce mixte.

Tous les mulets, dit le préjugé, sont des animaux viciés qui ne peuvent produire : aucun animal, quoique provenant de deux espèces, n'est absolument infécond, disent l'expérience et la raison; tous au contraire peuvent produire, et il n'y a de différence que du plus au moins; seulement on doit observer que dans les espèces pures, ainsi que dans les espèces mixtes, il y a de grandes différences dans la féeondité. Dans les premieres, les unes, comme les poissons, les insectes, ete. , se multiplient chaque année par milliers, par centaines ; d'autres, comme les oiseaux et les petits animaux quadrupèdes, se reproduisent par vingtaines, par douzaines; d'autres enfin, comme l'homme et tous les grands animaux ne se reproduisent qu'un à un. Le nombre dans la production est, pour aiusi dire, en raison inverse de la grandeur des animaux. Le eheval et l'âne ne produisent qu'un par an, et dans le même espace de temps les souris, les mulots, les cochons d'Inde produisent trente ou quarante. La fécondité de ces petits animaux est donc trente ou quarante fois plus grande; et en faisant une échelle des différents degrés de fécondité, les petits animaux que nous venons de nommer seront aux points les plus élevés, taudls que le cheval, ainsi que l'âne, se trouveront pres:que au terme de la moindre fécondité ; car il n'y a guère que l'éléphant qui soit encore moins fécond.

Dans les espèces mixtes, e'est-à-dire dans celles des animaux qui, comme le mulet, proviennent de deux espèces différentes, il y a, comme dans les especees pures, des deg̣rés différents de fécondité ou plutôt d'infécondité ; car les animaux qui viennént de deux espèees, tenant de deux natures, sont en général moins fíconds, parce qu'ils ont moins de convenanees entre eux (qu'll n'y en a dans les espèces pures, et cette infécondité est d'autant plus grande cue la fécondité naturelle des parents est moindre. Dès lors si les deux espèces du eheval et de l'âne, peu fécondes par eltes-mêmes, viennent à se mèler, l'infécondité primitive, loin de diminuer daus l'animal métis ne pourra qu'augmen- ter : le mulct sera non-seulement pius inféeund que son père et sa mère, mais peut-être le plus infécond de tous les animaux métis, parce que toutes les autres espèces mélangées dont on a pu tirer du produit, telles que celles du bouc et de la brebis, du chien et de la louve, du chardonneret et de la serine, ete., sont beaucoup plus fécondes que les especes de l'âne et du cheval. C'est à cette cause particulière et primitive qu'on doit rapporter l'infécondité des mulets et des baldeáux. Ce dernier animal est mème plus infécond que le premier, par une seconde cause encore plus particulière. Le mulet, provenant de l'âne et de la jument, tient de son père l'ardeur du tempérament, et par conséquent la vertu prolifique ì un très-haut degré, tandis que le bpardeau, provenant du cheval et de l'ânesse, est, comme soṇ père, moins puissant en amour et moins habile à engendrer ; d'ailleurs la jument, moins ardente que l'ânesse, est aussi plus féconde, puisqu'elle retient et conçoit plus aisément, plus sûrement. Ainsi tout concourti rendre le mulet moins inféeond que le bardeau ; car l'ardeur du tempérament dans le mâle, qui est si nécessaire pour la bonne génération, et surtout pour la nombreuse multiplication, nuit au contraire dans la femelle, et l'empêche presque toujours de retenir et de concevoir.

Ce fait est généralement vrai, soit dans les animaux, soit dans l'espèce humaine; les femmes les plus froides avec les hommes les plus chauds engendrent un grand nombre d'enfants : il est rare au contraire qu'une femme produise si elle est trop sensible au physique de l'amour. L'acte par lequel on arrive à la génération n'est alors qu'une flcur sans fruit, un plaisir sans effet : mais aussi dans la plupart des femmes qui sont purement passives, e'est comme dans le figuier dont la sève est froide, un fruit qui se produit sans fleur ; car l'effet de cet acte est d'autant plus sùr, qu'il est moius troubli dans la femelle par les convulsions du plaisir : clles sont si marquées daus quelques-unes et même si nuisibfes à la coneeption dans quelques femelles, telles que l'ânesse, qu'on est obligé de lcur.jetel de l'eau sur la croupe, ou mine de les frapper: rudement pour les calmer; sans ce secour's désagréable elles ne deviendraient pas mères, ou du moins ne le deviendraient que tard, lorsque, dans un áge plus araneé, la grandeardeur du tempérament serait étcinte ou ne subsisterait (ji’en partie. On est quelguefois obligé de se servir des 
mîmes moyens pour faireconcevoir les juments. Mais, dira-t-on, les chiemes et les chattes, qui paraissent ètre encore plus ardentes en amour que la jument et l'ânesse, ne manquent néanmoins jamais de concevoir; le fait que vous avancez sur l'infécondité des femelles trop ardentes en amour n'est done pas général et souffre de grandes exceptions. Je réponds que l'cxemple des chiennes et des chattes, au lieu de faire une exception à la règle, cu serait plutôt une confirmation; car, à quelque excès qu'ou veuille supposer les convulsions intérieures des organes de la chienne, elles ont tout te temps de se ealmer pendant la longue durée du temps qui se passe entre l'acte consommé et la retraite du mille, qui ne peut se sćparer tant que subsiste le gonflement el l'irritation des parties. II en est de mème de lia chatte, qui, de toutes les femelles, parait ètre la plusardente, puisqu'elleappelleses mâles par des cris lamentables d'amour, quiannoncent le plus pressant besoin : mais e'est comme pour le elien par une autre raison de conformation daus le mâle, que cette femelle si ardente ne manque jamais de concevoir : son plaisir très-vif dans l'accouplement est nécessairement mêlé d'une douleur presque aussi vive. Le gland du ('hat est hérissé d'épines plus grosses et plus poimantes que celles de sa langue, qui, comme l'on sait, est rude au point d'offenser la peau; dès lors l'intromission ne pent cetre que fort douloureuse pour la femelle, qui s'en plaint et l'annonce hautement par des cris encore plus perçants que les premiers : la douleur est si vive, que la chatte fait en ce moment tous ses efforts pour échapper, et le chat, pour la retenir, est forcé de la saisir sur le cou atvec ses dents, et de contraindre et soumettre ainsi par la force cette mème femelle amenée par l'amour.

Dans les animaux domestiques soignés et bien nourris, la multiplication est plus grande que dans lesanimaux sauvages; on le voit par l'exemple des chats et des chiens (qui produisent dans nos maisons plusieurs fois par an, tandis que le chat chau rage et le chicn. abandonnés à la scule nature, ne produisent qu'une seule fois chaque année. On le voit encore micux parl'exemple des oiseaux domestiques : y a-t-il dans aucune espèce d'oiseaux libres une fécondité comparable à celle d'une poule bien nourrie, bicn fitce par sou cog ? Et daus l'especec humaine, quelle différence entre la chétive propagation des Sauvages et l'immense population des nations civilisées et bien gouvernées! Mais nous no parlons ici que de la fécondité naturelle aux animaux dans leur état de pleine liberté, on en verra d'un coup d'ocil les rapports dans la Table suivante, de laquelle on pourra tirer quelques consciqueiices utiles à l'Histoire uaturelle. 


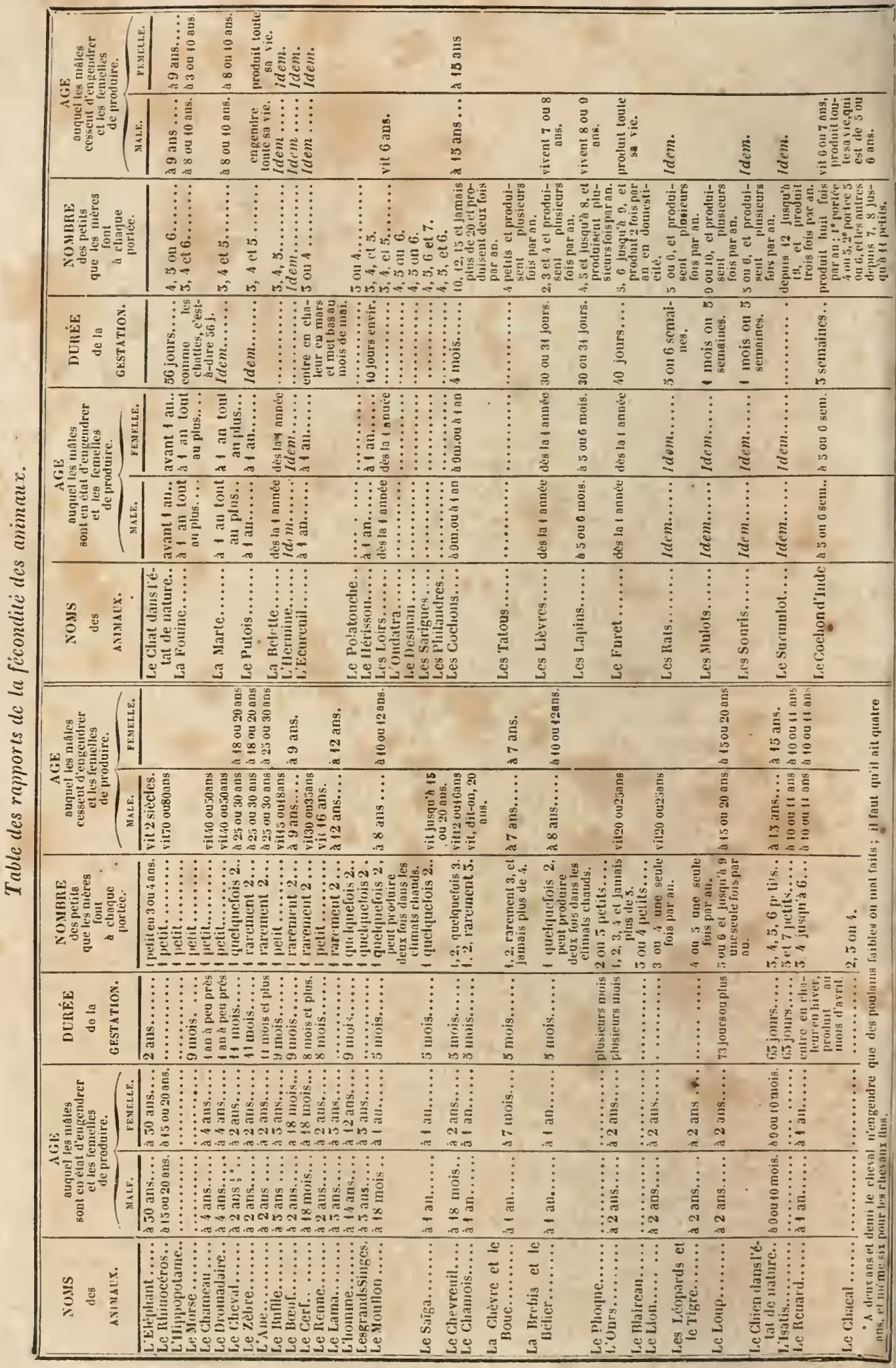


Voila l'ordre dans lequel la nature nous présente les différents degrés de la fécondité des animaux quadrupèdes. On voit que cette fécon. dité est d'autant plus petite que l'animal est plus grand. En général, cette mème échelle inverse de la fécondité relativement à la grandeur se trou ve dans tous les autres ordres de la nature vivante; les petits oiseaux produisent en plus grand nombre (que les grands : il en est de mème des poissons, et peut-ètre aussi des insectes. Mais, en ne considérant ici que les animaux quadrupèdes, on voit dans la table qu'il n'y a guère que le cochon qui fasse une exception bien marquée a cette espèce de règle: ear il devrait se trouver, par la grandeur de son corps, dans le nombre des animaux qui ne produisent que deux ou trois petits une seule fois par an, au lieu qu'il se trouve ètre en effet aussi f'écond que les petits animaux.

Cette table contient tout ce que nous savons sur la fécondité des animaux dans les espèces pures. Mais la fécondité dans les animaux d'espéces mixtes demande des eonsidérations partieulières; cette fécondité est, comme je l'ai dit, toujours moindre que dans les espèces pures. On en verra elairement la raison par une simple supposition. Que l'on supprime, par exemple, tous les mâles dans l'espice du cheval; et toutes les femelles dans celle de l'âne, ou bien tous les mâles dans l'espèce de l'àne, et toutes les femelles dans celle du cheval, il ne uaitra plus que des animaux mixtes, que nous avons appelés mulets et bardeaux, et ils najtront en moindre nombre que les chevaux ou les anes, puisqu'il y a moins de convenanees, moins de rapports de nature entre le cheval et l'ànesse ou l'âne et la jument, qu'entre l'àne et l'ânesse ou le cheval et la jument. Dans le réel, e'est le nombre des convenances ou des disconvenances qui eonstitue ou sépare les espèces; et puisque celle de l'âne se trouve de tout temps séparće de celle du cheval, il est clair qu'en mèlant ees deux espèces, soit par les màles, soit par les femelles, on diminue le nombre des convenances qui constituent l'espeec. Done les màles engendreront et les femelles produiront plus difficilement, plus rarement en conséquence de leur mélange; et mème ès espeees mélangées ne produiraient point du tout si leurs disconvenances étaicht un peu plus grandes. Le's mulets de toute sorte seront done toujours rare's dans leétat de nature; caur ee n’est qu'au défaut de'sat femelle naturelle, qu'un animal, de quelque espece qu'il soit, recherchera une autre femelle moins convenable pour lui, et à laquelle il eonviendrait moins aussi que son mâle naturel. Et quand mème ces deux animaux d'espèces différentes s'approcheraient sans répugnance, et se joindraient avee quelque empressement dans les temps du besoin de l'amour, leur produit ne sera ni aussi certain ma aussi frérfuent que dans l'espéce pure, ou le nombre beaucoup plus grand de ces mimes convenances fonde les rapports de l'appétit physique, et en multiplie toutes les sensatrons. Or", ce produit sera d'autant moins fréquent dans l'espèee mêlée que la fécondité sera moindre dans les deux espèces pures dont on fera le mélange; ('t le produit ultérieur de ces animaux mixtes provenus des espèces mèlées sera encore beaucoup plus rare que le premier; paree que l'animal mixte, héritier, pour ainsi dire, de la disconvenanee de nature qui se trouve entre ses père et mère, et n'étant lui-même d'aucune espèce, n'a parfaite convenance de nature avec aueun. Par exenple, je suis persuadé que le bardeau courrirait en vain sa femelle bardeau, et qu'il ne résulterait rien de eet accouplement: d'abord par la raison générale que je viens d'exposer, ensuite par la raison particulière du peu de fécondité dans les deux espèces dont cet animal mixte provient, et enlin par la raison encore plus particulière des causes qui empiehent souvent l'ìnesse de concevoir avec son mảle, et ù plus forte raison avee un male d'une autre espece: je ne crois done pas que ees petits mulets provenant du cheval et de l'ânesse puissent produire entre eux, ni qu’ils aient jamais formé lignée, parce qu'ils me paraissent réunir toutes les diseonvenances qui doivent amener l'infé. condité. Mais je ne prononeerai pas aussi affirmativement sur la nullité du produit de la mule et du mulet, paree que des trois cause's d'infécondité que nous venons d'exposer, la dernière n'a pas ie'i tout son effet: call la jument concevant plus faeilement que l'anesse, et l'äre étant plus ardent, plus chaud que le cheval, leur puissance respective de féenndite est plus grande, et leur prodnit moins rare que celui de l'anesse et du cheval; par consépuent le mulet sera moins inferond que le bardeau: neanmoins je doute beancoup que le mulet ait jamais engendre avere la mule, et je presume d'apres les exemples mémes des mules yqui ont mis 
bas, qu'elles devaient leur imprégnation à l'âne plutot qu'au mulet. Car on ne doit pas regarder le mulet comme le male naturel de la mule, quoique tous deux portent le méme nom, on plutòt n'en different que du maseulin au féminin.

Pour me faire mieux entendre, établissons pour un moment un ordre de parenté dans les espèces, comme nous en almettons un dans la parenté des familles. Le cheval et la jument seront frère et sœur d'espèce, et parents au premier degré. II en est de même de l'àne et de l'ânesse. Mais si l'on donne l'àne à la jument, ce sera tout au plus comme son cousin d'espèce, et eette parenté sera déjà du second degré; le mulet qui en résultera, participant par moitić de l'espèce du père et de celle de la mère, ne sera qu'au troisième degré de parenté d'espèce avee l'un et l'autre. Dès lors le mulet et la mule, quoique issus des mêmes père et mère, au lieu d'ètre frère et sœur d'espèce, ne seront parents (qu'au quatrième degré, et par conséquent produiront plus diffieilement entre eux que l'âne et la jument qui sont parents d'espèce au second degré. Et par la mème raison le mulet et la mule produiront moins aisément entre eux qu'avee lia jument ou avee l'âne, paree que leur parenté d'espèce n'est qu'au troisième degré, tandis qu'entre eux elic est au quatrième; l'infécondité qui commence à se manifester iei dès le second degré doit être plus marquée au trojsième, et si grande au quatrième qu'elle est peut-ètre alssolue.

En général, la parentè d'espèce est un de ces mystères profonds de la nature que l'homme ne pourra sonder qu'à force d'expériences aussi réitérées que longues et difficiles. Comment pourra-t-on comnaitre autrement que par les résultats de l'union mille et mille fois tentée des animaux d'espèces différentes, leur degré de parenté? l'ấue est-il parent plus proche du cheval que du zèbre? le loup est-il plus près du chien que le renard ou le ehacal? A quelle distanee de l'homme mettrons-nous les grands singes, qui Iui ressemblent si parfaitement par la conformation du eorps? Toutes les especes d'inimaux étaient-elles autrefo's ee qu'elles sont aujourd'hui? Icur nombre n'a-t-il pas augmenté ou plutôt diminué? les espèces faibles n'ont-elles pas été détruites par les plus fortes, ou par la tyrannie de l'homme, dont le nombre est devenu mille fois plus grand que celui d'aucune autre espèce d'animaux puissants? quels rap ports pourrions-nous établir entre cette parenté des espèces et une autre parenté mieux connue, qui est celle des différente's races dauns la même espèce? la race en géneral ne provient-elle pas, comme l'espèce mixte, d'une disconvenance à l'espèce pure dans les individus qui ont formé la première souche de la race? il y a pent-être, dans l'espice du chien, telle race si rare qu'elle est plus difficile à procréer que l'espéce mixte provenant de l'àne et de la jument. Combien d'autres questions à fitire sur cette seule matière, et qu'il y en a peu que nous puissions résoudre! que de faits nous seraient nécessaires pour pouvoir prononcer et mème conjecturer! que d'expérienees a tenter pour découvrir ees faits, les reconnaitre ou mème les prévenir par des conjectures fondées! Cependant, loin de se décourager, le philosophe doit applaudir a la nature, lors même qu'elle lui paraít avare ou trop mystérieuse, et se féliciter de ce qu'ả mesure qu'il lève une partie de son voile, elle lui laisse entrevoir une immensité d'autres objets tous dgnes de ses recherches. Car ce que nous connaissons déjà doit nous faire juger de ce que nous pourrons connaitre; l'esprit humain n'a point de bornes, il s'étend à mesure que l'univers se déploie; l'homme peut donc et doit tout tenter, il ne lui faut que du temps pour tout savoir. Il pourrait même en multipliant ses observations, voir et prévoir tous les phénomenes, tous les événements de la nature avee autant de vérité et de certitude, que s'il les déduisait immédiatement des causes : et quel enthousiasme plus pardonnable ou mème plus noble que celui de croire l'homme capable de reconnaltre toutes les puissanees, et découvrir par ses travaux tous les secrets de la nature!

Ces travaux consistent prineipalement ('n observations suivies sur les différents sujets qu'on veut approfondir, et en expériences raisonnées, dont le suceès nous apprendrait de nouvelles vérités : par exentple, l'union des animaux d'cspéces différentes, par laquelle seule on peut recounaitre leur parenté, n'a pas été assez tentée. Les faits que nous avons pu reeueillir, au sujet de cette union volontaire ou forcée, se réduisent à si peu de chose que nous ne sommes pas en état de prononcer sur l'existence réelle des jumarts.

On a donné ce nom jumart, d'abord aux animaux mulots ou métis, qu'on a prétendu pro- 
venir du taureau et de la jument; mais on a aussi appelé jumart le produit récl ou prétendu de l'ane et de la vache. Le docteur Shaw dit que dans les provinces de Tunis et d'Alger

"Il y a une espèce de mulet nommé Kumrach, qui vient d'un âne it d'une vache; que c'est une bête de charge, petite ì lia vérité, mais de fort grand usage; que ecux qu'il a rus n'avaient qu'une corne au pied comme l'âne, milis qu'ils étaient fort différents a tous écgards, ayant le poil lisse, et la rueue et la tète de vache, excepté qu'ils n'avaient point de eornes. "

Voilà done déjà deux sortes de jumarts : Ic premier qu'on dit provenir du taureau et de la jument, et le second de l'âne et de la vache. Et il est encore question d'un troisième jumart, qu'on prétend provenir du taureitu et de l'ânesse. Il est dit dans le Voyage de Vérolle, que, dans l'ile de Corse;

"Il y avait un auimal, portant des bagages, qui provient du taureau et che l'anesse, et que pour se le procurer on conve l'anesse avec une peiu de vache fralehe afin de tromper le taureau. ")

Mais je doute également de l'existence réelle de ces trois sortes de jumarts, sans cependant vouloir la nier absolument. de vais mème citer quelques faits particuliers, qui prouvent la réalité d'un amour mutuel et d'un accouplement réel entre des animaux d'espèces fort différentes, mais dont néaumoins il n'a rien résulté. lien ne parait plus éloigné de l'aimable earactère du chien que le gros instinct brut du cochon, et la forme du corps dans ces deux animaux est aussi diflérente que leur naturel; cependant j’ai sleux exemples d'un anour violent entre le chicn et la truie : eette année mème, 1774, dans le conrant de l'été, un chien épragneul de la plus grrande taille, voisin de l'habitation d'une truice en chale'ur', parut la prendre en grande passion; on les enferma ensemble pendant plusieurs jours, et tous les domestiques de la maison furent témoins de l'ardeur mutuelle de ces denx animaux; le chien fit meme des efforts prodigieux et très-réitérés pour s’accoupler arce la truice, mais la disconvenance dans les parties de la génciation empècha leur union. La meme chose est arrivée plusieurs années auparavant daus un licu voisin', de manière que le lait ne parut pas nouveau da la plu-

- A Billy, près Chanceau eu Bourgogac. part deceuxquien étaienttémoins.Lesanimaux, quuorque d'espèces très-différentes, se prennent donesouvent en affection, et peuvent par conséquent dans de eertaines circonstances se prendre entre eux d'une forte passion; car il est eertain que la seule chose qui ait empeché, dans ces deux exemples, l'union du chienavec la truie, ne vieut que de la conformation des parties qui ne peuvent aller ensemble; mais il n'est pas également certain que quand il y aurait eu intromission, et mème accouplement consommé, la production eut suivi. Il est souvent arrivé que plusieurs animaux d'espèces differentes se sont accouplés librement et siuns y ètre forcés; ces unions volontaires devainent etre prolifiques, puisqu'elles supposent les plus grands obstacles levés, la répugnance naturelle surmontée, et assez de convenance entre les partics de la géneration. Cependant ces accouplements, quoique volontaires, et qui sembleraient annoncer du produit, n'en donnent aucun; je puis en citer un exemple récent, et qui s'est pour ainsi dire passé sous mes yeux. Ein 1767 et anneés suivantes, dans ma terre de Buffon, le meunier avait une jument et un taureau gui hábitaient dans la même étable, et qui avaient pris tant de passion l'un pour l'autre, que daus tous les temps oì la jument se trouvait en chaleur, ie taureau ne manquait jamais de la couvrir trois ou quatre fois par jour, des qu'il se trouvait en liberté; ces aceouplements réiteres nombre de fois pendant plusieurs années donnaient aux maitres de ees animaux de grandes espérances d'en voir le produit. Cependant il n'en a janais rien resulté ; tous les habitants du lieu ont été témoins de l'accouplement très-reel et très-réitéré de ces deux animaux pendant plusieurs années, et en mème temps de la nullite du produit. Ce fait trés-certain parait douc prouver qu'au moins daus notre climat le taurenu n'engendre pas avee la jument, et éest ce qui me fait douter trés-léritimement de eutte première sorte de jumart. Je n'ai pas de faits aussi positifs à opposer contre la seconde surte de jumarts dont parle le docteur Slatw, et guil dit provenir de l'ane et de la vache. J'anoue meme que, quoique le nombre des disconvemances de nature paraisse it peru pres égal dans ees deux cas, le temojumagere positif d'un voyagerur aussi instruil yur le decterur Shaw semble domer plus de probabilite à l'existence de ces seconds jumarts, qu'il n'y eua pour les premicrs. 
Et, à l'égard du troisième jumart provenant du taureau et de l'ầesse, je suis bien persuadé, malgré le témoignage de Mérolle, qu'il n'existe pas plus que le jumart provenant du taureau et de la jument. Il y a encore plus de disconvenance, plus de distance de nature du taureau à l'ânesse qu'à la jument, et le fait que j'ai rapporté de la nullité du produit de la jument avec le taureau s'applique de lui-même, et, à plus forte raison, suppose le défaut du produit dans l'union du taureau avec l'ànesse.

\section{DE LA MULE.}

\section{EXEMPLES}

\section{D'ACCOUPLEMENT PROLIFIQUe de LA MUle} AVEC LE CHEVAL.

Nous avons dit, dans plusieurs endroits de notre onvrage, et surtout dans celui où nous traitons des mulets en particulier, que la mule produit quelquefois, surtout dans les pays chands. Nous pouvons ajouter, aux exemples que nous en avons donnés, une relation authentique que M. Schiks, consul des États-Généraux de Hollande, à Murcie en Espagne, a eu la bonté de m'envoyer, écrite eu espaguol, et dont voici la traduction :

(En 1763 , le 2 aovit, à huit heures du soir, chez le sieur Frameois Carra, habitant de la ville de Valence, une de ses mules, très-bien faite et d'un poil bai, ayant été saillie par un beau cheval gris de Cordoue, tit une très-belle pouline d'un poil alezan avec les crins noirs : cette pouline devint très-belle, et se trouva 'n état de servir de monture à l'âge de deux ans et demi. On l'admirait à Valence, car elle avait toutes les qualités d'une belle bète de l'espèce pure du cheval; elle était très-vive, et arvait beaucoup de jarret: on en a offert six cents écus à son maitre, qui n’a jamais voulu s'en défaire. Elle mourut d'une échaufficison, sans duute pour avoir été trop fatiguée ou montée trop tôt.

"En 1765 , le 10 juin, à einc heures du matin, la même mule de François Carra, qui avait été saillie par le mème cheval de Cordoue, fit une autre pouline aussi belle que la première et de la méme force, d'un poil gris sale et crins noirs; mais qui ne vécut que quatorze mois. "En 1767, le 31 janvier, cette même muie produisit pour la troisième fois, et c'était un beau poulain, mème poil gris sale, a vec les crins noirs, de la même force que les autres; il mourut àgé de dix-neuf mois.

"Le $1^{\text {er }}$ décembre 1769 , cette mule, toujours saillie par le mème cheval, fit une pouline aussi belle que les autres, qui mourut à vingt-un mois.

"Le 13 juillet 1771 , vers les dix heures du soir, elle fit un poulain, poil gris sale, très-fort, et qui vit encore alctuellement en mai 1777. Ces cinq animaux métis, mâles et femelles, vienuent d'un même cheval, lequel étant venu à mourir, François Carra en acheta un autre très-bon, du même pays de Cordone, le 6 mar's 1775 ; il était poil bai brun, avait une étoile au front, les pieds blancs de quatre doigts, et les crins noirs. Ce cheval, bien fait et vigoureux, saillit la mule sans que l'on s'en apercût, et, le 5 arril 1776, elle fit une pouline d'un poil alezan brûlé, qui avait aussi une étoile au front, et les pieds blancs comme le père; elle était d'une si belle tournure, qu'un peintre ne pourrait pas en faire une plus belle. Elle a les mèmes crins que les cinq autres, c'est aujourd hui une trèsbonne bête. On espère qu'elle réussira, car on en a un très-grand soin, et même plus que des autres.

"On ajoute que, lorsque cette mule mit bas pour la première fois, le bruit s'en répandit par toute la ville, ce qui y attira un cuncours de monde de tout àge et de tonte condition.

"En 1774, M. don André Gomez de la Véga, intendant de Valence, se fit domner !a relation des cinq productions de la mule pour la présen. ter au Roi. "

\section{LE ZEBRE.}

(LE CHEVAL ZÈBRE.)

Fanille des solipèdes, genre cheval.(Cuvier.)

Le zèbre est peut-être de tous les animaux quadrupèdes le mieux fuit et le plus élégam. ment vètu. Il a la figure et les grâces dı cheval, la légèreté du cerf, et la robe rayée de rubans noirs et blanes, disposés alternativ ement avec tant de régularité et de symétric, qu’il semble 
que la nature ait employé la règle et le compas pour ia peindre. Ces bandes alternatives de noir et de blanc sont d'autant plus singulières qu’elles sont étroites, parallèles et très-exactement séparées, comme dans une étoffe rayée; que d'ailleurs elles s'étendent non-seulement sur le corps, mais sur la tête, sur les cuisses et les jambes, etjusquue sur les oreilles et la queue; en sorte que de loin ect animal parait comme s'il était environné partout de bandelettes qu'on aurait pris plaisir et employé beatcoup d'art à disposer régulièrement sur toutes les parties de son corjs; dles en suivent les contour's ct en marquent si avantageusement la forme, quielles en dessinent les muscles eı s'élarøissant plus ou moins sur les parties plus ou moins charnues et plus ou moins arrondies. Dans la femelle, ces bandes sontalteruativement noires et blanches; dans le mâle, elles sont noires et jaunes: mais toujours d'une muance vive et brillante sur un poil court, fin et fourni, dont le lustre augmente encore la beautí des couleurs. Le zèbre est, en général, plus petit que le cheval et plus grand que l'âne; et equoiqu'on l'ait souvent comparé à ces deux animaux, qu'on l'ait mème appelé cheval survage et rine rayé, il n'est la copie ni de l'un ni de l'autre; il serait plutòt leur modèle, si dans la uature tout n'était pas également original, et si charpue espèce n'ayait pas un droit égal à la eréation.

Le zèbre n'est done ni un cheval ni une âne, il est de son espèce; car nous u'avous pas appris qu'il se mèle et produise avec l'un ou l'autre, quoique l'on ait souvent essayć de les approcher. On a présenté des ânesse's en chaleur à celui qui śtait l'année dernière 1761 à la Ménagerie de Versailles; il les a dédaignées, ou plutôt il n'en a été nullement ému; du moins le signe extéricur de l'émotion n'a point paru; cependant il jouait avee elles et les montait, mais Sans érection ni hennissement; et on ne peut guère attribuer cette froideur à une autre cause (qu'il la diseonvenance de nature; car ce zèbre, âgé de quatre ans, était à tout antre exereice fort vif et trìs-léger.

Le zebre n'est pas l'animal que les anciens mous ont indiqué sous le nom d'onagre. Ileviste dans le Levant, dans l'orient de l'Asie et dans la partie septentrionale de l'Alique une trisbelle race d'atres, yui, comme celle des plus beaux clicvaux, est originaire d'Arabie' : cotte

-11 y a deux sortes dânes eu Perse, les ancs du pays ıui race diffère de la race commune par la grandeur du corps, la légèreté des jambes, et le Iustre du poil ; ils sont de couleur uniforme, ordinairement d'un beau gris de souris, avec une croix noire sur le dos et sur les épaules ; quelquefois ils sont d'un gris plus clair arec une croix blonde. Ces ânes d'Afrique et d'Asic ", quoique plus beaux que ceux d'Europe, sortent également des onagres ou ánes sauvages, qu'on trouve encore en assez grande quantité dans la Tartaric orientale et mériclionale, la Perse, la Syrie, les îles de I'Arehipel et toute la Mauritanie. Les onargres ne different des ânes domestiques qué par les attributs de l'indépendance et de la liberté; ils sont plus forts et plus lécers, ils ont plus de courage et de vivaeité, mais ils sout les mêmes pour la forme du corps; ils ont seulement le poil beaueoup plus long, et cutte différence tient encore à leur état; car nos ànes auraient également le poil long, si l'on n'avait pas soin de les tondre à l'âge de quatre ou cinq mois : les anons ont dans les premiers temps le poil long, à peu près comme les jeunes ours. Le cuir des ânes sauvages est aussi plus dur que celui des ânes domestiques : on assure qu'il est chargé partout de petits tubercules, et que c'est arec cette peau des onagres quion fait, dans le Levant le cuir ferme et rrenu qu'on appelle chagrin, et que nous employons à différents usages. Mais ni les onagr's, ni les beaux ânes d'Arabie ne peuvent être regardés comme la souche de l'espèce du zebre, quoiqu'ils en approchent par la forme du corps et par la légèreté : jamais on n'a vu ni sur les uns, ni sur les

sont lents et pesants, comme les ines de nos pays, qui ne servent qu"à porter ules fardeaux; $c t$ une race d'iutes d'Arabie, yui sont de fort jolies lretes, et les premiers aues du monde: ils ont le poil poli, la lite liaule, les pieds lépers, le's levant avec aclion en marchant : on se s'en sert pue punr monture.. On les panse comme les chevaux.. lles espuces d'ecuyers le dressent a aller a l'amblo: ct leur allure est estrêmement douce el si prompte, yu'il fant saloper pour lus suive. Voyage de Chardin, tome 11 , page 27 . - Voyage ele Tavernier, tone 11. page 20.

4.es Maures qui viennent trafiquer au eap Vert, avaient amené leurs bagages et luurs denrées sur des ânes ; jeus de la peine à recomuaitre cut animal, taut il dail bran el bien ritu

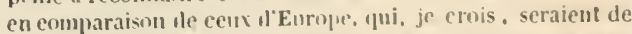
uxime, sile travail et la manicre dent on les charge ne con-

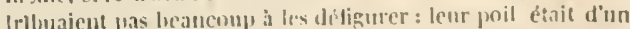
gris de somris fort bean ul hien lustri, sur leyuel la bande

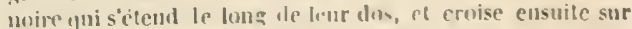
leurs ipanles, faisait un juli effet: ces atnes sont un peu plus granils,jue les mitres, mais ils out aus-i quelupe chose dlans

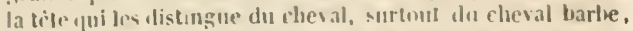
fui est comme naturel au pays, mais tomjours flus lact de taille. loyage au Séuezal par M. Alauson, page 118. 
autres, la variété régulière des couleurs du zèbre : cette belle espèce est singulière et unique dans son genre. Elle est aussi d'un climat différent de celui des onagres, et ne se trouve que dans les parties les plus orientales et les plus méridionales de l'Afriçue, depuis l'Éthiopie jusqu'au cap de Bonne-Espérance, et đe là jusqu'au Congo : elle n'existe ni en Europe, ni en Asie, ni en Amérique, ni même dans toutes les parties septentrionales de l'Afrique. Ceux que quelques royageur's disent avoir trouvés au Brésil, y avaient été transportés d'Afrique; ceux que d'autres racontent avoir vus en Perse' et en Turquie ${ }^{2}$, y avaient été amenés d'Éthiopie; et enfin ceux que nous avons rus en Europe sont presque tous venus du eap de BonneEspérance : cette pointe de l'Afrique est leur vrai climat, leur pays natal, où ils sont en grande quantité, et où les Hollandais ont employé tous leurs soins pour les dompter et pour les rendre domestiques, sans avoir jusqu'ici pleinement réussi. Celui que mous avons ru et qui a servi de sujet pour notre description, était très-sauvagè Jorsçu il arriva à la ménagerie du Roi, et il ne s'est jamais entièrement apprivoisé : cependant on est parvenu à le monter, mais il fallait des préeautions; deux hommes tenaient la bride pendant qu'un troisième était dessus : il avait la bouche très-dure, les oreilles si sensibles qu'il ruait dès qu'on voulait les toucher. I] était rétif comme un cheval vicieux, et têtu comme un mulet. Nais peut-ètre le cheval sauvage et l'onagre sont aussi peu traitables, et il y a toute apparence qui si l'on accoutumait dès

\footnotetext{
I Les amhassadeurs d'thiopie au Mogol devaient donner en présent une especce de petile mule, dont $\mathrm{j}^{*}$ ai vo la pean qui était une chose très-rare; il n'y a tigre si lien marqué, ni étolfe de soie a raies si bien rayce, ni avec tant de varjélé, d'ordre et de propurtion yu'elle l'ét til, Ilistuire de la révoluLiou du Hogol, par lir. Bernier. Ansiserdam, 1710, tone 1, page 181.

'Il arriva an ('aire un arubassadeur d'Éthiopie, ųui avait plusieurs présents pour le Grand-Seigneur, entre autres nn àne qui avait une peau forl belle, pourvi quielle fût naturelle. car je n'en vondrais pas répondre, ne l' ayant point examince. Cet anc avait la raie dn dus noire, el tout le reste dn corps étail bigarcé de raies'blanches, ct raies tanuées alternativement, larges cluacune diun doigt, ţui hi ceignaient tout le corys: la têle était exlrèmement lungue el bigarréc comme le corys; les oreilles noires, jannes el blanches; ses jambes, bigarrées de mème que le coṛıs, non pas en lung des jambes, mais a l'entour jusın'an bas en lacon de jarrelières, le tout. avec tant dordre el de mesure. prith n'y a puint de pean de ligre on de lropard si belle. Il nourut à cet ambassadeur denx anes pareils, par les cliemins, et il en portait les peaux pour présenter au (irand-Seigneur, avec celui qui étail vivant. Relation d'un vojage, par Thévenot, tome I, pages $\$ 73$ et 474 .
}

le premier âge le zèbre à l'obélssance et à la domestieité, il devieudrait aussi doux que l'âne et le cheval, et pourrait les remplacer tous deux.

\section{ADDITION AUX ARTICLES DE L'ANE ET DU ZÈBRE.}

L'âne domestique ou sauvage s'est trouvé dans presque tous les climats chauds et tempérés de l'ancien continent, et n'existait pas dans le nouveau lorsqu'on en fit la découverte. Mais maintenant l'espèce y subsiste arec fruit, et s’est mème fort multipliée depuis plus de deux siècles qu'elle y a été transportée d'Europe, en sorte qu'elle est aujourd'hư répandue à peu près également dans les quatre parties du monde. Au contraire, le zèbre qui nous est venu du cap de Bonne-Espérance semble être une espèce confinée dans les terres méridionales de l'Afrique, et surtout dans celles de la pointe de cette grande presqu'ile, quoique Lopez dise qu'on trouve le zébre plus sourent en Barbarie qu'au Congo, et que Dapper rapporte qu'on en reucontre des troupes dauns les forêts d'Angola.

Ce bel animal, qui, tant par la variéte de ses couleurs que par l'élégance de sa figure, est si supérjeur à l'âne, parait néanmoins lui tenir assez près pour l'espèce, puisque la plupart des voyageurs lui ont donné le nom d'cine rayé, parce rqu'ils ont été frappés de la ressemblance de sa taille et de sa forme, qui semblent au premier coup d'œil avoir plus de rapport a vee l'âne qu'avec le eheval. Car ce n'est pas aree les petits ânes communs qu'ils ont fait la comparaison du zèbre, mais avec les plus grands et les plus beaux de l'espèce. Cependant je serais porté à croire que le zèbre tient de plus près au cheral qu'à l'âne; car il est d'une figure si élégante, que, quoiqu'il soit en général plus petit que le cheval, il n'en est pas moins voisin de cette espèce à plusieurs égards; et ce qui parait confirmer mon opinion, e'est que, dans les terres du cap de Bonnc-Espérance, qui paraissent être le pays naturel et la vraie patrie du zèbre, on a remarqué aree quelque étonnement qu'il y a des chevaux tachetés sur le dos et sous le ventre, de jaune, de noir, de rouge et d'azur; et cette raison particulière est encore appuyće sur un fait général, qui est que, dans tous les climats, les ehevaux varient beaucoup plus que 
les Ánes par la couleur du poil. Néanmoins nous ne déciderons pas si le zèbre est plus près de l'espèce du cheval que de celle de l'âne; nous espérons seulement qu'on ne tardera pas à le savoir. Comme les Hollandais ont fait venir dans ces dernières années un assez grand nombre de ces beaux animaux, et qu'ils en ont même fait des attelages pour le prince stathouder, il est probable que nous serons bientôt micux informés de tout ce qui peut avoir rapport à leur nature. Sans doute on n'aura pas manqué d'essayer de les unir entre eux, et probablement avec les chevaux et les ànes, pour en tirer une race directe ou des races bátardes. Il y a en Hollande plusieurs personnes habiles qui cultivent l'histoire naturelle avec succes; ils réussiront peut-ètre mieux que nous à tirer du produit de ees animaux, sur lesquels on n'a fait qu'un essai it la Ménagerie de Versailles, en 1761 . Le zèbre mâle àgé de quatre ans qui y 'tait alors, ayant dédaigné toutes les ânesses - ('haleur, n'a pas cété présenté à des juments; p'ut-ètre aussi était-il trop jeune; d'ailleurs il lui,mancuait d'ètre habitué avec les femelles qu'on lui présentait; préliminaire d'autant plus nécessaire pour le succès de l'union des espèces diverses, que la nature semble meme l'exiger dans l'union des individus de mème espèee.

Le mulet fécond de Tartarie, que l'on y appelle $c$ sigithai, et dont uous avons parlé, pourrait bien être un animal de la mème espèce, ou tout an moins de l'espece la plus voisine de celle du zèbre; car il n’en diffère évidemment que par les couleurs du poil. Or, l'on sait que les différence's de lic couleur du poil ou des plumes est de toutes les difl'érences la plus légère et la plus dépendante de l'impression du climat. Le czigithai se trouve dans la Sibérie méridionale, au Thibet, daus la Diourie et en Tartarie. Gerbillon dit yu'on trouve ces animaux dans le pays des Mongoux et des Kabas, qu'ils dilfèrent des mulets domestiques, et qu'on ne peut les accoutumer a porter des fardeaux. Muller et Gmelin assurent qu'ils se trouvent en grand nombre chez les 'Tunguses, où on les chasse conme d'autre gibier; qu'en Sibérie, vers Borsja, dans les amnées sèches, on en voit un grand nombre, et ils ajoutent quiils sont comparables pour la figure, la grossenr et la couleur, à un cheval bai clair, exeepte la queue qui est comme eelle d'une vache, ct les oreilles fui sont fort lougues. Si ces voyagcurs qui ont ob- servé le czigithai, avaient pu le comparer en mème temps au zèbre, ils $y$ auraient peut-être trouvé plus de rapports que nous n'en supposons. Il existe dans le Cabinet de Pétersbourg des peaux bourrées de czigithai et de zebre : quelque différentes que paraissent ces deux peaux par les couleurs, clles pourraient appartenir également à des animaux de mẻme espèce ou du moins d'espèces très-voisines. Le temps seul perut sur cela détruire ou confirmer nos doutes. Mais ce qui parait fonder la présomption que le ezigrithai et le zèbre pourraient bien être de la mème espèce, c'est que tous les autres animaux de l'Afriçue se trourent également en Asie, et qu'il n'y aurait que le zebre seul qui ferait exception à ce fait đénéral.

Au reste, si le czigitlaai n'est pas le mème que le zèbre, il pourrait ètre encore le mème animal que l'onagre ou áne saurage de l'Asie. J'ai dit qu'il ne fallait pas confondre l'onagre arec le zèbre: mais je ne sais si l'on peut dire la mème chose de l'onagre et du ezigithai ; car il parait, en comparant les relations des voyageurs, qu'il y a différentes sortes d'ânes sau vages, dont l'onagre est la plus remarquable, et il se pourrait bien aussi que le cheval, l'âne, le zèbre et le ezigithai constituassent quatre espèces; et, dans le cas ou ils n'en feraient que trois, il est encore incertain si le ezigithai est plutòt un onagre qu'un zèbre, d'antant que quelques royageurs parlent de la légèreté de ces onagrres, et disent qu'ils courent aree assez de rapidité pour échapper it la poursuite des chasseurs à cheval, ce qu'ils ont également assuré du czigithai. Quoi qu'il en soit, le cheral, l'àne, le zèbre et le ezigithai sont tous du meme genre, et forment trois ou quatre branches de la mème famille, dont les deux premieres sont de temps immémorial réduites en domesticité, ee qui doit faire esperer qu'on pourra de mème y réduire les deux dernières, et en tirer peutétre beaucoup d'utilité.

DU CZIGITHA, DE L'ONAGRE ET DU ZĖBRE.

(LE CHEVAL CZIGITHAi, - LE CIIEVAL A.Te (Onagre), - LE CHEVAl, ZÉBRE.

On peut voir, dans l'article précédent, les doutes yui me restaient encore sur la différence ou sur l'identite d'espece de ces trois animaux. M. Forster a bien voulu me eommuniquer queltues éclaircissements, qui semblent prouver 
que ee sont réellement trois animaux différents, et qu'il y a même dans l'espèce du zèbre une varićté constante; voici l'extrait de ce qu'il m'a écrit sur ce sujet :

"On trouve dans le pays des Tartares Mongoux une grande quantité de chevaux sauvages ou larpans, et un autre animal appelé $c$ sigithai; ce qui dans la langue mongole signifie longue oreiile. Ces aninaux vont par troupes : on en voit quelques-uns dans les déserts voisins de l'empire de Russie et dans le grand désert Gobcée (ou Cobi); ils sont en troupe de vingt, trente et même cent. La vitesse de eet animal surpasse dc beaucoup celle du meilleur coursier parmi les chevaux; toutes les nations Tartares en eonviennent : une mauvaise qualité de cet animal, e'est qu'il reste toujours indomptable. Un Cosaque ayant attrapé un de ces jeunes ezigithais, et l'ayant nourri pendant plusieurs mois, ne put le conserver ; car il se tua lui-mème par les efforts qu'il fit pour s'échapper ou se soustraire à l'obéissance.

"Chaque troupe de czigithais a son chef, comme dans les tarpans ou chevaux sauvages. Si le czigithai-chef découvre ou sent de loin quelques chasseurs, il quitte sa troupe, et va seul reconnaitre le danger, et dès qu'il s'en est assuré, il donnc le signal de la fuite, et s'enfuit en effet suivi de toute sa troupe : mais si malheureusement ce clef est tué, la troupe n'étant plus conduite, se disperse, et les ehasseurs sont sûrs d'en tuer plusieurs autres.

"Les ezigithais se trouvent principalement dans les déscrts des Mongoux, et dans eeluiqu'on appelle gobéc : c'est une espèce moỳenne entre l'âne et le cheval; ce qui a donné oceasion au docteur Messehersmidt d'appeler eet animal, mulel fécond de Daouric, parce qu'il a quelque ressemblance avec le mulet, quoique réellement il soit infiniment plus beau. Il est de la grandeur d'un mulet de moyenne taille; la tête est un peulourde; les oreilles sont droites, plus longues qu'aux chevaux, mais plus courtes qu'aux mulets : le poitrail est graud, earré en bas et un peu comprimé. La crinière est courte et hérisséc, et la queuc est entierement semblable à celle de l'âne; les cornes des pieds sont petites. Ainsi le czigithai ressemble à l'ùe par la crinière, la queue et les sabots. Il a aussi les jambes moins charuues que le cheral, et l'encolure eneore plus légère et plus leste. Les pieds et la partic inféricure des jambes sont ininces et bien faits. L'épine du dos est droite et forméc comme celle d'un àne, mais cependant un peu plate. La couleur dominante dans ces animaux est lebrun jaunàtre. La tète, depuis les yeux jusqu'au mufle, est d'un fau ve jaunattre; l'intérieur des jambes est de cette même couleur; la crinière et la queue sont presque noires, et il y a le long du dos une bánde de brun noirâtre qui s'élargit sur le train de derrière, et se rétrécit vers la queue. En hiver, leur poil devient fort long et ondoye; mais en été il est ras et poli. Ces animaux portent la tète haute, et présenteut en courant le nez au vent. Les Tunguses et d'autres nations voisines du grand désert regardent leur chair comme une viande délicieuse.

"Outre les tarpans ou chevaux sauvages, et les czigithais ou mulets féeonds de Daourie, on trouve dans les grands déserts au-delà du Jaïk, du Yemba, du Sarason et dans le voisinage du lac Aral, une troisieme espèce d'animal, que les Kirghises et les Kalmouks appellent koulan ou khoulan qui parait être l'onager ou l'onagre des auteurs, et qui semble faire une nuance entre le czigithai et l'âne. Les koulans viventen été dans les grands déserts dont nous venons de parler, et vers les montagnes du Tamanda, et ils se retirent, à l'approche de l'hiver, vers les confins de la Perse et des Indes. Ils courent avec une vitesse incroyable; on n'a jamais pu venir à bout d'en dompter un seul, et il y en a des troupeaux de plusieurs mille ensemble. lls sont plus grands que les tarpans, mais moins que les czigithais. Leur poil est d'un beau gris, quelquefois avec une nuance légèrement bleuâtre, et d'autres fois avec un mélange de fauve; ils portent le long du dos une bande noire, et une autre bande de même couleur traverse le garrot, et descend sur les épaules. Leur queue est parfaitement scmblable à celle de l'àne, mais les oreilles sont moins grandes et moins amples.

"A l'égard des zèbres, j’ai eu oceasion de les bien exaniner dans mes séjoursitu cap de BouneEspérance, et jai reconnu dans cette espèce une variété qui diffère du zèbre ordinaire, en ce qu'au lieu de bandes ou raics brunes et noires dont le fond de son poil blane est rayé, celui-ci au contraire est d'un brun roussâtre, arec trèspeu de bandes larges et d'une teinte faible et blanchâtre; on a mème peine à recomnaitre et distinguer ces bandes blanchâtres dans quelques individus qui ont une couleur uniforme de brun roussâtre, et dont les bandes ne sont que des 
nuances peu distinetes d'une teinte un peu plus pále; ils ont, comme les autres zèbres, le bout du museau et les pieds blanchâtres, et ils leur ressemblent en tout, à l'exception des belles raies de la robe. On serait done fondé à prononcer que ce n'est qu'une variété dans eette espèce du zèbre : cependant ils semblent différer de ce dernier par le naturel, ils sont plus doux et plus obéissants; car on n'a pas d'exemple qu'on ait jamais pu apprivoiser assez le zébre rayé pour l'atteler à une voiture, tandis que ces zèbres à poil uniforme et brun sont moins revèches et s'accoutument aisément à la domesticlté. J'en ai vu un dans les campagnes du Cap, qui était attelé avec des chevaux à une voiture; et on m'assura qu'on élevait un assez grand nombre de ces animaux pour s'en servir à l'attelagge, parce qu'on a trouvé qu'ils sont à proportion plus forts cu'un cheval de mème táille. "

J'avais dit cu'on avait lait des attelages de zèbres pour le prince stathouder; ce fait, qui m'avait été assuré par plus d'une personne, n'est cependant pas vrai. M. Allamand, quej'ai eu si souvent oceasion de citer avec reconnaissance et avee des élogres bien mérités, m'a fait savoir quej'avais été inal informé sur ce fait; le prince stathouder n'a eu qu'un seul zèbre : mais M. Allamand ajoute dans sa lettre, au sujet de ces animaux, un fait aussi singulier qu'intéressant. Milord Clive, dit-il, en revenant de l'Inde, a amené avec lui une femelle zèbre, dont on lui avait fait présent au cap de Bonne-Espérance; apres l'avoir gardée quelque temps dans son pare en Angleterre, il lui donna un âne pour essayer s'il n'y aurait point d'aceouplement entre ces animaux : mais cette femelle zèbre ne voulut point s'en laisser approcher. Milord s'avisa de faire peindre cet âne comme un zèbre : la femıllle, dit-il, en fut la dupe, l'accouplement se fit, et il en est né un poulain parfaitement semblable à sa mère, et qui peut-ètre vit encore. La chose a été rapportée à M. Allamand par le général Carnat, ami partieulier de milord Clive, et lui a été confirméc par milord Clive fils. Milord Pitt a eu aussi la bonté de m'en écrire dans les termes suivants : "Feu milord Clive avait une tres-belle femelle de zebre gue j’ai vue à Clemnom, l'une de ses maisons de eampagne, avee un poulain mâle. (foal), provenant d'olle, qui n'avait pas chcore un an d'age, et qui avait été produit par le stratagème suivant. Lorsque la femelle zèbre fut en chaleur, on essaya plusieurs fois de lui presenter un âne qu'elle refusa constamment d'admettre : milord Clive pensa qu'en faisant peindre cet ắne, qui était de couleur ordinaire, et en imitant les couleurs du zèbre mâle, on pourrait tromper la femelle; ce qui réussit si bien qu'elle produisit le poulain dont on vient de parler.

" J'ai été dernièrement, e'est-à-dire cet été 1778 , ì Clemnom pour m'informer de ce qu'étaient devenus la femelle zèbre et son poulain, et on m'a dit que la mère était morte, et que le poulain avait été envoyé à une terre assez éloigruéc de milord Clive, oủ l'on a souvent essayé de le faire accoupler avee des ànesses, mais qu'il n'en est jamais rien résulté. "

Je ferai cependant, sur ces faits, une légère observation, e'est que j'ai de la peine à croire que la femelle zèbre ait r'ecu l'àne uniquement à cause de son bel habit, et qu'il y a toute apparence qu'on le lui a présentédans un moment oủ elle était en meilleure disposition que les autres fois. I faudrait d'ailleurs un grand nombre d'expériences, tant avec le cheval qu'avec l'âne, pour décider si le zèbre est plus près de l'un que de l'autre. Sa production avec l'âne indiquerait qu'il est aussi près que le cheval de l'espece de l'âne; car on sait que le cheval produit avee l'ânesse, et que l'âne produit avec la jument : mais il reste à recomaitre par l'expérience si le cheval ne produirait pas aussi bien que l'âne avec la femelle zèbre, et si le zebre mâle ne produirait pas avec la jument et avec l'ânesse. C'est au cap de Bonne-Espérance que l'on pourrait tentor ces accouplements avec succès.

\section{DU KWAGG OU COUAGGA.}

(Le Cheyal Coligga).

Famille des solipédes, genre cheval. (Cuvier.)

"Cet animal, dont je n'ai cu aucune commaissance (yu'apres l’impression des feuilles precédentes où il est fuestion de l'onagre et du zcbre, me parait ètre une espece batarde ou intermediaire entre le cheval et le zèbre, ou peut-itre entle le zibre et l'onagre. Voici ce que M. le professeur Allamand en a public nouvellement 
dans un supplément à l'édition de mes ouvrages imprimée en Hollande.

" Jusqu'à présent, dit ce savant naturaliste, on ne connaissait que le nom de cet animal et même encore très-imparfaitement, sans savoir quel quadrupède ce nom indiquait. Dans le journal d'un voyage entrepris dans l'intérieur de l'Afrique par ordre du gouverneur du cap de Bonne-Espérance, il est dit que les voyageurs virent, entre autres animaux, des chevaux sauvages, des ânes et des quachas. La signification de ce dernier mot m'était absolument inconnue, lorsque M. Gordon m'a appris que le nom de quachas était celui de kwagga, queles Hottentots donnent à l'auimal dont il s'agit, et que j'ai eru devoir retenir parce que, n'ayant jamais été décrit, ni mème connu en Europe, il ne peut ètre désigné que par le nom qu'il porte dans le pays dont il est originaire. Les raies dont sa peau est ornée le font d'abord regarder comme une variété dans l'espèce du zèbre, dont il diffère cependant à divers égards. Sa couleur est ${ }^{\circ}$ d'un brun foncé, et comme le zèbre, il est rayé très-régulièrement de noir depuis le bout du museau jusqu'au-dessus des épaules, et cette même couleur des raies passe sur une jolie crinière qu'il porte sur le cou. Depuis les épaules les raies commencentà perdre de leur longueur, et allant en diminuant, elles disparaissent à la région du ventre avant d'avoir atteint les cuisses. L'entre-deux de ces raies est d'un bruu plus clair, et il est presque blanc aux oreilles. Le dessous du corps, les cuisses et les jambes sont blanches; saqueue, qui est un peu plate, est aussi garnie de crins ou de poils de la mème conleur : la corne des pieds est noire; sa forme ressemble beaucoup plus à celle du pied du cheval qu'à la forme du pied du zèbre. On s'en convaincra en comparant la figare que j'eu donne avec celle de ce dernier animal. Ajoutez à cela cque le caractère de ces animaux est aussi fort différent; celui des couaggas est plus docile : car il n'a pas encore été possible d'apprivoiser les zèbres assez pour pouvoir les employer à des usages domestiques; au lieu que les paysans de la colonie du Cap attellent les couaggas à leurs charrettes qu'ils tirent très-bien ; ils sont robustes et forts : il est vrai qu'ils sont méchants, ils mordent et ruent; quand un chien les approche de trop près, ils le repoussent à grands coups de pied, et quelquefois ils le saisissent avec les dents; les hyènes même, que l'on nomme loups au Cap, n'osent pas les attaquer; ils marchent en troupes, souvent au nombre de plus de cent; mais jamais on ne voit un zèbre parmi eux, quoiqu'ils vivent dans les mèmes endioits.

"Tont cela semble indiquer que ces animaux sont d'espèces différentes : cependant ils ne diffèrent pas plus entre eux que les mulets different des chevaux ou des ânes. Les couagrgas ne seraient-ils point une race bâtarde de zèbres? Il y a en Afrique des chevaux sauvages blanes; Léon l'Africain et llarmol l'assurent positivement, et ce qui est plus authentique encore, e'est le témoignage de ces royageurs dont j'ai citéle journal : ils ont vu de ces chevaux blanes; ils ont vu aussi des ânes sauvages. Ces animaux ne peuvent-ils pas se mêler avec les zèbres et produire une race qui participera des deux espèces? J'ai rapporté ci-devant un fait qui prouve qu'une femelle zèbre, couverte par un âne, a eu un poulain. On ne peut guère douter que l'accouplement d'un cheval avec une zèbre ne fùt aussi prolifique. Si celui des chevaux avec des ânesses ne produit pour l'ordinaireque des mulets stériles, cela n'est pas constant; on a vu des mules avoir des poulains, et il est fort naturel de supposer que les chevaux ayant plus d'affinité avec les zèbres qu'arec les ânes, il peut résulter du mélange de ces animaux, d'autres animaux féconds capables de faire souche; et ceci est également applicable aux ânes, puisque les zèbres sont une espèce mitoyenne entre les chevaux et les ânes. Ainsi, je suis fort porté a croire que les couaggas ne sont qu'une race bâtarde de zèbres, qui, pour la figure et les caractères, tiemnent quelque chose des deux espèces, dont ils tirent leur origine.

"Quoi qu'il en soit, on a beaucoup d'obligation à M. Gordon de nous les avoir fait connaitre ; car e'est lui qui m'en a envoyé le dessin et la description. Il eu vit un jour deux troupes, l'une d'une dizaine de couaggas adultes, et l'autre composée uniquement de poulains qui couraient après leurs mères: il poussa son cheval entre ces deux troupes, et un des poulains ayant perdu de vue celle qui précédait, suivit aussitòt de lui-même le cheval, comme s'il enit été sa mère. L.es jeunes zèbres en font autant en pareil cas. MI. Gordon était alors daus le pays des Bosjemants, et fort éloigné de toute habitation : ainsi il fut obligé d'abandonner ce ponlain le leudemain faute de lait pour le nourrir, et il 


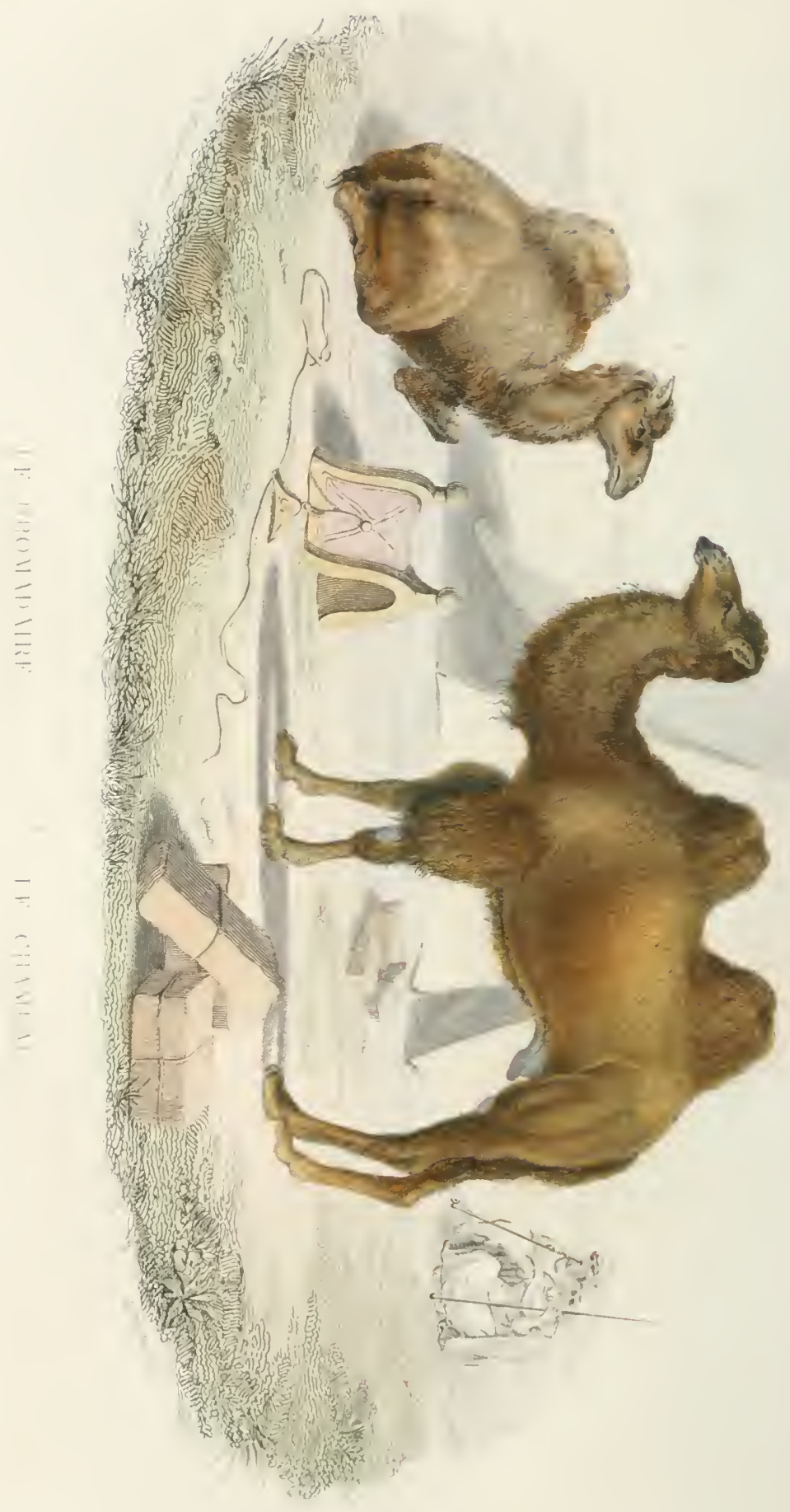


Je laissa courir où il voulut. II en a actuellement un autre qu'il réserve pour la ménagerie de monseigneur le prince d'Orange. N'ayant pas pu se proeurer un couagrga adulte, il n'a pu m'envoyer que le dessin d'un poulain : mais il me mande qu'il n'y a aucune différence entre un poulain et un couagga qui a fait toute sá ìne, si ce n'est dans sa grandeur, quic galle celle d'un zèbre, et dans la tête qui ('st à proportion un peu plus grosse dans le conagrga adulte. La dilférence qu'il y a entre les máles et les femelles est aussi très-petite.

"Depuis que le Cap est habité, ces animaux en ont quitté les envirous, et ils ne se trouvent plus que fort avant dans l'intérieur du pays. Leur cri est une espece d'aboiement tres-précipité, ou l'on distingue souvent la répétition de la syllahe liuah, liucah. Les Hottentots trouvent leur chair fort bomne; mais olle déplaît aux paysans hollandais par son gout fade.

"Le poulain (pui est iei représenté avait, depuis le bout du nuseau jusquà la queue, trois pie , sept poure's et trois lignes; le trinin de devalıl était baut de deux pieds et dix pouces, et celui de derrière était plus bis d'un pouce; sa queue étail longue de quatorze pouces. "

Voili tout ce que $\mathbf{~ 1 1 . ~ A l l a m a n d ~ a ~ p u ~ r e c u e i l l i r ~}$ sur l'histoire de cet animal; mais je ne puis m'empècher d'observer (qu'il palrait y avoir deux faits contraires daus le récit de M. Gordon : il dit en premier lien que les lespaysans desterres du Cap allellent les couaggas ib la charrelle, et qu'ils tirent liès-bien, ct ensuite il avoue qu’il n'a pu se procurer un couagga adulte pour ('i) fitire le dessin; il parail donc que ces animaux sont ranes dans c'es mèmes terres dı Cap, puisqu'il n'a pu fare dessiner quin poulain. Si l'espece ctait récluite en domestieité, il lui aurait été facile de se procurer un de ces animaux adultes. Nous esperous que ce naturaliste voyageur voudra bien nous donner de plus amples informations sur ect animal, qui me parait teujr au riche de phus près (pu'aucum autre.

\section{LE CHAMEAU \\ ET LE DROMADAIRE.}

(LE CRAMEAU A DEUX fOSSES, - LE CHAMEAO

A UNB BOSSE OU DHOMADAIRE.)

Ordre des ruminants sans cornes, genre chaneau. (Cuvier.)

Ces deux noms, dromadaire et chameau, ne désignent pas deux especes différentes, mais indiquent seulement deux races distinetes, ('t subsistantes de temps immemorial dans l'espéee du chameau. 1.e prineipal, et, pour áinsi dire, l'mixue caractère sensible, pail lequel ces deux races different, consiste en ce que le chameau porte deux bosses, et que le dromadaire n'en a uqu une; il est aussi plus petit et inoins iort que le chameau: mais tous deux se mélent, produisent ensemble, et les individus qui proviennent de cotte race croises, sont ceur giuj ont le plus de vigneur et qu'on prefere à tous le's auti'es. C('s motis, lssus du dromádaire et rlu chameau, forment une race secondaire yui se multiplie parcillemeut et qui se mèle aussi aree les races premicres; en sorte que, dans cette espéce, comme daus celles des autres animatix domestiques, il se trouve plusicurs varjetés dont les plus générales sont relatives à la différence des climats. Aristote a très-bien indiqué les deux races principales; la premicre c'cota-dire eelle à deux bosses, sous le nom de chameau de la Bactriane; et la seconde, sous celui de chameau a'drabie. On appelle les premiers chameaux tures', et les autre's chumu au.c arabes. Celte division subsiste aujourd'hui conme du temps d'Aristote; seulement il parait depuis que l'on a décousert les parties de l'Afripure et de l'Asie incommes aux anciems, que le dromadaire est sans companison plus uomhreux et plus généralement répandu que le ehaneall : celui-ci ne se trouvegucere que datus le Turquestan et daus puelques autle's endroits du Levant, tandis que Ie dromadaire, plus commun qu'aucume autre bète de somme en Arabice, se trouve de méme en grande quantité dans toute la partie septentrionale de l'Afirine, qui s'étend depuis la mer Méditerramce jusqu’au fleure Niger ; et quion le retroure en Esypte, en I'rerse, dans la Tartarie méridionale, et dans les parties septentrionales de l'Inde. Le dioma-

- Nuns abluns at mont sinai sur des chameaux. paree guil uiy a pas d'cau sur celle rumle. el que les aulre's anumaux ne peuvent pas fatiguer saus boire... Mais ces chameaus d $A$ - 
daire occupe donc des terres immeuses, et le chameau est borné à un petit terrain : le premier habite des régions arides et cliaudes; le second, un pays moins sec et plus tempéré, et l'espèce entière, tant des uns que des autres, parait être confinée dans une zone de trois ou quatre cents lieues de largeur, qui s'étend depuis la Mauritanie jusquà la Chine : elle ne subsiste ni au-dessus ni an-dessous de cette zone. Cet animal, quoique naturel aux pays chauds, craint cependant les climats où la chaleur est excessive : son espèce finit où commence celle de l'éléphant, et elle ne peut subsister ni sous le ciel brûlant de la zone torride, ni daus les climats doux de notre zone tempérée. Il parait être originaire d'Arabie; car non-seulement c'est le pays où il est en plus grand nombre, mais c'est aussi celui auquel il est le plus conforme. L'Arabie est le pays du monde le plus aride, et où l'eau est le plus rare: le chameau est le plus sobre des animaux et peut passer plusieurs jours sans boire. Le terrain est presque partout sec et sablonneux : le chameau a les pieds faits pour marcher dans les sables, et ne peut au contraire se soutenir dans les terrains humides etglissants. L'herbe et les pâturages manquant à cette terre, le bœuf $\mathrm{y}$ manque aussi, et le chameau remplace cette bète de somme. $0 \mathrm{n}$ ne se trompe guère sur le pays naturel des animaux en le jugeant par ces rapports de conformité : leur vraie patrie est la terre à laquelle ils ressemblent, c'est-à-dire à laquelle leur nature parait s'être entièrement conformée, surtout lorsque eette mème nature de l'animal ne se modifie point ailleurs et ne se prête pas à l'influence des autres climats. On a inutilement essayé de multiplier les chameaux cn Espagne, on les a vainement transportés en Amérique, ils n'ont réussi ni dans l'un ni dans l'autre climat, et dans les grandes Indes on n'en trouve guère au-delà de Surate et d'Ormus. Ce n'est pas qu'absolument parlant ils ne puissent subsister et produire aux Indes, en Espagne, en Amérique et mème dans des climats plus froids, comme en France, en Allemagne, etc.: en Ies tenant l'hiver dans des écuries chaudes, en les nourrissant a vec choix, les traitant avee rabie qui sont petits el différents de ccux dı Caire, qu vont en Sourje et en d'autres endroils. cheminent Irois on quatre jours sans boire... On va du Caire à lérusaleu, non fas sur ces petits cliameaux arabes comme ou mont Simaï, yui cst um chemin de montagnes, mais sur de griuds que lion appelle chameaux tures. Voyage de Pietro delia Valle, tome 1, I/dges 360 et 408. soin, en ne les faisant pas travailler et ne leg laissant sortir que pour se promener dans les beaux jours, on peut les faire vivre et mème espérer de les voir produire; mais leurs productions sont chétives et rares; eux-mêmes sont faibles et languissants : ils perdent donc toute leur valeur dans ees climats, et au lieu d'être utiles, ils sont trés à charge à ceux qui les élèvent; tandis que, dans leur pays natal, ils font, pour ainsi dire, toute la richesse de leurs maitres. Les Arabes regardent le chameau comme urs présent du ciel, un animal sacré, sans le secours duquel ils ne pourraient ni subsister, ni commercer, ni voyager. Le lait des chameaux fait leur nourriture ordinaire ; ils en mangent aussi la chair, surtout celle des jeunes qui est très-bonne à leur goût : le poil de ces animaux, qui est fin et moelleux, et qui se renouvelle tous les ans par une mue complète, leur sert à faire les étoffes dont ils s'habillent et se meublent. Avec leurs chameaux, non-senlement ils ne manquent de rien, mais mème ils ne craingnet rien ${ }^{1}$; ils peuvent mettre en un seul jour cinquante lieues de désert entre eux et leurs ennemis : toutes les armées du monde périraient à la suite d'une troupe d'Arabes; aussi ne sont-ils soumis qu'autant qu'il leur plait. Qu'on se figure un pays sans verdure et sans eau, un soleil brùlant, un ciel toujours sec, des plaines sablonneuses, desmontagnes encoreplus arides, sur lesquelles l'œil s'étend et le regard se perd sans pouvoir s'arrèter sur ancun objet vivant; une terre morte et, pour ainsi dire, écorchée par le vents, laquelle ne présente que des ossements, des cailloux jonchés, des rochers debout on renversés; un désert eutière. ment découvert, où le voyageur n'a jamais respirc sous l'ombrage, où rien ne l'accompagne, rien ne Jui rappelle la nature vivante: solitude absolue, mille fois plus affreuse que celle des forêts; car les arbres sont encore des êtres pour l'homme qui se voit seul; plus isolé, plus dénué, plus perdu dans ces licux vides et sans bornes, il voit partout l'espace comme son tombeau : la lumière du jour plus triste que l'ombre de la nuit, ne renait que pour éclairer sa nudité, son impuissance, et pour lui présenter l'horreur de sa situation, en reculant à ses yeux

' Les chameaux font la richesse des Arabes et Ionte Icui' force et Jeın sáreté ; car ils cmportent aı mojen de lcurs chancaux tous leurs effels dans les déserts, oủ ils noont pas à craindre leurs ennemis ni aucune invasion. L'Afrique d'Ogilby, page 12. 
les barrières du vide, en étendant autour de lui l'abime de l'immensité qui le sépare de la terre habitée, immensité qu'il tenterait en vain de parcourir; car la faim, la soif, et la chaleur brûlante pressent tous les instants qui lui restent entre le désespoir et la mort.

Cependant l'Arabe, à l'aide du chameau, a su franchir et mème s'approprier ces lacunes de la nature; elles lui servent d'asile, elles assurent son repos et le maintiennent dans sou indépendance. Mais de quoi les hommes saventils user sans abus? Ce mème Arabe, libre, iıdépendant, tranquille, et mème riche, au lieu de respeeter ses déserts comme les lemparts de sa liberté, les souille par le crime; il les traverse pour aller elıez des nations voisines, enlever des esclaves et de l'or; il s'en sert pour exercer son brigandage, dont malheureusement il jouit plus eneore que de sa liberté; car ses entreprises sont presque toujours heureuses. Malgré la défiance de ses voisins et la supériorité de leurs forces, il échappe à leur poursuite et emporte impunement tout ce qu'il leur a ravi. Un Arabe qui se destine à ce métier de pirate de terre s'endurcit de bonue heure à la fatigue des voyiges; il s'essaie a se passer du sommeil, ̀̀ souffrir la faim, la soif et la chaleur : en nicme temps il instruit ses chameaux, il les élève et les exerce dans cette mème vue; peu dejours après leur uaissance, il leur plic les jambes sous le ventre, il les contraint à demeurer à terre et les charge, dans cette situation, d'un poids assez fort qu'il les accoutume à porter et quil ne leur ote que pour leur en donner uu plus fort; au lieu de les laisser paitre à toute heure et boire à leur soif, il commence par régler leuts repas, et peu à peu les éloigne à de grandes distances, en diminuant aussi la guantité de la nourriture; lorsqu'ils sont un peu forts, il les exerce à la course; il les excite par l'exemple des chevaux et parvient í les rendre aussi légers et plus robustes '; enfin dès qu'il est sûr

\footnotetext{
4 Le Iromadaire est particulierement remarquable par sa srande vitesse ; las srabes discul qu'il peut faire autant de chemin ell un jour tu un de leurs meilleurs che vaux eu huit ou dix. lec. Brkh qui nuus comluisit au mout sinarictait monté

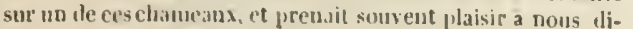
vertir pall la grande dilizence de sa monture; il puittait nntre caravine pour en lecounaftre une autre yue nous pou-

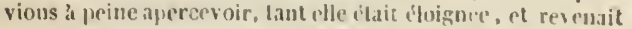
à nous en moins d"un thuart il'lueme. Vingage de shaw, lume I, page 311.-On éléve en Arabie une sorle de chameaux pun servir a la cuurse... IIs vout au frand trot et si vite yu'un cheval ne les peut suivre y̧u'an galop. Voyage de Chardin. bome II, page 28.
}

de la force, de la légèreté et de la sobriété de ses chameaux, il les charge de ce qui est nécessáire à sa subsistance et à la leur; il part avec eux, arrive sans être attendu aux confins du désert, arrête les premiers passants, pille les habitations écartées, cluarge ses chameaux de son butin: et s'il est poursuivi, s'il est forcé de précipiter sa retraite, e'est alors qu'il développe tous ses talents et les leurs; monté sur l'un des plus légers ', il conduit la troupe, la fait mascher jour et nuit presque sans s'arrêter, ni boire ni manger : il fait aisément trois cents lieues en huit jours ${ }^{2}$, et pendant tout ce temps de fatigue et de mouvement, il laisse ses chameaux chargés, il ne leur donne chaque jour qu'une heure de repos et une pelote de pate : souvent ils courent ainsi neuf ou dix jours sans trouver de l'eau, ils se passent de boire ${ }^{3}$ : et lorsque par hasard il se trouve une mare à yuelque dis. tance de leur route, ils sentent l'eau de plus d'une demi-lieue ${ }^{4}$; la soif qui les presse leur fait doubler le pas, et ils boivent en une seule fois pour tout le temps passé et pour autant de temps à venir ; car souvent leurs voyages sont de plusieurs semaines, et leurs temps d'abstinence durent aussi longtemps que leurs voyages.

En Turquie, en Perse, en Arabie, en Egypte, 'Les dromadaires vout si vite qu'il y in a yui font trentecinq ou quarante lieves en un jonr, et cuntinuent de la sorte huit ou dix jours par tes deserts, sans manger que furt peu. Tous les seigneurs arabes de la viumidie, et les Africains de la Lyhic, s'en servent comme de chevaux de poste, yuanl l'occasion se présente de faire une longue traite, et les unontent aussi dans le combat. L'A frique de Marmol, tone I, page 49.

${ }^{2}$ Les uromadiare's sont plus petits, plu- griles et plus légers que les chameaux, it ne serwiut guère yu'à purter des lommes; ils ont un bon trut, assez doux, th font faeilement quarante lienes par jour; il n'y a seulemeut qu"à se bien lenir; il $\mathrm{y}$ a des gins uni se fout lie: di'ssus de peur de tomber. Re. lation de Thévenot, tome I, jage żз.

${ }^{3}$ Le chameau pent se passi'r de boire pentant qualre ou cing jours: mue petite portion de féves et l'urge, on bien Ijuel jues murceaux de pite faile de fleur de farine, lui suffi. sent par jour four sa nourriture; e'est ce que j'ai soum clot ex. périmenté dans mon ıoyage du mont sïuaĩ : ıunique clıacuı de nos chameaux porlit sept quintaux an moins, et que now3 fissions des trailes de dix et yuelyurfois le yuinze heures par jour, à raison de deux milles et demi pill henre. Voyage de Shaw, tome 1 , page $511 .-$ Il y a de quai aduirer la patience avec laquelle les chameanx souffreut la suif; et la derniche fois (que je passai les déserts, d'uil la caravatle ne pent surtir en moins de soixante-ciny jours, nos chaneaux furent une fois neuf jours sans hoire, paree que pendant neuf jours de nuarelic nous ne trouvames pas aleau eu aucun lien. Vuyage de Tavernier, tome I, page 162.

4 Nous arrivimes a 1 u jays de collines, an pied desquelles se trouvaient de grandes uares ; uns elıar eaux, yui avaient passé neuf jours saus twire, sentirent l'eau diune demi lieue loin: ils se mireut à aller leur grand trot. jui est leur maniere de conrir, et culcant en foule dans ces mares, ils en rendirent al'abord l'eau troulde et bourbeuse, etc. Voyage de Taveruier, lewe 1, page 202 
en Barbarie, etc., le transport des marchandises ne se fait que par le moyen des chameaux '; c'est detoutes les voitures la plus prompte et la moins chère. Les marchands et autres passagers se réunissent en caravane pour éviter les insultes et les pirateries des Arabes : ces caravanes sont souvent très-nombreuses, et toujours composées de plus de chameaux que d'hommes. Chacun de ces chameaux est chargé selon sa force; il la sent si bien lui-même, que quand on lui donne une charge trop forte il la refuse ${ }^{2}$ et reste constamment couché jusçtı'à ce qu'on l'ait allégée. Ordinairement les grands chameaux portent un millier, et même douze cents pesant, les plus petits six à sept cents. Dans ces voyages de commerce on ne précipite pas leur marche : comme la route est souvent de sept ou huit cents lieues, on règle leur mouvement et leurs journées; ils ne vont que le pas et font chaque jour dix à douze lienes; tous les soirs on leur ôte leur charge, et on les laisse paître en liberté. Si l'on est en pays vert, dans une bonne prairie, ils prennent en moins d'une heure tout ce qu'i] leur faut pour en vivre vingtquatre, et pour ruminer pendant toute la nuit: mais rarement ils trouvent de ces bons pâturages, et cette nourriture délicate ne leur est pas nécessaire; ils semblent même préférer aux herbes les plus donces, l'absinthe, le chardon, l'ortie, le genêt, l'acassie, et les autres végétaux épineux; tant qu'jls trouvent des plantes à brouter ${ }^{3}$, ils se passent très-aisément de boire.

Au reste, cette facilitéqu'ils ont à s'abstenir lougtemps de boire n'est pas de pure habitude;

- Ciest une grande commodité que les chameaux pour la cbarge dn bagage et des marchandises „ן on transporte, par leur moyen, d tres-jeu de Irais... Les chameaux ont leur pas réglé, ainsi que leurs jonruées... Leur nourriture n'est point diflicile, ils vivent de cliardons, dorlies, etc... soulfrent la soif deux ou trois jours entiers. Voyage d'oléarius, tome I.

2 Ouand on les veut clarger, au cri de leur conducteur, ils fléchissent lesgenoux; que s'ils tardent à le faire, ou bien on leur frappe avec un biton, ou bien on leur abiisse le cou, el alors comine contraiuls et gémissants, à leur façon. ils fléchissent les genoux. mettent le ventre contre terre, et rlemenrent en cette posture jusqu'à ce qu’ayant élể clıargés, on leur commande de se relever; d'ou vient yu'ils ont au ventre, aux jambes el aux genoux de gros durillons du coité quils en fouchent la lerie; s'ils se senlent unettre de Irop pesants fardeaux, ils donnent des coups ile tète fort frétpuents a ceux qui les sirchargent, et jettent des cris lamentables; leur cluarge ordinaire est le donble de ce yue pourrait porter le plus fort mulet. Voyage din P. Philipje, page 369.

s Lorsquion charge le clatnean, il s alıaisse sur le veulre, et il ne souffre pas yu'on lui uselte plus de fardean yu'il n'en pent porter; il peut aussi passer plusieurs jours sans hoire, ponrvu curil trouve un peu dherbe a paitre. LAfricjue dogilby, page 12 c'est plutôt un effet de lear conformation. Il y a dans le chameau, indépendamment des quatre estomacs qui se trouvent d'ordinaire dans les animaux ruminants, une cinquième poche qui lui sert de réservoir pour conserver de l'eau. Ce cinquième estomac manque aux autres animaux et n'appartient qu'au chameau; il est d'une capacité assez vaste pour contenir une grande quantité de liqueur; elle y séjourne sans se corrompre et sans que les autres aliments puissent s'y mèler; et lor'sque l'animal est pressé par la soif, et qu'il a besoin de délayer les nourritures sèches et de les macérer par la rumillation, il fait remonter dans sa panse, et jusqu'à l'œsophage, une partie de cette eau par une simple contraction des muscles. C'est donc en vertu de cette conformation ti'ès. singulière, que le chameau peut se passer plusieurs jours de boire, et qu'il prend en une seule fois une prodigieuse quantité d'eau qui demeure saine et limpide dans ce réservoir, parce que les liqueurs du corps ni les sues de la digestion ne peuvent s'y mêler.

Si l'on réfléchit sur les difformités, ou plutôt sur les non-conformités de cet animal avec les autres, on ne pourra douter que sa nature n'ait été considérablement altérée par la contrainte de l'esclavage et par la continuité des travaux. Le chameau est plus anciemnement, plus complétement et plus laboricusement esclave qu'aucun des autres animaux domestiques : il l'est plus anciennement, parcequ il habite les climats où les hommes se sont le plus anciennement policés: ill'est plus complétement, parce que dans les autres espèces d'animaux domestiques, telles que celles du cheval, du chien, du bœuf, de la brebis, du cochon, etc., on trouve encore des individus dans leur état de nature, des animaux de ces mèmes espéces qui sont sauvages, et que l'homme ne s'est pas soumis : au lieu que dans le chamean l'espèce entière est esclave; on ne le trouve nulle part dans sa condition primitive d’indépendance et de liberté : enfin il est plus laborieusement esclave qu'aucun autre, parce qu'on ne l'a jamais nourri, ni pour le faste, comme la plupart des chevaux, ni pour l'amusemeut, comme presque tous les chiens, ni pour l'usage de la table, comme le bouf, le cochon, le mouton; que l'on n'en a jamais fait qu'une bête de somme, qu'on ne s'est pas mème donné la peine d'atteler ni de faire tirer, mais dont ou a regardé le corps 
comme une voiture vivante qu'on pouvait tenir chargée et surchargée, même pendant le sommeil; car', lor'squ on est pressé, on se dispense quelquefois de leur ôter le poids quiles accable, et sous lequel ils s'affaissent pour dormir les jambes pliées et le corps appuyé sur l'estomác : aussi portent-ils tous les empreintes de la servitude et les stigmates de la douleur : au bas de la poitrine, sur le strrnum, il y a une grosse et large callosité aussi dure que de la colne; il y en a de pareilles à toutes les jointures des jambes; et quoique ces callosités se trouvent sur tous les chamcaux, elles off'ent elles-mêmes la preuve (qu'elles ne sont pas naturelles, et qu'elles sont produites par l'exces de la contrainte et de lit douleur, ear souvent elles sont remplies de pus. Lat poitrine et les jambes sont done déformées par ces callosités; le dos est encore plus défiguré par la bosse double ou simple qui le surmonte. Les callosités se perpétuent aussi bien que les bosses jar la génération; et comme il est évident que cette première difformité ne provient que de l'habitude à laquelle on contraint ces animaux, en les foręant dis leur premier aige' ì se coucher sur l'estomac, les jambes plićes sous le corps, et à porter dans cette situation l' poids de leur corps et les fardeaux dont on les charge, on doit présumer aussi que la bosse ou les bosses du dos n'ont eu d'autre origine que la compression de ces mêmes fardeaux, qui, portant inégalement sur certains endroits du dos auront fait élever la chair et boursouftler la graisse et la peau : car ces bosses ne sont point osseuses, elles sont seulement composées d'une substance grasse et charmue, de la mème consistance à peu près que celle des tétines de vache : ainsi les callosités et les bosses seront également regardées comme des difformités produites par la continuité du travail et de la eontrainte du corps ; et ces difformités, qui d'iboril n'ont été qu'aceidentelles et individuelles, sont devenues grénérales et permanentes dans l'espece entière. L'on peut présumer de même yue la poèc qui contient l'eau, et qui n'est qu'un alurendiee de la panse, a été produite par l'extension forcéce de ce viscère ; l'ani-

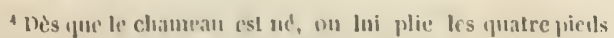

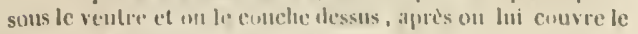

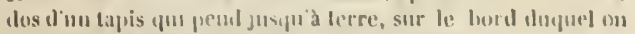
met yu.ulites de pierres, illin yüil ne se juisse lover, et ou le lasse en cet dall itsplate de yninze on vingl jours; dome cependant du lat a bure, mais pen sonvent, alin yu'il s'accuutumo a boire jern. Voygge de Taveruier, tom, 1, p. 161.
}

mal, après a voir souffert trop long̨temps la soif, prenant à la fois autant et peut-être pius d'eau que l'estomac ne pouvait en contenir, cette membrane se sera étendue, dilatée et prêtée peu à peu à cette surabondance de liquide; comme nous avous vu que ce mème estomac dans les moutons s'étend et aequiert de la rapacité proportionnellement au volume des aliments; qu'il reste très-petit dans les moutons (pue l'on nuurrit de pain, et qu'il devient tris-grand dans ceux auxquels on ne donne que de l'herbe.

On confirmerait pleinement, ou l'on détruirait absolument ces conjecture's sur les non-conformités du chamcau, si l'on rn trouvait de sauvages que l'on puit comparer ave les domestiçues : mais, comme je l'ai dit, ces animaux n'existent nulle part dans leur état naturel ; ou, s’ils existent, personne ne les a remarqués ui décrits: nous devons done supposer yue tout ce qu'ils ont de bon et de beau, ils le tieunent de la nature, et que ce qu'ils ont de défectueux et de difforme, leur vient de l'empire de l'homme et des travaux de l'esclavage. Ces pauves animaux doivent souffir beaucoup, car ils jettent des cris lamentables, surtout lorsqu'ou les surcharge; cependant, quoique contimuellement excédés, ils ont autant de cœur que de docilite; au premier signe' lls plient les genoux ('t s'accroupissent jusqu'à terre pour se laisser charger dans cette situition, ce qui évite à l'homme la peine d'élever les fardeaux à me grande hauteur : des qu'ils sont chargés ils se relèvent d'eux-mêmes sans ètreaidés ni soutenus. Cèlui qui les conduit, montésur l'un d'entre exux, les préède tous et leur fait prendre le mime pas qu'it sa monture; on n'a besoin ni de fouct ni d'éperou pour les exciter : mais, lor'surils erommencent à ètre fatigués, on soutient leur courage, ou plutot on charme leur ennui pir le chant ou par le son de quelque instrument; leurs conducteurs se relaient a elanter; et, lorsuüils veulent prolonger la route et doubler la journée, ils ne leur domment qu'une heure de repos, apres quoi, reprenant leur ehanson, ils les remettent en marche pour plusieurs heures de plus, et le chant ne finit que quand il fiut s'arreter: alors les ehameaux s'aceroupissent de

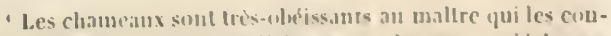

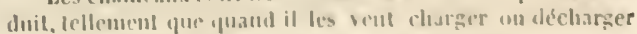
de: leurs fardesus, eu leur faisaul un seul sigue un heur disant une putcole, ils se haiswent et methout incontinent le veutre contre terre; ils sout de pelite vie cl le grand travait. Cosmog, du Levant, par Thevet, page 74. 
nouveau et se laissent tomber avec leur charge : an leur ote le fardeau en dénonant les cordes et laissant couler les ballots des deux còtés; ils restent ainsi aceroupis, couchés sur le ventre, et s'endorment au milieu de leur bagage qu'on rattache le lendemain avec autant de promptitude et de facilité qu'on l'avait détaché la veille.

Les callosités, les tumeurs sur la poitrine et sur les jambes, les foulures et les plaies de la peau, la chute entière du poil, la faim, la soif, la maigreur ne sont pas leurs seules incommodités, on les a préparés à tous ces maux par un ma! plus grand, en les mutilant par la castration. On ne laisse qu'un inâle pour huit ou dix femelles 'et tous les chameaux de travail sont ordinairement hongres : ils sont moins forts, sans doute, que les ehameaux entiers, mais ils sont plus traitables et servent en tout temps; au lieu que les entiers sout non-seulement indociles, mais presque furieux dans le temps du rut, qui dure quarante jours, et qui arrive tous les ans au printemps. On assure qu'alors ils écument continuellement, et cu'il leur sort de la gueule une ou deux vessies rouges de la grosseur d'une vessic de cochon. Dans ce temps, ils mangent très-peu, ils attaquent et mordent les animaux, les hommes et mème leur maitre, auquel dans tout autre temps ils sont très-soumis. L'accouplement ne se fait pas debout à la manière des autres quadrupèdes; mais la femelle s'accroupit et reçoit le mále dans la mème situation qu'elle prend pour reposer, dormir et se laisser elsarger. Cette posture, à laquelle on les habitue, devient, comme l'on voit, une situation naturelle, puisqu'ils la premnent d'euxmêmes dans l'accouplement. La femelle porte près d'un an; et, comme tous les autres grauds animaux, ne produit qu'un petit; son lait est abondant, épais, et fait une bonne nourriture, même pour les bommes, en le mèlant avec une plus grande quantité d'eau. On ne fait guère travailler les femelles; on les laisse paitre et produire en liberté. Le profit que l'on tire de leur produit et de leur lait surpasse peut-être celui qu'on tirerait de leur travail : cependant il y a des endroits où l'on soumet une grande partic des femelles, comme les mâles, à la castration afin de les faire travailler, et l'on prétend que cette opération, loin de diminuer leurs

\footnotetext{
' Les Africains et tous ceux yni veu!ent avoir de bons chameaux de charge, les tongrent et "'ell laissent qu'un entier pour dix femelles. L'Atrique de $\mathbf{M}$ armol, tome I, page 48 .
}

forees, ne fait qu'augmenter leur vigueur et leur embonpoint. En général, plus les chameaux sont gras et plus ils sont capables de résister à de longues fatigues. Leurs bosses ne paraissent être formées que de la surabondance de la nourriture; car dans de grands voyages où l'on est obligé de l'épargner, et où ils souffrent souvent la faim et la soif, ces bosses diminuent peu à peu, et se réduisent au point que la place et l'éminence n'en sont plus marquées que par la hauteur du poil, qui est toujours beaucoup plus long sur ces parties que sur le reste du dos : la maigreur du corps augmente à mesure que les bosses diminuent. Les Maures, qui transportent toutes les marchandises de la Barbarie et de la Numidie jusqu'en Éthiopie, partent avec des chameaux bien chargés, qui sont vigoureux et très-gras ' et ramènent ces mêmes chameaux si maigres, qu'ordinairement ils les revendent à vil prix aux Arabes du désert pour les engraisser de nouveau.

Les anciens out dit que ces animaux sont en état d'engendrel à l'âge de trois ans : cela me paraît douteux ; car à trois ans ils n'ont pas encore pris la moitié de leur accroissement. Le membre génital du mâle ${ }^{2}$ est, comme celui du taureau, très-long et très-mince : dans l'érection, il tend en avant comme celui de tous les autres animaux; mais, dans l'état ordinaire, le fourreau se retire en arrière, et l'urine est jetée entre les jambes de derrière, en sorte que les mâles et les femelles pissent de la mème manière. Le petit chameau tète sa mère pendant un an; et, lorsqu'on veut le ménager, pour le rendre dans la suite plus fort et plus robuste, on le laisse en liberté téter ou paître pendant les premières années, et on ne commence à le charger et ì le faire travailler qu'à l'âge de quatre ans. Il vit ordinairement quarante et même cinquante ans; cette durée de la vie étant plus que proportiounce au temps de l'acerois-

\footnotetext{
' Ouand les chamcaux commencent à faire voyage, il est nécessaire qu'ils soient gras; car on a expérimenlé qu'après que cet animal a marché quarante on cinquante jours sans manger d'orge, la graisse de sa bosse commence à dimiuuer, pnis celle du rentre et enfin celle des jambes, après quoi il ne jent plus jorter de charge... Les caravanes d'Afrique yui vont en Ethiopie ne se soncient point du retour, parce qu'elles ne rapportent rien de pesaut, et quand elles arrivent là, elles vendent les chameaux maigres, etc. L'Afrique de Marinol, tome 1, page $\mathbf{4 9}$.

${ }^{2}$ Encore que le chamean soit extremement grand, si esl-co que son membre, qui a pour te moins trois pieds de long ilest pas plus gros que le petit doigt. Voyage duléarins tome 1, page 354
} 
senrent, e'est sans aucun fondement que quelques auteurs ont avancé qu'il visait jusqu'à cent ans.

En réunissant sous un seul point de vue toutes les (jualités de cet animal et tous les avantages quel'on en tire, on ne pourra s'empêcher de le reconnaitre pour la plus utile et la plus précieuse de toutes les créatures surbordonnćes à l'homme. L'or et la soic ne sont pas les vraies richesses de l'Orient : c'est le chameau qui est le trésor de l'Asie; il vaut micux yue l'éléphant, cal' il travaille, pour ainsi dire, autant, et dépense peut-être vingrt fois noins: d'ailleurs l'espéce entiere en est soumise à l'homme, qui la propage et la multiplic autant qu'il lui plait; au lieu (fu'jl ne jouit pas de celle de l'éléphant qu'il ne peut multiplier, et dont il faut conquérir avec peine les individus les uns apres les autres. Le chameau vaut non-seulement micuxque l'éléphaut, mais peut-ètre vaut-il autant que le cheval, l'âne et le bouf tous réunis ensemble : il porte seul autant que deux mulets; il mange aussi peu que l'àne, et se nourrit d'herbes aussi grossières; la femelle fournit du lait pendant plus de temps que la vache; la chair des jeunes ehameaux est bonne et saine, comme eelle du veau; leur poil est plus beau, plus recherché yue la plus belle laine: jl n'y a pas jusqu'a l'ul's excriments dont on ne tire des choses utiles ; car le sel ammoniac se fait de leur urine, et leur fiente desséchée ct mise en poudre leur sert de litière, aussi hien qu'aux chevaux, avee lesquels ils voyagent souvent dans des pays ou l'on ne connait ni la paille, ni le foin: entin on fait des mottes de ectte mème fientequi brùlent ajsćment, et font une llamme aussi claire et prespue aussi vive (fue celle du bois sec : ecla meme est encore d'un grand sceours dans ces déserts où l'on ne trouve pas un arbre, et où, par le défaut de matières combustibles, le feu est aussi rare que l'eau.

\section{AdDition A L'article DU CHaMeaU ET DU DIONADAIRE.}

Nous n'avons presque rien a ajouter à ce que nous avons dit des chameaux et des dromadaires; nous ripporterous sculenent iei ee qu'en a écrit M. Nicbuhr dans sa Description le l'A. rabie, page 144.

" La plupart des chamcatux du pay's d'Iman sent de taille medioere et d'un broun tolair; ce-

IV. pendant on en roit aussi de grands et lourds, et d'un brun foncé. Lorsque les chameaux veulent s'accoupler, la femelle se couche sur les jambes; on lui lie les pieds de devant pour qu'elle ne puisse serelever. Le mâle, assis derrière comme un chien, touche la terre de ses deux pieds de devant. II parait froid pendant l'accouplement, et plus indolent cu'aucun animal; il faut le chatouiller quelquefois longtemps avant de pou voir l'exciter. L accouplement etant acheré, on recourre le mâle, on fait lever promptement la femelle en la frappant d'une pantoufle au derriere, tandis qu'une autre persomne la fait mareher. 11 en est de mème, diton, en Mésopotamic, en Natolic, ct probablement partout. "

J'ai dit yu'on avait transporté des chameaux ct des dromadaires aux fles Canaries, aux Antilles, au Pérou, et qu’ils n'avitient réussi nulle part dans le nouveau continent. I.e docteur Brown, dans son histoire de la Jamaï'que, assure y avoir vu des dromadaires que les Anglais y ont amenés en assez grand nombre dans ces derniers temps, et rue, quoiqu'ils y sulssistent, ils y sont néanmoins de peu de service, paree qu'on ne sait pas les nourir et les soigner convenablement. Ils ont néanmoins multiplié dans tous ees climats, et je ne doute pas qu'ils ne pussent meine produire en France. On peut voir dans la Gaselle du 9 juill 1755, que M. I3rinkenof', ayant faitaccoupler deschameaux dans ses terre's pres de berlin, a obtenu, le 21 mars de cette année 1775 , apres douze mois rivolus, un petit chameau qui se porte bien. Co fiat confirme eelui (pue j'ai cité de la production des chameaux et des dromadaires à Dresde, et je suis persuadé qu'en faisant venir avec les chameaux des domestiques arabes ou barbaresques accoutumés à les soigner, on viendrait à bout d'itablir chez nous ectte espece, que je regarde conme la plus utile de tous les animaux.

\section{DESCRIPTION DU DROVADAIRE.}

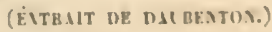

Le dromadaire et le clamesu sout de zramds animaux, l'une lizure tris-bizarre et fort estraurdinaire à nos yeux : ils ont le cou et les jambes fort lomerues, la tede petite, lit quene courte, et le dos charge d'une ou de lloux grosses bones qui s'elèrent aussi haut yue la tète de l'animal, un qui 
tombent recuurbées sur les côtés dı eorps. Ces animanx paraissent difformes, lorspue l'on compare leurs proportions et leurs attitudes à celles du clıeval ou du cerf, qui ont aussi le cou et les jambes fort lougs. La partie supérieure de l'encolure du dromadaire et du clameau ne s'è̀ve pas en ligne droite en sortant du garrot, comme la belle encolure du cheval, et n'a point de courbe en approehant de la tète, mais elle s'étend en avant aı sortir du garrot, et ensuite elle a un enfoncement encore plus marque que celui qui est nommé le Coup de hache, dans la fausse encolure des chevaux; le reste de la partie superieure de l'encolure du dromadaire et du clameau est en ligne droite jusçu’à la tête : an contraire la partie inférieure, au lien d'ètre en ligne droite depuis le poitrail jusçu'à la ganache, forme un angle très-saillant qui correspond à l'enfoncement de la partie sujérieure ; celte courbure du cou se trouve à environ le tiers le sa longueur depuis le garrot; les deux autres tiers sont dirigés en ligne verticale ou peu inclinee en avant : l'encolure mal faite et da petitesse de la tête donnent au dromadaire et au chameau un air faible et languissant.

Ces animaux ont le museau fort allongé, les orbites tes yeux très-saillants, les oreilles courtes, le corps étoffé, la croupe maigre et avalée, et les jambes mal faites; cenx (que $j$ 'ai observés aıaient les jarrets tournes en deliors et trop saillants en arrière, et les jambes de devant pliées anssi en arrière à l'entroit dı genou, qui était gros. Les quatre pieds sont aussi très-gros, urincipalement ceux de devant, presquue ronds dans leur contour, plats par-clessous et terminés en avant par deux grands ongles placès l'un contre l'autre et recourbẻs en tlessous. Les ongles sont pliés en gouttière par les cótes, et leur pointe rentre dans la plante du pied, yui est divisée dans son milien par un sillon longitudinal, peu profond, qui s'étend clepuis l'entre-tleux des ongles jusıu'au talon ; les deux ongles tiennent à deux doigts qui sont séparésl'un de l'autre par un sillon assez profond; il pénètre jusqu'à la substance de la plante du pied.

Le dronadaire et le chameau ne se couclient pas sur le còté, comme les clievaux et la plupart des atutres quadrupèdes; ils s'accroupissent de facon que les jambęs sont pliees, et que la poitrine et le ventre posent sur la terre : c'est pourcuoi il y a une large callosité au-dlessous du poitrasl sur la partie postérieure dı stermum, à l'endroit qui frappe et qui frotte le plus contre la terre: il y a aussi de pareilles callositcs, mais plus petites, aux jointures du coude et du genon des jambes de devant, à l'endroit de la rotule et sur les jarrets des jambes de derrière : res callosités sont mues et fort dures. J'ai vu un de ces animaux s'accroupir : il commençait par plier les jambes de derant jusıu’à un cer- tain point, mais passé ce pnint, il paraissait n'être plus le maitre de ce mouvement; le poids du corps surpassait ses forces, l'équilibre manquait, et tout à coupl l'animal tombait pesamment sur ses genoux: ensuite it pliait lentenent les jambes de derrière; mais, au lieu de maintenir l'égalité de ce mouvement, il se laissait aller lourdement sur l'articulation de la rotule : alors il abaissait ses coudes et ses jarrets, et enfin le bas du poitrail et le ventre descendaieni jusqu'à terre: cette chute était si précipitée que l'aninal se serait entamé la peau, si elle n'avait été défendue par des callosités; ou si ces callosités n'avaient pas été formées, elles n'anraient pas manqué de l'ètre bientôt. L'animal se relevait avec plus de facilité, mais il était sans agilité dans tous ses mouvements; s'il changeait desituation ou d'attitude, c'était avec peine qu'il mouvait ses jambes ou qu'il portait sa tète; il paraissait surclıargé de son propre poids. En état de repos, il ay̧ait un air de stupidité dans le maintien, ses yeux étaient mornes sans aucune vivacite; cependant on sait que les dromadaires et les chameaux ont beancoup de force et de docilitè, quils son mème trèsprompts à la course.

Le dromadaire difrère principalement du chameau, en ce qu'il n'a cu'une bosse; elle est placée sur le dos. Lesommet de la tète estrond et élevé; les lèrres s'étendent au devant du nez, le la longueur de deux ponces : celle de dessus est fendue dans le milieu par une scissure gui a un pouce quatre lignes de profondeur ; les narines ont deux pouces de longueur; il se troure entre elles un enfoncement dans la pean. Le dromadaire qui a servi de sujet pour cette description avait aussi un enfoncement en forme de gouttière assez profonde, le long du côté inférieur et autérieur du cou.

Cet animal était très-maigre et presque entièrement derarni de poil; il avait la peau ridée et couverte d'une crasse fort épaisse, qui était une sorte de gale : la chute du poil avait sans doute été causée en partie par cette maladie, et en partie par la unue; le poil qui restait était de couleur brune et noiratre dans quelques endroits : il y en avait de deux sortes'; l'un était doux et laineux, et l'autre plus qros, plus long et plus ferme; le poil qui se trouvait sur la tète, sur le cou et sur les jambes était court ; celui du corps avait environ six pouces de longueur; le bout de la queue était garni d'un puil gros et rude, comme dn crin de cheval, en partie noir et en partie gris : il avait un pied quatre punces de longueur; le milieu du dos ctait couvert d'un crin noir el gris, comme celni cela queue, mais plus fin, qui formait un groupe fort apparent, parce que re poil avait treize pouees de longueur; il était placè à l'enılroit de la bosse, qui avait été détruite en entier par la maigreur de l'a. nimal. 


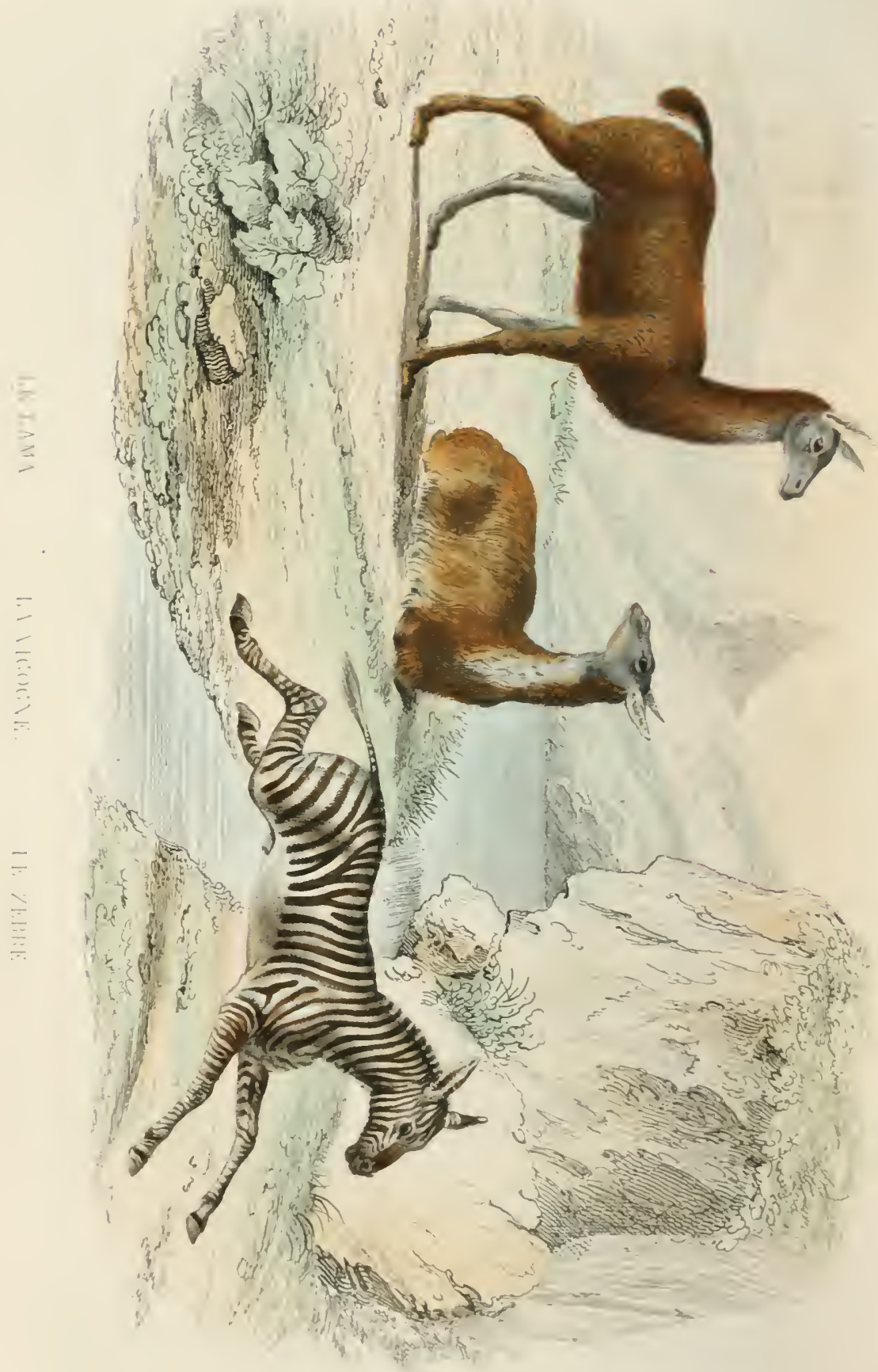




\section{DESCRIPTION DU CHAMEAU.}

(EXTHAJT DE DACHENTON )

II parait que le elıamean et le dromadaire sont des aninaux de mème espèce; la principale dilférence yui se trouve entre eux, cunsiste dins le nombre des losses qui sont sur le dos: le lromadaire n'en a qu'une et le clameau en a deux; celui qui a servi de snjet pour cente description avait le sommet de la tète peu clevé; des lèvres s'itenlaient au devant du nez de la longueur te trois nouces; celle du dessus citait fenclue dans le milieu par une seissure qui arait un pouce dix lignes de profondeur; cette seissure aloutissait à ın sillon qui s'ćtendait sur la lère jusquaux extrénités antérien. res des narines : elles etaient pliceses l'une contre l'autre, et formaient elacune une fente lousue de trois pouces quatre lignes; elles ctaient dirigrées obliquenent, le surte que l'extremite postirieure le l'une des narines se trouvait à frús de upuatre pouces de distance de l'extrénité de l’autre narine; il y avait an milieu de cet espace un tuliereule qui ctait garui du poil, comme la pean des alentuurs, et gui avait quinze lignes de largeur, dix lignes de longrueur de devant en arrière, et un demi-ponce de lıateur; le nez etait fort cleve; l'encolure ressemblait à celle du dromadaire ; mais il n'y a vait point legouttière sur le còté inférieur et anterieur ilu cou.

L'une des deux bosses de ce clıameau était placée sur la partic antirieure du dos près du ganrot, et l'antre sur les lombes; l'antérieure avait neuf pouces dehauteur et de lirgeur a la base, et trois pouces d'épaisseur dans le milien, et la posterieure huit pouces le hauteur et de largem; ct quatre pouces d'epaisseur au milieu; la hosse antérieure anait urois ponces de largenr et đl’épaisseur à son extrénité, et la pustirieure quatre : ces tleux losses étaicut rabattues sur le còte droit.

Ce ehauean avait perilu la plus granule partie de son poil, principalcurent les plus lon'ss des deux bosses; le poil de la plus grande partie ilu corjes de cet animal était d'une conleur fort iquivorque; de loin elle semblait ètre brune pille, mais sle près on joprcevait des teintes ole fauve irès-pilles et d'isalrolle pen apparentes; on y distinguait aussi un duvet très-touffu ıui avait jusqu'à trois ponces de lon-

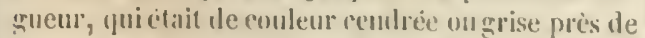
la racine, et fauve ou isibelle dans le reste le: son ctendue; ct: duvet citait entremèle ı!e puils un pen plus gros et plus longs, de couleur hrume rers la racine et fauve vers la pointe; fes liveres et les critrs du chanfrein elaient de cumleur roulde : il y arait une taelie de couleur dirriere les yeux et quelques teintes autum avec du noir; le sommet de la tète, les étés supérieur et inferieur du cou, les hosses, la partie inférieure et la prartic supcricure, de la face externe du bras $\in t$ lle l'avant-bras, et le bout de la quene étaient parnis de Inners poils tle couleur lrunc el nuire ou noiratre; ceux du bout de la quene avaient une coulenr rousse: les plus grands citaientloners d'un pied; le ventre, les genoux, les pieds et la quene, excepte le hout, avaient une couleur noire ou noirtitre.

L'extremité les bosses ctait percec, comne une ćcunoirc, le Irous, yui araicut près d'une lipne le diamètre, et qui ctaient ejumes les uns des autres diune ligne ou diune lizne et rlemie; il sor. tait de claque trou un flocon de ponl en forme de pinceau; il y avait des cils daus les deux paupières et quelipues soies ì l'endroit des,sourcils; il se truuvail de trosues callosilés sur la partie postivieure dn sternum, sur les coudes, sur les poi. grnets et sıI Ie's frenoux; celle du sternum elait la plus gramele; clle avait une ligure triangulaire clont le sommet clait e'n avant; ses còtes araicnt chacun seuf pouces le longueur, et la base seulement huit.

\section{LE I.AMA ET ILE PACO.}

\section{(LE LAMA DOMESTIQUe, - J,F L.IMA ALIACA.)}

Section des rumiuants sans cornes, genre chameau. (Cuvicr.)

Il y a exemple dans toutes les langues, qu on dome quelpuefois au mome animal deux noms diflérents, elont l'un se rapporte a son ctat de liberte et l'autre al celui de domesticite. Le sinnglier et le cochom ne font qui un animal, ct ces deux noms ne sont pas relatifs à la elifference de la natme, mais a celle de la eondition de ceite espèece, font une partic est susss l'mmpire do l'homme, et l'antre independinte. Il en est de mime des lamas et cles pacos, yni étaient les seuls animaux dome'stique s de's aneiens Américains. Cés noms sont eeux de leur that de domesticité : le lama saurage s'appelle huanacus

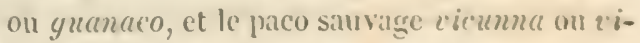
gogne. J'ai e'u ectte remarque necessilire pour civiter la coufusion des noms. Ce's animaux ne se trouvent pas dans laneicn eontinent, mais appartiement uniquement au uums cau; ils affectent meme de certaines terres, hors de lietendue descpuclles un me les troure plus; ils paraissent attache's à lit chaine des montanges qui sétend depuis la Nouvelle-Fspagne jusqu'aux tere's Magrillaniepues; ils habitent les regions

- On distingue trois e-jkces de lamas, qul sont : 10 le lama proprement dil: $2^{\circ}$ l'alfracu ou paco: 3 la vigugne. 
les plus élevées du globe terrestre, et semblent avoir besoin pour vive de respirer un air plus vif et plus léger que celui de nos plus hautes montagnes.

Il est assez singulier que, quoique le lama et le paco soient domestiques au Pérou, au Mexique, au Chili, comme les chevaux le sont en Europe ou les chameaux en Arabie, nous les connaissions à peine, et que depuis plus de deux siècles que les Espagnols règnent dans ces vastes contrées, aueun de leurs auteurs ne nous ait donné l'histoire détaillée et la description exacte de ces animaux dont on se sert tous les jour's : ils prétendeut ì la vérité qu'on ne peut les transporter en Europe, ni même les descendre de leurs hauteurs, sans les perdre, ou du moins sans risquer de les voir périr au bout d'un pẹtittemps; mais à Quito, à Lima, et dans beancoup d'iutres villes où il $\mathrm{y}$ a des gens lettrés, on aurait pu les dessiner; décrire et disséquer. Herrera dit peu de chose de ces animaux; Gareilasso n'en parle que.d'après les autres; Acosta et Grégoire de Bolivar sont ceux qui ont rassemblé le plus de faits sur l'utilité et les services quion tire des lamas et sur leur naturel : mais on ignore encore comment ils sont conformés intérieurement, combien de temps ils portent leurs petits; l'on ignore si ces deux espèces sont absolument séparées l'une de l'autre, si elles ne peuvent se mèler, s'il n'y a point entre elles de races intermédiaires, et beaucoup d'autres faits qui seraient nécessaires pour rendre leur histoire complete.

Quoiqu'on prétende qu'ils périssent lorsqu'on les éloigne de leur pays natal, il est pourtant certain que dans les premiers temps après la conquête du Pérou, et même encore longtemps après, l'on a transporté quelques lamas en Europe. L'animal dont Gessuer parle, sous le nom d'allocamélus, et dont il donne la figure, est un lama qui fut amené vivant du Pérou en Hollande, en 1558 : e'est le même dont Mattliole fait mention sous le nom d'ćlaphocamclus, et la description qu'il en dome est faite avec soin. On a transporté plus d'une fois des vigognes, et peut-ĉtre aussi des lamas, en Espagne, pour tâcher de les y maturaliser' ' : on devrait done être mieux instruit qu'on ne l'est sur la

\footnotetext{
- Il n'y a pas d'animal (uni marche aussi sûrement que le lama dans les rochers, parce cun'il s'aceroche par une espece d'éperon gu'il a naturellemeut an pied. Voyage de Coréal, tome I, page 352.
}

nature de ces animaux qui pourraient nous devenir utiles; car il est probable qu'ils réussiraient aussi bien sur nos Pyrénées et sur nos Alpes que sur les Cordilières.

Le Pérou, selou Grégoire de Bolivar, est le pays natal, la vraie patrie des lamas. On les conchuit, à la vérité, dans d'autres provinces, comme à la Nouvehe-Espagne, mais e'est plutôt pour la curiosité que pour l'utilité; au licu que dins toute l'étendue du Pérou, depuis Potosi jusqu'i Caracas, ces animaux sont en trèsgrand nombre. Ils sont aussi de la plus grande nécessité; ils font seuls toute la richesse des Indiens, et contribuent beaucoup à celle des Espagnols. Leur chair est bonne à manger, leur poil est une laine fine d'un excellent usage, et pendant tonte leur vie ils servent constammeut à transporter toutes les denrées du pays; leur eharge ordinaire est de ceut cinquante livres, et les plus forts en portent jusqu'à deux cent cinquante; ils font des voyages assez longs dans des pays impraticables pour tous les autres animaux; ils marchent assez lentement, et ne font que quatre ou cinq lieues par jour ; leur démarche est grave et ferme, leur pas assuré; ils descendeut des raviues précipitées, et surmontent des rochers escarpés, ou les hommes mème ne peuvent les accompagner ; ordiuairement ils marchent quatre ou cinqjour's de suite, après quoi ils reulent du repos, et prennent d'eux-mèmes uu séjour de vingt-quatre ou trente heures avaut de se remettre en marche. On les oceupe beaucoup au transport des riches matières que l'on tire des mines du Potosi : Bolivar dit que de son temps on employait à ce travail trois cent mille de ces animaux.

Leur aceroissement est assez prompt et leur vie n'est pas bien longue; ils sont en état de produire à trois ans, eu pleine vigneur jusqu'ì douze, et ils commencent ensuite it dépérir, en sorte qu’à quinze ils sont entièrement usés. Leur naturel parait ètre modelé sur celui des Américains; ils sont doux et flegmatiques, et font tout a vee poids et mesure. Lor'squ'ils royagent et qu'ils veulent s'arrèter pour quelques instants, ils plient les genoux avee la plus grande précaution, et baissent le corps en proportion afin d'empecher leur charge de tomber ou de se déranger; et dès qu ils entendent le coup de sifflet de leur conducteur, ils se relèvent avec les mèmes précautions et se remettent en marche. Ils broutent chemin faisant et partout ou 
ils trouvent de l'herbe : mais jamais ils ne mangent la nuit, quand même ils auraient jeủné pendant le jour; ils emploient ce temps à r'uminer. Ils dorment appuyés sur la poitrine, les pieds repliés sous le ventre, et ruminent aussi dans cette situation. Lorspu'on les excede de trevail et qu'ils suceombent une fois sous le fuix, il n'y a nul moyeri de les faire relever, on les frappe inutilement : la derniere ressource pour les aiguillonner, est de leur serrer les testicules, et souvent cela est inutile; ils s'obstinent à demeurer au lieu mème oủ ils sont tombés, et si l'on continue de les maltraiter ils se désespèrent et se tuent, en battant lit terre à droite et ì gauche avee leur tète. Ils ne se défendent ni des pieds ni des dents, et n'ont pour aiusi dire d'autres armes que celle's de l'indignation; ils crachent it la faee de ceux yui les insultent, et l'on prétend que rette salive, gu'ils lancent dåns hit colère, est âcre et mordicante, ilu point de faire lever des ampoules sur la peatu.

Le lama est haut d'environ guatle pieds, et son c'crejs, y compris le cou et la tête, en a cincy ou six de longueur; Ie eou seul a près de trois pieds de long. Cet, animal a la tête bien faite, les yeux grands, le muscau un peu allongé, les lèvres épaisses, la supérieure fendue et l'inférieure un peu pendante; il manrque de dents incisives et eanines à la mảchoire supéricure. Les oreilles sont longues de guatre poures; il les porte en avant, les dresse et les remue avee facilité. La (queue n'a guère que huit ponces de long; elle est droite, menue et ur peu relesée. I.es pieds sont fourchus eomme ceux du bocuf, mais ils sont surmontés d'un éperon en arrière, qui aide à l'animal à se retenir et it s'acerocher dans les pas difliciles. Il est couvert d'unc laine courte sur le dos, la croupe et la queue, mais fort longue sur les llanes et sous le ventre. Du reste, les lamas varient par les couleurs, il y en a de hlane's, de noirs et de mélés. Leur fiente ressemble in celledes ehères. Le mâle a le membrè génital menu et recourbé, en sorte qu'il pisse en arrière. C'est un animal très-lascif, et qui eependant a heaueoup de peine a s'aceoupler. La femelle a l'orilice des parties de la géénération très-petit; (elle se prosterne pour attendrele malle, et l'invite par ses soupirs; mais ilse passe toujours phusicurs heures et quelquefois un jour entice avant qu'ils puissent jour l'un de l'autre, et tout cee temps se passe it gémir, ì gronder, et surtout a se conspuer; ; comme ces longs préludes Ies fatiguent plus que la chose mème, on leur prète la main pour abréger, et on les aide a s'arranger. Ils neproduisent ordinairement qu'un petit, et tres - rarement deux. La mere n'a aussi gque deux mamelles, et le petit la suit au moment qu'il est né. La chair des jeunes est tres-bonne à manger, eelle des vieux est sèche et trop dure; en général, eelle des lamas domestiques est bien meilleure que eelle des sauvarges, et leur laine est aussi beaucoup plus donce. Leur neau estassez ferme; les Indiens en faisaient leur chaussure, et les Espagnols l'emploient pour faire des haruais. Ces animaux si utiles, et mème si nécessaires dans le pays qu'ils habitent, ne coutent ni entretien ni nourriture : comme ils ont le pied fourchu, il u'est pas nécessaire de les ferrer; la liline épaisse dont ils sont courerts dispense de les bater : ils n'ont besoin ni de grain, ni d'ivoine, ni de foin; l'herbe verte qu'ils broutent eux-memes leur suffit, et ils n'en prennent qu'en petite quantité; ils sont encore plus sobres sur la boisson : ils s'abreurent de leur sillive, (uui, dans eet animal, est plus abondante que dans aucun autre.

Le huanacus ou lama, dans l'état de nature, est plus fort, plus vif et plus léger gue le lama domestique; il court comme th cerf et grimpe comme le thamois sur les rochers les plus esearpés : sa laine est moins longue, et toute de couleur fauve. Quoique en pleine liberté, ces animaux se rassemblent ('n troupes, et sont quelquelois deux ou trois cents ensemble : lorsqu'ils apereoivent qquelqu'un, ils reggardent avee etonnement, sans marquer d'abord ui crainte ni plaisir; ensuite ils souftlent des marines et hennissent à peu près comme les chevaux, et entin ils prennent la luite tous ensemble vers le sommet des montagnes. IIs cherehent de préférence le coté du nord ('t la région froide; ils grimpent et síjournent souvent au-dessus de la ligne de neige : voyageant daus les glaces, et couverts de frimas, ils se portent mieux yus dans la région tempérie; autant ils sont nombreux et vigoureux dans les Sierras, qui sont les parties élevées des Cordilieres, autant ils sont rares et chétifs dinns les Lanos, qui sont au-dessous. On chasse ces lamas siluvages pour en aroir la toison: les chiens ont beaucoup de peine á les suivie; et si on leur donne le temps de gragner leurs rochers, le chasseur et les chicus sont contraints de les abandounc:- 
Ils paraissent craindre la pesanteur de l'air autant que la chaleur; on ne les trouve jamais dams les terres basses; et comme la chaîne des Cordilières, qui est élevée de plus de trois mille toises au-dessus du niveau de la mer, au Pérou, se soutient à peu près à cette mêmo élévation au Chili et jusqu'aux terres Magellaniques, on y trouve des huanacis ou lamas sauvages en grand nombre; au lieu que du côté de la Nouvelle-Espagne où cette chaine de montagnes se rabaișse considérablement, on n'en trouve plus, et l'on n'y voit çue des lamas domestiques, qu'on prend la peine d'y conduire.

Les pacos ou vigogues sont aux lamas une espèce succursale, à peu près comme l'àne l'est au cheval : ils sont plus petits et moins propres au service, mais plus utiles par leur dépouille; la longue et fine laine dont ils sont couverts est une marchandise de luxe aussi chère, aussi précieuse que la soie. Les pacos que l'on appelle aussi alpaques, et qui sont les vigognes domestiques, sont souvent toutes noires et quelquefois d'un bruu mêlé de fauve. Les vigognes ou pacos sauvages sont de couleur de rose sèche, et ectte couleur naturelle est si fixe qu"elle ne s'altère point sous la main de l'ouvrier : on fait de très-beaux gants, de très-bons bas avec cette laine de vigogne; l'on en fait d'excellentes couvertures et des tapis d'un très-grand prix. Cette denrée seule forme une branche dans le commerce des Indes espagnoles : le castor du Canada, la brebis de Kalmouquie, la chèvre de Syrie ne fournissent pas un plus beau poil; celui de la vigogne est aussi cher que la soie. Cet animal a beaucoup de choses communes avec le lama : il est du même pays, et comme lui il en est exelusivement, car on ne le trouve nulle part ailleur's que sur les Cordilières; il a aussi le même naturel et à peu près les mêmes mœurs, le mème tempérament. Cependant, comme sa laine est beaucoup plus lougue et plus toufiue que celle du lama, il parait craindre encore moins le froid; il se tient plus volontiers dans la neige, sur les glaces, et dans les contrées les plus froides : on le trouve en graude cyuantité dans les terres Magellaniques.

Les vigognes ressemblent aussi par la figurc aux lamas; mais elles sont plus petites, leurs jambes sont plus courtes et leur mulle plus riamassé : elles ont la laine de cou!eur de rose sèche un peu elaire; clles n'ont point de cornes. Elles habitent et paissent daus les cudroits les plus élevés des montagnes; la neige et la glace semblent plutôt les récréer que les incommoder. Elles ront en troupes et courent trìs-légèrement: clles sont timides, et des qu'elles apercoivent quelqu'un, elles s'enfuient en chassant leurs petits devant elles. Les anciens rois du Pérou en avaient rigoureusement défendu la chasse, parce qu'elles ne multiplient pas lyeaucoup ; ct aujourd'hui il y en a infiniment moins que dans le temps de l'arrivée des Espagnols. La chair de ces animaur n'est pas si bonne que celle des luanacus; on ne les recherche que pour leur toison et pour les bézoards qu'ils produisent. La manière dont on les prend prouve leur extrême timidité, ou, si l'on veut, leur imbécillité. Plusieurs hommes s'assembleut pour les faire fuir et les engager dans quelques passages étroits ou l'on a tendu des cordes a trois ou quatre pieds de haut, le long desquelles on laisse pendre des morecaux de linge ou de drap; les vigegnes qui arrivent à ces passa gres sont tellement intimidées par le mouvement de ces lambeaux agités par le vent, qu'elles n'osent passer au delà, et cu'elles s'attroupent et demeurent en foule, en sorte qu'il est facile de les tuer en grand nombre: mais s'il se trouve dans la troupe quelques huanacus, comme ils sont plus hauts de corps et moins timides que les vigognes, ils sautent par-dessus les cordes, et dès qu'ils ont domé l'cxemple, les vigognes sautent de même et échappent aux chasseurs.

A l'égard des vigognes domestiques ou pacos, on s'en sert comme des lamas pour porter des fardeaux : mais indépendamment de ce qu'étant plus petits ou plus faibles jls portent beaucoup moins, ils sont encore plus sujets à des caprices d'obstination; lor'squ'une fois ils se couchent avec leur eharge, ils se laisseraient plutòt haeher que de se relever. Les Indiens n'ont jamais fait usage du lait de ces animaux, parce qu'ils n'en ont qu'autant qu'il en faut pour nourrir leurs petits. Le grand profit que l'on tire de leur laine avait engagé les Espagnols à tâcher de les naturaliser en Europe; ils en ont transporté en Espagne pour les faire peupler, mais le elimat se trouva si peu convenable qu’ils y périrent tous. Cependaut comme je l'ai déjà dit, je suis persuadé que ces animaux, plus précicux encore que les lamas, pourraient réussir dans nos montagnes, et surtout dans les Pyrénées : ceux (pui les ont transportés en Espagne n'ont pas fait attention qu'au Pérou même ils ne sub. 
sistent que dans la région froide, c'est-à-dire dans la partic la plus élevéc des montagnes; ils n'out pas fait attention qu'on ne les trouve jamais dans les terres basses, et qu'ils meurent dans les pays chauds; qu'au contraire, ils sont encore aujourd'hui très-nombreux daus les terres voisines du détroit de Magellan, ou le froid est beaucoup plus grand que dans notre Europe méridionale, et que par conséquent il fallait, pour les conserver', les débar(juer non pas en Espagne, mais en lícosse ou mème 'n Norwége, et plus sûrement encore aux pieds des Pyrénées, des Alpes, ete., oil elles eussent pu grimper et atteindre la région qui leur convient. Je n’insiste sur cela que paree que j’imagine que ces animaux seraient une excellente aequisition pour l'Europe : et produiraicnt plus de biens réels que tout le metal du NoureauMonde (pui u'a ser vi qu’à nous charger d'un poids inutile, puisqu'on avait auparavant pour un gros d'or ou d'argent ce qui nous coute une once de ces mèmes métaux.

Les animatux qui se nourrissent d'herbes et qui habilent les hautes montagnes de l'Asie, et même de l'Afrígue, donnent les bézoards que l'on appelle oricntaux, clont les vertus sont les plus exaltées; ceux des montagnes de l'Europe, où la qualité des plantes et des herbes est plus tempérére, ne produisent que des pelotes sans vertu yu'on appelle ésagropiles; et clans l'A mériqueméridionale, tous les animaux çui liéquentent les montagnes sous la zone torride domnent d'autres bézoards que l'on appelle occielentau.r, qui sont eneore plus solicles, et peut-itre aussi qualifiés que les oricntaux. la vigogne surtout en fournit en grand nombre; le huanicus en donne aussi, et l'on en tire des eerfs et des chevreuils dans les montagnes de la Nouvelle-Esparne. Les lamas et les pacos ne domnent de beaux bézoards qu'autant qưils sont huamacus et vigogues, e'est-à-dire dans leur'état de liberté; ceux yu'ils produisent dans leur condition de servitude, sont petits, noirs et sans vertı : les meilleurs sont ceux qui ont une couleur de vert obsenr, et ils viement ordinairement des vigognes, surtout de celles (jui habitent les parties les plus élevées de la montagne, et curi paissent habituellement daus les neiges; de ees vigognes montagnardes, les fimelles comme les mâles produisent des bizoards, et res lézoards du Pérou timment le premier lang après les bézoards orientaux, qul sout beaucoup plus estimés que les bézoards de la Nouvelle-Espagne, qui sieuneni des cerfs, et sont les moins efficaces de tous.

ADDITION A L'ARTICLE DU LAJIA.

Nous donnons la figure d'un lama, dessiné d'après nature, et qui est eneore actuellement vivant (août 177\%) à l'école vétérinaire au chateau d'Alfort. Cet animal, amené des Indes espagnoles en Angleterre, nous fut envoyé au mois de novembre 1773 : il était jeune alors, et sa mère qui était avec lui est morte presque en arrivant; on en peut voir la peau bourrée et le corps injecté sous la peau, dans le beau eabinet anatomique de M. Bourgelat.

Quoique ce lama füt encore jeune, et que le transport et la domesticité cussent sans doute influé sur son áceroissement, et l'eussent en partie retardé, il avait néanmoins près de cina pieds de hauteur, en le mesurant en ligne droite, depuis le sommet de la tête jusqu'aux pieds de devant, et dans son état de liberté il devient considérablement plus grand et plus épais de corps. Cet animal est, dans le nouveau continent, le représentant du clameau dans l'aneien : il semble en être un beau diminutif, ear sa figure est élégante, et sans avoir aucune des difformités du chameau, il lui ticnt uéanmoins par plusieurs rapports et lui ressemble a plusicurs égards. Comme le ehameau, il est propre à porter des fardeanx; il.a le poil laineux, les jambes assez minees, les pieds courts et conformés à peu prés comme les jambes et les pieds du ehameau : mais il en differe en ce qu'il n'a point de bosse, qu'il a la queue courte, les oreilles longues, et qu'en général il est beaueoup mieux fait et d'une forme plus agréable par les proportions du corps. Son cou long, bien couvert de laine, et sa tite qu'il tient toujours háte, lui domment un air de noblesse et de légèreté que la nature a refusé au chameau. Ses oreilles longues de sept pouees, sur deux pouees daus leur plus arande largeur, se terminent en pointe et se tiement tonjours droites 'n avant ; clles sont garnics d"un poil ras ct noirattre. La tète est longue, légère et d'une forme élérante. Les yeux sont grands, moirs cit ornes daus les angles internes de grands poils noirs: le ne\% est plat et les narios sont ćautées; la lève supérieure est feudue et tellement séparic 
au devant des mâchoires qu'elle laisse paraitre les deux dents incisives du milieu, qui sont longues et plates, et au nombre de quatre à la màchoire inférieure : ces dents incisives manquent à la mâchoire supérieure, comme dans les autres animaux ruminants : il y a seulement einç mâehelières en haut comme en bas de chaque còté, ce qui fait en tout vingt dents mâchelières et quatre incisives. La tête, Je dessus du corps, de la eroupe, de la queue et des jambes, sont couverts d'un poil laineux couleur de musc un peu vineux, plus clair sur les joues, sous le cou et sur la poitrine, et plus foncé sur les euisses et les jambes, ou cette couleur devient brune et presque noire. Le sommet de la tête est aussi noirâtre, et e'est de là que part le noir qui se voit sur le front, le tour des yeux, le nez, les narines, la lèvre supérieure et la moitié des joues. La laine qui est sur le cou est d'un brun foncé, et forme comme une crinière qui prend du sommet de la tête et va se perdre sur le garrot: eette même coulcur brune s'étend, mais en diminuant de teinte, sur le dos, et y forme une bande d'un brun faible. Les cuisses sont couvertes d'une grande laine sur les parties postérieures, et cette longue laine est ell assez gros flocons; les jambes ne sont garnies que d'un poil ras d'un brun noirâtre. Les genoux de devant sont remarquables par leur grosseur, au lieu que dans les jambes de derrière il se trouve vers le milieu un espace sous la peau qui est enfoncé d'environ deux pouces. Les pieds sont séparés en deux doigts; la corne du sabot de chaque doigt est longue de plus d'un pouce et demi, et cette corne est noire, lisse, plate sur sa face interne, et arrondie sur sa face externe; les cornes du sabot des pieds de derrière sont singulières en ce qu'elles forment un crochet à leurs extrémités. Le tronçon de la queue a plus d'un pied de longueur; il est couvert d'une laine assez courte; cette queueressemble à une houppe: l'animal la porte droite, soit en marchant, soit en courant, et nême lorsqu'il est en repos et couché.

Longeur du Lama. . . . . . . . . . . . . $5.5 \%$

Ianteur du train de devant. . . . . . . . 5 550

Irauteur du train du derriére. . . . . . . . 556

IIauteu du rentre au-dessus de terre. . . . . $1 \begin{array}{llll}1 & 9 & 2\end{array}$

Lougneur de la tète, du bout des lérres jusqu'd l'occiput................ 011

Cet animal est fort doux, Il n'a ui colère ni méchanceté, il est même caressaut; il se laisse monter par celui qui le nourrit, et ne refuserait pas le même service à d'autres; il marche au pas, trotte et prend même une espèce de galop. Lorsqu'il est en liberté, il bondit et se roule sur l'herbe. Ce lama que je décris etait un màle: on a observé qu'il parait souvent être exeité par le besoin d'amour'. Il urine en arrière, et la verge est petite pour la grosseur de son corps. II avait passé plus de dix-huit mois sans boire au mois de mai dernier (1782); et il me parait que la boisson ne lui est pas nécessaire, attendu la gránde abondauce de salive dont l'intérieur de sa bouche est continuellement humecté.

On lit dans le Voyage du commodore Byron, qu'on trouve des guanaques, c'est-à-dire des lamas, à l'ile des Pingouins, et dans l'intérieur des terres jusqu'au cap des Vierges, qui forme au Nord l'entrée du détroit de Magellan. Ainsi ces animaux ne craignent nullement le froid. Dans leur état de uature et deliberté, ils marchent ordinairement par troupes de soixante ou quatre-vingts, et ne se laissent point approcher : cependant ils sont très-aisés à apprivoiser; car les gens de l'équipage du vaisseau de Byron, s'étant saisis d'un jeune lama, dont on admirait la jolie figure, ils l'apprivoisèrent au point qu'il venait leur lécher les mains. Le commodore Byron et le capitaine Wallis comparent cet animal au daim pour la grandeur, la forme et la couleur : mais WVallis est tombé dans l'erreur en disaut quiil a une bosse sur le dos.

\section{DE LA VIGOGNE.}

\section{(LE LAMA VIGOGNE.)}

Ordre des ruminants sans cornes, geme chameau. (Cuvier.)

La figure d'une viggogne mâle a été dessinée vivante a l'école vétérinaire en 1774 ; la dépouille empaillée se voit dans le cabinet de M. Bourgelat: cet animal est plus petit que le lama, et voici ses dimensions :

Longueur du corps mesuré en ligne droite, p. p. I. depuis le bout du nez jusqu'à l'origine de la quene............... \& 46 Hauteur du train de devaut. . . . . . . 249 Hauteur du traiu de derrière. . . . . . . 262 Hauteur du ventre au-dessus de terre . . . 1 \& 8 
p. p. 1 . Longueur de ia tête. . . . . . . . 0 0 6 Longueur des oreillies .......... 0 \% 4 Largeur des oreilles. . . . . . . . . . 015 Grandeur de l'oil. ............... 014 Distance entre l'ril et le bout du museau. . . $\quad 0070$

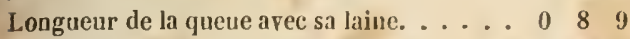

La vigogne a beaucoup de rapport et mème de ressemblance avec le lama, mais elle est d'une forme plus légère; ses jambes sont plus longues à proportion du corps, plus menues et mieux faites que celles du lama. Sa tête, qu'elle porte droite et haute suir un cou long et délié, Iui donne un air de légèreté, même dans l'état de repos; elle estaussi plus courte à proportion que la tête du lama; elle est large au front et étroite à l'ouverture de la bouche, ee qui rend la physionomie de eet animal fine et vive; et cette vivacité de physionomic est encore fort augmentée par ses beaux yeux noir's, dont l'orbite est fort grand, ayant seize lignes de longueur; l'os supérieur de l'orbite est fort relevé, et la paupière inféricure est blanche. Le nez est aplati, et les naseaux qui sont écartés l'un de l'autre sont, comme les lèvres, d'une couleur brune, mêlée de gris; la lèvre supériemre est fenduc comme celle du lama, et cette séparation est assez grande poor laisser voir dans la mâchoire inférieure deux dents incisives longues et plates.

La vigogne porte aussi les oreilles droites, longues et se terminant en pointe; elles sont nues en dedans et couvertes en dehors d'un poil court. La plus grande partie du corps de l'animal est d'un brun rougeattre tirant sur le vineux, et le reste est de couleur isiljelle; le dessous de la mâchoire est d'un blane jaune; la poitrine, le dessous du ventre, le dedans des cuisses et le dessous de la quene sont blanes. La laine qui pend sous la poitrine a trols pouces de longueur, et eelle qui couvre le corps n'a guère qu'un poneo; l'extrémitć de la cueue est garnie de lougue laine. Cet animal a le pied fourchu, séparé en cleux doigts qui s'éeartent lor'stu'il marehe; les sabots sont noirs, minees, plats pardessous et convexes par-dessus; ils ont un pouce de longueur sur neuf lignes de hauteur; et cinc lignes de largeur ou d'empattement.

Cette vigonne a véeu quatorze mois à l'école vétérinaire, et avait passé peut-itre autant de tenups en Angleterre; cependant elle n'était pas à beaucoup près aussi privée que le lama : elle nous a aussi paru d'un naturel moins sensible; car elle-ne donnait nulle marque d'attachement à la personne qui la soignait; elle cherchait mème à mordre lorsqu'on voulait la contraindre, et elle soufflait ou crachait continuellement au visage de ceux qui l'approchaient. On lui donnait du son see et quelquefors détrempé dans l'eau; elle n'a jamais bu d'eau pure ni d'aucune autre liqueur, et il parait que la vigogne a, comme le lama, une si grande abondancede salive, qu'ils n'ont nul besoin de boire. Enfin elle jette, comme le lama, son urine en arrière; ct par toutes ces ressemblances de nature, on peut regarder ces deux animaux comme des espèces du même genre, mais non pas assez voisines pour se mèler ensemble.

Lorsque j'ai éerit, en 1766 , l'histoire du lama et de la vigogne, je croyais qu'il n'y avait dans ee genre que ees deux espèces, et je pensais que l'alpaco ou alpaca était le même animal que la vigogne sous un nom différent; l'examen que j'ai fait de ces deux animaux, et dont je viens de rendre compte, m'avait encore confirmé dans cette idée: mais j’ai été récemment informé que l'alpaca ou paco, forme une troisième espèce qu'on peut regarder comme intermédiaire entre le lama et la vigogne. C'est à M. le marquis de Nesle cue je dois ces conuaissanees nouvelles. Ce seigneur, aussi zélé pour l'avancement des seiences que pour le bien public, a même formé le projet de faire venir des Indes espagnoles un eertain nombre de ces animaux, lamas, alpacas et viggognes, pour tâcher de les naturaliser et multiplier en France, et il serait tris à désirer que le gourernement voulut seconder ses vues, la laine de ces animaux étant, comme l'on sait, d'un prix inestimable. Les avantages et les diffieultés de ce projet sont présentés dans le mémoire suivant, qui a été donné à M. le marquis de Nesle par M. I'abbé Beliardy, dont le mérite est bien connu, et qui s'est trouvé à portée, par son long séjour en Espagne, d’être bien informé.

" Le nom de lama, dit-il, est un mot crénériqué que les Indiens du Pérou domment indifféremment à toutes sortes de bètes à laine. A vant la conquète des lispagnols, il n'y avait point de brebis en Amérique; ces conquérants les y ont introduites, et les Indiens du Pérou les ont appelíes lamas, paree qu'apparemment, dans leur langue, e’est le mot pour désignes tout animal laineux; cependant, dans les provinces de Cusco, Potosi et Tucuman, on dis- 
tingue trois espéces de lamas, dont les variétés leur ont fait assigner des noms différents.

" Le lama, dans son ćtat de nature et de liberté, est un animal qui a la forme d'un petit chameau. Il est de la hauteur d'un gros âne, mais beaucoup plus long; il a le pied fourchu comme les boufs; son cou à trente à quarante pouces de long; sa tête, qu'il porte toujours haute, ressemble assez à celle d'un poulain : une longue laine lui couvre tout le corps : celle du cou et du ventre est beaucoup plus courte.

" Cet animal est originairement sauvage; on en trouve encore en petites troupes sur des montages élevées et froides. Les naturels du pays l'ont réduit à l'état de domesticité, et on a remarqué qu'il vit également dans les climats claauds comme dans les plus froids; il produit aussi danș cet état. La femelle ne fait qu'un petit à chaque portée, et on n'a pu me dir'e de combien de temps est la gestation.

“ Jepuis que les Espagnols ont introduit dans le royaume du Pérou les chevaux et les mulets, l'usage des lamas et fort diminué; cependant on ne laisse pas de s'en servir encore, surtout pour les ouvrages de la campagne. On lc charge comme nous chargeons nos ânes, il porte de soixante-quinze à cent livres sur le dos. Il ne trotte ni ne galope, mais son pas ordinaire est si doux, que les femmes s'en servent de préféreuce à tọute autre monture. On les envoie paltre dans les campagnes en toute liberté, sans qu'ils cherchent.à s'enfuir. Outre le service domestiquequ'on en tire, on a l'avantage de profiter de leur laine. On les tond une fois l'an, ol'dinairement à la fin de juin; on emploie dans ces contrées leur laine aux mêmes usages que nous employons le crin, quoique cette laine soit aussi douce quenotre soie, et plus belle que celle de notre brebis.

"Le lama de la seconde espèce est l'alpaca. ret animal ressemble en général au lama; mais il en diffère en ce qu'il est plus bas de jambes et beaucoup plus large de corps. L'alpaca est absolument sauvage et se trouve en compagnie des vigognes. Sa laine cst plus fournie et beaucoup plus fine que celle du lama; aussi est-elle plus estimée.

" Iál troisième espèce est la vigogne, qu est encore semblable au lama, ì la réscrve qu'clle est bien plus petite; clle esl commelalpaca tout à fait sauvage. Quelques personnes de Lima en nourrisscut par rareté et par pure curiosité (mais on ignore si dans cet état ces animaux se multiplient et même s'ils s'accouplent). I.es vigognes, dans cet état de captivité, mangent à peu près de lout ce qu'on leur présente, du mais ou blé de turquie, du pain et toutes sortes d'herbes.

" La laine de la vigogne est encore plus fine que celle de l'alpaca; et ce n'est que pour avoir sa dépouille qu'on lui fait la guerre. Il y a dans sa toison trois sortes de laine : celle du dos plus foncé et plus fine est la plus estimée; ensuite celle des flanes qui est d'une conleur plus claire; et la moins appréciće est celle du ventre qui est argentée. On distingue dans le commerce ces trois sortes de laine par la différence de leur prix.

"Les vigognes vont toujour's par troupes assez nombreuses; elles se tiennent sur la croupe des montagnes de Cusco, de Potosi et du Tucuman, dans des rocher's âpres et des lieux sauvages; elles descendent dans les vallons pour paître. Lorsqu'on reut les chasser, on recherche leurs pas ou leur's crottes qui indiquent les endroits où on peut les trouver; car ces animaux ont la propreté et l'instinct d'aller déposer leur crottin dans le même tas... On commence par tendre des cordes dans les endroits par où elles pourraient s'échapper; ou attache de distance en distance à ces cordes des chiffons d'étoffes de différ'entes couleur's : cet animal est si timide qu'il n'ose franchir cette faible barrière. Les chasseurs fout grand bruit et tâchent de pousser' les vigognes contre quelques rocher's qu'elles ne puissent surmonter : l'extrême timidité de cet animal l'empêche de tourner la tête ver's ceux qui le poursuivent; dans cet état il se laisse prendre par les jambes de derrière, et l'on est sûi de n'cn pas manquer un: on a la cruauté de massacrer la troupe entièresur le lieu. Il y a des ordonnances qui défendent ces tueries, mais elles ne sont pas obscrvées. II serait cependant. aisé de les tondre lorsqu ils sont pris, et de se. ménagel une nouvelle laipe pour l'année suivante. Ces chasses produisent ordinairenent de eing cents à mille peaux de vigognes. Quand les chasseurs ont le malheur de trouver quelque alpaca daus leur battue, leur chasse est perdue : cet animal plus hardi sauve immancjuablement les vigognes; il franchit la corde sans s'effrayer ni s'embarrasser des chiffons yui flottent, rompt l'enceinte, et les vigognes le suivent. 
4 Dans toutes les Cordilières du nord de Lima, en se rapprochant de Quito, on ne trouve plus ni lamas, ni alpacas, ni vigognes dans l'état sauvage; cependant le lama domestique est fort commun à Quito, où on le charge et on l'emploie pour tous les ouvrages de la campagne.

" Si on voulait se procurer des vigognes en vie de la côte du sud du Pérou, il faudrait les faire descendre des provinees de Cusco ou Potosi au port d'Arica; là on les embarquerait pour l'Europe : mais la navigation, depuis la mer du Sud par le cap de Horn est si longue et sujette à tant d'événements, (qu'il serait peutêtre trìs-difficile de les conserver pendant la traversée. Le meilleur 'xpédient et le plus sûr', serait d'envoyer un bátiment exprès dans la rivière de la Plata; les vigognes (ju’on amrait lait prendre, sans les maltráiter, dans la jurovince de Tueuman, se trouveraient très à portée de descendre à Buenos-Ayres, et d'y ĉtre emlarquées. Mais il serait difticile de tronver ì Buenos-Ayres un bâtiment de retour préparé et arrangé pour le transport de trois ou quatre douzaines de vigognes : il n'en coûterait pas davantage pour l'armement en Europe d'un bîtiment destiné tout exprès pour cette commission, que pour le fret d'un navire trouvé par hasard à BuenosAyres.

"Il faudrait en conséquence charger une maison de commeree de Cadix, de faire armer un batiment espagnol pour la riviere de la Plata: cebâtiment, qui serait chargé en marchandises permises pour le compte du commeree, ne ferait aucun tort alux finances d'Espagne; on demanderait seulement la permission d'y mettre à bord un ou deux lrommes ehargés de la commission des vigognes pour le retour; ees lıommes seront munis de passe-ports et de recommandations efficaces du ministere d'Espagne, pour les gouvemeurs du pays, afin qu’jls soient aidés daus l'objet et pour le sucès de leur commission. Il faut nécessairement que de BuenosAyres on dome ordre it Siluta-Cruz de la Sierra, pour que des montagues de Tueuman on y amene en vie trois ou quatre douzaines de vigognes femelles, avee une demi-donzane de mâles, quelques alpacas et quelques lamas, moitié mấles et moitié femelles. Le baitiment sera arrangé de manière à less y reecevoil' et à les y placer commodément; e'est pour cela qu'il faudrait lui défendre de prendre aucume autre marchandise en retour, et lui ordonner de se rendre d'abord à Cadir, où les vigognes. se r’e poseraient, et où l'on pourrait ensuite les transporter en France... Une pareille expédition, dans les termes qu'on vient de la piojeter, ne saurait être fort cồteuse... On pourrait mèıne domner ordre aux officiers de la marine du roi, ainsi qu'à tous les bátiments qui reviennent de l'lle-de-France et de l'Inde, (que si par hasard ils sont jetés sur les côtes de l'A mérique ct obligés d'y ehercher un abri, de préférer la l'elâche dans la rivière de la Plata. Pendant qu'on serait occupé aux réparations du vaisseau, il faudrait ue rien épargner, avec les gens du pays, pour ohtenir quelques vigognes en vie, mâles et femelles, ainsi que quelques lamas et quelques alpacas. On tiouvera i Montevideo des Indiens qui font trente à quarante lieues par jour, qui iront à Santi-Ciruz de la Sierra, et yui s'acpuitteront fort bien de la commission... Cela serait d'autant plus facile, que les vaisseaux fiancais qui r'eviemnent de l'Ile-de-l rance ou de l'Inde, peuvent reelâcher à Montevideo, au lieu d'aller' à Sainte-Citherine, sur la còte du Brésil , comme il leur arrive très-souvent. Le ministre qui allrait contribué à enrichic le royaume d'un animal aussi utile, pourrait s'en applaudir comme de la conruête lá plus importante. Il est sulprenant que les jésuites n'aient jamais sonıcré il essayer de naturaliser les viggognes en Europe , cux qui, maîtres du Tucuman et du l'araguai, possédaient ce trésor au milieu de leurs missions et de leurs plus beaux établissements. "

Ce viémoire intéressant de N. l'abbé Bélialrdy, m’ayant été conmuniqué, j'en lis part à mon digne et respectible ami, H. de Tolozin, intendant du commerec, qui dans toutes les oceasions agit arce zele pour le bien public. II a done cru devoir consulter, sur ce Memoire et sur le projet qu’il contient, un homme intelligrent (M. de La liolie, inspecteur-géncial des manufactures ) ; ct voiei les observations qüil a faites à ce sujet :

" h'auteur du Mémoire, animé d'un zẻle très-louable, dit MI. de La Folic, propose comme une grande conquète ì fille jur un ministre, la population des lamas, aipatas et riggognes en France; mais il me permettra les reflesions suivantes :

"Les l.amas, ainsi nommés parles Péruviens. et Gurneros de la terra par les Espagnols, sont de bons animaux domestiques, tels que l'au- 
teur l'annonce. On observe seulement qu'ils ne peuvent point marcher pendant la nuit avec leurs charges : c'est la raison qui détermina les Espagnols à se servir de mulets et de chevaux. Au reste, ne considérons point ces animaux comme bêtes de charge (nos ânes de France sont bien préférables); lé point essentiel est leur toison : non-seulement leur laine est très-inféricure à celle des vigognes, comme l'observe l'auteur', mais elle a une odeur forte et désagréable qu'il est difficile d'enlever.

" La laine de I'alpaca est en effet, comme il le dit, bien supérieure à celle du lama; on la confond tous les jours avec celle de la vigogne, et il est rare que cette dernière n'en soit pas mêlée.

"Le lama s'apprivoise très-bien, comme l'observe l'auteur; mais on lui objecte que les Espagnols ont fait beaucoup d'essais chez eux, pour y naturaliser les alpacas et les vigognes. L'auteur, qui prétend le contraire, n'a pas eu à cet égard des éclaireissements fidèles. Plusieurs fois on a fait venir en Espagne une quantité de ces animanx, et on a tenté de les faire peupler; les épreuves qu'on a multipliées à cet égard ont été absolument infructueuses : ces animaux sont tous morts, et c'est ce qui est cause qu'on a depuis longtemps abandonné ces expériences.

" Il y aurait donc bien à craindre que ces animaux n'éprouvassent le mème sort en France. Ils sont accoutumés dans leur pays à une nourriture particulière : cette nourriture est une espèce de jonc très-fin, appelé ycho, et peut-être nỏs herbes de pâturages n'ont-elles pas les mèmes qualités, les mêmes principes nutritifs en plus ou en moins.

" La laine de vigogne fait de belles étoffes, mals qui ne durent pas autant que celles qui sont faites avec de la laine des lrebis. ")

Ayant reçu cette réponse satisfaisante à plusieurs égards, et qui confirme l'existence réelle d'une troisième espèce, c'est-à-dire de l'al paea, dans le genre du lama, mais qui semble fonder quelques doutes sur la possibilité d'élever ces animaux, ainsi que la vigogne, en Europe, je l'aí communiquée avec le mémoire précédent de M. Béliarly à plusieurs personnes instruites, et particulièrementà M. l'abbé Bexon, qui a fait sur ecla les observations suivantes :

* Je remarque, dit-il, que le lama vit dans les vallées basses ct chaudes du P'érou, aussi bien que dans la partie la plus froide de la sierra, et que par conséquent cee n'est pas la température de notre climat qui pourrait faire obstacle et l'empèeher de s'y habituer. (P'age 269.)

"A le considérer comme animal de monture, son pas est si doux que l'on s'en sert de préférence au cheval et à l'âne; il paraît de plus qu'il vit aussi durement que l'âne, d'une manière aussi agreste et sans exiger plus de soins.

"Il semble queles Espagnols eux-mêmes ne savent pas faire le meilleur ou le plus bel emploi de la laine du lama, puisqu'il est dit que quoique cette laine soit plus belle que celle de nos brebis el aussi douce que la soie, on l'em. ploie aux mêmes usages auxquels nous $\mathrm{cm}$ ployons le crin. ( Page 269.)

"L'alpaca, espèce intermédiaire entre le lama et la vigogne, et jusqu'ici peu connue, même des naturalistes, est encore entièrement sauvage; néanmoins c'est peut-être, des trois animaux péruviens, celui dont la conquête serait la plus intéressante, puisque avec une laine plus fournie et beaucoup plus fine que celle du lama, l'alpaca parait avoir une constitution plus forte et plus robuste que celle de la vigogne. (Ibid.)

"La facilité avec laquelle se sont nourries les vigognes privées que l'on a eues par curiosité à Lima, mangeant du mais, du pain et de toutes sortes d'herbes, garantit celle qu'on trouverait à faire en grand l'éducation de ces animaux. Une négligence inconcevable nous laisse ignorer si les vigognes privées que l'on a enes jusqu'ici, ont produit en domesticité; mais jene fais aucun doute que cet animal, sociable par instinct, faible par nature, et doué, comme le mouton, d'une timidité douce, ne se plùt en troupeaux rassemblés, et ne se propageât volonticrs dans l'asile d'un parc ou dans la paix d'une étable, et bien micux que dans les vallons sauvages, où leurs troupes fugitives tremblent sous la serre de l'oiscau de proie ou ì l'aspect du chasseur. ( $\boldsymbol{V}$. page 274.)

"La cruauté avec laquelle on nous ditquese font au Pérou les grandes chasses, ou plutôt Irs grandes tueries de vigognes, est une raison de plus de se bâter de sauver, dans l'asile domestique, une espèce précicuse que ces massacres auront bientôt détruite ou du moins affạblic au dernier point.

- Les dangers et les longueurs de la navigaa- 


$$
\text { . }
$$




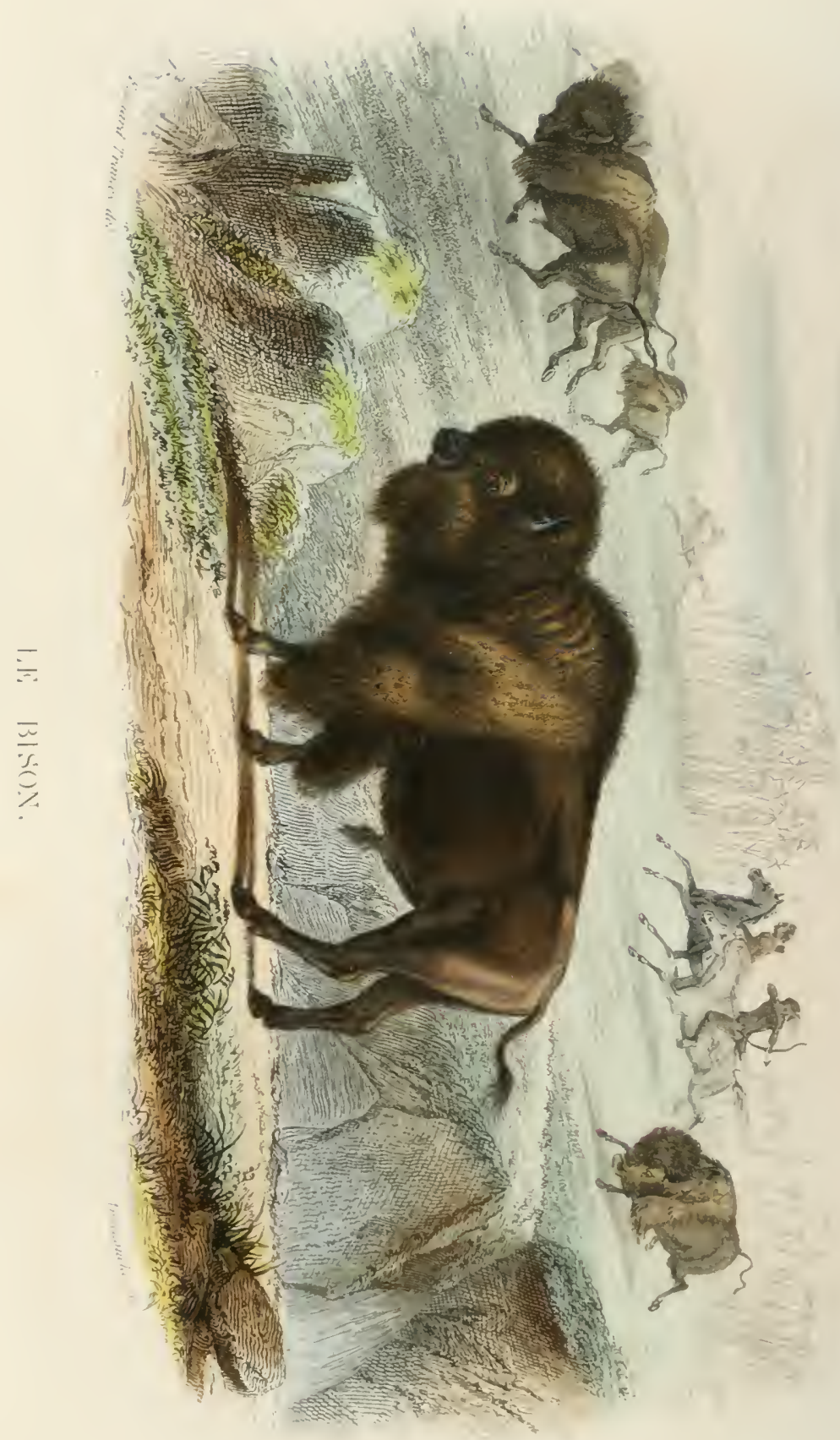


tion par le eap Horn me semblént, comme à M. Béliardy, être un grand obstacle à tirer les vigognes de la côte du Sud par Arica, Cuseo, ou Potosi; et la véritable route pour anener ces animaux précieux serait en effet de les faire desceridre du Tucuman par Rio de la l'lata, jusqu'à Buenos-Ayres, où un bâtiment, frété exprès et monté de gens entendus aux soins délieats qu'exigeraient ees animaux daus la traversće les amènerait à Cadix, ou mieux encore dans quelques-uns de nos ports les plus voisius des Pyrénées ou des Céveunes, ou il serait le plus convenable de commencer l'éducation de ees animaux dans une récrion de l'air analogne à eelle des Sicrras, d'où on les a fait descendre.

"Il me reste quelques remarques à fitre sur la lettre de M. de la Folic, yui ne me pasait offrir yue des doutes assez peu fondés et des difficultés assez légeres.

" $\mathbf{1}^{\circ} \mathrm{On}$ a vu que si le clieval et l'áne l'emportent par la constance du serviece sur le lama, colui-ci à son tour leur est préférable à d'autres écards; et d'ailleurs l'olojet est bien moins ici de considérer le lama comme bète de somme, que de le regarder conjointement avee la vigogne et l'alpaca, comme bétail à toison.

"20 Qui peut nous assurep qu'on ait fait en Fspagne beaucoup d'essais pour naturaliser ces animaux? et les essais supposés faits l'ont-ils été avee intelligrence? Ce n'est point dans une plaine clatude, mais, comme nous venons de l'iusinuer, sur des eroupes de montagnes voisjnes de la rigion des nejges, füil faut faire retrouver aux vigoernes un climat analogyuc à leur cliniat natal.

"30 C'est moins des vigngnes venues du Pérou que l'm pourrat espérer de formeg des troupeaux, que de leur mee wée en Europe; et c'est à ohtenir ectterace ct à la multiplier qu’il landnat diriger les premiers soins, gui saus doute devraient etre grands et eontinuels pour des animaux délicats et ainsi dépaysés.

" $4^{\circ}$ Quant ì l'herhe ycho, il est difficile de croire qu’elle ne puisse pas ètre remplacée par yuelyues-ums de nos gramens ou de nos joncs : mais s"il le fallait absolument, je proposerais de tramsportes l'herbe ycho elle-mème; il ne serait probablement pas plus difficile d'en fate. le semts que tout autre semis d'herbage, et il serait hemenx d'acyuriril une nouvelle espece de prairic artifieidle aree une nouvelle espice de troupeaux.
" 50 Et pour la erainte de voir dégénéser la toison de la vigogne transplantée, elle parait peu fourlée : il lien est pas de la virgogne comme d'une race domestique et factice perfectionnée, ou, si l'on veut, dégénérée tant qu'elle peut l'itre. telle que la chèrre d'Angora, qui en effet, quand on la transporte hors de la Syrie, perd en peu de temps sa beauté; la vigogne est daus l'état sauvarge; elle ne possède que ce que lui a donné la nature, et que la domesticité pourrait sans doute, comme dans toute autre espece, perfectionner pour notre usacre. "

l'adopte entierement ces réflexions trèsjustes de $\mathrm{I}$. J'abbé bexon, et je persiste à croire qu’il est aussi possible qu'jl serait important de naturaliser chez nous cés trois especes d'aumimax si utiles au Pérou, et qui paraissent si disposés à la domesticité.

\section{ILE BUFFLE, LE BONASUS,}

\section{L'AUROCHS, LE BISON ET LE ZEBBU.}

Section des rumiuants à corues, genue cheral. (Cusier'.)

Quoique le buffle soit-aujourd'hui enmmun en Grece et domestique en Italie, il n'était commu ni des Grees ni de's Romains ; ear il n'a jamais eu de nom dans la langue de ces peuples : le mot mème de luffle indique une origine étrangere, et n'a de racine ni daus la langne greecque ni dans la langue latine : en effet, eet animal est originaire des pays les plus chands de l'Afrique et des Indes, et n'a été transporté et naturalisé en ltalie que vers le septieme siecle. C'est mal a propos que les modernes lui ont appliqué le nom de bubalus, qui, en gree et en latin, indique à la vérité un anmal d'Afrique, mais très-différent du buflle, eomme il est aisé de le démontrer par les passages des au-

- On comalt maintenant sept cspeces du genre boruf, ce

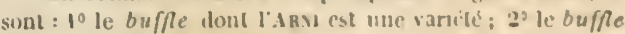
du can de Bonue-Esyerance; $3^{3}$ lu buflle musque de l" $A$. merique du Novil: lo l'yak uu buruf à que ue de clieral dus

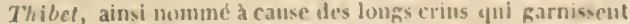
sa crouje $\mathrm{Cl}$ sil queves $5^{\circ}$ le bison d'.fmeri,jue ou buffalo; $6^{0}$ linuroshs: $7^{\circ}$ le luruf urdinaire, dout les zébus, on petils inulufs de liude a unc un eleux bouses, we sunt quie des va-

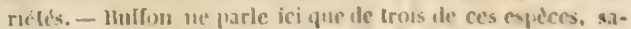
voir : 10 du butlle propuresuent dit: 20 do l"aurocls, ainst que

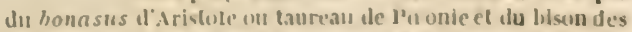
anciens, qu'il ne foml pas confundre arec le bison d'Ameriyue cu luffalo: $3^{\circ}$ du zebu. 
teurs anciens. Si l'on voulait rapporter le bubalus à un genre, il apparticudrait plutôt à celui de la grazelle cqu'à celui du bocuf ou du buffle. lielon ayant vu au Caile un petit bocuf à bosse, dilférent du buffle et du boeuf ordinaire, imagina que ce petit bouf pouvait ìtre le bubalus des anciens; mais s'il eût soigneusement comparé les caracteres domnés par les anciens au bubalus avec ceux de son petit bouf, il aurait lui-mène recomnu son erreur : et, d'ailleurs, nous pouvons en parler avee certitude, car nous avons vu vivant ce petit bocuf à bosse; et ayant eomparéla description que nous en avons faite avec celle de Belon, nous ne pouvons douter que ce ne soit le même animal. On le montrait à la foire à Paris, en 1752 , sous le nom de zébu. Nous arons adopté ce nom pour désignẹ cet animal ; car c'est une race particulicie de bouf et non pas une espèce de buffle ou de bubalus.

Aristote, en faisant mention des bœufs, ne parle que du bouf eommun, et dit seulement que chez les Arachotas (aux Indes), il y a des bocufs saúvages qui different des boufs ordinaires et domestiques, comme les sangliers different des cochons; mais dans un autre endroit que j’ai cité daus les notes ci-dessus, il donne la description d'un bœuf' sauvage de Poonie (province roisine de la Nacédoine), qu'il appelle brnasus. Ainsi le bouf orlinaire et le bonasus sont les seuls animaux de ce genre indiqués par Aristote; ct ce qui doit paraitre singulier, c'est que le bonasus, quoique assez amplement décrit par ce grand philosophe, n'a été reconnú mar aucun des naturalistes grees ou latins qui ont ćcrit après lui, et que tous n’ont fait que le copicr sur ce sujet; en sorie qu'aujourd'hui mème l'ou ne commait encore que le nom du bonusus, sans savoir quel est l'animal subsistant auquel on doive l'appliquer. Cependant, sil'on fait attention qu'Aristote, en parjant des bouf's săurages du climat tempéré, n’a indiqué que le bouasus, et fu'au contraire, les Grees et les Iatins des sičcles suivants n’out plus parlé du bonasus, mais ont indiqué ces boufis salurages sous les noms d'urus et de bison, on sera porté a croire que le honasus doit être l'un ou l'autre de ces animaux ; ct en effet, l'on veräi en comparant ce qu'dristote dit du honasus, avec ce que nous comnaissons du bison, qu’il est plus que probable que ees deux noms ne resignent que le mème animal. Jules César est te plemicl qui ait parlé de l'urus. Pline et Pausanias sont aussi les premiers qui aient annoneé le bison. Dés le temps de l'line, on domnait le nom de bubalus à l'urus ou au bison ; la confusion n'a fit qu'augnenter avec le temps; on a ajouté au bonasus, au buhalus, à l'ur'us, au bison, le catopleba, le thur, le bubalus de Belon, le bison d'Écosse, celuj d'Amériçue; et tous nos naturalistes ont fait autant d'espèces différentes qu'ils ont trouvé de noms. La vérité est jei enveloppée de tant de nuages, environnée de tant d'erreurs, quon me saura peut-être quelque gré d'avoir entrepris d'éclaircir cette partic de l'histoire naturelle, que la contriliété des témoignages, la variété des descripltions, la nultiplieité des noms, la diversité des lieux, la différence des langues et l'obscurité des temps semblaient avoir condamnée à des ténèbres éternelles.

Je vais d'abord présenter le résultat de mon opinion sur ce sujet, après quoi j'en domnerai les jieuves.

$1^{\circ}$ L'animal que nous connaissons aujourd'hui sous le nom de buffle n'était point connu des anciens.

$2^{\circ}$ Ce buffe, maintenant domestique en Europe, est le mène que le buffle domestique ou sauvare aux Indes et en Afrique.

$3^{\circ}$ Le bubalus des Grees et des Romains n'est point le buffle ni le petit bouf de Belon, mais l'animal que MM. de l'Acardénie des Sciences ont décrit sous le nom de rache de Barbarie, et nous l'appellerons bubale.

$4^{\circ}$ Le petit bouf de Belon, que nous ayons vu et que nous nommerons ziluu, I'est qu'une variété dans l'espèce du bocuf.

50 Le bonasus d'Alistote est le mime animal que le bison des Latins.

$6^{\circ}$ Le bison d Amérique pourrait bien venir originairement du bison d'Furope.

;o L'urus ou auroclss est le mème animal que notre taureau commun dans son état natulel et sauvage.

$8^{\circ}$ Enfin, le bison ne diffère de laurochs que par des variétés accidentelles, et par consćpguent i) est ; aussi bien que l'aurochs, de la méme espiee que le bouf domestique; en sorte que je crois pouvoir réduire à trois toutes les dénomiuations et toutes les espèces prétendues des naturalistes, tant anciens que modernes, ciesta-dirc à celles du bocuf, du buffle et du bubaic. 
Je ne doute pas que quelques-unes des propositions que je viens d'annoncer ne paraissent des assertions hasardées, surtout aux yeux de ceux qui se sout oceupés de la nomenclature des animaux, et qui ont essayé d'en donner des listes : eependant il n'y a aucune de ees assertions que je ne sois en état de prouver : mais avant d'entrer dans les discussions critiques qu'exige chacune de ces propositions cu particulier, je vais exposer les observations et les faits rui m'ont conduit dans cette recherche, et qui, m'ayant éelairé moi-même, serviront également à éclairer les autres.

II n'en est pas des animaux domestiques, à beaucoup d'égards, comme des animaux sauvages : leur nature, leur grandeur et leur forme sont moins constantes et plus sujettes aux variétés, surtout dans les panties exterieures de leur corps; linfluence du climat, si puissante sur toute la nature, agrit avee bien plus de force sur des ètres eaptifs que sur des ètres libres; la nourriture préparée par la main de l'homme, souvent iparonce et inal choisic, jointe à la dureté d'un cicl ćtranưrer, produisent avee le temps des altérations assez profondes pour devenir constantes, en se perpcituant pas les générations. de ne prétends pas dire gue cetfe cause générale d'altération soit isse\% puissante pour dénaturer essenticllement des sitres, dont l'enpreinte est aussi ferme que celle du moule des animaux; mais elle les change il certains chrards, elle les masque et les transforme à l'extérieur; elle supprime de certaines partics, ou leur en donne de nouvelles; elle les peint de couleurs varicies; et par son action sur. I'hilbitude du corps, elle inllue aussi sur le naturel, sur l'instinct et sur les qualités les plus intiricures: une seule partie modifice dans un tout aussi parfait que le corps d'un animal suffit pour que tout se ressente, en effet, de cette altération; et c'est par cette raison que nos animaux domestipues diflérent presque autant par le naturel et l'instinct que par la ligure de ecux dont its tirent leur premiere origine.

La brehis uous en fournit un exemple frappant : retle espere, telle yu'elle est anjourd hui, périrait en entier sous nos ? eur, et en fort peu de temps, si l'homme eessait de la soiennere, de la difendre: aussi est-clle trie-differente d'elleunine, tres-inferfente it son espece originaire. Mais pour ne parler ici que de ce equi fait notre uljet, nous verrous combien de varićtés les bocurs ont essuyces par les effets divers et diversement combinés dlu climat, de la nourrilure r't du traitement dans leur état dindépeudance et dans celui de domesticité.

La variété la plus générale et la plus remarquable dans les bouls domestiques et mème sauvages consiste dans rette espece de bosse qu'ils portent entre les deux épaules. On a appelé bisons cette race de bœufs bossus, et l'on a eru jusqu'ici que les bisons etaicnt d'une espéee différente de celle des boufs communs: mais comme nous sommes maintenant assurés que ces locufs à bosse produisent aree nos boufs, et que la bosse diminue des la premiere génération et disparait a la seconde ou a la troisieme, il est ćvident que cette loosse n'est qu'un earaetere aceidentel et variable, qui n'empiche pas que le bouf bossu ne soit de la méme espèce que notre bouf. Or, on a trousé autrefois clans les parties désertes de l'Europe des bocufs sauvages, les uns sinns bosse et le's autres avee une bosse: ainsi celte variété semble étre dans la nature mème; clle parait provenir de l'abondance et de la qualité plus substanticlle du páturage et des autres nourritures ; car nous ar ons remarqué sur les chameaux que quand ces animaux sont maigres ct mal nourris, ils n'ont pas même l'apparence de la bosse. Le houf sans bosse se nommait vrochs et turochs dans la langue des Germains, et le boeuf sauvarge í bosse se nommait visen dans eette mime langue. Les liomains, qui ne eonnassaient ni l'un ui l'autre de ees boufs sanvages avant de les avoir vus en Germanie, ont adopté ('es noms : de vrochs, ils ont fait urus, et de visen, bison; et ils n'ont pas imagincé que le bouf sauvage decrit par Aristote, sous le nom de bonusus, pouvait itre l'un ou l'autre de ces boufs, dont ils venaient de latiniser et de gréciser les noms germains.

Une antre difference qui se trouve entre l'anrochs et le bison est la longueur clu poil : lo cou, les épaules, le dessous de la crorge dans le bison sont couverts de poils tres-lones; au lieu que dlans l'aurochs, toutes ces partics ne sont revitues que d'un poil ass 'z court ot semblable à celui du corps, à l'evereption du front, qui cust garni de poil erepu. Nais cette difnerenee du poil est eneore plus aecidentelle que eolle de la bosse, et depend de meme de la nourriture et du climat, comme nous l'avons proure pour les cherres, les moutons, les chiens, les chats, les lapius, ete. Aiusi ni la bosse, ni la différenco 
dans la longueur et la quantité du poil ne sont des caractères spéeifiques, mais de simples variétés accidentelles qui ne divisent pas l'unité de l'espèce.

Une variété plus étendue que les deux autres, et à laquelle il semble que les naturalistes aient domné de concert plus de caractère qu'elle n'en mérite, c'est la forme des cornes : ils n'ont pas fait attention que dans tout notre bétail domestique, la figure, la grandeur, la position, la direction, et même le nombre des cornes, va- rient si fort qu'il serait impossible de prononcer quel est pour eette partie le vrai modèle de la nature. On voit des vaches dont les cornes sont plus courbées, plus rabaissées, presque pendantes; d'autres qui les ont plus droites, plus longues, plus relevées. Il y a des raees entières de brebis qui ont des cornes, quelquefois deux, quelquefois quatre, ete. Il y a des races de vaches qui n'en out point du tout, etc. Ces parties extérieures, et, pour ainsi dire, accessoires au corps de ces animaux, sont tout aussi peu constantes que les couleurs du poil, qui, comme l'on sait, varient et se combinent de toutes facons dans les animaux domestiques. Cette différence dans la figure et la direction des cornes, qui est si ordinaire et si fréquente, ne devait donc pas être regardée comme un caractère distinctifdes espèces : cependant, c'est sur ce scul caractère que nos naturalistes ont établi leurs espèces, et comme Aristote, dans l'indication qu'il donne du bonasus, dit qu'il a les cornes courbées en dedans, ils ont séparé le bonasus de tous Ies autres bœufs, et en ont fait une espèce particulière à la seule inspection des cornes et sans en avoir jamais ru l'individu. Au reste nous eitons sur cette variation des cornes, dans le bétail domestique, les vaches et les lrebis, plutôt que les taureaux et les béliers, parce que les femelles sont ici beaueoup plus nombreuses que les mâles, et que partout on peut observer trente vaches ou brebis pour un taureau ou un bélier.

La mutilation des animaux par la eastration semble ne faire tort qu'il l'individu et ne parait pas devoir influer sur l'espèce; cependant il est sûr que cet usage restreint d'un côté la nature et l'affaiblit de l'autre: un seul mâle condamné à trente ou quarante femelles ne peut que s'épuiser sans les satisfaire; et dans l'accouplement l'ardeur est inégale, plus faible dans le male qui jouit trop souvent, trop forte dans la femelle qui ne jouit qu'un instant: dès lors tontes les productions doivent tendre aux qualités féminines; l'ardeur de la mère étant au moment de la conception plus forte que celle du père, il naîtra plus de femelles que de mâles; et les mâles mêmes tiendrout lseaucoup plus de la mère quedu père. C'est sans doute par cette eause qu'il nait plus de filles que de garenons dans les pays où les hommes ont un grand nombre de femmes, au lieu que dans tous ceux où il n'est pas permis d'en avoir plus d'une, le màle conserve et réalise sa supériorité, en produisant en effet plus de mâles que de femeiles. Il est vrai que dans les animaux domestiques, on choisit ordinairement parmi les plus beaux ceux que l'on soustrait à la castration, et qu'on destine à devenir les pères d’une si nombreuse génération. Les premières productions de ce màle choisi seront, si l'on veut, fortes et vigoureuses : mais à foree de tirer des copies de ee seul et même moule, l'empreinte se déforme, ou du moins ue rend pas la nature dans toute sa perfection: la race doit par conséquent s'affaiblir, se rapetisser, dégénérer; et c'est peut-être par cette raison qu'il se trouve plus de monstres dans les animaux domestiques que dans les animaux sauvages, où le nombre des mâles qui concourent à la génération est aussi grand que celui des femelles. D'ailleurs, lor'squ'il n'y a qu'un mâle pour un grand nombre de femelles, elles n'ont pas la liberté de consulter leur goilt; la gaieté, les plaisirs libres, les douces émotions leur sont enlevées; il ne reste rien de piquant dans leurs amours; elles souffrent de leurs feux ; elles languissent en attendant les froides approehes d'uu mâle qu'elles n'ont pas ehoisi, qui souvent ne leur convient pas, ct qui toujour's les flatte moins qu'un autre qui se serait fait préférer. De ces tristes amours, de ees accouplements sans gout, doi rent naitre des jroduetions aussi tristes, des ètres insipides qui n'auront jamais ni le courage, ni la fierté, ni la force que la nature n'a pu propager dans ehaque espèee, qu'en laissant in tous les individus leurs facultés tout ontières, et surtout la liberté du choix ct mêne le hasard des reneontres. On sait par l'exemple des ehevaux que les races eroisées sont toujours les plus belles; on ne devatit done pas borner dans notre bétail les femelles à un seul mâle de leur pays, qui lui-mème ressemble déjà beaucoup à sa mère, et qui par conséquent, loin de relever l'espèce, ne peutque 
continuer à la dégrader. Les hommes ont préféré dans cette pratique leur commodité aux autres avantages; nous n'avons pas cherché à maintenir, à embellir la nature, mais à nous la soumettre et en jouir plus despotiquement : les máles représentent la gloire de l'espèce; ils sont plus courageux, plus fiers, toujours moins soumis; un grand nombre de màles dans nos troupeaux les rendrait moins dociles, plus difficiles à conduire, à garder : il a iallu même, dans ces esclaves du dernier ordre, supprimer toutes les têtes qui pouvaient s'élever.

A toutes ces causes de dégénération dans les animaux domestiques, nous devons encore en ajouter une autre, qui seule a dù produire plus de variétés que toutes les autres réunies; c'est le transport que l'homme a fait, dans tous les temps, de ces animaux, de climats en climats. Les boufs, les brebis et les clières ont été portés et se trouvent partout; partout aussi ces espèces ont subi les influences du climat ; partout elles ont pris le tempérament du ciel et la teinture de la terre; en sorte que rien n'est plus diffieile que de reconnaitre dans ce grand nombre de variétés celles qui s'éloignent le moins du type de la nature: je dis celles qui s'éloignent le moins, car il n'y en a peut-être aucune qu'on puisse regarder comme une copie parfaite de cette première empreinte.

Après avoir exposé les causes générales de variété dans les animaux domestiques, je vais donner les preuves particulieres de tout ce que j'ai avancé au sujet des boufs et des bulfles. J'ai dit : $1^{\circ}$ Que l'animal que nous cunnaissons aujourl'hui sous le nom de buffle n'élait pas connu des anciens Grees ni des Romains. Cela est évident, puisque aucun de leurs auteurs ne l'a décrit, qu'on ne trouve mème dans leurs ouvrages aucun nom qu'on puisse lui appliquer, et que d'ailleurs on sait, par les Annales d'Italie, que le premier buffle y fut amené vers la tin du sixiène siècle, l'an 595 .

$2^{\circ}$ Le buffle maintenant lomestique en $\mathrm{Eu}$ rope est le meme que le buffle sauvage ou domestique aux Indes ct en Afrique. Ceei n'a besoin d'antres preuves que de la comparaison de notre description du bufle, que nous avons vu vivant, avec les notices que les voyageurs nous ont donuées des buffle's le l'erse, du Nognol, de Bengale, d'Erypte, le Guinée, et du eap de Boune-Espérance; on verra que dans tous ces pays cet auimal est le méne, et qu'il ne differe de notre buffle que par de très-légères diffé. rences.

$3^{\circ}$ Le bubalus des Grees et des Latins n'est point le buffle ni le petit bauf de Belon; mais l'animal que $\mathbf{M} \boldsymbol{M}$. de l'Académie ont décrit sous le nom de vache de Barbarie. Voici mes preuves. Aristote met le bubalus avee les cerfs et les daims, et point du tout avee les bœufs : ailleurs il le cite avec les chevreuils, et dit qu'il se défend mal avec ses cornes, et qu'il fuit les animaux féroces et guerriers. Pline, en parlant des bœufs sauvages de Germanie, dit que c'est par ignorance que le vulgaire donne le nom de bubalus à ces bocufs, attendu que le bubalus est un animal d'Afrique, qui ressemble en quelque façon à un veau ou à un cerf. Le bubalus est donc un animal timide, auquel les cornes sont inutiles, qui n'a d'autre ressource que la fuite pour éviter les bẻtes féroces, qui par conséquent a de la légèreté, et tient pour la figure de celle de la vache et de celle du cerf : tous ces caractères, dont aucun ne convient au buffle, se trouvent parfaitement réunis dans l'animal dont Horace Fontana envoya la figure à Aldrovande, et dont MM. de l'Académie ont donné aussi la figure et la description sous le nom de vache de Barbarie; ct ils ont pensé, comme moi, que c'était le bubalus des anciens. Le zébu ou petit bœuf de Belon n'a aucun des caractères du bubalus; il en differe presque autant qu'un bouf differe d'une gazelle : aussi Belon est le seul de tous les naturalistes qui ait regardé son petit bœuf comme le bubalus des anciens.

$4^{0}$ Ce petil bauf de Belon n'est qu'une variété de l'espèce du bauf: nous le prouverons aisément, en renvoyant seulement à la figure de cet animal, donnée par Bclon, Prosper Alpin, Edwards, et à la description que nous en avous faite nous-mèmes; nous l'avons vu vivant: son conducteur nous dit qu'il venait d'Afrique, qu'on l'appelait zébu, qu'il était domestique, et (qu'on s'en servait pour monture. C'est en effet un aninal très-doux et même fort caressant, d'une figure agréable, quoique massive et un peu trop carrée : cependant il est tu tout si semblable à un bouf, que je ne puis en donner une idée plus juste, qu'en disant que si l'on regardait un taureau de la plus belle forme et du plus beau poil avec un verre qui dimlnuat les objets de plus de moitié, cette figuro rapetissée serait celle du zébu. 
On peut voir dans la note ci-dessous ' la deseription que j'ai faite de cet animal, lorsque je le vis en 1752 : elle s'aceorde très-bien avee lat figure et la deseription de Belon, que nous avons

1 Ce petit beuf ressemb'e parfaitennent à crlui de kelon: il a la croupe plus mucle et plus plpune yue des bonls ordiniaires; il est si dunx, si fomilier, yu'il leche comme un clisu et fait des carense, à tunt le munde ; c'est un t és-jo.i anmual, yui paralt avoir autunt d'intelligence que de dicilıté. Son con

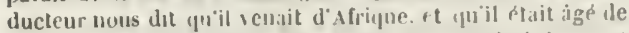
vingt el un mois; il était de c. ulenr hlanche, melée de jaune et d'un pen de runge; les pienls traieut tuut blane's; te puil, sur l'éplne du slus, était coul ur noirâtre, de la larzeur d'euv'run un pied, la uneue se néme coulenr. An milipn de rette bamle noire il y avait sur la crumpe une petite raie blanclie donil l.'s poils étaient hérissés et relevés en haul; Il navall poinl dc crinière, et le joil du tımpet étatt trés-petit, le poil un curıs furt ras. Il avait ciny pieds sept pouc's de longueur. mesuré en ligne droile, ciepuis le bout du unıseau jusıu'à l"urigine de la queue; cing pieds un pouce de circonlérence prise derritre les jambes de devant, ciny pieds dix pouces au milieu di corps sur le nombril, el ciny fieds un ponce au-dessus des jamber de de: rière. La tẻte avait deux pieds dix pusuces de circunférence prise devant les cornes; le museau un jicıl trois ponces de circonférence prise derrière les naseaux; la feıte de la gueule feruée u'était que de ouze pouces; les naseaux avaient denx pouces de lungueur et un ponce de lilgeur; il y avait dix pouces depuis le bout du museau jusqu'à l'oeil; les yeux étaient éloignés l'un de l’autre de six pouces en suivant la courbure de la tete, et en ligne droite de einq ponces; l'ceil avail deux pouces et demi de longueur (i'un angle a l'autre; l'anłle postéricur de l"ceil était éloigné de l'unverture de l'oreille de (juatre pouces; les oreilles étaient situées derrière et un peu à cóté des cornes; elles avaient six pouces dix lignes de longueur prises par derriere, neuI pouces trois lignes de circonférence à la racine, el qualre pouces qualı́ lignes de largeur a la base en suivant la courbure; il y avail qualre pouces trois lignes de distance eutre les denx cornes; elles avaient un pied deux ponces de longueur et six de circonférence à la base, et seulement un ponce et demi à six lignes de distance de leur extrémité; elles étaient de couleur de corne ordiuaire et noires vers le bout; il y avait un jird sejt pouces de distance entre les deux extrémilès des cornes; la distance entre les oreilles et les cornes était de deux pouces deux lignes; la longueur de la lètc depuis le bout du museau jusqu"a l'épaule était de deux pieds quatre ponces six ligneś ; le fanon pendait de trois pouces et demi au milieur du con, et senlement d'un pouce trois ligaes sous le sternum; le cou avajt trois pieds neuf pouces de circonfirence jrise préciséinent devaut la bosse un lonpe, qui élait exactement sur les épaules, au défaut du con, à un jied et un ponce de distance des cornes. Cette bosse était de chair en entier; clle avait un pied de longueur mesurée en ligne lroite, sept pouces de hautcur perpendiculaire et six punces d'épaissenr; le puil qui courrait lc dessus de celle bosse élait nuilátre el d'uu pouce et demi de longueur: les janbes de devant avdent quatre pouces neul lignes de longmenr depuis le coude jusı̨u an poignet; le coude a un pied six pouces de circonlerencer i le bras onze ponces de circunférence; le canun as ait lanit [un. ces de longueur et ciny pouces quatre lignes du circunférence a l'endroit le plus mince; la corne dens puuces ynatre ligues de longurur, ct l'ergot wir jouce; la jambe de derrière avait un pied leux pouces et dmmi de lunguenr, et uuze nous. ces truis lignes de circouférence à l'emulroil le plus petit; le jarret quatre pouces trois lignes de largenr; le canou un pied de longueur, ciny pouces huil lignes de cirembérence, urise au plus mince, et deux prouces el demi de largenr; la tgueue avait deux pieds trois lignes jus ju'au lout des vertebies, et deux piens dix pouces et demi jusiju au bout des joils yni touchaient a terre; les plus longs poils de la queue avaient eru devoir rapporter aussi, afin qu'on puissela comparer. P'rosper Alpin, qui a donné une m. tice et une figure de cet animal, dit qu'il s trouve en ligypte : sa description s'accorde encore avee la notre et avec celle de Belon; les seules différences qu'ou puisse remaryuer dans tontes trois ne tombent que sur les couleurs des cornes et du poil; le zébu de Belon était faure sous le ventie et brun sur le dos avec les cornes noires; celui de Prosper Alpin était roư, marqué de petites taches, arec les cornes de conleur ordinaire; le notre était d'un fause pâle, presque noir sur le dos, aree les cornes aussi de couleur ordinaire, e'est-á-djre de la mème couleur que les cornes de nos bœufs. Au reste, les figures de Belon et de Prosper Alpin pechent en ce que la loupe ou bosse que cet animal porte sul les épaules n'y est pas assez marquée: le contraire se trouve dans la figure qu’Edwards a nouvellemeut gravée de ce même animal, sur undessiu yui lui avait été communiqué par Hans Sloaue : la bosse est trop grosse, et d'ailleurs la figure est incomplète en cequ'elle a vraisemblablement eté dessiuée sur un animal fort jeune, dont les cornes étaient eucore naissantes : il venait des Indes orientales, dit lidwards, où l'on se sert de ces petits bœufs, comme nous nous servous des chevaux. Il est clair par toutes ees indieations, et aussi par la variété du poil et par la douceur du naturel de cet animal, que e'est une race de bœufs à bosse, qui a pris son origine dans l'état de domesticité, où l'on a choisi les plus petits individus de l'espece pour les propager; car nous ver:rons qu'en général les boufs à bosse domestiques sont, comme nos boufs domestiques, plus petits que les saurages, et ces faits seront confrimés par les témojynages des voyageurs que nous citel'ons dans la suite de cet article.

5." Le bonasus: d'Arislote est le méme que le bison des Lutims' '. Cette proposition ne peut ètre prouvée sans une discussion critique, dont j'éparsnerai le détail à mon lecteur. Gessner, qui était aussi savant littérateur que bon natu-

un pied truis ponces; la quene luut pouces de circonférence à la lase; le's huursés étaient ćluignées de l'anus d'un pied $\mathrm{Pt}$ deni en suivant la cuurbure du bas-ventre; les testicules n ${ }^{\circ} \mathrm{C}$ taient pras encore descendus dans les bourses. yui, cependant, p'ndaient de denx pouces ct leui ; il y avait quatre unamelles situcées comme celles du tanrean; la verge était d'un piad de longurur clemis les lumrses jusıju'au bout du fourreau.

- Le bunasus d'Aristute est le un'ue yue le bison des Latins: mais Cuvier les rapporle lous deus à l'espece de l'aurochs. 
raliste, et qui pensait comne moi que le bonasus pourrait bien être le bison, a examiné ct discuté plus soigneusement que persoune les notices qu'Aristote donne du bonasus, et il a en mème temps corrigé plusieur's expressions de la traduetion de Théodore Gaza, que cèpendant tous les naturalistes ont suivie sans examen : en me servant de ses lumieres, et eu supprimant des notices d'Aristote ce qu'elles ont d'obscur, d'opposé et méme de fibuleux, il $m$ ia paru qu'elles se l'éduisáient à ce qui suit : Le bonasus est un boeuf sauvage de Poconic; ; l est au moins aussi grand qu'un taureau domestique, et de la même forme; mais son cou est, depuis les épaules jusque sur ies yeux, couvert d'un long poil bien plus doux que le erin du cheval. I1 a la roix du bouf, les cornes assez courtes et (courbées en bas autour des oreilless; les jambes eouvertes de longs poils, doux comme lit laine, et la quene assez petite pour sa grandeur, yuoique an reste semblable à celle du boruf. II a, commele taureau, l'habitude de firire de la poussière avee les pieds; son cuir est dur, et sil chair tendre et bumue à manger. Par ces caractieres qui sont les sculs sur les(quels on puisse tabler dans les notices d'Aristote, on voit dujai combien le bonasus approche du bison. Tout convieut on effet à eet animal, à l'exception de la forme des cornes; mais, comme nous l'avons dit, la figure des comes varie beaucoup) daus ces animaux, saus yu'ils cessent pour cula d'ètre de la même espéce. Nous avons vil des corntes atiusi eourbées, qui provenaient d'un boxuf bossu d'Afrique, et nous prouverons tout a l'heme que ec bouf a bosse n'est autre chose que le bison. Nous pouvons aussi confirmer ce yue nous venons de dire, par la comparaison des témoignages des antemrs aneicns. Aristote domme le bonasus pour un bouf de Poonje; et Pausanias, en parlant des tinueaux de Preonic, dit en deux endroits diffórents que ces taureaux sont des bisons; il dit mîne expressément que les taureaux de Pronie qu il a vus dans les spectacles de Rome avaient des poils trés-longs sur la poitrine et antonr des mathoires. Endin, Jules César, Pline, l'ausanias, Solin, ete., ont tous, en parlant des houfs sauvages, cité l'aumehs et le bison; ils nont rien dit du bonasus. Il faudrait done supposer qu'en moins de quatre ou einq siceles lespece du bonasus se serat predue, si l'on ne vouloit pals convenir que ces deux noms bonasuset bisonn'indiquentyuelememe auimal. $6^{\circ}$ Les bisons d'Amérique pourraient bien venir originairement des bisons d'Europe. Nous avons déjá jeté les fondements de cette opinion dans notre discours sur les animaux des deux coutinents. Ce sont les expériences faites par M. de lit Nux qui nous ont éclairé; il nous a appris que les bisons ou boufs à bosse des Indes et de l'ifrique produisent aree les taureaux et vaches de l'Europe, et que la bosse n'est qu'un earactere aceidentel qui climinue dès la première génération ct dispinast a la seconde ou a la troisième. Puisque les lisous des Indes sont de la mime espece que nos baeufs, et ont pirr c'onséquent une mèmeorigine, n'e'st-il pas naturel d'étendre cette méme origine au bison d' $\mathrm{A}$ mérique? Rien ne s'oppose à cette supposition: tout semble au eontraire concourir a la prouver. Les lisons paraissent ètre originaires des pays froids ct tempérés; leur nom est tiré de la languc des Germains; les anciens ont dit (ju'ils se trouvient dans la partie de la Germanic voisine de la Seythie; actuellement on trouve encore des bisons dans le nord de l'Allemagne, en Pologrne, en Écosse : ils ont done pu passer en Amérique, ou en venir comme les autres animaux qui sont communs aux deux continents. La seule différence qui se trouve entre les bisons d'Europe et ceux d'Amériquc, é est que ces derniers sont plus petits : mais cette difiérence mème est une nouvelle présomption (jüils sont de la mène e'spèce; ear nous avons vu que généralement les animaux domestiøues ou sauvages, qui ont passé d'eux-mèmes ou qui out été transportes en Améripue, y sont tous devenus plus petits et cela sans ancume eveeption : d'ailleurs, tous les caracteres, jusupu'à reux de la bosse et des longs poils aux partices antérieures, sont absolument les memes dans les bisuns de l'Amérique et daus coux de l'Europe; ainsi nous ne pouvons nous refuser a les regarder, non-seulement comme des animaux de la meme espece, mais encore de la mème race'.

Tounue jélais sar le poiul de donure cel arlicle à l'imures-

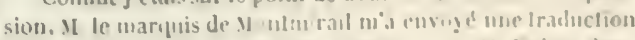

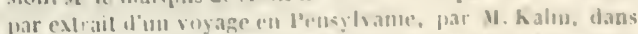

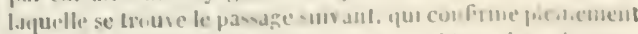

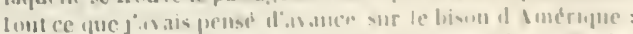

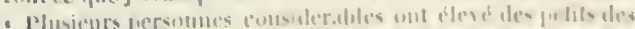

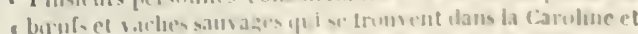

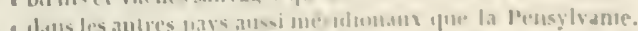

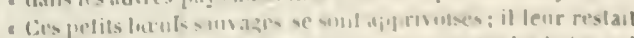

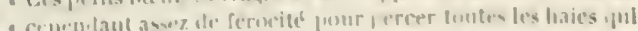

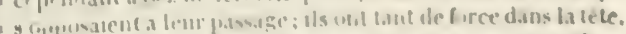

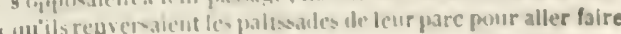
39. 
70 L'urus ou laurochs esl le même animal que notre taureau commun dans son élal naturel et sanvage. Ceei peut se prouver d'abord par la comparaison de la figure et de l'habitude entière du corps de l'aurochs, qui est absolument semblable à celle de notre taureau domestique; l'aurochs est sculement plus grand et plus fort, comme tout animal qui jouit de sa liberté l'emportera toujours par la grandeur et la force sur ceux qui depuis longtemps sont réduits à l'esclavage. L'iurochs se troure encore dans quelques provinces $d u$ Nord. On a quelquefois enlevé de jeunes aurochs à leur mère; et les ayant élevés, ils ont produit avec les taureaux et raches domestiçues : aiusi l'on ne peut douter qu'ils ne soient de la mème espèce.

$8^{\circ}$ Enfin le bison ne diffère de l'aurochs que par des variétés accidentelles, et par conséquent-ils sont tous deux de la même espèce que le bcenf domestique. La bosse, la longueur et la qualité du poil, la forme des cornes sont les seuls caractères par lesquels on puisse distinguer le bison de l'aurochs : mais nous avons vu que les bœufs à bosse produisent aree nos bœufs; nous savons d'ailleur's que la longueur et la qualité du poil dépendent dans tous les animaux de la nature du climat; et nous avons remarqué que dans nos bœufs, chèvres et moutons, la forme des cornes est ce qu'il y a de moins constant. Ces différences ne suffisent donc pas pour établir deux espèces distinctes: et puisque notre bœuf domestique d'Europe produit avec le bœuf bossu des Indes, on ne peut douter qu’à plus forte raison il ne produise avec le bison on bœuf bossu d'Europe. II y a dans les variétés presque innombrables de ces animaux, sous les différents elirnats, deux races primitives, toutes deux anciennement subsistantes dans l'ćtat de nature : le bœuf à bosse ou bison, et le bouf sans bosse ou l'aurochs. Ces races se sont soutenues, soit dans l'état libre et sauvage, soit dans celui de domesticité, et se sont répandues ou plutôt ont été transportées par les hommes dans tous les elimats de la terre: tous les bœufs domestiques sans bosse viennent originairement de l'aurochs, et tous

- ensuite tontes sorles de ravages dans les chanjus semés; el - quaud ils avaient ouvert le chemin, tout le froupean des va- clies domeslipures les suivail : ils s'acconylaienl eusemble, el - cela a formé une aulre espéce. "Voyage de II. Pierr Kahn, professeur 2 Abo, et membre de l'Académie des Scieuces de Suède, dans l’amérique septentrionale. Gottingue, 1757. page 330 . les bœufs à bosse sont :ssus du bison. Pour donner une idée juste de ces variétés, nous ferons une courte énumération de ces animaux, tels qu'ils se trouvent actuellement daus les différentes parties de la terre.

A commencer par le nord de l’Europe, le peu de boufs et de vaches qui subsistent en Islande sont dépourvus de cornes, quoiqu'ils soient de la même race que nos bœufs. La grandeur de ces animaux est plutôt relative à l'abondance et à la qualité des pâturages qu’à la nature du climat. Les Hollandais ont sourent fait venir des vaches maigres de Danemarck, qui s'engraissent prodigieusement dans leurs prairies et qui donnent beaucoup de lait : ces vaches de Danemarck sont plus grandes que les nottres. Les bœufs et vaches de l'Ukraine, dont les pâturages sont excellents, passent pour être les plus gros de l'Europe : ils sont aussi de la mème race que nos bœufs. En Suisse, où les têtes des premières montagnes sont couvertes d'une verdure abondante et fleurie, qu'on réserve uniquement à l'entretien du bétail, les bœufs sont une fois plus gros qu'en France, ou communément on ne laisse à ces animaux que les herbes grossières dédaignées par les che. vaux. Du maurais foir, des feuilles sont la nourriture ordinaire de nes bœufs pesıdant l'hiver, et au printemps, lorsqu'ils auraient besoin de se refiire, on les exclut des prairies : ils souffrent donc eneore plus au printemps que pendant l'hiver ; car on ne leur donne alors presque rien à l'étable, et on les conduit sur les chemins, dans les champs en repos, dans les bois, toujours à des distances éloignées et sur des terres stériles, en sorte qu'ils se fatigneint plus qu'ils ne se nourrissent. Enfin on leur permet en été d'entrer dans les prairies : mais elles sont dépouillées, elles sont encore brùlantes de la faux; et comme les sécheresses sont les plus grandes dans ce temps et que l'herbe ne peut se renouveler, il se trouve que dans toute l'année il n'y a pas une seule saison où ils soient largement ni convenablement nourris; e'est la seule cause qui les rend faibles, chétifs et de petite stature : car en Espagne et dans quelques eantons de nos provinees de France, où l'on a des patturages vifs et uniquement réservés aux bœufs, ils y sont beaucoup plus gr'os et plus forts.

In Barbarie et daus la plupart des provinces de l'Afrique ou les terrains sont sees et les pd- 
DU BUFFL, DU BUNASUS, etc.

turages maigres, les bœufs sont encore plus petits, et les vaches donnent beaucoup moins de lait que les nôtres, et la plupart perdent leur lait avee leur veau. Il en est de mème de quelques parties de la Perse, de lit basse Éthiopie et de la grande Tartarie, tandis que dans les mêmes pays, à d'assez petites distances, comme en Calmouquie, dans la haute Ethiopie et en Abyssinie, les boufs sont d'une prodigieuse grosseur. Cette différence dépend donc beaucoup plus de l'abondance de la nourriture que de la température du elimat : dans le Nord, dans les régions tempérées et dans les pays chnuds, on trouve également, et àde très-petites distances, des boufs petits ou gros, selon la (quantité des páturages et l'usage plus ou moins libre de la pâture.

La race de l'aurochs ou du bouf sans bosse occupe les zones froides it tempérées; elle ne s'est pas fort répandue vers les contrées du midli : au contraire, la race du bisou ou bouf à bosse rrmplit anjourd'hui toutes les provinees méridionales. Dans le continent entier des grandes Indes ', dans les îles des mers orientales et méridionales, dans toute l'Afrique, depuis le mont Atlas jusqu'au cap de Bonue-lispérance, on ne trouve pour ainsi dire que des bœufs à bosse, et il parait mème que cette race, qui a prévalu

'Les brufs qui tirent les carrosses dans Surale sont b!ancs, de belle taille, avec deux bosses, et de meme que de certaing chameanx, courent et galojent cumme les chevaux, avec de belles humsses, de brlles partures et quantité de. somm tl's au cou; de surte ıue yuand ils cumrent ou yu'ils galopent dans les rues, ils se fout rutenilre de loin; je puis rlire que cest quelque chose di plaisant el de tris-agréable a voir. () II ne se sert pas seulement de cos carrosses pour se juromener daus les villes de l'Inde, mais fncore à la campagne, el pour quelıp' voyage qu'on veuille entreprendre. Voyage de Pielro delia valle, tome VI. jage 275. - Les vintures dis Mogul. quit sont des es. pèces de carrosses à denx roues, sont aussi tirées par des boenfs, qui. quoique naturellement fiesauts et leuls dans leur marche, acyuièrent cependant, jar l'habiturle et jar un long exerclce, une grande facilité à tralner ces voiturs; de manière „uil n'y a guère d'animanx qui pussent avaucer tant qu'cux. La plupart di ees lurufs sont fort grands. el ont une

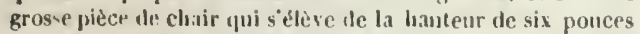
entre lenrs épaules. Voyage de Jian Oviugton. l'aris, 1725, tome I, pige 258 . - Les Inufs de Perst sont comne les noires, excepté vers les frontich's le l'Inte, ois ilsout la bosse on loujue sur le dos: on mang peu de hưf en tomt le pays. On ne l'éléve ıue pou la clarge ou jour le labourage; on ferre ceux dout on sese t à la cluarge a cause des moutagnes plerreuses où ils passent. Voyage de Chardin, tome II, page 28,-Les bouls te liengale ont ume espece d. busse sur li dos; nuus les trouvames aussi gras et d’ausi lun gunt qu'il y en ait flans ancun pray"; les plus grands et meilleurs ue se ven. dent que denx rixiluls. Voyage de la Comprazuie des fudes de Hollande, tume III. page 270 . - Les buruls de linzarate sunl falts comute les notres, sinon qu'ils ont une grosse bosse en. tre les épaules. Voyage de Mandelslo, tome II, page 234 dans tous les pays chauds, a plusieurs avantages sur l'autre. Ces bœufs à bosse ont, comme le bison, duquel ils sont issus, le poil beaucoup plus doux et plus lustré que nos bœufs, qui, comme l'aurochs, ont le poil dur et assez peu fourni. Ces boufs à bosse sont aussi plus légers à la course, plus propres à suppléer au service du eheval ', et en mème temps, ils ont un naturel moins brut et moins lourd que nos bœufs; ils ont plus d'intelligence et de docilité, plus de (qualités relatives cl senties dont on peut tirer parti : aussi sont-ils traités dans leur pays avec plus de soin que nous n'en donnons á nos plus heaux chevaux. La considération que les Indiens ont pour ees animaux est si grande ${ }^{2}$,

(Comme les brofs ne sout aucunement farouclies aux In. des, il y a beaucump de gens qui s'en servent pour faire des voyages, et qui les montent comme on fait les chevanx: l"al. lure pur l'oridinaire en est douec; on ne leur dunue, au lien de inors, qu une curdelette en deux. passée par le tendron des narines, cl on renverse par-rlessus la lèle du luruf un gros cordon attaclué à ces cordelelte: comme une bride, qui est arrè. tic par li bosse quil a sur le tevant du dos, ce que uos boufs noust jas; on lui met mue selle cumme à un clieval, et, pour peu yliou l'evcite à marcher. il va f.rt vile; il s'en Irouve qui courent aussi fort que de bons chesanx. On use de ces betes généralement par lou es les ludes, et on n'en attelle puint d'autres aux charrelles, aux carrusses et anx chariots qu ou fait trainer par autant le bouf; que la charge est jesante; on at. telle ces atuimaux avec nn long joug qui est an b sut du timen, et qu'on pose sur le con des deux luruis. et le cocher tient a la main le cordon oir sont attachées les cordeletles yui traversent les marines. II clation de Tlıéveruot, lone III, flage 131.Ce prince indien ét.it assis, lıi deusiène, sır un chariut qui était trainé par deux lunufs blance, uni avaieut le cuu fort court et une hosse entre les deux rpaules, mais if, etdient, au

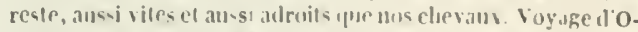
lésrins, lone I, jage $438 .-$ I.es deux lunfs qui ćtaicut altelés

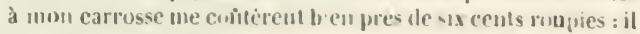
ue faut pats yue le leeteur s'cume we ce prix la, car il y a de ces humfs yui sunt forts, et yui funt iles voyages de soixante jourures a douze un quin/e lieues par jour, el toujours au Irot; ruaud ils ont fait la moitié de la junrucee, on leur donne a cliacun deux on trois pelottes de la grossenr de nos pains d'un sou, fau: es de fariue de froment, pétrie avec du beurre et dusucre unir, el le soir ils ont leur ortinatre de pois-cluclies concassés et trempés une demi-luente daus l'ean. Voyage de Taveruier, page $56 .-11$ y a tels de ces boufs tui suivraieut des clicvaux au grand trot; les fulus petits sumt lis julus legers: ce sont les fientils et surtont les Butianes et marchauds de Surate. qui se servent de ces bunfs pour tirer des voitures: it est singulier ıue, malgré leur vénéra! ion punr ces auinıax. ils ne Passem puint de sermpule de les emuluyer a ce service. Voyage de cirus-e, paze 25.

2 l'ris de la reiue ne sont que de grandes dames, et lon lul pare les pravés on planclies, et les paruis el clicundus par vi elle uluit passer, avec cette hiente de vache que j’ai déja dit: sur ifuoi je ne veux umblier de dire en jassant el var occasion, le grand houneur que ces prupules rendent a ces aches, pour vilanes, crasemses et loules rouvertes de lume quic.les soient. car ou le's laisse cutrer dans le pala is du mi, et partout oiz leur chemin sadinne. sans yuon leur refise jamals le pa-sage: ainsi le roi meıte et lous les plus grands seigneurs leur font place avec aulant dthonneur, de réverence et de respect quil 
qu'elle a dégénéré en superstition, dernier terme de l'aveugle respect. Le bouf, comme l'animal le plus utile, leur a paru le plus digne d'ètre révéré : de l'objẹt de leur vénération, ils ont fait une idole, une espèce de divinité bienfaisante et puissante; car on veut que tout ce qu'on respecte soit grand, et puisse faire beaucoup de mal ou de bien.

Ces bœufs à bosse varient peut-être encore plus que les nótres pour les couleur's du poil et la figure des cornes. Les plus beaux sont tout blanes, eomme les boufs de Lombardie. Il y en a qui sont dépourvus de cornes; il y en a qui les ont fort relevées, et d'autres si rabaissées qu'elles sont presque pendantes. II parait mème qu'on doit diviser eette race première de bisons ou boufs à bosse en deux races secondaires, l'une très-grande et l'autre très-petite; et cette dernière est celle du zébu. Toutes deux se trouvent à peu près dans les mêmes climats, et toutes deux sont également douces et faciles à conduire; toutes deux ont le poil fin et la bosse sur le los : cotte bosse ne dépend point de la conformation de l'épine ni de celle des os des épaules; ce n'est qu'une cxeroissance, une espèce de loupe, un morceau de chair tendre, aussi bonne à manger que la langue du bouf. Les loupes de certains bœenfs pèsent jusqu' $̇$ quarante et cinquante livres; sur d'autres elles sont bien plus petites. Quelcues-ums de ces bœufs ont aussi des cornes prodigieuses pour la grandeur; nous en avons une au Cabinet du Roi de trois pieds et demi de longueur et de sept ponces de diamètre à la base. Plusieurs voyageurs assurent en avoir vu, dont la capacité était assez grande pour contenir quinze et même vingt pintes de liqueur.

Dans toute l'Afrique, on ne connait point l'usage de la castration du gros bétail; et on le pratique peu dans les Indes '. Lorsqu'on soumet les taureaux à cette opération, ce n'est point en leur retranchant, mais en leur comprimant les testicules; et quoique les Indiens aient un assez grand nombre de ces animaux pour trainer leurs voitures et labourer leurs terres, ils n'cn élèvent pas à beaucoutp près autant que nous. Comme dans tous les pays chauds les vaches

en posible, et en font autant aux taureaux et boufs. Voyage de Francois Pyrard, lome I, pige A19.

- Lorsque les Indiens chatrent les taureanx, ce n'cst point per izetiou... C e t par une eompression de ligatures qui interceptent la nouriture porlée dans ces parlies. Voyage de Grosse, page 255. ont peu de lait, quoiqu'on n'y connalt guère le fromage et le beurre, et que la chair des veaux n'est pas aussi bonne qu'en Europe, on y multiplie moins les bêtes à cornes. D’ailleurs toutes ces provinces de l'A frique et de l'Asie méridionale étant beaucoup moins peuplées que notre Europe, on y trouve une grande quantité de bœufs sauvages, dont on prend les petits; ils s'apprivoisent d'eux-mêmes et se soumettent sans aucune résistance à tous les travaux domestiques; ils deviennent si dociles, qu'on les conduit plus aisément que des chevaux; il ne faut que la voix de leur maitre pour les alriger et les faire obéir; on les soigne, on les caresse, on les panse, on les ferre, on leur donne une nourriture abondante et ehoisie. Ces animaux élevés ainsi paraissent être d'une autre nature que nos bœufs, qui ue nous connaissent que par nos mauvais traitements : l'aiguillon, le bâton, la disette les rendent stupides, récaleitrants et faibles. En tout, comme l'on voit, nous ne savons pas assez que pour nos propres intérêts, il faudrait mieux traiter ce qui dépend de nous. Les hommes de l'état inférieur, et les peuples les moins policés semblent sentir mieux que les autres les lois de l'égalité et les nuances de l'inégalité naturelle : le valet d'un fermier' est, pour ainsi dire, de pair avec son maitre; les chevaux des Arabes, les bœufs des Hottentots sont des domestiques chéris, des compagnons d'exercice, des aides de travail, avec lesquels on partage l'habitation, le lit, la table. L'homme par cette communatité s'avilit moins que la hète ne s'élève et s'humanise : elle devient affectiomnée, sensible, intelligente; elle fait là par amour tout ce qu'elle ne fait iei que par la crainte : elle fait beaucoup plus; car comme sa nature s'est élevée par la douceur de l'éducation et par la continuité des attentions, elle devient capable de choses presque bumaines: les Hottentots élèvent des bœufs pour la guerre, ct s'en servent à peu près comme les Indiens des éléphants; ils instruisent ees bœufs à garder les troupeaux, à les conduire, à les tourner, les ramener, les défendre des étrangers et des bêtes féroces; ils leur apprennent à connaitre l'ami et l'ennemi, à entendre les signes, à obéir à la voix, ele. l.es hommes les plus stupides sont, comme l'on roit, les meilleurs précepteurs de bêtes; pourquoi l'homme le plus éclairé, loin de conduire les autres hommes, a-t-il tant de peine a se conduire lui-même? 
Toutes les parties méridionales de l'Afrique et de l'Asie sont donc peuplées de bœufs à bosse ou bisons, parmi lesquels il se trouve de grandes variétés pour la grandeur, la couleur, la figure des cornes, ete. : au contraire, toutes les contrées septentrionales de ees deux parties du monde et l'Europe entière, en y comprenant même les iles adjacentes, jusqun'aux Açores, ne sont peuplées que de bocufs sans bosse, qui tirent leur origine de l'aurochs; et de la mème manière que l'aurochs, qui est notre bocuf dans son état sauvage, est plus grand et plus fort que nos bocufs domestiques, le bison ou bouf à bosse sauvage est aussi plus fort et beaucoup plus grand que le boeuf domestique des lndes; il est aussi quelquefois plus petit, ecla dipend uniquement de l'alhondance de la nourriture. Au Nalabar, au Canada, en Abrssinie, it Madagasear, ou les prairies naturelles sont spacieuses et abondantes, on ne troure que d's bismnsd'une grandeur prodigiense : ('n A lirique et diuns l'A rabie Pétrée ', ou les terrains sont sees, on trouve des zébus ou bisous de la plus petite taille.

L'Amérique est actuellement peuplée partout de boeufs sans bosse, que les Espagnols et les antres Européens y ont successirement transportés. Ces hœuf's se sont multipliés et sont seulement devenus plus petits dans ees terres nouvelles. L'espèce en était alssolument inconmue daus l'A mérirgue méridionale; mais dinns toute la partie septentrionale jusqu ì la Floride, la Louisiane, et mème jusque aluprès du Vesique, les bisons ou boeul's it busse se sont trouvés e'n grande quantité. Ces bisons, qui habitaient autrefois les bois de la Germanie, de l'líosse et des autres terres de notre nord, ont probablement passé d'un continent à l'autre; ils sont devenus, comme tous les autres animaux, plus petits daus ce nouvean monde; et selon qu'ils se sont habitués,dans des climats plus ou moins froids, ils ont conservé des fourrures plus ou moins chaudes; leur poil est plus long et plus fourni, leur barbe plus longue à la baiede Hud-

I J'ai vu a Mascati, ville de l'Arahic-pé1réc, me autre es.

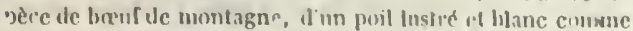
celıi de lherusine, si hien fait de corps. yüil ressmbluait plu-

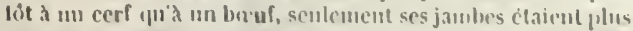
courtes, cependant fiucs el agl'es pur la cuurse; le cou plus comrt, la tale et la queuc comme refles du bormf, mais miens

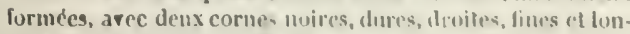

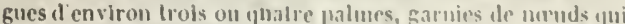

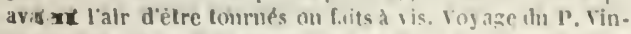
so:-sarie chap XII. Trauncliun de M. Ie maryuis de Mon sirell. son qu'au Mexique, et en général ce poil est plus doux que la laine la plus fine. On ne peut guère se refuser à croire que ces bisons du nouveau continent ne soient de la même espèce que ceux de l'ancien: ils en ont conservé tous les caractères principaux, la bosse sur lesépaules, les longs poils sous le museau et sur les parties antérieures du corps, les jambes et la quenc courte; et, si l'on se donne la peine de comparer ce cru'en ont dit Hernandès, Fernandès, et tous les autres historiens et voyageurs du Nouveau-Nonde, avec ce que les naturalistes anciens et modernes ont écrit sur le bison d'Europe, on sera convaineu que ce ne sont pas des animaux d'espéce différente.

Ainsi le bocuf sauvage et le bocuf domestique, le hocuf de l'Europe, de l'Asie, de l'Afrique et de l'Amérique, le bonasus, l'aurochs, le bison et le zébu sont tous des animaux d’une seule et mème espèce, qui, selon les climats, les nourritures et les traitements différents, ont subi toutes les variétés que nous venons d'exposer. Le brouf, comme l'animal le plus utile, est áussi le plus généralement répandu ; car, à l'exception de l'Amerique méridionale, on l'a trouvé partout : sa nature s'est également prêtée à l'ardeur ou à la rigueur des pays du midi et de ceux du nord. Il parait ancien dans tous les climats : domestique chez les nations eivilisées, saluvage dans les contríns désertes on chez les peruples non policés, il s'est maintenu pin ses propres forces dans l'citat de nature, et 11 'il jamais perdu les qualités relatives au service de l'homme. les jeunes veaux sanvages que l'on enlève it leur mère aux Judes et en Afrique deviennent en très-peu de temps aussi doux que ceux qui sont issus des rices domestiques, et cotte conformité de naturel prouve encore l'identité d'espice. La douceur du caractère dans les animaux indique la flexibilité physique de la forme du corps ; ear de toutes les espèces d'animaux dont nous avous trouvé le caractèce ducile, et que nous arons soumis it l'etat de domesticité, il n'y en a ancune qui ne présente plus de variétés que l'on n'en peut trouver dans les especes qui, par l'inflevibilité du caractère, sout denreurées saurages.

Si l'on demande laypuelle de ces deux races, de l'aurochs ou du bison, est la race première, la raee primitise des herufs, il me semble qu'on peut répondre d'une manière satisfaisante en tirant de simples inductions des faits que mous 
venons d'exposer. La bosse ou loupe de bison n'est, comme nous l'avons dit, qu'un caractère accidentel, qui s'efface et se pcrd dans le mélange des deux races; l'aurochs ou bœuf sans bosse est done le plus puissant et forme la race dominante : si c'était le contraire, la bosse, au lieu de disparaitre, s'étendrait et subsisterait sur tous les individus de ce mélange des deux races. D'ailleurs ectte bosse du bison, comme celle du ch'imcau, est moins un produit de la nature qu'un effet du travail, un stigmated'esclavage. On a, de temps immémorial, dans presque tous les pays de la terre, forcé les bœufs à porter des fardeaux : la charge habituelle et souvent excessive a déformé leur dos; et eette dilformité s'est ensuite propagée par les générations : ill n'est resté de bœufs non déformés que dans les pays où l'on ne s'est pas servi de ces animaux pour porter. Dans toute l'Afrique, dans tout le continent oriental, les bœufs sont bossus, parce qu'ils ont porté de tout temps des fardeaux sur lcurs épaules : en Europe, ou l'on ne les emploie qu'a tirer, ils n'ont pas subi cette altération, et aucun ne nous présente cette difformité : elle a vraiscmblablement pour cause première le poids et la compressiou des fardeaux, et pour cause scconde, la surabondance de la nourriture; car elle disparaît lorsque l'animal est maigre et mal nourri. Des boufs csclares et bossus se seront échappés ou auront été abandonnés dans les bois ; ils y auront fait une postérité sauvage ct chargée de la méme difformité, qui, loin de disparaitre, aura dù s'augmenter par l'abondance des nourritures dans tous les pays non eultivés, cn sorte que cette race secondaire aura peuplé toutes les terres désertes du nord et du midi, et aura passé dans le nouveau continent, comme tous les autres animaux dont la nature peut supporter le froid. Ce qui confirme et prouve encore l'identité d'espèce du bison et de l'aurochs, c'est que les bisons ou boufs à bosse du nord de l'Amérique ont une si forte odcur, qu'ils ont été appelés bceufs musqués par la plupart des royageurs; et qu'en même temps nous voyons, par le témoignage des olsservateurs, que l'aurochs ou bœuf sauvage de Prusse et de Lironie a cette même odeur de muse comme le bison d'Amérique.

De tous les noms que nous arons mis à la tète de ce chapitre, lesquels pour les naturalistes tant anciens que modernes faisaient au- tant d'espèces distinctes et séparées, il ne nous reste donc que le buffle et le bœuf. Ces deux animaux, quoique assez ressemblants, quoique domestiques sourent sous le mème toit et nourris dans les mêmes pâturages, quoique à portée de se joindre, et mème excités par leurs conducteurs, ont toujours refusé de s'unir : ils ne produisent ni ne s'accouplent ensemble. Leur nature est plus éloignée que celle de l'âne ne l'est de celle du cheval : elle parait même antipathique; car on assure que les vaches ne veulent pas nourrir les .petits buffles, et que les mères buffles refusent de se laisser teter par des veaux. Le buffle est d'un naturel plus dur et moins traitable que le bơuf; il obéit plus diffieilement, il est plus violent, il a des fantaisies plus brusques et plus fréquentes; toutes ses habitudes sont grossières et brutes : il est, après le cochon, le plus sale des animaux domestiques, par la difficulté qu il met à se laisser nettoyer et panser. Sa figure est grosse et repoussante, son regard stupidement farouche; il avance ignoblement son cou, et porte mal sa tête, presque toujour's penchée ver's la terre; sa voix est un mugisscment épouvantable, d'un ton beaucoup plus fort et plus grave que cclui d'un taureau; il a les membres maigres et la queue nue, la mine obseure, la physionomie noire comme le poil et la peau : il differe principalemeut du bœuf à l'extérieur' par cette couleur de la peau, qu'on aperçoit aisément sous le poil, qui n'est que peu fourni. Il a le corps plus gros et plus court que le bouf, les jambes plus hautes, la tete proportionnellement beaticoup plus petite, les cornes moins rondes, noires et en partic comprimées, un toupet de poil crépu sur le front: il a aussi la peau plus épaisse et plus dure que le bocuf; sa chair noire et dure est non-seulement désagréable au goût, mais répugnante àl'odorat. Le lait de la femelle buffle n'est pas si bon que celui de la vache; elle en fournit ecpendant en plus grande quantité. Dans les pays chauds, presque tous les fromages sont faits de lait de buffle. La chair des jeunes buffles encore nourris de lait n'en est pas meilleure. Le cuir seul vaut micux que tout le reste de la bête, dont il n'y a que la langue qui soit bonne à manger : ce cuir est solide, assez léger et presque impénétrablc. Comme ces animaux sont en général plus grainds et plus forts que les bœufs, on s'en sert utilement au labouragc; on les fait trainer et non pas porter des fardeaux. 
On les dirige, et on les contient au moyen d'un anneau qu'on leur passe dans le nez: deux buffles attelés ou plutòt enchaînés à un chariot, tirent autant que quatre forts chevaux : comme leur cou et leur tête se portent naturellement en bas, ils emploient en tirant tout le poids de leur corps, et cette masse surpasse de beaucoup celle d'un cheval ou d'un bouf de labour.

I. a taille et la grosseur du buftle indiqueraient seules qu'il est originaire des elimats les plus chauds. Les plus grands, les plus gros quadrupèdes appartiennent tous à la zone torride dans l'ancien continent; et le buffle, dans lordie de grandeur ou plutôt de masse et d'épaisseur, doit être placé après l'éléphant, le rhinocéros et l'hippopotame. Ia girafe et le chameau sont plus élevés, mais beaucoup moins épais, et tous sont également originaires et habitants des contrées méridionales de l'Afriçue ou de l'Asie. Cepeudant les buffles vivent et produisent en Italie, en France et dans les autres provinces tempérées: eeux que nous avons vus vivants à la Ménagrerie du Roi out produit deux outrois fois. Lal femelle ne fait qu'un petit et le porte environ douze mois; ce qui prouve encore la difiérenee de eette espèce à celle de la vache, qui ne porte que neuf mois. Il parait aussi que ces animaux sout plus doux et moins brutiux dans leur pays natal, et que plus le climat est chaud, plus ils sont d'un naturel docile: en F́gypte, ils sont plus traitables qu'en Italie; et aux ludes, ils le sout eucore plus qu'en Egypte. Ceux d'Italie ont aussi plus de poil que семx d'Eigypte, et ceux-('i plus que eeux des Indes' Leur fourure n'est jamais fournie, parce qu'ils sont originaires des pạs s chauds, et qu'en gé-

'Le buffle, à Malabar, est plus grand que le bouf, a peu pres fail de nẻme, il a la tète pluss longme el plus plate, les yeux plus grands et presrue fout haucs. les cormes plates pl souveut de deux pleds de long, les jimbes grosses el courtes: il est laid, presune sans poil, va lentement et porte des cliarges fort pesantis; on en roit par trompes romme des vaches, et its domuent tlu lait yni sert a faire du beutre et dı fromage leur clair est monue, yuoi,pue moins délicate yue celle du houf. Il nage parfaitement bien et Iraverse les plus grandes rivieres. On en voit le prives; mais il y en a de sauviges yui sont extrèmement dangerenx dichimat les lomues on les écrasaut lun seul cunp de lìte; ils sont moins à craindre daus les bois que fartont ailleurs. parre yue linrs coroues s'arrélent souvent anx branches, el tument le temps de luir à ceux qui en sont punrsuis is. le cnir de cos animans sert à

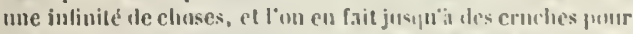
conserver de leau et des liyueurs: ceux de li coile de Walabar sont presinue: lous sauvage's, et il nint point délemulu aux étrangers de leur donner la classe o't ll'eu manger. lugage do Dellon, pages 110 et 111 . néral les gros animaux de ce climat nont polnt de poil ou n'en ont que très-peu.

Il y a une grande quant.te de buffles sauvages dans les eontrées de l'Afrique et des Indes, qui sont arrosées de rivières et où il se trouve de grandes prairies: ces buffles saurages vont en troupeaux et font de grands dégáts dans les terres eultivées; mais ils n'attaquent jamais les hommes, et ne courent dessus que ruand on vient de les blesser : alors ils sont tres-dangereux, ear ils vont droit à l'ennemi, le renversent et le tuent en le foulant aux pieds. Cependant ils eraignent beaucoup l'aspect du feu : la couleur rouge leur déplaît. Aldrovande, liolbe et plusieurs autres maturalistes et voyageurs assurent que persome n'ose se vètir de rouge dans le pays des bufles. Je ne sais si eette aversion du feu et de la couleur rouge est générale dans tous les buffles; ear dans nos boufs, il n'y en a que quelques-uns que le rouge effarouche.

Le bufle, comme tous les autres grands animaux des climats méridionaux, aime beaucoup a se vautrer et mène à séjourner dans l'eau; il nage très-bien et traverse hardiment les fleuves les plus rapides: comne il a les jambes plus hautes que le bœuf, il court aussi plus légèement sur terre. Les Nègres en Guinée, et les Indiens au Malabar, oil les buffles sauvages sont en grand nombre, severecnt souvent à les chasser: ils ne les poursuivent ni ue les attaquent de face; ils les atteudent, grimpés sur des arbres, ou cachés dans l'épaisseur de la foret, que les huflles ont de la peine á pénétrer a cause de la grosseur de leur eorps et de l'embarras de leurs eornes. Ces peuples trourent la chail' du buffle bome , et tirent un grand profit de leurs peaux et de leurs cornes, qui sont plus dures et meilleures que eelles du bouf. I'anjmal qu'on appelle à Congo empacassa ou pacassa, quoique très-mal décrit par les voyageurs, me parait ètre le buflle; conme celui dont ils ont parlé sous le nom d'empabumga ou impalunca, dans le mème pays, pourrait hien itre le bubale, duguel nous domnerons l'histoire avec eelle des gazelles dans c'e volume 


\section{ADDITIOY \\ AUX ARTICles DU BOEUF, DU BISOT, DU ZÉBU ET DU BUFFLE.}

Les boufs et les hisons we sont que deux races particulières, mais toutes deur de la mème espece, quoique le bison differe toujours du bouf, non-seulement par la loupe qu'il porte sur le dos, mais souvent encore par la qualité la quaptité et la longueur du poil. Le bison ou boeuf a bosse de Mndigascar réussit très-bien à l'lle-de-France; sa chair y est beaucoup meilleure yue celle de nos boufs venus d'Europe, et après quelques générations sa bosse s'efface entierement. II a le poil plus lisse, la jambe plus effiléc et les cornes plus longures que eeux de I'Europe. J'ai vu, dit M. de Qnerhoënt, de ees bœufs bossus qu'on amenait de Madagasear, qui en avaient d'uue grandeur' étonnante.

Le bison dont nous donnons ici la figure ', et que nous arons vu vivant, asait été pris jeune dans les forèts des parties tempérées de l'A mérique scptentrionale, ensuite amené en Europe, élevé en Ilollande, et acheté par un Suisse, qui le transportait de ville en ville dans une especee de grande cage, d'où il ne sortait point, et où il était mème altaché par la tète avec quatre cordes qui la lui tenaicnt étroitement assujettie. L'énorme criniere dont sa tête est entourée n'est pas du erin, mais de la lainc ondíe et divisée par flocons pendants eomme une vieille toison. Cette laine est très-fine, de mème que celle qui courre la loupe et tout le devant du eorps. Les parties qui paraissent nues dans la gravure ne le sont que dans de certains temps de l'année, et e'est plutòt en été qu'en hiver' car au mois de janvier toutes les parties du rorps étaient à peu près également couvertes d'une laine frisée très-fine et très-serrée, sous laquelle la peau paraissait d'un brun couleur de suie, au lieu que sur la bosse et sur les autres parties couverte's également d'une laine plus longue, la peau est de couleur tannéc. Cette bosse on loupe, qui est toute de chair, varie eomme lembonpoint de l'animal. Il ne nous a jaru différer de notre bouf d'lirrope que par cette loupe et par la laine. Quoiqu'il füt très-

Cel animal est le BOELp bisos ou buffalol des naturalistes mudernes. contraint, il n'était pas férnce; il se laissel: sn cher et caresser par ceux qui le soignaient

On doit croire quautrefois il y a eu des bxisons dans le Nord de l'Europe; Gessner a mẻne dit qu'il en existait de son temps en Ecosse. Cepandant, m'étant soigneusement informé de ce dُrnier fait, on m'a écrit d'Angleterre et d'Éasse qu'on n'en avait pas de memoire. M. Bell, dans son Voyage de Hussie à la Chine, parle de deux espices de boufs qu'il a vus dans les parties septentrionales de l'Asie, dont l'une est l'aurochs ou bouf sauvage, de méme race qae nos boeufs; et l'autre, dont nous arons donné 'indication d'apres Gmelin, sous le nom de vache de Tartarie ou vache grognante, nous parait étre de la mème espece que le bison. On en trouve la descruption dans notre ouvrage (coyez ci-après dans ce volume); et après avoir comparée cette vache grognante aree le bison, j'ai trouvé qu'elle lui ressemble par tous les caractères, à l'exception du grognement au icu du mugissement : mais j'ai présumé que ce groguement n'était pas une affection constante et générale, mais contingente et particulière, semblable a la grosse voix entrecoupée de nos taureaux, qui ne se fait entendre pleinement que dans le temps du rut; d'ailleurs j'ai été informé que le bison dont je donne la figure ne faisait jamais retentir sa roix, et que quand mème on lui causait quelque douleur vive, il ne se plaiguait pas, en sorte que son maitre disait qu'il était muet; et on peut penser que sa voix se serait développée de mème par un grognement oul par des sons entrecoupés, si, jouissant de sa liberté et de la présence d'une femelle, iı euit été excité par l'amour.

Au reste, les bœufs sont très-nombreux en Tartarie et en Sibérie. II y en a une fort grande quantité à Tobolsk, où les vaches courent les rues mème en hiver, et dans les campagnes oú on en voit un nombre prodigieux en été. Nous avons dit qu'en Irlande les boufs et les vacnes manquent sourent de cornes : e'est surtout dans les parties moridionales de l'ile ou les patturages ne sont point abondants, et daus les pays maritimes ou les fourriges sont fort rares, que se trouvent ces boeufs et ces vaches sans cornes; nouvelle preuve que ces parties excédantes ne sont produites que par la surabondance de la nourriture. Dans ces endroits voisins de la mer. l'on nourrit les vaches avec du poisson cuit daw l'eau etréduit en bouillieparle feu. Ces animaw 
sont non-sculement accoutumés à cette nourriture, mais ils en sout mème très-friands; et leur lait n'en contracte, dit-on, ni mau vaise odeur ni goût désagréable.

Les boufs et les vaches de Norirége sont en général fort petits. Ils sont un peu plus grands dans les iles qui bordent les cùtes de Norwége: différence qui provient de celle des páturages, et aussi de la liberté qu'on leur done de vivre dans ces lles sans contrainte; car on les laisse absolument libres, en prenant seulement la précaution de les faire accompagner de quelques bóliers accontumés á chercher eux-mènes leur nourriture pendant I'hiver. Ces béliers détourment la neige qui recouvie l'herbe, et les boufs les font retirer pour en manger. Ils deviennent, avec le temps, si farouches, qu'il faut les prendre avee des cordes. Au resto, ces vaches demi-sauvages donnent fort peu de lait; clles mangent, à défut d'autre fourage, de l'algue mélée avec du poisson bien boulli.

Il est assez singulier que les boufs a bosse ou bisons, dont la race paralt s'ètre étendue depuis Madagascar et la pointe de l'Afrique, et depuis l'extrémité des Indes orientales jusqu'en Sibéric, dans notre continent, et que l'on a retrouvée dans l'autre coutinent, jusqu'aux Illinols, ala Louislane, et mène jus(yu'nu Mexicue, naient jamais prsséles ter'resçul form(')t l'Isthme de Panama ; car on n'a trouvé uil borul's ni bisous dans aucune partie de l'Amériopue méridionale, quoique le climat leur convint parfaitement, et que les bocufs d'lurope y aleut multiplié plus quen ancun lien du monde. A Buenos- Avres et a quel(ques degrés encore au delà, ces animaux ont tellement multiplié et ont si bien renyoli le pays, que persomne ne daigne se les ajproprier; les chasseurs les tuent par milliers et seulement pour avoir les cuirs et la graisse. On les chasse à clieval; on leur coupe les jarrets avec une espece de haehe, ou on les prend daus des lacets fults avec une forte courrole de cuir. Dans l'ile de Sainte-Catherine, sur la eote du Brésil, on trouve quelques petits boeufs dont la chair est mollasse et désaugréable au gout : ce qui vient, alnsi yue leur petite taille, du déliunt et de la mauvaise qualitéde la nourriture; car faute de fourrage, on les nourrit de calebasses sanvaces.

En Afrique II y a de certaines contrés oi les boufs sont en tris-grand mmbre, Entre le enp Blanc et Sierra-Leone, on voil dans le's hois et sur les montignes des vaclues saturages ordi- nairement de eouleur brune, et dont les cornes sont noires et pointues ; elles multiplient prodigieusement, et le nomlre en seruit infin, si lef Européens et les Nègres ne leur faisaient pas continuellement la guerre. Dans les provinces de Dugurla et de Tremecen, et dans d'autres endroits de Barbarie, ainsi (jue dans les déserts de Numidie, on voit des vaches sau vages couleur de marron obseur, assez petites et fort légeres à la course, elles vont par troupes quelquefois de cent on de deux cents.

A Madagascar, les taureaux et les vaches de la meilleure espèce $\mathrm{y}$ ont été amenés des autres provinces de l'Africue'; ils ont une bosse sur le dos: les vaches doment si peu de lait, yuion pourait assurer (qu'une sache de Hollaude en fournit six fois plus. II y a claus cette ile de ces boufs à hosse ou bisons sauvages qui errent dans les forets; la chair de ces hisons n'est pas si bonne que celle de nos boufs. Dans les parties mérilionales de l'Asie, on trouve aussi des boufs siluvages; les chasseurs d'Agra ront les prendre dans la montagne de Vermer qui est euviromuće de bois : eelte montagne est sur le chemin de Surate à Goleonde. Ces vaches sauvages sont ordinairement belles et se veudent fort clier.

Le zélu semble effe un diminulif du bison, dont la race, ninsi yue cell: du banf, subit de très-standes variete's, surtout pour la glandeur. Lezébu, quoipue originairedespars trés-claauds, peut virre et produire dans nos pays tempérés. "J'ai vu, dit M. Collinson, grand nombrele ees a animaux dius les pare's de 11 . le due de Riche" mond, de.M. le dur de Portland, et dans d'itu" tres pares; ils y multipliaient et faisaiml des " veaux tous les ans, yui étilient les plus jolies " ereatures du monde : les pires et mere's ve" nalient de la Chine et des Indes orientales. I.a "lompe qüils portent sur les épanlesest une fois " plus grosse daus le mále que dams la femrelle, " qui est aussi d'une taille au-clessous de celle du " mâle. Le petit zébu lète sa mère comme les " autres veaux tetent les vache's; mais le lait " de la mere zábu tarit bientót dans notre cli" mat, et on acheve de les nourrir arec de a l'autre lait. On tua un de ces animaus ches. " M. Ie due de Richemsond; mais la eluir" ne " s'en est pas troure si bonne que e'elle du " basuf."

II se trour aussi dam: la race des bocufs sans bosse de tres-petits individus, et qui, comme le 
zébu, peuvent faire race particulière. Gemelli Carreri vit sur la route d'Ispahan à Schiras deux petites vaches que le bicha de la province envoyait au Roi, et qui n'étaient pas plus grosses que des veaux. Ces petites vaches, quoiquenourries de paille pour tout aliment, sont néanmoins fort grasses. Et il m'a paru qu'en général les zébus ou petits bisons, ainsi que nos bœufs de la plus petite taille, ont le corps plus charmu et plus gras que les bisons et les bœufs de taille ordinaire.

Nous avons très-peu de clıose à ajouter à ce que nous avons dit du buffle, page 504 et suivantes de ce volume. Nous dirons seulement qu'ac: Mogol on les fait eombattre contre les lions et les tigres, quoiqu'ils ne puissent guère se servir de leurs cornes. Ces animaux sont très-nombreux dans tous les climats cliauds, surtout dans les contrées marécageuses et voisinesdes fleures. L'eau ou I'humidité du terrain paraissent leur être eneore plus nécessaires que la chaleur du climat, et c'est par cette raison que l'on n'en trouve point en Arabie, dont presque toutes les terres sont arides. On chasse les bufllessauvages, mais avec grande précaution ; car ils sont trèsdangereux et viennent à l'homme dès qu'ils sont blessés. Niebuhr rapporte an sujet des buffles domestiques, que, drans quelques endroits, comme à Basra, on a l'usage, lorsqu'on trail la femelle du buffe, de lui fourrer la mainjusqu'au coude dans la vulve, parce que l'expérience a appris que cela leur faisait donner plus de laif : ce qui ne parait pas probable; mais il se pourrait que la femelle du buffle fit, comme quelques-unes de nos vaches, des efforts pour retenir son lait, et que cette espèce d'opération douce relâchât la contraction de ses mamelles.

Dans les terres du cap de Bonne-Espérance, le buffle est de la grandeur du bœuf pour le corps; mais il a les jambes plus courtes, la tète plus large; il est fort redouté. Il se tient souvent à la lisiere des bois; et comme il a la vue mauvaise, il y reste la tête haissée pour pouvoir mieux distinguer les objets entre les pieds des arbres; et lorsqu'il apereoit à sa portée quelque chose qui l’inquiète, il s'élance dessus en poussant des mugissements affreux, et il est fort difficile d'échapper à sa fureur. Il est moins à craindre dans la plaine; il a le poil roux et noir en quelques endroits; on en voit de nombreux troupeaux.

\section{AUTRE ADDITION}

\section{A L'ARTiCle de L'AURochs et dU BISON.}

M. Forster m'a informé que la race des aurochs ne se trouve actuellement qu'en Moscovie, et que les aurochs qui étaient en Prusse et sur les confins de la Iithuanie ont péri pendant la dernière guerre: mais il assure que les bisons sont encore communs dans la Moldavie. Le prince Démétrius Cantemir en parle dans sa description de la Moldavie (parlie I, chapitre VII.) "Sur les montagnes occidentales de la Moldavie, on trouve, dit-il, un animal que l'on appelle zimbr, et qui est indigène dans cette contrée : il est de la grandeur d'un bœuf commun; mais il a la tète plus petite, le cou plus long, le ventre moins replet et les jambes plus longues; ses cornes sont minees, droites, dirigées en haut, et leurs extrémités, qui sont assez pointues, ne sont que très-peu tournées en dehors. Cet animal est d'un naturel farouche; il est très-léger à la course; il gravit comme les chèvres sur les rochers escarpés, et on ne peut l'attraper qu'en le tuant ou le blessant a vec les armes à feu. C'est l'animal dont la tête fut mise dans les armes de la Moldavie, par Pragosh, le premier prince du pays. "Et comme le bison s'appelle en polonais zubr qui n'est pas éloigné de $z i m b r$, on peut croire que c'est le mème animal que le bison; car le prince Cantemir le distingue nettement du buffle, en disant que ce dernier arrive quelquefois sur les rives du Niester, et n'est pas naturel à ce climat; tandis qu'il assure que le zimbr se trouve dans les hautes montagnes de la partie occidentale de la Moldavie, où il le dit indigène.

Quoique les bœufs d'Europe, les bisons d'Amérique et les bœufs à bosse de l'Asiene differrent pas assez les uns des autres pour en faire des espèces séparées, puisqu iils produisent ensemble, cependant on doit les considérer comme des races distinctes qui conservent leurs caractères, à moins qu'elles ne se mêlent, et que par ce mélange ces caractères distinetifs ne s'effacent dans la suite des générations. Par exemple, tous les boufs de Sicile, qui sont certainement de la mème espèce que ceux de France, ne laissent pas d'en différer constamment par la forme des cornes qui sont très-remarquables par leur longueur et par la régularité de leur 
figure. Ces cornes n'ont qu'une légère courbure, et leur longueur ordinaire, mesurće en ligne droite, est ordinairement de trois pieds et quelquefois de trois pieds et demi ; clles sont toutes très-régulièrement contournées, et d'une forme absolument semblable; th sorte que tous les bœufs de cette lle se ressemblent autant entre ('ux par ce caractère, qu'ils diffèrent en cela des autres bœufs de l'Europe.

De même la race du bison a en Amérique une variété constante. Une tète nous a été communiquée par un savant de l'Universitéd'Edimbourg, M. Magwan, sous le nom de léte de bcuf musqué; et c'est en effet le même animal qui a été déerit par le P. Charlevoix, tome III, page 132 , et que nous avons eité. On voit pal" la grandeur et la position des cornes de ce boeuf ou bi:on musqué, qu'il diffère par ee earactère (lu bison dont nous avons domné la figure, et dont les c'orues sont très-différentes.

Celui-ci a été trouvé à la latitude de 70 degrés près de la baie de Baffin. Sa laine est beaucoup plus longue et plus touffue que celle des bisons qui habitent des contrées plus tempérées; il est gros comme un berul' al'turope de moyenue taille; le poil ou plutót la laine sous le cou et le ventre descend jusqu'il terre : il se nourrit de mousse blanche ou lichen comme le renne.

Les deux cornes de ce bison musqué se réunissent à leur base, ou plutot n'ont qu'une origine commune au sommet de la tète çui est longue de deux pieds yuatie pouces et demi, en la mesurant depuis le bout elu nez jusqu'a ce point oủ les deux cornes sont jointes; l'intervalle entre leurs extrémités est de deux pieds einq pouces et demi : la tète est si large que la distance du centre d'un ail it l'autre est d'un pied (quatre pouces du pied franceas. Nous renvoyons pour le reste de la description de cet animal is eelle qui a été domée par le P. Charlevoix, et que nous a vons eitée. M. Magwan nous a assuré que cette deseription de Charlevoix convenait parfiitement it cet animal.

J'ai dit (que, m'étant informé s'il subsistait encore des bisons en keosse, on m'a vait répondu qu'on u'en avait point de mémoire. M. Forster m'écrit à ce sujet que je u’ai pas été pleinement informé. "La raee des bisons blanes, dit-il, subsiste eneore en Eeosse, où les seigneurs et particulièrement le due de Hamilton, le due de Queenbury, et parmi les pairs anglais, le comte de Tankarville, ont conservé dans leurs pares de Chatelherault et de Drumlasrrig en Écosse, et de Chillingham dans le cointé de Northum. berland en Angleterre, cette race de bisons sauvages. Ces animaux tiennent encore de leurs ancètres par leur férocité et leur naturel sauvage : au moindre bruit ils prennent la fuite et courent avee une vitesse étonnante : te lorsqu'on veut s'en procurer quelqu'un, on est obligé de le tuer a coups de fusil : mais cette chasse ne se fait pastoujours sans danger, car si on he fait que blesser l'animal, bien loin de prendre la fuite, il court sur les chasseur's et les percerait de ses cornes s'ils ne trouvaient pas les moyens de l'éviter, soit en montant sur un anbre, soit en se sauvant dans quelques maisons.

"Quoique ce's bisons aiment la solitude, ils s'approchent cependant des habitations, lorsque la faim et la disette en hiver les forcent à venir prendre le foin qu'on leur fournit sous des hangar's. Ces bisons sauvages ne se mêlent jamais aree l'espeee de nos bœufs; ils sont blanes sur le corps, et ont le museau et les oreil!es noirs; leur grandeur est celle d'un bœuf commun de moyenne taille, mais ils ont les jambes plus Iongues et les eornes plus belles; les males pèsent euviron cinq eent trente livres, et les femelles environ quatre cents ; leur euir est meilleur que celui du bœuf commun. Mais ce qu'il y a de singulier, e'est que ces bisons ont perdu, par la durée de leur domesticité, les longs poils qu'ils portaient autrefois. Boëtius dit : Giynere solet ea silea boves cundid issimos in formam leonis jubam habentes, ete. lleser. regni Scotice, fol. xj. Or a a présent ils nout plus cette jube ou eriniere de longs poils, et sont par là devenus différents de tous les bisons ynui nous sont connus. •

\section{ADIDITION}

RELATIVE A LA VACHE DE TARTARIE.

(LE BOEIF YAK.)

M. Gmelin a domné, daus les noureaux Mémoires de l'A adémie de Peter'sbourg, la deseription dune vache de Tartarie qui parait au premier coup d'ail ètre d'une espèce différente de toutes celles dont nous avons parlé à l'article du buffle. "Cette vache, dit-il, que j'ai vue vivante - et que j'ai fait dessiner en Sibérie, venait de 
- Calmouquie; elle arait de longucur deux au* nes et demie de Russie. Par ce module on " peut juger des autres dimensions dont le des" sinateur a bien rendu les proportions. Le corps " ressemble à celui d'une vache ordinaire; les " cornes sont torses en dedans; le poil du corps a et de la tète est noir, à l'exception du front " et de l'épine du dos sur lesfunels il est blanc; " le cou a une crinière, ct tout le corps comme " celui d'un bouc est couvert d'un poil très-long, " et qui descend jusque sur les genoux, en sorte " que les pieds paraissent très-courts; le dos " s'élève en bosse; la queue ressemble à celle a du cheval; elle est d'un poil blanc et très" fourni; les pieds de devant sont noirs, ceux " de derrière blancs, et tous sont semblables à " ceux du bœuf; sur les talons des pieds de dera rière, il y a deux houppes de longs poils, l'une " en avant et l'autre en arrière, et sur les ta- lons des pieds dedevant il is'y a qu'une houppe - eu arrière. Les excréments sont un peu plus a solides que ceux des vaches; et lorsque cet * animal veut pisser, il retire son corps en ar" rière. Il ne mugit pas comme un bœuf, mais " il grogne .comme un cochon. Il est saurage " et même féroce; car à l'exception de l'homme " qui lui donne à manger, il donne des coups de " tète à tous ceux qui l'approchent. Il ne souf- fre qu'arec peine la présence des vaches do" mestiques; lorsqu'il en roit quelqu'une, il " grogne, ce qui lui arrive très-rarement en " toute autre circonstance. " M. Gmelin ajoute à cette description, qu'il est aisé de roir " que " c'est le même animal dont Rubruquis a fait " mention dans son Voyage de Tartarie... qu'il - y en a de deux espèces chez les Calmouques ; " la première, nommée sarluk, qui est celle mème - qưil vient de décrire; la seconde, appelée " chainuk, qui differe de l'autre par la gran" deur de la tète et des cornes, et aussi en ce " que la queue qui ressemble à son origine à " celle d'un cheral, se termine ensuite comme - celle d'une vache; mais que toutes deux sont " de mème naturel."

Il n'y a dans toute cette description qu'un seul caractère qui pourrait indiquer que ces vaches de Calmouquie sont d'une espèce particulière, c'est le grognement au lieu du mugissement; ear, pour tout le reste, ces vaches ressemblent si fort aux bisons que je ne doute pas ju'elles ne soient de leur espèce ou plutôt de sur race. D'ailleurs, quoique l'auteur dise que ces vaches ne muglssent pas, mais qu'elles grognent, il avoue cependant qu'elles grognent trèsrarement, et c'était peut-être une affection particulière de l'individu qu'il a vu, car Rubruquis et les autres qu'il cite ne parlent pas de ce grognement; peut-être aussi les bisons, lorsqu"ils sont irrités, ont-ils un grognement de colère; nos taureaux même, surtout dans le temps du rut, ont une grosse voix entrecoupée qui ressemble beaucoup plus à un grognement qu’à un mugissement. Je suis done persuadé que cette vache grognante (vacca grunniens) de M. Gmelin n'estautre chose qu'un bison, et ne fait pas une espèce particulière.

\section{NOUVELLE ADDITION}

\section{A L'ARTICLE DU BUFFL.}

J'ai reçu, au sujet de cet animal, de très-bonnes informations de la part de monsignor Caëtani, de Rome; cet illustre prélat y a joint une critique très-honnête et très-judicieuse de quelques méprises qui m'étaient échappées, et dont je m'empresse de lui témoigner toute ma reconnaissance en mettant sous les yeux du public ses savantes remarques, qui répandront plus de lumières que je n'avais pu le faire sur l'histoire naturelle de cet animal utile.

J'ai ditque : quoique le buffle soit aujourd'hui commun en Grèce et domestique en Italie, il n'élait connu ni des Grecs ni des Romains, et qu'il n'a jamais eu de nom dans la lıngue de ces peuples; que le mot même de buffle indique une origine étrangère, etn'a de racine ni dans la langue grecque ni dans la latine.... Que c'est mal à propos que les modernes lui ont appliqué le nom de bubalus, quien grec et en latin indique à la vérilé un animal d'Afrique, mais très différent du buffle, comme il estaisé de le démontrer par les passages des auteurs unciens; qu'cufin si l'on voulait rapporter le bubalus à un genre, il appartiendrait plutot à celui des chèrres ou ga zelles qu'à cclui du bouf ou du buffle.

Monsignor Caëtani observe, a que Robert Éticnne, dans le Thesaurus lingure latino, fait mention de deux mots qui viennent du gree, par lesquels on voit que les bœufs, sous le genre desquels les buffles sont compris, étaient nommés d'un nom presque semblable au nom ita- 
IIen bufalo: bupharus dicitur terra que arari facile potest; nam Pharos aratio est, sed et to. vis epilheton. Le même Étienne dit que le mot bupharus était l'épithète que l'on donnait à Hereule, paree qu'il mangeait des bœufs entiers. Tout le monde connailt la célèbre fète des Athéniens, appetée buphonia, qui se célébrait après les mystères en immolant un boeuf, dont le sacrifice mettait tellement fin à tout earnage, que l'on condamnait jusqu'au conteau qui a vait donné la mort au bouf immolé. Persome ni ignore que les Grees changeaient la lettre $n$ en $l$, comme le mot gree nabu en labu. Hérodote se sert du mot labunisus que Bérose dit nabunisus, comme nous l'enseigne Scaliger, De emendatione temporum, cap. VI, et les fragments de Bérose. De mème la parole grecque mneymon se changeait en mleymon; on peut eonsulter là-dessus Pitiseus, Lexicon, lill. N ; d'où il faut conchure que le mot buphonia pouvait s'écrire et se prononeer en gree bupholia. Pitiseus, Lexicon, anliquit. Rom. lit. $\mathrm{L}$, dit : Les Romains employerent souvent la lettre $l$ en place de l'r, à cause de la plus douce prononciation de la dernière; d'ou Calpurnius, au vers 39 de sa première églogue met flaxinca au lieu de fraxinea; et il est très-vraisemblable (qu'il s'est autorisé, pour ce ehangement, sur d'uneiens manuscrits. Le mème Pitiseus dit eneore que Bochart, dins sa Géographie, rassemble une grande ([uantité d'exemples de ce changement de $r$ en $l$. Enfin Moreri, dans son Dictionnaire, lettre $r$, dit elairement que la lettre $r$ se change en l, eomme capella de caper. D'après toutes ces autorités, il est difficile de ne pas croire que le mot bupharus ne soit le même que buphahus; d'où il suit que ce mot a une racine dans la langue grecque.

"Quant aux Latins, on voit dans Scaliger, Decausis Lingure lalince, qu'il fut un temps ou, au lieu de la lettre $f$, on écrivait et on pronouçait $b$, comme bruges pourfruges; on trouve aussi dans Cicéron, fremo qui vient du gree bremo; et entin Nonius Marcellus, De doctorum indagine, met sip hilum pour sibilum. Ce n'est done pas sans raison que lés latins ont pu nommer cet animal bubalus, et qu'Aldrovande en a fait buffelus, et les ltaliens bufuly. La langue italiense est pleine de mots latins eorrompus ; elle a souvent changé en $f$ le $b$ latin; c'est ainsi qu'elle a fait bifoleo de bibulcus, Lurlufo de tubera. Done bufalo vient de bubalus; et comme il a été démontré ci-dessus, buphalus n'est autre ehose que le buphar us; ce qui prouve la racine du nom buflle dans les langues greeque et latine. D)

Monsignor Caetani montre sans doute ici la plus belle érudition; ecpendant nous devons observer qu il prouve beaucoup micux la possibilité de dériver le nom du buflle de quelofues mots des laugues greerue ct latine, qu'il ne proure que réellement ee nom ait été elu usage chez les Latins ou les Grees; le mot bupharos signifie proprement un champ lihourable, et n’a pas de rapport plus décidé ali bufle qui au boeuf commun. Quand a l'épithète de munge-buruf donnce a llercule, on doit l'écrire buphagus it non pas bupharus.

Sur ee que j'ai dit, que le bujple, natif dos pays les plus chauds de l'Afrique et des Indes, ne jul transporté et naturatisé en Ilalie qu" vers le septieme siecle, monsiguor Caletani observe, "que la nature mème de cet animal donne le droit de douter quil puisse etre originaire de l'Afrique, pays ehaud et aride qui ne convient point au buffle, puisqu il se plait singulierement dans les marais et dans l'eau, où il se plonge volontiers pour se rafraichir; ressource quil trouverait difficilement en Afrique. Cette considération ne tire-t-elle pas une nouvelle force de l'aven que fait M. de Buffon lui-mème à l'article du chameau, qu'il n'y a point de bou fs e'n Arabie, à cause de la sécheresse du pays, d'autant plus que te boeuf ne parait pas anssi amant de l'eau que le buflle. Les marais P'ontins et les maremmes de Siemne sont en Italie les licux les plus farorables à ces animaux. Les marais Pontins surtout paraissent avoir été presque toujours la demeure des buftles : ce terrain humide et marécageux parait leur itre tellenent propre et naturel, que de tout temps le gourernement a cru deroir leur en assurer la jouissance. lin eonséquence les papes, de temps immémorial, ont fixé et determiné une partie de ces terrains pu'ils ont affectés uniguement à la nourriture des buffles; jen parle d'autant plus savamment que ma limille, proprictaire desdits terrains, at toujours eté oblig̣ée, et l'est encore aujourd'hui, par des bulles des papes, à les conserver uniquement pour la nourriture des bufles, sans pouvoir les ensemeneer."

II est tres-certain que, de toute l'Italie, les matrais Puntins sont les cantons les plus propres aux butiles; mais il me semble que mousignor 
Caètanj raisonne un peu trop rigoureusement quand il en infere que l'Afrique ne peut etre le pays de l'origine de ces animaux, commeaimant trop l'eau et les marécages pour ètre naturels à un climat si chaud; parce qu'on prouverait par le même argument, que l'hippopotame ou le rhinocéros n'appartiennent point à I'Afrique. C'est encore trop étendre la conséquence de ce que j'ai dit, qu'il n'y a point de bœufs ni de buffles en Arabie, à raison de la sécheresse du pays et du défaut d'eau, que d'en conclure la mème ehose pour l'Afrique; comme si toutes les contrées de l'Afrique étaient des Arabies, et comme si les rives profondément humectées du Nil, du Zaire, de la Gambia, comme si l'antique Palus Trilonides, n'étaient pas des lieux humides, et tout aussi propres aux buffles que le petit canton engorgé des marais Pontins.

- Eu respectant la réfutation que M. de Buffon fait de Belon, on ne conçoit pas pourquoi il soutient impossible la perfection de l'espèce du buffleen Italie. M. de Buffon sait mieuxque personne que presque tous les animaux éprouvent des changements dans leur organisation en changeant de climat, soit en bien, soit en mal, et cela peu ou beaucoup. La gibbe ou bosse est extreêmenent commune en Arabie; la rachétique est une maladie presque universelle pour les bêtes dans ces climats; le chaneau, le dromadaire, le rhinocéros et l'éléphant lui-même en sont souvent attaqués...

"Quoique M. de Buffon, daus son article du buffle, ne fasse point mention de l'odeur de musc de ces animaux, il n'en est pas moins vrai que cette odeur forte est naturelle et particulière aux buffles. J'ai même formé le projet de tirer le musc des excréments du buftle, à peu près comme en Égypte on fait le sel ammoniac avec l'urine et les excréments du chameau '. L'exécution de ce projet me sera facile, parce que, comme je l'ai dit plus haut, les pâturages des buffles, dans l'état ecclésiastique, sont dans les fiefs de ma famille...

" J'observe encore au sujet des boufs intelligents des Hottentots, dont parle M. de Buffon, que cet instinct particulier est une analogie avec les buftles qui sont dans les marais Pon-

\footnotetext{
4 Un tire le sel ammoniac par la combustion du fumier de chameau, de la suie que cette comblustion produit; et ce n'est assurément pas far les mèsmes noyens que lion ponrait extraire la partie odoraute et musıuée des excréments du buffe.
}

tins, dont la mémoire passe pour une chose unique...

" $\mathrm{Au}$ reste, on ne peut qu'ètre fort étonné de voir qu'un animal aussi intéressant et très. utile, n'ait jamais été peint ni gravé, tandis que Salvator Rosa et Étienne Bella, nous ont laissé des peintures et gravures des différents animaux d'Italie. II ćtait sans doute réservé au célèbre restaurateur de l'Histoire naturelle de l'enrichir le premier de la gravure de cet animal, encore tres-peu connu.

Dans un supplément àces premières réflexions, que m'avait envoyé M. Caëtani, il ajoute de nou velles preuves, ou du moins d'autres conjectures sur l'ancienneté des buffles en Italie, ct sur la connaissance qu'en avaient les Latins, les Grees et mème les Juifs : quoique ces détails d'érudition n'aient pas un rapport immédiatavee l'Histoire naturelle, ils peuvent y répandre quelques lumières, et c'est dans cette vue, a utant que dans celle d'en marquer ma reconnaissanceàl'auteur, queje crois devoir les publier ici par extrait.

" Je crois, dit M. Caëtani, avoir prouvé par les réflexions précédentes, que le burfle était connu des Grees et des Latins, et que son nom a racine dans ces deux langues. Quant à la latine, j'invoque encore en ma faveur l'autorité de Du Cange, qui, dans son Glossaire, dit au mot Bubalus: Bubalus, Bufalus, Buflus. II cite ce vers du septieme livre du quatrième poëme de Venance, évèque de Poitiers, célèbre poëte du cinquième siècle:

Seu validi bufali ferit inter cornua canıpum.

- Pour le mot Buflus, il est tiré de Alberlus Aquensis, lib. II, cap. 43 ; de Jules Scaliger, Exercil. 206, 1103 ; et de Lindembrogius, ad Ammiani lib XIII, etc., comme ou peut le voir dans Du Cange. Il est bien vrai que le cinquième siècle n'est pas celui de la bolle latinité ; cependant, comme il ne s'agit pas ici de la pureté et de l'élégance de la langue, mais d'un point seulenent grammatical, il ne s'ensuit pas moins que cet exemple indique un grand rapport du bubalus des Latins, du bufulo des Italiens et du buffle des Francais. Cette relation est encore prource d'une manière plus formelle, par un passage de Pline, au sujet de l'usage des Juifs de manger du chou a vec la chair du buffle.

"Une dernière observation sur la langue grecque, c'est que le texte le plus précis en faveuz du sentiment de M. de Buffon, est certai- 
nement celui de Bochart, qui, dans son Hierozoicon, pars I, lib. III, cap. 22, dit: Vocem gracam bubalon esse capro specicm; mais il est évident que cette autorité est la mème que celle d'Aristote, aussi bien que d'Aldrovande et de Jonston, qui ont dit la même chose d’apres ce philosophe.

" Au reste, il est facilc de démontrer que la connaissance du buffle remonte encore ane époque bien plus éloignće. Les inferprètes ct les commentateurs hébreux s'accordent tous a dire quil en est fait mention dans le Pentateurpue mème. Selon eux le mot jachinur signilie bufjec. I.es Septante, dans le Deuteronome, domnent la mème interprétition en traduisant juchmu par bubulus, et de plus la tradition constante des Héhreux a toujours été que le jachmor était le bullle: on peut rojr sur celal la ursion italienne de la Bible, par l)eodalli, el cedle d'Antoine Brucioli qui a précédé 1)codati....... line autre preuve que les aluifs ont eommu de tout temps le bulfile, ceest yu'au premiere liver des Rois, chap. $/ \mathrm{V}^{\prime}$, vers. $22 \mathrm{el} 23$, il est dit (qu'u) en servait sur la table de Silomon; et en elfet, e'était une des viandes ordonnces par la lecrislation des Juifs, et cet usiare subsiste encore aujourd'hui parni cux..... Les Juifs, tomme le dit fort bien M. de bufion, sonl les sculs a Rome qui tuent le bufje dems leurs bourheries mais il est a remaryucr qu'ils ue le maugent guere' (qu'avecl'assiasomnement des chour, et surtout le premier jour de leur annce, qui tombe toujours en septembie on outobre, fefe qui leur est ordomnes au chapitre VII (le l'lisode, vers. 14... I'line l'a dit expressément, cernes bubulas, alditis caulis, muymo ligni compendio percoquunt, liv. X. III, chap). 7. Ce texte est formel, ct en le rapproelsant de l'usage constant et perpéluel des duifs, on ne peut pas douter que P'line u'ait voulu parles du bul116... Cet usage des duils de Rome est ici du plus grand poids, paree que leurs familles, daus celte eapilale, sont ineontestablement les plus ancieme's de toutes les fomilles lomaines; depuis 'Titus jusqu'i mósent, ils n'ont jamais yuitte Rome, et leur ghrllo est enerere aujourd'sui le mime quartier que Juvenal clit yu’ils habitaicut anciennement. Ils ont conserve précicusement tontes leurs coutumes et usages; et guant à eelle d'assajsomner la viande du buflle avee les choux, la raison y a peut-itre autant de part gue la superstitron : te chou cu hebreu sappelle clerub, expression qui signifie aussi multiplica tion. Ce double sens leur ayant fait imaginer que le ehou ctait favorable a la multiplication, ils ont affecté ce légume a leur premier repas anmuel, comme étant un loon augure pour croitre et multiplier, selon le passage de la Ginese.

"Outre les preuves littérales de lancienneté de la connaissance du bufle, on peut concore la constater par des monuments authentic[ues. II est vai (juc ees monuments sont rares: mais leur rareté vient saus doute du mépris que le's Grecs a arient pour les superstitions iey pticunes, comme nous l'ensenene Hérodote; mépris qui ne permit pas aux artistes grees de s'oecuper d'un dieu aussi ladid et aussi vil a leurs veux que l'élait un boeuf ou un huffle.... I.es latins, serviles imitateurs des Grees, netrouvant point de modeles de cet animal, le negligerent igralement, en sorte que les monuments qui portent l'empreinte de cet animal, sont tres-rares...... Mais leur petit nombre suflit pour constater son ancienne existence dans ees contries. fe possede moi-meme une tète antipue de bufle qui a éte trouve dernierement dans une foujlle a la maison de plaisance de l'empereur Adrien, a Tivoli. Cette tète est un morecean d’atutant plus précieux, qu’il est unique daus Rome, ct lait d'ailleurs par main de maitle. Il est trés-y laij quion ne commalt aucun autre moreea antigne yui représente le hullie, ni aucune médaillo qui en offre la figure, quoi(pu'il y en ait leaneoup) yui portent differents inimaus...

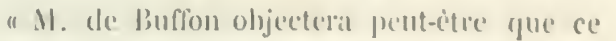
morecan de soulpture aura citi fint sans doute sur un buftle d'igrpte, ou de quelpue autre pays, et non al liome ni en Italie. Mais ('Il supposant ce fatit, dont il est presque impossible de fommir me premve ni pour ni entere, ill nen resultera pas moins que les Romains nont pas pu placer lit tite du buffle daus une superbe maison de plaisance d'empereme sams lui aro⿰彳 domei un nom, et yue par conscipuent ils en avaient enmatissanec.

"La téte dont il s"agit est si parfuitement reguliere, quille pallat avoir ete moulee sur une tite naturelle du buflle, de la maniere que

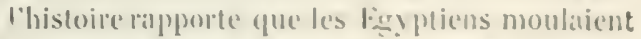
leurs statues smr les ciulatres memes.

"Au reste, je sommets eneore ees nour elles observations aux lumicressuperemes de .11. de Bufion. de nose pas me flitter yue chacune de mes preuves soit décisire : mius je pense quie 
toutes ensemble établissent que le bnffle était connu des anciens : proposition contraire à celle de l'illustre naturaliste que je n'ai pas eraint de combattre ici. J'attends de son indulgenee le pardon de ma témérilé, et la permission de mettre sous ses ycux quelques particularités du buffle, dont i! !'a peut-être pas connaissance, et qui ne sauraient être indifférentes pour un philssophe comme lui, qui a consacré sa vie à admirer et publier les merveilles de la nature.

"L'aversion du buffie pour la eouleur rouge est grénérale dans tous les buffles de l'Italie, sans exception; ce qui parait indicuer que ces animaux ont les nerfs optiques plus délicats que les quadrupedes connus. La faiblesse de la vue du buflle vient it l'appui de eette conjecture. En effet, ect animal parait souffrir impatiemment la lumiere: il voit mieux la nuit que le jour, et sa vue. est tellement courte et confuse, que si dans sa fureur il poursuit un homme, il suffit de se jeter it terre pour n'en être pas rencontré; ear le buffle le eherehe des yeux de tous côtés, sans s'apercevoir qu'il en est tout voisin.

"Les buflles ont une mémoire qui surpasse eelle de beaucoup d'autres animaux. Rien n'est si commun que de les voir retourner seuls et d'eux-mèmes ì leurs troupeaux, quoique d'une distance de quarante ou cinquante milles, comme de Rome aux marais Pontins. Les gardiens des jeunes buffles leur donnent à ehacun un lium, et pour leur apprendre à connaitre ce nom, ils le répetent souvent d'une manière qui tient du chant, en les caressant en mème temps sous la menton. Ces jeunes buffles s'instruisent ainsi en peu de temps, et n'oublient jamais ce nom, auquel ils répondent exactement el s'arrêtant, quoiqu'ils se trourent mèlés parmi un troupeau de deux ou trois milles buffles. L'habitude du buffle d'entendre ce nom cadencé, est telle, que sans cette espèee de chant il ne se laisse point approcher étant grand, surtout la femelle pour se laisser traire; et sa férocité naturelle ne lui permettant pas de se prèter à cette extraction artificielle de son lait, le gaudien qui veut traire la buffle est obligé de tenir son petit auprès d'elle, ou s'il est mort de la tromper en couvrant de sa peau un autre petit buffle quelconque; sans cette précaution, yni proure d'un coté la stupidité de la bufle, et de l'autre la lìnesse de son odorat, il est impossible de la traire. Si done la bufle refuse son lait, mème à un autre petit buffle que le sien, il n'est pas étonnant qu'elle ne se laisse point téter par le v cau, comme le remarque très-bien M. de Buffon.

"Cette circonstance de l'espèce de chant nó cessaire pour pouvoir traire la buffle femelle, rappelle ce que dit le moine Bacon dans ses observations (Iroyage en Asie, par Bergeron, tome II), gu'après Moal et les Tartares vers l'orient, il y a des raches qui ne permellent pas qu'on les traie à moins qu'on ne chanle; il ajoute ensuite, que la couleur rouge les rend furieuses au point qu'on risque de perdre la vie, si l'on se trouve autour d'elles. ll est indubitable que ces vaches ne sont autre chose que des buflies; ce qui prouve encore que cet animal n'est pas exclusirement des climats chauds.

(I Ia couleur noire et le goout désagréable de la ehair de buffle donneraient lieu de eroire que le lait participe de ces mauvaises qualités; mais au contraire il est fort bon, conservant sculement un petit goût musqué qui tient de celui de la noix museade. On en fait du beurre excellent, il a une saveur et ume blancheur supéricures à celui de la vache : cependant on n'en fait point dans la campagne de Pome, paree qu'il est trop dispendienx; mais on $y$ fait une grande consommation de lait préparé d'autres manieres. Ce (qu'on appelle communément œuf's de buffles sont des espéces de petits fromages auxquels on donne le forme d'œufs, qui sont d’un manger très-délicat. 11 y a une autre espèce de fromage que les Italiens nomment provatura, qui est aussi fait de lait de buftle; il est d'une qualité inférieure au premier; Ie menu peuple en fait grand usage, et les gardiens des buffles ne virent presque qu'arec le laitage de ces animaux.

"Le buflle est très-ardent en amour; il combat aree fureur pour la femelle; et quand la vietoire la lui a assuréc, il cherche à en jouirà l'éeart. La femelle ne met bas quau printemps et une seule fois l'année; elle a quatre mamelles et néanmoins ne produit qu'un seul petit; ou si par hasard elle en fait deux, sa mort est presque toujours la suite de cette fécondité. Elle produit deux anmées de suite et se repose la troisième, pendant liquelle elle demeure stérile quoiqu'elle recoive le mâle. Sa fecondité commence à liage de quatre ans, et finit à douze. Quand elle entre en chaleur elle appelle le málc par un mugissement particulier et le reçoit étant 


\section{DU BUFFLE.}

arrêtée, au lieu que la vache le reçoit quelquefois en marchant.

"Quoique le buffle naisse et soit élevé en troupeau, il conserve eependant sa férocité naturelle, en sortequ'on ne peut s'en servir à rien tant qu'il n'est pas dompté. On eommenec par marquer, ¿̇ l'âge de quatre ans, ces animaux avec un fer chaud, afin de pouroir distinguer les buflles d'un troupeau de ceux d'un autre... La marque est suivic de la castration, qui se fait à l'âge de quatre ans, non par compression des testicules, mais par incision et amputation. Cette opération parait néeessaire pour diminuer l'ardeur violente et furieuse que le buffle montre aux combats, et en mème temps le disposel" à reecvoir le jougg pour les différents usagnes auxquels on veut l'employer... l'eu de temps apres la eastration on leur passe un anneau de fer dans les narines... Matis la force et lat ferrocite du buffle exigent beaucoup d'irt pour parscuir a lui passer cet ameau. Apres l'aroir fait tomber au moyen d'une corde que l'on entrelace dans ses jambes, les hommes destincís à ecta se jettent sur lui pour lui lier les quatre pieds ens(mol)le, et lui passent dans les narines l'amneau de fer; ils lui délient ensuite les pieds et l'abandonneut ì lui-mème; le buflle furieux court d'un eoté et d'autre, et, en heurtant tout ce qu'il rencontre, cherche à se debarrasser de eet anneau; mais avee le temps it s'aceoutume iusensiblement, et l'habitude autant que la douleur l'amenent a lobéissince: on le conduit avee une corde que l'ou attache ì cet anneau, qui tombe de lui-mème par la suite au moven de l'effort continuel des conducteurs en tirant la corde; mais alors l'anneau est devenu inutile; ear l'animal deja vieux ne serefuse plus à son deroir.

- Le buffle parait eneore plus propre que le taureau à ces chasses dont on fitit des divertissements public's, surtout en Espagne. Aussi les seigneur's d'Italic qui tiennent des buflles dins leurs terres n'y emploient que ces animaux... La féroenté naturelle du buflle s'augmente lorsqu'clle est excitée, et rend cette chasse très-intéressante pour les speetateurs. lin eflet, le buflle poursuit l'homme avee acharnement jusque dans les maisons, dont il monteles escaliersavee une facilité particulicre; il se presente mème aux fenctres, dou il saute dans l'arene, franchissant encore les murs, lorsyuc les cris recloublés du peuple sout parvenus à le reudre furicux...
" Y'ai souvent éte témoin de ces chasses qu: se font dans les fiefs de ma famille. Les femmes mème ont le courage de se présenter dans l'arene; je me souviens d'en aroir su un exemple. dans ma mere.

"La fatigne et la fureur du buffle dans era sortes de chasses le font sucr beaucoup; sa sueur abonde d'un sel extrèmement âcre ct péncitrant; et ce sel parait nécessaire pour dissoudre la crasse dont sa peau est presque toujours cour verte...

"Le luffle est, comme l'on sait, un anima! ruminant; cet la rumination ctant tres-lis vorable a la digestion, il s'cusuit yue le buffle neest point suljet a faire des vents. Lubservation er. avait deja éte faite par $A$ ristote. dans lergued on lit: mullum cormulum unimul pedore...

" l.e terme de la vie du bufile est á peu près le méme que celui de la vie du beeuf, éest-il. dire a dix-huit ans, quoiqu’il y en ait qui $\mathrm{i}$ vent vingt-cing ans; les dents liv tombent assez communément quelgue temps avant de mourir. En Italic, il est rare qu'on leur laisse terminel leur carriere; après ligge de dluze ans, on cst dans l'usage de les engraisser et de les vendle ensuite aux Juifs de Rome: quelque's habilints de la campagne, forcés par la misère, s'en nourrissent aussi. Dans la terre du Labour viu royaume de Naples, et dans le patrimoine dis Saint-Pierre, on en fait un débit public deux fois la semaine. Les cornes du buffle sont re. cherehées et fort estimées : sa peau sert a fairo des liens pour les charrues, des cribles det couvertures de coffre's et de malle's; on ne l'en. ploie pas eomme celle du beruf à faire des se. melles de suuliers, parce qu'clle est trop pe. sante et qu'elle prend faceilement l'eau...

")ans toute létendue des marais P'ontins, il n'y a (ju un seul village yui fournisse les patte; ou les gardiens des buflles : ce village s'appells Cisterna, parce qu'il est dans une plaine 0 1 l'on n'a que de l'eau de citerne, et c'est l'un des fiels de ma famille... les habitan's, adon. ues presque tous a garler des troupeaux dis bufles, sont en méme temps les plus adroits et les plus passionne's pour les chasses dont il a cété parté ci-dessus....

" (Dnoique le buftle soit un auimal fort ct ro. buste. il est cependant delieat. en sorte qüil souftréégalement del'exces de la chaleur comme de leveces du froid; aussi dans le fort de l'élé le voit-on chercher l'ombre et l'eau, et daus 
l'hiver les forêts les plus épaisses. Cet instinet semble indiquer que le buffle est plutót originaire des elimats tempéres que des elimats trèschauds et très-froids.

"Outre les maladies qui lui sont communes a vec les autres animaux, il en est une particulière à son espèce et dont il n'est attaqué que dans ses premières années.... Cette maladie s'appelle Barbone, expression qui a rapport au siége le plus commun du mal, qui est ¿̀ la gorge et sous le menton. J'ai fait en dernier lieu un royage exprès pour ètre témoin du commeneement, des progrès et de la fin de cette maladie; je me suis mème fait accompagner d'un chirurgien et d'un médecin atin de pouvoir l'étudier, et acquérir une comnaissance précise et raisonnée de sa cause ou du moins de sa nature, à l'effet d'en offrir à $\mathrm{M}$. de Buffon une description exacte et systématique; mais ayant été averti trop tard, et la maladie, qui ne dure que neuf jours, étant déja cessée, je n'ai pu me procurer d'autres lumières que celles yui résultent de la pratique et de l'expérience des gardiens des troupeaux de buffles....

"Les symptơmes de cette maladie sont trèsfaciles à connaitre, du moins quant aux extérieurs. La lacrymation est le premier; l'animal refuse ensuite toute nourriture; presque en même temps sa gorge s'enfle considérablement, et quelquefois aussi le corps se gonfle en entier ; il boite tantôt des pieds de devant, tantôt de ceux de derrière; la langue est en partie hor's de la gueule, et est enviromnée d'une écume blanche que l'animal jette au dehor's...

"Les effets de ce mal sont aussi prompts que terribles; car en peu d'heures ou tout au plusen un jour, l'animal passe par tous les degrès de la maladie et meurt. Lorsfu'eile se déclare dans un troupeau, presque tous les jeunes buftles qui n’ont pas atteint leur troisième année en sont attaqués, et s'ils ne sont âgés que d’un an, ils périssent preseque tous; dans eeux qui sont àgés de deux ans, it y en a beaucoup qui n'en sont pas atteints, et mème il ch ćchappe grand nombre de ceux qui sont malides. Enfin, des que les jeunes buffles sont parrenus it trois ans, ils sont presque sur's d'échapper ; earil est fort rarequ'à cet âge ils en soient altaqués, et il n'y a pas d'exemple qu'au-dessus de trois ans aueun de ees animaux ait eu ectte maladie : elle commence done par les plus jeunes conme étant les plus firibles, et ecux qui tettent encore en sont les premières victimes; lorsque la mère, par la finesse de son odorat, sent dans son petit le germe de la maladie, elle est la première à le condamner en lui refusant la tette. Cette épizootie se communique avee une rapidité extraordinaire; en neuf jour's au plus un troupeau de jeunes buffles, quelque nombreux qu'il soit, en est presque tout infecté. Ceux qui prennent le mal dans les six preniers jours périssent assez souvent presque tous, au lieu que ceux qui n'en sont attaqués que dans les trois derniers jours échappent asse"z souvent, parce que depuis le sisieme jour' de l'épizootie la contagion va toujours en diminuant jusqu'au neuvième, qu'clle semble se réunir sur la tête d'un seul, dont elle fait, pour ainsi dire, sa victime d'cxpiation...

"Elle n'a point de saison fixe; seulement elle est plus commune et plus dangereuse au printemps et en été qu'en automne et en hiver.... Une observation assez générale, e'est qu'elle vient ordinairement lorsquaprès les chaleurs il tombe de la pluie qui fait pousser de l'herbe nouvelle; ce qui semblerait prouver que sa cause est une surabondance de chyle et de sang, occasionnée par ce pâturage nouveau, dont la saveur et la fraicheur invitent les petits buffles à s'en rassasier au delà du besoin. Une expérience vient à l'appui de cette réllexion: les jeunes buflles auxquels on a donné une nourriture saine et copieuse pendant l'hiver, s'abandomant avec moins d'avidité à l'herbe nouvelle du printemps, n'en sont pas attaqués autant que les autres et meurent en plus petit nombre. Dans les années de sécheresse, cette maladie se manifeste moins que dans les années humides; et ce qui confirme ee que je viens d'avancer' sur sa cause, e'est que le changement de pâturage en est le seul demi-remede : on les conduit sur les montagnes, où la pâture est moins abondante que dans la plaine, ce qui ne fait cependant que ralentir la fureur du mal sans le guérir. En vain les gardiens des troupeaux de bufles ont tenté les diffirents remedes que leur ont pu suggérer leur bon sens naturel et leurs faibles connaissances; ils leur ont appliqué à la gorge le bouton sle feu, ils les ont fait baigner dans l'eau de fleuve et de mer; ils ont séparé du troupean ceux qui étaient infectés, afin d'empècher la communication du mal; mais tout a été inutile: la contagion gagne igalement tous les troupcaux cusemble et sćparémeut; la morta- 
lité est toujours la même; la seul changement de pâturarge semble y apporter quelque faible adoucissement, et encore est-il presque insensible...

"La chair des buffles morts du burbone est dans un état de demi-putréfaction. Elle a été reconnue si dangereuse, qu'elle a réveillé l'attention du gouvernement, qui a ordonné, sous des peines lrés-sérères, de l'enterrer, et qui a défendu d'en manger...

"Quoique cette maladie semble páticulière aux bufles, elle ne laisse pas de se communiquel aux différents animaux qu'on éleve avee eux, comme poulitins, fatons et chevreatux, ee qui lui domne tous les caracteres d'unc épizuolic. Ia cobabitation ar ec les bullies malades, le seul contact de la peau de ceux (pui sont morts, suffisent pour infecter ces animaux, fui ont les mèmes symptùmes et bientòt la mème fiu... Eit mêne le cochon est sujet à la prendre; il en est attapué de la mème minière et daus le mème temps, et il en est souvent la vietime. II y a ecpendant quelque diflérence à e' sujet cutre le buffle et le cochon. $1^{\circ}$ Le buffle niest assailli par ce mal qu'une seule fois dans sa vie, et le corhon l'est jusqu'á deux fois daus la meme année; de maniere que edui pui a cule barbone cu aril, l'a souvent une seconde fois en octobre. $2^{0}$ II n'y a pas d'exemple yu'un bufle audessus de trois ans en ait rée altayué, ct le cochon y est sujet à tout âde; mais beaueoup moins cependant lorsquil est parrenu ì son conticr accroissement. 3o l'épizootic ne dure que neuf jours au plus daus les troupeaus de bullles, au lieu quelle exeree sa furcur sur le cochon pendant quinze jours, e't encore all delal : mais cette maladie n'est pais maturelle a son esperee, et ee n'est (jue par sil eommmunicalion avec les bulles quiil en est attiaqué.

a Le burbone itant prespure la seule maladie dangerense pour le buflle, ct clant en mème temps si meurtriere, que sureent de ces animaux qui cu sout attayués daus leur premicre annce, il est rare yui elle en épargne une vingtaine, il serait de la derniere importane de dćcouviri la cause de cette malindie pour y apporter remede. Les remaryues faifes justutat présent sont insuffisintes, parce quiclles noul pu étre yuc superficielles... Milis je me propose, des que cette épizoolie se maufestera de nouveatu, dialler une seconde fois sur les lieux, pour l'examiner a vee des personnes de l'art, afin de pouroir fournir a M. de Buffon une description qui le mette en état de donner, par son sentiment, des lumières certaines sur celte matiere. "

Quoique ce Mémoire de monsignor Caētani sur le buffle soit assez étendu dans l'extrait yne je viens d'en domner, je dois cependant avertir que j'en ai supprimé à regret un grand nombe de digressions tres-savantes, et de réllexions générales aussi solides qu'ingénieuses, mais (fui n'ayaut pas un rapport immédiat, ni meme assez prochain avee l'histoire naturelle du buffle, auraient paru déplacées dans cet article; et je suis persuade que l'illustre auteur me pardonnera ces omissions en faveur du molif, et qu’il recevia avec bonté les marques de rua recomaissance des instructions qu'il m’a fournie's. Sal grande érudition, biens superieure il la mienue, lui a fait trouver les racines, dans les langues greec(pue et latine, du nom de buffle; et les soins yu'il a pris de rechercher, dans les auleurs et dans les monuments anciens, tont ce yui peut avoir rappost à eet animal, donnent tant de poids a sa eritique, que j'y souseris avec plaisir.

D'autre part, les oceasions fré(fuentes qu'a eues M. Caètani de voir, d'oloservel et d'examiner de pres un tris-grand nombre de buftles dams les terres de sil tres-illustre maison, l ont mis à portéc de faire l’hisloire de leurs habitudes naturelles beaucoup mieux que moi qui 11'a vosage en llalic et a la ménarerie de Versailles, on jen ali fail lat description. Je suis done persuadé que mes lecteurs me situront erré d avoir insere elans ce supplément le Memoire de M. Calitani, et que lui-meme ne sera pas fälehé de paratre dans notre langue ave son propre style, auquel je n'ai presfue rien changé, paree qu'il est tres-bon, et que nous arous beateoup d’auleurs framearis qui neerivent pas si bien clans leur langue, que ce savant citranger écrit daus la nútre.

Au reste, j’ai déjà dit quil scrait fort ì désirer que lou put maturaliser en finnce cette espece d'animaus aussi puissants qu'utiles : je suis persuadé (pue leur mullipliention réussirait dims nos provimes, ou il se trouve des marais et des marenges, emmone dans le lourbomnais, en Champanenc, dams le liassigny, en Alsace, et meme daus les plaines le loug de la Sadone, aussi bien que dans les c'ndroits marécageux du pas d'Arles et des Landes de Bordeaux. L'im. 
pératrice de Russie en a fait venir d'Jtalie, et les a filit placer dins quelques-mes de ses provinces méridionales; ils se sont déjà fort multipliés dans le gouvernement d'Astracan et dans la Nouvelle-kussie. 11. Guldenstaedt dit ' que le climat et les piturages se sont trourés très-lavorables à ces animaux, qui sont plus robustes et plus forts au travail que des boufs. ('et exemple pent sullire pour nous cucourager à faire l'aequisition de cette espere utile, qui remplacerait celle des bœufs à tous égards, et surtout daus les temps ou la graucle mortalité de ces animaux fait un si grand tort à la culture de nos terres.

\section{UN ZÉBU.}

(LE boetjF ordinarre, Cuv.)

Section des ruminants à cornes, genre houf. (Cuvier.)

J'ai déjà fait mention de ce petit bocuf à l'article da buffle; mais comme il en est arrivé un ¿ la Nénagerie du Roi, depuis l'impression de cot article, nous sommes en état d'en parler oucore plus positivement et d'en donner ici la firure faite d'après nature, avec une deseription plus exacte que la première. J'ai aussi re('m) en faisant de nouvelles recherches, que es: petit bœuf, auquel j’ai domé le nom de zébu, est vaisemblablement le même animal qui se $n$ imme lant ou dant en Numidic, et dans quelgues autres provinees septentrionales de l'Afri(jue ou il est très-commun; ct enfin que ce mème n'm dant, qui ne devait appartenir ciu'i l'animal dont il est iei question, a été transporté, d Afrigue en Amérique, it un autre animal qui ne ressemble à colui-ci que par la grandeur du curps, et qui est d'une tout antre espèce. Ce d.nut d'Améripue est le tapir ou le moipouri; et p.u' qu'on ne le confonde pas ave le dant d'Afripuc, qui est notre zébu, nous en dommerons l'iistoire plus loin.

+ Discours sur les productions de la Russie, page 21.

\section{LA GIRAFE.}

Ordie des ruminants, section des ruminants à cornes, genre girafe. (Curier.)

La girafe est un despremiers, des plus beaux, des plus grands animaux, ct qui, sans ètre nuisible, est en mime temps l'un des plus inutiles. La disproportion énorme de ses jambes, doct celles de devant sont une fois plus longues que celles de derrière, fait obstacle à l'exercice de ses forces : son corps n'a point d'assictte, sa démarche est racillante, ses mouvements sont lents et contraints; clle ne peut ni fuir ses es:nemis dans l'état de liberté, ni servir' ses maitres dans celui de domestieité: aussi l'espèce en est peu nombreuse et a toujours été confinée dans les déserts de I Éthiopie et de quelques autres provinces de l'Afrique méridionale et des Indes. Comme ces contrées étaient inconnues des Grees, Aristote ne fait aucune mention de cet animal; mais Pline en parle, et Oppien le déerit cl'une manière qui n'est point équivoque. Le camclopardulis, dit cet auteur, a quelque ressemblance au cliameau; sa peau est tigrée comme celle de la panthère, et son cou est long comme celui du chameau; il a la tète et les oreilles petites, les pieds larges, les jambes longues, mais de hauteur fort inégale; celles de devant sont beaucoup plus élevées que celles de derrière, qui sont fort courtes et sembleut ramener à terre la croupe de l'animal; sur la tète, pres des oreilles, il y a deux éminences semblables à deux petites cornes droitcs : au reste, il a la bouche comme un cerf, les dents petites et blanches, les yeux brillants, la quene courte et garnie de poils noirs ì son extrémité. En ajoutant à cette description d'Oppien celles d'Héliodore ct de Straboil, l'on aura déja une idce assez juste de la girafe. Les ambassadeurs d'Ethiopie, dit llćliolore, amenèrent un animal de la grandcur d'un chamean, dont la peau était mirrenée de taches vives et de couleurs brillantes, et dont les parties postéricures du corps ćtaicnt beancoup trop basses, ou les parties anrérieures beatucoup trop élevées; le cou était menu, quoique partant d'un corps assez épais ; la tète ctait scmblable pour la forme ì celle du chameau, et pour la grandeur n'était guère que du double de celle de l'autruche; les yeux paraissaient teints de différentes couleurs. La dé. 


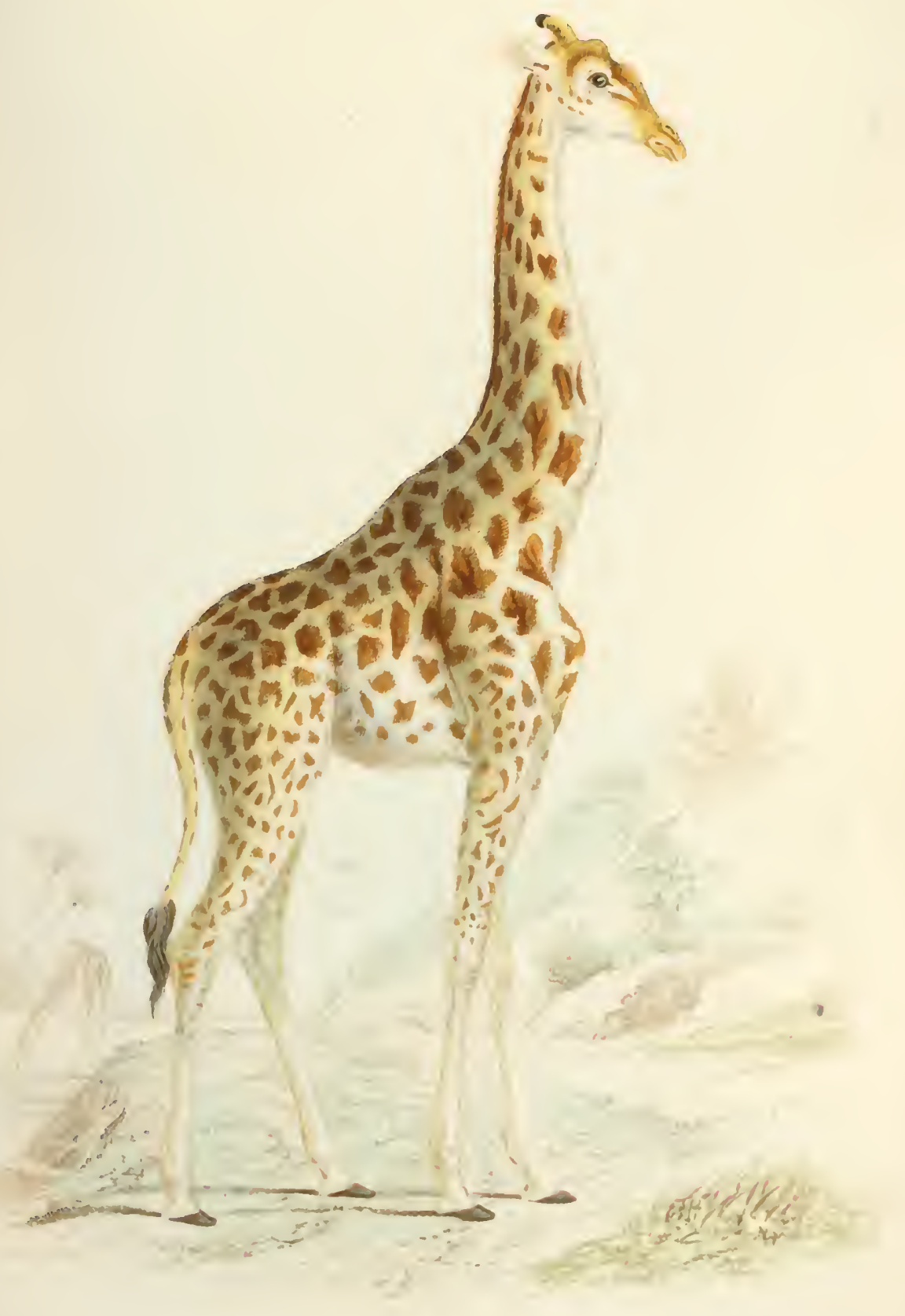

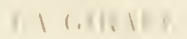



DE LA GIRAFE.

marehe de cet animal était différente de celle de tous les autres quadrupèdes, qui portent en marchant leurs pieds diagonalement, e'est-àdire le pied droit de devant avee le pied gauche de derriere; au lieu que la girafe marehe l'amble naturellement en portint les deux pieds gauche's ou les deux droits ensemble. C'est un animal si doux, (qu'on peut le conduire partout où l'on veut, avee une pelite corde pisséc autour de la tête. Il y a, dit Strabon, une sránde bète en Éthiopic, ([u'on appelle camelopardulis, quoiqu'elle ne ressemble en rien à la panthère, carr sa peau n'est pas marepuéc de mème; les taches de la panthere sont orbirulaires, et eefles de eet animal sout longue's ('t it peu pres semblables a eclles d'un faon ou jeune cerf qui a encore la livrée. Il a les parties postéricures du corps beaucoup) plus basses que les antéricures, en sorte que ver's lit croupe il n'est pas plus haut qu'un bocuf, et vers les épaules il a plus dle hauieur que le chameau. A juger de sal léreireté par eette disproportion, il ne doit pas eourir avee bien de la vitesse. Au reste, c'e'st un animal doux qui ne fait aucun mal, et (qui ne se unurrit que d'herbes et de fruilles. Le premier des modernes (pui ait ensuite donné une bonne deseription de la girafe est Belon. "J'ai vu, dit-il, " au chitcen du Caire, l'animal (ju'ils usomment " vulgairement zurnapa: les Latins l'ont an" ciennement appelé camelopardulis, d'un " nom composé de léopard et ehameau, car il " est bigarré eles taches de léopard, et a le " coul iong comme un chameau : c'est une brite " moult belle, de la plus dlouee nature (jui soit, " quasi comme une lorebis, et autant aimable "que nulle autre hète sauvage. Eille a lat tìte " presque semblable i celle d'un cerf, hormis la "grandeur, mais portant de petites cornes " mousses de six doigts de long, couretes de " poil ; mais en tant oin il y a distinetion de mile "il la femelle, relles des mâles sont plus linn" gues; mais alu dermenrant en tant le mille que - la femelle ont les oreille's grandes comme " d'une vache, la laurue d'un boeuf et mojere, " I'ayaut print de dents de'ssus la mâchelicere; " lecou long, droil et errole; les crins délies et a ronds, les jambers griles, hautes, et si bisses - par derriere, quielle semble átre dlebonit; ses " pieds sont semblable's iो ueur d'un becuf"; sil - cueve lui va pendante jusque dessus les jalpn rets, roude, atyant les poils plus gros trois " fois que n’est celui d'un eheval; clle est fort
" grêle au travers du corps, son poil est blanc " et roux. Sa manière de fuir est semblable à " celle d'un chameau; quand clle court, les " deux pieds de devant ront ensemble. Elle se " eouche le ventre contre terre ct a une dureté " a lat poitrine et aux cuisses comme un cha" meau. Elle ne saurait paitre en terre, étant "debout, salls blureir wrandement les jambes "de dlevant, eneore est-ce arce erande diffi"culté; pourequoi il est aisé à croire qu'elle ne " vit aux (hamps, sinon des branehes des ar"bres, ayant le cou aussi long, tellement yu" elle "pumrait arriver de la tète à li hauteur d'une "demi piquee."

La description de fillius me parait encore mienx faite que celle de lickon. "Jai iu (dit "Gillius, (elaip. IX) trois giralfes au Cilire; (elles "portent intelessus du front deus enrues de siv "pouees de longueur, at ilu milie'u du front un "tubereule éleré d"emsiron deux pouees, et "qui ressemble a une trovisieme cone. Cut anj" mal a seize pieds de hatuteur lersegu"il lese lat " tetc ; le cou seul a sept pieds, et il y a rimet"deur pieds depuis l'extrémité de la yucue "juspu'au bout du nez. L.es jambes de devant

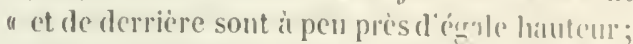
"mais les cuisses du devant sont si lonenes en " compuaison de celles du derricie, que le dos "de l'animal parat itre incliné ("omme un toit. "Tout le corps est marguri de grandes terelues " faures, de ligure a peu pries carréc.. II a le " pie I fourelau comme le hucuf, la levere supre-

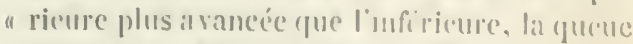
"menue avee du puil it lestrémite; il rumine

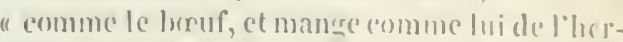
" lie; il a une criniere comme le cheval, depuis "le sommet de la tete jusque sur le dos. Lor:s" (qu’il marehe, il semble (qu”il boile mon-seule a ment des jambers, mais des llanes is droite et " il grache alternativement; et lorstpu’il ven?

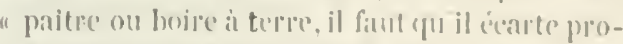
"digiensement les jambes de devint. "

Gessner cite Belon, pour andir dit que les colnes tombent is lit rirafe comme alu ditim. I'a-

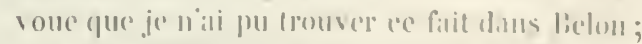
on voit qu'il dit sculement ici (que les romenes de lit girafe sont couvertes de pol: el il ue parle de cet animal que diuss un antre condroit, it l'occasion du daim uxis, wi il dit pue " la eirafe

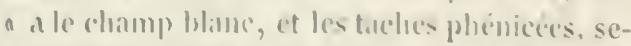
- mées par-alessus, assez larees, mais non pas "rousses comme laxis. "Cependant ce fait 
que je n'ai trouvé nulle part, serait un des plus importants pour décider de la nature de l. girafe; car si ses cornes tombent tous les ans, elle est du genre des cerfs, et au contraire si ses cornes sont permanentes, elle est de celui des boufs ou des chèvres : sans cette connaissance préeise, on ne peut pas assurer, comme l'ont fait nos nomenclateurs, que la girafe soit du genre des cerf's : et on ne saurait assez s'ćtomer qu'Hasselq̨uist, qui a donnć nourellement une très-longue, mais très-sèche deseription de eel animal, n'en ait pas mème indiqué la nature, et qu'après avoir entassé méthodiquement, e'est-it-dire en écolier, cent petits caractères inutiles, il ne dise pas un mot de la substance des cornes, et nous laisse ignorer si elles sont solides ou creuses, si elles tombent ou non; si ce sont, en un mot, des bois ou des cornes. Je rapporte ini eette deseription d'Hasselquist, non pas pour l'utilité, mais pour la singularité; en mème temps pour engager les voyageurs à se servir de leurs lumieres, et à ne pas renoneer à leurs yeux pour prendre la lunctte des autres; il est nécessaire de les prémunir contre l'usage de pareilles méthodes, avec lesquelles on se dispense de raisomner, et on se eroit d'autant plus savant que l'on a moins d'esprit. En sommes-nous en effet plus avancés après nous ètre ennuyés à lire cette énumération de petits caractères équiı oquues, inutiles? Et les descriptions des anciens et des modernes que nous avons citées ci-dessus, ne domment-elles pas de lanimal en question une image plus sensible et des idées plas nettes? C'est aux figures à suppléer à tous ces petits caractères, et le discours doit ètre réservé pour les grants; un seul coup d'œil sur une figure en apprend rait plus (qu'une parcille elescription qui devient d'autant moins claire qu'elle est plus minutieuse, surtout niétant point aceompagnée de la figure, qui seule peut soutenir l'idée prineipale de l'objet au milieu de tous ees traits variables, et de toutes ces pelites images qui servent plutòt à l'obscureir qu'a le représenter.

On nous a envoyé cette année ( 1769$)$ à l'Acildémie des Sciences un dessin et une notiee de la girafe, par laquelle on assure que cet animal, que l'on eroyait particulier à l'tithiopie, sc trouve aussi dans les terres voisines du cap de Bomne-Espérance. Nous eussions bien désiré que le dessin eût été un peu mieux tracé; mais c) n'est qu'un croquis informe et dont on ne pent faire aucun usage. A l'égard de la notice, comme elle contient une espèce de description, nous avons cru devoir la copier ici. "Dans un " voyage que l'on fit, en 1762 , à deux cents "lieues dans les terres du nord du cap de Bonne" Espérance, on trouva le camćlopardalis, dont " le dessin est ci-joint; il a le corps ressemblant " à un bœuf, et la tète et le cou ressemblent " au cheval. Tous ceux qu on a rencontrés sont "blancs avec des taches brunes. II a deux cor" nes d'un pied de long sur la tète, et a les " pattes fendues. I.es deux (qu'on a tués, et dont "la pean a été envoyée en Europe, ont été "mesurés comme il suit : la longueur de la " tète, un pied huit pouces; la hauteur, depuis " l'extrémité du pied de derant jusqu'au gar'ot, " dix pieds; et depuis le garrot jusqu'au-dessus " de la tète, sept pieds : en tout dix-sept pieds " de hauteur" la longueur depuis le garrot jus" qu'aux reins est de cinq pieds six pouces; " celle depuis les reins jusqu'à la queue, d'un " pied six pouces : ainsi la longueur du corps " entier est de sept pieds; la hauteur depuis les "pieds de derrière jusquaux reins est de huit " pieds eing pouces. II ne parait pas que cet " aninal puisse ètre de quelque service, vu la "disproportion de sa hauteur et de sa lon" gueur. Il se nourrit des fevilles de's plus " hauts arbres; et quand il veut boire oll pren"dre quelque chose à terre, il faut qu il se " mette à genoux. "

En recherehant dans les voyageurs ce quils ont dit de la girafe, je les ai trouvés assez d'accord entre cux : ils conviennent tous qu elle peui atteindre avee sa tète à seize ou dix-sept pieds de hauteur ctant clins sa situation naiurelle, e'est-a-dire posce sur ses quatre pitels; et que les jambes dlu devant sont une fois plas hautes que celles du derriere; en sorte que quand elle est assise sur sal croupe, il semble qu'elle soit enticienent elebout. Is comviennent aussi qu'a eause de celle disproportion clle ne peut pas courir vite; fur elle est l'un naturel tres-doux, et que prar rette qualiti aussi bien que pall toutes les autres habitudes phy siques, et meme par lat forme elu corps, elle approche plus die la ligure et fle la nature du chameau que de colle d'atuéun autre animal; qu'elle est du nombre des runinants, et equelle manque comme eux de dents incisises à la máchoire supérieure; ct l'on roit par le temoiguage 
de quelques-uns, qu'elle se trouve dans les parties méridionales de l'Afrique aussi bien que dans celle de l'Asie.

Il esí bien clair, par tout ce que nous venons d'exposer, que la girafe est d'une espèce unique et très-différente de toute autre : mais si on voulait la rapprocher de quelque autre'animal, ce serait plutôt du chameau que du cert ou du bœuf. Il est vrai qu'elle a deux petites cornes, et que le chameau n'en a point; mais clle a tant d'autres ressemblances avec eet animal, que je ne suis pas surpris que quelques voyageurs lui aient donné le nom de chameau des Indes. Dailleurs l'on ignore de quelle substance sont les cornes de la girafe, et parr conséquent si par cette partie elle approche plus des cerfs que des bœufs; et peut-ittre ne sont-elles ni du bois comme celles des cerfs, ni des cornes erenses comme celles des bxufs ou des chèvres. Qui sait si elles ne sont pas composées de poils réunis comme celies des rhinocéros, ou si elles ne sont pas d'une substance et d'une texture particuliere? Il ma paru que ce qui a vait induit les nomenclaterurs it metlre la girafe dans le genre des cerfs, e'est $1^{\circ}$ le prétendu passage de Belon, cité par Gessner, qui serait en effet déeisif, s`il était réel. $2011 \mathrm{me}$ semble que l'on a mal interprété les auteurs, ou mal entendu les voyageurs lorsqu'ils ont parlé du poil de ses cornes; l'ona cru qu'ils avaient roulu dire que les comes de la girafe étaient velues comme le refait des eerfs, ei de lit on a conclu cfu'clles citaient de même uaiure: mais l'on roit au contraire, par les notes eitées ci-dessus, que ces cormes de la girafe sont seulement enviromées et surmontées de grauds poils rudes et $n 0 n$ pas revetues d un duvet ou d'un velour's, comme le refint du cerí; et e'est ce qui pourrait porter à c'roire qu'elles sont eomposées de poils réunis ì peu pres comme celles du rhinocéros; leur extrémité, qui est mousse, favorise encore cette idée : et si l'on fuit altention que dans tous les animanx qui portent des bois au lieu de cornes, tols que les ćlans, les remmes, les cerfs, les daims et les chevreuils, ees bois sout toujours dirixés en branches ou andonillers, et qu'an contraire les eornes de la girafe sont simples et n'ont qu'une seule iige, on se persuadera aisément (ju'elles ne sont pas de mème nature, sans quoi l'analogie serait ici contierement violée. Le tubereule au milieu de la tète, qui, selon les royageurs; parait faire une troisième corue, vient encore à l'appui de cette opinion; les deux autres qui ne sont pas pointues, mais mousses à leur extrémité, ne sont peut-être que des tubereules semblables au premier et seulement plus élevés. Les femelles, disent tous les royageurs, ont des cornes comme les mâles, mais un peu plus petites. Si la girafe ctait en effet du genre des cerfs, l'analogrie se démentirait encor'e ici : car de tous les animaux de ce genre, il n'y a que la femelle du renne qui ait un bois; toutes les autres femelles en sont dénuées, et nous en avons donné la raison. D'autre coté, comme la girafe, a cause de l'excessive hauteur de ses jambes, ne peut paitre l'herbe qu'avee peine et difficulté; qu'elle se nourrit principalement et presque uniquement de fenilles et de boutons d'arbres, l'ou doit présumer que les comes qui sont le résidu le plus apparent du superflu de la nourriture organique, tiement de la nature de cette nourriture, et sont par conséquent d'une substance analorge au bois, et semblable à celle du bois de cerf. Le temps coufirmera l'une ou l'autre de ees conjectures. Un mot de plus dans la description d'Hasselpuist, si minutieuse d'ailleurs, aurait fixé ces doutes et déterminé nettement le genre de cet animal. Nais des écoliers qui n'ont que la gamme de leur maitre dans la tète, ou plutót dans leur poche, ne peuvent manquer de faire des funtes, des bévues, des omissions essenticlles: parce (qu'ils renoncent a l'esprit qui doit gruider tout observateur, et qu'ils ne voient que par une methode arbitraire et lautive, qui ne sert qu'à les empieher de réfléchir sur la mature et les rapports des objets qu'ils rencontrent, et desquels ils ne lont que calquer la deseription sur un mauvais modile. Comme dans le reel tout est différent l'un de l'autre, tout doit aussi itte traité diffé. remment; un seul grand caractere bien saisi décide quelquefois, et souvent fait plus pour la comnaissance de la chose, que mille autres petits indices : des qu'ils sont en grand nombre, ils deviennent nécessatrement éfuivoques et communs, et des lor's ils sont au moins superflus, s'ils ne sont pas unisibles à la comnaissance réelle de la nature, qui se joure des formules, échappe à toute methode, et ue pcut ètre aperçe que par la vue immédiate de l'esprit, ni janais saisie que par le coup d’oxil du génie. 


\section{ADDITION A L'ARTICLE DE LA GIRAFE.}

Nous donnons ici la figure de la girafe, d'après un dessin qui nous a été en royé du cap de Bonnc-Espérance, et que nous avons rectifié dans quelques points, d'après les notices de M. le chevalier Bruce'. Nous donnons aussi la figure des cornes de cet animal; nous ne sommes pas encore assurés que ces cornes soient permanentes comme celles des boufs, des gazelles, des chèvres, etc., ou, si l'on veut, comme celles des rhinocéros, ni qu'elles se renourellent tous les ans comme celles des cer fs, quoiqu'elles paraissent ètre de la même substance que le bois des cerfs; il semble qu'elles croissent pendant les premières années de la vie de l'animal, sans cependant s'élever jamais à une grande hauteur, puisque les plus longues que l'on ait vues n'a vaient que douze à treize ponces de longueur, et que communément elles u'ont que six ou huit pouces. C'est a M. Allamand, célèbre professeur à Leyde, que je dois la connaissance exacte de ces cornes. Voici l'extrait de la lettre quiil a écrite à ce sujet, le 31 octobre 1766 , à M. Daubenton, de l'Académie des Sciences:

"J'ai eu l'honneur de vous dire que j'avais jei une jeune girafe empaillée, et vous m'arez paru souhaiter, ainsi que M. de Buffon, dee connaitre la nature de ses cornes; cela m'a déterminé à en faire coupcr une que je vous envoie, pour vous en donner une juste idée. Vous observerez que cette girafe était fort jeune. Le gouverneur du Cap, de qui je l'ai reẹue, m'a écrit qu'elle avait été tueje conchée auprès de sa mère. Sa hauteur' n'est en effet que d'environ six pieds, et par conséquent ses cornes sont courtes et n'exeèdent guère la hauteur de deux pouces et demi; elles sont couvertes partout de ia peau bien garnie de poils, ct ceux qui terminent la pointe sont beacoup plus grands que les autres, et forment un pincean dont la hauteur excède celle de la corne. La base de ees cornes est large de plus d'un pouce : ainsi elle forme un cone obtus. Pour savoir si elle est ereuse ou solide, si e'est un bois ou une corne, je l'ai fait scier dans sa longueur aree le molceau du crâne auçuel elle était adlıérente; je l'ai trouvée solide et un peu spongieuse, sans doute parce qu'elle n'avait pas encore aequis toute sa consistance. Sa contexture est telle,

- Celle que nous donnons est faite d'aprìs nature. qu'il ne paraît point qu'elle soit formée de poils réunis comme celle du rhinocéros, et elle ressemble plus à celle du bois d'un cerf qu'à toute autre chose. Je dirais même que sa substance n'en diffère point, si j'étais sûr qu'une corne qu'on m'a donnée depuis quelques jours, pour une corne de girafe, et qui m'a été envoyéc sous ce nom, en fùt véritablement une. Elle est droite, longue d'un demi-pied et assez pointue; on y voit encore quelques vestiges de la peau dont elle a été recouverte, et elle ne diffère du bois d'un cerf que par la forme. Si ces observations ne vous suffisent pas, je vous enverrai avec plaisir ees deux cornes, pour que vous puissiez les examiner avec M. de Buffon. Je dois encore remarquer par rapport à cet animal, que je crois qu’on a exagéré, en parlant de la différence qưil y a entre la longueur de ses jambes de devant et celles de derrière; cette différence est assez peu sensible dans la jeune girafe quej'ai. "

C'est d'après ces cornes, envoyćes par MI. Allamand, que nous en donnons ici la figure.

Mais, inclépendamment de ces deux cornes ou bois gui se trouvent sur la tête de la femelle girafe, aussi bien que sur celle du mâle, il y a au milieu de la tète, presque à distance égale entre les narines et les yeux, une excroissance remarquable qui parait ètre un os couvert d'une peau molle, garnie d'un poil doux. Ce tubercule osseux a plus de trois pouces de longueur, et est fort incliné vers le front, c'est-à-dire qu'il fait un angle très-aigu avee l'os du nez. Les couleurs de la robe de cet animal sont d'un fauve clair et brillant, et les taches en général sont de figure rhomboidale.

Il est maintenant assez probable, par l'inspection de ces cornes solides et d'une substance semblable au bois des cerfs, que la girafe pourrait être mise dans le genre des cerfs; et cela ne serait pas douteux si l'on était assuré que son bois tombent tous les ans; mais il est bien décidé (fu'on doit la séparer du genre des bœufs et des autres animaux dont les cornes sont creuses. En attendant, nous considérons ce grand et bel animal comme faisant un genre particulier et unique, ce qui s'accorde très-bien avec les autres faits de la nature, qui, dans les grandes espèces, ne double pas ses productions; ear l'éléphant, le rhinocéros, l'hippopotame, et pent-ĉtre la girafe, sont des animaux qui forment des genres particuliers ou des espèces 
uniques, qui n'ont point d'espèces collatérales; c'est un privilége qui ne paraît accordé qu'à la grandeur de ces animaux, qui surpasse de beaucoup celle de tous les auties.

Dans une lettre que j’ai reçue de Hollande, et dont je n'ai pu lire la signature, on m'a envoyé la description et les dimensions d'une girafe, que je vais lærpporter ici.

"La girafe est l'animal le plus beau et le plus curieux que l'A frique produise. Il a vingtcinq pieds de longrueur, du bout de la tète ì la queue. On lui a donné le nom de chameauléopard, paree qu’il a quelque ressemblance au chameau par la forme de sa tete, par la longueur de son cou, ete., et (jue sa robe ressemble a celle des léopards, par les taches dispersées aussi régulierement. ()n en trouve à quatrevingts lieues clu cap de Bonne-Espérance, et encore plus communement à une profondeur plus grande. Cet animal a les dents comme les cerfs: ses deux cornes sont longues d'un pied; ellessont droites et grosses comme le bras, garnies de proils, et commecoupées à leur extrémité. l.e cou fait au moins la moitié de la longueur du corps, „ui, pour la forme, ressemble assez à celui du cheval. La queue serait aussi assez semblable; mais elle est moins garnic de poil que eelle du cheval. Les jambes ressemblent assez a celles d'un cerf; les pieds sont garnis de sabots très-noirs, obtus et écartés. Quand l'animal saute, il leve ensemble les deux pieds de devant, et ensuite les deux de derriere, comme un cheval qui aurait les deux jambes de devant attachées : il eourt unal et de mauvaise grace; on peut tres-aisément l'attraper à la course. II portetoujours la tète ties-hauie, et ne se uourrit yue des feuilles des arbres, ne pourant paitre l'herbe a terre à cause dc sa trop grande hauteur. Il est méme forcé de se mettre à genoux pour boire. Les femelles sont els géuélall d'un fiuve plus clair, et les males d'un fuuve brun. 11 y en a aussi de presepue blanes; les taehes sont brunes ou noires. Voici les dimensions d'un de ces animaux, dont les peaux ont été envoyées en limope.

Longueur de la léte. ..... Haterur du pied le devanl jusunian garrot.

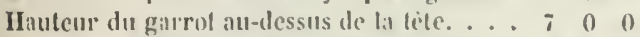
Longueur depuis le garol juspu'su reius. . ; 60 Longucur depuis les reins jusqu"ii la yneue. o 160 Hanteur depuis les pieds de derriere jusquaux reius.............
J'avais lirré cet article sur la girafe à l'im. pression, lorsque j’ai r’eçu, le 23 juillet 1775 , la belle édition que M. Schneider a faite de mon ouvrage, et dans laquelle j'ai vu, pour la premicre fois, les excellentes additions que M. Allamand y a jointes : je ne puis done micux faire aujourd'hui (que de copier en enticl ce que MM. Schneider et Allamand disent au sujet de cet auimal, lome IIII, page 17, de l'Ilistoire Naturelle, idition de Hollaude.

" M. de liufou blame, avec raison, nos nomenclateu's modernes, de ce quien parlant de la grirafe, ils me nous disent rien de la nature de ses colmes, yui stules peurent fournir le caractire prople a déterminer le genre auquel elle appartient, et de c'e quils se sont amusés à nous en faire une deseription seche et minutieuse, sans y joiudle aucune figure. Nous allons l'emédier at ce double défaut.

" M. Allamand, professeur d'histoire naturelle à l'université de leyde, a placé dans le cabinet des curiosités l'histoire naturelle de l'Université, la pean hour'ce d'une jeune girafe: il a bien voulu nous en communicuer le dessin, que nous avons fait graver dans la planche re, et il y a joint la description suivante :

"M. Tulbagh, gouverneur du cap de BomneEspérance, qui a enrichi le Cábinet de notre Académie de plusicurs curiosités maturelles tresrares, má cerit, en m'envoyant la jeune girafe que nous avons ici, quielle avait été tuce par ses chasseurs, fort avant dans les terres, coucheje aupres de sa mère, quelle tetait encore. Par lá il est constaté que la grirafe n'est pas particuliere a l Ethiopic, comme l'a cru Thévenot.

"Dés que je l'eus l'ceue, mon premier soin fut d'en examiner les cornes, pour éclan'cir le doute daus lequel est M. de buffon, sur leur substance. Elles ne sont point ereuses comme celles des bocufs it deschevres, mais solides comme le bois des cerfs, et d'une cousistance presque semblable; elles n'en different quicn ce qu'elle's sont minees, dloiteset simples, l'esta-dire sans ètre divisés e'n branches ou andouillers: : elles sont recouvertes dans toute leur longueur de la peau de l'animal ; et jusqu'aux trois quarts de lem hauteur, cette peau est chargée le poils courts, scmblables à coux qui courrent tout lo rorps; lers lenr extrimite, ecs poils deviement plus longs ; ils s'elevent environ trois 8 ; 0 l pouces au-dessus du bout mousse de la corne, 
et ils sont noil's; ainsi ills sont très-difiérents du duvet qu'on roit sur le refait les eeris.

"Ces cornes ne paraissent point ètre composées de ees poils réunis, eomme eelles du rhinocéros: aussi leur substance et leur texture est lout autre. Quand on les scie, suivant leur longueur, on voit que, comme les os, elles sont formées d'une lame dure qui en fait la surface extéricure, et qui renferme au redans un tissu spongieux : au moins cela est-il ainsi dans les colncs de ma jeune girafe : peut-ètre que les cormes d'une girafe adulte sont plus solides ; c'est ce que M. de Buffon est actuellement en état de déterminer : je lui ai envoyé une des cornes de ma girafe, avec celle d'une autre plus àgée, qu'un de mes amis a rẹue des Indes orientales.

"Quoique ces cormes soient solides comme celles des cerfs, je doute quelies tombent de même que ces dernières: elles semblent c̀tre une excroissance de l'os fiontal, comme los qui sert de noyau aux colnes creuses des boufs et des chìres; et il n'est guère possible qu'elles s'en détachent. Si mon doute sst fonde; la girafe fera un genre partieulier, différ'ut de ceux sous lesquels on comprend les ammaux dont les cornes tombent, et ceux qui ont les cornes creuses, mais permanentes.

"Les girafes adultes ont au milieu du frout un tubercule qui semble être le commencement d'une troisième corne : ce tubereule ne parait point sur la réte de la nòtre, qui viaisemblablement était encore trop jeune.

"Tous les auteurs, tant anciens cue moder-nes, qui ont décrit cet animal, disent qu'il y a une si grande différence entre la longueur de ses jambes, que celles de derant sont une fois plus liautes que eelles de derricre. Il n'est pas possible qu'ils se soient trompés sur un earactère si marqué; mais j'ose assurer (qu'à cet égard la girafe đloit changer beau coup en grandissant; car dans la jeune que nous avons jei, la hauteur des jambes postérieures égale eelle des jambes antérieures; ce qui n'empèche pas que le train de devant ne soit plus haut que celui de derrière, et cela à cause de la différence qu'il y a daus la grosseur du corps, comme ou le voit dans la figure: mais cette différence n'approche pas de ce qu'on en dit, comme on pourra le conclure par les dimensions que je vais donuer.

* Ie cou de la girafe est ce qui frappe le ol. ceux qui la voient pour la premiere fois : il n'y a atueun quadrupète qui l'ait aussi long, sans en exeepter le ehameau, qui d'ailleurs fait replier son : ou en direrses façons, ce qu'il ne parait pas que la girafe puisse faire.

"Sa couleur est d'uu blane sale, parsemé de taclies faures, ou d'un jaune pảle, fort près les unes des autres au cou, plus éloignées dans le reste du colps, et d'une figure qui approche du parallélogramme ou du rhombe.

" La queve est mince par rapport à la longueur et à la taille de l'animal; son extrémité est garnie de poils ou plutòt de crins noirs, qui ont sept à huit pouces de longueur.

"Une erinière composée de poils roussâtres, de trois pouces de longueur, et inclinée vers la partie postérieure du corps, s'étend depuis la tète tout le long du cou jusqu'à la moitié du dos; là, elle continue à la distance de quelques pouces : mais les poils qui la forment sont penchés ver's la tète, et près de l'origine de la queue elle semble recommencer, et s'étendre jusqu'à sou extrémité; mais les poils en sont fort courts et a peine les distingue-t-on de ceux qui couvrent le reste du corps.

"Ses paupières, tant les supérieures que les inferrieures, sont garnies de cils formés par une rangée de poils fort raides; on en voit de semblables, mais clair-semés et plus' longs antour de: lá bouche.

"Sa physionomie indique un animal doux et docile, et c est là ce qu'en disent ceux qui l'ont vue vivante.

"Cette description de la sirafe, ajoutée à ce qu'en dit M. de Buffon, d'après divers auteurs, et accompagnée de la figure que j'ai jointe ici, suffit pour en donner des idées plus justes que celles qu'on en a eues jusqu'à présent. Il u'y manque que les dimensions de ses prineipales parties; les roiei :

Longueur du corps entier mesuré eu ligne p. p. I. droite, depuis le bout du museau jusqu'à l'anns................. 5 7

Hanteur du train de derant. . . . . . . 450

Hanteur du train de derrière. ......4 400

Longueur de la lète, depuis le bout du nuseaı jusqu’à l'or'igine des cornes. . . . . . 0097

Circonférence du bout du muscau, prise derricre les naseanx............ 0 9 Circouférence de la téte, prise an-dessus des yeu................. 15 Contour de louverture de la bouche. .... 0 | 11 Distance entre les angles de la màchoire in- 
$\begin{array}{ccc}\text { p. } & \text { p. } & \text { I. } \\ 0 & 5 & 0\end{array}$

férieure......................... 0 3 0

Dislance entre les naseaux............. 0 , 0

Dislance entre les yeux, mesurée en ligne

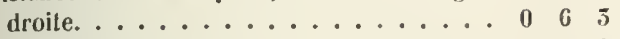

Longueur de l'oxil d'un angle à l'autre. . . . 0 o 199

Dislance entre les deux paupières ouverles. . $0 \begin{array}{lll}0 & 1 & 1\end{array}$

Distance entre l'angle anterieur et le boul des

lèvres. ........................... 0 (6 6

Distance entre l'angle postérieur et les cornes. 0,56

Longueur des cornes. .............. 0229

Dislance d'une corıe à l'iulul re, prise au bas. . $\quad \begin{array}{llll}0 & 1 & 9\end{array}$

Distance des cornes aux oreilles. . . . . $0 \begin{array}{lllll}0 & 2 & 9\end{array}$

Longueur des oreilles. . . . . . . . 0060

Largeur de la base, mesurée sur la courbure. $\begin{array}{llll}0 & 2 & ;\end{array}$

Distance eutre les deux oreilles, prise au bas. $0 \quad 4 \quad 6$

Longueur du cou. ..................... 48

Circonférence près de la lète. ...... 1000

Circonférence près des épaules. .....2 2000

Circonférence du corps, prise derrière les jambes de devant................. 3114

Circonférence devant les jambes de derviere. 5 i

Longueur du tronçon de la queue. ..... 1 5 5

Circonféreuce à sou origine. ............ $0 \begin{array}{llll} & 7 & 0\end{array}$

Hauteur des jambes de derant, depuis la plante des pieds jusquue sous la poitrine. . .

Hauteur des jambes de derrière, depuis la plante des pieds justpue sous le ientre. .

Longueur des sabots. ..........

Hauleur des sabots. . . .........

Largeur des deux sabots dans les pieds de de-

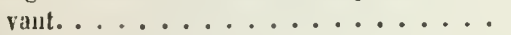

Largeul des deux sabots dans ses pieds de der-

rière................

Circonferrence des deux sahots réunis, prise sur les pieds de devant.........

Circonféreuce prise sur les pieds de derrière.

" Je ne donne point ici les circonférences du genou, du boulet, ni du paturon, non plus que les longueurs des différentes parties qui composent les jambes, paree qu'il ne m'a pas été possible de les prendre sur une peau bourrée, où ces differentes parties ne sont pas exactement déterminées. "

On voit, par cette description, non-seulement la grande intelligence, mais la circonspection et la prudence que M. Allamand met dins les sujets qu'il traite. J'aurais fait copier'sa planche pour accompagner sa deseription; mais conme j'en donne une autre, et que d'ailleurs sa girafe était fort jeune, j'ai cru que je devais m'en dispenser. Je ferai sculement une observation au sujet des cornes que le mème M. Allamand a eu la bonté de m'enroyer : je doute beaucoup que la plus longue ait appartenu ì une girafe; elle n'a nul rapport de proportion avec les autres, qui sont très-grosses, relativenent à lev longueu, tandis que celle-ci est menue, c'est-à-dire fort longue pour sa grosseur. Il est dit, dans la deseription anonyme rapportée ci-dessus, que les girafes adultes ont les comes longues d'un picd el grosses comme le bras; si celle-ci, qui est longue d'un demipied, était en effet une corne de girafe, elle serait deux fois plus grosse qu'elle ne l'est : d'ailleurs cette prétendue corne de girafe m'a paru si semblable à l:ı dague d'un daguet, e'est-ả-dire au premier bois d'un jeune cerf, que je crois qu'on peut, sans se tromper, la regarder comme telle.

Mais je seraisassez de l'avis de M. Allamand, au sujet de la nature des cornes de girafe : le tubcreule, qui, daus cet animal, fait pour ainsi dire une troisieme corne au milieu du chanfrein, ('e tubereule, dis-je, est cerlainement osseux; les deux pelites cornes sciées étaient adhérentes au crâne sans ètre appuyées sur des meules: elles doi vent done ètre regálidées comme des prolongements osseux de cette partie. J'ailleurs le poil ou plutot le crin dont elles sont enviromées et surmontées, ne ressemble en rien au velours du refait des eerfs ou des daims : ces crins paraissent être permanents, ainsi que la peau dont ils sortent; et des lors la corne de la girafe ne sera qu'un os qui ne diffère de celui de la vache que par son envelopne; celui-ci étant recouvert d'une substance cornée ou corne creuse, et celui de la girafe couvert seulement de poil et de peau.

\section{NOUVELLE ADDITION A L'ARTICLE DE IA}

\section{GIRAFE.}

Lorsque nous a vons donné la première ad dition à l'article de cet animal, dont la hauteur surpasse celle de tous les autres animaux quadrupedes, nous n'avions pu réunir encore que des notions imparfaites, tant par rapport à sa conformation, qu'il ses habitudes. A vec quelque soin que nous eussions comparé tout ce qui a été écrit an sujet de la girafe par les anciens naturalistes et les modernes, nous ignorions eneore si elle portait sur la tètedes bois on des cornes; et, quoique la figure que nous avons donnée de cet animal soit moins défectueuse qu'aucune de celles que l'on avait publiées a vant nous, cependant nous arons recomu qu'elle n'est point exacte à plusieurs égards. M. Gordon, obselvateur très-éclairé, que nousarons cité plusieurs 
fois avec élogre, a fait un second voyage dans l'intérieur de l'Afrique méridionale : il a vu et pris plusicurs girafes, et les ayant examinées aree attention, il en a envoyé à M. Allamand un dessin que j'ai fait copier et graver ; nuus y joindrons plusieurs détails intéressants sur les habitudes et la conformation de cet animal si remarquable par sa grandeur.

"Les girafes se trouvent, dit-il, vers le vingthuitième degré de latitude méridionale, dansles pays habités par des nègres, que les Ilottentots appellent Brinas ou Briquas; l'espece ne parait pas ètre répandue vers le sud au delà du vingtneuvième degré, et ne s'étend à l'est (qu'à cing ou six degrés du méridien du Cap. Les Caffres, qui habitent les côtes orientales de l'Afrique, ne connaissent point les girafes; il parait aussi qu'aucun voyageur n'en a vu sur les còtes occidentales de ce contineid, dont elles habiteut seulement l'intérieur. Elles sont confinées dans les limites que nous venons d'indiquer ver's le sud, l'est et l'ouest, et du còté du nord on les retrouve jusqu'cn Abỳssinie, et même dans la HauteEgypte.

"Lorsqueces animaux sont deboutet en repos, leur cou est dans une position verticale. Leur hanteur, depuis la terre juscu'au-dessus de la tête, est dans les adultes de quinze à seize pieds. La girafe que j’ai fait représenter, et dont la dépouille est dans le Cabinet de WI. Allamand, était haute de quinze pieds deux pouces. Sa longueur était peu proportionnée à sa hauteur. Elle n'avait que einq pieds cinq pouces de longueur de corps, mesurée en droite ligne depuis le devant de la poitrine jusqu'i l'anus. Le train de derant, mesuré depuis terre jusçu'an-dessus des épaules, avait neuf pieds onze pouces de hauteur ; mais celui de derričre ne était haut que de huit pieds deux ponces. "

On a cru qu’en général la grande différence de hauteur qui se trouve entre le derriere et le devaut de la girafe, provenait de l'inégalité de hauteur dans les jambes : mais M. Gordon a envoyé à M. Allamand tousles os d'une des jambes de devant et d'une des jambes de derriere; elles sont à peu près de la mème longueur, comme on pourra le voir par les dimensions rapporties it la fin de cet article, en sorte que linégalité des deux trains ne pent ètre attribucé à cette cause, mais provient de la erandeur des omoplates et des apophyses épineuses des vertébres du dos. L'os de l'omoplate a deux pieds de longucur, et les premières apophyses épineuses sont longuns de plus d'un pied; ce qui suffit pour que le train de devant soit plus élevé que celui de derrière d'envison un pied huit à neuf pouces, comme on peut le voir dans le squelette de cet animal que nous donnons ici.

La peau de la girafe est parsemée de taches rousses ou d'un fauve foncé sur un fond blanc. Ces taches sont très-prés l'une de l'autre, et de figure rhomboïdale ou ovale; et même ronde. La couleur de ces taches est moins foncée dans lea femelles ct dans les jeunes mâles que dans les adultes, et toutes en général deviennent plus brunes et mème noires à mesure que l'animal vieillit. Pline a écrit que le caméléopard, qui est le même animal que la girafe, avait des taches blanches sur un fond roussâtre; et en effet, lor'squ'on voit de loin une girafe, elle parait presque entièrement rousse, parce que les taches sont beaucoup plus grandes que les espaces qu'clles laissent entre elles, de façon que ces intervalles semblent ètre des taches blanches semées sur un iond roussâtre. La forme de la tête de la girafe a quelque ressenblance a vec celle de la tête d'une brebis : sa longueur est de plus de deux pieds; le cerveau est très-petit; elle est couverte de poils parsemés de taches semblablesá celles du corps, mais plus petites. La lèvre supérieure dépasse l'inférieure de plus de deux pouces; il ya huit dents ineisives assez petites dans la mùchoire inférieure; et, comme dans tont autre animal ruminant, il ne s'en trouve point dans la mâchoire supérieure.

Joseph Barbaro, cité par Aldrovande, a écrit quela girafe a une langue ronde, déliée, violette, longuede deux pieds, et qu'elle s'en sert comme d'une main pour cueillir les feuilles dont elle sc nourrit : mais cest une erreur, et $\mathbf{M}$. Gordon a reconnu daus toutes les girafes qu il a prises ct disséquées, que la langue de ces animaux ressemble, par la forme et la substance à la langue des gazelles; et il a recomnu aussi que leur structure interieure est à peu près la mème, et que la résicule du fiel est fort petite.

Les y enx sont grands, bien fendus, brillants, et le regard en est doux. Leur plus long diametre est de deux ponces neuf lignes, et les paupières sont garnies de poils longs et raides en forme de eils; et il n'y a point de larmier au bas des ycux.

La girafe porte au-dessus du fiont deux cornes un peu inclinées en arrière. Nous arions déjà 
pensé, d'après celle que M. Allamand nous avait envoyée, yu'elles ne tombaient point charque année comme les bois des cerfs', mais qu'ellesétalicut permanentes comme celles des boufs, des béliers, ete. Notre opinion a été entierement confirmée par les observations de M. Allamind, sur une tète décharnée qu'il a dans sa eolléction. Les cornes de la girafe sont une exeroissance de l'os du front, dont elles font partie , et surlequel elles s'élevent a Ja hauteur cle sépt poures; leur circonférence à la base est ale plus de neul ponces; leur extrémité est terminće par une espèce de gros bouton. Eilles sont recouvertes d'une jeau garnie de poils noirs, et plus lougrs vers l'extrénité, oi ils forment une sorte de pinceau qui mancue cependant a plusieurs judividus, vaisemblablement parce yu'ils les useut en se frottant contre les arbies. Ainsi les eornes de la grime ne sont pas des bois, mais des cornes comme celles des bocufs, et colles n'en different yue par leur enveloppe, les eornes des boxufs chant reufermées dans une substance cornce, et celles de la grirafe étant sculement recouvertes d'une peau crumic de poils.

Indépendamment de ces deux cornes, il y a au milieu du l'rout un tubereule (qu'on prendrait au premict' coup d'weil pour une troisieme entue, mais qui u'est qu'une excroissance spongrieusc de l'os frontal, d'environ quatre pouces de diitmètre sur deux pouces de hauteur. La peau qui le couvre est quelquelois calleuse et dimarnic de poil, à cause de l'habitude qu'ont ees anmaux de frotter leur tète coutre les arbres.

L.esoreilles ont huit àneuf pouce's de longueur; et l'ou remaryue entre les oreilles et les cornes deux protubérances composées de glandes, qui forment un asse'z gros volume.

Le cou a six pieds de longueur, ce qui domne it ehaque vertibre une si grande épaissemr. que le eon ne pent gruere se fléchir. Il cst à l'extericur garni en dessus d'une crinière qui commence à la tète, et qui se termine an-dessus des épinules dans les adultes, mais qui s'étend jusqu’au milicu du dos dans les jeunes giriales. I.es proils qui la composent sont loners de trois pouces, et forment des toulles alteruativement plus ou moins foncées.

I.a partie du dos qui est près des ripaules est fort elevér; il s'abaisse ensuite; il se releve et se rabaisse encorevers la yuene, yui est tres-minee et a deux pieds de longueur. Lille est comserte de poils tres-courts, ct son extréunité est garnie d'une touffe de poils noir's aplatis, très-forts et longs de deux pieds. Les Nègres se servent de ces crins de girafe pour lier les anneaux de fer et de cuirre qu'ils portent en forme de bracelet.

I.e ventre, cilevé au-dessus de terre de eing pieds sept pouces vers la poitrine, et seulement de cing pieds vers les jambes de derriere, est couvert de poils blanchitres. Les jambes sont tachetées comme le reste du corps, jusqu'au canon qui est salls tache et d'un blane sále.

Les sabots sout beaticoup plus hauts par devant que par derricere, et ne sont point surm;ontés d'ergots comme daus les autres animaux in picels fourchus.

D’apres tuutes les comparaisons yue l'on a,pu faire entre les mâles et les femelles, soit pour a forme, soit pour les couleurs, on u'y a pas trouve de difference semsible; et il n'y en a quine qui est rédle, (’est celle de la crandeur. les fumelles etant toujours plus petites que les màles. Elles ont quatre manelles, et eependant ne portent ordinairement qu'un petit; ce qui s'accorde avece ce rue nous savons de tous les syands animaux, qui communément ne produisent qu'un seul petit à charpue portéc.

Quoique le corps de ces animaux paraisse disproportienné dans plusicurs de leurs parties, ils liappent eependant les recrards, et attirent l'attention par leur beauté, lorsqu’ils sont debuut et qu'ils relevent leur tète. La donerur de leurs verix ammonce celle de leur naturel. Ils n'attaquent jamais les autres animax, ne donnent point de coups de tète, comme les biliers. et co viest que quand ils sont auy abois qu’ils be défendent arec les pieds, clont ils frappent alurs lit tere arec violence.

L.e pas de la cribife est un amble; elle porte ensemble le pied de deriere et celui de devant du mène cote; et dans sa démarelue le corps párait toujours se balancer. Lorsqu'clle veut preripiter son mourement, clle ue trotte pas, mais gilope en s'appuyant sur les pieds de derrice; et alors penr mainlenile l'épuilibre, le rou se porte en arriere, lorsquelle eleve ses pieds de devant, et en a vant, lorspuiclle les porse a terre : mais en genciral le's mourements de cet animal ne sont pas tres-rifs; eependant, comme ses jambes sont tres-longues, quille fait de trèsgrands pas, et qu'elle peut marcher de suite pendant tris-longtemps, il est difticile de la suirre et de l'atteindre, mème aree un bon eheral. 
Ces animaux sont fort doux, et l'on peut eroire qu'il est possible de les apprivoiser et de lesr'endre domestiques; néanmoins ils nele sont nulle part, et dans leur' état de liberté, ils se nourrissent des fetilles et des fruits des arbres, que, par la conformation de leur corps et la longueur de leur cou, ils saisissent avec plus de facilité que l'herbe qui est sous leur's pieds, et a laquelle ils ne peuvent atteindre qu'en pliant les genoux.

Leur chair, surtout celle des jeunes, est assez bonne a manger, et leurs os sont remplis d'une moelle que les Hottentots trouvent exquise : aussi ront-ils souvent il la ehasse des girafes, qu'ils fuent avee leurs fleches e'mpoisonnées. Le euir de ces animaux est épais d'un demi-pouce. Les Africains s'en servent à différents usages; ils en fout des vases ouils conservent de leau.

Les girafes laabitent uniquement dans les plaines : clles vont en petites troupes de eincy ou six, et quelquefois de dix ou douze; cependant l'espece n'est pas très-nombreuse. Quand elles se reposent, elles se couchent sur le ventre, ce qui jeur domne des callosités au bas de la poitrine et aux jointures des jambes.

Nous croyons deroir ajouter ici les dimensions d'une girafe tuée par M. Gordon dans le pays des grands Namaquas.

Hauleur mesurée en ligno droite, depuis la plante des pieds de devant jusqu'au-dessus du tubercule qui est sur la tête, lorsque I animal a le cou dressé perpendiculairement................. Is

Lougueur depuis le bout du museau le long du cou, on en suirant la courbure du corps jusqu'à l'origine de la queue. ...... 13

Longueur du corps depuis la poitrine jusqu'a l'anus en droite ligne. . . . . . . . 5 7 7 7

Longueur en suivant la courbure. . . . 5 5100

Ilauteur jusquau-dessus du garrot en ligne droite...................... 9110

Hauteur en suivant la courbure. . . . . 10 \& 0

Uauteur du train de derrière jusqun au-dessus de lı croupe en ligne droite. . . . . 820

Hauteur suirant l: courbure. . . . . . 888 8 8

Hauteur de la partie inférienre du corps audessus du terrain près de la poitrine. . . . 57

Hauteur entre les jambes de derriere. . . . 550

Circouference du corps derriève les jambes

de derant. . . . . . . . . . 1000

Circonférence devant les jambes de derrière. $8 \quad 4 \quad 6$

Longueur de la tète, depuis le bout dı museau jusque derrière les èminences qui sont entre les cornes et les oreilles. . . . . . . .

Distance entre le bout du museau el le milieu des уеиx. . . . . . . . . . . . . .
Longueur des reux. . . . . . . . . . p. p. 1.

Longueur de la prunelle dans sa plus grande dimension.................. 0030

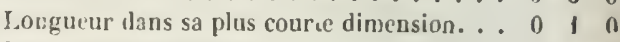
Longuenr les cornes. . . . . . . . . 0 т 0 Circonference des cornes á leur base. . . . 0 11 0 Circonférence des corues près lu sommet. . 0 i Dislauce entre les bases des cornes. . . . . . $0 \begin{array}{lll}0 & 2 & 0\end{array}$

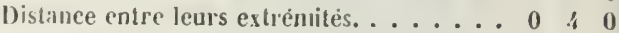

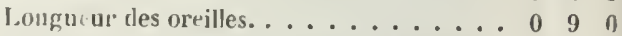
Circonférence des oreilles prés de leur base. . $\begin{array}{llll}0 & 11 & 0\end{array}$

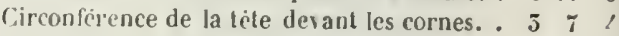
Circonfirence derriere les dents incisives. . . 1880 '.ongueur du con. ........... 5116 Circonfrence du con près de la tète. . . . . 2066

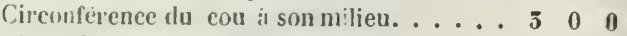
Circunference pres des èpaules. . . . . . . 5550

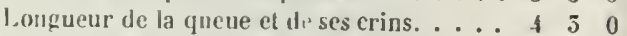
Longucur de la poitrine en ligne droite. . . 1 i 0 Longueur de la partie posterieure dı corps. 2 Longueur de l: jambe de devant, de; $c_{i}$ la plaste du jie 1 jusqua au cunde. . . . . . 52 z

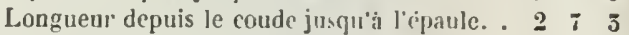

Circonférence de la jambe de derant, à l'endroit oủ elle est le pl::s mince. . . . . . 120 Circonférence à son milieu au-dessus du coude $\quad \begin{array}{llll}10 & 0\end{array}$

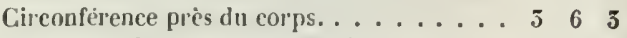
Longuenr des jambes de derrière, depuis la plante des pieus jusqu'an genou ...... $210 \quad 3$

Lorgueur depuis le genon jusquau hout du fènur..................... 2115 Circonference de la jambe de derrière á l’endroit le plus mince. ........... 116 Circonférence ì son milieu au-dessus du genou.................. 2 00 Circonfërence près du corps. . . . . . ; 00

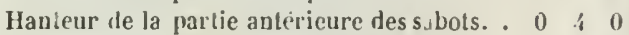
Hauteur de leur partie postérieure. . . . . . 0010 Longueur de la plante du pied de derant. . . $\quad 0 \quad 0 \quad 9 \quad 0$ Sa largeur. . . . . . . . . . . 006 Longueur de la plante du pied de derriere. . $0 \begin{array}{lll}0 & 8 & 0\end{array}$ Sa largeur................... 0 ( 55

\section{L'ÉLAN et LE RENNE.}

Ordre des ruminants, seclion des ruminauts a cornes . genre cerf. (Curier.)

Quoique l'élan et le renne soient deux animaux d'espèces différentes, nous arons cru devoir les réunir, paree qu il u'est guẻre possible de faire l'histoire de l'un, sans eniprunter beaucoup le celle de lautre; la plupart des aneiens auteurs, et méme des modernes, les ayant confoudus ou désignés par des dénominations équivoques quon pourrait appliq̣uerà toas deux. Les Grees ue connaissaient ni l'élan, nile remne; 


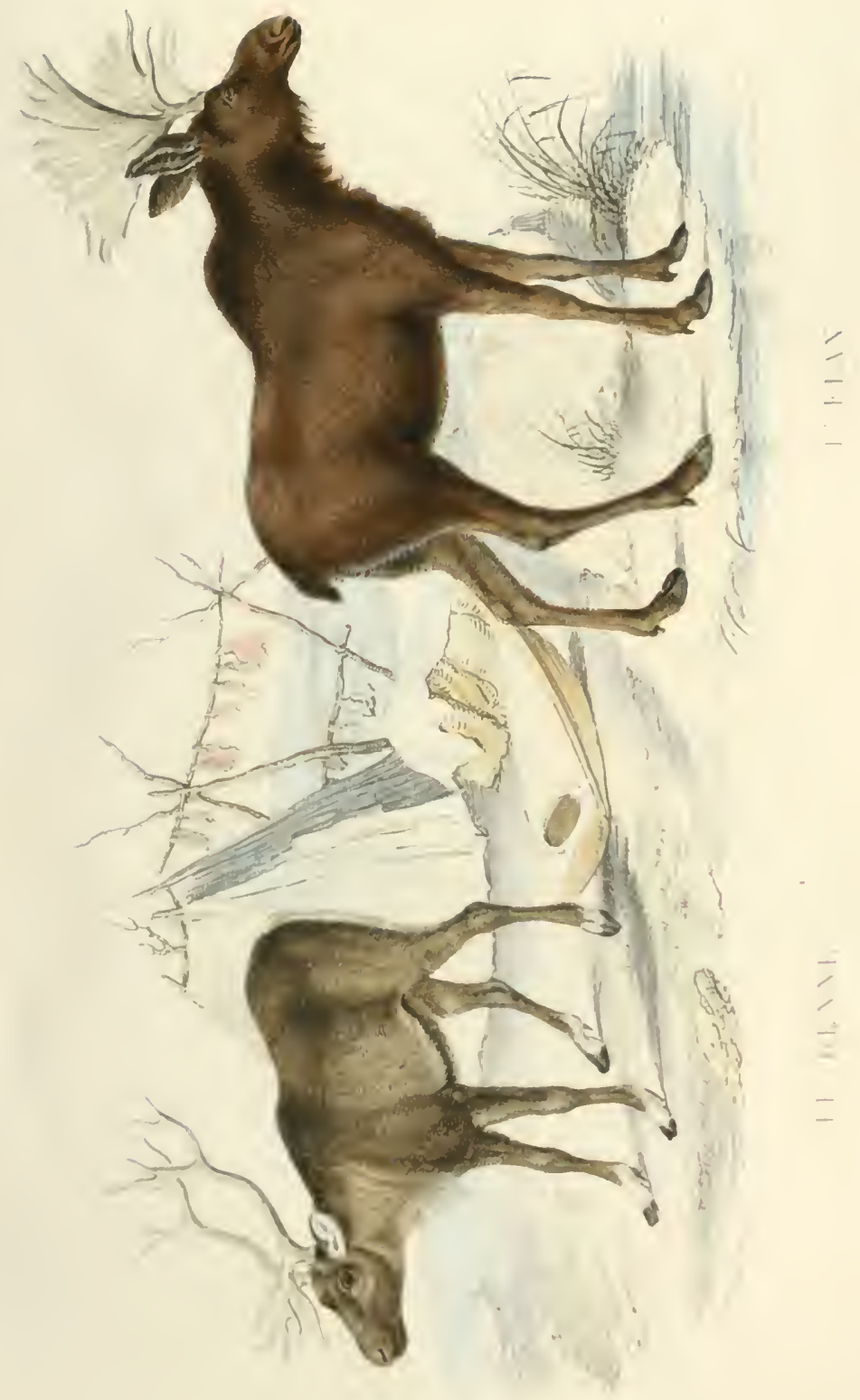



Arlstote n'en fait aucune mention : et chez les Latins, Jules César est le premier qui ait employé le nom alce. Pausanias, qui a écrit environ cent ans après Jules César, est aussi le premier auteur gree dans lequel on trouve ce méme nom ג̇hxì่; ; et Pline, qui était à peu près contemporain de Pausanias, a indiqué assez obscurément l'élan et le renne sous les noms alce, machlis et tarandus. On ne peut done pas dire que le nom alee soit proprement gree ou latin, et il parait avoir été tiré de la langue celtique, daus laquelle l'élan se nommait elch ou elk. Le nom latin du renne est encore plus incertain que celui de l'élan; plusicurs naturalistes ont pensé que c'était le muchlis de Pline, paree yue eet allterr, en parlant des animaux du nord, cite eu mème temps l'alce et le machlis, et qu'il dit de ce dernier yu'il est particulier à la Seandinavie, et gu'on ne l'a jamais vu à Rome, ni même dans toute l'ét(rndue de l'empire romain : cependant on trouve eneore dans les Commentaires de César un passage qu'on ne peut guère applifuer it un autre animal qu'au renne, et (pui semble prouver yu'il existait alors dans les forêts de la Germanie; et quinze siècles après Jules César, Gaston Phabus semble parler du renne sous le nom de rangier, comme d'un animal qui aurait existé de son temps dans nos forits de France; il en fait mème une assez bonne deseription, et il domne la manière de le prendre et de le ehasser. Comme sa deseription ne peut pas s'appliquer ì l'élan, et qu’il donne en mème temps la maniere de ehasser le ecrf, le laim, le cheveruil, le boupuetin, la chamois, ete., on ne peut pas dire que, dans l'article du rangier, il ait voulu parler d'aucun de ces animaux, ni yu'il se soit trompé dans l'application du nom. Il semblenit done, pat ese témoignages positifs, ryu'il existait jadis en France des rennes, du moins dans les lautes montagnes, telles que les l’yrénées, dout Gruston Plrebus était voisin, comme scigncur ct habitant du conté de Foix; et que, depuis ce temps, ils ont été détruits commo les eerfs, qui autrefois étitient communs dans eette contrée, et qui cependant n'existent plus aujourd'hui dans le Bigorre, le Couscrans, ni dans les provinees adjacentes. I1 est certain yue le renne ne se trouve actucllement que dans les pays le plus septentrionaux; mais l'on sait aussi que le climat de la france était autrefois heaucoup plus humide et plus froid par la quantité desbois et des mamais, yu il IV. ne l'est aujourd'hui. On voit par la lettre de l'empereur Julien, quelle était de son temps la rigueur du froid à Paris : la description qüil donne des glaces de la Seine ressemble parfaitement à celle que nos Canadiens font de celles du fleuve de Quebee. Les Gaules, sous la même latitude que le Canada, étajent, il y a deux mille ans, ce que le Canada est de nos jours, c'est-ìdire un climat assez froid pour nourrir les animaux qu'on ne trouve aujourd'hui que dans les provinees du Nord.

En comparant Jes témojgnages, et combinant les indications que je viens de eiter, il me parait done qu'il existait autrefois dans les forets des Gaules et de la Germanie, des ćlans et des rennes, et que les passages de César ne peuvent s'appliquer qu'a ces deux animaux. A mesure que l'on a défriché les terres et dessíché les eaux, la température du elimat sera devenue plus donce, et ces mèmes animaux, чpui u’aiment que le froid, auront d'abord abandonné le plat pays, et se seront retirés dans la ricrion des neiges, sur les hautes montagnes, ou ils subsistaient encore du temps de Gaston de Foix ; et s'il ne s'y en trouve plus aujourd'hui, e'est que cette mème température a toujours été en augmentant de chaleur par la destruction presque entière des forèts, par l'abaissement sueeessif des montagnes, par la diminution des eaux, par la multiplication des hommes, et par la suceession de leurs travaux et de l'augmentation de leur consommation en tout genre. Il me parait de mème que Pline a emprunté de Jules César presque tout ee qu'il a écrit de ces deux animaux, et qu'il est le premicr auteur de la confusion des noms; il eite en mime temps l'alce et le machlis, et naturellement on devrait eu eonchure que ces deux noms désignent deux animaux différents; cependant, si l'on remarque, $1^{\circ}$ (qu'il nomme simplement l'alce, saus autre indication ni description. quil ne le nomme. qu'une fois, et (que mulle part il n'en dit un mot de plus; 20 que lui seul a éerit le nom machlis, et quaucun autre auteur latin on gree n a employé ce mot, qui meme pirrait factice, ct qui, selon les conmentateurs de Pline, est remplace par celui d'alce dans plusieurs aneiens manuscrits; 30 yüil attribue au machlis tont de que. Jules Císidu dit de l'alce; on ne pomra douter que le passige de Pline ue soit erorompu, et que ces deux noms ne designent le meme animal, éest-il-dire l'eilan. Cette question une fois dér- 
dée, en déciderait une autre; le machlis étant l'élan, le tarandlus sera le renne: ce nom tarandus est encore un mot qui ne se troure dans aucun auteur avant Pline, et sur l'interprétation duquel les naturalistes ont beaueoup varié ; cependant Agricola et Éliot n'ont pas hésité de l'appliquer au renne, et par les raisons que nous venons de déduire nous souscrivons à leuravis. Au reste, on ne doit pas être surpris du silence des Grees au sujet de ces deux animaux, ni de lincertitude avec laquelle les Latins en ont parlé, puisque les elimats septentrionaux étaient absolument inconnus aux premiers, et n'étaient connus des seconds que par relation.

Or l'élan et le renne ne se trouvent tous deux que dans les pays du Nord; l'élan en deçà et le renne au delà du cercle polaire en Europe et en Asie : on les retrouve en Amérique à de moindres latitudes, parce que le froid y est plus grand qu'en Europe; le renne n'en craint pas la rigueur, même la plus excessive; on en voit au Spitzberg : il est commun en Groënland et dans la Laponie la plus boréale, ainsi que dans les parties les plus septentrionales de l'Asie. L'élan ne s'approche pas si près du pôle; il habite en Norwége, en Suède, en Pologne, en Lithuanie, en Russie, et dans hes provinees de la Sibérie et de la Tartarie, jusqu'au nord de la Chine. On le retrouve sous le nom d'orignal, et le renne sous celui de caribou, en Canada et dans toute la partie septentrionale de l'Amérique. Les naturalistes qui ont douté que l'orignal fût l'élan, et le caribou le renne, n’avaient pas assez comparé la nature avee les témoignages des voyageurs : ce sont certainement les mèmes animaux, qui, comme tous les autres dans ce nouveau monde, sont seulement plus petits que dans l'ancien eontinent.

On peut preudre des idées assez justes de la forme de l'élan et de celle du renne, en les conparant tous deur avec le eerf. L'élan est plus grand, plus gros, plus élevé sur ses jambes; il a le cou plus court, le poil plus long, le bois beaucoup plus large et plus massif que le cerf : le renne est plus bas, plus trapu; il a les jambes plus courtes, plus grosses, et les pieds bien plus larges; le poil très-fourni, le bois beaucoup plus long et divisé en un grand nombre de rameaux ',

- Il y a heaucoup de rennes qui ont deux corues, qui vont en arrière, comme les ont ordinairement les cerfs; il sort de ces deux cornes une brauche au nilieu plus petite, mais partafée aussi bien que le bois d'up cerl en plusieurs andoui]. terminés par des empaumures : au lieu que ce. lui de l'élan n'est, pour ainsi dire, que découpé et ehevillé sur la tranche. Tous deux ont de longs poils sous le cou, et tous deux ont la queue courte et les oreilles beaucoup plus longues que le cerf. Ils ne vont pas par bonds et par sauts comme le chevreuil ou le cerf; leur marche est une espèce de trot, mais si prompt et si aisé, qu'ils font dans le même temps presque autant de chemin qu'eux, sans se fatiguer autant; car ils peurent trotter ainsi, sans s'arrêter, pendant un jour ou deux. Le renne se tient sur les montagnes; l'élan n'habite que les terres basses et les forêts humides. Tous deux se mettent en troupes, comme le cerf, et vont de compagnie; tous deux peurent s'apprivoiser, mais le renne beaucoup plus que l'élan; celui-ci, comme le cerf, n'a nulle part perdu sa liberté, au lieu que le renne est devenu domestique chez le dernier des peuples; les Lapons n'ont pas d'autre bétail. Dans ce climat glacé, qui ne reçoit du soleil que des rayons obliques, où la nuit a sa saison comme le jour, où la neige couvre la terre dès le commençement de l'automne jusqu'à la fin du printemps, où la ronce, le genievre et la mousse, font seuls la verdure de l'été, l'homme pouvait-il espérer de nourrir des troupeaux? Le eheval, le bœuf, la brebis, tous nos autres animaux utiles, ne pouvant y trouver leur subsistance, ni résister à la rigueur du froid, il a fallu chereher, parmi les hòtes des forêts, l'espèce la moius sauvage et la plus profitable : les Lapons ont fait ce que nous ferions nous-mêmes, si nous venions à perdre notre bétail : il faudrait bien alors, pour y sup-

lers, qui est tournée sur le devant, el qui, à cause de celte situation el de cette figure, peut passer pour une troisieme corne, quoiqu'i] arrive encore plus fréqumment que chacune des grandes cornes pousse de soi une telle branclse; qu'ainsi elle a une autre petite come avancée vers le front, et que de celte manière il parait uon plıs truis cornes, mais yuatre, denx en arrière comıne au cerf, el deux en devaut, ce qui est particulier au renne... On a aussi yuelı̨ucfois Irouvé ype les corues des renues étaient ainsi disposées : deux courbes en arrière, deux plus petiti's montantes en haut, et deux encore moindres tournées en devant, ayant toutes lenrs andouillers. le tout n'ayant cependant qu'une seule racine, celles qui avantcent sur le front. aussi bieu que celles qui s"élèvent eu haut, n'étant. à proprenıent parler, que les rejetons des grandes cornes yue le renne porte courbées en arrière comme les cerfs. All reste, cela n'est pas furt ordiuaire. on voitplus freymemnent des remaes yni ont trois cornes, el le nombre de ceux qui en out quatre, comme nous l'avous expliqué, est encore plus grand: tout ceci doit s'entendre des mảles qui les onl grandes. larges et avec beaucoup de branches : car les femelles les ont plus petites, el elles n'y ont pas taut de rameaux. Histoire de la Laponie, par J. Scheffer. Paris, 1678, page 306 . 
pléer, apprivoiser les cerfs, les chevreuils de nos bois, et les rendre animaux domesticjues; etje suis persuadé qu'on eı viendıait à bout, et qu'on saurait bientòt en tirer autant d'utilité que les Lapons en tirent de leurs rennes. Nous devons sentir par cret exemple, justju'où s'étend pour nous la libéralité de la nature; nous n'usons pas a beaucoup près de toutes les richesses qu'elle nous offre, le fonds en est bien plus inmense que nous ne l'imarginons : elle nous a donné le cheval, le houf, la biebis, tous nos autres animaux domesti(pues, pour nous selvir, nous nourrir, nous vitir; et elle a encore des espèces de réserve, (qui pourraient suppléer à leur défaut, et (qu'il ne tiendrait (ju'à nous d'assujettir et de faire servir à nos besoins. L'homme ne sait pas asse\% ce que peut la mature, ni ce qu'il peut sur elle : au lieu de la rechercher dans ee (ju'il ue commait pas, il aime mieux en abuser dins tout ce (qu'il en connait.

En comparant les avantages que les Iapons tirent du renne apprivoisé avec ceux que nous retirous de nos animaux domesti(jues, on verra (que cet animal en vaut seul deux ou trois. On s'en sert comme du eheval, pour tirer des traîneaux, des voitures; il marche avee bien plus de diligrence et de légèıeté, fait aisément trente licues par jour, et court avec autant d'assurance sur la neige gelée que sur une pelouse. La femelle domme du lait plus substantiel et plus nourrissant que celui de la varelie; la chair de ect animal est trè-bonne à manerer; son poil fait une excellente fourrure, et la peau passée devient un cuir très-souple et trés-durable; ainsi le remne donne seul tout ee que nous tirons du cheval, du bouf et de la brebis.

La manièe dont les Ialpons élèvent et conduisent ces animaux mérite une attention particulière. Olaüs, Seheffer, Regnard, nous ont donné sur cela des dítails intéressants, que nous eroyous devoir présenter ici par extrait, en réformant ou supprimant les fitits sur lesquels ils se sont trompés. Le bois du reme, heaucoup plus grand, plus étendu, et divisós en un bien plus grand nombre de rameaux que evlui du cerf, discut ces anteurs, est une espèe de singularité admirable et monstrueuse. La nourriture de cet amimal, pendant l'liver, est une moussc blanche ru'il sait trourer sous les nelges épaisses en les fouillant aree son bois, et Jes détournant avec ses pieds; en été, il vit de boutons et de feuilles d'arbres, plutòt que dherbes, que les rameaux de son bois, avanrés en asant, ne lui primettent pas de brouter aisément. Il court sur lá neige et enfonce peu à eause de la largeur de ses pieds..... Ces animaux sont doux; on en fait des troupeaux qui rapportent beaucoup de profit a leur maitre. Le lait, la peau, les nofís, les os, les cornes des pieds, les hois, le poil, la chair, tout en est bor et utile. I.es plus richo's lapons ont des troupeaux de quatre ou eincl ecuts remes, les pauvies en ont dix ou doure : on les mene au páturage, on les ranene a l'etalile ou bien on les enferme dans des pares penclant la muit pour les mettre à l'abri de l'unsulte des loups. I.orsqu'on leur fait changer de climat, ils meurent en peu de temps. Autrefois Stenon, prince de Suede, eu euroya six à Frédérie, duc de llulstein; et moins anciennement, en 1 s33, Gustave, roi de Suede, en fit passer dix en Prusse, máles et femelles, cu'on lâclua daus les bois : tous périrent sans avoir produit, ni dans l'état de domesticité, ni dans celui de liberté. a J'aurais "bien voulu, dit M. Regnard, nener en France "quelques rennes en vie; plusieurs gens l'ont - tenté inutilement, et l'on en conduisit l'année - passée trois ou (quatre à Dantzich, où ils mou" rurent, ne pouvant s'acconmoder à ce cli" mat, (jui est trop elıaud pour cux. "

Il y a en laponie des rennes sauvages et des rennes domestiques. Dans le temps de la chaleur, on laclae les femelles daus les bois, on les laisse recherch (I les mâles sauvages; et conme ees rennes sauvages sont plus robustes et plus forts que les domestiques, on prefere ceux gui sont issus de ce melange pour les atteler au tralneau. Ces rennes sont moins doux que les autres; car nou-seulement ils refusent quelquefois d'obéir à celui qui lés guide, nais ils se retourment brus(juement eontre lui, l'attaquent à coups de pieds, en sorte qu'il n'a d'autre ressouree que de se couvrir de son traimeau, jusquà é que la colère de sa béte soit apaiséc. Au reste eutte voiture est si lérère, quion la manie et la retourne aisément sur soi; clle est garnie par-dessous de puax de jeunes rennes, le poil tourne contre la nège et couché en arriere, pour pue le traineau glisse plus facilement en avant ot recule moins disénent dans la montagne. Le renne attele n'a peur collier qu'un morceau de peau oú le poil est resté, 
d'où descend vers le poitrail un trait qui lui passe sous le ventre, entre les jambes, et va s'attacher à un trou qui est sur le devant du traineau. Le Lapon n'a pour gruides qu'une scule corde, attachée à la racine du bois de l'animal, qu'il jette diversement sur le dos de la bête, tantôt d'un côté et tantòt de l'autre, selen qu'il veut la diriger a droite ou à gauche. Elle peut farre quatre ou cing liemes par heure; mais plus cette manière de voyager est prompte, plus elle est incommode; il faut y ètre habituć, et travailler continuellement pour maintenir son traineau et l'empêcher de verser.

Les r'ennes ont à l'extérieur beaucoup de choses communes avec les cerfs, et la confol'mation des parties intérieures est pour ainsi dire la même. De eette eonformité de nature résultent des habitudes analogues et des effets semblables. Le renne jette son bois tous les ans, comme le cerf, et se clarge comme lui de venaison : il est en rut dans la même saison, e'est-à-dire vers la fin de septembre. I.es femelles, dans l'une et dans l'autre espèce, portent huit mois, et ne produisent (qu'un petit : les máles ont de même une très-mauvaise odeur dans ce temps de chaleur ; et parmi les femelles, comme parmi les biches, il s'en trouve quelques-unes qui ne produisent pas. Les jeunes rennes ont aussi, comme les faons dans le premier îge, le poil d'une couleur variée : il est d'abord d'un roux mêlé de jaume, et devient avec l'âge d'un brun presque noir. Chaque petit suit sá mère perdant deux ou trois ans, et ce n'est qu'à l’âge de quatre ans révolus que ees animaux ont aequis Jeur plein aceroissement. C'est aussi à cet âge qu'on commence à les dresser et les exercer au travail : pour les rendre plus souples, on leur fait subir d'avance la castration, et e'est avec les dents que les Lapons font eette opération. Les rennes entier's sont fiers et trop difticiles à manier : on ne se sert done que des hongres, parmi lesquels on choisit lesplus vifs et les plus légers pour courir au traineau, et les plus pesants pour voiturer à pas plus lents les provisions et les bagages. On ne garde qu'un mâle entier pour eing ou six femelles, et e'est à l'âge d'un an que se fait la castration. Ils sont eneore, comme les cerfs, sujets aux vers dans la mauvaise saison; il s'en engendre sul la fin de l'hivirune si grandequantité sous leur peau, qu'elle en est alors toute cribléc : ces trous de vers se referment en été, et aussi ce n'est qu'en automne que l'on tue les rennes pour en avoir la fourrure ou le euir.

Les troupeaux de cette espèce demandent beaucoup de soin : les rennes sont sujets à s'éearter, et reprennent volontiers leur liberté naturelle; il faut les suivre et les veiller de près; on ne peut les mener paître que dans des lieux dćcouverts, et pour peu que le troupeau soit nombreux on a besoin de plusieurs personnes pour les garder, pour les contenir, pour les rappeler, pour courir après ceux qui s'éloignent. Ils sont tous marqués, afin qu'on puisse les reeonnaitre : ear il arrive souvent, ou qu'ils s'égarent dans les bois, ou qu'ils passent à un autre troupeau. Enfin les Lapons sont continuellement occupés à ces soins; les rennes sont toutes leurs richesses, et ils savent en tirer toutes les commodités, ou, pour mieux dire, les nécessités de la vie : ils se couvrent depuis les pieds jusqu'à la tête de ces fourrures, qui sont impénétrables au froid et à l'eau : e'est leur habit d'hiver; l'été ils se servent des peaux dont le poil est tombé ; ils savent aussi filer ce poil; ils en recouvrent les nerfs (qu'ils tirent du corps de lanimal, et qui leur servent de cordes et de fil; ils en mangent la chair, en boivent le lait, et en font des fromages très-gras. Ce lait, épuré et battu, donne au lieu de beurre une espèce de suif. Cette particularité, aussi bien quela grande étendue du bois dans cet animal, et l'abondante venaison dont il est chargé daus le temps du rut, sont autant d'indices de la surabondanee de nourriture; et ce qui prouve encore que cette surabondance est excessive, ou du moins plus grande que daus aucune espèce, e'est que le remne est le seul dont la femelle ait un bois comme le mâle, et le seul encore dont le bois tombe et se renouvelle malgré la castration; car, dans les cerfs, les daims et les chevreuils qui out subi cette opération, la tète de l'animal reste toujours dans le mène état où elle était au moment de la castration. Ainsi le renne est de tous les animaux celui où le superflu de la matière nutritive est le plus apparent, et cela tientpeut-ètre moins à la nature de l'animal qu’à lá qualité de la nourriture; car cette mousse blanche qui fait surtout pendant l'hiver son unique alinent, est un lichen dont la substauce, semblable à eelle de la morille ou de la barbe de chève, est très-nourrissante et beaucoup plus chargée de moléeules organiques que les 
herbes, les feuilles ou les boutons des arbres: et e'est par cette raison que le renne a plus de bois et plus de venaison que le cerf, ct que les femelles et les hongres n'en sont pas dépourvus. C'est encore de là que vient la grande variété qui se trouve daus la grandeur, dans la figure et dans le nombre des andouiller's et dles rameaux du bois des rennes : les màles qui n'ont été ni chassés ni contruints, et qui se nourrissent largement et à souhait de eet aliment substantiel, ont.un bois prodigieux; il s'étend en arriere presque sur leur croupe, ct en avant au delá du museau : eelui des longres est moindre, quoique souvent il soit encore plus grand que le bois de nos cerfs; enfin celui que portent les femelles est encore plus petit. Ainsi ces bois varient, non-seulement comme les autres par l'âge, mais encore par le sexe et par la mutilation des màles : ees bois sont done si différents les uns des autres, qu'il n'est pas surprenaut que les auteurs qui ont voulu les decrire, soient si peu d'accord entre eux.

Une autre singularité que nous ne devons pas omettre, et qui est commune au renne et à l'élan, e'est que quand ees animaux courent ou seulement précipitent leurs pas, les cornes de leurs pieds font à chaque mouvement un bruit de eraquement si fort, qu'il semble que toutes les jointures des jambes se déboîtent: les loups, avertis par ce bruit ou par l'orleur de la bete, courent au devant, la saisissent et en viennent à bout, s'ils sont en nombre; car le remue se defend d'un loup seul : cus'est point avee son bois, lequel en tout lui muit plus quil ne lui sert, c'est avee les pieds de devant, qu'il a tries-forts : il en finpe le loup avee assez de violence pour l'étourdir ou l'écarter, et fuit ensuite avec assez de vitesse pour u'ètre plus atteint. Un ennemi plus dangereux pour lui, quoirue moins fré(juent et moins nombreux, e'est le rosomack ou gloulon: cet aumal, encore plus vorace, mais plus lourd yue le loup, ne poursuit pas le reme; il grimpe et se eache sur un arbre pour l'attendre au passage : des qu'il le voit a portee, il se lance dessus, s'attache sur son dos en y enfonģant les ongles, et lui entamant la tète ou le cou ave les dents, ne l'abandonne pas qu'il ne !nit égorgé. Il fait la mème guerre et enploie les mènes ruses contre l'ilin, yui est encore plus puissant et plus fort que le reme. Ce rosomack.ou glouton du nord est le mene animal que le carcajou ou quincajou de l'Amérique septentrionale : ses combats avec l'orjgnal sont fameux; et, comme nous l'avons dit, l'orignal du Canada est le même que l'élan d'Europe. Il est singulier que cet animal, qui n'est guère plus gros qu'un blaireau, vienne à bout d'un élan, dont la taille excède celle d'un grand cheval, et dont la force est telle, que d'un seul coup de pied il peut tuer un loup; mais le fait est attesté par taut de témoins, que l’on ne peut en douter.

L'élan et le renue sont tous deux du nombre des animaux ruminants; leur maniere de se nourrir l'indique, et l'iuspection des parties intérieures le démontre: épendant Tornæus Scheffer, Regnard, Hulden et plusieurs autres, ont écrit yue le renne ne ruminait pas: Ray a eu raison de dire que cela lui patraissait incroyable, et en effet le remne rumine comme le eerf et comme tous les autres animaux qui ont plusieurs estomars. La durée de la vie daus le renne domestique u'est que de quinze ou seize ans; mais il est a présumer que dans le renne sauvage elle est plus longue; cet animal étant quatre ans à croitre, doit vivre vingt-huit ou trente ans lorsqu'il est dans son état de nature. Les Lapons chassent les remmes sauvages de différentes facons, suivant les différentes saisons : ils se servent des femelles domestiques pour attirer les mâles sauvages dans le temps du rut'; ils les tuent à coups de mousquet, ou les tirent avec l'are, et décochent leurs fleches avec taut de raideur, que, malgré la prodigricuse épaisseur du poil et la fermeté du enir, il nen faut souvent qu'une pour tuer la bete.

thes Lapous cliassent les reumes avec des lilets, des halle.

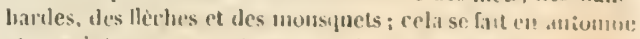

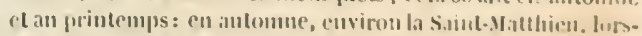
yue les remurs sont enu rut, los latpons se transpurtent anx endroils des forits on ils savent guil y il des remues mailes samvages; ils y mettent des renure femolle's deme'stepurs et ils les alt.ıchent à lles arbres : cetle fenclle appelle le tuide : ot lersyüil est sur le point ile la couvrir, le chassenr la tue anu

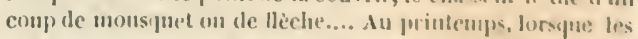

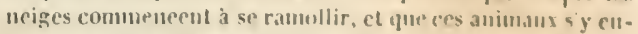
foncent et sy embarrasoput, les I.apons, chankds te leurs ra-

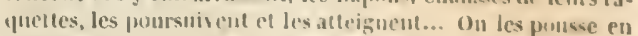
d'autres rencontres avec des chirns, yui les font donner dans les lilets: 11 se sert enliu diune sorto de rets, qui sumt des perclues entrulacés les tues daus les antre's, en forme de deux

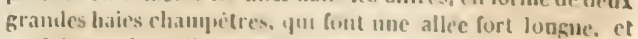
parfois de deux lienes, alin yue les remmes étant une fors poussés el cugagés dedaus, smeut eubu coutrants en fuyant le lonulier dans une grande fuse lante expres an bout di l vis rage. Scheiter, page 209. 
Nous avons recueilli les faits de l'histoire du remne avec d'autant plus de soin, et nous les avons préseutés avec d'autant plus de circonspection, que nous ne pouvions pas par nousmême nous assurer de tous, et qu'il n'est pas possible d'avoir ici cet animal vivant. Ayant témoigné mes regrets à cet égard à quelques-uns de mes amis, M. Collinson, membre de la Société royale de Londres, homme aussi recommandable par ses vertus que par son mérite littéraire, et avec lequel je suis lié d'amitié depuis plus de vingt ans, a eu la bonté de m'envoyer un dessin du squelette du renne, et j'ai reçu du Canada un foctus de Caribou ; au moyen de ces deux pièces et de plusieurs bois de rennes qui nous sont venus de différents endroits, nous avons été en état de vérifier les ressemblances générales et les différences principales du renne avec le cerf, comme on le verra dans la description des foetus, du squelette et des bois de cet animal.

A l'égard de l'élan, j'en ai vu un vivant, il y a environ quinze ans, que je voulus faire dessiner : mais comme il resta peu de jours à Paris, on n'eut pas le temps d'achever le dessin, et je n'eus moi-même que celui de vérifier la description que MM. del'Académie des Sciences ont autrefois donnée de ce mème animal, et de m'assurer qu'elle est exacte et très-couforme à la nature.

"L'élan (dit le rédacteur de ces Mémoires " de l'Académic) est remarquable par la lon" gueur du poil, la grandeur des oreilles, la pe" titesse de la queue et la forme de l'œil, dont " le grand angle est beaucoup fendu, de mème " quela gueule, quil'est bien plus qu'aux bœufs, " qu'aux cerfs, et qu'aux autres animaux qui " ont le pied fourché... L'élan que nous avons " disséqué était à peu près de la grandeur d'un " cerf; la longueur de son corps était de cinq " pieds et demi, depuis le bout du museau jus" qu'au commencement de la queue, qui n'était " longue que de deux pouces; sa tête n'avait " point de bois, parce que c'était une femelle; " et le cou était court, n'ayant que neuf pouces " de long et autant de large ; les oreilles avaient " neuf pouces de long sur quatre de large..... " La couleur du poil n'était pas fort éloignée de a celle du poil de l'âne, dont le gris approche " quelquefois de celui du chameau..... Mais ce " poil était d'ailleurs fort différent de celui de " l'âne, qui est beaucoup plus court, et de ce-
" lui du chamcau, qui l’a beaucoup plus délié; " la lougueur de ce poil était de trois pouces, et " sa grosseur égalait celle du gros crin du che" val : cette grosseur allait toujours en dimi" nuant vers l'extrémité, qui était fort pointue, " et vers la racine elle diminuait aussi, mais tout " à coup, faisant comme la poignée d'une lance: " cette poignée était d'une autre couleur que " le reste du poil, étant blanche et diapliane " comme de la soie de pourceau... Ce poil était "long comme à l'ours, mais plus droit, pluseourt " et plus couché, et tout d'une mème espèce; la "lèvre supérieure était grande et détachée des " genci es, mais non pas si grande que Solin l'a " décrite, et que Pline l'a faite à l'animal qu'il " appelle machlis. Ces auteurs disent que cette " bête est contrainte de paitre à reculons, afin " d'empêcher que sa lèvre ne s'engage eutre ses " dents. Nous a vons observé, dans la dissection, " que la nature a autrement pourvuà cet ineon" vénient par la grandeur et la force des mus" cles, qui sont particulièrementdestinés à élever " cettelèvre supérieure. Nous a vonsaussi trouvé " les articulations de la jambe fort serrées par " des ligaments, dont.la dureté et l'épaisseur " peut avoir donné lieu à l'opinion qu'on a eue " que l'alce ne peut se relever quand il est une " fois tombé.... Ses pieds étaient semblables à " ceux du cerf, mais beaucoup plus gros, et n'a" vaient d'ailleurs rien d'extraordinaire........ “ Nous avons observé que le grand coin de l'œil " était fendu en en-bas, beaucoup plus (qu'il " ne l'est aux cerfs, aux daims et aux chevreuils, " mais d'une façon particulière, qui est que cette " fente n'était pas selon la direction de l'ouver" ture de l'œil, mais faisait un angle avec la li" gne qui va d'un des coins de l'oil à l'autre; la " glande lacrymale inférieure avait un pouce et " demi de long sur sept lignes de large....... "Nous a vons trouvé dans le cerveau une partie " dont la grandeur avait aussi rapport avee l'o" dorat, qui est plus exquis dans l'élan que dans " aucun autre animal, suivant le témoignage de "Pausanias; car les nerfs olfactifs, appelés " communément les apophyses mamillaires, - étaicnt sans comparaison plus grands qu'en " aucun autre animal que nous ayons disséqué, " ayant plus de quatre lignes de diamètre.... "Pour ce qui est du morceau de chair que quel"ques auteurs lui mettent sur le dos, et les au" tres sous le menton, on peut dire que s'ils ne " se sont point trompés ou n'ont point été trop 
a crédules, ces choses étaient particulières aux " élans dont ils parjent. " Nous pouvons, à cet égard, ajouter notre propre témoignage à celui de MM. de l'Académie: dans l'élan que nous avons vu vivant, et qui était femelle, nous n'avons pas remarqué qu'il y eût une loupe sous le menton, ni sur la gorge : cependant M. Linnæus, qui doit connaître les élans mieux que nous, puisqu'il habite leur pays, fait mention de cette loupe sur la gorge, et la domne mène commre un earactère essentiel à l'élan: Alces, cermus cornibus, a caulibus palmatis, caruncula gulturali. Syst. nat., édit. X, pag. 66 . II n'y a d'autre moyen de concilier cette assertion de M. Limmæus avec notre négation, qu'en supposant cette loupe ou caroncule gullurale à l'élan mâle, que nous n'avons pas.vu ; et, si cela est, cet auteur n'aurait pas dû en faire un caractère essentiel à l'espèce, puisque la femelle ne l'a pas. Peut-être aussi cette caroncule est-elle une maladie commune parmi les élans, une espèce de goitre : ear dans les deux figures que Gressner donne de cet animal, la premiere, qui n'a point de bois, porte une grosse caroncule sous le cou; et à la seconde, qui représente un élan mâle avec son bois, il n'y a point de caroncule.

En général l'élan est un animal beaucoup plus grand et bien plus fort que le cerf et le renne "; il a le poil si rude et le cuir si dur, que la balle du mousquet peut à peine y pénétrer; il a les jambes très-fermes, avec tant de mouvement et deforce, surtout dans les pieds de devant, que d'un seul coup il peut tuer un homme, un loup, et même casser un arbre. Cependant on le chasse à peu près comme nous chassons le cerf, c'està dire à force d'hommes et de chiens : on assure que lorsqu'il est lancé ou poursuivi, il lui

- L'élansurpasse le renne de beaucoup en grandeur, élant égal aux pluıs grands clıevaux; l’élan, outre cela, a les cornes lien plus courles, el larges de deux paumes de main, les"fuelles ont aux côtés et par-devaut des andonillers en asse petil noubre; il n'a pas les pieds ronds, surlout cenx de devant, mais longs, dont il se bat rudement; il en perce les hommes et les chiens. II ne ressemble pas mienxan renne par la lẻle, quil a plus longne avec de gramles el grosses lères qui lui pendent. Sa couleur n'est pas si blauclie que celle du renne, mis elle tire egillenent par tent son corps sur un jame trìs-obscmr, mỏlé avec un grís cendré; et puls yuaud il marche, on nentenul pas te fruit des jointures to ses jambes, conune il arrive a lous les remes; enfiu quicompue a bien consiıléré l'un el l'antre aninal (ce yui mo'st plusicurs fois arrivé) y a remarıné taut le lifférences, ipn'il y a sujet de s't. tonner de ce yüil se tromve des personnes qui les premuent pour le inène. Schelfer, page 310. arrive souvent de tomber tout a coup ${ }^{1}$, sans a voir été ni tiré, ni blessé; de là on a présumé qu'il était sujet à l'épilepsie, et de cette présom. ption (qui n'est pas bien fondée, puisque la peur seule pourrait produire le mème effet) on a tiré cette consérquence absurde, que la corne de ses pieds devait guérir de l'épilepsie, et mème en préserver ; et ce préjugé grossicr a été si géuéralement répandu, qu'on voit encore aujourd'luui quantité de gens du peuple porter des bagues dont le chaton renferme un pelit morceau de corne d'élan.

Comme il y a très-peu d'honımes dans les parties septentrionales de l'Amérique, tous les animaux, et en particulier les élans, y sont (un plus grand nombre que dans le nord de l'Europe. I.es sauvages n'ignorent pas l'art de les cluasser et de les prendre; ils les suivent à la piste, quelquefois peudant plusieurs jours de suite, et à foree de constance et d'adresse, ils en viennent à bout. La chasse en hiver est surtout singulière. "On se sert, dit Denys, de ra"quettes, par le moyen desquelles on marche " sur la neige sans enfoncer... L'orignal ne fait " pas grand chemin, parce qu'il enfonce dams la a neige, ce qui le fatigue beaucoup ì cheminer; " il ne mange que le jet du bois de l'année: là " où les sauvages trouvaient le bois mangé , " ils rencontraient bientôt les bêtes qui n'c-n " étaient pas loin, et les approchaient facile. " ment, ne pouvant aller vite; ils leur lan-

- La clıasse ayant été préparéc le jour de devant, nons ne fômes pas à plus liuue portę de pistolet dans le bois, que nous avisaunes un élau, qui, couran! dev.un nous, tombalunt d'un coup sans avoir élé liré, ni avoir entendu lirer : cos qui mobligea de lemander à mon guide el iuterprèle d'ui venaıt que cet animal élail tombé de la sorte; à quoi il une réponilı que c'était du mal caduc, dupuel tous ces animanx sumt amigés, qui est la cause pour layuelle on les nomme ellends, yui vent dire misérables... et nélait ce mal qui les fait lumber, on aurait de la peine à les attraper, ce yue je vis peu après que le gentilhomme norvérien 'nt lué cel élan tlans son mal en poursuivant ensuite un autre pentant plus de deus heures sans pronvoir l'altraper. el pue nons nianrious jamais pris sans quil tombil. comme le premler, du meme mal caduc, apres avoir tue trois ules plus forts chiens de ce ferntihomme avec les pieds de levant, ce yui le lacha fort. et ne roulut pas classer davanlage... Il me domna pour témoignage d'amitié les pièls ganches de derrière des ćlans quil avait lués, une laisant entendre yue c'itail un renteder sunve-

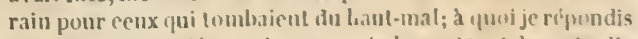
en riant, que je u'chnnais que ce piel ayant tant de vertu. lanimal yni le portait ne sen guérissait pasl'ayant toujours avee Ini : ce gentilhomme se fult à rire anssi, et dil fue javais raison, en ayaul dommé a phuseurs persmunes affigeses ole parril mal, qui u'avaient pas été ģuériés, et qu'il connaiscait anssi bien

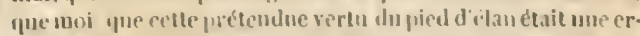

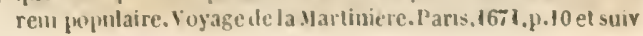


- caient un dard, qui est un grand bâton au a bout duquel est emmanché un grand os pointu a qui perce comme une épée. S'il y avait plu" sieurs orignaux d'une bande, ils les faisaient "fuir : alors les orignaux se mettaient tous "queue à quene, faisant un grand cercle d'une " lieue et demie ou deux lienes, et quelquefois " plus, et battaient si bien la neige à force de a tourner qu'ils n’enfonęaient plus ; celui de de" vant étant las se met derrière. Les sauvages " en embuscade les attendaient passer, et là les " dardaient : il y en avait un qui les poursui" vait toujours ; à chaque tour il en demeu" rait un, mais à la fin ils s'écartaient dans le " bois. " En comparant cette relation avec celles que nous avons déjà citées, on voit que l'homme sauvage et l'orignal de l'Amérique copient le Lapon et l'élan d'Europe aussi exactement l'un que l'autre.

\section{PREMIÉRE ADDITION A L'ARTICLE DU RENNE.}

Nous n’avons donné que la gravure du squelette du renne, n'ayant pu jusqu'alors nous procurer cet animal vivant, ou assez bien conservé pour le faire dessiner ; nous donnons ici la figure d'une femelle renne qui était vivante à Chantilly, dans les pares de S. A. S. monseigneur le prince de Condé, auquel le roi de Suède l'avait envoyée avec deux mâles de mème espèce, dont l'un mourut eu chemin, et le second ne vécut que tr’ès-peu de temps après son arrivée en France. La femelle a résisté plus longtemps; elle était de la grandeur d'une biche mais moius haute de jambes et plus épaisse de corps; elle portait un bois, comme les mâles, divisé de même par andouillers, dont les uns pointaient en devant et les autres en arrière; mais ce bois était plus court que celui des mâles. Voici la description détaillée avec les dimensions de cet animal, telles que M. de Sève me les a données :

"La hauteur du train de devant est de deux pieds onze pouces, et celle du train de derrière de deux pieds onze pouces neuf lignes. Son poil est épais et uni comme celui du cerf; les plus courts sur le corps ont au moins quinze ligues de longuenr. Il est plus long sous le ventre, fort court sur les jambes, et trè-long sur le boulet jusqu'aux ergots. La couleur du poil qui couvre le cor'ps est d'un brun roussàtre, plus ou mołns foncé dans différents endroits du corps , et mélangé ou jaspé plus ou moins d'un blanc jaundtre : sur une partie du dos, les cuisses : le dessus de la tète et le chanfrein, le poil est plus foncé, surtout au-dessus du larmicr que le renne a comme le cerf. Le tour de l'œil est noir. Le museau est d'un brun foncé, et le tour des naseaux noir ; le bout du museau jusqu'aux naseaux est d'un blane vif, ainsi que le bout de la mâchoire inféricure. L'or'eille est couverte en dessus d'un poil épais, blanc, tirant sur le fauve, mêlé de poil brun ; le dedans de l'oreille est garni de grands poils blanes. Le cou et la partie supérieure du corps sont d'un blanc jaunâtre ou fauve très-clair, ainsi que les grands poils qui lui pendent sur la poitrine au bas du cou. Le dessous du ventre est blanc. Sur les cótés, au-dessus du ventre, est une baude large et brune comme à la gazelle. Les jambes sont fort menues pour le corps : elles sont, ainsi que les cuisses , d'un brun foncé, et d'un blanc sale en dedans, de même que l'extrémité du poil qui couvre les sabots. Les pieds sont fendus comme ceux du cerf. Les denx ergots de devant sont larges et minces; les deux petits de derrière sont longs, assez minces et plats en dedans; ces quatre ergots sont très-noirs.

Longueur du corps, depuis le museau jusqu'à

l'anus, en ligne superficielle....... 5 5 12

La mème longueur mesurée en ligne droite. $4 \begin{array}{lll}4 & \mathbf{7}\end{array}$

Longueur de la tête jusqu'à l'origine des cor-

nes.................. 110

Circonférence du museau, prise derrière les naseaux................ 0 11 1

Onverture des narines.............. 0 ( 1 4

Contour de la bouche. ............. 0 7 78

Distance entre les angles de là måchoire inférieure..................... 018

Distance entre les angles de la mảchoire supérienre................ 0 2 29 Distance entre l'angle postéricur et l'oreille. $\begin{array}{lll}0 & 9 & 9\end{array}$ $\begin{array}{llll}\text { Distance enlre les angles antéricurs des yeux. } & 0 & 5 & 5\end{array}$ Circonférence de !a tète, prise devant les cornes....................... 0 9 95 Longucur des oreilles. . . . . . . . . 0 \& 1

Largeur de la base, mesurée sur la courbure exterieure............... 045

Distance entre les orcilles, prise en bas, suivaut la courbure du chignon. ...... 0 \& 7 Longueur du cou. ............. 0 10 0 Circonfèrence près de la tête. ...... 18 \& 10 Girconférence près les épaules. ....... 220 Hauteur du train de devant.. . . . . . 299

Hauteur du train de derrière. . . . . . . 211 Circonférence du corps, prise derrière les iambes de devant. ........... 385 
IC̀me circonfèrence derant les jambes de derriere................... 3110 I.ongueur du tronçon de la queuc. . . . . . $0 \begin{array}{lll}0 & 4 & 5\end{array}$ Circonfèrence à son originc. . . . . . . . $0 \begin{array}{llll}0 & 8 & 2\end{array}$ Longueur du bras, depuis le coude jusqua au genou. ............... 0112 Circonférence à l'endroit le plus gros.... 1135 Circonference du genou. . . . . . . . . 0.004 Longueur du canon. ............. 0 . 6 Circunférence à l'endroit le plus mince. . . . 0073 Circonférence du bonlet. . . . . . . . 0 . 5 5

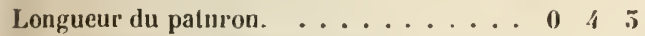
Circonférence du paturon. ............ 0 \% Circonférence de la couronne. . . . . . . 0 \% llauteur depuis le bas du pied jus(]n'au genou. $\begin{array}{llll}0 & 10 & 0\end{array}$ Longueur de la cuisse depuis la rotule jusqu'au jarret..................... 1005 Circonférence près le ventrc. ....... 110 5 Longueur du canon, ,lepuis le jarcet jusqu'au boulet. ................ 1 (0 0 Circonference................ 0 o 51 Longucur des ergots............. Hauleur des salrots. .............. 0 ( 16

Longueur depuis la pince jusqu'au talon dans les pieds de devant. ............. $0 \begin{array}{llll} & 6 & 3\end{array}$ Longueur dans les pieds de derrière. . . . . 0060 Largeur des deux sabots dans tes pieds de devant. ................... 030 La mène largeur dans ceux de derrière. . . $00 \begin{array}{lll}0 & 3 & 5\end{array}$ Circonférence des deux sabols dans les pieds

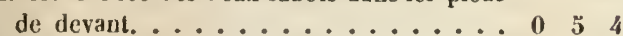

Circonference des deux sabots dans les pieds

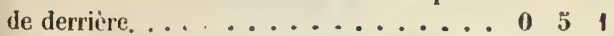
Longucur dn bois mesure en ligne droile. . 1 Et de l'origine à la branche plus courte et plus

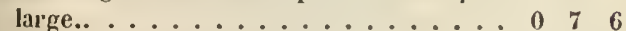

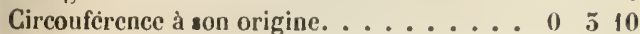

Au reste, il ne faut pas juger par la figure que nous donnons du renne, de l'étendue en longucur et en grosseur de son bois. 11 y a de ces bois qui s'étendent en arrière, depuis la tête de l'animal jusqu'it sa croupe, et qui pointent en avant par de grands andouillers de plus d'un pied de longueur. Les grandes cornes ou bois fossiles que I'on a trouvés dans plusieurs endroits, et notamment en Irlande, paraissent avoir appartenu à l'espèce du renne. J'ai été informé par M. Collinson, qu'il avait vu de ces grands bois fossiles qui avaient dix pieds d'intervalle entre leurs extrémités, avec des andouillers qui s'étendent en avant de la face de lanimal, comme dans le bois du remne.

C'est done à cette 'spèce et non pas à celle de l'élan que l'on doit rapporter les bois on cornes fossiles de l'animal que les Anglais ont appelé moose-deer; mais il faut néanmoins convenir qu'actueliement il u'existe pas de rennes assez grands et assez puissants pour porter des bois aussi gros et aussi longs que ceux qu'on a trouvés sous terre en Irlande, ainsi que dans quelques autres endroits de l'Europe, et même dans l'Amérique septentrionale.

Au reste, je ne connaissais (ju'une seule espèce de renne, auquel j'ai rapporté le caribou d'Amérique et le daim de Groënland, dont M. Edwards a donné la figure et la deseription, et ce n'est que depuis peu`d'années yue j’ai été informé (qu'il y en avait de deux especes, ou plutôt deux variétés, l'une beaucoup plus grande que l'autre. Le renne dont nous donnons jei la figure et la description est de la petite espèce, et probablement la mème que le daim du Groenland de M. Edwards.

Quelques voyageurs disent que le renne est le daim du nord, qu'il est sauvage en Groënland, et que les plus forts n'y sont que de la grosseur d'une génisse de deux ans.

Pontoppidan assure que les rennes périssent dans tous les pays du monde, à l'exception de ceux du nord, où il faut même qu'ils habitent les montagnes; mais il ajoute des choses moins croyables, en disant que leur bois est mobile, de façon que l'animal peut le plier en avant ou enarrière, etqu'il a au-dessus despaupières une petite ouverture dans la peau, par laquelle il voit un peu, quand une neige trop abondante l'empèche d'ouvrir les yeux. Ce dernier fait me parait imaginé, d'après l'usage de's Lapons, qui secouvreut les yeux d'un morceau de bois feudu; pour éviter le trop grand éclat de la neige, qui les rend aveugles en peu d'années, lorsquils n'ont pas l'attention de diminuer', par eette précaution, le reflet de cet lumiere trop blanche, qui fait grand mal aux yeux.

Une chose remarquable dans ces deux animaux, e'est le craquement qui se fait entendre dans tous leurs mouvements : il n'est pas mćme nécessaire pour cela que leurs jambes soient en mouvement. Il suffit de leur eauser yuelque surprise ou quelque crainte en les touchant, pour que ce eraquement se fasse entendre. (1n assure que la mème chose arrive á l'élan: mais nous n’avons pas été à portée de le vérifier. 
SECONDR ADDITION DE L'ÉDITEUR HOLLANDAIS. (M LE PROFESSEUR ALLAMLAND.)

\section{L'ÉLAN, LE Garibou ET LE RENNE.}

" C'est avec raison que M. de Buffon eroit que l'élan de l'Europe se trouve aussi dansl'Amérique septentrionale, sous le nom d'orignal. S'il y a quelque différence entre les animaux désignés par ces deu noms, elle ne consiste guère que dans la grandeur, qui, comme l'on sait, varie beaucoup suivant le climat et la nourriture; et encore même n'est-il pas bieu décidéquels sont ceux qui sont les plus grands. M. de Buffon croit que ce sont ceux d'Europe; et il est naturel de le croire, puisque l'on voit que les mêmes animaux sont constamment plus petits dans le Nouveau-Monde que dans l'aneien continent; cependant la plupart des voyageurs nous représentent l'orignal comme plus grand que notre élan. M. Dudley, qui en a envoyé une très-bonne deseription à la Société royale, dit que ses chasseurs en ont tué un qui était haut deplus de dix pieds ; il a besoin d'une pareille taille pour porter les énormes cornes dont sa tête est chargée, et qui pèsent cent cinquante, et même jusqu'à trois ou quatre cents livres, s'il en faut croire la Hontan.

" Mylord due de Richemond, qui se fait un plaisir de rassembler, pour l'utilité publique, tout ce qui peut contribuer à la perfection des arts et à l'augmentation de nos connaissances en histoire naturelle, a eu une femelle d'orignal qui lui avait été envoyée par M. le général Carleton, gouverneur du Canada, en 1766 . Elle n'avait alors qu'une année, et elle a vécu pendant neuf ou dix mois dans son pare de Goedvoed. Quelque temps avant qu'elle mourût, il en fit faire un dessiu fort exact, qu'il a eu la bonté de me communiquer. J'ai cru qu'on le verrait ici avec plaisir pour suppléer à celui que M. de Buffon n'a pas eu le temps de faire achever à Paris. Comme cette femelle était encore jeune, elle n'avait guère plus de cincr pieds de bauteur : sa couleur était d'un brun foncé par-dessus le corps, et plus clair par-dessous.

" J'ai aussi reçu du Canada la tête d'une femelle d'orignal plus âgée. Sa longueur, depuis le bout du museau jusqu'aux oreilles, est de deux pieds trois pouces; sa circonférence, prise des oreilles, est de deux pieds huit pouees; et près de la bouche, d'un pied dix pouces : ses oreilles sont longues de neuf pouces; mais conme cette tête est desséchée, on comprend que ees dimensions sont plus petites (jue dans l'animal vivant.

"M. de Buffon est aussi dans lidée que le caribou d'Amérique est le renne de Laponie; et l'on ne peut pas refuser de se rendre aux raisons par lesquelles il appuie son scntiment. J'ai domné une planche du renne, qui ne se troure point dans l'édition de Paris, e'est la ouzième du douzième tome : elle est une copie de celle qui a été publiée par le fameux peintre et graveur Ridinger, qui a dessiné l'animal d'après nature. Ici je erois devoir ajouter une autre planche qui représente le caribuu d'Amérique. C'est encore au due de Richemond quej'en suis redevable. Cet animal lui a été envoyé du Canada, et il a vécu assez longtemps dans son pare: soll bois ne faisait que eommencer à pousser quand il a été dessiné. Quoique je ne puisse rien dire pour l'éelaircissement de cette planche, je suis persuadé qu'on la verra ici avec plaisir ; c'est la seule qui représente au vrai le caribou. En la comparaut avec celle du renne, il paraitra d'abord qu'il y a une assez grande différence entre les deux animaux qui y sont représentés ; mais l'absence des cornes dans le caribou, change beaucoup sa physionomie. La différence entre ce caribou et le renue paraitra encore plus marquée, si l'on jette les yeux sur la $p l$. 4 . Elle représente un animal qui a été vu en 1 i69, à la foire d'Amsterdam. S'il en faut eroire les matelots qui le faisaient voir, il avait été pris daus la mer du nord, à 76 degrés de latitude, et environ à cinquante lieues de terre. Le capitaine Bré, de Sehiedam, qui commandait un vaisseau destiné à la pèche de la baleine, vit quatre de ces animaux nageant en pleine mer; il fit mettre d'abord quelques hommes dans la chaloupe, qui les suivirent à force de rames pendant près detrois heures sans pouvoir les atteindre : enfiu ils en attraperent deux qui étaient jeunes; l'un est mort avant que darriver en Hollande, et l'autre est celui dont je donne la figure, et qui a été montré à Amsterdam. Voilà l'bistoire de la prise de cet animal, telle qu'elle a été racontée par des matelots, qui disaient en avoir été les témoins. On ne sera pas fort disposéà la croire : la circonstance de ces animaux nageant à cincquaute lieues de toute terre est plus que suspecte. Le capitaine Bré aurait pu me donner là-dessus des informations plus sûres ; aussi 
ai-je voulu m'adresser à lui pour lui en demander; mais j'ai appris qu'il était parti pour un nouveau voyage dont il n'est pas encore de retour.

"Quoi qu'il en soit de cette histoire, cet animal venait sûrement d'un pays très-froid; la moindre chaleur l'incommodait, et pour le rafraichir on lui jetait souvent des seaux d'eau sur le corps, sans que son poil en parût movillé. Il n'y eut pas moyen de le conserver longtemps en vie : il mourut au bout de quatre mois à Groningue, où on le faisait voir pour de l'argent. On le donnait pour un renne, et e'en était véritablement un. Il ressemblait fort à ce daim de Groënland dont M. Edwards nous a conservé la figure, et que M. de Buffon a pris pour un lenne. Ces deux animaux ne diflèrent presque qu'en ce que le bois de ce daim est sans empaumures; nais les variétés que M. Jaubenton a trouvées entre les bois de renne qui sont dans le Cabinet dư roi nous prouvent assez que les empaumures n'ont rien de constant dans ces animaux, et que les caractères distinctifs qu'on ell voudrait tirer sont très-équivoques. ")

\section{Description du renne, par $M$. le professeur Allamand.}

"Le renue qui est représenté dans la $p l .4$ était un mâle. La couleur de son poil était d'un gris cendré à l'extrémité, mais blamehe ver's sa racine. Tout son corps était eouvert d'un duvet fort épais, d'où sortaient en divers endroits quelques poils assez laides, dont la pointe était brune. La partie inférieure de son cou se faisait remarquer par des poils de huit à neuf pouces, dont elle était toute couverte, et qui étaient beaucoup plus fins que des crins, et d'un beau blanc. Le bout de son museau était noir et velu. Chacune des perclies de son bois ćtait chargée de trois andouiller's; ceux qui sortajent de la partic inférieure étaient dirirrés en araut sur le front; ils se terminaient tous en pointe, et ce I'était (fu'à l'extrémité supérieure de chaque perche quion remarquait dles empaumures; mais vraisemblablement il en aurait paru d'autres, si l'animal avait véeu plus longtemps. Je vois par un dessin cue M. Camper a fait de cet animal, qui était plus doé de quatre mois, et qu'il a eu la bonte de me communquer, que les empaumures du haut du bois s'étaient clargies, qu'elles commengaient à former de nou- veaux andouillers, et que ceux qui sont représentés pointus dans notre planche avaient aequis plus de largeur.

"Ce renne avait les jambes plus courtes, mais plus fortes et plus grosses que celles du cerf. Ses sabots étaient aussi beaucoup plis larges, et par lả même plus propres à le soutenir sur la neige; le bout de l'un était placé sur l'extrémité de l'autre. Voiei les dimensions de ses principales parties.

p. P. 1 depuis le bout dı moseau jusqu'à l'anus. . $4 \begin{array}{lll}4 & 8 & 0\end{array}$ Ilauteur du train de devant. . . . . . . 280 llauteur du train de derrière. . . . . . 320 Longueur de la tite, depuis le bout du nusean jusqu'à l'urigiue des cornes. . . . . . $0 \begin{array}{llll}0 & 7 & 6\end{array}$ Longueur des corues. . . . . . . . 10 0 Longueur de l'andouiller qui est dirigé aıdevant de ta tèle. ............ o $4 \quad 49$

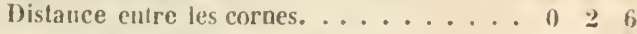
Distance entre i's deux naseanx. . . . . . 0012 Distance d'un nil a l'autre. . . . . . . 0 o

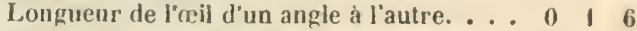
Ifanteur des jambes de derrière jusqu'à l'abdonen................. 210

Longueur de la queue. ........... 0

Circonférence du corps, prise autour du ven-

tre................... 420

" Ce renne n'est pas le seul qui ait paru dans nos provinces; M. le professeur Camper en a reçu un qui malheurcusement n’a vécu chez lui que vingt-quatre heures. Sa prompte mort est une perte pour l'histoire naturelle; si cet animal avait pu ètre observé pendant quelque temps par un homme aussi exact et penétrant que M. Camper, nous serions parfaitement instruits de tout ce qui le regarde. Cependant nous avons lieu de nous féliciter qu'il soit tombé en si bonnes mains. M. Camper l'a anatomisé avec soin, et if m'en a envoyé une description trèsintéressante, qui le fera connaitre mieux qu'il ne nous est commu par tout ce que les autres en ont dit jusqu à présent; on la lira ici avec plaisir : la voici done telle qu'il a bien voulu me la communiquer.

Observations sur le renne, failes a Groningue par $M$. le professcur $P$. Camper

"Le lenne quion m'avait envoyé de la Laponie par Drontheim et Amsterdam arriva à Croningue le 21 juin 1771 . Il était fort faible, nonseulement à cause de la fatigue du voyage et de 
la chaleur du climat, mais probablement surtout à cause d'un ulcère entre le bonnet ou deuxième estomac et le diaphragme, dont il mourut le lendemain. Dès qu'il fut chez moi, il mangea avec appétit de l'herbe, du pain et autres choses qu'on lui présenta, et il but assez copieusement. Il ne mourut pas faute de nourriture; car en l'ouvrant je trouvai ses estomaes et ses boyaux remplis. Sa mort fut lente et aceompagnée de convulsions qui étaient tantôt universelles et tantôt uniquement visibles à la tête : les yeux surtout en souffrirent beancoup.

" C'était un màle àgé de quatre ans. Tous les os de son squelette offraient encore les épiphyses; ce qui prouve qu'il n'avait pas atteint son plein accroissement, auquel il ne serait parvenu qu'à l'âge de cinq ans. Ainsi on en peut conclure que cet animal peut vivre au moins vingt ans.

"La couleur du corps était brune et mêlée de noir, de jaune et de blanc; le poil du ventre, et surtout des flanes, était blane avec des pointes brunes, comme dans les autres bètes fauves. Celui des jambes était d'un jaune foncé ; celui de la tète tirait sur le noir; celui des flanes était très-touffu; celui du cou et du poitrail était aussi fort épais et très-long.

"Le poil qui couvrait le corps était si fragile, qu'il se cassait transversalement dès qu'on le tirait un peu; il était d'une figure ondoyée, et d'une substance assez semblable à celle de la moelle des jones dont on fait les nattes; sa partie fragile était blanche. Le poil de la tête, du dessous du cou etdes jambes, jusqu'aux ongles, n'avait point cette fragilité; il était au contraire aussi fort que celui d'une vache.

"La couronne des sabots était recouverte de tous còtés d'un poil fort long. Les pieds de derrière avaient entre les doigts une pellicule assez large, faite de la peau qui couvrait le corps, mais parsemée de petites glandes.

"A la hauteur des couronnes des sabots, il y avait une espèce de canal qui pénétrait jusqu'à l'articulation du eanon avec les osselets des doigts : il était de la largeur du tuyau d'uneplume à éerire, et rempli de fort longs poils. Je n'ai pas pu découvrir un semblable eanal aux pieds de devant, et j'en ignore l'usage.

" La figure de cet animal différait beaueoup de celle qui a été déerite par les auteurs qui en ont parlé, et de celle que j'ai dessinée il y a deux ans, et cela parce qu'il était extrême- ment maigre. MM. Linnæus, les auteurs de l'Encyclopédie et Edwards, le dépeignent tous fort gras, et par conséquent plus rond et plus épais.

"Voici les dimensions de ses principales parties, prises avec le pied de Groningue, qui est un peu moins long que celui de France.

Longueur de la tête, depuis le bout du museau jusqu'a la nuque du cou. ...... 1220 Hauteur verticale de la tète, là où elle est la plus grosse................ 0 \% 80 Lougueur des oreilles. . . . . . . . . 0 . 50

Longueur des vertèbres du cou, entre la tête et la première cóte........... 100

Longueur du corps, depuis l'épaule jusqu'à l'extremité de l'ischion. . . . . . . . . 556 Longueur de l'omoplate. .......... 1 1 0 ( Longueur de l'os du bras. .......... 0110

Longueur du canou. . . . . . . . . 0 0 90

Longueur des doigts du pied de devant avec

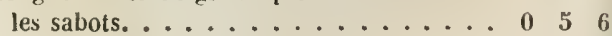

Longueur de l'os de la jambe. . . . . . 100

Longueur du canon. ........... 1 ( 0 ()

Lonqueur des doigts du pied de derrière arec les sabots.................. 060

Hauteur du train de devant. . . . . . . . 3 o 0 Longueur depuis le bout du museau jusqu'à l'anus. ................ 500

Distance entre l'os des iles et la rotule. . . . 1 \& 0

Distance entre l'extrémité de l'ischion et la rotule................. 1 \& 0

Hauteur de la partie inférieure du corps pardessus terre. ............ 160 Distance entre le poitrail et le penis. . . . 200 Longueur de l'espace qu'occupent les cỏtes dans les llanes du squelette. ....... 1 1) 0

"Les yeux ne diffèrent pas de ceux du daim on du cerf; la prunelle est transversale, et l'iris brun tirant surle noir; ses larmiers, semblables à ceux des cerfs, sont remplis d'une matière blanchâtre, résineuse, et plus ou moins transparente. 11 y a deux points lacrymaux et deux canaux, comme dans le daim. La paupière supérieure a des eils fort longs et noirs; elle n'est pas percée, comme l'ont prétendu quelques autcur's, elle est entière. L'évèque Pontoppidan, et sur son autorité M. Haller, ont même voulu rendre raison de cette perforation de la paupic̀re; ils l'ont jugée nécessaire dans un pays presque toujours couvert de neige, dont la blaircheur aurait pu nuire par son éclat aux yeux de ces animaux saus ec secours. Les hommes faits pour pouvoir vivre dans tous les climats préviennent autant qu'ils peuveut la céeité par des voiles ou de petites machines trouées, qui affai- 
blissent l'éclat de la lumière. Le renne, fait pour ce seul climat, n'avait pas besoin de ce mécanisme; mais il a cette membrane ou paupiere interne, si visible dans les oiseaux, et yui se trouve dans plusieurs quadrupèdes, sans y être mobile que dans un petit nombre. Cette membrane n'est pas non plus percée dans le renne; elle peut couvrir toute la corriée, jusqu'au petit angle de l'œil.

"Son nez est fort large, comme dans les vaches, et le museau est plus ou moins plat, couvert d'un poil loıng, grisâtre, et qui s'étend jusqu'à l'intérieur des narines. Les lèvres sont aussi revêtues de poils, exeepté un petit bo:d qui est noirâtre, dur et très-poreux. Les narines sont fortéloignées l'une del'autre. La lèvre inférieure est étroite, et la bouche très-fendue, comme dans la brebis.

" Il y a huit dents incisives à la mâchoire inféricure, mais très-petites, et très-lâchement attachées; il n'en a point à la mâchoire supérieure, non plus que les autres ruminants, mais j'ai cru y remarquer des erochets, quoiqu'ils ne paraissent pas encore hors des gencives; dans la màchoire inférieure, jen'en ai vu aucun indice. Les chevaux en ont aux deux mâchoires, mais il est rare que les juments en aient. Les daims, tant màles que femelles, n'en ont presque jamais ; mais j'ai préparé cet été la tête d'une biche nouvellement née, qui a un très-grand crochet ¿t la màchoire supérieure du còté gauche. La nature varic trop dans ectte partie, pour cu'on puisse y déterminer rien de constant. II y a six dents mâchelières à chaque eòté des deux màchoires, e'est-à-dire qu'il y en a vingt-quatre en tout.

" Je n'ai rien à remarquer au sujet des cornes: elles ne faisaient que de naitre. L'une avait un ponce et l'autre un pouce et demi de hauteur : lcur base était située entre l'orbite et l'oceiput, un peu plus près de ce dernier. Le poil qui les courrait était joliment contourné, et d'un gris tirant sur le noir ; en le voyant d'une certaine distance, on aurait pris les deux touffes de ee poil pour deux glandes souris posées sur la tête de l'allimal.

"l.e cou est court, et un peu plus arqué que eelui de la brebis, mais mojns que celui du chameau. Le corps parait robuste; le dos est un pen éfevé vers les épatules, et atssez droit partout ailleurs, ynoique les vertrbies soient un per formes en are.
"La queue est fort petite, recourbée en bas et très-garnie de poils.

"Les testicules sont très-petits, et ne paraissent point hors du corps. La verge n'est pas grande; le prépuce est sans poil , comme un nombril; il est fort ridé en dedans, et chargé ou couvert d'une croûte pierreuse.

"Les sabots sont grands, Jongs et convexes en dehors; mais ils n'avaient pas les bouts placés les uns sur les autres, comme ceux du renne que j'ai dessiné il y a deux ans. Les ergots sont aussi fort longs, et ceux des picds antérieurs touchaient à terre quand l'animal était dehout, mais ceux des pieds postérieurs étaient placés plus hant, et ne descendaient pas si bas : aussi les os des doigts en sont-ils plus courts.

"Ces huit ergots étaient creux, apparemment parce que l'animal ne les usait pas.

"Lesintestins étaient exactement semblables à ceux du daim. Il n'y avait point de vésicule du fiel; les reins étaient lisses et sans division; les poumons étaient grands; la trachée-artère était extrêmement large.

"Le cœur était d'une grandeur médiocre, et, comme celui du daim, ne contenait quin seul osselet. Cet osselet soutient la base de la valvule semilunaire de l'aorte, qui est opposéc aux deux autres, sur lesquelles les artères coronaires du cœur prennent leur origine. Ce mème osselet donne de la fermeté à la cloison membraneuse, qui est entre les deux sinus du cocur, et a la base de la valvule triglochine du ventricule dioit.

" Ce qui m'a paru de plus remarquable dans eet animal est une poehe membraneuse et fort large, placée sous la peau du cou, et qui prenait son origine entre l'os hyorde et le cartilage thyroide par un canal conique. Ce canal allait en s'élargissint, et se changeait en une espece de sac membraneux, soutenu par deur muscles oblongs. Cesmuseles tirent leurorigine de la partie inférieure de l'os lı̣ oude, préciscoment lit ou la base, los graniforme et les cornes se réunissent.

"Ces muscles sout plats, minees, lar'ges d'un demi-pouce, et descendent des deun coutes de lat poche jusqu'au milieu du sace, un le's tibre's se séparent et se perdent daus la membrane exterieure et musculeuse de lit poche; ils relevent e't soutiennent celte partic i peu pres cornme les cremastires souticunent of elevent le peritoine, yui c'st aulour dis te'sticules dans les singe's et autres animaux : mublables. 
- Cette poche s'ouvre dans le larynx, sous la racine de l'épiglotte, par un large orifice, qui admettait mon doigt très-aisément.

"Lorsque l'animal fait sortir avec force l'air des poumons, commequand il fait des mugissements, l'air tombe dans cette poche, l'enfle, et cause nécessairement une tumeur considérable à l'endroit indiqué; le son doit aussi nécessairement changer beaucoup par là : les deux muscles vident la poche de l'air quand l'animal cesse de mugir.

“ J'ai démontré, il y a vingt ans, une semblable poche dans plusieurs papions et guenons; et l'année passée j'ai eu occasion de faire voir à mes auditeurs qu'il y en avaitune double dansl'orangoutang. J'ell donnerai la description et la figure dans un mémoire, que je me propose de publier, sur la voix de l'homme et de plusieurs auimaux. Je ne saurais déterminer si la femelle renne a cette poche comme le mâle : dans les singes, les dcux sexes en sont pourvus; je ne me souviens pas de l'avoir trouvẻe dans le daim; la biche ne l'a pas. ".

\section{TROISIEME ADDITION A L'ARTICLE DU RENNE.}

Nous ajouterons à ce quẻ nous avons dit au sujet du craquement qui se fait entendre dans tous les mouvements du renne une observation que M. le marquis d'Amezaga a eu la bonté de nous communiquer. ' On pourrait croire, ditil, que ce bruit ou craquement vient des pinces du pied qui se frapperaient l'uue contre l'autre comme des castagnettes, d'autant que les rennes ont lepied long et plat. Je cherchai à reconnaitre d'où provenait ce bruit dans les rennes que le roi de Suède avait envoyés à S. A. S. Monseigneur le prince de Condé; je le demandai aux Lapons qui les avaient amenés. Ils touchèrent assez légerement l'un de ces rennes, et j'entendis le craquement sans pouroir distinguer d'où il venait. L'animal avait été touché si faiblement qu'il n'avait pas même changé de place ; je jugeai dès lors que le bruit ne venait pas de ses pinces; je me mis sur le ventre, et sans faire marcher le renne, je guettai le moment où il lèverait son pied. Des qu'il fit ce mouvement, j'entendis l'articulation du pied faire le bruit que j'avais entendu d'abord, mais plus fort, parce que ce mouvement avait été plus grand. Je restai dans la mème attitude pour m'assurer du craquement dans les pieds de derrière comme dans ceux de devant; j'entendis aussi celui du genou, mais bien moins fort que celui du pica, celui du jarret ne s'entend presque pas. "

Ces rennes sont morts tous denx à Chantilly de la mème maladie; c'est une inflammation à la gorge, depuis la langue jusqu'aux bronches du poumon. On aurait peut-être pu les guérir en leur donnant des breuvages rafraichissants; car ils se portaient très-bien, et étaient mème assez gras jusqu'au jour où ils ont été atteints cle cette inflammation. I!s paissaient comme des vaches, et ils étaient trés-avides de la mousse grise qui s'attaclie aux arbres.

Il est donc certain, par les observations de M. le marquis d'A mezaga, que dans les rennes ce n'est qu'aux articulations des os des jambes que se fait le craquement, et il est plus que probable qu'il en est de même dans l'élan et dans les autres animaux qui font entendre ce bruit.

En Laponie, et dans les provinces septentrionales de l'Asie, il y a peut-être plus de rennes domestiques que de rennes sauvages; mais dans le Groënland les royageur's disent qu'ils sont tous sauvages.

Ces animaux sont timides et fuyards, et sentent les hommes de loin. Les plus forts de ces rennes du Groënland ne sont pas plus gros qu'une génisse de deux ans, et c'est ce qui me fait présumer qu'ils sont de la petite espèce qu'Edwards appelle daims de Groënland, moins grands de plus d'un tiers que ceux de la grande espèce. Les uns et les autres perdent leur bois au. printemps, et leur poil tombe presque en même temps: ils maigrissent alors, et leur peau devient mince; mais en automne ils engraissent et leur peau s'épaissit. C'est par cette alternative, dit M. Anderson, que tous les animaux du nord supportent mieux les extrêmes du froid et du chaud; gras et fourrés en hiver, légers et sees durant l'été. Dans cette saison, ils broutent l'herbe tendre des vallons; dans l'autre, ils fouillent sous la neige et cherchent la mousse des rocher's. 
QUatrième AdDition A L'ARTicle du BENNE.

Extrait de lat lettre de M. le comte de Mellin, chambellan du roi de Prusse, datée du chàteau d'Anizow près Stettin, le 15 novembre 1787.

"J'ai encore l'honneur de communiquer à " monsieur le comte la gravure d'un renne mâle - que j'ai peint d'après nature: celle de la fe" melle et du faon, je l'attends tous les jours de " mon graveur, et j'aurai l'honneur de vous en " envoyer un exemplaire, si vous le désirez. Le " reme, forsque je l'ai peint, n'avait que deux - ans, et portait son second bois ; e'est pourquoi a il n'est pas eneore si large d'empaumure, et " chargé de tant de chevilles ou de cornichons, "que ceux que ces mêmes rennes portent pré" sentement. Il faut aussi remarquer que le gra* veur a fait une faute en domnant à la barbe pen" dante du renne la figure d'une erinière qu'on " dirait descendre du côté opposé. Si je puis, " monsieur, vous faire plaisir par des miniatures, " peintes en coulcur d'après nature, de ces ani" maux, que j'ai faites avec beaucoup de soin, " je vous les enverrai avec bien de la satisfac" tion.... S. A. S. monseigneur le margrave " de Brandebourg Schwedt, Frédéric Henri, " cousin du roi de Prusse, en a fait venir de la " Suède et de la Russie, et m'a domné la per" mission de les dessiner, de les mesurer et de " les ohserver. J'ai publié dans les mémoires de " la Société de Berlin, en allemand, les observa" tions que j'ai faites, et j'ai l'homneur de vous " en communiquer la substance. 11 y a, comme " vous le remarquez, monsienr le comte, deux * espèces ou plutòt deux varićtés, l'une beaucoup " plus grandle que l'autre, du renne; je les con- nais toutes deux. La différence entre ces deux " espèces est aussiremariquable qu'entre le eerf " et le daim. Les grands rennes, qui sont de la " taille de nos eerfs, furent envoyés de la pro" vince Mezeu, dans le gouvernement d'Ar" ehangel, provinee renommée pour avoir les " plus beaux et les plus grands rennes de toute la "Russie: ee sont deux mâles et drux femelles. " Deux fenselles et un male vinrent de la Suède, " qui u'ćtaient guère plus grands que nos daims, " c'est-à-dire les rennes femelles, car le mâle n'est " pas parvenu jusqu'ici, étant mort sur le " vaisseau. Voici quelques dimensions prinei" palesqui vous feront voir d'un eoup d' neil com. " bien les rennes de Russie surpassent en gran" deur ceux de Suède.

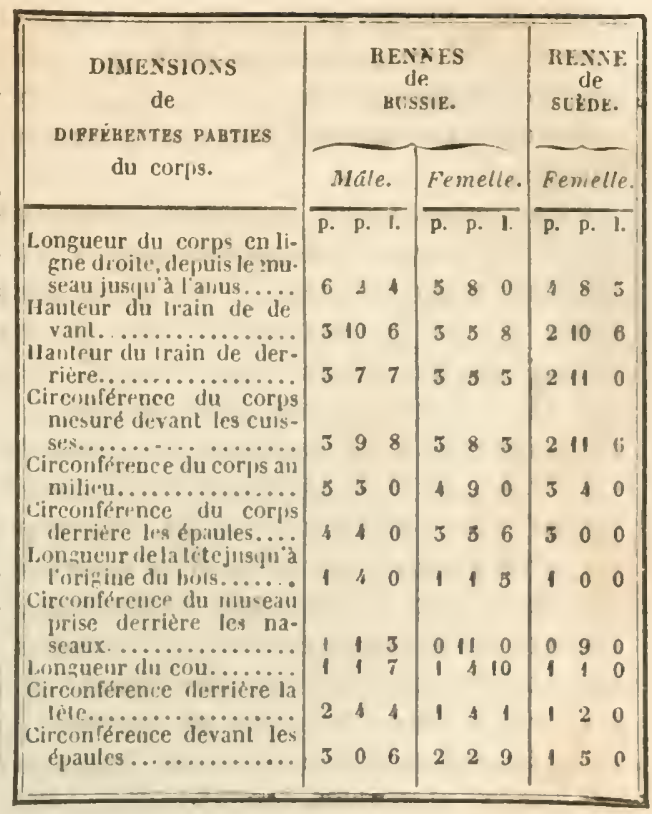

"Ce qui est très-remarquable, et dont cepen" dant aucun naturaliste ne fait mention, e'est "que les faons des rennes ont d'abord en mais. " sant des bossettes, et qu'âgés de quinze jours " ils ont déjà de petites dagues longues d'un " pouce, de manière qu'ils touchent au boispeu " de temps après leur mère. Les faons des ren" nes de Russie avaient le bois long d'un pied, " et chaque perche avait trois andonillers, au " lieu que ceux de Suède ne portaient que des " dagues moins longues, qui se séparaient au " bout en deux andouillers. La figure du daim " de Groëuland que donue M. Edwards me pa"rait ètre celle du faon de trois mois, à la cou"leur près, qui est toute différente. II est sin" gulier que les femelles, qui étaient pleines en " arrivant, et qui, depuis trois ans qu'elles sont " à Schwedt, ont mis bas chaque année un " faon, n'ont produit que des f'melles : ainsi je " ne salurais dire si les faons máles portent des " bois plus longs et plus ehargés d'andouillers "que les femelles; mais on peut le supposer en " jugeant de la grande différence qu'il y a entre " le bois du mâle et celui de la femelle. Les " faons naissent aux mois de juin et de juillet, " et ne portent pas de livrée; ils sont bruns, " plus foncés surle dos, et plus roux aux pieds, " au cou et au ventre : cependant celte couleur " se noireit tous les jours, et au bout de six se" maines, ils out le dos, les épaules, les cótés, "le dessus du cou, le frout et le nez d'un 
" gris noir; le reste est jaunâtre, et les pieds

- fauves. J'ai dit que les faons touchent au bois

" d'abord après leur mère; cela arrive au mois

" d'octobre, et e'est aussi alors que le rut com-

"mence.

"Les rennes mâles poursuivent longtemps

" les femelles avant d'en pouvoir jouir. Les fe-

" melles russes entraient en rut quinze jours

" plus tôt que les femelles de Suède; il y eut

* mème une femelle des faons russes qui, quoi-

" que âgée à peine de cinq mois, sonffrit, au

" commencement de novembre, les approches

" du mâle, et mit bas l'ammée suivante un faon

" aussi grand que les autres. Cela prouve que

"le développement des parties de la génération

" du renne est plus prompt que dans aucun au-

" tre animal de cette grandeur; peut-ètre aussi

" la plus grande chaleur de notre climat, et la

" nourriture abondante dont ils jouissent, a " hâtél'accroissement de ces rennes. Cependant " le bois que portent les rennes femelles, à l'âge

" de cinq mois, n'indiquerait-il pas une sur-

" abondance de molécules organiques, qui peut

" occasiomer un développement plus prompt

" des parties de la génération? Il se peut mème

"que les faons mâles soient en état d'engen-

" drer au même âge. Le comportement du

" renne mâle, que j'observais pendant le rut,

" ressemblait plus à celui du daim qu'à celui

" du cerf. En s'approchant de la femelle, il la

" caressait de sa langue, haussait la tête, et

" rayait comme le daim, mais d'une voix moins

"forte, quoique plus rauque. Il gonflait en

" mème temps ses grosses lèvres, et en faisant

" échapper l'air, il les faisait tremblotter contre

" les gencives; alors il baissait les jarrets des

" pieds de derrière, et je crus qu'i! couvrirait

" ainsi la femelle, qui semblait aussi l'attendre:

" mais, au lieu de cela, il fit jaillir beaucoup

" de semence sans bouger, après quoi jl était

" pendant quelques minutes comme perclus des

" pieds de derrière, et marchait avec peine.

" Jamais je ne l'ai vu couvrir de jour, mais e'é-

" tait toujours la nuit; ii s'y prêtait lentement

" et point en fuyant : comme les cerfs et les

" daims qui, ainsi que je l'ai souvent observé

" dans mes bois et dans mon parc, sautent sur

" les biches tout en courant, en les arrètant et

" les serrant quelquefois si rudement des pieds

" de devant, qu'ils leur enfoncent les ergots it

" travers la peau, et mettent leurs côtés en

u sang. Le rut commence à la mi-octobre, et
" finit à la fin du mois de novembie. Les ren" nes mâles ont pendant ce temps une odeur " de bouc extrêmement forte.

"On a fait des tentatives infructueuses pour " faire couvrir des biches ou des dains par le " renne. Le premier renne qui vint à Schwedt " fut pendant plusieurs années sans femelles; " et comme il parut ressentir les impressions du " rut, on l'enferma avec deux biches et deux " daines dans un parc, mais il n'en approchait " pas. On lui présenta des vaches l'année sui"vante, qu'il refusa constamnient, quoiqu'il at" taquât des femmes, et que plus il avançait " en âge, plus il devenait furieus pendantle "lut. Il donne non-seulement des coups vio"lents du haut de son bois, mais il frappe plus "dangereusement des pieds de devant. Je me " souviens qu'un jour' le renne étant sorti de la " ville de Schwedt, et se promenant par les " champs, il fut attaqué par un gros chien de " boucher; mais lui, sans s'épouvanter, se ca" bra et domna des pieds de devant un coup si " violent au chien, qu'il l'assomma sur la place. "Il n'avait pas de bois dans ce temps-là. Le " bois tombe aux màles vers Noël et au com" mencement de l'année, selon qu'ils sont plus " ou moins vieux, et ils l'ont refait au mois " d'août; les femelles au contraire muent au " mois de mai, et elles touchent au bois au " mois d'octobre; elles ont donc leur bois tout " refait au bout de cinq mois, au lieu que les " mâles y emploient huit mois : aussi les mâles, " passé cinq ans, ont des bois d'une longueur " prodigieuse; les surandouillers ont des em" paumures larges, ainsi que le haut des per" ches, mais il est moins gros et plus cassant " que celui du cerf ou du daim. C'est peut-ètre " aussi pour le garantir d'autant plus lor'squ'il " est encore tendre, que la nature l'a recouvert " d'une peau beaucoup plus grosse que celle " du refait du cerf ; car le refait dı remne est. " beaucoup plus gros que celui du cerf, et ce" pendant lor'squ'il a touché au bois, les perches " en sont bien plus minces. Le renne ne peut " guère blesser des andouillers, comme le cerf; " mais il frappedes empaumures du haut en bas; " ce que Gaston Phœbus a déjà très-bien ob" servé dans la description cu'il doune du rau" gier, page 97 de la Vinerie de Dufouil"loux...... Tous ceux qui ont donué l'histoire " du renne prétendent que le lait qu'on tire " des femelles ne doune pas de beurre; cela 
" dépend, je crois, ou de la nourritur'e, ou de "la manière de traiter le lait. Je fis traire à "Schwedt les rennes, et trouvai le lait execl"lent, ayant un goût de noiy; j'en pris avec " moi dans une bouteille pour en domner ì goû" tel chez moi, et fus très-surpris de voir à " mon arrivée que le cahotement rle ma voiture, - pendant trois heures de chemin qu'il faut faire a pour venir de Schwedt à mon chàteau, avait " changé ce lait en beur're ; il était blanc comme " celui de brebis, et d'un gouit admirable. Je * crois donc, fondé sur cette expérience, pou" voir assurer que le lait de remne domme de " tres-bon beurle s'il est battu d'abord anrès " avoil été tiré, car ce n'est que de la crême " toute pure. En Suède, on prétend que le lait " de remne a un gout rance et désagréable; " ici j’ai éprouvé le contraire. Mais en Suède " la pâture est tr’es-inférieure à celle d'Allemaa gne, ici les rennes paissent sur des prairies " de treile, et on les nourril d'orge, car l'a" voine, ils l'ont constamment refusée; ce " n'est que rarement qu'on leur donne du lichen "rangiferinus, qui croit ici en petite quantité " dalus nos bois, et ils le mangent avidement. "J'ai renarqué que le craquement que les ren" nes font entendre en marchant n'esí formé "que par' les pinces des sabots, qui se choquent, " et par les ergots qui frappent contre les sa" bots. On peut s'en convaincre aisément en " mettant un linge entre les pinces des sabots, " et en enveloppant les ergots de même : alor's - tout craquement cesse. Je crus, comme tout "le monde, que ce craquement se formait " entre le boulet et ie genon, quoique cela ne " me paruit guère possible; mais un cerf ap" privoisé, que j’ai dans mon pare, me fit en" tendre ur eracpuement pareil, quoique plus " sourd, lorsqu'il me suivait sur la pelouse ou " sur le gravier; et je vis trè-distinctement, en "l'ebservant de près, quec'étaient les pinces des " sabots (jui, en elaquant l'une contre l'autre, a formaicnt ec eraquement. En réitérant cette "observation sur les rennes, je me suis con"vaincu qu'il en est tout de mème avec eux. " Je remarefue aussi (que sans mareher ils font " entendre le mème craquement, lorsqu'on leur " cause quelque surprise ou quelque eminte en " les touehant subitement; mais eela provient " de ce qu'en se tenant dehout ils ont toujours " les sabots éloignés et distinetement séparés, " et que, dès qu'ils s'eftuaient ou yu'ils lèvent "le pied poul marcher, ils joignent subite"ment les pirices du sabot et craquent. Au reste. "c'est un événement très-remarquable pour un " naturaliste, que ces rennes se conservent et se " multiplient dans un pays où la température " du climat est bien plus douce que dans leur " patrie, dans un pays où les neiges ne sont " pas fré(quentes et les hivers bien moins rudes; " tandis çu'on a déjà tenté inutilement, depuis " le scizième siecle, de les naturaliser en Alle" magne, quoique alors le climat fût bien plus " rude et les hivers plus rigoureux. Le roi Fré" déric ler de Prusse en recut de la Suede, qui " moururent (quelques mois apres leur arrivée; a et cependant, dans ce temps-!i, il y avait dans " la Poméranie et dans la Marche, aiusi (qu'aux " environs de Berlin, beaucoup plus de marais " et bien plus de bois, et il y faisait, par cette " raison, beaucoup plus froid qu'à présent. II " y a présentement einq ans que ces rennes " subsistent et se multiplient ì Schwedt; et " étant voisin de cette petite ville, et S. A. R. " me permettant de venir souvent chez elle, " j'ai eu de fréquentes occasions de les roil et " de les observer; et tout ce (que jai eu l'hon" neur de vous dire au sujet de ces remnes est a le fruit de ces observations fiócyuemment réi" térées. ")

\section{CINQUiÈME ADDITION A L'ARTICLE DU RENNE.}

Extrait d'une lettre de Y. le chevalier de Buffon à M. le comte de Buffon. Lille, 50 mai 1.35 .

"Il vient d'arriver ici trois lennes, dont un " màle âgé de six ans, une femelle âgée de " trois ans, et une petite femelle âgée d'un an. "L'homme qui les conduit et qui les montre " pour de l'argent assure qu'il les a achetés " dans une peuplade de Lapons, nommée en " suédois Deger Forth Capel, daus la province "W'ertubollo, il guatre-ringt-dix milles (deux "cent soixante-dix lieues de Frauce) de Stoc"kolm, et huit milles (vilugt-(quatre lieues) " d'Uma. Il les a débarqués a Lubeck au mois " de novembre de l'amnce derniere. Ces trois "jolis animaux sont tries-familier's, te jemne " surtout joac comme un chien aree coux yui "le caressent; ils sont gras, fort galis, e't se a portent tress-bien.

"J'ai comparé, le livre à la main, ces remues

IV. 
"à la deseription que vous en faites: ellc est par" faite sur tous les points. Le mâle a un bois " couvert de duvet, comme le refait du cerf ; " ce bois est très-chaud au toucher; chaque "branche a dix-sept pouces de Iongueur "depuis la naissance jusqu'à l'extrémité, où " l'on commence à reconnaître deux andouil"lers, qui se forment à tête ronde et non poin" tue comme ceux du cerf. Ces deux branches " se séparent, leur courbure est en avant; elles - sont uniformes et de la plus belle venue. Les - delix andouillers qui sont près de la tête " croissent en avant en se rapprochant du nez "de l'animal, deviennent plats et larges avec " six petits andouillers; le tout imitant la forme "d'une main qui aurait six doigts éeartés, et le " reste du bois produisant beaucoup de rameaux " qui croissent presque tous en avant, autant * que j’ai pu en juger par un dessin très-mal * fait, que le maittre de ces rennes m’a présenté, " du dernier bois d'un renne qu'il a vendu en "Allemagne. Ce bois avait quatre pieds de hau" teur, et pesait vingt-sept livres. L'extrémité "de chaque branche se termine par de larges " palettes, qui portent de petits andouillers " comme celles qui sont près de la tête. La ré" gularité du jeune bois que j’ai vu et sa belle "venue, annoncent qu’il sera superbe.

"Ils mangent du foin, dont ils choisissent " les brins qui portent la graine. La chicorée " sauvage, les fruits et le pain de seigle, sont " la nourriture qu'ils préfèrent à toute autre. "Quand ils veulent boire, ils mettent un pied " dans le seau et cherchent à troubler l'eau en " la battant. Ils ont tous trois le mème usage, " et laissent presque toujours leur pied dans le " scau en buvant.

"La femelle a deux proéminenees qui annon" cent la naissance du refait ; la petite en a de " mème. J'ai vu le bois de la femelle de l'année " dernière, il n'est pas plus grand qu'un bois " de chevreuil; il est tortueux, noueux, et chav que branche est d'une forme très-irrégulière.

"J'y ai reconnu tous les earactères q̨ue votis " désignez : le eraquement des pieds lorsqu’ils " marchent et surtout après le repos; le poil "long et blanchâtre sous le cou ; leur forme, "qui tient de celle du bouf et du cerf, la tète " semblable à celle du bœuf; ainsi que les yeux; " la queve très-courte et semblable à celle du cerf; u le derricère de la croupe blanchâtre comme $\checkmark$ sur le cerf. Ce remue n'a, dans ses mouve-
" ments, ui ta pesanteur dubouf, ni la légereté " du cerf; mais il a la vivacité de ce dernier, " tempérée par sa forme, qui n'est pas aussi " svelte. Je les ai vus ruminant; ils se mettent " à genoux pour se coucher. Ils ont horreur des " chiens; ils les fuient avec frayeur, ou cher" chent à les frapper avec les pieds de devant. "Leur poil est d'un brun fauve; ce fauve se dé" grade jusqu’au blanchâtre sous le ventre, aux " deux côtés du cou et derrière la croupe.

"On remarque au-dessous de l'angle inté"rieur de chaque œil une ouverture longitudi" nale où il serait aisé de faire entrer un gros " tuyau de plume; c'est sans doute le larmier " de ces animaux.

" Les deux éperons qu'il ont à chaque jambe " en arrière sont gros, et assez longs pour que " la corne pointue dont ils sont armés pose a " terre lorsque l'animal marche; les éperons " s'écartent dans cette position, et l'animal mar" que toujours quatre pointes en marchant, " dont les deux de derrière entrent de quatre à " cinq lignes dans le sable. Cette conformation a doit leur être fort utile pour se cramponner " dans la neige.

"Le mâle a cinq pieds six pouces de lon"gueur depuis le bout du museau jusqu'à la " naissance de la quene, et trois pieds quatre - pouces de hauteur depuis la sole jusqu'au " garrot.

"La femelle, quatre pieds six pouces de lon"gueur, et trois pieds de hauteur.

" Le petit, quatre pieds un ponce de longueur, " et deux pieds sept pouces de hauteur; il croit "à vue d'œil.

"Ils ont huit petites dents incisives du plus " bel émail et rangées à merveille à l'extrémité " antérieure de la mâchoire inférieure, cinq " molaires de chaque côté au fond de la bouche. " Il y a un espace de quatre doigts entre les " molaires et les incisives de chaque cóté, dans " lecpuel espace il n'y a point de dents. La mâ" choire supérieure a de même et seulement " cincr molaires de chaque côté, au fond de lia " bouche, mais clle n'a aucune incisive.

"Le temps du rut est le même que celni du " cerf. La femelle a été couverte au mois de " novembre de l'année dernière, à quatre lieues "d'Upsal.

"En voilà bien long et peut-être beaucoup a trop sur des animaux que vous comnaissez " mieux que moi saus les avoir vus; mais 
a conune il n'en a point paru jusqu'ici de via vants en France, j'ai pensé que mes obser( vations pourraient vous être agréables, etc.»

\section{ADDITION A L'ARTICLE DE L'ÉLAN.}

Nous donnons ici la figure de l'élan mâle, que l'on a vu vivant à la foire Saint-Germain, en 1784; il n'avait pas encore trois ans. Les dagues de son bois n'avaient que deux pouces; les dernières étaient tombées dans le commeneement de janvier de la même annće; et comme il m'a paru nécessaire de donner une idée de ce même bois, lor'sque l'animal est adulte, j'ai fait représenter sa tête surmontée des bois. Ce jeune animal avait été pris à cinguante lieues au delàde Moscou ; et, au rapport de son conducteur, sa mère était une ou deux fois plus grande 'qu'il ne l'était à eet âge de trois ans. Il était déjà plus grand qu'un cerf, et beaucoup plus haut monté sur ses jambes; mais il ria point la forme élégante du cerf, ni la position noble et élevée de sa tête. Il semble que ce qui oblige l'élan à porter la tète basse, e'est qu'indépendamment de la pesanteur de son large bois, il a le cou fort court. Dans le cerf, le train de derriere est plus haut que celui de devant : dans l'élan, au contraire, le train de devant est le plus élevé, et ce crui paraît encore augmenter la hauteur du devant de son corps, c'est une grosse partic charnue qu'il a sur le dos au-dessus des épaules, et qui est couvertede poils noirs.

Les jaunhes sont longucs et d'une forme légrère; les boulets larges, surtout ceux de derriere; les pieds sont trés-forts, et les sabots, qui sont noirs, se touchent par leur extrémité, qui est menue et arrondic. Les deux ergots des pieds de devant ont deux pouces neuf lignes de longueur : ils sont longs, droits et plats, et ne se touchent point; mais leur extrémité touche presque à terre. Ceux des pieds de derrière ont de longueur, en ligne droite, deux pouees neuf lignes; ils sont plits, courbes, ćlevés au-dessus de terre de deux ponees eing lignes, et se touchent derriere le boulet. La queue est trescourle, et ne forme qu'un troncon couvert de poils.

Lat tète est d'une forme longue, un peu aplatie sur les cotes; los fiontal forme un creux entre les yeux; le nez est un peu bombe en dessus; le bout du nez est large, aplati, et faisant us peu gouttière au milieu; le nez et les uaseaux sont grisâtres. La bouche a d'ouverture en ligne droite quatre pouces trois lignes; il y a huit incisives dans la máchoire inférieure, et il n’y en a point dans la supérieure.

L'oil est saillant, l'iris d'un brun marron; la prunelle, lorscu'elle est à demi fermée, forne une ligne horizontale; la paupière supérieure est arojuée et garnie de poils noirs. L'angre antérieur de l'œil est ouvert; il forme, en se prolongeant, une espece de larmier. L'oreille est grande, élevéc et finissant en pointe arrondie; elle est d'un brun noiratre ('n clessus, et garnie en dedans de grands joils grisatles à la partic supéricure, et bruns noiràtres à l'inférieure.

On remarcyue au-dessous des machoires un grand flocon de poil noir; le cou est large, court et couvert de grands poils noiritres sur la partie supérieure, et gris roussàtres à l'inférieure.

La couleur dı corps de ce jeune animal était d’un brun foncé, mèlé de fauve et de gris; elle était presque noire sur les picds et le patturon, ainsi que sur le cou et la partic charmue au-dessus des épaules. Les pius lougs poils a vaient cinq pouces dix lignes; su! le cou, ils avaient six ponces six lignes; sur le dos, trois pouces : ecux du corps étaient grris à ieur racine, bruns dans leur longrueur, et faures à leur extrémité.

Les dimensions suivantes sont celles qu'avait ce jeune élan à la fin de mars 178.

Longueur du corps, mesure en ligue droite

depuis le houl du unseau jusqu it l'anus. . $6 \begin{array}{ccc}6 & 2 & 4\end{array}$

Longueur suirant la courbure du corps. . .

Hauteur du train de devant. . . . . . 4109

Haulcur du train de derriere. . . . . . A $4 \quad 9 \quad 2$

Longueur de la lite, depuis le boul du musean jusqu'ả l'origine du bois. . . . . . . 1 \& j

Longueur du bout du museau jusqu'à l'ixciput. .................... 197

Longueur du hout du unseau à linil. . . . 0 o $11 \quad 3$

Cirronfirence du museau, prise derriere les naseaux. .................. 161

Contour de bi honche. . . . . . . . 122

Distance eutre les augles de la milioire inferieure..................... 0 115

Distance entre le's naseaux en bas. . . . . 0 o

Dislance entre les deux paupieres lorsuguelles

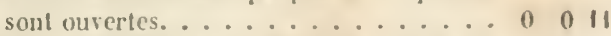

Distance cutre l'angle antirieur et le bout des lèrres. .................. 128

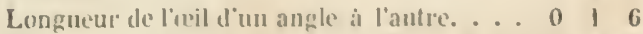

Distance entre l'angle posterieur et lonreille. . $0 \begin{array}{llll}0 & 5 & 4\end{array}$

Distance entre les angles antirieurs des yeux, mesurie en ligne droite. . . . . . . 0610

Circonfereuce de la tile, prise au devant du bois................2 2 ; 
Dislance entre les deux dagnes dn bois. . . . $0 \begin{array}{llll} & 0 & 4 & 7\end{array}$

Distance entre le bois et les oreilles. . . . . 0 0 1 11

Longueur des oreilles. .......... 0 0 10 (0 0

Longueur de la base, mesurée sur la cour-

bure extéricure. .............. 0 \% 76

Dislance entre les deux oreilles. . . . . . $04 \quad 4 \quad 8$

Longueur du cou.............. 118

Circonférence près de la tèı. ........ 2000

Cirrconférence près des épaules. . . . . . 2 2 9 10

Ilauteur des épaules. . . . . . . . . . 5109

Circonfèrence du corps, prise derrière les janbes de devant.............448

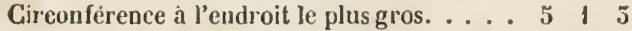

Circonference devant les jambes de derrière. $\quad \begin{array}{lll}4 & 9 & 3\end{array}$

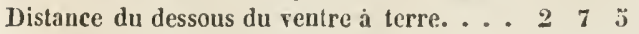

Longueur du tronçon de la queue. . . . . . 018

Circonférence de la queue à son origine. . . . $0 \begin{array}{llll}0 & 3 & 6\end{array}$

Longueur du canon dans les jambes de deraut................... 0109

Circonfér ence à l'endroit le plus miuce. . . . 00404

Girconférence du boulet. ......... 0 . 990

Longueur du paturon. .............. 00310

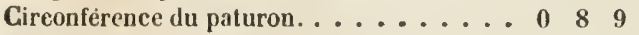

Longueur de la jambe depuis la rotule jusqu'au jarret. ............... 1 I 5 7 7

Circonference de la cuisse près du ventre. . 1445

Longueur du eanon. ............ 180

Circunference du canon. . . . . . . . . 0.007

Longueur des ergots. .......... 0229

Hauteur des sabots. .............. 0

Longueur depuis la pince jusqu'au talon, dans les pieds de devant. ......... 0 7 76

Longueur dans les pieds de derrière. . . . . $0 \begin{array}{llll}0 & 7 & 3\end{array}$

Largeur des deux sabots pris ensemble dans les pieds de devant. . . . . . . . . . 044

Largeur dans les pieds de derrière. . . . . . $0 \begin{array}{lll}0 & 3 & 4\end{array}$

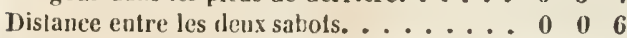

Circonférence des deux sabots réunis, prise sur les pieds de derant. ......... 01010

Circonférence prise sur les pieds de derrière. $\quad \begin{array}{lll}0 & 9 & 10\end{array}$

SUITE DE LA NOUVELLE ADDITION A L'ARTICLE DE L’ÉLAN.

Plusieurs voyageur's ont prétendu qu'il existe, dans l'A mérique septentrionale, des ćlans d'une taille beaucoup plus considérable que celle des élans d'Europe, et même de ceux qu'on trouve le plus communément en Amérique. M. Dudley, qui a envoyé à la Société royale de Londres une très-bonne deseription de l'orignal, dit que ses chasseurs en tuèrent un qui était haut de plus de dix pieds.

Jossclyn assure quion a trouvé dans l'Amérique septentrionale des élans de douze pieds de haut. Les voyageurs qui ont parlé de ces élans gigantesques domnent six pieds de longueur à leur bois; et suivant Josselyn, Jes extrémités des deux perehes sont élojgnées l'une de l'autre de deux brasses ou de dix à onze pieds. La llontan dit qu'il y a des bois d'élan d'Amérique qui pèsent jusqu'á trois et quatre cents livres. Tous ces réeits peuvent être exagérés, ot u'ètre fondés que sur les rapports infidèles des sauvages, qui prétendent qu'il existe a sept ou huit cents milles au sud-ouest du fort d'Y ork une espèce d'élan be̊aucoup plus grande que l'espece ordinaire, et qu'ils appellent waskesser : mais ce qui cependant pourrait faire présumer que ces récits ne sont pas absolument faux, e'est qu'on a trouvé en Irlande une grande quantité d'énormes bois fossiles, que l'on a attribués aux grands élans de l'Amérique septentrionale dont Josselyn a parlé, parce qu'aucun autre animål connu ne peut être supposé avoir porté des bois aussi grands et aussi pesants. Ces bois different de ceux des élans d'Europe, ou des élans ordinaires d'Amérique, en ce que les perches sont en proportion plus longues; elles sont garnies d'andouillers plus larges et plus gros, surtout dans les parties supérieures. Un de ces hois fossiles, composé de deux perehes, avait einc pieds eing ponces de longueur depuis son insertion dans le eràne, jusqu'i la pointe; les andouillers a vaient onze pouces de longueur; l'empaumure dix-huit pouces de largeur, et la distance entre les deux extrémités ćtait de sept pieds neuf pouces : mais cet énorme bois était cependant très-petit en comparaison des autres qui ont été trouvés également en Irlande. M. Wright a donné la figure d'un de ces bois qui avait huit pieds de long, et dont les deux extrémités étaient distantes de quatorze pieds. Ces très-grands bois fossiles ont peut-ètre appartenu à une espèce qui ne subsiste plus depuis longtemps, ni dans l'ancien ni dans le nouveau monde : mais s'il existe encore des indivilus semblables à ceux qui portaient ees énormes bois, l'on peut eroire que ee sont les elans que les Indiens ont nommés w'askesser; et des lor's les récits de M. Dudley, de Josselyn et de La Houtan, seraicut entièrement confirmés.

\section{L'AXIS.}

\section{(LE CERF AXIS.)}

Ordre des ruminants, sectiou des ruminants ì cornes, genre cerf. (Cuvier.)

Cet animal n'étant connu que sous les noms vagues de biche de Sardaigne, et de corf iiu 
Gange, nous avons cru devoir lui conserver le nom que lui a donné Belon, et qu'il avait $\mathrm{cm}$ prunté de Pline; parce qu'en effet les caracteres de l'axis de Pline peuvent convenir à l'animal dont il est ici question, et que le nom même n'a jamais été appliqué à quelque autre animal. Ainsi nous ne craignons pas de faire confusion, ni de tomber dans l'erreur, en adoptant cet ancien nom, et l'appliquant à un animal qui n'en avait point parmi nous; ear une dénomination générique, jointe à l'épithète du climat, n'est point un nom, mais une phrase par lacpuelle on confond un animal avec ceux de son genre, comme celui-ci avec le cerf, quoique peut-être il en soit réellement distinct, tant par l'espèce que par le climat. L'axis est à la vérité dlu petit nombre des animaux ruminants qui portent un bois comme lecerf; il a la taille et la légèreté dn daim; mais ce qui le distingue du cerf et du daim, e'est qu'il a le bois d'un cerf et la forme d'un dain ; que tout son corps est marqué de taches blanches, ćlégamment disposées et séparćes les unes des autres, et qu'enfin il habite les climats chauds; au licu que le cerf et le daim ont ordinairement le pelage d'une couleur uniforme, et se trouvent en plus grand nombre dans les pays froids et dans les régions tempérées que dans les climats chauds.

MM. de l'Académie des Sciences, en nous domant la figure et la description des parties interieures de eet animal, ont dit peu de chose de sa forme extérieure, et rien du tout de ce qui a rapport it son histoire : ils l'ont seulement appelé biche de Sardaigne, parce que probablement il leur était venu sous ce nom de la ménagerie du roi : mais rien n'indique gue eet animal soit originaire de Sardaigne; aueun autenr n'a dit qu iil existe dans cette ile comme animal sauvage, et l'on voit au contraire, parr les passages que nous avons cités, qu'il se trouve dans les contrées le's plus cliandes de l'A sie. Ainsi, la dénomination de biche de Sardaigne avait été faussement appliçuće : celle de cerf du Giange Ini conviendrait micux s'il était en effet de la mène espèce que le cerf, puisque la partic de !'Inde qu'arrose le Gange parait être son pays natal. Cependant il parait aussi quil se trouve en Barbarie ', et il est probable que le daim

'Les Arabes nomment anssi behker-el-u'asch une espèce ie daim, yut a précisement les cornes d'un eerf, mais yni riest pas si graml; cenx que jai vus avatent éte pris dans les unonlagues pies de Sgigala, et nont parı diun maturel fort moucheté du cap de Bonne-Espérance est encore le mème que celui-ci.

Nous avons dit qu'aucune espèce n'est plus voisine d'une autre que celle du daim l'est de celle du cerf; cependant l'axis parait encore faire une nuance intermédiaire entre les deux : il ressemble au daim par la grandeur du corps, par la longueur de la queue, par l'espèce de livrée qu'il porte toute la vie; et il n'en differe essentiellement que par le bois, qui est sans empaumures, et qui ressemble à celui du cerf. II se pourrait done que l'axis ne füt qu'une variété dépendante du climat, et non pas une espèce différente de celle du daim; ear, quoiqu’il soit origrinaire des pay's les plus chands de l'Asie, il subsiste et se multiplie aisément en Europe. Il y en a des troupeaux á la ménagerie de Versailles. Ils produisent entre eux aussi facilement que les dlaims : néanmoins on n’a jamais remarqué qu'ils se soient mêlés ni avee les daims, ni avec les cerfs, et c'est ce qui nous a fait présumer que ce n'était point une variété de l'un ou de l'autre, mais une espece particuliere et moyenne entre les deux. Cepentant comme l'on n'a pas fait des cixpériences dircetes et décisives ì ce sujet, et que l'on n'a pas employé les moyens nécessaires pour obliger ec's animaux à se joindre, nous n'assurerons pas positivement qu'ils soient d'espèces différentes.

L'on a déjài vu, dans les articles du cerf et du daim, combien ces animaux éprouvent de varictés, surtout par les couleurs du pail. L'espèce du daim et eclle du cerr, sans itte trèsnombreuses en individus, sont fort repandues: toutes deux se trouvent dans l'un et dans l'autre continent, et toutes deux sont sujettes in un assez grand nombre de variétés, qui paraissent former des races constantes. Les cerfs blanes, dont la race est très-anciemne, puisque les Grees et les Romains en ont fait mention, les petits cerfs bruns, que nous avons appelés cerfs de Corse, ne sont pas les seules variétís de cette espece : il y a en Allemagne une autre race de cerfs, qui est connue dans le pays sous le nom de brandhirtz, et de nos chasseurs sous celui de cerf des Ardennes. Ce cerf est plus grand que le cerf eommun, et il differe des autres cerfs nou-seulement par le peligge, qu'il a d'une couleur plus foncéce et presque noire, mais encore par un long poil (ju'il porte sur les epaules et doux et Iraitable; la feunelle d'a point de cornes, elc. Voyase du $u^{r}$ slıaw, page 313. 
sous le cou. Cettc espèce de crinière et de barbe lui domnant quelque rapport, la première avec le cheval et la seconde avec le bouc, les anciens ont donné à ce cerf les noms composés d'hippélaphe et de tragélaphe. Comme ces dénomina. tions ont occasionné de grandes discussions critiques; que les plus savants naturalistes ne sont pas d'aecord à cet égard, et que Gessner, Caïus et d'autres, ont dit que l'hippélaphe était l'élan, nous eroyons devoir donner jẹi les raisons qui nous ont fait penser différemment, et qui nous ont porté à croire que l'hippélaphe d'A ristote est le même animal que le tragélaphe de Pline, et que ces deux noms désignent également et uniquement le ecrf des Ardennes '.

Aristote donne à son hippélaphe une espèce de crinière sur le cou et sur le dessus des épaules, une espèce de barhe sous la gorge; un bois au málc; assez semblable à celui du chevreuil, point de cornes à la femelle. Il dit que l'hippélaphe est de la grandeur du cerf, et nait ehez les Arachotas (aux Indes), où l'on trouve aussi des bœufs sauvages, dont le corps est robuste, la peau noire, le mufle relevé, les cornes plus courbées en arrière que celles des bœufs domestiques. Il faut arouer que ces caractères de l'hippélaphe d'Aristote conviennent à peu près également à l'élan et au cerf des Ardennes; ils ont tous deux de longs poils sur le cou et les épaules, etd'autres iongs poils sous la gorge, qui leur font une espèce de barbe au gosier, et non pas au menton: mais l'hippélaphe n'étant que de la graudeur du cerf, differe en cela de l'élan, qui est beaucoup plus grand; et ce qui me parait décider la question, e’est que l'élan étant un animal des pays froids, n'a jamais existé chez les Arachotas. Ce pays des Arnchotas est une des provinees qu'Alexandre pirreourut dans son cxpédition des Indes : il est situé au delà des monts Cauease, entre la Perse et l'Inde. Ce climat chaud n'a jamais produit des élans, puisqu'ils peuvent à peine subsister dans les con-. trées tempérées, et qu'on ne lis trouve que dans le nord de l'un et de l'autre continent. Les eerfs au contraire n'affectent pas particulierement les terres du nord: on les trouve en grand nombre dans les elimats tempérés et chauds. Ainsi nous ne pouvons pas douter que cet hippélaphe d'Aristote, qui se trouve chez les

'L'hippélaphed'Aristote constitne une espece parliculière the cerf qui vit dans l'Inde. M. Cuvier a publié les caractires de cette espece.
Arachotas, et dans le même pays où se troure le buffle, ne soit le cerf des Ardennes, et non pas l'élan.

Si l'on compare maintenant Pline sur le tragélaphe, avec Aristote sur l'hippélaphe, et tous deux avec la nature, on verra que le tragélaphe est le mème animal que l'hippélaphe, le même que notre cerf des Ardennes. Pline dit que le tragélaphe est de l'espèce du cerf, et qu'il n'en differe que par la barbe, et aussi par le poil qu'il a sur les épaules. Ces caractères sont positifs, et ne peuvent s'appliquer qu'au cerf des Ardennes; car Pline parle ailleur's de l'élan, sous le nom d'alce. Il ajoute que le tragćlaphe se trouve auprès du Phase; ce qui convient ellcore au cerf, et non pas à l'élan. Nous croyons done ètre fondés à prononeer que le tragélaphe de Plinc et l'hippélaphe d'Aristote désignent tous deux le cerf que nous appelons cerf des $\mathrm{Ar}$ dennes; et nous croyons aussi que l'axis de Pline indique l'animal que 'l'on appelle vulgairement cerf du Gange. Quoique les noms ne fassent rien à la nature, e'est cependant rendre service à ceux qui l'étudient, que de les leur interpréter.

\section{LE CHEVREUIL DES INDES.}

\section{(LE CERF MUNTJAC.)}

Ordre des ruminants, section des ruminants à cornes. (Curier.)

Cet animal nous parait être d'unc espèce trèsroisine de celle de nos chevreuils d'Europe; néanmoins il en diffêre par un caractère assez essenticl pour qu'on ne puisse pas le considérer comme ne formant qu'une simple variété dans l'espèce du chevreuil; ce caractère consiste dans la structure des os supérieurs de la tète, sur lesquels sont appuyćes les meules qui portent te bois du chevreuil. C'est encorc au savant professeur M. Allamand, que je dois la connaissance de cet animal, et je ne puis micux faire que de rapporter ici la description qu'il en a publice dans le nouveau supplément it mon ourrage sur les animaux quidrupèdes.

"Nous avons vu, dans les articles précédents, que l'Afrique renferme grand nombre d'animaux qui n’ont jamais été déerits; cela n’est pas étonnant, l'intéricur de cette vaste partie 
du monde nous est presque encoré entièrement. incomnu. On a plus de raison d'être surpris que l'Asic , habitée en général par des peuples plus polices, et très-fréufuentée par les Européens, en fournisse souvent dont aucun voyageur n'a parlé; nous en avons un exemple dans le joli animal dont la description suit :

"Il a été envoyéde Bengale, en 1778, à feu iI. Vau der Stel, commissaire de la ville d'A msterlam; il est arrivé elacz luj en très-lıon état, et jl y a vécu pendant queleque temps. Ignorant le nom sous lequel il est connu dans le pays dont il est originaire, je lui ai domné celui de chevreuil, parce (ju'il lui ressemble par son bois ct par toute sa figure, ([uoirju'il soit beaucoup) plus petit. Celui de chevrotiu aurait mieux répoudu ì sa taille; mais ceux d'entre les chevrotins yui portent des cornes les ont creuses et non pas solides comme le sont eelles de l'animal dout nous parlons, qui parl consévuent en differe par un caractere essentiel. Il a plus de traits de ressemblance avec le ecrf; mais il en est trop différent par la grandeur, pour ([u'on puisse lui en fomner le nom; à peine a-t-jl deux pieds sept pouces de longueur, et sa plus grande hauteur' n'est (que d'un pied et demi.

"Le poil court, dont son corps est couvert, est blanc depuis sá racinejusyu'à la moitié de sa longueur ; l'extrémité en est brune, ce qui fait un pelage gris, où cepentant le brun domine, principaloment sur le dos et moins sous le ventre; l'intérieur des cuisses et le dessous du eou sont blanchâtres; les sabots sont noirs et surmontés d'une petite tache blanche; Jes ergots sout à peiue visibles.

"Sa tête, comme celle de la plupart des animaux mâles à pieds fourchus, est chargée de deux cornes qui offrent des singularités hien remarquables. Elles ont une origine comnume à la distance de deux pouces du bout du museau ; là elles commencent à s'écarter l'unc de l'autre, en faisaut un angle d'envirou quasante degre's sous la peau, qu'elles soulèvent d'une manièretrès-sensible; ensuite elles montent en ligne droite le long des lords de la tète, toujours recouvertes de la peau, mais de facon que l'oil peut les suivre avee autant de facilite que l'attouchement les fait decourir; car elles forment sur les os auxquels elles sont appliepuées, une arrite d'un travers de doigt al'elevation. parremues au laat de la tete, elles prement une autre direction; elles s'élèent perpendicu. lairement au-dessus de l'os frontal, jusq̧u'ì la hauteur de trois pouces, sans que la peau quí les environıc lả de tous côtés les ait quittées : à ce degré d'élévation, elles sont surmontées par ce qu'on nomme les meules et leurs pierrures dans les ecrfs; elles couronnent la peau qui reste en dessous. In milieu de ces meules les cornes contimuent i mouter, mais inégalement. I.a corne gauche s'élève jusqu'à la hauteur de trois ponces, et elle est recourbéc à son extrémité, qui se termine en pointe; elle pousse, presque inmédiatement au-dessus de la meule, un andonilles dirjgé en avant, de la longrueur d'un demi-pouce : la corue droite n'a que deux pouces et demi de longueur, et il en sort un andouiller plus petit encore que celui de la gauche; et dirjuré en arriere. I a figure (qui a été faite d'apres l'animal vivant, représente bien tout ce que je viens de dire. Ces cornes sout saus écorce: lisses et d'un blane tirant un peu sur ic jaume; elles sont sans perlures, et par consequent sans gouttières,

" Cet animal n'a pas vécu fort longtemps dans ce pays, et rien n'a jucliqué son âğe : ainsi j'ignore s'il aurait mis bas sa tête, comme les chevreuils, ou si cellequ'il avait était naissante, et serait devenue plus grande et plus chargee d'andouiller's.

"Si l'on regarde comme ume portion du bois cette partie qui a son origine prés du museau, qui s'étend sous la peau de la face, et qui en reste couverte jusqu'it la meule, on ue peut pas douter que ce bois me soit permanent; et dans ce eas cet animal offrira, de méme que la girafe, une anomalic tres-remarequable dans la classe des animaux qui ont du bois ou des cornes solides.

a Mais on sait que le bois des cerfs, des daims et des chevreuils, pose sur deux éminences de l'os frontal. Dans notre eherreuil indien, co's éminences sont des tubérosités beaucoup plus élevées, dont les prolongements s'étendint entre les yeux juspu'au museau, en s'appliquant fortement aux os du nez, si meme ils ne font pas eorps avec cux ; ear quelque effort que j'aie fait pour insinuer it travers la pean une pointe entre-denx, il m'n été impossible d'y réussir. Comme la dépouille de cet animal ne m'appartient pas, je recrette de n'avojr pas la permission d'ronlever la perau qui coure ces os, pour savoir au juste ce qui en est. Quoi qu'il en soit, il peut mettre bas sal tète avee nutant de 
facilité que le cerf, puisque posées sur le haut de ces éminences, les meules ne sont pas plus fortement adhérentes à ce point d'appui que dans les autres animaux qui perdent leur bois chaque année; ainsi je suis très-porté à croire qu'il le perd aussi : mais ce qu'il y a ici de certain, c'est que cette singulière enformation en forme une espèce particulière dans la classe des ruminants, et non pas une simple variété, telle qu'est le cuguacu-apara du Brésil, qui est à peu près de la mème grandeur.

"Au milieu du front, entre les deux prolongements des tubérosités dont je viens de parler, il y a une peau molle, plissée et élastique, dans les plis de laquelle on remarque une substance glandulense, d'où il suinte une matière qui a de lodeur.

(11 a huit dents incisives dans la mâchoire inférieure, et six dents molaires à chaque côté des deux mâchoires. Il a de plus deux crochets dans la mâchoire supérieure, comme le cerf, qui ne se trouvent point dans le chevreuil d'Enrope ; ces crochets se projettent tant soit peu en dehors, et ils font une légère impression sur la lèvre inférieure.

"Il a de beaux yeux bien fendus : au-dessous sont deux larmiers très-remarquables par leur grandeur et leur profondeur, comme ceux du cerf; ces larmiers, qui manquent au chevreuil, avec ses deux dents en crochets, m'ont fait dire ci-dessus, qu'il avait plus de traits de ressemblance avec le cerf qu'avec ce dernier animal.

"Il a la langue fort longue : il s'en servait non-seulement à nettoyer ses larmiers, mais encore ses yeux, et quelquefois même il la poussait au delà.

"Ses oreilles ont trois pouces en longueur; elles sont placées à un demi-ponce de distance de la partie inféricure des éminences qui soutiennent le bois. Sa queue est fort courte, mais assez large; elle est blanche en dessous.

"La figure de cet animal avait la mème grâce et la même élégance que celle de notre ehevreuil ordinaire; il paraissait mème être plus leste et plus éveillé. Il n'aimait pas à être touché de ceux qu'il ne connaissait point; il prenait cependant ce qu'ils lui présentaient ; il mangeait du pain, des carottes et toutes sortes d'herbes. Il était dans un pare, où il cntra en chaleur dans les mois de mars et d'avril : $\mathrm{fl}$ y avait avec lui une femelle d'axis yu'il tourmentait beaucoup pour la couvrir, mais il était trop petit pour y réussir; il mourut pendant l'hiver de $\mathbf{1 7 7 9}$. Voici ses dimensions :

Longueur du corps, depuis le bout du mup. p. t. seau jusqu'à l'origine de la queue. . . . 270 Hauteur du train de devant. ........ 140 Hauteur du train de derrière. . . . . . . 160 Longueur de la téte, depuis le bout du museau jusquaux oreilles......... 0 ; 0 Dislance cntre le bout du museau et l'extrèmité des prolongements des éminences de l'os frontal qui soutiennent le bois. . . . . . Longueur de ces prolongements jusqu'à l'endroit où ils s'elèreut au-dessus de la tètc. .

-_- - des éminences de l'os frontal, qui sont recouvertes de la pcau, et terminées par les meules. ....... dela corne gauche, depuis la meule jusqu'à son extrémité en ligne droite $\begin{array}{llll}0 & 5 & 0\end{array}$ - de son andouiller........... 0 . 0 de la corne droite, depuis sa meulc

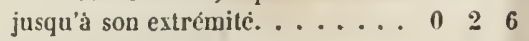
de son andouiller.......... 0 . 0 ( 4

Distance entre les cornes, mesuree sur l'os froutal. ................. 021

Circonférence des cornes au-dessous de la meule. ............... 0 o 20 Longueur des oreilles. . . . . . . . . 0 0 50 Longueur des yeux d'un angle à l'autre. . . 00110 Largeur des oreilles. ............. 020 Ouverture des yeux............. 0 \% 0 Longueur de la queue. . . . . . . . . 0 o 50 Circonférence du museau derrière les nascaur $\begin{array}{llll}0 & 4 & 0\end{array}$ - _- de la tète entre les cornes et les oreilles............. 0 11 0 du milieu du cou. ........ 100

- du corps, derrière les jambes de devant.............. 190 - du milieu du corps.. . . . . . . 1100 du corps derant les jambes de derrière............. 190

\section{LES MAZAMES.}

Section des ruminants à cornes, genre cerf. (Curier.)

Mazame, dans la langue mexicaine, était le nom du cerf, ou plutôt le nom du genre entier des cerfs, des daims et des chevreuils. Hernandès, Recehi et Fernandès, qui nous ont transmis ce nom, distinguaient deux espèces de mazames, tous deux communs au Mexiqueet dans la Nou velle-Espagne : Ic premier et le plus grand, auquel ils donment le nom simple de mazame, porte un bois semblable à celui du chevreuil d'Europe, e'est-à-dire un bois de six ì sept pouces de longueur, dont l'extrémité est diviscée en 
deux pointes, et qui n'a qu'un seul andouiller à la partie moyeune du merrain; le second, qu’ils appellent temamacame, est plus petit que le mazame, et ne porte qu'un bois simple ct sans andouillers, comme celui d'un daguet. II nous parait que ces deux animaux sont vraiment des chevreuils, dont le premier est absolument de la même espèce que le ehevreuil d'Europe, et le second n'en est qu'une varjété; il nous parait aussi que ces cherreuils ou mazames et temamacames du Mexique sont les mêmes que le cuguacu-apara et le cuguncu-élé du Brésil, et qu'à Caycnne le premier se nomme cariacou ou biche des bois, et le second petitcariacou ou biche des palétuviers. Quoique personne avant nous n'ait rapproché ees rapports, nous ne présumons pas qu'il y cuit eu sur cela ni difficultés ni doutes, si Scha ne s'était a visé de donner sous les noms de mazame et de témamaçame deux animaux tout différents : ee ne sont plus des chevreuils à bois solide et branchu, ce sont des gazelles à cornes creuses et torses : ce ne sont pas des animaux de la Nouvelle-Espagne, quoique l'auteur les donne pour tels, ce sont au contraire des animaux d'Afrique. Ces erreurs de Scba ont été adoptées par la plupart des auteurs qui ont écrit depuis; ils n'ont pas douté que ces animaux, indiqués par Scba sous les noms de masame ct de temamaçane, ne fussent des animaux d'Amérique, et les mêmes que ceux dont Hernandes, Rechi et Fernandes avaient fait mention : la confusion du nom a été suivie de la méprise sur la chose; ct en conséquence les uns ont indiqué ces animaux sous le noms de chevrotains, et les autres sous celui de gazelles ou de chèvres. Cependant il parait que M. Linnæus s'est douté de l'erreur, car il ne l'a point adoptéc: il a mis le mazame dans la liste des eerfs, et a pensé comme nous que ce mazame du Mexique est le mème animal que le cuguacu du Brésil.

Pour démontrer ce que nous venons d'avancer, nous poserons en fait qu'il n'y a ui gazelles ni chevrotains dans la Nouvelle-Espagne, non plus que diuns ancune autre partic de l'Amérique; qu'avant la découverte de ce nouveau monde, il n'y avait pas plus de ehèvres que de gazelles, et que toutes celles qui y sont à présent y ont été apportées de l'ancien eontinent; que le vrai mazame du Mexique est le mème aninal que le cugruacu-apara du Brésil ; que le nom cuguncu se prononec couguucou, et que par corruption cet animal s'anpẻlle à Cayenne cariacou, d'où il nous a éré envoyé vivant sous ce même nom cariacou, et nous en donnerons ici la description; ensuite nous rechercherons quelles peuvent être les espèces des deux animaux domnés par Scba sous les faux noms de mazame et de temamaçame ; car, pour détruire une erreur, il ne sufit pas de ne la pas adopter, il faut encore en constater la cause et en démontrer les effets.

Les gazelles et les cherrotains sont des animaux (qui n'habitent que les pays les plus chauds de l'ancien continent; ils ne peuvent vivre dans les contrées tempérées, et encore moins dans les pays froids; ils niont done pu, ni frécjuenter les terres du Noord, ni passer d'm continent à l'autre par ces mèmes terres : ainsi aucun voyageur, aucun historien du Nouveau-Monde n'a dit qu'il s'y trouvât nulle part des gazelles ou des chevrotains. Les cerfs et les che:reuils sont au contraire des animaux des climats froids et tempérés : ils ont done pu passer par les terres du Nord, et on les trouve en effet dans les deux continents. L'on a vul dans notre Histoire du Cerf, que le cerf du Canada est le même que celui d'Europe, rfu'il est sculement plus petit, et qu'il n'y a que quelques légères variétés dans la forme du bois et la couleur du poil : nous pouvons mème ajouter à ce que nous avons dit, qu’il y a en Amérique autant de varićtés qu'en Europe parmi les cerfs, et que néanmoins ils sont tous de la même espèce : l'une de ces variétés est le cerf de Corse, plus petit et plus brun que le cerf commun. Nous arons aussl parlé des cerfs et dles biches blanches, et nous avons dit que cette couleur provenait de leur état de domesticité. On les trouve en Amérique, aussi bien que nos cerfs communs et nos petits cerfs bruns : les Mexieains, qui élevaient ces eerfs blanes dans leurs pares, les appelaient les rois lles cerfs. Nais une troisième variété dont nous n'avons pas fait mention, e'est celle du cerf d'Allemagne, communément appelé cerf des Ardennes, Brandhirtz par les Allemands : il est tout au moins aussi grand que nos plus grands cerfs de Franec, et il en differe par des earnetères assez marquućs ; il est d'un pelage plus foncé et moins noirAtre sur le ventre, et il a sur le enu et la gorge de longs poils comme le boue, ee qui lui a fait donner par les anciens et les modernes le nom de tragélaphe ou bouccerf. Les chevrcuils se sont aussi trouvés ell 
Amérique, et méme en très-grand nombre; nous n'en connaissons en Europe que deux variétés, les roux et les bruns ; ceux-ci sont plus petits que les premiers, mais ils se ressemblent at tous autres égards, et ils ont tous deux le bois branchu. Le mazame du Mexique, le cuguacuapira du Brésil et le cariacou ou biche des bois de Cayenne, ressemblent en entier a nos chevreuils roux : il suffit d'en comparer les ủescriptions pour être convaincu que tous ces noms ne désignent que le mème animal; mais le temamaçame que nous croyons être le cuguacućté du Brésil, le petit cariacou ou biche des Palétuviers de Cayenne, pourraient être une variété différente de celle de l'Europe. Le tèmamacame est plus petit, et a aussi le ventre plus blane que le mazame, comme notre chevieuil brun a le ventre plus blanc et la taille plus petite que notre chevreuil roux; néanmoins il parait en différer par le bois, qui est simple et sans andouillers dans la figure qu'en a donnée Recchi : mais si l'on fait attention que dans nos cherrenils et nos cerfs, le bois est sans andouillers dans la première, et quelquefoís mème daus la seconde année de leur àge, on sera porté à croire que le temamaçame de Recchi était de cet àge, et que e'est par cette raison qu'il n'avait qu'un bois simple et sans andouillers. Ces deux animaux ne nous paraissent donc ètre que de simples variétés dans l'espèce du chevreuil; on pourra s'en convainere aisément en comparant les figures et les passages des auteurs que nous venons de citer, avec la figure et la description que nous donnons ici dlu cariacon qui nous est venu de Cayenne, et que nous avons nourri cn Bourgogne pendant quelques années; l'on verra, en insistant mème sur les différences, qu'elles ne sont pas assez grandes pour séparer le cariacou de l'espèce du chevreuil.

Il nous reste maintenant à rechercher ce que sont réellement les deux animaux donnés par Seba sous les faux noms de mazame et de temamaçame. La seule inspection des figures, indépendamment même de sa deseription, que nous avons citée dans les notes ci-dessus, démontre que ce sont des animaux dı genre des chères ou des gazelles, et non pas de eclui des erris ni des cherreuils. Le défaut de barbe et lit fixure des cormes prouvent que ce ne sont pas des chèves, mais des gazelles, ct en comparant ees figures de Seba arec les gazelles que nous avons décrites, j’ai recomnu que son prétendu temamaẹame de u. Nouvelle-Espagne est le kob ou petite vache brune du Sénégal: la forme, la couleur et la grandeur des cornes est la même; la cuuleur du poil est aussi la même, et differe de celle des autres gazelle; en ee qu'elle n'est pas blanche, mais fauve sous le ventre comme sur les flanes; et à l'égard du prétendu mazame, quoiqu'il ressemble en général aux gazelles, il diffère cependant en particulier de toutes celles dont nous avons ci-devant fait l'énumération; mais nous avons trou vé dans le Cabinet de M. Adanson, oú il a rassemblé les productions les plus rares du Sénégal, un animal empaillé que nous avons appelé nugor, à cause de la ressemblance de ses cornes avec celles du Nanguer. Cet animal se trouve dans les terres voisines de l'ìle de Gorée, d'où il fut envoyé à M. Adanson par M. Andriot, et il a tous les earactères que Seba donne à son prétendu mazame : il est d'un roux pâle sur tout le corps, et n'a pas le ventre blane comme les autres gazelles; il est grand comme un chevreuil; ses cornes n'ont pas six pouces de longueur; elles sont presque lisses, légèrement courbées et dirigées en avant, mais moins que celles du nanguer. Cet animal, donné par Seba sous le nom de mazame ou cerf d'Amérique, est done au contraire une chèvre ou gazelle de l'Afrique, que nous ajoutons ici sous le nom de nagor aux douze autres gazelles dont nous donnons l'histoire et la description '.

\section{LES CHEVROTAINS.}

Section des ruminants sans cornes, genre cher rotain. (Cuvier.)

L'on a donné en dernier lieu le nom de chrvrotain (tragulus) ì de petits animaux des pays les plus chauds de l'Afrique et de l'Asie', que les royageurs ont presque tous indiqués par la dénomination de petit cerf ou petite biche. En effet, les chevrotains ressemblent. en petit au cerf, par la figure du museau, par la légereté du corps, la courte queue et la forme de's jambes: mais ils en different prodigieusement par la taille, les plus grands cherrotains n'ćtant tout au plus que de la grandeur du lievre; d'ailleurs, ils n'ont point de bois sur la tite: les uns sont absolument sans cornes, et ceux

- Axtilore nagon, Cuv. 
ul en portent les opt creuses, annelées et ssez semblables à celles des gazelles. Leur etit pied fourchu ressemble aussi beaucoup Jus à celui de la gazelle qu'à celuj du cerf, t ils s'éloignent également des eerfs et des azelles, en ce quijls n'ont point de larmicrs u d'enfoncements au-dessous des yeux; par i ils serapprochent des ehèv'es : mais dans le éel ils ne sont ni cerfs, ni gazelles, ni clı̀vres, t font une ou plusieurs espèces à part. Selaa onne la description et les figures de einq cherotains: le premier, sous la dénomination de relite biche africaine de Guiné, rougealre, ans cornes; le second, sous celle de farn oujeune orf d'Afrique très-délié; le troisième, sous le orn dejeune cerf très-petil de Guinée ; le quaieme, sous la dénomination de pelite biche e Surinam, rougeütre ct marquetée de laches lanches; et le einquieme, sous celle de cerf 'Afrique à poil rouge. I) ces cinc chevrotains onnc's par Seba, le premier, le second et le visiène sont évidsmment le mème animal; le inquième, qui est plus grand que les trois preliers, et qui a le poil beaucoup plus long et 'un fauve plus foncé, ne nous parait être u’une variété de cette première espèce; le uatrième, que l'auteur indique comme un aninal de Surinam, n'est encore, à notre avis, u'une seconde variété de cette espèce, qui ne e trouve qu'en Afrique et dans les parties méidionales de l'Asie; et nous sommes tr'ès-portés croire que Seba a été mal informé lorsqu'il a it que cet animal venait de Surinam. Tous les oyageurs font mention de ees petits eerfs ou hevrotains au Sénégal, en Guince etaux glanles Indes : aucun ne dit les avoir vus en Améi(que; et si le chevrotain à peau tachée, dont arle Seba, venait en eflet de Suriuam, on doit résumer qu'il y avait été transporté de Guirée ou de quelque autre province méridionale le l'aneien continent. Mais il parait qu'il y a me seeonde espece de chevrotains récllement lifférnte de tous ceux que nous venons d'indifuer, qui ne nous semblent itre que de simples ariétés de la premiere. Ce second chevrotain orte de petites cornes (pui n'ont qu'un pouce le Jongrueur et antant de cireonférence; ces peites comes sont crenses, noirâtres, un peu ourbées, fort pointueset enviromnées à la base le trois ou quatre anneaux trausversitux. Nous oroms au Cibinet du lioi les pieds de eet aninal, avee une de ses cornes, et ees partics suf- fisent pour démontrer que c'est ou un chevrotain ou une gazelle beaucoup plus petite que les autres gazelles. Kolbe', en faisant mention de cette espece de chevrotains, a dit au hasard que ses cornes étaient semblables à celles du cerf, et qu'elles ont des branches à proportion de leur àge: c'est une erreur évidente, et que la seule inspection de ses cornes suffit pour démontrer.

Ces animaux sont d'urte figure cécrante, et très-bien proportionnés daus leur petite taille: ils font des sauts et des bonds prodigrieux, mais apparemment ils ne peuvent courir longtemps , (ar les Indiens les premnent à la course ${ }^{2}$; les Nègres les chassent de mòme et les tuent à coups de báton ou de petites zagaies: on les recherche beaucoup, parce que la chair en est excellente à manger.

Encomparant les témoignages des voyageurs, i) paraît $1^{0}$ (que le ehevrotain qui n'a point de cornes est le chevrotain des Indes orientales ${ }^{3}$; $2^{0}$ (que celui qui a des cornes est le cherrotain du Sénégal, appelé yuevei par les naturels du pays ${ }^{4} ; 3^{0}$ qu'il n'y a que le mâle du guevei qui porte des cormes ${ }^{5}$, et que la femelle, comme

1 A Congo, à Viga, en Guincé, et daus d'autres endroits jrès du cap de llonne-Esjêrance, on trouve une es] ièce de chèvre, a lagunclle je donne le nom de chivre de Congo; jamais elles ne sont plus grandes qu'un licvve, mais elles sunt d'une beantes et d'une symélrie admirables; leurs curnes sont semblables à celles du cerf, el ont aussi des branches à proportion de leur áce, elles ont les jambes forl jolio's et si jetile's yu' ion se sert sonvent de la parlie inferieme pour presser le labac daus la jipe, tont la division est forl serréc. On les munte en or ou en argent. Hescription du cap de Honue-Esperance, par kolbe, tome IIl, page $\mathbf{3} 9$.

${ }^{2}$ Les habitants d'une petile ile jrits Java apporlèrent des biches qui sont de la grosseur d'un lière, el ine ces Inıliıns attrayent a la conrse. Voyage de le tientil. l'aris, 1723, 1. III, page 73... Item, page 93.-En volei encore suse sorte: ce sont de jefits animanx parfaitemut jolis, avec de fort jelules cornes noiro's et des palles fort mennes yui, a propurlion de leur corps, sont passablement longnes, mais si ureumes yu० il y ell il yni ne passent point l'epaissent du bunt d'une puje? je voll en envoie une garnie l'or, etc. . Ces julits animam smbt patrèmement légers à la course et funl des sauls surpuruant? du moins purr de st petiles betes : jen ai vu de cems pue unu arions pris, tui saulaient par-dessus une muratle de dis a Ilouze pieds de haut. Les Negres les numment les rois de's cerfs. Vuyage de Cininée, jar Busman, jage 232.

SEE CUESRUTAIX IIGHE.

4 A.TII.OPE diCEUE.

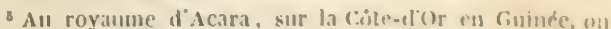

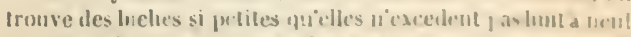
punces de hantcur: leurs jumbers ur smut pas plus grandee ol

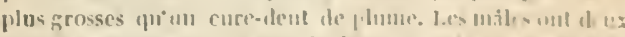

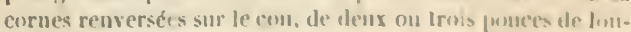
furvir: vlles sont sans bramelies on amilonillers, eontomrués, unires el luisantes commer du Jayel. liken nest plum mignom, plus prive el plus caressant pue ees fuelils animaus: mais tls sont diune si grande délicalcsse quils ne peuvent sutfrir la mer, el ynel,jue soin que les Européens aient pris pur en apr porter eu Europe, il leur a été muposibible d'y réussir. Vuyage. 
celle de la grimme, n'en porte point; $4^{0}$ que le chevrotain à peau marquetée de taches blanches ', et que Seba dit se trouver à Surinam, se trouve au contraire aux grandes Indes, et notamment à Ceylan, où il s'appelle memina. Jone l'on doit conclure qu'il n'y a (du moins jusqu'à ce jour) que deux especes de chevrotains, le memina ou chevrotain des Indes sans cornes, et le guevei ou chevrotain de Guinée à cornes; que les cinq chevrotains de Scba ne sont que des variétés du memina, et que le plus petit chevrotain, qu'on appelle au Sénégal guevei-kaior, n'est qu'une variété du guevei. Au reste, tous ces petits animaux ne peuvent vivre que dans les climats excessivement chauds; ils sont d'une si grande délicatesse cju'ona beaucoup de peine ì les transporter vivants en Europe, où ils ne peuvent subsister, et périssent en peu de temps; ils sont doux, familiers, et de la plus jolie figure; ce sont les plus petits, sans aucune comparaison, des animaux à pied fourchu : a ce titre de pied fourchu, ils ne doivent produire qu'en petit nombre, et, à cause de leur petitesse, ils doivent au contraire produire en grand nombre à chaque portée. Nous demandons a ceux qui sont à portée de les observer, de vouloir bien nous instruire sur ce fait; nous croyous qu'ils ne font qu'un ou deux petits à la fois, comme les gazelles, les chevreuils, etc.; mais peut-être produisent-ils plus souvent: car ils sont en très-grand nombre aux Indes, à Java, à Ceylan, au Sénégal, à Congo et dans les autres pays excessivement chauds, et il ne s'en trouve point en Amérique ni en aucune des contrées tempérées de l'ancien contincut.

\section{DESCRIPTION DU CHEVROTAIN.}

\section{(EXTRAIT DE DAUBENTON.)}

Le chevrotain est le plus petit des animaux à pied fourchu, au moins de tous ceux que nous connaissons; il n'a guère plus d'un pied de longueur depuis le bout du nez jusiju'à l'origine de la queue; la couleur fauve de son poil, ses jambes longues et dèlices, sa queue courte et un air de légèreté clans ses proportions, l'ont fait comparer au cerf, et lui en ont aussi fait donner le nom; la grande diffe-

de Desmarchais, tome I, pagc 31.-Voyez anssi l'Ilisloire générale des Voyages, par M.l'abbé Prevost, tome IV, page 75.

- AxtLlope mkMMIx rence qui est entre la taille deces animaux, a reodn le cherrotain plus remarquable qu'il ne l'aurait été s'il s'était trouvé plus gros ; on est surpris d'y voir un grand cerf en raccourci, un cerf adulte qui est anssi petit que l'embryon de notre cerf : mais, pour peu que l'on observe le chevrotain, on reconnait aisément qu'il est d'une espèce bien différente de celle du cerf.

Le museau a peu de largeur; le nez est aussi arancé que la lèvre supérieure, comme celui dı cerf, du daim, du chevreuil, et non pas reculé en arrière, comme le nez des boucs, des béliers et des gazelles; le museau a peu de largeur, les yeux sont grands, les jambes de derrière ont plus de longueur que celles de llevant, parce qu'elles ont les canons beaucoup plus longs; le chevrotain n'a point de larmiers, comme les cerfs, les gazelles, etc. ; mais il y a entre les secondes plaalanges des doigts, et principalement de ceux de derrière, un petit trou peu profond : ainsi la conformation du pied ressemble en quelque manière à celle du pied des gazelles;je n'ai point trouvé de brosses sur les jambes de devant, ni sur celles de derrière d'un jeune chevrotain conservé dans l'esprit-de-yin, ni sur la peau bourrée de deux adultes, qui sont les seuls que j'aie vus.

Le bout du museau du jeune clicrrotain, le dessus et les côtés de la tète, du cou, de la poitrine et du corps, la croupe, le côté postérieur de la queue, la face externe des oreilles, l'épaule, le bras, la face externe de l'avant-bras, de la jambe et de la cuisse, une partie de la face interne dela jambe, les canons et les pieds de devant, la partie postérieure, et les cútés des canons et des pieds de derrière avaient différentes teintes de fauve ou de roux; le dessus du clianfrein, de la tête, du cou et du corps étaient d'un roux sombre et mèlé de brun; le roux des janıes et des côtés de la tête, du cou et du corps était plus clair et presque fauve; le dessous de la uutchoire inferieure, la gorge, le dessous de la poitrine, le ventre, une partie de la face interne de la jambe et de l'avant-bras, la partieantérieure des canons et des pieds de derrière, et le còté antérieur de la queue, avaient une couleur blanchatre; le dessous lu cou était en partie de cette couleur et en partie de couleur faure; ce jeune cherrotain avait les dents incisives bien formées et les måchelicres commengaient à paraitre. 


\section{LE CHEVROTAIN DE CEYLAN.}

\section{(Le ChevectaIN MEMINA.)}

Section des ruminants sans cornes, genre chevrolain. (Cuvier.)

Nous avons ditque le ehevrotain à peau marfuctée de taches blanches, et que Seba dit se trouver à Surinam, ne se trouve point en Amérique, mais au contraire aux grandes Incles, où il s'appelle memina. Nous a vons reeu la dépouille d'un chevrotain de Ceylan sous ce nom memina, qui a une parfaite ressemblance avec la deseription que j'en ai publiée. En la comparant à celle du chevrotain, on verra que ces deux petits animalux sont également sans cornes, et qu'ils ne sont tous deux qu'une simple varicité daus la mème espece.

\section{IE CHEVROTAIN.}

\section{APIELE: A JAVA PETITE GAZELLE.}

\section{IE CIILVROTAIN DE JAVA.}

Section des ruminants sans cornes, genre cherctain. (Cirvier.)

Un chevrotain venu de Java, sous le nom de petite gizelle, nous parait ètre de la mème espèce a très-peu pres que celle du cherrotaiı memina de Ceylan : les seules diflérenees que nous puissions y remarquer ont qu'il n'a point, comme le memina, de bandes ou livrées sur le corps; le poil est seulement ondé ou jaspé de noir, sur un fond de couleur de muse foncé, avee trois bande's blanches distinctement malrquées sur la poitrine: le bout du nez est noir, et lis tète est plus arrondie etplus line que cetle du memina, et les sabots des pieds sont plus allongres. Cés différences assez légères pourraient n'ètre qu'individuelles, et ne doivent pas nous empècher de regarder ec chevrotain de Java comme une simple variété dans l'especee du memina de Ceylan. Au reste, nous n'alvous paseu d'autre indication sur ce petit animal, yui n'est eertainement pas du genre des gizclles, mais de celui des chevrotains.

\section{LE MUSC.}

\section{(LE CHEVROTAIN-PORTE-MISSC.)}

Seclion des rumiuants saus cornes, genre clierroldit? (Cusier.)

Pour achever en entier l'histoire des chevres, des grazelles, des cherrotilins et des autres animaux de cegenre, yui tous se trouvent dims l'ancien continent, il ne nous manque que eelle de l'animal aussi célebre que peu comu, duquel on tire le vrai muse. Tous les naturalistes modernes et la plupart des voyageur's de l'Asie en ont fait mention, les uns sous le nom de cerf, de chevreuil ou de chève du musc; les autres l'ont considéré comme un grand cluevrotain : et en effet il parait ètre d'une nature ambiguë et participante de celle de tous ces animaux, quoique en mème temps on puisse assurer que son espece est nue et différente de toutes les autres. Il est de la grandeur d'un petit chevreuil ou d'une gazelle, mais sa tête est sans cornes et sans bois; et par ce caractere, il ressemble an meminu ou chevrotain des lndes. Il a deux grandes dents eanines ou crochets a la mâchoire supéricure, et par là il s'ipproche encore du chevrotain, gui a aussi deux grandes dents canines a cette meme mâchoire : mais ce qui le distingue de tous les imimaux, e'est une espece de bourse d'emsiron deux ou trois pouces de diamètre qu'il porte pres du nombril, et dans laquelle se filtre la liqueur, ou plutót l'humeur grasse du muse, differente par son odeur et par sa consistance, de celle de la eivette. L.'s Grees ni les liomains n'ont filit aucune mention de eet animal du muse; les premiers qui l'aient indiqué sont Jes Arabes; Gessner, Aldrovande, Kircher ${ }^{1}$, et Borm en ont

1 Je dis tone, en premier lien, qu'il se truwe un cerlain cerf dans les provinces dn $\mathbf{X}$ insi ot de (iliamsl, lequel scut fort bon, et à yui les Chinois ont donné le $11+u$ de serelian.

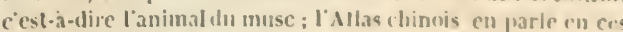
termu's: a J'our ne vons faire fass languir davantage lunchant - Ia siguification de ce nom on de ee unot muschus. Je vin - dirai ce que j'en ai vil plus d'une fois. Cet anumal a 1 ue cer.

- taine bosse an unmbril yui ressemble a une pelile In)urse. - jarce un'elle est entunede J'une juan fort didicale, el cun- verle diun poll forl dour el tres délid. Les cilunus aplellent - celle bute se, yul vent dine odeur. d'ui ils componsent ce - unot xehiany, tuli signifie l'ndeur de l'animal are nu se, mus. - chus. "Il a quatre pieds de longueur, il est ausa vite in'u cerf; loul, Ia différenee qu'il y a, cest que son poil est un peo plus nuir el qu'il a'a polnt de cornes comme lui. Les Chinois 
donné des notions plus étendues ; mais Grew ${ }^{1}$ est le seul qui en ait firitune description exacte d'apres lá dépouille del'animal, qui deson temps était conservée dans le Cabinet de la Société

mangent sa chair parce qu'elle est très-délicate. Les provinces de Suclien et de Junnan aboudent extraordinairement en ces sortes d'auinaux, el on peut dire çue de toutes lesconIrées de la chine, il n'y en a pas qui en aient eu si grande quantilé que les payss qui a)prochient le plus de l'O ccident. La Chine illustrée de Kircher, traduitc par d'Alquié, Ansterdan. 1610 , page 256.

4 Le cerf du musc sc trouve à la chine et aux Indes orientales : il n'est pas mal représenté dans le Muséum de Calcesrlariıs. La figure quen a donnée Kirclıcr (China illustrata) véche par le museau et par les pieds. Celle de Jonston est ahsurve; presipue partout cet aninal est unal décrit. Tous les anteurs counaissent dit Aldrovande $q u$ 'il $a$ deux cornes, exccpté simeon Sethi, ıui dit qu'il r'en a qu'une : ni l'un ni l'autre n'est vrai. Il en est de mẻuc de la description donnée par Scaliger, et ecsuite par Chiocco dans le Calceolarii Museın. elle est très-défectneuse; la meilleure est celle qui se t́ouve dans les Éphémérides d'Allenagne; cependant, en la comparaut avec celle que j'ai faite moi-mème, et que je vais domner ici, j'y ai trouvé quelques différences.

cet aninal a du bout du nez jusqu à la queue environ trois pieds, la tète cinq à six pouces de largeur; le bout du nez n'a pas un pouce de largeur, il est pointu et semblable à celui d'uu lévrier ; les oreilles rcsscnibient á celles du lapin, elles sunt droites et ont environ trois ponces de liauteur; la queve est droite aussi el n*a pas plus de deux pouces de longueur; les jambes de devant ont environ treize ou quatorze pouces de hauteur ; cet animal est du nombre des pieds fourchus, le pied est fendu profondément, armé en avant de deux cornes on sibots de jlus d'un pouce de lons, et en arrière de deur autres prestuue aussi grands; les pieds de derrière manguaient au sujet que je décris ici. Les poils de la tète et des jambes n'étaient longs que d'un deni-ponce et étaient assez fins; sous le ventre ils étaient un pcu plus gros et longs d"un pouce et demi; sur le dos et les fesses ils avaient trois ponces de longuteir, et ils étaient trois ou quatre fois plus gros que des soies de co hon, c'est-à-dire plus gros que dans aucun autre animal. Ces poils élaient marqués alternativement de bran cl de blanc depuis la racine jusquà l'extrémité; ils étaient bruns sur la tête et sur les jambes, blanclıâtres sous le ventre el sứrla ıqueue, oudés, c'est-à-dirc, un peu frisés sur la crompe elle ventre,plus donx an toucher que dans la plupart des autres auimaux. Ils sont aussi extrèmement légers tl diune textıac tris-peu compacte, car en Jes fendant el les regardant avec la ioupe, ils paraissent conme composés de petites vessies semblables a celles que l'on voit daus le tuyau des plumes, cu sorte qu'ils sont, pour ainsi dire, d'une subslance moycune entre celle des poils et des Inyaux de plume. De chayuc cótéde: la máchoire inférieure el un peu au-dessons ucs coins de la bouche, i] y a un pelit toupet de poils d'euviron trons yuarls de ponce de loug, durs, raides, d'égale granjeur, et assez sembliables a des suics de cocholi.

La vessie ou la liourse qui renferuc le munc a cnviron trois pouces de longneur sur dcux de largeur; clle est juoéminente ull-dessus dela peau du ventre. denviron un jouce "t demi...; ranimal a vinğt-six dents, seize dans la mâchoirc inféricurc, Jont huil incisives devant, et quatre molaires derrierc, et de chauje cólé aulant de molaircs dans la mảchoire supérieure, et à un pouce êt demi de distance de lexirémité du nez. Il y a de chaıuc cólé, dans celte mẻme michoirc supérienre, me défense ou dent canine d'environ denx pouces el denu de lons, courbec 'u arrière et en bas, et sc lerminant en pointc; ces uléfenses ne soul pas rondes, mais aplaties; clles sunt lar. ges diun demi-pouce, pen épaisses ct tranclıantes en arrićre, (') sorte qu'elles ressemblenlassez à une pelite fancille: il u'y royale de Londres. Cette deseription est en an glais, et jai cru devoi!' en donner ici la tradur" tion. Un an après la publication de cet ouvrar de Grew, en 1681, Luc Schrockius fit impri mer à Vienne en Autriche l'histoire de ect ani mal, dans laquelle on ne troure rien de for exact, ni d'absolument nouveau : nous com binerons seulement les faits que nous en pour rons tirer avec ceux qui sont épars dans les au tres auteurs, et surtout dans les voyageurs le plus récents; ct au moins, ne pouvant fair mieux, nous aurons rassemblé, non pas tout ce que l'on a dit, mais le peu que l'on sait au sujel de cet animal que nous n'arons pas vu, et que nous n'avons pu nous procurer. Par la description de Grew, qui est la seule piece authentique et sur laquelle nous puissions compter, il parait que cet animal a le poil rude et long, le museau pointu, et des défensesà peu près comme lecochon, et que par ces premiers rapports ils'approche du sanglier, et peut-être plus encore de l'animal appelé babiroussa, que les naturalistes ont nommé sanglier des Indes, lequel, arec plusieurs caracteres du cochon, a néaumoins comme l'animal du musc, la taille moins grosse et les jambes hautes et légères, comme celles d'un cerf ou d'un cherreuil. D'un autre coté, le cochon d'Amérique, que nous arons appelé pecari, a sur le dos une cavité ou bourse qui contient uue humeur abondante et très-odorante, et l'auimal du musc a cette mème bourse non pas sur le dos, mais sur le ventre. En général, aucun des animaux qui rendent des liqueurs odorantes, telles que le blaireau, le castor, le pecari, l'ondatra, le desman, la civette, le zibet, ne sont du genre des cerfs; ou des chevres. Ainsi nous serions portés à croile que l'animal du musc approche plus de celui des cochons, dont il a les défenses, šil avait en mème temps des dents incisives à la mâchoire supéricure; mais il manque de ces dents incisives : et, par ce rapport, il se rapproche des animaux ruminants, et surtout du chevrotain qui rumine aussi quoiqu'il n'ait pas de cormes. Mais tous ces indices extéricurs ne suffisent pas, ils ne peuvent que nous fournir des conjectures; l'iuspection seule des parties intérieures pent décider la nature de cet animal qui jusqu'à ce jour

a poinl de cornes sur la tète, ctc. l'assage que j"ai tradııt do langlais dans le livre qui a pour titre: Musienm Reg. SocieLatis, by Mehcmiah (irew, M, D. Lond. page 22 et 25. 
DI MUSC.

riest pas connue. J'avoue méme que ce n'est que pour ne pas ehoquer les préjugés du plus grand nombre que nous l'avons mis a la suite des shèvres, gazelles et chevrotains, quoirqu'il nous ait paru aussi éloigné de ce genre que d'aucun autre.

Marc Paul, Barbosa, Thevenot, le P. Philippe de Marini, se sont tous plus ou moins trompés dans les notices ' qu'ils ont données de cet animal : la seule chose vaic et sur laquelle ils s'aceordent, e'est que le muse se forme dans une poche ou tumeur qui est près du nombril de l'animal; et il parait par leurs témoignages et par ceux de quelques autres voyageurs,

1 raolo le décril de celte façn : II a le poil gros comme celui du cerf, les pieds et la quene comme une gazelle, et n'a point de corne non plus quielle. 11 a quatie dents en hast, longues de trois doigts, délicates et lilanclies comme l'ivoire. denx qui s'élèvent en haut et deux tournées en bas, et cet animal est heau à vnir. Dans la pleine lune, it lui vient nue anostume an ventre près du nomliril, et alors les chasscurs le prennent et ouvrent cet apostumr. Barbosa dit çüil est plus seniblable a la gazclle; mais il ne s'accorde pas avec les autres anteurs en ce qu'il dit qu'il a le poil blanc. Voici ses paroles : - Le muse se tronve dans de pelits animaux blancs cuni res- semblent aux gazelles et ıni ont des dents comtnoses élé- phants, mais plus petites. Il se forme à ces animaux une ma - nlère diapostume sous le ventre et sons la poitrine; et ynand - la nıatière est mùrie, il letır vient une telle démangeaison, - un'ils se frottent contre les arbres, et ce uni tombe en pectits - grains est le muse le plus excellent et Je plus parfait. o l.a description 'ne donne $M$. Thévenot convient encore moins avec les autres; il en parle en ces termes : \& II y a dans ces pays - un animal semblable d un renard par Ic musean, qui II" a jis - le corns plus gros aniun lievre; il a le poil de la conleur de - celni dn cerí et les dents comme celle d'un chicu; il pro - dult de très-excellent muse, il a an ventre une vessie guij est - pleine de sang corrompu, et e'est ce sang yui conmose le - muse on qui est le muse méme ; on la lui oble et on courre - anssitòt avec du euir l'endroit de la vessie quj est conpée, - alin d'enupécher yue lodenr ne se dissipe: mais a jurès que - I'opération ist faite la lièle ue demeure pluss Iongatempis en - vie.a La deseription d'Antoine l'igafetta, yni dit pue le musc est de la taille d'un chat, ne pent convenir avere celle des antres antenrs; la description que donne le P. I'hilippe de :larini uc convient pas tout à fait avec celle des autres anteurs, ear il dif que cet aummal a la tete semblable a celle d'un loup: et le l'. Kirelier dans la ligure gin'il en clome, le represente avec un groin de cochon, ce qui est jent-ètre la faute din gravenr uni lui tonne anssi des onoles, au lien un il a la corne fendue. Siméon Sethi s'éloigne encore pluss de la vérité (') nous représentant cel animal grand comme la licorne, el mène conmr étaut de ectte espéce. Visici ses paroles : a Le unuse de - mnindre valenr est crlui yu'on apporte des Judes, (nui tire - surr le noir; et le moindre de tons est celui uni vient sle la - Cluine. Tout ce musc se forme sous le nembril dim animal

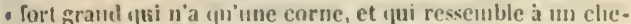
- vrenil; lorsifuili est en chialent, il se fant antuur ile sun nom- bril yn anas de siadg épais qui lui canse unc enllure, il la - donlenr l'empéclie alurs de lovire et de manger il se roule - a terre el met bas cette tmuenr remplie de s.mg hourberr - qui sétant caillé après un temps considéralıle, acomiert la " houme udeur. - Totti ees antenrs convienuent de la minière dont It muse se forme daus la vessie, ou tans la lumenr yu: parait an nombril de l'animal ynand il e'sten rut. Aneienues Relations des fude's el de la chine, paze $216 \mathrm{cl}$ suivantes. qu'il n'y a que le mâle qui produise Ic bou musc; que lin femelle a bien la même poche pris du nombril, mais que l'humeur qui s'y filtre n'a pas la même odeur : il parait de plus que eette tumeur du mâle ne se remplit de muse que dans le temps du rut; et que dans les autres temps, la quantité de ectte humeur est moindre et l'odeur plus faible.

A l'égard de la matière même du muse, son essence, e'est-i-dire sa substance pure est peutètre aussi peu connue riue la nature de l'animal qui le produit : tous les voy ageurs comviennent que cette drogue est toujours altérée et mèlée avec du sang ou d'autres drogues par ceux qui la vendent; les Chinois en augmentent nonseulement le volume par ce mélange, mais ils cherehent encore a en aummenter le poids, en y incorporant du plomb bien trituré. Le muse le plus pur et le plus recherché par les Chinois même est eclui que l'animal laisse eouler sur des pierres ou des trones d'arbre contre lesqueis il se frotte lorsque cette maticre devient irritante ou trop abondante dans la bourse oil elle se forme. Le musc qui se trouvedans la poche mème est rarement aussi bon, paree (qu'il n'est pas cneore muir, ou bien parec que ce I'est que dans la saison du rut qu'il acquiert toute sa force et tonte son odeur, et que dans celte mème saison l'animal cherclie à se dobarrasser de cette matiere trop exaltée qui lui cause alors des pientements et des démangreaisons. Chardin' et Tavernier ont tous deux bien dé-

1 J. crois que la plupart dn monde sait assez que le musc est lexcriment ct le pus llune bète yui ressemble à la clıevre saunage, exceuté yu'ville a le curps cl les jambes plus deil.es; elle se trouve dans la ll,ute-Tarturie, dans la chine segutentriomate qui lui est limitrophe, et an Grand-Thiluet, qui est un

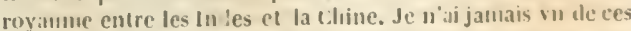
animan-la en vic. mais jen ai vu des peanx en bien des rnIrois: leu en tronve des portraits dans l'Ambiscarle des Ilalliuslicis en Chine, et dans la China illustrala du J". Kirclur : on dit communéunent unue le nuse est une suenr de cet inimil uni conle el qui sarnasse en une ressie delice prode le nombril; les Orientanr disent plas précısenent pu' il se furme un abces dans le corps de celle chère, jurclie tombilic. dout ilumucur vicole et démange, surtont lumine la luete est en chaleur: ifialors a force de se frotter cuntre les arbres

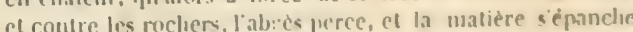
atI minu: cudroit entre tes nuscles et la pean, et en s'y aunas sant yorme une manicre de loupe on de vesif : que la clialeur interue ichanffe ce sang corromju et que cost entle

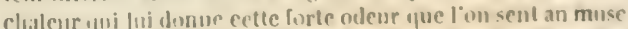
Les (1ricutanx alpellenl colle lessic le nomtril dn musr. et imssi le nomblit udorifiranl; Ie lon musc sapporte du Thibet: les crientaux l'ostimant ylus que celui de la ( hine suit

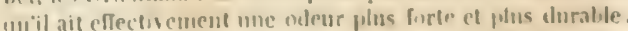
soit yne ce la leur pa: alse seulcuent arrivant jus frass rhez enx, parce yne le thribel en est plus procbe une la provinco 
crit les muyens dont les Orientaux se servent pour falsifier le muse : il fitut nécessairement que les marchands en augrmentent la quantité biet au delá de ee qu'on pourrait imaginer, puisque dans une seule anuce Tavernier ${ }^{1}$ en

Xinsi, qui est l'endroit de la Chine oul l'on fait le plus de musc. Le graul commerce de musc se fait à Boutan, ville célèbre dı royanme de Ilibet, les Patans yui vont lá en faire cmplette, le distribuent par toute l'Inde, d'ou on le transporte ensuite par toute la terre; les Pataus sont voisins de la l'erse et de la Ilaute-rartarie, sujets ou seulement tributaires du Grand-1Iogol. Les Indiens funt cas de cette diogue aromatique, tant pour l'usage que pour la recherche que l'on en fait ; ils l'emploient en leurs parfums et confections, et dans tout ce qu'ils ont accoutumé de préparer pour réveiller l'humeur aınoureuse, et pour rétablir la vigueur; les femmes s'en servent pour dissiper les vapeurs qui montent de la matrice au cerveau, en portant une vessie au nombril; et quand les vapeurs sont violentes et continuelles, elles prennent du musc hors de la vessie, l'enferıent dans un petit IInge fait comme un petit sac. et l'appliquent dans la partre que la pudeur ne permet jas de nommer.... On tient communément que lorsqu'on coupe le petit sac où est le musc, il en sort une odeur si forte, quil faut que le chasseur ait la bouche et le nez bien bouchés diun linge en plusieurs doubles; et que souventmalgré celte précaution, la force de l'odeur le fait saigner avec tant de violence quil en meurt. Je me suis informé de cela exactement; et comme en effet j’ai ouî raconter quelque cliose de semblable à cles Arméniens qui avaient été à Boutan, je crois que cela est vrai. Ma raisun est que cette drogue nacyuiert point de force avee le temps, mais qu'au contraire elle perd son odleur à la Iongne; or cette odeur est si forte aux Indes, que je ne l'ai janıais pu supporter. Lors yue je négociais du musc, je ne teuais toujours à l'air, un mouchoir sur le visage, loin de ceux yui inaniaient ces vessies, men rapportant a mon courtier, ce qui me fit bien connaitre dès lors que le musc est fort entètant et tout à fait insupportable quand il est frais tiré; j’ajoute (qu'il n’y a drogue au monde plus aisée à falsifier et plus sujette à l'être; il se trouve bien des bourses qui nesout que despeaux de l'animal, remplies de son sanget d'un peu de musc pour donner l'odeur, et non cette loupe que la sagesse de la nature forme proche le nombril pour recevoir cette espèce d'lumeur merveilleuse et odoriférante. Quant aux vraies vessies mème, lorsque le chasseur ne les trouve pas bien pleines, il presse le ventre de cet animal pour en tirer du sang dont il les remplit, car on tieut yuse le sang tu muse, et ıème sa cliair senteut bon; les marchands ensuite y mèlent du plomb, du sang de bouf et antres clroses propres à les apuesantir, qu'ils font entrer dedans à force. Lart dont les Orientaux se servent pour connaitre cette falsification, sans ouvrir la vessie est premièrenent an poids, à la main. l'cxpérience leur a fait conuaitre combien doit peser uue vessie nou altérée; le gont est leur seconde preuve, anssi les Indiens ne manquent jamais de mettre à la bouche de petits graius 'püils tirent des vessies lorsquils en achètent; le troisième, c'est de jurendre un fil trempé dans du sue d'ail et de le tirer au traver's de la vessie avec une aiguille; car si l'odeur d'ail se perd le nusc est bon; si le lil la gardeil est altéré. Voyages de Chardin. Amsterdam, 1711, tome I1, jages 16 et 17.

' La meilleure sorte et la plus grande quuantité de musc vient du royaume de lloutan, d'où on le porte à Patua, principale ville de Bengale, your négocier avec les gens de ces pays-lá tontle muse yui se negocie dans la Perse vient de la.... J'a eu la curiosité d'apporter la peau de cet animal à Paris, dont en voici la ligure.

Apres quon a tue cet animal, on lui coupe la vessiequi paralt sous le ventre de la grosseur d'un ouf, et qui est plus proche des parties géuitales que du nombril ; puis on tire de la resic le unse qui s'y tronve et qui est alurs comme du saug acheta seize cent soixante-treize vessies; ce qui suppose un nombre égal d'animaux auxquels cette vessie aurait été enlevée : mais comme ect animal n'est domestique nulle part, et que son espèce est confinée à quelques proviuees de l'O-

caillé; quand les paysans le veulent falsifier, ils mettent du foie et du sang de l'animnal laaché enseuble en la place đu musc qu'ils ont tiré; ce mélange produit dans les vessies, en deux ou trois années de temps, de certains petits animaux qui mangent le bon musc, de sorte que quand on vient a les ouvrir, on y trouve beaucoup de déchet; d'autres jaysans, quand its out coupé la vessie et tiré du muse ce qu'its en peuvent tirer, sans qu il y paraisse trop, remettent à la place de petits morceaux de plomb pour la rendre plus pesante; les mar. chands qui les aebètent et les transportent dans les paysétrangers, aiment bien mieux cette tromperie que l'autre, parce qu'il ne s'y engendre point de ces petits animaux; nais la tromperie est encore plus malaisée à découvrir, quand de la peau du ventre dn petit animal ils font de petites bourses qu'ils cousent furt proprement avec des filets de la mème peau et qui ressemblent aux véritables vessies, et ils remplissent ces bourses de ce qu'ils ont ôté des bonnes vessies avec le mé. lange frauduleux qu'ils $y$ veulent ajouter, à quoi il est diffieile que les marchands puissent rien connaitre; il est vrai que s'ils liaieut la vessie dès qu'ils l'ont coupée, sans lui donuer de l'air, et laisser le tempıs à l'odeur de perdre sa force ell s'évaporant, tandis qu'ils en tirent ce qu'ils en veulent ôter, il arriverait qu"en portant cette vessie au nez de quelqu'un le sang lui sortirait aussitót par la force de lodeur qui doit nécessairement ètre tempérée pour se rendre agréable sans nuire au cerveau. L'orleur de cet animal que j'ai ałporté a Paris était si forte, quili était impossible de le tenir dans ma chambre : il entêtait tout le moude au logis, et il fallut le mettre au grenier, ou entin mes gens lui coupèrent la vessie, ce qui n'a pas einpêché que la peau n’ait toujours retenu quelque chose de l'odeur. On ne commence à trourer cet animal (u'environ le cinquante-sixième degré ; mais au soixanticme, il y en a grande quantité, le pays étant rempli de forèts : il est vrai quau mois de février et mars, après que ces animaux out souffertla faim dans les pays ou ils sont, á cause des neiges qui tombent en quantité jusqua à dix ou douze pieds de haut, ils viennent du côté du midi, jusqu'à quaranté-quatre ou quarante-ciuq degrés pour manger du blé ou du riz nouveau, et cest ence temps-la que les paysaus les attendent au passage avec des piéges qu'ils leur tendent, et les tueut à coups defleches et de batons; quelques-uns d'eux m'ont assuré qu'ils sont si maigres et si lauguissants à cause de la faim qu'ils ont soufferte, que beaucoup se laissent prendre à la course. Il faut qu'il y ait une urodigiense quantité de ces animaux, chacun d'eux n'ayant qu'une ressie, et la philıs grosse quin'est ordinairenent (que comme un oruf de poule, ne ponvant fournir une demi-once de musc, it faut bien quelquefois trois ou yuatre de ces vessies pour en faire nue once.

Le roi de Dantan, de qui je parlerai an volume suivant, dans la description yue je ferai de ce royaume, eraignant que Ia tromıerie qui se fait au musc ne fit cesser ce négoce, d'autaut plus quon en tire aussi du Tuzquin et de la Cochineline qui est bien plus clier parce unuil n'y en a pas en aussi grande ıuantité; ce roi, dis-je, craignant que cette marchandise falsiliée ue déeriât le commerce de ses états, ordonna, il y a unelque temps, que tontes les ressies ne seraient point cousues, mais quelles seraicut apuortées onvertes à Boutau, qui est le lieu de sa résidence, pour y ètre visitees et seellies de son sceau; toutes celles quejaja achetées itaient de cette sorte, mais nonobstant toutes les précautions du roi, les pay saus ıes ouvrent subtilement, et y mettent, comme je l'ai dit, des petits morceaux de plonb, ce que les urarehands tolèrent, parce yise le plourh, ne gåte pas le nusc, ainsi que j’ai remarqub', ef ne fait tort que pour le poids. Dans un de mes voyages a l'atua, 
rient, il est impossible de supposer qu'elle est assez nombreuse pour produire une aussi grande quantité de cette matiere; et l'on ne peut pas douter que la plupart de ees prétendues poches ou vessies ne soient de petits saes artificiels faits de la peau mème des autres parties du corjes de l'animal, et remplis de son súng mêlé avec une très-petite quantité de vrai musc. Ein effet, cette odeur est peut-étre la plus forte de toutes les odeurs connues; il n'en faut gu'une tres-petite dose pour parfumer une grande (fuan)tité de matière : l'odeur se porte à une grande distanec; la plus petite particule suffit pour se faire sentir dans un espace considérable; et le parfun mème est si durable et si fixe, quia bout de plusienrs années il semble n'itroir pas perdu beaucoup de son activité.

\section{ADDITION A L'ARTICIE DU NeSC.}

Nons donnons la figure de l'animal du muse, que jai fait dessiner d'après la nature vivante. Cette figure manquait a mon ourrage, et n'a jamais été donnée que d'une maniere très-incorrecte par les autres naturalistes. II parait que ret animal, qui n'est commun que daus les parties orientales de l'Asic, pourrait s'hahitucr et peut-être mème se propager dans nos elimats; ear il n'exige pas des soins trop recherchés : il a vécu pendant trois ans dans un pare de M. le due de la Vrilliere, it lihermitage pres de Versáilles, oì il n'est arrivé quau mois de juin 1772 , après aroil été trois autres annces en chemin. Ainsi voili six années de captivité et de malaise, pendant lesfuefles il s'est très-bien soutenu, et il n'est pas mort de dépérissement, mais d'une maladie acejdentelle. On avait recommandé de le nourril' avee du riz crevé dans l'eau, de la mie de pain, mìlés asee de la mousse prise sur le trone et les branches de elhene : on al suivi exactement eette recette; il s'est toujours birn porté, et sa mort, en avril 1755, n’a ćté calusée que par une égagropile, e'est-ì-dire par une pelote ou glohe de son propre poil qu'il avait détaethé en se léchant et gu'il

Jarhelai scize cenl soirmule-Ireiee vessies, yui pesaienl deux

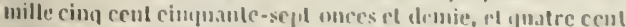
cinumante-rlenx onees hors de la vessic. l.es six Veyages de Jeau-13aplisle Tavernier (un Turyuic, cu l'erse $\mathrm{cl}$ aux Indes

A Hotien, 1713, lome 11, Lage 73 jusipid 78. IV. a vait avalé. M. Daubenton, de l'Académie des Sciences, qui a dissérjué cét animal, a trouvé cette pelote dans la caillette à l'orifice du pylore. Il ne craignait pas beatuoup le froid : néanmoins, pour l'en garantir, on le tenait en hiver dans une orangerie, et pendiunt toute cette sai. son il n'avait point d'odeur kle musc; mais il en répandait une assez forte en été, surtout dans les jours les plus chatuds. Lorsqu'il était en liberté, il ne marchait pas it pas comptés, mais courait en sautant, à peu prés comme un lieve.

Voici la deseription de eet animal que M. de Sève a faite a vee exactitude.

Le musc est un animal d'une jolie figure ; il a deux pieds trois pouess de longueur, vingt potees de hauteur au train de derricre, et dixneuf pouecs six lignes à celui de devant. Il est vif et lécer à la course et dans tous ses mouvements; ses jambes de derriere sont considérablenent plus longues et plus fortes que celles de devant. La nature l'a armé de deux défenses de chaque cóté de la mâchoire supéricure, qui sont larges, dirigées en bas et recourbées cn arrière; elles sont tranchantes sur leur borkl postéricur en finissant en pointe; leur longueur, au-dessous de la levre, est de dix-huit lignes, et leu. lirgeur d'une ligne et demic; elles sont de eouleur blanche, et leur substance est une sorte d'ivoire. Les yeux sont grands á proportion du corps, et l'iris est d'un brun roux; le bord des paupicres est de couleur noire, ainsi que les naseaux. Les oreilles sont grandes et larges, elles ont quatre pouees de hauteur sur deux pouces yuatre ou cincl lignes de largeur; elles sont garnies én dedans de grands poils d'un blane mélé de grisatre, et ell de'ssus de poils noir's roussit. tres mèlés de gris, comme celui du front "t du nez. Le noir du front est releré par une tache blanche qui se tromse au milicu : il s a du faure jaunatre all-dessus et all-dessous des yenx, mais le reste de la tete parait d'un gris d'ardoise. paree que le poil y est mélangé de noir et de blanc, comme edui du cou, ou il y a de plus

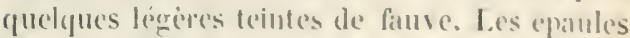
et les jambes de derant sont d'un hrun noir. ainsi que les pieds; mais cette coule'ur noilere est mouns foncre sur les culisses et les jamioes de derriere, ou il y a puelyuesteinte's de faure. les pieds sont pedits, cellx de derant ont denx ergots qui touchent lit terre et qui sont situés au talon; les sabols des pieds de derrière sont iué- 
gaux en longueur, l'intéricur étant considérablement plus long que l'extérieur; il en est de méme des ergots, dont l'interne est aussi bien plus long que i externe. Tous les sabots des pieds qui sont fundus comme ceux des chèrres sont de couleur noire, ainsi que les ergots. Le poil du dessus, du dessous et des eótés du corps est noiråtre, mélangé de teintes fauves, et mèmo de roussâtres en quelques endroits, parce qu'en général les poils, et surtout le plus longs, sont blanes sur la plus grande partic de lene longueur, tandis que leur extrémité est brune, noire ou de coulcur faure. Les erottes de cet animal sont tres-petites, d'un brun luisant et de forme allongee, et n'ont aneme odeur ; et le parfum que l'animal répand dans sa eabauc n'est guère plus fort que l'odeur' d'une civette. Au reste, le musc parait ètre un animal fort doux, mais en méme temps timide et craintif; il est remuant et très-agile dans ses mouvements, et il paraissait se plaire à sauter et à s'élancer contre un mur qui lui scrvait de point d'appui pour le renvoyer à l'opposite.

Comme M. Daubenton a domné à l'Académic des Sciences un bon mémoire au sujet de eet animal, nous croyons devoir en rapporter iei l'extrait.

"L'odeur forte et pénétrante du muse, dit-il, est trop sensible, pour que ce parfum n'ait pas été remarqué en même temps que l'animal qui le porte; aussi leur a-t-on donné à tous les deux le même nom de muse. Cet animal se trouve dans les royaumes de Boutan et de Tunquin, à la Chine et dans la Tartarie chinoise, et mème dans quelques partics de la Tartarie moscovite. Je erois que de temps immémorial il a été recherché par les habitants de ces contrées, parce que sa chair est très-bome à manger, et que son parfum a toujours dù faire un commerec; mais on ne sait pas en quel temps le muse a commencé à ètre conuu en Enrope, et même dans la partie oecidentale de l'Asie. Il ne parait pas que les Grees ni les Romains aient cu comnaissance de ec parfum, puisque Aristote ni Pline n'en ont fait aucune nention dans leurs éerits. I.es auteurs arabes sont les premier's qui en aient parlé. Sérapion domna une description de cet animal dans le lutitieme siede..

" Je l'ai vu, au mois de juillet ( $1 ; \div 2$ ), dans un pare de $\mathbf{M}$. de la Vrilliere, à Versailles; l'odeur du muse qui se répandait de temps en tenps, suivant la direction du reut, autour de l'enceinte ou était le portc-musc, aurait pu me scrvir de guide pour trouver ect an imal. Dés que je l'aperẹus, je recomnus dans sa fignure et dans ses attidudes beaucoup de ressemblance avecle eheveruil, la gazelle et le chevrotain; ancun animal de ee genre n’a plus delégereté, de souplesse et de viracité dims les mouvenents que le porte-muse. Il ressemble encore aux auimaus ruminants en ce qu'il a les pieds fourchus, ct qu'il manque de dents incisives à la måchoire supéricure: mais on ue peut le comparer qu’au chevrotain pour les deux défenses ou longues dents canines qui tiennenta la mâchoire de dessus, et sortent d'un pouec et demi au dehor's des lèries.

"La substance de ces dents est une sorte d'ivoire, comme eelle des défenses du babiroussa et de plusicurs autres especes d'animaux : mais les defenses du porte-muse ont une forme trèspartieulière; clles ressemblent à de petits conteaux courbes, placés au-dessous de la grueule, et dirigés obliquement de liaut en bas et de devant en arriere, leur hord postérieur est tranchant... Je crois qu'il s'cn sert à différents usages, suivant les circonstanees, soit pour couper les racines, soit pour se soutenir dans des endroits oil il ne peut pas trourer d'autre point d'appui, soit enfin pour se défendre ou pour attacuer...

"Le porte-muse n'a point de cornes; les oreilles sont longues, droites et très-mobiles; les deux dents blanches qui sortent de la gueule et les renflements qu'elles forment à la levre supérieure, donment à la physionomie du porte-muse, vu de face, un air singulier qui pourrait le faire distinguer de tout autre animal, á l'execption du cherrotain.

"Les couleurs du poil sont peu apparentes: au lieu de conleur décidce, il n'y a gue des teintes debrun, de faure et de blanchâtre, qui semblent changer lorsqu'on regarde l'animal sous différents points de vue, parce que les poils ne sont colorés en brun ou en fauve qu'd leur extrémité; le reste est blane et parait plus ou moins à différents aspects... Il y a du blane et du uoir sur les oreilles du porte-muse, et unt ítoile blanche au milicu du frout.

Cette étoile me parait être une sorte de livrée qui disparaitıa lorsque l'animal sera plus Aggé; ear je ne l'ai pas vue sur deux peaux de porte-muse qui m'ont été adressées pour le Cabinet dı Roi, par M. le Monnier, médecin du 
10), ie id part de madame la comtesse de Marsall... Les deux peaux dont il s'agit mont paru venir d'animaux adultes, l'un mâle et l'autre femelle; les teintes des coulcurs du poil y sont plus foncées que sur le jorle-musc vivant que je viens de décrire; il y a de plus sur la face inféricure du cou deux bandes blanchatles, latrges d'environ un pouce, qui s'étendent irrérgulierenent le long du cou, et qui forment une sorte d'ovale allongé, en se rejoignant en a vant sur la gorge, et en arriere entre les jambles de devant.

"Le muse est renfermé dans une poche placée sous le ventre à l'endroit du nombril; jen'ai vusur e porte-muse vivant que de petites cimineuces sur le milieu de son venter je u’ai pu les observer de près, paree que l'animal ne se laisse pas approcher... la poelie du muse tient al'une des peatux envoyées au Ciabinct du Roi : mais cette poche est desséchée; il II) il partu que si clle étail dans son état naturel, elle anrait au moins un ponce et demi de diametre; il y a dans le unilien un orilice très-sensible, dunt j’at tiré de la substatice du muse, tres-odorante et de couleur reusse... M. Gmelin, ayant observé la situation de cette poche sur deux matles, rapporte dans le qualrième volume des Mémoires de l'Académie impériale de l'élersboury, qu'clle était placéc au-devant et un peu it droite du prépuce...

"Le porte-muse differe de tout autre animal par la poche eju'il a sous le ventre ct qui enfer'me le muse; cependant, quoique ce ralactere soit unirque par sá siluation,.., il ne contribue nullement à détrminer la place du porte-musc parmi les quadrupedes, paree (ju'il y a des sub)stances orloriléruntes yui viennent d'animaux très-différents du porte-muse...

"L.es caracleres extérieurs du porte-muse, qui indiquent ses rapports aree les autres quatdrupedes, sont les pieds fourelius, les deux longues dents camines et les huit dents incisives de la machoire du dessus, sans qu’il y en ait daus colle du dessous. l'ar ees caracteres, le porte-muse resscmble plus au chevrotiain ru'à

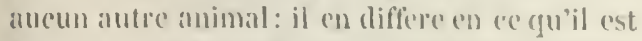
beaucoup plus grand; car il a plus d'um pied et demi de hauleme, prise depuis lo bas de's pieds de rlevant jusqu'atu-dlessus de's epranle's, timelis yue le cherotain n'a gurere plus d'un demipicd.

a Les dents molinires du porte-muse sont au nombre de six de chaque cóté de chacune des mảchoires: le cheviotain n'en a que quatre. 11 y a aussi de grandes différences entre ces deux animaux, pour la forme des dents molaires et des couleurs du poil. La poche du muse fait un caractere yui u'apparticnt (qu’all porte-muse mâle: la fernelle n'a ni poche, ni muse, ni dents canines, suivant les observations de M. Gmelin, que j’ai cité.

"Le porte-musc, que j’ai vu virant, paralt n'avoir point de queue. M. Gmelin a trouvé sur trois individus de cente esperen, au lieu de queue, un petit prolongement charum, long d'environ un poure... II y a des auteurs (fui ont fit représenter le porte-muse avec une queue hien appartente, quvique fort courte. Grew dit yualle a deux pouees de longucur; mais il u'a pas observé si ertte fartie renfermait des vertebres.

( )ans la description que M. Gmelin a faite du porte-muse, les visceres mont paru ressem. blants a ceux des animatix ruminants, surtout les quatre estomaes, dout le premier a trois convexités, comme dans les animaux saurages qui rumineut. Si l'on joint ce caractère à celui des deux dents eanines dans la màchoire dı dessus, le porte-muse ressemble plus, par ces deux caracticres, au cerf gu'it aucun autre animal ruminant, esecpté le chevrotain, au cas qu'il rumine, comme il y a lieu de le eroire.

"Ray dit (füil est doutcux que fe porte-nuse rumine. les gens yui soirnent eelui yue j’ai décrit vivant ne savent pas s'il rumine; je ne l'ai pas vu assez long-temps pour en juger par moimeme, mais je sais, par les observations de II. (innelin, yu'il a les oreranes de la rumiuation, et je crois gu'on le verra ruminer, etc., etc.

\section{LE SIIGA.}

\section{(L'ANTH.OHE SAIGA.)}

Tribu des ruminants a coenes creuses, benre antilope. (Cuvier.)

On trouve en Hongrie, en l'oloune, en Tar. tarie et dans lis Sihśrie mérichnale, une espèce

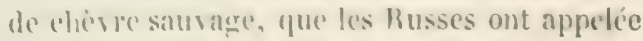
seignk un saigu, licpuedle, par la figure du corps et par le poril, lesscmalile a la cheore domestlyue; mais par la forme des cornes et le défaut de babe se rappoche beacoup des gazelles, 
et parait faire la mance entre ces deux gremres d'animaux : ear les cornes clu sauga sont tout a fait semblables à celles de la gazelle; elles ont la mẻme forme, les anneaux transversaux, les stries longitudinales, ete., et n'en different que par la couleur : les cornes de toutes les gazelles sont noires et opaques ; celles du saigra sont au contraire blanchâtres et transparentes. Cet animal a été indiqué par Gessmer sous le nom de colus, et par M. Gmelin, sous eelui de sciga. Les cornes que nous avons au Cabinet du Roi y ontété envoyées sous la dénomination de cornes de bouc de Hongrie: elles sont d'une matière si transparente et si nette qu'on s'en sert comme de l'écaille et aux mêmes usages. Par' les habitudes naturelles, le saigga ressemble plus aux gazelles qu'au bouquetin et au chamois : car il n'affecte pas les pays de montagnes; il vit comme les gazelles, sur les collines et dans les plaines; il est comme elles très-bondissant, très-léger à la course, et sa chair est aussi bien meilleure à manger que celle du bouquetin ou des autres chèvres sauvages et domestiques.

\section{ADDITION A L'ARTICLE DU SA ̈GA.}

M. Pallas pense que le saiga, qui se trouve en Hongrie, en Transylvanie, en Valachie et en Grèce, peut aussi se trouver dans l'ile de Candie; et il croit qu'on doit lui rapporter le strepsiceros de Belon. Je ne suis pas dı mème avis, et j’ai rapporté le strepsiceros de Belon au genre des brebis et non à celui des gazelles.

" Saïgis, saïga, dit M. Gmelin, est un animal qui ressemble beaucoup au cherreuil, sinon que ses cornes, au lieu d'être branchues, sont droites et permanentes (au lieu que celles du chevrenil sont annuelles). On ne comnait cet animal que dans quelques cantons de la Sibérie; car celui qn'on appelle sä̈ga dans la province d'Irkutzk est le muse. Cette espece de chève sauvage (le saiga) est assez commune dans certaines contrées : on en mange la chair ; cependant notre compagnie ne voulut point en gouter, vaisemblablement parce que nous n'y étions pas accoutumés, et que d'ailleurs il est dégoutant de voir daus ect auimal des vers mème de son vivaut, nichés entre la peau eharnue et l'épiderme; c'est une grande quantité de ver's blanes et gros, d'environ trois quarts de pouce de long et pointus des deux cotés. On trouve la même chose aux élans, aux remnes ct aux hi. ches: les vers de ces ehcrres paraissent être les mènes (que ceux de e's alitres animaux, et n'en différer que par la glosseur. Quoi qu'il en soit, il nous suffit d'avoir vu les vers pour ne point rouloir de cette viande, dont on nous dit d'ailleurs ruc le goût était exactenent semblable à cenle du cerf. "J'observerai que ce n'est que dans une saison, apres le temps du rut, que les cerfs, les élans, et probablement les saïgas, ont des vers sous la peau. Voyez ce que j'ai dit de la production de ces ver's à l'article du Cerf.

M. Forster m'a écrit, " que le saïga se trouve depuis la Moldavie et la liessarabie, jusqu'a la rivière d'Irtisch en Sibérie. Il aime les déserts sees et remplis d'alssinthes, aurones et armoises : qui font sa principale nourriture. II court très-vite, et il a l'odorat fort lin ; mais il n'a pas la vue bonne, paree qu'il a sul les yeux quatre petits corps spongieux qui servent à le défeudre du trop grand reflet de la lumière dans ces terrains, dont le sol est aride et blanc en été, et couvert de neige en hiver. Il a le nez large et l'odorat si fin, qu’il sent un homme de plus d'une liene lorsqu'il est sous le vent, et on ne peut même l'approcher que de l'autre côté du vent. On a observé que le saigga semble réunir tout ce qui est nécessaire pour bien courir : ila la respiration plus facile qu'aucun autre animal, ses poumons étant très-grauds, la trachée-al . tère fort large, et les narines, ainsi que les cornets du nez fort étendus; en sorte que la levre supérieure est plus longue que l’inféricure : elle parait pendante, et c'est probablement à cette forme des levres qu'on doit attribuer la maniere dont cet auimal pait; car il ne broute qu'en rétrogradant. Ces animaux vont la plupart en troupeaux, qu'on assure être quelquefois jus qu'au nombre de dix mille; cependant les voy. geurs modernes ne font pas mention de ers grauds attroupements: ce qui est plus certair. e'est que les mảles se réunissent pour défendro leurs petits et leur's femelles contre les attaque des loups et des renards; car ils forment ui cercle autour d'elles, et combattent courageusement ees animaux de proie. Arec quelquez soius, on vient à bout d'élever leurs petits et do les rendre privés: leur roir ressemble au bilement des brebis. Les femelles mettent bas au printemps, et ne font quiun chevreau à la fois et rarement deux, On cn mange la chair en hi. 


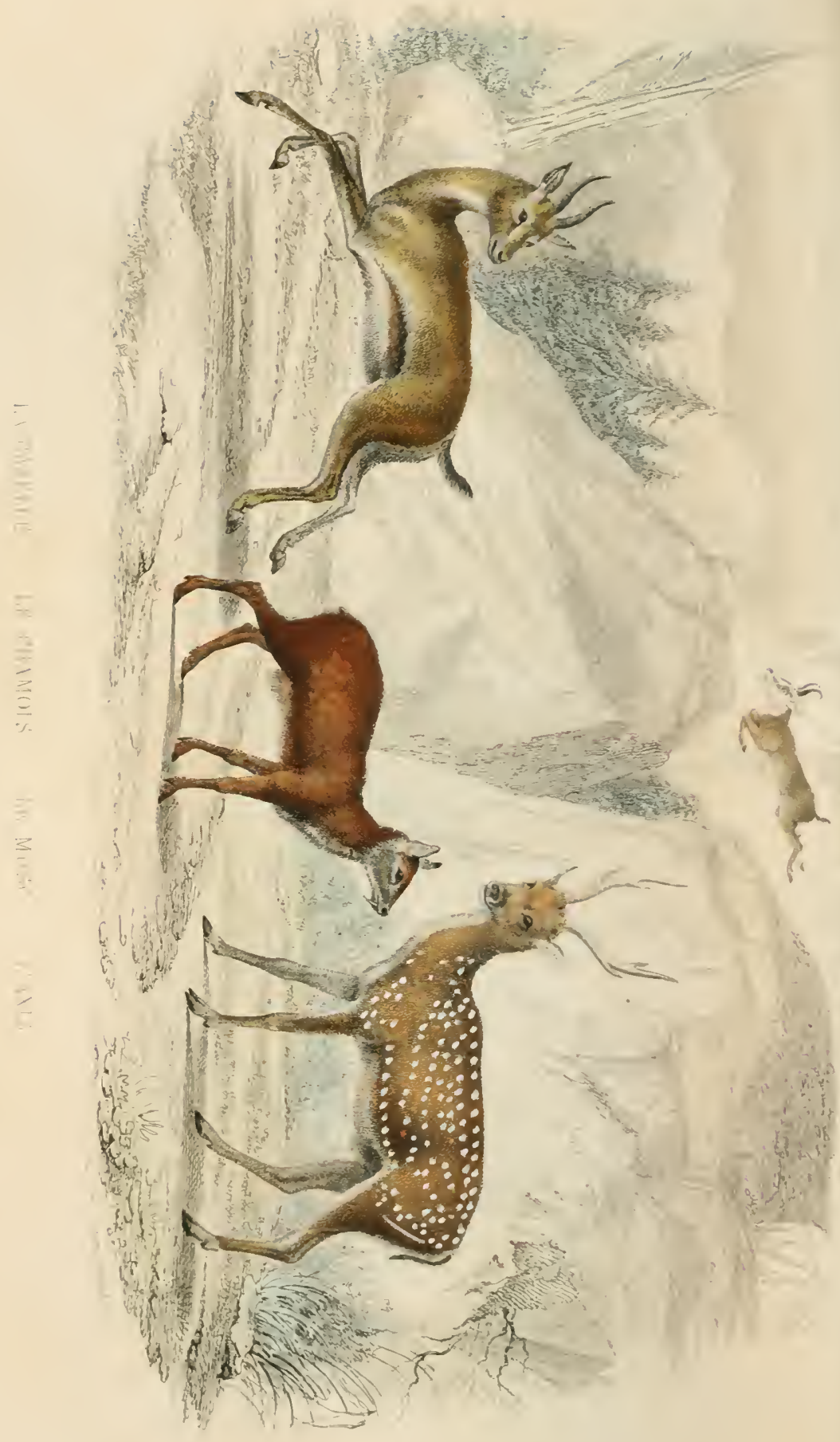


ver enmme un bon gibier; mais on la rejette on été a cause des vers qui s'engendrent sous la peatr. Ces animaux sont en chilleur con automne, et ils ont alors une forte odeur de muse. Les coriles de saiga sont trimsparentes, et estimées pour différents usigres; les Clinuis surtout les achitent assez cher. On trouve queldquefois des salgials a trois cornes, et mine on en voit qui n'er ont quitune serule, ce qui est c'rntirmé prar M. P'alliss; et il scmble gue ce'set le meme animall dont lizalezinshy parle, en disant : Aries campesstris (Burcen poluty) unius cornu instrurtues sprectulue in desertis locis uleru lirucluviam Oczolioviom usypue protensis.

" Le sitigat est de lat grandere d'une dhevre commune. Les cormes sont longules d'un pied, transpatrentes, d'un janne terne, riclées ('n bas d'anneaux et lisses a la pointe; cllles sont eourbées culloriere, et les pointe's se mapprochent. L.es oreilless sont droites et termince's en puinte mousse; la lète est arquée ou chl chanfrein, depuis le front jusyu'an mustau, et en lat regalrlint de profil, on lui trouse quelipue rapport ree eelle de la brebis. Le's mitrines sont grandes te en forme de fube. Il y a huit dents incisises à a màchoire inférieure; (clles ne tiement pas forc'oncint dans leurs alvioles, ef tombent alu moinlee choe. Il n'y a que les milles qui alient de's

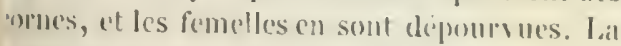

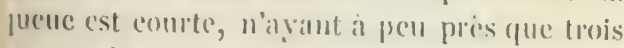
moces de longeneur: le poil du dessus et des

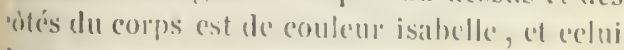
lu ventere est bline; il y a une ligne brume le

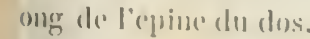

"Sillga est un mot tartitre, guni signifie dhevere allvake; mais rommuncoment ils appeillent le

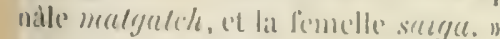

\section{I.ES GIZEIIILS.}

Opde des ruminamts, genre antilope. (Curiore)

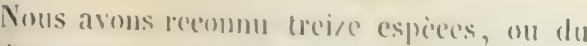
wins treize barietes bien distinctes dans les

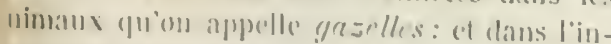

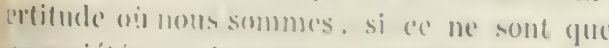

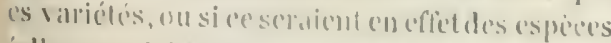

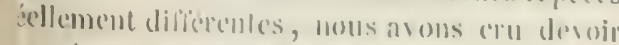

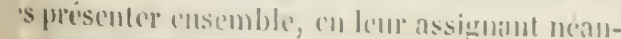

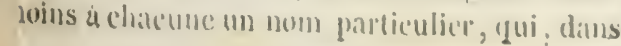

ie premier eas, ne sera qu'une dénomination précaire, et pourra, dans le srennd, devenir le nom spécifigue et propre à l'espèce. Le premier de ces animatur, et le seul anquel nous conserverons le nom générique de guzelle, est la gazelle commune yui se trouve en Syrie, en Mésopotamic et dans les autres provinces du Le. vant, anssi bien qu'en Barbrarie et daus toutes

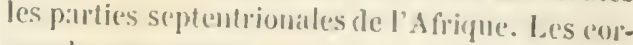
nes de ecelte galzelle ont emsiron un pied de longruerur; colles portent des ammeaux eatrers a ieur base, et ensuite des demi-anneanx jusrqu a une petite distince de leur extrémité, qui est lisse "t pointue; clles sont non-seulement environnces d'ammeanx, mais sillomees longitudinalement par de petites stries : les amneaux marquent les ammés de l'aceroissement; ils sont ordinairement all nombre de douze ou treize. Le's gilzelle's en grenciral, et celle-ci en particulicr, ressconblent beancoup au chevreuil, par la forme du erorps, par les fonctions naturelles, pall lis legerenté des mouvements, la glandeme et lat viviteites yeus, ete. Et comme le chevenil ne se trouve point clans les pays qu'habite la gazolle, on serait d'abord tente de croire quiclle

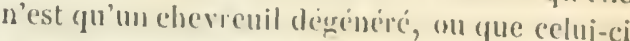
n'est qui une gazcille dematurée par l'inlluence du climat et par lesfet de la différente nourriture : mais les gilyedles different du cherreuil par lit niture des comes; celles du elsevreuil sont une espeere de bois solide, qui tombe et se renouvelle tous les ans, commer edui du cerf; les eormes des grizcilles, ill contraire', sunt creves ('t perminentes, comme cerlles de la chere. J):ailleurs le cheveruil n'a point de resicule du licl, au lielu que les gatzelles ont eette vesicule comme les che'vie's. Le'suazellesont, comme? he chereruil, des limmiers on cufoncements audevant de elataue (ril : ellle's lui ressemblent e'ne'ore parr la qualite du poil, par la blancheur des tesses et par les brosses quide's mut sur les jambe's; malis res lorosses dans le cherreuil sont sur les jamlues de derricere, au lieu gue diuss les ga gelles clles sont sul le's jambes de derant. les Eilzdld's paraisont done itre des animaus mipartis, intermadiates entre le cherrenil et lat chespe : mais lorsque l'an ansidere (pue le elieveruil ast un aninail yui se troure malement dins les dem continents: que le's cheres, an

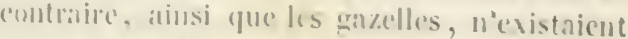
flis dauns le Noureau-Momde, on se persuade aisement yute en dewr espeers, fes cherreset les 
gazelles, sont plus voisines l'une de l'autre qu'elles ne le sont de l'espèce du cherreuil. Au reste, les seuls caractères qui appartiennent en propre aux gazelles, sont les anneaux transiersaux a vecles stries longitudinales sur les eornes, les brosses de poils aux jambes de devant, mue bande épaisse et bien marquée de poils noirs, bruns ou roux au bas des flanes, et enfin trois raies de poils blanchâtıes qui s'étendent longitudinalement sur la face interne de l'oreille.

La seconde gazelle est un animal qui se trouve au Sénégal ', ou M. Adanson nous a dit qu'on l'appelait kevel. Il est un peu plus petit que la gazelle commune, et à y,cu près de la grandeur de nos petits chevreuils. Il diffère aussi de la gazelle, en ce que ses yeux sont beaucoup plus grands, et que ses cormes, au lieu d'ètre rondes, sont aplaties surles còtés : cet aplatissement cles cornes n'est pas une différence qui provienne de colle du sexe; les gazelles màles et femelles les ont rondes; les kevels malles et femelles les ont plates, ou, pour mieux dire, comprimées. Aureste, lekevel ressemble en enticlà la gazelle, et a, comme elle, le poil court et fauve, les fesses ct le ventre blane, la queue noire, la bande brume au-dessous des flanes, les trois raies blanches dans les oreilles, les corues noires et enviromnées d'anneaux, les stries longitudinales entre les anneaux, ete.; mais il est vrai que le nombre de ces anneaux est plus grand dans le kevel que dans la gazelle : celle-ci n'en a ordinairement que douze ou treize: le kevel en a au moins quatorze et souvent juscu'à dix-huit et vingt. ( Joyez ci-uprès lu description du lerel.)

Le troisième animal est celui que nous appelJerons corine du nom korin ${ }^{2}$, qu’il porte au Sénégal. II ressemble beaucoup à la gazclle et au kevel; mais il est encore plus potit que le kevel, et ses cornes sont debeaucoup plusmenues, plus courtes et plus lisses que celles de la wazelle et du kevel, lesanneaux qui enviromment les cornes de la corine étant très-peu proéminents et à peine sensibles. M. Adanson, qui a bien voulu me communiquer la description qu'il a faite de cet animal, dit qu'il parait tenir' un peu du chamois, mais quil est beaucoup plus petit, n'ay ant que deux pieds et deni de longueur et moins de deus pieds de hauteur; (quil a les oreilles loneuses de quatre pouces et demi, la quene de trois pouces, les eornes de six pouces de longueur et de six

1. Arthopr gazfi.l.

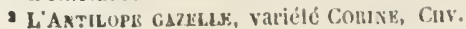

lignes seulement d'épaisseur; qu'elles sont distantes l'une de l'autre de deux pouces à leur nais sance, et de einç à six ponces à leur extrémité; qu'elles portent, au licu d'anneaux, des rides transversales, amnulaires, fort scrrées les unes contre les autres dans la partie inférieure, et beancoup plus distantes daus la partie supéricure de la corne; que ces rides, qui tiennent lieu danneaux, sont au nombre de près de soixante; qu'au reste, la corine a le poil court, luisant et fourni, fauve sur le dos et les flanes, blane sous le ventie et sous les cuisses, arec la (pueue noire, et qu'il y a dans cette même espèce de la corine des individus dont le corps est tigré de taches blanchâtres semées sans ordre.

Ces différences que nous renons dindiquer entre la gazelle, le kerel et la corine, quoique fort apparentes, surtout pour la corine, ne nous semblent pas essentielles ni suffisantes pour faire de ces animaux des espèces réellement différentes; ils se ressemblent si fort à tous autres égards, qu'ils nous paraissent au contraire être tous trois de la mème espèce, laquelle seulement a subi, par' l'iufluence du climat et de la nouriture, plus ou moins de varićtés : ear le kevel et la gazelle diffèrent beaucoup moins entre eux que la coline, dont les cornes surtout ne sont pas semblables à celles des deux autres; mais tous trois ont les mêmes habitudes naturelles, se rassemblent en troupes, vivent en société et se nourrissent de la móme manière; tous trois sont d'un naturel doux et s'accoutument aisément àla domesticité ; tous trois ont aussi la chair très-bonme à manger. Nous nous croyons donc fondés à conclure que la gazelle et le lievel sont certainement de la mème espèce, et qu'il est incertain si la corine n'est qu'une varicité de cetíc mème espèce, ou si e'est uise espèce diflérente.

Nous avons au Cabinet du Roi les dépouilles en tout ou en partie de ees trois différentes gązelles, et nous avous de plus une corne qui a beaueoup de ressemblance aree eclles de la salzelle et du kerel, mais (jui est beancoup plus grosse. Cette cornc est aussi gravéc dams Alliovande, lib. I, de Bisulcis, c. XXI. Sa grosscur et sa longueur semblent indiquer un animal plus arand que la gazelle commune, et elle nous parait appartenir it une gazelle que les Tures appellent lacircen, et les Persans ahu'. Cet ani-

I I thu des presans est un cerf, on cherrenil de Tarla. ric, el la corne liguréc cst celle de la chivie blene. 
mal, selon Oléarius, ressemble en quelque sorte à notredaim, sinon qu'il est plutòt ronx que fiuve, et que les cornes sont sans andouillers, couchées sur le dos, ete.; et selon M. Gmelin, qui le désigne sous le nom de dzheren, il ressemble au chevreuil, à l'exception des cornes, qui, comme celles du bourquetin, sont (reuses et ne tombent jamais. Cet auteur ajjoute qu'à mesure que les cornes prennent de l'aceroissement, le cartilage du larynx grossit au point de former sous la gorge une proéminence considérable lor'sque l'animal est âgé. Selon Kémpfer, l'ahu ne differe en rien du cerf pirr la figure; mais il se rapproche des chèves parr les eornes, (qui sont simples, noires, annelées jusqu'nu delí du milieu de leur longueur, ete. Quelgues autres voyageurs 'ont aussi fit mention de cetle espece de gazelle sous les noms corrompus de geiran et dle jairain, (ju’il est aisé de rapporter, anssi bien yue celui de dsheren, au nom prinitil Leiran. Cette gazelle est commune dans lá 'Tartarie méridionale, en P'rse, en Turruie, et parait aussi se trouver aux Indes orientales ?

Nous devons ajouter à ces quatre premières espieces ou races de gazelles deux autres animax qui leur ressemblent en beaucoup de choses: Ie premier s'appelle kobu au Sénégal, ou les Français l'ont nommé grande vache brune ${ }^{3}$; le second, que nous appellerons $k o b^{4}$; , est aussi un aumal du Sénégal, que les Français y ont appelé pelite vache brune. Les cornes du kob ont beaucoup de ressemblance et de rapport à celles de li gazclle et du kevel; mais la forme de la tète est différente, le museanu cst plus long, et il n'y a point d'enfoncements ou de larmiers sous les yeux. I.e koha est beaucoup plus grand que le kob : celui-ci est comme un daim, et celui-lir comme un cerf. Par les notices que nous a domnces M. Adanson, et que nous publions avec bien de la recomnaissance, il parait que le lioba ou grande vache brune a cing pieds de longueur, depuis l'extrémité dn museau

I Sur la route de Tauris a linm, nous vimes une espece dianimaux sauvages forl lmus a manger, que les l'ersaus appel. lenlgeirans un garzelles.... Voyage de ciencelli Carreri, tome II, page 65.-11 y a une inlinilé dle gazelles dans les déserts de lit Mesuputanic: les Tures les appellent jairain. Voyage de La Itmillaye le Gour, page 237.

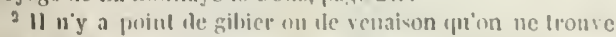

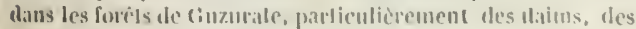
ehevienils, des alıus el des ines samvages. Voyage de Mau. delslo, Imur II, piage 195.

s'ANILORE h(1).1.

+ L'A.NTLLOSE KOB. jusqu'à l'origino de la queue; qu'il a la tète longue de quinze pouces, les oreilles de neuf, et les cornes de dix-neuf à vingt pouces; que ces cornes sont aplaties par les côtés et environnées de onze ou douze ameaux; au licu que celles dal liob ou petile vache brune n'ont que huit ou neuf anneaux, et ue sont longues que d'environ un pied. (Voyez ci-cprès les descriplions.)

Le septième animal de cette espèce ou de ce gemre est une gazellequi se trouve dans le Levant, et plus communémeut encore en Égypte et en Arabic. Nous l'appellerons de son nom arabe: algazel'. Cet animal est de la forme des autres gazelles, et à peu près de la grosseur d'un daim; mais ses colmes sont très-longues, assez meunes, peu courhées jusqu'ì leur extrémité, où elles se courbent da vantigre; clles sont noires et presque lisses, les anneaux étant tris-légers, excepté vers la hase ou ils sont un peu mieux marqués : elles ont près de trois pieds de longueur, tandis que celles de la gazellen' ont communément qu’un pied, celles du kevel quatorze ou quinze pouces, et eelles de la corine (lesquelles néanmoins ressemblent le plus à celles-ci) six ou sept pouces seulement.

Le huitième animal est eclui qu'on appelle vulgairement la gazelle du bésoard, que les Orientaux appellent pasan, et à laquelle nous conserverons ce $n \mathrm{~m}^{2}$. Une corne de ectte gazelle est très-bicn représentée dans les Éphéméricles d'Allemagne, et la figure de l'animal mème a été donnce par liompfer"; mais ectte figure de limmpfer peche en ce que les cornes ne sont pas assez longues ni assez droites, ct d'ailleurs sa description ne nous parait pals exacte; car it dit que eet animal du bezoard porte une barbe conme le boue, et neammoins la fign'e qu'il ('ll donne est sans barhe : ee qui nous parait plus conforme à la vérite; calr e'r géuéral les gazelles nout point de barbe, e'est mème le principal caractère qui les distingne des chevres. Cette gazelle est de lia grandeur de notre boue domestigue, et elle a le pril, la tigure et l'agilité du cerf. Nous avous vu de ect animal un erâne surmonte de ses cornes, ct deux autres cornes séparres. Le's comes gui sont gras ées dauns Aldrosande, de (Mud, bisulcis, pag. ici., cip. $\mathrm{X} . \mathrm{IT}$, de oryge, ressemblent beaucoup il celles-ci. Au reste, ce's deux

1 LiNTIIOPE AL.GIZELLE

2 Li.inthore OBiX. 
espèces, l'alga:el et le pasan, nous paraissent très-voisines l'une de l'autre; elles sont aussi du même elimat, et se trouvent dans le Levant, en Egypte, en Perse, en Arabie, ctc.; mais !'algazel n'habite guère que dans les plaines, et le pasan dans les montagnes. Leur chair est aussi trèsboune à manger.

La neuvième gazclle est un animal qui, selon M. Adanson, s'appelle nangueur ou nanguer au Sénégal '. Il a trois pieds et demi de longueur, deux pieds et demi de hauteur; il est de la forme et de la couleur du chevreuil, faure sur les parties supérieures du corps, blanc sous le ventre et sur les fesses, arec une tache de cette mème couleur sous le cou. Ses cornes sont permanentes comme eelles des autres gazelles, ct n'ont qu'environ six ou sept pouces de longueur; elles sont noires et rondes, mais ce qu'elles ont de très-particulier, c'est qu'elles sont fort courbées à la pointe en arant, à peu près comme celles du chamois le sont en arrière. Ces nanguers sont de très-jolis animaux et fort faciles à apprivoiser. Tous ces caractères, et. prineipalcment cclui des petites cornes recourbées en avant, m'ont fait penser que le nanguer pourrait bien être le dama ou daim des anciens. Cornua rupicapris in dorsum adunca, damis in adversum, dit Pline. Or, les seuls animaux qui aient les cornes ainsi courbées sont les nanguers, dont nous venons de parler: on doit done présumer que le nanguer des Africains est le dama des anciens; d'autant qu'on voit par un autre passage de Pline, que le dama me se trouvait qu'en Afrique; et qu'enfin par les témoignages de plusieurs autres auteurs anciens, on roit aussi que c'était un animal timide, dour, et qui n'avait de ressources que dans la légèreté de sa course. L'animal dont Caiius a donné la description ct la figure sous le uom de dama Plinii, se trourant, selon le témoignage méme de cet auteur, dans le nord de la Grande-Bretagne et en Espagne, ne peut pas ètre le daim de. Pline, puisque celui-ci dit qu'il ne se troure qu'eu Afrique. D'ailleur's cet animal, désigné par Caïus, porte une barbe de chère; et aucun des anciens n'a dit que la dama ent une barbe. Je crois done que ce prétendu dama, décrit par Caius, n'est qu'une chèvre, dont les cornes s'étant trourées un peu courbées en arant à leur extrémité, comme celles de la gazelle commune,

- lidatilupe inatiler. lui ont fait penser que ce pouvait être le dama des anciens; et d'ailleurs ce caractère de cornes recourbées en avant, qui est en effet l'indice le plus sûr du dama des anciens, n'est bien marqué que dans le nanguer d'Afrique. An reste, il parait par les notices de M. Adanson, qu'il y a trois espèces ou variétés de ces nanguers, qui ne different entre eux que par les couleur's du poil, mais qui tous ont les cornes plus ou moins courbées en avant.

La dixième gazelle est un animal très commun en Barbarie et en Mauritanie, que les Anglais ont appelé antilope', et auquel nous conserverons ce nom. Il est de la taille de nos plus grands cherreuils; il ressemble beaucoup à la gazelle et au kevel, et néanmoins il en diffère par un assez grand nombre de caractères, pour qu'on doive le regarder comme un animal d'une autre espèce. L'antilope a les larmiers plus grands que la gazelle : ses cornes ont environ quatorze pouces de longueur; elles se touchent, pour ainsi dire à la base, et sont distantes à la pointe de quinze ou seize pouces; elles sont environnées d'anneaux et de demi-anneaux moins relevés que ceux de la gazelle et du kevel ; et ce qui caractérise plus particulièrement l'antilope, c'est que les cornes ont une double flexion symétrique et très-remarquabłe; en sorte que les deux cornes prises ensemble représentent assez bien la forme d'une Iyre antique. L'autilope a, comme les autres gazelles, le poil fauve sur le dos et blanc sous le ventre; mais ces deux couleurs ne sont pas séparées au bas des flancs par une bande brune ou noire, comme clans la gazelle, le kievel, la corine, etc. Nous n'avons au Cabinet du Roi que le squelette de cet animal.

Il nous parait qu'il y a dans les antilopes, comme dans les autres ginzelles, des races ou des espèces différentes entre elles. $1^{0}$ Nous avons au Cabinet du Roi une corme (qu'on ne peut attribuer qu'it une antilope beaucoup plus grande que celle clont nous venons de parler, nous l'appclons lidmé, du nom que, selon le docteur Shaw, les Africains donnent aux antilodes. $2^{0}$ Yous arons vu au Cabinet de $\mathbf{1}$. le mar(puis de Marignỵ, dont le goùt s"étend également aux objets des beanx-arts et a ceux de la belle nature, unc espece d'arme offensive, composéc de deux cornes pointues et longues d'en-

\footnotetext{
1 L'AMTLOPE DES INUIS.
} 
viron un pied et demi, qui, par leur double flexion, nous paraissent appartenir à une antilope plus petite que les autres: elle doit être très-commune dans les Grandes-Indes, ear les prêtres gentils portent cette espece d'arme comme une marque de dignité. Nous appellerons cet animal antilope des Indes, dins l'illée où nous sommes que ce n'est qu'une simple variété de l'antilope d'Africque '.

En reprenant tous les animaux que nous venons d'exposer, nous a vons done déja douze espèces ou variétés distinctes dans les gazelles, savoir: $1^{\circ}$ la gazelle (ommune, $2^{\circ}$ le kevel, $3^{\circ}$ la corine, $4^{n}$ le tzeiran, 50 le koba ou grande vache brune, $6^{\circ}$ le kob ou petite vache brune, 70 l'algazel ou gazelle d'Égryte, 8') le pasan ou la prétendue gazelledu bézoard, $9^{\circ}$ le nanguer ou dama des anciens, $10^{\circ}$ l'antilope, $11^{\circ}$ le lidmée, $12^{\prime \prime}$ et enfin l'antilope des Indes. A près les avoir soigneusement comparées entre elles, nous crosons : $1^{0}$ que la gazelle commune, le kevel et la corine, ne sont que trois variétés de la mène espece; $2^{0}$ que le tzeiran, le koba ot le kols, sont tous trois des variétés d'une autre espèce; $3^{0}$ nous présumons que l'algazel et le pasan ne sont aussi que deux variétés de la mème espèce, et nous pensons que le nom de gazelle du bé. soard, qu'on a donné au pasan, n'est point un caractère distinctif; ear nous eroyons etre en état de prouver que le bézoard oriental ne vient pas seulement du pasan, mais de toutes les gazelles et chèves qui habitent les montagrnes de l'Asie; $4^{0}$ il nous parait que les nanguiers, dont les cornes sont courbées en avant, et qui font ensemble deux ou trois variétés particulières, ont été indiqués par les anciens sons le nom de dama; $5^{\circ}$ que les antilopes, qui sont au nombre de trois ou quatre, et qui different de toutes les autres par la double hesion de leurs cornes, ont aussi etć connues des anciens ct désignées par les noms de strepsiceros et d'addax. Tous ees animaux se trouvent en Asic et en $A$ frikue, e'est-à-dire dans l'ancien continent; et nous niajouterous pas à ces cine espèees principales qui conliemnent douze variétés très-distinctes, deux ou trois autres especes du Nouvean-Monde, auxpuclles on a aussi donné le nom vague de gazelles, quoiqu'elles soient différente's de toutes eclles que nous venons d'indiquer : ee serait augmenter la confusion, qui

liantiope proprement dite es! particulière aux Indes. n'est déjả que trop grande ici. Nous donnerons dans un autre article l'histoire de ces animanx d'Amérique, sous leur's vrais noms, mazame, temamacame, etc., et nous nous contenterons de parler actuellement des animaux de ce genre qui se trouvent en Afrique et en Asie : nous renvoyons mème à l'article suivant, pour plus grande clarté, et pour simplifier les objets, plusicurs autres animaux de ee méme climat d'Afrique et d'Asie, qu'on a cncore regardés eomine des gazelles ou comme des rbèvres, et qui cependant ne sont ni gazelles ni chèves, mais paraissent ètre intermédiaires entre les deux : ces animaux sont le bubale ou vache de Barloarie, le condoma, le guib, la chère de Girimme, cte., sans compter les cherrotains, qui ressemblent beaneoup aux plus petites chères ou gazelles, et dont nous ferons aussi un article partieulier.

Il est maintement aisé de voir 'ombien il était diflicile d'urranger toutes ces bètes, qui sont au nombre de plus de trente, dix chères, douze ou treize gazelles, trois ou quatre bubales, autant de chevrotains et de mazames, tous différents entre eux ; plusicur's absolument inconnus, les autres préscutés pèle-mède par les naturalistes, et tous pris les uns pour les autres par lis voyageurs. Aussi e'est pour la troisicme fois que j'écris aujourd'hui leur histoire, et jatroue que le travail est ici hien plus grand que le produit; mais au moins j'aurai fait ce qu'il itait possible de fatre avee lins materiaux donncis, et les connaissances acpuises que j'ai encore eu plus de peine à rassembler qu'a emploser.

En comparant les indieations que nous ont litissées les anciens, ct les notices que l'on trouve dans les autcurs modernes, ar ec les connaissances (que nous arons acepuises, nous recomnaitrons au sujet des gazclles: $1^{\circ}$ que le Jopxás d'Aristote n'est point la gazelle, mais le cherreuil, et que cependant ce méme mot Josxí; a été cmployé par Álien, non-seu. lement pour designer les chèves sauvage: en général, mais particulicrement la gazelle de Lybie on gazelle commune; $2^{\circ}$ (que le strep)siceros de Pline ou l'uddux des Africains est l'antilope; 3" que le dama de Pline est le nanguer de l'Afrique, et non pas notre daim, ni aucun autre animal d'Europe: $4^{\circ}$ que le $115 \%$ d'Aristote est le méme que le Vópxes d' Elien,

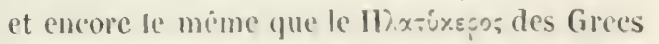
phus réeents; et que les I.atins ont adopté co 
mot plalyceros pour désigner le daim, animalium quorumdam cornua in palmas finxit natura, digitosque emisit ex iis, unde platycerotus rocant, dit Pline; 50 que le lluyxpros des Grecs est probablement la gazelle d'Éyypte ou celle de Perse, e'est-à-dire l'algazel ou le pasan. Le mot pygargus u'est employé par Aristote, que pour désigner un oiseau, et cet oiseau est l'aigle à quene blanche; mais Alien et Pline se sont servis du mème not pour désigner un quadrupède. Or l'étýmologie de pygargus indique : $1^{\circ}$ un animal à fesses blanches, tels que les chevreuils ou les gazelles; 20 un animal timide, les anciens s'imarinant que les fesses blanches étaint un indice de timidité, et attribuant l'intrépidité d'Hereule à ce qu'il arait les fesses noires. Mais comme presque tous les auteurs qui parlent du pygargus quadrupède; font aussi mention du chevreuil, il est clair que ce nom pygargus ne peut s'appliquer qu'à quelque espèce de gazelle diffé. rente du dorcas libyca ou gazelle commune et du strepsiceros ou antilope, desquels les mêmes auteurs ont fait aussi mention. Nous croyons done que le pygargus désigne l'algazel ou gazelle d'Égypte, qui devait être connue des Grees, comme elle l'était des Hébreux; car l'on trouve ee nom pygargus dans la version des septante (Deuteronome, cap. XIV), et l'ou roit que l'animal qu’il désigne est mis au nombre des animaux dont la chair était pure. Les Juifs mangenient donc souvent du pygargus, c'est-àdire de cette espèce de gazelle, qui est la plus comnune en Ligyte et dans les pays adjacents.

M. liussell, dans son Histoire maturelle du pays d'Alep, dit (qu'il y a auprès de cette ville deux sortes de gazelles, l'une qu'on appelle yazelle de Montagne, qui est la plus belle, dont le poil sur le cou et le dos est d'un biun foncé; l'autre, qu'on appelle gaselle de plaine, qui n'est ni aussi légèe ni aussi bien faite que la première, et dont la couleur du poil est plus pàle. Il ajoute que res animaux courent si vite et si longtemps, que les meilleurs chiens courants peuvent rarcment les forcer'sans lesccours d'un faucon.... qu'en hiver les gazelles sont maigres, et que néanmoins leur chair est de bon gout; qu'en été elle est chargée d'une graisse semblable à la venaison du daim; que les gazelles yu on nourrit à la maison ne sont pas aussi excellentes à manger que les gazelles sausages, etc. Par ce témoignage de M. Russell, et par celui de M. Hasselquist, on voit que ces gazelles d'Alep ne sont pas les gazelles communes, mais les gazelles d'Egypte, dont les cornes sont droites, longues et noires, et dont la chail est en effet excellente à manger. L'on voit aussi par ces témoignages que les gazelles sont des animaux à demi domestiques, que les hommes ont sourent et anciennement apprivoisés, et dans lesquels par conséquent il s'est formé plusicurs variétés ou races différentes, comme dans les autres animaux domestiques. Ces gazclles d'Alep sont donc les mêmes que celles que nous avons appelées Algazels; elles sont cheore plus communes dans la Thébaide et dans toute la haute Égrpte, qu'aux emvIrons d'Alep : elles se nourisscnt d'herbes aromatiques et le boutons d'arbrisseaux, surtout de ceux de l'arbre de sial, d'ambroisie, d'oseille sauvage, etc.; elles vont ordinairement par troupes ou plutòt par famille, c'est-à-dire cind ou six ensemble : leur cri est semblable à celui des chèvies. On les chasse non-seulement avec les chiens courants aidés du faucon, mais aussi arce la petite panthère que nous avons appelic once. Dans quelques endroits on prend les gazelles saurages arec des gazelles apprivoisées aux comes desquelles on attache un piége de cordes

Les antilopes, surtout les grandes, sont beaucoup plus communes en Afrique quaur Indes; elles sont plus fortes et plus farouches que Ies autres gazelles, desuruelles il est aisé de les distinguer par la double flexion de leurs cornes, et parec (ju'el'les n'ont point de bande noire ou brune au bas des flanes. Les antilopes moyennes sont de la grandeur et de la couleur du daim, elles ont les cornes fort noires, le ventre

\footnotetext{
4 Quand on ne veut point se servir d'un léopard appriroisé pour prendre les gazelies, on mène un male de gazelle privée, atujuel on met aux cornes une corle pui a divers tours et replis, et dout on attaclic les deux houls sons le ventre; lorsyuion a trouvé une compagnie d" gazelles, on laisse aller ce mâle: il va pour les joindre; le nade de la troupe s'as ance puur l'en

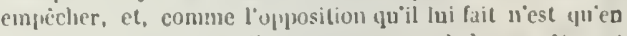
jomant avec ses cornes, il the manyue pas de les empètrer e. do sembarrasser avee son rival, en sorte que le chasseur s'en saisit adroitement ot l'emmène; mais il est plus aisé ile pren. diee les femelles, lit lation de Thévenot, lome III. - On se sert de la gazelle privée jumr prendre les sauvages dle cetle maniire : on lui attacle des lacs aux deux cornes, puis on la mène anx champs, aux endroits on il y en a de sanviges, el on la Lissce joner el situler arec les antres, lesquelles, venaut à g'en trelacer leurs cormes le; unes dans les autres, ell's s'attachent ersemble par le's lacs et petites cordes qu'on a lices aux curues de la tomestiqne; ct la sauvage se stntaut prise, s"effurce de se délier et tonnhe á terre avec la privée, el est prise par les indiens de cette façuu. Yojage de La Buallaje le Gouz, page ab7.
} 
très-blane, les jambes de devant plus courtes que celles de derrière. On les trouve en grand nombre daus les contrées du Tremeeen, du Duguela, du Tell et du Zaara. Elles sont propres et ne se couchent que dans des endroits sees et nets. Elles sont aussi très-légères à la course, très-attentives au danger, tres-vigilantes, en sorte que dans les lieux découverts elles regardent longtemps de tous cótés; et dès (ju'elles apercoivent un homme, un chien, ou (juelque autre ennemi, elles fuient de toutes leurs forees : cependant elles ont, avec eette timidité naturelle, une espece de courage, car lor'squ'clles sont surprises elles s'arrètent tout court et font face à ceux qui les attaquent.

En général, les gazelles ont les yeux noirs, grands, très-vifs et en mème temps si tendres, que les Orientaux en ont fait un proverbe, en comparant les beaux yeux d'une funme a ceux de la gazelle. Elles ont pour la plupart les jambes plus fines et plus déliées que le chevreuil; le poil aussi court, plus doux et plus lustré : leurs jambes de devant sont moins longues que celles de derrière, ce qui leur donne, comme au lière, plus de facilité pour courir en montant qu'en descendant. Leur légèreté est au moins égale à celle du chevreuil ; mais celui-ci bondit et saute plutòt qu'il ne court, au lieu que les gazelles courent uniformément plutòt qu'clles ue bondissent. La plupart sont fauves sur le dos, blanches sous le ventre aree une bande brune qui sépare ces deux couleurs au bas des flanes. Leur queue est plus ou moins grande, mais toujours garnie de poils assez loners et noirâtres; leurs oreilles sont droites, longues, asse\% ourertes dins leur milieu, et se terminent en pointe. Toutes ont le pied fourehu et conformé à peu près comme celui des moutons: toutes ont, mâles et femelles, des cormes permanentes, comme les ehères; les cornes des femelles sont seulement plus minces et plus courtes que eelles des mâles.

Voili toutes les conmaissances que nous ar ons pu aequérir au sujet des différentes espeices de gizelles, et à peu près aussi tous les licits qui ont rapport it leur maturel el à leurs habitudes. Voyons maintenant si les naturalistes ont cité fondés à n’attribuer qu'à un seul de ces animaux la production de la pierre fimense quion alppelle le bézourd oriental, et si cet animal est en eftet le pasen ou pazan qu'ils ont désigné spériliquement par le nom de gazclle du bí- zoard. En exammant ia aescryption et les figures de liompfer, qui a beaucoup écrit sur cette matiere, on doutera si e'est la gazelle commune ou le pasan, ou l'algazel quïl a voulu désigner, comme donnant exclusirement le rai bezourd oricntal. Si l'on consulte les autres naturalistes et les voyagreurs, on serait tenté de croire que ce sont indistinctement les gazelles, les chères sauvages, les chèrres domestiques, et mème les moutons, qui portent eette pierre 1 , dont pro-

4 A ciulconile, le rol a graule provision dexcellenis le zoards; les muntagnes oú paisscul les chèvres yui le: purleut sont à sejt un luil journées de Ilagnaguur; ils se vendent ordinairement ipuarante ecus la livre; lex longs snull les muillenrs; on ell trouve daus yuelyues vaches, qui sont beaucoup jlus grus yue coux des chevrea, unais un n'en fait pas taut de ras el ceux yuj sout le plus estunés de tums 3 e lirent diune espece de simzes qui sont un pru jlus rares, et ces bézoards soul petits i't lungs. Voy uge de Theivenot, lime 11, jage 295.-II se voit en l'erse de plus lrelles et de flus esyuses pierres lle béz.oards yu'eu jas une autre contrée de la terre : ou les lire du cole de cerlains lueues saurages, an ruie desyuels elles sout at. tache's. Voyage de Fegues, pag. At el 45. - Je deviais mettre an ranz̆ des arognes médicinale's le bézoard, yui est cetle purresi faneuse daus la nuédecine; c'est une pierre tendre yui se forme par peliienle*, comme croisseut les oigunns; on la Irouve dans le corps des boucs et des chères sauvages el dumestiques le long du golle Persiujue, dans la province du Corassan. qui est l ancieunesargiauc, jucomparablement ueilleure yue celle quiou a aux Indes dans le royame de Gulcunde: un.is parce que les clıèvres avaient été auruées le trois jomrnées de flays, il ue se trouva de hé ınards que dans quel ljues-unes, el encore n’était-ce yue de pelits morceaux; nous garláumes de ces chères quinze jours en vie; clles étaieut nuurries d’herbe verte commuse; on niy Iromva rien en les ouvrinl; je les gardai ce tem $\{s-l a ̉$ pour vérifier ce qul se dit, que cंest une lierl,e particuliere y̧ui, echaulfant ees animaux, produit celte pierre dans leur corps. Les naturalistes prisans disent yue pulus cet animal pult en des pays arides, el mange d'herlnes seches et clı uules, plus le bé zoard est salutare; le Corassan et le hord du gulfe Persique soul de ces pays secs et aride's naturelle inent s'il y eu a au moute : on truuvo tujours au cour de ces pierres quelyue' murceanx de ronce on d'autre bois antunr duyncl se coagnle l'humeur qui conjuse celte pierre; il fant ub.

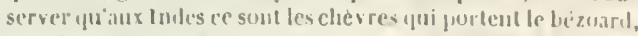
el yutan l'erse ce sonl les monlons et les buucs, ce qui fant

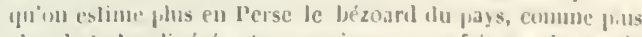
chand e' plus digéré, el yuts nime on ve fait pas de cas de lantre, qui on dome à quatre fois mellleur marclie: Je liezuard de Persese vend cinuguante-tjuatre livies le kuurag. yui c'sl un prids tle trois gros. Voy age de Clardin, tume II, page 16.-1.e lézuard oriental vient d'une provlnce du ruyaune de liol. conde en tirant au und, el il se tronve dalis la franse des che. vres... Les paysans, en litand le ventre de Ja clievre, cum simb combiru elle a de hizoards. el la vemben a f ropmertion

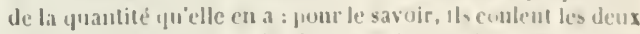

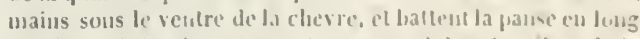
des deur citis, de surte yue luut se remil dans le milieu de la frause, et quils complent juste, en les titant. combien il y a

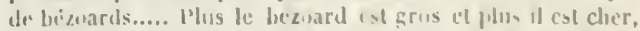

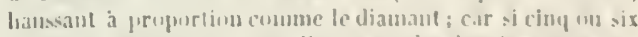

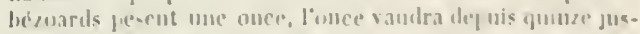

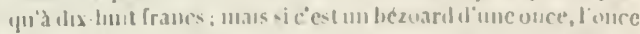

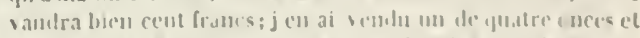

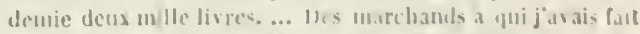

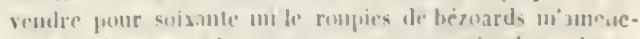
renl six chevres yul le purteut et yue je cumsulerai arec lossur. II faut arouer ypue ce sunt de belles betes, fort bautes el yoi 
bałlement la formation dépend plus de la tempirature du elimat et de la qualité des herbes, que de la nature et de l'espèce de l'animal. Si l'on voulait en croire Rumphius, Seba et quelques autres auteur's, le vrai bézoard oricntal, celui qui a le plus d'excellence et de vertu, proviendrait des singes et non pas des gazelles, des chevres ou des moutons; mais cette opinion de Rumphius et de Seba nest pas fondée: nous a vons vu plusieurs de ces concrétions auxquelles on donne le nom de bézourd de singes, et ces concrétions sont toutes différentes du bezoard oriental, (qui vient certainement d'un animal ruminant, el quion peut aisément distinguer, par sa forme et par sa substance, de tous les autres béroilrils: sa couleur est ordinairement d'un vert d'olive, brun en dehors et en dedans, et celle du bézoard qu'on appelle accidental est d'un petit jaune plus ou moins terue. La substance du premier est plus moelleuse et plus tendre, eolle du dernier est plus dure, plus sèche, et pour ainsi dire plus pétrée. D'ailleurs, comme le bézond oriental a eu une rogue prodigicuse, et qu'on en a fait-grande consommation dans les dernier's'siecles, puisqu'on s'en servait, en Europe et en Asie, dans tous les cas oủ nos médecins emploient aujourd'hui les cordiaux et les contre-poisons, ne doit-on pas présumer par ectte grande quantité qu'on en a consommée et que l'on consomme encore, que cette pierre vient d'un animal très-commun, ou plutòt qu'elle ue vient pas d'une seule espèce d'animal, mais de plusicurs animaux, et qu'elle se tire également des gazelles, des chèves et des moutons; mais que ces animaux ne penvent ia produire que daus de certains climats du Levant et des Indes?

ont un poil fin comme de la soie... Ils me dirent que l'une de ces cherres n'avait ruinn bétroard dans le ventre, el que les autres en avdient on deux, on trois, ou yuatre, ce quils me firent voir a l'henre même en leur hathant le ventre de la man.ere dont jo l’ai dit plus haut : ces six dhèves avaient dix-sept hézoards et une moutié comme une moitié de noisclle; le de. dans elait comme dinne crotle de chévre molle, ce- bézoards crniasant parmi la fiente qui eut dans le ventre de la chèvre : quelıues-uns une disaient que ces bézoards se prenaient contre le. Tus, d'antres soutenaiont que c était contre le curur, ct je ne fus jamais me bien felaircir de: la vertile .. Pour le be zoard yui vient dn singe, il est si fort que denx grains fout antant yue six do colui de's cluevres; mais il est fort rare, et se tronve parliculierencul datı. l'ile de Macassar ; celle sortr le liézoard esl rond, an liru que l'autre est dr diverses ligures : comme ces pierres, (fue l'on croit venir des simes, sont beaucump) jus rarea que les autres, elles sout aussi beauconp plus chères el plus recherchers; et quand on en Irouve une le la grosscur dinne noix, ti: yaudra quelıuefois plus de cent écns. Voyage de tavernier, some 15 , page 78 et surv,
Dans tout ee que l'ou a écrit sur ce sujet, nous n'avons pas trouvé une observation bien faite ni une seule raison décisive : il parait seulement par ce qu'out dit Monard, Garcias, Clusius, Aldrovande, Hernandès, etc., que le prétendu animal du bézoard oriental n'est pas la chèrre conmune et domestique, mais une espece dechevre sauvage qu'ils n'ont point caractérisée; de mème, tout ce que l'on peut conclure de c'e qu'a écrit Kompfer, e'est que l'animal du bézoard est une espèce de chève saurage ou plutót une espèce de gazelle, aussi très-mal décrite: mais, par les témoignaures de Therenot, Chardin et 'Tavernier, ill parait que cette pierre se tirc moiis des gazelles que des moutons et des chères sauvages ou domestiques; et ce qui parait donner plus de poids à ce que ces voyageurs en disent, e'est qu'ils parlent comme témoins occulaires, et que, quoiqu ils ne citent pas les gazelles au sujet du bézoard, il n'y a guère d'apparence qu'ils se soient trompés, et quils les aient prises pour des chevres, parce qu'ils les connaissaient bien, et qu'ils en font mention dans d'autres endroits de leurs relations. L'on ne dojt done pas assurer, commel'ont fait nos naturalistes modernes, que le bézoard orjental vicnt particulièrement et exclusivement d'une certaine espèce de gazelle; ct j'avoue qu après avoir examiné, nonseulement les témoigrnages des auteurs, mais les faits mámes qui pouvaient décider la question, je suis très-porté à croire que cette pierre vient également de la plupart des animaux runinants, mais plus communément des chevres et des gazelles. Elle est, comme l'on sait, formée par couches concentrijues, et contient sou vent aucentre quelıue matic̀'e étrangère. Nous avons recherché de quelle nature étaient ces matières, qui servent au bézoard oriental de noyau, pour tâcher de juger en couséqucuec de l'espece de l'animal qui les avait avalées. On trouve an centre de ces pierres de yetits cailloux, des noyaux de prunes, de mirobolans, de tamarin, des graines de eassie, et surtout des brains de paille et des boutons d'arlures : ainsi . l'on ne peut gruere attriluer cette production qu'aux animaux qui broutent les herbes et les feuilles.

Nous eroyons done que le bézoard oriental ne vient pas dun animal particulier, mais de plusieurs animanx différents, et il n'est pas difficile de concilice avec cette opinon les témoi- 
guages de la plupart des voyageurs; car en disant chatun des choses contraires, is n'auront pas laissé de dire tons à peu près la vérité. Les anciens, Grees et Latins, noont pas comnu le bézoard; Galien est le premier qui fasse mention de ses vertus contre le veniu; les Arabes ont beaucoup parléde ces mêmes vertus du bézoard: mais ni les Grees, ni les Latins, ni les Arabes n’ont indiqué préeisćment les animaux qui le produisent. Rabi Moses, Egyptien, dit senlement que quelques-uns pretendent que cette pierre se forme dans l'angle des yeux, et d'auties dans la vésicule du fiel des moutons en Orient : or , il y a dis bézoards on concrétions qui se fout on effet dans les angles des yeux et dans les larmiers des cerfs et de quelques atttres animaux; mais ces concrétions sont tresdiffrentes du bézoard oriental, et les concrétions de la vésienle du fiel sont toutes d'une matiere légère, huileuse et inflammable, yui ne ressemble point i la sulsstance du bezoard. André Lacuna, mélecin espagnol, dans ses Commentaires sur Dioscoride, dit que le bézoard oriental se tire d'une certaine espèce de chèrre samvage dans les montagnes de Perse. Amatus Lusitanus répète ce cjue dit Lacuna, et ajoute que cette chevre montagnarde est ressemblante au cerf. Monard, qui les cite tous trois, assure encore plus positivement que cette pierre se tire des parties intéricures d'une cherre de montagne aux Indes, à laquelle, dit-il, j’ai eru devoir donner le nom de cervi-capra, parre gurealle tient du eerle et de la chère, qu'elle est í peu près de la grandeur' et de la forme du r'erf, mais (qu'elle a, comme les chères, des cormes simples et fort recourloces sur le (los. Galleias ab) Horto (Dujardin) dit que dans le Corassin et en Perse, il y a mne espèce de bones appelée pasan, et (jue e'est dans l'estomac de ces boues que s'engendre le bézoard oriental ; que cette pierre se trouve non-senlement en Perse, mais aussi à Malacea et dans l'ile des Vaches, pres le eap Comorin; que dans la grande cquantité de boucs que l'on tuait pour la subsistance des troupes, on eherehait ees pierres dans l'estomac de ces animaux et qu'on y en trouvait assez eommunément. Clıristophe Acosta répele à ce sujet ce que disent Gareias et Momard, sans y rien ajouter de nouveau. Enfin, pour ne rien omettre de tout ce yui a rapport au détail historique de cette pierre, nous oloserverons que Kixmpfer, homme plus savint qu'observateur "vact, s'ítant trouré dans la province de Laar en Perse, assure étre allé avee des naturels tlu pays a la chasse du boue pasan, qui produit le bézoard; (qu'il dit en avoir, pour ainsi dire, vu tirer ectte pierre, et yu'il assure encore que le v'ai bezoard oriental vient de cet animal; qu à la vérité le bouc ahu, dont il donne aussi la figure, produit dans ce mème pays de's bézoutuds, comme le bouc pasan, mais quils sont fort inférieurs en qualiti. Par les figures qu’il don:ae de ces deux animaux, le pasan et l'ahu, on se. rait induit is croire flue lat premicerefirure reprecsente la gazelle commune plutót que le vai pasan : et par sa description on serait po:tci a imaginer que son pasan est en effet un bouc et non pas une gazelle, parce qu'il lui donne une barbe semblable a celle des chevres; et cutiu, par le nom ahu, qu'il domne a son autre bouc, aussi bien que par la seconde figure, on scrait fondé à reconnaitre le bouquetin plutot que le véritable abu, qui est notre tzeiran ou grosse gazclle. Ce qu'il y a de plus singrulier encore, e'est que Koempfer, qui semble vouloir décider l'espèce de cet animal du bézoard oricntal, et qui assure que c'est le bouc sauvage, appelé pasan, cite en mime temps un homme, (yu'i] dit très-digne de foi, lequel cependant assure avoir palpé les pierres de ée méme bézoard daus le ventre des gazelles à Goleonde. Ainsi tout ce qu'on peut tirer de positif' de ce (qu'a cerit liom) fer à ce sujet se réluit i ce que ce sont duxx espèces de chevres samvages et montagnarles, le pasan et l'ahu, qui portent le bézoard en Perse, et qu'atux Indes cette pierre se tromve aussi dans les grazelles. Chatrin dit positivement que le bezoard oriental se trouve daus les boues et chèv les sauvages et domestieques, le long du golfe Persicue et dans plusieurs provinees de: l'Inde; mais qu'en Perse on le trouve aussi dins les moutons. L.es vovageurs hollandilis disent de mème qu'il se produit dams l'estomante des brebis ou des eheves. Taverniel temoigne on core plus positivement que ce sont des cheves domestiques; il dit qu'eltes ont du poil lii: eomme de la soie, et quayant achetesix deocs cheves vivantes, il en avat tiré dix-sept bezoards enticis ct une portion grossc comme une moitie de noisette : et emsune il dit qu'il y a d'autres bézoards, que l'on croit venir des singes, dont les vertus sont encore plus grandes que celles du hézoard des chères; yuion en tire aussi des vaches, mais dont les rertus sont 
Inféricures, etc. Que doit-on inférer de cette variété d'opinions et de témoignages? qu'en peut-on conclure, sinon que le bézoard oriental ne vient pas d'une seule espèce d'animal, mais qu'on le trouve au contraire dans plusieurs animaux d'espèces différentes, et surtout dans les gazelles et dans les chèvres?

A l'égard des bézoards oceidentaux, nons pouvons assurer qu'ils ne vienment ni des chèvres ni des gazelles; car nous ferons voir, dans les articles suivants, qu'il n'y a ni chèvres, ni gazelles, ni même aucun animal qui approche de ce genre dans toute l'étendue du NouveauMonde: au lieu de gazelles, l'on n'a trouvé que des elıevreuils dans les bois de l'Amérique; au lieu de chèvres et de moutons sauvages, on a trouvé sur les montagnes du Pérou et du Chili des animaux tout différents, les lamas et les pacos, dont nous avons déjà parlé. Les anciens Péruviens n'avaient pas d'autre bétail, et en même temps que ces deux espèces étaient en partie réduites à l'état de domestieité, elles subsistaient en beaucoup plus grand nombre dans leur état de nature et de liberté sur les montagnes : les lamas sauvages se nommaient huanacus et les pacos vicunnas, d'où l'on a dérivé le nom de vigogne, qui désigne en effet le même animal que le paeos: tous deux, c'est-à-dire le lama et le paeos, produisent des bézoards, mais les domestiques plus rarement que les sauvages.

M. Daubenton, qui a examiné de plus près que personne la nature des bézoards, pense qu'ils sont composés d'une matière de même nature que celle qui s'attache en forme cle tartre brillant et coloré sur les dents des animaux ruminants. On verra dans la description qu'il a faite des bézoards, dont nous avons une collection très-nombreuse au Cabinet du Roi, ruelles sont les différences essentielles entre les bézoards orientaux et les bézoards oceidentaux. Ainsi les ehèvres des lndes orientales ou les gazelles de Perse ne sont pas les seuls animaux qui produisent des concrétions auxquclles on a donné le nom de bézoards : le eliamois, et peutêtre le bouructin des Alpes, les bones de Guince, et plusieurs autres animaux d'Amérique, donnent aussi des bézoards; et si nous comprenons sous cenom toutes les concrétions de cette nature que l'on trouve dans les animaux, nous pouvons assurer que la plupart des quadrupèdes, à l'cxeeption des carnassiers, produisent des bé- zoards, et que même il s'en troure đans les crocodiles et dans les grandes couleuvres.

Il faut done, pour avoir une idée nette de ces concrétions, en faire plusieurs classes; il faut les rapporter aux animaux qui les produisent, et en même temps reconnaltre les climats et les aliments qui favorisent le plus eette espèce de production.

$1^{0}$ Les pierres qui se forment dans la vessie, dans les reins del'homme etdesautres animaux, doivent être séparées de la classe des bézoards, et désirnées par le nom de calculs, leur substance étant toute différente de eelle des bézoards. On les reconinalt aisément à leur pesanteur, à leur odeur urineuse et à leur composition, qui n'est pas régulière, ni par couches minces et coneentriques, comme celle des bézoards.

$2^{0}$ Les concrétions que l'on trouve quaclquefois dans la vésicule du fiel et dans le foie de l'homme et des animaux ve doivent pas être regardées comme des bézoards. On les distingue facilement à leur légèreté, leur couleur et leur inflammabilité, et d'ailleurs elles ne sont pas for'mées par couches autour d'un noyau, comme le sont les bézorards.

$3^{0}$ Les pelotes que l'on troure assez souvent dans l'estomac des animaux, et surtout des ruminants, ne sont pas de vrais bézoards. Ces pelotes quel'on appelle égagropiles sont composées à l'intéricur des poils que l'animal a avalés en se léchant, ou des racines dures qu'il a broutées, et qu'il n'a pu digérer, ct à l'extérieur' elles sont pour la plupart enduites d'une substance visqueuse assez semblable à celle desbézoards : ainsi les égagropiles n'ont rien des bézoards que cette couche extéricure; et la seule inspectiou suffit pour distinguer les uns des autres.

$4^{0}$ On trouve souvent des égagropiles dans les animaux des elimats tempérés et jamais des bézoards. Nos bocufs et vaches, les chamois des Alpes, les pores-épies d'Italie ne produisent que des ég̨agropiles. Les animaux des pays les plus chauds ne donnent au contraire que des bézoards. L'éléphant, le rhinocéros, les boucs, les gazelles de l'A sie et de l'Afrique, le lama du Pérou, cte., produisent tous, au lieu d'égagropiles, des bézoards solides, dont la grosseur et la substanee varient relativement à la différence des animaux et des climats.

$5^{0}$ Les bézoards auxquels on a trouvé ou'supposé le plus de vertus et de propriétés sont les bézoards oricutaux, lesquels, comme nous l'a- 
vons dit, proviennent des chèvres, des gazelles et des moutons qui habitent sur les hautes montagnes de l'Asie; les bézoards d'une qualité inléricure, et qu'on appelle occidentaux, viennent des lamas et des pacos qui ne se trourent que dans les montagnes de l'Amérique méridionale; enfin les chèvres et les gazelles de l'Afrique donnent aussi des bézoards, mais qui ne sont pas si bons que ceux de l'Asie.

De tous ees faits, on peut conclure qu'en général les bézoards ne sont qu'un résidu de noulriture végétale, qui ne se trouve pas dans les animáux carnassiers, et qui ne se produit que dans ceux qui se nourrissent de plantes; que dans les montagnes de l'Asie méridionale, les herbes étant plus fortes et plus exiltées qu'en aucun autre endroit du monde, les bézoards qui en sont les résidus ont aussi plus de (pualité que tous les autres; qu'en Amérique oil la ehaleur est moindre, les herbes des montagnes ayant aussi moins de force, les bézoards qui en proviennent sont inféricurs aux premiers; et qu'enfin en Lurope ou les herbes sont failsles, et dans toutes les plaines des deux continents où elles sont grossieres, il ne se produit point de bézourds, mais seulement des égagropiles qui ne contiennent que des poils ou des racines, et des filaments trop durs que l'animal n'a pu digerer.

\section{ADDITION A L'ARTICLE DES GAZELLES ET DES ANTILOPES.}

Depuis l'année 1764 que j'ai publié le volume de l'Histoire naturelle dans lequel j'ai traité des gazclles et des chèvres étrangères, quelques vojageurs nituralistes ont reconnu en $A$ sie et en Africue de nouvelles espèces dans le genre de ees animaux, et ont domé des figures entières de quelques autres dont je n'ivais pu donner que quelques partıes détachées, comme les têtes, les cornes, ete. M. Pallas, doeteur en médecine, de l'université de Leyde, a publié à Amsterdam, en 1767 , un premier ourrage sous le nom de Miscellanea =oologica; et peu de temps après il en a donné une sceonde édition corrigéc et imprimée à Berlin daus la mème année, sous le titre de Spicilegia zoologica. Nous arons lu ces deux ouv rages avee satisfaction; l'auteur y montre partout autant de discernement que de connaissances, et nous donnarons l'extrait de ses observations.
D'autre part, MII. Forster père et fils, qui ont accompagné M. Cook dans son second voyage, ont eu la bonté de me communiquer Jes remarques et observations qu'ils ont faites sur les chères du eap de Bonne-Espérance, aussi bien que sur les lions marins, ours marins, etc., dont ils m'ont donné des figures très-bien dessinćes. J'ai reçu toutes ces instructions avee reconniassance, et l'on verra que ces savants naturalistes m'ont été d'un grand secours pour perfectionner l'histoire de ces animaux.

Enfin, M. Allamand, que je regarde comme l'un des plus savants naturalistes de l'liurope, ayant pris soin de l'édıtion qui se fait en Hollande de mes ouvages, y a joint d'execllentes remarques et de tres-bonnes descriptions de quelques animaux que je liai pas été à portée de voir. Je réunis ici toutes ces nouvelles connaissances qui mont cité communiquées, et je les joins à celles que j'ai aequises par moi-méme depuis l'annce 1764 jusulu'en 1780 .

M. Pallas impose aux gazelles et aux chères sauvages le nom générique d'untilopes, et il dit que les zoologistes méthodistes ont cu tort de joindre le grenre des gazelles à celui des cheveres, et qu'il en est plus éloigué que du genre de's brebis. La mature, selon lui, a placé ie genre des gazelles entre celui des cerfs et celui des chevres. Au reste, il convient avec moi, dins son second ourrage, que los gazelles ne se trouvent ni en Europe ni en Amérique, mais seulement en Asis, et surtout en Afrique ou les espèces en sont très-variées et fort nombreuses. Le chamois est, dit-il, le seul animal qu'on pour. rait regarder comme une gazelle européenne, et le bouquetin semble faire la nuanee entre le's chèvres et certaines espèces de gazclles. L'animal du muse, ajoute-t-il , et les eherrotains ne doivent point ètre rangés avec les gazelles, mais peuvent aller ensemble, parec que le's uns et les autres, daus les deux sexes, manquent de cornes, et ont de grandes dents ou défenses dans la máchoire supéricure.

Ce que je rapporte ici, d'après M. Pallas souflie quelques exceptions, cill il y a une espiece de chevrotinin dont le mille a des connes, et le chamois, quil pretend itre du gene des arizelles et non de celui des chiores, sunit néanmoins avee les cherres: on les a sourent vus s'accoupler, et l'on nous a mème assuré qu'ils araient produit ensemble. Le premicr fait es: 
certain et suffit seul pour démontrer que le chamois est non-sculenent du même genre, mais d'espèce très-voisine de celle de la chèvre commune.

Et d'ailleurs le genre des ehèvres et eelui des brebis est si voisin, qu'on peut les faire produire ensemble, comme j'en ai donné des exemples; ainsi l'on ne peut guère admettre un genre intermédiaire entre eux; de même que l'on ne doit pas dire que les gazelles, dont les cornes sont permanentes dans toutes les espèces, soient voisines du genre des chevrenils ou des cerfs, dont les bois tombent et se renouvellent chaque année. Nous ne nous arrèterons done pas plus longtemps sur cette discussion méthodique de M. Pallas, et nous passerons aux observations nourclles que nous avons faites sur chacun de ces animaux en particulier.

\section{ADdition A L'ARTICLE DEs Gazelles, RELA- TIYE AU KEVEL.}

M. Pallas me parait se tromper en avaneant que le kerel et la corine ne sont pas deux espèees différentes, mais le mâle et la femelle dans la même espèce de gazelle: s'il eût fait attention que j’ai déerit les deux sexes, ce savant naturaliste ne serait pas tombé dans eette méprise.

\section{NOUVELLE ADDITIOY A L'ARTICLE DES GAZELLES,} RELATIYEAU KOBA ET AU KOB.

J'ai donné, d'après M. Adanson, le nom de kuba ì un animal d'Afrique, que quelques royageurs ont appolé grande vache brune, et dont l'espèce n'est pas éloignće de celle du bub:le. J'ai donné de même le nom de kioba un animal un peu moins grand, et que les vorageurs ont appelé petile vache brune. Le koba est grand comme un eerf; et par conséquent approche de la grandeur du bubale, tandis que le kob n'est pas tout à fait si grand qu'un daim. M. Pallas dit que de toutes les antilopes, celle-ci lui parait être la plus voisine du genre des cerfs, le pelage étant semblable. Les cornes du kob ont à peu près un pied de longueur, ce qui ne s'accorde pas aree ce que dit M. Pallas, qui ne leur donne qu'un demi-pied; et ce qui me parait démontrer que M. Pallas n'avait pris cette mesure des cornes que sui in jeune individu, $c^{\circ}$ est que M. Forster m'a éerit qu'il avait rapporté du cap de Bonne-Espérance des cornes de cet animal kob, de méme grandeur, et toutes semblables a celles dont je viens de parler. Il dit que cet anjmal avait une tache triangulaire blanche au bas des cornes, que son pelage est en général d'un rouge brun, et il pense, comme moi, que le kob n'est qu'une rariété du koba : et que tous deux ne s'éloignent pas de l'espéce lu bubale.

\section{DESCRIPTION DE LA GAZELLE!.}

(EITRAIT DE DACBE.TON.)

La gazelle est un animal ruminant de la grandeur du clievrenil ; elle lui ressemble aussi beaucoup par les proportions du corps, mais elle en diffère entièrement par les cornes : au lieu d’être solides comme le bois du cerf, du renne, du chevreuil, etc., elles ont une cavité comme les cornes du taureau, du bélier, du houc, etc.; elles sont noirâtres, placées à une petite distance au-dessus des yeux et courbées en arrière et en bas, à l'exception de leur extrémité, qui se recourbe ubliquement en avant et en dedans; elles ont treize ou quatorze anneaux saillants, les premiers font tout le tour de la corne et ne laissent que peu de distance entre eux; les autres sont plus éloignés et nes'étenclent pas sur le còté posterieur; ils sont obliques, se trouvant posés plus bas sur le devant que sur les côtés de la corne; quelques uns de ces anneaux composent une spirale, elle ahoutit par ses deux extrémités à des an. neaux réguliers, yui par cette réunion semblent ètre fourchus ; le bout de la corne est lisse, il y a sur le reste de son ètendue de petites stries longitudinales; ces cornes ont à peu près la mème longueur que la tète sur denx sinuelettes de grazelles qui sont au Cabinet du Roi, dont l'un a été fait en Syrie.

La pran de la gazelle dont ce squelette a été tiré a aussi éte envorée au Cabinet; le dessus du chanfrein e. le front sont de conleur rousse avec me tache noire an milien; il y a de chaque cité dı chanfrein mue hande blanclse avec quelques teintes de roussàtıe, qui s'étendent depuis les narines jusqu'aux yeux; on roit au-dessous de cette bande une autre bande de couleur rousse, avec quelque apparence de noiràtre; il y a une tache d'un blanc ronssatre derrière l'ail et trois bandes longitudinales formees sur la face interne des oreilles par des poils blancs; la face externe des oreilles et le

\section{A.Itjlope GdZElle.}


reste de la tête à l'exception du bas de la mâchoire inférieure, le derrière et les cọtẻs du cou, le dos, la croupe, les còtés du corps, l'épaule, la cuisse, la face externe de l'avant-bras et de la jambe proprement dite, les canons et les pieds sont de couleur fauve plus ou moins foncée et teinte de roux ou de brun en plasieurs endroits; il y a quelque mclange de cette dernière couleur sur le corps, et une large bande preşuc entièrement brune qui s'étend sur le côté du corps, depuis l'ẹpaule jusque sur la cuisse; la face externe de l'avant-loras et les canons des (yuatre jambes sont roux, à l'exception de la face interne des canons des jambes de devant, qui est d'un fauve très-clair; le dtrrière des paturons et la couronne ont une couleur lorume foncée; le dessous de la máchoire inférieure, le devant du cou, la poitrine, le ventre, les fesses, la fa'c interne de l'avant-bras et de la jaube sont blancs; il y a au-dessus de la fice anterieure des canons des jambes de devant, un peu au-dessus du genoux, une brosse de poils couclıes en bas, plus longr, plus serrés et plus fermes que les autres; ces brosses sont brunes, mais en cicartant les puils on roit que ceux qui sont couverts ont une couleur fauve ou blanche; la gazelle a au devant de cliaque oil un larmier conme le cerf.

On a aussi envoyé de Syric au Cabinet une jeune gazelle conservée dans l'esprit-de-vin; ses dimensions sont rapportées dans la table; les cornes ne sont pas encore formees, mais on sent sur le front des tubercules qui indiquent leur origine; il y a au devant (ies orbites un larmier bien apparent, dont l'orilice est long de trois ou quatre lignes et place en forme de croissant contre le bond de l'orlvite; ce lirmier a deux lignes de profondeur. Le poil de la tète a des teintes de fauve, de roux et de blanchatue; en comparant cette gazelle avec la peau que jai décrite, on reconnait aisconent sur la petite gazelle d:s vestiges de la bande rousse du milien du chanfrein, de la bande blanclse et de la bande mèle de roux et de noiritre des còtes du chanfrein, et on apergoit le blanc dı dessons de l'uil; les trois bandes longitudinales formces par des pois sont dejit bien marquuces sum la face interne de l'oreille; les bords de cette face sont aussi couverts de poils; la face extcrue de l'orcille et toutes les partics qui sont de couleur fauve sur la gazelle alulte, ont ì peu près la mime couleur sur la petite gazelle dont il s'arit, mais ellen'a qu une couleur blincluitre ou fauve trè-claire sur les parties qui sont blanches dans l'autre: il y a du brun nojràtre sur les coites ulu corjes, sur la couronue, contre les sahots et sur la brosice, yui est dejì bien furmeje.

Je n’ai vu sur le rentre yue deux manelons placés d quatre pouces de distance de l'anns et près l'un de l'antre; mais je n'ai pu reconnaitre exactement la distance yui ciait entre deux, parce ıjue le ventre ayait été ouvert dans cet endroit; il se trouve dans les aines, à côté de chaque mamelon, une poche qui, étant ouverte, a environ dix lignes de diamètre à son entrée; elle s'étend en arrière, elle a sept lignes de profondeur; les parois infèrieures de chacune de ces poches sont formées par une duplicature cle la peau, comme li poche du sarigue femelle; mais celles de la gazelle ne paraissent pas avoir de rapport aux nouveau-rés, comme celles du sarigue; quoique les mamelons soient placés sur leurs bords, il s'est trouve dans leur fond un peu de matières graisseuse el blanchatre.

Les secondes platanges des doigts de la gazelle ne tiennent l'une à l'autreque paı leurs coites postérieurs, qui sont réunis par la peau; la partie infirieure des premicres plualanges n'a pas pilus d'adlierence; mais à l'endroit de l'articulation des secondes plıalanges, avec les Iroisiènes il y a une cloison forme par la peau qui alıaclie les deux doigts l'un a l'autre; cette cloison termine une cavite qui est entre les secondes plualanges des doigts et entre la partic infericure des premières; cette conformation des pieds le la gazelle ma paru peu differente de celle du pied du mouton et des autres animaux à pied fourclı; en ćcartant les sabots d'un mouton, on voit la cloison transversale yui est audessus des sabots, et la caviti qui se trouve au-dessus de la cloison.

\section{DESCRIPTION DE LA CORINE'}

La corine differe de la gazelle et du kevel par la forme des cornes et par le poil, qui a un peu plus de longueur; mais elle leur ressemble exactement par les couleurs ; celte ressemblance est si granule tans ces trois animaux, que l'on serait temte de croire qu'il seraient de mème espèce : quoique je naie vu que des peaux hourres du kevel et de la corine, il me semble upue sil y a des differences dans les proportions du corps, elles ne somt que tresligeres; ces trois animaux ont les jambes furt menues, les oreilles longues, la queue courte, des landes hlanclies sur la face externe des orcilles, des brosses aux jambes de devant, irois bamles rousses ou noiritres et deux blanches sur le chanfrein, ete.; mais il se trouve des differences I rès-apparentes dans les cornes, principalement dans celles de la corine; elles sont à proportion plus menues que les cornes de la gazelle et du kevel, et leurs anneaux sont beaucoup plus petits.

l.es cornes de la corine ont une courlure en arriere et en bas; il ! en a qui sont aussi un peu recourhese en iledans par l'extrunite, mais il parait que ce n'est que par accilent; comme elles sout menues, il arrive quelles sünclinent en differents

- Liatilope gazelle, variélé Conikx. 
sens, ou qu'elles se cassent par le bout; dans ce dernier cas l une est plus courte yue l'autre et lermince far une sorte de calus; j’ai vu cleux tètes de corines, dont les cornes navaient que des anneaux peu apparents et fort inéganx; ils étaient petits el serrés dans la parie inférieure de la corne, plus lurges et plus èloignés dans la partie supérieure; les anneaux des cornes d'une troisième tète ètaient plus ģros, et placés pour la plupart à de grandes distances. M. A danson ma fail roir une corne qu il a rapfiortẻe du Sénigal, qui est presque droite el plus petite que les autres,et gui n'a dans sa partie iuférieure que cinq anneaux et quelques inėgalités dans le reste de sa lun'zueur : mais ces pretites differences ne m’empêchent pas le croire que toutes ces ('ornes ne vienneut de curines de differents îges ou de sexes differents.

\section{DE LA GAZELLE}

ou

CILEYRE SAUTANTE DU CAP DE BONE-ESPÉnANCE.

(L'AXTtilope A Bourse.)

Ordre des ruminants, section des ruminants à cornes creuses, genre antilope. (Curier.)

Cet animal, d'après un dessin qui m'a été communiqué par M. Forster, et cqu'il a fait d'après nature vivante, me parait devoir être rapporté au geure des gazelles plutôt qu'à celui des chèvres, quoiqu'on l'ait appelé chèvre sautante. L'espèce de ces gazelles est si nombreuse dans les terres du Cap, où M. Forster les a vues, qu'elles arrivent quelquefois par milliers, surtout dans de certains temps de l'année, où elles passent d'une contrée à l'autre. Il m'a assuré qu'ayant vu, pendant son séjour en Afrique, un grand nombre de gazelles de plusieurs espèces, il a reconnu (jue la forme et la direction des cornes n'est pas un caractère bien constant, et que dans la mène espèce on trouve des individus dont les cornes sont de différentes grandeurs et contournées différemment.

Au reste, il parait que dans les terres du cap de Bonne-Espérance jl se trouve deux espèces de ces gazelles ou chères sautantes ; car on m'a donné undessin, dont l'animal porte le nom de klippspringer, sauteurde rochers, et dontnous parlerous dans l'article suivant' En comparant sa figure avec celle de la chevre sautante, on voit gue ce sauteur de rochers a les cormes plus droites et moins longues, la queue beaucoup plus courte, le pelage plus gris, plus uniforme que

\footnotetext{
- Cet animal est l'Axtllore hlippspriveer.
}

la chère sautante : ces différences me parult sent plus (que suflisantes pour en faire deux especes distinctes.

Voici les observations que M. Forster a faites sur la premicre especc de ces chèrres sautantes, qui jusqu'ici n'était pas bien connue.

"Les Ilollandais du cap de Bonne-Esnérance appellent, dit-il, ces aumaux springbok, chèrres sautantes. Elles habitent les terres intérieures de l'Afrique, et n'approchent les colonies du Cap que lor'sque la grande sécheresse ou le manque d'eau ct d'herbage les for'cent de changer de lieu; mais c'est alor's qu'on en voit des troupes depuis dix-mille jusqu'à cinquante nuille, quoiqu'elles sojent toujours accompagnées ou suivies par les lions, les onces, les léolıards, et les hicnes qu'on appelle au Cap chiens saurages, rui en dévorent une grande fuantité. L'arant-garde de la troupe, en s'approchant des habitations, a de l'embonpoint; le corps d'armée est en moins bonne chair, et l'arrière-garde est fort maigre et mourant de faim, mangeant jusqu'aux racines des plantes dans ces terrains pierreux; mais en s'en retournant, l'arrière garrle devient à son tour plus grasse, parce qu'elle part la première, et l'avant-garde, (quialors se trouve la dernière, devient plus maigre. Au reste, ces chèvres ne sont point peureuses lorsqu'elles sont ainsi rassemblées, et ce n'est mème qu'à coups de fouet ou de bâton qu'un homme peut passer à travers leur troupe. En les prenant jeunes, elles s'apprivoisent aisément; on pent les nourrir de lait, de pain, de blé, de feuilles de choux, etc. Les mâles sont assez pétulants et méchants même en domesticité, el ils domnent des coups de corues aux personnes qu'ils ne comuaissent pas; lorsqu'on leur jette des pierres, ils se mettent en posture de defense, et parent souvent le coup de pierre avecles cornes. L'ne de ces chères sautantes, îgée de trois ans, que nous ar ions prise au Cap et qui était fort farouche, s'apprivoisa sur le vaisseau, au point de venir prendre du pain dans la main, et elle devint si friande de tabac, (qu'elle en demandait avec empressement à ceux (qui en usaient; elle semblait le savourer et l'avaler avec avidité; on luj donna une assez grande quantité de tabac en feuille, qu’elle mangea de mème avec les côtes et les tiges de ces feuilles: mais nous remarquánes en mème temps que les chères d'Europe qu'on avait embar(juées sur le vajsseau pour avoir du lait, man. geaient aussi très-volontiers du tabac. 
- Les chèvres sautantes ont une longue tache blanche qui commence par une ligne au milieu du dos, et finit vers le croupion en s'élargissant; cette tache blanche n'est pas apparente sur le dos lorsque l'animal est trancuille, parce qu'elle est couverte par les longs poils fauves qui l'entourent: mais lorsqu'il satute ou bondit en baissant la tête, on voit alors eette grande tache blanclie it décourert.

"Les chevres sautantes sont de la grandeur des axis du Bengale: mais le corpes et les membres en sont plus délieats et plus délicis; les jambes sont plus halutes. Le pelage en géncial est d'un fauve jumnátre ou d'unc couleur de cannelle vive; la partie postéricure des pieds, une partie du cou, la poitrine, le ventre cet la quetie, sont d'un assez beall blane, a l'exeeption de l'extrémité de la çueue qui est noire. Le blane du ventre est bordé par une bande d'un brun rongeatre qui s'étend tout le long du llane; il y a aussi une bande de brun noiraitre chil deseend depuis les yeux jusqu'aux coins de la bouclie; et sur le front une antre bande triangulaire de faure jaunitre, qui deseend quelquefois jusque sur le musealu, ou clle finit en pointe, et qui en remontant sur le sommet de la tète, oit elle s'ćlimgit, se joint au fatuve jaunatre du dessus du ('orps : Ie reste de la tète est de couleur blanche; elle est de forme oblongue. Les narines sont étroites et en forme de croissant ; leur cloisoh répond a la division de la levresupérieure, rui e'st fendue, et e'est li fu'on remargue un amas de petites éminenees hémisphéricues, noires, dénuées de poils et toujours humides. L.es yeru sont grands, vil's et pleins de feu; l'iris est de couleur brune; sous l'angle anterieur de clinque ocil, il y a un larmicer dont l'oritice est presque rond. Les oreilles sont a peu pres aussi lonques que la terte enticere; clles forment diabord (II) tube assez citroit, s'ćlargissent ensuite et linissent en pointe mousse. Le eou est assez long, grèle et un peu comprimé sur les coités. I.es jambes de devant paraissent moins hautes que celles de derriere, qui sont diveregentes, de matmiere qu'en marehant l'mimal semble se balaneer de coté et d'autre. Le's salrots de's quatre pieds sont petits, de forme triangulaire et de couleur noire, de méme que les corne's qui ont onviron un pied de longueur, avee douze anneaux à compter depuis la base, et qui se terminent en une pointe lisse.

" Il semble que ees chivres sautantes aicnt quelque pressentiment de l'approche du malvais temps, surtout du vent de sud-est qui, au cap de Bonne-Espérance, est trẻs-orageux et très-violent ; c'est alor's quu'elles font des sarts et des bonds, et que la tache blanche qui eyt sur le dos et le croupion paraît à découvert: Ies plus vieilles commencent à sauter', et bientòt tout le reste de la troupe en fait de mème. Ia femelle dans cette espece a des cornes, ainsi que le mâle, et la corne qui est figurie dilns l'Histoire naturelle est celle d'un vicux mâle. Au reste, les cornes sont de figures si diffurentes dans ces animaux, que si on voulait ranger l'ordre des gazclles par'ce caraclere, il y aurait des chẻres silutantes dinus toutes le's divisions.

Apres avoir comparé ecte deseription de M. Forster", et lí ligure de ectte chevere sautante du Cáp, il pirrittait au premier coup d'œil que éc'st le meme animal que celui que M. Allamand appelle bonlebok, ct dont il donne la description et la figure dans le nouveau supplément à mon ouvrage, imprimé à Amsterdam cette année 1781; cependant j'avoue qu'il me reste eneore quelque doute sur' l'identité de ces deux especes, d'autant que la chèrre sautante est appelée springerbok et nou pas bonlebok par les Hollandiris du Cap.

Il se pourait done que celte chèvre sautante, déerite par M. Forster, fuit de la méme espice ou d'une espice tries-roisine de celle que M. Allamand a nommée la guzelle u bourse sur le dos, d'autant que tous deux s'aceordeut it dire qu'on n'apercoit la bande blanche qui est sur le dos que quand cette chevere ou gazdille court ou saute, et gu'on ne roit pas ee blane lorsqu'elle est en repos. Voici ce rue ce savant maturaliste en a public dans le supplement a mes ouviages.

DE IA GAZFLLE A BOLRSE SUR LE DOS.

PAR M. AILA.MAND.

avec sa sagacité ordinaire, M. de Buffon a éclairei tout ce qui a cité dit jusqu'à présent d'embronillé au sujct des crazelles : il en a cxactement dererit et determine toutes les differentes especes qui sont parromues à sa comnais. sance, et il en a ronnu plus que personne a rant lui ; mais dans la nombreuse liste yu il nous en a domice, il u'a pas cru qu'il les avart toutes comprises. Ces animaux habitent pour la plu- 
partl'Afrique, dont l'intérieur est presque encore entierement inconnu : ainsi on ne peut pas douter qu'il n'y en ait nombre d'espèces qui n'ont point été décrites. La gazelle dont je va!s parler en est une preuve; e'est à M. le capitaine Gordon que nous en sommes redevables. Cet officier, cue j'ai eu plus d'une fois occasion de nommer, joint à toutes les connaissances de l'art militaire un vif désir d'enrichir l'Histoire naturelle de nouvelles découvertes : e'est ce qui l'a déterminé, il y a quelques années, à entreprendre un voyage au cap de Bonne-Espérance, et à y retourner l'année passée, après avoir obtenu de la Compagnie des Indes un emploi de confiance qui ne pouvait être mieux excreé que par lui, mais qui ne l'empêchera point de pousser ses recherches comme naturaliste. Depuis (ju'jl y est arrivé, j'ai eu la satisfaction d'apprendre par ses lettres, qu'il a déjà découvert trois animaux, qu'il m'envoie, et qui jusqu'à présent n'ont point été vus en Europe. En les attendant avec impaticnce, je vais faire comnaitre la gazelle qui fera le sujet de cet article, et qu'il avait placée dans la ménagerie du prince d'Orange. C'était la seule cjui fut restée en vie d'une douzaiue qu'il avait amenées avec lui.

- Nous sommes redevables du dessin de cette gazelle à M. J. Temminck, receveur de la Compagnie des Indes, amateur bien connu par sa ménagerie précieuse d'oiseaux vivants, et par son cabinet d'oiseaux préparés très-rares. Cette gazelle ressemble presque en tout à la gazelle commune, décrite par MM. de Buffon et Daubenton. Elle a les cornes annelées et contournées de la même façon, et également noires: elle est de la môme couleur, aree les mèmes taches; elle est un peu plus grande, mais ce qui la distingue est une raie de poils blanes longue de dix pouces, qui au premier coup d'oil n'offre rien de particulier, et qui est placée sur la partie postérieure du dos, en s'étendant vers l'origine de la queue. Quand clle court, on est frappé de voir tout d'un coup cette raie s'ilargir et se convertir en une grande tache blanche qui s'étend presque de cóté et d'autre sur toute la croupe; voici comment cela s'opire : l'animal a sur le dos une espèce de bourse faite par la peau, qui, se repliant des deux cótés, lorme deux livres qui se touchent presque : le und de cette bourse est couvert de poils blancs, el c'est l'extrémité de ces poils qui, passant en- tre les deux lèrres, parait être une raie ou ligne blanche. Lorsque la gazelle court, cetto bourse s'ouvre, le fond blane parait à découvert; et dès qu'clle s'arrète, la bourse se referme. Cette belle gazelle n'a pas vécu long. temps dans ce pays; elle est morte quelques mois apres son arrivée. Elle était fort douce et eraintive; la moindre chose lui faisait peur et l'engageait à courir. J'ai joui très-souvent du plaisir de lui voir ouvrir sa bourse.

\section{LE KLIPPSPRINGER,}

ou

\section{SAUTEUR DES ROCHERS.}

\section{(L'AXTILOPE FitPRSPRIMGER.)}

Ordre des runinauts, section des rumioants à cornes, gente antilope. (Cuvier.)

Toici la seconde espèce de gazelle ou chère sautante, dont MII. Forster ont bien voulu me donner le dessin : a M. Kolbe est le seul, disentils, qui ait jamais parle de ce bel animal, le plus leste de tous ceux de son genre. 11 se tient sur les rochers les plus inaccessibles; et lorsqu'il apercoit un homme, il se retire d'abord vers des places qui sont entourées de précipices : il franchit d'un saut de grands intervalles d'une roche à l'autre, et sur des profoncicurs affreuses; et lorsqu'il est pressé par les chiens ou les chasseurs, il se laisse tomber sur de petites saillies de rocher, où l'on croirait qu'a peine il $y$ ent assez d'espace pour le receroir. Quelquefois les chasseurs, qui ne peurent les tirer que de trèsloin et à balle seule, les blessent, et les font tomber dans le fond des précipices. Leur chair est excellente a manger, et passe pour le meilleur gibier du pays. leur poil est léger, peu adhérent, et tombe aisément en toute saison : on s'en sert au Cap pour faire des matelas, et mème on pique avee ces poils des jupes de fermmes.

- Ce sauteur des rochers est de la grandeur de la chève commune, mais il a les jambes beancoup plus longues. Sa tite est arrondie; clle est d'un gris jaunâtre, marqueté par-ci parlà de petites raies noires; le muscau, les livires et les environs des yeux sont noir's; devant chaque ocil il y a un larmier avec un grand orifiee de forme oralc; les oreilles sont assez 
grandes et finissent en pointe. Les cornes ont environ cing ponces de longucur; elles sont droites et lisses à la pointe, mais ridées de quelques anneaux a la base : la femclle n'a point de cornes. Le poil du corps est d'un fauve jaunàtre; chatque poil est blanc à sa raciue, lrun ou noir au milieu; cet d’un jaune grrisâtre à l'extrémité; les pieds et les oreilles sont couverts de poils blauchâtres; la gucue est très-courte. ")

\section{DE LA GAZELLE PASAN.}

\section{(L'AXTHOPl: OHYX.)}

Ordre des ruminauls, scclion des Iruminanls à cornes creases, genre antilope. (Curier.)

M. Pallas pense avee moi que de pasan et l'algazel ne sont que deux varićtés de la mème espece. J'ai dit que ces deux espeeces, l'algazel et le pasan, me paraissaient tres-voisines l'une de l'autre, qu'dle's sont les memes climats, mais (gue néanmoins l’algazel n'habite guère que dans les plaines, ct le pasan daus les montagnes; c'est par cette scule différence des luabitules naturelles que j’ai cru (qu'on pouvait en faire deux especes. J'ai même dit positivement que je présumais que l'algazel et le pasan n'étaient que deux virićtés de la mème espèce, et j’ai été fort satisfilit de voir que M. Pallas est du même sentinent. Il dit, au sujet de ce dernier animal, que M. Houttuyn en a aussi domné une figure d'apres les tableaux de M. Burmann; mais je n’ai pás eu occasion de voir ces tableaux.

MII. Forster mont écrit (jue la gazclle pasan porte aussi le nom de chamois du $C(t))$, et celui de chère du bésourd, \{moinüil y ait une antre chevre du bézoard en ()rient, dont M. Gmelin le jeune a domme une description sous le nom de paseng, qui est diflérente du pasan. II ajoute, "fuedans la femelle les cornes ne sont pas aussi grandes que dans le male; yue ees cornes sont maryucies vers Iemrorigine d'une large bande noise en demi-cerele, qui s'étend jusqu'à une autre grande tache de mène couleur noire, lanuelle coure ru piutic le museau, dont l'extrémité est grise; rue, de plus, il y a deux bandes noires qui jurtent du musenu et s'étendent jusqu'aus rorues, et unc lignenoiro le long du dos yui se fermine au crompion et ! lorme une plaqgue triangulaire; qgu'un roit aussi une bande noire entre la jambe et la cuisse de de. vant, et une tache ovale de la mème couleur sur le genou ; yuc les pieds de derière sont aussi mar(jués d'une tache noire sous la jointure, et qu'il y a une ligne noire de longs poils le long du cou, au dessous duquel se trouve une espèce de fanon qui tombe sur la poitrine; qu'enfin le reste du corps est gris, à l'exception du ventre qui est blancinâtre, ainsi que les pieds.

"Cet animal, dit M. Forster, a prés de quátre pieds de hauteur, en le mesurant aux jambes de devant; les cornes ont jusqu'à trois pieds de longueur. Ces gazelles ne ront point en troupes, mais seulement par paires, et il me semble que e'est le mène animal que le parasol du Congo, dont parle le P. Charles de Piálisance. "

\section{AdDition a L'article dU PASH, PAR M. LE DOCTEUR ALLAMATD.}

"M. de Buffon a donné à la gazelle du bézocird le nom de pasan, qui est celui que les Orientaux lui donnent. Il n'en a vu que le cráne surmonté de ses cornes, dont M. Daubenton a doniné une description fort exacte. On trouve souvent de ces cornes dans les cabinets de euriosités naturelles; j'en ai placé deux daus celui de notre Université, qui mont été cnvoyćes du cap de Bonne-Espérance; mais l'a nimal qui les porte a été peu commu jusqu’à présent : je suis mème tenté de dire qu'il ne l'a point été du tout; ear je doute fort que ce soit le mime qui a été indiqué par Kompfer, sous le nom de pasen ou pasan. La deseription qu’il en a donnée ne lui eonvient point á plusicurs égards, et la ligure dont il l'a aceomprgnée, toute mau vise qu'elle est, représente surement un animal tout diltérent.

"Tous les autres auteurs qui ont parlé de la gazelle du bezoard sont peu d'aceorel entre eux, quoiqu'ils lui domment le mime nom pasan. Tavernicl, (qui cu a eu six vivantes, sc contente de dire yue ee sont de trés-jolies cheves, fort hautes rt qui unt un poil fin comme de la soie. Chatelin assure que le bizoard se trome aur Indes dians le corps de's boues et des elevies saurages et domestipues, et en l'erse dans le corpin des moutons. I.e P. I.abat a donné sule fierure de l'animal yui porte le bézoarle en Alrifuc, mais écot la copio do celle qu'a don ue l'omet dins sou Histoire des diogues, et 
qui est celle d'une chèvre avee des cornes chargées de denx ou trøis anduuiller's, c'est-d-dire d'un animal fabuleux. Clusius, ou plutot Garcias, dit que le bézoard se trouve dans le ventricule d'une sorte de bouc, dont il a fait représenter une corne; clle ne ressemble pas à celle de notre pasan. La figure qu'Aldrovande a donnće à cet animal est celle de l'antilope, et Klein a copié ce qu'il en dit. L'auteur de l'Histoire naturelle qui se publie en hollandais a fait représenter l'algazel pour l'animal qui fournit le bézoard.

"Que faut-il conclure de ces différentes descriptions et de plusieurs autres qu'on pourrait y ajouter? e'est qu'on tronve des bézoards dans diverses espèces de chèrres ou de gazelles, dont aucune n'est bien connue : ainsi ce u'est pas sansraison que jai dit que l'animal que je vais déerire a été inconuu jusqu'à présent, et qu'il était peu différent du pasan de Kœmpfer. On cn trouve cependant une figure passable, quoique fautive à bien des égards, dans les Delicice nalurce selectce de Knorr; mais cet auteur s'est sưrement trompé en le prenant pour la chèvre bléue de Kolbe; îl n'en a ni les cornes, ni la couleur, ni les sabots.

"C'est encore à H. ledocteur Klockner qu'on doit la connaissance de ce bel animal ; il a eu occasion d'en acheter une peau bien complète qu'il a préparée avec sa dextérité ordinaire. On lui a dit qu'elle a vait été envoyée du cap de BonneEspérance, et je u'eu doute pas, puisque les différ entes cornes que nous a vons ici nous viemnent de cet endroit; et de plus, e'est vraisemblablement le mẻme auimal qui a été tué par M. le capitaine Gordon, dont j'ai eu plus d'me fois occasion de citer le témoiguage. Cet oficier, étant à une assez grande distance du Cap, vit sortir d'un petit bois une très-belle chève qui avait des cornes fort longues et droites, et dont la tète était singulièrement bigarrée de couleurs tranchantes; il tira dessus à balle, et le coup l'ayant fait tomber, il accourait pour l'examiner' de près, mais l'Hottentot qui l'aceompagnait le retint, en lui disant que ees animaux étaient très-dangereux; qu’il arrivalit souvent que n'étant que blessés ou tombés de peur, ils se relevaient tout d'un coup, et, se jetiunt sur ceux qui les approchaient, ils les pereaient de leurs cornes qui sont très-pointues. Pour n'en avoir rien à craindre, il lui tira un second coup qui le sonvanquit qu'elle était bieu morte. Comme
M. Gordon est retourné au Cap, d'où nous avons bien des choses curieuses à attendıe de lui, je ne puis pas lui montı er la figure de uctre pasan, pour ètre assuré que c'est le mème anjmal qu'il a vu. La description que jen vais donner est tirée de ce que $\mathbf{H}$. Klockner m'en a écrit : ainsil'on peut compter sur son exactitude.

" La taille de cet animal est un peu plus petite que celle du condoma; la forme de sa tête ne ressemble point à celle du cerf ui à celle du boue; elle approche plus de celle du nanguer de M. de Bufion; mais le singuliermélange des couleurs dont elle est ornce le rend fort remarquable; le fond en est d'un beau blane. Fntre les deux cornes il y a une tacbe noire qui descend environ deux pouees sur le front, et qui, s'éteudant de còté et d'autre jusqu'á la moitié des cornes, y paraitrait carrée sans une petite pointe qui s'avance du côté du nez; une autre grande tache aussi noire couvre presque tout l'os du nez, et des deux côtés elle se joint avee deux bandes de même couleur, qui, prenant leur origine à la racine des cornes, traversent les yeux, et descendent jusqu'au dessous de la mâchoire inférieure, où elles deviennent brunes. De pareilles bandes noires qui passent par les yeux sont rares dans les quadrupèdes : il n'y a que le blaireau et le coati qui nous en fournissent des exemples; l'extrémité du museau est d'un blane de neige. L'on comprend que ce bizarre assemblage de couleurs offe un coup d'œil très-firappant; s'il se trou vait sur la gazelle du bézoard, ceux qui en ont parlé n’auraient par manqué d'en faire mention : Kímpfer l'aurait-il insinué en disant que, pour juger si ces animaux renferment des bézoards, ou observe leurs soureils et les traits de leur front; s'ils sont bien uoirs, e'est une bonne marque?

"Lepoil court qui courre les côtés, les cuisses et la croupe de cet animal, n'est guère moins remarquable par sa couleur: il est d'un gris cendré tirant sur le bleu, avec une légère teinte d'un rouge de fleur de pommier. Sa queue est brume presque jusqu'à son extrémité qui est uoire : cette couleur brune s'étend sur le dos, où elle forme une bande assez large, prolongée jusqu'aux épaules. Là les polls sont plus longs et se dirigent en tous sens, en figure d'étoile, et eontinuent de couvrir le dessus du cou; ils deviennent plus courts en s'approchant de la tête, sur laquelle ils disparaissent; ils sont tournés eu avant, et aiusi ils forment une espece de cri- 
njère; la partie inféricure des jambes de devant est hanche; mais il y a une tacle ovale de couleur de marron foncée, presque noire, yui commence au-dessous des sibots, et qui a cincppouces de longueur sur un pouce de largear. On voit une semblable tache sur les pieds de derriere, mais plus mèlés de poils blanes; elle s'étend tout le long de la face antérieure de la jambe, sur layuelle elle parait comme une simple ligne de couleur de plus en plus clinire, jusyu'a ee qu'elle se confonde ave des poils d un forun presque noir, qui couvient le devant des cuisses et qui y paraissent comme une bande large de trois ou yuatre doigts; cette bande est continuce sur la partic supérieure du corps, yu’clle sépare du ventre, et elle s'étend jusqu'iux jambes de devant, dont elle environnc le laut et descend même assez bass.

"On voit encore, aux deux cotés de lil eroupe, une autre grande tache ovale yui deseend pres. que jusqu'à la jamble; les poils qui la composent sont d'un brun clair tirant sur le jaune, et leur pointe est blanche. Sur le cou il y a une bande brune qui s'étend jusquaux jambes antéricures, ou l'on remaryue quelques restes de longrs poils, dout il semble que la gorge a été garnice.

a Les oreilles ressemblent assez d̀ eelles du condoma; leur longueur est de sept pouces, et leur largeur de quatre pouces et demi ; elles sont bordées au haut d'une rangée de poils brums. Les cornes sont presque droites, à une légere courbure pres qu'on a peine à remarguer; elles sont noires, et leur longueur est de deux pieds un poute, ce yui s)e faisait eroire pu’elle's n'etaicut pas eneore pall venues à toute Jeur hauteur. Celles yue j’ai placér's au Cabinet de notre Académie émalent deus piesls quatre pouces, et la cireonlérence de len base est de six pouces. Ces rornes sont tres-exactement représentées dans la fìgure (pu’en a donnée M. de Buffon, et on ne peut rien ajouter à la deseription cju'e'n a faile M. Danbenton : clles sont environnés d'anncaux obliçues jusqu’a la moitiéde leur longueur, et le reste en est Isse et terminé par une pointe fort aiguë.

"La eorne des pieds offre une singularité qu'il ne faut pas umelloe. La parlie inferieure de chareun des saloots a la fierrure d'un triangle isocele fort allongr, au lieu due daus less atutres anjmaux a pieds fourehus elle forme mo triangle presque éypulatéral. Ciette conligurition dome au pied du pasan une base plus étendue, et par lá mème plus de fermeté. Au-dessus du talor. il y a denx ergots noirs fort pointus et longs d'un pouce et demi. L.e port de cet animal a quelque chose de fort gracieux; et soit qu'on le range dans la classe des gazello's, à laquelle il parait qu'il appartient, puisqu'il n'a point de barbe, soit (ju’on le compte pármi les chèves, è súrement une espice très-distinguce par sa codleur et par ses taches, aussi bien que par ses cornes : il a le cou moins long que la plupart des aninaux de ce genre; mais cela ne diminue en rien sa beauté. Il est tres-vraisemblable, à en juger par la forme des cornes de ses pieds, oru'il habite sur les montagnes, et cela dans les lieux assezz éloiennés du Cap, puisque jusqu'à présent il n'a cé comnu que des Hottentots. Voici une table de ses dimensions :

Longueur du rorps, depuss le bout du museau jusqu'à l'srigine de la queue. . . . 4 |l 0 Hauleur du traiu de devant. . . . . . . 320 Hauteur du train de derrière. ....... 31 u Longueur de la tète, depuis le muscau jusqu'aux corues. ............. 078 Longueur des oreilles. ......... 0 9 7 10

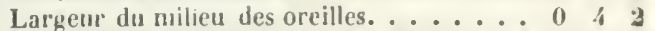
Longnenr des colues, prise en suivant leur courbure, qui est Irès-peu remarquable. . 218 Circonférence des cornes à leur base. . . . . 0067 Distance entre leurs bases. . . . . . . 0 0 0 Distance enlre leurs pointes. . . . . . . 11998 Longnenr de lit quene. .......... 1110 Longueur des plus longs poils de la quene. . $0 \begin{array}{ccc}0 & 9 & 0\end{array}$ Longucm des poils qui formeut la criniere. . 1128 Longuenr des salrots. .......... 048 J.eur circonference. ........... 0 \% 78 Epaissem de la peau. tant de la poitrine que

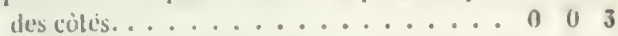

\section{LE CONDOMA.}

\section{(L'ANTILOHE COLDOCS OU COESDOES.)}

Ordre des rmunants, section des runinants à cornes creuses, genre atulilope. (Cuicr.)

M. Ie marquis de Marienny, qui ue perd pas la plus pelite oreasion de firvoriser les siences et les arts, m'a fait voir dans som tablunet la tite d'un animal (pue ju pris, an promice coup d'uil, pour e'elle d'un grand hulale; clle est s'mhlable a edle de nos phos grands cerfs : mais an lieu de prorter un bois solide et plein comme celui des cerlis, elle est surmoutćc de deux griundes corness 
creuses, portant arête comme celles des boues, et doublement fléchic comme celles des antilopes. Eu cherchant au Cabinet du Roi les morceaux qui pouvaient être relatifs à eet animal, nous avons trouvé deux eornes qui lui appartiemnent: la première, sans aueun indice ni étiquette, venait du Garde-Meuble de sa majesté; la seconde m'a été domrécen 1760, par M. Baurhis, commis de la nurine, sous le nom de condoma du cap de Bonne-Espérance. Nous avons eru devoir adopter ce nom, l'animal gu'il désigne n'ayant jamais été dénommé ni décrit.

Par la longueur, la grosseur et surtout par la double flexion des cornes, le condoma nous parait approcher beaueoup' de l'animal que Caïus a donné sous le nom de strepsiceros. Non-seulement la figure et les eontours des cornes sont absolument les mêmes, mais toutes les dimensions se rapportent presque exactement; et en comparant la deseription que M. Daubenton a faite de la tête du condoma avec celle du strepsiceros de Caïus, il m'a paru qu'on pouvait présumer que c'était le mème animal, surtout en faisant précéder notre jugement des réflexions suivantes : $1^{0}$ Caïus s'est trompé en donnant eet animal pour le strepsiceros des aneiens : cela me parait évident; car le sırepsiceros des anciens est certainement l'antilıpe, dont la tête est trèsdifférente de celle du cerf : or, Caius convient, et mème assure que son strepsiceros a la tête semblable à celle du cerf; donc ee strepsiceros n'est pas celui des anciens. $2^{0}$ L'animal de Caïus a, comme le condoma, les cornes grosses et longues de plus de trois pieds, et courertes de rugosités et non pas d'anneaux ou de tubercules; au lieu que le strepsiceros des anciens, ou l'antilope, a les cormes :nn-seulement beaucoup moins grosses et plus cuurtes, mais aussi chargées d'anneaux et de tubereules très-apparents. $3^{0}$ Quoique les cornes de la têle du condoma qui est au Cabinet de M. le marousis de Marigny aient été usées et polies, et que la corne qui vient du Garde-Meuble du roi ait même été travaillée à la surface, on voít cependant qu'elles n'étaient point chargées d'anneaux; et ecla nous a été dénnontré par celle que nous a domnce M. Baurhis, qui n'a point été touchée, et qui ne porte en effet que des rugosités, comme les eornes de bouc, etıon pas des anneaux comme celles de l'antilope. Or, Caïus dit lui-méme que les cornes de son strepsiceros me portent que des rugosités; donc ce strepsiceros n'est pas ceiuí des anciens, mais l'animal dont il est ici question, qui porte en effet tous les earactères que Caïus donne au sien.

En recherchant dans les voyageurs les notices qui pouvaient avoil rapport à cet animal remarquable par sa taille, et surtout par la grandeur de ses cornes, nous n'avons rien trouvé qui en approche de plus près que l'animal indiqué par Kolbe, sous le nom de chèvre sauvage du cap de Bonne-Espérance. "Cette ehèrre, dit-il, qui " chez les IIottentots n'a point reẹu de nom, et " que j'appelle chèvre saurage, est fort remar" quable à plusieurs égards : elle est de la taille " d'un grand cerf; sa tete est fort belle et ornée " de deux cornes unies, reeourbées et pointues, " de trois pieds de long, dont les extrémités " sont distantes de deux pieds. " Ces caractères nous paraissent convenir parfaitement à l'animal dont il est ici question : mais il est vrai que n'en ayant vu que la tête, nous ne pouvons pas assurer (que le reste de la description de Kolbe lui convienne également; nous le présumons seulement comme une chose vaisemblable qui demande à ètre vérifiée par des observations ultéricures.

\section{ADDITION A L'ARTICLE DU CONHOMA COESDOES.}

Il nous est arrivé une peau bien conser véc de condoma.M. le ehevalier'd'Auvillar's, lieutenantcolonel du régiment de Cambresis, en a aussi rapporté une, de laquelle $\mathrm{II}$. de Brosse, prenier président du parlement de Dijon, m’a envoyé une très-bome desiription qui se rapporte parfaitement avec tout ce que j'ai dit au sujet du condoma.

"L'animal entier, dit M. de Brosse, fut donné au ehevalier d'Auvillar's, au cap de BonneEspérance par M. Berğ, scerétaire du Conseil hollandais, comme venant de l'intérieur de l'Afrique, et d'un lieu situé à emviron eent lieues

\footnotetext{
- Depuis son front, tout le long de son dns, on voit une raie blanche ıni finit au-desvis de sa queue; unc autre raie de mome couleur coupe celte prenière an bas du cou, dont elle fait toul le lour ; il y en a drux antres de mcme nature, luue derrière les jambes de desant, el l'aulre devant les jambes de derriere; elles font toutes deux le tour du caips: le poil dont le reste de son corps est comvat lite sur le gris avec quaclques petiles laches rouges, exceplé celni qu'elle a sons le ventre, qui est llane: sa barbe esl grise et furt longuc: res jambes. quoinue longues, sunt bien proportionnées. Inecription du cap de Bonne-Espérance, jai Kulbe, lome III, pago 42.
} 
du Cap; on lui dit au'il s'appelait coesdoes. Il y a vait trois deces animaux morts, l'un plus grand, l'autre plus petit que celui-ci : il le fit très-exactement dépouiller de sa peau, qu'il a apportée en France; cette peau était assez épaisse pour faire des semelles de souliers. J'ai vu la peau entière: l'animal semblait ètre de la forme d'um petit bouf, mais plus haut sur ses jambes. Cette peau était colverle d'un poil gris de souris assez ras; il y avait une raie blanche le long de l'épine du dos, d'où deseendajent de chaque còté six cu huit raies transversales de même couleur blanche, il y arait aussi au bas des yeux deux raies blanches posées en chevron renversé, et de chaque coté de ees láies, deux taches de mème couleur: lehaut du cou était grarni de longs poils en formedecriniere, qui se prolongenient jusque sur le garrot. Les cornes, mesurées en ligne droite, avaient deux pieds ciny pouces sept lignes de longueur, et trois pieds deux pouees trois lignes en suivant exactement leurs triples sinuosités sur l'arête continue; l'intervalle entıe les cornes, à leurnaissance, n'était que d'un pouce six ligrues, et de deux pieds sept pouees à leurs extrémités; leur circonférence à la base était de huit pouces trois lignes: elles étaient bien faites, diminuajent régtilierement de grosseur en s'éloignant de leur maissance, et finissaient en pointe aiguë; elles étaient de coulcur grise, lisses et assez semblables, pour la substance, à celles du boue, avee quéques rugosités diuns le bas, mais sans aucume strie véritible. On pouvait enlever en entier cette corne juscu'au bout; apres avoir otécette cuveloppe cornée, mince et parfaitement évidée, il reste un os le moindre diametre, presfune aussi long, pareillement contourné, de couleur blane jounatre, mais mal lisse, d'une substanee lacise, peu compacte, frable et cellulaire. Is eorne du pied ressemblait i celle d'une grinisse de deux ans, et la queue était courte et garnic de poils assez loners à l'extrémité. "

Gette deseription faite par M. Ie président de Br ssse est tres-bonne; je l'ai confrontée avceles dépouilles de ee méme animal quejavais peeues pr asque en meme temps pour le Cabinet du Roi, et je n’ai rien trouvé à y ajouter ni retrancher.

M.M. Forster , qui ont vu cet animal vivant, m'ont eommuniqué les notices strivantes: "I.e coudoma on coestloes a quatre pieds de hauteur, mesuré aux jambes de devant, et les eromes ont trois pieds neuf pouces delongneur; leursextremités sout éloignées l'une de l'autre de deux pieds sept ou huit pouces; elles sont grises, mais blanchâtres à la pointe; leur arète suit toutes leurs inflexions ou courbures, et elles sont un peu comprimées et torses en hélice La femelle porte des cornes comme le mâle. Les oreilles sont larges, et la quene, qui n'a qu'un demipied de longueur, est brune à son origine, blanche sur le milieu, et noire à l'extrémité, qui est terminée par une touffe de poils assez longs.

"Le pelage est ordinairement gris et quelque. fois roussâtre. Il y' a sur le dos une ligne blanche qui s'étend jusqu à la queue; il descend de cette ligne sept barres de mème couleur blanche, dont quatre surles cuisses et trois sur les flancs. Dans quelques individus ces loares descendantes sont au nombre de huit et mèmede neuf; dansd'autres, il n'y en a que six; mais ceux qui en ont sept sont les plus communs II y a sur l'arète du cou une espèce de criniere formée de longrs poils. Le devant de la tête est noiratre, et du coin antérieur de chaque oil il part une ligne blanche qui s'étend sur le museau; le rentre et les pieds sont d'un gris blancâtre. Il y a des larmiers sous les yeux.

" Ces animaux se trouvent dans l'intérieur des terres du eap de Bonne-Espérance; ils ne vout point en troupes comme certaines espeecs de gazelles. Ils font des bonds et dles sauts surprenants: on en a vu franchir une porte grillée qui arait dix pieds de bauteur, quoiqu'il n'y eut que tres-peu d'espace pour pouvoir s'élancer. On peut les apprivoiser et les nourrir de pain, on en a cu plusieurs à la ménagerie du calp de Bonne-Esperance."

Nous ajouterous encore à ces observations l'excellente description de cet animal que M. Allamand vient de publier à la suite dlu quatrieme volume de nes Suppléments à l'll istore naturelle, edition de Ilullande; il y a joint une trés-belle figrue al'un indivilu beancoup plus grand que celui que j’ai fait dessiner et graver.

\section{AUTRE ADDITION}

a L'ARTICle du CoNdona ot Col:SDors, PAT M. LE PROYESSIIR ALLMIND.

Quoique les comes de l'animal à qui .I. de Buffon a donvé le uom de condoma soleut as- 
sez connues et se trouvent très-souvent dans les cabinets de curiosités naturelles, l'animal n'a jamais été déerit; il est pourtant assez remarquable pour mériter l'attention des voyageurs et des naturalistes.

“ M. de Buffon a eu raison de dire qu'il approchait beaucoup de l'animal queCaïus a donné sous le nom de strepsiceros, puisqu'on ne saurait douter que ce ne soit le mème, vn la parfaite conformité des cornes. Il soupconne aussi que ce pourrait bien ètre l'animal auquel Kolbe a clonné le nom de chèvre sauvage; et effectivement la description que celui-ei en a faite a quel(que rapport à celle que je vais donmer du condoma ; mais aussi il y a des différences notables, comme on s'en apercevra bientot.

- M. Pallas, qui dans ses Spicileyia zoologica, fasc. 1, page 17, a donné une bonneảeseription des cornes et de la tète du condoma, croit que M. de Buffon s'est trompé en prenant cet animal pour cette ehèvre sauvage, parce qu'il n'en a point la barbe. S'il n'a pas d'autre raisou que celle-là pour appuyer son avis, c'est lui qui s'est trompé, car le condoma a une barbe trèsremarcyuble.

"Mais sans nous arrèter aux conjectures qu'on a pu folmer sur la figure de cet animal, faisousle connaitr'e véritablement tel qu'il est, en lui conservant le nom de condoma que M. de Buffou lui a donné, quoique ce ne soit pas celui qu'on Iui domne au Cap, où on l'appelle coesdoes ou coudous. Nous avons eu la satisfaction d'eu voir un ici vi vant, qui a été envoyé du capde BonneEspérance, en 1776, à la méuagerie du prince d'Orange.

" Je lui ai rendu de fréquentes visites; frappé de sa beauté, je ne pouvais me lasser de l'admirer, el je renvoyais de jour à autre d'eu faire une description exacte : comme je me proposais d'y retourner pour le micux examiner, j'eus le clagrrin d'apprendre qu'il était mort; ct ainsi tout ce que j'en pourrais dire se réduirait à ce que ma mérnoire me fournirait. Heureusement, avant que d'être conduit à la ménagerie du prince, il avait passé par Amsterdam: là M. Schneider en fit faire le dessin.... et M. le docteur kilockner, qui ne perd aucune oceasion d'augmenter nos connaissances en fait d'histoire naturelle, l'examma avee les yeux d'un véritable observateur, et en fit une description, qu'il a eulabonté de me communiquer ; aiusic'est à lui qu'ou doit les priucipaux détails vù je vais cntrer.
" On est surpris au premier coup d'œil qu'oc jette sur cet animal : la légrèreté de sa inarche, la finesse de ses jambes, le poil court dont la plus grande partie de son corps est couverte, la manicre haute dont il porte sa te̊te, la grandeur de sa taille, tout cela annonce un trèsbeau cerf; mais les grandes et singulières colnes dont il est olné, les taches blanches qu'il a audessous des yeux, et les raies de mème couleur que l'on voit sur son corps, et qui ont quelque rapport à celles du zèbre, font qu'on l'en distingue bientòt, de facon cependant qu'on serait tenté de lui donner la préférence. La tête du condoma ressemble assez à celle du cerf; elle est couverte de poils bruns, avec un petit cercle de couleur roussâtre autour des yeux, du bord inférieur de chacun desquels part une ligne blawche, qui s'avance obliquement et en s'élargissant du côté du museau, et enfin se termine en pointe; de cóté et d'autres de ces lignes on voit trois taches rondes d'un blanc pâle, dont les deux supérieures sont de la grandeur d'une pièce de vingt sous, et celle qui est au-dessous, près du museau, est un peu plus grande. Les yeux sont noirs, bien fendus, et ont beaucoup de vivacité ; le bout du museau est noir et sans poils; les deux lèvres sont couvertes de poils blanes, et le dessous de la máchoire inférieure est garni d'une barbe grisâtre de la longueur de cinq à six pouces, qui se termine en pointe. La tète est surmontée de deux cornes, de couleur brune tirant sur le noir, et couvertes de rugosités ; elles ont une arête qui s'éteud sur toute leur longueur, excepté vers leur extrémité, qui est arrondie et qui se termine en une pointe noirâtre; elles ont une double flexion, comme celles des antilopes, et sont précisément telles que celles qui ont été déerites par MI. de Buffon et Daubenton. Leur longueur perpendiculaire n'était que de deux pieds un pouee huit lignes dans l'auimal que je décris; ce qui mo porte à croire qu'il n'avait pas encore acquis toute sa grandeur, car on trouve de ces cornes qui sont plus longues; jen ai placé deux paires au Cabinet de notre Académie, dont les plus courtes ont deux pieds cinq pouces en ligue droite, et trois pieds et demi en suivant les contour's ; la circonférence de leur base est de neuf pouces, et il y a entre leurs pointes une distance de deux pieds et demi.

"Les oreilles sont longues, larges et de la mème couleur que le corps, qui est couvert 
d'un poil fort court, d'une couleur fauve tirant sur le gris. Le dessus du cou est garni d'une espèce de crinière, composée de longs poils bruns, qui s'étendent depuis l'origine de la tète jusqu'au-dessus des épaules; là ils deviennent plus courts; changeant de couleur, ils forment, tout le long du dos jusqu' $\$$ la queue, une raie blanche; le reste du cou est couvert de semblables poils bruns et assez longs, particulièremient dans la partie inférieure jusqu'au-dessous de la poitrine. De chaçue coté de cette ligne blanche, qui est sur le dos, partent d'autres raies aussi blanches, de la largeur d'environ un pouce, qui descendent le long des cótés; ces raies sont au nombre de neuf, et la première est derrière les pieds de devant; il y en a quatre qui descendent jusqu'au ventre; la troisième est plus courte; les quatre dernières sont sur la croupe, comme on le voit dauns la figure.

"La queve est longue de plus d'un pied; elle est un peu aplatie et fournie de poils d'un gris blanchâtre sur les bords, et qui forment ì l'extrémité une toulfe d'un brun noiràtre. Les jambes sont déliées, mais nerveuses, sans cette touffe de poil ou brosse qui se trouve sur le haut des eanons des jambes postérieures des cerfs. La corne du pied est noire et fendue, comme celle de tous les animaux qui apparticnnent à cette classe.

"Cette description est celle du condoma de la ménagerie du prince d'Orange; cependant il ne faut pas croire que tous les condomas soient précisément marqués de la mème façon. M. Klockner a vu diverses peaux ou les raies blanches dilléraient par leur longueur et par lenr position : mais on comprend qu'une telle différence nest pas une variété qui mérite quelque attention. It y a une chose plus importante à remarquer ici, e'est que la plupart de ces peaux n'ont point de barbe, et l'on en voit une dans le cabinet de la Société de Harlem, qui est très-brien préparée pour représenter au vrai la figure de l'animal, mais aussi sans burbe. Y auratit-il done des condomas barbus et d'autres sans barbe? e'est ece que jai peine it eroire; et je pense, avee M. Klockner, que la barbe est tombée de cess peaux quand on les a propartées, et cela d'autant plus ejue sj on les regarde aree atlention, on voit la place on paraissent anoir été les poils dent lat barlo étitit composiée.

"Notre condona citait fort Ilons; il vivait on boune union aree les anmanax qui paissaicat avec lui dans le même parc; ct dès qu'l voyait quelqu'un s'approcher de la cloison qui était autour, il accourait pour prendre le pain qu'on lui offrait. On le nourrissait de riz, d'avoine, d'herbes, de foin, de earottes, etc. Dans son pays natal, il broutait l'herbe et mangeait les boutons et les feuilles des jeunes arbres, comme les cerfs et les bours.

"Quoique je l'aie vu très-fréquemment, je ne l'ai jamais entendu donner aucun son; mais M. Klockner m'apprend que sa voix était à peu près celle de l'âne.

"Voiei ses dimensions telles qu'elles ont été prises sur l'animal, par le mème II. Ḱlockner, sur la mesure pied-de-roi :

p. p. 1 .

Longueur du corps, depuis le bout du muscau jusıu’à la queve. .......... 580

Longueur de la léte, depuis le bout du nuseau jusqu'sux oreille's. ......... 100 I.ongupur de la téte juspu'aux cornes. . . . 0888 Longueur des cornes, unesurée en ligue droile. 218 Longurur der oreilles. .............. $088_{4}$ Havteur du lraiu de devant. ....... i 36 Hauleur du train de derrière. ....... 410 Circunférence du corps, derrièrc les jambes de devaul. ................... 440 Circonlérence du nulieu du corps. . . . . 458 Circunférence du corps devaut les jambes pos-

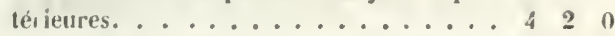

Longueur de la yueue........... 120

"En comparant cette deseription du condoma avee celle que holbe a donnée de la chèrre sauvage du cap de Bome-Esperance, et que M. de Buffon a inserée duns ce volume, on a la confirmation de ce que j'ai dit ei-devint ; e'est que le condoma ressemble, à quelques égards, à cette chève: il est de la mème taille; son poil est à peu prís de la mème couleur grise, et il a comme elle une barbe et des raies qui descendent depuis le dos sur les cótés. En voilit assez pour autoriser M. de Bufton à dite qu'il n’avait trouvé aucune notice d'animal qui approchât de plus prés du condoma que lia clierre stuvage de Kolbe; mais aussi j'ai ubserve qui'il y avait des différences remarquables entre ces deux animaux. Le nombre des raies blauches qui descendent sur leurs côtes neest pas le méne, et elles stunt difteremment ponses: la chèvee ne parait point avoir eres taches blanches qui sont all-dessous de's yeux du condoma, et qui sont (rop frappante's, pour qui un puisse supposer que holbe ail oublie d'eu parter; mais ee 
qui distingue prineipalement ces animaux, sont les cornes; celles de la chèvre sont dites simplement recourbées; ce qui n'exprime point eette double flexion, qui est si remarquable dans celles du condoma : aussi, dans la figure que Kolbe a ajoutée à sa deseription, la ehèvre y est représentée avec des cornes qui seraient tout à fait droites, sans une légère courbure au haut, à peine pereeptible.

"L'auteur d'une Histoire naturelle qui se publie en hollandais a donné la figure d'un animal tué sur les eôtes orientales d'Afrique, et dont le dessin lui a été communiqué par un médecin de ses amis. A en juger par les cornes, cet animal est un véritable condoma ; mais s'il est bien représenté, il a le corps plus lourd, et il n'a aucune des raies ni des taches blanches qui se trouvent sur eelui que nous avons déerit. M. Muller, qui travaille en Allemagne à éelaircir le Système de la Nature de Linnæus, a donné une planche coloriée, qui représente parfaitement le condoma."

\section{DE LA GAZELLE ANTILOPE.}

\section{(L'ANTILOPE DES INDES, OU L'ANTILOPE.)}

Ordre des ruminants, section des ruminants à cornes creuses, genre antilope. (Curier.)

M. Pallas observe, aree grande raison, qu'il y a des animaux, surtout dans le genre des chèvres sauvages et des gazelles, dont les noms domés par les anciens demeureront éternellement équiroques; celui decervi-capra, que j'ai dit ètre le mème animal que le strepsiceros des Grees ou l'adıx des Africains, doit être appliqué, suivant M. Pallas, à la gazelle que j'ai nommée l'antilope. Il dit, et e'est la vérité, qu'Aldrovande a donné le premier une bonne figure des cornes; et nous avons donné nonseulement les cornes, mais le squelette entier de cet animal. Je pensais alors qu'il était l'un des eincr que .III. de l'Aeadénie des Sciences avaient disséqués sous le nom de gazelle; mais M. Pallas me fournit de bonnes raisons d'en douter. Javais eru de méme que la eorne pouvait appartenir à une espèce diflérente de notre antilope; mais M. Pallas s'est assuré (ju'elle al)partient à cette espèee, et que la seule différence qu'il y ait, e'est que la corne représentée ap. partient \& l'animal adulte, tandis que les autres plus petites sont du même animal jeune.

J'ai dit que l'espèce de l'antilope paraissait avoir des races différentes entre elles, et j'ai insinué qu'elle se trouvait non seulement en Asie, mais en Afrique, et surtout en Barbarie, où elle porte le nom de lidmée. MI. Pallas dit la mème chose, et il ajoute à plusieurs faits historiques une bonne deseription de cet animal, dont nous eroyons devoil donner jei l'extrait :

"J'aj eu occasion, dit-il, d'examiner et de bien décrire ces animaux, qui vivent depuis dix ans dans la ménagerie de monseigneur le prince d'Orange, lesquels, quoique amenés de Bengale, en 1755 ou 1756 , non-seulement ont véeu, mais ont multiplié dans le climat de la Hollande; on les garde avec les axis ou daims mouchetés; ils vivent en paix et y élèı ent également leurs petits.

" Le premier mâle était déjà vieux lors de son arrivée, et la femelle était adulte. Ce mále est mort en 1766 ; mais la femelle était encore vivante alors, et quoiqu'elle fủt âgée de plus de dix ans, elle avait mis bas l'année précédente 1765 . Le mâle, qui était très-sauvage, ne s'est jamais apprivoisé ; la femelle au contraire est très-familière : on la fait aisément approcher et suivre en lui présentant du pain; elle se lève comme les axis sur les pieds de derrière pour y atteindre lorsqu'on le lui présente trop haut : cependant elle se fàche aisément dès qu'on la tourmente, elle donne méme des coups de tète comme un bélier; on voit alors sa peau et son poil frémir. Les jeunes, à l'exemple du père, sont sauvages et fuient lorsqu'on veut les approcher ; ils vont en troupes, marehant d'abord assez doucenent, cnsuite par petits sauts, et quand ils préeipitent leur fuite, ils bondissent et font des sauts qu'on ne peut eomparer qu'i ceux du cerf ou du chamois. Je u'ai jamais el1tendu leur voix ; cependant les gardes de la ménagerie déposent que, dans le temps du rut, les mảles ont une espèce de hennissement. On les nourrit comme les autres animaux ruminants , et ils supportent assez bien nos hivers; ils aiment la propreté, ear la troupe entière choisit un terrain pour aller faire ses ordures. Le temps de la chaleur des femelles n'est pas fixe; clles sont quelquefois pleines deux mois après avoir mis bas; les màles en usent en toutes saisons; ils ne s'en abstiennent que quand elles sont pleines. L'accouplement ne dure que très-peu 
de temps. La femelle porte près de neuf mois, ne produit qu'un petit qu'elle allaite, sans se refuser à en allaiter d'autres. Les petits restent couchés pendant huit jour's apres leur naissance, après quoi ils accompagnent la troupe. Les jeunes femelles suivent'les mères lorsqu'elles se séparent de la troupe... Ces animaux croissent pendant trois ans, et ce n'est guère qu'à cet age que les màles sont en état d'engendrer: les femelles sont muires de meilleure heure et peuvent produire à deux ans d'age. Dans les six premières années, il y a peu de différence entre les mâles et les femelles; mais ensuite les femelles se distinguent aisénent par une baude blanche sur les flanes pri's du dos, et par un caractère encore moins équivoque, e'est qu’il ne leur vient jamais de cornes sur la tête, tandis que dans le mâle on peut apercevoir les rudiments des cornes dès l'âge de sept mois, et ces cornes forment deux tours de vis, avec dix ou douzes rides à l'àge de trois ans : e'est alors aussi (yue les bandes blanclies du dos et de la tête commencent à s'évanouir; la couleur des épaules et du dos noircit; et le dessus du cou devient jaune : ces mèmes couleurs prennent une teinte plus foncée à mesure que l'animal avance en âge.... Les cornes croissent bien lentement.... Ces animaux, surtout après leur mort, ont une légère odeur qui n’est pas désagrúable, et qui est pareille í celle que les cerfs et les daims exhalent aussi apris leur mort..... Au reste, cet animal approche de l'espèce que M. de Buffon a appelée la gazclle, par la cou. leur moire des cotés du cou et lu corps, par les touffes de poil au-dessous des genoux, dans les jambes de devant; clle approche du tzeiran et de la grimme de M. de Buffon, pare que les femelles n'ont de cornes dans aucune de ees trois especes : mais elle diffère en général de toutes les autres gazelles en ce qu'il n'y a aucune espece ou le male et la femelle, devenus adultes, soient de couleurs aussi différentes que dans celle-ci."

M. Pallas donne en mine temps les figures du male et de la femelle en eleux planehes séparcés (qui mont paru tres-bonnes. Voici encore quelyues remarques de .M. I'allas sur les parties extérieures de cet animal :

" Il est à peu près de la même figure de notre daim d'burope; cependant il 'n diffère par la forme de la téte, et il lui cide en grandeur. Les narines sont ouvertes : la eloison uui les sépare est épaisse, nue et noire... Les poils du menton sont blancs, et le tour de la bouche brun; la langue est plane et arrondie : les dents de de. vant sont au nombre de huit; celles du milieu sont fort larges et bien tranchantes, et celles des còtés plus ajguës.... I.es yeux sont environnés d'une aire blanche, et l'iris est d'un brun jaunátre; il y a une raic blanche au-de-' vant des yeux, au commencement de layuelle se trouvent les narines. Les oreilles sont assez grandes, nues en dedans, bordées de poils blanes et couvertes en dehors d'un poil de la même couleur qque celui de la tète... Les jamhes sont longues et menues, mais celles de derrière sont un peu plus hautes que celles de devant: Ies sabots sont noirs, pointus, et assez serrés l'un contre l'autre. La queue est plate et nue par-dessous vers son origine. La verge du mále est appliquéc longitudinalement sous le ventre: le scrotum est si serré contre les cuisses, que l'un des testicules est devant et l'autre derrière. Le poil est très-fort et très-l'aide au-dessus du cou et au commencement du dos; il est blane comme neige sur le ventre et au-dedans des cuisses et des jambes, ainsi qu'au bout de la queue. D

\section{DE IA GAZELLE TZEIRAN.}

\section{(L'AXTILOPE BLeUf.)}

Ordre des ruminants, section des ruminants à cornes creuses, genre antilope. (Cuvier.)

M. Pallas remarque, avee raison, que messicurs llouttuyn et limmas ont en tort de nommel cervi-capra cette gazelle, d'autant plus qu'ils eitent en mime temps les figures du cervieipra de Dodard et de Jonston, qui sont trésdifférentes de celle de notre tzeïran: mais M. Pallas aurait dit adopter le nom de tzeran, que cette gazelle porte dans son pays matal, et l'on ne voit pas pourepuoi il a preferé de lui donner celui de p!ggargus. II a jugé par la grandeur des peaux que cet animal est plus grand que le dirim: la description qüil en donre ijoute peu de chose à eo fue nous en avons dit, et la signification da mot pygargus ne peut pas distinguer eette gazelle du chevreuil, ni meme de quelyues autres gazelles qui ont une grande tache blauche au-dessus do la quene. 
MM. Forster, père et fils, m'ont donné sur cet animal les notices suivantes : "Jusqu'iei on ignore, disent-ils, s'il y a des tzeirans en Afrique, et il parait qu'ils affectent le milieu de l'Asie. On les trouve en Turquie, en Perse, en Sibérie, dans le voisinage du lac Baikal, en Daourie et à la Chine. M. Pallas déerit une chasse à l'arc avec des flèches très-lourdes, qu'un grand nombre de chasseurs décochent à la fois sur ces animaux qui vont en troupes. Quoiqu'ils passent l'eau à la nage de leur propre mouvement, et pour aller ehereher leur pâture au delà d'une rivière, cependant ils ne s'y jettent pas lorsqu'ils sont poursuivis et pressés par les ehiens et par les hommes ; ils ne s'enfuient pas même dans les forêts voisines, et préfèrent d'attendre leurs ennemis. Les femelles entrent en chaleurà la fin de l'automne, et mettent bas au mois de juin. Les mâles ont sous le ventre, aux environs du prépuce, un sac ovale qui est assez grand, et dans lequel est un orifice particulier : ces saes ressemblent à la poche du muse; mais ils sont vides, et ce n'est pent-ètre que dans la saison des amours qu'il s'y produit quelque matière par sécrétion. Ce sont aussi les mâles qui ont des proéminences au larynx, lesquelles grossissent à mesure que les cornes prennent de l'aceroissement. On prend quelquefois des faons de tzeiran, qui s'apprivoisent tellement qu'on les laisse aller se repaitre aux champs, et qu'ils reviemnent régulièrement le soir à l'étable.Lorsqu'ils sont apprivoisés, ilsprennent en affection leur maitre. Ils vont en troupes dans leur état de liberté, et quelquefois ces troupes de tzeïrans sauvages se mèlent arec les troupeaux de bœufs et de veaux ou d'autres animaux domestiques; mais ils prennent la fuite à la vue de l'homme. Ils sont de la grandeur et de la couleur du chevreuil, et plus roux que fauves. Les cornes sont noires, un peu comprimées en bas, ridées d'anneaux, et courbées en arrière de la longueur d'un pied; la femelle ne porte point de cornes. "

Je vais ajouter à ces notices de MM. Forster la description du tzeïran que M. le professeur Allamand a publiée dans l'édition faite en Hollande de mes ourrages sur l'Histoire naturelle.

"On a vu, dit ee savant naturaliste, dans l'article où j'ai parlé dı pasan, que je doutais fort que l'animal auquel j'ai douné ce nom fût celui qu'on appelle ainsi dans l'Orient ; eependant je lui aí conservé ce nom , parce que c'est vraisemblablement le méme que le pasan de M. de Buffon. Une semblable raison m'engage à nommer 1 zeïran l'animal qui est représenté ( $p l . L X I I I)$. Par un heureux hasard, mais qui ne se présente qu'à ceux qui méritent d'en être favorisés, M. le docteur Klockner en a découvert la dépouille dans la boutique d'un marehand. Ces cornes sont les mêmes que celles que M. de Buffon a trouvées dans le Cabinet du Roi, et qu'il a jugé appartenir à une gazelle que les Turcs appellent $t z c i r r a n$, et les Persans $a h u$. Il en a porté ce jugement à cause de sa ressemblance avec les cornes que Kœmpfer a données à son tzeïran dans la figure qu'il en a fait graver ; mais cette figure est si mauvaise, qu'on ne peut guère se former une idée de l'animal qu'elle doit représenter; et d'ailleurs, comme M. de Buffon l'a remarqué, elle ne s'accorde point avec la description que Kœmpfer en a donnée, et même dans la planche on trouve le nom de $a h u$ sous la figure de l'animal qui, dans le texte, porte le nom de pasan, et celui de pasan sous la figure du tzeiran. Si le tzeïran de cet auteur est, comme M. de Buffon parait le supposer, le même animal que M. Gmelin a déerit dans ses Voyages en Sibérie, et qu'il a appalé dsheren, et dont il a donné la figure dans les nou veaux actes de l'Académie de SaintPétersbourg, sous le nom de caprea campestris gutturosa, il est encore plus douteux que la eorne trouvée dans le Cabinet du Roi lui appartienne ; car elle ve ressemble aucunement à celles que porte le dsheren de M. Gmelin, si au moins on peut eompter sur la figure qu'il en a publiée, et qui le représente avec de courtes cornes de gazelle, tandis que dans le texte il est dit qu'elles sont semblables à celles du bouquetin.

4 M. Pallas nomme le tzeirran antilope pygargus, et il lui donne des cornes pareilles à celles que M. de Buffon lui suppose, puisqu'il renvoie à la figure qu'il en a publiée; et eependant dans la deseription qu'il en a faite, il dit que ees cornes sont recourbées en forme de lyre, et plus petites à proportion que celles de la gazelle: or', il n'y a qu'à jeter les yeux sur la figure qu'il eite, pour se convaincre qu'clle représente une corne très-différente de celle qu'il déerit.

"Je ne déciderai point si l'animal dont je vais parler est le véritable tzeüran de Kœmpfer ou non : pour lui en conserver le nom, il me suf- 
fit qüil ait des cornes semblables à celles que M. de Buffon lui attribue; l'on n'en doutera pas si l'on compare la corne, quoique tronquée, rui est représentée avec celles que porte notre tzeiran; elles sont annelées de même, et rquelcues-uns de leurs anneaux se partagent en forme de fourche; leur courbure est aussi semblable, et leur grosseur ne parait pas différer, non plus que leur longueur, eomme on le verra en comparant les dimensions que nous en donnerons avec celles que M. Daubenton en a rapportées. Je n'oserai pas en dire autant de la corne qui est gravée dans Aldrovande, lib. I, de Bisulcis, prig. 757. Les anneaux de celle-ci me semblent être diflérents, aussi bien (que sa longueur, sa grosseur et sa courbure : cependant ce n'est pas sans raison que M. de Buffon croit que c'est la même que celle qu'il donne au tzeiran. Cet animal est rangé par Kœmpfer parmi ceux qui portent des bézoauds, et Aldrovande a fait representer eette corme dans le chapitre où il est question de ces animaux.

"J'ai déjà r'emarqué que c'est à M. le docteu. Klockner que l'on doit la découverte de notre tzeiran; et cest à lui aussi que l'on est redevable de la description que j'en vais faire. Il en a préparé la peau avec beaucoup de soin, et clle est actuellement un des principaux ornements du riche cabinet d'histoire naturelle que feu M. J.-C. Sylvius Van Lemuep, conseillel et échevin de la ville de Harlem, a laissé par testament à la Société hollandaise des Sciences, établie dans ladite ville. Celui de qui il acheta cette peau ne put lui dire de quel endroit elle avait été envoyće; mais la manière dont elle était empaçuetée, et quelques autres circonstanees, lui firent juger qu'elle venait du Cap.

"Cet animal a la grandeur et la figure d'un cerf, mais son front avance plus en devant : sa couleur' est d'un gris blanchâtre, où se trouvent quelques poils tirant sur le noir; sous le ventre, il est tout à fait blane; la tète est d'un gris plus sombre, et au-devant des yeux il y a une large tache d'un blane pale qui descend, en devemant moins large, presque jusuu'au coin de la bouche. Ses cornes forment un are de cercle, mais dont la courbure est plus forte que celle de la corme qui est représenté elles sont noires et ereuses; elles sont environnées d'anneaux circulaires jusqu'aux trois quarts de leur longueur, et ees anueaux sont plus éminents du coté intérieur que du côté opposé; le reste de ces cornes est fort lisse, et se termine en une pointe très-aiguẻ.

- L_es oreilles sont pointues et d'une longueur remar'quable à proportion de la tète.

- Le cou ressemble à celui d'un cerf, mais il est un peu plus mince. J.es poils qui le couvrent, tant en dessus qu'en dessous, sont singulièrement arrangés; sur une moitié ils sont dirigés vers en bas, et sur l'autre moitić ils sont tournés vers en haut. Un pareil arrangement a lieu sur le dos: sur la partie antérieure, les poils sont dirigés vers la tète, et sur la partie postérieure jusqu'ì la queue, ils sont placés en sens contraire, et ils sont d'une couleur plus sombre: de coté et d'autre du cou on voit des places de la grandeur d'un écu, où les poils sont disposés en rond et semblent partir d'un centre, comme autant de rayons diriggés un peu oblipuement vers la circouférence d'un cercle.

"La queue est plus longue que dans la plupart des animaux de ce geure, et elle est terninée par une touffe de poils.

- Les jambes ressemblent à celles d'un cerf, mais elles n'ont point de brosses de poils sur le genou; celles de devant sont tant soit peu plus courtes que celles de derrière; au lieu d'ergots an-dessus des talons, il y a une simple éminence ou bouton.

" En général, cet animal se rapproclse plus de la race des boucs que de toute autre espece: si c'est le tzcïran de líompfer', sa femelle n'a point de cornes ou n'en a que de trés-petites. On se folmera des idées plus justes de sa grandeur par les dimensions que M. Klockner en a prises.

Longueur du corps, mesurie le long du dos, depuis le bout du museau jusqu'a la queue. 5 $10 \quad 8$ Hauleur du train de derant. . . . . . . 3 6 9 Hautcur du lrain de der rière. . . . . . . 578 Longueur de la tête, depuis le commence-

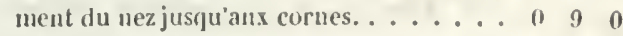

Longueur de la tete jusqu'aux oreilles. . . 1 1 0

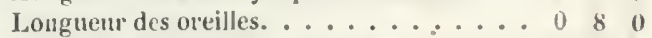

Longueur des cornes, prise en suirant leur courbure. ............2 22 Contour des cornes pris de la lite. . . . . $0 \begin{array}{lll}0 & 6 & 7\end{array}$

Circouference du corps derriere les jambes de devaut................... \& 0 5

Circourerence du milien du corps. ..... 426 Circonterenee devant les jambes de derrière. 4 i 4 Hanteur des jaubes de devant, depuis la plante du pied jusquá la puitrine. . . . 1118 Ilanteur des jambes de derrière...... 250 Lumgueur de la queue........... 095 
Longueur de la touffe de poils qui est au bout ae la queue. .............. 053

\section{DE LA CIİVTRE BLEUE'.}

- Cette antilope, dit M. Forster, est trèscommune au cap de Bonne-Espérance, où on l'appelle la chèvre bleue; cependant sa couleur n'est pas tout à fait bleue, et encore moins bleu céleste, conme Hall l'a supposé dans son Histoire des quadrupèdes, mais seulement d'un gris tirant un peu sur le bleuâtre : cette couleur n'est même occasionnée que par le reflet du poil qui est hérissé lorsque l'animal est vivant; car, dès qu'il est mort, le poil se couche ou s'applique sur le corps, et alor's tout le bleuâtre disparait entièrement, et on ne voit à la place qu'une conleur grise. Cet animal est plus grand que le daim d'Europe; son ventre est couvert de poils blancs, ainsi que les pieds; la teuffe de poils qui termine la queue est aussi blanche, et il y a sous chaque oeil une tache de cette même couleur; la queue n'a que sept pouces de longueur'; les cornes sont noires, ridées d'environ vingt anneaux, un peu courbées en arrière, et ont dix-huit ou vingt pouces de longueur; la femelle en porte aussi bien que le mâle. "

\section{LE GUIB.}

\section{(L'ANTILOPE GUIB.)}

Ordre des ruminanls, seclion des ruminants à cornes creuses, genre antilope. (Curicr.)

Le guib est un animal qui n'a été indiqué par aucun naturaliste, ni mème par aueun voyageur ; cependant il est assez commun au Sénégal, d'où M. Adanson en a rapporté les dépouilles, et a bien voulu nous les donner pour le Cabinet du Roi. 11 ressemble aux gazelles, surtout au nanguer, par la grandeur et la figure du corps, par la légèreté des jambes, par la forme de la tète et du museau, par les yeux, par les oreilles et par la longueur de la queue et le défaut de barbe; mais toutes les gazelles, et

- La chèvre bleue esł considéréc par les zoologisles conume appartenant à la mème espèce que l'antilop̧e décrite par Buffon et Allainaud sous le nom de tzeiran, ou antilope blcue. surtout les nanguers, ont le rentre d'un bean blanc, au lieu que le guib a la poitrine et le ventre d'un brun-marron assez foncé : il diffère encore des gazelles par ses cornes quı sont lisses, sans anneaux transversaux, et qui portent deux arêtes longitudinales, l'une en de; sus et l'autre en dessous, lesquelles forment un tour de spirale depuis la base jusqu'à la pointe: elles sont aussi un peu comprimées, et par ers parties le guib approche plus de la chèvre que de la gazelle : néanmoins il n'est ni l'une ni l'atitre; il est d'une espèce particulière qui nous pa. rait intermédiaire entre les deux. Cet animal est remarquable par des bandes blanches sur un fond de poil brun marron; ces bandes sont disposées sur le corps en long et en travers comme si c'était un harnais. Il vit en sociétí et se trouve par grandes troupes dans les plai. nes et les bois du pays de Podor. Comme M. Adanson est le premier qui ait observé le guib, nous publions ici bien volontiers la description qu'il en a faite et qu'il nous a commu. niquée'.

\section{LE BOSBOK.}

(L'ANTILOPE BOSBOK.

Ordre des ruminants, section des ruminauts à cornes creuses, genre antilope. (Cuvier.)

Voici encore une très-jolie gazelle, dont M. Allamand vient de publier la description dans le nouveau supplément à mon ouvrage sur les animaux quadrupèdes :

"Les Hollandais du cap de Bonne-Espérance donnent le nom de bosbok à une très-jolie gazelle. Ce mot, que j’ai conservé, signifie le

1 Guib chez les Nègres oualofes on jalofes. - Gazella corn:- bus rectis spiralihus; caput, rostrum, nasus, oculi uti nan. - guer. Cornua recta spiıalia, sjura prima nigra, uitida, sub- compressa, angulis duubus lateralibus, antice convesa, jone - plana, apice conico tcrctia... Aures uti nanguer intus sub- nudxe, quinque pollices longa... Cauda decem pollices lou- ga, pilis longis hirta. Dentes duo et triginta. Pedes uti nan- guer. Corpus totnm fere fulvum. Albe fascia sex utrinque - in dorso tianvers $x$, et fascix albx dux lungitudiuales ven- Iri laterales. Macula albe utrinque octo ad decem smpra fe- mora, ortuculatx. Collum subtus album el genæ allw; late- ra pedum interiura alba, macula alba, paulo infra oculos. - Fruns media nigıa, linea supra dorsum longitudinalis ui- gra, vcnter subtus niger, pars antica pedum anteriorum, un- gule el cormu nigra; longiludo al apice rostri ad auum - quatuor pedes cun dimidio; altitudo a pedibus posticis ad

- Jorsum duos pedes octo pollices; pili onues trevis.imi, lı-

- cidi, vix unum pollicem longi, corpori adpressi. Pulclırum - auimal a 1). Andriol missum, Notice manuserite, communiyuée par M. Adanson, de l'Académie royale des Sciences. 
bouc des bois, et c'est effectirement dans les forèts (ju'on trouve eette gazelle. Ses comes ont quelque rapport avee celles du ritbok; clles sonit drigées et courbées en avant, mais si légèrement (qu'on a peine à s'en apercervir : cependant, s'il n'y avait que cette différence dans la courbure des cornes, je n'hésiterais pas à r'cgarder le bosbok comme une variété dans l'espèce du ritbok; mais ils diffèrentsi fort ì d'antres égards, qu'on ne peut guère douter qu'ils n'appartiennent ì deux familles distinctes.

" I.e bosbok est plus petit que le ritbok; la longueur de son corps est de trois pieds six pouces, c'est-ì-dire d'environ un pied plus courte rue celle du ritbok. II en differe encore plus par les couleurs : le dessus de son corps est d'un brun fort obseur, mais qui tire un peu sur le roux à la tête et sous le cou; son ventre est blane, de mème que l'intérieur de ses cuisses et de ses jambes; il a aussi une taclıe blanche au basclu cou : les fesses ne sont pas banches, comme dans la plupart des autres gazelles, mais la croupe est parsemée de petites taches rondes, d'un blane qui se fait d'abord remarquer, et qui lui sont particulières : ses comes sont noires et torses en longues spirales, qui s'étendent au delà de la moitié de lemr hauteur : on voitsur son front une tache noire. Il n'a point de larmiers; ses oreilles sont longues et pointues, sa queue a près de six pouces, et elle est garnie de longs poils blanes; il a quatre mamelles, et ì leur còté les deux poches ou tubes qui se trourent dans le ritbok.

"L.es femelles different des màles en ce cut'elles n'ont point de cormes et qu'clles sont un peu plus rousses. N. Gordon, en m'envoyant le dessin de eet animal, y a joint la peau d'une fern Ile, oijjai trouvé les mèmes taches hlanches qui sont sur la croupe du màle.

" l.es bosboks ne se trouvent guère qü il soixantelieues du Cap; ils setiennent, comme jelai déjit dit, dans les bois, ou ils se font souvent entendre par une sorte d'aboiement assez semblable à celui du chicn.

\section{Dimension alu Bosbok.}

Longueur du corps, depuis le boul du museau, jusıu'a l'origine de la rquene. . . . . 5

Hanteu du traiu de devaut. . . . . . . . 2

-_- du train de derriere. . . . . . . .

Lorrgueur de la fïle, depurs le boul du mis.

reau jusqua la base des eornes. , .....

iv.

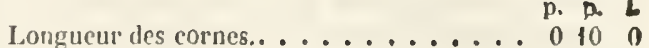
des oreilles............. 0060 de la qucue. ............ 060

\section{LA GRIMIIE.}

\section{(L'ANTILOPE GRINYE'}

Ordre des ruminants, section des ruminants à cornes creuses, gemre antilope. (Cuier.)

Cet animal n'est connu des naturalistes que sous le nom de chère de Grimm; ct comme nous ignorons celui qu'il porte dans son pays natal, nous ue pouvons micux faireque dadopter ectte dénomination précaire. On trouve une figure de cet animal dans les Éplsémérides d'Al. lemagne, qui a été copiéc dans la collection académique. Le docteur Herman Grimm est le seul avant nous qui en ait parlé, et ce qu’il cn a dit a été copié par Ray, et ensuite par tous ceux qui ont écrit sur la 1romenclature des animaux. Quoique sa deseription soit incomplète, elle désigne deux caractères si marqués, que nous ne croyons pas nous méprendre en présentant iei pour la chève de Grinm la tète d'un animal du Sénégal, qui nous a été donnée par MI. Adanson. Le premier de ces caractères est une énorme eavité au-dessous de clsaque xil, laquelle forme de chaque cótédu nez un enfoncement si grand dans la mâchoire supérieure, (qu'il ne laisse (qu'une laune d'os très-minee contre la cloison du nez; le second caractere est un bouquet de poils bien fourni et dirigé en haut sur le sommet de la tète. Ils suflisent pour distinguer la grimme de toutes les autres chèves ou gazelles : elle ressemble cependant aux unes et aux autres, non-seulement par la forme du corps, mais mème par les cornes, qui sont annelées vers la base et striées longitudinalement comme celles des autres gazelles, et en mème temps dirigies horizontalement en arriere, et très-courtes comme celles de la petite chèvre d'Afrique, dont nous avons parlé. Au reste, cet animal étant plus petit que les chiveres, les gazelles, ete., et ne portant que des cornes trèscourtes, nous parait fitre la nuance entre les chères, et les cherrotains.

Il y a apparence que dans l'espèce de la grimme, le male seul porte des cornes : car l'individu dont le docteur Grimm a donné la descrip. 
tion et la figure n'avait point de cornes; et la tête que nous a donnée M. Adanson porte au contraire deux cornes, à la vérité très-courtes et eachées dans le poil, mais eependant assez apparentes pour ne pouvoir échapper au dessinateur, et encore moins à l'observateur. Dailleurs on verra dans l'histoire des chevrotains, quie dans celui de Guinée le mâle seul a des cornes ; et ce'est ce qui nous fait présumer qu'il en est de même dans l'espèce de la grimme, qui à tous égards approche plus du chevrotain que d'aucun autre animal.

\section{ADDITION A L'ARTICLE DE LA GRIMME.}

Aux faits historiques que nous avons pu recueillir sur cet auimal, nous n'avons joint que la figure de deux têtes, l'une décharnée, et l'autre couverted'une partiede la peau.MM. Vosmaër et Pallas ont donué depuis des descriptions de ce joli animal, avec une bonne figure. Nous remarquerons que les têtes de la grimme, qui sont au Cabinct du Roi ont les cornes un peu courbes en avaut à leurs extrémités, au lieu que les cornes de la grimme de MM. Vosmaër et Pallas sont au contraire un peu courbes en arrière dans leur longueur. Les oreilles de la grimme qui estau Cabinet du Roi sont rondes à leur extrémité, au lieu que dans la figure donnée par MII. Pallas et Vosmaër, ces mêmes oreilles finissent en pointe. Serait-ce rariété de nature ou incorrection de dessin? La grinme de MM. Vosmaër et Pallas a le bout du nez noir, et une bande noire qui s'étend depuis le nez le long du chanfrein, et finit au bouquet ou à l'épi de poils qui est placé sur le haut du front. La tête qui est au Cabinet du lioi n’a point cette bande noire sur le chanfrein. Ces légères différences n'empèchent pas que ce ne soit le même animal, et nous allons donner ici un extrait de la description qu'en fait M. Vosmaër.

Il appelle cet animal petit bouc damoisenu de Guinée, apparemnent à cause de sa gentillesse et de l'élégance de sa figure; mais le nom ne fait rien àla chose, et nous lui conserverons celui de chèvie de Grimm, parce qu'il est comnu sous ce nom de tous les naturalistes.

( l'animal était mâle, dit II. Vosmaër ; il est des plus jolis et des plus mignons qu'on puisse voir : il fut curoyé de Guninée en Hollande avec treize autres de même espèce et des deux sexes, dont douze moururent pendant le voyage, et de ec nombre furent toutes les femelles; en sorte qu'il ne resta que deux mâles virants , que l'on mit dans la ménaq̨erie de Mr. le prince d'Orange, où l'un des deux mourut bientôt, pendant l'hi er de 1764 . Suivant nos informations, les femelles de ectte espèce ne portent point de cornes. Ces animaux sont d'un naturel fort timide; le bruit, et surtout le tonnerre les effraie beaucoup. Lorsqu'ils sont surpris, ils marquent leur épouvante en soufflant du nez subitement et avee forec.

"Celui qui est encore vivant dans la ménagerie de M. le prince d'Orange (en 1766), était d'abord sauvage : mais il est devenu, avec le temps, assez privé; il écoute quand on l'appelle par son nom tetje, et en l'approchant doucement avec un morceau de pain, il se laisse volontiers gratter la tête et le cou. Il aime la propreté, au point de ne jamais souffrir ancune petite ordure sur tout son corps, sc grattant souvent à eet effet, de l'un de ses pieds de derrière, et e'est ce qui lui a fait domner ici le nom de telje, dérivé de teltig, c'est-il-dire net ou propre; cependant si on le frotte un peu longtemps sur le corps, il s'attache aux doigts une poussière blanche, comme celle des chevaux qu'on étrille.

"Cet animal est d'une extrême agilité; et lorsqu'il est en repos, il tient souvent un de ses pieds de devant élevé et recourbé, ce qui lui donne un air très-agréable. On le nourrit aree du pain de seigle et des carottes; il mange volonticrs aussi des pommes de terre; il est ruminant, et il rend ses excréments en petites pelotes, dont le volume est fort considérable, relativeasent it sa taille..."

Le docteur Herman Grimm a dit que l'humeur jaumàtre, grasse et visqueuse qui suinte sur les cavités ou enfoncements que porte cet animal au-dessous des yeux, a une odeur qui participe du casteroum $t i$ du musc. M. Vosmaër observe que dans le sujet vivant qu’il déerit, il n'a pu decourrir la moindre odeur dans cette matière visqueuse, et il remarque, avee raison, que la figure donnée par Grimm est défectueuse a tous ćgards, représentant sur le devant de la tête une toufte de poils qui n'y est pas, et son sujet, qui était femselle, n’ayant point de corues; " au licu que le nòtre, dit M. Vosmaër, qui est mûle, en a d'assez grandes à proplortion de 
sa taille; ct au lieu de cettc haute ct droite touffe de poils, il a seulement entre les cornes un petit bouguet de poils quirs'élève un peru en pointe. Il est à très-peu près de la grandeur d'un chevreau de deux mois " (quoigue âgé probablement de trois ou quatre ans; je erois devoir faire cette observation, parce qu'il avait été envoyé avant l'hiver de 1764, et que H. Vosmaëra publié sa deseription en 1767). "II a les jambes fines et très-bien assorties à son corps; la tête belle et ressemblant assez à celle d'un chevreuil; l'œil vif et plein de feu ; le nez noir et sans poil, mais toujours humide; les narines en forme de croissant allongé; les bords du museau noirs. La lèvre supérieure, sans être fendue, parait divisće en deux lobes. Le menton a peu de poil, mais plus haut il y a de chaque còté une espéce de petite moustache, et sous le gosier un poireau garni de poil " (ce qui rapproche encore cet animal du geure des chèves, dont la plupart ont de même sous le cou des espèces de poireaux garnis de poils).

" La langue est plutót ronde qu'oblongue ou pointue... Les cornes sont noires, finement silJonnées du haut en bas, et longues d'environ trois pouces, droites sans la moindre courbure, et se terminant par le haut en une pointe assez aiguè. A leur base elles ont à peu près l'épaisseur de trois quarts de ponce; elles sont ormées de trois amneaux qui s'élevent un peu en arrière vers le corps.

"Les poils du front sont un peu plus droits que les autres, rudes, gris et hérissés à l'origine des cornes, entre lesquelles le poil de la tête se redresse encore davantage, et y forme une espèce de toupet pointu et moir, dont descend au milieu du front une raie de mème couleur qui vient se perdre dans le nez.

"Les oreilles sont grandes, et ont en dehors trois eavités ou fosscttes qui se dirigent du haut en bas. Au sommet, du côté intéricur, elles sont garnies d'un poil ras et blanchàtre; du reste nues et noirâtres. Les yeux sont assez grands et d'un brun foncé. Le poil des paupières est noir, serré et long aux paupières supérieures. Audessus des yeux se voient encore quelıues poils longuets, mais clair-semés ou plus clispersés.

- Des deux cotés, entre les yeux et le nez, se montre cette proprieté remar(pualsle e et singulière, qui fait d'abord recommitre ect animal, et dont nous avons dejia parle. Cette partie est moins élevée, nue et noire. Dans son milieu pa- raît une cavité ou fossctte, quỉ est comme calleuse et toujours humide; il en découle, maís en petite quantité, une liumeur visqueuse, gluante et gommeuse, qui, avee le temps, se dureit et devient noire. L'animal semble se débarrasser de temps à autre de cette matiere exerémentielle; ear on la trouve durcic et noire aux bâtons de sa loge, comme si elle y avait été essuycée. Quant a l'odeur, dont parlent Grimm et ses copistes, je n’ai pu la décomrir.

"Le cou, qui est médiocrement long, est couvert au bas d'un poil assez raide et gris jaunàtre, tel cue celui de la tète, mais blane au gosier et it la partic supésieure du cou, eu dessous.

"I.e poil du corps est noir et raide, quoique doux au toncher. Celui des parties antérieures est d'un beau gris clair ; plus en arriere, d'un brun très clair; vers le ventre, gris, et plus bas, tout ì fait blanc.

"Les jambes sont très-minces, noirátres au bas près des sabots. Les pieds de devant sont, par-devant jusqu'auprès des genoux, ornés d'une raie noire. Ils nont point d'ergots ou d'éperons ongulés, mais à leur place on voit une légère excroissance. Ces pieds sont fourehus, et pourvus de beaux sabots noir's, pointus et lisses.

"La queve est fort courte, blanche, et en dessus marquéc d'une bande noire. A l'égard des partics naturelles, elles sont fortes et consistent en un gros serotum noir, pendant entre les jannlses, aceompagné d'un ample prépuce. "

M Allamand a donné la méme figure de la grimme dans ses additions à mon ouvrage; mais il n'ajoute rien à ec qu'cn ont dit M.M. Pallas ct Wosmaër.

NOUVELLE ADITTION A L'ARTICLE DE LA GIRIMME.

Je dois ajouter à ce gue jai dit de ect animal quelques remarefues de Mili. Forster.

"Le docteur Grimm est le premier, disentils, qui ai decrit cet animal au cap de BonneEspérance; mais comme il n'en a vu que la femelle, linneus a cru (ju’elle appartenait au chevrotain a muse. M1. de Buflon a éte le premicr qui ait ranuge la grimme ave les gazelles; et après lui M. P'allis a ant examiné un mâle de cette especer a la menacrerie du prinee d'Orange, en a dome une belle et trè-exacte deseription. 
M. Vosmarip, dlrecteur de cette ménagerie, se plaignit amcrement que M. Pallas eùt donné le premice une connaissance exacte de cet animal au public; cependant il n'était pas capable de corrigei la description du savant Pallas, qui est un excellent zoologue. Étant au cap de BonneEspêrance, je fis l'acquisition d'une corne qu'on me donnait pour celle d'une chèvre plongeante (duykerbok); et j'appris qu'on l'appelait chèvre plongeante, parce qu'elle se tenait toujours parmi les broussailles, etque, desqu'elle apercevait un homme, elle s'élevait par un saut pour découvir sa position et ses mouvements, après quoi elle replongeait dans les broussailles, et s'enfuyait, etcle temps en temps reparaissait pour reconnaitre si elle était poursuivie. M. Pallas avait connaissance de cette chèvre plongeante, parce qu'il l'avait trouvée dans Kolbe; mais il ne savait pas que e'était le mème animal que la grimme : il l'appelle en latin capra nictitans. Je fus encore informé que dans cette espèce la femelle n'a point de cornes, mais qu'elle porte, comme le mâle, un petit toupet de poil sur le front. Les cornes n'ont que quatre pouees de longueur; elles sont droites, noires, ridées d'environ quatre ou einq anneaux peu distincts : elles m'ont paru un peu comprimées, avec une strie sans rides sur la face postérieure; le reste jusqu à la pointe en est lisse. On m'a aussi assuré que cette grimme n'excédait jamais la grandeur d'un faon de daim.

\section{DU NANGUER}

ET

DU NAGOR.

\section{(L'ANTilope Nanguer. - L'ANTILope ragor.)}

Ordre des ruminants, section des ruminants à cornes creuses, genre autilope. (Curier.)

Nous mettons ecs deux animaux ensemble, parce qu'ils ont un caractère commun qui n'appartient qu'à eux; c'est d'avoir les cornes recourbées en avant, au lieu que dans toutes les autres espèces de gazelles et de chèvres, les cornes sont recourbées en arrière ou tout à fait droites. J'ai dit, d'après M. Adamson, qu'il y avait trois variétés ou trois espèces de ces animaux, dont la première, c'est-î-dire le nanguer, paralt être le dama des anciens. M. Pallas nst du même avis: il dit que la femelle et le màlo natiguer ont également des corues; et il a re marrué, comme dans le kob, une disposition singulière dans les dents '.

La seconde espèce est le nagor: M. Pallas avait écrit dans son premiel" ourrage ( $\mathrm{M}$ iscellanea), que cet animal était le mazame de Seba: mais il avoue dans son sceond ourrage ( $S p$ : $c i$ legia), qu'il s'était trompé; ct il convient avec moi que ce n'est point le mazame d'A mérique, mais une gazelle d'Africque.

Au reste, l'espèce du nangucr parait être isolée et sans variété; mais celle du nagor a des espèces voisines, dont je clois la connaissance d MII. Forster : ils ont bien voulu me douner le dessin de la tête d'une de ces variétés du nagor clu cap de Bomme-Espérance, qui me parait différer du nagor, en ce que ce nagor du Cap a le museau un peu effilé, ct les cornes un peu moins cuurbées en arant que le nagor du Sénégal. Voici les notices qu ils m'ont dounées à ce sujet:

"La chève que l'on appelle steenboli ou bouquetin ", au cap cle Bonne-Espérance, nous parait être une variété du nagor donné par M. de Buffon. On trouve ces animaux sur les rochers qui font la pointe des terres du cap de Bomne-Espérance, et sur les plateaux de ces montagnes pierreuses, parmi les broussailles. Ils courent avee une très-grande vitesse, et font des sauts de huit a neuf pieds de hauteur; comme leur chair est très-bome à manger, on les chasse sans cesse, et lon en a beancoup détruit.

" Cet animal est de la grandeur d'une chèvre commune, d'environ deux pieds six pouces de hauteur. Son poil est d'un rouge brun sur le dos et les còtés du eorps, et d'un blane sale sous le ventre; il y a au-dessus des yeux, sous le cou et sur les fesses, une tache de cette dernière couleur blane sale : le puil des orcilles est fauve; clles sont arrondics à leur extremité. On voit sous chaque oil un larmier avec un petit orifice. I.es cornes n'ont que einq ou six pouces: de longueur; elles sont noires, ridćes à la base,

1. Solmm hujus animalis capul cum cornibus vidi, e quo dentium primorum in inferiore mavilla numerum plane singu arem esse didici : habel cnim lintum sernos quorum - duo medii latissimi, subobliyni , recta Iranstersa acie ler- minasular ; laterales vero parvi, lincares sumb. Pallas, $S_{p} l$. cilegia zoologica, pag. 8.

2 LANTILOPB STEXBOK. 
lisses à la pointe, extrêmement effilécs et courbées en avant. La queucest courte, à peu pr'ès comme celle des chèves ordináres.

"Une autre espèce ou variété du nagor, est l'animal que lon appelle an Cap grisbuli ou chevre grise'; elle differe du steenbock par la couleur de son poil (fui est gris, au lien que celui du steenbock est rouge brun. Ce gryshok est une seconde espece de nagor'; il est de la grandeur d'unechèvre commune, et il a les jambes plus longues que le steenbock à proportion du corps. Son poil ne parait gr'is que paree qu'il est mèlé de longs poils blanes; car, en voyant l'animal de pres, on s'apercoit que le foud en 'st d'un brun l'oussàtre ou marron : la tête et les pieds sont d'un brun plus clair que le corps, et le ventre est d'une couleur encore moins foncée; le museáu est noir ; les yeux sont environués de poils de cette mème couleur noire. Il y a, comme dans les autres chevres, des larmier's sous les ancrles antéricurs des yeux. Les oreilles sont ì peu près de mème longueur que la tète; elles sont de forme ovale et couvertes en dehors de poils courts et noirs. Les cornes ont environ cinc pouces de longueur; elles sont ridées d'un ou deux́ anneaux à la base, lisses vers la pointe qui est très-aiguë, courbées en avant et de couleur noire.

"Cette espèce de nagor se trouve toujours danslesplateaux au-dessus des montagnes, parmi les rochers, les broussailles et la bruyère. II u'est pas si léger à la course yue le steenbock, ear les ehiens l'atteignent (quelyuefois à la chasse. Sa chair est aussi bonne it manger pue celle du steenbock, et on les troure quelquefois ensemble sur les montagnes du eap de BomneEspérance.

"Une troisième espice de nagor" est le blekbok ou chève pale, qui ressemble presque en tout au steenbock, à l'execption de la couleur du poil qui est beaucoup plus pále, ee qui lui a fait domner son nom. "

En comparant ces trois animaux, d'après les notices que nous venons de eiter, il me parait qu'il n'y a tout an plus que denx especes distinctes, éest-ì-dire le nagor stecubock et le nagor grysbok, 't que le blckbock n'est qu'une variété du premier.

- Lamtilure gihseok.

\section{LE RITBOK.}

\section{(L'ANTILOPE RITBOK.)}

Ordre des ruminants, section des ruminauts à cornes creuses, geure autilope. (Cuvier.)

Cet animal me parait être une troisième varićté dans l'espèce dlu nagor : voici la description c[u'en á donnée M. Allamand, et que jai cru devoir rapporter sans y rien changer :

"L'animal dont le mále est représenté dans la $p l .375, f g .1$, et la femelle dans la $p l .375$, fig. 2, est nommé par les Hollandais, habitants du cap de Bonne-Espélance, rictrheebok, que l'on prononce ritrébok. C'est un mot composé qui signifie cherreuil des roseaux. Ce n'est pas un cherreuil : ainsi c'est mal à propos çu'on lui en clonne le nom. J'ai cru devoir lui laisser celui de riclbock ou ritbok, чui signifie boucdes roseaux : (quoicu'il soit aiusi composé, il ne paraitra pas tel aux Francais. Il ne m’a pas cté possible de lui conserver celui que les Hottentots lui donnent; ils appellent $\dot{a}, e i, \dot{a}$, en prononçant chacune de ces trois syllabes avec un clayuement de langue que nous ne saurions exprimer.

- Cet animal n'est pas un bouc, il n'en a pas la barbe; il n'a pas non plus toutes les marques auxruelles on peut reconnaitre les gazelles : cependant il appartient à leur classe plus qu'à toute autre. M. Gordon, qui men a envoyé les dessius et la peau. me mande que, quoique la race de ces animaux soit assez nombreuse, ils marchent cependant en petites troupes, et quelquefois méme le mále est seul avec sa femelle; ils se ticument pres des fontaines, parmi les roscaur, d'où ils ont tiré leur nom, et aussi dans les bois; il y en a d'une couleur différente, mais qui paraissent cependant ètre de la méme espéce, qui se tiennent le plus souvent sur les montagnes.

"Ceux dont nous parlons ici ont tout le dessus du corps d'un gris-cendié ; ils ont le dessous du ventre, la gorge et les lésses blanches : mais ils nont point eette bande roussitre ou noire qui separe la couleur du ventre d'avec celle du reste ducorps, et qui se trouve daus la plupart des autres gamelles. Leur tete est chargéc de deux cornes noiles, environnees d'anneaux jusquau delà de la moitic de leur longueur, mais ils ne sout yas fort proéminents; j'en ai compté dix 
sur celles de ces gazelles dont j'ai la peau bouirée. Ces cornes sont tournées en avant, et se terminent par une pointe lisse et fort aiguë: leur longueur est considérable pour la taille de l'animal; en droite ligne, elles ont dix pouces de hauteur, et, en suivant lcur courlsure, elles sont longues d'un picd trois pouces. Les oreilles sont aussi très-longues; elles sont blanches en dedans; près de chacune d'elles, il y a une tache chauve ou sans poils.

* Ces animaux ont de heaux yeux noirs et des larmiers au-dessuus; ils ont quatre mamelles, à côté descruelles il y a ces deux ourertures dans la peau, qui forment deux tubes, où l'on peut faire entrer le doigt, et dont il a été parlé dans l'article précédent sur les gazelles; leur queue est longue, plate et garnie de longs poils blanchâtres.

“ M. Gordon m'a envoyé la peau d'un autre individu de cette espèce, qui ressemble tout à fait par les cornes á celui que je viens de décrire, mais qui en differe par sa couleur, qui est d'un fauve roussàtre tı'ès-foncé : c'est apparemmeat un de ceux qui habitent les montagnes.

"Les femelles des ritboks ressemblent par leur couleur aux mâles; mais elles n'ont point de cornes, et elles sont plus petites, comme on pourra le voir par leurs dimensions, que je donnerai à la fin de cet article.

"Pour trouver ces animaux, il faut aller assez avant dans l'intérieur du pays. M. Gordon n'en a vu qu'à cent lieues du Cap.

"Leurs cornes tournées en devant font d"abord penser au nanguer décrit par M. de Buffon : mais ce dernier animal a les cornes beaucoup plus courbées en crochet vers leur pointe, et noins longues que celles du ritbok; il est aussi plus petit, sa couleur est différente, et il y a sur son corps beaucoup plus de blanc. 11 est vrai que M. Adanson a observé qu'il y a trois espèces ou variétés de ces nanguers qui ne diffèrent que par la couleur : ainsi la couleur ne suffit pas pour prononcer que ces animaux ne sont pas de la mème espèce, mais ce sont les cornesqui l'indiquent Je crois, a vec M. de Buffon, que le nanguer est le dama des anciens : on ne peut guère se refuser aux preuves qu'il en donne. Or, Pline compare les cornes du dama à celles du chamois, avec cette seule différence que ces derniers les ont tournées en arrière, au lieu que dans les autres elles sont tournées en avant. Cornua, dit-il, rupicapris in dorsum adunca, damisin adversum. Je doute que Pline se fùt exprimé ainsi, s’il avait voulu parler des cornes du ritbok; leur courbure n'a rien de commun avec celle des cornes du chamois. Les cornes de l'animal que M. de Buffon a nommé nagor leur ressemblent darantage; elles sont aussi dirigées en avant, mais légèrement : cepeudant elles sont beaucoup plus courtes que celles du ritbok, puisqu'elles ne s'élèvent pas à la hauteur de six pouces, et elles n'ont que deux ou trois anueaux près de la base, autant au moins qu'on en peut juger par la figure que M. de Buffon en a domnéc. Ajoutez à cela que le nagor' a une queue fort courte. Ces différences paraissent indiquer une diversité de race, et non pas une simple variété daus la même espèce. M. de Buffon croit que ce nagor est le même animal que Seba a représenté dans la X LII ${ }^{\text {e }}$ planche, figure 3 de son ouvrage, et auquel il a donné très-improprement le nom de mazame ou cerf d'Amérique. Mais ce prétendu cerf américain a les cornes tournées en arrière, assez grandes, et environnées d'une arêtc contournée en spirale, depuis la base presque jus. qu'à l'extrémité; et de plus, une fort grosse queue, caractères qui ne conviennent point au nagor.

"A cette occasion, je remarquerai encore que la quatrième figure de la même planche de Seba, aue je viens de citer, ne me parait pas représenter le kob ou la petite vache brune du Sénégal, comme le suppose M. de Buffon, mais le bubale, quion recomnaît à la conformation de ses cornes, et aux taches noires qu'il a sur les cuisses. M. Pallas l'a bien recounu : cependant il n'en est pas moins vrai que Seba s'est grossièrement trompé en appelant cet animal temamacama, et en le disant originaire de la Nouvelle-Espagne. "

\section{DIMENSIONS DU RITBOK MALE.}

Longueur du corps, depuis l'origine de la p. p. 1 queue jusqu'au bout du nuseau. ..... 4 5 Hauteur du train de devant. . . . . . . 29 , du train de derrière. ...... 50 Longueur de la tete, depuis le bout du museau jusqu'i la base des cornes. . 010 des cornes en ligne droile. .... 010 C en snirant la courbure. . . . . . 013

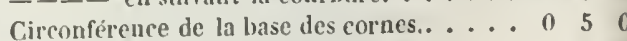
Distance entre les pointes des corues. . . . 0 10 _- entre leurs bases. ......... 020 
p. p. 1 . Longueur des oreilles. . . . . . . . 0 . 7 7 0 Distance entre leurs bases. . . . . . . . 040 Longueur de la queue .......... 0 H

DIMENSIONS DE LA FEHELLE DU RITBOK.

Longueur du corps, depuis l'origine de la

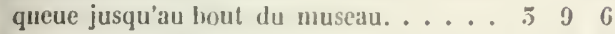
Hauteur du train de devant. . . . . . 276 - - - du train de derriere. . . . . . . 2926

Longueur des oreiltes. . . . . . . . 0 i 0 - . de la queun, ............. 01010

\section{LE BUBALE.}

\section{(L'A.TTLOPE BUBALE.)}

Ordre des ruminants, seclion des ruminants à cornes creuses, genre autilope. (Curier.)

Nous avons dit à l'artiele du Buffe, que les Latins modernes lui avaicut appliqué mal à propos le nom de bubalus : ce nom apparteuait aneiennement it l'aninal dont il est ici question, et cet animal est d'une nature trìs-ćloigncée de eclle du buffe; il resscmble au eerf, aux gazclles et au bouf, par (juclunes rapports assez sensibles : au cerf, par la grandeur et la figure du corps, et surtout pall la forme des jambes; mais il a des cornes permanentes ct fiites à peu prés comme eelles de's plus grosses gazelles, desquelles il approche par ce caractere et par les habitudes maturelles: cependaut il a la tète bealcoup plus longue que les gazelles et meme que le cerl' : cufin il ressemble au boeuf par la longueur du museatu et par la disposition des os de lit tète, daus layuelle, comme dans le bouf, te crâne ne dóborde pis 'n arriere au deli de l'os frontal. Ce sont ces différents rapports de conformation, joints a l'oubli de son ancien nom, qui ont fait donner an bubale, dans ees dernices temps, les dénominations composées de buselaphus, taureau-cerf, busula-cervina, vachebiche, vache de Barlarie, ete.; le nom mème de bubalus vient de bubulus, et par conséquent a été tiré des rapports de similitude de cet animal au bouf.

Le bubale a la tète étroite et très-allongée, les yeux placés très-haut, le front court ct étroit, les eornes permanentes, noires, grosses, chargées d'anmeaux très-gros aussi; elles prennent natissance fort près l'une de l'autre, et s'éloignent beaucoup à leut catrémité ; clles sont recourbées en arricre, et torses comme une vis dont le's pas seraient usés en devant et cu dessous : il a lés ćpátules élevées, de manière qu'elles forment une espèce de bosse sur le garrot; la queue est à peu pres longue d'un pied, et garnie d'un bouquet de crins à son extrémité; les orrilles sont semblables à celles de l'intilope. Kolbe a donné à cet animal le nom d'élan, quoiquil ne lui ressemble que par un caractere trés-superficiel. Le poil du bubale est, comme celui de l'élan, plus menu vers sa racine que daus son milieu et qu’i l'extrémité : cela est particulier à ces deux auimaux; car daus presquo tous les quadrupedes le poil est toujours plus gros à la racine qu'au milicu et à la pointe. $\mathrm{Ce}$ poil du bubale est à peu pres de la méme eou leur que celui de l'élan, quoique bcaucoup plus court, moins fourni et plus doux. Ce sont là les seules ressemblanees du bubale à l'élan : pour tout le reste, ces deux animanx sont al)solument différents l'un de l'autre; l'élan porte un bois plus large et plus pesant que celui du cerf, et qui de meme se renouvelle tous les ans; le bubale, au contraire, a des cornes qui ne tombent point, qui croissent pendaut toute la vie, et qui, pour la forme et la texture, sont scmblables à celles des gazelles : il lcur ressemble cneore par la figure du corps, la légèreté de la tète, l'allongement du cou, la position des yeux, des oreilles et des cornes, la forme et la longueur de la queue. M.M. de l'A cadémje des Scienees, auxquels cet animal fut présenté sous le nom de vache de Barbarie, et qui ont adopté cette dénomination, n'ont pas latissé que de le reconnattre pour le bubulus des anciens. Nous avons eru devoir rejeter la dénomination de vache de Barbarie, comme équisoque et composíc; mais nous ne pourons mieux faire, au reste, que de citer ici la description exacte ' qu'ils ont donnce de ect animal, et par laquelle on voit qu'il n'est ni gazelle, ni chève, ni vache, ni

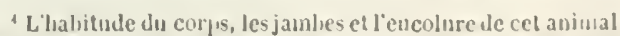
le fisi-aient mieux ressembler à un eer fqüa une vache, dont il niarait que les cornes, lesquelles élajeut encore différentes de celles des vaches en heaucunp de choses; elles prenaicnt leur uaissance fort uruelte l'une de l'autre, parec yue la teto

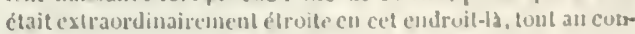
traire des vacloes, qui unt le Iront fort large, snit ant la remarque dlllomere; elle's daichl longues d'un pied, fort grosses, recumbies en arricre, llojes, turses conmule une vis, el usecs en devant et ell dessus, en sorte yue les coitrs clesés yui lormaicut la vis étaient la cutierenent eflaces; la quene uetait longue que de lreise pouces, en coupresuant un lan juct de crins longs de trois funces yu'clle avail a son extréuité; les oreilles etaicut sendlables à eelles de la gazelle, élaul garnies 
élan, ni cerf '; mais clu'il est d'une espècc particulière et différente de toutes les autres. Au reste, cet animal est le même que Caïus a décrit sous le nom de buselaphus, et je suis ćtonné que MII. de l'Académie n'aient pas fait cecte remarque a vant nous, puisque tous les caracteres que Caïus domne à son buselaphus, conviennent à lcur vache de Barbarie.

Nous arons au Cabinct du Roi : $1^{\circ}$ Un squelettc de bubale qui provient de l'animal que MII. de l'Academie des Seiences ont décrit et disséqué sous le nom de vache de Barbarie; $2^{\circ}$ Une tête beaucoup plus grosse que celle de ce squelette, et dont les cornes sont aussi beaucoup plus grosses et plus longues; $3^{\circ}$ Une autre portion de têtc avec les colnes qui sont tout aussi grosses que les précédentes, mais dont la forme et la direction sont différentes. 11 y a done dans les bubales, comme dans les gazelles, dans les antilopes, etc., des variétés pour la grandeur du corps et pour la figure des cormes : mais ces différences ne nous paraissent pas assez considérables pour en faire des espèces distinctes et séparées.

Le bubale est assez commun en Barbarie et dans toutes les parties septentrionales de l'Afrique: il est á peu près du même naturel que les antilopes; il a comme elles le poil court, le cuir noir et la chair boune à manger. On peut voir la description des parties intérieures de cet animal dans les Mémoires pour servir à l'histoire des Animaux, où MM. de l'Académie des Sciences en ont fait l'exposition anatomique, arec leur exactitude ordinaire.

en Iledaus d’un poil hlane en quelques endroits, Je reste étant pelé, et déconvrant un cuir parfaitement noir et lisse; les yeux étaient si hauts el si proches des cornes, que la tète paraissail n'avoir presque point de front; les mamelons du pis étaient très-nenus, très-courts, et seulement au nombre de deux, ce qui les rendait fort différents de cenx de nos vaches; les êuules élaient fortélevées, faisant entre l'extrémité dn con cl le commencement du dus une bosse... ll y a a pparence que cet animal doit c̀tre plutit pris pour le bubale des anciens que le petit luouf d'Afrique, que Belon décrit : car Solin compare le lubale au cerf. Oppien lui attribue des cornes recourbées en arriore, et Pline dit yüil tient du veau et du cerf. Mémoires pour servir a l'Histoire des Animanx, part. II, J. 25 el 26.

- Nula. Deux caractères essentiels séflarent le bubale du genre des cerfs; le jreuier, sont les cornes qui ne tombent pas; le sreond, cest la vésicule du liel qui se trouve dans le bubale el qui, comme l'on sait, manyue dans les cerfs, les daums, les chevreuils, tc. a la vésicule du fiel divent MII. de * Hcalcmie) était à la partie cave au côlé droil; elle était - altacliée par tonte sa moitié interne an foie, el la membrane - qui firisait la moitié de delırs élait mince. délicale et toute - plissée, élant entierement vide de fiel., Deseription anato. nnipue de la vache de lbarbarie; Mćnoire pour servir à l'llis. toire des Animaux, partie II, page 29.

\section{ADDITION A L'ARTICLE DU BUBALP.}

M. Pallas dit avoir vu le bubale virant : il est doux, mais d'une figure moins élégante et d'une forme plus robuste que les autres grandes gazelles; il a mème, par la grosseur de la tête, par la longueur de la queve et par la figure du corps, une assez grande ressemblance avee nos génisscs; il est plus haut qu'un ùne, et plus élevé sur le train de devant que sur celui de derrière. Les dents sont toutes larges, tronquées, égales; celles du milieu sont néannoins les plus grandes. La lèvre inféricure est noire et porte unc moustache ou plutòt un pctit faisccau de poils noirs de chaque côté. II a sur le muscau et le long du chanfrein une bande noirc terminéc sur le front par une touffe de poil placée en devant des cornes. Le reste de la courte description de M. Pallas s'accorde arce la mienne ct avec celle de MII. de l'Académie des Sciences, qui ont donné ect animal sous le nom de vache de Barbarie. J'olsserverai seulement que cet animal est assez différent de toutes les gazelles, pour qu'on doive le regarder comme faisant une espèce particulière ct moyenne entre celle des bœufs et celle du cerf, tandis que les gazelles forment la nuance entre les chères et les cerfs.

M. Forster soupconne que le bubale et le koba sont le mème animal, ou que du moins ils sont de deux espèces très-roisines. Il dit aussi que la grande vache brune ou cerf du Cap est le mème animal. Il a rapportéla peau d'un de ces prétendus cerfs du Cap, ctil dit a voir trouré que par tous ses caractères, il ressem. blait parfaitement au koba. Les chasscurs disent que ces animaux ne se trourcnt qu'à une grande profondeur dans les terres du Cap, et qu'ils ne vont jamais en troupes. "Ils disent aussi, ajoute II. Forster, que le bubale a quatre pieds de hauteur, et qu'il est en tout de la grandeur du cerf d'Europe; mais qu'il cst en mème temps d'une forme moins élégante.

"Le pelage de cet animalest d'un rouge brun, et le poil est lisse et ondoyé ; le ventre et les pieds sont d'une couleur plus palle. Il y a depuis les cornes jus(fu'au garrot une ligne noire, ainsi que sur le devant des pieds; mais dinns ceux de derrière, cette ligne noire est interrompue au genou. Denx autres bandes de mème conleur descendent de chargue còté de la téte, depuis le dessous des cornes jusqu atu musenu, qui est 
aussi rayé de noir. Ces deux dernières bandes sont surmontées d'une tache blanche, qui est placée tout auprès de l'origine de la corne. Il y a sur le front un épi de poils en étoile qqui se clirige en haut. Le's poils du inenton sont de conleur noire, longs d'environ un pouce et deni, et forment une espèce de barlıe auprès de lacyuelle on voit une tache noire. La queue est terminée par une touffe de longs poils de cette derniere couleur, et est longue de plus d'un pied. I a figure des cornes est absolument semblable a celle que M. de Buffon a fait graver; clles sont ridées de dix-neuf ou vingt anneaux, et ont environ vingt pouces de longueur.

\section{DU CAMAA.}

AUTIE ADDITION A L'AITICLE DU BUBALE '.

Après avoir cerit cet article sur le bubale, jai recu de la part de M. Allamand les obserrations suivantes, qui confirment ee que je viens de dire; il a joint à ces observations une figure dessince d'après l'animal vivant. Je vais de mème rapporter ici ce que MM. Gordon et Allamand ont observé et publié dans le nouveau Supplément à mon llistoire des animaux quadrupèdes, inpriuné à Amsterdam cette annéc 1781.

* Le bubale est un de ces animaux dont la peest répanduedans toute l'A frique; au moins se trouve-t-il dans les contréces méridionales et septentriouales de eette partie du monde. l'espece est tris-nombreuse près du cap de l'omneEspéranee, et on la retrouve dans la Bambrie. MM. de l'Academic royale des Sciences en ont décrit la femelle sous le nom de vache de Barburie, et M. de Buffon a prouvé, par des raisons qui me parajsent eonvalineantes, que notre bubite est le vai bubulus des ancieus cirees et Romains, qui surement n'ont pas connu les anmaux qui n'babitent qu'aux environs du Cap.

" MIM. de l’Académie des Sciences ont ajouté a la deserıption (qu’ils ont fitite de la femelle bubate, utue lighre qui est tries-xacte, mais qui ne sufiit pas pour faire comprendre ee que je

- Lastiloi'e camis. dirai sur ses différentes couleur's et sur la forme de ses cornes. Je donne ici la figure d'un màle. "Le dessin en est fuit d'après l'animal vivant, et j'en suis redevable à M. Gordon, qui m'a envoyé en mème temps la peau d'une femelle, que j'ai fait remplir et que j'ai placée dans le Cabinet de notre Acadénic. Suivant sa coutume, il a joint à eet enroi ses olservatious; elles me fourniront diverses particularités qui n'ont pas pu être conuues par M. de Buffon, qui n’ayant point vu le lubale, n'en a panlé que d'après M.M. de l'Aeadénie. Il est raiqu’il ne pouvait pas suive de meilleurs gruides; mais ee qu'ils ont dit de cet animal se borne presyue à une deseription anatomique.

" Le bubale est nommé c'rma par les Hottentots, et licama par les Cáfres. Sa longrueur, depuis le bout du museau juscyu'a l'origrine de la queue, est de six pieds quatre pouces six lignes; il a quatre pieds de haut : la circonférence de son corps, derriere les jambes de devant, est de quatre pieds deux pouces, ct devant les jambes de derriere, de yuatre pieds. On voit par ees dimensions qu'il est plus petit que le cimna décril duns ce volume. La couleur de son corps est d'un roux assez foncé sur le dos, mais qui s'éclaileit sur les còtés; le ventre est blane, de mime que la croupe, lintéricur des cuisses et les jambes, tant antérieures yue postéricures. Sur la partie extérieure des cuisses, il y a une grande titche noire qui s'étend sur les jambes: on voit une semblable tache sur les jambes de devant, laquelle commence pres du eorps et parrient cxterienrement jusqu'aux sillots, gui sont noirs aussi ; une bande de cette méme couleur, qui a son otrigine il la base des eorues et se termine au muscau, palltarge tout le desant de sa tète endeus parties

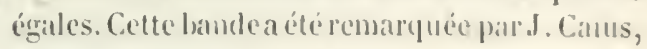
qui a domé mo bonne description da bubile, quil a nommé buseluphus. C'est lis scule quion voie sur les lemelles, dout tout le corpes cist convert de poils d'une meme rouleur rousse. Sa tete est assez lonerue at proportion de son corps: mais elle est fort citruile : elle n is gruere que six pouees dans lendruit le plus linere. Si's yeux, comme M.11. de l'deadenie l'unt observé, sunt situés fort haut : ils sont grands et vifs; leur eouleur est d'un noir yui tire un peu sur le bleu. Ses cornes, qui s elevent alu-dessus de sa títe, en s'écirtant un peru de chacfue cóte, sont presgue dioiles juspu'a la hauteur de six pouces; 
là elles s'avaneent obliquement en devant à peu près aussi jusqu'à la distance de six pouces, et ensuite, formant un nouvel angle, elles se tournent en arrière, comme la figure l'indique : elles sont noires; leurs bases se touchent et ont une circonférence de dix pouces : elles ont des anneaux saillants, comme des pas de vis qui seraient usés aux côtés, et qui s'étendent, mais quelquefois peu sensiblement, jusqu à la hauteur de huit ou dix pouces; la partie qui est retournée en arrière est lisse et se termine cn pointe; leurs extrémités sont éloignées environ d'un pied l'une de l'autre. Les femelles sont un peu plus petites que les mâles : aussi leurs cornes sont moins grosses et moins longues.

"Les bubales out des larmiers au-dessous des yeux, comme les cerfs. Leur (pueue, longue de plus d'un pied, est garnie en dessus d'une rangée de poils placés à peu près comme les dents d'un peigne.

"On a vu, dans l'artiele précédent, que le canna était nommé élan par les habitants du Cap. M. de Buffon, qui ignorait cela, et qui ne connaissait point eet animal, dont aueun royageur n'a parlé, a cru que sous le nom d'élan, lolbe avait désigné le bubale; mais ce que liolbe en dit ne lui convient pas. II assure que ce prétendu élan a la tête courte à proportion de son corps; que sa hauteur est de cinq pieds, et que la couleur de son corps est cendrée. Ce sont là autant de caractères qui se trouvent dans le canna, mais dont aucun n'est applicable au bubale. Je croirais plutôt que Kolbe en a parlé sous le nom de cerf d'Afrique; et e'est effectivement celui qu'on lui donne an Cap. Voici de quelle manière il en décrit les cornes : ses cornes sont d'un brun obseur, environnées comme d'urse espèce de petite vis, pointues et droiles jusqu'au milieu, où elles se recourbent tant soit peu; depuis là elles continuent à suivre une ligne droite, de manière qu'en dessus elles sont à peu près trois fois plus éloignćes l'une de l'autre qu'à la racine. On reconnait à cette deseription, toute imparfitite qu'elle est, les cornes du bubale; mais quoique kolbe assure qu'il a vu plus de dix mille de ces animaux, je donte qu'il en ait examiné un seul attentivement, puisqu'il dit que ce cerf africain est si semblable à ceux d'Europe, qu'il serait superllu de le déerire, et qu'il est persuadé que c'est le spieshirsch quion trouve commurment en Allemagne.
"Les bubales, de méme que les cannas, se sont éloignées des lieux habités du Cap, et se sont retirés dans l'intérieur du pays, où on les voit courir en grandes troupes, et avee une vitesse qui surpasse celle de tous les autres animaux; un cheval ne saurait les atteindre. M. Gordon n'en a jamais rencontré sur les montagnes; ceux qu'il a vus étaient toujour's dans les plaines. Leur eri est une espèce d'éternuement. Leur chair est d'un très-bon goút : les paysans qui sont éloignés du Cap en coupent des trauches fort minces, qu'ils font sécher au soleil, et qu'ils mangent souvent avee d'autres viandes au lieu de pain.

"Les femelles n'ont que deux mamelles, et pour l'ordinaire elles ne font qu'un petit à la fois : elles mettent bas en septembre et quelquefois aussi en avril.

"M. Pallas a donné une bonne deseription du bubale; et M. Zimmerman a soupconné que M. de Buffon pourrait s'ètre mépris en prenaut cet animal pour l'élan de Kiolbe. "

\section{DU GNOU oU NIOU.}

\section{(L'ANTILOPE GNOU.)}

Ordre des ruminants, section des ruminants à cornes creuses, genre antilope. (Cuvier.)

Ce bel animal, qui se trouve dans l'intérieur des terres de l'Afrique, n'était connu d'aueun naturaliste: milord Bute, dont on comait le gout pour les sciences, est le premier qui m'en ait donné connaissance, en m'envoyant un dessin colorić, au-dessus duquel était écrit : Feva heda ou bos-buffel, animal de trois pieds et demi de hauteur, à deux cents lieues du cap de BonneEspérance. Ensuite M. le vicomte de Querhoënt, qui a fait de très-bonnes observations dans ses demier's rovages, a bien voulu m'en contier le journal, dans lequel j’ai trouvé un autre dessin de ce méme animal, sous le nom de noù, aree la courte description suivante: " J'ai ru, dit-il, à la ménigerie du Cap, un quadrupede que les Hottentots appellent nou : il a tout le poil d'un brun très-foncé, mais une partic de sa crinic̀re, ainsi que sa queue et quelques longs poils autour des yeux sont blanes. Il est ordinairement de la taille d'un grand eerf; il a été amené au Cap de l'intérieur des terres 
nn octobre 1775. Aucun animal de cette espèce I'est encore arrivé en Europe; on n'y en a janais envoyé qu'un, qui est mort dans la traversée. On en voit beaucoup dans l'intérieu: du says; celui qui est à la ménageric du Cap, paraît assez doux; on le nourrit de pain, d'orge et d'herbe, ")

M. le vicomte Venerosi Pesciolini, commandant de l'ile de Groix, a aussi cu la bonté de m'envoyer, tout nouvellement, un dessin colorié de ce même animal, yni m'a paru un peu plus exact que les autres ; ce dessin était accompagné de la notice suivante :

"J'ai eru devoir vous envoyer, monsicur, la copie fidèle d'un ánimal trouvé á cent cincuante lieues de l'établissement principal des Hollandais, dans la baie de la Tahle, au Cap de BonneEspérance. Il fut rencontré avec la mère par un habitant de la campagne, pris et conduit au Cap, où il n'a vécu que trois jours; sa taille était eclle d'un moyen moulon du pays, et celle de sa mère égalait eclle des plus forts. Son nom n'est point conmu, parce que, de l'aveu mène des Hottentots, son naturel sauvage l'éloigne de tous les lieux fiérjuentés, et sa vitesse le soustrait promptement à tous les regards. Ces détails, ajoute M. de Vencrosi, ontété donnés par M. Bergh, fiseal du Cap."

On voit que cet animal est très-remarquable, non-seulement par sa grandeur, mais ('ncor'e par la beauté de sa forme, par sa crinière qu’il porte tout le long du cou, par sa longue queuc touffue, et par plusiems autres earactires qui semblent l'assimiler en partic au eheval ct en partic au bouf. Nous lui conserverous le nom de gnou (qui se prononce niou) qu'il porte dans son pays natal, et dont nous sommes plus suirs que de eclui de feva-heda; car voici ee que m'en a écrit M. Forster :

"Il se trouve au cap de Bonne-Espérance trois especes de boufs : $1^{\circ}$ notre boul commun d'Europe; $2^{\circ}$ le buffle, (fue jen'ai pas cu occision de décrire, et qui i beaucoup de sapport arec le luftle d'Europe; 3 o le gnou. Ce dernier animal ne s'est trouré qu'à eent quatre-vingts ou deux cents lieues du Cap), dans l'intéricur des terres de l'Africjue; on a tenté deux fois d'envoyer un de ces animaux en Hollande, mais ils sont morls dans la trarcrsée. J'ai vu une femelle de cette espece en 1775 ; elle citait âcréc de trois aus; rlle avait étélevép par un colon, dont l'habitation était à cent suixante lieues du
Cap, qui l'avait prise fort jeune avec un autre jeune mâle; il les éleva tous deux et les amena pour les présenter au gouverneur du Cap; cette jeune femelle, qui ćtait privée, fut soignée dans une étable et nourrie de pain bis et de feuilles de cloux; elle n'était pas tout à ficit si grande que le mâle de la mème portée. Sa fiente était comme celle des vaches communes. Elle ne souffiait pas volontiers lescaresses ni les attouchements, et, gnolque fort privée, (lle ne laissait pas de donner des coups de colnes et aussi des coups de pieds : nous eumes toutes les peines du monde d'en prendie les dimensions à cause de son indocilité. On nous a dit que lc gnou inale, dans l'état sauvage, est aussi farouche et aussi méchant que le buffle, quoiqu'il soit beaucoup moins fort. La jeune femelle dont nous venons de parler était assez douce; elle ne nous a jamais fait entendre sa voix ; clle ruminait comme les horufs : elle aimait a se promener dans la basse-cour, s’il ne faisait pas trop chaud; car par la grande clialeur elle se retirait à l'ombre ou dans son étable.

"Ce gnou femelle était de la grandeur d'un daim ou plutòt d'un âne; elle avait au garrot quarante pouces et demi de hauteur, mesure d'Angleterre, et était un peu plus basse des jambes de derriere, où elle n'avait que trenteneuf pouces. La tète était grande à proportion du corps, ayant quinze pouces et demi de longueur depuis les orvilles jusqu'au bout du mu seau : mais elle chat comprinnce des deux côtés, et vue de fiece elle paraissait citroite. Le muflie était carré, et les marines étaient en forme de croissant; il y asait dans la mâchoire infurieure huit dents incisires, semblables, par la forme, à celle du bouf commum. Les yeux ctaicnt fort écartés l'un de l'autre, et plaećs sur les cơtés de l'os frontal; ils ctticut grands, d'un brun noir, et paraissaient avoir un air de féroeité et de méchanceté, (que cependant l'ćdueattion et la domesticite avaicut modilié dans l'animal. Les orcilles étaient d'environ cinq jouces et demi de longueur et de forme semblible a celles du bouf commun. La longueur des cornes était de dix-lutuit ponces en les mesurant sur Ieur courbure; leur forme etait cylindriyue et leur couleur moine. Le corps étitit plus rond que celuidu baur, ef l'épine n'chat pas fort apparente, cest-i-dire fort cilevée, en sorte que lecorps du ghouscmblat. par la forme, approcher beatucoup de celui du cheval. Les épaules 
étaient musculeuses, cet les cuisses et les jambes moins charuues et plus fines que celles du bouf ; le croupe etait effifée et relevée, mais aplatie vers la queue, comme celle du cheval. Les pieds étaient légers et menus; ils avaient chacun deux sábots pomtus en devant, arrondis aux eôtés et de couleur noire. La queue avait vingt-lunit pouces de longueur, y compris les longs poils qui étaient à son extrémité.

" Tout le corps était revètu d'un poil court et ras, semblable à celui du eerf pour la couleur. Depuis le museau jusçu'à la hauteur des yeux, il y avait de longs poils rudes et hérissés en forme de brosse, qui entouraient presque toute cette partic : depuis les cornes jusquau garrot, il y avait une espèce de crinière formće de longs poils dont la racine est blanchâtre et la pointe noire ou brune; sous le cou on voyait une autre bande de longs poils qui se prolongeait depuis les jambes de devant jusqu'aux lougs poils blanes de la lèvre inférieure; et sous le ventre il y avait une touffe de très-longs poils auprìs dı nombril : les paupières étaient garnies de poil d'un brun noir, et les yeux étaient entourés partout de longs poils trèsforts et de couleur blanche. "

Je dois ajouter a cette description rue M. Forster a bien voulu me communicquer, les observations que $\mathrm{M}$. Ie professeur Allamand a faites sur cet animal vivant, qui est arrivé plus nouvellement en Hollande; ce savant naturaliste l'a fait imprimer à la suite du X $\mathrm{V}^{\mathbf{e}}$ volume de mon ouvrage sur l'histoire naturelle, édition de Hollande, et je ne puis mieux faire que de lá copier iei.

DU GNOU, PAR M. LE PROFLSSEUR ALLAMAND.

"Les anciens nous ont dit que l'A frique était fertile en monstres; par ce mot, il ne faut enteudre que des animaux incomus dans les autres parties du monde. C'est ee qu'on verifie encore de nos jours, lor'squ'on pénètre dins eette vaste réyion. On en a vu diver's exemples rlans les deseriptions d'animaux domnées par M. de Buffon, et dans celle du sanglier d'Afrique que j"y ai ajoutée. L.animal que je vais décrire en fournit une nouvelle preuve; la figure que j'rn donne iei a citégravée d'après un dessin envoyé du eap de Bonne-Espérance, mais dont je nai pas osé faire usage daus mes additions précén dentes à l'ourrage de M. de Buffon, parce que je le regardais comme la représentation d un animal fabuleux. J'ai été détrompé par MI. I6 capitaine Gordon, à qui je l'ai fait voir : c'cst un officier de mérite, que son goùt pour l'histoire naturelle, et l'envie de commitre les mocur's et les coutumes des peuples qui habitent la partie méridionale de l'Afrique ont conduit au Cap. De la il a pénétré plus avant dans l'intérieur du pays qu'aucun autre Européen, accompagné d'un seul Hottentot. II a bravé toutes les incommodites d'un voyage de deux cents lieues a tiaver's des régions incultes, et sans autres provisions pour sa nourriture que les végétaux qui lui étaient indirfués par son compagnon de voyage, ou le gibier que son fusil lui procurait. Sa curiosité a été bien récompensce par le grand nombre de choses rares qu'il a vues, et d'animaux dont il a rapporté les dépouilles.

"Dès qu'il cut vu le dessin dont je viens de parler, il m'apprit qu'il ne représentait point un animal chimérique, mais un véritable animal, dont la race était tres-nombreuse en Afrique. II en avait tué plusieurs, et il avait apporté la dépouille de deux tètes; il m'en a donné uue que j'ai placée au Cabinet de notre Académie.

"Daus le mème temps, on envoya du Cap un de ces animaux vivant, à la ménagerie du prince d'Orange, où il est actuellement et se porte tris-bien.

" Il est étonnant qu'un animal aussi gros et aussi singulier que celui-ei, et qui vaisemblablement se trouve dans les lieux où les Européens ont pénétré, ait été inconnu jusqu'à présent, ou qu'il ait été décrit si imparfaitement (ju'il a été impossible de s'en former aucune iclée. Il embarrassera assurément les nomenclateurs qui voudront le ranger sous quelquesunes des classes auxquelles ils rapportent I's difiérents quadrupèdes. 11 tient beaucoup dı cheval, du taureau et du cerf, saus être aucun de ces tro:s animaux. On ne manquera pas de lui donner un nom composé, propre à indiquer la ressemblance qu'il a arec eux.

"Les Hottentotsle nomment gnou, et je crois devoir adopter celte dénomination, en observant que le g ne doit pas ètre prononcé arce cette fermeté qüil a quand il commence un mot, mais qu'il ne doit servir qu'à rendre grasse l"ar"ticulation de l'n quile suit, comme il fait au milicu des mols claus seigneur, par excmple, unt- 
pagne et d'autres. C'est à M. Gordon que je dois la comnaissance de ce nom.

"Cet animal est ì peu près de la grandeur d'un anc. Sa hauteur est de trois pieds et demi : tout son eorps, al lexception des endroits que j'indiquerai dans la suite, est couvert d'un poil court comme celui du cerf", de couleur fauve, mais dont la pointe est blanchattre, (ro qui lui donne une légerse teinte de gris blane. Sil tète est grosse, et ressemble fort à eclle du boxuf; tout e devant est garni de longs poils noirs, yni s'étendent jusqu'an-dessons de's y cux, et rui contristent singulierement avee des poils de la meme longueur, mais fort blanc's, qui lui forment une barbe a la levre infiricure. Ses yeux sont moirs et hien fendus; les paupieres sont garnie's decils formés par de lonos poils blanes, paralleles is la peau, et qui font une espece d'étoile, au milieu de lacpuclle est l'oxil; au-dessus sont placés, en guise ile soureils, d'autres poils de la même couleur et très-longs. Au haut du front sont denx cornes noires, dont lat longueur, mesurée suivant l'ixe, est de dix-neuf poures : leurs bases, qui ont pres de dir-sept pouces de circonférence, se touchent et sont appliquée's au front dans une étenduc de six pouces; ensuite elles se courhent vers le haut, et se terminent ('II une pointe perpendienlaire et longrue de sept poneces, comme on peut le voir diuns la figure. Entre les cornes prend naissance une criniere épaisse, qui s'étend tout le long de la partie supérieure du éou jusquau dos : elle est formce pardes poils raides, lous cxaetement de la mime longueur, qui est de trois ponees; la partie infirieure en est blanchatre a pen pres jusqu'aux deux ticrs de la hauteur, et l'autre tiers con est noir. Derric̀re les cornes sont les orcilles, coulvertes de poils noirattese fort courts. Le dos e'st mii, et lat eroupe bessemble is eclle d'un jeune poulain; la cueuc est eomposée, comme ecelle dlu cheval, de loness crins blanes; sous le poitrail il y a une suite de longs poils noirs, qui s'itend depuis les jambes anterierures, lo long du cou et do lit parte inlérieure de la tede, jusen a la barbe blanche de la levere de dessous; fes jambers sont sembl):ahles ot diune finesse rigiale it eelle's du cerf, ou plutet de la hiche. Le pied est fourehu, e'omme celui de eo dernier amimal; les sibots ell sont noirs, unis ot surmontés ch arritere d'un seul ergot placé asse'z haut.

" l.e gnou n'a point de dents indeisives it la máchoire supéricure, mais il on a huit it l'infi- rieure : ainsi je ne doute pas qu'il ne rumine, quoique je n'ale pas pu m'en assurer par mes propres yeux, non plus que par le témoignagre de l'homme qui a soin de celui du prince d'Orange.

"Sans avoir l'air extrèmement féroce, il in. dique cependant qu'il n'aimerait pas qu'on s'approchat de lui. Lorsque j'essavais de le toucher a travers les barreaux de sa loge, il baissait la tite et faisait des efforts pour blesser, avee ses eornes, la main qui voulait le caresser. Jusqu' it présent il a ćté enferıné et obligé de se nourrtr des végcitaux qu'on lui a donnés; et il parait qu'ils lui consicunent, car il est fort et viroureux.

"La race, comme je l'ai remaryué, en est nombreuse et fort répandue dans l'Afrique. Si mes conjectures sont fondées, je suis fort porté a croire que ce niest pas seulement aux cmirons du cap de Bonne-lispérance qu'il habite, mais yu'il se trouse aussi en Abyssinie.

(1)ans la quatrieme Disserlation sur la crile orientule d'Afrique, depuis Mélinde jusqu'uu détroil de Brab-el-Mandel, ajoutée aux Vorages de Lobo, on lit ce passage : "II y a encore diuss "I'Ethiopie des ehevaux sauvages, qui ont les " crins et la tête comme nos chevaux et hen" nissent de mime; mais ils ont deur petiles " cornes toutes droites, et les pieds fourchus " comme ecux du hoeuf. Les Calfres appellent a ces animaux empophos.

"Cette deseription, tout imparfaite et filutive qu'elle est, comme la plupart de celle's que l.olue nous a données, parait convenir a notre gnon. Quel autre aninal connu y at-t.il, gui ressembla: a un cheval arec des eornes et des pieds fondus? la ressemblance serait plus grande cuncore si je pouvais dire qu"il hemnit; mais re'est ere dont je n’ai pas pu ètre instruit. Insqu'a preient persomne n'a entendu sa rois. Ne serail-ree point anssi le meme animal tont a parte le moine Cosmas? Voici ee qu'il en dit

"L.e trutecuu-cer\%. Cot animal se trouve on "líthiopie et dans les ludes. Il est prive: les lu" dienss en servent pour vilurep leurs matrdan" dises, prineipalement le poisre gü ils trans"portent d'un pans a un autre, daus dersots "fitits on forme de be'sinees. Ils tirent du lait de " e's animaus of en font du heurre : nous cn a maneions anssi la chatir, apres le's avoir boror" ge's eomme font les chretiens : pour les paiens, " ils les itssomment. Cette mime bete, daus l'É- 
" thiopie, est sauvage et ne s'apprivoise pas. "Ce taureau-cerf ne serait-il point le cheval " cornu et a pieds fendus de Lobo? Ils se trou"vent l'un et l'autre dans l'Éthiopie; tous les a deux ressemblent, à divers égards, au cheval, " au taureau et au cerf, c'est-i-dire au gnou. II " est vrai que, quoique les animaux des ludes " soient assez connus, jusqu'à présent personne " n'a dit qu'il y en cût qui ressemblassent à ce" lui dont il est question ici, et qui doit eepen" dant yêtre, sic est le même dont parle Cosmas, " Mais, dans un pays aussi habité que l'Inde, la "race ne pourrait-elle pas y avoir été éteinte par "Ie nombre des chasseurs qui ont travaillé à les " prendre ou à les tuer, soit pour les faire ser"vir de bête de somme, soit pour les manger? (i D'ailleurs est-il bien certain que cet animal ne " s'y trouve plus, ou qu'il ne se soit pas retiré " dans des lieux éloignés et solitaires, alin d'y " être plus en suircté? Il y a dans les déserts de a la provinee de la Chine, nommé Chensi, un a animal qu'on appelle cheval-cerf, que Du " Halde dit n'être qu'une espèce de cerf, guère " moins liaut que les petits chevaux des provin" ces de Se-lchuen et de Yun-nane : j'ai peine "à croire que la taille seule ait suffi pour faire " dommer à un cheval le surnom de cerf. Le " gnou ressemblant par sa tète et par ses cornes " au taureau, par sa crinière et par sa queue au " cheval, et par tout le reste de son corps au " cerf, il réunit tous les caractères qui peuvent " l'avoir fait nommer taureau-cerf par Cosmas " et cheval-cerf par les Chinois.

" Je serais mème tenté de croire que l'hippélaphe d'Aristote était notre gnou, si je n'avais pas contre moi l'autorité de $\mathbf{M}$. de Buffon, qui, fondé sur de boumes raisons, a prouvé que c’est le mème animal que le eerf des Ardenues et le tragélaphe de Pline. Je dirai eependant celles qui ont fait d'abord impression sur moi.

" L'hippélaphe, suivant Aristote, se trouve dans le pays des Aracholas, qui est situé entre la Perse et l'Inde, et par là mêne voisin de la patrie du gnou. Il a une erinière qui s'étend depuis la tête jusqu'au-dessus des épaules, rt qui n’est pas grande: Aristote la compare à celle du pardion, ou, comme l'écrit Gaza, de l'ipparaion, qui est vraisemblablement la girafe, laquelle a effectivement une criniere plus approchante de eelle du guou qu'aueun autre animal sauvige. Diodore de Sicile dit qu'il se trouve en Arabie, et qu'il est du nombre de ces animaux qui par- ticipent à deux formes différentes. Il est vral qu'il parle du tragélaphe; mais, comme je viens de le remarquer, d'après $\mathbf{M}$. de Buffon, c'est le même animal que l'hippéluphe. On trouvera dans la note le passage de Diodore ', tel qu'il a été rendu par Rhodomanus, et qui mérite d'être cité. Enfin, pour dernier trait de ressemblance, l'bippélaphe a une espèce de barbe sous le gosier, les pieds fourchus et à peu près de la grandeur du cerf. Tout cela se trouve aussi bien dans le gnou que dans le cerf des Ardennes; mais ce qui décide la question en faveur du sentiment de M. de Buffon, e'est que si Aristote a été bien instruit, l'hippélaphe a d's cornes comme le chevreuil, et que sa femelle n'en a point, ce qui ne convient pas à notre animal.

"Mais qu'il ait été conmu ou non, j'ai toujours été autorisé à dire qu'il avait été décrit sl imparfaitement, qu'on ne pouvait s'en former aucune fdée. Il constitue une espèce très-singulière, qui réunit en soi la force de la tête et des cornes du taureau, la légèreté et le pelage du cerf, et la beauté de la crinière, du corps et de la queue du cheval.

" Avec le temps, ne parviendra-t-on point d connaitre aussi la licorne, qu'on dit habiter les mêmes contrées, que la plupart des auteurs regardent comme un animal fabuleux, tandis que d'autres assurent en avoir vu et même en avoir pris de jeunes?

Je n'ai rien à ajouter ni à retrancher à cette bonne description, ni aux très-judicieuses réflexions du savant M. Allamand; et je dois même avertir, pour l'instruction de mes lecteurs, et pour la plus exacte connaissance de cet animal gnou, que le dessin qu'il a fait graver dans l'édition de Hollande de mon ouvrage me paralt plus conforme à la nature que celui de ma planche $378, f i g .1^{2}$ : les cornes surtout me semblent être mal représentées daus celle-ci, et l'espece de ceinture de poil que l'animal porte autour du museau me parait factice; en sorte que l'on doit avoir plus de confiance à la figure donnée par M. Allamand qu'àcelle-ei, et e'est par cette raison que je l'ai fait copier et graver.

- Quin etiam tragelaphi et huhali, pluraque duplicis for - ma animalia, ex diversissimis videlice naturis conlempe- rala, iltic in Arabia' procreanlur. Quorum singularis ıles- criplio longam sili inoram posccrel. Dioduri siculi bibliothecie hislorica libri qui smpersunt. Alusteludami, 1790, tom. I, piag. 163.

Élition de l'imprimeric royale. 


\section{LE COUDOUS}

ou

CANNA.

\section{(L'ANTILOPE CANMA.)}

Ordre des ruminants, seclion des ruminants à cornes creuses, genre antilope. (Cuvier.)

La classe des animaux ruminants est la plus nombreuse et la plus variée; elle contient, comme on vient de le voir, un très-grand nombre d'espèces, et peut-être un nombre encore plus grand de races distinctes, c'est-à-dire de variétés constantes. Malgré toutes nos recherches et les détails immenses dans lesquels nous avons été contraints d'entrer, nous avoucrons volontiers yue nous ne l'avons pas épuisée, et qu'il reste encore des animaux même très-remarquables que nous ne connaissons, pour ainsi dire, que par échantillons, souvent très-difficiles à rapporter au tout auquel ils appartiennent. Par exemple, dans la grande et très-grande quantité de cornes rassemblées au Cabinet du Roi, ou dispersées dans les collections des particuliers, et que nous avous, après bien des comparaisons, rapportées chacunc à l'animal duquel elles proviennent, il nous en est resté une sans étiquette, sans nom, absolument incomnue, et dont nous n'avions d'autres indices que ceux quion pouvait tirer de la chose mìme. Cette corne est tries-grosse, presque droite', et d'une substance ćpaisse et noire; ce n'est point un bols solide comme celui du cerf, mais une come creuse et remplie, comme celles des boeufs, d'un os qqui lui sert de noyau: elle porte depuis la base, et dinns la plus grande partie de sa longueur, une grosse arete ćpaisse et relevée d'environ un pouce; et quoique la corne soit droite, cette arète proćminente fait un tour et demi de spirale dans la partie inferieure, et s'eflace en entier dans la partic supérieure de la corne qui se termine en pointe: en tout, cette corne, différente de toutes les autres, nous paraissait seulement avoir plus de rapport avec celles du buftle cquarec aucune autre; mais nous ignorions le nom de l'animal, et ce n'est qu'cu dernier lieu et en eherehant dans le's differents cabincts, que nous avons trouvé diuss celui cle M. Dupleix un massarere surmonté de deus colnes semblables, et ectte portion de tite citilit ćt quetée: Cornes d'un animal à peu puèscommo un cheval, de couleur grisitre, avec une cri. nière comme un cheval au-devant de la têle; on l'appelle ici (à Pondichéry) coësdoës, qui doil se prononcer coudous. Cette petite découverte nous a fait grand plaisir ; mois cependant nous n'avons pu trouver ce nom coëscloës ou coudous dans aucun voyageur : l'étiquette seulement nous a appris que cet animal est de trèsgrande taille, ct gu'il se trouve dans les paysles plus chauds de l'Asie. Le buffle est de ce mème climat, et il a d'ailleurs une criniere au-dlessus de la tète : il est rai que ces cornes sunt courbes et aplaties, au licu que celles-ci sont rondes et droites, et e'est ce qui distingue ces deux animaux aussi bien que la couleur: car le buftle a la peau et le poil noirs; et, selon l'étiquctte, lo coudous a le poil grisâtre. Ces rapports nous en ont indiqué d'autres; les voyageurs en Asie parlent de grands buffles de liengale, de buffles roux, de bocufs gris du Mogol, qu on appelle nil-gauls; le coudous est peut-ètrel'un oul'autre de ees animaux; et les voyargeurs en Afrique, où les buffles sont aussi communs qu'en Asie, font une mention plus préeise d'une espece de buffle appeléc pacasse au Congo, qui par leu's indices nous parait être le coudous. "Sur la a route de Louanda, au royaume de Congo, " nous apercumes, disent-ils, deux pacasses quui " sont desanimaux assez semblablesaux buflles " et qui rugissent 'omme des lions; le mâle et la " femelle vont toujours de compagnie; ils sont " blanes, avec des taches rousses et noires, et " ont des oreilles de demi-aune de long, et les " cornes toules droiles. Quand ils voient quel" (qüun, ils ne fuient point ni ne font altu'un " naal, malisirgardent les passants. " Mous atrous dit ei-devant que l'animal appelé à Congo $\mathrm{mm}-$ pacesset ou pacelsse nous paraissait itte le buffle: écst en effet une espèce de buftle, mais qui en differe par la forme des cormes et lis couleur du poil ; e'est en un mot un coudous qui peutetre forme une espece siparée de ecolle du buffle, mais qui peut-itre aussi n'en est qu une vilricté.

\section{Andriox A L'Alticie DU CAXXA.}

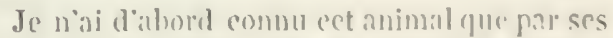

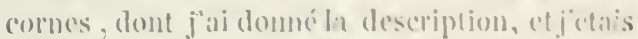
asse\% inecrlain, non-seulement sur son espece et sur son climat, mais metme sur le nom coib- 
dous qui servail d'étiquetle à ces cornes; mais aujourd'hui mes doutes sont dissipés, et c'est à M. Gordon et à M. Allamand que je dois la connaissance de cet animal, l'un des plus grands de l'Afrique méridionale. Il se nomme canna dans les terres des Hottentots, et roicilesobservations que ces savants naturailistes en ont publices cette aunée 1781 , dans un Supplément à l'édition de Hollande de mes ouvrages.

" M. de Buffon a été embarrassé à déterminer l'animal auquel avait appartenu une corne qu’il a trouvée au Cabinet du Roi, sans étiquette, et dont il a donné la figure. Deux semblables cornes qu'il a vues dans le cabinet de M. Dupleix, et qui étaient étiquetées, l'ont tiré en partie de son embarras; l'étiquette portait ceci: Cornes d'un animal à peu près comme un cheval, de conleur grisâtre avec une crinière comme un cheval au-derant de la tête; on l'appelle ici à Pondichéry coësdoës, qui doit se prononcer coudous.

"Cette description, toute courte qu'elle est, est cependant fort juste, mais elle ne suffisait pas a II. de Buffor pour lui faire connaitre l'animal qui y est désigné. Il a dù avoir recours aux conjectures, et il a soupconné, avec bealicoup de vraisemblance, que le coudous pouvait bien être une sorte de buffle on plutòt le nyl-ghau: effectivement ce dernier animal est celui dont les cormes ont le plus de rapport à celles dont il s'agit; et ce qui est dit dans l'étiquette lui convient assez, comme on peut le remarquer par la description que j'en ai domnée. Cependant cette corne est celle d'un autre animal, aucquel M. de Buffon n'a pas pu penser, parce qu'il n'a pas été encore décrit, ou que du moins il l'a été si imparfaitement, qu il était impossible de s'en former une juste ldée. Il était réservé á M. Gordon de nous le faire bien connaître; c'est à lui queje suis redevable de la figure quion en voit dans la $p l$. $V I I$, et des particularités qu'on va live.

"Kolbe est le seul gui en ait parlé sous le nom d'élan, qui ne lui convient point, puisqu'il en differe essenticllement par ses cornes, qui nout rien d'analogue à celles du véritable élan. Les Hottentots lui domnent le nom de canna, que je lui ai conservé : les Caffres le nomment impoof. C'est un des plus grands animaux à picas fourchus qu'on voie dans l'Afrique méridionale. Ira l'ongucur de celui qui est représenté ici, depuis le bout du museau jusqu'à l'origine de la queue, était de huit pieds deux pouces; sa hauteur était de cinq pieds, mesurée depuis la partie du dos qui est au-dessus des épaules, et qui forme lá une éminence assez remarquable; sa circonférence, derrière les jambes de devant, était de six pieds sept pouces, et devant les jambes postérieures de cinq pieds neuf pouces ; mais il faut observer qu'il était assez maigre; s'il avait eu son embonpuint ordinaire, il aurait pesé environ sept à huit cents lirres. La couleur de son corps était dun fauve tirant sur le roux, et il était blanchâtre sous le vell. tr'e ; sa tête etson cou étaient, d'un gris-cendré, et quelques-uns de ces animaux out tout le corps de cette couleur; tous ont au-devant de la tête des poils qui y forment une espèce de crinière.

"Jusqu'ici cette description s'accorde fort avec celle du coudous, et les cornes du cauna solit précisément semblables à celles que $\mathbf{M}$. de Buffon a décrites; ainsi on ne peut pas douter que le coudous de Pondichéry ne soit notre canna; mais je suis surpris, avee M. de Buffon, qu'on lui ait donné le nom de coudous, qui n'a jamais été employé par aucun voyageur dans les Indes; je soupconne qu'il a été emprunté des Hollandais qui ìécrivent effectivement cö̈doë ou coësdoës, et qui le prononcent coudous. Ils le donnent à l'animal que MI. de Buffon a nommé condoma, et qui par sa grandeur approche un peu du canna. Ces cornes, qui se trouvent dans le cabinet de M. Dupleix, nauraient-elles point été apportées du capde BouncEspérance à Pondichéry? Celui qui én a écrit I'étiquette, en suivant l'orthographe hollandaise, ne se serait mépris que sur le nom. Ce qui autorise ce soupçon, e'est le silence des voyageurs sur un animal aussi remarquable par sä grandeur que le canna. S'il habitait un pays autant fréquenté par les Européens que le sont les Indes, il est tı’è-vraisemblable que quelques-uns ell auraient parlé."

Je suis ici, commedans tout le reste, parfaitement de l'aris de M. Allamand, et je reconnais que le nom hollandais de coësdoés ou coudous doit rester à l'animal que j'ai nommé condoma, et que ce nom coudous avait été écrit mial à propos sur l'étiquette des cornes que nous l'econnaissons être celles du canna, dont il est ici question.

"Ces cornes, dit M. Allamand, étaient telles que M. de Buffon les a décrites; clles avajeut 
une grosse arête qui formait deux tours de spirale vers leur base; elles étaient lisses dans le reste de leur longucur, droites et noires; leurs bases étaient éloignées l'une de l'autre de deus pouces, et il y avait l'intervalle d'un pied entre leurs pointes; leur longueur était d'un pied et demi, mais elle varie dans les différents individus. Celles des femelles sont pour l'ordinaire plus menues, plus droites et plus longues; elles sunt creuses et soutenues par un os qui leur sert de noyau; ainsi elles ne tombent jamais. A cette occasion, M. Gordon m'écrit qu'on ne comnaît dans l'Afrique méridionale aueun animal qui perde ses cornes ; par conséquent il n'y a ni élans, ni cerfs, ni chevreuils. Kolbe seul les y a vus.

Le canna a un fanon très-remarquable qui lui pend au-devant de la poitrine, et qui est de la même couleur que la tête et le cou. Celui des femelles est moins grand; aussi sont-elles un péu plus petites que les mâles; elles ont moins de poils sur le front, et e'est presque en cela seulement que leurs figures different.

"J'ai déjà dit que Kolbe donne au canna le nom d'élan; et e'est eflectivement celui sous lequel il est connu au Cap, quoique très.improprement : ecpendant il a, comme notre élan du Nord, une loupe sous la gorge, de la hauteur d'un pouce, comme on peut le voir dans la figure. Si l'on en croit M. Linnæus, c'est là un caractère distinetif de l'élan, qu'il définit : Alces, cervus cornibus a caulibus palmatis, caruncula gutturali. Mais M. de Buffon remar'que, avec raison, que les élans femelles u'ont pas cette loupe, et qu'elle n'est par conséquent point un caractère essentiel à l'espèce. J'ignore si elle se trouve daus la femelle du cannal.

"Sa queue, qui est longue de deux pieds trois pouces, est termince par une touffe de longs poils ou crins noirs; ses sabots sont aussi noirs, et le peuple (sur la foi du nom) leur attribue la mème vertu (qu'à ceux de nos élans, e'est d'itre un souverian remide contre les convulsinus.

"II a quatie manelles et une vésicule du filel. (Moique sa tète, qui a un pied sept pouces le longueur, ressemble assez ì celle du cerf, alle n'a cependant point de larmicrs.

"Les cimnas sont presque tous détruits dans le voisinage du Cap, mais il ne fiut pas s'en b́loigner beaucoup pour en rencontrer; on en trouve dans les montagnes des Hottentots hollandais. Ces animaux marchent co trounes de cinquante ou soixante; quelquefóis mèmé on en voit deux ou trois cents ensemble près des fontaines. Il est rare de voir deux mâles dans une troupe de femelles, parce qu'alors ils se battent, et le plus faible se retire: ainsi les deux saxes sont souvent a part. Le pius grand marche ordinairement le premier : e'est un très-beau spectacle que de les voir trotter et galoper en tronpes. Si l'on tire un coup de fusil chargé à balle parmi eux, tout pesants qu'ils sont, ils sautent fort haut et fort loin, et grimpent sur des lieux escarpés, où il semble qu'il est impossible de parvenir. Quand on les chasse, ils courent tous contre le vent, et avee un bon cheval il est aisé de les couper dans leur marehe. Ils sont fort doux : ainsi on peut pénétrer au milieu d'une troupe, et choisir celui sur lerpuel on veut tirer, sans courir le moindre danger. Leur chair est une excellente venaison; on easse leurs os pour en tirer la moelle, qu'on fait rotir sous la cendre; elle a bon gouit et on peut la manger même sans pain. Leur peau est très-ferme; on s'en sert pour faire des ceintures ct des courroies. Les poils qui sont sur la tête des mâles ont une forte odeur d'urine, qu'ils contractent, dit-on, en léchant les femelles. Celles-ei ne font jamais (qu'un petit à la fois.

"Comme ees animaux ne sont point méchants, M. Gordon croit qu'on pourrait aisément les rendre domestiques, les faire tirer all chariot et les employer comme des bètes de somme; ce qui scrait une aequisition très-importante pour la colonie du Calp.

" M. Pallas a vu, dans le Cabinet de monseigneur le prince d'Orange, le squelette d'un eamna, et il l'a reconnu pour c̀tre l'elan de Kolloe. Il l'a rangé dans la classe des antilopes, sous la dénomination d'dntilope Oryx. Je n'examinerai pas les raisons qu'il a eues pout lui donner eette dernière épithete: je me contenterai de remarquer qu'il me parait douteux que le camna se trouve dans les parties septen. trionales de l'Afrique; au moins aucun royageur' ne le dit. S'il est particulier aux contrees méridionales de cette partie du monele, il n'est pas apparent que ce soit l'Oryx des anciens: d'ailleurs, suivant le témoignage de Pline, l'oryx était une chève saurigge, et il est peu vaisemblable que Pline, yui ne s'était pas formé un système de nomenclature comme nous autres 
modernes, ait donné le nom de elieviec à un aussi gros animal (juc le canna. )

A vant d'avoir recu ees remarques tres-judicicuses de M. Allamand, j'avais fait a peu ples les mèmes réllexions, et voici ce yue j'en altais écrit et mème livré à l'impression:

M. Pallas appelle cet animal $O r y x$, et le met au nombre de ses antilopes: mais ee nom me parait mal applicqué; je l'aurais néanmoins adopte si j'eusse pu penser que eet animal du capde Bonne-lispénance fut l'oryx des anciens; mais cela n'est ni vai ni mème varais(mblable. M. Pallas eroit que l'élan d'Africque, indiqué par liolbe, est le même animal que celui-ci, et je ne suis pas fort éloigné de ce scutiment, (quoique j'aie rapporté, page 599 de ce volume, l'élan d'Afrique de liolbe au bubale : mais soit qu'ilappartiemne cu effet au bubale ou au camma, il est certain que le nom d'élan lui a été trèsmal appliqué, puisque l'élan a des bois solides qui tombent tous les ans comme ceux du eerf, au lieu que l'animal dont il est ici (question porte deș corries creuses et permanentes, comme celle des bœufs et des chères.

Et ce qui me fait dire yue le nom d'oryx a été mal appliqué à cet animal par Mr. Pallas, et qu'il n'est pas l'oryx des anciens, e'est qu'ils ne comuaissaient qu'une assez petite partic de l'Asie et la seule portion de l'Afriçue qui s'étend le longr de la Méditerranée. Or, eet animal auquel M. Pallas donne le nom d'oryx, ne se trouve ni dans l'Asie mincure, ni dans l'Arabie, ni dans l'Égyte, ni dans toutes les terres de la Barbarie et de la Mauritanic. Ainsi l'on est fondé à présumer (qu'il ne pouvait être ni counu, ni nommé par les anciens.

M. Forster m'écrit (pu'il a vu une femelle de cette espèce en 1772 à la Ménagerie du cap de Bonne-lispérance, laquelle avait environ quatre pieds de hauteur, mesurée aux jambes de devant: "Elle portait, dit-il, une sorte de crinière le long du cou, qui s’étendait jusçu’aux épaules, où l'on royait aussi de tres-longs poils; il y avait une ligne noire sur le dos, et les genoux étaicnt de cette même conleur noire, ainsi que le nez et le museau; le pelage du corps était fauve et à peu prós semblable à celui du cerf: mais le ventre et le dedaus des jambes étaient blanchattes

" On voyait sous la gorge de cette femelle une proéminence de la grosseur d'une pomme, qul était formée par l'os du larynx, plus apparent et plus grand dans ectte espèce d'animal que dans toute autre.

" Ainsi la femelle canna a comme le mâle cetle proéminunce sous la grorge, au lieu que dans l'espece de notre élau du hord, le mále seul porte cet attribut.

"Toutes les dents incisives étaient, selon MI. Forster, d'une largeur considérable; mais celles du mrilieu étaient encore plus larges que les autres. Les ycux étaicnt vifis et pleips de feu La longueur des cornes élait d'ensiron un pied et demi ; et pour avoir une idée de leur position, il funt se les représenter comme formant un grand V en regarclant l'animal de face, et comme s'effaçut parfaitement l'une l'autre, en le re. gardant dans le sens trausversal. Co's cornes étaient noires, lisses dans leur plus grande longueur, arec quelques rides anmulaires vers ia base: on remarquait une arête mousse qui suivait les contours de la come, laquelle était droite dans sa dircetion, et un peu torse dans sa forme. Les oreilles étaient larges; les sabots des pieds fort petits à proportion dı corps; leur forme était triangulaire et leur couleur noire.

"Au reste, cette femclle était très-apprivoisće, et mangeait volonticr's du paiu, des feuilles de choux, et les prenait même dans la main: clle était dans sa (quatrième aunée; ct conme clle n'avait point de mâle, et quelle était en chaleur, elle sautait sur des antilopes et mème sur unc autruche cqui ćtaient dans le même parc. On assure que ces animaux se trouvent sur les hautes montagnes de l'intérieur des terres du Cap; ils font des sauts surprenants, et franchisscnt des murs de huit et juscu'à dix pieds de haut. "

\section{DU NIL-GAUT.}

\section{(L'ANTILOPE NIL-GAUT.)}

Ordre des rumiunts, section des ruminauts à cornes creuses, geure antilope. (Curier.)

Cet animal est celui (jue plusieurs voyageurs ont appele bouf gris du Mogol, quoiqu'il soit comnu sous le nom de nil-gaul daus plusieurs cuclroits de l“inde. Nous avons vu vivants le mále et la femelle dans le pare du chátıau royal de la Muctte, oi on les nourrit encore aujour- 
W'hui (juin 1774), et où on les laisse en pleine liherté.

Quoique le nil-gaut tienne du cerf par fe cou et la tête, et du bouf par les eornes cet la queuc, il est néanmoins plus élojgrncí de l'un ct de l'autre de ees gemres que de eelui des gazelles ou lis grandes cheves. Les clinbits chands de 'Asie et ceux de l'Afrique sont ecux ou les gandes esprees dles gazelles et de's eherre's sont ilus multiplices: on trouve dans les mèmes ieux ou à peu de distance les uns des antjes, e condomi, le bulsale, le kolsa, et le nil-gaut lont il est iei question. L'espice de barbe qui il a sous le cou et le poitrail, la disposition de ion pied et de ses sabots, plusicurs autres rapyorts de ecorformation a vec les grantes chiveres, e rapprochent de eette famille, plus que de relle des ecrfs ou de eelle des boculs : et dims es animaux d'Europe, e'est au chamois ru'on sourrait le eomparer plutiot qu'il tout autre aninal : mais dans la réalité le nil-graut est seul de inn gene, et d'un espere partieuliere qui ne ient au genre du bocul', du cerf, de la chevre, le la gazelle et du chamois, que par queleques "aractères ou rapports particuliers. II a, comme ous ces animaux, lit liteulté de ruminer; il court le mauvaise gráce et plus mal que le cerf, guoiIu'il ait lat tète et l'encolure aussi lómères : mais es janıbes sont plus massives et plus ine cales In hauteur, ecelles de derrière étant consideralement plus eourtes que celies de devaut; il orte la quene horizontalement en courant, et at tient basse et entre les jambes lorsqu'il est en epos. Le mâle a des erornes, et la femelle n'en a point; ce qui le rapproche enrore du genre les chères, dans lepuel d'ordinaire le femelle lia point de cormes; eclles du nil-gant sont erenes et ue tombent pas comme le hois des eerfs, les daims et des chevreuils; caractere qui le ipare absolument de ce genre d'animalux. :omme il vient d'un pays oi la chaleur est plus rande que dans notre elimat, il sera peut-ètre lifficile de le multiplier ici : ce serail néammoins me bonne acequisition a faire, paree que ect nimal, quoique vif et ragabond comme les chères, est assez doux pour se laisser réril', it juil domerait eomme elles de lat chair minnfeable, du bon suil", ct de's peaux plus cipitisse's

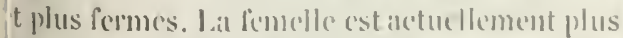
mone que le mile, et pillatit plus jeune; mitis Ile deviendra preut-ètie de la méme couleur rise aree l'inge
Voiei le délail de la deseription que j’ai faite de ces deux animaux avee $\boldsymbol{H}$. de Sève, qui les ¿ dessinés : le màle était de la grandeur d'un cerf de taille moyeme; les colnes n'avaient que six pouces de longueur, sur deux pouces neuf lignes de grosseur a la base. If niy avai point de dents incisires a la maichoire sups ricure; celles de lat màchoire inferieure étaient larges et peu longues : il y an une espace vide entre elles et les mitchelieres. Le train de derriere, dans le màle, est plus bas que a lui de de vant, et l'on voit une espece de hosse ou d'élévation sur les épaules, et cet endroit est frarni d'une petite eriniere qui prend du sommet de la tete et finit au milieu du dos : sur la poitrine se tronve une toulfe de longrs poils noirs. Le pelage de tous le eorps est d'un gris d'ardoise : mais la tète est gámie d'un poil plus fauve, mêlé de grisittre, et le tour des yeux d'un poil fauve clair, avee une petite tache blanche à l'angle de chaque oeil ; le dessus du nez est brun; les nascaux sont noirs avee une bande blanche u còté. Les oreilles sont fort grandes et larges, rayées de trois bandes noires vers leur extrémité. La face extéricure de l'oreille est d'un gris roussâtre, avee une tache blanclıe à l'extrémité. Le sommet de la tète est garni d'un poil noir mèlé de brun, qui forme sur te laut du front une espece de fer a cheval; il $y$ a sous Ic eou, près de la gorge, une grancle tache blanche; le ventre est gris d'ardoise comme le corps. Les jambes de devant e't les cuisses sont moires sur la face exterieure, et d'un gris plus foncé cque celui du corpss sur la fice intiricure. l.e pied est rourt et resscmble à celui du cert; les sabots en sont noirs : il y a sur la fice externe des pieds de devant une talde blanche, et sur linterne deux auta es taches de mème couleur. Les jambes de derriere sont beaucoup plus lintes que celles de devant: elles sont courertes de poils noiritres, ave deux grandes tiches blanches sur le's pieds, tant en dehors qu'en dedaus ; ct plus bas il y a de grands poils chattains qui forment une toulfe lirisede. Lal queve est d'un erris ardoise rers le milieu, et hlanehe sur les cotcés; clle est terminee par une touffe de grands poils noirs; fo dessous est en peau nue; les poils blume's de's cote's de la guene sont fort lones et ne sont point rouches sur la peau comme ecux des iutres parte's du corps, ils s'etendent an contraire en ligne droite de ehatgue cotc. Le fourreau de la verge est peu

59. 
apparent, et l'on a observé que le jet de l'urine est fort petit dans le mâle.

Il y a à l'École vétérinaire une peau bourrée d'un de ces animaux, qui diffère de celui qu'on vient de décrire par la couleur du poil qui est beaucoup plus brune, et par les cornes qui sont כlus grosses a leur base, et cependant moins grandes, n'ayant que quatre pouces et demi de longueur.

La femelle du nil-gaut, qui était au pare de la Nuette, vient de mourir au mois d'octolore 17.4; elle était bien plus petite que le mâle, et en mème temps plus svelte et plus haute sur' ses jambes; sa couleur était roussâtre, mélangée d'un poil fauve pâle et de poils d'un brun roux, au lieu que le pelage du màle était en général de couleur ardoisée. La plus grande différence qu'il y eutt entre cette femelle et son mâle, était dans le train de derrière, qu'elle avait plus élevé que celui de devant, tandis que e'est le contraire dans le mâle; et cette différence pourrait bien n'être qu'individuelle et ne se pas trouver dans l'espèce entière. Au reste, ce mâle et cette femelle se ressemblaient par tous les autres caractères extérieur's et même par les taches; ils paraissaient avoir un grand attachement l'un pour l'autre; ils se léchaient souvent, et quoi(qu'ils fussent en pleine liberté dans le pare, ils ne se séparaient que rarement, et ne se quittaient jamais pour longtemps.

M. William Hunter, docteur en médecine, membre de la Société de Londres, a donné, dans les Transactions philosophiques (volume LXI, pour l'année 1771, page 170), un Mémoire sur le nil-gant, avec une assez bonne figure. M. le Roy, de l'Aeadémie des Seienees de Paris, en ayant fait la traduction avec soin, j'ai cru faire plaisir aux amateurs de l'listoire naturelle de la joindre ici, d'autant que $\mathrm{M}$. Hunter a observé ect animal de beaucoup plus près que je n'ai pu le faire.

"On doit compter, dit M. IIunter, au nombre des richesses qui nous ont été apportées des Indes dans ces derniers temps, un bel animal appelé le nyl-ghau; il est fort ì souhaiter qu'il se propage en Angleterre, de manière à devenir un de nos animaux les plus utiles, ou au moins un de ceux qui parent le plus nos campagnes; il est plus grand qu'aueun des ruminants de ce pays-ci, excepté le bouf; il y a tout lieu de croire qu'on en tronvera la chair excellente; et bil peut être assez appriroisé pour s'accoutu- mer au travail, il y a toute apparence que : force et sa grande vitesse pourront être en: ployées arantigeusement.

"Les représentations exactes des animal par la peinture en donnent des idées beaucor plus justes que de simples deseriptions. Quico que jettera les yeux sur le portrait qui a 6 fait sous mes yeux par M. Stublo, eet excelle peintre d'animaux, ne sera jamais embarras de reconnaitre le nyl-ghau partout où il pour le rencontrer. Quoi qu'il en soit, je rais tent la deseription de cet animal, en y joignant $e$ suite tout ce que j'ai pu apprendre de son hi toire. Ce détail ne sera pas très-exact : mais I naturalistes auront une sorte de plaisir en a] prenont au moins cquelque chose de ce qui $r$ garde ce bel et grand auimal, dont jusqu'i nous n'avions ni descriptions ni peintures.

"Le uṛl-ghau mâle me frappa à la premiè vue, eomme étant d'une nature movemne ent le taureau et le cerf, à peu près comme no supposerions que serait un animal qui serait produit de ces deux espèces d'animaux; car est d'autant plus petit que l'un, qu'il est pl grand que l'autre; ct on trouve dans ses form un grand mélange de ressemblance à tous 1 deux ; son cor'ps, ses cornes et sil queue ressel blent assez à ceux du taureau; ct sa tête, sı cou et ses jambes, approchent beaucoup celles du cerf.

" $S a$ couleur. La couleur est en général ce drée ou grise, d'après le mélange des poils noi et blanes; la plupart de ces poils sont ì moił noirs et à moitié blanes : la partic blanche trouve du côté de la racine. La couleur de s jambes est plus foncée que celle du corps : en peut dire de mème de la tète, avec cet singularité que cette couleur plus foncée n'y c pas générale, mais seulement dans quelqu parties qui sont presque toutes noires; da quelques autres endroits, dont nous parlero plus bas, le poil est d'une belle couleur blanch

"Le tronc. La hanteur de son dos, ou il y une légère éminence au-dessus de l'omoplat est de quatre pieds un pouce (anglais); ct à partie la plus élevée immédiatement derrie les rcins, cette hautcur n'est que de quat pieds; la longueur du trone en général, vu profil depuis la racine du cou jusqu'it l'origi de la queue, est d'environ quatre pieds, qui est ì peu près la hauteur de l'animal ; facon que vu de profil, et iorsque ses jamb. 
it parallèles, son dos et ses membres forment trois eòtés d'un carré, dont le terrain sur fuel il est placé fait le yuatrieme. Il a yuatre 'ls dix pouces de circonférence immérliateint derriere les épaules, et quelque chose de is au-devant des jambes de derrière; mais te dernière dimension doit varier beaucoup, nme on l'imagnine bien, selon que l'animal a corps plus ou moins plein le nourriture.

"Son poil. Le poil sur le corps est en généplus rare, plus fort et plus raide que celui bouf; sous le ventre et aux parties supéures de ses membues, il est plus long et plus ux que sur les cótés et sur le dos; tout le ig du cou et de l'épine du dos, jusqu'à la parpostéricure de l'élévation qui est au-dessus s omoplates, le poil est plus noir, plus long plus redressé, formant une espece de courte nière rare et élevéc; les régrions ombilieale hypogastrique du ventre, l’intérieur des euis; , et toutes les parties qui sont recouvertes s la queuc, sont blanches; le prépuce n'est int marqué par une toul'ie de poils, et ce préce ne siille yue très-peu.

"Les teslicules. Les testicules sont oblongs, pendants comne dans le taureau; la queue scend jusqu'à deux pouces au-dessus de l'os talon; l'extrémité en est ornée de longs poils irs, ainsi que de quel(pues poils blanes, parulièrement du rôté de l'intérieur : la queue, l' cette face intérjeure, n'est point garnic de ils, excepté, comms on vient de le dire, rs son extrémité; mais à droite et à gáluche il a une bordure de longs poils blanes.

"Les jumbes. Les jambes sont minces en oportion de leur longrueur, non pas autant le eelles de notre cerl', mais plus que celles de s ta!ureaux; les jambes de devant ont un peu us de deux pieds sept pone's de long. Il y a le lache blanche sur la partie de dovant de alpue pied, presque, immédiatement au-dess de eharuue saloot, et une autre tache blanche us petite au-devant du canon, et an-dlessus chacume il y a mo touffo remarciuable de ngs poils blanes, (jui tourne autom en forme boueles pendintes. L.es sabots des jambes de vant paraissent itre d'une longueur trop ande : cette singularite chit fort remarguable ns chacun des cing myl ghrux que j’at vus;

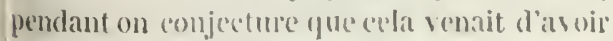
é renfermés, el, col'e liunimant dauns l'animal oit, la eonjerlure s'est linurée fondée.
"Le cou. Le cou est long et mince coinme dans le cerf; il y a à la gorge une belle tache de poils blanes de la forme d'un boucliel; et plus bas, au commeneement de l'arrondissement du cou, il y a une touffe de longs poils noirs en forme de barbe.

"La lèle. La tète est longue et mince; sa longueur, depuis les cornes jusqu'à l'extrémité du nez est d'environ un pied deux pouces trois quarts; la cloison qui sépare les narines avait été percée pour y passer une corle ou une bride, selon la maniere des Orientaux d'attacher et de mener le bétail.

"La bouche. La feute de la bouche est longue, et la mâchoire inférieure est blanche dans toute l'étendue de cette fente; la mâehoire supérieure n'est blanche qu'aux narines.

"Les denls. Il y a six dents molaires de chaque coté des màchoires, et huit incisives a la mâchoire inférieure; la premiere des incisives est fort large, et les autres plus petites en proportion de ce qu'elles sont placées plus en avant ou en alriere.

"Les yeux. I.es yeux en général sont d'un couleur foncée; ear toute la partie de la conjonctive qu'on peut voir est de cette coulcur: de profil, la cornée, et tout ce quion peut voir au travers, parait bleu comme l'acier bruni ; la pupille est ovale et transversalement oblongrue et l'iris est presque noir.

"Les oreilles. Les oreilles sont grandes et belles : elles ont plus de sept pouces de long, et s'élarovissent considérablement vers leur extrémite; elles sont blanches a leurs bords et dans lintéricur, excepté dans l'endroit ou deux bandes noires marguent le ereux de l'oreille.

"Les carnes. Les corres ont sept pouces de long; elles ont six pouces de tour à leur origine et diminuent par degrés; elles se terminent en une pointe mousse. Elles ont à leur origine trois faces plates, séparcés par autant d'angles: l'un de ces angles est eu devant de la corne, et par conséquent l'une des faces en formne le derricie; mais ectte forme triangulaire diminuc peu it per et se perd vers l'extrémité. Il y a sur la base, à l'origine des cornes, de lécers plis ou rides circulaires, dont le nombre correspond a l'àre. de l'animal. La corme elepuis la base juspu'en haut est mone, et le bout 'st d'une couleur fort foncée. Cescornes s'elevent en hatut et en arant. formant un angle fort obtus uvec le front nu la tace; elles sont legerement courbées; la con. 
eavité en est tournée vers l'intérieur ct un peu en devant; leur intervalle, a leur origine, est de trois pouces un quart, ¿t leur sommet de six pouces un quart, et dans l'intervalle du milieu un jeu moins de six pouces.

"Sa nourriture. 11 mange de l'avoine, mais pas avidement; il aime mieux l'herlbe et le foin ' ; cependant ce ([u'il aime encore davautage, e'est le pain de froment cu'il mange toujours avee délices. Quand il est altéré, il boit jusqu'à huit pintes d'eau.

"Sa fiente. Sa fiente est en forme de petites boules rondes de la grosseur d'une noix muscade.

"Ses mœurs. Quoiqu'on m'eût rapporté qu'il était extrèmement farouche, j’ai trouré, tant que je l'ai eu en ma garde, que c'était, dans le fond, un animal trè-doux, et qui paraissait aimer qu’on se familiarisât avee lui; léehant toujour's la main de celui qui le flatlait ou qui lui présentait du pain, et n'ayaut jamais tenté de se servir de ses armes pour blesser qui que ce soit. Le sens de l'odorat, dans cet animal, paralt très-fin et semble le guider dans tous ses mouvements. Quand quelque persome l'approche, il le flaire en faisant un eertain bruit : il en faisait autant quand on lui apportait à boire où à manger, et il ćtait si facilement offeusé par une odeur extraordinaire ou si cireonspect, qu'il ne voulait pas goùter le pain que je lui présentais, lorsque ma main avait touché de I'buile de térébenthine ou quelques liqueurs spiritueuses ${ }^{2}$.

"Sa manière de se battre est fort singuliere; Milord Clive l'a observéc sur deux mâles qui avaient été enfermés dans une petite enceinte, et il me l'a racontée comme il suit. "Ĺtant en" eore à une distance considérable l'un de l'au" tre, ils se préparèrent au combat, en tombant " sur leurs genoux de devant, et s'avineèrent

\footnotetext{
1. Le ginéral Carnal in'apprend quion ne fait pas de fiin - dus l"Inde; yue les chevaux sont numrris avee de l'herbe - fraichement compée, et avec une graine du genre des légu- Ir.es glion apprile gram.

2. Le général Carnat, rap porte, inns ynglaues ubservations - à ce sujet qu'ıl a bien vonlu ue communityer, yue tums les - animanx de l'espéce du cerf on! lodorat eatrèmenent fin; - ın'il a fréłucmment oloservé sur les cerfs apjurivoi-és, allx- quels on donne souvent diu pain, que si mu leur presente un

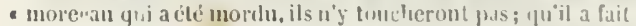

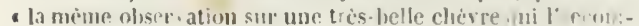

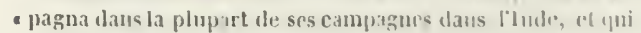
- lu fournissitil du luit, et yuen revunnaissance de ses servi- ces u avail amence en inglcterre aves lui.s
}

" l'un vors l'autre d'un pas assez rapide, en to " tillant toujours agenouillés de cette manièr. " et quand ils furent al rivés à queleques pas, " distance, ils firent un saut et s'élanecere "I'un contre l'autre."

"Pendant tout le temps que j"en eus det dans mon écurie, je remarquai que toutes l, fois yu'on voulait les toucher, ils tombaient si leurs genoux de devant, ce qui leur arrisa mème quelquefois lorsque je m'a vançais deval eux : mais comme ils ne s'élançaient jamais col tre moi, j'étais si loin de penser que cette po ture annoncait leur colere ou nne disposition a combat, que je la regardais au contraire comn une expression de timidité ou d'une grane douceur, ou méme d'humilité '.

"La femelle. La femelle differe tellement d mâle, cu'à peine pourrait-on les croire de même espece; clle est beaucoup plus petite: : el ressemble par sa forme et par' sa couleur jar nátre à une biche, et n'a point de cornes; el a quatre tettes, et l'on croit qu'clle porte nel mois ; quelquefois elle produit deux petits, ma le plus souvent elle n'en fait qu'un. Le uyl-gha mâle étant jeune ressemble beancoup par : couleur à la femelle, et par conséquent à u jeune cerf.

"Son espèce. Lorsqu’on nous présente u nouvel animal, il est souvent fort diffieile quelquefois même impossible de déterminer so espèce uniquement par ses caractères extérieur: mais lorsque cet animal est disséqué par u anatomiste habile dans l'anatomie comparéc alors la question se décide communément ave certitude.

"D’après les caractères extérieurs unique ment, je soupeonnai ou plutòt je crus que I nyl-ghau était un animal particulier et d'un espéce distinete. Quelyues-uns de mes amis I prirent pour un cerf; mais je fus convameugu')

" on pent eoncevoir l'intripulité ct la force avec laupuel - il silance contrenu olvet jur l'anecil te snivante, d'uu de

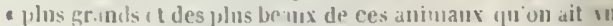
a en Angleterre. Il y a lit 11 de croire mine sue le chuc yn - épromva, dans celte occasion, fut la canse de sa mort if - arriva lientót apués. I' - que lanimal êt tit si pres de lui, ne croyant bas l'irriter,

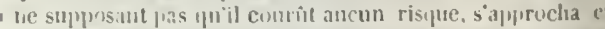
- ilehor's des palls oi il etait renformé; le nyl-ghan, ave l a vilesse d'un éclitil. s'il ma avec tunt ile force contre ce

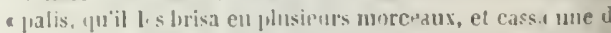

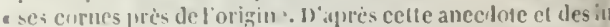

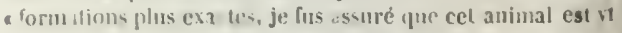
- cienx ot féroce dians le lemps du rut, quelyue doux et ap a privoiş quili suit dans d'autres temps. " 
iétait pas de ce genre, par la permanence de es cornes qui ne tombent pas. D'autres pensèent que c'était une antilope : mais les colnes ct z graudeur de l'animal me lirent croire encore ue ce n'en était pas nue; ct il arait tant de apport par sa forme, parliculièrement la fenelle, arcele cerf, que je ne pouvais pas le re,arder comme du mème grome que le tarrean. Jans le temps du rut, on mit un de ces màdes yy-ghau avec une biche; mais on ne remaryua i amour, ni meme aucune attention particuiere entre ces deux animaux. Enfun l'un de ses animaux étant mort, je fus assuré par mon irère, qui l'a dissérué, et qui a disséøué presspue ous les quadrupiodes conmus, que le myl-ghan st un animal d'une espece nouvelle.

- Son histoire. Plusicurs de ces animaux maes et femelles ont été apportés en Augleterre lepuis quelques amo's : les premiers furent moyés de ljombay en présent a my lord Clive; Is arriverentau mois d'anut 1767 ; il y en anat un mâle et l'autre femelle, et ils continuerent de produire dans ce pays-ci chargue ammcie. Quclyue temps apres, on cu amena deux autres qui furent présentés à la reine par M. Sukivan, et cette prineesse étant toujours disposéc à emeourager toute espece de recherches curieuses et utiles dans l'histoire naturelle, me fit donner lat permission de les anarler pendant quelque temps; cequi me mit à portér, nou-seulement de pouroir les décrire, et d'en alroir une peinture lien exacte, mais encore de disséguer, avec le secours de mon frère, l'animal mort, et d'u'n conserver la peau et le squelette. Mylord Clive a eu la bonté de me domner tous les éclairerissements (qu'il a pu me foumir pour en faire l'histoire, ainsi que le grencival Cianuat, et quelpues antres per'sonues.

"Ces animaux sont regardés comme des raretés dans tous les citablissements que nous ayons dans l'lude; ils y sont amenés de l'intericur du pays en présents anx mababs et autres persomnes considerables. I. Jord Clire, le grénéral Cimmat, M. Walsh, M. Watts et beancoup) d'antres persomnes fuli ont su une grande palltie de l'Inde, mont tous dit qưils ne l'anaint

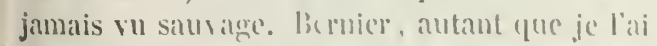
pu décomvir, est le seul anteme qui en fisse mention '. Dans te quatrieme rulume de ses

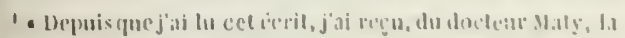

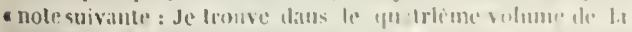

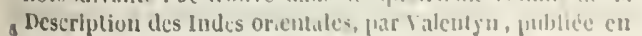

Mćmoires, il fait le récit d'un vovage qu’il cmtrepriter 166.4 , depuis Dellij jusqu'à la provinee de Cachemire, arec l'empereur mogol Aurengr zeb, qui alla daus e( paridis terrestre, comme le regradent les Indiens, pour éviter les chaleurs de l'été. En 'jillint de la chasse aui faisait l'amusement de l'empereur daus ce vovase, il décrit parmi rlusicurs autres animaux, le nylghau, mais sans lien dire de plus de cet animal, sinon rque quelquefois l'emprereur en turit un si grand ucmlore, (quil en distribuait des (puartiers tout entrers à tous ses omrahs; ce yui montre quils étaient en grand nombre, sauvages daus eclte contrée, et fu'm en regardait la chair ou la vande comme fort bonne ou délicieuse.

"Ceci parait s'iccorder arec la rareté dle ces animaux au bengale, a Vaudras et à Bombay. Cialdemire est une des provinees les plus sep)tembrionales de l'empire du Mlogol, et ce fut en allant de Delhi vers eette province que licruier vit l'empereur les chasser.

"Son nom. 1.e mot nyl-ghau (car telles sont les lettres eomposintes de ce nom, gui correspondent atu persan), (fuoi(pue prononcé comme s’il était érit nect-yau (en franeais nil-ga), signifie une vache bleue ou plutót un taureau bleu, gau étant mašulin. l.e mâle de ces animax a en cfe't de justes titres ì ce nom, nonseulement pal rapport ì sil ressemblance ave le tamrean, mais encore par la teinte bleuatre gui se fait remarefuer semsiblement dass la couleur de som enteps, mais il nen est multement de mime de la femolle gui a beancoup de ressemblance, et quant il la couleur et quaust il la forme aree motrecerí. I.es myl-rhatux qui sont venus ell Augletere ont éte juespue tous apportes de Surate ou de bombar, et ils paraissent muins rares elins cetle partio de linde que dans le Bengale; ee (pui domne lieu de conjecturer quils poumaient itre indigenes dams la provinee de Guzallate, l'une des jorosinces les plas aceidentales de lemplipe du Mlogrol, ctant situere atl nord de Surate, et s'etemdant juscpüit l'ocean Indien.

(1) In officier gui a demenre longtemps dans l'Incie a cerit pour obtenil toutes les comuais-

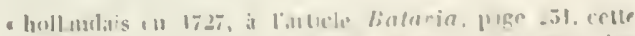

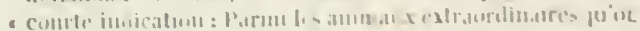

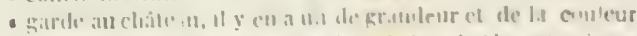

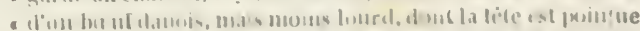

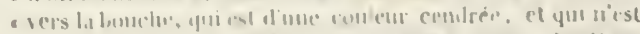

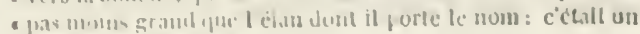
- jréscul dir il hául. 
sances et tous les éclaireissements qu'on pourrait se procurer sur cet animal. Nous espérons recevoir en conséfuence, dans le cours de l'année prochaine, quelques détails satislaisants à ce sujet, quoique les habitants de ces contrées, selon ce qu'en dit eet offieier, aient peu d'inclination pour l'histoire naturelle, et même en général pour toutes espèces de connaissances. .

En comparant la gravure de cet animal, donnée dans les Transactions philosophirjues, avec les dessinsque nous en a vons faits d'après nature, dans le pare de la Muette près Paris, nous avons reconnu que dans la gravure anglaise les oreilles sont plus courtes, les eornes un peu plus émous sées, le poil sous la partic du cou plus court, plus raide et ne faisant pas un flocon. Dans cette même gravure, on ne voit pas la toufle de poils qui est sur les éperons des pieds de derrière du mâle; enfin la crinière sur le garrot paraît aussi plus eourte que dans nos dessins : mais toutes ces petites différences n'empêchent pas que ce ne soit le même animal.

M. Forster m'écrit au sujet du nyl-ghau, " (que, quoique M. Hunter qui en a donné la deseription ait dit qu'il est d'un nouveau genre, il paraît cependant qu'il appartient à la classe des antilopes, et que ses mœurs et sa forme, comparés avec quelques-unes des grandes espèces d'antilopes, semblent prouver qu'on ne devrait pas l'en séparer. Il ajoute que l'animal décrit par le docteur Parsons est certainement le mème que le nyl-ghau; mais il croit que M. Parsons n'a pas bien remar(jué les pieds : car ils sont ordinairement marqués de blane dans tous ceux que l'on a vus depuis; et il dit, comme M. Hunter, que ees animaux avaient produit en Angleterre, et que même on l'a assuré qu'il y avait exemple d'une femelle qui avait fait deux petits à la fois."

\section{LE MOUFLON.}

ET LES AUTRES BREBIS.

Ordre des ruminants à cornes, genre brebis. (Cuvier.)

Les espèces les plus faibles des animaux utiles ont été réduites les premières en domesticité. L'on a soumis la brebis et la ehère, avant d'avoir dompté le cheval, le bocuf ou le chameau : on les a aussi transportées plus aisément de eliunats en climats; de la le grand nombre de val- riétés qui se trourcnt dans ces deur espèees, et la difficulté de reconnaitre quelle est la vrair souche de chacune. Il est certain, comme nous l'avons prouvé, que notre brebis domestique, telle qu'elle existe aujourd'hui ne pourrait sul)sister d'elle-même, e'est-à-dire súns le sceours de l'homme : il est done également certain que la nature ne l'a pas produite telle qu'elle est, mais que c'est entre nos mains qu'elle a dégénéré. Il faut par conséquent chercher parmi les animaux sauvages ceux dont elle approche le plus; il faut la comparer avec les brebis domesticuues des pays étrangers, exposer en mème temps les différentes causes d'altération, de changement et de dégénération, qui ont dû influer sur l'espece, et voir enfin si nous ne pourrons pas, comme dans celle du bœuf, en rappeler toutes les variétés, toutes les especes prétendues, à une race primitive.

Notre brebis, telle que nous la commaissons, ne se trouve qu'en Europe et dans quelques provinees tempérées de l'Asie. Transportée dans des pays plus chauds, comme en Guinée, elle perd sa laine et se couvre de poil ; elle y multiplie peu, et sa chail' n'a plus le mème gout. Dans les pays très-froids elle ne peut subsister: mais on trouve dans ces mêmes pays froids, et surtout en Islande, une race de brebis à plusicurs cornes, à queue courte, à laine dure et épaisse, au-dessous de laquelle, comme dans presque tous les animaux du nord, se troure une seconde fourrure d'une laine plus douce, plus fine et plus touffue : dans les pays chauds, au contraire, on ne voit ordinairement que des brebis à cornes courtes et à queue longue, dont les unes sont courertes de laine, les autres de poil, et d'autres eneore de poil mèlé de laine. La première de ces brebis des pays chauds est celle que l'on appelle communément mouton de Barbarie, mouton d'Arabic, laguelle ressemble entièrement i notre brebis domestique, à l'exception de la queue qui est si fort chargée de graisse, que souvent elle est large de plus d'un pied, et pèse plus de vingt livres. Au reste, cette brebis n'a ricn de remarquableque sa queue qu'elle porte, comme si on lui avait attaché un coussin sur les fesses. Dans eette race de brebis a grosse quene, il s'en trouve qui l'ont si longue et si pesante, qu'on leur domne une petite bronette pour la soutenir en marchaut. Dans le I.evant, cette brebis est courerte d'une trèsbelle laine; daus les pays ulus chituds, comme 
a Madagascar et aux Indes, elle est couverte de poils. La surabondance de la graisse, qui dans nos moutons se fixe sur les reins, descend dans ces brebis sur les vertebres de la queue; les autres parties du eorps en sont moins chargées que dans nos moutons gras. C'est au climat, it la nourriture et aux soins de l'homme qu'on doit rapporter cette variété; car ces brebis à litroes ou longues queues sont domestiques comme les nôtres, et même elles demandent beilucoup plus de soins et de ménagements. La race en est beaucoup plus répandue que celle de uos brebis : on la trouve communément en Tartarie, en Perse, en Syrie, en Eyypte, en Barbarie, en Ethiopie, au Mozambiqque, à Madagascar, et jusqqu'au cap de Bonne-Espérance.

On roit dans les îles de l'A rehipel, et principalement dans l'ile de Candie, une race de brebis domestiques, de laquelle Belon a donné la figure et lit description sous le nom de strepsi-cheros. Cette brebis est de la taille de nos brebis ordinaires; elle est, comme celles-ci, couverte de laine, et elle n'en differe que par les cornes, yq'elle a droites et camnelées en spirale.

Enfin, dans les contrées les plus chaudes de I'Afrique et des Indes, on trouve une race de grandes brebis à poil rude, à cornes courtes, à oreilles pendantes, avee une espèce de fanon et des pendants sous le con. Léon l'Africain et Niamol la nomment adimain, et les naturalistes la comnaissent sous les noms de bélier du Sénégal, bélier de Guincé, brebis d'Ango!a, ete. Elle est clomestique comme les autres et sujette de même à des variétés. C'est de toutes les brebis domestiques, celle qui parait approcher le plus de l'etat de nature; elle est plus grande, plus forte, plus légrere, et par conséquent plus capable qu'aneune autre de subsister par elle-mème. Mais comme on ne la troure que dius les pays les plus chauds, qu'elle ne peut souffrir le froid, et que dians son propre climat elle n'existe pas par efle-mème, comme animal sauvage, qu'au contraire clle ne subsiste que par le soin de l'homme, qu'elle n'est quimimal domestique, on ne peut pas la regarder comme la souche premicre ou la race primitive de laquelle toutes les autres auraient tire leur origine.

En considerunt done, dans l'ordre du elimat, les brebis qui sont purement domestiyues, nous avons, $1^{\circ}$ la brebis du Nord il plusieurs cornes, dont lit liine est rude et fort grossiere. lats bre- bis d'Islande, de Gothlande, de Moseovie, et plusieurs autres endroits du nord de l'Europe, ont toutes la laine grosse, et paraissent ètre de cette méme race.

$2^{0}$ Notre brebis, dont la laine est très-belle et fort fine dans les clinats doux de l'Espagne ct' de la Perse, mais qui dans les pays tres-chauls se change en un poil assez rude. Nous avons déji observé cette conformité de l'inlluenee des climats de l'lispagne et du Chorasan, province de Perse, sur le poil des chèvres, des chats, des lapins, et elle agit de nème sur la laine de's brebis, qui est tres-belle en Espagne, et plus belle encore dans cette partie de la Perse '.

$3^{\circ}$ La brebis à grosse queue, dont la laine est aussi fort belle dans les pays tempérés, tels que la Perse, la Syrie, I'linypte; mais qui daus des elimats plus chauds se change en poil plus ou moins rude.

$4^{\circ}$ La brebis strepsicheros ou moulon de Crete, qui porte de la laine comne les nôtres et leur ressemble, à l'exe'ption des corne's, qui sont droites et cannelées en vis.

$5^{\circ}$ L'adimain ou la grande brebis du Sénégral et des Indes, qui mule part n'est courerte de laine, et porte au contraire un poil plus ou moins court et plus ou moins rude, suivant la chaleur du climat. Toutes ces brebis ne sont que des va-

I On faisait antrefols à IIeschel, au pays de Clrorasın fron liere de l'erse), un grand cumnerce d" ces belles ficivix l'a-

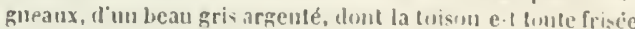
et plus délié que la suic. parce que celles que les monta-un's

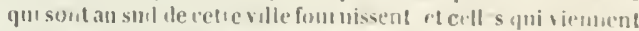

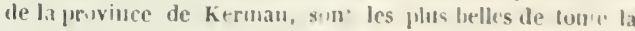

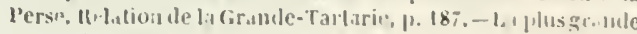
partie de ers linines, si bulles et si lines, s-trunsent lans i.l

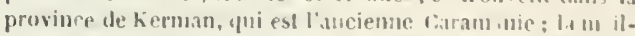
lenre se prend dani les m.utagmes vuisimes de la ville qui

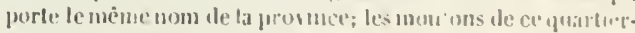

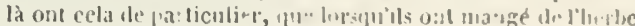

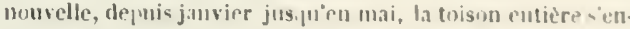

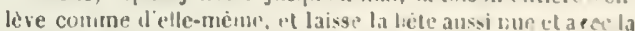

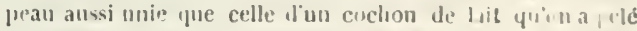

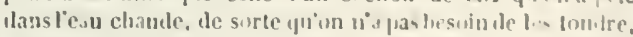
cumme on fat en France : ayant ainsi leve la laine de lenrs montons, ils l, battent, et li srus s'en all.mt, il ne demente

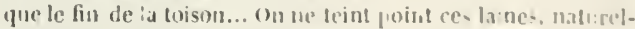

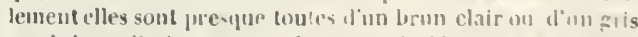
cendré, et il sén trouve fort jen de bluches. I oystride Taveruier, fome 1, page 150. - I.es numbus der Tarlates

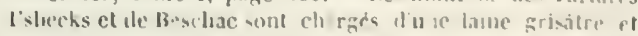

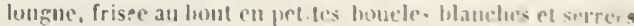

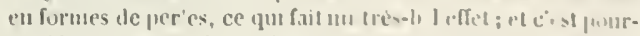

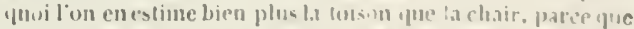

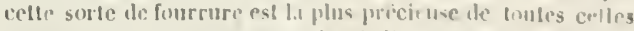

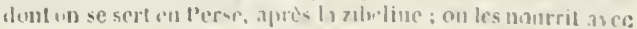

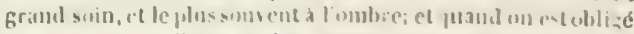
de les mener a linr, un les cure comme les cheraux, ces

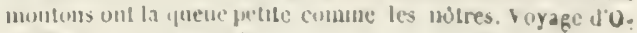
lians, lume 1 , page 5 ti. 
riétés d'une seulc ct mème espèce, et jroduiraient certainement toutes les unes avec les autres, puisque le bouc, Jont l'espèce est bien plus éloignée, produit ave: nos brebis, comne nous nous en sommes asstu és par l'exprérience. Mais quoique ees cing ou six races de brebis domestiques soient toutes des rariétés de la mème espèce, entièrement dlépendantes de la rliffésence du climat, du traitcment et de la nourriture , aucume de ces races ne parait être la souche primitive et commune de toutes; aucune n'est asscz forte, assez légrere, assez vive pour résister aux animaux carnassiers, pour les éviter, pour les fuir : toutes ont également besoin d'abri, de soin, de protection; toutes doivent donc ètre rogardćes comme des races dégénérées, formées des mains de l'homme, et par luj propagées pour son utilité. En mème temps qu'il aura nourri, cultivé, multiplić ces races domestiques, il aüa négligé, chassé, détruit la race sauvage, plus forte, moins traitable, et par conséquent plus incommode ct moins utile : elle ne se trouvera done plus qu'en petit nombre dams quelques endroits moins habités, ou clle aura pu se maintenir. Or, on trouve dans les montagnes de Grece, dans les jles de Chypre, de Sardaignc, de Corse, et dans les déserts de la Tajtarie, l'animal que nous avons nommé mouflon, et qui nous paraît être la souche primitive de toutes les brebis. Il existe dans l'état de nature, il subsiste et se multiplie sans le secours de l'homme, il ressemble plus qu'aueun autre aninal sauvagè à toutes les brebis domesticues ; il est plus vif, plus for' et plus léger qu'aucune d'cntre elles; il a la tète, le front, les yeux et toutc la face du bélier; il lui ressemble aussi par la forme des cornes et par l'habitude cuticre du corps ; enfin, il produit avec la brehis clomestique, ce qui seul suffirait pour démontrer qu'il est de la mène espèce et qu'il en est la souche. Ia seule disconvenance qu'il y ait entre le mouflon et nos brebis, e'est qu'il est couvert de poil et non de laine; mais nous avous vu que, même dans les brebis domestiques, la laine n'est pas un caractère essentiel; que c'est unc production du climat tempéré,puiscue dans les pays chauds ces mèmes brebis nont point de laine et sont toutes couvertes de poil, et que dans les pays tries-froids leur laine est encore aussi rude que du poil. Jès lors, il n'est pas étonnant que la brebis originaire, la brebis prinitive et sauvage, yui a dù souffir le froid et le chaud, vi- vre et se multiplier sans abri dans les bois, ne soit pas courerte d'une laine qu clle aurait bientót perdue dans les broussailles, d'une laine que l'exposition continuelle à l'air et à l'intempérie des saisons ammait en peu de temps altérée et changéc de nature. I'ailleurs, lorsqu'on fait accoupler le bouc arec la brebis domestique, le produit est uue espèce de mouflon; car c'est un agreau couvert de poil. Ce nest point un mulet infécond, c'est un métis qui remonte à l'espèce originaire, et qui paraît indiquer que nos chevres et nos brebis domestiques ont quelque chose de commun daus leus origine; et comme nous a vons recommu par l'expéricnce, que le bouc produit aisément avec la brebjs, mais que le bélier ne produit point avec la chevre, il n'est pas douteix que dans ces animaux, toujours considérés dans leur état de dégénération et de domesticité, la chèvre ne soit l'espèce dominante et la brebis l'espèce subordonnée, puisque le boue asit arec puissance sur la lrebis, et que le bélier est impuissant à produire avec la cherre. Ainsi notre brebis domestlque est une espèce bien plus dégénélée que celle de la chéve, et il y a tout lieu de croire que si l'on domait à la chève le mouflon, au lieu du bélier domestique, elle produirait des chevreaux qui remontelaient à l'espèce de la chèrre, comme les agncaux produits par le bouc et la brebis remontent à l'espece du bélicr.

Je seus que les naturalistes qui ont établi leurs méthodes, et jose dire, fondé toutes leurs comnaissances en histoire naturelle, sur la distinction de ruelques caractères particuliers, pourront faire ici ales objections, et je vais tàcher d'y r'époudre d'avance. Le premier caractere des moutons, dirout-ils, est de porter de la laine, et le premicr caractere des bélicrs est d'avoir Ies colnes courbées en cercle et tournóes en arriere, celui des boues est de les a voir plus droites et tommées en haut. Ce sont là, dirontils, les marques distinctives et les signes infial. liblesauxquels on recomnaitra toujoursles brebis et les chères; car, ilsne pourrout se dispenser d'avouer en mème tenips que tout le reste leur est commun : les unes et les autres nont point de dents incisives à la mâchoire supéricure, et en ont huit à l’inférieure; les unes et les autres n'ont point de dents canines : ces deux espexes ont également le pied fourchu; elles ont les colnes sims!es et permanentes; toutes deux ont les mamelles daus la mème région du veutre, 
toutes deux vivent d'herbes, etruminent. Leur organisation intérieure est encore bien plus semblable, ear elle parait etre alsolument la mème dans ees deux animanx; le même nombre et la mème forme pour les estomacs, lá mème disposition de viscères et d'intestins, la même sul)stance dans la clsair, la même rualité particulière dans la graisse et dans la liqueur séminale, le même temps pour la gestation, le mème temps encore pour l'aceroissement et pour la duréc de la vie. II ne reste doneque la laine et les cornes, parlesquelles on puisse di fférencier ces espieces. Mais, commenousl'avons déjà fait sentir, la laine est moins une substance de la nature, I[u'une production du climat aidé des soins de l'homme, et cela est démontré par le fait. la brełbis des pays chauds, la brebis des pays froids, la lnebis sauvage n'ont point de laine, mais du poil ; d'autre côté, les chèvres dauns dés climats trés-doux ont plutót de la laine que du poil, ear celui do la chère d'Augora est plus beau et plus fin que la laine de nos moutons. Ce earactère n'est done pas essentiel; il est purement accidentel et mème équivoque, puisqu'il peut également appartenir ou manquer à ces deux espèces, suivant les différents climats. Celui des connes parait être encore moins certain; elles rarient pour le nombre, pour la grandeur, pour la forme et pour la direction. Dans nos brebis domestiques, les bédier's ont ordinairement des cornes, et les brehis n'en out point. Cependant j'ai sourent u daus nos troupeaux des béliers sans cornes; et des brebis avee des cornes; j'ai non-seulement vu des brebis aree deux cornes, mais meme avee yuatre. Les brebis du Nord et d'Islande en ont quelyuefois jusqu'il huit. Daus les pays chauds, les béliers n'en ont que deux très-courtes, et souvent ils eu manquent, ainsi que les brebis. Daus les uns, les cornes sout lisse's et rondes; dins les autres, elles sont eiunclées et aplaties : la pointe, au lieu d'ètre tournéc en arriere, estruclquefois tournée en dehors ou en devant, cte. Ce earaetere n'est done pas plus constant que le premier, et par conséquent, is ne suffit pais pour établir des espèces dilférentes' la grosseur et la lon-

1 M. Linntus a fiil, avec misnn, six variétés ef mon pas six especes dans lit brebis demuestipue : 10 oris rustica con mula; $2^{\circ}$ anylica mutica, canda serotoque ad genun penululis; 5o hispanica cormula, sprira extrorsum lracla; 10 polt, ce-

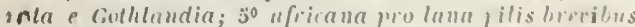
hivtn; $6^{\circ}$ laticanda ylalynta alabien. limu. Syst. Nill.

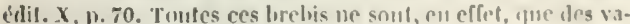
·étés, auxizuelles cet auteur aurail diu jointre l'ulimain ou gueur de la queue ne suffisent pas non plus pour constituer des espéces, puisque cette ga ue est your ainsi dire un membre artificiel qu'on fait grossir plus ou moins par lansiduté des soins et l'abondance de la bonne nourriture, et que d'aillenrs nous ruyons dans nos brebis domestiques des races, telles (que certaines brebis anglaises, qui ont la queue tres-longue en comparaison des brebis ordinaires. Cependaut les naturalistes modernes, unicuementappuyés sur ees diflérences des cormes, de la laine et de la grosseur de la queue, out ćtabli sept ou huit espéces différentes dims le genre des brebis. Nous Ies avons toutes réduites a une; du genre cntier nous ne faisons qu'une espeec; e't cette réduction nous parait si bicn fondée, que nous ne craigrous pas qu'clle soit démentie par (les observations ultéricures. Autant il nous a paru néeessaire, en composant l'histoire des animax sauvarges, ale les considiner en eux-memes un i un et indépendamment d'aucun genre, autant croyons-nous, au contraire, quil laut adopter, étendre les genres dans les animaux domestiques; et cela, parce que dans la nature il n'existe que des individus et des suites d'individus, c'estit-dire des espices; que nous n'avons pas influé sur eelles des animaux indépendints, et qu'au contraire nous avons altéré, modifié, ehangé celles des animaux domestiques. Nous avons done fait des genres plyysiques et réels, bien différents de ces genres métaphysiquues et arbitraires, qui n’out jamais existé qu’en idée. Ces gemres physiques sont réellement composés de toutes les especes que nous avons manices, modifices et chanuées; ct comme toutes ees espéces différemment altérées par la main de l'homme nont eependant quiure origrine commulic et unique dans la nature, le grenre entic ne doit former qu'une espiece. Lin écrivant, par exemple, l'histoire des tigres, nous avous admis autant d'espèces diflérentes de tigres qu'il s'en

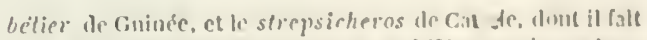
denx esfieces differenlis cutre elles et diffirentrs de nos bre-

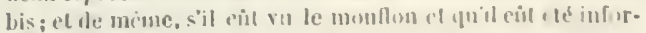

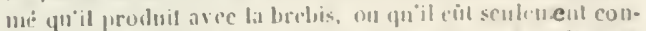
sulté le passaze de Pline an sujet du unusimun, Il ne l'aura t bas nis latm: le genre des che'v res. mais dans celui des brebs.

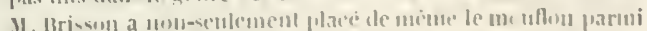

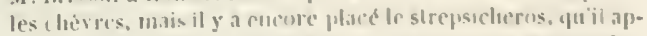

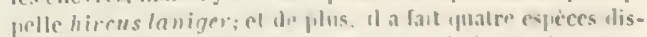

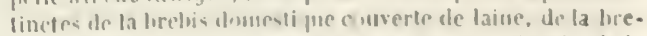

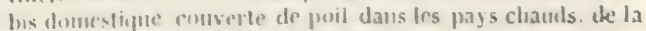

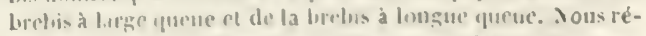
dulsuls, rommu liun sut, quaire esplees, sel 11 M. limnasus, et sepl especes, stur ant .I Hrissun, à une scule. 
trouve en effet dans toutes les parties de la terre, parce que nous sommes très-ertains que I homme n'a jamais manić, ni changé les espèces deces animaux intraitables (gui subsistent toutes telles que la nature les a produites. Il en est de même de tous les autres animanx libres et indépendants. Mais en faisant l'histoire des boufs ou des moutons, nous avons réduit tous les boufs à un seul boeuf, et tous les moutons à un seul mouton, parce qu'il est également certain que c'est l'homme, et non pas la nature, qui a produit les differentes races dont nous avous faitl'énumération. Tout concourt à appuyer cette idce, qui, quoique lumineuse par elle-mème, ne sera peut-ètre pas assez sentie. Tous les bœufs produisent ensemble; Jes expériences de M. de la Nux et les témoignages de MM. Méntzelius ct halm nous en ont assuré. Toutes les brebis produisent entre elles, avec le mouflon et même avec le bouc : mes propres expériences me l'ont appris. Tous les boufs ne font done qu'une espèce, et toutes les brebis n'en font qu'me autre, quelque étendiu qu'en soit le genre.

Je ne me lasserai jamais de répéter (vu l'ìm. portance de la chose) que ce n'est pas par de petits caractères particuliers que l'on peut juger la nature, et qu'on doit en différencier les espèces; que les méthodes, loin d'aroir éclairci l'histoire des animaux, n'ont au contraire servi qu'à l'obseurcir, en multipliant les dénominations, et les espèces autant rue les dénominations, sans aucune nécessité, en faisant des genres arbitraires que la nature ne connait pas, en confondant perpétuellement les ètres réels avec des ètres de raison; en ne nous domnant que de fausses idées de l'essence des espèces, en les milant ou les séparant sans fondement, sans connaissance, souvent sans avoir observé ni mème val les individus; et que e'est par cette raisoi qque nos nomenclateurs se trompent à tout moment et écrivent presque autant d'erreurs que de lignes: nous én arons cléji domné un si grand nombre d'exemples, qu'il faudrait une preveutios bien aveugle pour pouvoir en đjuter. Ni. Gmelin parle tres-sensćment sur ce sujet, et à l'occasion mème de l'animal dont il est ici question ${ }^{4}$.

4 a Les arguli on siepuie-barani, qui occupent, lit-il, les - munbigues de la stbérie mérodionale, dejuis le flenve Ir- tisch jusyu'an liamtschatka, somt des inimaux extremenent a vifs, el conte vivacilé semble les cachure de la classc des * uonlous, r les ranger plutot daus la classe des cerf's. J'en - joiudrai icl une courte description qui fora voir tyue ni la vi-
Nous sommes convaincus, comme le dit M. Gmelin, qu'on ne peut aequérir des connaissances de la nature, qu'en faisant un usage réfléchi de ses sens, en voyant, en observant, en

* vacité, vi la lenteur, ni la laiue, ni le poil dont l'animal est a couvert, ni les cornes courbes, ni les droites, ni les cornes a permanent's, ni celles ifue l'animal jette tous les ans, ne " sont des uarques suflisamment caractéristiques, par les " quellés la nature ảistingue ses classes; elle aime la variété, * et je suis persuadẻ unue si nous savluns inieux gouverner nos a scus, ils nou; condniraient souvent à des marques beaucoup " plus esscutielles, tuncliant la dilférence des animaux, que a ne nous les apprennent c.mmunément Jes lumières de notre " raison, qui presque tonjours ue tonclie ces marques dis. a tiuctives plue très-superficiellement. La forme extérieure de " l'aniual, ynant à la téte, at cous, aux pattes et à la qucue " courte, sace orde avec eclle du cr rf, à qui cel animal res-cma ble aussi, comme je l'ai dójà dit, par sa vivacité, si bien yqu'uu a dirait volontiers qu'il est encore plus sauvage. L'animal que a j'ai vu élait répnté d'avoir trois ans, cl cependant dix hommes " noscrent l'altajuer pour le dompter. Le plus gros de celle " espèce approche de la taille d'un daim; celui ıue j’ai vu " avait, de la terre jusquian haut de la tête, une aune et demic " de Rusie de lraul; sil longueur, dejuis l'eudroil d'vu nais. " sent les cornes, étail d'une aune trois quarts. Les cornes nais. " sent au-dessus et tuut près des ycux, droil devant les oreil* les, el les se courbent d'abord en arrière et ensuite en avanf, a coume un cercle; l'extrémité est tournéc un pru en hant " et en dehors; depuis leur nissance jusiju”a jen jres de la a mortié elles sout fort ridées; plu: haut elles sont plus unies, " sans cependaiil l'c̀tre toul à fail. C'est vraiscmblablement cie " cette forme des cornes ųue les Russes ont pris occasion de " domner à cel inimal le nom de mouton saurage. Sil'on " pent s'en rapporter aux récits des liabitants de ces cantuns, " Loute sa furce cuusiste dans ses corues. On dil yue les béliers " de colte espèce se batteut sonvent cn se pousant les uns les " autres avce les curnes, ct se les abaltent quelıjuefois, eusurie " qu'on trouve souvent sur Ja steppe de ces cornes, dout l'un* verlure : ipurés de la lète est as vez graude pour que les fuetits " renards de steppes sc servent souvent de ces casites pour a s'y retirer. Il est aisé de calculer fa force qu il faut pour abata tre une parcille corne, puistule ces cornes. Lant que l'ania mal est virant, anginentent continuellement d'épaisseur et " de longucur, et que l'endroit de lemr nassance an crâne ac" quiert tonjours une plus grande duretis. On prèt "nd qui unc " come bien venuc, en prenant la mesure sclon sa courbuse, " a jusquı denx aumes de long, qu'cile pèse cntre trente et " quaruate Jivres de Russie, et yu à sa maissa:ce elle est de "l'épaisseur du poing. Les cornes dé celui que jai vu élaieut " d'un jaune blauchátre; mais plus l'animal vieillit, plus ses a cornes tirent vers le brun et le nuirätre. 11 porte ses oreilles " extrèmement droites; clles sont pointues et passablement - larges. Les pieds ont des sabots fendus, et les pattes de de. " vant ont trois yuarts d'aunc de liaul; celles je derrière en - ont davantagc ; fuand l'animal.se licnt debout dans la plaine, - ses patles de devaut cont tronjours élendues et druites, celles - de derrièresont courbécs, ct cette courbure scmble dimi* uner, pins les endroils par oi l"animal passe sont escarpés. "Le enu a quelíues plis peuduts; la coulenr de tont le corpis * est grisâtre mélée de brun; le long du dos, il y a une raie jan. " uàtıe ou phintót rousciltre, ou couleur de rinard, ct l'ou coit " celle mene couleur au derricru, endedans d s palles ct au * venire, oì elle est un pen plus pâle. Celte conlem dure de- puis le commencenent d'xuit, pendant l'automne efl'hi-

- ver jusyu an printem is, a l'apjureche dujuel ces auinaux

" muent. el devienuen? pantont plus runssitres. La demiéne

* mose arrwe scrs la fiu de juillel, lelle? est la fignte des lić-

a jiers. Les chierres ou lemelles sont toujours plus petites; et * quoi ju clles aient parrildenent des comes, ces comes sont * très-petites et minces en cumparaison de celles que je viem 
comparant, ot en se refusant en mème temps la liberté téméraire de faire des méthodes, des petits systèmes nouveaux, daus lesquels on classe des êtres (que l'on u'a jamais vus, et dont on ne connaît que le nom : nom sonvent équivơque, obseur, mal appliqué et dont le faux emploi confond les idées daus le vague des mots, et noie la vérité daus le courant de l'erreur. Nous sommes aussi très-convaincus, après avoir vu des mouflons vivants, et après les avoir comparés à la description ci-dessus de M. Gmelin, que l'argali est le mème animal. Nous a vous dit qu'on le trouve en Europe, dans les pays assez chauds, tels quela Grèce, lesîles de Chypre, de Sardaigne et de Corse : néanmoins il se trouve aussi, et même en plus grand nombre, daus toutes les montagnes de la partie méridionale de la Sibérie, sous un elimat plutôt froid que tempéré; il paraît même y être plus grand, plus fort et plus vigoureux. Il a done pu peupler également le nord et le midi, et sa postérité, devenue domesticjue, apres avoil long-temps subi les max de eet état, aura dégéuéré, et pris, suivant les différents traitements et les climats divers, des caractères relatifs, de nouvelles habitudes de corplos, gui s'étant ensuite perpétuées par les gé-

- de décrile, et même ne grossissent guère avec l'age. Elles a sont tonjours a pron pres droites, nout presyue puriul de

- rides, el onl a pen près la forme de celles de nos bues "privés.

- Ies parties intérieures, dans ces animanx, sont confor- mírs comme daus les autres hêles yui munitunt : leslomac - est composé de yualre cuvilis frarticulières, 1 la ves vie du - fiel cst tres-considirable. I.eur chair esl bosma à manger,

* el a, a peu joès, le gont rle chevrenil ; la graisse surlunt a

a un gont télicieux, comme je l'a déjî remaryué ci-dessus,

- sur le lémoignage des nalious (ln Kanulschalka; la nourri-

- ture de l'animal est de l'herlus. Ils sacconjulent en au-

* tomme, et an printemps ils font nu on denx pelits.

- Par le peoil, le goill de la cluair, la ferme el la vivacilé, l’a- nimal appartient a la clase des cerós el des birdes; les cor-

- nos permanentes, yui ue tombent pas, lexchuent de colle

- classe; les cornes coubees en cercle lni donnent quelane

- ressemblance arec les montuns; le defant de laine di la vi-

- vacité l'en rlistiugnuent absolument; le proil, le sijome sur des

- rochers el hanlenrs, el lis frejuenls combals apjuro. lient

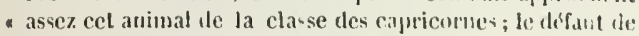

- harlie et les corues coubes leur reliuenil cello clisse. Ne

" pourrait on pas plutio regarder cel animal comme furmant

- une classe particulière, et le reconnailre frusr fo musiumu

- Jes auciens? En ef"u, il ressemble singulièrentent à la drs-

- cripliou yu col donne Pline, cl encore micux le savant liess-

- ner. "Ce plassage est tiré de la versiour russe, impriméc a Piterbbum en 1753, cu deux vol. ill-4", de la relation diun voyage far terre an Katulechatka, mar MM. Muller, de 1.a Crosicre +1 Guclin, antenr de lourtige doul l'original cet cu allemand; la traduction francaise ura clé commun qux́s. par M. de l'isle, de l'Acaténic lles sicionces. II col à lésirer quil la dome biontoil au public; cette relalion, curtens: par elle-mème, est en mème temps écrile par ı:u lıonune sic bon sens, et très-versé daus l'Histore maturclle. nérations, ont formé notre brebis domeslique et toutes les autres races de brebis nont nous arons parlé.

\section{ADDITION}

A L'ARTICIE DE LA bREBIS, ET A CEILI DU MOUFLON IET DES BREBIS ǴTRATGĖHE.

Je dome ici la figure de notre brebis commune, parec qu'elle u'a pas été bien renclue dalis le volume de notre ouvage gui renfurme l'histoile eles moutons.

Le dessin a'un bélier et d'une lorebis m'a bié envoyé par feu .I. Collinson, de la Socićté royale de Loudres, sous les noms de Traluchimn, ain t Íalachian eve, e'est-il-dire bélier et brebis de Valachie. Comme ect habile naturaliste est dócédé peu de temps aprés, je n’ai pu saroir si eette race de brebis, dont les cornes sont d'une forme assez différente de celle des autres, est commune en Valachic, ou si ce ne sont que denx individus qui se sont trouvés par hasard différer de l'espèce commune dos béliers et des brebis de ce même pays.

On montrait un bélice à la foire Saint-Germain, en 1774, sous le nom de bélierdu cap de Bonne-Espérance. Ce mème bélier avilit été présenté au publie l’année prééulente sous le nom de bélier du boyol à grosse queue; mais nous avons su qu'il aváit été acheté à Tunis, ('t nous avons jugé que cétait en effet un bolier de Barbarie, qui ne differe de celui dont nous donnons la figure (que par la (queue qui est heaucotip) plus courte, et en mème temps plus plate t t plus large à la partic superieure. La tìte est aussi proportionneflement plus grosse, et tient de eclie du bélier Ales Iudes; le corps est bie'n eonvert de laine, et lis jambes sont courtes, meme en comparaison de nos moutons ; Ies cornes sont alissi de forme et de grandeur un peu diflerentes cle eelles du mouton de Barlonrie. Nous l'avons nommé bélier de Tunis, pour le distinguer de l'autre, mais nous sommis persuarles que tous deux sont du mcine pays de la barbarie el de races très-roisines'.

- Le brilier de Tunis nufere de cenx de not re pays, uon sen lement par sil grosie el latge guteme, mais encore par ses pro portions; il eat phos has de jambers, et s.s lote parail forle et

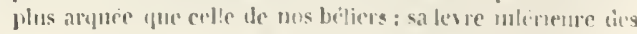
cend e'n pointe au bunt de la untchoire, ef fail le bec-ede-lievre. 
Enfin, l'on montrait de même un bélier à la foire Saint-Germain, en 1774 , sous le nom de Morvant de la Chine. Ce hélicr est singulier en ce qu'il porte sur le cou une espèce de crinière, ct qu il a sur le poitrail et sous le cou de trèsgrands poils qui pendent et forment une espèce de longue cravate, mélée de poils roux et de poils gris, longs d'environ dix ponces et rudes au toucher. Il porte sur le cou une criniere de poils droits, assez peu épaisse, mais qui s'étend jusque sur le milieu du dos. Ces poils sont de la mème couleur et consistance rue ceux de la cravate; seulement ils soint plus courts et mèlés de poils brums et noirs. La laine dont le eorps est eonvert est un peu frisée et douce au toucher à son extrémité, mais elle est droite et rude dans la partie qui avoisine la peau de l'animal : en général elle est longue d'environ trois ponces et d'un jaune clair. Les jambes sont d'uı roux foncé; la tête est tachetće de teintesplus ou moins fauves; la queue est fauve et blanche en plus grande partic, et pour la forme elle ressemble assez à la queue d'une vache, étant bien fournie de poils vers l'extrémité. Ce bélier est plus bas dejambesque les autres béliers auxquels on pourrait le comparer ; e'est à celni des Indes qu'il ressemble plus qu'ì aueun autre. Son ventre est fort gros et n'est élevé de terre que de quatorze ponces neuf lignes. $M$. de Sève, qui a pris les mesures et domé la description de cet animal, ajoute que la grosseur de son ventre le faisait prendre pour une brebis pleine. Les cornes

Ses cornes, qui font la volute, vont en arrière; elles ont six ponces mesmrées en ligne drotte, et dix pouces mue ligne de cireonvolution, sur denx pouces deux lignes de grosseur à l'origine; elles sont bl unches et annel es de rides comme dans les anlres béliers. Lis eornes qui passent par-des:us les oreil. les les reudent pendantes: flles sont larges et finissent en poinle. Cet animal domestique est fort lainenx, surtont sur le ventre, les cuisses, le cou, ct la unetie. Sa linue a plus de six ponces de loug en bien des endroits; clle ent blanche en géneral, à l'excepıtion pu'il y a du fauve foncé sur les oreilles, et que la phus gramle prartie de la tèle et les picds sont anssi ti un fauve foncé lirant sur le brun. Ce que ce belier a de sinsulier, cest la puene gui lui convre tout If derrière; elle a onze pronces de large sur treize poners nenf lignes le long; son épais. seur est de trois pouces onze lignes; cetie partie chatune est roule et finit en pointo (jar une petite vertelne ıni a inatce pouces trois lignes de longutur) en passant sous le ventre, entre les jambes on tombant tont droit. Pour lors le floe de laine du luut de la quene semble tuncher à terro : cette unfue est comme méflate dessus comme dessous, seufouce dans le milien, el y forme comm une faible gonltière; le d'ssus de cette yufue et la plus grante partie tle sou f́paissent sont convertes de grande laine blanche, mais le de"nstus de celle mène queue est sans poil ef d'une chair fraiche; de sorte que quaml on leve celte quicue, on croirait roil unc partie des fesses d'un enfant. sont à peu prìs comme eclles de nos béliers, mais les sabots des pieds ne sont point élevés et sont plus longs que ceux du bélier des Indes.

Nous avons dit, et nous le répétens ici, que le mouflon est la tige unique et primordiale de toutes les autres brebis, et qu'il est d'une nature assez robuste pour subsister dans les climals froids, tempérés et chauds; son poil est seulement plus ou moins épais, plus ou moins long, suivant les différents climats. Les béliers sauvages du Kantschatka, dit MI. Steller, ont l'allure de la chèrre et le poil du renne. Leurs cornes sont si grandes et si grosses, qu'il y en a quelqunes-unes qui pèsent jusqu’à vingt-eing à trente livres. On en fait des vases, des cuillers ct d'autres ustensiles. Ils sont aussi vifs et aussi légers que les chevreuils; ils habitent les montagnes les plus escarpées au milicu des précipices. Leur chair est délicate ainsi que la graisse qu'ils ont sur le dos; mais c'est pour a voir leurs fourrures qu'on se donne la peine de les chas ser.

Je crois qu'il reste actuellement très-peu ou plutót qu'il ne reste point 'du tout de vrais monflons dans l'ilc de Corse. Les gramels mouvements de guerre qui se sont passés lans cette île auront probablement amené leur destruction : mais on y troure encore des indices de leur ancienne existence, par la forme même des races de brebis qui y subsistent actuellement. Il y avait, au mois d'aouit 1774 , un bélier de Cor'se, appartenant à M. le duc de la Vrillière. Il n'était pas grand, mème en comparaison d'une belle brebis de France qu'on lui avait domnée pour compagne. Ce bélier était tout blanc, petit et bas de jambes, la laine lougue et par flocons. 11 portait quatre cornes larges et fort longues, dont les deux supéricures étaient les plus considérables, et ces cornes a vaient des rides comme celles du mouflon.

Daus les pays du nord de l'Europe, comme en Danemark et en Norwége, les brebis ne sont pas belles, et, pour en améliorer l'espiec, on fait de temps en temps venir des bélier's d'Angteterre. Dans les iles fui avoisinent la Norwége, on laisse les béliers en pleine campagne pendant toute l'aunée. Ils deviennent plus grands et plus gros, et ont la laine meilleure et plus belle que ceux qui sont soignés par les hommes. On prétend que ees bélicrs qui sont en pleine liberté passent toujours la nuit au cóté de l'ile d’où le vent doit venir le lendemain; ce qui sert d'a- 
rertissement aux mariniers, qui ont grand soin d'en faire l'observation.

En Islande, les béliers, Ies brehis et les moutons different principalement des nòtres, en ce qu'ils ont presque tons les cornes plus grandes et plus grosses. Il s'en trouve plusieurs (qui ont trois cornes, et quelques-uns qui en ont quatre, cinc et mème davantage. Cependant il ne faut pas eroire que cette particularité soit commune à toute la race des béliers d'Islande, et que tous y aient plus de deux cornes; car dans un troupeau de quatre ou cind cents moutons, on en trouve à peine trois ou quatre qui aient quatre ou cinq cornes. On envoie ceux-ci it Copenhague comme une rareté, et on les achète en Islande bien plus eher que les autres : ce qqui seul suffit pour prouver quỉils y sont trèsrares.

\section{DESCRIPTION DU MOUFLON.}

(ExTRait DE DAUbexto.i.)

Quoirgue le moutlon soit couvert de poil et non pas de laine, il a plus de rapport au lićlier (ju à aucun autre animal : car son chanfrein est arqué, et son front est moins élevé çue celui du bouc; il a un enfoncement an-devant de l'antle antéricur de l'wil; il a aussi, comme le hélier, les yeux placés plus près des cornes, et les oreilles moins longues que le bouc; les cornes ressemblent parfailement à celles llu bélier, car elles sont de couleur jauıłâtre et elles ont trois faces, elles forment un arc de cercle qui s’ètend par-dessus les oreilles, et elles sont dirigees obliquement en arrière et en deliors.

Le bout du museau et la face intérieure des oreilles du mouflon qui a servi de sujet pour cette description avaient une couleur hlanclie legèrement teinte de jaune ; la partie postorieure du clanfrem, le front, les cotés de la tète, la face extérieure des oreilles, la partie postérieure de la mî̀choire du dessous, et la gorge étaient de conleur mêlée de blanc, de gris et de brun cendré ; le blanc dominait antour des yeux et sur la gorge; les cotes du cou, l'espace qui est entre l'epaule et le coude, les flancs, la croupe, la quene, et la face extérieure de la cuisse el de la jambe avient une couleur fauve roussiture approchante de celle dı cerf ; le derrière de la tite, lipaule, le bris, l'asant-briss presine en entier, les coites de la poitrine et la fice interieure de la jambe ćtaient de couleur lurune ; cetle conleur formait une bande le long de lia fartie inferieure des flancs et sur le devant de la cuisse et d'une partie de la jambe; il y avait une autre bande noire yui s'étem\}ait le long de la face supérieuredu cou sur le garrot et le long du dos juspuau milieu; celte bande élait termince far une large laclie de la mème couleur; il y avait aussi anx cotés de la couleur blanclie de la gorge deux baniles noires qui se réunissaient au-dlessous de ce blanc ; la partie inférieure du cou et la partie antérieure de la poitrine étaient de conleur noire; le dessous de la partie postérieure de la poitrine, les aisselles, le conde, le crité posićrieur de l'avant-luas, le canon et tout le reste de la jimbe de levant, le ventre, le scrutum, le périnc, les aines, la face intérieure de la cuisse, le canon et le reste des jambes de derrière ctaient de couldur blanche mèlée d'une teinte de jaune et mème cle fauve julus ou moins apprarcnte dans différents endroils; i] y avail anssi un peu de gris et mème de blanc le claque côté de l'auus, à peu près comme sur le cerf.

Ce moution arait le poil dur el court, mais il était mort dans la mue à la lin de novembre; le plus lour poil avait jusłüì ‘juatre pouces el se trouvait au-devant de la poilrine; celni des autres parties du corps n'avait qu'environ un ponce ct demi de longueur. Ce moutlon pesait cinyuanteune livres et demie.

\section{DESCRIPTION}

\section{D'UN BÉLIER D'ISLANDE.}

(EXTRAIT DE DAEDENTON.)

I.e bélier d'Islantle ressemble à nos béliers pal la forme du corps el de la tète; il u'en diffère que par le nombre des cornes, prar la longnemr de la queue et par la qualite de sa laine. Le bilier dislande qui a servi de sujet pur cette lescription avait trois lomgues cornes placées, une de chatue côté du front et la troisième entre les deu: alutres; les deux corues latirales ctatient recourlues en lian et en dediuns, à peu prés comme celles de nos beiliers; la corne gauche se prolongeait en avaut et approchait de la bonche par son extremite, an point de nuire à l'anumal : aussi l'axait-on coupre par le hout; la corne du milieu étail dirigre en haut au sortir du front, sur la lon:surur de deux pouces, et plus loin elle se courhait à gauche jus(yu’à son extrémité : mais elle avait beancuup) muins de courluxe que les fornes laterales. Ces I rojis cornes noulaient pas plaries rigulièrtueut sur le front la corne druite paraissait ère daus le mame cubroit ou est la corme drobite des lediers qui u'en out que deux ; la rorne elu milieu et la corme zauche du bé. lier d'Islaule semblaieut sure à la place de la corne gauche des autres biliers, mais elles antıcıpaient 
aul delì de cette place sur le milieu du front et sur la tempe ganclıe; la corne du milien était la plus grande et toucliait par sa base aux deux cornes laliralrs; la come gauche élaiı plus petite que la droite.

La brehis d'Islande n'avait que deux cornes; celle dı côtẻ droit était dirigrée en arrière et recourbée en bas; la gauche était dirigée en dehors et trèsrecourhée en bas: la queue du mâle et de la femelle était très-courte.

La laiue du bèlier d'Islande différait beaucoup de celle de nos beliers, elle était grosse, longue, lisse, dure; elle avait jusqu’à huit pouces de longueur sur toutes les parties du corps, à l'exception de la tète, de la queue, du bas des jambes, etc.; sa couleur était brune roussâtre presque sur tout le corps ; la laine du dessous du cou et du devant de la poitrine éta.t noire ou noiràtre; parmi cette longue laine, il y en avait une autre plus fine, moins lisse, plus douce, plus courte, plus ressemblante à celle de nos mutons et de conleur cendrée; la laine de la tète ètait fort courte, elle avait une couleur faure très-pàle arec quelpues teintes de brun; le bout dı museau érait blanchâtre; la quene ėtait nuire ; le has des jambes avait un poil court, comme celui des jambes de nos beliers; il était mèlè de brum et de noiràtre, et il y avait du gris sur l genou et sur les quatre pieds. Ce bélier pesait tuatre-vingt-six livres et demie.

\section{DESCRIPTION}

\section{D'UN BÉLIER DES INDES.}

Le bẻlier des Indes a, comme notre hélier, le chaufrein arque, un enfoncement au-clevaut de l'angle antérieur de l'oxil, le front moins tlevé que celui du bouc, et les yeux placés plus près des cornes : mais la tète est fort allongée et aplatie sur les còtes du museau, qui a beaucoup de hauteur lurscyuion le regarde de protil, et yui parait fort mince lorsque l'on roit l'animal en face ; les oreilles sont longues et pendantes. Les cornes du belier les Indes qui a servi de sujet pour cette description avaient une couleur noire ou noiråtre : elles étaient courtes et contouruees en arc de cercle; elles s'etendaient obliquement en dehors et en arrière, et la pointe ètait lirigée en dedans, de façon que si on les avait prolongées dans la mène direction, elles seraient entrées dans le cou, lerrière la base des oreilles. Ces cornes avaient une face plate sur leur còté intérieur; l'extérieur était arronli pres de la base, mais vers la pointe il se trouvait comme sur les cornes de notre bélier une arète yıi divisait le cóté extérieur en deux faces. Il y avait sous la gorge deux glands conme ceux des boucs et deschèrres; la quene descemait presque jusqu'd terre.

Cet animal avait, au lieu de laine, un poil sem blable à celui du mouflon, non-seulement par sd longueur el sa cousistance, mais encore par ses couleurs; le chanfrein, le bout dı museau, l'endroit des sourcils, le dedans des oreilles, l'occipnt, les alentours des glands et le coude étaient de cou leur grise; il y avait aussi des poils de celte cou leur sur le milieu de la face extérieure desjambes, le sommet de la tète, le tour des yeux, la face ex. térieure des oreilles, la plus grande partie de la mâchoire infèrieure, la gorge, les glands, les còtés du cou et la partie postérieure du dessus, le dos, les coités du corps, la croupe, l'épaule, la face extériemre du bras et de la cuisse, et les quatre janbes étaient de couleur fauve plus ou moins foncée et teinte en quelques endroits de couleur brune, surtout à còté du genou et sur les flancs, oú il y avait une grande tache brune : la face intérieure de l'avant-bras et de la janıbe était presque entièrement brune; cette couleur paraissait aussi sur le devant les canons et des pieds : les còtés du museau, le dessus des yeux, le tour de la base des cornes, la partie anterieure du dessus du con et l'endroit des angles formés par les branclıes de la michoire inferieure, avaient une conleur noire on noirâtre ; le dessous du con et la partie antérieure de la poitrine étaient de couleur de marron; la partie postérieure de la poitrine et le ventre avaient une couleur fauve, påle et mẻme blanchåtre dans quelıues endroits; la queue était de couleur fauve et niêlée de gris et de brun sur environ un tiers de sa longueur, depuis son origine; le reste avait une couleur blanche légèrement teinte de jaune.

\section{LE BOUQUETIN,}

\section{(LA CHÈVRE BOUQUetix.)}

Ordre des rmminants à cornes, geure brebis (Cuvier.)

$$
\text { LE CHAMOIS, }
$$

(L'ANTILOPE CHAMOIS.)

Ordre des ruminants à cornes, genre autilope (Curier.)

\section{ET LES AUTRES CHÈrES'.}

Quoiqu'il y ait apparence que les Grees conmaissaient le houquetin et le chamois, ils ne les ont pas désignés par des dénominations particulières, ni mème par des caractères assez pré-

\footnotetext{
4 Cet arlicle renferme l'histoire et la description non-senlement du hou fuetin el du chamois, mais encore celles de quelques varielés lomestiques de la chevre ordinaile, qui conslitue une espic: tris-differente des deux premières.
} 
cis, pour qu'on puisse les reconnaître : ils ne les ont indiqués que sous le nom générique de chèvres sauvages. Vraisemblablement, ils présumaient que ces animaux étaient de la mème espèceque les chèvres domestiques, puisqu'ils ne leur ont point appliqué de noms propres, comrne ils l'ont fait à tous les animaux d'espèces différentes. Au contraire, nos naturalistes modernes ont tous regardé le bourjuetin et le chamois comme deux espèces réellement distinctes, et toutes deux différentes de celle de nos chèvres. Il y a des faits et des raisons pour et contre ces deux opinions, et nous allons les exposer en attendant que l'expérience nous apprenne si ces animaux peuvent se mêler et produire ensènble des individus féconds, et qui remontent a l'espèce originaire; ce qui seul peut décider la question.

Le bouquetin mâle diffère du chamois par lat longucur, la grosseur et la forme des cornes; it est aussi beaucoup plus grand de corps, et il est plus vigoureux et plus fort : eependant le bouquetin femelle a les cornes différentes de eelles du mâle, beaucoup plus petites et assez ressemblantes à celles du ehamois. D'ailleurs ces animaux ont tous deux les mèmes habitudes, les mimes mocurs et la mime patric : seulement le bouquetin, comme plus agile et plus fort, s'élève jusqu'au sommet des plus hautes montagnes; au lieu que le chamois n'en habite que le second étage : mais ni l'un ni l'autre ne se trouvent dans les plaines. Tous deux se fraient des chemins dans les neiges; tous deux franchissent les précipiees en bondissant de rocher's en rochers; tous deux sont couverts d'une peau ferme et solides, et vètus en hiver d'une double fourrure, d'un poil extérieur assez rude et d'un poil intéricur plus fin et plus fourni; tous deux ont une raie noire sur le dos; ils ont aussi la queue à peu piès de la même graudleur : Ic nombre des l'essemblances extérieures est si grand en compáraison des différences, et la conlormité des parties intéricures est si complète, qu'en raisommant en conséquence de tous ees rapports de similitude, on serait porté à eonelure que ees deux animianx ne sont pas d'une espèce réellement difiérente, mais que ee sont simplement des variétés coustantes d'une seule ct mine espice. D'ailleurs les bouquetins, aussi bien (pue ies chamois, lorsyuon les prend jemes el ru'on les élève avec les chères domesticues, s'apjuriroischit aisément, s accoutument à la domesti- cité, prennent les mêmes mœurs, vout comme elles eu troupcaux, reviennent de mème à l'étable, et vraisemblablement s'accouplent et produisent ensemble. J'avoue cependant que ce fait, le plus important de tous, et qui seul déeiderait la question, ne nous est pas connu. Nous n'avons pu savoir, ni par nous, ni par les autres, si les bouquetins et les channois produisent avee nos chèvres; seulement nous le soupconnons: nous sommes à ect égard de l'avis des anciens; et de plus, notre présomption nous parait fondée sur des analogies que l'expérience a rarement démenties.

Cependant (et voici les raisons contre) l'espèce du bouquetin et eelle du chamois sont toutes deux subsistantes dans l'état de nature, et toutes deux constamrnent distinctes. Le chamois vient quuelquefois de lui-même se mêler au troupeau des cherres domestiques; le bouquetin ne s'y mèle jamais, à moins qu'on ne l'ait apprivoisé. Le bouquetin et le bouc ont une trèslongue barbe, et le chamois in'en a point. Les corıes du chaınois mâle et femelle sont trespetites; celles du bouquetin inàle'sont si grosses et si longues, qu'on u'imaginerait pas qu'elles pussent appartenir a un animal cle cette taille; et le chanois parait dillurer du bourquetin et du bouc par la direction cle ses cornes, qui sont un peu inclinécsenavant dans leur partic inférieure, et courbées en arrière ì la poin te en forıne d hamecon : mais, comme nous l'avons déjà dit, en parlant des bocufs et des brebis, les cornes varient prodigieusement dans les animaux domestiques; elles varient beaucoup aussi dans les animaux sau vages suivant les différents climats. La femclle dans nos chevres n'a pas les cornes absolument semblables a celles de son male : les cornes du bouquetiu mile ne sont pas fort diffúrentes de celles du bouc; et comme la femelle du bouquetin se rapproche de nos chevres et même du chamois par la taille et par la pelitesse des cornes, ne pourrait-on pas on conclure que ces trois animatu, le boufuetin, le chamois et le bouc domestique, ne font en eftet qu'unc seule et mème espéce, mais dans laquelle les fe. melles sont d'une nature constante, et semblıbles entre elles; au lieu que les males subissent des varietes qui les rendent differents les uns des autres? Dius ce point de vue, qui niest peutetre pas aussi éloigné de la nature que l’ou pourmit l'imaginer, le buuquetin serait le mile dians la race originaire des cheves, et le chamors eu 
scrait la femelle. Je dis que ce point de vue n'est pas imaginaire, puisque I'on peut prouver par l'expérience qu'il y a des espèces dans la nature où la femelle peut également servir à des mâles d'espèces différentes et produire de tous deux : la brebis produit avec le bouc aussi bien qu'avec le bélier, et produit toujours des agneaux, des individus de son espèce; le bélier au contraire ne produit point avec la chèvre : on peut donc regarder la brebis comme une femelle commune à deux mâles différents, et par conséquent elle constitue l'espèce indépendamment du mâle. II en sera de même dans celle du bouquetiu; la femelle seule y représente l'espèce primitive, paree qu'elle est d'une nature constante: les mâles au contraire ont varié, et il y a grande apparence que la chèvre domestique, qui ne fait, pour ainsi dire, qu'une seule et même femelle avec celles du chamois et du bouquetin, produirait également avec ces trois différents mâles, lesquels seuls font variété dans l'espèce, et qui par corréquent n'en altèrent pas l'indentité, quoiqu'ils paraissent en ehanger l'unité.

Ces rapports, comme tous les autres rapports possibles, doivent se trouver dans la nature des choses : il parait même qu'en général les femelles contribuent plus que les mâles au maintien des espèces; car, quoique tous deux concourent à la première formation de l'animal, la femelle, qui seule fournit ensuite tout ce qui est nécessaire à son développement et à sa nutrition, le modifie et l'assimile plus à sa nature; ce qui né peut manquer d'effacer en beaucoup de parties les empreintes de la nature du mâle : ainsi lor'squ'on veut juger sainement une espèce, ce sont les fomelles qu'il faut examiner. Le mâle donne la moitié de la substance vi vante; la femelle en dome autant, et fournit de plus toute la matière nécessaire pour le développement de la forme : une belle femme a presque toujours de beaux enfants; un bel homme avec une femme laide ne produit ordinairement que des enfants encore plus laids.

Ainsi dans la même espèce, il peut y avoir quelquefois deux races, l'une masculine et l'autre féminine, qui toutes deux, subsistant et se perpétuant avec leurs caractères distinctifs, paraissent constituer deux espèces différentes; et e'est là le cils où il est, pour ainsi dire, impossible de fixer le terme entre ce que les naturalistes appellent espèce et variélé. Supposons, par exemple, qu'on ne donnàt constamment que des boucs à des brebis, et des béliers à d'autres, il est certain qu'après un certain nombre de générations, il s'établirait dans l'espèce de la brebis, une race qui tiendrait beancoup du bouc, et pourrait ensuite se maintenir par elle-même; car, quoique le premier produit du bouc avec la brebis remonte presque entièrement à l'espèce de la mère, et que ce soit un agneau et non pas un chevreau, cependant cet agneau a déjà le poil et quelques autres caractèteres de son père. Que l'on donne ensuite le même mâle, e'est-à-dire le bouc à ces femelles bàtardes, leur produit dans cette seconde génération approchera davantage de l'espèce du père, et encore plus dans la troisième, etc.; bientôt les caractères étranger's l'emporteront sur les caractères naturels, et cette race factice pourra se soutenir par elle-même et former dans l'espèce une variété dont l'origine sera très-difficile à reconnaitre. Or, ce qui se peut d'une espèce à une autre, se peut encore mieux dans la mème espèce : si des femelles très-vigoureuses n'ont constamment que des mâles faibles', il s'établira avec le temps une race féminine; et si en même temps des mâles très-forts n'ont que des femelles trop inférieures en force et en vigueur, il en résultera une race masculine, qui paraitra si différente de la première, qu'on ne voudra pas leur accorder une origine commune, et qu'on viendra par conséquent à les regarder comme des espèces réellement distinctes et séparées.

Nous pouvons ajouter à ces réflexions générales quelques observations particulières. M. Linnæus ' assure avoir vu en Hollande deux animaux du genre des chèvres, dont le premier avait les cornes très-courtes, très-rabattues, presque appliquées sur le crâne, et le poil long; le second avait les cornes droites, recourbées en arrière au sommet, et le poil court. Ces animaux, qui paraissaient être d'espèce plus éloignée que le chamois et la chèvre commume, ont

4 Je donte que M. Linnæus ait été bien iuformé an sujet du pays natal de cet animal, el je le crois originaire d'Afriłne; les raisons sur lespuelles je fonde ce donte et celle présomption. sunt : $1^{\circ}$ Quaucun auteur n'a dit que cette espèce de chève, non plus yue la elıère commıne se soient trouvies en Améripue; $2^{\circ}$ y trairc, à assurer (püil se troure en A hique des chevres giandes, moyeunes et peliles, toutes diflérentes les unes des autres; $5^{0}$ parce que nous arons vu un animal qui nous est parvemu sous le nom de bouc d'Afrique, lequel ressemble si for? à la descriplion du capra cornibus depressis, cle., le .I. Linnxus, que nous le regarduns coume lu mème auinal; aiısi nous nous croyons fondé à assurer yue ce!te petite esjucce de chère est originaite d'Afrique et non pas d'Ainérique. 
néanmoins produit ensemble; ce qui démontre que ces différences de la forme des cornes et de la longueur du poil ne sont pas des earacteres spécifiques et essentiels, puisque ces animaux n'ont pas laissé de produire ensemble, et que par conséquent ils doivent ètre regardés comme étant de la même espèce. L'on peut donc tirer de eet exemple l'induction très-vraisemblable, que le chamois et notre chèvre, dont les prineipales différences consistent de même dans la forme des cornes et la longueur du poil, ne laissent pas d'ètre de la même espèce.

Nous avons, au Cabinet du roi, le squelette d'un animal qui fut donné à la Ménagerie, sous le nom de capricorne. II ressemble parfaitement au boue domesticue par la charpente du corps et la proportion des os, et particulicrement au bouquetin par la forme de la mâchoire inférieure; mais il diffère de l'un et l'autie par' les cornes : celles du houcruetin ont des tubercules proéminents et deux arêtes longitudinales, entre lesquelles est une face antéricure bien marquée; celles du boue n'ont qu'une arête et point de tubereules : les cormes du capricorne n'ont qu'une arète, point de face antérieure, et ont en mème temps des rugosités sans tubercules, mais plus fortes que celles du bouc : clles indiquent done une race intermédiaire entre le bouquetin et le bouc domestique. De plus les cornes du capricorne sont courtes et recourbées à la pointe comme celles du chamois, et en mème temps elles sont comprimées et annelées : ainsi elles tiennent à la fois du boue, du bouquetin et du chamois.

M. Browne, dans son histoire de la Jamaïque, rapporte qu'on trouve actuellement dans cette ile : $\mathbf{1}^{0}$ la chèvre commune domestique en Europe; $2^{\circ}$ le chamois; $3^{\circ}$ le bouquetin. Il assureque ('es trois animaux ne sont point originaires d'Amérique, (ju'ils y ont été transportés d'Europe ; qu'ils ont, ainsi (que la brebis, dégrénéré daus cette terre nouvelle, (qu'ils y sont devenus plus petits; que la laine des brebis s'est clangée en poil rude comme celui de la chèvre; que le bouquetin parait ètre d'une race bâtarde, etc. Nous croyons done que la petite chèvre à cornes droites et recourbées au sommet, que M. Limnæus a vue en Hollande, et quil dit étre venue d'Américque, est le chamois de la Jamaï(ue, e’est-ìdire le chamois d'Europe, décénéré et devenu plus petit en Amérique; el que le bouquetin de la Jamaïque, que M. Browne appelle bouquelin biilard, est notre capricorne, (qui ne parait ètre en effet qu'un bouquetin décénéré, devenu plus petit, et dont les cornes atront varié sous le climat d'Amérique.

N. Daubenton, après avoir examiné scrupuleusement les rapports du chamois au boue et au bélier, dit qu'en général il ressemble plus au bouc cu'au bélier. l.es principales disconvenan. ces sont, après les cornes, la forme et la grandeur dufront, qui est moins élevé et plus court dans le chamois que dans le bouc; et la position du nez, qui est moins reculé que celui du bouc : en sorte que, par ces deux rapports, le chamois ressemble plus au bélier qu'au bone. Mais en supposant, comme il y a tout lieu de le présumer, que le chamois est une variété constante de l'espèce du boue, comme le dogue ou le lévirier sont des variétés constantes dans l'espèce du chien, on verra que ces différences dans la grandeur du front et dans la position du nez ne sont pas à beaucoup près si grandes dans le chamois, relativement au bouc, que dans le dogue, relativement au lévrier, lesquels cependant produisent ensemble et sont certainement de la mème espèce. D’ailleurs, comme le chamois ressemble au bouc par un grand nombre, et au bélier par un moindre nombre de caractères, si l'on veut en faire une espèce particulière, cette espèce sera nécessairement intermédiaire entre le bouc et le bélier. Or', nous avons vu que le boue et la brebis produisent ensemble: done le chamois, qui est intermédiaire entre les deux, et qui en mème temps est beaucoup plus près du bouc que du bélier par le nonbre des ressemblances, doit produire avec la chèvre, et ne doit par conséquent ètre considéré que comme une variété constante dans cette espèce.

Il est done presque prouvé que le chamois produirait avee nos chèvres, puisque ce même chamois, transporté et devenu plus petit en Amérique, produit arec la petite chève d'A frique. L.e chamois n'est done qu'une variété constante dans l'espèce de la chève, comme le dogue dans eclle du chien : et d'autre còté nous ne pouvons guère douter que le bouquetin ne soit la vraie chèvre, la chève primitive dans son état sauvage, et qu'il ne soit à l'égard des chèvres domestipues ce que le mouflon est à l'égard des brebis. Le bouquetin ou bouc saurage ressemble entierement et exactement au hone domestiçue par la conformation, l'organisation, le naturel et les habitudes physinues; il n'en differe 
que par deux légères différences, l'une à l'exté. ricur, et l'autre à l'untérieur : les cornes du bouquetin sont plus grandes que celles du bouc; elles ont deux arêtes longitudinales, celles du boue n'en ont qu'une; elles ont aussi de gros nœuds ou tubercules transversaux, qui marquent les années de l'accroissement, au lieu que celles des boues ne sont, pour ainsi dıre, marquées que par des stries transversales : la forme du corps est pour tout le reste absolument semblable dans le bouquetin et le bouc. A l'intérieur tout est aussi exactement pareil, a l'exception de la rate, dont la forme est ovale daus le bouquetin et approche plus de celle de la rate du chevreuil ou du cerf que de celle du bouc ou du bélier. Cette dernière différence pent provenir dı grand mouvement et du violent exereice de l'animal. Le bouquetin court aussi vite que le cerf, et saute plus légèrement que le chevreuil : il doit donc avoir la rate faite comme celle des meilleurs coureurs. Cette différence vient done moins de la nature que de l'habitude, et il est à présumer que si nos boues domestiques devenaient sauvages, et qu'ils fussent forcés à courir et ì sauter comme les boucquetios, la rate reprendrait bientòt la for'me la plus convenable à cet exercice; ct à l'égard de ses cornes, les différences, quoique très-apparentes, n'empèchent pas qu'elles ne ressemblent plus à celles du bouc qu'a celles d'aucun autre animal. Ainsi le bouquetin et le bouc étant plus voisins l'un de l'autre que d'aucun autre animal par cette partie mème, qui est la plus différente de toutes, l'on doit en conclure, tout le reste étant le même, que, malgré cette légère et unique disconvenance, ils sont tous deux d'une scule et même espèce.

Je considère done le bou juetin, le chamois et la chèvre domestique, comme une mème espèce, dans lacquelle les màles ont subi de plus grandes variétés que les femelles; et je trouve en même temps dans les chèvres domestiques des variétés secondaires, qui sont moins équivoques et qu'il est plus aisé de reconnaitre pour telles, parce qu'elles apparticment également aux mâles et aux femelles. On a vu que là chèvre d'Angora, quoique très-différente de la nòtre par le poil et par les cornes, est néanmoins de la mème espèce. On peut assurer lá nème chose du boue de Juda, duquel MI. limneus a eu raison de ne faịre qu'une variété de l'espèce domestipue. Cette chère, qui est commune en
Guincé, á Angole et sur les autres côtes d'Afrìque, we diffère, pour ainsi dire, de la nòtre qu'en ce qu'elle est plus petite, plus trapue, plus grasse : sa elaair est aussi bien meilleure à mangel"; on la préfére dans son pays au mouton, comme nous préférons ici le mouton à la chèvre. Il en est encore de mème.de la chèvre mambrine, ou chèvre du Levant, à longues oreilles pendantes. Ce n'est qu'une variété de la chèv'e d'Angora, qui a aussi les oreilles pendantes, mais moins longues que la chèvre mambrine. Les anciens comnaissaient ces deux chèvres, et ils n'en séparaient pas les espèces de l'espèce commune. Cette variété de la chèvre mambrine s'est plus étendue que celle de la chèvre d'Angora : car on trouve ces chèvres à très-longues oreilles en Égypte et aux Indes orientales, aussi bien qu'en Syrie. Elles donnent beảucoup de lait, qui est d'assez bon goût, et que les Orientaux préfèrent à celui de la vache et du buffle.

A l'égard de la petite chèvre que M. Linnæus a rue vivante, et øqui a produit avec le petit chamois d'Amérique, l'on doit penser, comme nous l'avous dit, qu'originairement elle a été transportée d'Afrique : car elle ressemble si fort à notre boue d'Afrique, qu'on ne peut guère douter qu'elle ne soit de cette espèce, ou qu'elle n'en ait au moius tiré sa première origine. Cette mème chève, déjả petite en Afrique, sera devenue encore plus petite en Amérique; et l'on sait par le témoignaige des voyageurs, qu'our-a solvent et depuis longtemps transporté d'Afrique, comme d'Europe en Amérique, des brebis, des cochons et des chères, dont les rac ces se sont maintenues daus ce nouveau monde, et $y$ subsistent encore aujourd'bui sans autre altération que celle de la taille.

En reprenant donc la liste des chèvres, et apres les aroir considérées une ì une et relativement intre elles, il me parait que de neuf ou dix especes dont parlent les nomenclateurs, l'on doit n'en faire qu'une. D'abord: $1^{\circ}$ le bouquetin est la tige et la souche principale de l'espèce; $2^{\circ}$ le capricorne n'est qu'un bouquetin batard ou plutòt dégénéré par l'influence du elimat; $3^{\text {t) }}$ le bouc domestique tire son origine de bonquetin, qui n'est lui-mème que le bouc Siturage ; fo le chamois n'est qu'une variété dans l'espéce de la chèvre, aree laquelle il doit, comme le bouquetin, se mèler et produire; 5o La petite chève à cornes droites et recour- 
bées a la pointe, dont parle M. Linuæus, n’est que le ehamois d'Europe, devenu plus petit en Amérique; $6^{\circ}$ l'autre petite chèvreà cornes rabattues, et qui a produit avee ce petit chamois d'Amérique, est le même que le boue d'Afrique, et la production de ces deux animaux prouve que notre chamois et notre chève domestique doivent de même produire ensemble, et sont par conséquent de la même espèce; $7^{0}$ la chèvre naine, qui probablement est la femellc du bonc d'Afrique, n'est, aussi bien que son mâle, qu'une variété de l'espèce commune; $8^{0}$ il en est de même du boue et de la chèvre de Juda, et ce ne sont aussi que des variétés de notre chèvre domestique; $9^{0}$ la chève d'Angora est encore de la même espèce, puisqu'elle produit aveenos chèvres ; $10^{\circ}$ la chèvre mambrineà très-grandes oreilles pendantes est une varićté dans la lace des chèves d'Angora. Ainsi ees dix animaux n'en font qu'un pour l'espèce; ee sont seulement dix races différentes produites par l'influenec du climat. Capro in mullas similitudines Iransfiguranlur, dit Pline; et en effet nous voyons, par cette énumération, que les chèvres, quoique dans le fond semblables entre elles, varient beaucoup pour la forme extérieure; et si nous comprenions, comme Pline, sous le nom générique de chèrres, non-seulement eelles dont nous venons de faire mention, mais encore le chevreuil, les gazelles, l'antilope, ete. , cette espèce serait la plus étendue de la nature, et contiendrait plus de races et de variétés que celle du chien. Mais Pline u'était pas assez bien informé de la différence réelle des espèces lorsquil a joint eelles du chevreuil, des gazelzelles, de l'antilope, ete., à l'espèce de la chèvre : ces animaux, quoique ressemblants à beaucoup d'égards à la chèvre, sont cependant tous d'espèces différentes; et l'on velra dans leur article combien les gazelles varient, soit pour l'espèce, soit pour les races, et combien, après l'énumération de toutes les chèves et de toutes les gazelles, il reste eneore d'autres animaux qui participent des uns ot des autres. Dans l'histoire entière des fuadrupèdes, je n'ai rien trouvé de plus difficile pour l'exposition, de plus confus pour la comnaissance, et de plus incertain pour latradition, que cette histoire des chères, des gazelles et des autres espéces qui y ont rapport. J'ai fuit mes efforts et employé toute mon atlention pour y porter quelque lu- ınière; ct je n'aurai pas regret à mon temps, si ce que j’en éeris aujourd'hui peut servir dans la suite à prévenir les erreurs, fixer les idées et aller au-devant de la vérité, en étendant les vues de ceus qui veulent étudier la nature. Mais revenons à notre sujet.

Toutes les chèrres sont sujettes à des ver tiges, et cela leur est commun avec le boucuetin et le chamois, aussi bien que le penchant qu'elles ont à grimper sur les rochers; et encore une autre habitude naturelle, qui est de léeher continuellement les pierres, surtout celles qui sont empreintes de salpêtre or de sel. On voit dans les Alpes des rochers creusés par la langue des chamois : ce sont ordinairement des pierres assez tendres et calcinables, dans lesquelles, comme l'on sait, il y a toujours une certaine quantité de nitre. Ces convenances de naturel, ces habitudes conformes, me paraissent encore être des indices assez sûrs de l'identité d'espéce dans ces animaux. Les Grees, comme nous l'avous dit, ne les ont pas séparés en trois especes différentes. Nos chasseurs, qui vraisemblablement n'avaient pas consulté les Grees, les ont aussi regardés comme étant de mème espèce. Gaston Plocbus, en parlant du bouquetin, ne l'indicue que sous le nom du bouc sauvaye : et le chamois (ju'il appelle ysarus et sarris n'est aussi, selon lui, qu'un autre bouc sauvage. I'avoue que toutes ces autorités ne font pas preuve complete; mais en les réunissant avec les laisons et les faits que nous venons d'exposer, ils forment au moins de si fortes présomptions sur l'unité d'espèce de ces trois animaux, qu'on ue peut guère en douter.

Le bouquetin et le chamois, que je regarde, l'un comme la tige mâle, et l'autre comme la tige femelle de l'espece des chèrres, ne se trouvent, aiusi que le mouflon, qui est la souche des brebis, fue dans les déserts et surtout daus les lieux escarpés des plus hautes montagnes; les Alpes, les Pyrénces, les montagnes de la Gréce et celles des illes de l'Archipel, sont presque les seuls endroits oì l'on trouve le boucuetin et le chamois. Quoique tous deux craignent la chaleur et n'habitent que la rógion des neiges et des glaces, ils craignent aussi la rigueur du fioid excessif. L'été ils demeurent au nord de leurs montagnes; l'hiver ils cherchent la face du midi, et descendent des sommets jusque dans les vallous. Ni l'un ni l'autre ne peurent se soutenir sur les glaces unies : mais pour peu que la neige y forme des aspérites, ils y mar- 
chent d'un pas ferme, et traversent en bondissant toutes les inégalités de l'espace. La chasse de ces animaux ', surtout celle du bouquetin, est très-pénible ; les chiens y sont presque inutiles : elle est aussi quelquefois dangereuse ; car lor'sque l'animal se trouve pressé, il frappe le

1 Chasse du hone sanvage : il y a deux sortes de boucs, les uns s'appellent boucs sauvages, el les autres ysarus, autrement dit sarris : les boncs sauvages sont anssi grands qu'un cerf, mais ne sont si longs ne si enjambés par hant, ores qu'ils aient antant de chair; jls onl antant d'aus que de grosses raies qu'ils ont au travers de leurs cornes..... lls ne portent que leurs perches, lesquelles sont grosses comme la jambe diun honme, selon qu'ils sont vieils. Ils ne jettent point ni ne muent leurs tètes : et tant plus ils ont de rales eu leurs cors, et plus leurs cors sont longs et plus gros, tant plus vieils sont les boucs. Ils ont graude barbe et sont bruns, de poil de lonp et bien velus, et ont une raie noire sur l'eschine et tout an long des fesses, et ont le ventre faure, les jaubes noires et derrière fanve; leurs pieds sont comme des antres boncs privés on chières; leurs traces sont grosses et grandes, et rondesplus que d'un cerf; leurs os sont à l'advenant d'un bouc privé el d'une chièvre, lors quills sont plus grus; ils uaissent en mai; la biche sauvage faonne, ainsi qu'uue biche-chièsre ou daine, mais alle n'a yu'um bouc à la fois, et l'allaite ainsi que fait une chièrre privée.

I.es boucs vivent d'lierbes, de foings, comme les autres bêtes donces.... Leurs fumées retirenl (quand elles sont formét's) sur la forme des fumfes d'un bonc on d'une cbièrre privée; les boncs vont au rut environ la Toussaints, et demenrent un mois en leurs chaleurs; et puisuue. leur rut est passé, ils se mettent en arilre, et prar cnseuble descendent les hantes montaignes et rocher's ou ils auront denieuré lout l'été, tant pour la neige que pour ce qu ils ne trouvent de quoi viander là sûs, non pas en un pays plain, nais vont vers les pieds des montaignes yuerir leur vie : et ainsi demeurent jusque vers l'asques, et lors ils remontent ès plus hautes montaignes yu'ils trourent, et chacun prend son buisson, ainsi que font les cerfs. Les chièvres alnrs se départent des boucs, et ront demeurer près des ruisseanx pour faonner et $\mathrm{y}$ demeurer tout le long de l'été; lors que les boucs sont loors divec les clièvres, attendant que le temps de lenr rut soit renu, ils courent sins aux gens et besies, et se combattent entre enx, ainsi yue les cerfs, mis non cle telle manière, car ils chantent plus laidement. Le bouc blesse d'un coup qu'il doune, non pas du bout de la tète, mais du milieu, tellement (jüil rompt les bras et les cuisses de ceux yuil alteint, et cncores yu'il ne fasse pas de plaie, si est ce que s"il acule un homme contre un arbre on contre terre, il le tuera. Le bouc est de telle nature, que si un homme, quelyue prissant et fort yn'il soit, lc frappe d'un barre de fer sur l'eschine, pour cela il ne baissera ne ployera l'eschine. Quant il est en rut, il a ie col gros à merveilles, voire est de telle nature, que encores qu'il tombât de dix toises de baut, il ne se ferait aucun mal.....

Du bouc dit ysarus on sarris : le bouc dit ysarns est de pareille forme que le précédent, et u’est guères julus grand ju'un bouc prive; il est de pareille nature que le bouc sau. vage.... Les deux sortes de boncs ont leur grelle et saison, et leur rut conme le cerf, et ce cuviron la Toussaints, et lor's on les doit cliasser jusıp’a leur rut ; et pour ce yu ils ne trowvent rien en hiver, ils mangent des pins et sapins ès bois, qui sont toujours verds, ce qui est leur réfreschement. L.eur jeau est chaude quand clle est corruyée en bonne saison: car le froid ni la pluic ne la peuvent percer, si le poil est delıors: lenr chair niest pas trop saine: car elle engendre lievre.... t.a clıasse du bouc n'est de grande unaltrise, parce qu'on ne jeut accompagner les chicus, ne aller avec eux à pied ne à cheval. Gaston Phobus, véneric de Dufouillonx, fenillets 68 et 69. chasseur d'un violent coup de tête etle renverse souvent dans le précipice voisin. Les chamois sont aussi vifs ', mais moins forts que les bou-

4 M. Perroud, entrepreneur des inines de cristal dans les Alpes, ayant amené un cluanois vivant à Versailles, nous a douné de bonnes informations sur les habitudes naturelles de cet animal, et nous les publions ici avec plaisir et reconnaissance. L Le cbanois est un animal sauvage et néannoins fort - docile; il n'lıabite que les inontagnes et les rochers; il est de - la grandeur l'une chèvre domestique, il lui ressemble en - beaucoup de choses, il est d'une vivacité charmante et d'une - agilité admirable. Le poil du clımois est court connme celuj - d'une hiche: au printemps il est d'un gris cendré, en été - d'un fanve de biche, en automne conleur de fanve brun mê* lé de noir, et en hiver d'un brun noirâtre. On tronve des

- chamois en (juantité dans les montagues du Haut-Dauphiné, a duPiémont, de la Savoic, de la Suisse et de l'A llemagne; les

- cliamois sont sociables entre eux, on les trouve deux, trois,

- yuatre, cing, six ensenule, et très-souvent par troupeaux de

" huit à dix, quinze ou vingt et plus; on en voit jusıu'à

- soixante et ıuatre-vingts ensemble, et quclquefois jusqua

- cent, qui sont dispersés par divers petits troupeanx sur le

- penchanl d'une même inontagne; les gros chamois mâles se - tiennent seuls et éloignés des autres, excejté dans le temps - du rut, (ju'ils šapproclsent des femelles et en écartent les - jeunes. ils ont alors une odcur tres-forte, comme les boucs, - et même encore plus forte; ils bêlent souvent $\mathrm{ct}$ courent - d'une montagne à l'autre : le temps de leur accouplement - est en octobre et novembic, il font leurs petits en mars et ه avril; une jeuue femelle prend le màle à un an el demi : - ils font un petit par portée et quelquefois dcux, mais assez - rarement: le petit suit sa nère jusın'an mois d'octobre, - quelqunefois plus longtemps, si les chasseurs ou les lumps ne - les dispersent pas : on assure quils vivent entre vingt ct a trente ans: la viande du chamois est bonne à manger; un - chamois bien gras anra jusunıà dix et douzc livres de sıif, - qui surpasse en dureté et bonté celui de la chèvrc; le sang - du chamois est estrèmement chand; on pétend (ju'il ap)a proche beaucoup du sang du bouquetin pour la 'jualité et - les vertus; ce sang peut servir aux nèmes usages que celui a du bonquetin, les effets eu sont les mèmes en en jrenant - une double dose; il est très-bon contre les pleurésies; il a * la propuriété de déeailler le sang et douvrir la trauspiration; - les chasseurs mélangent quelquefois le sang du bouquetin et - du chamois, d'autres fois ils vendent celui du chamois pour a dı sang de boncuetin; il est très-difticile den faire la dif- férence on la séparation, cela parait annoncer que le sang đlu - cliamois diffère très-pen de celui du bouquetin. On ne con- nait point de cri au clıanois; s'il a de la voix, c'est très-peu - de cliose; car on ne lui connait qu'un bclement fort bas, peu - sensible, ressemblant un peu à la voix d une cluèvre enronée; - écst par ce hèlement qu'ils s'appellent entre eux, surtont les - mères et les petits; mais quand ils ont peur on quilis aper- coivent leur ennemi ou quelque chose qu'ils ne peuvent pas - clistinguer, ils savertissent par un sifflement dont je vais - parler tout à l’heurc. La vuc dn chamois est des plus péné- trantes, il ny a rien le si fin (pue son odorat : quand il roit - un loomme distinctement, il le fixe pour un instant, et s'il en a cst près, il s'enfirit; il a l'ouic anssi fune que l'oulorat, car il - entend le muindre bruit; yuand le vent soufle un pen, et - une ce vent vient du cóté d'un lomme à lui, il le scntira de - jus d'une demi-lien? ; quand done il sent un quil entend - quelipue chose, et quil ne pcut pas en faire la découverte - par les yeux, il se met à siffler avec tant de force, que li's rochers ou les forćts eu retentisseut : s'ils sont plusieurs, ils a śen éfouvauteut tous : ce sifflement est aussi long que l'laa- leine pent tenir sans reprendre, il est d'abord fort aign et - baisse sur la tin; le cliamois se repose un instant, regarde de tuns cilés et recommeuce á sifller, il continue d'inter- valle en intervalle, il esl dans une agitation extrème, il 
quetins; ils sont en plus grand nombre, ils vont ordinairement en troupeaux : cependant il y en a beaucoup moins aụjourd hui qu'il n'y en avait autrefois, du moins dans nos Alpes et dans nos Pyrénées. Le nom de chamoiseurs, que l'on a

- frappe la terre du pied de devant et quelıuefois des deux, it a se jette sur des pierres grandes et hautes, il regarde, il conrt - gur des éminences, et quand il a découvert quelıue chose il - s'enfuit; le sifllement du màle est plus aigu que celui de la - femelle; ce sifllement se fait par les narines, et n'est pro- prement qu'un souffle aign trés-fort, semblable au son que a pourrait rendre un homme en tenant la fangne an palais, ayant les dents a peu près ferinées, les lèvres ouvcrtes et un * pen allongées, et (qui soufllerait vivement et long-temp)s. Le " chamois se nourrit des meilleures herbes; il choisit les parties - les plus dèticates des plantes, cumme la lleur ct les bourgeons - tendres; il est très-friand de quelques herbes aromatiques, - particulièrement de la carliue et du génijpy, uni sont les - jilantes qu'on croit les plus cltantes des dipes; il hoit trèsa pru cuand il mange de l'herbe verte, il aime beaucoup les - Ceuitlages et les petits bouts teutles des arbrisseaux; il ru- mine comme la chèvre après avvir mangé; la nourriture

* dont il fait usage farait aunoncer la grandc chateur de son

a tenpérament. On admire en cet animal deux beaux grauds

- yeus ronds yui unt du fen, riprésentant la vivacité de son

- naturel ; sa tête est couronnée de deux petstes cornes de la

- Iongueur de demi-pieıl jusırüà nenf ponces, d'un heau noir,

- posées dans le front, presque entre les yeux, an contraire de - celles des antres animanx qui se jettent en arricre, celles-ci a sortent cn avant sur les yenx et se recourbent a lenrs extréa nitís très-rondement et finissant en pointe fort aignë; il a ajuste fort joliment ses ureilles at la pwinte de ses cornes; il a a dleux lames de poil noir à côté de la face en descendant a "les corn"s; le reste de la féte est d'nu fauve hane qui ne " changc jamais de coulenr; on fait usage des cornes de cha" mois pour le's porter sur des camies; Ies cormes des femelles - sont plus petites et moins conrlies, les maréchanx s'en servent - pour tirer du sang aux chevaux. Les peaux de chamois g̨ne "I'on fitit passer à l'ajprét de la chamoiserie sont très-fortes, a nervenses et hien sonjles; on cu fait de tris-bonnes cu- lottes cn jaune on en noir pour monter à cheval, on eu fait - de très-bons gants et yuelıuefois des vestes pour la fatigne; a ces sortes d'habilicments sont d'une longue durée ct de trèsa grand u×age pour les artisans. Les clanois n'habitent qune ¿ les pays froids; on les truuve plus volontiers dans les rochers - escarpés et sunrcilleux que partout aillenrs ; ils fré fuentent

- les bois, mais ce ne sont yne les forèts hantes ct de la der- nière région : ces forèts sont plintées de sapins, de mélèses - et de hetres; ces animanx craignent si fort la chalenr, que, - pendant l'été, on ne les tronve jamais que dans les antres " des rochers, a liunbre, souvent parmi des tas de neiges cona gclés on de glaces, on dans ces forêts lıantes et bien couver- les tonjours du côté du penchant des montagnes ou rochers - scabrenx qui font face an nord, et yui somt à l'abri des - rayous du suleil; ils vont à la pature le matiu et le soir, et - rarement pendant la journé; ils parcourent les rochers - avec beancoup d aisance, les chiens ne peuvent pas les sui- vre dans toms les précipices; il uiy a rien de si admirable " que di les voir monter 'f descendre des rochers inaccessi- bies; ils ne montent ni ne descendent pas perpendiculaire- ment, mais en décrivant une ligne obliq̨ue et se jetant en * travers, surtmit en deseculant, ils se jott ent du hant en bas a an travers d'un rocher yni est à pen près perpendicnlaire, - de la hantenr de plus de vingt el trente pieds, sans qu'il y * ait la moindre plicere pour poser on retenir lenrs pireds; ils * Crappent le rocher trois à quatre fois des picds en se préci" pitant, et vont s'arriter à cynclỵe petite plice an-dlessous, * cui cet propre à les reteuir; il parait, à les voir daus les pres-

a cipices, qu'ils aient plutôt des ailes (que des jambes, si grande donné à tous les passeur's de peaux, semble indiquer que dans ce temps les peaux de chamois étaient la miticre la plus commune de leur métier; au lien qu'aujourd'hui ce sont les peauxde chèvres, de moutons, de cerfs, de chevrcuil et de daim, qui font plus que celles du cliamois, l'objet du travail et du commeree des chamoiseurs.

Et à l'égard de la proprićté spécifique que l'on attribue au sang du bouquetim pour de certaines maladies, et surtout pour la pleurésie, proprićté qu'on croyait particulièe a cet ani. mal, et qui par conséquent aurait indiqué qu'il était lui-même d'une nature particulière, on a recomnu que le sang du chamois, et même celui du bouc domestique avait les mèmes vertus

* est la force de leurs nerfs; on a prétendı que le clımois - s'accruclie par les cornes pour mouter et descenilre les ro" chers, je n'ai jamais vu qu'il se serve de ses cormes punr cet " usage; $j$ "en ai beaucoup in et j'rn ai tué filnsicurs, je n'ai * ju vérilier ce fait, je n'ai tronvé ancun cliasseur yui mait a assuré lavoir vu, ils ne m'en ont janais dit autre chose yue a ce que je viens dle dire. Si le chimois monte et descend ai" sément les rochers, cest par son agilité et la lorce de ses " jambes, il les a fort haute's et bien dégagées, celles de der- rière paraissent un yen plns longues ct tonjours recourhées, a cela les favorise pour s'élancer de loin; el quand ils se jet" tent de bjeu haut, ces jaunbes un peu repliées reçoivent lo a choe qu'ils funt en se preceipitint, elles font l'effet de deus a ressorts et rompent la force du conp. On yrétend yue yjuand - il y a plusienrs chanuis ensemble, il y cunil un qui fait sen- tinelle, ct rư il cst dépulé pour veiller a la sùreté des antres,

- jen ai vu plusieurs tronpeaux, naais je u'ai pis pu faire cette a distinction; il est vrai que turanel il y en a plusien's, il y en a a tonjours yni regardent pendint une les antres mangent, je a n'ai rien distingué en celia de plus particulier que clans un a Ironpeau de moutons : car le premier yni aperçoit quelque a chose yni lui est ctranger avertit les antres, ct dans un ina stant leur imprime à tous la meme crainte dont lui-mime a - été frauné. Penclant la rigucur de l'hiserce dans les grandes - vieiges, les chamois labitent les furits les juls hautes et sivent a de feuillages de sapin, de bonrgeons d'arbres, dartinsseanx a de quelyue ju'u d'herhes seches on rertes, s'ils en troua rent, qüils decourrent avec le pied; les forets un ils se plaia sent sunt celles yni sont remplies de précipices ct de roa chers; la chasse in chanois e-t tris-pienilule et extrem anent a difficile; celle yni est le plus en usage est de les tuer en les - surprenant a la faveur de quelyues iminences, de quetyues a rochers ou grosses pierres, en se glissaut adruitement de - loin, derricre et sans brnit, en examinant eneore si le vent - n'y sera pas contraire; yuand on arrive à portece, on s'aju-te a derrière ces éminenees on grusses jierres en se comchant a inclyuefois, ôtaut son chapen, ne sortant que la tite et le's a duch pour faire adroitement un couj, de frisil; les armes tlunt - ou se sert sont des carabines rayees, bicu ajustées ponr tires - de loin as ec nne senle balte, pur est forcée dans te canon, on

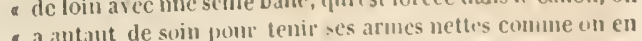
a a pour tirer au prix de laryurhuse; on fant anssi crtle chasse a comme un ferait celle du cerf on antres aninanx. en pos-

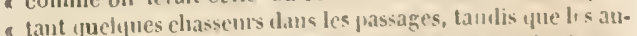
- Lres vent farre la battue et forcer le gificer; il est pilus a proa pos de faire ces battues prar des hommu's gu avec des chiens. " les chiens dispersent trop vite les chamois, et les éloignent " lout de snite à ynatre ou ciny lienes. 
lorsqu'on le nourrissait avee les herbes aromatiques, que le bouquetin et le chamois ont coutume de paitre; en sorte que par cette même propriété ces trois animanx paraissent encore se réunir à une seule et mẹme espèce.

\section{ADDITION}

AUX ARTICLES

DES CHÈVRES GRANDES ET PETITES.

DES CHÈVRES D'EUROPE.

Pontoppidan rapporte que les chèvres sont en Norwége en si grande quantité, que dans le seul port de Berghen, on embarque tous les ans juscpu'à quatre-vingt mille peaux de boues non apprètées, sans compter celles auxquelles on a déjà donnẹ la façon. Les ehèvres conviennent en effet beaucoup à la nature de ce pays; elles vont chercher leur nourriture jusque sur les montagnes les plus escarpées. Les mâles sont fort courageux, ils ne eraignent pas un loup seul, et ils aident mème les chiens à défendre le troupeau.

\section{DU BOUC DE JUDA.}

M. Bourgelat avait vivant ¿ l'École vétérinaire un boue de Juda, ou Juida, et il en conserve encore la dépouille dans son beau cabinet d'anatomic zoologique. Ce bouc était grand de corps; il avait deux pieds neuf pouces de longueur, sur un pied sept pouces de hanteur, tandis que le bélier des Indes n'avait que vingtquatre pouces et demi, sur dix-sept pouces de hauteur; la tête et tout le corps sont cou verts de grands poils blanes, le bout des narines noir; les cornes se touchent presque en naissant, s'écartent ensuite, et sont beaucoup plus longues que celles du premier bouc, anquel celui-ci ressemble par les pieds et par les sabots qui sont fort courts. Ces différences sont trop légères pour séparer ces deux animaux que nous eroyons être tous deux des variétés de la mème espeee.

Nous avons parlé des chèvres de Syrie à oreilles pendantes, qui sont à peu près de la grandemr de nos chèves, et qui peuvent produire a vec elles, même dans notre climat : mais il existe à Madagascar une chèvre considéra. blement plus grande, et qui a aussi les oreilles pendantes, et si longues, que lorsqu elle descend, les oreilles lui couvrent les yeux, cequi l'oblige à un mouvement de tête presque continuel pour les jeter en arrière; en sorte que quand on la poursuit elle cherehe toujours à grimper et jamais à descendre. Cette indication, qui nous a été donnée par M. Commerson, est trop suecincte pour qu'on puisse dire si cette chèvre est de la mème race que celle de Syrie, ou si c'est une race différente qui aurait également les oreilles pendantes.

M. le vicomte de Querhoënt nous a communiqué la note suivante :

"Les chèvres et ies cabris qu'on a lâchés à l'ile de l'Ascension y ont beaucoup multiplié; mais ils sont fort maigres, surtoutdans la saison sèche. Toute l'île est battue des sentier's qu'ils ont faits; ils se retirent la nuit dans les excavations des montagnes; ils ne sont jas toutà fait aussi grands que les chèvres et les cabris ordinaires; ils sont si peu vigoureux, qu'on les prend quelquefois à la course; ils ont presque tous le poil d'un brun foncé.

\section{NOUVELLE ADDITION}

AUX ARTICles DES CHL̀VRES ET DES BREBIS.

Nous avons ru un boue, dont les sabots avaient pris un accroissement extraordinaire; ce défaut ou plutôt cet excès est assez commun dans les boucs et les chèvres qui habitent les plaines et les terrains humides.

Il y a des chèvres beancoup plus fécondes que les autres, selon leur race et leur climat. M. Secretary, chevalier de Saint-Louis, étant à I.ille en Flandre en 1773 et 1774 , a vu chez madame Denizet, six beaux chevreaux qu'une chèvre avait produits d'une seule portée; cette même chèvre en avait produit dix dans deux autres portées, et douze dans trois portées précédentes.

Feu M. de la Nux, mon correspondant à l'île de Bourbon, m'a éerit qu'il y a aussi dans eette île, des races subsistantes depuis plus de quinze ans, provenant des chèvres de France et des boues des Indes; que nouvellement on s'était procuré des chèvres de Goa très-petites et trèsfécondes, qu'on a mèlées avec celles de France, 
ct qu'elles se sont perpétuées et fort multipliées. Jai rapporté dans l'article des mulets, les essais que j'ai faits sur le mélange des bones et les brebis; et ces essais démontrent (qu'on en obtientaisćment des métisqui ne diffèrent guère des agneaux que par la toison, qui est plutòt de poil que de laine. M. Roume de. Saint-Laurent, fait à ce sujet une observation qui est peut-ètre fondée. "Comme l'espèce des chèvres, dit-il, et celle des brebis produisent ensemble des métis nommés chabins, qui se reproduisent, il se pourrait que ce mélange eût inllué sur la masse del'espèce; et fùt la cause de l'effet que l'on a attribué au elimat des îles, où l'espèce de la ehèvre a dominé sur celle de la brehis. ")

On sait que les grandes brebis de Flandre produisent communément quatre agneaux eliaque ammée : ces grandes brebis de Flandre viennent originairement des Indes orientales, d'où elles ont été apportées par les Hollandais, il y a plus de cent ans; et l'on prétend avoir remarqué qu’en général les animaux ruminants qu’on a amenés des Indes en Europe, ont plus de fécondité que les races européenues.

M. le baron de Bock a eu la bonté de m'informer de quelques particularités que j'ignorais sur les variétés de l'espèce de la brebis en Europe. 11 m'éerit qu'il y cn a trois espèces en Moldavie, celle de montagne, eelle de plaine, et celle de bois. "Il est fort diffieile de se figurer, dit-il, la quantité innombrable de ees animaux qu'on y rencontre. Les marchands grees, pourvoyeurs du grand-seigneur, en achetaient au commencement de ce siecle plus de seize mille tous les ans, qüils menaient a Constantinople, uniquement pour l'usage de le euisine de Sa Hautesse. Ces brebis sont préférées ì toutes les autres, à cause du bon goùt et de la délicatesse de leur chair. Dans les plaines clles devienuent beaucoup plus grandes que sur les montagnes; mais elles y multiplient moins. Ces deux premières espèces sont réduites en servitude. La troisième, qu'on appelle brebis des bois, est entièrement sauvage; clle est aussi très-differente de toutes les brebis que nous connaissons: sa lève supéricure dépasse l'inférieure de deux potues, ce qui la force à paitre en reculant; le peu de longucur et le défaut de flexibilité dans son cou l'empèchent de tourner la tète de còté cl d'autre; d'ailleurs, qquoiqu’’lle ait les jambes tris-courtes, elle ne laisse pas de courir fort vite, et, ce n'est qu'avee gr'ande peine que les chiens peuvent l'atteindre; elle a l'odorat si fin qu'elle éveute, à la distance d'un mille d'Allemagne, le chasseur ou l'animal qui la poursuit, et prend aussitôt la fuite. Cette espèce se trouve sur les frontières de la Transylvanie, comme dans les forêts de Moldavie : ee sont des animaux très-sauvages et qu'on n'a pas réduits en domesticité ; cependant on peut apprivoiser les petits. Les naturels du pays en mangent la chair, et sa laine mêlée de poil ressemble à ces fourrures qui nous viennent d'Astracan. ")

Il me parait que cette troisieme brebis, dont M. le baron de Bock donne iej la description, d'après le prince Cantemir, est le mème animal que j'ai indiqué sous le nom de saïga, et qui se trouve par eonséquent en Molda vie et en Transylvanie, comme dans la Tartarie et dans la Sibérie.

Et à l'égard des deux premieres brebis, savoir celle de plaine et celle de montagne, je soupconne qu'elles ont beaucoup de rapports avee les brebis valachiennes, d'autant plus que M. le baron de Bock m'écrit, qu'ayant comparé les figures de ees brebis valachiennes avec sa description de la brebis des bois (saiga), elles ne lui ont paru avoir aueun rapport; mais qu'il est très-possible que ces brebis valachiennes soient les mèmes que celles qui se trouvent sur les montagnes ou dans les plaines de la Moldavie.

A l'égard des brebis d'Afrique et du cap de Bonne-Espérance, M. Forster a observé les particularités suivantes :

" Les brebis du cap de Bonne-Espérance ressemblent, dit-il, pour la plupart au bélier de Barbarie; néanmoins les Hottentots avaient des brebis lorsque les Hollandais s'y établirent: ces brebis ont, pour ainsi dire, une masse de graisse au lieu de queue. Les Hollandais amenerent au Cap des brebis de Perse, dont la queue est longue et très-grosse jusquà à une eertinine distance de l'origine, et ensuite mince jusqu“ì l's 'xtrémité. Les brebis que les Hollandais du Cap clèvent à présent sont d'une race moyenne entre les brebis de Perse et celles des Hottentots : on doit presumer que la graisse de la queue de ces anjmaux vient prineipalement de la nature on qualité de la pàture; après avoir été fondue, felle ne prend jamais de la consistance comme erelle de nos brehis d'Europe, et reste au contratire toujours liquicle comme l'huile. Les habitants du Cilp ne laissent pas néanmoins d'en tirer parti, 
rn ajoutant quatre parties de graisse prise aux rognons; ce qui compose un sorte.de matière qui a de la consistance et le goût mêne du saindoux que l'on tire des cochons; les gens du commun la mangent avec du pain, et l'emploient aussi aux mêmes usages que le sajndoux et le beurre. 'Tous les environs du Cap sont des terres arides et élevées, remplies de particules salines, qui, étaut entraînées par les eaux des pluies dans des espèces de petits laes, en rendent les eaux plus ou moins saumâtres. Les habitants n'ont pas d'autre sel que celui qu'ils ramassent dans ces mares et salines naturelles. On sait combien les brebis aiment le sel et combien il contribue à les engraisser; le sel exeite la soif, qư'elles étanchent en mangeant les plantes grasses et succulentes qui sont abondantes dans ces déserts élevés, telles que le sedum, l'euphorbe, le cotyledon, ete.; et ce sout apparemment ees plantes grasses qui donnent à leur graisse une qualité différente de celle qu'elle prend par la pàture des herbes ordinaires; car ces brebis passent tout l'été sur les montagnes qui sont couvertes de ces plantes succulentes; mais en automne on les ramène dans les plaines basses pour y passer l'hiver et le printemps : ainsi les brebis étant toujours abondamment nourries ne perdent rien de leur emboupoint pendant l'hiver. Daus les montagnes, surtont dans celles du eanton qu'on appelle Bochenland ou pays des chèvr's, ce sont des esclaves tirés de Madagasear et des Hottentots, avec quelques grands chiens, qui prennent soin de ces troupeaux et les défendent contre les hyènes et les lions. Ces troupeaux sont très-nombreux, et les vaisseaux qui vont aux Indes ou en Europe font leurs provisions de ces brebis; on en nourrit aussi les équjpages de tous les navires pendant leur séjour au Cap. La graisse de ees animaux est si copieuse, qu'elle occupe tout le croupion et les deux fesses, ainsi que la queue: mais il semble que les plantes grasses, suceulentes et salines qu'elles mangent sur les montagnes pendant l'été, et les plantes aromatiques et arides dont elles se nourrissent dans les plaines pendant l'hiver, servent à former deux différentes graisse's; ces dernières plantes ne doivent domner qu'une graisse solide et ferme, comme celle de nos brebis, qui se dépose dans l'omentum, le mésentère et le voisinage des rognons; tandis que la nourriture qui provient des plantes grasses, forme ertte graisse huileuse qui se dépose sur le crou- pion, les fesses et la queue. Il semble aussi que cette masse de graisse huileuse empêche l'aceroissement de la queue, qui de géneration en génération deviendrait plus courteet plus mince, et se réduirait peut-être à n'avoir plus que trois ou quatre articulations, comme cela se voit dans les brebis des Calmouques, des Mongous et des Kirghises, lesquelles n'ont absolument qu'un troncon de trois ou quatre articulations : mais comme le pays du Cap a beaucoup d'étendue, et que les pâturages ne sont pas tous de la nature de ceux que nous venons de décrire, et que de plus les brebis de Perse à queue grosse et courte y ont été autrefois introduites et se sont mêlées avec celles des Hottentots, la race bâtarde a conservé une quene aussi longue que celle des brebis d'Angleterre, avec cette différence que la partie qui est attenante au corps est déjà renflée de graisse, tandis que l'extrémité est mince comme dans les brebis ordinaires. Les pâturages à l'est du Cap n'étant pas exactement de la nature de ceux qui sont au nord, il est naturel que cela influe sur la constitution des brebis quirestent dausquelques endroits saus dégénération, et avec la queue longue et une bonne qualité de graisse aux fesses et au croupion, sans cependant atteindre cette monstrueuse masse de graisse par laquelle les brebis des Calmouques sont remarquables; et comme ces brebis ehangent sonvent de maitre, et sont menées d'un pâturageau nord du Cap à un antre à l'est, ou même dans le voisinage de la ville, et que les différentes races se mèlent ensemble, il. s'ensúit que les brebis du Cap ont plus ou moins conservé la longueur de leur queue. Dans notre trajet du cap de Bomne-Espérance à la Nouvelle-Zélande, en 1772 et 1773 , nous trouvàmes que ces brebis du Cap ne peuvent guère être transportées vivantes daus des elimats trèséloignés; car elles n'aiment pas à manger de l'orge ni du blé, n'y étant pas accoutumées, ni mème du foin qui n'est pas de bomme qualité au Cap : par conséfuent ces animaux dépérissaient de jour en jour ; ils furent attaqués du scorbut; leurs dents n'étaient plus fixes et ne pouvaient plus broyer la nourriture; deux bélier's et quatre brebis moururent, et il n'échappa que trois moutons du troupeau que nous avions embarqué. Après notre arrivéc à la Nouvelle-Zélande, on leur offrit toutes sortes de verdures : mais ils les refusèrent, et ce ne fut qu'après deux ou trois jours que je proposai d'examiner leurs dents; je 
eonseillai de Ies fixer avec du vinaigre, et de les nourrir de farine et deson trempés d'eau chaude. On préserva de cette manière les trois moutons (qu'on amena à Taïti, où on en fit présent au roi ; ils r'cprirent leur' graisse dans ce nouveau climat (n) moins de sept à huit mois. Pendant leur abstinence dans la traversée du Cap à la NouvelleZélande, leur queue s'était non-seulement dégraissée, mais décharuée et comme desséchce, ainsi que le eroupion et les fesses. "

M. de la Nux, habitant de l'ille de Bourbon, m'a écrit qu'il y a dans cette île unc race existante de ees brebis du cap de Bonne-Espérance, qu'on a mêlée avee des brebis venues de Surate, qui ont de grandes oreilles et la queue trèscourte. Cette dernière race s'est aussi mèlée avec celle des brebis à grande quene du sud de Madagascar, dont la laine n'est que faiblement ondée. La plupart des earactères de ces races primitives sont effacés, et on ne recomnait guère leurs variétés qu'à la longueur de la queue : mais il est certain que dans les iles de France et de Bourbon, toutes les brebis transportées d'Europe, de l'Inde, de Madagascar et du Cap, s'y sont mêlées et également perpétuées, et qu'il en est de mène des bouf́s grands et petits. Tous ces animaux ont été amenés de diflérentes parties du monde; car il n'y a vait dans ees deux iles, de France et de Bourbon, ni hommes, ni aucuns animaux terrestres, (juadrupedes ou reptiles, ni mème aucuns oiseanx que ceux de mer : le bouf, le cheval, le eerf, te eochon, les singes, fes perroquets, etc., y ont ćté apportés. A la vérité les singes n’ont pas encore passé ( en 1770 ) à l'ile de Bourbon, et l'on a grand intérèt d'en interdire l'introduction, pour' se garantir des même's dommages qu'ils causent à l'ìle de France. Les lièvres, les perdrix et les pintades y ont été apportés de la Chine, de l'lude ou de Madagasear : les pigcons, les ramiers, Ies tourterelles, sont pareillement venus de dehors. Les martins, ees oiseaux utiles auxquels les deux iles doivent la conservation de leurs récoltes, par la destruetion des santerelles, n'y sont que depuis vingt ans, quoiqu'il y ait peut-ètre déjji plusicurs centaines de milliers de ces oiseaux sur les deux iles. Les oiseaux james sont venus du Cap, et les bengalis de Bengale. On pourrait eneore nommer aujourd'hui les personnes auxquelles sont dues les importations de la plupart de ces espéees dians l'ile de Bourbon; en sorte qu'excepté les oiseaux d'eau, qui, comme l'ou salt, font des émigrations eonsidérables, on ne reconnait ancun être vivant qu'on puisse assigner pour ancien habitant des iles de France et de Bourbon. Les rats, qui s'y sont prodigieusement multipliés, sont des espèces européennes venues dans les vaisseaux.

\section{DESCRIPTION DU BOUQUETIN.}

(EXTRAIT DE DAUBENTON.)

Le bouquetin ressemble au bouc par la forme du corps; mais il en diffère par celle des cornes, qui sont plus grandes: elles ont sur le còtó antérieur une face entre deux arites longitudinales, dont l'interne est saillante et correspond î l'arẻte unique qui se trouve sur les cornes du bouc; il y a sur la face antérieure ‘les cornes du louquetin cles arètes transversales, saillantes, et terminées par des tubercules, placés sur l'arête longitudinale du cỏté interne de cette fice; ces tubercules sont d'autant plus nombreux que les cornes sont plus longues et que l'animal est plus àgé. Celui qui a servi dlesujet pour cette description était fort jeune, il n'avait point de barbe, la longueur des cornes et la circonférence de leur lase n’étaient que de six pouces et. demi, elles avaient plusieurs arètes transrersales sur leur face anterieure et seulement deux gros tubereules, l'un a la base de la corne et l'autre à un pouce plus haut; les arêtes transversales sont au nombre dle vingt sur de gran les cornes de bouquetin qui sont an Cibinet, et cuni ont denx pieds neuf ponces de longueur et neuf pouces de circonférence à la bise; les tuhercules sont fort petits sur la partie inférieure de ces cornes, et heancoup plus gros sur le reste de lenr étendue. l.es cornes a lu bounuetin ont une conleur noirâtre; elles sont dirigies obliçuement en arrière et en dehors, courbees en has, et queliquefois un peu recourbées en dedaus par l'extrémité; les bases des grandes cornes, dont je viens de faire mention, ne sont qu'à cincl lignes de distance l'une de l'antre, mais il y a un pied et demi entre leurs extrínités.

La plus grande jartie du corps du jeune honquetin qui fait le sujet de cette dencription, et yui monrut à la Mcinagerie de Versailles an plus fort de l'été, était d'une conleur cendrie trimle lle jaunatre, et il y avait dans quelpues endroits du fauve prile et du hrun noiratre; le bout du museau, les cótés de la tête et dı musean etaient de couleur cendrée claire, arce une lẹrgère teinte de jaunàtre, qui ètait un peu plus foncée sur la fice extcrieure des oreilles, sur le tlos el sur lés cótés du corpsis, et encore plus alprochante du faure sur la face pos 
licrieure et sur les cótés du cou, sur la croupe, sur les fésses, sur la face extérieure de l'avant-bras et de la jaube, et sur la face antéricure des canons; le rhanfrein, le front, le sommuet de la tète et l'occiput avaient une couleur brune avec un melange de lilanc, parce que les poils étaient bruns sur la plus srinde partie ole leur longueur, et blancs à la pointe. Il y arait une bante brune qui s'étendait depuis locciput le long du con, du dos et des lomhes jusqu’à la queue; la maichoire inférieure, à l'exception du menton, I'endroit des branches de cette mème màeloire, la face antérienre un con, les épaules, la face extérienre du bras et du coude, la plus srrande partie de la poitrine, le bas des côtés du corps, la quene, le genon, la face antérieure de lavant-bras el de la jamhe, le talon et les quatre pieds avaient une couleur brune plus on moins teinte de cendré ou de noiritre, et mèlée de faure dans quelques endroits; la face intérieure de l:oreille était nue, noirâtre et bordée de poils gris blanchâtres; la partie postérieure du milieu de la poitrine, le ventre, la face postérieure des jambes de devant ulepuis les coudes jusqu'au boulet, les aines, la face inférieure rle la cuisse et de la jambe, et une partie des faces postérieure et extérieure du canon les jambes de tlerrière avaient aussi une couleur grise blanchâtre, mèlè d'une légèrc teinte de jaubátre dans quelyues endroits; il y avait un épi sur l'occiput; la longueur des plus longs poils n'était que de quinze à seize lignes.

\section{DESCRIPTION DU CHAMOIS.}

ERTRA\&T DE DAURENTON.

Au premier coup d'ceil, le chamois parait ne différer clu houc que par les curnes; mais en l'observant arec plus rlattention, on voit yuil a le nez moins reculé en arriere que celui du houc, et par consćquent la lèvre supérieure moins saillante audevant cles uarines, et le front moins élevé, et il y a aussi moins de haul enr depuis le bas de la machoire du dessous juspu au chanfrein, au front el au sommul le la téte. A cet éraral le clsamois ressemble plus au beilier qu'au bouc, mais il n'a pas le chanfrein arqué eomme le bélicr, el en géneral il est plus ressemblant au houe; il a le rongon de la queue aussi court, mais ses jaunbes sont un peu plus grosses; il n'a point de loniss poils sous le menton en forme de harbe, ni tle glands an tevant te la partic supérieure du cou.

Les coines tu clamois sont placées au-nlessus de la partie posterieure des orbités, dirigeies en háut et un peu inclinces en dehors daus la plus gramle partic de leur longueur, depuis la bace el mine en avant dans leur partie inférieure; l'extrémité est recourbce en arrière et en bas comme un cro. cliet; la partie inférieure de ces cornes est presłpue ronile, le reste est aplati sur les còtés; elles ont une coulenr brune, de petites stries longitudinales, et des anneaux trausversiux très-peu apparents.

Le poil du chamois est plus long et beaucoup plus épais yue celıi du bouc; le dessus du museau, le clianfrein, l'entre-deux des yeux et des cornes, et le clerrière dle la tète d'un chamois, que jai décrit à la fiu de septembre, étaient de couleur fauve trèspâle; la lèvre du dessus, la mâchoire du dessous et la gorge étaient de mème couleur fauve; il y avait de chaque còté de la tète une large bande noirâtre; cette bande formait leux pointes en avant, dont l'une s'étendait jusqu'à la narine, et l'autre au-dessus des coins de la bouche et aul-dessus de la lèvre supérieure; cette bande entourait les yeux et allait jusqu'à la corne et jusqu’à J'oreille : il y avait aussi une tache de conleur faure au bas du front contre chaque mil; la face externe des oreilles ctait de couleur noirâtre; la face interne avait des teintes de fauve et de blanc; la pointe était noirâtre, une bande noire s'etendait depuis l'occiput le long dı cou, du dos et rle la croupe jusqu'au bout de la queue; les coites et Je dessous du cou, les còtis du corps et lle la croupe, l'épaule, la face externe dı bras, de la cuisse, du haut de l'avant-bras et du haut de la jambe étaient de couleur mclée de diffërentes teintes de fauve $\mathrm{t} t$ de centré, parce que claque poil tait de couleur cendrée claire sur la plus grande partie de sa longueur depuis la racine, et que la pointe arait dıfférentes teintes de fauve; les fesses étaient de couleur fauve claire mèlée de blanc, les puils ayant une couleur blanchâtre à la racine et unc couleur fauve pàle à la pointe: la poitrine était noirâtre, à l'exception le la partie posterieure du sternum qui itait fauve; le milieu de la partie anterrieure dn rentre arait aussi mue couleur fauve, la partie postérieure était noirâtre: la face interue du bras et de la cuisse, la face interne et le bas de la face externe de l'avant-bias et de la jambe proprement dite, et tout le reste dles quatre jambes etaieut de couleur noire ou noiratre, arec quelyues teintes de fauve sur le genou, sur le talon et sur les pieds. 


\section{DESCRIPTION}

DIS BÉZOARDS ORIENTAUX ETT OCCIDENTAUX.

On donne le nom de bézourd à plusieurs matières de nature très-différente : pour reconnaitre l'abus que l'on a fait de cette dénomination, il faut remonter à son étymologie. Soit qu'elle vienne du mot pazan ou pazar, qui est le $110 \mathrm{~m}$ du bouc en langue persane, ou du not beluzaar, qui signifie un contre-poison en hébreu ou en chaldéen, e'est une preuve que le nom de bézoardn'a d'abord été donné qu'à des concrétions qui se trouvent dims le eorps de quclques animaux de l'Asie. On ne sait pas préeisément quels sont ees animaux, mais il y a lieu de présumer, sur les relations des voyageurs, qu'ils ressemblent aux boues et aux gazelles; au moins il est certain qu'ils sont du nombre des animaux à pied fourchu qui ont des cornes : le bézoard (qu'ils doment est au dehor's et au dedaus de couleur d'olive brune foncée pour l'ordinaire et même noirâtre ; sa surface est luisante et polie.

Après la découverte de l'Amérique, on a aussi donnéle nom de bézoard à des concrétions qui se sont trouvées dans des animatux de cette partie du monde, et qui ont une couleur blanehâtre dans leur intéricur. Leur surface externe n'est pas aussi luisante ni aussi polie que celle des bézoards orientaux; elle a une couleur blanchâtre mêlée de jaune ou de noir, le plus souventavee des teintes brillantes, ([ui semblent être dorées ou bronzées. Pour distinguer ces concrétions de celles de l'Asie, on les a nommées bézoards occidentaux; et alor's le bézoard proprement dit et anciennement connu a été appelé bézoard oriental.

Tous les béozards sont composés de eouches concentripues, et plusieurs ont au ceutre un corps étranger, (qui est le noyau sur lequel porte leur première conche. On a trouvé dans les bézoards orientaux, des mareassites, du tale, des eailloux, du gravier, des pailles, des brins d'herbe, du bois, des semences de plantes ressembliant à celles des faséoles, des cerises, des milabolaus, de la casse, des timarins, de l'acacia d'Ligypte, ete. Ces differentes substances, et prineipalement les semenees de plantes qui sont au eentre des bezoards orientaux, toment lieu de eroire qu'ils se forment dians l'estomae ou dans les intestins des animaux : ear s'ils se trouvaient dans la vésicule du fiel, dans les reins, daus la vessie ou dans les autres eavités du corps, ils n'auraient pas si fréquemment pour noyau des substances qui ne peuvent y pénétrer que par des aceidents et des liasards fort extraordinaires. All contraire, ces substiuces entrent aisciment avece les aliments dans l'estomac et flans les intestins : j'ai trouvé daus la panse des boufs que j'ai disséqués grand nombre de graviers qui auraient pu faire le noyau de plusieurs bézoards.

Bontius dit que les bézoards orientaux sont dans le ventre des animaux qui les produisent; il y a de ces animaux dans différentes provinces de la Perse. Kompfer s'étant informé de ce que l'on peusait dans ces parys au sujet de la partie des animaux daus laquelle le bézoard se forme, rapporte que e'est le pylore ou le fond du quatrième estomac ; que si le bézoard ne s'y engendre pas, aumoins il y séjourne ct y prend de l'aceroissement; et que s'il n'est pas bien engagé dans les plis de l'estomac, il passe par le pylore, il suit le conduit intestinal, et il sort avee les excrements. Mais ces faits ne sont pas prouvés; aucun observateur n'a ouvert un animal portant des bézoards, pour saroir précisément quelles parties les renferment. Kœmpfer n’a traité du bézoard que sur des réeits dont la plupart sont peu vraisemblables.

J'ai fait me observation (pui peut dommer lieu de présumer que les bézoards se forment diuns l'estomate ou dans les intestins des animaux. J'ai remarqué sur les dents mâchelières des ruminants, tels que les boufs, les bélicrs, les boues, les buflles, les gazelles, les cerfs, les daims, les cherrenils, ete., une couche de matiere noirâtre et luisante, avec des teintes brillantes qui paraissent itre dorées ct bronzées. Diurs les endroits où cette matiere a de l'épaissent; elle recouvre un tartre blanchâtre. J'ai aussi vu sur plusieurs bézoards oecidentaus une couche de matiere ressemblant i celle qui revet les dents machelieres des amimaux ruminants; clle a les mèmes couleurs et les mémes teintes brillanfes ef dorées. Cette matiere ne peut venir que des herbes que broutent ees animanx et quils ma. chent : lorspu'ils ruminent, lessues qüils en ex. priment s'altachent a lent's dents et y forment une sorte de latre amalourue aux smis concrets des herbes erues, elont ils se nourrissent. On ne gent gruere douter yue les mènes sues, qui s'e. 
paississent et se durcissent sur les dents des animaux ruminants, ne s'épaississent et ne se durcissent aussi sur la face extérieure des couches des bézoards qui se trouvent dans leurs estomacs ou dans leurs intestins, puisque les bézoards occidentaux sont revêtus d'ıne matière ressemblant à eelle qui revèt les dents, et que le caractère singulier des reflets dorés et bronzés est aussi éclatant sur les bézoards que sur les dents. Les bézoards orientaux riont point de ces reflets, mais leur surface est aussi luisante que celle de la matière qui recouvre les dents; elle a le mème fond de coulcur, et leur substance parait avoir des rapports avec les sues conerets des herbes. On pourrait soupeonner qu'elle est composée en partie de ces sucs et en partie d'une matière tartareuse ou pierreuse, colorée par ces sucs conerets et mèlée avec eux : en observant au microscope la matièrequi est sur les dents, et celle du bézoard oriental , j'ai vu ces parties tartareuses ou pierreuses.

Le mème mélange de ces parties avec des sues concrets, qui s'attache aux dents, se fait aussi dans l'estomac et dans les intestins. Je suis porté à croire quiil y forme des bézoards en s'y pelotomnant ou en s'attachant aux noyaux de matières étrangères qui s'y trouvent. Dès qu'une premiere couche enveloppe un noyau, c'est déja un petit bézoard; en roulant sur les parois de l'estomac ou des intestius, il se polit comme la matière qui revèt les dents est polie par le frottement des levres, des joues et de la langue : une seconde couche succède à la première durant le repos de l'animal et dans d'autres circonstances qui arrêtent le mouvement du bézoard; cette couche prend du poli comme la premiere, et les autres se forment successivement de la même façon; lorsque l'on ouvre un bézoard, on voit que ces couches sont de différentes épaisseurs, mais elles ont toutes à peu près le mème poli sur leur face extérieure.

La forme des bézoards dépend de celle de leurs noyaux, principalement lorsqu'ils ne sont composés que d'un petit nombre de couches. La plupart sont ronds ou arrondis; il y en a d'oblongs, d'anguleux et de formes très-irrégulieres; plus ils deviement gros, plus ils s'ar" rondissent, parce que les endroits les plus saillants étant plus exposés au frottement, les couches y prennent moins d'épaisseur que dans les endroits plats ou concaves.
Lorsqu'un bézoard cesse d'acquérir de nouvelles couches, les anciennes s'usent et se détruisent dans les endroits les plus convexes; alor's on voit à l'extérieur leur épaisseur et leurs joints comme sur une agate-onyx : les bézoards ne perdent done rien de leur dureté dans le corps de l'animal, quoiqu'ils n'y prennent plus d'aceroissement. Comment peut-on croire, comme le dit Kompfer, qu'ils se ramollissent, se dissolvent et se détruisent, lorsque l'animal passe plusieurs jours sans manger? Le mème auteur ajoute, avec aussi peu de vraisemblance, que le bézoard n'est pas dur et solide dans le corps de l'animal ; qu'au contraire on l'en tire mou et friable, comme un jaune d'œuf durci dans l'eau bouillante; que pour conserver le bézoard dans son entier et dans tout son lustre, on le met dans la bouche pour lui donner le temps de se durcir : il est pourtant bien certain qu'il se polit dans le corps de l'animal durant tout le temps de sa formation, puisque toutes ses couches sont polies sur leurs faces extérieures. D'ailleurs en le tenant dans la bouche on ne lul donnerait pas plus de dureté ni de poli qu'il n'ạurait pu en prendre dans le corps de l'animal, puisqu'on le mettrait de nouveau dans un liell où il aurait à peu près la mème chaleur et la méme humidité. Il me semble que Ko mpfer avait été mieux instruit, lorsqu'il a dit que la formation du bézoard dépend de la qualité des herbes dont l'animal se nourrit. Les plantes glutineuses, aromatiques, résineuses, qui croissent sur les lieux élevés des pays chauds, paraissent en effet les plus propres pour la production du bézoard. Mais il y a peu de pays où les herbes reçoivent de la nature du sol, de la qualité de l'air et de l'action du soleil les sues propres à former des bézoards orientaux. La structure du corps doit aussi contribuer à cette formation : car il ne parait pas que toutes les espèces d’animaux produisent des bézoards, mème dans les pays chauds.

J'ai lieu de présumer que dans tous les pays les sues des herbes produisent sur les dents màchelières des différentes espèces d'animaux ruminants, dont j’ai déjà fait l'énumération. une matière qui a des reflets de couleur dorée ou bronzée : car je l'ai remarquée sur tous les individus de ees espèces que j’ai disséqués, ou dont j'ai seuJement vu les squelettes. Mais cette matière ne s'attache aux bézoards que dans les pays oì se trouvent les animaux qui donneut 
les bézoards occidentaux qui en sont revètus. On dit que c'est en Amérique; la matière brillante et dorée revèt leurs couches successives sans pénétrer dans l'intérieur de ces couches, ou au moins saus y porter sa couleur brune, comme dans le bézoard oriental : ear la substance intérieure des couches du bézoard occidental est blanche ou jaumâtre. Il y a lieu de croire que ce bézoard vient d'un animal ruminant, et que ceux qui ne sont pas revêtus de matière dorée viennent d'animaux yui n'ont rien de cette matière sur les dents. J'ai vu un b'zoard trouvé dans le colon d'un cheval; il n'a aucune écorce dorée : aussi lés dents du cheval n'en ont point; mais pourquoi les sues conerets qui forment celle écorce sur les bézoarls oceidentaux ne se mêlent-ils pas avec la partie tartareuse ou pierreuse, comme daus le bézoard oriental? Pourrjuoi la surface de cé bézoard nat-elle pas des reflets de coulcul' dorée ou brouzée, comme les bézoards occidentaux? Ces différences ne viennent peut-ìtre que de celles qui sont daus la qualicé des sucs des plantes et des parties pierreuses ou tartareuses; lorsque les partics cristallines sont abondantes ct pures, leur cristallisation se fait peut-ètre avec trop de foree pour permettre le mélange du sue coneret des plantes.

La cristallisation du bézoard oecidental est fort réguliere et parait tres-pure. Apres avoir cassé une des couches de ce bézoard, on aperçoit, à l'oeil ıu, dans l'épaisseur de lá couche, de petites stries transversales et brillantes : en les regardant au microscope on les trouve encore plus brillantes, et on reconuait (que ce sont des aiguilles rristallines, qui paraissent dirigées de dedans en dehors, depuis la face interne de la couche juscru'a la face externe. Les plus grandes de ees aiguilles s'étendent d'une face in l'autre, ellaissent entre elles des intervalles remplis par des aiguilles plus petites, qui tienuent aux grandes comme des branches à une tige. Toutescesaiguilles, grandes et petites, ontmoins de grosseur à leur origine que dans le reste de leur étendue; clles semblent naitre d'un point 'd'où sortent plusieurs aiguilles divergentes et dirigées plus oumoins obliquement, et les grandes aiguilles paraissent ètre un faisceau d'aiguilles plus petites. lilles sont toutes rayées transiersalenent par de petites lignes blanchatres, placées fort pros les unes eles autles, et paralleles aux faces de la couche: ces lignes in- diquent peut-être les différents degrés de l'accroissement de chaque aiguille. Celles cqui traversent les couches, et qui sont traver'sées ellesmèmes par des lignes parrallèles, peuvent, à ce (qu’il m'a paru jusqu“à présent, faire le caractere distinctif des bizoards occidentaux qui se forment dans les estomacs ou les intestius des animaux ruminants, comme il $y$ a lieu de le présumer á l'inspection des teintes dorées et bronzées qui sont sur la plupant de ces bézoards, dans lespuels j'ai vu des aiguilles traversées par des lignes paralleles. De onze de ees bézoarls rue j'ai obser'vis dans leur's parties internes, sept ont des \{'untes dorées et bronzées, quoiquelles manquent aux autres : je n'en suis pas moins porté á croire que ceux-ei ont aussi été formés dausles estomacs ou les intestins, paree qu'ils ont le mème caractere de cristallisation. Il y a d'autres bézoards que l'on pourrat regarder comme occidentaux, paree (qu'ils sont très-différents des bézoards orientaux, et qu'ils se forment daus les intestins des animaux : tel est le bézoard que j'ai dèja cité, et qui a été trouvé dans le colon d'un cheval de ce pays-ci, et d'autres bézoards dont il sera fait mention dans la suite de cet ouvrage.

Les médecins grees ne coumaissaient pas les bézoards: il parait que les Alabes recureut des Persans le bézoard oriental, et le regardèrent comme un contre-poison: en effet, on a reconnu que cette matière contient un sel volatil alkali, sulfureux et huileux, qui excite la transpir'ation et qui domne des forees. Mais on n'a jamais bien su si ces propriétés sont à un degreé éminent, même dans les bézoards orientaux : cependant on en a fait usage pendant longtemps, et on les emploie encore quelquefors. Si le bézoard était uu remède efficace, il se serait d'autant mieux maintenu en vogue, qu'il vient de loin, que son origine n est pas bien connue, et que le bézoard oriental se vend fort cher' '; ceux yui exaltent ses vertus prétendent qu'elles ne sont jamais éfuivoques, lorsqu'on emploie de vrais bézoarels. Mais plus j’ai observé les bézoards, et plus il m’a paru qu'il est aisé de recomnaitre ceux qui sont rpprètés. Quoique les bézoards orjentaux soient peu figcurés dans leurs parties intéricures, il serait tres-difficile de faire les aiguilles transiersales, (qui sont apparentes dans plusieurs de lurs couches, et il

I Sun f rix est de dix ou dunze livres le gros. 
est bien certain que l'on ne pourrait pas imiter la cristallisation du bézoard oceidental : on ne parviendrait pas même à contrefaire les pierres des reins, de la vessie, ete. D'ailleurs elles ne sont que trop communes, et elles ne méritent pas d'être fabriquées : car il n'y a pas lieu d'espérer (ju'elles fassent jamais de bien aux lrommes, pour tant de maux qu'elles leur causent. I.es moyens que l'on a indiqués afin de distinguer les vrais bézoards orientaux des bézoards fictices, sont tous fautifs. On pourrait les composer de manière qu'un fer rouge les percerait sans faire bouillonner leur substance, et on leur domnerait aisément une couleur qui laisserait des teintes olivâtres on verdâtres sur un papier enduit de craie, de céruse ou de chaux : on parviendrait aussi sans grande difficulté à les former par conches concentriques et polies sur leurs surfaces, à leur domner un noyau ct à imiter leurs couleurs. Mais avec toutes ees précautions, la supereherie sera découverte au premier coup d'œil, ou au moins à l'aide d'une loupe, si l'on enlève quelque partie de cette matière apprètée: au contraire on reconnaitra dans les vais bézoards, principalement daus les bézoards occidentaux, les caractères propres et inimitables de leur strueture, pour peu qu'on l'ait obscrvée.

\section{LES PHOQUUE, LES MORSES}

\section{ET LES LAMANTINS.}

Assemblons pour un instant tous les animaux quadrupèdes; faisons-en un groupe, ou plutòt formons-en une troupe dont les intervalles et les rangs représentent à peu près la proximité ou l'éloignement qui se trouve entre chaque espece; placons au centre les genres les plus nombreux, et sur les flanes, sur les ailes, ceur qui le sont le moins; resserrons-les tous dans le plus petit espaee, afin de les mieux roir, et nous trouverons qu'il n'est pas possible d'arrondir cette enceinte, que, quoique tous les animaux quadrupédes tieunent entre eux de plus prés (qu'ils ne tiennent aux antres ètres, il s'on troure né:umoins en grand nombre qui font des pointes au dehors, et semblent s'ćlancer pour atlemdre à diantres elasses de la mature. Les siriges tendent à s'ipprocher de l'homme et s'en approchent en eflet de très-près; les chaures. souris sont les siuges des oiseaux, qu'elles imitent par leur vol; les pores-épies, les hérissons, par les tuyaux dont ils sont couverts, semblent nous indiquer que les plumes pourraient appartenir a d'autres qu'aux oiseaux; les tatous, par lear tèt écailleux, s'approchent de la tortue et des crustacés; les castors, par les éeailles de leur queue, ressemblent aux poissons ; les four-miliers, par leur espèce de bec ou de trompe sans dents et par leur' longue langue, nous rappellent encore les oiseaux; enfin les plocyues, les morses et les lamantins font un petit corps à part, qui forme la pointe la plus saillante pour arriver aux cétacés.

Ces mots phoque, morse et lamantin, sont plutòt des dénominations génériques que des uomis spécitiques. Nous comprenons sous celle de phoque: $1^{\circ}$ le phoca des anciens, qui rraisemblablement est celui que nous avons fait représenter $; 2^{\circ}$ le phoque commun, yue nous appelons veau'marin; $3^{\circ}$ le grand phoque, dont M. Parsons a domé la description et la figure dans les Transactions philosophiques, $n^{0} 469$; $4^{n}$ le tres-grand phorgue, que l'on appelle lion marin, et dont lauteur du Voyage d'Anson a douné la description et les figures.

Par le nom de morse, nous entendons les animaux que l'on connait vulgairement sous celui de vaches marines ou bétes à la grande dent, dont nous comnaissons deux espèces, l'une qui ne se trouve que dans les mers du Nord, et l'autre qui n'habite au contraire que les mers du Midi, à laquelle nous avons donné le nom de dugon. Enfin, sous celui de lamantir, nous comprenons les animaux qu'on appelle manali, boufs marins de Saint-l)omingue, à Cayenne et dans les autres parties de l'Amérique méri dionale, aussi bien que le lamantin du Sénégal et des antres cotes de l'Afrique, qui ne nous parait ètre qu une variété du lamantin de l'A. mérique.

L.es phoques et les morses sont encore plus près des quadrupèdes que des ećtacés, parce qu'ils ont quatre espèces de pieds; mais les lamantins, qui n'ont que les deux de devant, sont plus cetacés que qualdrupèdes : tous different de's autres animaux par un grand caractere; ils sont les seuls qui puissent vivre également et daus l'ail et dans l'eau, les seuls par consépuent qu'on dut appeler amphibies. Dans I'lomme et dans les animanx terrestres et vivie 

pares, le trou de la cloison du cœur, qui permet au foetus de vivre sans respirer, se ferme au moment de la naissance, et deineure fermé pendant toute la vie : dans ces animaux, au contraire, il est toujours ouvert, quoique la mère les mette bas sur terre, (qu'au moment de leur naissance l'air dilate leurs poumons, et que la respiration commence et s'opère comme dans tous les animaux. Au moyen de cette ouverture dans la cloisondu cœur, toujours subsistante, et qui permet la communication du sang de la veine-cave àl'aorte, ces animaux ont l'avantage de respirer quand il leur plait, et de se passer de respirer quand il le faut. Cette propriété singulière leur est eommune à tous; mais elacun a d'autres facultés particulières dont nous parlerons en faisant, autant qu'il est en nous, l'histoire detoutes les espèces de ces animaux amphibies.

\section{LES PHOQUES.}

Ordre des amphibies, genre phoque. (Cuvier.)

En général, les phoques ont la tète ronde comme l'homme, le museau large comme la loutre, les yeux grands et placés haut; peu ou point d'oreilles externes, seulement deux trou auditifs aux côtés de la tête, des moustaches autour de la gueule, des dents assez semblables à celles du loup, la langue fourchue on plutot échancrée à la pointe, le eou bien dessiné; le corps, les mains et les pieds couverts d'un poil court et assez rude; point de bras ni d'avantbras apparents, mais deux mains ou plutôt deux membranes, deux peaux renfermant eing doigts et terminées par cinq ongles; deux pieds sans jambes tout pareils aux mains, seulement plus larges et tournés en arrière comme pour se réunir à une queue très-courte qu’ils accompagnent des deux côtés; le corps allongé comme celui d'un poisson, mais renflé vers la poitrine, étroit à la partie du ventre, sans hanches, sans croupe et sans euisses au-dehors ; animal d'autaut plus étrange qu'il parait fictif, et qu'il est le modèle sur lequel l'imagination des poëtes enfanta les tritons, les sirenes, et ces dieux de la mer à tète lunmaine, à corps de quadrupede, à queue de poisson; at le phoque règne en efiet dans eet empire nuet par sa voix, par sa figure, par son intelligence, par les facultés, en un mot, qui lui sont communes avec les hubitants de la terre, si supéricures il celles des poissons, qu'ils sembieut être non-seulement d'un autre ordre, mais d'un monde différent : aussi cet amphilsie, quoique d'une nature trèséloignée de celle de nos animaux domestiques, ne laisse pas d'être susceptible d'une sorte d'éducation. Un le nourrit en le tenant souvent dans l'eau; on lui apprend a saluer de la tète et de la voix; il s'accoutume atcelle de son maitre; il vient lor'squ'il s'entend appeler, et donne plusieurs autres signes d'inteiligence et de docilité.

II a le cerveau et le cervelet proportionnellement plus grands que l'homme, les sens aussi bons qu'aucun des quadrupedes, par conséquent le sentiment aussi vif, et l'intelligence aussi prompte; l'un et l'autre se marquent par sa donceur, par ses habitudes communes par ses qualités sociales, par son instinct très-rif pour sa femelle, et tres-attentif pour ses petits, par sa voix plus expressive et plus morlulée que celle des autres animanx. 11 a aussi de la force ct des armes; son eorps est ferme et grand, ses dents tranchantes, ses ongl's aigus. D'ailleurs il a desavantages particuliers, uniques, sur tous ceux qu'on voudrait lui comparer : il ne craint ni le froid ni le chaud; il vit indifféremment d'herbe, de ehair ou de poisson; it habite également l'eau, la terre et la glaee. Il est avee le morse le scul des quadrupèdes qui mérite le nom d'amphibie, le seul quiait le trou ovale du cour ouvert, le seul par conséquent yui puisse se passer de respirer, et aucquel l'élement de l'ean soit aussi eonvenable, aussi propre que eelui de lair. La loutre et le castor ne sont pas de r rais amphibies, puisque leur élément est l'air, et que, n'ayant pas eette ouverture dans la choison ducour, ils ne peurcut reste:" longtemps sous l'eau, et qu'ils sont obliqués d'en sortir ou d'élever leur tète au-dessus pour respirer.

Mais eesar antages, qui sont tres-grands, sont balancés par des imperfections qui sont encore plus graudes. Le veau marin est manchot ou plutòt estropié des (quatre membres; ses bras, ses cuisses et ses jambes sont presifue enticiement enfermes dans son eorps; il ne solt au dehors que les mains et les pieds, lesquels sont il la verité tous divisés en einq doigts ; mais ces doigts ne sont pas moliles séparement les uns des autres, étant réunis par une forte mem. brane; et ces extremites sont plutòt des nagenires que des mains et des pieds, des especes t'instruments faits pour nager et non pour maril 
cher. D'aillears les pieds étant dirigés en arrière, comme la queue, ne peuvent soutenir le corps de l'animal qui, quand il est sur terre, est obligé de se trainer comme un reptile, et par un mouvement plus pénible; car son corps ne pouvant se plier en are, comme celui du serpent, pour prendre successivement différents points d'appui, et avaneer aiusi par la réaction du terrain, le phoque demeurerait gisant au mème lieu, sans sa gueule et ses mains qu'il accroche à ce qu'il peut saisir ; et il s'en sert avec tant de dextérité qu'il monte assez promptement sur un rivage élevé, sur un rocher et même sur un glaçon, quoique rapide et glissant. II marche aussi beaucoup plus vite qu'on ne pourrait l'imaginer, et souvent, quoique blessé; il échappe par la fuite au chasseur.

Les phoques vivent en société, ou du moins en grand nombre dlans les mêmes lieux. Leur climat naturel est le nord, quoiqu'ils puissent vivre aussi dans les zones tempérées, et même daus les climats chauds; car on en trouve quelques-uns sur les rivages de presque toutes les mer's de l'Europe et jusque dans la Méditerranéc; on eu trouve aussi dans les mers méridionales de l'Afrique et de l'Amérique : mais ils sont infiniment plus communs, plus nombreux dans les mer's septentrionales de l'Asie, de l'Europe et de l'Amérique, et on les retrouve en aussi grande quantité dans celles quì sont voisines de l'autre pôle au détroit de Magellan, à l'ile de Juan Fernandès, etc. Il parait seulement que l'espèce varie, et que selon les différents climats elle change pour la grandeur, la couleur et même pour la figure. Nous avons vu quelques-uns de ces animanx vivants, et l'ou nous a envoyé les dépouilles de plusieurs autres: dans le nombre, nous en avons choisi deux pour les faire dessiner. Le premier est le phoque de notre Océan ', dont il y a plusieurs variétés : nous en avons vu un dont les proportions du corps paraissaient différentes; car il avait le cou plus court, le corps plus allongé et les ongles plus grands que celui dont nous donnons la figure : mais ces différences ne nous ont pas paru assez considérables pour en faire une espèce distincte et séparée. Le second ${ }^{2}$, qui est le phoque de la Méuiterranée et des mers du midi, et que nous présumons ètre le phoca des

\footnotetext{
1 C"est Ie proque comuun

2 C'est mo 9тани
}

anciens, parait être d'une autre espèce ; car il diffère des autres par la qualité et la couleur du poil qui est ondoyant et presque noir, tandis que le poil des premier's est gris et rude. Il en diffère encore par la forme des dents et par celle des oreilles; car il a une espèce d'oreille externe très-petite à la vérité, au lieu que les autres n'ont que le trou auditif sans apparence de conque. Il a aussi les deuts incisives terminées par deux pointes, tandis que les deux autres ont ces mèmes dents incisives unies et tranchantes i droit fil comme celles du chien, du loup et de tous les autres cquadrupèdes. Il a encore les bras situés plus bas, c'est-à-dire plus en arrière du corps que les autres, qui les ont placés plus en avant. Néanmoins ces disconvenances ne sont peut-être que des variétés dépendantes du climat, et non pas des différences spéciliques, attendu que dans les mèmes lieux, et surtout dans ceux où ces animaux abondent, on en trouve de plus grands, de plus petits, de plus gros, de plus minces, et de eouleur ou de poil différents, suivant le sexe et l'âge.

C'est par une convenance qui d'abord parait assez légère, et par quelques rapports fugitifs que nous avons jugé que ce second phoque était le phoca des anciens. On nous a assuré que l'individu que nous a vons vu venait des lndes, et il est au moins très-probable qu'il renait des mers du Levant : il était adulte, puisqu'il avait toutes ses dents; il était d'un einquième moins grand que les phoques adultes de nos mers, et des deux tier's plus petit que ceux de la mer Glaciale; car quoiqu'il eùt toutes ses dents, il n'avait que deux pieds trois pouces de longueur, tandis que celui que M. Parsons a décrit et dessiné a vait sept pieds et demi d'Angleterre, c'esti-dire sept pieds de Paris, quoiqu'il ne fùt pas adulte, puisqu'il n'avait encore que quelques dents : or , tous les caractères que les anciens donnent à leur phoca ne désignent pas un animal aussi grand, et conviennent à ce petit phoque qu'ils comparent souvent au castor et à la loutre, lesquels sont de trop petite taille pour ètre comparés avec ces gramds phoques du nord; et, ce qui a achevé de nous persuader que cc petit phoque est le phoca des anciens, c'est un rapport qui, quoique faux dans son objet, ne peut cependant avoir été imaginé que d'après le petit phoque dont il est ici question, et n'a jamais pu en aucune manière avoir été attribué aux phoques de nos cites, ni aux grands pho. 
ques du nord. Les anciens, en parlant du phocu, disent que son poil est ondoyant, et que par une sympathie naturelle il suit les mouvements de la mer; qu'il se couche en arric̀re clans le temps que la mer baisse, qu'il se relève en avan! Jorsque la maréc monte, et que cet effet singulier subsiste même dans les peaux longtemps après qu'elles ont été enlevées et séparées de l'animal : or, l'on n'a pu imagriner ce rapport ni cette propriété dans les plıogues de nos côtes, ni dans ceux du nord, puisqne le poil et des uns et des autres est court et raide; clle convicut au contraire en quelque facon à ce petit phoque dont le poil est ondoyant et beaucoup plus souple et plus long que celui des autres. En général les phoques des mers méridionales out le poil beaucoup plus fiu et plus doux que ceux des mers septeutriouales. D'ailleur's Cardan dit affirmativement que cette propriété, qui avait passé pour fabuleuse, a été trouvéc réelle aux Indes. Sans dommer ì cette assertion de Cardan plus de foi qu'il ne faut, elle indique au moins que c'est au phoque des Indes que cet effet arrive : il y a toute apparence que daus le fond ee n'est autre chose qu'un pliénomène électrique, dont les anciens et les modernes, ignorant la cause, ont attribué l'effet au flux et au reflux de la mer. Quoi qu'il en soit, les raisons que nous venons d'exposer sont suffisantes pour qu'on puisse présumer que ce petit phorpue est le phoc $a$ des anciens; et il y a aussi toute apparence que e'est celui que Rondelet appelle phoca de la Méditerranéc, lequel, selon lui, a le corps à proportion plus long et moins gros que le phoque de l'Océan. 1.e grand phoque dont M. Parsons a donné les dimensions et la figure, et qui venait vraisemblablement des mers septentrionales, paraît ètre d'une espèce différente des deux autres, puisque n'ayant encore presque point de dents et n'étant pas adulte, il ne laissait pas d'c̀tre plus que double en grandeur daus toutes ses dimensions, et qu’il avait par conséquent dix fois plus de volume et de masse que les autres. M. Parsons (ainsi que l'a très-bien remarcué $\mathbf{M}$. Klein ) a dit beaneoup de choses en peu de mots au sujet de cet aujmal. Conme les observations sout en auglais j'ai cru devoir en donner ici la traduction par extrait ${ }^{4}$.

- Ge veau marin se voyait a Lonilres en Charing-Cross, au muis de février" $1742-3 . . .$. Les tigures domnés par Aldro.
Voilà donc trois espèces de phoques qui sem. blent être différentes les unes desautres: le petit phoque noir des Indes et du Levant, le veau marin ou phociue de nos mers, et le crand phoque des mer's du nord, et e'est à la première espèe qu'il faut rapporter tout ce que les anciens ont écrit du phocu. Aristote connajssait assez bien cet animal, lorsqu'il a dit qu'il était d'une nature ambicruë et moyeune entre les animaux aquatiques et terrestres; que c'est un quadıupède imparfait et manchot; qu'il n'a point d'oreilles cxternes, mais seulement des trous très-apparents pour entendre; qu'il a la langue fourchue, des mamelles et du lait, et une petite queue comme un eerf : mais il paraît (jüil s'est trompé en assurant que eet animal n'a point de: fiel; il est certain qu'il en a au inoins la vésicule. M. Parsons dit, ¿ la vérité, que la vésicule du fiel, dans le griand phoque (ư'il a déerit, était fort petite : mais 11. Baubenton a tronvé dans notre ploque, qu'ii a disséqué, une vésicule du fiel proportionnée? a la grandeur du foie; MM. de l'Acadénie des Sciences, qui ont aussi trouvé cette vésicule du

vande, Johuston et d'autres, élant de protil, nous jeltent dans deux erreurs : la prenière, c'est qu'elles font praraitre le bras, qui cependant n'est pas visible au dehors dans quelpue position que soit l'animal; la secunde, c est qu'clles représentent les pieds comme deux nageoires, tandis que ce sout ie vrais pieds avec des membranes et cinc doigts t $t$ cinq ongles, el que Jes duigls sont cunuposés de trois articulations. Les ongles des pieds de devant sumt grands et larges; ces pleds sont assez semblables ci ceux d'une taupe; ils paraissent faits pour ranuer sur la terre et pour nager : il y a une membrane étroite cntro chayue doict; mais les pieds de derriere ont des membranes beancoup plus larges, et ils ne servent a l'animal pue pour rames daus l'eau... (iet animal etait femelle, et nourut le 16 lívrier 17 12-5. Il avail autur de la gueule de gramls poils d'une sulustance transparente et curuéc. Se- visceres étaient comme il suit; Ifs estomacs, les intestins, la vcssie, les reins, I s ureibre, le dia hrigme, les prumons, les grus vaisseaux du sans el les parties extérieures de la génération etaient comme dans la vache: La rate avait leux pieds de long, quatre pouces de large, ct était fort mince; le foric était compusé de six lobes, chacun de ces lohes était lung et mince comne la rate; la vésienle du fiel éta't fort petite. le crrur était long et mou dans sa contexture, ayant un trou ovale forl large, it les colonnes charuues fort grandes. Lans l'eslomac le plus las, il y avait cnvirom quatre lives peaant le petits caillomx tranchants et angulenx, comme si l'auimal les avait choisis pour hacher sa nouriture... l. e corus dr. la matrice était fuetıt er comparaison des deux cornes, yui ditaient tres-grandes cetres-ípalsses.. Les ovaires étaient. furt gros. cl les cormes de l. malrice étaient ouvertes par un frand trun du cilé des ovaires. Je doune ha figure de ces partie's... aussi bien ýue celle de l'animal, que j'ai dessins moi-mème avec le plus grand soin. Cit anumal ist vivipare, il allalte ses petits ; sa chair est ferme el musculeuse; il etant font jeune, quoinuil ent sept pieds et demi de lun-

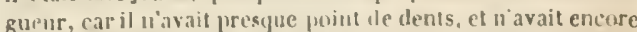

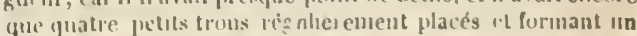
cimes antour du nombril, célaient les vestiges des fuatre mamelles yui devaient parailre avec le tcmps. Trase, l'bul., 110 s.9. pase 383 ce 386. 
fiel dans le phoque qu'ils ont déerit, ne disent pas qu'elle fit d'une petitesse remarquable.

Au reste, Aristote ne pouvait avoir aueune connaissance des grands phoques des mers glaciales, puisque de son temps tout le nord de l'Europe et de l'Asie était encore ineonnm; les Grees et mème les Romains regardaient les Gaules et la Germanie comme leur nord : les Grees surtout connaissaient peu les auimaux de ces pays; il y a donc toute vraisemblanee qu'Aristote, qui parle du phoca comme d'un animal commun, n'a entendu par ce nom que !e phoca de la Méditerranée, et (qu'il ne commaissait pas plus les phoques demotre Océau que les grands phoques des mers du nord.

Ces trois animaux, quoique différents par l'espèce, ont beaucoup de propriétés communes, et doivent ètre regardés comme d'une mome nature. Les femelles mettent bas en hiver; elles font leurs petits à terre sur un banc de sable, sur un rocher, ou dans une petite île et à quelque distance du continent; elles se tiennent assises pour les allaiter; et les nourrissent ainsi pendant douze ou quinze jours dans l'endroit ou ils sont nés, après quoi la mère emmène ses petits arec elle à la mer, où elle leur apprend à nager et à chereher à vivre; elle les prend sur son dos lorscu'ils sont fatigués. Comme chaque portée n'est que de deux ou trois, ses soins ne sont pas fort partagés, et leur édneation est bientôt achevée. D'ailleurs ces animaux ont naturellement assez dintelligence et beaucoup de sentiment; ils s'entendent, ils s'entr'aident et se secourent mutuellement : les petits reconnaissent leur mère au milieu d'une troupe nombreuse; ils entendent sa voix, et dès qu'elle les appelle, ils arrivent à elle sans se tromper. Nous ignorons combien de temps dure la gestation : mais, à en juger par celui de l'aceroissement, par la durée de la vie et aussi par la grandeur de l'animal, il parait que ce temps doit être de plusieurs mois, et l'aceroissement étant de quelques amnées, la durée de la vie doit ĉtre assez longue : jes suis mème très-porté a croire que ces animaux vivent beaucoup plus de temps qu'on n'a pu l'observer, peut-ĉtre cent ans et davantage : ear on sait que les cétacés en gérièal vivent bien plus lonstemps que les animaux quadrupedes; et comme le phoque fait une nuance entre les uns et les autres, il doit participer de la nature des premiers, et par conséquent virre plus que les derniers.
La voix du phoque peut se comparer à l'a boiement d'un ehien enroué; dans le premier âge, il fait entendre un eri plus clair, à peu près comme le miaulement d'un chat. I.es petits qu'on enlève à leur mère miaulent continuellement, et se laissent quelquefois mourir d inanition plutôt que de prendre la nourriture qu'on leur offre. Les vieux phoques aboient contre ceux qui les frappent, et font tous leurs efforts pour mordre et se venger. En général, ces animaux sont peu craintifs; même ils sont courageux. L'on a remarqué que le feu des éelairs ou le bruit du tomnerre, loin de les épouvanter, semble les réeréer; ils sortent de l'eau dans li tempête; ils quittent mème alors leurs glaẹons pour éviter le ehoc des vagues, et ils vont à terre s'amusel de l'orage et recevoir la pluic qui les réjouit beaucoup. Ils ont naturellement une mauvaise odeur, et que l'on sent de fort loin lorsqu'ils sont en grand nombre : il arrive souvent que quand on les poursuit ils lâchent leur's exeréments, qui sont jaunes et d'une odeur abominable. Ils out une quantité de sang prodigieuse; et comme ils ont aussi une grande surcharge de graisse, ils sont par cette raison d'une nature lourde et pesante. Ils dorment beancoup et d'un sommeil profond; ils aiment à dormir au soleil sur des glacons, sur des rochers, et on peut les approcher sans les éveiller; e'est la manière la plus ordinaire de les prendre. On les tire rarement avee des armes à feu, parce qu'ils ne meurent pas tout de suite, même d'unc balle dans la tête; ils se jettent à la mer et son perdus pour le chasseur : mais comme l'on peut les approcher de près lorsqu'ils sont endormis, ou même quand ils sont éloignés de la ner, parcequ'ils ne peuvent fuir que très-lentement, on les assonime à coups de bâton et de perehe. Ils sont très-durs et très-vivaces. "Ils ne meu" rent pas facilement, dit un témoin oeulaire; " ear, quoiqu’ils soient mortellement blessés, " qu'ils perdent presque tout leur sang et qu'ils " soient même écorchés, ils ne laissent pas de " vivre encore, et c'est quelque ehose d'affreux " que de les voir se rouler dans leur sang. C'est " ce que nous observimes à l'égard de celui que " nous tuàmes, et qui avait huit pieds de long, " eatraprès l'avoir écorché et dépouillé mèmo " de la plus grande partie de sa graisse, eepen" dant et malgré tous les coups qu'on lui avait "donnés sur la tète et sur le museau, il ne laisa sait pas de vouloir mordre encore : il saisit 
- méme une demi-pique qu'on lui présenta avec a presque autant de vigueur (que s'il n'eût point "été blessé : nous lui entonçâmes après cela " une demi-pirque alu travers du coeul ct du foie, "d'où il sortit encore autant de sang que d'un " jeune bouf. "Recueil des voyages du Nord, tome II, page 117 et suiv. Au reste, la chasse, ou si l'on veut la pèche de ces animaux n'est pas difficile et ne laissf; pas d'ètre utile, ear la chair n'en est pas mauvaise à manges' : la peau fait une bonne fourrure; les Américains s'en servent pour faire des ballons ru'ils remplissent d'air, et dont ils se servent comme de radeaux. L'on tice de leur graisse une livile plus claire et d'un moins mauvais goùt que celle du marsouin et des autres cétacés.

Aux trois espèces de phoques dont nous venons de parler il fuut peut-être, comme nous l'avons dit, en ajouter ume quatrieme dont l'auteur du voyage d'Anson a donné la figure et la description sous le nom de lion marin : elle est très-nombreuse sur les cótes des terres Magrellaniques et a l'ile de Juan Fernandes dans la mer du Sud. Ces lions marius ressemblent aux phoques ou veaux marins, qui sont fort communs dans ces mèmes parages : mais ils sont beaucoup plus grands; lorsqu'ils ont pris toute leur taille, ils peuvent avoir depuis onze jusqu'à dix-lnuit pieds de long, et en circonférence depuis se'pt ou buit pieds jusqu'à ouze. Ils sont si gras qu'après avoir percé et ouvert la peau, qui est épaisse d'un pouce, on trouve au moins un pied de graisse a vant de parvenir à la ellair. On tire d'un seul de ces animaux jusqu'a ciny cents pintes d'huile, mesure de Paris. Ils sont en mème temps fort sanguins; lorsqu'on les blesse profondément et en plusieurs endroits à la fois, on voit partout jaillir le sang avec beaucoup de foree. Un seul de ees animaix, aucuel on coupa la gorge, et dout on recueillit le sang, en donna deux barri(jues, sans tompter celui (qui restait dans les vaisseaux de son corps. Leur peau est couverte d'un poil court, d'une couleur tannée claire; mais leur quenc et leurs pieds sont noiratres. I.eurs doigts sont réunis par une membrane qui ne s'étend pas jusqu'à lemr extrémité, et qui daus chacun est terminée par un ongle. Ils different des autres phoques, non-seulement par la srandeur et la grosseur, mais encore par d'autres caracteres : les lions marins mailes ont une espéce de grosse crête ou trompe qui leur pend du bout de la máchoire supérieure, de la longueur de cinq ou six pouces. Cette partie ne se trouve pas dans les femelles; ce qui fait qu'on les distingue des mâles au premier coup d'œil, outre qu'elles sont beaucoup plus petites. I.es malles les plus forts se font un troupeau de plusieurs femelles, dont ils empèchent les autres mâlesd approcher. Ces animaux sont de vrais amphibies ; ils passent tout l'été dans la mer, et tout l'hiver à terre, et c'est dans eette saison que les femelles mettent bas: elles ne produisent qu'un ou deux petits, qu'elles allaitent, et qui sont en naissant aussi gros qu'un veau marin adulte.

Les lions marins, pendant tout le temps quils sont à terre, vivent de l'herbe qui eroit sur le bord des eaux courantes, et le temps qu'ils ne paissent pas, ils l'emploient à dornir dans la fange : ils palaissent d'un naturel fort pesant, et sont fort difficiles à réveiller ; mais ils ont la précaution de placer des màles en sentinelle autour de l'endroit ou ils dor'ment, et l'on dit que ces sentinelles ont grand soin de les éveiller des qu'on approche. Leurs eris sont fort bruyants et de tons différents : tantòt ils grognent comme des cochons, et tantòt ils hennissent comme des chevaux. Ils se battent souvent, surtout les màles qui se disputent les femelles, et se font de grandes blessures a coups de dents. La ehair de ces animaux n'est pas mauvaise à manger; la langue surtout est aussi homnc que celle du houf. 11 est très-facile de les tuer, car ils ne peuvent ni se défendre ni s'enfuir; ils sont si lourds qu'ils ont peine i se remuer, et eucore plus à se retourner; il fant seulement prendre garde à leurs dents, qui sont très-fortes, et clont ils pourraient blesser si on les approchait de face et de trop près.

Par d'autres observations comparcés à cellesci, et par quelques rapports que nous en déduirons, il nous parait que ees lions marius, qul se trouvent à la pointe de l'Amérique méridionale, se retrouvent, à quelques varietés près, sur les cótes septentrionales du mème continent. Les grands phoques des mers du Canada, dont parle benis sous le nom de loups marins, et qu'il distingme des petits veaux marins ordinaires, pourraient bien ètre de la mime espece que les lions marins des terres Magellaniques. l.eurs petits (dit cet auleur, qui est assez exact) sont en maissant plus gros que le plus gros pore que l'on voie, et plus longs. Or il est certain que les phoques ou veaux marius de notre Ocćan 
ne sont jamais de cette taille, quand même ils sont adultes : celui de la Méditerranée, c'està-dire le phoca des anciens, est encore plus petit, et il n'y a que le phoque décrit par M. Parsons dont la grandeur convienne à ceux de Denis. M. Parsons ne dit pas de quelle mer venait ce grand phoque : mais soit quil vîut de la mer septentrionale de l'Europe ou de celle de l'Amérique, il se pourrait qu'il fủt le mème que le loup marin de Denis, et le mème encore que le lion marin d'Anson; car il est de la mème grandeur, puisque n'étant pas encore adulte ni même à beaucoup près, il avait sept pieds de longueur. D'ailleurs, la différence la plus apparente, après celle de la grandeur, qu'il y ait entre le lion marin et le veau marin, e'est que dans l'espèce du lion marin le mâle a une grande crète à la mâchoire supérieure; mais la femelle n'a pas cette crète. M. Parsons n'a pas vu le mâle, et n'a décrit que la femelle, qui n'avait en effet point de crête, et qui ressemble en tout à la femelle du lion marin d'Anson. Ajoutez à toutes ces convenances un rapport encore plus précis, c'est que M. Parsons dit que son grand phoque avait les estomacs et les intestins comme une vache, et en mème temps l'auteur du Voyage d'Anson dit que le Iion marin ne se nourrit que d'herbes pendant tout l'été : il est donc très-probable que ces deux animaux sont conformés de mème, ou plutôt que ce sont les mèmes animaux très-différents des autres phoques, qui n'ont qu'un cstomac, et qui se nourrissent de poisson.

Woodes Rogers avait parlé, avant l'auteur du Voyage d'Anson, de ces lions marins des terres Magellaniques, et il les décrit un peu différemment. "Le lion mariu (dit-il) est une " créature fort étrange, d'une grosseur prodi" gieuse; ou en a vu de vingt pieds de long ou " au delà, qui ne pouvaient gùère moins peser a que quatre milliers : pour moi, j'en vis plu" sieurs de seize pieds qui pesajent pent-être " deux milliers : je m'étonne qu'avec tout cela " on puisse tirer tant d'huile du lard de ces " animaux. La forme de leur corps approche a assez de celle des veaux marins; mais ils ont - Ia peau plus épaisse que celle du bœuf, le poil " cotirt et rude, la tête beaucoup plus grosse à a proportion, la gueule fort grande, les yeux a d'une grossetir monstrueuse, etle museau qui - ressemble à celui d'un lion, arec de terribles - moustaches, dont le poil est si rude qu'il
" pourrait servir à faire des cure-dents. Vers la " fin du mois de juin, ces animaux vont sur l'ile " (de Juan Fernandès) pour y faire leurs petits, " qu'ils deposent à une portée de fusil du bord " de la mer : ils s'y arrètent jusqu’à la fin de " septembre sans bouger de la place et sans " prendre aucune nourriture; du moins on ne " les roit pas manger : j'cu observai moi-meme " quelques-uns qui furent huit jours entiers " dans leur gite, et qui ne l'auraient pas aban" douné si nous ne les avious effr'ayés.... Nous " vimes encore à l'ille de Lobos de la Mar, sur " la côte du Pérou, dans la mer du Sud, quel" ques lions marius, et beaucoup plus de veaux " marius."

Ces observations de Woodes Rogers, qui s'accordent assez avec celles de l'auteur du Voyage d'Anson, semblent prouver encore que ces animaux vivent d'herbes lorsqu'ils sont à terre; car il est peu probable qu'ils se passent pendant trois mois de toute nourriture, surtout en allaitant leurs petits. L'on trouve dans le recueil des Navigations aux Terres australes beaucoup de choses relatives à ces auimaux : mais ni les descriptions ni les faits ne uous paraissent exacts. Par exemple, il y est dit qu’à la còte du port des Kenar'ss, au détroit de Magellan, il y avait des loups marins si gros, que leur cuir étendu se trouvait de trente-six pieds de large : cela est certainement exagéré. II y est dit que sur les deux îles du port Désiré, aux terres Hagellauiques, ces animaux ressemblent ì des lious par la partie antérieure de leur corps, ayint la tète, le cou et les épaules garnis d'une très-longue crinière bien fournie. Cela est encore plus qu'exagéré ; car ces animaux ont seulement autour du cou un peu plus de poil que sur le reste du corps, mais ce poil n'a pas plus d'un doigt de long. Il y est encore dit qu'il y a de ces animaux qui ont plus de dix-huit pieds de long; que de eeux qui n'ont que quatorze pieds il $y$ en a des milliers, mais que les plus communs n'en out que cinq. Cela pourrait iuduireà croire qu'il y en aurait de deux espèces, l'une beaucoup plus grande que l'autre, parce que l'auteur ne dit pas que cette différence vienne de celle de l'àge, ce qui cependant était nécessaire à dire pour prévenir l'erreur. "Ces animaux, " dit Coréal, ouvrent toujours leur gueule : deux " hommes ont assez de peine à en tuer un avec " un épicu, qui est la meilleure arme dont on " puisse se servir. Une femelle allaite quatre ou 
- cinq petits, et chasse les autres petits qui a s'approchent d'elle, d'où je juge qu'elles ont " quatre ou cinq petits d'une ventrée. "Cette présomption est assez bien fondée; car le grand phoque décrit par M. Parsous avait quątre manelles situées de manière qu'elles formaient un carré dont le nombril érait le centre. J'ai cru devoir recueillir et présenter ici tous les faits qui ont rapport à ces animaux, qui sont peu comnus, et dont il serait à désirer que quelque voyageur habile nous domât la description, surtout celle des parties intérieures, de l'estomac, des intestins, etc.; car si l'ou s'en rapporte aux témoignages des voyageurs, ou pourrait croire que les lions marins sont de la classe des animaux ruminants, qu'ils ont plusicurs estomacs, et que par conséquent ils sont d'une espèce fort éloignée de celle des phorques ou veaux marius, qui certainement n'ont qu'uu estomac, et doivent être mis au nombre des animaux carnassier's.

\section{LE MORSE,}

OU LA VACHE MARINE

Ordre des amphibies, geure morse. (Guvier.)

Le nom de vache marine, sous lequel le morse est le plus généralement counu, a été très-mal appliqué, puisque l'animal qu’il désigne ne ressemble en rien à la vache terrestre; le nom d'éléphant de mer que d'autres lui ont donné est mieux imaginé, parce qu'il est fondé sur un rapport unique, et sur un caractère trè-apparent. Le morse a, comme l'éléphant, deux grandes défenses d'ivoire qui sortent de la mâchoire supérieure, et il a la tête conformée, ou plutôt déformée de la mème manière que l'éléphant, auquel il ressemblerait en entier par cette partic capitale, s'il avait une trompe: mais le morse est non-seulement privé de cet instrument qui sert de brass et de main à l'éléphant, 11 l'est eneore de l'usacre des varais bras et des jambes. Ces membres sont, comme dans les phoques, enfermés sous sá peau; il lie sort au dehors que les deux mains et les deux pieds. Son corps est allongé, renflé par la partie de l'avant, étroit vers celle de l'arriere, partout couvert d'un poil court; les doigts des pieds et

4 C'est le morse, cheval marin. des mains sont enveloppés dans une membrane, et terminés par des ongles courts et pointus : de grosses soies eu forme de moustaches environnent la gueule; la langue est échancrée: il n'y a point de conques aux oreilles, ete.; cll sorte qu'à l'exception des deux grandes défenses quilui changent la forme de la tète, ct des dents incisives qui lui manquent en haut ct en bas, le morse ressemble pour tout le reste au ploque; il est seulement beaucoup plus grand, plus (r)os et.plus fort. Les plus grands phoques nont tout au plus que sept ou huit pieds; le morse cu a communément douze, et il s'en trouve de scize pieds de longueur et de lsuit ou neuf pieds de tour. Il a encore de commun avee les phoques d'habiter les mémes lieux, et on les trouve presque toujours ensemble : ils ont beaucoup d'habitudes communes; ils se tiennent également daus l'eau, ils vont également a terre; ils montent de mème sur les glacous; ils allantent ét élevent de méme leurs petits; ils se nourrissent des mêmes aliments; ils vivent de mème en société et voyagent en grand nombre : mais l'espece du morse ne varie pas autant que celle du plsoque; il parait qu'il ne va pas si loin, qu'il est plus attaché à son climat, et que l'on en trouve trèsrarement ailleurs que dans les mers du Nord: aussi le phoque était conmu des anciens, et le morse ne l'était pas.

La plupart des voyageurs qui ont fréquenté les mers septentrionales de l'Asie, de l'Europe et de l'A mérique ont fait mention de cetanimal : mais Zorgdrager nous parait ctre celui qui en parle avec le plus de commaissance ; et j'ai cru devoir présenter ici la traduction et l'extrait de cet article de son ouvrage, qui ma céć communiqué par M. le mar(quis de Ilontnirail. "On " trouvait autrefois dans la baje d'llurisont ct " dans eelle de Klock beaucoup de inorses et " de phoques; mais aujourd'hui il cu reste fort " peu... Les uns et les autres se lemdent, dans " les grandes chaleurs de l'été, dans les plaines " qui en sont voisines, et on en voit quelquefuis " des troupeaux de quatre-vingls, cent et jus"qu'à deux c'ents, particulièrement des morses " qui peurent y rester quelques jours de suite, " et jusqu'à ce que la fiim les ramene à la ner.. "Ces animaux ressemblent beaucuup à l'exte"rieur aux phoques; mais ils sont plus forts et " plus gros. Hs ont eingdoigls aux pattes comme " les phoques; mais leurs ongles sont plus courts a et leur tête est plus épaisse, plus roude et plus 
* forte. La peau du morse, principalement vers " le cou, est épaisse d'un pouce, ridée et cou"verte d'un poil très-court de différentes cou" leurs. Sa mâchoire supéricure est armée de " deux dents d'une demi-anne ou d'une aune " de longueur : ces défenses, qui sont creuses à " la racine, deviennent encore plus grandes à mesure que l'animal vieillit; on en voit quel" quefois qui n'en out qu'une, parce qu'ils ont " perdu l'autre cn se battant, ou seulement en "vieillissant. Cet ivoire est ordinairement plus - cher que celui de l'éléplant, parce qu'il est * plus compacte et plus dur. La bouche du morse a ressemble à celle d'un bœuf ; elle est garnie n en haut et en bas de poils creux, pointus et " de l'épaisseur d'ui tuyau de paille; au-des" sus de la bonche, ìl y a deux naseaux desquels * ces animaux soufflent de l'cau comme la ba$\checkmark$ leine, sans cependant faire beaucoup de bruit. - Leurs yeux sont étincelauts, rouges et enflam" més pendant les chaleurs de l’été; et comme " ils ne peuvent souffir alor's l'impression que "l'eau fatit sur les yeux, ils se tiennent plus vo"lontiers dans les plaines en été que dans tout " autre temps... On voit beaucoup de morses " vers le Syitzberg... on les tue sur terre avec "des lances... On les chasse pour le profit " qu'on en tir'e de leur's dents et de lcur graisse; " l'huile en est presque aussi estimée que celle de " labaleine. Leur's deux dents valent autant que * toute leur graisse; l'intérieur de ces dents a " plus de valeur que l'ivoire, surtout dans les "grosses dents qui sont d'une substance plus a compacte et plus dure que les petites. Si l'on a vend un florin la livre de livoire des petites " dents, celui des grosses se vend trois ou qua" tre, et souvent cinq florins. Une dent médio" cre pèse trois livres..., et un mor'se ordinaire " fournit une demi-tomned'huile. Ainsi l'animal * entier produit trente-six florins; savoir : dix- huit pour ses deux dents, à trois florins la lia vre, et autant pour sit graissc... Autrelois on " trouvait de grands troupeaux de ces animaux " sur terre; mais nos vaisseaux, qui vont tous " les ans daus ce pays pour la pèche de la ba"leine, les ont tellement épouvantés, qu'ils se " sont r'ctirés dans les lieux écartés, et que " ceux qui y restent ne vont plus sur la terre en "troupes, mais demeurent dans l'eau ou dis"persés ' ẹi et lì sur les glaces. Lorsquon a

Nela. II faul que te nombre de ces animanx soit prodigieusement diminué, ou plutôt qu'ils se soient presque touy
" Joint un de ces animaux sur la glace ou dans "l'eau, on lui jette un harpon fort et fait ex. " près, et souvent ce harpon glisse sur sa peau " dure et épaisse : mais lorsqu'il a pénétré, on " tile l'animal avec un câble vers le timon de la " chaloupe, et on le tue en le percant avec une " forte lance faite exprès; on l'amène ensuite " sur la terre la plus voisine ou sur un glacon " plat: il est ordinairement plus pesant qu'un " l)œuf. On commence par l'écorcher et on jette " sa peau parce qu'elle n'est bonne à rien ' ; on " sépare de la tête avec une hache les deux dents, " ou l'on coupe la tète pour ne pas endomma" ger les dents, et on la fait bouillir dans une " chaudière ; après cela on coupe la graisse en " longues tranches et on la porte au vaisseau... " Les mor'ses sont aussi difticiles à suivre à force " de rames que les baleines; et on lance sou" vent en vain le harpon, parce qu'outre que la " baleine est plus aisée à toucher, le harpon ne " glisse pas aussi facilement dessus que sur le " morse... Onl'atteint souvent par trois fois avec " une lance forte etbien aiguisée avant de pouvoir " percer sa peau dure et épaisse; c'est pourquoi " il est nécessaire de chercher à frapper sur un " endroit où la peau soit bien tendue, parceque " partout où elle prète, on la percerait difficile" ment; en conséquence on vise avec la lance " les yeux de l'animal qui, forcé par ce mou"vement de tourner la tète, fait tendre la peau "vers la poitrine ou aux environs: alor's on " porte le coup dans cette partie et on retire la " lance au plus vite, pour empècher qu'il ne la " preune dans sa gueule et qu'il ne blesse celui " qui l'attaque, soit avec l'extrémité de ses " dents, soitavec la lance mème, commecela est

relirés vers des cótes encore inconnues, puişu'on trouve dans les relations des yoyages an Nord, ‘u'en 170 t, près de l'ile de Clierry, à soixante-quinze degrés quaranle-cinq unimtes tle lalitude, lésuipage d'un båtiment anglais rencontıa une prodigieuse quantité de mrorses lons couchés les uns auprès des aulres; que de plus de mille (jui formaicnt ce troupean, les Anglais n'en luèrent que quinze; mais quayant trouve mue graude (fuanlité de dents, ils en remplirut un tonneall entier : yu'avant le 13 juillet ils luèrent encore cent de ces animanx, dont ils n'emportèrent que les denls... qu'en 1706, d'antres Anglais en tuèrent sept on huit cents dans siz henres; en 1708, plus de nenf cen's dans sept lieures; en 1710 , luit cents en plusienes jours, et yune seul homme en tua quirante ayec une lance.

Vult. Zorgdrager ignorail apparenment quien fail un très-lsu euir de certle jeall. J'en ai vu des soupeutes de carrosse qui élitient trés-liantes el très-fermes. Andersun dit, d'a. pris Olluer, y.ion en filit anssi des sungles te des cordes de batcais. IIistoite nalurelle dı Groënland, tome 1I, page $\mathbf{1 6 0}$ nole. 
- arrivé quelquefois. Cependant cette attaque - sur un petit glaçon ne dure jamais longtemps, " parce que le morse, blessé ou non, se jette aus- sitôt dans l'eau, et par conséquent on préfère * de l'attaquer sur terre... Mais on ne trouve - ces animaux que dans des endroits peu fré- quentés, comme dans l'ile de Moffen derrière " le Worland, dans les terres qui enviromment " les baies d'Horisont et de Ḱlock, et ailleurs - dans des plaines fort écartées et sur des banes " de sable dont les vaisseaux n’approchent que "raresnent; ceux mème qu'on y rencontre, " instruits par les perséentions qu'ils ont es" suyces, sont tellement sur leurs gardes qu'ils " se tienuent tous assez près de l'eau pour pou"voir s'y précipiter promptement. I'en ai fait " moi-mème l'expérience sur le graud bane de " sable de lif derrière le Worland, où je ren" contrai une troupe de trente ou quarante de " ces animaux; les uns étaient tout au bord de " l'eau, les autres n'en étaient que peu éloignés. "Nous nous arrètâmes quelques heures avant " de mettre pied a terre, daus l'espérance qu'ils " s'engageraient un peu plus avant dans la a plaine, et comptant nous en approclser : mais " eomme cela ne nous réussit pas, les morses " s'étant toujours tenus sur leurs gardes, nous " abordâmes avee deux chaloupes en les dé" passant à droite et à gauche; ils furent pres" que tous dans l'eau au moment oi nous arri" vions ì terre, de sorte que notre chasse se ré" duisit à en blesser quelques-uns qui se jetè" rent diuns la mer de mème que ceux qui n'i" vaient pas été touchés, et nous n'eùmes que " ceux que nous tirámes de nouveau dans l'eau. " Anciennement et avant d'avoir été perséeu- tés, les morses s'avanciieut fort avant dans - les terres, de sorte que dans les hautes marées - ils étaient assez loin de l'eau, et que dans le " temps de la basse mer, la distance étant ena core beaucoup plus grande, on les abordait " aisément... On marchait de front vers ces ani- maux pour leur couper la retraite du cóté de " la mer; ils voyaient tous ees préparatifs sans " aweune crainte, et souvent charque chasseur " en tuait un a vant qu'il puit regagner l'eau. On " faisait une barriere de leurs eada rres et on laisa sait quelques gens it l'alfut pour assommer a ceux qui restaient. On en tuait quelquefois " trois on quatre cents... On voit par la prodi* gieuse quantité d'ossements de ce's animanx - dout la terre est jonchée, qu'ils ont été autre-
" fois très-nombreux... Quand ils sont blessés ils " deviennent furieux, frappant de cỏté et d'au" tre avec leurs dents; ils brisent les armes " ou les font tomber des mains de ceux qui les at" taquent, et à la fin, enragés de colère, ils met" tent leur tète entre leurs pattes ou nageoires, " et se laissent ainsi rouler dans l'eau... Quand " ils sont en grand nombre, ils deviennent si " audacieux, que pour' se secourir les uns les au" tres ils entourent les chaloupes, therchant à " les percer avec leurs dents ou à les renverser " en frappant contre le bord... Au reste cet " éléphant de mer, avant de connaitre l's hom" mes, ne eraignait aueun ennemi, paree qu'il " avait su dompter les ours cruels qui se tien( nent dans le Groënland, qu'on peut mettre au " nombre des voleurs de mer."

lin ajoutant il ces observations de MI. Zorgdrager eelles qui se trouvent dans le Recueil des voyages du Nord ', et les autres qui sont éparses

4. Ie cheval marin (morse) rewsemble assez au veau marin

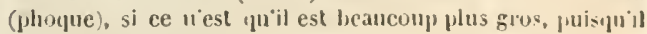
est de la grossenr d'un brruf; ses pattes sunt comue celles du veau mariı, et celle's du devint anssi bien que celles du derrière oul ciny doigls on gitfes, mais les ongles en sun y!us courts; il a anssi la téte plus grosse, fulus romde el fulus dure que le vean marin. Sı pean a bien un punce d"épaissenr, surtout autour du con; les uns l'ont converte d'un poil de conleur de somris, les antres out tres-peu de juil; ils sont ordi. nairement pleins de gales et d"écorchures, de sorte yuon dirait quon leur aurait enteve la pean, surtont autunr des jointures, ou elle est fort rider' ils unt à lit michoire d'est liaut denx grandes et longues alents. yui unt deux piods de loug et quelifuefois davantage; les jeunes nont point ces drefenses. mai, elles leur viemuenl arec läge... Cos deux dents sout phus estinces et plus cheres que l'ivoire; clle, sont whlides en dodaus, mins la racine en ist crense.. Cen anim.ux un l'unser-

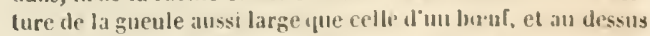

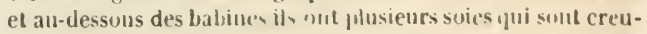
ses en dedans et de la grus-1ul' d'une paille... II unt au-ales-us de la barbe dien hant denx masux en forme de deni-cercle par vit ils rejettent l ean comme les baleines, ou is avec hien mons de bruit; lem's yeus sout ansez èlevés an-dessus du nc'z Ces yeux sunt aussi rouges ynue du sang lorsıue l animal ne lés tunrue pas, et je nai print ubserve de difiérence lursıa les Lournait; leurs oreilles sont p. ressembli nt a celles des vian marius; lem langue est frour le moins aussi grosse yue eelle diun luruf... Ils ont le cou si épais, unils vul de la feine a tomrner la tete, ce yui les ublige à lomruer extremement les yeux; ils unt la yuene cumrle comme celle des veanx marius. ("u un junt puint leur eulevir $r$ la graisst? cumme lou f.it amx veaux marius, frarce yu eذle est entrelarilée avec li chair... lour membre génit.ıl est un us dur

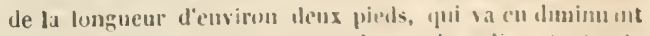
par le biut et yui est un peu conrbe far le unlien; tout pres du ventre ce mimbie est plat, mais lurs de la il est romal et lout convert de nerfs... Il y a apparence yue ces aninus vivent d'hrobes el de puissons lenr liente ressenuble à eolle du clu'val... Ouand ils julengent, ils se jettent la tete la prenu.ere daus l'ou comme les veaux uarius; ils dorment et romflent notl-seulement sur l.1 flace, mais aussi dums l'eau, de sorte quils paraisseut sumvent cumme s'ils itaient morts. Ils sont furieux et courageux; tant qu'ils somt elt vie, ils se defendent 
dans différentes relations, nous aurons une histoire assez complète decet animal. Ii parait que l'espèce en était autrefois beaucoup plus répandue qu'elle ne l'est aujourd hui ; on la trouvait dans les mers des zones tenıpérées, dans le golfe du Canada, sur les côtes de l' 1 cadie, ete. : mais elle est maintenant confinée dans les mers arctiques; on ne trouve des morses que dans cette zone froide, et mème il y en a peu dans les endroits fréqueutés, peu dans la mer Glaciale de l'Europe, et encore assez peu dans celles du Groëuland, du détroit de Davis et des autres parties du nord de l'Amérique, parce qu’à l'occasion de la pêche de la baleine on les a depuis longtemps inquiétés et chassés. Dès la fin du seizième siècle, les habitants de Saint-Malo allaient aux iles Ramées prendre des morses qui dans ce temps s'y trouvaient en grand nombre : il n'y a pas cent ans que ceux du PortRoyal au Canada enroyaient des barques au cap de Sable et au cap Fourchu à la chasse de ces animaux, qui depuis se sont éloignés de ces parages, aussi bien que de ceux des mers de l'Europe; car on ne les tronve en grand nombre que dans la mer Glaciale de l'Asie, depuis l'embouchure de l'Oby jusqu'à la pointe la plus orientale de ce continent, dont les cótes sont trèspeu fréquentées. On en voit fort rarement dans les mers tempérées. L'espèce qui se trouve sous la zone torride et dans les mers des Indes est différente de nos mor'ses du Nord : ceux-ci craignent vraisemblahlement ou la chaleur ou la salure des mers méridionales; et comme ils ne les ont jamais traversées, on ne les a pas trouvés vers l'autre pôle, tandis qu'on y voit les grands et les petits phoques de notre nord, et que même ils y sont plus nombreux que dans nos terres aretiques.

Cependant le morse peut vivreau moins quelque temps dans un climat tempéré. Eirard Worst dit avoir vu en Angleterre un de ces anjmaux sivant, et âgé de trois mois, que l'on ne mettait dans l'eau que pendant un petit espace de temps thaque jour, et qui se trainait et ram-

les uns les autres... Ils font tous leurs elforts pour déliurer ceux 1,uon a pris; ils se jettent à léuvi sur la chalonpe, mordaut et faisant des mucisipureuls épuvantubles : et si jar Jur gr.mul unmlue ils ololigent les hunumes à prenilie la fuite, il fum suivent fort bien la clualoupe jus ju'à ce qu'ils Ja perdent de vue... On ne les proul que puur leurs dents; mais, entre cent, un rien trousera quelyuefois yquin tpis ait les dents lu unes, pirce que lee unis sunt encore trop jemues, et yue les aiz'res wist les dents gätées. Recueil des Voyages du Nord, tome 11 . pait sur la terre: il ne dit pas qu'il fủt incommodé de la chaleur de l'air; il dit au contraire que lorsqu'on le touchait il avait la mine d'un animal furieux et robuste, et qu'il respirait tresfortement par les narines. Ce jeune murse était de la grandeur d'un veau, et assez ressemblant à uu phoque; il avait la tète ronde, les yeux gros, les narines plates et noires, quil ourrait et fermait à volonté ; il n'avait point doreilles, mais seulement deux trous pour entendre. L'ouverture de la gueule était assez petite : lit mâchoire supérieure était garnie d'une moustache de poils cartilagineux, gros et rudes; la mâchoire inférieure était triangulaire, la langue épaisse, courte, et le dedans de la sueule muni de côté et d'autre de dents plates. Les pieds de devant et ccux de derrière étaient larges, et l'arrière du corps ressemblait en entier à celui d uı phoque; cette partie de derrière rampait plutót qu'elle ne marchait: les pieds de devant étaient tournés en avant, et ceux de derrière en arrière: ils étajent tous divisés en cinq doigts, recou verts d'une forte membrane... La peau était épaisse, dure, et couverte d'un poil court et délié, de couleur cendrée. Cet animal grondait comme un sanglier, et quelquefois criait d'une voix grosse et forte. On l'avait apporté de la Nourelle-Zemble ; il n'avait point encore les grandes dents ou défenses, mais on royait à la mâchoire supérieure les bosses d'où elles devaient sortir. On le nourrissait avec de la bouillie d'avoine ou de mil; il suçait lentement plutòt qu'il ne mangeait; il approchait de son maître avec grand effort et en grondant; cependant il le suivait lorsquion lui présentait à manger.

Cette observation, qui domne une idée assez juste du morse, fait voir en mème temps qu’il peut virre dans un climat tempéré; néanmoins il ne parait pas qu il puisse supporter une grande chaleur, ni qu'il ait jamais fréquenté les mers du midi pour passer d'un pòleà l'autre. Plusieurs voyageurs parlent de vaches marines qu'ils ont vues dans les Indes, mais elles sont d'une autre espice : celle du mor'se est toujours aisée à reconnaitre par ses lonques défenses ; l'éléphant est le seul animal qui en ait de pareilies. Cette production est un effet rare dans la nature, puisque de tous les animaux terrestres et amphibies, l'élépliant et le morse, auxquels elle appartient, sont des espèces isolées, uniçues daus leur genre, ct qu'il n'y a aucune atitre espéce d'animal qui porte ce caractère. 
On assure que les morses ne s'accouplent pas à la manière des autres quadrupèdes, mais à l’ebours : il y a, comme dans les billeines, un gros et grand os daus le membre du mâle. ta fenclle met bas en hiver sur la terre ou sur la glace, et ne prodnit ordinairement qu'un petit, qui est eu naissant déjà gros cornme un cochon d'un am. Nous ignorons la durée de la grestation; mais à eu juger par celle de l'aceroissement, et alussi par la grandeur de l'animal, elle doit etre de plus de neuf mois. Les morses ue peuvent pas toujours rester dans l'eau; ils sont obligés d'aller à terre, soit pour allaiter leurs petits, soit pour d'autres besoins. Lorsqu'ils se trouvent dans la nécessité de grimper sur des rivages quelquefois escarpés, et sur des glacons, ils se servent de leurs défenses pour s'accrocher, et de leurs mains pour faire avancer la lourde masse de leur corps. On prétend qu'ils se nourrissent de coquillages qui sont attachés au foud de la mer, et (qu'ils se servent aussi de Ieur's défenses pour les arracher; d'autres disent qu'ils ne vivent que d'une certaine herbe à larges l'euilles qui croit dans la mer, et qu'ils ne mangent ni chair ui poisson: mais je crois ees opinions mal fondées, et il y a apparence que le morse vit de proie commele phoque, et surtout de harengs et d'autres petits poissons; car' il ne mange pas lorsyu'il est sur la terre, et c'est le besoin de nourriture qui le contraint de retourner à la mer.

\section{ADDITION}

\section{A L'ARTICLE DES MORSES OU VACHES MARIXLS.}

Nous ajouterons à ce que nous avons dit du morse quelques observations que M. Crantz a faites sur cet animal daus son voyage au Groënland.

"Unde ces morses, dit-il, avait dix-lıuit pieds de longueur, et à peu près autant de circonférence dans sa plus grande épaisseur' : sa peau n'était pas mnie, mais ridée par tout le corps et plus encore autour du cou ; sa graisse était blanche et ferme comme du lard, épaisse d'environ trois poures; la figure de sa tète était ovale; la bouche était si étroite, qu'on pouvait a peine y faire entrer le doigt; la levre inférieure est triangulaire, terminée en pointe, un peu avancée entre les denx longues défenses qui partent de la mâchoire supérieure; sur les deux lèvres et de chaque còté du nez, on voit une peau spongrieuse d'où sortent des inoustaches d'un poil épais et rude, longues de six ou sept ponces, tressées comrne une corde à trois brins, ce qui domne a cet animal une sorte de majesté liideuse. Il se nourrit principalement de moules et d'algue marine. I.es défenses avaient vingtsipt ponces de longueur, dont sept pouces étaient eachés dans l'épaisseur de la peau et dams les als éoles qui s'étendent juscju'au erâne: chaque défense pesait quatre lives et demie, et le crâne entier vingt-quatre livres. n

Selon le voyageur Kacheninnikow, les morse's, qu'il appelle cheraux marins, n'entrent pas, comme les phoques, daus les eaux douces et ne remontent pas les rivieres. "On roit peu de ces animaux, dit-il, dans les environs du Kantschatka, et si l'on en trouve ee n'est que dans les mers qui sont au norel; on en prend beaucoup auprès du cap Tehukotskoi, ou ils sont plus gros et plus nombreux que partunt ailleurs. Le prix de leur's dents dépend de leur grandeur et de leur poids : les plus chères sont celles qui pèsent vingt livres, mais elles sout fort rares; on en voit même peu qui pèsent djx à douze livres, leur poids ordiuaire d'étant que de cinq ou six livres."

Fréderie Martens avait déjà observé quelques-unes des habitudes naturelles de ces animaux; il assure qu'ils sont forts et courageux, et qu'ils se défendent les uns les autres arce une résolution extraordinaire. "L.olsque j'en blessais un, dit-il, les autres s'assemblaient autour du bateau, et le perenaient à coups de défenses; d'autres s'élevaient hors de l'eau et faisiaient tout leur possible pour s'elancer dedans. Nous en tuâmes plusieur's c'ntaines à l'ile de lioffen, et l'on se contente ordinarement d'en emporter la tète pour arracher les dífeuses.

Ces animaux, comme l'on sait, vont en tris grandes troupes, et ils étaicnt antrefois ('n quan. tité presque innombrable dans plusicurs endroits des mers septentrionales. M. Gmelin mpporte qu'en 1705 ct 1706 les Anglais cn tuerent, à l'ile de Cherry, sept à huit cents en six heures; qu'en 1708 ils en tuerent en sept heures neul cents; et en $1 ; 10$, en mo journce, huit cents. "On trouve, dit-il, les dents de ces animaux sur les bas bords de la mer : et il y a apparence que ces dents vicunent de erux qui meureat : on trouve en grand nombre de ces dents du coté 
des Tschutschis, où ces peuples les ramassent en monceaux pour en faire des outils. "

On voit par les relations de tous les voyageurs qui ont fréquenté les mers du nord qu'on a fait une énorme destruction de ces grands animaux, et que l'espèce en est actuellement bien moins nombreuse qu'elle ne l'était jadis; ils se sont retirés vers le nord et dans les lieux les moins fréquentés par les pêcheurs, qui n'en rencontrent plus dans les mèmes endroits où ils étaient anciennement en si grand nombre: nous verrons qu'il en est à peu près de mème des phoques et de tous ces amphibies marins, dont le naturel les porte à se réunir en troupeaux et à former une espèce de société ; l'homme a rompu toutes ces sociétés, et la plupart de ces animaux vivent actuellement dans un état de dispersion, et ne peuvent se rassembler qu'auprès des terres désertes et inconnues.

\section{LE DUGON}

Ordre des cétacés, section des célacés herbivores, genre dugon. (Cuvier.)

Le dugon est un animal de la mer de l'Afrique et des Indes orientales, duquel nous n'avons vu que deux têtes décharnées ou tronquées, et qui par cette partie ressemble plus au morse qu'a tout autre animal : sa tête est à peu près déformée de la même manière par la profondeur des alvéoles, d'oì naissent à la mâchoire supérieure deux dents longues d'un demi-pied; ces dents sont plutôt de grandes incisives que des défenses; elles ne s'étendent pas directement hors de la gueule comme celles du morse; elles sont beaucoup plus courtes et plus minces, et d'ailleurs elles sont situées au-devaut de la màchoire, et tout près l'une de l'autre, comme des dents incisives; au lieu que les défenses du morse laissent entre elles un intervalle considérable, et ne sont pas situées à la pointe, mais à cóté de la mâchoire supérieure. Les dents mâchelières du dugon different aussi, tant pour le nombre que pour la position et la forme, des dents du morse: ainsi nous ne doutons pas que ce ne soit un animal d'espèce différente. Quelques voyageurs qui en ont parlé l'ont confondu avec le lion marin. Inigo de Biervillas dit qu'on

- Ciest le dugon des Indes. tua près du eap de Bonne-Lspérance un lion marin qui avait dix pieds de longueur et quatre de grosseur, la tête comme celle d'un veau d'un an, de gros yeux alfreux, les oreilles courtes, avec une barbe hérissée, les pieds fort larges et les jambes si courtes que le ventre touchait a terre; et il ajoute qu'on emporta les deux défenses, qui sortaient d'uu demi-pied hor's de la gueule : ce dernier caractère ne convient point au lion marin, qui n'a point de défenses, mais des dents semblables à celles du phoque ; et e'est ce qui m'a fait juger que ce n'était point un lion marin, mais l'animal auquel nous donnons le nom de dugon. D'autres voyageur's me paraissent l'a voir indiqué sous la dénomination d'ours marin. Spilberg et Mandelslo rapportent "qu'a " l'ile Sainte-Élisabeth, sur les còtes d'Afrique, " il y a des animaux qu'il faudrait plutòtappe" ler des ours marins que des loups marins, " parce que par leur poil, leur couleur et leur " tète, ils ressemblent beaucoup aux our's, et " qu'ils ont seulement le museau plus aigu; qu'ils - ressemblent encore aux ours par les mou"vements qu'ils font et par la manière dont ils " les font, à l'exception du mouvement des jam" bes de derrière, qu'ils ne font que traîuer; " qu'au reste ces amphibies ont l'air affreux, " ne fuient point à l'aspect de l'homme, et mor" clent avec assez de force pour couper le fût " d'une pertuisane, et que, quoique boiteux des " jambes de derrière, ils ne laissent pas de " marcher assez vite, pour qu'un homme qui " court ait de la peine à les joindre. " Le Guat dit " avoir vu près du cap de Bonne-Espérance " une vache marine de couleur roussàtre; elle " avait le corps roud et épais, l'œil gros, les " dents ou défenses longues, le mufle un peu "retroussé; et il ajoute qu'un matelot lui as" sura que cet animal, dont il ne pouvait voir " que le devañt du corps, parce qu'il était dans "l'eau, avait des pieds. " Cette vache marine de Le Guat, l'ours marin de Spilberg et le lion marin de Biervillas me paraissent être tous trois le même animal que le dugon, dont la tète nous a été envoyée de l'Ile-de-France, et qui par conséquent se trouve dans les mers méridionales, depuis le cap de Bonne-Espérance jusqu'aux îles Philippines. Au reste, nous ne pourons pas assurer que cet animal, qui ressemble un peu au morse par la tète et les défenses, ait comme lui quatre pieds; nous ne le présumous que par analogie, et par l'indication des royageurs que 
nous avons cités : mais ni l'analogie n'est assez grande, ni les témoignages des voyageurs assez précis pour décider; et nous suspendrons notre jugement à cet égard, jusqu'à ce que nous soyons mieux informés.

\section{LE LAMANTIN '。}

Ordre des cétacés, section des cétacés herbirores, genre lamantin. (Cuvier.)

Dans le règne animal, e'est ici que finissent les peuples de la terre, et que commencent les peuplades de la mer. Le lamantin, qui n'est plus quadrupède, n'est pas entierement cétacé; il retient des premiers cleux pieds ou plutòt deux mains : mais les jambes de derrière, qui dans les phoques et les morses sont presque entierement engagées dans le corps, et raccourcies autant qu'il est possible, se trouvent absolument nulles et oblitérées dans le lamantin; au lieu de deux pieds courts et d'une queue étroite encore plus eourte, que les morses portent à leur arrière dans une direction horizontale, les lamantins n'ont pour tout cela qu'une grosse queue qui s'élargit en éventail dans cette mème direction, en sorte qu'au premier coup d'œil il semblerait que les premiers auraient une queue diviséc en trois, et que.dans les derniers ces trois parties se seraient réunies pour n'en former qu'une seule : mais par une inspection plus attentive, et surtout par la dissection, l'on voit qu'il ne s'est point fait de réunion, qu'il n'y a nul vestige des os des cuisses et des jambes, et que ceux qui forment la queue des lamantins sont de simples vertèbres isolées et semblables à celles des cétacés qui ı'ont point de pieds. Ainsi ces animaux sont cétacés par ces parties de l'arrière de leurs corps, et ne tiennent plus aux quadrupèdes que par les deux pierls ou deux mains qui sont en avant àl côté de leur poitrine. Dviedo me parait être le premier auteur qui ait domé une espèce d'histoire et de description du lamantin. "On le trouve assez fré" quemment, dit-il, sur les cotes do Saint-Do" mingue: e'est un tris-gros animal, d'une figure. " informe, qui a la tite plus grosse que celle " d'un bouf, les yeux petits, deux pieds ou

- Cest du lamantin d'Amérigur quil est principalement unuestion dans cet article.
" deux mains près de la tête, qui lui servent à " nager; il n'a point d'écailles, mais il est cou" vert d'une peau ou plutôt d'un cuir épais. C'est " un animal fort doux. Il remonte les fleuves, a et mange les herbes du rivage auxquelles il " peut atteindre sums sortir de l'eau. Il nage à "la surface : pour le prendre, on tache de s'en " approcher sur une nacelle ou un radeau, et " on lui lance une grosse fleche attachée à un " très-long cordeau; des qu'il se sent frappé " il s'enfuit et emporte arec; lui la fleche et le " cordeau à l'extrémité duquel on a soín d'at" tacher un gros morceau de liége ou de bois "léger pour servir de bonce et de renseigne" ment. Lorsque lanimal a perdu par cette bles" sure son sang et ses forces, il gagne la terre : " alors on reprend l'extrémité du cordeau, on " le roule jusqu'à ce qu'il n'en reste plus que " quelques brasses; et à l'aide de la vague on " tire peu à peu l'animal vers le bord, ou bien " on achève de le tuer dans l'eau à coups de " lance. Il est si pesant, qu'il fiut une voiture " attelée de deux bœufs pour le transporter. Sa " chair est cxcellente, et quand elle est fraiche, " on la mangerait plutôt comme du bøuf que " comme du poisson : en la découpant et la fai"sant sécher et mariner, elle prend a vec le temps " le goût de la chair du thon, et elle est encore " meilleure. Il y a de ces animaux qui ont plus " de quinze pieds de longueur sur six pieds d'é" paisseur. La partie de l'arrière du corps est " beaucoup plus menue et va toujours en dimi" nuant jusqu'il la quene, qui eusuite s’élargit " à son extremité. Comme les Fspagnols, ajoute "Ovicdo, donnent le nom de mains aux pieds " de devant de tous les (quadrupedes, et comme " cet animal n'a que des pieds de devant, ils lul " ont domné la dénomination d'animal à mains, "manati. Il u'a point d'oreilles evternes, mais - seulement deux trous par lesquels il entend. "Sa peau n'a que quelques poils assez rares; " elle est d'un gris cendré et de l'épaisseur d'un a ponce; on en fait des semelles de souliers, des " baudriers, etc. Ia femelle a deux mamelles " sur la poitrine, ot elle produit ordinairement "deux petits (qu'ello allaite. " Tous ces faits rapportés par Oviedo sont rrais, et il est singulier que Cieça, et plusieurs antres appres lui, aient assuré (yuc le lamantin sort souvent de l'eau pour aller paitre sur la tere : ils lui ont faussement attribué cette haloitude naturelle, induits en erreur par l'analogric du morse et des plıoques, qui 
soltent en effet de l'eau et séjournent à zerre; mais il est certain que le lamantin ne quitte jamais l'eau, et qüil préfere le séjour des eaux douces à celui de l'eau salée.

Clusius dit avoir vu et mesuré la peau d'un de cesanimaux, et l'avoir trouvée de seize pieds et demi de longueur, et de sept pieds et demi de largeur; les deux pieds ou les deux mains étaient fort larges, avec des ongles courts. Gomara assure qu'il s'en trouve quelquefois qui ont vingt pieds de longueur, et il ajoute que cés anirnaux fréquentent aussi bien les eaux des fleuves que celles de la mer. Il raconte qu'on en avait élevé et nourri un jeune dans un lac à Saint-Domingue peudant vingt-six ans; qu'il était si doux et si privé qu'il prenait doucement la nourriture qu'on lui présentait; qu’il entendait son nom, et que, quand on l'appelait, il sortait de l'eau et se trainait en rampant jusqu'à la maison pour y recevoir sa nourriture; qu'il semblait se plaire à enteudre la voix humaine et le chant des enfants, qu'il n'en avait nulle peur', qu'il les laissait asseoir sur son dos, et cqu'il les passait d'uu bord du lac à l'autre saus se plonger dans l'eau, et sans leur faire aucun mal. Ce fait ne peut ètre vrai dans toutes ses circonstances; il paraì accommodé à la fable du dauphin des anciens; car le lamantin ne peut absolument se trainer sur la terre.

Herrera dit peu de chose de plus au sujet de cet animal ; il assure seulement que, quoiqu’il soit très-gros, il nage si facilement qu'il ne fait aucun bruit dans l'eau, et qu'il se plonge dès qu'il entend quelque chose de loin.

Hernandès, qui a domné deux figures du lamantin, l'une de profil et l'autre de face, n'ajoute presque rien à ce que les autres auteurs espagnols en avaient écrit avaut lui; il dit seulement que les deux Océaus, c'est-à-dire la mer Atlautique et la mer Pacifique, aussi bien que les lacs, nourrissent une bète informe appelée manati, de laquelle ils donnent la description presque entièrement tirée d'Oviedo ; et tout ce qu'il y a de plus, c'est que les mains de cet animal portent cinq ongles semblables à ceux de l'homme; qu'il a le nombril et l'anus larges, la vulve comme celle d'une femme, la verge comme celle d'un cheral, la chair et la graisse comme celles d'un cochon gras, et enfin les côtes et les vlscères comme un taureau; qu'il s'accouple sur terre à la manière humaine, la femelle reuversée sur le dos, et qu'elle ne produit qu'un petit, qui est d'une grosseur monstrueuse en naissant. L'accouplement de ces anımaux ne peut se faire sur terre, comme le dit Heruandes, puisru'iis n'y peuvent aller, et il se faut dans l'eau sur un bas fond. Binet dit que le lamantin est grus eomme un bœuf, et tout rond comme un tommeau; qu'il a une petite tète et peu de queue; que sa peau est rude et épaisse comme celle d'un éléphant; qu'ii y en a de si gros, qu'on en tire plus de six cents livres de viande très-bonne à mauger; que sa graisse est aussi douce que du beure; que cet animal se plait dans les rivières proche de leur embouchure à la mer, pour y brouter l'berbe qui croit le long des rivages; quil y a de certains endroits, à dix ou douze lieues de Cayenne, où l'on en trouve en si grand nombre, que l'on peut dans un jour en remplir une longue barque, pourvu qu'on ait des gens qui se servent bien du harpon. Le P. du Tertre, qui décrit au long la chasse ou la pêche du lamantin, s'accorde presque en tout avec les auteur's que nous venons de citer : cependant il dit que cet aninal n'a que quatre doigts et quatre ongles à chaque maiı, et il ajoute qüil se nourrit d'une petite herbe qui croit dans la mer, qu'il la broute comme le bœuf fait celle des prés; et qu'après s'être rempli de cette pâture, $\mathrm{jl}$ cherche les rivières et les eaux douces, où il s'abreuve deux fois par jour; qu'après avoir bien bu et bieu mangé il s'endortt le mufle à demi hors de l'eau, ce qui le fait remarquer de loin; que la femelle fait deux petits qui la suivent partout; et que, si on prend la mère, on est assuré d'avoir les petits, qui ne l'abandonnent pas même après sa mort, et ne font que tournoyer autour de la barque qui l'emporte. Ce dernier fait me parait très-suspect; il est même contredit par d'autres voyageurs, qui assurent que le lamantin ne produit qu'un petit. Tous les gros animaux quadrupèdes ou cétacés ue produisent ordinairement qu'un petit; la seule analogie suffit pour (ju'on se refuse à croire que le lamantiu en produise toljours deux, comme l'assure le $\mathrm{P}$. du Tertre. Oexnelin remarque que le lamantin a la queue située comme les cétacés, et non pas comme les poissons à écailles, qui l'ont tous dans la direction verticale du dos au ventre, au lieu que la baleine et les autres cétacés ont la queue située transversalement, c'est-ì-dire d'un còté à l'autre du corps : il dit que le lamantin n'a point de dents de devant, 
mais seulement une callosité dure comme un os, avec laquelle il pince l'herbe ; cu'il a néanmoins trente-deux dents molaires; qu'il ne voit pas bien à cause de la petitesse de ses yeux, qui n'ont que fort peu d'humeur et point diris; qu'il a peu de cervelle; mais qu'au défaut de bons yeux il a l'oreille excellente; qu'il n'a point de langue; que les parties de la génération sont plus semblables à celles de l'homme et rle la femme cu'à celles d'aucun animal; que le lait des femelles, clont il assure avoir gouté, est d'un très-bon goùt; qu'elles ne produisent qu'un seul petit, qu'elles embrassent et portent a vec la main; qu'elles l'allaitent pendant un an, après quoi il est en état de se pourvoir luimême et de manger de l'herbe; que eet animal a, depuis le cou jusqu'à la queue, einquantedeux vertèbres; qu'il se nourrit comme la tortue, mais qu'il ne peut ni marcher ni ramper sur la terre. Tous ces faits sont assez exacts, et mème celui des cinquante-deux vertèbres; car M. Daubenton a trouvé dans l'embryon queil a disséqué vinğt-huit vertèbres dams la queme, seize dans le dos et six ou plutòt sept dans le cou. Seulement ee voyageur se trompe au sujet de la langue; elle ne manque point au lamantin : mais il est vrai qu'elle est attachée en dessous, et presquue jusqu'à som extrémité à la mâchoire inférieure. On trouve dans le Voyage aux îles de l'Amérique, Paris 1722, une assez bonne description du lamantin, et de la manière dont on le harponne : l'anteur est d'accord sur tous les faits principaux avec eeux que nous avons cités; mais il observe " que cet animal " est devenu assez rare aux Antilles, depuis que " les bords de la mer sont habités. Celıi qu’il " vit et qu'il mesura avait quatorze pieds neuf " pouces, depuis le bout du mulle jusqu'ż la " uaissance de la queue : il était tout roud jus" cu'à cet cndroit. Sa tête était gi'osse, sa çueule " large avec de grandes babines et yuelques " poils longs et rudes au-dessus. Ses yeux " étaient très-petits par rapport à sa tête, et ses " oreilles ne paraissaient que comme deux pe" tits trous : le cou est fort gros et fort court, et " sans un petit mouvement, qui le fait un peu a plier, il ne serait pas possible de distinguer la a tète du reste du corps. Quelques anteruss pré" tendent, ajoute-t-il, que cet animal se sert de a ses deux mains ou nageoires pour se traimer " sur terre je me suis soigrneusement informé "de ce fait; personne u'a vu cet animal à terre,
" et il ne lui est pas possible de mareher ni d'y "ramper, ses pieds de devaut ou ses mains ne "lui ser "rant que pour tenir ses petits pendant " qu'il leur donne à teter. La femelle a deux " mamelles rondes; je les mesurai, dit l'auteur : " elles avaient chacune sept pouces de diamètre (: sur environ quatre d'elévation; le mamelon " était gros comme le pouce et sortait d'un hon " doigt au dehor's. Le corps avait huit pieds " deux pouces de circonference; la queue itait " comme une large paltte de dix-neuf pouces " de long, et de quinze pouces dans sa plus " grande largeur, et l'épaisseur à l'extrémité "était d'environ trois pouces. La peau était " épaisse sur le dos pres(gue tomme un double " cuil de bouf, mais elle etait beaucoup plus " mince sous le ventre : elle est d'une coulear * d'ardoise !rune, d'un gros grain et rude, avec " des poils de mème couleur, clair-semés, gros " et assez longs. Ce lamantin pesait environ huit " cents livres; on avait pris le petit arec la mère: " il avait a peu pres trois pieds de long. On lit "ròtir à la broche le còté de la queue; on trou"va cette chair aussi bonne et aussi délicate " que du veau. L'herbe dont ces animaux se " nourrissent est longue de huit à dix pouces, " étroite, pointue, tendre et d'un assc\% beau " vert. On voit des endroits sur les bords et sur " les bas-fonds de la mer, où cette herbe est si "abondante, que le fond parait ètre une prai"rie; le tortues en mangent aussi, etc. "Le P. Magnin, de Fribour'r, dit que le lamantin mange ['herbe qu'il peut atteindre, sans cependant sortir de l'eau... (pu'il a les yeux petits et de la grosseur d'une noisette; les orcilles si fermées, qu’à peine il y peut entrer une aiguille; yu'au-dedans des oreille's se trouvent deux petits os percés; que les Indiens ont coutume de porter ces petits os pendus au eou eomme un bijou... et yue son cri ressemble à un petit mugissement.

Le P. Gumilla rapporte qu'il y a une infinité de lamantins dans les grands laes de l'Orénoque. "Ces animaru, dit-il, pèsent ehacun dea puis cinq cents jusqu'à sept eent cinquante "livres; ils se nourrissent d'herbes; ils ont les " yeux fort petits, et les trous des oreilles en" core plus petits; ils viennent paitre sur le ri"vage lorsque la rivièce est hasse la fomelle " met toujours bas deux petits, alle les porte à " ses mameiies arce se's bras, et les serre si "fort qu’ils ne s'en sépiurent jamais, quelıue 
n mouvement qu'elle fasse. I.es petits, lorsqu'ils " viennent de naître, ne laissent pas de peser a chacun trente livres; le lait qu'ils tettent est " très-épais. Au-dessous de la peau, qui est bien " plus épaisse que celle d'un bœuf, on trouve " quatre enveloppes ou couches, dont deux " sont de graisse et les deux autres d'une cbair " fort délicate et savoureuse; qui, étant ròtie, " a l'odeur du cochon et le goût du veau. Ces " animaux, lorsqu'il doit pleuvoir, bondissent " hors de l'eau à une hauteur assez considéra" ble. " Il paraît que le P. Gumilla se trompe comme le $\mathbf{P}$. du Tertre, en disant que la femelle produit deux petits : il est presque certain, comme nous l'avons dit, qu'elle n'en produit qu'un.

Enfin M. de La Condamine, qui a bien voulu nous donner un dessin qu'il a fait lui-même du lamantin sur la rivière des Amazones, parle plus précisément et mieux que tous les autres des habitudes naturelles de cet animal. "Sa " chair, dit-il, et sa graisse ont assez de rap" port à celle du veau; le P. d'Acuna rend sa " ressemblance avec le bœuf encore plus com" plète en lui donnant des cornes dont la na" ture ne l'a point pourvu. Il n'est pas amphi" bie à proprement parler, puisqu'il ne sort ja" mais de l'eau entièrement, et n'en peut sortir, " n'ayant que deux nageoires assez près de la " tête, plates et en forme d'ailerons, de quinze a à seize pouces de long, qui lui tiemnent lieu " de bras et de mains; il ne fait qu'avancer sa " tête hors de l'eau pour atteindre l'herbe sur "le rivage. Cehui que je dessinai, ajoute $\mathrm{M}$. de "La Condamine, était femelle; sa longueur " était de sept pieds et demi de roi, et sa plus " grande largeur de deux pieds. J'en ai vu de" puis de plus grands. Les yeux de cet animal * n'ont aucune proportion à la grandeur de son " corps; ils sont ronds et n'ont que trois lignes " de diametre : l'ouverture de ses oreilles est " encore plus petite et ne paraît qu'un trou " d'épingle. Le manati n'est pas particulier à " la rivière des Amazones; il n'est pas moins " commun dans l'Orénoque : il se trouve aussi, " quoique moins fréquemment, daus l'Oyapoc " et dans plusieurs autres rivières des en rirons " de Cayenne et des côtes de la Guiane, et " vraisemblablement ailleurs. C'est le même a qu'on nommait autrefois manati, et qu'on " nomme aujourd'hui lamanlin à Cayenne et a dans les Iles françaises d'Amérique; mais je
" crois l'espèce un peu différente. Il ne se ren" contre pas en haute mer ; il est même rare " près des embouchures des rivières : mais on " le trouve à plus de mille lieues de la mer dans " la plupart des grandes rivières qui descendent " dans celle des Amazones, comme dans le " Guallagá, lc Pastaça, etc.; il n'est arrêté, en " remontant l'Amazone, que jar le Pongo ( ca. " taracte) de Borja, au-dessus duquel on n'en " trouve plus."

Voilà le précis à peu près de tout ce que l'on sait du lamantin : il serait à désirer que nos ha. bitants de Cayemne, parmi lesquels il y a maintenant des personnes instruites et qui aiment l'histoire naturelle, observassent cet animal, et fissent la description de ses parties intérieures, surtout de celles de la respiration, de la digestion et de la génération. Il parait, mais nous n'en sommes pas sủr, qu'il a un grand os dans la verge, le trou ovale du cœur ou vert, les poumons singulièrement conformés, l'estomac divisé en plusieurs portions, qui peut-ètre forment plusieur's estomacs différents, commedans les animaux ruminants.

Au reste, l'espèce du lamantin n'est pas confinée aux mers et aux fleuves du NouveauMonde; il parait qu'elle existe aussi sur les côtes et dans les rivières de l'Afrique '. M. Adanson a vu des lamantins au Sénégal ; il en a rapporté une tête qu'il nous a donnée, et en mème temps il a bien voulu me communiquer la description qu'il a faite sur les lieux de cet animal, et je crois devoir la rapporter en entier. " J'ai vu beaucoup de ces animaux, dit M. Adan" son: Ies plus grands n'avaient que huit pieds " de longueur, et pesaient environ huit cents li" vres; une femelle de cinq pieds trois pouces " de long ne pesait que cent quatre-vingt-qua" torze livres. Leur couleur est cendrée noire; " les poils sont très-rares sur tout le corps; ils " sont en forme de soies longues de neuf lignes. " La tête est conique et d'une grosseur médiocre, " relativement au volume du corps; les yeux " sont ronds et très-petits : i'iris est d'un bleu " foncé et la pr'unelle noire; le museau est pres" que cylindrique; les deux mâchoires sont à " peu près également larges; les lèvres sont " charnues et fort épaisses; il n'y a que des " dents molaires tant à la máchoire d'en haut " qu'à celle d'en bas; la langue est de forme

- 11 s agit ici du I.amastro de SÉnégaz. 
" ovaie et attachée presque jusqu'à son extré" mité a la màchoire inférienre. Il est singulier, "continue M. Adanson, que presque tous les " auteurs ou voyageurs aient donné des oreilles " à cet animal : je n'ai pu en trouver dáns au" cun, pas même un trou assez fin pour pouvoil " $y$ introduire un stylet 4 . Il a deux bras ou na" geoires placés à l'origine de la tète, qui n'est " distinguée du tronc par aucune cspèce de " cou, ni par des épaules sensibles : ces blas " sont à peu près cylindriques, composés de " trois articulations principales, dont l'anté"rieure forme une espèce de main aplatic, clans " laquelle les doigts ne se distinguent que par * quatre ongles d'un rouge brun et luisant. La "queue est horizontale comme celle des balcines, et elle a la forme d'une pelle à four. Les femelles ont deux mamelles plus elliptiques que rondes, placées près de l'aisselle des bras.

"La peau est un cuil épais desix lignes sous le " ventre, de neufligues sur le dos, et d'un pouce " et demi sur la tète. La graisse est blanche et " épaisse de deux ou trois ponces : la chail" est " d'un rouge pâle, plus pàle et plus délicate que - celle du veau. Les nègres Oualotes ou Jaloa fes appellent cet animal lereou. Il vit d'hej" bes, et se trouve à l'embouchure du lleuve "Niger. "

On voit par cette description que Ie lamantin du Sénégal ne differe, pour ainsi dire, en rien de celui de Caveune; et par une comparaison faite de la tête de ce lamantin du Sénégal avec celle d'un foctus ${ }^{2}$ de lamantin de Cayenne, N. Daubenton présume aussi qu'ils sont de même espèce. Le témoignage des voyageurs s'aceorde avec notre opinion ; celui de Dampier surtont est positi?, et les observations qu'il a faites sur cet animal méritent de trouver place it'i. "Ce n'est pas sculement daus la riviere de "Blewfield, qui prend son origine entre les ri- vières de Nicarague et de Verague, que j’ai

1 No/a. 11 parait néanmoins certain que cet animal a des truss anditifs et externes. M. de Ia condamine vieut de m'assurer qu'il les a vus et mesurés, el que ces trous n'ont pas phus denc derni-ligne de tiamètre; el comme le lanantin a la facullé de les contracter el de les serrer, il est très-pussible qui ils aient échapues à la vue de Ml. Adanson, dimbant que ces trons sont tres-petits lors même que l'animal I s licnt ouverts.

${ }^{2}$ Nola. M. le chevalice Turgot, actucllenent gonvernems de la Guiane, et clui auparavisnt ava!t fät don au Cabinet du Roi de ce foelus de lmuntin, est maintemant bien a portée de cultiver son gont pour l'histuire maturello, et the nous enrichit' non-seulement de ses dons, mais de ses leunieres.
" v u des mana! es (lamantins); j'en ai aussi vu " dans la haie de Campêche, sur les cótes de " Bocea del Diago, et de Bocea del Loro, dans " la rivière de Darien et dans les petites iles " méridionales de Cuba. J'ai entendu dire (pu'il " s'en est tronvé yquel(jues-uns au nord de la "Jamaïque, et en grande quantité dans la rivière " de Surinam, qui est un pays fort bas. J'en " ái vu aussi à Mindanao, qui est une des îles "Philippines, et sur la cóte de la Youvelle. "Hollaude... Cet animal aime l'eau qui a u!! "goût de sel; aussi se tient-il communément " dans les rivières voisines dela mer : c'est peut"être poul cette raison qu'on n'en voit point "dans les mers du sud, où la còte est gémérale"ment haute, leau profonde tout proche de " terre, les vagues grosses, si ce n'est dans la " baie de Panama, ou cependant il n'y en a "point : mais les Indes occidentales étant, pour " ainsi dire, une grancle baie composće de plu" sieurs petites, sont ordinairement une terre " basse où les eaux, qui sont peu profondes, " fournissent une nourriture convenable au la" mantin. On le trouve quelquefois dans leau " salée, fuelquefois aussi dans l'eau douce, mais " jamais fort avant en mer. Ceux qui sont " à la mer et dans les licux où il n'y a ni rivières " ni bras de mer ou ils puissent entrer, viennent " néaumoins en vingt-quatre heures une fois ou "deux à l'embouchure de lá rivière d'eau douce " la plus voisine... Ils ne vienment j:mais à " terı'e ni dans une eau si basse qu'ils ne puissent " y nager. Leur chair est saine et de très-lon " govit; leur peau est aussi d'unc crrancle utilité. "Les lamantins et les tortues se trouvent ordi" nairement dans les mèmes endroits, et se " nourrissent des mèmes herbes qui croissent " sur les hauts-fouds cle la mer à quelques pieds " de profondeur sotis l'cau, et sur les rivages " bas que courre la marie. "

\section{ADDITION \\ A LARTICLE DES PHOQUES, PU'BLIÉE EX 1784.}

Lorsque j"a écrit sul les phoques, il y a plus de vingt ans', l'on n'en connaissait alors que deux ou trois especes : mais les voyageurs re-

'L'article jrécérlent a słé jublic en 1763. 
cents en ont reconnu plusieurs autres, et nous sommes maintenant en état de les distinguer et de leur appliquer les dénominations et les caractères qui leur sont propres. Je rectifierai done en (juclques points ce quej'ai dit au sujet de ces animaux, en ajoutant ici les nouveaux faits que j'ai pu recueillir.

J'établirai d'abord une distinction fondée sur la nature et sur un caractère très-évident, en divisant en deux le genre entier des phoques, savoir : les phoques qui ont des oreilles externes, et les phoques qui n'ont que de petits trous auditifs sans conque extérieure. Cette différence est non-seulement très-apparente, mais semble même faire un attribut essentiel, le manque d'oreilles extérieures étant un des traits par lesquels ces amphibies se rapprochent des cétacés, sur le corps desquels la nature semble avoir effacé toute espèce de tubérosités et de proéminences qui eussent rendu la peau moins lisse et moins propre à glisser dans les eaux; tandis que la conque externe et relevée de l'oreille paraît faire tenir de plus près aux quadrupèdes ceux des phoques qui sont pour vus de cette partie extérieure, qui ne manque à aucun animal terrestre.

Nous ne connaissons que deux espèces bien distinctes de phoques à oreilles : la première est celle du lion marin ', qui est très-remarquable par la crinière jaune qu'il porte autour du cou , et la seconde ${ }^{2}$, celle que les voyageurs ont indiquée sous le nom d'ours marin, et qui est composée de deux variétés très-différentes entre elles par la grandeur : nous joindrons donc à cette espèce le petit phoque à poil noir, qui, étant pourvu d'oreilles externes, ne fait qu'une variété dans l'espèce de l'ours marin. Des inductions assez plausibles m'avaient fait regarder alors ce petit ours marin, comme le jihoca des anciens : mais comme Aristote, en parlant du phoca, dit expressément qu'il n'a pas d'oreilles externes et seulement des trous auditifs, je rois qu'ou doit chercher ce phoca des anciens dans quelqu une des espèces de phocpue sans oreilles, dont nous allons faire l'énumération.

- Lótarib a crivière.

2 L'Otarib ocks marix.

\section{LES}

PHOQUES SANS OREILLES,

OU PIOQUES PROPREMENT DITS.

\section{LE GRAND PHOQUE A MUSEAU RIDÉ.}

PREMIÈre ESPÈCE. - LE PHOQUe A TROMPE.

Tribu des macrorhines, genre phoque. (Cuvier.

Nous connaissons neuf ou dix espèces ou variétés distinctes dans le genre des phoques sans oreilles, et nous les indiquerons ici dans l'ordre de leur grandeur, et par les caractères que les voyageurs ont saisis pour les dénommer et les distinguer les uns des autres.

La plus grande espèce est celle du phoque à museau ridé, dont nous avons déjà parlé sous le nom de lion marin, parce que plusieurs voyageurs, et particulièrement le rédacteur du Voyage d'Anson, l'avaient indicjué sous cette dénomination, mais mal à propos, puisque le vrai lion marin porte une crinière que celui-ci n'a pas, et qu'ils different encore entre eux par la taille et par la forme de plusieurs parties du corps; en sorte que le phoque à museau ridé n'a de commun avec le vrai lion marin que d'habiter les côtes et îles désertes, et de se trourer comme lui dans les mers des deux hémisphères. Il faut done se rappeler ici ce que nous arons déjà dit de ce grand phoque à museau ridé, sous le nom mal appliqué de lion marin. Danpier et Byron ont trouvé, comme Anson, ce phoque à l'ile de Juan Fernandès, et sur la còte occidentale des terres Magellaniques.M. de Bougainville, Dom Peruetti et Bernard Penrose, l'ont recomnu sur la cote orientale de ce continent, et aux iles Malouines ou Falkland. MII. Forster ont aussi vu deux femelles decette espèce dans une île à laquelle le capitaine Cook a dlouné le nom de Nouvelle-Géorgie, et qui est situće au cinquante-quatrième degré de latitude australe, dans l'océan Atlantique : ces deux femelles étaient endormies sur le rivage, et on les tua dans leur sommeil. D'autre èté, M. Steller a vu et décrit ce mème grand phoque à museau ridé dans l'ile de Bering et près des eótes de Kamtschatka. Cette grande espece se tronve done également dans les deux hémi. 
sphères, et probablement sous toutes les latitudes ${ }^{4}$.

Nous nommons aujourd'hui cet animal phoque à museau ridé, par ree qu’il a sur le nez une peau ridée et mobile, qui peut se remplir d'air ou se gonfler, et se gonfle en eft'et lorsifue l'animal est agité de quelque passion : mais nous devons observer que cette peau in forme de crète est monstrueuscment exagérée dans la figure domée par le rédacteur du Voyage d'Anson, et qu elle est réellement beaucoup plus petitedans la nature.

Ce grand et gros animal est d'un naturel trèsindolent; e'est mème de tous le's phoques c'elui qui paraît être le moins redoutable malgré sa forte taille. Penrose dit que ses matelots s'amusajent à monter sur ces phoques comme sur des chevaux, et que quand ils u'allaient pas assez vite, ils leur faisaient doubler le pas en les piquant à coups de stylet ou de couteau, et leur faisant meme des incisions dans la peau. Cependant M. Clayton, qui a fait mention de ee phoque, dans les Transactions philosophiques, dit que les mâles, comme eeux des autres phoques, sont assez méchants dans le temps de leurs amours.

Celui-ci est couvert d'un poil rude, trèscourt, luisant et d'uue coulcur cendréc, mêlée quelquefois d'une lécrère teinte d'olive; son corps, dont la longueur est ordinairement de quinze à dix-huit pieds anglais, et quelquefois de vingt-quatie à vingrt-einq, et assez épais auprès des épanles et va toujour's en diminuant jusqu’à la queue. Une femelle tuée par M. Forster n'avait que treize pieds de longueur, et en la supposant adulte, il y aurait une grande difrerence pour la taille entre les màles et les femelles dans eette espèce. La lèvre supérieure avance de beaucoup sur la levre inlérieure; la peau decette lèvre est mobile, ridée et boul'fie tout le long du museau; et cette peau, que l'animal remplit d'air à sou gré, peut ètre comparée, pour la forme. à la caroncule du dindon; et c'est par cee earactère qu'on l'a désigné sous le nom de phoque ì museau rielé. Il u'y a daus la tète que deux petits trous auditifs, et point d'orrilles externes. Les pieds de devant sont conformens eomme ceux du phorpue commun, mais ceux de derriere sont plus informes et faits en maniere de nareoires: en sorte que cet auimal, beaucoup plus fort et plus grand (fue notre phoque, est moins anile et

'Il s'agit ici du phoque à capuchun. encore plus imparfaitement conformé par les parties postérieures, et c'est probablement par eette raison qu'il parait indolent et ties-peu redoutable.

M. Clayton a fait mention d'un phoque qui se trouve dans l'hérinisplière austral; il dit quon le nomme furseal ou phoque i fourrure, parce que son poil est plus fommi que celui des auties phoques, quoique sa peau soit plus mince. Nous ne sommes pas en état de juger par d': ussi filbles indications si ce phơue à fourure est d'uno espèce voisine de culle du phoque à nuseauridé, à còté de laquelle M. Claston l'a placé; ou de celle de l'ours marin, dont la fourture est en effet bien plus fournie que celles des autres phoques.

\section{LE PHOQUE A VENTRE BLANC.}

SECONDE ESPÈCE. - LE PIOQUE NOIXE.

Tribu des stenorbines. (Cuvier.)

Ce grand phoque à ventre blanc, que nous avons vu vivant au mois de décembre $17 i 8$, est d'une espèce très-différente de celle du phoque à museau ridé; nous allons rapporter les observations que nous avons faites sur ce phoque, auxquelles nous ajouterons quelques faits qui nous ont été fournis par ses conducteurs.

Le regard de eet animal est doux, et son naturel n'est point farouche : ses yeux sont attentif's et semblent annoncer de liutelligence, ils expriment du moins les sentiments d'affection, d'attachement pour son maitre, auçuel il obéit avec toute complaisance: nous l'avous vu s'incliner à sa voix, se rouler, se tourner, lui tendre une de ses nageoires antérieures, se dresser en élevant son buste, èest-à-dire tout le devant de son corps, hors de la caisse remplie d'eau dans laquelle on le tenait enfermé; il répondait it sa voix ou a ses signes par un som rauque qui semblait partir du fond de la gorge; et fuon pourait comparer au beuglement enroué d'un jeune taureau. II parait que l'animal produit ee son en expirant l'air aussi bien qu'en l'aspirant; seulement il est un peu plus clair clans l'aspilation. et plus rauque daus l'expiration. Avant que son maitre ne l'eùt rendu docile, il mordiait très-riolemment lorsquion voulait le foreer à firire quelques mourements : 
mais, des (qu'il fut dompté, il devint doux, au point qu'on pouvait le toucher, lui mettre la main dans sa gueule et même se reposer saus crainte aupres de lui et appuyer le bras ou la tête sur la siemne. Lor'sque son maître l'appelait, il lui répondait, quelque élojgné qu’il fùt; Il semblait le chercher des yeux lorsyu'il ne le voyait pas; et dès qu'il l'apercevait, ap)res (puelques moments d'absence, il ne manquait pas d'en témoigner sa joie par une espèce de gros murmure.

Quand cet animal, qui était mâle, épronvait les irritations de l'amour, ee qui lui arrivait à peuprès de mois en mois, sa douceur ordinaire sé changeait tout à comp en une espèce de fureur qui le rendait dangereux; son ardeur se déclaraít alor's par des mugissements accompagnés d'une forte érection; il s'agitait et se tourmentait dans sa caisse, se dommait des mouvements brusques et inquiets, et mugissait ainsi pendant plusieur's heures de suite; e'est pardes eris assez semblables (qu'il exprimait son sentiment de douleur lor'squ'on le maltraitait; mais il avait d'autres accents plus doux, tres-expressifs et comme articulés, pour témoigner sa joie et son plaisir.

Dans ces accès de fureurs amoureuse, oceasionnés par un besoin que l'animal ne pouvait satisfaire pleinement et yui durait huit ou dix jours, on l'a vu sortir de sa caisse après l'a voir rompue; et dans ees moments il était fort dangereux et même féroce; car alors il ne comnaissait plus personne; il n'obéissait plus à la voix de son maître, et ce n'était (pu'en le laissant se calmer pendant quelques heures quil pouvait s'en approcher: il le saisit un jour par la manche, et l'on eut beaucoup de peine à lui laire làcher prise en lui ouvant la gueule avee un instrument. Une autre fois il se jeta sur un assez gros chien et lui écrasa la tète avee les dents; et il exercait aiusi sa fureur sur tous les objets fu'il rencontrait : ces accès d'amour l'échauffaient beaucoup; son corps se couvrit de gale, il maigrit ensuite, et enfin il mourut an mois d'aoùt 1779 .

Il nous a paru que cet animal avait la respiration fort longuc, ear il gardait l'ail assez longtemps et ne l'aspirait que par intervalles, entre lespuels ses narines élajent exactement fermées, ê dans cet état elles ne paraissent que comme deux gros traits marqués longitudinalement sur le bord du inuseau : il ne les ouvrogue pour rendre l'air par une forte expiration, ensuite pour en reprendre, après quoi il les referme comme auparavant; et souvent il se passe plus de deux minutes entre ehaque aspiration. L'air, dans ee mouvement d'aspiration, formait un bruit semblable à un reniflement très-fort ; il découlait presufue continuellement des narines une espèee de mucus blanchâtıe, d'une odeur désagréable.

Ce grand ploque, comme tous les animaux de ec genre, s'assoupissait et s'endormait plusieurs fois par jour; on l'entendait ronfler de fort loin; et lorsquil était endormi on ne l'éveillait qu'avec peine; il suffisait mème cu'il fuit assoupi pour que son maîtıe ne s'en fit pas entendre aisément; et ce n’était qu’en lui présentant près du nez quelques poissons, qu'on pouvait le tirer de son assoupissement; il reprenait dès lors du mouvement et même de la vivacité; il élevait la tète et la partie antérieure de son corps en se haussant sur ses deux palmes de devant jusqu'à la hauteur de la main qui lui présentait le poisson, car on ne le nourrissait pas avec d'autres aliments, et c'était principalement des carpes, et des anguilles qu'il aimait encore plus que les carpes: on avait soin de les assaisonner, (juoique erues, en les roulant dans du sel. I] lui fallait environ trente lives de ces poissons vivants et sanpoudrés de sel par vingt-quatre heures. 11 avalait tres-groulúment les anguilles tout entieres et mème les premières carpes qu'on lui offrait: mais dès qu'il avait avalé deux ou trois de ces earpes entières, il cherchait à vider les autres avant de les manger', et pour cela il les saisissait d'abord par la tète, qu'il ćerasait entre ses dents; ensuite il les laissait tomber, leur ouvait le ventre pour en tirer le fiel avec ses appendices, et finissait par les reprendre par la tète pour les avaler.

Ses excréments répandaient une odeur tresfétivic: ils citaient de couleur jaunatre et quelquefois liquides, et lorsqu'ils étaient solides ils avaient la forme d'une boule. Les conducteurs de cet animal nous assurèrent qu'il pouvait vivre plusicur's jour's et mème plus a' un mois sans être dans l'cau, pourvu néanmoins qu'on cùt soin de le bien laver tous les soirs avec de l'eau nette, et qu'on lui domnat pour boisson de l'eau claire et salće; car lorscu'il buvait de l'eau donce cl surtout de l'eau trouble, il en était toujours iucommodé.

T.e corps de ee grand phoque, comme celui 
de tous les animaux de ce genle, est ric forme presque cylindriøue : cependant il diminue de grosseur sans perdre sa rondeur en approchant de la quene. Son poids total pouvait être de six ou sept cents livres : sa longueur était de sept pieds et demi, depuis le bout du museau jusqu'il l'extrémité des nageoires de derrière; il ávait près de cinf pieds de circonférenee à l'endroit de son corps le plus épais, et seulement un pied neuf pouces de tour aupiès de l'origrine de lat gueue. Sa peau est couverte d'un poil court, très-ras, lustré et de couleur brune, mélangée de grisâtre, prinejpalement sur le cou et la tète ou il parait comme tigré; le poil est plus épais sur le dos et sur les cótés du corps que sous le ventre, où l'on remargue une grounde tache blanche qui se termine en pointe en se prolongeant sur les flaues; et e'est par ce caractere que nous a vons cru devoir le désigner en l'appetant le grand phoque à ventre blanc.

Les narines ne sont ni inclincées, ni posées horizontalement comme dans les (puarlrupèdes terestres, mais elles sont itendues verticalement sur l'extrémité du museau : elles sont longues rle trois ou quatre pouces, et s'étemdent depuis le haut du museau jusqu'a uu travers de doigt au-dessus de la levre superieure. Ces marines ou naseaux sont éloignnées l'une de l'autre d'environ cing pouces; et lorsqu'elles sont ouvertes, clles ont ehacme pres de deux pouces de largeur, et ressemblent alors à deux petits ovales resserrés par leurs extrénités.

Les yeux sont grands, bien ouverts, de couleur brume et assez semblables a ceux du boeuf; ils sont situés à cinq ponces de l'extrénité du nez, et la distance entre leur's angles internes est d'environ quatre pouces : lorsque l'animal est longtemps sans cntrer dans l'eau, son sangr s'échauffe et le blane des yeux devient rouge, surtout ver's les augles.

La gueule est assez grande et environnée de grosses soies ou moustaches presque s'mblables à des arètes de poissons : les máchoires étaient garnies de trente-deux dents lont jiumes et qui paraissaient usées; nous avous compté vingt máchelières, huit jucisives, et ([uatle canines.

l.es oreilles ne sont que deux petits trous prescuc cachés daus la jeau : ces trous sont plarés à environ rois pouces des yeux, et à lut ou neuí pouees du bout du sez; et quoiqu’ils n'aicut guèrequ'une ligne d'ouverture, l'animal parait néanmoins avoir l'oüe très-fine, puisyu’il ne mangue jamais d'obeir ou de répondre, mème de loin, à la voix de son maitre.

I.es pieds ou nageoil'es de devant, mesurées depuis l'endroit ou clles sortent du corps, jusqu'à leur extrémité, olıt environ quinze pouces de louguen' sur autint de largeur, lorsqu'elles sout entic̀rement déployées; elles out chacune cincf ongles noirs un peu courbés, et sont conformées de manière yue la doight du milieu est le plus court, cot les denx de còté les plus longs.

Les macoires de derrive ont la forme de celles de devant à leur extrémité, e'est-it-dirce que le doirgt du milieu est anssi plus court que ceux des colés; elles aceonpyagnent la queue et ont douze à treize pouces de longueur, sur envirou dix-sept pouces de largeur lorspue la membrane est entiijement étendue; elles sont grosses et charuues par les còtés, minees daus le milieu et découpées en festons sur les bords. Il n'y avait pas d'ongles apparents sur ees nageoires postérieures : mais ees ongles ne manquaient sans doute que par aecirlent, et parec que cet animal se toumentait beaucoup et frottait fortement ces nageoires de derrière contre le fond de sa caisse; la membrane méme de ees nageoires était usée par les frottements, et déchirée en plusieurs endroits.

La queue, qui est situćc entıe ces deux nageojres, n'a cuc quatre jouces de long sur trois de large; elle est de folme presque trianerulaire, large à sa naissance, et en pointe arrondie à son extremité; elle n'est pas fort ćpaisse et parait aplatie dans toute son érendue.

Ce grand plsogue fut pris le 2 s octobre 1777 , daus le goulfe Adriatique pres de la côte de Dalmatic, daus la petite ile de Gunnero a a deux cents milles de Venise; on lui avait donné plusieurs fois la cluasse sillus sucees, et il arait déja échappé cinf on sis fois en rompant les filets des pèhems : il était comm depuis plus de cinquante ans, au rapport des anciens pécheurs de cette còte, qui l'avaient souvent poursuivi, et qui croyaient que c'était a son grand âge ru’il devait sa grande taille; et ce. qui semble confirmer refte présomption, cest que ses dents etaient tres-jaunes et uscies, que soil poil était plus foncé en couleur que celui de lit plupart des phocpues yui nous sont connus, et (jue ses moustaches itaient longues, blanches et tres-ludes.

Cependant yuclques autres plocpues de la mème grandeur ont eté pris dans ce mème golfe 
Adriatioue, ilsont été vus et menés, commecelui-ci, en France et en Allemagne dès l'année 1760. Les conducteur's de ces animaux, ayant intélèt de les conserver vivants, ont trouvé le moyen de les guérir de quelques maladies qui leur' surviennent par leur état de gêne et de captivité, et que probablenent ils n'éprouvent pas dans leur état de liberté; par exemple, lorsqu'ils cessent de mangel' et refusent le poisson, ils les tirent hors de l'eau, leur font prendre du Iait mêlé avec de la thériague; ils les tiemnent chaudement en les enveloppant d'une couverture, et continuent ce traitement jusqu'à ce que l'animal ait repris de l'appétit et cu'il recoive avec plaisir sa nourriture ordinaire. Il arrive souvent que ces animaux refusent tout aliment pendant les cing ou six premiers jours après avoir été pris, et les pêcheurs assurent qu'on les verrait périr d'inanition si on ne les contraiguait pas à avaler une dose de thériaque avec du lait.

Nous ajouterons ici quelques olservations qui ont été faites par M. Sabarot de la Vernière, docteur cn médecine de la faculté de Montpellier, sur un grand phoque femelle, qui nous parait ètre de la méme espèce que le mâle dont nous renons de domner la description.

"Cet amphibie, dit-il, parut à Nimes dans l'automne de l'année 1 i 7 ; il était dans un cuvier rempli d'eau, et avait plus de six pieds de longueur; sa peau lisse et un peu tigrée affectait agrréablement la vue et le tact; sa tète, plus grosse que celle d'un veau, cn avait à peu près la figure, et ses yeux grands, saillants et pleins de feu, intéressaient les spectateurs; son cou très-souple se recourbait assez facilement, et ses mâchoircs armées de dents aiguës et trauehantes lui donnaient un air redoutable; on Iui voyait deux trous auditifs sans oreilles externes; il avait la gueule d'un louge de colail, et portait une moustache fort grande : deux nageoires en forme de main tenaient aux còtés du thorax, et le corps de l'animal se terminait en une quene qui était aecompagnée de deux nageoires latérales, lesquelles lui tenaient licu de pieds. Ce phoque, docile à la vois de son maitre, prenait telle position cu'il lui ordomnait : il s'élevait hor's de l'eau pour le caresser et le lécher. Il éteignait une thandelle du souffle de ses narines, qui sont percées d'une petite fente dans le milieu de leur étendue. Sa voix était un rugissemrnt obscur, mèlé quelquefois de gémisse- ment. Sol conducteur se couchait auprès de lui lorsqu’il était à sec. L'ean de son cuvier ćtait salée; et lorsqu'il s'y plongeait, il élevait de temps en temps la téte pour l'espirer. II vivait d'anguilles, qu'il dévol’ait dans l'eau. Il mourut à Nîmes, d'une maladie semblable à la morve des ehevaux; et il nous parut intérieure. ment conformé comme le veau mariı, dont rous ayez parlé, monsieur. Toici ce que la dissection m'apprit sur cet animal. Le trou ovale que vous dites ctre toujours ou vert dans ces animaux amphibies était exactement fermé par une mem. brane transparente, disposce en forme de poehe semi-lunaire. Je ne pus pas trowver le canal artériel. Son estomac était très-fort, et la tunique chamue paraissait comme marbrée. Le foie était composé de cinq lobes ainsi (que les reins, qui avaient onze pouces de hauteur : leur substance corticale était un amas de corps pentagones vasculeux, liés entre eux par un tissu cellulaire très-lâche. Les quatre tuniques des intestins se séparaient par la macération, et nous vimes tres-bien les membranes cellulaire, charnue, tendineuse et veloutée, ainsi que la disposition spirale entrelacée des trous qui servent de passage aux raisseaux salyguins qui percent ces tuniques, sans pouvoir ètre lésés par le resselrement péristaltique. La mauvaise odeur développée par le temps humide nous empècha de suive plus loin la dissection de cet animal; et j'ai l'honneur de vous offrir, monsieur, l'estomac entier de ce phoque, que j’ai conservé. "

Ayant répondu à M. de la Vernière qüil me ferait plaisir de menvover cet estomac ou sa description détaillée, et qu'il me paraissart probable que le trou ovale du cour, qui est ordinairement ouvert dans ces animaux, habitants de la mer, ne s'était fermé que par le changement d'habitules et sou séjour dans l'air, Ml. de la Verujiere me fit réponse le 20 janvice 1750 : "Que l'estomac de ce phoque n'avait point été injecté, et que c'était une simple insuftiation.Ce viscère, dit-il, me paraît contenir quelques çrains, qui font du bruit par la plus légère agitation.... Ét à l'égard de la membrane qui fermait le trou ovale, elle était semi-lunaire et disposée en forme de poehe ; le segment qui terminaii le bord concave du croissant me pirut plus dur; les limes yui formaient cette poche, quoique pellucides, ćtaient olganisées ou tissues de fibrestéxuliè us: je ne vis cependant pas de vaisseaux sangulus; elles glissaient l'une sur l'autre par la pression 
digitale, et paraissaient d'un tissu tendineux. Je ne sais pas si le changement d'habitudes que cet animal avait contracté, aurait pu former une membrane de eette structure; mais il me suflit, monsieur, que vous ell affirmiez la possibilité pour être de votre sentiment. Au reste, M. Montagnon, qui dissé(jua avec moi ee phoque, assure avoir remarqué qu’il avait plusieurs inflations dans les voies alimentaires, qui lui parurent être quatre estomacs; je n'ai pas vu cet animal ruminer, ni entendu dire cqu'il l'uminât."

M. de la Vernière a aprorté à Paris, au mois de novembre dernier, 1780 , cet estomac : et j'ai reeonnu qu'il ne formait qu'un seul viscere avec des poehes ou appendices, et non pas quatre estomaes semblables à ceux des animaux ruminants.

J'ai dit que le grand phorque dont M. Parsons a donné la deseription et la fignuredans les Transactions philosophiques, $11^{\circ} 469$, pourrait bien être le même que le lion marin d'Anson. A présent (que ce dernier animal est mieux connu et bien désigné par le nom de l'hoque à museau ridé, nous reconnaissons que le grand phoque de M. Parsons se rapporte bien mieux à ce phoque a ventre blane, dont nous venons de faire la deseription, quoique ee dernier soit plus petit; mais nous ne sommes pas convaincu de ce que ce savant médecin parait avoir observé sur la strueture intérieure de cet animal, et particulièrement sur celle de son estomae. M. Parsons m'écrivit, il y a plusieurs années, que ce phoque, qu'il a décrit dans les 'T'ransactions philosophiques, est très-réellement, par sa strueture intérieure, aussi différent des autres phoques, qu'une vache l'est d'un cheval : et il ajoutait qu'il a non-seulement disséqué ce grand phoque, mais deux petits phoques d'espèes diff'c'('utes, et qu'il avait trouvé que c'es deux petits phoques difféaient aussi entre eux par la conformation des partics intérieures, l'un de ces petits phoques ayant deux estomacs, et l'autre n'en ayant qu'un. Il me marquait encore, dius ectte lettre, que les espèces de ce gemre sont fort nombreuses; que le grand plrocque qu'il al disséqué avait une large poche imarsm inime remplie le poissons, et me autre poche yui communiquait belle-ci, laquelle était plejue de petites pjerres anguleuses; et de plus deux autres poches plus petites, qui contenaient de la matiere blanche ('t fluide qui passait daus le duodenum, et que certaine- ment ee grand phocque était, à tous égards, un animal ruminant.Quoique M. Parsons fủt un médecin célèbre, et qüil ait même publié de bons ouvrages de physigue, nous avons toujours douté des faits yu’our vient de lire, ne pouvant croile sur son seul témoi nake, qu'aucun animal du genre des phoques soit Iuminant, ni que leurs estomacs soient conformés comme ceux de la vache; il parait seulement que dans quel jues. ums de ces animaux, tels que celui dont M. de la Vernière a fait la dissection, l'estome est divisé, comme en plusieurs poches, par différents ćtranglements: mais cela n'est f'as suflisant pour faire mettre les phorjes au nombre des animaux ruminants; d'ailleurs ils ne vivent que de poissons, et l'on sait que tous les animaux qui ne se rotirissent que de proie, ne ruminent pás : ainsi on peut donc présumer avec fondement que les animaux du genre des phocjues n'ont pas plus la faculté de ruminer, que les loutres et autres amphibies gui vivent sur la terre et dans l'eau.

Il me parait aussi que le grand phoque dent parle M. Crantz, sous le nom d'ulsuk ou urlisuli, pourrait bien etre de la mème espèce que erlui de M. Parsons, (quoigüil soit encore pius grand, puisque 11 . Crantz dit qüil se trouse de ces phoques utsuk qui ont jusqu’à douze piexls de longueur et qui pesent huit cents livres.

Le grand phoque dout parle le l'. Charlevoix, et qu'il dit se trouver sur les cótes de l'deadie, pourrait bien ètre encore de la mème espece de celui-ci; cependant il olsserve que ces phocpues de l'Acadie ont le nez plus pointu que les atutres, et il ajoute, d'après Dem!s, qu'ils sont si gros, " que leurs pelits ont plus de volume de corps que nos plus grands pores; que peu de ten?ps apres quäls sont nés, le prere et la mere les amenent í l'eau, et de temps en temps, les ramènent à terre pour leur donner à téter; que la pèche s'en fait au mois de firripl pour avoil les petits, yui daus ce temps ne vont point a l'eau; quau premier bruit les peres et mères prenuent la fuite en jetant des cris pour alertir les petits de les suive; mais qu'on en tue um gland nombre avant quils puissent se jeter daus la mer.,

J'avoure (pue ees indications me sont pas assez. précises pour quon puisse promonecr sur l"identité ou la diversité de eses espèe's de phoyues dont nous vemons de parler: nous ne les rapportons ici yne pour servir de reusejguement 
aux voyageurs qui se irouveront à portée de les recomaitre, et qui pourront nous mieux instruire.

\section{LE PHOQUE A CAPUCHON.}

TROISIEME ESPECE.

Tribu des stemmatopes, genre phoque. (Cuvier.)

La troisième espece de grand phorgue est celle que les Groenlandais nomment neilsersoak; cet animal a pour attribut distinctif un capuchon de peau dans lequel il peut renfoncer sa tète juscu'aux yeux. les Danois et les Allemands l'ont appelé hlap-milse, ce qui signifie bonnet rabattu. Ce phoque, dit M. Crantz, est remarquable par la laine noire qui revèt la peau sous un poil blane, ce qui le fait paraitre d'une assez belle couleur grise; mais le caractère qui le distingue des autres phogines est ce capuchon d'une peau épaisse et velue qu'il a sur le front, et qu'on appelle cache-museau, parce que l'animal a la faculté d'abattre cette peau sur ses yeux, pour se garantir des tourbillons de sable et de neige que le vent chasse trop impétueusement.

Ces phoques font régulièrement deux voyages par an. Ils sont fort nombreux au détroit de Davis, et y résident depuis le mois de septem!re jusqu'au mois de mars; ils en sortent alors pour aller faire leurs petits à terre, et reviennent avec eux au mois de juin fort maigres et fort épuisés; il en partent une seconde fois en juillet. pour aller plus au nord, où ils trouvent probablement une nourriture plus abondante, car ils reviennent fort gras en septembre. Leur maigreur, dans les mois de mai et de juin, semble indiquer que e'est alor's la síison de leurs amours, et que dans ce temps ils oublient de manger, et jeûnent comme les lions et les ours marins.

\section{LE PHOQUE A CROISSAN'T.}

\section{QUATRIÈME TSPPĖCE.}

La quatrième espèce de grand phoque sans ormilus externes est appelée aliarsoak par les Groën'andais. Il differe du précédent par quel- ques earactères, et change de nom dans cette langue à mesure que son poil prend des teintes diffééentes : le fotus, qui est tout blanc et couvert d'un poil laineux, se nomme iblau. Dans la première année d'àge le poil est un peu moins blane, et l'animal s'appelle attarak; il devient gris dans la seconde année, et il porte le nom d'alteitsiak; il varie encore plus dans la troisieme, et on l'appelle aglektok; il est tacheté dans la quatrième, ce qui lui fait donner le nom de mileqtoq; et ce n'est qu'à la cinquième année que le poil est d'un beau gris-blane, et qu'il a sur' le dos deux eroissints noirs, dont les pointes se regardent; ce phoque est alors dins toute sa force, et il prend le nom d'altarsoak. J'ai cru deroir rapporter tous ces différents noms, pour que les voyageurs qui fréquenteront les ếtes du Groënland puissent recounaitre ces animaux.

La peau de ce phoque à croissant est revétue d'un poil raide et fort; son corps est couvert d'une graisse épaisse et dont on tire une huile qui, pour le gout, l'odeur et la couleur, ressemble assez à de la vieille huile d'olive.

Au reste, il me parait que c'est à eet animal qu'on peut rapporter la troisième espèce de phoque iudiquée par M. Íracheninnikow, qui porte, dit-il, de grands cercles couleur de cerise sur une fourrure jaunâtre, et qui se trouve dans la merorientale. M. Pallas rapporte aussi à cette espèce un phoque que l'on prend quelquefois aux embouchures de la Lena, de l'Obi et du Jenissei, et que les Russes appellent lièvre de mer (morslioizaelz), à cause de sa blancheur, les lièvres étant tout blancs dans ce pays pendant l'hiver. Si ce demier animal est en effet le même que l'altarsoak de M. Crantz, et que celui de M. Kracheninnikow, on voit qu'il se trouve non-seulement dans le détroit de Davis et aux environs du Groënland, mais encore sur les còtes de la Sibérie et jusqu'au Kanstchatka. Au reste, comme le poil de ce phoque à croissant prend différentes teintes de couleur arec l'âge, il se pourrait que les phoques gris, tachetés, tigrés et cerclés, dont parlent les voyagenrs du nord, ne fussent que les mèmes animaux, et tous de l'espèce du phoque à croissant, vit dans des àges différents; et dans ee cas nous serions fondé a lui rapporter encore une autre espice de phoque qui, sclon M. Kracheninnikow, a le ventre blane jaunatre, le reste de la peau palscmée de taches comme celles du léopard, etdont 
les petits sont blanes comme la neige lor'squ'ils viennent de naître.

\section{LE PHOQUE NEIT-SOAK.} CINQUILME ESPECE. - LE PHOQUL PUANT.

Lál einquième espèce de phoque sans oreilles externes est appelée neit-soali par les Groënlandais. Il est plus petit que les précédents; son poil est melé de soies brumes el aussi rudes que celles du cochon: la coulcur en est variée par de grandes taches, et il est hérissé comme celui de l'ou's marin.

\section{LE PHOQUE LAKTLK DE KAUTSCHATKA.} SIXIÈME ESPËCE ${ }^{\prime}$.

I a sixième espèce est eelle que les habitants de liamtschatka appellent lakhtak. Elle ne se prend qu'au delà du cinquante-sixième degré de latitude, soit dans la mer de Pengina, soit dans l'océm oriental, et parait être une des plus grandes du genre des phoques.

\section{LE PHOQUE GISSIGIAK.}

SEPTIÈME ESLi:C:.

La septieme espece de phoques sans oreilles externes est appelée hassigiak par les Groënlandais : la peau des jeunes est noire sur le dos et hlanche sous le ventre, et celle des vieux est ordinairement tigrée. Cette espèce n'est pas voyageuse et se trouve toute l'année à Balsriver.

\section{LE PIIOQUE COMMUN.}

$$
\text { IUUTİME ESPÈCミ. }
$$

La huitieme espèce est celle du phocpue commun d'Europe, dont nous arons donné la deseription, et que l'on nomme assez indifferemment veau marin, loup) marin, et chien marin.

- Celle espece et la suicunle niont pas élé classies par les naluralistes modernes.
On donne aussi ces mèmes noms à quelquesuns des antres phoques dont nous venons de parler. Cette espèce se trouve non-sculement dans la mer Baltique et dans tout l'Océan, depuis le Groẹnland jusqu'aux îles Canaries et au eap de Bonne-Espérance, mais encole dans la Méditerranée et dans la mer Noire. 11. Kracheninnikow et MI. Pallas disent qu'il y en a mème dans la mer Caspienne et dans le lac Baikal, ou l'eau est douce et non salée, ainsi que dans les lacs Onéga et Ladoga en Russie : ce qui semble prouver que cette espèce est presque universellement répandue, et qu'elle peut vivre également dans la mer et dans les eaux douees des climats froids et tempérés. Nous doninons la figure d'un de ces phoques que nous arons fait dessiner vivant, et qui pourrait bien ètre une variété dans cette espèce du phoque eommun, n'ayant que quelques légeres différences dans la forme du corps et dans les couleurs d" poil.

Le voyageur Denis parle d'une espèee de phoque, de taille moyenne, qui se trouve sur les còtes de l'A Acadic; et le P. Dutertre rapporte, d'après lui, que èes petits phoques ne s'éloignent jamais beaucoup du rivage. "Lorsqu'ils sont sur li terre, il y en a toujours quelqu'un . dit-il, qui fait sentinelle; au premier signal (qu'il donne, tous se jettent diuns la mer : au bout de quelque temps, ils se rapprochent de terre et s'élevent sur leurs pattes de derriere pour roir s'il n'y a rien à craindre; mais malgré cela on en prend un tres-grand nombre a terre, et il liest presque pas possible de les avoir autrement... .rais quand ees pl:oques entrent avec la marée dans les anses, il est aisé de les prendre en tres-grande quantité; on en ferme l'entrée avee des filets et des picux, on n'y laisse de libre qu'un fort petit espace par ou ees phoques se glissent dès que la marée est haute: on bouche cette ouv erture lies que la mer est retirée, et ees animaux étant lestés à sec, on n'a que la peine de les assommer. On les suit en canot dans les endroits ou il y en a beaucoup, et quand ils mettent la tète hors de l'eau pour res. pirer, on tire dessus : s'ils ue sont que blessés, on les prend sans peine; mais s'ils sont tués raides, ils vont d'abord au fond, oủ de gros chiens, dressés pour cette chasse, vont les pècher à sept ou huit brasses de profondeur. "

Ces huit ou neuf especes de ploques, dout nous venous de donuer les indirations, se trouvent pour la plupart aux cuvirons des terres les 
plus septentrionales dans les mer's de l'Europe, de l'Asie et de l'Amérique; tandis que le lion marin, l'ours marin et mêrne le phoque à mustau ridé se trouvent également répandus dans les deux hémisphères. Tous ces animaux, à l'exception du phoque à museau ridé et du phocque i i entre blane, sont connus par les Russes et autres peuples septentrionaux, sous les noms de chicn et de veau marin; il en est de même au Kamtschatka, aux îles Kouriles et ehez les Koriaques, ou on les appelle liolliha, betarkar et memel, ce qui signilie également veau marin dansles trois langues. "Ils ont tous la peau ferme et velue, comme les quadrupèdes terrestres, à cela près, dit M. Crantz, que le poil est épais, court et lisse dans la plupart, comme sil était huilé. Ces animaux ont les deux pieds de devant formés pour mareher, et ceux dederriere pour nager; à chaque pied il y a einq doigts, avec quatre jointures à chacun, armés d'ongles pour grimper sur les rochers ou se cramponner sur la glace; leurs pieds de derrière ont les doigts joints en patte d'oie, de sorte qu'en nageant ils se déploient comme un éventail. Ce sont des espèces d'amphibies; la mer est leur élément, et le poisson leur nourriture; ils vont dormir a terre, et même ils ronflent si profondément au soleil, qu'il est aisé de les surprendre. Ils courent des pieds de devant, et sautent ou s'élancelt avec ceux de derrière, mais si vite, qu'un homme a de la peine à les attraper. Ils ont des dents tranchantes et des poils au museau, forts comme des soies de sanglier... Leur corps est gros au milicu, et terminé en cône par les deux extrémités, ce qui les aide beancoup à nager. "

C'est sur les rochers et quelquefois sur la glace que ces animaux s'accouplent, et que les meres font leurs petits. Elles les allaitent dans l'eau, mais bien plus souvent à terre : elles les laissent aller de temps en temps à la mer; ensuite elles les ramènent á terre, et les exercent ainsi juscju'à ec qu'ils puissent faire, en nageant, de plus longs voyages.

Ton-senlement ces animaux fournissent aux Groëulandais le vêtement et la nourriture, mais leurs peaux sont encore employées à couvrir leurs tenles et leurs canots ; ils en tirent aussi de l'huile pour leurs lampes, et se servent des nerfs et des fibres tendineuses pour coudre leurs vitements; les boyaux, lien nettoyés et amincis, sont employés au lieu de verre pour leurs fenètres; et la vessie de ces animaux leur sert de vase pour contenir leur huile; ils en font séeher la chair pour la conserver pendant le temps qu'ils ne peuvent ni chasser ni pềcher : en un mot, les phoques font la prineipale ressource des Groënlandais, et e'est par cette raison qu'ils s'exercent de bonne heure à la chasse de ces animaux, et que celui qui réussit le mieux ae. quiert autant de gloire que s'il s'était distingué dans un comibat.

M. Kracheninnikow, qui a vu ces animaux au Kamtschatka, dit qu'ils remontent quelquefois daus les rivières en si grand nombre, que les petites îles éparses ou voisines des côtes de la mer en sont couvertes. En général, ils ne s'éloignent guère qu'à vingt ou trente lieues des côtes ou des iles, excepté dans le temps de leurs voyages : lorsqu'ils remontent les rivières, c'est pour suivre le poisson dont ils se nourrissent. Ils s'accouplent différemment des quadrupèdes: les femelles se renversent sur le dos pour recevoir le mâle; elles ne produisent ordinairement qu'un petit, ainsi que nous l'avons déja dit, dans les grandes espèces, et deux dans les petites. La voix de tous ces animaux, selon Kraeheninnikow, est fort désagréable; les jeunes ont un eri plaintif, et tous ne cessent de grogner ou murmurer d'un ton rauque. Ils sont dangereux dès qu'ou les a blessés : ils se défendent alors avec une sorte de fureur, lors mème qu'ils ont le crâne brisé en plusieur's pièces.

On voit, par tout ce que nous venons d'exposer, que non-seulement ce genre des phoques est assez nombreux en espèces, mais que chaque espèce est aussi très-nombreuse en individus, si l'on en juge par la quantité de ceux queles voyageur's ont trou yés rassemblés sur les terres nouvellement découvertes et aux extrémités des deux continents : ces còtes désertes sont eu effet le dernier asile de ees peuplades marines ciui ont fui les terres habitées, et ne paraissent plus que disper'sées dans nos mer's. Et réellement ees phocpues en bandes, ces troupeaux du vieux Protée, que les anciens nous ont si souvent peints, et ru`ils doivent a voir vus sur la Méditerranée, puisqu ils connaissaient très-peu l’Océan, ont presque disparu et ne se trouvent plus que dispersés près de nos còtes, où il n'est plus de désert qui puisse leur offrir la paix et la séeurité dont leurs grandes sociétés ont besoin: ils sont allés chereher ailleurs cette liberté qui est nécessaire à toute réunion sociale, et ne 
l'ont trouvée que dans les mers peu fréquenties, et sous les zones froides des deux pòles.

\section{LES PHOQUES A OREILLES.}

\section{L'OURS MARIN}

(OTARIE OURS MARIN.)

Tribu des macrorhins, genre phoque. (Cuvier.)

'Tous les phocues dont nous venons de parler u'ont que des trous auditifs et point d'oreilles externes; ct l'our's marin n'est pas le plus grand des phoques a oreilles, mais c'est celui dont l'espèce est la plus nombreuse et la plus répandue; c'est un animal tout diflérent de l'ours de mer blane, dont nous avons parlé eidevant; ce dernier est un (quadrupede du genre de l'our's terrestre, et l'our's marin dont il s'agit ici est un véritable amphibie de la famille des phoques. M. Forster, qui a vu plusieurs de ces animaux dans son royage avec le eapitaine Cook, et qui en a dessine quelques-uns, a bieu voulu me domner le dessin cl'apres lequel on a gravé la planche ; il m’a aussi communiqué plusieurs faits historiques sur leurs habitudes naturelles; et ses observations, réunies à celles de M. Steller et de quelques autres voyageurs, sufliront pour donner une comnaissance assez exacte de ect animal, qui jusqu'a present avait été confondu avee les alutres phorgues.

L'espèec de l'ours marin parait se trouver dans tous les occans; cal les voyageurs ont rencontré et reconnu ces animaux dans les mers de lir.quateur et sous toutes les falitudes jusqu'au cinquante-sixieme degre dans les deux hémisphères. Dampier est le premier qui en ait parté, et qui les ait indiqués sous le nom d'ours marin; quelcues autres navigateur's l'ont appelé phoque commun, paree qu on le trouve en effet très-eommunciment daus toutes les mers australes ou boréales : mais nous derons olserver que ee nom lui a été mal appliçué, puisquu'il appartient spéeifiçuement au phoque commun qui se trouve sur nus cotes d'Europe, qui n'est pas à beaueoup près aussi grand, et qui de plus n'a point d'oreilles extéricures.

De tous les animaux de ce genre, l'ours marin paait étre celui qui fait les plus grands voyages; son tempérament n'est pas soumis ou s'accommode à l'influence de tous les climats; on le trouve daus toutes les mers et autour des îles peu frécfuentées; on le rencontre en troupes nombreuses dans la mer de hamtschatka, et sur les iles inhabitées qui sont entre l'Asie et l'Amérique. M. Steller al eu le temps de l'observer à l'ile de Bering, après son malheureux naufrage; il nous apprend que ces animaux quittent au mois de juin les còtes de liamtschatka, et qu'ils y reviemment i la fin d'août ou au commen ement de septembre, pour y pas. ser l'automne et l'hiver. Dans le temps du départ, e'est-à-dire au mois de juill, les femclles sont prètes à mettre bas, et il paraît que l'objet du voyage de ces animaux e'st de s'éloigner le plus qu'ils peurent de toute terre habitée, pour faire tranyuillement leurs petits et se livrerensuite sans trouble áus plaisir's de l'amour, car les femelles entrent en chaleur un mois apres qu'elles ont mis bas; tous reviemment fort maigres ‘u mois d'aout ; ceux que M. Steller a disséqués dans cette saison n'asaient rien dans l'estomac ni dans les intestins, et il présume qu'ils ne mangent que peu ou point du tout tant quedurent leurs amours. Cette saison des plaisirs est en même temps celle des combats; les màles se battent avec furcur pour maiutenir lcur famille et en conserver la propriété; car lor's fu'un ours marin màle vicut pou! enlever à un autre ses filles adultes ou se's femmes, ou qu'il veut le chasser de sa place, le combat est sanglant et ne se termine ordinairement que par la mort de l'un des deus.

Chaque mâle a communément huit à dis femelles et quelyuefois yuimze ou vingt; il en est fort jaloux et les garde avec grand soin : il se tient ordinairement a la tète de toute sa fimmille, qui est composée de sés femelles et de leurs petits des deux sexes. Chaque famille se tient siparée, et yuoique ces animaux soient par milliers dans de certains endroits, les familles ne se melent jamais, et chacune forme une petite troupe, à la tète de laquelle est le chef màle qui les régit en maitre; cependant il arrive quelquefois que le chef d'une autre famille arrive au combat pour proteger un de ceux qui sont aux prises, et alors la guerre devient plus générale, et le vainyueur sempare de toute la famille des vaincus pu il réunit a la siemue.

Ces ours marins ne craignent aucun des au. fles animaux de la mer: eeprendant ils parais- 
sent fléchir devant le lion marin; car ils l'évitent avec soin et ne s'en approchent jamais, quoique souvent établis sur le même terrain : mais ils font une guerre cruelle a la loutre marine (saricovienne), qui étant plus petite et plus faible, ne peut se défendre contre eux. Ces animaux, qui paraissent très-féroces par les cornbats qu'ils se livrent, ne sont cependant ui dangereux ni redoutables; ils ne eherchent pas mème à se défendre contre l'homme, et ils ne sont à craindre que lorsqu'on les réduit au désespoir, et qu'on les serre de si près qu'ils ne peuvent fuir : ils se mettent aussi de mauvaise humeur lorsqu'on les provoque dans le temps qu'ils jouissent de leurs f'emelles; ils se laissent assommer plutót que de désemparer.

La manière dont ils vivent et agissent entre eux est assez remarquable; ils paraissent aimer passionnément leur famille : si un étranger vient à bout d'en enlever un individu, ils en témoignent leurs regrets en rersant des larmes; ils en versent encore lor'sque quelqu'un de leur famille, qu'ils ont maltraité, se rapproche et vient demander grâce. Ainsi, dans ces animaux, il paraît que la tendresse succède à la sévérité, et que e'est toujours à regrret qu'ils punissent leurs femelles ou leurs petits; le mâle semble ètre en même temps un bon père de famille et un chef de troupe impérieux, et jaloux de conserver son autorité, et qui ne permet pas cqu'on lui manque.

Les jeunes mâles vivent pendant quelque temps daus le sein de la famille, et la quittent lor'squ'ils sont adultes et assez forts pour se mettre à la tête de quelques femelles dont ils se font suivre, et cette petite troupe devient bientòt une famille plus nombreuse : tant que la vigueur de l'âge dure et qu'ils sont en état de jouir de leurs femelles, ils les régissent en maitres et ne les quiltent pas; mais lorsque la vieillesse a dimincé leurs forees et amorti leurs désirs, ils les abandonnent et se retirent pour vive solitaires. L'ennui ou le regret semble les reudre plus firoces; car ces vieux mâles retirés ne témoiguent aucune crainte, et ne fuient pas eomme les autres à l'aspect de l'homme; ils groudent en montrant les dents, et se jettent mème avec alldace contre eelui qui les attaque, saus jamais reculer ni fuir; en sorte qu'ils se laissent plutòt tuer que de prendre le parti de la retraite.

Les femelles, plus timides que les màles, ont un si grand attachement pour leurs petits, que, même dans les plus pressants dangers, elles ne les abandomnent qu'après avoir employé tout ce qu'elles ont de force et de courage pour les en garantir et les conserver; et souvent, quoique blessées, elles les emportent dans leur gueule pour les sauver.

M. Steller assure que les ours marins ont plusieurs cris difiérents, tous relatifs aux circonstances ou aux passions qui les agitent : lor'squ'ils sont tranquilles sur la terre, on distingue aisément les femelles et les jeunes d'avee les vieux mâles par le son de leurs voix, dont le mélange ressemble de loin aux bêlements d'un troupeau composé de moutons et de veaux; quand ils souffrent ou qu'ils sont ennuyés, ils beuglent ou mugissent, et lorsqu'ils ont été battus ou vaincus, ils gémissent de douleur, et font enteudre un sifllement d'affliction à peu près semblable au cri de la saricovienne; dans les combats ils rugissent et frémissent comme le lion; et enlin dans la joie et après la victoire, ils font un petit cri aigu, qu'ils réitèrent plusieurs fois de suite.

IIs ont tous les sens et surtout l'odorat tresbons; car ils sont avertis par ce seus même pendant le sommeil, et ils s'éveillent lorsyu'on s'avance vers eux, quoiqu'on en soit encore loin.

Ils ne marchent pas aussi lentement que la conformation de leurs pieds semblerait l'indiquer ; il faut mème itre bon coureur pour les atteindre: ils nagent avec beaucoup de célérité, et au point de parcourir en une heure une étendue de plus d'un mille d'Allemagne. Lorsuu'ils se délectent ou qu'ils s'amusent près du rivage, ils font dans l'eau différentes évolutions; lantot ils nagent sur le dos et tantòt sur le ventre; ils paraissent mème assez souvent se tenir dans une situation presque verticale; ils se roulent, ils se plongent et s'élancent quelquefois hors de l'eau, à la hauteur de quelques pieds : dans la pleinemer, ils se tiennent presque toujours sur le dos, saus néanmoins que l'on voie leurs pieds de devant, mais seulement ceux de derriere qu'ils ćlèvent de temps en temps au-dessus de l'eau; et comme ils ont le trou ovale du cœur ouvert, ils ont la faculté d'y rester longtemps sans avoir besoin de respirer. Ils prennent au foud de la mer les crabes et autres erustacés et coyuillages dont ils se nourrissent lorsque le poisson leur manque.

J.es femelles mettent bas au mois de juin, dans ìes illes désertes de l'hémisphère boréal; 
et comme elles entrent en chaleur au moís de juillet suivant, on peut en conclure que le temps de la grestation est au moins de dix mois : leurs portées sont ordinairement d'un seul, et trèsrarement de deux petits. l.es mâles en maissant sont plus gros et plus noirs que les femelles, qui deviennent bleuâtres avec l'âgre, et tachetées ou tigréesentre les jambes de devant : tous, mìles et femelles, maissent les yeux ouverts, et ont déja trente-deux dents; mais les dents canines ou défenses ne paraissent que quatre jours après. Les mères nourrissent leurs petits de leur lait jusgu'a leur retour sur les grandes terres, e'est-il-dire jusqu'it la fin d'anit; ces pertits dẹjà forts jouent souvent ensemble, et lors(ju'ils viemment à se battre, celui qui est vaincpueur est caressé par le père, et le vaineu est protégé et secouru par la mère.

Ils choisissent ordinairement le déclin du jour pour s'accouples : une heure auparavant le mile et la femelle entrent tous deux daus la mar; ils y nigent doncement ensemble et reviemnent ensuite à terre: la femelle, rui pour l'ordinaire sort de l'eau la première, se renver'se sur le dos, et le mâle la couvre dans ectte situation; il paraît très-ardent et très-actif; il presse si fort la femelle par som poids et par ses mourements, qu'il l'enfonce souvent dans le sable au point gu'il n'y a que sa tcite et les pieds (jui paraissent : pendant ce temps, qui est assez long, le male est si oceupc, (fu'ou peut en approcher sans crainte et meme le toucher avec la main.

Ces animaux ont le poil hérissé, épais et loug : il est de couleur noire sur le corps, et jauuaitre ou roussâtre sur les pieds et les flanes; il y a sous ce long poil une espece de f'eutre, e'està-dire un seeond poil plus court et fort doux qui est aussi de couleur roussittre : mais dans la vicillesse les plus longs poils deviennent gris ou blanes à la pointe, ce yui les fait paraitre d'une couleur grise un peu sombre; ils n'ont pas autour du cou de longs poils en forme de criniere comme les lions marins. I.es femelles diffèrent si fort des miles par la couleur, ainsi que par la grandeur, qu'on serait tenté de les prendre pour des animaus d'une autre espece : leurs plus longs poils varient, ils sont tiuntòt cendrés et tintot mèlés de roussitre. Les petits sont du plus beau noir en naissint; on lint de leurs peatux des fourlues qui sont tres-estimées : majs, des le quatrieme jour après leur maissance, il y a du roussâtre sur les pieds et sur les cỏtés dur ventre; c'est par cette raison rue l'on tue souvent les femelles yui sont pleines pour avoir la pealu du foctus qu'elles portent, parce que cette fourrure des fuetus est encore plus soyeuse et plus noire que celle des nouveau-nés.

I.e poids des plus grands our's marius des mers de Kamtschatka est d'environ vingt puds de Russie, e'est-il-dire de huit erents de nos liwes, et leur longueur u'excede pas huit á neuf pieds : il en est de mème de eeur qui se trouvent à la terre des litats, tet rans plusieurs iles de l'hémisphère austral, ou les vovirgeurs ont re. connu ces mèmes ours miluins, ct ('u ont obser ve d'autres bien plus petits.

Pendant les neuf mois que ees grands animaux séjou!nent sur les côtes du liamtschatka, c'est-iı-dire depuis le mois d'aout jusqu'au unois de juin, ils ont sous la peau un panniculegrais. seux de pres de quatie pouces sur le corps : la graisse des mâles est hujleuse et d'un gont tresdésagréable; mais celle des femelles, qui est moins abondante, est aussi d'un gout plus supportable : on peut manger de leur chair, etcelle des petits est meine assez bonlie, tandis yue celle des vieux est noire et de trè-manvais gont, (дuoiçue dépouillée de sa graisse; il n'y a que le cour et le foie qui soient manereables.

La longueur de celui qui a été décrit par M. Steller n'était que de sept pieds trois pouces, depuis le bout du museau jusqu'a l'evtrémité des nageoires de derriere; et de sept pieds un pouce six ligues depuis la mème extrémité du museau juscutau bout de la cqueue.

Si l'on compare l'our's mal'in avec l'ours terrestre, on ne leur trouvera d'autre ressemblance que par le squelette de la tète et par la forme de la partie antéricure du torps qui est ćpaisse et charnue. In tete dans son état naturel estrevètue d'un pannicule graisseux d'un pouce. d'épaisseur, ce qui la fait paraitre beaucoup plus londe que celle de lours de terre. Eille a en effet deux pieds cing ponces six lignes de tour derriere les oreilles, et n'est longue que d'emviron huit pouces, depuis le bout du museau jusquaux oreilles; mais apres l'avoir depouillee desa rraisse. le squelette de cette tete de l'ours marin est tres-lessemblant a celui de lours de terre. Du reste, la forme de e's deux animaux est tres-différente : le corps de l'ours marin est fort mince dans sa partic postérieure, et devient 
presque de figure conique, depuis les reins jusqu'auprès de la queue qui n'a que deux pouces de longueur; en sorte que la grosseur du corps, qui est de quatre pieds huit pouces de tour auprès des épaules, se réduit à un pied six pouces trois lignes auprès de la queue.

L'ours marin a des oreilles externes comme le iion marin et la saricovienne : ces oreilles ont un pouce sept lignes de longueur : elles sont pointues, coniques, droites, lisses et sans poil à l'extérieur; elles ne sont ouvertes que par une fente longitudinale que l'animal peut resserrer et fermer lorsqu'il se plonge en entier dans l'eau. Les yeux sont proćminents et gros à peu près comme ceux du bœuf; l'iris en est noir; ils sont garnis de cils et de paupières, et défendus comme ceux des phoques par une membrane qui prend naissance an grand angle de l'œil, et qui peut le recouvrir à la volonté de l'animal.

La gueule, depuis l'angle jusqu'au bout du museau, n'a qu'environ trois pouces de longueur; elle est garnie de moustaches dont les soies ont cinc pouces huit lignes de long : la lèvre supérieure déborde l'inférieure d'un pouce et demi, et la distance entre les deux lèvres, lorsque la gueule est ouverte, est d'environ quatre pouces; la langue qui est, comme celle de tous les phoques, un peu fourchue à son extrémité, a quatre pouces et demi ou cinq ponces de longueur.

Les dents sont très-pointues, et disposées dans chaque màchoire de manière que la pointe de chacune correspond exactement à l'intervalle qui sépare l'extrémité des autres; il y en a trente-six en tout, vingt en haut et seize en bas : $1^{0}$ dans la màchoire supérieure quatre dents incisives divisées en deux pointes à leur extrémité; $2^{0}$ deux canines, une de chaque còté, longues d'environ quatre ligues, lesquelles sont courbées en dedans; $3^{0}$ deux autres dents eanines ou défenses très-aiguës, une de chaque côté d'environ huit à ueuf lignes de longueur (c'est avec celles-ci que ces animaux se déchirent et se blessent cruellement); $4^{0}$ six autres dents de chaque côté qui sont aiguës comme toutes les autres, et qui occupent la place des molaires.

- Dans la mâchoire inférieure, il y a comme dans la supérieure, $\mathbf{1}^{0}$ quatre incisives sur le devant de la mâchoire; $2^{0}$ deux canines seulement, une de chaque còté; clles sont tranchantes sur la face intérieure et longues de plus d'un pouce : l'ours marin s'en sert dans les combats comme les sangliers se servent de leurs défenses; mais il n'y a pas de secondes dents canines comme dans la màchoire supérieure; $3^{0}$ einq dents de chaque côté qui sont pointues, et qui tiennent, comme dans la mâchoire supérieure, la place des dents molaires.

Un caractère qui est commun aux our's et aux lions marins, et qui les distingue de tous les aultres animaux, c'est la forme de leurs pieds; ils sont armés d'une pinne ou nageoire qui, dans les pieds de devant, réunit les doigts en une seule masse, tandís que, dans ceux de derrière, les doigts sont aussi unis par une pinne, et cu'ils ont à peu près la forme de ceux des oiseaux palmipèdes; les pieds de devant servent à l'animal à marcher sur la terre, et ceux de derrière ne lui sont utiles que pour nager ei se gratter; il les trâine après lui comme des membres nuisibles sur la terre; car ces parties de l'arrière du corps ramassent et accumulent sous son ventre du sable et de la vase en si grande quantité, qu'il est obligé de marcher circulairement; et e'est par cette raison qu'il ne peut grimper sur les rochers.

Les pieds antérieurs, dont la longueur est d'environ deux pieds, sur septà huit pouces de largeur, ne sont pas cachés en partie sous la peau comme ceux des phoques, mais ils sortent en entier. Ces pieds ou bras sont couverts de poil, à l'exception du car'pe, du métacarpe et des doigts dont la peau est noire, nue, lisse à la partie supérieure et ridée à la partie inférieure; ils sont à l'intérieur composés de l'os humérus, de ceux du bras, de l'avant-bras, du carpe, du métacarpe et des phalanges des doigts ; il y en a cing ì chaque pied, dont les ongles ont deux lignes de longueur; le pouce est le plus long des doigts, et les quatre autres vont toujours en diminuant de longucur jusqu'au cinquième et delnier qui est le plus court; le pouce, ainsi que le second doigt, sont eomposés de trois phalanges; le troisième et le quatrieme en ont quatre, et le cinquième n'en a que deux.

Les pieds postérieurs, dont la longueur totale est d'environ vingt à vingt-un pouces, sur une largeur de cinq ou six pouces, sont composés du fémur, du tibia, du péronć, du tarse, du métatarse et des phalanges des doigts : le tibia et le péroné sont cachés sous la peau du corps; le tarse et le métatarse paraissent à l'extér:eur et sont courerts de poils. Il y a aussi ciuc doigts armés chacun d'un ongle oblong, aigu, con- 
vexe en dessus et concave en-dessous. Ces ongles du pouce t d du doigt extéricur sont tréspetits; mais ceux des trois autres doigts ont environ un pouce de longueur, sur une largeur de quatre lignes à la base: ces doigts sont courts comme ceux des picds de devant, couverts d'une peau lisse en dessus et ricléc en dessous. Le pouce est d'un tiers plus large que les autres doigts; il est de la mème longueur que les trois suivants : mais le cincquieme est beaucoup plus court. Ces pieds de derrière sont moins épais (que ceux de devant, et les phalanges des doigts el sont plus larges, plus plates et plus minces; a l'extrémité des phalanges commencent des épiphyses cartilagineuses qui en rendent les extrémités assez semblables à celles des pieds des oiseaux palmipèdes, et la nageoirc est divisée en cinc à son extrimité. Le pouce n'a yue deux phalanges, mais les quatre autres doigts en ont chacun trois.

La verge est longue de dix à onze pouces; elle conticnt dans sa partie antérieure un os de près de einy pouces de longueur, semblable à celui qui se trouve dans la verge de la saricovienne; la peau du scrotum, qui est situéc sous l'anus, et qui renferme deux testicules de figure oblongue, est de couleur noire, ridée et sans poil. La femelle n'a quie deux mamelles situées près de lá vulve.

La longucur des intestins, dans l'individu déerit par MI. Steller, était de cent douze pieds cinq pouces, mesurés depuis l'œesophage jusuru'à l'anus; en sorte que pris tous ensemble, les intestins étaient seize fois plus longs que le corps de cet animal, dont la grandeur n'était que de scpt pieds un pouce six limnes, depuis le bout du museau jusqu'à l'extrémité des doigts des pieds de derriere. Dans un de ces animaux nouveau-nés, la longueur des intestins n'était que treize fois plus grande que celle du corps enticl.

Nous devons encore observer et répéter ici que le petit phoque noir a tant de rapport avee l'ours marin, qu'on ne peut se dissimuler que ee ne soit un individu qui appartient à cette espèce ou cui n'en est qu’une variété ' ; car il "essemble au grand ours marin par la forme du corps, par celle des pattes qui sont manchottes et entièrment dénuées de poil, par lit forme des dents incisires qui sont fondues à leur ex-

- Cot animal amphibie est l'OTaniz ne l'enux. trémité, par les oreilles qu'il a proéminentes a l'cstérieur', et enfin par la qualité soyeuse et la couleur noirâtre de sa fourrure. Et comme il est à présumer que cet animal, quoique de trèspetite taille, tait nćanmoins adulte, puisqu'il avait toutes ses dlents bien formées, on pourrait croire qu'il existe une seconde espece ou race d'ours marin plus petite que la première, et que e'est à eutte seconde espece qu'on doit rapporter ce que les voyageurs ont dit des petits onrs marins, qu'ils ont vus dans différents endroits de l'hémisphère austral, mais que jus(ju'icei l'on ne connaissait pas dans l'hémisplyere boréal.

Au reste, cette petite race ou espéce d'ours marin resscmble entierement à la grande, tant par les couleurs du poil et la forme du corps, que par les mœurs et les habitudes naturelles. Il parait seulement qu'étant bien plus petits, ils sont aussi bien plus timides que les grands.

"Ces animaux, dit M. de Pagès, ne eherehent qu ¿i se sauver du côté de la mer, et ne mordent jamais que ce qui se trouve directement sur lcur passage; plusieurs, en se sauvant, passaient mème entre nos jambes. Ils se familiarisent promptementavec les hommes. J'cu ai conser vé deux vivants pendant huit jours dans un cuvier de cinqpieds de diametre; Ie premierjourj'y avais ficit mettre de l'eau de la mer à la hauteur d'un demi-pied : mais comme ils faisaient des eflorts pour l'éviter', je les mis dans de l'eau douce; ils s'y trouvèrent aussi gènés et je les laissai à sce. Dè que l'eau était vidée, ils se secouaicut comme les chiens; ils se grattaient, se nettoyaient avec leur muscau, et se serraient l'un contre l'autre : ils étermuaient aussi comme les chiens.

"Lor'su'il faisait soleil, je les làchais sur le gaillark du vaisseau, oil ils ne cherehaient à fuir que quand ils royaicut la mer : sur terre ils se grattajent et même ils prenaient plaisir à se kaisser cratter par les hommes, aupres desquels ils marchaient assez familierement; ils allaient mime flairer Ies gens de l'ćpuipage, et ils aimaieut à grimper sur les licux élevés pour ètre mieux exposés au soleil.

"Ils avaient de l'amitic l'un pour l'autre; ils se frottaicnt et se glattajent mutuellement; et lorscpuon les sciparait ils cherehaient bieutút à se rejoindre; il suftisait d'en cmporter un pour se faire suive de l'autre. On leur offrit du poisson, du groëmon, du pain trempé dans de 
l'eau : ils flairaient et prenalent ce qu'on leur présentait; mais ils ne l'avalaient pas et le rendaient tout de suite. Le septième jour un d'eux 'ut des palpitations et des sanglottements trèsforts; il ouvrait la gueule en rendant une liqueur verdâtre, et il rongeait le bois de sa cuve : je le fis jeter à la mer. Le lendemain je lâchai "autre ưans une prairie, mais il n'y mangea vien ; je le chassai à la mer : d'abord il nageait assez lentement; mais s'étant plongé sous l'eau pendant fort longtemps, il revint i sa surface plus lestequ'auparavant: il venait apparemment de prendre de la nourriture. ")

M. de Pagès ajoute que les plus grands ours marins qu'il ait vus au eap de Bomne-Espérance n'avaient que quatre pieds de longueur, et que la plupart (apparemment les femelles et les jeunes) n'avaient que deux pieds et demi; ce qui differe prodigieusement pour la taille de l'espèee déerite par M. Steller.

" Le poil des jeunes est noirâtre, continue M. de Pagès; mais avee l'âge il devient d'un gris argenté à la pointe. Leurs dents sont petites; leurs moustaches assez longues : la physionomie est douce, et leur tête ressemble assez à celle d'un chien qui n'amrait que de petites oreilles; celles de ces ours marins sont étroites, peu ouvertes et nont que dix-sept à dix-lyuit lignes de longueur; le cou est gros et presque de niveau avee la tète : l'endroit le plus gros de l'aninual est la poitrine, d'où le corps va en diminuant jusqu'à la queue, qui n'a qu'environ deux pouces de longueur.

- Les pattes de devant sont formées par une membrane eartilagineuse qui a presque la forme de nageoires; cette meml)rane est plus forte à sa partie antérieure qu'en arrière : ces pattes ont cinq doigts qui ne s'étendent pas autant que la membrane; le plus intérieur est le mieux marqué, de même quue ses phalauges; les deux suivants le sont moins et les denx extéricurs le sont à peine : chaque doigt est armé d'un ongle très-petit et à peine visible, étant eaclsé par le poil.

"I.es pattes de derrière ont aussi einc doigts, dont les trois du milieu ont leurs phalanges et leurs ongles bien marqués : les autres sont moins caraetérisés à cet égard; ils ont un ongle trèspetit et tres-mince : tous ees doigts sont joints par unc membrane eomme celle de l'oie. "

\section{LE LION MARIN.}

(Lototale A CRINIÈre.)

Tribu des otaries, genre phoque. (Cuvier.)

La plus grande des espèces de phoques ì oreilles externes est celle du lion marin : il est, sans comparaison, plus puissant et plus gros que l'ours marin; cependant jusqu'à ce jour il était peu connu, et nous a rons déjả obser vé que le vrai lion marin dont il est iei question n'est pas l'animal auquel le rédaeteur du Voyage d'Anson a mal à propos appliqué ee nom; la figure représente le phoque à museau ridé, dont nous avons donné la description, et qui n'a ni oreilles externes ni crinière, et qua differe encore du lion marin par plusieurs autres earactères. Cette méprise ou plutôt cette fausse application de ce nom ne pouvait être rectifiée tant qu'on n'a pas comu distinctement l'un et l'autre de ces animaux; mais des vovageurs instruits nous ont réeemment mis en état de prononcer sur leurs différences, qui sont plus que suftisantes pour en faire, avec fondement, deux espèces, et même deux genres distincts et séparés.

M. Forster a vu des troupes de ces lions marins sur les côtes des terres Magellaniques, et dans quelques endroits de l'hémisphère austral ; d'autres royageurs ont reconnu ces mêmes lions marins dans les mers du nord, sur les îles Kuriles et au Kamtschatka. M. Steller a, pour ainsi dire, vécu au milieu d'eux peudant plusieurs mois dans l'ile de Béring. Ainsi l'espèce en est répandue dans les deux hémisphères, et peut-être sous toutes les latitudes, comme celle des ours marins, de la sarieovienne et de la plupart des phoques.

Les lions marins se tiennent et vont en grandes familles, cependant moins nombreuses que celles des ours marins avee lesquels on les voit quelquefois sur le mème rivage. Chaque famille est ordinairement composée d'un mâle adulte, de dix à douze femelles, et de quinze à vingt jeunes des deux sexes : il y a mème des màles qui paraissent avoir un plus grand nombre de femelles, mais il y en a d'autres qui en ont beaucoup moins. Tous nagent ensemble dans la rrer et demeur'nt aussi réunis lorsqu'ils se reposent sur la terre. La présence ou la voix de l'hounme les fait fuir et se jeter à l'eau; car quoique ces 
animaux soient bien plus grands et plus iorts que les ours marins, ils sont néanmoins plus timides; lorsqu'un homme les attaque avec un simple bâton, ils sedéfendent rarement et fuient en gémissant : jamais ils n'attaquent ni noffensent, et l'on peut se trouver au milieu d'eux sans avoir rien à eraindre; ils ne deviennent dangereux que quand on les blesse grièvement ou qu'on les réduit aux abois; la nécessité leur donne alors de la fureur; ils font fatee à l'ennemi ct combattent avee d'autant plus de courage qu'ils sont plus maltraités. Les chasseurs eherchent à les surprendre sur la terre plutot que dans la mer, parce qu'ils renversent souvent les barques lor'squ'ils se sentent hlessés. Comme ces animaux sont puissants, massifs et triesforts, e'est une espèce de gloile parmi les Kautschadales que de tuer un lion marin mâle; l'homme dans l'état de nature lait plus de eas que nous du courage personnel; ces sauvages, excités par cetle idée de gloire, s'exposent au plus grand péril ; ils vont ehereher les lions marins en errant plusieurs jours de suite sur les flots de la mer, sans autre boussole que le soleil et la lune; ordinairement ils les assomment à comps de perches, et quelquefois il leur lanceust des fleches empoisonnées (jui les font mourir en moins de vingt-quatre heures, ou bien ils les premnent vivants avec des eordes de lianes dont ils leur embarrassent les pieds.

Quoique ces animaux soient d'mn maturel brut et assez silurage, il paraît eependant (ju’à la longue ils se familiarisent avee l'homme. MI. Steller dit qu'en les traitant bien on pourrait les applivoiser : il ajoute cuu'ils s'étaient si bien accoutumés à le voir, qu'ils ne fuyaient plus à son aspect comme au commenement; qu'ils le regardaient paisiblement en le considérant avec une espéce d'attention; qu'enfin ils avaient si bien perdu toute crainte, qu'ils agissaient en toute liberté et mème s'accouplaient devant Iui. M. Forster dit aussi qu'il eu a v'u quelquesuns qui s'étaient sibien habitués à voir les hommes, (qu'iis suivaient les chaloupes en mer, et qu'ils avaient l'air d'cxaminer ce que l'on y faisait.

Cependant, (fuoiçue les lions marins soient d'un naturel plus doux que les ours marins, les miles se livent souvent entre cux des combats longs et sanglants; on en a vu qui avaient le corps entamé ct couvert de glandes cicatrices. Ils se battent pour défendre leurs femelles IV. contre un rival qui vient s'en saisir et les relever; après le combat le vainqueur devient le chef et le maitre de la famille entière du vaincu. Ils se battent aussi pour conserver la place que chaque mâle occupe toujours sur une grosse pierre qu'il a choisie pour domic·ile; et lorsqu'um autre mảle vient pour l'en chasser, le combat commence, et ne linit que par la fuite ou par la mort du plus faible.

Les femelles ne se battent jamais entre elles ni aree les mâles; elles semblent itre dans une dépendance absolue du chef de lá fumille : elles sont ordinairement suivies de leurs potits des deux sexes. Mais lorsulue deux mâles, c'est-itdire deux chef's de familles différentes sont aux prises, toutes les femelles arrisent avee leur suite porn èlre témoins du combat; et si le chef de quelque átre troupe arrive de même ì ce spectacle, et prend parti pour ou eontre l'un des deux combittants, son exemple est bientit suivi par plusieurs autres chefs, et alor's la hataille devient presque générale, et ne se termine que par une grande effusion de sang, et somvent par la mort de plusicurs de ees màles, dont les familles se réunissent au profit dies vaincfucurs. On a remarqué que les trop vieux mâles ne se mélent point dans ces combats ; ils sentent apparemment leur faiblesse; cal ils ont soin de se tenir éloignés, et de rester trancpuilles sur leurs pierres, sans néammoins permettre aux autres males ni meme aux femelles d'en alpprocher. Dans la mélée, la plupart des femelles oublient leurs pelits, et tiehent de s'éloigner du lieu de la seene en fuyant, ceçui suppose un naturel bien différent de eelui des ours mallins, dont les femelles emportent leurs petits , lorsqu'elles ne peuvent les défendre: cependant il y a quelquefois des meres liomnes gui emportent aussi leurs petits dans leur gueule; d'autres qui ont assez de naturel pour ue les point abandonner, et qui se font meme assommer sur la place en cherchant à les défendre, mais il faut que ce soit une exception; ear M. Steller dit positivement que ces femelles no paraissent avoir que tres-peu d'attatchement pour leurs petits, et que quand on les leur enlève, elles ne paraissent point en ètló émues; il ajoute qu'il a pris des petits plusieurs fois luimène devint le pere et la mere, sans courir le moindre ris(pue, et sans que ces animanx insensibles ou denatures se soient mis en devoir de les secourir ou de les venger. 
Au reste, dit-il, ce n'est qu'entre eux que les máles sont féroces et cruels; ils maltraitent rarement leurs petits ou leurs femelles; ils ont pour elles beaucoup d'attachement, et ils se plaisent à leurs earesses, qu'ils leur rendent aree complaisance. Mais ce (fui paraitrait sin. grulier, si l'on n'en avait pas l'exemple dans nos sérails, c'est que dans le temps des amours ils sont moins complaisants et plus fiers : il faut que la femelle fasse les premieres avances '; non-seulement le mâle sultan parait ètre indifférent et dédaigneux, mais il marque encore de la mauvase humeur, et ce n'est qu'après qu'elle a réitéré plusieurs fois ses prévenanees, qu’il se laisse toucher de sensibilité, et se rend ì ses instances : tous deux alors se jettent à la mer, iis y font différentes évolutions, et après avoir nagé doucement pendant quelque temps ensemble, la femelle revient la première à terre, et s'y renverse sur le dos pour attendre et recevoir son maitre. Pendant l'aceouplement, qui dure huit à dix minutes, le màle se soutient sur ses pieds de devant, et comme il a la taille d'un tiers plus grande que celle de la femelle, il la déborde de toute la tête.

Ces animaux, ainsi que les ours marins, choisissent toujours les iles désertes pour' y aller faire leurs petits, et s'y livrer ensuite aux plaisir's de l'amour. M. Forster, qui les a observés sur les côtes des terres Magellaniques, dit avoir été témoin de leurs amours et de leur accouplement dans les mois de décembre et janvier, c'est-ì-dire dans la saison d'été de ces climats. M. Steller, qui les a de mème observés sur les côtes de Kamtschatka et dans les îles voisines, assure gu'ils s'aceouplent toujours dans les mois d'aoùt et de septembre, et que les femelles mettent bas au mois de juillet. II parait done que dans les climats opposés, c'est toujours en été que les lions marins se recherchent, et que le

\footnotetext{
1 a L'acte d'amour est précédé de plusienrs caresses étran" ges; c'est le seve le plus faible ųui fait les arances... La fe- melle se tapit aux pieds dı mâle, rampant cent fois autour - de lui, et de tempis à antre rapprochacit son nusean du sien - comme pour le baiser: le muile, peídant celte cérémotie, " scmblait avoir de l'hmueur; il grondail el monlrail l's d'uts - à sa lemelle, comme s'il eùt voulu la mordre : à ce signal,

- la souple femelle, se retira, el viul ensuite recummence

- ses caresses el léclier les pieds du mảle. A prés un lonğ prè-

- ambule de cetle sorte, ils se jelèrent tons denx dans la mer

" el y lirent plusieurs lours en se poursuivant linu et lanlre;

- culin la femelle sortil la juremière sur le rivage, vi elle se " renversa sur le los; le mile, yui la suivail de frès, la con-

a vil daus celte siluation, et laceonplement dura huit on dix

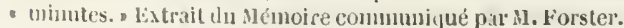

temps de la gestation est de près de onze mois; cependant le même Steller dit positivement que les femelles ne portent que neuf mois, comme s'il n'eût pas compté que de septembre et d'aoùt en juillet il n'y a pas neuf mois, mais dix et onze mois. Cies deux voyageurs que nous venons de citer ne s'aceordent pas sur le nombre des petits que la femelle produit à chaque portée; selon M. Steller, elle n'eu fait qu'un, et selon M. Forster, elle en fait deux : mais il se peut qu'elles ne produisent ordinairement qu'un ct quelquefois deux; il se peut aussi qu'elles soient moins fécondes au Kamtsehatka (ju'aux terres Magellaniques; et enfin il se peut que, comme les petits de l'année précédente suivent leur mère avee ceux de l'amnée suivaute, M. Forster ne les ait pas distingués, en voyant la femelle suivie de deux petits. Les mêmes voyageurs rapportent que ces animaux, et surtout les màles, ne mangent rien tant que durent leurs amours, en sorte qu'après ce temps ils sont toujours fort maigres et tres-épuisés; ceux qu'ils ont ouverts dans cette saison n'avaient daus leur estomac que de petites pierres, tandis que dans tout autre temps ils sont tresgras, et que leur estomac est farci des poissons et des crustacés qu'ils mangent en grandequantité.

La voix des lions marins est différente, selon l'àge et le sexe, et il est aisé de distinguer, mème de loin, le cri des mâles adultes, de celui des jeunes et des femelles : les màles ont un mugissement semblable á celui du taureau, et lorsqu'ils sont irrités, ils marquent leur colère par un gros ronflement : les femelles ont aussi une espece de mugissement, mais plus faible que celui du mâle, et assez semblable au beuglement d'un jeune veau; la voix des petits a beaucoup de rapport à celle d'un agneau âgé de quelques mois ; de sorte que de loin on eroirait entendre des troupeaux de boufs et de moutons qui seraient répandus sur les còtes, quoique ce ne soit réellement que des troupes de lions marins, dont les mugissements, sur des accents et des tons différents, se font entendre d'assez loin pour avertir les voyageur's qu'ils approchent de la terre, que les brumes, dansees parages, dérobent souvent à leurs yeux.

Les lions marins marchent de la mème manière que les ours marins, e'est-i-dire en se trainant sur la terre it l'aide de leurs pieds de devant; mais e'est encore plus pesamment et de plas manr ise guice. Il y en a qui sont si 
lourds, et ce sont probablement les vieux, qu'ils ne quittent pas la pierre qu'ils ont choisie pour leur siége, et sur lafuelle ils passent le jour entier à ronfler et à dormir. Les jeunes ont aussi moins de vivacité que les jeunes ours marins : on les trouve souvent endormis sur le rivage; mais leur sommeil est si peu profond, qu'au moindre bruit ils s'éveillent et fuient du còté de la mer. Lorsque les petits sont fatigués de nager, ils se mettent sur le dos de leur mère; mais le père ne les y souffre pas longtemps et les en fait tomber, comme pour les forcer de s'exereer et de se fortifier dans l'exereice de la nage. En général tous ees lions marins, tant adultes que jeunes, nagent avee beancoup de vitesse et de légèreté; ils peuvent aussi demeurer fort longtemps sous l'eau sams respirer. Ils exhalent une odeur forte et qui se r'épand au loin. Leur chair est presque noire et d'assez mauvais goût, surtout celle des mâles; cependant M. Steller dit que la chair des pieds ou nageoires de derrière est trè-bonne à manger, mais peut-être n'est-ce (pue pour des voyageurs, d'autant moins difficiles que ceux-ci manquaient, pour ainsi dire, de tout autre aliment; ils disent que la chair des jeunes est blanchâtre et pent se manger', quoigu'elle soit un peu fade et assez désagréable au gout : leur graisse est très-abondaute et assez semblable à celle de l'ours marin; et quoique moins huileuse que celle des autres phoques, elle n'en est pas plus mangeable. Cette grande quantité cle graisse et leur fourrure épaisse les défendent contre le froid dans les régions glaciales ; mais il semble qu'elles devaient leur' nuire dans les elimats chauds, d'autant qu'on ne s'est point apercu d'aueune mue dans le poil, ni de diminution de leur embonpoint dans quelque latitude qu'on les ait rencontrés : ces animaux amphibies différent donc en cela des animaux terrestres, qui ehangent de poil lorsqu'on les transporte dans des climats différents.

Le lion mariu diflère aussi de tous les autres animaux de la mos, par un caractere qui lui a lait donner son nom, et yui lui domme en eflet quelque ressemblanee extérienre aree le lion terrèstre : e'est une criniere dle poils ćpais, ondoyants, longs de deux a trois pouces ef de cou. leur jaune foncé, qui s'étend sur le front, les jours, le cou et la poitrine; cette erinière se hérisse lorsyu’il est irrité, ct lui domne mn air menacant. La femelle, qui a le colps plus court et plus mince que le mâle, n'a pas le moindre vestige de cette criniere; tout son poil est court, lisse, Juisant et d'une couleur jaunâtre assez clare : celui du mâle, à l'exception de la erinière, est de mème luisant, poli et court; seulement il est d'un fauve brunatre et plus foncé que celui de la femelle, il n'y a point de feutre ou petits poils lanugineux au-dessous des longs poils, comme dans l'ours marin. Au reste, la couleur de ees animaux varie suivant l'âge ; les vieux mâles ont le pelage fauve eomme les femelles, ei ils ont quelquefois du blanc sur le con et la téte; les jeunes ont oıdinairement la mème coulcur fauve foncée des mâles adultes; mais il y en a qui sont d'un brun presque noir, et d'autres qui sont d'un fauve påle comme les vieux et les femelles.

le poids de ce gros animal est d'enriron quinze à seize cents livies, et sa longueur de dix et douze pieds lor'squ'il a pris tout son accroissement; les femelles, qui sont beaucoup plus minces, sont aussi plus petites, et n'ont communément que sept à huit pieds de longueur : le corps des uns et des autres, dont le diamètre est à peu près égal au tiers de sa longueur, a presque partout une épaisseur égale, ct se présente aux yeux comme un gros cylindre, plutòt fait pour rouler que pour marcher sur la terre; aussi ce corps trop arrondi n'y trouve d'assiette que parce (qu'étant recouvert partout d'une graisse exeessive, il prète aisément aux inégalités du terrain et aux pierres sur lesquelles l'animal se couche pour reposer.

La tète parait ètre trop petite à proportion d'un corps aussi gros : le museau est assez semhlable à celui d'un gros dogue, étant un peu l'elevé et comme troutué à son extrémité; la lèvre supérieure déborde sur la lèvre inférieure, st toutes deux sont garnies de cinq rangs de soies rudes en forme de moustaches qui sont longues, noires, et s’étrudent le long de l'ou. verture de la gueule : ces soies sont des tuyaux dont on peut laire des curedents; clles deviennent blauches dans la vieillesse. Les oreilles sont coniques et longues seulement de six à sept ligrnes : leur cartilage est ferme et ride, et néanmoins elles sontrepliées vel's l'extromité ; la partie intérieure con est lisse, et la surfice extérieme est couverte de poil. les yeux son grands et proéminents; les carroneules des grands angles en sont fort apparentes et d'une couleur rouge assez vive, (n) solle yue les yeux de cet animal 
paraissent ardents et échauffés; l'iris en est vert et le reste de l'oeil est blane, varié de petits filets sanguins; il y a une membrane (membranı nictilans) à l'angle intéricur, qui peut au besoin recouvirir l'oil en entier à la volonté de l'animal; des sourcils composés de crins noirs assez forts surmontent les yeux. La langue est couverte de petites fibres tendineuses, et elle est un peu fourchue à son extrémité : le palais est cannelé et sillonné transversalement par des rides assez sensibles. Les dents sont au nombre de trente-six, comme dans l'ours marin, et sont disposées de mème : les incisives supérieures sont terminées par deux pointes, au lieu que les inférieures n'en ont qu'une; il y en a quatre taut en haut qu'en bas : les dents canines sout bien plus longues que les ineisives et d'une forme conique, un peu crochues à l'extrémité, avec une cannelure au côté intérieus. Il y a, comme dans l'ours marin, des doubles dents eanines à la mâchoire supérieure, qui sont placées l'une auprès de l'autre entre les incisives et les molaires, et une canine seulement de chaque côté à la mâchoire inférieure; mais tontes ces dents canines, ainsi que les incisives rt les molaires, sont du triple plus longues que celles de l'ours marin. Ces dents molaires sont au nombre de six de chaque côté daus la màchoire supérieure, et au nombre de cing seulement de chaque côté dans la màchoire inférieure; elles ont à peu près la même figure que les eanines: sculement elles sont plus courtes : on remarque sur ces dents molaires une proéminence ou tubérosité osseuse, qui paraît faire partie eonstituante de la dent.

Le lion marin, au lieu de pieds de devant, a des nageoires qui sortent de chaque côté de la poitrine; elles sont lisses et de couleur noiràtre sans apparence de doigts, avec une faible trace d'ongle au milieu, que l'on distingue à peine : cependant ces nageoires renferment cinc doigts avec des phalanges et leurs articulations; ces petits ongles ont la forme de tubereules arrondis, et sont d'une substance cornée; ils sont situés au tiers de la longueur de la nageoire en la mesurant depuis l'extrémité : la forme de la nageoire entière est celle d'un triangle allongé et tronqué vers la pointe, et elle est absolument dénuée de poil et comme crénelée sur la face intérieure.

Les nagcoires postérieures sont, comme celles de devant, couvertes d'une peau noirâtre. lisse et sans aucun poil : mais elles sont divisées à l'extérieur en cing doigts fort longs et aplatis, qui sont termincis par une membrane mince, comprimée et qui s'étend au delà de l'extrémitć des doigts; les petits ongles qui sont au-dessus de ces doigts ne servent à l'animal que pour se gratter le corps.

Dans les phoques, la conformation des pieds est trè-diftérente : tous ont des pattes en devant assez bien conformées, avec des doights distincts et bien marqués, qui sont seulement joints par une membrane; leurs pieds et leurs doigts sont aussi garnis de poil comme le reste du corps; au lien que dans le lion marin, comme dans l'ours marin, ees quatre extrémités sont plutôt des nageoires quedes pattes; aussi croyons-nous devoir rapporter à l'une ou l'autre de ces espèces du lion marin ou de l'ours marin ee que dit Frézier des phoques qui se trouvent sur les côtes oceidentales de l'Amérique. " Ils diffèrent, dit ce voyageur, des loups marins du nord, en ce que ceux-là ont des pattes, et que ceux-ci ont des nageoires allongées à peu près comme des ailes ver's les épaules, et deux autı'es petites qui enferment le croupion. La nature a néanmoins conservè au bout des grandes mageoires quelque conformité avee les pattes, ear on y remalque des ongles qui en terminent l'extrémité; peutêtre que ces animaux s'en serrent pour marcher a terre, ou ils se plaisent fort, et où ils portent leurs petits, qu'ils nourrissent de poisson... Ils jettent des eris comme les veaux, et c'est ce qui les a fait appeler veaux marins; mais leur tète r'essembleplutôt à celle dun chien qu'à tout autre animal; et c'est avee raison que les Hollandais les appellent chiens marins. Leur peau est couverte d'un poil fort ras et touffu, et leur chair est fort huileuse et de mauvais goùt... néanmoins les Indiens de Chiloé la font sécher, et en font leurs provisions pour se nourrir; les équipages des vaisseaux en tirent de l'huile pour leurs besoins. La pèche en est fort facile; on en approche sans peine sur la terre et sur la mer, et on les tue d'un seul coup sur le nez. $11 \mathrm{y}$ en a de différentes grandeurs : dans l' sud ils sont de la grosseur des forts màtins, $\mathrm{pt}$ au Pérou on en trouve qui ont plus de douze pieds de long. "

La verge du lion marin est à peu près de la gyosseur de celle du cheval; et la vulve, dans la femelle, est placée fort bas vers la queue, qui u'a qu'environ trois pouces delongueur Cette comrte? 
queue est de forme conique et couverte d'un poil semblable à celui du corps. Lor'scfue l'animat est dans une situation allongée, la queue se tronve eachée entre les n'ygeoires de derriere, qui dans cette situation sont très-voisines l'une de l'autre.

M. Forster nous a donné les dimensions suivantes, prises sur une femelle, qui probablement n'a vait pas encore acguis tout son accroissement :

Du bout du nez à l'extrimité des doigts du milien de li nageoire de dervière. . . . . . 6067

Du bout du nez jusqu'à l'extremitédela quene. 5 6 0

Du hout du nez juspu’a l'origine de la (juene. 5 . 5 0

Circonférence dı corps aux ṕpaules. ... 5 11 0)

Circonference de la lète derriere les oreilles. $2 \quad 1 \quad 5$

Longueur des nigeoires de devant. . . . . . . $19 \begin{array}{lll}0 & 9\end{array}$

Longueur des nageosires de derripre jusqu à

l'extrémité du pouce. ........... 1 . 50

Depuis l'extrémite de la léve suprieure à

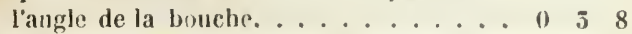

Depuis l'extrémité de la livre supérieure jus-

qu'a la base des oreilles. . . . . . . . 0 80

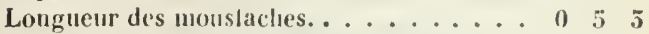

Longuem de la quene. . . . . . . 0210

Longueur de l'ongle Ju doigt du milien de la

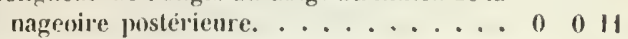

Hanteur des oreilles. . . . . . . . . . . 0070

Si l'on veut comparer tout ce que mous avous dit de l'ours marin avee ce que nous venons de dire du lion marin, on peut voir yüil y a beaucoup d'analosie entre ces animaux, tant par les habitudes naturelles que par plusieurs caract $c$ res extérieurs; néanmoins comme il y a des différences essenticlles, et que l'ou a quelquefois confondu ces deux espèces, il est bon de résumer ici leurs principales différences.

$\mathbf{1}^{\circ}$ Le lion marin a, comme le lion terrestre, une crinière fauve, et tout le reste de son poil est court, lisse, luisant et couché sur la peau, au lieu que l'ours marin n'a point de erinière, et cque le poil du cou et de tout le eorps est long et hérissé : il y a de plus, à la racine du long poil, un second poil plus eourt; cest une espece de fourrure ou feutre lanugineux, qui mantpue au lion marin.

$2^{0}$ La couleur du lion marin est fauve et jaunatre, tirant sur le lym, et à peu pres semblable a relle du lion terrestru; tandis que la couleur de l'uu's mariu est d'un brun foncé presque noil, moucheté quel(uefois de petits points blanes.

$3^{0}$ La taille des lionsmarins est ordinairement de dix à douze pieds, et celle des ours mirins les plus grauds u'excede jamais huit à neuf pieds.
$4^{0}$ Les lions marins sont indolents et fort lourds, et ils ne marquent que bien peu d'attachement pour leur progéniture; au contraire les ours marins sont très-rifs, et donnent des preuves d'un grand amour pour leurs petits, par les soins qu'ils on prenment.

$5^{0}$ linfin, quoique les lions et les ours marins soient souvent sur le neme terrain et dans les mémes eaux, cependant ils y vivent toujours en troupes séparées et éloignées les unes des autres; et s'ils sont assez voisius pour se mêler quelquefois, ce n'est jamais pour s'habituer ensemble et chacun rejoint bientòt sa fanille.

\section{I.LS IAMNNTINS.}

Nous avons dit que la nature semble avoir formé les lamantins pour faire la nuance entre les quadrupèdes amphibies et les cétacés : ces ètres mitoyens, placés au delà des limites de charfue classe, nous paraissent imparfaits, quoiqu'ils ne soient qu'extraordinaires et anormaux; ear en les considérant avec attention, I'on s'aperçoit bientot qu'ils possedent tout ce qui leur était nécessaire pour remplir la place qu'ils doivent oceuper dans la chaine des itres.

Aussi les lamantins, (puoicpue informes a l'extérieur, sont à l'intérieur trés-bien organisés ; et si l'on peut juger de la perfection d'organisation par le résultat du sentiment, ces animaux scront peut-ćtre plus parfaits que les autres à l'intćricur, car leur naturel et leur's mœurs semblent tenir quelque chose de l'intelligrence et des qualités sociales; ils ne craigrnent pas l'aspeet de l'homme, ils affectent mime de s'en approcher et de le suivre avec confiance et sécurité. Cet instinct pour toute société est au plus haut degré pour eclle de leurs semblables; ils se tiennent presque toujours en troupes et serrés les uns contre les autres avee leurs petits au milieud'eux, commepour lespréserver de toutaceident: tous se prètent dans le danger des secours mutuels; on en a vu essilyer d'arracher le harpou du corps de leurs compagnons blessés, et souvent l'on voit les petits suive de près le eadave de leur mère jusquau rivage, ou les podreurs les amenent en les tirant arece des cordes. Ils montiont autant de ficlélité dans leurs amours que d'attachement à leur société; le unâle n'a communément qu'une seule femelle 
qu'il accompagne constamment avant et après leur union. Ils s'accouplent dans l'cau, la femelle renversée sur le dos; car ils ne viennent jamais à terre, et ne peurent même se trainer dans la valse: ils ont le trou ovale du cœur ouvert, et par conséquent la femelle peut rester sous l'eau pendant la copulation.

Ces animaux ne se trouvent pas dans les hautes mers à une grande distance des terres; ils habitent au voisinage des côtes et des îles, et particulièrement sur les plages qui produisent les fucus et les autres herbes marines dont ils se nourrisseut : leur chair et leur graisse sont éga'lement bonnes à manger, et c'est par cette raison qu'on leur fait une guerre ernelle, et que l'espèce en est diminuée sur la plupart des côtes oì les hommes se sont habitués en nombre.

Nous connaissons quatre ou cing espèces de lamantins : tous ont la tète très-petite, le cou fort court, le eorps épais et très-gros jusqu'à l'endroit où commence la queue, et allant ensuite en dimiriuant de plus en plus jusquà l'origine de la pimne ou nageoire qui termine cette queue en forme d'un éventail étendu dans le sens horizontal; les yeux sont très-petits et orclinairement situés à égale distance, entre les trous auditifs et l'extrémité du museau; ees trous, qui leur' servent d'oreilles, sont indiqués par' deux petites ouvertures qu'on ne peut apercevoir (fu'au moyen d'une inspection attentive. La peau du corps est raboteuse, très-épaisse, et dans quelques espèces elle est parsemée de poils rares; la langue est étroite, d'une moyenue longueur, et assez menue relativement au volume du corps; la verge est placée dans un fourreau adhérent à la peau du ventre qui s'étend jusqu'au nombril. Les femelles ont la vulve assez graude, avec un clitoris apparent; cette partie n'est pas située comme dans les autres animaux au-dessous mais au-dessus de l'anus. Elles ont les mamelles placées sur la poitrine et très-proéminentes dans le temps de la gestation et de l'allaitement de leurs petits; mais dans tout antre temps elles ne sont apparentes que par leurs boutons.

Voilà les caractères généraux et communs à tous les lamantins; mais ily en a de particuliers par lesquels on peut distinguer les espèces : par exemple, le grand lamantin de Kamtschatka manque absolument de doigts et d'ongles dans les deux mains ou nageoires; il manque aussi de dents, et n'a dans chaque mâchoire qu'un os fort et robuste qui lui sert à broyer les aliments. au contraire les lamantins d'Amérique et d'A. frique ont des doigts et des ongles, et des dents molaires dans le fond de la gueule.

\section{LE GRAND LAMANTIN}

\section{DE KAMTSCHATKA.}

\section{(STELLÈre BORÉALE.)}

Ordre des cétacés, tribn des cétacés herbivores, genre lamantin. (Cuvier.)

Cette espèce se trouve en assez grand nombre dans les mer's orientales au delì de Kamtschatka, surtout aux environs de l'ile Bering, ou II. Steller en a décrit et mème disséqué quelques individus. Ce grand lamantin parait aimer les plages vaseuses des bords de la mer : il se tient aussi volontiers à l'embouchure des rivières; mais il ne les remonte pas pour se nourrir de l'berbe qui croitt sur leurs bords, car il habite constamment les eaux salées ou saumàtres. Il diffère donc à cet égard du petit lamantin de la Guiane et de celui du Sénégal, comme il eu diffère anssi par la grandeur du corps. Ses mains ou loras ne peurent lui servir à marcher sur la terre, et ne Ini sont utiles que pour nager. "J'ai vu, dit M. Steller, at reflux de la marée, un de cesanimaux à sec; il lui fut impossible de se mouvoir pour regagner le rivage, et on le tua sur la plage à coups de haches et de perches."

Ces grands lamantins que l'on voit en troupe autour de liile Bering sont si peu farouches qu'ils se laissent approcher et toncher avee la main : ils veillent si peu à leur sùreté, qu'aucun danger ne les émeut, et qu'à peine lèvent-ils la tète hors de l'eau lorsciu'ils sont menacés ou frappés, surtout dans le temps qu'ils premnent leur nourriture ; il faut les frapper très-rudement pour qu'ils premment le parti de s'éloigner : mais un moment après on les voit revenir au mème licu, et ils semblent avoir oublié le mauvais traitement qu'ils viemnent d'essuyer; et si la plupart des royageur's ne disaient pas à peu près la mème chose des autres espèces de lamantiıs, on croirait que ceux-ci ne sont si confiants et si peu saurages autour de l'ile déserte de Bering, que paree que l'expérience ne leur a pas encore appris ce qu'it en conte à tous ceux qui se familiarisent avec l'homme. 
Chaque mâle ne parait s'attacher qu'à une seule femelle, et tous deux sont ordinairement accompagnés ou suivis d'un petit de la dernière portée, et d'un autre plus grand de la portée précédente : ainsi dans cette espèce le produit n'est que d'un; et comme le temps de la gestation est d'environ un an, on peut en inférer que les jeunes ne quittent leurs père et mère que quand ils sont assez forts pour se conduire euxmêmes, et peut-être assez âgés pour devenir à leur tour les chefs d'une nouvelle famille.

Ces animaux s'accouplent au printemps, et plus souvent vers le déclin du jour qu'à toute autre heure : ils profitent cependint des moments où la mer est la plus tranquille, et préludent à leur union par des signes et des mouvements qui annoncent leurs désirs : la femelle nage doucement, en faisant plusieurs circonvolutions conme pour inviter le mâle, qui bientòt s'en approche, la suit de très-près, et attend impatiemment qu'elle se renverse sur Je dos pour le recevoir; dans ce moment il la couvre avee des mouvements très-vils. Ils sont non-seulement susceptibles des sentiments d'un amour fidèle et mutuel, mais aussi d'un fort attachement pour Jeur famille et mème pour leur espèee entière; ils se donnent des secours réciproques lorsqu'ils sont blessés; ils accompagnent ceux qui sont morts, et que les pècheurs trainent au bord de la mer. "J'ai vu, dit M. Steller, l'attachement de ees animaux l'un pour l'autre, et surtout celui du mâle pour sa femelle. Ein ayant harponné une, le mâle la suivit ì mesure qu'on l'entrainait au rivage, et les coups qu'on lui donnait de toutes parts ne purent le rebuter : il ne l'albandoma pas mème après sa mort; car le lendemain, comme les matelots allaient pour mettre en pièces la femelle qu'ils avaient tuée la veille, ils trouvèrent le mâle au bord de la mer, qui ne l'avait pas quittée.

On harponne les lamantins d'autant plus aisément qu'ils ne s'enfoneent presque jamais en entier sous l'eau : mais il est plus aisé d'avoir les adultes que les petits ou les jeunes, paree que ces dernicrs nagent beaucoup plus vite, et que souvent ils s'échappent en laissant le harpon teint de leur sang ou chargé de levr chair. Le harpon, dont la pointe est de fer, est attaché à une longue eorde; quatre ou cing hommes se mettent sur une barque; le premier qui est en avant tient et lance le harpon, et lorsqu'il a frappé et percé le lamantin, vingt-cinq ou trente hommes qui tienuent l'extrémité de la corde sur le rivage tâchent de le tirer à terre; ceux qui sont sur la barque tienuent aussi une corde (qui est attachée à la première, et ils ne cessent de tirer l'animal jusqu'it ce qu'il soit tout à fait hors de l'eau.

Le lamantin rend beaucoup de sang par ses blessures; " etj'ai remarqué, dit MI. Steller, que le sang jaillissait comme une fontaine, et qu'il s'arrêtait des que l'animal avait la tète plongée dans l'eau, mais que le jet se renouvelait tontes les fois qu'il l'élevait au-dessus pour respirer' : d'ou j’ai conclu que dans ces animaux, commo dans les phoques, le sang avait une double voie de eirculation; savoir, sous l'eau par le trou ovale du cour, et dans l'air par le poumon."

Les fucus et quelques autres herbesqui eroissent dans la mer sont la seule nourriture de ees animaux. C'est avec leurs lèrres, dont la substance est très-dure, qu'ils coupent la tige des herbes; ils enfoncent la tête daus l'eau pour' les saisir, et ne la relèvent que pour rendre l'air ct en prendre de noureau; en sorte que pendant qu'ils mangent, ils ont toujours la partie antéricure du corps dans l'eau, la moitié des flanes et de toute la partic postéricure au-dessus de l'eau. Lor'sun'ils sont rassasiés, ils se couchent sur le dos, sans sortir de l'eau, et dorment dams ('ettesituation fort profondément. Leur peau, qui est continuellement lavée, n'est pas plus nette; elle produit et nourrit une grande quantité de vermine que les mouettes et quelques autres oiseaux viennent manger sur leur clos. A u reste, ces lamantins, qui sont tres-gras au printemps et en été, sont si maigres en hiver", qu'on roit aisément sous la peau le dessin de leurs vertèbres et de leurs còtes; et e'est dams cette saison quion en reneontre quelques-uns qui ont péri entie les glaces flottantes.

La graisse, épaisse de plusieurs pouces, enveloppe tout le eorps de l'animal ; lorsqu'on l'expose au soleil, elle y prend la couleur jaune du beurre : elle cst de très-bon gouit et méme de bonne odeur; on la prélère á celle de tous les quadrupèdes, et la propriété qu'ille a d'ailleurs de pouvoir ètre conservéc longtemps, méme pendant les ehaleurs de leté, lui dome eneore un plus grand prix. On peut l'employer aux mèmes usages que le beurre et la manger de mème; celle de la quene surtout est très-delicate : elle brủle aussi très-bien sans odeur forte 
ni fumée désagréable. La chair' a le goùt de celle du bouf; seulement elle est moins tendre, et exige une plus longue cuisson, surtont celle des vieux, qu'il faut faire bouillir longtemps pour la rendre mangeable.

La peau est une espèce de cuir d'un pouce d'épaisseur, plus ressemblant à l'extéricur à l'écorce rude d'un arbre qu'ì la peau d'un animal; elle est de couleur noirâtre et sans poil : il y a seulement quelques soies rudes et longues autour des nageoires, antour de la gueule et dans l'intérieur des narines, ce qui doit faire présumer que le lamantin ne les a pas aussi souvent ni aussi longtemps fermées que les phoques, dont l'intérieur des narines est dénué de poil. Cette pean du lamantin est si dure, surtout lorsqu'elle est sèche, qu'on a peine à l'entamer avec la hache. Les 'Tschutchis s'enservent pour faire des nacelles, comme d'autres peuples du Nord en font a vec la peau des grands phoques.

Le lamantin décrit par M. Steller pesait deux cents puds de Russie, c'est-à-dire environ huit milliers; sa longueur était de vingt-trois pieds. La tète, fort petite en comparaison du corps, est de figure oblongue ; elle est aplatie au sommet, et va toujours en diminuant jusqu'à l'extrémité du museau qui est rabattu, de manière que la gnenle se trouve tout à fait au-dessous; l'ouverture en est petite et environnée de doubles lèvres, tant en haut qu'en bas. Les lèvres supérieures et inférieures externes sont spongieuses, épaisses et très-gonflées; l'on voit à leur surface un grand nombre de tubercules, et e'est de ces tubercules que sortent des soies blanches ou moustaches de quatre ou cinc pouces de longueur : ces lèvres font les mêmes mouvements que celles des chevaux lorsque l'animal mange. Les narines, qui sont situées vers l'extrémitédu museau, ont un pouce et demi de longueur, sur autant de largeur en viron, quand elles sont entièrement ouvertes.

La mâchoire inférieure est plus courte que la supérieure : mais ni l'une ni l'autre ne sont garnies de dents; il y a seulement deux os dur's et blanes, dont I'un est fixé au palais supérieur et l'autre à la mâchoire inférieure. Ces os sont eriblés de plusieurs petits trous; leur surface extérieure est néanmoins solide ct crénelée de manière que la nourriture se broie entre ces deux os en assez peu de temps.

Les yeux sont fort petits et sont situés précisément dans les points milieux, entre l'extré- mité du museau et les petits trous qui tiennent lieu d'oreilles. Il n'y a point de sourcils, mais dans le grand angle de chaque oil il se trouve une membrane cartilagineuse en forme de crête qui peut, comme dans la loutre marine (saricovienne), couvrir le globe de l'œil en entier, à la volonté de l'animal.

Il n'y a point d'oreilles externes : ce ne sont que deux trous de figure ronde, si petits que l'on pourrait á peine y faire entrer une plume à écrire; et comme ces conduits auditifs ont échappé à l'œil de la plupart des voyageurs, ils ont cru que les lamantins étaient sourds, d'autantqu'ils semblent être muets; car II. Steller assure que ceux de Kamtschatka ne font jamais entendre d'autre bruit que celui de leur forte respiration : cependant Ḱracheninnikow dit qu'il brait ou qu'il heugle, et le P. Magnin de Fribourg eompare le cri du lamantin d'Amérique à un petit mugissement.

Dans le lamantin du Kamtschatka, le cou ne se distingue presque pas du corps ; il est seulement un peu moins épais auprès de la tête que sur le reste de sa longueur. Mais un earactère singulier par lequel cet animal diffère de tous les autres animaux terrestres ou marins, c'est que les bras qui partent des épaules auprès du eou, et cui ont plus de deux pieds de longueur, sont formés et artieulés comme le bras et l'avant-bras dans l'homme. Cet avant-bras du lamantin finit avec le métacarpe et le carpe, saus aucun vestige de doigts ni d'ongles; caractères qui éloigneut encore cet animal de la classe des quadrupèdes; le carpe et le métacarpe sont environnés de graisse et d'une chair tendineuse, recourerte d'une peau dure et cornée.

On a compté soixante vertèbres dans ce lamantin, et la queue commenceà la vingt-sixiẻme et continue par trente-cinq autres; en sorte que le trone du corps n'en a que vingt-cinq. Le lamantin des Antilles en a cinquante-deux, depuis le cou jusqu'à l'extrémité de la queue. Dans un fœtus de lamantin de la Guiane, il y en avait vingt-huit dans la queue, seize dans le dos et six dans le cou, en tout cinquante. Ainsi en supposant qu'il y eùt sept vertèbres dans le cou du lamantin des Antilles, il en aurait en tout einquante-neuf. La queue va toujours en diminuant de grosseur, et sa forme extérieure est plutòt carrée qu'aplatie : dans celui de Kamtschatka, clle est terminée par une pinne ćpaisse et tris-dure qui s'élargit horizontalement, et 
dont la substance est à peu près pareille à celle du fanon de la baleine.

Le membre du mâle, (qui ressemble beaucoup à celui du cheval, mais dont le gland est encore. plus gros, a deux pieds et lemi de longuemr ; il est situé dans un fourreau adhérent à la peau du ventre et il s'étend jusqu'au nombril. Dans la femelle, la vulve est sifuce à huit pouces de distance au-dessus de l'anus; le elitoris est apparent, il est presque cartilagineux et long de six ligues. Les deux mamelles sont placées sur la poitrine: elles out environ six pouces de diamètre dans le temps de la gestation, et tant que la mère allaite son petit; mais daus tout autre temps efles n'ont que l'apparrnee d'une grosse verrue ou d'un simple bouton : le lait est gras et d'un roût à peu près semblable à celui de la brebis.

\section{LE GRAND LAMANTIN}

\section{DES ANTILLES.}

\section{(LE LAMANTIN D'AMÉMQUE.)}

Ordre des cétacés, tribu des cétacés herbivores, genre lamantin. (Cuvier.)

Nous appelons cette espèce le grand lamantin des Aulilles paree qu'elle parait se trouver encore aujourd'hui aux environs de ees îles, quoiqu'elle y soit néanmoins devenue rare depuis qu'elles sont bien peuplées. Ce lamantiı differe de celui de Kamtsehatka par les earastères suivants : la peau rude et épaisse n'est pas absolument nue, mais parsemée de quelques poils qui sont de couleur d'ardoise ainsi que la peau; il a dans les mains einc ongles apparents, assez semblables à ceux de l'homme; ces ongles sont fort courts; il a de plus, non-seulement une callosité osseuse au devant de chaque mîehoire, mais encore trente-deux dents molaires au fond de la gueule : et au contraire, il parait certain que dans le lamantin de Kamtschatka la peau est absolument dénuéede poil, les maius sans phalanges ni doigts ni ongles, et les mâchoires sans dents. Toutes ees différenees sont plus que suffisantes pour en faire deux espèees distinctes et séparées, Ces lamantius sont d'ailleurs très-différents par les proportions et par la grandeur du corps. Celui des Antilles est moins ground (fue celui de Kamtschatki ; il a aussi le corps mơns épais: sa longueur n'est que de douze, muatorze, quinze, dis-huit et rarement de vingt pieds, à moins qu'il ne soit très îgé. Celui qui est déerit dans le nouveau Voyage aux îles de l'A mérique, impriné à Paris en 1722 , n'avait que huit pieds de circonférence, sur quatorze de longueur; tandis que le lamantin de Kamtsehatka, dont nons renons de parler, avait environ dix-huit pieds de circonférence, et vingt-trois picds quelques pouces de longueur. Malgré toutes ces différences, ces deux espèces de lamantins se ressemblent pour tout le reste de leur conformation : ils ont aussi les mèmes hibitudes naturelles; tous deux également aiment la société de leur espèce, et sont d'un naturel doux, tranquille et eonfiant: ils semblent ne pas eraindre la présence de l'homme.

On voit les lamantins des Antilles toujours en troupes daus le voisinage des côtes et quelquefois aux embouchures des rivières, et e'est probablement ce qui a fait dire à Oviedo et à Gomara qu'ils fréquentaient aussi bien les eaux des fleuves que celles de la mer; cependant ce fait ne parait vrai que pour le petit lamantin dont nous parlerous dans la suite; et il parait certain que les grands lamantins des Antilles, non plus yue ceux de Kamtschatka, ne remontent point les rivieres, et se tiennent toujours dans les eaux salées et saumàties.

Le grand lamantin des Antilles a, comme celui de Kamtschatka, le cou fort court, le colps trò -gros et tros-épais juscju à l'endroit où commence la queue, qui va toujours en diminuant jusqu'à la pinne qui la termine. Tous deux ont encore les yeux fort petits, et de tres-petits trous au lieu d'oreilles: tous deux se nourrissent de fucus et d'autres herbes qui eroissent daus la mer, et Ieur chair et leur" craisse, lors(ju'ils ne sont pas trop vieux, sont également bonnes à mamger : tous deux ne produisent qu'un seul petit, que la mère embrasse et porte souvent entre ses mains; elle l'allaite pendant un an; après quoi il est en état de se pourvoil lui-mème et de manger de l'herle. Cependant, selon Oviedo, le lamantin des Antilles produirait deux petits : mais comme il parait pue dans eette espece, ainsi que dans eelle du lamantiu de Kamtschatka, les petits ne quittent leurs mères que deux ou trois ans apres leur naissance, il se pourait que eet auteur, ayant vu deux petits de portées différentes suive lit mime mire, il en eut conelu qu'clles produisaient en effet deux petits à la fois. 


\section{LE GRAND LAMANTIN}

\section{DE LA MER DES INDES.}

\section{(DUGON DES INDES.)}

Tribu des cétacès herbivores, genre dugon. (Cuvier.)

Nous avons rapporté ce que les voyageurs Leguat et Dampier ont dit des lamantins qu'ils ont vus à l'ile Rodrigue et aux Philippines, et qui nous paraissent avoir plusieurs rapports de ressemblance avec les grands lamantins des Antilles : cependant nous ne croyons pas qu'ils soient absolument de la même espèce; car il n'est guère possible que ces animax aient fait la traversée de l'Amérique aux grandes Indes; l'on verra dans l'article suivant les faits qui prouvent qu'ils ne peuvent voyager au loin ni parcourir les hautes mers ${ }^{1}$.

\section{LE PETIT LAMANTIN D'AMÉRIQUE.}

\section{(LE LAMANTIN D'AMÉRIQUE.)}

Tribu des cétacés berbirores, genre lamantin. (Cuvier.)

Cótte quatrième espèce, plus petite que les trois précédentes, est en mème temps plus nombreuse et plus répandue que la seconde dans les climats chauds du Nouveau-Monde : elle se trouve non-seulement sur presque toutes les coites, mais encore dans les rivières et les lacs qui se trouvent dans l'intérieur des terres de l'Américue méridionale, conme sur l'Orénoque, l'Oyapoe, l'Amazone, ete. : on les trouve aussi dans les rivières, et enfin dans la baie de Campèche et autour des petites îles qui sont au midi de celle de Cuba.

Les grands lamantins des Antilles ne quittent pas la mer; mais le petit lamantin préfère les caux douces et remonte dans les fleuves à mille lieues de distance de la mer. M. de la Condamine en a vu dans la rivière des Amazones jusqu'à la cataracte de Borja, au-dessus de laquelle il ne s'en trouve plus. Il parait que ces petits lamantins d'Amérique fréquentent alternativement les eaux de la mer, et celles des fleuves, selon qu'ils y trouvent de la pâture; mais ils ha-

4 Cet animal est le type d'un geure particutier, nommé dugon. bitent constamment sur les fonds élevés des côtes basses, et les riviẻres oủ croissent les herbes dont ils se nourrissent : on ne les rencontre jamais dans les endroits voisins des cotes escarpées ou les eaux sont profondes, ni dans les hautes mer's a de grandes distances des terres; car ils n'y pourraient vivre, puisqu'il ne parait pas qu'ils mangent du poisson ; ils ne fréquentent done que les endroits qui produisent de l'herbe; et c'est par cette raison qu'ils ne peuvent traverser les grandes mer's dont le fond ne produit point de végétaux, et où par conséquent ils périraient d'inanition : ainsi nous ne croyons pas que les lamantins de la mer cles Indes et ceux des côtes du Sénégal soient de même espèce que les lamantins d'Amérique petits ou grands.

Les vovageurs s'accordent à dire que le petit lamantin d'Amérique, dont il est ici question, se nourrit non-seulement des herbes qui croissent sous les eaux, mais qu'il broute encore celles qui bordent les rivages lorsqu'il peut les atteindre, en a vançant sa tète sans sorlir entièrement de l'eau : car il n'a pas plus que les autres lamantins la faculté de marcher sur la terre ni même de s'y trainer.

Les femelles, dans cette espèce, produisent ordinairement deux petits, au lieu que les grands lamantins n'en produisent qu'un. La mère porte ses deux petits sous chacun de ses bras et serrés contre ses mamelles, dout ils ne se séparent point quelque mourement qu'elle puisse se donner; et lorsqu'ils sont devenus assez forts pour nager, ils la suivent constamment et ne l'abandonnent pas lor'squ'elle est blessée, ni même après sa mort, car ils persistent ì l'accompagner lorsque les pècheurs la tirent avec des cordes pour l'amener au rivage.

La peau de ces petits lamantins adultes est, comme celle des grands, rude et fort épaisse : leur chair est aussi très-bonne à manger.

\section{LE PETIT LAMANTIN DU SENÉGAL.}

(LE LAMANTIN DU SÉNÉGaL.)

Tribu des cétacés herbivores, genre lanıutin. (Cuvier.)

Nous avous domné, d'aprè̀s M. Adanson, la description de ce petit lamantin du Sénégal, qui est de la même grandeur que celui de 
Cayenne, mais qui paraît en différer en ce qu'il a des dents molaires et quelques poils sur le corps; earactères qui suftisent pour le distinguer de celui d'A méricque, auquel les voyageurs ne donnent ni dents molaires ni poil sur le corps. Ainsi nous présumons qu'on peut compter cinq espéces de lamantins : la plemiere est le grand lamantin de Kamtschatka, (jui, comme nous l'avons dit, surpasse tous les autres en grandeur, et n'a ni dlents molaires ni ongles au bout des maius, ni poil sur le corps; la seconde, le grand lamantin des Antilles, qui a des dents molaires, des ongles et quelques poils sur le corps, et dont la longueur n'est au plus que de dix-huit à vingt pieds, tandis que celle du lamantin de Kamtschatka est de plus de vingttrois pieds; la troisième, le grand lamantin de la mer des lndes, (qui n'est pas encore bien comnu, mais đqui doit être d'une espece diffé. rente de celles du Kantschatka et des Antilles, puisqueni l'une nil'autrene penvent tra verser les hautes mers paree qu'elles ne produisent point les herbes dont ces animaux se nourrissent; la quatriène, le petit lamantiu de l'Amérique méridionale, qui fré(quente également les eaux sa. lées et les eaux douces, et dilfère heaucoup des trois premiers par la grandeur, qui est de plus des deux tier's au-dessous; it la eincpuiène, le petit lamantiu du Sénégal, (pui se troure dans plusicurs fleuves de l'A frique, comme le pelit lamantin de la Guiane, dans eeur de l'Amérique. Ces deux petites espices diflèrent en ee que la première n'a point de dents, et que les trous auditifs sont plus grands (pue daus la secoude.

Voili ce que j'ai pu reeueillir de moins incertain au sujet des diflérentes espèces de lamantins, qui, comme l'on voit, ne sont pas encoreparfaitement comnues. Quel(pues voyageurs ont parlé des lamantins des Philippines, et M. Forster m'a dit en avoir v'u aussi sur les cotes de la Nouvelle-IIollande; mais nous ignorons si ces espèees des Plilippines et de la Jouvelle-llollande peurent se rapporter à eclles dont nous venons de parler, ou sj elles en diflërent assez pour qu'on doive les regarder comme des especes dilferentes '.

' Ces aninaux sont de l'espèce th dugon.

\section{NOMENCLATURE}

\section{DES SINGLS.}

Comme endoctriner des écoliers, ou parler ì des hommes, sont deux choses différentes; que les premiers recoivent sans examen et mème avec avidite l'arbitraire comme le réel, le faux comme le v'ai, des qu'il leur est présenté sous la forme de clocuments; que les auties all contraire rejettent avec dégoùt ces mèmes documents lorsfu'ils ne sont pas fondés; nous ne nous servirons d'aucune des méthodes yu'on a imaginées pour entasser, sous le mème nom de singes, une multitude d'auimaux d'espèces difféjentes et même très-éloignées.

J'appelle singe un animal sans queue, dont la face estaplatic, dont les dents, les mains, les doigts et. les ongles ressemblent à ecux de l'homme, et qui, comme lui, masehe debout sur ses deux pieds. Cette définition, tircée de la naturemème de l'animal et de ses rapports avee celle de l'homme, exclut, comme l'ou voit, tous les animaux qui ont de's (jucues, tous ceux yui ont la face relevée ou le museau long; tous ceux qui ont les ongles courbés, crochus ou pointus; tous cerr qui marehent plus volontiers sur quatre que sur deux pieds. D'après ectienotion fixe et précise, voyons combien il esiste d'espéces d'ammaux auxquels on doive domner le nom de singe. Les anciens n'en commaissaient qu'une seule; le pilheros des Grees, le simia des latins, est un singe, un vai singe, et c'est eclui sur lequel Aristote, P'line ct Galien ont institué toutes les conyparaisons physiques, et fondé toutes les relations du singe à l'homme; mais ce pithèrue, ee singe des anciens, si ressemblant ì l'homme par la conformation cstérieure, et plus scmblable encore par l'organisation intérieure, en differe néaumoins par un attribut qui, quoique relatif cn lui-mème, n'en est cependant iei pas moins essentiel, éest la grandeur. Ia taille de l'homme en général est andessus de cinq pieds : celle du pithèrue n'atteint guère qu’au quart de edte hauteur ; aussi ce singe eùt-il encore cété plus ressemblant à l'homme, les anciens auraient eu raison de ne le res garder (que comme un homoneule, un main manqué, un pyomie capable tout au plus de combattre avee les grues, tandis que l'homme sait dompter l'éléphant et vancre le lion. 
Mais depuis les anciens, depuis la découverte des parties méridionales de l'Afrique et des lndes, on a trouré un autre singe arec cęt attribut de grandeur, un singe aussi haut, aussi fort que l'homme, aussi ardent pour les femmes que pour ses femelles; un singe qui sait porter des armes, qui se sert de pierres pour attaquer, et de bâtous pour se défendre, et qui d'ailleurs ressemble encore à l'homme plus que le pithè. que; car indépendamment de ce qu'il n'a point de queue, de ce que sa face est aplatic, que ses bras, ses mains, ses doigts, ses ongles sont pareils aux nôtres, et qu'il marche toujours debout, il a une espèce de visage, des traits approchants de ceux de l'homme, des oreilles de la nême forme, des cheveux sur la tète, de la barbe au menton, et du poil ni plus ni moins que l'homme en a dans l'état de nature. Aussi les habitants de son pays, les Indiens policés n'ont pas hésité de l'associer à l'espèce humaine par le nom d'orang-outang, homme saurage; tandis que les Nègres, presque aussi saurages, aussi laids que ces singes, et qui n'imaginent pas que pour être plus ou moins policé l'on soit plus ou noins honıme, leur ont donné un nom propre (pongo), mn nom de bète et non pas d'homme; et cet orang-outang, ou ce pongo, n'est en effet qu'un animal, mais un animal trèsingulier, que l'homme ne peut voir sans rentrer en lui-mème, sans se reconnaitre, sans se convaincre que son corps n"est pas la partie la plus essentielle de sa nature.

Voilà done deux animaux, le pithèyue et l'orangroutang, auxquels on doit applicquer le nom de singe, et il y en a un troisième auquel on ne peut guère le refuser, quoicu'il soit difforme, et par rapport à l'homme et par rapport au singe. Cet auimal, jusqu'à présent inconnu, et qui a été rapporté des Indes orientales sous le nom de gibbon. marche debout comme les deux autres, et a la face aplatie: il est aussi sans queue; mais ses bras, au lieu d'ètre proportionnés comme ceux de l'homme, ou du moins comme ceux de l'orang-outang ou du pithèque, à la hauteur du corps, sont d'une longneur si démesurée, que l'animal étant debout sur ses deux pieds, il touche encore la terre avec ses mains sans courber le corps et sans plier les jambes. Ce singe est le troisième et le dernier auquel on doive donner ce nom; c'est dans ce genre une espèce monstrueuse, hétéroclite, comme l'est dans l'espèce humaine la race des hommes à grosses jambes, dite de Saint-Thomas.

Après les singes, se présente une autre famille d'animaux, que nous indiquerons sous le nom générique de babouin; et pour les distinguer nettement de tous les autres, nous dirons que le babouin est un animal à queue courte, à facc allongée, à museau large et relevé, arce des dents canines plus grosses à proportion que celles de l'homme, et des callosités sur lesfesses. Par cette définition, nous excluons de cette famille tous les singes qui n'ont point dequeue, toutes les guenons, tous les sapajous et sagouins qui n'ont pas la quene courte, mais qui tous l'ont aussi longue ou plus longue que le corps, et tous les makis, loris et autres quadrumanes qui out le museau mince et pointu. Les ancieus n'ont jamais eu de nom propre pour ces animaux : Aristote est le seul qui parait avoir désigné l'un de ces babouins par le nom de simia porcaria ${ }^{4}$, encore n'en domne-t-il qu une indication fort indirecte. Les Italiens sont les premiers qui l'aieut uommé babuino; les Allemands l'ont appelé burion; les Francais babouin: et tous les auteurs qui, dans ces derniers sièrles, ont écrit en latin, l'out désignć par' le nom papio: nous l'appellerous nous-mème papion pour le distinguer des autres babouins qu'on a trouvés depuis dans les provinces méridionales de l'Afrique et des Indes. Nous comnaissous trois espèces de ces animaux, $1^{\circ}$ le papion ou $b a$ bouin proprement dit, dont nous venons de parler, qui se troure en Libye, en Arabie, etc., ct qui vraisemblablement est le simia porcaric d'Aristote; $2^{\circ}$ le mandrill, qui est un babouin encore plus grand que le papion, arec la face violette, le nez et les joues sillonnés de lides profondes et obliques, qui se trouve en Guinée et dans les parties les plus chaudes de l'Afrique; $3^{0}$ l'ouanderon, qui n'est pas si gros que le papion, ni si grand que le mandrill, dont le corps est moins épais, et qui a la tète et toute la face environnce d'une espèce de crinière tres-longue et très-épaisse. On le trouve à Ceylan, au Malabar et dans les autres provinces méridionales de l'Inde. Ainsi voila trois singes et trois babouins bien définis, bien sćparés, et tous

- Vola. Celte dénomination simia porcaria, qui ne se trouve que dans Aristıte, $t$ l qui n’a élé employéc par aneun autre auteur, élail néannuius une très-boune expressio: pour désigner le bahuuiu; car j'ai trouvé daus des voyagcurs, qui proliablement n'avaient jamais ln Arist"le, la mćme compdraison du musean dı bahouin a celui dı cochon; el d'ailleurs ces lenx auimaux se resemblent un peu par la forme du corps. 
six distinctement différents les uns des autres. Mais, comme la nature ne connaît pas nos dérinitions, qu'elle n'a jamais rangé ses ouvrages par tas, ni les êtres par genres; que sa marche au contraire va toujours par degrés, et que son plan est nuanee partout et s'étend en tout sens, il doit se trouver entre le genre du singe' ct celui dubabouin, quelque espèce intermédiaire qui ne soit précisément ni l'un ni l'autre, et qui cependant participe des deux. Cette espéce intermédiaire existe en effet, et e'est l'animal que nous appelons magot; il se trouve placé entre nos deux définitions : il fait la muance entre les singes et les bahouins; il differe des premiers, en ce qu'il a le museau allongé et de grosses dents eanines; il differe des seconds, parce qu'il n'a réellement point de queue, quojqu'il ait un petit appendice de peau qui a l'apparence d'une naissance de queue : il n'est par conséquent ni singeni bahouin, et tient en mème temps de la nature des deux. Cet animal, qui est fort commun dans la Haute Égypte, ainsi (qu'en Barharie, était connu des anciens; les Grees et les Latins l'ont nommé cynocéphale, paree que son museau ressemble assez à celui du dogue. Aiusi, pour présenter ces animaux, voici l'ordre dans leguel on doit les raurger : l'orang-outang ou ponuo, premier singe; le pilhèrue, second singe; le gibbon, troisicme singe, mais difforme; le cynocéphale ou magot, quatrieme singe ou premier babouin; le papion, prem ier babouin; le mandrill, second babouin; l'ouanderou, troisième babouin. Cet ordre n'est ni arbitraire ni fietif, mais relatif à l'échelle mème de la nature.

A près les singes et les babouins, se trouvent les guenons; c'est ainsi que j'appelle, d'après notre idiome ancien, les animax (pui ressemblent aux singes et aux babouins, mais (fui ont de longues queues, e'est-ì-dire des quenes aussi longues ou plus longues (pue le corps. I.e mot guenon a eu, daus e'es deruiers siecles, deux acceptions différentes de celle que nous lui donnons iei : l'on at cmployé ee mot yupnon, générillement pour désigner les singes de petite. taille ${ }^{2}$, et en mème temps on l'a employé palli-

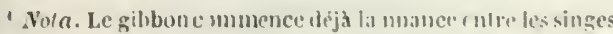

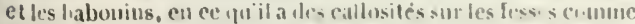

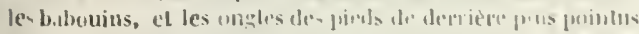

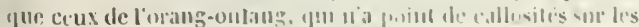

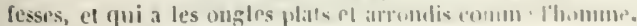

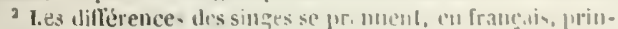

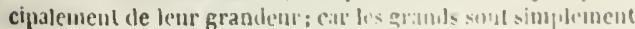

culièrement pour nommer la femelle du singe: mais plus anciennement nous appelions singes ou magots les singes sans quene, et guenons ou mones ceux qui avaient une longue queue : je pourrais le prouver par ruelques passages de nos voyagreurs ' des seizicme ou dix-septieme siecles. Le mot mème de guenon ne s'éloigne pas, et peut-être a été dérivé de kiebos ou liépos, nom que les Giees donnaient aux singes à longue queue. Ces liébos ou guenons sont plus petites et moins fortes que les babouins et les singes ; elles sont aisées a distinguer des uns et des auties, par cette differenee, et surtout par leur longue queue. On peut aussi les séparer aisément des makis, parce qu'elles n'ont pas le musean pointu, et qu'au lieu de six dents incisives qu'ont les makis, elles n'en ont que quatre commeles sinzes et les babouins. Nous en connaissons neuf espèces, que nous indiquerons chacune par un nom différent, afin d'éviter toute confusion. Ces nenf espèces de guenons sont: $1^{0}$ les maeaques; $2^{0}$ les patas; $3^{0}$ les malbrouks; $4^{0}$ les mangabeys; $5^{0}$ la mone; $t^{0}$ le callitriche; $7^{0}$ le moustae; $8^{0}$ le talapoin ; $9^{0}$ le doue. Les anciens Grees ne connaissaient que deux de ces guenons, la mone et le eallitriche, qui sont originaires de l'Arabie et des parties septentrionales de l'Afrique; ils navient aume notion des autres, parce qu'elles ne se trouvent que dius les provinces méridionales de l'Afrique et des Indes orientales, pays entierement inconnus dans le tenips d'Aristote. Co grand philosophe, et les Grees en général, étaient si attentifs à ne pas confondre les ètres par des noms communs et des lor's équivoques, yu'ayant appelé pithecos le singe sans quene, ils ont nommé licbos la guenon ou singe a longue queue : comme ils avilent recommu que ce's animax étaient d'especes différentes et méme assez éloinnées, ils leur avaient í thacun donné un nom propre, et ce nom était tiré du caractère le plus apparent.

appres singes, soit quils aient une quenc ou qu'ils n'en ateul point. on soit tuilis airnt le musean long comme un chien on quils l'aient cunt; t'l hes singes yui sont pelıl. wht ajpielés guenons. Mćmuires prour servir a lillotore des . Mii. mans, page 120.

Il y a an Tenegal plunienrs especes te sing s, comme des

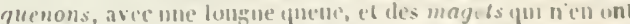

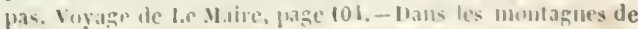
l'Ami i.pun méridionale, il so Irunve me espece de mones

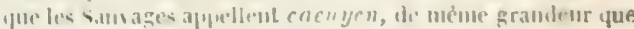

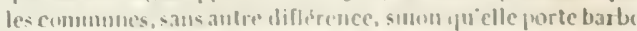
an minton . Are ces mones se trunvent force petilesbefrs

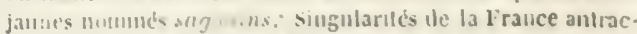

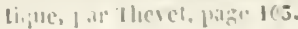


Tous les singes et babouins qu'ils connaissaient, c'sst-i-dire le prithèue ou singe proprement dit, le cynocephale ou mayol, et le simia porcaria ou papion, ont le poil d'une couleur ì peu près uniforme: au contraire la guenon que nous appelons ici mone, et que les Grees appelaient liébos, a le poil varié de couleurs différentes: on l'appelle mème vulgairement le singe varié; c'était l'espèce de guenon la plus commune et la mieux conmue du temps d'Aristote, et e'est de ce earactère qu'est dérivé le nom de kébos, qui désigne en gree la variété dans les conleurs. Ainsi tous les animaux de la classe des singes, babouins et guenons, indi(jués par Aristote, se réduisent à quatre, le pithecoss, le cynocéphalus, le simia porcaria et le kiebos, que nous nous eroyons fondés à représenter aujourd'hui comme étant réellement le pithèque ou singe proprement dit, te magot, le papion on babouin proprement dit, et la mone; parce que, nonseulement les earactères particuliers que leur donne Aristote leur conviennent en effet, mais eneore, paree que les autres espèces que nous avons indiquejes, et celles que nous indiquerons encore, devaient nécessairement lui ètre inconnues, puisqu'elles sont natives et exclusivement habitantes des terres où les royageur's grees n'avaient point encore pénétré de son temps.

J)eux ou trois siècles après celui d'Aristote, on trouve dans les anteurs grees deux nouveaux noms, crllithrix et cercopithecos, tous deux relatifs aux guenons ou singes à longue queue: ¿ mesure qu'on découvrait la terre et qu'on s'avanẹait vers le midi, soit en Afrique, soit en Asie, on trouvait de nouveaux animaux, d'autres espèces de guenons; et comme la plupart de ces guenons n'avaient pas, comme le kébos. les couleurs variées, les Grees imaginèrent de faire un nom générique cercopilhecos, e'est-àdire singe à queuc, pour désigner toutes les espèces de gutenons ou singes à longue queue; et ayant remarqué parmi ces nouv celles espèces une guenon d'un poil verdàtre ct de couleur vire, ils appelerent cette espece callithrix, qui signifie bera poil. Ce callithrix se trouve, en effit, thans la partie méridionale de la Mauritanie et daus les terres voisines du eap Vert : e'est la guenon que l'on comnat vulgairement sous le nom de singe vert; et comme nous rejetons dans cet ouvrage toutes les dénominations composées, nous lui avons conservé son non ancien, euilithrix ou callitriche.
A l'égard des sept autres espèces de gueuons que nous avons indiquées ei-dessus par les noms de macayue, patas, malbrouk, mangabey, moustac, talapoin et douc, elles étaient inconnues des Grees et des Latins. Le macaque est natif de Congo; le patas, du Sénégal; le mangabey, de Malagasear; le malbrouk, de liengale; le moustac, de Guinée; le talapoin, de Siam; et le douc, de la Cochinchine. Toutes ces terres étaient igalement ignnorées des anciens, et nous arons eu grand soin de conserver aux animaux cu'on y a trouvés les nums propres de leur pays.

Et comme la nature est constante dans sa marche, qu'elle ne va jamais par sauts, et que toujours tout est gradué, nuancé, on trouve entre les babouins et les guenons une espèce intermédiaire, comme celle du magot l'est entre les singes et les babouins : l'animal qui remplit cet intervalle, et forme cette espèce intermédiaire, ressemble beaucoup aux guenons, surtout au macaçue, et en mème temps il a le museau fort large, et la queue courte comme les babouins : nelui connaissant point de nom, nous l'arons appelé maimon, pour le distinguer des autres. Il se trouve à Sumatra : c'est le seul de tons ces animaux, tant babouins yue guenons, dont la queue soit dégrarnie de poil ; et e'est par cette raison que les auteur's qui cof ont parlé l'ont désigné par la dénomination de singe à queue ule cochon, ou de singe à queue de rat.

Voilà les animaux de l'ancien continent auxquels on a donné le nom commun de singe, quoiqu’ils soient non-seulement d'espèces ćloignées, mais mème de genres assez différents; et ce qui a mis le comble à l'erreur et à la confusion, c'est qu'on a donné e's mèmes noms de singe, de cynocéphale, de liebe, et de cercopitheque, noms faits, ily a quinze cents ans, par les Grees, à des animaux d'un nonveau monde qu'on n'a découverts (que depuis deux ou trois sièeles. On ne sedoutait pas qu'il n'existait dans les parties mériclionales de ce noureau continent aueun des animaux de l'Afriyue et des Indes orientales. On a trouvé en Amérique des hètes avee des mains et des doigts; ce rapplort seul a suffi pour qu'on les ait appelées singes, sans laire attention que pour transfírer un nom, il faut au moins que le genre soit le méme, et yue pour l'applinuer juste, il faut eneore que l'espèce soit identique: or', ces animaux d'Amérique, dont nous ferons deux class:s sous 
Jes noms de sapajous et de sagouins, sont très- 1 ecr par les comparer entre eux. Ces deux fadifférents de tous les sirges de l'Asie et de l'Afrique; et de la même manière qu'il ne se trouve dans le uouveau continent ni singes, ni babouins, ni guenons, il n'existe alussi ni sípájous, ni sagouins dans l'meien. Quoigue nous ayons déjà posé ees faits en général dans notre Discours sur les animaux de's deux continents, nous pouvons les prouver iei d'une manière plus particuliere, et démontrer que de dix-sept e'spèces auxquelles om perut rieluire tous le's animaux appelés singes dans l'ancien continent, et de douze ou treize aluxpuelles on a transferé cenom dans le nouveau, ancune u'est la mème, ni ne se trouve également dams les deux : calr sur ces dix-sept especes de l'ancien continent, it faut d'abord retrancher les trois ou cquatre singes yui ne se trouvent eertainement point en Américjue, et auxpuels les sapajous ot les sagrouins ne ressemblent point du lont. $2^{0}$ II fant ("I retranchere les trois on quatre babouins qui sont beaucoup plus gros que les sigouins ou les salpaijous, et qui sont aussi d'une figure trèsdifférente: il ne restedone que les neuf guenons auxifuelles on puisse lis comparrer. Or, toutes les guenons ont, aussi bien que les singes et les babouins, des carnctères éucuraux et partieuliers, yui les sejarent en entier des sapajous et des satgonins; le premier de ces caractères e'st d'avoir les fesses pelées, et des eallosités maturelles et inhérentes à ces parties; le second, e'est d'avoir des abajoues, e'est-it-dire des poches au bas des jones, ou elles peuvent gardeder teurs aliments; et le troisième, d'avoir la cloison des marines étroite, el ees mèmes narines ouvertes all-dessousdu ne\% comme celle's le l'homme. Les silpaijous et le's sagouins u'ont aucun de cees calrateteres; ils ont tous la eloison des narines fort ćpaisse, les narines ouvertes sur les còtés du nez et non pas en dessous; ils ont du poil sur les fesses et point de callosités; ils n'ont point d'abajoues : ils different done des enenons, nonseulement parl'espèce, mais mème par légenre. puisqu'ils n'ont ancun des caractères généraux yui leur sont communs à toutes; et ectte dilférence daus le genre eu suppose nécessairement de bien plus canders daus les especes, et démontre quielles sont trés-iloignées.

C'est done mal à propos (que lon a domére le nom de singe ct de yucnom aux supujous ot aux sagouins; il fillait leur conserver leurs noms, et, alu lieu de les associer aux singes, commenmilles different l'une de l'autre par un caractère remaryuable: tous les sapajous se servent de leur yueue comme d'un doigt, pour s'acerocher et meme pour silisir ce qu'ils ne peuvent prendre ar ec la main; les sagouins au contraire ne peurent se scrir de lenr quene pour cet usage; leur fire, leur's oreilles, leur poil sont anssi differents : on peut donce en faire aisément deux genre's distinets et séparés.

Sans nous servir de denominations yui ne peuvent s'appliquer qu'atux sineres, aux babouius et aux gucnons; saus employer des noms qui leur appartiennent et qu'on ne doit pas domner il d'autres, nous arvons litehe d'indiçuer (ons les sapaigous et tous les sigonins par les uoms propres qu'ils ont dans leur pays uatal. Nous commaissons six ou sept especees de sapajous et six esperee's de sagouins, dont la plupart ont de's varietés; nous en domnerons l'histoire et la deseription dans ce volume. Nous alvons recherehé leurs noms avee le plus grand soin dauns tous les auteurs, et surtout dans les royageur's, qui les ont indiqués les premiers. Ein général, lorsque nous n'arons pu savoip le nom que ehacun porte dans son pays, nous avous eru devoir le tirer de la nature meme de l'animal, e’est-i-dire d'un caractère gui scul fit suffisant pour le faire reconnaitre et distinguer de tous les autres. Lion verra dans chayne artiele les raisons qui nous ont fait adopter ces noms.

lit à l'égard des variétés, lesquelles daus la classe entière de ces animaux sont pent-ètre plus nombreuses que les especes, on les tronvera aussi tres-soigneusement eomparcies a chacomede leurs especes propres. Nous bonnaissons et nous arons cu, la plupart vivants, quarante de ces animaux plus ou moins différents entre eux. Il hous a paru quon devait les réduire a trente especes, saroir: trois silnges, une intermédiaire entre les singes et les habouins ; trois babouins, une intermédiaire chtre les babuuins et les guenons; neul guenoms, sept siphajous et six sagouins; et que tous les antres ue doivent. au moins pour la plupart, itre consilléres que comme de's varictes. Mais, comme nous ne sommes pas absolument eertains que equelquesunes de e's varietes ne puissent itte en effet des esperees distinetes. nous titcherons de leur donncr aussi des noms qui ne seront que précaires, supposé que ce ne soient que des varié- 
tés, et qui pourront devenir propres et spécifiques, si ce sont réellement des espèces distinctes et séparées.

A l'oceasion de tontes ces bêtes, dont quelques-mmes ressemblent si fort à l'homme, considérons pour un instant les animaux de la terre sous un nouveau point de vue : c'est sans rácison suffisante qu'on leur a donné génélalement à tous le nom de quadrupedes. Si les exceptions n'étaient qu'en petit nombre, nous u'attaquerions pas l'application de cette dénomination : nous avons dit, et nous sarons que nos définitions, nos noms, quelque grénéraux cqu’ils puissent être, ne comprennent jamais tout; qu'il existe toujours des êtres en-deça ct au-dclà; qu'il s'en trouve de mitoyens; que plusienrs, quoique placés en apparence au milieu des autres, ne laissent pas d'échapper à la liste; que le nom général qu'on vondıait leur imposer est une formule incomplète, une somme dont souvent ils ne font pas partie, parce que la nature ne doit jamais etre présentée que par unités et non par agrgrégats; parce que l'homme n'a imaginé les noms généraux que pour aider à sa mémoire, et tâcher de suppléer à la trop petite capacité de son entendement; parce qu'ensuite il en a fait abus, en regardant ce nom général comme quelque chose de réel; paree qu'enfin il a voulu y rappeler des ètres, et même des classes d'ètres, qui demandaient un autre nom. Je puis en domer et l'exemple et la preuve, sans sortir de l'ordre des quadrupèdes, qui, de tous les animaux sont ceux que l'homme connait le mieux, et auxquels il était par couséquent eı état de dommer les dénominations les plus précises.

Le nom de quadrupècles suppose que I'animal ait quatre pieds : s'il manque de deux pieds comme le lamantio, il n'est plus (quadrupède; s'il a des bras et des mains comme le singe, il n'est plus quadrupède; s'il a des ailes comne la chauve-souris, il n'est plus quadrupede; ct l'on fait alous de cette dénomination générale lorscu'on l'applique à ees animaux. Pour qu'il y ait de la précision dans les mots, il faut de la vérité dans les idées (qu'ils représentent. Faisons pour les mains un nom pareil à celui qu'on a filit pour les pieds, et alors nous dirons avee vérilé et précision, que l'homme est le seul qui soit bimane et bipède, paree qu'il est le seul qui ait deux mains et doux pieds; que le lamatitin u'est que limane; que la chanre-souris n'est que bipede, et que le singe est quadru mane. Maintenant appliquons eés nouvelles dé. nominations générales à tous les ètres particuliers auxquelles elles conviennent; car é est ainsi qu'il fant toujours voir la nature : nous trouvons que sur environ deux cents espèes d'animaux qui peuplent la surface de la terre, et auxquelles on a donné le nom commun de quødrupédes, il y a d'abord trente-cing espèces de singes, babouins, guenons, sapajous, sagouins et makis, (qu'on doit en retrancher, parce qu'ils sont quadrumanes; qu’à ces trente-cinq espèces, il faut ajouter celles du loris, du sarigue, de la marmose, du cayopollin, du tarsier, du phalanger, ete., qui sont aussi quadrumanes, comme les singes, guenons, sapajous, et sagouins; que par conséquent la liste des quadrumanes étant au moins de quarante espèces, le nombre réel des quadrupèdes est déjà réduit d'un cinquième; qu'ensuite ôtant douze ou quinze espèces de bipèdes, savoir : les chanvessouris et les rousscites, dont les pieds de devant sont plutôt des ailes que des pieds; et en retranchant aussi trois ou quatre gerboises qui ne peuvent marcher que sur les pieds de derrière, parce que ceux de devant sont trop courts; en otant encore le lamantin qui n'a point de pieds de derrière, les morses, le dugon et les phoques auxquels ils sont inutiles, ee nombre des quadrupèdes se trouvera dimiuué de presque un tiers; et si on voulait encore en soustraire les animaux qui se servent des pieds de devant comme de mains, tels que les ours, les marmottes, les coatis, les agoutis, les écureuils, les rats et beaucoup d'autres, la dénomination de quadrupède paraitra mal appliquée á plus de la moitié des animaux. Et en effet, les vrais quadrupèdes sont les solipèdes et les pieds fourchus; dès qu'on deseend à la classe des fissipèdes, on trouve des quadrumanes ou des quadrupèdes ambigus, qui se servent de leurs pieds de devant comme de maius, et qui doivent ètre séparés ou distingués des autres. Il y a trois especes de solipèdes, le cheval, le zèbre et l'âne; en y ajoutant l'éléphant, le rhinocéros, l'hippopotame, le chameau, dont les pieds, quoique terminés par des ongles, sont solides, et ne leur servent qu’à marcher, l'on a déjà sept especes auxquelles le nom de quadrupede convient parfaitement. Il y a un beaucoup plus grand nombre de pieds-fourchus que de solipèdes; les bœuf's, les béliers, les chèvres, les 
gazelles, les bubales, les cherrotains, le lama, la vigogne, la girafe, l'élan, le renne, les cerfs, les daims, les ehevreuils, ete., sont tous des pieds-fourchus et composent en tout un nombre d'environ quarante espèces. Ainsi voilà déjả cinquante animaux, e'est-i-dire, dix solipèdes et quarante pieds-fourchus, auxquels le nom de quadrupède a été bien appliqué. Dans les fissipèdes, le lion, le tigre, les panthères, le léopard, le lynx, le chat, le loup, le chien, le renard, l'hyène, les civettes, le blaireau, les fouines, les belettes, les furets, les pores-épie's, les hérissons, les tatous, les fourmilier's et les cochons, qui font la nuance entre les fissipedes et les pieds-fourchus, forment un nombre de plus de quarante autres espèces, auxquelles le nom de quadrupede convient aussi dans toute la rigueur de l'acception, parce que, ruoiqu'ils aient le pied de devant divisé en yuatre ou cincy doigts, ils ne s'en servent jamais comme de main : mais tous les autres fissipèdes, yui se servent de leurs pieds de devant pour saisir et porter à lcur gucule, ne sont pas de purs quadrupèdes; ces espèces, qui sont aussi au nombre de quarante, font une classe intermédiaire entre ies quadrupedes et les quadrumanes, et ne sont précisément ni des uns ni des autres. Il y a done daus le réel plus d'un (quart des animaux auxquels le nom de quadrupède disconvient, et plus d'une moitié aux(juels il ne convient pas dans tonte l'étendue de son acception.

Les (quadrumanes remplissent le grand intervalle qui se trouve entre l'homme et les quadrupèdes; les bimanes sont un terme moyen dans la distance encore plus grande de l'homme aux cétacés' : les bipèdes avee des ailes font la nuance des quadrupèdes aux oiseaux, et les fissipèdes, qui se servent de leurs pieds comme de mains, remplissent tous les degrés qui se trouvent entre les quadrumanes et les quadrupède's. Mais e'est nous arrèter assez sur cette rue; quelque utile qu'elle puisse ètre pour' la connaissance distincte des animaux, clle l'est encore plus par l'exemple, et par la nouvelle preuve qu'clle nous doune, qu'il n'y a aucume de nos définitions qui soit précise, aucun de nos termes généraux qui soit exact, lorsqu’on vient ì les applicuer en particulier aux choses ou anx ètres qu'ils représentent.

Nota. I)ans celle plurase cl dans toutes les autro sembla. oles, je noutends parter que de l'homme plysipue, cest atdire de la forme diı corps de l'hommc, comparée à la forme du coros des animaux.
Mais par quelle raison ces termes généraux, qui paraissent ètre le chef-d'œu re de la pensée, sont-ils si défectucux? pourquoi ces définitions, qui semblent n'être que les purs résultats de la combinaison des ètres, sont-elles si fautives dans l'appliealion? est-ce erreur' nécessaire, défaut de rectitude dans l'esprit humain? ou plutòt n'est-ce pas simple incapacité, pure impuissance de combiner et mème de voir à la fois un grand nombre de eloses? Comparons les cuvres de la nature alur ouvrages de l'homme, cherchons comment tous deur operent, et rovons sil'esprit, quelque actif, quelque étendu qu'il soit, peut aller de pair et suive lat mème matelie, sans se perdre lui-mème ou dans l'immensité de l'espace, ou dans les ténebres du temps, ou dans le nombre infini de la combinaison des étres. Que l'homme dirige la marehe de son esprit sul un oljjet (juedeonque : s'il roit juste, il prend li ligne droite, parcourt le moins d'espace ct $\mathrm{cm}-$ ploie le moius de temps possible pour atteindre à sou but. Combien ne lui faut-il pas déjà de réflexions et de combinaisons pour ne pas entrel" dans les ligues obliques, pour éviter les fuusses routes, les culs-de-sae, les rhemins creux qui tous se présentent les premier's, ct en si grand nombre, que le choix du vai sentier suppose la plus grande justesse de discernement! Cela cependant est possible, e'est-ii-dire n'est pas audessus des forees d'un bon esprit; il peut marcher droit sur' sa ligne e't sans sécearter'; voilà sa maniere d'aller la plus sure et la plus ferme: mais il va sur une ligne pour arriver it un point; et s'il veut saisir un autre point, il ne peut l'atteindre que par une autre ligne: la trame de ses idées est un fil délić, qui s'étend en loneuene sans autres dimensions. La nature au contraire ne fait pas un seul pas qui ne soit en tout sens; en marchant en ivalut, elfe sétend à còté et s"ilève au-dessus; efle parcourt et remplit à la fois les trois dimensions; et tandis yue l'homme n'atteint qu'un point, elle arrive au solide, cor embrasse le volume et pénetre la masse dans toutes leurs partics. Que font nos Plaidias lorsqu'ils donnent une forme a la matière brute? $\lambda$ forced art et de temps, ils parviement a faire une surface qui represente exartement les dehors de lobjet (juils se sont proposé; elatelue point de cette surface (juils ont erece leur a conité mille combinaisons : Icur genie a marehe droit sur autant de lignes qu'il y a de traits dans leur figure : le moindre écart l'aurait deformée Ce 
marbre si parfait qu'il semble respirer, n'est done cu'une multitude de points auxpuels l'artiste n'est arrivé qu'avee peine et successivement; parce que l'esprit bumain ne saisissant à 'a fois qu'une seule dimension, et nos sens ne s'applicpunt qu'aux surfaces, nous ne pouvons pénétrer la matière et ne savons que l'effleurer : la nature au contraire sait la brasser et la remuer à fond; elle produit ses formes par des actes presque instantanés; elle les développe en les étendant à la fois dans les trois dimensions; en même temps que son mouvement atteint à la surface, les forces pénétrantes dont elle est animée opèrent à l'intérieur; chaque moléeule est pénétrée; le plus petit atome, dès (qu'elle veut l'enployer, est forcé d'obéir : elle agit done en tout sens, elle travaille en avant, en arrière, en bas, en haut, à droite, à gauche, de tous côtés à la fois, et par conséquent elle embrasse nonseulement la surface, mais le volume, Ja masse et le solide entier dans toutes ses parties. Aussi quelle différence dans le produit ! quelle comparaison de la statue au corps organisé! mais aussi quelle inégalité dans la puissance! quelle disproportion dans les instruments! L'homme ne peut employer que la foree qu'il a; borné à une petite quantitéde mouvements qu'il ne peut communiquer que par la voie de l'impulsion, il ne peut agir que sur les surfaces, puisqu'en général la force d'impulsion ne setransmet que par le contact des superficies : il ne voit, il ne touche done que la surface des corps; et lorsque, pour tîcher de les mieux connaître, il les ouvre, les divise et les sépare, il ne voit et ne touche eneore que des surfaces: pour pénétrerl'intérieur, il lui faudrait une partie de eette force qui agit sur la masse, qui fait la pesanteur et qui est le principal instrument de la nature. Si l'homme pouvait disposer de cette force pénétrante, comme il dispose de celle d'impulsion, si seulement il avait un sens qui y füt relatif, il verrait le fond de la matière; il pourrait l'arranger en petit, comme la nature la travaille en grand. C'est done faute d'instruments que l'art de l'homme ne peut approcher de celui de la nature; ses figures, sesreliefs, ses tableaux, ses dessins ne sont que des surfaces ou des imitations de surfaces, pareeque les images qu'il reeoit par ses sens sont toutes superficielles . et qu'il n'a nul moyen de leur domer du corps.

Ce cqui est vrai pour les arts l'est aussi pour les sciences; sculement clles sont moins bornées, paree que l'espric est leur seuJ instrument ; parce que dans les arts il est subordonné aux sens, et que daus les seienees il leur commande, d'autant qu'il s'agit de eonnaitre et non pas d'opérer, de comparer et non pas d'imiter. Or l'esprit, quoique resserré par les sens, quoique souvent abusé par leurs faux rapports, n'en est ni moins pur ni moins aetif : l'homme qul a voulu savoir, a commeneé par les reetifier, par démontrer leurs erreurs; il les a traités comme des organes méeaniques, des instruments qu'il faut mettre en expérience pour les vérifier et juger de leurs effets. Marchant ensuite la balance à la main et le compas de l'autre, il a mesuré et le temps et l'espace; il a reconnu tous les dehors de la nature, et, ne pouvant en pénétrer l'intérieur par les sens, il l'a deriné par comparaison et jugé par analogie : il a trouvé qu'il existait dans la matière une force générale, différente de celle d'impulsion, une force qui ne tombe point sous nos sens, et dont par conséquent nous ne pouvons disposer, mais que la nature emploie comme son agent miversel; il a démontréque cette force appartenait ì toute matière également, e'est-à-dire proportionnellement à sa masse ou quantité réelle; que cette force ou plutôt son action s'étendalt à des distances immenses, en décroissant comme les espaces angmentent. Ensuite tournant ses vues sur les êtres vivants, il a vu que la chaleur était une autre force nécessaire à leur production; que la lumière était une matière vire, donće d'unc élasticité et d'une activité sans bornes; que la formation et le développement des ètres organisés se font par le concours de toutes ces forees réunies; que l'extension, l'aceroissement des corps vivants on végétants suit exaetement les lois de la foree attractive, et s'opère en effet en augmentant à la fois dans les trois dimensions; qu'un moule une fois formé doit, par ces mémes lois d'affinité, en produire d'autres tout semblables et ceux-ci d'autres encore saus aucune altération de la forme primitive. Combinant ensuite ces caractères communs, ces attributs égaux de la nature vivante et végétante, il a recomn qu'il existait, et dans l'une et dans l'autre, un fonds inépuisable et toujour's leversible de substance organique et vivante; substance aussi réelle, aussi durable que ia maticre brute; sulsstance permanente à jamais diuns son état de vie, comme l'autre dans son ćtat de mort; substance universellement répas- 
due, qui, passant des végétaux aux animaux par la voie de la nutrition, retournant des anjmaux aux végétaux par celle de la putréfaction, circule ineessamment pour animer les êtres. Il à vu que ees molécules organirgues tivantes existaient dians tous les corps organisés, qu'elles y étaient combinces en plus ou moins grande quantité avec la matiere morte, plus abondantes dans les animaux où tout est plein de vie, plus rares dans les véngétanx ou le mort domine et le vivant parait éteint, où l'or'ganique, surehargé par le brut, u’a plus ni mouvement progeressif, ni sentiment, ni chaleur, ni vie, et ne se manifeste que par le déve'oppe'ment et la reproduction; et réfléchissant sur la maniere dont l'un et l'autre s'opèrent, il a recomu que chatue être vivant est un moule anquel s'assimilent les substances dont il se nourrit; que e'est par cette assimilation que se firit l'acr'oissement du corps; que sou développement n'est pas une simple augmentation de volume, mais une extension dans toutes les dimensions, une péuétration de matière nouvelle dans tontes les parties de la masse; que ees parties augmentant proportionnellement aut tout, et le tout proportionnellement aux parties, la forme se conserve et demeure toujour's la mème juseju'it son développement entier'; qu'enfin le corps avant aecquis toute son étendue, la màme maticre jusqu'alors employée à son aceroissement est dès lors renvovée, eomme superflue, de toutes les parties auxqquelles elle s'était assimilée, et qu'en se réunissant dans un point commun, elle y forme un nouvel ctre semblable au premier, qui n'en diffère que du petit au grand, et qui n'a besoin, pour le représenter, que d'atteindre aux mémes dimensions en se développant it son tour par la meme voie de la nutrition. II a reconnu que l'homme, le quadrupède, le cétacé, l'oiseau, le reptile, l'insecte, l'arbre, la plante, l'herbe, se nourrissent, se déreloppent et se reproduisent par eette mime loi ; et que si la manicre dont s'exécutent leur nutrition et leur génération parait si différente, c'est que, quoique dépendante d'une eause générale et commune, clle ne peut s'exereer en particulier que d'une facon relative a la forme de ehacue espèce d'ítres; et chemin faisant (car il a fallu des sièces a l'esprit humain pour' arriver il ce's grandes vérités, desquelles tontes les autres dependent), il n’a cessé de comparer lés ètres ; il leur a domé des noms partieuliers pour les distinguer les uns des autres, et des noms généraux pour les réunir sous un mème point de vue: prenant son corps pour le modèle physique de tous les êtres vivants, et les ayant mesurés, sondés, comparés dans toutes leurs parties, il a vu que la forme de tout ce qui respire est à peu pres la mème; qu'en disséquant le singe, on pourait donner l'anatomie de l'homme; qui (1) prenant un autre animal, on trouvait toujours le mème fond d'organisation, les mèmes sens, les memes visceres, les mèmes os, la mème chair, le méme mourement dans les fluides, le mème jeu, la même action dans les solides; il a trouvédans tous un cœur, des veines et desartires; daus tous les mèmes organes de circulation, de respiration, de dirgestion, de mutrition, d'excrétion; dans tous une charpente solide, composúe des mèmes pièces à peu près asscmblées de la mime maniere; et ce plan toujours le meme, toujours suivi de l'homme au singe, du singe aux quadrupedes, des quadrum pédes aux eétacés, aux oiseanx, aux poissons, aux reptiles; ce plan, dis-je, bien saisi par l'esprit humain, est un exemplaire fidèle de la nature vivante, et la vie la plus simple et la plus générale sous laruelle on puisse la considérer : et lorsqu'on veut l'étendre et passer de eequi vit à ce qui végete, on voit ce plan, qui d'abord n alvait varié que par nuances, se déformer par degrés, des reptiles aux insectes, des insectes aux vers, des ver's aux zoophytes, des zoophytes aux plantes, et quoique altéré dans toutes ses parties extérieures, conserver néanmoins le mème fond, le mème caractere dont les traits prineipaux sont la mutrition, le développement et la reproduction; trats généraux et communs a toute substance organisée, traits éternels et divins que le temps, Inin d'eflacel' ou de détruire, ne fait que renonveler et rendre plus évidents.

Si de ec grand tableau des ressemblances dans lequel l'univer's vivant se présente comme ne faisant qu'une méme fimille, nous passons à ce lui des dincérence's, où chaque espece réelame une place isolée et doit avoir son portrait a part, on reconnaitra qu'at l'exeeption de quelgues es. pèces majeures, telles que l'dephant, le rlinocéros, l'hippopotame, le tigre, le lion, qui doivent aroir leur cadre, tous les autres semblent se reunir avee leurs voisins, et former des groupes de similitude's dégradees, de's genres que uos nomenclateurs ont présentés par un laeis de figures dont les unes se tienneut par les 
pieds, les autres parles dents, par les cornes, par le poil et par d'autres rapports encore plus petits. Et ceux mémes dont la forme nous paraît la plus parfaite, e'est-à-dire la plus approchante de la nôtre, les singes se présentent enscmble et demandent déja des yeux attentifs pour être distingués les uns des autres, parceque e'est moins à la forme qu'à la grandeur qu'est attaché le privilége de l'espèce isolée, et que l'homme luimême, quoique d'espèce unique, infiniment différente de toutes celles des animaux, n'étant que d'unc grandeur médiocre, est moins isolé et a plus de voisins que les grands animaux. On verra dans l'histoire de l'orang-outang, que si l'on ne faisait attention cu'à la figure, on pourrait également regarder cet anmal comme le premier des singes ou le dernier des hommes, parce cqu'à l'exception de l'âme, il ne lui manque rien de tout ce que nous a vons, et parce qu'il diffêre moins de l'homme pour le corps, qüil ne diffère des autres animaux auxyuels on a donné le mème nom de singe.

L’âme, la pensée, la parole ne dépendent done pas de la forme ou de l'organisation du corps; rien ne prouve mieux que e'est un don particulier et lait à l'homme seul, puisque l'orang-outang, qui ne parle ni ne pense, a néanmoins le corps, les membres, les sens, le cerveau et la langue entièrement semblables à l'homme, puisqu'i] peut faire ou contrefaire tous les mouvements, toutes les actions humaines, et que cependant il ne fait aucun acte de l'homme. C'est peut-être faute d'éducation? c'est encore faute d'équité dans votre jugement. Vous comparez, dira-t-on, fort injustement le singe des bois avec l'hommedes villes ; e'est à côté del'hommo sauvage, de l'homme aucuel l'éducation n'a rien transmis, qu'il faut le placer pour les juger l'un et l'autle. Et a-t-on une idée juste de l'homme dans l'état de pure nature? la tête couverte de cheveux hérissés, ou d'une laine crépne; la face voilée par une longue barbe, surmontée de deux croissants de poils encore plus grossiers, qui, par leur largeur et leur saillic, raceourcissent le front, et lui font perdre son caractère auguste, et non-seulement mettent les yeux dans l'ombre, mais les enfoncent et les arrondissent comme ceux des animaux; les lève'es épaisses et avancées; le nez aplati; le regard stupide et farouche; les oreilles, lecorps et les menbres velus; la peau dure comme un enir noir ou tanné; les ongles longs, épais et crochus; une semelle cal- leuse en forme de corne sous la plante des pieds: et pour attributs du sexe, des mamclles lon. gues et molles, la peau du ventre pendante jusque sur les genoux; les enfants se vautrant dans l'ordure et se traînant à quatre; le père et la mère assis sur leurs talons, tout hideux, tout couverts d'une crasse empestée. Et eette esquisse, tirée d’après le sauvage Hottentot, est encore un portrait flatté; car il y a plus loin de l'homme dans l'état cle pure nature à l'Hottentot, que de l'Hottentot à nous : chargez donc encore le tableau si vous voulezcomparer le singeàl'homme; ajoutez-y les rapports d'organisation, les convenances de tempérament, l'appétit réhément des singes mâles pour les fernmes, la mèmeconformation dans les parties génitales des deux sexes, l'écoulement périodique dans les femelles, et les mélanges forcés ou volontail'es des négresses aux singes, dont le produit estrentré dans l'une ou l'autre espèce; ct royez, supposé qu'elles ne soient pas la même, combien lintervalle qui les sépare est difficile à saisir.

Je l'avore, si l'on ne devait juger que par la forme, l'espèce du singe pourrait être prise pour une varićté dlans l'espèce humaine : le créateur' n'a pas voulu faire pour le corps de l'homme un modèle alssolument différent de celui de l'animal; il a compris sa forme, comme celle de tous les animaux, dans un plan général : mais en méme temps çu'il lui a départi cette forme matérielle semblable à celle du singe, il a pénétré ce corps animal de son souffle divin. S'il eût fait la mème faveur, je ne dis pas au singe, mais à l'espèce la plus vile, à l'animal qui nous parait le plus mal organisé, cette espèce serait bientót devenuc la rivale de l'homme; vivifiéc par l'esprit, elle eût primé sur les autres; elle eùt pensé, elle eût parlé. Quelque ressemblance (jüil y ait done entre l'Hottentot et le singe, l'intervalle qui les sépare est immense, piris qu’à l’intérieuril est rempli par la pensée, et au dehors par la parole.

Qui pourra jamais dire en (fщoi l'organisation d'un imbécile diffère decelle d'un autre homme? le défaut est certainement dans les organes matéricls, puisque l'imbécile a son âme comme un autre : or', puisque d'homme à homme, où tout est entierenent conforme et parfaitement semblable, une différence si petite, qu'on ne peut la saisir, suffit pour détruirc la pensée ou l'empècher de naitre, doit-on s'étonner qu'elle ne soit jamais née dans le singe, qui n'en a pas le principe? 
L'âme en général a son action propre et indépendante de la matière: mais comme il a plu a son divin auteur de l'unir avec le corps, l'exercice de ses actes particuliers dépend de la constitution des organes matériels ; et eette dépendance est non-seulement prouvée par l'exemple de l'imbécile, mais même démontrée par ceux du malade en délire, de l'homme cu santé qui dort, de l'enfant nouveau-né qui ne pense pas cneore, et du vieillard déerépit qui ne pense plus : il semble mème que l'effet principal de l'édueation soit moins d instruire l'ame ou de perfectionner ses opérations spirituelles, que de modifier les organes matériels, et de leur procurer l'état le plus favorable à l'exereice du principe pensant. Or, il y a deux éducations qui me paraissent devoir ètre soigneusement distinguées, paree que leurs produits sont fort différents : l'éducation de l'individı, qui est commune à l'homme et aux animaux, et l'éducationdel'espèce, qui n'appartientc|u'à l'homme. Un jeune aninal, tant par l'ineitition que par l'exemple, apprend, en quelques sernaines d'ige, à faire tout ce que ses père et mere font : il faut des anncées à l'enfant, parce qu'en naissant il est, sans comparaison, beaucoup moins avancé, moins fort et moins formé que ne le sont les petits animaux; il l'est même si peu, que dans ce premier temps il est mul pour l'esprit relativement à ce qu’il doit être un jour. L'enfunt ('st donc heatueoup plus lent que l'animal it recevoir l'édueation individuelle: mais par cetic raison mème il devient susceptible de celle de l'espèce; les secours multipliés, les soins eontinuels qu'exige pendant longtemps son état de faiblesse, entretiennent, augmententl'attachement des père et mère, et en soignant le corps ils cultivent l'esprit; le temps qu'il faut au premicr pour se fortifier, tourne au profit du second. Le commun des animaux est plus avancé pour les facultés du corps à deux mois, que l'enfunt ne peut l'etre a deux ans : il y a done douze fois plus de temps employé à sa première éducation, sans compter les fruits de celle qui suit, sans considérer que les animaux se détachent de leur's petits dès qu'ils les voient en état de se pourvoil' d'eux-mèmes; que dès lors ils se séparent, et bientòt ne se comnaissent plus; $\mathrm{en}$ sorte que tout attachement, toute ćlucilion cessent de très-bonme heure, ct des le moment où les secours ne sont plus nécessaires: or, ce temps d'éducaticn étant si court, le prroduit ne peut en être que très-petit, et il cor méme étonnant que les animaux aequierent en deux mois tout ce qui leur est nécessaire pour l'usage du reste de la vie; et si nous supposions quiun enfant, dans ce mème petit temps, devint assez formé, assez fort de eorps, pour quitter ses parents et s'en séparer sans besoin, sans retour, y aurait-il une difiérence apparente ct sensible entre cet enfant et fanimal ? quelque spirituels que fussent les parents, auraient-ils pu dans ce court espace de temps préparrer, modifier ses organcs, et établir la moindre communication de peusée entre leur áme et la sienne? pourraientils érciller sa mémoire, ni la toucher par des actes assez souvent réitérés pour y faire impression? pourrajent-ils mème exercer ou dégourdir l'organe de la parole? Il faut, a vant que l'enfunt proncnce un seul mot, que son oreille soit mille et mille fois frappée du même son; et a vant qu'il ne puisse l'appliquer et le prononeer a propos, il faut encore mille et mille fois lui présenter la mème combinaison du mot et de l'objet auquel il a rapport: l'éducation, qui seule peut développer son âme, veut done être suivie longtemps et toujours soutenue; si clle cessait, je ne dis pas à deux mois comme celle des animaux, mais mème à un an d'âge, l'âme de l'enfant qui n'aurait rien reçu serait sans exereice, et, faute de mouvement communiqué, demeurerait inactive comme celle de l'imbécile, à laquelle le défaut des organes empèehe que rien ne soit transmis; et it plus forte raison, si l'enfant était né dans l'état de pure nature, sæi: n'avait pour instituteur que sa mère hottentote, et qu'à deux mois d'ìge il füt assez formé de corps pour' se passer' de ses soins et s'en séparer pour toujours, eet enfint ne serait-il pas audessous de l'imbécile, et quant à l'extérieur tout à fait de pair avee les animaux? Mais dans ee meme état de nature, la première édueation, l'éducation de nécessité exige autant de temp\& que dans l'état eivil; paree que, dans tous deux, l'enfant est éralement fitible, égal'ment lent à croitre; que par conséquent il a besoin de secours pendant un temps égal; qu'enfin il périrait s'il était abandonné avant l’àge de trois ans. Or, cette habitude nécessaire, continuelle, et commune entre la mère et l'enfint pendant un si long temps, suffit pour qu'clle lui communique tout ee qu'elle possède; ct quand on voudrait supposer futussement que cette mère dans l'état de nature ne possede rien, pas meme la parole, 
cette longue habitude arec son enfant ne suffirait-elle pas pour faire naitre une langue? Ainsi cet état de pure nature, où l'on suppose l'àme sans pensée, sans parole, est un état idćal, imaginaire qui n’a jamais existé ; la néeessité de la longue habitude des parents à l'enfant produit la société au milieu du désert; la famille s'entend et par signes et par sons, et ce premier rayon d'intelligence, entretenu, cultivé, communiqué, a fait eusuite éclore tous les germes de la pensée: comme l'habitude n'a pu s'exercer, se soutenir si longtemps sans produire des signes mutuels etdes sons réciproques, ees sigues ou ces sons, toujours répétés et grravés peu à peu dans Ia mémoire de l'enfant, deviennent des expressions constantes; quelque courte qu'en soit la liste, e'cst une langue qui deviendra bientòt plus étendue si la famille augmente, et qui toujours suivra dans sa marche tous les progrès de la société. Dèsqu'elle commence à se former, l'éducation de l'enfant n'est plus une éducation purement individuelle, puisque ses parents lui communiquent non-seulement ce quijls tiennent de la nature, mais encore ce qu'ils ont reçu de leurs aieux et de la société dont ils font partie : ce n'est plus une communication faite par des individus isolés, qui, comme dans les animaux, se borneraient à transmettre leurs simples fucultés; c'est ume institution à laquelle lespèce entière a part, et dont le produit fait Ia base et le lien de la société.

Parmi les animaux même, quoique tous dépourvus du principe pensant, ceux dont l'éducation est la plus longue sont aussi ceux qui paraissent avoir le plus d'intelligence : l'éléphant, qui de tous est le plus lougtemps à croìtre, et qui a besoin des secours de sa mere pendant toute la première année, est aussi le plus intelligent de tous : le cochon d'Inde, auquel jl ne faut que trois semaines d'âge pour prendre tout son accroissement et se trourer en état d'ellgendrer, est peut-être par cette seule rajson l'un des plus stupides; et à l'égard du singe, dont il s'agit ici de déeider la nature, quelquc ressemblant qu'il soit à l'homme, il a néammoins nne si forteteinture d'animalité qu'elle se reconnait dès le moment de la naissance; car il est à proportion plus fort et plus formé que l'enfant, il croit beaucoup plus vite, les secours de la mere ne lui sont nécessaires que pendant les premiers mois, il ne reçoit qu'une éducation purement individuelle, et par couséquent aussi stérile que celle des autres animaux. Il est donc animal, et malgré sa resscmblance à l'homme, bien loin d'être le second dans notre espèce, il n'est pas le premier dans l'ordre des animaux, puisqu'il ri est pas le plus intelligent : c'est uniquement sur ce rapport de ressemblance corporclle qu'est appuyé le préjugé de la graude opinion qu'on s'est formée des facultésdu singe: il nous ressemble, a-t-on dit, tant à l'extéricur qu'à l'intérieur ; il doit done nonseulement nous imiter, mais faire encore de luimème tout ce que nous faisons. On vient de voir que toutes les actions qu'on doit appeler humainessont r'clatives à la société; qu'elles dépendent d'abord de l'âme et ensuite de l'éducation dont le principe physique est la nécessité de la longue habitude des parents à l'enfant; que dans le singe cette habitude est fort courte; qu'il ne reçoit, comme les autıes animaux, qu'une éducation purement individuelle, et qu'il n'est pas mème susceptible de celle de l'espèce ; par conséquent il ne peut rien faire de tout ce que l'homme fait, puisque aucune de ses actions n'a le même principe ni la même fin. Et à l'égard de I'imitation qui parait êtr'e le caractère le plus marqué, l'attribut le plus frappant de l'espèce du singe, et que le vulgaire lui accorde comme un talent unique, il faut, avant de décider, examiner si cette imitation est libre ou forcée. Le singe nous imite-t-il parce qu'il le veut, ou bien parce que sans le rouloir il le peut? J'en appelle sur cela volontiers à tous ceux qui ont observé cet animal sans prévention, et je suis convaincu qu'ils diront avee moi qu'il n'y a rien de libre, rien de volontajre dans cette imitation; le singe ayant des bras et des mains s'en sert comme nous, mais sans songer à nous : Ia similitude des membres et des organes produit nécessairement des mouvements, et quelquefois mème des suites de mourements qui lessemblent aux notres : étant conformé comme l'homme, le singe ne peut que se mouvoil comme lui; mais se mouroir de même n'est pas agir pour imiter. Qu'on donne à deux corps bruts la même impulsion; qu'on constrưise deux pendules, deux machines pareilles, elles se mouvront de mème, et l'on aurait tort de dire que ces corps bruts ou ces machines ne se meurent ainsi que pour s`imiter. II en est de même du siugerelativement au corps de l'homme; ce sent deux machines construites, organisécs de uème, trui par nécessité de nature se meurent à très- 



$$
\sqrt{9}
$$


peu près de la méme façon: néanmoins paritó n'est pas imitation; l'une git dans la maticre et l'autre n'existe (yuc par l'esprrit : I'imitation suppose le dessein d'imiter; le singe est incapable de former ce dessein, qui demande une suite de pensées; et par cette raison l'homme peut, s'il lo reut, imiter le singe, et le singe ne peut pas même vouloir imiter l'homme.

Et cette parité, qui n’est que le physique de l'imitation, n'est pas aussi complete ici que la similitude, dont cependant elle émane comme effet immédiat. Le singe resseml) le plus à l'homme par le corps et les membres que par l'usage qu'il en fait : en l'observant avec quelque attention on s'apercevara aisément que tous ses mourements sont brusques, intermittents, précipités; et qque pour les comparer à ceux de l'homme il faudrait leur supposer une autre ichllle ou plutòt un module différent. 'T'outes les actions du singe tiemnent de son éducation, qui est purement animale; elles nous paraissent ridicules, inconsepuentes, exlravagrantes, paree que nous nous trompons d'échelle en les rapportant à nous, et que J'unité qui doil leur servir' de mesure est très-différente de la nòtre. Comme sa nature est vive, son tempérament chaud, son naturel pétulant, qu'aucune de' ses affections lli éte mitigée par l'éducation, toutes ses habitudes sont exeessives el ressemblentheaturoup plus aux mouvements d'um maniayue yu'aux actions d'un homme ou même d'un muimal tranquille. C'est par la même raison que nous le trouvons indocile, et qu'il receoit difficilement les habitudes fu'on roudrait lui transmettre: il est insensible aux caresses et u'oúbit qu'au chàtiment; on peut le tenir en eaptirité, mais non pas en domesticité; toujours triste et reveche, toujours répugnant, grimacant, on le dompte plutòt yu'on ne le prive: aussi l'espèce n'il jitmais étó domestique nulle part; et par ee rapport, il est encore plus éloigné de l'homme que lat plupart des animaux ; car la dociliti suppose quelque analogie entre eelui qui donne et celui qui recoit : e'est une equalité relative qui ne peut etre exrerce que lorspu'il se trouve des deux parts un certian nombere fe ficultés communes, qui ne diflèrent entre elles que paree quadelles sont aclives dans le maltre et passires dans le sujet. () le passif du singe a moins de rapport nrec l'actif del'homme, guele passilduchienou de l'eléphant qu'il suflit de bien traiter pour leure communlyuer les sentimeuts doux et mène delieats de f'altil- chement fidele, de l'obéissance volontuire, du survice gratuit et du dérouement sans réserve.

Le singe est done plus loin de l'homme que la plupartdes autres animaux, par les qualités relatives: il en differe aussiberaucoup par le tempérament. L'homme peut habiter tous les elimats; il vit, il multiplie dans ceux du Nord et dans ceux du Midi : Ie singe a de la peine à vivredans les contrées tempérées et ne peut multiplier que dans les pays les plus chauds. Cette différence daus le tempérament en suppose d'autres dans l'organisation, qui, quoique cachees, n'en sont pas moins recelles; elle doit aussi influer beaucoup sur le naturel : l'excis de chalcur qui est nécessaire a la pleine vie de cet animal rend encessives toutes ses affections, toutes ses qualités; et il ne faut pas ehereher une autre cause a sa petulance, à sa lubricité, ct a ses atutres passions, qui toutes nous paraissent aussi violentes que désordonnées

Aussi cesinge, que le's philosophes, avec le vulgaire, ont regardé consune un cltre difficile í définir, dont la nature était aumoins équivoque et moyenne entre ecelle de l'homme et celledes animaux, n'est dans la vérité qu'un pur auimal, portant à l'extérieur un masque de ligure humaine, mais dénué à l'interveur de la pensée et de tout ce qui fail l'honme, un animil au-dessous de plusicurs autres par les foculfés relatives, et encore essentichement différent de J'homme par le natures, par le tempérament, et aussi prar la mesure du temps neecessaire a l'éducntion, à la gestation, à laceroissement du corps, à lit duree de la vie, c'est-di-dire frar toutes les habitudes ridles qui eonstiturent eo: qu'on appelle nalure dans un etre particulies.

\section{ILS ORANGS-OUINTGS.}

(u)

\section{LE POYGO ET LE JOCKO'}

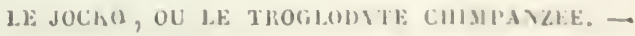

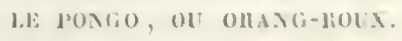

Ordre dis (qualrumanes, famille des simges proprement dits, ou de lancien rumment, loibu ites orangs. (cis)ier.)

Nous préscutons coss deux muimaus ensemble, paree yu’il se perut yunils ne libsent tous

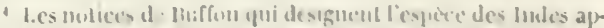

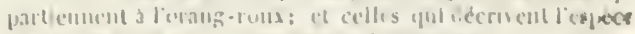
dafripul, ont (rint an trogleslyle chimpanze. 
deux (qu'une seule et même espèce. Ce sont de tous les singes ceux qui ressemblent le plus à l'lomme, ceux qui par conséquent sont les plus dignes d'etre observés. Nous avons vu le petit orang-outang ou le jocko vivant, et nous en avons conservé les dépouilles; mais nous ne pourons parler du pongo ou grand orang-outang gue d'après les relations des voyageurs. Si clles étaient fidèles, si souvent elles n'étaient pas obscures, fautives, exagérces, nous ne douterions pas qu'il ne füt d'une autre espèce que lc jocko, d'une espèce plus parfaite et plus vojsine encore de l'espèce de l'homme. Bontius qui ćtait médecin en chef à Batavia, et qui nous a laissé de bonnes observations sur l'histoire naturelle de cette partie des Indes, dit expressément qu'il a vu avec admiration quelques individus de cette espèce marchant debout sur leurs pieds, et entre autres une femelle (dont il donne la figure) qui semblait avoir de la pudeur, qui se couvrait de sa main al l'aspect des hommes qu'elle ne connaissait pas, qui pleurait, gémissait ef faisait lesautres actions humaines, de manière qu'il semblait que rien ne lui manquât que la parole. Mr. Linnæus dit, d'après lijoep et quelques autres voyageurs, que cette faculté même ne manque pas à l'orang-outang; qu'il pense, qu'il parle et s'exprime eri sifflant: il l'appelle homme nocturne, et en donne en même temps une description, par laquelle il ne scrait guère possible de cléeider si e'est un animal ou un homme. Seulement on doit remarquer que cet être, guel qu'il soit, n'a selon lui que la moitić de la hauteur de l'homme; et comme Bontius ne fait nulle mention de la grandeur de son orang-outang, on pourrait penser arce 11. Linnæus que e'est le mème : mais alor's cet orang-outang de Linnæus et de Bontius ne serait pas le véritable, qui est de la taille des plus grands lommes. Ce ne serait pas non plus eclui que nous appelons jocko et que jai vu virant : car quoiqu'il soit de la taille que II. l.innæus doune au sien, il en diflëre néanmoins par tous les autres earacteres. Je puis assurer, l'ayant vu plusicurs fois, que non-seulement il ne parle ni ne siffle pour' s'exprimer, mais mème qu'il ne fait rien qu'un chien bien instruit ne pùt faire : et d'ailleurs il diffère presque en tunt de la description que M. Linnæus donne de l'orang-outang, et se rapporte beaucoup mieux ¿ celle du salyrus du même autcur. Je doute done bea'xcoup de la vérité de la deseription de cet homme noclurne; je doute meme de son existence, et c'est probablement un négre blanc, un ehacrelas que les voyageurs, eités par M. Linnæus, auront mal vu et mal décrit. Car ces chacrelas ont en effet, comme l'homme nocturne de cet auteur, les chereux blanes, laineux et frisés, les yeux rouges, la vue faible, etc. Mais ce sont des hommes, et ces hommes ne sifflent pas et ne sont pas des pygmées de trente pouces de hauteur; ils pensent, parlent et agissent comme les autres hommes, et sont aussi de la même grandeur.

En écurtant done cet être mal décrit, en supposant aussi un peu d'exagération dans le récit de Bontius, un peu de préjugé dans ce qu'il raconte de la pudeur de sa femelle orang-outang, il ne nous restera qu'un animal, un singe, dont nous trourons ailleurs des indications plus précises. Edward Tison, célèbre anatomiste anglais, qui a fait une très-bonme deseription tant des parties extérieures qu intérieures de l'orangoutang, dit quili y en a de deux espèces, et que celui qu'il décrit n'est pas si grand que l'autre appelé barris ou baris par les vorageur's, et vulgairenent drill par les Anglais. Ce barr is ou drill est eri efict le grand orang-outang des Indes orientales ou le pongo de Guincé, et le pygmée décrit par Tysỏn est le jocko que nous avous vu vivant. Le philosople Gassendi ayant avancé, sur le rapport d'un voyageur nommè Saint-Amand, qu'il y avait daus l'ile de Java une espèce de créature qui faisait la nuance entre l'homme et le singe, on n'hésita pis ì nier le fait : pour le prouver, Peirese produisit une lettre d'un M. Noël (Nalulis) médecin, qui demeurait en Afrique, par laquelle il assure qu'on troure en Guinée de très-grands singes appelés barris, qui marehent sur deux pieds, qui ont plus de gravité et beaucoup plus d'intelligence que tous les autres singes ', et qui sont tres-ardents pour les femmes. Darcos, et cnsuite Nieremberg et Dapper disent à peu prèsles mèmes choses du barris. Battel l'appelle pongo, et assure "qu'il est dans toutes se's proportions sem"blable à l'homme; seulement qu'il est plus " grand; grand, dit-il, comme un géant; qu’ila "la face comme l'homme, les yeux enfoncés, " de longs cheveux aux côtés de la tète, le ri" sage nu et sans poils, aussi bien que les oreilles " et les mains; le corps légèremeut velu, et qu’il

- I.es délails ultéricurs sur les singes d $A$ frique se rappor. tent au Troglodite CHIMANZE. 
" ne differe de l'homme à l'extérieur quepar les a jambes, parce qu'il n'a que peu ou point de " mollets, que ecpendant il marche toujours " debout; qu'il dort sur les aubres et se con"struit une hutte, un abri contre le soleil et la " pluie; qu"il vit de fruits, et ne mange point de " chair; qu'il ne peut parler, quoi(qu'il ait plus "d'entendement que les autres animanx; que " quand les nègres font du feu dans les bois; " ees pongos viennent s'asseojr autour et se " chaulfer; mais qu'ils n'ont pas asse\% d'esprit " pour entretenir le feu en y mettant du bois, - cu'ils vont de compagnie, et tuent anelque" fois des nègres dans des lieux écartés; qu'ils " adtaquent même l'éléphant, qu'ils le frappent " à coups de bâton et le chassent de leurs bois; " qu'on ne peut prendre ees pongos vivants, "parce qu'ils sont si furts, (que dix hommes ne " suffiraient pas pour en dompter mu seul; qu'on " ne peut done attraper" que les petits tout jen" nes; que la mereles porte marehant debout, " et qu'ils se tiement attachés à son corps avec "les mains et les genoux; qu'il y a deux espè" ecs de ces singes très-ressemblauts à l'homme, " le pongo, qui est aussi grand et plus gros «qu'un homme, et l'enjocko qui est beaucoup " plus petit, ete. " C'est de ce passagre très-préeis que j'ai tiré les noms de pongo et de jocko. battel dit encore que lorsqu'un de ces animaux meurt, les autres couvrent son corps d'un amas de branches et de feuillages. Purchass ajoute, cll forme de note, que dans les conversations quil arait eues avee Battel il avait appris de lui qu'un Pongo lui enleva un petit nègre qui passal un an entier dans la société de ces animaux; qu'à son retour, ce petit nègre raconta qu'ils ne lui avaieut fait aucun mal; (que conmunément ils étaient de la hauteur de l'homme, mais qu'ils sont plus gros, et qu'ils ont à peu près le double du volume d'un homme ordinaire. Jobson assure avoir vu daus les endroits fiéquentés par ees animaux une.sorte d'habitation composée de branches entrelacées, qui pouvait servir du moins à les garantir de l'ardeur du soleil. " Jes singes de Guince (dit Bosman), " que l'on appelle smilten en flamand, sont de a couleur fauve, et deviennent extrimement - grands : j'en ai vu, ajoute-t-il, un de mes - propres yeux, qui avait einf pieds de haut... - Ces singes ont une assez vilaine figure, aussi " bien que ceux d'une seconde espèce qui leur " ressemblent en tout, si ce n'est que quatre de
" ceux-ci seraient à peine aussí gros qu'un de - la première espèce... On peut leur appiendre "presque tout ce yuel'on veut "Gauthier Schout ten dit "que le's singes appelés par les Indiens "orangs-outangs sont presque de la même î" gure et de la mème grandeur que les hommes; " mais qu'ils ont le dos et les reins tout courerts " de poil, sans en avoir néanmoins au-devant " du corps; que les femelles ont deux grosses " manelles; que tous ont le visage rude, le nez "plat, méme enfoncé, les oreilles comme les "hommes; qu'ils sunt robustes, agiles, hardis; " qu'ils se mettent en defense contre les loon" mes armés; qu'ils sont parsionnés pour les " femmes; qu’il n'y a point de surreté pour elles "a passer daus les bois, ou elles se trouvent " tout d'un coup attaquées ct violies par ces sin" ges. ") 1)ampier, Froger el d'autres vorageurs assurent quils enlevent de petites filles de huit ou dix ans, qu'ils les emportent au-dessus c'es arbres et qua on a mille peines à les leur óter. Nous pourons ajouter it tous ces témoinnages celui de M. de la Brusse, qui a écrit son voyage a la cưté d'Augole en 1738 , et dont on nous a communiqué l'extrait. Ce voyageur assure que les orings-outangs, qu'il appelle quimpezés, tàclient de surprendre des négresses; "quils les "gardent avec cux pour en jouir: qu'ils les " nourrisscnt trés-bien. J'ai connu, dit-il, a "Lowango une négresse qui etait restée trois "ans aree ces animaux. lls croissent de six á "scpt pieds de haut: ils sont d'une force sans "Egale; ils eabanent, et se servent de hitons " pour se défendre: ils ont la face plate, le nez " eamus et épaté, les oreilles plates sans hourre"let, la peau un peu plus claire que celle d'un " mulâtre, un poil long et chair semé daus plua sieurs parties du corps, le ventre extrème"ment tendı, les talons plats et élerés d'un "demi-pouce environ par derrière; ils mar. " ehent sur leurs deux pieds, et sur les quatre " quand ils en ont la fintaisie. Nous en achetá" mes deux jeunes, un mảle qui avait quatorze "lunes, et une femelle qui n'avait que douze lu" nes d'âge, ete."

Voila ce que nous avons trousé de plus précis et de plus certain au sujet du grand orangoutang ou pongo : et comme la grandeur est le seul caractere bien marqué par lequel il differe du jocko, je persiste à eroire qu'ils sont de la meme e'spece; car il y a ici deua chesespossi. bles : la première, que le jocko soit ute variét 
constante, c'est-à-dirc une race beaucoup plus petite que celle du pongo. A la vérité ils sont tous deux du mème elimat; ils virent de la méme façou, et devraient par consćquent se ressembler en tout puisqu'ils subissent ct reçoivent également les mêmes altérations, les mêmes influences de la terre et du ciel. Mais n'arons-nous pas dans l'espèce humaine un exemple de variété semblable? Le Lapon et le Finlandais, sous le même climat, different entre c!nx presque autant par la taille et beaucoup plus pour les autres attributs, que le jockio ou petit orang-uutang ne diffère du grand. La seconde chose possible, c'est que le jocko ou petil orang-outang que nous avons vu rivant, celui de Tulpius, celui de Tyson et les autres qu'on a transportés en Europe, n'étaient peutêtre tous que de jeunes animaux qui n'a vaient encor'e pris qu'une partie de leur aceroissement. Celui que j’ai vu avait près de deux pieds et demi de hauteur. Le sieur Nonfoux, auquel il uppartenait, m'assura qu'il n'avait que deux ans : il aurait done pu parvenir is plus de einq pieds de hauteur s'il ent vécu, en supposant son aceroissement proportionnel à celui de l'homme. L'orang-outang de Tyson était encore plus jeune, car il n'avait qu'environ deux pieds de hauteur, et ses dents n'étaient pas entièrement formées. Celui de Tulpius était à peu près de la grandeur de celui que j'ai vu; il cn est de mẻme de celui qui est gravé dans les Glanures de II. Edwards. Il est donc très-probable que ces jeunes animaux auraient pris a vec l'àge un aceroissement considérable, et que s'ils eussent été en liberté dans leur climat, ils auraient acquis la même hauteur, les mêmes dimensions que tes voyageurs domnent à leur grand orangoutang. Ainsi nous ne cousidérerons plus ces deux animaux comme différents entre eux, mais comme ne faisant qu'une scule et même espèce, en attendant que des commaissances plus précises détruisent ou confirment cette opinion qui nous parait fondée.

L'orang-outang que j'ai vu marchait toujour's debout sur' ses deux pieds, mème en portaut des choses lourdes; son air était assez triste, sa démarche grave, ses mouvements mesurés, son naturel doux et très-lifférent de celui des autres singes; il n'avait ni l'impatience du magot, ni la néchanecté du babouin, ni l"extravagance des guenons. Il avait été, dira-t-on, instruit et bien appris; mais les autres que je viens de citer, et que jelui compare, a vaient en de même leur éducation. Le signe et la parole suffisaient pour faire agir notre orang-outang; il fallait le batton pour le babouin, et le fouet pour tous les autres, qui n'obéissent guère qu’à la force des coups. J'ai vu cet animal présenter sa main pour reconduire les gens qui venaient le visiter, se promener gravement avec eux ct comme de compagnie; je l'ai vu s'asscoir a table, déployer sa serviette, s'en essuyer les lèvres, se servir de la cuiller et de la fourchette pour porter à sa bouche, verser lui-mème sa boisson dans un verre, le choquer lor'syu'il y était invité, aller prendre une tasse ct une soucoupe, l'apporter sur la table, y mettre du sucre, y versel du thé, le laisser refroidir pour le boire, ct tout cela sins autre instigation que les signes ou lit parole de son maitre, et sonrent de lui-mence. Il ne faisait du mal à prersonne, s'approchait mème avec eirconspection, et se présentait comme pour demander des eatresses. 11 aimait prodigieusement les bonbons, tout le monde lui en donnait; et comme il avait une toux fréquente et la poitrine attaquée, cette grande quantité de choses sucrées contribua sans doute à abréger sa vie. Il ne véeut à $\mathrm{Pa}$ ris qu'un été, et mourut l'hiver suivant à Londres. 11 mangeait presque de tont; seulement il préférait les fruits mûrs et sees à tous les autres aliments, 11 buvait du vin, mais en petite quantité, et le laissant volontiers pour du lait, du thé ou d'autres liqueursdouces. Tulpius, qui a donné une bomne description avee la figure d'un de ces animaux qu'on avait présenté vivant à Frédéric-Henri, prince d'Orange, en raconte les mêmes choses à peu près que celles que nous avons vues nous-mêmes, et que nous venons de rapporter. Mais si I'on veut reconnaitre ce qui appartient en propre à cet animal, et le distinguer de ce qu'il avait reçu de son maitre; si l'on veut séparer sa nature de son éducation, qui en effet lui était étrangère, puisqu'au lieu de la tenir de ses père et mère, il l'avait reçue des hommes, il faut comparer ces faits, dont nous avons été témoins, avec ceux que nous ont domués les voyageurs qui ont vu ces animaux dans leur état de nature, en liberté et en captivité. M. de la Brosse, qui a vait acheté l'un nègre deux petits orangs-outangs qui n'avaicnt qu'un an d'îge, ne dit pas si le nègre les avait éduqués; il parait assurer au contraire que c'était d'eux-mêmes quu'ils faisaient une 
grande partie des choses que nous avons rapportées ci-dessus. "Ces animaux, dit-il, ont * l'instinct de s'asseoir à table comme les liom" mes; ils mangent de tout sans distinction; is " se servent du couteau, de la cuiller et de lis " fourchette pour couper et prendre ee qu'on " leur sert su" l'assiette; ils boivent du vin et " d'autres liqueurs. Nous les portâmes à bord; " quand ils étaient à table, ils se faisaient cn* tendre des mousses lorsqu'ils avaient besoin " de quelque chose; et quelquefois, quand ees - enfants refusaient de leur donner ce quïls de" mandaient, ils se mettaient en colère, leur" " saisissaient les bras, les mordaient et les abat" taient sous eux... Le mâle fut malade en " racle: il se faisait soigner comme une per" sonne; il fut mème saigné deux fois au bras "droit : toutes les fois qu'il se trouva depuis "incommodé, il montrait son lras pour qu'on " le saigrnát, eomme s'il cût su que ecla lui " avait fait du bien."

Menri Grosse dit "qu'il se trouve de ces ani" maux vers le nord de Coromandel, dans les "forèts du domaine du raïa de Carnate; qu'on " c'l fit présent de deux, l'un mâle, l'autre fe"melle, a M. Horne, gouverneur de lombay; " qu'ils avaient à peine deux pieds de haut, " mais la forme entièrement humaine; qu'ils " marchaient sur leurs deux pieds, et qu'ils " étaicnt d'un blane pâle, sans atutres cheveux " ni poil qu'aux endroits où nous en avons " communément; que leurs actions étaient très" semblables pour la plupart aux actions bu* maines, et que leur mélaneolie faisait voir " qu'ils sentaient fort bien leur captivité; qu'ils "faisaient leur lit avec soin dans la eage dans " laquelle on les a vait emoyés sur le vaisseau; * que quand on les regardait, ils eachaient aree " Jeurs mains les parties que la modestie em" pêche de montrer. La l'imelle, ajoute-t-il, - mourut de maladie sur le vaisseau, et le mấle, " domnant toutes sortes de signes de doulem, " prit tellement à cœur la mort de sa compagne, " qu'il refusa de manger et ne lui surrécut pas " plus de deux jours.

Franeois Pyrard rapporte " quiil se trouve " daus la province de Sierra-Leona une espèce " d'animaux, appelée baris, qui sont gros et " membrus, lesquels ont une telle industrie, "que si on les nourrit et instruit de jeunesse, " ils servent comme une personne; qu'ils mar" chent d'ordiuaire sur les deux pattes ele del- "rière seulement; qu'ils pilent ce qu'on leur " donne à piler dans des mortiers; qu'ils vont "quérir de l'eau à la rivière dans de petites " cruches qu'ils portent toutes pleines sur leur " tête, mais qu'arrivant bientôt à la porte de la " maison, si on ne leur prend bientot leurs " cruches, ils les laissent tomber, et voyant la " eruche versée ct rompue, ils se mettent à " erier et à pleurer., "Le père du Jarric, cité par Nieremberg, dit la mème chose et presque dans les mèmes termes. Le témoignatge de Schoutten s'aceorde arec celui de Pyrard au sujet de l'éducation de ces animaux : "On en " prend, dit-il, avee des laes; on les apprivoise, " on leur apprend à marcher sur les pieds de "derrière, et à se servir des pieds de devant, "qui sont à peu pres comme des mains, pour "faire certains ourrages, et même ceux du " ménage, comme rincer des verres, donner à "boire, tourner la broche, ete. "J'ai vu il Jara " (dit le Guat) un singe fort extraordinaire; " e'était une fenrelle. Eille était de grande taille ( et marchait somvent fort droit sur les pieds " de derriere; alors elle cachait d'une de ses " mains l'endroit de son corps qui distinguait " son sexe; elle avait le visage sans antre poil " que celui des somreils, et elle ressemblait as" sez en général à ees faèes grotesques des fem"mes hottentotes yue jai vues au Cap; elle "faisait tous les jours proprement son lit, s"y " couchait la tète sur um oreiller et se courrait " d'une couverture. Quand elle avait mal à la " tète, elle se serrait d'un mouchoir, ete'était un - plaisir dle la voir ainsi eoiffée dans son lit. Je " pourrais en raconter diverses autres petites " elıoses qui paraissent extremenent singulic"res; mais j'avoue que je ne pouvais pas ad" mirer cela autant que le faisait la multitude, " paree que n'ignorant pas le desseiu qu'on avait "de porter cet animal en Europe pour le faire "voir, j'a vais beaucoup de penchant à supposel "qu'on l'avait dressé à la plupart des singeries " que le peuple regardait comme lui étant na. " turelles à la rérité e’ćtait une supposition. "Il mourut à la hauteur du eap de Bonne-Es" pérance, dans un vaisseau sur lequel j'étitis. "Il est certain que la figure de ce singe lessem" blait beaucoup à celle de l'homme, etc." Gemelli-Carreri dit en asoir $\$ un unui se plaignait comme un enliunt, qui marelıait sur les deus pieds de derriere, en portant sa natte sous son bras pour seconcher et dormil. Ces singes 
ajoute-t-il, paraissent a roir plus d'esprit que les hommes a certains égards : car, quand ils ne trouvent plus de fiuits sur Ies montagnes, ils ront au bord de la mer oủ ils attrapent des crabes, des huittres et autres choses semblables. Il y a une espèee d'huitres qu'on appelle taclaro, qui pèsent plusieurs lives, et qui sont sourent ouvertes sur le rivage: or, le singe craignant que quand il reut les manger, elles ne lui attrapent la patte en se refermant, il jette une pierre daus la coquille qui l'empèche de se fermer, et eusuite il mange l'huitre sans crainte.

"Sur les côtes de la rivière de Gambje, dit "Froger, les singes y sont plus gros et plus "méchants qu'en aucun endroit de l'Afrique; " les nègres les craignent, et ils ne peurent al"ler seuls dans la campagne sans courir risque "d'ètre attaqués par ees animaux qui leur pré" sentent un bâton et les obligent à se battre... "Souvent on les a vus porter sur les arbres * des enfants de sept à huit ans qu'on avait " une peine ineroyable à leur ôter. La plupart " des nègres* croient (que c'est une nation étran" gère qui est venue s'établir dans leur pays, " et que s'ils ne parlent pas, c'est qu'ils erai" gnent qu'on ne les oblige à travailler."

"On se passerait bien, dit un autre voya" geur, de voir a Macaçar un aussi grand nom" bre de singes, ear leur rencontre est souvent " funeste; il fant toujours ître bien armé pour " s'en défendre... Ils n'ont point de queue; ils " se tiemment toujour's droits comme des hom( mes, et he vont jamais que sur les deux pieds " de derrière."

Voilà du moins, à très-peu près, tout ce que les royageurs les moins crédules et les plus véridicues nous disent de cet animal ; j'ai cru devoir rapporter leurs passages en enticr, paree que tout peut paraitre important dans l'histoire d'une bête si ressemblante à l'homme : et pour (fu'on puisse prononcer avec encore plus de connaissance sur sa nature, nous allons exposer aussi toutes les différences qui éloignnent cette espèce de l'espéce humaine, et toutes les conformités qui l'en approchent. Il diffère de l'homme à l'extérieur par le nez, qui n'est pas proéminent, par le front, qui est trop court, par le menton, qui n'est pas relevé à la base, il a les oreilles proportionnellement trop grandes, les yeux trop roisius l'un de lautre, l'intervalle entre le nez et la bouche est aussi trop étendu : ce sont lia les seules diffúrenes de la face de lorang-outang avec le visage de l'homme. Le corps et les membres different en ce que les cuisses sont relativement trop courtes, les bras trop longs, les pouces trop petits, la paume des mains trop longue et trop serrée, les pieds plutòt faits comme des mains que commedes pieds humains: les parties de la grénération dı mảle ne sont différente's de celles de l'homme qu'en ce qu'il n'y a point de frein au prépuce; les parties de la femelle sont à l'extérieur fort semblables a celles de la femme.

A l'intérieur, cette espèce diffère de l'espèce liumaine par le nombre des còtes ; l'homme nen a que douze, l'orang-outang en a treize. il a aussi les vertèbres du cou plus courtes, les os du bassin plus serrés, les hanches plus plates, les orbites des yeux plus enfoncées; il u'y a point d'apophyse épincuse à la première vertèbre du cou ; les reins sont plus ronds que ceux de l'homme, ct les ureteres ont une forme différente, aussi bien (jue la vessie et la vésicule du fiel, qui sont plus étroites et plus longuesque dans l'homme; toutes lesautres parties du corps, de la tète et des membres, tant extérieures qu'intérieures, sont si parfaitement semblables à celles de l'homme, qu'on ne peut les comparer' sans admiration et sans ètre étonné que d'une conformation si pareille et d'une orgauisation qui est absolument la même, il n'en résulte pas les memes effets. Par exemple, la langue et tous les olganes de la voix sont les mèmes que dans l'homme, et cependant l'orang-outang ne parle pas; le cerveau est absolument de la mème forme et de la mème proportion, et il ne pense pas : y a-t-il une preuve plus évidente que la matière seule, quoique parfaitement organisée, ne peut produire ni la pensée ni la parole qui en est le signe, à moins qu'elle ne soit animée par un principe supérieur? L'homme et l'orang-outang sont les seuls qui aient des fesses et des mollets, et qui par conséquent soient faits pour marcher debout; les seuls qui aient la poitrine large, les épaules aplaties et les rertibles conformées l'un comme l'autre; les seuls dont Je cerveau, le cœur, les pounıons, le foie, la rate, le pancréas, l'estomac, les bovaux soient absolument parcils; les seuls qui aient l'appendice vermiculaire an cœcum. Eufu l'orang-outang ressemble plus à l'homme qüà aucun des animaux, plus mèms qu'aux babouins et aux guenons, non-seulement par toutes Jes partics que je vieus d'indiquer, mais 
encore par la largeur du visage, la forme du aràne, des mâchoires, des denis, des autres os de ra tête ct de la face, par la grosseur des doigts et du pouce, par la figure des ongles, par le nombre des vertèbres lombaires et sacrées, par celui des os du coceyx, et enfin par la conformité dans les articulations, dans la grandeur et la figure de la rotule, dans celle du stemum, cte.; en sorte qu'en cornparant cet animal avec eeux qui lui ressemblent le plus, comme avee le magot. le babouin ou la guenon, il se troure encore avoir plus de conformité avec l'homme qu'avee ces animaux, dout les especes ecpendant paraissent être si roisines de la sienne, qu'on les a toutes désignées par le même nom de singes: ainsi les Indiens sont excusables de l'avoir associé à l'espèce humaine par le $110 \mathrm{~m}$ d'orang-outang, homme siun ige, puisefu'il ressemble à l'homme par le eorps plus qu'il ne ressemble aux antres singes on at aueun autre animal. Comme equelques-uns des filits que nous venons d'exposey pourraicnt paraitre suspeets it ceux qui n'auraient pas vu cet animal, nous avons cru devoir les appuyer de l'autorité de deux célèbres anatomistes, Tyson ' ct Cowper,

'Lorang-outang ressemlle plus a l'homme qu' aux siuges ou aux gupnons; $1^{\circ}$ en ce yull a les poils des funules dirigés en

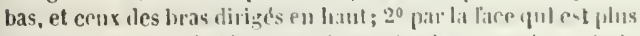
semblable a celle de lhomme, daut phis l.usge ot plus aplitic

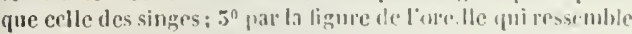

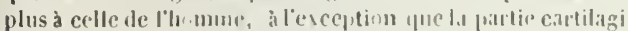
neuse est mince eomme daus lins singes: $8^{0}$ flat les loigls in

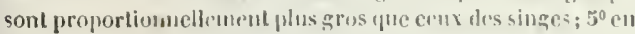
se qu'il est à tous égarls fait pour mardele delenul, an lim que les singes rt les guenems ne sont pas cunfurme's a colle lin;

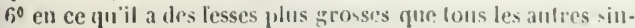
ges; $7^{\circ} \mathrm{en}$ ce rüil a des mullets anx jambes; $8^{\circ} \mathrm{cm}$ cr ynesa poitrine et ses épaules sont plus larges que celles des singes: $9^{0}$ son talon plus long; $10^{\circ} \mathrm{en}$ co yu il a lit membrane iulipeuce

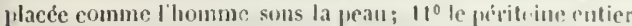
el non peré ou allongé, comuc il l'cest lausless suges; 120 les intestius fulı lougs que daus les singes; $15^{\circ}$ le tanal des inteslins de di férent diamètre. comme daus 1 homme. 1 non pas egal on à peu près igal, comme il l'ent d.us les singes; $14^{\circ} \mathrm{en}$ ce que le errem a l'appemlice vermiculate comme dans lhomme, tandis (pue cel appendice vermiculate man fue dans tous les autres sing's, el aussi en ce yue le cumnencemenl du colon n'eat pas si prolonge qu'il l'est dans les singes; $15^{\circ} \mathrm{en}$ ce qur les inser lions du conduil biliare et du comduit pancriati(pue u'ont quin seul orifice commun daus / houme et l'orang-outang. au lieu ynue ces incertions sout à deux punces tle distauce dans les gucuons ; $16^{\circ}$ en ce aue le calum eat plus long

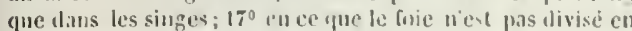
lubes cumme daus les siuges. m.is entier of d'une senle piece comme daus lihomme; $18^{\circ}$ en ce yuc les visiscanx biliares sont les mémes (fue daus l'homune; $19^{0}$ la rile la mèue: $20^{\circ}$ le

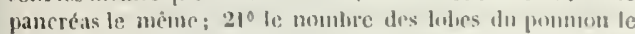

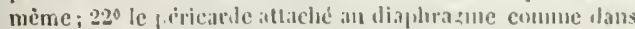
l'homme, el non pas comme il l'est dans les singes ou gue-

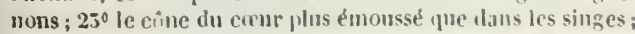
$21^{\circ}$ en ce quil n'a point d'abajoues ou poches an bas des joues qui l'ont cnsemble disséqué avec unc exactitude scrupuleuse, et qui nous ont donné les résultats des comparaisons qu'ils ont faites de tontes les partics de son corps aree celui de l'hom-

coume les autres singes el guenous; $25^{n}$ en ce qu'il a le cer. vean brauconp plis grand que ne l'unt les singes, $\in$ l lians lonlus ses parties exucloment conformé comme le cerveau de

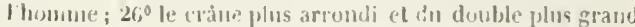
que dans les gnenrom; ; $27^{\circ}$ inutes les -ulures du cräne sembla-

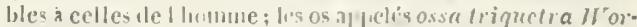

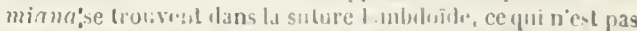

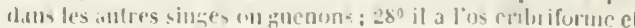

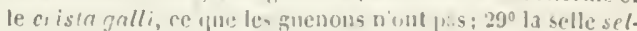

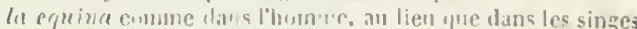

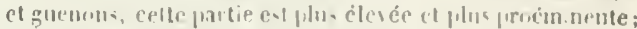

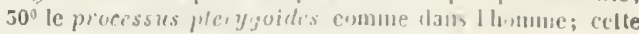
partic man.

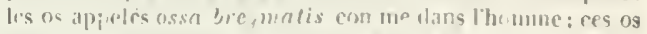

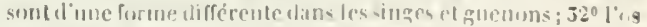
zy

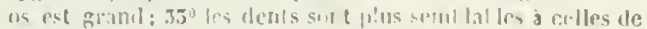

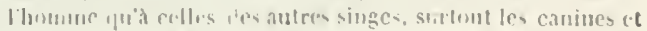

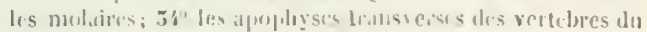
cun, 1 los sixisme et sputieme vertebres re-selublent plus à celles de l'humuc qu'd relles des singes t Ires gurbions;

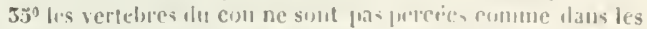

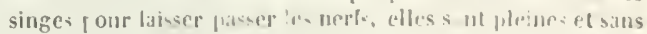

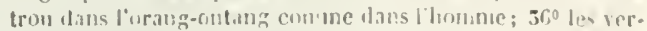

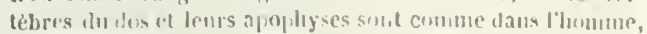

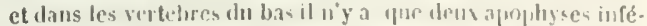

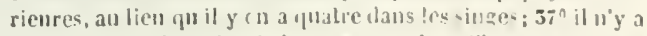
que cint verlelurs lombares comme ditus l'humme, au licu que daus los guenous il y ('u a six ou sept; $58^{\circ}$ les a pupluyses éfincuses des verlebues lombaires sout droitos comme dans

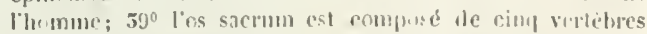

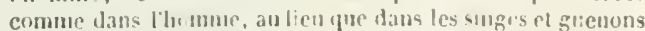

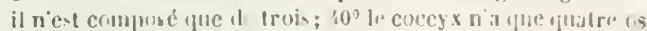
commir dans l'loumm, el ces us ne sont pas troutes, au lion pue dans les singes ol gurnums le corcyx est emmposi d'un pulus

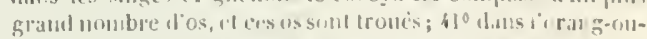

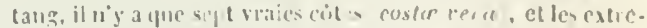
unilésules fausses ciles nother sont eat lagineuses. et les cüles

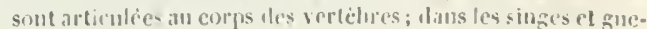

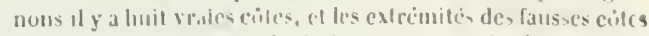

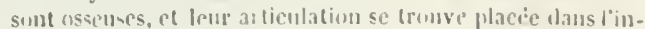

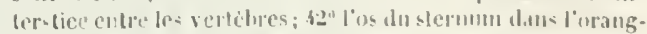
outang est large comme ditus l'lumune, el non pas droit comme dans los gurmons; $45^{\prime \prime}$ lis os des yuatre duigts sont plus gros qu'ils no le sont daus les singes: $16^{\circ} l^{\circ}$ os de lie cuisse, snit dans son articulaliun, soit a tonis anters égards, est sem-

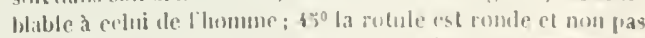

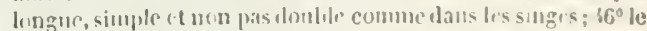
talon, le tarse ot le métatas se de louang-outang sont comme

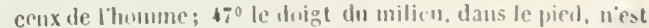

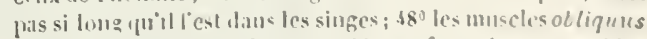
inferior cap,tis, my iformis al lireps fomoris snut somblables dans l orang-outang el daus l'homme, tantig yuils son différeuts daus les singes et guenous, et:

liorang-onlang diffire de l'iromune pulus yue des singes ou gucunns, $l^{j}$ cn ec une le funce est plus petit à proportion que celui de l'hummm, yuni fue crpemdant il soit pulus gros ifue celui des autres singes: $2^{\circ}$ eu ce yue la paune de l. u unim est plus lumanc el filus etroite que: lans l'houme: $3^{\circ}$ il dilfere de 1 lomme et approchm ales singes par la longurur des duggts de probs ; il differe de l'homme en ce quil a le gros daigh des

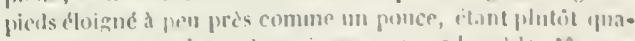

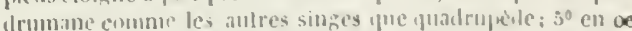

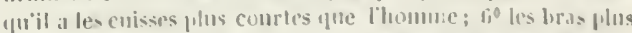
longs: $7^{\circ}$ cu ce qu il n'a pas les bonrses pendantes; 80 l'épifloon plus anple que dans thomme, $9^{\circ}$ la resicule du fiel 
me. J'ai eru devoir traduire de l'anglais, et présenter ici cet article de leurs ourrages, afin que tout le monde puisse mieux juger de la ressemblance presque entière de cet animal avec I'homme. J'olsserverai seulement, pour une plus grande intelligence de cette note, que les Anglais ne sont pas réduits comme nous à un seul llom pour désigner les singes; ils ont, comme les Grees, deux noms différents, l'un pour les singes sans queue, qu'ils appellent ape, et l'autre pour les singes à quene qu'ils appellent monkey. J'ai toujours traduit le mot monkey par celui de guenon, et le mot ape par celui de singe; et ces singes que Tyson désigne par le mot ape ne peuvent être que cerix que nous avons appelés le pithèque et le magot; et il y a même toute apparence que c'est au magot seul qu'on doit rapporter Ie nom ape ou singe de la comparaison de Tyson. Je dois observer aussi que cet anteur dome quelques caractères de ressemblance et de différence qui ne sout pas assez fondés : j’ai cru devoir faire sur cela cpuelques remarques. On trouvera pent-être que ce détail est long; mais il me semble cu'on ne peut pas

plus longue el [lus élroile; $10^{\circ}$ les reins plus ronds que dans I'homme, $\mathrm{t}$ les uretères différenls; $11^{0}$ la vessic plus longue; $12^{\circ} \mathrm{eu}$ ce y $7^{\circ} \mathrm{il}$ n’a point de frein au prépuce; $13^{\circ}$ les os de l'orkite rle l'u il trup enfoncés; $14^{\circ} \mathrm{en}$ ce qu'il n'a pas les denx cavilés au-dessons de la selle du turc (sella turcica) comme dins l'lomme; $15^{0}$ en ee gue les proressus mastoides et styluides som ti is-pelils et presiue nuls; $16^{\circ}$ en ce qu'il a les os dı uez plats; $17^{\circ}$ il diffère de l'homme en ce que les vertèbres din con sont conrles comme dans les singes, plates devaul et non pas rondes, et que lcurs apoplugses épincuses ne soril pas fourelmes comme dans l'homme; i $8^{\circ}$ en ce tun il n y a point d'apouhyse ép neuse dans la première vertìre du cou; $19^{\circ}$ il vilière de l'homme en ce qu'il a treize côtes de chajue coté, et une l"homme n'en a que florze: $20^{\circ}$ en ce que les us des iles sont parfaitement semblables à ceux des singes, rlant plus lougs, plus tilruits el moins concaves yue dans l'bonme; $21^{0}$ il differe de $1^{\prime h o m m e ~ e n ~ c e ~ q u e ~ l e s ~ m u s c l e s ~ s u i v a n t s ~: e ~}$ trouvent dans le corps humain et manquent daris celui de l'orang-ontang; savoir, occipital's, fronlales, tilatatores alarum nasi seu elevalores labii superioris, interspinales colli, glutai minimi, exlensor digitorum pedis bieris et transversulis pedis; $22^{\circ}$ les muscles qui ne traraisseul pas se trouver daus lorang-outang, et qui se Irouvenl quelyue fois dans l'homme, sont cenx (jion ajuelle pyramidales, caro musculosa quadiata; le long temlon et le corps charnu du muscle patmaire; les mnseles uttollens pl retraheus auriculum; $25^{\circ}$ les muscles élévateurs des clavicules sout dans l'orang-ontang comme dans les singes, et mon pas comme dans l'houme; $2 q^{0}$ les muscles pur lesquels l'orang-0ulang ressem. ble aux singes el differe de lhomme sont les suivants : longus culli pectoralis, latissimus dorsi, glutaus maximus et medius, psoas magnus ot jarrus, iliacus intermus et gasteronamius internus; $2 ; 0$ il dillere cucore de l'homme par la forme des unscles deltoides, pronator radii teres et ertensor pollicis brevis. Anatumie de l'orang-outang, par Tyson. Londres, 1699, in-10*

Celte deseription est celle d'un troglod yte chimpanze. Desm. 1829 examiner de trop près un être qui, sous la forme de l'homme, n'est cependant qu'un animal.

$1^{0}$ Týson donne comme un caractère particulier à l'homme et à l'orang-outang d'aroir le poil des épaules dirigé en bas, et celui des bras dirigé en haut. Il est vrai que la plupart des quadrupides ont le poil de toutes les parties du corps dirigé en bas ou en arrière, mais cela n'est pas sans exception. Le paresseux et le fourmilier ont le poil des parties antérieures du corps dirigé en arrière, et celui de la eroupe et des reins dirigé en avant : ainsi ce caractère n'est pas d'un grand poids dans la comparaison de cet animal à l'homme.

$2^{0}$ J'ai aussi retranché dans ma traduction les quatre premieres différences, qui, comme celles-ci, sont trop légères ou mal fondées. La première, c'est la différence de la taille; ce caractère est très-incertain et tout-à-fait gratuit puisque l'auteur dit Iui-même que son animal était fort jeune ; Ies seconde, troisième et quatrieme ne roulent que sur la forme du nez, la quantité du poil, et sur d'autres rapports aussi petits. Il en est de même de plusieurs autres que j’ai retranchées, par exemple, du vingtunic̀me caractère tiré du nombre des dents : il est certain que cet animal et l'homme ont le même nombre de dents, et que s'il n'en a vait que vingt-huit, comme le dit l'auteur', c'est qu'il était fort jeune, et l'on sait que I'homme dans sa jeunesse n'en a pas davantage.

$3^{0}$ Le onzième caractère des différences de l'auteur est aussi très-équivoque : les enfants ont les bourses fort relevées : cet animal étant fort jeune ne devait pas les a voir pendantes.

$4^{0}$ Le quarante-luuitième caractère des ressemblauces, et les trente, trente-unième, trentedeuxième, trente-troisième et trente-quatrième caractères des différences ne désignant que la présence ou la figure de certains muscles qui, dans l'espèce humaine, varient pour la plupart d'um indiridu à l'autre, ne doi vent pas être considérés comme des caractères essentiels.

$5^{n}$ Toutes les ressemblances et differences ti rées de parties trop petites, telles que les apophyses des vertebres, ou prises de la position de certaines parties, de leur grandeur, de leur grosseur, ne doivent aussi être considérées que comme des caractères accessoires, en sorte que tout le détail de cette table de Tyson peut se réduire aux différences et aux ressemblances cssentielles que nous avons indiquées. 
$6^{\circ}$ Je crois devoir insister sur quelques caraetères plus généraux, dont les uns ont été omis par Tyson, et les autres mal indiqués : $1^{\circ}$ l'o- $^{\prime}$ rang-outang est le seul de tous les singes qui n'ait point d'abajoucs, c'est-à-dire de poches au bas des joues; toutes les guenons, tous les babouins, et même le magot et le gibbon ont ces poches, où ils peuvent garder leurs aliments avant de les avaler : l'orang-outang seul a cette partie du dedans de la bouche faite comme l'homme; $2^{0}$ le gibhon, le magot, tous les babouins et toutes les guenons, à l'exception du doue, ont les fesses plates et des callosités sur ees parties : l'orang-outang est encore le seul qui ait les fesses renflées et sans callosités. Le doue les a aussi sans eallosités, mais elles sont plates et velues; en sorte qu'à eet égancl le doue fait la nuance entre l'orang-outang et les guenons, comme le gibbon et le magot font cette même nuance à l'égard des àbajoues, et le magot seul à l'égard des dents canines et de l'allongement du museau; $3^{\circ}$ l'orang-outang est le seul qui ait des mollets ou gras-de-jambes et des fesses charnues : ce caractère indique qu'il est de tous le mieux conformé pour mareher debout; seulement eomme les doigts de ses pieds sont fort longs, et que son talon pose plus diffieilement il terre que celui de l'homme, il court plus facilernent qu'il ne marehe, et il aurait besoin de talons artificiels plus élerés que ceux de nos souliers, si l'on voulait le faire marcher aisément et longtemps; $4^{0}$ quoique l'orang-outang ait treize eôtes, et que l'homme n'en ait que clouze, cette différence ne l'approche pas plus des babouins ou des guenons qu'elle l'éloigne de I'homme, paree que le nombre des eótes varie dans la plupart de ces espèecs, et que les uns de ces animaux en ont douze, d'autres onze et d'autres dix, ete.; en sorte que les seules différenees essentielles entre le corjus de cet animal et celui de l'homme, se réduisent à deux, savoir, la conformation des os du bassin et la conformation des pieds : ce sont là les seules parties considérables par lesquelles l'oranģ-outang ressemble plus aux autres singes quil ne ressemble à l'homme.

D'après eet exposé que j'ai fait avee toute l'exactitude dont je suis capable, on voit ce que l'on doit penser de eet animal. S'il y avait un degré par Ierjuel on puit descendre de la nature humaine à celle des animaux, si l'essenee de cette nisure consistait en cutier dans la forme du corps et dépendait de son organisation, ce singe se trouverait plus près de l'homme que d'aueun animal : assis au second rang des êtres, s'il ne pouvait commander en premier, il ferait au moins sentir aux autres sa supériorité, et s'efforeerait de ne pas obćir. Si l'imitation qui semble eopier de si près la pensée en était le vrai signe, ou l'un des résultats, ee singe sc trouverait eneore à une plus grande distance des animaux, et plus voisin de l'homme; mais, comme nous l'avons dit, l'intervalle qui l'en sćpare réellement n'en est pas moins immense; et la ressemblance de la forme, la eonformité de l'organisation, les mouvements d'imitation qui paraissent résulter de ees similitudes, ni ne le rapprochent de la nature de l'homme, ni même ne l'élèvent au-dessus de celle des animaux.

\section{Caractères distinctifs de celle cspèce.}

L'orang-outang u'a point d'abajoues, e'està-dire point de poches au-dedans des joues, point de queue, point de eallosités sur les fesses; il les a renflées et charnues : il a toutes les dents et même les eanines semblables à eelles de l'homme: il a la face plate, nue et basance, les orcilles, les mains, les pieds, la poitrine, le ventre aussi nus : il a des poils sur la tète qui desecndent en forme de chereux des deux ('òtés des tempes, du poil sur le dos et sur les lombes, mais en petite quantité ; il a cincy ou six pieds de hauteur, et marche toujours droit sur ses deux pieds. Nous n'arons pas été à portée de vérifier si les femelles sont sujettes, conme les fummes, à l'écoulement périodigue; mais nous le présumons, et par analogie nous ne pouvons guère en douter.

\section{ADDITION}

\section{A I'ARTICLE DES ORANGS-OUTANGS'.}

Nous avous dit que les orangs-outangs pou vaient former deux espeees. Ce mot indien, rui signifie homme sauvage. est en effet un nom générique; ct nous arous recomnu qu’il eviste réellement ef au moins deux espiecs bien dis-

- Ce supplémeul rouferme prine palement la description de

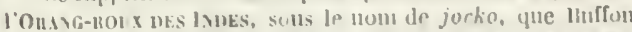

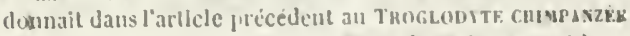
(Note de .M. Desmaresl.) 
tinctes de ces animaux : la première à laquelle, d'apris Battel, nous avons donné le nom de ponyo, et qui est bien plus grande rue la seconde espèce que nous arons nommée jocko, d'après le même voyageur. Comme il y a plus de vingt ans que j'ai éerit l'histoire de ces singes, je n'étais pas aussi bien informé que je le suis aujourd'hui, et jétais alors dans le doute si les deux espèces dont je viens de parler étaient réellement diflérentes l'une de l'autre par des earactères autres que la grandeur. Le singe que j'avais vu vivant, et auquel j'avais cru devoir donner le nom de jocko, parce qu'il n'a vait que deux pieds et demi de hauteur, était un jeune pongo, qui n'avait que deux ans d'àge, et serait parvenu à la hauteur de plus de cinq pieds; et comme ce très-jeune singe présentait tous les caractères attribués par les voyageurs au grand orang-outang ou pongo, j'avais elu pouvoir ne le regarder que comme une varjété; ce qui me faisait eroirequ'il se pouvait qu’il n'y eùt qu'une seule espece d'orang-oulang : mais ayant recu depuis des grandes Indes un orang-outang bien différent du pongo, et auquel nous arons recomnu tous les caractices gue les royageurs alonnent au jocko, nous pouvons assure que ces deux dénominations de pongo et jocko appartiemnent à deux especes léellement différentes, et qui, indépendamment de la grandeur, ont encore des caractères qui les distinguent.

Les principaux caracleres qui distinguent ces deux espèces, sont la graudeur, la diflérence de la couleur et de la quantité du poil, et le défaut d'ongle au gros orteil des pieds ou mains postériemres, qui toujours manque au jocko, et se trouve tonjours dans l'espèce du pongo. Il en est de même de leurs habitudes naturelles : le pongo marehe presque toujour's debout sur ses deux pieds de derriere, au lieu que le joeko ne prend eette attitude (jue rarement, et surtont lorsqu'il veut monter sur les arbres. Ainsi tout ce que j'ai dit le l'olang-ontang yue j’ai । u vivant et que je eroyais clre un jocko, doit au contritire s'attribuer al pongo, et s'accorde en effet avee tout ce que les royageurs les plus réeents ont observé sur les habitudes naturelles de ce grand orang-outang. Je dois mème observer que la figure de ee jeune pongo a été faite d'apres nature riłante, mais que le dessinateur l'a chargée dans quelques parties; et éest probablement cette différence entre celte figgure ct celle qu'a domée Bontius, qui a pu faire penser qu'elles ne représentaient pas le même animal. Cependant il est certain que la figure de Bontius est celle du grand orangoutang ou pongo adulte, et que celle que j’ai donnée représente le même orang-outang ou pongo jeune: d'ailleurs la figure donnée par Bontius est peut-ètre un peu trop lessemblante à l'espèce lıumaine. Tulpius a donné du pongro une figure encore plus imparfaite. C'est crncore ce même animal que Bosman a nommé smilten, que plusicurs voyageurs ont nommé barris, d'autres drill, et quelques autres qmimpezé '; sur quoi cependant nous devons observer que la plupart de ces derniers noms ont été appliqués indiffélemment au grand et au petit orangr-outang. C'est à ce grand orang-outang qu'ou doit rapporter les combats contre les negres, l'enlevement et le viol des négresses, et les autres actes de foree et de violence cités par les voyageurs.

Mais nous devons ajouter ì tout ce que nous en avons dit, les observations des naturalistes et des voyageurs qui ont été publiées, ou qui nous sont parvenues en différents temps, sur ce qui regarde ce pongo ou grand orang-outang. M. le chevaliej d'Obsonville a bieu voulu nous communiquel ce qu'il avait observé sur' eet animal, qu'il a vu et dérrit avee autant de sagacité que d'exactitude. "C'est, dit-il, de l'o" rang-outang qui a cinq pieds cle haut, qu'il est " ici question. Cet animal ne parait maintenant a exister que dans quelques parties de l'Afri" que, et des grandes îles à l'est de l'Inde. D’a" pres diverses informations, je crois pouroir " dire que l'on u'en voit plus dans la presqu'ile " en decà du Gange, et que même il est devenu " très-rare dans les contrées oì il propage ('n" core. Aurait-il été détruit par les bìtes féro. " ces, ou serait-il confoudu avec d'autres?

"Un de ees individus, que j'ai eu oceasion " de voir deux mois après qu'il fut pris, avait " quatre pieds huit ou dix pouces de haut. Une " teinte jaunatre paraissait dominer dans ses " yeux, qui étaient du reste petits et noirs. "Quoique ayant quelque chose de hagard, ils " annoncaient plutòt l'inquiétude, l'embaras " et le chagrin, que la férocité. Sa bouche était " fort grande, les os du nez très-peu proémi"nents, etceux des joues étaient fort saillants... "Son visage avait des rides; le fond le sa ear" nation était d'un blane bis ou basané; sa che-

1 Tous ces noms se rapportent au chimpanzée d'Alrique. 
" velure, longue de ruelques pouces, était " brunátre, ainsi que le poil du reste du corps, "qui était plus épais sur le dos que sur le " ventre: sa barbe était peu fournie, sa poi" trine Jarce, les fesses médiocrement char" nues, les cuisses couvertes, les jambes arquées; "les pouces de ses pieds, quoique un peu moins érartés des autres doigts que ceux des autres * singes, l'étaicnt cependant assez pour devoir - Ini procurer beaucoup de facilité, soit pour " grimper ou saisir...

" Je n'ai vu ce satyre qu'accroupi ou debout; " mais, quoiqque marehant habituellement droit, "il s'aidait, me dit-on, dans l'état de liberté, " des mains ainsi que des pieds, lorsqu'il élait " (question de courir ou de franchir un fossé; " peut-être même est-ce l'exercice de cette fil" culté qui contribue à entretenir dans l'espèce "la longueur un peu excessive des bras, carl'ex" trémité des doigts de ses mains approchait de " ses genoux. Ses parties génitales étaient assez " bien proportionnées; sa verge, en état d'incr" tie, était longue d'environ six pouces, et pa" raissait être celle d'un liomme circoneis.

a Je n'ai point vu de femelles, mais on dit " qu'elles ont les mamelles un peu aplaties.Leurs "parties sexuelles, conformées comme eelles " des femmes, sont aussi sujettes à un flux "menstruel périodique. Le temps de la gresta" tion est présumé être d'environ sept mois... "Elles ue propagent point dans l'état de servi" tude...

"Le mâle, dont je viens de parler, poussait " quelquefois une espèee de soupir élevé et pro"longé, ou bien il faisait entendre un eri sourd; " mais e'était lorsqu'on l'inquićtait on qu'on le " maltraitait : ainsi ces modulations de roix - n'expriment que l'impatience, l'ennui ou la " donlewr.

"Suivant les Judiens, ces animaux errent " dans les bois et sur les montagnes de difficile " aceès, et y virent en petites sociétés.

"Les orangs-outangs sont extremement saua vages; mais il paraît qu'ils sont peu méchants, " et qu'ils parviomnent assez promptement d " entendre ce qu'on leur commande... Leur ca"ratere ne pent se plier a la scrvitude; ils y " conservent toujours un fonds d'ennui et de " mélancolie profonde, qui, dégenérant en une " espèce de consomption ou de marasme, doit a bientòt terminer leurs jours. Les gens du pays - ont fait cette remarque, et elle me fut coufir-

" mée par l'ensemble de ce que je crus entre. " voir dans les regards et le maintien de l'indi" vidu dont il a été question. "

M. le professeur Allamand, dont j'ai eu si souvent oceasion. de faire l'élogre, a ajouté d'excellentes réflexions et de nouveaux faits à ce que j'ai dit des orangs-ou:tangs.

"L’histoire des singes était tres-embrouillée, " dit ee savant et judicieux naturaliste, avant " que M. de Buffon entreprit de l'éclaircir; nous " ne saurions trop admirer l'ordre qu'il y a ap"porté, et la préeision avec laquelle il a déter" miné les differentes especes de ces animaux, " qu'il était impossible de distinguer par les ca" lacteres qu"en avaicnt domnés les nomencla" teurs. Son histoire des orangs-outangs est un " chef-d'œuvre qui ne pouvait sortir que d'une " plume telle que la sienne; mais quoiqu'il y ait " rassemblé tout ce qui a été dit par d'autres " sur ces animaux singulier's, en y ajoutant ses " propres observations qui sont bien plus sủres, a et quoiqu'il y ait décrit un plus grand nom" bre de singes, qu'auem auteur n'en a décrit " jusqu'à présent, il ne faut pas croire eepen- dant qu'il ait épuisé la matière : la race des - singes contient une si grande variété d'es "pèces, qu’il est bien difficile, pour ne pas "dire impossible, de les comnaitre toutes; on en a apporte très-souvent en Hollande plusieurs, " que M. de Buffon, ni aucun naturaliste, n'i ja" mais vus. Un de mes am is, revenud'Amerique, " où il a séjourné pendant quelques ammées, et " qui y a porté les yeux d'un observateur judi" cieux, m'a dit qu'il y avait vu plus de (juatre"vingts espeeces différentes de sapajous et de sá"gonins; 11. de Buffon u'en a déerit que onze. "Il s'écoulera done encore bien du temps al valut "qu'on puisse parrenir a comnatte tous ces " animaux; et mème il est tres-douteux qu'on " en puisse jamais renir à bout, > l'éloigne " ment et la rature des lieux où ils habitent.

"II y a quelques annces qu'on apporta chez. "moi la tite et un pied d'un animal singulier" : " cette tète ressemblait tout it filit it eelle d"un " homme, excepté qu'elle itiit un peu moins " haute; rlle ctait bien garnie de longs che reux " noirs; la falce itait couverte partout de porls " courts; il "y'y avait pas morer de douter que " ee ne fut la tète d'un animal, mais qui, par "cette partic, ne differait presque point de "l'homme, et M. Albinus, ee grand anatomiste, a d̀ qui je la lis roir, fut de mon avis. Si l'on 
" doit juger, par cette tête, de la taille de l'a" nimal auquel elle avait appartenu, il devait " pour le moins avoir égalé celle d'un homme "de cing pieds. I.e pied qu'on montrait avec " cette tête, et (qu'on assurait être du même " animal, était plus long que celui d'un grand " homme.

" M. de Buffon soupconne qu'il y a un peu " d'exagération dans le récit de Bontius, et un * peu de préjugé dans ce qüil raconte des mar" ques d'intelligence et de pudeur de sa femelle * orang-outang : cependant ce qu'il en dit est " confirmé par ceux qui ont vu ces animaux * aux Indes; au moins j'ai entendu la mème " chose de plusieurs personnes qui avaient été a à Batavia, et qui sûrement ignoraient ce qu'en " a écrit Bontius. Pour savoir à quoi n’en tenir " là-dessus, je me suis adressé à M. Relian, " qui demeure dans cette même ville de Bata" via, où il pratique la chirurgie avec beaucoup " de succès : connaissant son goût pour l'his" toire naturelle, et son amitié pour moi, je - Iui avais écrit pour le prier de m'envoyer un " orang-outang, afin d'en orner le cabinet de " curiosités de notre académie; et en mêne " temps je lui arais demandé qu'il me commu* niquàt ses observations sur cet animal, en " cas qu'il l'eût vu. Voici sa réponse qu'on lira " avec plaisir; elle est datée de Batavia, le

" 13 janvier 1770.

" J'ai été extrèmement surpris, écrit M. Re" lian, que l'homme sauvage, qu'on nomme en " malais orang-outany, ne se trouve point dans " votre académie; c'est une pièce qui doit faire " l'ornement de tous les cabinets d'histoire na" turelle. M. Pallavicini, qui a été jei saband. * haar, en a amené deux en vie, míle et fe" melle, lorsqu'il partit pour l'Europe, en 1;59;

" ils étaient de grandeur humajne, et faisaient " précisément tous les mouvenents que font les " hommes, surtout avec leurs mains dont ils se " servaient comme nous. La fenelle avait des a mamelles précisément comme celles d'une n fenme, quoique plus pendantes; la po.trine " et le ventre étaieut sans poils, mais d'une " peau fort dure et ridée. Ils étaient tous les " deux fort honteux quand on les fixait toop; " alor's la femelle se jetait dans les bras du male, " et se cachait le visage dans son sein, ce qui " faisait un speetacle véritablement touchant; " e'est ce que j’ai vu de mes propres yeux. Ils - ne parlent point, mais ils ont un cri sembla.
" ble à celui du singe, a vec lequel ils ont le plus "d'analogie par rapport à la maniere de vivre, " ne mangeant que des firuits, des racines, des "herbages, et habitant sur des arbres dans les " bois les moins fréquentés. Si ces aninaux ne " faisalent pas une race à part qui se perpétue, " on pourlait les nommer des monstres de la a nature humaine. Le nom d'h'mmes surrages " qu'on leur donne leur vient du rapport qu'ils " ont extérieurement aree l'homme, surtout " dans leurs mouvements et dans une facon de " penser, qui leur est surement particulicre, et " qu' on ne remarque point dans les autres ani" maux; cal celle-ci est toute différente de cet " instinet plus ou moins développé qu’on voit " dans les animaux en général. Ce serait uu " spectacle bien curieux si l'on pourait obsel"ver ces hommes sauvages dans les bois, sans " en être apercu, et si l'on était témoin de leur's " occupations domestiques; je dis hommes sau"vayes, pour me conformer à l'usage ; car cette " dénomination n'est point de mon gout, parce " qu'elle présente d'abord une idée analogrue * aux saurages des terres inconnues, auxipuels " ces animaux-ei ne doivent point ètre compa" rés. L'on dit qu'on en trouve daus les mon" tagnes inaccessibles de Java; mais c'est dans " l'ile de Bornéo où il y en a le plus, et d'où " l'on nous envoie la plupart de ceux qu'on roit " ici de temps en temps. "

"Cette lettıe, continue M. Allamand, con" firme pleinement ce qu'a dit Bontius ; clle est " écrite par un témoin oculaire, par un homme " qui est lui-même observateur curicux et at" tentif, ct qui sait que ce qu'il assure avoir vu "a ćté vu aussi par plusicur's personnes, yui " sont actuellement ici, et que je suis à portíe " de consulter tous les jour's, pour m'assurel" " de la vérité de sa relation : ainsi, il n'y a pas " la moindre raison pour douter de la véité " de ce qu’il m'a mandé. Au récit de Bontius, " il ajoute la taille de ces orangs-outangs. Ils " sont de grandeur lıumaine; par conséifuent " ce ne sont pas les hommes nocturnes de l.iu" naxus, qui ne parvienment qu'a la moitié de " cette stature, et qui, suivant cet auteur, ont " l'admirable talent de parler" : il est vai que " c'est en sifllant, ce rui pourrait bien signifie" " qüils parlent comme les autles singes, ainsi a que lolsserve M. Relian. Je ue dirai rien du "degré d'intelligence que leur attribue mon cor" respondant; il „u'y a rien à ajouter aux ré 
a flexions de M. de Buffon sur cet article. Si " ceux que M. Pallavicini a embarqués avec " lui, quand il est venu en Europe, étaient ar" rivés ici en vie, on serait en état d'en rappor" ter plusieurs autres particularités qui seraient " vraisemblablement très-intéressantes : mais "Sans doute ils sont morts sur la route; au " moins est-il certain qu'ils ne sont pas parve" nus en Hollande. "

Nous croyons devoir ajouter ici ec que M. le professeur Allamand rapporte d'un grand singe d'Afrique, qui pourrait bien être une variété dans l'espèce du pongo ou grand orang-outang, par laquelle cette espece se rapprocherait du mandrill.

a Plusieurs personnes m'ont parlé d'un singe " qu'elles a vaient vuà Surinam, où il a vait ćté " apporté des cótes de Guinéc; mais fuisant " peu de fond sur des relations vagues de gens " qui, sans aucune comnaissance de l'bistoire " naturelle, examinent peu attentivement les " objets nouveaux qui se présentent à cux, je " me suis adressé à M. May, eapitaine de haut* bord au service de la province de Hollande. " Je savais qu'il avait été à Surinam pendont "que ect animal y était, et je ne doutais pas " qu'il ne l'y cût vu. Personne ne pouvait m'en "rendie un compte plus exact que lui : il est " aussi distingué par son goût pour toutes sortes "de sciences, que par les connaissances qui * forment un excellentofficier de mer. Voicice "que j'en ai appris :

"Etant avee son vaisseau sur les eôtes de

"Guinée, un de ses matclots y fit l'acequisition " d'un petit singe sáns queue, âgé d'environ " six mois, qui avait été apporté du royaume " de benin. De li ayant fait voile pour se ren"dre à Surinam, il arriva heureusement à P'a " ramaribo, ou il vit ce grand singe dont je " viens de parler. Il fut ćtomée en royant qu'il " était préeisément de liı mème espècé que èelui " qu'il a vait a son bord : il "y'y avait d'autre " différence entre ces animaux que ecelle de la (" taille; mais aussi était-elletrès-considérable, " puisque ce grand sincre arait ring pieds et "demi de hautem, handis yue celui de son ma" telot surpassitit it peine un pied. II n'avait " point de queue; son corps citiit courert d'un "poil brun, mais qui ctait assez peu touffus str "la poitrine pour laisser voir sa peau, yui citait "bleuattre. Il novait point de poil à la face; " son nez ćtait extrẻmoment longr et plat, et
" d'un très-beau bleu : ses joues étaient sillon" nées de rouge sur un fond uoirâtre; ses oreil"les ressemblaient a celles de l'homme; ses " fesses étaient nues et sans callosités. C'était " un måle, et il avait les parties de la géućra" tion d'un rouge éclatant. II marchait égale" ment sur deux pieds ou sur quatre; son at" titude favorite était d'etre assis sur les fesses. "Il était très-fort ; le maitre à qui il apparte" nait était un assez gros homme : M. Nay a " vu ce singe le prendre par le milieu du corps, "l'élever de terre avec facilité, et le jeter à la " distance d'un pas ou deux. On m'a assuré " qu'un jour il se saisit d'un soldat qui passait " tout prés de lui, et qu'il l'aurait emporté au " haut do l'arlore aut pied duyucl il était attaché, " si son maitre ue l'en cùt pas empèché. Il pa" laissait fort ardent pour les femmes. Il ćtait " depuis ume vingtaine d'années à Surinam, et (" il ne semblait pas avoir aecuuis encore son "plein aecroissement. Celui à qui il appartenait " assurait qu’il avait remarqué que sa hauteur " était aug̨mentée eneore cette année mème. "Un capitaine anglais lui en offrit cent gui" nées; il les refusa, et deux jours apres cet " animal mourut.

"En lisant ceci, on se rappellera d'abord le " mandrill, avec lequel ce singe a beaucoup de "rapport, tant pour la figure que pour la grau" deur et la force. Lál scule différence bien mar"quée qu'il y ait entre ces animaux consiste a dims la clueue qui, (puoique fort courte, se "trouve dans le mandrill, mais qui manque " tout à fait à l'autre.

"Voilà done une nouvelle espèce de singe " sans (queuc, hal)itant de l'Afrique, d'une taille " qui égille, si mème clle ne surpasse pas celle "de l'homme, et dont la durée de la vie parait " citre la meme, vu le temps qui lui est néces " saire pour accucíril toute sa grandeur. Co " singe ne pourrait-il pas ètre celui dont par"lent quelques voyigncurs, et dont les relations "ont été applicpuéces à l'orang-outang? A umoins " je serais fort porté ì croire que e'est le smit"len de Bosman, et le quimpezd de M. de la "Brosse : les deseriptions yutils en doment lui "ressemblent alsoce; et eelui dont parle Battel, "qui arait une longue cherelure, a bien l'air " d'etre de la mime esprece que celui dont jai " vu la tete; il ne parait en clifferer qu"en ec " quiil a le visage un "t sans poil."

Aous venons de presenter tous les faits que 45. 
nous avons pu recueillir au sujet du pongo ou grand orang-outang; il nous reste maintenant à parler du jocko ou petit orang-outang. Nous en donnons ici la figure, et nous en avons la dépouille au Cabinet du Roi. C'est d'après cette dépouille que nous nous sommes assurés que les prineipaux caractères par lesquels il diffère du pongo sont le défaut, ou, pour mieux dire, le manque d'ongle au gros orteil des pieds de derrière, la quantité et la couleur roussâtre du poil dont il est revêtu, et la grandeur qui est d'environ moitié au-dessus de la grandeur du pongo ou grand orang-outaıg. M. Allamand a vu cet animal vivant, et en a fait une très-bonne description; il en a donné la figure, planche II, dans l'édition faite en Hollande de mes ouvrages sur l'histoire naturelle.

* J'ai donné, a dit ce savant naturaliste, la " figure d'un singe sans queue, ou orang-oua tang qui m'avait été envoyé de Batavia. Cette - figure, faite d'après un animal qui avait été " longtemps dans de l'eau-de-vie, d'où je l'aa vais tiré pour le faire empailler, ne pouvait * que le représenter très-imparfaitement : je a crus cependant devoir la publier, parce qu'on - n'en avait alors aucune autre. Il me parais- sait différent de celui qui a été déerit par " Tulpius; depuis j'ai eu des raisons de eroire " que c'est le mème, sans que pour cela j'aie - trouvé meilleure la figure que cet auteur en - a donnée.

- Quelques années après, au commencement - de juillet 1776 , on envoya du cap de Bonne- Espérance à la ménageric de M. le prince " d'Orange une femelle d'un de ees animaux, a ct de la même espèce que celui quej'avais dé- crit. On a profité de cette occasion pour en " donner une figure plus exacte; on la voit dans - la planche $\boldsymbol{X}$ VIII.

" Flle arriva en bonne santé. Dès que j'en " fus averti, j'allai lui rendre visite, et ce fut * avec peine que je la vis attachée à un bloe - par une grosse chainc qui la prenait par le " cou, et qui la gênait beaucoup dans ses mou- vements. Je m'insinuai bientôt dans ses bon- nes gráces par les bonbons que je lui donnai, * et elle eut la complaisance de soufrir que je " l'examinasse tout à mon aise'.

" La plus grande partic de son corps était ' La description sulvante est celle d'une Jeune femelle de
lorang roux des Indeg
" couverte depoils roussatres partout à peu près " de la même longueur, excepté sur le dos oi " ils étaient un peu plus longs. 11 n'y en avait " point sur le ventre où la peau paraissait à nu; a mais quelques semaines après je fus fort sur" pris de voir cette même partie velue comme le " reste du corps. J'ignore si elle avait été cou" verte auparavant de poils qui étaient tombés, " ou s'ils y paraissaient pour la première fois. " L'orang-outang que Tulpius a déerit, et qui " était aussi une femelle, avait de mème le " ventre dénué de poils. Sa face était plate, ce" pendant un peu relevée vers le bas, mais " beaucoup moins que dans le magot et les " autres espèces de singes; elle était nue et " basanée, avec une tache autour de chaque " œil, et une plus grande autour de la bouche, " d'une couleur qui approchait un peu de la " couleur de chair. Elle avait les dents telles " que M. de Buffon les a décrites parmi les ca" ractères distinetifs des orangs-outangs. La par" tie inférieure de son nez était fort large et " très-peu éminente; ses narines étaient fort " distantes de sa bouche, à cause de la hauteur " considérable de sa lèvre supéricure; ses yeux " étaient environnés de paupières garnies de " cils, et au-dessus il y avait quelıues poils, " mais qui ne pouvaient pas passel pour des " soureils; ses oreilles étaient semblables à " celles de l'homme; ses gras dejambes étaicnt " fort peu visibles, on pourrait même dire "qu'elle n'en avait point; ses fesses étaient "velues, et ou ne remarquait pas qu'il y eút " des callosités.

"Quand elle était debout, sa longueur, depuis " la plante des pieds jusqu'au haut de la tète, " n'était que de deux pieds et demi. Ses bras " étaient fort longs; mesur's depuis l'aisselle " jusqu'au bout des doigts, ils a vaient vingt-trois " pouces : cependant, quand l'animal se dressait " sur ses pieds, ils ne touchaient pas à terre " comme ceux des deux gibloons décrits par "M. de Buffon. Ses mains et ses pieds n'étaient " point velus ; leur couleur était noirâtre, et ils " étaient aussi fort longs proportionnellement à " son corps : depuis le poignet juscu'au bout du " plus long doigt, la longueur de sa main était " de sept pouces, et celle de son pied, de huit; " le gros orteil n'avait point d'ongle, pendant " que le pouce et tous les autres dojgts en avaicut. "L'on voit, par cette deseription, qu'à la grann deur près, cette femelle était de la mème es- 
- pèce que l'animal que j'ai décrit ci-devant. a Elle était originaire de Bornéo; on l'avait en" voyéc de Batavia au cap de Bonne-Espérance " où elle a passé une année : de là elle est venue " à la ménagerie de M. le prince d'Orange, où " elle n'a pas vécu si longtemps; elle est morte " en janvier 1777.

"Elle n'avait point l'air méchant; elle don" nait volontiers la main à ceux qui lui présen" taient la leur. Elle mangeait sans gloutonnerie " du pain, des carottes, des fruits, ct même de " la viande rôtie; elle ne paraissait pas aimer " la viande erue; elle prenait li tasse qui con" teuait sa boisson d'une seule main, la portait à " sa bouche, et elle la vidait fort tranquillement.

" Tous ses mouvements étiient assez lents, et

" elletémoignait peu de vivacité; elle paraissait " plutôt mélancoliçue. Elle jouait avec une a couverture qui lui servait de lit, et souvent a elle s'oceupait à la déchires. Son attitude ora dinaire était d'ètre assise, avec ses cuisses et - ses genoux élevés : (fuand elle marchait, elle - était presque dans la mème posture; ses fesses " étaient peu éloignées de la terre. Je ne l'ai " point vue se tenir parfaitement debout sur a pieds, excepté quand elle voulait prendre " quelque chose d'élevé, et même encore alors a les jambes étaient toujours un peu plices, et * elle était vacillante. Ce qui me confirme dans a ce que j'en ai dit ci-devant, e'est que les ani- maux de cette espèce ne sont pas faits pour " marcher debout comme l'homme, mais comme - les autres quadrupèdes, quoique cette dernière a allure doive être aussi assez fittigante pour eux " à cause de la conformation de leurs mains. "Ils me paraissent principalement faits pour " grimper sur les arbres : aussi notre femelle a grimpait-elle volontiers contre les barres de la " fenêtre de sa chambre, aussi haut que le lui " permettait sa chaîne.

"M. Vosmäre, quil'a obser'vée pendant tout - le temps qu'elle a véen diuns la ménageriede "M. le prinee d'Orange, en a publice une fórt a bonne description, d'où j'ai tiré les dimensions " que j’en aidonnées, paree qu'elles étaient plus " justes que celles que j’avais prises sur l'animal " vivant et en monvement; il a été fort attentif " à examiner de près ses actions, et ce fu'il en " rapporte est très-intéressant. On aime à voir " on à lire le détiil les actions d'un animal qui * imite si bien les notres; nous sommes tentés * de lui accorder un degré d'intelligence supé-
" rieur à celui de toutes les autres brutes, quoi"que tout ce que nous admirons dans tout ce " qu'il fait soit une suite de la forme de son " corps, et particulièrement de ses mains dont (I il se sert avec autant de facilité que nous. Si " le chien avait de pareilles mains, et qu'il püt " se tenir debout sur ses pieds, il nous paral" trait bien plus intelligent qu'un singe. Pen" dant que cette femelle a été dans ce pays, " M. Vosmaër n'a pas remarqué qu'elle ait eu " des écoulements pérnodiques. Il en a donné, a en deux planches, trois figures qui la repré" sentent très-bien daus trois différentes atti" tudes.

"Dans le même temps que cet animal était " ici, il y avait à Paris une femelle gibbon, " comme je l'ai appris par la lettre de M. Dau" benton, qui me manda que son allure était à " peu près la mème que eelle que je vieus de dé" erire; elle courait étant presque debout sur ses " pieds, mais les jambes et les euisses étaient un " peu pliées, et quelcuefois la main touchait la " terre pour soutenir le corps chancelant; elle " était vacillante, lorsqu'ćtant debout elle s'ar" rêtait; elle ne portait que sur le talon, et rele- vait la plante du pied; elle ne restait que peu - de temps dans cette attitude, qui paraissait " forcée.

" M.Gordon, que je dois presque toujours ci" ter, m'a envoyé le dessin d'un orang-outang, " dontle roi d'Asham, pays situé à l'est du Beu" gale, avait faitprésent, aree plusieurs autres " euriosités, à M. Harwood, président du conseil " provincial de Dinagiapal. Le frère de $\mathbf{M}$. Har" wood l'apporta au Cap, et le donna á M. Gor" don, chez qui malheureusenent il ne vécut " qu'un jour. Sur le vaisseau il avait été attaqué " du scorbut, et en arrivant au cap de Bonne"Espérance il était si faible, qu'il mourut au " bout de vingt-quatre heures. Ainsi M. Gurdon " n'a eu que le temps de le faire dessiner, et ne a pouvant point me dommer ses propres obser"vations, il m'a communiqué ce que lui en " avait dit M. Harwood. Voici ce qu'il eu avait " appris.

"Cet orang-outang, nommé voulock dans le " pays dont il est originaire, était une femelle "qui avait régulierement ses écoulements péa riodiques, mais qui cessèrent dès qu'elle fut "attaquíe du scorbut. Elle était d'un caractère a fort donx: il ı'y avait que les singes qui lui - déplaisaient; elle ne pouvait pas les souffrir. 
- Elle se tenait toujour's droite en marchant; " elle pouvait mème courir très-rite. Quand el ie " marehait sur une table, ou parmi de la poree"laine, elle était fort attentive à ne rien casser. "Lorsqu'elle grimpait quelque part, elle ne fai" sait usage que de ses mains; elle avait les ge" noux comme un homme. Elle pouvait faire un " cri si aigu, que quand on était près d'clle, il " fallait se tenir les oreilles bouchées pour n'en " être pas étourdi. Elle prononçait sourent et " plusieurs fois de suite les syllabes de yacthou, " en insistant avec force sur la derniere. Quand " elle entendait quelque bruit approchant de ce" lui-là, elle commenȩait d'ubor'd aussi à crier; " si elle était contente, on lui entendait fuire un "grognement doux qui partait de la gorge. Lors" qu'elle était malade, elle se plaignait comme " un eufant, et cherchait à ètre secourue. Elle " se nourrissait de végétaux et de lait; jamais " elle n'avait voulu toucher à un animal mort, ni a manger de la viande; elle refusait mème de " manger sur une assiette où il y en avait eu. "Quand elle voulait boire, elle plongeait ses " doigts daus l'eau et les léchait. Elle se couvrait "volontiers aree des morceaux de toile, mais " elle ne voulait point souffrir d'habits. Dès - qu'elle entendait prononcer son nom, qui était " Jenny, elle venait: elle était ordinairement " assezmélancolique et pensive. Quand elle vou" lait faire ses nécessités, lorsqu'elle était sur le " vaisseau, elle se tenait à une corde par les " mains, et les faisait dans la mer.

"La longueur de son corps était de deux pieds " cinq pouces et demi; sa circonférence près de " la poitrine était d'un pied deux pouces, etcelle " de la partie de son corps la moins grosse était " de dix pouces et demi. Quand elle était en " santé, elle était mieux en ehair, et elle a vait " des gras de jambes. Le dessin que MI. Gordon " a eu la bonté de m'en envoyer a été fait lors" qu'elle était malade, ou peut-ètre lorscu'elle " était morte, et d'une très-grande maigreur": " ainsi il ne peut servir qu'it donner une idée de " la longueur et de la figure de sa face, qui me " parait ètre très-semblable á celle de la femelle " que nous avons eue ici. Je vois aussi par l'é" chelle qui est ajoutéc à ce dessin, que les di* mensions des différentes parties sontà peuprès " les mènes: mais il y a vait cette différcnec en" tre ces deux orangs-outangs, e'est que celui " de Bornéo n'avait point d'ongle au gros orteil n ou au ponce des pieds, au licu que celui d'A
" ham en arait, comme $\mathbf{I}$. Gordon mel'a mandé " bien expressement; anssi a-t-il eu som que " cet ongle futt représenté dlans le dessin. Cette " différence indiquerait-elle une diversité dans ( l'espèce entre des animaux qui semblent d'ail" leurs av oir tant de rapports entre eux, par des " earactères plus essentiels?"

Toutes ees observations de M. Allamand sont curieuses. Je ne doute pas plus que lui, que le nom orang-oulang ne soit une dénomination grénérique qui comprend plusieurs espèces, telles que le pongo et le jocko, et peut-ètre le singe dont il parle, comme en ayant vu la tète et le pied, et peut-ètre encore celui qui pourrait faire la nuance entre le pongo et le mandrill. M. Vosmaër a reçu, il y a quelques années, un individu de la petite espéce de ce genre, qui n'est probablement qu' un jocko : il en a fait un récit qui contient quelques faits que nous donnons par extrait dans cet article '.

"Le 29 juin 1776 , dit-il, l'on m'informa de (I'heureuse arrivée de cet orang-outang... c'é" tait une femelle. Nous avons apporté la plus " grande attention à nous assurer si elle était " sujette à l'écoulement périodique, sans rien " pouvoil' découvrir à cet égard. En mangeant, " elle ne faisait point de poches latérales au go" sier, commetoutes lesautres espèces de singes. " Elle était d'un si bon naturel, qu'on ne lui vit " jamais montrel la moindre marque de mé" chanceté ou de fâcherie; on pouvait sans " crainte lui mettre la main daus la bouche. "Son air avait quelque chose de triste... Elle " aimait la compagnie sans distinction de sexe, " donnant seulement la préférence aux gens qui " la soignaient journellement et qui lui faisaient "du bien, qu’ clle paraissait affectionner davan" tage; sourent lorsqu'ils se retiraient, elle se " jetait à terre, étantà la chaine, comme au dés" espoir, poussant des cris lamentables, et dé" chirant par lambeaux tout le linge qu'elle "pouvait attraper dès qu'elle se voyait seule. "Son garde ayant quelquefois la coutume de " s'asseoir auprès d'elleà terre, elle pr'enait d'au" tres fois du foin de sa litière, l'arrangeait à son " côté, et semblait par toutes ses démonstrations " l'inviter à s'asseoir auprès d'elle...

" La marche ordinaire de cet animal était a " quatre pieds comme les autres singes; mais il " pouvait bienaussi mareher debout sur lespieds

- c'est encore l'orang-roux des Indes. 
" de derrière, et muni d'un bon bâton, il s'y te" nait appuyé souvent fort longtemps : cepen" dant il ne posait jamais les pieds à plat, à la " facou de l'homme, mais recourbés en deliors, " de sorte qu'il se soutenait sur les côtés exté" rieurs des pieds de derrière, les doiggts retirés " en dedans, ce çui dénotait une aptitude à grim" per sur les arbres... Un matin nous le trou"vâmes déclaainé... et nous le vimes monter " avec une merveilleuse agilité contre les pou" tres et les lattes obliques du toit; on eut de la - peine à le reprendre. . Nous remarquàmesune " force extraordinaire dans ses muscles; on ne " parvint qu'avec beaucoup de peine à le cou" cher sur le dos; deux hommes vigoureux eu" rent chacun assez à faire à lui serrer les pieds, " l'autre à lui tenir la tète, et le quatrieme à " lui repasser le collier par-dessus la tète, et " à le fermer mieux. Daus cet état de liberté, " l'animal avait entre autres choses òté le boua chon d'une bouteille contenant un reste de " vin de Malaga, qu'il but jusqu'à la dernière " goutte, et remit ensuite la bouteille à sa mème " place.

"Il mangeait presque de tout ee qu'on lui " présentait. Sa nourriture ordinaire était du " pain, des racines, en particulier des carottes " jaunes, toutes sortes de firuits, surtout des "fraises; mais il paraissait singulièrement friand " de plantes aromatiques, comme du persil et " de sa racine. Il mangeait aussi de la viande " bouillie ou rotie, et du poisson. On nele royait " point chasser aux insectes dont les autres es- pèces de singes sont d'ailleurs si avides... Je " Jui présentai un moincau vivant... il en goûta " la chair et le rejeta bien vite. Dans la ména"gerie, et lorsqu'il etait tant soit peu malade, " jel'ai vu manger tant soitpeu de viande crue, " mais sans aucune mar'que de goùt. Je lui don" nai un ouf cru qu'il ourrit des dents, et suça " tout entier avec beaucoup d'appétit... Le róti " et le poisson étajent ses aliments favoris. On " lui avait appris à manger avec la cuiller et la " fourchette. Quand on Lui dommait des fraises " sur une assiette, e'était un plaisir de voir" " comme il les piquait une par une, et les por" tait à sa bouche arec la fourchette, tanclis "qu'il tenait cle l'autre patte l'assiette. Sa bois" son ordinaire était l'rau; mais il buvait trés" volonticrs toutes sortes de vins, et proncipale" ment le malaga. Luidonnait-on une bouteille, " il en tirait le bouchon arec la main et buvait a très-bien dehors, de même que hors d'un "verre à bière; et cela fait, il s'essuyait les "lèves comme une personne... Après avoir " mangé, si on lui donnait un cure-dent, il s'en " servait au même usage, que nous. Il tirait fort " adroitement du pain et autres choses hors " des poches. On m'a assuré qu'étant à bord du " navire, il courait librement parmi l'équipage, " joulait avee les matelots, et allait quérir comme " eux sa portion à la cuisme.

"A l'approche de la nuit, il allait se coucher... " Il ne dormait pas volontiers dans sa loge, de " peur, à ce qu'il me parut, d'y être enfermé. "Lorsqu'il voulait se coucher, il arrangeait le " foin de sa litière, le secouait bien, en appor" tait davantage pour former son chevet, se " mettait le plus souvent sur le còté, ct se coua vrait chaudement d'une couverture, étant " fort frileux.... De temps en temps nous Iui " arons vu faire une chose qui nous surprit ex" trèmement la première fois que nous en fûmes " témoins. Ayant préparé sa couche à l'ordi" naire, il prit un lambeau de linge qui était au" près de lui, l'étendit fort proprement sur le " plancher, mit du foin au milieu en relevant " les quatre coins du linge par-dessus, porta ce * paquet arec beaucoup d'adresse sur son lit " pour lui servir d'oreiller, tirant ensuite la " couverture sur son corps... Une fois me voyant " ourrir à la clef et refermer ensuite le cadenas " de sa chaine, il saisit un petit morceau de " bois... le fourra dans le trou de la serrure, le " tourmant et retournant en tout sens, et regar"dant si le cadenas ne s'ouvrait pas... On l’a ru " essayer d'arracher des crampons avec un gros " clou dont il se servait comme d'un levier. Un " joư lui ayant domé un petit chat, il le flaira " partout; mais le chat lui ayant égratigné le " bras, il ne voulut plus le toucher... Lorsqu'il " avait uriné sur le plancher de son gite, il l'es" suyait proprement avee un chiffon... Lors" qu'on allait le voir avec des bottes aux jam" bes, il les nettoyait arecun balai, et savait dea butcler les souliers avec autant d'adr'sse " yu'un domestique aurait pu le faire : il dé" nouait aussi fort bien les nœuds faits dans les " cordes, quelque scrrés qu'ils fussent, soit avec a sesdents, soit arec ses ongles...A y yant un verre " ou un barquet daus une main, et un báton "dans l'autre, on avait bien de la peine à le lui "óter, s'espuivant et s'escrimant contiuuelle" ment du båton pour le conserver. 
" Jamals on ne l'entendait pousser quelque a cri, si ce n'est lor'squ'il se trouvait seul, et " pour lors c'était d'abord un son approchant " de celui d'un jeune chien qui hurle; ensuite "il devcnait très-rude et rauque, ce que je ne " puis mieux comparer quau bruit que fait (" unc grosse scie en passant à travers le bois. "Nous avons déjà remarqué que cet animal " avait une force extraordinaire; mais elle " était surtout apparente daus les pattes de de" vant ou mains dont il se servait à tout... " pouvant lever et remuer de très-lourds far"deaux.

a Ses excréments, lorsqu'il se portait bien, " étaient en crottes ovales. Sa hanteur, mesurée " dcbout, était de deux pieds et demi rhéa naux.... Le ventre, surtout étant accroupi, a était gros et gonflé... Les tétins des mamelles " étaient fort petits et tout près des aisselles; le " nombril ressemblait beaucoup à celui d'une " persome.

"Les pieds de devant ou bras avaient, depuis * les aisselles jusqu'au bout des doigts du milieu, " un pied sept pouces; le doigt du milieu trois a pouces et demi, le premier un peu plus court, a le troisième un peu plus long, le quatrième, " ou petit doigt, beaucoup plus court; mais le * pouce l'est encore bien davantage. Tous les " doigts ont trois articulations; le pouce n'en a " que deux : ils sont tous garnis d'un ongle noir " et rond.

" Les jambes, depuis la hanche jusqu'au taa lon, avaient vingt pouces; mais le fémur me " parut à proportion beaucoup plus court que " le tibia. Ses pieds posés à plat étaient, depuis a le derrière du talon jusqu'au bout des doigts " du milieu, longs de huit pouces. Les doigts " des pieds sont plus courts que ceux des mains; " celui du milieu est aussi un peu plus long que " les autres; mais ici le pouce est heaucoupplus u court que celui de la main... et ces doigts des a pieds ont aussi des ongles noirs. I.e pouce ou " gros orteil, quin'a que deux articulations, est " absolument dépourvu d'ongle dans quatre sua jets de cette espèce asiatique.

"Le côté intérieur les pieds de devant et de " derrière est entièrement nu, sans poil, revètu a d'une peau assez douce, d'un noir fauve; mais " après la mort de l'animal, et pendant sa ma* ladie, cette peau étajt déjà devenue beaucoup * plus blanche : les doigts dos pieds do devant - et de deribectaient nussl sans poil.
"Les cuisses ne sont ni pelées, ni calleuses... " On ne pouvait apercevoir ni fesses, ni mollets a aux jambes, now plus que le moindre indice " de queue.

"Ia tête est par devant toute recouverte d'une " peau chauve, couleur de souris. Le museau ou " la bouche est un peu saillant, quoique pas tant " (qu'aux espèces de magots ; mais l'animal pou-. " vait aussi beaucoup l'avancer et le l'etirer. " I'ouverture de la bouche est fort large. Au" tour des yeux, sur les lèvres et sur le menton, " la peau était un peu couleur de chair; les " yeux sont d'un brun bleuâtre, dans le milieu " noirs; les paupières sont garnies de petits " cils. On voit aussiquelques poils au-dessusdes " yeux, ce que l'on ne peut pourtant pas bien " nommer des sourcils. Le nez est très-épaté et "large vers le bas; les dents de devant à la " mâchoire supérieure sont au nombre de qua" tre, suivies de chaque côté d'un intervalle " après leruel... vient une dent måchelière qui " est plus longue... L'on compte encore trois "dents molaires, dont la dernière est la plus " grosse. Le même ordre règne à la mâchoire " inférieure. Les dents sont fort semblables à " celles de l'homme... Le palais est de couleur " noire; le dessous de la langue est couleur " de chair.... La langue est longue, arrondie " par devant, lisse et douce; les oreilles sont " sans poils, et de forme humaine, mais plus " petites qu'elles ne sont représentées par d'au" tres.

"A son arrivée, l'animal n'avait point de " poil, si ce n'est du noir à la partie postérieure " du corps, sur les bras, les cuisses et les jam" bes... A l'approche de l'hiver, il acquit beau" coup plus de poil... Le dos, la poitrincet toutes " les autres parties du corps étaient couvertes " de poil chàtain clair... Les plus longs poils du " dos avaient trois pouces. $n$

\section{DESCRIPTION DU JOCKO ${ }^{\prime}$.}

(EXTRAIT DE DALUEXTON.)

Je n’ai vu que la pean bourrce et la plus grande. partie du squelette du jocko que l'on montrail a Paris en 1740 : il mourut l'annce suivante à Lon-

1 Cetle description esl celle dn TrOguonyta chusavize d'Afriquue, anquel Inffun, dans le Supplément à l'arlicle dea vorugg-outangs, doune it no!n de pongo, apres jui arvir al. Libue, davs lo preasuer antlicle, celui de josho. 
dres, ou il fut ouvert; on le rapporta ici clans de l'eau-de-vie, et on le mit an cabinet : dans la suite on a fait hourrer la peall et priparer le squelette. Ce singe avait éte pris en Afrique dans le fond du Cahon, sur la côte d'A ngole : ćtant dehout, il avait denx pieds yuatre ou ciny ponces le bautenr, depuis le talon jusqu'au sommet de lit tête. Ilétait plus grand que celui qui a été décrit par Tyson sous le nom de Pygmice, et qui n'avait guiere julus de deux piculs : après avoir comparé la description du pygméc de 'Tyson avec notre jocko, j'ai trouvé ces denx animanx si ressemblauts, qu'il y a tout licu de croire qu': étaient de mème espèce comme ils étxient de nème pays.

La peau (pui a servi de sujet pour cette description avait quelques poils durs sur le boril de la lèvre du dessıs et aı-rlevant de là mâchoi e du dessous; le reste de la face était nu, à l'exception des joues ou il y avait des poils semblahles à cenx du reste du corps. Il se Irouvait des cils aux deux paupières et quelyues poils à l'endroit des sourcils; il y en avait de gris sur le milieu du scrotum et autour de l'anus. Le poil de la tête n'ítait pas différent de celui du reste du corps, par sa coulemr noire ni par scs autres upalitis; le plus long se trouvait aux cótés de la face et sur les épaules; il avait deux pouces à dleux pouces et demi. Le poil ćtait assez. touffu pour convrir la peau sur la tète, le dos, les épaules, et sur la face externe des yuatre jambes; il était fort rare, et laissait voir la peausur la poitrine, sur les coites du ventre et sur la face interne des (fuatre jambes. Il chait lirigci en loas sur les cótés de la tête, et en haut sur le côté externe et postericur de la cuisse, et sur la rare evtrone de l'avant-bras, tandis yue le poil du hras cit dirige en bas, desorte que les pointes des poils etaient opposées les unes anx autres, il l'endroil du conde. Tyson donne la direction du puil de l'avant-loras iil jocko, comme un caractère commun avec l'homme; mais il est aussi commun avec plusieurs animaux.

Ne pouvant pas prendre des dimensions exactes sur une peau Jourrée, telle que la peiu du jocko qui est an Cabinet du $\mathrm{Roi}$, je rapporte clans une table les jurineipales dimensions yue "Tyson a prises sur son pyrmèe pui était vivant.

La tìte du joclio est à proportion moins grosse que celle de l'homme; elle a moins de laamlenr, moius de birgeur, et mème moinc de longrueur, quoipueles michuires soient heaucoup phos saillantes en arant. La hoite osseuse du crine a moins de capacite, principalement dans sa parlie postérieure; et cu grencral la tète du jocko est très-diflerente de celle de liommo par sa lignre. Les apophyses mastoisles sont rres-pen apparentes. Il 11 y avait point de suture coronale. Les grantes ailes de l'os splue. noide ne sont pis aussí étendıes gue lans l'homme; elles ne se prolongent pas entre l'os temporal et le fiontal jus(ju’à l'os pariètal : au contraire le temporal et le frontal s'articulent ensemble, et mêtue le temporal touclie à l'os de la pommette au-dcosus dı sphenoide; ce qui fait une grande difference dans la conformation ile la tète du jocko comparce à celle de l'homme aussi la tète du jocko a moins de lauteur depuis l'arcarle zyomatique juspu'au sommet. Les mâchoires sont plus longues que tlans l'homme, les os propres dı nez sout aussi plus longs; ils ne furment point de voite transversale avee ccux de la machoire; l'onverture des narines est placée plus bas que dans liomme : car clle est en entier au-dessous les orbites; elle a moins de lıanteur que dans l'homme, et sa partic inferieure est beaucoup plus éloignce du hori al ciolaire lle la michoire ; cest pourquoi te museau du jocko est allongé, et sa levrc supirieure est trés-longue. Les orbites des yeux som plus qrindes que celles le l'homme ; la cloison ossense qui les scipate à beaucoup moins de larseur : par conscquent les yeux sont moins èloinnes l'un de l'autre. Les orloites ont plus de lauteur que de largeur, tandis uque dins les hommes elles ont ordinairement plus de largen yue de lianteur, on an moins ces deux dimensius sont égales. La partie supérieure du bord des orbites est Irès-saillante, en formu le bourrelet y yui se continue sur le bas dlu front, depuis l'une des orbites ju-qu'à l'autı : ce bourrelet domne à l'os frontal du jucko une forme très-iliffirente tle celle de l'us frontal de l'homme, el scmble terminer le hinut de la face et en separer la plus grante part ic le l'us fruntal. La face dujocko ent termine un bas jar l'arcade alvéolaire de la michoire supérieure; ad base llu menton, au lieu l'ètre saillante en avant conmuse dans l'homme, est arrondic et inclince en arriere; aussi le jocko n'a-t-il point de menton clanm, saillant, el distingue de la levre inferieur. par un pli transversal, comme te menton de l'lomme. Jai fait la meine ulstrvation sur toules les antres especes des alimaux que j'ai vus en chail ou en squelette.

II ne restait dans le syucletle dont il s'arit que denx dents, qui étaient la steumde et la trobieme machelic̀re du cóte aluit lle la måchoire dı dessous ; elles ressumblaient il celles de l'homme.

En comparant les paroi: internes du craine lu jocko à celles du cralue de l'homme, on y lrouve aussi des differences tre's-marpuers dims les puopor. lions lle celle cavire; les fosse's sont moin grantes, il ny a prespue aucom venige de I cminence de l'us

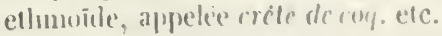

Le jorko doflere beameonp le l'homme par la simation de landirulations de la live aree le con, et par la direction du plan du gramel tron veceipital. Ce tron at les comblyles qui sont sur som lord se trourent places plus en arriere dans le jocho, c'esc 
à-dire plus près de l'occiput et plus loin de la face, et par consequent l'apophyse basilaire est beancoup fulus lougue. En supposant le jocko debout sur ses pieds, coume un homme, le plan du grand Iron occipital est dirigé obli(quement de bas en lıaut et de devant en arrière, de sorte que, s’il était prolonge en avant, il passerait au-dessous de la face du jucko; au contraire, dans l'honme, ce plan est à peı ruès lorizontal, et s'il était prolongé en avant, il passerait au-dessous des yeux. Cette différence eutre le jocko et l'homme, par rapport à l'articulation de la tête avec le cou, fait quel'humme aurait bien moins de facilité que le jocko à présenter son visage en avant, s'il posait ses mains à terre pour se meture dans l'attitude des quadrupèdes, et que le jucko est obligé d'incliner sa tête pour présenter sa face en avant, lorsquil est debout dans l'at titucle de l'homme.

\section{LE GIBBON.}

\section{(ORANG GIBBON.)}

Ordre des quadrumanes, tribu des gibbons, famille des singes. (Curier.)

Legibbon se tient toujours debout, lors même qu'il marche à quatre pieds, parce que ses bras sont aussi longs que son corps et ses jambes. Nous l'avons vu vivant; il n'avait pas trois pieds de hauteur, mais il était jeune, il était en captivité : ainsi l'on doit présumer qu'il u'avait pas encore acquis toutes ses dimensions, et que, dans l'état de nature, lorsqu'il est adulte, il parvient au moins à quatre pieds de hauteur. Il n'a nulle apparence de queue; mais le caractère qui le distingue évidemment des autres singes, c'est cette prodigieuse grandeur de ses bras, qui sont aussi longs que le corps et les jambes pris ensemble, en sorte que l'animal étant debout sur ses pieds de derrière, ses mains touchent encore à terre, et qu'il peut marcher à quatre pieds, sans que son corps se penche. Il a tout autour de la face un cercle de poils gris, de manière qu'elle se présente comme si elle était environnée d'un cadre rond: ce qui donne à ce singe un air très-extraordinaire. Ses yeux sont grands, mais enfoncés; ses oreilles, nues et bien bordées : sa face est aplatie, de couleur tannée et assez semblable à celle de l'homme. Le gibbon est après l'orang-outang et le pithèque, celui cuiapprocherait le plus de la figure lıumaine, si la longueur excessive de ses bras ne le rendait pas difforme : car, dans l'état de nature, l'homme aurait aussi une mine bien étrange; les cheveux et la barbe, s'ils étaient négligés, for . meraient autour de son visaye, un cadre de poil assez semblable à celui qui environne la face du giblon.

Ce singe nous a paru d'un naturel tranquille, et de mours assez douces; ses mouvements n'étaient ni trop brusques ni trop précipités: il prenait doucement ce qu on lui donnait à manger ; on le nourrissait de pain, de fruits, d'amandes, etc. Il craignait beaucoup le froid et l'humidité, et il n'a pas vécu longtemps hor's de son pays natal. Il est originaire des Indes orientales, particulièrement des terres de Coromandel, de Malaca et des îles Moluques '. Il parait cu'il se trouve aussi dans des provinces moins méridionales, et qu'on doit rapporter au gibbon le singe du royaume de Gannaure, frontière de la Chine, que quelques voyageurs ont indicqué sous le nom de $F$ efé ${ }^{2}$. Au reste cette espèce varie pour la grandeur et pour les couleurs du poil. II y en a deux au Cabinet, dont le second, quoique adulte, est bien plus petit que le premier et n'a que du brun dans tous les endroits oi l'autre a du noir; mais comme ils se ressemblent parfaitement à tous autres égards, nous ne doutons pas qu'ils ne soient tous deux d'une seule et même espèce.

\section{Caraclères distinclifs de cette espèce.}

Le gibbon n'a point de queue; il a les fesses pelées avee de légères callosités; sa face est plate, brune et environnée tout autour d'un cercle de poils gris; il a les dents canines plus grandes à proportion que celles de l'homme; il a les oreilles nues, noires et arrondies, le poil brun ou gris suivant l'àge ou la race, les bras excessivement longs : il marche sur les deux

1 Le P. Le Comte dit avoir vu aux Molnques une espèce de singe, marchaıt natureliement sur ses d'ux jieds, se servant de se- bras comne un homme, le visage à peu prè comme celui d'un llottent, mais le corjs lont couvert d'une espèce de laine grisis, étant exactement commre nu enfaul et exprimant parfailement ses passions el ses ajpétits. Il ajoule ıue ces vinges sont d'un naturel très-doux, yne pour montrer leur aflection aux personnes quils conuaissent, is l's embrassent et les baisent avec tles transports singuliers: yue l'un de ces singes. quil a vu, avail an moins qualre pieds de hanleur. qu'il élatil extrêmemenl adroil $\mathrm{e}^{\prime}$ encore plus agile. Mémoires sur la Cline, par Linis Le Comle, page 510.

3 bans le royamme de Gannaure, fromlière de la (hins, il se trouve un animal qui est fort rare, qu ils notnnent fcfé; il a presune la forme limmaine, les bras forts longs, le corps noir et velu, marche furt légerement el fort vite. Recucil des Voyages, elc. llonen, 1716 , tome 111. 



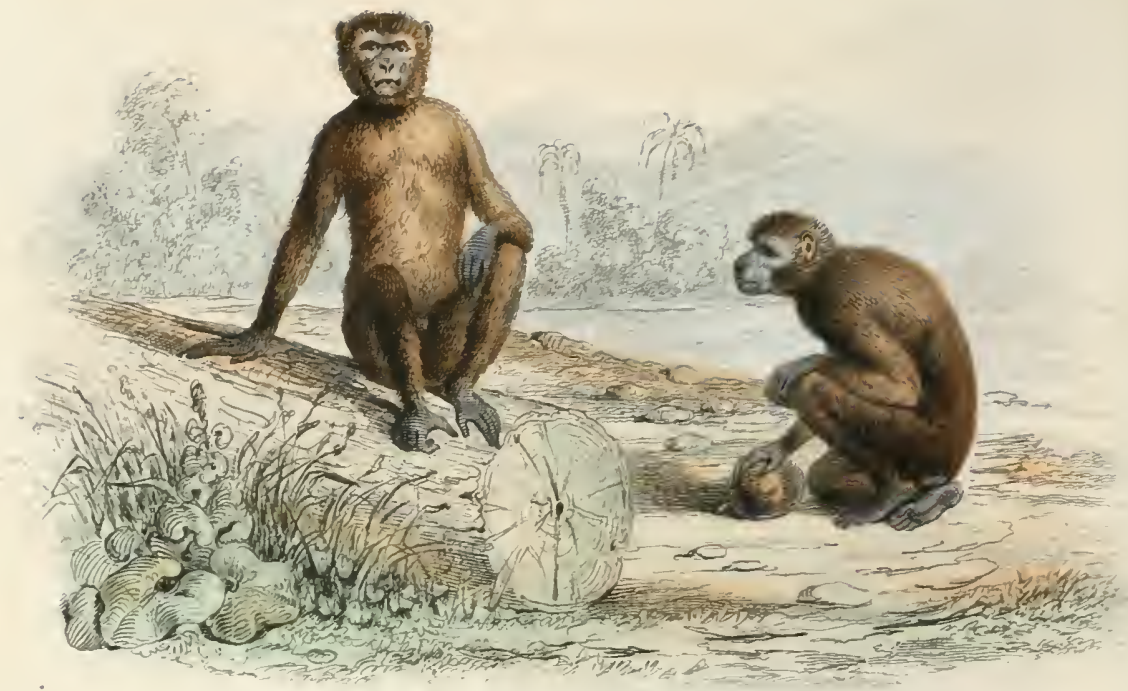

l.e M.MGO'I

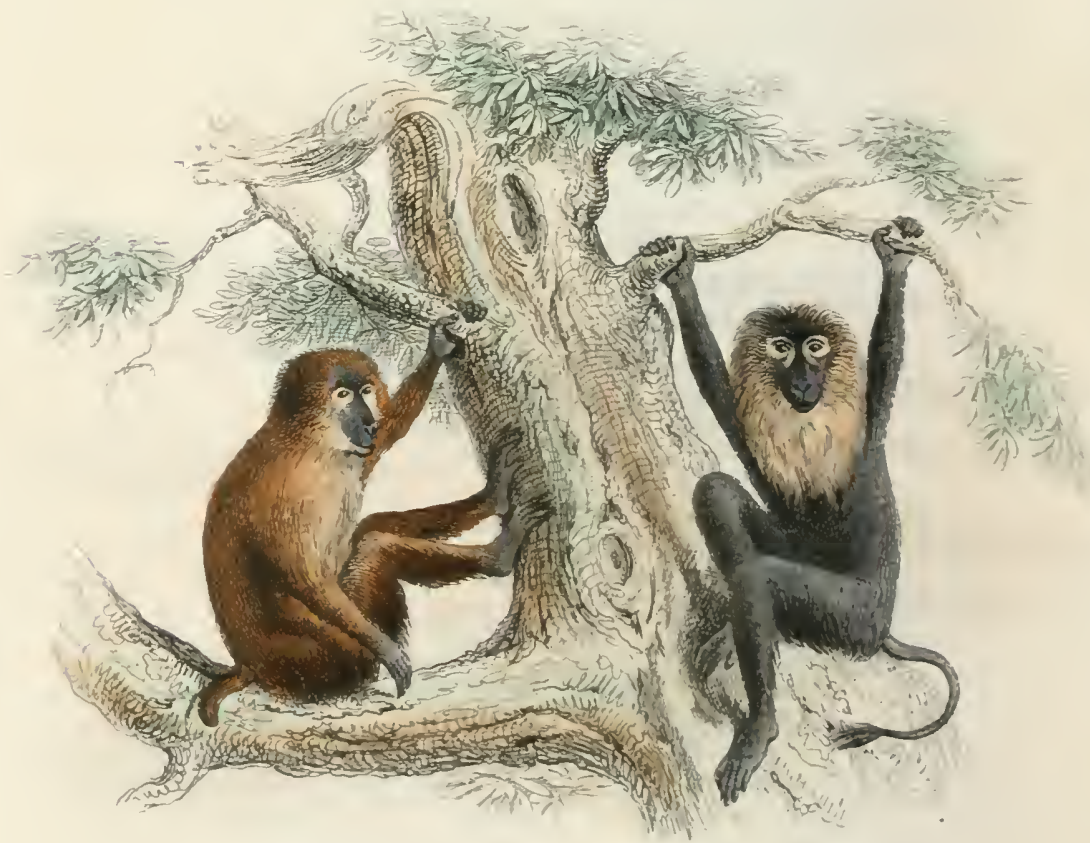

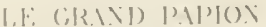

L.O I.1)Fik()! 
pieds de derrière; il a deux pieds et demi ou trois pieds de hauteur. La femelle est sujette, comme les femmes à un écoulement périodique de sang.

\section{LE MAGOT.}

\section{(LE MACAQUE Magot.)}

Orilre des quadrumanes, tribn des magots, famille des siuges. (Cuvier.)

Cet animal est de tous les singes, e'est-àdire de tous ceux qui n'ont point de quene ${ }^{2}$, crlui qui s'accommode le mieux de la température de notre climat. Nous en avons nourri un pendant plusieurs années; l'été il se plaisait à l'air, et l'hiver on pouvait le tenir dans une chambre sans feu. Quoiqu'il ne frit pas délicat, il ćtait toujours triste et souvent maussade; il faisait également la grimace pour marquer sa colère ou montrer son appétit: ses mouvements étaient brusquues, ses manière's grossières, et sa pliysionomie encore plus laide que ridieule; pour peu qu'il fùt agité de passion, il montrait et grinciat les dents en remuant la máchoire. II remplissait les poches de ses joues de tout ee qu'on lui donnait, et il mangeait généralement de tout, à l'exception de la viande erue, du fromage et d'autres choses fermentées; il aimait à se jucher, pour dormir, sur un barreau, sur une patte de fer. On le tenait toujours à la ehaine, parce que, malgré sa longue domesticité, il n'en était pas plus eivilisé, pas plus attaché à ses maitres; il avait apparenment été mal éduqué : ear j'en ai vu d'autres de la mème espèce, qui en tout étaient mieux, plus recomnissants, plus obćissants, mème plus gais, ct assez doeiles pour apprendre à danser, à gesticuler en ('adense et à se laisser tranquillement vètiret coiffer.

Ce singe peut aroir deux pieds et demi ou trois pieds de hauteur lorsqu'il est debout sur ses jambes de derriere : la femelle est plus petite que le male. II marche plus voloutiers à

- Isc magot est le mème animal que le vilhèque ou pilhecos d'Aristute, que Buffon comsiderait comme nue mepuere dislinele. Le cynoréphule do Buffom u’est aussi qu un m got.

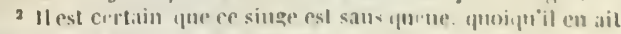
une lézère alparenee formice par un urtal appenclice de prat d'environ un demi-punce de longuenr, qun st trouse an-tles-

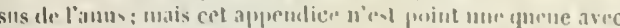
des verlebres, ee nest tuitum benut de peall qui ue tipht pas mène plus particulierement au coecjx que te reste de la perati. quatre pieds qu'à deux. Lorsqu'il est en repos, il est presque toujours assis, et son corps porte sur deux callosités très-éminentes, qui sont situées au bas de la région où devraient être les fesses; ;'anus est plus élevé: ainsi il est assis plus bas que sur le cul; aussi son corps est plusinclinis que celui d'un homme assis. Il differe du pylhérque ou singe proprement dit : $1^{\circ}$ en ee qu'il a le museiu gros et avancé comme un dongue, au lien que le pithèque a la face aplatie; $2^{\circ}$ en ce qu'il a de longues dents canines, tandis que le pithèque ne les a pas plus longrues a pro-

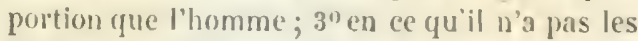
ongles des doigts itussi plats et aussi arrondis; et enfin parce qu'il est plus grand, plus trapu, et d'un naturel moins docile et moins doux.

Au reste, il y a quelques varietés dans l'espèce du magct; nous en arons su de differentes grandeurs et de poils plus ou moins foncés et plus ou moins fouruis : il parait mème que les cincl animaux dont Prosper Alpin a donné les figures et les indications sous le nom de Cynocephales, sont tous cing des magots, qui ne different que par la graudeur et par quelques autres caracteres trop légers pour qu'on doive en faire des espèces distinctes et séparces. Il parait aussi que l'espece en est assez généralement répandue dans tous les climats chauds de l'ancien eontinent, et qu'on la trouve également en Tartarie, en Arabie, en Ethiopie, au Malabar, en Barbarie, en Mauritanie et jusque dans les terres du cap de Bonne-Espérance.

\section{Caraclìres distinclifs de cetle espèce.}

Le magot n'a point de queue, quoiqu'il y ait un petit bout de peau qui en ait l'apparence : il a rles abrjoues, degrosses callosités prociminentes sur les fesse's; des dents eimines beaucoup plus longues à proportion que colles de lhomme; la fiec relerce par le bas en forme de museau, semblable a celui du dogrue. II a du duvet sur la face, du poil brun verdatre sur le corps et jaune blanchatre sous le ventre. II marche sur ses deux pieds de derriere, et plus souvent à quatre. Il a trois pieds ou trois pieds et demi de hauteur, et il parait qu'il y a dans eette espece des raees qui sont emeore plus grandes. Les femclles sont, comme les femmes, sujettes is un écoulement périodiçue de sang. 


\section{DESCRIPTION DU MAGOT.}

(EXTRAIT DE DAEBEYTOX.)

Le magot qui a servi de sujet pour cette description avait la tète grosse, le nez fort plat et le museau sallant; les dents canines étaient fort longuts, et les yeux petits; il n'y avait que très-peu d'utervalle entre les deux yeux; les orelles étaient courtes et nues, elles avaient beancoup de rapport à celles de l'lomme. La plıysionomie dı magot était triste; il ne l'animait jamais qu'en montrant les dents et en agitant rapilement la màchoire in férieure, au point le choquer à coups réitérés les dents de dessous contre celles de dessus. Le cou était court. L:anus semblait ètre posé plus laut rque dans les autres animaux; mais les parties du corps de cet animal que l'on pourrait comparer aux fesses de l'homme, parce que tout le corps portait dessus lorsulue l'animal était clans la situation d'un honme assis, se trouvaient au-rlevant de l'anus, an licu d'ètre de chaque còté conme dans l'homme; ces parties étaient dégarnies tle poils, calleuses et fort dures; elles formaient deux callosites qui avaient clacune deux pouces de longueur sur quinze lignes de largeur.

Il y a dans la bouche du magot, de chaque còté de la màchoire inférieure, l'entrée d'une poche qui s'étend le longr du cou : on a appelé ces poches des abajoues; l'animal y dépose des aliments, et les y garde pour les mâcher et les avaler dans un autre temps. J'ai nouri un magot pendant plus d'un an; il aimait beaucoup le vin : je l'ai vumanger et boire de tout ce que l'on servait sur la table, excepté la moutarle et les fromages fermentés; il les a toujours lefusés, sous quelque appàt que je les lui aie présentés. Je n’ai point trouvé d’abajones clans aucun des sapajous ni des sagrouins yue jai disséqués.

Le magot gui m'a servi de sujet pour cette description, avait des cils aux deux paupières, qui ćtaient entièrement nues et de couleur de elaair assez claire; le tour et l'entre-deux des yeux, le nez, la mâchoire superieure et les lèvres n’avaient que très-peu de poils et étaient de couleur de chair trèsbasance; les jones, le front, les coités de la lète, le cou, à l'exception de la gorge, le dos, les cótés du corps, les reins, les épaules, les hanches et la face exterieure des jambes de devant et de derrière, étaient garnis d'un poil assez touffu, qui avait jusıu’à deux jouces te longueur; re poil était de conleur trise, noirâtue tepuis la racine jusqu’à environ la moitie de sa longuenr; ensuite il élait d'un gris plus clair, et plus loin encore de couleur fauve verdatre; enlin l'extrcunite était noire. On ne voyait à l'exterieur yue la coulcur fauve verdà- tre et le noir; la måchoire inférieure, la gorge, le ventre, les aisselles, les aines, la face interieure des jambes de devant et de derrière étaient garnis d'un poil d'environ un pouce on un pouce et demi de longueur, et dc couleur jaunàtre très-pâle; la peau était blanchâtre; les doigts a vaient du poil, mais la plante des pieds était nue, le bout des doigts citait gros et arrondi, les ongles a vaient une conleur noire ou noiràtre, ceux des pouces élaient plats à peu près comme dans l'lomme; mais les ongles des doigts étaient courbés et disposés en gouttière sur leur longueur.

La tète du squelette du magot diffère de celle de l'homme, dı jocko et du gibbon, principalement par le museau, qui est plus long, par la situation de l'ouverture des narines, qui est placée plus bas au-dessous dies orbites des yeux, par l'étendue de ces orbites, qui sont plus petites, et par une arète transversale qui est sur l'occiput; cette arête se trouve rlans la plupart des quadrupèdes, elle sert d'attaclıe aux muscles qui soutienneut la tète; plus elle a d'épaisseur et de saillie, plus elle dénote l'effort que font ces muscles pour soutenir la tète des quadrupèdes et pour la relever, parce qu'elle n est pas en équilibre sur le cou comme celle de l'homme.

Le front du magot ne s'elève pas au-dessus des orbites; leur bord superieur forme un bourrelet trèssaillant en avant, et ce bourrelet s'étend d'une orbite à l'autre au-dessus du nez, ou il a une face presque perpendiculaire à celle des os propres du nez : ce mème bourrelet se prolonge sur le còtè extérieur des orbites, parce que l'apoplyyse orbitaire de l'os frontal et celle de l'os de la pommette sont très-grosses; l'arcade zygomatique est aussi plus convexe que dans l'tomme, le jocko et le grib. bun, et a plus de rapport à celle de la plupart des quadrupèdes. Les orbites des yeux ont beau. coup plus de largeur que de lauteur. L'ouverture des narines s'étend presque jusqu'au bord alvéolaire. La mâchoire infértieure diffère de celle de l'lomme, du jocko et du gibbon, en ce yue ses branclies sont moins recourbées et plus ressemblan. tes à celles de la mâchoire de la plupart des qua irupèdes.

Les dents du magot ressemblent à celles de l'homme pour le nombre; mais il y a de grandes differences pour la forme, principalement dans les canine's, qui sont ressemblantes à celles du gribhon nais de lieaucoup plus grandes. La premic̀e màclielière du dessous est à proportion plus grosse que dans l'lımme, elle presiente une longue face antériemre, formée par le frottement de la dent canine du dessus. La dernière màchelière de claṇue cóté des deux màchoires est la plus grosse, comme dans la plupart des animaux; ct au contraire de ce qui est dans l'homme, elle a sur clıaque face deux camnelures longitudinales. Il y a entre les incisives 
et les canines du dessus, et entre les canines et les màchelières du dessous, un espace vide dans lerput la clent canine de la màclioire opposée entre, lors. que la bouclie se ferme.

\section{LE PITHEQUE'}

Ordre des quadrumanes, tribu des magots, famille des singes. (Cuvier.)

*. Il y a, dit Aristote, des animaux dont la " nature est ambiguë, et tient en partic ale " l'homme et en partie du quadrupèle, tels que "les pithèques, les kèbes et les cynocéphules. "L.ekèbe est un pithèque avee une queue. I.e " eynocéphale est tout semblable au pithèque: " seulement il est plus grand et plus fort; et il " a le museau avancé, approchant presque de " celui du dogue, et c'est de là çu'on a tiré sou - nom; il est aussi de mocurs plus fóroces, et il " a les dents plus fortes que le pithèque et plus "ressemblantes à celles du chien. "I'après ce passage, il est clair que le pithèque et le cynocéphale indiqués par Aristote nont ni l'un ni l'autre de queue, puisqu'il dit que les pithèques qui ont une queue s'appellent kèbes, et que le cynocéphale ressemble en tout au pithèque, d̀ l'exception du museau, (qu'il a plus avancó, et des deuts (qu'il a plus grosses. Aristote fait llone mention de deux espèces de singes sans queue, le pithèque et le eynocéphale, et d'autres singes aveeune queue, qu'il appelle kebes. Maintenant, pour comparer ce (que nous connaissons avec ce qui était connu d'Aristote, mous observerons que nous avons vu trois especes de singes qui nont point de queue, savoil l'orang-outang, le gilbbon et le magot, et qu'aucune le ces trois espècesn'est le pithècue; car les cleux premieres, e'est-ì-dire l'orang-outang et le gibbon, n'étaient certainement pas counues d'A ristote, puisque ces animaux ne se trouvent que daus les parties méridionales de l'Afrique et des Indes (jui n'étaient pas déeouvertes dle son temps, et que d'ailleurs ils ont des caracteres tres-differents de eeux quil domne au pithèque. Mais la troisieme espece que nous appelons magol est le eynocéphule d'Aristote; il en a tous les earactères; il n’a point de quene; il a le muscau comme un dogue, et les deuts eauines grosses

- Co singe est un jenne magot. et longues : dailleurs il se trouve communément dans l'Asic-Jineure et laus les autres provinees de l'Orient qui étaient connues des Grees. Le pithèque est du mème pays, mais nous ne l'avons pas vu: uous ne le connálissons que par' le témoignage des auteurs ; et quoique, depuis vingt ans que nous recherclions les singes, cette espece ne se soit pas rencontrée sous nos yeux, nous ne dontous ecpendant pas qu'elle n'existe aussi réellement que celle du cynocéphale. Gessner et Jouston ont domué des figures de cesirge pitheque: MI. Brisson l'a indigué comme l'alyant vu; il le distingue du eyocéphale ou magot, qu'il désigne aussi connel'ayant vu, et il con. firme ce que dit Aristute, en assurant que ees deux animaux ${ }^{1}$ se ressemblent à tous écrards, à l'exception du museau, gui est court daus le j)ithèque ou singe proprement dit, et allongédans le cynocéphale. Nous avons dit que l'or'ang-outang, le pitheque, le gilbbon et le magot sont les seuls animaux auxquels on doive applipuer le nom générique de singe, paree qu’ils sont les seuls qui n'ont point de queue, et les seuls qui marchent plus volonticrs et plus souvent sur deux pieds yue sur quatre. L'orangr-outang et le gibbon sont tres-différents du pithergue et lu magrot; mais comme eeux-ci se ressemblent en tout, à l'exception de la grandeur des màchoires et de la grosseur des dents eanines, ils ont souvent été pris l'un pour l'autre : on les a toujours indiqués par le nom commun de singe; et míme dans les langues oì il y a un nom poul' les singes sans queue, et un autre nom pour les singes à queue, on u'a pas distingué le pitléque du magrot: on les appelle tous deux du nome nom $a f f$, cn allemand, ape, en anglais : cen'ist que dans la langue greenue que ees deux animax ont eu chacun leur nom; en ore le mot cinocéphnle est plutòt une dénomination adjective qu'un substantif propre, et c'est par cette raison que nous ne l'avons pas adopté.

- Race première des singes, ceux (pui noul poinl ale quane

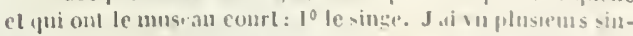
ges upui ne differaimul entre eux que par la grimulenr: lenr Gace, leurs oreille's et lenrs ungle's sunt i-sez semblalules an vi-

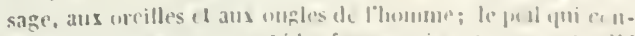

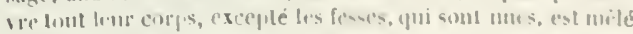

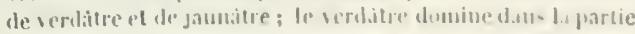
supérieure du eurps, et le jaunitre dans la parlue iulericure...

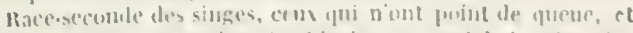

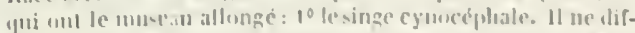
fère Ju singe que far son musean allonge, comure celui d mu

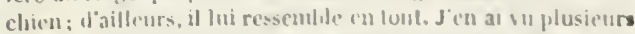
yui ne differatent entre cus equ par la grandeur. Briss., Reg. aเriu., pag. $189 \mathrm{cl} 191$. 
Il parait, par les témoignages des anciens, que le pithèque est le plus doux, le plus docile de tous les singes (qui leur étaient comnus, et qu'il était commun en Asie aussi bien que dans la Libye et dans les autres provinees de l'Afrique qui étaient fréquentées par les voyageurs grees et romains; c'est ce qui me fait présumer qu'on doit rapporter à cette espèce de singe les passarges suivants de Léon l'Africain et de Marmol : ils disent que les singes à longue queuc qu'on voit en Mauritanie, et que les Afrieains appellent mones, viennent du pays des Nègres; mais que les singes sans queue sont naturels et se trouvent en très-grande quantité dans les montagnes de Mauritanie, de Bougie et de Constantine. "Ils ont, dit Marmol, les pieds, les " mains, et, s'il faut ainsi dire, le visage de "l'homme, avec beaucoup d'esprit et de malice. " lls vivent d'herbes, de blé et de toutes sortes "de fruits qu'ils ront en troupes dérober dans "les jardins ou dans les champs : mais avant " que de sortir de leur fort, il y en a un qui " monte sur une éminence, d’où il déeouvre " toute la campagne, et quand il ne voit pa"raitre personne, il fait signe aux autres par " un cri pour les faire sortir, et ne bouge de là, " tandis qu'ils sont debor's : mais sitôt qu'il voit " venir quelqu'un, il jette de grands cris, etsau" tant d'arbre en arbre tous se sauvent dans les " montagnes. C'est une chose admirable que de "les voir fuir" car les femelles portent sur leur " dos quatre ou cinq petits, et ne laissent pas " avec cela de faire de grands sauts de bran" che en branche. 11 s'en prend quantité par " diverses inventions, quoiqu'ils soient fort fins. "Quand ils deviennent farouches, ils mordent; " mais pour peu qu'on les flatte, ils s'apprivoi" sent aisément. Ils font grand tort aux fruits " et au blé, paree qu'ils ne font autre chose " que de cueillir, couper et jeter par terre, soit " qu'il soit mù ou non, et en perdent beaueoup " plus qu'ils n'en mangent et qu'ils n'en em" portent. Ceux qui sont apprivoisés font des " ehoses incroyables, imitant l'homme en tout "ce qu'ils voient. " Kolbe rapporte les mêmes faits à peu près au sujet des singes du cap de Bonne-Lspérance; mais on voit, par la figure et la descriptionqu'il en donne, que ces singes sont des babouins (fui ont une quene courte, le museau allongé, les ongles pointus, ete., et qu'ils sont aussi beaucoup plus gros et plus forts que ces singes de Mauritanie. On peut done présu- mer que Kolbe a copie le passage de Marmol, et appliqué aux babouins du Cap les habitudes naturelles des pitheques de liauritanie.

Le pithèque, le magot et le babouin que nous avons appelé papion, étaient tous trois connus des anciens : aussi ces animaux setrouvent dans I'A sie-Mineure, enArabie, dans la Haute-Égypte et dans toute la partie septentrionale de l'Afrique. On pourrait done aussi appliquer ce passage de Marmol à tous trois : mais il est clair qu'il ne convient pas au babouin, puisqu'il y est dit que ces singes n'ont point de queue; et ce qui me fait présumer que ce n'est pas du magot, mais du pithèque que cet auteur a parlé, c'est que le magot n'est pas aisé à apprivoiser, qu'il ne produit ordinairement que deux petits et non pas quatre ou cinc, comme le dit Marmol; au lieu que le pithèque, qui est plus petit, doit en produire davantage; d'ailleurs il est plus doux et plus docile que le magot, qui ne s'apprivoise qu'ar ec peine et ne se prive jamais parfaitement. Je me suis convaincu par toutes ces raisons que ce n'est point au magot, mais au pithèque rqu'il faut appliquer ce passage des auteurs africains. II en est de même de celui de Rubruquis, où il est fait mention des singes du Cathay. Il dit "qu'ils ont en toutes choses la "forme et les facons des hommes.... qu ils ne " sont pas plus hauts qu'une coudée et tout cou"verts de poils; qu'ils habitent dans des caver" nes; que pourles prendre on y porte des bois" sons fortes et enivrantes.... qu'ils viennent, " tous ensemble groûter de ce breuvage en criant " chinchin, dont on leur a donné le nom de " chinchin, et qu'ils s'enivrent si bien qu'ils " s'endorment; en sorte que les chasseurs les " prennent aisément. " Ces caractères ne con"viement yu'au pithègue et point du tout au magot. Nous avons eu celui-ci virant, et nous ne l'arons jamais entendu crier chinchin; d'ailleurs il a beancoup plus d'une coudée de hauteur ct ressemble moins à l'homme que ne lo dit l'auteur. Nous avons eu les mèmes raisons pour appliquer au pithèque et non point au magot la figure et l'indieation de Prosper Alpin, par laquelle il assure que les petits singes sans queuc qu'il a vus en Égypte s'apprivoisent plus vite et plus aisémert que les autres; qu’ils ont plus d'intelligence et d'industrie, et qu'ils sont aussi plus gais et plus plaisants que tous les autres. Or, le magot est d'uue grosse et assez grande taille; il est maussade, triste, farouche, 
ct ne s'apprivoise qu a demi. Les caractères que donne ici Prosper Alpin à son singe sans queue ne conviennent donc en aucune maniere au magot, et ne peuvent appartenir à un autre animal qu'au pithèque.

\section{Caractères distinctifs de celle espèce.}

Le pithèque n'a point de queve; il n'a point les dents canines plus grandes à proportion que celles de l'homme; il a la face plate, les ongles plats aussi, ct arrondis comme ceux de l'homme; il marche sur ses deux pieds; il a environ une coudée, e'est-à-dire tout au plus un pied et demi de hauteur; son naturel est doux, et on l'apprivoise aisément. Les aneiens ont dit que la femelle est sujette à l'écoulement périodique, et l'analogie ne nous permet pas d'en douter.

\section{ADDITION A L'ARTICLE DU PITHÈQUE.}

Nous avons désigné, d'après Aristote, cet animal par tous les caracteres qui le distinguent des autres singes sans queue; et quoique nous ne l'eussions pas vu, nous ne doutions pas de son existence que plusieurs naturalistes regardaient conme incertaine. Depuis ce temps, M. Desfontaines, savant naturailiste et professeur au Jardin du Roi, a rencontré dans le royaume d'Alger un singe qu'il a reconnu pour le pithèque que j'avais indiqué. Il l'a nourri pendant plusicur's mois en Barbarie; et, à son retour en France, il a bien voulu m'en faire hommage; et j'ai eu la satisfaction de pouvoir reconnaitre tous ses caractères et ses habitudes naturelles, depuis plus d'un an que je l'ai vivant et sous mes yeux. Je l'ili fait dessiner dans deux attitude's de mouvements, e'est-à-dire, debout sur ses deux pieds de derrière, et sur ses quatre pieds; il est aussi représenté en petit, assis, troisième attitude qu'il prend lorsqu'il est en repos. Je dois domner d'abord les ebservations de M. Desfontaines, sur la nature et les mours de cet animal.

" Les singes pithiques, a dit ce savant natu"raliste, se trouvent diuns la forèt de Bougie, " du Colle et du Stora dans l'ancienne Numidic, "qui est aujourd'hui la province de Constan"tine, du royaume d'dleer Ils habitent par" ticulièrement ces contrées, et je n'ai pas oui " dire qu'on en cùt observé dans aucun au-
" tre licu de la Barbarie. Ils vivent en troupes " dans les forêts de l'Atlas, qui avoisinent la " mer, et ils sont si communs à Stora, que les " arbres des environs en sont quelquefois coll"verts. Ils se nourrissent de pommes de pin, " de glands doux , de figues d'Inde, de melons, " de pastèques, de légumes qu'ils enlèvent des " jardins des Arabes, quelques soins qu'ils pren" nent pour écarter ces animaux malfaisants. "Pendant qu'ils commettent leurs vols, il y en " a deux ou trois qui montent sur la cime des " arbres et des rochers les plus élevés, pour " faire sentinelle; et dès que eeux-ci aperçoi"vent quelqu'un, ou qu'ils entendent quelque " bruit, ils poussent, un cri d'alerte, et aussitòt " toute la troupe prend la fuite en emportant " tout ce qu'ils ont pu saisir.

"Le pithèque n'a guère que deux pieds de " hauteur lor'squ'il est droit sur ses jambes. 11 " peut marcher debout pendant quelque temps; " mais il se soutient avee difliculté dans cette " attitude qui ne lui est pas naturelle. Sa face " est presque nue, un peu allongée et ridée, ce " qui lui donne toujours un air vieux. Il a vingt" huit dents; les canines sont courtes et à peu " près semblables à celles de l'homme. Ses aba" joues ont peu de largeur; ses yeux sont ar"rondis, roussâtres et d'une grande vivacité; " les fesses sont calleuses, et, à la place de "la queue, il y a un petit appendice de peau, "long de cinq à six lignes. Les ongles sont " aplatis comme dans l'homme, et il se sert de " ses pieds et de ses mains aree beaucoup d'a" dresse, pour saisir les divers objets qui sont " ì sa portée : j'en ai vu qui déliaient leurs liens " avee la plus grande facilité. la couleur du "pithèque varie du fauve au gris : dans tous " ceux que jaai observés, une partie de la poi" trine et du ventre étaient recouverts d'une " large tache noirâtre. La verge est grèle et "pendante dans le mảle; les testicules ont peu "de volume.

"Quoique ees animaux soient très-lubriçues, " et qu'ils s'accouplent fréquemment dans l'état " de domesticité, comme j'ai eu oceasion de "l'olserver, il n'y a cependant pas d'exemple "qu'ils aient jamais produit dans eet état de " servitude, mème en Barbaric où l'on en élève " beaucoup dans les maisons des Francs. Lor's"qu'ils s'acconplent, le màte monte sur la fe" melle, qui ust il quatre pieds; il lui appuie " ceux de derriere sur les jumbes, et il l'exeite 
" au plaisir en lui clatouillant les cotés avec les " mains. Elle est sujette à un léger écoulement " périodique, et je me suis aperẹu que ses par" ties naturelles augrmentaient alors sensible" ment de volume.

" Dans l'état sauvage, elle ne produit ordi" nairement qu'un seul petit. Presque aussitôt " qu'il est né, il monte sur le dos de la mère, " lui embrasse étroitement le cou avec les bras, " et elle le transporte ainsi d'un lieu dans un " autre; souvent il se cramponne à ses mamel"les, ets'y tient fortement attaché.

"Celui de tous les singes avec lequel le pi" thèque a le plus de rapports est le magot, * dont il diffère cependant par des earactères " si tranchés, qu’il parait bien former une es" pèce distincte. Le magot est plus grand; ses " testicules sont très-volumineux; ceux du pi" thèque au contraire sont fort petits. Les "dents canines supérieures du magot sont al" longées comme les croes des chiens; celles du " pithèque sont courtes et à peu près sembla" bles à celles de l'homme. Le pithèque a des " mœurs plus douces, plus sociales yue le ma* got : celui-ci conserve toujours dans l'état de * domesticité un caractère méchant et même " féroce; le pithèque, au contraire, s'apprivoise " facilement et devient familier. Lorsqu'il a * élé élevé jeune, il mord rarement, quelque " mauvais traitement qu'on lui fasse subir. Il " est naturellement craintif, et il sait distinguer " avec une adresse étonnante ceux qui lui veu" lent du mal. Il se rappelle les mauvais traite" ments, et lorsqu'on lui en a souvent fait es" suyer, il faut du temps et des soins assidus " pour lui en faire perdre le souvenir. En re" vanche, il reconnait ceux cui lui font du bien; " il les caresse, les appelle, les flatte par des " cris et par des gestes tres-expressifs; il leur " donne même des signes d'attachement et de " fidélité; il les suit comme un chien, sans ja" mais les abandonner. La frayeur se peint sur "le visage du pithèque; j'ai souvent vu ces " animaux changer sensiblement de couleur " lor'squ'ils étaient saisis d'effroi. Ils annoncent " leur joie, leur crainte, leur's désirs, leur enuui " mème par des accents dilférents et faciles à " distinguer. Ils sont très-malpropres et lâchent " leurs ordures partout où ils se trouvent ; ils se " plaisent à mal faire, et brisent tout ce qui se - rencontre sous leur main, sans qu'on puisse les " en corriger, quelque châtiment qu'on leur in-
" flige.Les Arabes mangent la elaail dupithiçue, " et la regardent cornme un bon mets. ")

Je dois ajouter à ees remarques de M. Desfontaines les observations que j'ai faites moimême sur les habitudes naturelles, et même sul' les habitudes acquises de ce singe que l'on liourrit depuis plus d'un an dans ma maison. C est un mâle, mais qui ne paraît point avoir, comme les autres singes, aneume ardeur bien décidée pour les femmes. Son attitude de mouvement la plus ordinaire est de marcher sur ses quatre pieds; et ce n'est jamais que pendant quelques minutes qu'il marche quelquefois debout sur ses deux pieds, le corps un peu en avant, et les genoux un peu pliés. En général, il se balance en marchant; il est très-vif et presque tonjours en mouvement. Son plus grand plaisir est de sauter, grimper et s'accrocher à tout ce qui est à sá portée. Il parait s'ennuyer lorsqu'il est seul, car alors il fait entendre un cri plaintif. Il aime la compaguie, et lorsqu'il est en gaieté, il le marque par un grand nombre de culbutes et de petits sauts. Au reste il est d'un naturel fort doux, et ressemble par là aux orangs-outangs. Malgré sa grande vivacité, il mold très-rarement et toujours faiblement.

Cet individu avait au mois d'avril 1787 deux pieds eing pouces de hauteur, et lorscu'il se tenait debout sur ses pieds. Il était âgé de près de deux ans : il avait erù de près de six pouces en dix mois, et avait dans le mêne temps pris en proportion plus de grosscur et d'épaisseur de corps; son poil avait bruni, surtout à la racine. De tous les animaux de ce genı'e, le patas à bandeau blanc est celui auquel il ressemble le plus par la forme de la tète, qui est un peu allongée et aplatic au sommet; le front est assez court et couvert de poils, presque aussi longs que ceux de la tête; il a les yeux enfoncés et l'iris d'un jaune rougeâtre; l'os frontal au-dessus de l'orbite des yeux est saillant, et l'on ne voit autom de cette partie aucum poil disposé en forme de sourcils; il a des cils aux deux paupières; son nez est aplati et forme gouttière entre les deux narines qui sont posćes obliquement et s'inelinent en dedans : toute la face est de couleur de chair pâle, avec des poils noirâtres très-clair-semés, mais en plus grand nom bre autour de la bouche et sur le menton, au dessous duquel des poils eneore nombreux et d'un blane sale forment une espèce de petite barbe. Il a trente dents et denx alvéoles vides, 
d'ou il en était tombé deux autres. L'oreille est grande, ronde et large en bas, mince, sans rebord et presque sans poils; elle a ving-trois lignes de longueur, sur quinze lignes à sa plus grande largeur. Chaque poil est noirâtre, tant à sa racine qu'à son extrémité, et d'un jaune doré dans son milieu : ce qui présente à l'œil une couleur générale d'un brun jaunâtre sur la tète et sur tout le dessus du corps et des membres. Le ventre et la face intérieure des cuisses et des jambes sont d'un blanc sale, et les poils y sont plus courts et moins touffus : la plus grande partie de la peau de cette face intérieure et du ventre est d'un beau bleu; la peau du dessous des mains et des pieds est donce, brunâtre et sans poils; les ongles sont arrondis ct presque noirs; l'appendice de peau, qui est à la place de la queue, est souple, et n'a que six lignes de longueur.

\section{DU PETIT CYNOCÉPIALE.}

Ordre des quadrumanes, tribu des magots, famille des singes. (Cuvier.)

J'ai dit que le singe que nous avons appelé magot était le cynocéphale des anciens, et je crois mon opinion bien fondée. Mais il y a cieux espèces de cynocéphale, l'une plus grande, qui est en effet le magot, et l'autre plus petite. Ce petit cynocéphale est sans queue, et cet animal ne nous parait avoir été indiçué par aucun naturaliste, à l'exception de Prosper Alpin, qui s'exprime dans les termes suivants : "Je donne " ici, dit-il, planche 20 , figure 1, un petit " cynocéphale qui n’a point de queue. Il s'ap" privoise plus aisément, et est aussi plus " spirituel et plus gai que les autres eynocè"phaies. "On ne peut guere douter que ee ne soit le même animal. Nous aurions pu l'ilppeler petit magot; mais nous avons mieux aimé lui domner le nom de petit cynocéphale, parce qu'il diffère du magot en ce qu'il n'a pas les fesses pelées, et qu'il est courert d'un poil roux, et plus doux que le magot '; et e'est par' le caractère de n'avoir pas les fesses pelées, ainsi que par la grosseur et par la prolongation du museau, qu'il diflère aussi du pitlièque, avec lequel on pourrait le eoufoudle. I'ai dit que cette dernière espèce (le magot) se trouvait en Espagne dans les montagnes de Gibraltar. M. Col-

- Cet animal ue diffêre pas du magot.

iv. linson, qui doutait de ce fait, a éerit pour s'en informer. M. Charles Frédéric, commandant à Gilbraltar, lui a répondu que ces singes habitent en effet sur le côté de la montagne qui l'egarde la mer, qu'ils y sont nombreux, et que des personnes rignes de foi lui ont attesté qu'ils s'y multiplient '. C'est néanmoins le seul endroit de l'Europe ou l'on troure des singes dans leur état de nature.

\section{LE PAPION}

OU

\section{BABOUIN PROPREMENT DIT.}

\section{LE CYNOCÉPHALE PAPION. - LE CYNOCÉPHALE BABOUIN.}

Ordre des juadrumanes, tribu des cynocéphales, famille des siuges. (Cuvier ${ }^{2}$.)

Dans l'homme, la physionomic trompe, et la figure du corps ne décide pas de la forme de l'ame; mais dans les animaux, on peut juger du naturel par la mine, et de tout l'intérieur par ce qui parait au dehors : par exemple, en jetant les yeux sur nos singes et nos babouins, il est aisé de voir que ceux-ci doivent être plus sauvages, plus méchants que les autres; il y a les mênes diflérenees, les mêmes nuances dans les mœur's que dans les figures. L'orang-outang, qui ressenuble le plus à l'homme, est le plus intelligent, le plus grave, le plus docile de tous; le magot, qui commence ì s'éloigner de la forme humaine, et qui approche par le museau et par les dents caninies de celle des animaux, est brusque, désobéissant et maussade; et les babouins, qui ne ressemblent plus à l'hormme que. par les mains, et qui ont une queue, des ongles aigus, de gros museaux, ete., ont l'air de bete's féroces, et le sont en effet. J'ai vu vivant un babouin qui n'était point hideux, et ecpendant il faisait horreur : grincant continuellement l's dents, s'agitaut, se débattant avec colère, on était obligé de le tenir enfermé dans une ane de fer, dont il remuait si puissamment les barreaux aree ses mains, qu'il inspirait de lit crainte aux spectateurs. C'est un animal trapu,

- Lellre de fen M. Collinsun à M. de Buffun, dalée de Lonires le 9 férier 1761.

${ }^{2}$ Lanimal dout il s'aggit dans cet artichs cst le projion, et cenest yut subsidiairement yuil y estrraité dubabouin, (pue buffon ne distmguall pas de ce singe, commecspece. (Note de M. Desmaresl.) 
dont le corps ramassé et les membres nerveux indiquent la foree et l'agilité; qui, couvert d'un poil épais et long, parait cucore beaucoup plus grus qu'il n'est, mais qui, dans le réel, est si puissant et si fort, qu'il viendrait aisément à bout d'un ou de plusieur's hommes, s'iis n'etaient point armés '. D’ailleurs, il parait continuellement excité par cette passion qui rend furieur les animaux les plus doux : il est insolemment lubrique, et affecte de se montrer dans eet état, de se toucher, de se satisfairc seul au yeux de tout le monde; et cette action, l'une des plus honteuses de l'humanité, et qu'aucun animal ne se permet, copiée par la main du babouin, rappelle l'idée du vice, et rend abomiiable l'aspect de cette bite que la nature paralt aroir particulièrement vouce à cette espèee d'impudence; car dans tous les autres animaux, et méme dans l'homme, elle a voilé ces parties : dans le babouin, au contraire, elles sont tout à fait nues et d'autant plus éridentes que le eorps est courert de longs poils; il a de mème les fesses nues et d'un rouge couleur de sang, les bourses pendantes, l'anus décourcrt, la queue toujours levée. Il semble faire parade de tontes ces nudités, présentant son derrière plus souvent que sa tête, surtout dès qu'il aperçoit des fenmes, pour lesquelles il déploie une telle effronterie, qu'elle ne peut naitre que du desir le plus immodéré. Le magot et quelques autres ont bien les mèmes inelinations: mais comme ils sont plus petits et moins pétulants, on les rend modestes à coups de fouet, au lieu que le babouin est nor-seulcment incorrigible sur cela, mais intraitable à tous autres égards.

Quelque violente que soit la passion de ces animaux, ils ne produisent pas dans les pays tempérés; la femelle ne fait ordinairement qu'un petit qu'elle portc entre ses bras et attaché, pour ainsi dire, à sa mamelle : elle est sujette comme la femme à l'évacuation périodique, et cela Jui est commun arec toutes les autres femelles de singes qui ont les fesses nues. Au reste, ces babouins, quoique méchants et fèroces, ne sont pas du nombre des animaux carnassier's; ils se

- C'est à cetle esnèce qu'il fanl rapjorter l'animal apjelé $t$ tré-lré-lré-lré a llarlagascar. Il est dil Flacourl gl'os culume un veau de deux ans, il a la téte ronde el une face d'lomme, les pieds de devant et de derrière comme un singr, le puil friIotte, da quene conrle, les oreilles conme cilles ile l'homme; si ressembie an tanach décrit par Auhroist Paré : c'est un niansal solitaire; les gens du pays en ont grand peur. loyage à Madigasear, page 131 . nourrissent principalement de fruits, de racines et de grains : ils se réunissent et s'entendent pour piller les jardins; ils se jettent les fruits de main en main et pas-dessus les murs, et font de grands dégâts dans toutes les terres cultirées.

\section{Caractères distinctifs de cette espèce.}

I.e papion a des abajoues et de larges callosités sur les fesses, qui sont nues et de couleur de sang: il a la queue arcpuée et de sept ou huit pouces de long'; les dents canines beaucoup plus longues et plus grosses à proportion que eellcs de l'homme; le muscau très-gros et trèslong ; les oreilles nues, mais point bordées; le corps massif et ramassé; les membres gros et courts; les parties génitales unes et couleur de ehair'; le poil long et touffu, d'un brun roussâtre et de couleur assez uniforme sur tont le corps. Il marche plus sour ent à quatre qu'ł deur pieds; il a trois ou quatre pieds de hauteur lor'squ'il est dlebout. Il parait gu'il y a dans cette espece des races encore plus grandes et d'autres beaucoup plus petites. Le babouin que nous arons fait représenter est de la petite espece; nous l'avons soigneusement comparé au grand botbouin ou papion, et nous n'avons remarqué d'autres différences entre eux que celle de la gl'andeur'; et cette différence ne venait pas de celle de l'âgge, ear' le petit babouin nous a paru adulte comme le grand. Les femelles sont sujettes, comme les femnies, à un écoulement périodique ${ }^{2}$.

\section{LE BABOUIN DES BOIS.}

\section{(LE MAGOT DE L'IXDE.)}

Ordre des quadrunanes, tribn des maeaques, fanille des singes. (Curier.)

M. Pennant a fait connaitre cette espèce, conservée à Londres dians la collection de M. Lever. Ce babouin a le museau très-allongé et semblable à celui d'un chien; sa face est courerte d'une peau noire et un peu luisante : les pieds et les mains sont unis et noirs comme la

1 L'individu qui a sersi a celle description avait la queue tronyufe. Celte partic eulicre est très-lungue.

2 Celte petile csuce est le babonin proprement dit. Il hr: bite les cuntrécs septeutrionales de l'ifriyue. 
face, mais les ongles sont blancs. Le poil dece babouin est très-long et agréablement mélangé de noir et de brun. L'individu décrit par M. Pennant n'a vait que trois picels de haut; la quene n'avait que trois pouces de long, et le dessus en était très-garni de poil. Cet anima! se trou ve en Guince, ou les Angla is l'ont appelé l'hornme cles bois.

Nous croyous devoil placer ici la notice de trois autres bribouins, qui probablement ne sont que des variétés du babouin des bois, et que M. Pemnant á égilement vus diuns la collection de M. Lever.

Le premier de ees trois babouins, que M. Pennant a nommé le babouin jaune, avait la face noire, le museau allongé et des poils longs et bruns aur-dessus des yeux; les oreilles étaicut cachées dans le poil, dont la couleur était sur tout le corps d'un jaune mélangé de noir.

Il avait deux pieds de hauteur; il ne différait du babouin des bois que par sil taille, et parec qu'il avait les mains couvertes de poil.

Le second de ces trois babouins avait la face d'un brun foncé; son poil était d'un brun pàte sur la poitrine, d'un cendré obscur sur le corps et sur les jambes, et mélangé de jaune sur la tète. M. Pennant l'a appelé le babouin cendré.

Le tunisième avait la face bleuâtre, de longs poils au-dessus des yeux, et une touffe de poils derrière chaque oreille. Le poil qui garnissait la poitrine était cendré, mêlé de noir et de jaunatre. II a vait trois pieds de hauteur.

On voit que les earactères de ees trois babouins se ripprochent de si près de ecux du babouin des bois, qu'on ne doit les regrarder que comme de simples variétís d'une seule et mème espèce.

\section{LA GUENON A MUSEAU ALLONGÉ.}

(LB PAPION NOIR. - LA GUEYON A FACE ALLONGÉE. - LE SINGE NOII '.)

Ordre des quadrumanes, tribu des cynocciphales, famille des singes. (Curier.)

Cette guenon a en effet le muscau très-long, très-délié, et courert d'une preau mue et rougeàtre. Son poil est tres-long sur tout le corps, mais principalenent str les cipaules, la poitrine

- M. G. Cuvier rapporte tous ces synuny'mes à celle espèce. et la tête; la couleur en est d'un gris de fer mèlé de noil, excepté sur la poitrine et le ventre, oi clle est d'un cendré clair : la queue est tres-longue. Cet animal a deux pieds de haut lorscru il est assis; son naturel est fort doux. M. Penmant, qui l'a fait comaitre, ignorait son pays natal; mais il croyait qu'il avait été apporté d'Afrique.

Cotte espece ressemble beaucoup, par sa conformation, a ceelle dont nous parlons sous le nom de Bahouin a museau de chien; mais indépendamment de ses habitudes qui sont bien plus donces que ectles des babouins, elle en differe par les coulcurs de sun poil, et surtont par la longueur de sa querie.

\section{LE MANDRILL.}

\section{(LE CYYOCÉPILLE IIANDRILL.)}

Ordre des quadrumanes, trilsu des mandrills, fanille des singes. (Cuvier.)

Ce babouin est d'une laideur désagréable et dégoủtante: indépendamment de son nez tout plat, ou plutôt de deux naseaux dont découle continuellement une morve qu'il recueille aree la langue; indépendamment de son très-cros et long museau, de son corps trapu, de ses fesses couleur de sangr et de son anus apparent, et placé, pour ainsi dire, danns les lombes, il a cucore la face violette et sillonnée des denx cótés de rides profondes et longitudinales qui en angmentent beancoup la tristesse ct la difiormité. Il est aussi plus grand et peut-ètre plus fort que le papion; mais il est en mème temps plus tranquille et moins firoce. Nous donnons ici la figure du mâle et de Ir femelle, (que nous arons vus vivants : soit qu’ils ceussent été micux ćduqués, on que natureflement ils soient plus doux que le papion, ils nous ont paru plus traitalbles et moins inpudents sans ètre moins disagréables.

Cette espece de baboun se trouve à la Cinted'Or et dins les andres prosinee's méridionales de l'A Pripue, ou les Verores l'applellent buggo, et les Europecens mandrill. 11 parait quipres l'0rang-nutang. cest le plus grand de tous les singeset detoris lesbabouins. Smith ' raconte gu' on

Fin Gumie on apprells laogoe on beggo il mandrill, l'aniunal dont Il est ici yne slion, cl liun appelle ansoi pongo et

46. 
lui fit présent d'une femelle mandıill, qui n'était âgée que de six mois, et qui était déjà aussi grande à cet âge qu'un babouin adulte. Il dit aussi que ces mandrills marehent toujours sur deux pieds, qu'ils pleurent et quills gémissent comme des hommes, qu'ils ont une violente passion pour les femmes, et qu'ils ne manquent pas de les attaquer avec succès lor'squ'ils les trowvent à l'écart.

\section{C'aractères distinctifs de celle espèce.}

Le mandrill a des abajoues et des callosités sur les fesses: il a la queue très-courte, et seulement de deux ou trois pouces de long; les dents canines beaucoup plus grosses etplus longues à proportion que celles de l'homme; le museau très-gros et très-long, et sillonné des deux côtés de rides longitudinales, profondes et très-marquées; la face nue et de couleur bleuàtre; les oreilles nues aussi bien que le dedans des mains et des pieds; le poil long, d'un brun roussâtre sur le corps, et gris sur la poitrine et le ventre : il marche sur deux pieds plus souvent quesur quatre. Il a quatre pieds ou quatre pieds et demi de hauteur lorsqu'il est debout : il parait même qu'il y en a d'encore plus grands. Les femelles sont sujettes, comme les femmes, à l'écoulement périodique.

\section{LE CHORAS.}

Ce grand et gros babouin qu'on trouve dans les parties méridionales des grandes Indes ', et particulièrement dans l'ile de Ceylan, suivant quelques voyageurs, peut se distinguer des antres babouins par une touffe de poils qui se relève en forme de houppe au-dessus de sa tête, et par la couleur de sa peau sur le nez, qui forme

diill l'orang-outang; ces noms se ressemblent, ef sont vraisemblablement dérivés les uns des antres. Et en effet le pongo et le boggo, on, si l'on veut, le drill el le mandrill, ont plnsieurs caraclères communs; mais le premier ('sl un singe sans quene et presque sans poil, qui a la face aplatie et ovale. an lieu que le second est un babouin avec nne queue, de longs poils, et le museau gros el long. Le mot man, dans les langues allemande, anglaise, ele., signifie l'homme en geineral; et te mol drill, dans le jargon de quelyues-mues de nos provinces de France, comme en Bourgogne, signitic un homme vigoureux et libertin : les paysans disent, cंest un bon drill, c'est un maftre drill.

- Le choras est un mandrill mâle adulte qui lıabite l'A Írịue comme tous les autres individus de son espece. une bande d'un rouge très-vif, et sur le milieu de sa face dont les joues sont violettes.

M. Pennant en a vu, en 1779, un individu vivant qui avait cinq pieds de haut. Les oreilles de ce babouin sont petites et nues; son museau est très-allongé, et son nez paraît troncuué par le bout, ce qui lui donne de la ressemblance avec le boutoir d'un sanglicr. Ce boutoir, ainsi que toute la partie supérieure qui forme le nez, est d'un rouge très-éclatant; les joucs, comme dans le mandrill, sont d'un violet clair et trèsridées : l'ou verture de la bouche est très-petite.

Sa houppeest composée de poils noirâtres et très-longs : la tête, les bras et les jambes sont revêtus d'un poil court, dont la couleur' est mêlée de jaune et de noirâtre; des poils bruns trèslongs couvrent les épaules; ceux qui garnissent la poitrine sont aussi très-longs; les mains et les pieds sont noirs, et les ongles plats; la queue, dont le poil est fort touffu et assez court, $\mathbf{n}^{\prime} \mathbf{a}$ que quatre pouces de longueur; les fesses sont pelées ct d'un pourpre très-vif qui s'étend sur le derrière des cuisses.

Un babouin de cette espèce, âgé de trois ans, que nous avous vu vivant, a vait trois pieds un pouce de hauteur : son maitre l'avait acheté à Marseille deux ans auparavant, et il n'était alors pas plus gros qu'un petit sapajou. Il était trèsremarquable par les couleur's de la face et les parties de la génération : il avait le nez, les naseaux et la lèvre supérieure d'un rouge vif écarlate; il avait aussi une petite tache de ce même rouge au-dessous des paupières. Les yeux étaient environnés de noir et surmontés de poils touffus de même coulcur; les oreilles étaient pointues et de couleur brune; il portait sous le menton une barbe à flocons d'un blanc jaune, à peu près semblable à celle du mandrill. Les poils à còté des joues étaient d'un blanc sale et jaunâtre, mais longs et bien fouruis : ces poils hérissés se couchaient et diminuaient de longueur en gagnant le sommet de la tête, et les taches blanches au-dessus des oreilles étaient d'un poil très-court. Le milieu du front étail convert de poils noirs qui, s'élevant en pointe vers le sommet de la tète, y formaient une houppe, et s'étendaient en forme de crinière qui venait s'unir sur l'épine du dos à une raie noire, laquelle se prolongeait jusqu'à la queue. Le poil du corps était d'un brun verdâtre, mêlé de noir ; celui des flanes un peu ardoisé; et sur le ventre il était d'un blane sale un pell jaunâtre, 
Le poil était plus long sous le ventre que sur le dos. Le fourreau de la verge, ainsi que les callosités sur les fesses, étaient d'un rouge écarlate aussi vif que celui des naseaux, tandis que les testicules étaient d'un violet foncé, ainsi que la peau de l'intérieur des cuisses. Ce choras avait, en marchant ì quatre pattes, la même allure que le papion; le train de devant était sensiblement plus élevé que le train de derrière, les jambes de devant étant plus longues.

On a observé que cet animal se nourrissait de fruits, de citron, d'avoine, de noix qu'il écrasait entre ses dents, et qu'il avalait avec la coque; il les serrait dans ses abajoues qui pouvaient en contenir jusqu'à huit sans paraitre très-remplies. Il mangeait la viande cuite et refusait la erue; il aimait les boissons fermentées, telles que le vin et l'eau-de-vie. On a observé aussi que ce babouin était moins agile, plus grave et moins malpropre que la plupart des autres singes. Schreber dit qu'on montrait en Allemagne, en 1764, un de ces grands babouins qui avait grand soin de nettoyer sa hutte, d'en otter les exeréments, et qui mème se lavait souvent le visage et les mains avee sa salive. Tous les naturalistes qui ont vu ce babouin s'accordent à dire qu'il est très-ardent en amour, mème pour les femmes.

L'individu que M. Pennant a vu en Angleterre était d'une très-grande force; car il comparait son eri au rugissement du lion. Jamais il ne se tenait sur les pieds de derrière que lorsqu’il y était forcé par son conducteur; il s'asseyait souvent sur' ses fesses en se penchant en avant et en laissant tomber ses bras sur son ventre. Au reste, cet animal que nous avons nommé choras est le papio de Gessner : car la figure que ce naturaliste en a donnée est trèsconforme à celle que $\mathrm{M}$. Pennant a fait dessiner d'après l'animal vivant, et on ne l'a regardée comme défectueuse que parce quion la rapportait à notre papion, dont il differe principalement par les sillous et les couleurs rouges de la fice, ainsi que par la toulfe de poils qu'il porte au-dessus de sa tètc.

\section{L'OUANDEROU ET LE LOWANDO'.}

\author{
LE MACAQUE OUANDEROU. - LE MACAQUE
}

A CRINIĖRE.

Ordre des quadrumanes, tribu des macaques, famille des singes. (Curier.)

Quoique ces deux animaux nous paraissent être d'une seule et mème espèce, nous n'avous pas laissé de leur conserver à chacun le nom qu'ils portent dans leur pays natal, à Ceylan, parce qu'ils forment au moins deux races distinctes et constantes. L'ouanderou a le corps couvert de poils bruns et noirs, avec une large chevelure et une graude barbe blanches; au contraire le lowando a le corps couvert de poils blanchattres avec la chevelure et la barbe noires. Il y it encore dans le mème pays une troisième race ou variété qui pourrait bien être la tige commune des deux autres, parce qu'elle est d'une couleur uniforme et entièrement blanche, corps, chevelure et barbe. Ces trois animaux ne sont pas des singes, mais des babouins; ils en ont tous les caractères, tant pour la figure que pour le naturel; ils sont farouches et mème un peu féroces : ils ont le museau allongé, la queue courte, et sont à peu près de la mème grandeur et de la même force que les papions: ils ont seulement le corps moins ramassé, et paraissent plus faibles des parties de l'arriẻre du corps. Celui dont nous donnons la figure nous avait été présenté sous une fausse dénomination, tant pour le nom que pour le climat. Les gens auxquels il appartenait nous dirent qu'il venait du continent de l'A mérique méridionale, et qu'on l'appelait cayou-v'assou. Je reconnus bientòt que ce mot cayou-vassou est un terme brésilien, qui se prononce sajououassou, et qui signilie saprajou, et que par conséquent ce nom avait été mal appliqué, puisque tous les sapajous ont de très-longues queues, au lieu que l'animal dont il est ici question est un babouin à queue tres-courte. D'ailleurs, non-seulement cette espèce, mais mème aucune espèce de babouin ne se trouve en Amérique, ct par conséquent on s'citait aussi trompé sur l'indieation du climat; et cela arrive assez ordinairement, surtout à ces montreurs d'ours et de singes, qui, lorsqu'ils ignorent le climat et le

' Ce singe, selon P'. Cuvier, ne serailqpas une simple varielí de fouanderou, mals apparticndrait plutós aux entelles. 
nom d'un animal, ne mançuent pas de lui appliquer une dénomination étrangère, laquelle, vraie ou funsse, est également bonne pour l'usage qu'ils en font. Au reste, ees babonins-ouanderous, lorsqu'ils ne sont pas domptés, sont si méchants qu’on est obligé de les tenir dans une eage de fer, ou souvent ils s'agitent arec fureur; mais lorsquion les prend jeunes, on les apprivoise aisément, et ils paraissent même étre plus susceptibles d'éducation que les antres Jabouins. Les Indiens se plaisent a les instruire, et ils prétendent que les autres singes, c'est-àdire les guenons, respectent benueoup ees babouins, qui ont plus de gravité et plus d'intelligence qu'elles. Dans leur état de liberté, ils sont extrêmement sauvages, et se tiennent dans Ies bois. Si l'on en croit les voyageurs, cenx qui sont tout blanes sont les plus forts et les plus méehants de tous. Ils sont très-ardents pour les femmes, et assez forts pour les violer lorsqu'ils les trouvent seules, et souvent ils les outragent jusqu'à les faire mourir.

\section{Curactères distinclifs de cotte espèce.}

L'ouanderou a des abajoues et des eallosités sur les fesses, la quene de sept on huit ponces de long, les dents eanines plus longues et plus grosses que celles de l'homme, le museau gros et allongé, la tète environnée d'une large criniere et d'une grande barbe de poils rudes, le corps assez long et assez mince par le bas. 11 y a dans cette espèce des races qui varient par la couleur du poil : les uns ont celui du corps noir et la barbe blanehe; les autres ont le poil du corps blanchátre et la barbe noire. Ils marehent à quatre pieds plus souvent qu'à deux, et ils ont trois pieds ou trois pieds et demi de hatuteur lorsqu'ils sont debout. Les femelles sont sujettes à l'écoulement périodique.

\section{ADDITION}

\section{A L'ARTICLE DE L'OUANDEROU.}

M. Marcellus Bless m'a écrit (que les habitants de Ceylan appellent oswanderm ou vanderou des singres blanes qui ont une longue larbe. II ajoute qu'il en avait embarqué quatre pour les anener en Hollande aree lui, mais que tous śtaient morts en route, quoique les autres sin- ges amenés du même pays, et en même temps, eussent bien soutenu la fatigue du royage: ainsi l'ouanderou parait être l'espèce la plus délicate des singes du Ceylan. M. Marcellus Bless ajoute qu'il a eu chez lui, à Ceylan, un petit ouanderou, né depuis trois jours, et qu'il avait de la barbe autaut à proportion que les vieux : ce qui prouve qu'ils naissent avee eette barbe.

Nous avons aussi été iuformé que l'ouanderou, ainsi que le lowando, sont très-adroits, qu'ils s'apprivoisent avee peine, et qu'ordinairement ils visent peu de temps en eaptivité. Dans leur pays natal, la taille des plus forts, lor'srju'ils sont debout, est à peu près de trołs pieds et demi.

\section{LA GUENON A CRINIËRE?}

Ordre des quadrumanes, tribu des macaques, famille des singes. (Cuvier.)

Nous donnons eette dénomination à une guenon qui nous était inconnue, et qui a une criniere autour du cou et un flocon de poils au bout de la queue comme le lion. Elle appartenait à II. le due de Bouillon, et elle paraissait nonseulement adulte, mais âgée. Nous en donnons la figure dessinée d'après l'animal vivant; e’était un mâle, et il était assez privé : il vivait eneore en $17 \% 5$, à la ménagerie du roi à Vel. sailles. Voici la description que nous en avons faite.

II a deux pieds de longueur depuis le bout du nez jusqu'à l'origine de la queue, et dix-huit pouces de hauteur lorsqu'il est sur ses quatre jambes, qui paraissent longues à proportion de la longueur du corps. Il a la face nue et toute noire : tout le poil des iambes est de cette mème couleur, et quoique long et luisant, il parait court aux yeux paree qu’il est couché. Il porte une belle crinière d'un gris brun autour de la fitce, et une barbe d'une gris clair : cette criniere qui s'étend jusqu'an-dessus des yeux est mélée de poils gris, et dans son milieu elle est composée de poils noirs; elle forme une espéce d'enfoncement vers le sommet de la tête, et passe devant les oreilles, en venant se réunir sous le cou avee la barbe. Les yeux sont d'un

- Cuvier rapporte ce singe a l'espiece de l'ouanderou. F. 
brun foneé, le nez plat et les narines larges et écartées comme eelles de l'ouanderou, dont il a toute la pliysionomic par la forme du nez, de la bouche et de la màchoire supéricure, mais duquel il diffère tant par la erinic̀re que par la quene et par plusicurs autres earacteres. La queue est courerte d'un poil court et noil partout, avee une belle touffe de longs poils à l'extrémité, et longue de vingt-sept pouees. Le dessous de la queve près de son origine est sans poil, ainsi que les deux callosités sur lesquelles sassied ectie guenon. Les pieds et les mains sont un peu couverts de poils, à l'exception des doigts qui sont nus, de mème que les orvilles qui sont plates et arrondies ì leur extrémité, ct eachées par la crinière, en sorte cqu'on ne les aperecoit qu'en regardant l'animal de face. Nous conjecturons que eetle espèce de grande guenon à crinière se trouve en Abyssinie, sur le témoignage d'Alvarés qui clit qu'aux euvirons de Bernacasso il rencoutra de grands singes aussi gros que des brebis, qui ont une eriniere conme le lion, et qui ront par nombreuses compagnies.

\section{IE BABOUIN A MUSEAUDE CIIIEN".}

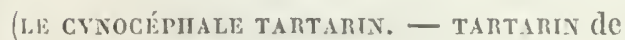
belon. - papron a perrugue.)

Ordre des quadrumanes, tribu des cynocéphales, famille des singes. (Curier.)

Ce babouin a le muscau très-allongé, trèsépais, et semblable a celui du chien, ce qui lui a fitit donner sa dúncmination. Sa face est converte d'une peau rouge, garnie de poils gris très-clair-semes, et lit plupart for't courts; ie bout du museau est violet, les yeux sont petits. Les cils des paupières superieures sont longs noirs et fouffus; mais ecux des paupieres infé rieures sont très-clairs-scmés. Les oreilles sont pointues et raclées dans le poil ; la tète est converte, tout autour de la fice, de poils touffus J'un grris plus ou moins mểé d'un vert jaunâ tre, dirinés en arrière, beaucoup plus loners au dessus de chaque oreille, et y formant une houppe bien foumie. Le's ilents incisives sont

- Ciest le mime que celni (qui est decrit sons le titre d'Addilion a l'urlicle du lowando. très-grandes, surtout les deux du milieu de la máchaire supéricure; eclles de la mâchoire inférieure sont inclincécs en arant: les dents canines sont très-longues; celles de dessus ont un pouce et demi de longueur, et avancent sur la leve inferieure. Le corps est gros et couvert d'un poil épais, de la même coulcur que celui de la tête, et très-long sur le derant et au milieu du corps. Le poil du ventre est blanchâtre; les callosités sur les fesses sont larges, proćminentes ct roussâtres; la qucue est velue, plus minee vers l'extrémité cu'a son origine, presque aussi longue que le corps, et eommunément relerée. Ce caractere suffirait pour faire distinguce le babouin à museau de chien du papion, qui a la queue tre's-courte, mais aree lequel le premier a eependant une très-grande ressemblarse, tant par sa conformation que par ses Jabitudes.

Le babouin à muscau de chien a les bras et les jambes forts, épais et couverts d'un poil touffu. Les mains et les pieds sont noirâtres et presque nus; tous les ongles sont arrondis et plats.

M. Edwards avait reeu un individu de cette espèe qui avait près de einq pieds de hauteur, et qui avait été pris dans l'Arabie. Cette espèce de babouin s'y rässcmble par centaines, ce qui oblige les proprićtaires des plantations de eafé à etre continuellement sur leurs gardes contre Ies cléplédations de ees animaux. Celui que 11. Edwards a vu vivant était fier, indomptable et si fort, quiil aurait terrassé aisément un homme fort et vigoureux. Son inclination pour les femmes s'exprimait d'une manière très-vioIente et tres-énergique. Quelqu'un étant allé le voir avee une jemne fille, et l'ayant embrissée devant ee bahouin pour exciter sa jalousie, l'snimal devint luricux; il saisit un pot d'etain qui était à sa portée, et le jeta avee tant de foree contre son pretendu rival, qui lui fit une blessure tres-considerable à la téte.

Au reste, eette espece se troure non-seulement en Arabie, mais encore en Alyyssinie, el Guine, et en géméral dans tout l'intérieur' de l'Afrique, jus(jưau eap) de Bonne-Espérance; ils y sont (igalement en grand nombre. Ils ont les mème's habitudes que les papions, et se réunissent de mème pour aller piller les jardins, plusieurs cusemble. Ils se nourrissent communement de fruits; ils aiment aussi les insectes, et particulièrement les fourmis, mais ils ne man. 
gent point de viande, à moins qu'elle ne soit cuite.

Malgré leur graude force, il est aisé de les priver lorsqu'ils sont jeunes, et quelques voyageurs ont dit qu'au cap de Bonne-Espérance on s'en servait quelquefois comme de chiens de garde. Ils ajoutent que lorsqu'on les frappe ils poussent des soupirs et des gémissements accompagnés de larmes.

\section{ADDITION}

\section{A L'ARTICle DU LOWANDO.}

Une gravure enluminéc m'a été envoyee d'Angleterre par feu M. Edwards, sous le nom de singe de Moco, parce qu'il lui était venu de Moco dans le golfe Persique. "Ce singe mále, “ m'écrit M. Edwards, que j'ai dessiné vivant, " était aussi ardent en amour qu'il était spiri" tuel..... Pendant que je faisais sa figure, un " jeune homme et une jeume femme vinrent le "voir : il parut désirer très-fort de s'approcher " de la femme; il la tirait fortement par ses ju" pons, tâchant de la faire tomber sur lui ; mais "le jeune homme l'ayant écarté et chassé, il fit a très-mauvaise mine, et, pour se venger, Il " lui jeta de toutes ses forces un gros pot d'é" tain qu'il trouva sous sa main. Il n'était néan" moins que de la taille d'un eufant de dix "ans."

L'espèce à laquelle ce singe de Moco nous parait appartenir est celle du lowando, dont nous avont parlé page 725. J'ai dit que quoique l'ouanderou et le lowando nous parussent être d'une seule et même espèce, nous ne laissions pas que de leur conser ver à chacun le nom qu'ils portent dans leur payss natal, paree qu'ils forment au moins deux races distinctes et constantes. L'ouanderou a le corps couvert de poils hruns et noirs, avec une large chevelure et une glande barbe blanches : au contraire, le lowando a le corps couvert de poils blanchâtres avec la chevelure et la barbe noires. Par ces derniers caractères, on voit que c'est en effet au lowando plutôt qu'à l'ouanderou qu'on peut rapporter l'animal dont nous donnons ici la figure; car les autres caractères, tels que la longueur de la queue, la forme du corps et celle des membres, sont communs à ees deux espèces, e'est-il-dire los mèmes daus l'ouanderou et le lorrando.
Au reste, ce lowando a ies fesses pelées, la face sans poil et de couleur de chair, jusqu'au bas ou elle est noire aussi bien que le nez. Il y a des poils au-dessus des yeux, en forme dt sourcils. La tête est coiffée de grands poils gri sátres, touffus et serrés, qui lui forment comme une large perruque dont les bords sont blanes et accompagnent la face. Les pieds et les mains sont noirs, les ongles un peu longs et en gouttière; la queue est d'une médiocre longueur et bien couverte de poils; les cuisses et les jambes sont garnies de poils d'un brun roussâtre. Le corps et les bras jusqu'au poignet sont revêtus de longs poils d'un blanc sale, et le dessus du dos est d'un poil brun, ce qui lui forme comme une pelisse qui lui tombe jusqu'aux reins. Cette lescription, qui n'est faite que d'après la gravure enluminée, ne peut pas être bien exacte, et je ne la donne que faute de plus grandes observations. Peut-être M. Edwards, qui m'avait envoyé cette gravure trois aus arant sa mort, aura-t-il laissé dans ses papiers ume deseription complète de ce même animal qu'il a dessiné vivant.

\section{LE MAIMON.}

\section{LE MIACAQUe MaIMON.}

Ordre des quadrumanes, tribu des macaques, famille des singes. (Curier.)

Les singes, les babouins et les guenens forment trois troupes qui laissent entre ell :s deux intervalles; le premier est rempli par le mago, et le second par le maimon : celui-ci fait la nuance entreles babouins et les guenons, comme le magot la fait entre les singes ct les babouins. En effet, le maimon ressemble encore atux babouins par son gros et large museau, par sa queue courte et arquee; mais il en differe et s'approche des guenons par sa taille qui est fort au-dlessous de celle des babouins, et par la douceur de son naturel. M. Edwards nous a donué la figure et la description de cet animal sous la dénomination de singe à queue de cochon. Ce caractère particulier suffit pour le faire reconnaître; car il est le seul de tous les babouins et guenons qui ait la queue nue, menue rt tournée comme ce!le du cochon. Il est à peu juès de la grandeur du magot, et ressemble si fort au ma- 
caque qu'on pourrait le prendre pour une variété de cette espèee, si sa queue n'était pas tout à fait différente. Il a la face nue et basanée, les yeux châtains, les paupières noires, le nez plat, les lèvres minces avec quelque poils raides, mais trop courtspour faire une moustacke anparente. Iln'a pas, comme les singes et les babouins, les bourses à l'extérieur et la verge saillante; le tout est eaché sous la peau : aussi le maimon, quoique très-vif et plein de feu, n'a rien de la pétulance impudente des babouins : il est doux, traitable et même earessant. On le trouve à Sumatra ', et vraisemblablement dans les autres provinces de l'Inde méridionale : aussi souffret-il avee peine le froid de notre climat. Celui que nous avons vu à Paris n'a véeu que peu de temps, et M. Edwards dit n'avoir gardé qu'un an à Londres celui qu'il a déerit.

\section{Caractìres dislinclifs le celle espèce.}

Le maimon a des abajones et des eallosités sur' les fesses, la queue nue, recoquillée et longue de cinc ou six pouces; les dents canines pas plus longues à proportion quecelles de l'homme; le museau très-large, les orbites des yeux fort saillantes au-dessus, la face, les oreilles, les mains et les pieds nus, et de couleur de chair ; le poil d'un noir olive sur le corps et d'un jaune roussâtre sur le veutre. Il marehe tantòt sur deux pieds tantòt sur quatre; il a deux pieds ou deux pieds et demi de hauteur' lorsçu'il est dehout. La femelle est sujettè l'écoulement périodicyue.

\section{LE MACAQUE A QUEUE COURTE ${ }^{2}$.}

Yous ne domnons cette dénomination à eet animal que funte d'un nom propre, et parre qu'il nous parait approcher un peu plus du ma-

\footnotetext{
- Le singe à quene de cochon de l'ile de Sumalra, daus la

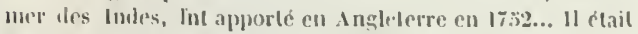
extrumement if el plén doetion : il élail approchint de lis

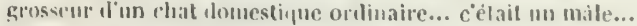
il a vicu un an eufre mes mains; je rencunlrai une femelle ale la meme épece, quion montrait par curiosile à I,ondres, clle élait la moif́é plus gorande yne unon mile: ils parutent fort clarmés de se voir ensemble quolipne ce fout leur première entrevue. Cilamure's d'Eulwards, pages 8 el 9.

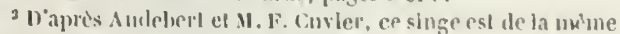

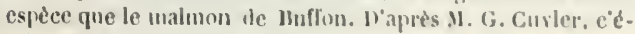

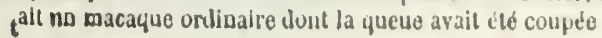

caque que des autres guenons. cependant il en diffère par un grand nombre de caractères mème essenticls. Il a la face moins iarge et plus eftilée, la queue beaucoup plus courte, les fesses nues, couleur de sang, aussi bien que toutes les parties voisines de la génération. Il n'a du maeaque que la queue, très-grosse a son origine, ou la peau forme des rides profondes, ee (qui le rend différent du maimon, on singe à queue de cochon, avec lequel il a néanmoins beaucoup de rapport par le earactère de la queue courte; ct comme ce macaque et le singe it queue de cnchon ont tous deux la cqueue beaucoup plus courte que les autres guenons, on peut les regarder conme faisant a cet égard la nuance cutre le genre des babouins, qui ont la queue courte, et celui des gruenons, qui l'ont très-longrie.

Tout le bas du corps de ce macague, qui était femelle, est couvert, depuis les reins, de grandes rides(qui forment des inérralités sur cette partie, et jusqu'à l'origine de la queue. Il a des aba joues et des callosités sur les fesses, qui sont d'un rouge très-vif, aussi bien que le dedans des euis. ses, le bas du ventre, l'anus, la vulie, ete. : mais on pourrait croire que l'animal ne porte cette belle couleur rouge que lorsqu'il est vivant et en bon état de santé; carr, ćtant tombé malade, elle disparut entiejement, et apressa mort (le 7 février 1778) ils n'en paraissait plus aueun vestige. Il etait aussi doux (qu'un petit chien : il aceueillait tous les hommes, mais il refusait les caresses des femmes, et, lorsqu'il était en liberté, il se jetait apres leurs jupons.

Ce macaque femelle n'a vait (que quinze poners de longueur. Son nez était aplati asee un enfoneement à la partie supérieure, qui était occasionné par le rebord de l'os frontal. L'iris de l'oil était jaunatte, l'oreille ronde et couleur de chair en dedans, oin elle étitit denuée de poil. A la partie supéricure de chaque oreille, on remarquait use petite découpure diffèrente, pour la forme et la position, de cerlle qui se trouse aux oreilles du macaque. La fare ainsi que le dessous de la mâhohere inferienre et du cour, étaient dénués de poils. Le dessus de la tète et du corps était jaune verelitre, mele d'un peu de gris; Je dessous du ventre. blanc, muancé de jatunitre; la face externe de's bras it des jambes était de couleur cendrce, melée de jaune, et la face interned un gris cendric dair; les pieds et les mains étaient d'un brun nointtre en dessous, et courerts en dessus de poils cendrés. L'ongle du 
pouce était plat, et les autres courbés en gouttiere. La queue était couverte, comme les jambes, de poils cendrés, mêlés de jaune : elle finissait tout d'un coup en pointe; son extrémité était noire, et sa longueur était en tout de sept pouces deux lignes. La dépouille de ce macaque est au Cabinet du Roi.

\section{LE PATAS A QUEUE COURTE!}

Il existe deux patas, l'un à bandeau noir, et l'autre à bandeau blanc; il y a aussi un autre patas à bandeau blanc, mais dont la queue est beaucoup plus courte que celle des autres. Cependant, comme il ne semble différer du patas a bandeau blanc que par ce seul caractère, nous ne pourons pas décider si c'est une espèce différente, ou une simple variété dans l'espèce: voici la description que nous en avous faite sur un individu dout la dépouille bien préparée se trouve an Cabinet du Roi. La queue n'a que ıeuf pouces de longueur, au lieu que celle des deux autres patas en a quatorze. Le diamètre de la queue était de dixà onze lignes à son origine, et de deux lignes seulement à son extrémité: en sorte que nous sommes assurés que l'animal n'en a rien retranché en la rongeant. La longeur de l'animal entier, depuis le bout du museau jusqu'à l'origgine de la queue, était d'un pied cing pouces dix lignes, ee yui approche autant qüil est possilule des mêmes dimensions du. corps des autres patas qui ont un pied six pouces. Celui-ci a la tète toute semblable à celle des autres, et il porte un bandeau depoils blanesaudessus des yeux, mais d'un blane plus sale que celuidupatas. Le corps est couvert sur le dos d'un poil gris cendré, dont l'extrémité est un peu teinte de fauve. Sur la tête et vers les reins le 'auve domine, et il est mêlé d'uu peu d'olivàtre. Le ventre, le dessous de l'estomac et de la poitrime, les còtés du cou et le dedaus des cuisses et des jambes sont d'un fauve mêlé de quelques teintes grises; les pieds et les mains sont couverts de poils d'un gris cendré mèlé de brunâtre. Le poil du dos à un pouce dix lignes de longueur; les jambes de devant sont couvertes de poils grris cendré, mèlé d'une teinte brune qui augmente et devient plus foncée en approchant des mains. Dans tout le reste ce singe

\footnotetext{
- C'est le uème animal que le maimon.
}

nous a paru parfaitement semblable aux autres patas.

\section{LE B.BOUIN \\ A LONGUES JAMBES.}

\author{
(LE MACAQUE BRUN. - LE MAGOT MAJMON.) \\ Ordre des quadrumanes, tribu des macaques, famille \\ des singes. (Cuvier.)
}

Ce babouin est plus haut monté sur ses jambes qu'aucun autre babouin, et même qu'aucune guenon; il a la face incarmate, le front noir et avancé en forme de bourrelet, le poil d'um brun mèlé de jaune verdátre sur la tète, le dos, les bras et les cuisses; blanchâtre sur là poitrine et sur le ventre; très-long et très-touffu sur le cou, ce qui fait paraitre son encolure très-grosse. Les callosités surles fesses sont larges et rouges; il a la queue très-courte, très-relevée, et presque entièrement dénuée de poil, surtout daus sa partie inférieure.

Ce babouin tient ordinairement ses pouces et ses gros orteils écartés, de manière à former un angle droit avec les autres doigts. Le gros orteil est un peu réuni par une membrane avec ledoigt qui l'a voisine; les ongles des pouces sont ronds et plats; ceux des autres doigts sont convexes et plus étroits.

Il se nourrit, ainsi que les autres babouins, de fruits, de feuilles de tabac, d'oranges, d'inseetes, et particulièrement de scarabés, de fourmis et de mouches qu'il saisit avec beaucoupd'adresse pendant qu'elles voleut. Lorsqu'on lui donne de l'avoine, il en remplit ses abajoues, dont il retire les grains l'un apres l'autre pour les peler. II aimeà boire de l'eau-de-vie, du vin, de la bière même jusqu'à s'enivrer. M. Hermamu, savant prol'esseur d'histoire naturelle à Strashourg, a vu vivants un mâle et une femelle de cette espèce; ils ne différaient l'un de l'autre que par la longueur de la queue, qui était de quatre pouces dans le mâle, et d'un pouce clans la femelle.

Cette femelle était fort douce; elle se laissait toucher sans peine et paraissait se plaire à ètre earessée : elle aimait beaucoup les enfants, mais clle paraissait hail les femmes.

II existe un animal qui ressemble presque entièrement à celui dont il est ici question, et (jui n'eu difière que par la queue, qui est beaucoup 
plus longue. L'estampe gravée et enluminée de cet auimal nous a été envoyéc par feu M. Ed. wards ; et comme ce naturaliste ne nous a domné aucun ćclaircissement sur cet individu, nous prévenons que le dessinateur employé par M Edwards s'est trompé, et que l'animal qu'il a représenté avait la queue aussi courte que le babouin a longues jambes, ct était absolument de la même espèce que celui-ci.

\section{LE MACAQUE ET L'AIGRETTE !}

\section{(LE CERCOCÉBE MACAQUE.)}

Ordre des quadrumanes, tribu des macarues, famille des singes. (Curier.)

De toutes les guenons ou singes à longue queue, le macaque est celui qui approche le plus des babouins; il a, comme cux, le corps court et ramassé, la tète grosse, le museau large, le nez plat, les joues ridées, et, en mème temps, il est plus gros et plus grand (que la plupart des autres guenons; il est aussi d'une laideur hideuse, en sorte qu'on pourrait le regarder comme une petite espèce de babouin, s'il n'en différait pas par la queue, (qu'il porte en are comme eux, mais qui est longue et bien touffue; au lieu que celle des babouins en général cst fort courte. Cette espèce est originaire de Congo et des autres parties de l'A frique méridionale; elle est nombreuse et sujette à plusieurs variétés pour la grandeur, les couleurs et la dispositiondu poil. Celui qu'llasselquist a décrit avait le corps long de plus de deux pieds, et eeux que nous ayons vus ne l'avaient guère que d'un pied et demi. Celui que nous appelous ici l'aigrelle, parce qu'il a sur le sommet de la tète un épion aigrette de poils, ne nous a paru qu'une variété du premier', aupuel il ressemble en tout, à l'exception de cette différence et de quelques autres légères variétés daus le poil. Ils ont tous deux les mocurs doures et sont assez dociles; mis, indépendamment d'une odeur de foumi ou de faux muse qu'ils répandent autour d'eux, ils sont si malpropres, si laids, et mème si aflreux lorsyu'ils font la grimace, gu'on me peut les regardel sans horreur et dégoùt. Ces rruenons rout souvent par trou-

- Ces deux singes me forment qu'une mème esjece : le macaque est le mále, et laigretle la feuclle. pes et se rassemblent, surtout pour voler des fruits et des légumes. Bosman raconte qu'elles prennent dans chaque patte un ou deus pieds de millio, autant sous leurs bras et autant dans l'ur bouche; qu'clles s'en retournent ainsi chargées, sautant contimuellement sur les pattes de derricre, et quequand on les poursuit, elles jettent les tiges de milhio qu'elles tenaient dans les mains et sous les bras, ne gardant que celles qui sont entre leurs dents, afin de pousoir fuir plus vite sur les ruatre pieds. Au reste (ajoute ce voyageur), elles examinent avec la dernière exactitude chaque tige de milhio qu'elles arrachent, et si elles ne leur plait pas elles la rejettent a terre et en arrachent d'auties : en sorte que par leur bizarre délicatesse clles causent beaucoup plus de dommage encore que par leurs vols.

\section{Caractères distinctifs de ces espèces.}

I.e macaryue a des abajoues et des callosités sur les fesses; il a la queuc longue à peu près comme la tète et le corps pris ensemble, d'euviron dix-huit à vingt ponces; la téte grosse, le museau très-gros, la face nue, livide ct ridée, les oreilles velues, le corps court et ramassé, les jambes courtes et grosses: le poil des parties supérieures est d'un cendré verdâtre, et sur la poitrine et le ventre d'un rris jaunatice. II porte une petite erête de poil au-dessus de la tète; il marche à quatre et quelquelois a deux pieds. La longueur de son corps, y compris celle do la tète, est d'emiron dix-huit ou vingt pouces. Il puraft qu'il y a dans cette espèce des races beaucoup plus grandes et d'autres plus petites, telles que celle qui suit.

L'aicrette ue nous parait étre qu'une variété du macaque; wle est plus petite d'environ un tiers dans toutes les diniensions : au lieu de la petite erite de poil (jui se troure au sommet de la tète du macaque, l'aigrette porte un epi dioit et pointu. Elle semble differer eneore du maeacue par le poil du frous gui est moir, au licu que sur le front du macayue il est verditre. II parait aussi que l'aigrette a ta queue plus longue que le mineapue, de proportion de la lonerueur du eorps. I.es femelles dins ees espee's sont sujettes, comme les femmes, d'ecoulenent per riodique. 


\section{LE PATAS.}

\section{(LA GUENON PATAS.)}

Ordre des quadrumanes, famille des singes, genre guenon. (Curier.)

Le patas est encore du même pays et à peu près de la même grosseur que le macaquue: mais il cn differe, en ee qu'il a le corps plus allongé, la face moins hideuse et le poil plus beau ; il est même remarq̨uable par la eouleur brillante de sa robe, qui est d'un roux si vif qu'elle paraît avoir été peinte. Nous avons vu deux de ces animaux qui font variété dans l'espèce : le premier porte un bandeau de poils noirs au-dessus des yeux, qui s'étend d'une oreille à l'autre; le second ne differe du premier que par la couleur de ce bandeau qui est blanc: tous deux ont du poil long au-dessous du menton et autour des jones, ce qui leur fait une belle barbe; mais le premier l'a jaune, et le second l'a blanche. Cette var'rété parait en indiquer d'autres dans la couleur du poil, et je suis fort porté à croire que l'espece de guenons couleur de chat sauvage dont parle Marmol, et qu'il dit venir du pays des Nègres, sont des variétés de l'espèce du patas. Ces guenons sont moins adroites que les autres, et en même temps elles sont extrêmement curieuses : "Je les ai vues, dit Brue, des" cendre du haut des arbres jusqu à l'extrémité " des branches pour admirer les barques à leur " passage; elles les considéraient quelque temps " et paraissaient s'entretenir de ce qu'elles " avaient vu; elles abandonnaient la place à celles " qui arrivaient après; quelcques-unes devinrent "fimilìres jusqu'à jeter des branches aux "Français, qui leur répondirent à coups de " fusil. Il en tomba quelques-unes, d'autres " demcurèrent blessées, et tout le reste tomba " dans une étrange consternation; une partic " se mit à pousser des eris affreux, une autre "à ramasser des pierres pour les jeter à leurs " ennemis; quelques-unes se viderent le veutre " dans leur main et s'efforeèrent d'envoyer ce " présent aux spectateur's; mais, s'apercevant à "la lin que le combat était du moins inégal, "elles prirent le parti de se retirer."

Il est à présumer que c'est cette méme espèce de guenons dont parle le Maire: "On ne " saurait exprimer, dit ce voyageur, le dégât - que les singes font dans les terres du Sénéga!, "lorsque le mil et les grains, dont ils se nour" rissent, sont en maturité. lis s'assemblent " quarrante ou cinquante; l'un d'eux demeure " en sentinelle sur un arbre, écoute et regarde " de tous côtés, pendant que les autres font la " récolte: dès qu’il aperęoit quelqu'un, il erie " comme un enragé pour avertir les autres, qui, " au signal, s'enfuient avec leur proie, sautant " d'un arbre à l'autre avee une prodigieuse agi. " lité : les femelles, qui portent leurs petits con" tre leur ventre, s'enfuient comme les autres, " et sautent comme si elles n'avaient rien."

Au reste, quoiqu'il y ait dans toutes les terres de l'Afrique un très-grand nombre d'espéces de singes, de babouins et de guenons, dont quelques-unes paraissent assez semblables, les voyageur's ont cependant remarqué qu'elles ne se mêlent jamais, et que pour l'ordinaire chaque espèce habite un quartier différent.

\section{Caractères distinctifs de cette espèce.}

Le patas a des abajoues, et des eallosités sur les fesses; sa queue est moins longue que la tète et le eorps pris ensemble; il a le sommet de la tête plat, le muscau long, le corps allongé, les jambes longues; il a du poil noir sur le nez et un bandeau étroit de mème couleur au-dessus des yeux, qui s'étend d'une oreille à l'autre: le poil de toutes les parties supérieures du corps est d'un roux presque rouge, et celui des parties de dessous, telles que la gorge, la poitrine et le ventre, est d'un gris jaunâtre. Il y a variété dans cette espèce pour la couleur du bandeau qui est au-dessus des yeux; les uns l'ont noir et les autres blane. Ils n'agitent pas leur mâchoire, comme le font les autres guenons lorsqu'elles sont en colère. Ils marehent à quatre pieds plus souvent qu'à deux, et ils ont environ un pied et demi ou deux pieds, depuis le bout du museau jusqu'à l'origine de la queue. Il parait, par le témoignage des voyageurs, qu'il y en a de plus grands. Les femelles sont sujettes, comme les femmes, à un écoulement périodique. 


\section{LE MALBROUCK}

\section{ET LE BONNET CHINOIS.}

\section{(LA GUENON MALBROCCK.)}

Ordre des quadrumanes, gente guenon. (Cuvier.)

\section{(LE MACAQUE BONNET CIINOIS.)}

Ordre des quadrumanes, genre macaque. (Cuvier.)

Ces deux guenons ou singes à longue queue nous paraissent ètre de la mème espèce, et cette espèee, quoique différente à quelques égards de celle du macaque, ne laisse pas d'en ettre assez voisine, pour que nous soyons dans le doute si le macaque, l'aigrette, le malbrouck et le bonnet chinois ne sont pas quatre variétés, c'est-ì-dire quatre races eonstantes d'une seule et même espèce. Comme ees animaux ne proluisent pas dans notre climat, nous n'avons pu aequérir par l'expérienee aucune comaissance sur l'unité ou la diversité de leur's espèces, et nous sommes réduits ì en juger par la différence de la figure et des autres attributs extérieurs. Le macaque et l'aigrette nous ont paru assez semblables pour présumer qu'ils sont de la mème espèce. Il en est de même du malbrouck et du bonnet chinois ; mais comme ils diffèrent plus des deux premiers qu'ils ne different entre eux, nous avons cru devoir les en séparer. Notre présomption sur la diversité de ees deux espèces est foudée : $1^{\circ}$ sur la différence de la forme extérieure; $2^{\circ}$ sur celle de la couleur et de la disposition du poil ; $3^{\prime \prime}$ sur les différences qui se trouvent dans les proportious du squelette de chacum de ces animaux, et enfin sur ce que les deux premiers sont natifs des contrées méridionales de l'Afrique, et que les deux dont il s'agit iei sont du pays de liengale. Cette dernière considération est d'un aussi grand poids qu'aucune autre; car nous arons prouve que dans les animaux sauvages et indépendants de l'homme, l'éloignement du climat est un indice assez sur de celui des especes. Au reste, le malbrouck et le bonnet chinois ne sont pas les seules espèces on raees de singes que l'on trouve au Bengale: il parait, par le temoignane des voyagents, qu'il y en a quatre varictés, sar oir' : des blane's, des noir's, des rouges et des gris. Ils disent que les noirs sont les plus aisés à apprivoiser : eeux-ei étaient d'un gris roussátre, et nous ont paru privés et mème assez dociles.
"Ces animaux, disent les voyageurs, déro" bent les fruits et surtout les cannes de sucre; " l'un d'eux fait sentinelle sur un arbre, pen" dant que les autres se chargent du butin : s'il a aperecoit quelqu'un, il crie houp, houp, houp, "d'une voix haute et distincte; au moment de "l'aris, tous jettent les cannes qu'ils tenaient " dans la main gauche, et ils s'enfuient en cou"rant à trois pieds, et s"ils sont vivement poul" suivis, ils jettent encore ce qu ils tenaient " daus la main droite, et se sauvent en grim. "pant sur les arlores, qui sont leurs demeures "ordinaires : ils sautent d'arbres en arbures; les "femelles mème chargées de leurs petits, qui "les tiemnent étroitement embrassées, sautent "aussi comme les autres, mais tombent qucl. "quefois. Ces animaux ue s'apprivoisent qu'à " demi; il faut toujours les tenir a la châne. "Ils ne produisent pas dans leur état de servi" tude, même daus leur pays; il faut qu'ils " soient en liberté dans leur's bois. Lorsque les "fruits et les plantes succulentes leur man" quent, ils mangent des insectes, et quelqque"fois ils descendent sur les bords des fleuves " et de la mer pour attraper des poissons et des " erabes. Ils mettent leur queue entre les pinces " du crabe, et dès qu'elles serrent, ils l'enlè"vent bruspuement et l'emportent pour le man"ger à leur aise. Ils cueillent le noix de cocos: " et savent fort hien en tirer la liquemr pour la "boire, et le noyau pour le manger. Ils boi"vent aussi du zari qui dégoutte par des bam"boches qu'on met expres á la eime des arbures "pour en attirer la liqueur, et ils se servent de "l'oceasion. On les prend par le moyen des " noix de eocos, ou l'on fait une petite ourer"ture; ils y fourrent la patte avee peine, parce "que le trou est étroit, et les gens qui sont is "l'afnit les prennent avant qu'ils puissent " se dégager. Dans les prowinces de l'Inde ha"bitées parr les Bramans, qui, comme l'on sait, "épargnent la vie de tous les animaux, les sin" ges, plus respectés encore que tous les an"tres, sont en nombre infini; ils vicnuent en "trompes dans les villes; ils entrent dans les "maisons à toute heure, en tonte liberté; en " sorte yue ceux qui vendent dis demrees, "et surtout des fruits, des lígumes, efe., ont "bien de la peine à les conserver. "Il y a dans Amadabad, eapitale du Guzarate, deux ou trois hopitaux d'animaux, ou l'ou nourrit les singes estropiés, invalides, et mème ceux 
qui sans être malades veulent y demeurer. Deux fois par semaine les singes du voisinage de cette ville se rendent, d'eux-mèmes, tous ensemble, daus ies rues; ensuite ils montent sur les maisons, yui ont clacune une petite terrasse, où l'on va coucher pendant les glandes chaleurs : on ne mancue pas de mettre ces deux jours-là sur ces petites terrasses, du riz, du millet, des cannes de sucre dans la saisou, et autres choses semblables; car, si par hasard les singes ne trouraient pas leur provision sur ces terrasses, ils rompraient les tuiles dont le reste de la maison est couvert, et feraient un grand désordre. Ils ne mangent rien sans le bien sentir auparavant; et lorsuju'ils sont repus, ils remplissent pour le lendemain les poches de leurs joues. Les oiseaux ne peuvent guère nicher sur les arbres dans les endroits où il y a beaucoup de singes; car ils ne manquent jamais de détruire les nids et de jeter les oufs par terre.

Les ennemis. les plus redoutables pour les singes ne sont ni le tigre ni les autles bètes féroces car ils leur écluappent aisément par leur léoèreté et par le choix de leur domicile au-dessus des arbres, où il n'y a que les scrpents qui aillent les chercher et sachent les surprendre. "Les singes, dit unvoyageur, sout en possession " d'ètre maîtres des forèts; car il n'y a ni tigres " ni lions qui leur disputent le terrain : ils n'ont " rien à craindre que les serpents, qui nuit " et jour leur font la guerre. II y en a de pro" digieuse grandeur, qui tout d'un coup ava" lent un singe; d'autres moins gros, mais plus " agiles, les vont chercher jusque sur les ar" bres... Ils épieut le temps où ils sont endor" mis, etc."

\section{Caractères distinctifs de ces espèces.}

Le malbrouck a des abajoues, et des callosités sur les fesses; la queuc à peu près longue comme la tète et le corps pris eusenuble, les paupic̀res conleur de chair, la face d'un gris centré, les yeux grands, le museau large et relevé, les oreilles grandes, minces ct couleur de chair. Il porte un bandeau de poils gris, comme la mone; mais au reste il a le poil d'une couleur uniforme, d'un jaune lrun sur les parties supéricures du corps, et d'un gris jaunâtre sur celles du dessous. Il marche à cuatre pieds, et il a environ un pied et demi de longueur depuis l'ex- trémité du museau jusqu'ì l'origine de la queue.

Le bonnet chinois parait être une variété du malbrouch; il en dilfère en ce qu'il a le poil du sommet de la tête disposé en forme de calotte ou de bomnet plat, et que sa queue est plus longue à proportion du corps. Les femclles, dans ces deux races, sont sujettes, comme lea femmes, à l'écoulement périodique.

\section{LA GUENON COURONNEE.}

Ordre des quadrumanes, ramille des singes, genre macąque. (Curier.)

Il existe une guenon dont l'espèce nous paralt très-roisine de celle du malbrouck, et eneore plus de celle du bonnet chinois dont nous arons parlé dans le même article. Cette guenon était à la foire Saint-Germain en 1774 : ses maitres l'appelaient le singe couronné, à cause du toupet en hérisson qui était au-dessus de sa tête; ce toupet formait une espèce de couronne qui, quoique interrompue par derrière, paraissait assez régulière en le regardant de face. Cet animal était mâle; ct une femelle de mẻme espèce, que nous a vons cu occasion de voir aussi, avait également sur la tête des poils hérissés, mais plus courts que ceux du mâle; ce qui prouve que si ce n'est pas une espèce, c'est au moins une variété constante. Ces poils, longs de deux pouces à deux pouces et demi, sont bruns à la racine, et d’un jaune doré juscqu'à leur extrémité ; ils s'élèvent en s'arançant en pointe vers le milieu du front, et remontent sur les côtés pour gagner le sommet de la tète, où ils se réunissent avec les poils qui couvrent le cou. Le poil est moins grand au centre de la couronne, et forme comme un vide au milieu; et en les couchant arec la main, ils paraissent partir eireulairement de la circonférence d'un petit espace qui est nu.

La face n'a que vingt-deux lignes depuis la pointe du toupet entre les yeux, jusqu'au bout du museau; elle est nue et sillonnée de rides plus on moins profondes. La lére inférieurc est noirâtre, et l'extrérnité des mâchoires est garnie de petits poils noirs clair-semés : le nez est large et aplati comme dans le malbrouck et dans le bon net chinois. Les veux sont grands, les paupière: arquées, et l'iris de l'œil couleur de cannelle mc. 
lee de verdâtre. Les côtés de la tête sont lég̨rement couverts de petits poils bruns et grisâtres, semés de qquelques poils jaunâtres. Les oreilles sont nues et d'un brun rougeattre; eiles sont arrondies par le has, et forment une pointe à l'autre extrómité. Le poil du corps est d'un brun musc, mêlé de teintes đ'un jaune foncé, qui domine sur les loras en delıors, aree de légères teintes grises en dedans. Ën général, le poil du corps et des bras ressemble pour la couleur it celuiqui forme la couronne de la tète; lescuisses et les jambes sont d'un jaune plus foncé et mẻlé de hrun; le dessous du corps et le dedans des bras et des jambes sont d'un blane tirant sur le gris. Les mains et les pieds sont couverts d'une peau d'un brun noiratre, avee de petits poils rares et noirs sur la partie supérieme. Les ongles sont en forme de gouttiere, et n'excèdent pas le bout des doigts. Cette guenon avait rongé une petite partie de sa queue, qui devait avoir treize ou (fuatorze pouces de longueur lorsfju’elle était cntiere. Cette quene est garnie de poils lorums, et ne sert point à l'animal pour' s'attacher : lorsqu'il la porte en l'air, elle flotte par ondulation. Cette guenon avait des ahajoues, et des eallosités sur les fesses; ces callosités étaient couleur de claair, en sorte que par ces deux derniers earactères aussi bien que par celui des longs poils, elle parait approcher desi pres de l'espèce de la guenon que nous áons appelée bonnel chinois, que l'on pourrait dire qu'elle n'en est qu'une variété. Il n’y a de différence tres-remarquable que daus la position des poils du sommet de la tète; lor'squ'on les couche avee la main, ils restent aplatis saus former ume sorte de calotie, comme on le voit dans le bonnet chinois.

La guenon gue M. Pennant a décrite sous le nom de bonneled monkey, ne nous parait être qu'une variété de cette guenon comromées.

\section{IE MANGABEY.}

\section{(LA GUENON ENFUMÉ, - LA GUENON MATGABEY.)}

Ordere des quadr:un: nues, famille des singes, genre gutuon. (Cuvier.)

Nous arons eu deux indivilus de ecte espece de guemons on singes à lougne quenc; lous denx nous out eté donnés sous la dénominalion de singes de Madagascar. Il est facile de les dis. tinguer de tous les autres par un caractère très* apparent : les mangabeys ont les paupières nues et d'une blandeu' frappante; ils ont aussi le museau gros, large et allongé, et un bourrelet saillant autour des yeux. Ils varient pour les couleurs ${ }^{1}$ : les uns ont le poil de la tête noir. celui du cou ct du dessus du corps brun fauve, et le ventre blane; les autres lont plus clair sur la tète et sur le corps, et ils different surtout des premiers par un large collier de poils blanes qui leur enviromment le cou et les joues : tous deux portent la queue relevée, et ont le poil long et touffu. Ils sont du meme pays que le vari; et comme ils lui ressemblent par i’allongement du museau, par la longrueur de la queue, par la maniere de la porter et par les variétés de la couleur du poil, ils me paraissent faire la nuance entre les makis et les guenons.

\section{Caraclères distinclifs de celle espèce.}

Le mangabey a des abajoues, et des callosités sur les fesses, la queue aussi longue que la tèto et le corps pris cnsemble. Il a un bourrelet proéminent autour des yeux, et la paupière supérieure d'une blancheur frappante. Son museau est gros et long, ses soureils sont d'un poil raicle et bérissé, ses oreilles sont nolres et presque nues; le poil des parties supérieures du corps est brun, el celui de's parties inferieures est gris. II y a varićté diuns cette espece, les uns étant de couleur uniforme, et les autres ayant un cerele de poil blanc en forme de collier autour du cou, et en forme de barbe antour des joues. Ils marchent à quatre pieds, et ils ont à peu près un piod et demi de longueur, depuis le bout du museau jusquà l'origine de la queue. Les femelles, daus ces espèces, sont sujettes, conme les femmes, à un écoulamont périodigue.

\section{LA MONE.}

\section{(LA GUEXOY MOXF.)}

Ordre des quadrumanes, famille des singes, genre guenou. (Cuvier.)

Ia mone est la plus commune des quenems nu sineres i longue quede; mus l'avous cue virante pendiut plusieurs anne's. C'est, areele magot,

- Ces deur variétés de mangabey appartiennent a deur espéces différentes. 
l'espèce gui s'accommode le nuieux de la température de notre climat : cela seul suffirait pour prouver qu'elle n'est pas originaire des pays les plus chauds de l'Afrique et des Indes méridionales; ct elle se trouve en effet en Barbarie, en Arabie, en Perse et dans les autres parties de l'Asie qui étaient connties des anciens; ils l'avaient désignée par le nom de kébos, cebus, scephus, à cause de la variété de ses couleurs Elle a en effet la face brune, avec une espèce de barbe mélée de blane, de jaune et d'un peu de noir; le poil du dessus de la tête et du cou, mêlé de jaune et de noir ; celui du dos mèlé de roux et de noir ; le ventre blanchâtre aussi bien que l'intérieur des cuisses et des jambes ; l'extérieur des jambes et les pieds noir's, la queue d'un gris foncé, deux petites taches blanches, une de chaque còté de l'origine de la queue, un croissant de poil gris sur le front, une bande noire depuis les yeux jusqu'aux oreilles, et depuis les oreilles jusqu’à l'épaule et au bras. Quer. ques-uns l'ont appelée nonne par corruption de mone; d'autres, à cause de sa barbe grise, l'ont appelée le vieillard; mais la dénomination vulgaire sous laquelle la mone est la plus connue, est celle de singe varié; et cette dénomiuation répond parfaitement au nom kébos que lui avaient donné les Grees, et qui par la définition d'Aristotedésigne une guenon ou singeà longue queue de couleur variée.

En général, les guenons sont d'un naturel beancoup plus doux que les babouins, et d'un caractere moins triste que les singes : elles sont vives jusqu'à l'extravagance et sans férccité, ear elles deviennent dociles dès qu'on les fixe par la erainte. La mone en particulier est susceptiblc d'éducation, et mène d'un certain attachement pour ceux qui la soignent : celle que nous avons nourrie se laissait toucher et enlever par' les gens qu'elle comnaissait ; mais clle se refusait aux autres et mème les mordait. Elle cherchait aussi à se mettre en liberté; on la tenait attachée avec une longue chaine, quand elle pouvait ou la rompre ou s'en délivier, elle s'enfuyait à la campagne, et quoiqu'elle ne revînt pas d'elle-mème, elle se laissait assez aisément reprendre par son maitre. Elle mangeait de tout, de la viande cuite, du pain et surtout des fruits ; elle cherchait aussi les araignées, les fourmis, les insectes. Elle remplissait ses abajoues, lorsqu'on Iui donnait plusieurs moreeaux de suite. Cette habitude est commune à tous les babouins et guenons, auxquels la nature a donné ces espèces de poches au bas des joules, où ils peuvent garder une quantité d'aliments assez grande pour se nourrir un jour ou deux.

\section{Caractères distinctifs de cette espèce.}

La mone a des abajoues, et des callosités sur les fesses; elle a la queue d'environ deux pieds de longueur, plus longue d'un demi-pied que la tête et le corps pris ensemble; la tète petite et ronde, le museau gros et court, la face couleur de chair basanée; elle porte un bandeau de poils gris sur le front, une bande de poils noirs qui s'étend des yeux aux oreilles, et des oreilles jus. qu'aux épaules et aux bras; elle a une espèce de barbe grise formée par les poils de la gorge et du dessous du cou, qui sont plus longs que les autres; son poil est d'un noir roussâtre sur le corps, blanchâtre sous le ventre; l'extérieur des jambes et les pieds sont noirs, la queue est d'un gris brun avee deux taches blanches de chaque còté de son origine. Elle marche à quatre pieds, et la longueur de sa tête et de son corps pris ensemble, depuis l'extrémité du museau jusqu'à l'origine de la queue, est d'euviron un pied et demi. La femelle est sujette, comme les femmes, à l'écoulement périodique.

\section{LE MONA'.}

Cet animal mâle, apporté de la côte de Gujnée, doit être regardé comme une variété dans l'espèce de la mone, à laquelle il ressemble assez par sa grosseur et la couleur du poil : il a seulement plus de légèreté dans les mouvements et dans la forme de ses membres; la tète a aussi plus de finesse, ce qui lui rend la physionomie agréable. Les oreilles n'ont point, comme celles de la mone, une échancrure sur le bord supé rieur, et ce sont là les caractères par lesquels il differe de la mone; mais au reste il a comme elle des abajoues, et des callosités sur les fesses. La face est d'un gris ardoisé ; le nez est plat et large, les yeux sont enfoncés, et l'iris en est orangé; la bouche et les mâchoires sont d'un ronge pâle; les joues sont garnies de grands poils grisâtres et jaunes verdâtres, qui lui forment comme une barbe épaisse qui s'étend jusque sous le menton. On voit au-dessus des yeux une bande noire qui se termine aux oreilles, lesquelles sont assez plates et noires, exeepté à

\footnotetext{
4 De mème espèce que la précédente.
} 


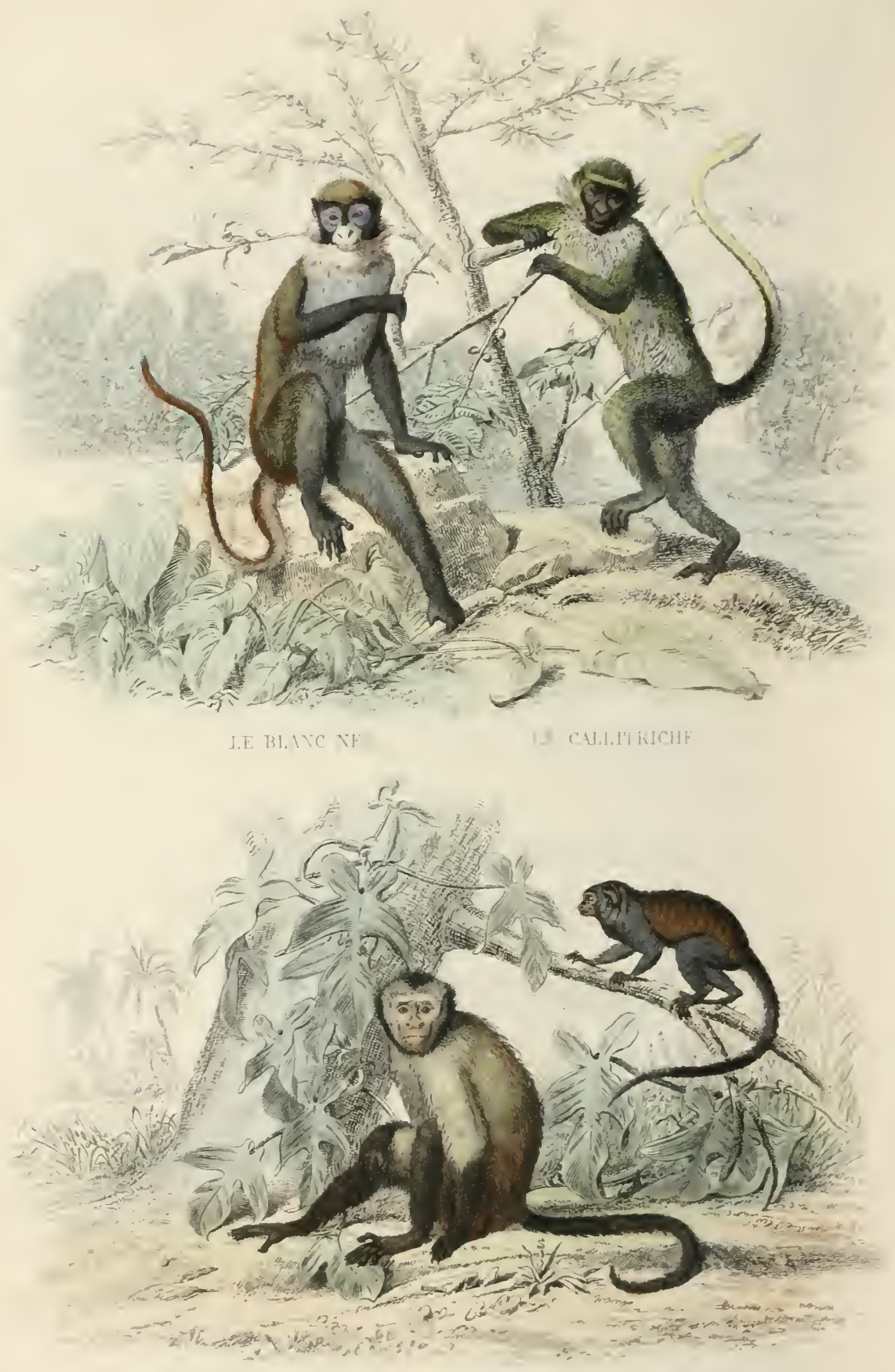

H. I'JuI (:RR:-

L.F 'I.IY TRI DFGRF. 
l'orifiee du canal auditif, qui est recouvert de grands poils grisâtres. On voit sur le front un bandeau blanc grisâtre, plus large au milieu et en forme de croissant. Le sommet de la tète et le derrière du cou sont couverts de poils verdâtres, mélangés de poils noirs. Le corps est couvert de poils bruns et jamnâtres, ce qui lui donne un reflet olivâtre. Les faces externes des bras et des jambes sont noires, et eette couleur tranche a vec celle des faces internes qui sont blanches, ainsi que tout le dessous du corps et du cou. Lia queue est très-longue, de plus de vingt pouces de longueur, et garnie de poils courts et noirítres. On rẹmarque de chaque côté de l'origine de la queue une tache blanehe de figure olslongue. Les pieds et les mains sont tout noirs, ainsi que le poignet.

Cetanimaln'était îgé que de deux ans; il a vait seize pouees quatre lignes de longueur depuis le museau jusqu'à l'anus. Les dents étaient au nombre de trente-deux, seize en haut eomme en bas, quatre incisives, deux eanines et deux mâchelières de chaque côté : les deux canines supérieures étaient beaucoup plus longues que les inféricures.

Au reste, le naturel de cette guenon paraît être fort doux; elle est mème craintive et semble peureuse. Elle mange volontiers du pain, des fruits ot des racines.

C'est le même animal auguel Limneus a donné le nom de cliana, te même que M. Schreber a nommé diane, et encore le même que M. Pennant appelle spotted monkey; mais ils se sont trompés en le confondant avec l'exquima de Maregrave qui, comme je l'ai dit, n'est qu'une variété du coaita d'Amérique, sapajou à queue prenante; au lieu que celui-ei est une guenon de l'ancien continent, dont la queue ll'est point préhensible.

\section{LE CALLITRICHE.}

\section{(r.a Guenon Callititche.)}

Ordre des quadrumaues, geure guenon, famille des siuges. (Cuvier.)

Callitlurix est un terme employé par Homère, pour exprimer en géméral la belle couleur du poil des animaux : cen'est que plusieurs sièeles après celui d'Ilomère que les Grees ont en particulier appliquı́ ec nom ì quelques espèces de guenons ou singes à longue queue, remarquables par la beauté des couleur's de leurpoil; mais il doit appartenir de préférence à celui dont il est ici question. Il est d'un beau vert sur le corps, d'un beau blanc sur la gorge et le ventre, et il a la face d'un beau noir : d'ailleurs il se trouve en Mauritanie et dans les terres de l'ancienne Carthage. Ainsi il y a toute apparence (qu'il était connu des Grees et des Romains, et que e'était l'une des guenons ou singes à longue queue auxquels ils donnaient le nom de callithrix. Il y a d'autres guenons de couleus blonde dans les terres voisines de l'Fgypte, soit du còté de l'Éthiopie, soit de celui de l'Arabie, que les anciens ont aussi désignées par le nom générique de callithrix. Prosper Alpin et Pietro della Vallée parlent de ces callitriches de couleur blonde. Nous n'avons pas vu eette espèce blonde, qui n'est peut-ètre qu'une variété de ceile-ci ou de celle de la mone, qui est très-commune dans ces mêmes contrécs.

Au reste, il parait que le callitriche ou singe $v e r l$ se trouve au Sénégal, aussi bien qu'en Mauritanie et aux îles du cap Vert. M. Adanson rapporte que les environs des bois de Podor, le long du fleuve Niger, sont remplis de singes verts. "Je n'aperçus ces singes, dit cet auteur, "que par les branches qu'ils eassaient au haut "des arbres, d'ou elles tombaient sur moi : ear "ils étaient d'ailleurs fort sileneieux et si lé" ger's dans leurs gambades, ru'il eût été diffi" cile de les entendre. Je n'allai pas plus loins " et j'en ruai d'abort? un, deux et même trois, " saus que les autres parussent effrayés : cepen" dant, lorsque la plupart se sentirent blessés, " ils eommencerent ì se mettre à l'abri; les un, " en se cachant ferriere les grosses branches, " les autres en descendant à terre; d'autres en"fin, et cétait le plus grand nombre, s'elan" caient de la pointe d'un arbre sur la eime d'un "autre... Pendant ce petit manége, je ennti" nuais toujours à tirer dessus, et $j$ 'cu tuai jus"qu'au nombre de vingt-trois en moins d'une " heure et dans un espace de vingt toises, sans " (ju'aweun d'eux ent jeté un seul eri, quoiqu'ils " se fussent plusieurs fois rassemblés par rom" pagnie en soureillant, grincant des dents et "faisant mine de vouloir mattacuer" "royage au Sénégal, par M. Adanson, page 1 is.

\section{Caractères distinctifs de cestle espèce.}

I.e callitriche a des abajoucs, et des callosités 
sur les fesses, la queue beaueoup plus longue que la tête et le corps pris ensemble; il a la tète petite, le museau allongé, la face noire aussi bien que les oreilles; il porte me bande étroite au lieu de soureils au bas du front, ct eete bande est de longs poils noirs. Il est d'un vert vif mêlé d'un peu de jaune sur le corps, et d'un blane jaunâtre sur la poitrine et le ventre : il marehe à quatre pieds, et la longueur de son corps, y compris celle de la tête, est d'environ quinze pouces. La femelle est sujette à l'écoulement périodique.

\section{LE MOUSTAC.}

\section{(LA GUENON MotsTaC.)}

Ordre des quadrumanes, genre guenon, famille des singes. (Cuvier.)

Le moustac nous paraît être du même pays que le macaque, paree qu'il a, comme lui, le corps plus court et plus ramassé que les autres guenons. C'est très-vraisemblablement le même animal que les voyageurs de Guinée ont appelé blanc-ne $z^{1}$, parce qu'en effet il a les lèvres au-dessous du nez d'une blancheur éelatante, tandis que le reste de sa face est d'un bleu noirâtre : il a aussi deux toupets de poils jaumes au-dessous des oreilles, ce qui lui donne l'air très-singulier : et comme il est en même temps d'assez petite taille, e'est de tous les singes à longue queue eelui qui nous a paru le plus joli.

\section{Caractères distinclifs de celte espèce.}

Le moustac a des abajoues, et des callosités sur les fesses, la queue beaucoup plus longue que la tète et le corps pris ensemble : elle a dix. neuf ou vingt pouces de longueur. Il a la face d'un noir bleuâtre aree une grande et large marque blanche en forme de chevron au-dessous du nez et sur toute l'étendue de la lère supérieure, qui est nue dans toute cette partie; clle est seulement bordée de poils noirs, aussi bien que la lèvre inférieure tout autour de la bouche. Il a le corps court et ramassé; il porte deux gros toupets de poil d'un jame vífau-dessous des oreilles; il a aussi un toupet de poil

\footnotetext{
- Le blanc-nez est une espèce particulière de gucnon dis. tincle de celle-ci.
}

hérissé au-dessus de la tête; le pon du corps est d'un cendré verdâtre; la poitrine et le ventre d'un cendré blanchâtre : il marche à quatre pieds, et il n'a qu'environ un pied de longueur, la tête et le corps compris. La femelle est sujette à l'ćcoulement périodique.

\section{LE TALAPOIN.}

\section{(LA GUENON TALAPOM.)}

Ordre des quadrumanes, genre guenon, famille des singes. (Cuvier.)

Cettc guenon est de petite taille et d'une assez jolie figure. Son nom paraitrait indiguer qu'elle se trouve à Siam, et dans les autres provinces de l'Asie orientale; mais nous ne pourons l'assurer : seulement, il est certain qu'elle est originaire de l'aneien continent et qu'elle ne se trouve point dans le nouveau, paree qu'elle a des abajoues, et des callosités sur les fesses, et que ces deux caractères n'appartiennent ni aux sagouins, ni aux sapajous, qui sont les seulsanimaux du Noureau-Monde qu'on puisse comparer aux guenons.

Cequi me porte à croire, indépendamment du nom, que cette guenon se trouve plus comnunément aux Indes orientales qu'en Afrique, e'est que les voyageurs rapportent que la plupart des singes de cette partie de l'Asie ont le poil d'un rert brun. "Les singes de Guzarate, " discnt-ils, sont d'un vert brun; ils ont la barbe " et les soureils longs et blanes. Ces animaux, "que les Banianes laissent multiplier à l'infini " par un prineipe de religion, sont si familiers, "qu'ils entrent dans les maisons à toute heure " et en si grand nombre que les marehands de " fruits et de confitures ont beaucoup de peine à " conserver leurs marchandises."

M. Edwards a domé la figure et la description d'une guenon, sous le nom de singe noir de moyenne grandeur, qui nous parait appiocher de l'espèce du talapoin plus que d'aucune autre. J'ai cru devoir en rapporter ieila deseription ', et renroyer à la figure dounée par

- Ce singe était à jen près de la taille d'un gros chat ; il élait d'un naturel doux, ne faisant mal à personnc... c élait un màle, et il était un pen vieux; sa tète etait assez ronde; la peau de son visage élait d'une couleur de cluair rembrunie, couverle de poils noirs assez clair-semés; les oreilles étaient faites comme celles de l'homme; les yeux etaleat duno 
M. Edwards, pour qu'on puisse comparer ces animaux : on verra qu'à l'exception de la grandeur et de la couleur, ils se ressemblent assez pour 'qu'on cloive présumerquece sont au moins deux espèces bien voisines, si ce ne sont pas des variétés de la même espèce. Dans ee cas, comme nous ne sommes pas surrs que notre talapoin soit natif des Indes orientales, et que M. Edwards assure que celui qu’il clécit renait de Guinée, nous rendrions le talapoin à ee mème climat, ou bien nous supposerions que eette espèce se trouve également dans les terres du midi de l'Afrique ct de l'Asie. C'est vraisemblablement cette mème espèce de singes noirs, décrits par M. Edwards, dont parle liosman, sous le nom de baurdmannetjes, et donit i. dit que la peau fait une bonne fourrure ${ }^{\text {. }}$.

\section{LE DOUC.}

\section{(LA GUENON DOUC.)}

Ordre des quadrumanes, genre guenon, famille des singes. (Cuvier.)

Le done est le demier de la classe des animaux que nous avous appelés singes, baboutins ct guenons. Sans ètre précisément d'aucun de ees trois genres, il participe de tous; il tient des guenons par sa queue longue, des babonins par sa grande taille, et des singes par sa face plate: il a de plus un caractere particulier, et par lequel il parait fiure la nuauce entre les guenons et les sapajous. Ces deux familles d'animaux different entre elies, en ee que les guenons ont les fesses pelées, et que tous les sapajous les ont couvertes de poil. Le doue est la seule des guenons qui ait ḋi poil sur les fesses comme les sa-

conleur de noisclte rougeitre, avec les pampitres noires, le noil élail long au-ilessousıles yeux, et lessourcils se joinnaient; il était long aussi sur les temues, cl convait en partic les orẹtles; la tète, le dos, les jamlies de devant el de derriere el la qucue eitient converts d'asnce longs poils d'un brun noiraitle, yni n'itail ni trop doux ni trop rule; la poilrine, le ventre, ele., élaient presigue sans poil, d'une conlenr de claair rembrunie, ayant des houls the sein à la proitrine. Jes quatre pattr's ctaicul faites a fien près conme lat main de limmue, chant couvertes d'une pem dluse el noire presplue sans poil;

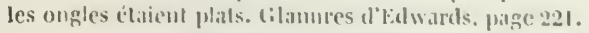

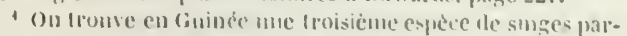
faitement jolis, yni unt pour lordinaire devix pieds de lamters; leur poil est extremement noil, de ia longuend d'un deigt et

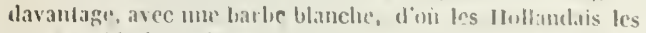
out appeclis baurdmannetjes : on fait dis bonnets de lene peau, et chingue fumrure soachicte ifualre ćcus. Voyage de Bosman, page 258. pajous. I! leur jessemble aussi par l'aplatissement du museau : mais en toui, il approche infiniment plus des gruenons que des sapajous, desquels il differe, en ce qu'il n'a pas la queue prenante, et aussi par plusicurs autres caractères essenticls. D'ailleurs l'intervalle qui sépare ees deux fumlles est immense, puisque le doue et toutes les guenons sont de l'aneiencontinent, tandis que tous les sapajous ne se trouvent que dans le nouveau. On pourrait clire aussi a vee quelque riison que le doueayant une longue queue comme les grueuons, et n'ryant pas comme elles de eallosités sur les fesses, il fait la muance entre les oranss-outangs el les gutenons, comme le gibbon la fait aussi à un autré égard, n’ayant point de sueue comme les orangs-outangs, mais ayaut des callosités sur les fesses comme les guenons. Indépendamment de ces rapports généraux, le doue a des caracteres particuliers par lesquels il est très-remarquable et fort aisé à distinguer de tous les singes, bahouins, guenons ou sapajous, mémeau premice coup d'œil ; sa robe, variée de toutes couleurs, semble indiquer l'ambiguité de sa nature, et en même temps diffeirencier son espèce d'une manière évidente. Il porte autour du cou un collier d'un brun pourpre, autour des joues une barbe blanche; il a les lèvres et le tour des yeux noirs, la face et les oreilles rouges, le dessus de la tête et le corps gris, la poitrine et le ventre jaune, les jambes blanches en bas, noires en haut; la quene blanche avec une large tache de même couleur sur les lombes; les pieds uroirs, avee plusicurs autres nuances de couleur. Il me parait que cet animal, qu'on a assuré venir de la Cochinchine, se troure aussi à Madagascar, et que e'est le mème gue Flaceourt indique soas le nom de sifuc dans les termes stivants: "A Ma" dagasear, il y a, dit-il, une autre espece de " guenuche blanche, quia un chaperon tanné, " et qui se tient le plus solivent sur les pieds " de derriere; elle a la queue blanche et denx "taches tammées sur les flancs : elle est plus "grande que lo rari (mococo, mais plus pe"tite que le aaricossi (rari). Cetle espèce s'ap"pelle sifuc, elle vit de féves; il y en a beau" coup ver's Andrivoure, Dambourlomb et "Ranafoulchy. " Le chaperon ou collier tamné, la «ueue blanche, les taches sur le's tianes sont des caractères qui indiquent assez clairement que re silice de Madirgasear est de lit meme es pece que le done de la Cochinchine. 
Les voyageurs assurent que les grands singes des parties mériclionales de l'A sie produi sent des bézoards qu'on trouve dans leur estomac, et dont la qualité est supérieure à celle des bézoards des chèvres et des gazelles. Ces grands singes des parties méridionales de l'Inde, sont l'ouanderou et le douc; nous croyons done que c'est à ces espèces qu'il faut rapporter la production des bézoards. On prétend que ces bézoards de singe sont toujour's d'une forme ronde, au lieu que les autres bézoards sont de différentes figures.

\section{Caractères distinctifs de cetle espèce.}

Le douc n'a point de callosités sur les fesses; il les a garnies de poil partout; sa queue, quoique longue, ne l'est pas autant que la tête et le corps pris ensemble. il a la face rouge et couverte d'uñ duvet roux, les oreilles nues et de même couleur que la face, les lèvres brunes, aussi bien que les orbites des yeux; le poil de couleurs très-vives et très-variées : il porte un bandeau et un collier d'un brun pourpre; il a du bianc sur le front, sur la tête, sur le corps, les bras, les jambes, etc., wne espèce de barbe d'un blane jaunàtre : il a du noir au-dessus du front et à la partie supérieure des bras; les parties du dessous du corps sont d'un gris cendré et d'un jaune blanchâtre; la quene est blanche, aussi bien que le bas des lombes : il marche aussi souvent sur deux pieds que sur quatre, et il a trois pieds et demi ou quatre pieds de hauteur lorsqu'il est debout. J'ignore si les femelles dans cette espèce sont sujettes à l'écoulement périodique.

\section{DESCRIPTION DU DOUC.}

\section{(extiait de DAUEenton.)}

Le douc est ale la grandeur du magot et du papion. Quoiqu'il ne reste de l'individı qui sert de sujet pour cette description ipe la pean bourrée et les os des mâchoires et des pieds, il me paraît que le douc a le museau moins long que celui du magot, les quatre jambes et les pieds de derrière à peu près aussi longrs : mais les pie Is de devant ont heancoup plus de longuenr. Quoinue le ponce soit très-petit, son extrémité ne s’ètend pas jusyu’au bout du métaearpe; il n'y a point de callosilés sur las fesses; les ongles sont un peu courbes et plies । en gouttière, excepté celni lu pouce des picds de derrière, qui est presque plat; leur conleur est noiràtre, de mène que celle de la juante ales pieds, celle des lèvres et du tour d's yeux; le reste de la face est roussâtre avec un petit ilnvel roux. Les oreilles sont petiles, nues, roussâtres comme la face; leur forme et leur couleur paraissent aroir éte al. térées par le des:échement.

Les couleurs du poil du dlouc le rendent très-remar(quable par leur viracité et par leur dispnsition ; elle est si extraordinaire, que cet animal semble avoir des vètements de différeutes couleurs, sur le front, sur la tète, sur le corns, sur les parties honteuses, le bras, lavant-luras, la cuisse et la jambe. Les tempes, les jones et la màchoire inférieure ont un lonso poil de couleur hlanchâtre, mêlée de jaunätre; il y a sur le bas du front un bandeau étroit qui s'ètend de chaque côté jusqu'à l'oreille, el qui est furmé par des poils de couleur de marron d'un roux-foncé; ces poils sont plus longs vers les oreilles que sur le milierr du front; il y a aussi sur le dessous et les cỏtés du cou un collier de mème couleur; le haut du front et la partie supérieure des bras sont noirs; le dessus, le derrière et les còtés de la tête, la partie inférieure des bras, le dos, la poitrine, le ventre et les côtés du corps ont des couleurs peu differentes de celles du petit-gृris; clıaque poil est d'un gris blanchâtre vers la racine; des couleurs noirâtres et grises verdàtres ou jaunâtres se succèdent jusqu'à quatre ou cinq fois dans le reste de son étendue; le jaunàtre est plus apparent sur lá poitrine et sur le ventre que sur la tête, les bras et le dos. L'avant-bras et le dessus du métacarpe sont de couleur blanchâtre, teinte de jaunatre; la quene est blanchâtre : il y a un espace triangulaire de cette mème couleur, placé à l'origine de la quene et au-dessus, il s'étend Ie long du pérince, et il occnpe le puhis et une partie du dedans des cuisses; il y a des couleurs de pelit-gris sons la cuisse, et des poils de conleur de marron roux foncé sur le bord de la tache blanche; le reste de chaque cuisse est noir, et cette couleur forme une ceinture andessus du pubis, enfin, les jambes proprement dites, et le dessus du métacarpe, sont de couleur de marron roux foncé, comme le collier et le handeau du front; les doigts des pietls de devant ont un poil noir; celui des doigts des pie:Is de derricre est tombé, il n'en reste que des brins qui sont unirs. La quene de ee douc a un pied sept pouces t

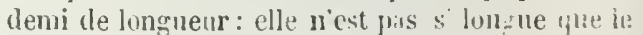
corps. 


\section{IA GUENON A LONG NEZ}

\section{(LA GUENON NaSIQUE.)}

Trdre des quadrumanes, genre guenon, famille des singes. (Cuvier.)

Cette guenon ou singe à la longue queue nous a été envoyce des grandes Indes, ct n'était connue d'ancun naturaliste, guoique très-remarquable par un trait apparent, et qui n'appartient à aueune des autres espèces deguenons, ni même à aucun autre animal. Ce trait est un nez large, proéminent, assez semblable par la forme à celui de l'homme, mais encore plus long, mince à son extrémité, et sur le milieu duquel règne un sillon qui semble le diviser en deux lobes. Les narines sout posées et ouvertes borizontalement comne celles de l'homme; leur ouverture est grande, et la cloison qui les sépare est mince : et comme le nez est très-allongé en avant, les narines sont éloignées des lèvres, étant situées à l'extrémité du nez. La face entiere est dénuée de poil conme le nez; la peau en est d'un brun mèlé de bleu et de rougeâtre. La tète est ronde, converte au sommet et sur toutes les parties postérieures, d'un poil touffu assez court et d'un brun marron. Les oreilles, cachées dans le poil, sont nues, minces, larges, de couleur noirâtre et de forme arrondie, avee une échancrure assez sensible it leur bord. Le front est court: les yeux sont assez grands et assez éloignés l'un cle l'autre; il n'y a ni sourcils, ni cils it la paupière inféricure, mais la paupière supérieure a cles cils assez longs. La bouche est grande et garnie de fortes dents eanines et de quatre incisives à chaqque mâchoire, semblables à celles de l'homme. Le eorps est gros et couvert d'un poil d'unbrun marron plus ou moins foncé sur le dos et sur les flanes, orangé sur la poitrine, et d'un fauve mèlé de grisâtre sur le rentre, les cuisses et les bras, tant au dedans qu'au dehor's.

Il y a sousle menton, autour du cou et sur les épaules, des poils bien plus longs que ceux du corps, et qui forment une espèce de camail dont la couleur contraste avec celle de la peau nue de la face. Cette guenon a, comme les autres, des callosités sur les fisses. Sa tueue est très-longue et garnie, en dessus ct en dessous, de poils fauves assez courts; ses mains et ses pieds, nus à l'untéricur, sont à l'extéricur couverts de poils courts et d'un fauve mêlé de gris. Elle a cing doigts tant aux mains qu'aux pieds, dont les ongles sont noirs; celui des pouces estaplati, et les autres sont convexes. Nous avons donné les principales dimensions de l'individu qui est au Cabinet du Roi : c'était un mâle, mais dont les parties de la géneration étaient trop altérées pour que nous a yons pu les décrire.

\section{LA GUENON A CAMLIL.}

(Le COLObe a CaMaIL..)

Ordre des quadrumanes, genre guenon, famille c'es singes. (Curier.)

Le sommet de la tète, le tour de lia face, le cou, les épaules et la poitrine de cette guenon, sont couverts d'un poil long, touffu, flottant, d'un jaune mêlé de noir, qui lui forme une sorte de camail. Elle a trois pieds de hauteur lorsqu'elle est debout, comme dans la figure, sur ses pieds de derriere. Elle a la face noire; le corps, les bras et les jambes sont garnis d'un poil très-court, luisant et d'un beau noir, ce qui fait ressortir la couleur de la queue, qui est d'un blane de neige et qui se termine par une touffe de poils également blanes. Tous les membres de eet animal sont très-déliés. 11 n'a que quatre doigts aux mains, comme le coaita, dont il diffère cependant par un très-grand nombre de carnctères, et prineipalement parles abajoues et par sa queue, qui u'est point prenante : aussi li'est-il pas du nombre des sapajous, qui tous appartiennent au nouveau continent; mais de celui des guenons, qui ne se trouvent que dans l'ancien.

Elle habite en effet dims les forèts de SierraLeone et de Guinée, où les Nègres Ini domneut le nom de roi des singes, apparemment à cause de la beauté de ses couleur's, et à cause de son camail qui représente une sorte de diadème; ils estiment fort sa fourrure, dont ils se font des ornements, et qu'ils emploient aussi à différents usages.

Nous ajoutons iei la notice d'une autre nouvelle espece de guenon que M. Pennant a déerite. lille a éte apporlée du méme pays que la guenon a camail, et elle lui ressemble par ses membres délies, par la longueur et le peu de grosseur do sa queue, et surtout en ce qu'elle a cing longs roigts aux pieds de derriere, et 
qu'elle n'en a que quatre aux pieds de devant. Son poil est notr au-dessus de la tète et sur les jambes, lai foncé sur le dos, et d'un bai très-clail' sur les joues, le dessous du corps et la tace intérieure des jambes et des bras. Elle nous parait être une variété dans l'espèce de la guenon \&े camail.

\section{LE BLANC-NEZ}

\section{(LA GUENOX BLAXC-NEZ.)}

Ordre des quadrumanes, genre guenon, famille des singes. (Curier.)

Nous croyons devoir placer ici lin article tiré des additions de M. Allamand: il contient la desiription d'une guenon appelée par les Hollandais blanc-nez, que je croyais être de la mème espèce que le moustac, mais qui est en effet d'une espèce différente.

4 M. de Buffon, dit M. Allamand, est porté à " croire que.la guenon que quelques voyageurs " nomment blanc-ne= est la mème que celle " qu'il a appelée moustac; et il se fonde sur le " témoignage d'Artus, qui dit qu'on roit à la "Côte-d'Or' des singes que les Hollarıdais nom" ment bianc-nez, parce que c'est la seule par" tie de leur corps rui soit de cette couleur; et "il ajoute qu'ils sont puants et farouches. Il se " peut que ces singes soient les mêmes que les " moustacs de M. de Buffon, quoique ceux-ci " aient la moustache et non le nez blanc; mais a il y en a une autre espèce en Guinée, qui a mérite à aussi juste titre le mème nom que je " lui donne. Son nez est effectivement couvert "d'un poil court, d'un blanc très-ćclatant, - tandis que le reste de sa face est d'un beau " noir, ce qui rend saillante cette partic, et fait "qu'elle frappe d'abord plus que toute autre. "J ai actuellement chez moi une guenon de " eette espèce, dont je suis redevable à M. Bu" tini, qui me l'a envoyée de Surinam, où clle a avait été apportée des còtes de Guinée. Ce " n'est point celle dont parle Artus, car elle " n'est ni puante ni farouche; c'est au contraire " le plus aimable animal que j'aie jamais vu. Il * est extrêmement familier arec tout le monde, " et on ne se lasse point de jouer avec lui, aree que jamais singe n'a joué de meilleure " grâce. Il ne déchire n ne gâte jamais rien : - s'il mord, c'est en badinant, et de facon que
* la main la plus délicate n’en remporte aucune " marque. Cependant il n'aime pas qu'on l'in" terrompe quand il mange, ou qu'on se moque " de lui quand il a manqué ce qu'il médite de " faire: alors il se met en colère, mais sa colère " dure peu, et il ne garde point de rancune. II " marche sur quatre pieds, excepté quand il " veut examiner quelque close qu'il ne con" nait pas; alors il s'eu approche en marchant " sul ses deux pieds seulcment. Je soupconne " que c'est le même dont parle Barbot, quand " il dit qu'il y a en Guince des siuges qui ont a la poitrine blanche, la barbe pointue de la " mème couleur, une tache blanche sur le bout " du nez, et une raie noirc autour du front. II " en apporta un de Bontri, qui fut estimé vingt " louis d'or, et je n’en suis pas surpris; sûre* ment je ne donnerais pas le mien pour ce - prix. La description de Barbot lui convient a fort, à l'exception de la couleur du corps qu'il " dit ètre d'un gris clair' moucheté.

" La race de ces guenons doit être nombreuse " aux côtes çe Guinée; au moins en voit-on " beaucoup aux établissements que les Hollan" dais y ont: mais quoique souvent ceux-ci aient " tenté d'en rapporter en Europe, ils nont pas " pu y réussir. La mienue est peut-ètre la seule " qui ait tenu bon contre le froid de notre cli" mat, et jusqu’à présent elle ne parait pas en " ètre affectée.

"Cet animal est d'une légèreté étonnante, ct " tous ses mourements sont si prestes, qu'il " semble voler platòt que sauter. Quandil est " trancuille, son attitude favorite est de repo" ser et soutenir sa tête sur un de ses pieds de " derrière, et alors on le dirait occupé de quel" que profonde méditation. Quand on lui offre " quelque chose de bon á manger, avant quede " le goniter, il le roule arec ses mains comme " un paitissier roule sa pâte.

\section{Caractères distinctifs de cetle espèce.}

"Le blane-nez a des abajoues, et des callosi" tés sur le's fesses. La longueur de son corps et " de sa tète pris ensemble est d'environ treize - pouces, et celle de sa queue de vingt. La cou"leur de la partie supérieure de son corps et " de sa queue est un aggréable mélange d'un " vert conleur d'olive et ùe noir, mais où ce" pendant le vert domine. Cette même couleur " s'étend sur la partic extérieure des cuisses et 
" des jambes, où plus elle approche des pieds, * plus elle devient noire. Les pieds sont sans " poil et tout à fait noirs, de même que les " ongles, qui sont plats

"Le menton, la gorge, la poitrine et le ven" tre sont d'un beau blanc, qui s'étend en " pointe prescrue au-dessous des oreilles. Le " dessous de la queue et la partie interne des " jambes et des bras sont d'un gris noiràtre. "Le front, le tour des yeux et des lèves, des " joues, en un mot, toute la face est noire, à "l'exception de la moitié inférieure du nez, re" marquable par une tache blanche presque " triangulaire, qui en occupe toute la largeur, " et qui se termine au-dessus de la lève en une " espèce de pointe, aux deux côtés de laquelle " sont posées les narines un peu obliquement. a Les oreilles sont sans poils et noirâtres; il en " part une raie aussi noire qui entoure cirell" lairement toute la partie supérieure dela tète, " dont le poil est tant soit peu plus long que " celui qui couvre le dos et forme une sorte " d'aigrette. Une ligne de poils blanes, qui a " son origine près de l'angle postérieur de l'œil, " s'étend de elıaque côté au-dessous des oreilles " et un peu plus loin, au milieu des poils noirs " qui couvrent eette partie. La racine du nez et " les yeux sont un peu enfoncés; ce qui fait pa" raitre le museau alfongé, puoiqu'il soit aplati. "Le nez est aussi fort plat dans toute sa lon" gueur, surtout dans cette partic qui est blan" che. Il n'y a point de poils autour des yeux, " ni sur une partic des joues; ceux qui courrent "le reste de la face sont fort courts. Les yeux " sont bien fendus; la prumelle en est fort " grande et.elle est entourćc d'un cercle jaume " assez large pour que le blauc reste caché sous "les paupieres. Les poils du menton sont plus " longs que ecux des autres parties, et forment " une barbe qui est surtout visible quand l'a" nimal a ses abajoues renplies de manger. Il " n'aime pas à l'avoir monillée, et il a soin de "l'essuyer, dés qu’il a bu, contre quelque " corps see. Je ne saurais dire si les femelles " de cette espece sont sujettes aux écoulements " périodiques; je n'en ai pu aperceroir aucune " marque dans eelle que j’ai. "

\section{LA GUENON}

\section{A NEZ BLANC PROEMINENT.}

(LA GUENON HOCHEUR.)

Ordre des quadrumanes, genre guenon, famille des singes. (Cuvier.)

Il y a grande apparenee, comme le soupcomne M. Allamand, ru'il y a plusicurs especes de guenons auxquelles on peut domner le nom de blanc-nez; mais on doit l'appliquer de préférence à celle qu'il vient de déerire, et lais ser le nom de moustac à celle dont j’ai déjà parlé.

On m'a apporté depuis, pour le Cabinet du Roi, une peau assez bien conservée d'une autre guenon, à laquelle on pourrait aussi donner le nom de blanc-nez, et qui a mème plusieurs autres rapports avec le blane-nez déerit par M. Allamand. Cette guenon était mâle, et celle de M. Allamand était femelle : on pourrait done croire que leur différence pourrait provenir de celle du sexe.

Ce mâle a seize pouces sept lignes, depuis le bout du museau jusqu'à l'origine de la queue, et la femelle dćerite par M. Allamand n'en avait que treize. Le nez, qui est tout blane, est remarquable par sa forme et sa couleur ; il est large sans être aplati, et proéminent sur toute sa longueur. Ce seul caractère serait sufiisant pour distinguer eet animal du blanc-nez décrit dans l'article précédent, qui n’avait pas le nez proéminent ou arrondi en-dessus, mais au contraire fort aplati. Le poil du corps est d'un brun noirìtre mèlé de gris, mais il est jaunâtre sur la tète : les bras et la poitrine sont aussi de couleur noiratie. Ce poil, tant du corps que des jambes et du dessus du corps, est long de treize lignes, et friséou erépu à peu près comme de la laine. Les orbites des yeux ont beaueoup de saillie, ce qui fuit paraitre l'œil enfoncé; l'iris en est jaunattre, et son ouverture est de trois lignes. Les paupières supérienres sont de couleur de chair, et les inférieures sont d'un brun rougeàtre : il y a du noir sur le nez et au-des sous des yeux. La mâchoire inféricure est couverte de poils gris mèles de roussitre; et sur les tempes, l'oceiput et le cou, les poils gris sont mélés de noir. Les oreilles sont de couleur rougeâtre et denuées de poils, ausi que la face 
qui est brune; elles ont un pouce six lignes de longueur, et onze lignes de largeur à la base. La queue a un pied neuf pouces trois lignes de longueur, quoiqu'elle ne soit pas entière, et qu'il $y$ manque quelques vertèbres; elle est couverte de poil noirâtre comme celui des jambes. Les pieds et les mains sont sans poil et de couleur brune tirant sur le noir : les pouces, surtout ceux des mains, sont plus menus que dans la plupart des singes et guenons.

Au reste, cet animal était encore jeune; car la verge était fort petite et eachée au fond du fourreau, qui ne paraissait pas excéder la peau du ventre, et d'ailleurs les testicules n'étaient pas encore apparents.

Mais ce que nous renons de dire ne suffit pas pour juger si cet animal et la femelle déerite par M Allamand sont deux espèces réellement distinctes, ou si l'on ne doit les regarder que comme deux simples variétés dépendantes du sexe; et ce ne sera que quand on aura vu un plus grand nombre de ces animaux qu'on pourra décider s'ils ṇe forment pas deux espèces, ou du moins deux variétés constantes et appartenant au màle comme à la femelle.

\section{LE ROLOWAY, OU LA PALATINE.} (LA GUENON DIANE.)

Ordre des quadrumanes, genre guenon, famille des singes. (Curier.)

"La guenon qui est représentée dans la " planche 13 ", dit M. Allamand, n'a point en" core été décrite : elle est actuellement vi- vante à Amsterdam, chez le sieur Bergmeyer, " dont la maison est connue, non-seulement de " tous les habitants de cette grande ville, mais " encore de tous les étrangers qui y arrivent; " et cela, parce qu'on voit toujours chez lui " plusieurs animaux rares qu'il fait venir à " grands frais des pays les plus éloignés. Cette " guenon lui a été envoyée des côtes de Guinée, " sous le nom de roloway, que j'ai cru devoir " Jui conserver. C'est un fort joli animal, doux " et caressant pour son maitre; mais il se défie " de ceux qu'il ne connait pas, et il se met en " posture de défense quand ils veulent s'en ap"procher ou le toucher.

I Yoyaz le yol, XY de cet ourrage, dultion de Hollande,
"Sa longueur, depuis l'origine de la quene " jusqu'au-dessus de la tête, est d'environ un " pied et demi. Le poil qui eouvre son dos est " d'un brun très-foncé et presque ncir : celui v qui est sur les flanes, les cuisses, les jambes " et la tête, est terminé par une pointe blan" ehâtre, ce qui le fait paraitre d'un gris obseur. "Les poils qui couvrent la poitrine, le ventre, " le contour des fesses et la partie intérieure " des bras et des cuisses, sont blanes; mais on a assure que cette couleur ne leur est pas na" turelle, et qu'en Guinée ils sont d'une belle " couleur orangée, qui se perd en Europe, et se " change en blanc, soit par l'influence du cli" mat, soit par la qualité de la nourriture. "Quand cette guenon est arrivée à Amster" dam, elle conservait encore quelques restes " de cette couleur orangée, qui se sont dissipés " peu à peu. Le sicur Bergmeyer en a reçu une " seconde depuis quelques mois, dont la partic " interne des cuisses est entièrement jaune : si " elle reste en vic, nous saurons avec plus de " certitude ce qu'il faut penser de ce change" ment de couleur.

" Ces guenons ont la face noire et de forme " presque triangulaire. Leurs yeux sont assez " grands et bien fendus; leur's oreilles sont sans " poil et peu éminentes. Un cercle de poils blan" châtres leur environne le sommet de la tête; "leur cou, ou plutòt le contour de la face, est " aussi recouvert d'une raie de longs poils blanes " qui s'étend jusqu'aux oreilles. Elles ont au " menton une barbe de la mème couleur, lon"gue de trois ou quatre pouces, qui se termine ( en deux pointes, et qui contraste singulière" ment avec le poil de la face. Quand elles sont " dans une situation où eette barbe repose sur " la poitrine, et se confond avec ses poils, on la " prendrait pour la continuation de ceux qui " forment le collier; ct alor's ces animaux vus à " une certaine distance, paritissent a voir autour " du cou une palatine scmblable à celles que " les dames portent en hiver; et mème je leur " en ai d'abord domné le nom, qui se trouve en" core seul sur la planche qui a été gravée, et " dans la table des articles de ec volume, qui " a été imprimée avant que je susse celui qu'elles " portent en Guince. Letr" qucue égale, pour la "longueur, celle de leur corps, et les poils qui "la recouvrent mont paru plus longs et plus " touffus que dans la plupart dles autres espè" ces. Lcurs fesses sont unes et calleuses. J'i- 
" gnore si elles sont sujettes aux écoulements a periodiques.

"Jonston a donné dans la planche 61 de " son Histoire des quadrupèdes, la figure d'un " singe qu’il a nommé cercopithecus meerkalz, " qui parait avoir quelque rapport avec notre " roloway. Je croirais même que c'est le même " animal qu'il a voulu représenter, si la figure "qüil en donne n'était pas une mauvaise co" pie d'une figure plus mauvaise encore du gua" riba, publice par Marcgrave."

\section{LA GUENON A FACE POURPRE.}

\section{(LA GUENON BARBIQUe.)}

Ordre des quadrumanes, genre guenon, fanille des siuges. (Cuvier.)

Cette guenon est remarquable par sa face et ses mains, quỉ sont d'un violet pourpre, et par une grande barbe blanche et triangulaire, courte et pointue sur la poitrine, mais s'étendant de chaque côté en forme d'aile jusqu'au delà des oreilles, ce qui lui donne quelque ressemblance a vec le palatine décrite dans l'article précédent.

Le poil du corps est noir; la queue est trèslongue et se termine par une houppe de poils blanes très-touffus. Cette espèce habite dans l'île de Ceylan, où on lui a donné quclquefois le nom d'ouanderou, ainsi qu'au bahouin que nous avous décrit sous ce nom. Ses habitudes sont tr'è-douces; elle demeure dans les bois, où elle se nourrit de fruits et de bourgeons. Iorsqu'on l'a prise, elle devient bientot privée et familière. On trouve également à Ceylan quelques guenons (jui sont entièrement blanches, mais (uui ressemblent pour tout le reste à la guenon a face pourpre, et cette variété de guenons blanches est assez rare.

\section{LA GUENON NEGRE.}

Ordre des quadrumanes, geure guenon, fanille des singes. (Cuvicr.)

Cette gnenon a été ainsi nommée à cause d'une sorte de ressemblance des traits de sa face ares ceux du visage des Negres. Sa filce est aplatie, et roprésente des rides qui s'étendent ol)liquement depuis le nez jusyu'au bas des joues. Le nez est large et aplati; les narines sont longues et évasées; la bouche grande et les levres épaisses; les oreilles larges et sans rebord saillant; le menton et les joues sont couverts jusqu'aux oreilles de poils assez longs, fins et jaunàtres. Cette guenon a le poil brun sur la téte; noirâtre sur le dos, les bras et les mains, un peu plus clair sur les cuisses et sur les jambes; clair-semé et jaunâtre sur la poitrine et sur le ventre. Les ongles sont allongés et convexes, exceptéceux des pouces, qui sont ronds et aplatis. La queue est aussi longue que le corps, et le poil qui la garnit est de même couleur que celui du dos. A u reste, l'espéce de cette gucnon est peut-être la plus petite de toutes celles de l'ancicn continent; car elle n'est guère plus grosse qu'un sagouin, et n’a communément que six ou sept pouces de longueur de eorps. Albert, Seba, Edwards et d'autres naturalistes (jui l'ont vue vivante, s'accordent sur la petitesse desa taille. Celle que cite Edwards était très-agile, assez douce, amusante par la légèreté de ses mouvements, et aimait beaucoup à jouer, surtout avec les petits chats. Son pays natal est la Guinée.

\section{LES SAPAJOUS ET LES SAGOUINS.}

Ordre des quadrumanes, genre sapajou, famille des singes. (Cuvier.)

Nous passons actuellement d'un continent à l'autre. Tous les animaux quadrumanes dont nous arous donné la description dans ce volume, et que nous avous complis sous les noms génériques de singes, babouins et gucnons, appartiennent exclusivement à l'ancien continent, et tous ceux dont il nous reste à faire menlion ne se trouvent au contraire que daus le Nouveau-Monde. Nous les distinguons d'abord par deux noms génériques, parce quon peut les diviser en deux classes; la première est celle des sapajeus, et la seconde celle des sagouins. Les uns et les autres ont les pieds conformés à peu près comme ceux des singes, des balbouins et des guenons : mais ils different des singes, en cequ'ils ont des queues; ils diffèrent des babouins et des guenons, en ce qu'ils n'ont ni poches au bas des joues, ni callosités sur les fesses : et enfin ils different de toustrois, c'esta-dire des singes, des babouns et des guenons, en ce que tous ceux-ci ont la cloison du nez. 
mince, et les narínes ouvertes à peu près comme celles de l'homme, au-dessous du nez; au lieu que les sapajous et les sagouins ont cette cloison des narines fort large et fort épaisse, et les ouvertures des narines placées à còté et non pas au-dessons du nez: ainsi les sapajous et les sagouins sont non-seulement spécifiquement, mais mème génćriquement différents des singes, des babouins et des guenons. Et lorsque ensuite on vient à les comparer entre eux, on trouve qu'ils diffèrent aussi par quelques caractères généraux; car tous les sajajous ont la cueue prenante, c'est-à-dire musclée de manière qu'ils peuvent s'en servir comme d'un doigt pour' saisir et prendre ce qui leur plait. Cette queue, qu'ils plient, qu'ils étendent, dont ils recoquillent ou développent le bout à leur volonté, et qui leur sert principalement à s'accrocher aux branches par son extrémité, est ordinairement dégarnie de poils en dessous et couverte d'une peau lisse. Les sagouins, au contraire, ont tous la queue proportionnellement plus longue que les sapajous; et en même temps ils l'ont entièrement velue, lâche et droite; en sorte qu'ils ne peuvent s'en servir' en aucune manière, ni pour saisir' ni pour s'accrocher. Cette différence est si apparente qu'elle suffit seule pour qu'on puisse toujour's distinguer uu sapajou d'un sagouin.

Nous comnaissons huit sapajous, que nous croyous pouvoir réduire à cinq espèces. La première est l'ouarine ou gouariba du Brésil. Ce sapajou est grand comme un renard, et il ne diffère de celui qu'on appelle alouate à Cayenne que par la couleur : l'ouarine a le poil noir, et l'alouate l'a rouge; et comme ils se ressemblent a tous autres égards, je n'en fais ici qu'une seule et mème espèce. La seconde est le coaita qui est noir comme l'ouarine, mais qui n'est pas si grand, et dont l'exquima nous parait être une variété. La troisième est le sajou ou sapajou proprement dit, yui est de petite taille, d'un poil brun, et quion connaît vulgairement sous le nom propre de singe-capucin: il y a dans cette espèce une variété que nous appellerons le sajou gris, et qui ne diffère de sajou brun que rar cette différence du poil. La quatrième espèce est le $s a \ddot{i}$, que les voyageur's ont appelé le pleureur; il est un peu plus grand que le sajou, et il a le museau plus large : nous en connaissons deux qui ne diffèrent que par la couleur du poil; le premier est d'un brun noirâtre, et le second d'un roux blanchâtre. Enfin, la cinquième espèce est le saimiri, qu'on appelle vulgairement le singe aurore ou sapajou oran$g e ́$ : celui-ci est le plus petit et le plus joli des sapajous.

Nous connaissnns de même six espèces de sagouins. Le premier et le plus grand de tous est le saki, qui a la queue couverte d'un poil si Jong et si touffu qu'on l'a nommé singe à queue, de renard. Il semble qu'il y ait variété dans cette espèce pour la grandeur; j'en ai vu deux qui paraissaient adultes, dont l'un était presque une fois plus grand que l'autre. Le second sagouin est le tamarin : il est ordinairement noir a vee les quatre pieds jaunes; mais il varie pour la conleur, car il s'en trouve de bruns mouchetés de jaune. Le troisième est l'ouistiti, qui est remarquable par les larges toupets de poil qui accompagnent sa face, et par sa queue annelée. Le quatrième est le marikina, qui a une crinière autour du cou et un flocon de poils au bout de la queue, comme le lion, ce qui lui a fait donner le nom de petit-lion. Le cinquième est le pinche, qui a la face d'un beau noir, avec des poils blanes qui deseendent du dessus et des côtés de la tête en forme de cheveux longs et lisses. Le sixième et le dernier est le mico, qui est le plus joli de tous, dont le poil est d'un blond argentin, et qui a la face colorée d'un rouge aussi vif que du vermillon. Nous alions donner l'histoire et la deseription de chacun de ces sapajous et de ces sagouins, dont la plu . part n'étaient ni dénommés, ni déerits, ni connus.

\section{L'OUARINE ET L'ALOUATE.}

\section{(L'Alouate OUARINe OU Guariba、 - L'Alouate Roux.)}

Ordre des quadrumanes, genre sapajou, famille des singes. (Guvier.)

L'ouarine et l'alouate sont les plus grands animaux quadrumanes du nouveau continent; ils surpassent de beaucoup les plus grosses guenons, et approchent de la grandeur des babouins : ils ont la qucue prenante, et sont par conséquent de la famille des sapajous, dans laquelle ils tiennent un rang bien distinet, nonseulement par leur taille, mais aussi par leur voix, qui retentit conme un tambour, et sc fait entendre à une très-grande distance. Marc- 
grave raconte que, "tous les jours, matin et " soir, les ouarines s'assemblent dans les bois; " que l'un d'entre eux prend une place élevée " et fait signe de la main aux autres de s'asseoir " autour de lui pour l'écouter; que, des qu’il " les voit placés, il commence un discours à " voix si haute et si précipitée, qu“à l'entendre " de loin, on croirajt qu'ils crient tous ensema ble; que cependant il n'y en a (ju'un seul, et " que, pendant tout le temps qu'il parle, tous "les autres sont dans le plus grand sileuce; " qu'ensuite, lors(qu'il cesse, il fait signe de la " main aux autres de répondle, et qừ l’ju" stant tous se mettent à crier ensmble, jus" qu'à ce que, par un autre signe de la main, * il leur ordomne le silence; que dans le mo" ment ils obéissent et se taisent; qu'enfin alors " le premier reprend son discours ou sa chanson, " et que ce n'est qu'après l'avoir encore écou" té bien attentivement qu’ils se séparent et " rompent l'assemblée. " Ces faits, dont Maregrave dit avoir été plusicurs fois témoin, pourraient bien être exagérés et assaisomnés d'un peu de merveilleux. Le tout n'est peut-être fondé que sur le bruit effroyable que font ces animaux : ils ont dans la gorge une espèce de tambour osseux dans la concavité duquel le son de leur voix grossit, se multiplie et forme des hurlements par écho; aussi a-t-on distingué ces sapajous de tous les autres par le nom de hurleurs. Nous n'arons pas ru l'oulrine, mais nous avons les dépouilles d'un alouate et un embrion desséché de cette mème espèce, dans lequel l'instrument du grand bruit, c'est-à-dire l'os de la gorge, est déjà très-sensible. Selon Maregrave, l'ouarine a la face largre et earrée, les yeux noirs et brillants, les oreilles courtes et arrondies, la queue nue à son extrémité, avec laquelle il s'aceroche et s'attache fermement à tout ce qu'il peut embrasser. Les poils de tout le corps sont noirs, longs, luisints et polis; des poils plus longs sous le meuton et sur la gorge lui forment une espèce de barbe onde. Le poil des mains, des pieds et d'une partie de la quene est brum. Le male est de la même couleur que la femclle, et il u’en differe qu'en ce qu'il est un peu plus gland. Les femeHes portent leurs petits sur le dos, et sanutent avee cetle charge de branches en branches et d'arbres en arbres : les petits embrassent avec les bras et les maius le corps de leur mère daus la partic la plus étroite, et s'y ticment ferme- ment attachés tant qu'elle est en mouvement. Au reste, ces animaux sont sauvages et méchants; on ne peut les apprivoiser ni même les dompter; ils rnordent cruellement; et, quoicqu'ils ne soient pas du nombre des animaux carnassiers et féroces, ils ne laissent pas d'inspirer de la erainte, tant par leur voix effroyable, que par leur air d'impudence. Comme ils ne vivent que de fruits, de légumes, de graines et de quelques insectes, leur chair n'est pas mauvaise à manger. "I.es chasseurs, dit Oexmelin, " apportirent sur le soir des singes qu'ils a vaient " tués dans les terres du eap Gracias-a-Dio : on "fit ròtil une partie de ces singes et bouillir " l'autre, ce qui nous sembla fort bon la chair " en est comme celle du lière, mais elle n'a " pas le mème guutt, étant un peu douceâtre : " e'est pourquoi il y faut mettre bcaucoup de " sel en la faisant cuire. La graisse en est jaune " comme celle du chapon, et plus même, et a " fort bon gout. Nous ne véeumes que de ces ani" maux pendant tout le tempsquenous fủmes là, " paree que nous ne trouvions pas autre chose; " si bien que tous les jours les cliasseurs en ap" portaient autant que nous en pouvions man" ger. Je fus curieux d'aller à cette chasse, et " surpris de l'instinct cqu'ont ees bètes de con" naitre plus particulierement que les autres " animanx ceux qui leur font la guerre, et de " chercher les moyens, quand ils sont attaqués, " de se secourir et de se défendre. I.orsque nous "les approchious, ils se joignaient tous ensem"ble, se mettaient à crier et faire un bruit " épouvantahle, et à nous jeter des branches " sèches qu'ils rompaient des arbres : il y en "avait mème qui faisaient leur saleté dans " leurs pattes, qu’ils nous euvoyaient à la tète. "J'ai remaryué aussi qu’ils ne s'abandonnent " jamais, et qu'ils sautent d'arbres en arbres si " subtilement que ecla éblouit la vue. Je vis " encore quils se jetaient à corps perdu de "branches en branches sans jamais tomber it "tere; car, avant qu'ils puissent ètre à bas, "ils s'acerochent ou avee leurs pattes ou avee " ha queue : ce qui fait que, quand on les tire à " coups defusil, at moins quion ne les tue tout "a fait, on ne les samrait avoir; car, lorsqu’ils " sont blessés, et mème mortellement, ils de"meurent toujours acerochés aux arbres, où ils "meurent souvent et ne tombent que par pie" ees. J'en ai vu de morts depuis plus de quatre " jours, qui penditient encore aux arbies; sı 
" bien que fort souvent on en tirait quinze ou " seize pour en avoir trois ou cquatre tout an "plus. Mais, ce qui me parut plus singulier, "c c'est qual moment que l'un d'eux est blessé, " on les voit s'assembler autour de lui, mettre " leurs doigts dans la plaie, et faire de même " (pue s'ils la voulaient sonder : alor's, s'ils roient " couler beaucoup de sang, ils la tiennent fer" mée pendant que d'autres apportent ciuelques "feuilles, qu'ils mâchent et poussent adroite" ment dans l'ourerture de la plaie. Je puis dire " avoir vu cela plusieurs fois, et l'avoir vu avec " admiration. Les femelles n'out jamais qu'un " petit, qu'elles portent de la même manière que " les Négresses portent leur enfant : ce petit, " sur le dos de sa mère, lui embrasse le cou "par-dessus les épaules avec les deux pattes " le devant; et des deux de derrière, il la tient " par le milieu du corps : quand elle veut lui " donner à téter, elle le prend dans ses pattes, " et lui présente la mamelle comme les fem" mes... On n'a point d'autre moyen d'avoir " le petit que de tuer la mère, car il ne l'aban" donne jamais ; étant morte, il tombe avec " elle, et alors on le peut prendre. Lorsque ces " animaux sont embarrassés, ils s'entr'aident " pour passer d'un arbre ou d'un ruisseau à un " autre, ou dans quelque autre rencontre que " ce puisse être.... On a coutume de les enten"dre de plus d'une grande lieue. "

Dampier confirme la plupart de ces fnits; néanmoins il assure que ces animaux produisent ordinairement deux petits, et que la mère eu porte un sous le bras et l'autre sur le dos. En général, les sapajous, mème de la plus petite espece, ne produisent pas en grand nombre; et il est très-vraisemblable que ceux-ci, qui sont les plus grands de tous, ne produisent qu'un ou deux petits.

\section{Caraclères distinctifs de ces espèces.}

I.'ouarine a les narines ouvertes à côté et non pas au-dessous du nez, la cloison des nalines très-épaisse : il n’a point d'abajoues, point de callosités sur les fesses; ces parties sont couvertes de poil eomme le reste du corps. Il a la quene prenante et tres-longue, le poil noir et lorig; et dans la gorge un gros os concave; il est de la grandeur d'un lérrier; le poil long qu'il a sous le cou lui forme une espèce de barbe ronde; il marche ordiuairement à quatre pieds.
L'alouate a les mêmes caractères que l'ouarine, et ne parait en différer qu'en ce qu'il n'a point de barbe bien marquée, et qu'il a le poil d'un rouge brun, au lieu que l'ouarine l'a noir. J'ignore si les femelles, dans ces espèces, sont sujettes à l'écoulement périodique; mais par analogie je présume que non, ayant obscrré généralement qu'il n'y arait que les singes, babouins et guenons à fesses nues, qui soient sujets à cet écoulement.

\section{ADDITION}

\section{A L'ARTicle de L'Alouate.}

L'on trouvera ici la figure du grand sapajou que nous arous appelé alouate, et qu'on nomme à Cayenne singe rouge : on le désigne aussi assez communément, aiusi que l'ouarine, par la dénomination de singe hurleur. L'alouate diffère de l'ouarine par la couleur, et par quelques caractères qu'on pourrait attribuer à la différence des contrées quills habitent. Sa figure manquait dans notre ouvrage, et nous l'a vons fait dessiner d'après une peau bourrée qui a été envoyée de Cayenne à M. Poissonnier, médecin du roi. L'ouarine ou le hurleur noir, quoique fort commun au Brésil, ne se tronve point à la Guyane, et nous n'avons pu nous en procurer un individu. L'alouate ou le hurleur ronge est au contraire très-rare au Brésil, et très-cominun dans les terres voisines de Cayenne.

Ce grand sapajou avait vingt-trois pouces et demi le longueur, et peut-ètre un pouce ou deux de plus, parce que la peau en est fort desséchée. La face est sans poil, le nez est aplati, les narines sont larges, les joues garnies sur les côtés de poils faures et clail'-semés avec de grands poils noirs au-dessus des yeux; et il y a quatre dents incisives au-derant de ehacune des mâchoires : les supérieures sont plus grosses et plus larges que les inférieures. Il y a aussi deux canines qui sont fort grosses à la base; et entre les incisives et les canines supéricures, do même qu'entre les canines et les mâcheliè!es inférieures, il se troure un espace vide, dans lequel la dent canine de la máchoire opposée entre lorsque la bouche se ferme. Nous u'arons pu voir les dents mâchelières, à eause du desséehement de la peau. Ce que ce sapajou a de particulier, outre sa grande taille, ce sont de 
longs poils d'un roux foncé sur les côtés de la tète et du cou, qui lui forment comme une grande barbe sous le menton. Il a les jambes et les bras fort courts relativement à la longueur de son corps. Les bras, depuis l'épaule au poignet, n'ont que dix ponees neuf lignes, et les euisses et les jambes jusqu'au talon, onze pouces huit lignes. La main, depuis le poignet jusqu’à l'extrémité du plus long doigt, a quatre pouces; et le pied, einq pouces deux lignes, depuis le talon jusqu'au bout du plus long doigt. Le dedans et le dessous des pieds et des mains est une peau nue, et le dessus est couv'ert de petits poils d'un brun roux. Le corps est trèsfourni de poils, surtout aux épaules où ils sont le plus longs, et ont jusqu'à deux pouces six lignes de longueur, tandis que le poil du corps n'a que treize ou quatorze lignes. Les bras sont bien couverts de poils sur leurs parties extél'ieures; mais leur partie intérieure est presque sans poil, et nous ne savons si ee manque de poil ne vient pas d'un défaut de eettepeau desséchée. La couleur générale du poil de ce sapajou l'a fait nommer singe rouge, paree qu'en effet il paralt rouge par l'opposition des couleurs des diflér'ents endroits où le poil est d'un roux brûlé, mèlé de teintes brunes et roussâtres, r.t cette couleur domine sur la barbe, sur la tête et sur l'intérieur des cuisses. Les bras, depuis le coude jusqu'au poignet, sont d'un brun roux très-foncé qui domine sur le fau ve au dedans du bras, lequel est néanmoins d'un fauve plus foncé que celui du corps. Le poil sous le ventre est du mème fauve que sur les reins; mais sur la partie de la poitrine voisine du cou il est mélangé de poils noirs plus longs que ceux du ventre. La queue est longue d'un pied sept pouces et demi, sur un pouce neuf lignes de diamètre à l'origine : elle va toujours en diminuant de grosseur, et n'est revêtue par-dessous que d'une peau sans poil sur une longueur de dix pouces vers l'extrémité; ce qui démontre que l'animal s'en sert pour s'attacher et s'acerocher, ou pour prendre les différentes choses qu'il veut amener à lui, comme le font les autres sapajous qui, tous, à l'exeeption de l'ouarine, sont plus petits que celui-ei. Au reste, cette queue, donl la peau est très-brune, est couverte en dessus de poils d'un roux brun.

On épie ou l'on poursuit ees animaux à la chasse, et la chair n'en est pas absolument mauvaise à manger, quoique toujours très-dure. Si l'on ne fait que les blesser sur un arbre, ils s'attachent à une branche par leur longue queue; et ne tombent à terre (que lorsqu'ils sont morts; quelquefois même ils ne se détachent que plus de vingt-quatre heures apres leur mort; la contraction dans les muscles qui replient le bout de la queue se conserve et dure pendant tout ce temps.

Ces gros sapajous mangent de différentes espèces de fruits. Ils ne sont pas féroces, mais ils causent de l'épou vante par leurs cris réitérés et presque continuels, qu'on entend de fort loin, et qui leur ont fait donner le nom de hurleurs. Ils ne font qu'un petit, que la mère porte sur le dos et prend entre ses bras pour lui donner a téter. Ceux qu'on élève dans les maisons ont l'air triste et morne, et ne font point ees gentillesses qu'on nomme eommunément des singeries : ils portent orảinairement la tête basse et ne se remuent qu'aree lenteur et nonchalance. Ils s'accrochent très-souvent avee le bout de leur queue, dont ils font un, deux ou trois tours, selon quïls veulent être plus ou moins fortement attachés. L'état de domesticité ehange leur humeur et influe trop sensiblement sur leurs habitudes naturelles, ear ils ne vivent pas longtemps en captivité; ils y perdent leur roix, ou du moins ils ne la font janais entendre, tandis qu'en liberté ils ne cessent de hurler : on entend leur cri plusieurs fois par jour dans les habitations voisines des forèts; leur carillon lugubre dure souvent quelques heures de suite. C'est ordinairement à deux heures après minuit qu'ils commeneent is hurler ou crier ; et ee cri, qui retentit au loin, se fait d'une manière singulière. Is aspirent fortement et pendant longtemps l'air, qu“ils rendent ensuite peu à peu, et ils fout autant de bruit en l'aspirant qu'en le rendant : cela dépend d'une conformation singulière dans l'organe de la voix. Ver's le milieu de la trachée-artère, on trouve une carité osseuse qui ressemble par sa forme extéricure au talon d'un soulier de femme : cette eavité osseuse est attachée par des ligaments membra. neux qui l'environnent; l'air poussé des poumons par la trachée-artère dans cette cavité, passe e'n montant par un canal membraneux, épais et sinueux, se rétrécissint et s'ourrant en maniere d'une bourse à cheveux : éest à l'en trée et il la sortie de ce conduit menbrancur. que l'air éprouve toutes les modifications qui forment les tons sucecssifs de leur forte roix. Les 
femelles ont un organeosseux comme les mâles.

Un observateur, qul a vu et nourri quelquesuns de ces animaux à Cayenne, m'a communiqué la note qui suit. "Les alouates habitent les " forèts humides qui sont près des eaux ou des - marais. On en trouve communément dans les "ilots boisés des grandes savanes noyées, et " jamais sur les montagnes de l'intéricur de la "Guyane. Ils vont en petit nombre, souvent " par couples et quelquefois seuls. Le cri, ou " plutót le rálement effroyable qu'ils font en" tendre, est bien capable d'inspircer de la ter"reur; il semble que les forèts retentissent des " hurlements de toutes les bètes féroces rassem" blées. C'est ordinairement le matin et le soir " qu'ils font ce bruit; ils le répètent aussi dans "le cours de la journée, et quelquefois pen" dant la nuit. Ce râlement est si fort et si va" rié, que l'on juge souvent qu'il est produit " par plusieurs de ees animaux, et l'on est sur" pris de n'en trouver que deux ou trois, et " quelquefois de n'en voir qu'un seul. L'alouate "vit rurement longtemps en captivité. Le mâle " est plus gros que la femelle; celle-ci porte " son petit sur son dos.

"Rien n'est plus difficile à tuer que ces ani" maux : il faut leur tirer plusieurs coups de fu" sil pour les achever, et tant qu'il leur reste a un peu de vie, et quelq̧uefois même après " leur mort, ils demeurent acerochés aux bran" ches par les pieds et la queue. Souvent le " chasseur s'impatiente de perdre son temps et " ses munitions pour un aussi mauvais gibier; " ear, malgré le témoignage de quelques voya" geurs, la chair n'en est pas bonue : elle est "presqque toujours d'une dureté excessive, " aussi est-eile exclue de toutes les tables : " e'est uniquement le besoin et la privation des " autres mets, qui en font manger aux habi"tants peu aisés et aux voyageurs."

J'ai dit que j'ignorais si les femclles ouarines étaient sujettes à l'écoulement périodique, et que je présumais qu'il n'y arait que les singes, les babouins et les guenons à fesses nues qui fussent sujets à cet éeoulement. Cette présomption était peut-ètre bien fondée ; ear M. Sonniui de Manoncourt dit s'ère assuré qu'ancune femelle, dans les grands et les petits sapajous et dans tous les sagouins, n'est sujette à cet écoulement. Il a remarqué de plus qu'en général les sapajous et les sagouins vivent en troupes dans es forets; qu'ils portent sur le dos leurs petits, qui les embrassent étroitement, et que, lorsque l'on tuc la mere, le petit, tombant avec elle, se laisse prendre: e'est mẻme, selon lui, le seul moyen d'en avoir de vivants.

Nous pouvons ajouter à ces observations, que la plupart des ces animaux, tels que l'alouate, l'ouarine, le conita, ete, ont une physionomic triste et mélancolique, et que néanmoins les mâles marquent assez insolemment beaucoup de désir pour les femmes.

A l'égard de l'organe de la voix de ces sapajous hurleurs, M. Camper, très-savant anatomiste, qui s'est occupé de la comparaison des organes rocaux dans plusieurs animaux, et particulièrement dans les singes, m'écrit au sujet de l'alouate dans les termes suivants:

"I'ai trouvé, dans le quinzième volume de " votre excellent ouvrage sur l'Histoire natu" relle, la description d'un os hyoide, qui ap" partient à l'alouate, et de près de huit pouces " de circonférence, etc.

"Mon ardeur pour dissécquer cet animal fut " d'autant plus animée, que vous me paraissiez " beancoup désirer de connaitre la conformation " singuliere de cette partie.

"M. Vieq-d'Azyr eut la bonté de me faire " voir deux os pareillement, lorsque j’étais à "Paris en $17 i 7$; le plus grand de ees os avait " un peu plus de huit pouces de circonférence.., " et je le dessinai arec empressement... Je vis " bien que la caisse osseuse., quoique très a mince, était la base de la langue; j'y distiu" guai même les articulations qui avaient servi " aux cornes de cet os; mais je ne compreuais "rien de sa situation, ni de sa connexion avec "les partics voisines....

"Curieux de connaitre un animal si extraor" dinaire, je fis des recherehes pour le trouver, " mais personne, même dans toute la Hollande, " ne possédait ce singe, quoique nous soyons " très à portée de l'avoir de Surinam et de nos " autres colonies de la Guyane, oủ il se trouve " en très-grand nombre; cependant je le trou"vai à la fin, au mois d'octobre de cette annće " 1 i i s, à Amsterdam, chez M. le docteur Clok" ner, naturaliste celèbre, dont vous connaitrez "le mérite par les additions que M. le profes" seur Allanand a ajoutées à l'édition hollan" daise de votre ouvrage.

"Retourné øn Frise à ma campagne, je ine " mis en der oir de satisfaire ma curiosité en dis" séquant l'orgaue de la roix de cet animal sin- 
a gulier....; et je vais, monsieur, vous faire " part de mes observations à ce sujet, en vous " envoyant la copie de mes dessins anatomi" ques, afin de vous donner avee plus de préci" sion une jdée de la structure de cette partie " intéressante.

- L'animal avait, depuis l'occiput jusqu'a "l'origine de la queuc, quinze pouces de lon" gueur, et douze pouces depuis la máchoire " inférieure, vers l'os pubis. La quene était " longue de vingt-deux pouces, y compris la " partie prenante qui l'était de dix.

Largeur de la tête, depuis l'occiput jusqu'à

l'extrémité du museau. ............ 0446

Largeur de la náchoire inférieure.. . . . . . $0 \begin{array}{lll}0 & 2 & 0\end{array}$

Longueur de l'os du bras. ............ 0 . 6

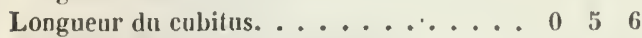

Longnenr de la paume de la main. . . . . $0 \begin{array}{llll}0 & 1 & 6\end{array}$

Longuenr des doigts. . . . . . . . . . $0 \begin{array}{lll}0 & 2 & 3\end{array}$

Longueur des cuisses. ........... 0 . 60

Longuenr des jamles. . . . . . . . . 0060

Longueur de la plante du pied. . . . . . . 0030

Longueur des orteils............ 0116

" La couleur du poil et la forme de toutes les " parties du corps et des menbres, étaient comme " vous les avez décrites.

(Ies dents incisives sont très-petites, ainsi " que les canines, et le museau est assez court.

"Les quatre premières figures représentent "l'organe de eet alouate; la einquième, l'os " hyoüde dont M. Vierg-d'Azyr m'a ficit pré" sent.

"La première et la seconde donnent les glan" des et les muscles du cou, la tête étant cou" chée sur la table. Toutes ces parties sont de " grandeur naturelle.

"Dans la troisième et la quatrième figure, on "voit l'organe de la voix en profil, et détaché - du cou. J'ai domié, autant que je l'ai pu, les " mèmes earactères aux parties analogues, afin "d'éviter la confusion.

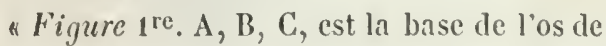
"la langue, couverte par les museles milio-hyoï-

- diens qui ne paraissent presque pas a cause " de leur délicatesse et de la transparence qu'ils " avaient aequise daus l'esprit de vin dans le"quel l'animal avait été conservé.

"I, G, H, les deux bianches de la máchoire "inféricure, converte par les massétìres $\mathrm{S}$ et " $\mathrm{R}$.

" D, le cartilage thyroidien; $\mathrm{E}$, le cricoüdien; " F, la trachéc-artère.

I, K, A, M, H, les deux glandes submaxil-
" laires très-considérables, et unies par-devant " en $\mathrm{K}$.

" $\mathrm{O}, \mathrm{P}, \mathrm{M}$ et $\mathrm{O}$ 4, les sterno-mastoïliens.

" $\mathrm{R}, \mathrm{Q}$, les muscles peaussiers ou latiscimi" colli, mis de côté.

( $\mathbf{A}, \mathbf{G}$, les génio-hyoïdiens : N, O, les ster" no-hyoïdiens.

"Figure 2. A, B, C, D, E, F, G, I, N, O, Q, a $\mathrm{R}$, comme dans la première figure.

" $\mathrm{S}$ T, thyrio-hyoïdien, dont l'insertion est " dans l'échancrure de la base de l'os hyoüdien ( $\mathrm{B}, \Theta, \Omega, f_{6} . \mathrm{s} .5$.

" T O, le sterno-thyroïdien, dont l'autre par" tie monte de W' en V. L'intervalle entre B, C, " $\mathrm{D}$, dépend de ce que la téte fut relevée en " haut sur la table. Dés que la tète forme un " angle droit aree le cou, l'éminence du earti" lage thyroïdien s'applique à l'échanerure de " la base de l'os hyoide, comme on leverra " dans la troisième firure.

"Figure 3. A, B, C, D, E, F, G, comme "dans les précédentes.

" B. $\Omega$, échanerure latérale de l'os hyoïde.

" $\Omega, \Gamma$, corne de cet os.

" $\Gamma, \Delta$, partic eartilagineuse de la corne.

( $\mathrm{D}, \mathrm{p}, \mathrm{k}, \mathrm{m}$, eartilage thyroidien.

a a, B, stylo-hyoïdien.

( $\mathrm{B}, \boldsymbol{\Omega}, \mathrm{u}, \mathrm{b}$, bucco-glosse.

( $\Gamma, \Omega$, u, cérato-glosse.

a $\Delta, \mathrm{f} . \mathrm{u}, \mathrm{e}$, stylo-glosse; $\mathrm{G}, \mathrm{e}, \mathrm{b}, \mathrm{d}$, génioa glosse; b, e, d, génio-hyoïde.

" g, h, l, $\mathbf{\Omega}$, thyro-hyoidien.

a $\mathrm{i}, \mathrm{n}$, glande thỵroidicne unie en $n$ avec " celle de l'autre edté.

" $\mathrm{K}, \mathrm{l}, \mathrm{m}$, erico-thyrö̈licn.

" $\mathrm{O}$, œsophage.

" $y, x$, langue dont le bord est ondové par "les dents, qui y ont imprimé leurs restiges.

" $\mathrm{q}, \mathrm{r}, \mathrm{l}$ '́piolotte : $r$ le petit cartilage entre " ectte partie et la pointe de l'arytenoidien, " s, t.

"Figure 4. A, B, B, , , , , .. D, p, K.

" K, E. $\mathbf{~}, \mathrm{I}, \mathrm{f}, \mathrm{e}, \mathrm{e}, \mathrm{G}$, eomme dans la figure 3.

"On y roit le cartillige thỵroidien et erieodien

" plus clairement; et l'articulation en $K$; anssi

a toutl'os de la langue avee sa cornes $د$, et celle

" du cartilage thy roidien p, entoure a vec la corne,

"du eité oppesisé, presque tont l'orsophage : il

"y manque encore les bonts que j"avinis mal-

"heureusement coupés, ne mattendant pas

"des extrimilés si longues.

"Figure 5. Celle-ei représente la base de l'os 
" hyoïde que m'a donné M. Vieq-d'Azyr, placé " comme dans ies figures 1 et 2.

" A, B, C, la partie antérieure.

" $B, C$, l'échancrure antérieure qui reçoit sur " ses bords les muscles sterno-hyoïdiens.

" $\Omega$ et $\Psi$, les cavités qui ont reçu les têtes " des cornes de l'os hyoide.

" $\mathbf{\Omega}, \Xi, \Psi, \boldsymbol{\Psi}$, la base de l'os hyoide qui re" çoit les muscles et l'attache de la langue.

" $\boldsymbol{\Omega}, \mathrm{O}, \mathrm{B}, \mathrm{\Psi}, \mathrm{II}$, les échancrures latérales.

" $\mathrm{B}$ ct C, deux pointes osseuses entre lesquelles " est la véritable base $\Omega$, I, $\Psi$ : il y une grande

"ouverture dans laquelle l'air poussé des pou" mons tombe, après avoir passé la fente de la " glotte.

"La voix, formée par la fentede la glotte, en" tre donc dans la caisse osseuse augmentée par "la partie membraneuse qui se trouve entre le " cartilage thyroïdien et cet os b, c, d, fig. $1^{\text {re }}$; " après quoi elle retounne par une ouverture " très-considérable qui est sous la racine de l'é" piglotte, dans le creux formé par l'épiglotte et " les cartilages arythénoïdiens au-dessus de la " fente. Cette mème voix passe en troisième lieu " par l'ouverture q, r, s, figure 3, dans le fond " de la bouche. L'organe forme donc une espèce " de flúte dont les chasseurs se servent pour " rappeler les chiens.

"Dans les babouins, j'ai trouvé que la base a de l'os hyoïde était aussi creuse, mais beaua coup moins; la poche membraneuse, au con" traire, est tres-considérable dans ces animaux, " et forme un boursouflement au cou quand ils * crient. La racine de l'épiglotte est perforée - dans ceux-ci comme dans le pithèque. Dans " les orangs-outangs, l'os hyoide est semblable " au notre; ils ont cependant deux poches mem" braneuses d'une grandeur considérable qui " descendent quelquefois sur l'os de la poitrine, " sur les os du bras, jusque vers le dos au-des" sus des omoplates; chaque poche a alors son " orifice distinct au-dessus de la fente de la " glotte. La modulation de la voix est donc im" possible dans ces animaux.

"Mais ce qui m'a paru fort extraordinaire, " e'est l'organe de la voix dans le renne, qui " est en tout conforme à celui des babouins, " comme je l'ai déjà indiqué dans mes obser" vations sur le renne, volume $X \boldsymbol{V}$ de votre "Histoire naturelle, édition de Hollande, - page 53.

- Jomme l'alouate que j’ai disséqué a vait dé-
" jà changé ses dents, il paralt avoir acquis sa " grandeur naturelle; mais en comparant le " grand os du Cabinet du Roi, et celui qui est " dans le cabinet de M. Vicq-d'Azyr, dont l'o"rifice est simple et sans les éminences pointues " B, C, figure 5, il parait qu'il y a deux espèces " d'alouates, et que la seconde est très-proba( blement près de deux fois plus grande que " celle dont nous venons de domer la descrip" tion : la grandeur de la eaisse osseuse sem" ble autoriser" cette conjecture. Le corps sera "donc de deux pieds et demi, ce qui fait pour " un tel animal déjả une taille gigantesque, " surtout lorsqu'il se tient debout sur ses deux " jambes postérieures, longues aussi de deux "pieds et demi."

Cette dernière réflexion de M. Camper est très-juste; car il y a des alouates et des ouarines qui ont plus de cinq pieds lorsqu'ils sont debout; et il est à désirer que ce célèbre anatomiste réunisse dans un seul ouvrage toutes les observations qu'il a faites sur les organes de la voix et de l'ouïe, et sur la conformation de plusieurs autres parties intérieures de différents animaux.

\section{DESCRIPTION DE L'ALOUATE.}

\section{(EXTaAT DE DACBENTON.)}

L'alouate qui a servi de sujet pour cette description était fort petit et paraissait fort jeune; il n'avait que cinq pouces quatre ou cinq lignes, depuis le sommet de la tête jusqu'à l'origine de la queue, dont la longneur était de sept pouces neuf lignes; elle avait sur le eôté inférieur une paume, yui s'étendait de la longueur de trois pouces, depuis l'extrémité de la quene, et qui dénotait que l'animal se servait de cetle partie comme d'un doigt pour se suspendre et pour saisir différentes choses. Ce petit animal ètait desseché et raccorni; cependant on royait distinctement que la tête était fort grosse à proportion de la grandeur du reste du corps; il avait le museau allongé, les yeux grands, le nez saillant à son origine, large et aplati par le bout; les ouvertures des narines se trouvaient fort èloignces l'une de l'autre et placées sur les còtés du nez'; les oreilles étaient

\footnotetext{
- J al remarqué cette conformation sur tous les sapajous et les sagouins que j’ai vus; et $j$ 'ai observé qu' au contraire les ouvertures des narines se trouvent an.dessous du nez, el ue sont séparées que par une cloison étroite dans les autres animaux de la classe des singes; $j j^{\circ}$ ai employé ce caractere dans une division méthodique de ces animaux.
} 
grandes, il y avait cinq doigts à clıaque pied; les ongles étaient jaunâtres et pliés en gouttière.

Les joues et le bout du museau avaient du poil qui était déjà long; le front, la tête, le corps, la queue et les jambes étaient couverts d'un poil fauve roussâtre; il n'y avait (ju'un duvet sur la poitrine et sur le ventre.

Quoique les différentes parties du corps de cet animal fussent déformées par le desséchement, il m'a paru que le noud de la gorge était à proportion plus gros que clans les autres animaux, et qu'il s'étendait entre les branches de la màchoire. A yant ouvert cette tubérosité, j'ai reconnu qu'elle était creuse et formée par une laue assez dure pour faire eroire qu'elle se serait ossilieje dans l'adulte; je n’ai pas douté que la tubérosité que je royais dans le jeune alouate clont il s'agit, ne fuit un indice très-apparent de la poche osseuse yui est dans la gorge de l'alouate, et qui rend sa voix trèsforte.

J'ai vu la peau d'un alonate adulte qui avait un pied onze pouces et demi de Jongueur, clepuis le bout du museau jusqu'à l'origine le la queue; me partie les os de la tète tenait à cette peau. Les dents étaient au nombre de trente-six comme dans les autres sapajous; les branches de la matchoire inférieure avaient beaucoup de haneur et de largeur, principalemeut a l'endroit de leur contour' elles laissaient entre elles un espace vide assez grand pour contenir la poelse ossemse qui est dans la gorge de l'aloate ; cette etendue de la machoire inférieure rendait la tète fort trosse, elle le paraissait encore plus qu'elle ne l'était réellement par la longuenr des poils de la gorge et des eotes de lil tête, qui avaient environ un pouce et demi; ceux des llancs étaient longs le près de trois pouces; le poil de la tête, de la face supérieure du cou, celui des quatre jambes, de la queue était brun avec les teintes cle roux et de couleur de marron; le poil du reste du corps avait une couleur rousse plus ou moins foncée dans différents endroits ; la peau était. épilée sur la poitrine et sur le ventre, il y resiait cependant quelques poils bruns. Cette peau a ait été envoyée de Cayenne; il y avait rint doigts à chaque pied, les ongles etaient noirs et plies en gonttière, eelui du ponce des pieds de derrière etait. fils large que les autres.

\section{LE COAITA ET L'EXQUIMA'.}

\section{(L'ATÉLE COAITA.)}

Orile des quadrumanes, genre sapajou, famille des singes. (Curier.)

\section{(LA GUENON DIANE.)}

Ordre des quadrumanes, genre guenou, famillo des singes. (Curier.)

Le coaita est, après l'ouarine ct l'alouate, le plus grand des sapajous; je l'ai vu vivant il l'hôtel de M. le duc de Bouillon, ou, par sil fitmiliarité, et même par ses taresses empressées, il méritait laffection de eeux qui le soignaient: mais, malgré les bons traitements et les soins, il ne put r'ésister aux froids de l'hiver de 1 \% 64 ; il mourut, et fut regretté de son maitre, qui cut la bonté de me l'envoyer pour le placer au Cabinet du Roi. J'en ai vu un autre chez M. le marquis de Montmirail ; eclui-ej était un mále, et le premier une femelle; tous deux étaient égralement traitables et bien apprivojsés. Ce sipajou, par son. naturel doux et docile, difière douc beaucoup de l'ouarine et de l'alouate, qui sont indomptables et farouches; il en dilfere aussi, en ce qu'il n'a pas, comme eux, une poche osseuse dans la gorge; il a, comme l'ourine, le poil noir, mais hérissé. II eı dilfère encore, aussi bien que de tous les autres sapajous, en ee qu'il n'a que quatre doigts aux mains, et que le pouce lui manque: par ce seul caractere et par Sä queue prenante, il est aisé de le distinguer des guemons, qui toutes ont la cqueue lâche et cinc doiogts aux mains.

L'animal que Maregrave appelle exquima est d'une espece tres-roisine de calle du coaila, et mine n'en est peut-ètre qu'une simple variété. 11 me parait que eet auteur a fait une faute lorsqu'il a dit que l'exquima était de Guince et de Congo: la figure qu'il en donne: suffit seule pour demontrer l'erreur; car eet animal y est représenté avee la queue recoruillée di l'extrémité, callactère qui u'appartient qu'aux seuls sapajous et point aux guenoms, qui toutes ont la queue liche ; or, nous somne's assurés qu’il n’y a en Guinis et au Congo que des gruenoms et point de silpajous; par consequent, l'usquima de Marerratre n'est pas, comme il le dit, une guenon ou.

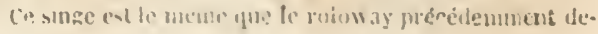


cercopithèque de Guinée, mais un sapajou à queue prenante, qui sans doute $\mathrm{y}$ avait été transporté du Brésil: le nom d'exquima ou quima, en ôtant l'article $e x$, et qui doit sc prononcer qouima, ne s'éloigne pas de quoaita, et c'est ainsi que plusieurs auteurs ont écrit le nom du coaita : tout concourt donc à faire croire que cet exquima de Marcgrave, qu'il dit être une guenon ou un cercopithèque de Guinée, est un sapajou du Brésil, et que ce n'est qu'une variété dans l'espèce du coaita, auquel il ressemble par le naturel, par la grandeur, par la couleur et par la queue prenante; la seule différence remarquable, c'est que l'exquima a du poil blanchàtre sur le ventre, et qu'il porte audessous du menton une barbe blanche, longue de deux doigts. Nos coaitas u'avaient ni ce poil blanc ui cette barbe. Mais ce qui me fait présumer que cette différence n'est qu'une variété dans l'espèce du coaita, c'est que j'ai reconnu, par le témoignage des voyageurs, qu'il y en a de blancs et de.noirs, les uns sans barbe et d'autres avec une barbe : "Il y a, dit Dampier, dans les " terres de l'Isthme de l'Amérique, de grands " troupeaux de singes, dont les uns sont blancs " et la plupart noirs; les uns oht de la barbe, " les autres n'en ont point: ils sont d'uue taille " médiocre... Ces animaux ont quantité de vers " dans les entrailles.... Ces singes sont fort drò« les, ils faisaient mille postures grotesques lors"que nous traversions les bois, ils sautaient " d'une branche à l'autre avec leurs petits sur " le dos; ils faisaient des grimaces contre nous, " craquetaient des dents et cherchaient l'occa" sion de pisser sur nous. Quand ils veulént " passer du sommet d'un arbre à l'autre, dont " les branches sont trop éloignées pour y pou" voir atteindre d'un saut, ils s'attachent à la " queue les uns des autres, et ils se brandillent - ainsi jusqu'à ce que le dernier attrape une " branche de l'arbre voisin, et il tire tout le "reste après lui." Tout cela, et jusqu'aux vers dans les entrailles, convient à nos coaitas; M. Daubenton, en disséquant ces animaux, y a trouvé une grande quantité de vers dont quelques-uns avaient jusqu à douze et treize pouces de longucur : nous ne pourons donc guère douter que l'exquima de Narcgrave ne soit un sapajou del'espèce même, ou de l'espèce très-roi- sine de celle du coaita.

Nous ne pouvous aussi nous dispenser d'ob. server que si l'animal indiqué par M. Limnæus sous le nom de diana, esten effet, commeil ledit, l'exquima de Marcgrave, il ą manqué dans sa description le caractère essentiel, qui est la queue prenante, et qui seul doit décider si ce diana est du genre des sapajous ou de celui des guenons, et, par conséquent, s'il se trouve dans l'ancien ou dans le nouveau continent.

Indépendamment de cette variété, dont les caractères sont très-apparents, il y a d'autres variétés moins sensibles dans l'espèce du coaita; celui qu'à décrit M. Brisson avait du poil blanchâtre sur toutes les parties inferieures du corps; au lieu que ceux que nous avons vus etaient entièrement noirs, et n'avaient que très-peu de poil sur ces parties inférieures, où l'on voyait la peau qui était noire comme le poil. Des deux coaitas dont parle M. Edwards, l'un était noir et l'autre était brun; on leur avait donné, ditil, le nom de singe-araignée, à cause de leur queue et de leurs membres, qui étaient fort longs et fort minces : ces animaux sont en effet fort effilés du corps et des jambes, et mal proportionnés.

On m'en présenta un, il y a plusieurs années, sous le nom de chamek', que l'on me dit venir des côtes du Pérou; j'en fis prendre les mesures et faire une description ${ }^{2}$ : je la rapporte ici pour

1 Ce singe est d'une espèce différente du coaita ; il en diffère priucipalement parce que ses mains sout pourrues d'un trés-yetit pouce sans ongle, qui dnanque au coaita. M. Geoffruy l'appelle AtèLE CHAyEK.

a Cet auimal venait de la côte de Bancet, au Pérou; i il était âgé de treize mois; il pesait euvirun six livres; il était noir par tout le cur $\mu s$; la face nue, avec une peau grenue et de couleur de mulàtre; le poil de denx a trois pouces ve longueur el un peu rude; les oreilles de méme couleur que la face el aussi dégarnies de poil, fort ressemblantes à celles de l'homme; la queue lungue d'un pied dix pouces, grossede ciny pouces de cirronférence à la base, et de onze ligues à l'extrémité; elle était ronde et garnie de poil en dessus et en dessous à sun origine, et sur une longueur de treize pouces, mais sans puil pardessous sur une longueur de neuf puuces à sun estréuité, où elle est aulatie par-dessous el sillounée dans son milieu, et ronde par-dessus; $I$ animal se sert de sa queue puur se suspendre et s'accrocher, il s'en sert aussi comme d'une cinquieme main pour saisir ce qu'il veut amener à lui ; il avait treıze yonces de longueur, depuis le bout du tez jusqu à l'origine de la queue; neuf pruces et deıni de circouféı ence derrière les bras, el un pied un pouce sur la pointe du sternum, qui est très-relevė; nenf pouces et demi devant les pattes de derrière; le cou avait cinq pouces et demi de circonférence; il n'y avait que deux manielles, placées presque sous les aisselles; la tete avait ciny ponces de circonfèrence prise a l'endroil le plus gros, et deux pouces au-dessous des y eux; le nez, treize ligues de longueur; les yeux étaient fort ressemblants à ceux d'un enfant, ils avajent neuf lignes de longneur d'un angle à l"autre; l'iris en elait brun et environné d'uru petıt cercle jausåtre ; la prunelle était grande, et il y avait d'un ceil à l'autre huit lignes de distance ; l'orcille avait un pouce six lignes de longueur et dix lignes de largeur; le tour de la bouche treize lignes; les bras 
qu'on puisse la comparer avee celle queM. Daubenton a faite du coaita, et reconmaître qu'à quelques variétés près, ce chamck du Pérou est le même animal que le coaita de la Guiane.

Ces sapajous sont intelligents et très-adroits; ils vont de compagnie, s'avertissent, s'aident et se secourent. La queue leur' sert exactement d'une cinquieme main ; il parait mèmequ'ils font plus de choses a vec la queue qu'avec les maius ou les pieds : la nature semble les avoil dédommagés par là du pouce qui leur manque. Onassure qu'ils péchent et prennent du poisson avec cette longue queue; et cela ne me parait pas incloyable, car nous avons vu l'un de nos coaitas prendre de même avec sa queue et amener à lui un éeureuil qu'on luiavait donné pour compagnon dans sa chambre. Ils ont l'adresse de casser l'écaille des huitres pour les nanger; et il est certain qu'ils se suspendent plusieurs les uns au bont des autres, soit pour trav erser un ruisseau, soit pour s'élancer d'un arbre à un autre. Ils ne produisent ordinairement qu'un ou deux petits, qu'ils portent toujours sur le dos. Ils mangent du poisson, des vers et des insectes; mais les fruits sont leur nourriture la plus ordinaire. Ils deviennent très-gras dans le temps de l'abondance et de la maturité des fruits, et l'on pretend qu'alors leur chair est fort bonne à manger.

\section{Caractères distinctifs de ces espèces.}

Le coaita n'a ni abajoues, ni callosités sur les fesses : il a la queue prenante et très-longue, la cloison des narines très-épaisse, et les narines ouvertes à cóté ct nou pas au-dessous du nez; il n'a que quatre doigts aux mains ou pieds de

six pouces trois lignes de lougneur et trois pouces de circonférence; l'avant-bras, six ponces de longricur et deux ponces et demi de circouférence; le reste de la maiı, cinq pouces de longueur: la paume de la main, un ponce Irois lignes de largeur; il avait aux mains quatre granis doigts garuis d'ongles, et un petit ponce sans ongle ıui n'étail long que de deux lisnes; l'index avait deux pouces deux lignes de longueur; le doigl du mileu, deux ponces el demi ; l'ammaire, deux pouces quatre lignes, el le pelit doigl, deux punces; les.ongles, trois lignes et demie à tuatre lignes de longueur; la jambe, six ponces jusıu'au genon, el yuatre ponces huit lignes de circonférence an plus gros; depuis le genou jusy̨u in talon, cim pouces quatre ligues, el trois ponees de circonfirence; le pied, einy fonees el deni de longneur; il avait aux pieds cinç doigls mieux proporlionnes que ceux des main:; le punce avait un pouce six lignes de longneur; l'index, llenx pouces; le doigt dı milien, deux ponces denx lignes; l'anmulaire, denx ponces, et le petil doigl, un pouce nenf lignes; le pied, deux pouces trois lignes de largeur. devant; il a le poil ct la peau noirs, la face nue et tamnée, les oreilles aussi nues et faites comme celles de l'homme; il a environ un pied et demi de longueur, et la queue est plus longue que le corps et la tète pris ensemble; il marche à quatre pieds.

L'exøuima est à peu pres de la même grandeur (jue le coaita : il a, comme lui, la queue prenante; mais il n'a pas de poil noir sur tout le corps. Il varie pour les couleurs; il y en a de noirs et de fauves sur le dos, et de blanes sur la gorge ct le ventre; il a d'ailleurs une barbe remarquable : néanmoins ces différences ne m’out pas paru suffisantes pour en faire deux espèces séparces, d'autant quiil y a des coaitas qui ne sont pas tout noirs, et qui out du poil blanchátre sur la gorge et le ventre. Les femelles, dans ces deux espèces, ne sont pas sujettes à l'écoulement périodique.

\section{ADDITION}

\section{A L'ARTicle du COAita.}

M. Vosmaër dit, page 5 de la description (pu'il a faite de cet animal, qu'il est étonné que M. de Buffon òte à la plus grande partie d'un genre d'animaux aussi connus que les singes, l'ancien nom de singe quon lui donne partout. La réponse est aisée : je ne leur ai point òté le nom général de singes, mais je l'ai seulement affecté de préférence aux especes de ces animaux qui, n'ayant point de queue, et marchant sur leurs deux pieds, ressemblent le plus à l'homme; et ce u'est que pour distinguer les différents genres de ces animaux, que je les ai divisés par einq noms génériques, savoir : les singes, les babouins, les guenons, les sapajous et les sagouins, dont les trois premiersgenres appartiennent aux climats chauds de l'ancien continent, et les deux derniers, aux climats chauds du nouveau continent.

"Il n'y a que M. de Buffon, dit M. Vos" maër, qui ait pris la peine de hien représenter " le coaita. Cependant, en le comparant arec " la figure (qu'il en donne, l'on s'apereevia bien" tòt qu'il est un peu trop maigre, que la face " est trop saillante, et que le dessinatcur a trop " allongé le museau. "Ia réponse à ceci est que j’ai vu l'animal vivant; que M. de Sève l'a dessiné; qüil est le plus habile dessinateur que 
nous ayons dans ce genre, et qu'ayant moimême soigneusement comparé le dessin avec l'auimal vivant, je n'en ai pas trouvé la représentation différente de la nature : aiusi la figure n'est pas trop maigre, ni la face trop saillante, ni le museau trop allongé; en sorte qu'il est probable que le coaita ou qouatlo dont H. Vosmaër donne la deseription était un animal plus gras, ou peut-ètre une variété dans l'espèce, qui differe de notre coaita par ces mêmes caractères dont M. Vosmaër reproche le défaut ì celui que M. de Sève a dessiné.

M. Vosmaer dit, page 10 de la mème description, que l'exquima de Maregrave, que Linnæus a indiqué sous le nom de diana, n'a point la queue prenante. "Nous pouvons, dit-il, as- surer M. de Buffon que le diana n'a point la " queue prenante, puisque nous l'avons vu vi" vant. " Je réponds que je ne doute point du tout de ce témoignage de $\mathrm{M}$. Vosmaër; mais que je doute très-fort que le diana de Linnæus soit l'exquima de Maregrave; et j'ajouterai qu'il n'y a point dans le nouveau continent d'animal du genre des sapajous et des coaitas, qui n'ait la queue prenante; en sorte que si le diana n'a pas la queue prenante, non-seulement il n'est pas voisiu du coaita par l'espèce, mais mème par le climat, puisque, n'ayant pas la queue prenante, il serait du gemre des guenons, et non pas decelui des sapajous. Je ne donne point ici la description de M. Vosmaër, parce que je n'y ai rien trouvé qui soit essentiellement différent de la nôtre, sinon que son coaita était aussi gras que le nôtre était maigre, etque M. Vosmaër lui a fait des yeux d'homme, au lieu de lui faire des yeux de singe.

Nous devons seulement ajouter à ce que nous avons écrit sur le coaita, que e'est le plis laid de tous les sapajous, et le plus grand après l'ouarine et l'alouate. Il habite, comme eux, les forêts humides; il vit des fruits de toutes les espèces de palmiers aquatiques, de batatas, etc.; il mange de préférence cenx du palmier commun. Sa queue, dégarnie de poil en dessous, vers l'extrémité, lui sert de main; lorsqu'il ne peut attcindre un objet avec ses longs bras, il a recours à sa queue, et ramasse les choses les plus minces, les brins de paille, les pièces de monnaie, etc. Il semble qu'il ait des yeux au bout de cette queue, tant le toucher en est délicat, ear il saisit avee sı quene plusieurs choses différentes; il l'introduit même dans des trous étroits, sans détourner la tête pour y voir. Au reste, dans quelque situation qu'il se tienne, sa queue est toujours acerochée, et il ne reste que malgré lui dans une place où elle ne peut avoir de prise.

Cet animal s'apprivoise aisément, mais il n'a nulle gentillesse. Il est peu vif, toujours triste et mélancolique; il semble éviter la vue des hommes; il penche souvent sa tête sur son estomac, comme pour la cacher : lorsqu'on le touche alors, il regarde en jetant un cri plaintif, et ayaut l'air de demander grâce. Si on lui présente quelque chose qu'il aime, il fait entendre un cri doux qui témoigne sa joie.

Dans l'état de liberté, ces animaux vivent en troupes très-nombreuses, et se livrent quelquefois à des actes de méchanceté; ils cassent des branches qu'ils jettent sur les hommes, et descendent à terre pour les mordre : mais un coup de fusil les disperse bientòt. Ces coaitas sauvages sont ordinairement très-gras, et leur graisse est jaune, mais ils maigrissent en domesticité. Leur chair est bonne et préférable à celle de toutes les autres espèces de sapajous : néanmoins ils ont l'estomac, les intestins et le foic remplis d'une quantité de vers longs, grêles et blanes. Ils sont aussi très-délicats et supportent difficilement les fatigues du voyage, et encore moins le froid de nos elimats; c'est probablement par cette raison et par sa longue domesticité, que le coaita dont nous avous donné la description et la figure était maigre et avait le visage allongé.

Les grands sapajous noirs que M. de La Borde indique sous le nom de guouata, dans les notes qu'il m'a communiquées, sont, selon lui, plus gros que les alouates ou grands sapajousronges. Il dit qu'ils ne sont point timides, qu'ils viennent à l'lomme armés d'une branche sèche, cherchant à le frapper, ou qu'ils lui jettent le fruit d'une espèce de palmier, qu'ils lancent plus adroitement que nous ne pourrions faire. Ils arrachent mème de leur corps les flèches qu'on leur a lancées, pour les renvoyer; mais ils fuient au bruit des armes à feu. Lorsqu'il y en a un de blessé et qu'il crie, les chasseurs doivent se retirer, à moins qu'ils n'aient avec cux des chiens, que ces animaux craignent beaucoup. Ils sautent de branches en branclies, auxquelles ils s'attachent par l'extrémité de leur quene. Ils se battent souvent entre eux. Ils vivent et se nourrissent comme les alouates ou 
grands sapajous rouges : ils s'apprivoisent aisément, mais ils sont toujours mormes et tristes. Lorsqu'on leur jette une pierre, ils portent la main devant la tête pour se garantil du coup.

\section{LE SAJOU.}

(LE SAPAJOU SAJOU.- LE SAPAJOU GRIS.)

Ordre des quadrumanes, genre sapajou, famille des singes. (Cuvier.)

Nous connaissons deux variétés daus cette espèce, le sajou brun, qu'on appelle vulgairement le singe-capucin; et le sajou gris, qui ne diffère du sajou brun que par les couleurs du poil. Ils sont de la même grandeur, de la même figure et du même naturel : tous deux sont très-vifs, très-agiles et 'très-plaisants par leur adresse et leur légèreté. Nous les avons eus vivants, et il nous a paru que de tous les sapajous ce sont eeux auxquels la température de notre elimat disconvenait le moins; ils y subsistent sans peine et pendant quelques années, pourvu qu'on les tienne dans une chambre à feu pendant l'hiver; ils peuvent mème produire, et nous en citerous plusicurs exemples. Il est nć deux de ces petits animaux chez madame la marguise de Ponpadour, à Versailles, un chez M. de Réaumur, à Paris, et un autre chez madame de Poursel, en Gàtinois : mais chaque portée n'est ici que d'un petit, au lieu que dans leur elimat, ils en font souvent deux. Aureste, ces sajous sont fantasques dans leurs goùts et dans leurs affections; ils paraissent avoir une forte inclination pour de certaines persomnes, et une grande aversion pour d'autres, et cela constamment.

Nous avons observé dlans ces animaux une singularité qui fait qu'on prend souvent les femelles pour les mâles; le elitoris est proémineut au dehors, et parait autant que la verge du mâle.

\section{Caraclères dislinctifs de celte espèce:}

Les sajous n'ont nỉ abajoues ni eallosités sur ies fesses : ils ont la face et les oreilles couleur de chair avee un peu de duret par-dessus; la cloison des narines épaisse, et les marines ouvertes a còté et nou pas au-dessous du nez; les yeux ehátaius et placés assez près l'un de l'au- tre; ils ont la queue prenante, nue par dessous à l'extrémité et fort touffue sur tout le reste de sa longueur. Les uns ont le poil noir et brun, tant autour de la face que sur toutes les parties supérieures du corps; les autres l'out gris autour de la face, et d'un fauve brun sur le corps : ils ont également les mains noires et nues. Ils n'ont qu'uu pied de longueur depuis l'extrémité du museau jusqu'a l'origrine de la queue; ils marchent à quatre pieds. Les femelles ne sont pas sujettes à l'écoulement périodique.

\section{A1)DITION}

A L'ARTICLE DU SAJOU BRUN.

On trouve dans une description de M. Vosmaër, imprimée à Amsterdam en 1770, l’espéce de notre sajou brum, donnée sous la dénomination d'espece rare de singe voltigeur américain qui n'a point cncore élé décrit, nommé le siffleur, ete. Cepondant il nous parait que c'est le même animal que le sajou brun, dont nous avons donné l'histoire et la description. Ce qui a pu faire écrire à M. Vosmaër que e'était une espèce nouvelle différente, c’est la propriété singulière, dit-il, de silfler; et j'avoue que je n'avais plus eru devoir filire mention de eette faculté de sifller de ce sajou, parce qu'elle est commune, non-seulement a tous les sipajous, mais mème aux ságouins : ainsi cette propriété n'est pas singulière, eomme le dit M. Vosmaër, et je ne puis douter que son singe rare, voltigeur el siffleur, ne soit le mème que notre sajou brun que l'on appelle vulgairement capucin, à cause de sa couleur, que les Nègres et les eréoles nomment improprement makaque, et enfin, que les Hollandais de Surinam, et même les naturels de la Guiane nomment mikou ou méékoé. Bien loin d'être rares, ee sont les plus communs, les plus adroits et les plus plaisants. Ils varient pour la couleur et la taille; et il est assez difficile de déterminer si ces différences constituent des especes $\checkmark$ rainent distinctes : on en peut dire autant des sais. II y a eependant dans les sajous une diftérence qui pourrait bien faire espece: l'on en roit dont la taille est incomparablement plus errande, et qui ont sur la tête, près des oreilles, un long bouquet de poils, ce qui leur a fait domner, à Cayenne, la dénomiuation de makaques cormus, et dont nous 
donnerons ci-après la description sous sou vrai nom de sajou corru.

La chair des sajous est meilleure que celle de l'alouate, mais moins bonne que celle des coaitas : ils ont aussi des vers dans l'estomac et dans les intestins, mais en plus petite quantité que les coaitas.

Ils font cntendre un sifflement fort et mouotoire, qu'ils répètent souvent; ils crient lorsçu’ils soni en colère, et secouent très-rivement la tète er articulant aussi vivement ces trois syllabes, $p i, c a, r o u$.

Ils vivent de fruits et de gros insectes dans l'état de liberté; mais ils mangent de tout ce qu'on leur donne lorsqu'ils sont apprivoisés : ils boivent du vin, de l'eau-de-vie, etc. Ils recherchent soigneusement les araignées, dont ils sont très-friands. Ils se lavent souvent les mains, la face et le corps aree leur urine. Ils sont malpropres, laseifs et indécents ; leur tempérament est aussi chaud que le climat qu'ils habitent. Lorsqu'ils s'échappent, ils brisent, bouleversent et déchirent tout. Ils se servent de leur queue pour s'accrocher et saisir, mais avec beaucoup moins d'adresse que les coaitas.

Comme ce sapajou s'appelle à la Guiane mikou, M. de La Borde m'a envoyé sous ce nom les notices suivantes. Il dit " qu'il y en a quatre " ou cinq espèces, et qu'ils sont très-communs " à Cayeune; que de tous les animaux de ce " genre, ce sont ceux qu'on aime le mieux gar" der dans les maisons; qu'on en voit fréquem" ment dans les grands bois, surtout le long des "rivières; qu'ils vont tonjours par troupes nom"breuses de plus de trente, et qu'ils sont farou" ches dans les bois, et très-doux lorsqu'ils " sont apprivoisés. On remarque aussi qu'ils " sont naturellement curieux. On peut les gar" der sans les contraindre ni les attacher. Ils " vont partout et reviennent d'eเax-mêmes; " mais il est vrai qu'ils sont ineommodes, parce " qu'ils dérangent toutes les petites choses qu'ils " peuvent déplacer. II y en a qui suivent leur * maitre partout. Les Indiens, qui sont très" froids, très-indifférents sur toutes choses, ai" ment néanmoins ces petits animaux : ils arrêa tent sourent leurs canots pour les regarder fajre " des eabrioles singulières, et santer de bran- ches en branches. Ils sont doux ct badins dès - qu'ils sont apprivoisés. Il y en a au moins " cinq espèces dans la Guiane, qui ne parais- sent différer que par des variétés assez légè-
" res : cependant elles ne se mêlent point ensem" ble. En peu de temps ils parcourent une forêt " sur la cime des arbres; ils vont constamment " dormir sur certaines espèces de palmier, ou " sur les comberouses, espèce de roseau très" gros. On en mange la chair à Cayenne."

\section{LE SAJOU NEGGRE.}

\section{(LE SAPAJOU NÈGRE.)}

Ordre des quadrumanes, genre sapajou, famille des singes. (Cuvier.)

Aux différents sapajous de moyenne et de petite taille, dont nous a vons donné la description sous les noms de sijou brun, sajou gris, saì, saï $\dot{a}$ gorge blanche, et saïmiri, nous devons ajouter le sapajou ou sajou nègre, qui nous parait être une variété constante dans l'espèce des sajous.

\section{LE SAJOU CORNU.}

\section{(LE SAPAJOU CORNu.)}

Ordre des quadrumanes, genre sapajou, famille des singes. (Curier.)

Cet animal est aisé à distinguer des autres sajous ou sapajous, par les deux bouquets de poils noirs en forme de cornes qu'il porte sur les cỏtés du sommet de la tête, et qui ont seize lignes de longueur, et sont distants l'un de l'autre à leur extrémité de deux pouces trois lignes.

Cet animal a quatorze pouces de longueur, depuis le bout du nez jusqu'à l'origine de la queue. Sa tète est oblongue, et son museau épais et couvert de poils d'un blane sale. Le nez est aplati par le bout, et la cloison des narines ćpaisse de huit lignes. Sa queue est longue de quatorze pouces une ligne; elle est recouverte de poils uoirs et finit en pointe. Le dos est de couleur roussàtre, mêlée de brun ct de grisâtre, ainsi que la face extérieure des cuisses qui sont grisâtres en dedans. Il y a sur le cou et le dos une raie brune qui se prolongejusqu'à la queue. Lepoil des côtés du corps a deux pouces quatre lignes de longueur; il est d'un fauve foncé, ainsi que celui du ventre; mais il y a du faure plus clair ou jaunâtre sur le bras, depuis l'épaule 
jusqu'au coude, ainsi que sur le cou et sur une partie de la poitrine. Au-dessous de ce fauve elair du bras, l'avant-bras ou la jambe de devant est couverte de poils noirs mêlés de roussâtre; celuidu front, des joues et des eótés de la tète est blanchâtre avee quelques nuances de fauve; il y a sur l'oceiput des poils noirs semblables à ceux des eorrues ou des aigrettes, mais moins longs, qui s'étendent et forment une pointe sur l'extrémité du cou. Les oreilles sont graudes et dénuées de poil ; celui du dessus des pieds et des maius est de couleur noire. Le pouce est plat, et tous les ongles sont courbés en forme de gouttière.

De tous les sapajous, le sajou brun est celui qui a le plus de rapport avee le sajou corıu; mais il u'a pas, comme ce dernier, de bouquet de poils en forme de corues sur la tète: ils se ressemblent tous deux par le noir qui est sur la face, l'avant-bras, les jambes, les pieds et la queue; seulement le sajou brun a plus de jaune sur le bras et le dessous du corps.

\section{LE SAI.}

\section{(LE SAPAJOU SAï. - LE SAPAJOU A GORGE BLANCIIE. )}

Ordre des quadrumanes, genre sapajou, famille des singes. (Cuvier.)

Nous avous vu deux de ces animaux qui ıous ont paru faire variété dans l'espèce : le premier a le poil d'un brun noirátre; le second, quenous avous appelé saī à gorge blanche, a du poil blane sur la poitrine, sous le eou et autour des oreilles et des joues; il diffère eneore du premier cn ce qu'il a la face plus dégarnie de poil: mais, au reste, ils se ressembleut en tout; ils sont du même naturel, de la mèmé grandeur et de la mème figure. Les voyageurs ont indiqué ces animaux sous le nom de pleureurs, parce qu'ils ont un eri plaintif, et que, pour peu qu'ou les contrarie, ils ont l'air de se lamenter; d'autres les ont appelés singes musqués, paree qu'ils ont, comme le maeaque, une odeur de faux muse; d'autres cufin leur ont donne le nom de macuque, qu'ils avaient emprunté du macaque de Guinée: mais les maeaques sont des guenons à queue lâche, et ceux-ei sont de la fanille des sapajous, car ils ont la queue prenante. Ils n'out que deux mamelles, et ne produisent qu'un ou deux petits; ils sont doux, dociles, et si craintifs, que leur cri ordinaire qui ressemble à celui du rat devient un gémissement dès qu'on les menace. Dans ee pays-ei, ils mangent des harnetons et des limacons de préférence à tous les autres aliments qu'on peut leur présenter; mais au Brésil, dans leur pays natal, ils vivent principalement de graines et de fruits sauvagrs qu'ils cueillent sur les arbres, ou ils dencurent et d'où ils ne descendent que rarement à terre.

\section{Caractères distinctifs de celle espèce.}

Les saïs n’ont ni abajoues, ni callosités sur les fesses : ils ont la eloison des narines fort épaisse, et l'ouverture des narines à còté et non pas audessous du nez; la face ronde et plate, les oreilles presfue nues: ils ont la gueue prenante, nue pardessous ver's l'extrémité, le poil d'un brun noirâtre sur les parties supćrieures du corps, et d'un fauve pàle ou mème d'un blane sale sur les parties inferieures. Ces animaux n'ont qu'un pied ou quatorze pouces de grandeur; leur queue est plus longue que le corps et la tète pris ensemble; ils marchent a quatre picds. Les femelles ne sout pas sujettes àl'écoulement périodique.

\section{LE SAIMIII.}

\section{(LE SAGOUIN SAÏMunr.)}

Ordre des quadrumanes, genre sagouin, famille des singes. (Curier.)

Le saïmiri est connu vulgairement sous le nom de sapajou aurove, de supajou orange et de sapajou jaune; il est asse commun à la Guiane, et e'est par cette raison que quelques voyageurs l'out aussi indiqué sous la dénomination de sapajou de Cayenne. Par la gentillesse de ses mouvements, par sa petite taille, par la couleur brillante de sa robe, par la grandeur et le feu de ses yeux, par son petit visage artondi, le saimiri a toujours eu la préférence sur tous les autres sapajous; et e'est en effet le plus joli, leplus mignon de lous : mais il estaussi le plus délicat ', le plus difficile à transporter et

- I.f sapajou de Cayenne est unr épéce de prelal ainge d'ue poil jaumatre; il a de gros yeus, la face blauche, le menton 
à conserver. Par tous ces caractères, et particulièrement encore par celui de la queue, il parait faire la nuance entreles sapajous et les sagouins, cál la queuc, sans être absolument inutile et lảche comme celle des sagouins, n'est pas aussi muscléc que celle des sapajous ; clle n'est, pour ainsi dire, qu'ì demi prenante, et, quoiqu'il s'en serve pour s'aider à monter et deseendre, il ne peut ni s'attacher fortement, ni saisir avec fermeté, ui amener à lui les choses qu’il désire; et l'on ne peut plus comparer cette queue à une main, comme nous l'avons fait pour les autres sapajous.

\section{Caractères distinctifs de cette espèce.}

Le saïmiri n'a ni abajoues ni callosités sur les fesses; il a la cloisou des narines épaisse, les narines ouvertes à côté et non pas au-dessous du nez; il n'a, pout ainsi dire, point de front; son poil est d'un jaume brillant : il a deux bourrelets de chair en forme d'anneau autour des yeux; il a le nez élevé à la racine et aplati à l'endroit des narines: la bouche petite, la face plate et nue ; les oreilles garnies de poil et un peu pointues; la queue à demi prenante, plus longue que le corps. Il n'a guère que dix ou onze pouces de longueur, depuis le bout du museau jusqu'à l'origine de la queue; il se tient aisément sur ses pieds de derrière, mais il marche ordinairement à quatre pieds. La femelle n'est pas sujette à l'écoulement périodique.

\section{ADDITION}

\section{A L'ARTICLE DU SAÏMIRT.}

Quelques observateurs qui ont demeuré à Cayenne nous ont assuré que les sapajous que j'ai nommés saïmiri vivent en troupes nombreuses, et que, quoiqu'ils soient fort alertes, ils sont cependant moins vifs que les petits sagouins auxquels j'ai donné le nom de tamarins; ils assurent de plus qu'ils prennent en captivité un ennui qui souvent les faitmourir. Néanmoins ces saimiris ne sont pas aussi délicats que les tamarins : on en connaît qui ont vécu quelques amnées en France, et qui ont résisté à une tra-

noir el la taille menue; il est alerle el caressant, mais il est aussi sensible au frud que les sagouins du Brésil. Relation du voyage de Gemnes, plar Froger, page 165. Paris, 1698. versée de mer pendant quatre mois dans les temps les plus froids de l'hiver. Ce sont de tous les sipajous ceux cui se servent le moins de leur queue. On remarque quelque variété dans la couleur du poil sur différents individus, mais ces variétés n'lndiquent peut-être pas toutes des espèces ni même des l'aces différentes.

\section{LI: SAKI. \\ (I.E SAKI A VEXTRE ROUX.)}

Ordre des quadrumanes, genre sagouin, famille des singes. (Cuvier.)

Le saki, que l'on appelle vulgairement singe à queue de renard, parce qu'il a la queue garnie de poils très-longs, est le plus grand des sagouins; lorsqu'il est adulte, il a environ dix-sept pouces de longueur au lieu que des cinq autres sagouins, le plus grand n'en a que neuf ou dix. Le saki a le poil très-long sur le corps, et encore plus long sur la queue; il a la face rousse et couverte d'un duvet blanchâtre: il est aisé à reconnaître et à distinguer de tous les autres sagouins, de tous les sapajous et de toutes les guenons, par les earactères suivants.

\section{Caractères distinctifs de cette espèce.}

Le saki n'a ni abajoues, ni callosités sur les fesses; il a la queue láche, non prenante et de plus d'une moitié plus longue que la tête et le corps pris ensemble; la cloison entre les narines fort épaisse et leurs ouvertures à côté; la face tamnée et couverte d'un duvet fin, court et blanchâtre, le poil des parties supérieures du corps d'un brun noir, celui du ventre et des autres parties inférieures d'un blanc roussâtre; le poil partout très-long et encore plus longsur la queue, dont il déborde l'extrémité de près de deux pouces : ce poil de la queue est ordinairement d'un brun noiràtre comme celui du corps. II parait qu'il y a variété dans cette espèce pour la conleur du poil, et qu'il se trouve des sakis qui ont le poil du corps et de la queue d'un fauveroussâtre. Cet animal marche à quatre pieds, et a près d'un pied et demi de longueur depuis l'extrémité du nez jusqu'à l'origine de la queue. Les femelles daus cette espèce ne sont pas sujettes à l'écoulcment périodique. 
L'YARQUE

ESPÈCE DE SAKI'

\section{(LE SAKI MOINE. - LE SAKI YARQUÉ.)}

Ordre des quadrumanes, gerure sagouin, famille des singes. Curier.)

Ce saki ou sagouin à queue touffue ne nous parait être qu'une variété du saki dont nous avons déjà parlé, et qui n’en differe que par les couleurs et leur distribution, ayant la face plus blanche et plus nue, ainsi.que le devant du corps blanc; en sorte qu'on pourrait croire que ces légères différences proviennent de l'âge ou des différents sexes de ces deux animaux. Nous n'avons pas eu d'autres informations à cetégard. M. de La Borde appelle yurqué cette mème espèce que nous avons appelée saki ; et c'est peutètre son véritable nom que nous ignorions. Voiei la notice qu'il en domme : "liyarqué a les còtés " de la face blancs, le poil noir, longr d'environ " quatre pouces; la queue touflue comme celle " du renard, longue d'environ un pied et demi, " avee laquelle il ne s'aceroche pas. Il est assez "rare et se tient dans le's broussailles. Ces ani" maux vont en troupes de sept ì huit et jus" qu'à douze. Ils se nourrissent de goyaves et " de monches à miel dont ils détruisent les ru" ches, et mangent aussi de toutes les graines " dont nous faisons usage. Ils ne font qu'un "pgtit, que la mere porte sur le dos." Ils sifflent comme les sapajous, et ront en troupes. On a remarqué des variétés dans lá couleur des différents individus de cette espece.

\section{LE: SAGOUIN,}

VULGAIREMENT APPELI: SIVGL DE NUIT.

(SAKI a VENTHE ROUX.)

Ordre des quadrumanes, geure sagouiu, famille des singes. (Cuvicr)

Ce sagouin est d'une espèce voisine de celle du saki; on l'appelle à Cayenne singe de nuit;

- M. Cieoffroy considère le saki yarque, décrit dius les nenf premières lignes lle cet arlicle, comme pumvant appar. tenir à soll sakt moine, pilhecia monachus, dont il présente le front large et découvert. Quant a Ia descriplion de le La llorde, il la rapporte au vrai sahi yarıue, pithecia leucocephala. mais il differe de l'yarqué dont nous venons de parler, ainsi que du saki dont nous avons dunné la description ci-dessus, par quelques caractères, et particulièrement par la distribution et la teinte des couleurs du poil, qui est aussi beaucoup plus touffu dans le sagouin appelé singe de nuil, que dans celui auquel on donne, dans le mème pays, le nom d'yarqué.

Cet animal m'a été envoyé de Cayenne par M. de La Borde, médecin du roi dans cette colonie. Il était adulte, et, selon ce naturaliste, l'espèce en est assez rare.

C'est une espèce particulière dans le genre des sagrouins. Il ressemble au saki par le poil qui lui environne la face, par celui qui couve tout le corps et les jambes de devant, et par sa longue queue touffue.

Longueur du corps, du boul du nez à l'ori-

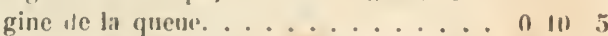
Longueur du trongon de la qqueue...... 0 () 11 5 Et arec te poil.............. 0126

La tête est petite, et la face environuée de longs poils touffus, de conteur jaune ou fauve pâle mèlée de brun fonéc. Cette couleur domine sur le corps et les jambes, paree que ces poils, qui sont d'un brun minime, ont la pointe ou l'extrémité d'un jaunc clair.

Lạ tẻte ressemble beaucoup it celle des autres sakis par la grandeur des yeux, les narines a large cloison et la forme de la face. Il y il audessus des yeux une tache blanchàtre. Un petit poil jaune pâle prend au-dessous des yeux, couvre les joues, s'étend sur le cou, le ventre et les.faces intérieures des jambes de derrière et de devant. II devient grisatre en s'approchant des poils brums des jambes et du corps. Sa quene, qui est grosse et fort touffue, linit en pointe à son extrémité. les pieds de derriere et de devant sont brunátres, et couverts de poils noirs.

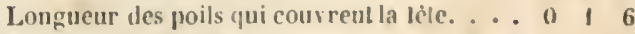

Longueur des poils qui sont sur le dos et sur

les coiles................... 0 5 0

Longueur des poils du rentre......... 0015

L.ongueur des poils de la queuc. . . . . . 0 " 3 


\section{LE TAMARIN.}

(L'OUISTITI TAMARIN. - LE TAMARIN AUX MAINS ROUSSES.)

Ordre des quadrumanes, genre ouistiti, famille des singes. (Cuvier.)

Cette espèce est beaucoup plus petite que la précédente, et en diffère par plusieurs caractères, principalement par la queue qui n'est couverte que de poils courts, au lieu que celle du saki est garnie de poils très-longs. Le tamarin est remarquable aussi par ses larges oreilles et ses pieds jaunes; c'est un joli animal, très-vif, aisé à apprivoiser, mais si délicat qu'il ne peut résister longtemps à l'intempérie de notre climat.

\section{Caractères distinctifs de cette espèce.}

Le tamarin n'a ni abajoues, ni callosités sur les fesses: il a la queue lâche, non prenante et une fois plus.longue que la tète et le corps pris ensemble; la cloison entre les narines fort épaisse et leurs ouvertures à côté; la face couleur de chair obscure ; les oreilles carrées, larges, nues et de la même couleur ; les yeux châtains, la lèvre supérieure fendue à peu près comme celle du lièvre; la tête, le corps et la queue garnis de poils d'un brun noir et un peu hérissés, quoique doux; les mains et les pieds couverts de poils courts d'un jaune orangé. Il a le corps et les jambes bien proportionnés, il marche à quatre pieds, et la tête et lecorps pris ensemblen'ontque sept ou huit pouces de longueur. Les femelles ne sont pas sujettes à l'écoulement périodique.

\section{LE TAMARIN NEGGE.}

\section{(OUISTITI NÈGRE.-TAJARIN NÈgRE.)}

Ordre des quadrumanes, genre ouistiti, famille des singes. (Cuvier.)

Nous donnons ici la description d'un tamarin à face noire, que nous avons appelé tamarin nègre, et qui ne difrère en effet du tamarin proprement dit que parce qu'il a la face noire, au lieu que l'autre l'a blanche, et parcequ'il a aussi le poil beaucoup plus noir; mais au reste, ces deux animaux, se ressemblant it tous égards, ne paraissent former qu'une variété d'une seule et mème espèce.
M. de La Borde dit que les sagouins tamarins sont moins communs que les sapajous. Ils se tiennent dans les grands bois, sur les plus gros arbres, et dans les terres les plus élerées; au lieu qu'en général les sapajous babitent les terrains bas, où croissent les forêts humides. II ajoute que les tamarins ne sont pas peureux, qu'ils ne fuient pas à l'aspect de l'homme, et qu'ils approchent mème d'assez près les liabitations. Ils ne font ordinairement qu'un petit, que la mère porte sur le dos. Ils ne courent presque pas à terre, mais ils sautent très-bien de branche en brauche sur les arbres. Ils vont par troupes nombreuses, et ont un petit eri ou sifflement fort aigu.

Ils s'apprivoisent aisément, et néanmoins ce sont peut-être de tous les sagouins ceux qui s'ennuient le plus en captivité. Ils sont colères, et mordent quelquefois assez cruellement lorsqu'on veut les toucher. Ils mangent de tout ce qu'ou Ieur donne, pain, viandes cuites et fruits. Ils montent assez volontiers sur les épaules et sur la tête des personnes qu'ils connaissent, et qui ne les tourmentent point en les touchant. Ils se plaisent beaucoup à prendre les puces aux chiens, et ils s'avisent quelquefois de tirer leur langue qui est de conleur rouge, en faisant en même temps des mouvements de tête singuliers. Leur chair n'est pas bonne à manger.

\section{L'OUISTITI.}

\section{(L'OUISTITI VULGaIRE.)}

Ordre des quadrumanes, genre ouistiti, famille des singes, (Curier.)

L'ouistiti est encore plus petit que letamarin; il n'a pas un demi-pied de longueur, le corps et la tête compris, et sa queue a plus d'un pied de long : elle est marquée, comme celle du mococo, par des amneaux alternativement noirs et blaucs; le poil en est plus long et plus fourni que celui du mococo. L'ouistiti a la face nue et d'une couleur de chair assez foncée ; il est coiffé fort singulièrement par deux toupets de lougs poils blanes au devant des oreilles, en sorte que, quoiqu'clles soient grandes, on ne les roit pas en regardant l'animal en face. M. Parsons a domné une très-bonne description de cet aniınal dans les Transactions philosophiques. En- 
suite M. Edwards en a donné une bonne figure dans ses Glanures : il dit en avoir vu plusieurs, et que les plus gros ne pesaient guère que six onces, et les plus petits quatre onces et demic; il observe très-judicicusement que e'e'st ì tort que l'on a supposé que le petit singe d'Éthiopie, dont Ludolph fait mention sous le nom de fonlies ou guereza, était le même animal que celui-ci : il est en effet très-certain que l'oustiti ni aucun autre sagouin ne se trouve en Kithiopie, et il est très-vraisemblable que le fonties ou guereza de Ludolph est ou le mococo, ou le loris, qui se trouvent dins les terres méridionales de l'aneien continent. M. Edwards dit encore que le sanglin (ouistiti), lorsqu'il est en bonne santé, a le poil très-fourni et très-touffu; que l'un de ceux qu'il a vus, et qui était des plus vigoureux, se uourrissait de plusicurs choses, comme de biscuits, fruits, légumes, insectes, limacons, et qu'un jour étant déchainé, il se jeta sur un petit poisson doré de la Chine qui était dans un bassin, qu'il le tua ct le dévora avidement; qu'ensuite on hui donna de petites anguilles qui l'eflrayèrent d'abord en s'entortillant autour de son cou, mais que bientot il s'en rendit maitre et les mangea. Enfin M. Edwards ajoute un exemple qui prouve que ces petits animaux pourraicut peut-être se multiplier dins les contrées méridionales de l'lsurope : "Ils ont, dit-il, produit des petits en Portugal, où le climat leur est fuvorable; ces petits sont d'abord fort laids, n'ayant presque point de poils sur le corps; ils s'attachent fortement aux tettes de leur mère; quand ils sont devenus un peu glands, ils se cramponnent fortement sur son dos ou sur ses épaules; et quand elle est lasse de les porter, elle s'en débarrasse en se frottant contre la muraille ; lorsqu'elle les a éeartés, le mâle en prend soin surle-champ et les laisse grimper sur son dos pour soulager la femelle. "

\section{Caractères distinctifs de cette espèce.}

L'onistiti n'a ni abajoues, ni callosités sur les fesses; il a la queue lâche, non prenante, fort touffue, annelie alteruativement de noir et de blane ou plutòt de lorun et de gris, et une fois plus longue que la tète et le eorps pris ensemble; la cloison des narines fort épaisse et leur's ouvertures à coté; la tète ronde, converte de poil noir au-dessus du front, sur le bas duguel il y a au-dessus du nez une marque blanche et sans poil : sa face est aussi presque sans poil et d'une couleur de chair foncée; il a des deux cótés de la téte au-devant des oreilles deux toupets de longrs poils blanes; ses oreilles sont arrondies, plates, ininces et nues; ses yeux sont d'un châtain rougeâtre; le corps est couvert d'un poil doux d'un gris cendré, et d'un gris plus clair, et mêlé d'un peu de jaune sur la gorge, la poitrine et le ventre : il marche à quatre pieds, et n'a souvent pas un demi-pied de longueur depuis le bout du nez jusqu'à l'origine de la queue. Les femelles ne sont pas sujettes a l'écoulement périodique.

\section{DESCRIPTION DE L'OUISTITI.}

(EXTBAIT DE DAUBENTON.)

Louistiti a la queue longue, le museau un peu saillant, la tìte petite et euvirounce d'un poil touffu et hérissé, qui entoure la face; les oreilles sont larges, roudes et presque nues, mais il y a au-devant près de la tempe et par derrière près de la face postirieure de l'oreille des poils longs qui ont jus(ju’à un pouce, et qui sont blancs ou nẻles de cendré et le gris; ces poils sont dirigés en arrière comme l'oreille, la courrent el s'etendent de beaucoup au delà en forme de panaclıe; la cloison des narines est fort large; le nez et le bout de la livre supérieure sont noiritres, le reste de cette lèvre, le bord de la lère iuferieure et le bas du front an-dessus du nez sont blancs; le haut du front et les joues ont une couleur brune. Les poils de prespue tontes les parties du corps de louistiti qui a servi de sujet ponr cette description sont longs et donx, de couleur mèlie de gris, le rousvitre et de noir ou de moiratre press de la racine; il $y$ a successivement de's teinti's de roux et de noir, et entin la pointe est grise on ronssatre: les poils du summet de la tète et de loceiput sont noiritres pres de la raciue, il y a du gris jaunatre an-dessus du noiràtre; lorsqu ils sont conehes en arrière, un ne voit que cette der. nière couleur. La màchoire inférieure, la gorge et le dessous du cou sont de couleur mile de cendré et de quelques teintes de jaunitre. La qneue est entouric d'anneaux itroits et alternativement noiritres et gris on jaunitres. Les plus longs poils du corps sunt sur les epaules, ils ont environ un ponce. Les ungles des doights sont grands, très-courbes, fort puntus, entièrement plics, et par consequent fort minces, excepte longle du ponce des pieds de derrière qui est petit, cours, large, arrondi et seulentent convese an lien d'ètre plie et recourbe. La plante des pieds est de couleur de chair. 
La tête du squelette de l'ouistiti est allongée; mais le museau a peu de longueur; aussi l'onverture des narines est à moitié entre les orbites à peu près comme dans l'homme, les orbites sont séparẻes par un large intervalle, leurs bords sont minces et saillants en avant. La màchoire inférieure a une apopliyse fort mince et fort etendue à l'endroit du contour de ses branches.

\section{LE MARIKINA.}

\section{(L'OUISTITI MARIKINA. - LE TAMARIN MARI- KINA.)}

Ordre des quadrumanes, genre ouistiti, famille des singes. (Cuvier.)

Lemarikina est assez vulgairement connu sous le nom de petit singe-lion: nous n'admettons pas cette dénomination composée, parce que le marikina n' est point un singe, mais un sagouin, et que d'ailleurs il ne ressemble pas plus au lion qu'une ałouette ressemble à une autruche, et qu'il n'a de rapport avec lui que par l'espèce de crinière qu'il porte autour de la face, et par le petit flocon de poils qui termine sa queue. Il a le poil touffu, long, soyeux et lustré; la tète ronde, la face brune, les yeux roux; les oreilles rondes, nues et cachées sous les longs poils qui enviromnent sa face : ces poils sont d'un roux vif, ceux du corps et de la queue sont d'un jaune très-pâle et presque blanc. Cet animal a les mèmes manières, la même vivacité et les mêmes inclinations que les autres sagouins, et il parait être d'un tempérament un peu plus robuste; car nous en avons vu un qui a vécu cinq ou six ans à Paris, avec la seule attention de le garder pendant l'hiver dans une chambre où tous les jours on allumait du feu.

\section{Caractères distinctifs de celle espèce.}

Le marikina n'a ni abajoues, ni callosités sur les fesses; il a la queue lâche, non prenante et presque une fois plus longue que la tête et le corps pris ensemble; la cloison entre les narines épaisse, ct leurs ouvertures à côté; il a les oreilles rondes et nues; de longs poils d'un rouxdoré antour de la face; du poil presque aussi long, d'un blanc jaunâtre et luisant sur tout le reste du corps, avec un flocon assez sensible à l'extrémité de la queue : il marche à quatre pieds, et n'a qu'environ huit ou neuf pouces de longueur en tout. La femelle n'est. pas sujette à l'écoulement périodique.

\section{LE PINCHE.}

\section{(L'OUistiti PINChE. - LE TAMARIN PINChe.)}

Ordre des quadrumanes, genre ouistiti, famille des singes. (Cuvier.)

Le pinche, quoique fort petit, l'est cependant moins que l'ouistiti, et même que le tamarin : il a environ neuf pouces de long, la tête et le corps compris, et sa queue est au moins une fois plus longue. Il est remarquable par l'espèce de chevelure blanche et lisse qu'il porte au-dessus et aux côtés de la tête, d'autant que cette couleur tranche merveilleusement sur celle de la face qui est noire et ombrée par un petit duvet gris; il a les yeux tout noirs, la queue d'un roux vif à son origine et jusqu'à près de la moitié de sa longueur, où elle change de couleur et devient d'un noir-brun jusqu'à l'extrémité; le poil des parties supérieures du corps est d'un brun-fauve; celui de la poitrine, du ventre, des mains et des pieds, est blanc; la peau est noire partout, mème sous les parties où le poil est blanc; il a la gorge nue et noire comme la face. C'est encore un joli animal et d'une figure très-singulière; sa voix est douce et ressemble plus au chant d'un petit oiseau qu'au cri d'un animal; il est très-délicat, et ce n'est qu'après de graudes précautious qu'on peut le transporter d'Amérique en Europe ${ }^{1}$.

\section{Caractères distinclifs de cette espèce.}

Le pinche n'a ni abajoues, ni callosités sur les fesses; il a la queue làche, non prenante et une fois plus longue que la tête et le corps pris ensemble; la cloisou entre les narines épaisse, et leurs ouvertures à còté; la face, la gorge et les

1 Nota. Voici ce que Lery dit an sujet de ee petil animal. - Il se trouve en celte terre du Brésil un marmol que les

"Sauvages appellent sagouin, non plus grand fqu'un escu-

" riau el de mème poil roux; mais quant à sa figure, le muf-

* lle comme celni d'un lion et lier de mème; c'est le plus joli

" petit anjmal que j'aie vu prar-là ; el de fait, s̈il était aussi aisé

- à repasser que la gnenon, il serait beaucoup plus estimé;

- mais outre quï il est si délicat qu'il ne peut endurer le bran-

- lement du navire sur la mer, encore est-il si glorieux que,

" pour pell de ficherie qui on lini fasse, il se laisse mourir do

" dépit. " Voyage de Jean de Lery, page 163. 
oreilles noires; de longs poils blaues en forme de cheveux lisses; le museau large, la face roude; le poil du corps assez long, brun fauve ou roux sur le corps jusqu'auprès de la queue où il devient orangé, blane sur la poitrine, le ventre, les mains et les pieds, où il est plus court que sur le corps; la queue d'un roux vil' à son origine et dans la première partie de sa longueur, ensuite d'un roux brun, et enfin noire à son extrémité : il maı che à quatre pieds et n'a qu'environ neuf pouces de longueur en tout. Les femelles ne sont pas sujettes à l'écoulement périodique.

\section{LE MICO.}

\section{(L'ouistiti Mico.)}

Ordre des quadrumanes, genre onistiti, fanille des singes. (Cuvier.)

C'est à M. de La Condamine tue nous devons la connaissance de cet animal : ainsi nous ne pouvons mieux faire que de rapporter ce qu'il en écrit dans la relation de son voyage sur la rivière des Amazones : "Celui-ei, dont le gon" verneur du Para m'avait fait présent, était "l'unique de son espèce qu'on eût vil dans le " pays. Le poil de son corps était argenté et de " la couleur des plus beaux cheveux blanes, ce"lui de sa queue était d'un marron lustré ap" procbant du noir. Il avait une autre singula" rité plus remarquable; ses oreilles, ses joues " ct son museau étaient teints d'un vermillon si " vif, qu'on avait peine à se persuader que cette " couleur füt naturelle. Je l'ai gardé pendant un " an, et il était encore en vie lorsque j'éerivais " ceei, presque à la vue des cotes de France, où " je me faisais un plaisir de l'apporter vivant. "Malgré les précautions continuelles rque je pre" nais pour le préserver du froid, la rigueur de " la saison l'a vraisemblablement fait mourir... "Tont ce que j'ai pu faire a été de le conserver " dans l'eau-de-vie, ce qui suflira peut-ètre pour " faire voir que je n'ai rien exagéré dans ma " description. "Par ee récit de M. de Lal Condamine, il est aisé de voir que la première espéce des animaux dont il parle est celui que nous avons appelé lamarin, et que le dernier anquel nous appliquons le nom de mico est d'une espèee très-différente et vraisemblablement beaucoup plus rare, puisque aneur auteur ni aucun voyageur avant lui n'en avait fait mention, quoique ce petit animal soit très-remarquable par le rouge vif qui anime sa face, et par' la beauté de son poil.

\section{Caractères dístinctifs de celte espèce.}

Le mico n'a ni abajoues, ni callosités sur les fesses: iL a la queue lâche, non prenante et d'environ moitié plus longue que la tète et le corps pris ensemble; la cloison des narines moins épaisseque les autres saqouins, mais leurs ouvertures sont situées de mème a còté et non pas au bas du nez: il a la face et les oreilles nues, et couleur de vermillon; le museau court; les yeux éloignés l'un de l'autre; les oreilles grandes; le poil d'un beau blanc-argenté, celui de la queue d'un brun-lustré et presque noir'; il marche à quatre pieds, et il n'a qu'environ sept ou huit pouces de longueur en tout. Les femelles ne sont pas sujettes al l'écoulement périodique.

\section{LES MAKIS.}

LE MAKI MOCOCO, - LE MAKI MONGOLS. - LE MAKI VARI.

Ordre des quadrumanes, feure nakis, famille des singes. (Curier.)

Comme l'on a douné le nom de maki à plusieurs animaux d'espéces différentes, nous ne pouvons l'employer que comme un terme générique, sous lequel noas comprendrons trois animaux qui se ressemblent assez pour ètre du même grenre, mais qui diffèrent aussi par un nombre de caracteres suflisant pour constituer des espèees évidemment différentes. Ces trois animaux ont tous une longue queue, et les pieds conformés comme les singes; mais leur museau est allongé conme celui d'une foume, et ils ont à la màchoire inférieure six dents incisires, au lieu que tous les singes n'en ont que quatre. I.e premier de ces aninaux est le mocock ou moeoco, que l'on comnait vulgairement sous le nom de maki à quene annelée. Le second est le mongous, appelé vulgairement maki brun : mais rette dénomination a été mal appliquée; car, dans eette espièe, il y en a de tout loruns, d'autres qui ont les joues et les pieds blanes, et encore diautres quí ont les jones noires et les pieds jaunes. l.e troisieme est lè vari, 
appelé par quelques-uns maki pie; mais eette démomination a été mal appliquée; car, dans cette espèce, outre ceux qui sont pies, c'est-àdire blanes et noirs, il y en a de tout blanes et de tout noirs. Ces quatre animaux sont tous originaires des parties de l'Afrique orientale, et notamment de Madagascar où on les trouve en grand nombre.

Le mococo est un joli animal, d'une physionomie fine, d'une figure élégante et svelte, d'un beau poil toujours propre et lustré : il est remarquable par la grandeur de ses yeux, par la hauteur de ses jambes de derrière qui sont beaucoup plus longues que celles de devant, et par sa belle et grande queue qui est toujours relevée, toujours en mouvement, et sur laquelle on compte jusqu'à trènte anneaux alternativement noir's et blanes, tous bien distincts et bien séparés les uns des antres. Il a les mœurs douces, et, quoiqu'il ressemble en beaucoup de choses aux singes, il n'en a ni la malice ni le naturel. Dans son état de liberté, il vit en société, et on le trouve à Madagascar par troupes de trente ou quarante. Dans celui de captivité, il n'est incommode que par le mouvement prodigieux qu'il se donne; c'est pour cela qu'on le tient ordinairement à la chaîne; car, quoique très-vif et très-éveillé, jl n'est ni méchant ni sauvage, il s'apprivoise assez pour qu'on puisse le laisser aller et venir sans craindre qu'il s'enfuie. Sa démarche est oblique comme celle de tous les animaux qui ont quatre mains au lieu de quatre pieds : il saute de meilleure grâce et plus légèrement qu'il ne marche. Il est assez silencieux et ne fait entendre sa voix que par un cri court et aigu, qu'il laisse pour ainsi dire échapper lorsqu'on le surprend ou qu'on l'irrite. Il dort assis, le museau incliné et appuyé sur sa poitrine. Il n'a pas le corps plus gros qu'un ehat, mais il l'a plus long; et il parait plus grand, paree qu'il est plus élevé sur ses jambes. Son poil, quoique très-doux au toucher, n'est pas couché, et se tient assez fermement droit. Le mococo a les partięs de la génération petites et cachées, au lieu que le mongous a des testicules prodigieux pour sa taille, et extrèmement apparents.

Le mongous est plus petit que le mococo; il a comme lui le poil soyeux et assez court, mais un peu frisé : il a aussi le nez plus gros que le mococo, et assez semblable à celui du vari. J'ai eu chez moi pendant plusieurs années un de ces mongous qui était tout brun : il avait l'œil jaune, le nez noir et les oreilles çourtes; il s'amusait à manger sa queue, et en avait ainsi détruit les quatre ou cinq dernières vertèbres. C'était un animal fort sale et assez incommode : on était obligé de le tenir à la chaîne; et quand il pouvait s'échapper, il entrait dans les boutiques du voisinage pour chercher des fruits, du sucre, et surtout des confitures dont il ouvrait les boltes : ou avait bien de la peine à le reprendre, et il mordait eruellement alors ceux qu'il connaissait le mieux. Il avait un petit grognement presque continuel; et lorsqu'il s'ennuyait et qu'on le laissait seul, il se faisait enteudre de fort loin par un coassement tout semblable à celui de la grenouille. C'était un mâle, et il avait les testicules extrêmement gros pour sa taille : il cherchait les ehattes, et même se satisfaisait avee elles, mais sans accouplement intime et sans production. Il craignait le froid et l'humidité; il ne s'éloignait jamais du feu et se tenait debout pour se chauffer. On le nourrissait avec du pain et des fruits. Sa langue était rude comme celle d'un ehat; et, si on le laissait faire, il léchait la main jusqu'à la faire rougir, et finissait souvent par l'entamer avec les dents. Le froid de l'hiver 1750 le fit mourir, quoirgu'il ne fût pas sorti du eoin du feu. Il était très-brusque dlans ses mouvements, et fort pétulant par instants ; cependant il dormait souvent le jour, mais d'un sommeil léger que le moindre bruitinterrompait.

Il y a dans c'ette espèce du mongous plusieurs variétés, non-seulement pour le poil, mais pour la grandeur; celui dont nous venons de parler était tout brun et de la taille d'un chat de moyenne grosseur. Nous en connaissons de plus grands et de bien plus petits : nous en arons vu un qui, quoique adulte, n'était pas plus gros qu'un loir. Si ce petit mongous n'était pas ressemblant en tout au grand, il serait sans contredit d'une espèce différente : mais la ressemblance entre ces deux individus nous a paru si parfaite, à l'exception de la grandeur, que nous avons cru devoir les réduire tous deux à la même espèce, sauf à les distinguer dans la suite par un nom différent, si l'on vient à acquérir la preuve que ces deux animaux ne se mêlent point ensemble, et qu'ils soient aussi différents par l'espèce qu'ils le sont par la grandeur.

Le vari est plus grand, plus fort et plus sauvage que le mococo; il est mème d'une méchanceté farouche dans son état de liberté. Les voyageurs disent a que ces animaux sont furieux 
" comme des tigres, et qu'ils font un tel bruit "dans les bois que, s'il y en a deux, il semble " qu'il y en ait un cent, et qu'ils sont très-diffi" ciles à apprivoiser. " En effet la voix du vari tient un peu du rugissement du lion, et elle est effrayante lorsquion l'entend pour la première fois : cette force étonnante de voix daus un anjmal qui n'est que de médiocre grandeur lépend d'une structure singulière dans la trachée-artère, dont les deux branches s'élargissent et forment une large coneavité avant d'aboutir aux bronches du poumon. Il differe donc beancoup du mococo par le naturel, aussi bien yue par la conformation; il a en général le poil beaucoup plus long, et en particulier une espèce de cravate de poils encore plus longs qui lui enviromne le cou, et quil fait un caractère très-apparent, par lequel il est aisé de le reconnaître ; car au reste il varie du blanc au noir et au pie par la couleur du poil, qui, quoique long et trèsdoux, n'est pas couché en arrière, mais s'élève prespue perpendiculairement sur la peau : il a le museau plus gros et plus long à proportion que le mococo, les oreilles beaucoup plus courtes et borlées de longs poils, les ycux d'un jaune orangé si foncé qu'ils en paraissent rouges.

Les mococos, les mongous et les varis sont du mène pays et paraissent ètre confinés à Madagasear, au Mozambique et aux terres voisines de ees iles: il ne parait par aucun témoignage des voyageurs qu'ou les ait trouvés nulle part ailleurs; il semble qu'ils soient dans l'ancien continent ce que sont dans le nouveau les marmoses, les eayopollius, les phalengers, qui ont quatre mains conme les makis, et qui, comme tous les autres animaux du NouveauMonde, sont fort petits en comparaison de ceux de l'ancien; et, à l'égard de la forme, les makis semblent laire la uuance entre les singes à louguequeue et les animaux fissipedes; ear ils ont quatre mains et une longue queue comme ees singes, et en même tempsils ont le museau long eomme les renards ou les fouines : eependant ils tiennent plus dles singes par les habitudes essenticlles, ear quoi qu'ils mangent quelquefois de la chair et (ju’ils se plaisent aussi à épier les oiseaux, ils sont cependant moins carnassiers que frugivorés, et ils préfèrent mème daus l'état de domesticite les fruits, les racines et le pain, à la chair cuite ou crue.

\section{ADDITION}

\section{A L'ART'ICLE DES MAKIS.}

\section{LE GRAND MONGOUS.}

(LE MAKI BRUN.)

Ordre des quadrumanes, genre makis, famille des singes. (Curier.)

Nous avons dit qu'il y a dans l'espèce du maki-mongous plusieurs variétés, non-seulement pour le poil, mais pour la grandeur. Celui que nous a vons décrit était de la taille d'un chat: ce n'était (ju'uu des plus petits, car celui dont je ciome la figure était au moins d'un tiers plus grand; et ectte différence ne pouvait provenir ni de l'âge, puisque j’avais fuit nourrir le premier pendant plusieurs annécs, ni du sexe, puisque tous deux étaient mâles : ce n’était donc qu'une variété peut-être individuelle: du reste ils se ressemblaient si fort qu'on ne peut pas douter qu'ils ne fussent de mème espèce. Les gens qui l'avaient apporté à Paris lui donnaicnt le nom de maki cochon. Il ne differait du premier que par le poil de la queue qui était beaucoup moins touffu et plus laineux, et par la forme de la queue qui allait en diminuant de grosseur jusqu'a l'extrémité; au lieu que dansle mongous la queue parait d'égale grosseur dans toute son étendue. 11 y a aussi quelque différenec dans la couleur du poil, celui-ci étant d'un brun beaucoup plus clair que l'autre; mais néanmoins ees légères variétés ne nous paraisscnt pas suffisantes pour faire de ces animaux deux espèces distinctes et séparées.

\section{LE MOCOCO.}

\section{(LE MAKI MOCOCO.)}

Ordre des quadrumanes, genre makis, famille des singes. (Cuvier.)

Les mococos ou makis mococos sont plus jolis et plus propres que les mongous; ils sont aussi plus familiers, et paraissent plus sensibles : ils ont, comme les singes, beancoup de goùt pour les fémmes. Ils sont très-doux et mème caressants; et quelques observateurs ont r'cmarqué qu'ils a vaieut une habitude naturclle assez 
singulière, e'est de prendre souvent devaut le soleil une attitude đ'admiration ou de plaisir. Ils s'asseyent, disent-ils, et ils étendent les bras en regardant cet astre : ils répètent plusieurs fois le jour cette sorte de démoustration, qui les occupe pendant des heures entières ; car ils se tournent vis-à-vis le soleil à mesure qu'il s'élève ou décline. a J'en ai nourri un, dit M. de " Manoncourt, pendant longtemps à Cayenne, " où il avait été apporté par un vaisseau venant " des Moluques. Cequi me détermina à en faire "l'emplette, ce fut sa constance à ne pas chan" ger de situation devant le soleil. Il était sur a la dumette du vaisseau, et je le vis pendant " une heure, toujours étendant les bras vers le " soleil, et l'on m'assura qu'ils a vaient tous cette " même habitude dans les Indes orientales.

Il me parait qne eette habitude observée par M. de Manoncourt vient de ce que ces animaux sont très-frileux. Le mongous que j'ai nourri pendant plusieurs années en Bourgogne se tenait toujours assis très-près du feu, et étendait les bras pour les chauffer de plus près. Ainsi je pense que l'habitude de se chauffer en déployant leurs bras, soit au feu, soit au soleil, est commune à ces deux espèces de makis.

\section{LE PETIT MAKI GRIS.}

(LE MAKI GRIS.)

Ordre des quadrumanes, genre makis, famille des singes. (Cuvier.)

Ce joli petit animal a été apporté de Madagascar par M. Sonnerat. Il a tout le corps, excepté la face, les pieds et les mains, couvert d'un poil ģrisâtre, laineux, mat et doux au toueher. Sa queue est très-longue, garnie d'un poil doux et laineux comme celui de tout le corps. Il tient beaucoup du mococo, tant par la forme extérieureque par ses attitudes et la légèreté de ses mouvements : cependant le mococo paraît être plus haut de jambes. Dans tous deux les jambes de devant sont plus courtes que celles de derrière.

La couleur grisatre de ce petit maki est comme jaspée de fauve pâle, parce que le poil, qui a un duvet gris-de-souris ì la ricine, est fauve-pâle à l'extrémité. Le poil a sur le corps six lignes de longueur, et quatre sous le ventre : tout le dessous du corps, à prendre depuis la machoire d'en bas, est blanc; mais ce blanc commence à se mèler de jaunâtre et de grisâtre sous le ventre, au-dedans des cuisses et des jambes.

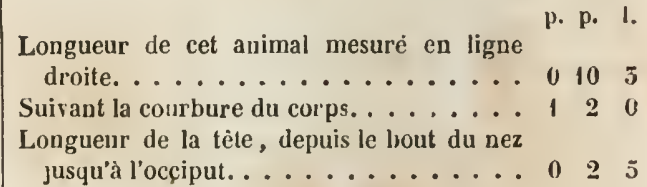

La tête est fort large au front et fort pointue au museau; ce qui donne beaucoup de finesse à la physionomie de cet animal. Le chanfrein est droit et ne se courbe qu'au bout du nez. Les yeux sont ronds et saillants.

p. p. I.

Les oreilles ont de hauteur. ......... 0000

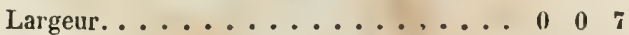

Elles sont differentes de celles des autres makis, qui les ont larges et comme aplaties sur l'extrémité. Celles de ce petit maki sont larges en bas et arrondies au bout; elles sont couvertes et bordées de poils cendrés. Le tour des yeux, des oreilles et les côtés des joues sont d'un cendré clair, ainsi quele dedans des cuisses et des jambes.

Les mains ou pieds de derant ont de longueur p. p. 1. depuis le poignet............ o o 14

Les doigts en sont minces et allongés; les deux du milieu, qui sont les plus grands, out. .................. 010

Les deux autres, qui sout les plus courts,

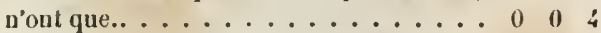
Le pouce a.................. 0 o $05 \frac{1}{2}$ Les pieds de derrière out de longueur, du talon au bout des doigts. ......... 0 \% 28 Le second doigt externe, qui est le plus

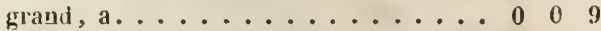
Le pouce, qui est large et plat, a ..... 0 o 0 s

Le premier doigt interne, qui est le plus court, a un ongle mince et crochu; les autres ont l'ongle plat et allongé : les quatre doigts sont de longueur inégale.

La queue a quinze pouces de longueur: elle est également grosse et couverte d'un poil laineux et de la mème couleur que le corps: les plus grands poils de l'extrémité de cette queue, où le fauve domine, ont sept lignes de luu. grueur. 


\section{AU'TRE ESPECE DE MAKL.}

(INDRI A LONGUE QUEUE.)

Je erois devoir joindre à l'espèce du petit maki gris un autre maki, que M. Sonnerat a de même rapporté de Madagascar, et qui ne differe du premier que par la teinte et la distribution des couleu's du poil.

Il a, comme tous les autres makis, un poil doux et laineux, mais plus touffu et en flocons conglomérés; ce qui fait paraitre son eorps large et gros. La tète est large, assez petite et courte: il n'a pas le museau aussi allongé (que le vari, le mongous et le mococo. Les yeux sont très-gros, et les paupières bordées de noirâtre. Le front est large; les oreilles courtes sont cachées dans le poil.

Il a les jambes de devant courtes en comparaison des jambes de derrière; ce qui rend, lorsquil marche, le train de derriere très-éleve eomme dans le mococo. La quene est longue de dix pouces dix lignes, eouverte d'un poil touffu, et de la même grosseur dans toute sa longueur.

La longueur de cet animal, du bout du nez à l'origine de la queue, le corps étendu, est de onze pouces six lignes. Sa tète a de Iongueur, du bout du nez il l'oceiput, deux ponce's trois lignes. Une grande tache noire qui se termine en pointe par le haut, couvre le nez, les naseaux et une partie de la màchoire supérieure. l.es pieds sont eouverts de poil fauve teinté de cendré; les doigts et les ongles sont noirs. Le pouce des pieds de derriere est grand et assez gros, avec un ongle large, mince et plat : ce premicr doigt tient au second par une membrane nuiràtre.

En général, la couleur du poil de l’animal est brune et d'un fauve cendré, plus ou moins foncé ell différents endroits, paree que Jes poils sont bruns dans leur longueur, et fauves à la pointe. Le dessous du eou, la gorge, la poitrine, le ventre, la face intérieure des quatre jambes, sont d'un blane sale teinté de faure; le brun domine sur la tète, le con, le dos, le dessus des bras et des jambes; le fauve cendré se montre sur les cótés du corps, les cuisses et une partie des jambes; un fauve plus foncé se voit atutour des oreilles, ainsi que sur la face externe des bris et des jambes jusqu'au talon ; toute la partic du dos roisine de la queue est blanche, teintée d'une couleur faure qui devient orangée sur toute la longueur de la queue.

\section{DESCRIPTION DES MAKIS.}

(ESTRAIT IYR DALBE.TTOY.)

Les makis ont le museau alloñe comme celui des crobes, mais monins «ros; ils ressemblent à tuus les singes, au sarigue, à la marınose, au cayojullin et an phalanger par la forme des pieds; mais ils ont plus de rapport aux singes ru’a ces animaux par les dents, quoiejue ce rapport ne soit pas exact. Les makis ont, comme tous les singes, ynatre dents incisive's en dessus; mais il y en a six en dessous, et par conséquent denx de plus que dans les singes: cependant les makis n'ont en tout jue trente-six dents, comme les sapajous, parce qu'il n'y a que dix dents mòchelières en haut, tandis que les sapajous en ont douze. Le nombre des deuts de tous les autres singes n'est que tle trente-deux, parce qu'ils ont de noins que les makis deux mâchelières dans la mâchoire du dessus et deux incisives dans celle du dessous. Le principal raprort des dents des makis à celles des singes consiste dans le nombre de quatre incisives à la màchoire du dessus, et la principale difference se trouve dans le nombre des in. eisives du dessous, qui est de six dans les mahis, et senlement de quatre dans les singes. Pour distinfnuer les makis de tous les autres puatimpèdes onn. uus, il suftit de réunir le caractire des six dents incisives de lin michonire du dessons avee celui de la lorme des pieds de derrière, qui ressemblent is cenx des singes, mais il faut nécessairement pate ces deux caracteres soient réunis: le nombre des dents incisives tant du dessus que du dessous ne suffirait pas seul, parce ıne la plupart des clıanves-souris, le pecari el le babiroussa ont, comme les makis, quatre incisives en dessuts et six en dessous.

Les dents incisives de la mâchoire inferieure qui sont an nombre de six, et les ciny doigts des pieds de derricre ressemblant mieux à ceux d'une main yừ ceux d’un pied, font donc un caractìre propre eu particulier aux miktis; ; puoique ce caractère soit compusc, il est moins complipue et d'un usage heaucoup plus facile que reux qui ont che empluyes dans les meilleures mithode's de nomenclature ponr distinguer les makis des autres quadrupédes. Par la meilhode de M. Lirissm, les mahis sont distingues tle plusieurs autres animaux, to parce guitis ne. manquent pas de tents: 20 quils ont des dents in. eisives; 5 yue les deux máchoires ont des incisives; to juils ont des ongles et non pras des sahots; 
$5^{\circ}$ qu'ils ont quatre dents incisives en dessus et six en dessous; et $6^{\circ}$ parce que les doigts sont séparés les uns des autres. Quoique le pecari et le babiroussa ressemblent aux makis par le nombre des dents incisives, le quatrième caractère empèche de les confondre avec les autres, parce que le pecari et le babiroussa ont des sabots et non pas des ongles comme les makis. J'avoue que la différence des ongles aux sabots, réunie avec le nombre des incisives, serait aussi sûre que la forme du pied de derrière pour faire le caractère distinctif des makis; mais il me semble que la forme du pied de derrière devrait être préférée, parce que les animaux qui ont les pieds de derrière conformés comme ceux des makis sont moins nombreux que les animaux qui ont des sabots au lieu d'ongles. L'auteur de la méthode a donné le sixième caractère pour distinguer les makis des chauves-souris, qui ont, comme les makis quatre incisives en dessus et six en dessous, mais dont les doigts des pieds de devant sont réunis par une membrane. Il y a une exception à faire par rapport au nombre des incisives; la chauve-souris que nous avons nommée le fer-ácheval n'a point du tout de dents incisives à la mâchoire supérieure, et elle n'en a que quatre à l'inférieure : on ne doit pas objecter à M. Brisson ce défaut de sa métlıode, parce que la chauve-souris, dont il est ici question, n'avait pas encore été observée lorsqu'il a fait cet ouvrage, quoiqu'elle soit commune dans ce pays-ci.

Je voudrais aussi trouver une raison pour défendre M. Linnæus au sujet d'une erreur qui me parait ètre dans sa division méthodique des quadrupèdes, relativement au nombre des dents du sanglier, des cochons, du pecari et du babiroussa, qui ont des rapports avec les makis par le nombre des dents incisives. M. Linnæus donne huit dents incisives inferieures aux cochons et au sanglier; cependant j’ai observé des animaux de cette espèce en assez grand nombre pour croire que ces dents sont constamment au nombre de six. J'ai v'u un pecari et deux têtes de babiroussa qui n'avaient aussi que six dents incisives en dessous comme les makis. M. Linnæus leur en donne huit; peut-être n'a-t-il pas eu !'occasion d'observer par lui-même les dents du pecari et du babiroussa comme celles des cochons et du sanglier : s'il avait vu une tête de babiroussa, il naurait pas dit que les dents canines du dessus percent l'os du front, car elles ne percent que l'os de la màchoire supérieure, au moins par leur racine; il est vrai qu'elles se recourbent en liaut, et qu'elles peuvent approcher du front par leur extrémité, mais il n'est pas rraisemblable que M. Limnæus ait voulu dire qu'elles percent l'os du front par leur extrémité : ce fait aurait bien mérité l'être énoncé plus clairement.

\section{LE LORIS.}

\section{(LE LORIS GRÊLE.)}

Ordre des quadrumanes, genre maki, famille des singes. (Curier.)

Le loris est un petit animal qui se trouve à Ceylan, et qui est très-remarquable par l'élé gance de sa figure et la singularité de sa conformation. Il est peut-être de tous les animaux celui qui a le corps le plus long relativement à sa grosseur : il a neuf vertèbres lombaires, au lieu que tous les autres animaux n'en ont que cinq, six ou sept, et c'est de là que dépend l'allongement de son corps, qui paraît d'autant plus long qu'il n'est pas terminé par une queue. Sans ce défaut de queue et cet excès de vertèbres, on pourrait le comprendre dans la liste des makis; car il leur ressemble par les mains et les pieds, qui sont à peu près conformés de même, et aussi par la qualité du poil, par le nombre des dents, et par le museau pointu. Mais indépendamment de la singularité que nous venons d'indiquer, et qui l'éloigne beaucoup des makis, il a encore d'autres attributs particuliers. Sa tête est tout à fait ronde, et son museau est presque perpendiculaire sur cette sphère; ses yeux sont excessivement gros et très-voisins l'un de l'autre; ses oreilles larges et arrondies sont garnies en dedans de trois oreillons en forme de petite conque. Mais ce qui est encore plus remarquable, et peut-être unique, c'est que la femelle urine par le clitoris, qui est percé comme la verge du mâle, et que ces deux parties se ressemblent parfaitement, même pour la grandeur et la grosseur.

M. Linnæus a donné une courte description de cet animal, qui nous a paru très-conforme à la nature; il est aussi fort bien représenté dans l'ouvrage de Seba, et il nous parait que c'est le même animal dont parle Thevenot daus les termes suivants : " Je vis au Mogol des singes " dont on faisait grand cas, qu'un homme avait " apportés de Ceylan; on les estimait parce " qu'ils n'étaient pas plus gros que le poing, ct " qu'ils sont d'une espèce différente des singes " ordinaires : ils ont le front plat, les yeux " ronds et grands, jaunes et clairs comme ceux " de certains chats; leur museau est fort pointu, " et le dedans des oreilles est jaune; ils n'ont " point de queuc.... Quand je les examinai, " ils se tenaient sur les pieds de derrière, et 
* s'embrassaient scuvent, regardant fixement "le monde sans s'effaroucher."

\section{LE I.ORIS DE BENGALE.}

\section{(LE NYCTICÈBE I)U BENGALE.)}

Cet animal nous paralt d'une espèce voisine de celle du loris dont nous avons donné ci-dlevant l'histoire, la description et la figure. M. Vosmaër en a donné, sous le nom de pairesiseux pentadaclyle du Bengale, une deseription que je crois devoir rapporter ici. "On peut sulfi" samment juger de la grandeur de cet animal, " sije dis yue sa longueur, depuis le sommet de "la tête jusquu'à l'anus, est cle treize pouces. " La figure qu'on en donne ici, et qui est tres" exacte, montrequelle est la conformation de " tout le corps. Il a la tête presque ronde, " n'ayant que le museau qui soit un peu pointu. "Les oreilles sont fort minces, ovales et droi" tes, mais prespue entièrement carhées sous " le poil laineux, et en dedans aussi velues. "Les yeux sont placés sur le devant du front, "immédiatement au-dessus du nez et tout pro" ehe l'un de l'autre; ils sont parfaitement or" bieulaires et fort gros a proportion du corps : "leur couleur est le brun obseur. I a prunelle " était fort petite de jour, quand on éveillait "l'animal; mais elle grossissait par degrés à " un point considérable. Lorscqu'il s'éveillait le " soir, et fu'on apportait la chandelle, on voyait " également cette prunelle s'étendre et occuper "à peu près toute la rondeur de l'oil. Le nez $\checkmark$ est petit, aplati en devant et ouvert sur les - côtés.

" La máchoire inférieure a au-devant clu mu" seau quatro dents incisives étroites ct plates, " suivies des deux cotés d'une plus grande, et " enlin deux grosses dents eaniues. Apres la " dent camine viennent de chaque côté eneme " deux dents rondes et pointues, faisant ainsi " en tout douze dents. Du reste, pour autant " que j'ai pu voir daus le museau, il y a cle " chayue côté deux ou trois màchelieres. Ia " màchoire supérieure n'a au-devant, dans le "milieu, que deux petites dents ćeartíes; un " peu plus loin, deux petites dents eanines, " une de ehaque cóté; encore deux dents plus " petites et deux ou trois machelieres; ee qui r fait en tout huit dents, sans compter les ma- a chelières. La langue est passablement épaisze " et longue, arrondic au-devant et rude.

u Le poil est assez long, fin et laineux, mais " rude au toucher. Sa coulcur est en géuéral le - gris ou cendré jaunatre clair, un pea plus " loux sur les flaucs et aux jambes. Autour des " yeux et des oreilles, la couleur est aussi un "peu plus foncée; et depuis la tẻte, tout le long " du dos regne une raie brune.

" Cet aniual a une apparesce de queue d'en"viron denx ou trois lignes de longueur.

" Les doionts des pirds de devint sont au - nombre de cing; le pouce est plus gros que " les autses doigts, dont celui du milieu est le " plus long; les ongles sont comme ceux de a l'bomme.

" Les doigts des pieds de derriere sont eon" formés de mẻme, il l'exception que, dans " ecux-ci, l'ongle da doigt anterienu est fort " long, et se termine en pointe aigue. Les doigts " me paraissent tous aroir trois articulations; " ils sont tant soit peu velus c"n dessus, mais " sans poil en dessous, et garnis l'une furte " pellicule lı'une.

" La longueur des pieds de devant est d'ena viron six pouces, et celle des pieds de dep" riere, d'environ huit pouces. II m'a paru itre "du sexe masculin."

Par l'inspection de la figure, ainsi que par la deseription de M. Yosmaer, il me parait que eet animal, qu'il nomme mal à propos le paresseux de Bengale, approche plus de l'espece di loris que de celle d'aucun autre animal, et que ees deux loris se trouvant également dans l'aneien contineut, on ne doit pas les dénommer par le nom de paressenx, ni les eonlondre aree l'unau et l'is (jui portent ce nom de paresseux, et qu'on ne trouve quen Amérique. Cependant M. Vosmace, qui n'est pas de ce seutiment, me firit it eet égard queleques objections auxquelles je vais repondre. Il dit, paye 7 : ".1. de liuf" fon nie que l'animal quion nomme propre"ment paresseux se trouve dans lancien " monde, en quoi il se trompe.

Reroxse. Je n'ai jamais parlé d'aucum animal qu'on nomme proprement paresseux ; j'ai seulement dit que l'unau et l'aï, qui sont deux animaux auxquels on dome igalenent le nom de paresseux, ne si trouvent en effet que daus le nouveau continent; et je persiste à nier aussi fermement aujourd'hui que ces deux animaux se trouvent nulle autre part qu'en Amérique. 
HISTOIRE NATURELLE

M. Vosmaër dit "que Seba donne deux pa« resseux de Ceylan, la mère avec son petit, " qui, a la figure, paraissent être de l'espèce ¿ de l'unau que M. de Buffon prétend n'exister " que dans le Nouveau-Monde. J'ai moi-même " acheté, dit M. Vosmaër, le plus grand des " deux, savoir" : la mère représentée dans Seba, " planche xixiv, et l'on doit avouer qu'il n'y " a guère de différence entre ce paresseux que "Seba dit ètre de Ceylan. La tète du premier " me parait seulement un peu plus arrondie et " un peu plus remplie, ou moins enfoncée au"près du nez que dans le dernier. Je conviens " qu'il est étonnant de voir tant de ressemblance " entre deux animaux de contrées aussi éloi" gnées que l'Asie et l'Amérique.... L'on peut " objecter à cela, comme M. de Buffon semble "l'insinuer, que ce paresseux peut avoir été " transporté de l'Amérique en Asie, c'est ce " ce qui n'est nullement croyable... Valentin dit "que ce paresseux se trouve aux Indes orien" tales, et Seba, qu'il l'a reçu de Ceylan.... "Laissons au temps à découvrir si le paresseux " de Seba, qui ressemble si bien à celui des "Indes occidentales, se trouve réellement aussi " dans l'île de Ceylan."

Réponse. Le temps ne découvrira que ce qui est déjà déeouvert sur cela ; c'est-à-dire que l'unau et l'ai d'Amérique ne se sont point trouvés, et ne se trouveront pas à Ceylan, à moins qu'on ne les y ait transportés. Seba a pu être trompé ou se tromper lui-même sur le climat de l'unau; et je l'ai remarqué très-préeisément, puisque j'ai rapporté à l'espèce de l'unau ces animaux de Seba, eomme on peut le voir dans la note, ici, $2^{\text {e }}$ vol.des Mammifères. II n'est donc pas douteux que ces animaux de Seba, la mère et le petit, ne soient en effet des unaux d'Amérique; mais il est également certain que l'espèce n'en existe pas à Ceylan, ni dans aucun autre lieu de l'ancien continent, et que très-réellement elle n'existe qu'en Amérique dans son état de nature. Au reste, eette assertion n'est point fondée sur des propositionsidéales, comme le dit M. Vosmaër, page 7, puisqu'elle est au contraire établie sur le plus grand fait, le plus général, le plus incomnu à tous les naturalistes avant moi : ce fait est que les animaux des parties méridionales de l'ancien continent ne se trouvent pas dans le nouveau, et que rćeiproquement ceux de l'Amérique méridionale ne se trouvent point dans l'aneien eontinent.
Ce fait général est démontré par un sl grand nombre d'exemples, qu'il présente une vérité, incontestable. C'est done sans fondement et sans raison que M. Vosmaër parle de ce fait comme d'une supposition idéale, puisque rien n'est plus opposé à une supposition qu'une vérité acquise et confirmée par une aussi grande multitude d'observations. Ce n'est pas que, philosophiquement parlant, il ne pût y avoir sur cela quelques exeeptions; mais, jusqu'à présent, l'on n'en connait aucune, et le paresseux pentadactyle du Bengale de M. Vosmaër n'est point du tout de l'espèce ni du genre du paresseux de l'Amérique, e'est-à-dire ni de l'unau ni de l'aï, dont les pieds et les ongles sont conformés trèsdifféremment de ceux de cet animal du Bengale: il est, je le répète, d'une espèce voisine de celle du loris, dont il ne semble différer que par l'épaisseur du eorps. Un coup d'œil de comparaison sur les figures de l'unau et de l'aĩ d'Amérique, et sur celle de ce prétendu paresseux d'Asie, suffit pour démontrer qu'ils sont d'espèces différentes et mème très-éloignées. M.Vosmaër avoue lui-même, page 10, qu'au premier coup d'œil, son paresseux pentadactyle et le loris de $M$. de Buffon ne semblent différer que très-peu. J'ai donc toute raison de le donner ici comme une espèce voisine de celle du loris; et quand même il en différerait beaucoup plus, il n'en serait pas moins vrai que ce paresseux pentadaetyle du Bengale n'est ni un unau ni un aï, et que, par conséquent, il n'existe pas plus en Amérique que les deux autres n'existent en Asie. Tous les petits rapports que M. Vosmaër trouve entre son paresseux pentadactyle et ces animaux de l'Amérique, ne font rien contre le fait, et il est bien démontré, par la seule inspection de ces animaux, qu'ils sont aussi différents par l'espèce qu'ils le sont par le climat; car je ne nie pas que ce pentadactyle de Bengale ne puisse ètre aussi lent, aussi lourd et aussi paresseux que les paresseux d'Amérique : mais cela ne prouve pas que ce soient les mèmes animaux, non plus que les autres rapports dans la maniere de vivre, dormir, ete. C'est comme si l'on disait que les grandes gazelles et les certs sont également légers à la course, qu'ils dorment et se nourrissent de mème, etc. M. Vosmaër fournit lui-mème une preuve que l'animal didactyle de Seba, qui est certainement l'unau, n'existe point à Ceylan, puisqu'il rapporte, d'après M. de Joux, qui a demeuré trente-deux 
ans dans cette île, (que cette espece (le didactyle) lui était inconnue. Il paraît done évidemment démontrè que l'unau et l'aï d'Amérique ne se trouvent point dans l'ancien continent, et que le paresseux pentadactyle est un animal d'une espèce très-différente des paresseux d'Amérique, et e'est tout ce que j'avais à prouver : je suis même persuadé que M. Vosmaër reconnaitra cette vérité, pour peu qu'il veuille y donner d'attention.

Il nous reste maintenant à rapjorter les observations que M. Vosmaer a faites sur le naturel et les moeurs de ce loris de Bengale. a Je " reçus, dit-il, eet animal singrulier le 25 juin " $1768 \ldots$... La curiosité de l'observer de près " m'engagea, malgré son odeur désagréable, it " le prendre dans ma chambre... II dormait " tout le jour et jusque vers le soir, et, se " trouvant iei en été, il ne s'èveillait qu'à huit " heures et demic du soir. Enfermé dans une " cage de forme carrée oblongue, garnie d'un " treillis de fer, il dormait constamment assis " sur son derrière tout aupres du treillis, la " tête penchée en avant entre les pattes anté" rieures repliées contre le ventre. Jaus cette " attitude, il se tenait toujours en dormant très"fermement attaché au treillis par les pattes " de derriere, et souvent encore par une des " pattes autérieures; ce qui me fait soupconner " que l'animal d'ordinaire dort sur les arbres,

" ef se tient attaché aux branches. Son mouve-

" ment, étant éveillé, était extrèmement lent,

" et toujour's le mème depuis le comnencement " jusquà la fin : se trainant de barre en barre,

" il en empoignait une par le haut avec les " pattes antérieures, et ne la quittait jamais " qu'une de ses pattes de devant n'enit saisi " lentement et bien fermement une autse barre a du treillis. Quand il rampait a terre sur le " foin, il se nowait avec lạ mème lenteur, - posant un pied après l'autre, comme s'il cût a été perclus; et, dans ce mouvement, il n'é"levait le corps que tant soit peu, et ne faisuit "que se trainer en avant, de sorte que, le plus " souvent, il y avait à peine un doight de distance " entre son ventre et la terre. En vain le chasa sait-on en passantun baton à travers le treillis, " il ne làchait pas pour cela prise; si on le pous" sait trop) rudenent, il mordait le bâton, et a e'était là toute sa défense.

" Sur le soir, il s'eveillait peu à peu, coumme a quelqu'un dout on interromprait le sommeil,
" après avoir veillé longtemps. Son premier " soin était de manger ; car de jour les moments "étaient trop précieux pour les ravir à son re" pos. Aprés s'être acquitté de cette fonetion, " assez vite encore pour un paresseux comme " lui, il se débárrassait du souper de la veille. "Son urine avait une odeur forte, pénétrante " et désagréable; sa fierite ressemblait à de pe" tites crottes de brebis. Son aliment ordinaire " au rapport du capitaine du vaisseau qui l'a" vait pris à bord, n'était que du riz euit fort "épais, et jamais on ne le voyait boire.

"Persuadé que cet animal ne refuserait pas " d'autre nourriture, je lui donnai une branche " de tilleul avec ses feuilles; mais il la rejeta. "Les fruits, tels que les poires et les ccrises, a étaient plus de son gout. Il mangeait volon" tiers du pain sece et du biseuit; mais, si on "les trempait dans l'eau, il n'y touchait pas. "Chatue fois quion lui présentait de l'eau, il se a contentait de la flairer sภns en boire. II ai" mait à lá fureur les oeufs... Souvent, quand " il mangeait, il se servait de ses pattes et de " ses doigts de devant comme les écureuils. Je " jugeai, par l'expérience des œufs, qu’il pour" rait manger aussi des oiseaux : en effet, lui "ayant donné un moineau vivaut, il le tua " d'abord d'un coup de dent, et le mangea tout " entier fort goulument... Curieux d'éprouver " si les insectes étaient aussi de son gout, je " lui jetai un hanneton vivant, il le prit dans " sa patte et le mangea en entier. Je lui donnai " ensuite un pinson, qu'il mangea aussi aree " beaucoup d'appetit; apres quoi il dormit le " reste de la journcée.

"Je l'ai vu souvent encore éveillé à deux " heures apres minuit; mais, des les six heures " et demie du matin, on le trouvait profondé"ment endormi, au point qu'on pouvait net" toșer sa cagresans troubler son repos. Pendant "lr jour, étant év cillé à foree d'ètre agacé, il se "fichait et mordait le bâton; mais le tout avec " un mouvement lent, et sous le eri continuel " et réitéré d'ai, $a i$, $a i$, trainant fort longtemps " chaque nï d'un son plaintif, langoureux et " tremblant, de la mense maniere qu'on le rap" porte du paresseux d'Amérique. Apres l"avoir "ainsi longtemps tourmenté et bien éveillé, il " rampait deux ou trois tours claus sa eage, - mais se rendormait tout de suite. "

C'est saus doute cette confornité dans le cri et dans la leuteur de l'ai de l'Amérique qui a 
porté M. Vosmaër à croire que c'était le même anlmal; mais, je le répète encore, il n'y a qu'à comparer seulement leurs figures pour être bien convaincu du contraire. De tout ce que M. Vosmaēr expose et dit à ce sujet, on ne peut conclure autre chose sinon qu'il y a dans l'ancien continent des animaux peut-être aussi paresseux que ceux du nouveau continent; mais le nom de paresseux, qu'on peut leur donner en commun, ne prouve nullement que ce soient des animaux du même genre.

Au reste, cet animal auquel nous avons donné la dénomination de loris de Bengale, parce que nous n'en connaissons pas le nom propre, se trouve, ou s'est autrefois trouvé dans des climats de l'Asie beaucoup moins méridionaux que le Berigale; car nous avons reconnu que la tête décharnée dont M. Daubenton a donné la description' et qui a été tirée d'un puits desséché de l'ancienne Sidon, appartient à cette espèce, et qu'on doit y rapporter aussi une dent qui m'a été envoyée par M. Pierre-Henri Tesdorpf, savant naturaliste de Lubeck. " Cette " dent, dit-il, m'a été envoyée de la Chine ; elle " est d'un animal peut-ètre encore inconnu à " tous les naturalistes; elle a la plus parfaite " ressemblance avec les dents cauines de l'hip" popotame, dont je possède une tête complète " dans sa peau. Autant que j'ai pu juger de la " deruière dent, aussi jolie et complète que pe" tite, quoiqu'elle ne pèse pas quatorze grains, " elle semble avoir toutson accroissement, parce " que l'animal dont elle est prise l'a déjà usée à " proportion aussi fortque l'hippopotame le plus " grand les sienmes. Le noir qu'on voit à chaque " côté de la pointe de la dent semble prouver " qu'elle n'est pas d'un animal jeune. L'émail " est aussi précisément de la mème espèce que " celui des dents canines de l'hippopotame, ce " qui me faisait présumer que ce très-petit ani" mal est cependant de la même classe que "l'hippopotame qui est si gros."

Je répondis, en 1771, à M. Tesdorpf, que je ne commaissais point l'animal auyuel a vaitappartenu cette dent; et ce n'est en effet qu'en 1775 que nous avons eu connaissance du loris de Bengale auquel elle appartient, aussi bien que la tête décharnée trouvéc dans le territoire de l'ancienne Sidon.

C'est au premier loris que j’ai décrit, au loris

- M. Cuvier a reconnu que cette tête appartient à l"espece du daman. de Bengale, qu'on peut rapporter le nom de the vangue, que $\mathbf{M}$. le chevalier d'Obsonville dit que cet animal porte dans les Indes orientales, et sur lequel il a bien voulu me donner les notices suivantes :

"Le thevangue, qui, selon M. d'Obsonville, " s'appelle aussi dans l'Inde le tatonneur, et " tongre en Tamoul, vit retiré dans les rochers " et les bois les plus solitaires de la partie mé" ridionale de l'Inde, ainsi qu'à Ceylan : malgré " quelques rapports d'organisation, il n'appar" tient ni à l'espèce du singe, ni à celle du makj ; a il est, à ce qu'on croit, peu multiplié.

“ En 1775, j'eus occasion d'acheter un the" vangue. Il avait, étant debout, un peu moins " d'un pied de haut, mais on dit qu'il y en a de " plus grands : cependant le mien paraissait être " tout formé ; car, pendant près d'un an que je a l'ai eu, il n'a point pris d'accroissement.

" La partie postérieure de sa tête, ainsi que a ses oreilles,paraisseut assez semblables àcelles " d'un singe; mais il avait le front à proportion " plus large, et aplati ; son museau, aussi effilé " et plus court que celui d'une fouine, se rele" vait au-dessous des yeux à peu près comme " celui des chiens épagneuls que l'on tire d'Es« pagne. Sa bouche, très-fendue et bien garnie " de dents, était armée de quatre canines lon" gues et aiguës. Ses yeux étaient grands et à " fleur de tète; l'iris en paraissait d'un gris brum " mêlé d'une teinte jaunâtre. Il avait le cou " court, le corps très-allongé. Sa grosseur au" dessus des hanches était de moins de trois " pouces decirconférence. Je le fis châtrer : ses " testicules, quoique proportionnellement fort " gros, étaient absolument renfermés dans la " capacité du bas-ventre; sa verge était déta" chée et couverte de son prépuce comme cclle " de l'homme... Il n'avait point de queue : ses " fesses étaient charnues et sans callosités; leur " carnation est-d'une blancheur douce et agréa" ble. Sa poitrine était large; ses bras, ses mains " et ses jambes paraissaient être bien formés : " cependant les doigts en sont écartés comme " ceux des singes. Le poil de la tête et du dos " est d'un gris sale tirant un peu sur le fauve; - celui de la partie antérieure du corps est « moins épais et presque blanchâtre.

« Sa démarche a quelque chose de contraint; " elle est lente au point de parcourir au plus " quatre toises en une minute : ses jambes étaient trop longues à proportion du corps, 
" pour qu'il pût courir commodément comme " les autres quadrupèdes; il allalt plus libre" ment debout, lors mème qu'il emportait un " oiseau entre ses pattes de devant.

"Il faisait quelquefois entendre une sorte de " modulation ou de sifflement assez doux : je " pouvais aisément distinguer le cri du besoin, " du plaisir, de la douleur, et même celui du " chagrin ou de l'impatience. $\mathrm{Si}$, par exemple, " j'essayais de retirer sa proie, alors ses regards " paraissaient altérés; il poussait une sorte " d'inspiration de voix tremblante et dont le " son était aigu. Les Indiens disent qu'il s'ac- couple en se tenant accroupi, et en se serrant "face à face avec sa femelle.

"Le thevangue diffère beaucoup des singes " par l'extérieur de sa conformation, mais en" core plus par le caractère et les habitudes : il " est né mélancolique, silencieux, patient, car" nivore et noctambule, vivant isolé avee sa " petite famille; tout le jouril reste accroupi, et " dort la tête appuyée sur ses deux mains réu" nies entre les cuisses. Mais, au milieu du som" meil, ses oreilles sont très-sensibles aux im" pressions du dehors, et il ne néglige point " l'occasion de saisir ce qui vient se mettre à sa " portée. Le grand soleil parait lui déplaire, et " cependant il ne parait pas que la pupille de " ses yeux se resserre ou soit fatiguée par le " jour qui entre dans les appartements...

"Celui que je nourrissais fut d'abord mis à " l'attache, et ensuite on lui donna la liberté. "A l'approche de la nuit, il se frottait les yeux, " ensuite, en portant attentivement ses regards " de tous còtés, il se promenait sur les meubles, " ou plutôt sur des cordes que j'avais disposées " à cet effet. Un peu de laitage et quelques fruits " bien fondants ne lui déplaisaient pas; mais il " n'était friand que de petits oiseaux ou d'in" sectes. S'il apercevait quelqu'un de ees der" niers objets, il s'approchait d'un pas allongé " et circonspect, tel que celui de quelqu'un qui " marche en tâtonnant et sur la pointe des pieds " pour aller en surprendre un autre. Arrivé " environ à un pied de distance de sa proie, il " s'arrêtait; alors se levant droit sur ses jam" bes, il avancait d'abord en étendant dou" cement ses bras, puis tout à coup il la sai" sissait et l'étranglait avee une prestesse sin" gulière.

"Ce malheureux petit animal périt par acci" dent. Il me paraissait fort attaché; j'avais "l'usage de le caresser après lui avoir donné à " manger. Les marques de sa sensibilité con" sistaient à prendre le bout de ma main et à le " serrer contre son sein, en fixant ses yeux à " demi ouverts sur les miens. "

\section{LE TARSIER.}

\section{(LE TARSIER AUX MAIXS ROUSSES.)}

Ordre des quadrumanes, genre tarsier, fanille des singes. (Curier.)

Nous avons eu cet animal par hasard et d'une personne qui n'a pu nous dire ni d'où il venait ni comment on l'appelait : cependant il est trèsremarquable par la longueur excessive de ses jambes de derrière; les os des pieds, et surtout ceux qui composent la partic supéricure dı tarse, sont d'une grandeur démesurée, et e'est de ee caractère très-apparent que nous arons tiré son nom. Le tarsier n'est cependant pas le seul animal dont les jambes de derriere soient ainsi conformées; la gerboise a le tarse encore plus long ; ainsi ce nom tarsier, que nous donnons aujourd'hui à cet animal, ne doit ètre pris que pour un nom précaire qu'il faudra ehanger lorsqu'on connaitra son vrai nom, e'est-i-dire le nom qu'il porte dans le pays qu'il habite. La gerboise se trouve eu Égypte, en Barbarie et aux Indes orientales. J'ai d'abord imaginé que le tarsier pouvait être du même continent et du même climat, parce qu'au premier coup d'œil il paraît lui ressembler beaucoup. Ces deux animaux sont de la même grandeur; tous deux ne sont pas plus gros qu'un rat de moyenne gros. seur, tous deux ont les jambes de derrière excessivement longues, et celles de devant extrémement courtes; tous deux ont la queue prodigieusement allongée et garnie de grands poils à son extrémité; tous deux ont de très-grands yeux, des oreilles droites, larges et ourertes; tous deux ont également la partie inférieure de leurs longues jambes dénuẹé de poil, tandis que tout le reste de leur corps en est couvert. Ces auimaux ayant de commun ces caractires trèssinguliers et qui n'appartiennent qu'ả eux, il semble quion devrait présumer qu'ils sont d'espéces voisines ou du moins d'espèces produites par le même ciel et la même terre : cependant, en les comparant par d'autres partics, l'on doit 
non-seulement en douter, mais même présumer le contrarre. Le tarsier a cinq doigts à tous les pieds; il a pour ainsi dire quatre mains, car ses einq doigts sont très-longs et bien séparés; le pouce des pieds de derrière est terminé par un ongle plat, et, quoique les ongles des autres doigts soient pointus, ils sont en même temps si courts et si petits qu'ils n'empêchent pas que l'animal ne puisse se servir de ses quatre pieds comme de mains. La gerboise, au contraire, n'a que quatre doigts et quatre ongles longs et courbés auxpieds de derant, et, au lieu du pouce, i) n'y a qu'un tubercule sans ongle: mais, ce qui l'éloigne encore plus de notre tarsier, c'est qu'elle n'a que trois doigts ou trois grands ongles aux pieds de derrière. Cette différence est trop s:ande pour qu'on puisse regarder ces animaux comne d'especes voisines, et il ne serait pas impossible cu'ils fussent aussi très-éloigués par le climat; car le tarsier, avec sa petite taille, ses quatre maius, ses longs doigts, ses petits ongles, sa grande queve, ses longs pieds, semble se rapprocher beaucoup de la marmose, du cayopollin et d'un autre petit animal que nous avons décrit sous le nom de phalanger. L'on voit que nous ne faisons ici qu'exposer nos doutes; et l'on`doit sentir que nous aurions obligation à ceux qui pourraient les fixer en nous indiquant le climat et le nom de ce petit animal.

\section{LE RA'T DE MADIGASCAR.}

(LE GALAGO DE IIADAGASCAR.)

Ordre des quadrumanes, genre tarsier, famille des singes. (Cuvier.)

Ce petit animal de Madagascar nous parait approcher de l'espèce de l'écureuil ou de celle du palmiste, plus que de celle du rat; car on nous a assuré qu'on le trouvait sur les palmiers. Nous n'avons pu obtenir de plus amplesindications sur cet animal. On doit seulement observer que, comme il n'a point d'ongles saillants aux pieds de derrière ni à ceux de devant, il parait faire une espèce particulière très-différente de celle des rats, et s'approcher de l'écureuil et du palmiste. Il semble qu'on peut rapporter à cet animal le rat de la côte sud-ouest de Madagasear, dont parlent les voyageurs hollandais ; ear ils disent que ces rats se tiemnent surles palmicrs, en mangent les fruits : qu’ils ont le corps long, le museau aigu, les pieds courts et une longue queue tachetée. Ces caractères s'accordent assez avec ceux que présente la figure que nous donnons ici du rat de Madagascar, pour qu'on puisse croire qu'il est de cette espèce.

Il a vécu plusieurs années chez madame la comtesse de Marsan. Il avait des mouvements très-vifs, mais un petit cri plus faible que celui de l'écureuil et à peu près semblable; il mange aussi comme les écureuils avec ses pattes de devant, relevant sa queue, se dressant et grimpant aussi de mème en écartant les jambes. II mord assez serré, et ne s'appriroise pas. On l'a nourri d'amandes et de fruits. Il ne sortait guère de sa caisse que la nuit, et il a très-bien passé les hivers dans uue chambre où le froid était tempéré par un peu de feu.

\section{ARTICLES}

\section{OMIS DANS L'HISTOIRE NATURELLE}

\section{DES QUADRUPÈDES.}

\section{LA IIUSARAIGNE DU BRÉSIL '.}

Nous indiquons cet animal par la dénomination du musaraigne du Brésil, parce que nous en ignorons le nom, et qu'il ressemble plus à la musaraigne qu'à aucun autre animal; il est cependant considérablement plus grand, ayant euviron cinq pouces depuis l'extrémité du museau jusqu à l'origine de la queue, qui n'a pas deux pouces, et qui par conséquent est plus courte à proportion que celle de la musaraigne communc; il a le museau pointu et les dents très-aiguës ; sur un fond de poil brun, on remarque trois bandes noires assez larges qui s'étendent longitudinalement depuis la tête jusqu'à la queue, au-dessous de laquelle on remarque aussi la bourse avec les testicules, qui sont pendants entre les pieds de derrière. Cet animal, dit Maregrave, jouait arec les chats, qui, d'ailleurs, ne se soucient pas de le manger; et c'est encore une chose qu'il a de commun avec la musarai-

\footnotetext{
1 Cet animal dont Buffon parlè d'apress Marcgrave es! to .
} talement inconnu des naturalistes modernes. 
gne d'Europe, que les chats tuent, mais qu'ils ne mangent jamais.

\section{SUPPLÉMENT AUX ARTICIES}

\section{DU DAIM ET DE L'AXIS'.}

M. le duc de Richemont avait dans son pare, en 1765 , une grande quantité de cette espèce de, daims, (fu'on appelle vulgairement cer/s du Gange, et que j'ai nommée axis. M. Colliuson m'a éerit qu'on lui avait assuré qu'ils engendraient avec les autres daims.

"Ils vivent volontiers avec eux, dit-il, et ne forment pas de troupes séparées. Il y a plus de soixante ans que l'on a eette espèce en Angleterre : elle y existe avant celle des daims noirs et des daims blanes, et mème avant celle du cerf, qui sont plus nouvelles dans l'ile de la Grande-Bretagne, et que je erois avoir été envoyées en France; car il n'y avait auparavant en Angleterre que le daim commun fallowdeer, et le chevreuil en cosse : mais indépendamment de cette première espèee de daims, il y a maintenant le daim axis, le daim noir, le daim fauve et le daim blanc. Le mélange de toutes ces couleurs fait que dams les pares il se trouve de très-belles variétés. "

Il y avait, en 1764, ¿̀ la ménagerie de Versailles, deux daims chinois, l'un mâle et l'autre femelle : ils n'avaient que deux pieds trois ou quatre pouces de hauteur; le corps et la queue étaient d'un brun minime, le ventre et les jam. bes fauveclair, les jambes courtes, le bois large, étendu et garni d'andouiller's. Cette espèce, plus petite que celle des daims ordinaires, et mème que celle de l'axis, n'est peut-ètre néanmoius qu'une variété de celui-ci, quoiqu’il en diffère en ee qu'il n'a pas de taches blanches; majs on a observé qu’au lieu de ees taches blanches, il avait en plusieurs endroits (quelques grands poils fauves, qui tranchaient visiblement sur le brun du corps. Au reste, la femelle était de la mème couleur que le mâle, et je présume que la race. pourrait non-seulenent se perpétuer en France; mais peut-être même se mêler avec relle de l'axis, d'atant que ees animaux sont également originaires de l'orient de l'Asie.

\footnotetext{
- Cet article doit ètre ajouté à celui de l'a sis.
}

\section{AVERTISSEMENT}

PLACB

\section{PAR ॥. LE COYTE DE LACÉPÉDE}

Au commencement du septième rolume du Supplément de l'édition des CEures de Buffon de l'Imprimeric royale.

Le public ayant désiré vivement jouir des derniers travaux de feu M. Ie comte de Buffon, qu'une longue et douloureuse maladie a enleré l'année dernière aux sciences et aux lettres, M. Ie comte de Buffon son fils, ainsi que M. le chevalier de Buffon son frère, et son exécuteur testamentaire, ont bien voulu me remettre les ouvrages manuserits qu'ils ont trouvés parmi les papiers de ce grand naturaliste, et confier le soin de diriger l'impression de ces ouvrages à celui qu'il avait chargé lui-mème de les continuer. J'ai cru ne pouvoir répondre convenablement à leur choix, ni bien remplir les intentions (qu'ils m'ont témoignées, qu'en publiant ces manuscrits tels qu'ils m'ont été remis. Feu II. de Buffon m'ayant souvent entretenu des projets qu'il avait formés pour ajouter à leur valeur, je sais qu'il se proposait d'y faire quelques changements. Il voulait particulièrement abréger plusieurs deseriptions qu'il avait fitites quelques années auparavant, les embellir par les couleurs brillantes qu'il savait employer avee tant d'art, les méler avec des considérations plus générales, présenter les rapports des diverses parties de son ou vrage dans de grands tableaux qui, comme autant d'oljets éclatants , auraient répandu sur l'eusemble une nouvelle Iunière et une chaleur plus vive; mais le génie de ce grand écrivain aurait pu seul terminer ses produetions. Ce volume sera done compose des articles laissés par $\mathbf{~ I . ~ d e ~ B u f f o n , ~ t e l s ~ q u ’ i l s ~}$ étaient lors(pu'il allait les perfectionner; jai eru seulement que l'on ne serait pas fäché de tronver, dans cet avertissement, l'indication des changements essentiels qu'il avait déterminés, et les noms des anteurs dans lesquels on verra des détitils plus étendus sur les animaux, dont il roulait completer l'histoire. J'ai pensé que ces obscrvations étaient autant d'hommages que je devais a sa mémoire, ainsi qu à l'amilué qưil m’a toujours témoignée.

Au reste, on trouscra dans ce volume qua- 
tre-vingt-deux planches très-précieuses, tant par l'exactitude et la beauté des dessius, que par la rareté de la plupart des animaux qu'elles représentent.

\section{Article des orangs-outangs.}

Le singe indiqué comme étant peut-être une variété par laquelle l'espèce du pongo ou graud orang-outang se rapprocherait du mandrill, est le choras, dont on pourra voir la description. Nous devons observer aussi que l'individu femelle, dont M. de Buffon rapporte les habitudes naturelles, d'après M. Vosmaër, est le même que celui dont il donue la description et l'histoire, d'après M. Allamand.

\section{Article du pithèque.}

La comparaison la plus exacte entre les divers pithèques apportés des côtes de Barbarie, et le singe si bien décrit par M. Daubenton, sous le nom de magot, a prouvé qu'ils appartiennent ả la même espèce, et qu'ils ne présentent que de légères différences relatives an sexe, ou qui disparaissent avec l'âge; mais un de nos confrères, M. Desfontaines, savant professeur du jardin du Roi, nous a confirmé qu ïl existait en Afrique, ainsi que l'out dit plusieurs royageurs, une espèce de singe sans queue, à laquelle il a laissé le nom de magot, daus les observations employées par MI. de Buffon, qui est en effet très-voisine de celle du magot, et qui en differe néanmoins par quelques caractères extérieurs, ainsi que par ses habitudes. C'est à ce dernier animal que l'on pourra appliquer le nom de simia-inuus donné au magot ou pithèque, par plusieurs naturalistes; et c'est à ce même animal qu'il faudra rapporter aussi la plus grande partie de ce qu'a dit II. de Buffon, des habitudes du singe connu depuis longtemps en Europe sous le nom de magot, et avec lequel les animaux appelés pithèques ne forment qu'une seule et même espèce. Au reste, très-peu de temps avant sa mort, M. de Buffou avait lui-même adopté cette opinion.

\section{Article du lowando.}

Le babouin que M. de Buffon avalt cru devoir rapporter à l'espèce du lowando, est absolument le même que le babouin à museau de shien, dont il parle dans l'article précédeut, d'après plusieurs naturalistes, et ç'e M. Linnée a nommé simia hamadryas.

\section{Article de la guenon à long nez.}

Des Cochinchinois qui sont venus au cabinet du Roi ont reconnu cet animal, dont on y conserve la dépouille. Ils nous ont appris qu il était très-commun dans leur pays, où on le nomme $k h i ̂$ doc, c'est-à-dire grand singe; il devient eil effet très-grand et très-gros. Il va par troupes nombreuses; il ne se nourrit que de fruits; son naturel est cependant presque féroce, et lorsqu'on l'attaque, il se défend avec beaucoup de force et de courage. M. Daubenton se propose de publier un mémoire au sujet de cet animal remarquable.

\section{Article du macaque à queue courte.}

Ce singe a de très-grands rapports avec celui dont M. Gmelin a parlé d'après M. Scopoli, et qui porte le nom de simia cynosuros (édition augmentée et corrigée du système de M. Linnée, vol. I, à Leipsick, 1788.)

\section{Article de l'alouate.}

Une planche jointe à cet article représeute un sapajou hurleur, dont M. de Buffon n'a laissé aucune description, et qui parait avoir de trèsgrands rapports avec l'alouate.

\section{Article du petit maki gris.}

Ce maki, ainsi que celui dont M. de Buffon donne la description daus l'article suivant, sont de l'espèce du maki appelée lemur laniger par M. Gmelin (ouvrage déjà cité).

\section{Article du loris du Bengale.}

On trouvera dans l'ouvrage déjà cité de M. Gmelin, les noms des divers auteurs qui ont fait commaitre ce loris : ce savant continuateur de M. Linnée lui a conservè le nom de lemur tardigradus, et M. de Buffon a été très-fondé à le regarder comme appartenant à l'espèce du loris dont il avait déjà traité.

\section{Article du Bizaam.}

M. Schreber en a parlé ( vol. III, page 425), et l'a fait représenter (planche CXV); M. Gmelin l'a nommé viverra tigrina. 
Article du pulois rayé de IInde.

C'est avec toute raison que $\mathrm{M}$. de Buffon a cru devoir séparer du genre des chats cet animal rayé, qui n'appartient pas cependant au gemredes putois, qui en est séparé par la forme ainsi que par la position de ses dents, et que M. Gmelin a placé parmi les viverra, sous le nom de viverra fasciata.

\section{Article du grand écureuil de la côte de Malabar.}

Cet écureuil, qui a beaucoup de rapports avec l'écureuil de Madagascar dont M. de Buffon a traité dans l'article suivant, est le même que celui que M. Gmelin a nommé le très-grand écureuil (sciurus maximus), et dont M. Schreber a donné la figure, vol. IV, planche CCXVII, $b$.

\section{Arlicle de l'aye-aye.}

M. Gmelin l'a nommé écureuil de Madagascar, à cause de sa conformation, qui le rapproche des écureuils, quoique ses habitudes l'en éloignent, ainsi que l'a tres-bien observé cet labile naturaliste; mais il ne faut pas le confondre avee l'écureuil de Madagascar, dont parle $M$. de Buffon et qui est un animal tout à fait différent, tant parses habitudes que par sa forme.

\section{Article du phalanger.}

Ce quadrupède, dont ont parlé_IM. Valentin, Pallas, Erxleben, Schreber et Pennant, a été nommé par M. Gimelin didelphis orientalis, et placé, à cause de sa conformation, dans le mème genre que le sarigue, la marmose, le cayopollin, etc. M. de Buffon parait avoir une opinion contraire en assurant que le phalanger n'est pas du mème genre que ces mèmes sarigue, cayopollin et marmose; mais nous devons observer que, dans cette note, ainsi que dans beaucoup d'autres endroits de ses ouvrages, M. de Buffon n'entend par genre, et quelquefois par classe, qu'une sorte de famille naturelle foudée sur une grande partie des caractères extérieurs des animaux, et en mème temps sur la grande ressemblance de leurs habitudes, quand bien mème les diverses espèces de cette famille ne présenteraient pas une conformation semblable dans les parties du corps dont les auteurs des divers ordres méthodiques considèrent la ressemblance ou la différence, pour rapprocher ou séparer les espèces.

\section{Article de la grande chauve-souris fer-de-} lance.

Cette espèce a quatre dents incisives à la mâchoire inférieure, sans en avoir à la supérieure. Le défaut de queue la distingue de la chauvesouris fer-à-cheval, a vec laquelle ellea beaucoup de rapports; et le nombre de ses dents la sépare de la chauve-souris musaraigne, qui a quatre dents incisives à chaque mâchoire.

\section{Article de la chauve-souris de la Guiane.}

Le nombre de ses dents incisives, ainsi que la forme de ses oreilles, empéche qu'on ne la confonde avee les chauves-souris déja décrites par les naturalistes, et dont aucune n'a, comme elle, la mâchoire supérieure sansíncisives, et la mâchoire inférieure armée seulement de deux dents incisives ou tranchantes. Cependant elle a de très-grands rapports avee celle que $\mathbf{~ I I . ~ G m e - ~}$ lin a comprise dans son ouvrage, sous le nom de vespertilio lepturus, quoicpue celle-ci ait quatre clents incisives à la mâchoire d'en bas; et ce qui les rapproche de plus près, c'est que les deux dents incisives qui garnissent la màchoire inférieure de la chaluve-souris dont il est ici question sont très-petites, et divisées en deux: de manière qu'on peut aisément croire qu'elle en a quatre à cette mème màchoire.

\section{Article du coendou à longue queue.}

C'est le mème animal que M. Brisson anommé grand porc-épic d'Amérique, dont Barrère a parlé, dont Maregrave a fait mention et donné la figure, et que M. Gmelin a regardé avee raison comme une variété du coendou ordinaire.

Article du Klipdas ou de la marmolte du cap de Bonnc-Espérance.

C'est le hyrax capensis de M. Gmelin. M. le comte de Mellin, cité par M. de Bufion, en a donué la description, la figure et l'histoire, dans les Mémoires des Curieux de la nature de Berlin. 


\title{
TABLE DES MATIEERS
}

\author{
CONTENUES DANS CE VOLUME.
}

\begin{tabular}{|c|c|c|c|}
\hline & ages. & & \\
\hline Animaux carnassiers. & 1 & La Sunris. & รั? \\
\hline Le Loup. & 12 & Addition à l'article de la Souris. & Ibid \\
\hline Addition à l'ạticle du Loup. & 16 & Description de la Souris. & 60) \\
\hline Description du Loup. (Extrait de Daubenton.) & 17 & Le Mulot. & lbil. \\
\hline Le Loup du Mexique. (Le Loup rouge.) & 18 & Description du Mulot. & 62 \\
\hline Le Loup noir. Ib & Ibid. & Le Rat-Percbal. & Ibid. \\
\hline Descriptiond'uu Loup noir. (Extrait de Daubenton.) & ) 19 & Le Porc-Épic de Malaca. & 65 \\
\hline Le Renard. & lbid. & Le Rat deau. & Ibid. \\
\hline Première addition à l'article du Renard. & 22 & Le Rat d'eau blanc. & 64 \\
\hline Deuxième audition. & 25 & Le Scherman ou Rat d'eau de Strasbourg. & Ibid. \\
\hline Description du Renard. (Extrait de Daubenton.) & Ibid. & Le Campagnol. & 65 \\
\hline LAlco. & 24 & Descriplioa du Campagnol. (Extrait de Daubenton) & n). 66 \\
\hline Le Blaireau. & 23 & Le Cochon d'Inde. & Ibid. \\
\hline Addilion à l'article du Blaireau. - Le Carajou. & 27 & L'Apéréa. & 67 \\
\hline Description du Blaireaı. (Estrait de Daubenton.) & 28 & Descriprion du Cochon d'Inde. (Extrait de Dau- & \\
\hline Le Kinkajou. & 29 & bentor). & Ibid. \\
\hline Addition à l'article du Kinkajou. & 52 & Le Herisson. & 68 \\
\hline La Loutre. & Ibid. & Addilion à l'article du Hèrisson. & 69 \\
\hline Premiere addition à l'article de la Loutre. & 55 & Description du IIérisson. (Extrait de Daubenton.) & 71 \\
\hline Deusieme addition. & 54 & La Musaraigne. & 73 \\
\hline Description de la Loutre (Extrait de Daulenton.) & 53 & Description de la Musaraigne. (Extrait de Dau- & \\
\hline La Fonine. It & Ibid. & benton.) & Ibici. \\
\hline Description de la Fouine. (Extrait de Daubenton.) & $5 i$ & La Musaraigne d'eau. & 涪 \\
\hline La Marle. Il & Ilbid. & La Musaraigne musquée de l'Inde. & Ibial. \\
\hline Description de la Marte. (Extrait de Daubenton.) & 58 & La Taupe ronge d'Anérique. & [luid. \\
\hline Le Putois. & 59 & La Taupe de Pensylranie. & Ibis. \\
\hline Description du Putois (Extrait de Daubenton.) & 40 & La Taupe doree. & 7.8 \\
\hline Le Furet. & 4.1 & La Taupe. & Ibid. \\
\hline Deseription du Furet. (Extrait de 1)aubenton.) & 42 & Addition à l'article de la Taupe. & 7 \\
\hline La Belette. & Ibid. & Deseription de la Taupe. (Extrait de Daubenton.) & Ibid. \\
\hline Prenière addition à l'article de la Belette. & 45 & La Taupe dn Canada. & -8 \\
\hline Deusicure addition. & 45 & La Chauve-S Iuris. & 79 \\
\hline Description de la Belette. (Extrait de Danbeuton.) & 49 & Description des Chaures-Souris. (Extrail de Dau- & \\
\hline L'Ilermine on le Roselet. II & Ibid. & henton.) & 81 \\
\hline Descripition de l'Ilermine. & 50 & La Cbaure-Souris ordinaire. (Le Vespertilion ma- & \\
\hline Le Perouasca. & 51 & & 85 \\
\hline L'Écureuil. & Ibid. & L'Oreillard. (Le Vespertilion Oreillard.) & Ibid. \\
\hline Additiou a l'article de l'Ĺcureuil. & 32 & La Nuctule. (L.e Vespertilion Noctule.) & i4 \\
\hline Le Pelit-Gris de Siberie. & 55 & La Seroline. (Le Vesperti'ion Sèrutine) & Ibiu. \\
\hline Description de l'Écurcuil. Extrait de Daubenton.) 1 & lbid. & La Pipistrelle. (Le Vespertilion P'ipistrelle.) & Ibid. \\
\hline Le Grand Écurenil du Malabar. & 54 & Lal Barbastelle. (Le Vespertilion Barbastelle.) & Ibial. \\
\hline L'Écureuil de Madag scar. & 53 & Le Fer-il-Cbeval (Le Rlinolphe Bifer.) & Ibill. \\
\hline Les Gnerlinguets. & Ibid. & La Roussette, la Rougette ct le Vampire. & 85 \\
\hline Le Rat. & 56 & Addition à l'article de la Rousselte et de la Ron- & \\
\hline Première addilion à l'arlicle du Rat & 58 & & s8 \\
\hline Deusiene addition. & Ibid. & Le Mlolosse à ventre blanc. & $9:$ \\
\hline Description du Rat. & Ibid. & Le Molosse Mulot-Volant. & Ibid. \\
\hline
\end{tabular}


Le Nyctèce Gampagnol volant.

Le Nyctère de la Thébaide.

Le Vespertilion Kirisoula.

La Chauve-Souris-Fer-de-Lance.

Descriplion de la Chauve-Somris-Fer-rle-I.ance.

Addilion à l'article des (. hanses-Souris.

Nouvelle addition. - Ia grande Serntine de la Guiane.

Du Vampire.

La Grande-Chanve-Souris-Fer-de-Lance de la Gniane.

Le Molosse Amplexicaude.

Le Loir.

Le Lejrot.

Le Muscardin.

Le Surnulot.

Le Pouc.

Le Zemni.

La Taupe di cap de Bonne-Espórance.

Addition a l'article de la Taupe du Cap de Buane-

Espérance.

La grande Tanpe d'Afripue.

La grande Taune du Cap.

Le T'ucan.

La Marmolte.

Description de la Marmotte.

Le Souslick.

Le Zisel.

Le Jevra clska, ou la Varmotte de Silrérie.

Le Bubik.

Le Monax ou Marmotte de Camiada.

La Narmolle de Kamtsclatka.

L'Ours. (L'Ours lyrun d'Europe.)

Addition à l'article de l'Onrs.

Description de l'Ours. (Extrait de Dauhrufun.)

L'Ours blanc.

Arldition i l'article de l'Our's blanc.

Le Cistor.

Arldition à l'arlicle dı Castor.

Description du Castor. (Extrait ve Daubentun.)

L'Ondatra et le Desman.

Le Raton.

Acldilion à l'article du Raton.

Deseription du Raton. (Extrait de Danbenton.)

Le Raton-Crabier.

I.e Coati.

Addition à l'article du Coati.

Autre addition.

Lidgouti.

Addition à l'article de l'Agonti.

L'Akouchi.

Adilition à l'arlicle de l'Akouchi.

Animaux de l'ancien continent.

Aumanx du Nouveau-.lionde.

Aninaax communs aus deus cuutineuts.

Le Lion.

Description du Lion. (Litrait de Danbenton.)

Les Tigres.

Le Tigre.

Addition à l'article du T'ıgre.

Description du Tigere. (Extrait de Manulentento.)

La Panthère, l’Once, et le I.épuaril.
Pages.

92

Le Jaguar de la ciuiane.

Itrid. Le Jaguar de la Jouvelle-lespaguc. 189

Ihid. Le Conguar. ll,id.

94 Addition a I article du Couguar. (Conguar de Pen-

93 silvanie.)

Cougnar noir. 191

96 Description du Conguar. (Extrait ic Daubenton.) 192

97 L'Ocelot. Jhil.

Le Margav el le Gueprit.

lbid. Arldition il l'article du Jaguar ou Léopard.

Ibid. Adclition à l'article dn Vargisy. Ibicl.

98 J.e Serval. 196

100) Description du Serval. (Extrait de Danbenton.) 197

101 Le Lynx, on Lonp-Cervier. Jhid.

Ibid. Description d'un Lyux. (Extrait de Daulenten.) 200)

102 Le Caracal. 201

Itsid. Description du Caracal (Extrait de Daubentun.) 202

105 Addition à l'article dı J jnx el à celui dı Caritcal.

(le Lynx du ('anada.) Ibid.

Ibid. Nouvelle addition à l'article du Lyax. 209

10 L L'llyene. 1 bill.

Ibid. Addition à l'article de l'Ilycine. 208

105 Descriplion de l'Ilyéne. (Extrail de Daubentun.) Il;id.

106 La Civelte et le Zibet. 209

108 Addition il l'article de la Circlle.

109 Description de la Civelte. (Extrait de Daubenton.) 21.4

110 La Genelle. Mid.

llid. Addilion à l'article de la Genetle. 29

III Nonvelle addition. Ibid.

Hid. Du Bizaam. 216

11:2 Troisieme addition à l'article de la Genelte. Itid.

Ibid. La Fossane. $21 \mathrm{i}$

116 Le Pulois rased le linde. 218

118 La Saricovirnue. !bid.

Ibid. Addlition il l'article de la Saricovienne. $\quad 219$

121 Line Loutre de Canada. Wid.

Ibid. De la Saricor ienne ou Loutre marine.

129 Le Surikate. 225

lhid. Addilion a l'article dı Surikate. 2026

151 Description du Surikate. (Extrait de Daubenton.) Ibid.

15. La Mangousle.

155 Addilion a l'article de la Mlangouste. 229

156 Description de la Mangouste. (Eistrait de Dauben-

158 Lon.) Ibid.

Ibid. Le Vansire. 250

130 Additiou à l'arlicle du Vansire. Ibid.

Ilid. Nowrelle addition. 251

Ibid. Deseription du Vansire (liurait de Daubenton.) Ibid.

1.1 La petite Fouine de Madagasear. 252

1.2 Le cirison. Ibid.

llidd. La Fouine de la Guiane.

Ibid. Le Tasra ou le Galera. 23:

130) La grande Marte de la Guiare. Ibid.

15. La Zibreline. Ibid.

169 Adilition a larticle de la Zitreline. 256

1 il l.e Pekan et le lisun.

175 Addition a l'article de l'Hermine. Ibid.

17i Les Mancrelles. 259

iis Inescription du Coase. (T.atrait de Danhenton.) 2 i:

his. La Mourfette du Chili. 245

isi) Lec cilouton. Ibid. 
Addition à l'article du Glouton.

Nouvelle addition.

Le Chacal et l'Adive.

Addition à l'article du Chacal.

Du petit Chacal ou Chacal-Adive.

L'Isatis.

De I'Isatis.

Le Chien de Sibérie.

L'Anonyme.

Le Sarigue ou l’Opossum.

Description du Sarigue. (Extrait de Daubenton.) 261

La Marmose.

Addition a l'article de la Marmose.

Description dela Marmose. (Extrait deDaubenton.) 264

Le Cayopollin.

Descriptiou du Gayopollin. (Extrait de Daubeuton.) 265

Le Philandre de Surinam.

Addition aux articles du Sarigue, de la Marmose et du Cayopollin.

Le Crabier.

Le Sarigue des Illinois.

Le Sarigue à longs poils.

Le Touan.

La petite Loutre de la Guiane.

Le Phalanger.

Additions et corrections à l'article du Phalanger. Ilid.

Le Polatouche.

Description du Polatouche. (Extrait de Daubenton.)

Le Taguan ou grand Écureuil volant.

Addition á l'article du Taguan.

Le Petil-Gris.

Description du Petit-Gris. (Extrait de Daubenton.)

Le Palmiste, le Barbaresque et le Suisse.

Addition à l'article du Palmiste.

Description du Paluiste. (Extrait de Daubenton-) Ibid.

Le Coquallin.

L'Aye-aye.

Le Cabiaj.

Addition à l'arlicle du Cabiai.

Description du Cabiai. (Extrait de Daubenton.)

Le Paca.

Addition à l'article du Paca.

Description du Paca. (Estrait de Daubenton.)

Le Hamster.

Addition à l'article du Hamsler ou Rat de blé.

Addition de l'éditeur bollandais à l'article du IIamster.

Description du Hamster. (Extrait de Daubenton.) 295

Le Leming.

Le Lèrot à queue dorée.

Les Gerboises.

La Gerboise ou Gerbo, et la Gerboise du Cap.

Addilion de M. le professeur Allamand à l'article de la Gerboise ou Gerbo.

Seconde addition à l'bistoire des Gerboíses, par M. Allanand.

Le Porc-Épic.

Description du Porc-Epic.

Le Coendou.

Additiou à l'article du Coendou. ages.

24 Description du Coendou. (Extrait de Danbenton) 510

246 Le Coendou à longue queue.

bid. L'Urson. 512

250 Description de l'Urson. (Extrait de Daubenton.) lbid.

bid. Le Tenrec et le Tendrac. 513

251 Addition à l'article du Tenrec. Ibid.

252 Addition à l'article du Tendrac. Ibid.

Ibid. Description du Tendrac et du Tenrec. (Extrail de Daubenton.)

Le Tamanoir, lc Tamandua et le Fourmilier. Ibid. Addition à l'article du Tamanoir. $\quad 319$ Addition à l'article du Tamandua. 520

Description du Tamanoir. (Extrait de Daubenlon.) 521

Description du Fourmilier. (Extrait de Daubenton) 5 $52 \cdot 2$

Le ['angolin et le Phatagin. 523

Description du Pangolin. 32.5

Le Gochon de terre. Ihid.

Les Tatous.

hid.

L'A par ou le Tatou à trois bandes. $\quad 529$

268 L'Encoubert ou le Tatou à six bandes. 550

269 Le Tatuète ou le Tatou à huit bandes.

270 Le Cachicame ou le Tatou à neuf bandes. Ibid.

Ibid. Le Kabasson ou le Tatou à douze bandes. 552

Ibid. Le Girquinçon ou le Tatou à dix-huit bandes. $\quad 553$

Addition à l'article des Tatous. $\quad 556$

Descrjption des Tatous. (Extrail de Daubenton.) $\quad 557$

Le Cachicanie ou le Tatou à neuf bandes. (Extrail du mème.)

Ibid.

Le Tatuete ou Talou à neuf bandes. (Extrait du mème.)

Le Kabassou ou Tatou à douze bandes. $\quad 540$

L'Encoubert ou Tatou à six bandes. (Extrait de Daubentou.)

L'Unau et l'Aĩ.

341

bid. Addition à l'article de l'Unau et de I'Aî. 544

281 Le Kouri ou le petit Unau. $\mathbf{5 4 5}$

Description de l'Unau. (Exlrait de Daubenton.) $\quad 5: 6$

Le Pecari ou le Tajacu. $\quad 5.7$

Addition à l'article du Pecari.

Autre addition au mène article. $\quad \mathbf{5 4 9}$

Le Babiroussa. $\quad 550$

Addition à l'article du Babirolissa.

Ibid. Le Tapir ou l'Anta. Ibid.

286 Addition à l'article du Tapir ou Maĩpouri. 352

289 Addition de I. le professeur Allamand à l'article

Ibid. dn Tapir. 557

991 De la Nature. - Première vue. $\quad 560$

De la Nature. - Seconde vuc. $\quad 564$

L'Eléphant. $\quad 371$

Première addition à l'article de l'Éléphant. $\quad 395$

Seconde addition. $\quad 596$

Description de l'Élépluant. (Extrait de Daubenton.) 599

Le Rbinocéros. $\quad 405$

Première addition à l'article du Rhinocéros. $\quad 409$

Scconde additiou au mème article par M. le pro-

fesseur Allamand. $\quad 410$

Deseripltion du Rhinocéros. (Extrait de Daubenton.) 412

De la Vlarmotte du Gap et du Daman. 414

Du Daman Israç. 415

Additions et corrections à l'article de la Marmclte du cap de Bonue-Espérauce. 418

510 Lilippopotame. 
Addition à l'artscle de l'Hippopotame.

Pages.

Addition au mème article de $\mathrm{H}$. le professeur Allamand.

Addition à l'histoire de l'IIippopotane, par M. le docteur Klockner, d'Amsterdam. - Notes.

Observations par le mẻme, en préparant la peau d'un Ilippopotame.

Nouvelle addition à l'article de l'Hippopotame.

Description de l'Hlippopotame. (Extrait de Daulienton.)

De la Dégénération des animaux.

Jes Mulets.

Table des rapports de la fécondilé des animıux.

De la Mule. - Exemples d'accouplement prolifique de la Mule avec le Cheval.

Le Zèbre.

Addition anx articles de l'A ue el du Zèbe.

Du Czigithai, de l'Onagre et du Zibre.

Du Kwagga, on Couagga.

Le Chameau et le Dromadaire.

Addition al l'article du Chameau el du Dromadaire. 48I

Description du Diomadaire. (Extrait de Daubenton.)

Description du Chamean. (Extrait du même.)

Le Lama el le Paco.

Addition a larticle dı Lama.

De la Vigogne.

Le Buffe, le Bonasus, l'Auroclıs, le Bison et le Zébu.

Addition aux arlicles du Brur, du Bison, dı Zeibu et du Butlle.

Autre addition à l'arlicle de l'Aurochs et du Bison.

Addition relative à la Vache de Tarlarie.

Nouvelle addition à l'article du Buffle.

Un Zébu.

La Girafe.

Addition à l'article de la Girafe.

Nouvelle addition au mème article.

I'Élan et le Renne.

Première addition à l'article du Renne.

Deuxième addilion de M. le professenr Allamand. - L'lilan, le Carilou et le Renne.

Description du Renue, par M. Ie professeur Allamand.

Observalions sur le Renne, faites ì Groningue par

M. le professeur Camper.

Troisicne addition al l'article du Renne.

Quatrième addition au méme article.

Cimpuieme addilion.

Addition à l'article de l'Ĺlan.

Suite de la nouvelle addition andit article.

I.Axis.

Le Chevrouil des Indes.

Les Mazames.

Les Chevrolains.

Deseription du Chevrotaiu. (Ex/rait de Daubeaton.)

Le Clıevrolain de Cerlan.

Le Cherrotain appele a Java petite Gazelle.

Le Muse.

Addilion à l'arlicle du Muse.

Le Saïga.

Ibid

487

488

libil.
Addition à l'arlicle du Saiga.

Pages.

564

567

Addition à l'article des Gazelles, et des Antilopes.

575

Addition à l'article des Grazelles, relatire au Kevel. 576

Nouvelle addlition au mème article, relative au

Koba et au Kols.

Ilid.

Description de la Gazelle.(Extrail de Daubenton.) Ibid.

Description de la Corine.

De la Cazelle ou Cherre Sautante du cap de BonnoEspérance.

De la Gazelle à bourse sur le dos, par M. Allamantl.

Le Klippspringer ou Sauteur des rochers.

La Gazelle Pasan. $\quad 581$

Addition à l'article du Pasan, par M. le docteur Allamand.

lbid.

Le Condoma. $\quad 543$

Addition á l'article du Condoma on Coestloes. $\quad 589$

Autre aduition au nème article par II. le professeur Allamand.

La Gazelle Antilope.

La Gazelle Tzeiran.

588

De la Chère bleue.

589

Le Guib.

Le Boshok.

La Grimme.

llid.

Ilid.

Addition à l'article de la (irimme.

Du Nanguer et du Nagor. $\quad 596$

Le Ritbok.

Le Bubale. 599

Addition a l'article du Bulsale. $\quad 600$

Du Camaa. - Antre addition à l'article du Bubale. 601

Du Gnou ou Nion. $\quad 602$

Du Guou, par M. le proressen Allamaud. 604

Le Couilons, ou Canra. 607

Addition à l'article du Canna. Ibid.

Le Nil-frant. 6f1)

Le Monflon et les antres brebis. $\quad 616$

Addition à l'article de la Brebis, dn Moufou et des Brebis étrangeres. 621

Description du Mouflon. (Extrait de l)aubenton.) 625

Deseription d'un Bélier d'l slande. (Estrait du méme auteur.) Ilvid,

Descriptiıu du Bélier des Indes. $6: 1$

5 位 Le Bouquetin, le Chamois et les autres Cherres. Ibid. 54.5 Addition aux articles des Chesres grandes et pe-

54.) tites. - Des Cherres d'inrope.

$5: 7$ Du Bouc de Juda. Ibid.

5 is Nouvelle addition anx articles des Cherres et des

Brebis. Ibid.

Deseription du Bonquetiu. (Fxtrait de Daubenton.) $\quad 6.55$

Deseription du Chanois. (Extrait du meme.) 656

Descrintion des Bizoards oricntaur et occiden-

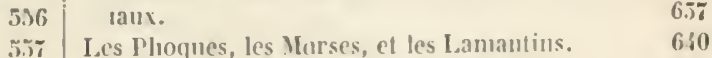

Ibid. Les Phocpues. $6: 1$

Ibill. Le Ylorse oul la Vache Marine. 6 it

561 Addition a l'article des Morses ou laches ma. s6.5 riues. 
Le Dugon.

Le Lamantin.

Addition à l'article des Phoques, publièe en 1784.

Les Phoques sans oreilles ou Phoques proprement dits. - Le Grand Phoque à museau ridé, première espèce.

Le Phoque à ventre blanc, seconde espèce. Le Phoque à capuchon, quatrième espèce.

Le Phoque à croissant, troisième espèce.

Le Phoque Neit-Soak, cinquieme espèce.

Le Phoque Laktak de Kamtschatka, sixième espèce. Ibid.

Le Phoque Gassigiack, septième espèce.

Le Phoque commum, huitième espèce.

Les Ploques à oreilles. - L'Ouı's marin.

Le Lion Marin.

Les Lamantins.

Le grand Lamantin de Kamtschatka.

Le grand Lamantin des Antilles.

Le grand Lamantin de la mer des Indes.

Le Petit Lamantin d'Amérique.

Le petit Lamantin du Sẻnégal.

Nomenclature des Singes.

Les Orangs-Outangs ou le Pongo et le Jocko.

Addition à l'article des Orangs-Outangs.

Description du Jocko. (Extrait de Daubenton).

Le Gibbon.

Le Magot.

Le Pithèque.

Addition à l'article du Pithèque.

Du Petit Crnocéphale.

Description du Magot. (Extrait de Daubentou).

Le Papion ou Babouin proprement dit

Le Babouiu des Bois.

La Guenon à museau allongè.

Le Mandrill.

Le Choras.

L'Ouanderon et le Lowando.

Addition à l'article de l'Ouanderou.

La Guenon à crinière.

Le Babouin à museau de chien.

Addition à l'article du Lowando.

Le Maimon.

Le Macaque à queue courte.

Le Patas à queue courte.

Le Babouin à longues jambes.

Le Macaque et l'Aigrette.

Le Patas.

Le Malbrouck et le Bonnet-Chinois.

La Guenon couronnée.

Le Mangabey.

sa Mone.
Pages.

652

6.5

65

Le Mloustac.

Le Talapoin.

Le Douc.

658

659

66.4

Ibid.

665

Ibid.

Ibid.

667

672

675

678

681

682

Ibid.

Ibid.

685

695

705

712

714

715

716

718

720

Ibid.

721

722

723

Ibid.

724

725

726

Ibid.

$72 \pi$

728

Ibid.

729

750

Ibid.

751

752

735

734

735

Ibid.

Le Mona. gous.
Pages.

756

757

738

Ibid.

739

7.60

741

La Guenon à long nez.

La Guenon à camail.

Le Blanc-nez.

L Guenon à nez blanc proéuinent.

Le Roloway ou la Palatine. $\quad 744$

La Guenon i face pourpre.

La Guenon nègre.

Les Sapajous et les Sagouins. Ibid.

L'Ouarine et l'Alouate. $\quad$ T46

Adition à l'article de l'Alouate.

Description de l'Alouate. (Extrait de Daubenton.) 75:

Le Coaita et l'Exquima.

Addition à l'article du Coaita. 755

Le Sajou.

Addition à l'article du Sajou brun. Ibid.

Le Sajou nègre. $\quad 758$

Le Sajou cornu. Ibid.

Le Saĩ. $\quad 759$

Le Saïmiri. lbid.

Addition à l'article du Saĩmiri. $\quad 760$

Le Saki. Ibid.

L'Yarqué, espèce de Saki. $\quad 761$

Le Sagouin, vulgairement appele Singe de nuit. Ibid.

Le Tamarin. $\quad \mathbf{7 6 2}$

Le Tamarin nègre. Ibid.

L'Ouistiti. Ibid.

Description de l'Ouistiti. (Extrait de Daubenton). 765

Le Marikina. $\quad \mathbf{7 6 4}$

Le Pinche. lbid.

Le Mico. 765

Les Makis. Ibid.

Addition à l'article des Makis. - Le grand Mon-

Le petit Maki gris. Ibid.

Autı'e espéce de Maki. - Le Vari à longue queue. 769

Description des Makis. - (Extrait de Daubenton.) Ibid.

Le Loris. $\quad \mathbf{7 7 0}$

Le Loris de Bengale.

Le Tarsier.

Le rat de Madagasear.

Articles omis dans l'Histoire aaturelle des quadrupèdes. - La Musaraigne du Brésil. Ibic.

Supplément aux articles du Daim et de l'Axis. 777

Avertissement de M. le comte de Lacépède. ibi J. 


, 

